\title{
Critical Mineral Resources of the United States- Economic and Environmental Geology and Prospects for Future Supply
}
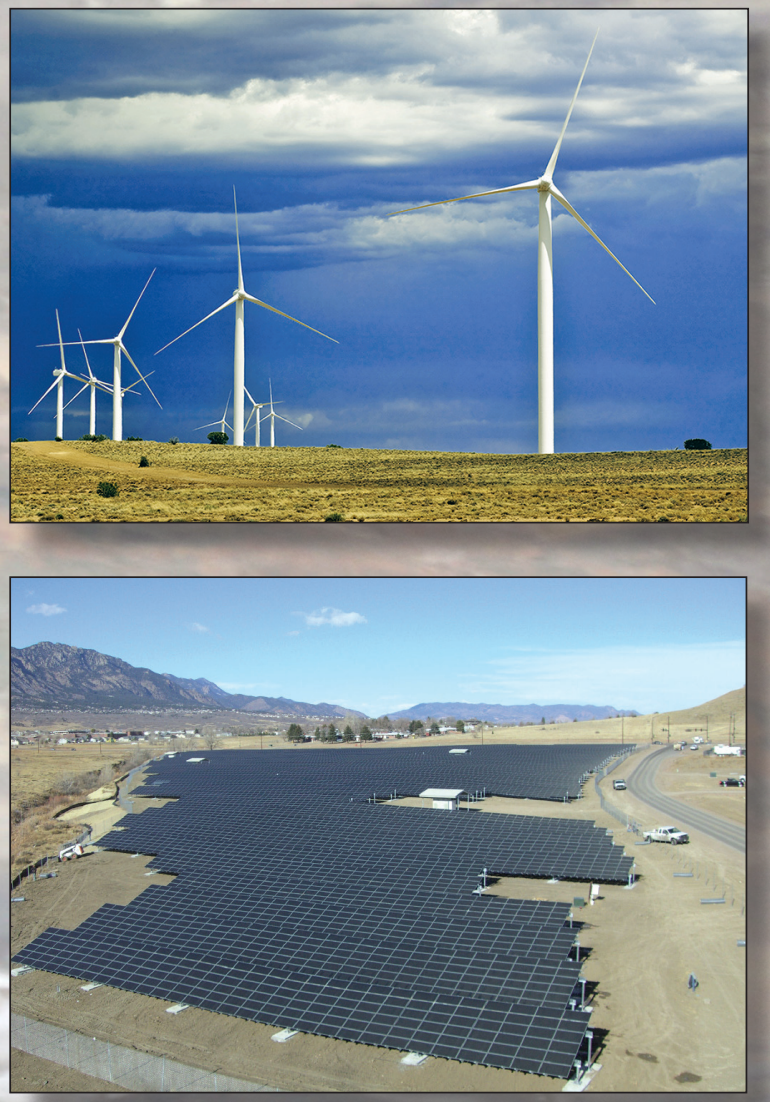

Professional Paper 1802

U.S. Department of the Interior U.S. Geological Survey 


\section{Periodic Table of Elements}

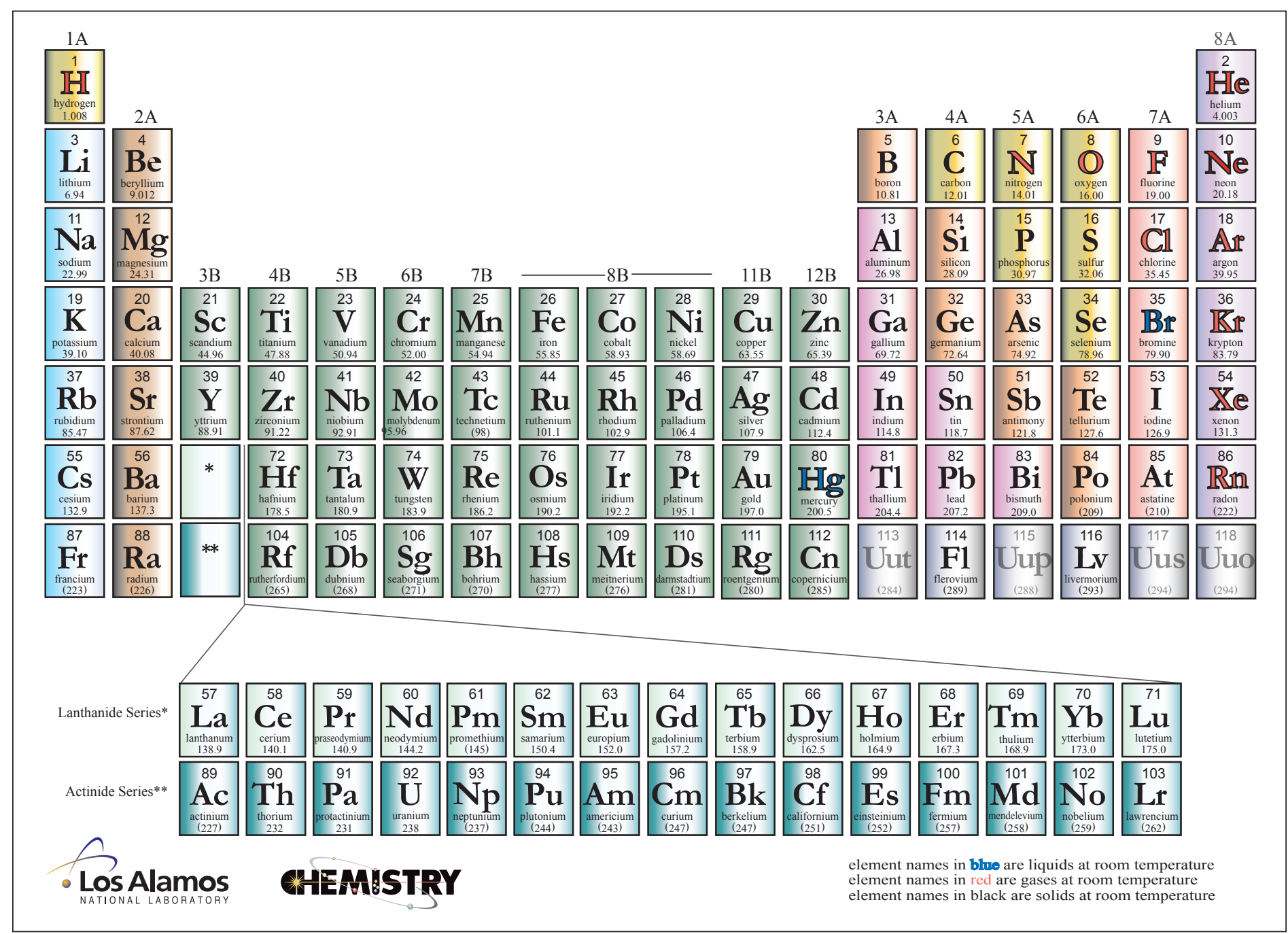

Modified from Los Alamos National Laboratory Chemistry Division; available at http://periodic.lanl.gov/images/periodictable.pdf.

Front cover (clockwise starting at top left).

Dry Lake Wind Power Project. This 63-megawatt-capacity facility in Arizona was the first utility-scale power project. The large wind turbines use generators that contain strong permanent magnets composed of neodymium-iron-boron. Photograph courtesy of Iberdrola Renewables, Inc., NREL 16701.

U.S. Air Force F-35 Lightning II Joint Strike Fighter. This and many other aerospace vehicles rely on electrical and mechanical components made of beryllium alloys. Photograph courtesy of the U.S. Air Force.

Flat-panel display and touchscreen devices. The screens are coated with indium-tin oxide, for which there are few chemical substitutes. Photograph by C.N. Mercer, U.S. Geological Survey.

Solar photovoltaic cells. This 2-megawatt ground-mounted array occupies the site of a former landfill at Fort Carson, Colorado. Tellurium is a critical component for the development of efficient thin-film photovoltaic cells that are needed for the production of electricity from sunlight. Photograph courtesy of the U.S. Department of Energy Western Area Power Administration.

Back cover. A handful of stibnite, which is the primary ore mineral for antimony. Antimony is widely used in plastics, rubbers, paints, and textiles, including industrial safety suits and some children's clothing, to make them resistant to the spread of flames. Photograph by Niki Wintzer, U.S. Geological Survey.

Front and back covers background image. Lithium-brine evaporating ponds at Clayton Valley, Nevada. Lithium has many uses, the most prominent being in batteries for cell phones, laptop computers, and electric and hybrid vehicles. Photograph by Doc Searls/CC-BY-2.0, http://commons.wikimedia.org/wiki/File:Chemetall_Foote_Lithium_Operation.jpg. 


\section{Critical Mineral Resources of the United States-Economic and Environmental Geology and Prospects for Future Supply}

Edited by Klaus J. Schulz, John H. DeYoung, Jr., Robert R. Seal II, and Dwight C. Bradley

Professional Paper 1802 


\title{
U.S. Department of the Interior \\ RYAN K. ZINKE, Secretary
}

\section{U.S. Geological Survey William H. Werkheiser, Acting Director}

\author{
U.S. Geological Survey, Reston, Virginia: 2017
}

For more information on the USGS — the Federal source for science about the Earth, its natural and living resources, natural hazards, and the environment-visit https://www.usgs.gov or call 1-888-ASK-USGS.

For an overview of USGS information products, including maps, imagery, and publications,

visit https://store.usgs.gov/.

Any use of trade, firm, or product names is for descriptive purposes only and does not imply endorsement by the U.S. Government.

Although this information product, for the most part, is in the public domain, it also may contain copyrighted materials as noted in the text. Permission to reproduce copyrighted items must be secured from the copyright owner.

Suggested citation:

Schulz, K.J., DeYoung, J.H., Jr., Seal, R.R., II, and Bradley, D.C., eds., 2017, Critical mineral resources of the United States-Economic and environmental geology and prospects for future supply: U.S. Geological Survey Professional Paper 1802, 797 p., https://doi.org/10.3133/pp1802.

\section{Library of Congress Cataloging-in-Publication Data}

Names: Schulz, K. J., editor. | Geological Survey (U.S.), issuing body.

Title: Critical mineral resources of the United States : economic and environmental geology and prospects for future supply / edited by Klaus J.

Schulz, John H. DeYoung, Jr., Robert R. Seal II, and Dwight C. Bradley.

Other titles: Economic and environmental geology and prospects for future supply | U.S. Geological Survey professional paper ; 1802.

Description: Reston, Virginia : U.S. Geological Survey, [2017] | Series:

Professional paper ; 1802 | Includes bibliographical references.

Identifiers: LCCN 2017005489| ISBN 9781411339910 | ISBN 1411339916

Subjects: LCSH: Mines and mineral resources--United States. | Strategic

materials--United States. | Industrial minerals--United States.

Classification: LCC TN23 .C67 2017 | DDC 333.8/50973--dc23 | SUDOC I

19.16:1802

LC record available at https://lccn.loc.gov/2017005489

ISSN 1044-9612 (print)

ISSN 2330-7102 (online) 


\section{Foreword}

From the Stone Age to the present, mineral commodities have been essential ingredients for building and advancing civilization. Products built with materials derived from mineral resources include homes and office buildings; cars and roads; computers, televisions, and smart phones; and jet fighters and other military hardware needed to defend the Nation. In short, minerals are essential to advance and protect modern society.

When the periodic table of elements was first established in the latter half of the 19th century, many of the elements were known to exist in nature, but relatively few were being used by society. Today, discovery of new uses for an increasing number of elements is enabling rapid innovations in technology and materials science. Advances in telecommunications, information technology, health care, energy production, and national defense systems have all been possible through the use of new mineral materials.

As the importance and dependence of specific mineral commodities increase, so does concern about their supply. The United States is currently 100 percent reliant on foreign sources for 20 mineral commodities and imports the majority of its supply of more than 50 mineral commodities. Mineral commodities that have important uses and face potential supply disruption are critical to American economic and national security. However, a mineral commodity's importance and the nature of its supply chain can change with time; a mineral commodity that may not have been considered critical 25 years ago may be critical today, and one considered critical today may not be so in the future.

The U.S. Geological Survey has produced this volume to describe a select group of mineral commodities currently critical to our economy and security. For each mineral commodity covered, the authors provide a comprehensive look at (1) the commodity's use; (2) the geology and global distribution of the mineral deposit types that account for the present and possible future supply of the commodity; (3) the current status of production, reserves, and resources in the United States and globally; and (4) environmental considerations related to the commodity's production from different types of mineral deposits. The volume describes U.S. critical mineral resources in a global context, for no country can be self-sufficient for all its mineral commodity needs, and the United States will always rely on global mineral commodity supply chains. This volume provides the scientific understanding of critical mineral resources required for informed decisionmaking by those responsible for ensuring that the United States has a secure and sustainable supply of mineral commodities.

The Nation was largely built on the products produced from its mineral deposits. The future will also be built on a foundation of minerals, many of which will continue to be discovered and produced from across the country.

Ryan K. Zinke

Secretary of the Interior 



\section{Preface}

Mineral commodities are vital for economic growth, improving the quality of life, providing for national defense, and the overall functioning of modern society. Minerals are being used in larger quantities than ever before and in an increasingly diverse range of applicationsfrom telecommunications (cell phones and computers), to renewable-energy generation (wind turbines, solar photovoltaics, and fuel cells), to clean forms of transportation (electric and hybrid cars). Until the mid-20th century, only about 15 metallic elements had much practical use. Today, nearly all the natural elements in the periodic table of elements have several significant uses. For example, the manufacture of a modern computer chip requires more than one-half of the elements in the periodic table. Even though many of the elements may be present in only small amounts, each is essential to the function and performance of the chip.

With the increasing demand for a considerably more diverse suite of mineral commodities has come renewed recognition that competition and conflict over mineral resources can pose significant risks to the manufacturing industries that depend on them. In addition, although mineral deposits may occur in many places around the world, production of many mineral commodities has become concentrated in relatively few countries (for example, tungsten, rare-earth elements, and antimony in China; niobium in Brazil; and platinum-group elements in South Africa and Russia), thus increasing the risk for supply disruption owing to political, social, or other factors. At the same time, an increasing awareness and sensitivity to potential environmental and health issues caused by the mining and processing of many mineral commodities may place additional restrictions on mineral supplies. These factors have led a number of Governments, including the Government of the United States, to attempt to identify those mineral commodities that are viewed as most "critical" to the national economy and (or) security if supplies should be curtailed. The lists of critical minerals compiled by Governments and other organizations vary in the number and individual rankings of mineral commodities included on them, but many of the lists include several of the same commodities. Rare-earth elements and platinum-group elements particularly are broadly viewed as critical.

This book presents resource and geologic information on the following 23 mineral commodities currently among those viewed as important to the national economy and national security of the United States: antimony (Sb), barite (barium, Ba), beryllium (Be), cobalt (Co), fluorite or fluorspar (fluorine, F), gallium (Ga), germanium (Ge), graphite (carbon, C), hafnium (Hf), indium (In), lithium (Li), manganese (Mn), niobium (Nb), platinum-group elements (PGE), rare-earth elements (REE), rhenium (Re), selenium (Se), tantalum (Ta), tellurium (Te), tin (Sn), titanium (Ti), vanadium (V), and zirconium (Zr). For a number of these commodities-for example, graphite, manganese, niobium, and tantalum — the United States is currently wholly dependent on imports to meet its needs.

The first two chapters deal with general information pertinent to the study of mineral resources. The introductory chapter (A) discusses the purposes of the volume, the distinctions between reserves and various categories of resources, and issues related to the classification of mineral resource "criticality." The second chapter (B) provides an overview of some of the environmental considerations related to the mining of nonfuel mineral resources, including the modern regulatory framework and development of geoenvironmental mineral-deposit models. 
Chapters C through V describe individual mineral commodities and include an overview of current uses of the commodity, identified resources and their distribution nationally and globally, the state of current geologic knowledge, the potential for finding additional deposits nationally and globally, and geoenvironmental issues that may be related to the production and uses of the commodity. These chapters are updates of the commodity chapters published in 1973 in U.S. Geological Survey Professional Paper 820, "United States Mineral Resources." In 1973, many of these commodities were only of minor importance, and resource and geologic information was often very limited and incomplete. In addition, little was generally known about geoenvironmental issues related to their production and use.

We would like to thank our colleagues for their contributions to and cooperation in all phases of the preparation of this book. The descriptions of geology, the origin of mineral deposits, and geoenvironmental chemistry in each chapter necessarily involve some scientific jargon, but much of the discussion is cast in less-technical language. Our hope is that the information provided will be of use to scientists and nonscientists alike.

Klaus J. Schulz

John H. DeYoung, Jr.

Robert R. Seal II

Dwight C. Bradley 


\section{Contents}

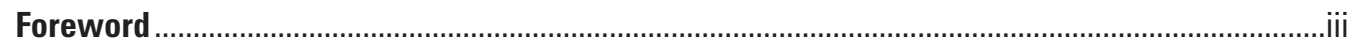

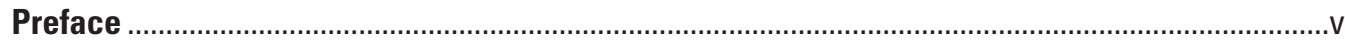

Chapter A. Critical Mineral Resources of the United States-An Introduction By Klaus J. Schulz, John H. DeYoung, Jr., Dwight C. Bradley, and Robert R. Seal II................A1

Chapter B. Environmental Considerations Related to Mining of Nonfuel Minerals By Robert R. Seal II, Nadine M. Piatak, Bryn E. Kimball, and Jane M. Hammarstrom .............B1

Chapter C. Antimony

By Robert R. Seal II, Klaus J. Schulz, and John H. DeYoung, Jr.

With contributions from David M. Sutphin, Lawrence J. Drew, James F. Carlin, Jr., and Byron R. Berger

Chapter D. Barite (Barium)

By Craig A. Johnson, Nadine M. Piatak, and M. Michael Miller

Chapter E. Beryllium

By Nora K. Foley, Brian W. Jaskula, Nadine M. Piatak, and Ruth F. Schulte

Chapter F. Cobalt

By John F. Slack, Bryn E. Kimball, and Kim B. Shedd.

Chapter G. Fluorine

By Timothy S. Hayes, M. Michael Miller, Greta J. Orris, and Nadine M. Piatak

Chapter H. Gallium

By Nora K. Foley, Brian W. Jaskula, Bryn E. Kimball, and Ruth F. Schulte

Chapter I. Germanium and Indium

By W.C. Pat Shanks III, Bryn E. Kimball, Amy C. Tolcin, and David E. Guberman.

Chapter J. Graphite

By Gilpin R. Robinson, Jr., Jane M. Hammarstrom, and Donald W. Olson

Chapter K. Lithium

By Dwight C. Bradley, Lisa L. Stillings, Brian W. Jaskula, LeeAnn Munk, and Andrew D. McCauley.

Chapter L. Manganese

By William F. Cannon, Bryn E. Kimball, and Lisa A. Corathers

Chapter M. Niobium and Tantalum

By Klaus J. Schulz, Nadine M. Piatak, and John F. Papp

Chapter N. Platinum-Group Elements

By Michael L. Zientek, Patricia J. Loferski, Heather L. Parks, Ruth F. Schulte, and Robert R. Seal II

Chapter 0. Rare-Earth Elements

By Bradley S. Van Gosen, Philip L. Verplanck, Robert R. Seal II, Keith R. Long, and Joseph Gambogi.

Chapter P. Rhenium

By David A. John, Robert R. Seal II, and Désirée E. Polyak P1

Chapter 0. Selenium

By Lisa L. Stillings. 
Chapter R. Tellurium

By Richard J. Goldfarb, Byron R. Berger, Micheal W. George, and Robert R. Seal II ........... R1

Chapter S. Tin

By Robert J. Kamilli, Bryn E. Kimball, and James F. Carlin, Jr. ...............................................S1

Chapter T. Titanium

By Laurel G. Woodruff, George M. Bedinger, and Nadine M. Piatak.................................... T1

Chapter U. Vanadium

By Karen D. Kelley, Clinton T. Scott, Désirée E. Polyak, and Bryn E. Kimball..........................U1

Chapter V. Zirconium and Hafnium

By James V. Jones III, Nadine M. Piatak, and George M. Bedinger

\section{Figures}

A1. Diagram showing increases in the use of elements over two decades of computer chip technology development.

A2. Diagram showing the mineral resource classification system used in this volume

B1. Graph showing population growth and the change in supporting land area from 3500 B.C. to 2100 A.D., with projections to 2050

B2. Graph showing dates associated with all the mine sites on the U.S. Environmental Protection Agency's National Priorities List

C1. World map showing locations of selected antimony deposits, mines, and major occurrences

C2. Pie chart showing major end uses of antimony as a percentage of antimony consumption in the United States in 2012.

C3. Graph showing world production, U.S. apparent consumption, and U.S. mine production of antimony from 1900 to 2012

C4. Pie charts showing percentages of contained antimony in U.S. imports for the period 2008-11, by source country

D1. Graph showing barite world production, U.S. production, and U.S. consumption from 1950 to 2011

D2. World map showing locations of selected barite deposits and districts, color-coded by deposit type

D3. Pie chart showing average annual barite production for the period $2007-11$, by country and amount in thousand metric tons

E1. World map showing locations of selected deposits of beryllium by the two major beryllium-bearing mineral types.

E2. Photographs showing the minerals bertrandite, which can contain up to 42 percent beryllium oxide, and industrial beryl, which can contain up to about 5 percent beryllium.

E3. Photographs illustrating some of the many uses of beryllium

E4. Pie charts showing reported end uses of beryllium consumed in the United States in $\mathbf{2 0 1 1}$ for the two main classes of products-performance alloys, and beryllium and composites

E5. A generalized cross section showing the geologic setting of and some example deposits for the major types of beryllium resources associated with rare-metal magma systems. 
E6. Location map and simplified geologic map of the Hellroaring Creek prospect, which is located west of Kimberley, British Columbia, Canada.....

E7. Generalized geologic cross section showing the setting of volcanogenic beryllium deposits and related deposit types, gelogic map of Spor Mountain area in Utah, photograph of beryllium tuff at Spor Mountain, and photograph of nodule from the Spor Mountain tuff.

E8. Graph showing general estimates of grade and tonnage for a variety of beryllium deposits, districts, and belts.

E9. Graph showing estimated global production of beryllium for 2000-11 E18

F1. Pie chart showing major end uses of cobalt as a percentage of consumption worldwide in 2011

F2. Graph showing world cobalt mine and refinery production and apparent consumption from 2007 to 2011

F3. Graph showing world cobalt mine production from 1950 to 2011

F4. Pie chart showing percentage of world cobalt mine production in 2011, by country

F5. Pie chart showing percentage of world cobalt mine production in 2011, by deposit type. F10

F6. Grade-tonnage plot for 214 cobalt deposits worldwide F11

F7. World map showing global distribution of major cobalt-bearing mineral deposits and selected smaller deposits that represent minor types.

F8. Pie charts showing proportions of cobalt contained in mineral deposits worldwide, by deposit type

G1. Photograph of a fluorite specimen from the Number 1 (Minerva) Mine, Cave-in-Rock subdistrict, Illinois-Kentucky fluorspar district

G2. Graph showing the solubility of fluorite as a function of temperature for complex $\mathrm{Na}-\mathrm{Ca}-\mathrm{Mg}-\mathrm{Cl}$ brines from ambient temperatures to $260^{\circ} \mathrm{C}$

G3. Chart showing eight minerals or mineral groups from which fluorine has been produced or may be produced in the future and a preliminary classification of hydrothermal fluorspar deposits by tectonic and magmatic association.

G4. World map showing locations of selected fluorspar deposits according to their tectonic and magmatic class as listed in figure G3B

G5. Map showing the locations of deposits in the Cantabrian salt-related carbonate-hosted mineral district in north-central Spain.

G6. Plot of fluorite grade versus tonnage for fluorspar deposits related to strongly differentiated granites, for carbonatite-related fluorspar deposits, and for veins from all classes of fluorspar deposits

G7. Graph showing sources of U.S. fluorspar supply from 1970 to 2011

H1. Photograph of gallium metal with an inset showing its position on the periodic table of elements

H2. Photographs showing examples of some current uses for gallium. . $\mathrm{H} 3$

H3. Charts showing U.S. and world gallium production and consumption from 2007 to 2012

H4. World map showing locations of selected mineral deposits, by type; gallium has been produced from these types of deposits.

H5. Cross sections showing the general geologic environments for the types of mineral deposits with which gallium is most commonly associated and from which gallium is typically extracted 
H6. Plot of the ratio of aluminum to gallium versus gallium content for bauxite deposits, volcanic rocks, and hydrothermally altered rocks of the McDermitt caldera, Nevada

H7. Photographs showing samples of bauxite ore and sphalerite ore, which are the primary mineralogical sources of gallium

11. Photograph of a concentrator photovoltaic solar power system. 13

12. Pie charts showing major end uses of germanium and indium as a percentage of world consumption in 2012 .

13. Photographs showing indium-tin oxide, which is a transparent conducting oxide, and examples of flat-panel display screens and touchscreens.

14. Map and schematic cross section showing the geology of the Red Dog mining district in Alaska and the stratigraphy of selected deposits in the district

15. Map showing the locations and geologic settings of selected volcanogenic massive sulfide, sedimentary exhalative, Mississippi Valley-type, and coal deposits and other types of deposits in southern China

16. Map showing the location of Kipushi-type deposits (including the Kabwe deposits) and major Neoproterozoic orogenic belts and basins in the Precambrian tectonic framework of southern Africa

17. Map showing indium-bearing tin-polymetallic ore deposits in Bolivia 112

18. Graph showing worldwide production of germanium and indium from 1995 to 2012

J1. Diagram showing the arrangement of carbon atoms in graphite.. J6

J2. World map showing locations of major graphite deposits and districts in the world, by commodity type

J3. Plot of grade and tonnage for some of the amorphous and crystalline graphite deposits listed in table $\mathrm{J} 3$, by deposit type.

J4. Pie chart showing average annual natural graphite production for the period $2006-10$, by country or region and amount.

K1. Graph showing world lithium production from 1900 to 2007, by deposit type and year...

K2. Pie chart showing major end uses of lithium as a percentage of world consumption in 2013

K3. Photographs showing some sources and uses of lithium

K4. World map showing locations of selected lithium-cesium-tantalum pegmatites and lithium granites

K5. World map showing locations of selected closed-basin lithium-brine, lithium-enriched oilfield brine, geothermal brine, lithium-clay, and lithium-zeolite deposits

K6. Histograms showing the broad correspondence in the age distributions of lithium-cesium-tantalum pegmatites, detrital zircons from modern river sands, and lithium resources in pegmatites.

K7. Schematic cross section showing the concentric arrangement of lithium-cesium-tantalum pegmatites around a parental granite pluton. K10

K8. Conceptual ore-deposit model for lithium brine.

K9. Plots of lithium grade and tonnage for selected world deposits. K13

L1. Charts showing world production, apparent consumption, and distribution of production of manganese ore from 2007 to 2011 
L2. Pie charts showing the sources and the annual average amounts of gross weight of U.S. imports of manganese ore, ferromanganese, and silicomanganese for the period 2008-11

L3. World map showing the location, relative size, and type of the major terrestrial manganese deposits listed in table L2 as well as subeconomic deposits in the United States

L4. Photographs showing examples of contrasting types of manganese ore

L5. Schematic diagram of the oceanic conditions necessary to form sedimentary manganese deposits that are not enriched in iron

L6. Photograph showing a dense carpet of ferromanganese nodules on the seabed off Johnston Island within the United States Exclusive Economic Zone near Hawaii.

L7. Photograph showing ferromanganese crust on carbonate rock from the Blake Plateau off the southeastern coast of the United States.

L8. Photograph of the Mamatwan open pit mine in South Africa

L9. Graphs showing the cumulative frequency of tonnages and grades of 39 marine sedimentary manganese deposits

M1. Photograph (central view) of the ATLAS detector in the Large Hadron Collider showing its eight superconducting barrel toroid magnets around the calorimeter

M2. Pie charts showing percentage of reported world consumption of niobium and tantalum, by material produced.

M3. Criticality matrix for niobium, tantalum, and selected other mineral commodities

M4. Photographs showing centimeter-size pyrochlore crystals from Uganda, and a tantalite crystal

M5. World map showing locations of selected niobium and tantalum mines, deposits, and occurrences, by deposit type

M6. Log-log plots of deposit grades and tonnages of tantalum and niobium, by deposit type

M7. Diagrams showing the subsurface geology of the Saint-Honoré carbonatite complex in southern Quebec, Canada, and a schematic north-south crosssection along line $A-A^{\prime}$ in $A$.

M8. Schematic cross-section of the Lovozero alkaline intrusion, Kola Peninsula, Russia, showing the relation among the three intrusive phases and the niobium mineralization contained in eudialyte and loparite.

M9. Schematic representation of regional lithium-cesium-tantalum rare-metalbearing pegmatite zoning above a parental granite

M10. Schematic cross-section of a concentrically zoned lithium-cesium-tantalum rare-metal-bearing pegmatite

M11. Bar chart showing niobium resources and reserves in Brazil, Canada, and the United States

M12. Bar chart showing global tantalum resources and reserves ......................................M21

M13. Bar charts showing global mine production of niobium and tantalum, from 2000 to 2011

M14. Pie charts showing percentage of average annual world production of niobium and tantalum, for the period 2007-11, by country 
N1. Graphs showing platinum and palladium consumption, by category of use, from 2000 to 2012 for the world, North America, and China.

N2. Photograph of gold mask with platinum highlights, from the period of La Tolita culture, Ecuador...

N3. World map showing locations of igneous intrusions and intrusive complexes that contain most of the world's platinum-group-element deposits, as well as the placer deposits that are mentioned in the text.

N4. Schematic block diagram showing changes in the form of igneous intrusions with depth and the relative occurrence of conduit-type, contact-type, and reef-type magmatic ore deposits

N5. Map showing the geology of the Siberian flood basalt province in Russia, which is the largest flood basalt province in the world N10

N6. Map showing the geology of the Noril'sk-Talnakh area and the location of nickel-copper-platinum-group-element deposits..

N7. Maps showing nickel-copper-platinum-group-element deposits in the Talnakh area, Russia

N8. Photograph of copper-rich massive sulfide ore exposed in a stope in the Oktyabr'sk Mine in the Talnakh area, Russia

N9. Map showing the Rustenburg Layered Suite of the Bushveld Complex, South Africa, the surface trace of significant orebodies, and cross sections through the central area and northeastern limb

N10. Photograph of the UG2 Chromitite at the Karee Mine in the western part of the Bushveld Complex, South Africa.

N11. Photograph of the base of the Merensky cyclic unit, a pegmatoidal pyroxenite, which contains the platinum-group-element-rich Merensky Reef.

N12. Geologic map and cross sections of the Great Dyke, Zimbabwe ................................N17

N13. Geologic map and cross section of the Stillwater Complex, Montana .........................N19

N14. Photograph of the Stillwater Mine in south-central Montana, looking southeast.

N15. Map showing the geology along the western margin of the Duluth Complex, Minnesota, with the surface projection of nickel-copper-platinum-groupelement deposits and exploration targets

N16. Maps illustrating the distribution of platinum deposits in the Ural Mountains, Russia

N17. Geology and imagery of the Uralian-type Kondyor Massif, which is located in eastern Siberia, Russia, north of the city of Khabarovsk

N18. Photograph and lithograph showing the morphology of platinum-iron-alloy nuggets derived from Uralian-type intrusions

N19. Maps illustrating platinum-group-element resources in southeastern Alaska ............N27

N20. Graph showing world platinum-group-element production, by country and year, from 1960 to 2011

N21. Pie chart showing world platinum-group-element production from 1960 to 2011, by country and amount, in metric tons.

N22. Plot showing the relation between tonnage and grade of remaining resources for conduit-type, reef-type, and other types of deposits enriched in platinumgroup elements

N23. Graphs showing the percent of contained metal against percent of deposits for the world's platinum-group-element (PGE) and porphyry copper deposits and for the top 30 percent of the world's PGE deposits.. 
N24. Graph showing contained platinum-group-element (PGE) and gold metal against the ratio of palladium to platinum for the major PGE deposits of the world ..................N32

N25. Three-dimensional block diagram showing the Merensky Reef interpolated down to 2 kilometers in the southern area of the western limb of the Bushveld Complex, South Africa

N26. Graph illustrating the exposed area and stratigraphic thickness of cumulates in more than 200 intrusions from around the world

N27. Geologic map of the Amphitheater Mountains and south-central Alaska showing the location and names of mafic-ultramafic complexes that are part of the Nikolai large igneous province

N28. Graphs showing platinum-group-element prices for platinum, palladium, rhodium, iridium, ruthenium, and osmium from 1880 to 2013 ..N44

01. Graph showing world mine production of rare-earth oxides, by country and year, from 1960 to 2012

02. Graph showing radii of the trivalent ions of the rare-earth elements as well as of cerium in the +4 valence state and europium in the +2 valence state

03. Photograph of the Mountain Pass Mine in San Bernardino County, California, which was the only active producer of rare-earth elements in the United States in 2013

04. World map showing locations of active or recently active rare-earth-element mines and ongoing advanced exploration projects.

05. Chondrite-normalized plot showing the rare-earth-element (REE) distribution in six different types of North American REE deposits.

P1. Photographs of rhenium and rhenium compounds ..................................................P2

P2. Pie chart showing major end uses of primary rhenium as a percentage of world consumption in 2012

P3. World map showing locations of major rhenium-bearing deposits listed in table P1

P4. Plot of rhenium grade versus deposit tonnage for major rhenium-bearing deposits in the world, including those shown in figure P3

P5. Cross sections illustrating rhenium occurrences in major deposit types from which rhenium is recovered or potentially recoverable.

P6. Pie chart showing world rhenium mine production in 2012 , by country and percent of world total.

01. Graph showing relative abundance of the chemical elements in Earth's upper crust

02. Graph showing end uses for selenium in the United States from 1975 to 2012 ..............03

03. Graph illustrating a mass balance for selenium in the United States from 1943 to 2015 .

04. Graph showing average annual prices of commercial-grade selenium from 1970 to 2010 .

05. Map showing selenium concentrations in coal samples, by region of the United States

Q6. Maps showing locations of seleniferous sedimentary outcrops and deposits and plant samples with significant selenium content

07. A predictive map of selenium source rocks associated with organic-rich depositional marine basins

08. Maps showing selenium concentrations in soils of the conterminous United States 
R1. World map showing locations of selected tellurium-enriched mineral occurrences discussed in the text, by deposit type

R2. Pie chart showing major end uses of tellurium as a percentage of world consumption in 2010 .

R3. Phase diagram showing speciation calculations for tellurium in a hydrothermal fluid at 300 degrees Celsius $\left({ }^{\circ} \mathrm{C}\right)$, as a function of $\mathrm{pH}$ and oxygen fugacity . R4

R4. Pie chart showing percentage of estimated world tellurium refinery production in 2013 , by country or region

S1. Pie chart showing major end uses of tin as a percentage of total consumption in the United States in 2014.

S2. Graph showing the average annual prices of tin metal from 1970 to 2010 ................... S5

S3. Ball-and-stick model of part of the crystal structure of cassiterite................................ S6

S4. Photograph of cassiterite crystals............................................................................ S6

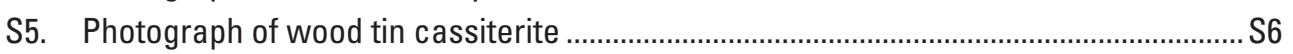

S6. Schematic vertical section across a typical hydrothermal mineralized granite cupola showing salient features of a shallow granite-related tin-mineralized system

S7. World map showing locations of major tin deposits and districts in the world, by deposit type

S8. Graph showing grades and resource tonnages of major tin deposits in the world, by deposit type or source.

S9. Pie chart showing percentage of world tin reserves in 2016, by country .......................... S12

S10. Pie chart showing estimated world mine production of tin in 2015 , by country and amount ................................................................................................ S12

S11. Map of Alaska showing the locations of selected tin deposits or occurrences ..........S15

T1. Chart showing common titanium-bearing oxide minerals and common titanium-bearing silicate minerals with their approximate titanium content

T2. Reflected-light photographs showing lamellae of hematite in ilmenite in hemo-ilmenite from the magmatic Lac Tio hemo-ilmenite deposit; and titaniferous magnetite and ilmenite from the magmatic La Blache iron-titanium-oxide deposit

T3. World map showing global distribution of titanium deposits, by size and type of depost.

T4. Bar chart comparing approximate titanium dioxide content in titanium deposits of different deposit types

T5. Plot of titanium dioxide grade and tonnage for selected igneous, metamorphic, and sedimentary deposits in the world, by deposit type.

T6. Pie charts showing percentage of estimated 2012 world mine production of ilmenite and rutile, and percentage of global reserves of ilmenite and rutile, by country

U1. World map showing locations of major vanadium deposits of the world, by deposit type.

U2. Pie chart showing percentage of world vanadium production in 2012 , by country

U3. Graph showing major end uses of vanadium in the United States from 1970 to 2011

U4. Photographs showing four examples of vanadium. U12

U5. Plot of grade and tonnage of vanadium deposits for which data were available. 
V1. Examples of sources and uses of zirconium and hafnium ............................................ V3

V2. Graphs showing global zirconium production and U.S. trade information for zirconium ores and concentrates

V3. World map showing locations of selected zirconium and hafnium deposits and regions with modern coastal placer systems V8

V4. Diagrams showing examples of coastal depositional systems with an emphasis on barrier island location, morphology, and depositional environments. V10

V5. Diagrams showing influences on and locations of placer formation in coastal environments.

\section{Tables}

A1. Crustal abundances of mineral commodities (elements) included in this volume .........A7

B1. Summary of selected Federal laws relevant to mine permitting .....................................B4

B2. Historical summary of mine sites placed on the U.S. Environmental Protection Agency's National Priorities List.

B3. Selected consortia devoted to identifying and implementing environmental best practices associated with mining

C1. Selected antimony minerals

C2. Estimated world production and reserves of antimony in 2013

C3. Potential additional sources of antimony ore and concentrate, by country.

E1. Selected properties of beryllium, which is a Group 2 alkaline earth metal

E2. Selected beryllium minerals E8

E3. Global and domestic types of magmatic-related beryllium resources E10

E4. Location, grade, tonnage, and other data for selected beryllium deposits of the world

F1. Location, grade, tonnage, and other data for selected cobalt deposits of the world.

F2. Cobalt concentrations in rocks, soils, waters, and air ...................................................F6

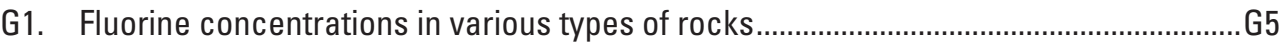

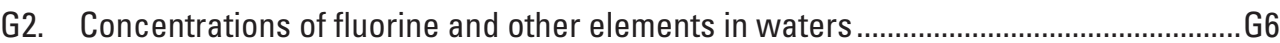

G3. Selected examples of the chemistry and mineralogy of mine waste generated at fluorspar mines ...................................................................................G34

H1. Selected properties of gallium, a Group 13 post-transition metal.....................................

H2. Gallium concentrations in rocks, ore, coal, soils, and natural waters .............................

H3. Selected gallium-bearing minerals_-Formula, content, and occurrence .....................H13

H4. Significant global and domestic deposit types from which gallium is obtained

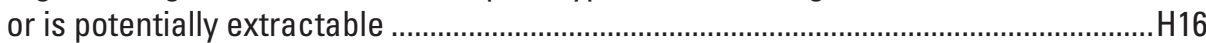

11. Classification of deposits that host germanium and indium resources .......................... I6

12. Average estimated annual refinery production of germanium and indium, by area, for 2011 and 2012 .

13. Germanium concentrations in rocks, soils, and waters............................................. I16

14. Indium concentrations in rocks, soils, waters, and air ............................................... 117

J1. Characteristics of graphite commodities, deposits, and uses, by commodity type....... J2

J2. Selected physical properties of graphite .......................................................................... J3

J3. Location, grade, tonnage and other data for selected graphite deposits and districts of the world 
J4. Estimates of world graphite resources, by country, commodity type, and resource category, in thousand metric tons of recoverable graphite.......................... J18

K1. Commercially and (or) scientifically important lithium-bearing minerals .......................K5

K2. Lithium concentrations in soils developed on various types of bedrock ....................... K15

L1. Estimated world manganese ore reserves in 2012 .....................................................

L2. Identified resources estimated for major land-based manganese deposits of the world

L3. Grade, tonnage, and quantity of contained manganese for eight manganese deposits and districts in the United States.

L4. Background and above-background concentrations of manganese in rocks, soils, waters, and air.....

M1. Selected properties of niobium and tantalum

M2. Selected niobium and tantalum oxide minerals and their end-member $\mathrm{Nb}_{2} \mathrm{O}_{5}$ and $\mathrm{Ta}_{2} \mathrm{O}_{5}$ contents or compositional range

M3. Major types of niobium and tantalum deposits, with key characteristics and examples

M4. Location, grade, tonnage, and other data for selected niobium-tantalum deposits of the world.

N1. Chemical formulas for selected platinum-group minerals as well as other common rock-forming minerals mentioned in this chapter

N2. Examples of rocks and ores with anomalous platinum-group-element concentrations that are not associated with magmatic deposits, by deposit type.

N3. Areas with significant placer platinum production, and estimates of cumulative production and grades.

N4. Identified platinum-group-element and gold resources, summarized by deposit type and location

N5. Igneous intrusions and intrusive complexes that contain more than 97 percent of the world's identified platinum-group-element (PGE) and gold resources, in order of total contained PGEs .

N6. Areal extent and stratigraphic thickness of layered intrusions with reef-type platinum-group-element deposits and some examples of large intrusions with no known deposits, in order of areal extent.

N7. Platinum-group-element concentrations in samples of upper crust, loess, river sediment, and marine pelagic sediment.

N8. Trace element geochemistry of waters from selected reef-type, contact-type, and conduit-type deposits

N9. Acid-base accounting for selected reef-type, contact-type, and conduit-type deposits

N10. Grade and tonnage of mineralized rock remaining in platinum-group-element-bearing mineral deposits.

01. List of the rare-earth elements found in natural deposits - the "lanthanides" plus yttrium

02. List of selected rare-earth-element-bearing and yttrium-bearing ore minerals ..........010

03. Active rare-earth mines, by deposit type 012

04. Advanced rare-earth-element (REE) exploration projects and the reported estimates of their REE resources, by deposit type. 
P1. Summary of rhenium, copper, and molybdenum grades, deposit tonnage, and amount of contained rhenium in the rhenium-bearing deposits shown in figure P3

P2. Rhenium data for selected porphyry copper and porphyry molybdenum deposits of the world. ..P38

P3. Rhenium concentrations in rocks, soils, biota, waters, and sediments ......................P20

01. Selenium minerals recognized by the International Mineralogical Association........... 044

02. A summary of selenium concentrations in various selenides and sulfides from deposits around the world

03. Selenium concentrations in sulfide minerals and other phases, in various deposit types 010

04. Selenium concentrations in copper-nickel ores in the Sudbury basin, Ontario, Canada ... 012

05. Selenium concentrations in selected Earth and lunar materials ....................................016

06. Estimated world selenium reserves in 2014 , in metric tons.......................................... 021

07. National Institutes of Health recommended dietary reference intakes (DRIs) for selenium

R1. Tellurium-bearing minerals, many of which are mentioned in this chapter ................... R5

S1. List of selected tin-bearing minerals ............................................................................... S3

S2. Location, grade, tonnage, and other data for selected tin deposits of the world with greater than 1,000 metric tons of contained tin...........................................S34

S3. Tin reserves of the world in 2016, in metric tons of contained tin .................................S11

S4. Tin concentrations in rocks, soils, waters, and air....................................................... S17

T1. Classification of selected titanium mineral deposits based on their geologic setting and the processes through which they were formed ...................................... T3

T2. Titanium resources of the United States .................................................................. T13

T3. Titanium mineral resources of the world (excluding the United States) for ilmenite (including titanomagnetite and leucoxene) and rutile (including anatase and brookite).

U1. Location, grade, tonnage, and other data for selected vanadium deposits

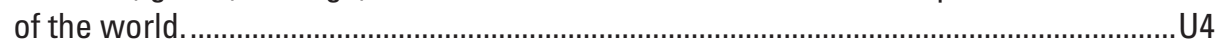

U2. Selected vanadium-bearing minerals, by deposit type............................................... U11

U3. Vanadium concentrations in rocks, soils, waters, and air. U23 


\section{Conversion Factors}

International System of Units to Inch/Pound

\begin{tabular}{|c|c|c|}
\hline Multiply & By & To obtain \\
\hline \multicolumn{3}{|c|}{ Length } \\
\hline angstrom $(\AA)$ (0.1 nanometer) & 0.003937 & microinch \\
\hline $\operatorname{angstrom}(\AA)$ (0.1 nanometer) & 0.000003937 & mil \\
\hline micrometer $(\mu \mathrm{m})$ [or micron] & 0.03937 & mil \\
\hline millimeter (mm) & 0.03937 & inch (in.) \\
\hline centimeter $(\mathrm{cm})$ & 0.3937 & inch (in.) \\
\hline meter $(\mathrm{m})$ & 3.281 & foot $(\mathrm{ft})$ \\
\hline meter $(\mathrm{m})$ & 1.094 & yard (yd) \\
\hline kilometer $(\mathrm{km})$ & 0.6214 & mile (mi) \\
\hline \multicolumn{3}{|c|}{ Area } \\
\hline hectare (ha) & 2.471 & acre \\
\hline square kilometer $\left(\mathrm{km}^{2}\right)$ & 247.1 & acre \\
\hline square meter $\left(\mathrm{m}^{2}\right)$ & 10.76 & square foot $\left(\mathrm{ft}^{2}\right)$ \\
\hline square centimeter $\left(\mathrm{cm}^{2}\right)$ & 0.1550 & square inch $\left(\mathrm{ft}^{2}\right)$ \\
\hline square kilometer $\left(\mathrm{km}^{2}\right)$ & 0.3861 & square mile $\left(\mathrm{mi}^{2}\right)$ \\
\hline \multicolumn{3}{|c|}{ Volume } \\
\hline milliliter (mL) & 0.03381 & ounce, fluid (fl. oz) \\
\hline liter $(\mathrm{L})$ & 33.81402 & ounce, fluid (fl. oz) \\
\hline liter (L) & 1.057 & quart $(\mathrm{qt})$ \\
\hline liter $(\mathrm{L})$ & 0.2642 & gallon (gal) \\
\hline cubic meter $\left(\mathrm{m}^{3}\right)$ & 264.2 & gallon (gal) \\
\hline cubic centimeter $\left(\mathrm{cm}^{3}\right)$ & 0.06102 & cubic inch $\left(\mathrm{in}^{3}\right)$ \\
\hline cubic meter $\left(\mathrm{m}^{3}\right)$ & 1.308 & cubic yard $\left(\mathrm{yd}^{3}\right)$ \\
\hline cubic kilometer $\left(\mathrm{km}^{3}\right)$ & 0.2399 & cubic mile $\left(\mathrm{mi}^{3}\right)$ \\
\hline \multicolumn{3}{|c|}{ Mass } \\
\hline microgram $(\mu \mathrm{g})$ & 0.00000003527 & ounce, avoirdupois (oz) \\
\hline milligram (mg) & 0.00003527 & ounce, avoirdupois (oz) \\
\hline $\operatorname{gram}(\mathrm{g})$ & 0.03527 & ounce, avoirdupois (oz) \\
\hline $\operatorname{gram}(\mathrm{g})$ & 0.03215075 & ounce, troy \\
\hline kilogram (kg) & 32.15075 & ounce, troy \\
\hline kilogram (kg) & 2.205 & pound avoirdupois (lb) \\
\hline ton, metric $(\mathrm{t})$ & 1.102 & ton, short $[2,000 \mathrm{lb}]$ \\
\hline ton, metric $(\mathrm{t})$ & 0.9842 & ton, long $[2,240 \mathrm{lb}]$ \\
\hline \multicolumn{3}{|c|}{ Deposit grade } \\
\hline gram per metric ton $(\mathrm{g} / \mathrm{t})$ & 0.0291667 & ounce per short ton $(2,000 \mathrm{lb})(\mathrm{oz} / \mathrm{T})$ \\
\hline \multicolumn{3}{|c|}{ Pressure } \\
\hline megapascal (MPa) & 10 & bar \\
\hline gigapascal (GPa) & 10,000 & bar \\
\hline \multicolumn{3}{|c|}{ Density } \\
\hline gram per cubic centimeter $\left(\mathrm{g} / \mathrm{cm}^{3}\right)$ & 62.4220 & pound per cubic foot $\left(\mathrm{lb} / \mathrm{ft}^{3}\right)$ \\
\hline milligram per cubic meter $\left(\mathrm{mg} / \mathrm{m}^{3}\right)$ & 0.00000006243 & pound per cubic foot $\left(\mathrm{lb} / \mathrm{ft}^{3}\right)$ \\
\hline \multicolumn{3}{|c|}{ Energy } \\
\hline joule (J) & 0.0000002 & kilowatthour (kWh) \\
\hline joule $(\mathrm{J})$ & $6.241 \times 10^{18}$ & electronvolt (eV) \\
\hline joule $(\mathrm{J})$ & 0.2388 & calorie (cal) \\
\hline kilojoule (kJ) & 0.0002388 & kilocalorie (kcal) \\
\hline
\end{tabular}


International System of Units to Inch/Pound - Continued

\begin{tabular}{|c|c|c|}
\hline Multiply & By & To obtain \\
\hline \multicolumn{3}{|c|}{ Radioactivity } \\
\hline becquerel (Bq) & 0.00002703 & microcurie $(\mu \mathrm{Ci})$ \\
\hline kilobecquerel (kBq) & 0.02703 & microcurie $(\mu \mathrm{Ci})$ \\
\hline \multicolumn{3}{|c|}{ Electrical resistivity } \\
\hline ohm meter $(\Omega-\mathrm{m})$ & 39.37 & ohm inch $(\Omega$-in.) \\
\hline ohm-centimeter $(\Omega$-cm) & 0.3937 & ohm inch $(\Omega$-in. $)$ \\
\hline \multicolumn{3}{|c|}{ Thermal conductivity } \\
\hline $\begin{array}{l}\text { watt per centimeter per degree } \\
\text { Celsius (watt } / \mathrm{cm}^{\circ} \mathrm{C} \text { ) }\end{array}$ & 693.1798 & $\begin{array}{l}\text { International British thermal unit } \\
\text { inch per hour per square foot per } \\
\text { degree Fahrenheit }\left(\mathrm{Btu} \text { in } / \mathrm{h} \mathrm{ft}^{2} \mathrm{~F}\right)\end{array}$ \\
\hline watt per meter kelvin $(\mathrm{W} / \mathrm{m}-\mathrm{K})$ & 6.9318 & $\begin{array}{l}\text { International British thermal unit } \\
\text { inch per hour per square foot per } \\
\text { degree Fahrenheit }\left(\mathrm{Btu} \text { in } / \mathrm{h} \mathrm{ft}^{2} \mathrm{~F}\right)\end{array}$ \\
\hline
\end{tabular}

Inch/Pound to International System of Units

\begin{tabular}{|c|c|c|}
\hline \multicolumn{3}{|c|}{ Length } \\
\hline mil & 25.4 & micrometer $(\mu \mathrm{m})$ [or micron] \\
\hline inch (in.) & 2.54 & centimeter $(\mathrm{cm})$ \\
\hline inch (in.) & 25.4 & millimeter $(\mathrm{mm})$ \\
\hline foot $(\mathrm{ft})$ & 0.3048 & meter $(\mathrm{m})$ \\
\hline mile (mi) & 1.609 & kilometer (km) \\
\hline \multicolumn{3}{|c|}{ Volume } \\
\hline ounce, fluid (fl. oz) & 29.57 & milliliter (mL) \\
\hline ounce, fluid (fl. oz) & 0.02957 & liter $(\mathrm{L})$ \\
\hline \multicolumn{3}{|c|}{ Mass } \\
\hline ounce, avoirdupois (oz) & $28,350,000$ & microgram \\
\hline ounce, avoirdupois (oz) & 28,350 & milligram \\
\hline ounce, avoirdupois (oz) & 28.35 & $\operatorname{gram}(\mathrm{g})$ \\
\hline ounce, troy & 31.10348 & $\operatorname{gram}(\mathrm{g})$ \\
\hline ounce, troy & 0.03110348 & kilogram (kg) \\
\hline pound, avoirdupois (lb) & 0.4536 & kilogram (kg) \\
\hline ton, short $(2,000 \mathrm{lb})$ & 0.9072 & ton, metric $(\mathrm{t})$ \\
\hline ton, long $(2,240 \mathrm{lb})$ & 1.016 & ton, metric $(\mathrm{t})$ \\
\hline \multicolumn{3}{|c|}{ Deposit grade } \\
\hline ounce per short ton $(2,000 \mathrm{lb})(\mathrm{oz} / \mathrm{T})$ & 34.285714 & gram per metric ton $(\mathrm{g} / \mathrm{t})$ \\
\hline \multicolumn{3}{|c|}{ Energy } \\
\hline kilowatthour (kWh) & $3,600,000$ & joule $(\mathrm{J})$ \\
\hline electronvolt $(\mathrm{eV})$ & $1.602 \times 10^{-19}$ & joule $(\mathrm{J})$ \\
\hline \multicolumn{3}{|c|}{ Radioactivity } \\
\hline microcurie $(\mu \mathrm{Ci})$ & 37,000 & becquerel (Bq) \\
\hline microcurie $(\mu \mathrm{Ci})$ & 37 & kilobecquerel (kBq) \\
\hline
\end{tabular}

Temperature in degrees Celsius $\left({ }^{\circ} \mathrm{C}\right)$ may be converted to degrees Fahrenheit $\left({ }^{\circ} \mathrm{F}\right)$ as follows:

$$
{ }^{\circ} \mathrm{F}=\left(1.8 \times{ }^{\circ} \mathrm{C}\right)+32
$$

Temperature in degrees Celsius $\left({ }^{\circ} \mathrm{C}\right)$ may be converted to kelvin $(\mathrm{K})$ as follows:

$$
\mathrm{K}={ }^{\circ} \mathrm{C}+273.15
$$

Temperature in degrees Fahrenheit $\left({ }^{\circ} \mathrm{F}\right)$ may be converted to degrees Celsius $\left({ }^{\circ} \mathrm{C}\right)$ as follows:

$$
{ }^{\circ} \mathrm{C}=\left({ }^{\circ} \mathrm{F}-32\right) / 1.8
$$




\section{Datum}

Unless otherwise stated, vertical and horizontal coordinate information is referenced to the World Geodetic System of 1984 (WGS 84). Altitude, as used in this report, refers to distance above the vertical datum.

\section{Supplemental Information}

Specific conductance is given in microsiemens per centimeter at 25 degrees Celsius $(\mu \mathrm{S} / \mathrm{cm}$ at $\left.25^{\circ} \mathrm{C}\right)$.

Concentrations of chemical constituents in soils and (or) sediment are given in milligrams per kilogram (mg/kg), parts per million (ppm), or parts per billion (ppb).

Concentrations of chemical constituents in water are given in milligrams per liter (mg/L), micrograms per liter $(\mu \mathrm{g} / \mathrm{L})$, nanogams per liter $(\mathrm{ng} / \mathrm{L})$, nanomoles per kilogram $(\mathrm{nmol} / \mathrm{kg})$, parts per million (ppm), parts per billion (ppb), or parts per trillion (ppt).

Concentrations of suspended particulates in water are given in micrograms per gram $(\mu \mathrm{g} / \mathrm{g})$, milligrams per kilogram $(\mathrm{mg} / \mathrm{kg})$, or femtograms per gram $(\mathrm{fg} / \mathrm{g})$.

Concentrations of chemicals in air are given in units of the mass of the chemical (milligrams, micrograms, nanograms, or picograms) per volume of air (cubic meter).

Activities for radioactive constituents in air are given in microcuries per milliliter $(\mu \mathrm{Ci} / \mathrm{mL})$.

Deposit grades are commonly given in percent, grams per metric ton $(\mathrm{g} / \mathrm{t})$-which is equivalent to parts per million (ppm) — or troy ounces per short ton (oz/T).

Geologic ages are expressed in mega-annum (Ma, million years before present, or $10^{6}$ years ago) or giga-annum ( $\mathrm{Ga}$, billion years before present, or $10^{9}$ years ago).

For ranges of years, "to" and (or) the en dash ("-") mean "up to and including."

\begin{tabular}{ll}
\hline \multicolumn{1}{c}{ Concentration unit } & \multicolumn{1}{c}{ Equals } \\
\hline milligram per kilogram $(\mathrm{mg} / \mathrm{kg})$ & part per million \\
microgram per gram $(\mu \mathrm{g} / \mathrm{g})$ & part per million \\
microgram per kilogram $(\mu \mathrm{g} / \mathrm{kg})$ & part per billion $\left(10^{9}\right)$ \\
\hline
\end{tabular}

\section{Equivalencies}

part per million $(\mathrm{ppm}): 1 \mathrm{ppm}=1,000 \mathrm{ppb}=1,000,000 \mathrm{ppt}=0.0001$ percent part per billion (ppb): $0.001 \mathrm{ppm}=1 \mathrm{ppb}=1,000 \mathrm{ppt}=0.0000001$ percent part per trillion (ppt): $0.000001 \mathrm{ppm}=0.001 \mathrm{ppb}=1 \mathrm{ppt}=0.0000000001$ percent

\section{Metric system prefixes}

$\begin{array}{lll}\text { tera- (T-) } & 10^{12} & 1 \text { trillion } \\ \text { giga- (G-) } & 10^{9} & 1 \text { billion } \\ \text { mega- (M-) } & 10^{6} & 1 \text { million } \\ \text { kilo- (k-) } & 10^{3} & 1 \text { thousand } \\ \text { hecto- (h-) } & 10^{2} & 1 \text { hundred } \\ \text { deka- (da-) } & 10 & 1 \text { ten } \\ \text { deci- (d-) } & 10^{-1} & 1 \text { tenth } \\ \text { centi- (c-) } & 10^{-2} & 1 \text { hundredth } \\ \text { milli- (m-) } & 10^{-3} & 1 \text { thousandth } \\ \text { micro- ( } \mu-) & 10^{-6} & 1 \text { millionth } \\ \text { nano- (n-) } & 10^{-9} & 1 \text { billionth } \\ \text { pico- (p-) } & 10^{-12} & 1 \text { trillionth } \\ \text { femto- (f-) } & 10^{-15} & 1 \text { quadrillionth } \\ \text { atto- (a-) } & 10^{-18} & 1 \text { quintillionth }\end{array}$




\section{Abbreviations and Symbols}

[This list is intended to help the reader identify the meanings of various abbreviations and symbols used in the text. To avoid unnecessary duplication, not all abbreviations and symbols are included. For example, symbols that are used in only a single table and that are identified in that table's headnote are not included here. Likewise, mineral names and their chemical formulas are not listed here]

$\alpha$-tin

$\beta$-tin

${ }^{\circ} \mathrm{C}$

$\delta-\mathrm{MnO}_{2}$

$\mu \mathrm{Ci} / \mathrm{mL}$

$\mu \mathrm{g} \mathrm{Al} / \mathrm{L}$

$\mu \mathrm{g} / \mathrm{d}$

$\mu \mathrm{g} / \mathrm{g}$

$\mu \mathrm{g} / \mathrm{kg}$

$\mu \mathrm{g} / \mathrm{L}$

$\mu \mathrm{g} / \mathrm{m}^{3}$

$\mu \mathrm{g} \mathrm{Mn/L}$

$\mu \mathrm{g} \mathrm{Mn} / \mathrm{m}^{3}$

$\mu \mathrm{g} \mathrm{V/L}$

$\mu \mathrm{m}$

3TG

$\AA$

AC

ADTI

AFRG

AIDS

AMD

AMT

API

APS

ATPC

ATSDR

BCMA

$\mathrm{Bq} / \mathrm{kg}$

ca.

CBMM

CCD

CCZ

CERCLA alpha-tin (also known as gray tin)

beta-tin (also known as white tin)

degree Celsius

delta-manganese dioxide

microcurie per milliliter

microgram of aluminum per liter

microgram per day

microgram per gram

microgram per kilogram

microgram per liter

microgram per cubic meter

microgram of manganese per liter

microgram of manganese per cubic meter

microgram of vanadium per liter

micrometer

tantalum, tin, tungsten, and (or) gold

angstrom

alternating current

Acid Drainage Technology Initiative

alkali-feldspar rhyolite-granite

acquired immunodeficiency syndrome

acid mine drainage

audio magnetotelluric

American Petroleum Institute

American Physical Society

Association of Tin Producing Countries

Agency for Toxic Substances and Disease Registry

beryllium-copper master alloy

becquerel per kilogram

circa (about)

Companhia Brasileira de Metalurgia e Mineração

carbonate compensation depth

Clarion-Clipperton zone

Comprehensive Environmental Response, Compensation, and Liability Act 


\begin{tabular}{|c|c|}
\hline CIGS & copper-indium-gallium-selenide \\
\hline $\mathrm{cm}$ & centimeter \\
\hline $\mathrm{cm}^{3}$ & cubic centimeter \\
\hline CMI & Critical Minerals Index \\
\hline Congo (Kinshasa) & Democratic Republic of the Congo \\
\hline CPV & concentrator photovoltaic \\
\hline CRD & carbonate replacement deposit \\
\hline$D C$ & direct current \\
\hline DOD & U.S. Department of Defense \\
\hline DOE & U.S. Department of Energy \\
\hline EA & environmental assessment \\
\hline $\mathrm{EC}_{50}$ & $\begin{array}{l}\text { effective concentration } 50 \text { (concentration that results in } \\
50 \text { percent exhibiting decreased functionality) }\end{array}$ \\
\hline EEZ & Exclusive Economic Zone \\
\hline Eh & oxidation potential \\
\hline EIS & environmental impact statement \\
\hline EMPA & electron microprobe analysis \\
\hline EPA & U.S. Environmental Protection Agency \\
\hline FCC & fluid catalytic cracking \\
\hline FONSI & finding of no significant impact \\
\hline $\mathrm{ft}$ & foot \\
\hline g & gram \\
\hline $\mathrm{g} \mathrm{CO}_{2}$-equiv/kWh & gram of $\mathrm{CO}_{2}$ equivalent per kilowatthour \\
\hline $\mathrm{g} / \mathrm{cm}^{3}$ & gram per cubic centimeter \\
\hline$g / d$ & gram per day \\
\hline $\mathrm{g} / \mathrm{L}$ & gram per liter \\
\hline $\mathrm{g} / \mathrm{t}$ & gram per metric ton \\
\hline $\mathrm{Ga}$ & giga-annum \\
\hline GARD & Global Acid Rock Drainage \\
\hline GWh & gigawatt-hour \\
\hline HDC & Hicks Dome Corp. \\
\hline HFSE & high-field-strength element \\
\hline HIV & human immunodeficiency virus \\
\hline HMIS & Hazardous Materials Identification System \\
\hline HREE & heavy rare-earth element \\
\hline HSLA & high-strength, low-alloy \\
\hline IARC & International Agency for Research on Cancer \\
\hline ICP-MS & inductively coupled plasma-mass spectrometry \\
\hline IED & improvised explosive device \\
\hline
\end{tabular}




\begin{tabular}{|c|c|}
\hline IMA & International Mineralogical Association \\
\hline INAP & International Network for Acid Prevention \\
\hline IOCG & iron oxide-copper-gold \\
\hline IREL & Indian Rare Earths Ltd. \\
\hline ISA & International Seabed Authority \\
\hline ISMI & International Strategic Minerals Inventory \\
\hline ITO & indium-tin oxide \\
\hline JORC & Joint Ore Reserves Committee (Australia) \\
\hline $\mathrm{kBq} / \mathrm{kg}$ & kilobecquerel per kilogram \\
\hline $\mathrm{kg}$ & kilogram \\
\hline $\mathrm{kg} \mathrm{CaCO}_{3} / \mathrm{t}$ & kilogram of calcium carbonate per metric ton \\
\hline $\mathrm{kg} / \mathrm{cm}^{2}$ & kilogram per square centimeter \\
\hline $\mathrm{kg} / \mathrm{m}^{3}$ & kilogram per cubic meter \\
\hline $\mathrm{kg} / \mathrm{t}$ & kilogram per metric ton \\
\hline km & kilometer \\
\hline $\mathrm{km}^{2}$ & square kilometer \\
\hline $\mathrm{km}^{3}$ & cubic kilometer \\
\hline KMML & Kerala Minerals and Metals Ltd. \\
\hline $\mathrm{lb}$ & pound \\
\hline $\mathrm{LC}_{50}$ & $\begin{array}{l}\text { lethal concentration } 50 \text { (concentration that kills } 50 \text { percent } \\
\text { of test population within a given timeframe) }\end{array}$ \\
\hline LCT & lithium-cesium-tantalum \\
\hline LED & light-emitting diode \\
\hline LIP & large igneous province \\
\hline LOEL & lowest observable effect limit \\
\hline $\log _{\log } \mathrm{O}_{2}$ & log of oxygen fugacity \\
\hline LREE & light rare-earth element \\
\hline $\mathrm{m}$ & meter \\
\hline M & molarity \\
\hline m.y. & million years \\
\hline $\mathrm{m}^{3}$ & cubic meter \\
\hline $\mathrm{Ma}$ & mega-annum \\
\hline MC-ICP-MS & multiple collector-inductively coupled plasma-mass spectrometry \\
\hline MDEO & Michigan Department of Environmental Quality \\
\hline MEND & Mine Environment Neutral Drainage \\
\hline $\mathrm{mg}$ & milligram \\
\hline $\mathrm{mg} \mathrm{Al} / \mathrm{kg}$ & milligram of aluminum per kilogram \\
\hline $\mathrm{mg} / \mathrm{d}$ & milligram per day \\
\hline $\mathrm{mg} / \mathrm{kg}$ & milligram per kilogram \\
\hline
\end{tabular}


xxiv

\begin{tabular}{|c|c|}
\hline $\mathrm{mg} / \mathrm{L}$ & milligram per liter \\
\hline $\mathrm{mg} / \mathrm{m}^{3}$ & milligram per cubic meter \\
\hline $\mathrm{Mkg} / \mathrm{yr}$ & million kilograms per year \\
\hline $\mathrm{mm}$ & millimeter \\
\hline MOFCOM & Ministry of Commerce (China) \\
\hline MRDS & Mineral Resources Data System (USGS) \\
\hline MRI & magnetic resonance imaging \\
\hline MRS & Materials Research Society \\
\hline MSS & monosulfide solution \\
\hline MTR & Maderia-Tore Rise \\
\hline MVT & Mississippi Valley-type \\
\hline NEPA & National Environmental Policy Act \\
\hline NFPA & National Fire Protection Association \\
\hline $\mathrm{ng} / \mathrm{L}$ & nanogram per liter \\
\hline $\mathrm{ng} / \mathrm{m}^{3}$ & nanogram per cubic meter \\
\hline $\mathrm{NI}$ & National Instrument \\
\hline NiMH & nickel-metal-hydride \\
\hline $\mathrm{NIOSH}$ & National Institute for Occupational Safety and Health \\
\hline $\mathrm{nm}$ & nanometer \\
\hline NMRI & nuclear magnetic resonance instruments \\
\hline NPL & National Priorities List (Superfund) \\
\hline NREL & National Renewable Energy Laboratory \\
\hline NSTC & National Science and Technology Council \\
\hline NTP & National Toxicology Program \\
\hline NYF & niobium-yttrium-fluorine \\
\hline OPEC & Organization of the Petroleum Exporting Countries \\
\hline $\operatorname{org}-\mathrm{Se}(-\mathrm{II})$ & organo-selenide \\
\hline OSHA & Occupational Safety and Health Administration \\
\hline PEM & proton exchange membrane \\
\hline PET & polyethylene terephthalate \\
\hline $\mathrm{pg} / \mathrm{L}$ & picogram per liter \\
\hline $\mathrm{pg} / \mathrm{m}^{3}$ & picogram per cubic meter \\
\hline PGE & platinum-group element \\
\hline PGM & platinum-group metal \\
\hline $\mathrm{pm}$ & picometer \\
\hline $\mathrm{ppb}$ & part per billion \\
\hline ppm & part per million \\
\hline ppt & part per trillion \\
\hline
\end{tabular}




\begin{tabular}{|c|c|}
\hline QSP & quartz-sericite-pyrite \\
\hline RDA & recommended daily allowance \\
\hline REE & rare-earth element \\
\hline REO & rare-earth oxide \\
\hline RF & radio-frequency \\
\hline SAF & submerged-arc furnace \\
\hline SAMREC & South African Code for Reporting Exploration Results \\
\hline $\mathrm{Se}(I I)$ & selenide \\
\hline $\mathrm{Se}(\mathrm{IV})$ & selenite \\
\hline $\mathrm{Se}(\mathrm{VI})$ & selenate \\
\hline SEC & U.S. Securities and Exchange Commission \\
\hline SEDEX & sedimentary exhalative \\
\hline SG & specific gravity \\
\hline SHRIMP & sensitive high-resolution ion microprobe \\
\hline SSV & sandstone-hosted vanadium \\
\hline SX-EW & solvent extraction-electrowinning \\
\hline TBT & tributyltin \\
\hline TBTCI & tributyltin chloride \\
\hline TВTO & bis(tri- $n$-butyltin) oxide \\
\hline $\mathrm{Te}(I I)$ & telluride \\
\hline $\mathrm{Te}(\mathrm{IV})$ & tellurite \\
\hline $\mathrm{Te}(\mathrm{VI})$ & tellurate \\
\hline TPT & triphenyltin \\
\hline TRE & Tantalus Rare Earths \\
\hline TREO & total rare-earth oxide \\
\hline TWA & time-weighted average \\
\hline U.S.C. & U.S. Code \\
\hline USGS & U.S. Geological Survey \\
\hline UST & unidirectional solidification texture \\
\hline VLF & very low frequency \\
\hline VMS & volcanogenic massive sulfide \\
\hline VRB & vanadium redox-flow battery \\
\hline VTM & vanadiferous titanomagnetite \\
\hline WGS 84 & World Geodetic System of 1984 \\
\hline WHO & World Health Organization \\
\hline wt. \% & weight percent \\
\hline
\end{tabular}





\section{Critical Mineral Resources of the United States-An Introduction}

By Klaus J. Schulz, John H. DeYoung, Jr., Dwight C. Bradley, and Robert R. Seal II

Chapter A of

Critical Mineral Resources of the United States-Economic and Environmental Geology and Prospects for Future Supply

Edited by Klaus J. Schulz, John H. DeYoung, Jr., Robert R. Seal II, and Dwight C. Bradley

Professional Paper 1802-A 


\section{Contents of Chapter A}

[Figure and table titles for all chapters are listed in the volume contents before the conversion factors table and list of abbreviations and symbols. A periodic table of the elements is on the inside front cover of the printed volume]

Abstract
Background..S. Mineral Supply Situation
Mineral Resource Classifications, Terms, and Definitions Used in This Volume
Joint Products, Byproducts, and Coproducts
Scarcity and Rarity
Cheral Commodities Selected for Inclusion in This Volume Since the Mid-1970s
Back to the Future
References Cited...A.
Appendix A1. What is Meant by “Critical" Minerals (or Materials)?




\title{
Critical Mineral Resources of the United States- An Introduction
}

\author{
By Klaus J. Schulz, John H. DeYoung, Jr., Dwight C. Bradley, and Robert R. Seal II
}

\section{Abstract}

Many changes have taken place in the mineral resource sector since the publication by the U.S. Geological Survey of Professional Paper 820, "United States Mineral Resources" (Brobst and Pratt, 1973), which is a review of the long-term United States resource position for 65 mineral commodities or commodity groups. For example, since 1973, the United States has continued to become increasingly dependent on imports to meet its demands for an increasing number of mineral commodities. The global demand for mineral commodities is at an allime high and is expected to continue to increase, and the development of new technologies and products has led to the use of a greater number of mineral commodities in increasing quantities to the point that, today, essentially all naturally occurring elements have several significant industrial uses. Although most mineral commodities are present in sufficient amounts in the earth to provide adequate supplies for many years to come, their availability can be affected by such factors as social constraints, politics, laws, environmental regulations, land-use restrictions, economics, and infrastructure.

This volume presents updated reviews of 23 mineral commodities and commodity groups viewed as critical to a broad range of existing and emerging technologies, renewable energy, and national security. The commodities or commodity groups included are antimony, barite, beryllium, cobalt, fluorine, gallium, germanium, graphite, hafnium, indium, lithium, manganese, niobium, platinum-group elements, rare-earth elements, rhenium, selenium, tantalum, tellurium, tin, titanium, vanadium, and zirconium. All these commodities have been listed as critical and (or) strategic in one or more of the recent studies based on assessed likelihood of supply interruption and the possible cost of such a disruption to the assessor. For some of the minerals, current production is limited to only one or a few countries. For many, the United States currently has no mine production or any significant identified resources and is largely dependent on imports to meet its needs. As a result, the emphasis in this volume is on the global distribution and availability of each mineral commodity. The environmental issues related to production of each mineral commodity, including current mitigation and remediation approaches to deal with these challenges, are also addressed.
This introductory chapter provides an overview of the mineral resource classifications, terms, and definitions used in this volume. A review of the history of the use and meaning of the term "critical" minerals (or materials) is included as an appendix to the chapter.

\section{Background}

In 1973, the U.S. Geological Survey (USGS) produced Professional Paper 820, "United States Mineral Resources" (Brobst and Pratt, 1973), a review of the long-term United States resource position for 65 mineral commodities or commodity groups. A main purpose of that volume was to provide nonspecialists with easily understandable factual information on the resources of the many mineral commodities that are important to the national economy, national security, and the everyday lives of U.S. citizens. More specifically, that volume addressed three basic questions about each mineral commodity:

“(1) How important is it to our present industrial civilization and standard of living? (2) how much of it do we have and to what extent is it economically and technologically available? and (3) how and where can we find more?" (Brobst and Pratt, 1973, p. 1).

The emphasis was on domestic mineral resources, but many chapters also include information on resources in other countries.

The economy and the national security of the United States are based directly or indirectly on minerals and, in the early 1970s, there was increasing recognition of and concern about the fact that the United States did not have adequate domestic supplies of many of the nonfuel minerals needed to sustain its economy (U.S. Geological Survey, 1975). In an analysis of the principal developments in U.S. mineral history and world mineral history since 1939, Cameron (1973) concluded that:

“(1) United States mineral production has greatly increased but has not kept pace with consumption. Self-sufficiency in minerals has declined, both overall and in numbers of minerals involved. 
(2) Since 1945, world mineral production has increased far more rapidly than United States production. The relative importance of the United States as a supplier of world minerals, raw and manufactured, has rapidly declined.

(3) World mineral consumption has increased far more rapidly than United States consumption. The United States is no longer the world's principal market for mineral raw materials, and it faces increasing competition for the world's mineral supplies." (Cameron, 1973, p. 25).

The volume "United States Mineral Resources" was produced to provide factual information on the Nation's mineral resources at the time and to inform policymakers and the public in efforts to frame national mineral policy.

\section{U.S. Mineral Supply Situation}

The conclusions reached by Cameron (1973) about the United States mineral position at that time are even more pertinent now, more than 40 years later. In 1980, the United States was more than 50 percent dependent on imports to meet its annual requirements for more than 20 major nonfuel mineral commodities; in 2014, that number had increased to more than 40 commodities (Fortier and others, 2015; U.S. Geological Survey, 2015b, p. 6). The United States was the world's leading producer of copper for much of the 20th century, but Chile became the leading copper-producing country in 1982 and has remained so. In 2014, China accounted for 20 percent or more of the world's mine production of more than 40 mineral commodities; these included the rare-earth elements, of which China accounted for 85 percent of world production; tungsten, 82 percent; antimony, 76 percent; germanium, 73 percent; mercury, 68 percent; graphite, 66 percent; fluorspar, 59 percent; and bismuth, 56 percent (U.S. Geological Survey, 2016).

As world population increases and the average standard of living improves, the global demand for mineral commodities is at an all-time high and is expected to continue to increase. Much of this demand is the result of industrialization in large developing countries, such as Brazil, China, and India.

In addition, the development of new technologies and products has led to the use of a greater number of mineral commodities in increasing quantities. In 1932, uranium and rare-earth elements had only minor uses, and the production or uses of such elements as gallium, germanium, rhenium, and several others were not even tracked. As of the first decades of the 21 st century, essentially all the naturally occurring elements have several significant industrial uses (Price, 2013). By way of example, in the 1980s, 12 elements were used in the manufacture of computer chips. A decade later, 16 elements were employed, and by 2006, as many as 60 elements were used in the manufacture of high-speed, high-capacity integrated circuits (fig. A1; National Research Council, 2008, p. 56-58).
In the 1970s, concerns regarding the adequacy of future supplies of minerals were raised owing to a perceived lack of world resources. Based on their finite occurrence, "limits to supply" of nonrenewable resources, such as minerals, was most famously predicted in a report by the Club of Rome (Meadows and others, 1972). The concerns raised in that report were based partly on results of previous studies. For example, the time-series analysis of metal production in mining districts of Europe by Hewett (1929) demonstrated cyclical patterns that were subsequently applied to the production histories of other nonfuel minerals and energy minerals (Lasky, 1951, 1955; Hubbert, 1956; Pazik, 1976). This type of analysis formed the basis of numerous studies that predicted that the highest level of production of some mineral commodities may soon be reached and that production is likely to decline from then on. This approach to studying future resource availability is often termed "peak minerals." Many of these studies, however, used estimates of mineral reserves (the economically extractable portion of resources at the time of determination) as a proxy for the Earth's resources, including those that have been discovered (identified resources), which, in turn, include those that are economic to produce (reserves) (Meadows and others, 1972; Cohen, 2007). This approach is flawed, because estimates of mineral reserves are a function of economic factors, such as metal prices and costs of recovery, which can vary considerably over time.

New geologic knowledge can result in changes to estimates of identified resources, including those identified resources that are economic (reserves) changing as well (Rustad, 2012; Gold, 2014; Meinert and others, 2016). Likewise, both the development of new extractive technologies and increased metal prices have resulted in mineral deposits previously considered subeconomic or marginally economic becoming viable sources for mineral production. In addition, improved methodologies for estimating undiscovered mineral resources, the discovery of new mineral deposit types, improved recycling technologies, higher processing efficiency, and longer product life have all helped allay fears that we are near peak supply of most mineral commodities. Today, therefore, it is generally recognized that, although mineral commodities are mostly nonrenewable on human time scales and are inherently finite, fears of resource depletion for most mineral commodities anytime soon are unwarranted.

Nonetheless, although most mineral commodities may be present in sufficient amounts in the earth to provide adequate supplies for some years to come, they are generally found concentrated only in small volumes in the crust and are not distributed evenly across the planet. As a result, no country today can be fully self-sufficient in meeting all its mineral resource needs. In addition, the availability of mineral commodities is not just a function of geologic accessibility but of such factors as social constraints, politics, laws, environmental regulations, land restrictions, economics, and infrastructure. Large deposits of a particular mineral commodity tend to account for the bulk of production, but these deposits 


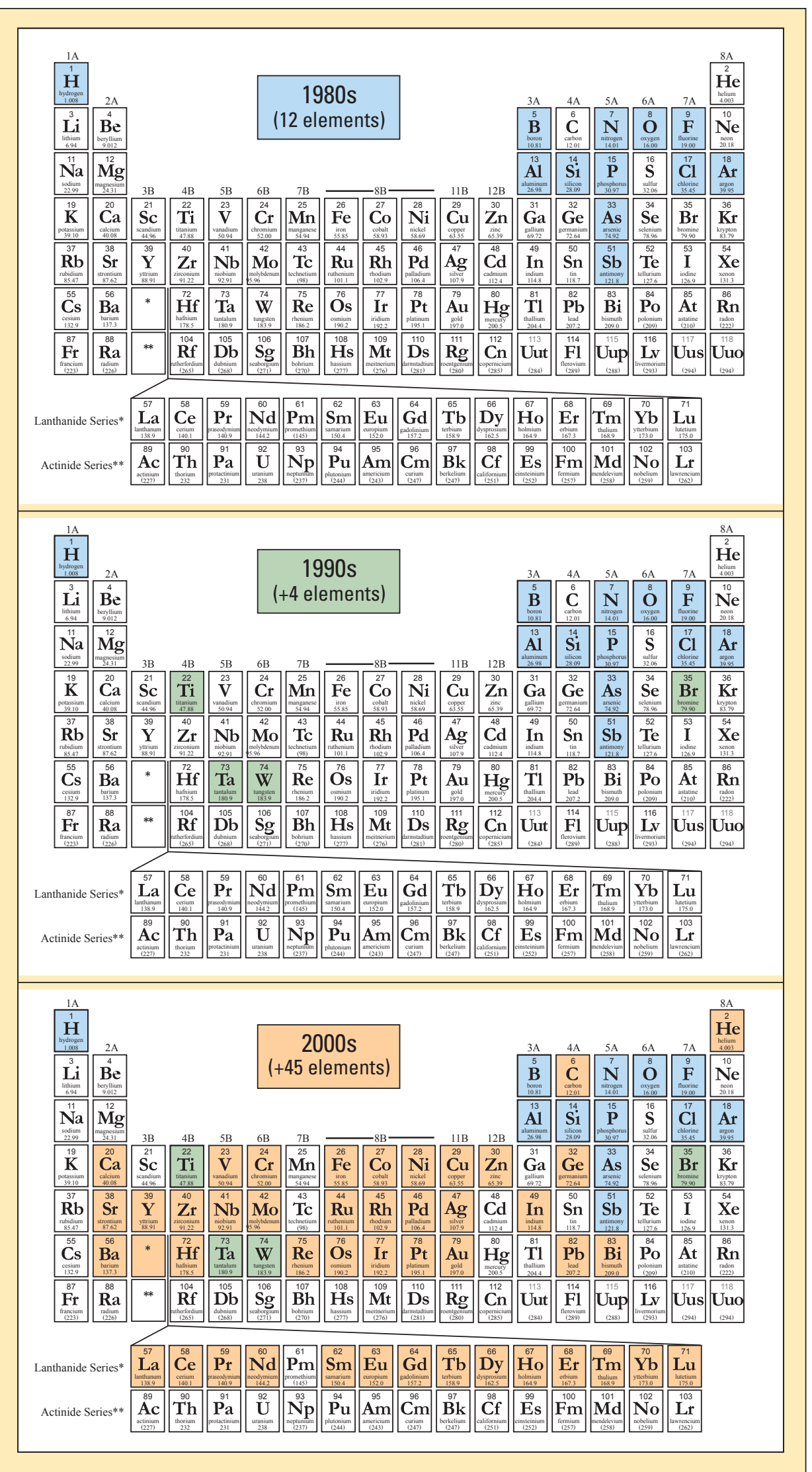

Figure A1. Diagram showing increases in the use of elements over two decades of computer chip technology development. Highspeed, high-capacity integrated circuits have gone from being made with $A, 12$ minerals or their elemental components in the 1980s to $B, 16$ in the 1990 s to $C$, more than 60 by the 2000s. Modified from National Research Council (2008, fig. 2.2). 
are few in number and geographically restricted. As a result, there is potential for local social and environmental issues or political manipulation to restrict or deny access to supply.

The sometimes-tenuous nature of the mineral supply chain received world attention in 2010 when China suddenly drastically cut its export quota for the rare-earth elements. The move highlighted the fact that China had a virtual monopoly on the short-term supply of rare-earth elements-elements that are essential to the renewable energy sector and many other high-tech applications globally. The rest of the world was left scrambling to find alternative and secure supplies. China is also the world's major producer of a number of other mineral commodities that are essential in high-tech applications, renewable energy, and national security, including antimony, bismuth, fluorspar, germanium, graphite, and indium (Price, 2013). These and other mineral commodities that are largely controlled by one country, such as cobalt (Democratic Republic of the Congo), niobium (Brazil), and platinum (South Africa), are also considered to be at high risk of supply disruption and would have high impact if supply restrictions should take place (McGroarty and Wirtz, 2012).

\section{Mineral Resource Classifications, Terms, and Definitions Used in This Volume}

Through the years, a variety of terms have been used to describe and classify mineral resources. Although some terms have gained wide use and acceptance, they are not always used with precisely the same meaning. Some basic terms and definitions are listed below. No attempt has been made to include a detailed listing of all mineral-resource-related terms and definitions; rather, emphasis is on those basic terms that are essential to proper understanding of the chapters in this volume. This terminology is intended to represent standard definitions and usage by the mineral industry and resource assessment community today. A more comprehensive discussion of mineral resource terms and definitions is presented in U.S. Bureau of Mines and U.S. Geological Survey (1980); Cox and others (1986); and U.S. Geological Survey National Mineral Resource Assessment Team (2000).

Mineral resources are classified based on a number of factors, such as their geologic and physical and (or) chemical characteristics (such as grade, mineralogy, tonnage, thickness, and depth) of the material in place; the economic viability of production based on costs of extracting, processing, and marketing the material at a given time; the level of certainty of estimates of physical and economic factors; and environmental and legal constraints on resource development. The mineral resource classification system used in this volume is shown in figure A2 (U.S. Bureau of Mines and U.S. Geological Survey, 1980).
When used in this volume, the terms listed below have the following meanings:

mineral occurrence. A mineral concentration that is considered valuable by someone somewhere, or that is of scientific or technical interest.

mineral deposit. A mineral concentration of sufficient size and grade that it might, under the most favorable of circumstances, be considered to have potential for economic development.

undiscovered mineral deposit. A mineral deposit believed to exist 1 kilometer or less below the surface of the ground, or an incompletely explored mineral occurrence or prospect that could have sufficient size and grade to be classified as a deposit.

ore deposit. A mineral deposit that has been tested and is known to be of sufficient size, grade, and accessibility to be producible to yield a profit.

resource. A mineral concentration of sufficient size and grade and in such a form and amount that economic extraction of a commodity from the concentration is currently or potentially feasible.

identified resources. Resources whose location, grade, quality, and quantity are known or estimatable from specific geologic evidence.

reserves. Identified resources that meet specified minimum physical and chemical criteria related to current mining and production practices and that can be economically extracted or produced at the time of determination.

undiscovered resources. Resources in undiscovered mineral deposits whose existence is postulated on the basis of indirect geologic evidence.

economic. Profitable extraction or production under defined investment assumptions has been established, analytically demonstrated, or assumed with reasonable certainty.

A mineral occurrence becomes a mineral resource only if there is a demand to use it - that is, inherent in the definition of a mineral resource is the necessity for there to be present or expected future demand for a mineral commodity in order for an occurrence of that mineral to be considered a resource. Note also that the quantity of the resource within each category is a stock variable (a measurement at a specific point in time), as contrasted with a flow variable, such as production (a measurement that covers a period of time). The quantity of resources (including reserves) is not static, and the assignment of the resource to a given category often changes over time.

The development of mineral resources into the category of reserves requires the creation of facilities to extract the ore, process it into a mineral product, and transport that product to the user. Although the quantity of production is a flow measure (amount per unit time- for example, tons per month or tons per year), the estimates of the amount available in each resource category (a stock variable) also changes over time as 


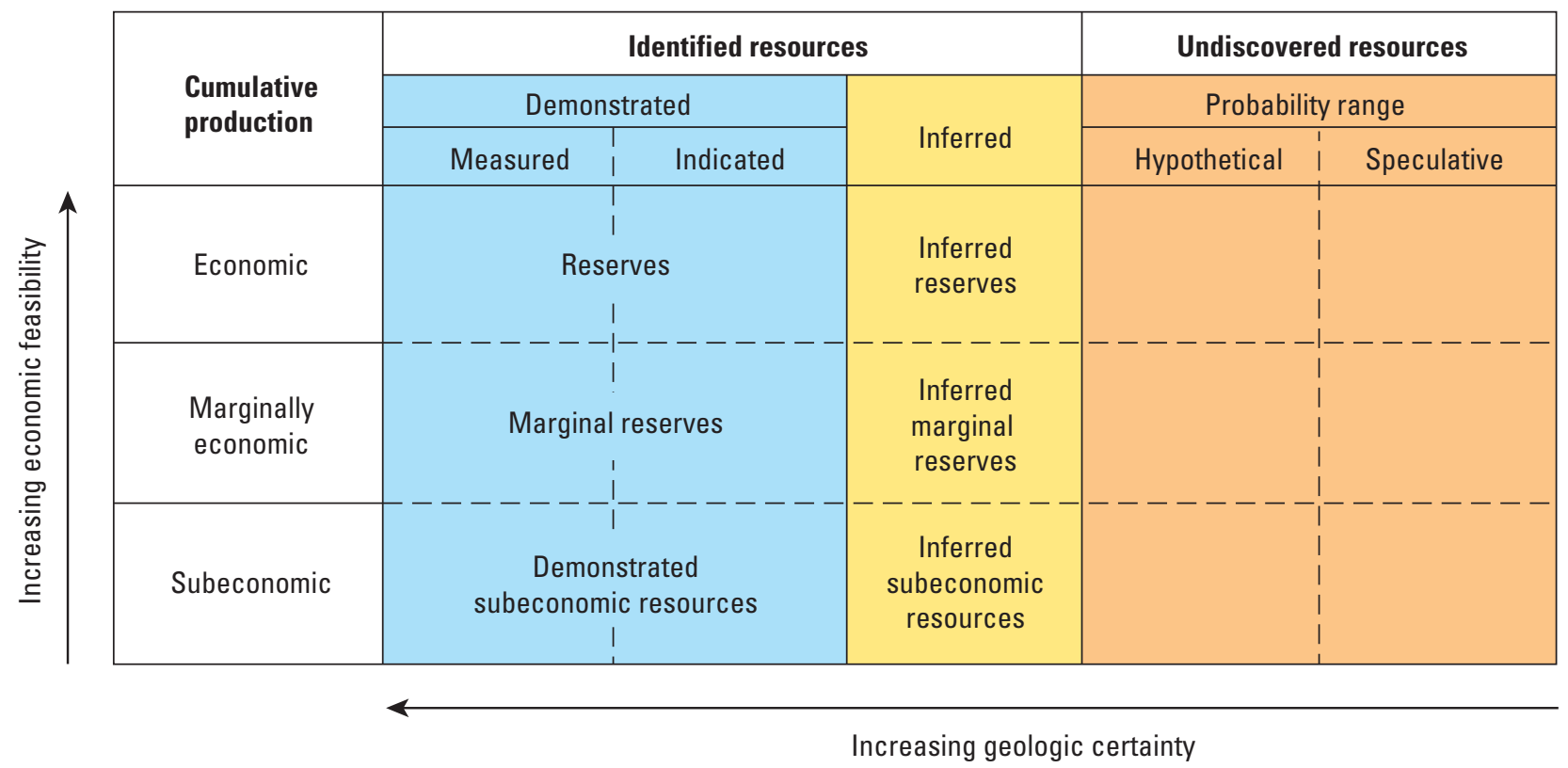

Figure A2. Diagram showing the mineral resource classification system used in this volume. Modified from U.S. Bureau of Mines and U.S. Geological Survey (1980).

production removes part of the resource; additional exploration results in the discovery of new deposits and provides new information about previously discovered deposits; advances in technology affect the costs and methods of mining, processing, and use; and changes in market conditions affect the economic viability of production. For example, in 1973, world reserves of cobalt were estimated to be 2.5 million metric tons of contained cobalt (U.S. Bureau of Mines, 1973, p. 39). Since then, more than 2.0 million metric tons of cobalt has been mined worldwide, yet world reserves of cobalt in 2015 were estimated to be 7.2 million metric tons of cobalt, which is almost triple the amount estimated in 1973, despite the depletion by mining of an amount equivalent to 80 percent of the 1973 reserve estimate (Shedd, 2015, 2016; U.S. Geological Survey, 2015a).

E.W. Zimmermann saw resources as a function of human wants and abilities. In the revised edition of his 1933 book, "World Resources and Industries-A Functional Appraisal of the Availability of Agricultural and Industrial Resources," he discussed the debate between "the static school who insists that 'resources are'," and "the dynamic, functional, operational school who insists that "resources become"" (Zimmermann, 1951, p. 11). He succinctly stated the relation between demand and resources as "Resources are not, they become."

\section{Joint Products, Byproducts, and Coproducts}

Many of the mineral commodities included in this volume are not produced as independent (also called individual, primary, or main) products; rather, they are produced (mined and [or] processed) along with other minerals. The terms used to describe the mineral commodities produced at a particular site can give an indication of their relative economic importance at that site. The terms, however, are not always used consistently across the industry.

The term "byproduct," for example, has been used to characterize any mineral commodity produced along with another as a "secondary product" (Kesler, 1994, p. 371) and (or) as a "secondary or additional product" (Thrush and others, 1968 , p. 157). Landsberg and others (1963, p. 479-483) used the terms "byproduct" and "coproduct" interchangeably in a detailed study of the future availability of natural resources to meet projected material use. Brooks (1965, p. 25-31), who was a senior contributor to that study, later described a "joint product" relationship when he developed his classification system for minor metals.

Brooks defined an individual product as one that is produced alone or with other minerals that are "of comparatively insignificant value." Joint products are called "byproducts" or "coproducts" depending upon their effect on the economic viability of the production process. If the joint product is needed to make the operation viable, it is a coproduct; if not, it is a byproduct. Changes in market conditions (prices and costs of production processes) and in applicable mining and processing technologies can change the status of joint products. With this caveat, the uses of the terms joint product, byproduct, and coproduct in this volume follow the definitions established by Brooks (1965). The revised version of the 1968 U.S. Bureau of Mines dictionary of mining and mineral terms published by the American Geological Institute in 1997 added a definition of "coproduct" that is cross-referenced to the definition of "byproduct" that is generally consistent with the classification developed by Brooks (American Geological Institute, 1997, p. 76, 124). 


\section{Scarcity and Rarity}

Analysis of mineral resources is linked to concerns about scarcity because resources are defined as physical quantities that can be extracted at a cost that is commensurate with current or potential profitable marketability. Brooks (1965, p. 22) explained the important distinction between physical rarity and economic scarcity; that is, rarity is determined by “.... an element's relative physical abundance in some specified portion of the earth" and scarcity is determined by the "...cost of acquisition under given conditions of time and place." The concepts of rarity and scarcity derive from different origins - rarity from the differentiation of the universe, over which humans have no control, and scarcity from many causes, of which human activity is often the sole determinant, such as monopolistic or oligopolistic market forces (Brooks, 1965, p. 22).

Three reasons why an element or mineral commodity may be scarce are rooted in geochemistry. First, rarity may result in scarcity; however, elements that have similar rarity as measured by average crustal abundance, such as cobalt and scandium, may have quite different scarcity as measured by market price. For example, in 2012, the price of cobalt was about 2.9 cents per gram ( $\$ 13$ per pound), whereas the price of scandium was $\$ 169$ per gram for metal ingots (Gambogi, 2014; Shedd, 2014). Because of market prices, cobalt was rare but not scarce, whereas scandium was both rare and scarce.

A second factor affecting the scarcity of an element is the concentration of the element above its average crustal abundance that is required to create an ore deposit (where the mineral can be extracted at a profit). The concentration above average crustal abundance needed to enable profitable mining is also dependent upon the byproducts and coproducts present in the deposit, ore mineralogy, grain size, consolidation of the material to be mined, and deposit depth and location. These characteristics are not accounted for in a ratio of the grade of an element in a deposit to its average crustal abundance. The necessary concentration with respect to average crustal abundance to make mining profitable varies considerably. Brooks (1976, p. 149) credited former USGS Director V.E. McKelvey with pointing out that titanium has been mined from deposits having grades below its average crustal abundance, whereas, for antimony, the concentration has needed to be as high as more than 300,000 times its crustal abundance for mining to be economic.

Finally, a mineral commodity may be scarce because of the lack of technology needed to effectively and economically mine and process ore material into a usable (and marketable) product. The need for such technology is dictated by the intended use. If a mineral commodity can be used effectively while containing some impurities, then the absence of processing technology to separate impurities is not a factor that contributes to scarcity. If removal of impurities is necessary, then the absence of such technology increases scarcity (Brooks, 1965, p. 23-24).

In "United States Mineral Resources," Erickson (1973) estimated the resource base - that is, the total amount of a mineral or metal in the earth (Lusty and Gunn, 2015, p. 266) - by using estimates of elemental concentrations in Earth's crust. In the present volume, the mineral commodities included have crustal abundances that range from 5,650 parts per million (ppm) (titanium) to $0.0007 \mathrm{ppm}$ (rhenium). The crustal abundance of the mineral commodities (elements) discussed in this volume are listed in table A1.

Some of the chapters in this volume give different elemental abundances than those presented in table A1. This reflects that different sources were used for the information and, in some cases, abundances were for the upper continental crust versus the total crust. Rudnick and Gao (2003) reviewed current estimates of the composition of continental crust and discussed the methods employed to derive the estimates.

\section{Mineral Commodities Selected for Inclusion in This Volume}

The use of terms such as "critical," deficient," "essential," and "strategic" to identify minerals or lists of minerals that are considered important by some observer(s) has a long and complicated history (appendix A1). In addition to implying a general level of importance, the word "critical" has been used to describe minerals or materials whose "criticality," as quantified by various analytical approaches, has been determined to exceed some specified limit. Some of the numerous studies that have been conducted to quantify or rank the criticality of selected mineral commodities have focused on the broad resource needs of current and emerging technologies (National Research Council, 2008; European Commission, 2010), whereas others have focused on certain sectors only, such as the energy sector (Massachusetts Institute of Technology, 2010; U.S. Department of Energy, 2011) or the national security sector (McGroarty and Wirtz, 2012). As a result, the mineral commodities classified as critical by each of these studies differ, although many of the findings include some of the same mineral commodities, such as some or all of the rare-earth elements and platinum-group elements.

The 23 mineral commodities or commodity groups selected for coverage in this volume (antimony, barite, beryllium, cobalt, fluorite, gallium, germanium, graphite, hafnium, indium, lithium, manganese, niobium, platinum-group elements, rare-earth elements, rhenium, selenium, tantalum, tellurium, tin, titanium, vanadium, and zirconium) have been listed as critical and (or) strategic in one or more of the recent studies based on assessed risks to their supply and (or) 
Table A1. Crustal abundances of mineral commodities (elements) included in this volume.

[Source: Jefferson Science Associates, LLC (2014). ppm, part per million]

\begin{tabular}{|c|c|c|}
\hline Element & Symbol & $\begin{array}{c}\text { Crustal abundance } \\
\text { (ppm) }\end{array}$ \\
\hline Titanium & $\mathrm{Ti}$ & 5,650 \\
\hline Manganese & $\mathrm{Mn}$ & 950 \\
\hline Fluorine & $\mathrm{F}$ & 585 \\
\hline Barium & $\mathrm{Ba}$ & 425 \\
\hline Carbon & $\mathrm{C}$ & 200 \\
\hline Zirconium & $\mathrm{Zr}$ & 165 \\
\hline Vanadium & $\mathrm{V}$ & 120 \\
\hline Cerium & $\mathrm{Ce}$ & 66.5 \\
\hline Neodymium & $\mathrm{Nd}$ & 41.5 \\
\hline Lanthanum & $\mathrm{La}$ & 39 \\
\hline Yttrium & $\mathrm{Y}$ & 33 \\
\hline Cobalt & $\mathrm{Co}$ & 25 \\
\hline Scandium & $\mathrm{Sc}$ & 22 \\
\hline Lithium & $\mathrm{Li}$ & 20 \\
\hline Niobium & $\mathrm{Nb}$ & 20 \\
\hline Gallium & $\mathrm{Ga}$ & 19 \\
\hline Praseodymium & $\operatorname{Pr}$ & 9.2 \\
\hline Samarium & Sm & 7.05 \\
\hline Gadolinium & $\mathrm{Gd}$ & 6.2 \\
\hline Dysprosium & Dy & 5.2 \\
\hline Erbium & Er & 3.5 \\
\hline Ytterbium & $\mathrm{Yb}$ & 3.2 \\
\hline Hafnium & $\mathrm{Hf}$ & 3 \\
\hline Beryllium & $\mathrm{Be}$ & 2.8 \\
\hline Tin & Sn & 2.3 \\
\hline Europium & $\mathrm{Eu}$ & 2 \\
\hline Tantalum & $\mathrm{Ta}$ & 2 \\
\hline Germanium & $\mathrm{Ge}$ & 1.5 \\
\hline Holmium & Но & 1.3 \\
\hline Terbium & $\mathrm{Tb}$ & 1.2 \\
\hline Lutetium & $\mathrm{Lu}$ & 0.8 \\
\hline Thulium & $\mathrm{Tm}$ & 0.52 \\
\hline Indium & In & 0.25 \\
\hline Antimony & $\mathrm{Sb}$ & 0.2 \\
\hline Selenium & $\mathrm{Se}$ & 0.05 \\
\hline Palladium & $\mathrm{Pd}$ & 0.015 \\
\hline Platinum & $\mathrm{Pt}$ & 0.005 \\
\hline Osmium & Os & 0.0015 \\
\hline Iridium & Ir & 0.001 \\
\hline Rhodium & $\mathrm{Rh}$ & 0.001 \\
\hline Ruthenium & $\mathrm{Ru}$ & 0.001 \\
\hline Tellurium & $\mathrm{Te}$ & 0.001 \\
\hline Rhenium & $\mathrm{Re}$ & 0.0007 \\
\hline
\end{tabular}

impact of potential supply restrictions. They are viewed as critical to a broad range of existing and emerging technologies, renewable energy, and national security (National Research Council, 2008; Massachusetts Institute of Technology, 2010; U.S. Department of Energy, 2011). They all have specialized and important applications in high-tech industrial, energy, defense, and (or) medical sectors, often with no effective substitutes. For some, current production is largely limited to only one or a few countries (for example, cobalt, niobium, rare-earth elements, and platinum-group elements), making their supply vulnerable to potential influence and disruption by such factors as civil unrest, political changes, natural disasters, environmental issues, and market manipulation. For many, the United States currently has neither mine production nor significant identified deposits and is largely dependent on imports to meet its resource needs.

This volume does not cover all 65 mineral commodities and commodity groups presented in "United States Mineral Resources" because the global resource picture for many of the major base, ferrous, and precious metals is already relatively well understood and documented, and the information on future sources of supply has not changed significantly in the past 40 years. Many of the commodities or commodity groups covered in the present volume, on the other hand, were considered less significant in the early 1970s because of their limited uses, and the documentation on them was sparse. In this volume, greater emphasis is placed on the global distribution of resources of these minerals than was the case in "United States Mineral Resources." In addition, for each mineral commodity, the text includes a discussion of the environmental issues related to its production, including current mitigation and remediation approaches to deal with these challenges.

Work on this volume began in 2013, and the writing and technical reviews of the chapters were completed between 2014 and 2016. As a result, there are some differences between chapters, particularly with respect to the most recent information regarding identified resources, reserves, and production.

\section{Changes Since the Mid-1970s}

The status of global mineral resources and mining has changed significantly since the publication of "United States Mineral Resources." The annual world production of most mineral commodities has increased markedly - in the case of the minerals covered in the chapters of this volume, the changes from 1973 to 2015 range from a modest 21 percent increase in annual tin production to a 2,800-percent increase (more than 29 times as much production!) for gallium. In light of this increased demand, concerns about possible weak links in the supply chains for mineral commodities have highlighted the need for reliable, regularly updated minerals information 
that is both broad in the scope of the mineral commodities covered and expansive in geographic reach. In addition, there is need for reliable assessments of the global distribution of mineral resources, their potential for supply disruption, and the environmental consequences of their production and use (Herrington, 2013).

Geologic knowledge and research technologies have also changed significantly since the publication of "United States Mineral Resources." During the 1960s, the theory of plate tectonics had been formulated and most geologists had embraced it, but as of the early 1970s, the implications for ore-deposit geology were still only dimly perceived. Today, several plate-tectonic processes are seen to control the genesis of most mineral-deposit types, and such other factors as paleoclimate and time in Earth history are also recognized as important.

Geologic maps remain the main prerequisite in the exploration for ore deposits, and the past four decades have seen huge strides in the amount and quality of geologic map coverage of the world, especially in the less developed countries. New software developments have made it possible for all geologists to use the once-specialized toolkit of satellite remote sensing. Methods of isotopic analysis have vastly improved, and it is now possible to date many ore deposits accurately and precisely, so that their origins can be understood in terms of the regional geologic and tectonic history. It is also possible to analyze a tiny sample of rock or ore chemically for virtually any element in the periodic table, including those elements that are the focus of this volume. All these scientific advances have helped to bring down the cost of mineral exploration and raise the probability of success. Despite these advances, however, continued research is essential for future geologists to find, and engineers to develop, mine, and process, increasing amounts of mineral resources to meet future needs.

Furthermore, as discussed by Seal and others (this volume, chap. B), people, governments, and corporations are much more aware than before of the environmental impacts of mineral resource extraction and use. Environmental challenges for the future remain, such as increased mine-waste and water management issues, including those caused by the effects of climate change, and the aspect of more energy-intensive mining operations.

\section{Back to the Future}

Despite the many changes in the status of global mineral resources and mining and the advances in geologic knowledge during the past 40 years, much of the previous analysis - and cautions - about mineral supplies and knowledge of them remains relevant. Cameron's (1973) statements about the U.S. mineral position, based on his analysis of U.S. mineral history and world mineral history since 1939, are perhaps even more pertinent today. McDivitt and Manners (1974, p. 10-11) wrote that in spite of the inescapable facts "that the total amount of each and every mineral is fixed and that use diminishes this given stock, ...the availability of minerals is expanded steadily by a growing knowledge of the world's geology, by the falling real costs of transport that allow minerals to be moved over ever-increasing distances, and by the development of techniques that permit the processing of different types of ore, often without more costly effort." They tempered expectations that these factors would keep major problems of inadequate mineral supplies at bay with cautions about how far into the future these expectations could be extended. At some point, increases in real costs for some minerals might result in changes in consumption, including the use of substitute materials.

Tilton (2003, p. 101-102) concluded that "depletion raises the specter of a world where resources are too costly to use rather than a world with no resources," but that "the past is not necessarily a good guide to the future," especially to the more distant future. He added that "More geologic information on the incidence and nature of mineral deposits, particularly subeconomic mineral deposits, could go a long way toward resolving this critical issue by providing useful insights on the nature and shape of cumulative supply curves" but that this information is not likely to become available soon because of the lack of economic incentives to gather information on deposits that are not currently profitable to develop (Tilton, 2003, p. 103).

Former mining industry executive Simon Strauss drew on his 1986 book, "Trouble in the Third Kingdom," when he delivered a presentation titled "The Appetite for Minerals" at a seminar at the USGS National Center on April 18, 1989. Mr. Strauss concluded that continued success in addressing mineral supply problems could be expected by stimulation of domestic production; increases in recycling, conservation, and substitution; and the use of stockpiles. When asked if that view might indicate a lack of need for further research on the geology of mineral deposits and on mining and mineral processing technology, such as that done by the USGS and the U.S. Bureau of Mines, Mr. Strauss replied that the contributions of those institutions were an important reason for his optimistic outlook, but that the role of those institutions in helping ensure adequate past and future mineral supplies was widely appreciated and that they would continue to perform those roles. The closure of the U.S. Bureau of Mines in 1996 indicates that the appreciation of the value of scientific research that provides the foundation for solving future resource problems should not be taken for granted. 


\section{References Cited}

Note: All Web links listed were active as of the access date but may no longer be available.

American Geological Institute, 1997, Dictionary of mining, mineral, and related terms: Alexandria, Va., American Geological Institute in cooperation with the Society for Mining, Metallurgy, and Exploration, Inc., 646 p.

Brobst, D.A., and Pratt, W.P., eds., 1973, United States mineral resources: U.S. Geological Survey Professional Paper 820, 722 p. [Also available at https://pubs.er.usgs.gov/publication/ pp820.]

Brooks, D.B., 1965, Supply and competition in minor metals: Washington, D.C., Resources for the Future, 147 p.

Brooks, D.B., 1976, Mineral supply as a stock, in Vogely, W.A., and Risser, H.E., eds., Economics of the mineral industries (3d ed.): New York, N.Y., American Institute of Mining, Metallurgical, and Petroleum Engineers, Inc., p. 127-207.

Cameron, E.N., 1973, The contribution of the United States to national and world mineral supplies, in Cameron, E.N., ed., The mineral position of the United States, 1975-2000: Madison, Wis., The University of Wisconsin Press, p. 9-27.

Cohen, David, 2007, Earth's natural wealth-An audit: New Scientist, v. 26, May, p. 34-41.

Cox, D.P., Barton, P.B., and Singer, D.A., 1986, Introduction, in Cox, D.P., and Singer, D.A., eds., Mineral deposit models: U.S. Geological Survey Bulletin 1693, p. 1-10. [Also available at https://pubs.usgs.gov/bul/b1693/.]

Erickson, R.L., 1973, Crustal abundance of elements, and mineral reserves and resources, in Brobst, D.A., and Pratt, W.P., eds., United States mineral resources: U.S. Geological Survey Professional Paper 820, p. 21-25. [Also available at https://pubs.er.usgs.gov/publication/pp820.]

European Commission, 2010, Critical raw materials for the EU-Report of the ad-hoc Working Group on defining critical raw materials: European Commission Enterprise and Industry, 85 p. [Also available at http://ec.europa.eu/ growth/sectors/raw-materials/specific-interest/critical/ index_en.htm.]

Fortier, S.M., DeYoung, J.H., Jr., Sangine, E.S., and Schnebele, E.K., 2015, Comparison of U.S. net import reliance for nonfuel mineral commodities - A 60-year retrospective (1954-1984-2014): U.S. Geological Survey Fact Sheet 2015-3082, December, 4 p., accessed March 7, 2016, at http://dx.doi.org/10.3133/fs20153082.

Gambogi, Joseph, 2014, Scandium: U.S. Geological Survey Mineral Commodity Summaries 2014, p. 140-141. [Also available at http://minerals.usgs.gov/minerals/pubs/ commodity/scandium/mcs-2014-scand.pdf.]
Gold, Russell, 2014, Why peak-oil predictions haven't come true-And probably won't: The Wall Street Journal, September 29, p. R1-R2.

Herrington, Richard, 2013, Road map to mineral supply: Nature Geoscience, v. 6, no. 11, p. 892-894. [Also available at http://dx.doi.org/10.1038/ngeo1947.]

Hewett, D.F., 1929, Cycles in metal production: Transactions of the American Institute of Mining and Metallurgical Engineers, v. 85, p. 65-93.

Hubbert, M.K., 1956, Nuclear energy and the fossil fuels, in Drilling and production practice: Washington, D.C., American Petroleum Institute, p. 7-25.

Jefferson Science Associates, LLC, 2014, It's elementalThe periodic table of elements: Jefferson Lab Web page, accessed November 25, 2014, at http://education.jlab.org/ itselemental/index.html.

Kesler, S.E., 1994, Mineral resources, economics and the environment: New York, N.Y., Macmillan College Publishing Company, Inc., 391 p.

Landsberg, H.H., Fischman, L.L., and Fisher, J.L., 1963, Resources in America's future-Patterns of requirements and availabilities, 1960-2000: Baltimore, Md., The Johns Hopkins Press, 1,107 p.

Lasky, S.G., 1951, Mineral industry futures can be predicted: Engineering and Mining Journal, v. 152, no. 8, August, p. 60-64.

Lasky, S.G., 1955, Mineral industry futures can be predicted-II: Engineering and Mining Journal, v. 156, no. 9, September, p. 94-96.

Lusty, P.A.J., and Gunn, A.G., 2015, Challenges to global mineral resource security and options for future supply, in Jenkin, G.R.T., Lusty, P.A.J., McDonald, I., Smith, M.P., Boyce, A.J., and Wilkinson, J.J., eds., Ore deposits in an evolving earth: London, United Kingdom, The Geological Society of London Special Publication 393, p. 265-276, accessed March 8, 2016, at http://dx.doi.org/10.1144/ SP393.13.)

Massachusetts Institute of Technology, 2010, Critical elements for new energy technologies, in MIT Energy Workshop on Critical Elements for New Energy Technologies, Cambridge, Mass., April 29, 2010: Cambridge, Mass., Massachusetts Institute of Technology,175 p. [Also available at https://energy.mit.edu/publication/critical-elements-fornew-energy-technologies/.]

McDivitt, J.F., and Manners, Gerald, 1974, Minerals and men (revised and enlarged edition): Baltimore, Md., The Johns Hopkins University Press, 175 p.

McGroarty, Daniel, and Wirtz, Sandra, 2012, Reviewing risk - Critical metals and national security: American Resources Policy Network Report, June 6, 34 p. 
Meadows, D.H., Meadows, D.L., Randers, Jørgen, and Behrens, W.W., III, 1972, The limits to growth-A report for the Club of Rome's project on the predicament of mankind: New York, N.Y., Universe Books, 205 p.

Meinert, L.D., Robinson, G.R., Jr., and Nassar, N.T., 2016, Mineral resources-Reserves, peak production, and the future, in Schmidt, Mario, ed., Consideration of abiotic natural resources in life cycle assessments: Resources (Special Issue), v. 5, no. 1, article 14, 14 p., accessed March 7, 2016, at http://dx.doi.org/10.3390/ resources5010014.

National Research Council, 2008, Minerals, critical minerals, and the U.S. economy: Washington, D.C., The National Academies Press, 245 p. [Also available at http://www.nap.edu/ catalog/12034/minerals-critical-minerals-and-the-us-economy.]

Pazik, George, 1976, Our petroleum predicament: Fishing Facts, v. 10, no. 11, November, p. 4-33.

Price, J.G., 2013, The challenges of mineral resources for society, in Bickford, M.E., ed., The impact of the geological sciences on society: Geological Society of America Special Paper 501, p. 1-19. [Also available at http://dx.doi.org/ 10.1130/2013.2501(01).]

Rudnick, R.L., and Gao, S., 2003, Composition of the continental crust, in Rudnick, R.L., ed., The crust, v. 3 of Holland, H.D., and Turekian, K.K., eds., Treatise on geochemistry: Oxford, United Kingdom, Elsevier-Pergamon, p. 1-64. [Also available at http://dx.doi.org/10.1016/ B0-08-043751-6/03016-4.]

Rustad, J.R., 2012, Peak nothing-Recent trends in mineral resource production: Environmental Science and Technology, v. 46, no. 3, p. 1903-1906, accessed November 14, 2014, at http://pubs.acs.org/doi/abs/10.1021/es203065g.

Shedd, K.B., 2014, Cobalt: U.S. Geological Survey Mineral Commodity Summaries 2014, February, p. 46-47. [Also available at http://minerals.usgs.gov/minerals/pubs/ commodity/cobalt/mcs-2014-cobal.pdf.]

Shedd, K.B., 2015, Cobalt: U.S. Geological Survey Mineral Commodity Summaries 2015, January, p. 46-47. [Also available at http://minerals.usgs.gov/minerals/pubs/ commodity/cobalt/mcs-2015-cobal.pdf.]

Shedd, K.B., 2016, Cobalt: U.S. Geological Survey Mineral Commodity Summaries 2016, January, p. 52-53. [Also available at http://minerals.usgs.gov/minerals/pubs/ commodity/cobalt/mcs-2016-cobal.pdf.]

Strauss, S.D., 1986, Trouble in the third kingdom-The minerals industry in transition: London, United Kingdom, Mining Journal Books Ltd., 227 p.
Thrush, P.W., and the staff of the Bureau of Mines, comps. and eds., 1968, A dictionary of mining, mineral, and related terms: Washington, D.C., U.S. Department of the Interior, Bureau of Mines, 1,269 p.

Tilton, J.E., 2003, On borrowed time? - Assessing the threat of mineral depletion: Washington, D.C., Resources for the Future, $158 \mathrm{p}$.

U.S. Bureau of Mines, 1973, Commodity data summaries: U.S. Bureau of Mines, January, 168 p.

U.S. Bureau of Mines and U.S. Geological Survey, 1980, Principles of a resource/reserve classification for minerals: U.S. Geological Survey Circular 831, 5 p. [Also available at https://pubs.er.usgs.gov/publication/cir831.]

U.S. Department of Energy, 2011, Critical materials strategy: Washington, D.C., U.S. Department of Energy, DOE/PI-0009, 191 p. [Also available at http://energy.gov/ sites/prod/files/DOE_CMS2011_FINAL_Full.pdf.]

U.S. Geological Survey, 1975, Mineral resource perspective 1975: U.S. Geological Survey Professional Paper 940, 24 p.

U.S. Geological Survey, 2015a, Cobalt statistics [through 2013; last modified January 30, 2015], in Kelly, T.D., and Matos, G.R., comps., Historical statistics for mineral and material commodities in the United States (2015 version): U.S. Geological Survey Data Series 140, 4 p., accessed March 13, 2016, at http://minerals.usgs.gov/minerals/pubs/ historical-statistics/. [Supersedes Open-File Report 01-006.]

U.S. Geological Survey, 2015b, Mineral commodity summaries 2015: U.S. Geological Survey, 196 p. [Also available at http://minerals.usgs.gov/minerals/pubs/mcs/2015/ mcs2015.pdf.]

U.S. Geological Survey, 2016, Mineral commodity summaries 2016: U.S. Geological Survey, 202 p., accessed March 7, 2016, at http://minerals.usgs.gov/minerals/pubs/mcs/2016/ mes2016.pdf.

U.S. Geological Survey National Mineral Resource Assessment Team, 2000, 1998 assessment of undiscovered deposits of gold, silver, copper, lead, and zinc in the United States: U.S. Geological Survey Circular 1178, 21 p. [A Portable Document (PDF) recompilation of USGS Open-File Report 96-96 and Circular 1178 was prepared by Paul Schruben and released as U.S. Geological Survey Open-File Report 02-198 in 2002.] [Also available at http://pubs.usgs.gov/ circ/c1178/c1178.pdf.]

Zimmermann, E.W., 1951, World resources and industriesA functional appraisal of the availability of agricultural and industrial materials ( 2 d ed.): New York, N.Y., Harper \& Brothers, $832 \mathrm{p}$. 


\section{Appendix A1. What is Meant by "Critical" Minerals (or Materials)?}

Problems resulting from the lack of domestic production of certain mineral commodities became apparent in World War I when "Minerals that were essential to the war effort ... could not be produced in adequate amounts from domestic sources..." (Cameron, 1986, p. 254). These became known as "strategic minerals." Charles Kenneth Leith has been credited with compiling the first of many lists of "strategic and critical minerals" when he was serving as a mineral adviser to the War Industries Board in 1917-this "unofficial" list was industrial in character, rather than defense oriented (Roush, 1939, p. 10). The first "official" list was prepared under the auspices of the Supply Division of the General Staff on January 20, 1921 (Pehrson, 1944, p. 339). The plethora of lists that followed seems to bear out an observation of a university administrator that ranking (and listing) things is "a part of the DNA of America" (Pope, 2013, p. 31). Roush (1939, p. 2-10) documented 15 different lists of strategic and critical minerals and materials created from 1917 through 1939; there were both official lists and unofficial lists that categorized minerals as strategic (from the standpoints of industrial needs, defense needs, or both), critical ("those minerals which might be expected to develop a shortage with increased demand, but which, with careful control of consumption and proper stimulation of production, might be maintained on a self-supporting basis"), essential ("essential materials neither strategic nor critical"), and deficient ("in a major degree" and "to a lesser degree"). In addition, there were several changes in the stated meaning of the terms and differences in their application over time, depending upon the perspective of the person or groups of persons compiling the lists (Roush, 1939, p. 3).

Pehrson (1944, p. 339-340) attempted to set the record straight in this regard by defining strategic materials as those that were essential for defense and for which the United States relied on foreign supply sources, and critical materials as those that were essential to defense but less difficult to obtain because they were less essential or had domestic supply sources. In 1944, the Army and Navy Munitions Board approved a new definition of "strategic and critical materials" (with no distinction between the two adjectives) as "...those materials required for essential uses in a war emergency, the procurement of which in adequate quantities, quality, and time is sufficiently uncertain for any reason to require prior provision for the supply thereof." In the Strategic and Critical Materials Stock Piling Act (50 U.S.C. §98), "The term 'strategic and critical materials" means materials that (A) would be needed to supply the military, industrial, and essential civilian needs of the United States during a national emergency, and (B) are not found or produced in the United States in sufficient quantities to meet such need."
Pehrson (1944, p. 341) documented the changes as to which minerals were classified as strategic, critical, essential, or strategic and critical in several lists since the first official list was compiled in January 1921. McKinstry (1948, p. xvii-xix) attributed the increased attention concerning strategic minerals in the 1940s to "geological economists" and observed that, in time of war, "almost all useful minerals become strategic" and information about where minerals occur and how soon and for how long they can be produced is "critical."

The American Geological Institute "Dictionary of Geological Terms" (1962, p. 113, 475) defined critical [materials] and strategic [materials] separately. The Commerce Department representative on the staff of the 1978-79 Presidential Review of Nonfuel Minerals Policy succinctly summarized the two-definition concept by saying, "Critical means you need it; strategic means you don't have it!" (William J. Kaestner, U.S. Department of Commerce, oral commun., 1978). In contrast, Evans (1993, p. 10) stated, "A material needed for military purposes is considered strategic and a material is termed critical if future events involving its supply from abroad threaten to inflict serious harm on a nation's economy" (DeYoung and others, 2006, p. 486).

The number of minerals classified as strategic, critical, vital, deficient, or strategic and critical (with frequent changes in definitions of the terms and as viewed from the perspectives of various stakeholders) increased from 4 in World War I, to 9 in 1939, to 52 later in World War II (Hewett, 1959, p. 191). In 1974, the President's Council on International Economic Policy reported on a list of 19 critical materials, but did not provide a definition of critical (Council on International Economic Policy, Executive Office of the President, 1974). A 1982 National Indicators System report on the domestic supply of critical minerals explained that classification of minerals as strategic or as critical changes over time across countries, industries, and users and that the determination of which minerals were "strategic and critical" was made by the executive branch of the Government. For the purposes of that report, the 15 "critical" minerals chosen were based on one or more of several considerations, including the large amounts used and resulting importance to the economy, strategic importance to national defense, special properties not readily found in other materials, reliance on imports for domestic consumption, and alloying properties (U.S. Bureau of Mines, 1982 , p. 2-3). In advocating a national geochemical census and increased support for basic research, Yoder (1982, p. 229) stated that all the minerals for which the United States was more than 50 percent import reliant in 1979 were critical to the economy and that they could be classified as "strategic" if 
they met one or more of four criteria describing their geologic availability, technology necessary to bring them to market in a timely fashion, the "possibility that unforeseen essential uses may develop," and the reliability of foreign sources. When the National Critical Materials Council was established in 1984, the enabling legislation (30 U.S.C. §§1801-1811) specified a definition for "materials," but not for "critical." Some lists that use "critical" as a modifier explicitly restrict the definition of critical to that applied to a particular end use, such as "energycritical" minerals (American Physical Society and the Materials Research Society, 2011; U.S. Department of Energy, 2011).

Conflicting uses of terms to describe critical and (or) strategic minerals led Archer $(1980$, p. 2) to question whether the cobalt in the turbine blades of a jet engine was more strategic or critical than the petroleum-based fuel or the materials used in constructing the runway. He concluded that the term "strategic" was used by some as an impressive synonym for "important" and that "criticality" as measured by the part that a mineral plays in everyday life, industry, and defense, is not related to its source of supply.

When they addressed their question, "How critical are critical materials?", Clark and Field (1985, p. 38-40) did not present a way to measure criticality but concluded, after examining statistics on net import reliance, that mechanisms to address short-term and long-term problems that might result from disruptions in mineral supplies were already in place (stockpiles, conservation, recycling, and development of alternative materials). Scientists in the Department of the Interior's Office of Minerals Policy and Research Analysis had already begun to develop a new measure, the Critical Minerals Index (CMI). They recognized that the "imports market share" measure ignored the two primary determinants of mineral criticality - supply risk and economic importance - and was thus of little use to policymakers in focusing attention on supply problems for specific minerals (Adams and others, 1979, p. 1-2). Two CMI components were identified for each mineral commodity - a Mineral Disruption Index (the likelihood of disruption of U.S. imports during the time period of consideration) and a Mineral Cost Index (the annual cost imposed by the import disruption; Adams and others, 1979, p. 4-5).

In 2008, these two components were used by the National Research Council's Committee on Critical Mineral Impacts on the U.S. Economy to develop a two-dimensional graphical approach to define and measure criticality, the "criticality matrix," which was applied to several nonfuel mineral commodities (National Research Council, 2008). Subsequent studies have added a third dimension (environmental implications) to the matrix, considered the implications of specifying a time dimension, added net present value calculations to the economic value (cost) dimension, and incorporated the determinants of risk into the vulnerability dimension (Erdmann and Graedel, 2011; Graedel and others, 2012;
Glöser and others, 2015; Graedel and Reck, 2015; Mayer and Gleich, 2015). Studies that have applied these approaches to produce quantitative measures of criticality have incorporated existing data series as surrogates for the components; for example, Silberglitt and others $(2013$, p. 4) used the Herfindahl-Hirschman Index (a measure of the concentration of market power and international trade) as a measure of the geographic concentration of mineral production and the World Bank's Worldwide Governance Indicators (a measure of the quality of governance in six dimensions) as a measure of supply risk where reliability of supply might be affected by political instability, government control of mineral production, or restrictive trade policies.

In 2016, the National Science and Technology Council (NSTC) issued a report that provided and applied a systematic methodology to screen for potentially critical minerals. The report summarized an interagency effort to develop a screening process to assess "potential criticality" based on three fundamental indicators: supply risk, production growth, and market dynamics. The screening was applied to 78 minerals or mineral commodities for each year from 1996 through 2013. This study defined critical minerals to be "those that have a supply chain that is vulnerable to disruption, and that serve an essential function in the manufacture of a product, the absence of which would cause significant economic or security consequence," and strategic minerals as "a subset of critical minerals and are those that are essential for national security applications" (National Science and Technology Council, 2016, p. ix).

In wrestling over the question of "Which materials are 'critical' and which are 'strategic'?", Simandl and others (2015, p. 59) concluded that "misunderstanding, miscommunications and potentially misrepresentations" can result from the lack of consistency in use of the terms "critical" and "strategic" and that "Which materials are considered critical depends to a large extent on the priorities and objectives of the organization or country that commissions the study." This observation about the necessarily subjective nature of determining criticality — depending upon who commissions a study about critical minerals, makes a list of critical minerals, or devises a process to define and measure criticality of minerals - has been stated explicitly in many studies and is implicit in all the rest. The economic concept of utility, how useful or satisfying a good, service, or action is to an individual, underlies the formation of priorities and objectives. In fact, as noted by Sears (2011), "it is impossible to compare utility levels of different people" and thus "modern utility theory does not allow the economist to combine individual utilities into one number for all society." Recognition of the role of perspective in determining what is "critical" or important and the attendant limitations of such determinations is a critical element in understanding what is meant by "critical" minerals. 


\section{Appendix A1 References Cited}

Note: All Web links listed were active as of the access date but may no longer be available.

Adams, R.L., White, B.A., and Grichar, J.S., 1979, Developing a critical minerals index-A pilot study: U.S. Department of the Interior, Office of Minerals Policy and Research Analysis, July, 52 p.

American Geological Institute, 1962, Dictionary of geological terms (3d ed.): Garden City, N.Y., Dolphin Books, 545 p.

American Physical Society and the Materials Research Society, 2011, Energy critical elements-Securing materials for emerging technologies: Washington, D.C., American Physical Society, 24 p., accessed March 20, 2016, at https://www.aps.org/policy/reports/popa-reports/upload/ elementsreport.pdf.

Archer, A.A., 1980, Definition of strategic materials and the means currently available to the United Kingdom to identify strategic sources and requirements, in Jones, M.J., ed., Availability of strategic minerals - Proceedings of the National Symposium on the Availability of Strategic Minerals, London, United Kingdom, November 20-21, 1979: London, United Kingdom, The Institution of Mining and Metallurgy, p. 1-3.

Cameron, E.N., 1986, At the crossroads - The mineral problems of the United States: New York, N.Y., John Wiley \& Sons, $320 \mathrm{p}$.

Clark, J.P., and Field, F.R., III, 1985, How critical are critical minerals?: Technology Review (Massachusetts Institute of Technology), v. 88, no. 6, August/September, p. 38-46.

Council on International Economic Policy, Executive Office of the President, 1974, Special report-Critical imported materials: Washington, D.C., U.S. Government Printing Office, 49 p. plus 1 appendix. [Also available at https://catalog.hathitrust.org/Record/000035158.]

DeYoung, J.H., Jr., McCartan, Lucy, and Gambogi, Joseph, 2006, What's been (and what will be) strategic-My metal or your paint?, in Reid, J.C., ed., Proceedings of the 42d Forum on the Geology of Industrial Minerals (Asheville, N.C., May 7-13, 2006): Raleigh, N.C., North Carolina Geological Survey Information Circular 34, p. 482-497, CD-ROM.

Erdmann, Lorenz, and Graedel, T.E., 2011, Criticality of non-fuel minerals - A review of major approaches and analyses: Environmental Science and Technology, v. 45, no. 18, p. 7620-7630, accessed March 27, 2016, at http://dx.doi.org/10.1021/es200563g.
Evans, A.M., 1993, Ore geology and industrial mineralsAn introduction ( $3 \mathrm{~d}$ ed.): Oxford, United Kingdom, Blackwell Science, 389 p.

Glöser, Simon, Espinoza, L.T., Gandenberger, Carsten, and Faulstich, Martin, 2015, Raw material criticality in the context of classical risk assessment: Resources Policy, v. 44, p. 35-46. [Also available at http://dx.doi.org/10.1016/ j.resourpol.2014.12.003.]

Graedel, T.E., Barr, Rachel, Chandler, Chelsea, Chase, Thomas, Choi, Joanne, Christoffersen, Lee, Friedlander, Elizabeth, Henly, Claire, Jun, Christine, Nassar, N.T., Schechner, Daniel, Warren, Simon, Yang, Man-yu, and Zhu, Charles, 2012, Methodology of metal criticality determination: Environmental Science and Technology, v. 46, no. 2, p. 1063-1070, accessed March 27, 2016, at http://dx.doi.org/10.1021/ es203534z.

Graedel, T.E., and Reck, B.K., 2015, Six years of criticality assessments - What have we learned so far?: Journal of Industrial Ecology, accessed March 27, 2016, at http://dx.doi.org/10.1111/jiec.12305.

Hewett, D.F., 1959, Charles Kenneth Leith, January 20, 1875-September 13, 1956-A biographical memoir: Washington, D.C., National Academy of Sciences, p. 180-204, accessed March 16, 2016, at http://www.nasonline.org/ member-directory/deceased-members/20001553.html.

Mayer, Herbert, and Gleich, Benedikt, 2015, Measuring criticality of raw materials - An empirical approach assessing the supply risk dimension of commodity criticality: Natural Resources, v. 6, p. 56-78, accessed March 27, 2016, at http://dx.doi.org/10.4236/nr.2015.61007.

McKinstry, H.E., 1948, Mining geology: Englewood Cliffs, N.J., Prentice-Hall, Inc., 680 p.

National Research Council, 2008, Minerals, critical minerals, and the U.S. economy: Washington, D.C., The National Academies Press, 245 p. [Also available at http:/www.nap.edu/ catalog/12034/minerals-critical-minerals-and-the-us-economy.]

National Science and Technology Council, 2016, Assessment of critical minerals - Screening methodology and initial application: Washington, D.C., Subcommittee on Critical and Strategic Mineral Supply Chains of the Committee on Environment, Natural Resources, and Sustainability of the National Science and Technology Council, March, 47 p.

Pehrson, E.W., 1944, What are strategic and critical materials?: Mining and Metallurgy, v. 25, no. 451, July, p. 339-341.

Pope, Justin, 2013, A look behind the rankings: Michigan Alumnus, Early Fall, p. 30-35. 
Roush, G.A., 1939, Strategic mineral supplies: New York, N.Y., McGraw-Hill Book Company, Inc., 485 p.

Sears, Louis, 2011, Jargon alert_-Utility: Region Focus (Federal Reserve Bank of Richmond), v. 15. no. 3, third quarter, p. 10., accessed March 7, 2016, via https://www.richmondfed.org/publications/.) [Also available at https://www.richmondfed.org/publications/research/ region_focus/2011/q3/q3.]

Silberglitt, Richard, Bartis, J.T., Chow, B.G., An, D.L., and Brady, Kyle, 2013, Critical materials-Present danger to U.S. manufacturing (Research report prepared for the National Intelligence Council): Santa Monica, Calif., RAND Corp., document RR-133-MC, 46 p., accessed March 9, 2016, at http://www.rand.org/pubs/research reports/RR133.html.
Simandl, G.J., Akam, Carlee, and Paradis, Suzanne, 2015, Which materials are "critical" and which are "strategic"?: Industrial Minerals, no. 578, December, p. 57-59.

U.S. Bureau of Mines, 1982, The domestic supply of critical minerals: U.S. Bureau of Mines, National Indicators System Report Number 9, May, 98 p.

U.S. Department of Energy, 2011, Critical materials strategy: Washington, D.C., U.S. Department of Energy, DOE/PI-0009, 191 p. [Also available at http://energy.gov/ sites/prod/files/DOE_CMS2011_FINAL_Full.pdf.]

Yoder, H.S., Jr., 1982, Strategic minerals-A critical research need and opportunity: Proceedings of the American Philosophical Society, v. 126, no. 3, p. 229-241. 


\section{Environmental Considerations Related to Mining of Nonfuel Minerals}

By Robert R. Seal II, Nadine M. Piatak, Bryn E. Kimball, and Jane M. Hammarstrom

Chapter B of

Critical Mineral Resources of the United States-Economic and Environmental Geology and Prospects for Future Supply

Edited by Klaus J. Schulz, John H. DeYoung, Jr., Robert R. Seal II, and Dwight C. Bradley

Professional Paper 1802-B 


\section{Contents of Chapter B}

[Figure and table titles for all chapters are listed in the volume contents before the conversion factors table and list of abbreviations and symbols. A periodic table of the elements is on the inside front cover of the printed volume]

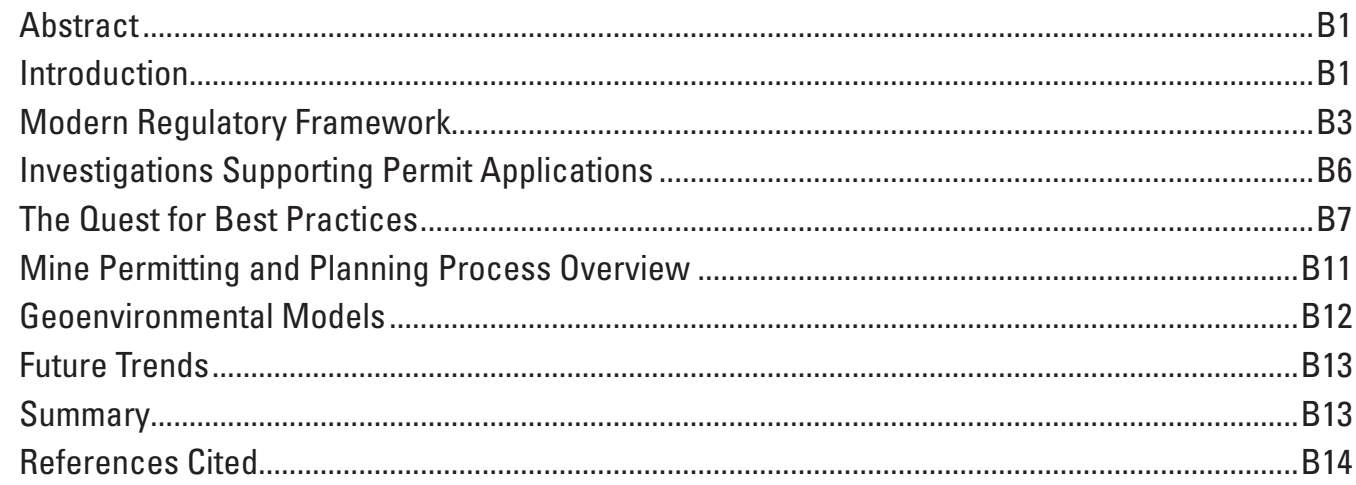

Suggested citation:

Seal, R.R., II, Piatak, N.M., Kimball, B.E., and Hammarstrom, J.M., 2017, Environmental considerations related to mining of nonfuel minerals, chap. B of Schulz, K.J., DeYoung, J.H., Jr., Seal, R.R., II, and Bradley, D.C., eds., Critical mineral resources of the United States-Economic and environmental geology and prospects for future supply: U.S. Geological Survey Professional Paper 1802, p. B1-B16, http://dx.doi.org/10.3133/pp1802B. 


\title{
Environmental Considerations Related to Mining of Nonfuel Minerals
}

\author{
By Robert R. Seal II, Nadine M. Piatak, Bryn E. Kimball, and Jane M. Hammarstrom
}

\section{Abstract}

Throughout most of human history, environmental stewardship during mining has not been a priority partly because of the lack of applicable laws and regulations and partly because of ignorance about the effects that mining can have on the environment. In the United States, the National Environmental Policy Act of 1969, in conjunction with related laws, codified a more modern approach to mining, including the responsibility for environmental stewardship, and provided a framework for incorporating environmental protection into mine planning. Today, similar frameworks are in place in the other developed countries of the world, and international mining companies generally follow similar procedures wherever they work in the world. The regulatory guidance has fostered an international effort among all stakeholders to identify best practices for environmental stewardship.

The modern approach to mining using best practices involves the following: (a) establishment of a pre-mining baseline from which to monitor environmental effects during mining and help establish geologically reasonable closure goals; (b) identification of environmental risks related to mining through standardized approaches; and (c) formulation of an environmental closure plan before the start of mining. A key aspect of identifying the environmental risks and mitigating those risks is understanding how the risks vary from one deposit type to another-a concept that forms the basis for geoenvironmental mineral-deposit models.

Accompanying the quest for best practices is the goal of making mining sustainable into the future. Sustainable mine development is generally considered to be development that meets the needs of the present generation without compromising the ability of future generations to meet their own needs. The concept extends beyond the availability of nonrenewable mineral commodities and includes the environmental and social effects of mine development.

Global population growth, meanwhile, has decreased the percentage of inhabitable land available to support society's material needs. Presently, the land area available to supply the mineral resources, energy resources, water, food, shelter, and waste disposal needs of all Earth's inhabitants is estimated to be 135 square meters per person. Continued global population growth will only increase the challenges of sustainable mining.

Current trends in mining are also expected to lead to new environmental challenges in the future, among which are mine-waste management issues related to mining larger deposits for lower ore grade; water-management issues related to both the mining of larger deposits and the changes in precipitation brought about by climate change; and greenhouse gas issues related to reducing the carbon footprint of larger, more energy-intensive mining operations.

\section{Introduction}

The development of mining was coincident with the beginning of the Stone Age when, more than 2.5 million years ago, ancestors of the human race first began fashioning tools out of stone. At the time, survival was likely the highest priority, and the health of the environment and the effects that mining had on it were likely of little, if any, concern. The world was probably considered vast and able to tolerate the seemingly minor effects of mining. This attitude has persisted for most of human history.

Early cultural development was punctuated by advances in mining and metallurgy (the science of extracting metals from ores). The Stone Age gave way to the Bronze Age roughly 5,300 years ago when use of weapons and implements made of bronze - an alloy of copper and tin - became widespread. The manufacture of bronze required not only the mining of copper and tin, but the smelting of it; that is, the extraction of the metal from ore minerals using heat. The Bronze Age was followed by the Iron Age roughly 3,200 years ago. The Iron Age is defined by the widespread use of weapons and implements made of iron. The smelting of iron ores requires much higher temperatures than does the smelting of copper or tin. Cultural milestones in human history have been accompanied by advances in mining and metallurgical methods and technologies, even down to the present day, and the need for mining and metallurgy is likely to endure far into the future. 
Evidence of the historical or prehistoric influence of mining on the environment is limited, and indications of significant societal concern about the environmental impacts of mining are even more scarce. Sediment cores from peat bogs, estuaries, lakes, and ice cores indicate that the dispersion of metals from mining and early smelting date back at least 5,000 years (Shotyk and others, 1996; Rosman and others, 1997; Leblanc and others, 2000; Lee and others, 2008; Lottermoser, 2010). In Georgius Agricola's landmark treatise on mining and metallurgy titled "De Re Metallica" [On the Nature of Metals (Minerals)], which was published in 1556, a year after his death, the author notes that ".... when the ores are washed, the water which has been used poisons the brooks and streams, and either destroys the fish or drives them away" (Agricola, 1950/1556).

In the United States, the earliest significant court case involving a dispute about the environmental impacts of mining concerned hydraulic mining of gravels in the Mother Lode gold belt of the Sierra Nevada Mountains. Hydraulic mining uses high-pressure "cannons" to direct water to erode ancient stream gravels and move the eroded sediment into channels where gold can be efficiently separated. Farmers in the Sacramento Valley of California filed lawsuits against hydraulic mining companies because of the effects that the sediment from the hydraulic gold mining was having on farmland downstream from the mines. This legal battle culminated with the Sawyer Decision in 1884, which effectively banned hydraulic mining (Kelley, 1956).

In the Eastern United States, significant legal action surrounded ore processing practices in the Copper Basin (or Ducktown Basin) mining district in Tennessee (Quinn, 1993). Numerous lawsuits filed between 1890 and 1930 focused on air pollution initially related to the open roasting of sulfide ores as preparation for copper smelting and, later, to the smelting itself. The released sulfur dioxide resulted in acid rain throughout the surrounding 250-square-kilometer $\left(\mathrm{km}^{2}\right)$ area, which destroyed much of the vegetation and led to extensive soil erosion. The long series of lawsuits ultimately reached the U.S. Supreme Court, which ruled against the mining companies. The Ducktown case was especially noteworthy in that it was the first air pollution case to be heard by the U.S. Supreme Court. The numerous lawsuits had the positive effect of encouraging the development of acid converters, which capture sulfur dioxide emissions from roasting and smelting and convert them to sulfuric acid, which is a valuable byproduct.

Today, the National Environmental Policy Act of 1969 (NEPA) (42 U.S.C. §4321 et seq.) serves as the basic national charter for environmental protection. Its passage represents a milestone in the history of environmental protection with respect to mining practices, and its effect has been significant for society, the mining industry, and the environment.

The realization that the environmental effects of mining done without regard for the environment cannot be absorbed by nature has been building for at least the past several centuries. The problem can be conceptualized using the idea of a "support square," as described by Skinner (1989), and amplified by Rutland (1997). A support square is equal to the hypothetically inhabitable area of the world divided by the population of the world; hence, the size of a support square is determined by the global population density. A support square represents the inhabitable land area needed to support all the resource needs of one human being. These needs include mineral resources, food, water, shelter, recreation, and waste disposal. If areas permanently covered by ice and areas above 5,000 meters $(\mathrm{m})$ are excluded, the inhabitable area of the world is roughly $133,000,000 \mathrm{~km}^{2}$.

Figure B1 illustrates how the size of the support square has changed over time as the population density of the planet has increased. Beginning with the Bronze Age, roughly 5,300 years ago (3300 B.C.), when the population of the world is estimated to have been 14 million people, each support square would have covered an area of $9.5 \mathrm{~km}^{2}$, or be approximately 3,080 $\mathrm{m}$ on a side. By the time Christopher Columbus discovered America (1492), the side of the support square was reduced to $560 \mathrm{~m}$. When the Declaration of Independence was signed in 1776 , the square was down to $400 \mathrm{~m}$ on a side. Today, the support square is only $135 \mathrm{~m}$ on a side and, by 2050 , more than $15 \mathrm{~m}$ is projected to be lost, leaving a square of only $119 \mathrm{~m}$ on a side to support an individual. In other words, society currently has only 11 percent of the per capita land area that it had in 1776, 6 percent of the per capita land area that it had when Columbus discovered America, and 0.2 percent of the per capita land area that it had at the beginning of the Bronze Age. This trend will continue with the currently projected population growth. Improved environmental stewardship during mining and all other extractive activities is essential to maintaining the quality of the land area available for use.

Responsible environmental stewardship related to mining is embodied in the concept of "sustainable mining." The term sustainable mining strikes many as an oxymoron, because it is commonly used in reference to the mining of nonrenewable mineral or energy resources. Sustainable development, or sustainability, however, is generally defined as the ability to meet current needs without hindering future generations from meeting their needs (Brundtland, 1987). Sustainable practices for mining have come to focus on the environmental, economic, and social well-being in areas where mining is proposed or is taking place. The environmental part typically includes aspects of water management, solid-waste management, reagent use and recycling, and greenhouse gas emissions (Mudd, 2008, 2010). This chapter presents an overview of environmental practices related to the permitting and development of active and new mines, and provides a context for the environmental considerations sections of the commodity-focused chapters in this book. 


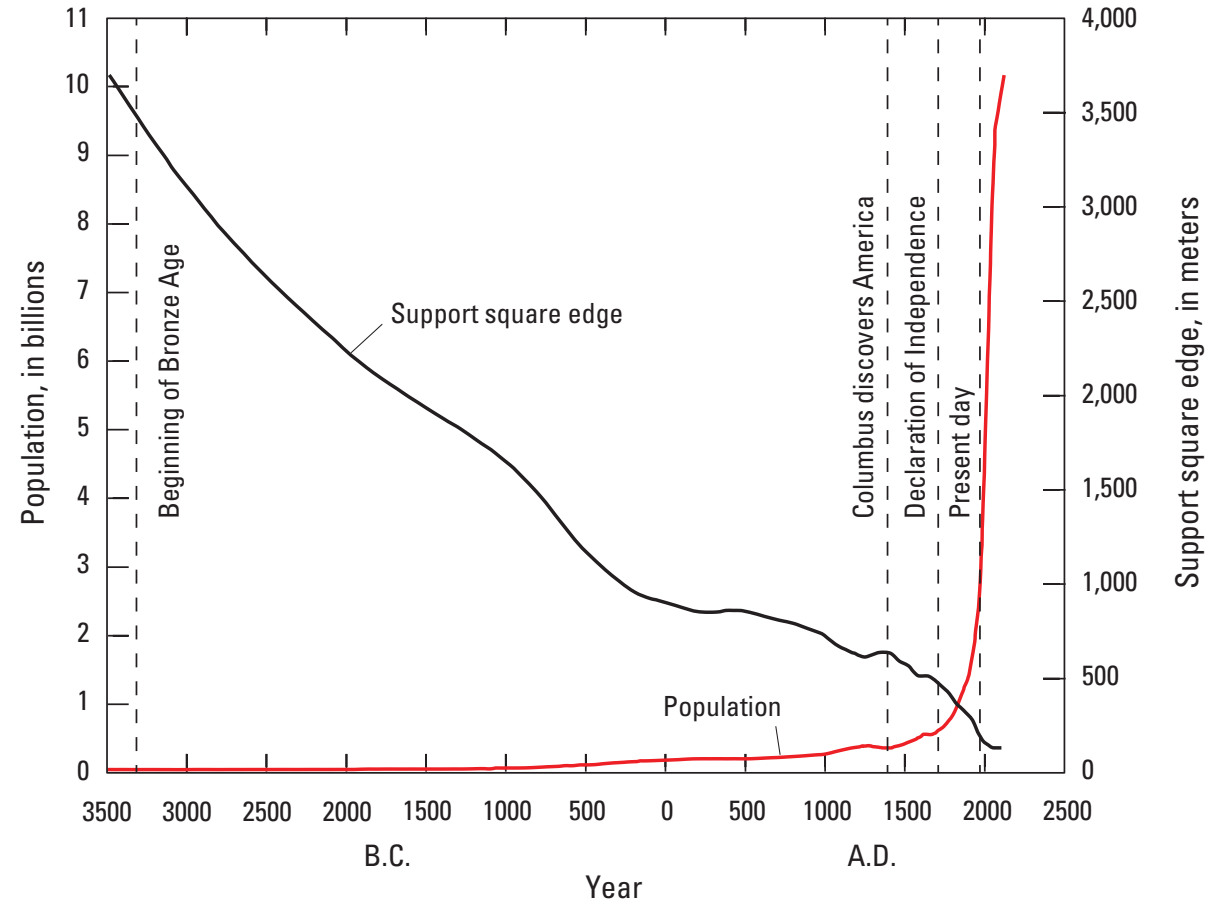

Figure B1. Graph showing population growth and the change in supporting land area from 3500 B.C. to 2100 A.D., with projections to 2050 . The support square edge (in meters $[\mathrm{m}]$ ) represents the amount of inhabitable land available to support each person alive on Earth. In 2016, the hypothetical support square was $135 \mathrm{~m}$ on a side; by 2050, the projected support square will have decreased to $119 \mathrm{~m}$ on a side. Based on projections by Skinner (1989) and Rutland (1997).

\section{Modern Regulatory Framework}

The regulatory framework for mine permitting in the United States is similar to that of other developed nations, but mining regulations in developing nations have tended to be absent or relatively weak. With globalization, however, less developed countries, such as Chile, where mining is a significant component of the gross domestic product, are reviewing and extending existing regulations to become more aligned with those of global partners, such as the United States, Canada, and the European Union (Espejo and others, 2012). Furthermore, major international mining companies generally follow similar approaches wherever they work, regardless of the presence or absence of local regulations. The following describes the development of the modern regulatory framework in the United States.

The National Environmental Policy Act of 1969 (NEPA), which was signed into law on January 1, 1970, serves as a basic national charter for environmental protection. It led to the establishment of the U.S. Environmental Protection Agency (EPA) in December 1970. The law provides the framework that Federal Government agencies use to evaluate the environmental effects of proposed Federal actions, such as the issuance of permits for mining or other industrial activities. An example of a specific action related to mining includes the issuing of permits for such mining-related activities as water withdrawal, exploratory drilling, wetland and (or) stream modifications, the transport of chemicals, and mine construction, among others. The framework put in place with the passage of the NEPA is known as the
"NEPA process" - a process that is used to evaluate the environmental effects of Federal projects or actions, including alternative actions. The NEPA process is a staged approach in which, in the absence of a categorical exclusion, an environmental assessment (EA) is performed and results in either a "finding of no significant impact" (FONSI) or a determination that an environmental impact statement (EIS) is required. A categorical exclusion classifies the action as not having a significant effect on environmental quality. An EA is a preliminary evaluation of the potential magnitude of environmental effects and alternatives. The identification in the EA of a potential for significant environmental impact leads to the requirement for an EIS. An EIS is a detailed assessment of potential environmental impacts and alternatives. A Federal land-management or regulatory agency may skip the initial steps of the NEPA process if it feels that a significant potential for adverse environmental impact exists and may proceed directly to requiring the preparation of an EIS. Proposed mining projects that require the action of a Federal agency typically result in the requirement for an EIS.

The passage of the NEPA led to the passage of additional legislation that provides the modern policy for environmental protection associated with mining and other commercial and industrial activities. In one example, a previous law - the General Mining Law of 1872, which had been enacted to promote development and settlement of publicly owned lands in the Western United States - had provisions for environmental protection; in follow-on legislation, the Federal Land Policy and Management Act of 1976 (43 U.S.C. §1701 et seq.) was passed to address such issues as the requirement for mine reclamation 
and its financial assurance. The NEPA process relies on these other laws and regulations to ensure that the potential for significant environmental impacts is addressed. The major laws relevant to proposed mining projects commonly include the Clean Water Act (33 U.S.C. §1251 et seq.), the Safe Drinking Water Act (42 U.S.C. $\$ 300 \mathrm{f}$ et seq.), the Clean Air Act (42 U.S.C. $\$ 7401$ et seq.), and the Endangered Species
Act (16 U.S.C. $\$ 1531$ et seq.), although many others may be relevant. Salient features of these acts are summarized in table B1. The Resource Conservation and Recovery Act (1976) (42 U.S.C. $\$ 6901$ et seq.), which governs the disposal of solid and hazardous wastes, specifically exempts waste generated during the extraction, beneficiation, and processing of minerals from regulation as hazardous waste.

Table B1. Summary of selected Federal laws relevant to mine permitting.

[EPA, U.S. Environmental Protection Agency]

\begin{tabular}{|c|c|c|c|}
\hline Act (abbreviation) & $\begin{array}{l}\text { Year } \\
\text { signed }\end{array}$ & Purpose & Implementation \\
\hline $\begin{array}{l}\text { National Environmental Policy Act of } 1969 \text { (NEPA) } \\
\text { (42 U.S.C. \$4321 et seq.), and amendments } \\
\text { https://www.gpo.gov/fdsys/pkg/USCODE-2014-title42/ } \\
\text { pdf/USCODE-2014-title42-chap55.pdf } \\
\text { See also: http://www2.epa.gov/laws-regulations/ } \\
\text { summary-national-environmental-policy-act } \\
\text { and } \\
\text { http://www.epa.gov/compliance/nepa/ }\end{array}$ & 1970 & $\begin{array}{l}\text { Promotes efforts that will prevent } \\
\text { or eliminate damage to the } \\
\text { environment and biosphere } \\
\text { and stimulate the health and } \\
\text { welfare of humankind by } \\
\text { providing information to } \\
\text { the public. }\end{array}$ & $\begin{array}{l}\text { EPA reviews documents to } \\
\text { determine if the environmental } \\
\text { alternative chosen will affect } \\
\text { the environment and to } \\
\text { determine if the agency that } \\
\text { wrote the documents provided } \\
\text { this information to the public. }\end{array}$ \\
\hline $\begin{array}{l}\text { Clean Water Act (CWA) (33 U.S.C. } § 1251 \text { et seq.), } \\
\text { and amendments } \\
\text { https://www.gpo.gov/fdsys/pkg/USCODE-2014-title33/ } \\
\text { pdf/USCODE-2014-title33-chap26.pdf } \\
\text { See also: http://www2.epa.gov/laws-regulations/ } \\
\text { summary-clean-water-act }\end{array}$ & 1972 & $\begin{array}{l}\text { Restores and maintains the } \\
\text { chemical, physical, and } \\
\text { biological integrity of the } \\
\text { Nation's waters; also } \\
\text { protects wetlands. }\end{array}$ & $\begin{array}{l}\text { EPA provides guidance to States } \\
\text { and tribes on the concentra- } \\
\text { tions of metals that will not } \\
\text { harm aquatic life or human } \\
\text { health so State and tribal } \\
\text { governments can set standards. }\end{array}$ \\
\hline $\begin{array}{l}\text { Safe Drinking Water Act of } 1974 \text { (SDWA) } \\
\text { (42 U.S.C. \$300f et seq.), and amendments } \\
\text { https://www.gpo.gov/fdsys/pkg/USCODE-2014-title42/ } \\
\text { pdf/USCODE-2014-title42-chap6A.pdf } \\
\text { See also: http://www2.epa.gov/laws-regulations/ } \\
\text { summary-safe-drinking-water-act } \\
\text { and } \\
\text { http://water.epa.gov/lawsregs/rulesregs/sdwa/ } \\
\text { index.cfm }\end{array}$ & 1974 & $\begin{array}{l}\text { Ensures safe drinking water } \\
\text { for the public. }\end{array}$ & $\begin{array}{l}\text { EPA sets legal limits on the } \\
\text { levels of certain contaminants } \\
\text { in treated drinking water and } \\
\text { provides oversight for States } \\
\text { and tribes for implementing } \\
\text { these standards. }\end{array}$ \\
\hline $\begin{array}{l}\text { Clean Air Act (CAA) (42 U.S.C. } \$ 7401 \text { et seq.), } \\
\text { and amendments } \\
\text { https://www.gpo.gov/fdsys/pkg/USCODE-2014-title42/ } \\
\text { pdf/USCODE-2014-title42-chap85.pdf } \\
\text { See also: http://www2.epa.gov/laws-regulations/ } \\
\text { summary-clean-air-act } \\
\text { and } \\
\text { http://www.epa.gov/air/caa/ }\end{array}$ & 1963 & $\begin{array}{l}\text { Ensures clean air at a national } \\
\text { level by controlling air } \\
\text { pollution. }\end{array}$ & $\begin{array}{l}\text { EPA develops and enforces } \\
\text { regulations to protect } \\
\text { the public from airborne } \\
\text { contaminants. }\end{array}$ \\
\hline $\begin{array}{l}\text { Endangered Species Act (16 U.S.C.\$1531 et seq.), } \\
\text { and amendments } \\
\text { https://www.gpo.gov/fdsys/pkg/USCODE-2014-title16/ } \\
\text { pdf/USCODE-2014-title16-chap35.pdf } \\
\text { See also: http://www2.epa.gov/laws-regulations/ } \\
\text { summary-endangered-species-act } \\
\text { and } \\
\text { http://www.fws.gov/endangered/laws-policies/ }\end{array}$ & 1973 & $\begin{array}{l}\text { Ensures that any action author- } \\
\text { ized, funded, or carried out by } \\
\text { a Federal agency is not likely } \\
\text { to jeopardize the continued } \\
\text { existence of any listed species } \\
\text { or result in the destruction or } \\
\text { adverse modification of critical } \\
\text { habitat of such species. }\end{array}$ & $\begin{array}{l}\text { The U.S. Fish and Wildlife } \\
\text { Service (FWS) or the National } \\
\text { Marine Fisheries Service } \\
\text { (NMFS), depending upon } \\
\text { location of the site, evaluates } \\
\text { potential risks to threatened } \\
\text { and endangered species } \\
\text { through consultation with } \\
\text { other Federal agencies. }\end{array}$ \\
\hline
\end{tabular}


The Comprehensive Environmental Response, Compensation, and Liability Act (CERCLA) (42 U.S.C. \$9601 et seq.), commonly known as "Superfund," can apply to mines during production or after closure. The EPA conducts and supervises investigations and cleanup actions at mine sites where hazardous substances have been released into the environment or when there is a threat of release. The CERCLA authorizes the following two types of response actions: long-term (remedial) cleanup and short-term (removal) cleanup. Cleanups may be done by the EPA; by other Federal agencies, such as the Bureau of Land Management or the U.S. Forest Service; States or municipalities; or the mining company or parties responsible for the contamination.

A key aspect of the NEPA process for mine permitting is the prediction of potential environmental impacts related to a proposed mining project as well as predictions regarding environmental conditions after mine closure. Information about the environmental characteristics of mineral deposits, mines, and resource extraction is available from a variety of sources; however, the types and sources of this information should be considered in an appropriate context. All information has value, but its usefulness has limitations. The types of information from various sources include studies of historical abandoned mines, studies in support of mine permit applications designed to "predict" mine waste behavior, studies of modern mines permitted under the NEPA or similar environmental regulations, studies of mines that began operation prior to NEPA, and studies of mines in developing countries.

Information from historical abandoned mines is useful for several reasons. In many cases, they represent "natural experiments" that have been underway for decades, centuries, or even millennia - time scales that are impossible to reproduce in the laboratory. Many of these historical mines were developed with no consideration for environmental protection because that was not a requirement for mine permitting, and because the full environmental ramifications of mining activities probably were not fully appreciated. As such, these sites may reflect "worst case" scenarios. Information from these sites has limitations, however, because certain deposit types may no longer be mined for specific mineral commodities, or mining and ore-processing methods may have changed. Thus, the nature of modern mine waste can be quite different from that at historical mines.

For example, the abandoned Elizabeth copper mine in Vermont was initially operated in the early to middle 1800 s as a source of copperas (ferrous sulfate heptahydrate$\mathrm{FeSO}_{4} \cdot 7 \mathrm{H}_{2} \mathrm{O}$ ), which served a variety of uses - as a disinfectant, dye, as dye mordant, and as a wood preservative. Copperas production ceased at the Elizabeth Mine in the 1880s as less expensive sources became available from the steel industry (Kierstead, 2001). The copperas was produced by controlled roasting of pyrrhotite $\left(\mathrm{Fe}_{1-\mathrm{x}} \mathrm{S}\right)$ accompanied by leaching of the resulting ferrous sulfate, which was then reconstituted as solid crystals in evaporation vats. When built in the 1800 s, these copperas roast beds were designed to encourage the oxidation of sulfide minerals and to drain leachate. These features contributed to the environmental legacy of the abandoned Elizabeth copper mine because acid mine drainage is the result of the oxidation of sulfide minerals, principally pyrite $\left(\mathrm{FeS}_{2}\right)$ and pyrrhotite, in the presence of water. Surface water and groundwater from the historical copperas roast beds had the worst water quality of all waters at the site in terms of low $\mathrm{pH}$ and high concentrations of potentially toxic dissolved metals (Seal and others, 2001). In contrast, seepage at the base of a mill tailings pile that was produced using more modern techniques from 1942 to 1958 (the pile contains fine-grained reject material from which the ore minerals have been removed) and deposited lower in the stream valley, had near neutral $\mathrm{pH}$, and the water-quality issues were restricted to high concentrations of dissolved iron and sulfate. Therefore, for the same ore, historical processing techniques and modern processing techniques may result in significantly different environmental impacts.

Other sources of useful information about the environmental characteristics of ore deposits and mines are the environmental impact statements and related documents associated with mine permit applications. These documents include geochemical and other data about pre-mining conditions, which are crucial for environmental monitoring during and after mining and for setting environmental closure goals. They also contain information about the environmental characteristics of expected mine waste, the acid-generating potential of various types of solid mine wastes, and the leachability of trace elements from these wastes. These documents make predictions about future environmental conditions to aid in the permit decisionmaking process, both for scenarios in which mitigation measurements are successfully implemented and those in which they are not implemented.

Case studies of modern mines in the United States permitted under the NEPA process are scarce in the scientific literature. Instead, some data may be found in publicly available EISs associated with mine expansion projects; for example, the Aqqaluk project at the Red Dog zinc mine in Alaska (Tetra Tech, Inc., 2009). These sources generally constitute representative information about the environmental characteristics of active mines. Mining operations in many developing countries do not adhere to the same standards followed in the United States and by major international mining companies worldwide, however. Therefore, environmental data from developing countries may not be an accurate reflection of international consensus on "best practices" for environmental protection.

Even more challenging is establishing a proper context for the environmental information available for historical mines that started mining before NEPA but that have continued to produce into more recent times. It is often difficult to distinguish historical legacy issues from effects related to modern mining activity, especially if data about specific sampling sites are not reported in sufficient detail. The issue of distinguishing legacy environmental signatures is especially problematic when trying to establish closure goals for mine sites that began operations before the era of more-extensive regulation (Alpers and Nordstrom, 2000; Nordstrom, 2008). 


\section{Investigations Supporting Permit Applications}

Mine permitting is a prescribed process under the NEPA. The NEPA process as applied to mining places an emphasis on protecting water resources through the Clean Water Act. The EPA guidance is summarized in "EPA and Hardrock MiningA Source Book for Industry in the Northwest and Alaska" (U.S. Environmental Protection Agency, 2003). The source book outlines an approach to evaluating the potential risks to water quality posed by mining. A key distinction between mining and other types of industrial, commercial, or municipal development is that a mine needs to be adapted to the site conditions where the ore deposit occurs. In contrast, factories, shopping malls, airports, and schools tend to be built on tracts of land that meet a variety of specific criteria to ensure safe development and protection of the environment and the public.

The EPA source book has largely been adopted by the international mining community to serve as an outline for premining environmental studies. It also forms the foundation of the following discussion. The Source Book describes a variety of data collection, testing, mine design, and data analysis methods necessary to accomplish a rigorous assessment. The approach requires that, as part of the permitting process, premining baseline conditions must be documented, ecosystem and human health risks must be assessed, and predictions must be made about post-closure environmental conditions through a mining impact assessment. Specific topics include impacts to surface water and groundwater hydrology, impacts to water quality, impacts to aquatic resources, and impacts to wetlands. Ecological and human health risks associated with nonaqueous pathways, such as windblown dusts, are also considered.

Mining operations have the potential to affect both surface-water and groundwater hydrology at the mine site and within the broader watershed. Therefore, it is essential to evaluate whether or not impacts will be expected and what their nature and extent will be. Necessary input for this assessment includes meteorological and hydrologic data and water-management plans for operational and post-closure phases, with the goal of determining a detailed water balance for the project. Meteorological and hydrologic data are best collected on a regular basis to capture seasonal and year-toyear variations and to characterize the duration and intensity of storm events. These pre-mining data provide a baseline from which to monitor changes brought about by mining and other effects, such as climate change. Surface-water and groundwater resources are required to be thoroughly characterized, including the establishment of surface-water monitoring sites and the installation of monitoring wells. Water-management plans describe how process water, mine drainage, and storm water are handled during mining and after closure.

Mining also has the potential to affect surface-water and groundwater quality during mining and after closure. A key aspect of evaluating potential impacts to water quality and other ecosystem services and human health is the detailed geochemical characterization of pre-mining baseline conditions in surface water, groundwater, sediments, and soils. Ore deposits represent anomalous concentrations of a variety of elements that typically go beyond the mineral commodities that are the focus of mining. These chemical anomalies can be manifested in all media (rock, water, soil, sediment, and biota) in the vicinity of the mine site and represent a natural part of these ecosystems. Because elevated concentrations are part of the natural ecosystem, these concentrations represent more realistic closure goals than generic regulatory guidelines.

Mine-waste characterization and designing a mine-waste management plan are important aspects of assessing the potential for water-quality impacts. There are several types of mine waste, and mine-waste characterization is commonly done in a staged approach. Materials that are characterized include waste rock (material removed to access the ore), spent ore, and the rock that forms the walls of the pit, if open pit mining is used to produce the ore. Spent ore can be either tailings or leach-pad waste (residue from moderately crushed rock that has had metals leached from it by reactive solutions). Tailings generally result from the concentration of ores from basemetal (such as copper, lead, zinc, and nickel) and other metal (such as iron, and some uranium, gold, and silver) mines. Ore is crushed to sand or silt size and transferred to vats that contain surfactant solutions. The vats are aerated, which produces bubbles in the solution. Specific minerals adhere to the bubbles, which rise to the top and are skimmed off. Depending on the specific ore and the chemical additives used, either ore minerals or gangue (waste) minerals will rise to the top. The waste, or tailings, from this process is disposed of in a variety of ways. Tailings can be pumped as a slurry to tailings ponds, dried and stacked in piles, or mixed with a binder and disposed of as a paste, which then solidifies. Leach-pad wastes are commonly associated with many copper, gold, silver, and uranium deposits. Ore is crushed and placed on impermeable liners, where it is leached with solutions designed to extract the mineral commodities of interest. Copper is commonly leached with a sulfuric acid solution, whereas gold and silver are leached with a cyanide solution. The leach pad residues are usually left in place for disposal, and a new pad is constructed for new ore. Closure of spent piles may involve regrading the pile and (or) capping it.

The potential mine waste is characterized using several types of tests. It is common for tests to be conducted on cores from exploratory drilling and on reject material from preliminary metallurgical testing. Acid-generating potential is a major concern for some types of ores and associated wastes because of their specific mineralogical and geochemical characteristics. One type of test is known as "acid-base accounting" and is used to estimate the ability of the material either to generate acid or to neutralize it. The mineral pyrite - fool's gold - is the main source of acid mine drainage, so the test estimates its abundance on the basis of the amount of sulfur in a sample. These tests estimate only the maximum acid-generating potential of a sample because a number of factors can limit the rate of acid-mine-drainage production. 
Acid-base accounting is categorized as a "static" test, because it is based on a single set of tests. In contrast, leaching tests of potential mine-waste material that span multiple weeks or years are known as "kinetic" tests. Kinetic tests not only provide information about the acid-generating potential of mine waste but also provide insights about the leachability of metals and other trace elements from the mine waste, as well as a timeframe for the reactions to occur. Humidity-cell tests are an example of a kinetic test. Humidity-cell tests, in which a sample is leached successively on a weekly basis in laboratory experiments that span weeks or years, provide better information about the ability of waste materials to produce acid and leach environmentally important trace elements. Laboratory kinetic tests can be improved upon by constructing similar experiments at a larger scale in the field. Here, the waste material is exposed to the natural variations of temperature and precipitation that the actual mine waste will be subject to rather than the constant, somewhat artificial conditions imposed by the bench-top experimental protocols. In any case, insights gained from pre-mining mine-waste characterization are typically refined as experience is gained during mine operation.

A mining impact assessment also requires that a number of design features be considered when evaluating potential impacts to water quality. Hydrologic characterization of mines is essential for understanding the risks associated with pit lakes or underground mine waters, and hydrologic characterization of the waste facilities provides insights about the exposure of surface water and groundwater to solid waste. Facilities have to be designed not only to accommodate typical seasonal variations in the amount of precipitation, but they also must be able to handle less common 500-year floods. The water-management, solid-waste-management, and wastewatermanagement plans are also critical. Permit applications are required to describe closure and reclamation plans, how these plans affect water quantity and quality, and what the long-term needs for active or passive treatment of the water will be. These details include the final state of waste-rock piles and tailing storage facilities, such as the nature of post-closure covers, and plans to manage drainage flows off or out of waste piles. Likewise, predictions must be made regarding long-term water quality in planned pit lakes.

Mining also has the potential to affect aquatic ecosystem resources adversely in a variety of ways that must be evaluated and described during the permitting process. Baseline characterization is needed to describe pre-mining fish and aquatic macro-invertebrate populations. Mine construction can affect riparian areas and influence infiltration. Water needed for ore processing and beneficiation can influence stream flow. Water-management structures, such as ditches and trenches, can channel the flow and influence the natural balance of erosion and sedimentation in a watershed, which can impair aquatic habitat. Dams and other barriers can impede the fish movement. Accidental releases of process water or mine drainage can degrade quality and affect aquatic biota. Plans for water treatment during operation and after closure must be described. All these factors are considered as part of the permitting process.

Wetlands represent a special case for potential impacts associated with mining because they are explicitly regulated under the Clean Water Act. They perform a variety of important environmental management and filtration functions, including groundwater recharge and discharge, flood storage and moderation, sediment trapping, and nutrient trapping and removal, and they provide habitat. The mine permitting process requires that wetland resources be fully documented.

\section{The Quest for Best Practices}

As previously noted, 1970 marks both the founding of the EPA and the start of the NEPA process that provided an environmental planning framework for modern mining sites. Passage of this law sparked a review of and an evolution in mining practices meant to protect the environment, and that review continues today. One measure of the success of the law and how it has improved environmental practices associated with metal mining in the United States is the decreased number of mining sites being designated as Superfund sites.

The EPA uses the Hazard Ranking System of CERCLA to evaluate the level of contamination at a site (U.S. Environmental Protection Agency, 2016). The Hazard Ranking System is a numerical screening system that assesses potential impacts to both human and environmental (ecological) health. It considers groundwater, surface water, soil, and air. The assessments are made to determine whether the level of contamination at a site is severe enough to warrant inclusion on the EPA's National Priorities List (NPL) (U.S. Environmental Protection Agency, 2015). Placement on the NPL designates a site as eligible for cleanup under the Federal Superfund program.

The NPL includes both mine sites and related facilities, such as smelters and mineral storage facilities. In the following discussion, only mine sites are addressed, however, because smelters and storage facilities lack the intimate link to local geologic and environmental conditions that mines do and can be located at some distance from a mine site. Furthermore, understanding the environmental impacts at modern mines that have also had historical production can be complicated by legacy issues that are unrelated to modern mining practices. Nonetheless, the history of site placement on the NPL can be considered an indication of the progress that has been made in environmental protection associated with mine development since the passage of the NEPA.

The first listing of mine sites on the NPL (that is, as Superfund sites) was published in 1983; all the mines listed in that year were old mines that had begun operating in 1900 or earlier, and some began operating as early as 1800 -more than 170 years before any sort of guidance on environmental protection was available. As of 2016, the NPL includes approximately 60 mine sites with diverse mining histories. Table B2 is a list of these mine sites, including the dates for 
Table B2. Historical summary of mine sites placed on the U.S. Environmental Protection Agency's National Priorities List.

[EPA, U.S. Environmental Protection Agency; ID, identification; NPL, National Priorities List; n.a., not applicable]

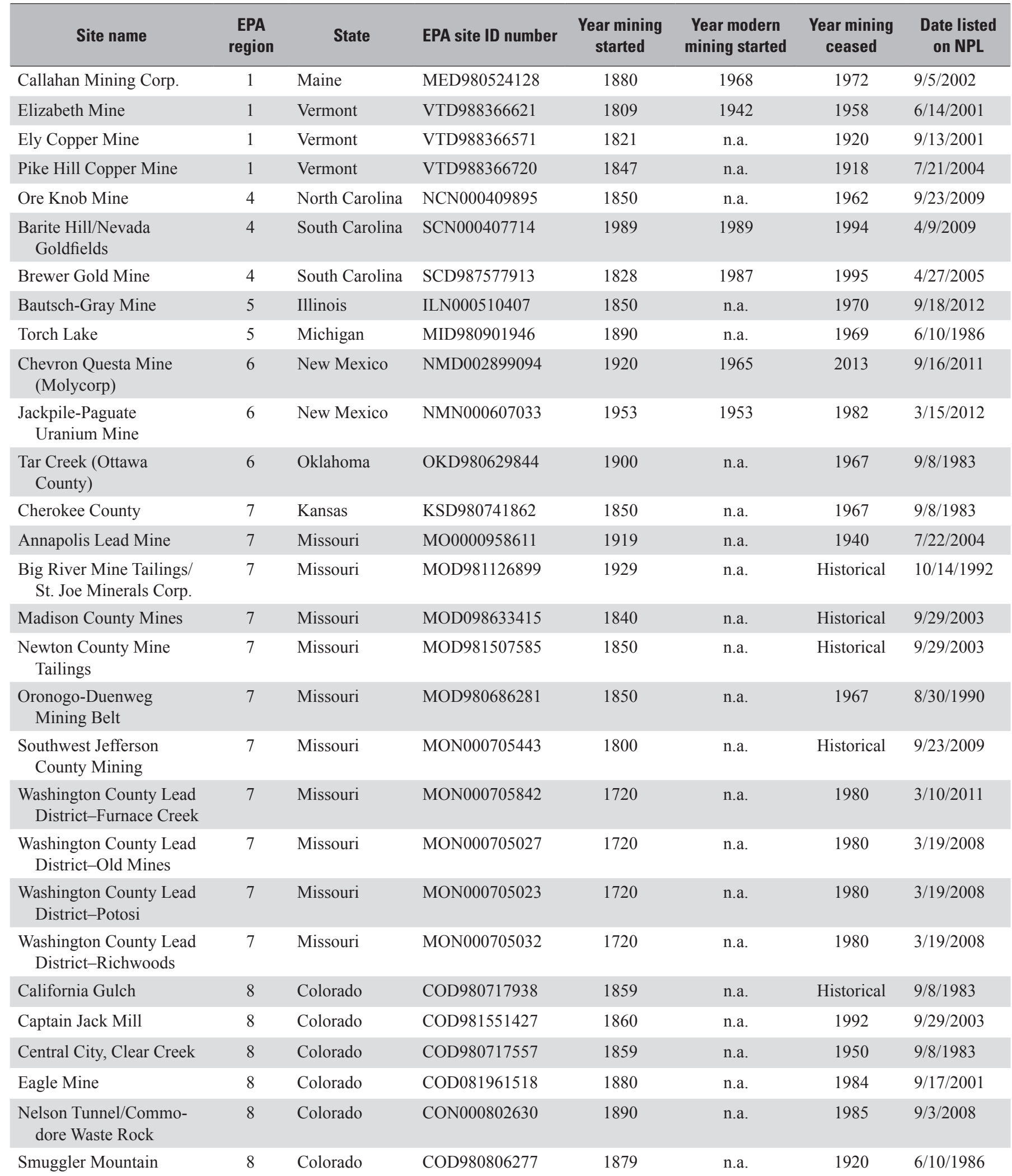


Table B2. Historical summary of mine sites placed on the U.S. Environmental Protection Agency's National Priorities List.-Continued [EPA, U.S. Environmental Protection Agency; ID, identification; NPL, National Priorities List; n.a., not applicable]

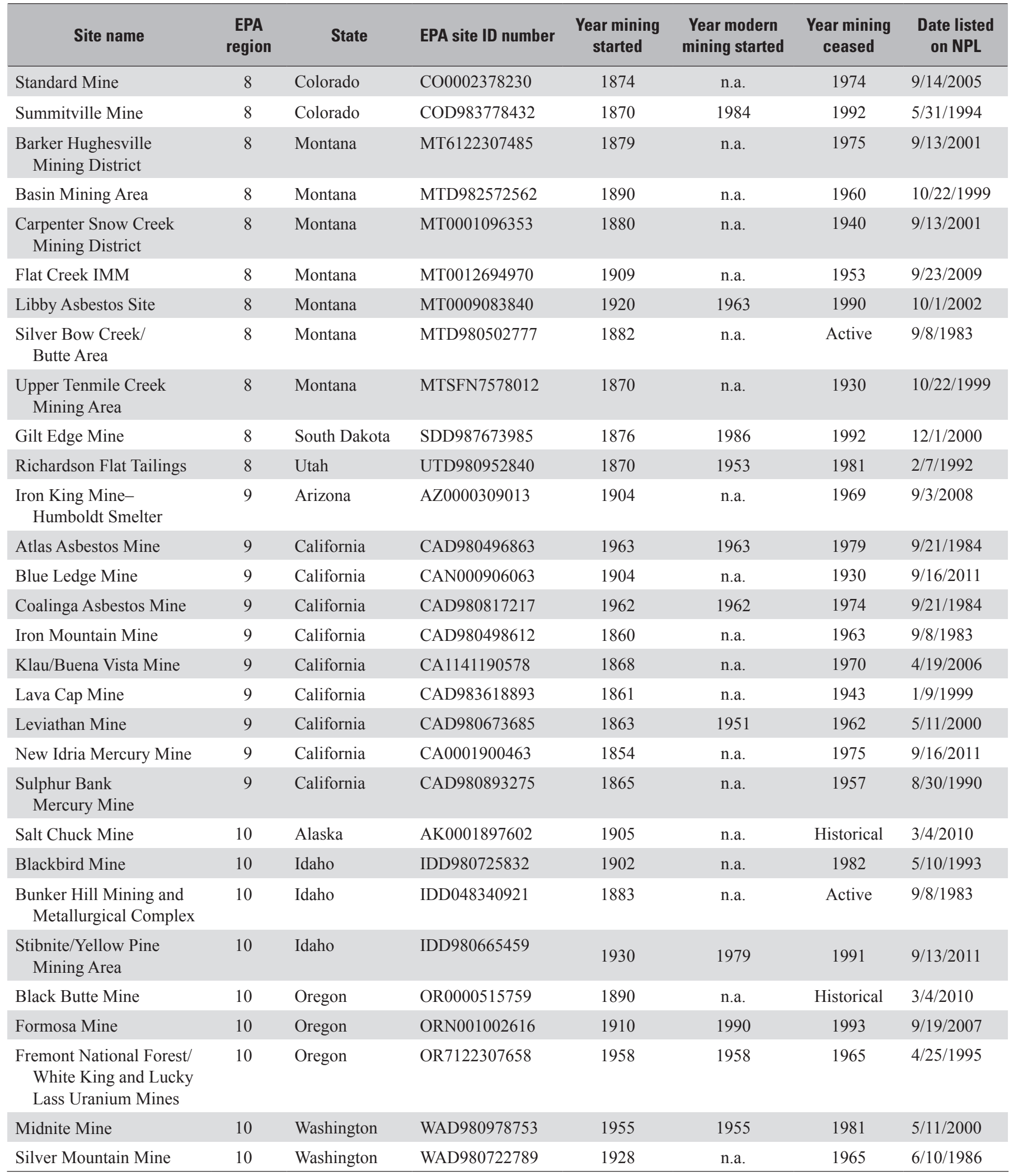


the historical start of mining, the start of modern-style mining, the end of mining (that is, when mining stopped), and the mine site's year of placement on the NPL. Figure B2 shows this information in graphical form.

A few of the sites, such as the Coeur d'Alene mining district in Idaho (Bunker Hill) and the Butte mining district in Montana, have been mined more or less continuously since the late 1800 s. Other historical mines saw early production and then became inactive because of ore depletion or significant decreases in metal prices, only to restart in modern times once metal prices increased or technological advances made production economically viable once again. Other sites began modern-style mining but before environmental protection requirements were in place (that is, before 1970). The term "modern-style mining" generally refers to mines that began operation after 1940, and is meant to include such practices as froth flotation for separation of ore concentrates as opposed to the hand-sorting of ores employed historically, and cyanide leaching of gold as opposed to mercury amalgamation. A final group of mines on the NPL is the set that went through the NEPA process for permitting.

The first mine that was permitted through the NEPA process (Summitville, Colorado) began operation under a new permit in 1984 and was designated as a Superfund site (placed on the NPL) in 1994 (table B2; fig. B2). Another mine permitted in 1979 (Stibnite/Yellow Pine, Idaho) was not listed on the NPL until 2011. For the mines listed on the NPL, the shortest time between the start of production and listing on the NPL is 3 years (Formosa, Oregon), and the longest time is 32 years (Stibnite/Yellow Pine, Idaho). The most recent mine to be permitted through the NEPA process and placed on the NPL began operation in 1990. No new mine permitted in the United States since 1990 has had significant enough environmental issues to warrant placement on the NPL, even though numerous mines have gone into production since 1990 (Long and others, 2010, p. 22).

For more than two decades, the quest for best environmental practices associated with mining has seen an increased level of coordination and cooperation among public and private stakeholders. It has motivated mining companies, government regulatory agencies, government land management agencies, government science agencies, and academia to work together to identify, investigate, and promote environmental best practices in mining. The level of cooperation among mining companies in this effort is especially notable because the companies seek competitive advantages over one another in most other aspects of their businesses. Collaborations on environmental best practices are generally made through consortia that involve various groups of stakeholders, professional conferences that facilitate the exchange of

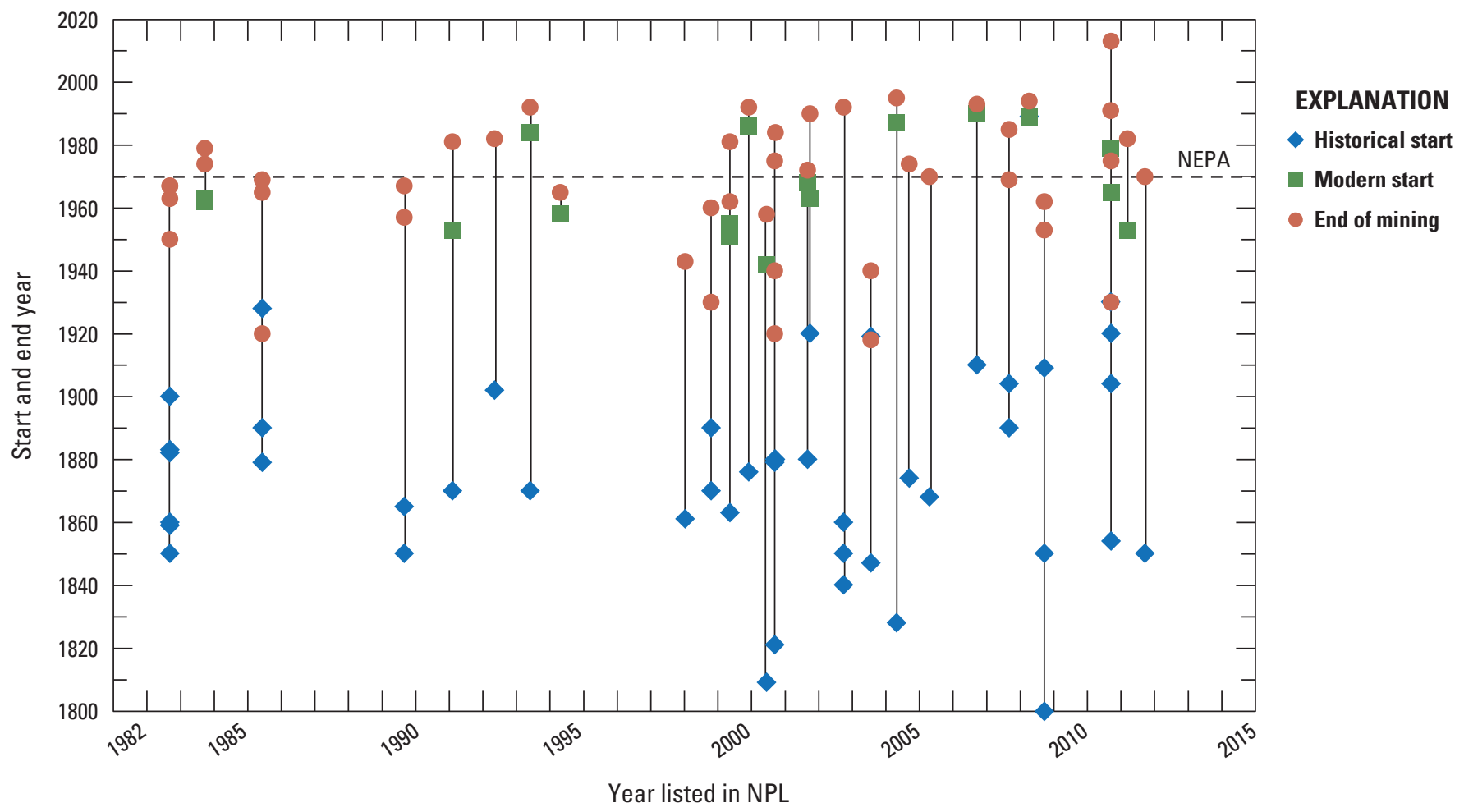

Figure B2. Graph showing dates associated with all the mine sites on the U.S. Environmental Protection Agency's National Priorities List (NPL). Dates, which correspond to those listed in table B2, include the historical start of mining, the start of modern-style mining, the end of mining, and the date of placement on the NPL. Vertical lines connect the dates for individual sites. The figure includes sites that started operation before the enactment of the National Environmental Policy Act (NEPA) of 1969 (42 U.S.C. $\$ 4321$ et seq.) as well as the one that started operating after its enactment. 
information, technology transfer efforts through workshops and other training courses, knowledge-gap-driven research, and the publication of print and Web-based resources.

Membership in these consortia spans the range of from highly selective membership to open membership (table B3). At the highly selective end are such groups as the International Network for Acid Prevention (INAP), which is made up of representatives from major mining companies. More inclusive organizations, such as the Canadian Mine Environment Neutral Drainage (MEND) program or the American Acid Drainage Technology Initiative (ADTI), include the mining industry, their consultants, government agencies at all levels, nongovernment organizations, and academia. Because of their overlapping goals, these consortia interact extensively, mostly through jointly sponsored professional conferences.

Numerous "best practices" publications and case studies have resulted from the efforts of these consortia. For example, the INAP produced its online Global Acid Rock Drainage Guide (GARD Guide), which describes best practices for the prediction, prevention, and management of drainage produced from sulfide mineral oxidation, including metal leaching and acid generation (International Network for Acid Prevention, 2014). Canada's MEND program releases best practices and case study reports on its Web site (http://mend-nedem.org).
The American ADTI publishes a series of workbooks on management technologies for waters affected by metal mining. To date, topics include the basics of metal-mining-influenced water (McLemore, 2008); the mitigation of metal-mininginfluenced water (Gusek and Figueroa, 2009); and the characteristics, predictive modeling, and sustainability of mine pit lakes (Castendyk and Eary, 2009). Other workbooks are in preparation.

\section{Mine Permitting and Planning Process Overview}

Mine permitting is a laborious process that must consider not only planning for mine development, but also planning for environmental protection during mining and after mine closure. The permitting process varies, depending on whether the mine will be located on private land, State land, or Federal land, although many aspects of the permitting process are similar among the location types.

In the United States, numerous permits are required to identify, develop, operate, and close a mine (Arizona Department of Mines and Mineral Resources, 2015). For State and Federal lands, permits may also be needed for

Table B3. Selected consortia devoted to identifying and implementing environmental best practices associated with mining.

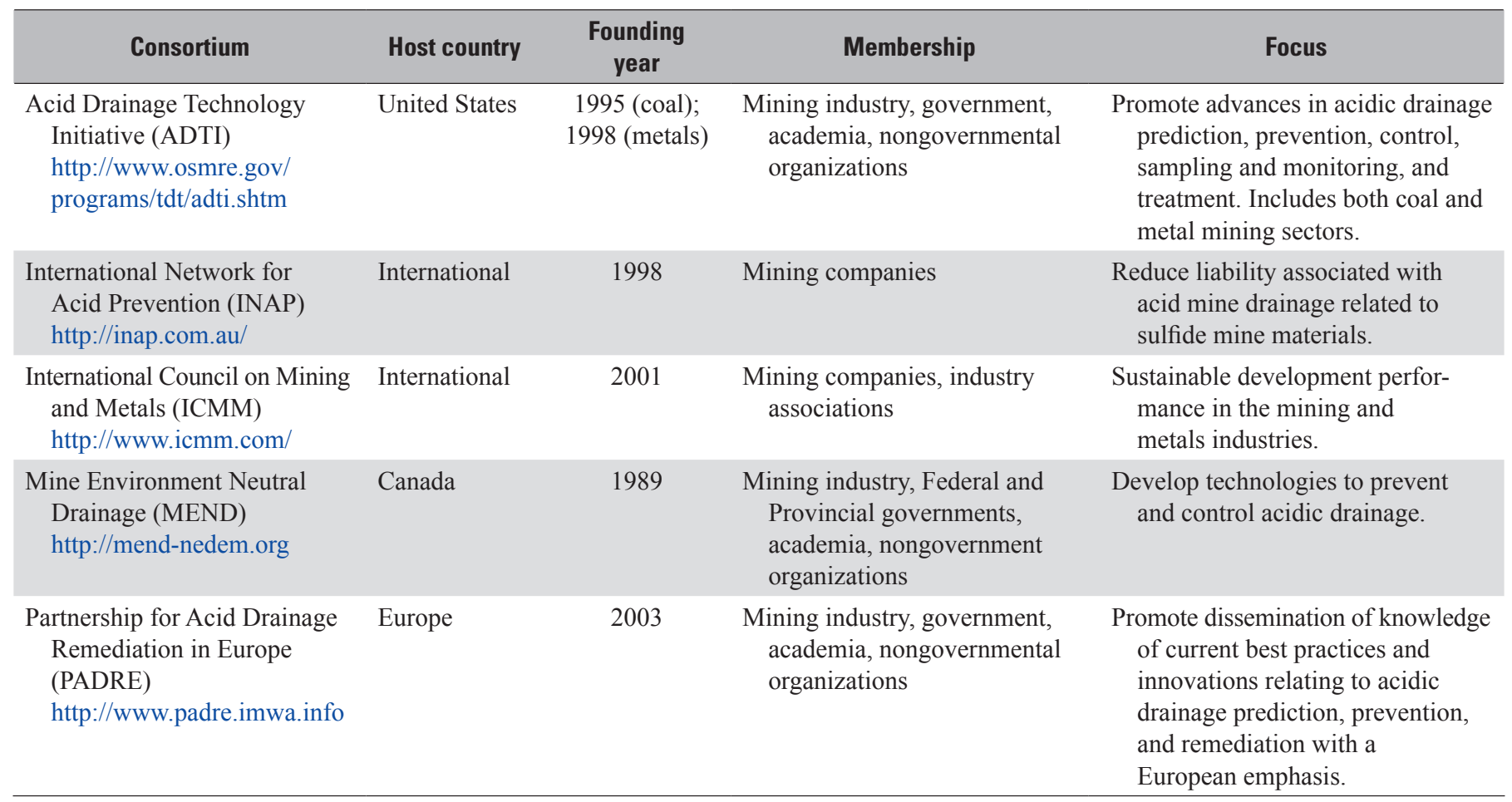


mineral exploration. Permits for groundwater use, surfacewater use, and wastewater treatment and discharge are also required. These permits are designed to protect water quality and quantity in groundwater aquifers, streams, lakes, and wetlands. They cover all aspects of water management at a mine site. The storage and use of chemicals, explosives, fuel, and oil at mine sites require a number of permits. Lease agreements must be established that include a geologic evaluation; an economic feasibility study; an environmental assessment; and mine operation, reclamation, and closure plans. The agreements must also include archeological and biological surveys. A number of permits govern water and solid-waste management at mine sites. A variety of air-quality permits may be required to cover emissions and dust. Permits also cover flood control, construction, and worker safety, among other aspects of mine operation.

Bonding, also known as financial assurance, is an important part of the mine permitting process. Companies are required to furnish a bond to cover the estimated costs of mine reclamation and closure. Financial assurance is a topic of significant concern during mine permitting because of the difficulty in making accurate estimates of reclamation and closure costs. Mining companies prefer to have bonds set as low as possible, whereas regulators seek to ensure that bonds are adequate for successful reclamation. A notable example of an inadequate bond is the Summitville Mine, which is a heap-leach gold-mining operation in Colorado. Galactic Resources Ltd. declared bankruptcy in 1992 and abandoned the site. The bond was $\$ 4.7$ million, and although the EPA and the State of Colorado obtained an additional \$28 million from the bankruptcy proceedings, the total cost of the cleanup has exceeded $\$ 150$ million, which has been funded mostly through Federal and State taxes (Warhurst and Mitchell, 2000).

The time required to permit, construct, and commission a mine in the United States can be significant. Long and others (2010, p. 22) summarized the permitting and production history for recent mines (including uranium) in the United States. The time from the start of permitting to initial production ranged from 2 to 22 years and averaged approximately 10 years. The comprehensive regulatory environment in the United States requires environmental studies, due diligence for financing, permit application and approval, and public participation at multiple steps in the process, each contributing to the time from the start of the process to initial production. This timeframe for permitting encompasses the time needed to discover and develop an orebody and to conduct the engineering studies necessary to design and build a mine.

\section{Geoenvironmental Models}

The environmental footprint of a mine is complex and depends upon a number of factors. Mine design, environmental protection planning, and closure must all be customized to the unique geologic and geographical characteristics of the deposit to be mined. In many cases, the quest for best environmental practices can obscure the important influences that the geologic characteristics of an ore deposit have on its environmental behavior. A means of linking the geologic characteristics of a mineral deposit to its potential environmental effects, either in its undeveloped state or as a mine, is through the "geoenvironmental model" concept developed by the U.S. Geological Survey (USGS). A geoenvironmental model of a mineral deposit is defined as "a compilation of geologic, geochemical, geophysical, hydrologic, and engineering information pertaining to the environmental behavior of geologically similar mineral deposits (a) prior to mining, and (b) resulting from mining, mineral processing, and smelting" (Plumlee and Nash, 1995, p. 5; Seal and Hammarstrom, 2003). Geoenvironmental models are currently largely descriptive in nature. They represent empirical compilations of data that provide a powerful predictive capability of possible ranges of environmental signatures. The models are best used as guidelines for potential ranges of environmental challenges that may apply to the site. They provide guidance for the early stages of mine development (prefeasibility stage) to be supplanted by site-specific data collected after a resource has been identified.

The geologic characteristics of a mineral deposit type influence approaches for mineral production, which, in turn, influence the potential environmental impacts. Geologic factors include the geographic distribution of mineral deposits; the depth of the mineral deposit; the mineralogy of the deposit; the grain size of the ore minerals; the ore grade; and the tonnage of ore (DeYoung and Singer, 1981). Climate is also an important factor in determining the environmental characteristics of a mineral deposit. Mineral deposits that are developed in wet climates have a greater probability of affecting surface-water resources, whereas impacts to groundwater resources are a greater concern in arid climates. The depth of the deposit dictates whether it will be developed by underground or open pit mining methods. Open pit mines require greater volumes of waste rock to be removed to access the ore. The mineralogy of the ore determines a number of the environmental properties of the ore and waste, such as their acid-generating potential. Pyritic waste rock requires special management to mitigate acid mine drainage. The grain size of the ore influences the distinction between ore and waste because fine grinding may be cost prohibitive. More grinding also increases the energy requirements for a mine, and therefore, its carbon footprint. The ore grade determines how much of the processed ore becomes waste. Further, the environmental footprint of a mineral deposit varies with its stage of mineral production; at the exploration stage, potential environmental impacts are the lowest, but the potential impact increases through the mine-development stage to the mineral-production (mining) stage (Eggert, 1994).

The USGS has been developing geoenvironmental mineral deposit models for more than two decades. Preliminary 
models were completed in 1995 (du Bray, 1995). Since then, individual deposit models have been refined, such as those for base- and precious-metal massive sulfide deposits and gold deposits (Seal and Hammarstrom, 2003). Furthermore, environmental features of mineral deposits have been included in updated mineral deposit models for a variety of mineral deposits, including Mississippi Valley-type lead-zinc deposits (Leach and others, 2010); porphyry copper deposits (John and others, 2010); volcanogenic massive sulfide deposits (Shanks and Thurston, 2012); porphyry molybdenum deposits (Taylor and others, 2012); stratiform chromite deposits (Schulte and others, 2012); beryllium deposits (Foley and others, 2012); sedimentary-hosted cobalt-copper-gold deposits (Slack, 2013); nickel-cobalt laterite deposits (Marsh and others, 2013); rare-earth-element deposits (Verplanck and others, 2014); and magmatic nickel-copper-(platinum-group-element) deposits (Schulz and others, 2014).

\section{Future Trends}

Future trends in mining will likely have major implications for environmental protection-some positive and some negative. Some of these trends are the result of the increasing challenge inherent in making new discoveries coupled with increased demand for mineral commodities and the associated increase in the price of those commodities. Other trends are the result of a desire for more sustainable mining practices. These trends include the move toward the mining of lowerore-grade, large-tonnage deposits; increasing awareness of the carbon footprint of mining operations; and addressing the water requirements for larger scale mining operations in a context of predicted global increases in drought conditions resulting from climate change.

The trend to mine lower grade, larger tonnage deposits is motivated by several factors (Mudd, 2007a, b; 2010). One is the depletion of high-grade deposits near Earth's surface, which has driven explorers to seek deposits at greater depth and (or) of lower grade. The lower grades necessitate finding deposits of larger size to achieve greater economies of scale. The economic feasibility of mining lower grade deposits has also been made possible by technological breakthroughs, such as solvent extraction and electrowinning of low-grade copper ore (a heap-leaching technique), in situ leaching for uranium, carbon-in-pulp extraction of gold, and other hydrometallurgical techniques. From an environmental perspective, these techniques will likely lead to larger waste rock piles and tailings storage facilities that will require mitigation and long-term management. Other trends that have important environmental ramifications include the use of more cyanide at gold mines, increased energy use, and increased water use.

Increased energy use is correlated with increased greenhouse-gas emissions (Mudd, 2007b, 2010). This correlation has raised concerns about greenhouse-gas emissions associated with mining and the carbon footprint of mining in general. The desire to lower the carbon footprint of mining has motivated recent research in the feasibility of storing carbon dioxide in mine waste through mineral-carbonation reactions. Mine waste that contains magnesium-silicate minerals appears to be the most amenable for carbon sequestration through the engineered formation of magnesium-carbonate minerals. Candidate mine wastes include those from platinum-groupmetal deposits, magmatic nickel-copper deposits, asbestos deposits, and diamond deposits (Rollo and Jamieson, 2006; Pronost and others, 2011; Vogeli and others, 2011; Assima and others, 2014). The volume of this material may contribute to the development of "carbon-neutral" mines in the future.

Water management is an important issue at mines, both because of the quantity of water used at mines and the potential effect of mining on water quality. Resolving this issue is likely to become more pressing in the future if the frequency of droughts increases owing to climate change, as is widely predicted. A number of factors influence water use at mines, including climate, the ore-processing method used, mine design (for example open pit, underground, and in situ leaching), mine size, and material transport (for example, by slurry pipeline or by truck). There is a strong correlation between lower grade ores and increased water use for base (copper, lead, nickel, and zinc) and precious-metal (gold, silver, and platinum-group metal) mines, uranium mines, and diamond mines (Mudd, 2008). Thus, the trend toward mining lower grade ores is likely to result in increased water use at future mine sites and to have greater impacts on water availability in areas around mines.

\section{Summary}

Although the connection between society and mining began in the Stone Age when human ancestors first began fashioning tools from stone, policies and laws for managing the impact of mining on the environment have been in place for only a few decades. The steady and rapid growth of the global population since the start of the Industrial Revolution means that the amount of land available to provide for all our material needs is continuing to decrease on a per capita basis. With this increasing population comes increased demand for mineral resources, and meeting this demand is likely to become more challenging as near-surface high-grade deposits are depleted. A future trend with respect to mining will probably be toward the mining of larger deposits with lower grade ores. This trend will pose new environmental challenges, including how to manage greater volumes of mine waste, how to deal with increased greenhouse gas emissions resulting from the mining of larger volumes of ore, and how to address the increased water-resource needs of larger scale mines while still meeting the water requirements of areas near the mine for such uses as agriculture, drinking water, and sanitation. 


\section{References Cited}

Note: All Web links listed were active as of the access date but may no longer be available.

Agricola, Georgius, 1950, De re metallica [On the nature of metals (minerals)] (H.C. Hoover and L.H. Hoover, trans.): New York, N.Y., Dover Publications, 638 p. Original work published in 1556. [Also available at http://www.gutenberg.org/ files/38015/38015-h/38015-h.htm.]

Alpers, C.N., and Nordstrom, D.K., 2000, Estimation of premining conditions for trace metal mobility in mineralized areas, in ICARD 2000 - Fifth International Conference on Acid Rock Drainage, Proceedings, v. 1: Littleton, Colo., Society for Mining, Metallurgy, and Exploration, p. 463-472.

Arizona Department of Mines and Mineral Resources, comp., 2015, Arizona mining permitting guide ( $2 \mathrm{~d}$ ed.): U.S. Department of the Interior, Bureau of Land Management, Arizona State Office, May, 187 p. [Also available at https://www.blm.gov/sites/blm.gov/files/documents/files/ az-mine-permit-guide.pdf.]

Assima, G.P., Larachi, Faïçal, Molson, John, and Beaudoin, Georges, 2014, Comparative study of five Québec ultramafic mining residues for use in direct ambient carbon dioxide mineral sequestration: Chemical Engineering Journal, v. 245, June 1, p. 56-64. [Also available at http://dx.doi.org/10.1016/j.cej.2014.02.010.]

Brundtland, G.H., 1987, Our common future-Report of the United Nations World Commission on Environment and Development: Oxford, United Kingdom, Oxford University Press, 59 p. [Also available at www.un-documents.net/ our-common-future.pdf.]

Castendyk, D.N., and Eary, L.E., eds., 2009, Mine pit lakesCharacteristics, predictive modeling, and sustainability: Littleton, Colo., Society for Mining, Metallurgy, and Exploration, Management Technologies for Metal Mining Influenced Water Series, v. 3, 304 p.

DeYoung, J.H., Jr., and Singer, D.A., 1981, Physical factors that could restrict mineral supply, in Skinner, B.J., ed., Economic Geology — 75th anniversary volume, 1905-1980: Lancaster, Pa., Economic Geology Publishing Co., p. 939-954.

du Bray, E.A., ed., 1995, Preliminary compilation of descriptive geoenvironmental mineral deposit models: U.S. Geological Survey Open-File Report 95-831, 272 p. [Also available at http://pubs.usgs.gov/of/1995/ofr-95-0831/.]

Eggert, R.G., 1994, Mining and the environment-An introduction and overview, in Eggert, R.G., ed., Mining and the environment - International perspectives on public policy: Washington, D.C., Resources for the Future, p. 1-15.
Espejo, Lesly, Kretschmer, Nicole, Oyarzún, Jorge, Meza, Francisco, Núñez, Jorge, Maturana, Hugo, Soto, Guido, Oyarzo, Paula, Garrido, Marcela, Suckel, Felipe, Amezaga, Jaime, and Oyarzún, Ricardo, 2012, Application of water quality indices and analysis of the surface water quality monitoring network in semiarid north-central Chile: Environmental Monitoring and Assessment, v. 184, no. 9, p. 5571-5588. [Also available at http://dx.doi.org/10.1007/s10661-011-2363-5.]

Foley, N.K., Hofstra, A.H., Lindsey, D.A., Seal, R.R., II, Jaskula, Brian, and Piatak, N.M., 2012, Occurrence model for volcanogenic beryllium deposits, chap. F of Mineral deposit models for resource assessment: U.S. Geological Survey Scientific Investigations Report 2010-5070-F, 43 p. [Also available at http://pubs.usgs.gov/sir/2010/5070/f/.]

Gusek, J.J., and Figueroa, L.A., eds., 2009, Mitigation of metal mining influenced water, v. 2: Littleton, Colo., Society for Mining, Metallurgy and Exploration, 164 p.

International Network for Acid Prevention, 2014, Global acid rock drainage guide: International Network for Acid Prevention, accessed April 13, 2016, at http://www.gardguide.com.

John, D.A., Ayuso, R.A., Barton, M.D., Blakely, R.J., Bodnar, R.J., Dilles, J.H., Gray, Floyd, Graybeal, F.T., Mars, J.C., McPhee, D.K., Seal, R.R., Taylor, R.D., and Vikre, P.G., 2010, Porphyry copper deposit model, chap. B of Mineral deposit models for resource assessment: U.S. Geological Survey Scientific Investigations Report 2010-5070-B, 169 p. [Also available at http://pubs.usgs.gov/sir/2010/5070/b/.]

Kelley, R.L., 1956, The mining debris controversy in the Sacramento Valley: Pacific Historical Review, v. 25, no. 4, p. 331-346.

Kierstead, M.A., 2001, History and historical resources of the Vermont copper belt, in Hammarstrom, J.M., and Seal, R.R., II, eds., Environmental geochemistry and mining history of massive sulfide deposits in the Vermont copper belt: Society of Economic Geologists Guidebook Series, v. 35, part II, p. 165-192.

Leach, D.L., Taylor, R.D., Fey, D.L., Diehl, S.F., and Saltus, R.W., 2010, A deposit model for Mississippi Valleytype lead-zinc ores, chap. A of Mineral deposit models for resource assessment: U.S. Geological Survey Scientific Investigations Report 2010-5070-A, 52 p. [Also available at http://pubs.usgs.gov/sir/2010/5070/a/.]

Leblanc, M., Morales, J.A., Borrego, J., and Elbaz-Poulichet, F., 2000, 4,500-year-old mining pollution in southwestern Spain-Long-term implications for modern mining pollution: Economic Geology, v. 95, p. 655-662. [Also available at http://dx.doi.org/10.2113/gsecongeo.95.3.655.] 
Lee, C.S.L., Qi, S.-H., Zhang, G., Luo, C.-L., Zhao, L.Y.L., and Li, X.-D., 2008, Seven thousand years of records on the mining and utilization of metals from lake sediments in central China: Environmental Science and Technology, v. 42, no. 13, p. 4732-4738. [Also available at http://dx.doi.org/10.1021/es702990n.]

Long, K.R., Van Gosen, B.S., Foley, N.K., and Cordier, Daniel, 2010, The principal rare earth elements deposits of the United States - A summary of domestic deposits and a global perspective: U.S. Geological Survey Scientific Investigations Report 2010-5220, 96 p. [Also available at http://pubs.usgs.gov/sir/2010/5220/.]

Lottermoser, B.G., 2010, Mine wastes-Characterization, treatment, and environmental impacts ( $3 \mathrm{~d}$ ed.): Berlin, Germany, Springer-Verlag, 400 p. [Also available at http://dx.doi.org/10.1007/978-3-642-12419-8.]

Marsh, Erin, Anderson, Eric, and Gray, Floyd, 2013, Nickelcobalt laterites - A deposit model: U.S. Geological Survey Scientific Investigations Report 2010-5070-H, 38 p. [Also available at http://pubs.usgs.gov/sir/2010/5070/h/.]

McLemore, V.T., ed., 2008, Basics of metal mining influenced water-Management technologies for metal mining influenced water, v. 1: Littleton, Colo., Society for Mining, Metallurgy and Exploration, 103 p.

Mudd, G.M., 2007a, An analysis of historic production trends in Australian base metal mining: Ore Geology Reviews, v. 32, nos. 1-2, p. 227-261. [Also available at http://dx.doi.org/10.1016/j.oregeorev.2006.05.005.]

Mudd, G.M., 2007b, Global trends in gold mining-Towards quantifying environmental and resource sustainability: Resources Policy, v. 32, nos. 1-2, p. 42-56. [Also available at http://dx.doi.org/10.1016/j.resourpol.2007.05.002.]

Mudd, G.M., 2008, Sustainability reporting and water resources - A preliminary assessment of embodied water and sustainable mining: Mine Water and the Environment, v. 27, no. 3, p. 136-144. [Also available at http://dx.doi.org/ 10.1007/s10230-008-0037-5.]

Mudd, G.M., 2010, The environmental sustainability of mining in Australia-Key mega-trends and looming constraints: Resources Policy, v. 35, no. 2, p. 98-115. [Also available at http://dx.doi.org/10.1016/j.resourpol.2009.12.001.]

Nordstrom, D.K., 2008, Questa baseline and pre-mining ground-water quality investigation. 25. Summary of results and baseline and pre-mining ground-water geochemistry, Red River Valley, Taos County, New Mexico, 2001-2005: U.S. Geological Survey Professional Paper 1728, 111 p. [Also available at http://pubs.usgs.gov/pp/1728/.]
Plumlee, G.S., and Nash, J.T., 1995, Geoenvironmental models of mineral deposits - Fundamentals and applications, chap. 1 of du Bray, E.A., ed., Preliminary compilation of descriptive geoenvironmental mineral deposit models: U.S. Geological Survey Open-File Report 95-831, p. 1-9. [Also available at http://pubs.usgs.gov/of/1995/ofr-95-0831/.]

Pronost, Julie, Beaudoin, Georges, Temblay, Joniel, Larachi, Faïçal, Duchesne, Josée, Hébert, Réjean, and Constantin, Marc, 2011, Carbon sequestration kinetic and storage capacity of ultramafic mining waste: Environmental Science and Technology, v. 45, no. 21, p. 9413-9420. [Also available at http://dx.doi.org/10.1021/es203063a.]

Quinn, M.-L., 1993, Industry and environment in the Appalachian Copper Basin, 1890-1930: Technology and Culture, v. 34, no. 3, p. 575-612. [Also available at http://www.jstor.org/stable/3106705.]

Rollo, H.A., and Jamieson, H.E., 2006, Interaction of diamond mine waste and surface water in the Canadian Arctic: Applied Geochemistry, v. 21, no. 9, p. 1522-1538. [Also available at http://dx.doi.org/10.1016/j.apgeochem.2006.05.008.]

Rosman, K.J.R., Chisholm, Warrick, Hong, Sungmin, Candelone, J.-P., and Boutron, C.F., 1997, Lead from Carthaginian and Roman Spanish mines isotopically identified in Greenland ice dated from 600 B.C. to 300 A.D.: Environmental Science and Technology, v. 31, no. 12, p. 3413-3416. [Also available at http://dx.doi.org/10.1021/ es970038k.]

Rutland, R.W.R., 1997, The sustainability of mineral use: AGSO Journal of Australian Geology and Geophysics, v. 17, no. 1, p. 13-25. [Also available at http://www.ga.gov.au/ corporate_data/81474/Jou1997_v17_n1_p013.pdf.]

Schulte, R.F., Taylor, R.D., Piatak, N.M., and Seal, R.R., II, 2012, Stratiform chromite deposit model: U.S. Geological Survey Scientific Investigations Report 2010-5070-E, 131 p. [Also available at http://pubs.usgs.gov/sir/2010/5070/e/.]

Schulz, K.J., Woodruff, L.G., Nicholson, S.W., Seal, R.R., II, Piatak, N.M., Chandler, V.W., and Mars, J.L., 2014, Occurrence model for magmatic sulfide-rich nickelcopper-(platinum-group element) deposits related to mafic and ultramafic dike-sill complexes, chap. I of Mineral deposit models for resource assessment: U.S. Geological Survey Scientific Investigations Report 2010-5070-I, 80 p. http://dx.doi.org/10.3133/sir20105070I.

Seal, R.R., II, and Hammarstrom, J.M., 2003, Geoenvironmental models of mineral deposits - Examples from massive sulfide and gold deposits, in Jambor, J.L., Blowes, D.W., and Ritchie, A.I.M., eds., Environmental aspects of mine wastes: Mineralogical Association of Canada Short Course Series, v. 31, p. 11-50. 
Seal, R.R., II, Kornfeld, J.M., Meier, A.L., and Hammarstrom, J.M., 2001, Geochemical settings of mine drainage in the Vermont copper belt, in Hammarstrom, J.M., and Seal, R.R., II, eds., Environmental geochemistry and mining history of massive sulfide deposits in the Vermont copper belt: Society of Economic Geologists Guidebook Series, v. 35, part II, p. 255-276.

Shanks, W.C. Pat, III, and Thurston, Roland, eds., 2012, Volcanogenic massive sulfide occurrence model, chap. C of Mineral deposit models for resource assessment: U.S. Geological Survey Scientific Investigations Report 2010-5070-C, 345 p. [Also available at http://pubs.usgs.gov/sir/2010/5070/c/.]

Shotyk, William, Cheburkin, A.K., Appleby, P.G., Fankhauser, Andreas, and Kramers, J.D., 1996, Two thousand years of atmospheric arsenic, antimony, and lead deposition recorded in an ombrotrophic peat bog profile, Jura Mountains, Switzerland: Earth and Planetary Science Letters, v. 145, nos. 1-4, p. E1-E7. [Also available at http://dx.doi.org/10.1016/S0012-821X(96)00197-5.]

Skinner, B.J., 1989, Resources in the 21 st century-Can supplies meet needs?: Episodes, v. 12, no. 3, p. 267-275.

Slack, J.F., ed., 2013, Descriptive and geoenvironmental model for cobalt-copper-gold deposits in metasedimentary rocks (ver. 1.1, March 14, 2014): U.S. Geological Survey Scientific Investigations Report 2010-5070-G, 218 p. [Also available at http://dx.doi.org/10.3133/sir20105070G.]

Taylor, R.D., Hammarstrom, J.M., Piatak, N.M., and Seal, R.R., II, 2012, Arc-related porphyry molybdenum deposit model, chap. D of Mineral deposit models for resource assessment: U.S. Geological Survey Scientific Investigations Report 2010-5070-D, 64 p. [Also available at http://pubs.usgs.gov/sir/2010/5070/d/.]

Tetra Tech, Inc., 2009, Red Dog Mine extension-Aqqaluk project-Final supplemental environmental impact statement, submitted to the U.S. Environmental Protection Agency: Anchorage, Alaska, Tetra Tech, Inc., 2 v., accessed June 3, 2015, at http://dnr.alaska.gov/mlw/ mining/largemine/reddog/.
U.S. Environmental Protection Agency, 2003, EPA and hardrock mining-A source book for industry in the Northwest and Alaska: Seattle, Wash., U.S. Environmental Protection Agency, 57 p., accessed June 3, 2015, at http://yosemite.epa.gov/ R10/WATER.NSF/Sole+Source+Aquifers/hardrockmining.

U.S. Environmental Protection Agency, 2015, SuperfundNational Priorities List (NPL): U.S. Environmental Protection Agency Web page, accessed April 13, 2016, at http://www2.epa.gov/superfund/superfund-nationalpriorities-list-npl.

U.S. Environmental Protection Agency, 2016, HRS toolbox: U.S. Environmental Protection Agency Web page, accessed April 13, 2016, at https://www.epa.gov/superfund/hrs-toolbox.

Verplanck, P.L., Van Gosen, B.S., Seal, R.R, and McCafferty, A.E., 2014, A deposit model for carbonatite and peralkaline intrusion-related rare earth element deposits: U.S. Geological Survey Scientific Investigations Report 2010-5070-J, 58 p. [Also available at https://dx.doi.org/10.3133/sir20105070j.]

Vogeli, J., Reid, D.L., Becker, M., Broadhurst, J., and Franzidis, J.-P., 2011, Investigation of the potential for mineral carbonation of PGM tailings in South Africa: Minerals Engineering, v. 24, no. 12, p. 1348-1356. [Also available at http://dx.doi.org/10.1016/j.mineng.2011.07.005.]

Warhurst, Alyson, and Mitchell, Paul, 2000, Corporate social responsibility and the case of Summitville Mine: Resources Policy, v. 26, no. 2, p. 91-102. [Also available at http://dx.doi.org/10.1016/S0301-4207(00)00019-2.] 


\section{Antimony}

By Robert R. Seal II, Klaus J. Schulz, and John H. DeYoung, Jr.

With contributions from David M. Sutphin, Lawrence J. Drew, James F. Carlin, Jr., and Byron R. Berger

Chapter C of

Critical Mineral Resources of the United States-Economic and Environmental Geology and Prospects for Future Supply

Edited by Klaus J. Schulz, John H. DeYoung, Jr., Robert R. Seal II, and Dwight C. Bradley

Professional Paper 1802-C 


\section{Contents of Chapter C}

[Figure and table titles for all chapters are listed in the volume contents before the conversion factors table and list of abbreviations and symbols. A periodic table of the elements is on the inside front cover of the printed volume]

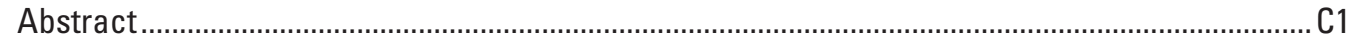

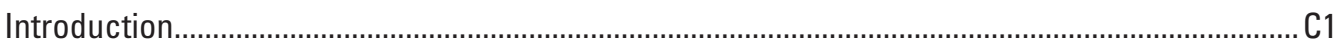

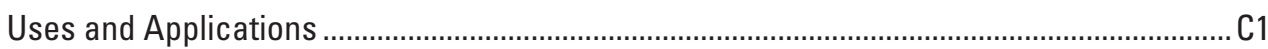

Demand, Availability of Supply, and Consumption .................................................................

Strategic and Critical Resource Issues .............................................................................. 4

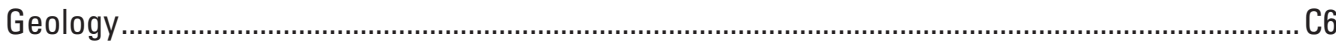

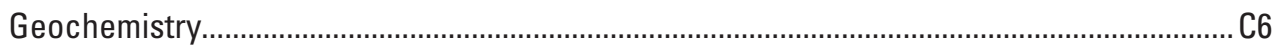

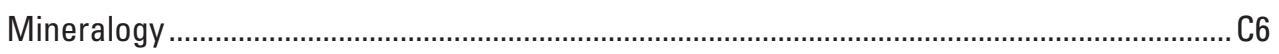

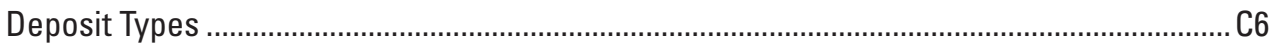

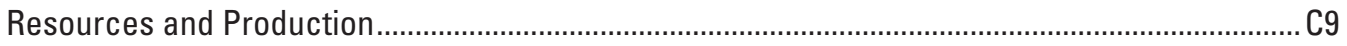

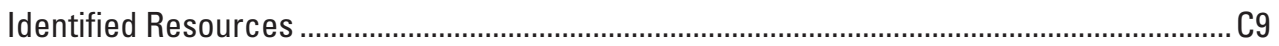

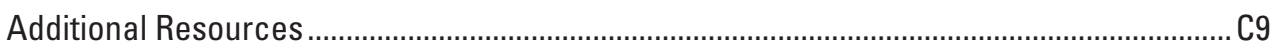

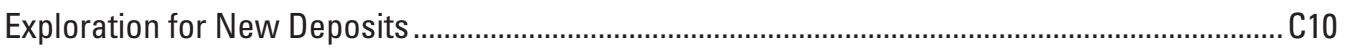

Environmental Considerations...............................................................................................

Sources and Fate in the Environment ............................................................................. C11

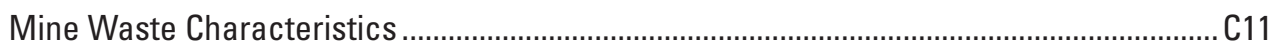

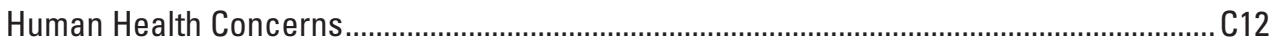

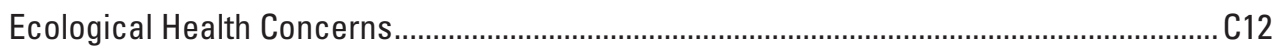

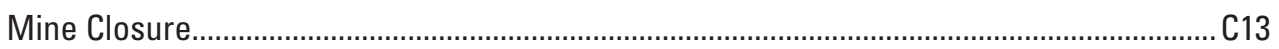

Problems and Future Research ......................................................................................

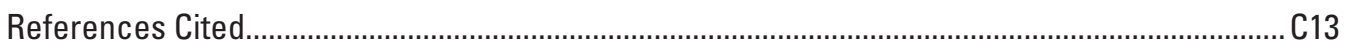

Suggested citation:

Seal, R.R., II, Schulz, K.J., and DeYoung, J.H., Jr., with contributions from David M. Sutphin, Lawrence J. Drew, James F. Carlin, Jr., and Byron R. Berger, 2017, Antimony, chap. C of Schulz, K.J., DeYoung, J.H., Jr., Seal, R.R., II, and Bradley, D.C., eds., Critical mineral resources of the United States-Economic and environmental geology and prospects for future supply: U.S. Geological Survey Professional Paper 1802, p. C1-C17, https://doi.org/10.3133/pp1802C. 


\title{
Antimony
}

\author{
By Robert R. Seal II, Klaus J. Schulz, and John H. DeYoung, Jr. \\ With contributions from David M. Sutphin, Lawrence J. Drew, James F. Carlin, Jr., and Byron R. Berger ${ }^{1}$
}

\section{Abstract}

Antimony is an important mineral commodity used widely in modern industrialized societies. The element imparts strength, hardness, and corrosion resistance to alloys that are used in many areas of industry, including in lead-acid storage batteries. Antimony's leading use is as a fire retardant in safety equipment and in household goods, such as mattresses. The U.S. Government has considered antimony to be a critical mineral mainly because of its use in military applications. The great majority of the world's antimony comes from China, and much of the remainder is shipped to China for smelting. Antimony resources are unevenly distributed around the world. China has the bulk of the world's identified resources; other countries that have identified antimony resources include Bolivia, Canada, Mexico, Russia, South Africa, Tajikistan, and Turkey. Resources in the United States are located mainly in Alaska, Idaho, Montana, and Nevada. The most significant antimony mineral deposits occur in geologic environments with a thick sequence of siliciclastic sedimentary rocks in areas with significant fault and fracture systems. The most common antimony ore mineral is stibnite $\left(\mathrm{Sb}_{2} \mathrm{~S}_{3}\right)$, but more than 100 other minerals also contain antimony. The presence of antimony in surface waters and groundwaters results primarily from rock weathering, soil runoff, and anthropogenic sources. Global emissions of antimony to the atmosphere average 6,100 metric tons per year. Empirical data suggest that the acid-generating potential of antimony mine waste is low.

\section{Introduction}

Antimony is a brittle, silver-white, shiny metal that has a specific gravity of 6.68 and a melting point of 630.5 degrees Celsius $\left({ }^{\circ} \mathrm{C}\right)$ (Miller, 1973). It is a poor conductor of heat and electricity. Antimony metal is too easily broken to be used by itself, but it imparts strength, hardness, and corrosion resistance to alloys (Miller, 1973). In addition, antimony does not readily oxidize and keeps its luster even in moist air and at elevated temperatures in the range of 100 to $250{ }^{\circ} \mathrm{C}$. At temperatures above its melting point, powdered antimony ignites and burns with a white-green flame. Antimony is resistant to attack by dilute hydrochloric acid and concentrated hydrofluoric acid. Small amounts of antimony (about 0.2 part per million [ppm]) are found in Earth's crust, making antimony about as rare as some of the heavy rare-earth elements (Eyi, 2012). Antimony rarely occurs as the native metal because of its strong affinity for sulfur and such other metals as copper, lead, and silver; it is typically found in sulfides, sulfosalts, oxides, antimonates, and antimonites (Boyle and Jonasson, 1984).

Identified resources of antimony are unevenly distributed around the world. Figure $\mathrm{C} 1$ shows the locations of selected antimony mines, deposits, and major occurrences. All the deposits that produce antimony are hydrothermal deposits. The mines that produce antimony fall into two main categoriesthose that produce antimony as their primary commodity and those that produce antimony as a byproduct of mining for other commodities. Antimony production is dominated by one country, China.

\section{Uses and Applications}

Antimony has been an important mineral through much of human history. For example, the ancient Egyptians and early Hindus used stibnite $\left(\mathrm{Sb}_{2} \mathrm{~S}_{3}\right)$, which is the major ore mineral for antimony, to produce black eye makeup as early as about 3100 B.C. Medieval alchemists thought that antimony could be used to convert lead into gold. Today, antimony is used in lead-acid storage batteries for backup power and transportation; in chemicals, ceramics, and glass; in flameretardant materials; and in heat stabilizers and plastics (fig. C2; Wang, 1919; Gibson, 1998; Carlin, 2011; Anderson, 2012).

Lead-acid storage batteries (the kind commonly used in automobiles) contain from 4 to 6 percent antimony alloyed with lead; antimony's resistance to corrosion is why so-called "lead" battery terminals are actually made of a lead-antimony alloy (Gibson, 1998). Lead-acid storage batteries account for more than two-thirds of the use of metallurgical antimony,

\footnotetext{
${ }^{1}$ Deceased.
} 


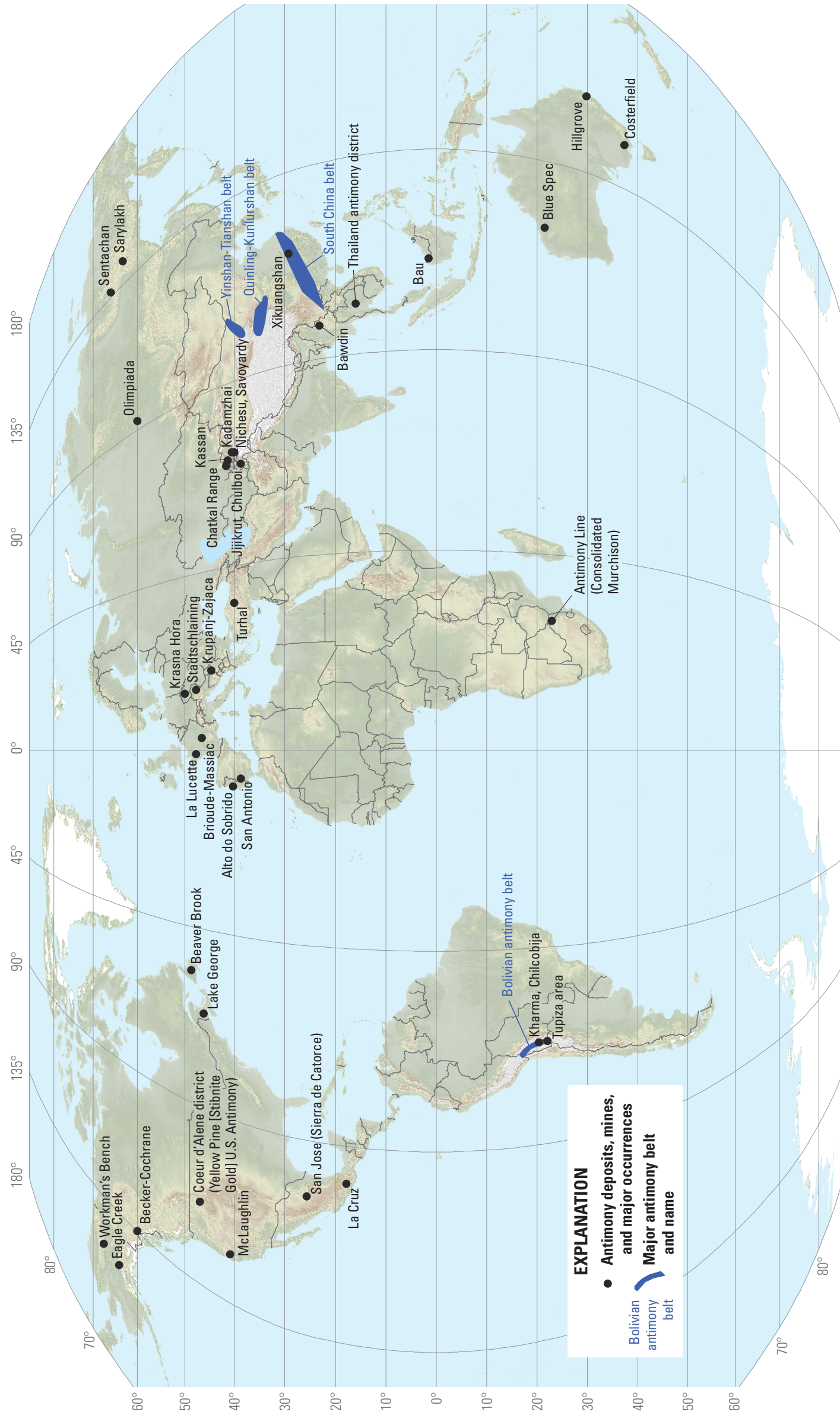

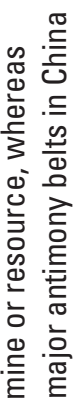

을 인

क ल

品 ट

के

凹 ल

인

응 윤

है त

के 을 든

ఏี ह స

क 등 은

क

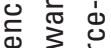

은 至

ज幽.

응 등

음 항응

E $\infty$ 응

은 응 응

के 홍

.

ज苛

능 웅

응 정

入

흐는 논

. 일

त

ర్

ป ঠ

प

등휴

艎

으 홍 응

잉 응 틀

은 흔

음 苞:

E U

흔 윰

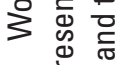

ฮ் 잉

言焉吉 


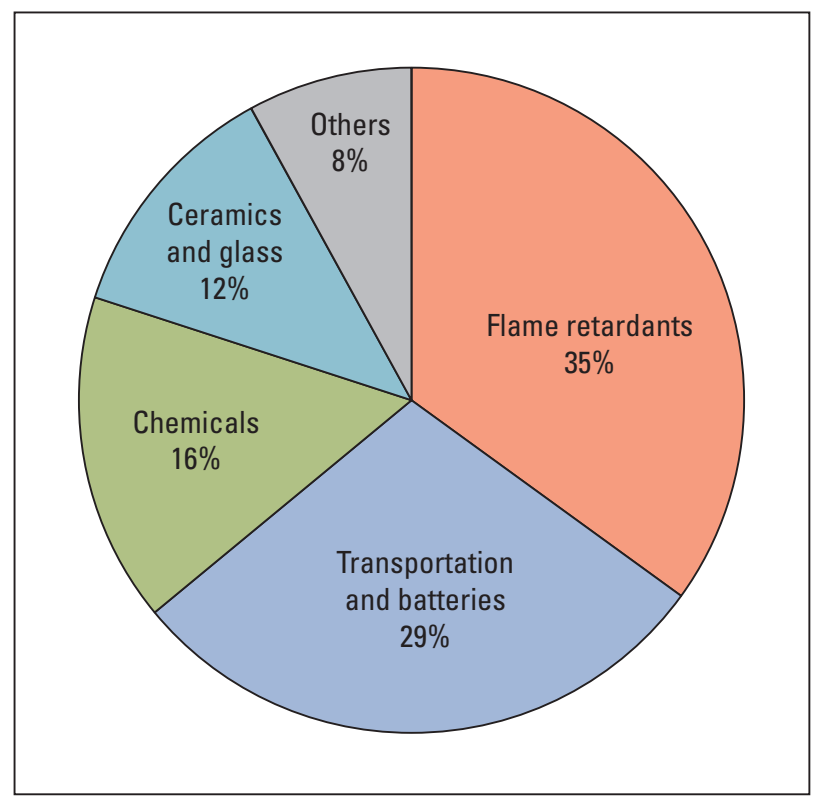

Figure C2. Pie chart showing major end uses of antimony as a percentage of antimony consumption in the United States in 2012. Data are from Carlin (2013b).

much of which is obtained from secondary (scrap) sources (Chegwidden and Bedder, 2012). Very high purity antimony metal (99.999+ percent pure) is used by the semiconductor industry in silicon wafers for making infrared detectors, diodes, and other devices, as well as for other applications. Anti-friction bearings, type metal for mechanical typesetting, solder (as much as 10 percent antimony, but typically much less), and decorative castings of Britannia metal ( 5 percent antimony) and pewter ( 7.5 percent antimony in modern products) also contain antimony. Graphite bearings are impregnated with antimony to increase heat tolerance. Antimony is used in nuclear reactors together with beryllium as startup neutron sources. "Antimony black" is finely ground metallic antimony used in bronzing for metals and plaster casts (Miller, 1973).

Antimony in the form of antimony trioxide $\left(\mathrm{Sb}_{2} \mathrm{O}_{3}\right)$ is used in the United States mainly as a flame retardant in adhesives, paints, papers, plastics, and sealants. Antimony trioxide is also used as a fire retardant backing on rubber and textile upholstery, typically with bromine- or chlorinebased halogenated compounds (European Flame Retardants Association, 2006). Major markets for flame retardants include electronics, plastics, and fabrics used in making children's clothing, aircraft and automobile seat covers, and bedding.

Other antimony compounds have a variety of uses. Antimony sulfide will combust in the presence of oxygen. It is a key combustion-supporting ingredient in the manufacture of ammunition primers, detonators, smoke-screen generators, visual range-finding shells, tracer bullets, and the striking surface of safety matches; it also provides the "glitter" effects in fireworks. The rubber industry uses antimony as a vulcanizing agent (Miller, 1973; Gibson, 1998). Antimony is also used in ceramics and glassmaking; for example, with suitable stabilizers and coloring additives, antimony trioxide glass can be made opaque to all visible light except long-wave infrared rays (Miller, 1973). Sodium antimonite $\left(\mathrm{NaO}_{3} \mathrm{Sb}\right)$ is used as a flame retardant, as well as for removing bubbles from glass (United States Antimony Corp., 2016).

Antimony also has several pharmaceutical uses. Organic antimony compounds, such as antiprotozoal drugs, are used in the treatment of certain parasitic diseases. Potassium antimonyl tartrate $\left(\mathrm{K}_{2} \mathrm{Sb}_{2}\left(\mathrm{C}_{4} \mathrm{H}_{2} \mathrm{O}_{6}\right)_{2}\right)$ was formerly used as a nauseant and expectorant, although this use has been abandoned because of the compound's toxicity and because it is difficult to administer (Abdi and others, 2003).

In an analysis of strategic mineral supplies prepared prior to World War II, Roush (1939, p. 238) stated that "Antimony has more uses of a direct military character than other members of the strategic group and probably more important uses than any of the others except mercury." In addition to serving as a combustion-supporting ingredient, antimony has important additional uses for the military, some of which were first exploited in the Russo-Japanese War of 1905 and, later, by the United States during World War I (Miller, 1973; Anderson, 2012). Antimony is a hardening agent in metals used in ball bearings, bullets capable of penetrating armor plate, and lead shot. It helps to strengthen cable sheaths, chemical pumps, foils, plumbing fixtures and pipes, roofing sheets, and tank linings. During World War II, the fireproofing compound antimony trichloride $\left(\mathrm{SbCl}_{3}\right)$ saved the lives of many American troops when it was applied to tents and vehicle covers. In a fire, antimony and chlorine recombine to form unstable compounds that remove oxygen from the air, smothering the flames (Gibson, 1998; Eyi, 2012).

\section{Demand, Availability of Supply, and Consumption}

Demand and production.-Historically, U.S. consumption of antimony has been primarily for automotive and military uses. In the United States, stibnite deposits and occurrences were first discovered in Nevada in the 1860s, and some antimony ore was produced by 1865 . Idaho's production started in the early 1890s (Miller, 1973). During World War I (fig. C3), the military use of antimony resulted in a shortage that was eased by increased domestic production (driven by higher prices) and by imports from Bolivia (Miller, 1973). Expanded use of storage batteries in automobiles and trucks beginning in the 1930s further increased antimony consumption. In the 1940 s, the many military applications for antimony during World War II escalated the demand for antimony; idle domestic mines were reopened, foreign mines expanded production, and secondary antimony recovered from scrap became a major supply source (Miller, 1973). In 1948, domestic mine production of antimony reached a record high of 5,890 metric tons, exceeding the previous high of 5,040 metric tons produced in 1943, owing 


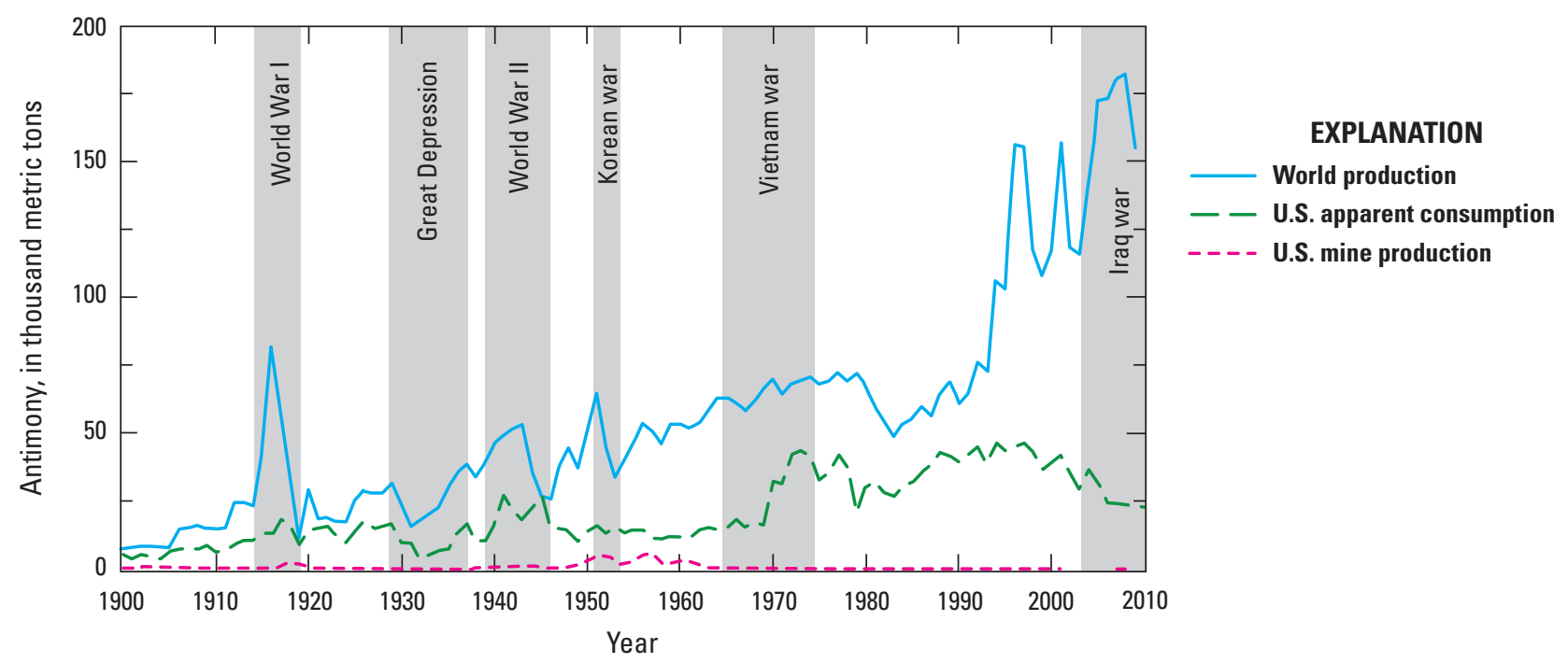

Figure C3. Graph showing world production, U.S. apparent consumption, and U.S. mine production of antimony from 1900 to 2012. Data are from U.S. Geological Survey (2016).

mainly to production from the Yellow Pine Mine in Idaho (Miller, 1973; Butterman and Carlin, 2004). Post-war domestic antimony production had returned to a lower level when the Korean war caused a temporary spike in production in the early 1950s. From the end of the Korean war to 2009, despite nearly unrivaled growth in automobile and truck sales and a building boom in the latter half of the 20th century, domestic mine production of antimony decreased; only in $1970 \mathrm{did}$ it equal or exceed 1,000 metric tons (Miller, 1973; Butterman and Carlin, 2004; U.S. Geological Survey, 2016).

Since about 1984, domestic antimony mine production has been limited to a few companies. In 2001, antimony mining in the United States stopped when the Sunshine silver mine in Idaho stopped producing antimony as a byproduct (Masters, 2007). Domestic antimony mine production was reported in only 1 year between 2001 and 2011 (U.S. Geological Survey, 2016).

From 1900 to 2008, world mine production increased by a factor of more than 24 , from 7,710 metric tons in 1900 to 185,000 metric tons in 2008 . In 2009 , world production decreased to 158,000 metric tons because of the economic recession but increased to 186,000 metric tons in 2011

(U.S. Geological Survey, 2016).

Supply.-In 2013, China produced about 80 percent of the world's supply of antimony. Its leading role in antimony production is greater than it is for any other minor metal (Masters, 2007). In 2006, as consumption of antimony decreased in most countries, China's burgeoning economy also made it the world's leading antimony consumer. However, a reduction in antimony mining and increased domestic consumption led China to look to foreign sources for supply of additional antimony ore and concentrate, including to Canada and Tajikistan, thus further reducing the production of smelted antimony metal and oxide in those countries from which China was importing antimony ores (Masters, 2007). In the United States, there is one active antimony smelter in Thompson Falls, Montana (United States Antimony Corp., 2016).

Consumption.-Apparent consumption of antimony in the United States is sensitive to fluctuations in the economy (fig. C3). In 1997, apparent consumption peaked at 46,600 metric tons, and it has been below that level ever since. In 2009, apparent consumption dropped to 21,200 metric tons, which was the lowest amount since 1979 (U.S. Geological Survey, 2016). The overall decrease in consumption may reflect industry's adjustment to the increase in the price of antimony over time (the price rose from $\$ 0.627$ per pound in 1999 to $\$ 2.80$ per pound in 2008); however, the low demand brought about by economic recession is evident in the continued drop in apparent consumption in 2009 , despite the decrease in price to $\$ 2.36$ per pound (Carlin, 2013a).

\section{Strategic and Critical Resource Issues}

In 2012, the United States obtained its supply of antimony from imports, particularly from China. In the period 2008 through 2011, the United States obtained 67 percent of its total imported antimony metal, ores and concentrates, and oxide from China; Mexico provided 15 percent; Belgium, 7 percent; Bolivia, 4 percent; and other countries, 7 percent (fig. C4; Carlin, 2013b).

In 2010, two actions by China caused reductions in that country's antimony production. Early in the year, the Government stated that it would not approve any new antimony projects until June 30, 2011. At about the same time, the Government shut down about 100 antimony smelters in its main antimony-producing region - an action that was aimed 


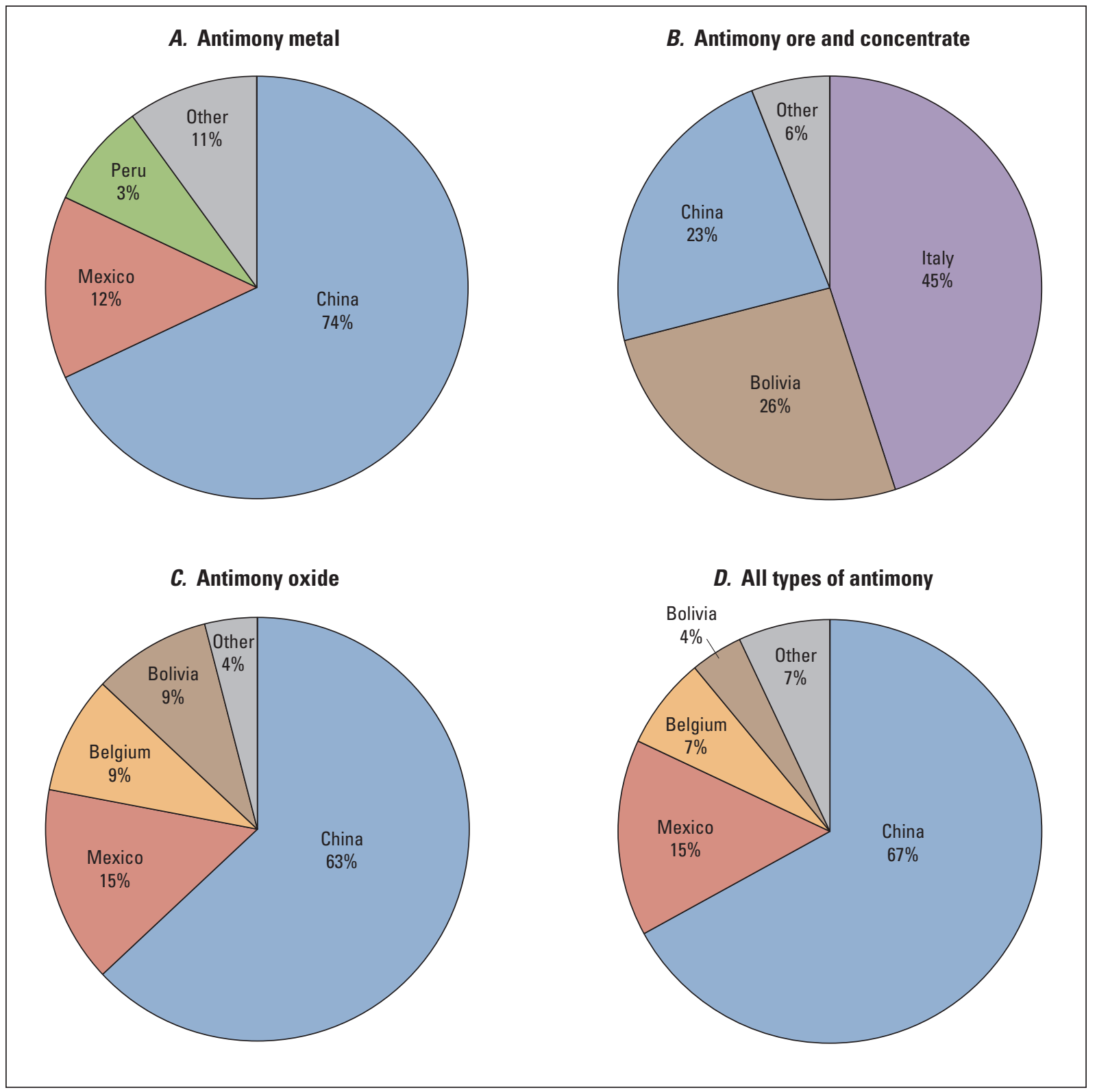

Figure C4. Pie charts showing percentages of contained antimony in U.S. imports for the period 2008-11, by source country. Data are from Carlin (2013b). A, Antimony metal; $B$, Antimony ore and concentrate; $C$, Antimony oxide; and $D$, All types of antimony.

at closing illegal mines and curbing pollution (Carlin, 2011). As recently as 2003, China had about 400 antimony producers, but by the end of 2011, that number had been reduced to about 14 to 18 qualified companies (Chegwidden and Bedder, 2012). In 2011, most ores and concentrates from Australia, Canada, Russia, and Tajikistan were exported to smelters in China, and Chinese antimony metal production had become increasingly dependent on these imports (Chegwidden and Bedder, 2012; Connelly and Rosart, undated).

If antimony supplies become limited, then compounds of chromium, tin, titanium, zinc, and zirconium could be substituted for antimony compounds in paint, pigments, and enamels; calcium, copper, selenium, strontium, sulfur, and tin can be substituted for antimony to harden lead and to replace antimony in lead-acid batteries, with enhanced performance in some cases (Eyi, 2012); and a number of organic compounds could be used as fire retardants. Such substitutes could make changes in production techniques and factory equipment necessary, however, and these substitutes have their own critical supply issues or could be more expensive to use. Barring market manipulation by a few dominant producers, recycling, mining, and smelter production are expected to meet the demand for antimony and antimony compounds for the foreseeable future. 


\section{Geology}

\section{Geochemistry}

The name antimony comes from the Greek words anti (opposed) and monos (solitude), meaning "against being alone," because antimony is most commonly found in nature in combination with other elements (Gibson, 1998). Antimony is a chalcophile element, meaning that it combines readily with sulfur; it also commonly combines with other metals, such as copper, lead, and silver, in a class of minerals known as sulfosalts (Miller, 1973). Although its concentration in continental crust $(0.2 \mathrm{ppm})$ is very low (Taylor and McLennan, 1995), it occurs in mineral deposits in concentrations ranging from trace amounts to major amounts ( $>10$ percent) of economic importance. It occurs either as distinct antimonybearing sulfide minerals (for example, stibnite), sulfosalt minerals (for example, tetrahedrite), rare antimonides (for example, aurostibite), or as a minor or trace constituent in sulfides (such as arsenopyrite and pyrite), arsenides, and sulfosalts. Antimony occurs in anomalous concentrations in the deposits of many metallic minerals, including those of base metals (such as copper, lead, and zinc) and precious metals (such as gold, silver, and platinum-group elements; Boyle and Jonasson, 1984). Because of its association with so many types of mineral deposits, antimony is a significant pathfinder element in geochemical prospecting surveys (Boyle and Jonasson, 1984).

\section{Mineralogy}

Antimony is found in more than 100 minerals (Boyle and Jonasson, 1984), of which 46 are listed in table C1 (Eyi, 2012). The most common antimony ore mineral is stibnite, which may contain traces of other metals, including copper, iron, gold, lead, and silver (Pohl, 2011). Stibnite occurs in numerous mineral deposit types (Cox and Singer, 1986). Antimony ore may also carry undesirable elements, such as arsenic and mercury (Pohl, 2011). Other antimonybearing minerals, such as boulangerite (a lead-rich mineral), bournonite, gudmundite (an iron-rich mineral), jamesonite, polybasite, pyrargyrite, tetrahedrite (a copper-rich mineral), and valentinite are or have been of minor economic importance as sources of antimony (Miller, 1973; Eyi, 2012). Aurostibite is common in gold deposits enriched in antimony (Boyle and Jonasson, 1984). Metallic accessory minerals commonly found with primary antimony ores are arsenopyrite, chalcopyrite, galena, gold, pyrite, pyrrhotite, sphalerite, and silver; common gangue minerals are quartz (predominantly), calcite, and barite (Miller, 1973). The most common supergene antimony minerals are bindheimite, kermesite, nadorite, senarmontite, and stibiconite (table $\mathrm{C} 1$ ).

\section{Deposit Types}

Antimony occurs in a variety of deposits of various ages, including epithermal veins, pegmatites, and replacement and hot-spring deposits (Miller, 1973). Ore-grade concentrations of antimony are not common, but antimony mines can be divided into the following two broad categories: primary antimony producers and byproduct antimony producers. This distinction also corresponds to the empirical differences between simple stibnite deposits and complex polymetallic deposits (Schwarz-Schampera, 2014). Simple quartz-stibnite vein and replacement deposits account for most of the current and recent mine production. They can form in several different types of hydrothermal systems, including the peripheral parts of orogenic gold deposits, intrusion-related gold deposits, porphyry copper and molybdenum deposits, polymetallic mesothermal vein deposits, and sediment-hosted Carlin-type gold deposits (Hofstra and others, 2013). They can also occur alone with no apparent association with other mineral deposits.

The most significant simple quartz-stibnite deposits include those in Bolivia, Canada, China, Russia, and South Africa. Important or representative deposits from these countries include the Kharma (Bolivia), Beaver Brook and Lake George (Canada), Xikuangshan (China), Sarylakh and Sentachan (Russia), and Consolidated Murchison (South Africa) deposits. The Yellow Pine deposit in Idaho and the U.S. Antimony Mine in Montana are the most important deposits that fit within this category in the United States (fig. C1).

The Cordillera Oriental in Bolivia contains more than 500 known antimony-gold deposits, which are typified by the Kharma deposit. The Kharma deposit consists of fissure veins dominated by stibnite with subordinate amounts of other sulfides (pyrite, arsenopyrite, and sphalerite) and sulfosalts (plagionite, fülöppite, and veenite), and minor amounts of aurostibite (Dill and others, 1995). The gold content is generally low (about $1 \mathrm{ppm}$ ) and the gold is difficult to recover. Quartz is the main gangue mineral, accounting for up to 90 percent of the veins, followed by siderite and calcite. The vein system is found in a fault zone that cuts Paleozoic fine-grained clastic rocks (argillites), which were deformed and later intruded by granitic rocks from the Permian to Jurassic Periods.

The two prime examples of simple stibnite deposits in Canada are the Beaver Brook deposit in central Newfoundland (Lake and Wilton, 2006) and the Lake George deposit in New Brunswick (Scratch and others, 1984; Seal and others, 1988). These two deposits share many geologic similarities. Both occur in fractures of fault systems hosted by Ordovician to Silurian siliciclastic sedimentary rocks, and they are both located near Siluro-Devonian granitic intrusions. The Beaver Brook deposit contains resources of 2.12 million metric tons at an average grade of 4.41 percent 
Table C1. Selected antimony minerals.

[Source: Anderson (2012). *, mineral is mentioned in the text of this chapter]

\begin{tabular}{|c|c|c|c|}
\hline Mineral name & Chemical formula & Mineral name & Chemical formula \\
\hline Andorite & $\mathrm{AgPbSb}_{3} \mathrm{~S}_{6}$ & Meneghihite & $\mathrm{Pb}_{4} \mathrm{Sb}_{2} \mathrm{~S}_{7}$ \\
\hline Annivite & $\mathrm{Cu}_{12}(\mathrm{Sb}, \mathrm{Bi}, \mathrm{As})_{4} \mathrm{~S}_{13}$ & Nadorite & $\mathrm{PbSbO}_{2} \mathrm{Cl}$ \\
\hline Arite & $\mathrm{Ni}(\mathrm{As}, \mathrm{Sb})$ & Native antimony & $\mathrm{Sb}$ \\
\hline Aurostibite* & $\mathrm{AuSb}_{2}$ & Polybasite* & $(\mathrm{Ag}, \mathrm{Cu})_{16} \mathrm{Sb}_{2} \mathrm{~S}_{11}$ \\
\hline Berthierite* & $\mathrm{FeSb}_{2} \mathrm{~S}_{4}$ & Pyrargyrite* & $\mathrm{Ag}_{3} \mathrm{SbS}_{3}$ \\
\hline Berthonite & $\mathrm{Cu}_{7} \mathrm{~Pb}_{2} \mathrm{Sb}_{5} \mathrm{~S}_{13}$ & Ramdohrite & $\mathrm{Ag}_{2} \mathrm{~Pb}_{3} \mathrm{Sb}_{3} \mathrm{~S}_{9}$ \\
\hline Bindheimite* & $\mathrm{Pb}_{2} \mathrm{Sb}_{2} \mathrm{O}_{6}(\mathrm{O}, \mathrm{OH})$ & Romeite & $(\mathrm{Ca}, \mathrm{Fe}, \mathrm{Mn}, \mathrm{Na})_{2}(\mathrm{Sb}, \mathrm{Ti})_{2} \mathrm{O}_{6}(\mathrm{O}, \mathrm{OH}, \mathrm{F})$ \\
\hline Bolivianite & $\mathrm{Ag}_{2} \mathrm{Sb}_{12} \mathrm{~S}_{19}$ & Senarmontite* & $\mathrm{Sb}_{2} \mathrm{O}_{3}$ \\
\hline Boulangerite* & $\mathrm{Pb}_{5} \mathrm{Sb}_{4} \mathrm{~S}_{11}$ & Stenhuggarite & $\mathrm{CaFeSbAs}_{2} \mathrm{O}_{7}$ \\
\hline Bournonite* & $\mathrm{PbCuSbS}_{3}$ & Stephanite & $\mathrm{Ag}_{5} \mathrm{SbS}_{4}$ \\
\hline Breithauptite & $\mathrm{NiSb}$ & Stibiconite* & $\mathrm{Sb}_{3} \mathrm{O}_{6}(\mathrm{OH})$ \\
\hline Cervantite & $\mathrm{Sb}_{2} \mathrm{O}_{4}$ & Stibiobismuthinite & $(\mathrm{Bi}, \mathrm{Sb})_{4} \mathrm{~S}_{7}$ \\
\hline Cylindrite & $\mathrm{Pb}_{3} \mathrm{Sn}_{4} \mathrm{Sb}_{2} \mathrm{~S}_{14}$ & Stibiocolumbite & $\mathrm{SbNbO}_{4}$ \\
\hline Dyscrasite & $\mathrm{Ag}_{3} \mathrm{Sb}$ & Stibiodomeykite & $\mathrm{Cu}_{3}(\mathrm{As}, \mathrm{Sb})$ \\
\hline Falkmanite & $\mathrm{Pb}_{3} \mathrm{Sb}_{2} \mathrm{~S}_{6}$ & Stibioluzonite & $\mathrm{Cu}_{3}(\mathrm{Sb}, \mathrm{As}) \mathrm{S}_{4}$ \\
\hline Famatinite & $\mathrm{Cu}_{3} \mathrm{SbS}_{4}$ & Stibiotantalite & $\mathrm{SbTaO}_{4}$ \\
\hline Franckeite & $\mathrm{Pb}_{5} \mathrm{Sn}_{3} \mathrm{Sb}_{2} \mathrm{~S}_{14}$ & Stibnite* & $\mathrm{Sb}_{2} \mathrm{~S}_{3}$ \\
\hline Freibergite & $(\mathrm{Cu}, \mathrm{Ag})_{12} \mathrm{Sb}_{4} \mathrm{~S}_{13}$ & Sulfo-antimonite & $\mathrm{Ag}_{2} \mathrm{~Pb}_{7} \mathrm{Sb}_{8} \mathrm{~S}_{20}$ \\
\hline Geocronite & $\mathrm{Pb}_{5}(\mathrm{As}, \mathrm{Sb})_{12} \mathrm{~S}_{8}$ & Tellurobismuthite & $(\mathrm{BiSb})_{2} \mathrm{Te}_{3}$ \\
\hline Gudmundite* & $\mathrm{FeSbS}$ & Tetrahedrite* & $\mathrm{Cu}_{12} \mathrm{Sb}_{4} \mathrm{~S}_{13}$ \\
\hline Horsfordite & $\mathrm{Cu}_{6} \mathrm{Sb}$ & Ullmannite & NiSbS \\
\hline Jamesonite* & $\mathrm{Pb}_{4} \mathrm{FeSb}_{6} \mathrm{~S}_{14}$ & Valentinite* & $\mathrm{Sb}_{2} \mathrm{O}_{3}$ \\
\hline Kermesite* & $\mathrm{Sb}_{2} \mathrm{~S}_{2} \mathrm{O}$ & Zinckenite & $\mathrm{PbSb}_{2} \mathrm{~S}_{4}$ \\
\hline Livingstonite & $\mathrm{HgSb}_{4} \mathrm{~S}_{7}$ & & \\
\hline
\end{tabular}

antimony (Lake and Wilton, 2006; Tallman and Evans, 1994). The Lake George deposit consists of two orebodies totaling slightly less than 2 million metric tons at average grades ranging between 3 and 4.2 percent antimony (Seal and others, 1988). The mineralization at both deposits is dominated by quartz-stibnite veins with lesser amounts of carbonate minerals (calcite or dolomite) and minor amounts of pyrite. Arsenopyrite and native antimony are important accessory phases at Lake George (Scratch and others, 1984; Seal and others, 1988). At Lake George, the veins range in thickness from 0.5 to 1.5 meters (m) (Scratch and others, 1984; Seal and others, 1988). The predominant alteration assemblages at Lake George are siliceous and phyllic; the siliceous alteration typically extends to less than 5 centimeters $(\mathrm{cm})$ from the edge of the vein, whereas the phyllic alteration can extend to more than $10 \mathrm{~m}$ from the vein (Seal and others, 1988). 
The Xikuangshan deposit in Hunan Province, China, is China's leading source of antimony (Panov and No, 1989; Wu, 1993; Fan and others, 2004) and has been worked since the 16th century (Eyi, 2012). The deposit consists of four large orebodies and several smaller ones. The deposit replaces Devonian carbonate rocks and consists predominantly of stibnite with trace amounts of pyrite, pyrrhotite, and sphalerite. The primary gangue minerals are quartz and calcite along with some secondary barite and fluorite (Wu, 1993; Fan and others, 2004). The ore is mostly in two stratiform, 2.5- to 5-m-thick mineralized beds or lenses that extend for several hundred to thousands of meters within a 45-m-thick carbonate sequence. The deposit covers an area of approximately 16 square kilometers $\left(\mathrm{km}^{2}\right)$, has an average grade of 4 percent antimony, and contains more than 2 million metric tons of antimony (Yang and others, 2006). Quartz-stibnite and calcite-stibnite ore assemblages account for more than 90 percent of the ore; barite-quartz-stibnite and fluorite-quartz-stibnite assemblages contain relatively minor amounts of ore (Fan and others, 2004). The dominant alteration that accompanied mineralization was silicification; there is also some sericitic, argillic, and pyritic alteration (Yang and others, 2006). Igneous rocks are notably absent in the vicinity of the Xikuangshan deposit (Wu, 1993). In addition to simple quartz-stibnite deposits, China also has important antimony-gold-tungsten deposits (Wu, 1993).

The largest antimony deposits in Russia are the Sarylakh and the Sentachan antimony-gold deposits in the Yakutiya region of eastern Russia. Estimates of the resources contained in these deposits vary. GeoProMining Ltd. reported that these two deposits contain 5 percent of the world's antimony reserves with an average grade of 14 percent antimony (Nossoff, 2012). The company also estimated that the Sarylakh deposit contains 10 grams per metric ton $(\mathrm{g} / \mathrm{t})$ gold and that the Sentachan deposit contains $32 \mathrm{~g} / \mathrm{t}$ gold. Bortnikov and others (2010, p. 339) estimated that the Sarylakh deposit contains 180,000 metric tons of antimony ore grading 20 percent antimony along with 40 metric tons of gold ore grading $8 \mathrm{~g} / \mathrm{t}$ gold, and that the Sentachan deposit contains 110,000 metric tons of antimony ore grading 30 percent antimony along with 20 metric tons of gold ore grading $35 \mathrm{~g} / \mathrm{t}$ gold. Baltukhaev and Solozhenkin (2009) reported that the two deposits contain 200,000 metric tons of antimony with grades of 12 to 18 percent antimony at Sarylakh and 24.6 percent antimony, $38.2 \mathrm{~g} / \mathrm{t}$ gold, and $13.4 \mathrm{~g} / \mathrm{t}$ silver at Sentachan. Another source (Porter GeoConsultancy Pty Ltd., 2010) reported ore grades at Sentachan to be 25 percent antimony, $37 \mathrm{~g} / \mathrm{t}$ gold, and $13.4 \mathrm{~g} / \mathrm{t}$ silver, and resources at Sarylakh to be 2.17 million metric tons at grades of 6 percent antimony and $6 \mathrm{~g} / \mathrm{t}$ gold, for a total of 130,000 metric tons of contained antimony.

The Sarylakh and Sentachan deposits are hosted by deformed Triassic siliciclastic sedimentary rocks (sandstones, siltstones, and shales) that later were intruded by granitic rocks. The area was also subject to related volcanic activity. The deposits, which are separated by 400 kilometers $(\mathrm{km})$, are located along a major regional fault zone (Bortnikov and others, 2010). The orebodies are controlled by faults and are dominated by quartz and stibnite. Important, although less abundant, minerals include ankerite, arsenopyrite, berthierite, bournonite, chalcopyrite, chalcostibite, galena, native gold, pyrite, and sphalerite. The antimony mineralization and the gold mineralization are paragenetically distinct from one another at these deposits (Bortnikov and others, 2010). At Sentachan, the mineralized zones reach a maximum thickness of $6 \mathrm{~m}$; at Sarylakh, the thickness varies from 0.8 to $17 \mathrm{~m}$.

In South Africa, the Consolidated Murchison Mine is the most important antimony deposit on South Africa's Antimony Line, and it is representative of mineralization along a significant Archean shear zone (Jaguin and others, 2012). Mineralization is predominantly hosted by quartzmuscovite schists and occurs as quartz-carbonate veins bearing stibnite and berthierite with associated pyrite and arsenopyrite (Muff, 1978).

The Yellow Pine deposit in Valley County, Idaho, contains the largest antimony resource in the United States (Miller, 1973) and produced intermittently from 1932 through 1992. Mining in the area began when gold was discovered in 1900; antimony recovery with gold was first recognized in 1929 (Palencia and Mishra, 1986, p. 9). The antimony occurs partly in small high-grade quartz-stibnite veins, rarely more than a foot wide, and in large low-grade zones of disseminated stibnite in shear zones in quartz monzonite of the Idaho batholith (White, 1940). Two periods of mineralization are recognized (White, 1940): the first consists of pyrite, arsenopyrite, and gold; the second consists of antimony and silver. The Yellow Pine deposit was being re-evaluated in 2014 as part of the Stibnite Gold project (formerly known as Golden Meadows project) (Huss and others, 2014).

The U.S. Antimony Mine in western Montana is the second largest simple quartz-stibnite vein deposit in the United States. It had significant production in the past, but was closed in 1983; the mine's production and reserves are estimated to be nearly 15,400 metric tons of antimony (Hofstra and others, 2013). The deposit is located on the north side of a major east-west-trending wrench fault system (the Lewis and Clark line). The quartz-stibnite veins occur near the contact between quartzite and phyllite in the uppermost Prichard Formation. The veins can be as large as $1 \mathrm{~km}$ long and $1 \mathrm{~m}$ wide and contain 60 percent stibnite; accessory sulfide minerals include arsenopyrite, pyrite, sphalerite, and chalcopyrite (Hofstra and others, 2013). Additional potentially important byproduct sources of antimony include the polymetallic veins at the Sunshine silver mine in the Coeur d'Alene mining district, Idaho. 


\section{Resources and Production}

\section{Identified Resources}

In 2013, the largest identified resources of antimony were located in Bolivia, China, Mexico, Russia, South Africa, and Tajikistan. Resources in the United States are located mainly in Alaska, Idaho, Montana, and Nevada. World reserves total about 1.3 million metric tons of contained antimony (table $\mathrm{C} 2$ ). Onethird of these reserves are located in China (Guberman, 2014).

In a study of large deposits of several mineral commodities, Laznicka (1999) noted that the world's 24 giant and supergiant antimony deposits contained a total of 6.97 million metric tons of antimony. Laznicka estimated the total global endowment to be between 7.1 and 7.5 million metric tons of antimony.

There are abundant identified antimony resources available, but the bulk of those resources are in a few very large deposits that are not evenly distributed across the globe. Today's market favors large deposits that are conducive to high-volume bulk-mining techniques. The United States and the countries of the Western Hemisphere appear to have mostly small deposits that are uneconomic to mine under current and foreseeable conditions.

In 2012, Midas Gold Corp. (the owner) contracted for a preliminary economic assessment to be done of the indicated and inferred mineral resources at the Golden Meadows project in Idaho to demonstrate the potential for positive economic returns and identify areas requiring additional work. A subsequent prefeasibility study of the project (renamed the Stibnite Gold project) was completed in 2014. The property includes three zones of gold-antimony-silver mineralization within an area of significant historical mining activity. Past production was reported from the Hanger Flats (1928-38), Yellow Pine (1938-92), and West End (1978-97) deposits (Huss and others, 2014, p. 6-7-6-9). Conventional open pit methods were being considered for mining the three deposits, all of which are located within $3 \mathrm{~km}$ of each other and may in fact represent one large mineralized zone. The 2014 study estimated indicated and inferred resources to be about 130 million metric tons at grades of about $1.6 \mathrm{~g} / \mathrm{t}$ gold and 0.06 percent antimony (Huss and others, 2014, p. 1-10).

\section{Additional Resources}

Antimony resources that may be mined in the future are likely to be those tied directly to deposits of precious metals, copper, lead, and (or) zinc, similar to those from which most domestic antimony has historically been recovered as a byproduct or coproduct. Gold is an important joint product with antimony, but gold-antimony veins are commonly mined just for their gold. Because the presence of antimony makes gold more difficult and more expensive to process (the antimony interferes with the heap-leaching agent by consuming oxygen and hindering the effect of cyanide on the gold ore), some amount of gold ore that has a high antimony grade may be stockpiled (Eyi, 2012).
Table C2. Estimated world production and reserves of antimony in 2013 , in metric tons of antimony.

[e, estimated; NA, not available; n.r., not reported]

\begin{tabular}{lrc|}
\hline \multicolumn{1}{c}{ Country } & Production $^{\mathbf{1}, \text { e }}$ & Reserves $^{\mathbf{2}}$ \\
\hline Australia & 3,275 & n.r. \\
Bolivia & 5,081 & 310,000 \\
Burma & 9,000 & n.r. \\
Canada & 76 & n.r. \\
China & 120,000 & 3460,000 \\
Kyrgyzstan & 1,200 & n.r. \\
Mexico & 294 & n.r. \\
Russia & 8,700 & 350,000 \\
South Africa & 2,400 & 27,000 \\
Tajikistan & 4,675 & 50,000 \\
Turkey & 4,600 & n.r. \\
Other countries & NA & 4150,000 \\
World total & 159,000 & $1,300,000$ \\
\hline
\end{tabular}

${ }^{1}$ From Guberman (2015).

${ }^{2}$ From Guberman (2014) and National Bureau of Statistics of China (2014).

${ }^{3}$ In 2009, the Chinese Ministry of Land and Resources reported reserves of 2,460,000 metric tons; however, high-grade antimony reserves in Lengshuijiang, Hunan Province, China, are near exhaustion (Chegwidden and Bedder, 2012, p. 5).

${ }^{4}$ Includes estimated reserves for countries listed as "n.r." above.

A post-World War II evaluation of domestic mined resources concluded that "the United States has no deposits, from which the ore is mined principally for antimony, that are large enough or rich enough to compete with foreign sources in normal times" (Shaum and others, 1948, p. 53). This situation has not changed since that report was completed. If the United States could no longer import antimony in quantities to meet its needs, then additional domestic production may be obtainable from base- and precious-metal deposits and from areas of identified base-metal, gold, silver, and tungsten mineralization (Miller, 1973). These sources may include undiscovered resources in parts of the United States and other nations of the Western Hemisphere, as well as Australia, South Africa, and other trading partners of the United States. Table C3 lists some potential near-term sources of antimony ore and concentrate (Chegwidden and Bedder, 2012).

Enhanced recovery of antimony from precious-metal deposits may represent the most readily available source of antimony if demand were to increase rapidly. The Sunshine silver mine in Idaho was a significant producer of byproduct antimony from a deposit of silver-rich tetrahedrite (a common ore mineral in silver deposits). The mine stopped recovering antimony before its closure in early 2001 (Carlin, 2003). In addition, antimony can be recovered as a byproduct from some base-metal refining, for example, from Mississippi Valley-type lead deposits in the United States. 
Table C3. Potential additional sources of antimony ore and concentrate, by country.

[Sources: Chegwidden and Bedder (2012, p. 10) and Huss and others (2014)]

\begin{tabular}{|c|c|}
\hline Country & Notes \\
\hline Australia & $\begin{array}{l}\text { The Hillgrove Mine, which closed in late 2015, might be reopened. Other deposits in New South Wales and } \\
\text { Western Australia are being evaluated. }\end{array}$ \\
\hline Bolivia & The San Antonia de Turiri Mine may be developed. \\
\hline Burma & $\begin{array}{l}\text { Exports of antimony concentrates increased from 1,200 metric tons in } 2002 \text { to } 14,100 \text { metric tons in } 2011 \text {. } \\
\text { There may be capacity for a further increase in output. }\end{array}$ \\
\hline Canada & $\begin{array}{l}\text { At least three companies have been exploring antimony deposits in Newfoundland and Labrador, the } \\
\text { Yukon Territory, and New Brunswick. }\end{array}$ \\
\hline China & Tibet may increase output. \\
\hline Mexico & U.S. Antimony Corp. expected to increase production from Los Juarez deposit in Coahuila State. \\
\hline Russia & $\begin{array}{l}\text { In the Far East, increased production may come from Sentachanskoe and Ilinskoe; new deposits, such as } \\
\text { Udereiskoe and Zhipkoshinskoe, were being developed in eastern Siberia. }\end{array}$ \\
\hline South Africa & There may be recovery of production at the Consolidated Murchison Mine. \\
\hline Tajikistan & $\begin{array}{l}\text { Output reached about } 8,000 \text { metric tons per year of concentrate from a plant with a capacity of } 30,000 \text { metric tons } \\
\text { per year; there may be potential for a further increase in output. The mercury content of the ore is a concern. }\end{array}$ \\
\hline Turkey & Possible new production in projects near Gediz in Kütahya Province as well as Niğde and Izmir Provinces. \\
\hline United States & $\begin{array}{l}\text { Midas Gold Corp.'s Stibnite Gold project in central Idaho is a large low-grade gold-antimony property that } \\
\text { includes the Hanger Flat, Yellow Pine, and West End deposits. }\end{array}$ \\
\hline
\end{tabular}

\section{Exploration for New Deposits}

Most undiscovered primary antimony deposits will likely be located in geologic settings similar to those where antimony deposits are known to occur. From what is known about where these deposits form, rocks of any age that were deposited in the world's sedimentary basins on active continental margins are permissive for the occurrence of antimony deposits, especially rocks in those basins with known antimony deposits. In the United States, these types of sedimentary rocks located in the Cordillera of Alaska, and in California, Idaho, Montana, and Nevada would be prime targets. Areas within large-scale shear zones and strike-slip fault zones, such as those in Nevada, are potentially favorable areas for antimony fissure-vein deposits. In Arkansas, California, Idaho, Montana, Nevada, Washington, and other States, rocks near to, on trend with, and similar to those with known antimony occurrences could be explored for additional undiscovered antimony deposits.

The empirical association of hydrothermal antimony deposits with fine-grained sedimentary rocks, especially carbonaceous shales or their metamorphosed equivalents, may be a reflection of the antimony enrichments commonly found in these types of rocks. The continental crust averages 0.2 ppm antimony (Taylor and McLennan, 1995), yet average shales contain 1.5 ppm (Li and Schoonmaker, 2003), and black shales average $5.0 \pm 0.5 \mathrm{ppm}$ (Ketris and Yudovich, 2009). Although the source, transport, and concentration mechanisms will likely vary among deposit types, a fertile source region may be essential to the formation of economic deposits. Further, Pitcairn and others (2006) demonstrated a significant depletion in antimony and other elements (arsenic, gold, mercury, molybdenum, silver, and tungsten) with increased metamorphic grade in the Alpine and Otago schists of New Zealand. These findings suggest that highgrade metamorphism $\left(>400^{\circ} \mathrm{C}\right)$ may mobilize antimony into hydrothermal fluids that may form quartz-antimony veins at lower temperature under favorable conditions. The combination of siliciclastic sedimentary rocks and an egress pathway for hydrothermal fluids from high-temperature source regions is common to most of the significant simple quartz-stibnite deposits described in the Geology section above. An association with major structural fault systems that could access deeper regional metamorphic fluids is found at the Xikuangshan deposit (China), the Sentachan and Sarylakh deposits (Russia); the Antimony Line (South Africa), and the U.S. Antimony Mine (Montana). In contrast, igneous heat sources associated with more local fault and fracture zones are found at the deposits in Bolivia and at the Lake George and Beaver Brook deposits in Canada.

Historically, very little prospecting has been directed solely toward antimony (Miller, 1973). Most exploration that resulted in the incidental discovery of an antimony deposit has been the result of prospecting for another mineral commodity, such as copper, gold, lead, and silver. Exploration for antimony deposits usually includes techniques commonly employed to find other mineral deposits, such as geochemical soil and rock sampling, ground geophysical surveying, geologic mapping, and drilling. Surveys of mercury-vapor haloes in soil are helpful for identifying sulfide deposits of antimony, the base metals, mercury, gold, and tin (Fursov, 1990). 


\section{Environmental Considerations}

\section{Sources and Fate in the Environment}

Environmental aspects of antimony have been summarized by Rish (2004). The environmental aqueous chemistry of antimony has been reviewed by Filella and others (2002a, b). Antimony in waters results primarily from rock weathering, soil runoff, and anthropogenic sources. Global emissions of antimony to the atmosphere average 6,100 metric tons per year, which includes 3,500 metric tons per year from anthropogenic sources (energy production, mining, smelting, and waste incineration) and 2,600 metric tons per year from natural sources (including, in order of contribution to atmospheric antimony, dust, volcanoes, sea aerosols, forest fires, and biogenic sources; Filella and others, 2002a). Seawater contains approximately 0.2 part per billion ( $\mathrm{ppb}$ ) dissolved antimony, and uncontaminated surface waters (streams, rivers, and lakes) contain less than $1 \mathrm{ppb}$ (Filella and others, 2002a). In surface water, pentavalent antimony species $\left(\mathrm{Sb}^{5+}\right)$ dominate over trivalent species $\left(\mathrm{Sb}^{3+}\right.$ ) (Filella and others, $2002 b$ ). The solubility of antimony in water at room temperature reaches $90 \mathrm{ppm}$ in oxygenated waters, $13 \mathrm{ppm}$ in anoxic waters, and $1.2 \mathrm{ppm}$ in anoxic and sulfidic waters (Tourky and Mousa, 1948; Krupp, 1988).

Data are available for antimony concentrations in soils and plants. In their national geochemical survey of soil in the United States, Smith and others (2013) report concentrations of antimony that range from less than 0.05 to $630 \mathrm{ppm}$, with a mean value of less than $0.9 \mathrm{ppm}$. Filella and others (2002a) summarized published data for sediments that ranged from less than $0.005 \mathrm{ppm}$ in uncontaminated areas to up to $12,500 \mathrm{ppm}$ in areas around a smelter. Antimony concentrations in plants do not show a strong correlation with soil concentrations; plant concentrations range from less than 0.1 to 500 ppm (Boyle and Jonasson, 1984; Rish, 2004).

Antimony is mined primarily from quartz-stibnite vein deposits. Modern environmental baseline characterization studies of antimony deposits have not been reported; however, Ritchie and others (2013) report background (upstream) concentrations of antimony in surface water and sediments from mineralized areas of the historic Kantishna Hills district in Alaska that range from 2.7 to $4.2 \mathrm{ppb}$ and from 91 to $968 \mathrm{ppm}$, respectively. Austria (1971) reported antimony concentrations of soils up to $500 \mathrm{ppm}$ in the vicinity of the Lake George antimony deposit in New Brunswick, Canada.

\section{Mine Waste Characteristics}

Information on antimony mine waste is extremely limited. Historically, small, high-grade (about 35 to 70 percent antimony) deposits have been mined, but modern production comes from larger, lower grade deposits, which have a median tonnage of 0.09 million metric tons, a maximum tonnage of
3 million metric tons, a median grade of 3.6 percent antimony, and a maximum grade of more than 7.0 percent antimony (Bliss and Orris, 1986a-c). The Xikuangshan deposit in Hunan Province, China, which is the world's largest antimony deposit, is an anomaly. The deposit, which has an average grade of 4 percent antimony, is estimated to contain more than 2 million metric tons of antimony (Yang and others, 2006).

The mineralogical character of the ores greatly influences the geochemistry of the mine waste. The ores are typically predominantly stibnite and quartz, with subordinate amounts of calcite, pyrite, arsenopyrite, and native antimony, hosted mostly by siliciclastic or carbonate sedimentary rocks (Wu, 1993). The most common secondary antimony minerals in mineral deposits are kermesite $\left(\mathrm{Sb}_{2} \mathrm{~S}_{2} \mathrm{O}\right)$, senarmontite $\left(\mathrm{Sb}_{2} \mathrm{O}_{3}\right)$, and stibiconite $\left(\mathrm{Sb}_{3} \mathrm{O}_{6}(\mathrm{OH})\right)$. Thus, the elements of greatest environmental concern are predominantly antimony and arsenic.

The acid-generating potential of mine waste is expressed in terms of the amount of calcium carbonate it would take to neutralize it; it is measured in kilograms of calcium carbonate per metric ton $\left(\mathrm{kg} \mathrm{CaCO}_{3} / \mathrm{t}\right)$ of mine waste (Price, 2009; International Network for Acid Prevention, 2011). The acid-generating potential resides primarily in pyrite. Mine waste can also have acid-neutralizing potential, which resides in carbonate minerals, such as calcite, and in some silicate minerals, such as feldspars.

Limited data are available on the acid-generating potential of antimony mine waste. Klimko and others (2011) investigated the acid-generating potential of mill tailings at two abandoned stibnite mines in Slovakia. One had a neutral $\mathrm{pH}$ (7 to 8), whereas the other had an acidic $\mathrm{pH}$ (3 to 5). Acid-base accounting results indicated that the neutral tailings had an acid-generating potential that was negligible as well as a modest acid-neutralizing potential (70 to $120 \mathrm{~kg} \mathrm{CaCO}_{3} / \mathrm{t}$ of tailings). In contrast, the acidic tailings had a low acidgenerating potential $\left(0.8\right.$ to $\left.2.8 \mathrm{~kg} \mathrm{CaCO}_{3} / \mathrm{t}\right)$ and a low acid-neutralizing potential ( 16 to $18 \mathrm{~kg} \mathrm{CaCO}_{3} / \mathrm{t}$ ) that was nonetheless higher than the acid-generating potential. The acid-neutralizing potential to acid-generating potential ratios ranged between 5.7 and 22.6, which suggests a low potential for acid generation. The presence of carbonate minerals, such as calcite, and only minor amounts of pyrite in the mine waste from antimony deposits in general suggest that the acidneutralizing potential is likely to exceed the acid-generating potential of the mine wastes (Price, 2009; International Network for Acid Prevention, 2011).

Mine-drainage data from abandoned antimony mines support this conclusion (Wilson and others, 2004; Casiot and others, 2007; Majzlan and others, 2007), although some sites can generate acid drainage. Ritchie and others (2013) and Eppinger and others (2002) found low pH (2.5 to 5.6) in pore water and seeps from tailings piles in the abandoned mines in the Kantishna district, Alaska, but the receiving creeks immediately downstream of the mines had nearneutral $\mathrm{pH}(6.1$ to 8.3$)$. 


\section{Human Health Concerns}

Belzile and others (2011) have summarized the general aspects of antimony exposure to humans. The Agency for Toxic Substances and Disease Registry (ATSDR) has developed a toxicological profile for antimony (Agency for Toxic Substances and Disease Registry, 1992). In general, trivalent antimony $\left(\mathrm{Sb}^{3+}\right)$ is more toxic than pentavalent antimony $\left(\mathrm{Sb}^{5+}\right)$. In humans, antimony can result in diseases of the liver, respiratory and cardiovascular systems, and skin (Wu and others, 2011). Compared to trivalent arsenic, trivalent antimony is 5 times less cytotoxic and 10 times less genotoxic (Rish, 2004).

The U.S. Environmental Protection Agency (EPA) (2009) has set a maximum contaminant limit of 6 ppb for antimony and $10 \mathrm{ppb}$ for arsenic for drinking water. The World Health Organization (WHO) drinking water guideline is $20 \mathrm{ppb}$ for antimony and $10 \mathrm{ppb}$ for arsenic (World Health Organization, 2008). In the Xikuangshan mining district, which includes three mines that produce from China's largest antimony deposit and an associated smelter, Wu and others (2011) found 100 percent of drinking water samples collected in a roughly $300-\mathrm{km}^{2}$ surrounding area exceeded the maximum contaminant limit of $6 \mathrm{ppb}$ for antimony set by the EPA. Concentrations ranged from 8.1 to $152 \mathrm{ppb}$ antimony. They concluded that mine drainage and smelter wastes were the dominant sources. In contrast, the arsenic concentration of most samples was below the maximum contaminant limit. Wu and others (2011) also investigated the dietary intake of antimony by local residents and found that their daily intake exceeded WHO guidelines and were several orders of magnitude higher than those found in other parts of the world, none of which approached the WHO tolerable daily intake guideline. The greatest sources in the daily dietary uptake were rice (33 percent), vegetables ( 26 percent), drinking water (19 percent), and meat and poultry (19 percent) (Wu and others, 2011).

The concentrations of antimony and arsenic in soils in the Xikuangshan mining district also exceed EPA regional screening levels (U.S. Environmental Protection Agency, 2015). Wang and others (2010) collected 23 soil samples within $15 \mathrm{~km}$ of the mines. Antimony concentrations ranged from 10 to 2,159 ppm, of which 96 percent exceeded the EPA residential soil regional screening level for antimony (39 ppm). More than 80 percent of soil samples also exceeded EPA residential guidelines for arsenic. Local exceedances of the residential guidelines were also found for cadmium, chromium, lead, manganese, and mercury.

\section{Ecological Health Concerns}

National ambient-water-quality criteria with respect to freshwater organisms are not available from the EPA for antimony; however, Suter (1996) presents both acute and chronic ecological screening benchmarks for antimony. The acute toxicity value is $985 \mathrm{ppb}$ (also expressed as 985 micrograms per liter $[\mu \mathrm{g} / \mathrm{L}]$ ) and the chronic toxicity value is $104 \mathrm{ppb}$. No guidelines are available for sediment.

Information about surface water impacts from antimony mines is limited to an active mining district in China and several small abandoned mines throughout the world. Several sources of mine drainage data are available. In their study of the abandoned Goesdorf antimony mine in Luxembourg, Filella and others (2009) compiled mine drainage data for antimony mines from around the world (Australia, Italy, New Zealand, Scotland, and Slovakia). Majzlan and others (2007) presented mine-drainage data from the Pezinok Mine in Slovakia. Eppinger and others (2002) and Ritchie and others (2013) investigated surface water quality in the Kantishna district, Alaska. Casiot and others (2007) provide additional data from an antimony mine in France. Data are also available from New Zealand (Wilson and others, 2004). Collectively, the $\mathrm{pH}$ of surface water downstream of mines is near neutral (6.2 to 8.5), which is a reflection of the low acid-generating potential of the ore and mine waste and the significant acidneutralizing potential provided by carbonate minerals in the mineralized assemblages.

Ponded water on mine waste, pore water in tailings, and seeps from mine waste in the Kantishna district in Alaska have been documented as having low pH (2.5 to 5.6) (Eppinger and others, 2002; Ritchie and others, 2013). Information on the dissolved concentrations of sulfate $(<0.5$ to $2,115 \mathrm{ppm})$ and iron ( $<10$ to $3,000 \mathrm{ppb})$ in mine waters and surrounding surface waters is limited (Casiot and others, 2007), but their concentrations are moderate, which is a reflection of the typically limited pyrite contents of these ores. Dissolved antimony concentrations range from less than 0.3 to $55,000 \mathrm{ppb}$, and dissolved arsenic concentrations range from less than 1 to 3,509 ppb. Thus, mine drainage from antimony mines can locally exceed both acute and chronic ecological guidelines for antimony and arsenic. Information on other trace elements is lacking, with exception of surface waters in the vicinity of the Slate Creek deposit in the Kantishna district. All trace element concentrations were in the subparts-per-million range $(<1.0 \mathrm{ppm})$, except for iron $(<170 \mathrm{ppm})$, manganese $(<6.5 \mathrm{ppm})$, aluminum $(<3.7 \mathrm{ppm})$, and zinc $(<1.6 \mathrm{ppm})$, all in mine waters (Eppinger and others, 2002).

The geochemistry of mine waters and surface waters in the Xikuangshan mining district in China was investigated by Liu and others (2010). The samples included stream waters in the district, seepage from waste piles, and mine water. The $\mathrm{pH}$ of the samples was comparable to those from the abandoned mines discussed above and ranged from 7.7 to 8.3. Dissolved sulfate concentrations in surface water samples were significantly higher at Xikuangshan (46 to $1,267 \mathrm{ppm}$ ) than those at an abandoned mine in France (Casiot and others, 2007). Dissolved antimony concentrations at Xikuangshan (330 to $11,400 \mathrm{ppb}$ ) were significantly higher than most values from abandoned mines elsewhere in the world. 


\section{Mine Closure}

The nature of mine closure for antimony mines depends primarily on the method of mining. Most antimony deposits are exploited as underground mines. The most common solid waste from underground mines is mill tailings, which are disposed in some sort of tailings storage facility.

The long-term fate of tailings storage facilities depends upon the nature of the tailings and the method by which the facility is constructed. Some facilities can be regraded, capped, and revegetated. These facilities may have seepage and, depending upon the acid-generating potential of the material, may require some form of water treatment. Some of the tailings could be placed back in the mined-out workings, depending upon how the orebody was mined; however, the entire volume of tailings cannot be placed back in the mine workings because of the volume expansion caused by crushing and milling the ore.

\section{Problems and Future Research}

A major problem facing the countries that depend upon stable and secure supplies of a critical mineral commodity such as antimony for their industry and defense needs is the uneven distribution of resources and production around the world. Finding new resources in countries other than China could be a challenge for antimony-consuming nations. Knowledge of how quickly the United States and the rest of the world could develop additional production by adding capacity to existing mines, by reactivating nonoperating mines, or by bringing newly discovered deposits online is essential to understanding the effect of supply shortfalls in the event that China, which is the dominant producer, was to reduce antimony exports. Since 2011, production of antimony in China has declined and its antimony reserves may be declining as well (Guberman, 2015).

Although antimony occurs in several different deposit types of various ages, ore-grade concentrations of antimony are not common, and economically minable deposits of stibnite are generally small and discontinuous. This makes exploration for antimony deposits challenging. Detailed geologic studies would be required to understand the tectonic history of ancient continental margins and sedimentary basins as well as the relation of antimony deposits to that history in order to enhance the possibility of delineating areas that are prospective for undiscovered antimony resources.

From an environmental perspective, no clear case study of the behavior of antimony and related trace elements in a modern mine setting using current best practices exists. The toxicity of aqueous antimony species to aquatic organisms is a notable gap in knowledge. Knowledge of the toxicity of antimony in sediments is also limited.

\section{References Cited}

Note: All Web links listed were active as of the access date but may no longer be available.

Abdi, Y.A., Gustafsson, L.L., Ericsson, Örjan, and Hellgren, Urban, 2003, Handbook of drugs for tropical parasitic infections (2d ed.): Bristol, Pa., Taylor and Francis, 181 p.

Agency for Toxic Substances and Disease Registry, 1992, Toxicological profile for antimony and compounds: Atlanta, Ga., U.S. Department of Health and Human Services Public Health Service, September, 160 p., accessed October 5, 2015, at http:/www.atsdr.cdc.gov/

toxprofiles/tp23.pdf.

Arce-Burgoa, O.R., and Goldfarb, R.J., 2009, Metallogeny of Bolivia: Society of Economic Geologists Newsletter, no. 79, October, p. 1, 8-15.

Anderson, C.G., 2012, The metallurgy of antimony: Chemie der Erde-Geochemistry, v. 72, suppl. no. 4, p. 3-8. [Also available at http://dx.doi.org/10.1016/j.chemer.2012.04.001.]

Austria, V.B., Jr., 1971, The Cu, Pb, Zn, Mn, Mo and Sb content of stream and spring sediments, York County, New Brunswick: Fredericton, New Brunswick, Canada, Mineral Resources Branch, Department of Natural Resources, Report of Investigations no. 14, 18 p., 7 pls.

Baltukhaev, G.I., and Solozhenkin, P.M., 2009, Concentration of gold-antimony ores in the Sakha Republic (Yakutia): Russian Journal of Non-Ferrous Metals, v. 50, no. 3, p. 199-205. [Also available at http://dx.doi.org/10.3103/ s106782120903002x.]

Belzile, Nelson, Chen, Y.-W., and Filella, Montserrat, 2011, Human exposure to antimony-I. Sources and intake: Critical Reviews in Environmental Science and Technology, v. 41, no. 14, p. 1309-1373. [Also available at http://dx.doi.org/ 10.1080/10643381003608227.]

Bliss, J.D., and Orris, G.J., 1986a, Descriptive model of simple Sb deposits-Model 27d, in Cox, D.P., and Singer, D.A., eds., Mineral deposit models: U.S. Geological Survey Bulletin 1693, p. 183-184. [Also available at http://pubs.er.usgs.gov/publication/b1693.]

Bliss, J.D., and Orris, G.J., 1986b, Grade and tonnage model of disseminated Sb deposits-Model 27e, in Cox, D.P., and Singer, D.A., eds., Mineral deposit models: U.S. Geological Survey Bulletin 1693, p. 187-188. [Also available at http://pubs.er.usgs.gov/publication/b1693.]

Bliss, J.D., and Orris, G.J., 1986c, Grade and tonnage model of simple Sb deposits-Model 27d, in Cox, D.P., and Singer, D.A., eds., Mineral deposit models: U.S. Geological Survey Bulletin 1693, p. 184-186. [Also available at http://pubs.er.usgs.gov/publication/b1693.] 
Bortnikov, N.S., Gamynin, G.N., Vikent'eva, O.V., Prokof'ev, V.Y., and Prokop'ev, A.V., 2010, The Sarylakh and Sentachan gold-antimony deposits, Sakha-YakutiaA case study of combined mesothermal gold-quartz and epithermal stibnite ores: Geology of Ore Deposits, v. 52, no. 5, p. 339-372. [Also available at http://dx.doi.org/ 10.1134/s1075701510050028.]

Boyle, R.W., and Jonasson, I.R., 1984, The geochemistry of antimony and its use as an indicator element in geochemical prospecting: Journal of Geochemical Exploration, v. 20, no. 3, p. 223-302. [Also available at http://dx.doi.org/ 10.1016/0375-6742(84)90071-2.]

Butterman, W.C., and Carlin, J.F., Jr., 2004, Mineral commodity profiles-Antimony: U.S. Geological Survey Open-File Report 03-019, 35 p. [Also available at http://pubs.er.usgs.gov/publication/ofr0319.]

Carlin, J.F., Jr., 2003, Antimony, in Metals and minerals: U.S. Geological Survey Minerals Yearbook 2001, v. I, p. 7.1-7.7. [Also available at http://minerals.usgs.gov/ minerals/pubs/commodity/antimony/060401.pdf.]

Carlin, J.F., Jr., 2011, Antimony: U.S. Geological Survey Mineral Commodity Summaries 2011, p. 18-19. [Also available at https://minerals.usgs.gov/minerals/pubs/ commodity/antimony/mcs-2011-antim.pdf.]

Carlin, J.F., Jr., 2013a, Antimony (Sb), in Metal prices in the United States through 2010: U.S. Geological Survey Scientific Investigations Report 2011-5188, p. 7-9. [Available only at http://pubs.er.usgs.gov/publication/sir20125188.]

Carlin, J.F., Jr., 2013b, Antimony: U.S. Geological Survey Mineral Commodity Summaries 2013, p. 18-19. [Also available at https://minerals.usgs.gov/minerals/pubs/ commodity/antimony/mcs-2013-antim.pdf.]

Casiot, C., Ujevic, M., Munoz, M., Seidel, J.L., and Elbaz-Poulichet, F., 2007, Antimony and arsenic mobility in a creek draining an antimony mine abandoned 85 years ago (upper Orb basin, France): Applied Geochemistry, v. 22, no. 4, p. 788-798. [Also available at http://dx.doi.org/10.1016/ j.apgeochem.2006.11.007.]

Chegwidden, Judith, and Bedder, Jack, 2012, AntimonyChanges in the pattern of supply and demand: Roskill Information Services presentation, April 26, 33 p., accessed October 6, 2016, at https://www.roskill.com/ news/download-roskills-paper-on-the-changes-in-supplyand-demand-for-antimony/.

Connelly, John, and Rosart, Jason, [undated], Beaver Brook antimony mine-Metal mining modifications: Energy Digital Global Energy Portal, 2 p., accessed June 1, 2012, at http://www.energydigital.com/reports/beaver-brookantimony-mine-metal-mining-modifications.
Cox, D.P., and Singer, D.A., eds., 1986, Mineral deposit models: U.S. Geological Survey Bulletin 1693, 379 p. [Also available at http://pubs.er.usgs.gov/publication/b1693.]

Dill, H.G., Weiser, T., Bernhardt, I.R., and Kilibarda, C.R., 1995, The composite gold-antimony vein deposit at Kharma (Bolivia): Economic Geology, v. 90, p. 51-66. [Also available at http://dx.doi.org/10.2113/gsecongeo.90.1.51.]

Eppinger, R.G., Briggs, P.H., Crock, J.G., Meier, A.L., Sutley, S.J., and Theodorakos, P.M., 2002, Environmentalgeochemical study of the Slate Creek antimony deposit, Kantishna Hills, Denali National Park and Preserve, Alaska, chap. 8 of Wilson, F.H., and Galloway, J.P., eds., Studies by the U.S. Geological Survey in Alaska, 2000: U.S. Geological Survey Professional Paper 1662, p. 123-141. [Also available at http://pubs.er.usgs.gov/publication/pp1662.]

European Flame Retardants Association, 2006, Flame retardant fact sheet-Antimony trioxide $\left(\mathrm{Sb}_{2} \mathrm{O}_{3}\right)$ : Brussels, Belgium, European Flame Retardants Association, 4 p., accessed October 6, 2015, at http://www.cefic-efra.com/ images/stories/factsheet/ATOFactsheet106-1_00.pdf.

Eyi, Emin, 2012, Antimony uses, production, prices: London, United Kingdom, Tristar Resources plc, 14 p., accessed October 6, 2015, at http://www.tri-starresources.com/ upload-images/TRI_00_120410_R_D_TRISTAR\%20 ANTIMONY\%20PRIMER\%20JAN\%202012_F.pdf.

Fan, Delian, Zhang, Tao, and Ye, Jie, 2004, The Xikuangshan $\mathrm{Sb}$ deposit hosted by the Upper Devonian black shale series, Hunan, China: Ore Geology Reviews, v. 24, nos. 1-2, p. 121-133. [Also available at http://dx.doi.org/10.1016/ j.oregeorev.2003.08.005.]

Filella, Montserrat, Belzile, Nelson, and Chen, Y.-W., 2002a, Antimony in the environment-A review focused on natural waters-I. Occurrence: Earth-Science Reviews, v. 57, nos. 1-2, January, p. 125-176. [Also available at http://dx.doi.org/10.1016/s0012-8252(01)00070-8.]

Filella, Montserrat, Belzile, Nelson, and Chen, Y.-W., 2002b, Antimony in the environment-A review focused on natural waters-II. Relevant solution chemistry: Earth-Science Reviews, v. 59, nos. 1-4, November, p. 265-285. [Also available at http://dx.doi.org/10.1016/S0012-8252(02)00089-2.]

Filella, Montserrat, Philippo, Simon, Belzile, Nelson, Chen, Yuwei, and Quentel, François, 2009, Natural attenuation processes applying to antimony-A study in the abandoned antimony mine in Goesdorf, Luxembourg: Science of the Total Environment, v. 407, no. 24, p. 6205-6216. [Also available at http://dx.doi.org/10.1016/j.scitotenv.2009.08.027.]

Fursov, V.Z., 1990, Mercury vapor surveys-Technique and results, in Kesler, S.E., ed., Soil and rock gas geochemistry: Journal of Geochemical Exploration, v. 38, nos. 1-2, p. 145-155. [Also available at http://dx.doi.org/10.1016/ 0375-6742(90)90098-u.] 
Gibson, R.I., 1998, Type-cast-Antimony, the metallic sidekick, sets the world on fire and puts it out: Geotimes, February, p. 58. [Also available at http://www.gravmag.com/ antimony.shtml.] (Geotimes magazine became Earth magazine on September 1, 2008.)

Guberman, D.E., 2014, Antimony: U.S. Geological Survey Mineral Commodity Summaries 2014, p. 18-19. [Also available at https://minerals.usgs.gov/minerals/pubs/ commodity/antimony/mcs-2014-antim.pdf.]

Guberman, D.E., 2015, Antimony [advanced release], in Metals and minerals: U.S. Geological Survey Minerals Yearbook 2013, v. I, p. 6.1-6.8, accessed March 7, 2016, at http://minerals.usgs.gov/minerals/pubs/commodity/ antimony/myb1-2013-antim.pdf.

Hofstra, A.H., Marsh, E.E., Todorov, T.I., and Emsbo, P., 2013, Fluid inclusion evidence for a genetic link between simple antimony veins and giant silver veins in the Coeur d'Alene mining district, ID and MT, USA: Geofluids, v. 13, no. 4, p. 475-493. [Also available at http://dx.doi.org/10.1111/ gfl.12036.]

Huss, C.E., Kirkham, G.D., Martin, C.J., Marek, J.M., Anderson, A.R., Kinder, R.C., and Kowalewski, P.E., 2014, Stibnite gold project-Prefeasibility study technical report: Tucson, Arizona, M3 Engineering + Technology Corp. for Midas Gold Corp., December 15, 650 p. [Also available at http://www.midasgoldcorp.com/i/pdf/Midas-Gold-StibniteGold-Project-2014-PFS.pdf.]

International Network for Acid Prevention, 2011, Global acid rock drainage guide: International Network for Acid Prevention, accessed November 10, 2011, at http://www.gardguide.com.

Jaguin, J., Poujol, M., Boulvais, P., Robb, L.J., and Paquette, J.L., 2012, Metallogeny of precious and base metal minerali-zation in the Murchison Greenstone Belt, South AfricaIndications from $\mathrm{U}-\mathrm{Pb}$ and $\mathrm{Pb}-\mathrm{Pb}$ geochronology: Mineralium Deposita, v. 47, no. 7, p. 739-747. [Also available at http://dx.doi.org/10.1007/s00126-012-0422-7.]

Ketris, M.P., and Yudovich, Ya.E., 2009, Estimations of Clarkes for carbonaceous biolithes-World averages for trace element contents in black shales and coals: International Journal of Coal Geology, v. 78, no. 2, p. 135-148. [Also available at http://dx.doi.org/10.1016/j.coal.2009.01.002.]

Klimko, Tomáš, Lalinská, Bronislava, Majzlan, Juraj, Chovan, Martin, Kučerová, Gabriela, and Christin, Paul, 2011, Chemical composition of weathering products in neutral and acidic mine tailings from stibnite exploitation in Slovakia: Journal of Geosciences, v. 56, no. 3, p. 327-340. [Also available at http://dx.doi.org/10.3190/ jgeosci.104.]
Krupp, R.E., 1988, Solubility of stibnite in hydrogen sulfide solutions, speciation, and equilibrium constants, from 25 to $350^{\circ} \mathrm{C}$ : Geochimica et Cosmochimica Acta, v. 52, no. 12 , p. 3005-3015. [Also available at http://dx.doi.org/10.1016/ 0016-7037(88)90164-0.]

Lake, J.W.L., and Wilton, D.H.C., 2006, Structural and stratigraphic controls on mineralization at the Beaver Brook antimony deposit, central Newfoundland, in Pereira, C.P.G., and Walsh, D.G., eds., Current research: St. John's, Newfoundland and Labrador, Canada, Newfoundland Labrador Department of Natural Resources, Geological Survey Report, no. 06-1, p. 135-146. [Also available at http://www.nr.gov.nl.ca/mines\&en/geosurvey/publications/ cr2006/lake.pdf.]

Laznicka, Peter, 1999, Quantitative relationships among giant deposits of metals: Economic Geology, v. 94, p. 455-473. [Also available at http://dx.doi.org/10.2113/

gsecongeo.94.4.455.]

Laznicka, Peter, 2010, Giant metallic deposits-Future sources of industrial metals: Berlin, Germany, SpringerVerlag, $834 \mathrm{p}$.

Li, Y.-H., and Schoonmaker, J.E., 2003, Chemical composition and mineralogy of marine sediments, in McKenzie, F.T., ed., Sediments, diagenesis, and sedimentary rocks, v. 7 of Holland, H.D. and Turekian, K.K., eds., Treatise on geochemistry: Oxford, United Kingdom, Elsevier-Pergamon, p. 1-35. [Also available at http://dx.doi.org/10.1016/ b0-08-043751-6/07088-2.]

Liu, Faye, Le, X.C., McKnight-Whitford, Anthony, Xia, Yunlong, Wu, Fengchang, Elswick, Erika, Johnson, C.C., and Zhu, Chen, 2010, Antimony speciation and contamination of waters in the Xikuangshan antimony mining and smelting area, China: Environmental Geochemistry and Health, v. 32, no. 5, p. 401-413. [Also available at http://dx.doi.org/10.1007/s10653-010-9284-z.]

Majzlan, Juraj, Lalinská, Bronislava, Chovan, Martin, Jukovič, L'ubomír, Milovská, Stanislava, and Göttlicher, Jörg, 2007, The formation, structure, and ageing of Asrich hydrous ferric oxide at the abandoned $\mathrm{Sb}$ deposit Pezinok (Slovakia): Geochimica et Cosmochimica Acta, v. 71, no. 17, p. 4206-4220. [Also available at http://dx.doi.org/10.1016/j.gca.2007.06.053.]

Masters, H.B., 2007, Antimony—2006 (Last updated August 17th): Mining Journal Online, accessed May 1, 2012, at http://www.mining-journal.com/focus/ special-reports/antimony-2006-last-updated-august-17th/. [Available by subscription only.]

Miller, M.H., 1973, Antimony, in Brobst, D.A., and Pratt, W.P., eds., United States mineral resources: U.S. Geological Survey Professional Paper 820, p. 45-50, accessed October 6, 2015, at http://pubs.er.usgs.gov/publication/pp820. 
Muff, Rolf, 1978, The antimony deposits in the Murchison Range of the northeastern Transvaal, Republic of South Africa: Berlin, West Germany, Gebrüder Borntraeger, Monograph series on mineral deposits, no. 16, 90 p.

National Bureau of Statistics of China, [2014], China statistical yearbook 2014: Beijing, China, National Bureau of Statistics of China, China Statistics Press, accessed August 9, 2016, via http://www.stats.gov.cn/tjsj/ndsj/2014/ indexeh.htm.

Natural Earth, 2014, Small scale data: Natural Earth map dataset, scale 1:110,000,000, accessed June 23, 2014, at http://www.naturalearthdata.com.

Nossoff, S.I., 2012, GeoProMining-A story of success in the CIS region: CERBA Russia and Eurasia Mining Conference, Toronto, Ontario, Canada, March 6, presentation, 25 p., accessed October 6, 2015, at http://www.cerbanet.org/ intranet/Documents/Regional Office - Toronto/ Events/2012_Mining_conference/PPT/SESSION1_Panel2 Sergei I. Nossoff, GeoProMining Group First Vice President, Investments, Strategy and Business Development, GeoProMining Group.pdf.

Palencia, C.M., and Mishra, C.P., 1986, Antimony availability-Market economy countries: U.S. Bureau of Mines Information Circular 9098, 20 p.

Panov, B.S., and No, Li, 1989, The Xiguanshan antimony deposit, China: International Geology Review, v. 31, no. 1, p. 100-110. [Also available at http://dx.doi.org/10.1080/ 00206818909465865.]

Pitcairn, I.K., Teagle, D.A.H., Craw, Dave, Olivo, G.R., Kerrich, Robert, and Brewer, T.S., 2006, Sources of metals and fluids in orogenic gold deposits - Insights from the Otago and Alpine schists, New Zealand: Economic Geology, v. 101, p. 1525-1546. [Also available at http://dx.doi.org/10.2113/gsecongeo.101.8.1525.]

Pohl, W.L., 2011, Economic geology principles and practiceMetals, minerals, coal and hydrocarbons-Introduction to formation and sustainable exploitation of mineral deposits: Hoboken, N.J., Wiley-Blackwell, 663 p. [Also available at http://dx.doi.org/10.1002/9781444394870.]

Porter GeoConsultancy Pty Ltd., 2010, Nezhdaninskoye, Sentachan, Sarylakh-Siberia, Sakha-Yakutia, Russia-Main commodities-Au Sb: Porter GeoConsultancy Pty Ltd. Web page, accessed April 15, 2015, at http://www.portergeo.com.au/ database/mineinfo.asp? mineid $=\operatorname{mn} 646$.

Price, W.A., 2009, Prediction manual for drainage chemistry from sulphidic geologic materials: Ottawa, Ontario, Canada, Natural Resources Canada, MEND Report 1.20.1, December, 579 p. [Also available at http://mend-nedem.org/ wp-content/uploads/1.20.1_PredictionManual.pdf.]
Rish, M.A., 2004, Antimony, chap. 4 of Merian, E., Anke, M., Ihnat, M. and Stoeppler, M., eds., Elements and their compounds in the environment-Occurrence, analysis, and biological relevance ( $2 \mathrm{~d}$ ed.): Weinheim, Germany, Wiley-VCH Verlag, p. 659-670.

Ritchie, V.J., Ilgen, A.G., Mueller, S.H., Trainor, T.P., and Goldfarb, R.J., 2013, Mobility and chemical fate of antimony and arsenic in historic mining environments of the Kantishna Hills district, Denali National Park and Preserve, Alaska: Chemical Geology, v. 335, January, p. 172-188. [Also available at http:// dx.doi.org/10.1016/j.chemgeo.2012.10.016.]

Roush, G.A., 1939, Strategic mineral supplies: New York, N.Y., McGraw-Hill Book Company, Inc., 485 p.

Schwarz-Schampera, Ulrich, 2014, Antimony, in Gunn, Gus, ed., Critical metals handbook: Hoboken, N.J., Wiley and Sons, p. 70-98. [Also available at http://dx.doi.org/10.1002/ 9781118755341.ch4.]

Scratch, R.B., Watson, G.P., Kerrich, R., and Hutchinson, R.W., 1984, Fracture-controlled antimony-quartz mineralization, Lake George deposit, New Brunswick-Mineralogy, geochemistry, alteration, and hydrothermal regimes: Economic Geology, v. 79, p. 1159-1186. [Also available at http://dx.doi.org/10.2113/gsecongeo.79.5.1159.]

Seal, R.R., II, Clark, A.H., and Morrissy, C.J., 1988, Lake George, southwestern New Brunswick-A Silurian, multi-stage, polymetallic (Sb-W-Mo-Au-base metal) hydrothermal centre, in Taylor, R.P., and Strong, D.F., eds., Recent advances in the geology of granite-related mineral deposits: Canadian Institute of Mining and Metallurgy, Special Volume 39, p. 252-264.

Shaum, J.H., White, D.E., and Zadra, J.B., 1948, Antimony, chap. 11 of U.S. Bureau of Mines and U.S. Geological Survey, Mineral resources of the United States: Washington, D.C., Public Affairs Press, p. 52-56.

Smith, D.B., Cannon, W.F., Woodruff, L.G., Solano, Federico, Kilburn, J.E., and Fey, D.L., 2013, Geochemical and mineralogical data for soils of the conterminous United States: U.S. Geological Survey Data Series 801, 19 p., accessed October 6, 2015, at http://pubs.usgs.gov/ds/801/.

Suter, G.W., II, 1996, Toxicological benchmarks for screening contaminants of potential concern for effects of freshwater biota: Environmental Toxicology and Chemistry, v. 15, no. 7, p. 1232-1241. [Also available at http://dx.doi.org/10.1002/ etc.5620150731.]

Tallman, P., and Evans, D.T.W., 1994, Geology of stibnite mineralization at the Hunan Line prospects, central Newfoundland: Current Research, Newfoundland Department of Mines and Energy, Geological Survey Branch, Report 94-1, p. 263-271. [Also available at http://www.nr.gov.nl.ca/nr/mines/ geoscience/publications/currentresearch/1994/tallman.pdf.] 
Taylor, S.R., and McLennan, S.M., 1995, The geochemical evolution of the continental crust: Reviews of Geophysics, v. 33, no. 2, p. 241-265. [Also available at http://dx.doi.org/ 10.1029/95rg00262.]

Tourky, A.R., and Mousa, A.A., 1948, 150. Studies on some metal electrodes_-Part V-The amphoteric properties of antimony tri- and pentoxide: Journal of the Chemical Society (Resumed), p. 759-763. [Also available at http://dx.doi.org/10.1039/jr9480000759.]

United States Antimony Corp., 2016, Home page: United States Antimony Corp., accessed August 11, 2016, at http://www.usantimony.com/.

U.S. Environmental Protection Agency, 2009, Drinking water contaminants - Standards and regulations - National primary drinking water regulations - Table of contaminants: U.S. Environmental Protection Agency Web page, accessed October 5, 2015, at http://water.epa.gov/drink/ contaminants/\#Primary. (Updated tables are also available via https://www.epa.gov/risk/.)

U.S. Environmental Protection Agency, 2015, Regional screening levels (RSL) summary table_-November 2012: U.S. Environmental Protection Agency, accessed March 7, 2015, via http://www.epa.gov/reg3hwmd/risk/ human/rb-concentration_table/Generic_Tables/docs/ master_sl_table_run_NOV2015.pdf.]

U.S. Geological Survey, 1996, Global 30 arc-second elevation (GTOPO30): Reston, Va., U.S. Geological Survey dataset (digital elevation model), accessed June 23, 2014, at https://lta.cr.usgs.gov/GTOPO30.

U.S. Geological Survey, 2016, Antimony statistics, in Kelly, T.D., and Matos, G.R., comps., Historical statistics for mineral and material commodities in the United States (2016 version): U.S. Geological Survey Data Series 140, 4 p., accessed June 14, 2016, at http://minerals.usgs.gov/ minerals/pubs/historical-statistics/.

Wang, Ch'ung-yu, 1919, Antimony-Its history, chemistry, mineralogy, geology, metallurgy, uses, preparations, analysis, production, and valuation; with complete bibliographies ( $2 \mathrm{~d}$ ed.): London, United Kingdom, Charles Griffin \& Company, Ltd., 217 p.
Wang, Xiangqin, He, Mengchang, Xie, Jun, Xi, Jianghong, and Lu, Xiaofei, 2010, Heavy metal pollution of the world largest antimony mine-affected agricultural soils in Hunan Province (China): Journal of Soils and Sediments, v. 10, no. 5, p. 827-837. [Also available at http://dx.doi.org/ 10.1007/s11368-010-0196-4.]

White, D.E., 1940, Antimony deposits of a part of the Yellow Pine district, Valley County, Idaho: U.S. Geological Survey Bulletin 922-I, p. 247-279.

Wilson, N.J., Craw, D., and Hunter, K., 2004, Contributions of discharges from a historic antimony mine to metalloid content of river waters, Marlborough, New Zealand: Journal of Geochemical Exploration, v. 84, no. 3, p. 127-139. [Also available at http://dx.doi.org/10.1016/j.gexplo.2004.06.011.]

World Health Organization, 2008, Guidelines for drinking-water quality_Volume 1-Recommendations (3d ed., incorporating first and second addenda): Geneva, Switzerland, World Health Organization, 668 p., accessed October 6, 2015, at http://www.who.int/water_sanitation_health/dwq/fulltext.pdf.

Wu, Jiada, 1993, Antimony vein deposits of China: Ore Geology Reviews, v. 8, nos. 3-4, p. 213-232. [Also available at http://dx.doi.org/10.1016/0169-1368(93)90017-s.]

Wu, Fengchang, Fu, Zhiyou, Liu, Bijun, Mo, Changli, Chen, Bin, Corns, Warren, and Liao, Haiqing, 2011, Health risk associated with dietary co-exposure to high levels of antimony and arsenic in the world's largest antimony mine area: Science of the Total Environment, v. 409, no. 18, p. 3344-3351. [Also available at http://dx.doi.org/10.1016/ j.scitotenv.2011.05.033.]

Yang, D.-S., Shimizu, Masaaki, Shimazaki, Hidehiko, Li, X.-H., and Xie, Q.-L., 2006, Sulfur isotope geochemistry of the supergiant Xikuangshan Sb deposit, central Hunan, China-Constraints on sources of ore constituents: Resource Geology, v. 56, no. 4, p. 385-396. [Also available at http://dx.doi.org/10.1111/j.1751-3928.2006.tb00291.x.] 



\section{Barite (Barium)}

By Craig A. Johnson, Nadine M. Piatak, and M. Michael Miller

Chapter D of

Critical Mineral Resources of the United States-Economic and Environmental Geology and Prospects for Future Supply

Edited by Klaus J. Schulz, John H. DeYoung, Jr., Robert R. Seal II, and Dwight C. Bradley

Professional Paper 1802-D 


\section{Contents of Chapter D}

[Figure and table titles for all chapters are listed in the volume contents before the conversion factors table and list of abbreviations and symbols. A periodic table of the elements is on the inside front cover of the printed volume]

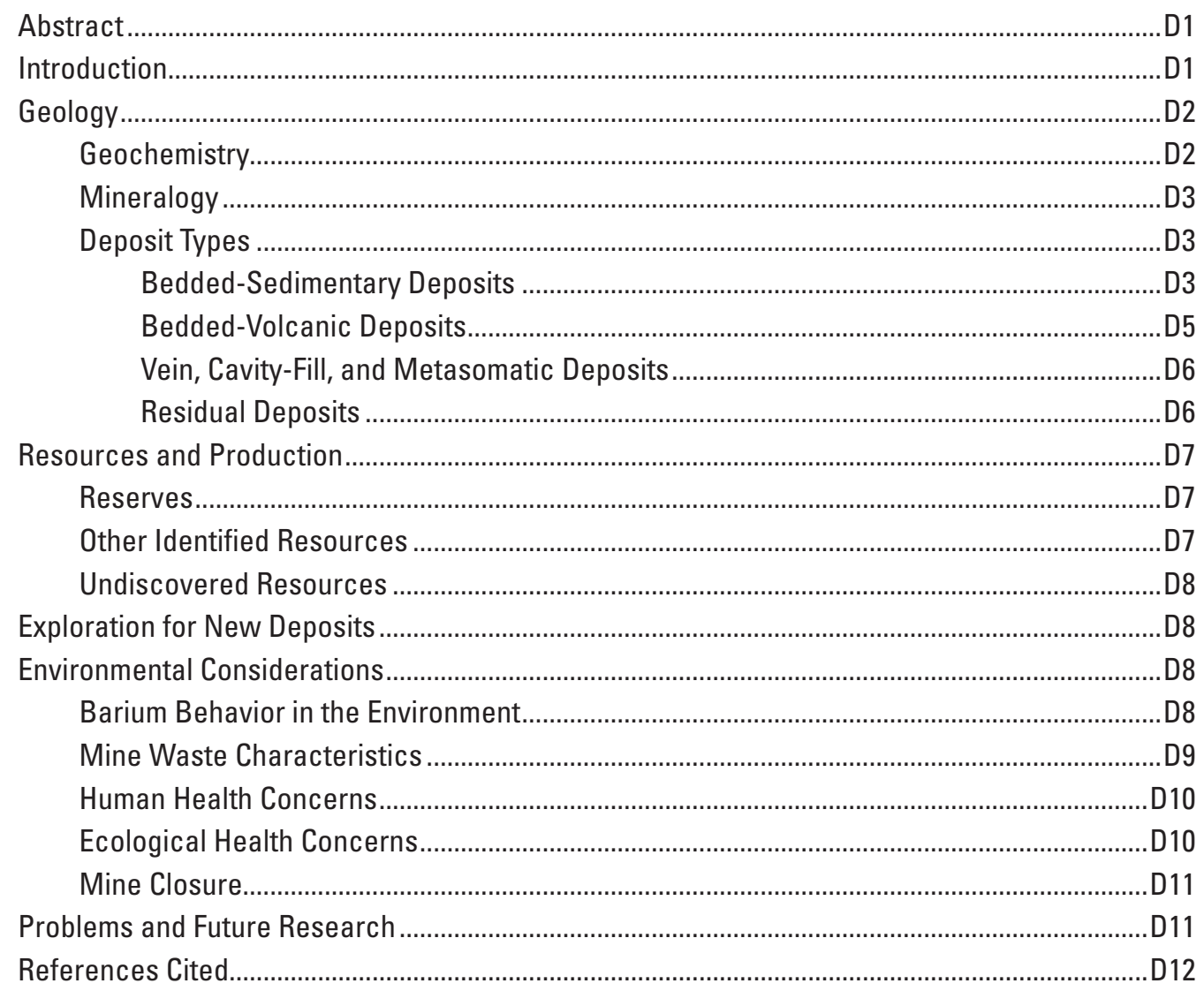




\title{
Barite (Barium)
}

\author{
By Craig A. Johnson, Nadine M. Piatak, and M. Michael Miller
}

\section{Abstract}

Barite (barium sulfate, $\mathrm{BaSO}_{4}$ ) is vital to the oil and gas industry because it is a key constituent of the mud used to drill oil and gas wells. Elemental barium is an additive in optical glass, ceramic glazes, and other products. Within the United States, barite is produced mainly from mines in Nevada. Imports in 2011 (the latest year for which complete data were available) accounted for 78 percent of domestic consumption and came mostly from China.

Barite deposits can be divided into the following four main types: bedded-sedimentary; bedded-volcanic; vein, cavity-fill, and metasomatic; and residual. Beddedsedimentary deposits, which are found in sedimentary rocks with characteristics of high biological productivity during sediment accumulation, are the major sources of barite production and account for the majority of reserves, both in the United States and worldwide. In 2013, China and India were the leading producers of barite, and they have large identified resources that position them to be significant producers for the foreseeable future. The potential for undiscovered barite resources in the United States and in many other countries is considerable, however. The expected tight supply and rising costs in the coming years will likely be met by increased production from such countries as Kazakhstan, Mexico, Morocco, and Vietnam.

Barium has limited mobility in the environment and exposed barium in the vicinity of barite mines poses minimal risk to human or ecosystem health. Of greater concern is the potential for acidic metal-bearing drainage at sites where the barite ores or waste rocks contain abundant sulfide minerals. This risk is lessened naturally if the host rocks at the site are acid-neutralizing, and the risk can also be lessened by engineering measures.

\section{Introduction}

Barite (barium sulfate, $\mathrm{BaSO}_{4}$ ) is an industrial mineral commodity that is used primarily in the drilling of oil and gas wells. The mineral commodity is also referred to as baryte or barytes. It is a key constituent of drilling mud, which is the fluid pumped into the oil or gas well to lubricate the bit and drill stem, remove rock chips, prevent collapse of well walls, and prevent blowouts if overpressured strata are encountered. Barite has an unusual combination of properties - high density, softness, and chemical inertness - that make it exceptionally well suited for this purpose. Other minor uses of the mineral include its use as an additive for friction materials, paints, plastics, rubbers, and other products; feedstock for chemical manufacturing; and shielding in X-ray and gammaray applications. Barium, which constitutes 59 percent of barite by weight, is used in ceramic glazes, enamels, optical glass, primers, signal flares, steel hardeners, welding fluxes, and a variety of other products. The mineral witherite (barium carbonate, $\mathrm{BaCO}_{3}$ ) is another source of barium that accounts for only a small fraction of current production. The barium in witherite is more highly concentrated than in barite (barium constitutes 70 percent of witherite, by weight). Furthermore, barium is more easily liberated from witherite than it is from barite because witherite is readily dissolved by acids. On the other hand, witherite normally occurs in deposits that are smaller and more discontinuous than barite deposits, and they are thus more difficult to mine.

Barite is a critical mineral commodity because of its uses in the exploration for and development of petroleum and natural gas resources. Drilling activity accounts for nearly 95 percent of domestic consumption and about 90 percent of global consumption. Economic deposits of barite are relatively common and are found in many countries. Although prices have risen substantially in recent years, the commodity remains relatively inexpensive. Thus, it is unlikely that the oil and gas industry will have a need for substitutes in the short term. All the likely substitutes (celestite, hematite, ilmenite, and magnetite) present significant drawbacks. The principal strategic concern with respect to barite is that adequate supplies be available at low cost in the geographic regions that are currently being explored for oil and gas resources and in geographic regions that will be explored in the future.

Until 1950, output of barite from U.S. mines equaled or exceeded domestic consumption. In succeeding years (fig. D1), domestic consumption outpaced production from U.S. mines by a steadily increasing margin, so that by 1980 , 


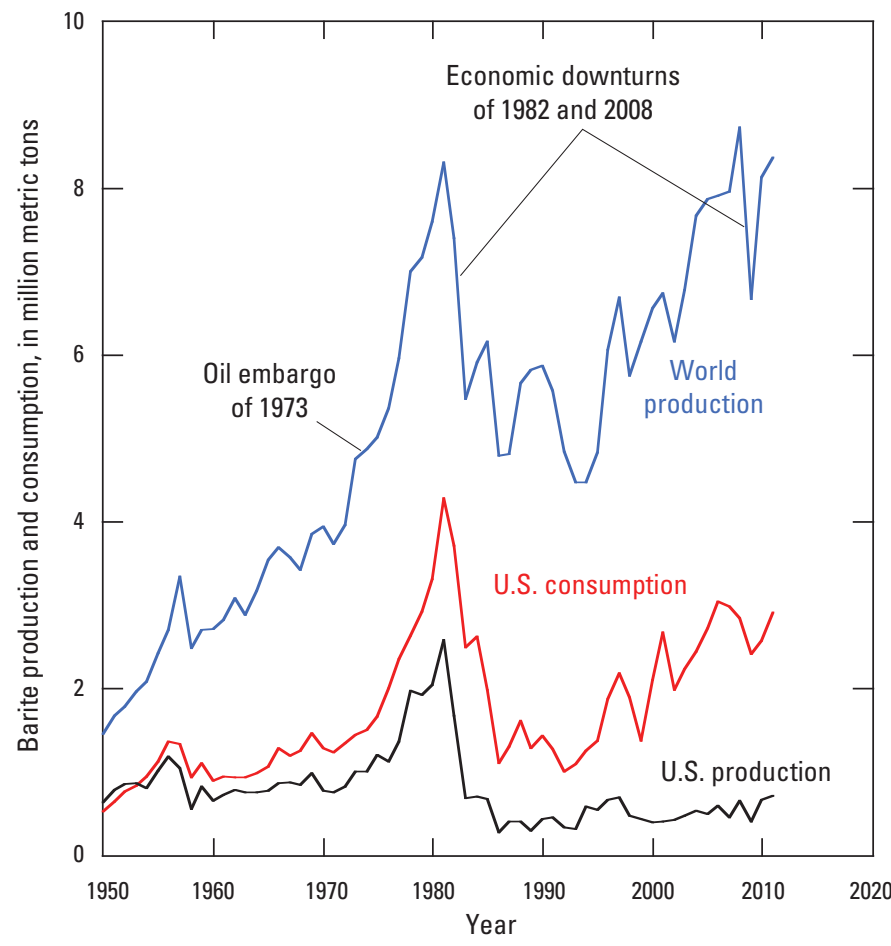

Figure D1. Graph showing barite world production, U.S. production, and U.S. consumption from 1950 to 2011. Data are from Kelly and Matos (2013).

imports accounted for some 46 percent of U.S. consumption. Barite production declined precipitously during the economic downturn of 1982. Since then, output from U.S. mines has remained relatively low, and increases in demand have been satisfied mainly by imported barite. In 2011 (the latest year for which complete data were available), import reliance was 78 percent (Miller, 2013).

Historically, domestic barite has come from mines in Arkansas, Georgia, Illinois, Missouri, Tennessee, and Nevada. At present, barite is produced primarily from mines in Nevada that exploit high-grade deposits; this barite requires only crushing, sizing, and jigging to meet the American Petroleum Institute (API) specifications for use in the oil industry. The API has two specifications for drilling-grade barite that differ only in specific gravity (SG) - 4.1 SG and 4.2 SG. Both specifications correspond to a barite content of about 90 weight percent. The 4.1 SG specification was introduced in 2010 at the request of Nevada barite producers to extend Nevada's barite reserves and avoid the major capital investments that would be required to continue producing 4.2 SG material. The majority of barite now mined and processed in Nevada is 4.1 SG material. Deposits that are lower in grade or that contain deleterious gangue minerals can require more involved and more expensive beneficiation procedures, including wet grinding, magnetic separation, and froth flotation.

The active U.S. mines are open pit operations. They produce neither coproducts nor byproducts, so mine output depends exclusively on the economics of barite. At some mines in other countries, fluorite $\left(\mathrm{CaF}_{2}\right.$, also known as fluorspar), galena $(\mathrm{PbS})$, sphalerite $(\mathrm{ZnS})$, and (or) gold- or silver-bearing minerals are present and are recovered, so production at some locations can depend partly on the economics of other mineral commodities. Drilling activity in the Great Plains of the United States, in the Western United States, and in Western Canada are the major markets for barite produced from Nevada mines. Drilling activity in the Gulf of Mexico and in the eastern and midwestern parts of the United States relies heavily on imported barite, mainly from China.

A wealth of information on the geology and geochemistry of barite can be found in previous overviews by de Brodtkorb (1989), Clark and others (1990), Brobst (1973, 1994), Harben and Kuzvart (1997), Hanor (2000), and Jewell (2000). Information on barite as a mineral commodity has been provided by Ampian (1985), Coffman and Kilgore (1986), Harben (2002), Mills (2006), Roskill Information Services, Ltd. (2006), and Miller (2012).

\section{Geology Geochemistry}

Barium occurs in the geologic environment mainly as the divalent cation $\mathrm{Ba}^{2+}$. This ion is larger than most other divalent cations, and, consequently, barium is not easily accommodated in common rock-forming minerals. During fractional crystallization of silicate magmas, barium becomes concentrated in the residual silicate liquid. It is also concentrated in silicate liquids produced by partial melting. The barium content of average upper continental crust is estimated to be 0.0624 weight percent (Rudnick and Gao, 2003). Granitic rocks typically have somewhat higher barium content than average continental crust, and basaltic rocks typically have somewhat lower barium content. The range of barium content of shales spans approximately the same range as the barium content of granitic rocks.

Barium substitutes extensively for the nearly-as-large $\mathrm{Pb}^{2+}$ and $\mathrm{Sr}^{2+}$ cations in minerals that contain these elements, and less extensively for the somewhat smaller $\mathrm{Ca}^{2+}$ and $\mathrm{K}^{+}$ ions; substitution for $\mathrm{K}^{+}$requires a coupled substitution to maintain charge balance. In common igneous rocks, barium is present as a trace or minor element in potassium feldspar and mica where it substitutes for $\mathrm{K}^{+}$. Less extensive substitution is seen for $\mathrm{Ca}^{2+}$ in amphibole, apatite, calcite, plagioclase feldspar, and pyroxene. In common sedimentary rocks and hydrothermal deposits, barium occurs mainly in barite or organic matter. The presence of trace amounts of barite in many sedimentary rocks reflects the fact that sulfate $\left(\mathrm{SO}_{4}^{2-}\right)$ is the stable form of sulfur in most Earth-surface environments, and the formation constant for barite (barium sulfate, $\mathrm{BaSO}_{4}$ ) is quite large. Although barite is highly stable in oxidizing (sulfate-stable) environments, it can be readily dissolved in reducing hydrogen sulfide $\left(\mathrm{H}_{2} \mathrm{~S}\right)$ stable environments. This attribute has important implications for the formation of barite deposits and for environmental aspects of barite mining. 


\section{Mineralogy}

Barite is typically white or colorless. Crystals tend to be tabular and have habits that reflect the orthorhombic symmetry of the barite lattice. Fibrous, nodular, and massive forms are also common. The mineral has a hardness of 3 to 3.5 on the Mohs scale, which is about the same hardness as copper, and it has a density of 4.48 grams per cubic centimeter $\left(\mathrm{g} / \mathrm{cm}^{3}\right)$, which is roughly twice that of common rocks. Barite has multiple good cleavages.

Natural barite is relatively pure, generally showing only minor replacement of barium by strontium (less than 7 percent) or lead. The relative purity is convenient from a resource perspective because commercially important properties that depend on mineral chemistry, such as density and solubility, can be expected to vary little no matter where the barite is found. Most barite deposits have low impurity levels because (a) deposits typically form as precipitates from aqueous fluids, and (b) barium partitions more strongly into the sulfate mineral than strontium, lead, and other potential impurities. Calcium replacement of barium is also restricted in natural occurrences.

Deposits of barite invariably contain gangue minerals, the abundance and identity of which vary from one deposit type to another. The most common gangue minerals are quartz or other forms of silica (chert, drusy quartz, and jasperoid), sulfide minerals (galena, marcasite, pyrite, and sphalerite), clay minerals, carbonates (calcite and siderite), and iron oxides. Organic matter can also be present at concentrations up to several weight percent.

Witherite is colorless. Crystals commonly take the form of pseudohexagonal dipyramids. Witherite has a hardness of 3.5 on the Mohs scale and a density of $4.3 \mathrm{~g} / \mathrm{cm}^{3}$. It is readily distinguished from barite by the fact that it effervesces in cold acids. The mineral typically contains small amounts of strontium and calcium substituting for barium. Witherite is normally found in veins within sedimentary rocks where it is associated with galena and, less commonly, anglesite, barite, and barytocalcite. Witherite can also form as an alteration product of barite and can itself be altered to barite.

Other barium minerals are known, but none occur in deposits as large, concentrated, and widespread as barite. Although these are not currently mined, some may merit consideration as future sources of barium, particularly where they occur in deposits that have other valuable minerals. Noteworthy examples are benstonite $\left((\mathrm{Ba}, \mathrm{Sr})_{6}(\mathrm{Ca}, \mathrm{Mn})_{6} \mathrm{Mg}\left(\mathrm{CO}_{3}\right)_{13}\right)$, which is a secondary mineral in various barium-rich rocks (Hood and Steidl, 1973); sanbornite $\left(\mathrm{BaSi}_{2} \mathrm{O}_{5}\right)$, which occurs in metasomatic zones associated with granitic rocks in the Big Creek-Rush Creek district of California (Alfors and others, 1965); and celsian $\left(\mathrm{BaAl}_{2} \mathrm{Si}_{2} \mathrm{O}_{8}\right)$, which is locally abundant in a metamorphosed barium deposit near Aberfeldy, Scotland (Coats and others, 1980). Other minerals that can contain significant barium are todorokite $\left((\mathrm{Na}, \mathrm{Ca}, \mathrm{K}, \mathrm{Ba}, \mathrm{Sr})_{0.3-0.7}(\mathrm{Mn}, \mathrm{Mg}, \mathrm{Al})_{6} \mathrm{O}_{12} \bullet 3.2-4.5 \mathrm{H}_{2} \mathrm{O}\right)$, which is a common constituent of deep-sea ferromanganese nodules, and romanechite $\left(\mathrm{BaMn}_{9} \mathrm{O}_{16}(\mathrm{OH})_{4}\right)$, which is a mineral currently mined for manganese.

\section{Deposit Types}

Barite deposits can be classified into the following four groups on the basis of physical characteristics, geochemical characteristics, and geologic setting: (1) bedded-sedimentary; (2) bedded-volcanic; (3) vein, cavity-fill, and metasomatic; and (4) residual. This classification scheme resembles schemes that have been used previously (Brobst, 1958; Clark and others, 1990), but it has been modified somewhat to accommodate newly discovered deposits and results of more recent geologic studies. The locations of deposits or districts that are either relatively large or representative of the four groups are shown in figure D2. Numerous other deposits, both mined and unmined, have also been identified (Roskill Information Services, Ltd., 2006).

\section{Bedded-Sedimentary Deposits}

Bedded-sedimentary deposits are stratiform bodies of massive or near-massive barite within sedimentary successions that typically contain organic-rich shale, mudstone, or chert. The deposits can be quite large, with resources up to tens of millions of tons, and they tend to occur in districts rather than as isolated occurrences. The barite beds vary in thickness from centimeters to 100 meters or more and can extend for kilometers along strike. The barite can be dark in color, reflecting the presence of organic carbon, and it commonly occurs in one of the following four forms: massive, laminated, nodular, or rosette. Gangue minerals include clays, iron oxides (hematite, limonite, or magnetite), quartz, and pyrite or other sulfide minerals. Beneficiation can be simpler than for ores from other deposit types. Bedded-sedimentary deposits are the major source of worldwide barite production, and they also account for the majority of world reserves.

The bedded-sedimentary type of barite deposit can be associated with stratiform sulfide mineralization of sufficient quantity and grade that the districts are better known as resources for lead, zinc, or other metals. In principle, sulfide mineralization could be employed as an exploration guide to undiscovered barite deposits, but the economics normally favor the reverse: barite is employed as a guide to sulfide deposits. The nature of the association between barite and sulfides varies considerably. Barite and sulfide crystals can be intergrown, as in the Red Dog deposit in Alaska (Kelley and others, 2004); barite and sulfide layers can be thinly interbedded, as in the Tom and Jason deposits in the Selwyn basin of northwestern Canada (Goodfellow, 2004); or discrete barite bodies can lie adjacent to sulfide deposits, as in the Meggen and Rammelsberg deposits in Germany (Krebs, 1981; Large and Walcher, 1999), the Ballynoe and Silvermines deposits in Ireland (Mullane and Kinnaird, 1998), and the Aggeneys-Gamsberg district in South Africa (McClung and others, 2007). Barite deposits can also occur in the same district as stratiform sulfide deposits but be separated from them by distances of hundreds or thousands of meters, as in the Tea, Gary, Moose, Pete, and Oro barite deposits of 


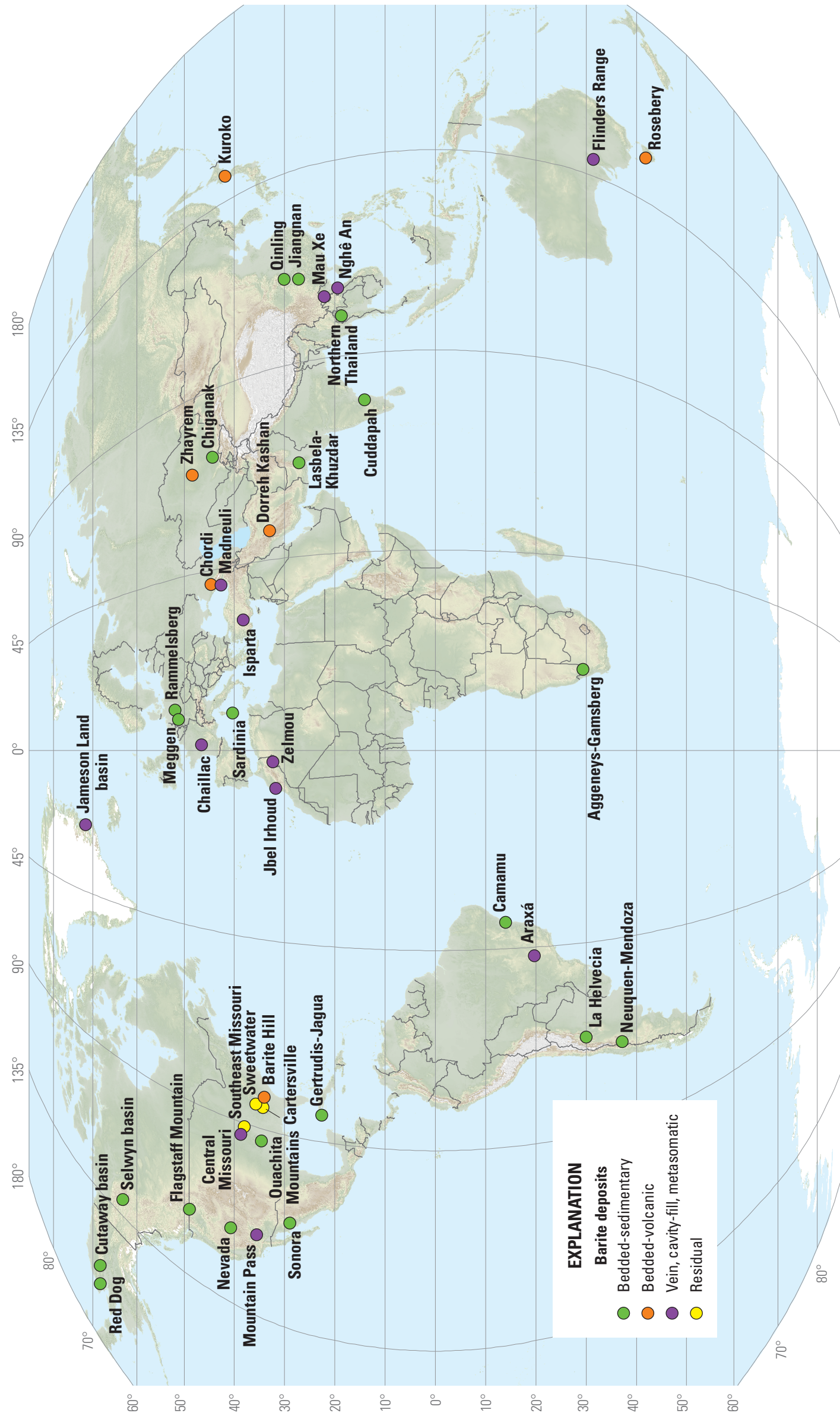

흔

空䆓

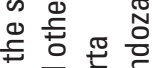

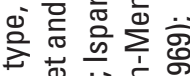

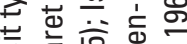

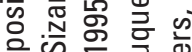

क क

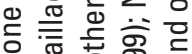

든 는 응

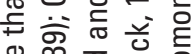

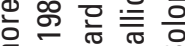

Q

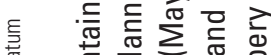

要 $\quad$ 政

要

语

旁

늘

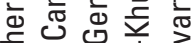

3 is

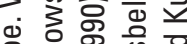

을응

要

잉

응 엠

入े 힌

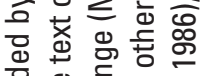

记

흐는

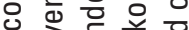

论言言 盖

잉

은

응

드응 응 뜨

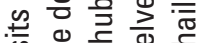

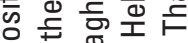

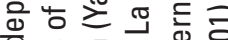

응

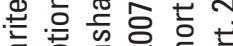

西.

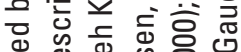

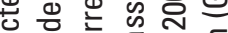

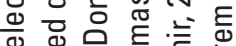

舟

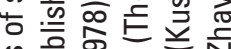

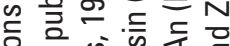

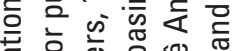

政

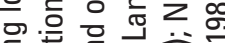

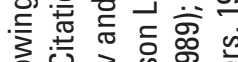

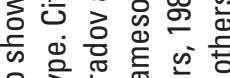
논 다을

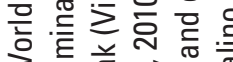

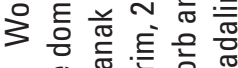
언. os

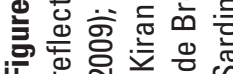


the Selwyn basin (Lydon and others, 1985; Butrenchuk and Hancock, 1997) and the Anarraaq, Gull Creek, Moil, and Su barite deposits of the Red Dog district (Johnson and others, 2004). Other bedded-sedimentary barite deposits occur without sulfides. Examples of these include the deposits of the Ouachita Mountains of Arkansas (Zimmermann and Amstutz, 1989), the Nevada barite belt (Papke, 1984), the Cutaway basin in Alaska (Schmidt and others, 2009), the Sonora area of Mexico (Poole and others, 1991), the Cuddapah district in India (Neelakantam and Roy, 1979), and the Qinling and Jiangnan regions in southern China (Wang and Li, 1991; Wang, 1996).

Bedded-sedimentary barite associated with sulfide mineralization owes its origin to subsea-floor fluid flow systems that can span lateral distances of hundreds of kilometers or more; these flow systems are directly or indirectly related to the flow systems that give rise to the metal sulfide deposits (Lydon and others, 1985; Emsbo, 2000). The fluids typically migrate through pore spaces in buried sediments and sedimentary rocks toward extensional fault zones located along the margins of depositional basins. Barite deposits form where the ascending fluids, which carry $\mathrm{Ba}^{2+}$ ions scavenged from organic matter or from trace barite in the underlying sediments, encounter and mix with sulfate-bearing pore fluids or seawater. Where the mixing occurs within the sediment, barite precipitates as interstitial cement or replacements of preexisting minerals, such as calcite. Where the mixing occurs by fluid seepage onto the sea floor, barite particles form in the water column and then accumulate on the sediment surface. Because barite is not decomposed by seawater, preexisting deposits can be reworked by sea-floor erosion, and the barite can become reconcentrated in submarine channels.

The origin of bedded-sedimentary barite that lacks sulfide mineralization is more controversial. This deposit type has been attributed to an oceanographic process that operates beneath waters with high biological productivity (Jewell, 2000). Decomposition of sinking organic matter promotes anoxic conditions by consuming dissolved oxygen, and it also releases organic-bound barium. The released barium combines with seawater sulfate to form barite, which accumulates on the sea floor at the interface between anoxic and oxic water masses. An alternative proposal (Lydon and others, 1985) holds that the deposits form at sea-floor vents for fluids whose chemical composition, temperature, or oxidation state are not conducive to sulfide precipitation. This proposal has been strengthened by the discovery of barite deposits on the modern continental margins at locations where sedimentary formation waters are emerging from fault-controlled seeps (Torres and others, 2003; Clark and others, 2004; Koski and Hein, 2004; Johnson and others, 2009).

Bedded-sedimentary barite deposits form in marine basins in association with sediments characteristic of high biological productivity. The deposits are most common in sedimentary strata of early or middle Paleozoic age, but they have also been found in strata of Archean, Proterozoic, and Mesozoic age. Concentrations of barite nodules have been identified in Cenozoic age rocks (Bogoch and others, 1987;
Stamatakis and Hein, 1993), but there are no identified deposits of Cenozoic age that are of sufficient grade and size to consider mining. The presence or absence of sulfide mineralization has been proposed to reflect different tectonic settings for the depositional basins, one of which is underlain by continental crust - a source of zinc and lead (Maynard and Okita, 1991). This proposal has been controversial (Turner, 1992), but tectonic setting undoubtedly influences sulfide formation in some way because it can affect important parameters of the ore-forming process, including the availability of heat to drive fluid movement, the nature of the fault systems that serve as channels for flow, and the structure and oxidation state of the overlying basin.

\section{Bedded-Volcanic Deposits}

Bedded-volcanic deposits are stratiform bodies of massive or near-massive barite within stratigraphic successions containing igneous rocks - typically both felsic and mafic volcanic varieties - and sedimentary rocks. The barite can occur in large high-grade deposits (up to 90 percent $\mathrm{BaSO}_{4}$ ) or can be intergrown or interbedded with copper, lead, zinc, or gold- or silver-bearing sulfide minerals. The deposits tend to occur in districts, and individual barite \pm sulfide bodies can be closely spaced enough that both barite and metals are exploited by a single mining operation. Barite resources at individual mines can range up to millions of tons. Gangue minerals are typically clays, quartz, or sulfides. Whereas bedded-volcanic deposits have been significant sources of barite in the past (in Japan, for example; Marumo, 1989), they are presently a minor source compared with beddedsedimentary deposits.

Examples of bedded-volcanic deposits are the kurokotype deposits of northern Honshu and southern Hokkaido, Japan (many of which are better known for their copper, lead, precious metals, and zinc; Marumo, 1989), the Barite Hill deposit in the Carolina slate belt of South Carolina (Clark and others, 1999), and deposits that occur in a belt extending westward from the Madneuli deposit in the Republic of Georgia through Turkey and Bulgaria to northern Algeria (Kekeliya and others, 1984; Migineishvili, 2005).

Bedded-volcanic barite deposits form at submarine volcanic centers at divergent, convergent, and, in some cases, transform plate boundaries (Marumo, 1989; Herzig and others, 1993; Hein and others, 1999). Barium is scavenged from the volcanic edifice and underlying rocks by seawater that is heated by magmas and circulated by convection. In convergent-margin volcanic-arc settings, additional fluid may be supplied to the convection system by crystallizing magmas. Barite deposits form where the hot barium-bearing fluids are expelled onto the sea floor and encounter cold sulfate-bearing seawater. Like the bedded-sedimentary deposits, the beddedvolcanic deposits have analogs on the modern sea floor, but these are located near active submarine volcanoes mostly away from continental margins (Kusakabe and others, 1990; Urabe and Kusakabe, 1990). 


\section{Vein, Cavity-Fill, and Metasomatic Deposits}

Barite deposits included in the vein, cavity-fill, and metasomatic classification occupy faults, breccia zones, solution-collapse, or other fluid-permeable structures in which barite has either filled open spaces or replaced adjacent rock. The deposits are commonly tabular and extend along structures, often discontinuously, that can be traced for hundreds or thousands of meters. The vein deposits can attain thicknesses of several tens of meters. Gangue minerals include carbonates (calcite, siderite), fluorite, quartz, and pyrite or other sulfide minerals. The deposits tend to occur in districts or in linear distributions. This deposit type has been a source of highpurity barite for use in fillers and ceramics, which generally requires a grade of at least 95 percent $\mathrm{BaSO}_{4}$. In some mining operations, barite is a byproduct or coproduct of fluorite, lead, or zinc production. The economic advantage of producing barite as a byproduct or coproduct from deposits of this type tends, however, to be offset by higher mining costs because underground mines or large open pits are required to exploit ore zones that commonly have steep dips.

Examples of vein barite deposits are found in the Culpeper, Hartford-Deerfield, and Newark basins in the Eastern United States (Robinson and Woodruff, 1988), the North Pennine and South Pennine orefields of England (Ixner and Vaughan, 1993), and the Greater Caucasus in the Republic of Georgia (particularly the Chordi deposit) (Tvalchrelidze and Shcheglov, 1990). Some vein barite deposits are located in districts that are better known for their lead-zinc sulfide deposits (Mississippi Valley-type), as in the Pennine orefields. A direct association with Mississippi Valley-type sulfide mineralization is characteristic of cavityfill barite deposits, such as those of the Central Missouri and Southeast Missouri districts, the Sweetwater district of Tennessee (Leach, 1980; Kaiser and others, 1987), and the Jbel Irhoud and Zelmou deposits of Morocco (Valenza and others, 2000). Cavity-fill deposits are more irregular in form; they tend to be restricted to a particular sedimentary stratum or sequence of strata. District-wide zoning is apparent in rare cases, as in the South Pennine orefield where a region of barite-dominant deposits is bounded on the east by a region of fluorite-dominant deposits and on the west by a region of calcite-dominant deposits.

Metasomatic barite deposits included in this grouping are associated with alkalic or carbonatite complexes. The best example in the United States is found at Mountain Pass in California, where a body of rock that has been mined for rare-earth elements contains approximately 20 to 25 percent barite (Castor and Nason, 2004). The barite is not presently recovered. The Araxá deposit, which lies within the alkalineultramafic Barreiro complex in Minas Gerais, Brazil, is capped by a 150 - to 230 -meter-thick regolith that has been leached of carbonate minerals and contains approximately 20 percent barite (Woolley, 1987). The Mau Xe deposit in northern Vietnam is another carbonatite-associated deposit that is composed of about 51 percent barite (Kusnír, 2000).
These deposits are resources for other mined commodities that are more valuable than barite - rare-earth elements for Mountain Pass and both rare-earth elements and niobium for Araxá and Mau Xe. Thus, any barite production from them would be as a byproduct or coproduct. The same is likely to be true for other examples of this deposit type.

In detail, deposits of the vein, cavity-fill, and metasomatic category have diverse origins, but they share a basic genetic attribute- the ore constituents are transported by one or more high-temperature fluids (100 degrees Celsius or hotter) that are channeled along structurally controlled pathways. Depending on the specific location, the source of ore constituents varies from predominantly sedimentary rocks to predominantly igneous rocks, as has been shown for the deposits of central Europe (Dill and Nielsen, 1987). Barite associated with carbonatite complexes is of igneous origin but can be either a precipitate from hydrothermal fluids or a crystallization product of a carbonate melt. The mechanism by which fluids were heated also varies from one location to another. The fluids that formed the U.S. midcontinent deposits were heated as they circulated to deep levels in an extensional tectonic setting where the geothermal gradient was elevated, whereas the fluids that formed the central Europe deposits were heated by igneous intrusions (Dill and Nielsen, 1987). In carbonatite-associated deposits, heat was supplied by intruded carbonatite magma. The tectonic settings are also diverse. Many vein deposits are found in narrow rift basins that contain red beds and other terrigenous sedimentary rocks, whereas cavity-fill deposits are commonly found in carbonate platforms that developed along the margins of marine basins. Carbonatites are unusual rocks that originate by low degrees of partial melting of mantle material beneath continental rifts.

\section{Residual Deposits}

Residual barite deposits are poorly consolidated materials that form by weathering of preexisting deposits. Clay minerals, quartz, and unweathered rock fragments are typically present in the deposits. Iron oxides, metal sulfides, and sulfide weathering products may also be present. Within the United States, residual deposits are found in the Cartersville area of Georgia (Reade and others, 1980), the Southeast Missouri district (Leach, 1980; Kaiser and others, 1987), and the Sweetwater district of Tennessee (Kesler, 1996). These deposits formed by weathering of cavity-fill barite mineralization contained in limestone or dolostone host rocks. Residual barite deposits can also form from weathering of other deposit types. For example, baritehematite gossan at the Mount Lyell Mine in western Tasmania was produced by weathering of bedded-volcanic barite and sulfide mineralization (Solomon and others, 1969). At Araxá, Brazil, the defined ore reserve is a weathered regolith leached of carbonate minerals (Woolley, 1987). At Mount Lyell and Araxá, weathering resulted in residual enrichment of barite and upgrading of the deposit. 


\section{Resources and Production}

\section{Reserves}

Barite reserves tend to be defined only a few years prior to production because (a) drilling activity - the major market for barite-fluctuates in ways that are difficult to forecast farther in advance, and (b) the ease of extraction and ore processing allows for faster and less expensive mine startup than for many other mined commodities. Consequently, there is a general tendency for mined reserves to be replaced regularly by new reserves. A boom in oil and gas exploration resulting from a combination of increasing global demand for oil and gas, high oil prices, and expanded use of hydraulic fracturing in development of unconventional oil and gas resources has resulted in dramatically increased global consumption of barite. Reserves of high-grade barite are being depleted, but they exceed demand by a large margin, both in the United States and worldwide. Thus, this mineral commodity is unlikely to become severely depleted in the foreseeable future.

Problems with costs of current sources of supply are evident, however. Consumers have become dependent on low-cost barite supplied by China and India, which together accounted for about 65 percent of world production in 2011. Prices for Chinese and Indian barite have risen substantially in recent years, with prices for barite from China increasing nearly sixfold in the past 10 years. Consumers are seeking alternative sources of low-cost barite to reduce the dependence on China and India for supplies. Global barite resources are extensive, but the exploration and development of these resources may not proceed in direct response to changes in the price or supply of the commodity. In recent years, even while barite prices rose steeply, little exploration took place. Currently, however, indications are that exploration and development work is expanding domestically and internationally in such countries as Kazakhstan, Liberia, Mexico, and Zimbabwe.

An additional consideration is that transportation is a major factor in the total cost of barite (Coffman and Kilgore, 1986). Long transport distances can add substantially to the overall price of the commodity, particularly if shipping is by rail or truck rather than by sea. Thus, supplies of lowcost barite for oil and gas producers depends partly on the proximity of barite mines to the drilling activity and whether transportation can be by low-cost ocean shipping.

Solutions to problems of tight supply and rising costs will likely include increased production from such countries as Kazakhstan, Mexico, Morocco, and Vietnam, and new production from nontraditional sources, such as Greenland and Zimbabwe. Other solutions that have been proposed include developing application-appropriate specifications and grades in order to preserve existing barite resources, using blended weighting agents, expanding the use of managed-pressure drilling techniques, and implementing recycling (Newcaster, 2012). Barite consumption is forecast to increase by about 30 percent by 2016, with likely fluctuations in the availability of supply.

\section{Other Identified Resources}

Recent production from existing mines, by country, is shown in figure D3. Total world production averaged 7.97 million metric tons per year for the 5-year period starting in 2007. China was the leading producer $(4,020$ thousand metric tons per year, or 50 percent of global production), India was second (1,190 thousand metric tons per year, or 15 percent), Morocco was third (630 thousand metric tons per year, or 7.9 percent), and the United States was fourth (574 thousand metric tons per year, or 7.2 percent). The top eight countries accounted for about 92 percent of global production.

In 2011, output from U.S. mines was 710,000 metric tons (Miller, 2013). For the foreseeable future, Nevada mines are expected to be the major domestic producers. Current producers have gathered extensive data on Nevada barite resources to plan future mining activities, and at least one producer was expanding production capacity. Renewed production is possible from Arkansas, which last mined barite in the early 1980s and has identified economic deposits in the Ouachita National Forest that could be developed. In addition, important new resources have been identified during the past 20 years in northern Alaska. These are bedded-sedimentary barite deposits at the Red Dog district in the western Brooks Range and in the Cutaway basin in the central Brooks Range. The barite endowment of the Red Dog district could be in excess of 1 billion metric tons (Kelley and Jennings, 2004). These deposits are not currently mined, and most lie far from roads or other existing infrastructure; however, they are in close proximity to a region of active oil and gas exploration on the north slope of Alaska and to possible future exploration

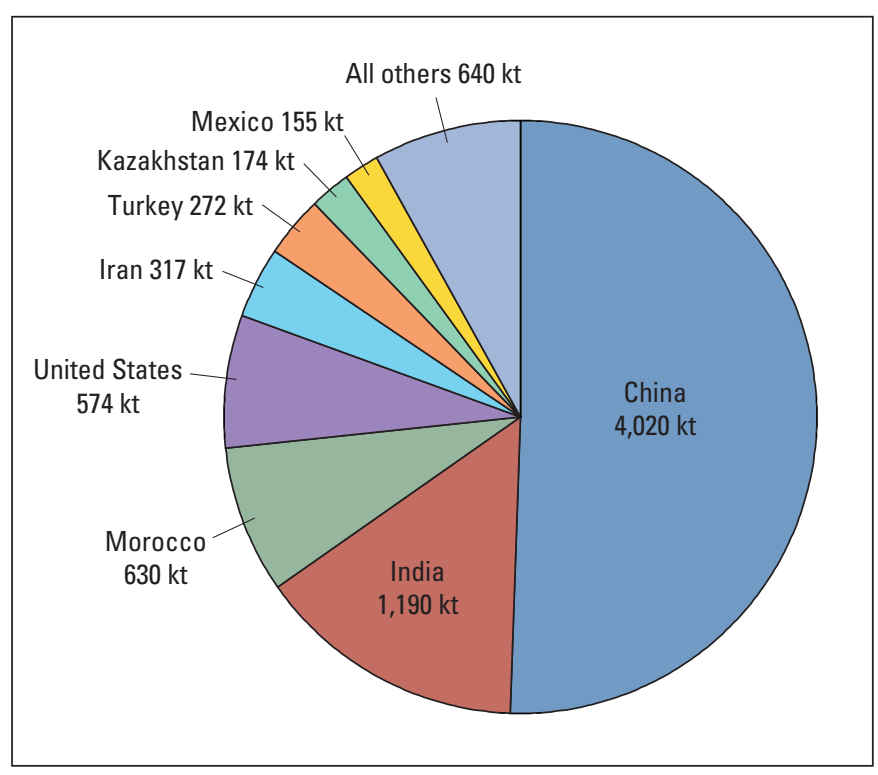

Figure D3. Pie chart showing average annual barite production for the period 2007-11, by country and amount (in thousand metric tons [kt]). World production during this 5-year period averaged 7.97 million metric tons per year. Data are from Miller (2012). 
in Arctic regions of North America, Europe, and Asia. The Cutaway basin deposits lie within the National Petroleum Reserve-Alaska.

The largest identified resources of barite on a global scale are found in the Qinling and Jiangnan regions of southern China and the Cuddapah district of India. Tonnage estimates have varied widely, but all suggest that the amounts of barite available for mining are quite large. For example, recent estimates for one of the larger deposits in China, the Gangxi deposit in Hunan Province, have ranged from more than 80 million metric tons (Roskill Information Services, Ltd., 2006) to 453 million metric tons grading between 63.6 and 77.3 percent $\mathrm{BaSO}_{4}$ (Kamitani and others, 2007). The compilation of published data by Kamitani and others (2007) lists seven barite deposits in southern China that exceed 5 million metric tons. The Mangampeta deposit in the Cuddapah district in India has been estimated to contain 73.4 million metric tons with a specific gravity of 3.8 or greater, 50 percent of which has a specific gravity of 4.2 or greater (Clark and Basu, 1999).

\section{Undiscovered Resources}

The potential for the discovery of new barite resources in the United States and in many other locations in the world is considerable. Bedded-sedimentary deposits are probably the most attractive target for exploration because they have the potential to produce mud-grade barite with minimal ore processing. In addition, the most common geologic setting for this deposit type - organic-rich chert-mudstone-shale successions of early to middle Paleozoic age - exists in many regions of the world. Barite is easily overlooked or misidentified, so there is good potential for unrecognized deposits in recognized districts. Figure D2 provides a guide to a number of districts with current or past production from beddedsedimentary deposits, but many others likely occur.

Another potential source is byproduct barite or barium at mineral deposits that will be mined in the future primarily to recover other mineral commodities. Foremost among these are carbonatite deposits, which are potential sources of rare-earth elements and several other mineral commodities, and baritedominant hydrothermal deposits in relatively shallow water along active volcanic arc systems.

\section{Exploration for New Deposits}

Exploration for barite deposits has traditionally been carried out by direct examination of outcrop or by chemical analysis of stream sediment in areas where the geologic setting is favorable. Barium in stream sediment, in both the fine size fraction and the heavy-mineral fraction, has proven to be a good guide to bedded mineralization (Coats and others, 1981).
Geophysical methods have been used to delineate deposits or to identify barite accumulations that are shallowly buried. Gravity methods exploit the large density contrast that exists between massive barite bodies and most of the rock types that enclose them (Uhley and Scharon, 1954; Schmidt and others, 2009). Very-low-frequency electromagnetic methods have also provided useful information where barite, which has low resistivity, is contained in conductive host rocks (Coats and others, 1981).

\section{Environmental Considerations}

\section{Barium Behavior in the Environment}

Barium has limited mobility in the environment because it tends to form insoluble compounds under common Earth-surface conditions and does not form soluble organic complexes. The barium released from minerals during weathering tends to precipitate as barite (barium sulfate, $\mathrm{BaSO}_{4}$ ), witherite (barium carbonate, $\mathrm{BaCO}_{3}$ ), or other minerals, or to adsorb onto clay minerals, oxides, or hydroxides. Barite is practically insoluble in oxidizing environments and is highly resistant to weathering. The solubility of most barium compounds increases as conditions become reducing or acidic (Jaritz, 2004).

Barium in the environment comes mostly from natural rock weathering, but anthropogenic contributions can be important, particularly emissions related to copper smelting, steel production, and automobile manufacturing (Reimann and de Caritat, 1998). Combustion of coal and diesel and incineration of waste both release bariumbearing particulates to the atmosphere (Agency for Toxic Substances and Disease Registry, 2007). In the United States, atmospheric barium concentrations have been reported to range from 0.00015 to 0.95 microgram per cubic meter (U.S. Environmental Protection Agency, 1984). Barium concentrations in soil usually reflect the composition of the underlying bedrock, but dispersal of fly ash or sludge from landfills and application of phosphate fertilizers can lead to elevated levels of barium in the soil (International Programme on Chemical Safety, 2001; Kabata-Pendias and Mukherjee, 2007). Surface soils (top 5 centimeters [cm]) in the conterminous United States average 518 parts per million (ppm) barium with values ranging from less than 5 to $4,770 \mathrm{ppm}$ (parts per million equals grams per metric ton; $1 \mathrm{ppm}$ equals 0.0001 percent; Smith and others, 2013).

The concentration of barium in natural waters is controlled by the solubility of barium compounds, the tendency of barium to adsorb onto particulates, and the availability of dissolved sulfate or carbonate to form insoluble salts (Agency for Toxic Substances and Disease Registry, 2007). The concentration of barium in surface waters ranges from 7 to 15,000 parts per billion (ppb) (Jaritz, 2004). 
Gaillardet and others (2003) reported a worldwide river water average of $23 \mathrm{ppb}$. Suspended solids and sediments commonly contain more barium than the water. The global average for barium in suspended river sediment is $522 \mathrm{ppb}$ (Viers and others, 2009). A study of the Rhine River near Darmstadt showed a barium concentration of $480 \mathrm{ppb}$ in the suspended material compared with $39 \mathrm{ppb}$ in the water (Hoffmann and Lieser, 1987). Barium in seawater averages $6 \mathrm{ppb}$, which is lower than the concentration in most freshwater because barite tends to precipitate as freshwater enters the ocean (Jaritz, 2004). The barium content in seawater varies among different oceans and with latitude and depth (International Programme on Chemical Safety, 2001).

The contents of barium and other elements in waters, sediments, and soils in the vicinity of barite deposits can be above average, depending on the type of deposit, the extent of the outcrop of ore and overburden, the climate, and other factors. Barium can be leached by groundwaters in some locations, such as in regions of Kentucky, northern Illinois, New Mexico, and Pennsylvania, where the presence of barite in bedrock has given rise to relatively high barium concentrations in groundwater (Agency for Toxic Substances and Disease Registry, 2007).

Barite in drilling muds can be recycled in some situations. The procedure involves removing barite from the mud by centrifuging and returning it to the active drilling system; this recycling of barite can help ensure compliance with fluid discharge requirements in environmentally sensitive areas. For the most part, barite is recycled only because drilling mud is continuously circulated through a reserve pit to allow cuttings to settle, and the mud is then reused during the drilling of a particular well.

The U.S. Environmental Protection Agency classifies oil and gas drilling fluids as "special wastes," which are exempt from amendments to the Resource Conservation and Recovery Act (P.L. 94-580) issued by Congress in 1980. As a result, the methods for handling and disposal of oilfield waste fluids vary from one State to another (McFarland and others, 2009). Various methods are employed to dispose of drilling fluids containing barite, including onsite burial, landfill disposal, land application, salt cavern injection, and disposal at sea. The most common practice on land is onsite burial. After well completion, the fluid is pumped into the reserve pit, allowed to dry, and then either mixed with soil from the pit berms or simply covered with soil. At other locations, drilling fluids are transported to a landfill or are land-applied, which allows naturally occurring microbes in the soil to metabolize, transform, and assimilate the waste constituents. Salt cavern injection involves pumping waste drilling fluids into cavities in underground salt deposits. Specific regulations apply to ocean disposal of drilling fluids, particularly for fluids that are oil based or synthetic (Drilling Waste Management Information System, undated).

Barium in electronic devices and other manufactured products is not recovered. Recycling supplies less than
1 percent of worldwide barium consumption (Graedel and others, 2011).

\section{Mine Waste Characteristics}

The solid wastes produced at barite mines vary widely in volume, mineralogy, and chemistry because of the variation in the types and sizes of deposits, in the compositions of the host rock and gangue, and in the ore processing methods. At bedded deposit mines, barite of high purity can often be obtained with minimal processing. Waste from operations of this type consists of host rock and gangue minerals. Common host rock types include alluvium, black shale, chert, dolostone, limestone, mudstone, and siltstone; igneous rocks can be important in some locations. Common gangue minerals include carbonates, clays, iron oxides, quartz, and minor sulfide minerals. Sulfide minerals are typically sparse enough that waste rock piles and tailings impoundments have low potential for acid drainage, as at the Argenta Mine in Nevada (U.S. Bureau of Land Management, 2010). In locations where bedded deposits are hosted by dolostone or limestone, the potential for acid drainage is lessened by the capacity of these rock types to neutralize acidity. This phenomenon may be responsible for the lack of acidity in groundwaters in the vicinity of the Mangampeta Mine in India (Nagaraju and others, 2006a). Waste rock can be of sufficiently high quality that the material is suitable for use as aggregate. On the other hand, wall rocks exposed in open pits can be acid-generating (U.S. Bureau of Land Management, 2010), in which case, pit lakes that develop after mine closure warrant remediation. In addition, soils developed on waste piles can have elevated concentrations of barium and other metals contained in the host rocks, as in the region surrounding the Mangampeta Mine in India where soils locally contain significant amounts of boron, chromium, and nickel (Raghu, 2001).

Vein barite deposits and bedded barite closely associated with massive sulfide mineralization normally require froth flotation to separate barite from fluorite, galena, pyrite, sphalerite, or other minerals. At these operations, waste rock and tailings can have higher sulfide contents and correspondingly greater potential for acidic metal-bearing drainage. The acid-neutralization capacity of host rocks and gangue minerals can be a significant control of acid drainage. Granite host rocks, for example, have less acid-neutralizing capacity than limestones or dolostones. At mines where carbonate rocks are important constituents of the bedrock, acid drainage can be lessened naturally, such as at the Magnet Cove copper-leadzinc-gold-barite mine in Nova Scotia, where surface waters are acidic only very locally (Whitehead and Macdonald, 1998). Unlike copper, iron, lead, manganese, zinc, and many other metals, barium is not particularly mobile in acid drainage because barite resists dissolution. Dispersal of barium from mining operations is mainly by physical erosion and transport of barite particles. 


\section{Human Health Concerns}

No adverse human health effects have been linked to barite mining in the United States. In general, the toxicity of barium depends on its chemical form. Soluble barium compounds, such as barium chloride, barium hydroxide, and barium nitrate, can be toxic to humans, animals, and plants, whereas barium sulfate (barite) is effectively nontoxic because the barium is not bioaccessible. In fact, barium sulfate is routinely ingested by patients undergoing gastrointestinal $\mathrm{X}$-rays (Jaritz, 2004). Barium carbonate is only slightly soluble in water, but it is toxic to humans because it dissolves in the gastrointestinal tract (Agency for Toxic Substances and Disease Registry, 2007). There is no evidence that barium compounds are carcinogenic or cause genotoxicity in humans or animals, although the available data are limited (International Programme on Chemical Safety, 2001).

The barium content of drinking water, food, and soils is rarely high enough to present a human health concern. Dietary intake of barium is mostly from drinking water. The maximum contaminant level for drinking water in the United States is 2.0 ppm (U.S. Environmental Protection Agency, 2009), whereas the World Health Organization guideline is $0.7 \mathrm{ppm}$ (World Health Organization, 2004). Drinking waters in the United States have a median barium concentration of $0.043 \mathrm{ppm}$, and more than 90 percent of U.S. cities were found to contain less than $0.1 \mathrm{ppm}$ (Dufor and Becker, 1964). High concentrations of barium in drinking water can result in gastrointestinal disturbances and muscular weakness, and lead eventually to high blood pressure and cardiovascular disease (Agency for Toxic Substances and Disease Registry, 2007; Health Canada, 2012). For barium concentrations up to $10 \mathrm{ppm}$, however - which have been observed in certain regions of the United States, including Illinois and Iowa (Brenniman and others, 1981) - the links to high blood pressure and cardiovascular risk factors have been called into question (Wones and others, 1990). In some situations, food can be a significant source of dietary barium. Dairy and meat products tend to be lower in barium than vegetables, but Brazil nuts, seaweed, fish, and some plants can be high in barium (Jaritz, 2004; Agency for Toxic Substances and Disease Registry, 2007). Consumption of vegetables grown on barite-contaminated garden soils has been suggested as a human exposure pathway near a barite mine in northwestern Croatia (Frančišković-Bilinski and others, 2007). For soils, the noncancer screening level is $1,500 \mathrm{ppm}$ in residential settings and 19,000 ppm in industrial settings (U.S. Environmental Protection Agency, 2012). The level for industrial settings is many times higher than the $4,770 \mathrm{ppm}$ maximum concentration reported in a survey of soils in the conterminous United States (Smith and others, 2013), but the level for residential settings is exceeded by some of the reported soil concentrations.
The individuals at greatest risk of barium exposure are workers at mines, ore processing plants, and manufacturing facilities for barium-containing products. Epidemiological studies have reported cases of baritosis stemming from dust exposure during mining and grinding of barium ores (Pendergrass and Greening, 1953; Doig, 1976; Seaton and others, 1986). Baritosis is a benign lung disease that does not result in medical disability and appears to be reversible on a time scale of several years (Seaton and others, 1986). In the United States, workplace exposure to soluble barium compounds is limited to 500 micrograms of barium per cubic meter of air per 8-hour period (Occupational Safety and Health Administration, 2013). Some barite deposits contain enough quartz that respirable silica can be a concern at mine and mill sites. Risks can be mitigated, however, by using dust masks and water sprayers or other dust suppression techniques (Mills, 2006).

\section{Ecological Health Concerns}

No adverse toxicological effects of barium on plants or wildlife have been reported near barite mines or elsewhere. Barium accumulates only slightly from soil to plant and from plant to animal (International Programme on Chemical Safety, 2001); however, high soil barium contents have been shown to inhibit growth in some terrestrial plants (International Programme on Chemical Safety, 2001). For the United States, a soil screening guideline of $500 \mathrm{ppm}$ has been proposed for phytotoxicity (Efroymson and others, 1997), but this benchmark has only limited data to support it. Some soluble barium compounds are toxic to animals; for example, barium carbonate - the mineral witherite where it occurs naturally - is sufficiently toxic that it is used as a rodenticide (Jaritz, 2004).

In the aquatic environment, barium can have toxic effects on some organisms (water fleas, or Daphnia magna), but limited data suggest that the risk to fish and aquatic plants is likely to be less. Barium accumulates only slightly in aquatic life (Reimann and de Caritat, 1998). Suter (1996) proposed secondary acute and chronic water-quality benchmarks for freshwater biota of 69.1 and $3.8 \mathrm{ppb}$, respectively, but these values were determined using fewer data than normally required to establish levels. Lethal concentrations for water fleas and freshwater amphipods (Hyalella azteca; 50 percent mortality in laboratory tests) are greater than $1,000 \mathrm{ppb}$, which is significantly higher than the proposed benchmark (Borgmann and others, 2005).

Ecological health concerns associated with the mining and processing of barite ores arise more from disturbance of host rocks and associated minerals than from the barite itself. The carbonaceous shales or siltstones associated with many bedded-sedimentary barite deposits typically contain minor amounts of pyrite (1 to 2 weight percent on average) and 
significant amounts of some metals (chromium, manganese, vanadium, and zinc typically exceed $100 \mathrm{ppm}$ ) (QuinbyHunt and others, 1989). Weathering of these lithologies in waste rock piles can potentially lead to acidic metal-bearing drainage, the release of which can have deleterious effects on aquatic life. The same potential would exist at barite mining operations that treat sulfide-bearing ores and produce sulfide-bearing tailings. As discussed, the presence of acidneutralizing rocks would tend to lessen this problem.

Drilling mud is disposed of at or near the drilling site. Dispersal of this material can have deleterious effects on plants, including slowed growth of both seeds and plant, and reduction in yields, although these effects could also relate to other constituents of drilling mud (Ferrante, 1981). Barite alone has been shown to cause toxicity to freshwater fish only at very high concentrations (Ferrante, 1981). In some jurisdictions, such as Alaska, restrictions are placed on the metal content of the barite used in drilling mud (less than $3 \mathrm{ppm}$ cadmium and less than 1 ppm mercury; Harben, 2002).

\section{Mine Closure}

Most active barite mines worldwide, and all active mines in the United States, are open pit operations. After mining ceases, open pits can be left open and fenced. A pit lake will form if the depth of the excavation exceeds the depth of the water table. The lake water may or may not be acidic and metal-bearing depending on the abundance of sulfide minerals and the acid-neutralizing capacity of rocks exposed in the pit walls and immediate vicinity. Poor water quality may require that the lake be drained and the water treated, followed by backfilling of the pit. Openings to any underground workings are typically sealed.

Waste rock piles, mill sites, and other surface disturbances are graded and contoured. The area is typically revegetated by seeding or planting. At least one scrub species (Prosopis juliflora) grows prolifically and sequesters barium and metals (Nagaraju and others, 2006b). For some waste rock and tailings, a possible alternative to grading and revegetation is removal and sale of the material for use as aggregate or fill. This has been common practice at barite mines in France, Germany, Spain, and the United Kingdom (European Commission, 2009).

\section{Problems and Future Research}

Several unresolved questions regarding the origin of bedded-sedimentary barite deposits have implications for exploration. Perhaps the most important is whether the barium is derived from organic matter that decomposes as it sinks to the floor of a sedimentary basin or from fluids ascending faults or other structurally controlled pathways toward the basin floor. The correct answer to this question may differ from one district to another and will dictate whether new deposits are likely to be sought in locations where water column oxicanoxic transitions intersected the basin floor or in the vicinity of basin-bounding faults.

Other outstanding questions regard the relationship of barite deposits to deposits of other useful minerals. The reason that there is a close spatial and temporal relationship between bedded-sedimentary barite deposits and zinc-leadsilver sulfide deposits in some sedimentary basins but not in others is not fully understood. Evidence has been presented that bedded-sedimentary barite deposits are one member of a large family of mineral deposits in sedimentary basins that includes not only lead-zinc-silver deposits but also deposits of gold, phosphate rock, vanadium, and several other mineral commodities (Emsbo, 2000; Emsbo and others, 2005). If predictable relationships are identified among these deposit types on the basis of accurate models for their origin, then explorers could likely be able to identify stratigraphic intervals in sedimentary basins that present the highest probability of new discoveries for a variety of mineral commodities.

Finally, if pursued, advances in mineral processing could make it possible for barite to be profitably recovered as a coproduct or byproduct where ores are being mined for zinc, lead, rare-earth elements, or other mineral commodities. These advances could help meet the broader goal of increasing the efficient use of mined materials and reducing the amount of mining and ore processing waste that requires remediation. 


\section{References Cited}

Note: All Web links listed were active as of the access date but may no longer be available.

Agency for Toxic Substances and Disease Registry, 2007, Toxicological profile for barium and barium compounds: Atlanta, Ga., U.S. Department of Health and Human Services, Public Health Service, August, 184 p. plus 4 appendixes, accessed March 20, 2013, at http://www.atsdr.cdc.gov/toxprofiles/tp24.pdf.

Ahsan, S.N., and Mallick, K.A., 1999, Geology and genesis of barite deposits of Lasbela and Khuzdar districts, Balochistan, Pakistan: Resource Geology, v. 49, p. 105-111.

Alfors, J.T., Stinson, M.C., Matthews, R.A., and Pabst, Adolph, 1965, Seven new barium minerals from eastern Fresno County, California: American Mineralogist, v. 50, p. 314-340.

Ampian, S.G., 1985, Barite, in Knoerr, A.W., ed., Mineral facts and problems, 1985 ed.: U.S. Bureau of Mines Bulletin 675, p. 65-74.

Bogoch, Ron, Buchbinder, Binyamin, and Nielsen, Heimo, 1987, Petrography, geochemistry, and evolution of barite concretions in Eocene pelagic chalks from Israel: Journal of Sedimentary Petrology, v. 57, no. 3, p. 522-529. [Also available at http://dx.doi.org/10.1306/212F8B7F-2B2411D7-8648000102C1865D.]

Borgmann, Uwe, Couillard, Yves, Doyle, Patrick, and Dixon, D.G., 2005, Toxicity of sixty-three metals and metalloids to Hyalella azteca at two levels of water hardness: Environmental Toxicology and Chemistry, v. 24, no. 3, p. 641-652. [Also available at http://dx.doi.org/ 10.1897/04-177R.1.]

Brenniman, G.R., Kojola, W.H., Levy, P.S., Carnow, B.W., and Namekata, Takeshi, 1981, High barium levels in public drinking water and its association with elevated blood pressure: Archives of Environmental Health, v. 36, no. 1, p. 28-32. [Also available at http://dx.doi.org/10.1080/ 00039896.1981.10667602.]

Brobst, D.A., 1958, Barite resources of the United States: U.S. Geological Survey Bulletin 1072-B, 130 p. [Also available at http://pubs.er.usgs.gov/publication/b1072B.]

Brobst, D.A., 1973, Barite, in Brobst, D.A., and Pratt, W.P., eds., United States mineral resources: U.S. Geological Survey Professional Paper 820, p. 75-84. [Also available at http://pubs.er.usgs.gov/publication/pp820.]

Brobst, D.A., 1994, Barium minerals, in Carr, D.D., ed., Industrial minerals and rocks, 6th ed.: Littleton, Colo., Society for Mining, Metallurgy, and Exploration, Inc., p. 125-134.
Butrenchuk, S.B., and Hancock, K.D., 1997, Barite in British Columbia: British Columbia Ministry of Employment and Investment, Geological Survey Branch Open File 1997-16, 145 p. [Also available at http://www.empr.gov.bc.ca/Mining/ Geoscience/PublicationsCatalogue/OpenFiles/1997/Documents/ OF1997-16.pdf.]

Cassedanne, Jacques, 1989, Brazilian stratabound barite ore fields, in de Brodtkorb, M.K., ed., Nonmetalliferous stratabound ore fields: New York, N.Y., Van Nostrand Reinhold, p. 69-92.

Castor, S.B., and Nason, G.W., 2004, Mountain Pass rare earth deposit, California, in Castor, S.B., Papke, K.G., and Meeuwig, R.O., eds., Betting on industrial mineralsProceedings of the 39th Forum on the Geology of Industrial Minerals, Reno/Sparks, Nevada, May 18-24, 2003: Reno, Nev., Nevada Bureau of Mines and Geology Special Publication 33, p. 68-81.

Clark, S.H.B., and Basu, P.K., 1999, Geologic setting and origin of the Mangampeta barite deposit, India, in Stanley, C.J., and others, eds., Mineral deposits-Processes to processing - Proceedings of the Fifth Biennial SGA Meeting and the Tenth Quadrennial IAGOD Symposium, London, United Kingdom, 22-25 August 1999: Rotterdam, Netherlands, A.A. Balkema, p. 1085-1088.

Clark, S.H.B., Gallagher, M.J., and Poole, F.G., 1990, World barite resources-A review of recent production patterns and a genetic classification: Transactions of the Institution of Mining and Metallurgy-Section B-Applied Earth Sciences, v. 99, p. B125-B132.

Clark, S.H.B., Gray, K.J., and Back, J.M., 1999, Geology of the Barite Hill gold-silver deposit in the southern Carolina slate belt: Economic Geology, v. 94, p. 1329-1346.

Clark, S.H.B., Poole, F.G., and Wang, Zongcheng, 2004, Comparison of some sediment-hosted, stratiform barite deposits in China, the United States, and India: Ore Geology Reviews, v. 24, p. 85-101.

Coats, J.S., Smith, C.G., Fortey, N.J., Gallagher, M.J., May, Frank, and McCourt, W.J., 1980, Stratabound barium-zinc mineralization in Dalradian schist near Aberfeldy, Scotland: Transactions of the Institution of Mining and Metallurgy — Section B-Applied Earth Sciences, v. 89, p. B110-B129.

Coats, J.S., Smith, C.G., Gallagher, M.J., May, Frank, Parker, M.E., and Fortey, N.J., 1981, Stratabound barium-zinc mineralisation in Dalradian schist near Aberfeldy, ScotlandFinal report: National Environment Research Council Institute of Geological Sciences Mineral Reconnaissance Programme Report 40, 116 p. 
Coffman, J.S., and Kilgore, C.C., 1986, Barite availabilityMarket economy countries, a minerals availability appraisal: U.S. Bureau of Mines Information Circular 9115, 25 p.

de Brodtkorb, M.K., ed., 1989, Nonmetalliferous stratabound ore fields: New York, N.Y., Van Nostrand Reinhold, 332 p.

de Brodtkorb, M.K., Schalamu, I.B.A., and Ametrano, Silvia, 1989, Barite and celestite stratabound ore fields in Argentina, in de Brodtkorb, M.K., ed., Nonmetalliferous stratabound ore fields: New York, N.Y., Van Nostrand Reinhold, p. $41-68$.

Dill, Harald, and Nielsen, Heimo, 1987, Geochemical and geological constraints on the formation of unconformityrelated vein baryte deposits of central Europe: Journal of the Geological Society of London, v. 144, no. 1, p. 97-105.

Doig, A.T., 1976, Baritosis-A benign pneumoconiosis: Thorax, v. 31, no. 1, p. 30-39.

Drilling Waste Management Information System, [undated], Fact sheet-Discharge to ocean: Drilling Waste Management Information System, accessed July 19, 2013, at http://web.ead.anl.gov/dwm/techdesc/discharge/.

Dufor, C.N., and Becker, Edith, 1964, Public water supplies of the 100 largest cities in the United States, 1962: U.S. Geological Survey Water Supply Paper 1812, 364 p.

Efroymson, R.A., Will, M.E., Suter, G.W., II, and Wooten, A.C., 1997, Toxicological benchmarks for screening contaminants of potential concern for effects on terrestrial plants - 1997 revision, report prepared for the U.S. Department of Energy by Lockheed Martin Energy Systems, Inc.: Oak Ridge, Tenn., Oak Ridge National Laboratory, ES/ER/TM-85/R3, November, 68 p. and two appendixes, accessed March 13, 2013, at http://www.esd.ornl.gov/programs/ecorisk/documents/ tm85r3.pdf.

Emsbo, Poul, 2000, Gold in sedex deposits: Reviews in Economic Geology, v. 13, p. 427-437.

Emsbo, Poul, Hofstra, A.H., Johnson, C.A., Koenig, Alan, Grauch, Richard, Zhang, Xing-chun, Hu, Rui-zhong, Su, Wen-chao, and Pi, Dao-hui, 2005, Lower Cambrian metallogenesis of south China-Interplay between diverse basinal hydrothermal fluids and marine chemistry, in Mao, Jingwen, and Bierlein, F.P., eds., Mineral deposits research-Meeting the global challengeProceedings of the eighth biennial SGA meeting, Beijing, China, 18-21 August, 2005: Berlin, Springer-Verlag, p. $115-118$.

European Commission, 2009, Reference document on best available techniques for management of tailings and waste-rock in mining activities: Brussels, Belgium, European Commission, 511 p., accessed March 13, 2013, at http://eippcb.jrc.es/reference/BREF/mmr_adopted 0109.pdf.
Ferrante, J.G., 1981, Fate and effects of whole drilling fluids and fluid components in terrestrial and freshwater ecosystems - A literature review: U.S. Environmental Protection Agency, EPA 600/4-81-031, 50 p., accessed November 6, 2013, via http:/nepis.epa.gov/EPA/html/ Pubs/pubalpha_F.html.

Frančišković-Bilinski, Stanislav, Bilinski, Halka, Grbac, Renata, Žunić, Josip, Nečemer, Marijan, and Hanžel, Darko, 2007, Multidisciplinary work on barium contamination of the karstic upper Kupa River drainage basin (Croatia and Slovenia) - Calling for watershed management: Environmental Geochemistry and Health, v. 29, no. 1, p. 69-79.

Gaillardet, J., Viers, J., and Dupré, B., 2003, Trace elements in river waters, in Drever, J.I., ed., Surface and ground water, weathering, and soils, v. 5 of Holland, H.D., and Turekian, K.K., eds., Treatise on geochemistry: Oxford, United Kingdom, Elsevier-Pergamon, p. 225-272. [Also available at http://www.sciencedirect.com/science/article/pii/ B0080437516051653.]

Gauert, Christoph, 2001, Genetic aspects of mineralization and chemical zonation in the sediment-hosted Dalnesapadny $\mathrm{Pb}-\mathrm{Zn}$-Cu-barite deposit, Zhayrem, central Kazakhstan, in Piestrzynski, Adam, Speczik, S., Pasava, J., Gize, A., Sass-Gustkiewics, M., Leach, D., Muchez, Philippe, Oszczepalski, S., Brown, A., Blundell, D.J., Kotlinski, R., Herzig, P., Plimer, I., Kozlowski, A., Mikulski, S., Seltmann, R., Heinrich, C.A., Kucha, H., Stumpfl, E., and Thalhammer, O., eds., Mineral deposits at the beginning of the 21 st century-Proceedings of the joint SGA-SEG meeting, Krakow, Poland, 26-29 August 2001: Lisse, Netherlands, Swets \& Zeitlinger, p. 273-276.

Goodfellow, W.D., 2004, Geology, genesis and exploration of SEDEX deposits, with emphasis on the Selwyn basin, Canada, in Deb, Mihir, and Goodfellow, W.D., eds., Sediment-hosted lead-zinc deposits - Attributes and models of some major deposits in India, Australia, and Canada: New Delhi, India, Narosa Publishing, p. 24-99.

Graedel, T.E., Allwood, Julian, Birat, J.-P., Buchert, Matthias, Hagelüken, Christian, Reck, B.K., Sibley, S.F., and Sonnemann, Guido, 2011, What do we know about metal recycling rates?: Journal of Industrial Ecology, v. 15, no. 3, p. 355-366. [Also available at http://dx.doi.org/10.1111/j.1530-9290.2011.00342.x.]

Hahn, Lothar, Koch, K.E., and Wittekindt, Hanspeter, 1986, Outline of the geology and mineral potential of Thailand: BGR Geologisches Jahrbuch Reihe B, no. 59, 49 p.

Hanor, J.S., 2000, Barite-celestine geochemistry and environments of formation: Reviews in Mineralogy and Geochemistry, v. 40, p. 193-275. [Also available at http://dx.doi.org/10.2138/rmg.2000.40.4.] 
Harben, P.W., 2002, The industrial minerals handybookA guide to markets, specifications, and prices, 4th ed.: London, United Kingdom, Industrial Minerals Information Services, $412 \mathrm{p}$.

Harben, P.W., and Kuzvart, Milos, 1997, Industrial mineralsA global geology: London, United Kingdom, Industrial Minerals Information Plc., 476 p.

Health Canada, 2012, Guidelines for Canadian drinking water quality - Summary table: Ottawa, Ontario, Canada, Health Canada, Water, Air and Climate Change Bureau, Healthy Environments and Consumer Safety Branch, accessed February 21, 2013, at http:/www.hc-sc.gc.ca/ewh-semt/ alt_formats/pdf/pubs/water-eau/2012-sum_guide-res_ recom/2012-sum_guide-res_recom-eng.pdf.

Hein, J.R., Koski, R.A., Embley, R.W., Reid, J.A., and Chang, S.-W., 1999, Diffuse-flow hydrothermal field in an oceanic fracture zone setting, northeast Pacific-Deposit composition: Exploration and Mining Geology, v. 8, nos. 3-4, p. 299-322.

Herzig, P.M., Hannington, M.D., Fouquet, Y., Stackelberg, U., and Petersen, S., 1993, Gold-rich polymetallic sulfides from the Lau back arc and implications for the geochemistry of gold in sea-floor hydrothermal systems of the southwest Pacific: Economic Geology, v. 88, p. 2182-2209. [Also available at http://econgeol.geoscienceworld.org/content/ 88/8/2182.full.pdf.]

Hoffmann, Peter, and Lieser, K.H., 1987, Determination of metals in biological and environmental samples: The Science of the Total Environment, v. 64, nos. 1-2, p. 1-12.

Hood, W.C., and Steidl, P.F., 1973, Synthesis of benstonite at room temperature: American Mineralogist, v. 58, p. 341-342.

International Programme on Chemical Safety, 2001, Barium and barium compounds: Geneva, Switzerland, World Health Organization Concise International Chemical Assessment Document 33, 57 p., accessed March 8, 2013, at http://www.who.int/ipcs/publications/cicad/en/cicad33.pdf.

Ixner, R.A., and Vaughan, D.J., 1993, Lead-zinc-fluoritebaryte deposits of the Pennines, North Wales and the Mendips, in Pattrick, R.A.D., and Polya, D.A., eds., Mineralization in the British Isles: London, United Kingdom, Chapman and Hall, p. 355-418.

Jaritz, Michael, 2004, Barium, in Merian, E., Anke, M., Ihnat, M., and Stoeppler, M., eds., Elements and their compounds in the environment ( $2 \mathrm{~d}$ ed.): Weinheim, Germany, Wiley-VCH, p. 627-634. [Also available at http://dx.doi.org/10.1002/9783527619634.]
Jewell, P.W., 2000, Bedded barite in the geologic record, in Glenn, C.R., Prévôt-Lucas, Liliane, and Lucas, Jacques, Marine authigenesis_-From global to microbial: Society of Economic Paleontologists and Mineralogists Special Publication 66, p. 147-161. [Also available at http://www.surfacegeology.earth.utah.edu/publications/ Jewell_SPEM_SpecPub_2000.pdf.]

Johnson, C.A., Emsbo, Poul, Poole, F.G., and Rye, R.O., 2009, Sulfur- and oxygen-isotopes in sediment-hosted stratiform barite deposits: Geochimica et Cosmochimica Acta, v. 73, p. 133-147. [Also available at http://dx.doi.org/10.1016/ j.gca.2008.10.011.]

Johnson, C.A., Kelley, K.D., and Leach, D.L., 2004, Sulfur and oxygen isotopes in barite deposits of the western Brooks Range, Alaska, and implications for the origin of the Red Dog massive sulfide deposits: Economic Geology, v. 99, p. 1435-1448. [Also available at http://dx.doi.org/ 10.2113/gsecongeo.99.7.1435.]

Kabata-Pendias, Alina, and Mukherjee, A.B., 2007, Trace elements from soil to human: Berlin, Germany, SpringerVerlag, $550 \mathrm{p}$.

Kaiser, C.J., Kelly, W.C., Wagner, R.J., and Shanks, W.C., III, 1987, Geologic and geochemical controls of mineralization in the southeast Missouri barite district: Economic Geology, v. 82, p. 719-734. [Also available at http://dx.doi.org/ 10.2113/gsecongeo.82.3.719.]

Kamitani, Masaharu, Okumura, Kimio, Teraoka, Yoji, Miyano, Sumiko, and Watanabe, Yasusi, 2007, The mineral deposit data of mineral resources map of east Asia: Geological Survey of Japan, scale 1:3,000,000, text.

Kekeliya, S.A., Tvalchrelidze, A.G., and Yaroshevich, V.Z., 1984, The geological and physicochemical conditions of formation of massive-sulfide-barite-base-metal deposits: International Geology Review, v. 26, p. 1437-1444.

Kelley, K.D., and Jennings, Scott, 2004, A special issue devoted to barite and $\mathrm{Zn}-\mathrm{Pb}-\mathrm{Ag}$ deposits in the Red Dog district, western Brooks Range, northern Alaska: Economic Geology, v. 99, p. 1267-1280. [Also available at http://dx.doi.org/10.2113/gsecongeo.99.7.1267.]

Kelley, K.D., Leach, D.L., Johnson, C.A., Clark, J.L., Fayek, Mostafa, Slack, J.F., Anderson, V.M., Ayuso, R.A., and Ridley, W.I., 2004, Textural, compositional, and sulfur isotope variations of sulfide minerals in the Red Dog $\mathrm{Zn}-\mathrm{Pb}$ Ag deposits, Brooks Range, Alaska-Implications for ore formation: Economic Geology, v. 99, p. 1509-1532. [Also available at http://dx.doi.org/10.2113/gsecongeo.99.7.1509.] 
Kelly, T.D., and Matos, G.R., 2013, Historical statistics for mineral and material commodities in the United States: U.S. Geological Survey Data Series 140, accessed March 22, 2013, at http://minerals.usgs.gov/ds/2005/140/.

Kesler, S.E., 1996, Appalachian Mississippi Valley-type deposits-Paleoaquifers and brine provinces, in Sangster, D.F., ed., Carbonate-hosted lead-zinc deposits[Society of Economic Geologists] 75th anniversary volume: Littleton, Colo: Society of Economic Geologists Special Publication 4, p. 29-57.

Kiran Yildirim, Demet, 2010, Mineralogy and petrology of barite mineralization in Sarkikaraagac-Isparta, Turkey: Geological Society of America Abstracts with Programs, v. 42 , p. 110 .

Koski, R.A., and Hein, J.R., 2004, Stratiform barite deposits in the Roberts Mountains allochthon, Nevada-A review of potential analogs in modern sea-floor environments, chap. H of Contributions to industrial-minerals research, Bliss, J.D., Moyle, P.R., and Long, K.R., eds.: U.S. Geological Survey Bulletin 2209-H, 17 p. [Also available at http://pubs.usgs.gov/bul/b2209-h/.]

Krebs, Wolfgang, 1981, The geology of the Meggen ore deposit, in Wolfe, K.H., ed., Handbook of stratabound and stratiform ore deposits, v. 9: Amsterdam, Netherlands, Elsevier, p. 509-549.

Kusakabe, Minoru, Mayeda, Shingo, and Hakamura, Eizo, 1990, $\mathrm{S}, \mathrm{O}$ and $\mathrm{Sr}$ isotope systematics of active vent materials from the Mariana backarc basin spreading axis at $18^{\circ} \mathrm{N}$ : Earth and Planetary Science Letters, v. 100, p. 275-282.

Kusnír, Imrich, 2000, Mineral resources of Vietnam: Acta Montanistica Slovaca, v. 2, p. 165-172. [Also available at http://actamont.tuke.sk/pdf/2000/n2/10kusnir.pdf.]

Large, D., and Walcher, E., 1999, The Rammelsberg massive sulphide $\mathrm{Cu}-\mathrm{Zn}-\mathrm{Pb}$-Ba-deposit, Germany-An example of sediment-hosted, massive sulphide mineralisation: Mineralium Deposita, v. 34, issues 5-6, p. 522-538.

Leach, D.L., 1980, Nature of mineralizing fluids in the barite deposits of central and southeast Missouri: Economic Geology, v. 75, p. 1168-1180. [Also available at http://dx.doi.org/10.2113/gsecongeo.75.8.1168.]

Lydon, J.W., Goodfellow, W.D., and Jonasson, I.R., 1985, A general model for stratiform baritic deposits of the Selwyn basin, Yukon Territory and District of Mackenzie: Geological Survey of Canada Paper 85-1A, p. 651-660.

Marumo, Katsumi, 1989, The barite ore fields of kuroko-type of Japan, in de Brodtkorb, M.K., ed., Nonmetalliferous stratabound ore fields: New York, N.Y., Van Nostrand Reinhold, p. 201-231.
Maynard, J.B., and Okita, P.M., 1991, Bedded barite deposits of the United States, Canada, Germany, and China-Two major types based on tectonic setting: Economic Geology, v. 86, p. 364-376. [Also available at http://dx.doi.org/ 10.2113/gsecongeo.86.2.364.]

Maynard, J.B., Morton, John, Valdes-Nodarse, E.L., and Diaz-Carmona, A., 1995, Sr isotopes of bedded baritesGuide to distinguishing basins with $\mathrm{Pb}-\mathrm{Zn}$ mineralization: Economic Geology, v. 90, p. 2058-2064. [Also available at http://dx.doi.org/10.2113/gsecongeo.90.7.2058.]

McCallum, W.S., 1990, Oraparinna barite deposits: Australasian Institute of Mining and Metallurgy Monograph Series 14, p. 1159-1161.

McClung, C.R., Gutzmer, Jens, Beukes, N.J., Mezger, Klaus, Strauss, Harald, and Gertloff, Ellen, 2007, Geochemistry of bedded barite of the Mesoproterozoic AggeneysGamsberg Broken Hill-type district, South Africa: Mineralium Deposita, v. 42, p. 537-549.

McFarland, M.L., Feagley, S.E., and Provin, T.L., 2009, Land application of drilling fluids - Landowner considerations: College Station, Tex., Texas AgriLife Extension Service, 5 p., accessed September 24, 2013, at http://soiltesting. tamu.edu/publications/SCS-2009-08.pdf.

Migineishvili, Ramaz, 2005, Hybrid nature of the Madneuli $\mathrm{Cu}-\mathrm{Au}$ deposit, Georgia: Geochemistry, Mineralogy and Petrology [Bulgarian Academy of Sciences], v. 43, p. 128-132.

Miller, M.M., 2012, Barite [advance release], in Metals and minerals: U.S. Geological Survey Minerals Yearbook 2011, v. I, p. 9.1-9.8, accessed March 22, 2013, at http://minerals.usgs.gov/minerals/pubs/commodity/barite/ myb1-2011-barit.pdf.

Miller, M.M., 2013, Barite: U.S. Geological Survey Mineral Commodity Summaries 2013, p. 24-25, accessed February 6, 2013, at https://minerals.usgs.gov/minerals/ pubs/commodity/barite/mcs-2013-barit.pdf .

Mills, Paul, 2006, Barium minerals, in Kogel, J.E., Trivedi, N.C., Barker, J.M., and Krukowski, S.T., eds., Industrial minerals $\&$ rocks - Commodities, markets, and uses, 7th ed.: Littleton, Colo., Society for Mining, Metallurgy, and Exploration, Inc., p. 219-225.

Mullane, M.M., and Kinnaird, J.A., 1998, Synsedimentary mineralization at Ballynoe barite deposit, near Silvermines, Co. Tipperary, Ireland: Transactions of the Institution of Mining and Metallurgy - Section B-Applied Earth Sciences, v. 107, p. B48-B61. 
Nagaraju, Arveti, Suresh, Sama, Killham, Ken, and Hudson-Edwards, Karen, 2006a, Hydrogeochemistry of waters of Mangampeta barite mining area, Cuddapah basin, Andhra Pradesh, India: Turkish Journal of Engineering and Environmental Science, v. 30, p. 203-219.

Nagaraju, Arveti, Swathi, A., and Hudson-Edwards, Karen, 2006b, Porsopis juliflora on barite mine tailings-A case study from Mangampeta region, Cuddapah district, Andhra Pradesh, India, in Barnhisel, R.I., ed., Proceedings of the 10th Billings Land Reclamation Symposium, Billings, Montana, June 5-8, 2006: Lexington, Ky., Billings Land Reclamation Symposium and American Society of Mining and Reclamation, p. 580-591.

Natural Earth, 2014, Small scale data-Natural Earth map dataset, scale 1:110,000,000, accessed June 23, 2014, at http://www.naturalearthdata.com.

Neelakantam, S., and Roy, Sabyasachi, 1979, Baryte deposits of Guddapah basin: Records of the Geological Survey of India, v. 112, p. 51-64.

Newcaster, John, 2012, North America drilling barite outlook: Oilfield Minerals Outlook 2012, Houston, Tex., June 19-21, presentation, [unpaginated].

Occupational Safety and Health Administration, 2013, Regulations (Standards 29 CFR), Part no. 1910 - Occupational safety and health standards - Toxic and hazardous substances - 1910.1000 Table Z-1, Limits for air contaminants: Washington, D.C., U.S. Department of Labor, accessed February 15, 2013, at http://www.osha.gov/pls/oshaweb/ owadisp.show_document?p_table=standards\&p_id $=9992$.

Padalino, Giorgio, Tocco, Sandro, and Violo, Maurizio, 1989, Stratabound and karstic deposits of barite in Sardinia, in de Brodtkorb, M.K., ed., Nonmetalliferous stratabound orefields: New York, N.Y., Van Nostrand Reinhold, p. 165-200.

Papke, K.G., 1984, Barite in Nevada: Nevada Bureau of Mines and Geology Bulletin 98, 125 p.

Pendergrass, E.P., and Greening, R.R., 1953, BaritosisReport of a case: Archives of Industrial Hygiene and Occupational Medicine, v. 7, no. 1, p. 44-48.

Poole, F.G., Madrid, R.J., and Oliva-Becerril, J.F., 1991, Geological setting and origin of stratiform barite in central Sonora, Mexico, in Raines, G.L., Lisle, R.E., Schafer, R.W., and Wilkinson, W.H., eds., Geology and ore deposits of the Great Basin, v. 1: Reno, Nev., Geological Society of Nevada, p. 517-522.
Quinby-Hunt, M.S., Wilde, Pat, Orth, C.J., and Berry, W.B.N., 1989, Elemental geochemistry of black shales - Statistical comparison of low-calcic shales with other shales, abs. in Metalliferous black shales and related ore depositsProgram and abstracts: U.S. Geological Survey Circular 1037, p. 8-15. [Also available at http://pubs.usgs.gov/ circ/1989/1037/report.pdf.]

Raghu, V., 2001, Accumulation of elements in plants and soils in and around Mangampeta and Vemula barite mining areas, Cuddapah district, Andhra Pradesh, India: Environmental Geology, v. 40, p. 1265-1277. [Also available at http://dx.doi.org/10.1007/s002540100308.]

Reade, E.H., Power, W.R., Keeners, M.J., and White, D.H., 1980, Barite deposits in the Cartersville district, Bartow County, Georgia, in Frey, R.W., ed., Excursions in southeastern geology, v. II: Falls Church, Va., American Geological Institute, p. 379-384.

Reimann, Clemens, and de Caritat, Patrice, 1998, Chemical elements in the environment: Berlin, Germany, SpringerVerlag, 397 p. [Also available at http://dx.doi.org/10.1007/ 978-3-642-72016-1.]

Robinson, G.R., Jr., and Woodruff, L.G., 1988, Characteristics of base-metal and barite vein deposits associated with rift basins, with examples from some early Mesozoic basins of eastern North America, in Froelich, A.J., and Robinson, G.R., Jr., eds., Studies of the early Mesozoic basins of the Eastern United States: U.S. Geological Survey Bulletin 1776, p. 377-390.

Roskill Information Services, Ltd., 2006, The economics of barytes, 10th ed.: London, United Kingdom, Roskill Information Services, Ltd., $254 \mathrm{p}$.

Rudnick, R.L., and Gao, S., 2003, Composition of the continental crust, in Rudnick, R.L., ed., The crust, v. 3 of Holland, H.D., and Turekian, K.K., eds., Treatise on geochemistry, v. 3: Oxford, United Kingdom, Elsevier-Pergamon, p. 1-64. [Also available at http://dx.doi.org/10.1016/B0-08-043751-6/03016-4.]

Schmidt, J.M., Glen, M.G., and Morin, R.L., 2009, The Longview/Lakeview barite deposits, southern National Petroleum Reserve, Alaska (NPRA) —Potential-field models and preliminary size estimates, in Haeussler, P.J., and Galloway, J.P., eds., Studies by the U.S. Geological Survey in Alaska, 2007: U.S. Geological Survey Professional Paper 1760-C, 29 p. [Also available at http://pubs.usgs.gov/ $\mathrm{pp} / 1760 / \mathrm{c} /$. 
Seaton, Anthony, Ruckley, V.A., Addison, John, and Brown, W.R., 1986, Silicosis in barium miners: Thorax, v. 41, no. 8, p. 591-595.

Sizaret, Stanislas, Marcoux, Eric, Boyce, Adrian, Jébrak, Michel, Stevenson, Roos, and Ellam, Rob, 2009, Isotopic (S, Sr, Sm/ $\mathrm{Nd}, \mathrm{D}, \mathrm{Pb}$ ) evidences for multiple sources in the Early Jurassic Chaillac F-Ba ore deposit (Indre, France): Bulletin de la Société Géologique de France, v. 180, no. 2, p. 83-94, [Also available at http://dx.doi.org/10.2113/ gssgfbull.180.2.83.]

Smith, D.S., Cannon, W.F., Woodruff, L.G., Solano, Federico, Kilburn, J.E., and Fey, D.L., 2013, Geochemical and mineralogical data for soils of the conterminous United States: U.S. Geological Survey Data Series 801, 19 p. [Also available at http://pubs.usgs.gov/ds/801/.]

Solomon, M., Rafter, T.A., and Jensen, M.L., 1969, Isotope studies on the Rosebery, Mount Farrell and Mount Lyell ores, Tasmania: Mineralium Deposita, v. 4, issue 2, p. 172-199.

Stamatakis, M.G., and Hein, J.R., 1993, Origin of barite in Tertiary marine sedimentary rocks from Lefkas Island, Greece: Economic Geology, v. 88, p. 91-103. [Also available at http://dx.doi.org/10.2113/gsecongeo.88.1.91.]

Suter, G.W., II, 1996, Toxicological benchmarks for screening contaminants of potential concern for effects on freshwater biota: Environmental Toxicology and Chemistry, v. 15, no. 7, p. 1232-1241. [Also available at http://dx.doi.org/ 10.1002/etc.5620150731.]

Thomassen, B[jørn], 2007, Barite and celestite in central East Greenland: Geological Survey of Denmark and Greenland Fact Sheet 14, 2 p. [Also available at http://www.geus.dk/ minex/go_fs14.pdf.]

Torres, M.E., Bohrmann, Gerhard, Dube, T.E., and Poole, F.G., 2003, Formation of modern and Paleozoic stratiform barite at cold methane seeps on continental margins: Geology, v. 31, no. 10, p. 897-900. [Also available at http://dx.doi.org/ 10.1130/G19652.1.]

Turner, R.J.W., 1992, Bedded barite deposits in the United States, Canada, Germany, and China-Two major types based on tectonic setting - A discussion: Economic Geology, v. 87, p. 198-200. [Also available at http://dx.doi.org/10.2113/gsecongeo.87.1.198.]

Tvalchrelidze, A.G., and Shcheglov, V.I., 1990, A mineralogicalgeochemical model for the genesis of vein barite ore: International Geology Review, v. 32, issue 7, p. 721-733.

Uhley, R.P., and Scharon, H.L., 1954, Gravity surveys for residual barite deposits in Missouri: Mining Engineering, v. 6 , no. 1 , p. 52-56.
Urabe, Tetsuro, and Kusakabe, Minoru, 1990, Barite silica chimneys from the Sumisu Rift, Izu-Bonin Arc-Possible analog to hematitic chert associated with kuroko deposits: Earth and Planetary Science Letters, v. 100, issue 1-3, p. 283-290.

U.S. Bureau of Land Management, 2010, Argenta Mine expansion-Baker Hughes Drilling Fluids-Draft environmental assessment: U.S. Bureau of Land Management Environmental Assessment NV063-EA06-101, 85 p. plus 6 appendixes, accessed March 15, 2013, at http://clearinghouse.nv.gov/public/Notice/2010/ E2010-230.pdf.

U.S. Environmental Protection Agency, 1984, Health effects assessment for barium: U.S. Environmental Protection Agency EPA 540/1-86-021, 18 p. plus appendix, accessed March 11, 2013, at http://www.epa.gov/nscep/index.html.

U.S. Environmental Protection Agency, 2009, National primary drinking water regulations: U.S. Environmental Protection Agency EPA 816-F-09-004, May, 6 p., accessed March 12, 2013, at http://water.epa.gov/ drink/contaminants/upload/mcl-2.pdf.

U.S. Environmental Protection Agency, 2012, Regional screening levels (RSL) summary table November 2012: U.S. Environmental Protection Agency accessed November 6, 2013, at http://www.epa.gov/reg3hwmd/ risk/human/rb-concentration table/Generic Tables/ index.htm.

U.S. Geological Survey, 1996, Global 30 arc-second elevation (GTOPO30): Reston, Va., U.S. Geological Survey dataset (digital elevation model), accessed June 23, 2014, at https://lta.cr.usgs.gov/GTOPO30.

Valenza, Katia, Moritz, Robert, Mouttaqi, Abdellah, Fontignie, Denis, and Sharp, Zachary, 2000, Vein and karst barite deposits in the western Jebilet of MoroccoFluid inclusion and isotope $(\mathrm{S}, \mathrm{O}, \mathrm{Sr})$ evidence for regional fluid mixing related to central Atlantic rifting: Economic Geology, v. 95, p. 587-606. [Also available at http://dx.doi.org/10.2113/gsecongeo.95.3.587.]

Viers, Jérôme, Dupré, Bernard, and Gaillardet, Jérôme, 2009, Chemical composition of suspended sediments in world rivers-New insights from a new database: Science of the Total Environment, v. 407, no. 2, p. 853-868. [Also available at http://dx.doi.org/10.1016/j.scitotenv.2008.09.053.]

Vinogradov, V.I., Kheraskova, T.N., and Petrova, S.N., 1978, Formation of stratiform barite deposits in the siliceous units of Kazakhstan: Lithology and Mineral Resources, v. 13, no. 2, p. 238-247. 
Wang, Zhongcheng, 1996, Upper Sinian to lower Paleozoic stratiform barite, witherite, metal-sulfide and associated deposits in marine black shale and chert of the Qinling Region, 30th International Geological Congress Field Trip Guide: Beijing, Geological Publishing House, 18 p.

Wang, Zongcheng, and Li, Guizhi, 1991, Barite and witherite deposits in Lower Cambrian shales of south ChinaStratigraphic distribution and geochemical characterization: Economic Geology, v. 86, p. 354-363. [Also available at http://dx.doi.org/10.2113/gsecongeo.86.2.354.]

Whitehead, Nancy, and Macdonald, A.S., 1998, Dispersion of tailings from the Walton $\mathrm{Ba}-\mathrm{Cu}-\mathrm{Pb}-\mathrm{Zn}$ mine site, Nova Scotia: Atlantic Geology, v. 34, issue 3, p. 171-184.

World Health Organization, 2004, Barium in drinking waterBackground document for development of WHO guidelines for drinking-water quality: World Health Organization WHO/SDE/WSH/03.04/76, accessed March 8, 2013, at http://www.who.int/water_sanitation_health/dwq/ chemicals/barium.pdf.
Wones, R.G., Stadler, B.L., and Frohman, L.A., 1990, Lack of effect of drinking water barium on cardiovascular risk factors: Environmental Health Perspectives, v. 85, p. 355-359.

Woolley, A.R., 1987, Alkaline rocks and carbonatites of the world - Part 1-North and South America: London, United Kingdom, British Museum of Natural History, 216 p.

Yaghubpur, Aam, 2003, Mineral deposits in metallogenic belt east of Zagros thrust fault, in Eliopoulos, Demetrios, ed., Mineral exploration and sustainable development, Proceedings of the 7th biennial SGA meeting on mineral exploration and sustainable development, Athens, Greece, August 24-28, 2003: Amsterdam, Netherlands, IOS Press, p. $1249-1252$.

Zimmermann, R.A., and Amstutz, G.C., 1989, Barite deposits of Arkansas, in de Brodtkorb, M.K., ed., Nonmetalliferous stratabound ore fields: New York, N.Y., Van Nostrand Reinhold, $332 \mathrm{p}$. 


\section{Beryllium}

By Nora K. Foley, Brian W. Jaskula, Nadine M. Piatak, and Ruth F. Schulte

Chapter E of

Critical Mineral Resources of the United States-Economic and Environmental Geology and Prospects for Future Supply

Edited by Klaus J. Schulz, John H. DeYoung, Jr., Robert R. Seal II, and Dwight C. Bradley

Professional Paper 1802-E

U.S. Department of the Interior

U.S. Geological Survey 


\section{Contents of Chapter E}

[Figure and table titles for all chapters are listed in the volume contents before the conversion factors table and list of abbreviations and symbols. A periodic table of the elements is on the inside front cover of the printed volume]

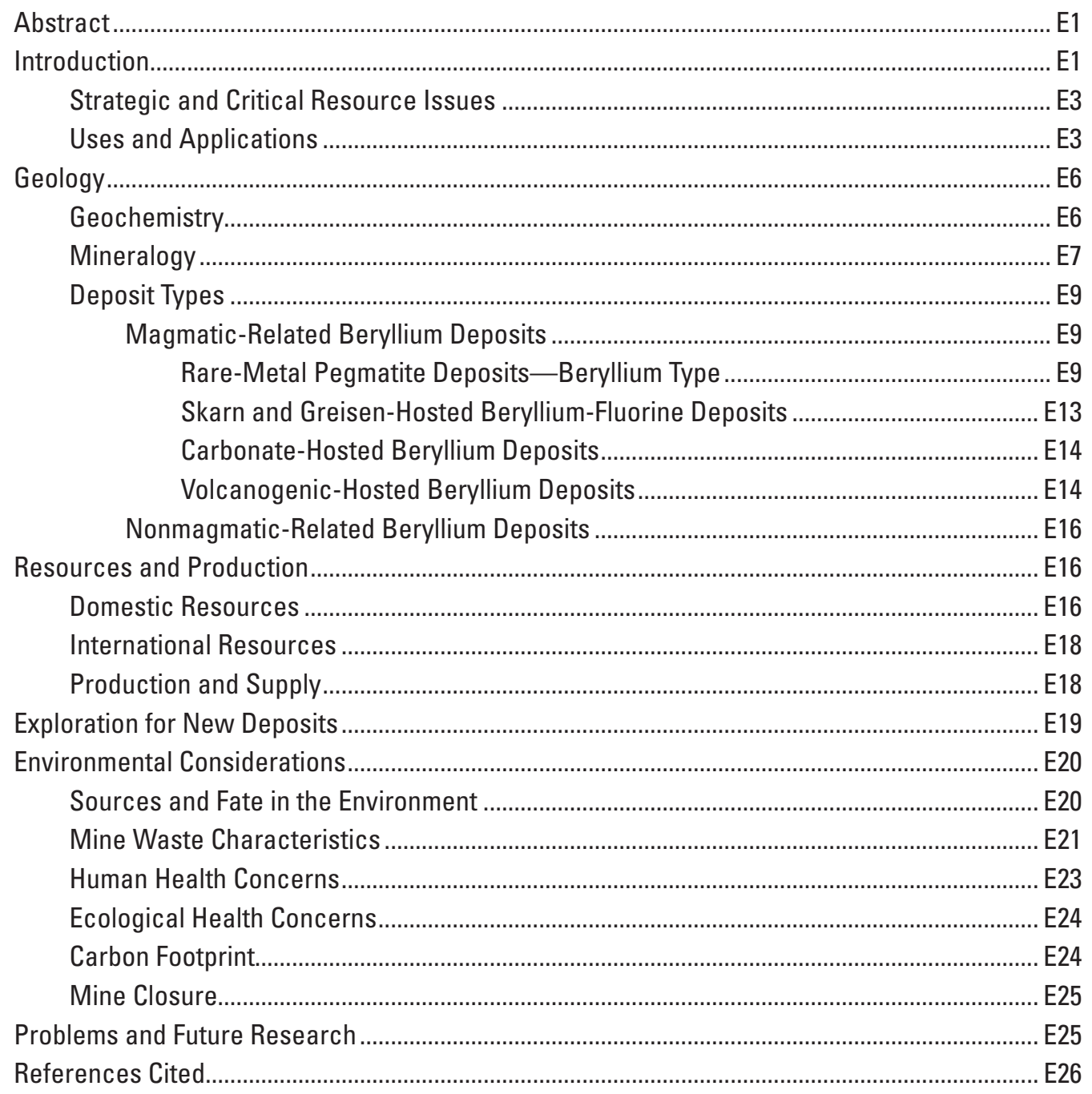




\title{
Beryllium
}

\author{
By Nora K. Foley, Brian W. Jaskula, Nadine M. Piatak, and Ruth F. Schulte
}

\section{Abstract}

Beryllium is a mineral commodity that is used in a variety of industries to make products that are essential for the smooth functioning of a modern society. Two minerals, bertrandite (which is supplied domestically) and beryl (which is currently supplied solely by imports), are necessary to ensure a stable supply of high-purity beryllium metal, alloys, and metal-matrix composites and beryllium oxide ceramics. Although bertrandite is the source mineral for more than 90 percent of the beryllium produced globally, industrial beryl is critical for the production of the very high purity beryllium metal needed for some strategic applications. The current sole domestic source of beryllium is bertrandite ore from the Spor Mountain deposit in Utah; beryl is imported mainly from Brazil, China, Madagascar, Mozambique, and Portugal. High-purity beryllium metal is classified as a strategic and critical material by the Strategic Materials Protection Board of the U.S. Department of Defense because it is used in products that are vital to national security. Beryllium is maintained in the U.S. stockpile of strategic materials in the form of hotpressed beryllium metal powder.

Because of its unique chemical properties, beryllium is indispensable for many important industrial products used in the aerospace, computer, defense, medical, nuclear, and telecommunications industries. For example, high-performance alloys of beryllium are used in many specialized, hightechnology electronics applications, as they are energy efficient and can be used to fabricate miniaturized components. Beryllium-copper alloys are used as contacts and connectors, switches, relays, and shielding for everything from cell phones to thermostats, and beryllium-nickel alloys excel in producing wear-resistant and shape-retaining high-temperature springs. Beryllium metal composites, which combine the fabrication ability of aluminum with the thermal conductivity and highly elastic modulus of beryllium, are ideal for producing aircraft and satellite structural components that have a high stiffnessto-weight ratio and low surface vibration. Beryllium oxide ceramics are used in a wide range of applications, including missile guidance systems, radar applications, and cell phone transmitters, and they are critical to medical technologies, such as magnetic resonance imaging (MRI) machines, medical lasers, and portable defibrillators.

The United States is expected to remain self-sufficient with respect to most of its beryllium requirements, based on information available at the time this chapter was prepared (2013). The United States is one of only three countries that currently process beryllium ores and concentrate them into beryllium products, and these three countries supply most of the rest of the world with these products. Exploration for new deposits in the United States is limited because domestic beryllium production is dominated by a single producer that effectively controls the domestic beryllium market, which is relatively small and specialized, and the market cannot readily accommodate new competition on the raw material supply side.

\section{Introduction}

This chapter provides an overview of the main types of mineral resources from which beryllium is extracted and refined. Beryllium is a mineral commodity that is used in a variety of industries to make products that are important for modern society. It updates the work of Griffitts (1973) on the history and then-current status of domestic resources of beryllium. Advances in understanding the geochemistry of beryllium (table E1), the mineralogy (table E2), and the genesis of current and potential sources of beryllium (tables E3 and E4), the global distribution of beryllium resources (fig. E1), and the consequences of mining these resources all contribute to a better sense of the factors that can influence beryllium supply and demand in a global market. Two distinct classes of deposits currently account for most beryllium ores; they are (a) volcanic and carbonate-hosted deposits that contain the mineral bertrandite, and (b) pegmatite deposits that have an abundance of the mineral beryl (fig. E2). The primary global provider of bertrandite is a single worldclass deposit of the volcanogenic beryllium type located in the United States near Spor Mountain, Utah. Beryllium is also derived from beryl found in rare-metal pegmatite deposits 


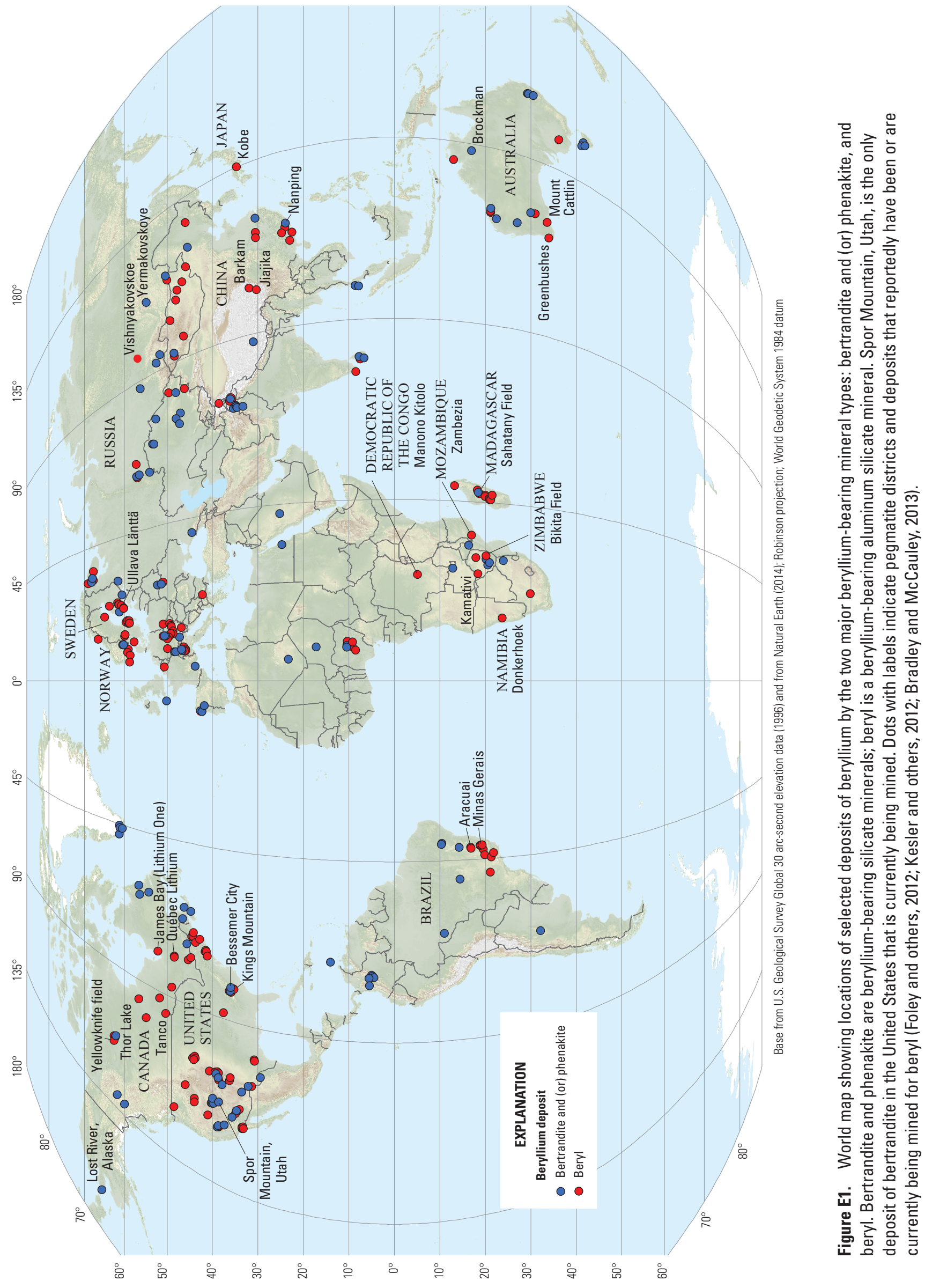



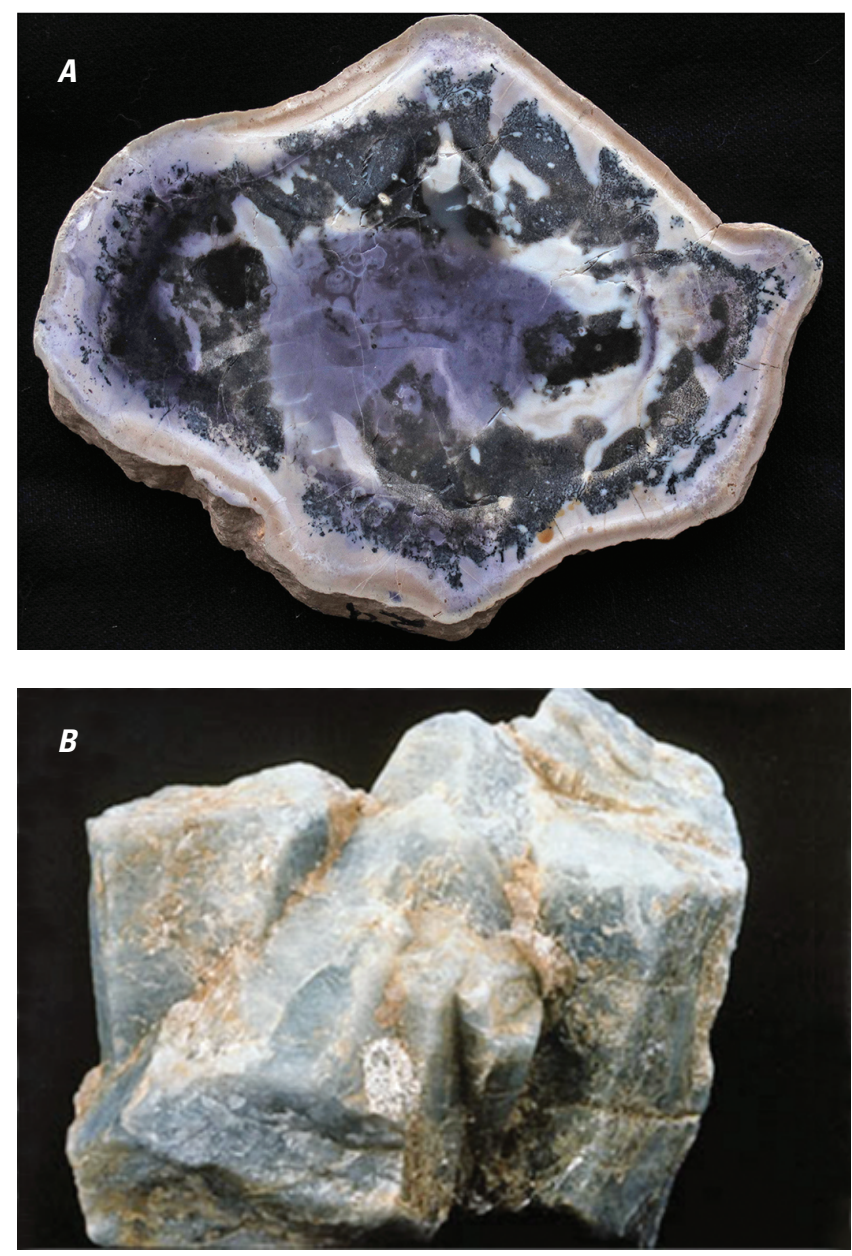

Figure E2. Photographs showing the minerals bertrandite, which can contain up to 42 percent beryllium oxide, and industrial beryl, which can contain up to about 5 percent beryllium. Photograph $A$ is a nodule of fluorite, opal, and quartz that contains about 1 percent beryllium as bertrandite (Foley and others, 2012). Photograph $B$ is beryl from a pegmatite of the lithium-cesium-tantalum family and shows typical green coloration in an assemblage of quartz and mica (U.S. Geological Survey archive).

(mainly of the lithium-cesium-tantalum [LCT] family), which are widely distributed throughout the world. These pegmatite ores provide the beryllium industry with the beryllium metals and metal-oxides of various levels of purity that are essential in the production of many special alloys and ceramics. In addition, some isotopes of beryllium metal (including ${ }^{10} \mathrm{Be}$ and ${ }^{7} \mathrm{Be}$ ) are used by research scientists to understand many geologic processes. Some important uses of beryllium isotopes are as a petrogenetic index to trace (a) the connection between sediment subduction and island arc volcanism to show whether sediments are younger than about 3 to 4 months in age, and (b) climatic changes as reflected in soils, snow, and ice.

\section{Strategic and Critical Resource Issues}

High-purity beryllium metal is classified as a strategic and critical material by the Strategic Materials Protection Board of the U.S. Department of Defense (DOD) because it is used in products that are vital to national security (U.S. Department of Defense, 2009). The DOD is required by the Board to continue to take special actions to maintain a long-term domestic supply because domestic beryllium production capabilities have diminished over time. As a result, a partnership between the DOD and Materion Corp. of Ohio was established to ensure a long-term stable domestic supply of primary beryllium metal, and the United States continues to maintain a stockpile of beryllium metal for use during a national emergency. As of December 31, 2011, the National Defense Stockpile goal for hot-pressed beryllium metal powder was 45 metric tons. In 2015, the goal, now updated to include vacuum-cast beryllium metal, was 47 metric tons. In 2015, the inventory held 78 metric tons, a surplus of 31 metric tons. Although bertrandite (fig. E2A) is the source mineral for more than 90 percent of beryllium produced globally, industrial beryl (fig. E2B), which has been supplied in recent years by imports, is critical in the production of ultra-highpurity beryllium metal. Ultra-high-purity beryllium is made exclusively from beryl, as beryl typically has fewer impurities (for example, fluorine and uranium) than bertrandite. Berylsourced ultra-high-purity beryllium is most effectively used in nuclear applications, where the absence of uranium in the beryl allows for safe and timely disposal of nuclear waste, and in foil for use as X-ray windows for medical applications. Thus, at the present time, both volcanogenic beryllium and LCT pegmatite resources are needed to ensure a stable supply of beryllium for strategic and critical applications.

\section{Uses and Applications}

Because of its chemical properties, beryllium metal is indispensable in many industrial applications. Products made from beryllium (fig. E3) are used in the aerospace, computer, defense, medical, nuclear, and telecommunications industries (Jaskula, 2013a).

Complex processing techniques and high costs (the price of beryllium generally ranges from $\$ 150$ to $\$ 225$ per pound) restrict the use of beryllium to applications where performance is critical and for which there are no practical alternatives. Although it is such a light metal, beryllium is strong and refractory; it is also highly resistant to corrosion because it readily develops an oxide film, and it has high thermal conductivity (table E1). Strategic military applications for high-purity beryllium metal include housings for optical targeting systems used for real-time imagery and surveillance in both manned helicopters and unmanned aerial systems and beryllium mirrors for ensuring vibration-free 
A. James Webb Space Telescope

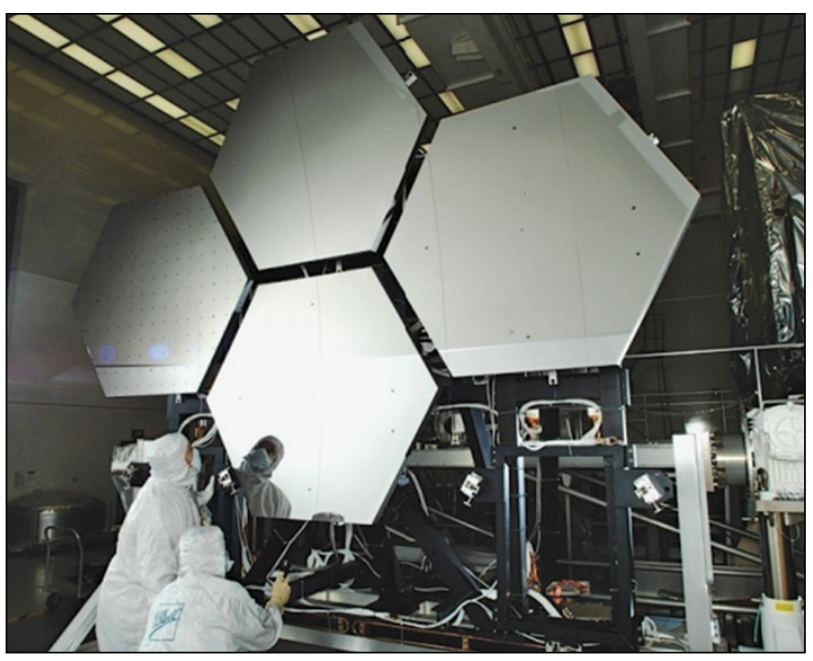

B. Be-Cu alloy connectors

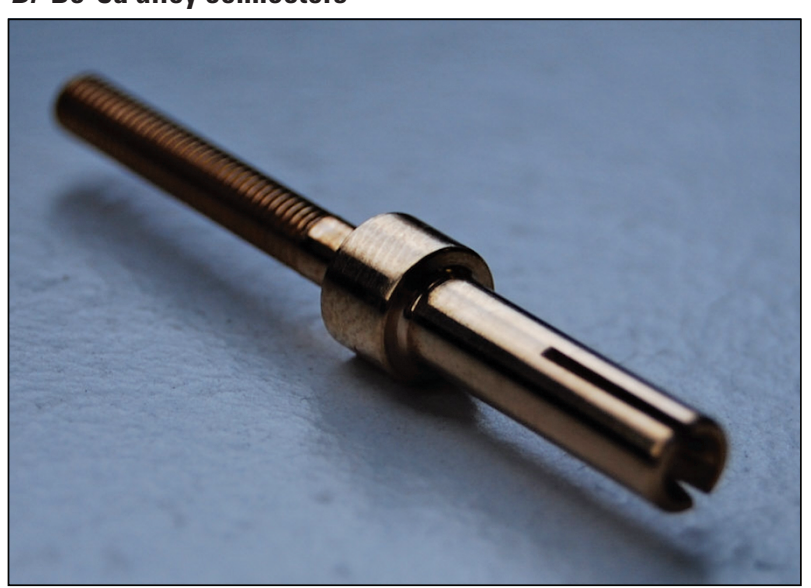

C. Al-In-Be-P LEDs

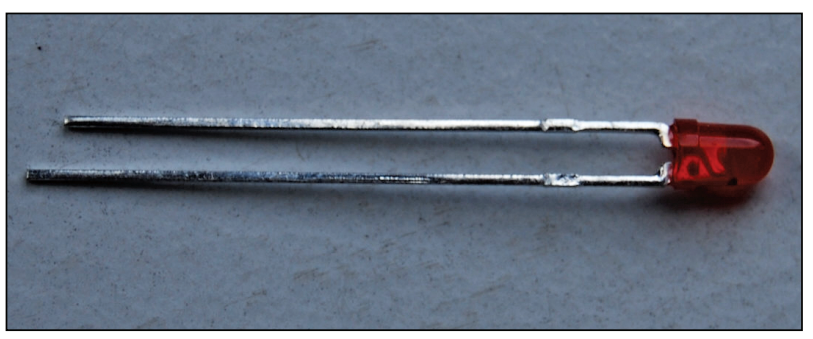

Figure E3. Photographs illustrating some of the many uses of beryllium. $A$, Beryllium metal has been used to make mirrors of powerful telescopes. $B$, Beryllium-copper (Be-Cu) alloys are used to make contacts and connectors, switches, relays, and shielding for everything from cell phones and computers to thermostats, high-definition televisions, and automobiles, as well as electrical connectors necessary for next-generation Thermal Ionization Mass Spectrometers, and electrical contacts in cell phones and computers. $C$, Metal matrix composites of beryllium are used in high-performance electronics for aluminum-indiumberyllium-phosphorus light-emitting diode (LED) pins, which provide superior performance in high-voltage heat-producing circuits. (Photograph $A$ is courtesy of Ball Aerospace; photographs $B$ and $C$ are courtesy of Spectromat Massenspektrometer $\mathrm{GmbH}$.) paths for targeting and firing controls in battle tanks and guided missile defense systems. Beryllium metal is also integral to the airborne equipment used to detect and destroy improvised explosive devices (IEDs) and tactical mines. Because beryllium metal is transparent to X-rays, it is also used to produce metallic glasses, thin foils, and mirrors. Beryllium glasses and foils are used in medical X-ray imaging and detector applications, for beryllium mirrors in satellites, for telescope optics, and in optical guidance systems. For example, mirror segments for the James Webb Space Telescope (fig. E3A) are made from beryllium.

When combined with copper, aluminum, and other metals, beryllium is used to produce light and very strong alloys needed for aerospace, automobile, and computer technologies; oil and gas drilling equipment; musical instruments; medical devices; and telecommunications equipment. Alloys are used in many specialized electronics applications, as they are energy efficient and can be used to fabricate miniaturized components. Beryllium-copper alloys (fig. E3B) are used to make contacts and connectors, switches, relays, and shielding to everything from cell phones and computers to thermostats, high-definition televisions, and automobiles. Beryllium-nickel alloys excel in producing wear-resistant and shape-retaining high-temperature springs, contacts, and connectors. Berylliumaluminum alloys are prepared for applications where critical weight, stiffness, and thermal specifications must be met. Beryllium-metal composites (fig. E3C) combine the fabrication ability of aluminum with the thermal conductivity and highly elastic modulus of beryllium. These qualities are valuable for producing aircraft and satellite structural components that have a high stiffness-to-weight ratio and low surface vibration.

Beryllium oxide is an excellent refractory material that is produced from beryllium metal, and it has some interesting uses in ceramics. In high-performance electronics, heat dissipation and electrical insulation are of critical importance for the electrical circuits to function effectively. Beryllium oxide ceramics provide superior thermal management performance in heat-producing circuits, such as those carrying high currents, where there is little airflow, or where the circuits are exposed to high ambient temperatures. These types of ceramics are used in a wide range of applications, including missile guidance systems, radar applications, and cell phone transmitters. Beryllium oxide in ceramic form is used to make high-performance semiconductor parts for radio equipment because it has good thermal conductivity and is a good electrical insulator. Semiconductor devices that use beryllium oxide ceramics instead of aluminum oxide between the silicon chip and the metal mounting base tend to last longer because the beryllium oxide ceramics provide more heat resistance. Beryllium ceramics are also vital to critical medical technologies, such as magnetic resonance imaging (MRI) machines, medical lasers, and portable defibrillators, because they are used to build parts of high-performance microwave devices, vacuum tubes, magnetrons, and gas lasers that are used in such medical devices. 
The uses of materials produced from beryllium in certain specialized applications are expected to expand rapidly with advances in technology. For example, work is underway to develop a viable manufacturing process for nuclear fuel that contains both beryllium and uranium oxides because, in spite of the high cost of beryllium relative to that of uranium (the price of U235 was about $\$ 43$ per pound in 2013 compared with beryllium's cost of $\$ 150$ to $\$ 225$ per pound), beryllium fuels may be longer lasting, more efficient, and safer than conventional nuclear fuels (Kim and others, 2010). Because the cost of beryllium is high compared with the cost of many other materials, less expensive materials are substituted where possible. For example, in some less-demanding applications, copper alloyed with Ni-Si, Sn, Ti, or Sn-P may be substituted for high-cost beryllium-copper alloys, and aluminum nitride or boron nitride may be substituted for high-cost beryllium oxide with no loss in performance. The substitution of high-strength grades of aluminum metal, pyrolytic graphite (an ultra-thin graphite film with a thermal conductivity up to four times greater than that of copper), silicon carbide, steel, or titanium metal for beryllium metal or composites, however, can result in substantially reduced performance.

A snapshot of uses of beryllium in the United States for the main classes of products by market share for 2011 are shown in figure E4. Performance alloys include the berylliumcopper and beryllium-aluminum alloys that consume most of the beryllium produced globally. Beryllium and composites include high-purity metals and metal-matrix composites and ceramics. Sales of performance alloys (fig. E4A) are about 600 percent greater than sales of the beryllium metal, composites, and ceramics sectors combined (fig. E4B). For beryllium metal and composites, defense and science applications accounted for approximately one-half of company sales in 2011, which was an 8 percent decrease compared with that of 2010; the decrease was thought to be owing to Government funding delays. Sales increased, however, for industrial component and commercial aerospace applications of both alloys and composites owing to an increase in the production of X-ray window assemblies. Sales for energy applications of performance alloys increased slightly in 2011 compared with those of 2010 (Materion Corp., 2012a). Sales of ceramic products decreased slightly in 2011 after increasing by more than 50 percent in 2010 owing largely to increased shipments for applications within the telecommunications infrastructure market (Materion Corp., 2012a). Worldwide beryllium consumption is predicted to increase to 506 metric tons per year of contained beryllium by 2017 owing to sustained consumption from the computer and telecommunications infrastructure markets and the growing automotive electronics market (Global Industry Analysts, Inc., 2012). Developing markets in Asia and Latin America are also expected to increase consumption even though miniaturization in component manufacturing is requiring less beryllium than before for many uses.

Recycling efforts are important because of the huge energy savings that recycled beryllium brings to manufacturing. Manufacturing beryllium products from recycled sources requires only 20 percent of the energy required to manufacture beryllium products from ore. China, Kazakhstan, and the United States are the only countries that are currently capable of processing recycled scrap. Beryllium is recycled from new scrap generated during the manufacture of beryllium-containing components as well as from postconsumer scrap collected from end users worldwide. Owing to the long lifetime of many beryllium products, the technical difficulty of recycling beryllium (because of its use in complex alloys), and the low concentration of beryllium present in many consumer products, the percentage of scrap in the recycling flow was previously estimated to be between

Table E1. Selected properties of beryllium, which is a Group 2 alkaline earth metal.

[Source: Lide (2005, p. 14-39). Å, angstrom; Be, beryllium; BeH, beryllium hydride; ${ }^{\circ} \mathrm{C}$, degree Celsius; $\mathrm{eV}$, electronvolt; $\mathrm{g} / \mathrm{cm}^{3}$, gram per cubic centimeter; GPa, gigapascal; J/mol K, joule per mole kelvin; K, kelvin; $\mathrm{kJ} / \mathrm{mol}$, kilojoule per mole; Mpa, megapascal; $\mathrm{n} \Omega$-m, nano ohm-meter; ppm, part per meter; $\mu \mathrm{m} / \mathrm{m} \mathrm{K}$, micrometer per meter kelvin; $\mathrm{W} / \mathrm{m} \mathrm{K}$, watt per meter kelvin]

\begin{tabular}{|c|c|}
\hline Property & Value \\
\hline Atomic number & 4 \\
\hline Atomic weight & 9.012182 \\
\hline Isotopes & $\begin{array}{l}12 \text { known radioisotopes; }{ }^{9} \mathrm{Be} \\
\text { is the only stable isotope; } \\
{ }^{10} \mathrm{Be} \text { has a half-life of } \\
1.39 \text { million years }\end{array}$ \\
\hline Density at $293 \mathrm{~K}\left(\mathrm{~g} / \mathrm{cm}^{3}\right)$ & 1.8477 \\
\hline Melting point $\left({ }^{\circ} \mathrm{C}\right)$ & 1,287 \\
\hline Boiling point $\left({ }^{\circ} \mathrm{C}\right)$ & 2,469 \\
\hline Heat of fusion $(\mathrm{kJ} / \mathrm{mol})$ & 12.2 \\
\hline Heat of vaporization $(\mathrm{kJ} / \mathrm{mol})$ & 297 \\
\hline Molar heat capacity $(\mathrm{J} / \mathrm{mol} \mathrm{K})$ & 16.443 \\
\hline Hardness (Mohs scale) & 5.5 \\
\hline Vickers hardness (Mpa) & 1,670 \\
\hline Electrical resistivity at $20^{\circ} \mathrm{C}(\mathrm{n} \Omega-\mathrm{m})$ & 36 \\
\hline Thermal conductivity (W/m K) & 200 \\
\hline Thermal expansion at $25^{\circ} \mathrm{C}(\mu \mathrm{m} / \mathrm{m} \mathrm{K})$ & 11.3 \\
\hline Young’s modulus (GPa) & 287 \\
\hline Crystal structure & Hexagonal \\
\hline Magnetic ordering & Diamagnetic \\
\hline Electron configuration & $1 s^{2} 2 s^{2}$ \\
\hline Ionic radius $(\AA)$ & 0.27 \\
\hline First ionization potential $(\mathrm{eV})$ & 9.32 \\
\hline Second ionization potential $(\mathrm{eV})$ & 18.21 \\
\hline Common valance states & $\begin{array}{c}+2, \text { rarely }+1 \\
(\text { BeH molecule })\end{array}$ \\
\hline $\begin{array}{l}\text { Abundance, upper continental crust } \\
\text { (ppm) }\end{array}$ & $\begin{array}{c}\text { About } 1.9 \\
(\mathrm{Hu} \text { and } \mathrm{Gao}, 2008)\end{array}$ \\
\hline
\end{tabular}




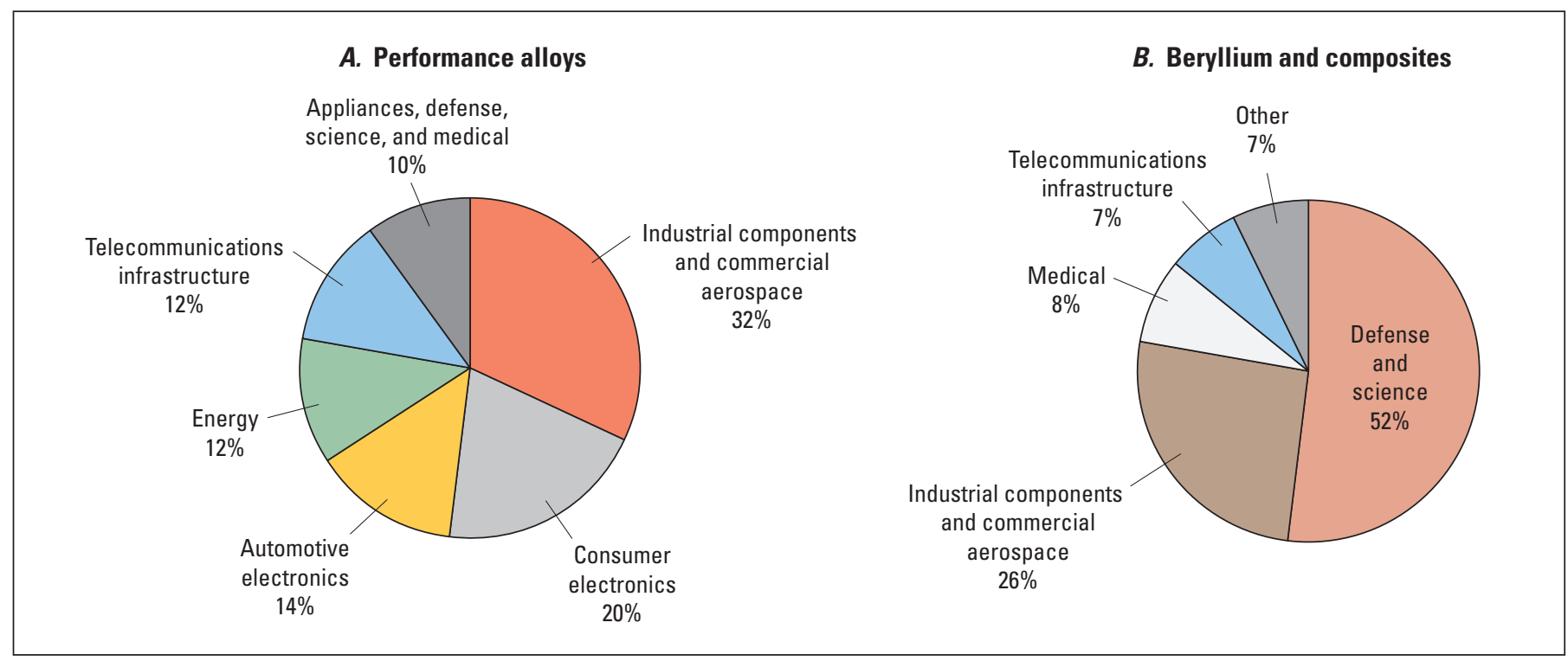

Figure E4. Pie charts showing reported end uses of beryllium consumed in the United States in 2011 for the two main classes of products$A$, performance alloys, and $B$, beryllium and composites (metals and ceramics). Usage is shown as a percentage of market share (Materion Corp., 2012a).

10 and 25 percent, based on data collected for 2000 through 2005 (Graedel and others, 2011). Recent information from Materion, however, shows that an extensive worldwide recycling program for beryllium products is currently achieving a 40 percent recovery rate of beryllium from both of its new and postconsumer scrap sources (Jaskula, 2013a).

\section{Geology}

\section{Geochemistry}

Beryllium (table E1) is a member of Group 2 of the periodic table of elements; however, it has distinct differences in its crystal chemistry from other elements in the group, and these differences contribute to beryllium's fundamentally unique attributes. Beryllium has 12 known isotopes and only $1,{ }^{9} \mathrm{Be}$, is stable. Of the radiogenic isotopes of beryllium, the most stable are ${ }^{10} \mathrm{Be}$, which has a half-life of 1.39 million years, and ${ }^{7} \mathrm{Be}$, which has a half-life of about 53 days; most of the others decay in milliseconds. Beryllium is the lightest of the alkaline earth elements, and its low atomic number (4) results in high first and second ionization potentials (9.32 and 18.21 electronvolts, respectively). As a consequence, beryllium can readily strip (or ionize) electrons from other uncharged atoms, and, owing to its small size (ionic radius of about 0.27 angstroms (Shannon, 1976), $\mathrm{Be}^{2+}$ has a strong tendency to polarize the electron clouds of the ligands to which it binds, forming bonds of shared electrons in compounds (Wuensch, 1972). These are strong and short chemical bonds that generate compounds displaying great hardness and high melting temperatures.
Beryllium generally behaves as a hard acid (Pearson, 1963), preferentially forming complexes with hard ligands, such as carbonate, fluoride, and hydroxide. Because of its extremely small size, beryllium is not easily displaced by other elements in crystals and tends to form distinct minerals. Studies of the speciation and solubility of beryllium minerals at temperatures to 300 degrees Celsius $\left({ }^{\circ} \mathrm{C}\right.$ ) for $\mathrm{Be}^{2+}$ (its only known oxidation state in aqueous solution) suggest that beryllium is most likely to be transported in low-temperature hydrothermal fluid as a fluoride or fluoride-carbonate complex (Wood, 1992, and references therein). Over a wide range of temperatures and $\mathrm{pH}$, the solubility of beryllium as a simple ion and its hydrolysis products are much less than 1 part per million (ppm) in solution. Thus, once formed, most beryllium minerals persist in surficial environments.

Beryllium is the 47th most abundant element found in Earth's crust (Emsley, 2001), and it is widely distributed in many rocks types (Hörmann, 1978). Beryllium behaves as a lithophile element in that it combines readily with oxygen to form light beryllium oxide compounds, which leads to its enrichment in Earth's crust rather than in the core. The concentration in primitive mantle is inferred to be about 60 parts per billion (ppb) beryllium (Taylor and McLennan, 1985, 1995), whereas estimates of the concentration of beryllium in the upper continental crust range from 1.9 to $3.1 \mathrm{ppm}$ beryllium (table E1), which is an increase of more than fortyfold. This also accounts for the notable increases in beryllium concentrations in highly evolved volcanic and plutonic rocks, in granitic pegmatites, and in alkalic rocks compared with mantle compositions. In granite, the averages vary from $5 \mathrm{ppm}$ beryllium (in biotite granite) to $10 \mathrm{ppm}$ beryllium (in muscovite and two-mica granite) (Hörmann, 1978; Taylor and 
McLennan, 1985, 1995). Nepheline syenite and fluorine-rich topaz-bearing rhyolites are even more enriched in beryllium than common felsic rocks. For example, alkalic rocks from Lovozero, Murmansk Oblast, Russia, contain beryllium in the range of about 3 to $24 \mathrm{ppm}$ beryllium, and some fluorine-rich topaz-bearing volcanic rocks in the Western United States have average contents of $50 \mathrm{ppm}$ beryllium (Hörmann, 1978). Extreme enrichments are encountered in some unique rocks; for example, the Ilímaussaq complex in southern Greenland has peralkaline nepheline syenites that contain from 7 to 44 ppm beryllium - including some unusual rocks that have between 330 and 1,970 ppm beryllium (Engell and others, 1971) — and the Cornudas Mountains deposit in New Mexico, which has nepheline syenites that contain up to $150 \mathrm{ppm}$ beryllium (McLemore and Guilinger, 1993). Most beryllium-rich pegmatites have bulk beryllium contents of less than 250 to 420 ppm beryllium (London and Evensen, 2002), although some albitic pegmatites have bulk contents in the range of from 360 to $720 \mathrm{ppm}$ beryllium, which can be highly concentrated in specific zones within zoned granitic pegmatites (Černý, 2002). Hydrothermal processes can further concentrate beryllium in both pegmatite and volcanogenic systems. For example, altered rock (griesen) around a granite pluton at the Boomer Mine in Colorado contains up to 2.3 percent beryllium, by weight, and volcanic tuff altered by heated circulating waters at Spor Mountain, Utah, may contain up to 3,600 ppm beryllium (Foley and others, 2012). Weathering of beryllium-enriched igneous rocks results in clay-bearing sedimentary rocks that serve as an important reservoir of beryllium in Earth's crust. Metamorphism of such rocks as crustal plates subducted at convergent boundaries plays a critical role in the recycling of beryllium. Anatectic processes in the subduction zone cause partial melting of the crust, which releases the lithophile component in the rocks and generates beryllium-enriched magmas that are the source for new granitic rocks, thus completing the beryllium geochemical cycle.

\section{Mineralogy}

More than 100 distinct minerals that contain beryllium as an essential component of the mineral structure are known to occur in nature; these include arsenate, borate, hydroxide, oxide, phosphate, and silicate types. The relative stabilities of the major beryllium minerals (table E2) and their occurrence in diverse geologic environments are well established (Beus, 1966; Barton and Young, 2002; Černý, 2002).

Beryl is the main beryllium ore mineral in plutonic systems and metamorphic environments, whereas bertrandite and phenakite are the predominant ore minerals in nearsurface volcanogenic and carbonate-hosted deposits. A number of other beryllium-bearing minerals, such as chrysoberyl and helvite, have reportedly been mined in small amounts from some deposits.
Beryl (fig. E2) is the primary beryllium silicate mineral that forms in rocks at high temperatures, and it has relatively widespread natural abundance (Barton, 1986; Barton and Young, 2002, and references therein). Beryllium saturation, and thus beryl solubility, varies as a function of the activities of beryllium, aluminum, and silicon. Beryl saturation can occur in granitic melts containing about $50 \mathrm{ppm}$ beryllium at temperatures of $400{ }^{\circ} \mathrm{C}$ (London, 2005). Beryl has the ability to incorporate high and variable amounts of cesium, sodium, and water in large channels in its crystal structure and may show isomorphic substitutions of lithium for beryllium and magnesium, and iron and scandium for aluminum. These factors result in beryl being stable over a large range of temperature and pressure conditions and account for its presence in diverse geologic environments. The lower stability limit of beryl occurrence varies from 200 to $350{ }^{\circ} \mathrm{C}$, depending on the compositions of coexisting minerals.

Beryl is the predominant beryllium phase in zoned granitic rare-element pegmatite environments where it occurs with other rare minerals of commercial importance, such as cesium, lithium, and tantalum, as well as clays, feldspar, muscovite, and high-purity quartz (London and Kontak, 2012; Glover and others, 2012). In general, beryl is the only source of beryllium found in pegmatite deposits, although chrysoberyl is locally abundant in some pegmatites (table E2) (Linnen and others, 2012). Other occurrences of beryl include its presence in miarolitic cavities in volcanic rocks related to topaz-bearing igneous systems; for example, red beryl in the Wah Wah Mountains of Utah (Keith and others, 1994).

Bertrandite is the stable mineral in surface environments, as it forms at or below a temperature of $250{ }^{\circ} \mathrm{C}$, and phenakite is stable at temperatures greater than $250^{\circ} \mathrm{C}$. Phenakite hydrates to bertrandite at lower temperatures (Barton, 1986). Bertrandite and phenakite are commonly found with beryl in carbonate-hosted skarn deposits and greisen associated with granite intrusions. Bertrandite is the predominant host for beryllium in volcanogenic deposits and occurs with phenakite in veins in carbonate replacement deposits. Precipitation in epithermal environments can result in cryptocrystalline and possibly colloidal bertrandite having variable amounts of molecular water that is readily lost on heating. The variety of bertrandite at Spor Mountain, Utah, reportedly has chemical and physical properties intermediate between colloidal bertrandite and bertrandite proper (Montoya and others, 1962).

The beryllium content in minerals in which it occurs as a substitute for another element, such as the important rock-forming minerals, is typically $10 \mathrm{ppm}$ or less and rarely exceeds 100 ppm (London and Evensen, 2002). Several minerals have been reported to incorporate beryllium in higher amounts (that is, $>0.1$ weight percent beryllium oxide, or $350 \mathrm{ppm}$ beryllium). These include clay minerals of the smectite group that reportedly can contain up to 2.8 weight percent beryllium oxide as either crystallographic substitution or ionic adsorption on clay surfaces (Montoya and others, 1962). 
Table E2. Selected beryllium minerals.

[Sources: Barton and Young (2002), Grew (2002), Foley and others (2010), and Jaskula (2013b). BeO, beryllium oxide; —, limited or no commercial use]

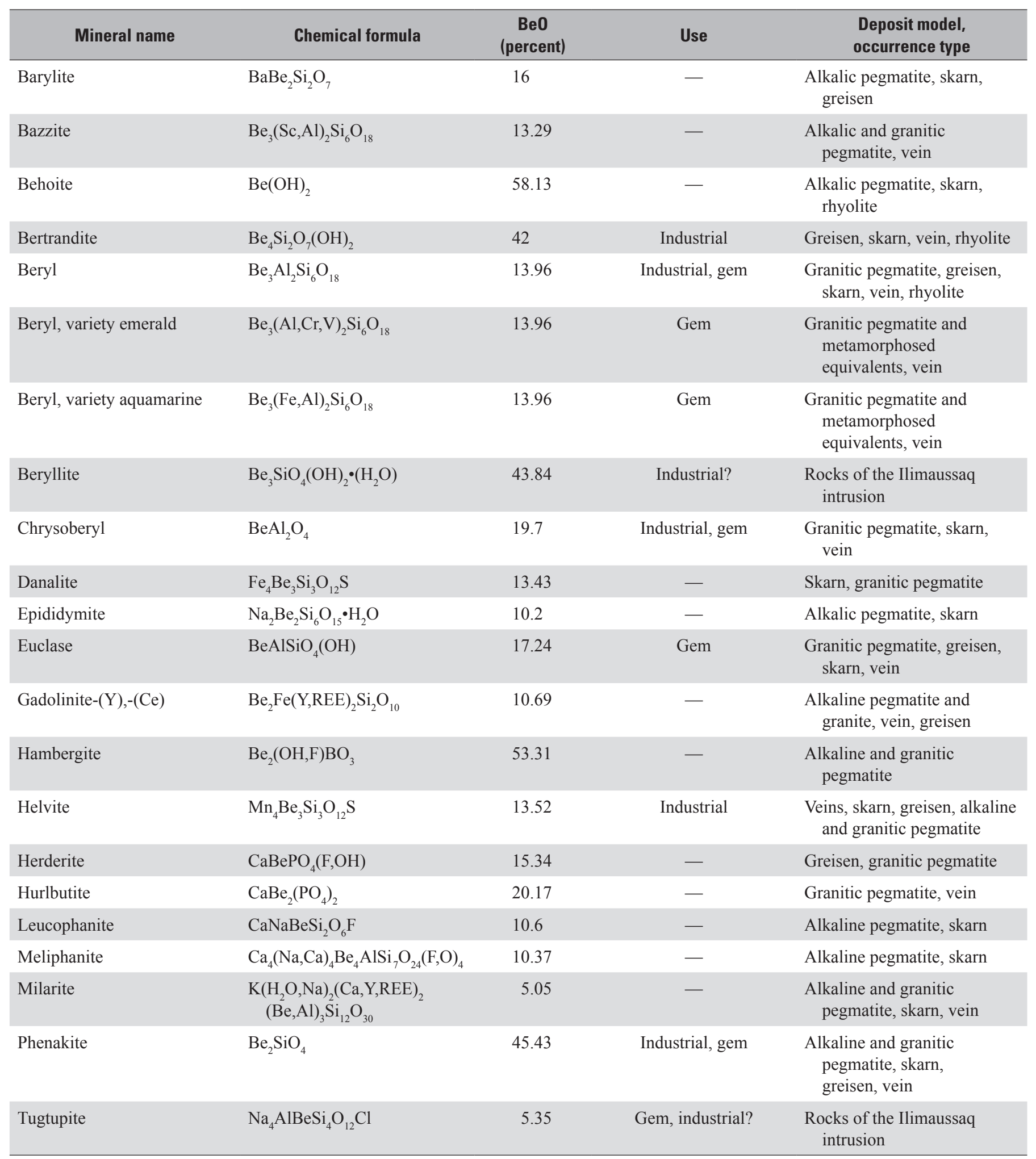




\section{Deposit Types}

\section{Magmatic-Related Beryllium Deposits}

Beryllium deposits are most commonly associated with geologic environments that show a clear link to magmatic processes (Barton and Young, 2002; Černý, 2002). Magmatic-related beryllium deposits can be characterized in terms of (a) the petrologic association of the igneous rocks, (b) the type of associated country rock, and (c) the nature of the depositional environment (table E3).

Magmatic-related beryllium deposits and occurrences are found in two general rock types - alkaline to peralkaline and metaluminous to peraluminous - which are distinguished on the basis of whole-rock chemistry. The deposit types can be divided into those associated with rare-metal enriched felsic intrusions and related volcanic sequences and pegmatite bodies, and those that form where rare-metal enriched magmas interact with adjacent country rocks. Thus, rare-metal plutons and related pegmatite deposits containing beryl; skarn and greisen deposits containing bertrandite, beryl, and phenakite; and volcanogenic and carbonate-hosted deposits of mainly bertrandite are the types associated with large-scale magmatic systems (for example, fig. E5). Of these, lithiumrich pegmatites that contain beryl in high-grade pockets (Bradley and McCauley, 2013) and large-tonnage, high-grade volcanogenic beryllium deposits (Foley and others, 2012) are economically important at present (table E3, shown in shading; modified from Barton and Young, 2002).

\section{Rare-Metal Pegmatite Deposits-Beryllium Type}

Many plutons of gabbro, granite, and syenite composition contain minor amounts of beryl; however, in general, only rare-metal granitic pegmatites contain beryl in sufficient quantities to mine. Although granitic pegmatites are widespread and relatively common, rare-metal pegmatites make up only about 0.1 percent of the total fraction (Laznicka, 2006). Rare-metal pegmatites (table E3; fig. E5) that contain relatively abundant beryl include those of the rare element class, lithium subclass, beryl type (LCT family) and those of the miarolitic class, REE subclass, topaz-beryl type (niobium-yttrium-fluorine [NYF] family), and of the miarolitic class, lithium subclass, beryl-topaz type (LCT family) (Černý and others, 2012, table 1). Of these, the most important sources of industrial beryl are granitic pegmatites of the rare-element LCT family. Miarolitic LCT-family and NYF-family pegmatites (fig. E6) are mainly sources of gemstone beryl. Industrial beryl is also produced from more complex types of pegmatite; for example, Anjanabonoina pegmatites in Antananarivo Province, Madagascar, which have a mixed NYF-LCT signature (Martin and De Vito, 2005). Many pegmatite districts that are of interest now for lithium and niobium originally attracted attention for other rare metals, especially beryllium, tantalum, and tin, and industrial minerals, such as feldspar, micas, and high-purity silica (Glover and others, 2012; Kesler and others, 2012).
Most granitic pegmatites of the LCT family show peraluminous compositions (table E3; fig. E5) that are characteristic of S (or sedimentary)-type granites, which form from anatexis, or melting, of metamorphosed pelitic rocks owing to the crustal thickening that is typically associated with subduction and continental collision (Černý and others, 2012). LCT pegmatites have been linked to subduction zones because of the high abundance of granitic pegmatites in orogenic belts (Martin and De Vito, 2005), although others affiliate them with a post-tectonic phase of evolution in continentalcollision belts (Tkachev, 2011). Nonetheless, the geochemical character of LCT pegmatites depends on their derivation from previously unmelted, mica-rich metamorphic rocks because muscovite-paragonite-phengite and biotite group minerals carry the distinguishing rare elements (Černý and others, 2012). The presence of diverse fluxing components, such as boron, flourine, and phosphorus, in addition to water, in the metamorphosed juvenile sediments that make up the peraluminous sedimentary-type source materials are thought to have an essential role in the formation of LCT pegmatites because they mobilize the rare metals, including $\mathrm{Be}, \mathrm{Cs}, \mathrm{Nb}, \mathrm{Rb}, \mathrm{Sn}$, and $\mathrm{Ta}$, into the fluid phase (Linnen and others, 2012).

Rare-metal pegmatites typically occur as halos that encircle large leucocratic plutons or as swarms that extend into country rock adjacent to these intrusions. The best quality deposits are found in zoned pegmatites where beryl is mined from certain, typically highly fractionated, pegmatite zones; from massive vein and fracture fillings; and from replacement bodies in complexly heterogeneous pegmatites. Important pegmatite districts for beryl mining (fig. E1) occur in Brazil (in the Rio Doce Valley and adjacent areas in the State of Minas Gerais; the city of Campina Grande in the State of Rio Grande do Norte; Cristais-Berilandia in the State of Ceara; and Rio Jequitinhonha [Jequitinhonha River] in the State of Minas Gerais); Portugal (in the Covas do Barroso pegmatite district, Viseu); Mozambique (at Alto Ligonhain in the Province of Zambezia); Canada (at the Bernic Lake Mine-commonly known as the Tanco Mine - on the shore of Bernic Lake in the Province of Manitoba; and at the James Bay (Lithium One) Mine on the shore of James Bay in the Province of Quebec); Namibia (at Karibib); Zimbabwe (at the Bikita Field in the Province of Masvingo); and China (Kesler and others, 2012). Pegmatite districts located in weathered granites of southeastern China-for example, the city of Nanping in Fujian Province - may supply some of the reported Chinese production, although little information is available on resource types for beryllium from China. Subeconomic occurrences in the United States that were mined historically include pegmatite bodies of North Carolina (at the Kings Mountain crushed rock quarry near Bessemer City), South Dakota (at Tin Mountain Mine in the Black Hills; Sabey, 2006), and New Hampshire. For example, pegmatites at the Palermo Mine on Bald Mountain near North Groton, New Hampshire, and at Beryl Mountain near South Acworth, New Hampshire, produced much of the beryllium for the U.S. Manhattan Project. 
Table E3. Global and domestic types of magmatic-related beryllium resources.

[Modified from Barton and Young (2002). Shading indicates information for deposits that are economically important at present. For each petrologic association listed, the following is included: 1, frequency of known occurrences (abundant, common, uncommon, rare) and end use for which the beryllium is most valuable (gems, industrial beryllium); 2 , the main beryllium-bearing phase(s); and 3, one or more example localities. "Transbaikalia" is the conventional spelling of the "Zabaykal'ye" region. LCT, lithium-cesium-tantalum; NYF, niobium-yttrium-fluorine. Locality abbreviations: Colo., Colorado; Ill., Illinois; N.C., North Carolina; N.H., New Hampshire; N. Mex., New Mexico; Nev., Nevada; Tex., Texas; UK, United Kingdom; Va., Virginia; Mt., Mount; Mtn., mountain; 一, not applicable]

\begin{tabular}{|c|c|c|c|c|c|c|}
\hline \multirow{2}{*}{\multicolumn{2}{|c|}{$\begin{array}{c}\text { Petrologic } \\
\text { association }\end{array}$}} & & \multicolumn{4}{|c|}{ Host rock (type of mineralization) } \\
\hline & & & $\begin{array}{c}\text { Igneous } \\
\text { (pegmatitic, late-stage } \\
\text { plutonic, volcanic glasses) }\end{array}$ & $\begin{array}{l}\text { Aluminosilicate } \\
\text { (greisen, veins) }\end{array}$ & $\begin{array}{c}\text { Carbonate } \\
\text { (skarn, replacement) }\end{array}$ & $\begin{array}{l}\text { Mafic/ultramafic } \\
\text { (blackwall, vein) }\end{array}$ \\
\hline \multirow{9}{*}{ 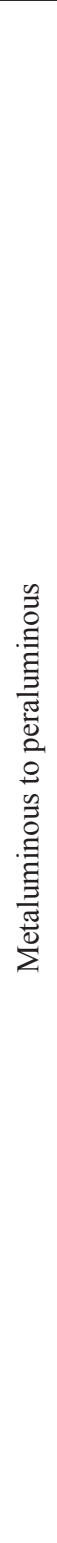 } & \multirow[b]{3}{*}{ Granite } & 1 & $\begin{array}{l}\text { Common?/Industrial-beryllium } \\
\text { resource? }\end{array}$ & $\begin{array}{l}\text { Abundant/gems } \pm \text { industrial- } \\
\text { beryllium resource? }\end{array}$ & $\begin{array}{l}\text { Abundant/industrial- } \\
\text { beryllium resource }\end{array}$ & $\begin{array}{l}\text { Common/gems, } \\
\text { emerald }\end{array}$ \\
\hline & & 2 & Lithium micas, beryl & Beryl, phenakite & $\begin{array}{l}\text { Phenakite, chrysoberyl, } \\
\text { bertrandite, helvite }\end{array}$ & $\begin{array}{l}\text { Beryl, chrysoberyl, } \\
\text { phenakite }\end{array}$ \\
\hline & & 3 & $\begin{array}{l}\text { Beauvoir, France; } \\
\text { Sheeprock, Utah }\end{array}$ & $\begin{array}{l}\text { Sherlova Gora, Russia; } \\
\text { Mt. Antero, Colo.; } \\
\text { Aqshatau, Kazakhstan; } \\
\text { Erzgebirge, Germany; } \\
\text { Cornwall, UK; Boomer } \\
\text { Mine, Pikes Peak, Colo. }\end{array}$ & $\begin{array}{l}\text { Lost River, Alaska; } \\
\text { Mt. Wheeler, Nev.; } \\
\text { Mt. Bischoff, Australia; } \\
\text { McCullough Butte, } \\
\text { Nev. }\end{array}$ & $\begin{array}{r}\text { Reft River, Russia; } \\
\text { Khaltro, Pakistan; } \\
\text { Carnaiba, Brazil }\end{array}$ \\
\hline & $\begin{array}{l}\text { Granitic } \\
\text { pegmatite } \\
\text { (LCT-type) }\end{array}$ & 3 & $\begin{array}{l}\text { Minas Gerais, Brazil; } \\
\text { Bernic Lake, Canada; } \\
\text { Transbaikalia, Russia; } \\
\text { Greenbushes, Australia; } \\
\text { Bikita, Zimbabwe; } \\
\text { Donkethoek, Namibia; } \\
\text { Sahatany Valley, Madagascar; } \\
\text { King’s Mountain, N.C. }\end{array}$ & - & - & - \\
\hline & \multirow{2}{*}{$\begin{array}{l}\text { Granitic } \\
\text { pegmatite } \\
\text { (NYF-type) }\end{array}$} & 1 & $\begin{array}{l}\text { Abundant/gems and major } \\
\text { industrial-beryllium resource }\end{array}$ & & & \\
\hline & & 2 & Beryl & & & \\
\hline & \multirow{3}{*}{ Rhyolite } & 1 & Common/no economic value? & Rare/gems, red beryl & $\begin{array}{l}\text { Uncommon/principal } \\
\text { industrial-beryllium } \\
\text { resource }\end{array}$ & \multirow{3}{*}{ - } \\
\hline & & 2 & Beryllium in glass or micas & Beryl & Bertrandite & \\
\hline & & 3 & $\begin{array}{l}\text { Macusani, Peru; Spor Mtn., Utah; } \\
\text { topaz rhyolites, Western United } \\
\text { States; Warm Springs, N. Mex. }\end{array}$ & $\begin{array}{l}\text { Wah Wah Mtns., Utah; } \\
\text { Black Range, N. Mex.; } \\
\text { Spor Mtn., Utah }\end{array}$ & $\begin{array}{l}\text { Spor Mtn., Utah; } \\
\text { Aguachile, Mexico; } \\
\text { Sierra Blanca, Tex. }\end{array}$ & \\
\hline
\end{tabular}


Table E3. Global and domestic types of magmatic-related beryllium resources.-Continued

[Modified from Barton and Young (2002). Shading indicates information for deposits that are economically important at present. For each petrologic association listed, the following is included: 1, frequency of known occurrences (abundant, common, uncommon, rare) and end use for which the beryllium is most valuable (gems, industrial beryllium); 2 , the main beryllium-bearing phase(s); and 3, one or more example localities. "Transbaikalia" is the conventional spelling of the "Zabaykal'ye" region. LCT, lithium-cesium-tantalum; NYF, niobium-yttrium-fluorine. Locality abbreviations: Colo., Colorado; Ill., Illinois; N.C., North Carolina; N.H., New Hampshire; N. Mex., New Mexico; Nev., Nevada; Tex., Texas; UK, United Kingdom; Va., Virginia; Mt., Mount; Mtn., mountain; 一, not applicable]

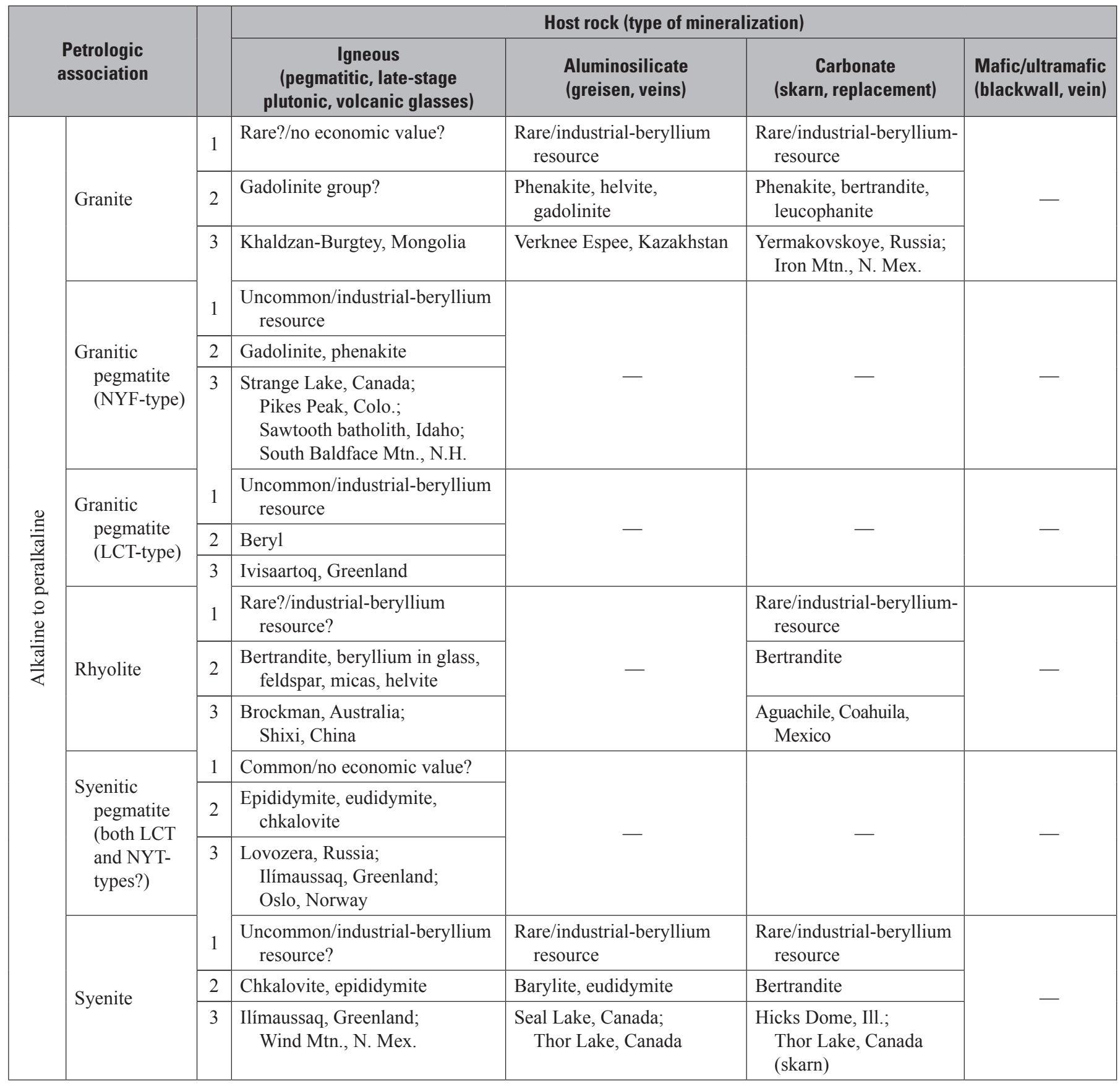




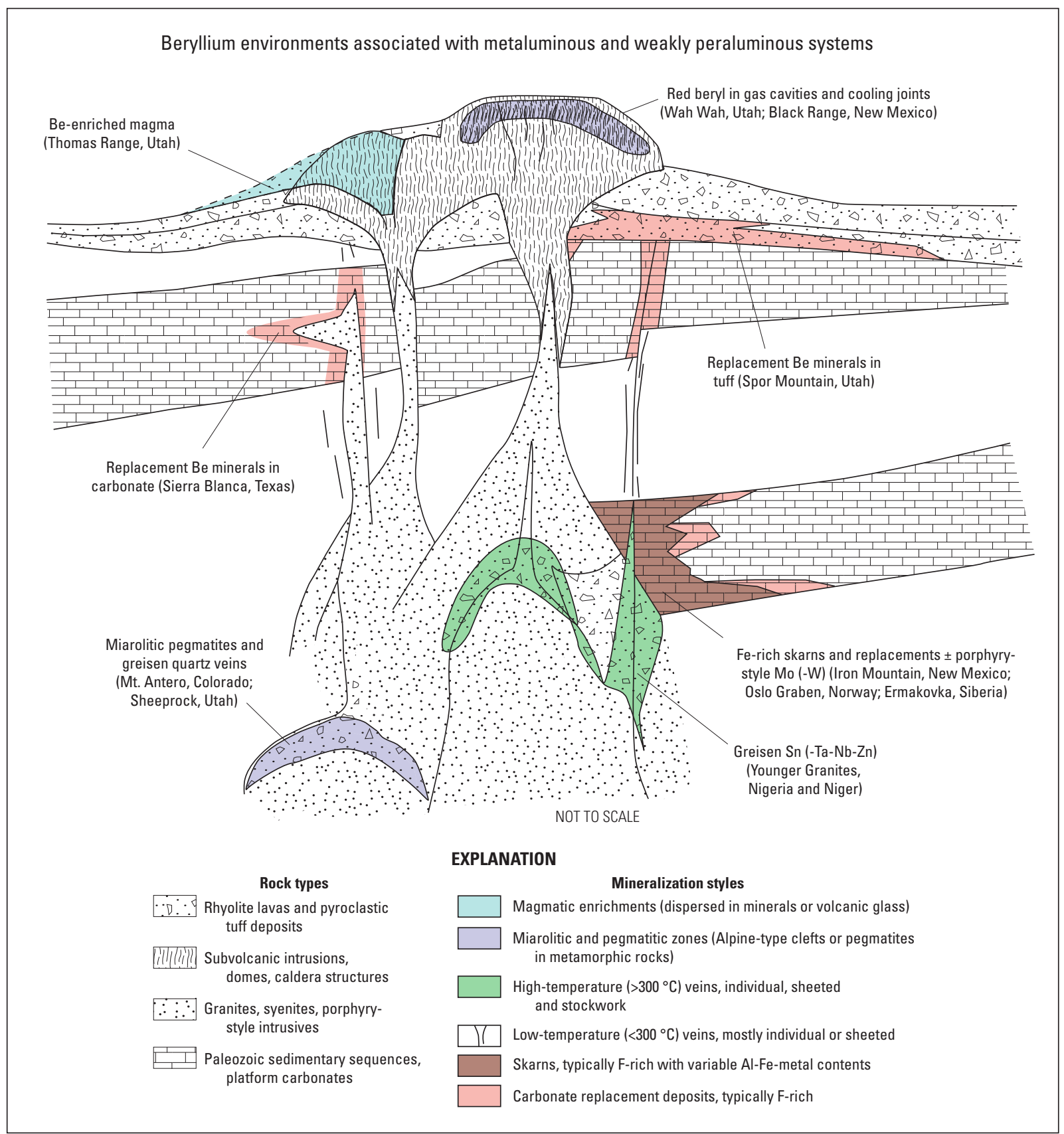

Figure E5. A generalized cross section showing the geologic setting of and some example deposits for the major types of beryllium resources associated with rare-metal magma systems. The cross section also shows the relation of volcanogenic beryllium deposits, such as the one at Spor Mountain, Utah, to other types of deposits that are associated with magmas of this general composition. Modified from Barton and Young (2002). ${ }^{\circ} \mathrm{C}$, degree Celsius. Elements: $\mathrm{Al}$, aluminum; Be, beryllium; F, fluorine; Fe, iron; Mo, molybdenum; $\mathrm{Nb}$, niobium; $\mathrm{Sn}$, tin; Ta, tantalum; W, tungsten; $\mathrm{Zn}$, zinc 

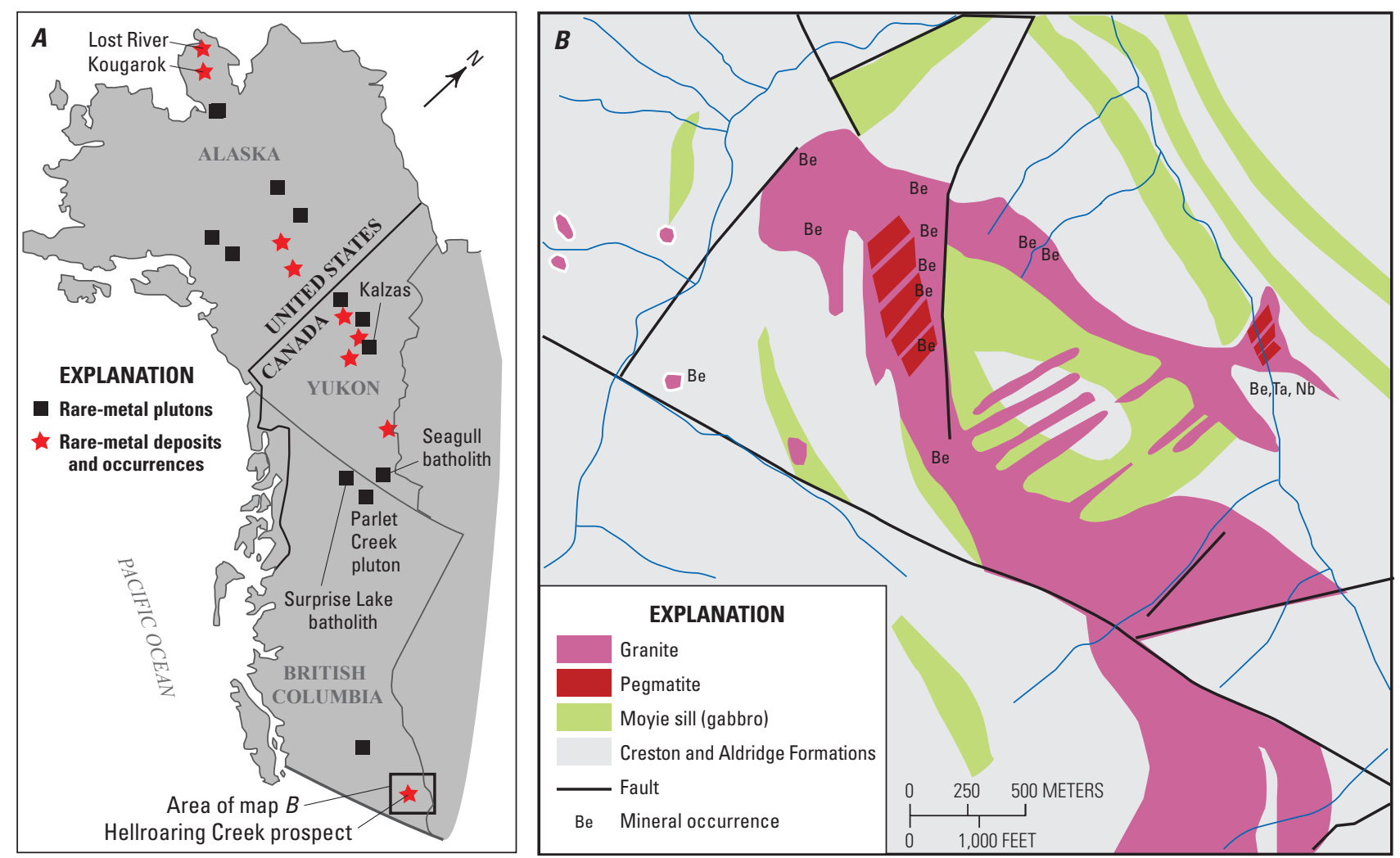

Figure E6. Location map and simplified geologic map of the Hellroaring Creek prospect, which is located west of Kimberley, British Columbia, Canada. Location map $A$ shows the distribution of potential rare-metal-bearing granite and pegmatite deposits of the Canadian and Alaskan Cordillera and of rare-metal deposits associated with the plutons. Geologic map $B$ shows the pegmatite and granite-related beryllium-bearing rare-metal mineralization at the Hellroaring Creek prospect. Maps modified from Soloviev (2011). Be, beryllium; Nb, niobium; Ta, tantalum

Most pegmatite deposits consist of a few thousand tons of rock, although the largest contain as much as 1 million metric tons. For example, the Tanco deposit in Manitoba, Canada, is a large, mineralogically complex, and strongly zoned LCT pegmatite that contains an estimated 900,000 metric tons of beryllium ore. The Tanco pegmatite is part of the rare-metal-bearing Bernic Lake pegmatite group (Černý, 2005) and is currently being mined for cesium, rubidium, and spodumene (a lithium-bearing mineral). Ores of the Tanco pegmatite contain greater than $350 \mathrm{ppm}$ beryllium, which is an enrichment factor of 180 over bulk continental crust, in addition to $13,900 \mathrm{ppm}$ lithium, 236,000 ppm cesium, 28,900 ppm rubidium, and greater than $1,200 \mathrm{ppm}$ tantalum (Stilling and others, 2006). Beryl at Tanco and in many other large complex pegmatite deposits occurs both as fine-grained rinds and as crystal up to 20 centimeters $(\mathrm{cm})$ in length in pockets in albitic aplite, which is a fine-grained granitic rock. In contrast, the Hellroaring Creek prospect, which is located west of the city of Kimberley in the Province of British Columbia, Canada (fig. E6A), is a chemically and mineralogically simple lithium-pegmatite body that has indicated resources of 500,000 metric tons grading 0.1 percent beryllium oxide (Soloviev, 2011). In this case, the pegmatite intrudes an overlying granitic stock, and pockets of beryl are distributed in both granite and pegmatite (fig. E6B). The pockets have a relatively simple mineralogy of beryl (with crystals up to greater than $30 \mathrm{~cm}$ in length), muscovite, and quartz. The prospect is located in an extensive trend of rare-metal granites, pegmatites, and related deposits of the Cordilleras of North America (fig. E6A). These range from small and uneconomic beryl pegmatite deposits of Idaho and Montana (Stoll, 1950) to significant beryllium deposits of Seward Peninsula, Alaska (for example, the Lost River skarn deposit).

\section{Skarn and Greisen-Hosted Beryllium-Fluorine Deposits}

Beryllium-bearing skarn and greisen deposits occur in association with many large rare-metal-enriched granitic and syenitic plutons. These deposit types, which form by metasomatic replacement processes in the mineralized contact zone between the intruding pluton and the country rock, typically have phenakite, bertrandite, and helvite-group minerals. Skarns form by high-temperature alteration of 
carbonate country rocks, and greisens form by alteration of rocks of alumino-silicate compositions. They often display a distinctive texture of rhythmically banded replacements containing alternating light and dark layers of beryllium minerals, fluorite, magnetite, and silicates. Fluorine-beryllium skarn and greisen deposits associated with, for example, tin deposits of the Seward Peninsula, Alaska, such as the Lost River beryllium skarn deposit (Alexsandrov, 2010), and those in Russia's Far East, such as the Yermakovskoye deposit in the Kizhinginskiy Khrebet [Kizhinginskiy Ridge] area of the Republic of Buryatia, are localized in the contact aureoles of carbonate rocks intruded by high-silicon (leucocratic), fluorine-rich granites (Reyf, 2008). The beryllium is contained in veins and vugs in fluorite and calc-silicate altered limestone and argillized granite. Beryl, helvite-group minerals, and phenakite occur along with calcite, fluorite, garnet, quartz, topaz, tourmaline, zinnwaldite (a lithium-mica), and sulfide minerals. Skarn deposits near Changning City in Hunan Province, China (Lin and others, 1995), may supply some of the beryl currently mined in China. Beryllium-fluorine skarn and greisen deposits of this type are deep, high-pressure analogs of carbonate-hosted beryllium deposits, and, where present, may represent the roots of volcanogenic beryllium systems (fig. E6).

\section{Carbonate-Hosted Beryllium Deposits}

Carbonate-hosted beryllium deposits form in carbonate rock sequences where rare-metal and lithophile-enriched volcanic rocks intrude and mineralize carbonate rocks, depositing beryllium minerals in replacement fronts (fig. E6). These types of beryllium deposits occur near Sierra Blanca, Texas, and Aguachile, Mexico. At Sierra Blanca, beryllium-rich fluorite deposits occur in association with peralkalinemetaluminous volcanic rock sequences. The deposits occur within Cretaceous limestones beneath an intrusive contact with an overlying rhyolite laccolith. The rhyolite laccoliths of Round Top Mountain near Sierra Blanca are strongly peraluminous and have anomalous beryllium and fluorine contents (Rubin and others, 1987, 1988, 1990). The rhyolites also contain elevated amounts of $\mathrm{Li}, \mathrm{Nb}, \mathrm{Rb}$, rare-earth elements (REEs), Th, Y, Zn, and cryolite. The beryllium mineralization at Aguachile occurs as replacements and fillings in limestone that was brecciated when it was intruded by a rhyolite dike near the ring fault of a caldera; the rhyolite is peraluminous, although related igneous rocks are peralkaline (McLemore, 2010a). Bertrandite is present with calcite and quartz in fluorite-rich deposits in limestone, and the principal orebody has approximately 0.3 percent beryllium oxide.

At the present time, no domestic carbonate-hosted beryllium deposits are known to be economic; however, they can be important indicators of the potential presence of volcanogenic beryllium deposits. For example, a number of small and irregularly shaped beryllium-rich zones are present in carbonate rocks located stratigraphically beneath the bedded tuff that hosts world-class volcanogenic beryllium ores at Spor Mountain (McLemore, 2010a; Materion Corp., 2012a, b).

\section{Volcanogenic-Hosted Beryllium Deposits}

Beryllium deposits of the volcanogenic type (Barton and Young, 2002; Foley and others, 2012, and references therein) form by replacement of carbonate fragments found in lithic tuff, which is a rock composed of compacted volcanic ash, glass, and rock fragments. Host rocks are typically rare-metalenriched volcanic rhyolite lavas and related tuffs and ash flows that are metaluminous to peraluminous in composition and enriched in fluorine and other lithophile-elements (Be, $\mathrm{Ce}, \mathrm{Li}, \mathrm{Rb}, \mathrm{REEs}, \mathrm{Sn}, \mathrm{Th}, \mathrm{Tl}$, and U) (fig. E7A). The classic tectonic setting is an extensional environment where young igneous rock sequences overlie older dolomite, limestone, quartzite, and shale sequences. The deposits form as the result of magmatic processes that produce fluorine-, beryllium-, and gas-rich rhyolite melts. Degassing of the melts causes explosive volcanism that rips up carbonate and another rock fragments as magmas vent to the surface through fractures in the limestone sequences. The hot magma interacts with groundwater, which causes a hydrovolcanic eruption that dumps fine ash, beryllium-rich volcanic glasses, and fragments of carbonate and other rock in wedged-shaped base surge deposits that thin away from the vent structures (fig. E7B; Burt and others, 1982). This mix of magmatic and hydrothermal fluids is capable of leaching beryllium from the volcanic glass and precipitating it as bertrandite when the hydrothermal fluid encounters carbonate fragments in the tuff. Beryllium is removed from devitrifying glass as a fluoride complex in the cooling fluid. Upon encountering carbonate rock, calcium from the rock fragment and fluorine from the fluid combine to form the mineral fluorite, and the beryllium reacts with silica in the fluid to make bertrandite; this leads to essentially simultaneous deposition of fluorite and bertrandite. These post-magmatic processes play an important role in the development of economic volcanogenic beryllium deposits because they concentrate the beryllium into high-grade ore zones. The size and grade of a volcanogenic beryllium deposit is thought to be related to the distribution of carbonate lithic-rich zones in the host beryllium tuff and the duration and efficiency of the mineralizing hydrothermal system.

Volcanogenic ores of beryllium are produced at Spor Mountain, Utah, from elongate deposits in Miocene-aged tuffs composed of glass, ash, carbonate fragments, and other rock fragments (fig. E7B). The bertrandite occurs as submicroscopic grains mixed with fine-grained fluorite, opal, and calcite in layered nodules that replace carbonate in the tuff (fig. E7C; Lindsey, 1998). The median concentration of unaltered glass melt (59 ppm beryllium) in Spor Mountain tuff (Adams and others, 2009) is about eight times that left in intensely altered glass (7 ppm beryllium), which suggests that almost 90 percent of the original beryllium in the glassy tuff matrix was redeposited in the mineralized carbonate rock fragments.

Only a small number of volcanic rocks and beryllium deposits of this type are known, and most are subeconomic (table E3; fig. E1). These include domestic rare-metal-bearing volcanic occurrences at The Honeycombs (more commonly 

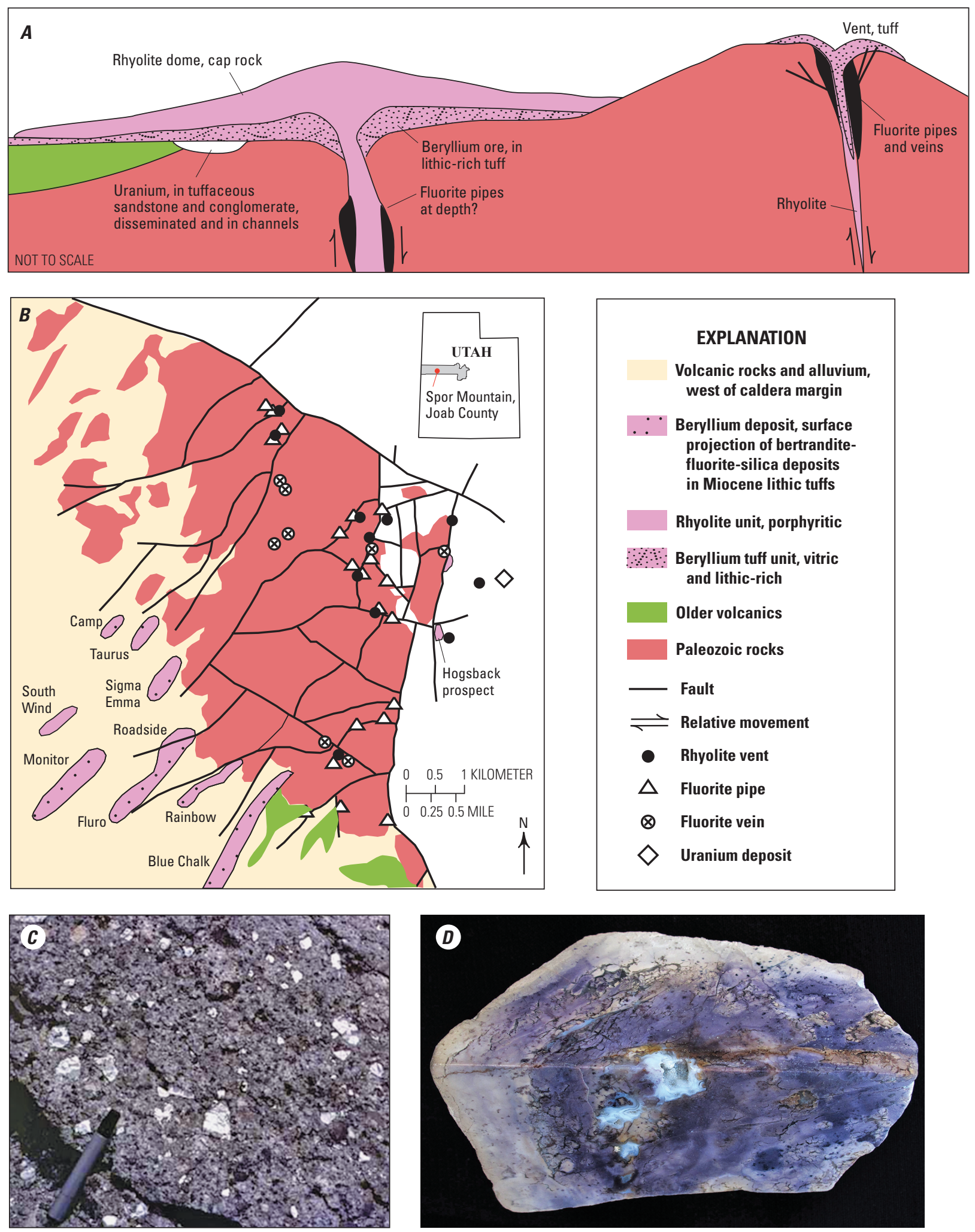

Figure E7. A, Generalized geologic cross section showing the setting of volcanogenic beryllium deposits and related deposit types relative to volcanic vent structures, host tuff, and overlying cap rocks. B, Gelogic map of Spor Mountain area, Utah, showing the distribution of beryllium deposits, fluorite pipes, carbonate rocks, and volcanic rocks. Modified from Lindsey (1998) and Foley and others (2012). C, Photograph of beryllium tuff at Spor Mountain showing dolomite clasts (white) replaced by fluorite, clay, chalcedonic quartz, and manganese oxide. D, Photograph of nodule from the Spor Mountain tuff showing an interior of opal and purple fluorite and an outer zone of opal and fluorite; nodules can contain as much as a few percent beryllium oxide $(\mathrm{Be} 0)$ as bertrandite. The nodule shown is about 20 centimeters wide. Photographs $C$ and $D$ are by D.A. Lindsey, U.S. Geological Survey. 
known as Honeycomb Hills), Utah, and at the Apache Warm Springs volcanogenic beryllium deposit at the Ojo Caliente No. 2 mining district, New Mexico. The Honeycombs are two small eroded domes of topaz-bearing alkali rhyolite and tuff located about 30 kilometers $(\mathrm{km})$ (20 miles) west of Spor Mountain; the prospect contains small amounts of beryllium and fluorite. Similar prospects throughout New Mexico and Utah are also small and of low grade (McLemore, 2010a). Globally, rare-metal metallogenic provinces favorable for volcanogenic beryllium deposits are restricted to a small number of locations, including the peralkaline Niobium tuff of the State of Western Australia, which contains the Brockman deposit (table E3) (Ramsden and others, 1993; Taylor and others, 1995a, b); the Macusani tuff of the Peruvian Altiplano (Pichavant and others, 1988a, b); and peraluminous to peralkaline volcanic rocks of the Teg-Ula deposit in GoviAltay Province, Mongolia (Kovalenko and Yarmolyuk, 1995), and in Shixi, Zhejiang Province, China (Lin, 1985). At the Brockman deposit, beryllium occurs in low-grade lenses of $\mathrm{Nb}-\mathrm{REE}-\mathrm{Ta}-\mathrm{Zr}$ mineralization associated with the pyroclastic eruption of a Paleoproterozoic magma enriched in volatiles. The tuff hosts rare-metal deposits with proven reserves of about 4.3 million metric tons containing 0.44 percent $\mathrm{Nb}_{2} \mathrm{O}_{5}$ and 50 to $1,500 \mathrm{ppm}$ beryllium. Beryllium-bearing ash-flow tuffs also occur in the vicinity of the town of Macusani in the Puno Region of southeastern Peru (Pichavant and others, 1988a, b). The highly peraluminous rocks that compose the Neogene volcanic field near Muscani may be a northernmost expression of the Bolivian tin belt. The tuffs contain elevated concentrations of beryllium (about 15 to $37 \mathrm{ppm}$ ) but no known beryllium deposits. Deposits and occurrences of beryllium in Mongolia and Siberia, Russia, reportedly are hosted by fluorine-rich igneous suites, such as those typically associated with volcanogenic beryllium deposits. The deposits are mostly associated with granite and are of the skarn or greisen type. In Mongolia, however, the central Gobi volcanic zone contains fluorine-bearing rhyolite, beryllium-rich tuff, and REE-rich alkaline volcano-plutonic rocks that compose part of a late Mesozoic rare-metal metallogenic belt within the Transbaikal-Mongolian rare-metal province (Kovalenko and Yarmolyuk, 1995).

\section{Nonmagmatic-Related Beryllium Deposits}

Beryllium minerals also occur in a variety of nonmagmatic hydrothermal, metamorphic, and sedimentary environments; in most cases, these occurrences are subeconomic. Shear-zone deposits form in metamorphic terranes by local redistribution of materials during deformation. Metamorphic host rocks may include felsic metavolcanics, metasedimentary rocks, marbles and metabasites, and, thus, shear-zone deposits are found in blackwall (mafic rock), greisen, skarn, and vein settings. They are uncommon occurrences of beryl and phenakite and are typically mined as gem emerald (Grundmann and Morteani, 1989). Basinal brine deposits consist of greisens and veins formed by replacement of aluminosilicate host rock by low-temperature basinal brines with unsubstantiated or unknown connections to magmatic systems. Classic examples include the emerald deposits of Muzo and Chivor, in the Department of Boyacá, Colombia, where beryl and euclase are exclusively mined as gemstones. Placer deposits containing beryl are common and historically have provided both industrial beryllium ore and gemstones (Sinkankas, 1981). Deposits of this type are known in the State of Minas Gerais, Brazil, and in Madagascar and Sri Lanka. Nonmagmatic deposits can be a source of industrial beryl; however, most are mined as gemstones of beryl-type minerals, such as aquamarine, chrysoberyl (variety alexandrite), and emerald, as well as euclase, phenakite, and tugtupite (table E2). Gemstones are a distinct mineral commodity and are not covered in this chapter, but they are covered elsewhere (see, for example, Olson, 2016).

\section{Resources and Production}

Identified resources of beryllium worldwide have been estimated to be more than 80,000 metric tons (Jaskula, 2013a). About 65 percent of these are in U.S. resources of bertrandite, and the rest are in resources of beryl in other countries. Beryllium grades and resource tonnages for volcanogenic beryllium deposits, LCT pegmatites, and selected other deposit types are shown for the purpose of general comparison in figure E8. World beryllium reserves are not sufficiently well delineated to report consistent figures for all countries.

\section{Domestic Resources}

Domestic carbonate-hosted and volcanogenic deposits of beryllium occur in New Mexico, Texas, and Utah. The deposits range in size from small (Iron Mountain in New Mexico) to world class (Spor Mountain in Utah) (table E4; fig. E8).

Exploration sites thought to host the large deposits are described below. It is unlikely that other domestic beryllium deposits will be mined in the near future because the Spor Mountain deposit contains sufficient beryllium reserves to meet expected demand.

Spor Mountain, Utah.-At yearend 2011, Materion Corp. (2011) reported proven domestic reserves of bertrandite at Spor Mountain of 5.75 million dry tons at an average grade of 0.265 percent beryllium (about 0.8 percent beryllium oxide). The bertrandite contains about 15,200 metric tons of beryllium. Figure E8 shows ore grade and tonnage estimates for Spor Mountain based on a cutoff grade of 0.23 percent beryllium.

Lost River, Alaska.-The Lost River Mines, which are located in the western part of Seward Peninsula, were mined intermittently for tin from 1904 through 1955. Near the mines, a limestone of Early Ordovician age is partly replaced by silicate minerals and cut by numerous veinlets containing silicates, ore minerals, and fluorite. A granite pluton and dikes 


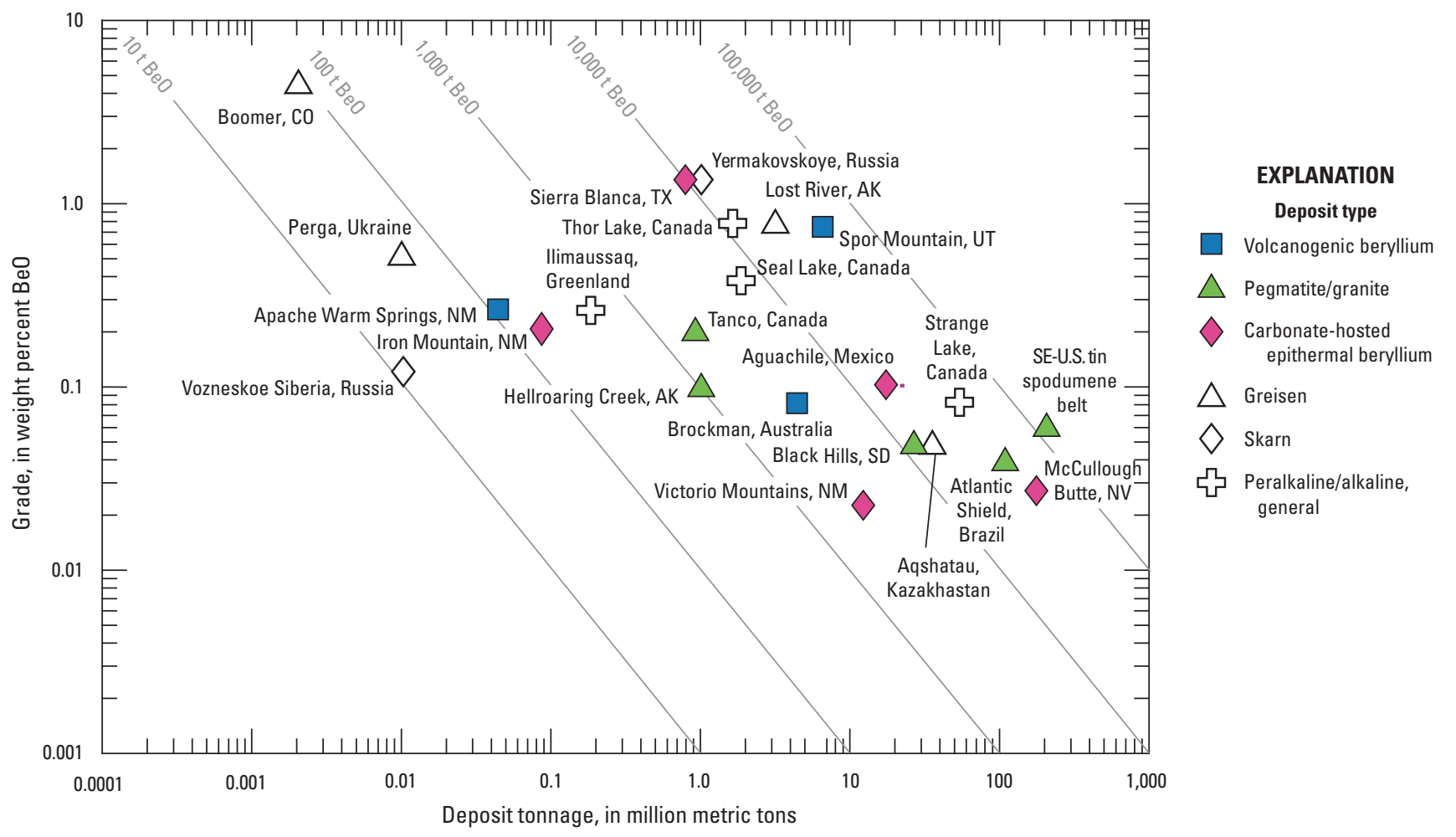

Figure E8. Graph showing general estimates (using data from table E4) of grade and tonnage for a variety of beryllium $(\mathrm{Be})$ deposits, districts, and belts that have a potential for minable beryllium resources. Diagonal lines are isolines of contained beryllium oxide, in metric tons ( $t$ ). The available data for deposits of these types are sparse; some of the deposit information has been compiled using poorly documented past production, reserve, and resource information-data types that are typically not combined for use in a single plot of grade versus tonnage. Be0, beryllium oxide. Locality: AK, Alaska; CO, Colorado; NM, New Mexico; NV, Nevada; SD, South Dakota; SE-U.S., Southeastern United States; TX, Texas; UT, Utah

that underlie the deposit are greisenized. The fine-grained ore of diaspore, euclase, fluorite, mica, tourmaline, and white chrysoberyl forms replacement veins, pipes, and stringer lodes in limestone. The beryllium content of the bulk ore ranges from 0.11 to 0.54 percent ( 0.31 to 1.50 percent beryllium oxide); high-grade nodules of chrysoberyl, diaspore, fluorite, and mica contain as much as 6 percent beryllium oxide (Sainsbury, 1963, 1964a, b; Dobson, 1982).

Apache Warm Springs, New Mexico._Exploration for volcanic-hosted beryllium deposits in New Mexico has focused on the Sierra Cuchillo and San Mateo Mountains, which extend across Socorro and Sierra Counties (McLemore, 2010b, undated). Bertrandite at the Apache Warm Springs property at Sierra Cuchillo occurs in small quartz veins and stringers in fractures and disseminations in a 28-millionyear-old rhyolite and ash-flow tuff showing intense alteration to clay minerals. Drilling by BE Resources Inc. of Toronto, Ontario, Canada, identified mineralized zones in altered rhyolite; however, assays from 13 exploration boreholes revealed grades of beryllium oxide well below the cutoff grades determined from the company's beryllium oxide benchmarking project (BE Resources Inc., 2011). In addition, beryl has been produced from New Mexico pegmatites in Grant, Mora, Rio Arriba, San Miguel, and Taos Counties, and the majority of the beryl production (about 770 metric tons of beryl) came from the Harding pegmatite in Taos County.

Sierra Blanca, Texas.-Beryllium-fluorine mineralization at Round Top Mountain, Sierra Blanca, is found with fluorite and replaces limestone adjacent to rhyolite (Rubin and others, 1988). The Sierra Blanca rhyolite is one of six laccoliths of similar age (36.2 \pm 0.6 mega-annum [Ma]) (Henry, 1992). Cyprus Beryllium Corp. reported resources and reserves of 850,000 metric tons averaging 1.5 percent beryllium oxide ( 0.5 percent beryllium), although the reported data were not compliant with National Instrument (NI) 43-101 guidelines (Rubin and others, 1990).

Tin-Spodumene Belt, North Carolina and South Carolina.Pegmatite dikes in the tin-spodumene belt of North Carolina and South Carolina contain an average of about 0.05 percent beryllium oxide (Griffitts, 1973). The pegmatites also contain cassiterite, columbite, feldspar, mica, and spodumene. Resource estimates for the entire tin-spodumene belt suggest 747,000 metric tons of beryl (111,400 metric tons of beryllium oxide) (Griffitts, 1954, p. 10). Individual pegmatite districts (for example, Bessemer City and Kings Mountain, North Carolina) have in the range of 36,000 metric tons of beryl (equivalent to about 5,400 metric tons of beryllium oxide). Little beryl is found in the Piedmont province outside of the tin-spodumene belt. 
Black Hills, South Dakota.-The Tin Mountain district in the Black Hills includes more than 24,000 pegmatites associated with the peraluminous Harney Peak granite of Paleoproterozoic age. Only about 2 percent of pegmatites in the district are zoned, and these have been mined for muscovite, potassium-feldspar, and rare metals, such as $\mathrm{Be}, \mathrm{Cs}, \mathrm{Li}, \mathrm{Nb}, \mathrm{Ta}$, and $\mathrm{Sn}$. The most highly differentiated pegmatites, such as at the Tin Mountain and the Bob Ingersol Mines, are dikes with lepidolite, petalite, and spodumene mineralization (Krogstad and others, 1993; Walker and others, 1986; Sirbescu and Nabelek, 2003).

\section{International Resources}

Pegmatite beryl deposits are found throughout the world (figs. E1 and E8). The more significant global exploration sites for nonpegmatite beryllium resources are as follows:

Yermakovskoye, Russia.-The Yermakovskoye beryllium deposit occurs in a large block of carbonate rock with a sedimentary sequence preserved in a field of gabbroic plutons, alkali granite, and leucogranite. The phenakitemicrocline-fluorite ores formed at about $225 \mathrm{Ma}$ by replacement of limestone (Kislov and others, 2010; Lykhin and others, 2010). The deposit has an average grade of 1.3 percent beryllium oxide (about 0.5 percent beryllium) and may be the largest beryllium deposit in Russia (Reyf, 2008), although as of 2011, no beryllium was being produced from this deposit. East Siberian Metals Corp. (a subsidiary of Metropol Group) and JSC Ulba Metallurgical Plant of Kazakhstan reportedly had completed a predesign phase for resuming mining and the technical design for a processing plant. The new plant would produce beryllium hydroxide for delivery to China, Japan, and Kazakhstan for metal and alloy processing. Russia is not known to produce any domestic beryllium metal currently; imports from Russia are most likely sourced from Kazakhstan (Jaskula, 2013b).

Thor Lake, Northwest Territories, Canada.-The Thor Lake rare-metals group of deposits, and specifically the North $\mathrm{T}$ deposit, reportedly host one of the highest grade beryllium resources known in the world. An NI 43-101-compliant resource estimate prepared by Wardrop Engineering Inc. of Canada in 2007 confirmed an indicated resource in one subzone of the North T deposit of greater than 450,000 metric tons grading 0.98 percent beryllium oxide. The primary beryllium ore mineral in the North $\mathrm{T}$ deposit is phenakite. The owner, Avalon Rare Metals Inc., saw no near-term economic potential for the North $\mathrm{T}$ beryllium deposit and had no immediate plans to initiate development (Avalon Rare Metals Inc., 2013).

\section{Production and Supply}

The recent annual worldwide production of beryllium (mainly from China, Mozambique, Portugal, and the United States) was estimated to be 260 metric tons in 2011. Of that output, more than 235 metric tons of contained beryllium was derived from deposits at Spor Mountain (Jaskula, 2013a, b). In 2011, pegmatite beryllium deposits accounted for about 25 metric tons of contained beryllium. Global trends show an increase in estimated production of beryllium for the United States and China for the period 2000 through 2012 (fig. E9). During pegmatite mining for other minerals, beryl is frequently stockpiled for processing at a later time. World production and the United States share of world production have a high degree of uncertainty because China, which is known to be a significant producer, does not report its beryl production.

Countries that produce beryl ore include Brazil, China, Madagascar, Mozambique, and Portugal. Nigeria, Kazakhstan, and Uganda may also produce beryl ore, but information is inadequate to make reliable estimates of output. Nations that produced gemstone beryl may also have produced some beryl ore for industrial use. The United States is the world's leading producer of bertrandite ore, and Materion Corp., which was the sole domestic producer, accounted for 91 percent of estimated world beryllium ore production in 2011. China, Kazakhstan, and the United States are the only countries known to process beryllium ores and concentrates into beryllium products. Materion Corp. has manufactured products in the form of foil, rods, sheets, and tubes, and a variety of other customized shapes at plants in Elmore, Ohio, and Fremont, California, and beryllium oxide ceramic products at a plant in Tucson, Arizona.

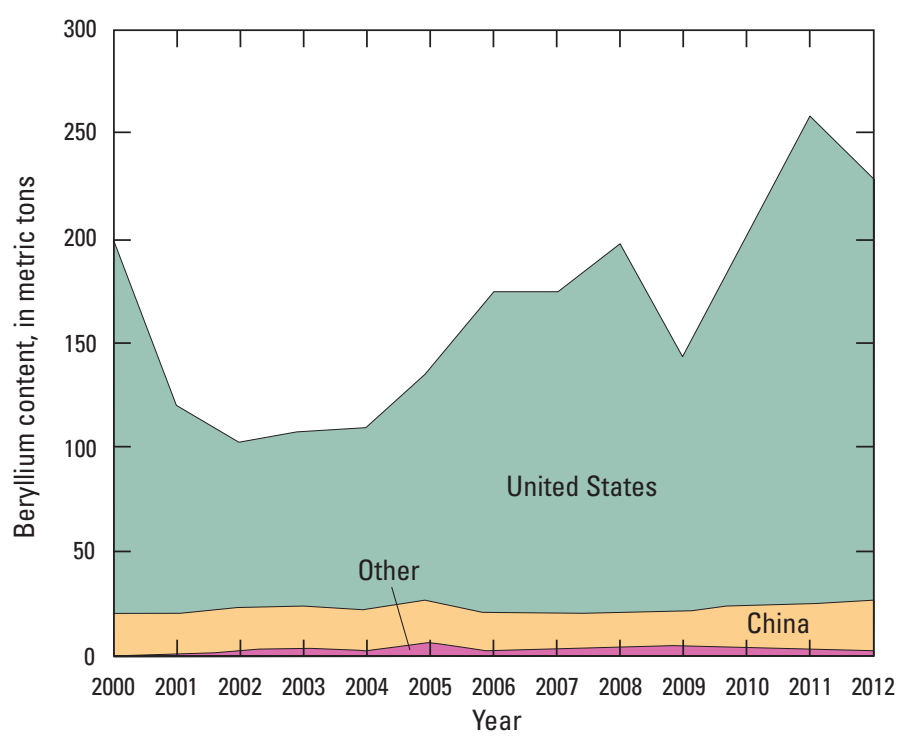

Figure E9. Graph showing estimated global production of beryllium for 2000-11. The layers of the graph are placed one above the other, forming a cumulative total. Data are from U.S. Geological Survey (2007-15). 
In the United States, Materion converts bertrandite from open pit mines in Utah and imports beryl ore (at a ratio of 90 percent bertrandite to 10 percent beryl) into beryllium hydroxide at operations near Delta, Utah, in an effort to extend its domestic bertrandite reserves. Because beryl has fewer impurities than bertrandite, Materion also processes imported beryl alone as a means of producing very high purity beryllium (Stephen Freeman, President, International Business Development, Materion Corp., oral commun., January 10, 2013). Some of the beryllium hydroxide is shipped to Elmore, Ohio, where Materion converts it into the primary feed material used to make beryllium metal products, including beryllium-copper master alloy (BCMA), metal, or oxide; in the past, some of the primary feed material was sold to NGK Insulators, Ltd. of Japan. Materion ceased producing beryllium metal in 2000 when its facility was closed owing to obsolescence. Since that time, the company has obtained beryllium metal from the National Defense Stockpile and through imports from Kazakhstan.

In 2011, Materion built a new primary beryllium facility in partnership with the DOD to ensure the availability of high-quality domestic beryllium metal to meet critical defense needs. Under its Defense Production Act Title III Program, the DOD invested in a public-private partnership with Materion to build a new $\$ 90.3$ million primary beryllium facility in Elmore, Ohio. The construction was completed in 2011. Materion provided assets, research and development, and technology valued at approximately $\$ 23.2$ million to the project; the balance was funded by the DOD. Plant capacity was reported to be 73 metric tons per year of high-purity beryllium metal; approximately two-thirds of the facility's output is to be allocated for defense and Government-related end uses, and the remaining output is to go to the private sector (Metal Bulletin, 2010; Materion Corp., 2012a).

Kazakhstan's Ulba Metallurgical Plant, which was a subsidiary of JSC National Atomic Company "Kazatomprom," reported that it supplied about 26 percent of the world's beryllium products in 2011 compared with 3 percent in 1999. The Ulba Metallurgical Plant reportedly produced these products from stockpiled beryllium concentrate imported mainly from Russia. The concentrate stockpile, which was built up before the breakup of the Soviet Union, was forecast in 2003 to be sufficient to support production for about 30 years (Metal Bulletin, 2003; McNeil, 2006; Kazatomprom JSC, 2012).

More recent reports (2015) indicated that only a few years of supply remain in the concentrate stockpile. In 2015, it was estimated that the Ulba Metallurgical Plant produced about 90 metric tons of beryllium contained in berylliumcopper alloys, beryllium oxide ceramics, and beryllium metal. Owing to anticipated demand for beryllium, Russia is in the process of resuming mining and constructing a processing plant at the Yermakovskoye deposit in the Siberian Republic of Buryatiya. The new plant will produce beryllium hydroxide for export to the Ulba Metallurgical Plant in Kazakhstan, as well as to China and Japan for processing into beryllium metal and beryllium alloys. The annual mining and processing capacities are estimated at 25,000 metric tons per year of bertrandite ore and 130 metric tons per year of beryllium hydroxide. In 2015, Russia announced it would produce its own beryllium metal on a commercial scale by 2020 .

China's Shuikoushan Non-Ferrous Metals Co., Ltd. processed beryllium ores and produced beryllium products in various forms at its 6th Smelting Plant in Songbai, Changning City, Hunan Province. The plant had an estimated production capacity of 150 metric tons per year of beryllium oxide and 1,500 metric tons per year of BCMA (McNeil, 2006). Fuyun Hengsheng Beryllium Industry Co., Ltd.'s refinery (a joint venture among Xinjiang Nonferrous Metals Industry Group, Xinjiang Henghe Investment Co., Ltd., and Xinjiang Nonferrous Metals Industry Group Nonferrous Metals Co.) was designed to produce 100 metric tons per year of beryllium oxide and 800 metric tons per year of BCMA. The refinery is located in Fuyun County in northwestern Xinjiang Uygur Autonomous Region (China Non-Ferrous Metal Import \& Export Xinjiang Corp., undated). In 2015, it was estimated that China produced about 65 metric tons of beryllium contained in beryllium-copper alloys, beryllium oxide ceramics, and beryllium metal at these two plants. Approximately 20 metric tons of the beryllium was sourced from domestic ore and 45 metric tons was obtained from ore derived from foreign sources, most likely Kazakhstan's Ulba Metallurgical Plant.

\section{Exploration for New Deposits}

Early exploration methods to map the occurrence of deposits in highly evolved felsic rocks and fluorine-rich hydrothermal systems used a neutron-sourced gamma ray spectrometer capable of rapid semiquantitative field analysis of the beryllium contents of rocks (Meeves, 1966). Current exploration and assessment methods are based on identifying favorable geotectonic settings, beryllium-bearing magmatic rock suites, and local and regional alteration patterns that might target economic mineralization (Foley and others, 2012). Magnetic, gravity, and seismic data are useful in identifying large-scale igneous suites in favorable geotectonic settings that have a potential to contain volcanogenic beryllium deposits. Rhyolitic rocks rich in fluorine and beryllium that show evidence of explosive volcanism, such as unsorted carbonate rock fragments in breccias and vent structures capable of tapping the sources of rhyolitic magma and mineralizing fluids at depth, are a favorable volcanic host rock. The richest beryllium ore zones may be associated with mineralized carbonate-fragment-rich deposits of tuff. The presence of fluorite and uranium deposits suggests the presence of fluids capable of transporting sufficient amounts of beryllium to form a deposit (Lindsey, 1975). Hydrothermal alteration minerals, especially the presence of abundant lithium-smectite, and geochemical halos of elements, including Be, Ce, F, Ga, Li, $\mathrm{Nb}$, and $\mathrm{Y}$, occur in rocks surrounding deposits (Lindsey and others, 1973). Economic deposits are likely to be made up of 
many small mineralized lenses that, as a whole, may cover 50 square kilometers or more but that individually may cover only hundreds of square meters. For example, the surface expression of the Apache Warm Springs deposit is approximately 10 meters by 40 meters - comparable in size to one of the smaller individual deposits at Spor Mountain.

Exploration for beryl-rich LCT pegmatites is typically carried out within major known pegmatite fields where field relations are clear and discoveries of new pegmatite bodies may be readily mined (Bradley and McCauley, 2013). In areas where bedrock is well exposed, pegmatites stand out because they are light-colored, have large crystals, and are resistant to weathering relative to surrounding country rocks. An initial exploration step is the identification of appropriate granitic rock types, although, because pegmatites can invade any rock type, the absence of granite in surface exposures does not eliminate the potential occurrence of LCT pegmatites. In areas where exploration has been minimal, first-order criteria, as established in Bradley and McCauley (2013), are an orogenic hinterland (mountain-building) setting, rocks having metamorphic grades suggesting conditions of medium pressure and medium to high temperatures, and the presence of evolved granites and common granitic pegmatites. Pegmatites that show a regional mineralogical and geochemical zoning pattern concentric about the inferred parental granite are favorable for beryl. Exploration and assessment for LCT pegmatites are guided by a number of important field and laboratory observations. Because beryl is associated with the highly fractionated pegmatite zones and because these may constitute only 1 to 2 percent of a field, mineralogical and geochemical variations in granite-pegmatite zones are important (Selway and others, 2005). For example, beryl reportedly shows color changes from green-brown to pink-white, with increasing fractionation in more evolved bodies (Trueman and Černý, 1982). Also, mapping of chemical changes in specific minerals, such as increasing rubidium in potassium feldspar, increasing lithium in white mica, increasing manganese in garnet, and increasing tantalum and manganese in columbite-tantalite, may be used to locate LCT pegmatite bodies within larger fields of common pegmatite. Many LCT pegmatites show haloes of alkali elements (cesium, lithium, and rubidium) in surrounding wall rocks and soils that have been used to locate buried rare-metal pegmatites (Galeschuk and Vanstone, 2005, 2007). In weathered environments, anomalies of $\mathrm{As}, \mathrm{Be}, \mathrm{Sb}$, and $\mathrm{Sn}$ and resistant minerals, such as cassiterite, in soils may also indicate LCT pegmatite (Smith and others, 1987).

Exploration for new deposits is limited in North America because domestic beryllium production is dominated by a single producer (Materion Corp.) that effectively controls the relatively small and specialized domestic beryllium marketa market that cannot readily accommodate new competition on the raw material supply side. Many new discoveries of volcanic-hosted bertrandite are extensions of known deposits. Further exploration and mining of beryl from pegmatite is unlikely in the United States given the current high costs associated with labor-intensive beryl extraction.

\section{Environmental Considerations}

\section{Sources and Fate in the Environment}

The behavior of beryllium in the environment is dominated by its low solubility in water and that it is commonly found in solid form. Natural beryllium in the atmosphere is mostly from dust sources, including windblown dust and volcanic eruptions. The main anthropogenic source of beryllium in the atmosphere is from the combustion of coal and fuel oil, followed by beryllium processing and municipal waste combustion (National Research Council, Committee on Beryllium Alloy Exposures, 2007). Globally, the atmospheric content of beryllium varies between 0.3 and 300 parts per trillion (ppt) (0.1 to 100 nanograms per cubic meter $\left[\mathrm{ng} / \mathrm{m}^{3}\right]$ ) (Kabata-Pendias and Mukherjee, 2007). Beryllium concentrations in air in rural areas of the United States ranged from 0.08 to $0.2 \mathrm{ppt}\left(0.03\right.$ to $\left.0.06 \mathrm{ng} / \mathrm{m}^{3}\right)$ and in urban areas ranged from less than 0.3 to $18 \mathrm{ppt}\left(0.1\right.$ to $\left.6.7 \mathrm{ng} / \mathrm{m}^{3}\right)$; up to $224 \mathrm{ppt}$ $\left(82.7 \mathrm{ng} / \mathrm{m}^{3}\right)$ was reported in the vicinity of a beryllium processing plant in Pennsylvania (Bruce and Odin, 2001). The average upper crustal abundance of beryllium is $1.9 \mathrm{ppm}$ (Hu and Gao, 2008) and natural soils are reported to contain between 0.48 to $3.52 \mathrm{ppm}$ beryllium (Kabata-Pendias and Mukherjee, 2007). In the conterminous United States, the concentration in surface soils ( 0 to $5 \mathrm{~cm}$ depth) averages $1.3 \mathrm{ppm}$ and ranges from less than 0.1 to $17.3 \mathrm{ppm}$ (Smith and others, 2013).

In waterways, the natural weathering of rocks and soils, deposition of atmospheric beryllium, and industrial wastewater effluents are the main sources of beryllium. The mobility of beryllium in the aqueous environment is limited because of the poor solubility of most beryllium compounds and its affinity to bind with clay minerals and organic compounds; beryllium commonly resides in sediment or soils. Beryllium mobility is enhanced under acidic water conditions and may be found as a dissolved cation (beryllium ${ }^{2+}$ ) or may form soluble fluorine and organic complexes (Kabata-Pendias and Mukherjee, 2007). At near-neutral pH, which is typical of most surface and groundwaters, beryllium is controlled by the formation of beryllium hydroxide, which is a low solubility phase. Globally, rivers commonly contain between less than 0.008 and $0.6 \mathrm{ppb}$ beryllium and have an average of $0.009 \mathrm{ppb}$ beryllium (Gaillardet and others, 2003). Surface waters in the United States have a mean concentration of $0.07 \mathrm{ppb}$ beryllium; groundwaters contain comparably low concentrations, and seawater contains even lower concentrations (Eckel and Jacob, 1988; Bruce and Odin, 2001). Beryllium concentrations in industrial effluents are several orders of magnitude higher and range from 30 to $170 \mathrm{ppb}$ (Bruce and Odin, 2001).

Pre-mining baseline geochemical data for beryllium deposits are sparse. LCT pegmatite deposits may exhibit enrichments in $\mathrm{B}, \mathrm{Cs}, \mathrm{F}, \mathrm{Li}$, and $\mathrm{Rb}$ in surrounding soils and waters. These enrichments form as surrounding country rock is hydrothermally altered as a result of pegmatite emplacement (Bradley and McCauley, 2013), and they can persist in soils 
that develop when the rocks are weathered. For example, the Tanco pegmatite in Canada has alteration halos of lithium and rubidium over the buried deposit (Trueman and Černý, 1982). In general, volcanogenic beryllium deposits may have enriched halos of F, Li, Mo, Nb, REEs, Sn, Ta, Th, U, and W in surrounding volcanic rocks and mineralized tuff; therefore, soils and waters in the vicinity may contain anomalous concentrations of the elements (Foley and others, 2012). The stream waters near the Yermakovskoye deposit in Russia contain naturally elevated concentrations of $\mathrm{Cu}, \mathrm{F}, \mathrm{Fe}, \mathrm{Hg}$, Mn, Mo, and Zn (Kislov and others, 2010). The solubility of beryllium minerals is low under most naturally occurring conditions; thus, beryllium contents are not expected to be anomalous in waters draining beryllium deposits, although soils may be enriched.

\section{Mine Waste Characteristics}

Mine waste is material that is generated during ore extraction and processing at the mine site as part of the mining operation; it has no economic value. The volume and characteristics of the mine waste depend on the deposit type exploited and its size, whether multiple mineral commodities are being recovered, and the mining and processing methods used. Mine waste also includes waste generated in the chemical conversion of concentrated beryllium ores to beryllium hydroxide at the mine site. Additional processing steps to convert beryllium hydroxide to beryllium metal, oxides, or alloys also create waste; this type of waste is not discussed in this paper because these operations are commonly conducted at processing plants distant from the mine sites. In general, the mining of beryl and bertrandite ores creates mine waste that is similar in composition to the rocks that host the beryllium-containing minerals because the ores grades are low (table E4).

The ore from the bertrandite deposit at Spor Mountain, Utah, contains about 1 percent or less bertrandite; therefore, nearly all of the mined and processed ore becomes waste. Mining at Spor Mountain occurs with a stripping ratio of overburden to ore of $23: 1$, which indicates that significant amounts of overburden also have to be disposed of (Hawkins, 2001). At Spor Mountain, the composition of the mineralized tuff and the overlying rhyolite is likely representative of the bulk geochemical characteristics of the waste material. Quaternary alluvium overlying the mineralized tuff and rhyolite is mainly Pleistocene sediments of Lake Bonneville. The geochemical characteristics of the mineralized tuff at Spor Mountain have been summarized by Lindsey (1975), and, for the most part, reflect the rhyolitic protolith $(\mathrm{Si}>\mathrm{Al}>\mathrm{K}>\mathrm{Ca} \approx \mathrm{Na}>\mathrm{Fe} \approx \mathrm{Mg}$ ) with trace-element enrichments in beryllium, fluorine, lithium, thorium, and uranium relative to unmineralized counterparts. The mineralogy of the tuff is dominated by clays, cristobalite, potassium-feldspar, and quartz; calcite and dolomite clasts are locally important. Fluorite and manganese oxides are locally abundant in the ore assemblages, and uranium is thought to be bound in fluorite and opal (Lindsey, 1981). The lack of sulfide minerals and the presence of carbonate minerals as clasts suggest that the waste material is net-alkaline (has a $\mathrm{pH}$ greater than 7); this measure indicates that the rocks will not contribute acid to surrounding bodies of water as they weather.

At the Yermakovskoye Mine site in Russia (fig. E1), future mining and processing of the ore reserves is expected to extract 8.5 million cubic meters of rock from an open pit operation and to produce 830,000 cubic meters of tailings during its approximate 20-year mine life (Kislov and others, 2010). The ore minerals of fluorite (about 20 percent fluorite), bertrandite, and phenakite are associated with albite, calcite, dolomite (about 12 percent carbonate), microcline, and quartz with minor amounts of sulfides, including galena, pyrite, and sphalerite. Mine tailings from production that ended in 1989 contains up to $241 \mathrm{ppm}$ beryllium, which is well above background concentrations in the area, which are between 1.5 and 9.9 ppm beryllium (Kislov and others, 2010). The reopening of this mine site as proposed would include a processing facility that would use flotation to separate the sulfides, which would create sulfide-rich tailings, followed by beryllium and fluorite flotation, which would create additional tailings. The sulfur content of the ore is up to 0.37 percent sulfur, including the contribution from pyrite, which can generate acid upon weathering. Sulfide tailings could be potentially acid generating, but the high carbonate content of other mine waste may help neutralize the acid generated.

Beryl in pegmatites can be associated with a range of host rock types, but, in general, processing of pegmatite ores generates mill tailings of relatively simple mineralogy. Enriched zones of beryl (approximately 2 percent) usually are associated with muscovite, plagioclase, potassium-feldspar, and quartz and may be from zones in which amblygonite, feldspar, and spodumene are recovered (Sabey, 2006). Beryl has also been found in quartz veins that contain cassiterite, molybdenite, wolframite, and other minerals. Enriched-beryl zones commonly consist of a few thousand tons of rock, with the largest containing up to 1 million metric tons. When it was in operation, the Tanco Mine generated tailings that were predominantly feldspar with some mica, quartz, pollucite, and spodumene when the ore was processed to recover spodumene and tantalum (Solylo, 2012). Tailings produced after beryl separation would likely be compositionally similar. Additional insight into the mineralogy of mine waste from pegmatite deposits was gained from experiments conducted on recovering beryl from several small operations that were mining spodumene in Arizona, Colorado, New Mexico, and Canada. Quartz and feldspar tailings from gangue as well as mica-schist tailings from overburden were generated. Also, in a later processing step to concentrate the beryl, apatite and iron-bearing gangue minerals, including garnet, pyroxene, and tourmaline, were separated with a magnetic separator, which generated additional waste (Bhappu and Fuerstenau, 1964). Other research on recovering beryl from the former Foote Mine near Kings Mountain, North Carolina, generated predominantly feldspar and quartz tailings along with separate 
Table E4. Location, grade, tonnage, and other data for selected beryllium deposits of the world.

[Compiled from Griffitts (1954, 1973), Barton and Young (2002), Sabey (2006), Secher and Appel (2007), Brush Engineered Materials, Inc. (2009), and McLemore (2010a). Be, beryllium; BeO, beryllium oxide; \%, percent; —, no data]

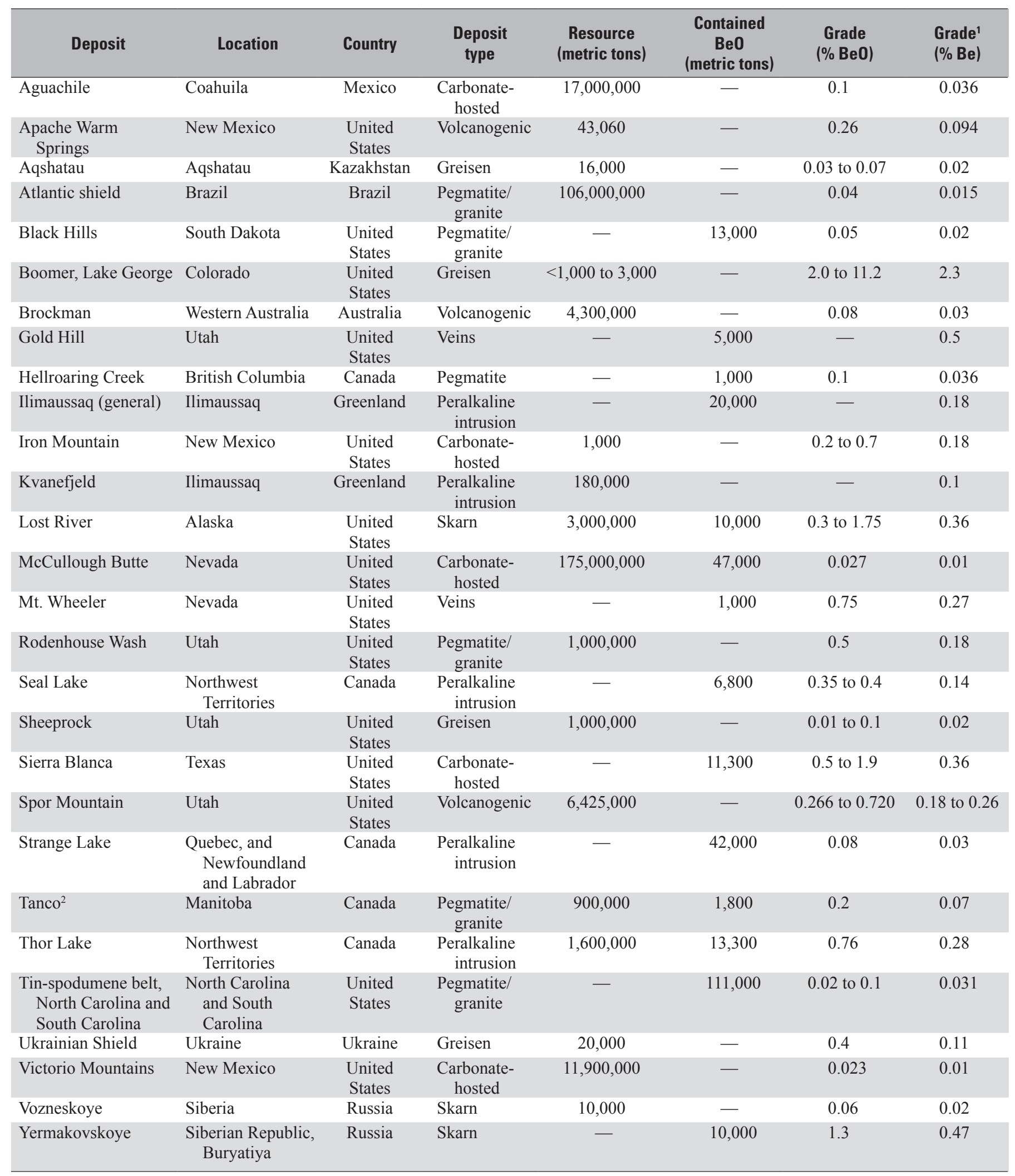

${ }^{1}$ Grade used for constructing figure E9.

${ }^{2}$ Also known as Bernic Lake. 
beryl, mica, and spodumene concentrates (Browning, 1961). In addition, discarded spodumene tailings at the mine, which consisted of feldspar and quartz with minor amounts of mica, spodumene (approximately 5 percent), and beryl (approximately 0.5 percent) were reprocessed to recover beryl, spodumene, and, sometimes, feldspar (Browning and others, 1964).

In addition to the waste rock, overburden, and mill tailings generated at beryllium mine sites, converting the concentrated beryllium ores to beryllium sulfate and subsequently to beryllium hydroxide produces additional waste. To remove impurities and waste minerals, the beryllium is extracted, purified, and precipitated using organic or other solutions. The waste solutions and precipitates from various steps are discarded in waste ponds and may be acidic. Waste ponds may be neutralized and diluted to offset high corrosivity and reduce the overall concentrations of $\mathrm{Be}, \mathrm{Cr}, \mathrm{Cu}, \mathrm{Se}$, and cyanide. Waste solutions containing uranium are commonly transferred to separate storage ponds and shipped elsewhere for U-metal recovery. Waters in the ponds are commonly evaporated to generate a solid waste product (U.S. Environmental Protection Agency, 1989). One study that examined the characteristics of red mud solid waste resulting from the fluoride separation process for beryl ore found that it was composed mainly of aluminum, iron, and silicon, with significant amounts of beryllium (Bhat and others, 2002). For example, red mud at a processing facility in India contained 0.4 to 0.6 percent beryllium, and approximately one-half of the beryllium was leached using water (based on laboratory experiments), which suggests that much of the beryllium in red mud is mobile in surficial environments (Bhat and others, 2002).

\section{Human Health Concerns}

Beryllium is toxic and a human carcinogen that can impair the function of the blood vessels, endocrine glands, heart, and liver (Taylor and others, 2003; Kabata-Pendias and Mukherjee, 2007). The general population is exposed to beryllium mainly from ingestion of beryllium-containing food and water, with smaller contributions from inhalation of dust (Bruce and Odin, 2001). Ingested beryllium is less likely than inhaled beryllium to cause health concerns because most beryllium that is ingested passes through the body without entering the bloodstream. In contrast, beryllium particles inhaled can dissolve in the lungs and move to the bloodstream or remain in the lungs for up to years after exposure has ceased.

An international guideline value for beryllium in drinking water has not been established because beryllium is "rarely found in drinking water at concentrations of health concern," according to the World Health Organization (2011, table 8.9, p. 179). For the United States, however, the maximum contaminant level for beryllium in drinking water is $4 \mathrm{ppb}$ (U.S. Environmental Protection Agency, 2009). Beryllium concentrations in excess of this drinking water standard are unlikely because most beryllium compounds and minerals are poorly soluble in water. According to the U.S. Environmental Protection Agency (EPA) (2009), consumption of waters exceeding action levels may lead to intestinal lesions. The average concentration of beryllium in drinking water in the United States is $0.19 \mathrm{ppb}$ (which is significantly less than the guidelines), and ranges from 0.01 to $1.22 \mathrm{ppb}$ (Agency for Toxic Substances and Disease Registry, 2002; Sabey, 2006). As for soils, screening levels based on human health risk in the United States have been established to determine whether levels of contamination at hazardous waste sites warrant further investigation or site cleanup. The noncancer screening level for beryllium in residential soils is $160 \mathrm{ppm}$, and in industrial soils, it is 2,000 ppm (U.S. Environmental Protection Agency, 2013). As previously stated, the range in beryllium concentrations in surficial soils of the United States are from less than 0.1 to $17.3 \mathrm{ppm}$ (Smith and others, 2013), although orders of magnitude higher concentrations can be found in soils, such as those formed by weathering of beryllium-rich rocks.

Human health concerns from exposure to beryllium are mostly associated with inhaling airborne particles during the mining and processing of beryllium ores and the manufacturing of beryllium-containing products. The occupational threshold exposure level value for beryllium in the atmosphere is $5 \mathrm{ppb}$ ( 2 milligrams per cubic meter $\left[\mathrm{mg} / \mathrm{m}^{3}\right]$ ) for an 8 -hour exposure period and $68 \mathrm{ppb}\left(25 \mathrm{mg} / \mathrm{m}^{3}\right)$ for a 30 -minute exposure period (National Institute for Occupational Safety and Health, 2005). The level of occupational exposure to beryllium inhalation has decreased from early years of beryllium production in the 1930s to modern workday environments (National Institute for Occupational Safety and Health, 2005). Processing facilities implement safety procedures to minimize exposure that include regularly washing hands and laundering clothes; personal safety equipment, such as respirators; and the collection of dusts, fumes, and mists (Petkof, 1985).

Beryllium dust and fumes have been recognized to cause chronic beryllium disease, which is a debilitating and potentially lethal lung disease, and its precursor, beryllium sensitization, which is an immune system disorder. The human health risk is variable among the different sectors of the beryllium industry, and only mining and ore processing that occur at the mine site are considered here. A study of workers from the Spor Mountain Mine and mill reported that beryllium exposure levels during mining and milling were generally less than the threshold exposure level of $5 \mathrm{ppb}$ ( 2 micrograms per cubic meter $\left[\mu \mathrm{g} / \mathrm{m}^{3}\right]$ ) (Deubner and others, 2001). Another study at the site by Stefaniak and others (2008) reported that concentrations in the air among various work areas ranged from 0.003 to $6 \mathrm{ppb}\left(0.001\right.$ to $\left.2.1 \mu \mathrm{g} / \mathrm{m}^{3}\right)$. There may be a lower risk of sensitization and of developing chronic beryllium disease from beryllium during mining and ore (both bertrandite and beryl) processing than during other phases of beryllium manufacturing, including the production of beryllium oxide, beryllium ceramics, and copper-beryllium alloys (Deubner and others, 2001, 2011). 
Deubner and others (2011) hypothesize that the decreased risk is because the beryllium-containing materials found at the Spor Mountain facility dissolve faster in lung fluid than do other beryllium-containing materials. The physicochemical properties of beryllium, such as chemical composition, particle size, and specific surface area, influence bioavailability and may be more important than the exposure concentration in determining risk of developing beryllium sensitization or chronic beryllium disease (National Research Council, Committee on Beryllium Alloy Exposures, 2007; Stefaniak and others, 2008). In addition, genetic susceptibility is likely an additional risk factor (Taylor, Ding, and others, 2003).

Although inhalation is the main industrial exposure pathway of concern, skin exposure to beryllium may result in it entering the body, contributing to sensitization and causing irritation, lacerations, and chemical ulcers, and granulomas (Epstein, 1991; Day and others, 2006; National Research Council, Committee on Beryllium Alloy Exposures, 2007; Duling and others, 2012). Duling and others (2012) found the beryllium from bertrandite ores from Spor Mountain dissolves in artificial sweat as well as synthetic lung fluids.

Radiation exposure from uranium or thorium associated with volcanogenic beryllium ore may be a human health concern during mining and processing operations, although specific case studies could not be identified. Nonetheless, anomalous amounts of uranium (up to $200 \mathrm{ppm}$ ) and thorium (up to $150 \mathrm{ppm}$ ) are associated with the beryllium ores at Spor Mountain (Lindsey, 1981). If uranium is concentrated in waste generated from converting ore to beryllium hydroxide, precautions need to be taken when handling the waste.

\section{Ecological Health Concerns}

Beryllium is toxic to plants and animals; however, similar to human health concerns, ecological issues are associated mainly with the mining and manufacturing of beryllium. In uncontaminated areas, the concentration of beryllium in plants is commonly low (less than $1 \mathrm{ppm}$ ), and soils tend to contain beryllium in forms that are unavailable to plants (Bruce and Odin, 2001; Rossman, 2004). In some cases, beryllium is present as soluble salts in soils (for example, beryllium chloride $\left[\mathrm{BeCl}_{2}\right]$ and beryllium sulfate $\left[\mathrm{BeSO}_{4}\right]$ ) that are bioavailable and potentially may cause toxic effects, including reduced growth and degradation of some proteins and enzymes, and may inhibit the uptake of calcium, magnesium, and phosphorus. Toxicity of beryllium to plants has been observed for soil concentration ranges of from 10 to $50 \mathrm{ppm}$ (Kabata-Pendias and Mukherjee, 2007). Additionally, soils with concentrations of beryllium between 20 and $40 \mathrm{ppm}$ have been shown to affect the survival and reproduction of soil invertebrates (Kuperman and others, 2006). Also, beryllium, both inhaled and ingested, has been shown to be acutely toxic to mammals in laboratory tests, but information regarding toxicity to wildlife was not found (Bruce and Odin, 2001).

Beryllium in water and stream or lake sediment is not significantly concentrated by aquatic organisms or accumulated within the food chain (Bruce and Odin, 2001). In laboratory tests, beryllium (administered as soluble salts) is acutely toxic to a variety of freshwater fish and water fleas (Daphnia magna), but toxicity varied widely depending on the species studied and the test conditions; soft and acidic waters had the highest toxicity associated with the lowest concentrations of beryllium (Bruce and Odin, 2001, and references therein). Water-quality criteria and stream-sediment guidelines for the protection of aquatic life are generally lacking; however, the EPA does provide lowest observable effect limits (LOELs) as guidance for acute and chronic toxicity to aquatic life for beryllium of $130 \mathrm{ppb}$ and $5.3 \mathrm{ppb}$, respectively (U.S. Environmental Protection Agency, 1980). Also, Suter (1996) suggests secondary acute and chronic aquatic ecosystem guidelines for surface waters of $271 \mathrm{ppb}$ and $5.09 \mathrm{ppb}$ beryllium, respectively. These guidelines are generally higher than the mean concentration of $0.07 \mathrm{ppb}$ beryllium reported for surface waters in the United States (Eckel and Jacob, 1988). In general, the concentrations needed to cause toxicity to aquatic organisms from the dissolution of bertrandite or beryl would likely occur only in soft waters with acidic $\mathrm{pH}$ values.

The mining and processing of beryllium ores may enrich waters and soils in potentially toxic trace elements and contaminate the ecosystem at some mine sites. For example, water from the open pit at a previously mined, skarn-related, beryllium-fluorite deposit in Russia (the Yermakovskoye deposit) contained elevated concentrations of some elements, including $\mathrm{Cu}, \mathrm{Fe}, \mathrm{Mn}, \mathrm{Mo}, \mathrm{Mg}, \mathrm{Pb}$, and $\mathrm{Zn}$, that exceeded local standards for water bodies used for fishery purposes. Additionally, sediment at the bottom of the pit was contaminated with $\mathrm{As}, \mathrm{Be}, \mathrm{Cd}, \mathrm{Pb}$, and $\mathrm{Zn}$, and the concentrations of lead and zinc exceeded values above which effects to aquatic biota are likely. Mine waste piles contained concentrations of beryllium that were above the maximum allowable concentrations (Kislov and others, 2010). The natural background contents of some of the elements, such as $\mathrm{Cu}, \mathrm{Fe}, \mathrm{Mn}, \mathrm{Mo}$, and $\mathrm{Zn}$, in local streams and melt waters were also elevated and above environmental guidelines, which made it difficult to distinguish the contamination from mining compared to pre-mining concentrations associated with the mineralized area. According to Kislov and others (2010), the pasture vegetation in the local area may contain high amounts of beryllium from the deposition of contaminated dust, and the agricultural uses of the land should be limited.

In contrast to the mine site in Russia, the Spor Mountain deposit is characterized by an arid climate, a lack of surface water, and low concentrations of beryllium and uranium in both the volcanic host rock and ore materials. Ecosystem issues related to beryllium mining are not known in the vicinity of the Spor Mountain deposit.

\section{Carbon Footprint}

Beryllium has the potential to reduce the carbon footprint from energy production because of its potential for use in wind 
energy and hydrogen storage and fuel cell applications. IBC Advanced Alloys Corp. of Canada and a Washington, D.C.based clean-energy consulting company are working to commercialize wind energy applications of beryllium. The use of beryllium is expected to increase wear resistance in wind turbines, and thus reduce the cost of operations (IBC Advanced Alloys Corp., 2013; Jaskula, 2013a). IBC has also collaborated with Hydrogen Link Inc. of Canada to advance research on the use of beryllium in hydrogen fuel storage. Lithium-beryllium hydrides have the highest viable hydrogen capacity at reasonable temperatures and can be used for small-scale applications, such as laptops and other portable devices (IBC Advanced Alloys Corp., 2010).

\section{Mine Closure}

The post-mining landscape at beryllium mines depends on the deposit type and size, the mining and processing methods, the climate, and regulations regarding mine closure. Open pits, shafts, and adits from underground operations, processing facilities, and mine and processing wastes may need to be addressed for mine closure; some mines are not reclaimed. For example, remediation efforts were not undertaken when production ceased in 1989 at the Yermakovskoye deposit in Russia (Kislov and others, 2010). The shallow open pit covered a surface area of 277,000 square meters. The pit floor was at least $70 \mathrm{~m}$ deep at the deepest part, and the pit contained a few meters of water (Kislov and others, 2010). Future plans for the site included resuming mining and building a processing plant. Construction was expected to begin in 2013 (Jaskula, 2013b). The life of the mine was expected to be 17 to 20 years (Kislov and others, 2010). Eventually, mine closure will involve stabilizing disturbed surfaces, reclaiming soils, waters, and stream sediments at and near the mine site, and addressing any issues associated with the open pit, waste-rock piles, and tailings.

Similar remediation efforts may also be undertaken at the Spor Mountain Mine after mining there ceases. The mining operations thus far have created several elongated open pits created to exploit the large sheet-like orebodies. Stockpiles of ore and waste piles of overburden material cover areas that are hundreds of meters in diameter.

Beryl is typically mined from small-scale operations using minimal mining equipment, commonly as a byproduct of feldspar and mica mining. Mining of ore is typically in quantities ranging from a few kilograms to hundreds of tons (Sabey, 2006). These types of operations commonly do not have mine closure plans. Some operations where beryl is mined as a byproduct are larger operations, and they leave a landscape of waste rock, tailings, and open pits after mining has ceased. For example, the flooded open pit at the Foote Mine in the Kings Mountain district, North Carolina, is several hundreds of meters in diameter, and waste rock and tailings cover an even larger area that is devoid of vegetation.

\section{Problems and Future Research}

Research efforts into understanding the factors that may affect future supplies of beryllium include developing assessment models for new deposits, conducting experimental studies on beryllium at conditions applicable to biochemical processes occurring in surface environments, and devising new and more efficient extraction technologies for both raw ore and recycled products. These are described in more detail below.

Assessment models.-Assessing for beryllium in volcanogenic systems is problematic at present because there is only one known and essentially unique economic deposit. Comprehensive modern geologic and geochemical studies of the exemplary deposit at Spor Mountain and comparative studies of additional regions and related deposit types (carbonate-hosted and fluorite deposits) - for example, the central Gobi volcanic zone in Mongolia, and the REE-rich alkaline volcano-plutonic rocks within the TransbaikalMongolian rare-metal province, Siberia - are needed to provide for more widely applicable deposit models and assessment methods. New approaches to evaluating the geologic availability of beryllium are also needed to assess pegmatite resources and other rare-metal systems, such as rare-metal granites, pegmatites, and skarn and greisen rocks of Alaska, where economics may require extraction and recovery of byproducts and coproducts (such as $\mathrm{Be}, \mathrm{Cs}, \mathrm{F}, \mathrm{Li}$, $\mathrm{Nb}, \mathrm{Si}, \mathrm{Ta}$, and so forth).

Experimental studies.-Thermodynamic data on beryllium in various fluid-melt systems are needed to gain a better understanding of transport mechanisms for beryllium in a magmatic-hydrothermal environment and in fluorine-rich magmatic systems having rare-metal granites and associated beryllium-enriched pegmatites. These data have practical implications for resource and environmental assessment because they are needed to model these specialized geologic environments.

Environmental aspects.-The advent of new technologies and new products that use beryllium in conjunction with other elements, such as beryllium oxide enhanced nuclear fuel pellets, will likely require further study into the possible effects of use and disposal of complex and hazardous alloys, manufactured products, and waste materials.

Extraction technologies.-Improved extraction technologies may eventually be devised to handle materials that are currently below cutoff grades for volcanogenic deposits. Better refining methods may also be developed to separate contaminants (for example, $\mathrm{Al}, \mathrm{BeO}, \mathrm{C}, \mathrm{Fe}, \mathrm{Mg}$, and $\mathrm{Si}$ ) from raw beryllium minerals so that very high purity beryllium metal can be made from any beryllium source mineral.

Recycling.-As production levels and uses increase, the percentage of recycled beryllium from both new and old scrap may be expected to increase if separation technologies are improved. 
New markets.-Materials producers will continue to work closely with users, especially the aerospace and defense industries, to meet advances in end-use products and to ensure that new materials are developed to meet high-performance requirements. According to some industry experts, the global beryllium market forecast is for consumption to reach greater than 500 metric tons per year within 5 years and for the growth in consumption to be shaped by upward trends in some important end-use application areas (Global Industry Analysts, Inc., 2012). In particular, growing security concerns are proposed to increase the demand for beryllium in defense applications. Further, the advent of new alloys of beryllium with aluminum is expected to drive the beryllium market in the United States and other countries as new products are developed. If successful, the beryllium oxide enhanced nuclear fuel pellet could increase demand for beryllium substantially.

\section{References Cited}

Note: All Web links listed were active as of the access date but may no longer be available.

Adams, D.T., Hofstra, A.H., Cosca, M.A., Todorov, T.I., and Marsh, E.E., 2009, Age of sanidine and composition of melt inclusions in quartz phenocrysts from volcanic rocks associated with large Mo and Be deposits in the Western United States [abs.]: Geological Society of America, v. 41, no. 7, p. 255.

Agency for Toxic Substances and Disease Registry, 2002, Toxicological profile for beryllium: Atlanta, Ga., U.S. Department of Health and Human Services, Public Health Service, September, 247 p. plus 4 appendixes, accessed March 28, 2013, at http://www.atsdr.cdc.gov/ toxprofiles/tp4.pdf.

Alexsandrov, S.M., 2010, Skarn-greisen deposits of the Lost River and Mount Ear ore field, Seward Peninsula, Alaska, United States: Geochemistry International, v. 48, no. 12, p. 1220-1236. [Also available at http://dx.doi.org/ 10.1134/S0016702910120062.]

Avalon Rare Metals Inc., 2013, Beryllium: Avalon Rare Metals Inc. Web page, accessed March 28, 2013, at http://www.avalonraremetals.com/rare_earth_metal/ rare_metals/beryllium/.

Barton, M.D., 1986, Phase equilibria and thermodynamic properties of minerals in the $\mathrm{BeO}-\mathrm{Al}_{2} \mathrm{O}_{3}-\mathrm{SiO}_{2}-\mathrm{H}_{2} \mathrm{O}$ (BASH) system, with petrologic applications: American Mineralogist, v. 71, nos. 3-4, p. 277-300.

Barton, M.D., and Young, Steven, 2002, Non-pegmatitic deposits of beryllium - Mineralogy, geology, phase equilibria and origin, in Grew, E.S., ed., Beryllium-Mineralogy, petrology and geochemistry: Reviews in Mineralogy and Geochemistry, v. 50, p. 591-691. [Also available at http://dx.doi.org/10.2138/rmg.2002.50.14.]
BE Resources Inc., 2011, Warm Springs project: Toronto, Ontario, Canada, BE Resources Inc., unpaged, accessed July 11, 2013, at http://www.beresources.ca/Projects/ WarmSprings.htm.

Beus, A.A., 1966, Geochemistry of beryllium and genetic types of beryllium deposits: San Francisco, Calif., W.H. Freeman, 401 p.

Bhappu, R.B., and Fuerstenau, M.C., 1964, Recovery of valuable minerals from pegmatitic ores: Socorro, N.Mex., New Mexico Bureau of Geology and Mineral Resources Circular 70, 29 p.

Bhat, P.N., Ghosh, D.K., and Desai, M.V., 2002, Immobilisation of beryllium in solid waste (red-mud) by fixation and vitrification: Waste Management, v. 22, no. 5, p. 549-556.

Bradley, Dwight, and McCauley, Andrew, 2013, A preliminary deposit model for lithium-cesium-tantalum (LCT) pegmatites: U.S. Geological Survey Open-File Report 2013-1008, 7 p. [Also available at http://pubs.usgs.gov/of/2013/1008/.]

Browning, J.S., 1961, Flotation of spodumene-beryl ores: Mining Engineering, v. 17, no. 7, p. 706-708.

Browning, J.S., McVay, T.L., and Bennett, P.E., 1964, Continuous flotation of beryl from spodumene mill tailings, Foote Mineral Company, Kings Mountain, N.C.: U.S. Bureau of Mines Report of Investigations 6466, 24 p.

Bruce, R.M., and Odin, Mark, 2001, Beryllium and beryllium compounds: World Health Organization, Concise International Chemical Assessment Document 32, 71 p., accessed February 28, 2013, at http://apps.who.int/iris/ bitstream/10665/42369/1/9241530324.pdf.

Brush Engineered Materials, Inc., 2009, Transforming our world and yours-Annual report: Mayfield Heights, Ohio, Brush Engineered Materials, Inc., 122 p.

Burt, D.M., Sheridan, M.F., Bikun, J.V., and Christiansen, E.H., 1982, Topaz rhyolites-Distribution, origin, and significance for exploration: Economic Geology, v. 77, p. 1818-1836. [Also available at http://dx.doi.org/10.2113/gsecongeo.77.8.1818.]

Černý, Petr, 2002, Mineralogy of beryllium in granitic pegmatites, chap. 10 of Grew, E.S., ed., BerylliumMineralogy, petrology, and geochemistry: Reviews in Mineralogy and Geochemistry, v. 50, p. 405-444. [Also available at http://dx.doi.org/10.2138/rmg.2002.50.10.]

Černý, Petr, 2005, The Tanco rare-element pegmatite deposit, Manitoba-Regional context, internal anatomy, and global comparisions, in Linnen, R.I., and Samson, I.M., eds., Rare element geochemistry and mineral deposits: St. Johns, Newfoundland and Labrador, Canada, Geological Association of Canada Short Course Notes, v. 17, p. $127-158$. 
Černý, Petr, London, David, and Novák, Milan, 2012, Granitic pegmatites as reflections of their sources: Elements, v. 8, no. 4, p. 289-294. [Also available at http://dx.doi.org/10.2113/gselements.8.4.289.]

China Non-Ferrous Metal Import \& Export Xinjiang Corp., [undated], Copper \& nickel mining: China Non-Ferrous Metal Import \& Export Xinjiang Corp, accessed October 8, 2008, at http:/www.cniecxj.com/F/03/CustomColumn/ top.asp?fatherid $=002003 \&$ menuid $=002003007$.

Day, G.A., Stefaniak, A.B., Weston, A., and Tinkle, S.S., 2006, Beryllium exposure-Dermal and immunological considerations: International Archives of Occupational and Environmental Health, v. 79, no. 2, p. 161-164. [Also available at http://dx.doi.org/10.1007/s00420-005-0024-0.]

Deubner, D., Kelsh, M., Shum, M., Maier, L., Kent, M., and Lau, E., 2001, Beryllium sensitization, chronic beryllium disease, and exposures at a beryllium mining and extraction facility: Applied Occupational and Environmental Hygiene, v. 16 , no. 5 , p. 579-592.

Deubner, D.C., Sabey, P., Huang, W., Fernandez, D., Rudd, A., Johnson, W.P., Storrs, J., and Larson, R., 2011, Solubility and chemistry of materials encountered by beryllium mine and ore extraction workers-Relation to risk: Journal of Occupational and Environmental Medicine, v. 53, no. 10, p. 1187-1193.

Dobson, D.C., 1982, Geology and alteration of the Lost River tin-tungsten-fluorine deposit, Alaska: Economic Geology, v. 77, p. 1033-1052. [Also available at http://dx.doi.org/ 10.2113/gsecongeo.77.4.1033.]

Duling, M.G., Stefaniak, A.B., Lawrence, R.B., Chipera, S.J., and Abbas Virji, M., 2012, Release of beryllium from mineral ores in artificial lung and skin surface fluids: Environmental Geochemistry and Health, v. 34, no. 3, p. 313-322. [Also available at http://dx.doi.org/10.1007/ s10653-011-9421-3.]

Eckel, W.P., and Jacob, T.A., 1988, Ambient levels of 24 dissolved metals in US surface and ground waters, in American Chemical Society Division of Environmental Chemistry 196th Meeting Preprints, v. 28, no. 2, p. 371-372.

Emsley, John, 2001, Nature's building blocks-An A-Z guide to the elements: Oxford, United Kingdom, Oxford University Press, 538 p.

Engell, John, Hansen, John, Jensen, Margrethe, Kunzendorf, Helmar, and Løvborg, Leif, 1971, Beryllium mineralization in the Ilimaussaq intrusion, south Greenland, with description of a field beryllometer and chemical methods: Copenhagen University, Mineralogical and Geological Museum, Contributions to Mineralogy, v. 82, no. 33, 40 p. (Reprinted from Grønlands, Geologiske Undersøgelse Rapport 33.)
Epstein, P.E., 1991, Cutaneous effects of beryllium, in Rossman, M.D., Preuss, O.P., and Powers, M.B., eds., Beryllium-Biomedical and environmental aspects: Baltimore, Md., Williams \& Wilkins, p. 113-117.

Foley, N.K., Hofstra, A.H., Lindsey, D.A., Seal, R.R., II, Jaskula, Brian, and Piatak, N.M., 2012, Occurrence model for volcanogenic beryllium deposits, chap. F of Mineral deposit models for resource assessment: U.S. Geological Survey Scientific Investigations Report 2010-5070-F, 43 p. [Also available at http://pubs.usgs.gov/sir/2010/5070/f/.]

Gaillardet, J., Viers, J., and Dupré, B., 2003, Trace elements in river waters, in Drever, J.I., ed., Surface and ground water, weathering, and soils, v. 5 of Holland, H.D., and Turekian, K.K., eds., Treatise on geochemistry: Oxford, United Kingdom, Elsevier-Pergamon, p. 225-227. [Also available at http://dx.doi.org/10.1016/B0-08-043751-6/05165-3.]

Galeschuk, C.R., and Vanstone, P.J., 2005, Exploration for buried rare element pegmatites in the Bernic Lake area of southeastern Manitoba, in Linnen, R.L., and Samson, I.M., eds., Rare-element geochemistry and mineral deposits: St. Johns, Newfoundland and Labrador Ottawa, Ontario, Canada, Geological Association of Canada Short Course Notes 17, p. 159-173.

Galeschuk, C., and Vanstone, P., 2007, Exploration techniques for rare-element pegmatite in the Bird-River Greenstone Belt, southeastern Manitoba, in Milkereit, B., ed., Proceedings of Exploration 07-Fifth Decennial International Conference on Mineral Exploration, Paper 55, p. 823-839.

Global Industry Analysts, Inc., 2012, Global beryllium market to reach 505.6 metric tons by 2017, according to new report by Global Industry Analysts, Inc.: San Jose, Calif., Global Industry Analysts, Inc. press release, March 5, accessed March 5, 2012, at http:/www.strategyr.com/ pressMCP-2629.asp.

Glover, A.S., Rogers, W.Z., and Barton, J.E., 2012, Granitic pegmatites - Storehouses of industrial minerals: Elements, v. 8, no. 4, p. 269-273. [Also available at http://dx.doi.org/ 10.2113/gselements.8.4.269.]

Graedel, T.E., Allwood, Julian, Birat, J.-P., Buchert, Matthias, Hagelüken, Christian, Reck, B.K., Sibley, S.F., and Sonnemann, Guido, 2011, What do we know about metal recycling rates?: Journal of Industrial Ecology, v. 15, no. 3, p. 355-366. [Also available at http://dx.doi.org/10.1111/j.1530-9290.2011.00342.x.]

Grew, E.S., 2002, Mineralogy, petrology and geochemistry of beryllium-An introduction and list of beryllium minerals, in Grew, E.S., ed., Beryllium-Mineralogy, petrology, and geochemistry: Reviews in Mineralogy and Geochemistry, v. 50, p. 1-76. [Also available at http://dx.doi.org/10.2138/ rmg.2202.50.01.] 
Griffitts, W.R., 1954, Beryllium resources of the tin-spodumene belt, North Carolina: U.S. Geological Survey Circular 309, 12 p. plus 3 pls. [Also available at https://pubs.er.usgs.gov/ publication/cir309.]

Griffitts, W.R., 1973, Beryllium, in Brobst, D.A., and Pratt, W. P., eds., United States mineral resources: U.S. Geological Survey Professional Paper 820, p. 85-93. [Also available at http://pubs.er.usgs.gov/publication/pp820/.]

Grundmann, G., and Morteani, G., 1989, Emerald mineralization during regional metamorphism-The Habachtal (Austria) and Leydsdorp (Transvaal, South Africa) deposits: Economic Geology, v. 84, p. 1835-1849. [Also available at http://dx.doi.org/10.2113/gsecongeo.84.7.1835.]

Hawkins, Greg, 2001, Open pit surgical mining of bertrandite ores at the world's largest beryllium deposit!, in Simandl, G.J., Holland, J., Dunlop, S., and Rotella, M.D., eds., Industrial minerals in Canada, program and extended abstracts for the 37th Forum on the Geology of Industrial Minerals, Victoria, British Columbia, Canada: Forum on the Geology of Industrial Minerals, v. 37, p. 105-106.

Henry, C.D., 1992, Beryllium and other rare metals in Trans-Pecos, Texas: Bulletin of the West Texas Geological Society, v. 31, p. 1-15.

Hörmann, P.K., 1978, Beryllium, in Wedepohl, K.H., ed., Handbook of geochemistry, v. 2, pt. 1: Berlin, West Germany, Springer-Verlag, p. 4-B-1 to 4-O-1, 1-6.

$\mathrm{Hu}$, Zhaochu, and Gao, Shan, 2008, Upper crustal abundance of trace elements - A revision and update: Chemical Geology, v. 253, nos. 3-4, p. 205-221. [Also available at http://dx.doi.org/10.1016/j.chemgeo.2008.05.010.]

IBC Advanced Alloys Corp., 2010, IBC Advanced Alloys signs agreement to advance lithium beryllium metal hydrides hydrogen storage technology: Vancouver, British Columbia, Canada, IBC Advanced Alloys Corp., August 4, accessed March 27, 2013, at http://www.ibcadvancedalloys. com/news/2010/08/04/2010/ibc-advanced-alloys-signsagreement-to-advance-lithium-beryllium-metal-hydrideshydrogen-storage-technology/.

IBC Advanced Alloys Corp., 2013, Beryllium aluminum alloysBeralcast ${ }^{\circledR}$ Alloys: IBC Advanced Alloys Corp., accessed March 27, 2013, at http://www.ibcadvancedalloys.com/ products/beryllium-aluminum-alloys-beralcast-alloys/.

Jaskula, B.W., 2013a, Beryllium [advance release]: U.S. Geological Survey Mineral Commodity Summaries 2013, p. 28-29. [Also available at http://minerals.usgs.gov/ minerals/pubs/commodity/beryllium/mcs-2013-beryl.pdf.]

Jaskula, B.W., 2013b, Beryllium, in Metals and minerals: U.S. Geological Survey Minerals Yearbook 2011, v. I, p. 11.1-11.7, accessed March 1, 2013, at http://minerals. usgs.gov/minerals/pubs/commodity/beryllium/myb12011-beryl.pdf.
Kabata-Pendias, Alina, and Mukherjee, A.B., 2007, Trace elements from soil to human: Berlin, Germany, SpringerVerlag, 550 p.

Kazatomprom JSC, 2012, Consolidated financial statements-As at and for the year ended December 31, 2011: Almaty, Kazakhstan, Kazatomprom JSC, March 20, 79 p., accessed July 9, 2012, at http://www.kazatomprom.kz/ sites/default/files/FS_2011_eng.pdf. [Also available at http://www.kazatomprom.kz/en/content/investors/investors/ reports/financial-statements.]

Keith, J.D., Christiansen, E.H., and Tingey, D.G., 1994, Geological and chemical conditions of formation of red beryl, Wah Wah Mountains, Utah, in Blackett, R.E., and Moore, J.N., eds., Cenozoic geology and geothermal systems of southwestern Utah: Utah Geological Association Publication, no. 23, p. 155-169.

Kesler, S.E., Gruber, P.W., Medina, P.A., Keolwian, G.A., Everson, M.P., and Wallington, T.J., 2012, Global lithium resources - Relative importance of pegmatite, brine and other deposits: Ore Geology Reviews, v. 48, p. 55-69. [Also available at http://dx.doi.org/10.1016/j.oregeorev.2012.05.006.]

Kim, S.K., Ko, W.I., Kim, H.D., Revankar, S.T., Zhou, W., and Daeseong, Jo, 2010, Cost-benefit analysis of BeO-UO nuclear fuel: Progress in Nuclear Energy, v. 52, no. 8, p. 813-821. [Also available at http://dx.doi.org/10.1016/ j.pnucene.2010.07.008.]

Kislov, E.V., Imetkhenov, A.B., and Sandakova, D.M., 2010, The Yermakovskoye fluorite-beryllium depositAvenues for improving ecological security of revitalization of the mining operations: Geography and Natural Resources, v. 31, no. 4, p. 324-329. [Also available at http://dx.doi.org/10.1016/j.gnr.2010.11.004.]

Kovalenko, V.I., and Yarmolyuk, V.V., 1995, Endogenous rare metal ore formations and rare metal metallogeny of Mongolia: Economic Geology, v. 90, p. 520-529. [Also available at http://dx.doi.org/10.2113/gsecongeo.90.3.520.]

Krogstad, E.J., Walker, R.J., Nabelek, P.I., and Russ-Nabelek, Carol, 1993, Lead isotopic evidence for mixed sources of Proterozoic granites and pegmatites, Black Hills, South Dakota, USA: Geochimica et Cosmochimica Acta, v. 57, no. 19, p. 4677-4685. [Also available at http://dx.doi.org/10.1016/0016-7037(93)90192-Y.]

Kuperman, R.G., Checkai, R.T., Simini, Michael, Phillips, C.T., Speicher, J.A., and Barclift, D.J., 2006, Toxicity benchmarks for antimony, barium, and beryllium determined using reproduction endpoints for Folsomia candida, Eeisenia fetida, and Enchytraeus crypticus: Environmental Toxicology and Chemistry, v. 25, no. 3, p. 754-762.

Laznicka, Peter, 2006, Giant metallic deposits-Future sources of industrial metals: Berlin, Germany, Springer-Verlag, 732 p. 
Lide, D.R., ed., 2005, CRC handbook of chemistry and physics (86th ed.): Boca Raton, Fla., CRC Press, 2,544 p.

Lin, Desong, 1985, A preliminary study on genesis of an altered volcanic type beryl deposit in south China: Mineral Deposits, v. 3, accessed April, 25, 2013, at http://en.cnki.com.cn/ Article_en/CJFDTOTAL-KCDZ198503002.htm.

Lin, Yin, Pollard, P.J., Hu, Shoixi, and Taylor, R.G., 1995, Geologic and geochemical characteristics of the Yichun Ta-Nb-Li deposit, Jiangxi Province, south China: Economic Geology, v. 90, p. 577-585. [Also available at http://dx.doi.org/10.2113/gsecongeo.90.3.577.]

Lindsey, D.A., 1975, Mineralization halos and diagenesis in water-laid tuff of the Thomas Range, Utah: U.S. Geological Survey Professional Paper 818-B, 59 p. [Also available at http://pubs.er.usgs.gov/publication/pp818B/.]

Lindsey, D.A., 1981, Volcanism and uranium mineralization at Spor Mountain, Utah, in Goodell, P.C., and Waters, A.C., eds., Uranium in volcanic and volcaniclastic rocks: American Association of Petroleum Geologists Studies in Geology, no. 13, p. 89-98.

Lindsey, D.A., 1998, Slides of the fluorspar, beryllium, and uranium deposits at Spor Mountain, Utah: U.S. Geological Survey Open-File Report 98-524, unpaged, accessed January 13, 2014, at http://pubs.usgs.gov/of/1998/ ofr-98-0524/.

Lindsey, D.A., Bradley, L.A., Gardner, J., and Merritt, V., 1973, Mineralogical and chemical data for alteration studies, Spor Mountain beryllium deposits, Juab County, Utah: U.S. Geological Survey Report 31, available from U.S. Department of Commerce National Technical Information Service, Springfield, Va., as report PB-220-552, $27 \mathrm{p}$.

Linnen, R.L., Van Lichtervelde, Marieke, and Černý, Petr, 2012, Granitic pegmatites as sources of strategic metals: Elements, v. 8, no. 4, p. 275-280. [Also available at http://dx.doi.org/10.2113/gselements.8.4.275.]

London, David, 2005, Geochemistry of alkali and alkaline earth elements in ore-forming granites, pegmatites and rhyolites, in Linnen, R.L., and Samson, I.M., eds., Rareelement geochemistry and mineral deposits: Ottawa, Ontario, Canada, Geological Association of Canada Short Course Notes 17, p. 17-43.

London, David, and Evensen, J.M., 2002, Beryllium in silicic magmas and the origin of beryl-bearing pegmatites: Reviews in Mineralogy \& Geochemistry, v. 50, no. 1, p. 445-486. [Also available at http://dx.doi.org/10.2138/ rmg.2002.50.11.]

London, David, and Kontak, D.J., 2012, Granitic pegmatitesScientific wonders and economic bonanzas: Elements, v. 8, no. 4, p. 257-261. [Also available at http://dx.doi.org/ 10.2113/gselements.8.4.257.]
Lykhin, D.A., Kovalenko, V.I., Yarmolyuk, V.V., Sal'nikova, E.B., Kotov, A.B., Anisimova, I.V., and Plotkina, Yu.V., 2010, The Yermakovsky beryllium deposit, western Transbaikal region, Russia_-Geochronology of igneous rocks: Geology of Ore Deposits, v. 52, no. 2, p. 114-137. (Originally published in Geologiya Rudnykh Mestorozhdenii, 2010, v. 52, no. 2, p. $126-152$.)

Martin, R.F., and De Vito, C., 2005, The patterns of enrichment in felsic pegmatites ultimately depend on tectonic setting: Canadian Mineralogist, v. 43, no. 6, p. 2027-2048. [Also available at http://dx.doi.org/10.2113/gscanmin.43.6.2027.]

Materion Corp., 2011, Brush performance alloys: Materion Corp. Web site, accessed July 13, 2011, at http://materion.com/ Products/Alloys/CopperBerylliumCastingAlloys.aspx.

Materion Corp., 2012a, Annual report-2011: Cleveland, Ohio, Materion Corp., 109 p. [Also available at http://investor.shareholder.com/materion/annuals.cfm.]

Materion Corp., 2012b, Materion Corporation reports second quarter earnings: Cleveland, Ohio, Materion Corp. press release, July 27, accessed July 27, 2012, at http://investor.shareholder.com/materion/releasedetail. cfm?ReleaseID=696108.

McLemore, V.T., 2010a, Beryllium deposits in New Mexico and adjacent areas: Socorro, N. Mex., New Mexico Bureau of Geology and Mineral Resources Open-File Report 533, 105 p., accessed March 28, 2012, at http://geoinfo.nmt.edu/ publications/openfile/downloads/500-599/533/ofr_533.pdf.

McLemore, V.T., 2010b, Geology, mineral resources, and geoarchaeology of the Montoya Butte quadrangle, including the Ojo Caliente No. 2 mining district, Socorro County, New Mexico: Socorro, N. Mex., New Mexico Bureau of Geology and Mineral Resources Open-File Report 535, 106 p., accessed March 28, 2012, at http://geoinfo.nmt.edu/ publications/openfile/downloads/OFR500-599/526-550/535/ ofr_535.pdf.

McLemore, V.T., undated, Beryllium deposits in New Mexico and adjacent areas: Socorro, N. Mex., New Mexico Bureau of Geology and Mineral Resources, 1 p., accessed May 26, 2013, at http:/geoinfo.nmt.edu/staff/mclemore/ documents/BE_seg_mclemore_rev.pdf.

McLemore, V.T., and Guilinger, J.R., 1993, Geology and mineral resources of the Cornudas Mountains, Otero County, New Mexico and Hudspeth County, Texas: New Mexico Geological Society Guidebook, 44th Field Conference, Carlsbad Region, New Mexico and West Texas, p. 145-154. [Also available at http://nmgs.nmt.edu/publications/guidebooks/ downloads/44/44_p0145_p0153.pdf.]

McNeil, David, 2006, Beryllium-2005/6: Mining Journal Online, accessed May 24, 2007, at http:/www.miningjournal.com/home.aspx. 
Meeves, H.C., 1966, Nonpegmatitic beryllium occurrences in Arizona, Colorado, New Mexico, Utah, and four adjacent States: U.S. Bureau of Mines Report of Investigations $6828,68 \mathrm{p}$.

Metal Bulletin, 2003, Ulba seeks to fulfill its potential: Metal Bulletin, no. 8784, June 23, p. 8.

Metal Bulletin, 2010, (AMM) Brush Wellman set to commission beryllium plant: Metal Bulletin, August 6, accessed September 20, 2010, at http://www.metalbulletin.com/.

Montoya, J.W., Havens, R.J., and Bridges, D.W., 1962, Beryllium-bearing tuff from Spor Mountain, UtahIts chemical, mineralogical and physical properties: U.S. Bureau of Mines Report of Investigations 6084, 15 p.

National Institute for Occupational Safety and Health, 2005, NIOSH pocket guide to chemical hazards: Department of Health and Human Services (DHHS) NIOSH Publication No. 2005-149, accessed March 28, 2013, via http://www.cdc.gov/niosh/npg/default.html.

National Research Council, Committee on Beryllium Alloy Exposures, 2007, Health effects of beryllium exposureA literature review: Washington, D.C., The National Academies Press, 109 p., accessed July 12, 2011, at http://www.nap.edu/catalog/12007.html.

Natural Earth, 2014, Small scale data: Natural Earth map dataset, scale 1:110,000,000, accessed February 12, 2014, at http://www.naturalearthdata.com/.

Olson, D.W., 2016, Gemstones [advance release], in Metals and minerals: U.S. Geological Survey Minerals Yearbook 2013, v. I, p. 29.1-29.25, accessed June 27, 2016, at http://minerals.usgs.gov/minerals/pubs/commodity/ gemstones/myb1-2013-gemst.pdf.

Pearson, R.G., 1963, Hard and soft acids and bases: Journal of the American Chemical Society, v. 85, no. 22, p. 3533-3539. [Also available at http://dx.doi.org/10.1021/ja00905a001.]

Petkof, Benjamin, 1985, Beryllium, in Knoerr, A.W., ed., Mineral facts and problems-1985 edition: U.S. Bureau of Mines Bulletin 675, p. 75-82.

Pichavant, Michel, Kontak, D.J., Briqueu, Louis, Valencia-Herrera, Jacinto, and Clark, A.H., 1988a, The Miocene-Pliocene Macusani Volcanics, SE Peru-II, Geochemistry and origin of a felsic peraluminous magma: Contributions to Mineralogy and Petrology, v. 100, no. 3, p. $325-338$.

Pichavant, Michel, Kontak, D.J., Valencia-Herrera, Jacinto, and Clark, A.H., 1988b, The Miocene-Pliocene Macusani Volcanics, SE Peru-I, Mineralogy and magmatic evolution of a two-mica aluminosilicate-bearing ignimbrite suite: Contributions to Mineralogy and Petrology, v. 100, no. 3, p. 300-324.
Ramsden, A.R., French, D.H., and Chalmers, D.I., 1993, Volcanic-hosted rare-metals deposit at Brockman, Western Australia-Mineralogy and geochemistry of the Niobium tuff: Mineralium Deposita, v. 28, no. 1, p. 1-12.

Reyf, F.G., 2008, Alkaline granites and Be (phenakitebertrandite) mineralization-An example of the Orot and Ermakovka (Yermakovskoye) deposits: Geochemistry International, v. 46, no. 3, p. 213-232. (Originally published in Geokhimiya, v. 46, no. 3, p. 243-263.) [Also available at http://dx.doi.org/10.1134/S0016702908030014.]

Rossman, M.D., 2004, Beryllium, chap 2.1 of Merian, E., Anke, M., Ihnat, M., and Stoeppler, M., eds., Elements and their compounds in the environment - Occurrence, analysis and biological relevance (2d ed.) - V. 1, General aspects: Weinheim, Germany, Wiley-VCH, p. 575-586.

Rubin, J.N., Price, J.G., Henry, C.D., and Koppenaal, D.W., 1987, Cryolite-bearing and rare metal-enriched rhyolite, Sierra Blanca Peaks, Hudspeth County, Texas: American Mineralogist, v. 72, nos. 11-12, p. 1122-1130.

Rubin, J.N., Price, J.G., Henry, C.D., and Kyle, J.R., 1990, Geology of the beryllium-rare earth element deposits near Sierra Blanca, Texas: Society of Economic Geologists Field Trip Guidebook, 1990 Annual Meeting, Dallas, Tex., 10 p.

Rubin, J.N., Price, J.G., Henry, C.D., Pinkston, T.L., Tweedy, S.W., Koppenaal, D.W., Peterson, S.B., Harlan, H.M., Miller, W.T., Thompson, R.J., Grabowski, R.B., Laybourn, P.S., Schrock, G.E., Johnson, A., Staes, D.G., Gaines, R.V., and Miller, F.H., 1988, Mineralogy of beryllium deposits near Sierra Blanca, Texas, in Torma, A.E., and Gundiler, I.H., eds., Precious and rare metal technologies, Proceedings; Symposium on Precious and Rare Metals, Albuquerque, N. Mex., April 6-8, 1988: Amsterdam, Netherlands, Elsevier, p. 601-614.

Sabey, P., 2006, Beryllium minerals, in Kogel, J.E., Trivedi, N.C., Barker, J.M., and Krukowski, S.T., eds., Industrial minerals and rocks - Commodities, markets, and uses, 7th ed.: Littleton, Colo., Society for Mining, Metallurgy, and Exploration, p. 263-274.

Sainsbury, C.L., 1963, Beryllium deposits of the western Seward Peninsula, Alaska: U.S. Geological Survey Circular 479, 23 p. [Also available at https://pubs.er.usgs.gov/ publication/cir479.]

Sainsbury, C.L., 1964a, Association of beryllium with tin deposits rich in fluorite: Economic Geology, v. 59, p. 920-929. [Also available at http://dx.doi.org/10.2113/ gsecongeo.59.5.920.]

Sainsbury, C.L, 1964b, Geology of the Lost River Mine area, Alaska: U.S. Geological Survey Bulletin 1129, 80 p., 10 sheets. [Also available at https://pubs.er.usgs.gov/ publication/b1129.] 
Secher, K., and Appel, P., 2007, Gemstones of Greenland: Geology and Ore, no. 7, Geological Survey of Denmark and Greenland, accessed January 8, 2014, at http:/www.geus.dk/ minex/go07-uk.htm.

Selway, J.B., Breaks, F.W., and Tindle, A.G., 2005, A review of rare-element ( $\mathrm{Li}-\mathrm{Cs}-\mathrm{Ta}$ ) pegmatite exploration techniques for the Superior Province, Canada, and large worldwide tantalum deposits: Exploration and Mining Geology, v. 14, nos. 1-4, p. 1-30. [Also available at http://dx.doi.org/10.2113/gsemg.14.1-4.1.]

Shannon, R.D., 1976, Revised effective ionic radii and systematic studies of interatomic distances in halides and chalcogenides: Acta Crystallographica Section AFoundations, v. 32, no. 5, p. 751-767. [Also available at http://dx.doi.org/10.1107/S0567739476001551.]

Sinkankas, John, 1981, Emerald and other beryls: Radnor, Penn., Chilton Book Co., 665 p. (Republished in 1989 by Geoscience Press, Prescott, Ariz.)

Sirbescu, M.-L.C., and Nabelek, P.I., 2003, Crystallization conditions and evolution of magmatic fluids in the Harney Peak granite and associated pegmatite, Black Hills, South Dakota-Evidence from fluid inclusions: Geochimica et Cosmochimica Acta, v. 67, no. 13, p. 2443-2465.

Smith, D.B., Cannon, W.F., Woodruff, L.G., Solano, Federico, Kilburn, J.E., and Fey, D.L., 2013, Geochemical and mineralogical data for soils of the conterminous United States: U.S. Geological Survey Data Series 801, 19 p., accessed January 7, 2014, at http://pubs.usgs.gov/ds/801/.

Smith, R.E., Perdrix, J.L., and Davis, J.M., 1987, Dispersion into pisolitic laterite from the Greenbushes mineralized Sn-Ta pegmatite system, Western Australia: Journal of Geochemical Exploration, v. 28, nos. 1-3, p. 251-265. [Also available at http://dx.doi.org/10.1016/0375-6742(87)90051-3.]

Soloviev, S.G., 2011, Compositional features and rare metal mineralization of the Hellroaring Creek Stock, southeastern British Columbia (NTS 082F/09), in Geological fieldwork 2011: Victoria, British Columbia, Canada, Ministry of Energy and Mines, Paper 2012-1, p. 181-197. [Also available at http://www.empr.gov.bc.ca/Mining/Geoscience/ PublicationsCatalogue/Fieldwork.]

Solylo, P.R., 2012, Mobility of elements from cesium formate residue emplaced on pegmatite tailings, Bernic Lake, Manitoba, Canada: Winnipeg, Manitoba, Canada, University of Manitoba, M.S. thesis, 215 p. [Also available at http://mspace.lib. umanitoba.ca/bitstream/1993/8892/1/Solylo_Patrick.pdf.]

Stefaniak, A.B., Chipera, S.J., Day, G.A., Sabey, Phil, Dickerson, R.M., Sbarra, D.C., Duling, M.G., Lawrence, R.B., Stanton, M.L., and Scripsick, R.C., 2008, Physicochemical characteristics of aerosol particles generated during the milling of beryllium silicate ores-Implications for risk assessment: Journal of Toxicology and Environmental Health, Part A, v. 71, no. 22, p. 1468-1481. [Also available at http://dx.doi.org/10.1080/15287390802349883.]
Stilling, Andrew, Černý, Petr, and Vanstone, P.J., 2006, The Tanco pegmatite at Bernic Lake, Manitoba-XVI, Zonal and bulk compositions and their petrogenetic significance: Canadian Mineralogist, v. 44, no. 3, p. 599-623. [Also available at http://dx.doi.org/10.2113/gscanmin.44.3.599.]

Stoll, W.C., 1950, Mica and beryl pegmatites in Idaho and Montana: U.S. Geological Survey Professional Paper 229, 64 p. [Supersedes U.S. Geological Survey Open-File Report 49-7.]

Suter, G.W., II, 1996, Toxicological benchmarks for screening contaminants of potential concern for effects on freshwater biota: Environmental Toxicology and Chemistry, v. 15, no. 7, p. 1232-1241. [Also available at http://dx.doi.org/ 10.1002/etc.5620150731.]

Taylor, S.R., and McLennan, S.M., 1985, The continental crustIts composition and evolution; an examination of the geochemical record preserved in sedimentary rocks: Oxford, United Kingdom, Blackwell Scientific Publishing, 312 p.

Taylor, S.R., and McLennan, S.M., 1995, The geochemical evolution of the continental crust: Reviews of Geophysics, v. 33, no. 2, p. 241-265. [Also available at http://dx.doi.org/ 10.1029/95RG00262.]

Taylor, T.P., Ding, Mei, Ehler, D.S., Foreman, T.M., Kaszuba, J.P., and Sauer, N.N., 2003, Beryllium in the environment-A review: Journal of Environmental Science and Health, Part A-Toxic/Hazardous Substances and Environmental Engineering, v. 38, no. 2, p. 439-469.

Taylor, W.R., Esslemont, G., and Sun, S.-S., 1995a, Geology of the volcanic-hosted Brockman rare-metals deposit, Halls Creek mobile zone, northwest Australia-II, Geochemistry and petrogenesis of the Brockman volcanics: Mineralogy and Petrology, v. 52, p. 231-255.

Taylor, W.R., Page, R.W., Esslemont, G., Rock, N.M.S., and Chalmers, D.I., 1995b, Geology of the volcanic-hosted Brockman rare-metals deposit, Halls Creek mobile zone, northwest Australia-I, Volcanic environment, geochronology and petrography of the Brockman volcanics: Mineralogy and Petrology, v. 52, p. 209-230.

Tkachev, A.V., 2011, Evolution of metallogeny of granitic pegmatites associated with orogens throughout geologic time, in Sial, A.N., Bettencourt, J.S., and De Campos, C.P., eds., Granite-related ore deposits: Geological Society of London Special Publications 350, p. 7-23. [Also available at http://dx.doi.org/10.1144/SP350.2.]

Trueman, D.L., and Černý, Petr, 1982, Exploration for rare-element granitic pegmatites, in Cerný, P., ed., Granitic pegmatites in science and industry: Winnipeg, Manitoba, Canada, Mineralogical Association of Canada, Short Course Handbook, no. 8, p. 463-493. 
U.S. Department of Defense, 2009, Analysis of national security issues associated with strategic materials: Federal Register, v. 74, no. 34, February 23, p. 8061-8064.

U.S. Environmental Protection Agency, 1980, Ambient water quality criteria for beryllium: Washington, D.C., U.S. Environmental Protection Agency, EPA 440 5-80-024, 81 p., accessed March 28, 2013, at http:/www.epa.gov/ waterscience/criteria/library/ambientwqc/berryllium80.pdf.

U.S. Environmental Protection Agency, 1989, Development document for effluent limitations guidelines and standards for the nonferrous metals manufacturing point source category, v. 7, Primary beryllium, primary nickel and cobalt, secondary nickel, secondary tin: Washington, D.C., U.S. Environmental Protection Agency, EPA 440/1-89-019.7, 717 p., accessed December 31, 2013, at https://nepis.epa.gov/ Exe/ZyPDF.cgi/00001D1C.PDF?Dockey=00001D1C.PDF.

U.S. Environmental Protection Agency, 2009, National primary drinking water regulations: U.S. Environmental Protection Agency, EPA 816-F-09-004, May, 6 p., accessed March 21, 2013, at http://water.epa.gov/drink/contaminants/ upload/mcl-2.pdf.

U.S. Environmental Protection Agency, 2013, Regional screening levels (formerly PRGs), RSL table (Last updated November 2013): U.S. Environmental Protection Agency, accessed January 7, 2014, at http://www.epa.gov/region9/ superfund/prg/.
U.S. Geological Survey, 1996, Global 30 arc-second elevation (GTOPO30): Reston, Va., U.S Geological Survey dataset (digital elevation model), accessed February 12, 2014, at https://lta.cr.usgs.gov/GTOPO30.

U.S. Geological Survey, 2007-15, Beryllium, in Metals and minerals: U.S. Geological Survey Minerals Yearbook 2004-2013, v. I, variously paged.

Walker, R.J., Hanson, G.N., Papike, J.J., and O’Neil, J.R., 1986, Nd, O, and $\mathrm{Sr}$ isotopic constraints on the origin of Precambrian rocks, southern Black Hills, South Dakota: Geochimica et Cosmochimica Acta, v. 50, no. 12, p. 2833-2846.

Wood, S.A., 1992, Theoretical prediction of speciation and solubility of beryllium in hydrothermal solution to $300{ }^{\circ} \mathrm{C}$ at saturated vapor pressure-Application to bertrandite/ phenakite deposits: Ore Geology Reviews, v. 7, no. 4, p. 249-278.

World Health Organization, 2011, Guidelines for drinkingwater quality (4th ed): Geneva, Switzerland, World Health Organization, 541 p., accessed June 27, 2013, at http://www.who.int/water_sanitation_health/ publications/2011/dwq_guidelines/en/index.html.

Wuensch, B.J., 1972, Beryllium, in Wedepohl, K.H., ed., Handbook of geochemistry, v. 2, pt. 1: Berlin, West Germany, Springer-Verlag, p. 4-A-8, 1-2. 


\section{Cobalt}

By John F. Slack, Bryn E. Kimball, and Kim B. Shedd

Chapter F of

Critical Mineral Resources of the United States-Economic and Environmental Geology and Prospects for Future Supply

Edited by Klaus J. Schulz, John H. DeYoung, Jr., Robert R. Seal II, and Dwight C. Bradley

Professional Paper 1802-F

U.S. Department of the Interior

U.S. Geological Survey 


\section{Contents of Chapter $\mathbf{F}$}

[Figure and table titles for all chapters are listed in the volume contents before the conversion factors table and list of abbreviations and symbols. A periodic table of the elements is on the inside front cover of the printed volume]

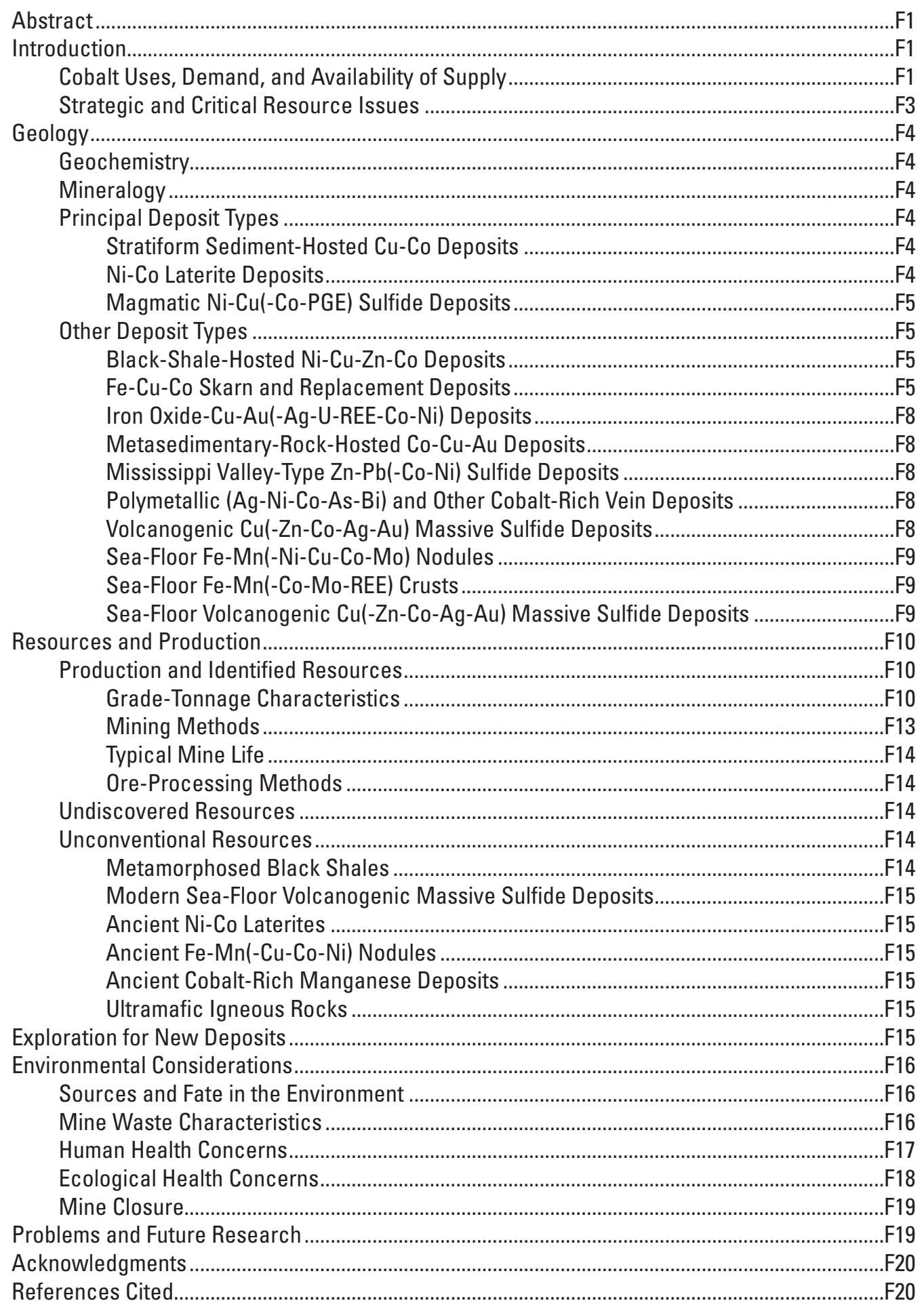

Suggested citation:

Slack, J.F., Kimball, B.E., and Shedd, K.B., 2017, Cobalt, chap. F of Schulz, K.J., DeYoung, J.H., Jr., Seal, R.R., II, and Bradley, D.C., eds., Critical mineral resources of the United States-Economic and environmental geology and prospects for future supply: U.S. Geological Survey Professional Paper 1802, p. F1-F40, http://dx.doi.org/10.3133/pp1802F. 


\title{
Cobalt
}

\author{
By John F. Slack, Bryn E. Kimball, and Kim B. Shedd
}

\section{Abstract}

Cobalt is a silvery gray metal that has diverse uses based on certain key properties, including ferromagnetism, hardness and wear-resistance when alloyed with other metals, low thermal and electrical conductivity, high melting point, multiple valences, and production of intense blue colors when combined with silica. Cobalt is used mostly in cathodes in rechargeable batteries and in superalloys for turbine engines in jet aircraft. Annual global cobalt consumption was approximately 75,000 metric tons in 2011; China, Japan, and the United States (in order of consumption amount) were the top three cobaltconsuming countries. In 2011, approximately 109,000 metric tons of recoverable cobalt was produced in ores, concentrates, and intermediate products from cobalt, copper, nickel, platinumgroup-element (PGE), and zinc operations. The Democratic Republic of the Congo (Congo [Kinshasa]) was the principal source of mined cobalt globally ( 55 percent). The United States produced a negligible amount of byproduct cobalt as an intermediate product from a PGE mining and refining operation in southeastern Montana; no U.S. production was from mines in which cobalt was the principal commodity. China was the leading refiner of cobalt, and much of its production came from cobalt ores, concentrates, and partially refined materials imported from Congo (Kinshasa).

The mineralogy of cobalt deposits is diverse and includes both primary (hypogene) and secondary (supergene) phases. Principal terrestrial (land-based) deposit types, which represent most of world's cobalt mine production, include primary magmatic $\mathrm{Ni}-\mathrm{Cu}(-\mathrm{Co}-\mathrm{PGE})$ sulfides, primary and secondary stratiform sediment-hosted $\mathrm{Cu}$-Co sulfides and oxides, and secondary Ni-Co laterites. Seven additional terrestrial deposit types are described in this chapter. The total terrestrial cobalt resource (reserves plus other resources) plus past production, where available, is calculated to be 25.5 million metric tons. Additional resources of cobalt are known to occur on the modern sea floor in aerially extensive deposits of Fe-Mn(-Ni-Cu-Co-Mo) nodules and Fe-Mn(-Co-Mo-rareearth-element) crusts. Legal, economic, and technological barriers have prevented exploitation of these cobalt resources, which lie at water depths of as great as 6,000 meters, although advances in technology may soon allow production of these resources to be economically viable.

Environmental issues related to cobalt mining concern mainly the elevated cobalt contents in soils and waters. Although at low levels cobalt is essential to human health (it is the central atom in the critical nutrient vitamin $\mathrm{B}_{12}$ ), overexposure to high levels of cobalt may cause lung and heart dysfunction, as well as dermatitis. The ecological impacts of cobalt vary widely and can be severe for some species of fish and plants, depending on various environmental factors.

\section{Introduction}

\section{Cobalt Uses, Demand, and Availability of Supply}

Cobalt is a technologically important metal that has many diverse uses, including in batteries, superalloys, and cemented carbides and diamond tools (fig. F1). Globally, the leading use is in the manufacture of cathode materials for rechargeable batteries, primarily lithium-ion, nickel-cadmium, and nickel-metal-hydride batteries, which are used in consumer electronics, electric and hybrid-electric vehicles, energy storage units, and power tools. Superalloys are alloys developed for high-temperature service where relatively high mechanical stress is encountered and where surface stability is frequently required. The principal use for superalloys is in parts for turbine engines for jet aircraft and terrestrial energy generation. Cemented carbides, which are composite materials made of cobalt and tungsten carbide, are used as cutting tools and wear-resistant components by the metalworking, mining, oil and gas drilling, and construction industries. Diamond tools are similar to cemented carbides in that cobalt is the matrix that binds the wear-resistant particles together. Cobalt is used to make permanent and soft magnetic alloys. Cobaltbearing steels include high-speed steels for cutting tools and maraging steels, which are characterized by their great strength, toughness, and workability. Other cobalt-bearing alloys are characterized by their resistance to corrosion and (or) wear or by their particular thermal expansion properties. Additional chemical applications for cobalt include animal 
feed additives; bonding agents in steel-belted radial tires; catalysts for chemical, petroleum, and other industries; drying agents for paint; glass decolorizers; ground coat frits for porcelain enamels; humidity indicators; magnetic recording media; pigments; and vitamin $\mathrm{B}_{12}$.

In recent years, annual global cobalt consumption (shown as "apparent consumption" in fig. F2) has generally trended upward to approximately 75,000 metric tons. World apparent consumption is the sum of apparent consumption calculated for individual countries; the calculation for each country uses reported data for production, trade, and stock variations, where available. China, Japan, and the United States (in order of consumption amount) are the top three cobalt-consuming countries (Cobalt Development Institute and World Bureau of Metal Statistics, 2011; Cobalt Development Institute, 2012).

From 1950 to 2011, global mine production of cobalt increased by more than an order of magnitude (fig. F3). In 2011, approximately 109,000 metric tons of recoverable cobalt was produced in ores, concentrates, and intermediate products from cobalt, copper, nickel, platinum-group-element (PGE), and zinc operations (fig. F2). More than one-half of the world's cobalt was mined in the Democratic Republic of the Congo (Congo [Kinshasa]). Other leading countries where cobalt was mined are shown in figure F4 (Shedd, 2013a). Trends in cobalt mineral exploration and supply are discussed in Wilburn (2012), Menzie and others (2013), and Shedd (2013a). Deposit types from which cobalt currently is mined are discussed in the Resources and Production section

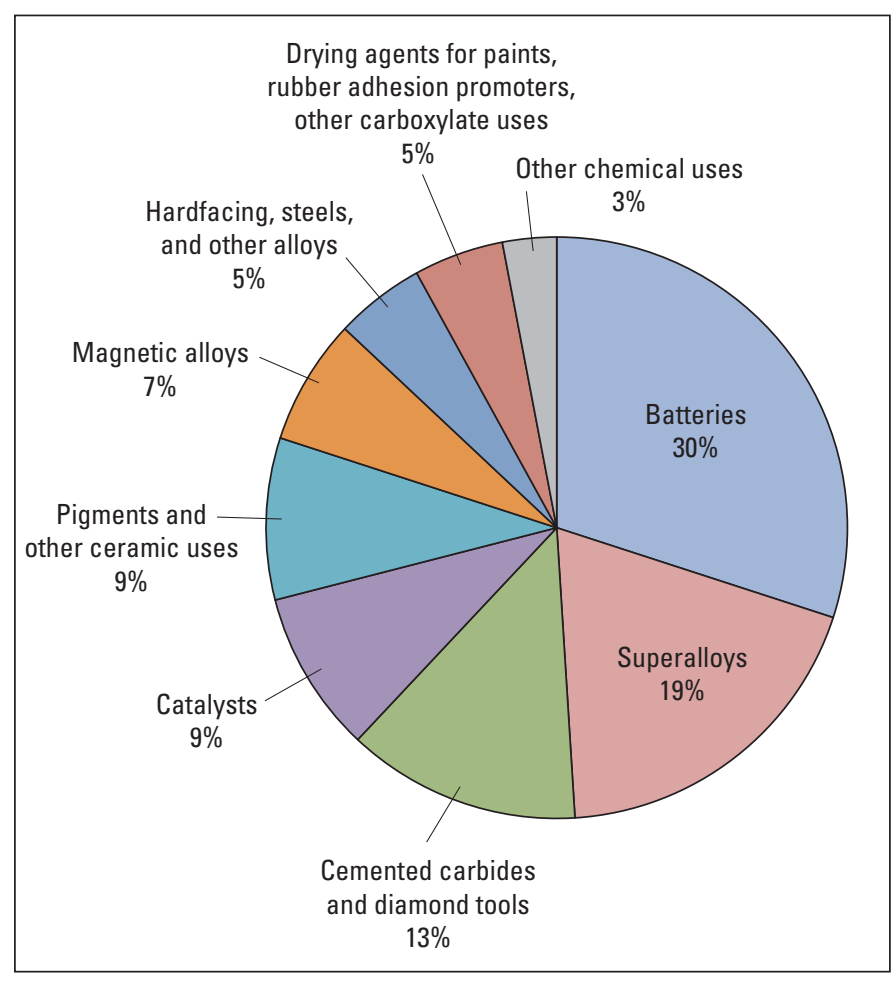

Figure F1. Pie chart showing major end uses of cobalt as a percentage of consumption worldwide in 2011. Data are from the Cobalt Development Institute (2012). of this chapter. Table F1 (back of chapter) gives locations and grade-tonnage data for significant cobalt deposits of the world.

In 2011, the United States produced a negligible amount of byproduct cobalt as an intermediate product from Stillwater Mining Co.'s PGE mining and refining operation in southeastern Montana. Since then, minor amounts of byproduct cobalt in nickel concentrate have been produced from Lundin Mining Corp.'s underground Eagle Mine, which is a highgrade magmatic $\mathrm{Ni}-\mathrm{Cu}(-\mathrm{Co}-\mathrm{PGE})$ sulfide orebody located northwest of Marquette, Michigan, where mining began in 2014. No U.S. production was from mines in which cobalt was the principal commodity. Other projects in the feasibility and development stages include Formation Metals Inc.'s underground cobalt mine to be constructed in a strata-bound $\mathrm{Co}-\mathrm{Cu}-\mathrm{Au}$ deposit in the Blackbird district (part of the Idaho cobalt belt) in Lemhi County and PolyMet Mining Corp.'s open pit mine to be constructed in the NorthMet Cu-Ni-CoPGE deposit in the Duluth Complex, which is a large mafic intrusive complex in northeastern Minnesota. Cobalt would be produced as a byproduct from the NorthMet project.

China was the leading refiner of cobalt in 2011, with much of its production coming from cobalt ores, concentrates, and partially refined materials imported from Congo (Kinshasa). Other significant sources of refined cobalt were Australia, Belgium, Canada, Congo (Kinshasa), Finland, Norway, and Zambia. Refined cobalt from Belgium and Finland was wholly or mainly produced from imported material, respectively (Shedd, 2013a).

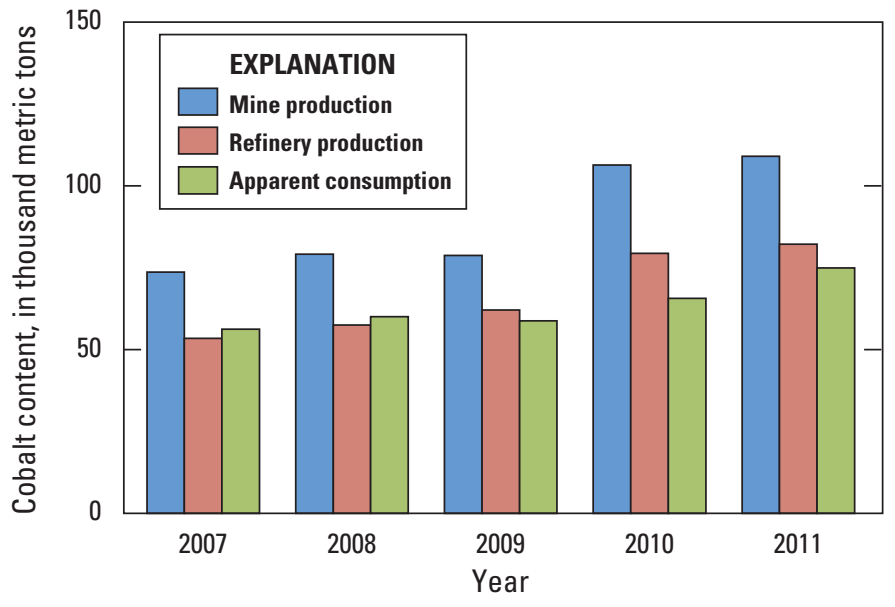

Figure F2. Bar chart showing world cobalt mine and refinery production and apparent consumption from 2007 to 2011. Mine production consists of the recoverable cobalt content of ores, concentrates, and intermediate products from cobalt, copper, nickel, platinum-group-element, and zinc operations. World apparent consumption is the sum of apparent consumption calculated for individual countries. The calculation for each country uses reported data for production, trade, and stock variations, where available. Apparent consumption data are from the Cobalt Development Institute and World Bureau of Metal Statistics (2011) and the Cobalt Development Institute (2012); production data are from Shedd (2013a). 


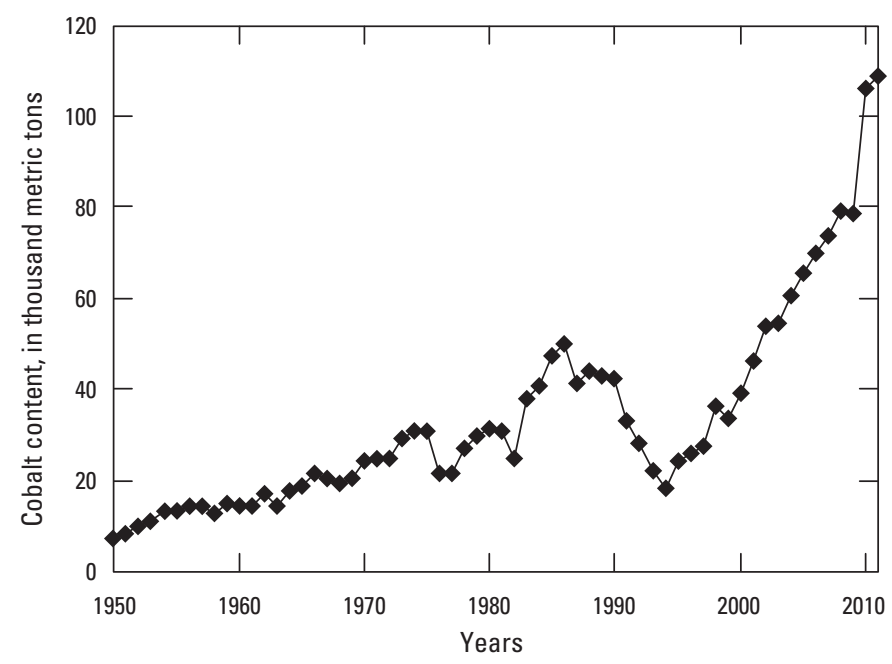

Figure F3. Graph showing world cobalt mine production from 1950 to 2011. Production consists of the recoverable cobalt content of ores, concentrates, and intermediate products from cobalt, copper, nickel, platinum-groupelement, and zinc operations. Data are from U.S. Geological Survey (2013).

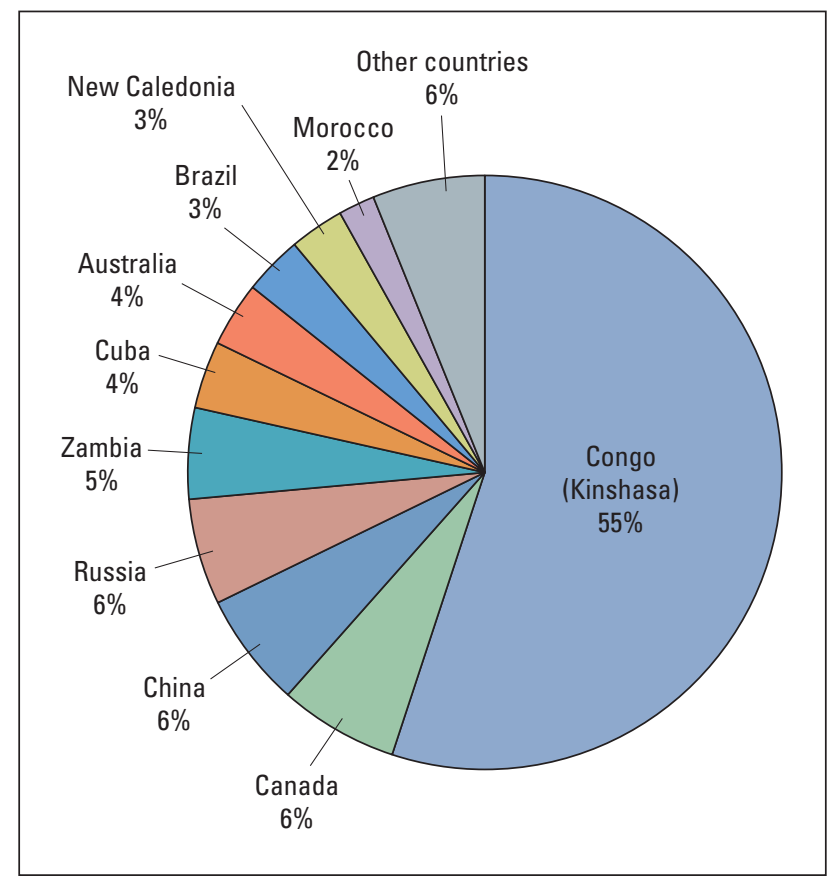

Figure F4. Pie chart showing percentage of world cobalt mine production in 2011, by country. The sources of production are cobalt, copper, nickel, platinum-group-element, and zinc operations. Data are from Shedd (2013a). Congo (Kinshasa) is a short-form name for Democratic Republic of the Congo.

More than one-half of the world's cobalt supply is mined in Congo (Kinshasa). This country has a high risk index for doing business owing to poor infrastructure, resource nationalism, a high perception of corruption, and a lack of transparency as well as wars during the 1990s to early 2000s, persistent tension in the eastern part of the country with substantial risk of civil war, and conflicts with neighboring Rwanda (Bedder, 2013; The Coface Group, undated). Although civil unrest in the eastern part of Congo (Kinshasa) has not affected the cobalt-producing areas, problems with infrastructure (particularly power and transportation) and reviews of and changes to mining contracts have slowed some of the potential growth in mine development and production. In spite of these issues, the copper-cobalt mining industry in Congo (Kinshasa) has significantly recovered from the collapse in production that took place in the 1990s (Shedd, 2013a).

The United States is highly reliant on imports for its cobalt needs. In recent years, approximately 75 to 80 percent of the U.S. cobalt supply has come from imports and releases from the National Defense Stockpile; the remaining 20 to 25 percent has been from recycled scrap. This high reliance on imports increases the potential for supply disruption and high prices during supply shortfalls. The leading source of refined cobalt for the United States is China (Shedd, 2013a, b). Spencer, 2016). 


\section{Geology}

\section{Geochemistry}

Cobalt is a silvery gray metal with diverse uses based on certain key properties, including hardness, wear-resistance when alloyed with other metals, low thermal and electrical conductivity, high melting point, multiple valences, and production of intense blue colors when combined with silica. Cobalt also is ferromagnetic, and it retains this property at the highest temperature of any metal. Although pure cobalt is not found in nature, cobalt-bearing minerals and compounds are numerous and widespread. The ionic radius of cobalt is 0.72 angstroms $(\AA)$ for $\mathrm{Co}^{2+}$ and $0.63 \AA$ for $\mathrm{Co}^{3+}$, both of which are similar to the ionic radii of $\mathrm{Mg}^{2+}, \mathrm{Mn}^{4+}, \mathrm{Fe}^{2+}, \mathrm{Fe}^{3+}$, and $\mathrm{Ni}^{2+}$, thus allowing substitution under favorable conditions for these elements by cobalt within many minerals and other phases. Among common rock types, the highest average cobalt content occurs in ultramafic igneous rocks, such as dunite and serpentinite, which contain, on average, 109 and 115 parts per million (ppm) cobalt, respectively (table F2); mafic igneous rocks such as basalt contain, on average, about 47 ppm cobalt. For comparison, Earth's bulk continental crust, including all rock types, contains $29 \mathrm{ppm}$ cobalt, on average. Lower cobalt contents characterize shale (which averages $19 \mathrm{ppm}$ ), as well as granite and related felsic igneous rocks (which average 2 to $3 \mathrm{ppm}$ ) (table F2).

\section{Mineralogy}

The mineralogy of cobalt deposits is diverse and includes both primary (hypogene) and secondary (supergene) phases. In primary deposits, most cobalt is recovered from sulfide minerals, such as carrollite $\left(\mathrm{Cu}\left(\mathrm{Co}, \mathrm{Ni}_{2} \mathrm{~S}_{4}\right)\right.$, pentlandite $\left((\mathrm{Fe}, \mathrm{Ni}, \mathrm{Co})_{9} \mathrm{~S}_{8}\right)$, linnaeite $\left(\mathrm{Co}_{3} \mathrm{~S}_{4}\right)$, and siegenite $\left((\mathrm{Co}, \mathrm{Ni})_{3} \mathrm{~S}_{4}\right)$; arsenide minerals, such as skutterudite $\left((\mathrm{Co}, \mathrm{Fe}, \mathrm{Ni}) \mathrm{As}_{2-3}\right)$ and safflorite $\left((\mathrm{Co}, \mathrm{Fe}) \mathrm{As}_{2}\right)$; and sulfarsenide minerals, including cobaltite (CoAsS) and glaucodot $((\mathrm{Co}, \mathrm{Fe}) \mathrm{AsS})$. Cobaltiferous pyrite and pyrrhotite - $(\mathrm{Fe}, \mathrm{Co}) \mathrm{S}_{2}$ and $(\mathrm{Fe}, \mathrm{Co})_{1-\mathrm{x}} \mathrm{S}$, respectivelyare mined in some deposits. Among secondary cobalt-rich phases, which form during surficial weathering, one of the most important historically was erythrite $\left(\mathrm{Co}_{3}\left(\mathrm{AsO}_{4}\right)_{2} \bullet 8 \mathrm{H}_{2} \mathrm{O}\right)$, which is a bright pink mineral also known as "cobalt bloom." In modern mining of secondary cobalt-rich deposits, the principal economic phases, in addition to erythrite, are heterogenite $(\mathrm{CoO}(\mathrm{OH}))$ and asbolane $\left((\mathrm{Ni}, \mathrm{Co})_{2-\mathrm{x}} \mathrm{Mn}(\mathrm{O}, \mathrm{OH})_{4} \cdot \mathrm{nH}_{2} \mathrm{O}\right)$, plus local heazlewoodite $\left((\mathrm{Ni}, \mathrm{Co})_{3} \mathrm{~S}_{2}\right)$, together with cobaltiferous oxyhydroxides, including goethite $\left(\mathrm{Fe}^{3+} \mathrm{O}(\mathrm{OH})\right)$, limonite $\left(\mathrm{FeO}(\mathrm{OH}) \cdot \mathrm{nH}_{2} \mathrm{O}\right)$, and lithiophorite $\left(\mathrm{AlMnO}_{2}(\mathrm{OH})_{2}\right)$. With respect to the cobaltiferous oxyhydroxides, it is unclear from studies to date whether the contained cobalt is present in the crystal structure or adsorbed onto surfaces.

\section{Principal Deposit Types}

Cobalt deposits of economic or potential economic importance are diverse in terms of their geologic setting, age, morphology, mineralogy, geochemistry, origin, and gradetonnage relations (for example, Crockett and others, 1987; Smith, 2001; British Geological Survey, 2009). The principal deposit types that account for most of the world's cobalt mine production are stratiform sediment-hosted $\mathrm{Cu}-\mathrm{Co}$ deposits, $\mathrm{Ni}-\mathrm{Co}$ laterite deposits, and magmatic $\mathrm{Ni}-\mathrm{Cu}(-\mathrm{Co}-\mathrm{PGE})$ sulfide deposits. These deposit types, together with selected examples, are described below.

\section{Stratiform Sediment-Hosted Cu-Co Deposits}

Most of the world's cobalt is produced as a byproduct of copper mining in sediment-hosted $\mathrm{Cu}-\mathrm{Co}$ deposits that form strata-bound and commonly stratiform zones within siliciclastic or carbonate strata (Hitzman and others, 2005). Important ore hosts in some deposits are giant breccias that originated by the dissolution of former salt beds. Globally, the deposits contain chalcopyrite, pyrite, and carrollite, plus minor amounts of bornite and chalcocite, in gangue material composed mainly of potassium feldspar, muscovite, biotite, albite, quartz, and carbonate. The ages of the mineralization are principally Neoproterozoic and Permian, but some important deposits are Mesoproterozoic. Although current genetic models differ in some respects, the consensus opinion is that metalliferous saline hydrothermal fluids were introduced at low to moderate temperatures during diagenesis and the early stages of deformation and metamorphism (see Zientek and others, 2013).

The greatest amount of contained cobalt in this deposit type occurs in the Central African Copperbelt in Congo (Kinshasa) and Zambia (Selley and others, 2005; Taylor and others, 2013). Large deposits in this region from which byproduct cobalt is currently or has been produced include Kamoto, KOV, and Tenke Fungurume, all in Congo (Kinshasa) (El Desouky and others, 2010; Fay and Barton, 2012), and Nkana in Zambia (Brems and others, 2009).

\section{Ni-Co Laterite Deposits}

Laterites are red regoliths that develop in humid tropical climates during the weathering of diverse types of bedrock. Those that developed on ultramafic bedrock may contain important Ni-Co deposits (Freyssinet and others, 2005; Butt and Cluzel, 2013). Ni-Co laterites locally contain abundant scandium and, rarely, elevated concentrations of PGEs. $\mathrm{Ni}$-Co laterite deposits consist of the following layers, from top to bottom: overburden, limonite, saprolite, and weathered ultramafic source rocks. Ore zones of laterite deposits range in thickness from about 10 meters $(\mathrm{m})$ to as much as $40 \mathrm{~m}$ in some cases, and generally contain more than 1 percent nickel and less than 0.15 percent cobalt. Limonite developed over 
ultramafic rocks tends to have higher cobalt grades, whereas saprolite has higher nickel grades. Metal accumulation involves supergene processes and several key variables, including primary bedrock lithology, climate history, topography, and structural preparation (that is, the fracture or joint density of bedrock). Ages of the deposits typically are mid-Tertiary to Holocene; some fossil Ni-Co laterites are known. Major ore constituents include the following: (a) nickeliferous serpentine (garnierite), talc, and chlorite; (b) nickel- or cobalt-bearing clays (for example, nontronite, and montmorillonite); (c) erythrite, heterogenite, asbolane, heazlewoodite, and millerite; and (d) goethite, limonite, and lithiophorite. The gangue (non-ore) material may include various amounts of quartz, amorphous silica, clays, and serpentine.

The Kalgoorlie and the Murrin Murrin deposits in Western Australia (Elias and others, 1981; Gaudin and others, 2005) and the Goro deposit in New Caledonia (Wells and others, 2009) are examples of some of the world's many large $\mathrm{Ni}-\mathrm{Co}$ laterite deposits. The manganiferous Nkamouna Co-Ni deposit in Cameroon is one of the few laterites known for which cobalt would be the principal economic metal to be mined (Lambiv Dzemua and Gleeson, 2012).

\section{Magmatic Ni-Cu(-Co-PGE) Sulfide Deposits}

Large resources (including reserves) of cobalt are contained in $\mathrm{Ni}-\mathrm{Cu}(-\mathrm{Co}-\mathrm{PGE})$ sulfide deposits hosted in mafic and ultramafic igneous rocks (Naldrett, 2004; Eckstrand and Hulbert, 2007). This deposit type comprises semimassive to massive sulfides that occur within or near the basal zones of layered intrusive complexes, in discordant magmatic conduits, and within ultramafic intrusions and lava flows. The ages of the deposits, which approximate those of the host intrusions, range from Archean to Tertiary. Nickel is the principal metal commodity, and it is accompanied by subequal proportions of copper in most deposits; cobalt and PGEs are mining byproducts. Cobalt resides mainly in cobaltiferous pentlandite and, to a lesser extent, in linnaeite. The gangue minerals consist mostly of primary magmatic minerals, such as olivine, pyroxene, and plagioclase. Mineralizing processes involve magmatic segregation of sulfides and, in some deposits, hydrothermal mobilization into post-magmatic structures.

Deposits of this type that currently feature significant byproduct production of cobalt include Voisey's Bay in Newfoundland and Labrador, Canada (Naldrett and Li, 2007); the Sudbury district in Ontario, Canada (Ames and Farrow, 2007); and the Norilsk-Talnakh district in Siberia, Russia (Naldrett and others, 1996).

\section{Other Deposit Types}

Types of deposits that on a global scale have produced relatively minor amounts of cobalt include the following: (a) black-shale-hosted Ni-Cu-Zn-Co, (b) Fe-Cu-Co skarn and replacement, (c) iron oxide-Cu-Au(-Ag-U-REE-Co-Ni), (d) metasedimentary-rock-hosted Co-Cu-Au, (e) Mississippi Valley-type $\mathrm{Zn}-\mathrm{Pb}(-\mathrm{Co}-\mathrm{Ni}$ ), (f) polymetallic (Ag-Ni-CoAs-Bi) and other cobalt-rich veins, and ( $g$ ) volcanogenic $\mathrm{Cu}(-\mathrm{Zn}$-Co-Ag-Au) massive sulfides. Identified cobalt deposits on the sea floor, which may be mined in the future, include $\mathrm{Fe}-\mathrm{Mn}(-\mathrm{Ni}-\mathrm{Cu}-\mathrm{Co}-\mathrm{Mo})$ nodules, Fe-Mn(-Co-Mo-REE) crusts, and volcanogenic $\mathrm{Cu}(-\mathrm{Zn}-\mathrm{Co}-\mathrm{Ag}-\mathrm{Au})$ massive sulfides.

\section{Black-Shale-Hosted Ni-Cu-Zn-Co Deposits}

Black shales are well known for containing elevated contents of many metals of economic interest, including $\mathrm{Cu}$, $\mathrm{Mo}, \mathrm{Ni}, \mathrm{Zn}, \mathrm{Co}, \mathrm{Cd}, \mathrm{Ag}, \mathrm{Au}, \mathrm{Se}, \mathrm{Cr}, \mathrm{V}$, U, and PGEs (for example, Desborough and Poole, 1983; Coveney, 2003). Metals concentrated in black shales may reside in pyrite; organic matter; aluminosilicate minerals, such as illite; and locally in sphalerite and chalcopyrite. Some deposits contain very high contents of molybdenum, nickel, zinc, and (or) vanadium within primary sedimentary beds or laminae. In other deposits, high contents of cobalt formed by hydrothermal leaching, mobilization, and concentration into sulfide minerals during deformation and regional metamorphism.

One of the few black-shale-hosted deposits from which byproduct cobalt is recovered is the giant Talvivaara orebody in central Finland, which is being mined for nickel, zinc, and copper (Loukola-Ruskeeniemi and Lahtinen, 2013).

\section{Fe-Cu-Co Skarn and Replacement Deposits}

Pluton-related skarn and replacement deposits form by the introduction of hydrothermal fluids into chemically reactive rocks, mainly carbonate (limestone and dolostone), and by metasomatic processes that introduce metals and other components into the precursor strata. These deposits occur proximal or distal to intrusive bodies and contain a diverse suite of metals (Megaw, 1998; Meinert and others, 2005). Sulfide minerals may include pyrite, pyrrhotite, chalcopyrite, sphalerite, and galena, together with abundant magnetite in some deposits. Cobaltiferous deposits generally contain mainly copper residing in chalcopyrite; cobalt occurs in cobaltite or cobalt-rich pyrite. In replacement deposits, which commonly are located distal from pluton contacts, gangue minerals typically include quartz or carbonate. The gangue minerals of skarn deposits, which occur near plutons, are generally different and include garnet, pyroxene, amphibole, epidote, olivine, plagioclase, and (or) scapolite.

The Cornwall and the Morgantown (Grace Mine) Fe-Cu-Co deposits, which are two of only a few large cobaltiferous skarn deposits in the world, are located in southeastern Pennsylvania (Lapham, 1968) but are no longer operating. Another large deposit of this type, although it lacks significant amounts of iron, is Ruby Creek in northwestern Alaska (Bernstein and Cox, 1986). The Mount Elliott $\mathrm{Cu}-\mathrm{Au}(-\mathrm{Co}-\mathrm{Ni})$ skarn deposit in Queensland, Australia, differs in that it contains a significant amount of gold (Wang and Williams, 2001). 
Table F2. Cobalt concentrations in rocks, soils, waters, and air.

[DOE, U.S. Department of Energy; EPA, U.S. Environmental Protection Agency; cm, centimeter; ppm, part per million; $\mu \mathrm{g} / \mathrm{g}$, microgram per gram; $\mu \mathrm{g} / \mathrm{L}$, microgram per liter; $\mu \mathrm{m}$, micrometer; $\mathrm{ng} / \mathrm{m}^{3}$, nanogram per cubic meter]

\begin{tabular}{|c|c|c|c|c|}
\hline $\begin{array}{l}\text { Environment } \\
\text { and (or) location }\end{array}$ & $\begin{array}{c}\text { Cobalt } \\
\text { concentration }\end{array}$ & Unit & Notes & Reference(s) \\
\hline \multicolumn{5}{|c|}{ Rocks } \\
\hline Bulk continental crust & 29 & ppm & Average & Taylor and McLennan (1995) \\
\hline Lower continental crust & 35 & ppm & Average & Taylor and McLennan (1995) \\
\hline Granite & 2.4 & ppm & Average & Krauskopf and Bird (1995) \\
\hline Pyroxenite (alpine-type) & 55.2 & ppm & Average & Gülaçar and Delaloye (1976) \\
\hline Serpentinite (alpine-type) & 115 & ppm & Average & Gülaçar and Delaloye (1976) \\
\hline Shale & 19 & ppm & Average & Krauskopf and Bird (1995) \\
\hline United States & 29 to 940 & ppm & $\begin{array}{l}\text { Near mining in the Idaho } \\
\text { copper belt }\end{array}$ & Giles and others (2009) \\
\hline Conterminous United States & 0.5 to 160 & ppm & $\begin{array}{l}0 \text { to } 5 \mathrm{~cm} \text { depth; median is } \\
7.2 \mathrm{ppm}\end{array}$ & Smith and others (2005) \\
\hline Conterminous United States & 1.8 to 14 & ppm & $\begin{array}{l}\text { O horizon, if present; median } \\
\text { is } 3 \mathrm{ppm}\end{array}$ & Smith and others (2005) \\
\hline Conterminous United States & 0.9 to 143 & ppm & A horizon; median is $7.1 \mathrm{ppm}$ & Smith and others (2005) \\
\hline Conterminous United States & 0.7 to 191 & ppm & $\mathrm{C}$ horizon; median is $7.8 \mathrm{ppm}$ & Smith and others (2005) \\
\hline Western United States & 7.1 & ppm & Mean for $20 \mathrm{~cm}$ depth & Shacklette and Boerngen (1984) \\
\hline Eastern United States & 5.9 & ppm & Mean for $20 \mathrm{~cm}$ depth & Shacklette and Boerngen (1984) \\
\hline Congo (Kinshasa) & 17 to 33 & ppm & $\begin{array}{l}0 \text { to } 5 \mathrm{~cm} \text {; distant from } \\
\text { African copper belt mines }\end{array}$ & Narendrula and others (2012) \\
\hline Congo (Kinshasa) & 204 to 6,150 & ppm & $\begin{array}{l}0 \text { to } 5 \mathrm{~cm} \text {; near African } \\
\text { copper belt mines }\end{array}$ & Narendrula and others (2012) \\
\hline Egypt & 13 to 25 & ppm & 0 to $20 \mathrm{~cm}$; distant from industry & Zohny (2002) \\
\hline Egypt & 26 to 65 & ppm & $\begin{array}{l}0 \text { to } 20 \mathrm{~cm} \text {; pollution from } \\
\text { industry }\end{array}$ & Zohny (2002) \\
\hline Sweden & 0.5 to 2.3 & ppm & $\begin{array}{l}\text { Range of profile developed on } \\
\text { quartzite and gniess }\end{array}$ & Tyler (2004) \\
\hline Proposed DOE benchmark & 20 & ppm & $\begin{array}{l}\text { Contaminant screening bench- } \\
\text { mark for terrestrial plants }\end{array}$ & Efroymson and others (1997) \\
\hline Soil-quality guideline & 40 & ppm & $\begin{array}{l}\text { Canadian agricultural } \\
\text { soil guideline }\end{array}$ & $\begin{array}{l}\text { Canadian Council of Ministers } \\
\text { of the Environment (2013) }\end{array}$ \\
\hline
\end{tabular}


Table F2. Cobalt concentrations in rocks, soils, waters, and air--Continued

[DOE, U.S. Department of Energy; EPA, U.S. Environmental Protection Agency; cm, centimeter; ppm, part per million; $\mu$ g/g, microgram per gram; $\mu \mathrm{g} / \mathrm{L}$, microgram per liter; $\mu \mathrm{m}$, micrometer; $\mathrm{ng} / \mathrm{m}^{3}$, nanogram per cubic meter]

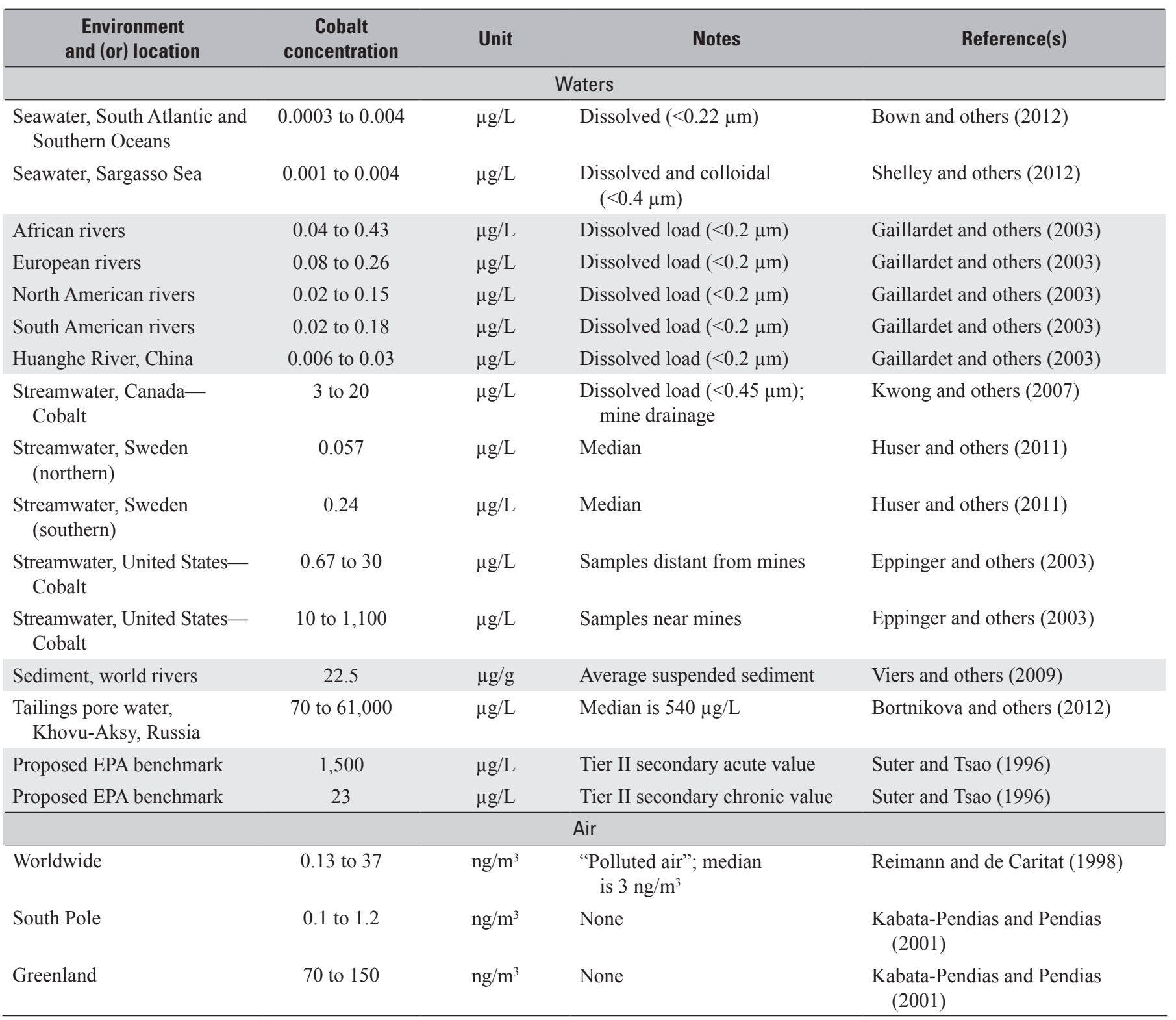




\section{Iron Oxide-Cu-Au(-Ag-U-REE-Co-Ni) Deposits}

The iron oxide-Cu-Au(-Ag-U-REE-Co-Ni) class of mineral deposits is globally important as a major source of copper, gold, and in some cases, silver, uranium, and rareearth elements (REEs) (Williams and others, 2005). These iron oxide-copper-gold (IOCG) deposits are mainly of Late Archean, Proterozoic, and Mesozoic ages, and they occur either near plutons or in metamorphic terranes without a clear link to intrusive bodies. Their ore mineralogy is dominated by magnetite, hematite, chalcopyrite, bornite, and gold, with concentrations in some deposits of uraninite, bastnäsite (or bastnaesite), monazite, cobaltite, glaucodot, bismuthinite, native bismuth, arsenopyrite, millerite, molybdenite, and galena; common gangue minerals are fluorite, barite, and quartz; and tourmaline is present locally. This deposit type is thought to have originated from one of the following fluid types and sources: magmatic-hydrothermal, metamorphic, and evaporitic brine.

Very large IOCG deposits that contain appreciable amounts of cobalt include, in Australia, the Olympic Dam deposit in South Australia (Reynolds, 2000) and the Ernest Henry deposit in Queensland (Mark and others, 2000), and in Brazil, the Sossego deposit (Monteiro and others, 2008).

\section{Metasedimentary-Rock-Hosted Co-Cu-Au Deposits}

$\mathrm{Co}-\mathrm{Cu}-\mathrm{Au}$ deposits hosted in metasedimentary rocks are strata-bound zones of semimassive to locally massive sulfides within deformed and metamorphosed siliciclastic strata chiefly of Proterozoic age (Slack, 2013). The mineralized zones range from strata-bound and discordant to stratiform and include lenses, veins, and breccias. The deposits consist of cobaltite and (or) other cobalt-rich sulfarsenide or sulfide minerals, or cobaltiferous pyrite, together with chalcopyrite and magnetite, in a gangue of quartz, muscovite, biotite, chlorite, potassium feldspar, albite, and (or) scapolite, accompanied in many deposits by minor amounts of tourmaline. The origins of these deposits are thought to be varied; a range of mineralizing processes, from diagenetic to epigenetic (the latter occurring both before and during metamorphism) are thought to be involved. In some deposits, geochronological and geochemical evidence suggests links to granitic and (or) gabbroic plutons, but the origin of most deposits of this type - and sources of the hydrothermal fluids and metals - are enigmatic.

The largest tonnages of cobalt in this deposit type are contained in the Blackbird district of east-central Idaho (Slack, 2013, and references therein), the Kuusamo belt of northeastern Finland (Vanhanen, 2001), and the NICO deposit in the Northwest Territories in Canada (Goad and others, 2000). Cobalt deposits of this type in the Modum district in Norway, especially those at the Skuterud Mine (Grorud, 1997), were historically important as the major European source of blue pigment used during the 17 th and 18 th centuries.

\section{Mississippi Valley-Type Zn-Pb(-Co-Ni) Sulfide Deposits}

Strata-bound $\mathrm{Zn}-\mathrm{Pb}(-\mathrm{Co}-\mathrm{Ni})$ sulfide concentrations hosted by carbonate strata are termed Mississippi Valley-type (MVT) deposits (Leach and others, 2005; Paradis and others, 2007). These deposits typically consist of various proportions of sphalerite and galena in a gangue of fluorite or barite; quartz is uncommon. The principal cobalt mineral is carrollite. Most deposits of this type are Phanerozoic, although a few Proterozoic examples are known. Mineralization characteristically involves the migration of low-temperature, highly saline brines and the subsequent precipitation of ore and gangue minerals as open-space fillings of paleokarst structures or as replacement zones in carbonate rocks.

MVT deposits generally lack high cobalt contents, but a few, such as the Mine La Motte-Fredericktown and the Higdon deposits in Missouri (Seeger, 2008; Parra and others, 2009) have produced minor amounts of cobalt as a byproduct of the mining of lead and zinc.

\section{Polymetallic (Ag-Ni-Co-As-Bi) and Other Cobalt-Rich Vein Deposits}

Cobalt-rich vein deposits fill fractures and faults within metasedimentary or metaigneous rocks of Proterozoic or younger age (Kissin, 1992). The majority of these deposits were mined for silver and cobalt; some also produced byproduct copper, lead, zinc, gold, uranium, and (or) barite. In these types of deposits, multistage mineralization is common, typified by a diverse ore mineralogy consisting of native silver and native bismuth, gold, argentite, rammelsbergite, safflorite, skutterudite, gersdorffite, niccolite, uraninite, arsenopyrite, pyrite, pyrrhotite, sphalerite, galena, bornite, chalcopyrite, tetrahedrite, and $\mathrm{Sb}-\mathrm{As}-\mathrm{Ag}$ sulfosalts. Gangue minerals may include quartz, carbonate, fluorite, and (or) barite. The origins of these deposits vary widely and include mineralization by magmatically derived hydrothermal fluids, metamorphic fluids, basinal brines, and meteoric waters.

Economically, the most important vein deposits have been those in the Erzgebirge region of the Czech Republic and Germany (Hermann, 2005), the Kongsberg district of southern Norway (Neumann, 1944), the Cobalt district of Ontario, Canada (Marshall and Watkinson, 2000), and the Bou Azzer district of Morocco (Bouabdellah and others, 2016).

\section{Volcanogenic $\mathrm{Cu}(-\mathrm{Zn}-\mathrm{Co}-\mathrm{Ag}-\mathrm{Au})$ Massive Sulfide Deposits}

Volcanogenic massive sulfide (VMS) deposits occur in marine volcanic and volcanosedimentary belts of Archean to Holocene age and are mined principally for copper, zinc, lead, silver, and gold (Galley and others, 2007; Shanks and 
Thurston, 2012). These deposits precipitate from hydrothermal fluids on the sea floor within irregular chimneys and mounds, and in the subsurface within strata-bound or discordant zones. The major sulfide minerals are pyrite, pyrrhotite, chalcopyrite, and sphalerite; some deposits have appreciable amounts of galena, tetrahedrite, and gold. Gangue minerals may include quartz, muscovite, chlorite, siderite, and barite. Most VMS deposits lack elevated contents $(>0.1$ weight percent) of cobalt but several have higher grades, especially deposits hosted predominantly by ultramafic or mafic volcanic rocks. Extensive research on this deposit type has allowed the development of refined genetic models that involve subsea-floor emplacement of igneous magma that drives hydrothermal convection and seawater entrainment, coupled with upflow of metalliferous hydrothermal fluids and subsequent sulfide precipitation (see Shanks and Thurston, 2012, and references therein).

Among ancient deposits, the few that have significant amounts of contained cobalt include Outukumpu in central Finland (Peltonen and others, 2008), Windy Craggy in northwestern British Columbia, Canada (Peter and Scott, 1999), and Deerni in Qinghai Province, China (Hou and others, 1999).

\section{Sea-Floor Fe-Mn(-Ni-Cu-Co-Mo) Nodules}

Ferromanganese nodules on the modern sea floor contain large resources of several metals, including nickel, copper, cobalt, and molybdenum (Hein and others, 2013). These nodules occur mainly on abyssal plains at depths of 3,500 to $6,500 \mathrm{~m}$, having formed by the precipitation of iron and manganese oxyhydroxide phases from seawater and pore fluids within enclosing sediments. The growth rates of nodules vary greatly, from a few millimeters per million years, where components are precipitated only from seawater, to as much as 250 millimeters per million years, where precipitation is dominantly from pore fluids. Nodule diameters typically are 2 to 8 centimeters $(\mathrm{cm})$. Major constituents are delta-manganese dioxide $\left(\delta-\mathrm{MnO}_{2}\right)$, todorokite, and other similar manganates, with lesser amounts of birnessite, iron oxyhydroxides, and detrital aluminosilicate minerals. Metals of economic interest, such as cobalt, are sorbed onto surfaces of the manganese oxyhydroxides, where they are retained by surface oxidation processes. The formational ages of the nodules generally are no older than the Holocene owing to dissolution of manganese oxides within anoxic pore fluids during diagenesis, but ancient nodules of Miocene and Cretaceous age also are known.

The best-documented and largest nodule fields are located in the Pacific Ocean between the Clarion and Clipperton fracture zones, in the Cook Islands Exclusive Economic Zone (EEZ), in the Penrhyn-Samoa Basin, the Peru Basin, and in the Pioneer area of the central Indian Ocean (Hein and others, 2013).

\section{Sea-Floor Fe-Mn(-Co-Mo-REE) Crusts}

Ferromanganese crusts on the modern sea floor also represent immense resources of cobalt, molybdenum, REEs, and other metals (Glasby and others, 2010; Hein and others, 2013). These crusts occur on seamounts, plateaus, and spreading ridges at relatively shallow depths of 800 to $3,000 \mathrm{~m}$. Growth rates of the crusts are extremely slow, generally in the range of 1 to 6 millimeters per million years owing to precipitation of components only from seawater. The thickness of the crust varies from less than $1 \mathrm{~cm}$ to as much as $26 \mathrm{~cm}$, and the thickest parts occur on the oldest seamounts. The principal minerals are $\delta-\mathrm{MnO}_{2}$, iron oxyhydroxides, and carbonate fluorapatite, together with local goethite and minor amounts of detrital minerals, such as quartz and feldspar. The incorporation of cobalt and other metals occurs by processes similar to those that take place in ferromanganese nodules.

The greatest resources in ferromanganese crusts are located in the Pacific prime crust zone of the central equatorial Pacific Ocean (Hein, 2002). Other regions contain appreciable resources, however, such as in the Nameless, Unicorn, and Maderia-Tore Rise (MTR) zones of the northeastern Atlantic Ocean (Muiños and others, 2013), and the Afanasiy-Nikitin seamount in the Indian Ocean (Parthiban and Banakar, 1999).

\section{Sea-Floor Volcanogenic Cu(-Zn-Co-Ag-Au) Massive Sulfide Deposits}

More than $100 \mathrm{VMS}$ deposits have been discovered on the modern sea floor (Hannington and others, 2005). Cobaltiferous examples are few and limited to occurrences in ultramafic rocks. These relatively cobalt-rich VMS deposits are present in serpentinite, which is a rare lithology on the modern sea floor, having been exposed by detachment faulting and core complex formation that raise deeper rocks of the lower oceanic crust and upper mantle to the ocean floor. The major sulfide minerals present in ancient VMS deposits hosted in basalt are chalcopyrite, isocubanite, pyrite (locally cobaltiferous), sphalerite, and wurtzite; the gangue minerals consist of abundant serpentine and smectite, in addition to chlorite.

The Rainbow vent field on the Mid-Atlantic Ridge (Bogdanov and others, 2002) has VMS deposits that contain the greatest amount of cobalt known among modern sea-floor VMS deposits. Other deposits of this type that are found on the Mid-Atlantic Ridge occur in the Logatchev (Mozgova and others, 1999) and the Nibelungen fields (Melchert and others, 2008). 


\section{Resources and Production}

\section{Production and Identified Resources}

Figure F5 shows cobalt production in 2011, by deposit type. Cobalt production from Congo (Kinshasa) and most of the output from Zambia was as a byproduct of the copper mining of stratiform sediment-hosted $\mathrm{Cu}$-Co deposits. Cobalt mine production from most other countries was as a byproduct of nickel mining. Production from Cuba and New Caledonia was from Ni-Co laterite deposits. Production from Canada and Russia and most of the production from China was from magmatic Ni-Cu(-Co-PGE) sulfide deposits. Production from Australia and Brazil was from Ni-Co laterite and magmatic $\mathrm{Ni}-\mathrm{Cu}(-\mathrm{Co}-\mathrm{PGE})$ sulfide deposits. Only in Morocco was cobalt produced as the principal commodity from a current mining operation; the deposits in Morocco are hydrothermal polymetallic veins.

The proportion of cobalt produced from different deposit types has varied over time. During the 1990s, production from stratiform sediment-hosted $\mathrm{Cu}$-Co deposits was relatively low owing to a period of civil unrest in Congo (Kinshasa) and a major collapse at the Kamoto Mine in Congo (Kinshasa) in 1990. The percentage of production from Ni-Co laterite deposits has increased since the mid-1990s owing to development of second-generation hydrometallurgical processes for

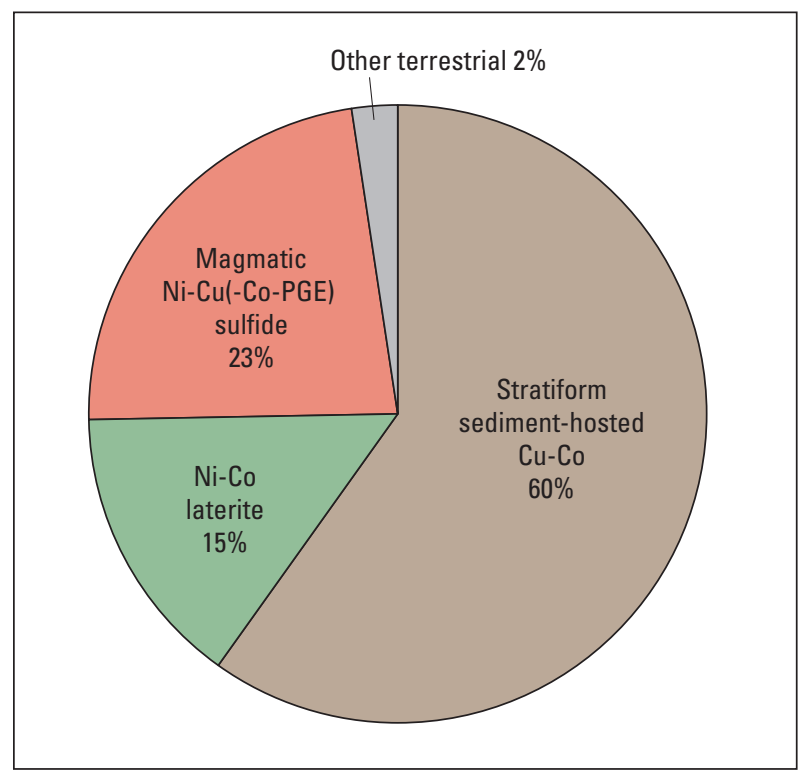

Figure F5. Pie chart showing percentage of world cobalt mine production in 2011, by deposit type. Other terrestrial deposits are grouped together and include black-shale-hosted $\mathrm{Ni}-\mathrm{Cu}-\mathrm{Zn}-\mathrm{Co}$ deposits, polymetallic (Ag-Ni-Co-As-Bi) and other cobalt-rich veins, and volcanogenic $\mathrm{Cu}(-\mathrm{Zn}-\mathrm{Co}-\mathrm{Ag}-\mathrm{Au})$ massive sulfide deposits. No recoverable cobalt was known to be produced in 2011 from deposit types not listed. The sources of production are cobalt, copper, nickel, platinumgroup-element (PGE), and zinc operations. $\mathrm{Ag}$, silver; As, arsenic; $\mathrm{Au}$, gold; $\mathrm{Bi}$, bismuth; $\mathrm{Co}$, cobalt; $\mathrm{Cu}$, copper; $\mathrm{Ni}$, nickel; $\mathrm{Zn}$, zinc refining those ores and investment by a Canadian company in one of the laterite operations in Cuba.

\section{Grade-Tonnage Characteristics}

The grade-tonnage plot in figure F6, which combines all types of cobalt-bearing mineral deposits and districts, shows a large range in the amounts of contained cobalt. In the figure, several to many deposits are grouped into districts for some areas (such as Sudbury, Ontario, Canada, and Norilsk-Talnakh, Russia) because, in these cases, grade and tonnage data for the individual deposits were not available. The sizes of the plotted deposits and districts, which include past production, reserves, and other resources (where known) are given in table F1. The summation of reserves and other resources has the potential to introduce double-counting when data are from reports in which reserves are included as part of resources. In table F1, where possible, reserves were not included when the potential for such double-counting was identified. Past production is included to give an indication of the original size of the deposit before mining. For many deposits - especially stratiform sediment-hosted $\mathrm{Cu}-\mathrm{Co}$, Ni-Co laterites, and magmatic $\mathrm{Ni}-\mathrm{Cu}(-\mathrm{Co}-\mathrm{PGE})$ sulfides - cumulative past production is small compared with the amount of cobalt contained in reserves and other resources. Figure F7 shows the global distribution of the largest cobalt deposits on land and on the sea floor; the terrestrial deposits shown in the figure also include selected small deposits that represent minor deposit types.

The total terrestrial cobalt resource (plus past production, where available) calculated from data in table F1 (back of chapter) is 25.5 million metric tons, which is very similar to the terrestrial cobalt resource of 26.1 million metric tons presented in a recent independent study by Mudd and others (2013). Among terrestrial deposits, contained cobalt can vary by three orders of magnitude or more (fig. F6). Most types of cobalt deposits contain between 5,000 and 500,000 metric tons of cobalt. The largest tonnages (greater than 500,000 metric tons of contained $\mathrm{Co}$ ) are present in numerous magmatic $\mathrm{Ni}-\mathrm{Cu}(-\mathrm{Co}-\mathrm{PGE}$ ) sulfide deposits (some grouped into districts, such as Sudbury), several stratiform sediment-hosted $\mathrm{Cu}-\mathrm{Co}$ deposits, and numerous lateritic Ni-Co deposits. Similarly, cobalt grades differ greatly - mostly low grades ( 0.01 to 0.2 percent cobalt) for magmatic $\mathrm{Ni}-\mathrm{Cu}$ (-Co-PGE) sulfide deposits, intermediate grades ( 0.03 to 0.2 percent cobalt) for the majority of lateritic Ni-Co deposits, and relatively high grades ( 0.03 to 1.0 percent cobalt) for most stratiform sediment-hosted $\mathrm{Cu}-\mathrm{Co}$ deposits. The highest average grades (about 1.5 percent cobalt) are in relatively small cobalt-rich vein deposits of the Bou Azzer district in Morocco. As shown in figures F6 through F8, the largest amount of cobalt on land is contained within stratiform sediment-hosted $\mathrm{Cu}-\mathrm{Co}$ deposits (41 percent) and lateritic Ni-Co deposits (36 percent), followed at much lower proportions by that in magmatic Ni-Cu(-Co-PGE) sulfide deposits ( 15 percent) and other terrestrial deposits ( 8 percent), of which the greatest portion is in VMS deposits (2.7 percent). 


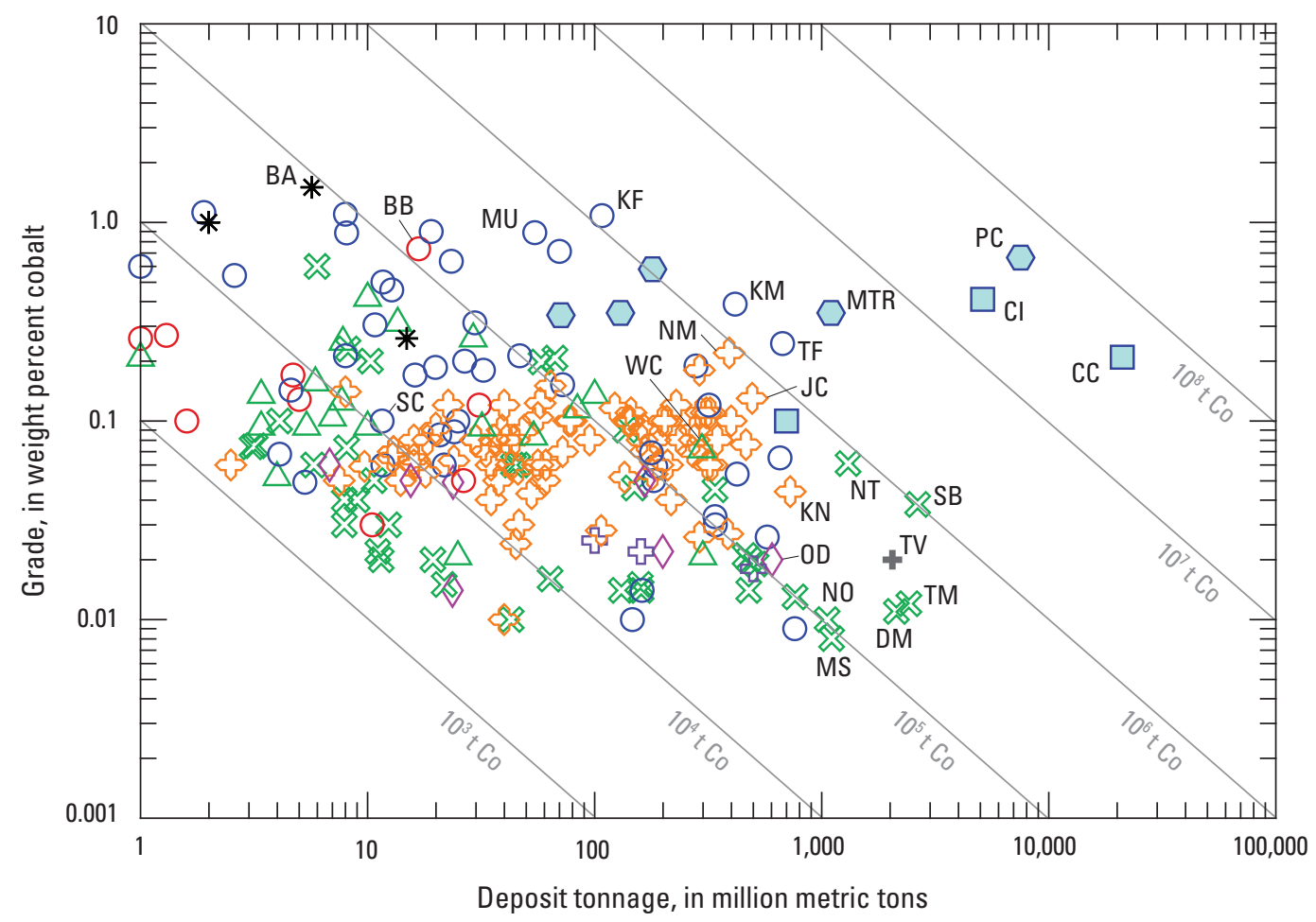

\begin{tabular}{ll} 
& \multicolumn{2}{c}{ EXPLANATION } \\
Cobalt deposit type
\end{tabular}

Figure F6. Grade-tonnage plot for 214 cobalt deposits worldwide. Grades and tonnages include production plus reserves plus other resources where known; reserve and resource data are from publicly available reports and company Web sites (see table F1), but in some cases are not defined by a National Instrument 43-101 standard, Joint Ore Reserves Committee code, or similar mineral-resource classification scheme. Labeled deposits represent most of those containing more than 500,000 metric tons $(t)$ of cobalt, many of the U.S. deposits, some examples of the less common deposit types, and some that are discussed in the text. Small deposits-those with less than 1,000 metric tons of cobalt-are not shown. Diagonal lines are isolines of contained cobalt, in metric tons. Abbreviations: BA, Bou Azzer (Morocco); BB, Blackbird (Idaho); CC, Clarion-Clipperton zone (Pacific Ocean); $\mathrm{Cl}$, Cook Islands Exclusive Economic Zone (Pacific Ocean); DM, Dumont (Canada); JC, Jacaré (Brazil); KF, Kisanfu (Congo [Kinshasa]); KM, KamotoKOV-Musonoi-Mupine deposits (Congo [Kinshasa]); KN, Kalgoorlie Nickel (Australia); MS, Mesaba (Minnesota); MTR, Maderia-Tore Rise (Atlantic Ocean); MU, Mutanda (Congo [Kinshasa]); NM, Nkamouna (Cameroon); NO, Northmet (Minnesota); NT, Noril'sk Talnakh (Russia); OD, Olympic Dam (Australia); PC, Pacific prime crust zone (Pacific Ocean); SB, Sudbury (Canada); SC, Sheep Creek (Montana); TF, Tenke Fungurume (Congo [Kinshasa]); TM, Twin Metals (Minnesota); TV, Talvivaara (Finland); WC, Windy Craggy (Canada) 


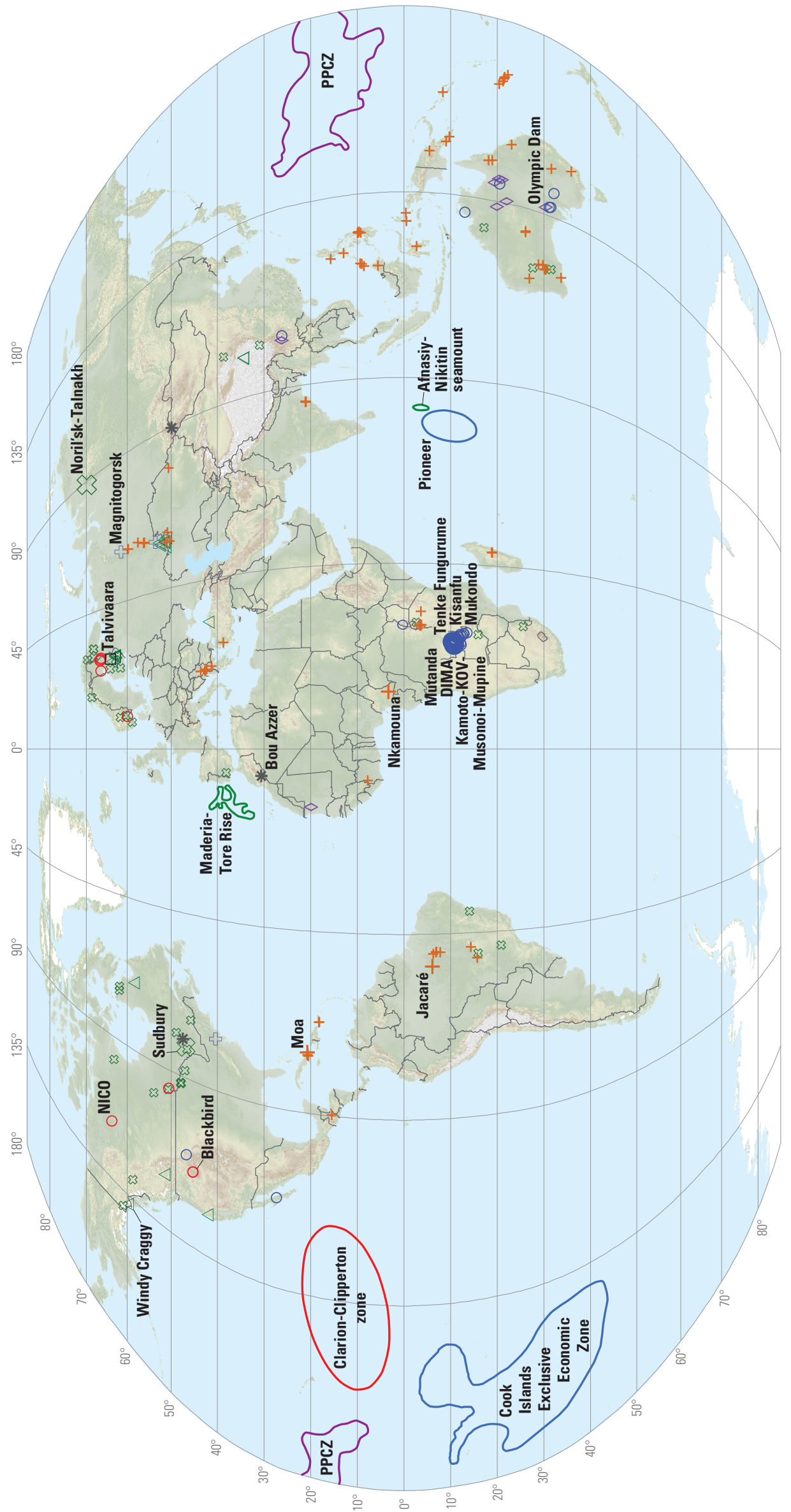

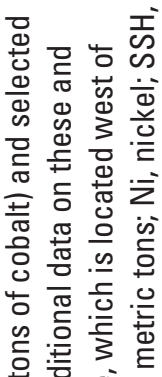

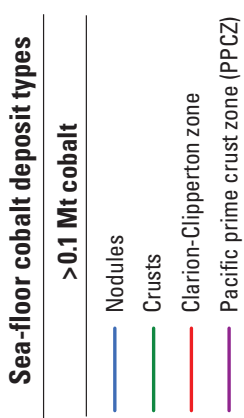

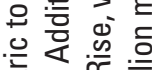

峁范

응을 한

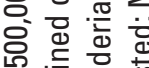

的

$\rightleftarrows$ 원

눙

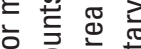

을 항

तั

엉

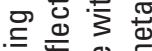

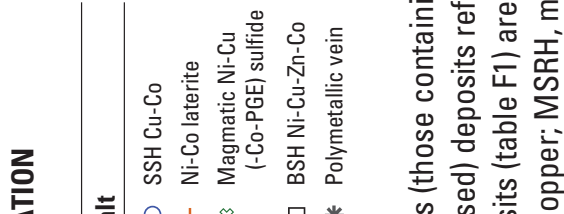

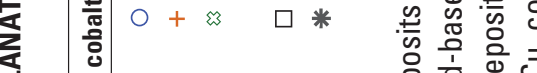

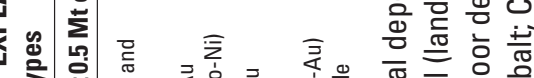

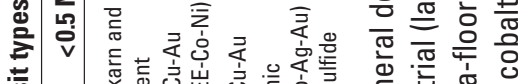

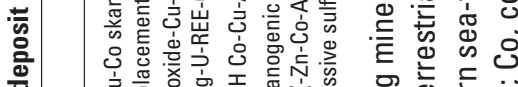

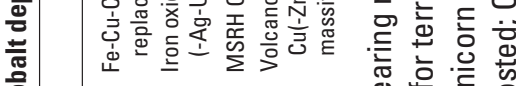

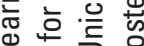

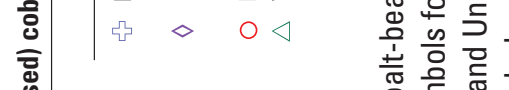

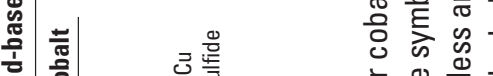

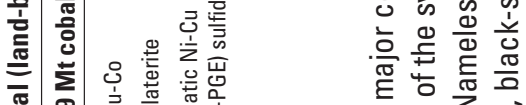

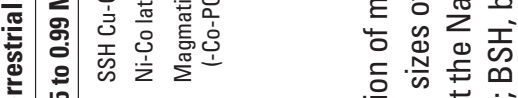

离

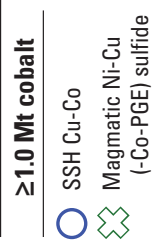

$\stackrel{\oplus}{\rightleftarrows} \stackrel{0}{\leftrightarrows}$

舟

त्ष

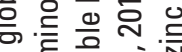

.

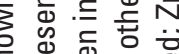

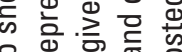

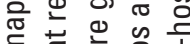

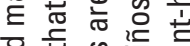

은 点

s. 0

용

下客类

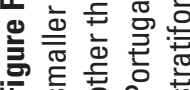




\section{A. Terrestrial deposits}

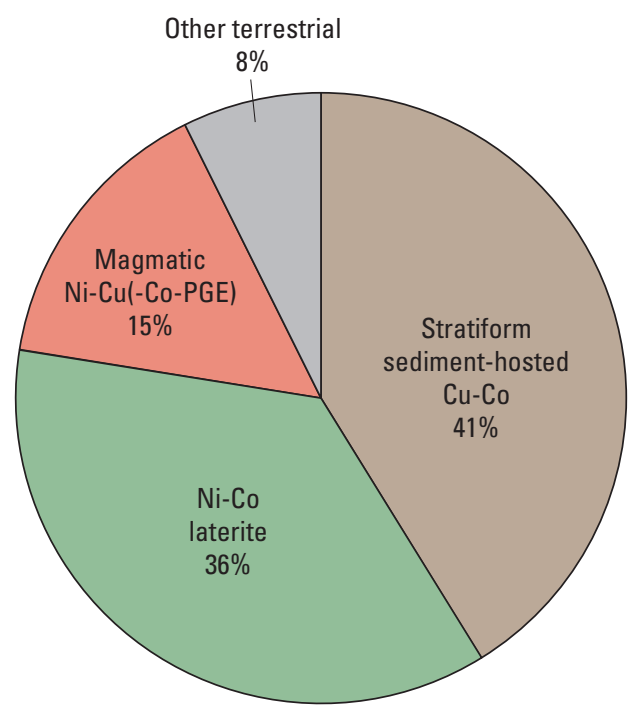

\section{B. Terrestrial and sea-floor deposits}

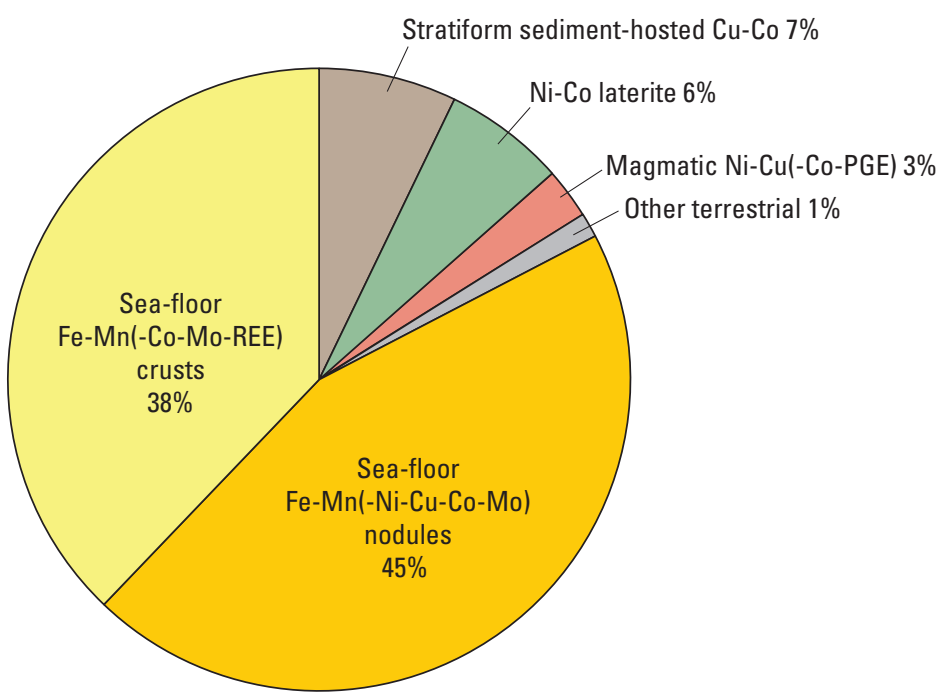

Figure F8. Pie charts showing proportions of cobalt contained in mineral deposits worldwide (cumulative past production plus reserves plus other resources), by deposit type, for $A$, terrestrial deposits, and $B$, terrestrial and sea-floor deposits. Mine production in 2011 from terrestrial deposit types is shown in figure F5. Globally, the amount of cobalt contained in reserves plus other resources in identified mineral deposits is significantly more than the amount of cobalt contained in past production. Co, cobalt; $\mathrm{Cu}$, copper; $\mathrm{Fe}$, iron; Mn, manganese; Mo, molybdenum; Ni, nickel; PGE, platinum-group element; REE, rare-earth element

The United States has 0.64 million metric tons of cobalt contained in several deposit types (table F1). The vast majority occurs within magmatic Ni-Cu(-Co-PGE) sulfide deposits of the Duluth Complex in northeastern Minnesota (which include the Nokomis deposit [291,000 metric tons], the Northmet deposit [92,400 metric tons], and the Mesaba deposit [89,000 metric tons]), and in metasedimentary-rock-hosted $\mathrm{Co}-\mathrm{Cu}-\mathrm{Au}$ deposits of the Blackbird district in east-central Idaho (123,000 metric tons). Much smaller amounts of cobalt are present within the Sheep Creek (Black Butte) stratiform sediment-hosted $\mathrm{Cu}-\mathrm{Co}-\mathrm{Ag}$ deposit in western Montana (17,700 metric tons) and the Eagle magmatic $\mathrm{Ni}-\mathrm{Cu}(-\mathrm{Co}-\mathrm{PGE})$ deposit in northern Michigan (4,000 metric tons). Resources also may be present in the Ni-Co laterites of southern Oregon and northern California (Foose, 1991, 1992). Compared with the estimated global terrestrial resources (plus past production, where available) of 25.5 million metric tons of cobalt, the United States has only 2.5 percent of the total amount of cobalt contained in mined ore (past production) plus reserves plus other resources.

On a global scale, the largest resources of cobalt occur in modern sea-floor ferromanganese nodules and crusts. Identified resources for eight different areas, each containing 0.2 to 50 million metric tons of cobalt, have been reported. Crusts tend to have slightly higher cobalt grades but a similar range in deposit sizes. Significantly, the amount of cobalt in the Pacific prime crust zone in the Pacific Ocean (fig. F6) is three to four times the cobalt reserves contained in all known terrestrial deposits (Hein and others, 2013).

Production of cobalt during the next several decades will likely be dominated by the mining of Ni-Co laterites and stratiform sediment-hosted $\mathrm{Cu}$-Co deposits, with lesser contributions from magmatic $\mathrm{Ni}-\mathrm{Cu}$ (-Co-PGE) sulfide deposits. The giant cobalt resources present in modern sea-floor ferromanganese nodules and crusts (table F1; fig. F6) will probably be mined in the future, but given the technological challenges, environmental issues, and uncertain economics involved in such deep-sea mining ventures, it is unclear when these sea-floor mineral resources might be exploited profitably for cobalt production.

\section{Mining Methods}

The mining of cobalt deposits is done by conventional underground and open pit methods. Underground mining is used for most magmatic Ni-Cu(-Co-PGE) sulfide, iron oxide$\mathrm{Cu}-\mathrm{Au}(-\mathrm{Ag}-\mathrm{U}-\mathrm{REE}-\mathrm{Co}-\mathrm{Ni})$, volcanogenic $\mathrm{Cu}-(\mathrm{Co}-\mathrm{Zn}-\mathrm{Ag}-\mathrm{Au})$ massive sulfide, and metasedimentary-rock-hosted $\mathrm{Co}-\mathrm{Cu}-\mathrm{Au}$ deposits. In contrast, open pit mining is the predominant method used for stratiform sediment-hosted $\mathrm{Cu}-\mathrm{Co}$ and $\mathrm{Ni}-\mathrm{Co}$ laterite deposits. Ore from the black-shale-hosted Talvivaara $\mathrm{Ni}-\mathrm{Cu}-\mathrm{Zn}$-Co deposit in Finland - the only one of its type presently being mined - is extracted from large open pits. 


\section{Typical Mine Life}

The mine life for cobalt-bearing deposits depends on a variety of parameters, but it is ultimately limited by the size of the resource and the development of reserves, which is the economically extractable portion of the demonstrated resource. Mines that produce cobalt generally are worked for decades. For example, several stratiform sediment-hosted $\mathrm{Cu}-\mathrm{Co}$ deposits in the Central African Copperbelt have been mined for more than 50 years, such as Chibuluma, which began production in 1955 and is still being mined (Metorex Pty Ltd., 2013). In some other countries, mining started earlier and continues to the present day; for example, the magmatic $\mathrm{Ni}-\mathrm{Cu}(-\mathrm{Co}-\mathrm{PGE})$ sulfide deposits at the Creighton Mine in the Sudbury district of Ontario were first worked in 1901 (Python Mining Consultants, 2013); mining of the cobalt-rich veins in the Bou Azzer district of Morocco began in 1928 (Ahmed and others, 2009), and mining of the magmatic Ni-Cu(-Co-PGE) sulfide deposits of the Norilsk-Talnakh district in Russia began in 1936 (Naldrett, 2004). Possibly the longest period of production has come from the Thio Ni-Co laterite mine in New Caledonia, which was first mined in 1880 and is still being mined (Eramet Group, 2013).

\section{Ore-Processing Methods}

Cobalt-bearing ores are processed by a wide variety of extractive metallurgical techniques, depending on the type of ore, the availability of energy, environmental concerns, market demand for primary products and byproducts, and overall project economics. Ni-Co laterite ores generally require minimal beneficiation before being refined. Ores from magmatic $\mathrm{Ni}-\mathrm{Cu}(-\mathrm{Co}-\mathrm{PGE})$ sulfide and stratiform sediment-hosted $\mathrm{Cu}-\mathrm{Co}$ deposits are processed by standard rock crushing and grinding techniques, typically followed by froth flotation to produce mineral concentrates, which are then refined to recover the metals (De Cuyper, 1988).

The ores or concentrates can be processed in one of the following ways: (a) leaching, (b) roasting and then leaching, or (c) smelting and then leaching. The resulting solutions are purified and refined to separate out the individual metals. The purification and refining are generally carried out by one or more hydrometallurgical and (or) electrometallurgical methods, including chemical precipitation, electrowinning, hydrogen reduction, ion exchange, and solvent extraction. Leaching of cobalt-bearing ores can be done at various temperatures and pressures using acids or other solutions, such as ammonia, ammonia-ammonium carbonate, chloride, or chlorine (Kerfoot and Weir, 1988). For more detailed information on the processing of cobalt ores, see, for example, Crundwell and others (2011).

In a few cases, leaching is accelerated by the introduction of bacteria. For example, ore from the black-shale-hosted Talvivaara deposit in Finland is processed by bio-heapleaching
(Saari and Riekkola-Vanhanen, 2012). Bacterial leaching was also used at Kasese, Uganda, to recover cobalt from stockpiled pyrite concentrates that were generated during earlier copper mining.

\section{Undiscovered Resources}

Because stratiform sediment-hosted $\mathrm{Cu}-\mathrm{Co}, \mathrm{Ni}-\mathrm{Co}$ laterite, and magmatic $\mathrm{Ni}-\mathrm{Cu}(-\mathrm{Co}-\mathrm{PGE})$ sulfide deposits are the sources of the greatest amount of cobalt production and contain the largest reserves of cobalt, most undiscovered resources of cobalt are likely to occur in these same deposit types. Descriptive and genetic models for such deposits are relatively well developed; hence, the exploration for new orebodies probably will target geologic terranes that host known deposits. In the case of stratiform sediment-hosted $\mathrm{Cu}-\mathrm{Co}$ deposits, prospective geologic settings have been thoroughly documented (for example, Hitzman and others, 2005; Taylor and others, 2013), yet potentially favorable terranes exist in many remote parts of the world where modern deposit models have not been applied. A similar situation exists for Ni-Co laterite deposits in that, despite a robust understanding of key ore-forming processes (for example, Freyssinet and others, 2005; Butt and Cluzel, 2013), areas that may contain deeply weathered ultramafic rocks have not been well explored. For magmatic Ni-Cu(-Co-PGE) sulfide deposits, the most important undiscovered resources are likely to be present in mafic and ultramafic igneous rocks, including large intrusive complexes (Naldrett, 2004; Eckstrand and Hulbert, 2007). The global distribution of such complexes is well known for those exposed at the surface, but in some remote parts of the world, buried mafic intrusive complexes still await discovery.

\section{Unconventional Resources}

\section{Metamorphosed Black Shales}

The black-shale-hosted Talvivaara Ni-Cu-Zn-Co deposit in Finland contains an average of 200 ppm cobalt (LoukolaRuskeeniemi and Lahtinen, 2013); however, the economic part of this deposit is located within remobilized structures in which lower metal contents of the surrounding Proterozoic black shale were increased during deformation and metamorphism. Epigenetic cobalt enrichment has also been described for the Permian Kupferschiefer Cu-Ag-Au-PGE deposits in Germany and Poland, where elevated cobalt contents occur preferentially within small, paragenetically late veins (Schmidt and Friedrich, 1988; Sun and Püttmann, 1997). Other black shales may have potential for containing low-grade cobalt deposits, such as the Upper Devonian-Lower Mississippian Chattanooga Shale in the Southeastern United States that typically has $70 \mathrm{ppm}$ cobalt but locally contains as much as 300 ppm (Leventhal and others, 1983). 


\section{Modern Sea-Floor Volcanogenic Massive Sulfide Deposits}

Some VMS deposits on the modern sea floor contain elevated amounts of cobalt. Documented examples of high contents of cobalt in deposits on the Mid-Atlantic Ridge are all in settings underlain by ultramafic rocks, including in the Rainbow vent field (Bogdanov and others, 2002), in the Logatchev field (Mozgova and others, 1999), and in the Nibelungen field (Melchert and others, 2008). Samples of massive sulfide rock from the Logatchev field have as much as 1,310 ppm cobalt (Murphy and Meyer, 1998). None of these modern deposits has been explored sufficiently for resource delineation, however, because of their occurrence at relatively deep water depths of 3,000 m or more, which are considered unfavorable for the profitable mining of such deposits (Herzig and others, 2002). Despite this constraint, ultramafic-hosted modern VMS deposits may represent a resource for cobalt.

\section{Ancient Ni-Co Laterites}

Because Ni-Co laterite deposits of Cretaceous or younger ages are the predominant source of cobalt mined today (fig. F7; Berger and others, 2011), ancient laterites-if preserved and not eroded - could represent a nonconventional resource for nickel and cobalt. Gleeson and Herrington (2005) evaluated this potential, using the data of Bárdossy and Aleva (1990) on time periods of extensive global weathering, to suggest that fossil Ni-Co laterites preferentially formed during the Carboniferous, late Permian, Eocene-Oligocene, Miocene, and Pliocene, if favorable settings (including tropical to subtropical climates) existed at those times (see Thorne and others, 2012). Two examples of ancient laterites are the Çaldağ Ni-Co deposit in Turkey and the Ni-Co laterites of Greece, which formed during the Late Cretaceous to Eocene and Late Jurassic to Cretaceous, respectively (Çağatay and others, 1983; Valeton and others, 1987). Even older formational ages are possible, although paleoclimatic conditions during the Paleozoic and Precambrian are not well known.

\section{Ancient Fe-Mn(-Cu-Co-Ni) Nodules}

Ancient $\mathrm{Fe}-\mathrm{Mn}(-\mathrm{Cu}-\mathrm{Co}-\mathrm{Ni})$ nodules are also a possible nonconventional resource of cobalt. Fossil nodules have been described from Miocene strata in Chile (Achurra and others, 2009) and Cretaceous strata in West Timor, Indonesia (Margolis and others, 1978). In both cases, however, the metal contents in the ancient nodules are much lower than those in modern nodules on the Pacific Ocean floor; such low metal concentrations may reflect shallow formation on continental slopes above the carbonate compensation depth (CCD). Metal-rich ancient nodules are most likely to be found within strata that formed in deepwater, abyssal plain settings below the CCD. These types of strata are generally carried on top of subduction zones and hence are not preserved, except in sedimentary sequences that are obducted onto continents.

\section{Ancient Cobalt-Rich Manganese Deposits}

Cobalt-rich manganese deposits occur in Pliocene alkaline basalts of the Calatrava region in central Spain (Crespo and Lunar, 1997). These unusual manganiferous deposits, which contain up to 1.7 weight percent cobalt, are interpreted to have formed in a hot-spring environment within a predominantly subaerial volcanic sequence. Although the known cobalt deposits are small, the potential may exist for larger deposits elsewhere in this volcanic field and also within other subaerial alkaline basaltic provinces that display evidence of hot-spring environments.

\section{Ultramafic Igneous Rocks}

The highest cobalt concentrations in common rock types are in ultramafic igneous rocks, including dunite, peridotite, and pyroxenite, and in altered varieties, such as serpentinite. Dunite tends to have the greatest contents because this rock type consists mainly of olivine, which is a ferromagnesian silicate mineral that preferentially concentrates cobalt. The average cobalt contents in dunite and serpentinite are 109 and 115 ppm, respectively (Gülaçar and Delaloye, 1976); hence, these rock types potentially could become largetonnage and low-grade cobalt resources if the extraction of cobalt from olivine and serpentine can be made commercially viable. The large amount of energy required to extract such cobalt suggests that this type of deposit has only a small chance of being developed and mined, however.

\section{Exploration for New Deposits}

Because of the diversity of deposit types that contain economic cobalt concentrations, exploration methods vary greatly. In the exploration for stratiform sediment-hosted $\mathrm{Cu}-\mathrm{Co}$ deposits, prospecting may involve the integration of data from soil geochemical surveys, as well as structure, stratigraphy, geophysical, and drilling data. For lateritic $\mathrm{Ni}-\mathrm{Co}$ deposits, key exploration criteria are the presence of deeply weathered ultramafic rocks, development of a thick lateritic profile, and optimum topography and rainfall required to effectively concentrate cobalt and nickel within the weathering zone. Geochemical sampling, including of vegetation, is typically effective in locating Ni-Co laterite deposits. Many magmatic $\mathrm{Ni}-\mathrm{Cu}(-\mathrm{Co}-\mathrm{PGE})$ sulfide deposits occur within large mafic intrusive complexes where refined deposit models and local geologic knowledge can be used to focus exploration to geophysics and drilling. Exploration for this deposit type is centered on the basal zones of the complexes using mainly electrical and magnetic geophysical methods. 


\section{Environmental Considerations}

Cobalt is an essential nutrient for most life, but it can cause toxic effects when present in solids or waters at concentrations that are significantly enriched relative to normal background levels. Such elevated concentrations may result from cobalt mining, processing, manufacturing, and use. Consequently, an understanding of the behavior of cobalt in the environment can assist in developing technologies and working practices that do not lead to potentially toxic concentrations of cobalt during its production and use. The control, mitigation, and prevention of potential environmental impacts from mining and related processing facilities will vary depending on the deposit type, but they are also dependent on regulations in place within the host country, State, and local area. Therefore, no attempt is made herein to describe every type of mine and its potential for cobalt pollution. Instead, the focus is on some of the better documented environmental impacts associated with cobalt mining.

\section{Sources and Fate in the Environment}

In weathering environments at Earth's surface, cobalt typically occurs in the +2 and +3 oxidation states, and may dissolve from host minerals and form complexes with hydroxide, fluoride, sulfate, phosphate, chloride, and (or) organic material. The behavior of cobalt in weathering environments follows that of iron and manganese. Manganese oxide minerals, in particular, have a strong capacity to sorb dissolved cobalt. Much of the literature about the behavior of dissolved cobalt focuses on optimizing cobalt sorption to various natural and synthetic solids as a means of removing dissolved cobalt from solution (for example, Chen and others, 2011).

The tendency for cobalt to be dissolved and transported largely depends upon the $\mathrm{pH}$ and temperature of weathering solutions. Because cobalt typically is concentrated in sulfide and arsenide minerals, it can be expected to be relatively mobile under some weathering conditions because of the instability of these minerals at Earth's surface. Dissolution of sulfide minerals, in particular, releases metals and forms sulfuric acid, and the low $\mathrm{pH}$ values thus produced allow higher concentrations of metals to be dissolved - potentially causing the environmental problem known as acid mine drainage (AMD). Metals, including cobalt, which are dissolved in AMD can be naturally attenuated through precipitation, sorption to (oxyhydr)oxide minerals, or dilution by mixing with water at circumneutral $\mathrm{pH}$; if not fixed in this manner, these metals are transported downstream and become more widely dispersed in the environment.

Natural concentrations of cobalt in rocks, soils, waters, and air are given in table F2. The cobalt content in soil varies widely depending upon the type of parent rock, but soils unaffected by pollution from industry generally contain a range of 0.5 to $30 \mathrm{ppm}$ cobalt (Shacklette and Boerngen, 1984; Hutchinson and Symington, 1997; Tyler, 2004; Smith and others, 2005; Narendrula and others, 2012). Cobalt concentrations in seawater are 0.0003 to 0.004 micrograms per liter ( $\mu \mathrm{g} / \mathrm{L}$, or parts per billion) (Bown and others, 2012; Shelley and others, 2012). In streams and rivers, cobalt concentrations vary from 0.006 to $0.43 \mu \mathrm{g} / \mathrm{L}$ (Gaillardet and others, 2003; Huser and others, 2011). Elevated background concentrations of as high as $30 \mu \mathrm{g} / \mathrm{L}$ cobalt have been reported near Cobalt, Idaho (Eppinger and others, 2003). Suspended particulates in world rivers contain an average of 22.5 micrograms per gram cobalt (Viers and others, 2009). Cobalt occurs naturally in the atmosphere within mineral dust particles. In relatively clean air over the South Pole, cobalt ranges from 0.1 to 1.2 nanograms per cubic meter $\left(\mathrm{ng} / \mathrm{m}^{3}\right)$ (Kabata-Pendias and Pendias, 2001, and references therein).

Concentrations of cobalt in the environment that are higher than background concentration can result from mining and ore processing (table F2). For example, soils near mines and processing facilities may contain as much as 22 to 6,150 ppm cobalt (Hutchinson and Symington, 1997; Zohny, 2002; Giles and others, 2009; Narendrula and others, 2012). Likewise, streams near the mining towns of Cobalt, Ontario, Canada, and Cobalt, Idaho, have 3 to $20 \mu \mathrm{g} / \mathrm{L}$ and 10 to $1,100 \mu \mathrm{g} / \mathrm{L}$ cobalt, respectively (Kwong and others, 2007; Gray and Eppinger, 2012). Extremely high cobalt concentrations of 70 to $61,000 \mu \mathrm{g} / \mathrm{L}$ (median is $540 \mu \mathrm{g} / \mathrm{L}$ ) occur in the pore waters of mine waste impoundments at the Khovu-Aksy Mine in Russia (Bortnikova and others, 2012). Cobalt also can be emitted to the atmosphere during the metal refining process; air affected by industry may contain 0.13 to $37 \mathrm{ng} / \mathrm{m}^{3}$ cobalt (Reimann and de Caritat, 1998, and references therein).

\section{Mine Waste Characteristics}

Mine waste is generally considered to be the material that originates and accumulates at a mine site but has no current economic value (Lottermoser, 2010); it includes both solid and liquid waste. The character of the waste generated from cobalt mining varies according to the geology of the deposit and the methods used to extract the ore. Mine wastes produced by the extraction of copper and nickel ores from which cobalt is produced typically consist of waste rock, tailings, and possibly pit lakes. Tailings are the residual silt- to fine sand-sized grains generated from ore grinding and processing, and generally are stored in dams or ponds.

The mining of cobalt typically produces large volumes of solid and liquid waste. Estimates for the amounts of solid waste generated from the mining of many deposits are difficult to obtain. The mining of laterite deposits requires the stripping of overburden before extraction of the exposed ore. As a result, reclamation of the mined area is often a significant issue, as soil needs to be reestablished and revegetated. Further, once the nickel and cobalt have been extracted, a volume of material nearly equal in volume to the original deposit must be secured in tailings so that it cannot be a source 
of contamination. Laterite deposits typically are between 20 and 200 million metric tons (table F1). In addition, laterite ores that are mined and then leached to recover nickel and cobalt can generate large amounts of metal-rich sludge that must be contained in impoundments, which are known as "dry stacks" (Power and others, 2011), or, if deemed environmentally safe, combined with additives to revegetate mined areas (Powers and Siemens, 1983).

Other open pit mines, such as those that are used to develop many strata-bound copper deposits, can be quite deep (for example, Taylor and others, 2013). A constraint on their economic viability is the stripping ratio, which determines how much waste rock must be moved. For example, the large $\mathrm{Cu}-\mathrm{Co}$ mine at Tenke Fungurume (Congo [Kinshasa]) has an approximate stripping ratio of 3.3:1 (International Mining, 2012), which means that 3.3 metric tons of rock must be moved to extract 1 metric ton of ore. The result is that large volumes of rock must be moved and managed, and waste rock must be placed in holding areas and secured. Underground mines, such as those typically used to mine certain sulfide ore deposits (magmatic $\mathrm{Ni}-\mathrm{Cu}$ sulfide deposits and some stratiform sediment-hosted $\mathrm{Cu}-\mathrm{Co}$ deposits), generally produce less waste than open pit mines; however, the waste commonly is highly reactive because of its high content of sulfide minerals. These minerals are capable of producing significant amounts of AMD, which, if not contained, must be remediated. One example of waste generated from a past-producing sulfidebearing cobalt mine is the Blackbird Mine near Cobalt, Idaho, which was mined intermittently from 1949 to 1960, yielding 4.8 million metric tons of waste rock and 2 million metric tons of tailings, and resulting in AMD (U.S. Environmental Protection Agency, 2012).

Solid mine waste includes overburden (the soil and rock that overlie an orebody that must be removed to access the ore in an open pit mine) and gangue (the material that surrounds or is mixed with the valuable metallic minerals in the ore deposit). The mineralogy of solid mine waste in cobalt-rich deposits tends to be similar to the mineralogy of the deposit, except that the proportion of ore minerals is lower relative to gangue minerals. Because of their association with sulfide minerals, trace elements present in many cobalt-bearing deposits and wastes typically include $\mathrm{As}, \mathrm{Au}, \mathrm{Bi}, \mathrm{Co}, \mathrm{Cr}$, $\mathrm{Cu}, \mathrm{Pb}$, Se, and $\mathrm{Zn}$, and locally include $\mathrm{Ag}, \mathrm{Ba}, \mathrm{Fe}, \mathrm{Hg}, \mathrm{Mg}$, $\mathrm{Ni}, \mathrm{Sb}, \mathrm{Sc}, \mathrm{Sn}, \mathrm{Ti}, \mathrm{V}$, and PGEs (Evans and others, 1995; Foose and others, 1995; Lindsey and others, 1995). Common elements associated with lateritic Ni-Co deposits are Al, Co, $\mathrm{Cr}, \mathrm{Fe}, \mathrm{Mg}, \mathrm{Mn}, \mathrm{Ni}$, and $\mathrm{Si}$ (Watling and others, 2011; Lambiv Dzemua and others, 2013). Under oxidizing and acidic $(\mathrm{pH}<3)$ weathering conditions, which would be expected in mine waste having little to no acid-neutralizing capacity (such as those typically found in some stratiform sediment-hosted $\mathrm{Cu}-\mathrm{Co}$ deposits, nearly all magmatic $\mathrm{Ni}-\mathrm{Cu}$ (-Co-PGE) sulfide deposits, and in metasedimentary-rock-hosted $\mathrm{Co}-\mathrm{Cu}-\mathrm{Au}$ deposits), many of the aforementioned accessory elements are expected to be mobile (Smith and Huyck, 1999). The acid-neutralizing capacity of some stratiform sediment-hosted
$\mathrm{Cu}-\mathrm{Co}$ deposits is predicted to be greater owing to the presence of such gangue minerals as calcite and dolomite. For example, the paste $\mathrm{pH}$ of tailings samples from the mines in the Central African Copperbelt are as high as 6.9 at the Mindolo Mine and 8.5 at the Chambishi Mine (Sracek and others, 2010). Zinc in carbonate-hosted sulfide deposits of the Central African Copperbelt can make up a large percentage of the total dissolved metals that drain from the deposits and associated waste piles (Plumlee and others, 1999). Lateritic $\mathrm{Ni}$-Co deposits generally lack acid-generating minerals, so the likely oxidizing and circumneutral $(5<\mathrm{pH}<8)$ weathering conditions in these and carbonate-bearing, stratiform sediment-hosted $\mathrm{Cu}$-Co deposits allow many of the accessory elements listed above to be less mobile or immobile (Smith and Huyck, 1999).

Liquid waste includes ore-processing fluids that are stored onsite, as well as natural water that interacts with solid mine waste. Liquid mine waste can occur as surface water, groundwater, and soil pore water within and surrounding the mine site. As an example of liquid mine waste at a former cobalt mine, surface water draining from the Blackbird Mine near Cobalt, Idaho, is contaminated with $\mathrm{As}, \mathrm{Co}, \mathrm{Cr}$, $\mathrm{Cu}, \mathrm{Fe}, \mathrm{Mn}, \mathrm{Ni}, \mathrm{Pb}$, and $\mathrm{Zn}$ (Agency for Toxic Substances and Disease Registry, 1995). Cobalt concentrations in the waters in surrounding creeks may be nearly 70 times higher than background values (10 to 2,000 $\mu \mathrm{g} / \mathrm{L}$ cobalt), as well as have high copper (10 to $1,800 \mu \mathrm{g} / \mathrm{L}$ copper), and arsenic ( 0.45 to $6.2 \mu \mathrm{g} / \mathrm{L}$ arsenic) concentrations (Mok and Wai, 1989). A survey of streams within the broader Idaho cobalt belt revealed elevated concentrations (in $\mu \mathrm{g} / \mathrm{L}$ ) of cobalt ( 0.67 to 1,100$)$, copper ( 1 to 2,000 ), arsenic (less than 0.2 to 44$)$, and iron (28 to 3,800) (Eppinger and others, 2003). Metal contamination of groundwater, surface water, soil, and stream sediments near the Blackbird Mine, as a result of runoff from waste rock, tailings, and mill debris, led to the proposed addition of the Blackbird Mine to the U.S. Superfund National Priorities List in 1993 (U.S. Environmental Protection Agency, 2012). Acid mine drainage like that at the Blackbird Mine may be typical for historic mining districts, but, with modern controls, similar damage can generally be avoided or the harmful effects can be mitigated.

\section{Human Health Concerns}

The Agency for Toxic Substances and Disease Registry (2004) provides a useful summary of the health effects of cobalt on humans. The general public is most likely to be exposed to cobalt through consumption of food and drinking water. Human dietary intake of cobalt typically ranges from 10 to 30 micrograms per day (Schrauzer, 2004). Occupational exposure generally results from inhalation of cobalt-bearing dust during cobalt processing and industrial activities that use cobalt, although the current use of appropriate protective equipment is thought to effectively minimize such exposure to levels that do not cause harm. At low levels, cobalt is essential 
to human health, particularly because it is the central atom in the critical nutrient vitamin $B_{12}$. Overexposure to high levels of cobalt, however, may cause lung and heart dysfunction, as well as dermatitis.

Isotopes of cobalt range from ${ }^{50} \mathrm{Co}$ to ${ }^{71} \mathrm{Co}$. The naturally occurring isotope is ${ }^{59} \mathrm{Co} .{ }^{60} \mathrm{Co}$, which has a half-life of 5.27 years and is the most commercially important radioactive isotope of cobalt, is made by placing ${ }^{59} \mathrm{Co}$ in a nuclear reactor for 1.5 to 2 years (Reimann and de Caritat, 1998). ${ }^{60} \mathrm{Co}$ is used in commercial and medical applications. The Agency for Toxic Substances and Disease Registry (2004) stated that exposure to radiation from radioactive cobalt can damage cells and potentially cause nausea, vomiting, diarrhea, bleeding, coma, cancer, and, in rare cases, death. Additionally, nonradioactive cobalt does not appear to cause cancer in humans or animals when ingested, but when inhaled, animals have shown cancer development. More recently, the National Toxicology Program (NTP), made up of three U.S. Government health organizations, listed nonradioactive cobalt sulfate and cobalt-tungsten carbide in the Report on Carcinogens as reasonably anticipated to be human carcinogens (National Toxicology Program, 2014a, b). Beyond these listings, the NTP's recent report revealed that there is not enough unequivocal evidence connecting cancer development in humans with exposure to cobalt and cobalt compounds (National Toxicology Program, 2016).

Primary and secondary drinking water regulations for cobalt currently do not exist in the United States, but the Occupational Safety and Health Administration (2013) has set an exposure limit of 0.1 milligram per cubic meter for cobalt-bearing dust in workplace air over an 8-hour workday. Likewise, the U.S. Nuclear Regulatory Commission $(2013 \mathrm{a}, \mathrm{b})$ limits radioactive cobalt in workplace air to $1 \times 10^{-6}$ microcuries per milliliter $(\mu \mathrm{Ci} / \mathrm{mL})$ of ${ }^{57} \mathrm{Co}$ and $7 \times 10^{-8} \mu \mathrm{Ci} / \mathrm{mL}$ of ${ }^{60} \mathrm{Co}$.

Mining of cobalt-rich ore deposits can potentially mobilize elements that are known human toxins. Perhaps the best-known examples of the effects of elements that are known human toxins are the neurological impacts of lead on children (Holecy and Mousavi, 2012) and the carcinogenic effects of arsenic in drinking water (Gupta and others, 2012). Other commonly associated elements, such as nickel, copper, and zinc, also have the potential to affect human health when present above threshold concentrations in air, drinking water, and soil resources. The current U.S. National Ambient Air Quality Standard for lead is 0.15 microgram per cubic meter (U.S. Environmental Protection Agency, 2013), and the current U.S. primary and secondary drinking water standards for arsenic, lead, and copper are $0.01,0.0$, and 1.3 milligrams per liter $(\mathrm{mg} / \mathrm{L})$, respectively (U.S. Environmental Protection Agency, 2016). Canadian agricultural soil quality guidelines for nickel, copper, lead, and zinc are 50, 63, 70, and 200 milligrams per kilogram ( $\mathrm{mg} / \mathrm{kg}$, which is equivalent to ppm), respectively (Canadian Council of Ministers of the Environment, 2013).

\section{Ecological Health Concerns}

Many studies focus on the ecological impacts of cobalt bioaccessibility in the environment. Various organisms, including fish, amphibians, crustaceans, insects, and plants, are used in chronic (lower doses over longer time periods) and acute (higher doses over shorter time periods) tests of a substance toxicity. The aquatic toxicity of cobalt depends on multiple factors, including its chemical form (for example, free cobalt ion $\left[\mathrm{Co}^{2+}\right]$, cobalt(II) chloride $\left[\mathrm{CoCl}_{2}\right]$, and cobalt (II) sulfate $\left.\left[\mathrm{CoSO}_{4}\left(\mathrm{H}_{2} \mathrm{O}\right)_{x}\right]\right)$ and ambient physicochemical factors, such as $\mathrm{pH}$, temperature, and overall water chemistry. One of several useful measurements used in toxicity tests is the lethal concentration that leads to 50 percent mortality $\left(\mathrm{LC}_{50}\right)$ after exposure to a substance for a certain amount of time. Another commonly used measure of toxicity is the effective concentration that results in 50 percent of the tested population exhibiting decreased functionality $\left(\mathrm{EC}_{50}\right)$, such as inhibited growth.

The freshwater amphipod Hyalella azteca is known to be sensitive to dissolved cobalt, exhibiting a 1-week $\mathrm{LC}_{50}$ of $16 \mu \mathrm{g} / \mathrm{L}$ in soft water and $61 \mu \mathrm{g} / \mathrm{L}$ in hard water (Borgmann and others, 2005). The toxic effects of cobalt on this and other species decrease with increasing water hardness because less toxic ions like $\mathrm{Ca}^{2+}$ and $\mathrm{Mg}^{2+}$ are able to outcompete $\mathrm{Co}^{2+}$ for biological sites. Acute toxicity tests with dissolved cobalt chloride and the freshwater green alga Chlorella vulgaris resulted in an $\mathrm{EC}_{50}$ of $530 \mu \mathrm{g} / \mathrm{L}$ cobalt, based on inhibited growth over 96 hours (Rachlin and Grosso, 1993). Fish appear to be more resistant to dissolved cobalt. For example, acute toxicity tests with dissolved cobalt (ranging from 0 to $2,000 \mathrm{mg} / \mathrm{L}$ ) and rainbow trout (Oncorhynchus mykiss) showed no lethality and an $\mathrm{LC}_{50}$ value of $1.4 \mathrm{mg} / \mathrm{L}$ cobalt after 2 and 3 days of exposure, respectively (Marr and others, 1998). Interestingly, when this latter species was exposed to solutions containing dissolved copper only, dissolved cobalt only, or a mixture of the two metals, toxicity for time periods greater than 2 days decreased in the following order: $250 \mu \mathrm{g} / \mathrm{L}$ $\mathrm{Co}+\mathrm{Cu}, 50 \mu \mathrm{g} / \mathrm{L} \mathrm{Co}+\mathrm{Cu}, \mathrm{Cu}$ only, and Co only (Marr and others, 1998). These results indicate that exposure to the combination of dissolved cobalt and copper, which is closer to actual environmental conditions, is more toxic than exposure to either metal alone. Some regions of the United States have adopted secondary acute and chronic screening benchmarks of $1,500 \mu \mathrm{g} / \mathrm{L}$ cobalt and $23 \mu \mathrm{g} / \mathrm{L}$ cobalt, respectively, for aquatic freshwater life (Suter and Tsao, 1996).

Although cobalt may be toxic to some species, it is an essential nutrient for many life forms, primarily because it is an integral component in vitamin $B_{12}$ (Schrauzer, 2004). Microorganisms are responsible for the biosynthesis of natural vitamin $B_{12}$. Some microorganisms secrete enzymes known as siderophores, which are known to have a high capacity for dissolving iron from relatively insoluble minerals, thereby increasing the bioavailability of iron in iron-limited environments. Recent work has shown that a commonly studied siderophore has a binding capacity for cobalt that is five 
orders of magnitude greater than that for iron (Duckworth and others, 2009). Microorganisms may use siderophores to increase cobalt solubility and bioavailability in cobalt-limited environments as a means of contending with the generally low cobalt concentrations in the environment ( $\mathrm{Bi}$ and others, 2010). Microorganisms are responsible for synthesizing vitamin $B_{12}$ in the gut of ruminants, including those that humans depend on for food, such as cows and sheep. Cobaltdeficient sheep and cattle may experience weight loss and frequent miscarriages, but such symptoms are often curtailed by adding cobalt salts to feed and cobalt additives to soil (Schrauzer, 2004).

Fewer studies have focused on the toxic effects of cobalt on higher level plants. The cobalt content of food plants varies widely (from 1.1 to 380 micrograms per kilogram) and depends upon the soil conditions and the species (Kabata-Pendias and Pendias, 2001, and references therein). This dependence is illustrated by a study that tested the phytotoxicity of cobalt to barley (Hordeum vulgare L.), oilseed rape (Brassica napus L.), and tomato (Lycopersicon esculentum L.) in 10 different soils collected from around the world ( $\mathrm{Li}$ and others, 2009). The $\mathrm{EC}_{50}$, based on decreased shoot growth and biomass, was highly variable. The most sensitive $\mathrm{EC}_{50}$ was $7 \mathrm{mg} / \mathrm{kg}$ of cobalt for oilseed rape growing in soil from Athens (Georgia), and the least sensitive $\mathrm{EC}_{50}$ was $1,708 \mathrm{mg} / \mathrm{kg}$ of cobalt for barley growing in soil from Brécy (France). The bladder campion (Silene vulgaris [Moench] Garcke) plant is native to Europe and is widespread in North America. This species has the capacity for high metal tolerance, as expressed by seedling specimens collected in Canada from mine tailings near Cobalt, Ontario, having a greater ability to withstand elevated arsenic, cobalt, and nickel concentrations in the growth medium than counterparts collected from an uncontaminated site near Baymouth, Ontario (Paliouris and Hutchinson, 1991). For healthy terrestrial plant growth, some regions of the United States have adopted a soil screening benchmark of $20 \mathrm{mg} / \mathrm{kg}$ cobalt (Efroymson and others, 1997). The Canadian agricultural soil quality guideline for cobalt is $40 \mathrm{mg} / \mathrm{kg}$ (Canadian Council of Ministers of the Environment, 2013).

\section{Mine Closure}

Most recent and new mining operations include closure plans that address issues related to the mine's footprint. A mine's footprint includes the waste left on site and locally affected soil and water, as well as ecological impacts, such as habitat destruction and loss of biodiversity. Long-term plans for closed mining operations where cobalt is an economic byproduct also depend upon country, state, and local regulations. Following mining in many cobalt-rich deposits, a typical long-term mine closure issue is the potential for AMD derived from the site. Acidic drainage may seep from waste piles or tailings ponds. Common methods for treating AMD include active water treatment facilities, passive limestone-lined channels, or constructed wetlands (Plumlee and Logsdon, 1999). The end result of both active and passive approaches is the eventual precipitation of dissolved metals. Precipitated metals in passive wetland systems tend to be more stable under the prevailing anoxic conditions, whereas the metal-rich precipitates that result from active treatment facilities form a sludge that can be similar to Ni-Co laterite processing wastes, and both materials can cause environmental problems if not disposed of responsibly.

At large mines, mine waste is typically consolidated into pits and submerged under water, forming a tailings pond or impoundment. Acid-generating minerals are less reactive under water, but any seepage usually needs to be treated. A tailings impoundment in the Chambishi catchment in Zambia covers 1.6 hectares and is submerged during the wet season, but becomes completely dry by the middle of the dry season (von der Heyden and New, 2004). The acid-neutralizing capacity of the Chambishi tailings is sufficient to attenuate groundwater cobalt, nickel, and zinc concentrations to within local drinking water guideline levels, but evaporation in the tailings impoundment causes precipitation of metal-bearing evaporite minerals that can be mobilized as wind-blown dust during the dry season (von der Heyden and New, 2004). Likewise, dried tailings pond dust has settled in soils near the Tuva cobalt plant (Khovu-Aksy Mine site, Russia), contributing to soil arsenic concentrations as high as $540 \mathrm{mg} / \mathrm{kg}$ (Bortnikova and others, 2012).

Another common long-term mine-closure issue related to the mining of cobalt-rich deposits is the generation of large volumes of waste rock and tailings piles. These waste piles have the potential to become unstable and can be a source of metal-rich dust. If the use of mine waste as backfill into mine workings is not an option, waste pile stability and dust-generating issues can often be addressed through grading and covering of the piles with vegetation. Securing waste piles and prevention and treatment of AMD typically are taken into account in the long-term costs of active and proposed metal mining projects.

\section{Problems and Future Research}

Several types of studies could benefit the delineation of new cobalt resources for the future and the mining and processing of known cobalt deposits. First would be better geologic models for cobalt-rich ores, which could be used in the exploration for new deposits. Second would be improved methods for increased recovery of cobalt from $\mathrm{Ni}$-Co laterites based on the typically lower recovery rates for cobalt relative to nickel (Xu and others, 2005); in situ leaching of laterite deposits could also be evaluated. Third would be the development of processes for the efficient and economic recovery of cobalt from silicate minerals, such as olivine in dunite and other types of ultramafic rocks. Fourth, and last, would be technological advances to help make the mining and extraction 
of cobalt from deep-sea ferromanganese nodules and crusts economically profitable.

Considerable challenges exist for the profitable extraction of cobalt from sea-floor resources in ferromanganese nodules and crusts (figs. F6 and F8). These cobalt resources lie at water depths of as great as $6,000 \mathrm{~m}$, so technological, economic, and legal barriers have prevented their exploitation to date. The International Seabed Authority has developed guidelines for the environmental impact statement (EIS) that must be submitted to governing bodies by companies applying for licenses to explore and mine sea-floor mineral deposits. According to the EIS guidelines, developers must address all environmental and social issues that could result from the mining activity, as well as the relevant mitigation measures (International Seabed Authority, 2012). Discussion of all potential issues is beyond the scope of this work. Interested readers can find more information in the various technical reports published online by the International Seabed Authority (2015).

Processing of sea-floor ferromanganese nodules and crusts would likely take place on land, so some of the same mine-waste issues for terrestrial cobalt resources will also apply to sea-floor resources. Additionally, perhaps one of the most controversial issues involving sea-floor mining is the potential impact on benthic, middepth, and pelagic ecosystems. Benthic ecosystems on abyssal plains are particularly threatened by mining in the Clarion-Clipperton zone (CCZ). The understanding of abyssal, benthic ecosystems has grown rapidly in the past several decades. An international effort to evaluate the biodiversity in the CCZ revealed that "high, unanticipated, and still poorly sampled levels of species diversity for all three sediment-dwelling faunal components (foraminifera, nematodes, and polychaetes) [exist] at [the] individual study sites" (International Seabed Authority, 2008, p. 2). These findings led to the recommendation that "marine protected areas" be maintained throughout the CCZ in order to preserve abyssal biodiversity (International Seabed Authority, 2008). Another major environmental concern relates to wastewater being discharged from the ships carrying out the sea-floor mining. This waste could contain crushed nodules and trace metals, and has the potential to disrupt photosynthesis by pelagic organisms and, being colder and denser than surface water, change the natural circulation patterns in the water column (Markussen, 1994). As a result, current conceptual designs are engineered to separate nodules from waste material (for example, clay, sediments, and muddy water) and to return waste to the sea floor at water depths of nearly $5,000 \mathrm{~m}$, so as not to disturb the middepth and pelagic ecosystems (for example, Agarwal and others, 2012). As sea-floor mineral exploration continues and if mining begins in the future, the scientific community likely will be documenting its impacts on ocean life.

\section{Acknowledgments}

We thank Michael P. Foose (U.S. Geological Survey) and Andrew G. Gunn (British Geological Survey) for thorough and constructive reviews of the manuscript, and John H. DeYoung, Jr. (U.S. Geological Survey) for editorial suggestions. Comments by David Weight and Paul Marsh (The Cobalt Development Institute), and William Stubblefield (Oregon State University) are also appreciated. Keith Labay (U.S. Geological Survey) helped create the deposit location maps, and Suzanne Nicholson (U.S. Geological Survey) provided additional editorial comments after the technical review was complete.

\section{References Cited}

Note: All Web links listed were active as of the access date but may no longer be available.

Achurra, L.E., Lacassie, J.P., Le Roux, J.P., Marquardt, C., Belmar, M., Ruiz-del-Solar, J., and Ishman, S.E., 2009, Manganese nodules in the Miocene Bahía Inglesa Formation, north-central Chile-Petrography, geochemistry, genesis and palaeoceanographic significance: Sedimentary Geology, v. 217, nos. 1-4, p. 128-139. [Also available at http://www.sciencedirect.com/science/article/pii/ S0037073809000761.]

African Eagle Resources Plc., 2013, Projects—Dutwa projectResource-Table 1-JORC Mineral Resource statement, as at September 2012: African Eagle Resources Plc. Web page, accessed April 12, 2013, at http://www.africaneagle.co.uk/ dutwa-resources.asp.

African Rainbow Minerals Ltd., 2011, Mineral resources and reserves 2011: African Rainbow Minerals Ltd., 31 p., accessed May 20, 2016, at http://www.arm.co.za/im/files/ annual/2011/download/ARM-resources-and-reserves-2011.pdf.

Agarwal, B., Hu, P., Placidi, M., Santo, H., and Zhou, J.J., 2012, Feasibility study on manganese nodules recovery in the Clarion-Clipperton zone, v. 2 of Shenoi, R.A., Wilson, P.A., and Bennett, S.S., eds., Seabed exploitation-The LRET Collegium 2012 Series: Highfield, Southhampton, United Kingdom, University of Southampton, 128 p. [Also available at http://www.southampton.ac.uk/engineering/ research/groups/fsi/lrf/lrf_collegium_2012_book_series.page.]

Agency for Toxic Substances and Disease Registry, 1995, Blackbird Mine, Cobalt, Lemhi County, Idaho: Atlanta, Ga., U.S. Department of Health and Human Services, Public Health Service Public Health Assessment, CERCLIS No. IDD980725832, accessed March 26, 2013, at http://www.atsdr.cdc.gov/hac/pha/pha.asp?docid=1040\&pg=0. 
Agency for Toxic Substances and Disease Registry, 2004, Toxicological profile for cobalt: Atlanta, Ga., U.S. Department of Health and Human Services, Public Health Service, CAS no. 7440-48-4, April, 417 p. plus 5 appendixes accessed March 26, 2013, at http://www.atsdr.cdc.gov/ ToxProfiles/tp.asp? $\mathrm{id}=373 \&$ tid $=64$.

Ahmed, A.H., Arai, Shoji, and Ikenne, Moha, 2009, Mineralogy and paragenesis of the Co-Ni arsenide ores of Bou Azzer, Anti-Atlas, Morocco: Economic Geology, v. 104, p. 249-266. [Also available at http://dx.doi.org/10.2113/ gsecongeo.104.2.249.]

Albidon Ltd., 2007, Munali nickel deposit: Albidon Ltd. Web page, accessed April 22, 2013, at http://albidon.com/ our-projects/zambia.html.

Altona Mining Ltd., 2013, Resource and reserve estimatesFinland-Kylylahti Mine mineral resource and ore reserve estimates: Altona Mining Ltd. Web page, accessed April 12, 2013, at http://www.altonamining.com/finland/ resource-and-reserve-estimates.

Ames, D.E., and Farrow, C.E.G., 2007, Metallogeny of the Sudbury mining camp, Ontario, in Goodfellow, W.D., ed., Mineral deposits of Canada-A synthesis of major deposittypes, district metallogeny, the evolution of geological provinces, and exploration methods: Geological Association of Canada Special Publication no. 5, p. 329-350.

Armstrong, Tracey, Puritch, Eugene, and Yassa, Antoine, 2010, Technical report on the Allammaq, Expo, Ivakkak, Mequillon, Mesamax and Puimajuq Ni-Cu-PGE deposits of the Nunavik nickel project, Nunavik, Quebec, NI 43-101 technical report prepared for Goldbrook Ventures Inc. [Filing date April 14, 2010]: P\&E Mining Consultants Inc., accessed May 23, 2016, at www.sedar.com. [Goldbrook Ventures was taken over by Jilin Jien Nickel Industry Co., Ltd. in 2012.]

Baja Mining Corp., 2011, Resource and reserve [Boleo deposit]: Baja Mining Corp., accessed April 20, 2013, at http://www.bajamining.com/static/downloads/ Resource\%20\&\%20Reserve.pdf.

Banakar, V.K., 2010, Deep-sea ferromanganese deposits and their resource potential for India: Journal of the Indian Institute of Science, v. 90, no. 4, p. 535-541.

Bárdossy, György, and Aleva, G.J.J., 1990, Lateritic bauxites: New York, N.Y., Elsevier, Developments in Economic Geology Series, v. 27, 624 p., 24 pls.

Bedder, Jack, 2013, Cobalt production in the DRC-Major changes, minor implications?: The Cobalt Conference, Shanghai, China, May 22-23, presentation, 31 p., accessed June 11, 2013, via http://www.thecdi.com/.
Berger, V.I., Singer, D.A., Bliss, J.D., and Moring, B.C., 2011, Ni-Co laterite deposits of the world - Database and grade and tonnage models: U.S. Geological Survey Open-File Report 2011-1058, 26 p. [Also available at http://pubs.usgs.gov/ of/2011/1058/.]

Bernstein, L.R., and Cox, D.P., 1986, Geology and sulfide mineralogy of the Number One orebody, Ruby Creek copper deposit, Alaska: Economic Geology, v. 81, p. 1675-1689. [Also available at http://dx.doi.org/ 10.2113/gsecongeo.81.7.1675.]

Bi, Yuqiang, Hesterberg, D.L., and Duckworth, O.W., 2010, Siderophore-promoted dissolution of cobalt from hydroxide minerals: Geochimica et Cosmochimica Acta, v. 74, no. 10, p. 2915-2925. [Also available at http://dx.doi.org/10.1016/ j.gca.2010.02.028.]

Bogdanov, Y.A., Bortnikov, N.S., Vikent'ev, I.V., Lein, A.Y., Gurvich, E.G., Sagalevich, A.M., Simonov, V.A., Ikorskii, S.V., Stavrova, O.O., and Apollonov, V.N., 2002, Mineralogical-geochemical peculiarities of hydrothermal sulfide ores and fluids in the Rainbow field associated with serpentinites, Mid-Atlantic Ridge $\left(36^{\circ} 14^{\prime} \mathrm{N}\right)$ : Geology of Ore Deposits, v. 44, no. 6, p. 444-473. [Translated from Geologiya Rudnykh Mestorozhdenii, 2002,44(6), 510-542.]

Borgmann, Uwe, Couillard, Yves, Doyle, Patrick, and Dixon, D.G., 2005, Toxicity of sixty-three metals and metalloids to Hyalella azteca at two levels of water hardness: Environmental Toxicology and Chemistry, v. 24, no. 3, p. 641-652. [Also available at http://dx.doi.org/10.1897/04-177R.1]

Bortnikova, S., Bessonova, E., and Gaskova, O., 2012, Geochemistry of arsenic and metals in stored tailings of a Co-Ni arsenide-ore, Khovu-Aksy area, Russia: Applied Geochemistry, v. 27, no. 11, p. 2238-2250.

Bown, J., Boye, Marie, and Nelson, D.M., 2012, New insights on the role of organic speciation in the biogeochemical cycle of dissolved cobalt in the southeastern Atlantic and the Southern Ocean: Biogeosciences, v. 9, no. 7, July 27, p. 2719-2736, accessed March 19, 2016, at http://dx.doi.org/ 10.5194/bg-9-2719-2012.

Bouabdellah, Mohammed, Maacha, Lhou, Levresse, Gilles, and Saddiqi, Omar, 2016, The Bou Azzer Co-Ni-Fe-As $( \pm \mathrm{Au} \pm \mathrm{Ag}$ ) district of central Anti-Atlas (Morocco) - A long-lived Late Hercynian to Triassic magmatic-hydrothermal to low-sulphidation epithermal system, in Bouabdellah, Mohammed, and Slack, J.F., eds., Mineral deposits of north Africa: Berlin, Germany, Springer-Verlag, p. 229-247.

Brems, D., Muchez, Ph., Sikazwe, O., and Mukumba, W., 2009, Metallogenesis of the Nkana copper-cobalt South orebody, Zambia: Journal of African Earth Sciences, v. 55, nos. 3-4, p. 185-196. [Also available at http://dx.doi.org/ 10.1016/j.jafrearsci.2009.04.003.] 
British Geological Survey, 2009, Cobalt: Keyworth, Nottingham, United Kingdom, British Geological Survey Mineral Profile, August, 19 p., accessed March 19, 2016, at http://www.bgs.ac.uk/mineralsuk/statistics/mineralProfiles.html.

Broken Hill Prospecting Ltd., 2013, Cobalt deposits [Pyrite Hill and Big Hill]: Broken Hill Prospecting Ltd. Web page, accessed April 9, 2013, at http://www.bhpl.biz/projects/ cobalt-deposits/.

Butt, C.R.M., and Cluzel, Dominique, 2013, Nickel laterite ore deposits - Weathered serpentinites: Elements, v. 9, no. 2, p. 123-128. [Also available at http://dx.doi.org/10.2113/ gselements.9.2.123.]

Çağatay, Ahmet, Altun, Yılmaz, and Arman, Bülent, 1983, The mineralogy of Çaldağ (Manisa-Turgutlu) lateritic iron, nickel-cobalt deposits: Bulletin of the Mineral Research and Exploration [Institute of Turkey], v. 95-96, p. 81-96, plus 3 pls. [Also available at http://dergipark.ulakbim.gov.tr/ bulletinofmre/issue/view/5000012082.]

CAMEC Plc., 2007, Central African Mining and Exploration Company Plc. ("CAMEC" or "the company") Democratic Republic of the Congo acquisition and production update: CAMEC Plc., March 1, accessed April 22, 2013, at http://www.resourceinvestor.com/2007/03/02/camec-drc-update.

Canadian Council of Ministers of the Environment, [2013], Canadian soil quality guidelines for the protection of environmental and human health, chap. 7 of Canadian environmental quality guidelines: Winnipeg, Manitoba, Canada, Canadian Council of Ministers of the Environment, accessed April 16, 2016, at http://ceqg-rcqe.ccme.ca/en/index.html.

Chalice Gold Mines Ltd., 2012, Agreement to acquire the Mount Oxide copper-cobalt project in Queensland, Australia: Perth, Western Australia, Australia, Chalice Gold Mines Ltd., 5 p. plus 3 appendixes, accessed April 12, 2013, at http://www.chalicegold.com/investor-relations/asxannouncements/2008.html.

Chen, Liang, Huang, Yan, Huang, Lingli., Liu, Bin, Wang, Gang, and Yu, Shaoming, 2011, Characterization of $\mathrm{Co}$ (II) removal from aqueous solution using bentonite/iron oxide magnetic composites: Journal of Radioanalytical and Nuclear Chemistry, v. 290, p. 675-684. [Also available at http://dx.doi.org/10.1007/s10967-011-1337-y.]

Chen, W.T., and Zhou, M.-F., 2012, Paragenesis, stable isotopes, and molybdenite Re-Os isotope age of the Lala iron-copper deposit, southwest China: Economic Geology, v. 107, p. 459-480. [Also available at http://dx.doi.org/ 10.2113/econgeo.107.3.459.]

Cobalt Development Institute and World Bureau of Metal Statistics, 2011, Annual cobalt statistics 2008 to 2010: Guildford, United Kingdom, Cobalt Development Institute and World Bureau of Metal Statistics, June, CD-ROM.
Cobalt Development Institute, 2012, Cobalt facts-Cobalt supply \& demand 2011: Guildford, United Kingdom, Cobalt Development Institute, accessed March 8, 2013, at http://www.thecdi.com/cobaltfacts.php.

Compass Resources NL, 2007, Resources-Base and specialty metals - Global base and specialty metals - Browns: Compass Resources NL Web page, accessed June 30, 2016 , at https://web.archive.org/web/20070829110319/http:// compassnl.com.au/resources_base_specialty_metals.htm.

Coveney, R.M., Jr., 2003, Metalliferous Paleozoic black shales and associated strata, in Lentz, D.R., ed., Geochemistry of sediments and sedimentary rocks-Evolutionary considerations to mineral deposit-forming environments: St. John's, Newfoundland, Canada, Geological Association of Canada, Mineral Deposits Division, GEOText 4, p. 135-144.

Crespo, A., and Lunar, R., 1997, Terrestrial hot-spring Co-rich Mn mineralization in the Pliocene-Quaternary Calatrava Region (central Spain), in Nicholson, K., Hein, J.R., Bühn, B., and Dasgupta, S., eds., Manganese mineralization - Geochemistry and mineralogy of terrestrial and marine deposits: Geological Society of London Special Publication 119, p. 253-264. [Also available at http://dx.doi.org/10.1144/GSL.SP.1997.119.01.16.]

Crockett, R.N., Chapman, G.R., and Forrest, M.D., 1987, International Strategic Minerals Inventory summary report-Cobalt: U.S. Geological Survey Circular 930-F, 54 p. [Also available at https://pubs.er.usgs.gov/publication/ cir930F.]

Crundwell, F.K., Moats, M.S., Ramachandran, Venkoba, Robinson, T.G., and Davenport, W.G., 2011, Extractive metallurgy of nickel, cobalt and platinum-group metals: Amsterdam, Netherlands, Elsevier, 610 p. [Also available at http://www.sciencedirect.com/science/book/ 9780080968094.]

De Cuyper, J., 1988, Milling of cobalt ores_-An overview, in Tyroler, G.P., and Landolt, C.A., eds., Extractive metallurgy of nickel and cobalt, Proceedings of the symposium sponsored by the $\mathrm{CuNiCo}$ and Non-Ferrous Pyrometallurgy Committees of the Metallurgical Society, January 25-28, 1988: Phoenix, Ariz., The Metallurgical Society, Inc., p. 187-210.

Desborough, G.A., and Poole, F.G., 1983, Metal concentrations in some marine black shales of the United States, in Shanks, W.C., III, ed., Cameron volume on unconventional mineral deposits: New York, N.Y., Society of Mining Engineers, p. 99-110.

Direct Nickel Pty Ltd., 2013, Mambare nickel project: Direct Nickel Pty Ltd. Web page, accessed April 14, 2013, at http://www.directnickel.com/mambare-mine/. 
Duckworth, O.W., Bargar, J.R., Jarzecki, A.A., Oyerinde, Oyeyemi, Spiro, T.G., and Sposito, Garrison, 2009, The exceptionally stable cobalt(III)-desferrioxamine B complex: Marine Chemistry, v. 113, January, p. 114-122.

Duluth Metals Ltd., 2012, Project summary [Twin Metals (Nokomis) deposit]: Toronto, Ontario, Canada, Duluth Metals Ltd., accessed March 22, 2013, at http://www.duluthmetals.com/ s/ProjectSummary.asp.

Eckstrand, O.R., and Hulbert, L.J., 2007, Magmatic nickelcopper-platinum group element deposits, in Goodfellow, W.D., ed., Mineral deposits of Canada-A synthesis of major deposit-types, district metallogeny, the evolution of geological provinces, and exploration methods: Geological Association of Canada Special Publication no. 5, p. 205-222.

Efroymson, R.A., Will, M.E., Suter, G.W., II, and Wooten, A.C., 1997, Toxicological benchmarks for screening contaminants of potential concern for effects on terrestrial plants-1997 revision, report prepared for the U.S. Department of Energy by Lockheed Martin Energy Systems, Inc.: Oak Ridge, Tenn., Oak Ridge National Laboratory, ES/ER/TM-85/R3,

November, 68 p. and two appendixes, accessed March 26, 2013, at http://www.esd.ornl.gov/programs/ecorisk/documents/ tm85r3.pdf.

Eilu, Pasi, ed., 2012, Mineral deposits and metallogeny of Fennoscandia: Espoo, Finland, Geological Survey of Finland Special Paper 53, 401 p.

El Desouky, H.A., Muchez, Philippe, Boyce, A.J., Schneider, Jens, Cailteux, J.L.H., Dewaele, Stijn, and von Quadt, Albrecht, 2010, Genesis of sediment-hosted stratiform copper-cobalt mineralization at Luiswishi and Kamoto, Katanga copperbelt (Democratic Republic of Congo): Mineralium Deposita, v. 45, no. 8, p. 735-763.

Elias, M., Donaldson, M.J., and Giorgetta, N.E., 1981, Geology, mineralogy, and chemistry of lateritic nickelcobalt deposits near Kalgoorlie, Western Australia: Economic Geology, v. 76, p. 1775-1783. [Also available at http://dx.doi.org/10.2113/gsecongeo.76.6.1775.]

Eppinger, R.G., Briggs, P.H., Rieffenberger, Betsy, Van Dorn, Carol, Brown, Z.A., Crock, J.G., Hageman, P.H., Meier, Allen, Sutley, S.J., Theodorakos, P.M., and Wilson, S.A., 2003, Geochemical data for stream sediment and surface water samples from Panther Creek, the Middle Fork of the Salmon River, and the main Salmon River, collected before and after the Clear Creek, Little Pistol, and Shellrock wildfires of 2000 in central Idaho: U.S. Geological Survey Open-File Report 01-0161, 32 p. (This report was superceded by U.S. Geological Survey Open-File Report 2003-152.) [Also available at http://pubs.usgs.gov/of/2003/152/.]

Eramet Group, 2013, Mining centres: Eramet Group brochure, 4 p., accessed April 9, 2013, at http://www.eramet.com/sites/ default/files/eramet_nickel_division_mining_centres.pdf.
Evans, K.V., Nash, J.T., Miller, W.R., Kleinkopf, M.D., and Campbell, D.L., 1995, Blackbird Co-Cu deposits, chap. 17 of du Bray, E.A., ed., Preliminary compilation of descriptive geoenvironmental mineral deposit models: U.S. Geological Survey Open-File Report 95-831, p. 145-151. [Also available at http://pubs.usgs.gov/of/1995/ofr-95-0831/.]

Fay, I., and Barton, M.D., 2012, Alteration and ore distribution in the Proterozoic Mines Series, Tenke-Fungurume $\mathrm{Cu}-\mathrm{Co}$ district, Democratic Republic of Congo: Mineralium Deposita, v. 47, no. 5, p. 501-519. [Also available at http://dx.doi.org/10.1007/s00126-011-0391-2.]

First Quantum Minerals Ltd., 2011, First Quantum Minerals issues updated resource and reserve estimates and progress report for Kevitsa project: Vancouver, British Columbia, Canada, First Quantum Minerals Ltd., accessed April 18, 2013, at http://www.marketwire.com/press-release/First-QuantumMinerals-Issues-Updated-Resource-Reserve-EstimatesProgress-Report-Kevitsa-TSX-FM-1419900.htm.

Foose, M.P., 1991, Deposits containing nickel, cobalt, chromium, and platinum-group elements in the United States, in Gluskoter, H.J., Rice, D.D., and Taylor, R.B., eds., Economic geology, U.S.- The geology of North America: Boulder, Colo., The Geology Society of America, v. P-2, p. 87-102. [Also available at http://ebooks.geoscienceworld.org/content/economic-geology-us.]

Foose, M.P., 1992, Nickel—Mineralogy and chemical composition of some nickel-bearing laterites in southern Oregon and northern California, in DeYoung, J.H., Jr., and Hammarstrom, J.M., eds., Contributions to commodity geology research: U.S. Geological Survey Bulletin 1877, p. E1-E24. [Also available at http://pubs.usgs.gov/bul/ 1877/report.pdf.]

Foose, M.P., Zientek, M.L., and Klein, D.P., 1995, Magmatic sulfide deposits, chap. 4 of du Bray, E.A., ed., Preliminary compilation of descriptive geoenvironmental mineral deposit models: U.S. Geological Survey Open-File Report 95-831, p. 28-38. [Also available at http://pubs.usgs.gov/ of/1995/ofr-95-0831/.]

Freeport-McMoRan Copper \& Gold Inc., 2013, Form 10-K2012: Freeport-McMoRan Copper \& Gold Inc., accessed February 18, 2016, at http://investors.fcx.com/investorcenter/financial-information/annual-reports-and-proxy/ default.aspx.

Freyssinet, P., Butt, C.R.M., Morris, R.C., and Piantone, P., 2005, Ore-forming processes related to lateritic weathering, in Hedenquist, J.W., Thompson, J.F.H., Goldfarb, R.J., and Richards, J.P., eds., Economic Geology—One hundredth anniversary volume, 1905-2005: Littleton, Colo., Society of Economic Geologists, p. 681-722. [Appendixes are on a CD-ROM inside the back cover.] 
Gaillardet, J., Viers, J., and Dupré, B., 2003, Trace elements in river waters, in Drever, J.I., ed., Surface and ground water, weathering, and soils, v. 5 of Holland, H.D., and Turekian, K.K., eds., Treatise on geochemistry: Oxford, United Kingdom, Elsevier-Pergamon, p. 225-272. [Also available at http://dx.doi.org/10.1016/B0-08-043751-6/05165-3.]

Galley, A.G., Hannington, M.D., and Jonasson, I.R., 2007, Volcanogenic massive sulphide deposits, in Goodfellow, W.D., ed., Mineral deposits of Canada-A synthesis of major deposit-types, district metallogeny, the evolution of geological provinces, and exploration methods: Ottawa, Ontario, Canada, Geological Association of Canada Special Publication no. 5, p. 141-161.

Gaudin, A., Decarreau, A., Noack, Y., and Grauby, O., 2005, Clay mineralogy of the nickel laterite ore developed from serpentinised peridotites at Murrin Murrin, Western Australia: Australian Journal of Earth Sciences, v. 52, no. 2, p. 231-241.

Geovic Mining Corp., 2013, Cameroon cobalt-Nkamouna: Denver, Colo., Geovic Mining Corp. Web page, accessed April 12, 2013, at http://www.geovic.net/projects.php.

Gifford, Mark, Cox, Dallas, Christie, Monte, and Sherrit, Ruth, 2011, Technical report for the Agata nickel laterite project, Mindanao, Philippines, NI 43-101 technical report prepared for Mindoro Resources Ltd.: South Brisbane, Queensland, Australia, Ausenco, 448 p. plus 2 appendixes, accessed April 12, 2013, at http://www.mindoro.com/i/ pdf/NI_43_101_Technical_Report_20_12_2011.pdf.

Giles, S.A., Granitto, Matthew, and Eppinger, R.G., 2009, Selected geochemical data for modeling near-surface processes in mineral systems: U.S. Geological Survey Data Series 433, CD-ROM. [Also available at http://pubs.usgs.gov/ds/433/.]

Glasby, G.P., Mountain, Bruce, Vineesh, T.C., Banakar, Virupaxa, Rajani, Ramesh, and Ren, Xiangwen, 2010, Role of hydrology in the formation of Co-rich Mn crusts from the equatorial N Pacific, equatorial S Indian Ocean and the NE Atlantic Ocean: Resource Geology, v. 60, no. 2, June, p. 165-177.

Gleeson, S.A., and Herrington, R.J., 2005, Nickel laterites through geological time [abs.]: Geological Society of America Abstracts with Programs, v. 37, no. 7, p. 240. [Also available at https://gsa.confex.com/gsa/2005AM/ webprogram/Paper90999.html.]

Glencore International plc., 2011, Mutanda report: Glencore International plc., accessed April 22, 2013, at http://www.hkexnews.hk/listedco/ listconews/sehk/2011/0513/00805_1074520/ EWPGLENCORE-20110511-44.pdf.
Goad, R.E., Mumin, A.H., Duke, N.A., Neale, K.L., Mulligan, D.L., and Camier, W.J., 2000, The NICO and Sue-Dianne Proterozoic, iron oxide-hosted, polymetallic deposits, Northwest Territories-Application of the Olympic Dam model in exploration: Exploration and Mining Geology, v. 9, no. 2, p. 123-140.

Gray, J.E., and Eppinger, R.G., 2012, Distribution of $\mathrm{Cu}, \mathrm{Co}, \mathrm{As}$, and $\mathrm{Fe}$ in mine waste, sediment, soil, and water in and around mineral deposits and mines of the Idaho cobalt belt, USA: Applied Geochemistry, v. 27, no. 6, p. 1053-1062. [Also available at http://dx.doi.org/10.1016/j.apgeochem.2012.02.001.]

Grorud, Hans-Fredrik, 1997, Textural and compositional characteristics of cobalt ores from the Skuterud mines of Modum, Norway: Norsk Geologisk Tidsskrift, v. 77, p. 31-38. [Also available at http://foreninger.uio.no/ngf/ ngt/pdfs/NGT_77_1_031-038.pdf.]

Gülaçar, O.F., and Delaloye, M., 1976, Geochemistry of nickel, cobalt and copper in alpine-type ultramafic rocks: Chemical Geology, v. 17, p. 269-280. [Also available at http://dx.doi.org/10.1016/0009-2541(76)90041-3.]

Gunson Resources Ltd., 2013, Annual report 2012: West Perth, Western Australia, Australia, Gunson Resources Ltd., accessed February 18, 2016, at http://www.strandline.com. $\mathrm{au} / \mathrm{irm} /$ content/annual-reports.aspx?RID=326. [Company changed its name to Strandline Resources Ltd. in 2014.]

Gupta, V.K., Nayak, Arunima, Agarwal, Shilpi, Dobhal, Rajendra, Uniyal, D.P., Singh, Prashant, Sharma, Bhavtosh, Tyagi, Shweta, and Singh, Rakesh, 2012, Arsenic speciation analysis and remediation techniques in drinking water: Desalination and Water Treatment, v. 40, nos. 1-3, p. 231-243. [Also available at http://dx.doi.org/10.1080/19443994.2012.671250.]

Hannington, M.D., de Ronde, C.E.J., and Petersen, Sven, 2005, Sea-floor tectonics and submarine hydrothermal systems, in Hedenquist, J.W., Thompson, J.F.H., Goldfarb, R.J., and Richards, J.P., eds., Economic Geology_One hundredth anniversary volume, 1905-2005: Littleton, Colo., Society of Economic Geologists, p. 111-142. [Also available at http://eprints.uni-kiel.de/6271/.] [Appendixes are on a CD-ROM inside the back cover.]

Hard Creek Nickel Corp., 2013, Summary_-Turnagain project preliminary economic assessment: Vancouver, British Columbia, Canada, Hard Creek Nickel Corp., 4 p., accessed April 12, 2013, at http://www.hardcreek.com/i/pdf/ FACT-SHEET_AMC_PA_December-2011_Mark.pdf.

Hein, J.R., Mizell, Kira, Koschinsky, Andrea, and Conrad, T.A., 2013, Deep-ocean mineral deposits as a source of critical metals for high- and green-technology applicationsComparison with land-based resources: Ore Geology Reviews, v. 51, June, p. 1-14. [Also available at http://dx.doi.org/10.1016/j.oregeorev.2012.12.001.] 
Hein, James, 2002, Cobalt-rich ferromanganese crustsGlobal distribution, composition, origin and research activities, in International Seabed Authority, Polymetallic massive sulphides and cobalt-rich ferromanganese crusts - Status and prospects: Kingston, Jamaica, International Seabed Authority Technical Study no. 2, p. 36-89. [Also available at https://www.isa.org.jm/documents/polymetallic-massivesulphides-and-cobalt-rich-ferromanganese-crusts-statusand-prospects.]

Hermann, Steffen, 2005, Geologie, erzgänge und mineralisation der Lagerstätte Schneeberg/Sachsen [Geology, ores and mineralization of the Lagerstätte Schneeberg/Sachsen]: Lapis, v. 30, p. 30-40.

Heron Resources Ltd., 2013, Kalgoorlie nickel project: Heron Resources Ltd. Web page, accessed April 22, 2013, at http://www.heronresources.com.au/knp.php.

Herrington, R.J., Zaykov, V.V., Maslennikov, V.V., Brown, Dennis, and Puchkov, V.N., 2005, Mineral deposits of the Urals and links to geodynamic evolution, in Hedenquist, J.W., Thompson, J.F.H., Goldfarb, R.J., and Richards, J.P., eds., Economic Geology - One hundredth anniversary volume, 1905-2005: Littleton, Colo., Society of Economic Geologists, p. 1069-1095. [Appendixes are on a CD-ROM inside the back cover.]

Herzig, P.M., Petersen, S., and Hannington, M.D., 2002, Polymetallic massive sulphide deposits at the modern seafloor and their resource potential, in International Seabed Authority, Polymetallic massive sulphides and cobalt-rich ferromanganese crusts-Status and prospects: Kingston, Jamaica, International Seabed Authority, ISA Technical Study no. 2, p. 2-35. [Also available at https://www.isa.org.jm/ documents/polymetallic-massive-sulphides-and-cobalt-richferromanganese-crusts-status-and-prospects.]

Hitzman, Murray, Kirkham, Rodney, Broughton, David, Thorson, Jon, and Selley, David, 2005, The sedimenthosted stratiform copper ore system, in Hedenquist, J.W., Thompson, J.F.H., Goldfarb, R.J., and Richards, J.P., eds., Economic Geology - One hundredth anniversary volume, 1905-2005: Littleton, Colo., Society of Economic Geologists, p. 609-642. [Appendixes are on a CD-ROM inside the back cover.]

Holecy, E.G., and Mousavi, Aliyar, 2012, Lead sources, toxicity, and human risk in children of developing countries-A mini-review: Environmental Forensics, v. 13, no. 4, p. 289-292. [Also available at http://dx.doi.org/ 10.1080/15275922.2012.729010.]

Hou, Z.-Q., Deng, Jian, Sun, H.-T., and Song, S.-H., 1999, Volcanogenic massive sulfide deposits in China-Setting, feature, and style: Exploration and Mining Geology, v. 8, no. $3-4$, p. $149-175$.
Huser, B.J., Köhler, S.J., Wilander, A., Johansson, K., and Fölster, J., 2011, Temporal and spatial trends for trace metals in streams and rivers across Sweden (1996-2009): Biogeosciences, v. 8, p. 1813-1823. [Also available at http://dx.doi.org/10.5194/bg-8-1813-2011.]

Hutchinson, T.C., and Symington, M.S., 1997, Persistence of metal stress in a forested ecosystem near Sudbury, 66 years after the closure of the O'Donnel roast bed: Journal of Geochemical Exploration, v. 58, no. 2-3, p. 323-330. [Also available at http://dx.doi.org/10.1016/ S0375-6742(96)00067-2.]

International Mining, 2012, Tenke Fungurume copper/cobalt mine progressing well with phase 2 expansion in the DRC: International Mining, January 4, accessed November 19, 2013, at http://www.im-mining.com/2012/01/04/tenke-fungurumecoppercobalt-mine-progressing-well-with-phase-2-expansionin-the-drc/.

International Seabed Authority, 2008, Biodiversity, species ranges, and gene flow in the abyssal Pacific nodule provincePredicting and managing the impacts of deep seabed mining: Kingston, Jamaica, International Seabed Authority Technical Study no. 3, 38 p. [Also available at http://www.isa.org.jm/ files/documents/EN/Pubs/TechStudy3.pdf.]

International Seabed Authority, 2012, Environmental management needs for exploration and exploitation of deep sea minerals: Kingston, Jamaica, International Seabed Authority Technical Study no. 10, 47 p. [Also available at http://www.isa.org.jm/files/documents/EN/Pubs/TS10/ index.html.]

International Seabed Authority, 2015, Documents and publications: International Seabed Authority Home page, accessed December 1, 2015, at https://www.isa.org.jm/documentsand-publications.

Jervois Mining Ltd., 2013, Summervale (NSW): Cheltenham, Victoria, Australia, Jervois Mining Ltd. Web page, accessed April 15, 2013, at http://www.jervoismining.com.au/ index.cfm? siteaction=tenement\&tenementid $=19$.

Kabata-Pendias, Alina, and Pendias, Henryk, 2001, Trace elements in soils and plants ( $3 \mathrm{~d}$ ed.): Boca Raton, Fla., CRC Press, $413 \mathrm{p}$.

Kerfoot, D.G.E., and Weir, D.R., 1988, The hydro and electrometallurgy of nickel and cobalt, in Tyroler, G.P., and Landolt, C.A., eds., Extractive metallurgy of nickel and cobalt, Proceedings of the symposium sponsored by the CuNiCo and Non-Ferrous Pyrometallurgy Committees of the Metallurgical Society, January 25-28, 1988: Phoenix, Ariz., The Metallurgical Society, Inc., p. 241-267.

Kissin, S.A., 1992, Five-element (Ni-Co-As-Ag-Bi) veins: Geoscience Canada, v. 19, no. 3, p. 113-124. [Also available at https://journals.lib.unb.ca/index.php/GC/article/ view/3768/4282.] 
Kolb, Jochen, Sakellaris, G.A., and Meyer, F.M., 2006, Controls on hydrothermal Fe oxide-Cu-Au-Co mineralization at the Guelb Moghrein deposit, Akjoujt area, Mauritania: Mineralium Deposita, v. 41, no. 1, p. 68-81. [Also available at http://dx.doi.org/10.1007\%2Fs00126-005-0041-7.]

Krauskopf, K.B., and Bird, D.K., 1995, Introduction to geochemistry (3d ed.): New York, N.Y., McGraw-Hill, Inc., $647 \mathrm{p}$.

Kwong, Y.T.J., Beachemin, S., Hossain, M.F., and Gould, W.D., 2007, Transformation and mobilization of arsenic in the historic Cobalt mining camp, Ontario, Canada: Journal of Geochemical Exploration, v. 92, nos. 2-3, p. 133-150. [Also available at http://doi.org/10.1016/j.gexplo.2006.08.002.]

Lambiv Dzemua, Gideon, and Gleeson, S.A., 2012, Petrography, mineralogy, and geochemistry of the Nkamouna serpentinite-Implications for the formation of the cobaltmanganese laterite deposit, southeast Cameroon: Economic Geology, v. 107, p. 25-41. [Also available at http://dx.doi.org/ 10.2113/econgeo.107.1.25.]

Lambiv Dzemua, Gideon, Gleeson, S.A., and Schofield, P.F., 2013, Mineralogical characterization of the Nkamouna Co-Mn laterite ore, southeast Cameroon: Mineralium Deposita, v. 48, p. 155-171. [Also available at http://dx.doi.org/10.1007/s00126-012-0426-3.]

Lapham, D.M., 1968, Triassic magnetite and diabase at Cornwall, Pennsylvania, in Ridge, J.D., ed., Ore deposits of the United States, 1933-1967, The Graton-Sales Volume: New York, N.Y., American Institute of Mining, Metallurgical, and Petroleum Engineers, Inc., v. I, p. 72-94.

Leach, D.L., Sangster, D.F., Kelley, K.D., Large, R.R., Garven, Grant, Allen, C.R., Gutzmer, Jens, and Walters, Steve, 2005, Sediment-hosted lead-zinc depositsA global perspective, in Hedenquist, J.W., Thompson, J.F.H., Goldfarb, R.J., and Richards, J.P., eds., Economic GeologyOne hundredth anniversary volume, 1905-2005:

Littleton, Colo., Society of Economic Geologists, p. 561-607. [Appendixes are on a CD-ROM inside the back cover.]

Leventhal, J.S., Briggs, P.H., and Baker, J.W., 1983, Geochemistry of the Chattanooga Shale, Dekalb County, central Tennessee: Southeastern Geology, v. 24, no. 3, p. 101-116.

Li, H.-F., Gray, Colin, Mico, Carolina, Zhao, F.-J., and McGrath, S.P., 2009, Phytotoxicity and bioavailability of cobalt to plants in a range of soils: Chemosphere, v. 75, no. 7, p. 979-986. [Also available at http://dx.doi.org/ 10.1016/j.chemosphere.2008.12.068.]

Lindsey, D.A., Woodruff, L.G., Cannon, W.F., Cox, D.P., and Heran, W.D., 1995, Sediment-hosted Cu deposits, chap. 28 of du Bray, E.A., ed., Preliminary compilation of descriptive geoenvironmental mineral deposit models: U.S. Geological Survey Open File Report 95-831, p. 214-224. [Also available at http://pubs.usgs.gov/of/1995/ofr-95-0831/.]
Lottermoser, B.G., 2010, Mine wastes-Characterization, treatment, and environmental impacts ( $3 \mathrm{~d}$ ed.): Berlin, Germany, Springer-Verlag, 400 p. [Also available at http://dx.doi.org/10.1007/978-3-642-12419-8.]

Loukola-Ruskeeniemi, Kirsti, and Lahtinen, Hannu, 2013, Multiphase evolution in the black-shale-hosted Ni-Cu-ZnCo deposit at Talvivaara, Finland: Ore Geology Reviews, v. 52, August, p. 85-99. [Also available at http://dx.doi.org/ 10.1016/j.oregeorev.2012.10.006.]

Lundin Mining Corp., 2012, Aguablanca NI 43-101: Lundin Mining Corp., accessed April 12, 2013, at http://www.lundinmining.com/s/Aguablanca.asp.

Margolis, S.V., Ku, T.L., Glasby, G.P., Fein, C.D., and Audley-Charles, M.G., 1978, Fossil manganese nodules from Timor-Geochemical and radiochemical evidence for deep-sea origin: Chemical Geology, v. 21, nos. 3-4, p. 185-198. [Also available at http://dx.doi.org/10.1016/ 0009-2541(78)90044-X.]

Mark, Geordie, Oliver, N.H.S., Williams, P.J., Valenta, R.K., and Crookes, R.A., 2000, The evolution of the Ernest Henry Fe-oxide-( $\mathrm{Cu}-\mathrm{Au})$ hydrothermal system, in Porter, T.M., ed., Hydrothermal iron oxide copper-gold \& related depositsA global perspective: Adelaide, South Australia, Australia, PGC Publishing, v. 1, p. 123-136.

Markussen, J.M., 1994, Deep seabed mining and the environment-Consequences, perceptions, and regulations, in Bergesen, H.O., and Parmann, Georg, eds., Green Globe yearbook of international co-operation on environment and development: Oxford, United Kingdom, Oxford University Press, p. 31-39.

Marr, J.C.A., Hansen, J.A., Meyer, J.S., Cacela, D., Podrabsky, T., Lipton, J., and Bergman, J.L., 1998, Toxicity of cobalt and copper to rainbow trout-Application of a mechanistic model for predicting survival: Aquatic Toxicology, v. 43, no. 4, p. 225-238. [Also available at http://dx.doi.org/ 10.1016/S0166-445X(98)00061-7.]

Marshall, Dan, and Watkinson, D.H., 2000, The Cobalt mining district - Silver sources, transport and deposition: Exploration and Mining Geology, v. 9, no. 2, p. 81-90. [Also available at http://dx.doi.org/10.2113/0090081.]

Megaw, P.K.M., 1998, Carbonate-hosted Pb-Zn-Ag-CuAu replacement deposits-An exploration perspective, in Lentz, D.R., ed., Mineralized intrusion-related skarn systems: Mineralogical Association of Canada Short Course Series, v. 26, p. 337-358.

Meinert, L.D., Dipple, G.M., and Nicolescu, Stefan, 2005, World skarn deposits, in Hedenquist, J.W., Thompson, J.F.H., Goldfarb, R.J., and Richards, J.P., eds., Economic GeologyOne hundredth anniversary volume, 1905-2005: Littleton, Colo., Society of Economic Geologists, p. 299-336. [Appendixes are on a CD-ROM inside the back cover.] 
Melchert, B., Devey, C.W., German, C.R., Lackschewitz, K.S., Seifert, R., Walter, M., Mertens, C., Yoerger, D.R., Baker, E.T., Paulick, H., and Nakamura, K., 2008, First evidence for high-temperature off-axis venting of deep crust/mantle heat-The Nibelungen hydrothermal field, southern MidAtlantic Ridge: Earth and Planetary Science Letters, v. 275, p. 61-69.

Menzie, W.D., Soto-Viruet, Yadira, Bermúdez-Lugo, Omayra, Mobbs, P.M., Perez, A.A., Taib, Mowafa, Wacaster, Susan, and staff, 2013, Review of selected global mineral industries in 2011 and an outlook to 2017: U.S. Geological Survey Open-File Report 2013-1091, 33 p. [Also available http://pubs.usgs.gov/of/2013/1091.]

Metallica Minerals Ltd., 2013, Resource tables: East Brisbane, Queensland, Australia, Metallica Minerals Ltd. Web page, accessed April 22, 2013, at http:// www.metallicaminerals.com.au/resource-tables.]

Metals X Ltd., 2013, Globally significant nickel project: West Perth, Western Australia, Australia, Metals X Ltd. Web page, accessed April 22, 2013, at http://www.metalsx. com.au/nickel/.

Metorex Pty Ltd., 2013, Metorex mineral resources and ore reserves: Metorex Pty Ltd. Web page, accessed April 22, 2013, at http://www.metorexgroup.com/.

Minara Resources Pty Ltd., 2005, Purchase of Sons of Gwalia non-gold assets: Perth, Western Australia, Australia, Minara Resources Pty Ltd., accessed April 22, 2013, at http://www.minara.com.au/.

Minara Resources Pty Ltd., 2011, Annual report 2010: Perth, Western Australia, Australia, Minara Resources Pty Ltd., accessed April 22, 2013, at www.minara.com.au/files/ docs/329_2010_Annual_Report_to_Shareholders.

Mirabela Nickel Ltd., 2012, Reserves and resources [Santa Rita]: Perth, Western Australia, Australia, Mirabela Nickel Ltd. Web page, accessed April 14, 2013, at http://www.mirabela.com.au/reserves.asp.

Mithril Resources Ltd., 2013, Project overview [Basil coppercobalt deposit]: Norwood, South Australia, Australia, Mithril Resources Ltd., accessed April 12, 2013, at http://www.mithrilresources.com.au/projectoverview.php.

Mok, W.M., and Wai, C.M., 1989, Distribution and mobilization of arsenic species in the creeks around the Blackbird mining district, Idaho: Water Research, v. 23, no. 1, p. 7-13. [Also available at http://dx.doi.org/10.1016/0043-1354(89) 90054-7.]

Monteiro, L.V.S., Xavier, R.P., de Carvalho, E.R., Hitzman, M.W., Johnson, C.A., de Souza Filho, C.R., and Torresi, Ignácio, 2008, Spatial and temporal zoning of hydrothermal alteration and mineralization in the Sossego iron oxide-coppergold deposit, Carajás mineral province, Brazil—Paragenesis and stable isotope constraints: Mineralium Deposita, v. 43, no. 2, p. 129-159. [Also available at http://dx.doi.org/ 10.1007/s00126-006-0121-3.]
Mosier, D.L., Berger, V.I., and Singer, D.A., 2009, Volcanogenic massive sulfide deposits of the world-Database and grade and tonnage models: U.S. Geological Survey Open-File Report 2009-1034, 46 p. [Also available at http://pubs.usgs.gov/of/2009/1034/.]

Mount Isa Mines Ltd., 2012, Mount Isa copper: Mount Isa Mines Ltd., accessed April 22, 2013, at http://www.mountisamines.com.au/EN/aboutXMIM/ Pages/CopperInMountIsa.aspx. [Company was acquired by Glencore plc in May 2013.]

Mozgova, N.N., Efimov, Andrey, Borodaev, Y.S., Krasnov, S.G., Cherkashov, G.A., Stepanova, T.V., and Ashadze, A.M., 1999, Mineralogy and chemistry of massive sulfides from the Logatchev hydrothermal field (14 degrees $45^{\prime} \mathrm{N}$ MidAtlantic Ridge): Exploration and Mining Geology, v. 8, no. 3, p. 379-395.

Mudd, G.M., Weng, Z., Jowitt, S.M., Turnbull, I.D., and Graedel, T.E., 2013, Quantifying the recoverable resources of by-product metals - The case of cobalt: Ore Geology Reviews, v. 55, November, p. 87-98. [Also available at http://dx.doi.org/10.1016/j.oregeorev.2013.04.010.]

Muiños, S.B., Hein, J.R., Frank, Martin, Monteiro, J.H., Gaspar, Luis, Conrad, Tracey, Pereira, H.G., and Abrantes, Fátima, 2013, Deep-sea Fe-Mn crusts from the northeast Atlantic Ocean-Composition and resource considerations: Marine Georesources \& Geotechnology, v. 31, no. 1, p. 40-70. [Also available at http://dx.doi.org/ 10.1080/1064119X.2012.661215.]

Murphy, P.J., and Meyer, G., 1998, A gold-copper association in ultramafic-hosted hydrothermal sulfides from the Mid-Atlantic Ridge: Economic Geology, v. 93, p. 1076-1083. [Also available at http://dx.doi.org/10.2113/ gsecongeo.93.7.1076.]

Mustang Minerals Corp., 2013, Makwa nickel: Toronto, Ontario, Canada, Mustang Minerals Corp., accessed April 15, 2013, at http://www.mustangminerals.com/ projects/makwa/.

Naldrett, A.J., 2004, Magmatic sulfide deposits-Geology, geochemistry, and exploration: Berlin, Germany, SpringerVerlag, $727 \mathrm{p}$.

Naldrett, A.J., and Li, Chusi, 2007, The Voisey's Bay deposit, Labrador, Canada, in Goodfellow, W.D., ed., Mineral deposits of Canada-A synthesis of major deposit-types, district metallogeny, the evolution of geological provinces, and exploration methods: Geological Association of Canada Special Publication no. 5, p. 387-408.

Naldrett, A.J., Fedorenko, V.A., Asif, Mohammed, Lin, Shushen, Kunilov, V.E., Stekhin, A.I., Lightfoot, P.C., and Gorbachev, N.S., 1996, Controls on the composition of Ni-Cu sulfide deposits as illustrated by those at Noril'sk, Siberia: Economic Geology, v. 91, p. 751-773. [Also available at http://dx.doi.org/10.2113/ gsecongeo.91.4.751.] 
Narendrula, R., Nkongolo, K.K., and Beckett, P., 2012, Comparative soil metal analysis in Sudbury (Ontario, Canada) and Lubumbashi (Katanga, DR-Congo): Bulletin of Environmental Contamination and Toxicology, v. 88, no. 2, p. 187-192. [Also available at http://dx.doi.org/10.1007/ s00128-011-0485-7.]

National Toxicology Program, 2014a, Cobalt sulfate, in Report on Carcinogens (13th ed.): Research Triangle Park, N.C., U.S. Department of Health and Human Services, Public Health Service, accessed May 9, 2016, at http://ntp.niehs.nih.gov/ntp/ roc/content/profiles/cobaltsulfate.pdf.

National Toxicology Program, 2014b, Cobalt-tungsten carbidePowders and hard metals, in Report on Carcinogens (13th ed.): Research Triangle Park, N.C., U.S. Department of Health and Human Services, Public Health Service, accessed May 9, 2016, at http://ntp.niehs.nih.gov/ntp/roc/content/ profiles/cobalttungstencarbide.pdf.

National Toxicology Program, 2016, Report on carcinogensMonograph on cobalt and cobalt compounds that release cobalt ions in vivo: Research Triangle Park, N.C., U.S. Department of Health and Human Services, Public Health Service, April 22, variously paged, accessed May 3, 2016, at http://ntp.niehs.nih.gov/ ntp/roc/monographs/cobalt_final_508.pdf

Neumann, Henrich, 1944, Silver deposits at Kongsberg: Norges Geologiske Undersøkelse, v. 162, 133 p.

Nickel Asia Corp., 2011, Ore resources and reserves: Taguig City, Philippines, Nickel Asia Corp., accessed April 22, 2013, at http://www.nickelasia.com/oreReserves.html.

Nilsson, John, Simpson, R.G., and McKenzie, William, 2011, Expansion feasibilty [sic] study for the Tenke Fungurume Mine, Katanga Province, Democratic Republic of Congo [sic], NI 43-101 technical report prepared for Lundin Mining Corp. [Filing date December 15, 2011]: Nilsson Mine Services Ltd., GeoSim Services Inc., and Global Management Corp., December 15, 203 p., accessed June 30, 2016, at http://www.sedar.com.

Occupational Safety and Health Administration, 2013, Cobalt, metal, dust and fume (as Co): Occupational Safety and Health Administration, accessed March 27, 2013, at http://www.osha.gov/dts/chemicalsampling/data/ CH 229100.html.

Owen, M.L., and Meyer, L.H.I., 2013, NI 43-101 technical report on the Eagle Mine, Upper Peninsula of Michigan, USA, prepared for Lundin Mining Corp.: Penryn, United Kingdom, Wardell Armstrong International, July, 241 p. plus 3 appendixes, accessed April 1, 2014, at http://www.lundinmining.com/i/ pdf/2013-07-26_EagleMine_NI43-101.pdf.

Paliouris, Georgia, and Hutchinson, T.C., 1991, Arsenic, cobalt, and nickel tolerances in two populations of Silene vulgaris (Moench) Garcke from Ontario, Canada: New Phytologist, v. 117, p. 449-459. [Also available at http://dx.doi.org/10.1111/j.1469-8137.1991.tb00009.x.]
Panoramic Resources Ltd., 2012, Resources \& reserves, Savannah project: Perth, Western Australia, Australia, Panoramic Resources Ltd., accessed April 14, 2013, at http://www.panoramicresources.com/media//RESOURCESAND-RESERVES---Nickel.pdf.

Paradis, Suzanne, Hannigan, Peter, and Dewing, Keith, 2007, Mississippi Valley-type lead-zinc deposits, in Goodfellow, W.D., ed., Mineral deposits of Canada-A synthesis of major deposit-types, district metallogeny, the evolution of geological provinces, and exploration methods: Geological Association of Canada Special Publication no. 5, p. 185-204.

Parra, L.A., Childers, G.A., Fifarek, R.H., Guillemette, R.N., Palmer, J.R., and Taylor, D.R., 2009, Rediscovering southeast Missouri Mississippi Valley-type $\mathrm{Pb}-\mathrm{Zn}$ deposits - The cobalt-nickel enriched Higdon deposit, Madison and Perry Counties [abs.]: Geological Society of America Abstracts with Programs, v. 41, no. 7 , p. 86

Parthiban, G., and Banakar, V.K., 1999, Chemistry and possible resource potential of cobalt rich ferromanganese crusts from the Afanasiy-Nikitin seamount in the Indian Ocean: The Indian Mineralogist, v. 33, no. 1, p. 125-132. [Also available at https://www.researchgate.net/ publication/27668543_Chemistry_and_possible_resource potential of cobalt rich ferromanganese crust from Afanasiy-Nikitin_seamount_in_the_Indian_Ocean.]

Peltonen, P., Kontinen, A., Huhma, H., and Kuronen, U., 2008, Outokumpu revisited-New mineral deposit model for the mantle peridotite-associated $\mathrm{Cu}-\mathrm{Co}-\mathrm{Zn}-\mathrm{Ni}-\mathrm{Ag}-\mathrm{Au}$ sulphide deposits: Ore Geology Reviews, v. 33, nos. 3-4, p. 559-617. [Also available at http://dx.doi.org/10.1016/ j.oregeorev.2007.07.002.]

Peter, J.M., and Scott, S.D., 1999, Windy Craggy, northwestern British Columbia - The world's largest Besshi-type deposit: Reviews in Economic Geology, v. 8, p. 261-295. [Also available at https://www.researchgate.net/publication/ 257437794_Windy_Craggy_northwestern_British_Columbia The_world's_largest_Besshi-type_deposit.]

Petruk, W., Jambor, J., and Boyle, R.W., 1971, History of the Cobalt and Gowganda area: Canadian Mineralogist, v. 11, no. 1, December, p. 1-11. [Also available at http:// canmin.geoscienceworld.org/content/11/1/1.full.pdf + html.]

Pirajno, Franco, 2013, The geology and tectonic settings of China's mineral deposits: Dordrecht, Germany, Springer, 679 p. [Also available at http://dx.doi.org/10.1007/978-94-007-4444-8.]

Plumlee, G.S., and Logsdon, M.J., 1999, An Earth-system science toolkit for environmentally friendly mineral resource development, in Plumlee, G.S., and Logsdon, M.J.,eds., The environmental geochemistry of mineral deposits-Part A, Processes, techniques, and health issues: Littleton, Colo., Society of Economic Geologists, Reviews in Economic Geology Series, v. 6A, p. 1-27. 
Plumlee, G.S., Smith, K.S., Montour, M.R., Ficklin, W.H., and Mosier, E.L., 1999, Geologic controls on the composition of natural waters and mine waters draining diverse mineral-deposit types, in Plumlee, G.S., and Filipek, L.H., eds., The environmental geochemistry of mineral depositsPart B, Case studies and research topics: Littleton, Colo., Society of Economic Geologists, Reviews in Economic Geology Series, v. 6B, p. 373-409.

Polymet Mining Corp., 2013, Form 20-F-2013: Toronto, Ontario, Canada, Polymet Mining Corp., accessed April 22, 2013, at http://www.polymetmining.com/ investors/financial-reports/.

Power, G., Gräfe, M., and Klauber, C., 2011, Bauxite residue issues-I. Current management, disposal and storage facilities: Hydrometallurgy, v. 108, nos. 1-2, p. 33-45. [Also available at http://dx.doi.org/10.1016/ j.hydromet.2011.02.006.]

Powers, L.A., and Siemens, R.E., 1983, Examination of effluents generated from processing domestic laterites: U.S. Bureau of Mines Report of Investigations 8797, 13 p. [Also available at http://stacks.cdc.gov/view/cdc/10479/ cdc_10479_DS1.pdf.]

Prokin, V.A., and Buslaev, F.P., 1999, Massive copper-zinc sulphide deposits in the Urals: Ore Geology Reviews, v. 14, no. 1, p. 1-69. [Also available at http://dx.doi.org/10.1016/ S0169-1368(98)00014-6.]

Prophecy Platinum Corp., 2013a, Shakespeare: Vancouver, British Columbia, Canada, Prophecy Platinum Corp., accessed April 19, 2013, at http://prophecyplat.com/ project_shakespeare.php.

Prophecy Platinum Corp., 2013b, Wellgreen: Vancouver, British Columbia, Canada, Prophecy Platinum Corp., accessed April 12, 2013, at http://prophecyplat.com/ project_wellgreen.php.

Puget Ventures Inc., 2013, Karakul cobalt deposit: Vancouver, British Columbia, Canada, Puget Ventures Inc., accessed April 12, 2013, at http://cobaltinvestingnews.com/64-pugetventures-inc-advanced-cobalt-property-werner-west-cobalt-mine/.

Python Mining Consultants, 2013, History of nickel mining in Sudbury: Hamilton, Ontario, Canada, Python Mining Consultants, accessed April 9, 2013, at http:// www.pythongroup.ca/mining-news/article/id/37.

Rachlin, J.W., and Grosso, A., 1993, The growth response of the green alga Chlorella vulgaris to combined divalent cation exposure: Archives of Environmental Contamination and Toxicology, v. 24, no. 1, p. 16-20.

Reimann, Clemens, and de Caritat, Patrice, 1998, Chemical elements in the environment-Factsheets for the geochemist and environmental scientist: Berlin, Germany, SpringerVerlag, 398 p.
Reynolds, Lachlan, 2000, Geology of the Olympic Dam $\mathrm{Cu}-\mathrm{U}-\mathrm{Au}-\mathrm{Ag}-\mathrm{REE}$ deposit, in Porter, T.M., ed., Hydrothermal iron oxide copper-gold \& related deposits-A global perspective: Adelaide, South Australia, Australia, PGC Publishing, v. 1, p. 93-104.

Rose, A.W., Herrick, D.C., and Deines, Peter, 1985, An oxygen and sulfur isotope study of skarn-type magnetite deposits of the Cornwall type, southeastern Pennsylvania: Economic Geology, v. 80, p. 418-433. [Also available at http://dx.doi.org/10.2113/gsecongeo.80.2.418.]

Saari, P., and Riekkola-Vanhanen, M., 2012, Talvivaara bioheapleaching process: Journal of the Southern African Institute of Mining and Metallurgy, v. 112, no. 12, p. 1013-1020. [Also available at http://www.saimm.co.za/ Journal/v112n12p1013.pdf.]

Schmidt, F.-P., and Friedrich, G.H., 1988, Geologic setting and genesis of Kupferschiefer mineralization in West Germany, in Friedrich, G.H., and Herzig, P.M., eds., Base metal sulfide deposits in sedimentary and volcanic environments - Proceedings of the DMG-GDMB-SGA meeting, Aachen, 1985: Berlin, West Germany, SpringerVerlag, Society for Geology Applied to Mineral Deposits Special Publication no. 5, p. 25-59.

Schrauzer, G.N., 2004, Cobalt, in Merian, E., Anke, M., Ihnat, M., and Stoeppler, M.S., eds., Elements and their compounds in the environment - Occurrence, analysis and biological relevance: Weinheim, Germany, Wiley-VCH Verlag GmbH, p. 825-839.

Searle, P.J., 2015, Cobalt-Market balance in 2020s?: The Cobalt Conference, Toronto, Ontario, Canada, May 20-21, presentation, 21 p., accessed May 27, 2015, via http://www.thecdi.com/.

Seeger, C.M., 2008, History of mining in the southeast Missouri lead district and description of mine processes, regulatory controls, environmental effects, and mine facilities in the Viburnum Trend subdistrict, chap. 1 of Kleeschulte, M.J., ed., Hydrologic investigations concerning lead mining issues in southeastern Missouri: U.S. Geological Survey Scientific Investigations Report 2008-5140, 33 p. [Also available at http://pubs.usgs.gov/sir/2008/5140/.]

Selley, David, Broughton, David, Scott, Robert, Hitzman, Murray, Bull, Stuart, Large, Ross, McGoldrick, Peter, Croaker, Mawson, Pollington, Nicky, and Barra, Fernando, 2005, A new look at the geology of the Zambian copperbelt, in Hedenquist, J.W., Thompson, J.F.H., Goldfarb, R.J., and Richards, J.P., eds., Economic Geology - One hundredth anniversary volume, 1905-2005: Littleton, Colo., Society of Economic Geologists, p. 965-1000. [Appendixes are on a CD-ROM inside the back cover.] 
Shacklette, H.T., and Boerngen, J.G., 1984, Element concentrations in soils and other surficial materials of the conterminous United States: U.S. Geological Survey Professional Paper 1270, 105 p. [Also available at http://pubs.usgs.gov/ $\mathrm{pp} / 1270 /$.

Shanks, W.C. Pat, III, and Thurston, Roland, eds., 2012, Volcanogenic massive sulfide occurrence model, chap. C of Mineral deposit models for resource assessment: U.S. Geological Survey Scientific Investigations Report 2010-5070-C, 345 p. [Also available at http://pubs.usgs.gov/sir/2010/5070/c/.]

Shedd, K.B., 2013a, Cobalt, in Metals and minerals: U.S. Geological Survey Minerals Yearbook 2011, v. I, p. 19.1-19.21. [Also available at http://minerals.usgs.gov/ minerals/pubs/commodity/cobalt/index.html\#myb.]

Shedd, K.B., 2013b, Cobalt: U.S. Geological Survey Mineral Commodity Summaries 2013, p. 46-47. [Also available at https://minerals.usgs.gov/minerals/pubs/commodity/cobalt/ mcs-2013-cobal.pdf.]

Shelley, R.U., Sedwick, P.N., Bibby, T.S., Cabedo-Sanz, P., Church, T.M., Johnson, R.J., Macey, A.I., Marsay, C.M., Sholkovitz, E.R., Ussher, S.J., Worsfold, P.J., and Lohan, M.C., 2012, Controls on dissolved cobalt in surface waters of the Sargasso Sea-Comparisons with iron and aluminum: Global Biogeochemical Cycles, v. 26, no. 2. [Also available at http://dx.doi.org/10.1029/2011GB004155.]

Slack, J.F., ed., 2013, Descriptive and geoenvironmental model for cobalt-copper-gold deposits in metasedimentary rocks (ver. 1.1, March 14, 2014): U.S. Geological Survey Scientific Investigations Report 2010-5070-G, 218 p. [Also available at http://dx.doi.org/10.3133/sir20105070G.]

Smith, C.G., 2001, Always the bridesmaid, never the brideCobalt geology and resources: Institution of Mining and Metallurgy Transactions, v. 110, sec. B (Applied Earth Science), p. B75-B80.

Smith, D.B., Cannon, W.F., Woodruff, L.G., Garrett, R.G., Klassen, Rodney, Kilburn, J.E., Horton, J.D., King, H.D., Goldhaber, M.B., and Morrison, J.M., 2005, Major- and trace-element concentrations in soils from two continentalscale transects of the United States and Canada: U.S. Geological Survey Open-File Report 2005-1253, 20 p. [Also available at https://pubs.usgs.gov/of/2005/1253/.]

Smith, K.S., and Huyck, L.O., 1999, An overview of the abundance, relative mobility, bioavailability, and human toxicity of metals, in Plumlee, G.S., and Logsdon, M.J., eds., The environmental geochemistry of mineral deposits_Part A, Processes, techniques and health issues: Littleton, Colo., Society of Economic Geologists, v. 1, p. $29-70$.
Spencer, Edward, 2016, Cobalt supply and demand-A global perspective: : The Cobalt Conference, Seoul, Republic of Korea, May 11-12, presentation, 22 p., accessed June 23, 2016, via http://www.thecdi.com/.

Sracek, O., Mihaljevič, M., Kř́bek, B., Majer, V., and Veselovský, F., 2010, Geochemistry and mineralogy of $\mathrm{Cu}$ and Co in mine tailings at the copperbelt, Zambia: Journal of African Earth Sciences, v. 57, nos. 1-2, p. 14-30. [Also available at http://dx.doi.org/10.1016/j.jafrearsci.2009.07.008.]

Staples, L.P., Bernier, S.B., Lane, G.S., Penswick, D.P., Scott, C.C., Murphy, B.A., and Bertrand, V.J., 2012, Technical report on the Dumont project, Launay and Trécesson Townships, Quebec, Canada, prepared for Royal Nickel Corp.: Vancouver, British Columbia, Canada, Ausenco Solutions Canada Inc., no. 2139-RPT-003, July 18 (revision of report dated June 22, 2012), accessed April 14, 2013, at http://www.royalnickel.com/_docs/ dumont-jun-22-2012.pdf.

Starfield Resources Inc., 2013, Ferguson Lake mineralization: Toronto, Ontario, Canada, Starfield Resources Inc., accessed April 14, 2013, at http://starfieldres.com/SiteResources/ ViewContent.asp?DocID=134\&v1ID=\&RevID=335\&lang=1.

Sun, Y.-H., and Püttmann, Wilhelm, 1997, Metal accumulation during and after deposition of the Kupferschiefer from the Sangerhausen basin, Germany: Applied Geochemistry, v. 12, no. 5, p. 577-592. [Also available at http://dx.doi.org/10.1016/ S0883-2927(97)00015-2.]

Suter, G.W., II, and Tsao, C.L., 1996, Toxicological benchmarks for screening potential contaminants of concern for effects on aquatic biota-1996 revision: Oak Ridge, Tenn., Lockheed Martin Energy Systems Inc., ES/ER/ TM-96/R2, variously paged, accessed March 3, 2013, at http:/www.esd.ornl.gov/programs/ecorisk/documents/ tm96r2.pdf.

Talvivaara Mining Company plc, 2013, Operations-Mineral resources: Espoo, Finland, Talvivaara Mining Company plc, accessed April 9, 2013, at http://www.talvivaara.com/ operations/Mineral_resources.

Taylor, C.D., Causey, J.D., Denning, P.D., Hammarstrom, J.M., Hayes, T.S., Horton, J.D., Kirschbaum, M.J., Parks, H.L., Wilson, A.B., Wintzer, N.E., and Zientek, M.L., 2013, Descriptive models, grade-tonnage relations, and databases for the assessment of sediment-hosted copper depositsWith emphasis on deposits in the Central African Copperbelt, Democratic Republic of the Congo and Zambia: U.S. Geological Survey Scientific Investigations Report 2010-5090-J, 154 p. and data files. [Also available at http://pubs.usgs.gov/sir/2010/5090/j/sir2010-5090j_text.pdf.]

Taylor, S.R., and McLennan, S.M., 1995, The geochemical evolution of the continental crust: Reviews of Geophysics, v. 33, no. 2, p. 241-265. [Also available at http://dx.doi.org/ 10.1029/95rg00262.] 
Teck Resources Ltd., 2010, Mesaba Ni-Cu project—2010 IPS field trip: Vancouver, British Columbia, Canada, Teck Resources Ltd., June 7, accessed April 14, 2013, at http://www.d.umn.edu/prc/Pt\%20Symp\%20FT/Mesaba.pdf.]

The Coface Group, [undated], Congo, the Democratic Republic of the: Paris, France, The Coface Group, accessed March 11, 2013, at http://www.coface.com/CofacePortal/ COM_en_EN/pages/home/risks_home/country_risks/ country_file/Congo, the Democratic Republic of the? extraUid $=572108$.

Thorne, R.L., Roberts, Stephen, and Herrington, Richard, 2012, Climate change and the formation of nickel laterite deposits: Geology, v. 40, no. 4, p. 331-334. [Also available at http://dx.doi.org/10.1130/G32549.1.]

Tiger International Resources Inc., 2006, Sabah Tavai nickel project applied for by Tiger International: Laguna Hills, Calif., Tiger International Resources Inc. press release, April 3, 2 p., accessed April 12, 2013, at http:// www.tigerresources.com/newsrel/Apr3-06.pdf.]

Tintina Resources Inc., 2016, Black Butte copper project: Vancouver, British Columbia, Canada, Tintina Resources Inc., accessed March 30, 2016, at http://www.tintinaresources.com/ assets/docs/ppt/2016_tau_cp.pdf.

Tyler, Germund, 2004, Vertical distribution of major, minor, and rare elements in a Haplic Podzol: Geoderma, v. 119, nos. 3-4, p. 277-290. [Also available at http://dx.doi.org/ 10.1016/j.geoderma.2003.08.005.]

U.S. Environmental Protection Agency, 2012, Explanation of significant differences for the record of decision for the Blackbird Mine, Lemhi County, Idaho: U.S. Environmental Protection Agency, 16 p. plus 1 attachment, accessed March 26, 2013, at http://www.epa.gov/region10/pdf/sites/ blackbird_mine/blackbirdmine_ESD_053112.pdf.

U.S. Environmental Protection Agency, 2013, National ambient air quality standards (NAAQS) - Lead ( $\mathrm{Pb})$ standards-Table of historical Pb NAAQS: U.S. Environmental Protection Agency, accessed February 18, 2013, at http://www.epa.gov/ttn/naaqs/standards/pb/s_pb_history.html.

U.S. Environmental Protection Agency, 2016, National primary drinking water regulations: U.S. Environmental Protection Agency Web page, accessed May 3, 2016, at http://water.epa.gov/drink/contaminants/index.cfm.

U.S. Geological Survey, 2013, Cobalt statistics, in Kelly, T.D., and Matos, G.R., comps., Historical statistics for mineral and material commodities in the United States (2013 version): U.S. Geological Survey Data Series 140, accessed December 17, 2013, at http://pubs.usgs.gov/ds/2005/140/.

U.S. Nuclear Regulatory Commission, 2013a, Cobalt-57: U.S. Nuclear Regulatory Commission Web page, accessed March 27, 2013, at http://www.nrc.gov/reading-rm/ doc-collections/cfr/part020/appb/Cobalt-57.html.
U.S. Nuclear Regulatory Commission, 2013b, Cobalt-60: U.S. Nuclear Regulatory Commission Web page, accessed March 27, 2013, at http://www.nrc.gov/reading-rm/ doc-collections/cfr/part020/appb/Cobalt-60.html.

Valeton, I., Biermann, M., Reche, R., and Rosenberg, F., 1987, Genesis of nickel laterites and bauxites in Greece during the Jurassic and Cretaceous, and their relation to ultrabasic parent rocks: Ore Geology Reviews, v. 2, no. 4, p. 359-404. [Also available at http://dx.doi.org/10.1016/0169-1368(87)90011-4.]

Vangold Resources Ltd., 2013, Uganda - Gold, nickel, platinum, copper, and cobalt-Kilembe: Vancouver, British Columbia, Canada, Vangold Resources Ltd., accessed April 12, 2013, at http://www.vangold.ca/s/Kilembe.asp.]

Vanhanen, Erkki, 2001, Geology, mineralogy, and geochemistry of the $\mathrm{Fe}-\mathrm{Co}-\mathrm{Au}(-\mathrm{U})$ deposits in the Paleoproterozoic Kuusamo schist belt, northeastern Finland: Geological Survey of Finland Bulletin 399, 229 p.

Viers, Jérôme, Dupré, Bernard, and Gaillardet, Jérôme, 2009, Chemical composition of suspended sediments in world rivers-New insights from a new database: Science of the Total Environment, v. 407, no. 2, p. 853-868. [Also available at http://dx.doi.org/10.1016/j.scitotenv.2008.09.053.]

von der Heyden, C.J., and New, M.G., 2004, Groundwater pollution on the Zambian copperbelt-Deciphering the source and the risk: Science of the Total Environment, v. 327, nos. 1-3, p. 17-30. [Also available at http://dx.doi.org/ 10.1016/j.scitotenv.2003.08.028.]

Votorantim Group, 2006, Metals [reserves and resources]: São Paulo, Brazil, Votorantim Group, accessed April 22, 2013, via http://www.votorantim.com.br/en-US/Pages/home.aspx.]

Wang, S.-Q., and Williams, P.J., 2001, Geochemistry and origin of Proterozoic skarns at the Mount Elliott $\mathrm{Cu}-\mathrm{Au}(-\mathrm{Co}-\mathrm{Ni})$ deposit, Cloncurry district, NW Queensland, Australia: Mineralium Deposita, v. 36, no. 2, p. 109-124. [Also available at http://link.springer.com/ article/10.1007\%2Fs001260050292.]

Watling, H.R., Elliot, A.D., Fletcher, H.M., Robinson, D.J., and Sully, D.M., 2011, Ore mineralogy of nickel lateritesControls on processing characteristics under simulated heap-leach conditions: Australian Journal of Earth Sciences, v. 58, no. 7, p. 725-744. [Also available at http://dx.doi.org/ 10.1080/08120099.2011.602986.]

Wells, M.A., Ramanaidou, E.R., Verrall, Michael, and Tessarolo, Christian, 2009, Mineralogy and crystal chemistry of "garnierites" in the Goro lateritic nickel deposit, New Caledonia: European Journal of Mineralogy, v. 21, no. p. 467-483. [Also available at http://dx.doi.org/10.1127/ 0935-1221/2009/0021-1910.] 
Wilburn, D.R., 2012, Cobalt mineral exploration and supply from 1995 through 2013: U.S. Geological Survey Scientific Investigations Report 2011-5084, 16 p. [Also available at http://pubs.usgs.gov/sir/2011/5084/.]

Williams, P.J., and Pollard, P.J., 2001, Australian Proterozoic iron oxide-Cu-Au deposits-An overview with new metallogenic and exploration data from the Cloncurry district, northwest Queensland: Exploration and Mining Geology, v. 10, no. 3, p. 191-213. [Also available at http://dx.doi.org/ 10.2113/0100191.]

Williams, P.J., Barton, M.D., Johnson, D.A., Fontboté, Lluís, de Haller, Antoine, Mark, Geordie, Oliver, N.H.S., and Marschik, Robert, 2005, Iron oxide copper-gold depositsGeology, space-time distribution, and possible modes of origin, in Hedenquist, J.W., Thompson, J.F.H., Goldfarb, R.J., and Richards, J.P., eds., Economic Geology - One hundredth anniversary volume, 1905-2005: Littleton, Colo., Society of Economic Geologists, p. 371-405. [Appendixes are on a CD-ROM inside the back cover.]

Wilson, A.B., Causey, J.D., Denning, P.D., Hayes, T.S., Horton, J.D., Kirschbaum, M.J., Parks, H.L., Taylor, C.D., and Zientek, M.L., 2013, Appendix A-Relational database of sediment-hosted copper deposits, resources, and production in the Central African Copperbelt, Democratic Republic of the Congo and Zambia, in Taylor, C.D., Causey, J.D., Denning, P.D., Hammarstrom, J.M., Hayes, T.S., Horton, J.D., Kirschbaum, M.J., Parks, H.L., Wilson, A.B., Wintzer, N.E., and Zientek, M.L., Descriptive models, grade-tonnage relations, and databases for the assessment of sedimenthosted copper deposits - With emphasis on deposits in the Central African Copperbelt, Democratic Republic of the Congo and Zambia: U.S. Geological Survey Scientific Investigations Report 2010-5090-J, p. 103-144. [Also available at http://pubs.usgs.gov/sir/2010/5090/j/.]
Xstrata plc, 2011, Mineral resources \& ore reserves: Xstrata plc, accessed April 22, 2013, at http://www.xstrata.com/ publications/reservesandresources/.

Xu, Y.-B., Xie, Y.-T., Yan, Lan, and Yang, R.-D., 2005, A new method for recovering valuable metals from low-grade nickeliferous oxide ores: Hydrometallurgy, v. 80, no. 4, p. 280-285. [Also available at http://dx.doi.org/10.1016/ j.hydromet.2005.08.007.]

$\mathrm{Xu}$, Yong, and Zhu, Xinyou, 2000, Cobalt deposits in the central China orogenic belt: Acta Geologica Sinica, v. 74, no. 3, p. 540-543.

Zientek, M.L., Hayes, T.S., and Hammarstrom, J.M., 2013, Overview of a new descriptive model for sediment-hosted stratabound copper deposits, chap. 1 of Taylor, C.D., Causey, J.D., Denning, P.D., Hammarstrom, J.M., Hayes, T.S., Horton, J.D., Kirschbaum, M.J., Parks, H.L., Wilson, A.B., Wintzer, N.E., and Zientek, M.L., Descriptive models, grade-tonnage relations, and databases for the assessment of sediment-hosted copper deposits - With emphasis on deposits in the Central African Copperbelt, Democratic Republic of the Congo and Zambia: U.S. Geological Survey Scientific Investigations Report 2010-5090-J, p. 2-16. [Also available at http://pubs.usgs.gov/sir/2010/5090/j/.]

Zijin Mining Group Co. Ltd., 2010, Information of Deziwa and Ecaille C copper-cobalt projects: Longyan, Fujan, China, Zijin Mining Group Co. Ltd., accessed April 22, 2013, at www.zjky.cn/portals/1/1tn20100507861.pdf.

Zohny, E.A.M., 2002, Cobalt in alluvial Egyptian soils affected by industrial activities: Journal of Environmental Sciences (China), v. 14, no. 1, p. 34-38. 
Table F1 
Table F1. Location, grade, tonnage, and other data for selected cobalt deposits of the world.

[Tonnage and grade include reserves, other resources, and past production (where available). WGS 84, World Geodetic System of 1984; negative values for latitude indicate that the deposit is in the Southern Hemisphere; negative values for longitude indicate that the deposit is in the Western Hemisphere; Congo (Kinshasa), Democratic Republic of the Congo; EEZ, Exclusive Economic Zone; Mt, million metric tons; \%, percent. Element: Ag, silver; Au, gold; As, arsenic; Bi, bismuth; Co, cobalt; Cu, copper; Fe, iron; Mn, manganese; Mo, molybdenum; Ni, nickel; REE, rare-earth elements; Zn, zinc]

\begin{tabular}{|c|c|c|c|c|c|c|c|}
\hline \multirow[b]{2}{*}{ Deposit } & \multirow[b]{2}{*}{ Country } & Latitude & Longitude & \multirow[b]{2}{*}{$\begin{array}{c}\text { Tonnage } \\
\text { (Mt) }\end{array}$} & \multirow[b]{2}{*}{$\begin{array}{l}\text { Grade } \\
(\% \text { Co })\end{array}$} & \multirow{2}{*}{$\begin{array}{c}\text { Co } \\
\text { content } \\
\text { (Mt) }\end{array}$} & \multirow{2}{*}{$\begin{array}{l}\text { Principal data source } \\
\text { and notes }\end{array}$} \\
\hline & & \multicolumn{2}{|c|}{$\begin{array}{l}\text { (decimal degrees } \\
\text { WGS 84) }\end{array}$} & & & & \\
\hline \multicolumn{8}{|c|}{ Stratiform sediment-hosted Cu-Co deposits } \\
\hline Browns & Australia & -13.07 & 131.08 & 84.0 & 0.120 & 0.101 & Compass Resources NL (2007) \\
\hline Emmie Bluff & Australia & -31.10 & 137.17 & 25.0 & 0.100 & 0.025 & Hitzman and others (2005) \\
\hline Mount Gunson & Australia & -31.45 & 137.25 & 11.7 & 0.060 & 0.007 & Hitzman and others (2005) \\
\hline Mount Isa & Australia & -20.57 & 139.47 & 182.0 & 0.050 & 0.091 & Mount Isa Mines Ltd. (2012) \\
\hline Pyrite Hill-Big Hill & Australia & -32.12 & 141.20 & 20.8 & 0.085 & 0.018 & Broken Hill Prospecting Ltd. (2013) \\
\hline Windabout & Australia & -31.30 & 137.16 & 18.7 & 0.050 & 0.009 & Gunson Resources Ltd. (2013) \\
\hline Tangdan (Dongchuan) & China & 26.12 & 103.17 & 146.8 & 0.010 & 0.015 & Hitzman and others (2005) \\
\hline Deziwa & Congo (Kinshasa) & -10.78 & 25.77 & 319.4 & 0.120 & 0.383 & Zijin Mining Group Co. Ltd. (2010) \\
\hline Dilala East & Congo (Kinshasa) & -10.70 & 25.47 & 19.1 & 0.900 & 0.172 & Metorex Pty Ltd. (2011) \\
\hline DIMA & Congo (Kinshasa) & -10.74 & 25.38 & 280.0 & 0.189 & 0.530 & Wilson and others (2013) \\
\hline Disele & Congo (Kinshasa) & -10.75 & 26.25 & 4.1 & 0.068 & 0.003 & Wilson and others (2013) \\
\hline Écaille C & Congo (Kinshasa) & -10.76 & 26.12 & 21.8 & 0.060 & 0.013 & Zijin Mining Group Co. Ltd. (2010) \\
\hline Etoile (Ruashi) & Congo (Kinshasa) & -11.63 & 27.58 & 52.6 & 0.300 & 0.158 & Metorex Pty Ltd. (2011) \\
\hline Kababankola & Congo (Kinshasa) & -10.73 & 26.42 & 1.9 & 1.120 & 0.021 & Wilson and others (2013) \\
\hline Kabolela & Congo (Kinshasa) & -10.69 & 26.45 & 11.7 & 0.501 & 0.059 & Wilson and others (2013) \\
\hline Kakanda & Congo (Kinshasa) & -10.74 & 26.40 & 32.4 & 0.180 & 0.058 & Wilson and others (2013) \\
\hline Kalukundi-Kii & Congo (Kinshasa) & -10.62 & 25.91 & 12.8 & 0.457 & 0.058 & Wilson and others (2013) \\
\hline Kambove & Congo (Kinshasa) & -10.85 & 26.61 & 46.9 & 0.213 & 0.100 & Wilson and others (2013) \\
\hline Kamfundwa & Congo (Kinshasa) & -10.81 & 26.59 & 26.8 & 0.200 & 0.054 & Wilson and others (2013) \\
\hline $\begin{array}{l}\text { Kamoto-KOV- } \\
\text { Musonoi-Mupine }\end{array}$ & Congo (Kinshasa) & -10.72 & 25.40 & 416.0 & 0.387 & 1.608 & Wilson and others (2013) \\
\hline Kananga & Congo (Kinshasa) & -10.68 & 25.48 & 8.1 & 0.884 & 0.072 & Wilson and others (2013) \\
\hline Kazibizi & Congo (Kinshasa) & -10.83 & 26.57 & 1.0 & 0.600 & 0.006 & Wilson and others (2013) \\
\hline Kipapila & Congo (Kinshasa) & -12.02 & 27.90 & 2.6 & 0.540 & 0.014 & Wilson and others (2013) \\
\hline Kipoi Central & Congo (Kinshasa) & -11.26 & 27.10 & 4.6 & 0.143 & 0.007 & Wilson and others (2013) \\
\hline Kipoi North & Congo (Kinshasa) & -11.26 & 27.10 & 5.3 & 0.049 & 0.003 & Wilson and others (2013) \\
\hline Kisanfu & Congo (Kinshasa) & -10.77 & 25.98 & 108.0 & 1.080 & 1.166 & $\begin{array}{l}\text { Freeport-McMoRan Copper \& } \\
\quad \text { Gold Inc. (2013) }\end{array}$ \\
\hline Luishia & Congo (Kinshasa) & -11.17 & 27.01 & 72.3 & 0.152 & 0.110 & Wilson and others (2013) \\
\hline Luiswishi & Congo (Kinshasa) & -11.51 & 27.42 & 8.0 & 1.100 & 0.088 & Wilson and others (2013) \\
\hline Lupoto & Congo (Kinshasa) & -11.60 & 27.26 & 24.1 & 0.088 & 0.021 & Wilson and others (2013) \\
\hline M'Sesa & Congo (Kinshasa) & -10.85 & 26.58 & 8.0 & 0.213 & 0.017 & Wilson and others (2013) \\
\hline $\begin{array}{l}\text { Mukondo (includes } \\
\text { C19 and C21) }\end{array}$ & Congo (Kinshasa) & -10.73 & 26.35 & 70.0 & 0.714 & 0.500 & CAMEC Plc (2007) \\
\hline Mutanda & Congo (Kinshasa) & -10.79 & 25.81 & 299.5 & 0.59 & 1.767 & Glencore International plc (2011) \\
\hline Mutoshi & Congo (Kinshasa) & -10.65 & 25.51 & 10.8 & 0.304 & 0.033 & Wilson and others (2013) \\
\hline Tenke Fungurume ${ }^{1}$ & Congo (Kinshasa) & -10.58 & 26.19 & 674.0 & 0.245 & 1.651 & Nilsson and others (2011) \\
\hline Tilwezembe & Congo (Kinshasa) & -10.80 & 25.69 & 23.4 & 0.637 & 0.149 & Wilson and others (2013) \\
\hline
\end{tabular}


Table F1. Location, grade, tonnage, and other data for selected cobalt deposits of the world.—Continued

[Tonnage and grade include reserves, other resources, and past production (where available). WGS 84, World Geodetic System of 1984; negative values for latitude indicate that the deposit is in the Southern Hemisphere; negative values for longitude indicate that the deposit is in the Western Hemisphere; Congo (Kinshasa), Democratic Republic of the Congo; EEZ, Exclusive Economic Zone; Mt, million metric tons; \%, percent. Element: Ag, silver; Au, gold; As, arsenic; Bi, bismuth; Co, cobalt; $\mathrm{Cu}$, copper; Fe, iron; Mn, manganese; Mo, molybdenum; Ni, nickel; REE, rare-earth elements; Zn, zinc]

\begin{tabular}{|c|c|c|c|c|c|c|c|}
\hline \multirow[b]{2}{*}{ Deposit } & \multirow[b]{2}{*}{ Country } & Latitude & Longitude & \multirow{2}{*}{$\begin{array}{c}\text { Tonnage } \\
\text { (Mt) }\end{array}$} & \multirow{2}{*}{$\begin{array}{l}\text { Grade } \\
(\% \text { Co })\end{array}$} & \multirow{2}{*}{$\begin{array}{c}\text { Co } \\
\text { content } \\
\text { (Mt) }\end{array}$} & \multirow{2}{*}{$\begin{array}{l}\text { Principal data source } \\
\text { and notes }\end{array}$} \\
\hline & & \multicolumn{2}{|c|}{$\begin{array}{c}\text { (decimal degrees } \\
\text { WGS 84) }\end{array}$} & & & & \\
\hline \multicolumn{8}{|c|}{ Stratiform sediment-hosted Cu-Co deposits-Continued } \\
\hline Boleo & Mexico & 27.33 & -112.30 & 424.5 & 0.054 & 0.231 & Baja Mining Corp. (2011) \\
\hline Kilembe & Uganda & 0.22 & 30.05 & 16.2 & 0.170 & 0.028 & Vangold Resources Ltd. (2013) \\
\hline $\begin{array}{l}\text { Baluba-Muliashi- } \\
\text { Luanshya }\end{array}$ & Zambia & -13.50 & 28.38 & 339.0 & 0.033 & 0.111 & Wilson and others (2013) \\
\hline Chambishi Southeast & Zambia & -12.66 & 28.05 & 178.0 & 0.069 & 0.123 & Wilson and others (2013) \\
\hline $\begin{array}{l}\text { Chibuluma- } \\
\text { Chibuluma West }\end{array}$ & Zambia & -12.92 & 28.08 & 19.9 & 0.186 & 0.037 & Wilson and others (2013) \\
\hline Kalumbila & Zambia & -12.21 & 25.35 & 340.0 & 0.030 & 0.102 & Wilson and others (2013) \\
\hline Malundwe & Zambia & -12.16 & 25.75 & 162.0 & 0.014 & 0.023 & Wilson and others (2013) \\
\hline Mindola-Nkana N-S & Zambia & -12.80 & 28.18 & 656.0 & 0.065 & 0.429 & Wilson and others (2013) \\
\hline Nama & Zambia & -12.26 & 27.62 & 185.8 & 0.059 & 0.109 & Wilson and others (2013) \\
\hline \multicolumn{8}{|c|}{$\mathrm{Ni}$-Co laterite deposits } \\
\hline $\begin{array}{l}\text { Bell Creek-Neck- } \\
\text { Minnamoolka }\end{array}$ & Australia & -18.14 & 144.79 & 18.4 & 0.050 & 0.009 & Metallica Minerals Ltd. (2013) \\
\hline Cawse & Australia & -30.38 & 121.15 & 217.0 & 0.040 & 0.087 & Berger and others (2011) \\
\hline Claude Hills & Australia & -26.00 & 129.30 & 33.3 & 0.070 & 0.023 & Metals X Ltd. (2013) \\
\hline Ora Banda & Australia & -30.24 & 121.00 & 30.0 & 0.080 & 0.024 & Berger and others (2011) \\
\hline Ravensthorpe & Australia & -33.65 & 120.40 & 386.0 & 0.027 & 0.104 & Berger and others (2011) \\
\hline Summervale/Westlynn & Australia & -31.55 & 147.17 & 16.0 & 0.064 & 0.010 & Jervois Mining Ltd. (2013) \\
\hline Weld Range & Australia & -26.82 & 117.75 & 330.0 & 0.060 & 0.198 & Minara Resources Pty Ltd. (2005) \\
\hline Wingellina & Australia & -26.06 & 128.97 & 347.7 & 0.080 & 0.278 & Metals X Ltd. (2013) \\
\hline Yerilla & Australia & -29.73 & 122.04 & 135.4 & 0.052 & 0.070 & Heron Resources Ltd. (2013) \\
\hline Young & Australia & -35.77 & 148.82 & 167.0 & 0.070 & 0.117 & Jervois Mining Ltd. (2013) \\
\hline Jacaré & Brazil & -6.21 & -52.86 & 495.0 & 0.130 & 0.644 & Berger and others (2011) \\
\hline Niquelandia & Brazil & -14.35 & -48.40 & 56.3 & 0.060 & 0.034 & Berger and others (2011) \\
\hline Santa Fe & Brazil & -15.67 & -51.12 & 61.0 & 0.060 & 0.037 & Berger and others (2011) \\
\hline Serra do Tapa & Brazil & -6.85 & -49.33 & 60.3 & 0.050 & 0.030 & Berger and others (2011) \\
\hline Vale dos Sonhos & Brazil & -6.97 & -49.26 & 13.0 & 0.070 & 0.009 & Berger and others (2011) \\
\hline
\end{tabular}


Table F1. Location, grade, tonnage, and other data for selected cobalt deposits of the world._Continued

[Tonnage and grade include reserves, other resources, and past production (where available). WGS 84, World Geodetic System of 1984; negative values for latitude indicate that the deposit is in the Southern Hemisphere; negative values for longitude indicate that the deposit is in the Western Hemisphere; Congo (Kinshasa), Democratic Republic of the Congo; EEZ, Exclusive Economic Zone; Mt, million metric tons; \%, percent. Element: Ag, silver; Au, gold; As, arsenic; Bi, bismuth; $\mathrm{Co}$, cobalt; $\mathrm{Cu}$, copper; Fe, iron; Mn, manganese; Mo, molybdenum; Ni, nickel; REE, rare-earth elements; $\mathrm{Zn}$, zinc]

\begin{tabular}{|c|c|c|c|c|c|c|c|}
\hline Deposit & Country & $\begin{array}{r}\text { Latitude } \\
\text { (decima } \\
\text { WG }\end{array}$ & $\begin{array}{l}\text { Longitude } \\
\text { degrees } \\
84)\end{array}$ & $\begin{array}{l}\text { Tonnage } \\
\text { (Mt) }\end{array}$ & $\begin{array}{l}\text { Grade } \\
(\% \text { Co })\end{array}$ & $\begin{array}{c}\text { Co } \\
\text { content } \\
\text { (Mt) }\end{array}$ & $\begin{array}{c}\text { Principal data source } \\
\text { and notes }\end{array}$ \\
\hline \multicolumn{8}{|c|}{ Ni-Co laterite deposits-Continued } \\
\hline Vermelho & Brazil & -6.24 & -49.75 & 290.0 & 0.026 & 0.075 & Berger and others (2011) \\
\hline Vila Oito & Brazil & -7.79 & -49.35 & 12.9 & 0.065 & 0.008 & Berger and others (2011) \\
\hline Waga & Burundi & -3.56 & 29.91 & 35.0 & 0.040 & 0.014 & Berger and others (2011) \\
\hline $\begin{array}{l}\text { Nkamouna (includes } \\
\text { Mada) }\end{array}$ & Cameroon & 3.27 & 13.81 & 391.5 & 0.220 & 0.860 & Geovic Mining Corp. (2013) \\
\hline Moa & Cuba & 20.60 & -74.96 & 290.0 & 0.180 & 0.522 & Berger and others (2011) \\
\hline Sechol & Guatemala & 15.43 & -89.66 & 36.1 & 0.080 & 0.029 & Berger and others (2011) \\
\hline Bhimatangar & India & 21.01 & 85.74 & 63.9 & 0.150 & 0.096 & Berger and others (2011) \\
\hline Kansa & India & 21.06 & 85.86 & 40.9 & 0.080 & 0.033 & Berger and others (2011) \\
\hline Saruabil & India & 21.06 & 85.82 & 18.4 & 0.080 & 0.015 & Berger and others (2011) \\
\hline Gag Island & Indonesia & -0.45 & 129.88 & 240.0 & 0.080 & 0.192 & Berger and others (2011) \\
\hline Halmahera/Weda Bay & Indonesia & -0.50 & 127.94 & 277.0 & 0.090 & 0.249 & Berger and others (2011) \\
\hline La Sampala & Indonesia & -2.70 & 121.93 & 162.0 & 0.080 & 0.130 & Berger and others (2011) \\
\hline Tiuba-Biankouma & Ivory Coast & 7.74 & -7.62 & 293.0 & 0.110 & 0.322 & Berger and others (2011) \\
\hline Gornostai & Kazakhstan & 50.61 & 78.76 & 9.7 & 0.059 & 0.006 & Berger and others (2011) \\
\hline Kempirsai & Kazakhstan & 50.34 & 58.28 & 179.7 & 0.054 & 0.097 & Berger and others (2011) \\
\hline Tavai & Malaysia & 5.58 & 117.33 & 270.0 & 0.070 & 0.189 & $\begin{array}{l}\text { Tiger International } \\
\text { Resources Inc. (2006) }\end{array}$ \\
\hline Goro & New Caledonia & -22.31 & 166.93 & 323.0 & 0.110 & 0.355 & Berger and others (2011) \\
\hline Kouaoua & New Caledonia & -21.42 & 165.74 & 30.0 & 0.080 & 0.024 & Berger and others (2011) \\
\hline Nakety & New Caledonia & -21.51 & 166.05 & 229.0 & 0.120 & 0.275 & Berger and others (2011) \\
\hline Nepoui & New Caledonia & -21.22 & 165.04 & 16.0 & 0.080 & 0.013 & Berger and others (2011) \\
\hline Thio & New Caledonia & -21.62 & 166.18 & 208.0 & 0.100 & 0.208 & Berger and others (2011) \\
\hline Tiébaghi & New Caledonia & -20.45 & 164.22 & 39.2 & 0.090 & 0.035 & Berger and others (2011) \\
\hline Mambare & $\begin{array}{l}\text { Papua New } \\
\text { Guinea }\end{array}$ & -9.00 & 147.70 & 162.5 & 0.090 & 0.146 & Direct Nickel Pty Ltd. (2013) \\
\hline Ramu & $\begin{array}{l}\text { Papua New } \\
\text { Guinea }\end{array}$ & -5.53 & 145.19 & 143.2 & 0.100 & 0.143 & Berger and others (2011) \\
\hline Wowo Gap & $\begin{array}{c}\text { Papua New } \\
\text { Guinea }\end{array}$ & -9.68 & 148.96 & 190.0 & 0.060 & 0.114 & Berger and others (2011) \\
\hline
\end{tabular}


Table F1. Location, grade, tonnage, and other data for selected cobalt deposits of the world.—Continued

[Tonnage and grade include reserves, other resources, and past production (where available). WGS 84, World Geodetic System of 1984; negative values for latitude indicate that the deposit is in the Southern Hemisphere; negative values for longitude indicate that the deposit is in the Western Hemisphere; Congo (Kinshasa), Democratic Republic of the Congo; EEZ, Exclusive Economic Zone; Mt, million metric tons; \%, percent. Element: Ag, silver; Au, gold; As, arsenic; Bi, bismuth; Co, cobalt; $\mathrm{Cu}$, copper; Fe, iron; Mn, manganese; Mo, molybdenum; Ni, nickel; REE, rare-earth elements; Zn, zinc]

\begin{tabular}{|c|c|c|c|c|c|c|c|}
\hline \multirow[b]{2}{*}{ Deposit } & \multirow[b]{2}{*}{ Country } & Latitude & Longitude & \multirow[b]{2}{*}{$\begin{array}{c}\text { Tonnage } \\
\text { (Mt) }\end{array}$} & \multirow[b]{2}{*}{$\begin{array}{l}\text { Grade } \\
(\% \text { Co })\end{array}$} & \multirow{2}{*}{$\begin{array}{c}\text { Co } \\
\text { content } \\
\text { (Mt) }\end{array}$} & \multirow[b]{2}{*}{$\begin{array}{l}\text { Principal data source } \\
\text { and notes }\end{array}$} \\
\hline & & \multicolumn{2}{|c|}{$\begin{array}{c}\text { (decimal degrees } \\
\text { WGS 84) }\end{array}$} & & & & \\
\hline Acoje/Zambales & Philippines & 15.72 & 120.04 & 72.3 & 0.070 & 0.051 & Berger and others (2011) \\
\hline $\begin{array}{l}\text { Agata/Bolobolo/ } \\
\text { Karihatag }\end{array}$ & Philippines & 9.28 & 125.52 & 35.0 & 0.060 & 0.021 & Gifford and others (2011) \\
\hline Cagdianao & Philippines & 9.92 & 125.67 & 8.0 & 0.140 & 0.011 & Berger and others (2011) \\
\hline Ipilan & Philippines & 8.97 & 117.98 & 77.0 & 0.100 & 0.077 & Berger and others (2011) \\
\hline Mindoro & Philippines & 12.94 & 121.07 & 315.0 & 0.060 & 0.189 & Berger and others (2011) \\
\hline Nonoc & Philippines & 9.84 & 125.62 & 144.7 & 0.110 & 0.159 & Berger and others (2011) \\
\hline Guanajibo & Puerto Rico ${ }^{3}$ & 18.13 & -67.16 & 44.4 & 0.080 & 0.036 & Berger and others (2011) \\
\hline Las Mesas & Puerto Rico ${ }^{3}$ & 18.19 & -67.10 & 22.7 & 0.120 & 0.027 & Berger and others (2011) \\
\hline Akkermanov & Russia & 51.21 & 58.23 & 40.0 & 0.010 & 0.004 & Berger and others (2011) \\
\hline Buruktal & Russia & 50.85 & 60.83 & 79.0 & 0.100 & 0.079 & Berger and others (2011) \\
\hline Cheremshanskoe & Russia & 56.12 & 60.30 & 45.0 & 0.024 & 0.011 & Berger and others (2011) \\
\hline Lipovskoe & Russia & 57.43 & 61.11 & 46.0 & 0.057 & 0.026 & Berger and others (2011) \\
\hline Rogozhinskoe & Russia & 56.17 & 60.26 & 2.5 & 0.060 & 0.002 & Berger and others (2011) \\
\hline Serovskoe & Russia & 59.71 & 60.56 & 52.8 & 0.043 & 0.023 & Berger and others (2011) \\
\hline Kambalda & Australia & -31.64 & 121.65 & 67.0 & 0.207 & 0.139 & Naldrett (2004) \\
\hline Mt. Keith & Australia & -27.71 & 120.53 & 478.0 & 0.014 & 0.067 & Naldrett (2004) \\
\hline $\begin{array}{l}\text { Savannah (Sally } \\
\text { Malay) }\end{array}$ & Australia & -17.35 & 128.02 & 8.1 & 0.073 & 0.006 & Panoramic Resources Ltd. (2012) \\
\hline $\begin{array}{l}\text { Americano do Brasil } \\
\text { (Salgado) }\end{array}$ & Brazil & -16.10 & -50.08 & 7.9 & 0.040 & 0.003 & Votorantim Group (2006) \\
\hline Fortaleza de Minas & Brazil & -21.00 & -48.50 & 10.3 & 0.200 & 0.021 & Votorantim Group (2006) \\
\hline Santa Rita & Brazil & -14.19 & -39.73 & 159.3 & 0.015 & 0.024 & Mirabela Nickel Ltd. (2012) \\
\hline Dumont & Canada & 48.65 & -78.44 & $2,134.2$ & 0.011 & 0.226 & Staples and others (2012) \\
\hline Ferguson Lake & Canada & 62.92 & -96.97 & 44.2 & 0.080 & 0.035 & Starfield Resources Inc. (2013) \\
\hline Makwa (Maskwa) & Canada & 50.47 & -95.43 & 19.1 & 0.010 & 0.002 & Mustang Minerals Corp. (2013) \\
\hline
\end{tabular}


Table F1. Location, grade, tonnage, and other data for selected cobalt deposits of the world.-Continued

[Tonnage and grade include reserves, other resources, and past production (where available). WGS 84, World Geodetic System of 1984; negative values for latitude indicate that the deposit is in the Southern Hemisphere; negative values for longitude indicate that the deposit is in the Western Hemisphere; Congo (Kinshasa), Democratic Republic of the Congo; EEZ, Exclusive Economic Zone; Mt, million metric tons; \%, percent. Element: Ag, silver; Au, gold; As, arsenic; Bi, bismuth; $\mathrm{Co}$, cobalt; $\mathrm{Cu}$, copper; Fe, iron; Mn, manganese; Mo, molybdenum; Ni, nickel; REE, rare-earth elements; $\mathrm{Zn}$, zinc]

\begin{tabular}{|c|c|c|c|c|c|c|c|}
\hline \multirow[b]{2}{*}{ Deposit } & \multirow[b]{2}{*}{ Country } & Latitude & Longitude & \multirow{2}{*}{$\begin{array}{c}\text { Tonnage } \\
\text { (Mt) }\end{array}$} & \multirow{2}{*}{$\begin{array}{l}\text { Grade } \\
(\% \mathrm{Co})\end{array}$} & \multirow{2}{*}{$\begin{array}{c}\text { Co } \\
\text { content } \\
\text { (Mt) }\end{array}$} & \multirow{2}{*}{$\begin{array}{l}\text { Principal data source } \\
\text { and notes }\end{array}$} \\
\hline & & \multicolumn{2}{|c|}{$\begin{array}{l}\text { (decimal degrees } \\
\text { WGS 84) }\end{array}$} & & & & \\
\hline $\begin{array}{l}\text { Nunavik (includes } \\
\text { Mesamax) }\end{array}$ & Canada & 61.57 & -73.26 & 27.1 & 0.048 & 0.013 & $\begin{array}{l}\text { Armstrong, Puritch, and Yassa } \\
\quad(2010)\end{array}$ \\
\hline Raglan & Canada & 61.59 & -74.29 & 44.0 & 0.060 & 0.026 & Xstrata plc (2011) \\
\hline Sudbury & Canada & 46.63 & -81.38 & 2,648 & 0.038 & 1.006 & Naldrett (2004) \\
\hline Thompson & Canada & 53.76 & -98.81 & 150.0 & 0.046 & 0.069 & Naldrett (2004) \\
\hline Turnagain & Canada & 58.48 & -128.83 & 763.0 & 0.013 & 0.102 & Hard Creek Nickel Corp. (2013) \\
\hline Voisey’s Bay & Canada & 45.50 & -73.57 & 137.0 & 0.090 & 0.123 & Naldrett (2004) \\
\hline Hitura & Finland & 63.84 & 25.05 & 19.4 & 0.020 & 0.004 & Eilu (2012) \\
\hline Kevitsa & Finland & 67.70 & 29.97 & 435.4 & 0.015 & 0.064 & First Quantum Minerals Ltd. (2011) \\
\hline Kotalahti & Finland & 62.52 & 27.68 & 12.4 & 0.030 & 0.004 & Eilu (2012) \\
\hline Laukunkangas & Finland & 62.05 & 28.77 & 7.9 & 0.030 & 0.002 & Eilu (2012) \\
\hline Stormi & Finland & 61.33 & 24.90 & 9.0 & 0.040 & 0.004 & Eilu (2012) \\
\hline Bruvann (Råna) & Norway & 68.33 & 16.94 & 43.0 & 0.010 & 0.004 & Eilu (2012) \\
\hline Ertelien & Norway & 60.07 & 10.05 & 3.1 & 0.074 & 0.002 & Eilu (2012) \\
\hline Flåt & Norway & 58.60 & 7.87 & 3.2 & 0.075 & 0.002 & Eilu (2012) \\
\hline $\begin{array}{l}\text { Stormyra (including } \\
\text { Dalen) }\end{array}$ & Norway & 61.34 & 9.66 & 11.1 & 0.022 & 0.002 & Eilu (2012) \\
\hline Aguablanca & Spain & 37.85 & -6.18 & 6.0 & 0.600 & 0.036 & Lundin Mining Corp. (2012) \\
\hline Kabanga & Tanzania & -2.87 & 30.58 & 58.2 & 0.198 & 0.115 & Xstrata plc (2011) \\
\hline Eagle & United States & 46.75 & -87.90 & 5.2 & 0.080 & 0.004 & Owen and Meyer (2013) \\
\hline $\begin{array}{l}\text { Mesaba (Babbitt/ } \\
\text { Minnamax) }\end{array}$ & United States & 47.63 & -91.88 & $1,106.5$ & 0.008 & 0.089 & Teck Resources Ltd. (2010) \\
\hline Northmet & United States & 47.60 & -91.97 & 923.9 & 0.010 & 0.092 & Polymet Mining Corp. (2013) \\
\hline $\begin{array}{l}\text { Twin Metals } \\
\qquad \text { (Nokomis) }^{4}\end{array}$ & United States & 47.80 & -91.76 & $2,425.9$ & 0.012 & 0.291 & Duluth Metals Ltd. (2012) \\
\hline Munali & Zambia & -16.00 & 28.00 & 27.7 & 0.069 & 0.019 & Albidon Ltd. (2007) \\
\hline \multicolumn{8}{|c|}{ Black-shale-hosted Ni-Cu-Zn-Co deposits } \\
\hline Talvivaara & Finland & 63.98 & 28.17 & 2,053 & 0.020 & 0.411 & $\begin{array}{l}\text { Talvivaara Mining Company Plc } \\
\text { (2013) }\end{array}$ \\
\hline
\end{tabular}


Table F1. Location, grade, tonnage, and other data for selected cobalt deposits of the world.—Continued

[Tonnage and grade include reserves, other resources, and past production (where available). WGS 84, World Geodetic System of 1984; negative values for latitude indicate that the deposit is in the Southern Hemisphere; negative values for longitude indicate that the deposit is in the Western Hemisphere; Congo (Kinshasa), Democratic Republic of the Congo; EEZ, Exclusive Economic Zone; Mt, million metric tons; \%, percent. Element: Ag, silver; Au, gold; As, arsenic; Bi, bismuth; Co, cobalt; $\mathrm{Cu}$, copper; Fe, iron; Mn, manganese; Mo, molybdenum; Ni, nickel; REE, rare-earth elements; Zn, zinc]

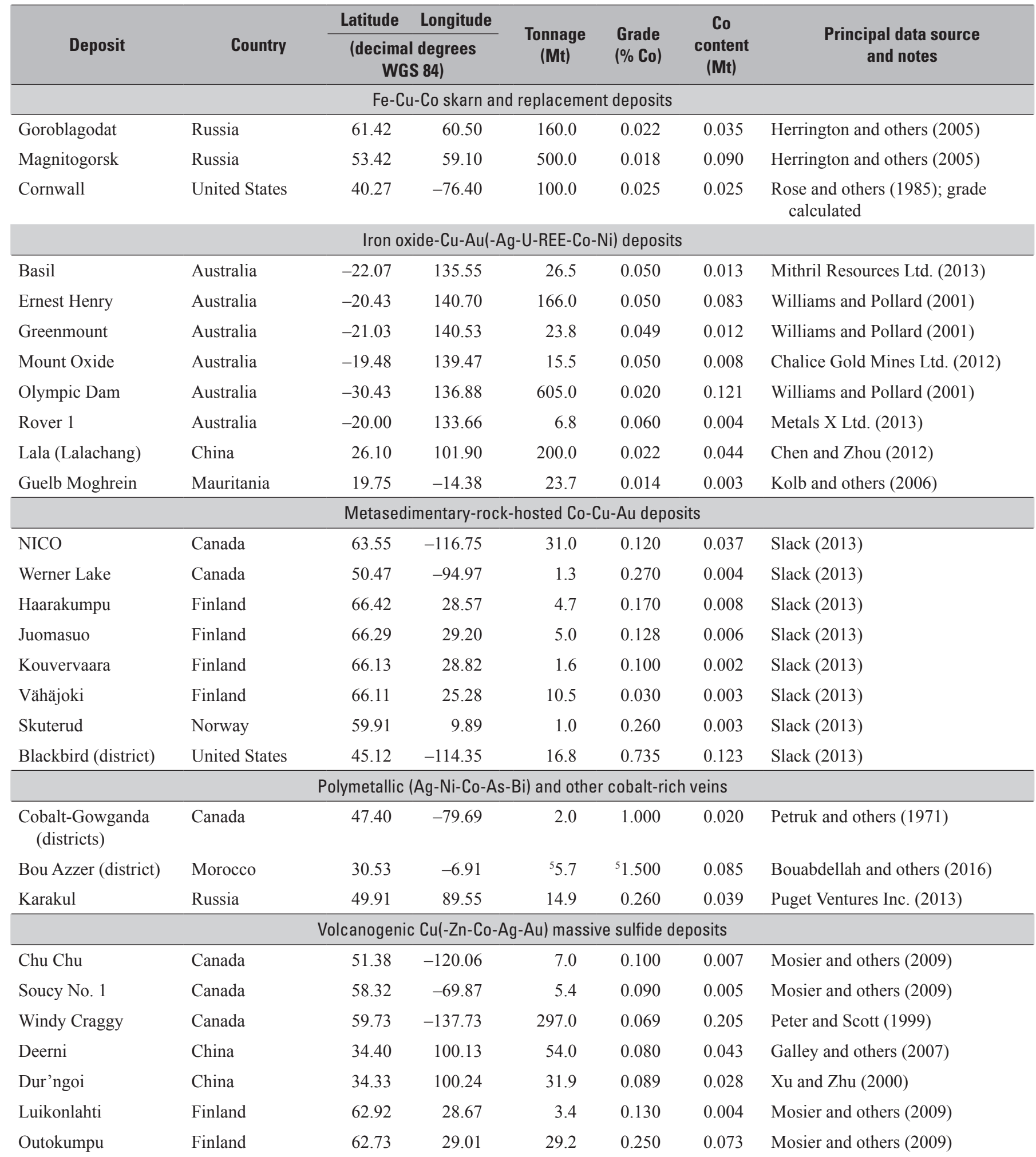


Table F1. Location, grade, tonnage, and other data for selected cobalt deposits of the world._Continued

[Tonnage and grade include reserves, other resources, and past production (where available). WGS 84, World Geodetic System of 1984; negative values for latitude indicate that the deposit is in the Southern Hemisphere; negative values for longitude indicate that the deposit is in the Western Hemisphere; Congo (Kinshasa), Democratic Republic of the Congo; EEZ, Exclusive Economic Zone; Mt, million metric tons; \%, percent. Element: Ag, silver; Au, gold; As, arsenic; Bi, bismuth; Co, cobalt; Cu, copper; Fe, iron; Mn, manganese; Mo, molybdenum; Ni, nickel; REE, rare-earth elements; Zn, zinc]

\begin{tabular}{|c|c|c|c|c|c|c|c|}
\hline \multirow[b]{2}{*}{ Deposit } & \multirow[b]{2}{*}{ Country } & Latitude & Longitude & \multirow{2}{*}{$\begin{array}{c}\text { Tonnage } \\
\text { (Mt) }\end{array}$} & \multirow{2}{*}{$\begin{array}{l}\text { Grade } \\
(\% \text { Co })\end{array}$} & \multirow{2}{*}{$\begin{array}{c}\text { Co } \\
\text { content } \\
\text { (Mt) }\end{array}$} & \multirow{2}{*}{$\begin{array}{l}\text { Principal data source } \\
\text { and notes }\end{array}$} \\
\hline & & \multicolumn{2}{|c|}{$\begin{array}{c}\text { (decimal degrees } \\
\text { WGS 84) }\end{array}$} & & & & \\
\hline $\begin{array}{l}\text { Outokumpu } \\
\text { (Kylylahti) }\end{array}$ & Finland & 62.72 & 29.00 & 7.8 & 0.240 & 0.019 & Altona Mining Ltd. (2013) \\
\hline $\begin{array}{l}\text { Outokumpu } \\
\text { (Saramäki) }\end{array}$ & Finland & 62.94 & 29.13 & 3.4 & 0.090 & 0.003 & Eilu (2012) \\
\hline Outokumpu (Vuonos) & Finland & 62.76 & 29.09 & 5.9 & 0.150 & 0.009 & Eilu (2012) \\
\hline $\begin{array}{l}\text { Gaiskoye (Gai and } \\
\text { Gai East) }\end{array}$ & Russia & 51.46 & 58.49 & 300.0 & 0.020 & 0.060 & Prokin and Buslaev (1999) \\
\hline Letneye & Russia & 51.06 & 59.37 & 10.0 & 0.090 & 0.009 & Prokin and Buslaev (1999) \\
\hline Sibaiskoye & Russia & 52.70 & 58.63 & 100.0 & 0.130 & 0.130 & Prokin and Buslaev (1999) \\
\hline Kure (Asikoy) & Turkey & 41.81 & 33.69 & 13.6 & 0.300 & 0.041 & Mosier and others (2009) \\
\hline Turner Albright & United States & 42.00 & -123.76 & 4.0 & 0.050 & 0.002 & Mosier and others (2009) \\
\hline \multicolumn{8}{|c|}{ Sea-floor Fe-Mn(-Ni-Cu-Co-Mo) nodules } \\
\hline Pioneer & Indian Ocean & -14.00 & 74.00 & 700.0 & 0.100 & 0.700 & Banakar (2010) \\
\hline $\begin{array}{l}\text { Clarion-Clipperton } \\
\text { zone }\end{array}$ & Pacific Ocean & 10.00 & -140.00 & $21,100.0$ & 0.209 & 44.00 & Hein and others (2013) \\
\hline $\begin{array}{l}\text { Pacific prime } \\
\text { crust zone }\end{array}$ & Pacific Ocean & 15.00 & 160.00 & $7,533.0$ & 0.664 & 50.00 & Hein and others (2013) \\
\hline
\end{tabular}

${ }^{1}$ Data for Tenke Fungurume include results for 7 deposits: Fwaulu, Fungurume, Kansalawile, Kwatebala, Mambilima, Mwadinkomba, and Tenke.

${ }^{2}$ Data for Kalgoorlie Nickel include results for 10 deposits: Big Four, Black Range, Bulong, Ghost Rocks, Goongarrie Hill, Goongarrie South, Highway, Kalpini, Siberia, and Siberia North.

${ }^{3}$ Territory of the United States.

${ }^{4}$ Cobalt data from D.M. Peterson, Duluth Metals Ltd., written commun. to J.F. Slack, March 25, 2013.

${ }^{5}$ Size and grade estimated. 


\section{Fluorine}

By Timothy S. Hayes, M. Michael Miller, Greta J. Orris, and Nadine M. Piatak

Chapter G of

Critical Mineral Resources of the United States-Economic and Environmental Geology and Prospects for Future Supply

Edited by Klaus J. Schulz, John H. DeYoung, Jr., Robert R. Seal II, and Dwight C. Bradley

Professional Paper 1802-G

U.S. Department of the Interior

U.S. Geological Survey 


\section{Contents of Chapter G}

[Figure and table titles for all chapters are listed in the volume contents before the conversion factors table and list of abbreviations and symbols. A periodic table of the elements is on the inside front cover of the printed volume]

Abstract
Introduction Ases, Applications, and Consumption
Geology
Geochemistry.
Fluorine in Rocks.

Suggested citation:

Hayes, T.S., Miller, M.M., Orris, G.J., and Piatak, N.M., 2017, Fluorine, chap. G of Schulz, K.J., DeYoung, J.H., Jr., Seal, R.R., II, and Bradley, D.C., eds., Critical mineral resources of the United States-Economic and environmental geology and prospects for future supply: U.S. Geological Survey Professional Paper 1802, p. G1-G80, http://dx.doi.org/ 10.3133/pp1802G. 


\title{
Fluorine
}

\author{
By Timothy S. Hayes, M. Michael Miller, Greta J. Orris, and Nadine M. Piatak
}

\section{Abstract}

Fluorine compounds are essential in numerous chemical and manufacturing processes. Fluorspar is the commercial name for fluorite (isometric $\mathrm{CaF}_{2}$ ), which is the only fluorine mineral that is mined on a large scale. Fluorspar is used directly as a fluxing material and as an additive in different manufacturing processes. It is the source of fluorine in the production of hydrogen fluoride or hydrofluoric acid, which is used as the feedstock for numerous organic and inorganic chemical compounds.

The United States was the world's leading producer of fluorspar until the mid-1950s. In the mid-1970s, the U.S. fluorspar mining industry began to decline because of foreign competition. By 1982, there was essentially only a single U.S. producer left, and that company ceased mining in 1996. Consumption of fluorspar in the United States peaked in the early 1970s, which was also the peak period of U.S. steel production. Since then, U.S. fluorspar consumption has decreased substantially; the United States has nonetheless increased its imports of downstream fluorine compounds, such as, in order of tonnage imported, hydrofluoric acid, aluminum fluoride, and cryolite. This combination of no U.S. production (until recently) and high levels of consumption has made the United States the world's leading fluorspar-importing country, in all its various forms.

The number of fluorspar-exporting countries has decreased substantially in recent decades, and, as a result, the United States has become dependent on just a few countries to supply its needs. In 2013, the United States imported the majority of its fluorspar from three countries, which were, in descending order of the amount imported, Mexico, China, and South Africa.

Geologically, in igneous systems, fluorine is one of a number of elements that are "incompatible." These incompatible elements become concentrated in the residual magma while the common silicates crystallize upon magma ascent and cooling, leading to relatively high fluorine concentrations in the more evolved or differentiated igneous rocks and in hydrothermal deposits associated with those evolved igneous rocks. In sedimentary rocks, fluorine's highest concentrations are found in phosphorites because fluorine substitutes for hydroxyl ions in apatite, which leads to fluorine concentrations of, typically, from 2 to 4 weight percent in phosphorites. Because of the presence of fluorine, phosphate fertilizer manufacturers can produce a fluorosilicic acid byproduct. Most deposits mined for fluorine are hydrothermal, however, and consist of fluorine minerals that precipitated from hot water. Magmatic brines and brines from deep within sedimentary basins that have high concentrations of dissolved fluoride are the mineralizing fluids for various types of hydrothermal fluorspar deposits. Relatively dilute hydrothermal fluids that formed in some volcanic rocks can also transport sufficient fluoride to form a high-grade fluorspar deposit. Fluorite has low solubility in a common range of hydrothermal temperatures, particularly from about 160 degrees Celsius $\left({ }^{\circ} \mathrm{C}\right)$ down to $60^{\circ} \mathrm{C}$. The increasing fluorite solubility below $60^{\circ} \mathrm{C}$ partly explains why some water with exceptionally high levels of dissolved fluorine are found even at ambient temperatures in evaporitic lake basins in some East African Rift valleys in Kenya and Tanzania. The geologic conditions that led to the high concentrations there are known to exist in a number of other places in the world as well, including, perhaps, places in the Basin and Range province of the United States.

Eight minerals or mineral groups have sufficient fluorine in their structures to be considered as possible ores of the element; they are bastnaesite (also spelled bastnäsite) and other fluorocarbonates, cryolite, sellaite, villiaumite, fluorite, fluorapatite (in phosphorites), various phyllosilicates, and topaz. Fluorite is currently the only mineral that is mined for fluorine, and no mineral except fluorite is likely to become a source of commercially produced fluorine as a primary product as long as supplies from relatively thick and highgrade fluorite deposits continue to be available.

At least seven classes (which include one subclass) of hydrothermal fluorite deposits are recognized; they are classified according to their tectonic and (or) magmatic settings, as follows: (1) carbonatite-related fluorspar deposits; (2) alkaline-intrusion-related fluorspar deposits; (3) alkaline-volcanic-related epithermal fluorspar deposits; (4) Mississippi Valley-type fluorspar deposits (and a subclass of salt-related carbonate-hosted fluorspar deposits); (5) fluorspar deposits related to strongly differentiated granites; 
(6) subalkaline-volcanic-related epithermal fluorspar deposits; and (7) fluorspar deposits that appear to be conformable within tuffaceous limy lacustrine sediments. An eighth class (not hydrothermal) is that of fluorspar deposits concentrated in soils and weathered zones; that is, residual fluorspar deposits. Generally, fluorspar deposits related to strongly differentiated granites have larger tonnages and lower grades than carbonatite-related fluorspar deposits, which, in turn, have larger tonnages and lower grades than fluorspar vein deposits from various other classes.

The United States has a few identified resources of fluorspar, most notably the Klondike II property in the IllinoisKentucky fluorspar district located about 8 kilometers southwest of Salem, Kentucky, which has a large vein that contains at least 1.6 million metric tons at a grade of 60 percent $\mathrm{CaF}_{2}$ (Feytis, 2009). Additional fluorspar resources of lower grade but larger tonnage have been identified at Hicks Dome in the Illinois-Kentucky fluorspar district and at Lost River near the western tip of the Seward Peninsula in Alaska, along with a couple of dozen smaller, higher grade resources.

Internationally, new mines that either opened before the beginning of 2013 or were scheduled to open soon after that time include the Nui Phao tungsten-fluorspar-bismuthcopper-gold deposit in northern Vietnam; the St. Lawrence project in Newfoundland, Canada, which is located in a well-known fluorspar district; the Bamianshan deposit, which is related to a strongly differentiated granite in northwestern Zhejiang Province, China, near some of that Province's large, subalkaline-volcanic-related epithermal veins; and the Nokeng project in South Africa, which is also related to a strongly differentiated granite. Other deposits in northwestern Australia, Nevada (United States), Norway, South Africa, and Sweden have been identified and could be put into production within just a few years.

Among undiscovered resources, an interesting possibility might be to produce a fluorine product from evaporitic, highfluorine, high-pH sodium-carbonate brines like Lake Magadi (Kenya) and Lake Natron (Tanzania) in Africa's Eastern Rift Valley. In addition, apparently conformable fluorspar deposits in tuffaceous limy lacustrine sediments, such as those in Italy, are likely to occur in similar young alkalic volcanic settings elsewhere in the world.

Modern geophysical and geochemical exploration techniques have typically not been brought to bear in exploration for new fluorspar deposits, although such techniques are likely to be used in future exploration. The tendency for fluorine to dissolve in significant concentrations in water at low temperature allows both surface water and groundwater to be used as sampling media in geochemical exploration. Evolved-graniterelated fluorspar deposits may be particularly susceptible to geophysical exploration methods because crystalline rocks that form a basement to sedimentary sections can be approximately defined with gravity and magnetic methods, and magnetitebearing skarns can be directly detected with magnetic surveys.
Environmental considerations of fluorine mining focus especially on drinking water, where high fluorine concentrations can lead to tooth decay; dental and skeletal fluorosis; and bone and cartilage conditions, including genu valgum, which is the crippling bone deformity more commonly known as knock knee. Trace amounts of other elements in fluorspar ores are a concern at some deposits; for example, high beryllium concentrations in alkaline-volcanic-related epithermal deposits or high cadmium concentrations associated with Mississippi Valley-type and salt-related carbonate-hosted fluorspar deposits.

Future research might include testing whether fluorine can be extracted economically from high-pH, sodiumcarbonate brines and exploring for new occurrences of apparently conformable fluorspar deposits in tuffaceous limy lacustrine sediments outside of the Latium Region of Italy. Other promising new areas of research could be studies of fluorspar deposit fluid inclusion compositions by quadrupole mass spectrometry, by noble gas mass spectrometry on irradiated fluid inclusions, or by chlorine isotopes, while also measuring the chemistry of the same fluid inclusions either by bulk crush-and-leach methods or by laser ablation-inductively coupled plasma mass spectrometry. Advanced studies of fluid inclusion chemistry could be applied beneficially to some of the enigmatic large epithermal fluorspar veins at various places in the world, where they might determine those deposits' possible relationships to igneous intrusions, or to dissolved salt, or to heated meteoric water in volcanic sections, or perhaps to all three. This knowledge could help focus new exploration.

\section{Introduction}

Fluorine is an essential element for a number of industries, including aluminum production, steelmaking, gasoline refining, glass manufacturing, and the production of enamels, insulating foams, refrigerants, and uranium for nuclear power. The United States, which is the world's second-ranked consumer of fluorine products (Miller, 2012), obtains most of its supply through imports from Mexico. China is the world's leading fluorspar producer. It produced more than 60 percent of the world's output in 2012 (Miller, 2013). Fluorspar, which is the commercial name for fluorite (isometric $\mathrm{CaF}_{2}$ ) (fig. G1), is the only mineral that is mined at large scale for fluorine. The importance of fluorine in numerous civilian and military uses and the dependence of the United States on a limited number of foreign suppliers are reasons why fluorine is considered to be a critical element for the United States. Beginning in World War II, or just after, and ending in 2009, fluorspar was judged to be of such importance that it was one of the strategic and critical minerals that were stockpiled by the U.S. Government. Starting in 2001, substantial decreases in exports of fluorspar from China have led to decreases in the world supply. 


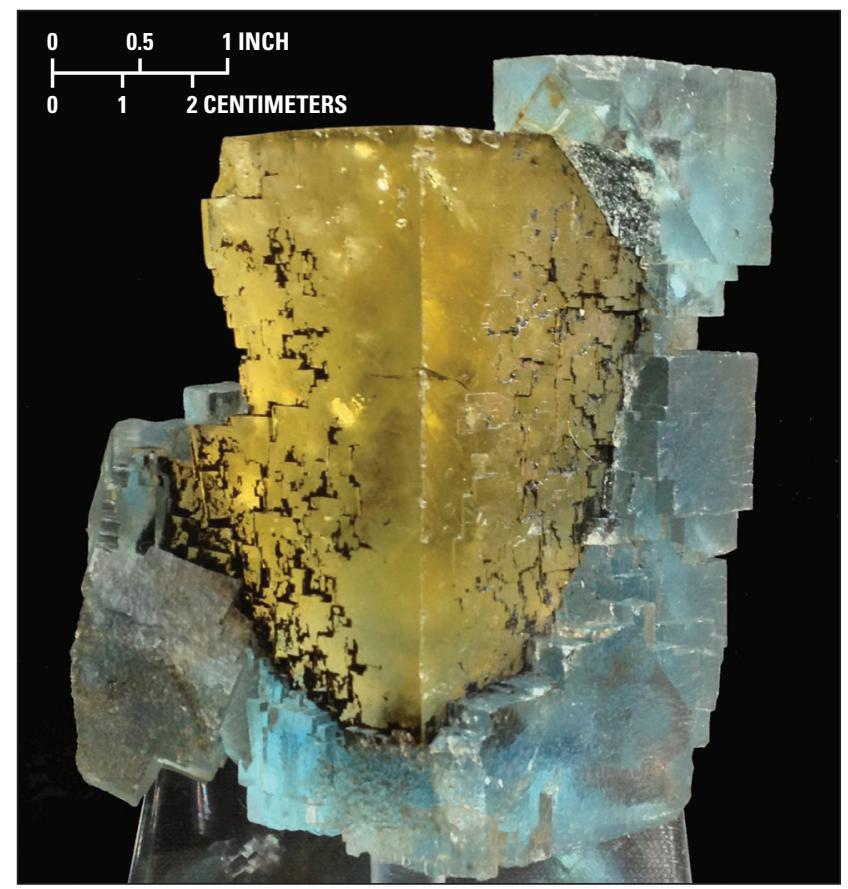

Figure G1. Photograph of a fluorite specimen from the Number 1 (Minerva) Mine, Cave-in-Rock subdistrict, IllinoisKentucky fluorspar district, showing the paragenesis (sequence of mineral deposition), including (1) yellow fluorite number 2 , (2) a redissolution surface visible particularly at the upper right beneath the blue fluorite, (3) pyrobitumens (black coating), and (4) blue fluorite (which is paragenetically equivalent to purple fluorite number 2 over most of the district). Worldwide, fluorite is the only mineral mined on a large scale solely for its fluorine content. Photograph courtesy of the Mineralogical and Geological Museum at Harvard University, Bannister Collection, MGMH 124614, (C) Copyright 2012, President and Fellows of Harvard College. All rights reserved.

\section{Uses, Applications, and Consumption}

Fluorspar is used directly as a fluxing material in ceramics, glassmaking, and steelmaking; as an additive in welding rod coatings; and for other, minor, uses. Fluorspar is the feedstock for fluorine chemicals, most of which are manufactured after fluorspar is converted to hydrogen fluoride; that is, hydrofluoric acid (HF). The major uses for HF are the manufacture of aluminum fluoride, synthetic cryolite, and fluorocarbons, but it is also used in the production of high-octane gasoline and in concentrating uranium; in glass etching, metal pickling, and oil and gas well treatment; and in the electronics industry. HF is used in the manufacture of a host of fluorine chemicals used in agrichemicals, dielectrics, metallurgy, mouth washes and toothpastes, pharmaceuticals, and wood preservatives.
There are three principal market grades of fluorsparacid, ceramic, and metallurgical. Specifications for the acid grade and metallurgical grade are generally well defined, but the requirements set by individual consumers may vary in detail.

Acid-grade fluorspar (sometimes called "acidspar") is defined as containing more than 97 percent $\mathrm{CaF}_{2}$, although material with a lower $\mathrm{CaF}_{2}$ content can be used by manufacturers of HF (for example, those in Russia) if the remaining impurities are acceptable. Major impurities include calcium carbonate and silica content, which commonly have maximum allowable contents of 1.0 percent each. Limits are normally placed on other minor but relevant impurities, such as arsenic, phosphates, sodium chloride $(\mathrm{NaCl})$, and sulfide sulfur or total sulfur. Arsenic and phosphate impurities are the most problematic because they are difficult to remove during ore beneficiation and because they have detrimental effects on HF production. If purchased as a wet flotation concentrate, the maximum allowable moisture content of the fluorspar is 10 percent water $\left(\mathrm{H}_{2} \mathrm{O}\right)$; if purchased as a dried concentrate, the specification for acid and ceramic grades is usually a maximum of 0.10 percent $\mathrm{H}_{2} \mathrm{O}$. Particle size requirements for fluorspar may vary by customer, but generally the specification calls for the bulk ( 85 to 95 percent) to be able to pass through a 150 -micrometer $(\mu \mathrm{m}$; or 0.15 -millimeter $[\mathrm{mm}])$ screen.

In the United States, the use of ceramic-grade fluorspar has declined, and some former consumers of ceramic-grade fluorspar now use acid-grade fluorspar. The two ceramic grades for fluorspar are no. 1 (90 to 95 percent $\mathrm{CaF}_{2}$ ) and no. 2 (85 to 90 percent $\mathrm{CaF}_{2}$ ). Some domestic and foreign fluorspar suppliers still offer ceramic-grade fluorspar, but because practically every ceramic-grade user has its own specifications, suppliers tend to tailor their products to specific consumers or to offer several product grades that fall between metallurgical grade and acid grade. Customers may specify limits on the amounts of calcium carbonate, ferric oxide, lead sulfide, zinc sulfide, and silica present in the fluorspar.

In the United States, metallurgical-grade fluorspar ("metspar") generally contains a minimum of 80 percent $\mathrm{CaF}_{2}$ and can range as high as 93 percent $\mathrm{CaF}_{2}$. Steel mills are the major users of metspar, and their purchase specifications limit the content of silica to between 4 and 10 percent, and that of calcium carbonate, to between 4 and 9 percent. The standard size specifications for metallurgical-grade fluorspar gravel are that 100 percent of the gravel must be able to pass through a $63-\mathrm{mm}$ screen and that a maximum of 15 percent must be able to pass through a $9.5-\mathrm{mm}$ screen. In markets outside of the United States, the acceptable level of $\mathrm{CaF}_{2}$ content may be lower (depending on the country), and the acceptable level of silica content may be higher than in the U.S. specification. 


\section{Geology}

\section{Geochemistry}

Fluorine is one of the five halogen elements, along with chlorine (the most common), bromine, iodine, and astatine (which is the rarest). Fluorine has only one known chemical valence: -1 . It has an ionic radius of 1.36 angstroms $(\AA)$, which allows it to substitute readily for the hydroxyl ion (which has an ionic radius of $1.40 \AA$ ) in mineral structures (Fleischer and Robinson, 1963). Fluorine substitutes less commonly for chloride and oxygen ions.

\section{Fluorine in Rocks}

In igneous systems, fluorine is one of a number of elements that are largely incompatible, in that they do not readily go into the common silicate minerals that crystallize from the melt. As a result, they become concentrated in the residual magma during differentiation. Early in differentiation, as mafic silicates and calcium-feldspars crystallize from the melt, the fluorine and silica (and typically As, B, Be, Cs, Dy, K, Li, Lu, Mn, Mo, Nb, Sb, Sc, Sn, Ta, Tb, Th, Tl, U, $\mathrm{W}, \mathrm{Y}, \mathrm{Yb}$, and $\mathrm{Zr}$ ) increase in concentration in the residual magma (Hildreth, 1981). This happens in both subalkaline and alkaline magmas, although the alkaline magmas may achieve higher fluorine concentrations (table G1; Shawe, 1976, p. 5). Fluorine's incompatibility broadly leads fluorite to be found in economic concentrations close to and within differentiation end-product rock types throughout the world, such as granites, syenites, and carbonatites, and their shallowly intrusive and extrusive equivalents. Shawe (1976) described and discussed several additional trends of fluorine in igneous rocks, some of which are not wholly predictable from the element's general incompatibility. Typical igneous-rock fluorine concentrations are given in table G1.

Because of fluorine's incompatibility, it may also occur in high concentrations in volcanic gases as well as in sublimates formed from the gases (White and Waring, 1963, table 1). Rocks altered by such gases similarly contain substantial amounts of fluorine; the fluorine is substituted mainly into hydroxyl sites in alteration micas and clay minerals, but in some places, the abundant fluorine occurs as fluorite.

In sedimentary rocks, fluorine's highest syngenetic concentrations (concentrations formed at the time of sedimentation) are found in phosphorites because of the element's substitution for hydroxyl ions in apatite, which is the principal phosphorous-bearing mineral in phosphorites; this process yields fluorapatite. Phosphorites typically have greater than 2 weight percent fluorine and may (rarely) have more than 4 weight percent (Gulbrandsen, 1966, table 1; Cheney and others, 1979, tables 3 and 6). Concentrations of fluorine in typical sedimentary rocks are given in table G1.

Fluorine geochemistry in metamorphic rocks is not well known. Fluorine is present primarily in biotite and muscovite in metamorphic rocks, and it tends to be concentrated in micas as water is lost during prograde metamorphism. Pyroxeneplagioclase granulites may contain fluorine-rich micas (up to 3.3 weight percent fluorine in biotite) (Bose and others, 2005). A few concentrations of fluorine in typical metamorphic rocks are given in table G1.

\section{Fluorine in Water}

Most deposits mined for fluorine are hydrothermal (that is, the fluorine minerals have precipitated from hot water), so understanding the geochemistry of fluorine in water is important for understanding how fluorine deposits are formed. Table G2 is a listing of some typical concentrations of fluorine in various types of water. Surprisingly, fluorine can dissolve in high concentrations (concentrations of more than 1,000 parts per million [ppm]) in low-temperature water with high $\mathrm{pH}$ and a low calcium concentration (Kilham and Hecky, 1973; Jones and others, 1977). This is especially true for waters in contact with rocks that have high fluorine contents, especially young volcanic rocks. In such rocks, the glassy components commonly have the highest fluorine concentrations and are inherently unstable at surface conditions, releasing fluorine as they are altered. As with the other halogens at low temperature, fluorine occurs commonly as a free ion in water, whereas there is a tendency for greater complexing at higher temperatures.

Fluoride, like many other dissolved components, is found at high concentrations in brines of various origins. Magmatic brines and brines from deep within sedimentary basins are potential mineralizing fluids for various types of hydrothermal fluorspar deposits. Another important feature of fluorine geochemistry in water is that fluorite has minimum solubility in a common range of hydrothermal temperatures, particularly from about 160 degrees Celsius $\left({ }^{\circ} \mathrm{C}\right)$ down to about $60{ }^{\circ} \mathrm{C}$ (fig. G2). Its solubility increases with increasing temperature, as is the case for many dissolved components. Experiments by Richardson and Holland (1979), however, show that, unlike most minerals, the solubility of fluorite increases as temperature drops below $60{ }^{\circ} \mathrm{C}$ down to $0{ }^{\circ} \mathrm{C}$ (fig. G2). Over this temperature range, the tendency of the mineral to precipitate from solution decreases as the temperature decreases. Fluorine's high solubility in cool, calcium-poor, high-pH water from young volcanic rocks is related to this retrograde solubility. The high fluorine concentrations are found specifically in waters poor in calcium and high in carbonate, where fluorite does not control fluorine's solubility. 
Table G1. Fluorine concentrations in various types of rocks.

[Without extremes** means that statistical outliers have not been included in calculating the mean. They are shown as part of the range. no., number; ppm, part per million; b.d.l., below method detection limit; —, no data]

\begin{tabular}{|c|c|c|c|c|}
\hline \multirow{2}{*}{ Rock type (location) } & \multirow{2}{*}{$\begin{array}{c}\text { No. of } \\
\text { samples }\end{array}$} & \multicolumn{2}{|c|}{ Fluorine concentration (ppm) } & \multirow{2}{*}{ Source(s) } \\
\hline & & Range & Mean & \\
\hline \multicolumn{5}{|c|}{ Igneous rocks-Intrusive } \\
\hline Gabbro, diabase & 26 & 50 to 1,100 & 420 & 6 \\
\hline Granodiorite and granite, without extremes** & 93 & 20 to 2,700 & 810 & 6 \\
\hline Alkalic intrusives & 100 & - & 2,640 & 13 \\
\hline Granite (mostly Silver Plume, central Colorado), without extremes** & 459 & 70 to 260,000 & 1,100 & 15 \\
\hline Granite, (mostly Pikes Peak, central Colorado), without extremes** & 284 & 60 to 170,000 & 1,116 & 15 \\
\hline \multicolumn{5}{|c|}{ Igneous rocks-Extrusive } \\
\hline Andesite & 77 & b.d.1. to 780 & 210 & 6 \\
\hline Andesite & 85 & - & 630 & 13 \\
\hline Phonolite & 14 & 860 to 1,490 & 930 & 6 \\
\hline Phonolite (Eastern Rift, Kenya and Tanzania) & 2 & 2,100 to 2,200 & 2,150 & 11 \\
\hline Trachyandesite (Eastern Rift, Tanzania) & 1 & - & 1,400 & 11 \\
\hline Nephelinites (Eastern Rift, Kenya and Tanzania) & 20 & 1,000 to 4,900 & 2,480 & 11 \\
\hline Peralkaline trachyte (Eastern Rift, Kenya and Tanzania) & 4 & 1,700 to 3,600 & 3,070 & 12 \\
\hline Melilite, leucitite, and carbonatite (Western Rift, Uganda) & 4 & 1,400 to 3,000 & 2,500 & 1,4 \\
\hline Alkali rhyolite (Eastern Rift, Kenya) & 4 & 1,700 to 6,800 & 3,870 & 2 \\
\hline \multicolumn{5}{|c|}{ Metamorphic rocks } \\
\hline Carbonaceous or dark sandstones & 11 & - & 400 & 8 \\
\hline Varicolored sandstones & 23 & - & 320 & 8 \\
\hline Pale, nearly white, sandstones & 12 & - & 280 & 8 \\
\hline Shales, without extremes & 79 & 10 to 7,600 & 800 & 6 \\
\hline Pierre Shale & 22 & 560 to 880 & 682 & 5 \\
\hline Limestones, without extremes** & 98 & b.d.1. to 1,210 & 220 & 6 \\
\hline Dolostones & 14 & 110 to 400 & 260 & 6 \\
\hline Anhydrite rock & 3 & b.d.1. to 350 & 121 & 7 \\
\hline Halite rock & 7 & b.d.1. to 130 & 31 & 7 \\
\hline Phosphorite (Phosphoria Formation, United States) & 60 & - & 31,000 & 9 \\
\hline Phosphorite ( 8 mining areas worldwide) & 8 & 30,500 to 41,000 & 36,560 & 14 \\
\hline
\end{tabular}

${ }^{1}$ Sources of analyses: 1, Holmes and Harwood (1932); 2, Bowen (1937); 3, Higazy (1954); 4, von Knorring and DuBois (1961); 5, Tourtelot (1962); 6, Fleischer and Robinson (1963); 7, Stewart (1963); 8, Pettijohn (1963, p. S16); 9, Gulbrandsen (1966); 10, Bell and Powell (1969); 11, Gerasimovskiy and Savinova (1969); 12, MacDonald and others (1970); 13, Shawe (1976); 14, Cheney and others (1979); and 15, Wallace (2010). 
Table G2. Concentrations of fluorine and other elements in waters.

[Deposit types: 1. carbonatite-related, 2. alkaline-intrusion-related, 3. alkaline-volcanic-related epithermal, 4a. Mississippi Valley-type (MVT), and 4b. saltrelated carbonate-hosted. Chemical abbreviations: $\mathrm{F}$, fluorine; $\mathrm{CO}_{3}$, carbonate; $\mathrm{HCO}_{3}$, bicarbonate; $\mathrm{HF}$, hydrogen fluoride; $\mathrm{SO}_{4}$, sulfate; $\mathrm{Cl}$, chlorine; $\mathrm{SiO}$, silica; $\mathrm{Ca}$, calcium; Fe, iron; $\mathrm{Mg}$, magnesium; $\mathrm{Na}$, sodium; $\mathrm{K}$, potassium; $\mathrm{Cu}$, copper; $\mathrm{Pb}$, lead; $\mathrm{Zn}$, zinc; $\mathrm{CaCO}_{3}$, calcium carbonate (calcite). calc'd, value was calculated using SOLVEQ software (Reed, 1982) and assuming charge balance and saturation with quartz, muscovite, dolomite, fluorite, pyrite, and galena or sphalerite. Units of measure: ${ }^{\circ} \mathrm{C}$, degree Celsius; ppm, part per million; equiv. wt. \%, equivalent weight percent; $\mathrm{g} / \mathrm{kg}$, gram per kilogram; $\mu \mathrm{S} / \mathrm{cm}$, microsiemens per centimeter. n.a., not applicable; - , not determined or not reported; i.d., identification; no. or n, number]

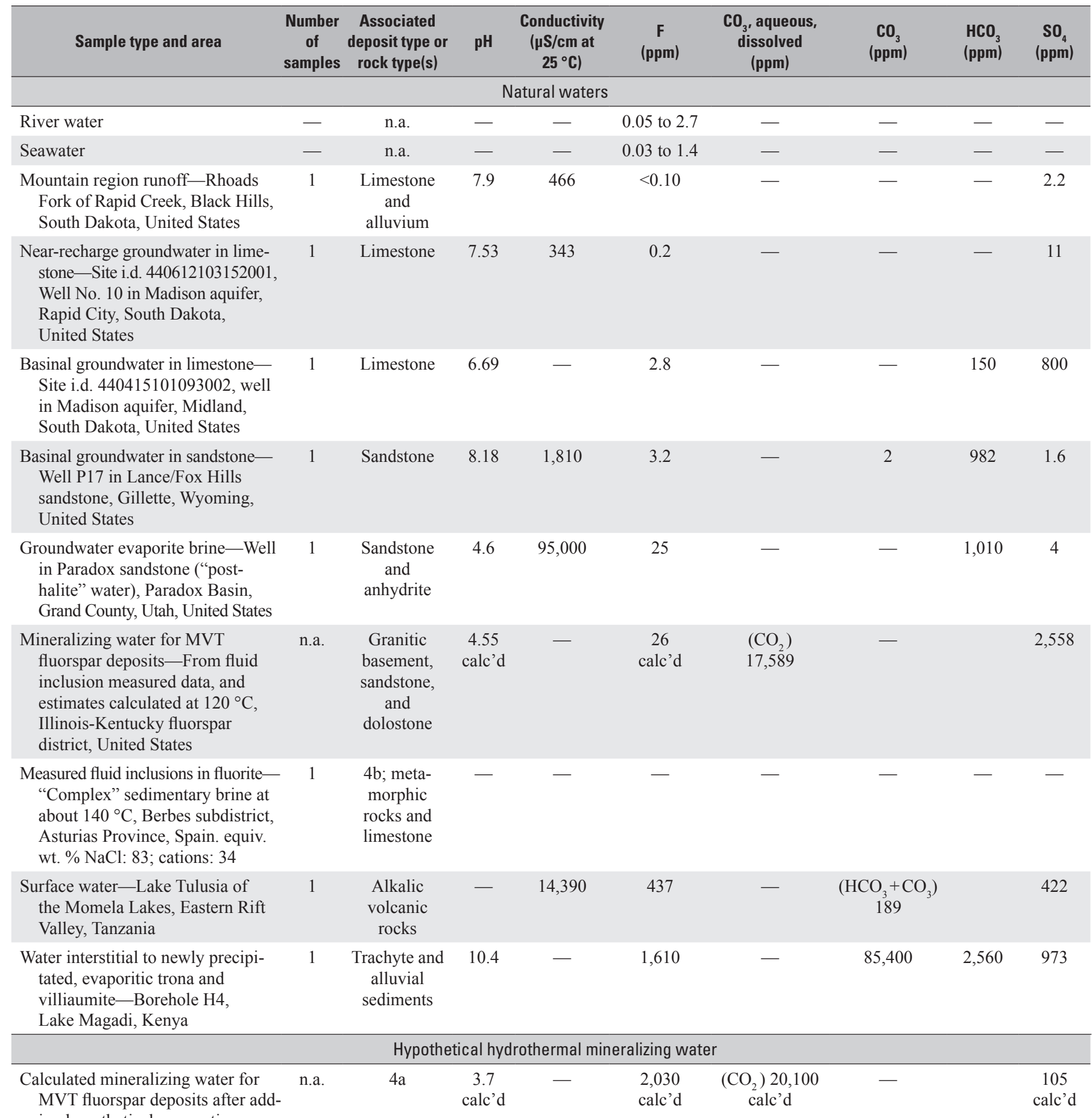
ing hypothetical magmatic gas with $0.5 \mathrm{~g} / \mathrm{kg} \mathrm{CO}$ and $0.5 \mathrm{~g} / \mathrm{kg}$ $\mathrm{HF}$ and heating to $300^{\circ} \mathrm{C}$, Illinois-Kentucky fluorspar district, United States 
Table G2. Concentrations of fluorine and other elements in waters.-Continued

[Deposit types: 1. carbonatite-related, 2. alkaline-intrusion-related, 3. alkaline-volcanic-related epithermal, 4a. Mississippi Valley-type (MVT), and 4b. saltrelated carbonate-hosted. Chemical abbreviations: $\mathrm{F}$, fluorine; $\mathrm{CO}_{3}$, carbonate; $\mathrm{HCO}_{3}$, bicarbonate; $\mathrm{HF}$, hydrogen fluoride; $\mathrm{SO}_{4}$, sulfate; $\mathrm{Cl}$, chlorine; $\mathrm{SiO}$, silica; $\mathrm{Ca}$, calcium; Fe, iron; $\mathrm{Mg}$, magnesium; $\mathrm{Na}$, sodium; $\mathrm{K}$, potassium; $\mathrm{Cu}$, copper; $\mathrm{Pb}$, lead; $\mathrm{Zn}$, zinc; $\mathrm{CaCO}_{3}$, calcium carbonate (calcite). calc'd, value was calculated using SOLVEQ software (Reed, 1982) and assuming charge balance and saturation with quartz, muscovite, dolomite, fluorite, pyrite, and galena or sphalerite. Units of measure: ${ }^{\circ} \mathrm{C}$, degree Celsius; ppm, part per million; equiv. wt. \%, equivalent weight percent; $\mathrm{g} / \mathrm{kg}$, gram per kilogram; $\mu \mathrm{S} / \mathrm{cm}$, microsiemens per centimeter. n.a., not applicable; —, not determined or not reported; i.d., identification; no. or n, number]

\begin{tabular}{|c|c|c|c|c|c|c|c|c|c|c|c|}
\hline$\underset{(p p m)}{\text { Cl }}$ & $\begin{array}{c}\mathrm{SiO}_{2} \\
(\mathrm{ppm})\end{array}$ & $\begin{array}{c}\mathrm{Ca} \\
(\mathrm{ppm})\end{array}$ & $\begin{array}{c}\mathrm{Fe} \\
(\mathrm{ppm})\end{array}$ & $\underset{(\mathrm{ppm})}{\mathbf{M g}}$ & $\underset{(p p m)}{\mathrm{Na}}$ & $\underset{(p p m)}{K}$ & $\underset{(p p m)}{C u}$ & $\begin{array}{c}\mathbf{P b} \\
(\mathrm{ppm})\end{array}$ & $\underset{(\mathrm{ppm})}{\mathrm{Zn}}$ & $\begin{array}{c}\text { Alkalinity } \\
\text { (ppm as } \\
\mathrm{CaCO}_{3} \text { ) }\end{array}$ & Source(s) ${ }^{1}$ \\
\hline \multicolumn{12}{|c|}{ Natural waters-Continued } \\
\hline- & - & - & - & - & - & - & - & - & - & - & 15 \\
\hline 3.1 & 9 & 66 & 0.005 & 23 & 1 & 0.6 & $<0.001$ & $<0.001$ & $<0.003$ & 219 & 20 \\
\hline 1 & - & 38 & - & 19 & 2.6 & 1.6 & 0.002 & - & 0.01 & 171 & 20 \\
\hline 30 & 17 & 2.7 & 17 & 0.4 & 370 & 4 & $<0.001$ & 0.001 & $<0.003$ & - & 6 \\
\hline 241,000 & - & 52,700 & 750 & 39,200 & 5,990 & 18,800 & 6 & 6 & 60 & - & 1 \\
\hline $\begin{array}{l}92,200 \\
\text { calc'd }\end{array}$ & 59 & 4,994 & $\begin{array}{l}.00094 \\
\text { calc'd }\end{array}$ & 6,099 & 42,016 & $\begin{array}{l}3,310 \\
\text { calc'd }\end{array}$ & - & $\begin{array}{c}0.14 \\
\text { calc'd }\end{array}$ & $\begin{array}{c}0.68 \\
\text { calc'd }\end{array}$ & - & 11 \\
\hline
\end{tabular}

$\begin{array}{cccccccccc}646 & 5 & 3.2 & - & 6.1 & 4,600 & 726 & - & - & - \\ 68,400 & 513 & - & - & - & 115,000 & 1,430 & - & - & -\end{array}$

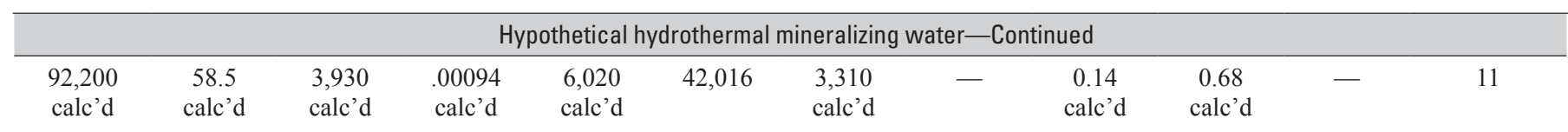


Table G2. Concentrations of fluorine and other elements in waters.-Continued

[Deposit types: 1, carbonatite-related; 2, alkaline-intrusion-related; 3, alkaline-volcanic-related epithermal; 4a, Mississippi Valley-type (MVT); and 4b, saltrelated carbonate-hosted. Chemical abbreviations: $\mathrm{F}$, fluorine; $\mathrm{CO}_{3}$, carbonate; $\mathrm{HCO}_{3}$, bicarbonate; $\mathrm{HF}$, hydrogen fluoride; $\mathrm{SO}_{4}$, sulfate; $\mathrm{Cl}$, chlorine; $\mathrm{SiO}$, silica; $\mathrm{Ca}$, calcium; Fe, iron; $\mathrm{Mg}$, magnesium; $\mathrm{Na}$, sodium; $\mathrm{K}$, potassium; $\mathrm{Cu}$, copper; $\mathrm{Pb}$, lead; $\mathrm{Zn}$, zinc; $\mathrm{CaCO}_{3}$, calcium carbonate (calcite). calc'd, value was calculated using SOLVEQ software (Reed, 1982) and assuming charge balance and saturation with quartz, muscovite, dolomite, fluorite, pyrite, and galena or sphalerite. Units of measure: ${ }^{\circ} \mathrm{C}$, degree Celsius; ppm, part per million; equiv. wt. \%, equivalent weight percent; $\mathrm{g} / \mathrm{kg}$, gram per kilogram; $\mu \mathrm{S} / \mathrm{cm}$, microsiemens per centimeter. n.a., not applicable; - , not determined or not reported; i.d., identification; no. or n, number]

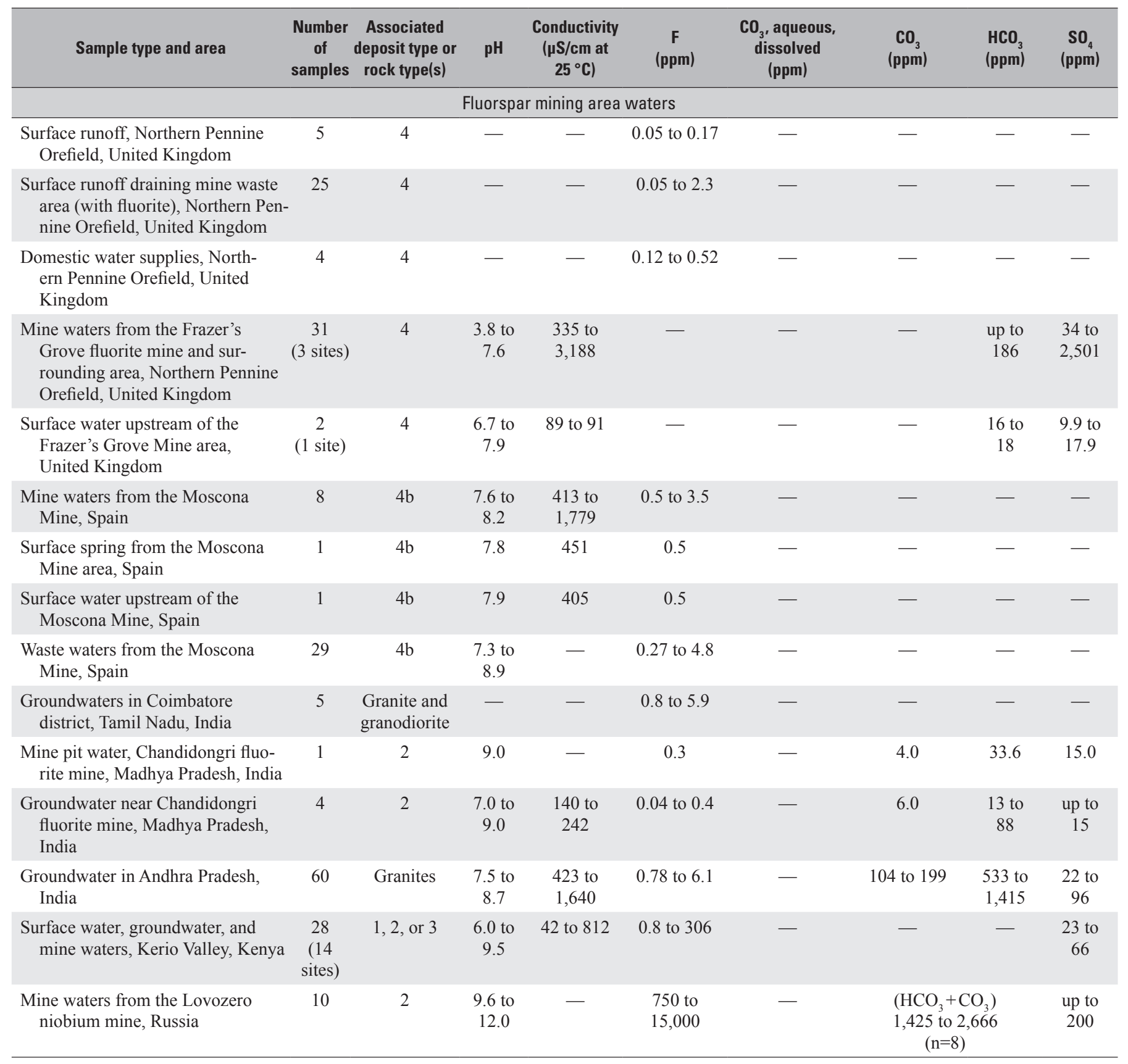

${ }^{1}$ Sources: 1, White (1965); 2, Hall and Friedman (1963); 3, Kraynov and others (1969); 4, Kilham and Hecky (1973); 5, Jones and others (1977);

6, Henderson (1985); 7, Fuge and Andrews (1988); 8, Busby and others (1991); 9, Leach and others (1991); 10, Davies (1994); 11, Plumlee and others (1995); 12, Chatterjee and Mohabey (1998); 13, Narayana and others (2000); 14, Johnson and Younger (2002); 15, Kabata-Pendias and Mukherjee (2007); and references therein; 16, Jacks and others (2005); 17, Roqueñí and others (2005); 18, Sánchez and others (2009); and 19, Arveti and others (2011); 20, U.S. Geological Survey (2016). 
Table G2. Concentrations of fluorine and other elements in waters.-Continued

[Deposit types: 1. carbonatite-related, 2. alkaline-intrusion-related, 3. alkaline-volcanic-related epithermal, 4a. Mississippi Valley-type (MVT), and 4b. saltrelated carbonate-hosted. Chemical abbreviations: $\mathrm{F}$, fluorine; $\mathrm{CO}_{3}$, carbonate; $\mathrm{HCO}_{3}$, bicarbonate; $\mathrm{HF}$, hydrogen fluoride; $\mathrm{SO}_{4}$, sulfate; $\mathrm{Cl}$, chlorine; $\mathrm{SiO}$, silica; $\mathrm{Ca}$, calcium; Fe, iron; $\mathrm{Mg}$, magnesium; $\mathrm{Na}$, sodium; $\mathrm{K}$, potassium; $\mathrm{Cu}$, copper; $\mathrm{Pb}$, lead; $\mathrm{Zn}$, zinc; $\mathrm{CaCO}_{3}$, calcium carbonate (calcite). calc'd, value was calculated using SOLVEQ software (Reed, 1982) and assuming charge balance and saturation with quartz, muscovite, dolomite, fluorite, pyrite, and galena or sphalerite. Units of measure: ${ }^{\circ} \mathrm{C}$, degree Celsius; ppm, part per million; equiv. wt. \%, equivalent weight percent; g/kg, gram per kilogram; $\mu \mathrm{S} / \mathrm{cm}$, microsiemens per centimeter. n.a., not applicable; —, not determined or not reported; i.d., identification; no. or n, number]

\begin{tabular}{|c|c|c|c|c|c|c|c|c|c|c|c|}
\hline$\underset{(\mathrm{ppm})}{\mathrm{Cl}}$ & $\begin{array}{c}\mathrm{SiO}_{2} \\
(\mathrm{ppm})\end{array}$ & $\begin{array}{c}\text { Ca } \\
(\mathrm{ppm})\end{array}$ & $\begin{array}{c}\mathrm{Fe} \\
(\mathrm{ppm})\end{array}$ & $\underset{(\mathrm{ppm})}{\mathbf{M g}}$ & $\underset{(p p m)}{\mathrm{Na}}$ & $\underset{(p p m)}{K}$ & $\underset{(\mathrm{ppm})}{\mathrm{Cu}}$ & $\begin{array}{c}\mathrm{Pb} \\
(\mathrm{ppm})\end{array}$ & $\begin{array}{c}\mathrm{Zn} \\
(\mathrm{ppm})\end{array}$ & $\begin{array}{c}\text { Alkalinity } \\
\text { (ppm as } \\
\left.\mathrm{CaCO}_{3}\right)\end{array}$ & Source(s) ${ }^{1}$ \\
\hline \multicolumn{12}{|c|}{ Fluorspar mining area waters-Continued } \\
\hline - & - & - & - & - & - & - & - & - & - & - & 7 \\
\hline - & - & - & - & - & - & - & - & - & - & - & 7 \\
\hline- & - & - & - & - & - & - & - & - & - & - & 7 \\
\hline up to 258 & - & 52 to 673 & $\begin{array}{c}<0.1 \text { to } \\
68\end{array}$ & $\begin{array}{l}9.4 \text { to } \\
215\end{array}$ & 9.1 to 38 & $\begin{array}{c}4.9 \text { to } \\
33.7\end{array}$ & - & - & $\begin{array}{c}<0.1 \text { to } \\
111\end{array}$ & - & 14 \\
\hline - & - & - & $<0.1$ & - & - & - & - & - & $\begin{array}{c}<0.05 \text { to } \\
2.7\end{array}$ & - & 17 \\
\hline- & - & - & $<0.1$ & - & - & - & - & - & $<0.05$ & - & 17 \\
\hline- & - & - & $<0.1$ & - & - & - & - & - & $<0.05$ & - & 17 \\
\hline- & - & - & - & - & - & - & - & - & - & - & 17 \\
\hline- & - & - & - & - & - & - & - & - & - & - & 16 \\
\hline 11 to 48 & 16 to 67 & - & 0.1 to 0.8 & - & - & - & $\begin{array}{c}0.01 \text { to } \\
0.08\end{array}$ & - & - & 26 to 414 & 10 \\
\hline 8 to 85 & $\begin{array}{l}140 \text { to } \\
13,000\end{array}$ & up to 1 & - & $\begin{array}{c}0.6 \text { to } \\
140\end{array}$ & $\begin{array}{c}3,680 \text { to } \\
26,000\end{array}$ & 35 to 250 & $\begin{array}{c}0.3 \text { to } 0.9 \\
(n=3)\end{array}$ & $\begin{array}{c}0.02 \text { to } \\
0.03 \\
(\mathrm{n}=3)\end{array}$ & $\begin{array}{c}0.4 \\
(n=1)\end{array}$ & - & 3 \\
\hline
\end{tabular}


Figure G2. Graph showing the solubility of fluorite $\left(\mathrm{CaF}_{2}\right)$ as a function of temperature for complex $\mathrm{Na}-\mathrm{Ca}-\mathrm{Mg}-\mathrm{Cl}$ (sodium-calciummagnesium-chloride) brines from ambient temperatures ( 25 degrees Celsius [ $\left.\left[{ }^{\circ} \mathrm{C}\right]\right)$ to $260^{\circ} \mathrm{C}$. Total ionic strength for each combination of salts was 4 moles per liter. At each molarity (M) of $\mathrm{CaCl}_{2}+\mathrm{MgCl}_{2}$, the ratio of calcium to magnesium was 9 to 1 . Curvatures in the dashed parts of the curves are inferred. Except for pure sodium chloride ( $\mathrm{NaCl}$ ) brine compositions, the solubility curves at different complex chloride salt molarities all have a maximum temperature of fluorite deposition below which the solubility (the opposite of deposition) of fluorite increases with decreasing temperature. At those temperatures (those below the maximum temperature of fluorite deposition), fluorite is said to have retrograde solubility; that is, fluorite solubility increases as temperature decreases. First, temperatures near the laboratory maxima of fluorite deposition have commonly been measured in fluid inclusion microthermometry studies of actual fluorspar deposits (for example, Richardson and Pinckney, 1984). Second, the retrograde solubility at low temperatures is explanation for relatively high concentrations of fluorine in water measured in several surface water or shallow groundwater environments (for example, Lake Magadi, Kenya; Jones and others, 1977). Graph is from Richardson and Holland (1979, fig. 5). $\mathrm{CaCl}_{2}$, calcium chloride; $\mathrm{MgCl}_{2}$, magnesium chloride

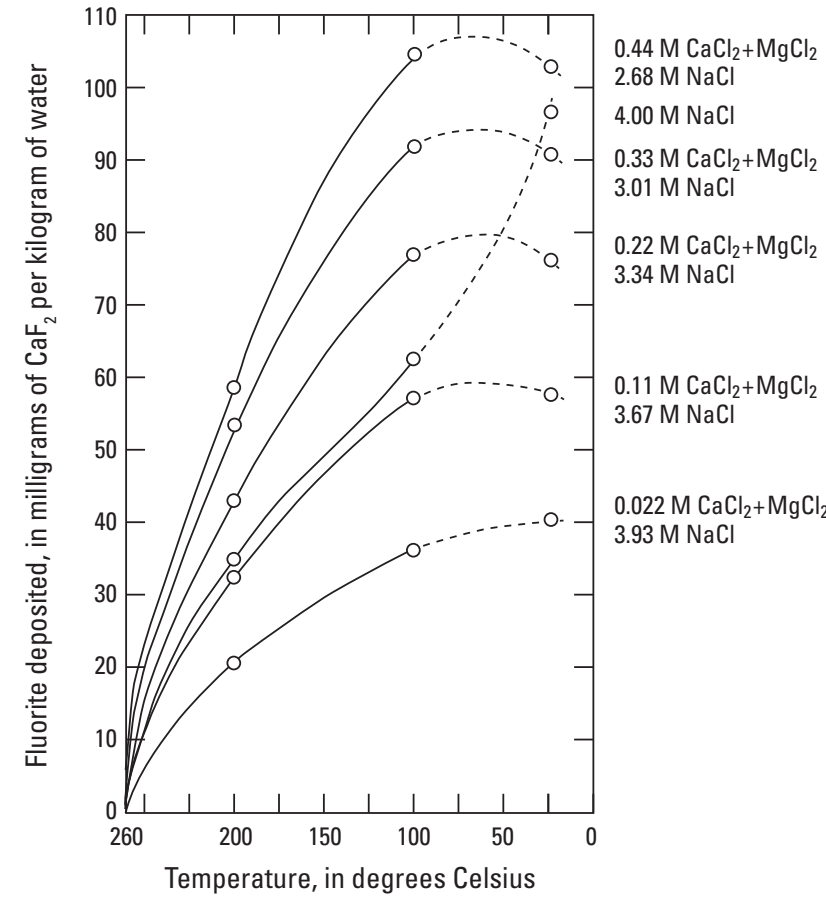

the fluorine-bearing hydrothermal solutions encountered magnesium-rich diabase (that is, shallowly intrusive basaltic rock) in the fault or vein walls (Ellmies and others, 1999). Apparently, the magnesium in the basaltic wall rock was used in precipitating sellaite, rather than fluorite. The situation is not geologically unique; sellaite is found in several different fluorite-bearing deposits in dolomite host rocks-for example, at Mount Bischoff, Tasmania, Australia (Kwak and Askins, 1981); at the Shepherd and Murphy Mine in the Moina district, Tasmania, Australia (Bottrill and Baker, 2008); at the Xianghuapu Mine in Linwu County, Hunan Province, China (Yuzhou, 1990); and at the Yaroslavskoye tin deposit in Primorskiy Kray, Russia (Bailey, 1980). In all these cases, magnesium from the dolomite was probably used in precipitating sellaite in preference to fluorite. In a few other occurrences, sellaite is found in rocks where calcium had earlier been removed by hydrothermal alteration, thus favoring the sellaite over fluorite (Imai and others, 1985; Pfaff and others, 2012).

Villiaumite (isometric $\mathrm{NaF}$ ) occurs within trona (monoclinic $\mathrm{Na}_{3}\left(\mathrm{HCO}_{3}\right)\left(\mathrm{CO}_{3}\right) \cdot 2 \mathrm{H}_{2} \mathrm{O}$, ) in eastern Africa. Trona is the raw material for sodium carbonate (that is, washing soda or soda ash). In some valleys of the East African Rift system, trona is precipitating because of evaporation of the closed basin lakes. With high enough concentrations of villiaumite in the trona ore, it could become a feasible byproduct and might be recovered as a source of fluorine. The trona deposits of eastern Africa are located close to peralkaline to alkaline volcanic rocks. An analysis of water pumped from within newly precipitated Lake Magadi trona is given in table G2. 


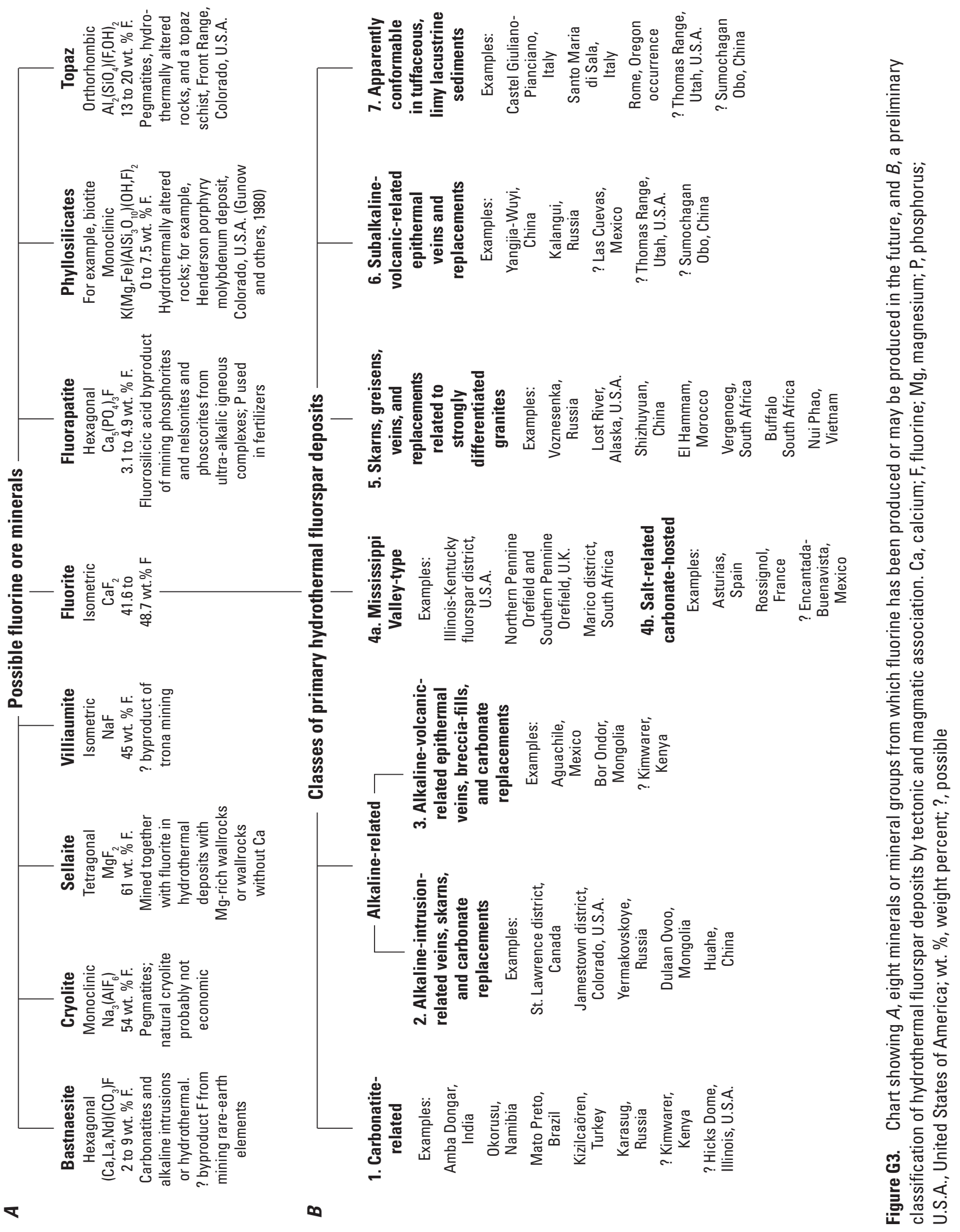


Fluorite is the most common mineral that contains high concentrations of fluorine (fig. G3). Fluorite is typically almost transparent, and it has perfect octahedral cleavage. It is softer than quartz, harder than calcite, and unreactive in weak acids, so it is typically readily distinguishable from calcite and quartz, with which it is commonly associated. Fluorite occurs as a minor gangue mineral in many types of hydrothermal ore deposits; for example, epithermal gold, silver, and uranium deposits; porphyry molybdenum ( \pm tungsten) deposits; pegmatites; iron oxide-copper-gold deposits; and typically zinc-dominated Mississippi Valley-type (MVT) deposits. In the deposit types shown in figure $\mathrm{G} 3 B$, fluorite is the major economic mineral, although coproduct or byproducts $\mathrm{Au}$, barite, $\mathrm{Be}, \mathrm{Bi}, \mathrm{Cu}, \mathrm{Li}, \mathrm{Mo}, \mathrm{Nb}, \mathrm{Pb}, \mathrm{REEs}, \mathrm{Sb}, \mathrm{Sn}, \mathrm{W}$, and $\mathrm{Zn}$, can be found in the various types of fluorspar deposits.

In many fluorspar deposits, it is clear that fluorine in a hydrothermal solution reacted with calcium from the wall rocks to form fluorite. In limestone wall rocks, the reaction for fluorite precipitation can be modeled as follows:

$$
2 \mathrm{HF}+\mathrm{CaCO}_{3} \rightarrow \mathrm{CaF}_{2}+\mathrm{H}_{2} \mathrm{O}+\mathrm{O}_{2}
$$

Where the above reaction occurs and calcium is conserved (because the density of calcite is 2.71 grams per cubic centimeter $\left[\mathrm{g} / \mathrm{cm}^{3}\right]$ and the density of fluorite is $3.18 \mathrm{~g} / \mathrm{cm}^{3}$ ), new open space (or porosity) results. In fact, at standard temperature and pressure, about 15 percent of the original limestone (calcium carbonate $\left[\mathrm{CaCO}_{3}\right]$ ) volume becomes new porosity. New crystals of fluorite grow into the open space as terminated crystals, and the result is that, in most carbonate replacement deposits, fluorite occurs as wellformed cubic or cube-octahedral crystals (fig. G1) of many different colors; blue, green, purple, white, yellow, and clear are typical. Reactions similar to (1) can be written for other calcium sources, such as dolomite or plagioclase, most with the effect that new porosity is created if calcium is conserved.

Fluorapatite (hexagonal $\left.\mathrm{Ca}_{5}\left(\mathrm{PO}_{4}\right)_{3} \mathrm{~F}\right)$ currently accounts for only minor amounts of fluorine production, but it constitutes a very large potential supply if needed in the future. Fluorapatite is the major mineral in sedimentary phosphorite deposits, which typically have a fluorine grade of 2 to 4 weight percent fluorine. Phosphorite is a sedimentary rock composed principally of phosphate minerals. Phosphorite deposits can exceed 1 billion metric tons of ore. Phosphorites are mined in many places in the world as a source of fertilizer. Byproduct fluorine is already captured at some of the operations and is either converted to synthetic cryolite (a form in which it can be used readily in aluminum refining) or to fluorosilicic acid for use in drinking water fluoridation. Currently, the supply of fluorine obtained from phosphorites is determined by the demand for fertilizer - once the fertilizer demand is met, no additional byproduct fluorine is produced.

Fluorine is found in a number of silicate minerals, but, apparently, no feasible process to recover fluorine from any silicate structure has been developed. Topaz (orthorhombic $\left.\mathrm{Al}_{2}\left(\mathrm{SiO}_{4}\right)(\mathrm{F}, \mathrm{OH})_{2}\right)$ is a fluorine-bearing mineral found in pegmatites, some hydrothermally altered rocks, and an apparently unique topaz-rich schist in Colorado's Front Range (Sheridan and others, 1968).

Fluorine occurs in at least trace concentrations in most mica and clay (phyllosilicate) minerals; biotite (monoclinic $\left.\mathrm{K}(\mathrm{Mg}, \mathrm{Fe})_{3}\left(\mathrm{AlSi}_{3} \mathrm{O}_{10}\right)(\mathrm{OH}, \mathrm{F})_{2}\right)$ (fig. $\left.\mathrm{G} 3 A\right)$ is one example of fluorine in phyllosilicates. In the phyllosilicates, fluorine substitutes for the $\mathrm{OH}^{-}$ion in interlayer sites between the sheets of linked alumina octahedrons and silica tetrahedra. Theoretically, it should be easier to recover fluorine from such mineralogic sites than from topaz, in which the fluorine and hydroxyl ions link together adjacent alumina octahedrons; however, the relatively small amount of fluorine available in the phyllosilicates (fig. G3A) discourages any attempts to recover fluorine from them. The maximum amount of fluorine measured in phyllosilicates to date is 7.5 weight percent from biotite from a hydrothermal vein from the Henderson porphyry molybdenum deposit in Clear Creek County, Colorado (Gunow and others, 1980).

\section{Deposit Types}

Fluorspar deposits occur in a wide variety of geologic environments. The lower part of figure G3 (fig. G3B) is a preliminary classification of hydrothermal fluorspar deposits by their tectonic and (or) magmatic environments. All seven of the classes are hydrothermal, but there is a great variation of fluid temperatures and compositions among them, and they clearly represent various tectonic and magmatic settings, although there is some ambiguity in classification of certain deposits. The seven classes of primary hydrothermal fluorspar deposits shown in figure G3B are discussed below.

Worldwide, many fluorspar deposits are found closely associated in space with igneous rocks of several different types. Understanding distinctions between several types of igneous rocks is needed in order to recognize the various magmatic and tectonic environments that are represented. Following are explanations for the terms subalkaline, peralkaline, alkaline, and carbonatitic, with generalities about the tectonic environments represented by each of these compositional types of igneous rocks.

Peralkaline igneous rocks are igneous rocks in which the molecular proportions of sodium and potassium exceed the proportions of aluminum (molar $\mathrm{Na}_{2} \mathrm{O}+\mathrm{K}_{2} \mathrm{O}>\mathrm{Al}_{2} \mathrm{O}_{3}$ ). In such rocks, the amounts of sodium and potassium are greater than can be accommodated in sodium and potassium feldspars and must be taken up in other crystallizing minerals; for example, aegerine (monoclinic $\mathrm{NaFeSi}_{2} \mathrm{O}_{6}$, a pyroxene mineral) or riebeckite (monoclinic $\mathrm{Na}_{2}\left(\mathrm{Fe}^{2+}, \mathrm{Mg}\right)_{3} \mathrm{Fe}_{2}{ }^{3+} \mathrm{Si}_{8} \mathrm{O}_{22}(\mathrm{OH})_{2}$, an amphibole mineral). Subalkaline rocks are those that have more than enough aluminum to make the sodium and potassium feldspars, with the excess combining with calcium and silica to crystallize calcium-bearing plagioclase. In most alkaline rocks, however, the molecular proportions of sodium and potassium are so great that not even the minerals with anomalously high levels of sodium and potassium - that is, 
sodic and potassic pyroxenes and amphiboles, such as aegerine and riebeckite, respectively — can take up the excess of alkali molecules; consequently, minerals called feldspathoids, such as nepheline (hexagonal $(\mathrm{Na}, \mathrm{K}) \mathrm{AlSiO}_{4}$ ), sodalite (isometric $\mathrm{Na}_{4}\left(\mathrm{Si}_{3} \mathrm{Al}_{3}\right) \mathrm{O}_{12} \mathrm{Cl}$ ), leucite (tetragonal $\mathrm{K}\left(\mathrm{AlSi}_{2}\right) \mathrm{O}_{6}$ ), and melilite (tetragonal $(\mathrm{Ca}, \mathrm{Na})_{2}(\mathrm{Al}, \mathrm{Mg})\left(\mathrm{Si}, \mathrm{Al}_{2} \mathrm{O}_{7}\right)$, which have more alkalies and aluminum than do feldspars, crystallize instead of the alkali feldspars. Alkaline melts also commonly have concentrations of silica $\left(\mathrm{SiO}_{2}\right)$ that are too small to make any quartz after the crystallization of feldspars or feldspathoids; these melts are thus termed "undersaturated." The end member of the alkaline rocks has very little silica at all. These are carbonatites - rare igneous rocks that are composed of more than 50 volume percent carbonate minerals that crystallized from a magma. Carbonatites occur together with syenites and other nepheline-rich intrusive rocks in complexes within which the carbonatite is typically the last rock type intruded.

As a gross generality, subalkaline igneous rocks are the dominant types intruded or erupted in both continental and island arcs along convergent plate boundaries, most peralkaline rocks are instead unrelated to active compressional orogenies at convergent plate margins (they are "anorogenic"), and alkaline igneous rocks and carbonatites are found intruded through mostly thick continental crust remote from convergent margins. Both the anorogenic peralkaline intrusives and the alkaline complexes may relate broadly or directly to rifts through continental crust.

For each different type of magmatic associationsubalkaline, peralkaline, alkaline, or carbonatitic - the associated fluorspar deposits are, almost without exception, related to the most differentiated (latest intruded and crystallized, least iron and magnesium-rich, and most silica rich for other than the carbonatites) igneous rocks of the igneous province. So, for subalkaline magmatic provinces, the fluorspar deposits are found almost exclusively with granites that have high contents of incompatible elements. The granites associated with the fluorspar deposits typically have only biotite as a ferromagnesian mineral. For the peralkaline anorogenic igneous provinces, the fluorspar deposits are also associated with granites, particularly aegerine granites and riebeckite granites. For the alkaline complexes, the fluorspar deposits are most closely related to syenites, and only rarely to trachytes, or pyroxene-nepheline rocks. And for the carbonatite complexes, the fluorspar deposits are found most closely associated with the carbonatites themselves.

For association with volcanic rocks rather than intrusive rocks, the situation is parallel. The fluorspar deposits are nearly ubiquitously associated with rhyolites. They are nearly nowhere associated with the basalts.

\section{Carbonatite-Related Fluorspar Deposits}

Fluorite deposits associated with carbonatites and other ultra-alkaline rocks occur on every continent (fig. G4). In such deposits, it is common that the carbonate (commonly calcite) that makes up the carbonatite is partially replaced or veined by fluorite or is cut by a stockwork of fluorite veinlets. The country rock in contact with carbonatite may be altered (fenitized) by hydrothermal fluids and also mineralized with fluorite. At the Fission (Richardson) deposit in Ontario, Canada, and the Speewah deposit in Kimberley, Western Australia, Australia, the deposits have the general form of a vein or dike, although the carbonate minerals appear to be igneous and to contain minerals that are distinctive to igneous carbonatites, such as bastnaesite, parisite (rhombohedral $\left.\mathrm{Ca}(\mathrm{Ce}, \mathrm{Nd}, \mathrm{La})_{2}\left(\mathrm{CO}_{3}\right)_{2}\right)$, or pyrochlore (isometric $\left.(\mathrm{Na}, \mathrm{Ca})_{2} \mathrm{Nb}_{2} \mathrm{O}_{6}(\mathrm{OH}, \mathrm{F})\right)$. Two examples of carbonatiteassociated fluorspar deposits that have been well studied are the Okorusu deposit located in the Otjozondjupa Region of Namibia (Kogut and others, 1997; Shivdasan-Gebhardt and Hagni, 2008) and the Amba Dongar deposit located in Gujarat State, India (Deans and others, 1972; Gwalani and others, 1993; Simonetti and Bell, 1995; Simonetti and others, 1995; Palmer and Williams-Jones, 1996; Doroshkevich and others, 2009). At the Amba Dongar deposit, studies of the fluid compositions (Palmer and Williams-Jones, 1996) and the radiogenic isotopes (Simonetti and Bell, 1995) suggest that, despite temperatures of fluorite mineralization of $160{ }^{\circ} \mathrm{C}$ and less, there was a small component of igneous-derived magmatic water mixed with dominant meteoric water (that is, groundwater derived ultimately from rain and recharged from the surface) in the mineralizing fluids.

\section{Alkaline-Intrusion-Related Fluorspar Deposits}

Alkaline-intrusion-related fluorspar deposits are fluorite-bearing deposits that are in close spatial association with granites that contain aegerine and (or) riebeckite, or are in association with syenites, any of those igneous rocks commonly being porphyritic (Teng and Strong, 1976; Lykhin and others, 2010). A distinction is arbitrarily drawn between these types of deposits and a large number of other fluorspar deposits that are associated with extrusive alkali rhyolites or trachytes (that is, volcanic equivalents of syenites) where intrusive rocks are not found nearby. It is somewhat common for deposits of both classes to contain either bertrandite or phenakite and, at some places, lithium minerals, such as lithium-rich white mica (Lykhin and others, 2010; Obolenskiy and others, 2010). Some also contain economic concentrations of niobium, REEs, tantalum, and zirconium (Kovalenko and Yarmolyuk, 1995). The Yermakovskoye deposit in Buryatiya Republic, Russia, which was the first of the Russian alkaline- intrusion-related deposits to be mined, has small skarns - that is, bodies of calcium-silicate minerals with additional valuable minerals that have replaced limestone adjacent to intrusive rocks - and bodies with veinlet stockworks of fluorite-phenakite or of fluorite-bertrandite, and in which the fluorite commonly totals 20 volume percent (Kislov and others, 2010; Lykhin and others, 2010). Phenakite is rhombohedral $\mathrm{Be}_{2} \mathrm{SiO}_{4}$, and bertrandite is orthorhombic $\mathrm{Be}_{4} \mathrm{Si}_{2} \mathrm{O}_{7}(\mathrm{OH})_{2}$, so these deposits are commonly also deposits 


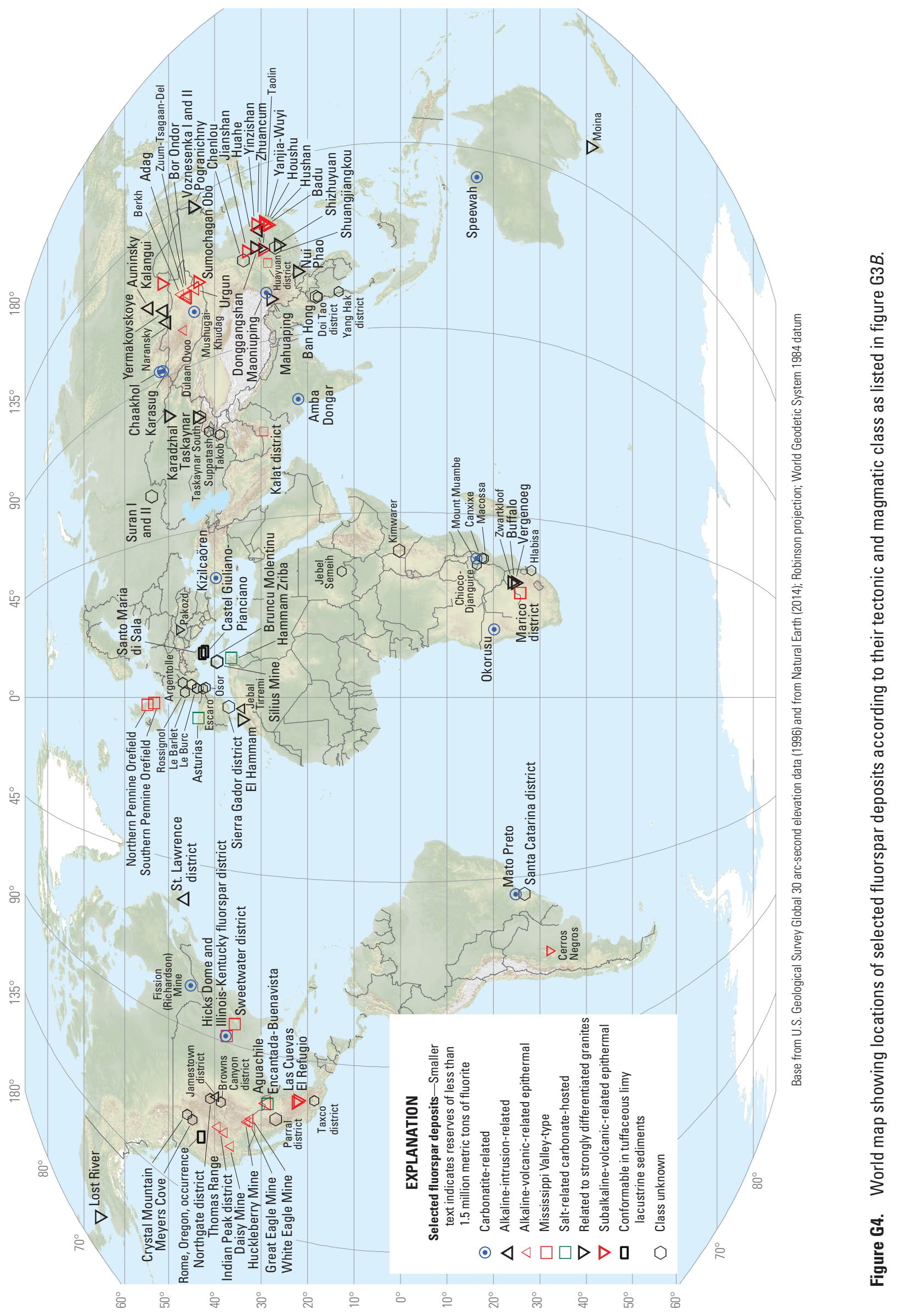


of beryllium. Other alkaline-intrusion-related deposits are located in the St. Lawrence district in Newfoundland, Canada, where large, discrete fluorspar veins cut across peralkaline granite (Van Alstine, 1944). Other districts, such as the Jamestown district in Boulder County, Colo., have ore contained mainly in breccia bodies that may grade laterally to veins (Goddard, 1946). Studies suggest that the fluids that formed these deposits had temperatures that ranged from $500{ }^{\circ} \mathrm{C}$ down to about $100{ }^{\circ} \mathrm{C}$ (Nash and Cunningham, 1973; Strong and others, 1984). The fluids also had a great range of salinities. Those results and oxygen isotope studies suggest that the mineralizing fluids were mixtures of magmatic and meteoric waters, and the relatively high contents of REEs in the fluorite supports that conclusion (Strong and others, 1984). At Yermakovskoye, magmatic fluids have been well documented (Reyf, 2004, 2008) and include (a) a magmatic brine highly enriched in beryllium, manganese, and molybdenum, with additional cerium, lanthanum, lead, and zinc concentrations, and (b) a carbon dioxide $\left(\mathrm{CO}_{2}\right)$-rich fluid enriched only in beryllium with a homogenization temperature of between 335 and $355^{\circ} \mathrm{C}$ and relatively low salinity of 2.4 to 8.2 equivalent weight percent $\mathrm{NaCl}$. These two fluids seem likely to be the products of the boiling of a common ancestor hydrothermal fluid.

\section{Alkaline-Volcanic-Related Epithermal Fluorspar Deposits}

Northern Mexico and Kenya have fluorspar deposits and occurrences that are related to alkaline volcanic rocks. Examples of such deposits are located at Aguachile, Coahuila de Zaragoza, Mexico (McAnulty and others, 1963), and at Kimwarer, Elgeyo/Marakwet County, Kenya (Nyambok and Gaciri, 1975). These deposits are also in contact with or are hosted by carbonates (limestone or calcite marble). The igneous rock type that is most closely associated in time with ore at Aguachile is rhyolite porphyry, which occurs in a ring dike around a central plug of quartz-microsyenite porphyry. The microsyenite contains 7 volume percent riebeckite and another 8 volume percent chlorite that is an alteration product of former riebeckite (Levinson, 1962). Several other small districts are related to similar rocks in Coahuila de Zaragoza, Mexico, as, perhaps, are the deposits of the very large Encantada-Buenavista district of Mexico (Temple and Grogan, 1963; Kesler, 1977; González-Partida and others, 2003). Fluorspar deposits in the Eagle Mountains of Hudspeth County, Texas, are related to igneous rocks of the same igneous province (Gillerman, 1948). The Hidalgo del Parral district in Chihuahua, Mexico, is also related to alkali rhyolites (Pickard, 1974).

The Kimwarer deposits in Kenya, though hosted in Precambrian calcite marbles and other gneissic rocks, are most closely related in time to Tertiary phonolites of the East African Rift volcanic rocks (Nyambok and Gaciri, 1975). Phonolite is a volcanic rock that consists essentially of alkali feldspar and a feldspathoid mineral (the feldspathoid mineral is nepheline for the rocks near Kimwarer). Because the phonolites are not in contact with fluorspar ore anywhere at Kimwarer, it is possible that these deposits are instead related to unexposed (still buried) carbonatitic rocks. Carbonatites are found in several places in or near the East African Rift valleys. In these volcanic-related deposits, low temperatures and generally low salinities suggest that the mineralizing fluids were dominated by meteoric waters. Fluid inclusion homogenization temperatures are generally no greater than $175^{\circ} \mathrm{C}$, and salinities are commonly less than 10 equivalent weight percent $\mathrm{NaCl}$ (Kesler, 1977; González-Partida and others, 2003). Although intrusive rocks may be present, they may have served only as heat sources to cause convection of the groundwaters through fluorine-rich alkali rhyolite source rocks. Alternatively, and more likely, the magmas that contributed to the volcanic rocks also evolved a late-stage water-rich phase, which contributed to the mineralizing waters and thus at least small amounts of magmatic components to the deposits. Although the conditions and chemistry of the hydrothermal fluids were generally similar throughout this class, the geometry of mineralized bodies varies greatly. Some are discrete, large veins (Kimwarer). Others are carbonatehosted breccia pipes or breccias along contacts with intrusions (Aguachile). Yet others are peneconformable replacement bodies in carbonates, which are known in the United States as bedding-replacement deposits (Weller and others, 1952; Gillerman, 1948) and in Spanish-speaking countries as mantos (for example, the Encantada-Buenavista district in Mexico; Temple and Grogan, 1963). A peneconformable configuration means that the replacement bodies lie within and parallel to the bedding of the sedimentary host rocks, yet have lateral boundaries that cut across those host rocks.

Some have suggested that other fluorspar deposits of the Western United States and Mongolia are related to alkaline volcanic rocks (Lindsey, 1982; Lkhamsuren and Hamasaki, 1998), but there is some doubt that the associated volcanic rocks should truly be called alkaline in the sense that the word is used above. Lindsey (1982) describes the deposits of the Thomas Range, Utah, as being related to rhyolites of the latest magmatic stage in the area-those rocks typically have a peralkaline composition. The rhyolites of the Thomas Range (the Topaz Mountain rhyolites) have phenocrysts of sanidine, biotite, and plagioclase, and lack any aegerine or riebeckite. They are alkali feldspar rhyolites, but the rocks are probably not truly of the alkaline series as that term is used above in defining the distinction between subalkaline, peralkaline, and alkaline.

The deposits of the Thomas Range are probably better assigned to the class of epithermal deposits related to subalkaline volcanic rocks (see below in the section titled Subalkaline-Volcanic-Related Epithermal Fluorspar Deposits). The rhyolite associated with fluorspar deposits in the Thomas Range contains topaz phenocrysts; it is very fluorine-rich. Some well-known fluorspar deposits in Colorado - in the Browns Canyon district of Chaffee County (Van Alstine, 1969) and in 
the Northgate district of Jackson County (Steven, 1960) - are also most closely associated in time with topaz rhyolites, which are not rocks in the alkaline series (Burt and others, 1982); hence, those deposits are also probably best assigned to the class of epithermal deposits related to subalkaline volcanic rocks. The topaz rhyolites of western North America do not, however, date from times of the major andesitic volcanic fields and granodiorite batholiths like those of the Sierra Nevada Range. Rather, they post date such rocks in each area where they occur, and they belong to groups of rocks believed to have formed by partial melting of continental crust. Numerous deposits in Mongolia are described as being related to "trachytic rhyolite" and "rhyolite differentiated from trachy-basalts" (Lkhamsuren and Hamasaki, 1998). Whereas true trachytes (volcanic rocks containing alkali feldspar, minor iron-magnesium-silicate minerals, minor plagioclase, and no quartz) typically are alkaline, the term "trachytic" describes a texture of lath-shaped phenocrysts of alkali feldspar that are subparallel to one another in a volcanic rock; the texture does not require the rocks to be truly alkaline. The Late Mesozoic Mongolian volcanic rocks are not described as riebeckite- or aegerine-bearing, and those volcanic rocks again include some topaz rhyolites (Kovalenko and others, 1971). The very fluorine-rich topaz rhyolites are seemingly the rocks that are the most closely associated with fluorspar deposits. Bulnayev and Kaperskaya (1995) demonstrated that fluorspar deposits in Mongolia are most frequently associated with rhyolites among the volcanic rocks there.

\section{Mississippi Valley-Type Fluorspar Deposits}

Mississippi Valley-type (MVT) deposits of leadzinc(-fluorspar-barite) are among the best understood of all hydrothermal ore deposits. These deposits formed in carbonate aquifer rocks where there was interaquifer groundwater mixing of the following two brines: (a) a metalliferous and (or) fluorine-rich brine that escaped upward from a confined lower aquifer under artesian pressure, and (b) a second brine, probably more sulfide-rich (Wenz and others, 2012), that migrated laterally, also under artesian pressure, and was confined above, typically by a shale bed (Plumlee and others, 1994, 1995; Bouch and others, 2006; Stoffel and others, 2008; Ingebritsen and Appold, 2012; Wenz and others, 2012). Both brines likely had their origins as deep basinal groundwaters. A variety of geohydrologic situations allow the brine of the lower aquifer to escape confinement and rise to mix with the second brine in the upper aquifer. The simplest situation that leads to mixing may be where fracturing connects the two aquifers, as in a vein deposit or a breccia body, regardless how the breccia originated. A second and very important mixing situation is where a confining bed pinches out laterally between the two aquifer units (a "shale edge"). Upward escape of lower-aquifer fluids will be focused adjacent to the pinchedout confining bed. This can result in very large deposits arrayed along and above the pinchout, stratigraphically at the level of the upper aquifer; this is the situation with most of the ores of the Southeast Missouri lead district, the Tri-State (Missouri-Kansas-Oklahoma) district, and the Pine Point district in the Northwest Territories, Canada (Brockie and others, 1968; Rhodes and others, 1984; Palmer and Hayes, 1989). A number of other geohydrologic situations allow the fluids of the lower aquifer to escape and mix with the groundwater of upper aquifers, but these situations are less common. The studied brine mixtures (represented by fluid inclusions) from MVT deposits originated by evaporation of seawater, but the mixed fluids also show effects from dolomitization and sulfate reduction along the travel paths and generally show only small amounts of salt redissolution (Viets and others, 1997).

The type of deposits that occur in the Mississippi Valley in the United States resulted from water in gravity-driven regional groundwater flow systems that affected many tens of thousands of cubic kilometers of rock, with recharge in or near collisional orogenic mountain belts like the Ouachita Mountains (Leach and Rowan, 1986). Fluids traveled down through deep basins, then up, driven by artesian pressure from the elevated recharge area, across the cratonic margins towards the craton centers. The regional nature of the mineralizing systems is demonstrated in places where the sequence of mineral precipitation (that is, the paragenesis) of hydrothermal minerals that have partially filled many different kinds of rock porosity can be correlated from MVT district to district, and through all of the former aquifer rocks in between, across hundreds of kilometers (Hayes and others, 1990; Hayes and Anderson, 1992).

Districts of the MVT class that contain significant amounts of fluorite account for 3 of the 10 largest sources of fluorspar in the world (appendix G1). These are the IllinoisKentucky fluorspar district in the United States, the Northern Pennine Orefield and the Southern Pennine Orefield in the United Kingdom, and the Marico district of North West Province, South Africa.

Richardson and Pinckney (1984) established that oscillatory growth layering in fluorite crystals within the Cave-in-Rock subdistrict (Hardin County, Illinois) of the Illinois-Kentucky fluorspar district could be correlated from mine to mine throughout an area of about 8.5 by 2.5 kilometers $(\mathrm{km})$. By correlating generations of hydrothermal carbonates, Hayes and Anderson (1992) extended the correlation of hydrothermal minerals throughout the IllinoisKentucky fluorspar district, then correlated that paragenesis with that of the Central Tennessee (Elmwood-Gordonsville) zinc district, and with the paragenesis of the Central Kentucky district. The total area with correlatable paragenesis of hydrothermal minerals partially filling the former porosity in carbonates from Early Ordovician through Mississippian age is $600 \mathrm{~km}$ east-west by $300 \mathrm{~km}$ north-south and averages slightly more than $2 \mathrm{~km}$ thick, thus yielding about 350,000 cubic kilometers of rock affected by this single MVT system (Hayes and Anderson, 1992). The correlations may extend even farther - perhaps to the Upper Mississippi Valley district in southern Wisconsin (Heyl and West, 1982) and to 
the Findlay arch in northwestern Ohio (Carlson, 1983). The Illinois-Kentucky-Central Tennessee MVT system differs markedly from that of the Ozark Region of southern Missouri, northern Arkansas, southeastern Kansas, and northeastern Oklahoma, however, where no fluorite is found. Furthermore, in the Illinois-Kentucky fluorspar district, thin dikes and sills of mafic igneous rock are fairly numerous and a few small plugs of intrusive breccia occur. Hicks Dome in the northwestern portion of the district is thought to be underlain by a larger related igneous body, but that remains unproven.

In the Illinois-Kentucky fluorspar district, the dikes and sills are likely near-surface indicators of larger igneous masses at depth, and the igneous rocks related to these dikes are likely the cause of the district's unique richness in fluorine among the MVT deposits. This district hosts 62 known dikes and sills that are 1 to 12 meters $(\mathrm{m})$ thick and intruded along faults or bedding planes. It also hosts eight known "diatremes" (brecciated volcanic pipes) that are approximately upright and cylindrical with diameters from a few tens of meters to nearly $200 \mathrm{~m}$ (Denny and others, 2008; Anderson and Sparks, 2012).

Almost all the district's igneous rocks studied to date were originally ultramafic and alkalic. Where fresh, the dike and sill rocks are dark green and porphyritic to inequigranular. Their major primary minerals are olivine, phlogopite, melilite, garnet, apatite, perovskite, and magnetite with secondary serpentine, chlorite, and iron-rich calcite. Differentiates from the magmas that produced these dikes would be expected to be syenites and perhaps could include carbonatite. The xenoliths in the diatremes include aegerine syenite (Bradbury and Baxter, 1992, p. 15), and the rocks in places are nepheline-bearing (Lewis and Mitchell, 1987). The neodymium-samarium isochron age of MVT fluorite mineralization from five mines in the Cave-in-Rock subdistrict is $277.0 \pm 15.6$ mega-annum (Ma), or million years before present (Early Permian) (Chesley and others, 1994), which overlaps entirely the four best-dated igneous rocks in the district that would together give an age range of 266.5 to $273.4 \mathrm{Ma}$ (Early Permian), inclusive of all uncertainties (Reynolds and others, 1997; Fifarek and others, 2001). Where the igneous rocks are in contact with MVT mineralization, the phlogopite of the igneous rocks is hydrothermally altered to illite.

Hicks Dome appears to be the thermal center for hydrothermal mineralization in the Illinois-Kentucky fluorspar district. Deep drilling at Hicks Dome has encountered mineralization with elemental and mineralogical signatures that suggest alkalic igneous rock and possibly carbonatite, which agrees with the widespread but small occurrences of alkaline ultramafic rock in the greater district. The dome is underlain at depths of from $450 \mathrm{~m}$ to perhaps $1,000 \mathrm{~m}$ by fluorite-baritecemented breccias that contain anomalous concentrations of Be, Nb, Th, Ti, Y, and REEs (Brown and others, 1954; Kirkemo, 1978). Across the district, fluid inclusion homogenization temperatures in fluorite from growth zones late within the sequence of banding described by Richardson and Pinckney (1984) decline regularly from the center of Hicks Dome $\left(175^{\circ} \mathrm{C}\right)$, to the flanks of the dome $\left(150^{\circ} \mathrm{C}\right)$, to the
Cave-in-Rock subdistrict $\left(150\right.$ to $\left.132^{\circ} \mathrm{C}\right)$, to mines central to the district in Kentucky $\left(130\right.$ to $\left.120^{\circ} \mathrm{C}\right)$, to the southern margin of the district $\left(128\right.$ to $\left.117^{\circ} \mathrm{C}\right)$, to the most distant outliers of the district $\left(<50^{\circ} \mathrm{C}\right.$ ?) (Taylor and others, 1992). This concentric zonation of homogenization temperatures around Hicks Dome has the same generally concentric form as contours of lead isotopes from galena (Heyl and others, 1966) and contours of silver and antimony content of galena (Hall and Heyl, 1968). Thus, the Illinois-Kentucky fluorspar district records a single large mineralizing system that was likely influenced in some way by magmatism at or near Hicks Dome. It is not inferred that magmatic fluids migrated outward from Hicks Dome; only that it was the highest temperature area of the district and probably has intrusive rocks at depth.

Plumlee and others (1995) used reaction path modeling to try to better understand the Illinois-Kentucky fluorspar district. They modeled a mineralizing fluid that had the measured compositions for major elements from fluid inclusions in fluorite (Hall and Friedman, 1963; Richardson and others, 1988) and assumed saturation with respect to dolomite, quartz, muscovite, pyrite, sphalerite, galena, and fluorite at $120^{\circ} \mathrm{C}$ and a $\mathrm{pH}$ of 4.55 . They could not reproduce the district's MVT ores in terms of phase abundance or paragenesis until they modeled the addition of 0.5 gram of $\mathrm{HF}$ and 0.5 gram of $\mathrm{CO}_{2}$ to each kilogram of the initial fluid. In the HF- and $\mathrm{CO}_{2}$-modified models, they found that any or all of the following resulted in copious amounts of fluorite precipitation: (a) cooling the fluid from 150 to $142{ }^{\circ} \mathrm{C}$, (b) replacement of limestone, and (c) mixing of the fluid with another fluid with different concentrations of calcium and fluorine. Plumlee and others (1995) concluded that HF from alkaline igneous sources, particularly at Hicks Dome, was added to regional MVT metals-transporting fluids to produce the district's fluorite-rich MVT ores. The fluorite-rich ores formed where alkaline igneous rocks and their evolved magmatic fluids intruded into an ongoing regional MVT mineralizing system that extended to at least the Central Tennessee and Central Kentucky districts.

Exposed or geophysically indicated alkalic magmatic source rocks have not been identified at either of the Pennine orefields nor in the Marico district, which are the other identified fluorite-rich MVT districts. Dunham (1948) speculated that the Weardale Granite, which forms the basement to the sedimentary host rocks of the Northern Pennine Orefield, was a heat source simply from decay of elevated concentrations of radioactive elements within it, and that convection of mineralizing meteoric groundwaters through the fracturing systems was set up around the Weardale Granite because of the anomalous heat. Bau and others (2003) suggested that sources of REEs and yttrium in the fluorite of the Southern Pennine Orefield were relatively pure marine sedimentary carbonates, and that, in contrast, the sources for the Northern Pennine Orefield were aluminosilicate rocks, which is consistent with the Weardale Granite being a source for REEs in the Northern Pennine Orefield fluorite. 
The Bushveld Complex is located relatively near the Marico MVT district in South Africa. The large Buffalo fluorspar deposit (Limpopo Province) and the very large Vergenoeg fluorspar deposit (Gauteng Province) are located near the center of the Bushveld Complex and at its highest structural level (appendix G1). Buffalo and Vergenoeg appear to be related to strongly differentiated Bushveld Complex granites (deposit type 5 of fig. G3B). In a contact zone that surrounds the Bushveld intrusives, the Marico fluorspar ores have been metamorphosed by the heat from the intrusions (Martini, 1976), so it was not possible for Bushveld-age hydrothermal fluids from those granites to provide fluorine for the preexisting MVT fluorspar deposits.

\section{Salt-Related Carbonate-Hosted Fluorspar Deposits}

Leach and others (2005, appendix A, table A1) consider salt-related carbonate-hosted deposits to be part of their classification of MVT deposits and have given them an alternate subclass name ("salt dome related"). According to the authors, only 5 of their 247 example MVT deposits worldwide are said to be salt dome related. Indeed, these deposits have the same simple mineralogy, the same kinds of orebody geometries, similar parageneses, and probably the same types of local geohydrologic controls (various scenarios that produce interaquifer groundwater mixing) as the MVT deposits within the Mississippi Valley itself. In figure G3, saltrelated carbonate-hosted deposits are shown to be a subclass of MVT deposits. What MVT and salt-related carbonatehosted deposits do not share, however, is their regional and temporal geologic settings, along with other details that result from the differences in their settings.

Salt deposits themselves are commonly found on passive continental margins that formed in the arid tropics or in failed arms of the rifts extending inland from passive continental margins (aulacogens). Thus, in contrast with the MVT deposits of the Mississippi Valley, which are associated in time and distantly in space with collisional orogenic belts, the saltrelated carbonate-hosted deposits are in many places clearly associated with continental rifting, with passive margins, or with aulacogens. The salt-related classification originated with French scientists who studied deposits in Algeria and Tunisia where the salt is Triassic (Charef and Sheppard, 1987; Orgeval, 1994; Perthuisot and Rouvier, 1995; Sheppard and others, 1997); however, the best example of these types of deposits are from the Miocene to recent Red Sea margins (El Aref and Amstutz, 1983; Hayes and others, 2002). The U.S. Gulf of Mexico margin, where the Middle to Upper Jurassic Louann Salt is located, also has deposits of this type (Price and others, 1983; Kyle and Saunders, 1997; Saunders and Swann, 1994), but none has been proven economic to mine.

Differences between MVT deposits and salt-related carbonate-hosted zinc-lead-fluorite-barite deposits are important considerations for exploration. The sedimentary sections that host salt-related carbonate-hosted deposits contain evaporites, which typically form major parts of the local sedimentary section and, at places, exceed one-half of the total sedimentary thickness. Although evaporites are present in traces in the sedimentary sections of the MVT deposits of the Mississippi Valley, none appear to be as much as 5 percent of the thickness of the involved section anywhere within $100 \mathrm{~km}$ of a deposit (although adjacent basins have considerably more; for example, the Michigan Basin). Salt-related carbonate-hosted zinc-lead-fluorite-barite deposits differ from the MVT deposits by having paragenetic sequences of hydrothermal minerals that cannot be correlated for even as much as tens of kilometers. Connected secondary porosity needed for long-distance transport of hydrothermal brines does not generally exist in strongly fault-segmented continental rifts and early passive margins.

Although many of the salt-related zinc-lead-fluoritebarite deposits are located close to salt deposits, with some actually within the cap rocks of salt domes, the critical role of the salt is probably not in creating sites for mineralization, such as caprock hosts, nor in creating structural paths for the required interaquifer groundwater mixing. Rather, the critical role of salt in these deposits is probably that it dissolves in mineralizing brines to supply chloride and thus provides high solubilities of zinc, lead, iron, and barium as chloride complexes in those mineralizing brines (Hayes and others, 2001, 2002). Spatial association with salt and the presence of fluid inclusions in ore minerals that demonstrate the process of dissolving preexisting salt to create an ore solution are true indicators of this class. Spatial association is not necessary if the fluid inclusions contain redissolved salt-as demonstrated from the $\mathrm{Cl}^{-}: \mathrm{Br}^{-}$and $\mathrm{Na}^{+}: \mathrm{Br}^{-}$ratios (Carpenter, 1978; Hanor, 1987; Kesler and others, 1995) — as a major component in the ore fluids.

Fluorspar deposits in the Asturias region of Spain are the best known examples of fluorine-rich deposits of this class as a result of some recent work on the composition of the deposits' fluids (Sánchez and others, 2009). The geographic association of the deposits with Late Triassic salt in diapirs is shown in figure G5, which shows as well the locations of zinc-lead-(fluorspar-barite-copper-iron) deposits and siderite iron deposits of the enclosing and larger Cantabrian region (Velasco and others, 1994). The zinc-lead-(fluorspar-baritecopper-iron) deposits and the siderite iron deposits probably all originated from the same general mineralizing events; all these deposits are probably salt-related carbonate-hosted deposits (Grandia and others, 2003). In studies of the microthermometry and composition of fluid inclusions in the Asturias deposits, Sánchez and others (2009) identified two discrete fluids that mixed to precipitate fluorspar ore: a simple sodium-chloride-dominated groundwater with salinities of 0 to 8.2 equivalent weight percent, and a complex sodium chloride-calcium chloride brine with salinity of 9 to 25 equivalent weight percent sodium chloride. They found that the complex higher-salinity brine had $\mathrm{Cl}^{-}: \mathrm{Br}^{-}$and $\mathrm{Na}^{+}: \mathrm{Br}^{-}$ratios that demonstrated a large proportion of halite dissolution. A comparable degree of halite dissolution was 

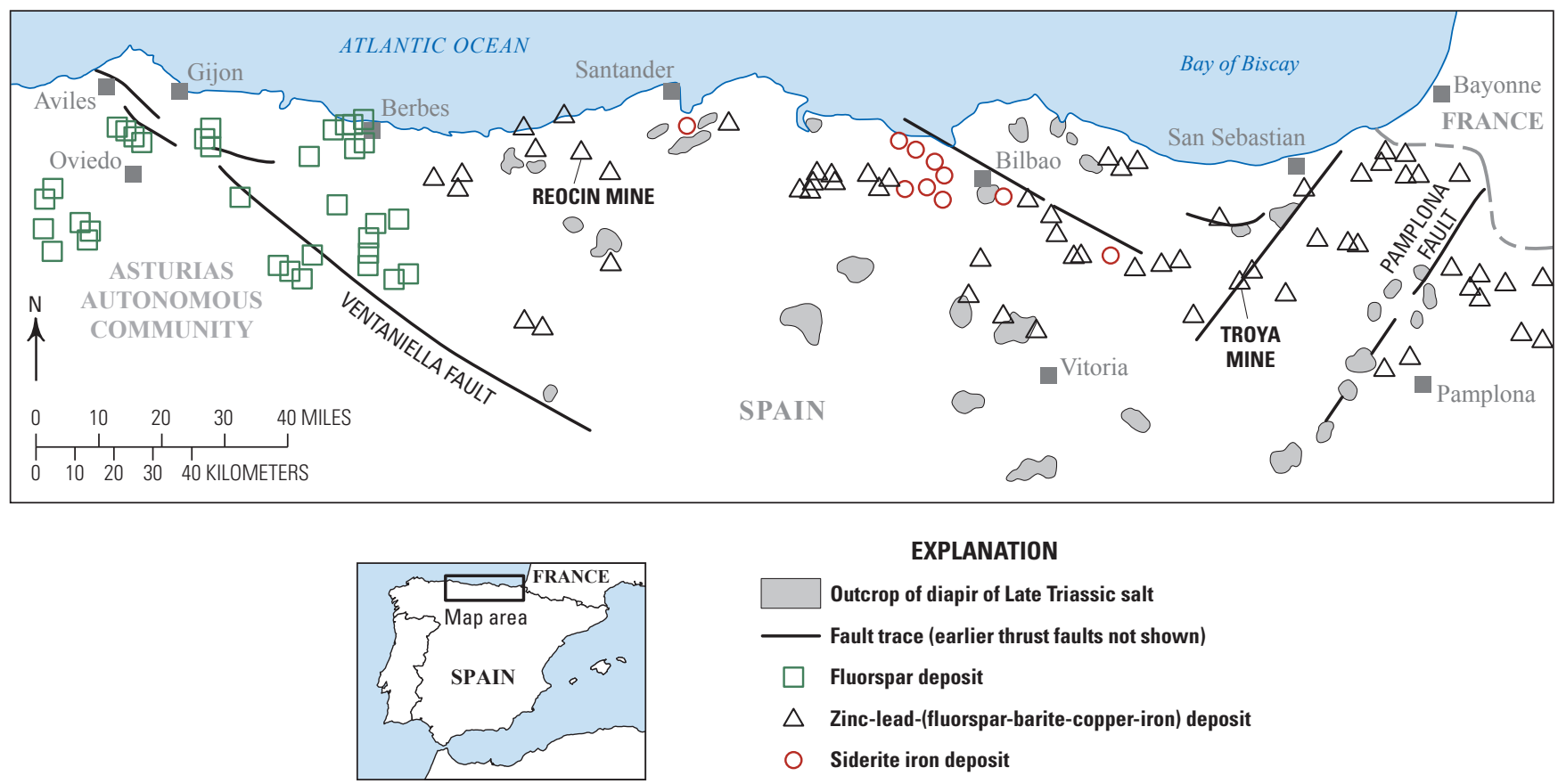

EXPLANATION

Outcrop of diapir of Late Triassic salt

- Fault trace (earlier thrust faults not shown)

Fluorspar deposit

$\triangle$ Zinc-lead-(fluorspar-barite-copper-iron) deposit

Siderite iron deposit

Figure G5. Map showing the locations of deposits in the Cantabrian salt-related carbonate-hosted mineral district in north-central Spain. The locations of the fluorspar mines and occurrences and the base map of the Asturias Autonomous Community on the west are modified from Garcia-Iglesías and Loredo (1994), and the locations of siderite iron deposits, zinc-lead-(fluorspar-barite-copper-iron) deposits, and outcrops of Late Triassic salt diapirs, as well as the base map of the eastern two-thirds of the area, are modified from Velasco and others (1994).

nowhere measured among sphalerite fluid inclusions from 12 different MVT districts, including all of the districts of the Mississippi Valley itself (Viets and others, 1997). Sánchez and others (2009) found that the Asturias complex halite dissolution brine also had very high metal contents; that is, up to 500 ppm zinc, 170 ppm lead, and 480 ppm barium - or about one order of magnitude greater than those found in most other metalliferous basinal brines (Land, 1995; Hanor, 1997). The Asturias fluorspar deposits were also samarium-neodymium isotopically dated, yielding an age of $185 \pm 29 \mathrm{Ma}$ (Early Jurassic) (Sánchez and others, 2006). This date demonstrates the association with rifting instead of collisional tectonics, because in the Early Jurassic Period, the Asturias region of Spain and the rest of Western Europe were in the process of renewed rifting along the middle Atlantic rift following upon the initial rifting that took place during the Permian Period (Yilmaz and others, 1996).

Many other fluorspar deposits of the western part of Europe appear to share many of the characteristics of the deposits of Asturias. Similar hypersaline brines at temperatures of from 81 to $165^{\circ} \mathrm{C}$ and salinities of from 17 to as much as 26 equivalent weight percent $\mathrm{NaCl}$ were found in northeastern (Catalonia) Spain's Berta, Osor, and Rigros veins (Cardellach and others, 2003; Piqué and others, 2008); in the Muscadroxiu-Genna-Tres Montis-S'Acqua Frida veins (Silius Mine) (Boni and others, 2009) and other veins in southern Sardinia, Italy (Belkin and others, 1984); in the Le Burc vein in the Massif Central (Midi-Pyrénées
Region, France; Deloule, 1982); and in the Rossignol vein (Centre Region, France) and exhalative sediment (Sizaret and others, 2004). Four of these locations are shown in fig. G4. Each of these fluorite deposits has been isotopically or geologically constrained to have formed between the Early Jurassic Period and Early Cretaceous Period and is related to the renewed rifting of the middle Atlantic (Sizaret and others, 2004; Munoz and others, 2005; Piqué and others, 2008).

The above deposits are all probably examples of the general salt-related carbonate-hosted class and related to rifting, even where the wall rocks are Hercynian basement rocks. A characteristic magmatic rock of some continental rifts or rifted margins is peralkaline, however, and, consequently, each of the deposits could instead be of the alkaline-intrusionrelated type, with the intrusive rocks buried and providing mainly just the heat to produce hydrothermal circulations. The deposits at Hansonburg in Socorro County, New Mexico, have been called MVT (Putnam and others, 1983; Norman and others, 1985), despite their setting adjacent to the Rio Grande Rift, which hosts a number of epithermal, alkaline-volcanicrelated fluorspar deposits (Van Alstine, 1976). Recent results demonstrate that the Hansonburg hydrothermal fluids had from 13 to 49 percent asthenospheric magmatic chlorine (Partey and others, 2009), so the deposits are also alkaline-intrusionrelated. Deposits of the Encantada-Buenavista district in Coahuila de Zaragoza, Mexico (fig. G4) have been shown to have fluid inclusions with homogenization temperatures of from 75 to $170{ }^{\circ} \mathrm{C}$ and salinities of from 7.8 to 15.4 equivalent 
weight percent $\mathrm{NaCl}$; that is, complex brines of probably sedimentary origin (González-Partida and others, 2003). On that basis, the Encantada-Buenavista deposits are labeled salt-related carbonate-hosted in figure G4. They are probably related to the salt-bearing Jurassic basin adjacent to the west. Kesler (1977), however, had earlier concluded that these and other deposits in the same Cretaceous limestone host rocks in Coahuila de Zaragoza, Mexico, were deposited from boiling, probably partly magmatic, fluids. Many of the deposits are at contacts with rhyolitic or trachytic high-level intrusive rocks (Temple and Grogan, 1963; Pickard, 1974; Kesler, 1977). As with Hansonburg, the Encantada-Buenavista district is likely to prove to have some magmatic component, thus validating its classification as both salt-related carbonate-hosted and related to peralkaline igneous rocks.

\section{Fluorspar Deposits Related to Strongly Differentiated Granites}

Fluorspar deposits are known to be present in association with strongly differentiated granites with a considerable range of compositions of the granite, from rather ordinary monzogranites, to two-mica granites, to tin granites. Generally, the greater the differentiation, the more common the occurrence of associated fluorspar deposits. Although the general behavior during differentiation is similar to that in alkaline granites, the associated metals and deposit types are distinct from the metals and deposit types associated with alkaline intrusive rocks. Deposits with the subalkaline granites include fluorite-rich tin and tungsten skarns, fluoriterich veins with tin and (or) tungsten, some with antimony, and fluorite-rich greisen deposits, and, fewer in number, disseminated or stockwork fluorspar deposits. Molybdenum and bismuth are additional elements that are commonly anomalous in these deposits. Greisens are rocks composed principally of muscovite (or lithium-rich white mica) and quartz with lesser abundances of one or more of the following: bertrandite, beryl, cassiterite, columbite-tantalite, fluorite, phenakite, topaz, tourmaline, and wolframite. Minor sulfides are found in greisens, principally pyrite, but locally others as well, including molybdenite. Although greisens appear to form by hydrothermal alteration of intrusive igneous rocks, a distinguishing feature is that feldspars are absent and have presumably been altered to the white mica.

Among the end-member granites that are included in the broad class of strongly differentiated granites, two-mica granites are those with both muscovite and biotite, which, given those two aluminous micas and the presence of both plagioclase and alkali feldspars, are invariably strongly peraluminous. (In peraluminous igneous rocks, molar $\mathrm{Al}_{2} \mathrm{O}_{3}>\left(\mathrm{Na}_{2} \mathrm{O}+\mathrm{K}_{2} \mathrm{O}\right)$.) Tin granite is also a very specific type of granite (Tischendorf, 1978; Hudson and Arth, 1983). Tin granite can be porphyritic, seriate, or equigranular in texture, but all are light-colored peraluminous biotite granites, and all are small offshoots of large granodiorite-to-granite batholiths from which the tin granite evolved by fractional crystallization. The tin granites are found in stable cratonal regions and not in continental or oceanic arcs (Hudson and Arth, 1983). Fluorspar deposits associated with tin granites have a variety of geometries (veins; replacements; skarns at intrusive contacts; greisens in small, upward projections on the granite body's roof [that is, endogreisens in granitic cupolas]; and greisens in wall rocks of the granite [that is, exogreisens]). Lithium-rich annite is an important characteristic mineral in tin granites. It was earlier termed "zinnwaldite." Annite is the iron-rich end member of the biotite solid solution - that is, monoclinic $\mathrm{K}_{2} \mathrm{Fe}_{6}\left(\mathrm{Si}_{6} \mathrm{Al}_{2} \mathrm{O}_{20}\right)(\mathrm{OH})_{4}$. In lithium-rich annites, the lithium substitutes for aluminum and iron in this mineral and produces micas of the zinnwaldite series.

To date, fluorspar deposits related to strongly differentiated granites have been identified on every continent except South America and Antarctica (fig. G4 and appendix G1). They probably also occur on those two continents as well but simply have not yet been discovered. Tin-granite end members have not been found in the Andean magmatic belts, however, because those belts appear to be composed entirely of intrusive rocks of oceanic and continental arcs (Steve Ludington, U.S. Geological Survey, retired, written commun., December 6, 2013).

At places, assignment of a deposit to the class associated with strongly differentiated granites is very obvious, but at others, it is not as clear. For example, the very large Vergenoeg deposit in South Africa is near to but not in contact with granites that host tin deposits. The granites are part of the Bushveld Complex and are related to the platinoid-metal-, chromium-, vanadium-, and copper-nickel-bearing rocks of the layered mafic to ultramafic rocks of the lower part of the Bushveld Complex (Hatton and Sharpe, 1989). The Vergenoeg deposit is an approximately carrot-shaped, root-downward mass of very iron-rich igneous (or metasomatic? - that is, formed by replacement from hydrothermal fluids) rocks that cuts intermediate to felsic Rooiberg volcanic rocks. Those Rooiberg volcanic rocks are thought to have been derived by partial melting of upper crustal rocks that lay above the intrusion of the enormous, lobate, sill-like body of the Bushveld Complex and are considered to be the eruptive products of the magmas that became Bushveld granites and granophyres (Kleemann and Twist, 1989; Schweitzer and others, 1997). Vergenoeg ore consists of very coarse-grained (pegmatitictextured) fayalite-magnetite-siderite-fluorite rock that contains an average of 28 percent $\mathrm{CaF}_{2}$ and less than 30 percent $\mathrm{SiO}_{2}$. Flat-lying deposits of fluorite-hematite are located nearby in three directions from the pipe; these deposits are interpreted by Crocker (1985) as tuffs of unusual composition that erupted from the pipe. The average REE pattern of Vergenoeg fluorite precisely parallels that of average Bushveld granite but the fluorite has slightly less than one-tenth the concentrations found in the granites (Goff and others (2004). The origin of the Vergenoeg deposit remains uncertain, but its classification as related to strongly differentiated granite is indicated by the parallel REE patterns. 
Definitely within the class of deposits associated with strongly differentiated granites are the Voznesenka and the Pogranichny deposits in Russia's Far East Region (Ryazantseva, 1998; Sato and others, 2003) and the Lost River prospect in Nome Borough, Alaska (Dobson, 1982). These are fluorite deposits in which tin granites and related greisens are exposed literally within the map limits of the fluorspar deposits, although the tin granites themselves are not fluorspar ore. These deposits contain related cassiterite-bearing tin skarn that is very distinctive because the skarn (known as "wrigglite") is rich in magnetite and vesuvianite and has a tortuously sinuous mineralized structure formed by layers that are a millimeter or less in thickness (Kwak and Askins, 1981). Cassiterite, which is the major ore mineral of tin, is tetragonal $\mathrm{SnO}_{2}$ and vesuvianite, which is the calc-silicate mineral of the skarn, is tetragonal $\mathrm{Ca}_{19}$ $\mathrm{Fe}(\mathrm{Mg}, \mathrm{Al})_{8} \mathrm{Al}_{4}\left(\mathrm{SiO}_{4}\right)_{10}(\mathrm{OH})_{10}$. Magnetite is isometric $\mathrm{Fe}_{3} \mathrm{O}_{4}$. The fluorspar ores, which are replacements of former carbonate sedimentary rocks by minerals deposited from hydrothermal solutions, contain micas that are very lithium- and fluorinerich, so the ores may also be termed fluorspar greisens. Most of the same features are found at Moina in Tasmania, Australia (Kwak and Askins, 1981) and, apparently, at Bamianshan in Zhejiang Province, China (Han and others, 2012).

The El Hammam deposit in the Meknès-Tafilalet Region of Morocco; the Yinkuangchong deposit in Hengyang Prefecture, Hunan Province, China; and the Taskaynar deposit in Kazakhstan have spatial association to granitic rocks, but the description of the granites is not detailed enough to determine if they are strongly differentiated, much less whether they are tin granites or two-mica granites. The fluorspar ores at these places contain tin, tungsten, bismuth, or molybdenum minerals, and that association of elements leads to the deposits' tentative classification as related to strongly differentiated granites. The veins at El Hammam contain minor amounts of stannite (tetragonal $\mathrm{Cu}_{2} \mathrm{FeSnS}_{4}$ ) and bismuthinite (orthorhombic $\mathrm{Bi}_{2} \mathrm{~S}_{3}$; Cheilletz and others, 2010). At Yinkuangchong, two types of mineralized bodies are recognized. The lesser type consists of quartz veins that contain some amount of cassiterite. The larger polymetallic-fluorspar bodies are silicified breccias that contain minor amounts of scheelite (tetragonal $\mathrm{CaWO}_{4}$ ) (Chen and others, 1996). The carbonate replacement body at Taskaynar contains cassiterite in a pre-fluorite stage of the paragenetic sequence, and there is a halo of rocks that are high in molybdenum surrounding the deposit (Koplus and others, 1977).

\section{Subalkaline-Volcanic-Related Epithermal Fluorspar Deposits}

Many fluorspar deposits worldwide occur in association with subalkaline volcanic rocks. Subalkaline volcanic rocks, in contrast to alkaline and peralkaline volcanic rocks, do not have an excess of potassium and sodium over what is needed for feldspars. They commonly contain both plagioclase and an alkali feldspar. They are typically saturated with silica, and thus quartz crystallized as a late mineral from the differentiating melt. Subalkaline volcanic rocks are the most common rocks of continental arcs, and andesites are the most common rocks among the subalkaline volcanic rocks.

Fluorspar deposits associated with subalkaline volcanic rocks are the most plentiful in China, and many are found in Zhejiang Province along the county's southeastern coast (fig. G4). Chen and others (1996) and Zhang and others (1997) describe the geology of fluorspar deposits in Zhejiang Province. Most of the deposits are described as simple large veins that have no close spatial association and no obvious genetic association with plutonic or shallowly intrusive igneous rocks. Some veins of the Yangjia-Wuyi district are continuous for more than $15 \mathrm{~km}$ along strike with thicknesses of 2.3 to $5.8 \mathrm{~m}$. The ore is not continuous along strike, but ore shoots are typically separated by just $15-$ to $46-\mathrm{m}$ intervals of quartz-rich and fluorite-poor parts of the veins. The YangjiaWuyi veins cut a section of Jurassic-aged intermediate to dominantly felsic volcanic rocks that are intercalated with sedimentary rocks. The section is dominated by rhyolitic tuff but is interlayered with limestone, quartzite, tuffaceous siltstone, and, locally, with shale and mudstone (Chen and others, 1996; Zhang and others, 1997). The veins include gangue minerals of quartz, chalcedony, opal, calcite, and barite, and small amounts of pyrite (isometric $\mathrm{FeS}_{2}$ ), apatite (hexagonal $\mathrm{Ca}_{5}\left(\mathrm{PO}_{4}\right)_{3}(\mathrm{~F}, \mathrm{OH}, \mathrm{Cl})$ ), and kaolinite (triclinic $\left.\mathrm{Al}_{2} \mathrm{Si}_{2} \mathrm{O}_{4}(\mathrm{OH})_{2}\right)$. Wall rocks are altered with the addition of quartz, a lesser amount of kaolinite, and local pyrophyllite (monoclinic $\mathrm{AlSi}_{2} \mathrm{O}_{5}(\mathrm{OH})_{2}$ ), carbonates, chlorite (monoclinic $\left.(\mathrm{Mg}, \mathrm{Al}, \mathrm{Fe}, \mathrm{Li}, \mathrm{Mn}, \mathrm{Ni})_{46}(\mathrm{Si}, \mathrm{Al}, \mathrm{B}, \mathrm{Fe})_{4} \mathrm{O}_{10}(\mathrm{OH}, \mathrm{O})_{8}\right)$, and pyrite. The ore and gangue mineralogy as well as the fluid temperatures and salinities are consistent with epithermal conditions (Chen and others, 1996). Isotopic studies are insufficient to address the origins of the fluids, but meteoric water was probably dominant. The fluorspar deposits in Zhejiang Province have been dated at 70 to $90 \mathrm{Ma}$ by a samarium-neodymium isochron on fluorite and calcite (Li and others, 1998). Studies of neodymium and strontium isotopes are interpreted to indicate that most of the neodymium and strontium was derived from the Precambrian metamorphic rocks lying below the host rock, and that the remainder was derived from the Mesozoic volcanic and sedimentary wall rocks themselves ( $\mathrm{Li}$ and others, 1998). Although the deposits contain a record of multiple igneous events dating from 135 through 97 Ma with various chemical signatures, the intrusive rocks from $97 \mathrm{Ma}$ are those that, in time, could have contributed in small proportions to the mineralizing fluids. Those rocks, which belong to a high-potassium subalkaline suite of volcanic rocks (Lapierre and others, 1997), are peraluminous granites of an apparently ordinary continental arc. In these epithermal systems, the role of the high-potassium subalkaline volcanic rocks as sources for fluorine may have been more important than that of the granites, which may have merely been heat sources needed to cause groundwater convection. In other countries, also, the deposits associated with subalkaline volcanic rocks tend to be simple epithermal veins with crystals that grow symmetrically inward from both vein walls. 
Other deposits that may tentatively be included in the class of epithermal fluorite deposits associated with subalkaline volcanic rocks are the Las Cuevas deposit in the State of San Luis Potosi, Mexico, and the nearby mines at El Realito and El Refugio in Guanajuato State, Mexico. Each of these three deposits is at the faulted and brecciated contact of limestone and rhyolite breccia (Ruiz and others, 1980). The rhyolites are part of a province of high-potassium subalkaline rocks (Ruiz, 1983) that lies east of the main subalkaline Sierra Madre Occidental volcanic complex. Although the rhyolite lying along one wall of the Las Cuevas orebody is relatively fluorine-rich, and although Ruiz (1983) showed that the composition of the Las Cuevas deposit fluorite reflects the composition of its local wall rocks (including that rhyolite), the Las Cuevas rhyolite is not one of the "topaz rhyolites" that were erupted at approximately the same time as the Las Cuevas rhyolite, that have the highest fluorine of any volcanic rocks in the region, and that have associated tin mineralization in the Mexican tin belt (Huspeni and others, 1984). Clark and others (1982) included these deposits together with those in a belt to the north, including Aguachile in Pico Etereo district, and El Tule district in Coahuila de Zaragoza, Mexico, which are associated with peralkaline rhyolites, as well as deposits of the Eagle Mountains in Hudspeth County, Tex., which are associated with a quartz syenite intrusion. That inclusion appears questionable based on the contrast in chemistry of the volcanic rocks near Las Cuevas, El Realito, and El Refugio compared with the chemistry of volcanic rocks associated with the deposits in Coahuila. The rhyolites at those three deposits are part of a high-potassium subalkaline province; they are not peralkaline like the rhyolites in Coahuila.

The Sumochagan Obo deposit in China's Inner Mongolia Autonomous Region may also belong in the class of epithermal fluorspar deposits associated with subalkaline volcanic rocks. It is a large, rich deposit approximately conformable with the layering of calcareous tuffs and tuffaceous limestones (Nie and others, 2008) within a high-potassium subalkaline volcanic and sedimentary pile (Xu, 2009) of Early Permian age (appendix G1). At its closest point, the deposit is about $1,200 \mathrm{~m}$ distant from a peraluminous granite intrusion $(\mathrm{Xu}$ and others, 2008) into that volcanic pile. It thus resembles the other deposits listed in this section in its tectonic and magmatic setting; however, its tuffaceous limy host rock and its approximately conformable geometry would perhaps allow it to be alternatively placed in the class of apparently conformable deposits within tuffaceous limy lacustrine sediments.

\section{Fluorspar Deposits Apparently Conformable Within Tuffaceous Limy Lacustrine Sediments}

A number of deposits in the Latium Region of westcentral Italy make up the class of apparently conformable deposits within tuffaceous limy lacustrine sediments, together with a single fluorite occurrence in southeastern Oregon, and, as noted above, possibly the Sumochagan Obo deposit in China. The deposits in Latium, Italy, are fine grained with more than 85 weight percent of the fluorite less than $40 \mu \mathrm{m}$ (that is, silt and clay size), and, in fact, the proportion of fluorite in the Latium Region resource increases as the grain size decreases (Mastrangelo, 1976, p. 31). In an apparently conformable occurrence near Rome, Oregon, the fluorite grain size is predominantly less than $1 \mu \mathrm{m}$ (Sheppard and Gude, 1969). The occurrence at Rome, Oreg., is in Pliocene rock (1.8 to $5.3 \mathrm{Ma}$ ). If Sumochagan Obo belongs within this class, then it must have been considerably modified from its original form because fluorite in the deposit has grain sizes of from 110 to $6,370 \mu \mathrm{m}$; that is, it has the grain sizes of very fine sand to fine conglomerate using standard grain sizes for sand. The texture of the "primary industrial ore" of Sumochagan Obo is "sugar-granular" (Yong and others, 2011, p. 14); thus, it ranges from coarse to very coarse sand. That the grain size of the Sumochagan Obo ore would have coarsened since the time of its deposition is reasonable. The deposit is in Early Permian age rocks (about $270 \mathrm{Ma}$ ), whereas the Italian deposits are in Pleistocene to Pliocene age rocks ( 0.9 to $3.7 \mathrm{Ma})$.

The deposits of the Latium Region appear to be conformable with layering in a mixed volcanic and sedimentary section, and they appear to constitute a hydrothermal sediment interlayered within lake-deposited tuffaceous limy mudstone and siltstone. The volcanic rocks of this region are alkaline, varying from trachytic tuffs to leucitites to phonolites to tephrites (the series of names of alkalic volcanic rocks just listed is from richest to poorest in alkali feldspar; all are undersaturated with silica). Most of the volcanic rocks contain leucite, analcime (isometric or monoclinic $\mathrm{Na}\left(\mathrm{AlSi}_{2}\right) \mathrm{O}_{6} \cdot \mathrm{H}_{2} \mathrm{O}$ ), or nepheline. Flat-lying volcanic rocks dominate the section, but lake-deposited and lesser amounts of stream-deposited sedimentary rocks occur in multiple places in the section. The Latium Region is pockmarked by maar lakes (that is, lakes formed in shallow volcanic craters), which occur in the same 40-by-110-km zone as the fluorspar deposits. Maar lakes are nearly circular, have no volcanic cone, and have very steep walls. They are produced by single volcanic explosions caused by magma intruding into groundwater-rich rocks, which changes the groundwater explosively to steam, which then throws the overlying rocks upward and outward. Although a number of Latium Region fluorspar deposits were mined in the past, most notably the Castel Giuliano-Pianciano deposit, little of the fluorite was recovered, probably because of the very fine grain sizes of the minerals, and no deposit there is currently being mined despite the presence of identified resources.

The Latium Region deposits consist of various proportions of fluorite, barite, apatite, calcite, and quartz (or chalcedony), and the overall grades are from 37 to 83 weight percent $\mathrm{CaF}_{2}$. The content of barite varies inversely with that of fluorite. The deposits are from $1 \mathrm{~m}$ thick to as much as $15 \mathrm{~m}$ thick over areas of up to tens of square kilometers. The host 
lacustrine rocks include beds of diatomite, but diatoms (fossils consisting of silica that are each the size of a sand grain or less) are not typically found in the fluorspar resource. From a 1976 symposium about the deposits, the majority opinion was that the fluorspar deposits had formed from fumarolic or hydrothermal solutions that discharged onto the floors of maar lakes (Matteucci, 1976). A strong support of that hypothesis was that, at places, a tawny, plastic earthy facies of fluoriterich rock is slump-folded but overlain by an undeformed white-to-yellowish gray gritty facies of fluorite-rich rock.

The occurrence near Rome, Oreg., underlies an area of about 18 square kilometers $\left(\mathrm{km}^{2}\right)$ with an average thickness of about $2.3 \mathrm{~m}$ and an average grade of about 2.65 weight percent $\mathrm{CaF}_{2}$. Using semiquantitative X-ray diffraction, Sheppard and Gude (1969) found a regular set of changes in fluorite content and in other authigenic minerals through the section of basaltic tuffs and lacustrine tuffaceous mudstone. An overlying yellow tuff section appears to have lost fluorine, perhaps during a weathering period that produced alkaline, sodium bicarbonate $\left(\mathrm{NaHCO}_{3}\right)$-type soil waters. The climate and local rock compositions would probably have led to developing the same kind of $\mathrm{NaHCO}_{3}$-rich water of high $\mathrm{pH}$ as was found in the Eastern Rift Valley of eastern Africa that had anomalously high concentrations of fluorine (table G2) (Kilham and Hecky, 1973), although probably at considerably lesser concentrations in Oregon. Probably the once glassy components of that yellow tuff altered to the zeolite minerals clinoptilolite (monoclinic $(\mathrm{Na}, \mathrm{K})_{6}\left(\mathrm{Al}_{6} \mathrm{Si}_{30}\right) 0_{72} \cdot 20 \mathrm{H}_{2} \mathrm{O}$ ), phillipsite (monoclinic $\mathrm{K}\left(\mathrm{Ca}_{0.5}, \mathrm{Na}\right)_{2}\left(\mathrm{Al}_{3} \mathrm{Si}_{5}\right) \mathrm{O}_{16} \cdot 6 \mathrm{H}_{2} \mathrm{O}$ ), and erionite (hexagonal $\left.\mathrm{K}_{2} \mathrm{NaCa}_{1.5} \mathrm{Mg}\left(\mathrm{Al}_{8} \mathrm{Si}_{28}\right) \mathrm{O}_{72} \cdot 28 \mathrm{H}_{2} \mathrm{O}\right)$. Beneath it, the fluoritebearing tuffaceous mudstone became enriched in calcite, fluorite, quartz (or chalcedony), and mordenite, a potassiumrich zeolite (orthorhombic $\mathrm{K}_{2.8} \mathrm{Na}_{1.5} \mathrm{Ca}_{2}\left(\mathrm{Al}_{9} \mathrm{Si}_{39}\right) \mathrm{O}_{96} \cdot 29 \mathrm{H}_{2} \mathrm{O}$ ). Although some parts of their geologic settings are shared, there is no observed or predicted evidence that the same mechanism might have created the conformable fluorite deposits of the Latium Region, Italy, and the occurrence at Rome, Oreg. At just 2.65 percent $\mathrm{CaF}_{2}$, the Rome, Oreg., occurrence is unlikely ever to be considered economic for mining.

\section{Residual Fluorspar Deposits}

Many fluorspar deposits of the world were first discovered in residuum, and many constituted ore at the surface, particularly where costs allowed the ore to be hand sorted. Residual fluorspar deposits were well known in the IllinoisKentucky fluorspar district in the United States, where the carbonate gangue of the veins, predominantly calcite, and the limestone wall rocks were dissolved away during weathering (Weller and others, 1952, p. 29). Residual ore extended to depths locally as great as $30 \mathrm{~m}$. A large volume of the ore in the Marico district in North West Province, South Africa, is residual, where it is termed "kokkoman." Large bodies of kokkoman can exceed 50 percent $\mathrm{CaF}_{2}$ (Martini, 1986; Ryan, 1986). The ore is residually enriched by the dissolving away of dolomite from the host rocks during weathering. Residual fluorite deposits were also widespread in the northern area of fluorspar production in Thailand near the Ban Hong deposit (fig. G4; Fulton and Montgomery, 1983).

\section{Fluorine Recovery From Brines}

Fluorine products are not currently recovered from brines anywhere in the world. As pointed out by Shawe (1976, p. 22), however, production of a fluorine product from a brine is a distinct possibility, perhaps in the near future. A number of other mineral commodities are produced from brines, for example, lithium (Kunasz, 1974; Ericksen and others, 1978). If a fluorine product is produced from a brine, it would not be a brine similar to those that produce lithium, however. Fluorine-rich brines are very alkaline ( $\mathrm{pH}$ commonly about 10 ), are dominated by sodium (Na) and bicarbonate $\left(\mathrm{HCO}_{3}^{-}\right)$, and are brines from which trona is precipitating. The brine from Lake Magadi, Kenya (table G2), is an example of such a fluorine-rich brine from within the trona sediment that makes up the floor of the lake. This is the area from which villiaumite has been identified in the trona (Nielsen, 1999). The surface water of Lake Magadi averages about 1,360 ppm fluorine, and intrastratal brines from boreholes in bottom sediments average about 1,200 ppm (Jones and others, 1977). At present, there is no process by which fluorine can be recovered from the water even with such high concentrations; however, because fluorite has been observed in calcareous rocks where they are in contact with this high-fluorine water, and where the fluorite has replaced calcite (Surdam and Eugster, 1976), it is likely that addition of calcium by almost any means is a possible way to extract the fluorine from the water (for example, see Aldaco and others, 2007). The water could be run across a bed of ground limestone (the area has caliche developed in several levels of the Tertiary and Quaternary stratigraphy - Eugster, 1980); however, production of an aluminum-fluoride $\left(\mathrm{AlF}_{3}\right)$ product might be preferable. Possibly, bauxite could be reacted with fluorine-rich brine to make an $\mathrm{AlF}_{3}$ product directly.

\section{Fluorspar Deposit Grades and Tonnages by Deposit Class}

From the previous discussions, it could be expected that the deposit classes have different typical grades and tonnages. The only published previous attempt to examine fluorspar deposit grades and tonnages systematically was Orris (1992), who restricted her study to fluorspar veins. The advent of measures such as Canadian Government National Instrument (NI) 43-101 reports and the South African Code for Reporting Exploration Results (SAMREC)-compliant resource and reserve estimates has made information on the grades and tonnages of many more fluorspar deposits publicly available since the 1992 study. 


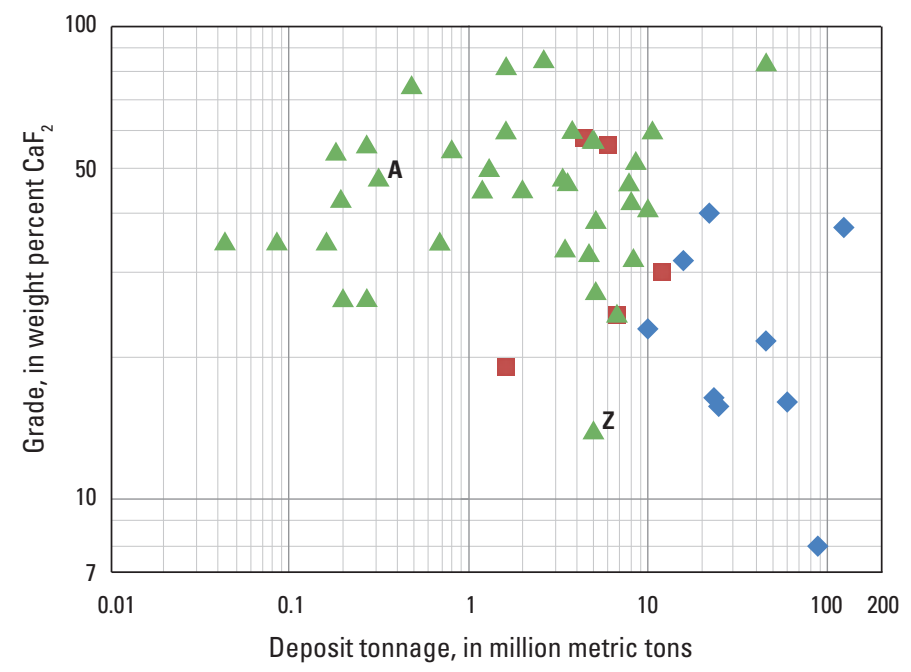

EXPLANATION

- Carbonatite-related fluorspar deposits

- Fluorspar deposits related to strongly differentiated granites

A Vein fluorspar deposits of all classes

Fluorspar mine that closed

A Argentolle

Z Zwartkloof

Figure G6. Plot of fluorite $\left(\mathrm{CaF}_{2}\right)$ grade versus tonnage for fluorspar deposits related to strongly differentiated granites, for carbonatite-related fluorspar deposits, and for veins from all classes of fluorspar deposits. Two vein fluorspar mines that failed because of either insufficient grade (Zwartkloof; Z) or insufficient tonnage (Argentolle; $A$ ) are identified on the plot. Data are from table G1-1; deposits whose grade and tonnage are plotted are listed in the footnote.

Figure G6 is a plot of fluorspar deposit grades and tonnages made from the data in appendix G1. The plotted grades and tonnages have not been exhaustively vetted to assure their validity. A number of pitfalls are possible in the reporting of deposit grades and tonnages by private interests. The data in appendix G1 have come from many different sources, so the resulting plot presents data collected using a wide variety of reporting criteria. If the majority of the data used are valid, then the overall trends shown on the plot are probably real.

In figure G6, deposits with vein geometry have been treated as a single category regardless of their class in figure $\mathrm{G} 3 B$, but deposits without vein- or dike-like geometry (that is deposits associated with carbonatites, and deposits associated with strongly differentiated granites) are each treated separately. The plot in figure G6 probably includes a few small occurrences in which only the resources considered to be sufficient to assure the next planned advance of mining were reported, although in cases where this could be confirmed, the deposit was not plotted. A number of other occurrences that were mined, but then closed, or that were mined intermittently only when prices were high have been included. Examples are the Huckleberry (Carlton County), the White Eagle (Sierra and Grant Counties), and the Great Eagle (Grant County) occurrences in New Mexico; the Canxixe (Sofala Province), the Mount Muambe (Tete Province), and the Macossa (Manica Province) occurrences in Mozambique; and the Jebel Sumayh occurrence in North Kordofan State, Sudan. Consequently, not all the plotted deposit grades and tonnages are for reserves (resources that were profitable to mine). The reasons why unprofitable resources were included is explained below.

Although individual classes on the plot appear to show very little tendency for tonnage and grade to systematically covary or to vary inversely, the three deposit classes together appear to show that, of reported deposits, high-grade fluorspar deposits tend to be smaller in tonnage, and lower grade deposits tend to be larger in tonnage. That overall inverse relation is common to deposits of many different kinds of mineral commodities. The lack of reporting for low-grade, low-tonnage deposits also is a contributing factor to the inverse relation observed with the reported data. The plot shows that economic fluorspar veins are generally smaller and higher grade than economic carbonatite-related fluorspar deposits which are, in turn, generally smaller and of higher grade than economic fluorspar deposits associated with strongly differentiated granite. These results may be overly simplistic, however, because some veins have barite, lead, and zinc byproducts or coproducts; some carbonatite-related deposits have niobium and barite byproducts; and some granite-related deposits have tin, tungsten, and possibly antimony, bismuth, and (or) molybdenum byproducts or coproducts.

On the plot in figure G6, the Zwartkloof deposit in the Warmbaths district of Limpopo Province, South Africa, which is a deposit related to strongly differentiated granite, is labeled Z, and the Argentolle deposit, Bourgogne Region, France, which is a vein deposit probably of the salt-related carbonate-hosted type, is labeled A. The Zwartkloof Mine operated only from 1971 to 1973 and was closed when the operating company concluded that the grade of the deposit (13.7 percent $\mathrm{CaF}_{2}$ ) was insufficient (Brian Hodge, consultant on world fluorspar deposits, written commun., April 29, 2013). The deposit at Argentolle was mined from 1971 to 1982, and was also abandoned as uneconomic. Zwartkloof and Argentolle are important because an imaginary line connecting the two on the grade vs. tonnage plot (fig. G6) divides the plot into two parts, one to the right and up from the line; the other to the left and down from the line. That line approximately marks a boundary between deposits that, as of late 2015, were viably economic (right and up) and those that were uneconomic (left and down, including Zwartkloof and Argentolle, themselves).

The approximate boundary formed by the line between $\mathrm{A}$ and $\mathrm{Z}$ should not be considered a permanent and rigid divider between economically favorable and unfavorable grades and tonnages of fluorspar deposits. For example, that line certainly expresses some aspects of mining history, showing, on that boundary, at least two deposits that were 
historically considered minable but that have become uneconomic in the modern fluorspar world market. Also, a deposit that is being explored may likely pass from lower left to upper right - from uneconomic to economic - by crossing the line horizontally (that is, becoming larger with the knowledge gained by additional drilling), although a deposit might cross the line vertically (that is, become higher grade as high-grade drilling results are achieved once the best part of the deposit is reached through exploration).

In any case, the plot provides a measure with which to compare the resources of new deposits or deposits still in exploration with typical fluorspar deposit grades and tonnages; the farther to the right and up, the better. The deposits in Las Cuevas, Mexico, and Vergenoeg, South Africa, are the two deposits that are farthest up and to the right of that imaginary line between $\mathrm{A}$ and $\mathrm{Z}$.

\section{Resources and Production}

\section{Identified Resources in the United States}

The United States has numerous moderate-tonnage (that is, tens of thousands of metric tons to up to a few hundred thousand metric tons) but high-grade fluorspar deposits scattered across seven States (Idaho, Illinois, Kentucky, Montana, Nevada, New Mexico, and Utah). Some larger tonnage but lower grade deposits have also been identified in Alaska, Illinois, Nevada, and Tennessee.

Some moderate-tonnage high-grade fluorspar deposits and one large-tonnage low-grade deposit have been identified in the Illinois-Kentucky fluorspar district. The Anabelle Lee, the Denton, and the Minerva Number 1 Mines (Hardin County, Ill.) in the Illinois-Kentucky fluorspar district closed in 1996 with ore still in the faces of each mine and some limited tonnages of drilled resources identified at each (Richard Yancy, former Ozark-Mahoning Co. mine geologist at the three mines, oral commun., March 11, 2013). Since that time, exploration and development in the Illinois-Kentucky fluorspar district has taken place at the Klondike II project, which is located about $8 \mathrm{~km}$ southwest of Salem, Ky., in Livingston County. Production began in 2012 (W.H. Anderson, Kentucky Geological Survey, oral commun., October 22, 2014). The Klondike II deposit is located on the Pittsburgh Fault and constitutes a vein resource of at least 1.6 million metric tons of ore grading 60 percent $\mathrm{CaF}_{2}$ (Feytis, 2009). A decline has been driven from the surface to allow rubber-tire mechanized underground mining. Plans are in place to ramp up production to 200,000 metric tons per year during a period of several years. Other exploration is ongoing nearby and to the northeast in southern Crittenden County. Farther north, Hicks Dome Corp. (HDC) has continued to hold and explore the company property since obtaining its first leases in 1970 .

Since the HDC property was first leased, several different partners have worked together in joint ventures with HDC, although each left the partnership within a few years. The last public announcement of tonnage and grade at Hicks Dome was reported by Kirkemo (1978) and totaled just 11.3 Mt at a grade of 11.5 percent $\mathrm{CaF}_{2}$. This estimate was made when only 12 exploration core holes had been completed, however. Since that time, tens of additional holes have been drilled, many of these encountering similar mineralization. Still, this is a relatively low-grade fluorspar deposit, although its tonnage as now known is doubtlessly significantly larger than that previous estimate of $11.3 \mathrm{Mt}$. With the known geology of Hicks Dome, production of fluorspar as a byproduct or coproduct of REE mining could possibly take place if the property comes into production (Kirkemo, 1978). Fluorite mineralization at Hicks Dome is found in breccias that also contain substantial concentrations of beryllium, niobium, REEs, thorium, and yttrium, as well as local concentrations of zinc, lead, and barite.

Lost River, Alaska, mentioned earlier, is the largest identified resource of fluorspar in the United States outside of the Illinois-Kentucky fluorspar district. Tin and fluorspar could possibly be produced as coproducts, along with tungsten and possibly beryllium as byproducts if a mine can operate profitably in that remote location and extreme climate. Additional resources in the Western United States have been identified in southwestern Utah, along the flanks of the Rio Grande Rift in New Mexico and Texas, in two small districts in Idaho, in one place in Montana, and in at least two places in Nevada. Among identified resources in the Western United States, the McCullough Butte deposit, which is located $19 \mathrm{~km}$ southwest of Eureka, Nevada, appeared to be in an advanced stage of exploration at the end of 2013. Several exploration programs had been conducted at the property in the past; the latest one was by Tertiary Minerals plc, which also owns the Storuman deposit in Lappland Province, Sweden, and the Lassedalen fluorspar deposit in Buskerud County, Norway. McCullough Butte is a skarn deposit in limestone along its contact with a quartzite adjacent to and extending away from dikes of Late Cretaceous two-mica granite porphyry (Barton, 1982). Tertiary Minerals has announced a Joint Ore Reserves Committeecompliant estimate of 6.1 million metric tons of indicated resources at a grade of 10.8 percent $\mathrm{CaF}_{2}$, and 80.3 million metric tons of inferred resources at a grade of 10.7 percent $\mathrm{CaF}_{2}$ at a cutoff grade of 8 percent $\mathrm{CaF}_{2}$ (Tertiary Minerals plc, 2015). The geology and topography of the McCullough Butte deposit would allow for open pit mining.

In the Eastern United States, low-grade resources have been identified in the Sweetwater (MVT) district in Tennessee. With the exception of the deposits in the IllinoisKentucky fluorspar district described above and possibly the McCullough Butte deposit, none of the resources in the United States would appear to be economic at this time, given competition with Mexican and South African imported HF and fluorspar.

The success of the project at the recently discovered Klondike II deposit in Kentucky demonstrates that there probably are still additional deposits to discover in old districts. The Klondike II deposit has been described as 
being $18 \mathrm{~m}$ thick, $91 \mathrm{~m}$ vertically from the surface to the bottom of the ore, and about 1,200 $\mathrm{m}$ along the strike of the vein, and as containing 3.6 million metric tons of proven ore (reported as 60 feet wide, 300 feet deep, more than 4,000 feet long, and containing about 4 million short tons) (Anderson and Moodie, 2010). That an orebody of such size would have escaped discovery for some 140 years since the district was recognized as a major source of fluorspar is perhaps surprising, but it is not remarkable. The district has several tens of known veins and areas of bedding replacement ores. The aggregated total strike length of faults with known fluorspar mineralization along them is conservatively estimated to be $350 \mathrm{~km}$. A scientist from the Kentucky Geological Survey (W.H. Anderson, Kentucky Geological Survey, oral commun., January 24, 2014) who has worked in the Illinois-Kentucky fluorspar district now and again since 1989 says that exploration along those faults is generally thorough enough to preclude additional orebodies, but points to the following two areas that are thought to have remaining potential: (1) the area of the Rock Creek graben southwest of the Ohio River in Kentucky for new discoveries of bedding replacement deposits, and (2) the extension of the Tabb faults southeastward beyond the Senator, Eddie Crowder, and Williamson Mines that form the current-day southeastern limit of the district for new discoveries of vein ores.

\section{Identified Resources in Other Countries}

The Nui Phao fluorspar-tungsten-bismuth-copper-gold deposit in Thai Nguyen Province, Vietnam, about $80 \mathrm{~km}$ north-northwest of Hanoi, began operations at the end of April 2013 after an extended period of permitting, land acquisition, and other preparations. The deposit is being mined by open pit, and it is projected to provide nearly 214,000 metric tons per year of $\mathrm{CaF}_{2}$ for 20 years, as well as about 5,620 metric tons per year of tungsten, 2,675 metric tons per year of bismuth, and 588,000 grams per year of gold. Paragenetically, early mineralization at Nui Phao is a tungsten skarn thought to be related to the intrusion of a Triassic biotite granite. Later hydrothermal overprint thought to be related to the intrusion of a Cretaceous two-mica granite is of pyrrhotitefluorite-albite greisen (Richards and others, 2003; Masan Group, 2013).

In South Africa, the Nokeng fluorspar project, which is located on a property that borders the Vergenoeg Mine in northern Gauteng Province, was scheduled to start mine construction in late 2012, with production targeted for the second quarter of 2014. As of February 2014, construction had apparently not yet started, and no further information that explains the reason for the delay was available. The project planned to mine two orebodies - the Plattekop deposit and the Outwash Fan deposit. Together, the deposits contain SAMREC-compliant reserves of about 12.2 million metric tons of 27.2 percent $\mathrm{CaF}_{2}$ (Clay and de Wit, 2009). The Plattekop deposit is a conformable layer within the local
Vergenoeg Suite stratigraphy that overlies the Vergenoeg fluorite-magnetite-fayalite-sulfide breccia pipe. The Plattekop deposit is a 6- to 27-m-thick layer of hematite-fluorite within a sequence of ferruginous agglomerates, tuffs, felsites, and ironstones. Its outcrop, which forms a hilltop, extends from a sharp contact with the pipe southeastward for about 1,200 m. The Outwash Fan deposit occurs 7.6 km south-southeast from Plattekop Hill and extends for another $3.5 \mathrm{~km}$ from there. The Outwash Fan ore is in a 1- to 9-m-thick layer of fluoritebearing conglomerate or sedimentary breccia intercalated among laminated fine grits, quartzites, bedded ironstones, cherts, and conglomerates. The orebodies are planned to be mined by separate open pits. Fluorspar is to be recovered by flotation to make acid-grade concentrates, and a production rate of 180,000 metric tons per year of $\mathrm{CaF}_{2}$ is expected (Clay and de Wit, 2009).

Also in South Africa, the Doornhoek deposit in North West Province is simply the eastward extension of the Witkop MVT dolomite-hosted fluorspar deposit in the Marico district. The Doornhoek owners "planned to initiate underground development, feasibility studies and design" (Roberts, 2012, p. 38.). No additional information from the company was available.

The Speewah fluorspar deposit in Western Australia, Australia (which contains 6.7 million metric tons grading 24.6 percent $\mathrm{CaF}_{2}$ ), was purchased by a Chinese company, Jiangxi Yunfeng. The project was undergoing a preproduction feasibility study (Mining Atlas, 2016).

The Lassedalen fluorspar mine (which contains 4 million metric tons grading 24.6 percent $\mathrm{CaF}_{2}$ ) in Buskerud County, southwestern Norway, was scheduled by Tertiary Minerals to be reopened in 2012, but the latest available company releases suggest that prefeasibility study drilling would be conducted with the purpose of completing a Joint Ore Reserves Committee (JORC)-compliant estimate of reserves (Tertiary Minerals plc, 2014). The deposit is adjacent to one of the Permian peralkaline granites of the Oslo graben (Ineson and others, 1975). Tertiary Minerals' Storuman deposit in Sweden was somewhat nearer to being ready to mine; the deposit is a replacement deposit along bedding in Cambrian sandstones. This has been called an MVT deposit, based on nearby sphalerite-galena-fluorite-calcite-bearing ores occurring in fractures within the Precambrian basement with strongly saline fluid inclusions that homogenize mostly from 80 to $200{ }^{\circ} \mathrm{C}$ and also, in the fluorite, contain hydrocarbon inclusions (Billström and others, 2012). The class assignment is also based on analogy with the zinc-lead deposit at Laisval, located nearby, that formed in the same host rocks in the mid-Silurian Period, a time when thrust-belt compressional mountains were thrown up just tens of kilometers to the west (Sherlock and others, 2005). The JORC-compliant resource estimate for Storuman is 25.0 million metric tons of indicated resources grading 10.28 percent $\mathrm{CaF}_{2}$ and 2.7 million metric tons of inferred resources grading 9.57 percent $\mathrm{CaF}_{2}$. Tertiary Minerals planned to submit its mining lease application in the first quarter of 2014 and its environmental permit application 
sometime in 2014. The company planned to begin development of the Storuman Mine in 2016 and to start production in 2017. The mine had a planned mine life of at least 18 years at a production rate of roughly 160,000 metric tons per year of $\mathrm{CaF}_{2}$. The deposit appears to be open in at least two directions, however, and additional drill holes indicate mineralization in both directions.

In China, a probably relatively large tungsten-tinbismuth-molybdenum-fluorite deposit was found in western Zhejiang Province within the past several years. It is called Bamianshan, and although there is considerable geologic literature on the deposit already, its exact location and grade and tonnage have apparently not been reported. The deposit is geologically interesting because it is clearly related to a strongly differentiated granite (Liu and others, 2012), and it is located close to several large epithermal deposits related to subalkaline volcanic rocks, including (in decreasing order of size) Yangjia-Wuyi, Houshu, Hushan, and Badu.

In Newfoundland, Canada, the St. Lawrence fluorspar project, which has had exploration ongoing for nearly a decade by Canada Fluorspar, Inc., appears to be becoming active again, after a period of pause and review. Arkema, Inc. of France became a joint-venture partner with Canada Fluorspar in May 2012, stimulating a review of the project's costs that began in about September 2012. The project issued an updated preliminary feasibility study in 2013 (Lecuyer and others, 2013). No new startup date had then been announced. The project planned to mine two large veins, the Blue Beach North and the Tarefare veins, which cut Late Devonian or Early Mississippian peralkaline granite (Van Alstine, 1944; Teng and Strong, 1976; Strong and others, 1984). This mining district was last active in 1978, but mining had been documented there for up to 45 years before that time, and some records indicate that it had been mined as early as 1870 by early French settlers. Total indicated and inferred resources on the Blue Beach North and Tarefare veins combined are 10.05 million metric tons grading 41 percent $\mathrm{CaF}_{2}$ (Lecuyer and others, 2013). Plans were in place to produce about 131,000 metric tons per year of acidspar.

In the United Kingdom, British Fluorspar was formed as a successor of Minmet UK, Ltd., and the company has reopened the Milldam Mine on Hucklow Edge Rake in the Southern Pennine Orefield (Hodge, 2012). British Fluorspar restarted mining in March 2013 and sent its first shipments in May 2013 (Lismore-Scott, 2013). Milldam Mine was part of the holdings of the former Glebe Mines, last a subsidiary of INEOS Flúor, and Glebe had been separated from an acquisition of INEOS Flúor's fluorochemical business by Mexichem Flúor on April 1, 2010. That had led to an end, for a time, to fluorspar mining in the United Kingdom, as of the end of 2010, although Mexichem had continued to operate the fluorochemical production facilities of the former ICI/INEOS using acidspar imported from Mexico.

Summarizing the above, there are multiple new fluorspar mines being started up or reopened around the world, including a mine in China as well as at least one mine each in five other countries. Four of those five mines (excluding the Milldam Mine) planned cumulative production of about 770,000 metric tons per year of fluorspar within a few years. Additional resources have been identified in Australia, South Africa, Tunisia, the United States, and probably a few other countries. Hodge (2012) was clearly correct in his conclusion that "... there should be no serious supply shortages providing a pragmatically sensible and ongoing rapport is established ... between consumers and producers."

Miller (2013) estimated the reserves of fluorspar of various countries for which information was available at that time. In units of 100 percent $\mathrm{CaF}_{2}$ and rounded to the nearest million metric tons, they are as follows, from most to least reserves among the top eight countries: South Africa, 41 million metric tons; Mexico, 32 million metric tons; China, 24 million metric tons; Mongolia, 22 million metric tons; Spain, 6 million metric tons; Namibia, 3 million metric tons; Kenya, 2 million metric tons; and Brazil, 1 million metric tons. Reserve data were not available for Kazakhstan, Morocco, Russia, and the United States. As discussed above, reserves from Vietnam and Canada and additional reserves from the United States can be expected to enter this list soon. Reserves in the remainder of the world were estimated to be 110 million metric tons totaling, together with the eight countries for which reserves were reported, about 240 million metric tons. The world's total identified resources were estimated to be 500 million metric tons of contained fluorspar (Miller, 2013).

\section{Undiscovered Resources in the United States}

A preliminary model for large, high-grade fluorspar deposits has been developed based on deposits in Mexico. Such deposits as Las Cuevas (San Luis Potosi State), Realito (Guanajuato State), and El Refugio (Guanajuato State) are localized along faulted and brecciated contacts between Cretaceous limestone and Tertiary rhyolite, east of the main volcanic arc that is slightly older than the rhyolite. The fluorspar-related rhyolites are post-convergent and extension-related and are not derived from the same arc (or any arc) (Steve Ludington, U.S. Geological Survey, retired, written commun., 2013). Deposits in Texas in a belt parallel to the Rio Grande from El Paso to Big Bend National Park share most if not all of these characteristics, but the deposits are too small to mine profitably (McAnulty, 1974). Modern exploration has not taken place in these areas. Elsewhere along the Rio Grande Rift are numerous fluorspar occurrences and deposits (Van Alstine, 1976), some of which are fairly large (Hansonburg district, New Mexico, for example). Modern exploration techniques have not been applied in those areas either.

Iron Mountain, N.M., is a fluorine-, beryllium-, and tungsten-bearing skarn related to a strongly differentiated granite (Jahns and Glass, 1944), and this type of mineralizing system has formed many large deposits around the world (fig. G4). 
The presence of additional strongly differentiated granites in southwestern New Mexico is predictable, perhaps, by the numerous occurrences of wood tin related to rhyolite flows and domes in that region (Maxwell and others, 1986). A oneto-one relation between rhyolites with wood tin and strongly differentiated granites has not been demonstrated, however.

The province of Late Cretaceous two-mica granites described by Barton and Trim (1991), including the granite porphyry related to the McCullough Butte deposit in Eureka County, Nev., could be examined closely to determine if others of those granites have related fluorite-bearing skarns. Likewise, the province of tin granites on the Seward Peninsula in Alaska (Hudson and Arth, 1983) might contain additional fluorspar skarn-and-greisen deposits similar to the Lost River deposits. Other areas of Alaska with tin greisen mineralization have been explored but with little attention paid to the associated fluorspar (Hudson and Reed, 1997).

The Basin and Range province of the United States in Nevada and parts of Arizona, California, Oregon, and Utah may contain lacustrine brines that have extractable fluorine. Taking Lake Magadi (Kenya) and Lake Natron (Tanzania) discussed earlier in this chapter as examples, the water in and beneath Alkali Lake in Lake County, Oreg., could be an analogous evaporitic brine from which fluorine might be recoverable. That playa lake has magadiite (monoclinic $\left.\mathrm{NaSi}_{7} \mathrm{O}_{13}(\mathrm{OH})_{3} \cdot 3 \mathrm{H}_{2} \mathrm{O}\right)$ and trona precipitated as evaporites in the lake's recent sediments (Rooney and others, 1969), which are the same two minerals that characterize the evaporite minerals of Lake Magadi and Lake Natron. Chemical data for water from several sites around the Alkali Lake basin from 1969 and 1970, however, show a maximum fluoride concentration of only 12.75 milligrams per liter $(\mathrm{mg} / \mathrm{L})$, which is about 100 times less than the largest concentrations at Lake Magadi (Newton and Baggs, 1971, p. 18-30). The highest fluorine value comes from a water sample with a $\mathrm{pH}$ of 10 and total dissolved solids of 74,850 mg/L, both also highest among the 13 water-sample analyses from the Alkali Lake area. Together, these water chemical values appear to indicate that some of the same evaporationdominated processes are operating at Alkali Lake as operate at Lake Magadi and Lake Natron. Other basin and range lakes with recent evaporitic precipitates of trona include Big Soda Lake located northwest of Fallon, Nev. (Vanderburg, 1940); Searles Lake, California (Smith, 1979); and Deep Springs Lake, Calif. (Jones, 1965). Water analyzed by Jones (1965, p. A30) from near Deep Springs Lake had concentrations up to $171 \mathrm{ppm}$ fluorine. Although this sample was anomalous, the fluorine concentration is still roughly 10 times smaller than in Lake Magadi. Most of the water analyses reported in Smith (1979) at Searles Lake did not include fluorine among the analytes, but eight did. The highest fluorine concentration among those eight samples was $35 \mathrm{ppm}$, which is approximately 10 times the typical fluorine concentration in lowtemperature surface water or groundwater, but it is still far below a concentration that would be economically interesting for its fluorine content.

\section{Undiscovered Resources in Other Countries}

Conclusions from the analysis in the Identified Resources in Other Countries section are extensible to the subject of worldwide undiscovered fluorine resources; in short, the world likely has no shortage of deposits yet to be discovered. Many deposits probably remain to be discovered on every continent. Deposits of every type (fig. G3) almost certainly remain to be discovered, though some general additional guidelines for exploration can be helpful to supplement deposit-type models.

In the category of undiscovered resources, perhaps the most interesting is the possibility of producing a fluorine product from the high-fluorine, high-pH, sodium-carbonate brines of Lake Magadi (Kenya) and Lake Natron (Tanzania) in the East African Rift system. Also, apparently conformable fluorspar deposits in tuffaceous limy lacustrine sediments, such as those in Italy, are likely to occur in similar young alkalic volcanic settings elsewhere in the world.

\section{Production and Consumption}

Fluorspar mining began in the United States at various locations between 1820 and 1840. The first commercial production appears to have been in 1837 from a vein in Trumbull, Fairfield County, Connecticut. The existence of fluorspar in Illinois and Kentucky was known from the early 19th century, but it was not until 1871 that the first commercial shipments from Kentucky to a glassworks in Baltimore were recorded (Ladoo, 1927, p. 2-3). Production was limited by demand to at most a few thousand metric tons per year until the late 1880s when demand for its use as a flux in steelmaking was bolstered by the introduction of the openhearth-furnace steelmaking process. The United States was the world's leading producer of fluorspar until it was surpassed by Mexico in the mid-1950s (McDougal and Roberts, 1958).

U.S. domestic fluorspar production peaked during World War II at 375,000 metric tons in 1944 (Miller, 2002). In the post-World War II period, a booming economy and increasing consumer demand for products containing aluminum, fluorochemicals (especially chlorofluorocarbons), and steel continued to push U.S. consumption of fluorspar upward. Domestic production, however, was unable to keep up with rising demand and in the mid-1970s, the domestic fluorspar mining industry began to decline because of foreign competition. In 1996, primary fluorspar mining in the United States ceased, although small amounts continued to be recovered as a byproduct of quarrying activities in southern Illinois (fig. G7). Consumption of fluorspar peaked in the early 1970s, which was, not coincidentally, also the peak period of U.S. steel production. Thereafter, decreasing steel production, a change in consumption practices by the steel industry, and the ban on chlorofluorocarbons when it was found that they were responsible for the "ozone hole" above Antarctica resulted in a general decrease in U.S. fluorspar consumption. From that time, consumption stabilized and then began to 


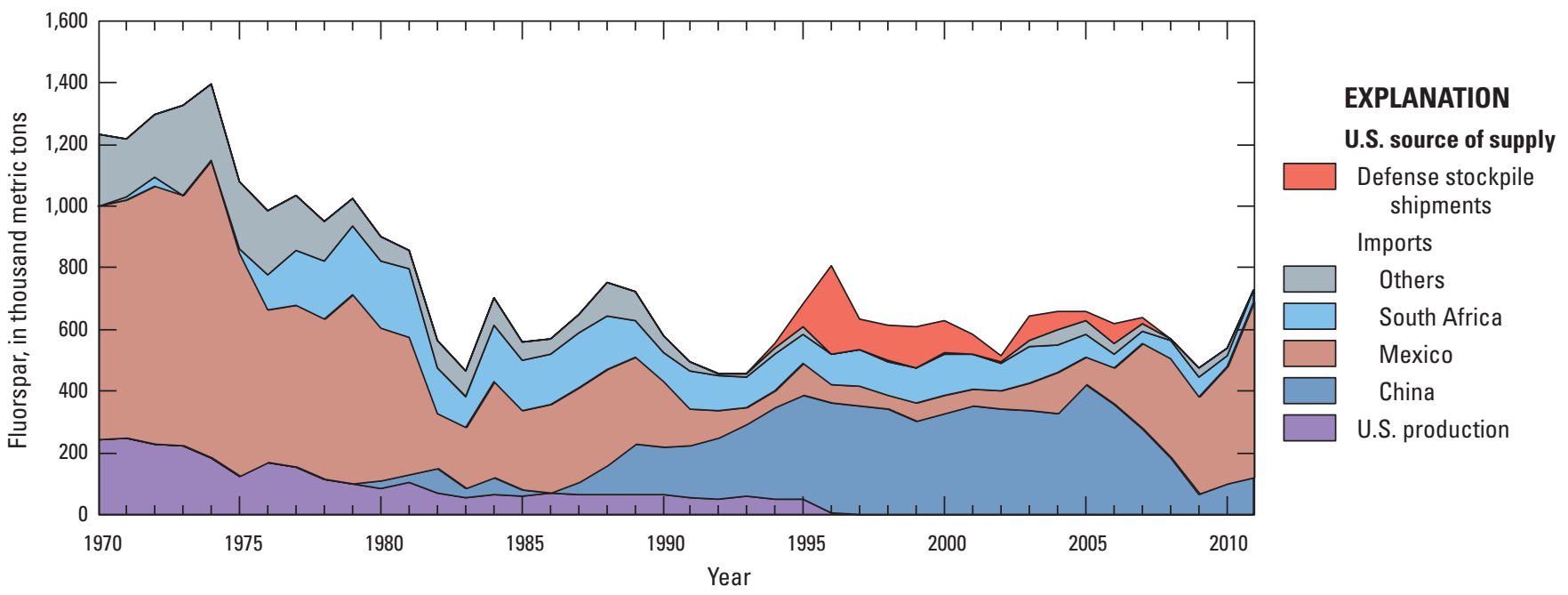

Figure G7. Graph showing sources of U.S. fluorspar supply from 1970 to 2011. The layers of the graph are placed one above the other, forming a cumulative total. Data are from U.S. Bureau of Mines (1972-96) and U.S. Geological Survey (1997-2016).

increase slowly as replacement fluorocarbon compounds, such as hydrochlorofluorocarbons and hydrofluorocarbons, were introduced into the market (U.S. Bureau of Mines, 1972-96; U.S. Geological Survey, 1997-2016).

Despite substantial domestic production for much of the 20th century, the United States has been a net importer of fluorspar since the early 20th century. Sources of supply for the United States have changed over the years. Beginning during the period of peak U.S. consumption, the United States sources of supply have been dominated by a few countries - China, Mexico, and South Africa (fig. G7). In addition, between 1993 and 2006, the U.S. fluorspar supply was augmented by sales from the National Defense Stockpile. In 2012, annual world production and consumption was about 7 million metric tons. The leading fluorspar producing countries were, in descending order, China, Mexico, Mongolia, and South Africa, which together accounted for 89 percent of estimated world production (Miller, 2016).

The global supply of fluorspar available for export decreased between 2001 and 2012 because of the substantial decreases in exports from China. China began exporting significant amounts of fluorspar in the 1960s, and the first exports to the United States took place in 1980 (fig. G7). China was the world's leading fluorspar exporter from the early 1990 s to 2008 or 2009 . Beginning in the early 2000s, China's fluorspar exports started to decrease as its domestic consumption increased. Producers outside of China were unable to increase production capacity to make up for the reduction in global supply. At the same time, global industrial activity increased, resulting in increased demand for fluorspar and higher prices (U.S. Bureau of Mines, 1972-96; U.S. Geological Survey, 1997-2016).

In recent decades, the United States annual fluorspar consumption has ranged from 500,000 to 700,000 metric tons per year, although "fluorine" consumption is higher because the United States imports significant amounts of $\mathrm{HF}$ as well as aluminum fluoride and synthetic cryolite. In 2012, the United States imported 133,000 metric tons of HF (equivalent to 293,000 metric tons of acid-grade fluorspar) and 58,100 metric tons of aluminum fluoride and synthetic cryolite (equivalent to an additional 85,000 metric tons of acid-grade fluorspar; Miller, 2016).

Fluorine, mostly in the form of fluorspar, is expected to continue to be important to the United States owing to its use in the manufacture of diverse materials and products necessary to the U.S. economy. The United States will continue to be import-reliant for most of its fluorspar needs, although in 2012, mine production began at the Klondike II fluorspar mine in the Illinois-Kentucky fluorspar district, mentioned earlier (Feytis, 2009). An additional fluorine resource exists in the form of fluorosilicic acid, which is produced as a byproduct of phosphoric acid production in the phosphate fertilizer industry. In 2012, U.S. phosphate reserves were estimated to contain about 100 million metric tons of 100 percent $\mathrm{CaF}_{2}$-equivalent, and world reserves were estimated to contain 4.7 billion metric tons of 100 percent $\mathrm{CaF}_{2}$-equivalent. In 2012, about 70,000 metric tons per year of 100 percent basis fluorosilicic acid was produced and used in the United States mostly for water fluoridation, although fluorosilicic acid can be used to produce aluminum fluoride, and the technology exists to convert it to HF (Miller, 2013).

The United States does have some remaining resources of fluorspar, and those were discussed in the previous section on Identified Resources in the United States. Internationally, several new mines either have been opened recently or are expected to open in the next few years, as discussed in the previous section on Identified Resources in Other Countries. 


\section{Exploration for New Deposits}

None of the deposit types listed in figure G3 has been found in any oceanic geologic terrane, so apparently only continental rock terrains are favorable. Fluorite is commonly associated with end-member igneous differentiates, so exploration will profit from focusing on granites (all types, but particularly those not related to arc magmatism; that is, anorogenic granites), syenites, and carbonatites, and their volcanic equivalents. Fluorite is commonly found replacing limestone or dolostone. Thus, the optimal areas to explore are carbonates intruded by anorogenic granites, syenites, or carbonatites and carbonates in contact with anorogenic rhyolite or trachyte. The continental rifting association of salt-related carbonate-hosted fluorspar deposits could also be used to guide exploration; continental rifts have associated fluorspar deposits owing to their associated salt deposits and (or) their associated peralkaline to alkaline intrusive and volcanic rocks.

More specifically, provinces with strongly differentiated granites could be targeted for fluorspar skarn-and-greisen deposits. Although most of the belts of tin granites of the world have been identified, most of these belts have not been thoroughly explored for either tin or fluorspar. Some of the belts are located in places that are difficult to explore owing either to climate (for example, the Seward Peninsula tin granite province in Alaska and the Southeast Asian tin granite province) or other factors (for example, political risk in the Nigerian province). Taylor $(1979$, p. 6) has mapped 42 tin provinces worldwide, and provided consistently structured packages of information on 23 of these provinces (Taylor, 1979, p. 491-511). Not all of the provinces that have tin deposits have tin granites, however.

No fluorspar deposits analogous to those of the Latium Region, Italy, have been discovered to date, but that they would be unique in the world seems unlikely. The broadest scale indicator for these types of deposits would appear to be young alkalic volcanic rocks with interlayered lacustrine sedimentary rocks, and such volcanic rocks are widespread across the globe. As an initial test, a keyword search of geologic literature conducted on the combination of terms "phonolite" and "maar," and a second search conducted on "trachyte" and "maar" yielded 15 areas of the world (in addition to central Italy). They are (1) the Czech Republic, (2) southern Italy, (3) northern South Africa, (4) western Germany, (5) east-central Germany, (6) southern Germany, (7) Hungary, (8) central France, (9) the Canary Islands, Spain, (10) Slovakia, (11) Shandong Province, eastern China, (12) Hawaii, (13) Big Bend National Park, Tex., (14) Pinacate volcanic field, northwestern Mexico, and (15) western Cameroon (including maar Lake Nyos in North-West Region, where a catastrophic lake-water overturn released $\mathrm{CO}_{2}$ from depth in the lake and killed 1,700 people in 1986). Among these areas, the Canary Islands and Hawaii seem unlikely possibilities because no economic fluorspar deposits are known to occur on any oceanic islands. The Big Bend area of Texas, on the other hand, is firmly within the belt of fluorspar deposits in that region. Also, the Aguachile deposit in Coahuila State, Mexico, consists of limestone replacements adjacent to rhyolite porphyry ring dikes of a caldera; these replacement deposits may have formed beneath a caldera lake.

As mentioned previously, an unconventional source of fluorine could be brines from Lake Magadi and Lake Natron along the East African Rift, as well as other places where such alkaline evaporite brines may occur.

In the past, exploration for fluorspar deposits has not used methods comparably sophisticated with those used in exploring for such minerals as gold and copper. Most deposits have been found by simply following up occurrences of outcropping fluorite. It was common for mines to drill only enough to establish a few years' worth of reserves ahead of the mining operation. This has probably begun to change since the advent of such requirements as those of the Canadian Government NI 43-101 reports and Australia's JORC-compliant resource and reserve estimates. The requirements of such publicly released documents has encouraged the estimation of total deposit resources to be known before financing and various government permitting approvals are granted, or it has at least encouraged the definition of resources adequate for many years of mine life. Even just a few decades ago, geophysical methods were seldom used in exploration for fluorspar. Geochemical exploration methods were slightly more common, but still not heavily used. The future probably will see the use of increasingly sophisticated geophysical and geochemical methods of exploration.

Grogan $(1960,1964)$ was of the opinion that geochemical prospecting was not well adapted to finding fluorspar deposits because he thought that fluorite is too effectively dispersed, being soft and extremely cleavable. Geochemical prospecting for fluorspar deposits has succeeded in some areas, however. Van Alstine (1965) demonstrated effective results from sampling and analyzing rock or soil for fluorine in various areas within the Browns Canyon district in Chaffee County, Colo. In addition, geochemical prospecting was shown to be effective in an area near the Osor vein in the eastern Pyrenees in Spain's Catalonia Autonomous Region (Schwartz and Friedrich, 1973). Near Osor, broad-scale prospecting using measured fluoride in surface water identified target areas of 3 to $10 \mathrm{~km}^{2}$. Dry stream-sediment samples narrowed the search to targets of less than $1 \mathrm{~km}^{2}$ and led geologists to mineralized outcrops. Then, fluoride in soil samples was used to map small areas and guide placement of drill holes. The work resulted in discovery of an area of fluorite veinlet stockwork. In addition, surface waters proved to be an effective medium for district-scale exploration. This is likely because of the relatively high solubility of fluorine at low temperatures and because of fluorite's increasing solubility with decreasing temperature below about $60^{\circ} \mathrm{C}$ (fig. G2).

Three different studies (Graham and others, 1975; Deering and others, 1983; and Ebbott and others, 1985) have 
shown that groundwater sampled from wells revealed areas of high fluorine concentration broadly centered on areas of fluorite-bearing MVT mineralization. This method would not be applicable in areas of greenfield exploration because the distribution of water wells into a target aquifer would be insufficient in remote areas. The method is applicable in the agricultural areas of central North America, although only in defining an area of tens of square kilometers as anomalous.

An extensive rock geochemical study of the Taskaynar deposit related to a strongly differentiated granite in Kazakhstan demonstrated that several additional elements had primary dispersion patterns similar to that of fluorine, and, consequently, might be used as "pathfinders" in exploration, especially to guide exploration drilling. The Taskaynar deposit is hosted by sandstone that lies above limestone with nearby "porphyrite" and granodiorite. The elements Ag, As, $\mathrm{Ba}, \mathrm{La}, \mathrm{Mo}, \mathrm{Sr}, \mathrm{Y}$, and $\mathrm{Yb}$ all had primary dispersion patterns that were as far-reaching from the ore as fluorine itself. The dispersion patterns of lead, zinc, and sodium+potassium were somewhat more restricted around the orebody, but also had abundance boundaries parallel to the fluorine boundaries, and both showed control by fracturing (Koplus and others, 1977).

In exploring for skarn-and-greisen fluorspar deposits related to strongly differentiated granites, several more sophisticated methods could be brought to bear. Gravity and magnetic geophysical studies could be used to determine the depths to crystalline rocks through sedimentary cover, with the magnetics also directly targeting magnetite-bearing skarn. For a deposit standing upright and arrayed around a granitic cupola on a larger batholith, detailed magnetic surveys could help identify magnetite-bearing skarn, probably forming a magnetic ridge in a partial ring around a magnetic low, the low produced by greisen with a nonmagnetic pyritemuscovite(-fluorite) assemblage. Fluorspar system-related but locally developed semimassive sulfide bodies typically rich in sphalerite-pyrrhotite-arsenopyrite can be detected by a number of different methods that show anomalies in rock conductivities. An airborne electromagnetic survey using the Barringer INPUT (induced pulse transient) method detected such a sulfide-rich body at the Ar Ridaniyah fluorite-bearing tin skarn system located $200 \mathrm{~km}$ west of Riyadh, Saudi Arabia, in 1967 (Canadian Aero Mineral Surveys, Ltd. and Arabian Geophysical and Surveying Company, 1967).

Most vein fluorspar deposits of various types are also detectable using methods that measure conductivities. Successful exploration of fluorite veins in granitic terrain using the combination of very low frequency (VLF) electromagnetics and audio-magnetotelluric (AMT) methods was reported by Zhang and others (2010). Vein fluorspar deposits are amenable to discovery by such methods despite the low conductivity of fluorite. Anomalous amounts of saline groundwater in fractured porous rock of fault zones mineralized by fluorite and (or) metallic sulfide minerals associated in minor concentrations with the vein fluorite are detectable. In China, VLF electromagnetics provided clear resolution of veins and accurate positioning of their location near the surface, and AMT methods provided accurate location of the veins at greater depth (Zhang and others, 2010). These methods could work effectively as long as the host rocks of the veins have high resistivities (that is, low conductivities) so that the vein zones contrast sufficiently.

\section{Environmental Considerations}

\section{Sources and Fate in the Environment}

Fluorine is chemically and biologically active. It readily forms hydrogen fluoride or combines with metals to make fluoride compounds, some of which are relatively stable, such as calcium fluoride (fluorite). The weathering of rocks and soils may release dissolved fluoride into the environment, and fluoride is added to drinking water in some countries, which is then released into surface water in municipal wastewater. Clay content, $\mathrm{pH}$, temperature, and the concentrations of aluminum, calcium, magnesium, phosphorus, and hydroxides all influence the dissolved fluoride content of water. Fluoride compounds generally are most soluble and thus mobile under acidic conditions. In contrast, alkaline conditions in the presence of carbonates limit the mobility of fluorine in the environment; fluorine is fixed by reaction with carbonates to form stable fluorides. In the absence of carbonates, however, alkaline evaporitic conditions yield the greatest known solubility of fluorine at ambient temperature (table G2). Also, fluorine is easily sorbed by clay minerals (Kabata-Pendias and Mukherjee, 2007). As previously mentioned, fluorite tends to dissolve as temperature decreases (that is, it has "retrograde" solubility) under most earth-surface temperatures $\left(60^{\circ} \mathrm{C}\right.$ to freezing, depending on the composition of the water; Richardson and Holland, 1979).

Fluorine is present in most natural waters. River waters commonly contain between 0.05 to $2.7 \mathrm{ppm}$ fluorine, whereas seawater generally contains between 0.03 to $1.4 \mathrm{ppm}$ with a median of approximately $1.3 \mathrm{ppm}$ fluorine (table G2). High concentrations of fluorine have been shown to be present in waters in regions of volcanic activity or granitic bedrock, particularly in arid areas, and where fluorite or phosphates are mined and processed. China, East Africa, and India have the most extensive areas of high-fluorine groundwaters (Jacks and others, 2005). Table G2 includes examples of both naturally occurring and mine-influenced concentrations of fluorine in waters. One extreme example of naturally occurring concentrations of fluorine in surface waters is in Africa's Eastern Rift Valley in Kenya and Tanzania where concentrations reached $437 \mathrm{ppm}$ from the weathering of volcanic rocks; evaporation also concentrates the fluorine in the water, locally elevating the fluorine concentration to above $2,000 \mathrm{ppm}$ in closed basin lakes in that setting (table G2; Kilham and Hecky, 1973; Jones and others, 1977). An example of anomalous mine-affected waters is that within mine workings at the 
now-closed Lovozero niobium mine in Russia that were highly alkaline ( $\mathrm{pH} 9.6$ to 12 ) and contained extreme concentrations of fluorine (1 to 1.5 percent) and silica (1 to 1.3 percent) (table G2; Kraynov and others, 1969).

The amount of fluorine in soils is a reflection of its content in parent rocks as influenced by soil-forming processes, soil texture, and climatic conditions. Concentrations of fluorine in most soils range between 150 to $400 \mathrm{ppm}$ (Kabata-Pendias and Mukherjee, 2007). For soils in the conterminous United States, fluorine concentrations average $430 \mathrm{ppm}$ and range from less than 10 to $3,700 \mathrm{ppm}$ (Shacklette and Boerngen, 1984). The lowest fluorine content is found in sandy soils under humid climate conditions and the highest content is in clay soils and soil derived from mafic rocks (Kabata-Pendias and Mukherjee, 2007). High levels of fluorine (more than 1,000 ppm) have commonly been reported for uncontaminated soils derived from fluorine-rich bedrock (Fuge and Andrews, 1988; Ermakov, 2004). Contaminated soils surrounding aluminum processing plants, china clay production facilities, and phosphate-fertilizer factories have been reported to contain between 2,000 and 3,600 ppm fluorine (Kabata-Pendias and Pendias, 2001).

The major natural source of atmospheric fluorine in the environment is volcanic activity, with sea-salt spray and suspension of soil by wind as additional natural sources. Anthropogenic sources include mining and processing of phosphorites, apatites, and fluorite; production of cement, bricks, steel, aluminum and other metals; combustion of coal; and production and use of fertilizers, fluorine-bearing pesticides, and drugs, plastics, and refrigerants (Ermakov, 2004). Fluorine is removed from the atmosphere primarily by wet deposition either as particulate fluorides or by dissolving into atmospheric water. Fluorine concentrations in the atmosphere are variable. The ambient air concentration of gaseous fluoride varies from 0.01 to 2.1 parts per billion ( 0.01 to 2.1 micrograms per cubic meter) in the United States and Canada, with about 75 percent as hydrogen fluoride (Bourgeau and others, 1996).

The geochemical signatures in soils and waters associated with fluorspar deposits before mining are variable because fluorite is common in a wide range of geologic environments. The chemistry of soils, streams, and groundwaters near fluorspar deposits reflect the composition of the ore and host rock, the structure of the deposit, and the climatic conditions. Streamwater and groundwater near deposits may not display the same geochemical signature as soils and stream sediments because some of the enriched elements occur in relatively stable insoluble minerals. For example, soils and weathered rock associated with carbonatite deposits may be naturally enriched in $\mathrm{Ba}, \mathrm{Fe}, \mathrm{Nb}, \mathrm{P}$, REEs, Th, Ti, $\mathrm{U}$, and $\mathrm{Zr}$, and stream sediments downstream from deposits commonly contain anomalous abundances of $\mathrm{Ba}, \mathrm{Nb}, \mathrm{Th}$, and REEs (Modreski and others, 1995). The content of such elements as Nb, REEs, Th, and $\mathrm{U}$ may not be anomalous in streamwaters, however, because they are present in relatively stable, insoluble minerals (Modreski and others, 1995). The pre-mining environment around alkaline- to peralkaline-related deposits may contain anomalous concentrations of some of the same elements as carbonatites, including $\mathrm{Be}, \mathrm{Li}, \mathrm{Nb}, \mathrm{REEs}$, and $\mathrm{Ta}$. Streamwaters near the Yermakovskoye deposit in Russia contained naturally elevated concentrations of $\mathrm{Cu}, \mathrm{F}, \mathrm{Fe}, \mathrm{Hg}$, $\mathrm{Mn}, \mathrm{Mo}$, and $\mathrm{Zn}$. In addition, native soils near the deposit contained anomalous concentrations of As, $\mathrm{Ba}, \mathrm{Be}$, and $\mathrm{F}$ (Kislov and others, 2010). Natural metal-rich acidic drainage could be significant from deposits associated with significant pyrite or other sulfides. Carbonates are nearly ubiquitous at fluorspar deposits and may neutralize the acid generated by sulfides by removing many trace elements from the solution. In MVT deposits, iron, lead, and zinc from the weathering of associated sulfides may occur in anomalous concentrations in soils and stream sediments; however, at most deposits, elevated concentrations of these metals are not present because carbonate rocks limit the dispersion of trace elements by precipitating them as carbonates (Leach and others, 1995).

In the United States, some fluoride compounds are recycled in industrial settings. For example, synthetic fluorite is recovered from uranium enrichment and, to a lesser extent, from petroleum alkylation and stainless-steel pickling, producing on the order of a few thousand metric tons per year. In addition, aluminum producers recycle hydrofluoric acid and fluorides from smelting operations, and hydrofluoric acid is recycled in the petroleum alkylation process (Miller, 2013). New methods are being developed to recover fluoride from industrial wastewaters. One of these methods produced a nearly pure synthetic fluorite ( $>97$ percent) that can be used for the manufacture of hydrofluoric acid (Aldaco and others, 2007).

\section{Mine Waste Characteristics}

Mine waste is the material generated during ore extraction and processing at the mine site that has no direct economic value. The volume and characteristics of the waste material depend on the type of deposit and its size, the commodity or commodities recovered, and the mining and processing methods used. A summary of the mineralogy, chemistry, and volume, if available, of mine waste generated at several fluorspar mines is presented in table G3.

In general, overburden may need to be removed or host rock separated from the fluorite-rich ores as the first step of ore extraction; the fluorite-poor material becomes waste rock and can be backfilled into mine workings or pits, disposed of in waste piles, or, depending on the composition, used or sold for reuse (for example, as aggregate for construction purposes). The next step is to concentrate the fluorite in the ore. This is accomplished using a variety of methods, which typically include crushing and grinding followed by gravity separation and (or) flotation. The gangue minerals become the major components of waste tailings; common gangue minerals 
include calcite, dolomite, quartz, sulfides, and (or) barite, and, for carbonatite-related deposits, possibly apatite. Gravity separation is most often used to separate fluorite from calcite and silicates. Chemical flotation is used, however, when barite, celestite, or sulfide minerals are present, as they are denser than fluorite. Tailings generated from flotation are usually disposed of as an aqueous slurry into a tailings impoundment, where they are allowed to dry.

It is common for mine waste to contain a significant amount of fluorite as a result of inefficient or nonrecovery in years past; at some places, the fluorite content is high enough that the waste can be reprocessed using current methods (most commonly flotation) to recover most of the remaining fluorite. For example, mine waste and tailings from several locations in Kentucky (Crittenden and Livingston Counties) were reprocessed during World War II to meet the increased demand for fluorite (Fine, 1948). The tailings and waste rock contained a significant amount of fluorite (up to 59 percent), as well as calcite, chert, clay, and quartz; a minor amount of barite; and some lead and zinc sulfides (table G3). Another example of mine waste with a significant amount of fluorite (up to 17 percent total fluoride) is from fluorite and lead-zinc mines from the Northern Pennine Orefield and the Southern Pennine Orefield in the United Kingdom (table G3; Cooke and others, 1976; Fuge and Andrews, 1988). Modern recovery in fluorite operations is generally more efficient than in earlier operations.

\section{Human Health Concerns}

Fluorine is essential for some organisms but, like most substances, in excess, is highly toxic. Soluble forms of fluorine are absorbed into the body through the mouth lining, stomach, and intestines. Nearly all fluorine in the human body is in the form of fluorapatite, which is resident mostly in the bone, teeth, and cartilage (Ermakov, 2004). The primary chronic exposure route of concern for fluorine compounds is oral ingestion of drinking water, food, and fluoride-containing dental products. Inhalation and dermal exposure to $\mathrm{HF}$ is an acute occupational exposure that can occur (Agency for Toxic Substances and Disease Registry, 2003).

Fluorine is important for hard teeth in humans. In the United States, artificially fluoridated water commonly contains between 0.7 and 1.2 ppm fluorine (National Research Council, 2006). Fluorine deficiency in humans (less than 0.3 to $0.5 \mathrm{ppm}$ in drinking water) leads to tooth decay and osteoporosis. Also, animals with diets low in fluorine have exhibited slow growth, reproduction issues, and higher mortality (Ermakov, 2004). On the other hand, consumption of water with high concentrations of fluorine may lead to dental and skeletal fluorosis (that is, mottling of the tooth enamel, and pain and damage to bones and joints, respectively) starting at concentrations of $1.5 \mathrm{ppm}$ and becoming severe at greater than $6 \mathrm{ppm}$ (Reimann and de Caritat, 1998). Other health effects related to a high intake of fluorine include endocrine effects and carcinogenic changes, particularly in bone (National Research Council, 2006). According to the U.S. Environmental Protection Agency (2002), the no-observable-effect level for dental fluorosis based on children is approximately $1.0 \mathrm{ppm}$ fluoride, whereas crippling skeletal fluorosis, the most severe stage of skeletal fluorosis, was not observed in adults at consumption levels of up to 4 ppm fluoride. In the United States, primary and secondary drinking water standards have been established for fluorine. The primary drinking water standard (maximum limit of 4 ppm fluorine) was established to prevent adverse health effects and the secondary standard (maximum limit of $2.0 \mathrm{ppm}$ fluorine) was established to reduce adverse cosmetic consequences (U.S. Environmental Protection Agency, 2009). A recent review of the U.S. drinking water guidelines by the National Research Council (2006) suggests that the maximum contaminant level of $4 \mathrm{ppm}$ should be lower. For comparison, the World Health Organization reports a guideline value of $1.5 \mathrm{ppm}$ (World Health Organization, 2008).

Skeletal deformations and the crippling bone deformities of genu valgum (that is, knock knee) have been reported to occur in regions in India, Kenya, and Tanzania where high levels of fluorine ( 3 to $8 \mathrm{ppm}$ ) are present in drinking water (Ermakov, 2004). Also, surface water, groundwater, and mine water from Kerio Valley, Kenya, in Africa's Eastern Rift Valley, reaches $305 \mathrm{ppm}$, with average values greater than 25 ppm fluoride (table 2; Davies, 1994); tooth decay, dental and skeletal fluorosis, and osteochondral conditions are common in this area. Regional groundwater studies in China and Mexico also link high fluorine groundwaters to high fluorine rocks and fluorspar mines with some documentation of serious human health effects (Fuhong and Shuqin, 1988; Mahlknecht and others, 2004).

Although severe human health effects from high fluoride in drinking water are not commonly reported in the United States, naturally occurring fluoride concentrations in waters do exceed U.S. drinking water standards in several areas. In 1992, approximately 10 million people had public water supplies that were naturally fluoridated. The concentration of fluoride in 14 percent of those people's drinking water supplies were between 2.0 and 3.9 ppm; about 2 percent of those people's water supplies had concentrations equal to or greater than $4.0 \mathrm{ppm}$ fluoride. The highest, but not necessarily typical, concentrations were found in Colorado, Oklahoma, New Mexico, and Idaho, with maximum values of greater than $10 \mathrm{ppm}$ fluoride (National Research Council, 2006). In Texas, where groundwater makes up about 60 percent of the drinking water consumed, well water from a northwest region in the state exceeded the drinking water standard of $4 \mathrm{ppm}$ fluoride in more than 50 percent of the samples (Agency for Toxic Substances and Disease Registry, 2003). For those areas with fluoride greater than $4 \mathrm{ppm}$ in the drinking water, the Agency for Toxic Substances and Disease Registry recommends buying bottled drinking water. 
Table G3. Selected examples of the chemistry and mineralogy of mine waste generated at fluorspar mines.

[Elements: Ca, calcium; Cd, cadmium; Cu, copper; F, fluorine; Fe, iron; Ni, nickel; P, phosphorus; Pb, lead; S, sulfur; Si, silicon; Zn, zinc. Abbreviations and symbols: ppm, part per million; wt. \%, weight percent; —, not determined or not reported; ?, identification uncertain]

\begin{tabular}{|c|c|c|c|}
\hline $\begin{array}{l}\text { Tailings and mine waste } \\
\text { (pre-World War II) }\end{array}$ & $\begin{array}{l}\text { Several locations in Crittenden } \\
\text { and Livingston Counties, } \\
\text { Kentucky, United States }\end{array}$ & $\begin{array}{l}\text { Mississippi } \\
\text { Valley-type }\end{array}$ & $\begin{array}{l}\text { Fluorite ( } 13 \text { to } 59 \text { wt. \%), calcite ( } 2 \text { to } 28 \text { wt. \%), quartz } \\
\text { ( } 8 \text { to } 65 \text { wt. } \%) \text {; usually with smaller amounts of clay, } \\
\text { barite ( } 0 \text { to } 2 \text { wt. \%), Pb, } \mathrm{Zn}, \text { Fe sulfides (sphalerite, } \\
\text { galena, pyrite) }\end{array}$ \\
\hline Tailings & Southern Pyrenees, France & $\begin{array}{l}\text { ?Salt-related, } \\
\text { carbonate- } \\
\text { hosted }\end{array}$ & $\begin{array}{l}\text { Quartz, shale, iron hydroxides, fluorite (1 to } 5 \text { wt. \%), } \\
\text { iron carbonate, iron/copper sulfides }\end{array}$ \\
\hline Mine waste ${ }^{1}$ & Hammam Zriba Mine, Tunisia & $\begin{array}{l}\text { Salt-related, } \\
\text { carbonate- } \\
\text { hosted }\end{array}$ & $\begin{array}{l}\text { Quartz, barite, calcite }>\text { K-feldspar, sylvite }>\text { plagioclase, } \\
\text { fluorite, limonite, zeolites, opaque minerals }\end{array}$ \\
\hline Mine waste & $\begin{array}{l}\text { Northern Pennine Orefield and } \\
\text { Southern Pennine Orefield, } \\
\text { United Kingdom }\end{array}$ & $\begin{array}{l}\text { Mississippi } \\
\text { Valley-type }\end{array}$ & $\begin{array}{l}\text { Barite ( } 16 \text { to } 23 \text { wt. \%), aluminosilicates ( } 20 \text { to } 51 \mathrm{wt} \% \text { ), } \\
\text { calcium carbonate ( } 15 \text { to } 32 \mathrm{wt} . \%) \text {, fluorite, among } \\
\text { others }\end{array}$ \\
\hline
\end{tabular}

${ }^{1}$ Chemistry is for a partial digestion procedure (that is, silicates were not completely digested).

For soils, screening levels based on human health risk in the United States have been established based on the use of the land (residential versus industrial) to determine whether concentrations of elements or compounds at sites warrant further investigation or site cleanup. Screening levels for noncancer health effects are $3,100 \mathrm{ppm}$ fluoride and 4,700 ppm fluorine (soluble fluoride) for residential land use and 41,000 ppm for fluoride and 61,000 ppm for fluorine (soluble fluoride) for industrial land use (U.S. Environmental Protection Agency, 2012). Natural soils in the United States, even those developed on fluorine-rich rocks, will almost never contain such concentrations, and if so, only in isolated small areas; however, such concentrations may be more common in soils located in industrial areas.

Other human health concerns related to fluorine are related to the mining and processing of fluorspar ores, which may expose workers to dust or, for some types of ores, radiation. Silica is associated with many types of ore, including fluorspar, and may be inhaled during mining and milling operations and can cause silicosis. In addition, inhaling high amounts of fluorspar dust during ore processing can lead to health issues that include gastric, intestinal, circulatory system, and nervous system problems, and, in the long term, anemia, weight loss, bone and teeth defects, pulmonary lesions, and bronchitis (Osinsky and Stellman, 1998). In the United States, the permissible exposure limits in air for fluorine in an 8-hour working day is $0.3 \mathrm{ppm}$ (0.2 milligram per cubic meter) (Occupational Safety and Health Administration, 2013). Dust control should be carefully enforced for mining and processing of ores from any type of fluorspar deposit. In addition to dust, human health issues have been documented from exposure to radiation during the mining of deposits related to peralkaline granite in the St. Lawrence district in Newfoundland, Canada. In this district, higher incidences of lung cancer were reported for underground miners exposed to high levels of radon and its progeny during fluorspar mining; mining started in the 1930s and continued until 1978. In the early 1960s, mechanical ventilation was installed, which decreased radon to levels below the exposure limit (Morrison and others, 1998).

An additional human health concern associated with mining operations that process ores using flotation techniques, which include some fluorspar mines, is the failure of tailings impoundments. Although rare, collapse of tailings dams can destroy property and cause injuries, fatalities, and environmental damage. For example, a fluorspar mine in Italy that used flotation to process ores from 1961 to 1985 stored tailings and waste in two large tailings impoundments. In 1985, approximately 180,000 cubic meters $\left(\mathrm{m}^{3}\right)$ of tailings slurry was inadvertently released and flowed into a valley, destroying a small town and causing destruction in another small town; this event caused 268 deaths and 100 injuries. The failure was owing to construction errors and a lack of operational monitoring during tailings deposition (Luino and De Graff, 2012). In more recent times, technical and scientific investigations on tailings impoundments and new legislation and regulations for stricter control and monitoring are helping to minimize tailings dam failures. 
Table G3. Selected examples of the chemistry and mineralogy of mine waste generated at fluorspar mines.-Continued

[Elements: Ca, calcium; Cd, cadmium; Cu, copper; F, fluorine; Fe, iron; Ni, nickel; P, phosphorus; Pb, lead; S, sulfur; Si, silicon; Zn, zinc. Abbreviations and symbols: ppm, part per million; wt. \%, weight percent; _, not determined or not reported]

\begin{tabular}{ccccccccccccc}
\hline $\mathbf{p H}$ & $\begin{array}{c}\mathbf{C a} \\
(\mathbf{w t} \%)\end{array}$ & $\begin{array}{c}\mathbf{F} \\
(\mathbf{w t} . \%)\end{array}$ & $\begin{array}{c}\mathbf{F e} \\
(\mathbf{w t} . \%)\end{array}$ & $\begin{array}{c}\mathbf{P} \\
\text { (wt. \%) }\end{array}$ & $\begin{array}{c}\mathbf{S} \\
\text { (wt. \%) }\end{array}$ & $\begin{array}{c}\mathbf{S i} \\
(\mathbf{w t} . \%)\end{array}$ & $\begin{array}{c}\mathbf{C d} \\
(\mathbf{p p m})\end{array}$ & $\begin{array}{c}\mathbf{C u} \\
(\mathbf{p p m})\end{array}$ & $\begin{array}{c}\mathbf{N i} \\
(\mathbf{p p m})\end{array}$ & $\begin{array}{c}\mathbf{P b} \\
(\mathbf{p p m})\end{array}$ & $\begin{array}{c}\mathbf{Z n} \\
(\mathbf{p p m})\end{array}$ & Reference \\
\hline- & - & - & - & - & 0.03 to & - & - & - & - & $<500$ to & 1,000 to & Fine \\
& & & & & 2.2 & & & & & 8,200 & 38,300 & $(1948)$
\end{tabular}

\begin{tabular}{|c|c|c|c|c|c|c|c|c|c|c|c|c|}
\hline- & - & - & $\begin{array}{c}3.5 \text { to } \\
7\end{array}$ & - & - & $\begin{array}{c}37 \text { to } \\
42\end{array}$ & - & - & - & - & - & $\begin{array}{c}\text { European } \\
\text { Commission } \\
\text { (2009) }\end{array}$ \\
\hline- & 7.8 & - & 0.31 & 0.11 & 0.3 & - & 36 & 34 & 0.5 & 3,420 & 12,100 & $\begin{array}{c}\text { Yoshida } \\
\text { and others } \\
(2002)\end{array}$ \\
\hline $\begin{array}{c}6.2 \text { to } \\
7.7\end{array}$ & - & $\begin{array}{c}2.3 \text { to } \\
17.4\end{array}$ & - & $\begin{array}{c}0.001 \text { to } \\
0.06\end{array}$ & - & - & $\begin{array}{c}8 \text { to } \\
28\end{array}$ & $\begin{array}{c}32 \text { to } \\
67\end{array}$ & $\begin{array}{c}30 \text { to } \\
65\end{array}$ & $\begin{array}{c}4,360 \text { to } \\
30,800\end{array}$ & $\begin{array}{c}2,020 \text { to } \\
20,360\end{array}$ & $\begin{array}{c}\text { Cooke } \\
\text { and others } \\
(1976)\end{array}$ \\
\hline
\end{tabular}

\section{Ecological Health Concerns}

Only small amounts of fluorine are taken up by plants from soils. Terrestrial plants from uncontaminated soils usually do not contain greater than $30 \mathrm{ppm}$ fluorine and likely do not require fluorine (Kabata-Pendias and Mukherjee, 2007). Plants, in particular tea plants (Camellia sinensis), however, can accumulate up to 2,000 ppm fluorine in areas with high soil concentrations. Levels of fluorine in soils between 200 and 2,000 ppm have been shown to result in toxicity to plants (that is, phytotoxicity) (Ermakov, 2004). Food plants commonly contain between 0.1 and $11 \mathrm{ppm}$ (Kabata-Pendias and Mukherjee, 2007). Fluorine on and within the plant parts can enter the food chain by animals foraging on the plants, and toxic threshold values for fluorine in fodder has been reported to be in the range of 20 to $50 \mathrm{ppm}$ (Ermakov, 2004). Fluorine toxicity in dairy cattle has resulted in lower reproduction and lower milk production (Swarup and others, 1998). Studies on minks and screech owls reported effects on fertility and reproduction success when fluorine concentrations reached hundreds of ppm in food (Aulerich and others, 1987; Pattee and others, 1988). Marine aquatic organisms have been shown to accumulate fluorine, and fluorine concentrations are commonly an order of magnitude higher (for example, $500 \mathrm{ppm}$ compared with $50 \mathrm{ppm}$ ) in sea organisms compared with freshwater fish and land organisms because of the generally higher fluorine levels in seawater compared to freshwater (Ermakov, 2004). Industrial releases of high amounts fluorine in waterways have had toxic effects on aquatic organisms (Davies, 1994; Agency for Toxic Substances and Disease Registry, 2003). Water-quality criteria and stream-sediment guidelines for the protection of aquatic life are generally lacking. Suter (1996), however, suggested an estimate of the highest concentration in surface water to which an aquatic community can be exposed briefly (that is, acute exposure) and indefinitely (that is, chronic exposure) without resulting in an unacceptable effect; these secondary acute and chronic aquatic ecosystem guidelines, established with fewer data than regulatory guidelines, are 19.2 and 1.18 ppm fluorine, respectively. These guideline concentrations are higher than those found in the vast majority of natural surface waters in the United States.

The mining and processing of ores may enrich waters and soils in potentially toxic elements and can cause ecological health concerns at some mine sites. Several examples from a few different fluorspar deposit types are discussed below. In general, ecosystem impact studies are more frequently conducted for sulfide-containing deposits, such as MVT deposits, because sulfides can generate acid and contribute to the release of some potentially toxic trace elements into the environment. Several studies have been conducted regarding the environmental impact of mining lead and fluorspar from MVT deposits in the Northern Pennine Orefield and Southern Pennine Orefield of the United Kingdom. The mine waste from the mines contains high concentrations of some trace elements as shown in table G3. Waters from one mine contained high concentrations of, in order of greatest environmental concern, zinc (up to $111 \mathrm{ppm}$ ), manganese (up to $138 \mathrm{ppm}$ ), iron (up to $68 \mathrm{ppm}$ ), and sulfate (up to 2,501 ppm), and, although most waters were near neutral, some were acidic, likely from sulfides in shales and mudstones (table G2; Johnson and Younger, 2002). Fluorine concentrations in soils surrounding mines in the Northern Pennine Orefield reach up to $20,000 \mathrm{ppm}$; surface waters, up to $2.3 \mathrm{ppm}$ fluorine, and 
grasses up to about $400 \mathrm{ppm}$ fluorine (table G2; Fuge and Andrews, 1988). A study of plants growing on mine waste in both the Northern Pennine Orefield and the Southern Pennine Orefield revealed fluoride concentrations of up to $4,500 \mathrm{ppm}$ in leaves and up to 10,000 ppm in seeds; the plants did not shown signs of phytotoxicity (Cooke and others, 1976). Some waste piles have been revegetated to create natural ecosystems, and small mammals living on and near the revegetated piles have been shown to contain significantly higher levels of cadmium, fluorine, and lead and somewhat higher levels of zinc than do small mammals living in uncontaminated areas (Wright and others, 1978; Andrews, Johnson, and Cooke, 1984, 1989a, b: Andrews, Cooke, and Johnson, 1989). Geeson and others (1998) suggested health problems affecting young lambs living in the vicinity of old mines or smelters in the Southern Pennine Orefield may be related to the excess lead as well as fluorine in their diets.

Ecological health impacts have also been studied at a peralkaline to alkaline-intrusion-related fluorspar deposit in Russia that contains only a minor amount of sulfides. Waters from the open pit at the previously mined Yermakovskoye beryllium-fluorine deposit contained elevated concentrations of some elements, including $\mathrm{Cu}, \mathrm{Fe}, \mathrm{Mg}, \mathrm{Mn}, \mathrm{Mo}, \mathrm{Pb}$, and $\mathrm{Zn}$, all of which exceeded local standards for water bodies used for fishery purposes. In addition, sediment at the bottom of the pit was contaminated with $\mathrm{As}, \mathrm{Be}, \mathrm{Cd}, \mathrm{Pb}$, and $\mathrm{Zn}$, and the concentrations of $\mathrm{Pb}$ and $\mathrm{Zn}$ exceeded values above which effects to aquatic biota are likely. Mine waste piles contained concentrations of beryllium that were above the maximum allowable concentrations (Kislov and others, 2010). The natural background contents of some of the elements, such as $\mathrm{Cu}, \mathrm{F}, \mathrm{Fe}, \mathrm{Mn}, \mathrm{Mo}$, and $\mathrm{Zn}$, in local streams and melt waters are also elevated and above ecological-health guidelines, making it difficult to distinguish the contamination from mining from the pre-mining concentrations associated with the mineralized area. According to Kislov and others (2010), the pasture vegetation in the local area may contain high levels of beryllium from the deposition of contaminated dust, and the agricultural uses of the land should be limited.

The potential ecosystem health concern associated with the Moscona Mine, which is a salt-related carbonate-hosted fluorspar deposit in Asturias, Spain, is related to aqueous fluoride; acidic metal-rich mine drainage from the weathering of sulfides is not an issue because of neutralization by associated carbonates. Waters from within the underground mine and from a surface spring are saline (800 to 1,700 microsiemens per centimeter conductivity), have near neutral $\mathrm{pH}$ ( $\mathrm{pH} 7.6$ to 8.2), and contain elevated levels of fluoride ( 0.5 to $3.5 \mathrm{ppm}$ ), carbonate, and sulfate (table G2; Roqueñí and others, 2005). Also, each year approximately $200,000 \mathrm{~m}^{3}$ of wastewater from the mine is discharged into a nearby stream, which results in fluoride concentrations of up to $4.8 \mathrm{ppm}$. The release of this water, some of which exceeds the secondary chronic surface water guideline for the protection of aquatic life as suggested by Suter (1996), may be a threat to the health of the local ecosystem: however, decant ponds were constructed to reduce the contamination of the nearby stream (Roqueñí and others, 2005).

\section{Carbon Footprint}

A new fluorine-based compound, hydrofluoroolefin, is recommended as a refrigerant for air conditioning in motor vehicles to replace an existing compound, chlorofluorocarbon, currently in use. The new compound has a lower global warming potential, which is a relative measure of the warming effects of greenhouse gases, than the fluorocarbon compound and has been approved by the U.S. Environmental Protection Agency as a replacement (U.S. Environmental Protection Agency, 2011). Another advantage of the replacement compound is that it may contribute to the reduction of ozone concentrations in the stratosphere.

\section{Mine Closure}

The post-mining landscape at mines, including fluorspar mines, depends on the deposit type and size, the character of the host rock, the mining and processing methods, the climate, and the regulations in place regarding mine closure. Open pits, shafts and adits from underground operations, processing facilities, mine and processing wastes, and drainage from the site may need to be addressed for mine closure. One example of a remediated mine site in the United States is the Burlington Mine, which was the largest fluorspar deposit in the Jamestown district in Boulder County, Colo.; this site was reclaimed through a Voluntary Clean Up action, which is a State cooperative program that encourages voluntary cleanup of contaminated industrial and commercial properties (O'Shea-Stone, 2011). The mine produced fluorspar, in addition to some silver, lead, and uranium, from 1920 to 1973; limited remediation was conducted at the time of mine closure, and a Voluntary Clean Up action was conducted within the past 10 years. Prior to the recent cleanup, the landscape included a large vegetation-free, acidic, waste pile, a mine adit and shaft openings, and subsidence features. In addition, water draining from the waste pile flowed into a nearby creek. The remediation efforts consisted of consolidating acid-generating waste rock, closing of the adit and shafts, filling subsidence pits, limiting surface water and groundwater interaction with waste materials and mine workings, adding soil amendments (including lime, soil, and compost) to waste rock piles and disturbed soils, and site-wide revegetation. In 2008, remediation efforts were considered successful by State and Federal agencies based on improved water quality, minimal erosion from the site, removal of safety hazards, and the establishment of a natural and functional self-sustaining plant community (O'Shea-Stone, 2011).

Other mines have not been reclaimed. For example, remediation efforts were not undertaken when production 
ceased in 1989 at the Yermakovskoye beryllium-fluorine deposit in Russia. The surface area of the open pit is 277,000 square meters with a depth of at least $70 \mathrm{~m}$, and it contains a few meters of water in the bottom (Kislov and others, 2010). The impact to the ecosystem from the mined landscape was discussed in the previous section. Future plans for the site include resuming mining and construction of a processing plant; construction was expected to begin in 2013 (Jaskula, 2013). An estimated 8,500,000 $\mathrm{m}^{3}$ of rock will be extracted from an open pit operation, including ore and waste rock (Kislov and others, 2010). The combined volume of sulfide-rich and nonsulfide-rich tailings generated will be about $830,000 \mathrm{~m}^{3}$. Eventually, mine closure will involve stabilizing disturbed surfaces and reclaiming soils, waters, and stream sediments at and near the mine site.

\section{Problems and Future Research}

The Klondike II Mine (Livingston County, Ky.) began production in 2012, the Nui Phao Mine (Thai Nguyen Province, Vietnam) began production in 2013, and, until late 2013, the Nokeng Mine (Gauteng Province, South Africa) had been scheduled to start production in the second quarter of 2014. A number of other projects were projected to begin mining in the 2015-17 timeframe. With these new supplies, Chinese domination of the world fluorspar market is likely to lessen. Also, China's reduced exports of fluorspar in response to the need for fluorspar by their own industries may be compensated for with production from other countries.

The possible extraction of fluorine from alkaline, $\mathrm{NaHCO}_{3}$-type evaporite brines is a subject deserving of additional research. Extraction of resources from brines has proven very cost effective for some mineral commodities, such as borax, lithium, potash, and soda ash. Lake Magadi (Kenya) and Lake Natron (Tanzania) within the Eastern Rift Valley contain large resources of surface and interstitial water with fluorine concentrations in excess of 1,000 ppm. Because the existing trona mining operation does not recover the villiaumite from the solid trona, it would seem a boon to remove fluorine from the brines, possibly allowing two new product streams - an evaporating pond product of fluorine-poor trona and a solid fluorine product of some type.

Exploration focused on discovery of new, apparently conformable fluorspar deposits in tuffaceous limy lacustrine sediments also could be fruitful. In the Latium Region of Italy, deposits were marginally economic because of difficulty recovering the fine-grained fluorite, but other regions may have deposits that do not have that problem. The Latium deposits are in a minimally eroded young volcanic terrane that is specifically ultrapotassic and alkaline. That set of parameters can be matched at multiple places in the world; for example, Italy's Pantelleria Island in the Mediterranean Sea between Sicily and Tunisia. The deposits in Italy could be studied further, possibly to include exploration of the nearby maar lakes to see if mineralization processes are ongoing in their bottom sediments.

Three types of research in recent years on the composition of fluid inclusions in hydrothermal ore deposits have led to greatly increased understanding of the sources of the hydrothermal fluids. These are quadrupole mass spectrometry (Landis and Hofstra, 1991), noble gas mass spectrometry on irradiated fluid inclusions (Kendrick and others, 2002), and study of chlorine isotopes in inclusion fluids (Partey and others, 2009). Each of these methods has succeeded in defining magmatic contributions to hydrothermal fluids where magmatic involvement had previously been in question. These methods are especially effective when combined with determination of cation concentrations and halogen ratios $\left(\mathrm{Na}^{+}: \mathrm{Br}\right.$ and $\left.\mathrm{Cl}^{-}: \mathrm{Br}^{-}\right)$in the same hydrothermal fluids. The ratios can help define any component of redissolved halite within the fluids. The combined methods on elemental composition of solutes in the hydrothermal fluid can separate the fluids of saltrelated carbonate-hosted systems from those of other systems with sedimentary brines as ore fluids (Sánchez and others, 2009 , for example). These modern methods are likely to prove valuable when extended to additional deposits and districts. For deposits whose relation to igneous rocks is equivocal, such studies would provide critical new genetic knowledge. The fluid inclusion studies are even more effective when combined with modern isotopic age determination (Chesley and others, 1994; Sánchez and others, 2006; Munoz and others, 2005). These multifaceted methods have made clear the processes and tectonic setting that produced fluorspar and base-metal deposits in Western Europe of the class that here are called salt-related carbonate-hosted deposits. A promising place to apply this combination of methods is Las Cuevas in San Luis Potosi State, Mexico.

\section{Acknowledgments}

Our USGS colleagues John DeYoung, Steve Ludington, Klaus Schulz, and Hendrik van Oss provided astute reviews that improved both the presentation and content of this chapter. Dr. Brian Hodge, well known worldwide consultant on fluorspar deposits, provided an early critique of our classification of fluorspar deposit types by tectonic or magmatic environment (fig. G3B), but this should not be taken to indicate that he supports that classification. Dr. Hodge also provided many references to published tonnages and grades of fluorspar deposits, some of which appear in the compilation in appendix G1. With that information, he also provided congenial discussion of grades, tonnages, and information sources. As with figure G3, however, we the authors, not Dr. Hodge, are responsible for the tabulation of appendix G1, including any poorly discriminating choices of statistics that appear there. Keith Labay helped create the deposit location maps, and Suzanne Nicholson provided additional editorial comments after the technical review was complete. 


\section{References Cited}

Note: All Web links listed were active as of the access date but may no longer be available.

Agency for Toxic Substances and Disease Registry, 2003, Toxicological profile for fluorides, hydrogen fluoride, and fluorine: Atlanta, Ga., U.S. Department of Health and Human Services, Public Health Service, September, 356 p. plus 4 appendixes, accessed April 30, 2013, at http://www.atsdr.cdc.gov/toxprofiles/tp.asp?id=212\&tid=38.

Aldaco, R., Garea, A., and Irabien, A., 2007, Calcium fluoride recovery from fluoride wastewater in a fluidized bed reactor: Water Research, v. 41, no. 4, p. 810-818. [Also available at http://dx.doi.org/10.1016/j.watres.2006.11.040.]

Anderson, W.H., and Moodie, Boyce, III, 2010, Stop 1Klondike II Mine, in Smath, R.A., comp., Selected areas within the western Kentucky fluorspar district and the Illinois fluorspar district and a tour of the Ben E. Clement Mineral Museum-Kentucky Society of Professional Geologists fall field trip guide, October 23, 2010: Lexington, Ky., Kentucky Society of Professional Geologists, Field Conference Guidebook, p. 14-15. [Also available at http://www.kspg.org/pdf/2010\%20KSPG\%20 field\%20guide\%20REPLACEMENT\%20PAGES.pdf.]

Anderson, W.H., and Sparks, T.N., 2012, Mines and minerals of the western Kentucky fluorspar district: Kentucky Geological Survey Series XII, Map and Chart 201, scale 1:50,000. [Also available at http://kgs.uky.edu/ kgsweb/olops/pub/kgs/MC201_12.pdf.]

Andrews, S.M., Cooke, J.A., and Johnson, M.S., 1989, Distribution of trace element pollutants in a contaminated grassland ecosystem established on metalliferous fluorspar tailings. 3-Fluoride: Environmental Pollution, v. 60, nos. 1-2, p. 165-179. [Also available at http://dx.doi.org/ 10.1016/0269-7491(89)90225-x.]

Andrews, S.M., Johnson, M.S., and Cooke, J.A., 1984, Cadmium in small mammals from grassland established on metalliferous mine waste: Environmental Pollution, Series A, Ecological and Biological, v. 33, no. 2, p. 153-162. [Also available at http://www.sciencedirect.com/science/ article/pii/0143147184901752.]

Andrews, S.M., Johnson, M.S., and Cooke, J.A., 1989a, Distribution of trace element pollutants in a contaminated grassland ecosystem established on metalliferous fluorspar tailings. 1-Lead: Environmental Pollution, v. 58, no. 1, p. 73-85. [Also available at http://dx.doi.org/10.1016/ 0269-7491(89)90238-8.]
Andrews, S.M., Johnson, M.S., and Cooke, J.A., 1989b, Distribution of trace element pollutants in a contaminated grassland ecosystem established on metalliferous fluorspar tailings. 2-Zinc: Environmental Pollution, v. 59, no. 3, p. 241-252. [Also available at http://dx.doi.org/10.1016/ 0269-7491(89)90229-7.]

Arveti, Nagaraju, Sarma, M.R.S., Aitkenhead-Peterson, J.A., and Sunil, K., 2011, Fluoride incidence in groundwaterA case study from Talupula, Andhra Pradesh, India: Environmental Monitoring and Assessment, v. 172, no. 1, p. 427-443. [Also available at http://dx.doi.org/10.1007/ s10661-010-1345-3.]

Aulerich, R.J., Napolitano, A.C., Bursian, S.J., Olson, B.A., and Hochstein, J.R., 1987, Chronic toxicity of dietary fluorine to mink: Journal of Animal Science, v. 65, no. 4, p. 1759-1767. [Also available at http://dx.doi.org/10.2527/ jas1987.6561759x.]

Bailey, J.C., 1980, Formation of cryolite and other aluminofluorides-A petrologic review: Bulletin of the Geological Society of Denmark, v. 29, p. 1-45. [Also available at http://2dgf.dk/xpdf/bull29-01-02-1-45.pdf.]

Barton, M.D., 1982, Some aspects of the geology and mineralogy of the fluorine-rich skarn at McCullough Butte, Eureka County, Nevada: Carnegie Institution of Washington Year Book, v. 81, p. 324-328.

Barton, M.D., and Trim, H.E., 1991, Late Cretaceous twomica granites and lithophile-element mineralization in the Great Basin, in Raines, G.L., Lisle, R.E., Schafer, R.W., and Wilkinson, W.H., Jr., eds., Geology and ore deposits of the Great Basin-Symposium proceedings-Sponsored by the Geological Society of Nevada and United States Geological Survey, April 1-5, 1990: Reno, Nev., Geological Society of Nevada, v. 1, p. 529-538. [Also available at http://www.geo.arizona.edu/ mdbarton/MDB_papers_pdf/ Barton[91_LEM2mica_GSN.pdf.]

Bau, Michael, Romer, R.L., Lüders, Volker, and Dulski, Peter, 2003, Tracing element sources of hydrothermal mineral deposits - $\mathrm{REE}$ and $\mathrm{Y}$ distribution and $\mathrm{Sr}-\mathrm{Nd}-\mathrm{Pb}$ isotopes in fluorite from MVT deposits in the Pennine Orefield, England: Mineralium Deposita, v. 38, no. 8, p. 992-1008. [Also available at http://dx.doi.org/10.1007/s00126-003-0376-x.]

Belkin, H.E., de Vivo, Benedetto, and Valera, Roberto, 1984, Fluid inclusion study of some Sarrabus fluorite deposits, Sardinia, Italy: Economic Geology, v. 79, p. 409-414. [Also available at http://dx.doi.org/10.2113/gsecongeo.79.2.409.]

Bell, Keith, and Powell, J.L., 1969, Strontium isotopic studies of alkalic rocks-The potassium-rich lavas of the Birunga and Toro-Ankole regions, east and central equatorial Africa: Journal of Petrology, v. 10, no. 3, p. 536-572. 
Billström, Kjell, Broman, Curt, Schneider, Jens, Pratt, Warren, and Skogsmo, Göran, 2012, Zn-Pb ores of Mississippi Valley type in the Lycksele-Storuman district, northern Sweden-A possible rift-related Cambrian mineralisation event: Minerals, v. 2, no. 3, p. 169-207. [Also available at http://dx.doi.org/10.3390/min2030169.]

Boni, Maria, Balassone, Giuseppina, Fedele, Luca, and Mondillo, Nicola, 2009, Post-Variscan hydrothermal activity and ore deposits in southern Sardinia (Italy) - Selected examples from Gerrei (Silius vein system) and the Iglesiente district: Periodico di Mineralogia, v. 78, no. 3, p. 19-35. [Also available at http://dx.doi.org/10.2451/ 2009pM0010.]

Bose, Sankar, Das, Kaushik, and Fukuoka, Masato, 2005, Fluorine content of biotite in granulite-grade metapelitic assemblages and its implications for the Eastern Ghats granulites: European Journal of Mineralogy, v. 17, no. 5, p. 665-674. [Also available at http://dx.doi.org/10.1127/ 0935-1221/2005/0017-0665.]

Bottrill, R.S., and Baker, W.E., 2008, A catalogue of the minerals of Tasmania: Rosny Park, Tasmania, Australia, Mineral Resources Tasmania, Tasmanian Geological Survey Bulletin, v. 73, 254 p.

Bouch, J.E., Naden, Jonathan, Shepherd, T.J., McKervey, J.A., Young, Brian, Benham, A.J., and Sloane, H.J., 2006, Direct evidence of fluid mixing in the formation of stratabound $\mathrm{Pb}-\mathrm{Zn}-\mathrm{Ba}-\mathrm{F}$ mineralization in the Alston Block, north Pennine orefield (England): Mineralium Deposita, v. 41, no. 8, p. 821-835. [Also available at http://dx.doi.org/10.1007/ s00126-006-0093-3.]

Bourgeau, M., Clapin, D., Foster, K., Jones, R., Prior, M., Shepherd, M., and Walsh, P., 1996, National ambient air quality objectives for hydrogen fluoride (HF) - Science assessment document: Ottawa, Ontario, Canada, CEPA/ FPAC Working Group on Air Quality Objectives and Guidelines, DQ3.1.1, Report No. 6211-19-018, 122 p., accessed April 17, 2013, at http://www.bape.gouv.qc.ca/sections/ mandats/ap50_rio_tinto_alcan/documents/DQ3.1.1.pdf.

Bowen, N.L., 1937, Recent high-temperature research on silicates and its significance in igneous geology: American Journal of Science, ser. 5, v. 33, no. 193, p. 1-21. [Also available at http://dx.doi.org/10.2475/ajs.s5-33.193.1.]

Bradbury, J.C., and Baxter, J.W., 1992, Intrusive breccias at Hicks Dome-Hardin County, Illinois: Illinois State Geological Survey Circular 550, 23 p. [Also available at http://hdl.handle.net/2142/44637.]

Brockie, D.C., Hare, E.H., Jr., and Dingess, P.R., 1968, The geology and ore deposits of the Tri-State district of Missouri, Kansas, and Oklahoma, in Ridge, J.D., ed., Ore deposits of the United States, 1933-1967; the Graton-Sales Volume: New York, N.Y., American Institute of Mining, Metallurgical and Petroleum Engineers, v. 1, p. 400-430.
Brown, J.S., Emery, J.A., and Meyer, P.A., Jr., 1954, Explosion pipe in test well on Hicks Dome, Hardin County, Illinois: Economic Geology, v. 49, p. 891-902. [Also available at http://dx.doi.org/10.2113/gsecongeo.49.8.891.]

Bulnayev, K.B., and Kaperskaya, Yu.N., 1995, Genetic significance of the distribution of some REE in Transbaykalian and Mongolian Late Mesozoic volcanites and fluorites: Geochemistry International, v. 32, no. 8, p. 72-78.

Burt, D.M., Sheridan, M.F., Bikun, J.V., and Christiansen, E.H., 1982, Topaz rhyolites - Distribution, origin, and significance for exploration: Economic Geology, v. 77, p. 1818-1836. [Also available at http://dx.doi.org/10.2113/ gsecongeo.77.8.1818.]

Busby, J.F., Plummer, L.N., Lee, R.W., and Hanshaw, B.B., 1991, Geochemical evolution of water in the Madison Aquifer in parts of Montana, South Dakota, and Wyoming: U.S. Geological Survey Professional Paper 1273-F, p. F1-F89. [Also available at http://pubs.er.usgs.gov/ publication/pp1273F.]

Canadian Aero Mineral Surveys Ltd. and Arabian Geophysical and Surveying Company, 1967, Airborne EM "Input" system, vol. 2, Ad Dawadimi area: Report for Saudi Arabian Directorate General of Mineral Resources, unnumbered report, 39 p., 6 figs., 18 maps.

Cardellach, Esteve, Canals, Àngels, and Grandia, Fidel, 2003, Recurrent hydrothermal activity induced by successive extensional episodes-The case of the Berta F-( $\mathrm{Pb}-\mathrm{Zn})$ vein system (NE Spain): Ore Geology Reviews, v. 22, nos. 1-2, p. 133-141. [Also available at http://dx.doi.org/10.1016/ s0169-1368(02)00112-9.]

Carlson, E.H., 1983, The occurrence of Mississippi Valleytype mineralization in northwestern Ohio, in Kisvarsanyi, Geza, Grant, S.K., Pratt, W.P., and Koenig, J.W., eds., International Conference on Mississippi Valley type lead-zinc deposits, 2d, Rolla, Mo., 1982, Proceedings: Rolla, Mo., University of Missouri-Rolla, p. 86-112.

Carpenter, A.B., 1978, Origin and chemical evolution of brines in sedimentary basins, in Johnson, K.S., and Russell, J.A., eds., Thirteenth Annual Forum on the Geology of Industrial Minerals, Norman, Okla., May 12-14, 1977, Proceedings: Oklahoma Geological Survey Circular 79, p. 60-77. [Also available at http://www.ogs.ou.edu/pubsscanned/Circulars/ circular79.pdf.]

Charef, Abdelkrim, and Sheppard, S.M.F., 1987, Pb-Zn mineralization associated with diapirism-Fluid inclusion and stable isotope $(\mathrm{H}, \mathrm{C}, \mathrm{O})$ evidence for the origin and evolution of the fluids at Fedj-el-Adoum, Tunisia: Chemical Geology, v. 61, nos. 1-4, p. 113-134. [Also available at http://dx.doi.org/10.1016/0009-2541(87)90032-5.] 
Chatterjee, M.K., and Mohabey, N.K., 1998, Potential fluorosis problems around Chandidongri, Madhya Pradesh, India: Environmental Geochemistry and Health, v. 20, no. 1, p. 1-4. [Also available at http://dx.doi.org/10.1023/ A:1006529925395.]

Cheilletz, Alain, Gasquet, Dominique, Filali, Fouad, Archibald, D.A., and Nespolo, Massimo, 2010, A late Triassic ${ }^{40} \mathrm{Ar} /{ }^{39} \mathrm{Ar}$ age for the El Hammam high-REE fluorite deposit (Morocco) - Mineralization related to the Central Atlantic magmatic province?: Mineralium Deposita, v. 45, no. 4, p. 323-329. [Also available at http://dx.doi.org/ 10.1007/s00126-010-0282-y.]

Chen Xianpei, Gao Jiyuan, and Cao Junchen, 1996, Barite and fluorite deposits of China, in Editorial Committee of the Mineral Deposits of China, eds. [Responsible ed., Liu Nailong], Mineral deposits of China, v. 5: Beijing, China, Geological Publishing House, p. 52-117.

Cheney, T.M., McClellan, G.H., and Montgomery, E.S., 1979, Sechura phosphate deposits, their stratigraphy, origin, and composition: Economic Geology, v. 74, p. 232-259. [Also available at http://dx.doi.org/10.2113/gsecongeo.74.2.232.]

Chesley, J.T., Halliday, A.N., Kyser, T.K., and Spry, P.G., 1994, Direct dating of Mississippi Valley-type mineralization-Use of Sm-Nd in fluorite: Economic Geology, v. 89, p. 1192-1199. [Also available at http://dx.doi.org/ 10.2113/gsecongeo.89.5.1192.]

Clark, K.F., Foster, C.T., and Damon, P.E., 1982, Cenozoic mineral deposits and subduction-related magmatic arcs in Mexico: Geological Society of America Bulletin, v. 93, no. 6, p. 533-544. [Also available at http://dx.doi.org/10.1130/ 0016-7606(1982)93\%3C533:cmdasm\%3E2.0.co;2.]

Clay, A.N., and de Wit, D.R., 2009, Definitive feasibility study on the Nokeng Fluorspar Mine (Pty) Limited's Nokeng fluorspar project in the form of a competent person's report and valuation, report prepared for Sephaku Holdings, Ltd.: Johannesburg, South Africa, Venmyn Rand (Pty), Ltd., 159 p., accessed May 10, 2013, at http:/www.sephakuholdings.co.za/b/files/CPR_fluorspar_dec09.pdf.]

Cooke, J.A., Johnson, M.S., Davidson, A.W., and Bradshaw, A.D., 1976, Fluoride in plants colonising fluorspar mine waste in the Peak District and Weardale: Environmental Pollution, v. 11, no. 1, p. 9-23. [Also available at http://dx.doi.org/ 10.1016/0013-9327(76)90003-3.]

Crocker, I.T., 1985, Volcanogenic fluorite-hematite deposits and associated pyroclastic rock suite at Vergenoeg, Bushveld Complex: Economic Geology, v. 80, p. 1181-1200. [Also available at http://dx.doi.org/10.2113/gsecongeo.80.4.1181.]

Davies, T.C., 1994, Water quality characteristics associated with fluorite mining in the Kerio Valley area of western Kenya: International Journal of Environmental Health Research, v. 4, no. 3, p. 165-175. [Also available at http://dx.doi.org/10.1080/09603129409356814.]
Deans, T., Sukheswala, R.N., Sethna, S.F., and Viladkar, S.G., 1972, Metasomatic feldspar rocks (potash fenites) associated with the fluorite deposits and carbonatites of Amba Dongar, Gujarat, India: Institution of Mining and Metallurgy Transactions, v. 81, no. 783, p. B1-B9.

Deering, M.F., Mohr, E.T., Sypniewski, B.F., and Carlson, E.H., 1983, Regional hydrogeochemical patterns in ground water of northwestern Ohio and their relation to Mississippi Valley-type mineral occurrences: Journal of Geochemical Exploration, v. 19, nos. 1-3, p. 225-241. [Also available at http:/www.sciencedirect.com/science/article/ pii/0375674283900195.]

Deloule, E., 1982, The genesis of fluorspar hydrothermal deposits at Montroc and Le Burc, the Tarn, as deduced from fluid inclusion analysis: Economic Geology, v. 77, p. 1867-1874. [Also available at http://dx.doi.org/10.2113/ gsecongeo.77.8.1867.]

Denny, F.B., Goldstein, Alan, Devera, J.A., Williams, D.A., Lasemi, Zakaria, and Nelson, W.J., 2008, The IllinoisKentucky fluorite district, Hicks Dome, and Garden of the Gods in southeastern Illinois and northwestern Kentucky, in Maria, A.H., and Counts, R.C., eds., From the Cincinnati Arch to the Illinois Basin-Geological field excursions along the Ohio River Valley: Boulder, Colo., Geological Society of America Field Guide, v. 12, p. 11-24. [Also available at http://dx.doi.org/10.1130/2008.fld012(02).]

Dobson, D.C., 1982, Geology and alteration of the Lost River tin-tungsten-fluorine deposit, Alaska: Economic Geology, v. 77, p. 1033-1052. [Also available at http://dx.doi.org/ 10.2113/gsecongeo.77.4.1033.]

Doroshkevich, A.G., Viladkar, S.G., Ripp, G.S., and Burtseva, M.V., 2009, Hydrothermal REE mineralization in the Amba Dongar carbonatite complex, Gujarat, India: The Canadian Mineralogist, v. 47, no. 5, p. 1105-1116. [Also available at http://dx.doi.org/10.3749/canmin.47.5.1105.]

Dunham, K.C., 1948, Geology of the Northern Pennine Orefield, v. 1, Tyne to Stainmore-Economic memoir covering the areas of 1:50,000 and one-inch geological sheets 19 and 25, and parts of 13, 24, 26, 31, 32 (England and Wales): London, United Kingdom, H.M. Stationery Office, British Geological Survey, 300 p.

Ebbott, K.A., Krothe, N.C., Shaffer, N.R., and Berg, J.H., 1985, Hydrogeochemical reconnaissance study in Washington County, Indiana [abs.], in Berg, J.H., ed., The Geological Society of America, North-Central Section, 19th annual meeting: Geological Society of America Abstracts With Programs, v. 17, no. 5, p. 286.

El Aref, M.M., and Amstutz, G.C., 1983, Lead-zinc deposits along the Red Sea coast of Egypt-New observations and genetic models on the occurrences of Um Gheig, Wizr, Essel and Zug El Bohar: Stuttgart, West Germany, Gebrüder Borntraeger, Monograph Series on Mineral Deposits, no. 21, 103 p., 1 pl. 
Ellmies, R., Germann, K., Krupenin, M.T., Möller, P., and Echtler, H.P., 1999, The fluorite-sellaite deposits of Suran, Bashkir Meganticline, Urals, in Stanley, C.J. and others, eds., Mineral deposits-Processes to processing Proceedings of the Fifth Biennial SGA Meeting and the Tenth Quadrennial IAGOD Symposium, London, United Kingdom, August 22-25, 1999: Brookfield, Vt., A.A. Balkema, p. 841-844.

Ericksen, G.E., Vine, J.D., and Ballón A.R., 1978, Chemical composition and distribution of lithium-rich brines in Salar de Uyuni and nearby salars in southwestern Bolivia: Energy, v. 3, no. 3, p. 355-363. [Also available at http://dx.doi.org/10.1016/0360-5442(78)90032-4.]

Ermakov, V.V., 2004, Fluorine, chap. 9.1 of Merian, E., Anke, M., Ihnat, M., and Stoeppler, M., eds., Elements and their compounds in the environment-Occurrence, analysis and biological relevance ( $2 \mathrm{~d}$ ed.): Weinheim, Germany, Wiley-VCH, p. 1415-1421. [Also available at http://dx.doi.org/10.1002/9783527619634.ch60a.]

Eugster, H.P., 1980, Lake Magadi, Kenya and its precursors, chap. 15 of Nissenbaum, A., ed., Hypersaline brines and evaporitic environments-Proceedings of the Bat Sheva Seminar on Saline Lakes and Natural Brines: New York, N.Y., Elsevier, p. 195-232.

European Commission, 2009, Reference document on best available techniques for management of tailings and waste-rock in mining activities: Brussels, Belgium, European Commission, January, variously paged, accessed November 4, 2014, at http://eippcb.jrc.ec.europa.eu/ reference/BREF/mmr_adopted_0109.pdf.

Feytis, Alex, 2009, Fluorspar supply fortified: Industrial Minerals Web page, September 21, accessed January 9, 2010, at http://www.indmin.com/Article/2299402/Fluorsparsupply-fortified.html.

Fifarek, R.H., Denny, F.B., Snee, L.W., and Miggins, D.P., 2001, Permian igneous activity in southeastern Illinois and western Kentucky_-Implications for tectonism and economic resources [abs.]: Geological Society of America Abstracts with Programs, v. 33, no. 6, p. A-420. [Also available at https://gsa.confex.com/gsa/2001AM/ finalprogram/abstract_14266.htm.]

Fine, M.M., 1948, Concentration of fluorite from tailings and mine waste rock in Crittenden and Livingston Counties, Ky.: U.S. Bureau of Mines Report of Investigations 4370, 21 p. [Also available at http://hdl.handle.net/2027/ mdp.39015078467555.]

Fleischer, Michael, and Robinson, W.O., 1963, Some problems of the geochemistry of fluorine, in Shaw, D.M., ed., Studies in analytical geochemistry: Toronto, Ontario, Canada, University of Toronto Press in cooperation with the Royal Society of Canada Special Publication no. 6, p. 58-75.
Fuge, Ronald, and Andrews, M.J., 1988, Fluorine in the UK environment: Environmental Geochemistry and Health, v. 10, nos. 3-4, p. 96-104. [Also available at http://dx.doi.org/ 10.1007/bf01758677.]

Fuhong Ren, and Shuqin Jiao, 1988, Distribution and formation of high-fluorine groundwater in China: Environmental Geology and Water Sciences, v. 12, no. 1, p. 3-10. [Also available at http://dx.doi.org/10.1007/bf02574820.]

Fulton, R.B., and Montgomery, Gill, 1983, Fluorite and cryolite, in Lefond, S.J., ed., Industrial minerals and rocksNonmetallics other than fuels (5th ed.): New York, N.Y., American Institute of Mining, Metallurgical, and Petroleum Engineers, v. 2, p. 732-744.

Garcia-Iglesías, Jesús, and Loredo, Jorge, 1994, Geological, geochemical, and mineralogical characteristics of the Asturias fluorspar district, northern Spain: Exploration and Mining Geology, v. 3, no. 1, p. 31-37. [Also available at http://www.cim.org/en/Publications-and-TechnicalResources/Publications/Technical_Papers/1994/1/BULL1994-01-08.aspx.]

Geeson, N.A., Abrahams, P.W., Murphy, M.P., and Thornton, I., 1998, Fluorine and metal enrichment of soils and pasture herbage in the old mining areas of Derbyshire, UK: Agriculture, Ecosystems, and Environment, v. 68, no. 3, p. 217-231. [Also available at http://dx.doi.org/10.1016/ s0167-8809(97)00153-9.]

Gerasimovskiy, V.I., and Savinova, Y.N., 1969, Fluorine contents of volcanic rocks in the rift zone of East Africa: Geochemistry International, v. 6, no. 6, p. 1124-1128. [Originally published in Geokhimiya, no. 12, p. 1466-1471.]

Gillerman, Elliot, 1948, The bedding-replacement fluorspar deposits of Spar Valley, Eagle Mountains, Hudspeth County, Texas: Economic Geology, v. 43, p. 509-517. [Also available at http://dx.doi.org/10.2113/gsecongeo.43.6.509.]

Goddard, E.N., 1946, Fluorspar deposits of the Jamestown district, Boulder County, Colorado: Colorado Scientific Society, Proceedings, v. 15, no. 1, 47 p.

Goff, B.H., Weinberg, R., Groves, D.I., Vielreicher, N.M., and Fourie, P.J., 2004, The giant Vergenoeg fluorite deposit in a magnetite-fluorite-fayalite REE pipe-A hydrothermallyaltered carbonatite-related pegmatoid?: Mineralogy and Petrology, v. 80, nos. 3-4, p. 173-199. [Also available at http://dx.doi.org/10.1007/s00710-003-0012-6.]

González-Partida, E., Carrillo-Chávez, A., Grimmer, J.O.W., Pironon, J., Mutterer, J., and Levresse, G., 2003, Fluorite deposits of Encantada-Buenavista, Mexico-Products of Mississippi Valley-type processes: Ore Geology Reviews, v. 23, nos. 3-4, p. 107-124. [Also available at http://dx.doi.org/10.1016/s0169-1368(03)00018-0.] 
Graham, G.S., Kesler, S.E., and Van Loon, J.C., 1975, Fluorine in ground water as a guide to $\mathrm{Pb}-\mathrm{Zn}-\mathrm{Ba}-\mathrm{F}$ mineralization: Economic Geology, v. 70, p. 396-398. [Also available at http://dx.doi.org/10.2113/gsecongeo.70.2.396.]

Grandia, Fidel, Canals, Àngels, Cardellach, Esteve, Banks, D.A., and Perona, Joaquim, 2003, Origin of ore-forming brines in sediment-hosted $\mathrm{Zn}-\mathrm{Pb}$ deposits of the BasqueCantabrian Basin, northern Spain: Economic Geology, v. 98, p. 1397-1411. [Also available at http://dx.doi.org/10.2113/ gsecongeo.98.7.1397.]

Grogan, R.M., 1960, Fluorspar and cryolite, in Gillson, J.L., ed., Industrial minerals and rocks-Nonmetallics other than fuels (3d ed., completely revised): New York, N.Y., American Institute of Mining, Metallurgical, and Petroleum Engineers, p. 363-382.

Grogan, R.M., 1964, Finding sources of fluorine [abs.]: Mining Engineering, v. 16, no. 1, p. 65.

Gulbrandsen, R.A., 1966, Chemical composition of phosphorites of the Phosphoria Formation: Geochimica et Cosmochimica Acta, v. 30, no. 8, p. 769-778. [Also available at http://dx.doi.org/10.1016/0016-7037(66)90131-1.]

Gunow, A.J., Ludington, Steve, and Munoz, J.L., 1980, Fluorine in micas from the Henderson molybdenite deposit, Colorado: Economic Geology, v. 75, p. 1127-1137. [Also available at http://dx.doi.org/10.2113/gsecongeo.75.8.1127.]

Gwalani, L.G., Rock, N.M.S., Chang, W.-J., Fernandez, S., Allègre, C.J., and Prinzhofer, A., 1993, Alkaline rocks and carbonatites of Amba Dongar and adjacent areas, Deccan igneous province, Gujarat, India-1. Geology, petrography and petrochemistry: Mineralogy and Petrology, v. 47, nos. 2-4, p. 219-253. [Also available at http://dx.doi.org/10.1007/ bf01161569.]

Hall, W.E., and Friedman, Irving, 1963, Composition of fluid inclusions, Cave-in-Rock fluorite district, Illinois, and Upper Mississippi Valley lead-zinc district: Economic Geology, v. 58, p. 886-911. [Also available at http://dx.doi.org/10.2113/gsecongeo.58.6.886.]

Hall, W.E., and Heyl, A.V., 1968, Distribution of minor elements in ore and host rock, Illinois-Kentucky fluorite district and Upper Mississippi Valley zinc-lead district: Economic Geology, v. 63, p. 655-670. [Also available at http://dx.doi.org/10.2113/gsecongeo.63.6.655.]

Han Yuchuan, Xia Xuehui, Pang Siyu, and Xu Shaokang, 2012, Hydrothermal sedimentary mineralization of the super-large Bamianshan fluorite deposit in Zhejiang Province, China: Acta Geologica Sinica (English ed.), v. 86, no. 3, p. 762-768. [Also available at http://dx.doi.org/ 10.1111/j.1755-6724.2012.00701.x.]

Hanor, J.S., 1987, Origin and migration of subsurface sedimentary brines: Tulsa, Okla., Society of Economic Paleontologists and Mineralogists, Short Course Series Lecture Notes, no. 21, 247 p.
Hanor, J.S., 1997, Controls on the solubilization of lead and zinc in basinal brines, in Sangster, D.F., ed., Carbonatehosted lead-zinc deposits-[Society of Economic Geologists] 75th anniversary volume: Littleton, Colo., Society of Economic Geologists Special Publication no. 4, p. 483-500.

Hatton, C.J., and Sharpe, M.R., 1989, Significance and origin of boninite-like rocks associated with the Bushveld Complex, in Crawford, A.M., ed., Boninites: London, United Kingdom, Unwin Hyman, p. 174-208.

Hayes, T.S., and Anderson, W.H., 1992, Regionwide correlation of the hydrothermal paragenesis of the Illinois-Kentucky fluorspar district [extended abs.], in Goldhaber, M.B., and Eidel, J.J., eds., Mineral resources of the Illinois Basin in the context of basin evolution-St. Louis, Missouri, January 22-23,1992-Program and Abstracts: U.S. Geological Survey Open-File Report 92-1, p. 19-22. [Also available at http://pubs.er.usgs.gov/publication/ofr921.]

Hayes, T.S., Palmer, J.R., and Rowan, E.L., 1990, Correlation of hydrothermal dolomite generations across the Mississippi Valley-type mineralizing system of the Ozark Region [abs.], in Pratt, W.P., and Goldhaber, M.G., eds., U.S. Geological Survey-Missouri Geological Survey symposium-Mineral resource potential of the Midcontinent; program and abstracts, St. Louis, Missouri, April 11-12, 1989: U.S. Geological Survey Circular 1043, p. 10. [Also available at http://pubs.usgs.gov/circ/1990/1043/report.pdf.]

Hayes, T.S., Sutley, S.J., Al-Shanti, Mahmoud, Al-Shammary, Abdullah, Al-Eissa, Abdullah, Nadra, Aymon, and Siddiqui, A.A., 2001, Jabal Dhaylan district, Saudi Arabia-Salt-related carbonate-hosted zinc-lead deposits formed in the Red Sea early passive margin, in Piestrzyński, Adam, and others, eds., Mineral deposits at the beginning of the 21 st centuryProceedings of the Joint Sixth Biennial SGA-SEG Meeting, Kraków, Poland, 26-29 August 2001: Lisse, Netherlands, A.A. Balkema, p. 137-140.

Hayes, T.S., Sutley, S.J., Kadi, K.A., Balkhyour, M.B., Siddiqui, A.A., Beshir, Zacharia, and Hashem, H.I., 2002, Jabal Dhaylan zinc-lead deposits - Geologic setting, genesis, and 1996-2000 exploration programs: Saudi Geological Survey Open-File Report SGS-OF-2001-5, 71 p.

Henderson, Thomas, 1985, Geochemistry of ground-water in two sandstone aquifer systems in the northern Great Plains in parts of Montana and Wyoming - Regional aquifer system analysis: U.S. Geological Survey Professional Paper 1402-C, p. C1-C84. [Also available at http://pubs.er.usgs.gov/publication/pp1402C.]

Heyl, A.V., Delevaux, M.H., Zartman, R.E., and Brock, M.R., 1966, Isotopic study of galenas from the Upper Mississippi Valley, the Illinois-Kentucky and some Appalachian Valley mineral districts: Economic Geology, v. 61, p. 933-961. [Also available at http://dx.doi.org/10.2113/gsecongeo.61.5.933.] 
Heyl, A.V., and West, W.S., 1982, Outlying mineral occurrences related to the Upper Mississippi Valley mineral district, Wisconsin, Iowa, Illinois, and Minnesota: Economic Geology, v. 77, p. 1803-1817. [Also available at http://dx.doi.org/10.2113/gsecongeo.77.8.1803.]

Higazy, R.A., 1954, Trace elements of volcanic ultrabasic potassic rocks of southwestern Uganda and adjoining part of the Belgian Congo: Geological Society of America Bulletin, v. 65 , no. 1, p. 39-70. [Also available at http://dx.doi.org/ 10.1130/0016-7606(1954)65[39:teovup]2.0.co;2.]

Hildreth, Wes, 1981, Gradients in silicic magma chambersImplications for lithospheric magmatism: Journal of Geophysical Research, v. 86, no. B11, p. 10153-10192. [Also available at http://dx.doi.org/10.1029/jb086ib11p10153.]

Hodge, Brian, 2012, Fluorspar illuminated: Industrial Minerals, no. 541, October, p. 39-52. [Also available at http://www.indmin.com/pdfs/697/86771/ Fluorspar\%20illuminated4\%201.pdf.]

Holmes, Arthur, and Harwood, H.F., 1932, Petrology of the volcanic fields east and south-east of Ruwenzori, Uganda: Quarterly Journal of The Geological Society of London, v. 88, February, p. 370-442. [Also available at http://dx.doi.org/ 10.1144/gsl.jgs.1932.088.01-04.16.]

Hudson, Travis, and Arth, J.G., 1983, Tin granites of Seward Peninsula, Alaska: Geological Society of America Bulletin, v. 94, no. 6, p. 768-790. [Also available at http://dx.doi.org/ 10.1130/0016-7606(1983)94\%3C768:tgospa\%3E2.0.co;2.]

Hudson, T.L., and Reed, B.L., 1997, Tin deposits in Alaska, in Goldfarb, R.J., and Miller, L.D., eds., Mineral deposits of Alaska: Lancaster, Pa., Economic Geology Publishing Co., Economic Geology Monograph Series no. 9, p. 450-465.

Huspeni, J.R., Kesler, S.E., Ruiz, Joaquin, Tuta, Zane, Sutter, J.F., and Jones, L.M., 1984, Petrology and geochemistry of rhyolites associated with tin mineralization in northern Mexico: Economic Geology, v. 79, p. 87-105. [Also available at http://dx.doi.org/10.2113/gsecongeo.79.1.87.]

Imai, Hideki, Kawasaki, Masashi, Yamaguchi, Mitsuo, and Takahashi, Mikio, 1985, Mineralization and paragenesis of the Huanzala Mine, central Peru: Economic Geology, v. 80, p. 461-478. [Also available at http://dx.doi.org/10.2113/ gsecongeo.80.2.461.]

Ineson, P.R., Mitchell, J.G., and Vokes, F.M., 1975, K-Ar dating of epigenetic mineral deposits; an investigation of the Permian metallogenic province of the Oslo region, southern Norway: Economic Geology, v. 70, p. 1426-1436. [Also available at http://dx.doi.org/10.2113/gsecongeo.70.8.1426.]

Ingebritsen, S.E., and Appold, M.S., 2012, The physical hydrogeology of ore deposits: Economic Geology, v. 107, p. 559-584. [Also available at http://dx.doi.org/10.2113/ econgeo.107.4.559.]
Jacks, Gunnar, Bhattacharya, Prosun, Chaudhary, Vikas, and Singh, K.P., 2005, Controls on the genesis of some highfluoride groundwaters in India: Applied Geochemistry, v. 20, no. 2, p. 221-228. [Also available at http://dx.doi.org/ 10.1016/j.apgeochem.2004.07.002.]

Jahns, R.H., and Glass, J.J., 1944, Beryllium and tungsten deposits of the Iron Mountain district, Sierra and Socorro Counties, New Mexico, with a section on the beryllium minerals: U.S. Geological Survey Bulletin 945-C, 35 p., 14 pls. [Also available at http://pubs.er.usgs.gov/publication/ b945C.]

Jaskula, B.W., 2013, Beryllium [advance release], in Metals and minerals: U.S. Geological Survey Minerals Yearbook 2011, v. I, p. 11.1-11.7, accessed March 1, 2013, at http://minerals.usgs.gov/minerals/pubs/commodity/ beryllium/myb1-2011-beryl.pdf.

Johnson, K.L., and Younger, P.L., 2002, Hydrological and geochemical consequences of the abandonment of Frazer's Grove carbonate hosted $\mathrm{Pb} / \mathrm{Zn}$ fluorspar mine, North Pennines, UK, in Younger, P.L., and Robins, N.S., eds., Mine water hydrogeology and geochemistry: Geological Society of London Special Publication, v. 198, p. 347-363. [Also available at http://dx.doi.org/10.1144/gsl.sp.2002. 198.01.24.]

Jones, B.F., 1965, The hydrology and mineralogy of Deep Springs Lake, Inyo County, California: U.S. Geological Survey Professional Paper 502-A, 56 p. [Also available at http://pubs.er.usgs.gov/publication/pp502A.]

Jones, B.F., Eugster, H.P., and Rettig, S.L., 1977, Hydrochemistry of the Lake Magadi Basin, Kenya: Geochimica et Cosmochimica Acta, v. 41, no. 1, p. 53-72. [Also available at http://dx.doi.org/10.1016/0016-7037(77)90186-7.]

Kabata-Pendias, Alina, and Mukherjee, A.B., 2007, Trace elements from soil to human: Berlin, Germany, SpringerVerlag, $550 \mathrm{p}$.

Kabata-Pendias, Alina, and Pendias, Henryk, 2001, Trace elements in soils and plants ( $3 \mathrm{~d}$ ed.): Boca Raton, Fla., CRC Press, 413 p.

Kendrick, M.A., Burgess, R., Pattrick, R.A.D., and Turner, G., 2002, Hydrothermal fluid origins in a fluorite-rich Mississippi Valley-type district —Combined noble gas ( $\mathrm{He}, \mathrm{Ar}, \mathrm{Kr}$ ) and halogen $(\mathrm{Cl}, \mathrm{Br}, \mathrm{I})$ analysis of fluid inclusions from the South Pennine ore field, United Kingdom: Economic Geology, v. 97, p 435-451. [Also available at http://dx.doi.org/ 10.2113/gsecongeo.97.3.435.]

Kesler, S.E., 1977, Geochemistry of manto fluorite deposits, northern Coahuila, Mexico: Economic Geology, v. 72, p. 204-218. [Also available at http://dx.doi.org/10.2113/ gsecongeo.72.2.204.] 
Kesler, S.E., Appold, M.S., Martini, A.M., Walter, L.M., Huston, T.J., and Kyle, J.R., 1995, Na-Cl-Br systematics of mineralizing brines in Mississippi Valley-type deposits: Geology, v. 23, no. 7, p. 641-644. [Also available at http://dx.doi.org/10.1130/0091-7613(1995)023\%3C0641: ncbsom\%3E2.3.co;2.]

Kilham, Peter, and Hecky, R.E., 1973, Fluoride — Geochemical and ecological significance in East African waters and sediments: Limnology and Oceanography, v. 18 , no. 6 , p. 932-945. [Also available at http://dx.doi.org/10.4319/ lo.1973.18.6.0932.]

Kirkemo, Harold, 1978, Final report-OME exploration project; OME-6873 (fluorspar-beryllium-rare earthsthorium-niobium), Hicks Dome Property, Hardin County, Illinois: U.S. Geological Survey, Office of Minerals Exploration, November, variously paged. [Also available at http://minerals.usgs.gov/dockets/scans/il/ome/6873_OME.pdf.] (Note: Downloaded file is $189 \mathrm{MB}$ in size.)

Kislov, E.V., Imetkhenov, A.B., and Sandakova, D.M., 2010, The Yermakovskoye fluorite-beryllium deposit—Avenues for improving ecological security of revitalization of the mining operations: Geography and Natural Resources, v. 31, no. 4, p. 324-329. [Also available at http://dx.doi.org/ 10.1016/j.gnr.2010.11.004.]

Kleemann, G.J., and Twist, David, 1989, The compositionallyzoned sheet-like granite pluton of the Bushveld ComplexEvidence bearing on the nature of A-type magmatism: Journal of Petrology, v. 30, no. 6, p. 1383-1414. [Also available at http://dx.doi.org/10.1093/petrology/30.6.1383.]

Kogut, A.I., Hagni, R.D., and Schneider, G.I.C., 1997, The Okorusu, Namibia, carbonatite-related fluorite deposits, and a comparison with the Illinois-Kentucky fluorite district/ Hicks Dome, in Sangster, D.F., ed., Carbonate-hosted lead-zinc deposits-[Society of Economic Geologists] 75th anniversary volume: Littleton, Colo., Society of Economic Geologists Special Publication no. 4, p. 290-297.

Koplus, A.V., Puzanov, L.S., and Zubov, M.A., 1977, Endogenic geochemical halos of concealed fluorspar mineralization of Kazakhstan (as in the Taskaynar-Yuzhnyy deposit): International Geology Review, v. 19, no. 12, p. 1441-1447. [Also available at http://dx.doi.org/ 10.1080/00206817709471157.]

Kovalenko, V.I., Kuz'min, M.I., Antipin, V.S., and Petrov, L.L., 1971, Topaz-bearing quartz keratophyre (ongonite), a new variety of subvolcanic igneous vein rock: Doklady Akademia Nauk, S.S.S.R., Earth Science Sections, v. 199, nos. 1-6, p. 132-134.

Kovalenko, V.I., and Yarmolyuk, V.V., 1995, Endogenous rare metal ore formations and rare metal metallogeny of Mongolia: Economic Geology, v. 90, p. 520-529. [Also available at http://dx.doi.org/10.2113/gsecongeo.90.3.520.]
Kraynov, S.R., Mer'kov, A.N., Petrova, N.G., Baturinskaya, I.V., and Zharikova, V.M., 1969, Highly alkaline (pH 12) fluosilicate waters in the deeper zones of the Lovozero massif: Geochemistry International, v. 6, no. 4, p. 635-640.

Kunasz, I.A., 1974, Lithium occurrence in the brines of Clayton Valley, Esmeralda County, Nevada, in Coogan, A.S., ed., Fourth Symposium on Salt, Houston, Texas, April 8-12, 1973, Proceedings: Cleveland, Ohio, Northern Ohio Geological Society, v. 1., p. 57-66. [Also available at http://www.worldsaltsymposium.org/download/lithiumoccurrence-in-the-brines-of-clayton-valley-esmeralda-county/.]

Kwak, T.A.P., and Askins, P.W., 1981, Geology and genesis of the F-Sn-W(-Be-Zn) skarn (wrigglite) at Moina, Tasmania: Economic Geology, v. 76, p. 439-467. [Also available at http://dx.doi.org/10.2113/gsecongeo.76.2.439.]

Kyle, J.R., and Saunders, J.A., 1997, Metallic deposits of the Gulf Coast Basin-Diverse mineralization styles in a young sedimentary basin, in Sangster, D.F., ed., Carbonate-hosted lead-zinc deposits-[Society of Economic Geologists] 75th anniversary volume: Littleton, Colo., Society of Economic Geologists Special Publication no. 4, p. 218-229.

Ladoo, R.B., 1927, Fluorspar-Its mining, milling, and utilization, with a chapter on cryolite: U.S. Bureau of Mines Bulletin 244, 185 p. [Also available at http://digital.library. unt.edu/ark:/67531/metadc12426/m1/1/.]

Land, L.S., 1995, Na-Ca-Cl saline formation waters, Frio Formation (Oligocene), south Texas, USA—Product of diagenesis: Geochimica et Cosmochimica Acta, v. 59, no. 11, p. 2163-2174. [Also available at http://dx.doi.org/ 10.1016/0016-7037(95)00098-k.]

Landis, G.P., and Hofstra, A.H., 1991, Fluid inclusion gas chemistry as a potential minerals exploration tool-Case studies from Creede, CO, Jerritt Canyon, NV, Coeur d'Alene district, ID and MT, southern Alaska mesothermal veins, and mid-continent MVT's: Journal of Geochemical Exploration, v. 42, no. 1, p. 25-59. [Also available at http://dx.doi.org/10.1016/0375-6742(91)90059-4.]

Lapierre, H., Jahn, B.M., Charvet, J., and Yu, Y.W., 1997, Mesozoic felsic arc magmatism and continental olivine tholeiites in Zhejiang Province and their relationship with the tectonic activity in southeastern China: Tectonophysics, v. 274, no. 4, p. 321-338. [Also available at http://dx.doi.org/ 10.1016/s0040-1951(97)00009-7.]

Leach, D.L., Plumlee, G.S., Hofstra, A.H., Landis, G.P., Rowan, E.L., and Viets, J.B., 1991, Origin of late dolomite cement by $\mathrm{CO}_{2}$-saturated deep basin brines-Evidence from the Ozark region, central United States: Geology, v. 19, no. 4, p. 348-351. [Also available at http://dx.doi.org/ 10.1130/0091-7613(1991)019\%3C0348:ooldcb\%3E2.3.co;2.] 
Leach, D.L., and Rowan, E.L., 1986, Genetic link between Ouachita foldbelt tectonism and the Mississippi Valley-type lead-zinc deposits of the Ozarks: Geology, v. 14, no. 11, p. 931-935. [Also available at http://dx.doi.org/10.1130/ 0091-7613(1986)14\%3C931:glboft\%3E2.0.co;2]

Leach, D.L., Sangster, D.F., Kelley, K.D., Large, R.R., Garven, Grant, Allen, C.R., Gutzmer, Jens, and Walters, Steve, 2005, Sediment-hosted lead-zinc deposits-A global perspective, in Hedenquist, J.W., Thompson, J.F.H., Goldfarb, R.J., and Richards, J.P., eds., Economic Geology—One hundredth anniversary volume, 1905-2005: Littleton, Colo., Society of Economic Geologists, p. 561-607. [Appendixes are on a CD-ROM inside the back cover.]

Leach, D.L., Viets, J.B., Foley-Ayuso, Nora, and Klein, D.P., 1995, Mississippi Valley-type Pb-Zn deposits, chap. 30 of du Bray, E.A., ed., Preliminary compilation of descriptive geoenvironmental mineral deposit models: U.S. Geological Survey Open-File Report 95-831, p. 234-243. [Also available at http://pubs.usgs.gov/of/1995/ofr-95-0831.]

Lecuyer, N.L., Agnerian, Hrayr, and Peach, A.D., 2013, Technical report-Updated preliminary feasibility study of the St. Lawrence fluorspar project, Newfoundland and Labrador, Canada, NI 43-101 report prepared for Canada Fluorspar (NL) Inc. [Filing date March 15, 2013]: Toronto, Ontario, Canada, Roscoe Postle Associates Inc., 248 p., accessed December 10, 2014, at http://www.canada fluorspar.com/pdf/2013-03-06NI43101Report.pdf. [Also available at http://www.sedar.com]

Levinson, A.A., 1962, Beryllium-fluorine mineralization at Aguachile Mountain, Coahuila, Mexico: American Mineralogist, v. 47, p. 67-74. [Also available at http://www.minsocam.org/ammin/am47/am47_67.pdf.]

Lewis, R.D., and Mitchell, R.H., 1987, Alnöite intrusions associated with rifting in the New Madrid seismic zone, 1987 [abs.]: Geological Society of America Abstracts with Programs, v. 19, no. 7, p. 745.

Li Changjiang, Xu Youlang, and Jiang Xuliang, 1998, Neodymium and strontium isotope geochemistry of WuyiDongyang fluorite deposits, Zhejiang Province, southeast China, in Proceedings of the Ninth Quadrennial IAGOD Symposium-Papers presented at the symposium on topics related to general problems on the genesis of ore deposits and on studies of the ore geology of specific districts or deposits: Stuttgart, Germany, E. Schweizerbart'sche Verlagbuchhandlung, p. 259-268.

Lindsey, D.A., 1982, Tertiary volcanic rocks and uranium in the Thomas Range and northern Drum Mountains, Juab County, Utah: U.S. Geological Survey Professional Paper 1221, 71 p. [Also available at http://pubs.er.usgs.gov/ publication/pp1221.]
Lismore-Scott, Siobhan, 2013, Fluorspar-Developing projects for 'at-risk' mineral: Industrial Minerals, no. 551, p. 47-50, August. [Also available at http://www.indmin.com/ Article/3233636/Channel/204638/Fluorspar-Developingprojects-for-at-risk-mineral.html.]

Liu Daorong, Yan Shengxian, Chen Yin, Wang Meihua, and Zheng Dan, 2012, Geochemical characteristics of the Yanqian high-F granite and its relationship with the newtype Bamianshan fluorite deposit in northwest Zhejiang Province: Geology and Prospecting, v. 48, no. 5, p. 884-893. [In Chinese with English abstract.]

Lkhamsuren, Jargalyn, and Hamasaki, Satoshi, 1998, Fluorite deposits in Mongolia-An outline: Bulletin of the Geological Survey of Japan, v. 49, no. 6, p. 309-318. [Also available at https://www.gsj.jp/data/bull-gsj/49-06_08.pdf.]

Luino, F., and De Graff, J.V., 2012, The Stave mudflow of 19 July 1985 (northern Italy) — A disaster that effective regulation might have prevented: Natural Hazards and Earth System Sciences, v. 12, p. 1029-1044. [Also available at http://dx.doi.org/10.5194/nhess-12-1029-2012.]

Lykhin, D.A., Kovalenko, V.I., Yarmolyuk, V.V., Kotov, A.B., and Kovach, V.P., 2010, The Yermakovsky deposit, western Transbaikal region, Russia-Isotopic and geochemical parameters and sources of beryllium-bearing granitoids and other rocks: Geology of Ore Deposits, v. 52, no. 4, p. 289-301. [Also available at http://dx.doi.org/10.1134/ s1075701510040045.]

MacDonald, R., Bailey, D.K., and Sutherland, D.S., 1970, Oversaturated peralkaline glassy trachytes from Kenya: Journal of Petrology, v. 11, no. 3, p. 507-517. [Also available at http://dx.doi.org/10.1093/petrology/11.3.507.]

Mahlknecht, J., Steinich, B., and Navarro de León, I., 2004, Groundwater chemistry and mass transfers in the Independence aquifer, central Mexico, by using multivariate statistics and mass-balance models: Environmental Geology, v. 45, no. 6, p. 781-795. [Also available at http://dx.doi.org/ 10.1007/s00254-003-0938-3.]

Martini, J.E.J., 1976, The fluorite deposits in the Dolomite Series of the Marico district, Transvaal, South Africa: Economic Geology, v. 71, p. 625-635. [Also available at http://dx.doi.org/10.2113/gsecongeo.71.3.625.]

Martini, J.E.J., 1986, The Zeerust fluorspar deposits, western Transvaal, in Anhaeusser, C.R., and Maske, S., eds., Mineral deposits of southern Africa, v. I: Johannesburg, South Africa, Geological Society of South Africa, p. 837-841, 1 pl. in pocket.

Masan Group, 2013, Nui Phao: Masan Group Web page, accessed May 9, 2013, at http://www.masangroup.com/ masanresources/en/projects/nui-phao. 
Mastrangelo, Federico, 1976, I giacimenti [The deposits], in Le fluoriti sedimentarie Laziali [Latium sedimentary fluorspars]: Societa Italiana di Mineralgia e Petrologia [Society of Mineralogy and Petrology of Italy] Rendiconti [Statements], v. XXXII, no. 1, p. 29-46. [Also available at http://rruff.info/rdsmi/V32/V32.html.]

Matteucci, Elio, 1976, Ipotesi e problemi genetici [Genetic hypotheses and problems], in Le fluoriti sedimentarie Laziali [Latium sedimentary fluorspars]: Societa Italiana di Mineralgia e Petrologia [Society of Mineralogy and Petrology of Italy] Rendiconti [Statements], v. XXXII, no. 1, p. 47-63. [Also available at http://rruff.info/rdsmi/ V32/V32.html.]

Maxwell, C.H., Foord, E.E., Oakman, M.R., and Harvey, D.B., 1986, Tin deposits of the Black Range tin district, in Clemmons, R.E., King, W.E., Mack, G.H., and Zidek, J., eds., Truth or Consequences region-New Mexico Geological Society Thirty-Seventh Annual Fall Field Conference, October 16-18, 1986: Socorro, N. Mex., New Mexico Geological Society 37th Annual Fall Field Conference Guidebook, p. 273-281. [Also available at http://nmgs.nmt.edu/publications/guidebooks/ downloads/37/37_p0273_p0281.pdf.]

McAnulty, W.N., Sr., 1974, Fluorspar in Texas: Texas Bureau of Economic Geology Handbook 3, 31 p. [Also available at http://www.lib.utexas.edu/books/landscapes/detail_viewer. php?work_id=297877.]

McAnulty, W.N., Sewell, C.R., Atkinson, D.R., and Rasberry, J.M., 1963, Aguachile beryllium-bearing fluorspar district, Coahuila, Mexico: Geological Society of America Bulletin, v. 74, no. 6, p. 735-743, 2 pls. [Also available at http://dx.doi.org/10.1130/ 0016-7606(1963)74[735:abfdcm]2.0.co;2.]

McDougal, R.B., and Roberts, L.C., 1958, Fluorspar and cryolite, in Metals and minerals (except fuels): U.S. Bureau of Mines Minerals Yearboook 1957, v. I, p. 499-516.

Miller, M.M., 2002, Fluorspar, in Metals and minerals: U.S. Geological Survey Minerals Yearbook 2000, v. I, p. 29.1-29.13. [Also available at http://minerals.usgs.gov/ minerals/pubs/commodity/fluorspar/index.html\#myb.]

Miller, M.M., 2012, Fluorspar: U.S. Geological Survey Mineral Commodity Summaries 2012, p. 56-57. [Also available at https://minerals.usgs.gov/minerals/pubs/ commodity/fluorspar/mcs-2012-fluor.pdf.]

Miller, M.M., 2013, Fluorspar: U.S. Geological Survey Mineral Commodity Summaries 2013, p. 56-57. [Also available at https://minerals.usgs.gov/minerals/pubs/ commodity/fluorspar/mcs-2013-fluor.pdf.]

Miller, M.M., 2016, Fluorspar [advance release], in Metals and minerals: U.S. Geological Survey Minerals Yearbook 2012, v. I, p. 26.1-26.11. [Also available at https://minerals.usgs.gov/ minerals/pubs/commodity/fluorspar/myb1-2012-fluor.pdf.]
Mining Atlas, 2016, Speewah: Mining Atlas, accessed July 29, 2016, via https://mining-atlas.com/project/ Speewah-Fluorspar-Mine-Project.php.

Modreski, P.J., Armbrustmacher, T.J., and Hoover, D.B., 1995, Carbonatite deposits (Model 10; Singer, 1986a), chap. 6 of du Bray, E.A., ed., Preliminary compilation of descriptive geoenvironmental mineral deposit models: U.S. Geological Survey Open-File Report 95-831, p. 47-49. [Also available at http://pubs.usgs.gov/of/1995/ofr-95-0831/.]

Molycorp, Inc., 2015a, Molycorp Mountain Pass: Molycorp, Inc. Web page, accessed October 19, 2015, at http://www.molycorp.com/about-us/our-facilities/molycorp-mountain-pass/.

Molycorp, Inc., 2015b, Molycorp to move its Mountain Pass rare earth facility to 'care and maintenance' mode: Greenwood Village, Colo., Molycorp, Inc. press release, August 26, accessed October 29, 2015, at http://www.molycorp.com/ molycorp-to-move-its-mountain-pass-rare-earth-facility-tocare-and-maintenance-mode/.

Morrison, H.I., Villeneuve, P.J., Lubin, J.H., and Schaubel, D.E., 1998, Radon-progeny exposure and lung cancer risk in a cohort of Newfoundland fluorspar miners: Radiation Research, v. 150 , no. 1, p. 58-65. [Also available at http://dx.doi.org/10.2307/3579646.]

Munoz, Marguerite, Premo, W.R., and Courjault-Radé, Pierre, 2005 , Sm-Nd dating of fluorite from the worldclass Montroc fluorite deposit, southern Massif Central, France: Mineralium Deposita, v. 39, no. 8, p. 970-975. [Also available at http://dx.doi.org/10.1007/s00126-004-0453-9.]

Narayana, B.L., Mallikharjuna Rao, J., Subba Rao, M.V., Murthy, N.N., and Divakara Rao, V., 2000, Geochemistry and origin of Early Proterozoic Dongargarh Rapakivi granite complex, central India-An example for magma mixing and differentiation: Gondwana Research, v. 3, no. 4, p. 507-520. [Also available at http://dx.doi.org/10.1016/ s1342-937x(05)70757-7.]

Nash, J.T., and Cunningham, C.G., Jr., 1973, Fluid-inclusion studies of the fluorspar and gold deposits, Jamestown district, Colorado: Economic Geology, v. 68, p. 1247-1262. [Also available at http://dx.doi.org/10.2113/gsecongeo. 68.8.1247.]

National Research Council, 2006, Fluoride in drinking waterA scientific review of EPA's Standards: Washington, D.C., The National Academies Press, 531 p., accessed April 18, 2013, at http://www.nap.edu/catalog.php?record_id=1157.

Natural Earth, 2014, Small scale data: Natural Earth map dataset, scale 1:110,000,000, accessed February 12, 2014, at http://www.naturalearthdata.com/. 
Newton, V.C., Jr., and Baggs, Donald, 1971, Geologic evaluation of the Alkali Lake disposal site: State of Oregon, Department of Geology and Mineral Industries Open-File Report O-71-2, 93 p. [Also available at http://www.oregongeology.org/pubs/ofr/O-71-02.pdf.]

Nie FengJun, Xu DongQin, Jiang SiHong, and Liu Yan, 2008, Geological features and origin of Sumoqagan Obo superlarge independent fluorite deposit, Inner Mongolia: Kuangchuang Dizhi [Mineral Deposits], v. 27, no. 1, p. 1-13 [in Chinese with English abstract]. [Also available at http://caod.oriprobe.com/articles/13546494/Geological_ features_and_origin_of_Sumoqagan_Obo_superlarge _ independent.htm.]

Nielsen, J.M., 1999, East African magadi (trona)—Fluoride concentration and mineralogical composition: Journal of African Earth Sciences, v. 29, no. 2, p. 423-428. [Also available at http://dx.doi.org/10.1016/s0899-5362(99)00107-4.]

Norman, D.I., Ting, Wupoa, Putnam, B.R., III, and Smith, R.W., 1985, Mineralization of the Hansonburg MississippiValley-type deposit, New Mexico-Insight from composition of gases in fluid inclusions: Canadian Mineralogist, v. 23, no. 3, p. 353-368. [Also available at http://canmin.geoscienceworld.org/content/23/3/353.]

Nyambok, I.O., and Gaciri, S.J., 1975, Geology of the fluorite deposits in Kerio Valley, Kenya: Economic Geology, v. 70, p. 299-307. [Also available at http://dx.doi.org/10.2113/ gsecongeo.70.2.299.]

Obolenskiy, A.A., Rodionov, S.M., Ariunbileg, Sodov, Dejidmaa, Gunchin, Distanov, E.G., Dorjgotov, Dangindorjiin, Gerel, Ochir, Hwang, D.-H., Sun, Fengyue, Gotovsuren, Ayurzana, Letunov, S.N., Li, Xujun, Nokleberg, W.J., Ogasawara, Masatsugu, Seminsky, Z.V., Smelov, A.P., Sotnikov, V.I., Spiridinov, A.A., Zorina, L.V., and Yan, Honquan, 2010, Mineral deposit models for northeast Asia, chap. 3 of Nokleberg, W.J., ed., Metallogenesis and tectonics of northeast Asia: U.S. Geological Survey Professional Paper 1765, p. 3-1-3-75. [Also available at http://pubs.usgs.gov/pp/1765/p1765.pdf.]

Occupational Safety and Health Administration, 2013, Regulations (Standards 29 CFR), Part no. 1910Occupational safety and health standards - Toxic and hazardous substances-1910.1000 Table Z-1, Limits for air contaminants: Washington, D.C., U.S. Department of Labor, accessed February 15, 2013, at http://www.osha.gov/ pls/oshaweb/owadisp.show_document?p_table=standards\& p_id $=9992$.

Orgeval, J.J., 1994, Peridiapiric metal concentration-Example of the Bou Grine deposit (Tunisian Atlas), in Fontboté , L., and Boni, M., eds., Sediment-hosted $\mathrm{Zn}-\mathrm{Pb}$ ores: Berlin, Germany, Springer-Verlag, Society for Geology Applied to Mineral Deposits Special Publication no. 10, p. 354-389. [Also available at http://dx.doi.org/10.1007/978-3-66203054-7_19.]
Orris, G.J., 1992, Grade and tonnage model of fluorite veins [Model 26b], in Orris, G.J., and Bliss, J.D., eds., Industrial minerals deposit models-Grade and tonnage models: U.S. Geological Survey Open-File Report 92-437, p. 29-31. [Also available at http://pubs.er.usgs.gov/publication/ ofr92437.]

O'Shea-Stone, Maureen, 2011, Burlington Mine VCUP case history-An ecological approach to mine site remediation, in Tailings and Mine Waste 2011—Proceedings of the 15th International Conference on Tailings and Mine Waste, Vancouver, British Columbia, Canada, November 6-9, 2011: Vancouver, British Columbia, Canada, Norman B. Keevil Institute of Mining Engineering, University of British Columbia, 14 p. [Also available at http://www.infomine.com/ library/publications/docs/O'Shea-Stone2011.pdf.]

Osinsky, D., and Stellman, J.M., 1998, Minerals and agricultural chemicals, chap. 62 of Stellman, J.M., ed., Encyclopedia of occupational health and safety, 4th ed., v. 3, pt. 9 , p. 62.1 -62.41. [Also available at http://www.ilocis.org/ documents/chpt62e.htm.]

Palmer, D.A.S., and Williams-Jones, A.E., 1996, Genesis of the carbonatite-hosted fluorite deposit at Amba Dongar, India-Evidence from fluid inclusions, stable isotopes, and whole rock-mineral geochemistry: Economic Geology, v. 91, p. 934-950. [Also available at http://dx.doi.org/ 10.2113/gsecongeo.91.5.934.]

Palmer, J.R., and Hayes, T.S., 1989, Late Cambrian lithofacies and their control on the Mississippi Valley-type mineralizing system in the Ozark Region (extended abs.), in Schindler, K.S., ed., U.S. Geological Survey research on mineral resources, 1989, Fifth Annual V.E. McKelvey Forum on Mineral and Energy Resources: U.S. Geological Survey Circular 1035, p. 51-54. [Also available at http://pubs.usgs.gov/circ/1988/1035/report.pdf.]

Partey, F., Lev, S., Casey, R., Widom, E., Lueth, V.W., and Rakovan, J., 2009, Source of fluorine and petrogenesis of the Rio Grande Rift-type barite-fluorite-galena deposits: Economic Geology, v. 104, p. 505-520. [Also available at http://dx.doi.org/10.2113/gsecongeo.104.4.505.]

Pattee, O.H., Wiemeyer, S.N., and Swineford, D.M., 1988, Effects of dietary fluoride on reproduction in eastern screech-owls: Archives of Environmental Contamination and Toxicology, v. 17, no. 2, p. 213-218. [Also available at http://dx.doi.org/10.1007/bf01056027.]

Perthuisot, V., and Rouvier, H., 1995, Lead-zinc deposits related to Triassic evaporites in diapiric structures of the eastern Maghreb [abs.], in Leach, D.L., and Goldhaber, M.B., eds., Extended abstracts - International field conference on carbonate-hosted lead-zinc deposits [Proceedings of International Field Conference on the Scientific and Economic Aspects of Carbonate-Hosted Lead-Zinc Deposits, St. Louis, Mo.]: Littleton, Colo., Society of Economic Geologists, p. 239-241. 
Pettijohn, F.J., 1963, Chemical composition of sandstonesExcluding carbonate and volcanic sands, chap. S of Fleischer, Michael, ed., Data of geochemistry (6th ed.): U.S. Geological Survey Professional Paper 440-S, 21 p. [Also available at http://pubs.er.usgs.gov/publication/pp440S.]

Pfaff, Katharina, Staude, Sebastian, and Markl, Gregor, 2012, On the origin of sellaite $\left(\mathrm{MgF}_{2}\right)$-rich deposits in Mg-poor environments: American Mineralogist, v. 97, no. 11-12, p. 1987-1997. [Also available at http://dx.doi.org/10.2138/ am.2012.4113.]

Pickard, G.W., 1974, Geology of Mexican fluorspar deposits, in Hutcheson, D.W., ed., A symposium on the geology of fluorspar-Proceedings of the Ninth Forum on Geology of Industrial Minerals, Paducah, Ky., April 26-28, 1973: Lexington, Ky., Kentucky Geological Survey Special Publication, series X, no. 22, p. 23-30.

Piqué, Àngels, Canals, Àngels, Grandia, Fidel, and Banks, D.A., 2008, Mesozoic fluorite veins in NE Spain record regional base metal-rich brine circulation through basin and basement during extensional events: Chemical Geology, v. 257, nos. 1-2, p. 139-152. [Also available at http://dx.doi.org/ 10.1016/j.chemgeo.2008.08.028.]

Plumlee, G.S., Goldhaber, M.B., and Rowan, E.L., 1995, The potential role of magmatic gases in the genesis of Illinois-Kentucky fluorspar deposits; implications from chemical reaction path modeling: Economic Geology, v. 90, p. 999-1011. [Also available at http://dx.doi.org/10.2113/ gsecongeo.90.5.999.]

Plumlee, G.S., Leach, D.L., Hofstra, A.H., Landis, G.P., Rowan, E.L., and Viets, J.G., 1994, Chemical reaction path modeling of ore deposition in Mississippi Valley-type $\mathrm{Pb}-\mathrm{Zn}$ deposits of the Ozark Region, U.S. Midcontinent: Economic Geology, v. 89, p. 1361-1383. [Also available at http://dx.doi.org/10.2113/gsecongeo.89.6.1361.]

Price, P.E., Kyle, J.R., and Wessel, G.R., 1983, Salt dome related zinc-lead deposits, in Kisvarsanyi, Geza, Grant, S.K., Pratt, W.P., and Koenig, J.W., eds., International Conference on Mississippi Valley Type Lead-Zinc Deposits, 2d, Rolla, Mo., Proceedings: Rolla, Mo., University of Missouri-Rolla, p. 558-571.

Putnam, B.R., III, Norman, D.I., and Smith, R.W., 1983, Mississippi Valley-type lead-fluorite-barite deposits of the Hansonburg mining district, in Chapin, C.E., and Callender, J.F., eds., Socorro region II-New Mexico Geological Society Fall Field Conference Guidebook, v. 34, October 13-15: Socorro, N. Mex., New Mexico Geological Society, p. 253-259. [Also available at http://nmgs.nmt.edu/publications/guidebooks/downloads/34/34_p0253_p0260.pdf.]

Reed, M.H., 1982, Calculation of multicomponent chemical equilibria and reaction processes in systems involving minerals, gases and an aqueous phase: Geochimica et Cosmochimica Acta, v. 46, no. 4, p. 513--528. [Also available at http://dx.doi.org/10.1016/0016-7037(82)90155-7.]
Reimann, Clemens, and de Caritat, Patrice, 1998, Chemical elements in the environment-Factsheets for the geochemist and environmental scientist: Berlin, Germany, SpringerVerlag, 398 p.

Reyf, F.G., 2004, Immiscible phases of magmatic fluid and their relation to $\mathrm{Be}$ and Mo mineralization at the Yermakovka F-Be deposit, Transbaikalia, Russia: Chemical Geology, v. 210, nos. 1-4, p. 49-71. [Also available at http://dx.doi.org/10.1016/j.chemgeo.2004.06.004.]

Reyf, F.G., 2008, Alkaline granites and Be (phenakitebertrandite) mineralization-An example of the Orot and Ermakovka deposits: Geochemistry International, v. 46, no. 3, p. 213-232. (Originally published in Geokhimiya, v. 46, no. 3, p. 243-263.) [Also available at http://dx.doi.org/ 10.1134/s0016702908030014.]

Reynolds, R.L., Goldhaber, M.B., and Snee, L.W., 1997, Paleomagnetic and ${ }^{40} \mathrm{Ar} /{ }^{39} \mathrm{Ar}$ results from the Grant intrusive breccia and comparison to the Permian Downeys Bluff sill-Evidence for Permian igneous activity at Hicks Dome, southern Illinois Basin: U.S. Geological Survey Bulletin 2094-G, 16 p. [Also available at http://pubs.er.usgs.gov/ publication/b2094G.]

Rhodes, D., Lantos, E.A., Webb, R.J., and Owens, D.C., 1984, Pine Point orebodies and their relationship to stratigraphy, structure, dolomitization, and karstification of the Middle Devonian barrier complex: Economic Geology, v. 79, p. 991-1054. [Also available at http://dx.doi.org/10.2113/ gsecongeo.79.5.991.]

Richards, J.P., Dang, T., Dudka, S.F., and Wong, M.L., 2003, The Nui Phao tungsten-fluorite-copper-gold-bismuth deposit, northern Vietnam - An opportunity for sustainable development: Exploration and Mining Geology, v. 12, nos. 1-4, p. 61-70. [Also available at http://dx.doi.org/ 10.2113/0120061.]

Richardson, C.K., and Holland, H.D., 1979, Fluorite deposition in hydrothermal systems: Geochimica et Cosmochimica Acta, v. 43, no. 8, p. 1327-1335. [Also available at http://dx.doi.org/10.1016/0016-7037(79)90122-4.]

Richardson, C.K., and Pinckney, D.M., 1984, The chemical and thermal evolution of the fluids in the Cave-in-Rock fluorspar district, Illinois; mineralogy, paragenesis, and fluid inclusions: Economic Geology, v. 79, p. 1833-1856. [Also available at $\mathrm{http}: / / \mathrm{dx}$.doi.org/10.2113/gsecongeo.79.8.1833.]

Richardson, C.K., Rye, R.O., and Wasserman, M.D., 1988, The chemical and thermal evolution of the fluids in the Cave-in-Rock fluorspar district, Illinois; stable isotope systematics at the Deardorff Mine: Economic Geology, v. 83, p. 765-783. [Also available at http://dx.doi.org/ 10.2113/gsecongeo.83.4.765.] 
Roberts, Jessica, 2012, Projects in the pipeline-New sources threaten to topple China's fluorspar dominance: Industrial Minerals, April, p. 35-38. [Also available http://www.indmin.com/Article/2997061/Projects-in-thePipeline-New-sources-threaten-to-topple.html.]

Rooney, T.P., Jones, B.F., and Neal, J.T., 1969, Magadiite from Alkali Lake, Oregon: American Mineralogist, v. 54, nos. 7-8, p. 1034-1043. [Also available at http:// www.minsocam.org/ammin/am54/am54_1034.pdf.]

Roqueñí, N., Ugarte, L.C., Martínez, G.M., and Alvarez, J.V., 2005, Fluoride contamination of water stream in Moscona Mine area, Asturias, in Mine Water 2005-Mine closureInternational Mine Water Association Congress, 9th, Oviedo, Spain, Proceedings: Wendelstein, Germany, International Mine Water Association, p. 507-511. [Also available at http://www.imwa.de/docs/imwa_2005/ IMWA2005_071_Roqueni.pdf.]

Ruiz, Joaquin, 1983, Geology and geochemistry of fluorite ore deposits and associated rocks in northern Mexico: Ann Arbor, Mich., University of Michigan Ph.D. dissertation, 202 p.

Ruiz, Joaquin, Kesler, S.E., Jones, L.M., and Sutter, J.F., 1980, Geology and geochemistry of the Las Cuevas fluorite deposit, San Luis Potosi, Mexico: Economic Geology, v. 75, p. 1200-1209. [Also available at http://dx.doi.org/10.2113/ gsecongeo.75.8.1200.]

Ryan, P.J., 1986, The Witkop fluorspar mine near Zeerust, western Transvaal, in Anhaeusser, C.R., and Maske, S., eds., Mineral deposits of southern Africa, v. I: Johannesburg, South Africa, Geological Society of South Africa, p. 843-849, 1 pl. in pocket.

Ryazantseva, M.D., 1998, Excursion I-The Voznesenka ore district, in Seltmann, R., Gonevchuk, G., and Khanchuk, A., eds., Anatomy and textures of ore-bearing granitoids of Sikhote Alin (Primorye region, Russia) and related mineralization-Excursion guidebook: Potsdam, Germany, GeoForschungsZentrum Potsdam, p. 9-22.

Sánchez, V., Corbella, M., Fuenlabrada, J.M., Vindel, E., and Martín-Crespo, T., 2006, Sr and Nd isotope data from the fluorspar district of Asturias, northern Spain: Journal of Geochemical Exploration, v. 89, nos. 1-3, p. 348-350. [Also available at http://dx.doi.org/10.1016/j.gexplo.2005.11.058.]

Sánchez, V., Vindel, E., Martín-Crespo, T., Corbella, M., Cardellach, E., and Banks, D., 2009, Sources and compositions of fluids associated with fluorite deposits of Asturias (N Spain): Geofluids, v. 9, no. 4, p. 338-355. [Also available at http://dx.doi.org/10.1111/j.1468-8123.2009.00259.x.]

Sato, Kohei, Suzuki, Kazuhiro, Nedachi, Munetomo, Terashima, Shigeru, Ryazantseva, M.D., Vrublevsky, A.A., and Khanchuk, A.I., 2003, Fluorite deposits at Voznesenka in the Khanka Massif, Russia - Geology and age of mineralization: Resource Geology, v. 53, no. 3, p. 193-211. [Also available at http://dx.doi.org/10.1111/j.1751-3928.2003.tb00169.x.]
Saunders, J.A., and Swann, C.T., 1994, Mineralogy and geochemistry of a cap-rock $\mathrm{Zn}-\mathrm{Pb}-\mathrm{Sr}-\mathrm{Ba}$ occurrence at the Hazlehurst salt dome, Mississippi: Economic Geology, v. 89, p. 381-390. [Also available at http://dx.doi.org/ 10.2113/gsecongeo.89.2.381.]

Schwartz, M.O., and Friedrich, G.H., 1973, Secondary dispersion patterns of fluoride in the Osor area, Province of Gerona, Spain: Journal of Geochemical Exploration, v. 2, no. 2, p. 103-114. [Also available at http://dx.doi.org/ 10.1016/0375-6742(73)90009-5.]

Schweitzer, J.K., Hatton, C.J., and De Waal, S.A., 1997, Link between the granitic and volcanic rocks of the Bushveld Complex, South Africa: Journal of African Earth Sciences, v. 24, nos. 1-2, p. 95-104. [Also available at http://dx.doi.org/10.1016/s0899-5362(97)00029-8.]

Shacklette, H.T., and Boerngen, J.G., 1984, Element concentrations in soils and other surficial materials of the conterminous United States: U.S. Geological Survey Professional Paper 1270, 105 p. [Also available at http://pubs.er.usgs.gov/publication/pp1270.

Shawe, D.R., ed., 1976, Geology and resources of fluorine in the United States, with sections by D.R. Shawe, R.E. Van Alstine, R.G. Worl, A.V. Heyl, R.D. Trace, R.L. Parker, W.R. Griffitts, C.L. Sainsbury, and J.B. Cathcart: U.S. Geological Survey Professional Paper 933, 99 p. [Also available at http://pubs.er.usgs.gov/publication/pp933.]

Sheppard, R.A., and Gude, A.J., III, 1969, Authigenic fluorite in Pliocene lacustrine rocks near Rome, Malheur County, Oregon, chap. D of Geological Survey research 1969: U.S. Geological Survey Professional Paper 650-D, p. D69-D74. [Also available at http://pubs.er.usgs.gov/ publication/pp650D.]

Sheppard, S.M.F., Charef, A., and Bouhlel, S., 1997, Diapirs and $\mathrm{Zn}-\mathrm{Pb}$ mineralization-A general model based on Tunisian (N. Africa) and Gulf Coast (U.S.A.) deposits, in Sangster, D.F., ed., Carbonate-hosted lead-zinc deposits[Society of Economic Geologists] 75th anniversary volume: Littleton, Colo., Society of Economic Geologists Special Publication no. 4, p. 230-243.

Sheridan, D.M., Taylor, R.B., and Marsh, S.P., 1968, Rutile and topaz in Precambrian gneiss, Jefferson and Clear Creek Counties, Colorado: U.S. Geological Survey Circular 567, 7 p. [Also available at http://pubs.er.usgs.gov/publication/ cir567.]

Sherlock, S.C., Lucks, Tim, Kelley, S.P., and Barnicoat, Andy, 2005, A high resolution record of multiple diagenetic events - Ultraviolet laser microprobe Ar/Ar analysis of zoned K-feldspar overgrowths: Earth and Planetary Science Letters, v. 238, nos. 3-4, p. 329-341. [Also available at http://dx.doi.org/10.1016/j.epsl.2005.07.018.] 
Shivdasan-Gebhardt, Purnima, and Hagni, R.D., 2008, Fluorspar deposits at Okorusu, Namibia, with emphasis upon electron microprobe analyses of carbonatite minerals and fluorite fluid inclusion temperatures and salinities, in Australasian Institute of Mining and Metallurgy, Ninth International Conference for Applied MineralogySeptember 8-10, 2008, Brisbane, Queensland, AustraliaProceedings: Carlton, Victoria, Australia, Australasian Institute of Mining and Metallurgy, Publication Series no. 8/2008, p. 631-641.

Simonetti, Antonio, and Bell, Keith, 1995, Nd, Pb, and Sr isotope systematics of fluorite at the Amba Dongar carbonatite complex, India; evidence for hydrothermal and crustal fluid mixing: Economic Geology, v. 90, p. 2018-2027. [Also available at http://dx.doi.org/10.2113/gsecongeo.90.7.2018.]

Simonetti, A., Bell, K., and Viladkar, S.G., 1995, Isotopic data from the Amba Dongar carbonatite complex, west-central India-Evidence for an enriched mantle source: Chemical Geology, v. 122, nos. 1-4, p. 185-198. [Also available at http://dx.doi.org/10.1016/0009-2541(95)00004-6.]

Singleton, R.H., 1989, The mineral industry of Denmark and Greenland, in Area reports-International: U.S. Bureau of Mines Minerals Yearbook 1987, v. III, p. 257-274. [Also available at http://images.library.wisc.edu/EcoNatRes/ EFacs2/MineralsYearBk/MinYB1987v3/reference/ econatres.minyb1987v3.rsingleton.pdf.]

Sizaret, Stanislas, Marcoux, Eric, Jébrak, Michel, and Touray, J.C., 2004, The Rossignol fluorite vein, Chaillac, France-Multiphase hydrothermal activity and intravein sedimentation: Economic Geology, v. 99, p. 1107-1122. [Also available at http://dx.doi.org/10.2113/gsecongeo.99.6.1107.]

Smith, G.I., 1979, Subsurface stratigraphy and geochemistry of Late Quaternary evaporites, Searles Lake, California, with a section on Radiocarbon ages of stratigraphic units, by Minze Stuiver and George I. Smith: U.S. Geological Survey Professional Paper 1043, 130 p. [Also available at http://pubs.er.usgs.gov/publication/pp1043.]

Steven, T.A., 1960, Geology and fluorspar deposits, Northgate district, Colorado: U.S. Geological Survey Bulletin 1082-F, p. 323-422, 4 pls. [Also available at http://pubs.er.usgs.gov/ publication/b1082F.]

Stewart, F.H., 1963, Marine evaporites, chap. Y of Fleischer, Michael, ed., Data of geochemistry (6th ed.): U.S. Geological Survey Professional Paper 440-Y, p. Y1-Y53. [Also available at http://pubs.er.usgs.gov/ publication/pp440Y.]

Stoffel, B., Appold, M.S., Wilkinson, J.J., McClean, N.A., and Jeffries, T.E., 2008, Geochemistry and evolution of Mississippi Valley-type mineralizing brines from the Tri-State and Northern Arkansas districts determined by LA-ICP-MS microanalysis of fluid inclusions: Economic Geology, v. 103, p. 1411-1435. [Also available at http://dx.doi.org/ 10.2113/gsecongeo.103.7.1411.]
Strong, D.F., Fryer, B.J., and Kerrich, R., 1984, Genesis of the St. Lawrence fluorspar deposits as indicated by fluid inclusion, rare earth element, and isotopic data: Economic Geology, v. 79, p. 1142-1158. [Also available at http://dx.doi.org/10.2113/gsecongeo.79.5.1142.]

Surdam, R.C., and Eugster, H.P., 1976, Mineral reactions in the sedimentary deposits of the Lake Magadi region, Kenya: Geological Society of America Bulletin, v. 87, no. 12, p. 1739-1752. [Also available at http://dx.doi.org/10.1130/ 0016-7606(1976)87\%3C1739:mritsd\%3E2.0.co;2.]

Suter, G.W., II, 1996, Toxicological benchmarks for screening contaminants of potential concern for effects on freshwater biota: Environmental Toxicology and Chemistry, v. 15, no. 7, p. 1232-1241. [Also available at http://dx.doi.org/ 10.1002/etc.5620150731.]

Swarup, D., Dwivedi, S.K., Dey, S., and Ray, S.K., 1998, Fluoride intoxication in bovines due to industrial pollution: The Indian Journal of Animal Sciences, v. 68, no. 7, p. 605-608.

Taylor, C.D., Rowan, E.L., Goldhaber, M.B., and Hayes, T.S., 1992, A relationship between Hicks Dome and temperature zonation in fluorite in the Illinois-Kentucky district-A fluid inclusion study [extended abs.], in Goldhaber, M.B., and Eidel, J.J., eds., Mineral resources of the Illinois Basin in the context of basin evolution-St. Louis, Missouri, January 22-23,1992 [program and abs.]: U.S. Geological Survey Open-File Report 92-1, p. 62-64. [Also available at http://pubs.usgs.gov/of/1992/0001/report.pdf.]

Taylor, R.G. [with chaps. by Cuff, C.], 1979, Geology of tin deposits: Amsterdam, Netherlands, Elsevier Scientific Publishing Co., Developments in Economic Geology Series, no. $11,543 \mathrm{p}$.

Temple, A.K., and Grogan, R.M., 1963, Manto deposits of fluorspar, northern Coahuila, Mexico: Economic Geology, v. 58, p. 1037-1053. [Also available at http://dx.doi.org/ 10.2113/gsecongeo.58.7.1037.]

Teng, H.C., and Strong, D.R., 1976, Geology and geochemistry of the St.. Lawrence peralkaline granite and associated fluorite deposits, southeast Newfoundland: Canadian Journal of Earth Sciences, v. 13, no. 10, p. 1374-1385. [Also available at http://dx.doi.org/10.1139/e76-142.]

Tertiary Minerals plc, 2014, Building a strategic position in the fluorspar sector - Company presentation, August 20, 2013: Tertiary Metals plc, accessed February 11, 2014, at http://www.tertiaryminerals.com/downloads/Tertiary $\% 20$ Minerals\%20plc\%20Company\%20Presentation $\% 2020 \% 20$ August $\% 202013$.pdf.

Tertiary Minerals plc, 2015, MB fluorspar project, Nevada, USA: Tertiary Minerals plc Web page, accessed January 24, 2016, at http://www.tertiaryminerals.com/ projects/fluorspar-projects/mb-fluorspar-nevada-usa/. 
Tischendorf, G., 1978, Geochemical and petrographic characteristics of silicic magmatic rocks associated with rare-element mineralization, in Štemprok, Miroslav, ed., Metallization associated with acid magmatism: Prague, Czechoslovakia, Ústřední Ústav Geologický [Central Geological Survey], v. 2, p. 41-96.

Tourtelot, H.A., 1962, Preliminary investigation of the geologic setting and chemical composition of the Pierre Shale, Great Plains region: U.S. Geological Survey Professional Paper 390, 74 p., 4 pls. [Also available at http://pubs.er.usgs.gov/publication/pp390.]

U.S. Bureau of Mines, 1972-96, Minerals yearbook 1970-1994: U.S. Bureau of Mines, variously paged. [The Minerals Yearbook 1970 through 1993 is also available at http://minerals.usgs.gov/minerals/pubs/ usbmmyb.html; the Minerals Yearbook 1994 is available at http://minerals.usgs.gov/minerals/pubs/myb.html.]

U.S. Environmental Protection Agency, 2002, Fluorine (soluble fluoride) (rev. December 3, 2002)-Integrated risk information system summaries, in Integrated risk information system: Washington, D.C., U.S. Environmental Protection Agency Chemical Assessment Summary, CASRN 778241-4, accessed April 16, 2013, at http://www.epa.gov/iris/ subst/0053.htm.

U.S. Environmental Protection Agency, 2009, National primary drinking water regulations: U.S. Environmental Protection Agency EPA 816-F-09-004, May, 6 p., accessed April 17, 2013, at http://water.epa.gov/drink/contaminants/ upload/mcl-2.pdf.

U.S. Environmental Protection Agency, 2011, Protection of stratospheric ozone-New substitute in the motor vehicle air conditioning sector under the Significant New Alternatives Policy (SNAP) Program: Federal Register, v. 76, no. 60, March 29, accessed April 30, 2013, at http:// www.gpo.gov/fdsys/pkg/FR-2011-03-29/html/2011-6268.htm.

U.S. Environmental Protection Agency, 2012, Regional screening levels (RSL) summary table-November 2012: U.S. Environmental Protection Agency, accessed March 12, 2013, at http://www.epa.gov/reg3hwmd/ risk/human/rb-concentration_table/Generic_Tables/pdf/ master_sl_table_run_NOV2012.pdf.

U.S Geological Survey, 1996, Global 30 arc-second elevation (GTOPO30): Reston, Va., U.S Geological Survey dataset (digital elevation model), accessed February 12, 2014, at https://lta.cr.usgs.gov/GTOPO30.

U.S. Geological Survey, 1997-2016, Minerals yearbook 19952012: U.S. Geological Survey, variously paged. [Also available at http://minerals.usgs.gov/minerals/pubs/myb.html.]

U.S. Geological Survey, 2016, National Water Information System (NWISWeb) - Water quality data for South Dakota: U.S. Geological Survey database, accessed October 12, 2016, at http://nwis.waterdata.usgs.gov/sd/nwis/qw.
Van Alstine, R.E., 1944, The fluorspar deposits of St. Lawrence, Newfoundland: Economic Geology, v. 39, p. 109-132. [Also available at http://dx.doi.org/10.2113/gsecongeo.39.2.109.]

Van Alstine, R.E., 1965, Geochemical prospecting in the Browns Canyon fluorspar district, Chaffee County, Colorado, chap. D of Geological Survey research 1965: U.S. Geological Survey Professional Paper 525-D, p. D59-D64. [Also available at http://pubs.usgs.gov/pp/0525-D/report.pdf.]

Van Alstine, R.E., 1969, Geology and mineral deposits of the Poncha Springs NE quadrangle, Chaffee County, Colorado, with a section on Fluorspar mines and prospects, by R.E. Van Alstine and D.C. Cox: U.S. Geological Survey Professional Paper 626, 52 p., 6 pls. [Also available at http://pubs.er.usgs.gov/publication/pp626.]

Van Alstine, R.E., 1976, Continental rifts and lineaments associated with major fluorspar districts: Economic Geology, v. 71, p. 977-987. [Also available at http://dx.doi.org/10.2113/ gsecongeo.71.6.977.]

Vanderburg, W.O., 1940, Reconnaissance of mining districts in Churchill County, Nev.: U.S. Bureau of Mines Information Circular 7093, 57 p.

Velasco, F., Herrero, J.M., Gil, P.P., Alvarez, L., and Yusta, I., 1994, Mississippi Valley-type, SEDEX, and iron deposits in Lower Cretaceous rocks of the Basque-Cantabrian Basin, northern Spain, in Fontboté, Lluís, and Boni, Maria, eds., Sediment-hosted Zn-Pb ores: New York, N.Y., Society for Geology Applied to Mineral Deposits Special Publication no. 10, p. 246-270.

Viets, J.G., Hofstra, A.H., and Emsbo, Poul, 1997, Solute compositions of fluid inclusions in sphalerite from North American and European Mississippi Valley-type ore deposits; ore fluids derived from evaporated seawater, in Sangster D.F., ed., Carbonate-hosted lead-zinc deposits[Society of Economic Geologists] 75th anniversary volume: Society of Economic Geologists Special Publication no. 4, p. $465-482$.

von Knorring, O., and DuBois, C.G.B., 1961, Carbonatitic lava from Fort Portal in western Uganda: Nature, v. 192, no. 4807, p. 1064-1065. [Also available at http://dx.doi.org/ 10.1038/1921064b0.]

Wallace, A.R., 2010, Fluorine, fluorite, and fluorspar in central Colorado: U.S. Geological Survey Scientific Investigations Report 2010-5113, 61 p., 6 pls., 1 CD-ROM. [Also available at http://pubs.er.usgs.gov/publication/ sir20105113.]

Weller, J.M., Grogan, R.M., and Tippie, F.E., 1952, Geology of the fluorspar deposits of Illinois: Illinois State Geological Survey Bulletin no. 76, 147 p. [Also available at http://hdl.handle.net/2142/43663.] 
Wenz, Z.J., Appold, M.S., Shelton, K.L., and Tesfaye, Samson, 2012, Geochemistry of Mississippi Valley-type mineralizing fluids of the Ozark Plateau-A regional synthesis: American Journal of Science, v. 312, no. 1, p. 22-80. [Also available at http://dx.doi.org/10.2475/01.2012.02.]

White, D.E., 1965, Saline waters of sedimentary rocks, in Young, Addison, and Galley, J.E., eds., Fluids in subsurface environments-A symposium-The Transactions of the 6th Annual Meeting of the Southwestern Federation of Geological Societies, at Midland, Texas, January 30 and 31 and February 1, 1964: American Association of Petroleum Geologists Memoir no. 4, p. 342-366.

White, D.E., and Waring, G.A., 1963, Volcanic emanations, chap. K of Fleischer, Michael, ed., Data of geochemistry (6th ed.): U.S. Geological Survey Professional Paper 440-K, 29 p. [Also available at http://pubs.usgs.gov/pp/0440k/ report.pdf.]

World Health Organization, 2008, Guidelines for drinkingwater quality-Volume 1-Recommendations (3d ed., incorporating first and second addenda): Geneva, Switzerland, World Health Organization, 668 p., accessed March 28, 2013, at http://www.who.int/water_sanitation_health/dwq/gdwq3rev/ en/index.html.

Wright, D.A., Davison, A.W., and Johnson, M.S., 1978, Fluoride accumulation by long-tailed field mice (Apodemus sylvaticus L.) and field voles (Microtus agrestis L.) from polluted environments: Environmental Pollution, v. 17, no. 4, p. 303-310. [Also available at http://dx.doi.org/ 10.1016/0013-9327(78)90095-2.]

Xu DongQing, 2009, Geological setting, features, and origin of the Sumochagan Obo super-large fluorite mineralized district [abs.]: Beijing, China, Chinese Academy of Geological Sciences, 3 p. accessed June 12, 2012, at http://www.dissertationtopic.net/doc/1535306.

Xu DongQing, Nie FengJun, Jiang SiHong, Zhang Wanyi, and Qian MingPing, 2008, Yanshanian peraluminous granite in Sumochagan area, Inner Mongolia: Yanshi Kuangwuxue Zazhi (Acta Petrologica et Mineralogica), v. 27, no. 2, p. 89-100. [In Chinese with English abs.]

Yilmaz, P.O., Norton, I.O., Leary, D., and Chuchla, R.J., 1996, Tectonic evolution and paleogeography of Europe, in Ziegler, P.A., and Horvàth, F., eds., Peri-Tethys memoir 2Structure and prospects of Alpine basins and forelands: Paris, France, Mémoire du Musée National d'Histoire Naturelle [Memoir of the National Museum of Natural History] series, v. 170, p. 47-60, 30 pls. in accompanying case.
Yong Huang, Changchun Wang, Yonggang Wu, Hong Gao, Liqing Yu, and Anson $\mathrm{Xu}, 2011$, Technical report on Sumochaganaobao fluorite mine, Siziwangqi Wulanchabu city, Inner Mongolia Autonomous Region, The People's Republic of China, report for China Shen Zhou Mining and Resources, Inc.: Vancouver, British Columbia, Canada, SRK Consulting Inc., 73 p., accessed July 3, 2012, at http://www.chinaszmg.com/pdf/SCN230_Report_Sumo_ Fluorite_Mine_110718.pdf.

Yoshida, Mitsuo, Kallali, Hamadi, Ayari, Fethia, and Kotah, Takayuki, 2002, Characterization of open-dumped solid waste at Hammam Jedidi barite mine and Hammam Zriba fluorite mine, northern Tunisia, in EPCOWM'2002Proceedings of International Symposium on Environmental Pollution Control and Waste Management, January 7-10, 2002, Tunis, Tunisia, p. 287-292. [Also available at $h$ ttp://www.geocities.jp/epcowmjp/EPCOWM2002/ 287-292Yoshida.pdf.]

Yuzhou Li, 1990, Be-bearing perthitic rock-Its alteration and significance in ore exploration: Geology and Prospecting, v. 26 , no. 6 , p. $29-35$.

Zhang, L., Wei, W., Jin, S., Ye, G., Jia, D., Dong, H., and Xie, C., 2010, Integrated VLF and AMT survey for the exploration of a fluorite deposit at eastern Inner Mongolia, China [abs.]: San Francisco, Calif., American Geophysical Union Fall Meeting Abstracts, abs. no. NS41B-1514.

[Also available at http://adsabs.harvard.edu/abs/ 2010AGUFMNS41B1514Z.]

Zhang Ronghua, Hu Shumin, Wang Jun, Yu Wenbing, and Xu Leiming, 1997, Fluorite mineralization in the Mesozoic volcanic terrains of eastern China, in Pei Rongfu, ed., Proceedings of the 30th International Geological CongressEnergy and mineral resources for the 21st centuryGeology of mineral deposits-Mineral economics: Utrecht, Netherlands, VSP International Science Publishers, v. 9, p. 393-403. 


\section{Appendix G1. Selected Fluorspar Districts, Deposits, and Prospects of the World}

The tabulations contained in this appendix do not include all world fluorspar deposits and districts, nor even all the largest of them. They instead include characteristic examples of fluorspar deposits and districts scattered throughout the world and provide examples of all fluorspar deposit classes in as many places as possible. Collectively, the tables include most large fluorspar deposits and districts. All the deposits that were compiled in examinations of the distributions of fluorspar vein deposit grades and tonnages by Orris (1992) are included. The grades and tonnages listed here have not been confirmed by the U.S. Geological Survey (USGS), and the USGS does not endorse or assure any of the grade and tonnage measurements. The grades and tonnages of deposits are listed as given in the general geologic and mining literature, unrevised by any additional knowledge. Some of the values given probably reflect only the resources known at a particular instant of time, although, where possible, the listed values are thought to be the total identified resources, and have included past production and unmined resources of the deposits or prospects.

The division between large and small deposits was made arbitrarily in a way that placed the largest 20 deposits in China from the tabulation of Kamitani and others (2007) in the large (L) class and all others in China in the small (S) class. The boundary between $\mathrm{L}$ and $\mathrm{S}$ classes by that procedure lies at about 1.5 million metric tons of total calcium fluoride $\left(\mathrm{CaF}_{2}\right)$.

Where possible, the deposits were located on imagery from Google Earth, and where Google Earth is listed as the source of location data, the latitude and longitude provided are directly from Google Earth; these latitudes and longitudes have not been corrected to any of the accepted standard geodetic spheroids, such as World Geodetic System 1984 (WGS 84). Latitude and longitude from Google Earth, in degrees, were rounded to four decimal places, which correspond approximately to the nearest 1 -second of latitude or longitude. Where possible on Google Earth imagery, the latitude-longitude location is placed on the headframe of the shaft of the working or abandoned underground mine, or in the approximate center of the open pit mine. Any other placement of the location point is explained in the Comments column. Negative values for latitude indicate that the deposit is in the Southern Hemisphere; negative values for longitude indicate that the deposit is in the Western Hemisphere.

The table is sorted alphabetically by continent, then alphabetically by country, then alphabetically by deposit name. The complete reference citations corresponding to the reference callouts in the table appear at the end of this appendix. The grades and tonnages of selected deposits have been plotted in text figure G6; those that are included in that graph are listed at the end of this table.

The following is the key to the the identification numbers given in the deposit class column in the table:

1. Carbonatite-related

2. Alkaline-intrusion-related veins, skarns, and carbonate replacements

3. Alkaline-volcanic-related epithermal veins, breccia-fills, and carbonate replacements

4a. Mississippi Valley-type

4b. Salt-related carbonate-hosted

5. Skarns, greisens, veins, and replacements related to strongly differentiated granites

6. Subalkaline-volcanic-related epithermal veins and replacements

7. Apparently conformable in tuffaceous, limy lacustrine sediments

8. Deposit class uncertain or not known 
Table G1-1. Selected fluorspar districts, deposits, and prospects of the world.

[*Deposit is included in the Orris (1992) grade and tonnage modeling of fluorite veins. **Grade and tonnage data are from Kamitani and others (2007); for these entries, it is not clear whether these are the total resources of each deposit or just a resource currently available to the mine that may be subject to updating with further exploration. ***Location data are from the Mineral Resources Data System (MRDS). The key to the identification numbers in the deposit class column is on page G53. Deposit size: $\mathrm{L}$, identified resources are greater than 1.5 million metric tons of $\mathrm{CaF}_{2} ; \mathrm{S}$, identified resources are less than 1.5 million metric tons of $\mathrm{CaF}_{2}$; n.a., not available. Elements and compounds: $\mathrm{Ag}$, silver; $\mathrm{Au}$, gold; $\mathrm{BeO}$, beryllium oxide; $\mathrm{Bi}$, bismuth; $\mathrm{CaF}_{2}$ calcium fluoride; $\mathrm{Cd}$, cadmium; $\mathrm{Cu}$, copper; Fe, iron; Ge, germanium; In, indium; Mo, molybdenum; Nb, niobium; Pb, lead; REE, rare-earth element; Sn, tin; Sr, strontium; Th, thorium; U, uranium; $\mathrm{W}$, tungsten; Y, yttrium; Zn, zinc. Units of measure: g/t, gram per metric ton; km, kilometer; m, meter; Mt, million metric tons; \%, percent]

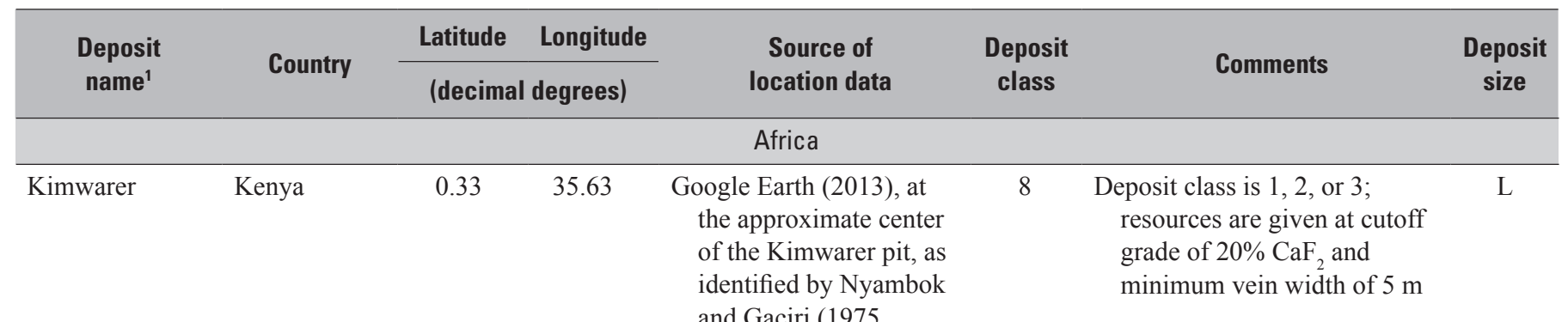
and Gaciri (1975, figs. 2 and 5)

\begin{tabular}{|c|c|c|c|c|c|c|c|}
\hline *El Hammam & Morocco & 33.56 & -5.81 & $\begin{array}{l}\text { Google Earth (2013), Van } \\
\text { Alstine and Schruben } \\
\text { (1980) and Cheilletz and } \\
\text { others (2010) }\end{array}$ & 5 & None & $\mathrm{L}$ \\
\hline $\begin{array}{l}\text { *Chioco- } \\
\text { Djanguire } \\
\text { area }\end{array}$ & Mozambique & -16.40 & 32.58 & $\begin{array}{l}\text { Van Alstine and Schruben } \\
\text { (1980) }\end{array}$ & 8 & None & $\mathrm{S}$ \\
\hline Mount Muambe & Mozambique & -16.32 & 34.08 & $\begin{array}{l}\text { Woolley and Kjarsgaard } \\
\text { (2008) }\end{array}$ & 1 & None & $\mathrm{S}$ \\
\hline *Okorusu & Namibia & -20.07 & 16.77 & $\begin{array}{l}\text { Woolley and Kjarsgaard } \\
\text { (2008) }\end{array}$ & 1 & None & $\mathrm{L}$ \\
\hline *Buffalo & South Africa & -24.48 & 28.66 & $\begin{array}{l}\text { Google Earth (2013); } \\
\text { see comments }\end{array}$ & 5 & $\begin{array}{l}\text { Location given is centered } \\
\text { between } 3 \text { open pits }\end{array}$ & $\mathrm{L}$ \\
\hline *Hlabisa & South Africa & -28.13 & 31.90 & $\begin{array}{l}\text { Van Alstine and Schruben } \\
\text { (1980) }\end{array}$ & 8 & None & $\mathrm{S}$ \\
\hline Vergenoeg & South Africa & -25.26 & 28.58 & Google Earth (2013) & 5 & $\begin{array}{l}\text { Some interpret that the deposit } \\
\text { class is } 1\end{array}$ & $\mathrm{~L}$ \\
\hline
\end{tabular}

\begin{tabular}{|c|c|c|c|c|c|c|c|}
\hline Marico district & South Africa & -25.72 & 26.09 & Google Earth (2013) & $4 a$ & None & $\mathrm{L}$ \\
\hline
\end{tabular}


Table G1-1. Selected fluorspar districts, deposits, and prospects of the world.-Continued

[*Deposit is included in the Orris (1992) grade and tonnage modeling of fluorite veins. **Grade and tonnage data are from Kamitani and others (2007); for these entries, it is not clear whether these are the total resources of each deposit or just a resource currently available to the mine that may be subject to updating with further exploration. ***Location data are from the Mineral Resources Data System (MRDS). The key to the identification numbers in the deposit class column is on page G53. Deposit size: $\mathrm{L}$, identified resources are greater than 1.5 million metric tons of $\mathrm{CaF}_{2} ; \mathrm{S}$, identified resources are less than 1.5 million metric tons of $\mathrm{CaF}_{2}$; n.a., not available. Elements and compounds: $\mathrm{Ag}$, silver; $\mathrm{Au}$, gold; $\mathrm{BeO}$, beryllium oxide; $\mathrm{Bi}$, bismuth; $\mathrm{CaF}_{2}$ calcium fluoride; $\mathrm{Cd}$, cadmium; $\mathrm{Cu}$, copper; Fe, iron; Ge, germanium; In, indium; Mo, molybdenum; Nb, niobium; Pb, lead; REE, rare-earth element; Sn, tin; Sr, strontium; Th, thorium; U, uranium; W, tungsten; Y, yttrium; Zn, zinc. Units of measure: g/t, gram per metric ton; km, kilometer; m, meter; Mt, million metric tons; \%, percent]

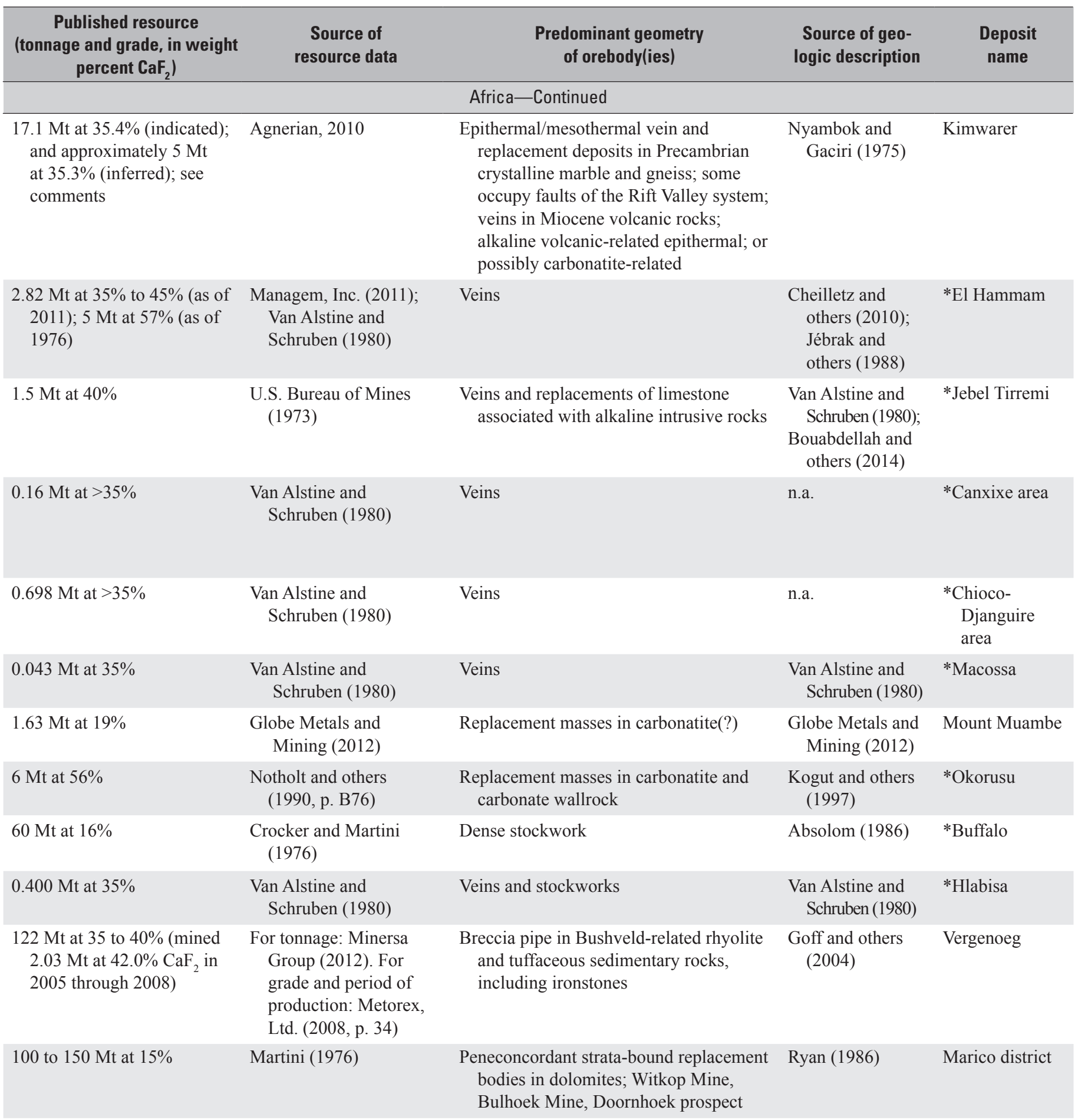


Table G1-1. Selected fluorspar districts, deposits, and prospects of the world._Continued

[*Deposit is included in the Orris (1992) grade and tonnage modeling of fluorite veins. **Grade and tonnage data are from Kamitani and others (2007); for these entries, it is not clear whether these are the total resources of each deposit or just a resource currently available to the mine that may be subject to updating with further exploration. ***Location data are from the Mineral Resources Data System (MRDS). The key to the identification numbers in the deposit class column is on page G53. Deposit size: $\mathrm{L}$, identified resources are greater than 1.5 million metric tons of $\mathrm{CaF}_{2} ; \mathrm{S}$, identified resources are less than 1.5 million metric tons of $\mathrm{CaF}_{2}$; n.a., not available. Elements and compounds: $\mathrm{Ag}$, silver; $\mathrm{Au}$, gold; $\mathrm{BeO}$, beryllium oxide; $\mathrm{Bi}$, bismuth; $\mathrm{CaF}_{2}$ calcium fluoride; $\mathrm{Cd}$, cadmium; $\mathrm{Cu}$, copper; Fe, iron; Ge, germanium; In, indium; Mo, molybdenum; Nb, niobium; Pb, lead; REE, rare-earth element; Sn, tin; Sr, strontium; Th, thorium; U, uranium; $\mathrm{W}$, tungsten; Y, yttrium; Zn, zinc. Units of measure: g/t, gram per metric ton; km, kilometer; m, meter; Mt, million metric tons; \%, percent]

\begin{tabular}{|c|c|c|c|c|c|c|c|}
\hline \multirow{2}{*}{$\begin{array}{c}\text { Deposit } \\
\text { name }^{1}\end{array}$} & \multirow{2}{*}{ Country } & Latitude & Longitude & \multirow{2}{*}{$\begin{array}{c}\text { Source of } \\
\text { location data }\end{array}$} & \multirow{2}{*}{$\begin{array}{c}\text { Deposit } \\
\text { class }\end{array}$} & \multirow{2}{*}{ Comments } & \multirow{2}{*}{$\begin{array}{l}\text { Deposit } \\
\text { size }\end{array}$} \\
\hline & & \multicolumn{2}{|c|}{ (decimal degrees) } & & & & \\
\hline \multicolumn{8}{|c|}{ Africa-Continued } \\
\hline$*$ Zwartkloof & South Africa & -24.86 & 28.17 & Google Earth (2013) & 5 & & $\mathrm{~S}$ \\
\hline
\end{tabular}

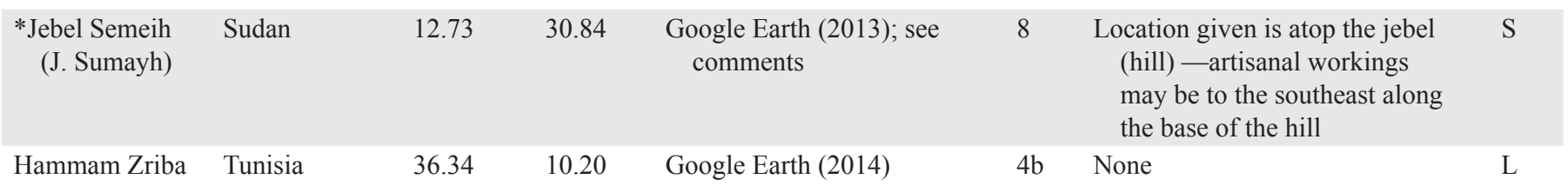

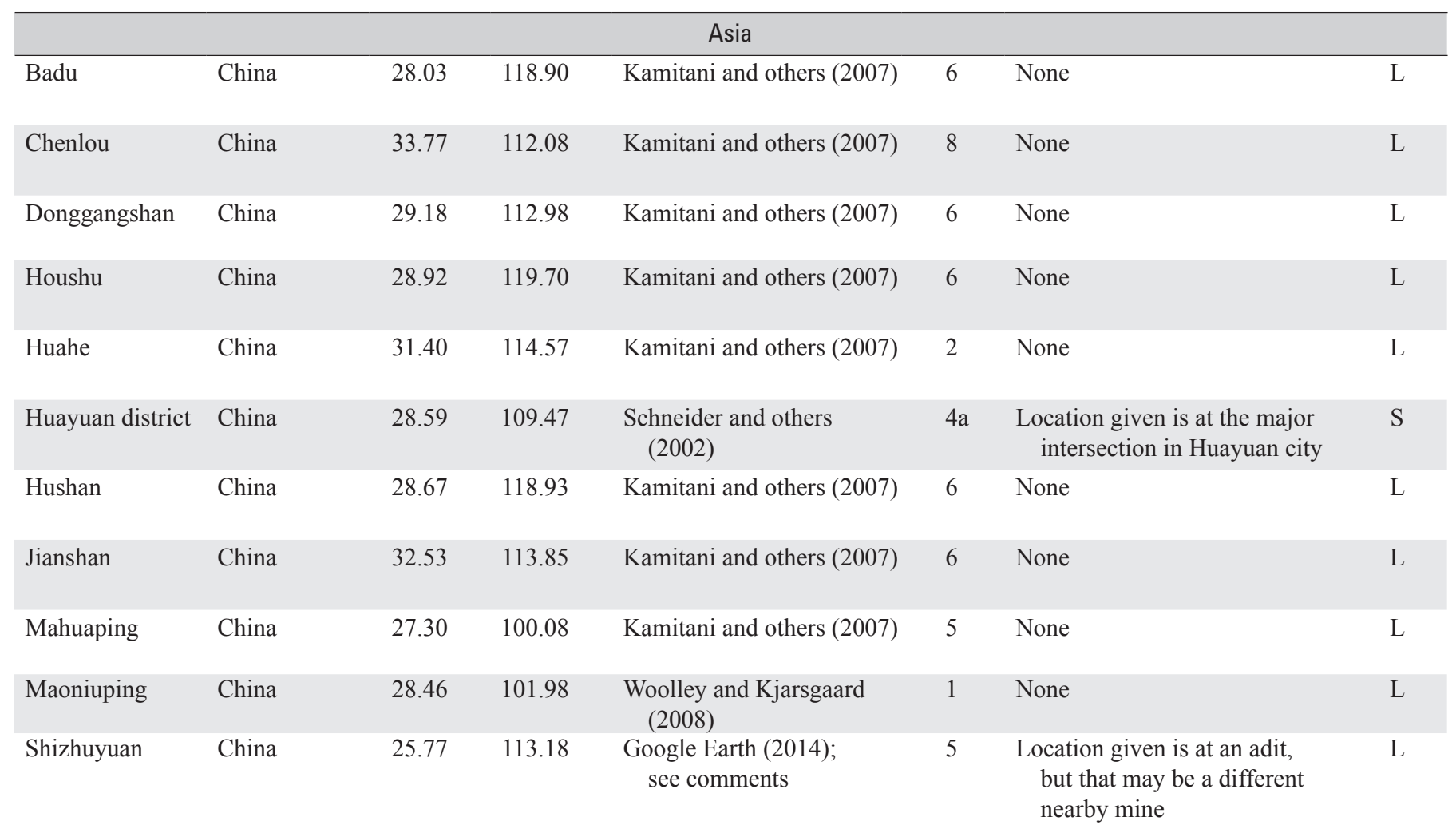

$\begin{array}{lllllll}\text { Shuangjiangkou } & \text { China } & 26.95 & 112.87 & \text { Kamitani and others (2007) } & 8 & \text { None }\end{array}$


Table G1-1. Selected fluorspar districts, deposits, and prospects of the world.-Continued

[*Deposit is included in the Orris (1992) grade and tonnage modeling of fluorite veins. **Grade and tonnage data are from Kamitani and others (2007); for these entries, it is not clear whether these are the total resources of each deposit or just a resource currently available to the mine that may be subject to updating with further exploration. ***Location data are from the Mineral Resources Data System (MRDS). The key to the identification numbers in the deposit class column is on page G53. Deposit size: $\mathrm{L}$, identified resources are greater than 1.5 million metric tons of $\mathrm{CaF}_{2} ; \mathrm{S}$, identified resources are less than 1.5 million metric tons of $\mathrm{CaF}_{2}$; n.a., not available. Elements and compounds: $\mathrm{Ag}$, silver; $\mathrm{Au}$, gold; $\mathrm{BeO}$, beryllium oxide; $\mathrm{Bi}$, bismuth; $\mathrm{CaF}_{2}$ calcium fluoride; $\mathrm{Cd}$, cadmium; $\mathrm{Cu}$, copper; Fe, iron; Ge, germanium; In, indium; Mo, molybdenum; Nb, niobium; Pb, lead; REE, rare-earth element; Sn, tin; Sr, strontium; Th, thorium; U, uranium; W, tungsten; Y, yttrium; Zn, zinc. Units of measure: $\mathrm{g} / \mathrm{t}$, gram per metric ton; km, kilometer; m, meter; Mt, million metric tons; \%, percent]

\begin{tabular}{|c|c|c|c|c|}
\hline $\begin{array}{c}\text { Published resource } \\
\text { (tonnage and grade, in weight } \\
\text { percent } \mathrm{CaF}_{2} \text { ) }\end{array}$ & $\begin{array}{l}\text { Source of } \\
\text { resource data }\end{array}$ & $\begin{array}{l}\text { Predominant geometry } \\
\text { of orebody(ies) }\end{array}$ & $\begin{array}{l}\text { Source of geo- } \\
\text { logic description }\end{array}$ & $\begin{array}{l}\text { Deposit } \\
\text { name }\end{array}$ \\
\hline \multicolumn{5}{|c|}{ Africa-Continued } \\
\hline $7 \mathrm{Mt}$ at $13.7 \%$ & $\begin{array}{l}\text { Brian Hodge, consultant } \\
\text { on world fluorspar } \\
\text { deposits, written } \\
\text { commun., (2013), } \\
\text { based on contempo- } \\
\text { rary data published by } \\
\text { the operating company }\end{array}$ & Veins & $\begin{array}{l}\text { Van Alstine and } \\
\text { Schruben } \\
(1980)\end{array}$ & *Zwartkloof \\
\hline$\sim 0.2 \mathrm{Mt}$ at about $26.5 \%$ & $\begin{array}{l}\text { Van Alstine and } \\
\text { Schruben (1980) }\end{array}$ & Vein & $\begin{array}{l}\text { Van Alstine and } \\
\text { Schruben (1980) }\end{array}$ & $\begin{array}{r}\text { *Jebel Semeih } \\
\text { (J. Sumayh) }\end{array}$ \\
\hline $\begin{array}{l}5 \mathrm{Mt} \text { at } 15 \text { to } 35 \% \text {, or } 6 \mathrm{Mt} \\
\text { at } 50 \%\end{array}$ & $\begin{array}{l}\text { Bouhlel and others } \\
\text { (1988) or Van Alstine } \\
\text { and Schruben (1980) }\end{array}$ & $\begin{array}{l}\text { Peneconcordant replacement bodies in } \\
\text { limestone; dolomitizatioin of wallrocks }\end{array}$ & $\begin{array}{l}\text { Souissi and others } \\
\text { (1997) }\end{array}$ & Hammam Zriba \\
\hline \multicolumn{5}{|c|}{ Asia-Continued } \\
\hline $5.1 \mathrm{Mt}$ at $50.8 \% * *$ & $\begin{array}{l}\text { Kamitani and others } \\
\text { (2007) }\end{array}$ & n.a. & n.a. & Badu \\
\hline $2.5 \mathrm{Mt}$ at $67.25 \% * *$ & $\begin{array}{l}\text { Kamitani and others } \\
\text { (2007) }\end{array}$ & n.a. & n.a. & Chenlou \\
\hline $\begin{array}{l}5.97 \mathrm{Mt} \text { at } 30.49 \% * * \text { (plus } \\
\text { recoverable } \mathrm{Pb} \text { and } \mathrm{Zn} \text { ) }\end{array}$ & $\begin{array}{l}\text { Kamitani and others } \\
\text { (2007) }\end{array}$ & n.a. & n.a. & Donggangshan \\
\hline $7.7 \mathrm{Mt}$ at $46.6 \% * *$ & $\begin{array}{l}\text { Kamitani and others } \\
\text { (2007) }\end{array}$ & Vein & n.a. & Houshu \\
\hline $3.72 \mathrm{Mt}$ at $60 \% * *$ & $\begin{array}{l}\text { Kamitani and others } \\
\text { (2007) }\end{array}$ & Veins & Wen (1998) & Huahe \\
\hline n.a. & n.a. & $\begin{array}{l}\text { Peneconcordant strata-bound replacement } \\
\text { bodies in carbonates }\end{array}$ & $\begin{array}{l}\text { Schneider and } \\
\text { others }(2002)\end{array}$ & Huayuan distric \\
\hline $8.5 \mathrm{Mt}$ at $51.5 \% * *$ & $\begin{array}{l}\text { Kamitani and others } \\
\text { (2007) }\end{array}$ & n.a. & n.a. & Hushan \\
\hline 4.8 Mt at about $57.5 \% * *$ & $\begin{array}{l}\text { Kamitani and others } \\
\text { (2007) }\end{array}$ & Veins & $\begin{array}{l}\text { Chen and others } \\
\text { (1996) }\end{array}$ & Jianshan \\
\hline $\begin{array}{l}10.02 \mathrm{Mt} \text { at } 22.96 \% * * \text { (plus } \\
\text { recoverable } \mathrm{W} \text { and } \mathrm{Bi} \text { ) }\end{array}$ & $\begin{array}{l}\text { Kamitani and others } \\
\text { (2007) }\end{array}$ & Skarn and greisen veinlet stockwork & $\begin{array}{l}\text { Kamitani and } \\
\text { others }(2007)\end{array}$ & Mahuaping \\
\hline n.a. & n.a. & n.a. & n.a. & Maoniuping \\
\hline $\begin{array}{l}46 \mathrm{Mt} \text { at } 21.7 \% \text { (plus } \mathrm{W}, \mathrm{Sn} \text {, } \\
\mathrm{Bi} \text {, and } \mathrm{Mo} \text { ) }\end{array}$ & $\begin{array}{l}\text { Brian Hodge, consultant } \\
\text { on world fluorspar } \\
\text { deposits (written } \\
\text { commun., 2013); that } \\
\text { grade and tonnage } \\
\text { given also by Somerley } \\
\text { Ltd. (2011, p. 35) }\end{array}$ & $\begin{array}{l}\text { Large skarns, greisens, and stockworks in } \\
\text { limestone adjacent to biotite granite }\end{array}$ & $\begin{array}{l}\text { Mao and others } \\
\text { (1996) }\end{array}$ & Shizhuyuan \\
\hline $4.03 \mathrm{Mt}$ at $60.26 \% * *$ & $\begin{array}{l}\text { Kamitani and others } \\
(2007)\end{array}$ & n.a & n.a. & Shuangjiangkou \\
\hline
\end{tabular}


Table G1-1. Selected fluorspar districts, deposits, and prospects of the world.-Continued

[*Deposit is included in the Orris (1992) grade and tonnage modeling of fluorite veins. **Grade and tonnage data are from Kamitani and others (2007); for these entries, it is not clear whether these are the total resources of each deposit or just a resource currently available to the mine that may be subject to updating with further exploration. ***Location data are from the Mineral Resources Data System (MRDS). The key to the identification numbers in the deposit class column is on page G53. Deposit size: L, identified resources are greater than 1.5 million metric tons of $\mathrm{CaF}_{2} ; \mathrm{S}$, identified resources are less than 1.5 million metric tons of $\mathrm{CaF}_{2}$; n.a., not available. Elements and compounds: $\mathrm{Ag}$, silver; $\mathrm{Au}$, gold; $\mathrm{BeO}$, beryllium oxide; Bi, bismuth; $\mathrm{CaF}$, calcium fluoride; $\mathrm{Cd}$, cadmium; $\mathrm{Cu}$, copper; Fe, iron; Ge, germanium; In, indium; Mo, molybdenum; Nb, niobium; Pb, lead; REE, rare-earth element; Sn, tin; Sr, strontium; Th, thorium; U, uranium; W, tungsten; Y, yttrium; Zn, zinc. Units of measure: g/t, gram per metric ton; km, kilometer; m, meter; Mt, million metric tons; \%, percent]

\begin{tabular}{|c|c|c|c|c|c|c|c|}
\hline $\begin{array}{l}\text { Deposit } \\
\text { name }^{1}\end{array}$ & Country & & Longitude & $\begin{array}{c}\text { Source of } \\
\text { location data }\end{array}$ & $\begin{array}{l}\text { Deposit } \\
\text { class }\end{array}$ & Comments & $\begin{array}{l}\text { Deposit } \\
\text { size }\end{array}$ \\
\hline \multicolumn{8}{|c|}{ Asia-Continued } \\
\hline $\begin{array}{l}\text { Sumochagan } \\
\text { Obo }\end{array}$ & China & 43.12 & 111.27 & Google Earth (2012) & 6 & $\begin{array}{l}\text { Deposit class instead may be } 7 \text {, } \\
\text { and the deposit geologically } \\
\text { older and grain-coarsened } \\
\text { than other } 7 \mathrm{~s} \text {. Deposit class } \\
\text { may be } 5 \text {; grades to skarn in } \\
\text { the same beds to the south }\end{array}$ & $\mathrm{L}$ \\
\hline Taolin & China & 29.37 & 113.45 & $\begin{array}{l}\text { Roedder and Howard } \\
\text { (1988) }\end{array}$ & 5 & None & $\mathrm{S}$ \\
\hline Yangjia-Wuyi & China & 28.99 & 119.89 & $\begin{array}{l}\text { Google Earth (2012); } \\
\text { see comments }\end{array}$ & 6 & $\begin{array}{l}\text { Location given is at Yangjia in } \\
\text { an open cut along a vein }\end{array}$ & $\mathrm{L}$ \\
\hline Yinzishan & China & 30.58 & 119.87 & Kamitani and others (2007) & 6 & $\begin{array}{l}\text { Deposit class instead } \\
\text { may be } 5\end{array}$ & $\mathrm{~L}$ \\
\hline
\end{tabular}

$\begin{array}{llllllll}\text { Amba Dongar } & \text { India } & 22.00 & 74.06 & \text { Google Earth (2014) } & 1 & \text { None } & \text { L } \\ \text { Karadzhal } & \text { Kazakhstan } & 49.87 & 78.04 & \begin{array}{c}\text { Google Earth (2016); } \\ \text { probable location; }\end{array} & 5 & \begin{array}{c}\text { Location given at left is } \\ 170 \text { km southwest of Semey, } \quad \text { (resource }\end{array}\end{array}$
$\begin{array}{ll}\text { probable location; } & 170 \mathrm{~km} \text { southwest of Semey, (resource } \\ \text { see comments } & \text { Kazakhstan, as given by Ulba at right is }\end{array}$ Metallurgical Plant Joint considStock Co. (2015). Location ered ungiven at left "lies on the likely to northern exo-contact of the be a total granite massif [of the Degelen resource) Mountains]" on geology map of (Böttger and others, 1998, p. 127, 203). The location is marked as "Karadzhal" on a map in Vakulchuk and Gjerde (2014, p. 16). That location is interpreted as a large excavation on a low-resolution image presented by Google Earth

$\begin{array}{llcccccc}\begin{array}{l}\text { Taskainar } \\ \text { (Taskaynar) }\end{array} & \text { Kazakhstan } & 43.13 & 75.14 & \text { Seltmann and others (2012) } & 5 & \text { None } \\ \begin{array}{l}\text { Taskainar } \\ \text { (Taskaynar) } \\ \text { South }\end{array} & \text { Kazakhstan } & 43.15 & 75.10 & \text { Seltmann and others (2012) } & 8 & \text { None } & \text { L } \\ \begin{array}{l}\text { Adag } \\ \text { Mongolia }\end{array} & 46.50 & 109.33 & \text { Kamitani and others }(2007) & 3 & \text { None } \\ \text { Berkh } & \text { Mongolia } & 47.77 & 111.17 & \text { Google Earth }(2013) & 3 & \text { None }\end{array}$


Table G1-1. Selected fluorspar districts, deposits, and prospects of the world.-Continued

[*Deposit is included in the Orris (1992) grade and tonnage modeling of fluorite veins. **Grade and tonnage data are from Kamitani and others (2007); for these entries, it is not clear whether these are the total resources of each deposit or just a resource currently available to the mine that may be subject to updating with further exploration. ***Location data are from the Mineral Resources Data System (MRDS). The key to the identification numbers in the deposit class column is on page G53. Deposit size: $\mathrm{L}$, identified resources are greater than 1.5 million metric tons of $\mathrm{CaF}_{2} ; \mathrm{S}$, identified resources are less than 1.5 million metric tons of $\mathrm{CaF}_{2}$; n.a., not available. Elements and compounds: $\mathrm{Ag}$, silver; $\mathrm{Au}$, gold; $\mathrm{BeO}$, beryllium oxide; $\mathrm{Bi}$, bismuth; $\mathrm{CaF}_{2}$ calcium fluoride; $\mathrm{Cd}$, cadmium; $\mathrm{Cu}$, copper; Fe, iron; Ge, germanium; In, indium; Mo, molybdenum; Nb, niobium; Pb, lead; REE, rare-earth element; Sn, tin; Sr, strontium; Th, thorium; U, uranium; W, tungsten; Y, yttrium; Zn, zinc. Units of measure: g/t, gram per metric ton; km, kilometer; m, meter; Mt, million metric tons; \%, percent]

\begin{tabular}{|c|c|c|c|c|}
\hline $\begin{array}{c}\text { Published resource } \\
\text { (tonnage and grade, in weight } \\
\text { percent } \mathrm{CaF}_{2} \text { ) }\end{array}$ & $\begin{array}{l}\text { Source of } \\
\text { resource data }\end{array}$ & $\begin{array}{l}\text { Predominant geometry } \\
\text { of orebody(ies) }\end{array}$ & $\begin{array}{l}\text { Source of geo- } \\
\text { logic description }\end{array}$ & $\begin{array}{c}\text { Deposit } \\
\text { name }\end{array}$ \\
\hline \multicolumn{5}{|c|}{ Asia-Continued } \\
\hline $20 \mathrm{Mt}$ at $56.52 \%$ & $\begin{array}{l}\text { Kamitani and others } \\
\text { (2007) }\end{array}$ & $\begin{array}{l}\text { Peneconcordant strata-bound } \\
\text { replacement(?) body in tuffaceous } \\
\text { limestone, within section mixed with } \\
\text { high-K calcalkaline volcanics, nearby } \\
\text { peraluminous granite intrusive }\end{array}$ & $\begin{array}{l}\text { Chen and others } \\
\text { (1996) }\end{array}$ & $\begin{array}{l}\text { Sumochagan } \\
\text { Obo }\end{array}$ \\
\hline
\end{tabular}

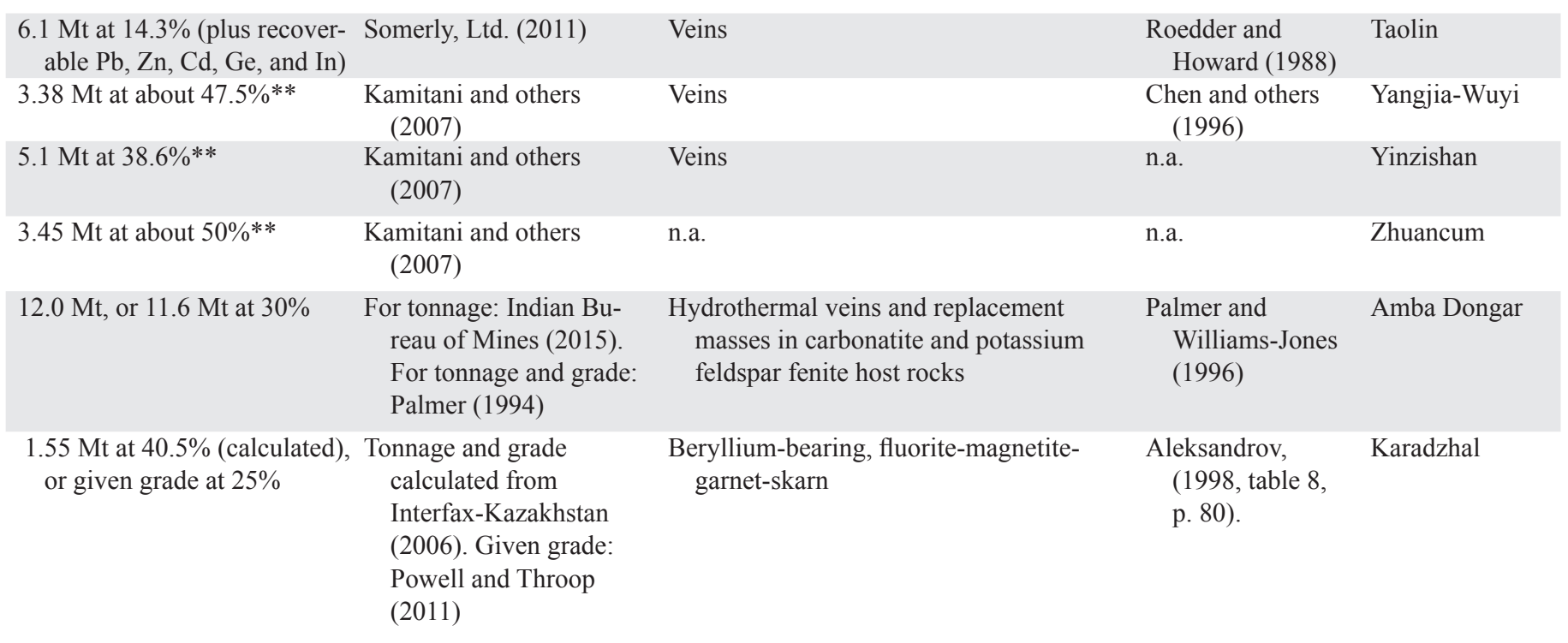

\begin{tabular}{|c|c|c|c|c|}
\hline$>15.625 \mathrm{Mt}$ at $32 \%$ & $\begin{array}{l}\text { Calculated from Seltmann } \\
\text { and others (2012) and } \\
\text { Koplus and others (1977) }\end{array}$ & $\begin{array}{l}\text { Mineralized breccia at limestone/silici- } \\
\text { clastics contact associated with "porphyrite" } \\
\text { dikes or with granodiorite sill }\end{array}$ & $\begin{array}{l}\text { Koplus and others } \\
\text { (1977) }\end{array}$ & $\begin{array}{l}\text { Taskainar } \\
\text { (Taskaynar) }\end{array}$ \\
\hline$>5 \mathrm{Mt}$ fluorite & $\begin{array}{l}\text { Seltmann and others } \\
\text { (2012) }\end{array}$ & n.a. & n.a. & $\begin{array}{l}\text { Taskainar } \\
\text { (Taskaynar) } \\
\text { South }\end{array}$ \\
\hline 4.6 Mt at about $33 \% * *$ & $\begin{array}{l}\text { Kamitani and others } \\
\text { (2007) }\end{array}$ & $\begin{array}{c}\text { Adularia-sericite epithermal vein associated } \\
\text { with alkaline basalt-trachyte-rhyolite series }\end{array}$ & $\begin{array}{l}\text { Lkhamsuren and } \\
\text { Hamasaki (1998) }\end{array}$ & Adag \\
\hline $1.6 \mathrm{Mt}$ at $81.8 \% * *$ & $\begin{array}{l}\text { Kamitani and others } \\
\quad \text { (2007) }\end{array}$ & $\begin{array}{l}\text { Adularia-sericite epithermal veins } \\
\text { associated with alkaline basalt-trachyte- } \\
\text { rhyolite series }\end{array}$ & $\begin{array}{l}\text { Lkhamsuren and } \\
\text { Hamasaki } \\
\text { (1998) }\end{array}$ & Berkh \\
\hline
\end{tabular}


Table G1-1. Selected fluorspar districts, deposits, and prospects of the world.-Continued

[*Deposit is included in the Orris (1992) grade and tonnage modeling of fluorite veins. **Grade and tonnage data are from Kamitani and others (2007); for these entries, it is not clear whether these are the total resources of each deposit or just a resource currently available to the mine that may be subject to updating with further exploration. ***Location data are from the Mineral Resources Data System (MRDS). The key to the identification numbers in the deposit class column is on page G53. Deposit size: $\mathrm{L}$, identified resources are greater than 1.5 million metric tons of $\mathrm{CaF}_{2} ; \mathrm{S}$, identified resources are less than 1.5 million metric tons of $\mathrm{CaF}_{2}$; n.a., not available. Elements and compounds: $\mathrm{Ag}$, silver; $\mathrm{Au}$, gold; $\mathrm{BeO}$, beryllium oxide; $\mathrm{Bi}$, bismuth; $\mathrm{CaF}_{2}$ calcium fluoride; $\mathrm{Cd}$, cadmium; $\mathrm{Cu}$, copper; Fe, iron; Ge, germanium; In, indium; Mo, molybdenum; Nb, niobium; Pb, lead; REE, rare-earth element; Sn, tin; Sr, strontium; Th, thorium; U, uranium; $\mathrm{W}$, tungsten; Y, yttrium; Zn, zinc. Units of measure: g/t, gram per metric ton; km, kilometer; m, meter; Mt, million metric tons; \%, percent]

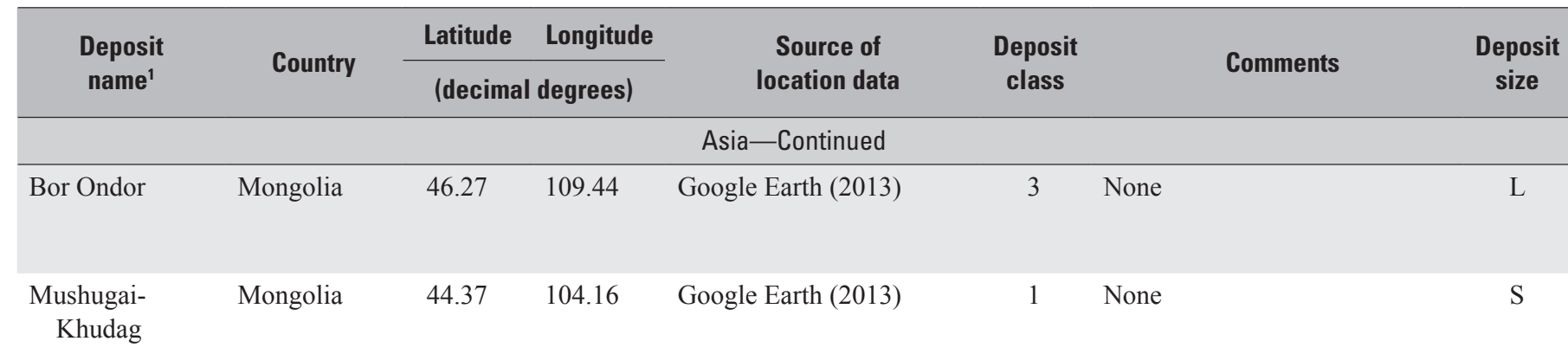

\begin{tabular}{|c|c|c|c|c|c|c|c|}
\hline Urgun (Örgön) & Mongolia & 44.71 & 110.74 & Google Earth (2013) & 3 & None & $\mathrm{L}$ ? \\
\hline $\begin{array}{l}\text { Zuum-Tsagaan- } \\
\text { Del }\end{array}$ & Mongolia & 46.37 & 110.04 & Google Earth (2013) & 3 & None & $\mathrm{S}$ \\
\hline Kalat district & Pakistan & 29.44 & 67.15 & $\begin{array}{l}\text { Durrani (1980) and } \\
\text { Google Earth (2014) }\end{array}$ & $4 \mathrm{a}$ & None & $\mathrm{S}$ ? \\
\hline Auninsky & Russia & 54.90 & 113.12 & $\begin{array}{l}\text { Ocean Policy Research } \\
\text { Foundation (2012) }\end{array}$ & 2 & None & $\mathrm{L}$ \\
\hline Chailag-Khem & Russia & 51.91 & 92.40 & Bolonin and others (2009) & 1 & None & $\mathrm{L}$ \\
\hline Kalangui & Russia & 51.01 & 116.53 & Google Earth (2013) & 6 & None & $\mathrm{L}$ \\
\hline Karasug & Russia & 51.31 & 92.13 & $\begin{array}{l}\text { Transcribed from the } \\
\text { map of Nikiforov and } \\
\text { others (2005) }\end{array}$ & 1 & None & $\mathrm{L}$ \\
\hline
\end{tabular}

$\begin{array}{ccccc}\text { Naransky } & \text { Russia } & 50.92 & 105.62 & \begin{array}{c}\text { Ocean Policy Research } \\ \text { Foundation (2012) }\end{array} \\ & \text { None }\end{array}$


Table G1-1. Selected fluorspar districts, deposits, and prospects of the world.-Continued

[*Deposit is included in the Orris (1992) grade and tonnage modeling of fluorite veins. **Grade and tonnage data are from Kamitani and others (2007); for these entries, it is not clear whether these are the total resources of each deposit or just a resource currently available to the mine that may be subject to updating with further exploration. ***Location data are from the Mineral Resources Data System (MRDS). The key to the identification numbers in the deposit class column is on page G53. Deposit size: $\mathrm{L}$, identified resources are greater than 1.5 million metric tons of $\mathrm{CaF}_{2} ; \mathrm{S}$, identified resources are less than 1.5 million metric tons of $\mathrm{CaF}_{2}$; n.a., not available. Elements and compounds: $\mathrm{Ag}$, silver; $\mathrm{Au}$, gold; $\mathrm{BeO}$, beryllium oxide; $\mathrm{Bi}$, bismuth; $\mathrm{CaF}_{2}$ calcium fluoride; $\mathrm{Cd}$, cadmium; $\mathrm{Cu}$, copper; Fe, iron; Ge, germanium; In, indium; Mo, molybdenum; Nb, niobium; Pb, lead; REE, rare-earth element; Sn, tin; Sr, strontium; Th, thorium; U, uranium; W, tungsten; Y, yttrium; Zn, zinc. Units of measure: $\mathrm{g} / \mathrm{t}$, gram per metric ton; km, kilometer; m, meter; Mt, million metric tons; \%, percent]

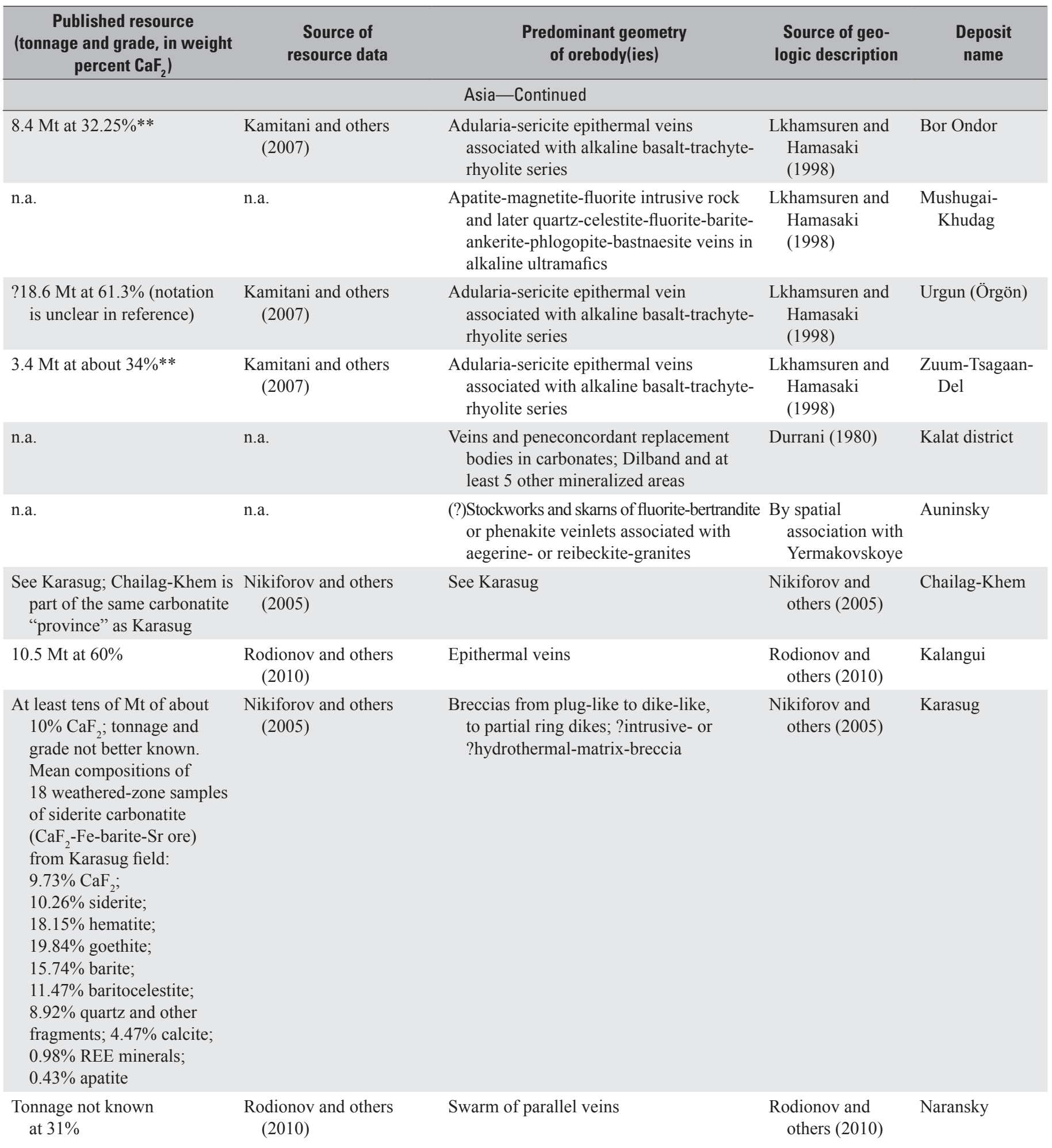


Table G1-1. Selected fluorspar districts, deposits, and prospects of the world.—Continued

[*Deposit is included in the Orris (1992) grade and tonnage modeling of fluorite veins. **Grade and tonnage data are from Kamitani and others (2007); for these entries, it is not clear whether these are the total resources of each deposit or just a resource currently available to the mine that may be subject to updating with further exploration. ***Location data are from the Mineral Resources Data System (MRDS). The key to the identification numbers in the deposit class column is on page G53. Deposit size: L, identified resources are greater than 1.5 million metric tons of $\mathrm{CaF}_{2} ; \mathrm{S}$, identified resources are less than 1.5 million metric tons of $\mathrm{CaF}_{2}$; n.a., not available. Elements and compounds: $\mathrm{Ag}$, silver; $\mathrm{Au}$, gold; $\mathrm{BeO}$, beryllium oxide; Bi, bismuth; $\mathrm{CaF}$, calcium fluoride; $\mathrm{Cd}$, cadmium; $\mathrm{Cu}$, copper; Fe, iron; Ge, germanium; In, indium; Mo, molybdenum; Nb, niobium; Pb, lead; REE, rare-earth element; Sn, tin; Sr, strontium; Th, thorium; U, uranium; W, tungsten; Y, yttrium; Zn, zinc. Units of measure: g/t, gram per metric ton; km, kilometer; m, meter; Mt, million metric tons; \%, percent]

\begin{tabular}{|c|c|c|c|c|c|c|c|}
\hline $\begin{array}{l}\text { Deposit } \\
\text { name }^{1}\end{array}$ & Country & $\begin{array}{l}\text { Latitude } \\
\text { (decimal }\end{array}$ & $\begin{array}{l}\text { Longitude } \\
\text { degrees) }\end{array}$ & $\begin{array}{l}\text { Source of } \\
\text { location data }\end{array}$ & $\begin{array}{l}\text { Deposit } \\
\text { class }\end{array}$ & Comments & $\begin{array}{l}\text { Deposit } \\
\text { size }\end{array}$ \\
\hline \multicolumn{8}{|c|}{ Asia-Continued } \\
\hline $\begin{array}{l}\text { Suran I \& } \\
\text { Suran II }\end{array}$ & Russia & $\begin{array}{l}\text { Possibly } \\
53.84\end{array}$ & $\begin{array}{l}\text { Possibly } \\
57.81\end{array}$ & $\begin{array}{l}\text { Google Earth (2014); } \\
\text { see comments }\end{array}$ & 8 & $\begin{array}{l}\text { Deposit class is most likely } \\
\text { 6. Location is uncertain. } \\
\text { That given by Ocean Policy } \\
\text { Research Foundation (2012) is } \\
\text { inconsistent with description } \\
\text { in Ellmies and others (1999) }\end{array}$ & $\mathrm{L}$ \\
\hline $\begin{array}{l}\text { Voznesenka and } \\
\text { Pogranichny } \\
\text { (the } \\
\text { Yaroslavskoye } \\
\text { or Yoroslavsky } \\
\text { Mine) }\end{array}$ & Russia & 44.17 & 132.19 & $\begin{array}{l}\text { Google Earth (2013); } \\
\text { center of the } \\
\text { Voznesenka pit }\end{array}$ & 5 & $\begin{array}{l}\text { Grade is rounded to the nearest } \\
5 \% \text { from the mean of seven } \\
\text { ore samples reported by } \\
\text { Kupriyanova and Shpanov } \\
\text { (1997, p. 385) and four } \\
\text { ore samples reported by } \\
\text { Ryazantseva (1998, p. 22). } \\
\text { Tonnage includes B and } \\
\text { C1 categories, which are } \\
\text { approximately equivalent to } \\
\text { "measured" and "indicated" } \\
\text { resources, respectively }\end{array}$ & $\mathrm{L}$ \\
\hline
\end{tabular}

\begin{tabular}{|c|c|c|c|c|c|c|c|}
\hline $\begin{array}{l}\text { Yermakovskoye } \\
\text { (Yermakovska, } \\
\text { Yermakovsky, } \\
\text { Ermakovsky, } \\
\text { Ermakovskoye) }\end{array}$ & Russia & 51.67 & 109.56 & Google Earth (2013) & 2 & None & $\mathrm{L}$ \\
\hline Takob & Tajikistan & 38.84 & 68.94 & $\begin{array}{l}\text { Google Earth }(2012) ; \\
\text { see comments }\end{array}$ & 8 & $\begin{array}{l}\text { Location given is at the village } \\
\text { of the same name }\end{array}$ & S? \\
\hline Doi Tao district & Thailand & 17.88 & 98.78 & Gardner and Smith (1965) & 8 & None & $\mathrm{S} ?$ \\
\hline $\begin{array}{c}\text { Yang Hak } \\
\text { district }\end{array}$ & Thailand & 13.37 & 99.47 & Gardner and Smith (1965) & 8 & None & $\mathrm{S} ?$ \\
\hline
\end{tabular}

$\begin{array}{llllll}\text { Suppatash } \quad \text { Uzbekistan } & 41.21 & 70.53 & \text { Seltmann and others (2012) } & 8 & \text { None }\end{array}$


Table G1-1. Selected fluorspar districts, deposits, and prospects of the world.-Continued

[*Deposit is included in the Orris (1992) grade and tonnage modeling of fluorite veins. **Grade and tonnage data are from Kamitani and others (2007); for these entries, it is not clear whether these are the total resources of each deposit or just a resource currently available to the mine that may be subject to updating with further exploration. ***Location data are from the Mineral Resources Data System (MRDS). The key to the identification numbers in the deposit class column is on page G53. Deposit size: $\mathrm{L}$, identified resources are greater than 1.5 million metric tons of $\mathrm{CaF}_{2} ; \mathrm{S}$, identified resources are less than 1.5 million metric tons of $\mathrm{CaF}_{2}$; n.a., not available. Elements and compounds: $\mathrm{Ag}$, silver; $\mathrm{Au}$, gold; $\mathrm{BeO}$, beryllium oxide; $\mathrm{Bi}$, bismuth; $\mathrm{CaF}_{2}$ calcium fluoride; $\mathrm{Cd}$, cadmium; $\mathrm{Cu}$, copper; Fe, iron; Ge, germanium; In, indium; Mo, molybdenum; Nb, niobium; Pb, lead; REE, rare-earth element; Sn, tin; Sr, strontium; Th, thorium; U, uranium; W, tungsten; Y, yttrium; Zn, zinc. Units of measure: $\mathrm{g} / \mathrm{t}$, gram per metric ton; km, kilometer; m, meter; Mt, million metric tons; \%, percent]

\begin{tabular}{|c|c|c|c|c|}
\hline $\begin{array}{c}\text { Published resource } \\
\text { (tonnage and grade, in weight } \\
\text { percent } \mathrm{CaF}_{2} \text { ) }\end{array}$ & $\begin{array}{l}\text { Source of } \\
\text { resource data }\end{array}$ & $\begin{array}{l}\text { Predominant geometry } \\
\text { of orebody(ies) }\end{array}$ & $\begin{array}{l}\text { Source of geo- } \\
\text { logic description }\end{array}$ & $\begin{array}{l}\text { Deposit } \\
\text { name }\end{array}$ \\
\hline \multicolumn{5}{|c|}{ Asia-Continued } \\
\hline n.a. & n.a. & Veins & $\begin{array}{l}\text { Ellmies and others } \\
\text { (1999) }\end{array}$ & $\begin{array}{l}\text { Suran I \& } \\
\quad \text { Suran II }\end{array}$ \\
\hline $\begin{array}{l}22 \mathrm{Mt} \text { at about } 40 \% \text { (Note } \\
\text { that this tonnage disagrees } \\
\text { dramatically from that given } \\
\text { in Nokleberg and others } \\
\text { (1996). Calculations of } \\
\text { tonnage using deposit maps } \\
\text { and sections with reasonable } \\
\text { assumptions of average ore } \\
\text { density yield results more } \\
\text { than an order of magnitude } \\
\text { smaller than the tonnage } \\
\text { given by Nokleberg and } \\
\text { others (1996) [450 Mt]) }\end{array}$ & $\begin{array}{l}\text { Tonnage: United } \\
\text { Company RUSAL } \\
\text { (2012). Grade: see } \\
\text { comments }\end{array}$ & $\begin{array}{l}\text { Fluorite skarn and greisen-veinlet } \\
\text { stockwork in limestone enveloping } 2 \\
\text { separated greisenized granite cupolas }\end{array}$ & $\begin{array}{l}\text { Kupriyanova } \\
\text { and Shpanov } \\
\text { (1997); } \\
\text { Ryazantseva } \\
\text { (1998); Sato } \\
\text { and others } \\
\text { (2003); and } \\
\text { Obolenskiy and } \\
\text { others (2010) }\end{array}$ & $\begin{array}{l}\text { Voznesenka and } \\
\text { Pogranichny } \\
\text { (the } \\
\text { Yaroslavskoye } \\
\text { or Yoroslavsky } \\
\text { Mine) }\end{array}$ \\
\hline $\begin{array}{l}0.875 \mathrm{Mt} \text { at } 17.7 \% \text { (plus } \\
0.97 \% \mathrm{BeO} \text { ) (reserves as } \\
\text { of } 2007 \text { for the mine's } \\
\text { proposed re-opening; past } \\
\text { production not available) }\end{array}$ & Kislov and others, (2010) & Small skarns and stockworks & $\begin{array}{l}\text { Lykhin and others } \\
\qquad(2010)\end{array}$ & $\begin{array}{l}\text { Yermakovskoye } \\
\text { (Yermakovska, } \\
\text { Yermakovsky, } \\
\text { Ermakovsky, } \\
\text { Ermakovskoye) }\end{array}$ \\
\hline n.a. & n.a. & n.a. & n.a. & Takob \\
\hline$>3.55 \mathrm{Mt}$ at $46.6 \%$ & $\begin{array}{l}\text { Gardner and Smith } \\
\text { (1965) }\end{array}$ & Veins cutting metasedimentary rocks & $\begin{array}{l}\text { Gardner and } \\
\quad \text { Smith (1965) }\end{array}$ & Ban Hong \\
\hline n.a. & n.a. & Veins cutting porphyritic granite & $\begin{array}{l}\text { Gardner and } \\
\quad \text { Smith (1965) }\end{array}$ & Doi Tao district \\
\hline n.a. & n.a. & $\begin{array}{l}\text { Veins cutting granite, phyllite, } \\
\text { and quartzite }\end{array}$ & $\begin{array}{l}\text { Gardner and } \\
\text { Smith (1965) }\end{array}$ & Yang Hak district \\
\hline $\begin{array}{l}\text { 12.4 Mt at } 37.4 \% \text { (plus barite, } \\
\text { REE }[\Sigma \mathrm{REE}=3 \%] \text {, and } \\
\text { Th }[0.2 \%] \text { ) }\end{array}$ & Engin (1988) & $\begin{array}{l}\text { Veins, breccia-fills, and replacements in } \\
\text { alkalic (aegerine-bearing) tuffs near } \\
\text { phonolite plugs. REE minerals, including } \\
\text { bastnaesite, brockite, florencite, and } \\
\text { monazite, suggest a relation to carbonatite }\end{array}$ & Kirikoglu (2002) & $\begin{array}{l}\text { Kizilcaören (also } \\
\text { known as } \\
\text { Beylikahir) }\end{array}$ \\
\hline $5.147 \mathrm{Mt}$ at $27.5 \%$ & ITE-Uzbekistan (2012?) & Epithermal vein in volcanic host rocks & $\begin{array}{l}\text { State Committee } \\
\text { of the Republic } \\
\text { of Uzbekistan } \\
\text { for Geology } \\
\text { and Mineral } \\
\text { Resources } \\
\text { (2011?) }\end{array}$ & Suppatash \\
\hline
\end{tabular}


Table G1-1. Selected fluorspar districts, deposits, and prospects of the world.-Continued

[*Deposit is included in the Orris (1992) grade and tonnage modeling of fluorite veins. **Grade and tonnage data are from Kamitani and others (2007); for these entries, it is not clear whether these are the total resources of each deposit or just a resource currently available to the mine that may be subject to updating with further exploration. ***Location data are from the Mineral Resources Data System (MRDS). The key to the identification numbers in the deposit class column is on page G53. Deposit size: $\mathrm{L}$, identified resources are greater than 1.5 million metric tons of $\mathrm{CaF}_{2} ; \mathrm{S}$, identified resources are less than 1.5 million metric tons of $\mathrm{CaF}_{2}$; n.a., not available. Elements and compounds: $\mathrm{Ag}$, silver; $\mathrm{Au}$, gold; $\mathrm{BeO}$, beryllium oxide; $\mathrm{Bi}$, bismuth; $\mathrm{CaF}_{2}$ calcium fluoride; $\mathrm{Cd}$, cadmium; $\mathrm{Cu}$, copper; Fe, iron; Ge, germanium; In, indium; Mo, molybdenum; Nb, niobium; Pb, lead; REE, rare-earth element; Sn, tin; Sr, strontium; Th, thorium; U, uranium; $\mathrm{W}$, tungsten; Y, yttrium; Zn, zinc. Units of measure: g/t, gram per metric ton; km, kilometer; m, meter; Mt, million metric tons; \%, percent]

\begin{tabular}{|c|c|c|c|c|c|c|c|}
\hline \multirow{2}{*}{$\begin{array}{l}\text { Deposit } \\
\text { name }^{1}\end{array}$} & \multirow{2}{*}{ Country } & Latitude & Longitude & \multirow{2}{*}{$\begin{array}{c}\text { Source of } \\
\text { location data }\end{array}$} & \multirow{2}{*}{$\begin{array}{l}\text { Deposit } \\
\text { class }\end{array}$} & \multirow{2}{*}{ Comments } & \multirow{2}{*}{$\begin{array}{l}\text { Deposit } \\
\text { size }\end{array}$} \\
\hline & & \multicolumn{2}{|c|}{ (decimal degrees) } & & & & \\
\hline \multicolumn{8}{|c|}{ Asia-Continued } \\
\hline Nui Phao & Vietnam & 21.65 & 105.67 & $\begin{array}{l}\text { Richards and others (2003) } \\
\text { and Google Earth (2014) }\end{array}$ & 5 & $\begin{array}{l}\text { Other commodity grades for } \\
\text { the } 52.5 \mathrm{Mt} \text { : W, } 0.21 \% \text {; } \\
\mathrm{Bi}, 0.10 \% \text {; } \mathrm{Cu}, 0.21 \% \text {; } \\
\mathrm{Au}, 0.22 \mathrm{~g} / \mathrm{t}\end{array}$ & $\mathrm{L}$ \\
\hline
\end{tabular}

\begin{tabular}{|c|c|c|c|c|c|c|c|}
\hline \multicolumn{8}{|c|}{ Australia } \\
\hline Moina & Australia & -41.49 & 146.07 & $\begin{array}{l}\text { Google Earth (2013); } \\
\text { see comments }\end{array}$ & 5 & $\begin{array}{l}\text { Location given is for the village } \\
\text { of the same name }\end{array}$ & $\mathrm{L}$ \\
\hline
\end{tabular}

\begin{tabular}{ccccccc} 
Speewah & Australia & -16.41 & 127.98 & Gwalani and others (2010) & 1 & None \\
\hline Europe
\end{tabular}

\begin{tabular}{lcccc}
\hline *Argentolle & France & Possibly & Possibly & Google Earth (2013); \\
& & 46.97 & 4.08 & see comments
\end{tabular}

Location uncertain. The given $\mathrm{S}$

location is at an industrial site between the villages of Les Chaux and Crot Morin, Burgundy, France. The two villages are $1.74 \mathrm{~km}$ distant from one another.

\begin{tabular}{|c|c|c|c|c|c|c|c|}
\hline *Escaro & France & 42.54 & 2.31 & Google Earth (2013) & 8 & Either class $4 b$ or 2 & $\mathrm{~S}$ \\
\hline Montroc & France & 43.82 & 2.38 & Google Earth (2013) & 8 & Either class $4 \mathrm{~b}$ or 2 & $\mathrm{~S}$ \\
\hline Le Burc & France & 43.87 & 2.41 & $\begin{array}{l}\text { Google Earth (2013); } \\
\text { see comments }\end{array}$ & 8 & $\begin{array}{l}\text { Either class } 4 \mathrm{~b} \text { or } 2 \\
\text { location uncertain }\end{array}$ & S \\
\hline Rossignol & France & 46.42 & 1.31 & Google Earth (2013) & 8 & Either class $4 \mathrm{~b}$ or 2 & $\mathrm{~S}$ \\
\hline *Pakozd & Hungary & 47.22 & 18.51 & Google Earth (2013) & 5 & $\begin{array}{l}\text { Location is among a group } \\
\text { of exploration trenches }\end{array}$ & $\mathrm{S}$ \\
\hline $\begin{array}{l}\text { Bruncu } \\
\text { Molentinu }\end{array}$ & $\begin{array}{l}\text { Italy } \\
\text { (Sardinia) }\end{array}$ & 39.44 & 9.48 & Google Earth (2013) & 8 & None & $\mathrm{L}(?)$ \\
\hline $\begin{array}{l}\text { *Muscadroxiu- } \\
\text { GennaTres } \\
\text { Montis- } \\
\text { S'Acqua Frida } \\
\text { (Silius Mine) }\end{array}$ & $\begin{array}{l}\text { Italy } \\
\text { (Sardinia) }\end{array}$ & 39.52 & 9.26 & Google Earth (2013) & 8 & Either class $4 \mathrm{~b}$ or class 5 & $\mathrm{~L}$ \\
\hline $\begin{array}{l}\text { Castel Giuliano- } \\
\text { Pianciano }\end{array}$ & Italy & 42.07 & 12.14 & $\begin{array}{l}\text { Google Earth (2013); } \\
\text { see comments }\end{array}$ & 7 & $\begin{array}{l}\text { Location given is at outcrop } \\
\# 5 \text { of Mastrangelo ( } 1976 \text {, } \\
\text { p. } 44-45) \text {, fairly central to } \\
\text { the fluorspar body }\end{array}$ & $\mathrm{L}$ \\
\hline $\begin{array}{l}\text { Santo Maria } \\
\text { di Sala }\end{array}$ & Italy & 42.58 & 11.75 & $\begin{array}{l}\text { Google Earth (2013); } \\
\text { see comments }\end{array}$ & 7 & $\begin{array}{l}\text { Location given is at outcrop \#1 } \\
\text { of Mastrangelo }(1976, p .41) \text {, } \\
\text { towards the north-west of the } \\
\text { fluorspar body }\end{array}$ & $\mathrm{L}$ \\
\hline
\end{tabular}


Table G1-1. Selected fluorspar districts, deposits, and prospects of the world.-Continued

[*Deposit is included in the Orris (1992) grade and tonnage modeling of fluorite veins. **Grade and tonnage data are from Kamitani and others (2007); for these entries, it is not clear whether these are the total resources of each deposit or just a resource currently available to the mine that may be subject to updating with further exploration. ***Location data are from the Mineral Resources Data System (MRDS). The key to the identification numbers in the deposit class column is on page G53. Deposit size: $\mathrm{L}$, identified resources are greater than 1.5 million metric tons of $\mathrm{CaF}_{2} ; \mathrm{S}$, identified resources are less than 1.5 million metric tons of $\mathrm{CaF}_{2}$; n.a., not available. Elements and compounds: $\mathrm{Ag}$, silver; $\mathrm{Au}$, gold; $\mathrm{BeO}$, beryllium oxide; $\mathrm{Bi}$, bismuth; $\mathrm{CaF}_{2}$ calcium fluoride; $\mathrm{Cd}$, cadmium; $\mathrm{Cu}$, copper; Fe, iron; Ge, germanium; In, indium; Mo, molybdenum; Nb, niobium; Pb, lead; REE, rare-earth element; Sn, tin; Sr, strontium; Th, thorium; U, uranium; W, tungsten; Y, yttrium; Zn, zinc. Units of measure: g/t, gram per metric ton; km, kilometer; m, meter; Mt, million metric tons; \%, percent]

\begin{tabular}{|c|c|c|c|c|}
\hline $\begin{array}{c}\text { Published resource } \\
\text { (tonnage and grade, in weight } \\
\text { percent } \mathrm{CaF}_{2} \text { ) }\end{array}$ & $\begin{array}{l}\text { Source of } \\
\text { resource data }\end{array}$ & $\begin{array}{l}\text { Predominant geometry } \\
\text { of orebody(ies) }\end{array}$ & $\begin{array}{l}\text { Source of geo- } \\
\text { logic description }\end{array}$ & $\begin{array}{l}\text { Deposit } \\
\text { name }\end{array}$ \\
\hline \multicolumn{5}{|c|}{ Asia-Continued } \\
\hline $\begin{array}{l}52.5 \mathrm{Mt} \text { at } 8.0 \% \text { (plus } \\
\text { recoverable } \mathrm{W}, \mathrm{Cu}, \mathrm{Au}, \text { and } \\
\mathrm{Bi} \text { (proven and probable) }\end{array}$ & Masan Group (2012) & Skarn and greisen veinlet stockwork & $\begin{array}{l}\text { Richards and } \\
\text { others (2003) }\end{array}$ & Nui Phao \\
\hline
\end{tabular}

\begin{tabular}{|c|c|c|c|c|}
\hline \multicolumn{5}{|c|}{ Australia-Continued } \\
\hline $\begin{array}{l}24.6 \mathrm{Mt} \text { at } 15.7 \% \\
\text { (plus } \mathrm{Sn}, \mathrm{W}, \mathrm{Fe} \text { ) }\end{array}$ & Bucci and others (2012) & Skarn & $\begin{array}{l}\text { Kwak and Askins } \\
\text { (1981) }\end{array}$ & Moina \\
\hline $6.7 \mathrm{Mt}$ at $24.6 \%$ & $\begin{array}{l}\text { Gwalani and others } \\
\text { (2010) }\end{array}$ & $\begin{array}{l}\text { Vein/dike of "replacement fluorite rock" } \\
\text { and carbonatite cutting dolerite }\end{array}$ & $\begin{array}{l}\text { Alvin and others } \\
\quad(2004)\end{array}$ & Speewah \\
\hline \multicolumn{5}{|c|}{ Europe-Continued } \\
\hline $0.313 \mathrm{Mt}$ at $48 \%$ & Bouladon (1989) & $\begin{array}{l}\text { Vein cutting Mississippian volcanics and } \\
\text { fine-grained granite basement rocks }\end{array}$ & $\begin{array}{l}\text { Marchand and } \\
\text { others (1976) }\end{array}$ & *Argentolle \\
\hline
\end{tabular}

\begin{tabular}{|c|c|c|c|c|}
\hline $1.5 \mathrm{Mt}$ at $50 \%$ & Clarke (1980) & $\begin{array}{l}\text { Peneconcordant strata-bound replacement } \\
\text { body in carbonates }\end{array}$ & Bouladon (1989) & *Escaro \\
\hline $1.3 \mathrm{Mt}$ at $50 \%$ & Deloule (1982) & Vein & Deloule (1982) & Montroc \\
\hline $1.2 \mathrm{Mt}$ at $45 \%$ & Bouladon (1989) & Vein & Bouladon (989) & *Le Barlet \\
\hline $0.48 \mathrm{Mt}$ at $75 \%$ & Bouladon (1989) & Vein & Bouladon (989) & Le Burc \\
\hline $0.8 \mathrm{Mt}$ at about $55 \%$ & Sizaret and others (2004) & $\begin{array}{l}\text { Vein "venting to distal" stratiform barite } \\
\text { body with minor amounts of fluorite }\end{array}$ & $\begin{array}{l}\text { Sizaret and others } \\
\text { (2004) }\end{array}$ & Rossignol \\
\hline $0.0187 \mathrm{Mt}$ at $46 \%$ & Morvai (1982) & $\begin{array}{l}\text { Veins in schist near contact with } \\
\text { peraluminous granite }\end{array}$ & Morvai (1982) & *Pakozd \\
\hline n.a. & n.a. & Vein & $\begin{array}{l}\text { Cortecci and } \\
\text { others (1987) }\end{array}$ & $\begin{array}{l}\text { Bruncu } \\
\text { Molentinu }\end{array}$ \\
\hline $8.0 \mathrm{Mt}$ at $\sim 42.5 \%$ & $\begin{array}{l}\text { Fulton and Montgomery } \\
\text { (1994) }\end{array}$ & Veins & $\begin{array}{l}\text { Boni and others } \\
\text { (2009) }\end{array}$ & $\begin{array}{l}\text { *Muscadroxiu- } \\
\text { GennaTres } \\
\text { Montis- } \\
\text { S'Acqua Frida } \\
\text { (Silius Mine) }\end{array}$ \\
\hline $\begin{array}{l}10 \text { to } 15 \mathrm{Mt} \text { at } 33 \% \text { to } 50 \% \\
\text { (plus barite) }\end{array}$ & Matteucci (1976) & $\begin{array}{l}\text { Stratiform body in tuffaceous lacustrine } \\
\text { silt/mudstone/marl within peralkaline } \\
\text { volcanic pile }\end{array}$ & $\begin{array}{l}\text { Mastrangelo } \\
\quad(1976)\end{array}$ & $\begin{array}{l}\text { Castel Giuliano- } \\
\text { Pianciano }\end{array}$ \\
\hline $\begin{array}{l}40 \text { to } 50 \mathrm{Mt} \text { at about } 12 \% \\
\text { (plus barite) }\end{array}$ & Matteucci (1976) & $\begin{array}{l}\text { Stratiform body in tuffaceous lacustrine } \\
\text { silt/mudstone/marl within peralkaline }\end{array}$ & $\begin{array}{l}\text { Mastrangelo } \\
\text { (1976) }\end{array}$ & $\begin{array}{l}\text { Santo Maria } \\
\text { di Sala }\end{array}$ \\
\hline
\end{tabular}


Table G1-1. Selected fluorspar districts, deposits, and prospects of the world.-Continued

[*Deposit is included in the Orris (1992) grade and tonnage modeling of fluorite veins. **Grade and tonnage data are from Kamitani and others (2007); for these entries, it is not clear whether these are the total resources of each deposit or just a resource currently available to the mine that may be subject to updating with further exploration. ***Location data are from the Mineral Resources Data System (MRDS). The key to the identification numbers in the deposit class column is on page G53. Deposit size: $\mathrm{L}$, identified resources are greater than 1.5 million metric tons of $\mathrm{CaF}_{2} ; \mathrm{S}$, identified resources are less than 1.5 million metric tons of $\mathrm{CaF}_{2}$; n.a., not available. Elements and compounds: $\mathrm{Ag}$, silver; $\mathrm{Au}$, gold; $\mathrm{BeO}$, beryllium oxide; $\mathrm{Bi}$, bismuth; $\mathrm{CaF}_{2}$ calcium fluoride; $\mathrm{Cd}$, cadmium; $\mathrm{Cu}$, copper; Fe, iron; Ge, germanium; In, indium; Mo, molybdenum; Nb, niobium; Pb, lead; REE, rare-earth element; Sn, tin; Sr, strontium; Th, thorium; U, uranium; $\mathrm{W}$, tungsten; Y, yttrium; Zn, zinc. Units of measure: g/t, gram per metric ton; km, kilometer; m, meter; Mt, million metric tons; \%, percent]

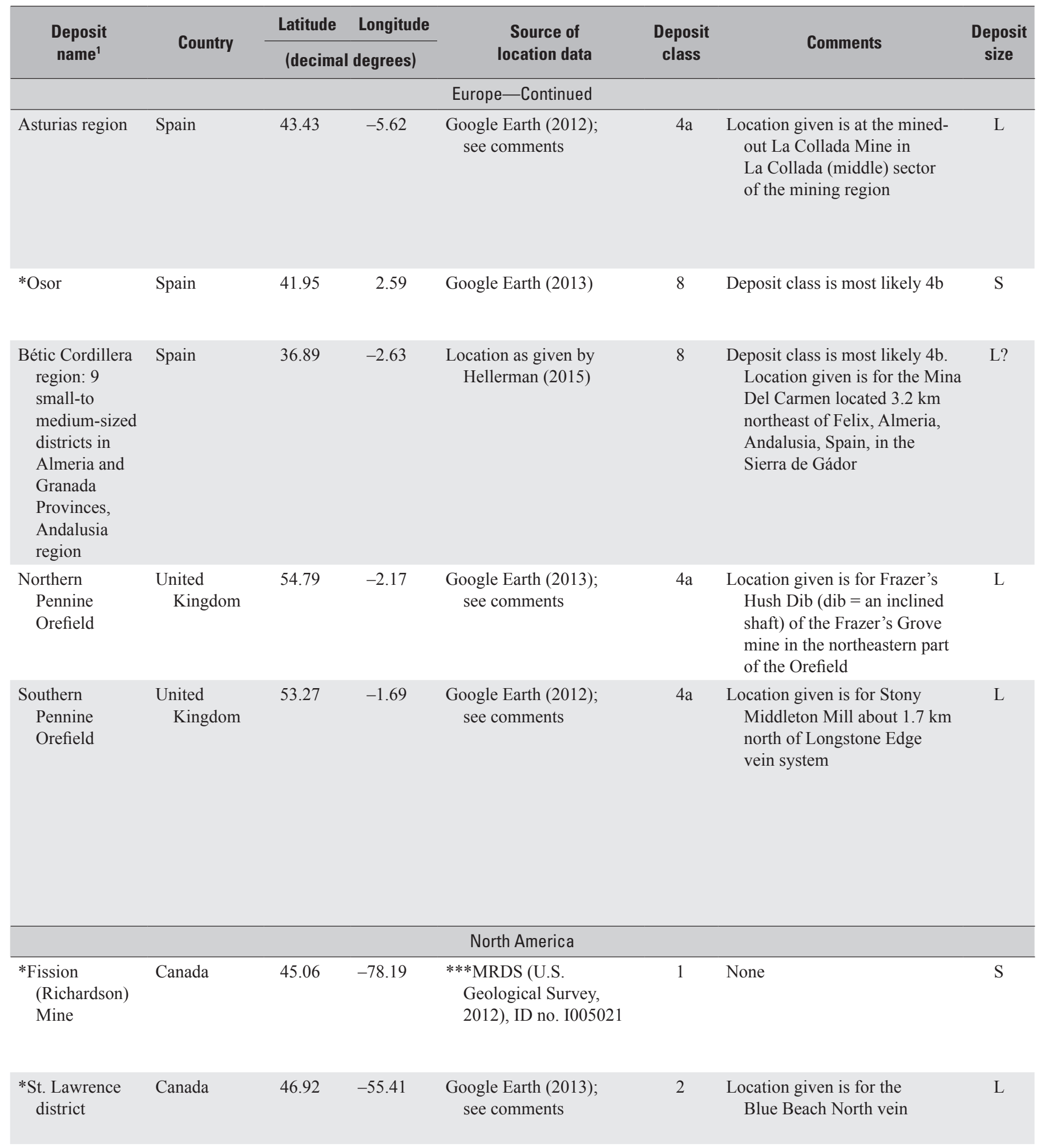


Table G1-1. Selected fluorspar districts, deposits, and prospects of the world.-Continued

[*Deposit is included in the Orris (1992) grade and tonnage modeling of fluorite veins. **Grade and tonnage data are from Kamitani and others (2007); for these entries, it is not clear whether these are the total resources of each deposit or just a resource currently available to the mine that may be subject to updating with further exploration. ***Location data are from the Mineral Resources Data System (MRDS). The key to the identification numbers in the deposit class column is on page G53. Deposit size: $\mathrm{L}$, identified resources are greater than 1.5 million metric tons of $\mathrm{CaF}_{2} ; \mathrm{S}$, identified resources are less than 1.5 million metric tons of $\mathrm{CaF}_{2}$; n.a., not available. Elements and compounds: $\mathrm{Ag}$, silver; $\mathrm{Au}$, gold; $\mathrm{BeO}$, beryllium oxide; $\mathrm{Bi}$, bismuth; $\mathrm{CaF}_{2}$, calcium fluoride; $\mathrm{Cd}$, cadmium; $\mathrm{Cu}$, copper; $\mathrm{Fe}$, iron; Ge, germanium; In, indium; Mo, molybdenum; Nb, niobium; Pb, lead; REE, rare-earth element; Sn, tin; Sr, strontium; Th, thorium; U, uranium; W, tungsten; Y, yttrium; Zn, zinc. Units of measure: $\mathrm{g} / \mathrm{t}$, gram per metric ton; km, kilometer; $\mathrm{m}$, meter; $\mathrm{Mt}$, million metric tons; \%, percent]

\begin{tabular}{|c|c|c|c|c|}
\hline $\begin{array}{c}\text { Published resource } \\
\text { (tonnage and grade, in weight } \\
\text { percent } \mathrm{CaF}_{2} \text { ) }\end{array}$ & $\begin{array}{l}\text { Source of } \\
\text { resource data }\end{array}$ & $\begin{array}{l}\text { Predominant geometry } \\
\text { of orebody(ies) }\end{array}$ & $\begin{array}{l}\text { Source of geo- } \\
\text { logic description }\end{array}$ & $\begin{array}{l}\text { Deposit } \\
\text { name }\end{array}$ \\
\hline \multicolumn{5}{|c|}{ Europe-Continued } \\
\hline $15 \mathrm{Mt}$ at about $38.5 \%$ & $\begin{array}{l}\text { Sánchez and others } \\
\text { (2009) and Garcia } \\
\text { Iglesias and Loredo } \\
\text { (1994) }\end{array}$ & $\begin{array}{l}\text { (1) Veins; (2) Peneconcordant strata-bound } \\
\text { replacement bodies in calcite-cemented } \\
\text { sandstone capped by marl-clay; and } \\
\text { (3) Peneconcordant strata-bound bodies } \\
\text { in "red breccia/conglomerate" imme- } \\
\text { diately overlying basement of limestone } \\
\text { and slate, also capped by marl-clay }\end{array}$ & $\begin{array}{l}\text { Garcia Iglesias } \\
\text { and Loredo } \\
\text { (1994) }\end{array}$ & Asturias region \\
\hline $2 \mathrm{Mt}$ at $45 \%$ & $\begin{array}{l}\text { Lipperheide Wicke and } \\
\text { Barrenechea Guimon } \\
\text { (1983) }\end{array}$ & Vein & $\begin{array}{l}\text { Piqué and others } \\
\text { (2008) }\end{array}$ & *Osor \\
\hline $\begin{array}{l}\text { Single deposit; for example, } \\
\text { Mina Lújar, Granada, as of } \\
\text { 1987: } 2.275 \mathrm{Mt} \text { proven and } \\
\text { probable at } 34 \% \text { (plus } \\
1.85 \% \mathrm{~Pb} \text { ) }\end{array}$ & $\begin{array}{l}\text { Marina and Vazquez } \\
\text { Guzmán (1987) }\end{array}$ & $\begin{array}{l}\text { Veins and peneconcordant strata-bound } \\
\text { replacement bodies in carbonates }\end{array}$ & $\begin{array}{l}\text { Martin and others } \\
\text { (1987) }\end{array}$ & $\begin{array}{l}\text { Bétic Cordillera } \\
\text { region: } 9 \\
\text { small-to } \\
\text { medium-sized } \\
\text { districts in } \\
\text { Almeria and } \\
\text { Granada } \\
\text { Provinces, } \\
\text { Andalusia } \\
\text { region }\end{array}$ \\
\hline n.a. & n.a. & $\begin{array}{l}\text { Veins and lesser peneconcordant } \\
\text { strata-bound replacement bodies } \\
\text { in carbonates }\end{array}$ & Dunham (1983) & $\begin{array}{l}\text { Northern Pennine } \\
\text { Orefield }\end{array}$ \\
\hline $\begin{array}{l}\text { Estimated, for example, } \\
\text { * Sallet Hole No. } 1 \text { Adit } \\
\text { deposit on Longstone Edge: } \\
2.5 \text { Mt at } 40 \% \text { to } 50 \% \text {; This } \\
\text { grade and tonnage have not } \\
\text { been used in figure G6 }\end{array}$ & $\begin{array}{l}\text { Calculated tonnage } \\
\text { estimate uses the } \\
\text { predicted rate of } \\
\text { production for } 1990 \\
\text { from Bramley (1990) } \\
\text { projected for the full } \\
\text { mine life-1965 to } \\
\text { 1999. This method } \\
\text { of estimation was } \\
\text { suggested by } \\
\text { Dr. Brian Hodge }\end{array}$ & $\begin{array}{l}\text { Veins and lesser peneconcordant } \\
\text { strata-bound replacement bodies } \\
\text { in carbonates }\end{array}$ & $\begin{array}{l}\text { Dunham (1983); } \\
\text { Mason (1974) }\end{array}$ & $\begin{array}{l}\text { Southern Pennine } \\
\text { Orefield }\end{array}$ \\
\hline \multicolumn{5}{|c|}{ North America-Continued } \\
\hline $0.27 \mathrm{Mt}$ at $26.7 \%$ (plus U) & $\begin{array}{l}\text { Canada Department of } \\
\text { Energy, Mines, and } \\
\text { Resources (1984) }\end{array}$ & $\begin{array}{l}\text { Calcite-fluorite-apatite vein/dikes in the } \\
\text { Bancroft carbonatite province }\end{array}$ & $\begin{array}{l}\text { ***MRDS } \\
\text { (U.S. Geological } \\
\text { Survey, 2012), } \\
\text { record no. } \\
\text { I005021 }\end{array}$ & $\begin{array}{l}\text { *Fission } \\
\text { (Richardson) } \\
\text { Mine }\end{array}$ \\
\hline $10.04 \mathrm{Mt}$ at $41 . \% *$ & $\begin{array}{l}\text { Agnerian and others } \\
\text { (2011) }\end{array}$ & Large veins cutting aegerine granite & $\begin{array}{l}\text { Van Alstine (1944) } \\
\text { and Strong and } \\
\text { others (1984) }\end{array}$ & $\begin{array}{l}\text { *St. Lawrence } \\
\text { district }\end{array}$ \\
\hline
\end{tabular}


Table G1-1. Selected fluorspar districts, deposits, and prospects of the world.—Continued

[*Deposit is included in the Orris (1992) grade and tonnage modeling of fluorite veins. **Grade and tonnage data are from Kamitani and others (2007); for these entries, it is not clear whether these are the total resources of each deposit or just a resource currently available to the mine that may be subject to updating with further exploration. ***Location data are from the Mineral Resources Data System (MRDS). The key to the identification numbers in the deposit class column is on page G53. Deposit size: $\mathrm{L}$, identified resources are greater than 1.5 million metric tons of $\mathrm{CaF}_{2} ; \mathrm{S}$, identified resources are less than 1.5 million metric tons of $\mathrm{CaF}_{2}$; n.a., not available. Elements and compounds: $\mathrm{Ag}$, silver; $\mathrm{Au}$, gold; $\mathrm{BeO}$, beryllium oxide; $\mathrm{Bi}$, bismuth; $\mathrm{CaF}_{2}$ calcium fluoride; $\mathrm{Cd}$, cadmium; $\mathrm{Cu}$, copper; Fe, iron; Ge, germanium; In, indium; Mo, molybdenum; Nb, niobium; Pb, lead; REE, rare-earth element; Sn, tin; Sr, strontium; Th, thorium; U, uranium; $\mathrm{W}$, tungsten; Y, yttrium; Zn, zinc. Units of measure: g/t, gram per metric ton; km, kilometer; m, meter; Mt, million metric tons; \%, percent]

\begin{tabular}{|c|c|c|c|c|c|c|c|}
\hline $\begin{array}{l}\text { Deposit } \\
\text { name }^{1}\end{array}$ & Country & $\begin{array}{r}\text { Latitude } \\
\text { (decima }\end{array}$ & $\begin{array}{l}\text { Longitude } \\
\text { I degrees) }\end{array}$ & $\begin{array}{c}\text { Source of } \\
\text { Iocation data }\end{array}$ & $\begin{array}{l}\text { Deposit } \\
\text { class }\end{array}$ & Comments & $\begin{array}{l}\text { Deposit } \\
\text { size }\end{array}$ \\
\hline \multicolumn{8}{|c|}{ North America-Continued } \\
\hline Aguachile & Mexico & 29.26 & -102.54 & $\begin{array}{l}\text { Google Earth (2013) and } \\
\text { McAnulty and others } \\
(1963)\end{array}$ & 3 & None & $\mathrm{L}$ \\
\hline $\begin{array}{l}\text { Encantada- } \\
\text { Buenavista }\end{array}$ & Mexico & 28.54 & -102.50 & $\begin{array}{l}\text { Google Earth (2012); } \\
\text { see comments }\end{array}$ & $4 a(?)$ & $\begin{array}{l}\text { Location given is for Las Sabinas } \\
\text { Mine near southeastern } \\
\text { extreme of district, which } \\
\text { stretches more than } 30 \mathrm{~km} \\
\text { northwestward from there }\end{array}$ & $\mathrm{L}$ \\
\hline Parral district & Mexico & 26.85 & -105.86 & $\begin{array}{l}\text { Google Earth (2014); } \\
\text { see comments }\end{array}$ & 8 & $\begin{array}{l}\text { Location given is for the } \\
\text { Frisco Mine }\end{array}$ & $\mathrm{L}$ \\
\hline
\end{tabular}

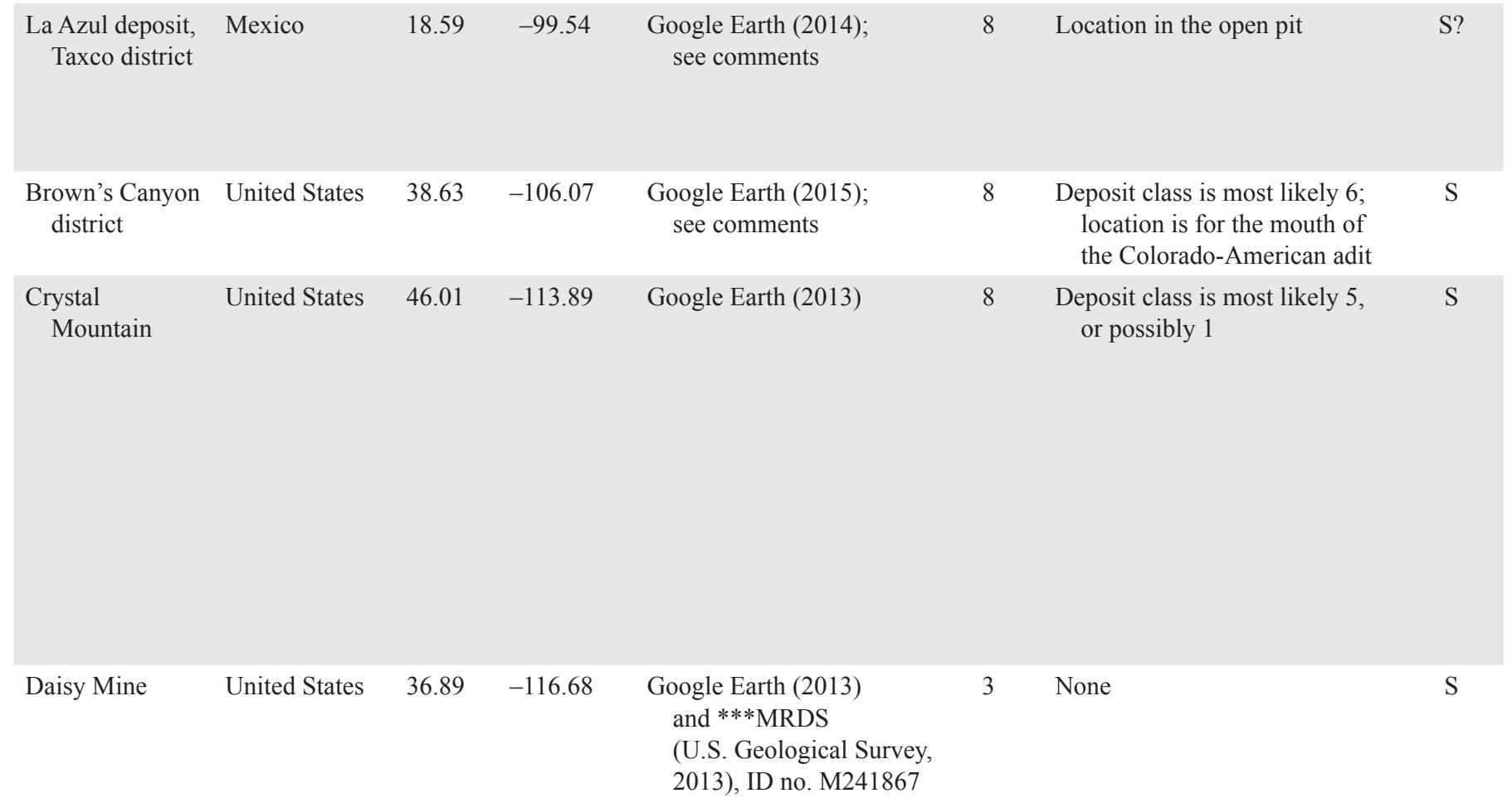


Table G1-1. Selected fluorspar districts, deposits, and prospects of the world.-Continued

[*Deposit is included in the Orris (1992) grade and tonnage modeling of fluorite veins. **Grade and tonnage data are from Kamitani and others (2007); for these entries, it is not clear whether these are the total resources of each deposit or just a resource currently available to the mine that may be subject to updating with further exploration. ***Location data are from the Mineral Resources Data System (MRDS). The key to the identification numbers in the deposit class column is on page G53. Deposit size: $\mathrm{L}$, identified resources are greater than 1.5 million metric tons of $\mathrm{CaF}_{2} ; \mathrm{S}$, identified resources are less than 1.5 million metric tons of $\mathrm{CaF}_{2}$; n.a., not available. Elements and compounds: $\mathrm{Ag}$, silver; $\mathrm{Au}$, gold; $\mathrm{BeO}$, beryllium oxide; $\mathrm{Bi}$, bismuth; $\mathrm{CaF}_{2}$ calcium fluoride; $\mathrm{Cd}$, cadmium; $\mathrm{Cu}$, copper; Fe, iron; Ge, germanium; In, indium; Mo, molybdenum; Nb, niobium; Pb, lead; REE, rare-earth element; Sn, tin; Sr, strontium; Th, thorium; U, uranium; W, tungsten; Y, yttrium; Zn, zinc. Units of measure: $\mathrm{g} / \mathrm{t}$, gram per metric ton; km, kilometer; m, meter; Mt, million metric tons; \%, percent]

\begin{tabular}{|c|c|c|c|c|}
\hline $\begin{array}{c}\text { Published resource } \\
\text { (tonnage and grade, in weight } \\
\text { percent } \mathrm{CaF}_{2} \text { ) }\end{array}$ & $\begin{array}{l}\text { Source of } \\
\text { resource data }\end{array}$ & $\begin{array}{l}\text { Predominant geometry } \\
\text { of orebody(ies) }\end{array}$ & $\begin{array}{l}\text { Source of geo- } \\
\text { logic description }\end{array}$ & $\begin{array}{l}\text { Deposit } \\
\text { name }\end{array}$ \\
\hline \multicolumn{5}{|c|}{ North America-Continued } \\
\hline $\begin{array}{l}\text { For example, }>0.6 \mathrm{Mt} \text { at about } \\
70 \% \text { (produced from } 1966 \\
\text { to } 1972 \text { ) (plus Be, } 0.3 \% \text { ) }\end{array}$ & Pickard (1974) & $\begin{array}{l}250 \mathrm{~m} \text {-high, } 50 \mathrm{~m} \text {-wide replacement bodies } \\
\text { in carbonates along their contact with } \\
\text { peralkaline rhyolite-porphyry ring dike }\end{array}$ & $\begin{array}{l}\text { McAnulty and } \\
\text { others (1963) }\end{array}$ & Aguachile \\
\hline $\begin{array}{l}\text { For example, Las Sabinas } \\
\text { concession: } 13 \mathrm{Mt} \text { at } 60 \%\end{array}$ & $\begin{array}{l}\text { Mexichem (2012) and } \\
\text { Hodge (2012) }\end{array}$ & $\begin{array}{l}\text { Peneconcordant strata-bound replacement } \\
\text { bodies (mantos) in carbonates }\end{array}$ & $\begin{array}{l}\text { Gonzalez-Partida } \\
\text { and others } \\
(2003)\end{array}$ & $\begin{array}{l}\text { Encantada- } \\
\text { Buenavista }\end{array}$ \\
\hline
\end{tabular}

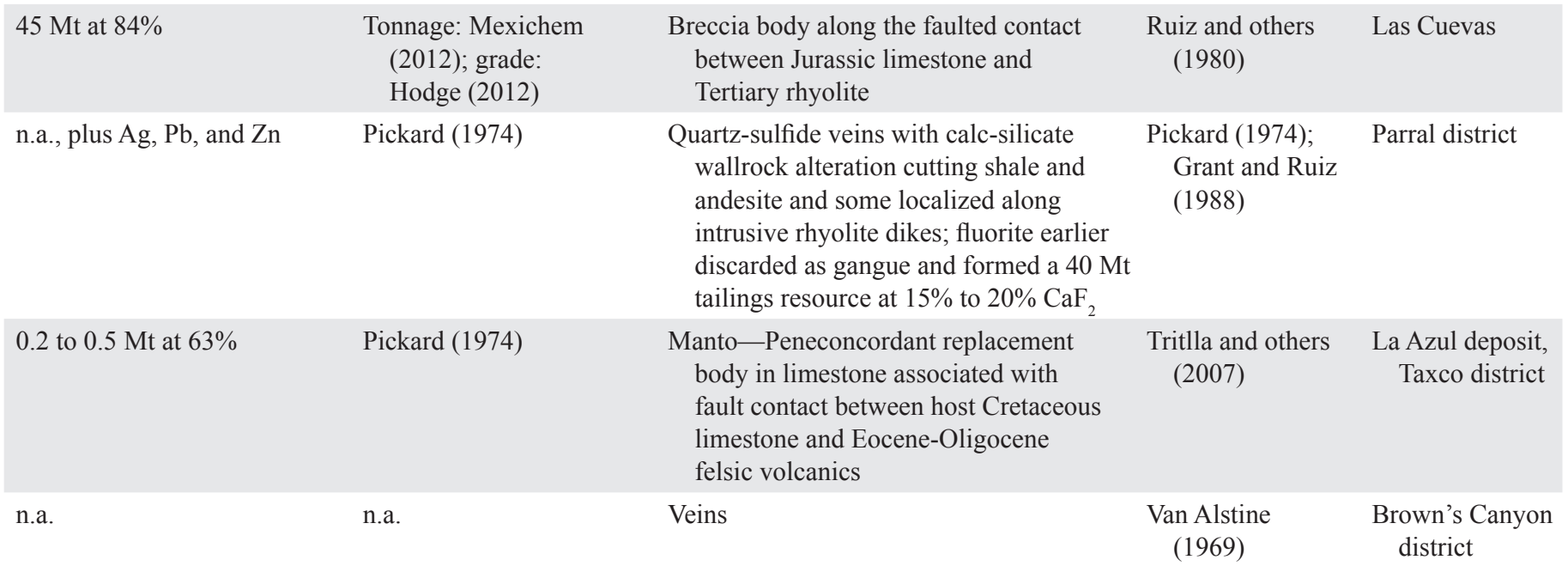

\begin{tabular}{|c|c|c|c|c|}
\hline $\begin{array}{l}\text { Unknown tonnage at } 97.2 \% \\
\text { (plus trace } \mathrm{U}, \mathrm{Th}, \mathrm{Nb}, \\
\text { and REE) }\end{array}$ & Sahinen (1962) & $\begin{array}{l}\text { Massive, sill-like erosional remnants lying } \\
\text { relatively flat atop (Idaho batholith) } \\
\text { biotite granite; one body enveloped } \\
\text { in coarse quartz; contains thortveitite } \\
\text { (monoclinic [ } \mathrm{Sc}, \mathrm{Y}] \mathrm{Si}_{2} \mathrm{O}_{7} \text { ), a mineral } \\
\text { elsewhere found in pegmatites, in one } \\
\text { tin skarn, in a U-Be- } \mathrm{Zr} \text {-mineralized } \\
\text { breccia related to granite intrusion, } \\
\text { and at Franklin, New Jersey, as well as } \\
\text { fergusonite (tetragonal [Ce, Nd, La, Y] } \\
{[\mathrm{Nb}, \mathrm{Ti}] \mathrm{O}_{4} \text { ), a mineral elsewhere found }} \\
\text { with carbonatites or pegmatites }\end{array}$ & $\begin{array}{l}\text { Sahinen (1962) } \\
\text { and Parker and } \\
\text { Havens (1963) }\end{array}$ & $\begin{array}{l}\text { Crystal } \\
\text { Mountain }\end{array}$ \\
\hline n.a. & n.a. & $\begin{array}{l}\text { Fault-controlled replacement body in } \\
\text { limestone }\end{array}$ & $\begin{array}{l}\text { Cornwall and } \\
\text { Kleinhampl } \\
(1961)\end{array}$ & Daisy Mine \\
\hline
\end{tabular}


Table G1-1. Selected fluorspar districts, deposits, and prospects of the world.-Continued

[*Deposit is included in the Orris (1992) grade and tonnage modeling of fluorite veins. **Grade and tonnage data are from Kamitani and others (2007); for these entries, it is not clear whether these are the total resources of each deposit or just a resource currently available to the mine that may be subject to updating with further exploration. ***Location data are from the Mineral Resources Data System (MRDS). The key to the identification numbers in the deposit class column is on page G53. Deposit size: $\mathrm{L}$, identified resources are greater than 1.5 million metric tons of $\mathrm{CaF}_{2} ; \mathrm{S}$, identified resources are less than 1.5 million metric tons of $\mathrm{CaF}_{2}$; n.a., not available. Elements and compounds: $\mathrm{Ag}$, silver; $\mathrm{Au}$, gold; $\mathrm{BeO}$, beryllium oxide; $\mathrm{Bi}$, bismuth; $\mathrm{CaF}_{2}$ calcium fluoride; $\mathrm{Cd}$, cadmium; $\mathrm{Cu}$, copper; Fe, iron; Ge, germanium; In, indium; Mo, molybdenum; Nb, niobium; Pb, lead; REE, rare-earth element; Sn, tin; Sr, strontium; Th, thorium; U, uranium; $\mathrm{W}$, tungsten; Y, yttrium; Zn, zinc. Units of measure: g/t, gram per metric ton; km, kilometer; m, meter; Mt, million metric tons; \%, percent]

\begin{tabular}{|c|c|c|c|c|c|c|c|}
\hline $\begin{array}{l}\text { Deposit } \\
\text { name }^{1}\end{array}$ & Country & $\begin{array}{c}\text { Latitude } \\
\text { (decima }\end{array}$ & $\begin{array}{l}\text { Longitude } \\
\text { ( degrees) }\end{array}$ & $\begin{array}{c}\text { Source of } \\
\text { location data }\end{array}$ & $\begin{array}{l}\text { Deposit } \\
\text { class }\end{array}$ & Comments & $\begin{array}{l}\text { Deposit } \\
\text { size }\end{array}$ \\
\hline \multicolumn{8}{|c|}{ North America-Continued } \\
\hline *Great Eagle & United States & 32.73 & -108.68 & $\begin{array}{l}\text { Google Earth (2013) } \\
\text { and ***MRDS } \\
\text { (U.S. Geological Survey, } \\
\text { 2013), ID no. D009524 }\end{array}$ & 3 & None & $\mathrm{S}$ \\
\hline $\begin{array}{l}\text { *Huckleberry } \\
\text { Mine }\end{array}$ & United States & 33.32 & -108.82 & $\begin{array}{l}\text { Google Earth (2013) } \\
\text { and ***MRDS } \\
\text { (U.S. Geological Survey, } \\
\text { 2013), ID no. US35038 }\end{array}$ & 3 & None & $\mathrm{S}$ \\
\hline
\end{tabular}

\begin{tabular}{|c|c|c|c|c|c|c|c|}
\hline $\begin{array}{l}\text { Indian Peak } \\
\text { district }\end{array}$ & United States & 38.22 & -113.83 & $\begin{array}{l}\text { Google Earth (2013), } \\
\text { and } * * * \text { MRDS } \\
\text { (U.S. Geological Survey, } \\
\text { 2013), ID no. W006953 }\end{array}$ & 3 & $\begin{array}{l}\text { Location point is at the } \\
\text { Cougar Spar Mine }\end{array}$ & $\mathrm{S}$ \\
\hline Lost River & United States & 65.48 & -167.16 & $\begin{array}{l}\text { MRDS (U.S. Geological } \\
\text { Survey, 2013), ID } \\
\text { no. A016009 }\end{array}$ & 5 & $\begin{array}{l}\text { Location point is at the } \\
\text { "New No. } 3 \text { Adit" of Plate } 2 \\
\text { of Sainsbury (1964) }\end{array}$ & $\mathrm{L}$ \\
\hline Meyers Cove & United States & 44.85 & -114.50 & $\begin{array}{l}\text { Google Earth (2013) and } \\
\quad \text { Cox (1954) }\end{array}$ & 8 & $\begin{array}{l}\text { Location point is at Big Lead } \\
\text { Mine. Deposit class is most } \\
\text { likely } 6\end{array}$ & $\mathrm{~S}$ \\
\hline $\begin{array}{l}\text { Northgate } \\
\text { district }\end{array}$ & United States & 40.92 & -106.27 & $\begin{array}{l}\text { Google Earth (2013) and } \\
\text { Steven (1960) }\end{array}$ & 8 & $\begin{array}{l}\text { Location point is at Pender } \\
\text { Mine. Deposit class is most } \\
\text { likely } 3\end{array}$ & $\mathrm{~L}$ \\
\hline $\begin{array}{l}\text { Spor Mountain } \\
\text { district (Thom- } \\
\text { as Range) }\end{array}$ & United States & 39.70 & -113.17 & $\begin{array}{l}\text { Google Earth (2013) and } \\
\text { Staatz and Osterwald } \\
(1959)\end{array}$ & 3 & $\begin{array}{l}\text { Location point is at the } \\
\text { Ben Hill Mine, pit } 1\end{array}$ & $\mathrm{~S}$ \\
\hline $\begin{array}{l}\text { Sweetwater } \\
\text { district }\end{array}$ & United States & 35.60 & -84.46 & $\begin{array}{l}\text { Google Earth (2013); } \\
\text { see comments }\end{array}$ & $4 a$ & $\begin{array}{l}\text { No actual mine or exploration } \\
\text { workings. Location given is for } \\
\text { the center of the town square } \\
\text { of Sweetwater, Tennessee }\end{array}$ & $\mathrm{L}$ \\
\hline
\end{tabular}


Table G1-1. Selected fluorspar districts, deposits, and prospects of the world.-Continued

[*Deposit is included in the Orris (1992) grade and tonnage modeling of fluorite veins. **Grade and tonnage data are from Kamitani and others (2007); for these entries, it is not clear whether these are the total resources of each deposit or just a resource currently available to the mine that may be subject to updating with further exploration. ***Location data are from the Mineral Resources Data System (MRDS). The key to the identification numbers in the deposit class column is on page G53. Deposit size: $\mathrm{L}$, identified resources are greater than 1.5 million metric tons of $\mathrm{CaF}_{2} ; \mathrm{S}$, identified resources are less than 1.5 million metric tons of $\mathrm{CaF}_{2}$; n.a., not available. Elements and compounds: $\mathrm{Ag}$, silver; $\mathrm{Au}$, gold; $\mathrm{BeO}$, beryllium oxide; $\mathrm{Bi}$, bismuth; $\mathrm{CaF}_{2}$ calcium fluoride; $\mathrm{Cd}$, cadmium; $\mathrm{Cu}$, copper; Fe, iron; Ge, germanium; In, indium; Mo, molybdenum; Nb, niobium; Pb, lead; REE, rare-earth element; Sn, tin; Sr, strontium; Th, thorium; U, uranium; W, tungsten; Y, yttrium; Zn, zinc. Units of measure: $\mathrm{g} / \mathrm{t}$, gram per metric ton; km, kilometer; m, meter; Mt, million metric tons; \%, percent]

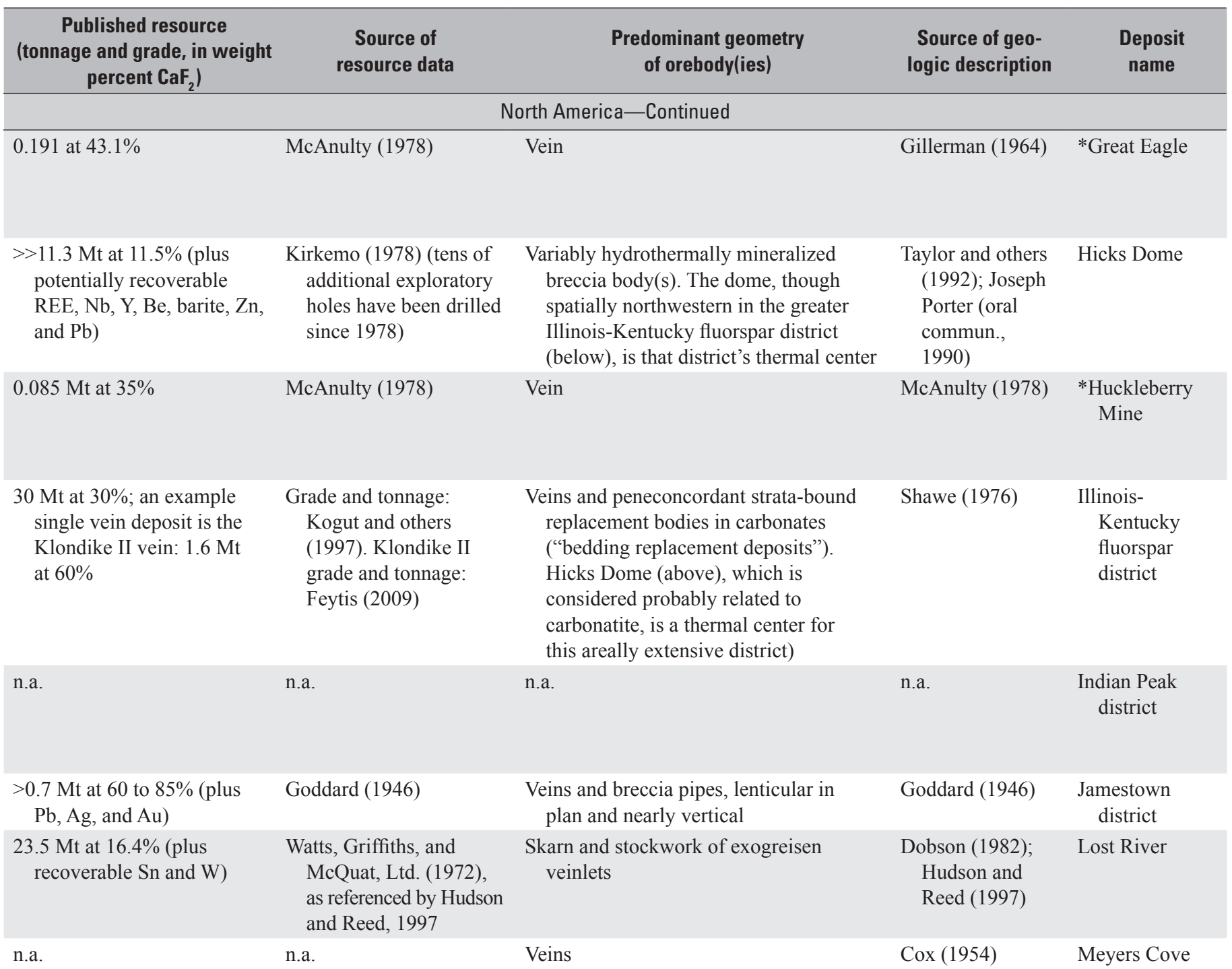

\begin{tabular}{|c|c|c|c|c|}
\hline n.a. & n.a. & Veins & Steven (1960) & $\begin{array}{c}\text { Northgate } \\
\text { district }\end{array}$ \\
\hline $\begin{array}{l}\text { Typically } 0.84 \mathrm{~m} \text { thickness at } \\
3.98 \%\end{array}$ & $\begin{array}{l}\text { Sheppard and Gude } \\
\text { (1969) }\end{array}$ & $\begin{array}{l}\text { Conformable layer in tuffaceous lacustrine } \\
\text { silt/mudstone within basalts }\end{array}$ & $\begin{array}{l}\text { Sheppard and } \\
\text { Gude (1969) }\end{array}$ & $\begin{array}{l}\text { Rome } \\
\text { occurrence }\end{array}$ \\
\hline 0.033 at $45 \%$ (plus Be, $\mathrm{U})$ & Bullock (1976) & Breccia pipes & $\begin{array}{l}\text { Staatz and } \\
\text { Osterwald } \\
(1959)\end{array}$ & $\begin{array}{l}\text { Spor Mountain } \\
\text { district }\end{array}$ \\
\hline
\end{tabular}
peneconcordant replacement bodies in carbonates 
Table G1-1. Selected fluorspar districts, deposits, and prospects of the world.-Continued

[*Deposit is included in the Orris (1992) grade and tonnage modeling of fluorite veins. **Grade and tonnage data are from Kamitani and others (2007); for these entries, it is not clear whether these are the total resources of each deposit or just a resource currently available to the mine that may be subject to updating with further exploration. ***Location data are from the Mineral Resources Data System (MRDS). The key to the identification numbers in the deposit class column is on page G53. Deposit size: $\mathrm{L}$, identified resources are greater than 1.5 million metric tons of $\mathrm{CaF}_{2} ; \mathrm{S}$, identified resources are less than 1.5 million metric tons of $\mathrm{CaF}_{2}$; n.a., not available. Elements and compounds: $\mathrm{Ag}$, silver; $\mathrm{Au}$, gold; $\mathrm{BeO}$, beryllium oxide; $\mathrm{Bi}$, bismuth; $\mathrm{CaF}_{2}$ calcium fluoride; $\mathrm{Cd}$, cadmium; $\mathrm{Cu}$, copper; Fe, iron; Ge, germanium; In, indium; Mo, molybdenum; Nb, niobium; Pb, lead; REE, rare-earth element; Sn, tin; Sr, strontium; Th, thorium; U, uranium; $\mathrm{W}$, tungsten; Y, yttrium; Zn, zinc. Units of measure: g/t, gram per metric ton; km, kilometer; m, meter; Mt, million metric tons; \%, percent]

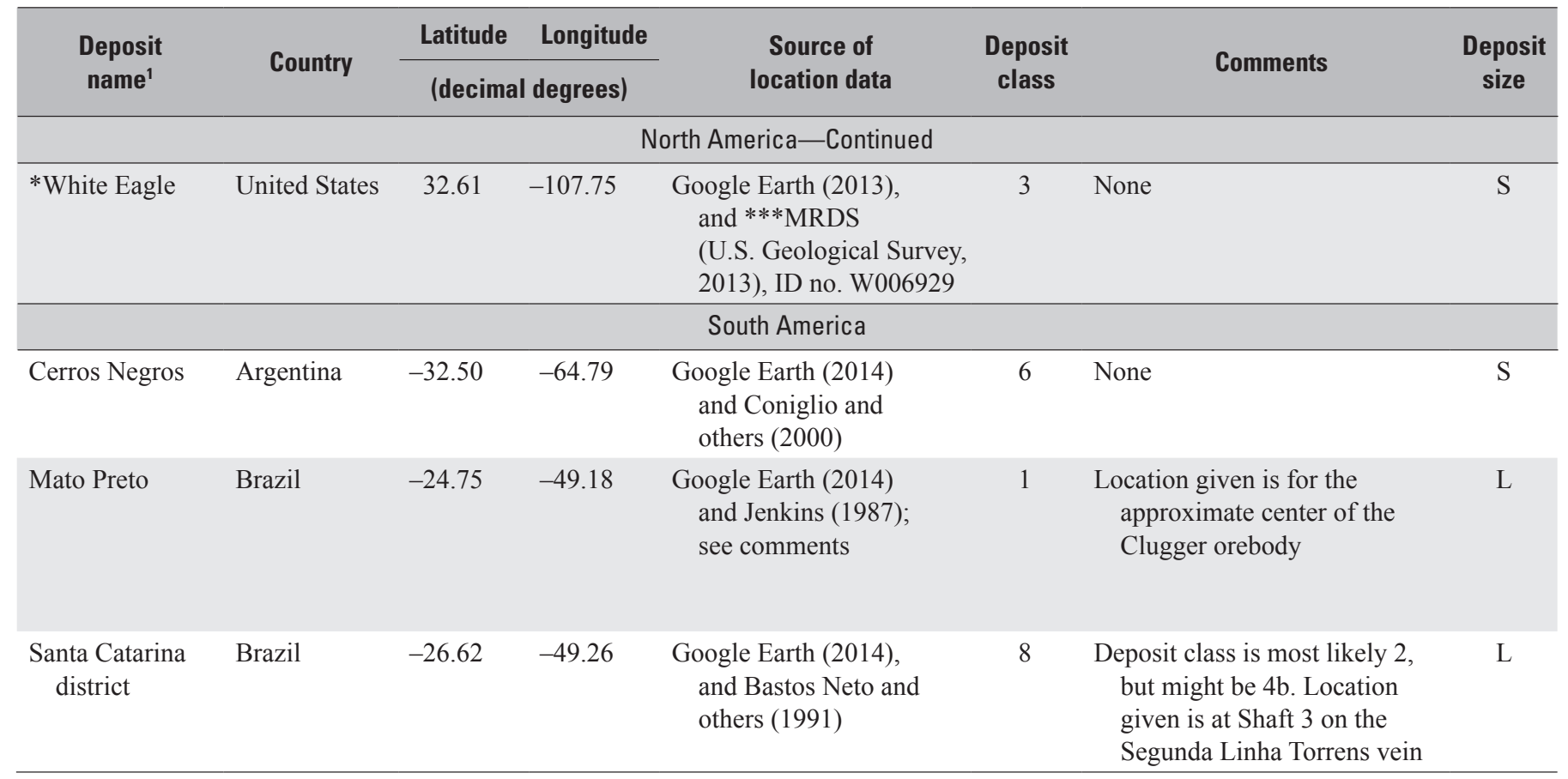

${ }^{1}$ Grade and tonnage information from the following deposits have been plotted in text figure G6.

Fluorspar vein or vein-and-replacement deposits
1. El Hammam, Morocco
2. Canxixe, Mozambique
3. Chioco-Djanguire, Mozambique
4. Macossa, Mozambique
5. Zwartkloof, South Africa
6. Jebel Semeih, Sudan
7. Houshu, China
8. Huahe, China
9. Hushan, China
10. Jianshan, China
11. Yangjia-Wuyi, China
12. Yinzishan, China
13. Adag, Mongolia
14. Berkh, Mongolia
15. Bor Ondor, Mongolia
16. Zuum-Tsagaan-Del, Mongolia
17. Kalangui, Russia
18. Ban Hong, Thailand
19. Suppatash, Uzbekistan
20. Speewah, Australia

Carbonatite-related fluorspar deposits

21. Argentolle, France

22. Montroc, France

23. Le Barlet, France

24. Le Burc, France

25. Rossignol, France

26. Muscadroxiu-Genna Tres MontisS'Acqua Frida, Sardinia, Italy

27. Osor, Spain

28. Fission (Richardson), Canada

29. Blue Beach North vein, St. Lawrence district, Canada

30. El Refugio Mine, Mexico

31. Las Cuevas Mine, Mexico

32. Great Eagle, New Mexico, United States

33. Huckleberry Mine, New Mexico, United States

34. Klondike II deposit, Illinois-Kentucky fluorspar district, United States

35. White Eagle, New Mexico, United States

36. Cerros Negros, Argentina
1. Mount Muambe, Mozambique

2. Okorusu, Namibia

3. Amba Dongar, India

4. Speewah, Australia

5. Mato Preto, Brazil

Skarn, greisens, and replacement fluorspar deposits related to strongly differentiated granites
1. Buffalo, South Africa
2. Vergenoeg, South Africa
3. Mahuaping, China
4. Shizhuyuan, China
5. Taskainar (Taskaynar), Kazakhstan
6. Voznesenka I \& Pogranichny, Russia
7. Nui Phao, Vietnam
8. Moina, Tasmania, Australia
9. Lost River, Alaska, United States 
Table G1-1. Selected fluorspar districts, deposits, and prospects of the world.-Continued

[*Deposit is included in the Orris (1992) grade and tonnage modeling of fluorite veins. **Grade and tonnage data are from Kamitani and others (2007); for these entries, it is not clear whether these are the total resources of each deposit or just a resource currently available to the mine that may be subject to updating with further exploration. ***Location data are from the Mineral Resources Data System (MRDS). The key to the identification numbers in the deposit class column is on page G53. Deposit size: $\mathrm{L}$, identified resources are greater than 1.5 million metric tons of $\mathrm{CaF}_{2} ; \mathrm{S}$, identified resources are less than 1.5 million metric tons of $\mathrm{CaF}_{2}$; n.a., not available. Elements and compounds: $\mathrm{Ag}$, silver; $\mathrm{Au}$, gold; $\mathrm{BeO}$, beryllium oxide; $\mathrm{Bi}$, bismuth; $\mathrm{CaF}_{2}$ calcium fluoride; $\mathrm{Cd}$, cadmium; $\mathrm{Cu}$, copper; Fe, iron; Ge, germanium; In, indium; Mo, molybdenum; Nb, niobium; Pb, lead; REE, rare-earth element; Sn, tin; Sr, strontium; Th, thorium; U, uranium; W, tungsten; Y, yttrium; Zn, zinc. Units of measure: g/t, gram per metric ton; km, kilometer; m, meter; Mt, million metric tons; \%, percent]

\begin{tabular}{|c|c|c|c|c|}
\hline $\begin{array}{c}\text { Published resource } \\
\text { (tonnage and grade, in weight } \\
\text { percent } \mathrm{CaF}_{2} \text { ) }\end{array}$ & $\begin{array}{l}\text { Source of } \\
\text { resource data }\end{array}$ & $\begin{array}{l}\text { Predominant geometry } \\
\text { of orebody(ies) }\end{array}$ & $\begin{array}{l}\text { Source of geo- } \\
\text { logic description }\end{array}$ & $\begin{array}{l}\text { Deposit } \\
\text { name }\end{array}$ \\
\hline \multicolumn{5}{|c|}{ North America-Continued } \\
\hline $0.179 \mathrm{Mt}$ at $54.3 \%$ & McAnulty (1978) & Vein & McAnulty (1978) & *White Eagle \\
\hline \multicolumn{5}{|c|}{ South America-Continued } \\
\hline $0.27 \mathrm{Mt}$ at $56 \%$ & $\begin{array}{l}\text { Coniglio and others } \\
\text { (2000) }\end{array}$ & Vein & $\begin{array}{l}\text { Coniglio and } \\
\text { others (2000) }\end{array}$ & Cerros Negros \\
\hline $2.65 \mathrm{Mt}$ at $60 \%$ & Jenkins (1987) & $\begin{array}{l}\text { Lensatic hydrothermal masses replacing } \\
\text { calcitic carbonatite and lesser syenite, } \\
\text { enveloping phonolite dikes intruded } \\
\text { along the contact between carbonatite } \\
\text { and nepheline syenite }\end{array}$ & $\begin{array}{l}\text { Woolley (1987) } \\
\text { and Jenkins, } \\
(1987)\end{array}$ & Mato Preto \\
\hline n.a. & n.a. & Veins & $\begin{array}{c}\text { Bastos Neto and } \\
\text { others }(1991)\end{array}$ & $\begin{array}{l}\text { Santa Catarina } \\
\text { district }\end{array}$ \\
\hline
\end{tabular}




\section{Appendix G1 References Cited}

Note: All Web links listed were active as of the access date but may no longer be available.

Absolom, S.S., 1986, The Buffalo fluorspar deposit, Naboomspruit district, in Anhaeusser, C.R., and Maske, S., eds., Mineral deposits of southern Africa: Johannesburg, Geological Society of South Africa, v. 2, p. 1337-1341, 1 map in folder pocket.

Agnerian, Hrayr, 2010, Kimwarer fluorspar project, Kimwarer, Kerio Valley, Kenya, technical report prepared for Kenya Fluorspar Company, Ltd.: Toronto, Ontario, Canada, Scott Wilson Roscoe Postle Associates, Inc., January 15, 189 p.

Agnerian, Hrayr, Lecuyer, N.L., Bailey, Ray, and Wawrzkow, Michel, 2011, Preliminary feasibility study of the St. Lawrence fluorspar project, Newfoundland and Labrador, Canada, NI 43-101 technical report prepared for Canada Fluorspar (NL), Inc. [Filing date May 11, 2011]: Toronto, Ontario, Canada, Roscoe Postle Associates, Inc., April 29, 246 p., accessed November 19, 2012, via http://www.sedar.com/search/search_form_pc_en.htm.

Aleksandrov, S.M., 1998, Geochemistry of skarn and ore formation in dolomites: Utrecht, Netherlands, VSP BV, 300 p.

Alvin, M.P., Dunphy, J.M., and Groves, D.I., 2004, Nature and genesis of a carbonatite-associated fluorite deposit at Speewah, East Kimberley region, Western Australia: Mineralogy and Petrology, v. 80, nos. 3-4, p. 127-153. [Also available at http://dx.doi.org/10.1007/s00710-003-0015-3.]

Bastos Neto, Artur, Charvet, Jacques, Touray, J.-C., and Dardenne, Marcelle, 1991, Evolution tectonique du district à fluorine de Santa Catarina (Brésil) en relation avec l'ouverture de 1'Atlantique Sud [Tectonic evolution of the Santa Catarina fluorite district (Brazil) in relation with the South Atlantic opening]: Bulletin de la Société Géologique de France [Geological Society of France Bulletin], v. 162, no. 3, p. 503-513. [In French with English abs.]

Bolonin, A.V., Nikiforov, A.V., Lykhin, D.A., and Sugrakova, A.M., 2009, The Chailag-Khem fluorite-barium-strontium rare earth carbonatite occurrence, in the western Sayan Range, Russia: Geology of Ore Deposits, v. 51, no. 1, p. 17-32. [Also available at http://dx.doi.org/10.1134/ S1075701509010024.]

Boni, Maria, Balassone, Giuseppina, Fedele, Luca, and Mondillo, Nicola, 2009, Post-Variscan hydrothermal activity and ore deposits in southern Sardinia (Italy) - Selected examples from Gerrei (Silius vein system) and the Iglesiente district: Periodico di Mineralogia, v. 78, no. 3, p. 19-35. [Also available at http://dx.doi.org/10.2451/2009pM0010.]
Böttger, G., Denecke, C. Görner, R., Viehweg, M., Krause, H., and Schneider, L., 1998, Evaluation of the suitability of the sites and facilities at Degelen and Azgir in the Republic of Kazakhstan as a final repository for radioactive wasteFinal report prepared by $\mathrm{C} \& \mathrm{E}$ Consulting und Engineering $\mathrm{GmbH}$ and Stoller Ingenieurtechnik: Luxembourg, Luxembourg, European Commission, Publication no. EUR 17633 EN, 217 p. [Also available at http://bookshop.europa.eu/en/ evaluation-of-the-suitability-of-the-sites-and-facilities-atdegelen-and-azgir-in-the-republic-of-kazakhstan-as-a-finalrepository-for-radioactive-waste-pbCRNA17633/.]

Bouabdellah, Mohammed, Castorina, Francesca, Bodnar, R.J., Banks, David, Jébrak, Michel, Prochaska, Walter, Lowry, Dave, Klügel, Andreas, and Hoernle, Kaj, 2014, Petroleum migration, fluid mixing, and halokinesis as the main ore-forming processes at the peridiapiric Jbel Tirremi fluorite-barite hydrothermal deposit, northeastern Morocco: Economic Geology, v. 109, p. 1223-1256. [Also available at http://dx.doi.org/10.2113/econgeo.109.5.1223.]

Bouhlel, S., Fortuné, J.-P., Guilhaumou, N., and Touray, J.-C., 1988, Les minéralisations stratiformes à F-Ba de Hammam Zriba, Jebel Guébli (Tunisie nord orientale)_L'apport des études d'inclusions fluides à la modélisation génétique [Stratiform F-Ba mineralization at Hammam Zriba, Jebel Guebli (northeast Tunisia) - The contribution of fluid inclusion studies to genetic modeling]: Mineralium Deposita, v. 23, no. 3, p. 166-173. [In French with English abs. Also available at http://dx.doi.org/10.1007/bf00204295.]

Bouladon, J., 1989, France and Luxembourg, in Dunning, F.W., Garrard, P., Haslam, A.W., and Ixer, R.A. eds., Southwest and Eastern Europe, with Iceland, v. 4-5: London, United Kingdom, Institution of Mining and Metallurgy, Mineral Deposits of Europe Series, p. 37-104.

Bramley, J.V., 1990, Fluorspar mining in Derbyshire: Mining Magazine, v. 163, no. 5, November, p. 328-333.

Bucci, Louis, Chan, Gavin, and Povey, Brian, 2012, Independent technical assessment of the assets of TNT Mines Limited, report prepared for TNT Mines Limited: Melbourne, Victoria, Australia, SRK Consulting (Australasia) Pty. Ltd., 118 p., accessed December 8, 2012, at http:/www.tntmines.com.au/ documents/TNTMines-technical_report_2012dec.pdf.

Bullock, K.C., 1976, Fluorite occurrences in Utah: Utah Geological and Mineral Survey Bulletin, no. 110, 89 p.

Canada Department of Energy, Mines and Resources, 1984, Canadian mineral deposits not being mined in 1983: Canada Department of Energy, Mines and Resources Bulletin 198, May, 308 p. 
Cheilletz, Alain, Gasquet, Dominique, Filali, Fouad, Archibald, D.A., and Nespolo, Massimo, 2010, A late Triassic ${ }^{40} \mathrm{Ar} /{ }^{39} \mathrm{Ar}$ age for the El Hammam high-REE fluorite deposit (Morocco)Mineralization related to the Central Atlantic magmatic province?: Mineralium Deposita, v. 45, no. 4, p. 323-329. [Also available at http://dx.doi.org/10.1007/s00126-010-0282-y.]

Chen Xianpei, Gao Jiyuan, and Cao Junchen, 1996, Barite and fluorite deposits of China, in Editorial Committee of the Mineral Deposits of China, eds. [Responsible ed. Liu Nailong], Mineral deposits of China, v. 5: Beijing, China, Geological Publishing House, p. 52-117.

Clarke, Gerry, 1980, Industrial minerals of France: Industrial Minerals, no. 159, December, p. 23-55.

Coniglio, Jorge, Perez-Xavier, Roberto, Pinotti, Lucio, and D’Eramo, Fernando, 2000, Ore-forming fluids of vein-type fluorite deposits of the Cerro Aspero Batholith, southern Cordoba Province, Argentina: International Geology Review, v. 42, no. 4, p. 368-383. [Also available at http://dx.doi.org/10.1080/00206810009465088.]

Cornwall, H.R., and Kleinhampl, F.J., 1961, Geology of the Bare Mountain quadrangle, Nevada: U.S. Geological Survey Geologic Quadrangle Map GQ-157, scale 1:62,500, accessed October 8, 2015, at http://pubs.er.usgs.gov/ publication/gq157.

Cortecci, G., Reyes, E., Leone, G., and Turi, B., 1987, Sulfur, oxygen, carbon, and strontium isotope geochemistry of the Sarrabus-Gerrei mining district, southeastern Sardinia, Italy: Economic Geology, v. 82, p. 1592-1610. [Also available at http://dx.doi.org/10.2113/gsecongeo.82.6.1592.]

Cox, D.C., 1954, Fluorspar deposits near Meyers Cove, Lemhi County, Idaho: U.S. Geological Survey Bulletin 1015-A, 21 p., 5 pls. [Also available at http://pubs.er.usgs.gov/ publication/b1015A.]

Crocker, I.T., and Martini, J.E.J., 1976, Fluorspar, in Coetzee, C.B., ed., Mineral resources of the Republic of South Africa (5th ed.): Pretoria, South Africa, South Africa Geological Survey Handbook no. 7, p. 357-363.

Deloule, E., 1982, The genesis of fluorspar hydrothermal deposits at Montroc and Le Burc, the Tarn, as deduced from fluid inclusion analysis: Economic Geology, v. 77, p. 1867-1874. [Also available at http://dx.doi.org/10.2113/ gsecongeo.77.8.1867.]

Dobson, D.C., 1982, Geology and alteration of the Lost River tin-tungsten-fluorine deposit, Alaska: Economic Geology, v. 77, p. 1033-1052. [Also available at http://dx.doi.org/ 10.2113/gsecongeo.77.4.1033.]
Dunham, Kingsley, 1983, Ore genesis in the English PenninesA fluoritic subtype, in Kisvarsanyi, Geza, Grant, S.K., Pratt, W.P., and Koenig, J.W., eds., International Conference on Mississippi Valley Type Lead-Zinc Deposits, 2d, Rolla, Mo., 1982, proceedings: Rolla, Mo., University of Missouri-Rolla, p. 86-112.

Durrani, N.A., 1980, Structural control and genesis of the fluorspar deposit near Dilband and the surrounding areas, in Proceedings of the International Committee on Geodynamics, Group 6, Meeting Peshawar, November 23-29, 1979: Geology Bulletin, University of Peshawar [Pakistan], Special issue, v. 13, p. 199-206. [Also available at http://nceg.uop.edu.pk/GeologicalBulletin/Vol-13-1979/ Vol-13-1979-Paper22.pdf.]

Ellmies, R., Germann, K., Krupenin, M.T., Möller, P., and Echtler, H.P., 1999, The fluorite-sellaite deposits of Suran, Bashkir Meganticline, Urals, in Stanley, C.J., and others, eds., Mineral deposits - Processes to processing Proceedings of the Fifth Biennial SGA Meeting and the Tenth Quadrennial IAGOD Symposium, London, United Kingdom, August 22-25, 1999: Brookfield, Vt., A.A. Balkema, p. 841-844.

Engin, Tandogan, 1988, General geological setting \& mineral resources of Turkey, in Griffiths, J.B., and Dickson, E.M., eds., Turkey's industrial minerals_-Production, potential, investment and trade: Industrial Minerals supplement, March, p. 5-11.

Feytis, Alex, 2009, Fluorspar supply fortified: Industrial Minerals Web page, accessed January 9, 2010, at http:/www.indmin.com/ Article/2299402/Fluorspar-supply-fortified.html.

Fraga, M.P., 1991, Geology and mineralization of the El Realito Mine, Rio Santa Maria district, Guanajuato, Mexico, in Salas, G.P., ed., Economic geology, Mexico: Boulder, Colo., Geological Society of America, Geology of North America series, v. P-3, 287-289.

Fulton, R.B., and Montgomery, G., 1994, Fluorspar, in Carr, D.D., and others, eds., Industrial minerals and rocks (6th ed.): Littleton, Colo., Society for Mining, Metallurgy, and Exploration Inc., p. 509-522.

Garcia Iglesias, Jesús, and Loredo, Jorge, 1994, Geological, geochemical, and mineralogical characteristics of the Asturias fluorspar district, northern Spain: Exploration and Mining Geology, v. 3, no. 1, p. 31-37. [Also available at http://www.cim.org/en/Publications-and-TechnicalResources/Publications/Technical_Papers/1994/1/BULL1994-01-08.aspx.]

Gardner, L.S., and Smith, R.M., 1965, Fluorspar deposits of Thailand: Bangkok, Thailand, Department of Mineral Resources, Report of Investigation no. 10, 42 p., 3 pls. 
Gillerman, Elliot, 1964, Mineral deposits of western Grant County, New Mexico: New Mexico Bureau of Mines and Mineral Resources Bulletin 83, 213 p., illustrations folded in pocket.

Globe Metals and Mining, 2012, Project profile, Mount Muambe REE-fluorite project: Globe Metals and Mining Web page, 2 p., accessed February 26, 2013, at http://www.globemetalsandmining.com.au/Files/Projects/ Mount-Muambe/Project-Flyer-\%28Muambe\%29-English.aspx.

Goddard, E.N., 1946, Fluorspar deposits of the Jamestown district, Boulder County, Colorado: Colorado Scientific Society, Proceedings, v. 15, no. 1, 47 p.

Goff, B.H., Weinberg, R., Groves, D.I., Vielreicher, N.M., and Fourie, P.J., 2004, The giant Vergenoeg fluorite deposit in a magnetite-fluorite-fayalite REE pipe-A hydrothermallyaltered carbonatite-related pegmatoid?: Mineralogy and Petrology, v. 80, nos. 3-4, p. 173-199. [Also available at http://dx.doi.org/10.1007/s00710-003-0012-6.]

González-Partida, E., Carrillo-Chávez, A., Grimmer, J.O.W., Pironon, J., Mutterer, J., and Levresse, G., 2003, Fluorite deposits of Encantada-Buenavista, Mexico - Products of Mississippi Valley-type processes: Ore Geology Reviews, v. 23, nos. 3-4, p. 107-124. [Also available at http://dx.doi.org/ 10.1016/s0169-1368(03)00018-0.]

Google Earth, 2012-16, Various latitude and longitude data from Google Earth online database: Google Inc. Web site, available at https://www.google.com/earth/.

Grant, G.J., and Ruiz, Joaquin, 1988, The Pb-Zn-Cu-Ag deposits of the Granadeña Mine, San Francisco del OroSanta Barbara district, Chihuahua: Economic Geology, v. 83, p. 1683-1702. [Also available at http://dx.doi.org/ 10.2113/gsecongeo.83.8.1683.]

Gwalani, L.G., Rogers, K.A., Demény, A., Groves, D.I., Ramsay, R., Beard, A., Downes, P.J., and Eves, A., 2010, The Yungul carbonatite dykes associated with the epithermal fluorite deposit at Speewah, Kimberley, AustraliaCarbon and oxygen isotope constraints on their origin: Mineralogy and Petrology, v. 98, nos. 1-4, p. 123-141. [Also available at http://dx.doi.org/10.1007/s00710-009-0102-1.]

Hellerman, I.E., 2015, Patrimonio minero de Andalucía oriental-Las Minas de Sierra de Gador: I. Eberhard Hellermann, personal Web page, accessed July 7, 2015, at http://mining-andaluz.de/?page_id=1745. [In English.]

Hodge, Brian, 2012, Fluorspar illuminated: Industrial Minerals, no. 541, October, p. 39-52. [Also available at http://www.indmin.com/pdfs/697/86771/ Fluorspar\%20illuminated4\%201.pdf.]
Hudson, T.L., and Reed, B.L., 1997, Tin deposits in Alaska, in Goldfarb, R.J., and Miller, L.D., eds., Mineral deposits of Alaska: Lancaster, Pa., Economic Geology Publishing Co., Economic Geology Monograph Series, no. 9, p. 450-465.

Indian Bureau of Mines, 2015, Gujurat, in Part I-State reviews (52d ed.) (final release): Nagpur, India, Indian Minerals Yearbook 2013, v. I, September, p. 11-1-11-7.

Interfax-Kazakhstan, 2006, Ulbynsk metallurgic plant intends to put in operation the concentrating mill for processing the fluorspar of Karadzhal field: Kazakhstan Stock Exchange Web page, accessed July 19, 2016, at http://www.kase.kz/ news/show/1005873.

ITE-Uzbekistan, [2012?], List of mineral deposits in Uzbekistan: ITE-Uzbekistan, 32 p., accessed March 21, 2013, at http:// www.ite-uzbekistan.uz/ITE-ADVERT/List_depositsEng.pdf.

Jébrak, M., Touray, J.C., and Giret, P., 1988, Geochemical characteristics and genesis of fluorite deposits in Morocco, in Zachrisson, Ebbe, ed., Proceedings of the Seventh Quadrennial IAGOD [International Association on the Genesis of Ore Deposits] Symposium, Luleå, Sweden, August 18-22, 1986: Stuttgart, West Germany, E. Schweizerbart'sche Verlagsbuchhandlung, p. 187-195.

Jenkins, R.E., II, 1987, Geology of the Clugger fluorite deposit, Mato Preto, Parana, Brazil: Revista Brasileira de Geosciencias, v. 17, no. 3, p. 288-294.

Kamitani, Masaharu, Okumura, Kimio, Teraoka, Yoji, Miyano, Sumiko, and Watanabi, Yasushi, 2007, Mineral resources map of east Asia: Japan, Geological Survey of Japan, National Institute of Advanced Industrial Science and Technology, scale 1:3,000,000.

Kirikoglu, M.S., 2002, Kizilcaoren carbonatitic fluoritebarite-thorium and rare earth deposits, northwest Anatolia, Turkey, in Seeger, C.M., ed., Proceedings of the 38th Forum on the Geology of Industrial Minerals, St. Louis Mo., April 28-May 3, 2002: Jefferson City, Mo., Missouri Department of Natural Resources, Geological Survey and Resource Assessment Division, Report of Investigations no. 74 , p. $157-166$.

Kirkemo, Harold, 1978, Final report-OME exploration project; OME-6873 (fluorspar-beryllium-rare earthsthorium-niobium), Hicks Dome Property, Hardin County, Illinois: U.S. Geological Survey, Office of Minerals Explorations, November, variously paged. [Also available at http://minerals.usgs.gov/dockets/scans/il/ome/6873 OME.pdf.] (Note: Downloaded file is $189 \mathrm{MB}$ in size.)

Kislov, E.V., Imetkhenov, A.B., and Sandakova, D.M., 2010, The Yermakovskoye fluorite-beryllium depositAvenues for improving ecological security of revitalization of the mining operations: Geography and Natural Resources, v. 31, no. 4, p. 324-329. [Also available at http://dx.doi.org/10.1016/j.gnr.2010.11.004.] 
Kogut, A.I., Hagni, R.D., and Schneider, G.I.C., 1997, The Okorusu, Namibia, carbonatite-related fluorite deposits, and a comparison with the Illinois-Kentucky fluorite district/ Hicks Dome, in Sangster, D.F., ed., Carbonate-hosted lead-zinc deposits - [Society of Economic Geologists] 75th anniversary volume: Littleton, Colo., Society of Economic Geologists Special Publication no. 4, p. 290-297.

Koplus, A.V., Puzanov, L.S., and Zubov, M.A., 1977, Endogenic geochemical halos of concealed fluorspar mineralization of Kazakhstan (as in the Taskaynar-Yuzhnyy deposit): International Geology Review, v. 19, no. 12, p. 1441-1447. [Also available at http://dx.doi.org/10.1080/ 00206817709471157.]

Kupriyanova, I.I., and Shpanov, E.P., 1997, Beryllium-fluorite ores at the Voznesensk ore district (Primorskii Krai, Russia): Geology of Ore Deposits, v. 39, no. 5, p. 442-455.

Kwak, T.A.P., and Askins, P.W., 1981, Geology and genesis of the F-Sn-W(-Be-Zn) skarn (wrigglite) at Moina, Tasmania: Economic Geology, v. 76, p. 439-467. [Also available at http://dx.doi.org/10.2113/gsecongeo.76.2.439.]

Lipperheide Wicke, Federico, and Barrenechea Guimon, Alberto, 1983, A review of the Spanish fluorspar industry and its role in world markets, in Coope, B.M., and Clarke, G.M., eds., Proceedings of the 5th 'Industrial Minerals' International Congress, Madrid, Spain, April 25-28, 1983: London, United Kingdom, Metal Bulletin PLC, p. 51-59.

Lkhamsuren, Jargalyn, and Hamasaki, Satoshi, 1998, Fluorite deposits in Mongolia-An outline: Bulletin of the Geological Survey of Japan, v. 49, no. 6, p. 309-318. [Also available at https://www.gsj.jp/data/bull-gsj/49-06_08.pdf.]

Lykhin, D.A., Kovalenko, V.I., Yarmolyuk, V.V., Kotov, A.B., and Kovach, V.P., 2010, The Yermakovsky deposit, western Transbaikal region, Russia-Isotopic and geochemical parameters and sources of beryllium-bearing granitoids and others rocks: Geology of Ore Deposits, v. 52, no. 4, p. 289-301. [Also available at http://dx.doi.org/10.1134/ s1075701510040045.]

Managem, Inc., 2011, Rapport annuel, 2011 [Annual report 2011]: Casablanca, Morocco, Managem, Inc., 127 p. [In French.]

Mao Jingwen, Li Hongyan, Shimazaki, Hidehiko, Raimbault, Louis, and Guy, Bernard, 1996, Geology and metallogeny of the Shizhuyuan skarn-greisen deposit, Hunan Province, China: International Geology Review, v. 38, no. 11, p. 1020-1039.

Marchand, L., Joseph, D., Touray, J.C., and Treuil, M., 1976, Criteres d'analyse géochimique des gisements de fluorine basés sur l'étude de la distribution des lanthanidesApplication au gite de Maine (71-Cordesse, France) [Criteria of geochemical analyses of fluorite deposits based on study of the distribution of the lanthanides-Application to the Maine deposit (71-Cordesse, France)]: Mineralium Deposita, v. 11, no. 3, p. 357-379. [Also available at http://dx.doi.org/10.1007/BF00203085.]
Marina, E.F., and Vazquez Guzmán, Fernando, 1987, The mining industry in Spain: Madrid, Spain, Instituto Geologico y Minero de España, 178 p. [Errata slip inserted.]

Martin, J.M., Torres-Ruiz, J., and Fonboté, L., 1987, Facies control of strata-bound ore deposits in carbonate rocks-The $\mathrm{F}-(\mathrm{Pb}-\mathrm{Zn})$ deposits in the Alpine Triassic of the Alpujárrides, southern Spain: Mineralium Deposita, v. 22, no. 3, p. 216226. [Also available at $h t t p: / / d x . d o i . o r g / 10.1007 / b f 00206613$.

Martini, J.E.J., 1976, The fluorite deposits in the Dolomite Series of the Marico district, Transvaal, South Africa: Economic Geology, v. 71, p. 625-635. [Also available at http://dx.doi.org/10.2113/gsecongeo.71.3.625.]

Masan Group, 2012, Nui Phao resources and reserves: Masan Group Web page, accessed March, 3, 2014, at http://www.masangroup.com/masanresources/en/ projects/nui-phao/resources-reserves.

Mason, J.E., 1974, Geology of the Derbyshire fluorspar deposits, United Kingdom, in Hutcheson, D.W., ed., A symposium on the geology of fluorspar-Proceedings of the Ninth Forum on Geology of Industrial Minerals, Paducah, Ky., April 26-28, 1973: Lexington, Ky., Kentucky Geological Survey Special Publication, series X, no. 22, p. 10-22.

Mastrangelo, Federico, 1976, I giacimenti [The deposits], in Le fluoriti sedimentarie Laziali [Latium sedimentary fluorspars]: Società Italiana di Mineralogia e Petrologia [Society of Mineralogy and Petrology of Italy] Rendiconti [Statements], v. XXXII, no. 1, p. 29-46. [Also available at http://rruff.info/rdsmi/V32/V32.html.]

Matteucci, Elio, 1976, Ipotesi e problemi genetici [Genetic hypotheses and problems], in Le fluoriti sedimentarie Laziali [Latium sedimentary fluorspars]: Società Italiana di Mineralogia e Petrologia [Society of Mineralogy and Petrology of Italy] Rendiconti [Statements], v. XXXII, no. 1, p. 47-63. [Also available at http://rruff.info/rdsmi/ V32/V32.html.]

McAnulty, W.N., 1978, Fluorspar in New Mexico: New Mexico Bureau of Mines and Mineral Resources Memoir, no. 34, 64 p.

McAnulty, W.N., Sewell, C.R., Atkinson, D.R., and Rasberry, J.M., 1963, Aguachile beryllium-bearing fluorspar district, Coahuila, Mexico: Geological Society of America Bulletin, v. 74, no. 6, p. $735-743,2$ pls. [Also available at http://dx.doi.org/10.1130/ 0016-7606(1963)74[735:abfdcm]2.0.co;2.]

Metorex, Ltd., 2008, Metorex Limited annual report: ShareData Online Web page, 130 p., accessed March 3, 2014, at http://www.sharedata.co.za/Data/000886/pdfs/METOREX_ ar_08.pdf.

Mexichem, 2012, Mexichem Fluor: Fluorspar 2012 Conference, Vancouver, British Columbia, Canada, October 22-24, 2012, presentation, 35 p., accessed March 3, 2014, at http://www.metalbulletin.com/Event Details/0/5035/ Fluorspar-2012.html. 
Minersa Group, 2012, Minersa fluorspar expansion: Minersa Group press release, June 11, accessed March 3, 2014, at http://www.minersa.com/eng/news_details.php?id=8.

Misra, K.C., Kopp, O.C., Paris, T.A., and Linkous, M.A., 1989, Mississippi Valley-type fluorite-barite-sphalerite mineralization in the Sweetwater district, Tennessee: Carbonates and Evaporites, v. 4, no. 2, p. 211-230. [Also available at http://dx.doi.org/10.1007/bf03175108.]

Morvai, G., 1982, Hungary, in Dunning, F.W., Mykura, W., and Slater, D., eds., Mineral deposits of Europe-Southeast Europe: London, United Kingdom, The Institution of Mining and Metallurgy, Mineral Deposits of Europe Series, v. 2, p. 13-54.

Nikiforov, A.V., Bolonin, A.V., Sugorakova, A.M., Popov, V.A., and Lykhin, D.A., 2005, Carbonatites of central TuvaGeological structure and mineral and chemical composition: Geology of Ore Deposits, v. 47, no. 4, p. 326-345.

Nokleberg, W.J., Bundtzen, T.K., Dawson, K.M., Eremin, R.A., Goryachev, N.A., Koch, R.D., Ratkin, V.V., Rozenblum, I.S., Shpikerman, V.I., Frolov, Y.F., Gorodinsky, M.E., Melnikov, V.D., Ognyanov, N.V., Petrachenko, E.D., Pozdeev, A.I., Ross, K.V., Wood, D.H., Grybeck, Donald, Khanchuk, A.I., Kovbas, L.I., Nekrasov, I. Ya., and Sidorov, A.A., 1996, Significant metalliferous and selected non-metalliferous lode deposits and placer districts for the Russian Far East, Alaska, and the Canadian Cordillera: U.S. Geological Survey OpenFile Report 96-513-A, 385 p. [Also available at http:// pubs.er.usgs.gov/publication/ofr96513A.]

Notholt, A.J.G., Highley, D.E., and Deans, T., 1990, Economic minerals in carbonatites and associated alkaline igneous rocks: Transactions of the Institution of Mining and MetallurgySection B, Applied Earth Sciences, v. 99, p. B59-B80.

Nyambok, I.O., and Gaciri, S.J., 1975, Geology of the fluorite deposits in Kerio Valley, Kenya: Economic Geology, v. 70, p. 299-307. [Also available at http://dx.doi.org/10.2113/ gsecongeo.70.2.299.]

Obolenskiy, A.A., Rodionov, S.M., Ariunbileg, Sodov, Dejidmaa, Gunchin, Distanov, E.G., Dorjgotov, Dangindorjiin, Gerel, Ochir, Hwang, D.-H., Sun, Fengyue, Gotovsuren, Ayurzana, Letunov, S.N., Li, Xujun, Nokleberg, W.J., Ogasawara, Masatsugu, Seminsky, Z.V., Smelov, A.P., Sotnikov, V.I., Spiridinov, A.A., Zorina, L.V., and Yan, Honquan, 2010, Mineral deposit models for northeast Asia, chap. 3 of Nokleberg, W.J., ed., Metallogenesis and tectonics of northeast Asia: U.S. Geological Survey Professional Paper 1765, p. 3-1-3-75. [Also available at http://pubs.usgs.gov/pp/1765/p1765.pdf.]

Ocean Policy Research Foundation, 2012, Resources-Mineral resources-Fluorite: Development and Operation Program for Environmental Sustainability in East Eurasia [JANSROP-GIS] Web page, accessed February 4, 2013, at http://jansrop.sof.or.jp/.
Orris, G.J., 1992, Grade and tonnage model of fluorite veins [Model 26b], in Orris, G.J., and Bliss, J.D., eds., Industrial minerals deposit models-Grade and tonnage models: U.S. Geological Survey Open-File report 92-437, p. 29-31. [Also available at http://pubs.er.usgs.gov/publication/ ofr92437.]

Palmer, D.A.S., 1994, Geology and geochemistry of the Amba Dongar carbonatite-hosted fluorite deposit, India: Montreal, Quebec, Canada, McGill University, M.S. thesis, 109 p.

Palmer, D.A.S., and Williams-Jones, A.E., 1996, Genesis of the carbonatite-hosted fluorite deposit at Amba Dongar, India-Evidence from fluid inclusions, stable isotopes, and whole rock-mineral geochemistry: Economic Geology, v. 91, p. 934-950. [Also available at http://dx.doi.org/ 10.2113/gsecongeo.91.5.934.]

Parker, R.L., and Havens, R.G., 1963, Thortveitite associated with fluorite, Ravalli County, Montana, in Geological Survey research 1963; short papers in geology and hydrology, articles 1-59: U.S. Geological Survey Professional Paper 475-B, article no. 2, p. B10-B11. [Also available at http://pubs.er.usgs.gov/publication/pp475B.]

Pickard, G.W., 1974, Geology of Mexican fluorspar deposits, in Hutcheson, D.W., ed., A symposium on the geology of fluorspar-Proceedings of the Ninth Forum on Geology of Industrial Minerals, Paducah, Ky., April 26-28, 1973: Lexington, Ky., Kentucky Geological Survey Special Publication, series X, no. 22, p. 23-30.

Piqué, Àngels, Canals, Àngels, Grandia, Fidel, and Banks, D.A., 2008, Mesozoic fluorite veins in NE Spain record regional base metal-rich brine circulation through basin and basement during extensional events: Chemical Geology, v. 257, nos. 1-2, p. 139-152. [Also available at http://dx.doi.org/10.1016/j.chemgeo.2008.08.028.]

Powell, Jim, and Throop, Brandon, 2011, Minor metals, major potential: Montreal, Quebec, Canada, Laurentian Bank Securities, May 6, 60 p., accessed July 20, 2016, at https://www.vmbl.ca/Actions/1/ Multi-metal\%20Initiating\%20Coverage_May2011.pdf.

Richards, J.P., Dang, T., Dudka, S.F., and Wong, M.L., 2003, The Nui Phao tungsten-fluorite-copper-gold-bismuth deposit, northern Vietnam-An opportunity for sustainable development: Exploration and Mining Geology, v. 12, nos. 1-4, p. 61-70. [Also available at http://dx.doi.org/ 10.2113/0120061.]

Rodionov, S.M., Khanchuk, A.I., Obolenskiy, A.A., Ogasawara, Masatsugu, Seminskiy, Z.V., Prokopiev, A.V., Timofeev, V.F., and Nokleberg, W.J., 2010, Middle Jurassic through Quaternary metallogenesis and tectonics of northeast Asia, chap. 8 of Nokleberg, W.J., ed., Metallogenesis and tectonics of northeast Asia: U.S. Geological Survey Professional Paper 1765, p. 8-1-8-137. [Also available at http://pubs.usgs.gov/pp/1765/p1765.pdf.] 
Roedder, E., and Howard, K.W., 1988, Taolin Zn-Pb-fluorite deposit, People's Republic of China-An example of some problems in fluid inclusion research on mineral deposits: Journal of the Geological Society (London), v. 145, no. 1, p. 163-174. [Also available at http://dx.doi.org/10.1144/ gsjgs.145.1.0163.]

Ruiz, Joaquin, Kesler, S.E., Jones, L.M., and Sutter, J.F., 1980, Geology and geochemistry of the Las Cuevas fluorite deposit, San Luis Potosi, Mexico: Economic Geology, v. 75, p. 1200-1209. [Also available at http://dx.doi.org/10.2113/ gsecongeo.75.8.1200.]

Ryan, P.J., 1986, The Witkop fluorspar mine near Zeerust, western Transvaal, in Anhaeusser, C.R., and Maske, S., eds., Mineral deposits of southern Africa, v. I: Johannesburg, South Africa, Geological Society of South Africa, p. 843-849, $1 \mathrm{pl}$. in pocket.

Ryazantseva, M.D., 1998, Excursion I-The Voznesenka ore district, in Seltmann, R., Gonevchuk, G., and Khanchuk, A., eds., Anatomy and textures of ore-bearing granitoids of Sikhote Alin (Primorye region, Russia) and related mineralization-Excursion guidebook: Potsdam, Germany, GeoForschungsZentrum Potsdam, p. 9-22.

Sahinen, U.M., 1962, Fluorspar deposits in Montana: Montana Bureau of Mines and Geology Bulletin, no. 28, 38 p.

Sainsbury, C.L., 1964, Geology of the Lost River Mine area, Alaska: U.S. Geological Survey Bulletin 1129, 80 p., 10 sheets. [Also available at https://pubs.er.usgs.gov/ publication/b1129.]

Sánchez, V., Vindel, E., Martín-Crespo, T., Corbella, M., Cardellach, E., and Banks, D., 2009, Sources and composition of fluids associated with fluorite deposits of Asturias (N Spain): Geofluids, v. 9, no. 4, p. 338-355. [Also available at http://dx.doi.org/10.1111/j.1468-8123.2009.00259.x.]

Sato, Kohei, Suzuki, Kazuhiro, Nedachi, Munetomo, Tershima, Shigeru, Ryazantseva, M.D., Vrublevsky, A.A., and Khanchuk, A.I., 2003, Fluorite deposits at Voznesenka in the Khanka Massif, Russia-Geology and age of mineralization: Resource Geology, v. 53, no. 3, p. 193-211. [Also available at http://dx.doi.org/10.1111/ j.1751-3928.2003.tb00169.x.]

Schneider, Jens, Boni, Maria, Lapponi, Fabio, and Bechstädt, Thilo, 2002, Carbonate-hosted zinc-lead deposit in the Lower Cambrian of Hunan, south China - A radiogenic $(\mathrm{Pb}, \mathrm{Sr})$ isotope study: Economic Geology, v. 97, p. 1815-1827. [Also available at http://dx.doi.org/10.2113/gsecongeo.97.8.1815.]
Seltmann, Reimar, Shatov, Vitaly, and Yakubchuk, Alexander, 2012, Mineral deposits database and thematic maps of central Asia (Kazakhstan, Kyrgyzstan, Uzbekistan, Tajikistan): London, United Kingdom, Natural History Museum, Department of Earth Sciences, Centre for Russian and Central EurAsian Mineral Studies (CERCAMS), ArcMap 9.2 GIS package, scale 1:1.5 million.

Shawe, D.R., ed., 1976, Geology and resources of fluorine in the United States, with sections by D.R. Shawe, R.E. Van Alstine, R.G. Worl, A.V. Heyl, R.D. Trace, R.L. Parker, W.R. Griffitts, C.L. Sainsbury, and J.B. Cathcart: U.S. Geological Survey Professional Paper 933, 99 p. [Also available at http:// pubs.er.usgs.gov/publication/pp933.]

Sheppard, R.A., and Gude, A.J., III, 1969, Authigenic fluorite in Pliocene lacustrine rocks near Rome, Malheur County, Oregon, chap. D of Geological Survey research 1969: U.S. Geological Survey Professional Paper 650-D, p. D69-D74. [Also available at http://pubs.er.usgs.gov/ publication/pp650D.]

Sizaret, Stanislas, Marcoux, Eric, Jébrak, Michel, and Touray, J.C., 2004, The Rossignol fluorite vein, Chaillac, FranceMultiphase hydrothermal activity and intravein sedimentation: Economic Geology, v. 99, p. 1107-1122. [Also available at http://dx.doi.org/10.2113/gsecongeo.99.6.1107.]

Somerley, Ltd., 2011, Market report on tungsten, fluorspar, bismuth and copper, report prepared for Masan Group: Hong Kong [China], Somerley, Ltd., August, 77 p., accessed June 5, 2014, at http://www.masangroup.com/static/uploads/ block/somerly-report-en-6.pdf.

Souissi, F., Danduran, J.L., and Fortuné, J.P., 1997, Thermal and chemical evolution of fluids during fluorite deposition in the Zaghouan Province, north-eastern Tunisia: Mineralium Deposita, v. 32, no. 3, p. 257-270. [Also available at http://dx.doi.org/10.1007/s001260050091.]

Staatz, M.H., and Osterwald, F.W., 1959, Geology of the Thomas Range fluorspar district, Juab County, Utah: U.S. Geological Survey Bulletin 1069, 97 p., 12 pls. [Also available at $\mathrm{http}: / /$ pubs.er.usgs.gov/publication/b1069.]

State Committee of the Republic of Uzbekistan for Geology and Mineral Resources, [2011?] Mineral resource of the Uzbekistan-New opportunities for Japanese investors [Presentation]: Japan-Uzbekistan Network for Investment Environment Improvement Web page, 30 p., accessed February 26, 2013, at http://www.jp-ca.org/navoiforum/ materials/no.3/1georogiya.pdf.

Steven, T.A., 1960, Geology and fluorspar deposits, Northgate district, Colorado: U.S. Geological Survey Bulletin 1082-F, p. 323-422, 4 pls. [Also available at http://pubs.er.usgs.gov/ publication/b1082F.] 
Strong, D.F., Fryer, B.J., and Kerrich, R., 1984, Genesis of the St. Lawrence fluorspar deposits as indicated by fluid inclusion, rare earth element, and isotopic data: Economic Geology, v. 79, p. 1142-1158. [Also available at http://dx.doi.org/10.2113/gsecongeo.79.5.1142.]

Taylor, C.D., Rowan, E.L., Goldhaber, M.B., and Hayes, T.S., 1992, A relationship between Hicks Dome and temperature zonation in fluorite in the Illinois-Kentucky district-A fluid inclusion study [extended abs.], in Goldhaber, M.B., and Eidel, J.J., eds., Mineral resources of the Illinois Basin in the context of basin evolution-St. Louis, Missouri, January 22-23,1992 [program and abs.]: U.S. Geological Survey Open-File Report 92-1, p. 62-64. [Also available at http://pubs.usgs.gov/of/1992/0001/report.pdf.]

Trace, R.D., and Amos, D.H., 1984, Stratigraphy and structure of the Western Kentucky fluorspar district: U.S. Geological Survey Professional Paper 1151-D, p. D1-D41, 1 pl. [Also available at http://pubs.er.usgs.gov/publication/pp1151D.]

Tritlla, Jordi, Levresse, Gilles, Corona-Esquivel, Rodolfo, Banks, D.A., Lamadrid, Hector, Bourdet, Julien, and PintoLinares, P.J., 2007, Epigenetic, low-temperature, carbonatehosted $\mathrm{Pb}-\mathrm{Zn}-\mathrm{Cu}-\mathrm{Ba}-\mathrm{F}-\mathrm{Sr}$ deposits in México-A Mississippi Valley-type classification, in Alaniz-Álvarez, S.A., and Nieto-Samaniego, Á.F., eds., Geology of MéxicoCelebrating the centenary of the Geological Society of México: Boulder, Colo., Geological Society of America, Geological Society of America Special Paper series, v. 422, p. 417-432. [Also available at http://dx.doi.org/10.1130/ 2007.2422(15).]

Ulba Metallurgical Plant Joint Stock Co., 2015, Ulba Fluorine Complex LLP: Ulba Metallurgical Plant Joint Stock Co. Web page, accessed November 9, 2015, at http://www.ulba.kz/ en/branch2.htm.

United Company RUSAL, 2012, UC RUSAL to increase its stake in Yaroslavsk GRK to $100 \%$ : United Company RUSAL press release, accessed February 28, 2014, at http://www.rusal.ru/en/press-center/news_details. aspx?id $=6543 \& i b t=13 \& a t=0$.

U.S. Bureau of Mines, 1973, Morocco: Mineral Trade Notes, v. 70, no. 10, October, p. 23-29. [Also available at http://hdl.handle.net/2027/mdp.39015068576142? urlappend $=\% 3$ Bseq $=249$.]
U.S. Geological Survey, 2012-15, Mineral Resources Data System: U.S. Geological Survey database, available at http://mrdata.usgs.gov/mrds/.

Vakulchuk, Roman, and Gjerde, Kristian, with Tatiana Balikhina and Kazbek Apsalikov, 2014, Semipalatinsk nuclear testingThe humanitarian consequences: Oslo, Norway, Norwegian Institute of International Affairs Report no. 1.2014, 35 p., accessed June 26, 2016, at http://large.stanford.edu/courses/ 2014/ph241/powell2/docs/vakulchuk.pdf. [(Report prepared for the Second Conference on Humanitarian Impact of Nuclear Weapons in Nayarit, Mexico, February 13-14, 2014.]

Van Alstine, R.E., 1944, The fluorspar deposits of St. Lawrence, Newfoundland: Economic Geology v. 39, p. 109-32. [Also available at http://dx.doi.org/10.2113/gsecongeo.39.2.109.]

Van Alstine, R.E., 1969, Geology and mineral deposits of the Poncha Springs NE quadrangle, Chaffee County, Colorado, with a section on Fluorspar mines and prospects, by R.E. Van Alstine and D.C. Cox: U.S. Geological Survey Professional Paper 626, 52 p., 6 pls. [Also available at http://pubs.er.usgs.gov/publication/pp626.]

Van Alstine, R.E., and Schruben, P.G., 1980, Fluorspar resources of Africa: U.S. Geological Survey Bulletin 1487, $25 \mathrm{p} ., 1 \mathrm{pl}$. [Also available at http://pubs.er.usgs.gov/ publication/b1487.]

Watts, Griffiths, and McQuat, Ltd., 1972, Preliminary feasibility report on the Lost River fluorite-tin-tungsten: Toronto, Ontario, Canada, Lost River Mining Company, Ltd., 291 p.

Wen Lu, 1998, Fluorspar, in Wen Lu, Chinese industrial minerals (Griffiths, Joyce, ed.): Worchester Park, Surrey, United Kingdom, Industrial Minerals Information, Ltd., p. 68-75.

Woolley, A.R., 1987, Alkaline rocks and carbonatites of the world - Part 1-North and South America: London, United Kingdom, British Museum of Natural History, 216 p.

Woolley, A.R., and Kjarsgaard, B.A., 2008, Paragenetic types of carbonatites as indicated by the diversity and relative abundances of associated silicate rocks-Evidence from a global database: Canadian Mineralogist, v. 46, no. 4, p. 741-752. [Also available at http://dx.doi.org/10.3749/ canmin.46.4.741.] 


\section{Gallium}

By Nora K. Foley, Brian W. Jaskula, Bryn E. Kimball, and Ruth F. Schulte

Chapter $\mathrm{H}$ of

Critical Mineral Resources of the United States-Economic and Environmental Geology and Prospects for Future Supply

Edited by Klaus J. Schulz, John H. DeYoung, Jr., Robert R. Seal II, and Dwight C. Bradley

Professional Paper 1802-H

U.S. Department of the Interior

U.S. Geological Survey 


\section{Contents of Chapter H}

[Figure and table titles for all chapters are listed in the volume contents before the conversion factors table and list of abbreviations and symbols. A periodic table of the elements is on the inside front cover of the printed volume]

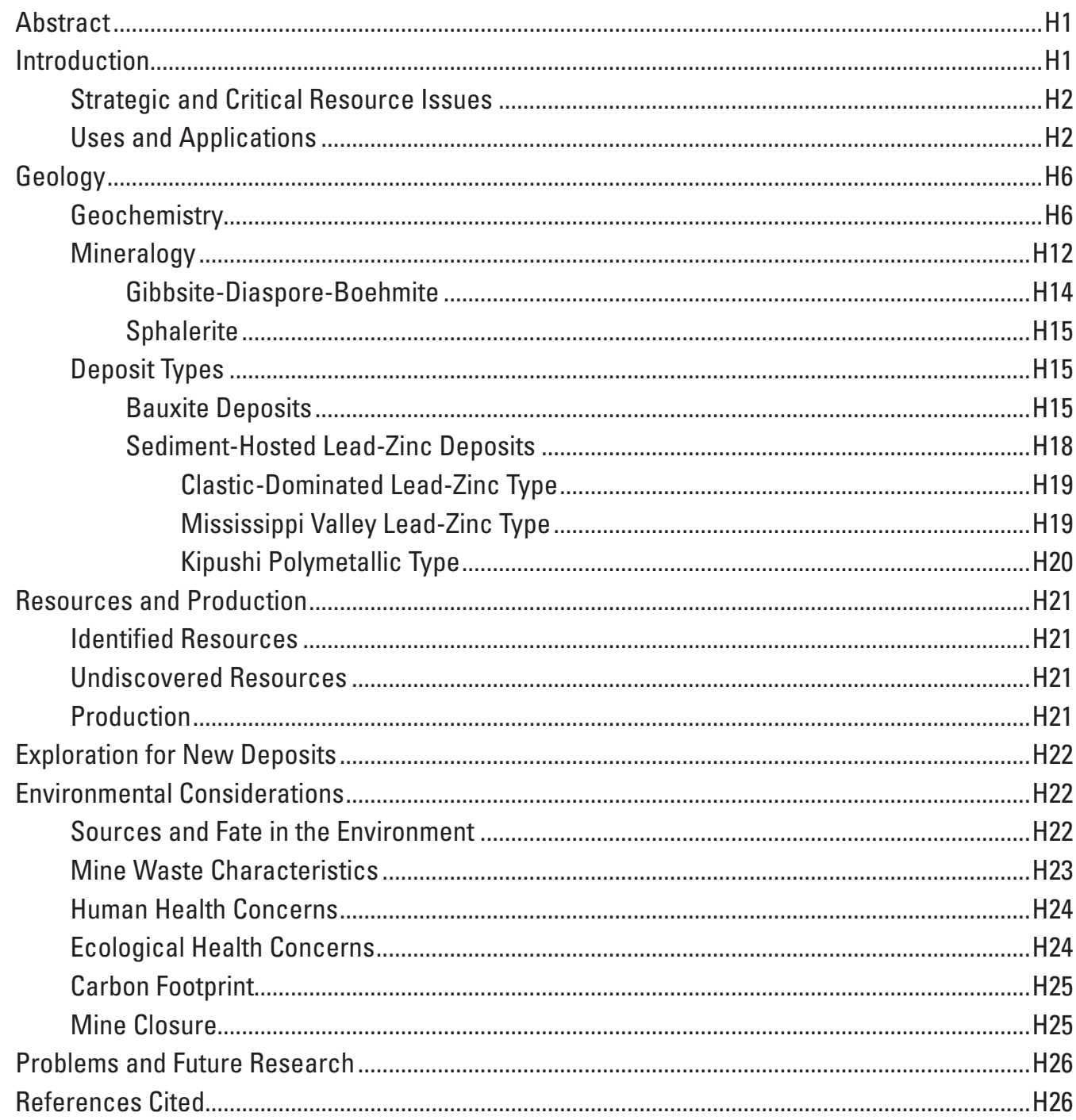




\title{
Gallium
}

\author{
By Nora K. Foley, Brian W. Jaskula, Bryn E. Kimball, and Ruth F. Schulte
}

\section{Abstract}

Gallium is a soft, silvery metallic element with an atomic number of 31 and the chemical symbol Ga. Gallium is used in a wide variety of products that have microelectronic components containing either gallium arsenide (GaAs) or gallium nitride $(\mathrm{GaN})$. GaAs is able to change electricity directly into laser light and is used in the manufacture of optoelectronic devices (laser diodes, light-emitting diodes [LEDs], photo detectors, and solar cells), which are important for aerospace and telecommunications applications and industrial and medical equipment. GaAs is also used in the production of highly specialized integrated circuits, semiconductors, and transistors; these are necessary for defense applications and high-performance computers. For example, cell phones with advanced personal computer-like functionality (smartphones) use GaAs-rich semiconductor components. $\mathrm{GaN}$ is used principally in the manufacture of LEDs and laser diodes, power electronics, and radio-frequency electronics. Because GaN power transistors operate at higher voltages and with a higher power density than GaAs devices, the uses for advanced GaN-based products are expected to increase in the future. Gallium technologies also have large power-handling capabilities and are used for cable television transmission, commercial wireless infrastructure, power electronics, and satellites. Gallium is also used for such familiar applications as screen backlighting for computer notebooks, flat-screen televisions, and desktop computer monitors.

Gallium is dispersed in small amounts in many minerals and rocks where it substitutes for elements of similar size and charge, such as aluminum and zinc. For example, gallium is found in small amounts (about 50 parts per million) in such aluminum-bearing minerals as diaspore-boehmite and gibbsite, which form bauxite deposits, and in the zinc-sulfide mineral sphalerite, which is found in many mineral deposits. At the present time, gallium metal is derived mainly as a byproduct of the processing of bauxite ore for aluminum; lesser amounts of gallium metal are produced from the processing of sphalerite ore from three types of deposits (sediment-hosted, Mississippi Valley-type, and volcanogenic massive sulfide) for zinc. The United States is expected to meet its current and expected future needs for gallium through imports of primary, recycled, and refined gallium, as well as through domestic production of recycled and refined gallium. The U.S. Geological Survey estimates that world resources of gallium in bauxite exceed 1 billion kilograms, and a considerable quantity of gallium could be present in world zinc reserves.

\section{Introduction}

The existence of gallium was first predicted in 1871 by Dmitri Mendeleev, a Russian chemist who published the first periodic table of elements (Mendeleev, 1871). Mendeleev noted a gap in his table and named the missing element "eka-aluminum" because he determined that its location was one place away from aluminum in the table (fig. H1). Mendeleev thought that the missing element (gallium) would be

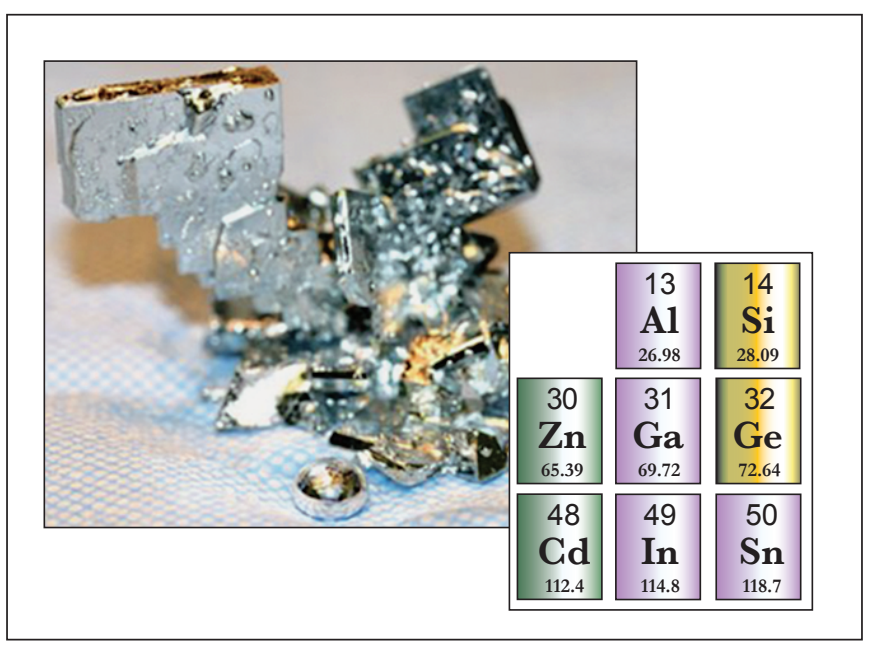

Figure H1. Photograph of gallium metal with an inset showing its position on the periodic table of elements. The gallium crystals shown in the photograph grew in a tank of liquid gallium. The drop in the foreground fell off the crystal as the liquid slowly cooled below a temperature of about 30 degrees Celsius. Photograph courtesy of Afshin Yaghmaei, Simulated Planetary Interiors Lab, Department of Earth and Space Sciences, University of California, Los Angeles. 
very much like aluminum in its chemical properties, and he was right. The French chemist Paul-Emile Lecoq de Boisbaudran discovered gallium in sphalerite in 1875 using spectroscopy. Lecoq de Boisbaudran isolated gallium metal by electrolysis of gallium hydroxide in a potassium hydroxide solution. He named the element "gallia" after the Latin name for his native land of France (Gallia, or Gaul).

Solid gallium has a low melting temperature (about 29 degrees Celsius $\left[{ }^{\circ} \mathrm{C}\right]$ ) and an unusually high boiling point (about $2,204{ }^{\circ} \mathrm{C}$ ) (table $\mathrm{H} 1$ ), so that gallium is a liquid across a wider range of temperatures than any other element. Because of these properties, the earliest uses of gallium were in high-temperature thermometry and in metal alloys that melt easily. The development of gallium arsenide as a direct band-gap semiconductor in the 1960s led to what are now some of the most well-known uses of gallium - in feature-rich, application-intensive, third- and fourth-generation smartphones and in data-centric networks.

\section{Strategic and Critical Resource Issues}

Gallium first became recognized as a strategic and critical metal during World War II because it was a necessary component of a stable gallium-plutonium alloy that was developed as part of the Manhattan Project and used to make a reliable atomic bomb. Gallium is currently important for U.S. manufacturing because of its expanding uses for novel thin-film photovoltaics, especially those of the copper-indium-gallium(di)selenide (CIGS) semiconductor type, and it is particularly important for clean energy technologies. Gallium is currently produced as a byproduct of the mining of other mineral commodities - mainly zinc, copper, and aluminum - and the mining technologies used are optimized for the extraction of those primary mineral commodities. The small market for gallium as a specialty metal creates little incentive for refiners of zinc, copper, and aluminum ores to invest in improvements to increase byproduct recovery of gallium. Because of the likelihood of rapid growth in the areas of photovoltaics and clean energy technologies, a potential exists for bottlenecks in the gallium supply pipeline. Production of gallium is limited by market factors that influence the production of the principal mineral commodity, whether it is zinc or aluminum.

\section{Uses and Applications}

A wide variety of products have microelectronic components that contain either gallium arsenide (GaAs) or gallium nitride $(\mathrm{GaN})$. GaAs is able to change electricity directly into laser light and is used in the manufacture of optoelectronic devices (laser diodes, light-emitting diodes [LEDs], photo detectors, and solar cells), which are important for aerospace and telecommunications applications and industrial and medical equipment. GaAs is also used in the production of highly specialized integrated circuits, semiconductors, and transistors; these are necessary for defense applications and high-performance computers. For example, smartphones (cell phones with advanced computer-like functionality) use GaAsrich semiconductor components (fig. $\mathrm{H} 2 A$ ). $\mathrm{GaN}$ is employed principally in the manufacture of LEDs and laser diodes, power electronics, and radio-frequency (RF) electronics. Because $\mathrm{GaN}$ power transistors operate at higher voltages and with a higher power density than GaAs devices, the applications for advanced GaN-based products are expected to increase in the future. The CIGS direct band-gap semiconductor was developed to make lightweight, flexible, and durable thin-film photovoltaics that have a high absorption coefficient; these attributes have potential applications in the manufacture of efficient solar cells (fig. $\mathrm{H} 2 B$ ). Because of its high boiling temperature, gallium is used to make thermometers designed to measure very high temperatures, and because of its silvery color and ability to form metal alloys, gallium is used to make brilliant mirrors. The fundamental properties of thermal convection in liquid gallium metal are employed to study aspects of planetary and astrophysical magnetohydrodynamics.

Gallium can be replaced by other materials in some applications, but for others, it has no effective substitutes. Liquid crystals made from organic compounds are used in visual displays as substitutes for LEDs. Researchers also are working to develop organic-based LEDs that may compete with GaAs in the future. Indium phosphide components can be substituted for GaAs-based infrared laser diodes in some specific-wavelength applications, and helium-neon lasers can be used in place of GaAs lasers in visible laser diode applications. Silicon is the principal competitor with GaAs in solar-cell applications. GaAs-based integrated circuits are used in many defense-related applications because of their unique properties, and there are no effective substitutes for GaAs in these applications. GaAs in heterojunction bipolar transistors is being substituted by silicon-germanium in some applications.

In 2012, imports of gallium and GaAs wafers, which were valued at about $\$ 32$ million, continued to satisfy almost all U.S. demand for gallium. GaAs and $\mathrm{GaN}$ electronic components represented about 99 percent of domestic gallium consumption (fig. H3). About 70 percent of the gallium was used in integrated circuits (both analog and digital), including those in defense applications, high-performance computers, and telecommunications. Optoelectronic devices for use in aerospace and telecommunications applications, consumer goods, industrial equipment, medical equipment, and so forth, as well as a small amount for research and development, represented the remaining 30 percent of gallium consumption.

Gallium prices decreased throughout 2012 when significant increases in gallium production from 2007 to 2012 (fig. H4) exceeded the declining demand from LED producers. Gallium production capacity in China 
expanded tremendously from 2008 to 2012 on the expectation of a strong LED-based backlighting market, which failed to materialize. In January 2012, the price for low-grade gallium metal (with a purity of 99.099 percent compared with a purity of 99.99999 for the higher grade) averaged $\$ 580$ per kilogram. By July, the average price for low-grade gallium metal had decreased to $\$ 320$ per kilogram, and by early October, to \$280 per kilogram.

Markets continued to expand for GaAs- and GaN-based products in 2012. GaAs demand mainly results from cell phones and other high-speed wireless applications. In 2012, GaAs demand increased owing to the rapid increase in the use of feature-rich, application-intensive, third- and fourthgeneration smartphones, which contain up to 10 times the amount of GaAs compared with standard cellular handsets. Smartphones accounted for 37 percent of all handsets sold in 2012. Owing to the increased amounts of GaAs in smartphones and the increased use of GaAs-based LEDs in general lighting and automotive applications, the value of sales in the GaAs market is forecast to reach $\$ 650$ million by 2017 at an annual growth rate of nearly 11 percent (Jaskula, 2013b).

Owing to the large power-handling capabilities, highswitching frequencies, and higher voltage capabilities of GaN technology, GaN-based products, which historically have been used in defense and military applications, have begun to gain acceptance in the cable television transmission, commercial wireless infrastructure, power electronics, and satellite markets. The value of sales for the $\mathrm{GaN}$ power device market was expected to reach $\$ 178$ million by 2015 at an annual growth rate of nearly 29 percent (Jaskula, 2013b).

In 2012, the worldwide LED market, which was a significant driver for GaN-based technologies, increased by only 1.5 percent in revenues from that of 2011 owing to slower-than-expected growth in the LED backlighting market and to lower LED prices, as production was outpacing demand. Although televisions were increasingly being built with LED backlighting in 2012, improvements in technology required up to 50 percent fewer LEDs. LED-backlit televisions accounted for 63 percent of the television market in 2012 and were forecast to account for 93 percent of market sales in 2013. By 2014, the strongest market segments for sales of LEDs were expected to be in general lighting, followed by signs and automotive applications.

Sustained high prices for energy continued to spark interest in solar energy in 2012. Sales of CIGS semiconductors for use in the production of high-efficiency solar cells was slower than expected, however, owing to a complicated manufacturing process that has impeded commercial mass production of CIGS panels. Decreased prices of silicon-based solar cells also affected demand for the more expensive CIGS technology. These two factors resulted in a large oversupply of CIGS modules that caused prices to decrease by 20 percent in 2011 and to remain low throughout 2012. In an effort to keep CIGS technology viable and competitive, CIGS manufacturers began in 2011 to trim production costs, improve module conversion efficiencies, and increase the use of CIGS-based photovoltaics in commercial rooftops.

The following sections of this chapter provide an overview of the principal types and global distribution of domestic and global resources of gallium (fig. H4). This information updates the report by Weeks (1973).
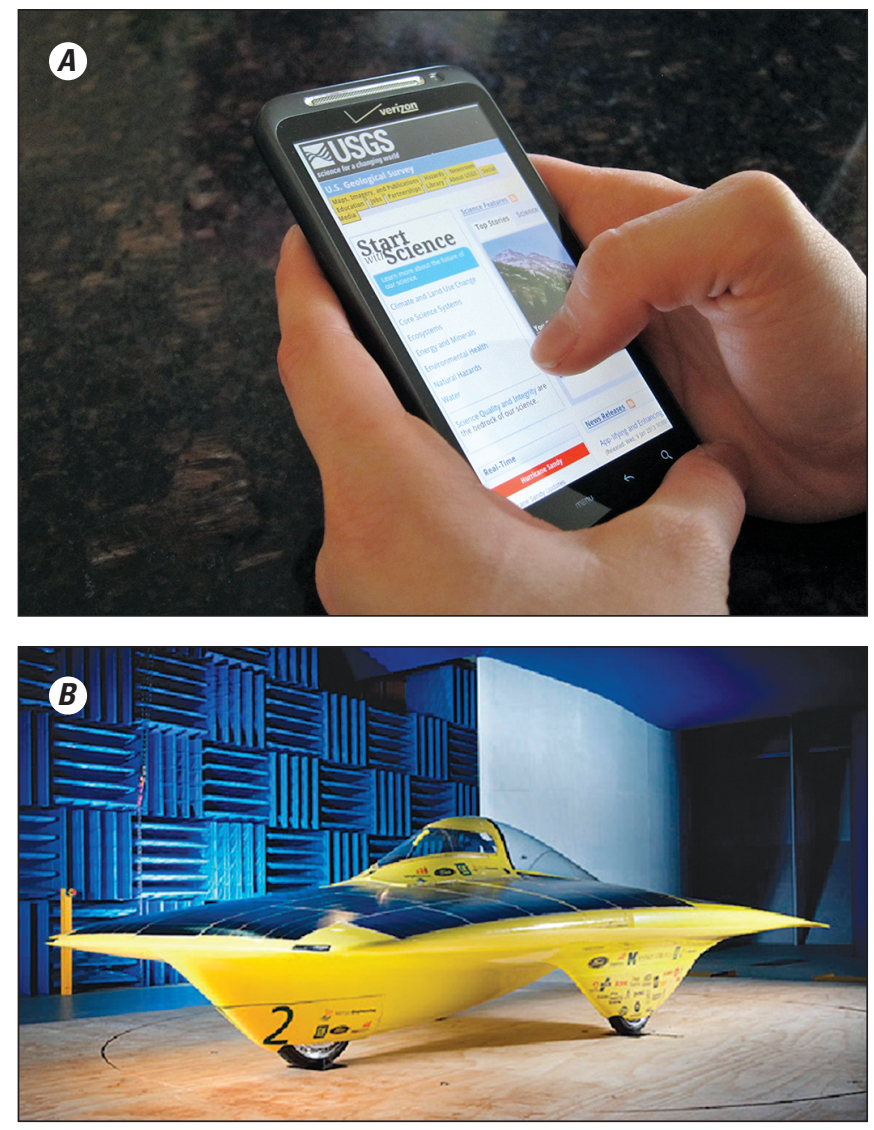

Figure H2. Photographs showing examples of some current uses for gallium. $A$, Cell phone that has advanced computer-like functionality (that is, a smartphone), which contains galliumbased semiconductor components and, consequently, up to 10 times the amount of gallium arsenide ( $\mathrm{GaAs}$ ) than is used in standard cell phones. $B$, Experimental three-wheel car displaying high-efficiency, triple-junction $\mathrm{GaAs}$ solar cells. Such solar cells have many experimental applications; this three-wheel car, the Continuum, which was built at the University of Michigan, weighs 220 kilograms and is covered with about 2,500 aerospace-grade GaAs-type solar cells. Photograph of experimental car courtesy of the University of Michigan. 


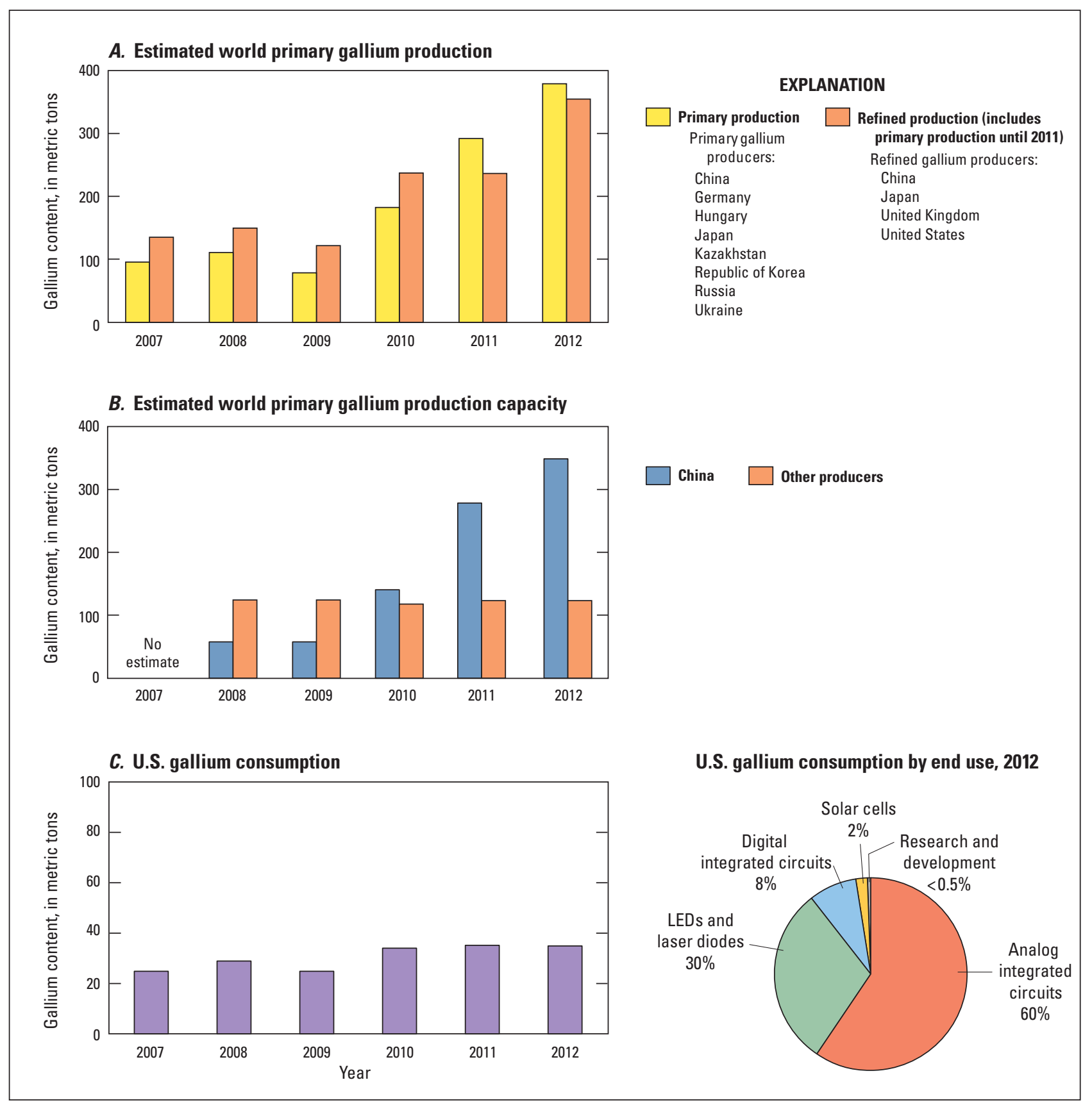

Figure H3. Charts showing U.S. and world gallium production and consumption from 2007 to 2012. A, Estimated world primary gallium production and refined gallium production from 2007 to 2012. B, Estimated world primary gallium production capacity for China and the rest of the world from 2008 to 2012. C, Gallium consumption in the United States from 2007 to 2012, and major end uses of gallium as a percentage of U.S. consumption in 2012. Percentages in the pie chart have been rounded and consequently do not add to 100 . LEDs, light-emitting diodes 

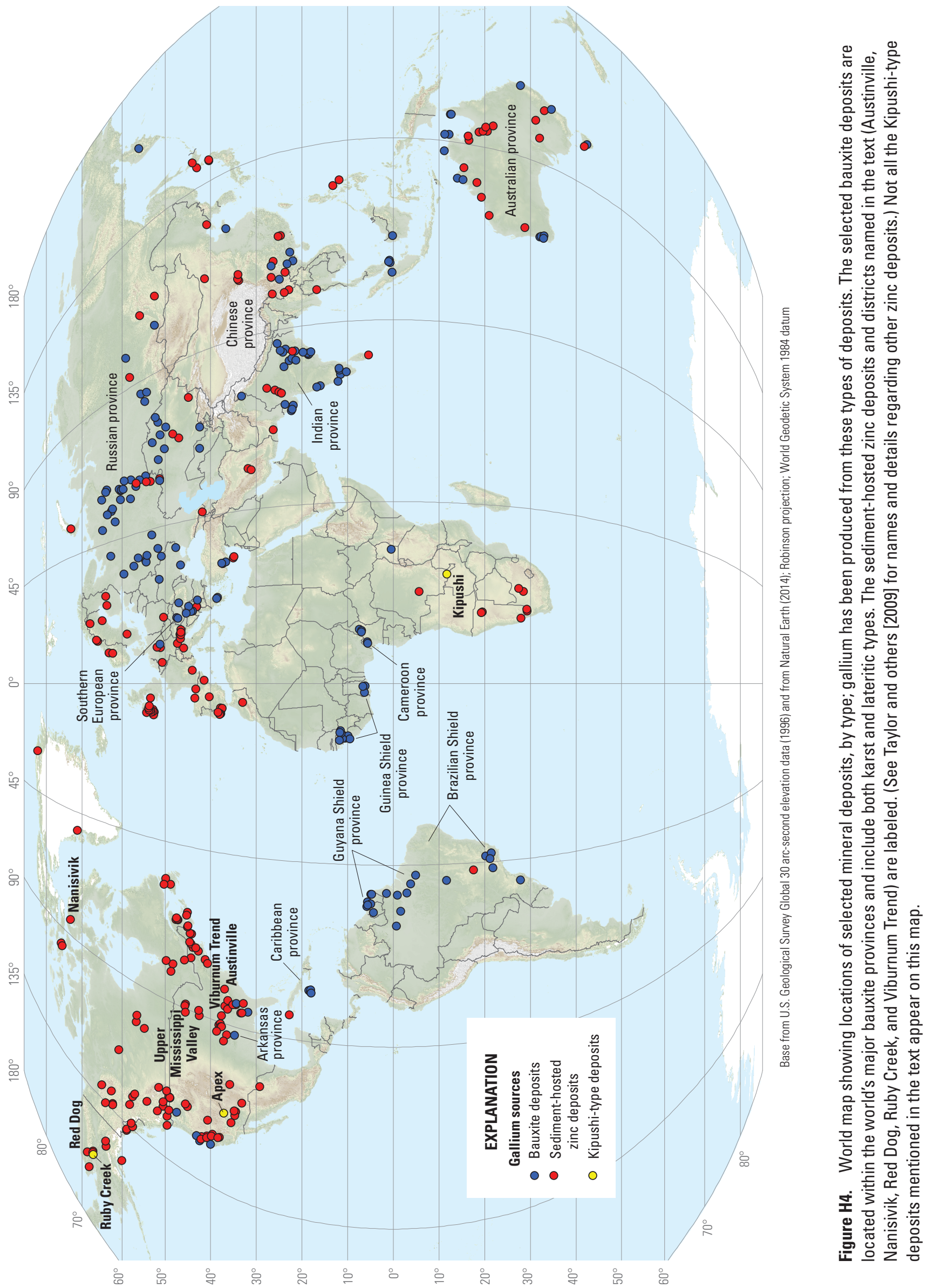


\section{H6 Critical Mineral Resources of the United States-Gallium}

\section{Geology}

Gallium occurs in low amounts in a diverse group of geologic environments and is found most commonly in association with deposits of aluminum and zinc (fig. H5), which are its immediate neighbors in the periodic table of elements (fig. H1). The average abundance of gallium in Earth's crust is generally less than 19 parts per million (ppm) (table H2). Because of the rarity of gallium in most geologic environments, minerals containing gallium as an essential structural component are also rare (table H3). Because gallium occurs as a minor or trace element in many minerals, there are a large number of rock types and tectonic settings for mineral deposits that are known to contain gallium in potentially extractable amounts (table H4). At the present time, the majority of the world's supply of newly mined gallium metal comes from bauxite and sediment-hosted lead-zinc deposits (fig. H4). Gallium is currently derived as a byproduct of the processing of bauxite ore for aluminum, with lesser amounts produced from residues resulting from the processing of sphalerite ore for zinc.

\section{Geochemistry}

Gallium is a soft, silvery post-transition metal with an atomic number of 31 (table H1; fig. H1) that is very much like aluminum in its chemical properties. The chemical similarities between gallium and aluminum, which include a trivalent oxidation state, a similar atomic radius, tetrahedral or octahedral coordination in minerals, and amphoterism (that is, they can act as both acid and base in reactions), result in their generally synchronous geochemical behavior. Gallium is found primarily in the trivalent oxidation state; mixed-oxidation state compounds containing both $\mathrm{Ga}^{1+}$ and $\mathrm{Ga}^{3+}$ (ionic radius of about 0.62 angstrom $[\AA]$ ) occur but are not common (Eagleson, 1994, p. 438). In compounds, gallium exhibits a chemical similarity to $\mathrm{Al}^{3+}$ (ionic radius of about $0.54 \AA$ ), $\mathrm{Fe}^{3+}$ (ionic radius of about $0.69 \AA$ ) and $\mathrm{Zn}^{2+}$ (ionic radius of about $0.72 \AA$ ) (Shannon, 1976) and can substitute for these elements in the common rock-forming minerals (Burton and Culkin, 1978). Other elements typically found in geochemical association with gallium include cadmium, indium, germanium, silicon, and tin (fig. H1). Under certain geochemical conditions, these elements can be separated in near-surface environments - for example, by changes in $\mathrm{pH}$ or redox conditions - because their acid/base and electronic properties are sufficiently different (table H1).

The aqueous geochemistry of gallium was studied by Wood and Samson (2006, and references therein) based on a number of earlier works. Trivalent gallium is also the most common oxidation state of gallium metal in aqueous solution and, owing to the high charge, the hydrated ions of gallium are
Pearson hard acids (Pearson, 1963), which favor the formation of complexes with hard ligands, such as fluoride, hydroxide, phosphate, and sulfate. In aqueous solutions, gallium is predicted to occur mainly in fluoride and hydroxide complexes (Wood and Samson, 2006). Solubility products of most solid phases containing gallium are generally not available; however, the limited available solubility data constrain the maximum concentrations of gallium to be expected in aqueous fluids to the subparts-per-million to subparts-per-billion (or micrograms per liter) range (Wood and Samson, 2006), and this is evident in the values seen for hydrothermal fluids, river waters, and seawater (table H2). The hydrolysis of $\mathrm{GaOOH}(\mathrm{s})$ (solid gallium oxyhydroxide) occurs at low $\mathrm{pH}$, and its speciation is strongly dominated by $\mathrm{Ga}(\mathrm{OH})_{4}^{-}$in the $\mathrm{pH}$ range of natural solutions at $25^{\circ} \mathrm{C}$. At increasing temperature, the amount of $\mathrm{Ga}(\mathrm{OH})_{2}{ }^{+}$and $\mathrm{Ga}(\mathrm{OH})_{3}{ }^{\circ}$ becomes significant, although at $300{ }^{\circ} \mathrm{C}, \mathrm{Ga}(\mathrm{OH})_{4}^{-}$remains the predominant species. A comparison of the geochemical behavior of gallium and aluminum in natural fluids indicates that $\mathrm{Ga}(\mathrm{OH})_{4}$ exhibits a chemical behavior very similar to that of $\mathrm{Al}(\mathrm{OH})_{4}^{-}$ (Wood and Samson, 2006). The low solubility of $\alpha-\mathrm{GaOOH}(\mathrm{s})$ (in the absence of fluoride or strong organic ligands at low temperatures) is consistent with the immobility of gallium relative to most other elements, except aluminum, during weathering and alteration processes. This immobility leads to the accumulation of gallium in some bauxites and kaolins, and in the high-alumina hydrothermal alteration halos that form around many mineral deposits (for example, epithermal, porphyry, and volcanogenic deposits).

Figure H5. (page H7) Cross sections showing the general geologic environments for the types of mineral deposits with which gallium is most commonly associated and from which gallium is typically extracted. $A$, Karst bauxite deposits, which form by deep weathering and transport of material in carbonate rock-dominated sequences; unlabeled patterns show detritus. $B$, Lateritic bauxite deposits, which form mainly by deep weathering of material in silicate rock-dominated sequences. $A$ and $B$ modified from Retallack (2010). C, Sediment-hosted lead-zinc deposits, which form in passive margin environments. $D$, Clastic-dominated-type lead-zinc deposits, which may form by brine reflux in shales and deep-water carbonates. $E$, Mississippi Valley-type lead-zinc deposits, which form by replacement in platform carbonate sequences. $C, D$, and $E$ modified from Kelley and others (1995); Bradley and Leach (2003); Leach, Sangster, and others (2005); and Leach, Taylor, and others (2010). 


\section{A. Karst bauxite deposits}

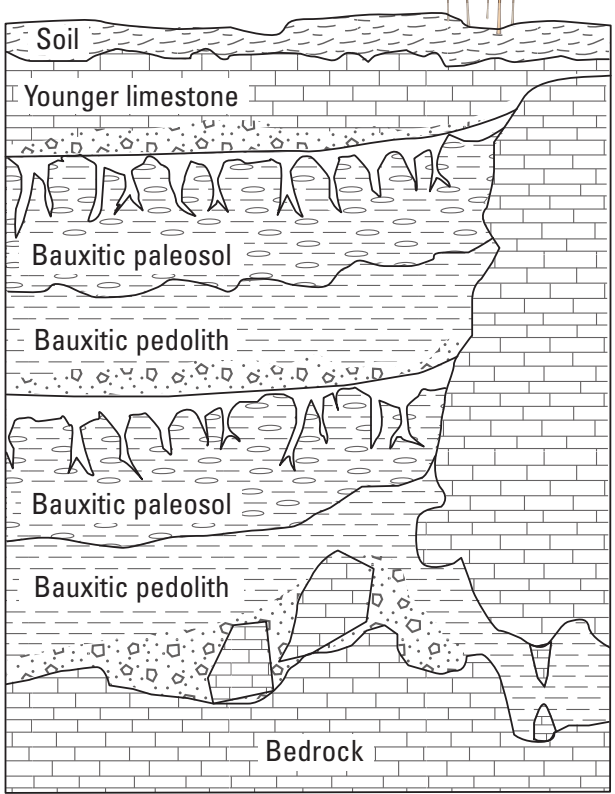

\section{B. Lateritic bauxite deposits}

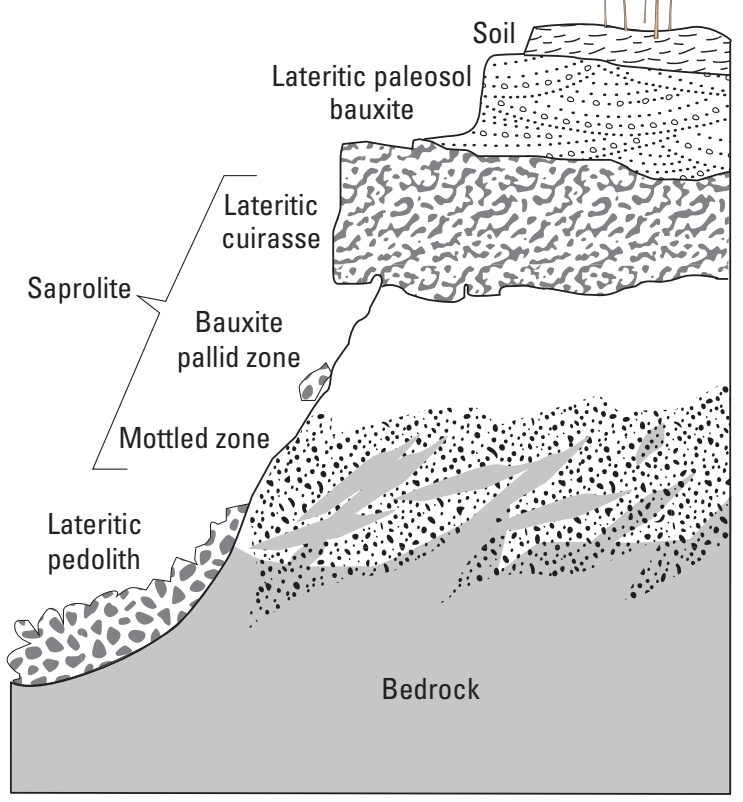

\section{Sediment-hosted lead-zinc deposits}

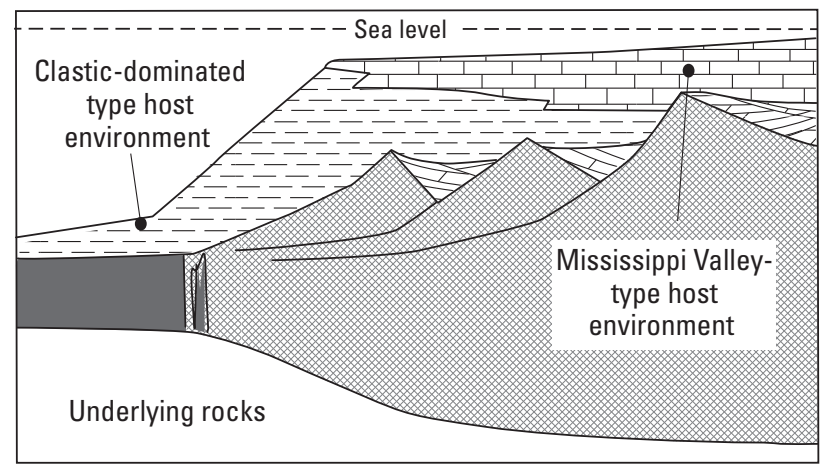

EXPLANATION (part $C$ )

Mafic and ultramafic rocks

Carbonate and minor
clastic rocks of the
passive margin platform

E. Mississippi Valley-type lead-zinc deposits

\section{Clastic-dominated-type lead-zinc deposits}

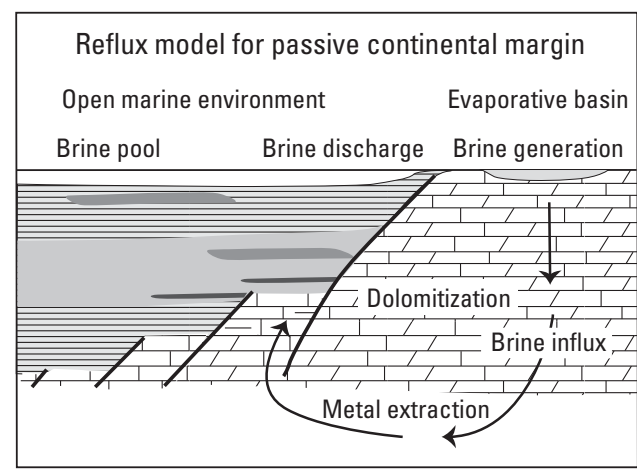

EXPLANATION (part $D$ )

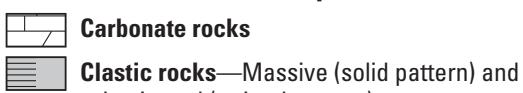

laminated (striped pattern)

Lead-zinc ores in clastic rocks

C Carbonate turbidites

Fault

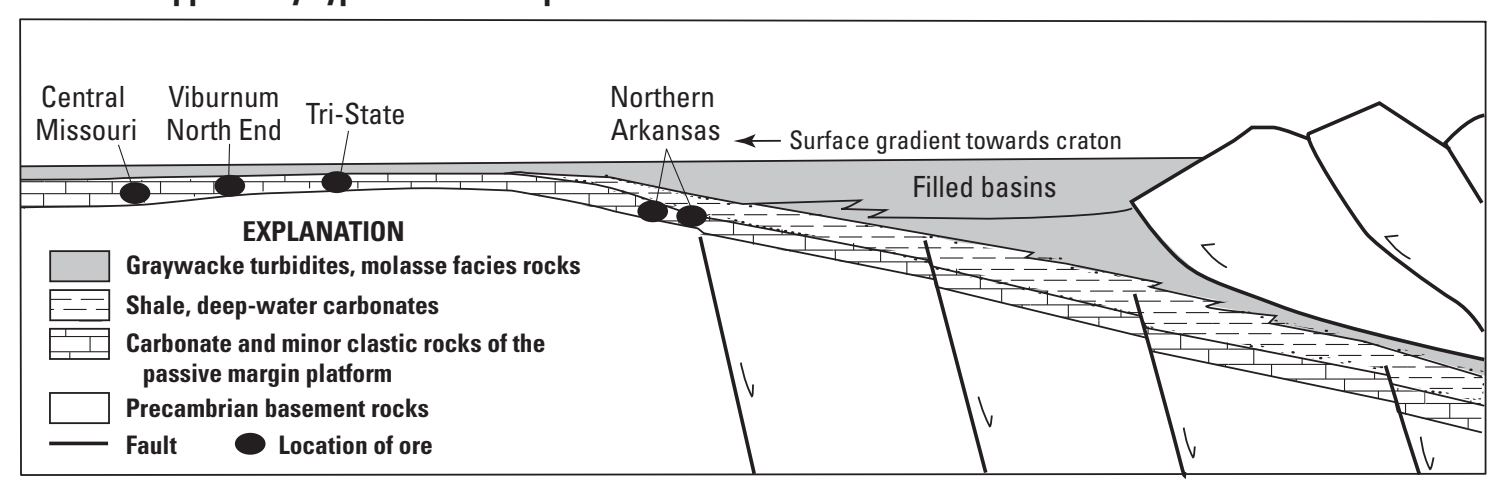

ALL FIGURES NOT TO SCALE 
Table H1. Selected properties of gallium, a Group 13 posttransition metal.

[Sources: Instytutu Problem Materialoznavstva (1968) and Lide (2005, p. 14-39). A, angstrom; ${ }^{\circ} \mathrm{C}$, degree Celsius; cm, centimeter; eV, electronvolt; $\mathrm{g} / \mathrm{cm}^{3}$, gram per cubic centimeter; GPa, gigapascal; $\mathrm{J} / \mathrm{mol}-\mathrm{K}$, joule per mole kelvin; K, kelvin; kJ/mol, kilojoule per mole; $\mathrm{n} \Omega-\mathrm{m}$, nano ohm-meter; $\mu \mathrm{m} / \mathrm{m}-\mathrm{K}$, micrometer per meter kelvin; W/m-K, watt per meter kelvin]

\begin{tabular}{|c|c|}
\hline Property & Description \\
\hline Symbol & $\mathrm{Ga}$ \\
\hline Atomic number & 31 \\
\hline Atomic weight & 69.723 \\
\hline Isotopes & $\begin{array}{l}24 \text { radioisotopes; }{ }^{69} \mathrm{Ga},{ }^{71} \mathrm{Ga} \\
\text { are stable isotopes; }{ }^{67} \mathrm{Ga} \text { has } \\
\text { a half-life of about } 3.3 \text { days }\end{array}$ \\
\hline Density at $293 \mathrm{~K}\left(\mathrm{~g} / \mathrm{cm}^{3}\right)$ & 5.91 \\
\hline Melting point $\left({ }^{\circ} \mathrm{C}\right)$ & 29.7646 \\
\hline Boiling point $\left({ }^{\circ} \mathrm{C}\right)$ & 2,204 \\
\hline Heat of fusion $(\mathrm{kJ} / \mathrm{mol})$ & 5.59 \\
\hline Heat of vaporization $(\mathrm{kJ} / \mathrm{mol})$ & 254 \\
\hline Molar heat capacity (J/mol-K) & 25.86 \\
\hline Hardness (Mohs scale) & 1.5 \\
\hline Brinell hardness (GPa) & 0.06 \\
\hline $\begin{array}{l}\text { Electrical resistivity at } 20^{\circ} \mathrm{C} \\
\quad(\mathrm{n} \Omega-\mathrm{m})\end{array}$ & 270 \\
\hline Thermal conductivity (W/m-K) & 40.6 \\
\hline $\begin{array}{l}\text { Thermal expansion at } 25^{\circ} \mathrm{C} \\
(\mu \mathrm{m} / \mathrm{m}-\mathrm{K})\end{array}$ & 18 \\
\hline Young's modulus (GPa) & 9.8 \\
\hline Crystal structure & Orthorhombic \\
\hline Magnetic ordering & Diamagnetic \\
\hline Electron configuration & {$[\mathrm{Ar}] 4 \mathrm{~s}^{2} 3 \mathrm{~d}^{10} 4 \mathrm{p}^{1}$} \\
\hline Ionic radius $(\AA)$ & 0.62 \\
\hline First ionization potential $(\mathrm{eV})$ & 5.999 \\
\hline Second ionization potential $(\mathrm{eV})$ & 20.51 \\
\hline Third ionization potential (eV) & 30.71 \\
\hline Common valance states & Primarily +3, also $+2,+1$ \\
\hline
\end{tabular}

Gallium is the 34th most abundant element found in Earth's crust (Emsley, 2001), and it is widely distributed in low amounts in many rock types (table H2). The average values for gallium in igneous rocks vary considerably, from a low of about 5 ppm gallium or less in ultramafic rocks to a range of 10 to $22 \mathrm{ppm}$ for most mafic to intermediate rocks, and to about 16 to $35 \mathrm{ppm}$ gallium for granitic rocks (Burton and Culkin, 1978). Alkaline rocks, particularly nepheline syenites, granites, and related pegmatites, have generally higher ranges, from 20 to 70 ppm gallium (Burton and Culkin, 1978). Values of gallium in shale, sandstone, and carbonates are 19 ppm, 12 ppm, and 4 ppm, respectively (Mielke, 1979), and gallium in loess averages about 14 ppm (McLennan and Murray, 1999).

Gallium contents of rocks may be increased by greisenization, albitization, hydrothermal alteration, and weathering processes, including saprolitization and lateritization. In general, the bulk content of gallium in a given rock type corresponds to the composition and bulk content of feldspar and mica in the rock. Alteration processes that selectively remove mobile elements from aluminosilicate minerals result in relative increases in the concentrations of gallium, aluminum, and other less mobile elements in all rock types. The chalcophile behavior of gallium contributes to its concentration in sulfide ores, which can contain hundreds of parts per million gallium (Burton and Culkin, 1978). In hydrothermal systems related to sulfide mineralization and in residual deposits formed by surficial weathering, the lithophile and chalcophile tendencies of gallium work in opposition in terms of enrichment, as sulfide and aluminosilicate minerals compete for gallium.

The value of the ratio of aluminum to gallium (the $\mathrm{Al}$ :Ga ratio) has been used as an indicator of gallium enrichment because it is thought to be relatively constant in most types of crustal rocks (Burton and Culkin, 1978). The value of the $\mathrm{Al}: \mathrm{Ga}$ ratio in various common rock types can range from 5,000 to 40,000. It is lower, in the range of 1,000 to 10,000 , in alkaline igneous rocks and in sedimentary rocks produced by intense weathering (Burton and Culkin, 1978; Tervek and Fay, 1986). Rytuba and others (2003) evaluated the geochemical behavior of gallium in igneous rocks using the worldwide GEOROC (Geochemistry of Rocks of the Oceans and Continents) database (Max Planck Institute, 2002). They found that volcanic rocks from convergent-margin environments with about 8 to $30 \mathrm{ppm}$ gallium had values of $\mathrm{Al}$ : Ga that increased from about 3,000 to 8,000 with increasing aluminum content. They concluded that gallium is not enriched by petrologic processes in more evolved silicic volcanic rocks, such as peralkaline rocks, because the Al:Ga ratio did not correlate with increasing quartz $\left(\mathrm{SiO}_{2}\right)$ content or alkalinity. A comparison of the data for volcanic rocks worldwide, hydrothermally altered rocks of the McDermitt caldera near the McDermitt Mine in Humboldt County, Nevada (from Rytuba and others, 2003), and globally distributed bauxite deposits shows that gallium concentration is higher in rocks that have lower ratios of $\mathrm{Al}$ :Ga owing to hydrothermal alteration and (or) intense weathering (fig. H6). Because the Al:Ga ratio can be quite variable in natural waters (table H2) owing to differences in the mobility of gallium and aluminum in aqueous solutions, the Al:Ga ratio has been used effectively to model the behavior of trace metals as a result of surficial weathering processes (Hieronymus and others, 1990; Shiller and Frilot, 1996) and in ocean waters (Orians and Bruland, 1988; Shiller, 1998) and river waters (Shiller, 1998; Shiller and Frilot, 1996). 
Table H2. Gallium concentrations in rocks, ore, coal, soils, and natural waters.

[FOREGS, Forum of European Geological Surveys, now EuroGeoSurveys; Ga, gallium; ICP-MS, inductively coupled plasma-mass spectrometry; XRF, $\mathrm{X}$-ray fluorescence. Units of measure: $\mathrm{cm}$, centimeter; $\mathrm{m}$, meter; mm, millimeter; ppb, part per billion; ppm, part per million; $\mu \mathrm{g} / \mathrm{L}, \mathrm{microgram}$ per liter; $\mu \mathrm{m}$, micrometer. - , no data]

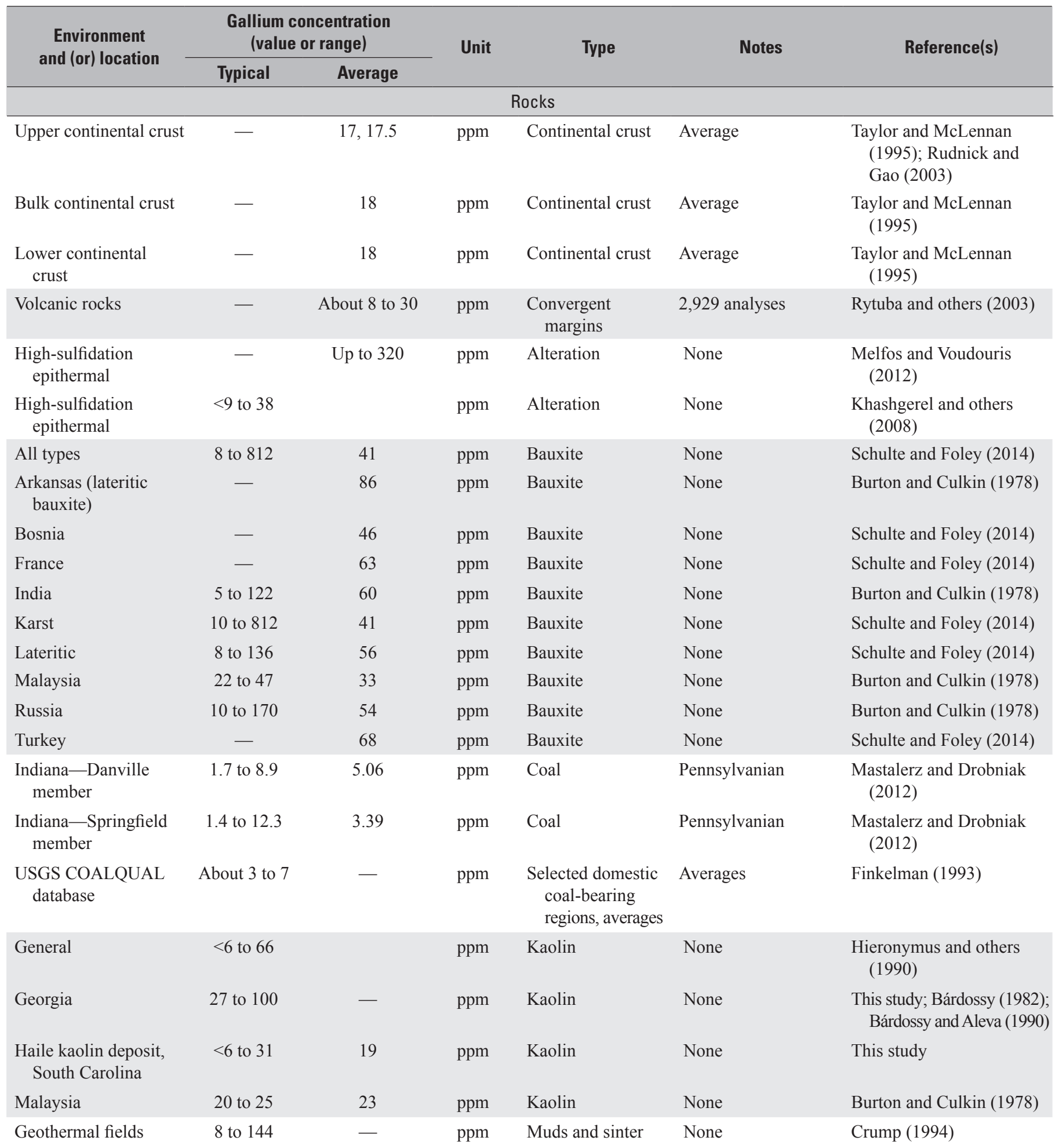


Table H2. Gallium concentrations in rocks, ore, coal, soils, and natural waters._-Continued

[FOREGS, Forum of European Geological Surveys, now EuroGeoSurveys; Ga, gallium; ICP-MS, inductively coupled plasma-mass spectrometry; XRF, $\mathrm{X}$-ray fluorescence. Units of measure: $\mathrm{cm}$, centimeter; $\mathrm{m}$, meter; $\mathrm{mm}$, millimeter; ppb, part per billion; ppm, part per million; $\mu \mathrm{g} / \mathrm{L}$, microgram per liter; $\mu \mathrm{m}$, micrometer. - , no data]

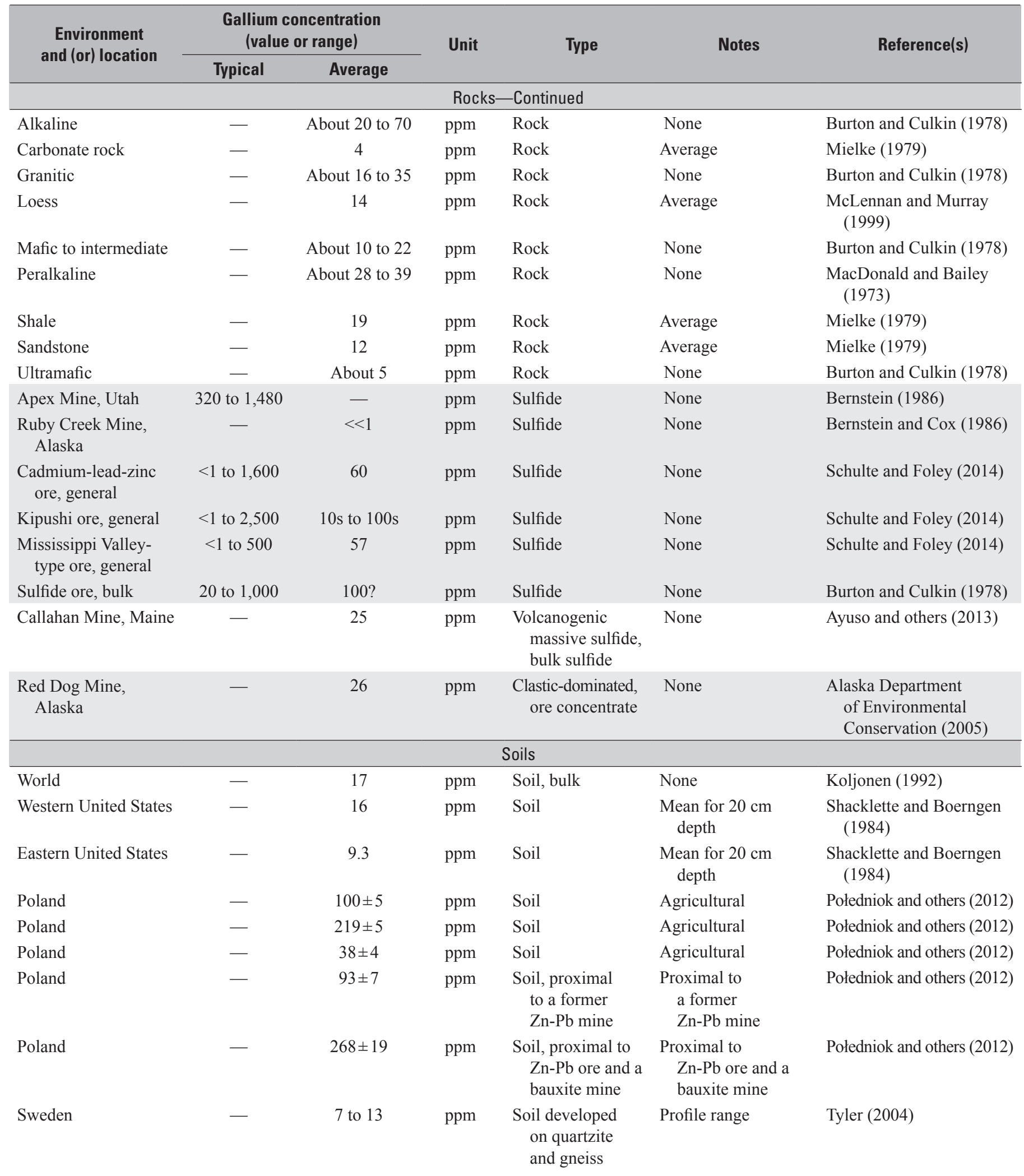


Table H2. Gallium concentrations in rocks, ore, coal, soils, and natural waters.-Continued

[FOREGS, Forum of European Geological Surveys, now EuroGeoSurveys; Ga, gallium; ICP-MS, inductively coupled plasma-mass spectrometry; XRF, $\mathrm{X}$-ray fluorescence. Units of measure: $\mathrm{cm}$, centimeter; m, meter; mm, millimeter; ppb, part per billion; ppm, part per million; $\mu \mathrm{g} / \mathrm{L}, \mathrm{microgram}$ per liter; $\mu \mathrm{m}$, micrometer. - , no data]

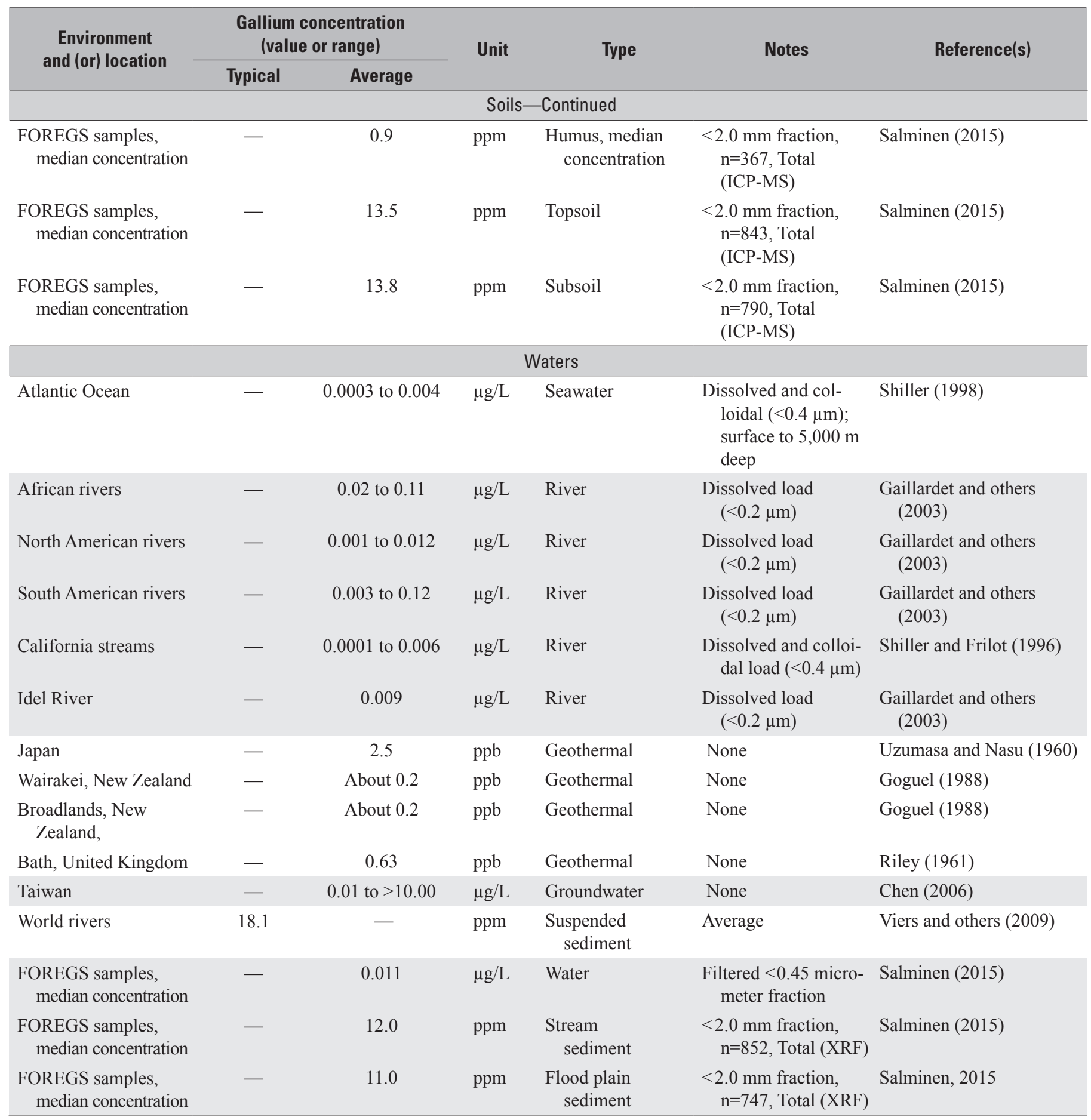




\section{H12 Critical Mineral Resources of the United States-Gallium}

\section{Mineralogy}

Gallium is an essential structural component of only a few minerals that form in nature. Gallium is dispersed, however, in low amounts in many minerals and rocks, where it substitutes for elements of similar size and charge (table H3). Because gallium minerals are too rare in nature to serve as a primary source of the element or its compounds, most gallium is produced from minerals containing less than $100 \mathrm{ppm}$ gallium (table H3), where the gallium may occur as inclusions, as stoichiometric or nonstoichiometric substitutions, or as adsorbed ions or molecules.

Four gallium-rich minerals have been recognized (approved) by the International Mineralogical Association, Commission on New Minerals, Nomenclature and Classification (table H3). These include the sulfide gallite, which has about 35 weight percent gallium; gallobeudantite, which is an alunite of variable gallium content; and the hydroxide minerals sohngeite and tsumgallite, both of which contain about 60 weight percent gallium. These minerals have been identified in association with carbonate-hosted copperlead-zinc deposits at the Tsumeb Mine in the Oshikoto Region,
Namibia (Frimmel and others, 1996, and references therein). Gallite occurs as a primary sulfide mineral and is essentially a common copper sulfide, chalcopyrite $\left(\mathrm{CuFeS}_{2}\right)$, in which gallium replaces iron in the crystal structure. Typical occurrences of gallite are as inclusions in sphalerite $(\mathrm{ZnS})$. Because gallite has a chalcopyrite structure, it may occur as either epitaxial overgrowths or inclusions as "chalcopyrite disease" (Barton and Bethke, 1987) in sphalerite. Gallobeudantite, sohngeite, and tsumgallite are supergene minerals resulting from surficial oxidation of other gallium-bearing minerals. Gallium also substitutes in many minerals, including silicates, sulfides, and hydroxides, in concentrations ranging from parts per million to weight percent (table H3). For example, significant amounts occur in krieselite (about 20 weight percent gallium), which is the germanium analog of topaz, and in gallium-rich plumbogummite, where it may fill one-third of the aluminum sites (about 25 weight percent gallium). Major rock-forming minerals, however, contain significantly less than 1 percent gallium, and most minerals have less than $100 \mathrm{ppm}$ gallium. Feldspars and micas are the dominant host minerals for gallium in most igneous and sedimentary rocks. For example, gallium has been reported at relatively

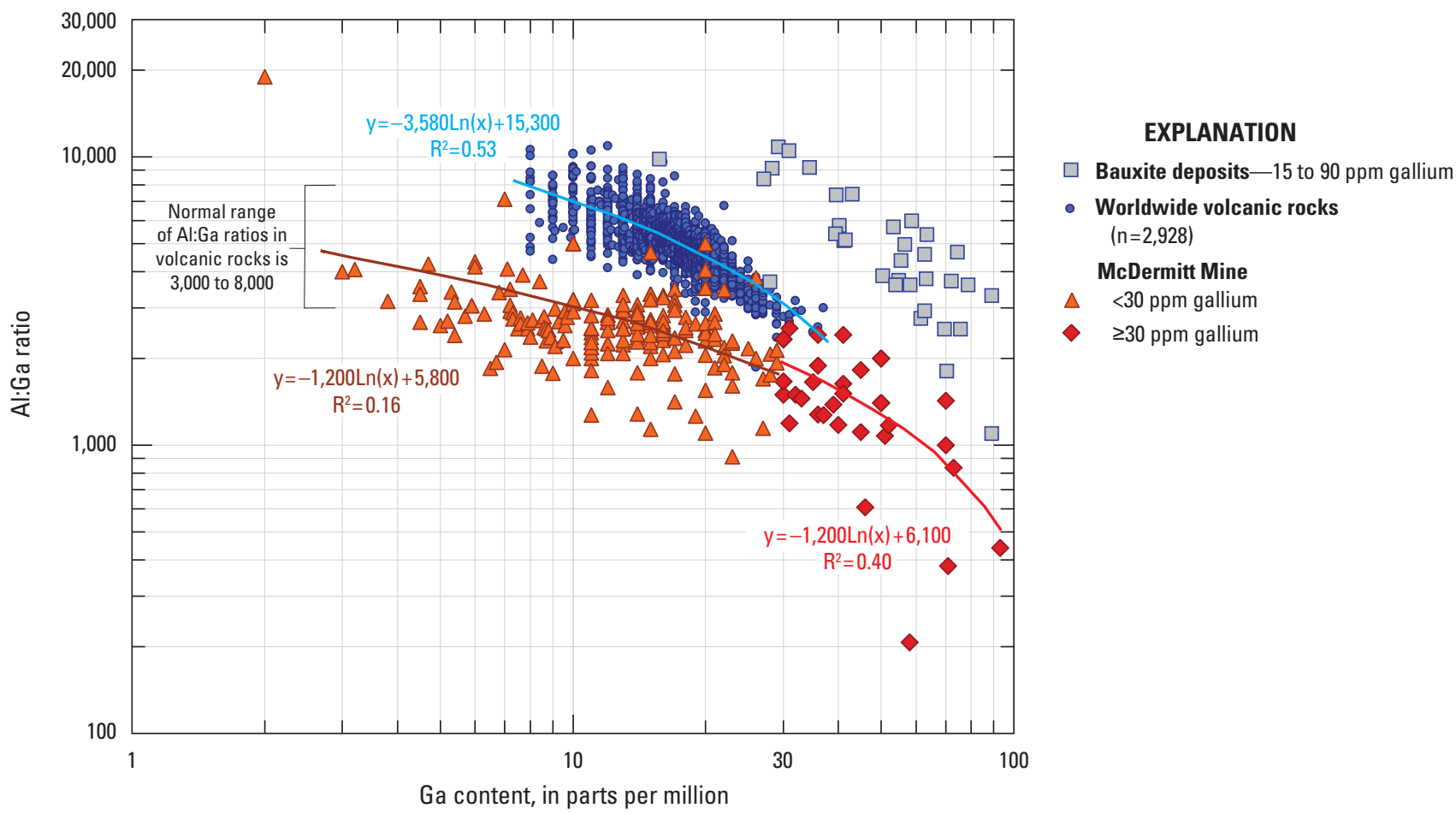

Figure H6. Plot of the ratio of aluminum to gallium (Al:Ga, log scale) versus gallium content (in parts per million [ppm], log scale) for bauxite deposits, volcanic rocks, and hydrothermally altered rocks of the McDermitt caldera, Nevada. Results from the McDermitt Mine, Nev., are included for comparison; see text for details. Equations define slope of lines drawn through datasets for comparison; $R^{2}$ value is a measure of goodness of the fit of the line to the data. Modified from Rytuba and others (2003) with the addition of data for various globally distributed bauxite deposits from Schulte and Foley (2014). 
Table H3. Selected gallium-bearing minerals—Formula, content, and occurrence.

[Compiled from Burton and Culkin (1978), Bernstein (1986), Dutrizac and others (1986), Tervek and Fay (1986), Frimmel and others (1996), Schlüter and others (2003), Ye and others (2011), and Schulte and Foley (2014). b.d.l., below detection limit; ppm, part per million; $\sim$, approximately. Elements: Al, aluminum; $\mathrm{Cu}$, copper; Fe, iron; $\mathrm{Ga}$, gallium; $\mathrm{Pb}$, lead; $\mathrm{Zn}$, zinc]

\begin{tabular}{|c|c|c|c|c|}
\hline Mineral name & Chemical formula & Ga content & Group & Deposit model, occurrence type \\
\hline Gallite & $\mathrm{CuGaS}_{2}$ & 35.32 & Sulfide & $\begin{array}{l}\text { Carbonate-hosted } \mathrm{Cu}-\mathrm{Pb}-\mathrm{Zn} \text {; } \mathrm{Pb}-\mathrm{Zn}-\mathrm{Cu} \\
\text { Tsumeb Mine in Namibia }\end{array}$ \\
\hline Gallobeudantite & $\mathrm{PbGa}_{3}\left[\left(\mathrm{AsO}_{4}\right),\left(\mathrm{SO}_{4}\right)\right]_{2}(\mathrm{OH})_{6}$ & 14.55 , variable & Alunite & $\begin{array}{l}\text { Carbonate-hosted } \mathrm{Cu}-\mathrm{Pb}-\mathrm{Zn} \text {; supergene, } \\
\text { Tsumeb Mine in Namibia }\end{array}$ \\
\hline Tsumgallite & $\mathrm{GaO}(\mathrm{OH})$ & 59.93 & Hydroxide & $\begin{array}{l}\text { Carbonate-hosted } \mathrm{Cu}-\mathrm{Pb}-\mathrm{Zn} \text {; supergene, } \\
\text { Tsumeb Mine in Namibia }\end{array}$ \\
\hline \multicolumn{5}{|c|}{ Minerals with nonessential gallium } \\
\hline Krieselite & $(\mathrm{Al}, \mathrm{Ga})_{2}\left(\mathrm{GeO}_{4}\right)(\mathrm{OH})_{2}$ & 20.3 weight percent & $\begin{array}{l}\text { Topaz group, } \\
\text { germanate }\end{array}$ & Ge analog of topaz \\
\hline Eyselite & $\mathrm{FeGe}_{3} \mathrm{O}_{7}(\mathrm{OH})$ & $6,900 \mathrm{ppm}$ & Hydroxide & $\begin{array}{l}\text { Carbonate-hosted } \mathrm{Cu}-\mathrm{Pb}-\mathrm{Zn} ; \mathrm{Pb}-\mathrm{Zn}-\mathrm{Cu} \\
\text { Tsumeb Mine in Namibia }\end{array}$ \\
\hline Ovamboite & $\mathrm{Cu}_{20}(\mathrm{Fe}, \mathrm{Cu}, \mathrm{Zn})_{6} \mathrm{~W}_{2} \mathrm{Ge}_{6} \mathrm{~S}_{32}$ & $4,600 \mathrm{ppm}$ & $\begin{array}{l}\text { Sulfide, germanite } \\
\text { group }\end{array}$ & Massive sulfide base-metal ores \\
\hline Calvertite & $\mathrm{Cu}_{5} \mathrm{Ge}_{0.5} \mathrm{~S}_{4}$ & $3,500 \mathrm{ppm}$ & Sulfide & $\begin{array}{l}\text { Carbonate-hosted } \mathrm{Cu}-\mathrm{Pb}-\mathrm{Zn} ; \mathrm{Pb}-\mathrm{Zn}-\mathrm{Cu} \\
\text { Tsumeb Mine in Namibia }\end{array}$ \\
\hline $\begin{array}{l}\text { Ferrohogbomite- } \\
\text { 2N2S }\end{array}$ & $\begin{array}{l}(\mathrm{Fe}, \mathrm{Zn}, \mathrm{Mg}, \mathrm{Al})_{6} \mathrm{Al}_{14}(\mathrm{Ti}, \mathrm{Fe})_{2} \\
\quad \mathrm{O}_{30}(\mathrm{OH})_{2}\end{array}$ & $1,600 \mathrm{ppm}$ & Oxide & High grade Fe-oxide deposits \\
\hline Maikainite & $\mathrm{Cu}_{20}(\mathrm{Fe}, \mathrm{Cu})_{6} \mathrm{Mo}_{2} \mathrm{Ge}_{6} \mathrm{~S}_{32}$ & $1,500 \mathrm{ppm}$ & $\begin{array}{l}\text { Sulfide, germanite } \\
\text { group }\end{array}$ & $\begin{array}{l}\text { Volcanogenic massive sulfide, sedimentary } \\
\text { exhalative, and Mississippi Valley-type } \\
\text { base-metal deposits. (1) Maikain deposit, } \\
\text { Kazakhstan, and (2) Tsumeb deposit, } \\
\text { Namibia }\end{array}$ \\
\hline Gibbsite & $\mathrm{Al}(\mathrm{OH})_{3}$ & About 50 ppm & Oxide, hydroxide & Bauxite-silicate; bauxite-karst \\
\hline Diaspore & $\alpha-\mathrm{AlO}(\mathrm{OH})$ & About $50 \mathrm{ppm}$ & Oxide, hydroxide & Bauxite-silicate; bauxite-karst \\
\hline Boehmite & $\gamma-\mathrm{AlO}(\mathrm{OH})$ & About $50 \mathrm{ppm}$ & Oxide, hydroxide & Bauxite-silicate; bauxite-karst \\
\hline Kaolinite & $\mathrm{Al}_{2} \mathrm{Si}_{2} \mathrm{O}_{5}(\mathrm{OH})_{4}$ & About 50 to $200 \mathrm{ppm}$ & Silicate & Kaolins; bauxite-silicate; bauxite-karst \\
\hline Halloysite & $\mathrm{Al}_{2} \mathrm{Si}_{2} \mathrm{O}_{5}(\mathrm{OH})_{4}$ & About 50 to $200 \mathrm{ppm}$ & Silicate & Kaolins; bauxite-silicate; bauxite-karst \\
\hline Jarosite & $\mathrm{KFe}\left(\mathrm{SO}_{4}\right)_{2}(\mathrm{OH})_{6}$ & 0.7 weight percent & Sulfite & Supergene \\
\hline Limonite & $\mathrm{FeO}(\mathrm{OH}) \cdot \mathrm{nH}_{2} \mathrm{O}$ & 2 weight percent & Hydroxide & Supergene \\
\hline Goethite & $\mathrm{FeO}(\mathrm{OH})$ & $200 \mathrm{ppm}$ & Hydroxide & Supergene \\
\hline Renierite & $(\mathrm{Cu}, \mathrm{Zn})_{11}(\mathrm{Ge}, \mathrm{As})_{2} \mathrm{Fe}_{4} \mathrm{~S}_{16}$ & 0.04 to $400 \mathrm{ppm}$ & $\begin{array}{l}\text { Sulfide, germanite } \\
\text { group }\end{array}$ & Massive sulfide base-metal ores \\
\hline Germanite & $\mathrm{Cu}_{26} \mathrm{Fe}_{4} \mathrm{Ge}_{4} \mathrm{~S}_{32}$ & 0.09 to $900 \mathrm{ppm}$ & $\begin{array}{l}\text { Sulfide, germanite } \\
\text { group }\end{array}$ & Massive sulfide base-metal ores \\
\hline Feldspar group & $\begin{array}{l}\mathrm{NaAlSi}{ }_{3} \mathrm{O}_{8}, \mathrm{CaAl}_{2} \mathrm{Si}_{2} \mathrm{O}_{8} \\
\quad \mathrm{KAlSi}_{3} \mathrm{O}_{8}\end{array}$ & $\begin{array}{l}\text { b.d.1. to } 100 \mathrm{ppm} \text {, rarely } \\
\text { up to } 4,000 \mathrm{ppm}\end{array}$ & Silicate & Felsic igneous rocks \\
\hline
\end{tabular}

${ }^{1}$ Approved by the International Mineralogical Association, Commission on New Minerals, Nomenclature and Classification. 
high concentrations ( 0.05 weight percent) in feldspars from the Nechalacho layered nepheline-aegirine syenite suite at Thor Lake in the Northwest Territories, Canada (Tervek and Fay, 1986); however, most feldspar contains much less than 200 ppm gallium (table H3). Gallium is retained in clay minerals, such as kaolinite and smectite, and in aluminum hydroxide minerals during weathering, which accounts for the higher gallium contents in many clay-bearing rocks and bauxites (table H2). At the present time, gallium is derived mainly from aluminum hydroxide minerals, including boehmite, diaspore, and gibbsite $\left(\mathrm{Al}(\mathrm{OH})_{3}\right)$, which form in deeply weathered deposits of bauxite (fig. H7A) (Dutrizac and others, 1986; Bernstein and Waychunas, 1987; Moskalyk, 2003). Significant amounts of gallium are also produced from zinc sulfide deposits where sphalerite (fig. $\mathrm{H} 7 B$ ) is the main carrier (Moskalyk, 2003). Gallium (and germanium) can also be enriched in other sulfide minerals, such as bornite, enargite, galena, and luzonite (Hörmann, 1978). Weathering of gallium-bearing sulfide minerals can lead to gallium-enriched sulfate and hydroxide minerals, and in oxidized environments, gallium commonly occurs in plumbojarosite and hydrogoethite (Burton and Culkin, 1978). At the Apex Mine in Summit County, Utah, jarosite (a potassium-iron-sulfate mineral) reportedly contains concentrations of up to 1 weight percent gallium (Bernstein, 1986).

\section{Gibbsite-Diaspore-Boehmite}

Gibbsite forms in weathering environments by a series of reactions generated during the hydrolysis of feldspar and other aluminosilicate minerals in rocks undergoing saprolitization (Foley and Ayuso, 2013, and references therein). The proportion of gibbsite-diaspore-boehmite increases at the expense of kaolinite in more intensely weathered rocks, such as bauxites and laterites (Soler and Lasaga, 1996). In these environments, as a result of burial diagenesis or low-grade regional metamorphism, gibbsite transforms to boehmite $(\gamma-\mathrm{AlO}(\mathrm{OH}))$ by dehydration, and turns into diaspore $(\alpha-\mathrm{AlO}(\mathrm{OH}))$ after compaction. Gallium in these minerals may be found as substitutions for trivalent aluminum or it may form as a separate phase (table H3). Sohngeite, which is the gallium analog of gibbsite, has a similar stability, and it transforms readily into tsumgallite $(\mathrm{GaO}(\mathrm{OH}))$ in aqueous solution (table H3). The unit cell parameters of tsumgallite mostly resemble diaspore compared with gibbsite or boehmite (Schlüter and others, 2003). Gallium hydroxide minerals rarely form as discrete phases; rather, they generally occur in supergene parts of carbonate-hosted polymetallic replacement deposits, such as at the Tsumeb Mine in Namibia (Frimmel and others, 1996). Diaspore and tsumgallite are isostructural, have similar crystal chemical characteristics, and are the most
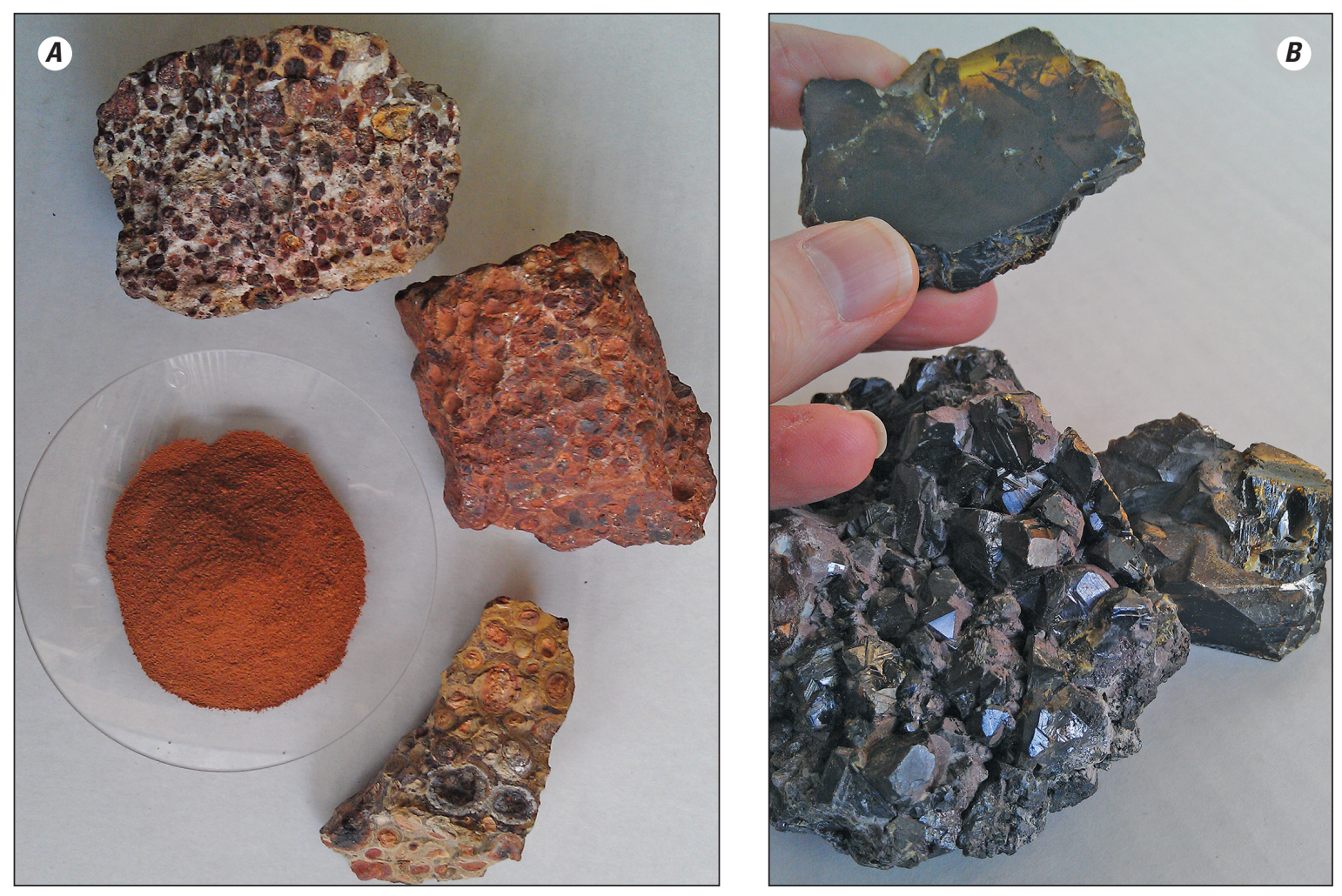

Figure H7. Photographs showing samples of $A$, bauxite ore, and $B$, sphalerite ore, which are the primary mineralogical sources of gallium. The three samples of bauxite are from U.S. Geological Survey (USGS) collections and the powdered bauxite ore sample was provided by E.L. Bray, USGS. The sphalerite ore is from the Creede district, San Juan County, Colorado. 
stable hydroxides of aluminum and gallium, respectively. Thus, gallium, in the form of $\mathrm{GaO}(\mathrm{OH})$, is more likely to be enriched in diaspore than in the other aluminum hydroxides.

\section{Sphalerite}

Sphalerite (fig. $\mathrm{H} 7 B$ ) is an important source of gallium in spite of the generally low concentrations in natural samples (table H3) because it is abundant in a wide variety of mineral deposits (table H4). Gallium enrichment in sphalerite under hydrothermal conditions results from its weak chalcophile behavior, which is similar to that of zinc. Gallium is thought to be incorporated in sphalerite by a coupled substitution of two $\mathrm{Zn}$ for $\mathrm{Ga}$ plus either $\mathrm{Ag}, \mathrm{Cu}, \mathrm{Ge}$, In, or $\mathrm{Sn}$ to maintain a balanced charge (Johan and others, 1983; Johan, 1988; Cook and others, 2009). The highest known concentrations of gallium in sphalerite (2.1 to 3.7 weight percent gallium occur in sulfide nodules in the Qingzhen (EH3) chondrite (Rambaldi and others, 1986), which is a range that matches experimental determinations (Krämer and others, 1987; Ueno and Scott, 2002). Sphalerite from gallium-rich low temperature carbonate-hosted lead-zinc deposits of Namibia (Khusib Spring Mine in the Otjozondjupa Region and the Tsumeb Mine) show a range of from hundreds to more than 3,000 ppm gallium (Melcher and others, 2006). In general, however, concentrations in most sphalerites rarely exceed $100 \mathrm{ppm}$ gallium. For example, sphalerite from clasticdominated lead-zinc deposits of the Red Dog Mine in the Northwest Arctic Borough of Alaska contains an average of 26 ppm gallium (Alaska Department of Environmental Conservation, 2005), whereas zinc ores from U.S. Mississippi Valley-type deposits average about 50 ppm gallium (Moskalyk, 2003). Gallium contents can vary widely in volcanogenic massive sulfide deposits, even within a single district or within individual sphalerite grains from a deposit. For example, some individual deposits within the Bonnifield mining district in Alaska (such as the Anderson Mountain deposit in Denali Borough and the Fosters Creek zone) can contain anywhere from 20 to $275 \mathrm{ppm}$ gallium in sphalerite, whereas others (the West Tundra Flats deposit in Southeast Fairbanks Borough) have less than $1 \mathrm{ppm}$ gallium in sphalerite (Foley and others, 2008; Dusel-Bacon and others, 2011; Dusel-Bacon and others, 2012). Sphalerite from the Callahan Mine in Hancock County, Maine (Ayuso and others, 2013), shows a range of from less than $3 \mathrm{ppm}$ to up to $105 \mathrm{ppm}$ gallium in single, 1- to 5-millimeter (mm)-wide crystals (table H3).

\section{Deposit Types}

The principal deposit types (table H4) and significant global and domestic deposits (fig. H4) from which gallium metal is currently being obtained are emphasized here; however, other deposit types that have gallium in potentially extractable amounts are included in table H4. Although gallium is found in a diverse group of mineral deposit types, current sources are limited to a small number of deposit types because gallium is produced mainly as a byproduct. More than 80 percent of the world's refined gallium is obtained from bauxite deposits (Jaskula, 2013b). The balance is derived from operations that collect zinc residues from a variety of zinc deposit types; the residues are combined prior to the gallium extraction cycle. Among zinc deposits, gallium concentrations tend to be high in carbonate-hosted replacement deposits and Mississippi Valley-type deposits, and variably enriched in clastic-dominated systems and volcanogenic massive sulfide deposits, whereas skarns are universally low in gallium (Cook and others, 2009). Gallium and other metals produced from zinc-refining residues are derived largely from such deposits as the Red Dog zinc mine in Alaska (Tervek and Fay, 1986). Other sources include volcanogenic massive sulfide deposits; for example, the Tizapa Mine in Mexico (Dowa Holdings Co., Ltd., 2013). Carbonate-hosted lead-zinc deposits of the Kipushi-type - for example, the Apex Mine in Utah - have the potential to produce gallium (and germanium) as a primary product. The two major types of gallium sourcesbauxite deposits and sediment-hosted lead-zinc depositsare described below.

\section{Bauxite Deposits}

Bauxite is mined for a number of products that have commercial application in abrasive, cement, chemical, metallurgical, and refractory industries. Approximately 70 to 80 percent of the world's dry bauxite production is processed into aluminum metal (Freyssinet and others, 2005), and these are the ores from which most gallium metal is currently derived. Bauxite is a rock that consists mostly of fine-grained aluminum minerals, notably boehmite, diaspore, and gibbsite, in mixtures with lesser amounts of iron oxides, typically goethite and hematite, kaolinite, and small amounts of anatase (Bárdossy and Aleva, 1990). Some bauxites form as accumulations of clayey remnants within paleokarst disconformities in limestone sequences; these are referred to as karst bauxites (fig. H5A). Karst bauxite is typically black to gray in color because of the presence of admixed organic matter and, in some instances, minerals that form in chemically reduced environments, such as pyrite (Bárdossy, 1982). Another type of bauxite, lateritic bauxite, occurs in parts of thick altered profiles formed by lateritization of aluminosilicate rocks (fig. H5B) (Retallack, 2010). Lateritization is a complex integration of surficial biological, chemical, and physical processes that result in thick sequences of intensely weathered saprolite and soil. Laterites are a form of ferricrete that can occur as horizons within a soil profile. By definition, periods of lateritization record exceptionally intense, regionally widespread weathering under tropical temperature regimes with ample water (Bárdossy and Aleva, 1990); thus, lateritic bauxites occur in thick profiles formed by deep tropical weathering. A combination of climate, tectonics, geomorphology, and hydrogeological factors are required to produce deposits that make up productive bauxite ore districts and provinces (fig. H4; Bogatyrev, Zhukov, and Tsekhovsky, 2009). 


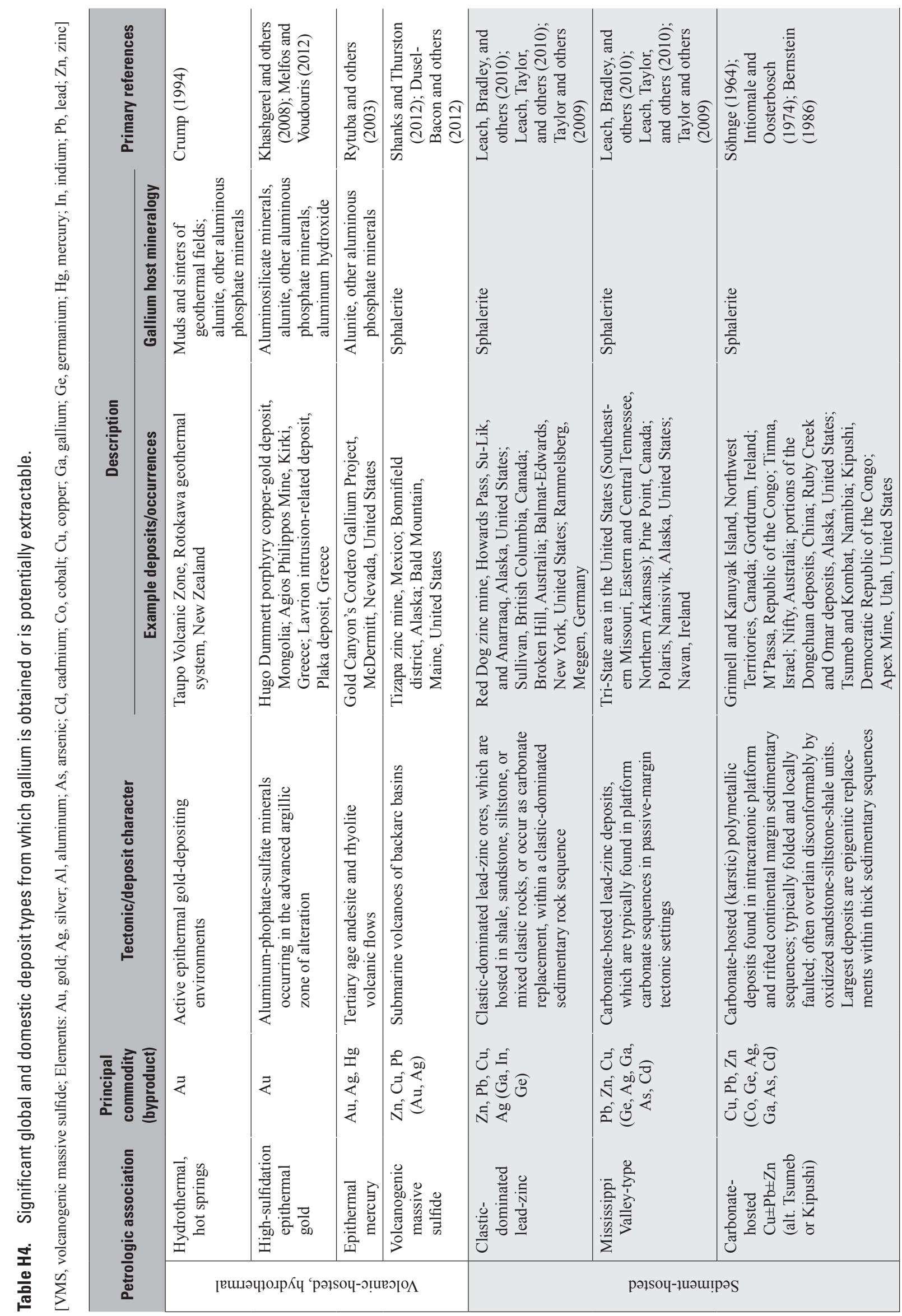


Geology H17

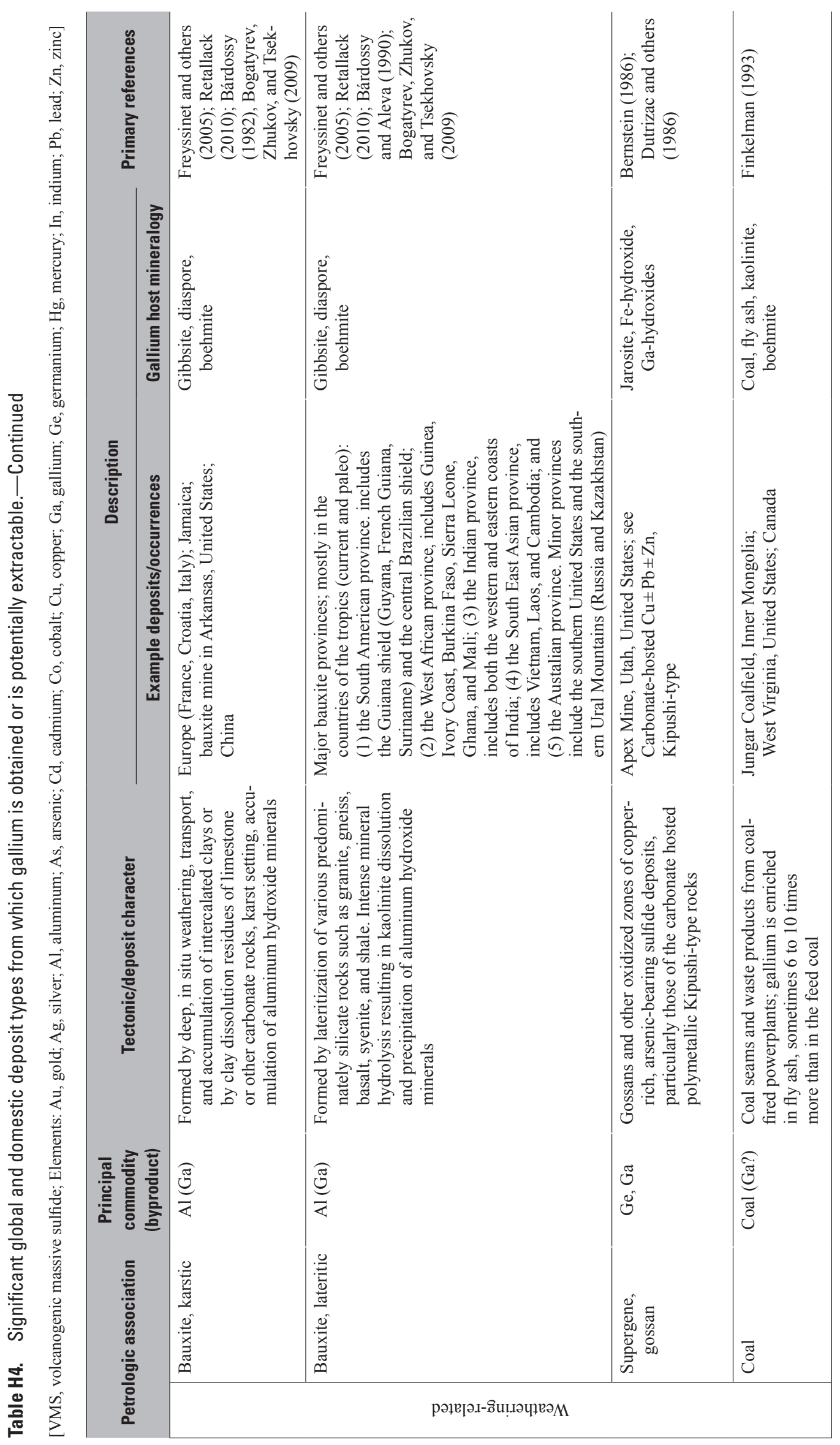


The formation of large and superlarge deposits is thought to require more than 10 million years or the superposition of several intense weathering epochs.

Various models for the origin of laterites and lateritic bauxites (for example, McFarlane, 1976; Brimhall and others, 1991; Retallack, 2010) have included both (a) elemental removal by hydrolysis and chemical leaching, and (b) elemental addition by mineral precipitation or fluvial or atmospheric deposition (for example, eolian dust) to explain the chemical compositions and volume and mass losses in bauxites. Bauxites usually form in the pallid soil zone (fig. $\mathrm{H} 5 B$ ) but can occur in the $\mathrm{B}$ or $\mathrm{C}$ horizons of exceptionally thick profiles (Retallack, 2010). Lateritic bauxites typically have distinctive pisolitic textures and red colors (fig. H7A). Karst bauxites that form by transport and redeposition of lateritic bauxite clays and rubble in paleokarst depressions may retain the laterite characteristics of color and texture (Retallack, 2010). The extreme weathering conditions that contribute to bauxite formation remove virtually all the alkalis and alkaline earths, leaving only the relatively immobile component of the original rock; as a result, paleosols within bauxites and soils that form on bauxite are classified as oxisols (U.S. Natural Resources Conservation Service, Soil Survey Staff, 2000).

Bauxite deposits form in a diverse array of geologic and tectonic environments over a wide range of geologic time (for example, Bárdossy, 1982; Bárdossy and Aleva, 1990; Retallack, 2010). An extensive study of well-characterized and dated bauxites (Retallack, 2010) showed that although the oldest known bauxites formed on the Arabian Shield at about 3,500 mega-annum (Ma, or million years ago), bauxites are most abundant in rocks formed since about $100 \mathrm{Ma}$ owing to better preservation of the rock record (Wilkinson and others, 2009). Bauxites show an uneven distribution through time that is consistent with evidence supporting their correlation with paleoclimatic events of intense weathering, possibly related to greenhouse gas emissions, which lasted for geologic time intervals of less than about 100,000 years (Valeton, 1983; Retallack, 2010). Bauxite formation during these events had an expanded distribution from the Quaternary (between the Tropics of Cancer and Capricorn) to encompass areas near the Arctic and Antarctic Circles (Retallack, 2010). As a consequence, greenhouse gas events of the past, which are shown to have influenced the distribution of aluminum ores (Retallack, 2010), are also associated with gallium ores.

Bauxite, lateritic bauxite, and karst bauxite are rocks that have concentrations of aluminum exceeding about 45 percent by weight, by definition (Valeton, 1972). This reflects a high proportion of hydroxide minerals with aluminum contents on the order of about 60 or more percent alumina by weight. Bauxite generally is defined as rock with 20 percent or less total iron, whereas lateritic bauxite, in addition to a high percentage of aluminum, can have greater than 20 percent total iron, which is generally ferric owing to oxidation unless reducing conditions prevail locally. The limited mobility of aluminum and gallium in near-surface environments accounts for gallium enrichment in bauxite and related materials (soils, kaolins, and ball clays) derived from deep weathering of crustal rocks. Overall, bauxite contains concentrations in the range of 8 to $800 \mathrm{ppm}$ gallium, with most values in the range 40 to $80 \mathrm{ppm}$ gallium (table $\mathrm{H} 2$ ). The world average concentration of gallium in bauxite was initially estimated to be $52 \mathrm{ppm}$ (Burton and Culkin, 1978), and additional data have not changed that value significantly. For example, carbonate-hosted bauxites from central and southern Europe display average concentrations of about $50 \mathrm{ppm}$ gallium (Schroll, 1999); bauxites from Arkansas range from 50 to $100 \mathrm{ppm}$ gallium (average $86 \mathrm{ppm}$ ); and bauxite from India has a similar range of 5 to $122 \mathrm{ppm}$ gallium (table H2). High gallium values are reported in bauxite originating from alteration of alkali rocks (for example, nepheline syenite of Russia ranges up to $170 \mathrm{ppm}$ gallium) and in some unusual karst deposits (table H2). In general, however, there appear to be no significant differences in gallium concentrations of karst- or lateritic-type bauxites (Schulte and Foley, 2014).

\section{Sediment-Hosted Lead-Zinc Deposits}

Sediment-hosted lead-zinc deposits are historically the most significant sources of zinc, and these deposits are mined throughout the United States and the world (Leach, Bradley, and others, 2010). The largest and most economically important sediment-hosted deposits for zinc production are the clastic-rock-dominated and carbonate-rock-dominated (Mississippi Valley-type) subtypes (Leach, Marsh, and others, 2004; Leach, Bradley, and others, 2010; Leach, Taylor, and others, 2010); these are the main types of sulfide deposits from which gallium metal is obtained at present because they are currently the predominant sources of zinc ore. Carbonatehosted polymetallic deposits of the Kipushi (or Tsumeb) type are of minor importance for zinc production; however, they are considered separately here because they have high gallium content relative to other deposit types of the sediment-hosted class and are historic gallium producers for the United States. Much of the following discussion is summarized from a number of seminal review studies of sediment-hosted leadzinc deposits, including Leach and Sangster (1993), Leach, Viets, and others (1995); Leach, Marsh, and others (2005); Leach, Sangster, and others, (2005); Groves and Bierlein (2007); Leach, Bradley, and others (2010); and Leach, Taylor, and others (2010).

Sediment-hosted lead-zinc deposits form in rocks of widely varying geologic age and tectonic environment (figs. $\mathrm{H} 5 \mathrm{C}$ through $\mathrm{H} 5 E$ ). In general, these deposits are hosted by large-scale sedimentary systems consisting of a variety of siliciclastic and carbonate rocks and have no direct genetic association with igneous activity. Many deposits in the sediment-hosted class display transitional features, and the distinctions among some of the deposit types are subjective. Most sediment-hosted deposits occur in sedimentary rock sequences that were originally deposited in extensional rift or passive-margin settings. There is an apparent uneven distribution of sediment-hosted deposits through time that is 
attributed to their genesis in large-scale sedimentary systems and to continued recycling of the sedimentary rock record within the evolving tectonic and geochemical systems of Earth through geologic time. Tectonic setting, depositional environment, and host-rock lithology influence the mineral chemistry of the contained sulfide minerals, including their trace element characteristics. The ores consist mainly of galena, sphalerite, and generally lesser amounts of iron sulfides, which may be marcasite or pyrite. In addition to lead and zinc, gallium, germanium, and silver can be important constituents; copper is generally quite low, except in the Kipushi-type deposits, but can be economically important in all these deposits. Laminated ore textures and a layered morphology are generally characteristic of clastic-dominated deposits, whereas Mississippi Valley-type deposits generally exhibit abundant evidence for epigenetic and replacement ores. Nonetheless, some clastic-dominated ores show replaced sediments in early or burial diagenetic environments and some Mississippi Valley-type deposits display laminated ore textures.

\section{Clastic-Dominated Lead-Zinc Type}

The most definitive characteristic of clastic-dominated deposits as described by Leach, Marsh, and others (2005) is their occurrence in clastic rock-dominated sedimentary sequences formed mainly in passive margins, continental rifts, continental sag basins, and back-arc basins (figs. H5C and $\mathrm{H} 5 \mathrm{D}$ ). The orebodies are typically hosted in (in order of predominance) shale, sandstone, siltstone, carbonate, or mixed clastic rocks and their metamorphosed equivalents. They may also occur as carbonate replacement ores within a clastic-rock-dominated sedimentary sequence.

The vast majority of clastic-dominated deposits globally occur in Proterozoic basins that formed between 2.02 billion years ago - the age of the earliest known deposit of these ores - and about 1.85 to 1.58 billion years ago, which reflects a major period of clastic-dominated lead-zinc deposition in Australia and India. The appearance of clasticdominated deposits in the Precambrian period corresponds to a time of formation of large and long-lived basins on stable cratons that followed the Great Oxidation Event at about 2.4 to 1.8 billion years ago. The formation of clastic-dominated deposits is related to enhanced oxidation of sulfides in the crust (which released sulfate to the hydrosphere and lead and zinc to sediments); the development of major redox and compositional gradients in the oceans; the first formation of significant sulfatebearing evaporates, red beds, and oxidized aquifers; and the evolution of sulfate-reducing bacteria (Leach, Bradley, and others, 2010, p. 593). A number of clastic-dominated lead-zinc deposits also formed during the Carboniferous Period along passive margins in sedimentary-evaporite belts of Pangea and were deposited after the second oxidation event.

Mineralogical and geochemical evidence suggests that clastic-dominated ore fluids were principally hot metalliferous basinal brines (for example, Badham, 1981; Lydon, 1983; Cooke and others, 2000). For example, the brines that deposited sphalerite at the Red Dog deposit in Alaska had temperatures in the range of 100 to $200{ }^{\circ} \mathrm{C}$ and salinities from 14 to 19 weight percent $\mathrm{NaCl}$ equivalent (Leach, Marsh, and others, 2004). The dominant sulfide minerals present are sphalerite (which is generally the most common sulfide mineral) and lesser amounts of galena and the iron sulfides, marcasite, pyrite, or pyrrhotite; chalcopyrite and sulfosalt minerals may be present in minor amounts (Large, 1981, 1983; Lydon, 1983; Large and others, 2005). The sulfide minerals form lens-like bodies that are interbedded with fine-grained dark clastic and chemical sedimentary rocks. Carbonate minerals (ankerite, calcite, dolomite, and siderite), barite and quartz, siliceous shale, and low-grade silica-replaced rocks are common and can be gradational into massive ore. Ore from these deposits (table H4) generally contains less than $100 \mathrm{ppm}$ gallium, with a typical range of 5 to $50 \mathrm{ppm}$ gallium (table H2). For example, the Red Dog deposit (fig. H4) is hosted by organic-rich mudstone and shale of the Mississippian Kuna Formation (Kelley and others, 2004), and zinc concentrate from the deposit has $26 \mathrm{ppm}$ gallium (Alaska Department of Environmental Conservation, 2005). Other elements in association with clastic-dominated lead-zinc deposits include $\mathrm{Ag}, \mathrm{Al}, \mathrm{As}, \mathrm{Au}, \mathrm{B}, \mathrm{Ba}, \mathrm{Cd}, \mathrm{Co}, \mathrm{Cu}, \mathrm{Fe}, \mathrm{Ge}, \mathrm{Hg}, \mathrm{Mn}, \mathrm{Mo}, \mathrm{Ni}$, and Sb (Briskey, 1986; Kelley and others, 1995).

\section{Mississippi Valley Lead-Zinc Type}

Carbonate-hosted lead-zinc deposits are found throughout the world, and large famous examples occur in central North America; hence, they are generally referred to as Mississippi Valley-type deposits. The most important characteristics of Mississippi Valley-type deposits (Sangster, 1990; Leach and Sangster, 1993; Leach, Sangster, and others, 2005) are that they occur globally in dolostone and limestone that formed in platform carbonate sequences. They are commonly related to extensional domains inboard of contractional tectonic belts or continental extensional basins transitional to passive margin basins (figs. $\mathrm{H} 5 \mathrm{C}$ and $\mathrm{H} 5 E$ ). The ores are usually located at flanks of basins, orogenic forelands, or foreland thrust belts inboard of the clastic-rock-dominated passive margin sequences. Numerous lines of evidence have established that the metals were carried in fluids derived mainly from evaporated seawater and driven within the carbonate sequences by large-scale tectonic events.

More than 80 percent of Mississippi Valley-type deposits are hosted by rocks formed during the Phanerozoic Eon; less than 20 percent occur in Precambrian rocks (Sangster, 1990; Leach, Bradley, and others, 2001; Leach, Sangster, and others, 2005; Kesler and Reich, 2006). Increased oxygenation of the oceans following the second oxidation event of the atmosphere in the late Neoproterozoic Era led to an abundance of evaporites, oxidized brines, and a dramatic increase in the volume of coarse-grained and permeable carbonates in Paleozoic carbonate platforms. Most Phanerozoic-hosted Mississippi Valley-type deposits formed in the carbonate platform sequences during Devonian to Permian time as a 
result of tectonic events generated by the assimilation of Pangea. A lesser number formed during Cretaceous to Tertiary time when microplate assimilation affected the western margin of North America and Africa-Eurasia.

These ores consist mainly of galena, sphalerite, and generally lesser amounts of iron sulfides. Copper and silver are important constituents in some of these deposits (for example, deposits of the Irish subtype and some deposits of the Viburnum Trend). Gangue minerals are dominantly carbonates (ankerite, calcite, dolomite, and siderite), with typically minor amounts of barite. Silicification of the host rocks (or quartz gangue) is generally minor, but may be abundant in a few deposits. Minor minerals associated with Mississippi Valleytype mineralization differ widely between individual districts, and minor and trace metals also vary (Lavery and others, 1994). Minor elements and element associations can include $\mathrm{Ag}, \mathrm{As}, \mathrm{Au}, \mathrm{Ba}, \mathrm{Bi}, \mathrm{Cd}, \mathrm{Co}, \mathrm{Cu}, \mathrm{Ga}, \mathrm{Ge}, \mathrm{In}, \mathrm{Fe}, \mathrm{Hg}, \mathrm{Mn}, \mathrm{Mo}$, $\mathrm{Ni}, \mathrm{Sb}, \mathrm{Sn}$, and Tl (Hall and Heyl, 1968; Hagni, 1983; Viets and others, 1992; Leach, Taylor, and others, 2010).

In Mississippi Valley-type deposits, gallium is primarily in sphalerite, which typically can contain from 0.02 to more than $500 \mathrm{ppm}$ gallium (table H4). The overall content of gallium in studied deposits averages about $58 \mathrm{ppm}$; however, averages for individual deposits can vary widely, from 6 to $130 \mathrm{ppm}$ gallium.

\section{Kipushi Polymetallic Type}

Kipushi-type deposits are relatively rare, epigenetic, discordant deposits of $\mathrm{Cu}-\mathrm{Zn}-\mathrm{Pb}-\mathrm{Ag}-\mathrm{As}-\mathrm{Sb}-\mathrm{Ge}-\mathrm{Ga}$-bearing ores that occur in carbonate platform rock sequences and are typically associated with karst, solution collapse breccias, and related features, such as salt diapirs (fig. H5F; Hitzman and others, 2005). The most important characteristics of these deposits are their geologic setting and distinctive polymetallic mineralogy. Considerable controversy remains concerning whether these deposits have an igneous affinity; however, most are classified as sediment-hosted deposits. Deposits of the Kipushi type (fig. H4) include world-class polymetallic orebodies at Tsumeb and Khusib Springs in Namibia (Söhnge, 1964), and at Kipushi (in the Democratic Republic of the Congo) in the Zaire-Zambia copper belt (Intiomale and Oosterbosch, 1974). Domestic deposits of this type include orebodies at the Ruby Creek Mine in Alaska (Hitzman, 1986; Bernstein and Cox, 1986; Selby and others, 2009) and at the Apex Mine in Utah (Bernstein, 1986). Other large deposits included in this group in the past are, in Australia, the Mount Isa Mine in the State of Queensland, and the Cooley and Ridge deposits of the McArthur River Mine in the Northern Territory (Bernstein and Cox, 1986; Hitzman, 1986; Selby and others, 2009); more recent studies, however, suggest that these deposits are better classified as clastic-dominated-type deposits because they are mainly lead-zinc orebodies in dolomitic siltstones, mudstones, and sandstones formed in a continental sag basin (Cooke and others, 2000; Leach, Marsh, and others, 2005; Leach, Bradley, and others, 2010; Taylor and others, 2009).
Features of Kipushi-type deposits that are similar to aspects of clastic-dominated-type and Mississippi Valley-type deposits include the general platform carbonate setting, a lack of spatially associated igneous intrusions, regional-scale ore fluid migration (as evidenced by the widespread occurrence of mineralization over thousands of square kilometers in the largest deposits), and ore localization in solution collapse breccias. The orebody at Kipushi-type deposits forms a highly irregular subvertical pipe at the faulted boundary of dolomitic shale and marine dolomite, commonly within breccia zones, and prospecting for copper-rich ores is focused on paleokarst structures that are possibly related to salt diapirs (Intiomale and Oosterbosch, 1974). The Khusib Springs deposit, which is a lens-shaped sulfide orebody up to 10 meters in thickness and elongated parallel to the bedding, replaces locally brecciated limestone of the lower Tsumeb subgroup. The origin of the breccia pipes is probably related to the erosion and karstification of the Hüttenberg Formation (Hughes and others, 1984; Hughes, 1987); however, there is some evidence that hydrothermal brecciation and silicification occurred during mineralization (Chetty and Frimmel, 2000; Kamona and Günzel, 2007). Fluid inclusion studies have also established that mineralizing fluids for Kipushi-type deposits are comparable to or higher than those of typical Mississippi Valley-type deposits and clastic-dominated lead-zinc deposits (see above). Ore-stage minerals contain highly saline fluids (17 to 43 weight percent $\mathrm{NaCl}$ equivalent) in inclusions with homogenization temperatures that vary from about 100 to $380^{\circ} \mathrm{C}$; the fluids were generated in postorogenic, extensional settings (Misiewicz, 1988; Chetty and Frimmel, 2000; Selby and others, 2009; Haest and others, 2009; van Wilderode and others, 2012).

Kipushi-type deposits are distinguished from Mississippi Valley-type deposits by having significantly higher trace element concentrations and more diverse mineralogy (Frimmel and others, 1996). Primary minerals include enargite, galena, and pyrite, and a zinc-rich tennantite; locally abundant zones of bornite, chalcocite-digenite, and chalcopyrite; galena, pyrite (cobaltiferous), pyrrhotite, and iron-poor sphalerite. Late-stage phases include carrollite and copper-thiogermanate minerals, pearceite-polybasite, native silver, tetrahedrite, and silver-tennantite. Additional minerals identified in some deposits include covellite, a tungsten-bearing germanite, germanium-bearing stannoidite, and stromeyerite. Gangue minerals include barite and bariumsilicate minerals, calcite, chlorite, dolomite, fluorite, sparse quartz, and siderite. Ore minerals in Kipushi-type deposits can have gallium contents that range from hundreds of parts per million gallium to about 60 weight percent gallium (tables H2 and H3). Compared with other sediment-hosted ore systems, Kipushi-type deposits are characterized by marked enrichments in germanium and rhenium (Schneider and others, 2007). Many weathered deposits of this type contain gallium-bearing secondary minerals formed largely through supergene processes (table H3). For example, at the Apex Mine in Utah, the primary ore is inferred to be similar 
to bornite-chalcopyrite-tennantite-galena-sphalerite ore of a Kipushi type, although the Apex orebodies are almost completely oxidized to germanium-bearing hydrogoethite and gallium-bearing (up to about 1 percent gallium) jarosite.

\section{Resources and Production}

\section{Identified Resources}

The U.S. Geological Survey (USGS) estimates that world resources of gallium in bauxite exceed 1 billion kilograms and that a considerable quantity of gallium could be present in world zinc resources (Bray, 2013). Using USGS information coupled with data on global bauxite provinces (Bogatyrev and Zhukov, 2009), comparable estimates of geologically available gallium in bauxite reserves and resources (of nearly 1.4 million metric tons and 4 million metric tons, respectively) have been suggested (Dittrich and others, 2011). Analogous estimates of world resources of gallium in zinc resources have not been made owing to insufficient data. The United States is expected to meet its current and expected future needs for gallium through imports of primary gallium from these resources, from imports of recycled and refined gallium, and from domestic production of recycled and refined gallium.

Identified bauxite resources of the world are about 55 to 75 billion metric tons and occur in Africa (32 percent), Oceania (23 percent), South America and the Caribbean (21 percent), Asia (18 percent), and elsewhere (6 percent) (Bray, 2012). Lateritic bauxite deposits make up approximately 90 percent of global bauxite resources, and aluminum production is mainly from these deposits (Freyssinet and others, 2005). Karst bauxite deposits are more scattered in distribution and are mined mainly in eastern Europe and the Caribbean islands (Bárdossy, 1982). Domestic bauxite deposits consist mainly of subeconomic resources that are not generally suitable for alumina production owing to their high silica content; thus, recovery of gallium from these deposits is unlikely. Although domestic resources of bauxite are inadequate to meet either short- or long-term U.S. demand, the United States has essentially inexhaustible subeconomic resources of aluminum in materials other than bauxite. These are primarily clay deposits, which also contain gallium in amounts comparable to those of bauxite (30 to $50 \mathrm{ppm}$ gallium) (table H2). Identified zinc resources of the world are about 1.9 billion metric tons (Tolcin, 2013). Mississippi Valley-type deposits, which are widespread in North America, account for about 38 percent of the global resources of lead and zinc in sediment-hosted ore deposits; significant zinc resources are also contained in clastic-dominated deposits of Alaska (fig. H4; Leach, Marsh, and others, 2005).

The estimates given here apply to total gallium content; only a small percentage of gallium metal in bauxite and zinc ores is recoverable using current methods because processing techniques to separate aluminum, zinc, and other byproduct metals (for example, germanium and indium) compete for gallium in source materials. Factors controlling gallium recovery are typically proprietary, and scant literature is available on the general operating practices of companies involved in gallium production. The potential remains for additional gallium production given more efficient and improved extraction technologies and market-driven economic incentives.

\section{Undiscovered Resources}

The USGS has conducted no quantitative mineral resource assessments focused on undiscovered domestic or global resources of bauxite since the work of Patterson and others (1986). Because the major bauxite provinces of the world are well established and have been intensely explored, most of the significant bauxite deposits globally are thought to be known (Freyssinet and others, 2005). The major bauxite provinces (fig. H4) occur in the following five major regions: (a) the South American region - the Guiana shield (French Guiana, Guyana, Suriname) and the central Brazilian shield; (b) the West African region-Burkina Faso, Ghana, Guinea, Ivory Coast, Mali, and Sierra Leone; (c) the Indian region - the western and eastern coasts; (d) Southeast AsiaCambodia, Laos, and Vietnam; and (e) the Australian region. Other bauxite provinces occur in the southern United States (Arkansas region), the Caribbean, the southern Ural Mountains (Russia and Kazakhstan), and China.

The most recent USGS National Mineral Resource Assessment identified areas of the United States that have significant potential for undiscovered resources of zinc (Schruben, 2002). The estimate of the amount of zinc in undiscovered U.S. deposits ranged from a 90-percent probability of at least 130 million metric tons to a 10-percent probability of at least 290 million metric tons. The mean estimate of zinc in undiscovered deposits was 210 million metric tons. Nearly 40 percent of the zinc was thought to be contained in undiscovered Mississippi Valley-type deposits. Other major deposit types were sedimentary exhalative (31 percent), volcanogenic massive sulfide (15 percent), and polymetallic replacement ( 8 percent) deposit types. At that time, the total identified zinc resources in the United States were estimated to be 99 million metric tons. No comparable estimates of undiscovered global resources of zinc have been made.

\section{Production}

In 2012, world primary gallium production was estimated to be 273 metric tons (fig. H4A). China, Germany, Kazakhstan, and Ukraine were the leading producers; countries with lesser output were Hungary, Japan, the Republic of Korea, and Russia. Refined gallium production was estimated to be about 354 metric tons; this estimate includes primary gallium production and some scrap refining. China, Japan, the United Kingdom, and the United States were the principal producers of refined gallium. Gallium was recycled from new scrap in Canada, Germany, Japan, the United Kingdom, and 
the United States. World primary gallium production capacity in 2012 was estimated to be 474 metric tons; refinery capacity, 270 metric tons; and recycling capacity, 198 metric tons (Jaskula, 2013a). Imports of gallium into Japan and the United States (the two leading consuming countries) were used as the basis for estimating world gallium production. In addition, Metal Bulletin (2013) provided an updated Chinese gallium production estimate, expanding the estimate of China's production considerably owing to the substantial capacity increases of China's gallium operations (fig. H4B).

No domestic production of primary gallium was reported in 2012. Molycorp Inc. recovered gallium from scrap materials, predominantly those generated during the production of GaAs. Molycorp's facility in Blanding, Utah, has the capability to produce about 50 metric tons per year of high-purity gallium. The company recovered gallium from its customers' scrap on a fee basis and purchased scrap and low-purity gallium for processing into high-purity material.

\section{Exploration for New Deposits}

Most domestic exploration for gallium is done as a second-order effort related to new discoveries of zinc resources because U.S. bauxite resources are currently subeconomic. Exploration is active in the United States and globally for all types of large-tonnage zinc deposits, which constitute a major source for gallium (Emsbo, 2009; Taylor and others, 2009; Leach, Bradley, and others, 2010). There is some evidence that partitioning of gallium may be influenced by the amount of sphalerite in bulk ore, leading to a dilution effect, such that the largest zinc deposits of a given type may be expected to have relatively lower gallium contents (Cook and others, 2009). This, however, may have little effect on resource estimation because economic factors that support gallium extraction are tilted in favor of large tonnage values for the principal commodity over small changes in grade for a byproduct element. The most gallium-enriched sedimenthosted ores are the Kipushi-type deposits, which are mined for copper, lead, silver, and zinc and byproduct antimony, arsenic, germanium, and gallium; some deposits of this group may contain gallium (and germanium) in amounts that justify extraction as a primary product. Active exploration efforts are underway in the major Kipushi-type provinces of the Central African copperbelt-Kipushi and Tsumeb. Important domestic examples of Kipushi-type deposits include the Ruby Creek deposit in Alaska and the Apex deposit in Utah. Additional domestic exploration efforts are focused on gallium resources associated with epithermal mineralized and hydrothermally altered volcanic rock suites.

Ruby Creek deposit, Alaska.-This deposit is located along the northern flank of the Cosmos Hills near the boundary between a carbonate platform and a shale basin within the Ambler district. The 1-kilometer-diameter body of hydrothermal dolostone is one of several similarly mineralized occurrences in the Cosmos Hills. The Ruby Creek deposit contains more than 90 million metric tons of 1.2 percent copper, plus elevated contents of silver, cobalt, germanium, gallium, and zinc (Hitzman, 1986). The metacarbonate sequence consists primarily of thin-bedded to massive metadolostone and marble that is locally graphitic or phyllitic and contains thin micaceous layers interpreted as airfall tuffs (Hitzman, 1986; Hitzman and others, 1986). The presence of coeval volcanogenic massive sulfide deposits just north of the Ruby Creek deposit is possible evidence for regionally extensive hydrothermal activity, perhaps related to igneous activity associated with continental extension (Hitzman and others, 1986; Selby and others, 2009).

Apex deposit, southwestern Utah.-This deposit has served as the only primary source in the world for the production of gallium and germanium. The Apex Mine operated intermittently from 1884 to 1962 , and more than 7,000 metric tons of copper, 5,600 kilograms of silver, and small amounts of gold and lead were produced. The mine was reopened in 1985 with plans to produce gallium and germanium (Washington County Historical Society, 2013). At that time, the mine was estimated to contain 220,000 metric tons of ore grading 0.064 percent germanium, 0.032 percent gallium, 1.63 percent copper, 0.77 percent lead, 1.58 percent zinc, 0.50 percent arsenic, 16.73 percent iron, and 38 grams per metric ton silver (Bernstein, 1986). Surface dumps from the old mine contained an additional 45,000 metric tons of material grading 0.037 percent germanium, 0.019 percent gallium, and 1.55 percent copper. Similar deposits may occur in association with copper in fault-hosted breccias in Pennsylvanian limestone near Hansonburg, New Mexico (Eveleth and Lueth, 2009).

Cordero Gallium Project, Humboldt County, Nevada.-This project is reportedly North America's largest known primary gallium occurrence (Rêserva International LLC, 2008). Anomalous gallium mineralization occurs over a wide area in and around the historic Cordero and McDermitt mercury mines. There are indications that a number of high-grade "feeder zones" occur through the deposit, which also hosts significant occurrences of rare-earth elements. The resources for the project above a cutoff grade of $30 \mathrm{ppm}$ gallium are estimated to exceed 13 million metric tons (Rêserva International LLC, 2008).

\section{Environmental Considerations}

\section{Sources and Fate in the Environment}

In weathering environments, gallium is generally immobile and is only slightly less reactive than aluminum (Shiller and Frilot, 1996). The tendency for gallium to be dissolved and transported depends upon its chemical form, which in turn depends largely upon the $\mathrm{pH}$ and temperature of weathering solutions. Gallium associated with bauxite at a $\mathrm{pH}$ near 4 and a weathering solution temperature of $25^{\circ} \mathrm{C}$ would be expected to remain as a solid (for example, $\mathrm{Ga}(\mathrm{OH})_{3}$ 
or $\mathrm{GaO}(\mathrm{OH})$ ), but can theoretically dissolve to form aqueous hydroxide complexes $\left(\mathrm{Ga}(\mathrm{OH})_{3}\right.$ or $\mathrm{Ga}(\mathrm{OH})_{4}$ at $\mathrm{pH}$ values $>4$ and $\mathrm{Ga}(\mathrm{OH})$ and $\mathrm{Ga}(\mathrm{OH})_{2}$ at $\mathrm{pH}$ values $<4$; Bénézeth and others, 1997; Diakonov and others, 1997). Gallium is expected to be transported in soils, streams, and rivers in the solid phase as small particulates because of the low solubility of gallium minerals in natural waters.

Gallium associated with sulfide minerals is more mobile based on the instability of sulfides at Earth's surface. Dissolution of sulfide minerals releases metals and sulfuric acid, and the acidic $\mathrm{pH}$ values allow higher concentrations of metals to be dissolved in solution — potentially causing the environmental problem known as acid mine drainage (AMD). Under acidic conditions, gallium would most likely form dissolved complexes with sulfate and (or) chloride (for example, $\mathrm{GaSO}_{4}^{+}$or $\mathrm{GaCl}^{-}$) (Wood and Samson, 2006). Metals dissolved in AMD can be naturally attenuated through precipitation, sorption to oxyhydroxide minerals, or dilution by mixing with water at circumneutral $\mathrm{pH}$; otherwise, metals are transported downstream.

Examples of natural concentrations of gallium in soil, water, and air are given in table H2. Gallium contents in soils range from 3 to 70 milligrams per kilogram $(\mathrm{mg} / \mathrm{kg})$ (or 3 to 70 ppm) (Kabata-Pendias and Pendias, 2001), and concentrations as high as $220 \mathrm{mg} / \mathrm{kg}$ have been observed in agricultural soil (Połedniok and others, 2012). Gallium generally behaves like aluminum in the environment, but, under certain $\mathrm{pH}$ and redox conditions, the two elements may be separated. As a result, values of the ratio of gallium to aluminum (Ga:Al ratio) can aid in detecting gallium enrichment in various materials. Shiller and Frilot (1996) showed that the Ga:Al ratio of parent rocks (and residual soils) and streambed solids were similar, whereas the $\mathrm{Ga}: \mathrm{Al}$ ratio in nearby streams was higher than those in parent rocks. The concentration of gallium in these streams ranged from 0.0001 to 0.006 micrograms per liter $(\mu \mathrm{g} / \mathrm{L}$ ) (or 0.0001 to 0.006 parts per billion). These concentrations are generally lower than the 0.001 to $0.12 \mu \mathrm{g} / \mathrm{L}$ range of dissolved gallium found in large rivers around the world and are comparable to gallium concentrations measured in the Atlantic Ocean (Shiller, 1998). Compared with dissolved species, gallium is highly concentrated in small particulates in river water, with a global average of $18.1 \mathrm{mg} / \mathrm{kg}$ in suspended sediment (Viers and others, 2009). Gallium occurs naturally in the atmosphere as part of mineral dust particles and has been measured to be less than 0.14 nanograms per cubic meter $\left(\mathrm{ng} / \mathrm{m}^{3}\right)$ at the South Pole (Kabata-Pendias and Pendias, 2001).

Mining and ore processing can hasten the weathering process and can lead to above-background concentrations of gallium in soil and water (table $\mathrm{H} 2$ ). For example, gallium concentrations ranging from 93 to $270 \mathrm{mg} / \mathrm{kg}$ have been observed in soils near bauxite and lead-zinc mine sites in Poland (Połedniok and others, 2012). In addition, anthropogenic release of gallium to the atmosphere occurs during coal combustion, ore processing, and semiconductor manufacturing, leading to concentrations as high as 1 to $12 \mathrm{ng} / \mathrm{m}^{3}$ near industrial areas (Chen, 2007; Kabata-Pendias and Mukherjee, 2007). Likewise, dissolved and colloidal concentrations of gallium in groundwater near semiconductor manufacturing areas in China have been measured to be greater than $10 \mu \mathrm{g} / \mathrm{L}$ (Chen, 2006). The recycled content, or proportion of scrap, used in gallium production is between 10 and 25 percent, but the fraction of gallium in discarded products that get recycled is less than 1 percent (Graedel and others, 2011). One of the main challenges of gallium recycling is that it is commonly comingled with other "specialty metals" in high performance alloys, making recovery technologically and economically unfeasible (Reck and Graedel, 2012). Given the importance of gallium in thin-film photovoltaic cells and integrated circuits, however, gallium recycling is likely to increase in the future (Graedel, 2011).

\section{Mine Waste Characteristics}

Mine waste is generally considered to be the material that originates and accumulates at a mine site that has no current economic value (Lottermoser, 2010), and it includes both solid and liquid waste. Gallium associated with bauxite is usually mined by open pit or underground methods and then refined through the Bayer process, which can lead to large volumes of processing waste. Based on its appearance, bauxite (or alumina) processing waste is commonly referred to as red mud. Red mud depositories are connected with alumina processing plants and are not necessarily located at the mine site. For example, four active plants in the United States predominantly process alumina ore from overseas (Bray, 2012). On October 4, 2010, a breached red mud depository released between 600,000 to 700,000 cubic meters of material from the Ajka Timfoldgyar Zrt alumina plant in Hungary (Reeves and others, 2011). This spill was unprecedented both in scale (the spill covered an estimated 800 hectares of land [Ruyters and others, 2011]) and in its delivery of trace elements across such a vast area (Mayes and others, 2011).

Bauxite ore results from extreme chemical weathering, and many elements that were originally present in the parent rock have been leached away. The exceptions are minor elements that can sorb to or coprecipitate with aluminum and iron (oxyhydr)oxide minerals that make up the ore and waste. For example, in addition to $\mathrm{Al}$ and $\mathrm{Fe}$, bauxite processing waste has been shown to contain elevated concentrations of As, $\mathrm{Cr}, \mathrm{Ga}, \mathrm{Mo}, \mathrm{Ni}$, and V (Mayes and others, 2011). Bauxite mine and processing waste generally lacks acid-generating minerals, so these elements are expected to remain immobile under oxidizing and near-neutral $(5<\mathrm{pH}<8)$ weathering conditions as long as abundant iron-rich particles are present (Smith and Huyck, 1999).

Waste products that result from mining sediment-hosted deposits usually consist of waste rock, tailings piles, and possibly pit lakes. For example, the cumulative volume of tailings generated at the Red Dog Mine, which is a clasticdominated lead-zinc deposit, totaled 27.4 million metric tons in 2006 , and it is projected to total 88 million metric tons 
by 2031 (SRK Consulting [Canada] Inc., 2007). The largest U.S. Environmental Protection Agency Superfund site occurs in the Tri-State zinc mining district and contains an estimated 91 million metric tons of waste rock (U.S. Environmental Protection Agency, 2006). The district contains a large number of Mississippi Valley-type lead-zinc deposits and covers approximately 1,800 square kilometers of Kansas, Oklahoma, and Missouri (Leach, Taylor, and others, 2010). The mineralogy of the mine waste associated with these deposits reflects the mineralogy of the unmined deposit, except that the proportion of lead-zinc-copper sulfides, such as chalcopyrite, galena, and sphalerite, is reduced relative to the gangue minerals (barite, calcite, dolomite, pyrite, and quartz) (Kelley and others, 1995; Leach, Viets, and others, 1995). Because of their association with sulfides and secondary minerals, such elements as Ag, Al, As, Au, B, Ba, Cd, Co, Fe, Ga, Ge, Hg, $\mathrm{Mn}, \mathrm{Mo}, \mathrm{Ni}$, and $\mathrm{Sb}$ can also be found in clastic-dominated deposits (Briskey, 1986; Kelley and others, 1995). Likewise, Mississippi Valley-type deposits can contain minor to trace amounts of $\mathrm{Ag}, \mathrm{As}, \mathrm{Au}, \mathrm{Ba}, \mathrm{Bi}, \mathrm{Cd}, \mathrm{Co}, \mathrm{Cu}, \mathrm{F}, \mathrm{Fe}, \mathrm{Ga}, \mathrm{Ge}$, In, $\mathrm{Mo}, \mathrm{Ni}, \mathrm{Pb}, \mathrm{Sb}, \mathrm{Sn}$, and $\mathrm{Tl}$ (Leach, Viets, and others, 1995; Foley, 2002a). Under oxidizing and acidic $(\mathrm{pH}<3)$ weathering conditions, which would be expected in clastic-dominated mine waste having little to no acid-neutralizing capacity and significant pyrite content, many of these elements are mobile (Smith and Huyck, 1999). The acid-neutralizing capacity of carbonate-hosted mine waste is greater, however, and the oxidizing and circumneutral $(5<\mathrm{pH}<8)$ conditions that prevail during weathering would cause most of the elements listed above to be less mobile or immobile (Smith and Huyck, 1999). An important exception is zinc, which can make up a large percentage of the total dissolved metals draining from Mississippi Valley-type deposits (Plumlee and others, 1999). A review of the environmental geochemistry of platform carbonate-hosted sulfide deposits identifies surface disposal of tailings as a potential environmental concern, especially if $\mathrm{As}, \mathrm{Cd}, \mathrm{Tl}$, and $\mathrm{Zn}$ are present, because airborne dust may contain metal particulates (Foley, 2002a). A study of the Austinville lead-zinc mine in Wythe County, Virginia (Foley, 2002b), shows that residual soils near a Mississippi Valleytype deposit can be acidic enough to influence the mobility of metals in surface environments and that this is especially true for Mississippi Valley-type deposits that have high jasperoid and pyrite content.

\section{Human Health Concerns}

Study of the health effects of gallium on humans largely focuses on exposure to synthetic gallium arsenide (GaAs) by workers in the semiconductor industry, where small GaAs particles can be inhaled or ingested (Flora, 2000). The toxicity of GaAs may result from the arsenic (because arsenic trioxide may be released from GaAs after absorption); gallium toxicity, however, though not well studied, has not been ruled out (Chitambar, 2010). Humans can tolerate intravenous infusions of gallium nitrate during medical treatments for diseases such as cancer (Chitambar, 2010), but the long-term effects of human exposure to gallium in drinking water and soil resources remain unknown. Gallium does not appear in the U.S. Clean Water Act, and the Occupational Safety and Health Administration (OSHA) does not consider gallium metal to be hazardous, although some State governments include gallium in their right-to-know lists (Ziegler and others, 2004).

Given their similar chemical characteristics, the health effects of gallium may be similar to those of aluminum. The Agency for Toxic Substances and Disease Registry (ATSDR) provides a useful summary of the human toxicology of aluminum (Agency for Toxic Substances and Disease Registry, 2008). Exposure to aluminum by the general public is most likely to occur through consumption of food, water, and aluminum-bearing medicines (such as antacids or antidiarrheal agents). Occupational exposure to aluminum is most likely to occur during ore processing and product fabrication. Most ingested or inhaled aluminum is not absorbed by the body, although absorption can vary depending upon the chemical form and particle size. Overexposure to aluminum can affect the nervous system, causing impaired performance in motor, sensory, and cognitive function. In addition, aluminum workers may suffer respiratory effects, such as impaired lung function and fibrosis. The United States national secondary drinking water regulation for aluminum, which is a nonenforceable guideline, ranges from 50 to $200 \mu \mathrm{g} / \mathrm{L}$ (U.S. Environmental Protection Agency, 2013b). Most surface waters contain aluminum concentrations below $100 \mu \mathrm{g} / \mathrm{L}$ (Agency for Toxic Substances and Disease Registry, 2008).

Mining of deposits where gallium is a byproduct can potentially mobilize elements that are known human toxins; these elements have the potential to affect human health when present above threshold concentrations in air, drinking water, and soils. These concentrations can be exceeded near mine sites. The best known examples are the neurological effects of lead on children (Holecy and Mousavi, 2012) and the carcinogenic effects of arsenic in drinking water (Gupta and others, 2012). The current U.S. National Ambient Air Quality Standard for lead is 0.15 micrograms per cubic meter (U.S. Environmental Protection Agency, 2013a), and current U.S. primary and secondary drinking water standards for lead, zinc, and copper are 0,5 , and 1 milligrams per liter $(\mathrm{mg} / \mathrm{L})$, respectively (U.S. Environmental Protection Agency, 2013b). Canadian agricultural soil quality guidelines for lead, zinc, and copper are 70, 200, and $63 \mathrm{mg} / \mathrm{kg}$, respectively (Canadian Council of Ministers of the Environment, 2007).

\section{Ecological Health Concerns}

Relatively few studies focus on the ecological effects of gallium mobility in the environment. Fish tend to be sensitive to low concentrations of dissolved metals, and they are therefore useful indicators of contamination in aquatic systems. One of several useful endpoints used in toxicity tests is the lethal concentration that leads to 50 percent mortality $\left(\mathrm{LC}_{50}\right)$ after exposure to a substance for a certain amount of time. 
A study on the acute toxicity of dissolved gallium to carp (Cyprinus carpio Linnaeus) revealed a mean $\mathrm{LC}_{50}$ value of $95.6 \pm 14.3 \mathrm{mg} / \mathrm{L}$ after 96 hours of exposure (Betoulle and others, 2002). Chronic toxicity tests with dissolved gallium and developing rainbow trout (Oncorhynchus mykiss) revealed a mean $\mathrm{LC}_{50}$ value of $3.5 \mathrm{mg} / \mathrm{L}$ after 28 days of exposure (Birge and others, 1980). In acute toxicity tests with saltwater organisms, $\mathrm{LC}_{50}$ values ranged from 12 to $55 \mathrm{mg} / \mathrm{L}$ of gallium after 24, 48, or 96 hours of exposure (Onikura and others, 2005). Gallium is typically not included in the suite of elemental concentrations reported in studies of mine waste water chemistry, so these $\mathrm{LC}_{50}$ values cannot be compared with likely gallium concentrations in mining environments.

The ecological effects of gallium may be similar to those of aluminum given their similar behavior in the environment. When brown trout (Salmo trutta Linnaeus) were exposed to stream water samples of various $\mathrm{pH}$ levels and aluminum concentrations, the healthiest populations were observed in waters with $\mathrm{pH}$ above 5.0 and aluminum concentrations below $20 \mu \mathrm{g} / \mathrm{L}$; significantly higher aluminum concentrations in gills were observed in moribund fish, suggesting that complications with respiration contributed to their decline (Andrén and Rydin, 2012). In toxicity tests with tropical freshwater algal and zooplankton species, $\mathrm{LC}_{50}$ values for aluminum increased with increasing dissolved organic carbon concentrations (Trenfield and others, 2012), suggesting that the affinity of aluminum for complexing with organic carbon renders it less toxic. The National Ambient Water Quality Criteria recommended for the protection of aquatic life and adopted by some regions in the United States are 750 micrograms of aluminum per liter $(\mu \mathrm{g} \mathrm{Al} / \mathrm{L})$ of water (acute) and $87 \mu \mathrm{g} \mathrm{Al} / \mathrm{L}$ of water (chronic) (Suter and Tsao, 1996). Because aluminum is more mobile under acidic conditions, plants growing in acidic soils may suffer from aluminum toxicity, which is known to inhibit root growth and crop yields (Kabata-Pendias and Mukherjee, 2007). As a result, some regions of the United States have adopted a soil screening benchmark of $50 \mathrm{ppm}$ of soil for terrestrial plants, as recommended by Oak Ridge National Laboratory (Efroymson and others, 1997).

The ecological effects of other elements that gallium is associated with are relatively well documented. For example, in toxicity tests with aquatic invertebrates incubated with mine tailings from Mississippi Valley-type deposits, Besser and Rabeni (1987) showed that increased concentrations of dissolved cadmium, lead, and zinc correlated with decreased survival and growth (Besser and Rabeni, 1987). Likewise, various fish species experienced rapid mortality when exposed to increasing dissolved zinc concentrations, but this effect decreased with increasing calcium, magnesium, and sodium concentrations (De Schamphelaere and Janssen, 2004). High metal concentrations in soils can also cause phytotoxicity. Zinc is a micronutrient for many plant species, but when highly concentrated in soils, it can inhibit a plant's metabolic functions and cause deficiencies in other essential nutrients, such as copper, iron, manganese, and phosphorus (Nagajyoti and others, 2010, and references therein).

\section{Carbon Footprint}

Gallium has potential application in the effort to reduce the carbon footprint from energy production because of its use in efficient thin-film photovoltaic cells (solar panels) (Miles and others, 2007). The copper-indium-gallium-(di)selenide (CIGS) alloy, among others, is an attractive thin-film product because of its high efficiency and relatively low material and manufacturing costs (Kaneshiro and others, 2010). In a comparative study of lifecycle greenhouse gas emissions for various technologies, Kim and others (2012) found that estimates for the carbon footprint of CIGS technologies under test conditions are about 26 grams of $\mathrm{CO}_{2}$ equivalent per kilowatthour ( $\mathrm{g} \mathrm{CO}_{2}$-equiv/ $\mathrm{kWh}$ ), which compares well with older technologies that have greenhouse gas emissions in the range of 39 to $110 \mathrm{~g} \mathrm{CO}_{2}$-equiv $/ \mathrm{kWh}$ (Fthenakis and others, 2008). The CIGS photovoltaic cells are in the initial stages of commercialization, but they are expected eventually to compete with other forms of energy production as economies of scale permit future cost reductions (Miles and others, 2007; Rockett, 2010). With the rapid evolution of the thin-film photovoltaic cell industry, the recyclability of generated products and the potential for leaching of toxic elements from improperly disposed products would need to be addressed.

\section{Mine Closure}

Most recent and new mining operations include closure plans that address issues related to the mine footprint, which includes waste left onsite and locally affected soil and water, as well as ecological effects, such as habitat destruction and loss of biodiversity. Bauxite mines can be particularly prone to soil and habitat loss given that many are located in tropical, biodiverse locations. A study of a 10-year-old reforested area at a closed bauxite mine in Brazil showed that, although the reforestation program created adequate recovery conditions, recovery of native flora was influenced by the uneven return of important seed-dispersing animals (Parrotta and others, 1997). At one of the largest bauxite mine operations in the State of Western Australia, Australia, the Alcoa World Alumina Australia company clears the Jarrah (Eucalyptus marginata) forest before developing an open pit mine; after extracting bauxite, the company returns the topsoil and spreads Jarrah seeds at a rate of approximately 550 hectares per year (Gardner and Bell, 2007).

With respect to mining in zinc deposits, mine closure issues often relate to the stability of large waste piles and tailings dams, and the potential for acid mine drainage from the site. Mine waste pile stability is commonly addressed through grading and covering dewatered piles. Acid mine drainage can be addressed with active water treatment facilities, passive limestone-lined channels, or constructed wetlands (Plumlee and Logsdon, 1999). The end result of both active and passive approaches is precipitation of dissolved metals. Precipitated metals in reconstructed wetland systems tend to be more stable under the prevailing anoxic conditions, 
whereas the metal-rich precipitates that result from active treatment facilities form a sludge that can be similar to the metal-rich bauxite processing residues. At large mines, mine waste is typically consolidated into pits and submerged under water, forming a tailings pond. Acid-generating minerals are less reactive under water, but seepage is typically monitored and, if necessary, treated. At such sites as the Red Dog Mine in Alaska, seepage from the tailings ponds may need to be treated in perpetuity (U.S. Environmental Protection Agency, 2010). Failure of tailings pond impoundments can cause catastrophic flooding (McDermott and Sibley, 2000). Thus, plans for securing waste piles and prevention and treatment of acid mine drainage are important aspects of long-term active and proposed metal mining projects.

\section{Problems and Future Research}

Future research efforts related to gallium resources are likely to be directed at understanding the factors that may affect future supplies. Such research could include developing improved assessment models, conducting experimental studies, and seeking new and more efficient extraction and recycling technologies.

Assessment models.-Improved models could help in locating new and unconventional resources. Efforts focused on incorporating additional geochemical and mineralogical data into existing mineral deposit and grade tonnage models (for zinc and bauxite deposits) can contribute to the development of quantitative grade-tonnage models and new approaches to evaluating the geologic availability of gallium as a byproduct. New models to estimate the occurrence of gallium in polymetallic resources of the Kipushi type could also contribute to more accurate quantitative assessments of the geologic availability of gallium. Also, models can assist in the evaluation of resources of gallium currently locked up in unprocessed mine waste, such as the extensive waste piles left over from the mining of Mississippi Valley-type deposits in the midcontinent region of the United States.

Experimental studies.-Studies of gallium at conditions applicable to biochemical processes occurring in surface environments would provide for a better understanding of the natural gallium lifecycle and the potential issues related to gallium waste disposal.

New technologies.-Devising new and more efficient extraction technologies for both raw ore and recycled products would help prevent or alleviate future bottlenecks in the supply chain that may result from increased demand.

Recycling.-Because so little gallium in used products gets recycled, greater gallium recycling efficiency in the future can reduce reliance on mining of primary gallium resources. Future research could be focused on improving gallium recycling from current products, as well as future product design that allows greater gallium recycling efficiency.

\section{References Cited}

Note: All Web links listed were active as of the access date but may no longer be available.

Agency for Toxic Substances and Disease Registry, 2008, Toxicological profile for aluminum: Atlanta, Ga., U.S. Department of Health and Human Services, Public Health Service, September, 310 p. plus 4 appendixes. [Also available at http://www.atsdr.cdc.gov/ToxProfiles/tp22.pdf.]

Alaska Department of Environmental Conservation, 2005, table 2-1, Composition of Red Dog lead and zinc concentrates, accessed March 6, 2013, at http://dec.alaska.gov/ spar/csp/docs/reddog/03dmts_ra_tables-april2005.pdf.

Andrén, C.M., and Rydin, E., 2012, Toxicity of inorganic aluminum at spring snowmelt-In-stream bioassays with brown trout (Salmo trutta L.): Science of the Total Environment, v. 437, p. 422-432. [Also available at http://dx.doi.org/10.1016/j.scitotenv.2012.08.006.]

Ayuso, R.A., Foley, N.K., Seal, R.R., II, Bove, Marianna, Civitillo, Diego, Cosenza, Antonio, and Grezzi, Giuseppe, 2013, Lead isotope evidence for metal dispersal at the Callahan $\mathrm{Cu}-\mathrm{Zn}-\mathrm{Pb}$ mine - Goose Pond tidal estuary, Maine, USA: Journal of Geochemical Exploration, v. 126-127, p. 1-22 . [Also available at http://dx.doi.org/ 10.1016/j.gexplo.2012.12.013.]

Badham, J.P.N., 1981, Shale-hosted Pb-Zn depositsProducts of exhalation of formation waters?: Institution of Mining and Metallurgy, Transactions, Section BApplied Earth Science, v. 90, p. B70-B76.

Bárdossy, György, 1982, Karst bauxites-Bauxite deposits on carbonate rocks: Amsterdam, Netherlands, and New York, N.Y., Elsevier Scientific Pub. Co., 441 p., 5 pls. and 4 app. in pocket.

Bárdossy, György, and Aleva, G.J.J., 1990, Lateritic bauxites: New York, N.Y., Elsevier, Developments in Economic Geology Series, v. 27, 624 p., 24 pls.

Barton, P.B., Jr., and Bethke, P.M., 1987, Chalcopyrite disease in sphalerite-Pathology and epidemiology: American Mineralogist, v. 72, nos. 5-6, p. 451-467.

Bénézeth, Pascale, Diakonov, I.I., Pokrovski, G.S., Dandurand, J.-L., Schott, Jacques, and Khodakovsky, I.L., 1997, Gallium speciation in aqueous solution. Experimental study and modelling - Part 2. Solubility of $\alpha-\mathrm{GaOOH}$ in acidic solutions from 150 to $250^{\circ} \mathrm{C}$ and hydrolysis constants of gallium (III) to $300^{\circ} \mathrm{C}$ : Geochimica et Cosmochimica Acta, v. 61, no. 7 , p. 1345-1357. [Also available at http://dx.doi.org/10.1016/S0016-7037(97)00012-4.] 
Bernstein, L.R., 1986, Geology and mineralogy of the Apex germanium-gallium mine, Washington County, Utah: U.S. Geological Survey Bulletin 1577, 9 p. [Also available at http://pubs.er.usgs.gov/publication/b1577.]

Bernstein, L.R., and Cox, D.P., 1986, Geology and sulfide mineralogy of the Number One orebody, Ruby Creek copper deposit, Alaska: Economic Geology, v. 81, p. 1675-1689. [Also available at http://dx.doi.org/ 10.2113/gsecongeo.81.7.1675.]

Bernstein, L.R., and Waychunas, G.A., 1987, Germanium crystal chemistry in hematite and goethite from the Apex Mine, Utah, and some new data on germanium in aqueous solution and in stottite: Geochimica et Cosmochimica Acta, v. 51, no. 3, p. 623-630. [Also available at http://dx.doi.org/ 10.1016/0016-7037(87)90074-3.]

Besser, J.M., and Rabeni, C.F., 1987, Bioavailability and toxicity of metals leached from lead-mine tailings to aquatic invertebrates: Environmental Toxicology and Chemistry, v. 6, no. 11, p. 879-890. [Also available at http://dx.doi.org/ 10.1002/etc.5620061109.]

Betoulle, S., Etienne, J.C., and Vernet, G., 2002, Acute immunotoxicity of gallium to carp (Cyprinus carpio L.): Bulletin of Environmental Contamination and Toxicology, v. 68, no. 6, p. 817-823. [Also available at http://dx.doi.org/ 10.1007/s00128-002-0028-3.]

Birge, W.J., Black, J.A., Westerman, A.G., and Hudson, J.E., 1980, Aquatic toxicity tests on inorganic elements occurring in oil shale, in Gale, Charles, ed., Oil shale symposiumSampling analysis and quality assurance, March 1979, Proceedings: Cincinnati, Ohio, U.S. Environmental Protection Agency, EPA-600/9-80-022, p. 519-534. [Also available at http://babel.hathitrust.org/cgi/pt?id=coo.3192400432 3303; view=1up;seq=531.]

Bogatyrev, B.A., and Zhukov, V.V., 2009, Bauxite provinces of the world: Geology of Ore Deposits, v. 51, no. 5, p. 339-355. [Also available at http://dx.doi.org/10.1134/ S1075701509050018.]

Bogatyrev, B.A., Zhukov, V.V., and Tsekhovsky, Yu.G., 2009, Formation conditions and regularities of the distribution of large and superlarge bauxite deposits: Lithology and Mineral Resources, v. 44, no. 2, p. 135-151. [Also available at http://dx.doi.org/10.1134/S0024490209020035.]

Bradley, D.C., and Leach, D.L., 2003, Tectonic controls of Mississippi Valley-type lead-zinc mineralization in orogenic forelands: Mineralium Deposita, v. 38, no. 6, p. 652-667. [Also available at http://dx.doi.org/10.1007/s00126-0030355-2.]

Bray, E.L., 2012, Bauxite and alumina [advance release], in Metals and minerals: U.S. Geological Survey Minerals Yearbook 2011, v. I, p. 10.1-10.13, accessed March 9, 2013, at http://minerals.usgs.gov/minerals/ pubs/commodity/bauxite/myb1-2011-bauxi.pdf.
Bray, E.L., 2013, Bauxite and alumina: U.S. Geological Survey Mineral Commodity Summaries 2013, p. 26-27. [Also available at https://minerals.usgs.gov/minerals/pubs/ commodity/bauxite/mcs-2013-bauxi.pdf.]

Brimhall, G.H., Chadwick, O.A., Lewis, C.J., Compston, William, Williams, I.S., Danti, K.J., Dietrich, W.E., Power, M.E., Hendricks, David, and Bratt, James, 1991, Deformational mass transport and invasive processes in soil evolution: Science, v. 255, no. 5045, p. 695-702. [Also available at http://dx.doi.org/10.1126/science.255.5045.695.]

Briskey, J.A., 1986, Descriptive model of sedimentary exhalative $\mathrm{Zn}-\mathrm{Pb}$-Model 31a, in Cox, D.P., and Singer, D.A., eds., Mineral deposit models: U.S. Geological Survey Bulletin 1693, p. 211-215. [Also available at http://pubs.er.usgs.gov/ publication/b1693.]

Burton, J.D., and Culkin, F., 1978, Gallium, in Wedepohl, K.H., ed., Handbook of geochemistry, v. 2, pt. 3: Berlin, West Germany, Springer-Verlag, p. 32-D-7.

Canadian Council of Ministers of the Environment, 2007, Canadian soil quality guidelines for the protection of environmental and human health, chap. 7 of Canadian environmental quality guidelines: Winnipeg, Manitoba, Canada, Canadian Council of Ministers of the Environment accessed February 15, 2013, at http://www.ccme.ca/ publications/ceqg_rcqe.html.

Chen, H-W., 2006, Gallium, indium, and arsenic pollution of groundwater from a semiconductor manufacturing area of Taiwan: Bulletin of Environmental Contamination and Toxicology, v. 77, no. 2, p. 289-296. [Also available at http://dx.doi.org/10.1007/s00128-006-1062-3.]

Chen, H-W., 2007, Characteristics and risk assessment of trace metals in airborne particulates from a semiconductor industrial area of northern Taiwan: Fresenius Environmental Bulletin, v. 16, no. 10, p. 1288-1294.

Chetty, D., and Frimmel, H.E., 2000, The role of evaporites in the genesis of base metal sulphide mineralisation in the Northern Platform of the Pan-African Damara belt, Namibia - Geochemical and fluid inclusion evidence from carbonate wall rock alteration: Mineralium Deposita, v. 35, no. 4, p. 364-376. [Also available at http://dx.doi.org/ 10.1007/s001260050247.]

Chitambar, C.R., 2010, Medical applications and toxicities of gallium compounds: International Journal of Environmental Research and Public Health, v. 7, no. 5, p. 2337-2361. [Also available at http://dx.doi.org/10.3390/ijerph7052337.]

Cook, N.J., Ciobanu, C.L., Pring, Allan, Skinner, William, Shimizu, Masaaki, Danyushevsky, Leonid, Saini-Eidukat, Bernhardt, and Melcher, Frank, 2009, Trace and minor elements in sphalerite-A LA-ICPMS study: Geochimica et Cosmochimica Acta, v. 73, no. 16, p. 4761-4791. [Also available at http://dx.doi.org/10.1016/j.gca.2009.05.045.] 
Cooke, D.R., Bull, S.W., Large, R.R., and McGoldrick, P.J., 2000, The importance of oxidized brines for the formation of Australian proterozoic stratiform sediment-hosted $\mathrm{Pb}-\mathrm{Zn}$ (sedex) deposits: Economic Geology, v. 95, p. 1-18. [Also available at http://dx.doi.org/10.2113/gsecongeo.95.1.1.]

Crump, M.E., 1994, A new source of gallium-Geothermal muds, in The Australasian Institute of Mining and Metallurgy, New Zealand Branch, 28th annual conference, Wairakei, 17-19 August 1994: Australasian Institute of Mining and Metallurgy New Zealand Branch Conference, 28th, Wairakei, New Zealand, 1994, (published in Taupo, New Zealand, by the New Zealand Branch), p. 207-208.

De Schamphelaere, K.A.C., and Janssen, C.R., 2004, Bioavailability and chronic toxicity of zinc to juvenile rainbow trout (Oncorhynchus mykiss) - Comparison with other fish species and development of a biotic ligand model: Environmental Science and Technology, v. 38, no. 23, p. 6201-6209. [Also available at http://dx.doi.org/10.1021/ es049720m.]

Diakonov, I.I., Pokrovski, G.S., Bénézeth, Pascale, Schott, Jacques, Dandurand, J-L., and Escalier, Jocelyne, 1997, Gallium speciation in aqueous solution-Experimental study and modelling - Part 1 . Thermodynamic properties of $\mathrm{Ga}(\mathrm{OH})_{4}^{-}$to $300{ }^{\circ} \mathrm{C}$ : Geochimica et Cosmochimica Acta,v. 61, no. 7, p. 1333-1343. [Also available at http://dx.doi.org/10.1016/S0016-7037(97)00011-2.]

Dittrich, T., Seifert, T., and Gutzmer, J., 2011, Gallium in bauxite deposits [abs]: Mineralogical Magazine, Goldschmidt Conference Abstracts 2011, v. 75, no. 3, sec. D, p. 765.

Dowa Holdings Co., Ltd., 2013, Dowa Metals and MiningOverview of operations with a section on the zinc business and the rare metals business_-Japan's largest zinc smelting plant: Tokyo, Japan, Dowa Holdings Co., Ltd., accessed February 1, 2013, at http://www.dowa.co.jp/en/jigyo/ metalmine_summary.html.

Dusel-Bacon, Cynthia, Foley, N.K., Slack, J.F., Koenig, A.E., and Oscarson, R.L., 2012, Peralkaline- and calc-alkalinehosted volcanogenic massive sulfide deposits of the Bonnifield district, east-central Alaska: Economic Geology, v. 107, p. 1403-1432. [Also available at http://dx.doi.org/10.2113/econgeo.107.7.1403.]

Dusel-Bacon, Cynthia, Slack, J.F., Koenig, A.E., Foley, N.K., Oscarson, R.L., and Gans, K.D., 2011, Whole-rock and sulfide-mineral geochemical data for samples from volcanogenic massive sulfide deposits of the Bonnifield district, east-central Alaska: U.S. Geological Survey Open-File Report 2011-1171, 43 p. [Also available at http://pubs.usgs.gov/of/2011/1171/.]

Dutrizac, J.E., Jambor, J.L., and Chen, T.T., 1986, Host minerals for the gallium-germanium ores of the Apex Mine, Utah: Economic Geology, v. 81, p. 946-950. [Also available at http://dx.doi.org/10.2113/gsecongeo.81.4.946.]
Eagleson, Mary, translator; Jakubke, H.-D., and Jeschkeit, Hans, eds., 1994, Concise encyclopedia chemistry: New York, N.Y., Walter de Gruyter, 1201 p.

Efroymson, R.A., Will, M.E., Suter, G.W., II, and Wooten, A.C., 1997, Toxicological benchmarks for screening contaminants of potential concern for effects on terrestrial plants - 1997 revision, report prepared for the U.S. Department of Energy by Lockheed Martin Energy Systems, Inc.: Oak Ridge, Tenn., Oak Ridge National Laboratory, ES/ER/TM-85/R3, November, 68 p. and two appendixes, accessed March 4, 2013, at http:/www.esd.ornl.gov/programs/ecorisk/documents/ tm85r3.pdf.

Emsbo, Poul, 2009, Geologic criteria for the assessment of sedimentary exhalative (sedex) Zn-Pb-Ag deposits: U.S. Geological Survey Open-File Report 2009-1209, 21 p. [Also available at http://pubs.usgs.gov/of/2009/1209/.]

Emsley, John, 2001, Nature's building blocks-An A-Z guide to the elements: Oxford, United Kingdom, Oxford University Press, 538 p.

Eveleth, R.W., and Lueth, V.W., 2009, Old Hansonburg, one of New Mexico's forgotten mining camps, in Lueth, V.W., and others, eds., Geology of the Chupadera Mesa-New Mexico Geological Society 60th annual Field Conference, October 7-10, 2009 (1st edition): New Mexico Geological Society Field Conference, 60th, Socorro, N.M., Annual fall field conference guidebook, p. 399-406.

Finkelman, R.B., 1993, Trace and minor elements in coal, in Engel, M.H., and Macko, S.A., eds., Organic geochemistry-Principles and applications: New York, N.Y., Plenum Press, p. 593-607, 7 pls.

Flora, S.J.S., 2000, Possible health hazards associated with the use of toxic metals in semiconductor industries: Journal of Occupational Health, v. 42, p. 105-110. [Also available at http://dx.doi.org/10.1539/joh.42.105.]

Foley, N.K., and Ayuso, R.A., 2013, Rare earth element mobility in high-alumina altered metavolcanic deposits, South Carolina, USA: Journal of Geochemical Exploration, v. 133, p. 50-67. [Also available at http://dx.doi.org/ 10.1016/j.gexplo.2013.03.008.]

Foley, N.K., 2002a, Environmental chemistry of platform carbonate-hosted sulfide deposits, chap. E of Seal, R.R., II, and Foley, N.K., eds, Progress on geoenvironmental models for selected mineral deposit types: U.S. Geological Survey Open-File Report 02-195 (On-line version 1.0), p. 87-100.

Foley, N.K., 2002b, A geoenvironmental lifecycle modelThe Austinville platform carbonate deposit, Virginia, chap. F of Seal, R.R., II, and Foley, N.K., eds., Progress on geoenvironmental models for selected mineral deposit types: USGS Open-File Report 02-195 (Online version 1.0), p. 101-107. 
Foley, N.K., Dusel-Bacon, Cynthia, Koenig, Alan, and Schulte, Ruth, 2008, Comparative study of rare trace metals associated with massive sulfide deposits of the Bonnifield district, Alaska [abs], in Belkin, H.E., ed., Program and abstracts - Ninth Pan-American conference on research on fluid inclusions, in memory of Edwin RoedderPACROFI IX - U.S. Geological Suvey, Reston, Va., USA, June 2-5, 2008: Reston, Va., U.S. Geological Survey, 64 p.

Freyssinet, P., Butt, C.R.M., Morris, R.C., and Piantone, P., 2005, Ore-forming processes related to lateritic weathering, in Hedenquist, J.W., Thompson, J.F.H., Goldfarb, R.J., and Richards, J.P., eds., Economic Geology-One hundredth anniversary volume, 1905-2005: Littleton, Colo., Society of Economic Geologists, p. 681-722. [Appendixes are on a CD-ROM inside the back cover.]

Frimmel, H.E., Deane, J.G., and Chadwick, P.J., 1996, PanAfrican tectonism and the genesis of base metal sulfide deposits in the northern foreland of the Damara orogen, Namibia, in Sangster, D.F., ed., Carbonate-hosted leadzinc deposits - [Society of Economic Geologists] 75th anniversary volume: Littleton, Colo., Society of Economic Geologists Special Publication no. 4, p. 204-217.

Fthenakis, V.M., Kim, H.C., and Alsema, Erik, 2008, Emissions from photovoltaic life cycles: Environmental Science and Technology, v. 42, no. 6, p. 2168-2174. [Also available at http://dx.doi.org/10.1021/es071763q.]

Gaillardet, J., Viers, J., and Dupré, B., 2003, Trace elements in river waters, in Drever, J.I., ed., Surface and groundwater, weathering, and soils, v. 5 of Holland, H.D., and Turekian, K.K., eds., Treatise on geochemistry: Oxford, United Kingdom, Elsevier-Pergamon, v. 5, p. 225-272. [Also available at http://dx.doi.org/10.1016/B0-08-043751-6/05165-3.]

Gardner, J.H., and Bell, D.T., 2007, Bauxite mining restoration by Alcoa World Alumina Australia in Western AustraliaSocial, political, historical, and environmental contexts: Restoration Ecology, v. 15, supplement s4, p. S3-S10. [Also available at http://dx.doi.org/10.1111/j.1526100X.2007.00287.x.]

Goguel, R., 1988, Ultra-trace metal analysis of New Zealand geothermal waters by ICP-MS, in Proceedings of the Conference on Trace Elements in New ZealandEnvironmental, Human and Animal, Lincoln College, Canterbury, New Zealand, November 30-December 2, 1988: New Zealand Trace Elements Group, p. 263-270.

Graedel, T.E., 2011, On the future availability of the energy metals: Annual Review of Materials Research, v. 41, p. 323-335. [Also available at http://dx.doi.org/10.1146/ annurev-matsci-062910-095759.]
Graedel, T.E., Allwood, Julian, Birat, J.-P., Buchert, Matthias, Hagelüken, Christian, Reck, B.K., Sibley, S.F., and Sonnemann, Guido, 2011, What do we know about metal recycling rates?: Journal of Industrial Ecology, v. 15, no. 3, p. 355-366. [Also available at http://dx.doi.org/10.1111/ j.1530-9290.2011.00342.x.]

Groves, D.I., and Bierlein, F.P., 2007, Geodynamic settings of mineral deposit systems: Journal of the Geological Society, London, United Kingdom, v. 164, no. 1, p. 19-30. [Also available at http://dx.doi.org/10.1144/ 0016-76492006-065.]

Gupta, V.K., Nayak, Arunima, Agarwal, Shilpi, Dobhal, Rajendra, Uniyal, D.P., Singh, Prashant, Sharma, Bhavtosh, Tyagi, Shweta, and Singh, Rakesh, 2012, Arsenic speciation analysis and remediation techniques in drinking water: Desalination and Water Treatment, v. 40, nos. 1-3, p. 231-243. [Also available http://dx.doi.org/10.1080/19443994.2012.671250].

Haest, Maarten, Muchez, Philippe, Dewaele, Stijn, Boyce, A.J., Von quadt, Albrecht, and Schneider, Jens, 2009, Petrographic, fluid inclusion and isotopic study of the Dikulushi $\mathrm{Cu}-\mathrm{Ag}$ deposit, Katanga (D.R.C.)-Implications for exploration: Mineralium Deposita, v. 44, no. 5, p. 505-522. [Also available at http://dx.doi.org/10.1007/s00126-009-0230-x.]

Hagni, R.D., 1983, Minor elements in Mississippi Valleytype ore deposits - Unconventional deposits in low grade environments, chap. 7 of Shanks, W.C., III, ed., Cameron volume on unconventional mineral deposits: New York, N.Y., Society of Mining Engineers, p. 71-88.

Hall, W.E., and Heyl, A.V., 1968, Distribution of minor elements in ore and host rock, Illinois-Kentucky fluorite district and Upper Mississippi Valley zinc-lead district: Economic Geology, v. 63, p. 655-670. [Also available at http://dx.doi.org/10.2113/gsecongeo.63.6.655.]

Hieronymus, B., Kotschoubey, B., Boulegue, J., Benedetti, M., Godot, J.M., and Truckenbrodt, W., 1990, Aluminum behaviour in some alterites of eastern Amazonia (Brazil): Chemical Geology, v. 84, nos. 1-4, p. 74-77. [Also available at http://dx.doi.org/10.1016/0009-2541(90)90168-7.]

Hitzman, M.W., 1986, Geology of the Ruby Creek copper deposit, southwestern Brooks Range, Alaska: Economic Geology, v. 81, p. 1644-1674. [Also available at http://dx.doi.org/10.2113/gsecongeo.81.7.1644.]

Hitzman, M.W., Proffett, J.M., Jr., Schmidt, J.M., and Smith, T.E., 1986, Geology and mineralization of the Ambler district, northwestern Alaska: Economic Geology, v. 81, p. 1592-1618. [Also available at http://dx.doi.org/ 10.2113/gsecongeo.81.7.1592.] 
Hitzman, Murray, Kirkham, Rodney, Broughton, David, Thorson, Jon, and Selley, David, 2005, The sedimenthosted stratiform copper ore system, in Hedenquist, J.W., Thompson, J.F.H., Goldfarb, R.J., and Richards, J.P., eds., Economic Geology - One hundredth anniversary volume1905-2005: Littleton, Colo., Society of Economic Geologists, Inc., p. 609-642. [Appendixes are on a CD-ROM inside the back cover.]

Holecy, E.G., and Mousavi, Aliyar, 2012, Lead sources, toxicity, and human risk in children of developing countriesA mini-review: Environmental Forensics, v. 13, no. 4, p. 289-292. [Also available at http://dx.doi.org/10.1080/ 15275922.2012.729010.]

Hörmann, P.K., 1978, Germanium B-M, O, in Wedepohl, K.H., ed., Handbook of geochemistry, v. 2, pt. 3: Berlin, West Germany, Springer-Verlag, p. 31-D-10.

Hughes, M.J., 1987, The Tsumeb ore body, Namibia, and related dolostone-hosted base metal ore deposits of Central Africa: Johannesburg, South Africa, University of the Witwatersrand, Doctor of Science thesis, $448 \mathrm{p}$.

Hughes, M.J., Welke, H.J., and Allsopp, H.L, 1984, Lead isotopic studies of some Late Proterozoic stratabound ores of central Africa: Precambrian Research, v. 25, nos. 1-3, p.137-139. [Also available at http://dx.doi.org/ 10.1016/0301-9268(84)90029-9.]

Instytutu Problem Materialoznavstva, 1968, Handbook of the physicochemical properties of the elements: New York, N.Y., IFI-Plenum, 941 p.

Intiomale, M.M., and Oosterbosch, R., 1974, Géologie et géochmie du gisement de Kipushi, Zaire [The geology and geochemistry of the Kipushi deposit, Zaire], in Bartholomé, Paul, ed., Gisements stratiformes et provinces cupriféres [Stratiform copper deposits and provinces]: Liège, Belgium, Centenaire de la Société Géologique de Belgique, p. 123-164.

Jaskula, B.W., 2013a, Gallium: U.S. Geological Survey Mineral Commodity Summaries 2013, p. 58-59.

[Also available at https://minerals.usgs.gov/minerals/pubs/ commodity/gallium/mcs-2013-galli.pdf.]

Jaskula, B.W., 2013b, Gallium [advance release], in Metals and minerals: U.S. Geological Survey Minerals Yearbook 2011, v. I, p. 27.1-27.9, accessed March 1, 2013, at https://minerals.usgs.gov/minerals/pubs/commodity/ gallium/myb1-2011-galli.pdf.

Johan, Z., 1988, Indium and germanium in the structure of sphalerite-An example of coupled substitution with copper: Mineralogy and Petrology, v. 39, nos. 3-4, p. 211-229. [Also available at http://dx.doi.org/10.1007/BF01163036.]
Johan, Z., Oudin, E., and Picot, P., 1983, Analogues germanifères et gallifères des silicates et oxydes dans les gisements de zinc de Pyrénées centrales, France-Argutite et carboirite, deux nouvelles espèces minérales [Germanium and gallium analogues of silicates and oxides in zinc deposits of central Pyrenees, France-Argutite and carboirite, two new mineral species]: Tschermaks Mineralogische und Petrologische Mitteilungen [Tschermak Mineralogical and Petrological Releases], v. 31, nos. 1-2, p. 97-119.

Kabata-Pendias, Alina, and Mukherjee, A.B., 2007, Trace elements from soil to human: Berlin, Germany, SpringerVerlag, 550 p.

Kabata-Pendias, Alina, and Pendias, Henryk, 2001, Trace elements in soils and plants ( $3 \mathrm{~d}$ ed.): Boca Raton, Fla., CRC Press, 413 p.

Kamona, A.F., and Günzel, A., 2007, Stratigraphy and base metal mineralization in the Otavi Mountain Land, northern Namibia-A review and regional interpretation: Gondwana Research, v. 11, no. 3, p. 396-413. [Also available at http://dx.doi.org/10.1016/j.gr.2006.04.014.]

Kaneshiro, Jess, Gaillard, Nicolas, Rocheleau, Richard, and Miller, Eric, 2010, Advances in copper-chalcopyrite thin films for solar energy conversion: Solar Energy Materials and Solar Cells, v. 94, no. 1, p. 12-16. [Also available at http://dx.doi.org/10.1016/j.solmat.2009.03.032.]

Kelley, K.D., Leach, D.L., Johnson, C.A., Clark, J.L., Fayek, M., Slack, J.F., Anderson, V.M., Ayuso, R.A., and Ridley, W.I., 2004, Textural, compositional, and sulfur isotope variations of sulfide minerals in the Red Dog $\mathrm{Zn}-\mathrm{Pb}-\mathrm{Ag}$ deposits, Brooks Range, Alaska - Implications for ore formation: Economic Geology, v. 99, p. 1509-1532. [Also available at http://dx.doi.org/10.2113/99.7.1509.]

Kelley, K.D., Seal, R.R., II, Schmidt, J.M., Hoover, D.B., and Klein, D.P., 1995, Sedimentary exhalative $\mathrm{Zn}-\mathrm{Pb}-\mathrm{Ag}$ deposits (Model 31a; Briskey, 1986), chap. 29 of du Bray, E.A., ed., Preliminary compilation of descriptive geoenvironmental mineral deposit models: U.S. Geological Survey Open-File Report 95-831, p. 225-233. [Also available at http://pubs.usgs.gov/of/1995/ofr-95-0831/.

Kesler, S.E., and Reich, M.H., 2006, Precambrian Mississippi Valley-type deposits - Relation to changes in composition of the hydrosphere and atmosphere, in Kesler, S.A., and Ohmoto, Hiroshi, eds., Evolution of early Earth's atmosphere, hydrosphere, and biosphere - Constraints from ore deposits: Boulder, Colo., Geological Society of America, Geological Society of America Memoir, v. 198, p. 185-204.

Khashgerel, Bat-Erdene, Kavalieris, Imants, and Hayashi, Kenichiro, 2008, Mineralogy, textures, and whole- rock geochemistry of advanced argillic alteration-Hugo Dummett porphyry $\mathrm{Cu}-\mathrm{Au}$ deposit, Oyu Tolgoi mineral district, Mongolia: Mineralium Deposita, v. 43, no. 8, p. 913-932. [Also available at http://dx.doi.org/10.1007/s00126-008-0205-3.] 
Kim, H.C., Fthenakis, Vasilis, Choi, J.-K., and Turney, D.E., 2012, Life cycle greenhouse gas emissions of thin-film photovoltaic electricity generation: Journal of Industrial Ecology, v. 16, Supplement S1, p. s110-s121. [Also available at http://dx.doi.org/10.1111/j.1530-9290.2011.00423.x.]

Koljonen, T., ed., 1992, Suomen Geokemian Atlas, osa 2Moreeni [The geochemical atlas of Finland, Part 2-Till]: Espoo, Finland, Geological Survey of Finland, p. 106-125.

Krämer, V., Hirth, H., Hofherr, M., and Trah, H.-P., 1987, Phase studies in the systems $\mathrm{Ag}_{2} \mathrm{Te}-\mathrm{Ga}_{2} \mathrm{Te}_{3}, \mathrm{ZnSe}-\mathrm{In}_{2} \mathrm{Se}_{3}$ and $\mathrm{ZnS}-\mathrm{Ga}_{2} \mathrm{~S}_{3}$ : Thermochimica Acta, v. 112, no. 1, p. 89-94.

Large, D.E., 1981, The geochemistry of sedimentary rocks in the vicinity of the Tom $\mathrm{Pb}-\mathrm{Zn}-\mathrm{Ag}$ deposit, Yukon Territory, Canada: Journal of Geochemical Exploration, v. 15, nos. 1-3, p. 203-217. [Also available at http://dx.doi.org/10.1016/0375-6742(81)90063-7.]

Large, D.E., 1983, Sediment-hosted massive sulphide leadzinc deposits - An empirical model, in Sangster, D.F., ed., Sediment-hosted stratiform lead-zinc deposits - A short course sponsored by the Mineralogical Association of Canada and held immediately prior to the 1983 annual meeting in Victoria, B.C., May 11-13: Mineralogical Association of Canada Short Course Series, v. 9, p. 1-29.

Large, R.R., Bull, S.W., McGoldrick, P.J., Derrick, G.M., Carr, G.R., and Walters, Steve, 2005, Stratiform and strata-bound $\mathrm{Zn}-\mathrm{Pb}-\mathrm{Ag}$ deposits of the Proterozoic sedimentary basins of northern Australia, in Hedenquist, J.W., Thompson, J.F.H., Goldfarb, R.J., and Richards, J.P., eds., Economic Geology_One hundredth anniversary volume, 1905-2005: Littleton, Colo., Society of Economic Geologists, p. 931-963. [Appendixes are on a CD-ROM inside the back cover.]

Lavery, N.G., Leach, D.L., and Saunders, J.A., 1994, Lithogeochemical investigations applied to exploration for sediment-hosted lead-zinc deposits, in Fontboté, Lluis, and Boni, Maria, eds., Sediment-hosted Zn-Pb oresSociety for Geology Applied to Mineral Deposits special publication: New York, N.Y., Springer-Verlag, v. 10, p. $393-428$.

Leach, D.L., and Sangster, D.F., 1993, Mississippi Valleytype lead-zinc deposits, in Kirkham, R.V., Sinclair, W.D., Thorpe, R.I., and Duke, J.M., eds., Mineral deposit modeling: International Conference on Mineral Deposit Modeling, Ottawa, Ontario, Canada, 1990, Geological Association of Canada Special Paper 40, p. 289-314.
Leach, D.L., Bradley, D.C., Huston, D.L., Pisarevsky, S.A., Taylor, R.D., and Gardoll, S.J., 2010, Sediment-hosted leadzinc deposits in Earth history: Economic Geology, v. 105, p. 593-625. [Also available at http://dx.doi.org/10.2113/ gsecongeo.105.3.593.]

Leach, D.L., Bradley, Dwight, Lewchuk, M.T., Symons, D.T.A., de Marsily, Ghislain, and Brannon, Joyce, 2001, Mississippi Valley-type lead-zinc deposits through geological timeImplications from recent age-dating research: Mineralium Deposita, v. 36, no. 8, p. 711-740. [Also available at http://dx.doi.org/10.1007/s001260100208.]

Leach, D., Marsh, E., Bradley, D., Gardoll, S., and Huston, D., 2005, The distribution of SEDEX Pb-Zn deposits through Earth history, in Mao, Juingwen and Bierlein, F.P., eds., Mineral deposit research-Meeting the global challengeProceedings of the Eighth Biennial SGA Meeting, Beijing, China, August 18-21, 2005: Heidelberg, Switzerland, Society for Geology Applied to Mineral Deposits, p. 145-149.

Leach, D.L., Marsh, Erin, Emsbo, Poul, Rombach, C.S., Kelley, K.D., Reynolds, Jim, and Anthony, Mike, 2004, Nature of hydrothermal fluids at the shale-hosted Red Dog $\mathrm{Zn}-\mathrm{Pb}-\mathrm{Ag}$ deposits, Brooks Range, Alaska: Economic Geology, v. 99, p. 1449-1480. [Also available at http://dx.doi.org/10.2113/gsecongeo.99.7.1449.]

Leach, D.L., Sangster, D.F., Kelley, K.D., Large, R.R., Garven, Grant, Allen, C.R., Gutzmer, Jens, and Walters, Steve, 2005, Sediment-hosted lead-zinc deposits-A global perspective, in Hedenquist, J.W., Thompson, J.F.H., Goldfarb, R.J., and Richards, J.P., eds., Economic GeologyOne hundredth anniversary volume, 1905-2005: Littleton, Colo., Society of Economic Geologists, p. 561-607. [Appendixes are on a CD-ROM inside the back cover.]

Leach, D.L., Taylor, R.D., Fey, D.L., Diehl, S.F., and Saltus, R.W., 2010, A deposit model for Mississippi Valley-type lead-zinc ores, chap. A of Mineral deposit models for resource assessment: U.S. Geological Survey Scientific Investigations Report 2010-5070-A, 52 p.

Leach, D.L., Viets, J.B., Foley-Ayuso, Nora, and Klein, D.P., 1995, Mississippi Valley-type $\mathrm{Pb}-\mathrm{Zn}$ deposits (Models 32a, b; Briskey, 1986a, b), chap. 30 of du Bray, E.A., ed., Preliminary compilation of descriptive geoenvironmental mineral deposit models: U.S. Geological Survey Open-File Report 95-831, p. 234-243. [Also available at http://pubs.usgs.gov/ of/1995/ofr-95-0831/.]

Lide, D.R., ed., 2005, CRC handbook of chemistry and physics (86th ed.): Boca Raton, Fla., CRC Press, 2,544 p. 
Lottermoser, B.G., 2010, Mine wastes-Characterization, treatment, and environmental impacts ( $3 \mathrm{~d}$ ed.): Berlin, Germany, Springer-Verlag, 400 p. [Also available at http://dx.doi.org/10.1007/978-3-642-12419-8.]

Lydon, J.W., 1983, Chemical parameters controlling the origin and deposition of sediment-hosted stratiform lead-zinc deposits, in Sangster, D.F., ed., Sediment-hosted stratiform lead-zinc deposits-A short course sponsored by the Mineralogical Association of Canada and held immediately prior to the 1983 annual meeting in Victoria, B.C., May 11-13: Mineralogical Association of Canada Short Course Series, v. 9 , p. $175-250$.

Macdonald, Ray, and Bailey, D.K., 1973. Chemistry of igneous rocks - Part 1, The chemistry of the peralkaline oversaturated obsidians: U.S. Geological Survey Professional Paper $440 \mathrm{~N}-1,36 \mathrm{p}$.

Mastalerz, Maria, and Drobniak, Agnieszka, 2012, Gallium and germanium in selected Indiana coals: International Journal of Coal Geology, v. 94, p. 302-313. [Also available at http://dx.doi.org/10.1016/j.coal.2011.09.007.]

Max Planck Institute, 2002, Geochemistry of rocks of the oceans and continents database (GEOROC): Max Planck Institute for Chemistry database, accessed March 1, 2013, at http://georoc.mpch-mainz.gwdg.de/.

Mayes, W.M., Jarvis, A.P., Burke, I.T., Walton, Melanie, Feigl, Viktória, Klebercz, Orsolya, and Gruiz, Katalin, 2011, Dispersal and attenuation of trace contaminants downstream of the Ajka bauxite residue (red mud) depository failure, Hungary: Environmental Science and Technology, v. 45, p. 5147-5155. [Also available at http://dx.doi.org/10.1021/ es200850y.]

McDermott, R.K., and Sibley, J.M., 2000, The Aznalcóllar tailings dam accident-A case study: Mineral Resources Engineering, v. 9, no. 1, p. 101-118.

McFarlane, M.J., 1976, Laterite and landscape: New York, N.Y., Academic Press, 151 p., 4 pls.

McLennan, S.M., and Murray, R.W., 1999, Geochemistry of sediments, in Marshall, C.P., and Fairbridge, R.W., eds., Encyclopedia of geochemistry: Boston, Mass., Kluwer Academic, p. 282-292.

Melcher, F., Oberthur, R., and Rammalmair, D., 2006, Geochemical and mineralogical distribution of germanium in the Khusib Springs $\mathrm{Cu}-\mathrm{Zn}-\mathrm{Pb}-\mathrm{Ag}$ sulfide deposit, Otavi Mountain Land, Namibia: Ore Geology Reviews, v. 28, p. 32-56.

Melfos, Vasilios, and Voudouris, P.Ch., 2012, Geological, mineralogical, and geochemical aspects for critical and rare metals in Greece: Minerals, v. 2, no. 4, p. 300-317. [Also available at http://dx.doi.org/10.3390/min2040300.]
Mendeleev, Dmitri, 1871, The periodical regularity of the chemical elements: Annalen der Chemie und Pharmacie, Supplement-band, v. 8, p. 133-229.

Metal Bulletin, 2013, China and minor metals-What next?: Metal Bulletin, May 10, accessed May 19, 2013 at http://www.metalbulletin.com/Article/3195423/

China-and-minor-metalswhat-next.html.

Mielke, J.M., 1979, Composition of the Earth's crust and distribution of the elements, in International Association of Geochemistry and Cosmochemistry, Review of research on modern problems in geochemistry, v. 16: Paris, France, United Nations Educational, Scientific and Cultural Organization, p. 13-39.

Miles, R.W., Zoppi, Guillaume, and Forbes, Ian, 2007, Inorganic photovoltaic cells: Materials Today, v. 10, no. 11, p. $20-27$. [Also available at http://dx.doi.org/ 10.1016/S1369-7021(07)70275-4.]

Misiewicz, J.E., 1988, The geology and metallogeny of the Otavi Mountain Land, Damara Orogen, SWA/Namibia, with particular reference to the Berg Aukas $\mathrm{Zn}-\mathrm{Pb}-\mathrm{V}$ deposit-A model of ore genesis: Grahamstown, South Africa, Rhodes University, Master of Science Dissertation, 143 p. [Maps and illustrations.]

Moskalyk, R.R., 2003, Gallium-The backbone of the electronics industry: Minerals Engineering, v. 16, no. 10, p. 921-929. [Also available at http://dx.doi.org/10.1016/ j.mineng.2003.08.003.]

Nagajyoti, P.C., Lee, K.D., and Sreekanth, T.V.M., 2010, Heavy metals, occurrence and toxicity for plantsA review: Environmental Chemistry Letters, v. 8, no. 3, p. 199-216. [Also available at http://dx.doi.org/10.1007/ s10311-010-0297-8.]

Natural Earth, 2014, Small scale data: Natural Earth map dataset, scale 1:110,000,000, accessed June 23, 2014, at http://www.naturalearthdata.com.

Onikura, N., Nakamura, A., and Kishi, K., 2005, Acute toxicity of gallium and effects of salinity on gallium toxicity to brackish and marine organisms: Bulletin of Environmental Contamination and Toxicology, v. 75, no. 2, p. 356-360. [Also available at http://dx.doi.org/10.1007/s00128-0050761-5.]

Orians, K.J., and Bruland, K.W., 1988, The marine geochemistry of dissolved gallium-A comparison with dissolved aluminum: Geochimica et Cosmochimica Acta, v. 52, no. 12, p. 2955-2962. [Also available at http://dx.doi.org/ 10.1016/0016-7037(88)90160-3.] 
Parrotta, J.A., Knowles, O.H., and Wunderle, J.M., Jr., 1997, Development of floristic diversity in 10-year-old restoration forests on a bauxite mined site in Amazonia: Forestry Ecology and Management, v. 99, nos. 1-2, p. 21-42.

Patterson, S.H., Kurtz, H.F., Olson, J.C., and Neeley, C.L., 1986, World bauxite resources: U.S. Geological Survey Professional Paper 1076-B, 151 p. [Also available at http://pubs.er.usgs.gov/publication/pp1076B.] .

Pearson, R.G., 1963, Hard and soft acids and bases: Journal of the American Chemical Society, v. 85, no. 22, p. 3533-3539. [Also available at http://dx.doi.org/10.1021/ ja00905a001.]

Plumlee, G.S,. and Logsdon, M.J., 1999, An Earth-system science toolkit for environmentally friendly mineral resource development, in Plumlee, G.S. and Logsdon, M.J., eds., The environmental geochemistry of mineral depositsPart A, Processes, techniques, and health issues: Littleton, Colo., Society of Economic Geologists, v. 1, p. 1-27.

Plumlee, G.S., Smith, K.S., Montour, M.R., Ficklin, W.H., and Mosier, E.L., 1999, Geological controls on the composition of natural waters and mine waters draining diverse mineral-deposit types, in Plumlee, G.S. and Filipek, L.H., eds., The environmental geochemistry of mineral deposits - Part B, Case studies and research topics: Littleton, Colo., Society of Economic Geologists, Reviews in Economic Geology Series, v. 6B, p. 373-432. [Also available at http://ebooks.geoscienceworld.org/content/ the-environmental-geochemistry-of-mineral-deposits.]

Połedniok, J., Andrzej, K., and Zerzucha, P., 2012, Spectrophotometric and inductively coupled plasma-optical emission spectroscopy determination of gallium in natural soils and soils polluted by industry-Relationships between elements: Communications in Soil Science and Plant Analysis, v. 43, no. 8, p. 1121-1135. [Also available at http://dx.doi.org/10.1080/00103624.2012.662561.]

Rambaldi, E.R., Rajan, R.S., Housley, R.M., and Wang, D., 1986, Gallium-bearing sphalerite in a metal- sulfide nodule of the Qingzhen (EH3) chondrite: Meteoritics, v. 21 , p. 23-31.

Reck, B.K., and Graedel, T.E., 2012, Challenges in metal recycling: Science, v. 337, no. 6095, p. 690-695. [Also available at http://dx.doi.org/10.1126/science.1217501.]

Reeves, H.J., Wealthall, G., and Younger, P.L., 2011, Advisory visit to the bauxite processing tailings dam near Ajka, Vesprém County, western Hungary: Keyworth, United Kingdom, British Geological Survey Open Report OR/11/006.
Rêserva International LLC, 2008, Executive summary of the "NI 43-101 Technical Report and Resource Estimation for the Cordero Gallium Project, Humboldt County, Nevada, USA," prepared for Gold Canyon Resources, Inc.: Reno, Nev., Rêserva International LLC, January, 2 p.

Retallack, G.J., 2010, Lateritization and bauxitization events: Economic Geology, v. 105, p. 655-667. [Also available at http://dx.doi.org/10.2113/gsecongeo.105.3.655.]

Riley, J.P., 1961, Composition of mineral water from the hot spring at Bath: Journal of Applied Geochemistry, v. 11, p. 190-191.

Rockett, A.A., 2010, Current status and opportunities in chalcopyrite solar cells: Current Opinion in Solid State and Materials Science, v. 14, no. 6, p. 143-148. [Also available at http://dx.doi.org/10.1016/j.cossms.2010.08.001.]

Rudnick, R.L., and Gao, S., 2003, Composition of the continental crust, in Rudnick, R.L., ed., The crust, v. 3 of Holland, H.D., and Turekian, K.K., eds., Treatise on geochemistry: Oxford, United Kingdom, Elsevier-Pergamon, p. 1-64. [Also available at http://dx.doi.org/10.1016/ B0-08-043751-6/03016-4.]

Ruyters, S., Mertens, J., Vassilieva, E., Dehandschutter, B., Poffijn, A., and Smolders, E., 2011, The red mud accident in Ajka (Hungary) - Plant toxicity and trace metal bioavailability in red mud contaminated soil: Environmental Science and Technology, v. 45, no. 4, p. 1616-1622. [Also available at http://dx.doi.org/10.1021/es104000m.]

Rytuba, J.J., John, D.A., Foster, Andrea, Ludington, S.D., and Kotlyar, Boris, 2003, Hydrothermal enrichment of gallium in zones of advanced argillic alteration-Examples from the Paradise Peak and McDermitt ore deposits, Nevada, chap. C of Contributions to industrial-minerals research: U.S. Geological Survey Bulletin 2209-C, accessed January 1, 2012, at http://pubs.usgs.gov/bul/b2209/.

Salminen, R., ed., 2015, Geochemical atlas of EuropePart 1, Background information, methodology, and maps: Espoo, Finland, Geological Survey of Finland database, accessed September 25, 2015, at http://weppi.gtk.fi/publ/ foregsatlas/index.php.

Sangster, D.F., 1990, Mississippi Valley-type and sedex leadzinc deposits - A comparative examination: Transactions of the Institution of Mining and Metallurgy, Section BApplied Earth Science, v. 99, p. B21-B42.

Schlüter, Jochen, Klaska, K.-H., Adiwidjaja, Gunadi, and Gebhard, Georg, 2003, Tsumgallite, $\mathrm{GaO}(\mathrm{OH})$, a new mineral from the Tsumeb Mine, Tsumeb, Namibia: Neues Jahrbuch für Mineralogie-Monatshefte, v. 2003, no. 11, p. 521-527. [Also available at http://dx.doi.org/ 10.1127/0028-3649/2003/2003-0521.] 
Schneider, J., Melcher, F., and Brauns, M., 2007, Concordant ages for the giant Kipushi base metal deposit (DR Congo) from direct $\mathrm{Rb}-\mathrm{Sr}$ and $\mathrm{Re}-\mathrm{Os}$ dating of sulfides: Mineralium Deposita, v. 42, no. 7, p. 791-797. [Also available at http://dx.doi.org/10.1007/s00126-007-0158-y.]

Schroll, Erich, 1999, Gallium-Element and geochemistry, in Marshall, C.P., and Fairbridge, R.W., eds., Encyclopedia of geochemistry: Boston, Mass., Kluwer, p. 257-259.

Schruben, Paul, 2002, Assessment of undiscovered deposits of gold, silver, copper, lead, and zinc in the United StatesA portable document (pdf) recompilation of USGS OFR 96-96 and Circular 1178: U.S. Geological Survey Open-File Report 2002-198.

Schulte, R.F., and Foley, N.K., 2014, Compilation of gallium resource data for bauxite deposits: U.S. Geological Survey Open-File Report 2013-1272, 14 p., 3 separate tables. [Also available at http://dx.doi.org/10.3133/ofr20131272.]

Selby, David, Kelley, K.D., Hitzman, M.W., and Zieg, Jerry, 2009, Re-Os sulfide (bornite, chalcopyrite, and pyrite) systematics of the carbonate-hosted copper deposits at Ruby Creek, southern Brooks Range, Alaska: Economic Geology, v. 104, p. 437-444. [Also available at http://dx.doi.org/10.2113/gsecongeo.104.3.437.]

Shacklette, H.T., and Boerngen, J.G., 1984, Element concentrations in soils and other surficial materials of the conterminous United States: U.S. Geological Survey Professional Paper 1270, 105 p. [Also available at http://pubs.usgs.gov/pp/1270/.]

Shanks, W.C., III, and Thurston, Roland, eds., 2012, Volcanogenic massive sulfide occurrence modelchap. C of Mineral deposit models for resource assessment: U.S. Geological Survey Scientific Investigations Report 2010-5070-C, 345 p. [Also available at http://pubs.usgs.gov/sir/2010/5070/c/.]

Shannon, R.D., 1976, Revised effective ionic radii and systematic studies of interatomic distances in halides and chalcogenides: Acta Crystallographica Section AFoundations, v. 32, no. 5, p. 751-767.

Shiller, A.M., 1998, Dissolved gallium in the Atlantic Ocean: Marine Chemistry, v. 61, nos. 1-2, p. 87-99. [Also available at http://dx.doi.org/10.1016/S0304-4203(98)00009-7.]

Shiller, A.M., and Frilot, D.M., 1996, The geochemistry of gallium relative to aluminum in Californian streams: Geochimica et Cosmochimica Acta, v. 60, no. 8, p. 1323-1328. [Also available at http://dx.doi.org/ 10.1016/0016-7037(96)00002-6.]

Smith, K.S., and Huyck, H.L.O., 1999, An overview of the abundance, relative mobility, bioavailability, and human toxicity of metals, in Plumlee, G.S., and Logsdon, M.J, eds., The environmental geochemistry of mineral depositsPart A, Processes, techniques and health issues: Littleton, Colo., Society of Economic Geologists, v. 1, p. 29-70.
Söhnge, P.G., 1964, The geology of the Tsumeb Mine, in Haughton, S.H., ed., The geology of some ore deposits in southern Africa, v. 2: Johannesburg, South Africa, Geological Society of South Africa, p. 367-382.

Soler, J.M., and Lasaga, A.C., 1996, A mass transfer model of bauxite formation: Geochimica et Cosmochimica Acta, v. 60, no. 24, p. 4913-4931. [Also available at http://dx.doi.org/10.1016/S0016-7037(96)00319-5.]

SRK Consulting (Canada) Inc., 2007, Red Dog Mine closure and reclamation plan-SD B3-Plan of operations for tailings and water management - Report prepared for Teck Cominco Alaska, Inc.: Vancouver, British Columbia, Canada, SRK Consulting (Canada) Inc., SRK Project Number 1CT006.003, 8 p. [Also available at http://dnr.alaska.gov/mlw/mining/largemine/reddog/ publicnotice/pdf/sdb3.pdf.]

Suter, G.W., II, and Tsao, C.L., 1996, Toxicological benchmarks for screening potential contaminants of concern for effects on aquatic biota—1996 revision: Oak Ridge, Tenn., Lockheed Martin Energy Systems Inc., ES/ER/TM-96/R2, variously paged, accessed March 4, 2013, at http://www.esd.ornl.gov/ programs/ecorisk/documents/tm96r2.pdf.

Taylor, R.D., Leach, D.L., Bradley, D.C., and Pisarevsky, S.A., 2009, Compilation of mineral resource data for Mississippi Valley-type and clastic-dominated sediment-hosted leadzinc deposits: U.S. Geological Survey Open-File Report 2009-1297, $42 \mathrm{p}$.

Taylor, S.R., and McLennan, S.M., 1995, The geochemical evolution of the continental crust: Reviews of Geophysics, v. 33, no. 2, p. 241-265. [Also available at http://dx.doi.org/ 10.1029/95RG00262.]

Tervek, R.W., and Fay, J.E., 1986, Gallium-An overview, markets, supplies and occurrence, in Elliott, I.L., and Smee, B.W., GEOEXPO/86-Exploration in the North American Cordillera-Proceedings of a symposium jointly sponsored by the Association of Exploration Geochemists and the Cordilleran Section, Geological Association of Canada, University of British Columbia, Vancouver, B.C., Canada, May 12th-14th, 1986: Vancouver, British Columbia, Canada, Geological Association of Canada, p. 209-212.

Tolcin, A.C., 2013, Zinc: U.S. Geological Survey Mineral Commodity Summaries 2013, p. 188-189. [Also available at https://minerals.usgs.gov/minerals/pubs/commodity/zinc/ mcs-2013-zinc.pdf.]

Trenfield, M.A., Markich, S.J., Ng, J.C., Noller, B., and van Dam, R.A., 2012, Dissolved organic carbon reduces the toxicity of aluminum to three tropical freshwater organisms: Environmental Toxicology and Chemistry, v. 31, no. 2, p. 427-436. [Also available at http://dx.doi.org/10.1002/ etc.1704.] 
Tyler, Germund, 2004, Vertical distribution of major, minor, and rare elements in a Haplic Podzol: Geoderma, v. 119, nos. 3-4, p. 277-290. [Also available at http://dx.doi.org/ 10.1016/j.geoderma.2003.08.005.]

Ueno, TeIchi, and Scott, S.D., 2002, Phase equilibria in the system $\mathrm{Zn}-\mathrm{Fe}-\mathrm{Ga}-\mathrm{S}$ at $900{ }^{\circ} \mathrm{C}$ and $800{ }^{\circ} \mathrm{C}$ : The Canadian Mineralogist, v. 40, p. 563-570. [Also available at http://dx.doi.org/10.2113/gscanmin.40.2.563.]

U.S. Environmental Protection Agency, 2006, Assessment of the potential costs, benefits, and other impacts of chat use in transportation projects: Washington, D.C., U.S. Environmental Protection Agency, Office of Solid Waste, Reference no. S.2006.1, 81 p.

U.S. Environmental Protection Agency, 2010, Record of Decision by the U.S. Environmental Protection Agency Region 10 for the Red Dog Mine Extension Aqqaluk Project: Washington, D.C., U.S. Environmental Protection Agency, 15 p. [Also available at http://www.epa.gov/ region10/pdf/permits/npdes/ak/red-dog-aqqaluk-rod.pdf.]

U.S. Environmental Protection Agency, 2013a, National ambient air quality standards (NAAQS) — Lead (Pb) standards - Table of historical Pb NAAQS: U.S. Environmental Protection Agency, accessed February 18, 2013, at http://www.epa.gov/ttn/naaqs/standards/pb/ s_pb_history.html.

U.S. Environmental Protection Agency, 2013b, National primary drinking water regulations: U.S. Environmental Protection Agency, EPA 816-F-09-004, May, 6 p., accessed February 15, 2013, at http://water.epa.gov/drink/ contaminants/index.cfm.

U.S. Geological Survey, 1996, Global 30 arc-second elevation (GTOPO30): Reston, Va., U.S. Geological Survey dataset (digital elevation model), accessed June 23, 2014, at https://lta.cr.usgs.gov/GTOPO30.

U.S. Natural Resources Conservation Service, Soil Survey Staff, 2000, Keys to soil taxonomy: Blacksburg, Virginia, Pocahontas Press, 600 p.

Uzumasa, Y., and Nasu, Y., 1960, Chemical investigations of hot springs in Japan: LVII. Gallium in hot springs. Nippon Kagaku Zasshi, v. 81, p. 732.

Valeton, Ida, 1972, Bauxites: New York, N.Y., Elsevier, 206 p.

Valeton, Ida, 1983, Paleoenvironment of lateritic bauxites with vertical and lateral differentiation, in Wilson, R.C.L., ed., Residual deposits_-Surface-related weathering processes and materials: London, United Kingdom, Geological Society of London, Special Publication, v. 11, p. 77-90. van Wilderode, J., Heijlen, W., De Muynck, D., Schneider, J., Vanhaecke, F., and Muchez, Ph., 2012, The Kipushi $\mathrm{Cu}-\mathrm{Zn}$ deposit (DR Congo) and its host rocks-A petrographical, stable isotope $(\mathrm{O}, \mathrm{C})$ and radiogenic isotope (Sr, Nd) study: Journal of African Earth Sciences, v. 79, p. 143-156. [Also available at http://dx.doi.org/10.1016/ j.jafrearsci.2012.11.011.]

Viers, Jérôme, Dupré, Bernard, and Gaillardet, Jérôme, 2009, Chemical composition of suspended sediments in world rivers-New insights from a new database: Science of the Total Environment, v. 407, no. 2, p. 853-868. [Also available at http://dx.doi.org/10.1016/j.scitotenv.2008.09.053.]

Viets, J.G., Hopkins, R.T., and Miller, B.M., 1992, Variations in minor and trace metals in sphalerite from Mississippi Valley-type deposits of the Ozark region-Genetic implications: Economic Geology, v. 97, p. 1897-1905. [Also available at http://dx.doi.org/10.2113/gsecongeo.87.7.1897.]

Washington County Historical Society, 2013, Apex Mine (aka Pen Mine, Dixie Apex Mine, Utah-Eastern Mine): St. George, Utah, Washington County Historical Society Web page, accessed September 26, 2015, at http://wchsutah.org/mining/apex-mine.php.

Weeks, R.A., 1973, Gallium, germanium, and indium, in Brobst, D.A., and Pratt, W. P., eds., United States mineral resources: U.S. Geological Survey Professional Paper 820, p. 237-246. [Also available at http://pubs.er.usgs.gov/ publication/pp820.]

Wilkinson, B.H., McElroy, B.J., Kesler, S.E., Peters, S.E., and Rothman, E.D., 2009, Global geologic maps are tectonic speedometers - Rates of rock cycling from area-age frequencies: Geological Society of America Bulletin, v. 121, nos. 5-6, p. 760-779. [Also available at http://dx.doi.org/ 10.1130/B26457.1.]

Wood, S.A., and Samson, I.M., 2006, The aqueous geochemistry of gallium, germanium, indium, and scandium: Ore Geology Reviews, v. 28, no. 1, p. 57-102. [Also available at http://dx.doi.org/10.1016/j.oregeorev.2003.06.002.]

Ye, Lin, Cook, N.J., Ciobanu, C.L., Yuping, Liu, Qian, Zhang, Tiegeng, Liu, Wei, Gao, Yulong, Yang, and Danyushevskiy, Leonid, 2011, Trace and minor elements in sphalerite from base metal deposits in South China-A LA-ICPMS study: Ore Geology Reviews, v. 39, no. 4, p. 188-217. [Also available at http://dx.doi.org/10.1016/j.oregeorev.2011.03.001.]

Ziegler, T.L., Divine, K.K. and Goering, P.L., 2004, Gallium, chap. 9 of Merian, E., Anke, Manfred, Ihnat, Milan, and Stoeppler, Markus, eds., Elements and their compounds in the environment-Occurrence, analysis and biological relevance: Weinheim, Germany, Wiley-VCH Verlag, v. 2, p. 775-786. [Also available at http://dx.doi.org/ 10.1002/9783527619634.ch30.] 



\section{Germanium and Indium}

By W.C. Pat Shanks III, Bryn E. Kimball, Amy C. Tolcin, and David E. Guberman

Chapter I of

Critical Mineral Resources of the United States-Economic and Environmental Geology and Prospects for Future Supply

Edited by Klaus J. Schulz, John H. DeYoung, Jr., Robert R. Seal II, and Dwight C. Bradley

Professional Paper 1802-1

U.S. Department of the Interior

U.S. Geological Survey 


\section{Contents of Chapter I}

[Figure and table titles for all chapters are listed in the volume contents before the conversion factors table and list of abbreviations and symbols. A periodic table of the elements is on the inside front cover of the printed volume]

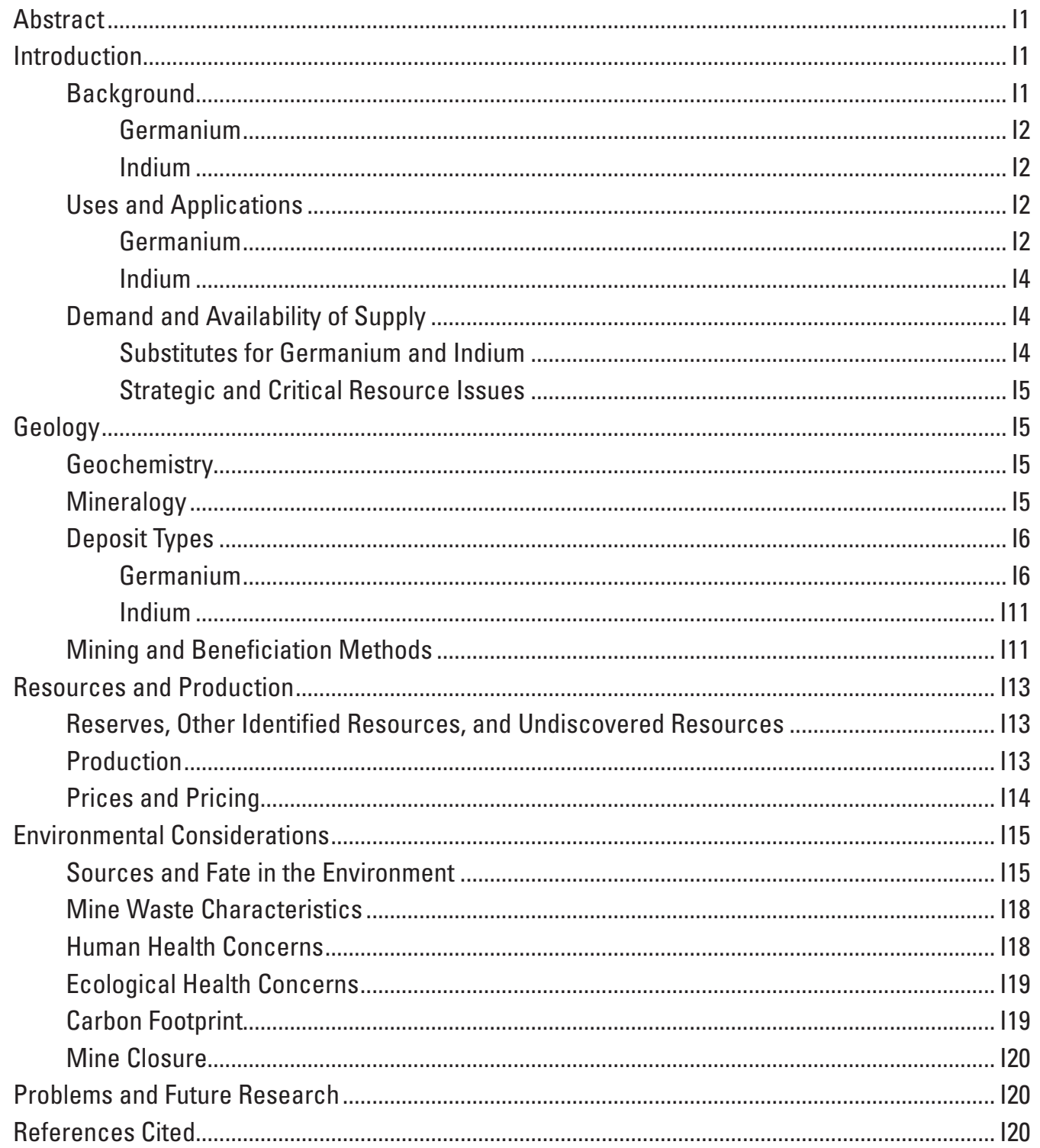




\title{
Germanium and Indium
}

\author{
By W.C. Pat Shanks III, Bryn E. Kimball, Amy C. Tolcin, and David E. Guberman
}

\section{Abstract}

Germanium and indium are two important elements used in electronics devices, flat-panel display screens, light-emitting diodes, night vision devices, optical fiber, optical lens systems, and solar power arrays. Germanium and indium are treated together in this chapter because they have similar technological uses and because both are recovered as byproducts, mainly from copper and zinc sulfides.

The world's total production of germanium in 2011 was estimated to be 118 metric tons. This total comprised germanium recovered from zinc concentrates, from fly ash residues from coal burning, and from recycled material. Worldwide, primary germanium was recovered in Canada from zinc concentrates shipped from the United States; in China from zinc residues and coal from multiple sources in China and elsewhere; in Finland from zinc concentrates from the Democratic Republic of the Congo; and in Russia from coal.

World production of indium metal was estimated to be about 723 metric tons in 2011; more than one-half of the total was produced in China. Other leading producers included Belgium, Canada, Japan, and the Republic of Korea. These five countries accounted for nearly 95 percent of primary indium production.

Deposit types that contain significant amounts of germanium include volcanogenic massive sulfide (VMS) deposits, sedimentary exhalative (SEDEX) deposits, Mississippi Valley-type (MVT) lead-zinc deposits (including Irish-type zinc-lead deposits), Kipushi-type zinc-lead-copper replacement bodies in carbonate rocks, and coal deposits.

More than one-half of the byproduct indium in the world is produced in southern China from VMS and SEDEX deposits, and much of the remainder is produced from zinc concentrates from MVT deposits. The Laochang deposit in Yunnan Province, China, and the VMS deposits of the Murchison greenstone belt in Limpopo Province, South Africa, provide excellent examples of indium-enriched deposits. The SEDEX deposits at Bainiuchang, China (located in southeastern Yunnan Province), and the Dabaoshan
SEDEX deposit (located in the Nanling region of China) contain indium-enriched sphalerite. Another major potential source of indium occurs in the polymetallic tin-tungsten belt in the Eastern Cordillera of the Andes Mountains of Bolivia. Deposits there occur as dense arrays of narrow, elongate, indium-enriched tin oxide-polymetallic sulfide veins in volcanic rocks and porphyry stocks.

Information about the behavior of germanium and indium in the environment is limited. In surface weathering environments, germanium and indium may dissolve from host minerals and form complexes with chloride, fluoride, hydroxide, organic matter, phosphate, or sulfate compounds. The tendency for germanium and indium to be dissolved and transported largely depends upon the $\mathrm{pH}$ and temperature of the weathering solutions. Because both elements are commonly concentrated in sulfide minerals, they can be expected to be relatively mobile in acid mine drainage where oxidative dissolution of sulfide minerals releases metals and sulfuric acid, resulting in acidic $\mathrm{pH}$ values that allow higher concentrations of metals to be dissolved into solution.

\section{Introduction}

\section{Background}

This chapter provides an update of the U.S. Geological Survey (USGS) assessment of germanium and indium resources published in the early 1970s (Weeks, 1973); developments in shorter-term resource availability are addressed in the periodical USGS minerals information reports (part of the U.S. Bureau of Mines from 1925 through 1995). Germanium and indium are in significant demand for hightechnology applications, and this has led to many studies of concentrations and distributions in primary mineral deposits, advances in extraction technology for these byproduct elements, increased attention on recycling, a flourishing field developing new applications for these elements and their compounds, and consideration of the impacts that increased consumption could have on the environment. 
Critical Mineral Resources of the United States-Germanium and Indium

\section{Germanium}

In 1864, English chemist John Newlands postulated the existence of an element that would be intermediate between silicon and tin in his scheme of elemental octaves (Newlands, 1864). In 1871, the salient properties of the undiscovered element were predicted by the Russian chemist Dmitri Mendeleev (Weeks, 1932), who called it ekasilicon (beyond silicon). In 1886, the element was isolated from the silver sulfide mineral argyrodite $\left(\mathrm{Ag}_{8} \mathrm{GeS}_{6}\right)$ and described by the German chemist Clemens Winkler (1886), who named it germanium, after his native country. More than one-half century elapsed after the isolation of germanium before its first commercial use in diodes and transistors was developed.

Germanium is a hard, brittle, grayish-white, semiconducting element that has electrical properties between those of a metal and an insulator. Germanium is metallic in appearance and has unique properties that make it critical to the function of numerous commercial, industrial, and military applications. It is consumed as a pure element or in compound form, depending on the application.

\section{Indium}

Indium was discovered in 1863 by German chemists Ferdinand Reich and H.T. Richter during a spectrographic analysis of sphalerite ore samples from Freiberg, Germany (Reich and Richter, 1863). They named the element indium after the distinctive indigo-blue line in its emission spectrum. Indium remained only a scientific curiosity for years following its discovery; little was known about its occurrence apart from the Freiberg ore.

Indium is a soft, lustrous, silvery-white metal with a low melting point relative to other metals. It is ductile and malleable, even at cryogenic temperatures; it has high wettability when melted and is resistant to thermal fatigue.

\section{Uses and Applications}

\section{Germanium}

Multiple stages of the germanium production process yield germanium compounds and metals that are designed for specific applications. Concentrated germanium is chlorinated and distilled to form the first usable product in the refining process, germanium tetrachloride $\left(\mathrm{GeCl}_{4}\right)$, which is a colorless liquid that is used primarily as a reagent in the production of fiber-optic cable. Germanium tetrachloride can be hydrolyzed and dried to produce germanium dioxide $\left(\mathrm{GeO}_{2}\right)$, which is another commonly used compound. Germanium dioxide is a white powder that is used to manufacture certain types of optical lenses and as a catalyst in the production of plastic polyethylene terephthalate (PET) resin.
Germanium dioxide can be reduced with hydrogen to produce a germanium metal powder, which is subsequently melted and cast into first-reduction bars. The germanium bars are then zone-refined (a process that involves melting and cooling germanium bars to isolate and remove impurities and ultimately yield extremely pure germanium) to produce electronic-grade germanium metal. Zone-refined germanium metal can then be grown into crystals and sliced for use as semiconductors or recast into forms suitable for lenses or window blanks in infrared optical devices (Bleiwas, 2010).

Germanium owes its usefulness to at least five salient properties. First, it is an intrinsic semiconductor, which in the pure state - that is, in the absence of contaminant elements in its crystal structure - will conduct electricity, albeit poorly. It is particularly effective as a conductor at high frequencies and low operating voltages. Second, germanium is transparent to part of the infrared electromagnetic spectrum, whether in the crystalline or glassy states. Third, like silicon, germanium is a glass-former, able to form extended three-dimensional networks of more or less randomly ordered germaniumoxygen tetrahedra. Fourth, it has an exceptionally high refractive index. Fifth, it exhibits low chromatic dispersion. These five properties, singly and sometimes in combination, determine the usefulness of germanium in electronics devices, night vision devices, fiber-optic cable, optical lens systems, and solar power arrays. A sixth property, of specific value to plastic bottle and container manufacturing - a single but commercially important use - is the ability of germanium to catalyze the polymerization of the plastic PET resin without undesirable coloring of the plastic product.

Germanium is relatively strong and is easily machined into infrared lenses and windows for infrared optical devices. Infrared imaging devices are used extensively by the military and law-enforcement agencies for surveillance, reconnaissance, and target-acquisition applications. Infrared optical devices improve a soldier's ability to operate weapon systems in harsh conditions effectively, and they are increasingly used in remotely operated unmanned weapons and aircraft. Infrared optical devices are also used for border patrol and by emergency response teams for conducting search-and-rescue operations.

Germanium substrates are used to form the base layer in multijunction solar cells, which are the highest efficiency solar cells currently available. The substrates are produced from high-purity, single-crystal germanium ingots that are sliced into wafers and polished. Ultrathin layer combinations of materials are "grown" on top of the germanium substrate, and each layer captures a specific part of the solar spectrum and converts it into electricity. These multijunction cells are the preferred type for use in space-based solar power applications because of their high energy-conversion efficiency and strength at minimal size (fig. I1).

Terrestrial-based photovoltaic installations are a potential growth area for germanium use (Bleiwas, 2010). Solar 
powerplants that use concentrator technology composed of lenses or mirrors that focus high concentrations of direct sunlight onto germanium-based multijunction solar cells have emerged as viable sources for large-scale renewable energy generation. Germanium substrates are also used in high-brightness light-emitting diodes (LEDs) for backlighting liquid crystal display televisions and in vehicle headlights and tail lights.

Germanium tetrachloride is used to manufacture fiberoptic cables. Germanium is added to the pure silica glass core of the fiber-optic cable to increase its refractive index and minimize signal loss over long distances. Global demand for fiber-optic cable has increased significantly in recent years as technological advances have required ever-increasing bandwidth to transmit and receive data.

The major end uses for germanium worldwide are estimated to be fiber-optic systems ( 30 percent), infrared optics ( 25 percent), polymerization catalysts ( 25 percent), electronics and solar electric applications (15 percent), and other uses, including for chemotherapy, metallurgy, and phosphors ( 5 percent) (fig. I $2 A$ ). The domestic end-use distribution is different and is estimated to be infrared optics (50 percent), fiber-optic systems (30 percent), electronics and solar electric applications (15 percent), and other uses, including for chemotherapy, metallurgy, and phosphors (5 percent) (Guberman, 2013a). Germanium is not used in polymerization catalysts in the United States.

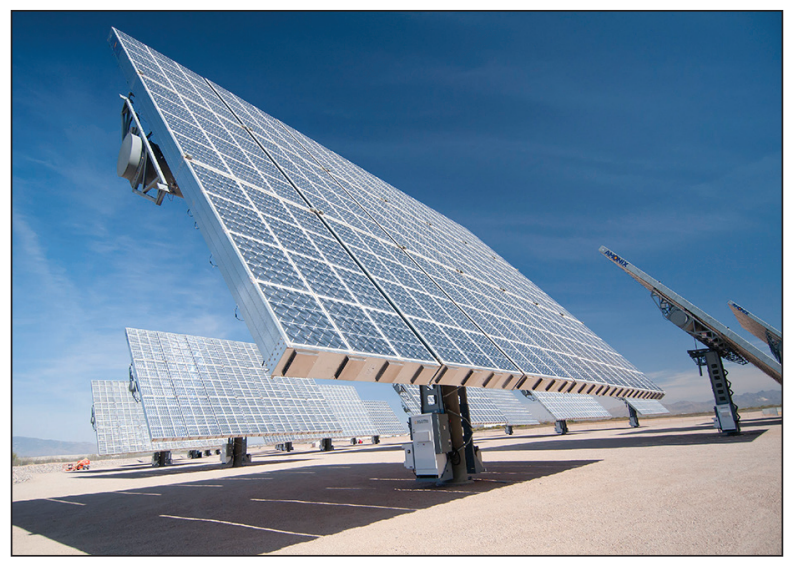

Figure I1. Photograph of a concentrator photovoltaic (CPV) solar power system which, in 2013, earned a National Renewable Energy Laboratory (NREL) outdoor efficiency rating of 34.9 percent under international standard operating test conditions for concentrator photovoltaics - a new world record. Solar powerplants such as this that use lenses or mirrors to focus high concentrations of direct sunlight onto germanium-based multijunction solar cells have emerged as viable sources for large-scale renewable energy generation (Bleiwas, 2010; BusinessWire, 2013). Photograph courtesy of Arzon Solar, LLC.
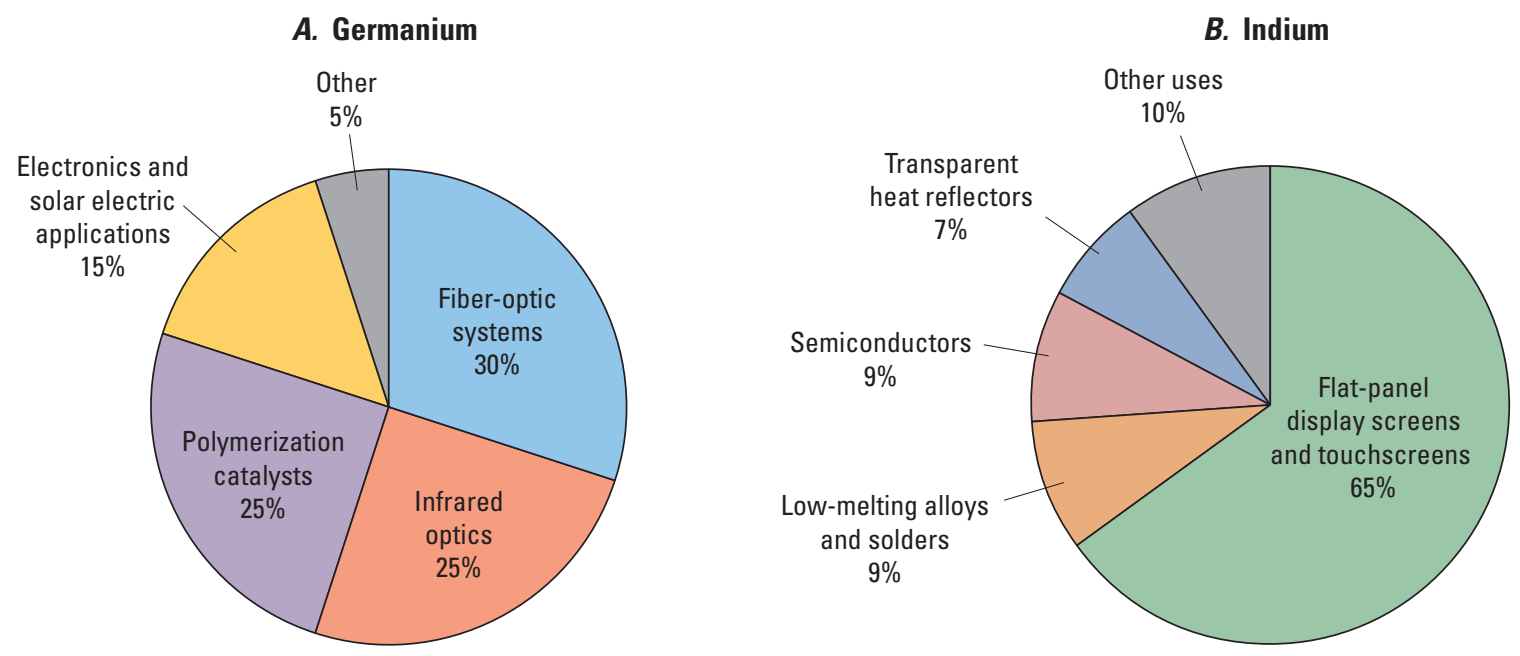

Figure 12. Pie charts showing major end uses of $A$, germanium and $B$, indium as a percentage of world consumption in 2012 . Data are from Guberman (2013a) and Tolcin (2013a). 


\section{Indium}

Indium metal with purities of up to 99.99995 percent is converted to different shapes and forms that have different uses. High-purity indium metal ingots are commonly used to produce indium compounds; indium shot is used in vapor deposition and plating applications; and indium wire, ribbon, and foil are typically used for soldering.

Indium is consumed mostly (65 percent) for the production of tin-doped indium oxide (or indium-tin oxide [ITO]), which is a transparent conducting oxide used in virtually every flat-panel display screen and touchscreen (figs. I2B and I3). ITO is typically deposited as a thin-film coating on the display surface, where it transforms incoming electrical data into an optical form. Most ITO production is concentrated in Japan, although significant quantities are also produced in China, the Republic of Korea, and Taiwan.

Alloys and solders are the second-ranked end use of indium globally (9 percent). Indium-containing solders have lower crack propagation and improved resistance to thermal fatigue compared with tin-lead solders. Indium-containing solders also inhibit the leaching of gold components in electronic apparatus. Certain types of indium alloys can be used as bonding agents between nonmetallic materials, such as glass, glazed ceramics, and quartz. Indium also is used in dental alloys and in white-gold alloys. Other indium alloys have been used as a substitute for mercury and in nuclear control rods.
Another important use of indium is in semiconductor materials for LEDs and laser diodes ( 9 percent). Indium antimonide, indium arsenide, or indium phosphide can be used as the substrate for indium-based semiconductors, and several indium-containing compounds can be used as the epitaxial layer (or substrate coating), such as indium-gallium-arsenide. Indium-based LEDs are used predominantly to transmit data optically and, to a lesser extent, in LED displays. Indiumbased laser diodes are used in fiber-optic communications.

\section{Demand and Availability of Supply}

\section{Substitutes for Germanium and Indium}

Germanium.- Silicon can be a less-expensive substitute for germanium in certain electronic applications. Some metallic compounds can be substituted in high-frequency electronics applications and in some LED applications. Zinc selenide and germanium glass substitute for germanium metal in infrared applications systems but commonly at the expense of performance. Titanium has the potential to be a substitute as a polymerization catalyst.

Indium.-The indium-containing compound ITO, which is used as the transparent conducting film in many flat-panel display screens and touchscreens, has few substitutes. Various groups, however, have recently explored using antimony tin oxide, carbon nanotube coatings, and a number of other compounds to substitute for ITO in flat-panel and flexible display screens (Tolcin, 2013a).

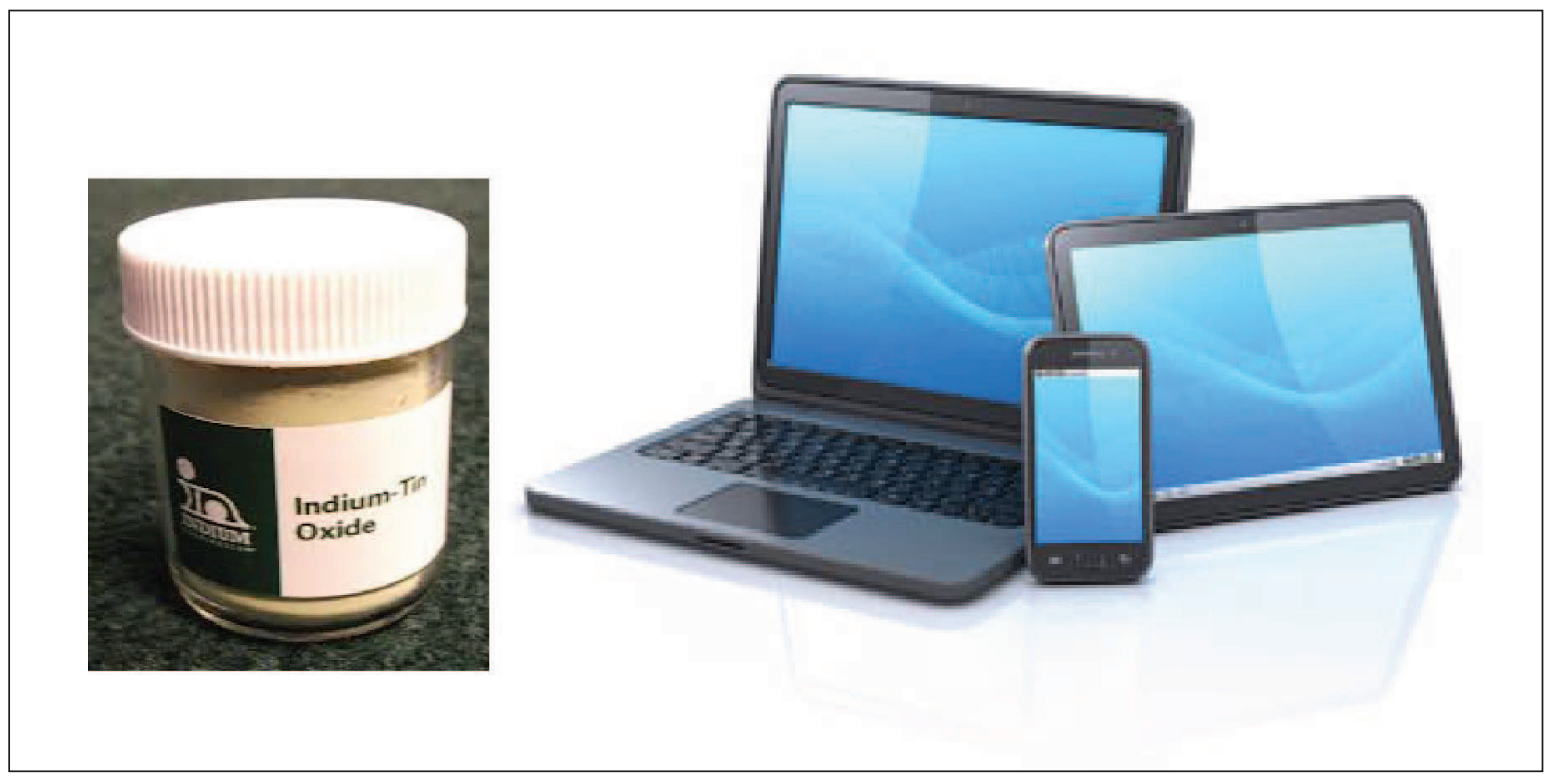

Figure 13. Photographs showing $A$, indium-tin oxide (ITO), which is a transparent conducting oxide, and $B$, examples of flat-panel display screens and touchscreens. ITO is typically deposited as a thin-film coating on the display surface where it transforms incoming electrical data into an optical form. Photograph $A$ courtesy of Indium Corp.; photograph B courtesy of Cl Systems, Inc. 


\section{Strategic and Critical Resource Issues}

Germanium.-The extensive use of germanium for military and commercial applications has made it a critical material in the United States and the rest of the world. Germanium was included in the National Defense Stockpile in 1984 and was more recently added to a stockpile program in China. In 2010, the European Union included germanium in a list of raw materials of critical concern for its member countries owing to its expected economic importance and relative supply risk (European Commission, 2010).

Few adequate substitutes exist for germanium for applications that are important for defense and law enforcement, such as infrared optics and substrates for solar cells in satellites. Most germanium production is concentrated in a few countries - Canada, China, Finland, and Russia. The United States is dependent on imports for its germanium consumption. As a byproduct metal, the supply of germanium is heavily reliant on zinc production. It has been estimated that less than 5 percent of the germanium contained in zinc concentrates reaches refineries that are capable of extracting and producing germanium.

Indium.- Indium can be considered a critical material for display technology because there are few substitutes. Because indium is recovered as a byproduct of zinc production, the supply of primary indium is determined by the supply of zinc, regardless of the market demand for indium. Additionally, a large portion of the indium contained in zinc ores and concentrates is not recovered - most zinc smelters are not equipped to extract indium. At the few smelters that do include indiumprocessing circuits, the average indium recovery rate is only about 50 percent (ranging from 30 to 80 percent) (Jorgenson and George, 2004). Increased consumption of indium is expected to be satisfied by increased recycling and additional primary supply through improved recovery rates, the construction of new plants, and expansions at existing recovery circuits (Alfantazi and Moskalyk, 2003).

\section{Geology}

\section{Geochemistry}

Germanium.-Germanium has a crustal abundance of 1.6 parts per million (ppm), making it about the 50th most abundant element. In elemental form, germanium is a hard, gray-white metalloid with an atomic number of 32 . It is a Group 4A element in the periodic table and has properties similar to its neighbors silicon and tin. Germanium most commonly exists in the +4 and +2 valence states and commonly substitutes for silicon or tin.

Aqueous germanium (as $\mathrm{Ge}^{4+}$ ) forms complexes with fluoride, hydroxide, phosphate, and sulfate in low-temperature environments. At hydrothermal temperatures (up to
300 degrees Celsius $\left.\left[{ }^{\circ} \mathrm{C}\right]\right)$, the principal complex is germanic acid $\left(\mathrm{H}_{4} \mathrm{GeO}_{4}\right)$, but germanium-fluoride complexes may be important at high-fluorine concentrations (Wood and Samson, 2006). Germanium concentrations of up to about 300 parts per billion (ppb) have been reported for some geothermal waters (Höll and others, 2007). Further evidence for hydrothermal transport comes from germanium concentrations of up to $20 \mathrm{ppm}$ in hydrothermal sinter deposits in New Zealand geothermal systems (Krupp and Seward, 1987) and of up to about $270 \mathrm{ppm}$ in modern sea-floor hydrothermal sulfide deposits (Bischoff and others, 1983).

Indium.- Indium has an average crustal abundance of about $49 \mathrm{ppb}$ and is the $61 \mathrm{st}$ most abundant element. Elemental indium is very soft, lustrous, metallic, and malleable, and it has a very low melting point of $156.6^{\circ} \mathrm{C}$. It is a Group 3A element in the periodic table and has chemical properties similar to its group neighbors gallium and thallium. Indium most commonly occurs in the +3 valence state.

Schwarz-Schampera and Herzig (1999) reported indium concentrations of up to $590 \mathrm{ppm}$ in modern sea-floor hydrothermal sulfide deposits of the Valu Fa Ridge in the Lau Basin of the western Pacific Ocean, so indium clearly is transported and deposited in hydrothermal systems. Seward and others (2000) experimentally determined that indium is complexed by chloride in aqueous solutions at temperatures of up to $350{ }^{\circ} \mathrm{C}$.

Chaplygin and others (2007) have shown that abundant indium - of up to 4.75 weight percent in sphalerite - occurs at fumaroles of the Kudriavy volcano on Iturup Island in the Kuril Islands, Russia. The fumarole deposits form at 400 to $750^{\circ} \mathrm{C}$, showing that vapor transport in high-temperature systems is also possible.

\section{Mineralogy}

Germanium.-Germanium can occur as the following rare minerals (with approximate compositions): argyrodite $\left(\mathrm{Ag}_{8} \mathrm{GeS}_{6}\right)$, germanite $\left(\mathrm{Cu}_{13} \mathrm{Fe}_{2} \mathrm{Ge}_{2} \mathrm{~S}_{16}\right)$, renierite $\left((\mathrm{Cu}, \mathrm{Zn})_{11}(\mathrm{Ge}, \mathrm{As})_{2} \mathrm{Fe}_{4} \mathrm{~S}_{16}\right)$, or briartite $\left(\mathrm{Cu}_{2}(\mathrm{Fe}, \mathrm{Zn}) \mathrm{GeS}_{4}\right)$. Germanium is primarily recovered as a byproduct from zinc, silver, lead, and copper ores, however. Laser ablation and inductively coupled plasma-mass spectrometry (ICP-MS) traverses across minerals by Ye and others (2011) have shown that germanium occurs in true solid solution in sulfide minerals and is most strongly enriched in sphalerite from Mississippi Valley-type (MVT) deposits, which are stratabound, carbonate-hosted lead-zinc deposits that form epigenetically from basinal brines at low to moderate temperatures (typically 150 to $225^{\circ} \mathrm{C}$ ).

Indium.-Indium forms a few minerals, such as dzhalindite $\left(\mathrm{In}(\mathrm{OH})_{3}\right)$ and indite $\left(\mathrm{Fe}^{+2} \mathrm{In}_{2} \mathrm{~S}_{4}\right)$, but is not found concentrated into significant deposits. Indium is primarily produced as a byproduct from zinc ores. Ye and others (2011) provide evidence that indium, like germanium, is in true solid solution in sphalerite. 


\section{Deposit Types}

\section{Germanium}

Germanium does not form specific deposits, but rather occurs as a byproduct in a variety of deposit types that contain copper, gold, lead, silver, and zinc. Germanium concentrations in sphalerite from these deposits are typically a few hundred parts per million. Because byproduct production comes from metallurgical operations that are commonly fed by concentrates from any number of different deposits and locations, it is difficult to track germanium production back to a specific deposit. The example deposits discussed below, however, are known to be significant contributors to major germaniumproducing facilities.

Types of deposits that contain significant germanium include volcanogenic massive sulfide (VMS) deposits, sedimentary exhalative (SEDEX) deposits, Mississippi Valleytype (MVT) lead-zinc deposits (including Irish-type lead-zinc deposits), and Kipushi-type zinc-lead-copper replacement bodies in carbonate rocks (table I1; Höll and others, 2007). Germanium is most enriched in the Kipushi-type deposits, but worldwide production is mostly from low-temperature stratiform sphalerite deposits (where mineralization follows stratigraphic layering) and strata-bound sphalerite deposits (where mineralization may cross-cut strata but is restricted to a particular stratigraphic unit).

Sedimentary exhalative deposits.-The Red Dog zinclead-silver mining district (fig. I4) in the western Brooks Range of northern Alaska contains several zinc-lead-silver sulfide bodies and prospects separated into thrust fault slices (Johnson and others, 2015). The four primary deposits of the Red Dog Mine have reserves and resources totaling 141 million metric tons at grades of 16.6 weight percent zinc and 4.6 weight percent lead (Jennings and King, 2002). The deposits are hosted in the Mississippian Kuna Formation black shales and mudstones that were deposited in a closed extensional basin that experienced euxinic conditions (Johnson and others, 2015).

Kelley and others (2004) showed that the deposits in the Red Dog district have a complex paragenetic history that they divide into four stages: (1) shallow subsurface impregnation of unconsolidated muds with abundant barite $\left(\mathrm{BaSO}_{4}\right)$ and early brown sphalerite, (2) subsea-floor deposition of yellow-brown sphalerite with barite, (3) deposition of red-brown sphalerite, and (4) faulting and tectonic brecciation accompanied by deposition of late tan sphalerite. Kelley and others (2004)

Table I1. Classification of deposits that host germanium and indium resources.

[Elements: Ag, silver; As, arsenic; Au, gold; Ba, barium; Be, beryllium; Bi, bismuth; Cd, cadmium; Co, cobalt; Cr, chromium; Cu, copper; Fe, iron; Ga, gallium; Ge, germanium; Hg, mercury; In, indium; Mn, manganese; Mo, molybdenum; Ni, nickel; Pb, lead; PGE, platinum-group elements; Re, rhenium; Sb, antimony; Se, selenium; Sn, tin; Te, tellurium; Tl, thallium; U, uranium; W, tungsten; Zn, zinc]

\begin{tabular}{|c|c|c|c|}
\hline Deposit type & Short name & Characteristics & $\begin{array}{c}\text { Metals present } \\
\text { (and source of information) }\end{array}$ \\
\hline $\begin{array}{l}\text { Volcanogenic massive } \\
\text { sulfide deposits }\end{array}$ & VMS & $\begin{array}{l}\text { Stratiform } \mathrm{Cu}-\mathrm{Pb}-\mathrm{Zn} \text { sulfide deposits in submarine } \\
\text { mafic to felsic volcanic terranes that form at the } \\
\text { sea floor by venting of hydrothermal fluids driven } \\
\text { by magmatic heat and volatiles }\end{array}$ & $\begin{array}{l}\mathrm{Cu}-\mathrm{Zn}-\mathrm{Pb}-\mathrm{Au}-\mathrm{Ag} \text { with } \mathrm{Be}, \mathrm{Bi}, \mathrm{Cd} \text {, } \\
\mathrm{Co}, \mathrm{Cr}, \mathrm{Ga}, \mathrm{Ge}, \mathrm{Hg}, \mathrm{In}, \mathrm{Mn}, \mathrm{Mo}, \\
\mathrm{Ni}, \mathrm{Se}, \mathrm{Sn}, \mathrm{Te}, \text { and PGE (Shanks } \\
\text { and Thurston, 2010) }\end{array}$ \\
\hline $\begin{array}{l}\text { Sedimentary exhalative } \\
\text { deposits }\end{array}$ & SEDEX & $\begin{array}{l}\text { Stratiform, often finely laminated, } \mathrm{Zn}-\mathrm{Pb}-\mathrm{Ag} \text { sulfide } \\
\text { deposits in carbonaceous and pyrite shales and } \\
\text { siltstones that form by exhalation of hydrothermal } \\
\text { fluid on the sea floor without any direct igneous } \\
\text { association }\end{array}$ & $\begin{array}{l}\text { Zn-Pb-Ag with As, Bi, Cd, Co, } \\
\text { Cu, Ga, Ge, Hg, In, Mn, Ni, Sb, } \\
\text { Se, Sn, and Tl (Goodfellow and } \\
\text { Lydon, 2007; Kelley and others, } \\
\text { 2004; Slack and others, 2004) }\end{array}$ \\
\hline $\begin{array}{l}\text { Mississippi Valley-type } \\
\mathrm{Zn}-\mathrm{Pb} \text { deposits }\end{array}$ & MVT & $\begin{array}{l}\text { Strata-bound epigenetic } \mathrm{Zn}-\mathrm{Pb} \text { sulfide replacement } \\
\text { deposits along faults and permeable zones and open- } \\
\text { space fill in solution collapse breccias in dolostone } \\
\text { and limestone. Not associated with igneous activity }\end{array}$ & $\begin{array}{l}\mathrm{Zn}-\mathrm{Pb} \text { with } \mathrm{Cu}, \mathrm{Ni} \text {, and } \mathrm{Co} \text { (Leach } \\
\quad \text { and others, 2005) }\end{array}$ \\
\hline $\begin{array}{l}\text { Polymetallic } \mathrm{Zn}-\mathrm{Sn} \\
\text { vein and fissure- } \\
\text { filling deposits }\end{array}$ & $\begin{array}{l}\text { Polymetallic } \\
\text { vein } \\
\text { deposits }\end{array}$ & $\begin{array}{l}\text { Polymetallic sulfide veins forming dense arrays in } \\
\text { volcanic rocks, eroded volcanic-intrusive complexes, } \\
\text { porphyry stocks, and associated breccia }\end{array}$ & $\begin{array}{l}\mathrm{Zn}-\mathrm{Cu}-\mathrm{Pb}-\mathrm{Sn}-\mathrm{In} \text { with } \mathrm{Ag}, \mathrm{As}, \mathrm{Bi} \\
\mathrm{Co}, \mathrm{Ga}, \mathrm{Mn}, \mathrm{Ni}, \mathrm{Sb}, \mathrm{Se} \text {, and } \mathrm{W} \\
\text { (Ishihara and others, 2011) }\end{array}$ \\
\hline $\begin{array}{l}\text { Coal and lignite } \\
\text { deposits }\end{array}$ & None & $\begin{array}{l}\text { Ge concentrated in organic matter of coal seams that } \\
\text { have been affected by hydrothermal activity and } \\
\text { are generally associated with siliceous layers }\end{array}$ & $\begin{array}{l}\text { Ge in coal with } \mathrm{As}, \mathrm{Ba}, \mathrm{Sb}, \mathrm{U} \text {, } \\
\text { and } \mathrm{W}\end{array}$ \\
\hline
\end{tabular}



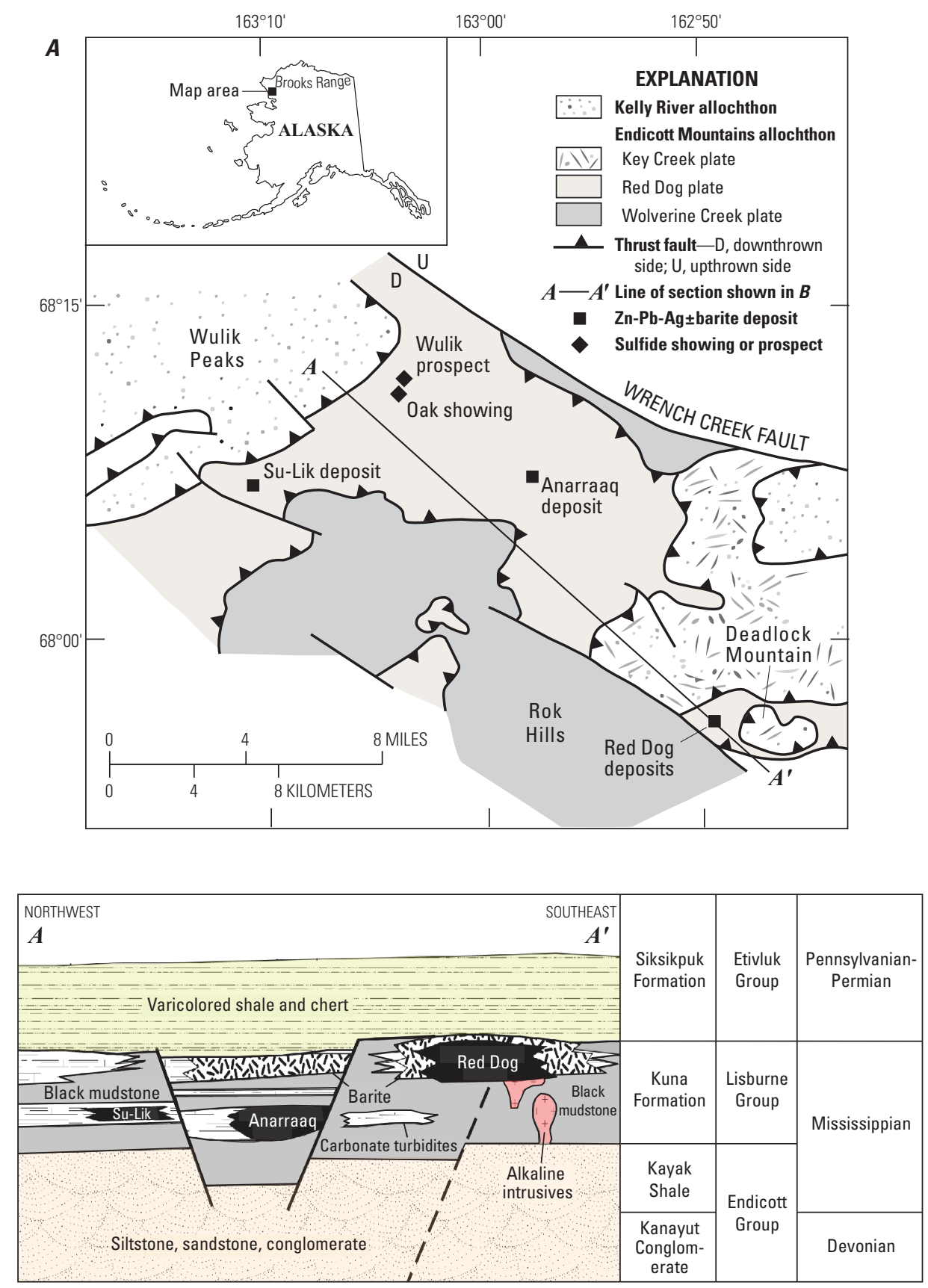

VERTICAL EXAGGERATION ×20

Figure 14. Map and schematic cross section showing the geology of the Red Dog mining district in Alaska and the stratigraphy of selected deposits in the district. A, Simplified geology of the Red Dog district in the western Brooks Range, Alaska, and the locations of major zinc-lead-silver $(\mathrm{Zn}-\mathrm{Pb}-\mathrm{Ag}) \pm$ barite deposits. The exposure is distal to known sulfide deposits, but sulfide showings have been identified nearby. Modified from Johnson and others (2015), De Vera and others (2004), and Young (2004). B, Stratigraphic positions of $\mathrm{Zn}$ - Pb-Ag sulfide deposits and barite deposits in the Red Dog district. This geologic section has Jurassic-Cretaceous thrust faulting removed, so the structural plates above the Red Dog plate are not shown and originally underlying strata have been restored. Modified from Johnson and others (2015) and Kelley and Jennings (2004). 
Critical Mineral Resources of the United States-Germanium and Indium

further show that sphalerite from all four stages is enriched in germanium and that the average concentrations range from 104 to $249 \mathrm{ppm}$. The highest germanium values occur in low-iron, lower temperature, late tan sphalerite. Most of the germanium produced at metallurgical facilities at Trail, British Columbia, Canada, likely comes from sphalerite concentrates from the Red Dog district.

The Fankou lead-zinc deposit in Guandong Province, China, is a carbonate-hosted strata-bound deposit hosted in Devonian to Carboniferous carbonates and shales (Höll and others, 2007). Gu and others (2007) cite evidence for the classification of the Fankou deposit as SEDEX with both stratiform and cross-cutting mineralization. Since mining began in the 1960s, the Fankou Mine has produced 150,000 metric tons of lead-zinc sulfide containing about 15 weight percent lead and zinc combined; the sulfide is also enriched in sphalerite that contains from 30 to $170 \mathrm{ppm}$ germanium (Xuexin, 1984; Höll and others, 2007).

Irish-type carbonate-hosted lead-zinc deposits have characteristics of both MVT and SEDEX deposits. The Silvermines-Lisheen group of deposits in the Midlands basin of County Tipperary, Ireland, formed by replacement of lower Carboniferous carbonate sediments near the sea floor and represent potentially important deposits of germanium. Wilkinson and others (2005) reported that microprobe analysis of minerals from drill core samples of the Lisheen deposit determined the germanium concentrations to be 400 to $900 \mathrm{ppm}$ in sphalerite, 200 to $1,300 \mathrm{ppm}$ in galena, and 200 to $1,000 \mathrm{ppm}$ in tennantite $\left((\mathrm{Cu}, \mathrm{Fe})_{12} \mathrm{As}_{4} \mathrm{~S}_{13}\right)$.

Despite these favorable reports, no production of byproduct germanium was reported by Vedanta Resources plc of India, which owned the Lisheen deposit.

Mississippi Valley-type deposits.-The GordonsvilleElmwood zinc-lead district in Tennessee hosts examples of zinc-rich MVT deposits that formed in collapse breccias related to large cavernous underground areas; these deposits, on average, have grades of about $400 \mathrm{ppm}$ germanium in zinc ore concentrate (Misra and others, 1996). Other MVT deposits in the United States average about $50 \mathrm{ppm}$ germanium in sphalerite. The Gordonsville Mine near Nashville, Tennessee, has produced 45,000 metric tons per year of zinc, and byproduct germanium production has been significant. In 2010, Nyrstar N.V. of Switzerland reopened the zinc mines in the Carthage mineral district in Tennessee, which includes the Elmwood, Gordonsville, and Cumberland Mines (Nyrstar N.V., 2016). The company reported production of 109,000 metric tons of zinc concentrate from these mines in 2012; the concentrates were processed at Nyrstar's Clarksville, Tenn., roast leach electrowin smelter complex, which produced a germanium concentrate as well as cadmium metal, copper sulfate, sulfuric acid, synthetic gypsum, and zinc metal (Nyrstar N.V., 2013, p. 6, 23).
The Huize MVT deposit, which is located in Carboniferous dolomites and limestones of China's eastern Yunnan Province (fig. I5), is one of the largest MVT deposits in China. The Huize Mine produces, in order of abundance, zinc-lead and byproduct silver, germanium, and cadmium (fig. I5; Ye and others, 2011).

Kipushi-type $\mathrm{Zn}-\mathrm{Pb}$-Cu replacement bodies in carbonate rock.-The most significant carbonate-hosted zinc-leadcopper deposits that contain notable amounts of germanium are the Kipushi deposit in the Democratic Republic of the Congo (Congo [Kinshasa]) and the Kabwe deposits in Zambia (fig. I6; Kampunzu and others, 2009). Kipushi-type deposits are strata-bound irregular pipelike sulfide bodies in platform carbonate rocks. Collapse breccias, faulting, and stratiform lensoidal sulfide bodies are commonly associated with Kipushi-type deposits. The Kipushi deposit is hosted in the upper Katangan Kundelungu Group (760 to 565 megaannum [Ma]) that consists of alternating carbonate rocks, shales, and sandstones. Schneider and others (2007) report concordant ages of $451.1 \pm 6.0 \mathrm{Ma}$ and $450.5 \pm 3.4 \mathrm{Ma}$ from direct rubidium-strontium and rhenium-osmium isochron dating, respectively, of ore-stage zinc-copper-germanium sulfides. Further, this age of ore formation indicates that mineralization is related to crustal fluids related to Ordovician extension.

Germanium averages $68 \mathrm{ppm}$ in bulk samples in the Kipushi deposit and occurs substituted in sulfide minerals, although it sometimes occurs in separate copper-irongermanium sulfide minerals. The actual amount of byproduct germanium production from mining is unknown.

Coal and lignite deposits. - China is a major producer of germanium from coal. The Lincang lignite mine, which is located close to Lincang City in Yunnan Province, is a significant source of germanium; the mine produces 16 metric tons of high-grade germanium dioxide $\left(\mathrm{GeO}_{2}\right)$ annually, of which 90 percent is exported (fig. I5; Höll and others, 2007). Germanium is produced at the Lincang Mine from a lower lignite unit that is close to the contact with germanium-rich granitic rocks below. Hu and others (2009) report that the Lincang deposit contains 1,000 metric tons or more of germanium at a grade of $850 \mathrm{ppm}$. Germanium-rich coal seams are interbedded with siliceous rocks, including siliceous limestones, whereas other nearby seams that do not have the association with siliceous rocks are barren of germanium. The siliceous rocks have oxygen and carbon isotope characteristics that suggest a hydrothermal origin. Hu and others (2009) propose that hydrothermal fluids first leached germanium from granitic rocks. The fluids were then discharged as hot springs along fault zones into Miocene basins where the germanium was concentrated in lignite seams within stratiform siliceous and siliceous-limestone deposits. 


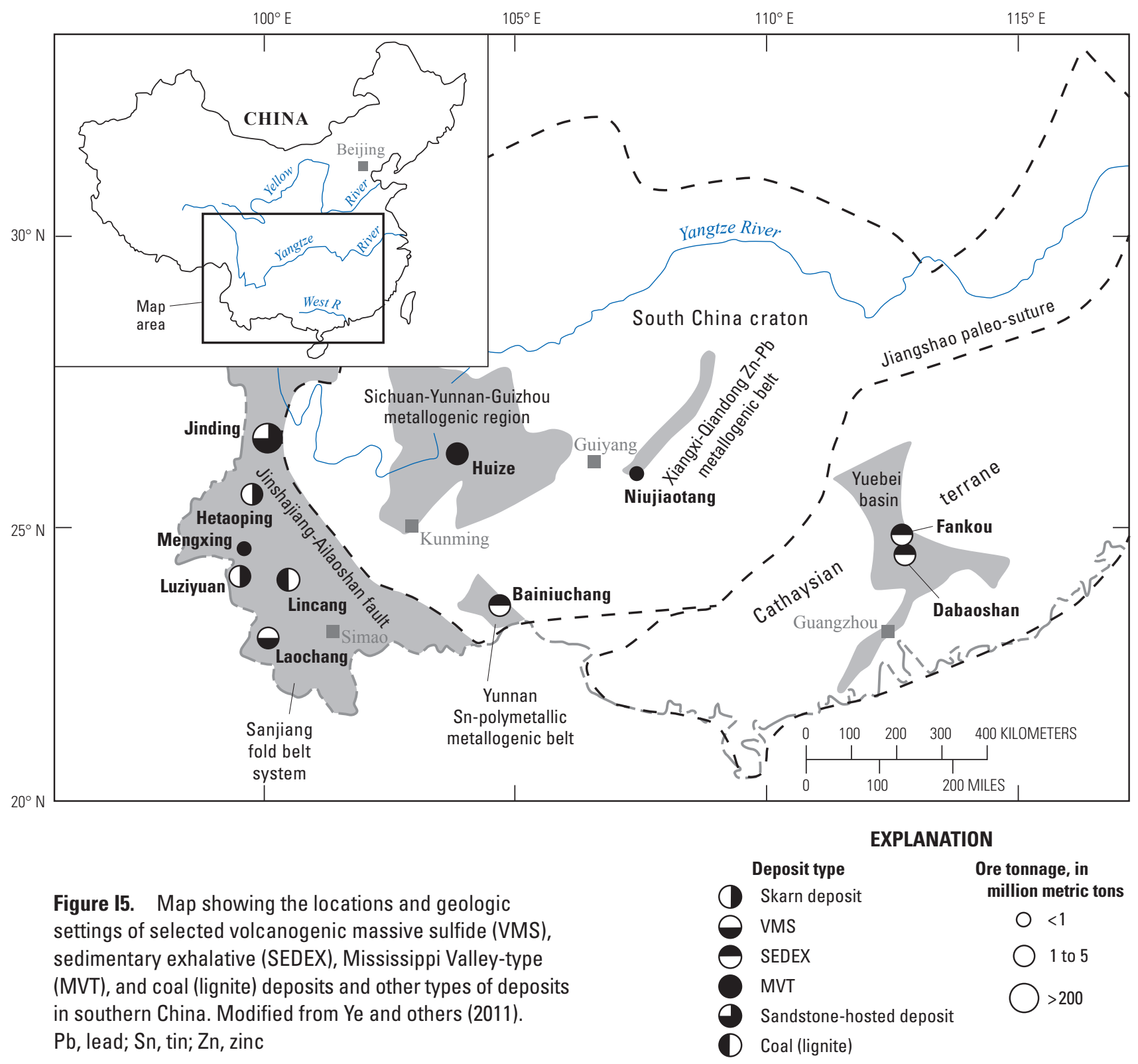




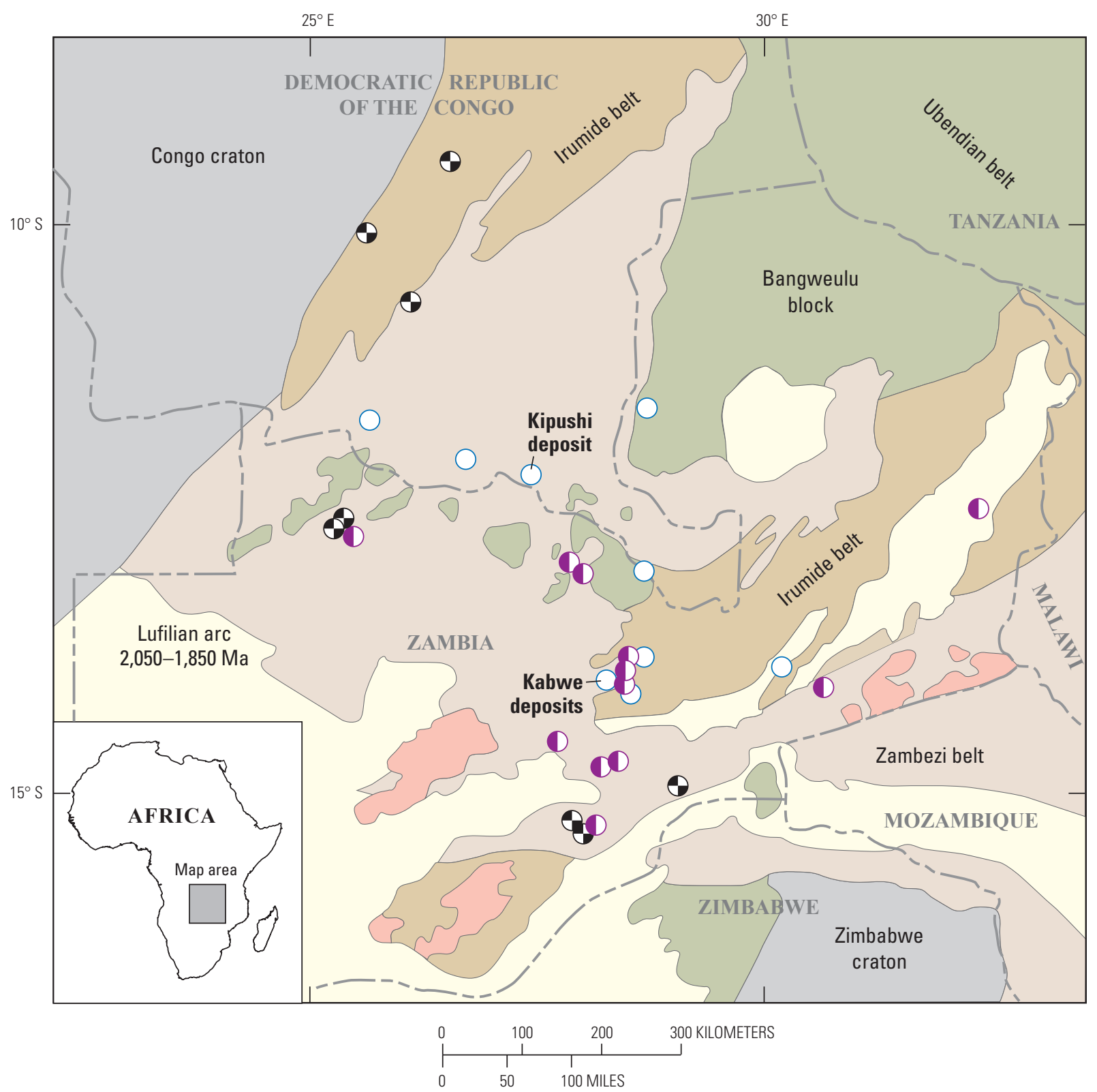

\section{EXPLANATION}

Age and type of rock

\section{Paleozoic to recent}

Neoproterozoic to Paleozoic granitoids

Neoproterozoic metasediments

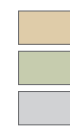

Mesoproterozoic quartzite and schist Paleoproterozoic granite gneiss Archean craton
Deposit type

$\mathrm{Zn}-\mathrm{Pb}$

(D) $\mathrm{Zn}$

$\ominus \mathrm{Pb}$

Figure 16. Map showing the location of Kipushi-type deposits (including the Kabwe deposits) and major Neoproterozoic orogenic belts and basins in the Precambrian tectonic framework of southern Africa. Modified from Kampunzu and others (2009). Pb, lead; Zn, zinc 


\section{Indium}

Approximately one-half of the byproduct indium in the world is produced at smelters located in southern China, but the Republic of Korea, Japan, Canada, Belgium, and Peru (in order of output) also produce significant byproduct indium. More than one-half of the material for the smelters in China comes from VMS and SEDEX deposits, and much of the remaining production comes from MVT deposits. It is difficult to decipher which VMS, SEDEX, and MVT deposits in the world provide the zinc feedstock processed at the Chinese smelters, however.

Volcanogenic massive sulfide deposits.-The Laochang deposit in Yunnan Province, China (fig. I5), and the VMS deposits of the Murchison greenstone belt in Limpopo Province, South Africa, provide excellent examples of indiumenriched VMS deposits. The Laochang deposit, which is hosted by a lower Carboniferous volcano-sedimentary sequence, occurs at the junction between southeast- and northwest-trending basement faults. Sphalerite samples analyzed by Ye and others (2011) have indium contents of up to $544 \mathrm{ppm}$ but average about $200 \mathrm{ppm}$.

The dozen or so VMS deposits of the Archean Murchison greenstone belt in South Africa occur in a felsic volcanic back-arc basin that was accreted to a continental margin (Schwarz-Schampera and others, 2010; Zeh and others, 2013). The VMS deposits typically consist of lower temperature zinc-rich sea-floor sulfide mineralization that, in some cases, is overprinted by higher temperature copper-rich mineralization. Indium is closely associated with copper-rich ores, and indium concentrations range from 24 to $641 \mathrm{ppm}$ in the Maranda $\mathrm{J}$, Romotshidi, and Solomons deposits of the Murchison greenstone belt (Schwarz-Schampera and others, 2010).

Sedimentary exhalative deposits.-The SEDEX deposit at Bainiuchang, China, is located in southeastern Yunnan Province (fig. I5). Mineralization occurs in stratiform massive sulfide lenses in mid-Cambrian dolomite, limestone, and sandstone. Indium in sphalerite at Bainiuchang averages $71 \mathrm{ppm}$ but shows large fluctuations, from 4 to $262 \mathrm{ppm}$ (Ye and others, 2011).

The Dabaoshan SEDEX deposit is located in the Nanling region of China and occurs at the contact between Devonian argillaceous limestones and underlying sandstones and shales (fig. I5). The deposit contains about 40 lenses of zinc-lead ore, and pyritic copper zones occur on the margins of some lenses. Indium in sphalerite of the Dabaoshan deposit averages $300 \mathrm{ppm}$ and shows little variation in the samples studied by Ye and others (2011).

Polymetallic tin vein deposits.-Polymetallic tin deposits of Bolivia (including the Bolívar, Hauri Hauri, Porco, Potosí, and San Lorenzo deposits, and others) constitute a major potential source of indium. Total indium metal resources in the Bolivian polymetallic tin deposits are estimated to be 12,000 metric tons (Ishihara and others, 2011). The polymetallic tin belt that occurs in the Eastern Cordillera of the Andes Mountains of Bolivia (Ishihara and others, 2011) is underlain by Paleozoic marine sedimentary rocks overlain and intruded by Cenozoic felsic volcanic and intrusive rocks that are associated with the mineralization (fig. I7). Deposits occur as dense arrays of narrow, elongate zinc sulfide and cassiterite $\left(\mathrm{SnO}_{2}\right)$ veins that occur in volcanic rocks, eroded volcanic-intrusive complexes, porphyry stocks and associated breccia, and Paleozoic sedimentary rocks. Individual Bolivian polymetallic tin deposits have indium contents in composite ore samples or zinc concentrates of $584 \mathrm{ppm}$ at Bolívar, 3,080 ppm at Hauri Hauri, 499 ppm at Porco, $292 \mathrm{ppm}$ at Potosí, and 1,080 ppm at San Lorenzo (Ishihara and others, 2011; Murakami and Ishihara, 2013).

\section{Mining and Beneficiation Methods}

Germanium.-Germanium is initially recovered from the leaching of zinc residues or coal ash followed by precipitation of a germanium concentrate. The extraction of germanium from its ores includes two stages - the production of a germanium concentrate by retorting, roasting, or pyrometallurgy and deposition of germanium sulfide or oxide. Concentrates are chlorinated to germanium tetrachloride $\left(\mathrm{GeCl}_{4}\right)$ and subsequently purified by hydrolysis to germanium dioxide $\left(\mathrm{GeO}_{2}\right)$, reduced pyrolytically with hydrogen gas $\left(\mathrm{H}_{2}\right)$ to germanium metal powder, and melted into bars (Butterman and Jorgenson, 2005).

Indium.- Indium is recovered as a byproduct during the refining process of other base-metal ores and concentrates, most commonly the zinc ore mineral sphalerite. Several complex and proprietary methods have been developed to extract indium from different source materials; however, a generalized recovery process is described, as follows, by Alfantazi and Moskalyk (2003). Waste products generated during the zinc refining process, such as dusts, fumes, residues, and slag, are collected and treated for the recovery of indium. These materials are first leached with hydrochloric or sulfuric acid to dissolve the indium into an aqueous solution. The solution then undergoes a solvent extraction process to increase the concentration of indium in the solution. Next, indium is removed from the solution by means of cementation, and the resulting indium sponge is cast into anodes for electrolytic refining to produce indium metal of standard-grade purity (99.97 or 99.99 percent). 


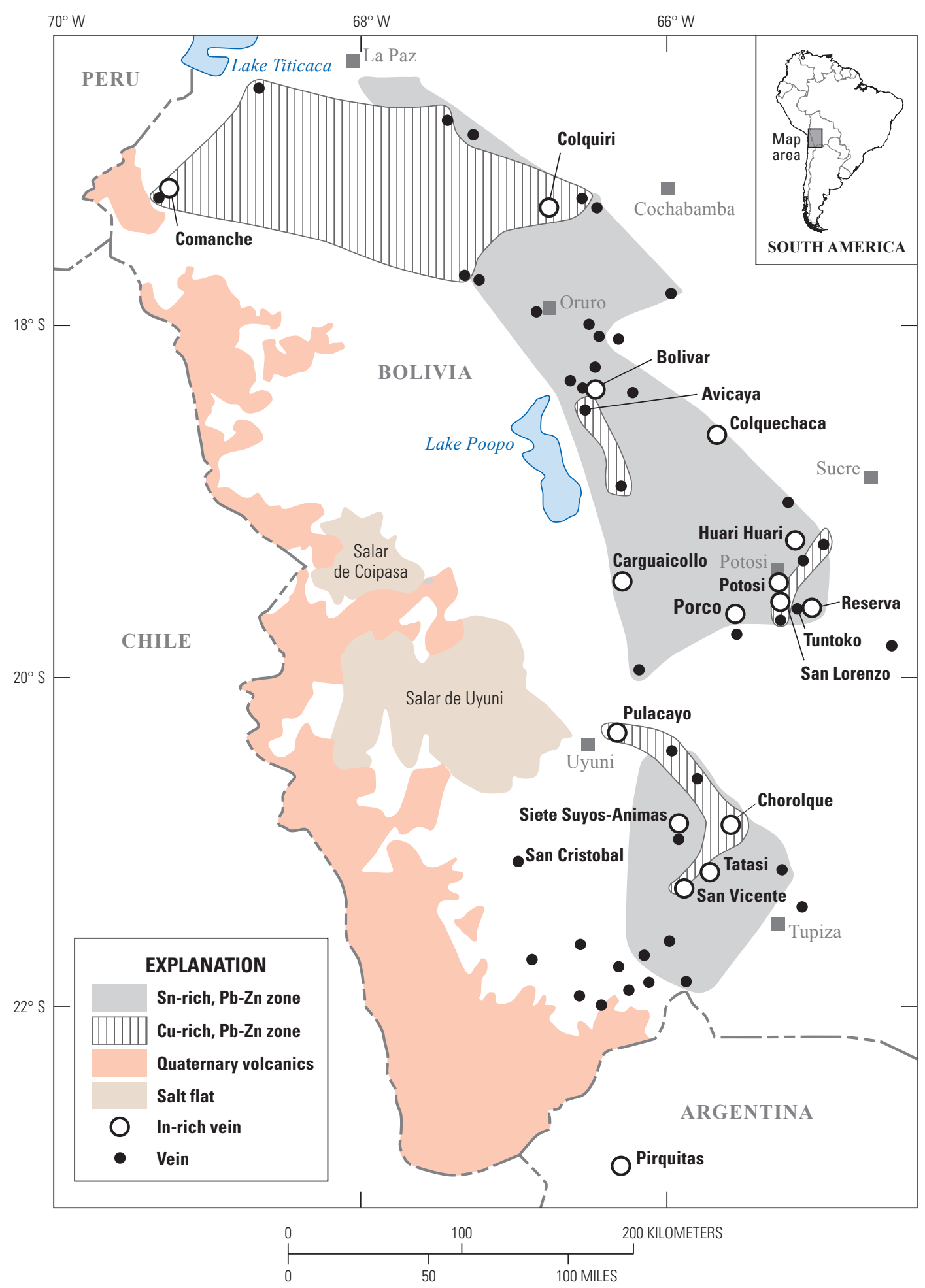

Figure 17. Map showing indium-bearing tin-polymetallic ore deposits in Bolivia. Modified from Ishihara and others (2011); copper-rich zone is from Schwarz-Schampera and Herzig (2002). $\mathrm{Cu}$, copper; In, indium; Pb, lead; Sn, tin; Zn, zinc 


\section{Resources and Production}

\section{Reserves, Other Identified Resources, and Undiscovered Resources}

Estimating reserves of either germanium or indium is difficult because they are byproduct commodities that come from a wide variety of ore deposit types. For example, both germanium and indium come largely from the zinc ore mineral sphalerite. Global zinc reserves are estimated to be 250 million metric tons, and domestic U.S. reserves are estimated to be 11 million metric tons. Accurately converting these values to reserves for germanium or indium would require an intensive program of chemical analyses for these elements in sphalerite, and there are insufficient data available to calculate average concentrations in all the relevant deposits, which is a necessary step in determining reserves. Guberman (2013a) estimated U.S. reserves for germanium to be 450 metric tons.

Germanium and indium are closely associated with currently produced zinc, copper, and tin-polymetallic ores, and coal deposits (Weeks, 1973; Schwarz-Schampera and Herzig, 2002; Höll and others, 2007; Bleiwas, 2010). Much of the ore that might provide byproduct germanium and indium currently is processed without separation of these constituents. The extent of recovery in the future will depend on (a) a continued increase in demand for indium and germanium, (b) better metallurgical recovery technology from sulfides and other materials, and (c) careful implementation of recycling of electronic products and production waste. Ores of metals other than zinc (especially some copper-tin ores), coal deposits, and fly ash from coal burning, have potential significant concentrations of germanium and indium and might become important sources. It is unlikely that exploration for deposits containing germanium and indium will be conducted solely because the deposits contain these byproduct elements. Two deposits have been developed primarily for production of germanium or indium. The indium-producing Toyoha Mine in Hokkaido Prefecture, Japan, closed in 2006 and the germanium-producing Apex Mine in Utah closed in 1992.

The Toyoha Mine, which is a lead-zinc-silver-indium vein deposit located near Sapporo, Japan, was until recently the world's leading indium producer (30 metric tons per year), but the mine was closed when ore reserves were exhausted. The deposit consists of a series of steeply dipping zinc-leadsilver-copper-tin-indium veins that occur across an area 500 meters (m) long and 2,500 $\mathrm{m}$ wide and has vein widths of up to $30 \mathrm{~m}$. Total indium production from the Toyoha Mine was estimated to be 5,000 metric tons, based on an average indium grade of $138 \mathrm{ppm}$ (Shimizu and Morishita, 2012).

The Apex Mine near Saint George, Utah, was the first mine in the world devoted primarily to production of gallium and germanium when it was reopened in 1986 (Bernstein, 1986). The Apex deposit was mined from 1884 to 1962 for copper, lead, and silver, which removed the copper-rich ores.
Gallium and germanium mining after 1986 focused mainly on azurite, goethite, hematite, jarosite, limonite, malachite, and minor amounts of other metal arsenates, carbonates, oxides, and sulfates. These minerals occur in dolomitized and silicified breccia, gouge, and fissures in steeply dipping fault zones within the gently dipping Pennsylvanian Callville Limestone. Germanium is concentrated (up to 7,000 ppm) mostly in the goethite, hematite, and limonite (Bernstein, 1986). Reserves of 247,000 metric tons at an average grade of 1,000 ppm germanium were estimated in 1986 (Ludington and others, 2006). Production was reported as 2,555 kilograms of germanium in 1986 (Burgin, 1988, p. 485). Cox and Singer (1986) and Ludington and others (2006) consider the Apex deposit to be a Kipushi-type deposit.

Although deposit and mine development exclusively for germanium and indium is unlikely, two promising deposits that could be sources of production primarily for these minerals have recently been described. Ludington and others (2006) report small base-metal deposits in Paleozoic limestone in the Gold Butte area and the Tramp Ridge area in Clark County, Nevada. These are unlikely ever to be significant sources of copper, lead, silver, or zinc; however, they may contain potentially significant concentrations of gallium and germanium, as well as cobalt. The characteristics of these deposits indicate clearly that they can be considered to be Kipushi-type deposits (Ludington and others, 2006).

Another prospect of interest is the Crypto zinc-copperindium project in Juab County, Utah, which contains copper and zinc skarn deposits in Paleozoic limestones (Nilsson and others, 2010). Indium concentrations average about $31 \mathrm{ppm}$, and indium resources are estimated to be about 475 metric tons of contained indium.

\section{Production}

Worldwide production of both germanium and indium has increased dramatically over the past several decades. Figure I8 shows the increases in global production since 1999 (Guberman, 2013a; Tolcin, 2013a). Production of each commodity in individual countries in 2011 and 2012 are discussed separately below.

Germanium.- In 2011, the world's total production of germanium was estimated to be 118 metric tons (table I2). This total includes germanium recovered from zinc concentrates, fly ash from coal burning, and recycled material. Worldwide, primary germanium was recovered in Canada from zinc residues (concentrates) shipped from the United States (specifically, the Red Dog zinc-lead mine in Alaska and a previously idled zinc mine complex in Tennessee); in China, from zinc residues and coal from multiple sources; in Finland, from zinc residues (concentrates) originating in Congo (Kinshasa); and in Russia, from coal from domestic sources on Sakhalin Island in Sakhalinskaya Oblast' (Höll and others, 2007). The vast majority of germanium production was concentrated in Canada and China (Bleiwas, 2010). 


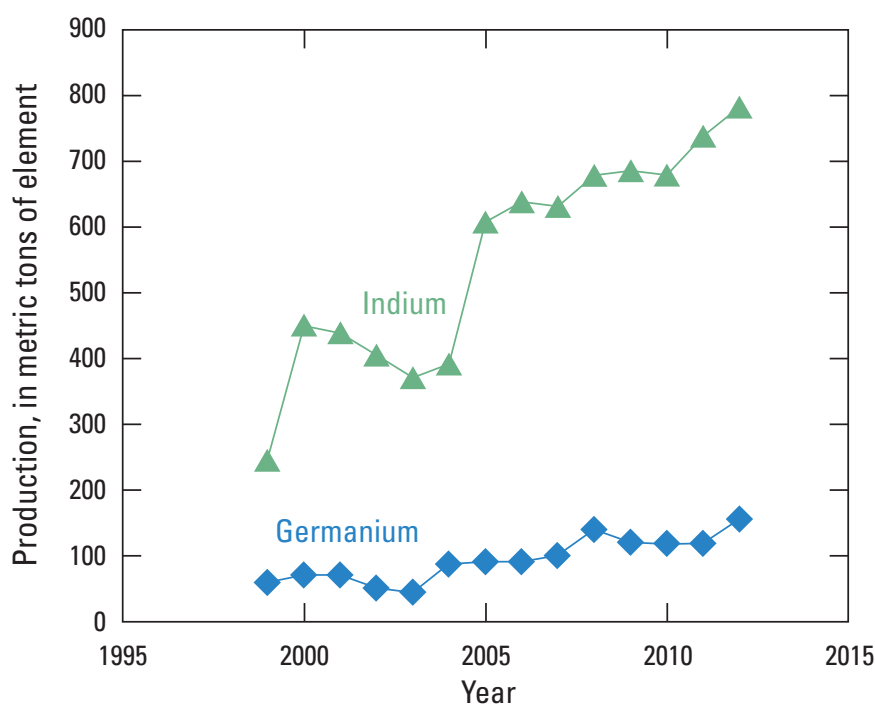

Figure 18. Graph showing worldwide production of germanium and indium from 1995 to 2012. Production of both minerals increased significantly. Graph was compiled using data from Jorgenson and George (2004), Guberman $(2013 a, b)$ and Tolcin $(2013 a, b)$.

Table 12. Average estimated annual refinery production of germanium and indium, by area, for 2011 and 2012.

[Sources: Guberman, 2013a, 2014; Tolcin, 2013a, 2014. W, withheld to avoid disclosing proprietary data; - , zero production; n.d., no data]

\begin{tabular}{|c|c|c|}
\hline \multirow[t]{2}{*}{ Country } & \multicolumn{2}{|c|}{$\begin{array}{c}\text { Refinery production } \\
\text { (metric tons) }\end{array}$} \\
\hline & 2011 & 2012 \\
\hline \multicolumn{3}{|c|}{ Germanium } \\
\hline United States & 3 & W \\
\hline China & 80 & 105 \\
\hline Russia & 5 & 5 \\
\hline Other countries ${ }^{1}$ & 30 & 40 \\
\hline World total & 118 & 150 \\
\hline \multicolumn{3}{|c|}{ Indium } \\
\hline United States & - & - \\
\hline Belgium & 30 & 30 \\
\hline Brazil & 5 & n.d. \\
\hline Canada & 75 & 62 \\
\hline China & 380 & 405 \\
\hline Japan & 70 & 71 \\
\hline Korea, Republic of & 70 & 165 \\
\hline Peru & n.d. & 11 \\
\hline Russia & 5 & 13 \\
\hline Other countries & 27 & 25 \\
\hline World total & 662 & 782 \\
\hline
\end{tabular}

${ }^{1}$ Germanium production in Canada is substantial, but exact figures are proprietary, so Canadian production is included with "Other countries."
Owing to the value of refined germanium, new scrap generated during the manufacture of fiber-optic cables, infrared optical fiber, and substrates is typically reclaimed and fed back into the production process. Recycling of germanium recovered from used materials, such as fiber-optic window blanks in decommissioned military vehicles or fiber-optic cables, has increased during the past decade. A germanium refinery in Utica, New York, produces germanium tetrachloride for optical fiber production. Another refinery in Quapaw, Oklahoma, produces refined germanium compounds for the production of fiber optics, infrared devices, and substrates for electronic devices.

Indium.-Globally, primary production of indium metal in 2011 was estimated to be about 662 metric tons, of which about one-half was produced in China (table I2). Other leading producers were Belgium, Canada, Japan, and the Republic of Korea. These five countries accounted for almost 95 percent of primary indium production. Major production facilities outside of China included Teck Resources Ltd.'s Trail lead-zinc metallurgical complex in Canada, Korea Zinc Ltd.'s Onsan lead-zinc smelter in the Republic of Korea, Dowa Metals and Mining Co. Ltd.'s Akita zinc smelter in Japan, and Umicore NV's Hoboken preciousmetals refinery in Belgium (Guberman, 2013a; Tolcin, 2013a).

In the United States, indium metal was not produced as a byproduct at any smelters or refineries. Domestic production of indium consisted of upgrading imported indium metal and powder. Indium Corp. of America and Umicore Thin Film Products accounted for the majority of U.S. production of indium metal and products.

\section{Prices and Pricing}

Germanium.-Germanium is traded through longterm supply contracts and individual trades between large consumers and suppliers as well as private trading houses. The terms of such trades are generally unavailable publicly, and a market price, in the conventional sense, does not exist. Publicly available price quotes actually represent estimates of representative prices in trades being executed on a particular day, which are compiled through recurring interviews with individual traders. Germanium prices have fluctuated on a regular basis owing to supply disruptions and increases in consumption of germanium for emerging applications. Germanium dioxide prices in 2012, for example, increased by 49 percent to $\$ 1,375$ per kilogram in late September, up from $\$ 925$ per kilogram in mid-March (Guberman, 2013a, b). Because germanium commonly is produced as a byproduct of zinc, the supply and price of germanium is often affected by the zinc market. Germanium metal trades at a significantly higher price than germanium dioxide, reflecting the value added and cost of this further refining.

Indium.-The average indium price in 2012 was $\$ 530$ per kilogram. In 2011, indium prices fluctuated between a high of $\$ 785$ at the beginning of the year and a low of $\$ 485$ in July, ending the year at approximately $\$ 540$ per kilogram (Tolcin, 2013a, b). 


\section{Environmental Considerations}

Germanium and indium are becoming increasingly more important to society, given their increasing use in microelectronic applications. Compared with more-abundant industrial metals, such as lead and zinc, information about the behavior of germanium and indium in the environment is limited.

\section{Sources and Fate in the Environment}

In surface weathering environments, germanium and indium may dissolve from host minerals and form complexes with chloride, fluoride, hydroxide, organic compounds, phosphate, or sulfate. In dissolved form, germanium and indium most often occur in the +4 and +3 oxidation states, respectively (Wood and Samson, 2006). The behavior of germanium in weathering environments mirrors that of silicon, so measurement of germanium-to-silicon ratios in diatoms (single-celled alga with a cell wall of silica) in rivers and oceans has been used as a tool to document weathering of silicate rocks through geologic time (for example, Froelich and others, 1992). Indium has no equivalent relationship with another element in weathering environments, but it does tend to co-precipitate with iron and manganese oxyhydroxide minerals in weathering environments (Kabata-Pendias and Mukherjee, 2007). Germanium has a particular affinity for organic material, which may be one of the mechanisms of germanium enrichment in coal.

The tendency for germanium and indium to be dissolved and transported largely depends upon the $\mathrm{pH}$ and temperature of weathering solutions. Both elements are commonly concentrated in sulfide minerals and are therefore relatively mobile under most weathering conditions because of the instability of sulfide minerals subjected to near-surface oxidizing conditions. Oxidative dissolution of sulfide minerals releases metals and sulfuric acid, resulting in the environmental problem known as acid mine drainage (AMD). Metals, including germanium and indium, dissolved in acidic drainage can be attenuated through precipitation, sorption to (oxyhydr)oxide minerals, or dilution by mixing with water at circum-neutral $\mathrm{pH}$; otherwise, metals are transported downstream.

Examples of natural concentrations of germanium in soil and water are given in table I3. Germanium contents in soils generally range from 0.5 to $2.3 \mathrm{ppm}$ (Shacklette and Boerngen, 1984; Eriksson, 2001), and concentrations as high as $173 \mathrm{ppm}$ have been observed in soil in Sweden (Eriksson, 2001). Germanium concentrations in seawater range from nearly 0.05 to 13 parts per trillion (ppt) (Froelich and others, 1985; Santosa and others, 1997; Ellwood and Maher, 2003); seawater germanium concentrations follow a typical nutrient profile, as the surface water is more depleted of germanium than the bottom water (Froelich and others, 1985). Seawater germanium concentrations are generally lower than the 2 to $80 \mathrm{ppt}$ range (mean is $7 \mathrm{ppt}$ ) observed for uncontaminated rivers around the world (Froelich and others, 1985; Mortlock and Froelich, 1987; Gaillardet and others, 2003). Geothermal waters contain higher germanium contents, as evidenced by the range observed in hot springs $(1,500$ to $6,800 \mathrm{ppt})$ in the Cascade Range, United States (Siebert and others, 2006). Compared to dissolved forms, germanium is highly concentrated in small particulates in river water; the global average in suspended sediment is $1,230,000 \mathrm{ppt}(1.23 \mathrm{ppm})$ (Viers and others, 2009).

Examples of natural concentrations of indium in soil, water, and air are given in table I4. The general worldwide indium content in soils ranges from 0.01 to $0.5 \mathrm{ppm}$ (KabataPendias and Pendias, 2001). Indium concentrations in soils in the United States range from less than 0.02 to $0.12 \mathrm{ppm}$ (Smith and others, 2005), and in soils in Sweden, from less than 0.04 to $0.07 \mathrm{ppm}$ (Eriksson, 2001). Indium concentrations in seawater generally range from 0.003 to $1.23 \mathrm{ppt}$ (Amakawa and others, 1996; Alibo and others, 1999; Nozaki, Lerche, Alibo, and Snidvongs, 2000; Obata and others, 2007), although dissolved and particulate indium in seawater near Japan has been measured to be as high as 4.7 and $35 \mathrm{ppt}$, respectively (Miyazaki and others, 2012). Rivers and lakes in Japan contain dissolved indium in concentrations ranging from 0.16 to 3.2 ppt (Nozaki, Lerche, Alibo, and Tsutsumi, 2000; Miyazaki and others, 2012), whereas indium in particulate matter in rivers in Japan can be as high as 12.8 ppt (Miyazaki and others, 2012). Indium occurs naturally in the atmosphere as part of mineral dust particles; indium concentrations of 0.05 and 20 picograms per cubic meter $\left(\mathrm{pg} / \mathrm{m}^{3}\right)$ of air have been measured in remote regions (Kabata-Pendias and Pendias, 2001, and references therein).

Above-background concentrations of germanium and indium in the environment can result from mining and ore processing, particularly of zinc, lead, and sometimes copper sulfide ores. Total emissions of indium to the atmosphere from copper and zinc production were estimated to be between 11,000 and 39,000 kilograms per year during 1983 (Nriagu and Pacyna, 1988). Air indium concentrations over more-industrialized regions may range from 20 to $1,200 \mathrm{pg} / \mathrm{m}^{3}$ (Kabata-Pendias and Pendias, 2001, and references therein). Likewise, the concentration of indium in air near a leadsmelting complex was measured as $5,800 \mathrm{pg} / \mathrm{m}^{3}$ (Ragaini and others, 1977). In addition to mining and ore processing inputs, anthropogenic release of germanium to the atmosphere occurs during coal combustion. For example, dissolved median germanium concentrations in world rivers are $7 \mathrm{ppt}$ in locations distant from and $24 \mathrm{ppt}$ in locations proximal to coal combustion centers, respectively (Froelich and others, 1985).

The recycled content, or proportion of scrap, used in germanium and indium production is between 25 and 50 percent, and the fraction of germanium and indium in discarded products that get recycled is less than 1 percent (Graedel and others, 2011). One of the main challenges of germanium and indium recycling is that these metals are often comingled with other "specialty metals" in high performance alloys, making recovery technologically and economically unfeasible (Reck and Graedel, 2012). Given the importance of germanium and indium in emerging technologies, however, germanium and indium recycling is likely to increase in the future. 
Table I3. Germanium concentrations in rocks, soils, and waters.

[cm, centimeter; ppm, part per million; ppt, part per trillion; $\mu \mathrm{m}$, micrometer]

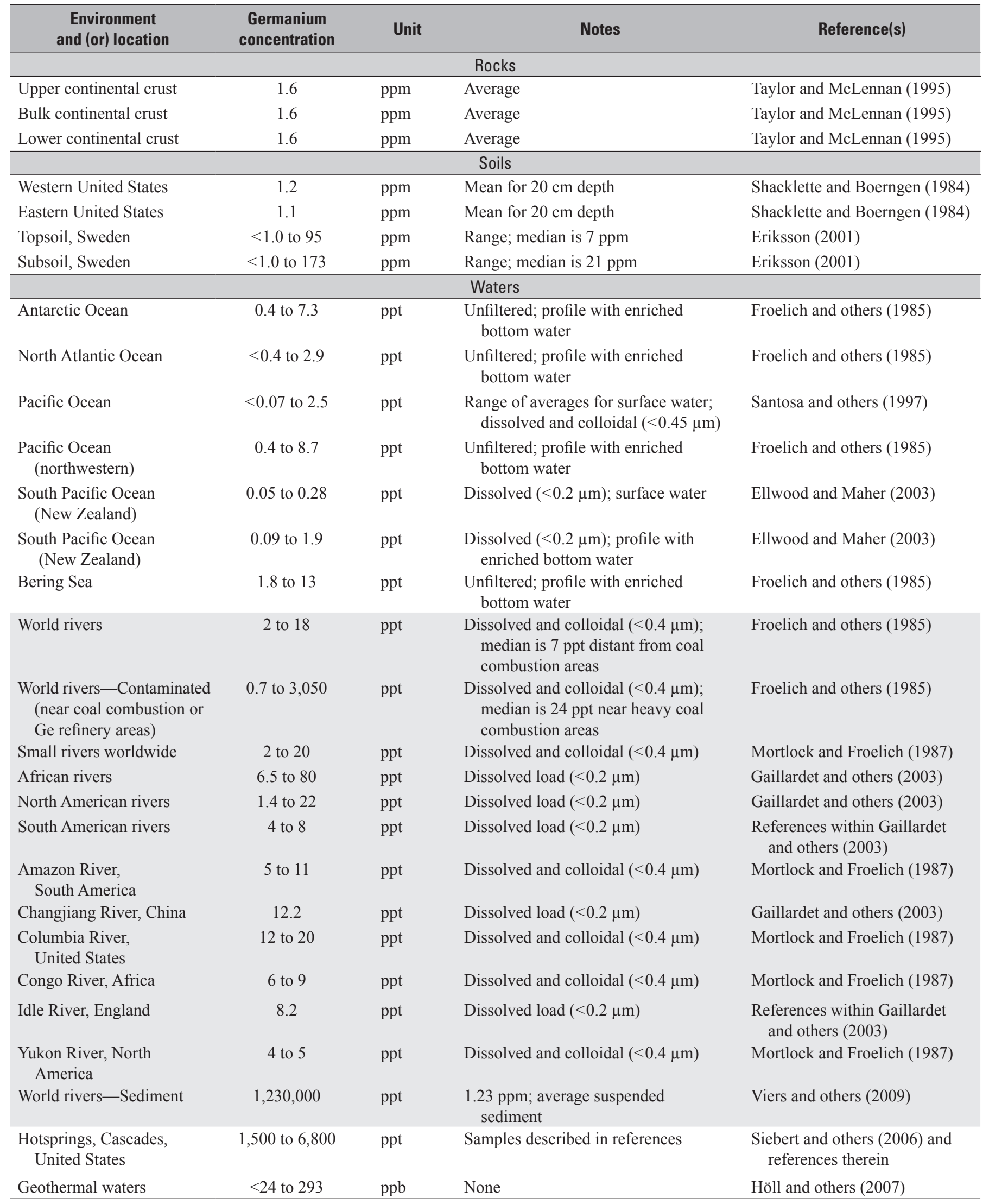


Table 14. Indium concentrations in rocks, soils, waters, and air.

[b.d.1., below detection limit; cm, centimeter; $\mu \mathrm{m}$, micrometer: ppm, part per million; ppt, part per trillion; $\mathrm{pg} / \mathrm{m}^{3}$, picogram per cubic meter]

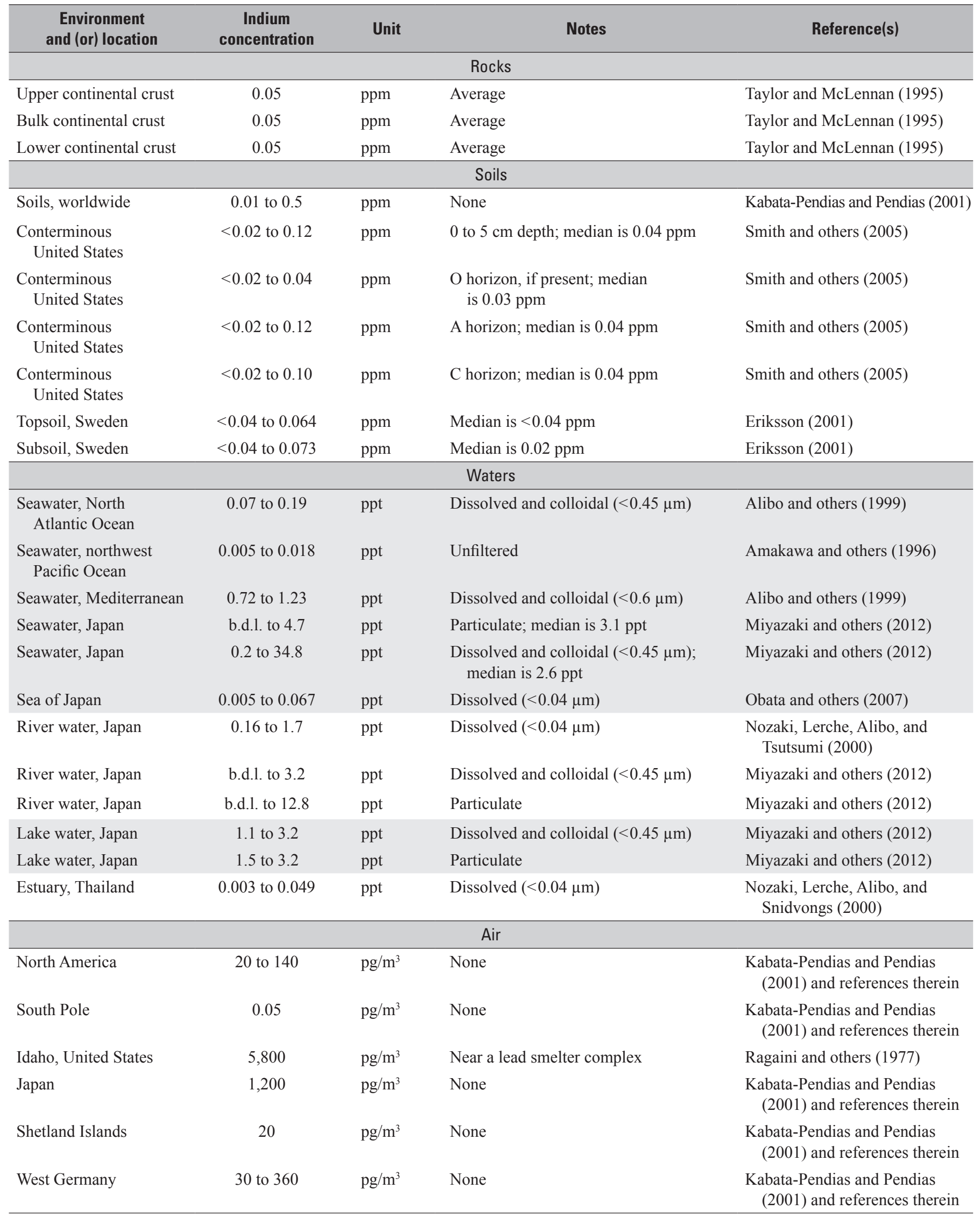




\section{Mine Waste Characteristics}

Mine waste is generally considered to be the material that originates and accumulates at a mine site that has no current economic value (Lottermoser, 2010); it includes both solid and liquid waste. Mine waste that results from extraction of germanium- and indium-bearing copper-lead-zinc ore usually consists of waste rock and tailings piles, and possibly pit lakes. Tailings are the residual silt- to fine-sand-sized grains that result from ore grinding and processing, and they are usually disposed of in waste dumps. Germanium is often recovered from ores in SEDEX zinc-lead-silver deposits, such as at the Red Dog Mine in Alaska, and from MVT lead-zinc deposits, such as those in the Tri-State mining district, which covers approximately 1,800 square kilometers of Kansas, Oklahoma, and Missouri (Butterman and Jorgenson, 2005). Indium can be concentrated in ores in vein stockwork tin and tungsten deposits, such as the Mount Pleasant Mine in New Brunswick, Canada, and in VMS deposits, such as the Kidd Creek Mine in Ontario, Canada (Jorgenson and George, 2004). The tonnage of tailings generated at the Red Dog Mine totaled 27.4 million metric tons in 2006 and is projected to total 88 million metric tons by 2031 (SRK Consulting (Canada) Inc., 2007). The Tri-State mining district is the largest U.S. Environmental Protection Agency Superfund site in the United States (Leach and others, 2010); the estimated total tonnage of waste rock at this site is 91 million metric tons (U.S. Environmental Protection Agency, 2006). In 1999, the Kidd Creek mining and metallurgical operation stored more than 100 million metric tons of tailings over an area of approximately 1,200 hectares (Al and Blowes, 1999).

The mineralogy of the mine waste in germanium- and indium-enriched deposits tends to be similar to the mineralogy of the deposit, except that the proportion of sulfides, such as sphalerite, galena $(\mathrm{PbS})$, and chalcopyrite $\left(\mathrm{CuFeS}_{2}\right)$, is reduced relative to typical gangue minerals, such as barite $\left(\mathrm{BaSO}_{4}\right)$, calcite $\left(\mathrm{CaCO}_{3}\right)$, dolomite $\left((\mathrm{Ca}, \mathrm{Mg})\left(\mathrm{CO}_{3}\right)_{2}\right)$, pyrite $\left(\mathrm{FeS}_{2}\right)$, pyrrhotite $\left(\mathrm{Fe}_{1-\mathrm{x}} \mathrm{S}\right)$, and quartz $\left(\mathrm{SiO}_{2}\right)($ Kelley and others, 1995; Leach and others, 1995; Taylor and others, 1995). For example, tailings from the Kidd Creek deposit contain (in weight percent) quartz and various silicates ( 75 to 85 ), pyrite (10 to 25 ), carbonate minerals ( 7 to 8 ) pyrrhotite (1 to 2), and sphalerite and chalcopyrite (1 to 2) (Al and others, 1994). Indium-enriched VMS deposits may also contain anhydrite $\left(\mathrm{CaSO}_{4}\right)$ and gypsum $\left(\mathrm{CaSO}_{4} \cdot 2 \mathrm{H}_{2} \mathrm{O}\right)$, chlorite $(\mathrm{Mg}, \mathrm{Fe})_{3}(\mathrm{Si}, \mathrm{Al})_{4} \mathrm{O}_{10}(\mathrm{OH})_{2}(\mathrm{Mg}, \mathrm{Fe})_{3}(\mathrm{OH})_{6}$, and magnetite $\left(\mathrm{Fe}_{3} \mathrm{O}_{4}\right)$ as gangue minerals (Taylor and others, 1995). Some deposits undergo appreciable weathering before discovery, which can result in oxidized zones on the surface of orebodies known as gossan. Minerals that precipitate from the weathering of ore minerals in gossan commonly include amorphous silica $\left(\mathrm{SiO}_{2}\right)$, goethite $(\mathrm{FeO}(\mathrm{OH}))$, jarosite $\left(\mathrm{KFe}_{3}^{\mathrm{III}}(\mathrm{OH})_{6}\left(\mathrm{SO}_{4}\right)_{2}\right)$ and other hydroxysulfate minerals, scorodite $\left(\mathrm{FeAsO}_{4} \cdot 2 \mathrm{H}_{2} \mathrm{O}\right)$, and secondary sulfide minerals, such as chalcocite $\left(\mathrm{Cu}_{2} \mathrm{~S}\right)$ and covellite $(\mathrm{CuS})$ (Taylor and others, 1995).
Because of their association with sulfide and secondary minerals, elements such as $\mathrm{Ag}, \mathrm{Al}, \mathrm{As}, \mathrm{Au}, \mathrm{B}, \mathrm{Ba}, \mathrm{Bi}, \mathrm{Cd}$, $\mathrm{Co}, \mathrm{Cu}, \mathrm{F}, \mathrm{Fe}, \mathrm{Ga}, \mathrm{Hg}, \mathrm{Mn}, \mathrm{Mo}, \mathrm{Ni}, \mathrm{Pb}, \mathrm{Sb}, \mathrm{Sn}$, and $\mathrm{Zn}$ can be found in germanium- and indium-enriched mineral deposits (Briskey, 1986; Kelley and others, 1995; Leach and others, 1995; Taylor and others, 1995). During oxidizing and acidic $(\mathrm{pH}<3)$ weathering conditions, which may be expected in mine waste with little to no acid-neutralizing capacity, many of these accessory elements are expected to be mobile (Smith and Huyck, 1999). The acid-neutralizing capacity of carbonate-hosted MVT mine waste is expected to be greater, however, resulting in the accessory elements listed above being less mobile or immobile under oxidizing and circum-neutral $(5<\mathrm{pH}<8)$ weathering conditions (Smith and Huyck, 1999). The exception is zinc, which can make up a large percentage of total dissolved metals draining from MVT deposits (Plumlee and others, 1999).

\section{Human Health Concerns}

Both germanium and indium have no known physiological role in human biochemical functions, and thus are considered to be nonessential. Germanium and indium can be ingested through food and inhaled with dust in industrial environments. For example, workers in an indium ingot manufacturing plant who were exposed to insoluble indium compounds through inhalation showed higher concentrations of indium in plasma and urine relative to a control group (Hoet and others, 2012). Germanium toxicity is generally low, and germanium does not appear to be carcinogenic; to the contrary, the organic germanium compound spirogermanium has been shown to destroy cancer cells (Gerber and Léonard, 1997, and references therein). Excessive ingestion of germanium has taken place owing to the belief that germanium in supplements has antioxidant properties. This has led to renal failure and renal and multiorgan dysfunction (Glei, 2004, and references therein). Unlike solid germanium compounds, the gas germane $\left(\mathrm{GeH}_{4}\right)$ is highly toxic and can be lethal at concentrations near $150 \mathrm{ppm}$ or higher (Glei, 2004, and references therein). As a result, the U.S. Occupational Safety and Health Administration (OSHA) has set a permissible exposure limit of $0.2 \mathrm{ppm} \mathrm{GeH}_{4}$ over an 8-hour workday (Occupational Safety and Health Administration, 2013a).

The human toxicity of indium is relatively well documented, partly because the short half-life of radioactive ${ }^{111}$ In lends itself to use in nuclear medicine to study inflammatory processes and tumors (Madden and others, 2004, and references therein). Industrial workers may be exposed to insoluble indium compounds, such as indium arsenide, indium phosphide, and ITO, all of which have proven to be toxic to animals. Chronic (low doses over extended time periods) exposure to inhaled indium phosphide, in particular, has shown carcinogenic effects in animals (Tanaka and others, 2010). A few case studies of workers exposed to insoluble indium compounds have shown that inhaled indium can cause interstitial lung damage (Hamaguchi and others, 2008, and 
references therein). Furthermore, among the metal arsenic compounds used in the semiconductor industry, indium arsenide has proven to cause the greatest impairment to lung function (Tanaka, 2004, and references therein). To prevent negative effects from occupational indium exposure, OSHA has set a limit of 0.1 milligram per cubic meter for indium-bearing dust in workplace air over an 8-hour workday (Occupational Safety and Health Administration, 2013b).

Mining of zinc-lead-copper deposits, where germanium and indium may be byproducts, can potentially mobilize elements that are known human toxins. Lead and arsenic are perhaps the best-known examples of chemicals that are released into the environment through mining and that end up in drinking water. Lead is known to affect the neurological development of children (Holecy and Mousavi, 2012), and arsenic is known to have carcinogenic effects (Gupta and others, 2012). Other associated elements also have the potential to affect human health when present above threshold concentrations in air, drinking water, and soil. The current U.S. National Ambient Air Quality Standard for lead is 0.15 micrograms per cubic meter (U.S. Environmental Protection Agency, 2013b), and the current U.S. primary and secondary drinking water standards for lead, copper, and zinc are 0,1 , and 5 milligrams per liter $(\mathrm{mg} / \mathrm{L})$, respectively (U.S. Environmental Protection Agency, 2013a). Canadian agricultural soil quality guidelines for copper, lead, and zinc are 63, 70, and 200 ppm, respectively (Canadian Council of Ministers of the Environment, 1999). These concentrations are sometimes exceeded near mine sites and ore processing plants.

\section{Ecological Health Concerns}

Relatively few studies have focused on the ecological impacts of germanium and indium mobility in the environment. One of several useful endpoints used in toxicity tests is the lethal concentration that leads to 50 percent mortality $\left(\mathrm{LC}_{50}\right)$ after exposure to a substance for a certain amount of time. Fish tend to be sensitive to low concentrations of dissolved metals, and they are therefore useful indicators of contamination in aquatic systems. Chronic toxicity tests with dissolved germanium (in the form of $\mathrm{GeO}_{2}$ ) and developing rainbow trout (Oncorhynchus mykiss) revealed a mean $\mathrm{LC}_{50}$ value of $0.05 \mathrm{mg} / \mathrm{L}$ after 28 days of exposure (Birge and others, 1980). Another aquatic organism that is commonly used in toxicity studies is the freshwater amphipod Hyalella azteca. The 1-week $\mathrm{LC}_{50}$ for germanium incubated with $H$. azteca was $0.21 \mathrm{ppm}$ in soft water and more than $3.15 \mathrm{ppm}$ in hard water (Borgmann and others, 2005). An in vitro study of the effects of indium nitrate $\left(\mathrm{In}\left(\mathrm{NO}_{3}\right)_{3}\right)$ on fish cells revealed that cell proliferation was significantly reduced at indium concentrations of $356 \mathrm{ppm}$ (3-day exposure) and 677 ppm (1-day exposure) (Zurita and others, 2007). Exposure of indium nitrate to the bacterium Aliivibrio fischeri, the alga Chlorella vulgaris, and the cladoceran Daphnia magna resulted in 50 percent of populations exhibiting decreased functionality over a range of effective concentrations $\left(\mathrm{EC}_{50}\right)$, with the most sensitive $\mathrm{EC}_{50}$ being inhibited bioluminescence of $A$. fischeri at $6 \mathrm{ppm}$ indium (Zurita and others, 2007). These indium concentrations are orders of magnitude greater than those in reported natural systems (table I4). Germanium and indium are usually not included in the suite of elements in studies of the chemistry of mine waste water, however, so the toxicity endpoint concentrations cannot be compared to likely germanium and indium concentrations in mining environments.

Plant tissues contain from 50 to $754 \mathrm{ppm}$ germanium and 1 to $2 \mathrm{ppm}$ indium (Kabata-Pendias and Mukherjee, 2007), although neither element is known to have any physiological function in plants. In a study of barley seedlings exposed to nutrient solutions with varying germanium concentrations, roots and shoots accumulated greater amounts of germanium with increasing germanium concentrations, and the only toxic effects observed were necrosis of primary leaves at concentrations greater than $1.45 \mathrm{ppm}$ germanium (Halperin and others, 1995). The effects of indium on plants remain unknown.

The ecological impacts of major metals with which germanium and indium are associated are relatively well documented. For example, in toxicity tests with aquatic invertebrates incubated with lead-zinc mine tailings from the Tri-State mining district, Besser and Rabeni (1987) showed that increased concentrations of dissolved cadmium, lead, and zinc correlated with decreased survival and growth (Besser and Rabeni, 1987). Likewise, various fish species experienced rapid mortality when exposed to increasing dissolved zinc concentrations, but this effect decreased with increasing calcium, magnesium, and sodium concentrations (De Schamphelaere and Janssen, 2004). High metal concentrations in soils can also cause phytotoxicity. Zinc is a micronutrient for many plant species, but, when highly concentrated in soils, it can inhibit a plant's metabolic functions and cause deficiencies in other essential nutrients, such as copper, iron, manganese, and phosphorus (Nagajyoti and others, 2010, and references therein).

\section{Carbon Footprint}

Indium is used in some of the most efficient thin-film photovoltaic cells (solar panels) (Miles and others, 2007) and has potential to help reduce the carbon dioxide $\left(\mathrm{CO}_{2}\right)$ emissions from energy production. The copper-indiumgallium-diselenide (CIGS) alloy, among others, is becoming an increasingly preferred thin-film product because of its relatively low material and manufacturing costs (Kaneshiro and others, 2010). The CIGS photovoltaic cells are in the initial stages of commercialization, but they are expected eventually to compete with other forms of energy production as economies of scale permit future cost reductions (Miles and others, 2007; Rockett, 2010). The recyclability of generated products and the potential for leaching of toxic elements from improperly disposed of industrial products are subjects that no doubt will need to be addressed as the use of thin-film photovoltaic cells increases. 


\section{Mine Closure}

Most recent and new mining operations include closure plans that address issues related to the mine footprint. A mine's footprint includes the waste left on site and locally impacted soil and water, as well as ecological impacts, such as habitat destruction and loss of biodiversity. Following mining in copper-lead-zinc deposits, where germanium and indium may be byproducts, a common mine closure issue is the potential for AMD from the site. Acidic drainage may seep from waste piles or tailings ponds, and common remediation methods include active water treatment facilities, passive limestone-lined channels, or constructed wetlands (Plumlee and Logsdon, 1999). The end result of both active and passive approaches is eventual precipitation of dissolved metals. Precipitated metals tend to be more stable under the prevailing anoxic conditions in passive wetland systems, whereas the metal-rich precipitates that result from active treatment facilities form a sludge that can cause environmental problems if not responsibly treated.

At large mines, mine waste is often consolidated into pits and submerged under water, forming a tailings pond or impoundment. Acid-generating minerals typically are less reactive under water because of limited oxygen, but any seepage usually needs to be treated. At sites like the Red Dog Mine, seepage from the tailings pond will need to be treated in perpetuity (U.S. Environmental Protection Agency, 2010). The massive tailings impoundment near the Kidd Creek Mine is designed to have a conical shape. This limits the amount of tailings that may oxidize in near-surface unsaturated zones and contribute soluble metals, which allows more control over the AMD effluent discharged at the periphery of the impoundment (Al and Blowes, 1999). When the potential for AMD exists at a mine site, a common mine closure plan includes conducting water-quality surveys before, during, and after mining.

Another common mine closure issue related to mining in germanium- and indium-enriched deposits is the creation of large, dry mounds of mine-waste. These waste piles have the potential to become unstable and can be a source of metal-rich dust. If using mine waste as backfill into mine workings is not an option, mine waste pile stability and dust-generating issues can often be addressed through grading and covering piles with vegetation. Securing waste piles and prevention and treatment of AMD are typically figured into the long-term costs of active and proposed metal mining projects.

\section{Problems and Future Research}

Weeks (1973) and Brobst and Pratt (1973) pointed out that resource studies of minor byproduct metals are limited by inadequate data, and that is still true today. The sources of the materials that are processed at smelters for byproduct germanium and indium are often either not carefully tracked or the information is considered proprietary. Data on the distribution of germanium and indium are improving but currently are still not sufficient to understand content variations in different deposits and especially in different zones in given deposits. Additional systematic analytical data are needed to establish the overall grades of germanium and indium in different deposits, and the potentially economic resources that might be available in such deposits. The most promising areas of research involve studies of the distribution of germanium and indium in copper and zinc ore deposits and coal deposits, and the making of a systematic compilation of local and regional variations.

Significant concentrations of these elements are not currently recovered in the processing of other ores, particularly zinc and (or) copper ores; the addition of more recovery facilities and improvement in metallurgical techniques could significantly increase supplies. Finally, recycling of germanium and indium from electronic products and from manufacturing waste is presently a significant contributor to the production of these mineral commodities, and improving the recycling processes could help increase supplies significantly (Bleiwas, 2010).

\section{References Cited}

Note: All Web links listed were active as of the access date but may no longer be available.

Al, T.A., and Blowes, D.W., 1999, The hydrogeology of a tailings impoundment formed by central discharge of thickened tailings-Implications for tailings management: Journal of Contaminant Hydrology, v. 38, no. 4, p. 489-505. [Also available at http://dx.doi.org/ 10.1016/s0169-7722(99)00007-8.]

Al, T.A., Blowes, D.W., Jambor, J.L., and Scott, J.D., 1994, The geochemistry of mine-waste pore water affected by the combined disposal of natrojarosite and base-metal sulphide tailings at Kidd Creek, Timmins, Ontario: Canadian Geotechnical Journal, v. 31, no. 4, p. 502-512. [Also available at http://dx.doi.org/10.1139/t94-059.]

Alfantazi, A.M., and Moskalyk, R.R., 2003, Processing of indium-A review: Minerals Engineering, v. 16, no. 8, p. 687-694. [Also available at http://dx.doi.org/10.1016/ s0892-6875(03)00168-7.]

Alibo, D.S., Nozaki, Yoshiyuki, and Jeandel, Catherine, 1999, Indium and yttrium in North Atlantic and Mediterranean waters - Comparison to the Pacific data: Geochimica et Cosmochimica Acta, v. 63, nos. 13-14, p. 1991-1999. [Also available at http://dx.doi.org/10.1016/s00167037(99)00080-0.]

Amakawa, Hiroshi, Alibo, D.S., and Nozaki, Yoshiyuki, 1996, Indium concentration in Pacific seawater: Geophysical Research Letters, v. 23, no. 18, p. 2473-2476. [Also available at http://dx.doi.org/10.1029/96gl02300.] 
Bernstein, L.R., 1986, Geology and mineralogy of the Apex germanium-gallium mine, Washington County, Utah: U.S. Geological Survey Bulletin 1577, 9 p. [Also available at http://pubs.er.usgs.gov/publication/b1577.]

Besser, J.M., and Rabeni, C.F., 1987, Bioavailability and toxicity of metals leached from lead-mine tailings to aquatic invertebrates: Environmental Toxicology and Chemistry, v. 6, no. 11, p. 879-890. [Also available at http://dx.doi.org/ 10.1002/etc.5620061109.]

Birge, W.J., Black, J.A., Westerman, A.G., and Hudson, J.E., 1980, Aquatic toxicity tests on inorganic elements occurring in oil shale, in Gale, Charles, ed., Oil shale symposiumSampling, analysis, and quality assurance, March 1979, Proceedings: Cincinnati, Ohio, U.S. Environmental Protection Agency, EPA-600/9-80-022, p. 519-534. [Also available at http://babel.hathitrust.org/cgi/pt?id=coo.3192400432 3303; view=1 up;seq=531.]

Bischoff, J.L., Rosenbauer, R.J., Arascavage, P.J., Baedecker, P.A., and Crock, J.G., 1983, Sea-floor massive sulfide deposits from $21^{\circ} \mathrm{N}$, East Pacific Rise; Juan de Fuca Ridge; and Galapagos Rift—Bulk chemical composition and economic implications: Economic Geology, v. 78, p. 1711-1720. [Also available at http://dx.doi.org/10.2113/ gsecongeo.78.8.1711.]

Bleiwas, D.I., 2010, Byproduct mineral commodities used for the production of photovoltaic cells: U.S. Geological Survey Circular 1365, 10 p., accessed November 30, 2015, at http://pubs.er.usgs.gov/publication/cir1365.

Borgmann, Uwe, Couillard, Yves, Doyle, Patrick, and Dixon, D.G., 2005, Toxicity of sixty-three metals and metalloids to Hyalella azteca at two levels of water hardness: Environmental Toxicology and Chemistry, v. 24, no. 3, p. 641-652. [Also available at http://dx.doi.org/10.1897/04-177r.1.]

Briskey, J.A., 1986, Descriptive model of sedimentary exhalative $\mathrm{Zn}-\mathrm{Pb}$ - Model 31a, in Cox, D.P., and Singer, D.A., eds., Mineral deposit models: U.S. Geological Survey Bulletin 1693, p. 211-212. [Also available at http://pubs.er.usgs.gov/ publication/b1693.]

Brobst, D.A., and Pratt, W P., eds., 1973, United States mineral resources: U.S. Geological Survey Professional Paper 820, 722 p., accessed November 30, 2015, at http://pubs.er.usgs.gov/ publication/pp820.

Burgin, L.B., 1988, The mineral industry of Utah, in Area reports-Domestic: U.S. Bureau of Mines Minerals Yearbook 1986, v. II, p. 475-490.

BusinessWire, 2013, Amonix achieves world record 35.9\% PV module efficiency rating at NREL: BusinessWire, August 20, accessed April 14, 2016, at http://www.businesswire.com/ news/home/20130820005361/en/Amonix-Achieves-WorldRecord-35.9-PV\%C2\%A0Module-Efficiency.
Butterman, W.C., and Jorgenson, J.D., 2005, Mineral commodity profiles - Germanium: U.S. Geological Survey Open-File Report 2004-1218, 19 p., accessed November 30, 2015, at http://pubs.er.usgs.gov/publication/ofr20041218.

Canadian Council of Ministers of the Environment, 1999, Canadian soil quality guidelines for the protection of environmental and human health, in Canadian environmental quality guidelines, chap. 7 of Canadian environmental quality guidelines: Winnipeg, Manitoba, Canada, Canadian Council of Ministers of the Environment, accessed February 15, 2013, at http://ceqg-rcqe.ccme.ca/en/index.html.

Chaplygin, I.V., Mozgova, N.N., Mokhov, A.V., Koporulina, E.V., Bernhardt, H.-J., and Bryzgalov, I.A., 2007, Minerals of the system ZnS-CdS from fumaroles of the Kudriavy volcano, Iturup Island, Kuriles, Russia: The Canadian Mineralogist, v. 45, no. 4, p. 709-722. [Also available at http://dx.doi.org/ 10.2113/gscanmin.45.4.709.]

Cox, D.P., and Singer, D.A., eds., 1986, Mineral deposit models: U.S. Geological Survey Bulletin 1693, 379 p. [Also available at http://pubs.er.usgs.gov/publication/b1693.]

De Schamphelaere, K.A.C., and Janssen, C.R., 2004, Bioavailability and chronic toxicity of zinc to juvenile rainbow trout (Oncorhynchus mykiss) - Comparison with other fish species and development of a biotic ligand model: Environmental Science and Technology, v. 38, no. 23, p. 6201-6209. [Also available at http://dx.doi.org/10.1021/ es049720m.]

De Vera, J., McClay, K.R., and King, A.R., 2004, Structure of the Red Dog district, western Brooks Range, Alaska: Economic Geology, v. 99, p. 1415-1434.

Ellwood, M.J., and Maher, W.A., 2003, Germanium cycling in the waters across a frontal zone-The Chatham Rise, New Zealand: Marine Chemistry, v. 80, nos. 2-3, p. 145-159. [Also available at http://dx.doi.org/10.1016/ s0304-4203(02)00115-9.]

Eriksson, Jan, 2001, Concentrations of 61 trace elements in sewage sludge, farmyard manure, mineral fertilizer, precipitation and in oil and crops: Swedish Environmental Protection Agency Report 5159, 69 p. [Also available at http://www.naturvardsverket.se/Documents/ publikationer/620-6246-8.pdf.]

European Commission, 2010, Report forecasts shortages of 14 critical mineral raw materials: European Commission press release IP-10-752, June 17, 3 p., accessed March 2, 2016, at http://europa.eu/rapid/press-release_ IP-10-752_en.htm. [Additional information accessed April 7, 2016, at http://ec.europa.eu/growth/sectors/ raw-materials/specific-interest/critical/index_en.htm.] 
Froelich, P.N., Blanc, V., Mortlock, R.A., Chillrud, S.N., Dunstan, W., Udomkit, A., and Peng, T.-H., 1992, River fluxes of dissolved silica to the ocean were higher during glacials - $\mathrm{Ge} / \mathrm{Si}$ in diatoms, rivers, and oceans: Paleoceanography, v. 7, no. 6, p. 739-767. [Also available at http://dx.doi.org/10.1029/92pa02090.]

Froelich, P.N., Hambrick, G.A., Andreae, M.O., Mortlock, R.A., and Edmond, J.M., 1985, The geochemistry of inorganic germanium in natural waters: Journal of Geophysical Research-Oceans, v. 90, no. C1, p. 1133-1141. [Also available at http://dx.doi.org/10.1029/jc090ic01p01133.]

Gaillardet, J., Viers, J., and Dupré, B., 2003, Trace elements in river waters, in Drever, J.I., ed., Surface and ground water, weathering, and soils, v. 5 of Holland, H.D., and Turekian, K.K., eds., Treatise on geochemistry: Oxford, United Kingdom, Elsevier-Pergamon, p. 225-272. [Also available at http://dx.doi.org/10.1016/B0-08-0437516/05165-3.]

Gerber, G.B., and Léonard, A., 1997, Mutagenicity, carcinogenicity and teratogenicity of germanium compounds: Mutation Research, v. 387, no. 3, p. 141-146. [Also available at http://dx.doi.org/10.1016/s1383-5742(97)00034-3.]

Glei, Michael, 2004, Germanium, chap. 10 of Merian, Ernest, Anke, Manfred, Ihnat, Milan, and Stoeppler, M.S, eds., Elements and their compounds in the environmentOccurrence, analysis and biological relevance: Weinheim, Germany, Wiley-VCH Verlag GmbH, pt. 3, p. 787-793. [Also available at http://dx.doi.org/10.1002/ 9783527619634.ch31.]

Goodfellow, W.D., and Lydon, J.W., 2007, Sedimentary exhalative (SEDEX) deposits, in Goodfellow, W.D., ed., Mineral deposits of Canada-A synthesis of major deposittypes, district metallogeny, the evolution of geological provinces, and exploration methods: Geological Association of Canada, Special Publication no. 5, p. 163-184.

Graedel, T.E., Allwood, Julian, Birat, J.-P., Buchert, Matthias, Hagelüken, Christian, Reck, B.K., Sibley, S.F., and Sonnemann, Guido, 2011, What do we know about metal recycling rates?: Journal of Industrial Ecology, v. 15, no. 3, p. 355-365. [Also available at http://dx.doi.org/10.1111/ j.1530-9290.2011.00342.x.]

Guberman, D.E., 2013a, Germanium: U.S. Geological Survey Mineral Commodity Summaries 2013, p. 64-65, accessed November 30, 2015, at http://minerals.usgs.gov/minerals/ pubs/commodity/germanium/mcs-2013-germa.pdf.

Guberman, D.E., 2013b, Germanium (Ge), in Metal prices in the United States through 2010: U.S. Geological Survey Scientific Investigations Report 2012-5188, p. 55-57, accessed May 24, 2016, at http://pubs.usgs.gov/ $\operatorname{sir} / 2012 / 5188 /$.
Guberman, D.E., 2014, Germanium: U.S. Geological Survey Mineral Commodity Summaries 2014, p. 64-65, accessed September 12, 2016, at https://minerals.usgs.gov/minerals/ pubs/commodity/germanium/mcs-2014-germa.pdf.

Gu, Lianxing, Zaw, Khin, Hu, Wenxuan, Zhang, Kaijun, $\mathrm{Ni}$, Pei, He, Jinxiang, Xu, Yaotong, Lu, Jianjun, and Lin, Chunming, 2007, Distinctive features of Late Palaeozoic massive sulphide deposits in South China: Ore Geology Reviews, v. 31, p. 107-138. [Also available at http://dx.doi.org/10.1016/j.oregeorev.2005.01.002.]

Gupta, V.K., Nayak, Arunima, Agarwal, Shilpi, Dobhal, Rajendra, Uniyal, D.P., Singh, Prashant, Sharma, Bhavtosh, Tyagi, Shweta, and Singh, Rakesha, 2012, Arsenic speciation analysis and remediation techniques in drinking water: Desalination and Water Treatment, v. 40, nos. 1-3, p. 231-243, [Also available at http://dx.doi.org/10.1080/19443994.2012.671250.]

Halperin, S.J., Barzilay, Adam, Carson, Matthew, Roberts, Cory, and Lynch, Jonathan, 1995, Germanium accumulation and toxicity in barley: Journal of Plant Nutrition, v. 18, no. 7 , p. 1417-1426. [Also available at http://dx.doi.org/ 10.1080/01904169509364991.]

Hamaguchi, T., Omae, K., Takebayashi, T., Kikuchi, Y., Yoshioka, N., Nishiwaki, Y., Tanaka, A., Hirata, M., Taguchi, O., and Chonan, T., 2008, Exposure to hardly soluble indium compounds in ITO production and recycling plants is a new risk for interstitial lung damage: Occupational and Environmental Medicine, v. 65, no. 1, p. 51-55. [Also available at http://dx.doi.org/10.1136/ oem.2006.029124.]

Hoet, Perrine, De Graef, Emmy, Swennen, Bert, Seminck, Théo, Yakoub, Yousof, Deumer, Gladys, Haufroid, Vincent, and Lison, Dominique, 2012, Occupational exposure to indium-What does biomonitoring tell us?: Toxicology Letters, v. 213, no. 1, p. 122-128. [Also available at http://dx.doi.org/10.1016/j.toxlet.2011.07.004.]

Holecy, E.G., and Mousavi, Aliyar, 2012, Lead sources, toxicity, and human risk in children of developing countriesA mini-review: Environmental Forensics, v. 13, no. 4, p. 289-292. [Also available at http://dx.doi.org/10.1080/ 15275922.2012.729010.]

Höll, R., Kling, M., and Schroll, E., 2007, Metallogenesis of germanium-A review: Ore Geology Reviews, v. 30, nos. 3-4, p. 145-180. [Also available at http://dx.doi.org/ 10.1016/j.oregeorev.2005.07.034.]

Hu, R.-Z., Qi, H.-W., Zhou, M.-F., Su, W.-C., Bi, X.-W., Peng, J.-T., and Zhong, Hong, 2009, Geological and geochemical constraints on the origin of the giant Lincang coal seam-hosted germanium deposit, Yunnan, SW China-A review: Ore Geology Reviews, v. 36, nos. 1-3, p. 221-234. [Also available at http://dx.doi.org/ 10.1016/j.oregeorev.2009.02.007.] 
Ishihara, Shunso, Murakami, Hiroyasu, and Marquez-Zavalia, M.F., 2011, Inferred indium resources of the Bolivian tinpolymetallic deposits: Resource Geology, v. 61, no. 1, p. 174-191. [Also available at http://dx.doi.org/10.1111/ j.1751-3928.2011.00157.x.)

Jennings, Scott, and King, A.R., 2002, Geology, exploration history and future discoveries in the Red Dog district, western Brooks Range, Alaska, in Cooke, D.R., and Pongratz, June, eds., Giant ore deposits-Characteristics, genesis and exploration: Hobart, Tasmania, Australia, University of Tasmania, National Key Centre, Centre for Ore Deposit Research Special Publication, v. 4, p. 151-158.

Johnson, C.A., Dumoulin, J.A., Burruss, R.A., and Slack, J.F., 2015, Depositional conditions for the Kuna Formation, Red Dog Zn-Pb-Ag-barite district, Alaska, inferred from isotopic and chemical proxies: Economic Geology, v. 110, p. 1143-1156. [Also available at https://pubs.geoscienceworld.org/ economicgeology/issue/110/5/.]

Jorgenson, J.D., and George, M.W., 2004, Mineral commodity profile-Indium: U.S. Geological Survey Open-File Report 2004-1300, 20 p., accessed November 30, 2015, at http://pubs.er.usgs.gov/publication/ofr20041300.

Kabata-Pendias, Alina, and Mukherjee, A.B., 2007, Trace elements from soil to human: Berlin, Germany, Springer,-Verlag, 550 p.

Kabata-Pendias, Alina, and Pendias, Henryk, 2001, Trace elements in soils and plants ( $3 \mathrm{~d}$ ed.): Boca Raton, Fla., CRC Press, 413 p.

Kampunzu, A.B., Cailteux, J.L.H., Kamona, A.F., Intiomale, M.M., and Melcher, F., 2009, Sediment-hosted $\mathrm{Zn}-\mathrm{Pb}-\mathrm{Cu}$ deposits in the Central African Copperbelt: Ore Geology Reviews, v. 35, nos. 3-4, p. 263-297. [Also available at http://dx.doi.org/ 10.1016/j.oregeorev.2009.02.003.]

Kaneshiro, Jess, Gaillard, Nicolas, Rocheleau, Richard, and Miller, Eric, 2010, Advances in copper-chalcopyrite thin films for solar energy conversion: Solar Energy Materials and Solar Cells, v. 94, no. 1, p. 12-16. [Also available at http://dx.doi.org/10.1016/j.solmat.2009.03.032.]

Kelley, K.D., and Jennings, Scott, 2004, A special issue devoted to barite and $\mathrm{Zn}-\mathrm{Pb}-\mathrm{Ag}$ deposits in the Red Dog district, western Brooks Range, northern Alaska: Economic Geology, v. 99, p. 1267-1280. [Also available at http://dx.doi.org/10.2113/gsecongeo.99.7.1267.]

Kelley, K.D., Leach, D.L., Johnson, C.A., Clark, J.L., Fayek, M., Slack, J.F., Anderson, V.M., Ayuso, R.A., and Ridley, W.I., 2004, Textural, compositional, and sulfur isotope variations of sulfide minerals in the Red Dog $\mathrm{Zn}-\mathrm{Pb}-\mathrm{Ag}$ deposits, Brooks Range, Alaska-Implications for ore formation: Economic Geology, v. 99, p. 1509-1532. [Also available at http://dx.doi.org/10.2113/gsecongeo.99.7.1509.]
Kelley, K.D., Seal, R.R., II, Schmidt, J.M., Hoover, D.B., and Klein, D.P., 1995, Sedimentary exhalative $\mathrm{Zn}-\mathrm{Pb}-\mathrm{Ag}$ deposits (Model 31a; Briskey, 1986), chap. 29 of du Bray, E.A., ed., Preliminary compilation of descriptive geoenvironmental mineral deposit models: U.S. Geological Survey Open-File Report 95-831, p. 225-233, accessed November 30, 2015, at http://pubs.usgs.gov/of/1995/ ofr-95-0831/CHAP29.pdf.

Krupp, R.E., and Seward, T.M., 1987, The Rotokawa geothermal system, New Zealand-An active epithermal gold-depositing environment: Economic Geology, v. 82, p. 1109-1129. [Also available at http://dx.doi.org/10.2113/ gsecongeo.82.5.1109.]

Leach, D.L., Bradley, D.C., Huston, David, Pisarevsky, S.A., Taylor, R.D., and Gardoll, S.J., 2010, Sediment-hosted lead-zinc deposits in earth history: Economic Geology, v. 105, p. 593-625. [Also available at http://dx.doi.org/ 10.2113/gsecongeo.105.3.593.]

Leach, D.L., Sangster, D.F., Kelley, K.D., Large, R.R., Garven, Grant, Allen, C.R., Gutzmer, Jens, and Walters, Steve, 2005, Sediment-hosted lead-zinc depositsA global perspective, in Hedenquist, J.W., Thompson, J.F.H., Goldfarb, R.J. and Richards J.P., eds., Economic Geology_One hundredth anniversary volume, 1905-2005: Littleton, Colo., Society of Economic Geologists, p. 561607. [Appendixes are on a CD-ROM inside the back cover.]

Leach, D.L., Viets, J.B., Foley-Ayuso, Nora, and Klein, D.P., 1995, Mississippi Valley-type Pb-Zn deposits (Models 32a, b; Briskey, 1986a, b), chap. 30 of du Bray, E.A., ed., Preliminary compilation of descriptive geoenvironmental mineral deposit models: U.S. Geological Survey Open-File Report 95-831, p. 234-243, accessed November 30, 2015, at http://pubs.usgs.gov/of/1995/ofr-95-0831/CHAP30.pdf.

Lottermoser, B.G., 2010, Mine wastes-Characterization, treatment, and environmental impacts ( $3 \mathrm{~d}$ ed.): Berlin, Germany, Springer-Verlag, 400 p. [Also available at http://dx.doi.org/10.1007/978-3-642-12419-8.]

Ludington, Steve, Haxel, G.B., Castor, S.B., McLaurin, B.T., and Flynn, K.S., 2006, Mineral resource potential of the Gold Butte A, Gold Butte B, Virgin Mountain (Gold Butte C), Whitney Pocket, Red Rock Spring, Devil's Throat, and Gold Butte Townsite areas of critical environmental concern, Clark County, Nevada, chap. C of Ludington, Steve, ed., Mineral resource assessment of selected areas in Clark and Nye Counties, Nevada: U.S. Geological Survey Scientific Investigations Report 2006-5197, p. C1-C55. [Also available at http://pubs.usgs.gov/sir/2006/5197/ sir2006-5197c.pdf.] 
Madden, E.F., Anderson, C.J., and Goering, P.L., 2004, Indium, chap. 12 of Merian, Ernest, Anke, Manfred, Ihnat, Milan, and Stoeppler, Markus, eds., Elements and their compounds in the environment-Occurrence, analysis and biological relevance: Weinheim, Germany, WileyVCH Verlag GmbH, pt. 3, p. 801-809. [Also available at http://dx.doi.org/10.1002/9783527619634.ch33.]

Miles, R.W., Zoppi, Guillaume, and Forbes, Ian, 2007, Inorganic photovoltaic cells: Materials Today, v. 10, no. 11, p. 20-27. [Also available at http://dx.doi.org/10.1016/ s1369-7021(07)70275-4.]

Misra, K.C., Gratz, J.F., and Lu, Changsheng, 1996, Carbonatehosted Mississippi Valley-type mineralization in the ElmwoodGordonsville deposits, Central Tennessee zinc district-A synthesis, in Sangster, D.F., ed., Carbonate-hosted lead-zinc deposits-[Society of Economic Geologists] 75th anniversary volume: Littleton, Colo: Society of Economic Geologists Special Publication no. 4, p. 58-73.

Miyazaki, A., Kimura, A., and Tao, H., 2012, Distribution of indium, thallium, and bismuth in the environmental water of Japan: Bulletin of Environmental Contamination and Toxicology, v. 89, no. 6, p. 1211-1215. [Also available at http://dx.doi.org/10.1007/s00128-012-0851-0.]

Mortlock, R.A., and Froelich, P.N., 1987, Continental weathering of germanium $-\mathrm{Ge} / \mathrm{Si}$ in the global river discharge: Geochimica et Cosmochimica Acta, no. 8, v. 51, p. 2075-2082. [Also available at http://dx.doi.org/ 10.1016/0016-7037(87)90257-2.]

Murakami, Hiroyasu, and Ishihara, Shunso, 2013, Trace elements of indium-bearing sphalerite from tin-polymetallic deposits in Bolivia, China and Japan - A femto-second LA-ICPMS study: Ore Geology Reviews, v. 53, p. 223-243. [Also available at http://dx.doi.org/10.1016/ j.oregeorev.2013.01.010.]

Nagajyoti, P.C., Lee, K.D., and Sreekanth, T.V.M., 2010, Heavy metals, occurrence and toxicity for plants-A review: Environmental Chemistry Letters, v. 8, no. 3, p. 199-216. [Also available at http://dx.doi.org/10.1007/s10311-010-0297-8.]

Newlands, J.A.R., 1864, On relations among the equivalents: Chemical News, v. 10, August, p. 94-95. [Also available at http://web.lemoyne.edu/giunta/newlands.html.]

Nilsson, John, Major, Ken, Durston, Keith, Tietz, P.G., Ristorcelli, Steven, and Staargaard, C.F., 2010, Preliminary economic assessment of the Crypto zinc-copper-indium project, Juab County, Utah: Vancouver, British Columbia, Canada, Lithic Resources Ltd., 148 p. plus 5 appendixes, accessed November 30, 2015, at http://www.inzincmining.com/ _resources/Lithic_Resources_Crypto_PEA_Report-opt.pdf.
Nozaki, Yoshiyuki, Lerche, Dorte, Alibo, D.S., and Snidvongs, Anond, 2000, The estuarine geochemistry of rare earth elements and indium in the Chao Phraya River, Thailand: Geochimica et Cosmochimica Acta, v. 64, no. 23, p. 3983-3994. [Also available at http://dx.doi.org/10.1016/ s0016-7037(00)00473-7.]

Nozaki, Yoshiyuki, Lerche, Dorte, Alibo, D.S., and Tsutsumi, Makoto, 2000, Dissolved indium and rare earth elements in three Japanese rivers and Tokyo Bay-Evidence for anthropogenic Gd and In: Geochimica et Cosmochimica Acta, v. 64, no. 23, p. 3975-3982. [Also available at http://dx.doi.org/10.1016/s0016-7037(00)00472-5.]

Nriagu, J.O., and Pacyna, J.M., 1988, Quantitative assessment of worldwide contamination of air, water and soils by tracemetals: Nature, v. 333, no. 6169, p. 134-139. [Also available at http://dx.doi.org/10.1038/333134a0.]

Nyrstar N.V., 2013, Strategy into action-Annual report 2012: Zurich, Switzerland, Nyrstar N.V., 205 p., accessed March 1, 2016, at http://www.nyrstar.com/investors/en/ Pages/reportspresentations.aspx?ff $1 \mathrm{n}=$ Year\&ff $1 \mathrm{v}=2012$.

Nyrstar N.V., 2016, Nyrstar Tennessee mines: Zurich, Switzerland, Nyrstar N.V., February, 2 p., accessed March 1, 2016, at http://www.nyrstar.com/operations/ Documents/Fact\%20Sheet\%20TENNESSEE\%20EN.pdf.

Obata, Hajime, Alibo, D.S., and Nozaki, Yoshiyuki, 2007, Dissolved aluminum, indium, and cerium in the Sea of Japan and the Sea of Okhotsk - Comparison to the marginal seas of the western North Pacific: Journal of Geophysical Research-Oceans, v. 112, no. C2, 10 p. [Also available at http://dx.doi.org/10.1029/2006jc003944.]

Occupational Safety and Health Administration, 2013a, Chemical sampling information-Germanium tetrahydride, CAS no. 7782-65-2: U.S. Department of Labor, Occupational Safety and Health Administration Web page, accessed November 30, 2015, at http://www.osha.gov/dts/ chemicalsampling/data/CH_243200.html.

Occupational Safety and Health Administration, 2013b, Chemical sampling information-Indium and compounds (as In), CAS no. 7440-74-6: U.S. Department of Labor, Occupational Safety and Health Administration Web page, accessed November 30, 2015, at http://www.osha.gov/dts/ chemicalsampling/data/CH_247101.html. 
Plumlee, G.S., and Logsdon, M.J., 1999, An Earth-system science toolkit for environmentally friendly mineral resource development, in Plumlee, G.S., and Logsdon, M.J., eds., The environmental geochemistry of mineral deposits-Part A, Processes, techniques, and health issues: Littleton, Colo., Society of Economic Geologists, Reviews in Economic Geology Series, v. 6A, p. 1-27. [Also available at http://ebooks.geoscienceworld.org/content/ the-environmental-geochemistry-of-mineral-deposits.]

Plumlee, G.S., Smith, K.S., Montour, M.R., Ficklin, W.H., and Mosier, E.L., 1999, Geologic controls on the composition of natural waters and mine waters draining diverse mineral-deposit types, in Plumlee, G.S., and Filipek, L.H., eds., The environmental geochemistry of mineral deposits - Case studies and research topics: Littleton, Colo., Society of Economic Geologists, Reviews in Economic Geology Series, v. 6B, p. 373-432. [Also available at http://ebooks.geoscienceworld.org/content/ the-environmental-geochemistry-of-mineral-deposits.]

Ragaini, R.C., Ralston, H.R., and Roberts, N., 1977, Environmental trace metal contamination in Kellogg, Idaho, near a lead smelting complex: Environmental Science and Technology, v. 11, no. 8, p. 773-781. [Also available at http://dx.doi.org/10.1021/es60131a004.]

Reck, B.K., and Graedel, T.E., 2012, Challenges in metal recycling: Science, v. 337, no. 6095, p. 690-695. [Also available at http://dx.doi.org/10.1126/science.1217501.]

Reich, Ferdinand, and Richter, H.T., 1863, Vorläufige notiz über ein neues metall: Journal für Praktische Chemie, v. 89, no. 1, p. 441-448. [Also available at http://dx.doi.org/ 10.1002/prac.18630890156.]

Rockett, A.A., 2010, Current status and opportunities in chalcopyrite solar cells: Current Opinion in Solid State and Materials Science, v. 14, no. 6, p. 143-148. [Also available at http://dx.doi.org/10.1016/j.cossms.2010.08.001.]

Santosa, S.J., Wada, Satoshi, Mokudai, Hiroshige, and Tanaka, Shigeru, 1997, The contrasting behaviour of arsenic and germanium species in seawater: Applied Organometallic Chemistry, v. 11, no. 5, p. 403-414. [Also available at http://dx.doi.org/10.1002/(sici)10990739(199705)11:5\%3C403::aid-aoc596\%3E3.3.co;2-w.]

Schneider, Jens, Melcher, Frank, and Brauns, Michael, 2007, Concordant ages for the giant Kipushi base metal deposit (DR Congo) from direct $\mathrm{Rb}-\mathrm{Sr}$ and $\mathrm{Re}-\mathrm{Os}$ dating of sulfides: Mineralium Deposita, v. 42, no. 7, p. 791-797. [Also available at http://dx.doi.org/10.1007/s00126-007-0158-y.]
Schwarz-Schampera, Ulrich, and Herzig, P.M., 1999, Indium geology, mineralogy, and economics-A review: Hannover, Germany, Berichte zur Lagerstätten- und Rohstofforschung, Bundesanstalt für Geowissenschaften und Rohstoffe, 182 p.

Schwarz-Schampera, Ulrich, and Herzig, P.M., 2002, IndiumGeology, mineralogy, and economics: Berlin, Germany, Springer, $257 \mathrm{p}$.

Schwarz-Schampera, Ulrich, Terblanche, Hennie, and Oberthür, Thomas, 2010, Volcanic-hosted massive sulfide deposits in the Murchison greenstone belt, South Africa: Mineralium Deposita, v. 45, no. 2, p. 113-145. [Also available at http://dx.doi.org/10.1007/s00126-009-0266-y.]

Seward, T.M., Henderson, C.M.B., and Charnock, J.M., 2000, Indium (III) chloride complexing and solvation in hydrothermal solutions to $350^{\circ} \mathrm{C}$ - An EXAFS study: Chemical Geology, v. 167, nos. 1-2, p. 117-127. [Also available at http://dx.doi.org/10.1016/s0009-2541(99)00204-1.]

Shacklette, H.T., and Boerngen, J.G., 1984, Element concentrations in soils and other surficial materials of the conterminous United States: U.S. Geological Survey Professional Paper 1270, 105 p., accessed November 30, 2015, at http://pubs.er.usgs.gov/publication/pp1270.

Shanks, W.C. Pat, III, and Thurston, Roland, eds., 2012, Volcanogenic massive sulfide occurrence model, chap. C of Mineral deposit models for resource assessment: U.S. Geological Survey Scientific Investigations Report 2010-5070-C, 345 p. [Also available at http://pubs.usgs.gov/sir/2010/5070/c/.]

Shimizu, Toru, and Morishita, Yuichi, 2012, Petrography, chemistry, and near-infrared microthermometry of indiumbearing sphalerite from the Toyoha polymetallic deposit, Japan: Economic Geology, v. 107, p. 723-735. [Also available at http://dx.doi.org/10.2113/econgeo.107.4.723.]

Siebert, Christopher, Ross, Andy, and McManus, James, 2006, Germanium isotope measurements of high-temperature geothermal fluids using double-spike hydride generation MC-ICP-MS: Geochimica et Cosmochimica Acta, v. 70, no. 15, p. 3986-3995. [Also available at http://dx.doi.org/ 10.1016/j.gca.2006.06.007.]

Slack, J.F., Kelley, K.D., Anderson, V.M., Clark, J.L., and Ayuso, R.A., 2004, Multistage hydrothermal silicification and Fe-Tl-As-Sb-Ge-REE enrichment in the Red Dog Zn$\mathrm{Pb}-\mathrm{Ag}$ district, northern Alaska - Geochemistry, origin, and exploration applications: Economic Geology, v. 99, p. 1481-1508. [Also available at http://dx.doi.org/10.2113/ gsecongeo.99.7.1481.] 
Smith, D.B., Cannon, W.F., Woodruff, L.G., Garrett, R.G., Klassen, Rodney, Kilburn, J.E., Horton, J.D., King, H.D., Goldhaber, M.B., and Morrison, J.M., 2005, Major- and trace-element concentrations in soils from two continentalscale transects of the United States and Canada:

U.S. Geological Survey Open-File Report 2005-1253, 20 p., accessed November 30, 2015, at http://pubs.er.usgs.gov/ publication/ofr20051253.

Smith, K.S., and Huyck, L.O., 1999, An overview of the abundance, relative mobility, bioavailability, and human toxicity of metals, in Plumlee, G.S. and Logsdon, M.J., eds., The environmental geochemistry of mineral deposits-Part A, Processes, techniques and health issues: Littleton, Colo., Society of Economic Geologists, v. 1, p. 29-70.

SRK Consulting (Canada) Inc., 2007, Red Dog Mine closure and reclamation plan-SD B3-Plan of operations for tailings and water management - Report prepared for Teck Cominco Alaska, Inc.: Vancouver, British Columbia, Canada, SRK Consulting (Canada) Inc., SRK Project Number 1CT006.003, 8 p. [Also available at http://dnr.alaska.gov/ $\mathrm{mlw} / \mathrm{mining} /$ largemine/reddog/publicnotice/pdf/sdb3.pdf.]

Tanaka, Akiyo, 2004, Toxicity of indium arsenide, gallium arsenide, and aluminium gallium arsenide: Toxicology and Applied Pharmacology, v. 198, no. 3, p. 405-411. [Also available at http://dx.doi.org/10.1016/j.taap.2003.10.019.]

Tanaka, Akiyo, Hirata, Miyuki, Kiyohara, Yutaka, Nakano, Makiko, Omae, Kazuyuki, Shiratani, Masaharu, and Koga, Kazunori, 2010, Review of pulmonary toxicity of indium compounds to animals and humans: Thin Solid Films, v. 518, no. 11, p. 2934-2936. [Also available at http://dx.doi.org/10.1016/j.tsf.2009.10.123.]

Taylor, C.D., Zierenberg, R.A., Goldfarb, R.J., Kilburn, J.E., Seal, R.R., II, and Kleinkopf, M.D., 1995, Volcanicassociated massive sulfide deposits (Models 24a-b, 28a; Singer, 1986a, b; Cox, 1986), chap. 16 of du Bray, E.A., ed., Preliminary compilation of descriptive geoenvironmental mineral deposit models: U.S. Geological Survey Open-File Report 95-831, p. 137-144. [Also available at http://pubs.usgs.gov/of/1995/ofr-95-0831/.]

Taylor, S.R., and McLennan, S.M., 1995, The geochemical evolution of the continental crust: Reviews of Geophysics, v. 33, no. 2, p. 241-265. [Also available at http://dx.doi.org/ 10.1029/95RG00262.]

Tolcin, A.C., 2013a, Indium: U.S. Geological Survey Mineral Commodity Summaries 2013, p. 74-75, accessed November 30, 2015, at http://minerals.usgs.gov/minerals/ pubs/commodity/indium/mcs-2013-indiu.pdf.
Tolcin, A.C., 2013b, Indium (In), in Metal prices in the United States through 2010: U.S. Geological Survey Scientific Investigations Report 2012-5188, p. 66-68, accessed May 24, 2016, at http://pubs.usgs.gov/sir/2012/5188/.

Tolcin, A.C., 2014, Indium: U.S. Geological Survey Mineral Commodity Summaries 2014, p. 74-75, accessed September 12, 2016, at http://minerals.usgs.gov/minerals/ pubs/commodity/indium/mcs-2014-indiu.pdf.

U.S. Environmental Protection Agency, 2006, Assessment of the potential costs, benefits and other impacts of chat use in transportation projects: Washington, D.C., U.S. Environmental Protection Agency Office of Solid Waste, Reference no. S.2006.1, 81 p.

U.S. Environmental Protection Agency, 2010, Record of Decision by the U.S. Environmental Protection Agency Region 10 for the Red Dog Mine Extension Aqqaluk Project: Washington, D.C., U.S. Environmental Protection Agency, 15 p. [Also available at http://www.epa.gov/ region10/pdf/permits/npdes/ak/red-dog-aqqaluk-rod.pdf.]

U.S. Environmental Protection Agency, 2013a, National primary drinking water regulations: U.S. Environmental Protection Agency, EPA 816-F-09-004, May, 6 p. [Updated version available at http://water.epa.gov/drink/ contaminants/index.cfm.

U.S. Environmental Protection Agency, 2013b, NAAQS [National ambient air quality standards] table: U.S. Environmental Protection Agency Web page, accessed April 7, 2016, at https://www.epa.gov/criteria-air-pollutants/ naaqs-table.

Viers, Jérôme, Dupré, Bernard, and Gaillardet, Jérôme, 2009, Chemical composition of suspended sediments in world rivers-New insights from a new database: Science of the Total Environment, v. 407, no. 2, p. 853-868. [Also available at http://dx.doi.org/10.1016/j.scitotenv.2008.09.053.]

Weeks, M.E., 1932, The discovery of the elements. XV. Some elements predicted by Mendeleeff: The Journal of Chemical Education, v. 9, no. 9, p. 1605-1619. [Also available at http://dx.doi.org/10.1021/ed009p1605.]

Weeks, R.A., 1973, Gallium, germanium, and indium, in Brobst, D.A., and Pratt, W.P., eds., United States mineral resources: U.S. Geological Survey Professional Paper 820, p. 237-246, accessed November 30, 2015, at http://pubs.er.usgs.gov/publication/pp820.

Wilkinson, J.J., Eyre, S.L., and Boyce, A.J., 2005, Ore-forming processes in Irish-type carbonate-hosted $\mathrm{Zn}$-Pb deposits - Evidence from mineralogy, chemistry, and isotopic composition of sulfides at the Lisheen Mine: Economic Geology, v. 100, p. 63-86. [Also available at http://dx.doi.org/10.2113/100.1.0063.] 
Winkler, Clemens, 1886, Germanium, Ge, ein neues, nichtmetallisches element: Berichte der deutschen chemischen Gesellschaft, v. 19, no. 1, p. 210-211. [Also available at http://dx.doi.org/10.1002/cber.18860190156.]

Wood, S.A., and Samson, I.M., 2006, The aqueous geochemistry of gallium, germanium, indium and scandium: Ore Geology Reviews, v. 28, no. 1, p. 57-102. [Also available at http://dx.doi.org/10.1016/j.oregeorev.2003.06.002.]

Xuexin, Song, 1984, Minor elements and ore genesis of the Fankou lead-zinc deposit, China: Mineralium Deposita, v. 19, no. 2, p. 95-104. [Also available at http://dx.doi.org/ 10.1007/bf00204667.]

Ye, Lin, Cook, N.J., Ciobanu, C.L., Yuping, Liu, Qian, Zhang, Tiegeng, Liu, Wei, Gao, Yulong, Yang, and Danyushevskiy, Leonid, 2011, Trace and minor elements in sphalerite from base metal deposits in South ChinaA LA-ICPMS study: Ore Geology Reviews, v. 39, no. 4, p. 188-217. [Also available at http://dx.doi.org/10.1016/ j.oregeorev.2011.03.001.]
Young, L.E., 2004, A geologic framework for mineralization in the western Brooks Range, Alaska: Economic Geology, v. 99 , p. 1281-1306.

Zeh, Armin, Jaguin, Justine, Poujol, Marc, Boulvais, Philippe, Block, Sylvain, and Paquette, J.-L., 2013, Juvenile crust formation in the northeastern Kaapvaal Craton at $2.97 \mathrm{Ga}-$ Implications for Archean terrane accretion, and the source of the Pietersburg gold: Precambrian Research, v. 233, p. 20-43. [Also available at http://dx.doi.org/10.1016/ j.precamres.2013.04.013.]

Zurita, J.L., Jos, Angeles, del Peso, Ana, Salguero, Manuel, Cameán, A.M., López-Artíguez, Miguel, and Repetto, Guillermo, 2007, Toxicological assessment of indium nitrate on aquatic organisms and investigation of the effects on the PLHC-1 fish cell line: Science of the Total Environment, v. 387, nos. 1-3, p. 155-165. [Also available at http://dx.doi.org/ 10.1016/j.scitotenv.2007.07.057.] 



\section{Graphite}

By Gilpin R. Robinson, Jr., Jane M. Hammarstrom, and Donald W. Olson

Chapter $\mathrm{J}$ of

Critical Mineral Resources of the United States-Economic and Environmental Geology and Prospects for Future Supply

Edited by Klaus J. Schulz, John H. DeYoung, Jr., Robert R. Seal II, and Dwight C. Bradley

Professional Paper 1802-J

U.S. Department of the Interior

U.S. Geological Survey 


\section{Contents of Chapter J}

[Figure and table titles for all chapters are listed in the volume contents before the conversion factors table and list of abbreviations and symbols. A periodic table of the elements is on the inside front cover of the printed volume]

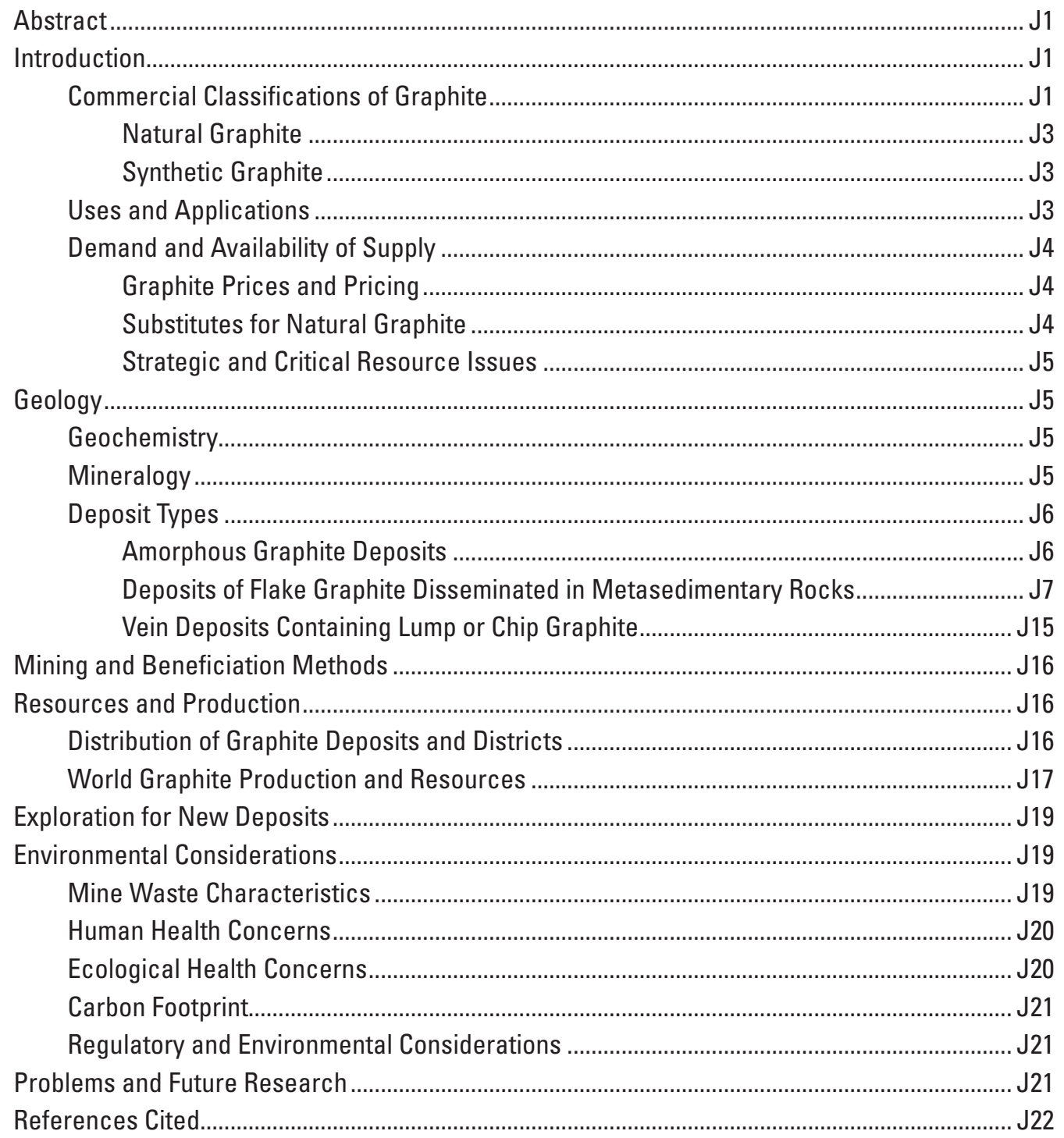




\title{
Graphite
}

\author{
By Gilpin R. Robinson, Jr., Jane M. Hammarstrom, and Donald W. Olson
}

\section{Abstract}

Graphite is a form of pure carbon that normally occurs as black crystal flakes and masses. It has important properties, such as chemical inertness, thermal stability, high electrical conductivity, and lubricity (slipperiness) that make it suitable for many industrial applications, including electronics, lubricants, metallurgy, and steelmaking. For some of these uses, no suitable substitutes are available. Steelmaking and refractory applications in metallurgy use the largest amount of produced graphite; however, emerging technology uses in large-scale fuel cell, battery, and lightweight high-strength composite applications could substantially increase world demand for graphite.

Graphite ores are classified as "amorphous" (microcrystalline), and "crystalline" ("flake" or "lump or chip") based on the ore's crystallinity, grain-size, and morphology. All graphite deposits mined today formed from metamorphism of carbonaceous sedimentary rocks, and the ore type is determined by the geologic setting. Thermally metamorphosed coal is the usual source of amorphous graphite. Disseminated crystalline flake graphite is mined from carbonaceous metamorphic rocks, and lump or chip graphite is mined from veins in high-grade metamorphic regions. Because graphite is chemically inert and nontoxic, the main environmental concerns associated with graphite mining are inhalation of fine-grained dusts, including silicate and sulfide mineral particles, and hydrocarbon vapors produced during the mining and processing of ore. Synthetic graphite is manufactured from hydrocarbon sources using high-temperature heat treatment, and it is more expensive to produce than natural graphite.

Production of natural graphite is dominated by China, India, and Brazil, which export graphite worldwide. China provides approximately 67 percent of worldwide output of natural graphite, and, as the dominant exporter, has the ability to set world prices. China has significant graphite reserves, and China's graphite production is expected to increase, although rising labor costs and some mine production problems are developing. China is expected to continue to be the dominant exporter for the near future. Mexico and Canada export graphite mainly to the United States, which has not had domestic production of natural graphite since the 1950s. Most graphite deposits in the United States are too small, low-grade, or remote to be of commercial value in the near future, and the likelihood of discovering larger, higher-grade, or favorably located domestic deposits is unlikely. The United States is a major producer of synthetic graphite.

\section{Introduction}

Graphite, which is a soft form of elemental carbon, is an industrial mineral commodity that is produced only in small amounts globally-worldwide production of approximately 1 million metric tons of graphite concentrate was reported as yearly production from 2010 to 2012 (Olson, 2012, 2013). The word graphite is derived from the Greek word for writing, graphein, which reflects the long use of graphite (mixed with clay) for the "lead" in pencils. The unique physical and chemical properties of graphite, particularly coarse crystalline graphite, make it useful for many industrial applications, and for some of those uses, no suitable substitutes are available. Although graphite is widely disseminated in many types of metamorphic and some igneous rocks, most occurrences have no economic importance. The significant deposits of graphite are found in carbonaceous sedimentary rocks that have been subjected to regional or contact metamorphism and in veins precipitated from fluids.

\section{Commercial Classifications of Graphite}

Sources of commercial graphite include both natural graphite mined from rock and synthetic graphite manufactured from other carbonaceous materials. For commercial purposes, natural graphite is classified into the following three categories, according to its crystallinity, grain size, and morphology: amorphous, crystalline (flake), and crystalline (lump or chip). These commodity classes differ in the level of purity of the graphite, the proposed industrial use, the price, and the geologic setting in which the graphite occurs (table J1). Descriptions of (a) the graphite commodity classes and their industrial uses, and (b) their associated deposit types, geologic settings, and producing deposit locations are given 
Table J1. Characteristics of graphite commodities, deposits, and uses, by commodity type.

[Descriptions of graphite commodity classes and their industrial uses, commodity prices, and classes of associated deposit types and geologic settings are summarized from information in Klar (1958), Weis (1973), Krauss and others (1988), Sutphin (1991a-c), Simandl and Kenan (1997a-c), Taylor (2006), and Olson $(2011,2012,2013)$. NA, not applicable; $\mu \mathrm{m}$, micrometer; cm, centimeter; ${ }^{\circ} \mathrm{C}$, degree Celsius; m, meter; $\$$, U.S. dollar]

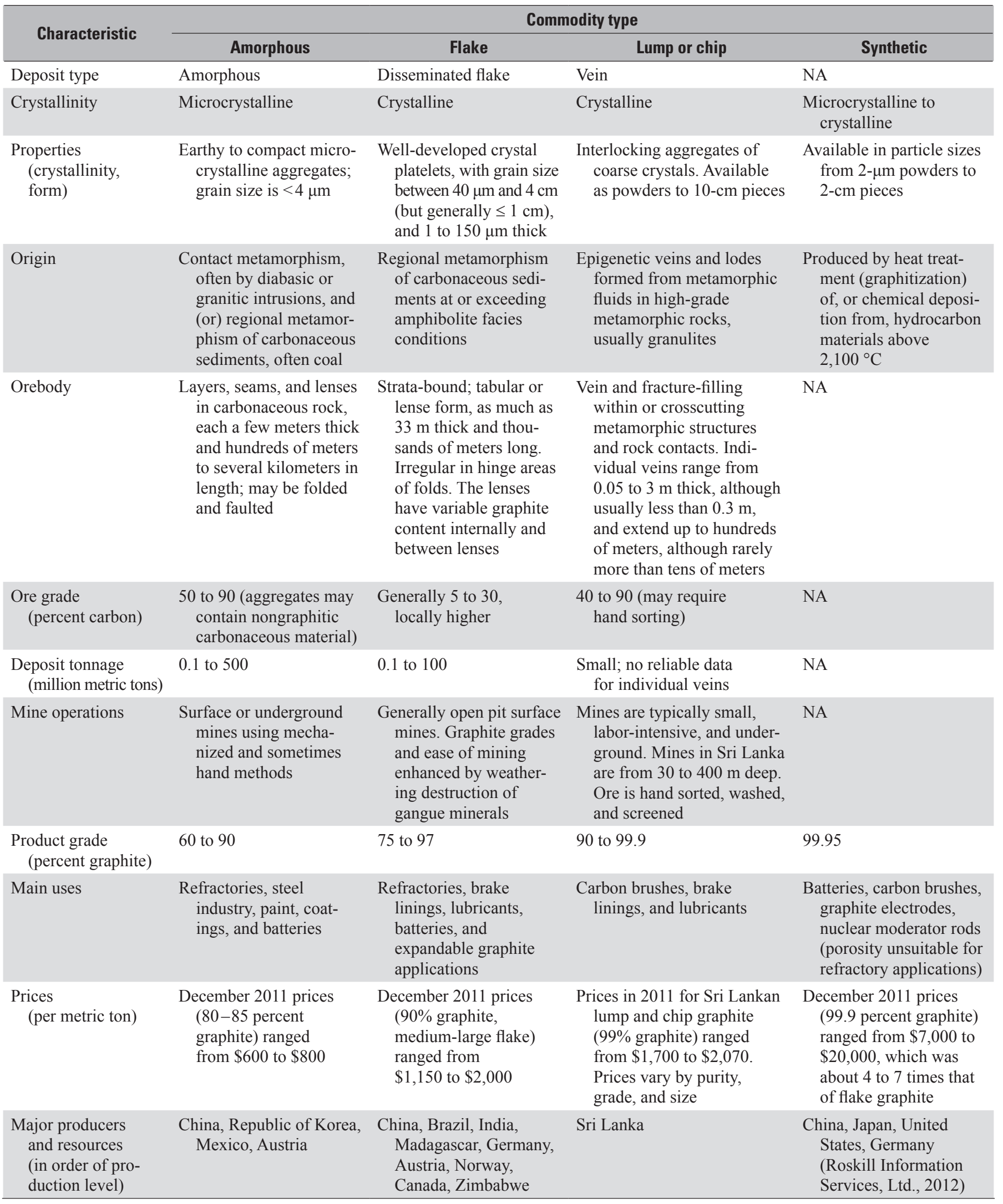


by Klar (1958), Weis (1973), Krauss and others (1988), and Taylor (2006). Descriptive models of the geology and characteristics of the deposit types that produce graphite are given by Sutphin and Bliss (1990), Sutphin (1991a-c), and Simandl and Kenan $(1997 \mathrm{a}-\mathrm{c})$. A summary of information from these and other sources follows.

\section{Natural Graphite}

Natural graphite is mined from deposits in metamorphic rocks, such as marble, schist, and gneiss, and from accumulations in vein deposits. Natural graphite typically forms as a result of metamorphism (regional or contact) of accumulations of organic matter in sedimentary rocks. Commercial deposits of graphite occur in three types of geologic settings that generally correspond to the following commodity classes (table J1):

a. "Amorphous graphite" is the commercial designation for earthy to compact fine-grained graphite that generally results from thermal metamorphism of coal. Commercial deposits typically contain more than 1 million metric tons of ore that is more than 75 percent carbon. Both the raw ore and the commodity may contain nongraphitic carbonaceous material in addition to graphite.

b. "Flake graphite" is the commercial designation for well-developed crystal platelets of graphite that are between 40 micrometers $(\mu \mathrm{m})$ and 4 centimeters $(\mathrm{cm}-$ but generally less than or equal to $1 \mathrm{~cm}$ ) in size and that are disseminated in beds of carbonaceous sediments that have been subjected to amphibolite-facies or higher grade regional metamorphism. Commercial deposits generally contain more than 200,000 metric tons of ore that grade greater than 8 percent graphite. Disseminated flake graphite deposits are located in belts of crystalline metamorphic rock that are predominately Archean to late Proterozoic in age.

c. "Lump or chip" is the commercial designation for interlocking aggregates of coarse graphite crystals that occur as veins or fracture-fillings in igneous and crystalline metamorphic rocks that commonly are of Precambrian age. The only commercial deposits occur in Sri Lanka where families of veins that are up to 3 meters $(\mathrm{m})$ thick and which consist of 60 to 95 percent graphite are mined to depths of 30 to $650 \mathrm{~m}$ (Touzain and others, 2010). The ore may be hand sorted to provide a product grade that exceeds 90 percent. No reliable data on the tonnages of individual vein deposits are available, but most of the deposits are small and likely do not exceed 100,000 metric tons.

\section{Synthetic Graphite}

Most of the graphite used by industries in the United States is synthetic. Synthetic graphite of high purity is produced by heat treatment (graphitization) of, or chemical deposition from, hydrocarbon materials above 2,100 degrees Celsius $\left({ }^{\circ} \mathrm{C}\right)$. High-temperature processing is required to transform the precursor carbon forms to a graphite structure and to vaporize impurities, which include hydrogen, metals, nitrogen, organic compounds, and sulfur in the source materials. As a result of this treatment, synthetic graphite is more than 99.9 percent graphite, but it has slightly higher porosity, lower density, lower electrical conductivity, and a much higher price than natural flake graphite. Synthetic graphite is available in particle sizes ranging from $2-\mu \mathrm{m}$ powders to $2-\mathrm{cm}$ pieces; the morphology varies from flakey in fine powders to irregular grains and needles in coarser products.

\section{Uses and Applications}

Graphite has physical and chemical properties of both metals and nonmetals, which make it ideally suited for many industrial and technology applications. The metallic properties include high thermal and electrical conductivity (table J2). The nonmetallic properties include inertness to most chemical reagents (strong acids, bases, solvents, and fluxes), high thermal resistance, low thermal expansion, and excellent cleavage and lubricity (slipperiness). In a nonoxidizing atmosphere, graphite remains stable to temperatures above $3,000{ }^{\circ} \mathrm{C}$. Graphite has a hardness of 1 to 2 on the Mohs scale and is thus extremely soft.

Table J2. Selected physical properties of graphite.

[Modified from Krauss and others (1988). $\mathrm{g} / \mathrm{cm}^{3}$, gram per cubic centimeter; ${ }^{\circ} \mathrm{C}$, degree Celsius; watt $/ \mathrm{cm}{ }^{\circ} \mathrm{C}$, watt per centimeter per degree Celsius; $\Omega$-cm, ohm-centimeter]

\begin{tabular}{|c|c|}
\hline Property & Description \\
\hline Composition & Carbon \\
\hline Color & Gray to black, metallic luster \\
\hline Hardness (Mohs scale) & 0.5 to 1 \\
\hline Density $\left(\mathrm{g} / \mathrm{cm}^{3}\right)$ & 2.09 to 2.26 \\
\hline Morphology & $\begin{array}{l}\text { Hexagonal system; perfect basal } \\
\text { cleavage; usually platy }\end{array}$ \\
\hline Melting point & $\begin{array}{l}\text { About } 3,550{ }^{\circ} \mathrm{C} \text { in nonoxidizing } \\
\text { conditions; decomposes above } \\
600^{\circ} \mathrm{C} \text { in oxidizing conditions }\end{array}$ \\
\hline Miscellaneous & $\begin{array}{l}\text { Chemically inert; nontoxic; high ther- } \\
\text { mal and electrical conductivity; high } \\
\text { lubricity (natural lubricant) }\end{array}$ \\
\hline $\begin{array}{l}\text { Thermal conductivity } \\
\left.\text { (watt } / \mathrm{cm}^{\circ} \mathrm{C}\right)\end{array}$ & $\begin{array}{l}a \text { axis: } 4.0 \\
c \text { axis: } 0.8\end{array}$ \\
\hline $\begin{array}{l}\text { Thermal expansion } \\
\text { coefficient }\left(1 /{ }^{\circ} \mathrm{C}\right)\end{array}$ & $\begin{array}{l}a \text { axis: } 1 \times 10^{-7} \\
c \text { axis: } 140 \times 10^{-7}\end{array}$ \\
\hline $\begin{array}{l}\text { Electrical resistivity } \\
\qquad\left(\Omega \text {-cm } \times 10^{4}\right)\end{array}$ & $\begin{array}{l}a \text { axis: } 1 \text { to } 100 \\
c \text { axis: } 10,000\end{array}$ \\
\hline
\end{tabular}




\section{J4 Critical Mineral Resources of the United States-Graphite}

Some of the major end uses of graphite are in brake linings, refractories, and steelmaking. Batteries, brushes for electrical motors, foundry materials, fuel cells, and hightemperature lubricants are additional end uses of graphite. Graphite forms intercalation compounds with alkali metal vapors - usually potassium, lithium, rubidium, and cesiumwhere the metal ions fit between the planar carbon sheets of the graphite structure. These compounds have applications in the energy sector and other technologies. The industrial uses and associated commercial value of natural graphite depend on the characteristics and crystallinity of the mined graphite (table J1).

Fine-grained microcrystalline graphite powder (amorphous graphite) is used extensively in foundry and refractory applications, as a source of carbon in steelmaking, and in other applications where additions of graphite improve the manufacturing process or end product. Coarse-grained crystalline graphite in the form of separate lamellar crystals (flake graphite) has high value and is used in high-temperature lubricants, high-quality foundry and refractory ware, powder metallurgy, coatings, and battery and fuel cell applications. Crystalline flake graphite accounted for about 50 percent of natural graphite usage in the United States in the past decade.

Massive crystalline graphite from vein deposits (lump or chip graphite) has the highest purity and grain size of the natural graphite sold commercially. Because of its purity and crystallinity, many of the highest quality electrical motor brushes and other current-carrying carbon products use formulations of graphite from vein deposits.

Synthetic graphite is used in many applications that require high-purity graphite, including anticorrosion products, batteries, carbon brushes, coatings, conductive fillers, electrodes and electrolytic processes, fuel cell bipolar plates, and nuclear moderator rods. Synthetic graphite is unsuitable for foundry applications because of its increased porosity relative to natural graphite. Synthetic graphite is used in more applications in North America than natural graphite and accounts for a significant share of the graphite market.

\section{Demand and Availability of Supply}

No natural graphite was reported to have been mined in the United States in 2010 (Olson, 2012), and the major domestic sources of industrial graphite included imports of natural graphite, mostly from China, Mexico, Canada, Brazil, and Madagascar (in order of tonnage of imports), and synthetic graphite manufactured from carbonaceous materials. In 2010, 65,400 metric tons of natural graphite valued at an estimated $\$ 52$ million was reported to have been imported into the United States for domestic consumption and 134,000 metric tons of synthetic graphite valued at an estimated $\$ 1.07$ billion was reported to have been produced in the United States (Olson, 2012).

\section{Graphite Prices and Pricing}

Graphite is not traded on any commodity exchange. Commodity prices are subject to negotiation between buyer and seller and depend on carbon content, flake size and distribution (for crystalline flake), and the amount and nature of impurities. China is the dominant global natural graphite producer and has been the world price setter for decades. Four price series for graphite commodities based on production and value data reported by the U.S. Geological Survey (Olson, 2013) and Roskill Information Services, Ltd. (2012) are given in table J1. They are (a) microcrystalline (amorphous) graphite powder (from Mexico), which is currently in a long-term decline in importance because its low-technology end uses are becoming obsolete; (b) crystalline flake, which has become the most important natural graphite commodity in the past few decades and accounts for 80 to 90 percent of the value of U.S. imports of natural graphite; (c) lump graphite from Sri Lanka, which is a specialty product because its relatively high price results in low demand, and (d) synthetic graphite, which is a specialty product used primarily for applications that require high purity; its high price also limits demand. The price of microcrystalline (amorphous) graphite powder (80 to 85 percent carbon) ranged from $\$ 600$ to $\$ 800$ per metric ton in 2011; that of flake graphite (90 percent graphite) ranged from $\$ 1,150$ to $\$ 2,000$ per metric ton; Sri Lankan lump and chip graphite (99 percent graphite), from $\$ 1,700$ to $\$ 2,070$, depending on purity, grade, and particle size; and synthetic graphite (99.9 percent graphite), from $\$ 7,000$ to $\$ 20,000$ per metric ton, which is about four to seven times that of flake graphite (table J1).

In 2010, graphite prices increased more rapidly for crystalline flake graphite than for amorphous graphite owing to increased demand for crystalline graphite used in friction material applications, such as brake linings, high-quality refractories, and lubricants, and in the manufacturing of graphite foils and long-life alkaline batteries (Industrial Minerals, 2010).

\section{Substitutes for Natural Graphite}

The most common substitutes for natural graphite are other forms of carbon. Manufactured synthetic graphite powders and graphite recovered from discarded foundry and manufactured materials can substitute for natural graphite in some applications, depending on the relative price. In steelmaking and some foundry applications, petroleum coke, anthracite, and synthetic graphite can be used instead of natural graphite. Synthetic graphite and natural graphite powder are commonly substituted for each other, or mixtures containing both kinds are prepared for customers (Taylor, 2006). Crystalline graphite is recovered from some foundry and refractory materials, although its recovery cost makes it noncompetitive relative to natural graphite for some applications (Weis, 1973; Olson, 2013). 


\section{Strategic and Critical Resource Issues}

Graphite is considered a critical and strategic mineral because of its essential applications in the aerospace and energy sectors (such as refractory and foundry applications in the steel and metal industries and use in high-temperature lubricants, high-strength lightweight composite materials, batteries, modern nuclear reactors, fuel cells, electric motors, and evolving electronic applications that anticipate rapid growth in demand for graphite). The high concentration of resource supply from few countries could increase the commodity's susceptibility to market manipulation or disruption (Krauss and others, 1988; Taylor, 2006; European Commission, 2014). The United States has not produced natural graphite since the 1950s; China, Mexico, and Canada, in order of import supply, are the dominant sources of graphite imports to the United States (Olson, 2013). China has very low labor and production costs, and, with aggressive marketing, it established dominance in the world market in the 1980s (Taylor, 2006; Olson, 2013). China's graphite production is expected to increase and remain dominant in the world graphite market for the near future (Olson, 2013). China's rapidly growing domestic market for graphite may restrict future exports, however, which has raised concerns about possible supply shortages of graphite, particularly crystalline flake graphite, needed for anticipated large-scale fuel cell and battery applications; such applications could dramatically increase world demand for graphite (Taylor, 2006; Olson, 2013; Olson and others, 2016).

Graphite has played an important role in the emerging noncarbon energy sector and is used in several new energy applications. In energy production applications, graphite is used in pebbles for modular nuclear reactors and in highstrength composites for wind, tide, and wave turbines. In energy storage applications, graphite is used in bipolar plates for fuel cells and flow batteries, in anodes for lithium-ion batteries, in electrodes for supercapacitors, in high-strength composites for fly wheels, in phase change heat storage, and in solar boilers. In energy management applications, graphite is used in high-performance thermal insulation and in silicon chip heat-dissipation applications. These new energy applications commonly use specialty graphite products with such properties as extreme purity ( $>99.9$ percent graphite), very large or small (nano) particle size, and perfect crystallinity. Current graphite capacity may not be adequate for the increasing demands of these new energy applications, which, when fully implemented, may require double the current graphite supply, especially of high-purity crystalline flake graphite (O’Driscoll, 2010; Olson and others, 2016).

\section{Geology \\ Geochemistry}

Carbon is the fourth most abundant element in the solar system, and in terms of its abundance in Earth's crust, is ranked about 12 th to 17 th in abundance, with an estimated crustal concentration between 180 and 270 parts per million. The abundance of carbon in Earth's crust is difficult to determine because carbon stores exist and cycle between rock, sediment, atmosphere, biosphere, and ocean reservoirs. The behavior of carbon in its geochemical cycle is influenced by the form in which the carbon occurs. Most of the carbon in Earth's crust (approximately 80 to 90 percent) is contained in carbonate minerals in carbonate rocks. Most of the remaining carbon in the Earth system occurs in living and fossil organic matter and as carbon dioxide $\left(\mathrm{CO}_{2}\right)$ in the atmosphere or dissolved in the ocean. These remaining carbon forms dominate the carbon cycle. Graphite makes up only a small proportion of the carbon in Earth's crust, probably less than 0.5 percent, and much of this graphite likely formed by high-temperature thermal alteration of organic matter from biogenic sources deposited in sedimentary rocks and subsurface reservoirs. The mineral graphite is stable and inert in the crustal environment and is unchanged under surface weathering conditions. Burial and thermal metamorphism tends only to recrystallize graphite. Therefore, graphite is largely isolated from the overall carbon cycle.

\section{Mineralogy}

Graphite is one of four forms of crystalline elemental carbon; the others are carbon nanotubes, diamond, and fullerenes. Graphite crystallizes in the hexagonal system, with rhombohedral symmetry, commonly forming six-sided tabular crystal flakes. It occurs naturally in metamorphic rocks and in some igneous rocks. Well-crystallized graphite flakes have a black metallic luster, whereas microcrystalline material is black and earthy with an amorphous appearance.

The crystal structure of graphite consists of carbon atoms tightly arranged in parallel-stacked ( $c$ axis, fig. J1), planar honeycomb-lattice sheets ( $a$ axis, fig. J1). When the graphite structure is only a 1-atom-thick planar sheet, it is called graphene.

The physical properties of graphite are listed in table J2. Many properties listed in table $\mathrm{J} 2$ vary by crystallographic orientation ( $a$-axis and $c$-axis values, table J2) because of differences in bonding within ( $a$ axis, fig. J1) and between lattice sheets ( $c$ axis, fig. J1). The intraplanar ( $a$ axis) covalent bonding in graphite sheets is strong, but the electrostatic interlayer ( $c$ axis) forces holding the sheets together are weak, resulting in delocalized electrons that are free to move between sheets, which separates the sheets and allows them to 
Figure J1. Diagram showing the arrangement of carbon atoms in graphite, which consists of stacks of parallel sheets of carbon atoms (red circles in the figure), with each sheet containing hexagonal arrays of carbon atoms. Each carbon atom within a sheet is connected to its three nearest neighbors by covalent bonds that separate the atoms by a distance of 1.415 angstroms $(\AA)$-an angstrom is one ten-billionth of a meter. The stacked sheets (shown here in their $A$ and $B$ orientation) are held together by weak intermolecular van der Waals' forces and are separated from each other by a distance of $3.354 \AA$. The arrangement of atoms defined by the dashed lines portrays one hexagonal $(2 \mathrm{H})$ unit cell of graphite. Modified from Kraus and others, 1989.

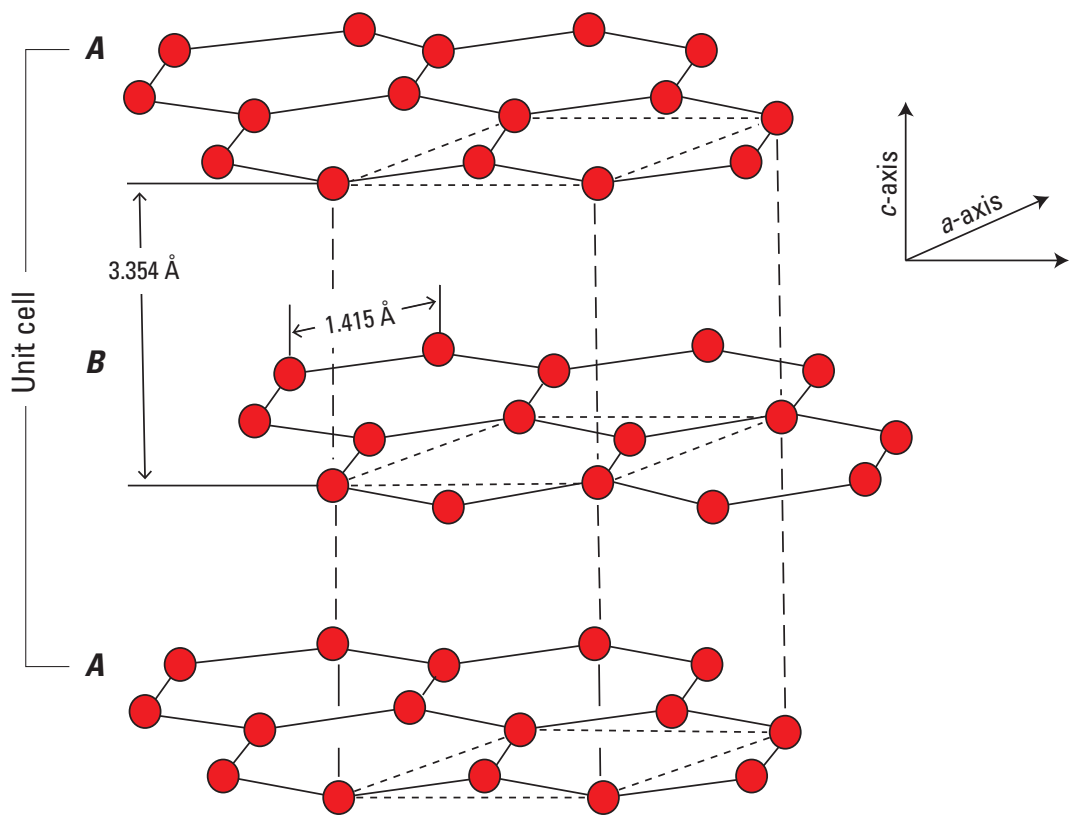

slide across one another easily. This gives graphite a density of 2.09 to 2.26 grams per cubic centimeter $\left(\mathrm{g} / \mathrm{cm}^{3}\right)$, perfect basal (one-plane) cleavage, softness ( 0.5 to 1 on the Mohs scale), a greasy feel, and self-lubricating properties that make it useful as a lubricant. The ratio of force required to induce gliding of graphite sheets relative to compression force is low, resulting in high lubricity. These delocalized interlayer electrons also give graphite its high electrical and thermal conductivity. Graphite is the most electrically and thermally conductive of the nonmetallic elements ( $a$-axis values, table J2); however, the intraplanar covalent bonds are very strong and require high energy to break them. These bonding properties make graphite chemically inert and physically stable at high temperatures (refractory). Graphite resists chemical attack by most reagents and is infusible in most common fluxes. Thermal oxidation of graphite in the presence of oxygen begins at about $300^{\circ} \mathrm{C}$, and the rate increases with temperature; however, it is stable in a nonoxidizing atmosphere to above $3,000{ }^{\circ} \mathrm{C}$. Graphite sublimes between $3,300{ }^{\circ} \mathrm{C}$ and $3,500{ }^{\circ} \mathrm{C}$ at 1.033 kilograms per square centimeter $\left(\mathrm{kg} / \mathrm{cm}^{2}\right)$ and it melts at approximately $3,550{ }^{\circ} \mathrm{C}$ at a triple point under a pressure of $88 \mathrm{~kg} / \mathrm{cm}^{2}$. Graphite is flexible but not elastic. All these properties combined make graphite desirable for many industrial applications.

\section{Deposit Types}

Natural graphite is a common constituent of metasedimentary rocks and is mined in three geologic settings: (a) microcrystalline (amorphous) graphite deposits formed by metamorphism of coal, petroleum, or carbon-rich sediments, (b) disseminated flakes in metamorphic rock (flake graphite), and (c) graphite vein deposits (lump or chip graphite). Similar to most industrial mineral commodities, the economics of a deposit depend on its location and transportation costs to markets in addition to deposit grade, size, and mining characteristics. Impurities in the deposit, such as silica, sulfides, or biotite, may limit the economic potential of a deposit.

\section{Amorphous Graphite Deposits}

Amorphous graphite deposits, which are formed by thermal metamorphism of coal, petroleum pools, or other highly carbonaceous sedimentary rocks, contain earthy to compact masses of microcrystalline graphite. Deposits may consist of multiple layers, seams, and lenses containing 50 to 90 percent carbon; each deposit is a few meters thick and up to a kilometer in length and lies within clastic metasedimentary rocks. The carbon content of amorphous deposits is dependent on the amount of carbon present in the original sediments, and the grade, tonnage, and purity of the deposit depend upon the characteristics of the precursor coal sequence or carbonaceous material. Deposits in metamorphosed massive coal seams may contain as much as 90 percent graphitic carbon, whereas deposits in other carbonaceous sediments or impure coal sequences commonly range from 25 to 60 percent carbon.

Chemical and isotopic biomarkers found in natural graphite provide evidence of its origin from ancient biological material. Amorphous graphite deposits occur in geologic settings and environments where coal and other organicrich sedimentary rocks, such as oil shale, occur, including (a) shoreline, fluvial-deltaic, and alluvial fan depositional environments in passive continental margin settings, and (b) lacustrine and shallow inland seas and margins in foreland, continental, sag, or intracontinental rift basin settings. Host rocks include conglomerate, metagraywacke, quartzite, and schist. The thermal metamorphism is commonly caused by 
crosscutting diabasic or granitic intrusions with associated hornfels alteration of host rocks. Hornfels is a hard metamorphic rock formed by contact metamorphism of sedimentary rocks close to intrusive igneous bodies.

Graphite does not form until temperatures exceed $300^{\circ} \mathrm{C}$ to $400{ }^{\circ} \mathrm{C}$ (Landis, 1971). The degree of metamorphism controls the degree of graphitization, and the ratio of graphite to nongraphitic carbon varies, but typically increases towards the heat source. Mineral impurities include meta-anthracite, anthracite, quartz, mica, pyrite, and other sulfides. Most currently mined deposits typically contain at least 80 percent carbon in deposits exceeding 1 million metric tons.

The world's main sources of amorphous graphite are the metamorphosed coal deposits in Sonora, Mexico; Siberia, Russia; and the large coal province stretching from China into the Korean peninsula (table J3). The deposits in Sonora, Mexico, are the most significant deposits of amorphous graphite in the Western Hemisphere. They occur in a series of beds in an area 30 kilometers $(\mathrm{km})$ long by $15 \mathrm{~km}$ wide located $60 \mathrm{~km}$ southeast of Hermosillo. In the district, the orebodies average $3 \mathrm{~m}$ in thickness, but deformation can produce seams up to $7 \mathrm{~m}$ wide. Grades exceed 75 percent contained graphite and some contain as much as 95 percent. The Moradillas deposit (Lourdes area, Mexico) has been reinterpreted as formed from a graphitized hydrocarbon protolith owing to its vein-like structure and lack of evidence that it is metamorphosed coal (Taylor, 2006). In the United States, small amorphous graphite deposits occur in metamorphosed coal deposits in the Narragansett Basin, Rhode Island, and in deposits in northern Michigan. An additional U.S. example occurs at Raton, New Mexico, where a basalt dike intersects a coal seam.

\section{Deposits of Flake Graphite Disseminated in Metasedimentary Rocks}

A large proportion of worldwide graphite production is derived from deposits of disseminated flake graphite found in metamorphic rocks, such as paragneiss (a gneiss derived from sedimentary rock), quartzite, and, sometimes, marble. These deposits formed when preexisting carbonaceous matter in the host sedimentary rock was converted to graphite during regional metamorphic conditions at or exceeding medium-pressure and medium-to-high-temperature conditions (amphibolite facies). These metamorphic conditions are sufficient to crystallize fully ordered graphite (Hoefs and Frey, 1976) and recrystallize the rock matrix. The precursor host rocks of these deposits are interpreted as occurring in depositional settings where organic-rich sediments accumulate and are preserved. These settings include sediment-starved intracratonic and continental margin basins with low-oxygen conditions at depth to accumulate organic sediments, and periods of transgression (compare with, for example, Wilde and others, 1999), when sea level rises relative to land, preserving organic-rich sediments without erosion. The sedimentary rocks that are deposited during transgression may be deposited directly on existing basement rocks of the crust and are termed supracrustal rocks.

The metamorphic conditions sufficient to form these deposits occur in the roots of continental mountain belts formed by deformation of Earth's crust, and significant postmetamorphic uplift and erosion are required to expose deposits in minable settings. Alumina-rich paragneiss, quartzites, and marbles at or near the highest grade of regional metamorphism at medium pressure (granulite facies) are favorable host rocks for flake graphite deposits because of their granular texture, coarse grain size, and low mica content. Supracrustal metasedimentary belts with these metamorphic features are termed crystalline metamorphic basement; their worldwide distribution has been mapped by Chorlton (2007). Most flake graphite deposits are located in Precambrian crystalline metamorphic basement (fig. J2), principally of Neoarchean to Proterozoic eras; however, deposits could occur in crystalline basement of any age. Precambrian supracrustal metamorphic belts appear to be more extensive, and metamorphosed to higher grades, than Phanerozoic belts (Chacko and others, 1987).

The principal flake graphite deposits occur as stratabound lenses or layers; individual lenses in deposits are as much as tens of meters thick and hundreds of meters long. The lenses have variable graphite content, both within themselves and from one lens to another. The graphite content of a typical deposit varies from about 8 to 15 percent carbon, but the grade can vary from as low as 3 percent to about 60 percent carbon locally in individual deposits and between deposits. In Madagascar, one rich lens was reported to contain 60 percent graphite, and grades in the Kigluaik Mountains graphite district, Alaska, exceed 50 percent graphite in some areas (Coats, 1944). In paragneiss-hosted deposits, gangue (non-ore) minerals include in order of general abundance, feldspar, biotite, pyroxene, garnet, and sulfide minerals. Gangue minerals in carbonate-hosted deposits include calcite, pyroxene, feldspar, garnet, and sulfides. Flake graphite in crushed ore is separated from mineral impurities using washing, screening, flotation, and, sometimes, leach methods.

The highest graphite grades commonly are associated with rock contacts between marble and paragneiss or quartzite, lenses in fault zones, in segregations within fold crests, and in structures that acted as channels for metamorphic fluids, all suggesting structural control of mineralization. Although most carbon in these deposits is thought to be present in the original sedimentary rocks, some carbon enrichment may be caused by processes involving internal or external buffering or mixing of metamorphic fluids (Lamb and Valley, 1984; Newton, 1986).

Crystals in each deposit vary from a fraction of a millimeter to a few centimeters in size, usually reflecting the grain size in the parent rock. Most currently mined flake graphite deposits typically contain at least 8 to 12 percent graphitic carbon in deposits exceeding 0.5 million metric tons. Graphite is stable in the weathering environment; deposit grades and ease of mining are enhanced by weathering destruction of other minerals. Some deposits become so weathered that they can be mined with shovels and other hand tools. 
Table J3. Location, grade, tonnage and other data for selected graphite deposits and districts of the world.

[The names, locations, and descriptions of most of the deposits are taken from the International Strategic Minerals Inventory (ISMI) graphite inventory (Krauss and others, 1988) and the U.S. Geological Survey Mineral Resources Data System (MRDS; U.S. Geological Survey, 2012). Identification number is keyed to the deposits shown in figure J2. Negative values for latitude indicate that the deposit is in the Southern Hemisphere; negative values for longitude indicate that the deposit is in the Western Hemisphere. Record types are from the MRDS. Ore type is characterized as amorphous, crystalline, flake, or lump (includes chip), as defined in table J1. "Weathering" indicates surface ores that have been deeply weathered, which lowers mining costs. Development status of the deposit is given as follows: Current, current or recent mine activity; Past, past producer with no current mining; Prospect, an unmined deposit with characterized resources; Occurrence, an unmined deposit with uncharacterized resources. Tonnage of ore has been updated from the values in the MRDS and is given in metric tons or, alternatively, is categorized as large (likely exceeds 1 million metric tons but is not well characterized) or small (likely is less than 100,000 metric tons). \%, percent; —, unknown; WGS 84, World Geodetic System of 1984]

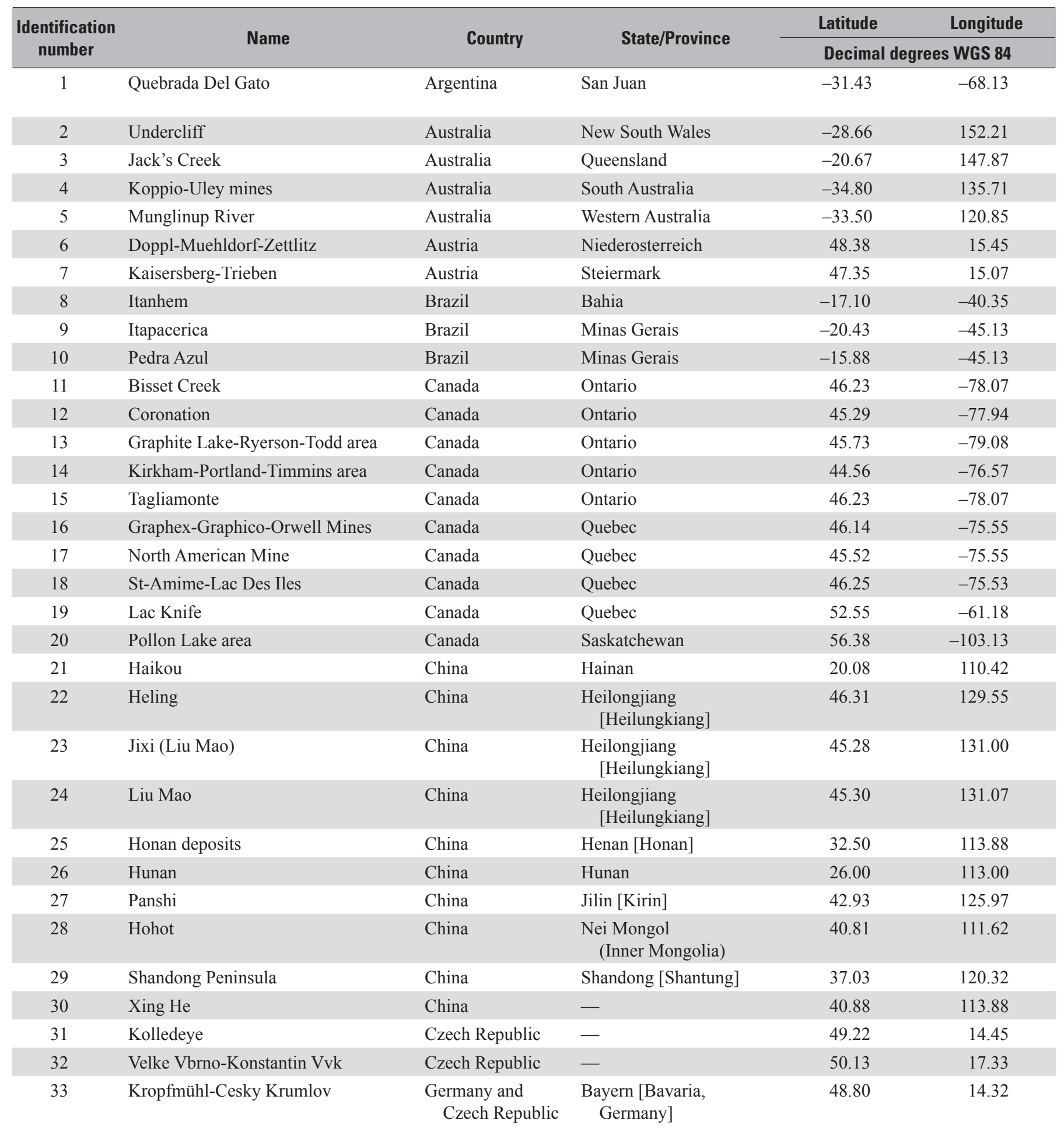


Table J3. Location, grade, tonnage and other data for selected graphite deposits and districts of the world.—Continued

[The names, locations, and descriptions of most of the deposits are taken from the International Strategic Minerals Inventory (ISMI) graphite inventory (Krauss and others, 1988) and the U.S. Geological Survey Mineral Resources Data System (MRDS; U.S. Geological Survey, 2012). Identification number is keyed to the deposits shown in figure J2. Negative values for latitude indicate that the deposit is in the Southern Hemisphere; negative values for longitude indicate that the deposit is in the Western Hemisphere. Record types are from the MRDS. Ore type is characterized as amorphous, crystalline, flake, or lump (includes chip), as defined in table J1. "Weathering" indicates surface ores that have been deeply weathered, which lowers mining costs. Development status of the deposit is given as follows: Current, current or recent mine activity; Past, past producer with no current mining; Prospect, an unmined deposit with characterized resources; Occurrence, an unmined deposit with uncharacterized resources. Tonnage of ore has been updated from the values in the MRDS and is given in metric tons or, alternatively, is categorized as large (likely exceeds 1 million metric tons but is not well characterized) or small (likely is less than 100,000 metric tons). \%, percent; —, unknown; WGS 84, World Geodetic System of 1984]

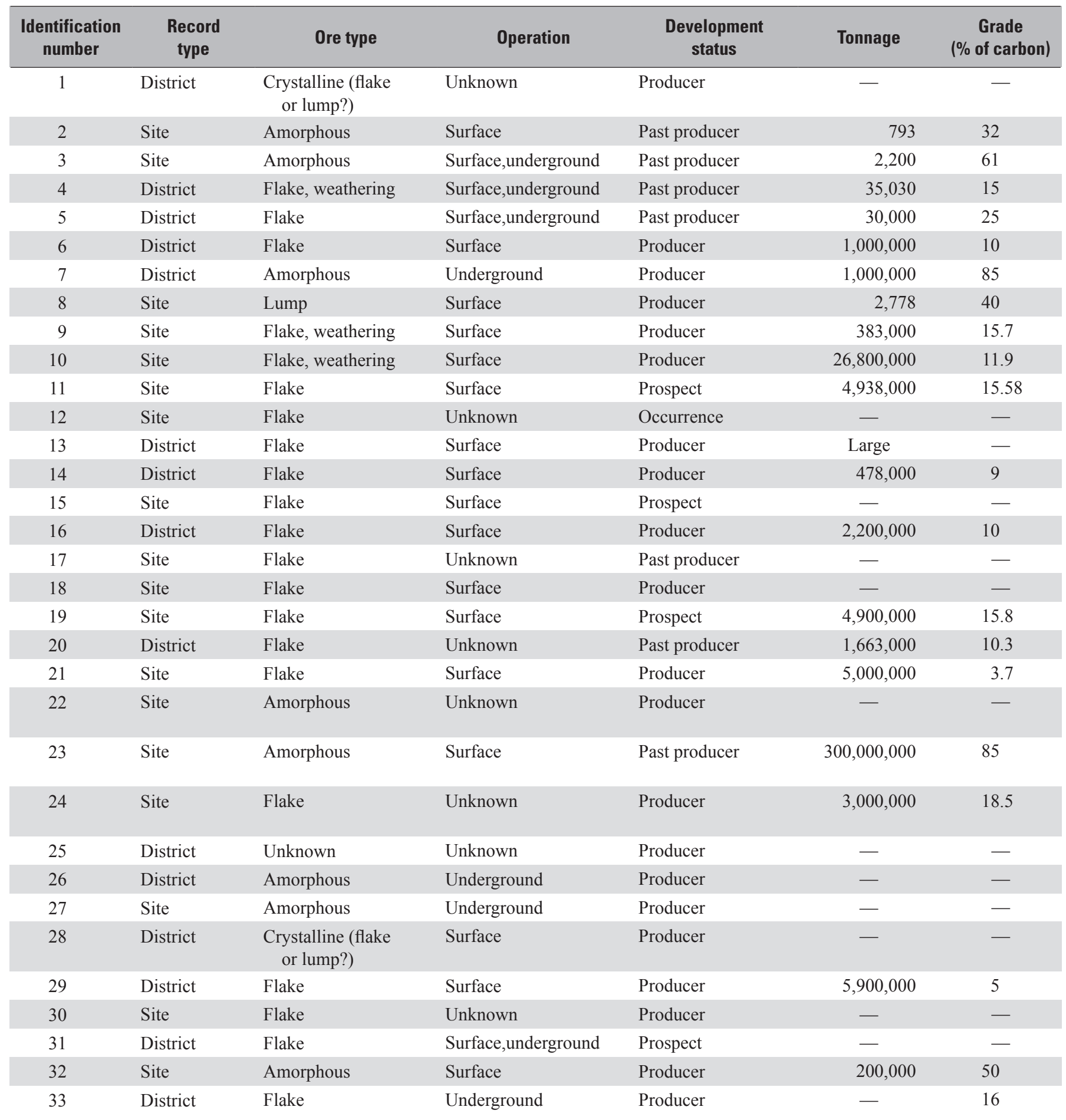


Table J3. Location, grade, tonnage and other data for selected graphite deposits and districts of the world.—Continued

[The names, locations, and descriptions of most of the deposits are taken from the International Strategic Minerals Inventory (ISMI) graphite inventory (Krauss and others, 1988) and the U.S. Geological Survey Mineral Resources Data System (MRDS; U.S. Geological Survey, 2012). Identification number is keyed to the deposits shown in figure J2. Negative values for latitude indicate that the deposit is in the Southern Hemisphere; negative values for longitude indicate that the deposit is in the Western Hemisphere. Record types are from the MRDS. Ore type is characterized as amorphous, crystalline, flake, or lump (includes chip), as defined in table J1. "Weathering" indicates surface ores that have been deeply weathered, which lowers mining costs. Development status of the deposit is given as follows: Current, current or recent mine activity; Past, past producer with no current mining; Prospect, an unmined deposit with characterized resources; Occurrence, an unmined deposit with uncharacterized resources. Tonnage of ore has been updated from the values in the MRDS and is given in metric tons or, alternatively, is categorized as large (likely exceeds 1 million metric tons but is not well characterized) or small (likely is less than 100,000 metric tons). \%, percent; —, unknown; WGS 84, World Geodetic System of 1984]

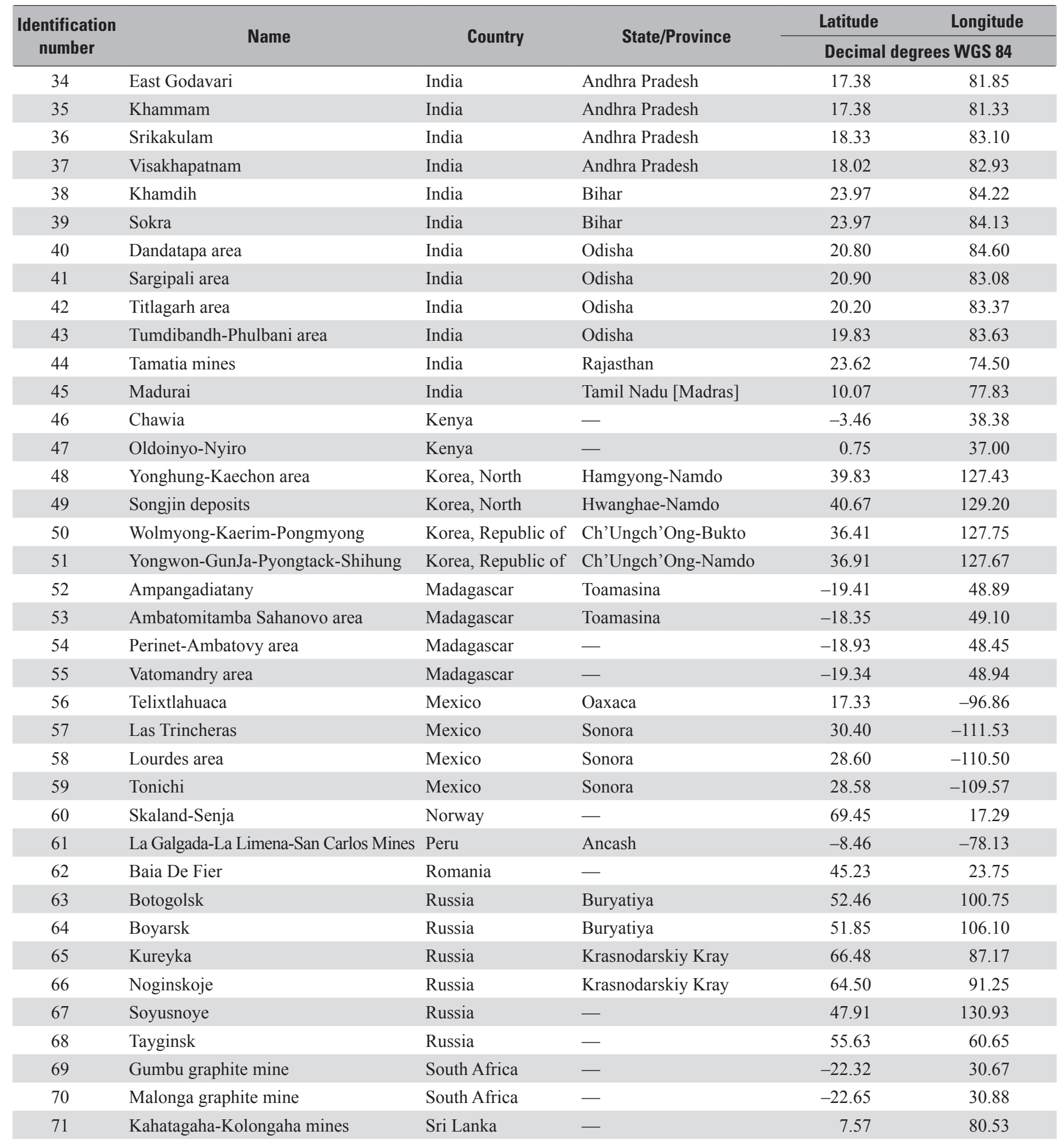


Table J3. Location, grade, tonnage and other data for selected graphite deposits and districts of the world.—Continued

[The names, locations, and descriptions of most of the deposits are taken from the International Strategic Minerals Inventory (ISMI) graphite inventory (Krauss and others, 1988) and the U.S. Geological Survey Mineral Resources Data System (MRDS; U.S. Geological Survey, 2012). Identification number is keyed to the deposits shown in figure J2. Negative values for latitude indicate that the deposit is in the Southern Hemisphere; negative values for longitude indicate that the deposit is in the Western Hemisphere. Record types are from the MRDS. Ore type is characterized as amorphous, crystalline, flake, or lump (includes chip), as defined in table J1. "Weathering" indicates surface ores that have been deeply weathered, which lowers mining costs. Development status of the deposit is given as follows: Current, current or recent mine activity; Past, past producer with no current mining; Prospect, an unmined deposit with characterized resources; Occurrence, an unmined deposit with uncharacterized resources. Tonnage of ore has been updated from the values in the MRDS and is given in metric tons or, alternatively, is categorized as large (likely exceeds 1 million metric tons but is not well characterized) or small (likely is less than 100,000 metric tons). \%, percent; —, unknown; WGS 84, World Geodetic System of 1984]

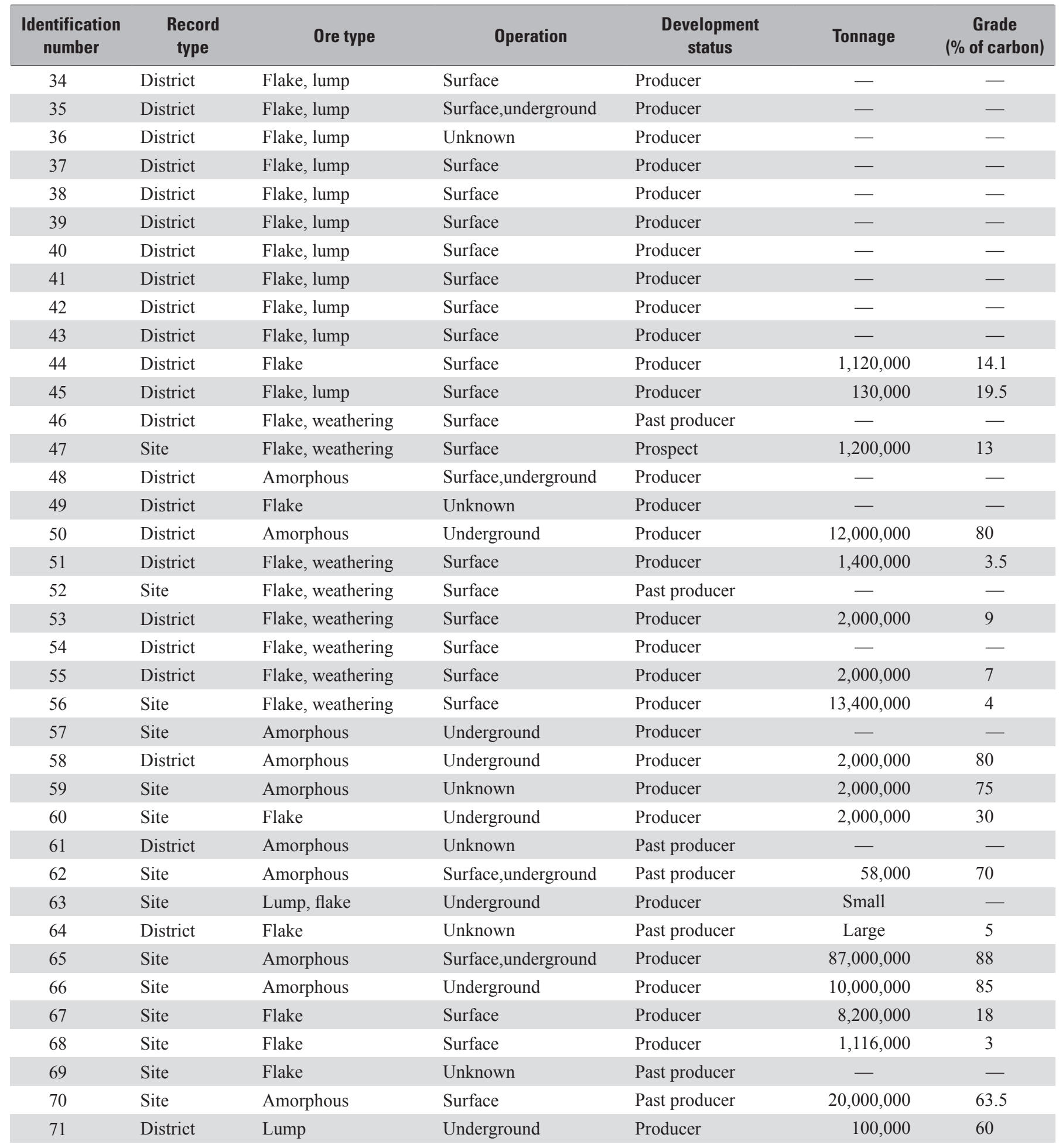


Table J3. Location, grade, tonnage and other data for selected graphite deposits and districts of the world.—Continued

[The names, locations, and descriptions of most of the deposits are taken from the International Strategic Minerals Inventory (ISMI) graphite inventory (Krauss and others, 1988) and the U.S. Geological Survey Mineral Resources Data System (MRDS; U.S. Geological Survey, 2012). Identification number is keyed to the deposits shown in figure J2. Negative values for latitude indicate that the deposit is in the Southern Hemisphere; negative values for longitude indicate that the deposit is in the Western Hemisphere. Record types are from the MRDS. Ore type is characterized as amorphous, crystalline, flake, or lump (includes chip), as defined in table J1. "Weathering" indicates surface ores that have been deeply weathered, which lowers mining costs. Development status of the deposit is given as follows: Current, current or recent mine activity; Past, past producer with no current mining; Prospect, an unmined deposit with characterized resources; Occurrence, an unmined deposit with uncharacterized resources. Tonnage of ore has been updated from the values in the MRDS and is given in metric tons or, alternatively, is categorized as large (likely exceeds 1 million metric tons but is not well characterized) or small (likely is less than 100,000 metric tons). \%, percent; —, unknown; WGS 84, World Geodetic System of 1984]

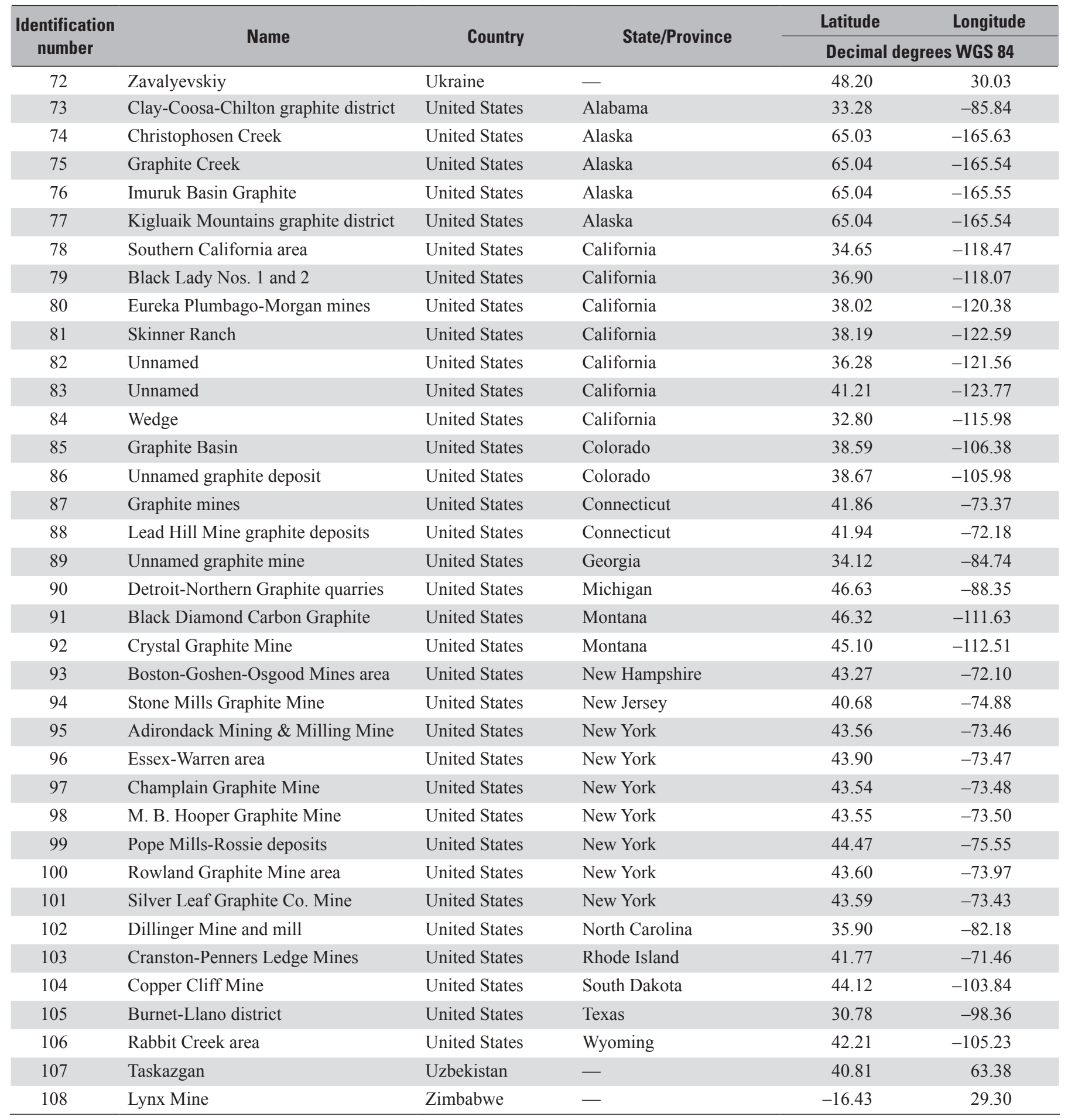


Table J3. Location, grade, tonnage and other data for selected graphite deposits and districts of the world.—Continued

[The names, locations, and descriptions of most of the deposits are taken from the International Strategic Minerals Inventory (ISMI) graphite inventory (Krauss and others, 1988) and the U.S. Geological Survey Mineral Resources Data System (MRDS; U.S. Geological Survey, 2012). Identification number is keyed to the deposits shown in figure J2. Negative values for latitude indicate that the deposit is in the Southern Hemisphere; negative values for longitude indicate that the deposit is in the Western Hemisphere. Record types are from the MRDS. Ore type is characterized as amorphous, crystalline, flake, or lump (includes chip), as defined in table J1. "Weathering" indicates surface ores that have been deeply weathered, which lowers mining costs. Development status of the deposit is given as follows: Current, current or recent mine activity; Past, past producer with no current mining; Prospect, an unmined deposit with characterized resources; Occurrence, an unmined deposit with uncharacterized resources. Tonnage of ore has been updated from the values in the MRDS and is given in metric tons or, alternatively, is categorized as large (likely exceeds 1 million metric tons but is not well characterized) or small (likely is less than 100,000 metric tons). \%, percent; —, unknown; WGS 84, World Geodetic System of 1984]

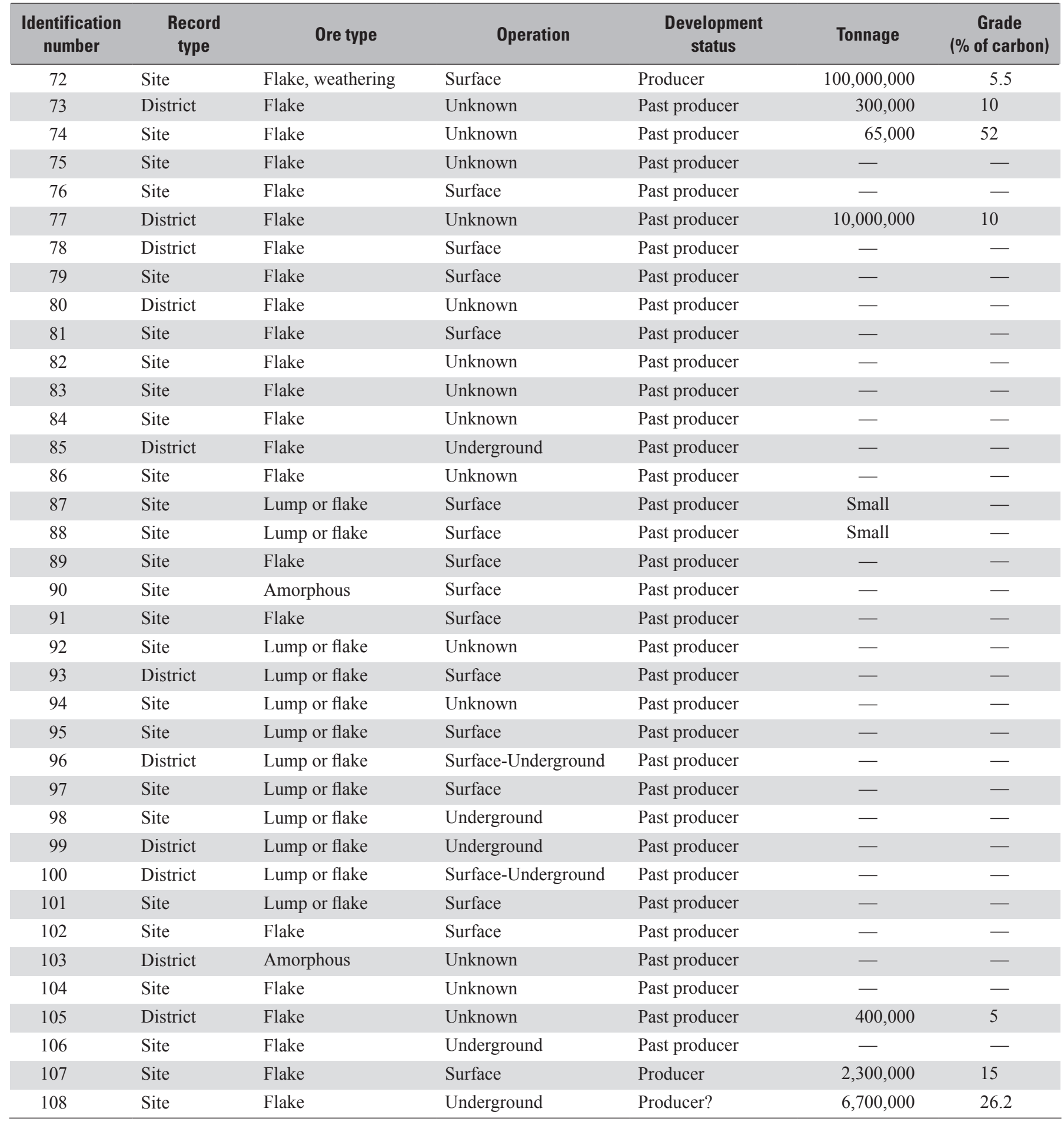




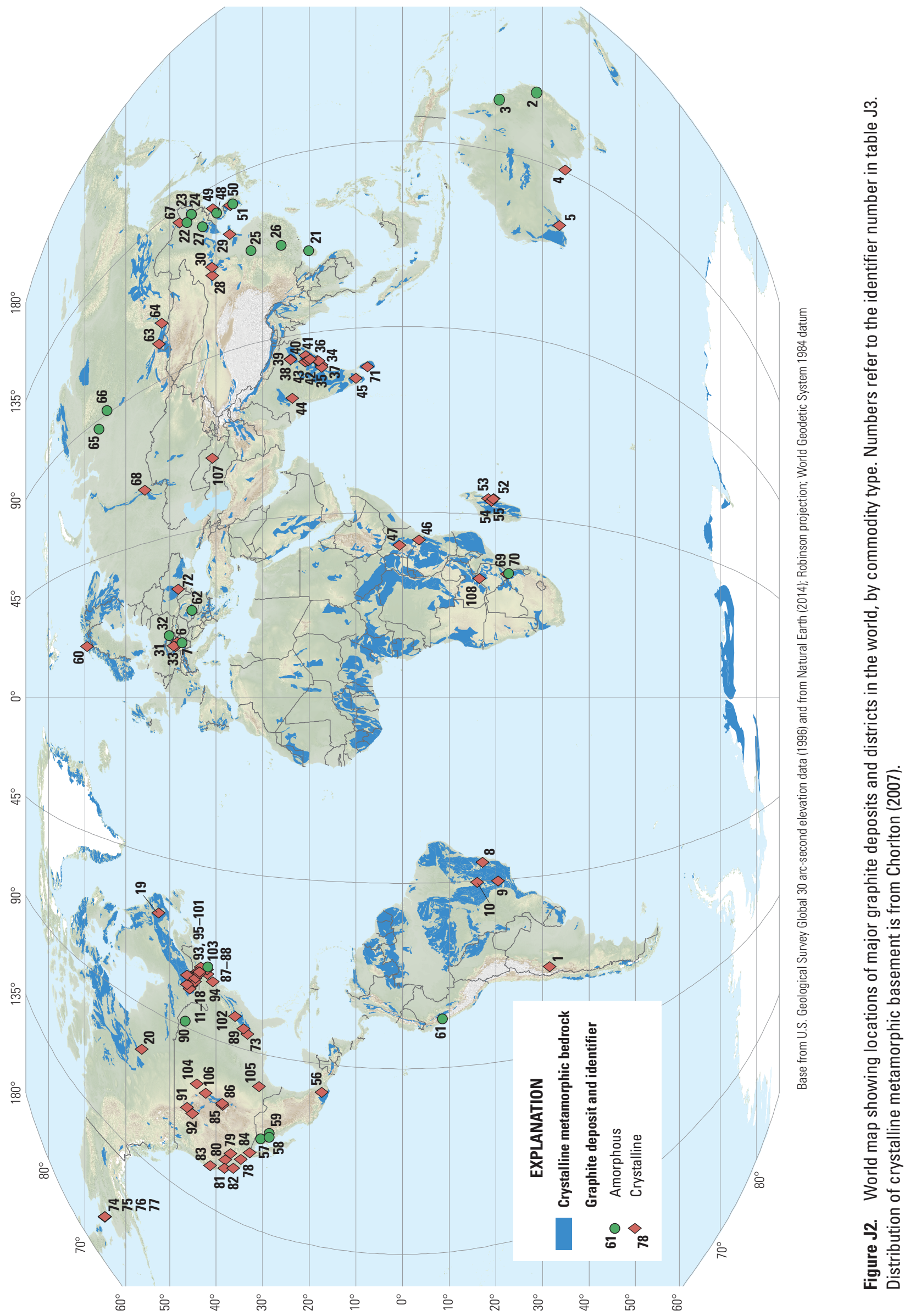


The world's main sources of crystalline flake graphite are the deposits in Brazil, Canada, China, India, and Madagascar. Probably the largest resources of high-grade crystalline flake graphite in the world are in China (Jixi district) and the island country of Madagascar. The deposits in both areas occur in belts of Neoarchean to late Proterozoic micaceous gneiss and schist that are interpreted to be associated with a series of mountain-building events related to the formation of the Gondwana supercontinent about 600 million years ago (Wilde and others, 1999), named the Pan-African orogeny. Pan-African age supracrustal metamorphic belts also occur in areas in Western Australia, eastern India, and Sri Lanka; these areas also host significant flake graphite deposits located in the most productive graphite-bearing regions of the world (fig. J2).

Graphite-rich horizons in Madagascar occur over a distance of more than $800 \mathrm{~km}$ in the eastern half of the island. Individual deposits are graphite-rich layers that range from $3 \mathrm{~m}$ to more than $35 \mathrm{~m}$ in thickness and extend up to a few kilometers. Ore grades average 4 to 10 percent graphite, but grades are reported to be as high as 60 percent in some areas. The flake graphite deposits in the State of Minas Gerais, Brazil, are mined from graphite-bearing soils overlying extensively weathered host rock with grades of 12 to 16 percent graphite; the ore is mined by front-end loader or shovel. Shandong Province in China is a major flake graphite producer. The flake graphite deposits in the vicinity of Jixi, China, are mined from deformed lenses and discordant layers of graphite schist and gneiss in paragneiss; graphite content ranges from 15 percent in the gneiss to up to 45 percent in the schists, with local flake graphite resources exceeding 360 million metric tons (Wilde and others, 1999). Little is known about the deposits in Russia and India.

Large disseminated flake graphite deposits occur at a number of places in the Grenville Province metamorphic belt in Canada's Quebec and southeastern Ontario Provinces, and small deposits associated with Grenville series marble, gneiss, and pegmatites also occur in the Adirondack Mountains west and northwest of Ticonderoga, New York (Alling, 1918). The Grenville Province is a southwest-trending belt of deformed high-grade supracrustal metamorphic rocks of Mesoproterozoic age that is exposed across 2,000 km from Labrador, through Quebec, into southeastern Ontario, and continues in the subsurface a further $3,000 \mathrm{~km}$ to Texas and Mexico. The Lac Knife graphite deposit at Fermont, Quebec, has high-grade ore hosted by migmatized quartz-feldspar (biotite) gneiss. The host rock is the southern extension of carbonaceous shales and sandstones that have been deformed and metamorphosed in the crosscutting Grenville Province metamorphic belt.

Deposits of flake graphite in the United States have been mined in Alabama, Alaska, and Texas. The deposits of the Clay-Coosa-Chilton graphite district, Alabama, occur in two parallel layers and lenses in the Ashland quartz-mica schist that contain 1 to 5 percent disseminated flake graphite (Pallister and Thoenin, 1948). The layers and lenses range from $6 \mathrm{~m}$ to more than $35 \mathrm{~m}$ in thickness, dip gently, and occur in a northeast-trending 1- to 3-km-wide belt that extends for more than $90 \mathrm{~km}$. The deposits are weathered to depths of $35 \mathrm{~m}$. The deposits in the Burnet-Llano district, Texas, occur in the Precambrian Packsaddle schist and show a wide range of graphite content and flake size (Needham, 1946). The graphite flake deposits in the Kigluaik Mountains graphite district, Alaska (Coats, 1944) represent the largest known domestic graphite resource, but are located in a rugged and remote area with high mining costs.

\section{Vein Deposits Containing Lump or Chip Graphite}

Crystalline graphite of the lump or chip commodity type is generally found in well-defined veins composed almost entirely of graphite that cut high-grade metamorphic rocks or as accumulations along intrusive contacts of pegmatites with marbles or paragneiss. The veins form in high-grade regional metamorphic environments where metasedimentary belts are invaded by igneous rocks. In some areas, the veins are localized in granulite-facies domains within the broader regional metamorphic belt (Chamberlain and Rumble, 1988).

Graphite-bearing veins form within or crosscut metamorphic structures, rock contacts, and folds. The veins range from thin films to massive bodies that are more than $3 \mathrm{~m}$ thick and may extend for hundreds of meters, although they usually extend for less than tens of meters. The veins consist largely of coarse, platy, or needlelike interlocking crystals of graphite. Mineral impurities depend largely upon the host rock; quartz, feldspar, pyroxene, and calcite are common. Ore grades range from 40 to more than 90 percent graphitic carbon; the percentage largely depends on the amount of wallrock contained with the ore material. Hand sorting may be required to provide lump concentrates of high purity.

Graphite vein deposits are found in similar settings as disseminated flake graphite deposits, and they may be spatially associated with them. The Sri Lankan graphite deposits, which are the only economically significant examples of the vein-type deposits, occur in high-grade metamorphic rocks of Neoarchean to Proterozoic age. Most vein deposits and prospects occur in crystalline metamorphic basement rocks of Neoarchean to late Proterozoic age, although deposits may be of any age. The graphite in these deposits occurs as veins in fractures and structures that are emplaced near or after peak metamorphic conditions.

It is clear that the carbon in the vein deposits has been transported by metamorphic or replacement processes, presumably aided by metamorphic or other fluids; however, the nature of the processes responsible for the precipitation of graphite in the veins is uncertain and controversial, and may vary between deposits. Most veins are hosted in high-grade metamorphic rocks; however, graphite precipitation may take place after the most intense deformation and thermal conditions of regional metamorphism have been achieved, as suggested by the localization of veins in brittle structures that are not disturbed by penetrative deformation associated with metamorphism and veins that crosscut syntectonic intrusives 
(Rumble and Hoering, 1986; Rumble and others, 1986). In some veins, low-temperature minerals, such as prehnite, occur with graphite. Textural evidence and age determinations on zircon inclusion rims in graphite (Zeitler and others, 1990), however, indicate that some veins were emplaced during or soon after peak metamorphic conditions and that the hydrothermal systems responsible for vein formation may also be responsible for the high-grade metamorphic conditions found in their immediate vicinity (Chamberlain and Rumble, 1988). Carbon isotope studies of the vein deposits show a wide range in isotopic composition between and within districts; this variation may be explained by varying carbon sources from two crustal reservoirs: (a) reduced biogenic carbon, and (b) carbonate minerals (Rumble and Hoering, 1986). The most probable processes resulting in graphite precipitation in veins likely include rock-fluid redox reactions, such as oxidation of methane $\left(\mathrm{CH}_{4}\right)$-bearing fluids or reduction of $\mathrm{CO}_{2}$-bearing fluids by wall rock (internal or external buffering), cooling of hot fluids saturated with respect to graphite, and mixing of fluids with differing $\mathrm{CH}_{4}$ and $\mathrm{CO}_{2}$ contents (Rumble and others, 1986).

The United States has small graphite vein deposits in New Hampshire, Connecticut, the Adirondacks of New York, and Montana; these deposits are largely of only scientific interest. The Crystal Graphite Mine near Dillon, Montana, is the largest known graphite vein deposit in the United States. At this deposit, veins up to $60 \mathrm{~cm}$ thick and $15 \mathrm{~m}$ long occur in fractures in gneiss and pegmatite (Bastin, 1912); the fractures and veins formed after the peak of metamorphism in these rocks (Ford, 1954).

\section{Mining and Beneficiation Methods}

Natural graphite is mined from both open pit and underground mine operations (table J3). Production from open pit operations is less expensive and is preferred where the overburden can be removed economically. Most crystalline flake deposits are mined using open pit methods; the exception is some steeply dipping bodies with high-grade minable lenses containing 15 percent or more contained carbon (table J3). Graphite is stable in the weathering environment, and intensely weathered crystalline flake deposits, such as those in Brazil, Kenya, Madagascar, and Oaxaca, Mexico, can be easily and profitably mined using open pit methods. Underground mining methods are used in some amorphous deposits in China, Europe, the Republic of Korea, and Mexico, and vein deposits in Sri Lanka, where the ore intervals are deep and of high grade ( $>80$ percent contained carbon). Beneficiation processes for graphite vary from simple hand sorting and screening of high-grade ore at some amorphous graphite deposits and at the Sri Lankan vein operations to multistage crushing, screening, washing, and flotation cycles required to produce high-quality and high-purity graphite flake and powder products. No refining of amorphous graphite ore is needed for most uses.

\section{Resources and Production}

\section{Distribution of Graphite Deposits and Districts}

The world map in figure $\mathrm{J} 2$ shows the location of 108 natural graphite deposits and districts characterized as: (a) amorphous deposits that result from thermal or contact metamorphism of highly carbonaceous sediments, usually graphitized coal beds, or (b) crystalline deposits of either disseminated flake graphite, which have resulted from regional metamorphism of carbonaceous sediments under conditions exceeding amphibolite facies, or coarse graphite aggregates (lump or chip) in fracture-filling veins cutting igneous and metamorphic rocks. Both of the crystalline deposit types (flake, or lump and chip) are mostly located in crystalline metamorphic bedrock (fig. J2), consisting primarily of coarsegrained quartzofeldspathic metasedimentary rocks at high metamorphic grades (Chorlton, 2007).

Table J3 describes the features of the 108 natural graphite deposits and districts shown in figure $\mathrm{J} 2$ that are known to have produced graphite or are significant prospects with potential for future development. A number of deposits and districts with past production, particularly those in the United States, have grade and tonnage characteristics that render the deposits subeconomic under current conditions; these are included to identify broad areas and regions that may be future sources of graphite production or may contain undiscovered deposits. The names, locations, and descriptions of most of the deposits in table J3 are taken from the International Strategic Minerals Inventory (ISMI) graphite inventory (Krauss and others, 1988) and the U.S. Geological Survey Mineral Resources Data System (MRDS) (U.S. Geological Survey, 2012). Figure J3 shows the deposit grade (percent carbon) and tonnage reported for some of the deposits in table J3, characterized by deposit type. The lowest tonnage and grade deposits in figure $\mathrm{J} 3$ are

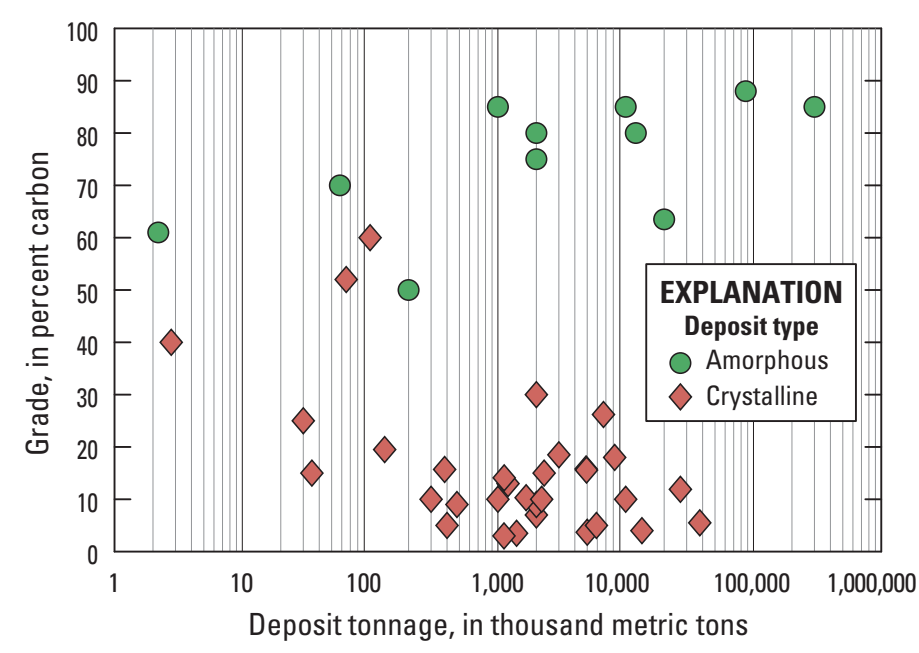

Figure J3. Plot of grade (carbon) and tonnage for some of the amorphous and crystalline graphite deposits listed in table $\mathrm{J} 3$, by deposit type. The table also gives additional resource data, and sources. 
subeconomic under current market conditions; typical ranges of commercial grades and deposit tonnage, by commodity type, are given in table J1.

\section{World Graphite Production and Resources}

Natural graphite is produced by more than 20 nations, but world production is dominated by China, India, and Brazil. Figure J4 shows the average level and amounts of natural graphite produced worldwide by area from 2006 to 2010, based on data from Olson (2011). During this period, China accounted for approximately 67 percent of worldwide production of natural graphite, and established itself as the dominant exporter with the ability to set world prices. China became a major global supplier of graphite in the 1980s owing in part to very low production costs and aggressive marketing. India and Brazil are significant worldwide exporters of graphite whereas Mexico and Canada export mainly to the United States.

Global graphite resources are large relative to annual global consumption, and undoubtedly extensive, but their extent is poorly known because resources of industrial mineral commodities typically are not fully delineated and reported far in advance of development. Complete estimates of graphite resources are likely not available for any single major graphite district in the world. Table J4 tabulates conservative estimates for recoverable graphite resources for a number of major graphite-producing nations. Reserves of natural graphite (that is, the identified, delineated, and reported world resources that are considered to warrant economic exploitation at the time of reserve determination) are equivalent to 81 million metric tons. Approximately 26 percent of reserves are crystalline (flake and vein type [lump or chip]) graphite materials for which demand is increasing. Other identified resources beyond reserves ("Other identified resources" in table J4) are about an additional 1.4 billion metric tons, leading to an estimate of total identified graphite resources of approximately 1.5 billion metric tons worldwide. Approximately one-half of this total resource estimate is flake graphite. Future exploration is likely to result in the discovery of world resources that are many times this estimate; however, many new discoveries are likely to be located in remote areas with high mining costs and limited access to infrastructure and industrial markets that use graphite. The Lac Knife deposit in Quebec, Canada, is an example of a relatively recent discovery in a remote setting (Bonneau and Raby, 1990).
Future discoveries of amorphous and flake graphite deposits in the conterminous United States are likely to be limited by favorable geology and preexisting exploration coverage. The coal fields of the United States are well explored and delineated, and past igneous activity in the coalfields is either absent or of such limited scale that the chance of finding amorphous graphite deposits of commercial size and grade is negligible. Furthermore, with the exception of Alaska, crystalline metamorphic rocks that could potentially host flake and vein (lump or chip) graphite deposits have limited extent and exposure in the United States, and most of the crystalline basement that is present is well characterized. The identified flake graphite deposits in the Kigluaik Mountains of Alaska indicate potential for additional deposits in surrounding areas; however, these are likely to occur in remote areas with rugged terrain and limited infrastructure, and such deposits would be a great distance from graphite markets and have high mining costs. The weathered low-grade crystalline flake deposit districts in Alabama and Texas may provide future domestic sources of graphite if flake graphite prices increase, because of the ease of mining the deposits and their proximity to markets.

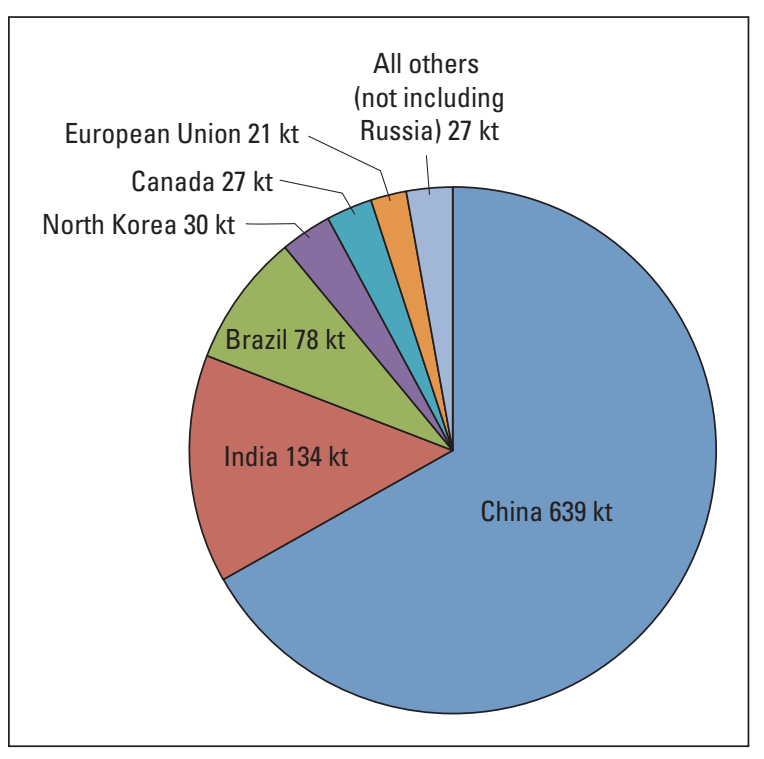

Figure J4. Pie chart showing average annual natural graphite production for the period 2006-10, by country or region and amount (in thousand metric tons $[k t]$ ). The tonnages are estimated based on data reported in Olson (2011). 
Table J4. Estimates of world graphite resources, by country, commodity type, and resource category, in thousand metric tons of recoverable graphite.

[Resources reported for recoverable amorphous, flake, or crystalline (vein-type) commodity categories. Resource categories: (a) Reserves are demonstrated resources of recoverable natural graphite considered to warrant economic exploitation at the time of reserve determination; (b) Other identified resources are estimates of characterized recoverable resources beyond those reported as reserves; only part of this estimate would be economic; and, (c) Total identified resources includes reserves and other identified resources. Data are adapted from Olson (2013) and Taylor (2006) and rounded to two significant figures. NA, not available]

\begin{tabular}{|c|c|c|c|c|}
\hline Country & Type & Reserves & $\begin{array}{l}\text { Other } \\
\text { identified } \\
\text { resources }\end{array}$ & $\begin{array}{c}\text { Total } \\
\text { identified } \\
\text { resources }^{1}\end{array}$ \\
\hline Austria & Amorphous & 50 & 1,100 & 1,200 \\
\hline Brazil & Flake & 360 & 3,400 & 3,800 \\
\hline Canada & Flake & 1,500 & 4,200 & 5,700 \\
\hline \multirow[t]{2}{*}{ China } & Amorphous & 55,000 & NA & NA \\
\hline & Flake & 6,000 & 350,000 & 360,000 \\
\hline Czech Republic & Flake & 900 & 12,000 & 13,000 \\
\hline Germany & Flake & 130 & 690 & 820 \\
\hline India & Flake & 735 & 13,000 & 14,000 \\
\hline Madagascar & Flake & 940 & 180,000 & 180,000 \\
\hline \multirow[t]{2}{*}{ Mexico } & Amorphous & 3,100 & 10,000 & 13,000 \\
\hline & Flake & 106 & 320 & 430 \\
\hline \multirow[t]{2}{*}{ North Korea } & Amorphous & 1,000 & 30,000 & 31,000 \\
\hline & Flake & 700 & 1,400 & 2,100 \\
\hline Norway & Flake & 200 & 260 & 460 \\
\hline \multirow[t]{2}{*}{ Republic of Korea } & Amorphous & 20 & 2,100 & 2,100 \\
\hline & Flake & 6 & 74 & 80 \\
\hline Romania & Amorphous & 300 & NA & 300 \\
\hline \multirow[t]{2}{*}{ Russia, with Ukraine } & Amorphous & 1,000 & 560,000 & 560,000 \\
\hline & Flake & 6,400 & 94,000 & 100,000 \\
\hline \multirow[t]{2}{*}{ Sri Lanka } & Crystalline, vein & 50 & 400 & 450 \\
\hline & Flake & 1,800 & 7,000 & 8,800 \\
\hline \multirow[t]{2}{*}{ United States ${ }^{2}$} & Amorphous & 0 & 5,900 & 5,900 \\
\hline & Flake & 0 & 280 & 280 \\
\hline Zimbabwe & Flake & 600 & 1,200 & 1,800 \\
\hline Other & Flake & 280 & 920 & 1,200 \\
\hline Total & Amorphous & 60,000 & 750,000 & 810,000 \\
\hline Total & Flake & 21,000 & 670,000 & 690,000 \\
\hline Total & Crystalline, vein & $\mathbf{5 0}$ & 400 & 450 \\
\hline Total & By resource category & 81,000 & $1,400,000$ & $1,500,000$ \\
\hline
\end{tabular}

${ }^{1}$ Total identified resources includes reserves and other identified resources.

${ }^{2}$ Other identified resources includes Alabama, Alaska, and New York. 


\section{Exploration for New Deposits}

Prospecting for graphite deposits consists primarily of outcrop examination, trenching, and sampling, usually followed by drilling. Because of its chemical inertness, graphite resists weathering, and outcrops containing graphite and residual soils containing conspicuous graphite flakes may be evident. Knowledge of areal geology and the geologic features and settings of different graphite deposit types and associated deposits, such as coal, can be used to identify promising exploration targets. The Lac Knife flake graphite deposit was initially discovered during routine geologic mapping. When interest developed, the prospect was trenched by shovel, followed by further surface excavation, and later systematically characterized at depth by more than 99 drill holes. All this activity occurred during a more than 30-year time period (Bonneau and Raby, 1990).

Because of the high electrical conductivity of graphite (in deposits where individual graphite flakes are touching), a variety of electromagnetic methods have been used to search for deposits, principally flake graphite deposits. Electro-magnetic geophysical methods measure variations in the electrical conductivity of the ground caused by changes in mineral content, properties, or subsurface features. The methods rely on the process of electromagnetic induction that describes how a conductive material, such as graphite, will interact with a magnetic field. Surveys are conducted by using either surface or airborne methods; all methods use a transmitter and receiver coil spaced in standard configurations. The different methods use different operating frequencies to provide a range of depth penetrations and resolution needed for different applications. High-frequency electromagnetic systems are best for locating small shallow targets; lower frequency systems are used to investigate deeper subsurface conditions or define regional targets. The relative merits of various geophysical techniques in detecting graphite deposits are discussed by Goosens (1982, p. 136).

Graphite flakes may be found in stream sediment samples collected during exploration geochemical surveys. The presence of sulfides and vanadium-bearing garnet (goldmanite) may also be an indicator. There is a positive correlation between carbon, uranium, and vanadium contents in some deposits (Li and others, 1985), and positive vanadium, nickel, and (or) uranium anomalies in soil associated with graphite beds were reported by Tichy and Turnovec (1978) and may be considered a geochemical indicator of graphite deposits. These geochemical features probably relate to the depositional environment and trace element content of the protolith and likely vary among deposits. Therefore, it may be difficult to use these features effectively in grassroots exploration for graphite deposits.

\section{Environmental Considerations}

Because of the chemically inert, nontoxic nature of graphite, the main environmental concerns associated with graphite mining are (a) the presence of other minerals that can occur with graphite, and (b) inhalation of graphite particles or fine-grained silica minerals in graphite during mining and processing. For example, the iron sulfide minerals pyrite and pyrrhotite are present in amounts ranging from a trace to several percent in some graphite deposits. These minerals can cause acid-rock drainage if exposed to air and water in waste rock or tailings. Graphite in soils and stream or river sediments is inert and poses no known terrestrial or aquatic risks.

\section{Mine Waste Characteristics}

The volumes and mineralogical characteristics of mine wastes depend on the size and type of deposit, as well as the mining and processing practices employed. For open pit mines, the amount of overburden that must be stripped prior to the onset of mining contributes to the mine waste. Ore processing for disseminated flake graphite typically includes milling, flotation, screening, and drying. The resulting mine waste and flotation tailings are composed of the minerals that make up the host rocks, typically schists and gneisses composed mainly of quartz and feldspars. Other silicate minerals in these rocks include pyroxenes, amphiboles, micas, garnet, and sillimanite. These are all moderate- or slow-weathering minerals (Jambor, 2003). Quartz persists in the environment, whereas feldspars weather to clays. Fast-weathering, potentially acid-producing sulfide minerals, such as pyrite and pyrrhotite, are reported at some deposits. The yellow iron sulfate mineral jarosite, which is an indicator of acidic conditions, is a common weathering product of pyritic, gneiss-hosted graphite deposits (Simandl and Kenan, 1997b). Calcite and other carbonate minerals may be present in gangue and can provide acid neutralization if present in sufficient amounts.

The largest known flake graphite deposit, the Zavalyevskiy deposit in Ukraine, has total resources on the order of 100 million metric tons with reserves of 6.4 million metric tons containing 5 to 7 percent graphite (Zavalyevskiy Graphite Ltd., 2013). The ore is kaolinized gneiss that contains garnet, biotite, chlorite, pyroxene, quartz, and sillimanite. Both garnet and crushed stone products are recovered from the ore. The graphite ore is processed by flotation to produce a high-purity graphite concentrate (86 to 97 percent graphite) and ash (10 to 13 percent graphite). Graphite orebodies in graphite schist at the Liu Mao Mine in China are elevated in vanadium ( 0.2 percent vanadium pentoxide $\left.\left[\mathrm{V}_{2} \mathrm{O}_{5}\right]\right)$, titanium $\left(0.5\right.$ percent titanium dioxide $\left.\left[\mathrm{TiO}_{2}\right]\right)$, and uranium ( 0.004 percent $\mathrm{U})$. These elemental concentrations 
are attributed to garnet intergrown with graphite in the deposit (Wilde and others, 1999). In Canada, a composite grab sample for metallurgical testing at the Trout Lake (also known as Treelined Lake) graphite prospect in southern Ontario contains 1.8 percent sulfur, which is attributed to 4.5 percent pyrrhotite in the sample; the preliminary test indicated that pyrrhotite removal by screening and flotation would be required to obtain a salable graphite product (Kuehnbaum and Zebruck, 2002). At the Bissett Creek flake graphite deposit in Ontario, both ore and waste rock are recognized as potential acid generators (Systèmes Gèostat International Inc., 2007). The graphite occurs in a calcareous biotite-amphibole-quartzofeldspathic gneiss with disseminated graphite, pyrite, pyrrhotite, and trace chalcopyrite. Graphite concentrations range from about 1 to 10 percent; the sulfide minerals constitute 1 to 5 percent of the rock. Mine plans call for underwater tailings storage and the addition of carbonate-bearing material to the waste dump to neutralize acid potential. In contrast, at the Eagle deposit in British Columbia, high-purity flake graphite is quarried from quartz-rich sands, and slightly alkaline sand and aggregate byproducts are marketed as construction materials.

Amorphous graphite deposits range from about 300 to 800 million metric tons of ore and have higher average graphite grades than other types of graphite deposits (table J1). The ore is essentially the entire graphitized unit. The associated waste primarily is any overburden that must be removed to access the deposit. Mineral impurities in amorphous graphite deposits reflect the compositions of the protolith coal or sediment (Simandl and Kenan, 1997a). In the Bohemia region of the Czech Republic, elevated concentrations of vanadium and nickel anomalies are associated with amorphous graphite deposits (Tichy and Turnovec, 1978). Waste material described as graphite gangue at the Jixi deposit in China contains zinc, nickel, and mercury (Liu and Man, 2007).

Vein graphite from Sri Lanka, which is significant for its purity and high degree of crystallinity, is mined underground at the Bogala Mine (370 m deep) and Kahatagaha-Kolongaha Mine (650 m deep). Total inferred reserves for these two mines are about 400,000 metric tons. At these mines, graphite veins are blasted with dynamite. When the fumes clear, the ore is hauled to the surface and then hand cobbed and graded; no further processing is required, so no tailings or large waste piles are produced (Ranasinha and Uragoda, 1972). Hydrothermal minerals associated with the graphite from Sri Lanka include apatite, biotite, calcite, chalcopyrite, pyrite, and quartz. The average chemical contents reported for different vein graphite morphologies from the Bogala and the Kahatagaha-Kolongaha Mines reported by Touzain and others (2010) are as follows: 93 to 99 percent carbon, 0.06 to 1.06 percent iron oxide $\left(\mathrm{Fe}_{2} \mathrm{O}_{3}\right), 0.05$ to 0.45 percent silicon dioxide $\left(\mathrm{SiO}_{2}\right), 0.01$ to 0.19 percent sulfur, and 0.004 to 0.82 percent calcium oxide $(\mathrm{CaO})$.

\section{Human Health Concerns}

The primary human health concern associated with graphite mining is inhalation of dust and fumes generated during mining and processing. Graphite is not considered to be toxic and is not a listed carcinogen, although crystalline silica (a common impurity in graphite) is considered to be carcinogenic. Graphite is considered a nuisance dust. The time-weighted average (TWA) recommended exposure level set by the U.S. National Institute for Occupational Safety and Health (NIOSH) is 2.5 milligrams per cubic meter.

Chronic exposure to graphite dust is associated with pneumoconiosis, a group of lung diseases associated with chronic exposure to mineral and metallic dusts. Graphite pneumoconiosis was recognized in the 1940s in graphite workers in Sri Lanka based on similarities to pneumoconiosis in coal miners (Uragoda, 1997). The fact that graphite always contains some quartz (typically about 2 percent but up to 10 percent) raised concerns that graphite pneumoconiosis was actually a slow developing form of silicosis (Ranasinha and Uragoda, 1972). A review of 605 cases of graphite pneumoconiosis reported in the literature and experimental studies on animals concluded that although many years of occupational exposure to pure graphite may cause disease, most studies indicate that mixed-dust inhalation is a more likely cause of lung disease (Hanoa, 1983). Implementation of dust abatement protocols in mining and processing has resulted in decreased incidence of lung disease in graphite workers since the 1970s.

\section{Ecological Health Concerns}

The environmental fate and effects of dispersed graphite flakes were addressed in a study of the use of graphite flakes in a dust cloud to obscure visual and electromagnetic observation of military operations under battlefield conditions (Driver and others, 1993). Graphite mixed with fog oil and dispersed as an aerosol provides a chemically inert obscurant used to protect movements of troops and equipment. Dispersion of airborne plumes of these mixtures can deposit graphite on soil, vegetation, and water surfaces or pose inhalation risks to wildlife. Although obscurant releases are short-term events ( $\sim 30$ minutes), airborne distribution and surface deposition of flake graphite can occur many kilometers downwind of the release site. Deposited graphite persists in the environment, so the repeated use on military training sites warranted an evaluation of potential ecological impacts. These studies are not directly applicable to graphite mining and processing, but they do demonstrate that graphite flakes likely pose little or no chemical risk to the environment. The series of experiments described by Driver and others (1993) showed that (a) graphite flakes are not toxic to soil invertebrates (oligochaeta, or earthworms), (b) no adverse effects on terrestrial plants (corn and cucumber) were noted in soils amended with graphite flakes in 
concentrations up to 0.5 percent, by weight, and (c) a 48-hour acute aquatic toxicity test toward daphnia (water fleas) using graphite suspensions was toxic; however, iron contaminants in the graphite may explain the toxicity. The long-term effects of obscurant flake graphite on exposed avian and mammalian wildlife are unknown.

\section{Carbon Footprint}

The term "carbon footprint" refers to the amount of carbon dioxide $\left(\mathrm{CO}_{2}\right)$ emitted in a 1-year period. According to GrafTech International Holdings, Inc. (2013), natural graphite has a substantially lower carbon footprint for both $\mathrm{CO}_{2}$ emissions and energy consumption during mining and processing than other mineral commodities for which data are available, such as aluminum or copper, on an equivalent mass, volume, or yearly production basis. Cost- and energy-efficient technologies that could reduce $\mathrm{CO}_{2}$ to synthetic graphite could lower $\mathrm{CO}_{2}$ emissions and produce inert graphite, providing an industrial option to sequester carbon from the atmosphere (Xu and others, 2005).

\section{Regulatory and Environmental Considerations}

The environmental requirements for natural graphite, which is an inert, nontoxic substance, are limited to dust control and control of organic vapors that may arise during mining or processing of graphite ores or the fabrication of graphite products. Given the current and likely future absence of graphite mining in the United States, no other domestic regulatory or environmental requirements are anticipated.

\section{Problems and Future Research}

Major shifts in U.S. consumption of natural graphite by end use are underway and include a long-term decrease in the use of amorphous graphite for refractory and other applications and an increase in the use of flake graphite, particularly for emerging energy and high-technology applications (Taylor, 2006). In addition, shifts in the global graphite supply and exports are anticipated as China's rapidly growing domestic market for graphite, coupled with their developing mine production problems and rising labor costs, may serve to limit Chinese exports in the future, particularly of crystalline flake graphite; meanwhile, anticipated large-scale fuel cell and battery applications could dramatically increase world demand for graphite (Taylor, 2006; Olson, 2013; Olson and others, 2016). For the near future, however, China's graphite production is expected to increase and its dominance of world production to continue (Olson, 2013). Possible disruptions to global supplies are likely to be temporary or sporadic because identified reserves in China are sufficient to support new mines and additional production. In addition, exploration for new flake graphite deposits is ongoing, and additional deposits are near development in Canada and elsewhere (Olson, 2013; Olson and others, 2016).

Other than scientific studies on some vein graphite deposits of scientific (not commercial) interest, little recent geologic characterization and study has been undertaken on graphite deposits in the United States, and exploration for new deposits has not taken place. The lack of exploration is chiefly because known deposits are considered noncommercial, large areas of the country lack the geologic conditions and settings thought necessary to form economic graphite deposits, graphite supplies have been reliably available from foreign sources for many years, and synthetic graphite is increasingly used for many applications. As earlier noted by Weis (1973), research and development of better techniques to beneficiate low-grade flake graphite ores would be needed to support a viable domestic industry.

Studies on the temporal variation of carbon deposition and preservation and the behavior of organic matter and graphite under metamorphic and hydrothermal conditions might provide additional insights into the occurrence and distribution of high-grade flake graphite deposits. Many of the important flake graphite deposits worldwide occur in Precambrian crystalline metamorphic rocks, and most of these occur in Pan-African age supracrustal metamorphic belts. In addition, many of these deposits have grades exceeding 15 percent contained carbon, which exceeds the typical carbon content range of organic-bearing shales (Vine and Tourtelot, 1970). It is not known whether these deposits represent unusual protoliths - for example, saprolitic alginate (oilshale), unusual periods or regions of biological productivity and preservation of organic matter, or if they record some carbon enrichment owing to mechanical deformation or precipitation of graphite by processes involving internal or external buffering or mixing of metamorphic fluids. 


\section{References Cited}

Note: All Web links listed were active as of the access date but may no longer be available.

Alling, H.L., 1918, The Adirondack graphite deposits: Albany, N.Y., New York State Museum Bulletin 199, 172 p.

Bastin, E.S., 1912, The graphite deposits of Ceylon, with a description of a similar graphite deposit near Dillon, Montana: Economic Geology, v. 7, p. 419-443.

Bonneau, J., and Raby, R., 1990, The Lake Knife graphite deposit: Mining Magazine, v. 163, no. 1, p. 12-18.

Chacko, T., Kumar, G.R.R., and Newton, R.C., 1987, Metamorphic P-T conditions of the Kerala (South India) khondalite belt, a granulite facies supracrustal terrain: The Journal of Geology, v. 95, no. 3, p. 343-358.

Chamberlain, C.P., and Rumble, D., 1988, Thermal anomalies in a regional metamorphic terrain-An isotopic study of the role of fluids: Journal of Petrology, v. 29, p. 1215-1232.

Chorlton, L.B., 2007, Generalized geology of the worldBedrock domains and major faults in GIS format; a smallscale world geology map with an extended geological attribute database: Geological Survey of Canada Open File 5529, 48 p., CD-ROM.

Coats, R.R., 1944, Graphite deposits on the north side of the Kigluaik Mountains, Seward Peninsula, Alaska: U.S. Geological Survey Open-File Report 10, 8 p.

Driver, C.J., Ligotke, M.W., Landis, W.G., Downs, J.L., Tiller, B.L., Moore, E.B., Jr., and Cataldo, D.A., 1993, Environmental and health effects review for obscurant graphite flakes - Report prepared for the U.S. Army Chemical and Biological Defense Agency: Richland, Wash., Pacific Northwest Laboratory, 28 p.

European Commission, 2014, Critical raw materials for the EUReport of the ad-hoc Working Group on defining critical raw materials: Brussels, Belgium, and Luxembourg, Luxembourg, European Commission, 41 p., accessed September 19, 2015, at http://ec.europa.eu/growth/sectors/raw-materials/ specific-interest/critical/index_en.htm.

Ford, R.B., 1954, Occurrence and origin of the graphite deposits near Dillon, Montana: Economic Geology, v. 49, p. $31-43$.

Goosens, P.J., 1982, Graphite deposits of the Precambrian and their mining development, in Natural Resources and Energy Division, United Nations Department of Technical Cooperation for Development, The development potential of Precambrian mineral deposits: New York, N.Y., Pergamon Press, p. 123-155.
GrafTech International Holdings, Inc., 2013, About natural graphite: GrafTech International Holdings, Inc., accessed September 19, 2015, at http://aetpublic.wiredviews.com/ getdoc/411491a4-0d68-4781-993e-7d992adfa2d4/TradeShows.aspx.

Hanoa, Rolf, 1983, Graphite pneumoconiosis - A review of etiologic and epidemiologic aspects: Scandinavian Journal of Work, Environment, and Health, v. 9, no. 4, p. 303-314.

Hoefs, J., and Frey, M., 1976, The isotopic composition of carbonaceous matter in a metamorphic profile from the Swiss Alps: Geochimica et Cosmochimica Acta, v. 40, p. 945-951.

Industrial Minerals, 2010, Graphite prices rising daily: Industrial Minerals, June 29, accessed September 15, 2019 , at http://www.indmin.com/Article/2620429/Graphite-pricesrising-daily.html.

Jambor, J.L., 2003, Mine-waste mineralogy and mineralogical perspectives of acid-base accounting, chap. 6 of Jambor, J.L., Blowes, D.W., and Ritchie, A.I.M., eds., Environmental aspects of mine wastes: Mineralogical Association of Canada Short Course Series, v. 31, p. 117-145.

Klar, G., 1958, The important graphite deposits of the world: Mining Magazine, v. 98, p. 137-142.

Krauss, U.H., Schmidt, H.W., Taylor, H.A., Jr., and Sutphin, D.M., 1988, International Strategic Minerals Inventory summary report-Natural graphite: U.S. Geological Survey Circular 930-H, 29 p. [Also available at https://pubs.er.usgs.gov/ publication/cir930H.]

Kuehnbaum, R., and Zebruck, G., 2002, Treelined Lake graphite deposit-Beneficiation study: Megagraphite Inc. Treelined Lake Project report, 10 p. plus details of tests, accessed September 19, 2015, at http:// www.geologyontario.mndmf.gov.on.ca/mndmfiles/afri/ data/imaging/52L08SW2010//52L08SW2010.Pdf.

Lamb, W., and Valley, J.W., 1984, Metamorphism of reduced granulites in low- $\mathrm{CO}_{2}$ vapor free environment: Nature (London), v. 312, November 1, p. 56-58. [Also available at http://dx.doi.org/10.1038/312056a0.]

Landis, C.A., 1971, Graphitization of dispersed carbonaceous material in metamorphic rocks: Contributions to Mineralogy and Petrology, v. 30, p. 34-45.

Li, C., Yue, J., and Zhang, Y., 1985, Research on geological background and origin of Liu Mao graphite deposits, Heilongjiang Province, in Cheng, Y., ed., International Symposium on Metallogeny of the Early Precambrian: Abstracts, Organizational Committee of the International Symposium of Metallogeny, China, p. 108-109.

Liu, Wen-yong, and Man, Xiu-liu, 2007, Evaluation and content of heavy metal pollution in mine areas wasteland of Jixi: Journal of Soil and Water Conservation, v. 6, p. 70-74. 
Natural Earth, 2014, Small scale data: Natural Earth map dataset, scale 1:110,000,000, accessed February 12, 2014, at http://www.naturalearthdata.com/.

Needham, A.B., 1946, Mining and milling operations of Southwestern Graphite Co., Burnet County, Texas: U.S. Bureau of Mines Information Circular 7339, 7 p.

Newton, R.C., 1986, Fluids of granulite facies metamorphism, in Walther, J.V., and Wood, B.J., eds., Fluid-rock interactions during metamorphism: Berlin, Springer, p. 36-59.

O'Driscoll, Mike, 2010, Minerals meet in Miami heat: Industrial Minerals, no. 510, February 25, accessed September 19, 2015, at http://www.indmin.com/ Article/2398524/Minerals-meet-in-Miami-heat.html/.

Olson, D.W., 2011, Graphite (natural): U.S. Geological Survey Mineral Commodity Summaries 2011, p. 68-69, accessed February 25, 2013, at https://minerals.usgs.gov/minerals/ pubs/commodity/graphite/mcs-2011-graph.pdf.

Olson, D.W., 2012, Graphite, in Metals and minerals: U.S. Geological Survey Minerals Yearbook 2010, v. I, p. 32.1-32.10, accessed November 12, 2012, at http://minerals.usgs.gov/minerals/pubs/commodity/ graphite/myb1-2010-graph.pdf.

Olson, D.W., 2013, Graphite (natural): U.S. Geological Survey Mineral Commodity Summaries 2013, p. 68-69, accessed February 25, 2013, at https://minerals.usgs.gov/minerals/ pubs/commodity/graphite/mcs-2013-graph.pdf.

Olson, D.W., Virta, R.L., Mahdavi, Mahbood, Sangine, E.S., and Fortier, S.M., 2016, Natural graphite demand and supply-Implications for electric vehicle battery requirements, in Wessel, G.R., and Greenberg, J.K., eds., Geoscience for the public good and global developmentToward a sustainable future: Geological Society of America Special Paper 520, p. SPE520-08, April 19, accessed June 30, 2016, at http://dx.doi.org/10.1130/2016.2520(08).

Pallister, H.D., and Thoenin, J.R., 1948, Flake graphite and vanadium investigations in Clay, Coosa, and Chilton Counties, Alabama: U.S. Bureau of Mines Report of Investigations 4366, $81 \mathrm{p}$.

Ranasinha, K.W., and Uragoda, G.G., 1972, Graphite pneumoconiosis: British Journal of Industrial Medicine, v. 29, p. $178-183$.

Roskill Information Services, Ltd., 2012, Natural and synthetic graphite - Global industry markets and outlook, 8th ed.: London, Roskill Information Services, Ltd., 413 p.

Rumble, D., III, and Hoering, T.C., 1986, Carbon isotope geochemistry of graphite vein deposits from New Hampshire, U.S.A.: Geochimica et Cosmochimica Acta, v. 50 , no. 6 , p. $1239-1247$.
Rumble, D., III, Duke, E.F., and Hoering, T.C., 1986, Hydrothermal graphite in New Hampshire-Evidence of carbon mobility during regional metamorphism: Geology, v. 14 , no. 6 , p. $452-455$.

Simandl, G.J., and Kenan, W.M., 1997a, Microcrystalline graphite, in Geological fieldwork 1997, British Columbia Ministry of Employment and Investment, Paper 1998-1, p. 24O-1-24O-3.

Simandl, G.J., and Kenan, W.M., 1997b, Crystalline flake graphite, in Geological fieldwork 1997, British Columbia Ministry of Employment and Investment, Paper 1998-1, p. 24P-1-24P-3.

Simandl, G.J., and Kenan, W.M., 1997c, Vein graphite in metamorphic terrains, in Geological fieldwork 1997, British Columbia Ministry of Employment and Investment, Paper 1998-1, p. 24Q-1 to 24Q-3.

Sutphin, D.M., 1991a, Descriptive model of amorphous graphite, Model 18k, in Orris, G.J., and Bliss, J.D., eds., Some industrial mineral deposit models - Descriptive deposit models: U.S. Geological Survey Open-File Report 91-11A, p. 9-10.

Sutphin, D.M., 1991b, Descriptive model of disseminated flake graphite, Model 37f, in Orris, G.J., and Bliss, J.D., eds., Some industrial mineral deposit models - Descriptive deposit models: U.S. Geological Survey Open-File Report 91-11A, p. 55-57.

Sutphin, D.M., 1991c, Descriptive model of graphite veins, Model 37g, in Orris, G.J., and Bliss, J.D., eds., Some industrial mineral deposit models-Descriptive deposit models: U.S. Geological Survey Open-File Report 91-11A, p. 58-60.

Sutphin, D.M., and Bliss, J.D., 1990, Disseminated flake graphite and amorphous graphite deposit types-An analysis using grade and tonnage models: Canadian Mining and Metallurgical Bulletin, v. 83, no. 940, p. 85-89.

Systèmes Gèostat International Inc., 2007, Preliminary assessment on the Bissett Creek graphite property of Industrial Minerals Canada: NI 43-101 technical report, prepared for Industrial Minerals Canada Inc.: Montreal, Canada, Systèmes Gèostat International Inc., November, 121 p.

Taylor, H.A., 2006, Graphite, in Kogel, J.E., Trivedi, N.C., Barker, J.M., and Krukowski, S.T., eds., Industrial minerals and rocks (7th ed.): Littleton, Colo., Society for Mining, Metallurgy, and Exploration Inc., p. 507-518.

Tichy, L., and Turnovec, I., 1978, On possible geochemical identification of graphite in south Bohemia [in Czech]: Geologicky Pruzkum, v. 20, p. 73-75.

Touzain, P., Balasooriya, N., Bandaranayake, K., and Descolas-Gros, C., 2010, Vein graphite from the Bogala and Kahatagaha-Kolongaha Mines, Sri Lanka-A possible origin: The Canadian Mineralogist, v. 48, no. 6 , p. 1373-1384. 
Uragoda, C.G., 1997, A cohort study of graphite workers in Sri Lanka: Occupational Medicine, v. 47, no. 5, p. 269-272.

U.S. Geological Survey, 1996, Global 30 arc-second elevation (GTOPO30): Reston, Va., U.S Geological Survey dataset (digital elevation model), accessed February 12, 2014, at https://lta.cr.usgs.gov/GTOPO30.

U.S. Geological Survey, 2012, Mineral Resources Data System: U.S. Geological Survey database, accessed April 4, 2012, at http://mrdata.usgs.gov/mrds/.

Vine, J.D., and Tourtelot, E.B., 1970, Geochemistry of black shale deposits - A summary report: Economic Geology, v. 65 , p. $253-272$.

Weis, P.L., 1973, Graphite, in Brobst, D.A., and Pratt, W.P., eds., United States mineral resources: U.S. Geological Survey Professional Paper 820, p. 277-283. [Also available at http://pubs.er.usgs.gov/publication/pp820.]
Wilde, S.A., Dorsett-Bain, H.L., and Lennon, R.G., 1999, Geological setting and controls on the development of graphite, sillimanite and phosphate mineralization within the Jiasmusi Massif-An exotic fragment of Gondwanaland located in north-eastern China?: Gondwana Research, v. 2, no. 1 , p. $21-46$.

Xu, A., Indala, S., Hertwig, T.A., Pike, R.W., Knopf, F.C., Yaws, C.L., and Hopper, J.R., 2005, Development and integration of new processes consuming carbon dioxide in multi-plant chemical production complexes: Clean Technology Environmental Policy, v. 7, p. 97-115.

Zavalyevskiy Graphite Ltd., 2013, Home page: Zavalyevskiy Graphite Ltd. Web site, accessed September 19, 2015, at http://zvgraphit.com.ua/en/.

Zeitler, P.K., Barreiro, B., Chamberlain, C.P., and Rumble, D., III, 1990, Ion-microprobe dating of zircon from quartz-graphite veins at the Bristol, New Hampshire, metamorphic hot spot: Geology, v. 18, p. 626-629. 


\section{Lithium}

By Dwight C. Bradley, Lisa L. Stillings, Brian W. Jaskula, LeeAnn Munk, and Andrew D. McCauley

Chapter K of

Critical Mineral Resources of the United States-Economic and Environmental Geology and Prospects for Future Supply

Edited by Klaus J. Schulz, John H. DeYoung, Jr., Robert R. Seal II, and Dwight C. Bradley

Professional Paper 1802-K

U.S. Department of the Interior

U.S. Geological Survey 


\section{Contents of Chapter K}

[Figure and table titles for all chapters are listed in the volume contents before the conversion factors table and list of abbreviations and symbols. A periodic table of the elements is on the inside front cover of the printed volume]

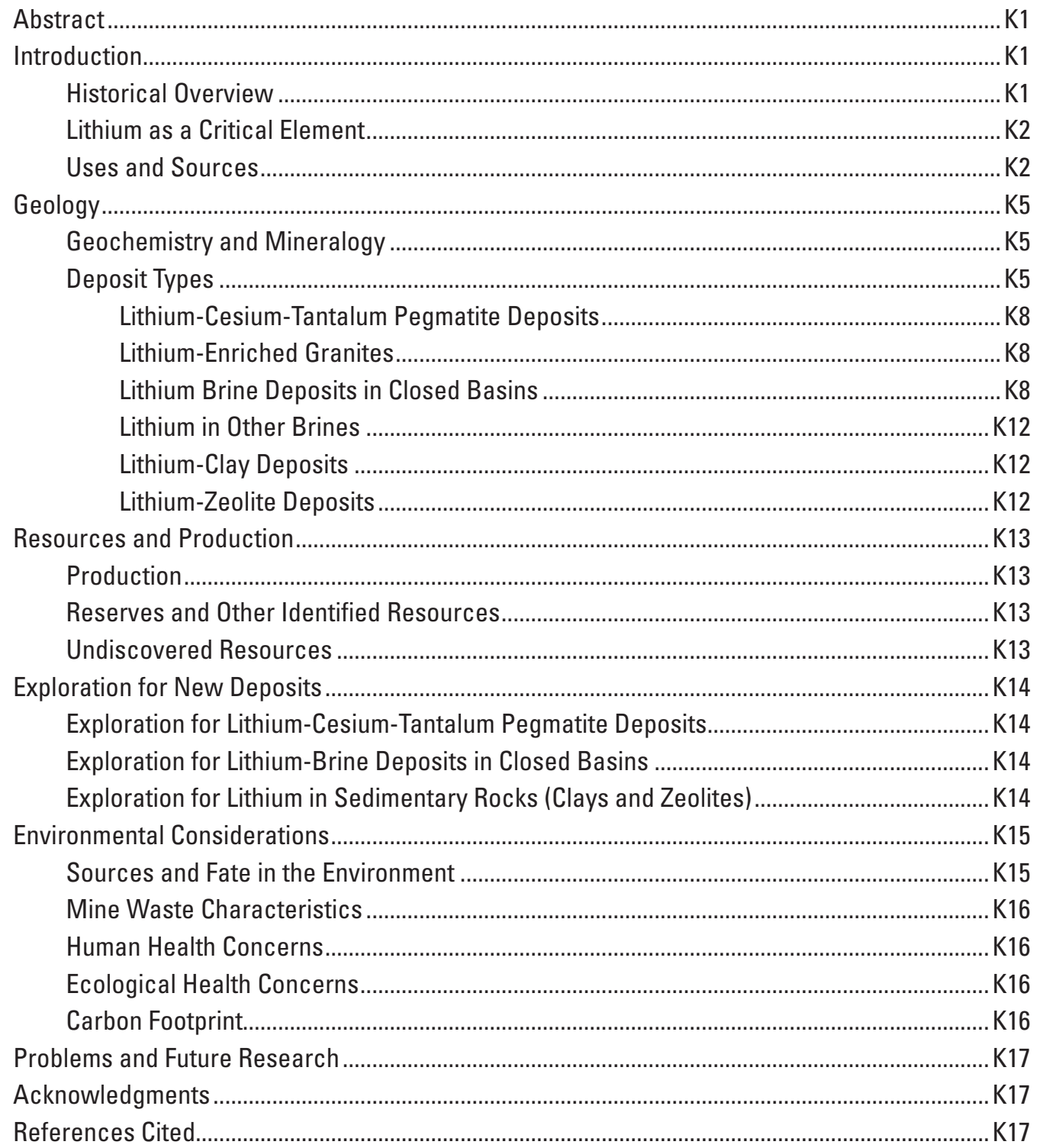




\title{
Lithium
}

\author{
By Dwight C. Bradley, Lisa L. Stillings, Brian W. Jaskula, LeeAnn Munk, and Andrew D. McCauley
}

\section{Abstract}

Lithium, the lightest of all metals, is used in air treatment, batteries, ceramics, glass, metallurgy, pharmaceuticals, and polymers. Rechargeable lithium-ion batteries are particularly important in efforts to reduce global warming because they make it possible to power cars and trucks from renewable sources of energy (for example, hydroelectric, solar, or wind) instead of by burning fossil fuels. Today, lithium is extracted from brines that are pumped from beneath arid sedimentary basins and extracted from granitic pegmatite ores. The leading producer of lithium from brine is Chile, and the leading producer of lithium from pegmatites is Australia. Other potential sources of lithium include clays, geothermal brines, oilfield brines, and zeolites. Worldwide resources of lithium are estimated to be more than 39 million metric tons, which is enough to meet projected demand to the year 2100 . The United States is not a major producer at present but has significant lithium resources.

\section{Introduction}

\section{Historical Overview}

Lithium (from the Greek lithos, for stone) is the first metal in the periodic table. It was recognized as an element in 1817 when the Swedish chemist Johan Arfvedson analyzed the mineral petalite. Useful amounts of lithium metal were first isolated in 1855 by August Matthiessen and, independently, by Robert Bunsen, after whom the Bunsen burner was named (Emsley, 2011). By this time, lithium had been found in other silicate minerals (lepidolite and spodumene) and had been detected in trace quantities in plants, seawater, spa waters, and the human body (Emsley, 2011). In 1869, Dmitiri Mendeleev correctly positioned it adjacent to the alkali metal sodium in his then-revolutionary periodic table of elements.

Petalite, lepidolite, and spodumene are found in granitic pegmatites. The first significant lithium mining began in 1898 at the Etta pegmatite in South Dakota. In the early 1900s, other pegmatite mines in California, South Dakota, and New Mexico also began lithium production, and the
United States dominated the global supply (Norton, 1973). The process of extracting lithium from brine was also first developed in the United States. The earliest production of lithium from brine took place in 1938 as a byproduct of sodium carbonate production at Searles Lake, California. A larger lithium-brine deposit at Clayton Valley, Nevada, began production in 1966. Today, brine resources dominate the lithium industry.

In the 1970s, when the U.S. Geological Survey (USGS) published Professional Paper 820, "United States Mineral Resources" (Brobst and Pratt, 1973), lithium was a relatively obscure mineral commodity that did not even warrant an entire chapter of its own (Norton, 1973). Since then, the global resource picture for lithium has changed considerably. In 1973, the United States was still the world's leading lithium producer; today, U.S. production lags far behind that of Chile, Australia, and several other nations. Additionally, two new classes of ore deposits - lithium clays and lithium zeoliteshave been recognized. Between 1975 and 2005, world lithium production increased by a factor of about five (fig. K1), and more growth is anticipated.

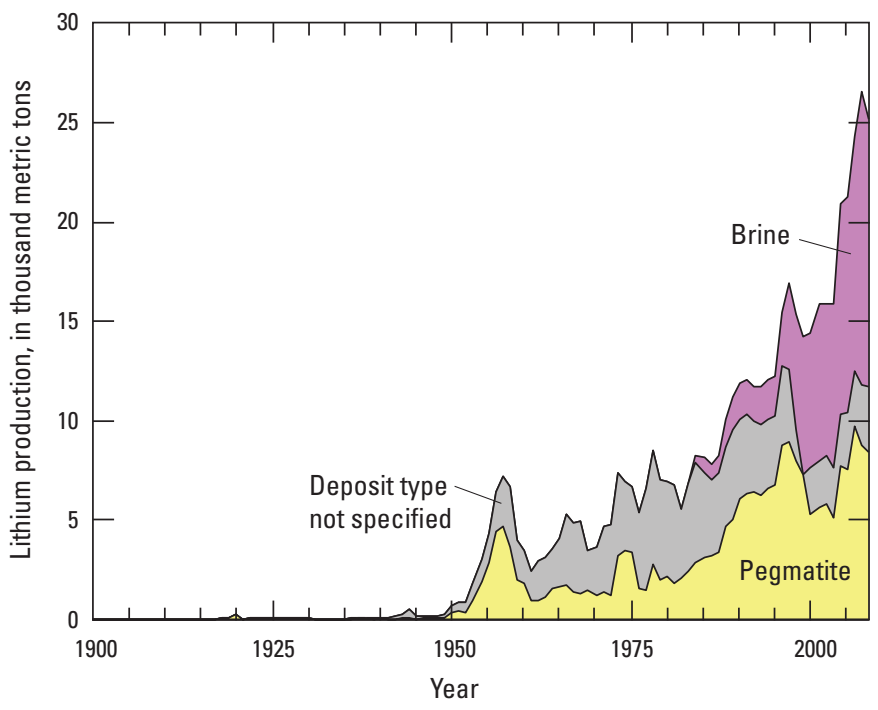

Figure K1. Graph showing world lithium production from 1900 to 2007, by deposit type and year. The layers of the graph are placed one above the other, forming a cumulative total. Modified from Mohr and others (2010). 
Many advances in understanding lithium geology were spurred by the 1973 oil embargo. Lithium was - and still is - seen as a strategic mineral commodity that could contribute toward U.S. energy independence. At that time, the USGS launched a major research effort on lithium resources that lasted for several years and involved dozens of researchers. Initial results were presented in a multichapter USGS Professional Paper (Vine, 1976), and final results were summarized by Vine (1980). After about 1980, national concerns about energy self-sufficiency ebbed, and studies in lithium-resource geology fell into neglect for more than a quarter century.

A recent revival of interest in lithium has been driven by the threat of global warming from the burning of fossil fuels, combined with the recognition that a transition to electric and hybrid vehicles, which are powered by lithium batteries, could substantially reduce the Nation's carbon footprint and its reliance on foreign oil (U.S. Department of Energy, 2010). Recent summaries of the global lithium resource picture include those by Evans $(2008,2012,2014)$, Yaksic and Tilton (2009), Mohr and others (2010), Gruber and others (2011), and Kesler and others (2012).

\section{Lithium as a Critical Element}

Lithium has been listed as one of the critical or nearcritical elements in various recent studies based largely on its importance in green technologies. It was one of the 15 mineral commodities studied by participating countries in the International Strategic Minerals Inventory (ISMI) of the 1980s and 1990s (Anstett and others, 1990). The National Research Council (2008) concluded that lithium, although not critical at the time of the 2008 assessment, could potentially become critical depending on the level of growth of new uses, such as hybrid vehicle batteries. In the U.S. Department of Energy's Critical Materials Strategy (2010), lithium is included as 1 of 16 key elements. The 2011 joint report of the American Physical Society Panel on Public Affairs and the Materials Research Society on energy-critical minerals included lithium as 1 of 29 key elements for green technology.

\section{Uses and Sources}

Lithium has many uses. Worldwide lithium consumption in 2013 by end use was estimated to be as follows (fig. K2): ceramics and glass, 35 percent; rechargeable batteries, 29 percent; lubricating greases, 8 percent; continuous casting mold flux powders, 6 percent; air treatment, 5 percent; and polymer production, 5 percent; primary batteries, 2 percent; primary aluminum production, 1 percent; and other uses, 9 percent (Merriman, 2014).

Ceramics and glass are expected to continue to be the leading end uses for lithium for years to come. In glassmaking (Garrett, 2004), lithium makes the process more economical by reducing the melting point and decreasing viscosity.

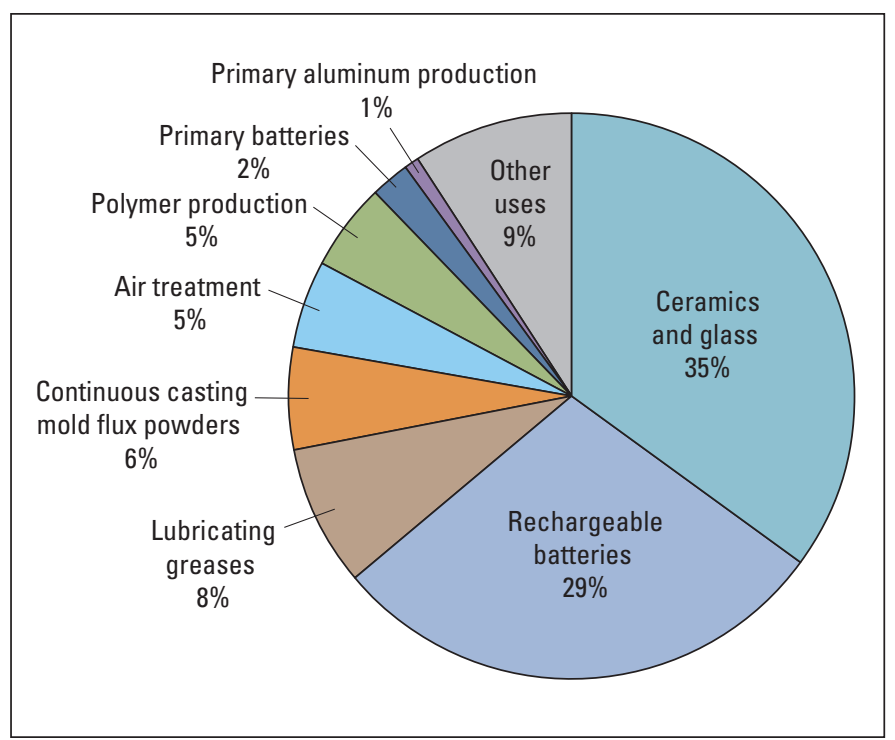

Figure K2. Pie chart showing major end uses of lithium as a percentage of world consumption in 2013. Data are courtesy of David Merriman, Roskill Information Services, Ltd., written commun., May 2014.

The addition of 0.1 to 4 percent lithium oxide $\left(\mathrm{Li}_{2} \mathrm{O}\right)$, to various glasses increases hardness and reduces thermal expansion. A common application is in glass stovetops; where ordinary window-glass would shatter, lithium-bearing glass can withstand large temperature swings and rough use. In the ceramics industry, lithium is used to make porcelain enamels, glazes, and tiles; as in glassmaking, a small amount of lithium lowers the melting temperature and reduces thermal expansion in the resulting ceramic product (Garrett, 2004).

Production of batteries, which currently rank second among the end uses of lithium, will likely see increased production in the next few years as the production of electric and hybrid vehicles increases. Production will result in increased capacity utilization of the vehicle battery plants that are currently being built worldwide. Battery manufacturing has the largest growth potential of any sector of the lithium industry; several major automobile companies are developing lithium-ion batteries (fig. K3H). Demand for rechargeable lithium batteries now exceeds that of rechargeable nonlithium batteries for use in cellular telephones, cordless tools, MP3 players, and portable computers and tablets. Nonrechargeable lithium batteries are used in calculators, cameras, and watches (Jaskula, 2013).

Other uses of lithium are not widely appreciated by consumers. Lithium is a minor but key ingredient in the electrolytic refining of aluminum. Lightweight lithium-aluminum alloys have applications in the aerospace industry. For example, the fuel tank of the NASA space shuttles used an aluminumlithium alloy (Garrett, 2004). Lithium, as lithium stearate or similar compounds, is widely used as a high-performance lubricant in automotive, aircraft, industrial, marine, and military applications (Garrett, 2004). As of 1993, 60 percent of all industrial lubricants contained lithium, typically at concentrations of 1 to 2 percent. Lithium chloride and bromide are among the best available 
substances for absorbing water; thus, these salts are used in air conditioning systems to reduce humidity while simultaneously cooling the air. Since the 1940s, pharmaceuticals containing lithium compounds have been used to control bipolar disorder. Finally, the lighter of two lithium isotopes, ${ }^{6} \mathrm{Li}$, was used in the production of tritium $\left({ }^{3} \mathrm{H}\right)$ after World War II by the U.S. Atomic Energy Commission and later by the U.S. Department of Energy in the production of nuclear weapons (Garrett, 2004).

Lithium is traded in three forms: mineral concentrates, mineral compounds, and refined metal. Lithium mineralsmainly spodumene, petalite, and lepidolite - are mined from pegmatites and are used mostly as feedstock for glasses and ceramics. Most lithium compounds (for example, lithium carbonate, lithium chloride, and lithium hydroxide) are obtained from brines. Lithium metal (fig. K $3 G$ ) is obtained by electrolysis from lithium chloride.

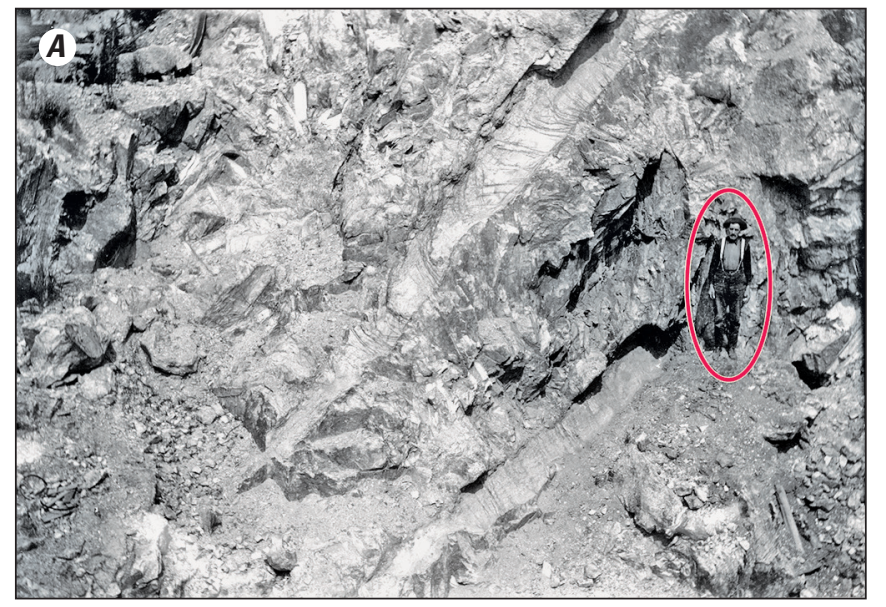

The prices of lithium metal and lithium compounds are not published; however, approximate values can be gleaned from a variety of industry sources. Battery-grade lithium carbonate is currently valued at between $\$ 6,500$ and $\$ 7,000$ per metric ton. In 2010, Japan imported lithium metal valued at $\$ 33.36$ per pound, or $\$ 73,546$ per metric ton.

Lithium is the element of choice in the various applications listed above. Substitutes do exist, however, in batteries, ceramics, greases, and manufactured glass. For example, calcium and aluminum soaps can substitute for stearates in greases; calcium, magnesium, mercury, and zinc can be used as anode materials in batteries; sodic and potassic fluxes can substitute for lithium in ceramics and glass manufacturing; and composite materials of boron, glass, or polymer fibers can be used in place of aluminum-lithium alloys (Jaskula, 2013).

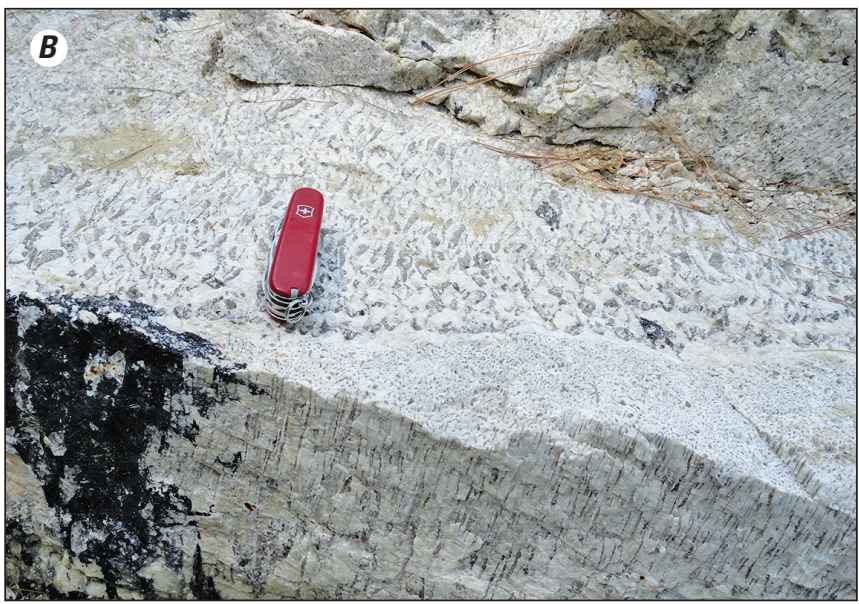

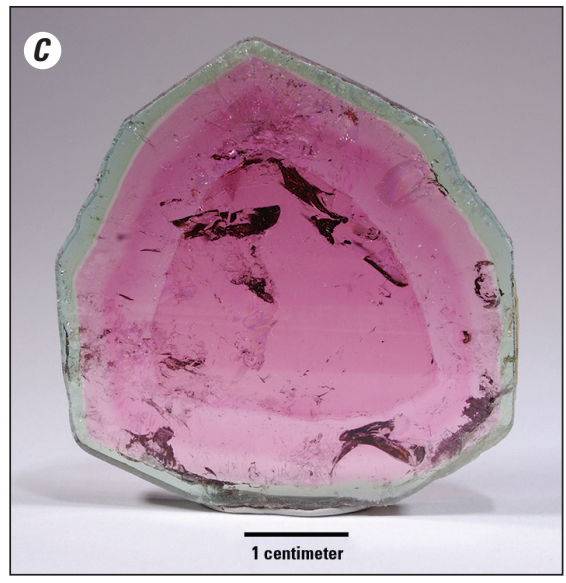

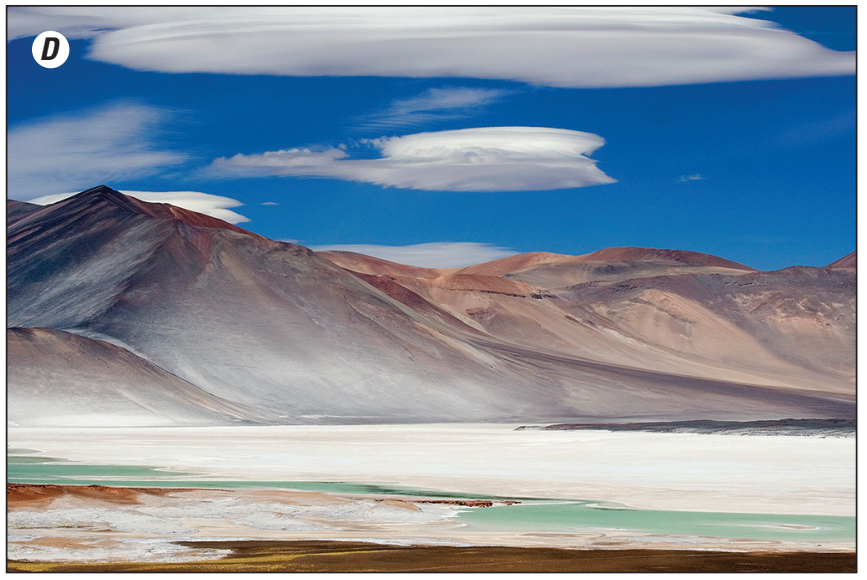

Figure K3. Photographs showing some sources and uses of lithium. $A$, Molds of giant spodumene crystals in the Etta lithium-cesium-tantalum (LCT) pegmatite, Black Hills, South Dakota; note miner for scale. From Schaller (1916). $B$, Graphic granite, which is an intergrowth of quartz and feldspar that is characteristic of pegmatites. This granite is part of the Havey pegmatite in Maine. By Dwight C. Bradley. C, Elbaite, also known as watermelon tourmaline, which is a lithium-bearing gemstone. In 1973, a single gem-filled pocket in a pegmatite in Maine produced about 2 metric tons of tourmaline that would be valued today (for gems and mineral specimens) at about $\$ 40$ million. This sample is from the Dunton Mine in Newry, Maine. Courtesy of the Mineralogical \& Geological Museum at Harvard University (speciman number MGMH 125525. Dunton Mine, Newry, Maine. Copyright 2012. President and Fellows of Harvard College; all rights reserved). D, Salar de Atacama in Chile, where lithium brines are pumped from the shallow subsurface. By Luca Galuzzi (www.galuzzi.it)/CC-BY-SA-2.5 (http://commons.wikimedia.org/wiki/File:Miscanti_Lagoon_San_Pedro_de_Atacama_Chile_Luca_Galuzzi_2006.jpg). 

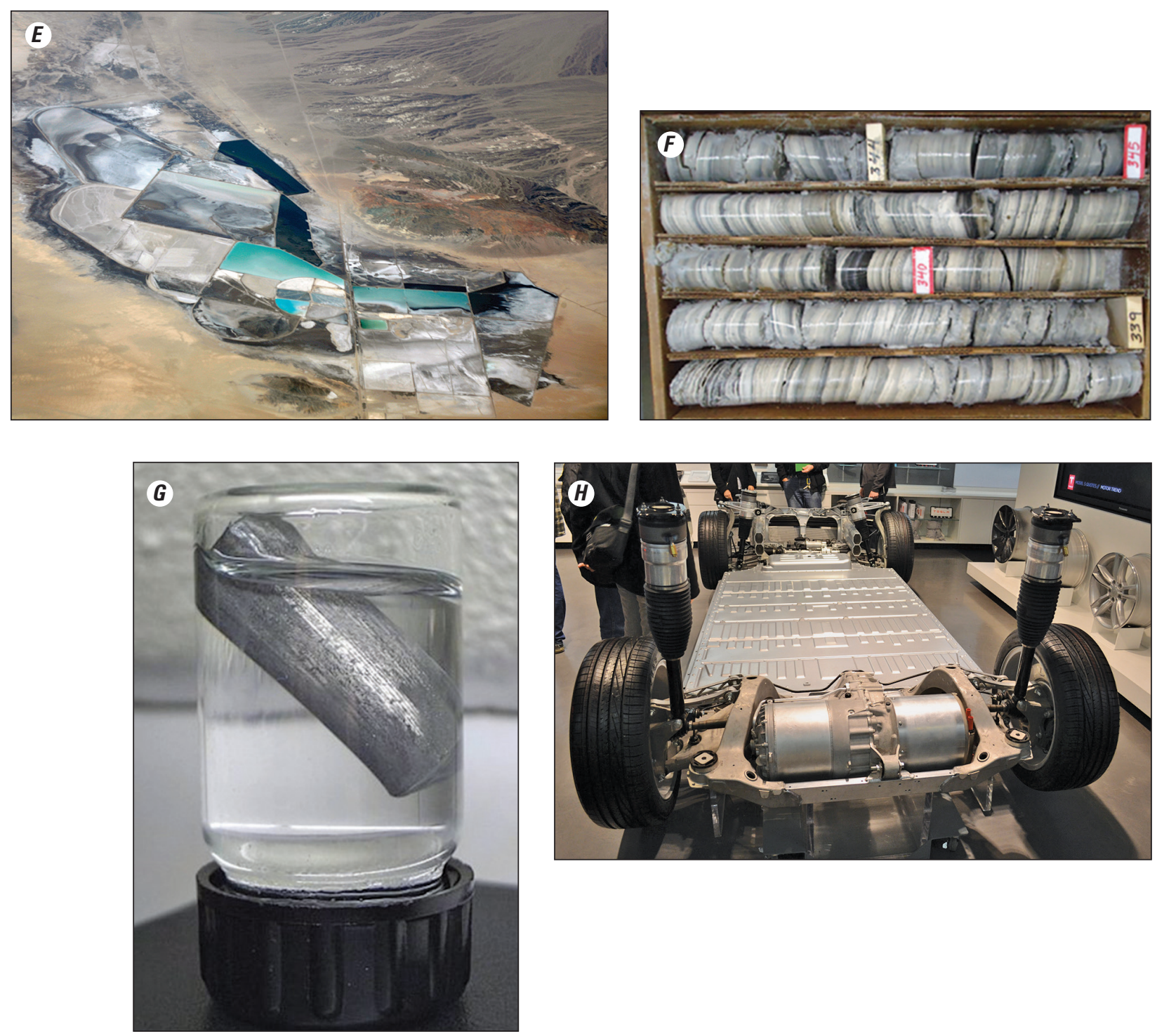

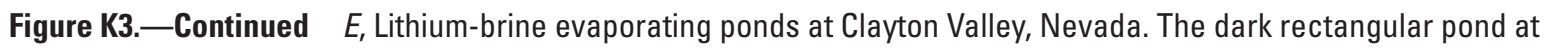
the upper center of the image is 1.7 kilometers long. By Doc Searls/CC-BY-2.0 (http://commons.wikimedia.org/wiki/ File:Chemetall_Foote_Lithium_Operation.jpg). F, Drill core through a sequence of Pliocene-age lake sediments containing lithium clay (hectorite) from Fish Lake Valley, Nev. (for location, see fig. K5, inset). Markers indicate depth in feet below the ground surface. Hectorite is present in the tan and gray layers of siltstone and claystone. By Lisa L. Stillings. G, Lithium metal is so light that it floats in oil, and so reactive that it cannot be stored in air or water. By W. Oelen/CC-BY-SA-3.0 (http://commons.wikimedia.org/wiki/File\%3ALithium_element.jpg). $H$, View into a Tesla Model S® electric car showing the lithium-ion battery covering much of the chassis. Various battery configurations in electric vehicles use between about 10 and 22 kilograms of lithium. By Oleg Alexandrov/CC-BY-SA-3.0 (http://commons.wikimedia.org/wiki/File:Tesla_Motors_ Model_S_base.JPG). 


\section{Geology \\ Geochemistry and Mineralogy}

In most geologic settings, lithium is found only as a trace element, measured in parts per million ( $\mathrm{ppm}$ ). Earth's mantle contains $1.6 \mathrm{ppm}$ lithium and the oceanic crust contains $4.3 \mathrm{ppm}$ (Sun and McDonough, 1989). The upper continental crust (that is, rocks typically at Earth's surface on land) contains an average of 20 ppm lithium (McLennan, 2001); at this abundance, lithium ranks about 30th among the elements, behind copper but ahead of lead, tin, and silver.

Lithium is classed as a large-ion lithophile element: as a cooling magma starts to crystallize minerals, lithium stays in the remaining melt until near the end. Active plate tectonics over Earth's history have concentrated lithium in the continental crust through the partial melting of the mantle beneath mid-ocean ridges and volcanic arcs. The melt, or magma, rises and then cools to become new rock in Earth's crust, bringing much of the available lithium with it. Among the common rock or sediment types, the highest lithium concentrations are in shales (which average $66 \mathrm{ppm}$ ), deep-sea clays (which average $57 \mathrm{ppm}$ ), and low-calcium granites (which average $40 \mathrm{ppm}$ ) (Faure, 1998 and references therein). These trace concentrations are insufficient for an ore deposit or even for the formation of minerals in which lithium is part of the chemical formula. When present only in trace concentrations such as these, lithium atoms substitute for other metals (typically magnesium) in common rock-forming minerals.
Lithium minerals form only when rare combinations of favorable factors line up. Most of the known lithium minerals are found in coarsely crystalline granites known as lithium-cesium-tantalum (LCT) pegmatites. In terms of lithium resources, the most important minerals are spodumene and petalite (both lithium aluminum silicates) and the pink mica lepidolite (potassium lithium aluminum silicate). The main lithium mineral in sedimentary rocks is the clay hectorite. More information on lithium minerals is provided in table $\mathrm{K} 1$.

Lithium is extremely soluble. During weathering of rocks, it tends to be removed in solution and carried to the sea by rivers. Thus, lithium would be expected to have built up in the oceans in the same way that a buildup of sodium has made the oceans salty. Yet, remarkably, seawater contains less than $1 \mathrm{ppm}$ lithium. The likely explanation is that seawater lithium is scavenged in trace quantities by clay minerals and accumulates in sea-floor oozes.

\section{Deposit Types}

Present and potential sources of lithium worldwide are broken down by deposit type, as follows: closed-basin brines, 58 percent; pegmatites (including lithium-enriched granites), 26 percent; lithium-clays (hectorite), 7 percent; and oilfield brines, geothermal brines, and lithium-zeolites (jadarite), 3 percent each (Evans, 2012). Figures K4 and K5 show the worldwide distributions of lithium deposits.

Table K1. Commercially and (or) scientifically important lithium-bearing minerals.

[Chemical compositions are from Barthelmy (2014)]

\begin{tabular}{|c|c|c|c|}
\hline Mineral name & Chemical formula & $\begin{array}{l}\text { Lithium } \\
\text { (weight } \\
\text { percent) }\end{array}$ & Geologic setting \\
\hline Amblygonite & $(\mathrm{Li}, \mathrm{Na}) \mathrm{Al}\left(\mathrm{PO}_{4}\right)(\mathrm{F}, \mathrm{OH})$ & 3.44 & $\begin{array}{l}\text { Pegmatite intrusions in orogenic belts; solid solution with } \\
\text { montebrasite }\end{array}$ \\
\hline Elbaite & $\mathrm{Na}(\mathrm{Li}, \mathrm{Al})_{3} \mathrm{Al}_{6}\left(\mathrm{BO}_{3}\right)_{3} \mathrm{Si}_{6} \mathrm{O}_{18}(\mathrm{OH})_{4}$ & 1.89 & $\begin{array}{l}\text { Tourmaline group. Pegmatite intrusions in orogenic belts. } \\
\text { Includes the gem form watermelon tourmaline }\end{array}$ \\
\hline Eucryptite & $\mathrm{LiAlSiO}_{4}$ & 5.51 & Pegmatite intrusions in orogenic belts \\
\hline Hectorite & $\mathrm{Na}_{0.3}(\mathrm{Mg}, \mathrm{Li})_{3} \mathrm{Si}_{4} \mathrm{O}_{10}(\mathrm{OH})_{2}$ & 0.54 & Hydrothermal alteration of volcanic ash in arid, closed basins \\
\hline Jadarite & $\mathrm{LiNaB}_{3} \mathrm{SiO}_{7}(\mathrm{OH})$ & 3.38 & Hydrothermal alteration of volcanic ash in arid, closed basins \\
\hline Lepidolite & $\mathrm{K}(\mathrm{Li}, \mathrm{Al})_{3}(\mathrm{Si}, \mathrm{Al})_{4} \mathrm{O}_{10}(\mathrm{~F}, \mathrm{OH})_{2}$ & 3.58 & Pegmatite intrusions in orogenic belts \\
\hline Montrebasite & $\mathrm{LiAl}\left(\mathrm{PO}_{4}\right)(\mathrm{OH}, \mathrm{F})$ & 4.74 & Pegmatite intrusions in orogenic belts \\
\hline Petalite & $\mathrm{LiAlSi}_{4} \mathrm{O}_{10}$ & 2.09 & Pegmatite intrusions in orogenic belts \\
\hline Spodumene & $\mathrm{LiAlSi}_{2} \mathrm{O}_{6}$ & 3.73 & $\begin{array}{l}\text { Pegmatite intrusions in orogenic belts. Gem forms are triphane } \\
\text { (yellow), kunzite (pink), and hiddenite (green) }\end{array}$ \\
\hline Zabuyelite & $\mathrm{Li}_{2} \mathrm{CO}_{3}$ & 18.79 & Evaporite mineral (rare) \\
\hline
\end{tabular}




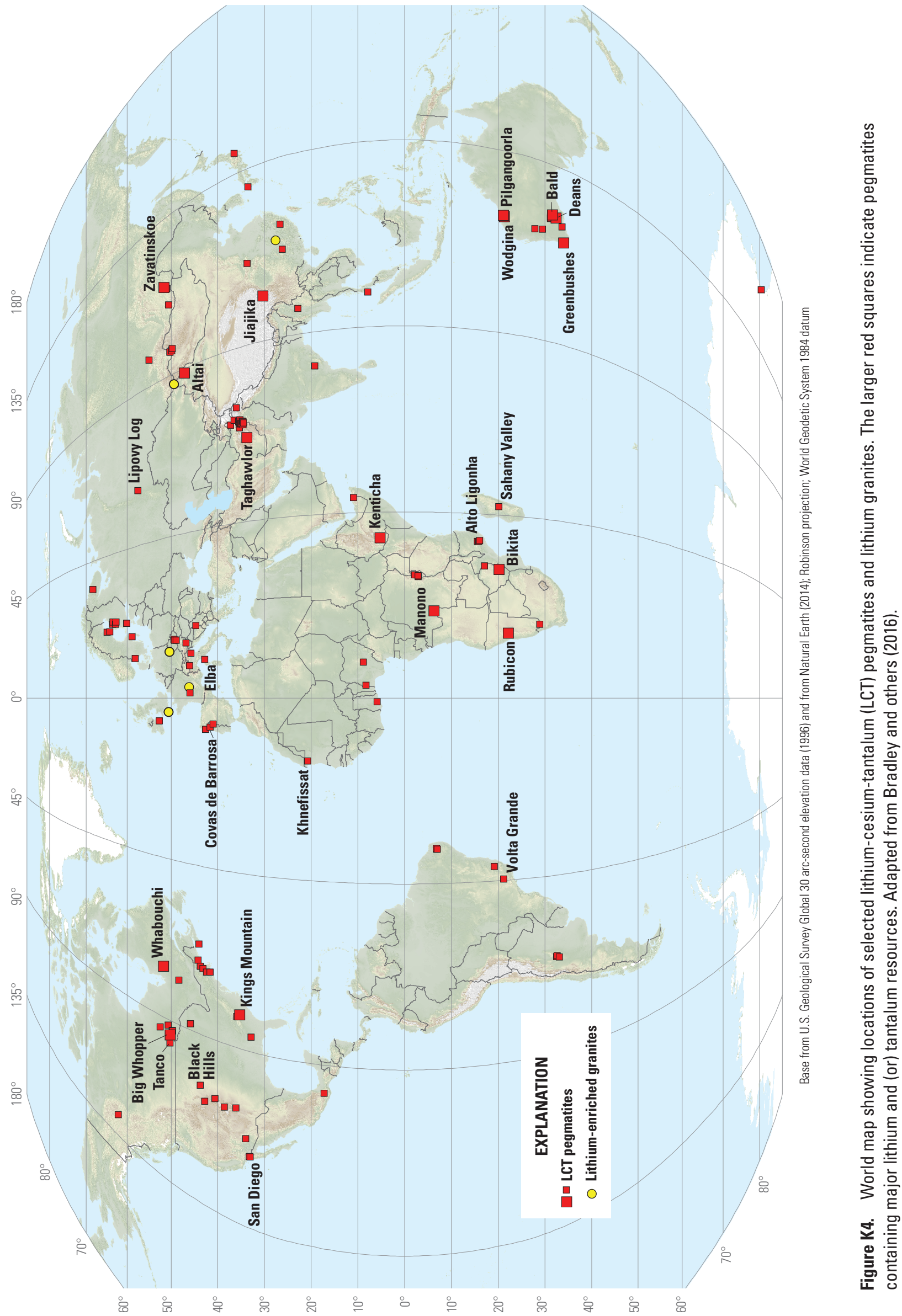




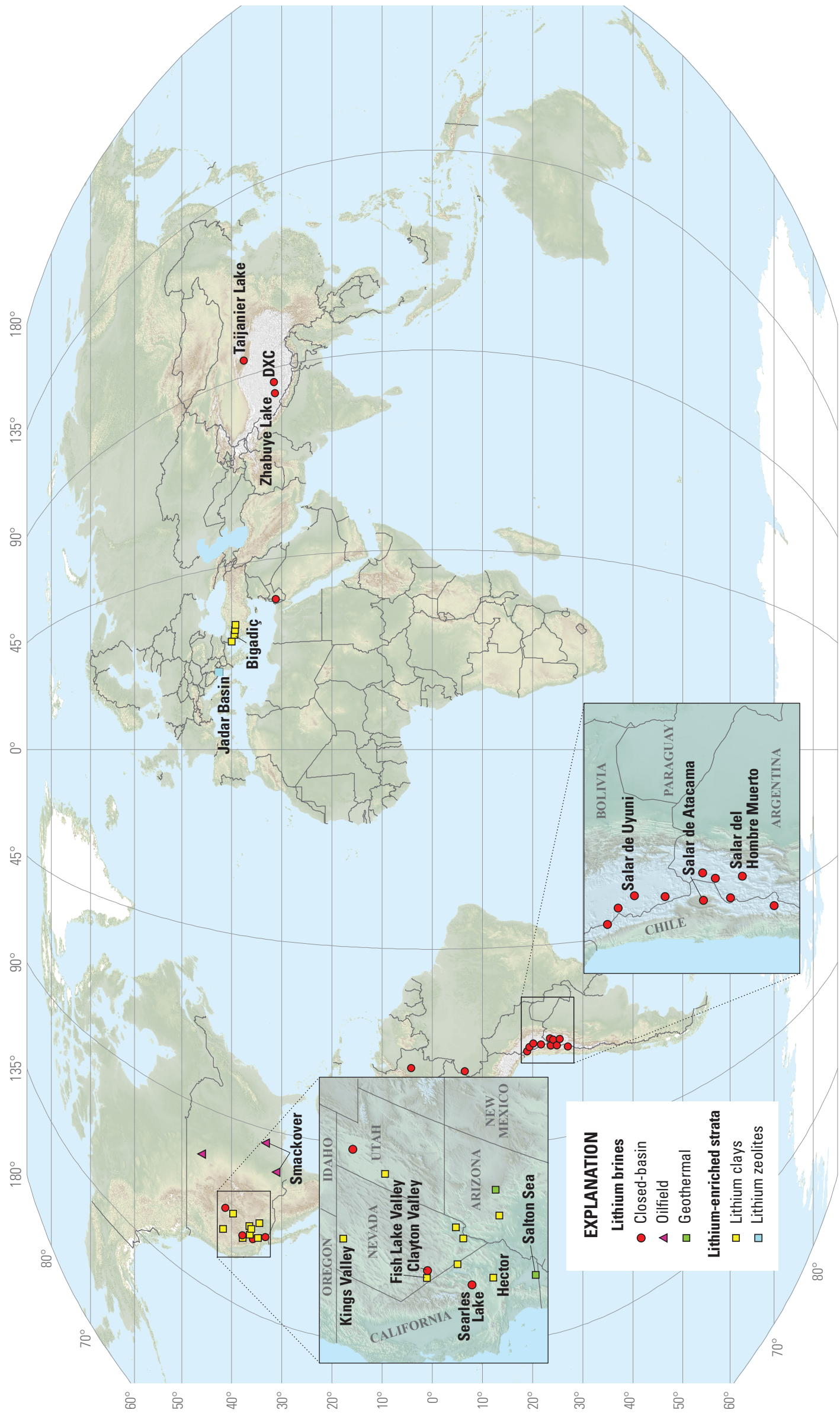

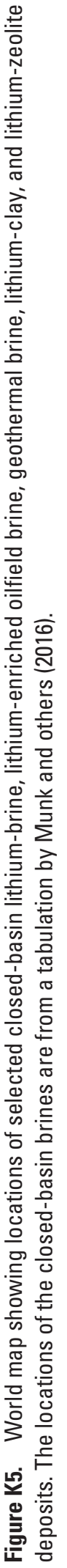




\section{Lithium-Cesium-Tantalum Pegmatite Deposits}

Granitic pegmatites are igneous rocks distinguished by an extremely coarse but variable grain size and by other unique textures, particularly what are known as graphic intergrowths (fig. K3 B; London, 2008). Pegmatites are composed primarily of the major minerals in granite, namely quartz, albite (sodium feldspar), potassium feldspar, and the white mica muscovite, plus smaller amounts of garnet, tourmaline, biotite, and apatite. In addition to the lithium minerals petalite, lepidolite, and spodumene, LCT pegmatites may contain the cesium ore mineral, pollucite; the tantalum ore mineral, columbitetantalite; the beryllium ore mineral, beryl; and the tin ore mineral, cassiterite. More information on tantalum, beryllium, and tin resources in LCT pegmatites can be found in Foley and others (this volume, chap. E), Schulz and others (this volume, chap. M), and Kamilli and others (this volume, chap. S). LCT pegmatites may also yield gemstones and high-value museum specimens of rare minerals. Gemstones include the beryl varieties aquamarine, emerald, and heliodor; the lithiumbearing tourmaline variety elbaite ("watermelon tourmaline") (fig. $\mathrm{K} 3 \mathrm{C}$ ); and the spodumene varieties hiddenite, kunzite, and triphane. LCT pegmatites are also mined for feldspars, muscovite, and ultrapure quartz. The diversity of mineral species in the most complex LCT pegmatites is impressive; at the Tanco deposit in Manitoba, Canada, for example, 105 minerals have been identified (London, 2008). LCT pegmatites are famous among geologists and mineral collectors for their huge crystals. The largest spodumene crystal yet found is 14 meters (m) long (from South Dakota) (fig. K3A); the largest beryl crystal, $18 \mathrm{~m}$; and the largest potassium feldspar crystal, $49 \mathrm{~m}$ (Rickwood, 1981). These finds are all the more remarkable because pegmatites are believed to have crystallized in a matter of days to years (London, 2008).

The main producers of lithium from pegmatites are Australia, Brazil, China, Portugal, and Zimbabwe. The world has hundreds of known deposits (fig. K4), and some of these (for example, in Quebec, Canada) contain large reserves of lithium that have not been mined. The United States is not currently producing lithium from pegmatites, although large reserves remain in the Kings Mountain pegmatite district in North Carolina. Other domestic deposits are too small to be viable under current or likely market conditions. Kesler and others (2012) estimated lithium resources for 20 of the world's most important pegmatite deposits or districts.

Bradley and McCauley (2013) and Bradley and others (2017) have summarized tectonic factors in pegmatite genesis. LCT pegmatites are found in the metamorphic-igneous hinterlands of orogenic belts and are a consequence of plate convergence. Most LCT pegmatites formed during collision between continents or microcontinents and are associated with aluminum-rich granites that originated by melting of metamorphosed sedimentary rocks. Dozens of pegmatites in the Appalachians formed during the protracted collision between Africa and North America that took place 370 million to 275 million years ago.
LCT pegmatites can be dated using isotope geochronology. The age is a function of the ratio of the abundances of a radioactive isotope and its decay product. In pegmatites, the minerals columbite-tantalite, monazite, and zircon are dated by exploiting the decay of uranium-238 to lead-206. LCT pegmatites from six continents have now been dated (Bradley and McCauley, 2013). The oldest one, which is located in Australia, formed at about 2,829 mega-annum (Ma, or million years before present) and the youngest, in Italy, at about $7 \mathrm{Ma}$ (McCauley and Bradley, 2014). The global age distribution is episodic, with a few peak times separated by long intervals of few or no pegmatites (fig. K6). The age peaks at 2,638; 1,809; $962 ; 485 ; 309 ; 274$; and 97 Ma correspond to times when Earth's continents were being assembled into supercontinents (Bradley, 2011).

Even the biggest LCT pegmatites are much smaller than typical granitic plutons, which commonly have areas of greater than 10 square kilometers $\left(\mathrm{km}^{2}\right)$. The Greenbushes pegmatite in Western Australia, which is large for an LCT pegmatite, is 3 kilometers $(\mathrm{km})$ long and a few hundred meters across (Partington and others, 1995). On a regional scale, LCT pegmatites tend to occur in districts alongside fertile granites, with the highest concentration of lithium and other incompatible elements in the more distal pegmatites (fig. K7). Individual pegmatites take various shapes, ranging from tabular dikes and sills to irregular bodies.

\section{Lithium-Enriched Granites}

Some muscovite-bearing granites include zones that are enriched in the elements lithium, tantalum, tin, and fluorine. At the Yichun Mine in Jiangxi Province, China, the top of a biotite-muscovite granite grades into muscovite granite and then into lepidolite granite, which has been mined for lithium and tantalum (Schwartz, 1992). Lithium-enriched granites are closely related to LCT pegmatites, and the two have not been distinguished from one another in recent global assessments of lithium resources (for example, Kunasz, 2006; Evans, 2008; Yaksic and Tilton, 2009; Naumov and Naumova, 2010; and Gruber and others, 2011).

\section{Lithium Brine Deposits in Closed Basins}

Closed-basin brine deposits contain an estimated 58 percent of the world's identified lithium resources (Evans, 2012). Lithium brine deposits are accumulations of saline groundwater that are enriched in dissolved lithium. The locations of the world's major lithium brine deposits are shown on the map in figure K5. The producing deposits have average lithium concentrations that range from 160 to 1,400 ppm and estimated resources of 0.3 to 6.3 million metric tons of lithium (Munk and others, 2016). The producing deposits are located in Asia, North America, and South America, and lie within the northern and arid latitudinal belts on either side of the equator. These deposits share a number of characteristics, including 
A. Age distribution of LCT pegmatites

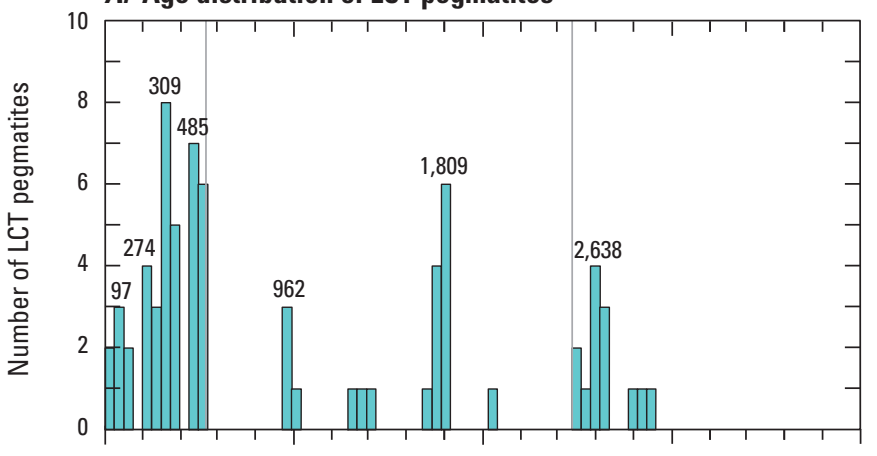

B. Age distribution of detrital zircons from modern river sands

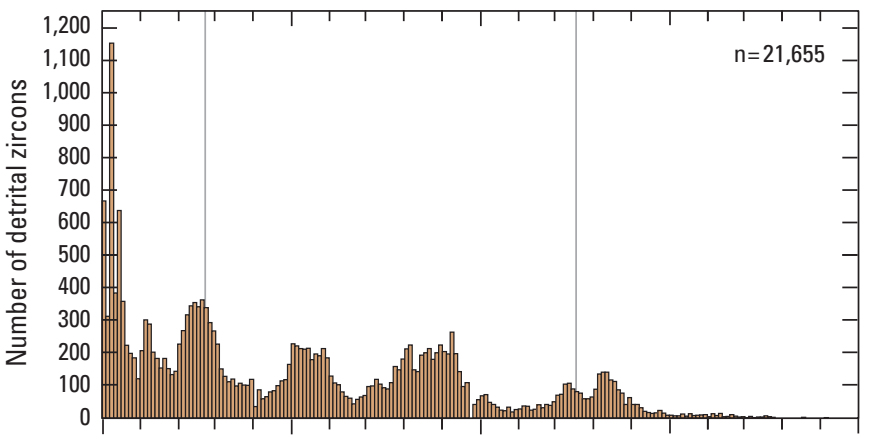

C. Age distribution of lithium resources in pegmatites

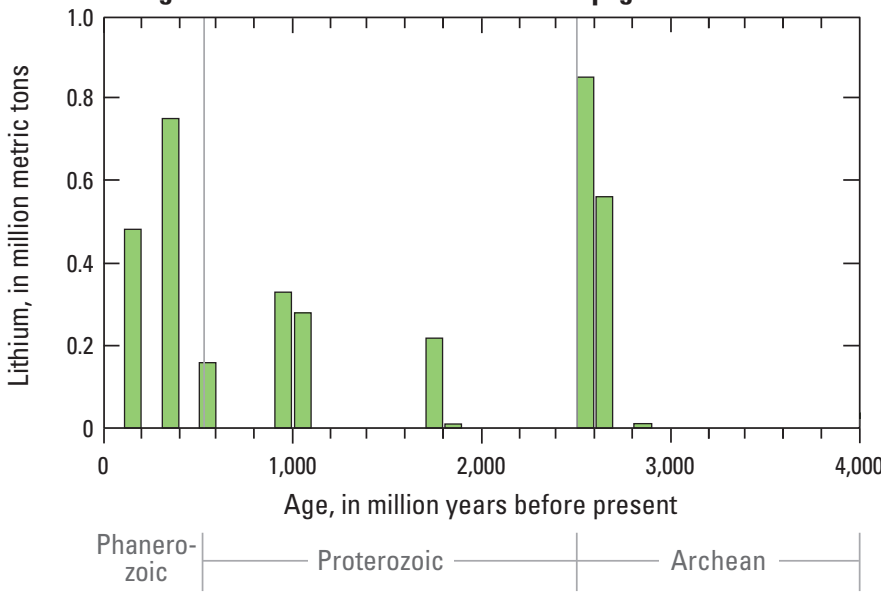

Figure K6. A, Histogram of the number of lithiumcesium-tantalum (LCT) pegmatites formed per 50-million-year interval as a function of geologic time showing their episodic genesis (McCauley and Bradley, 2013, 2014). $B$, Histogram showing the age distribution of detrital zircon in modern sand as a function of time. Maxima are interpreted as times when supercontinents were being assembled and minima as times when they were together. LCT pegmatites are thus linked to supercontinent assembly. From Voice and others (2011). C, Histogram showing global lithium resource in pegmatites per 100-million-year interval as a function of geologic time. Note the broad correspondence between all three plots. Modified from McCauley and Bradley (2014). the following: (a) an arid climate; (b) closed basin containing a salt lake or salt flat; (c) tectonically driven subsidence; (d) associated igneous or geothermal activity; (e) lithium-bearing source rocks; (f) one or more adequate aquifers, to host the brine reservoir; and (g) sufficient time to concentrate a brine. Key aspects of the proposed lithium-brine deposit model are shown in figure $\mathrm{K} 8$.

The lithium brine deposit in Clayton Valley, Nev., is a well-studied example that can be used to highlight some of the key characteristics of this kind of deposit. Lithium has been produced from brine in Clayton Valley since the 1960s. It is not a particularly notable basin - it has a relatively small footprint of about $100 \mathrm{~km}^{2}$ and a total lithium resource of about 0.3 million metric tons-but it is better understood than the rest.

Clayton Valley is one of about 150 basins in the Basin and Range Province of the Western United States that formed when the western $1,000 \mathrm{~km}$ of North America was profoundly reshaped because of interactions with adjacent plates in the Pacific Ocean. A computer animation of this process in available on the Internet (Atwater, 2011). In the past 15 million years, Nevada has been stretched in an east-west direction to about twice its former width. The basins are one of many consequences of this process. The basins are relatively flat regions where the Earth's former surface has subsided over geologic time, and the resulting depressions have been filled with sediment, typically hundreds to thousands of meters thick.

The Basin and Range Province is dry. Its aridity is partly owing to its position in the northerly of Earth's two low-latitude dry belts and partly to a double rain-shadow cast by two of the highest mountain ranges in the contiguous United States (the White Mountains and the Sierra Nevada, the latter of which reaches $4,421 \mathrm{~m}$, or $14,505 \mathrm{feet}$ ). The region is so dry that most of the basins are closed; that is, surface waters (mostly snowmelt) can flow in but not out. Inflowing waters bring in dissolved calcium, magnesium, potassium, sodium, and less abundant elements, such as lithium. These elements have built up over time, either in permanent lakes (such as Utah's Great Salt Lake) or in ephemeral lakes that sometimes dry out completely, leaving a salar (salt pan or playa) covered by evaporite minerals. Halite (sodium chloride, or common rock salt) is the best known of these minerals. As a salt lake dries out, lithium behaves somewhat differently than other dissolved metals because it is more soluble. Rather than crystallizing an evaporite mineral, lithium remains in solution and ends up in a bitter-tasting residual brine. This brine is denser than fresh water and sinks into the subsurface where it collects in one or more aquifers (zones or layers of porous and permeable rock or sediment). At Clayton Valley, lithiumenriched brine is pumped from six different aquifers that all lie within a few hundred meters of the surface.

The lithium in Clayton Valley is thought to have come from various sources; some of it was weathered from rocks or sediments by rain, snowmelt, or groundwater, and some 


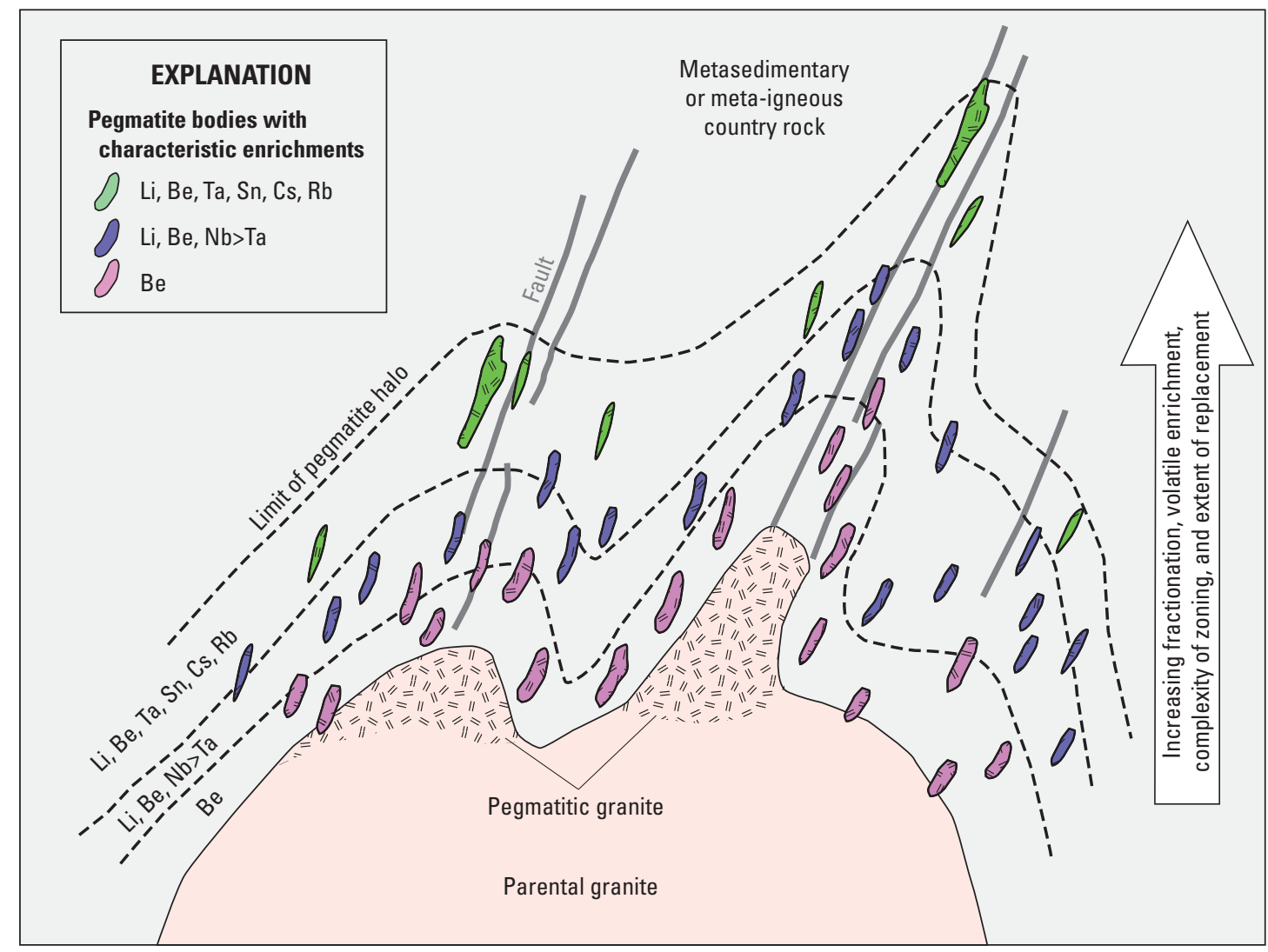

NOT TO SCALE

Figure K7. Schematic cross section showing the concentric arrangement of lithium-cesium-tantalum (LCT) pegmatites (small purple, blue, and green bodies) around a parental granite pluton. In this model, common pegmatites form near the parent, whereas pegmatites with enrichments in incompatible elements (indicated by chemical symbols) and corresponding rare minerals form farther away. Modified from Galeschuk and Vanstone (2005) and Trueman and Černý (1982). Be, beryllium; Cs, cesium; Li, lithium; Nb, niobium; Rb, rubidium; $\mathrm{Sn}$, tin; Ta, tantalum

was brought in by hydrothermal waters that rose from anomalously hot rocks below the basin (fig. K8). Before intense pumping disrupted the groundwater system beneath Clayton Valley, these hydrothermal waters came to the surface at two hot springs.

The arid climate needed to form the brine is also a key to production, because the first step in the extraction of lithium is solar evaporation. In Clayton Valley, brine carrying an average of $160 \mathrm{ppm}$ lithium is pumped to the surface and evaporated in a succession of nine artificial ponds that cover a total area of $16 \mathrm{~km}^{2}$ (fig. K3E) (Garrett, 2004). In each pond in the chain, brine enters at one end, loses some of its water during the ensuing weeks or months, and is drained or pumped from the other end into the next pond. Multiple ponds are used so as to keep separate the various evaporite minerals that crystallize out in sequence. It takes nearly 2 years to achieve a concentrate that is both enriched in lithium (to 5,000 ppm) and depleted in other, more abundant, elements. This "mother liquor" is pumped from the last pond to a chemical plant for production of lithium carbonate and lithium hydroxide. A more complete description of the extraction of lithium from brine is provided in Garrett (2004).

The same general conditions that made the Clayton Valley brines have created even larger deposits in the Andes Mountains of South America and in Tibet in central Asia (fig. K5). The world's most significant lithium district is the Salar de Atacama, on the Altiplano of Chile (fig. K3D), which is one of the driest places on Earth. The Salar de Atacama is a huge salt flat that covers an area of about $2,100 \mathrm{~km}^{2}$, which is roughly two-thirds the size of Rhode Island. It is surrounded by active volcanoes and cut by active faults. The salar is fed by a combination of snowmelt from nearby mountains and hydrothermal fluids from below. At an average of 1,400 ppm lithium, the brine is far richer than at Clayton Valley. The total reserve is more than 20 times greater, at an estimated 7.5 million metric tons of lithium. 


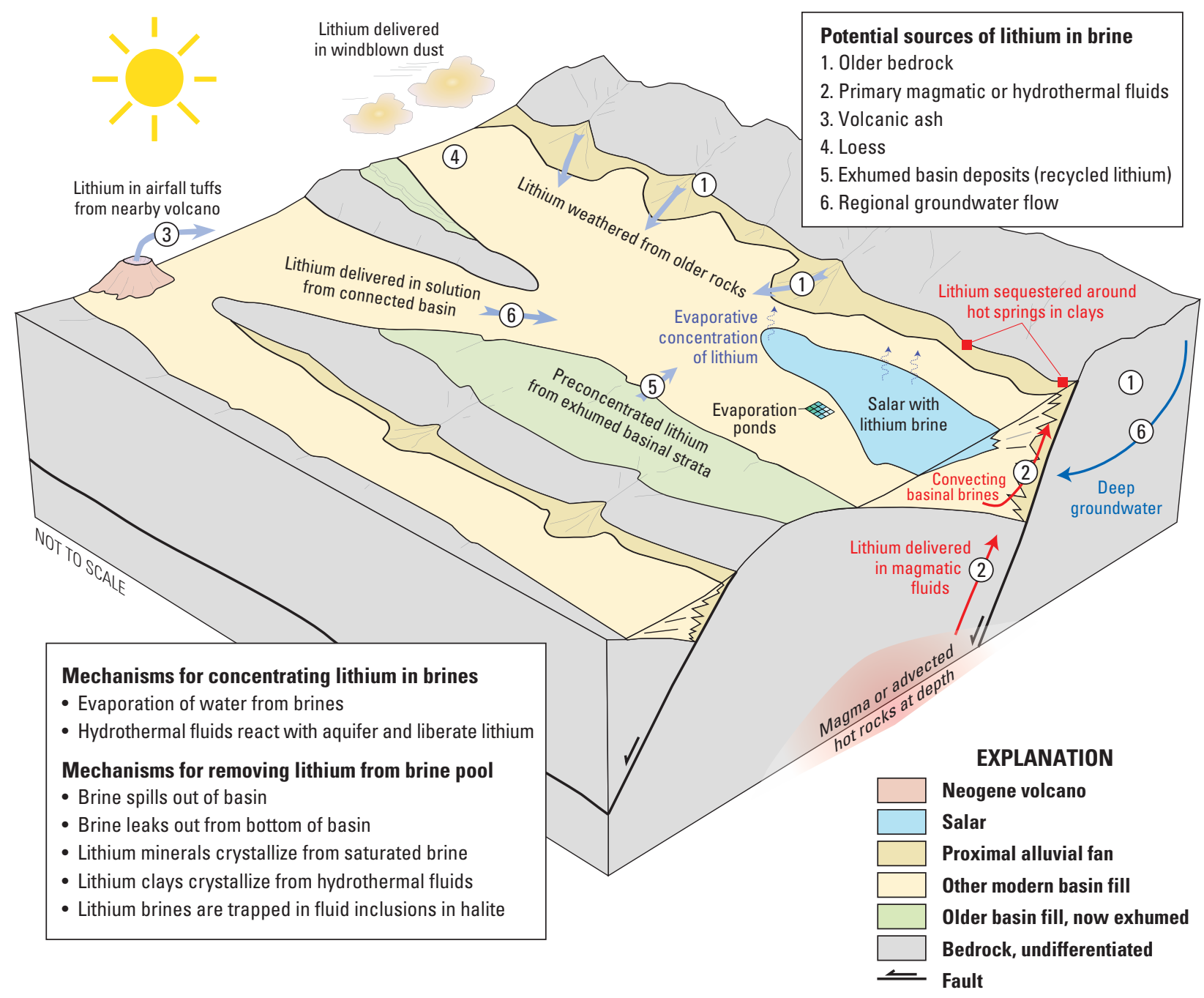

Figure K8. Conceptual ore-deposit model for lithium brine. An extensional basin is shown, but basins in active contractional and strike-slip tectonic settings are also prospective, the requirement being that the basin is closed. From Bradley and others (2013) and Munk and others (2016). 
Another notable deposit is the Salar de Uyuni in Bolivia. With an estimated 9 million metric tons of lithium at an average concentration of about 320 ppm (Jaskula, 2013), it is likely the largest accumulation of lithium in the world (Gruber and others, 2011). Despite its size, it is not yet in production. One difficulty is an abundance of dissolved magnesium, which hampers the evaporative concentration of lithium by causing it to precipitate prematurely as an impurity in magnesium salts.

The most noteworthy of several lithium brine systems in China is at Zabuye Lake, Tibet. It is the only known closed basin in which a lithium salt (specifically, $\mathrm{Li}_{2} \mathrm{CO}_{3}$, or zabuyelite) precipitates as part of the evaporite mineral sequence, and the only basin in a recent global compilation where volcanism or hydrothermal activity has not been reported (Munk and others, 2016). The brines have an average concentration of $700 \mathrm{ppm}$ and an estimated resource of about 1.5 million metric tons of lithium (Gruber and others, 2011).

\section{Lithium in Other Brines}

Deep oilfield brines may contain up to several hundreds of parts per million lithium. Evans (2008) reported high tonnages of lithium contained in oilfield brines in Arkansas, North Dakota, Oklahoma, Texas, and Wyoming, with lithium concentrations of up to $700 \mathrm{ppm}$. One of the best-known of the oilfield brines is contained in the Smackover Formation in the Gulf Coast area of the south-central United States (Collins, 1976). In some places, the brine contains up to 692 milligrams per liter $(\mathrm{mg} / \mathrm{L})$ lithium. The brine occupies pore space in an approximately 200-m-thick limestone at depths of 1,800 to $4,800 \mathrm{~m}$. The brine has been interpreted to be trapped seawater that was subsequently hydrothermally enriched in lithium and other trace elements (Garrett, 2004).

Oilfield brines have two drawbacks as potential lithium resources. First, they typically occur at much greater depths (greater than $1 \mathrm{~km}$ ) than closed-basin brines. Second, unless they happen to be located in an arid climate, recovery of lithium using the expedient and inexpensive method of solar evaporation will not be feasible (Bradley and others, 2013).

Geothermal brines are another potential source of lithium. These fluids traditionally derive their value from their contained heat, which can be converted to mechanical energy_but some geothermal fluids contain anomalous dissolved metals, including lithium. Reportedly, lithium is now being recovered by Simbol, Inc. from a geothermal brine in the Salton Sea area along the California-Mexico border (Simbol, Inc., 2013).

\section{Lithium-Clay Deposits}

A small subset of the world's clay deposits is enriched in lithium. Lithium-bearing clay deposits contain an estimated 7 percent of the world's lithium resources (Evans, 2012).
Analysis of lithium-enriched clays from several occurrences in the Western United States revealed that they all show enrichments in magnesium, fluorine, and lithium - a combination attributed to hydrothermal processes (Stillings and Morissette, 2012). Hectorite (fig. K3F), which is a member of the smectite family of clay minerals, appears to be the most widespread, but Stillings and Morissette (2012) also found lithiumenriched clays of the illite family, as well as illite-smectite mixtures. Hectorite is a silicate of sodium, magnesium, and lithium and contains about one-half percent lithium (table K1). Lithium-clay deposits, prospects, and occurrences are shown in figure K5.

The most significant lithium-clay resource so far discovered is the Kings Valley hectorite deposit, located within the McDermitt caldera complex, which is an extinct volcanic center in northern Nevada. The McDermitt area had extensive volcanism during the Miocene; at least five collapsed vents and resurgent domes have been recognized within the complex. The lithium clays occur in hydrothermally altered, volcanic-derived sediments of lakes that occupied the caldera (Rytuba and Glanzman, 1979). Recovery of lithium by leaching the clay with sulfuric acid has proven feasible (Eggleston and Hertel, 2008). The deposit is being developed for production, but lithium production has not yet begun (Western Lithium Corp., 2015).

Clays that happen to contain lithium have been mined in Arizona, California, and elsewhere in Nevada. These deposits were or are mined not for their lithium content but rather for their physical properties, which make them good additives to, in order of value, drilling muds, paints, and cosmetics. Hectorite gets its name from such a deposit at Hector, Calif., where lake beds of volcanic ash were altered by hydrothermal fluids that came up along a fault zone (Ames and others, 1958). At least two other deposits in the Southwestern United States have been similarly interpreted (Norton, 1965; Wilkerson and others, 2001). In Turkey, the world-class Bigadiç borate deposit, which formed in the hydrothermally altered sediments that fill a rift-related lacustrine basin, contains associated hectorite (Helvaci and others, 2004).

\section{Lithium-Zeolite Deposits}

The only documented lithium-zeolite deposit is from a Neogene basin system in the Balkan region of Eastern Europe (fig. K5). Miocene-age lake beds in the Jadar basin include oil shale, carbonate rocks, evaporites, and tuff (Obradović and others, 1997). These strata have been authigenically overgrown by massive layers of jadarite, which is a recently recognized boron-lithium silicate mineral of the zeolite family (Stanley and others, 2007). The jadarite layers are reportedly several meters thick. This single jadarite deposit contains an estimated 3 percent of the world's lithium resource (Evans, 2012). 


\section{Resources and Production}

\section{Production}

Global annual production of lithium has been increasing since the mid-1900s; in 2012, it was about 37,000 metric tons (fig. K1; Jaskula, 2013). The world has hundreds of lithium deposits, prospects, and occurrences (figs. K4 and K5) but only a few of them are currently producing. The present-day supply of lithium comes from pegmatite deposits and closed-basin brines. The main pegmatite producers are Australia, Brazil, China, Portugal, and Zimbabwe. The main brine producers are Argentina, Chile, China, and the United States. The various other deposit types have potential as future contributors.

The United States imports most of the lithium that it consumes. In 2012, the country's net import reliance was greater than 70 percent (Jaskula, 2013).

\section{Reserves and Other Identified Resources}

Global lithium resources total more than 39 million metric tons, which is nearly three thousand times current annual production. Of this resource, the USGS currently estimates there to be approximately 13 million metric tons of reserves; that is, resources that are demonstrated (measured and indicated categories) to be and are currently economically recoverable. These figures have changed in recent years, and various experts have reported a wide range of values based on somewhat different methods and assumptions (Gruber and others, 2011). An important additional aspect of the global lithium outlook is recycling, which was not figured into the above resource estimates. Lithium-ion battery recycling is expected to play a major role in the supply of lithium in the medium to

A. Lithium resources in LCT pegmatites

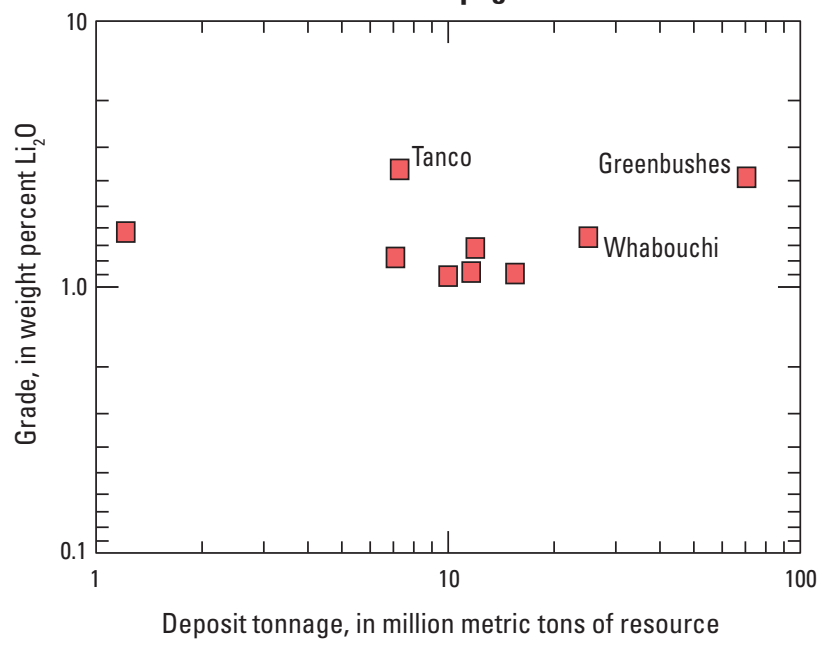

long term. Lithium can be recycled indefinitely, whereas oil can be used only once. Resources of lithium are expected to satisfy demand into the next century (Evans, 2012).

Although current domestic lithium production is small, the United States is endowed with a substantial lithium resource. Gruber and others (2011) estimated the domestic lithium resource to be about 10.2 million metric tons. This includes the Kings Mountain pegmatite district in North Carolina (5.9 million metric tons of lithium), the Kings Valley hectorite deposit in Nevada (2.0 million metric tons), and various closed-basin, geothermal, and oilfield brines (2.3 million metric tons).

\section{Undiscovered Resources}

Exploration for lithium deposits has never been as intense as it has been for other metallic resources, such as gold and copper, so it is likely that large, economically viable lithium deposits remain to be discovered. Now that a potentially very large lithium battery market exists for hybrid and electric vehicles, more exploration is being done, and new deposits will likely be discovered. The USGS contributes to this effort by developing mineral deposit models, which provide a conceptual basis for modern mineral exploration. New models have been developed for both LCT pegmatites (Bradley and McCauley, 2013; Bradley and others, (2017) and lithium brines (Bradley and others, 2013; Munk and others, 2016).

Plots of grade versus tonnage are shown in figure K9 for lithium in pegmatites and brines; these give an indication of the sizes of deposits that might remain to be found. The two parameters, deposit grade and deposit tonnage, vary across a wide range of values for most of the common lithium deposit types.

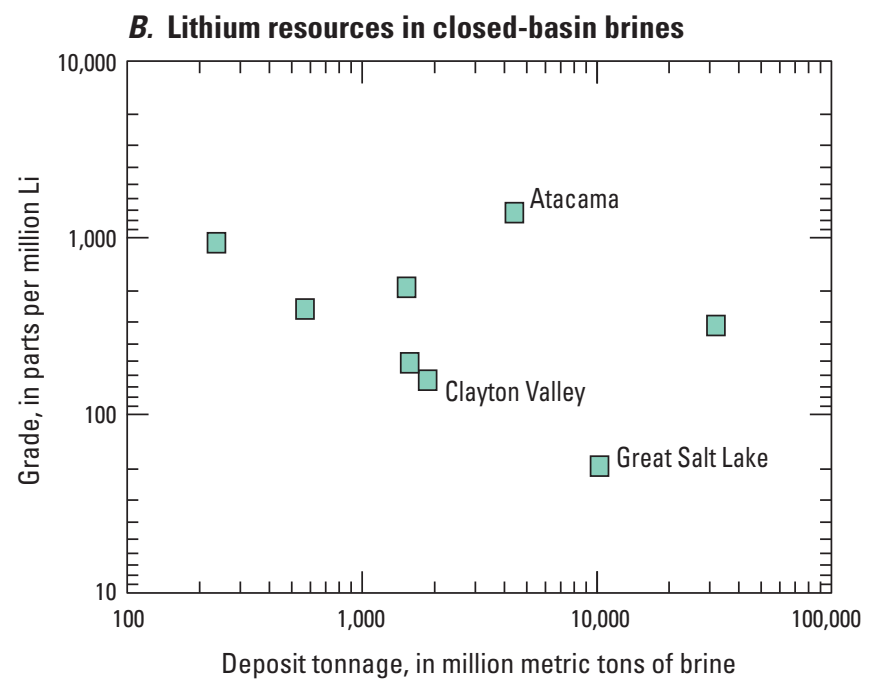

Figure K9. Plots of lithium grade and tonnage for selected world deposits. These plots give an indication of the sizes of deposits that might remain to be found for $A$, lithium-cesium-tantalum (LCT) pegmatites, and $B$, closed-basin brines. Data for the LCT pegmatites are from Bradley and others (2017), and data for the closed-basin brines are from Munk and others (2016). Some of the deposits discussed in the text are labeled. 


\section{Exploration for New Deposits}

\section{Exploration for Lithium-Cesium-Tantalum Pegmatite Deposits}

The search for new LCT pegmatite districts begins with the knowledge that all LCT pegmatites were emplaced into orogenic belts (Bradley and McCauley, 2013). The global age distribution (fig. K6) provides a first-order filter in the search for new LCT pegmatites in unexplored regions. The potential for giant deposits seems greatest in Archean (2,500 Ma and older) collision zones. Most LCT pegmatites intruded metamorphosed sedimentary rocks, typically at conditions of medium pressure and medium to high temperatures (greenschist to amphibolite facies) (Černý, 1992). New deposits are likely to be found within a few kilometers of a "fertile" granite, which generally are large enough (typically several square kilometers in area) to be known already from routine geologic mapping. Fertile granites are identified by the presence of distinctive minerals, such as muscovite, tourmaline, and garnet; by anomalously high concentrations of such trace elements as cesium, lithium, rubidium, tin, and tantalum; and by low concentrations of the major elements calcium, iron, and magnesium (Selway and others, 2005). Around a fertile granite, the more distal LCT pegmatites are more likely to be enriched in lithium (fig. K7). Weathering of LCT pegmatites can result in both soil anomalies and indicator minerals. Smith and others (1987) demonstrated that arsenic, beryllium, antimony, and tin form a 12-by-20-km halo in lateritic soils around the Greenbushes pegmatite; niobium, tantalum, and boron form a smaller, 1-by-5-km halo. Cassiterite, tantalite, elbaite, and spessartine are sufficiently dense and durable to serve as heavy indicator minerals that can be found by panning unconsolidated sediments.

\section{Exploration for Lithium-Brine Deposits in Closed Basins}

The most critical factor that determines if a sedimentary basin can accumulate lithium brine is whether or not the basin is closed. All the lithium-brine basins in figure $\mathrm{K} 5$ are closed, and all have a saline lake or a salar (that is, a salt flat or salt-encrusted depression). Closed basins form because of tectonic processes, but they are maintained only where, over longer timespans, evaporation exceeds precipitation. If the long-term rate of precipitation in a basin increases sufficiently, lake water will eventually overtop some point along the drainage divide and drain away, carrying with it any dissolved lithium. Mean annual temperature does not appear to be a critical factor; values range through an order of magnitude from about 0 degrees Celsius $\left({ }^{\circ} \mathrm{C}\right.$ ) to $23{ }^{\circ} \mathrm{C}$ (Munk and others, 2016). Judging from the present-day population of basins, the favorable zones lie between about $19^{\circ}$ and $37^{\circ}$ north or south latitude (Bradley and others, 2013; Munk and others, 2016). Lithium-brine resources are found in a range of active tectonic settings, from extensional, to strike-slip, to contractional (Bradley and others, 2013; Munk and others, 2016). All but one of the lithium-brine basins show evidence for elevated heat flow, as revealed by the presence of young volcanoes, hot springs, and (or) geothermal resources. Evidence of older hydrothermal activity is seen in several instances and should be regarded as a favorable characteristic. For example, at Clayton Valley, some Miocene to Pliocene basinal deposits were hydrothermally enriched in hectorite; this probably took place a few million years ago, before the lithium-enriched basinal strata were uplifted and exposed. Hectorite concentration haloes have been reported from several basins that lack lithium brines in the U.S. Basin and Range Province (Vine, 1980). In such cases, a hectorite halo may be all that remains of a former brine system that has since leaked away. Like lithium brines, borate deposits appear to be hybrids involving both hydrothermal and evaporative processes; their presence is a favorable indicator for lithium brines. Source rocks, such as felsic, glassy tuffs that have abundant and readily leached lithium, are favorable indicators of a nearby lithium brine deposit (Price and others, 2000).

\section{Exploration for Lithium in Sedimentary Rocks (Clays and Zeolites)}

The depositional environments of deposits, prospects, and occurrences in the Basin and Range Province share the following characteristics: they are all found in lake sediments, the sediments contain ash or other volcanic materials, and there is evidence of alteration by hydrothermal fluids (AsherBolinder, 1982, 1991). Borate deposits share the same general characteristics, and, accordingly, the presence of borates is a favorable indication for lithium clays. In the Basin and Range Province, borate deposits were extensively prospected in the late 1800 s and early 1900s, and many deposits and prospects were found. Lithium clays are not as obvious in these settings as are the common borate minerals; significant lithium resources may thus have been overlooked.

The lithium zeolites at Jadar, Serbia, compose the only known deposit of this type. Accordingly, exploration guidelines must be based on this occurrence, which formed in an extensional tectonic regime and is hosted in Miocene-age lake beds that include oil shale, carbonate rocks, evaporites, oil shale, and tuff (Obradović and others, 1997). 


\section{Environmental Considerations}

\section{Sources and Fate in the Environment}

Lithium in the environment can be derived from both natural and anthropogenic sources. As noted already, lithium is present in trace quantities in most rocks and natural waters and is a major component only in certain rare pegmatite minerals, clays, zeolites, and brines. Potential anthropogenic lithium sources include mine wastes, and after disposal, the wide range of manufactured products.

In soils, lithium is found in detrital and authigenic minerals and, to a lesser extent, in the organic fraction (Heier and Billings, 1978; Ribas, 1991; Schrauzer, 2002). Its concentration depends upon the parent rock (table K2); a study of Scottish soils shows the highest lithium concentrations are found in soils that develop over claystones and metamorphosed felsic rocks. The top 10 centimeters of a soil profile can be poorer in lithium than lower layers because lithium is leached by weathering solutions and can be incorporated into underlying clay minerals (Mitchell, 1964; Ribas, 1991). Shacklette and others (1973) observed that soils from the Western United States are more enriched in lithium than are those in the Eastern United States, with mean values of $23.3 \mathrm{ppm}$ lithium and $17.3 \mathrm{ppm}$ lithium, respectively. Cannon and others (1975) found a difference between the lithium contents of sediments in hydrologically open and closed basins in the Basin and Range Province of California and Nevada. In open basins, the lithium concentrations are relatively low, ranging from 0 to $150 \mathrm{ppm}$. In contrast, the range of lithium concentrations in hydrologically closed basins is 30 to $2,000 \mathrm{ppm}$, and lacustrine clays have a median value of $700 \mathrm{ppm}$ lithium. The difference is owing to hydrological flow patterns; in open basins, dissolved salts are continually carried off by outflowing waters.

Although lithium is not required for the growth of plants, they are known to assimilate it, typically in the range of 0.2 to $30 \mathrm{ppm}$ (Aral and Vecchio-Sadus, 2008). More extreme values have also been reported; for example, matrimony vine (Lycium barbarum) from Arizona contained 1,120 ppm lithium (dry weight) (Sievers and Canon, 1973). A study of plants from 20 basins in Nevada and California demonstrated that native plants grown in arid basins absorb more lithium than those in more humid regions. Cannon and others (1975) reported median lithium concentrations of 22.8 ppm (dry weight) from Magnoliopsida (also known as dicotyledons) in arid basins compared with $1.3 \mathrm{ppm}$ from humid regions of the United States (Bertrand, 1952, 1959). Cannon and others (1975) reported that plants growing in hot-spring discharge zones appear to have died from accumulation and precipitation of evaporative salts; these "fossilized root crowns" of salt can contain 1,000 ppm lithium.

Being a highly soluble element, lithium is commonly found as a dissolved species in both groundwater and surface water. This property makes lithium useful as a conservative tracer in hydrogeological studies (Bencala and others, 1990). There is evidence, however, that lithium may be removed from solution through sorption onto suspended clays. For example, in Saline Valley, Calif., 98 percent of lithium is lost from solution during surface flow from the spring to the playa (Lombardi, 1963). Lithium substitutes readily for magnesium in the clay structure because of the similar ionic radii of the two elements, and this isomorphic substitution is likely responsible for the affinity of lithium for clays. Plant uptake is another mechanism by which lithium can be removed from solution, especially soil solution. There is a much greater uptake of lithium by plants in acid soils, as acidity increases the solubility of metals (Schrauzer, 2002; Lenntech, 2007).

The use of lithium batteries is anticipated to increase in the future in response to the increasing demand for electric vehicles. The increased use of lithium in batteries is in turn expected to result in increased recycling of lithium from batteries. Recent press reports of explosions and fires associated with lithium batteries (for example, Mouawad and Drew, 2013) could cause concern about lithium recycling. Spent lithium batteries contain virtually no lithium metal, however, because it has all been converted to lithium oxide by the time the battery stops working (National Electrical Manufacturers Association, 2001). Lithium oxide is unreactive; unlike lithium metal, it does not produce hydrogen gas upon exposure to water, and it does not catch fire. Both HMIS (Hazardous Materials Identification System) and NFPA (National Fire Protection Association) give it a " 0 " rating for flammability and physical (reactivity) hazard risks (Alpha Aesar, 2012; Sigma Aldrich, 2014). It is a health hazard (a " 3 " rating by HMIS and NFPA) because it is corrosive and can cause serious eye and skin damage upon contact. Disposal of spent batteries in a modern municipal solid waste facility is not likely to present a lithium hazard, however. Lithium oxide is slightly to moderately soluble - a maximum of $6.67 \mathrm{~g}$ of $\mathrm{Li}_{2} \mathrm{O}$ can dissolve in $100 \mathrm{~g}$ of water $\left(\mathrm{H}_{2} \mathrm{O}\right)$ at $0{ }^{\circ} \mathrm{C}$ (ESPI Metals, 1993).

Table K2. Lithium concentrations (in parts per million) in soils developed on various types of bedrock.

[Sources: Mitchell (1964), as reported in Heier and Billings (1978)]

\begin{tabular}{|c|c|c|c|c|c|c|c|c|}
\hline \multicolumn{3}{|c|}{ Igneous } & \multicolumn{4}{|c|}{ Metamorphic } & \multicolumn{2}{|c|}{ Sedimentary } \\
\hline Olivine gabbro & Andesite & Granite & Serpentinite & Quartzite & Granitic gneiss & Quartz mica schist & Shale & Sandstone \\
\hline 30 & 50 & 7 & 30 & 15 & 70 & 200 & 60 & 20 \\
\hline
\end{tabular}




\section{Mine Waste Characteristics}

Mine-waste characteristics vary with the type of lithium deposit. Only two types of deposits - pegmatites and closedbasin brines - have produced mine wastes.

The mining history of lithium pegmatites may affect the mineralogy of tailings and waste piles that remain. Tin was the original target of mining at Kings Mountain (Kesler, 1942, 1955, 1961), suggesting that lithium-bearing minerals may still remain in dumps from that era. Mineral processing of the pegmatite minerals involved crushing, wet grinding, sieving, gravity concentration, flotation, and collection with fatty acid amines. Tailings were discharged to storage ponds (Garrett, 2004) that likely contain some lithium. In 1969, mineral processing was changed to improve the recovery of lithium. The new process involved calcining (heating) the spodumene concentrate after collection, then leaching the calcine with hot water. Yet even with this newer process, all the lithium still was not recovered.

Another source of lithium to waste and tailings piles can be through dissolution of the lithium minerals in the grinding and sieving steps of processing. For example, spodumene is fairly insoluble in water and dilute acids, but a small amount of dissolution has been observed during ore processing and concentration (Aral and Vecchio-Sadus, 2008). The dissolved lithium will be transported with the processing water and may concentrate in tailings ponds that have concentrations ranging up to $13 \mathrm{ppm}$.

The production of lithium by evaporation of closed-basin brines produces various evaporite minerals in the sequence of ponds. Details vary among the deposits owing to differences in brine chemistry. Precipitates at Clayton Valley include clay, calcium carbonate, calcium sulfate, hydrated magnesia, potassium-sodium sulfate, and potassium-sodium chloride (Garrett, 2004).

\section{Human Health Concerns}

Lithium is not considered an essential element for life, but it is present in most organisms in trace quantities (Léonard and others, 1995; Lenntech, 2007). The normal human intake is about 2 milligrams per day ( $\mathrm{mg} / \mathrm{d}$ ) (Léonard and others, 1995), and the human body contains about 7 milligrams (mg). Ingested lithium is absorbed from the intestines and excreted through the kidneys, and the half-life in the body is about 24 hours (Freeman and Freeman, 2006; Aral and VecchioSadus, 2008).

In the realm of human health, lithium is best known as the leading treatment for the debilitating symptoms of bipolar disorder. Modern use of lithium compounds for this purpose dates from pioneering work after World War II in Australia by John Cade (Mitchell and Hadzi-Pavlovic, 2000). About 4 percent of people — or nearly 300 million out of the present world population-will suffer from bipolar disorder at some point in their lives (Ketter, 2010). The number who treat the condition with lithium is unknown but undoubtedly is in the millions. A typical dosage is $1,800 \mathrm{mg} / \mathrm{d}$ of lithium carbonate (Drugs.com, 2013).

Lithium can be toxic. In fact, the United States banned the use of medicinal lithium between 1949 and 1970 for this reason (Strobusch and Jefferson, 1980). Aral and Vecchio-Sadus (2008) summarized the various harmful effects and noted that a dose of $5 \mathrm{~g}$ of lithium can be fatal to humans. No lithium poisoning has been reported from industrial applications, however (Aral and Vecchio-Sadus, 2008).

\section{Ecological Health Concerns}

Lithium affects metabolism, neuronal communication, and cell proliferation in many organisms in addition to humans. It disturbs the development of invertebrates (Léonard and others, 1995), and, in rats, it has been reported to reduce the number in a litter and the weight of the offspring and to cause incomplete ossification (Domingo, 1994). One of several useful endpoints used in toxicity tests is the concentration that leads to 50 percent mortality (lethal concentration 50 , or $\mathrm{LC}_{50}$ ) after exposure to a substance for a certain amount of time. For earthworms exposed to soil containing lithium, the $\mathrm{LC}_{50}$ value was 70 milligrams per kilogram $(\mathrm{mg} / \mathrm{kg})$ after 7 weeks of exposure (Fischer and Molnár, 1997). The sensitivity of fish to lithium was measured in a series of 96-hour tests, which revealed an $\mathrm{LC}_{50}$ value that ranged from $13 \mathrm{mg} / \mathrm{L}$ for fathead minnows to greater than $100 \mathrm{mg} / \mathrm{L}$ for other fish species. Lithium concentrations of $1.2 \mathrm{mg} / \mathrm{L}$ immobilized the tiny crustacean Daphnia magna in 64 hours, and a dose of $1.7 \mathrm{mg} / \mathrm{L}$ of lithium prevented the formation of embryos in fish eggs (Kszos and Stewart, 2003).

\section{Carbon Footprint}

Lithium's potential importance to the world's carbon budget derives from its use in lightweight, rechargeable car batteries. Over the course of a hypothetical lifetime of 150,000 miles $(240,000 \mathrm{~km})$, today's average gasolinepowered car will produce about 63,450 kilograms of carbon dioxide based on values from the U.S. Environmental Protection Agency, Office of Transportation and Air Quality (2011). This greenhouse gas will go directly from the tailpipe to the atmosphere, where it will contribute to global warming; some of it will later end up dissolved in seawater, where it will contribute to further ocean acidification, harming or killing fish and shellfish. The carbon dioxide output of an electric car depends largely on the means of charging its battery, but in all cases - even if the electricity comes from a coal-fired powerplant - the output of carbon dioxide is lower than for a gasoline-powered car (Notter and others, 2010). In the bestcase scenario, where the battery is recharged from renewable hydroelectric, wind, tidal, or solar power, the carbon dioxide output (beyond infrastructure costs) is negligible. 


\section{Problems and Future Research}

As is the case for most of the critical elements, lithium resources have not been as thoroughly studied as some conventional metallic resources, such as copper and lead. Basic research on the better-known lithium deposit types (pegmatites and brines) as well as on the newer deposit types (clays and zeolites) would help identify new resources and could ensure that a transition from fossil fuels to renewable energy sources is not limited by the supply of lithium.

For LCT pegmatites, the overarching question is why some orogenic belts are well-endowed with these deposits, whereas other seemingly similar belts are not? The connections between LCT pegmatites and tectonics have yet to be unraveled at the level of detail that would aid in exploration. Although most LCT pegmatites are found in orogenic belts that formed during continental collision, there is no obvious explanation for why particular pegmatites formed where and when they did. To address this problem would require tight geochronology for the pegmatite, for the orogenic belt in which it occurs, and for any associated sedimentary basins. Such an effort is now technologically possible.

A similar question applies to lithium brines-Why have these deposits formed in only a small subset of closed basins in arid regions? In the U.S. Basin and Range Province, for example, about 150 basins share the same basic characteristics, but only a few have lithium brines. Another key question involves the timescale of lithium-brine genesis-Are lithiumenriched brines like fossil fuels, or are they renewable on short time scales?

Lithium-clay (hectorite) and lithium-zeolite (jadarite) deposits have not been systematically studied. Mineral-deposit models would be useful to guide exploration efforts for both types. Lithium-clay deposits, which can be studied at the surface, are also of interest as potential examples of fossil lithium-brine systems that once operated at depth.

Lithium is neither an ecological nor a human health concern when it is present at ambient conditions. As global lithium consumption rises during the next few decades, however, environmental issues related to the production, routine daily use, and disposal of lithium products will warrant additional research.

\section{Acknowledgments}

We would like to thank technical reviewers Nora Foley and Klaus Schulz and volume editor John DeYoung for suggestions that significantly improved the manuscript. Keith Labay helped create the deposit location maps and Suzanne Nicholson provided additional editorial comments after the technical review was complete.

\section{References Cited}

Note: All Web links listed were active as of the access date but may no longer be available.

Alpha Aesar, 2012, Lithium oxide: Alpha Aesar safety data sheet, stock number 41832, review date August 16, 2012, 4 p., accessed July 10, 2014, at http://www.alfa.com/ content/msds/USA/41832.pdf.

American Physical Society Panel on Public Affairs and the Materials Research Society, 2011, Energy critical elementsSecuring materials for emerging technologies: Washington, D.C., American Physical Society, 28 p. 19 p. plus 2 appendixes. [Also available at http://www.aps.org/policy/reports/ popa-reports/upload/elementsreport.pdf.]

Ames, L.L., Jr., Sand, L.B., and Goldich, S.S., 1958, A contribution on the Hector, California, bentonite deposit: Economic Geology, v. 53, p. 22-37. [Also available at http://dx.doi.org/10.2113/gsecongeo.53.1.22.]

Anstett, T.F., Krauss, U.H., Ober, J.A., and Schmidt, H.W., 1990, International strategic minerals inventory summary report—Lithium: U.S. Geological Survey Circular 930-I, 28 p. [Also available at http://pubs.er.usgs.gov/publication/ cir930I.]

Aral, Hal, and Vecchio-Sadus, Angelica, 2008, Toxicity of lithium to humans and the environment-A literature review: Ecotoxicology and Environmental Safety, v. 70, no. 3, p. 349-356. [Also available at http://dx.doi.org/ 10.1016/j.ecoenv.2008.02.026.]

Asher-Bolinder, Sigrid, 1982, Lithium-rich clays, in Erickson, R.L., ed., Characteristics of mineral deposit occurrences: U.S. Geological Survey Open-File Report 82-795, p. 225-229.

Asher-Bolinder, Sigrid, 1991, Descriptive model of lithium in smectites of closed basins, in Orris, G.J., and Bliss, J.D., eds., Some industrial mineral deposit models-Descriptive deposit models: U.S. Geological Survey Open-File Report 91-11-A, p. 11-12. [Also available at http://pubs.er.usgs.gov/publication/ofr9111A.]

Atwater, Tanya, 2011, Northeast Pacific and western North American plate tectonic history, animation: Santa Barbara, Calif., University of California, Santa Barbara, accessed September 16, 2013, at http://emvc.geol.ucsb.edu/2_infopgs/ IP4WNACal/bNEPacWNoAmer.html.

Barthelmy, David, 2014, Mineralogy database: Webmineral database, accessed April 14, 2014, at http://webmineral.com. 
Bencala, K.E., McKnight, D.M., and Zellweger, G.W., 1990, Characterization of transport in an acidic and metal-rich mountain stream based on a lithium tracer injection and simulations of transient storage: Water Resources Research, v. 26, no. 5, p. 989-1000. [Also available at http://dx.doi.org/ 10.1029/WR026i005p00989.]

Bertrand, Didier, 1952, Sur la répartition du lithium chez les Phanérogames [The distribution of lithium in phanerogams]: Comptes Rendus Hebdomadaires des Séances de l'Académie des Sciences [Weekly Reports of the Meetings of the Academy of Sciences], v. 234, January-June, p. 2102-2104.

Bertrand, Didier, 1959, Nouvelles recherches sur la répartition du lithium chez les Phanérogames [New investigations of the distribution of lithium in phanerogams]: Comptes Rendus Hebdomadaires des Séances de l'Académie des Sciences [Weekly Reports of the Meetings of the Academy of Sciences], v. 249, July-September, p. 787-788.

Bradley, D.C., 2011, Secular trends in the geologic record and the supercontinent cycle: Earth-Science Reviews, v. 108 , nos. 1-2, p. 16-33. [Also available at http://dx.doi.org/10.1016/j.earscirev.2011.05.003.]

Bradley, Dwight, and McCauley, Andrew, 2013, A preliminary deposit model for lithium-cesium-tantalum (LCT) pegmatites: U.S. Geological Survey Open-File Report 2013-1008, 7 p. [Also available at http://pubs.usgs.gov/of/2013/1008/.]

Bradley, D.C., McCauley, A.D., and Stillings, L.L., 2017, Mineral-deposit model for lithium-cesium-tantalum pegmatites: U.S. Geological Survey Scientific Investigations Report 2010-5070-O.

Bradley, D.C., Munk, LeeAnn, Jochens, Hillary, Hynek, Scott, and Labay, Keith, 2013, A preliminary deposit model for lithium brines: U.S. Geological Survey OpenFile Report 2013-1006, 6 p. [Also available at http://pubs.er.usgs.gov/publication/ofr20131006.]

Brobst, D.A., and Pratt, W.P., eds., 1973, United States mineral resources: U.S. Geological Survey Professional Paper 820, 722 p. [Also available at http://pubs.er.usgs.gov/ publication/pp820.]

Cannon, H.L., Harms, T.F., and Hamilton, J.C., 1975, Lithium in unconsolidated sediments and plants of the Basin and Range Province, southern California and Nevada: U.S. Geological Survey Professional Paper 918, 23 p. [Also available at http://pubs.er.usgs.gov/publication/pp918.]

Černý, P, 1992, Geochemical and petrogenetic features of mineralization in rare-element granitic pegmatites in the light of current research: Applied Geochemistry, v. 7, no. 5, p. 393-416. [Also available at http://dx.doi.org/10.1016/ 0883-2927(92)90002-K.]
Collins, A.G., 1976, Lithium abundances in oil field waters, in Vine, J.D., ed., Lithium resources and requirements by the year 2000: U.S. Geological Survey Professional Paper 1005, p. 116-123. [Also available at http://pubs.er.usgs.gov/ publication/pp1005.]

Domingo, J.L., 1994, Metal-induced developmental toxicity in mammals-A review: Journal of Toxicology and Environmental Health, v. 42, no. 2, p. 123-41.

Drugs.com, 2013, Lithium: Accessed May 9, 2014, at http://www.drugs.com/pro/lithium.html - i4i_section_id_ bd99c041-bd36-49a6-aad5-6fe469a6bd06.

Eggleston, Ted, and Hertel, Mark, 2008, Kings Valley lithium project, Nevada, USA, NI 43-101 technical report, prepared for Western Lithium Canada Corp., Project no. 160237 [Filing date January 21, 2009]: Phoenix, Ariz., AMEC E\&C Services Inc., December 15, variously paged, accessed November 5, 2015, at http://www.sedar.com.

Emsley, John, 2011, Nature's building blocks-An A-Z guide to the elements: Oxford, Oxford University Press, 538 p.

ESPI Metals, 1993, Material safety data sheet for lithium oxide: ESPI Metals Material Safety Data Sheet. CAS number 12057-24-8, accessed July 10, 2014, at http://www.espimetals.com/index.php/msds/650-lithium-oxide.

Evans, R.K., 2008, An abundance of lithium: Raleigh, N.C., North Carolina State University, accessed February 2012, at http://www.che.ncsu.edu/ILEET/phevs/lithium-availability/ An_Abundance_of_Lithium.pdf.

Evans, R.K., 2012, An overabundance of lithium?: Lithium Supply \& Markets Conference, 4th, Buenos Aires, Argentina, January 23-25, 2012, Presentation, unpaginated.

Evans, R.K., 2014, Lithium, chap. 10 of Gunn, Gus, ed., Critical metals handbook: Hoboken, N.J., Wiley, p. 230-260.

Faure, Gunter, 1998, Principles and applications of geochemistry-A comprehensive textbook for geology students: Upper Saddle River, N.J., Prentice Hall, 600 p.

Fischer, Ernö, and Molnár, László, 1997, Growth and reproduction of Eisenia fetida (Oligochaeta, Lumbricidae) in semi-natural soil containing various metal chlorides: Soil Biology and Biochemistry, v. 29, nos. 3-4, p. 667-670. [Also available at http://dx.doi.org/10.1016/S00380717(96)00193-9.]

Freeman, M.P., and Freeman, S.A., 2006, Lithium-Clinical considerations in internal medicine: The American Journal of Medicine, v. 119, no. 6, p. 478-481. [Also available at http://dx.doi.org/10.1016/j.amjmed.2005.11.003.] 
Galeschuk, C.R., and Vanstone, P.J., 2005, Exploration for buried rare element pegmatites in the Bernic Lake region of southeastern Manitoba, in Linnen, R.L., and Samson, I.M., eds., Rare-element geochemistry and mineral deposits: St. Johns, Newfoundland and Labrador, Canada, Geological Association of Canada, Short Course Notes, v. 17, p. 159-173.

Garrett, D.E., 2004, Handbook of lithium and natural calcium chloride (1st ed.): Boston, Mass., Elsevier, 476 p.

Gruber, P.W., Medina, P.A., Keoleian, G.A., Kesler, S.E., Everson, M.P., and Wallington, T.J., 2011, Global lithium availability-A constraint for electric vehicles?: Journal of Industrial Ecology, v. 15, no. 5, p. 760-775. [Also available at http://dx.doi.org/10.1111/j.1530-9290.2011.00359.x.]

Heier, K.S., and Billings, G.K., 1978, Lithium, in Wedepohl, K.H., ed., Handbook of geochemistry, v. 2, pt. 1: Berlin, West Germany, Springer-Verlag, p. 3-A-1 to 3-A-7.

Helvaci, Cahit, Mordogon, Hasan, Çolak, Mümtaz, and Gündogan, Ibrahim, 2004, Presence and distribution of lithium in borate deposits and some recent lake waters of west-central Turkey: International Geology Review, v. 46, no. 2, p. 177-190. [Also available at http://dx.doi.org/10.2747/0020-6814.46.2.177.]

Jaskula, B.W., 2013, Lithium: U.S. Geological Survey Mineral Commodity Summaries 2013, p. 94-95, accessed May 9, 2014, at https://minerals.usgs.gov/minerals/pubs/ commodity/lithium/mcs-2013-lithi.pdf.

Kesler, S.E., Gruber, P.W., Medina, P.A., Keoleian, G.A., Everson, M.P., and Wallington, T.J., 2012, Global lithium resources-Relative importance of pegmatite, brine and other deposits: Ore Geology Reviews, v. 48, October, p. 55-69. [Also available at http://dx.doi.org/10.1016/ j.oregeorev.2012.05.006.]

Kesler, T.L., 1942, The tin-spodumene belt of the Carolinas, a preliminary report: U.S. Geological Survey Bulletin 936-J, p. 245-269, 5 plates. [Also available at http://pubs.er.usgs.gov/ publication/b936J.]

Kesler, T.L., 1955, The Kings Mountain area, in Russell, R.J., ed., Guides to southeastern geology: New York, N.Y., Geological Society of America, p. 374-387, sketch maps.

Kesler, T.L., 1961, Exploration of the Kings Mountain pegmatites: Mining Engineering, v. 13, no. 9, September, p. 1063-1068.

Ketter, T.A., 2010, Diagnostic features, prevalence, and impact of bipolar disorder [abs.]: The Journal of Clinical Psychiatry, v. 71, no. 6, p. e14. [Also available at http://dx.doi.org/10.4088/ JCP. $8125 \mathrm{tx} 11 \mathrm{c}$.
Kszos, L.A., and Stewart, A.J., 2003, Review of lithium in the aquatic environment-Distribution in the United States, toxicity and case example of groundwater contamination: Ecotoxicology, v. 12, no. 5, p. 439-447. [Also available at http://dx.doi.org/10.1023/A:1026112507664.]

Kunasz, I.A., 2006, Lithium resources, in Kogel, J.E., Trivedi, N.C., Barker, J.M., and Krukowski, S.T., eds., Industrial minerals and rocks-Commodities, markets, and uses (7th ed.): Littleton, Colo., Society for Mining, Metallurgy and Exploration, p. 599-614.

Lenntech, 2007, Lithium and water-Reaction mechanisms, environmental impact and health effects: Delft, South Holland, Netherlands, Lenntech, accessed September 16, 2013, at http://www.lenntech.com/elements-and-water/lithiumand-water.htm.

Léonard, A.J., Hantson, P.E., and Gerber, G.B., 1995, Mutagenicity, carcinogenicity and teratogenicity of lithium compounds: Mutation Research/Reviews in Genetic Toxicology, v. 339, no. 3, p. 131-137. [Also available at http://dx.doi.org/10.1016/0165-1110(95)90007-1.]

Lombardi, O.W., 1963, Observations on the distribution of chemical elements in the terrestrial saline deposits of Saline Valley, California: China Lake, Calif., U.S. Naval Ordnance Test Station, 42 p.

London, David, 2008, Pegmatites: Ottawa, Ontario, Canada, Mineralogical Association of Canada, Canadian Mineralogist Special Publication, v. 10, 347 p., CD-ROM included.

McCauley, A., and Bradley, D., 2013, The secular distribution of granitic pegmatites and rare-metal pegmatites [abs.], in PEG2013-The 6th International Symposium on Granitic Pegmatites, Attitash, N.H., 2013, Contributions: New Orleans, La., Rubellite Press, p. 92-93. [Also available at http://pegmatology.uno.edu/news_files/PEG2013_Abstract Volume.pdf.]

McCauley, Andrew, and Bradley, D.C., 2014, The global age distribution of granitic pegmatites: The Canadian Mineralogist, v. 52, no. 2, p. 183-190. [Also available at http://dx.doi.org/10.3749/canmin.52.2.183.]

McLennan, S.M., 2001, Relationships between the trace element composition of sedimentary rocks and upper continental crust: Geochemistry Geophysics Geosystems, v. 2, no. 4, 24 p. [Also available at http://dx.doi.org/ 10.1029/2000GC000109.]

Merriman, David, 2014, More motion, less e-motion-Is 2014 the year lithium regains its traction?: Sixth annual Lithium Supply \& Markets Conference, Montreal, Quebec, Canada, May 20-22 2014, Presentation. 
Mitchell, P.B., and Hadzi-Pavlovic, Dusan, 2000, Lithium treatment for bipolar disorder: Bulletin of the World Health Organization, v. 78, no. 4, p. 515-517.

Mitchell, R.L., 1964, Trace elements in soils, chap. 8 of Bear, F.E., ed., Chemistry of the soil ( $2 \mathrm{~d}$ ed.): New York, N.Y., Reinhold, p. 320-368.

Mohr, Steve, Mudd, Gavin, and Giurco, Damien, 2010, Lithium resources and production-A critical global assessment: Sydney, New South Wales, Australia, CSIRO Minerals Down Under Flagship, Cluster report 1.4, October, 99 p. [Also available at https://www.uts.edu.au/sites/default/ files/Mohretal2010lithiumresourcesandproduction.pdf.]

Mouawad, Jad, and Drew, Christopher, 2013, Praised but fire prone, battery fails test in 787: The New York Times, January 17, p. A1, accessed September 16, 2013, at http://www.nytimes.com/2013/01/18/business/insidethe-787-an-unsettling-risk-for-boeing.html.

Munk, L.A., Hynek, S.A., Bradley, D.C., Boutt, D.F., Labay, K., and Jochens, H., 2016, Lithium brines-A global perspective: Reviews in Economic Geology, v. 18, p. 339-365.

National Electrical Manufacturers Association, 2001, Spent consumer lithium batteries and the environment: National Electrical Manufacturers Association, March, 1 p., accessed September 16, 2013, at http://www.nema.org/Policy/ Environmental-Stewardship/Documents/SpentConsumer_ Lithium_Batteries_and_the_Environment.pdf.

National Research Council, 2008, Minerals, critical minerals, and the U.S. economy: Washington, D.C., National Academies Press, 245 p. [Also available at http://www.nap.edu/ catalog/12034/minerals-critical-minerals-and-the-us-economy.]

Natural Earth, 2014, Small scale data: Natural Earth map dataset, scale 1:110,000,000, accessed June 23, 2014, at http://www.naturalearthdata.com.

Naumov, A.V., and Naumova, M.A., 2010, Modern state of the world lithium market: Russian Journal of NonFerrous Metals, v. 51, no. 4, p. 324-330. [Also available at http://dx.doi.org/10.3103/S1067821210040127.]

Norton, J.J., 1965, Lithium-bearing bentonite deposit, Yavapai County, Arizona, chap. D of Geological Survey Research 1965: U.S. Geological Survey Professional Paper 525-D, p. D163-D166, accessed May 1, 2014, at http://pubs.usgs.gov/ pp/0525-D/report.pdf.

Norton, J.J., 1973, Lithium, cesium, and rubidium-The rare alkali metals, in Brobst, D.A., and Pratt, W.P., eds., United States mineral resources: U.S. Geological Survey Professional Paper 820, p. 365-378. [Also available at http://pubs.er.usgs.gov/publication/pp820.]
Notter, D.A., Gauch, Marcel, Widmer, Rolf, Wäger, Patrick, Stamp, Anna, Zah, Rainer, and Althaus, H.-J., 2010, Contribution of Li-ion batteries to the environmental impact of electric vehicles: Environmental Science and Technology, v. 44, no. 17, p. 6550-6556. [Also available at http://dx.doi.org/10.1021/es903729a.]

Obradović, Jelena, Djurdjević-Colson, Jelena, and Vasić, Nebojša, 1997, Phytogenic lacustrine sedimentationOil shales in Neogene from Serbia, Yugoslavia: Journal of Paleolimnology, v. 18, no. 4, p. 351-364. [Also available at http://dx.doi.org/10.1023/A:1007907109399.]

Partington, G.A., McNaughton, N.J., and Williams, I.S., 1995, A review of the geology, mineralization, and geochronology of the Greenbushes pegmatite, Western Australia: Economic Geology, v. 90, p. 616-635. [Also available at http://dx.doi.org/10.2113/gsecongeo.90.3.616.]

Price, J.G., Lechler, P.J., Lear, M.B., and Giles, T.F., 2000, Possible volcanic source of lithium in brines in Clayton Valley, Nevada, in Cluer, J.K., Price, J.G., Struhsacker, E.M., Hardyman, R.F., and Morris, C.L., eds., Geology and ore deposits 2000-The Great Basin and beyond-Symposium proceedings: Reno, Nev., Geological Society of Nevada, p. 241-248.

Ribas, Bartholomé, 1991, Lithium, chap. 17 of Merian, Ernest, and Clarkson, T.W., eds., Metals and their compounds in the environment-Occurrence, analysis, and biological relevance: New York, N.Y., VCH Publishers, v. 2, p. 1015-1023.

Rickwood, P.C., 1981, The largest crystals: American Mineralogist, v. 66, nos. 9-10, p. 885-907.

Rytuba, J.J., and Glanzman, R.K., 1979, Relation of mercury, uranium, and lithium to the McDermitt caldera complex, Nevada-Oregon: Nevada Bureau of Mines and Geology, Papers on Mineral Deposits of Western North America, Report 33, p. 109-117. [Also available at http://pubs.er.usgs.gov/publication/70043142.]

Schaller, W.T., 1916, Mineralogic notes, series 3: U.S. Geological Survey Bulletin 610, 164 p., 5 pls. [Also available at http://pubs.er.usgs.gov/publication/b610.]

Schrauzer, G.N., 2002, Lithium-Occurrence, dietary intakes, nutritional essentiality: Journal of the American College of Nutrition, v. 21, no. 1, p. 14-21. [Also available at http://dx.doi.org/10.1080/07315724.2002.10719188.]

Schwartz, M.O., 1992, Geochemical criteria for distinguishing magmatic and metasomatic albiteenrichment in granitoids-Examples from the Ta-Li granite Yichun (China) and the Sn-W deposit, Tikus (Indonesia): Mineralium Deposita, v. 27, no. 2, p. 101-108. [Also available at http://dx.doi.org/10.1007/BF00197092.] 
Selway, J.B., Breaks, F.W., and Tindle, A.G., 2005, A review of rare-element ( $\mathrm{Li}-\mathrm{Cs}$ - $\mathrm{Ta}$ ) pegmatite exploration techniques for the Superior Province, Canada, and large worldwide tantalum deposits: Exploration and Mining Geology, v. 14, nos. 1-4, p. 1-30. [Also available at http://dx.doi.org/10.2113/gsemg.14.1-4.1.]

Shacklette, H.T., Boerngen, J.G., Cahill, J.P., and Rahill, R.L., 1973, Lithium in surficial materials of the conterminous United States and partial data on cadmium: U.S. Geological Survey Circular 673, 8 p. [Also available at http://pubs. er.usgs.gov/publication/cir673.]

Sievers, M.L., and Canon, H.L., 1973, Disease patterns of Pima Indians of the Gila River Indian Reservation of Arizona in relation to the geo-chemical environment [abs.]: Univ. of Missouri Symposium on Trace Elements in Environmental Health, v. 7, p. 57-61.

Sigma-Aldrich, 2014, Lithium oxide (ver. 4.4): Sigma-Aldrich Material Safety Data Sheet, product number 374725, revision date June 28, 2014, accessed July 10, 2014, at http://www.sigmaaldrich.com/safety-center.html.

Simbol, Inc., 2013, Who we are: Pleasanton, Calif., Simbol, Inc., accessed May 9, 2014, at http://www.simbolmaterials.com/ who_we_are.htm.

Smith, R.E., Perdrix, J.L., and Davis, J.M., 1987, Dispersion into pisolitic laterite from the Greenbushes mineralized Sn-Ta pegmatite system, Western Australia: Journal of Geochemical Exploration, v. 28, nos. 1-3, p. 251-265. [Also available at http://dx.doi.org/10.1016/03756742(87)90051-3.]

Stanley, C.J., Jones, G. C., Rumsey, M.S., Blake, Christopher, Roberts, A.C., Stirling, J.A.R., Carpenter, G.J.C., Whitfield, P.S., Grice, J.D., and Lepage, Yvon, 2007, Jadarite, $\mathrm{LiNaSiB}_{3} \mathrm{O}_{7}(\mathrm{OH})$, a new mineral species from the Jadar basin, Serbia: European Journal of Mineralogy, v. 19, no. 4, p. 575-580. [Also available at http://dx.doi.org/ 10.1127/0935-1221/2007/0019-1741.]

Stillings, L.L., and Morissette, C.L., 2012, Lithium clays in sediments from closed-basin, evaporative lakes in the Southwestern United States: Abstracts with ProgramsGeological Society of America, v. 44, no. 7, p. 210.

Strobusch, A.D., and Jefferson, J.W., 1980, The checkered history of lithium in medicine: Pharmacy in History, v. 22 , no. 2 , p. $72-76$.

Sun, S.-S., and McDonough, W.F., 1989, Chemical and isotopic systematics of oceanic basalts-Implications for mantle composition and processes: Geological Society Special Publications, v. 42, p. 313-345. [Also available at http://dx.doi.org/10.1144/GSL.SP.1989.042.01.19.]
Trueman, D.L., and Černý, Petr, 1982, Exploration for rareelement granitic pegmatites, in Cerný, P., ed., Granitic pegmatites in science and industry: Winnipeg, Manitoba, Canada, Mineralogical Association of Canada, Short Course Handbook, no. 8, p. 463-493.

U.S. Department of Energy, 2010, Critical materials strategy: Washington D.C., U.S. Department of Energy, 166 p. [Also available at http://energy.gov/sites/prod/files/piprod/ documents/cms_dec_17_full_web.pdf.]

U.S. Environmental Protection Agency, Office of Transportation and Air Quality, 2011, Greenhouse gas emissions from a typical passenger vehicle: Washington, D.C., U.S. Environmental Protection Agency, Office of Transportation and Air Quality, EPA-420-F-11-041, 5 p. [Also available at http://nepis.epa.gov/Exe/ZyPDF.cgi/ P100CZFN.PDF?Dockey=P100CZFN.PDF.]

U.S. Geological Survey, 1996, Global 30 arc-second elevation (GTOPO30): Reston, Va., U.S. Geological Survey dataset (digital elevation model), accessed June 23, 2014, at https://ta.cr.usgs.gov/GTOPO30.

Vine, J.D., ed., 1976, Lithium resources and requirements by the year 2000: U.S. Geological Survey Professional Paper 1005, $162 \mathrm{p}$.

Vine, J.D., 1980, Where on earth is all the lithium? with a section on Uranium isotope studies, Fish Lake Valley, Nevada, by J.R. Dooley, Jr.: U.S. Geological Survey Open-File Report 80-1234, 107 p. [Also available at http://pubs.usgs.gov/of/1980/1234/report.pdf.]

Voice, P.R., Kowalewski, M., and Eriksson, K.A., 2011, Quantifying the timing and rate of crustal evolutionGlobal compilation of radiometrically dated detrital zircon grains: Journal of Geology, v. 119, no. 2, p. 109-126.

Western Lithium Corp., 2015, [Untitled company report]: accessed September 22, 2015, at http://www.westernlithium.com/wp-content/ uploads/2015/01/WLCMERGESEPT2015e.pdf.

Wilkerson, G., Vredenburgh, L., Serenko, T.J., and Eyde, T.H., 2001, The Franklin Wells hectorite deposit, Inyo County, California, in Reynolds, R.E., ed., The changing face of the east Mojave Desert and Abstracts from the 2001 Desert Symposium: Fullerton, Calif., Desert Studies Consortium, California State University, p. 61-64.

Yaksic, Andrés, and Tilton, J.E., 2009, Using the cumulative availability curve to assess the threat of mineral depletionThe case of lithium: Resources Policy, v. 34, no. 4, p. 185-194. [Also available at http://dx.doi.org/10.1016/ j.resourpol.2009.05.002.] 



\section{Manganese}

By William F. Cannon, Bryn E. Kimball, and Lisa A. Corathers

Chapter L of

Critical Mineral Resources of the United States-Economic and Environmental Geology and Prospects for Future Supply

Edited by Klaus J. Schulz, John H. DeYoung, Jr., Robert R. Seal II, and Dwight C. Bradley

Professional Paper 1802-L

U.S. Department of the Interior

U.S. Geological Survey 


\section{Contents of Chapter L}

[Figure and table titles for all chapters are listed in the volume contents before the conversion factors table and list of abbreviations and symbols. A periodic table of the elements is on the inside front cover of the printed volume]

Abstract
Introduction
Uses, Applications, and Consumption
Strategic and Critical Resource Issues
Manganese Commodities
Secondary Enrichment (Supergene) Deposits
Seabed Deposits
Ferromanganese Nodules
Ferromanganese Crusts
Mineralogy
Deposit Types
Land-Based Deposits

Suggested citation:

Cannon, W.F., Kimball, B.E., and Corathers, L.A., 2017, Manganese, chap. L of Schulz, K.J., DeYoung, J.H., Jr., Seal, R.R., II, and Bradley, D.C., eds., Critical mineral resources of the United States-Economic and environmental geology and prospects for future supply: U.S. Geological Survey Professional Paper 1802, p. L1-L28, http://dx.doi.org/10.3133/ pp1802L. 


\title{
Manganese
}

\author{
By William F. Cannon, Bryn E. Kimball, and Lisa A. Corathers
}

\section{Abstract}

Manganese is an essential element for modern industrial societies. Its principal use is in steelmaking, where it serves as a purifying agent in iron-ore refining and as an alloy that converts iron into steel. Although the amount of manganese consumed to make a ton of steel is small, ranging from 6 to 9 kilograms, it is an irreplaceable component in the production of this fundamental material. The United States has been totally reliant on imports of manganese for many decades and will continue to be so for at least the near future. There are no domestic reserves, and although some large low-grade resources are known, they are far inferior to manganese ores readily available on the international market. World reserves of manganese are about 630 million metric tons, and annual global consumption is about 16 million metric tons. Current reserves are adequate to meet global demand for several decades. Global resources in traditional land-based deposits, including both reserves and rocks sufficiently enriched in manganese to be ores in the future, are much larger, at about 17 billion metric tons. Manganese resources in seabed deposits of ferromanganese nodules and crusts are larger than those on land and have not been fully quantified. No production from seabed deposits has yet been done, but current research and development activities are substantial and may bring parts of these seabed resources into production in the future. The advent of economically successful seabed mining could substantially alter the current scenario of manganese supply by providing a large new source of manganese in addition to traditional land-based deposits.

From a purely geologic perspective, there is no global shortage of proven ores and potential new ores that could be developed from the vast tonnage of identified resources. Reserves and resources are very unevenly distributed, however. The Kalahari manganese district in South Africa contains 70 percent of the world's identified resources and about 25 percent of its reserves. South Africa, Brazil, and Ukraine together accounted for nearly 65 percent of reserves in 2013. The combination of total import reliance for manganese, the mineral commodity's essential uses in our industrialized society, and the potential for supply disruptions because of the limited sources of the ore makes manganese among the most critical minerals for the United States.

Manganese is the 12th most abundant element in Earth's crust. Its concentration varies among common types of rocks, mostly in the range of from 0.1 to 0.2 percent. The highest quality manganese ores contain from 40 to 45 percent manganese. The formation of these ores requires specialized geologic conditions that concentrate manganese at several hundred times its average crustal abundance. The dominant processes in forming the world's principal deposits take place in the oceans. As a result, most important manganese deposits occur in ancient marine sedimentary rocks that are now exposed on continents as a result of subsequent tectonic uplift and erosion. In many cases, other processes have further enriched these manganiferous sedimentary rocks to form some of today's highest grade ores. Modern seabed resources of ferromanganese nodules cover vast areas of the present ocean floor and are still forming by complex interactions of marine microorganisms, manganese dissolved in seawater, and chemical processes on the seabed.

Manganese is ubiquitous in soil, water, and air. It occurs most often in solid form but can become soluble under acidic conditions. Manganese mining, like any activity that disturbs large areas of Earth's surface, has the potential to produce increases in manganese concentrations that could be harmful to humans or the environment if not properly controlled. Although manganese is an essential nutrient for humans and most other organisms, overexposure can lead to neurotoxicity in humans. Workers at manganese mining and processing facilities have the greatest potential to inhale manganese-rich dust. Without proper protective equipment, these workers may develop a permanent neurological disorder known as manganism. Each manganese mine is unique and presents its own suite of potential hazards and preventative measures. Likewise, various nations have their own sets of standards to ensure safe mining, isolation of mine waste, treatment of mine waters, and mine closure and restoration. Interest in mining trace metals contained in ferromanganese nodules and crusts on the seabed has increased rapidly in the past decade. Prime areas for future research include overcoming the technological challenges presented by mining as deep as 6,500 meters below sea level and understanding and mitigating the potential impacts of seabed mining on marine ecosystems. 


\section{Introduction}

Manganese, which is a ferrous metal, is an irreplaceable element in modern industrial economies, and it is consumed in large quantities by all industrialized nations. Manganese is important because of its desulfurizing, deoxidizing, and alloying properties, as well as its other chemical properties. An abundant and stable long-term supply of manganese is critical to the United States and other industrialized nations, as well as to developing countries. The United States has no manganese production or reserves of manganese ore and is totally reliant on imports of this mineral commodity.

\section{Uses, Applications, and Consumption}

In metallurgical applications, manganese is used predominantly as an alloying addition in steel. It is used as well in refining iron ore to metallic iron prior to the steelmaking process. Manganese has no known substitutes in the overall conversion of iron ore to steel, so steel cannot be produced without manganese. Steel and cast iron production together provide the largest market for manganese (historically accounting for 77 to 90 percent of manganese consumption in the United States), although manganese is also used as an alloy with nonferrous metals, such as aluminum and copper.

Nonmetallurgical applications of manganese include battery cathode production (mainly synthetic manganese dioxide); soft ferrites (manganese-zinc ferrites) used in electronics; micronutrient additives in fertilizers and animal feed (manganese sulfate and manganous oxide); water treatment chemicals (potassium permanganate and manganese dioxide); and other chemicals (manganese dioxide), such as those used as a colorant for automobile undercoat paints, bricks, frits, glass, textiles, and tiles. The product "manganese violet" is used for coloration in cosmetics, glazes used by artists, plastics, and powder coatings.

In the United States, manganese is imported in the following three principal forms: ore (minimally processed natural manganese concentrations), and the alloys ferromanganese and silicomanganese (both of which are products of the refining of natural ores). Because the United States imports nearly all the manganese that it consumes and because U.S. manufacturers typically do not maintain large stocks of manganese, the consumption of both ore and alloys can be estimated from the imports. For the period 2007 to 2011, the U.S. average apparent consumption of manganese from manganese dioxide, ferromanganese, and manganese metal was 739,000 metric tons of contained manganese. Steelmaking accounted for 78 percent of U.S. consumption; batteries, another 7 percent; and other uses, including chemicals, nonferrous alloys, and cast iron, the remaining 15 percent (Corathers, 2013a).

\section{Strategic and Critical Resource Issues}

The U.S. Department of Defense rates manganese as one of the most critical mineral commodities for the United States because it is both essential for industry and has no substitutes, and because of the potential for and the likely effects of supply disruptions (fig. L1; National Research Council, 2008). Geopolitical concerns have led to a long-term goal of identifying and ensuring supplies that are not susceptible to disruption.

On a global scale, manganese reserves - that is, material that can be mined economically under present-day conditionsare more than adequate to supply the world's industries with manganese for many decades, but those materials are unequally distributed geographically. Only a relatively few nations produce large amounts of manganese (three countries account for 60 percent of production in 2011). The United States is 100 percent reliant on imports. Many industrialized nations, including many countries in Europe, as well as Canada and Japan, are also largely reliant on imports for their supply of manganese.

Identified manganese resources include identified economic deposits (reserves) as well as a substantially larger amount of naturally occurring manganese-rich rocks that are not proven to be economically minable today but that could become economically viable in the future. Some types of deposits (including volcanogenic deposits, hydrothermal vein, and karst-related deposits), mines, and ore-forming processes have local importance but are only of minor significance from a national and global perspective.

\section{Manganese Commodities}

Most manganese materials in the United States are used in metallurgical processes. The major manganese commodities for this purpose are manganese ore and manganese alloys.

Manganese ore is the primary source of manganese used in the manufacture of manganese ferroalloys. Virtually all manganese ores are subjected to some form of beneficiation to achieve a concentrated product that has greater manganese content and fewer undesirable impurities. The manganese content of the more commonly used and traded ores, concentrates, nodules, and sinter for metallurgical purposes is in the approximate range of 38 to 55 percent. A manganese content of 48 percent is considered standard as a pricing basis.

From 2007 to 2011, global manganese ore production averaged 13.2 million metric tons of contained manganese, and production was led by, in order of percent of global production, South Africa, Australia, and China (table L1; fig. L1B). From 2008 to 2011, the United States imported a total of 1.9 million metric tons of manganese ore on a grossweight basis. The leading sources of these imports were, in order of the quantity supplied, Gabon, Australia, South Africa, and Brazil (fig. L2A). Between 2008 and 2012, the average 


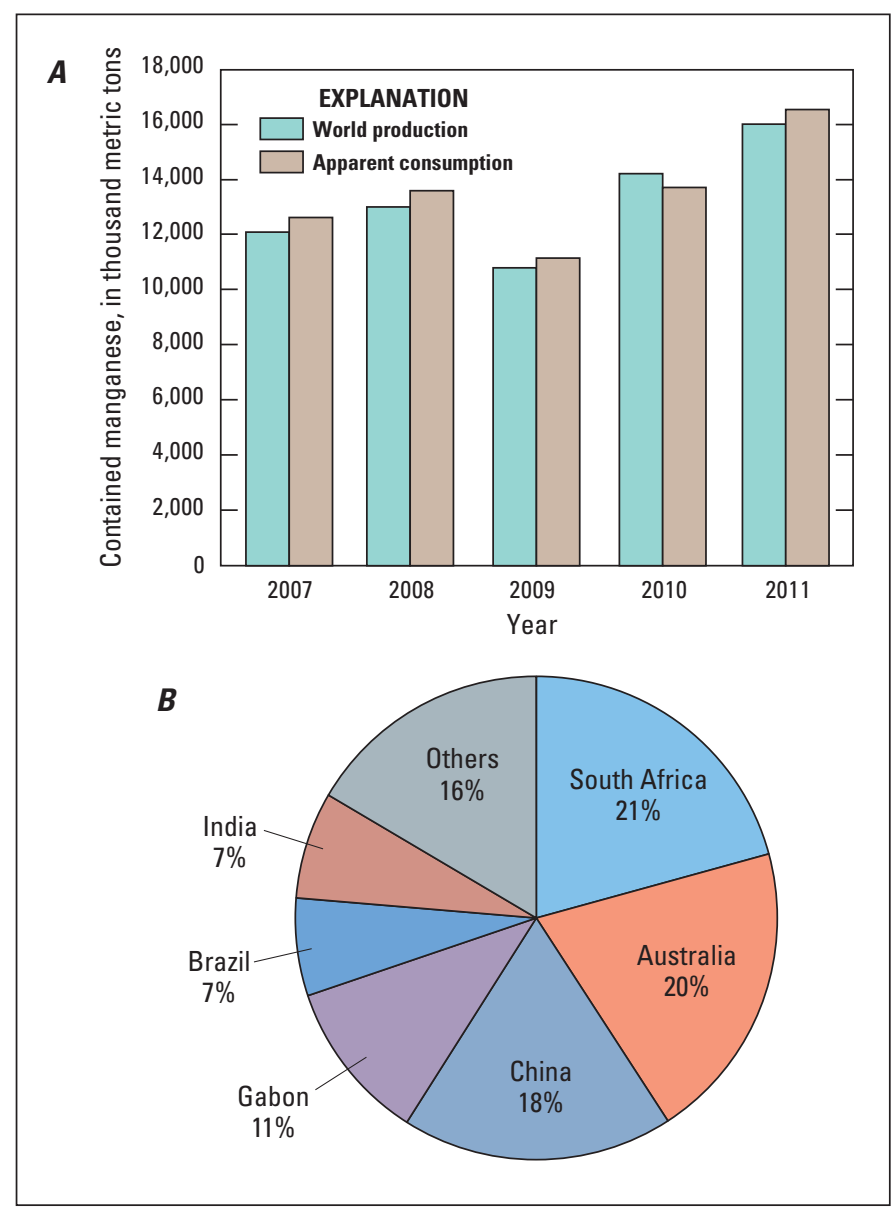

Figure L1. A, Bar chart showing world production of manganese ore (contained manganese) from 2007 to 2011 compared with world apparent consumption. Average annual production for the period was 13.2 million metric tons. $B$, Pie chart showing distribution of manganese ore (contained manganese) production, by country and percent of world total, for the same period (Corathers, 2013a; International Manganese Institute, 2012).

Table L1. Estimated world manganese ore reserves in 2012, in thousand metric tons of contained manganese.

[Data are from Corathers (2013b); NA, not available]

\begin{tabular}{|lc|}
\hline \multicolumn{1}{|c|}{ Country } & Reserves \\
\hline United States & None \\
\hline Australia & 97,000 \\
\hline Brazil & 110,000 \\
\hline Burma & NA \\
\hline China & 44,000 \\
\hline Gabon & 27,000 \\
\hline India & 49,000 \\
\hline Kazakhstan & 5,000 \\
\hline Malaysia & NA \\
\hline Mexico & 5,000 \\
\hline South Africa & 150,000 \\
\hline Ukraine & 140,000 \\
\hline Other countries & Small \\
\hline World total & $\mathbf{6 3 0 , 0 0 0}$ \\
\hline
\end{tabular}

\section{A. Manganese ore (gross weight)—470,000 metric tons}

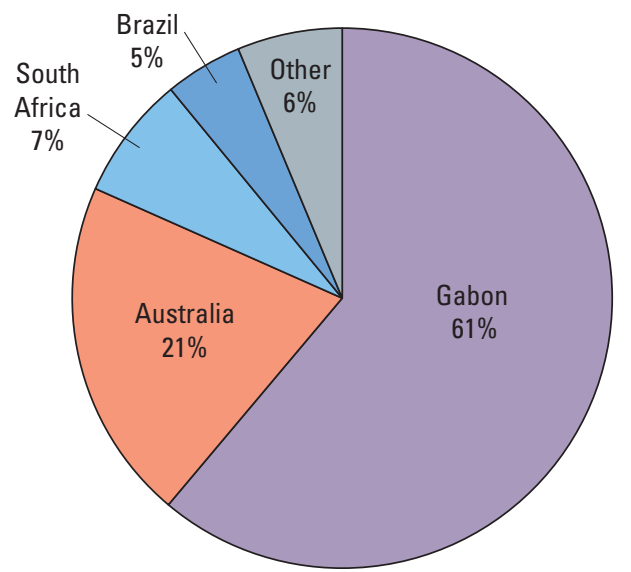

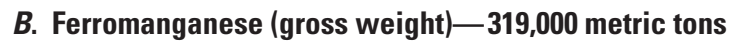

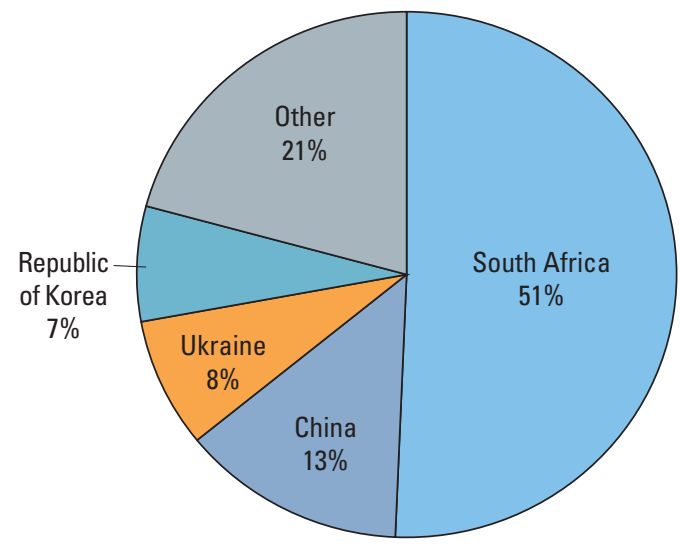

C. Silicomanganese (gross weight) $-285,000$ metric tons

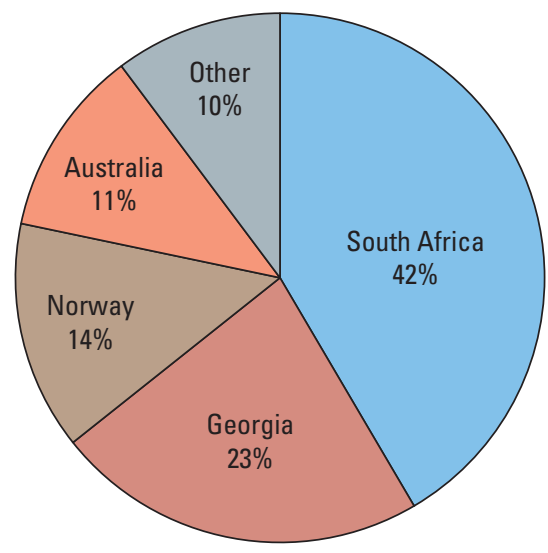

Figure L2. Pie charts showing the sources (by country) and the annual average amounts (by percentage of the total supplied) of gross weight of U.S. imports of $A$, manganese ore; $B$, ferromanganese; and $C$, silicomanganese for the period 2008-11. The tonnage numbers shown are the average annual gross weight of the imports. Data are from Corathers (2011-16). 
annual amount of manganese ore that was reported to the U.S. Geological Survey (USGS) as having been consumed domestically was 480,000 metric tons (gross weight).

The key manganese ferroalloys are ferromanganese, which is subdivided into standard (high-carbon), mediumcarbon, and low-carbon grades, and silicomanganese.

High-carbon ferromanganese is smelted directly in either a blast furnace or an electric submerged-arc furnace (SAF), and silicomanganese is smelted in an SAF. Silicomanganese is the manganese ferroalloy that is used predominantly throughout the world, including in the United States. Silicomanganese is smelted in a similar manner to that of high-carbon ferromanganese, except that a more siliceous charge, usually in the form of quartz, quartzite, or an ore having high silica content, is used. When an SAF is used, high-carbon ferromanganese and silicomanganese can be produced interchangeably. Production of refined grades of manganese ferroalloys, such as mediumand low-carbon ferromanganese, involves two additional stages using such equipment as a converter or a direct arc furnace. From 2006 to 2010, global ferromanganese and silicomanganese production (by gross weight) averaged 5.4 million metric tons per year and 9.2 million metric tons per year, respectively.

As of 2013, there were two producers of manganese alloys in the United States-Eramet Marietta, Inc. and Felman Productions Inc. Eramet Marietta generally produces silicomanganese and all grades of ferromanganese at its plant in Marietta, Ohio. Felman Productions produces silicomanganese at its plant in Letart, West Virginia. Even with this domestic production, the United States imported a total of 1.3 million metric tons of ferromanganese and 1.1 million metric tons of silicomanganese (gross-weight basis) from 2008 to 2011. The leading sources of these imports, by country, are shown in figure $\mathrm{L} 2(B$ and $C$ ).

The information and discussion presented in this chapter are based entirely on published scientific and technical literature and contain no new conclusions or interpretations. Rather, this chapter presents a summary of the vast literature on the geology and resources of manganese that are the result of more than a century of research on this important mineral commodity.

\section{Geology}

\section{Geochemistry}

Manganese is the 12th most abundant element in Earth's crust and is thus considered to be a relatively abundant metal. Average crustal rocks contain about 0.1 percent manganese, but manganese concentration varies according to rock type. Mafic rocks, such as basalt, typically contain about 0.16 percent manganese, whereas granitic rocks contain about 0.06 percent. Manganese ores contain a minimum of 15 percent manganese, but most ores are considerably higher grade, ranging up to about 50 percent manganese. The formation of manganese ore, therefore, requires a geochemical system that concentrates manganese by at least 150 times its average crustal abundance and by as much as 500 times for the higher grade ores. An additional specialized set of conditions is required to produce strong manganese enrichment without concentrating iron, with which manganese shares many chemical similarities and is commonly compositionally correlated. Manganese ores have a much higher manganese-toiron ratio than do typical crustal rocks. Virtually all manganese ores have formed as a result of the transport of manganese in water solutions, at least for short distances, and precipitation of manganese minerals out of those solutions in sufficiently high concentrations and volumes to form minable orebodies. Understanding the factors that control manganese solubility in water and the behavior of manganese-bearing water at scales from meters to that of ocean basins is the key to understanding manganese metallogenesis.

Manganese is a potentially mobile element and occurs in three oxidation states in nature $(+2,+3,+4)$. The solubility and mobility of manganese in various solutions is strongly controlled by the acidity $(\mathrm{pH})$ and oxidation potential (Eh) of manganese-bearing solutions, which include surface water, ocean water, and high-temperature fluids in various subsurface environments. In general, manganese solubility is highest in more acidic (lower $\mathrm{pH}$ ) conditions and less oxidizing (lower Eh) conditions in which dissolved manganese exists primarily in the most soluble +2 oxidation state. The transport of large quantities of manganese to sites of ore formation, therefore, generally requires the existence of oxygen-poor (low Eh) ocean water or surface water. This is in contrast to the typical state of modern surface and ocean water, in which the oxidation potential is sufficiently high to make manganese essentially insoluble. The variability in chemical behavior of manganese under differing $\mathrm{pH}$ and Eh conditions results in many situations in which manganese can be concentrated to potentially economic concentrations. A full review of the geochemistry of manganese as it relates to manganese ore formation is beyond the scope of this summary report; for greater detail and specificity than is provided here, see for example, Roy (1988), Varentsov (1996), Nicholson and others (1997), and Maynard (2003, 2010).

The vast majority of manganese ores have formed at the ambient conditions of Earth's surface, both subaerial and submarine, and the discussion below concentrates on the geochemical behavior of manganese in these settings. Many manganese deposits are a direct result of deposition of manganese-rich sediment layers on the seabed, both in present-day oceans and oceans of the geologic past. In addition, secondary enrichment of manganese-rich marine sedimentary rocks by later continental weathering (supergene ores) has produced many high-grade manganese ore deposits. In both cases, large-scale transport of dissolved manganese in seawater and deposition of manganese from seawater are crucial components of manganese metallogeny. The most significant sources of dissolved manganese in seawater are (a) dissolved manganese in rivers entering the oceans, (b) manganese released from marine sediments by post-depositional alteration, and (c) manganese from deep-sea hydrothermal vents. 
On continents, most manganese occurs in trace amounts in reduced $(+2)$ form in silicate and carbonate minerals. It can be released by continental weathering where some of it is dissolved in surface water and eventually transported by rivers to the world's oceans. Because surface waters are generally well oxidized, the solubility of manganese is very low. The Mississippi River, for instance, shows manganese solubility that varies seasonally but averages only a few micrograms per liter (Shiller, 1997). Although this is a low concentration, it is still much higher than manganese in open oceans. Substantially more manganese is delivered by rivers to the oceans as fine-grained suspended sediments, which either contain manganese within minerals or have manganese adsorbed to their surface. Although this manganese does not immediately affect the dissolved manganese pool of the oceans, it is an important flux of manganese to seabed sediments from which it is later mobilized by reducing reactions in the upper layers of the sedimentary sequence.

Seabed hydrothermal vents are also a significant source of manganese. The character of these fluids is summarized by Tivey (2007). Vent fluids commonly have manganese concentrations measured in thousands of micrograms per liter, which is several orders of magnitude greater than typical river waters. Such vents are arrayed along active spreading centers in all the world oceans.

The formation of marine sedimentary manganese deposits, in which the contained manganese is delivered to the site of sedimentation by seawater, generally requires that such seawater be less oxidized than typical seawater in order to sustain an elevated solubility of manganese. Such seawater can exist both as layers of reduced oxygen (oxygen minimum zones) in open oceans and as highly reduced sulfidic seawater that can form in the deepwater mass in stratified oceans in restricted basins. Recent reviews of manganese mineralization (Maynard, 2003, 2010) provide further discussion of these conditions, as does the discussion below regarding deposit types.

\section{Mineralogy}

Manganese occurs as a trace element in many minerals, but the ore minerals are limited to a suite of manganese oxides, hydroxides, carbonates, and silicates. Manganese ores are commonly fine-grained or microscopic mixtures of several different manganese minerals whose accurate characterization has long been a problem. They can seldom be accurately identified solely by visual examination. Modern analytical techniques have led to revisions of older data on the composition and mineral structure of many manganese minerals. This has led, in turn, to revised descriptions in more recent literature of the mineralogy of many manganese deposits.

A full list of manganese ore minerals classified by deposit type is given in Dorr and others (1973), and details of chemical composition, crystal structure, and relative abundance are provided by Maynard (2003). In spite of the complexity of manganese minerals and their variable occurrence in individual ore deposits, a few generalizations allow characterization of many aspects of the ore mineralogy. The most common manganese minerals within ore deposits are manganese oxides, followed by manganese carbonates. Manganese carbonates, however, are the most voluminous manganese minerals when all manganeseenriched rocks - many of which are sub-ore grade - are considered. Among oxides, pyrolusite (a simple manganese oxide) and cryptomelane (a potassium-bearing oxide) are the most widely reported, although not necessarily the most voluminous. The carbonate minerals are rhodochrosite (a manganese carbonate) and kutnahorite (a calcium-manganese carbonate). Rhodochrosite is by far the most widely recognized manganese carbonate, but kutnahorite is abundant in the vast Kalahari manganese ores of South Africa. In addition, the manganese hydroxide manganite is a very widely occurring ore mineral, as is the manganese silicate mineral braunite. Descriptions of some of the characteristics of these most abundant of the manganese minerals are given below.

Rhodochrosite.-The carbonate mineral rhodochrosite $\left(\mathrm{MnCO}_{3}\right)$ is the most widely reported manganese mineral in known deposits, including currently subeconomic deposits. It is the principal ore mineral at Molango, Mexico, and at many deposits in China. Production of a usable manganese product from rhodochrosite requires processing to convert manganese carbonate to manganese oxides. Rhodochrosite deposits are also important as protores (lower grade precursors for higher grade supergene deposits) in which oxidation and leaching at Earth's surface has converted the original carbonate mineral to manganese oxides and hydroxides and commonly increased the manganese concentration to ore grade.

Braunite.-Braunite $\left(\mathrm{Mn}^{2+} \mathrm{Mn}^{3+}{ }_{6}\left(\mathrm{SiO}_{4}\right) \mathrm{O}_{8}\right)$ is generally classified as a silicate mineral, although it contains less than 10 weight percent silicon dioxide, or silica $\left(\mathrm{SiO}_{2}\right)$. It is a major ore mineral in the Kalahari manganese district in South Africa; in Groote Eylandt, Australia; and in several districts in India. It is also a major mineral in volcanogenic manganese deposits, which are not discussed in detail in this chapter.

Cryptomelane.-Cryptomelane $\left(\mathrm{K}\left(\mathrm{Mn}^{4+}, \mathrm{Mn}^{2+}\right)_{8} \mathrm{O}_{16}\right)$, a potassium-bearing manganese mineral, is a highly oxidized ore mineral in several major manganese-producing regions, including in Brazil, Gabon, and South Africa.

Manganite.-Manganite $(\mathrm{MnO}(\mathrm{OH}))$ is a manganese hydroxide that forms commonly by oxidation at or near Earth's surface as a result of circulating groundwater. It is a significant mineral in major supergene deposits, such as those in Gabon and Ghana, as well as in parts of the Kalahari district in South Africa.

Pyrolusite.-Pyrolusite $\left(\mathrm{MnO}_{2}\right)$ is a compositionally simple manganese oxide. It forms in a variety of oxidizing conditions, especially in cases of higher acidity (lower $\mathrm{pH}$ ). It is a major ore mineral in many significant mining districts, including in Brazil, Gabon, Ghana, the Republic of Georgia, and South Africa. 


\section{Deposit Types}

Over the years, many classifications of manganese deposits have been proposed, typically based on details of mineralogy, type of associated rocks, and the geometric form of the deposits. For this summary, we use a simple classification of (a) land-based deposits consisting mostly of ancient marine sediments and zones of secondary enrichment developed within them that can be further subdivided based on the geologic environment in which they formed and the processes responsible for manganese concentrations, and (b) modern seabed deposits, which are found widely on the modern ocean floor. This discussion excludes several deposit types, such as volcanogenic, karst, and hydrothermal vein deposits, which are widespread but generally small. Although they may be important locally, their total manganese production potential is small relative to the three major deposit types (marine sedimentary, secondary enrichment, and seabed) and has only a small effect on national and global supply and demand. The global distribution of the major manganese deposits, their size, and deposit type are shown in figure L3.

\section{Land-Based Deposits}

\section{Manganese Deposits in Marine Sedimentary Rocks}

The vast majority of land-based manganese resources occur as extensive layers of manganese-rich sedimentary rocks, some of which formed as long as 2.5 billion years ago. These rocks formed on ancient seabeds (fig. L4) and have since become part of continents through tectonic processes of uplift and continental accretion. They may be of sufficiently high manganese content to constitute ores themselves, or they may be protores in which additional natural concentrating mechanisms increased the manganese content enough to form commercial ores. A recent compilation of the chemical composition of sedimentary manganese deposits of the world indicates that average manganese grade is about 24 percent and iron content is 4.3 percent (Maynard, 2010). These figures indicate that average sedimentary manganese deposits are low-grade ore, at best. Most ores currently being mined are the higher grade portion of these deposits or zones of secondary enrichment developed within them. These averages also illustrate an essential feature of sedimentary manganese deposits - the extremely efficient separation of iron from manganese during deposit formation. Whereas manganese is concentrated, on average, roughly 250 times its average crustal abundance in marine sedimentary deposits, iron occurs at concentrations near its average abundance.

Two types of sedimentary manganese deposits can be distinguished based on the nature of rocks with which they are interlayered and, by inference, the character of ocean water from which they were precipitated: (a) manganiferous sediments that occur independent of iron concentrations; and (b) manganiferous sediments interlayered with ferruginous strata, including the vast Kalahari deposits of South Africa that occur as interlayers in a banded iron formation. The essential difference between the two is the degree of oxygen depletion in ocean waters that varies from anoxic or suboxic (in which the solubility of both manganese and iron are enhanced - for instance, the Kalahari manganese district in South Africa), to euxinic and sulfidic (in which manganese solubility is enhanced but iron solubility is depressed - for instance, Groote Eylandt in Australia).

\section{Manganese Deposits Without Iron Enrichments}

Many sedimentary manganese deposits of the world occur in sedimentary sequences that are devoid of iron enrichments and that are themselves not enriched in iron compared with the average crustal abundance of manganese. The larger of such deposits include Molango in Mexico, Groote Eylandt in Australia, the deposits of the Black Sea region, and many deposits in China. These relatively low-iron deposits are thought to have formed in shallow marine settings adjacent to stratified oceans that contained a low oxygen deepwater mass, as illustrated in figure L5. In such water masses, dissolved hydrogen sulfide is locally present (euxinic conditions), which causes iron to be precipitated as sulfide minerals in black shale and leaves very low concentrations of dissolved iron in the seawater. Because there is no comparable manganese sulfide phase under these conditions, dissolved manganese concentrations $\left(\mathrm{Mn}^{2+}\right)$ remain high (Cannon and Force, 1983; Force and Cannon, 1988). This type of ocean water is a reservoir from which manganese deposits can be formed by precipitation of the dissolved manganese caused by the mixing of the manganese-rich deep ocean water with the more oxidized surface waters. Because of the increased Eh conditions, the water becomes saturated in dissolved manganese, and manganese-rich sediments can be precipitated.

These conditions occur most often in nearshore shallow water on continental shelves (fig. L5). Consequently, manganese beds are interlayered with other sediments typical of those settings. The character of these types of manganese deposits is quite variable, depending on local conditions at the eventual deposition sites. For instance, the variety in the types of manganese ores described for the Groote Eylandt deposit are related to local variations in the seabed topography and distance from the coastline (Frakes and Bolton, 1992).

A modern analog for the creation of manganese deposits without iron enrichment is the Black Sea (Cannon and Force, 1983; Force and Cannon, 1988). Deep euxinic waters of the Black Sea contain concentrations of manganese greater than 300 micrograms per liter $(\mu \mathrm{g} / \mathrm{L})$, whereas oxidized surface water contains less than $1 \mu \mathrm{g} / \mathrm{L}$. The concentration of iron in the euxinic water is less than $5 \mu \mathrm{g} / \mathrm{L}$ (Maynard, 2010). Thus, these deep waters are poised to precipitate manganeserich sediments devoid of iron enrichments when oxidized. Circulation of water in the Black Sea produces upwelling of deep waters onto a shallower shelf to the north where manganese-rich sediments are being precipitated on the present seabed. 

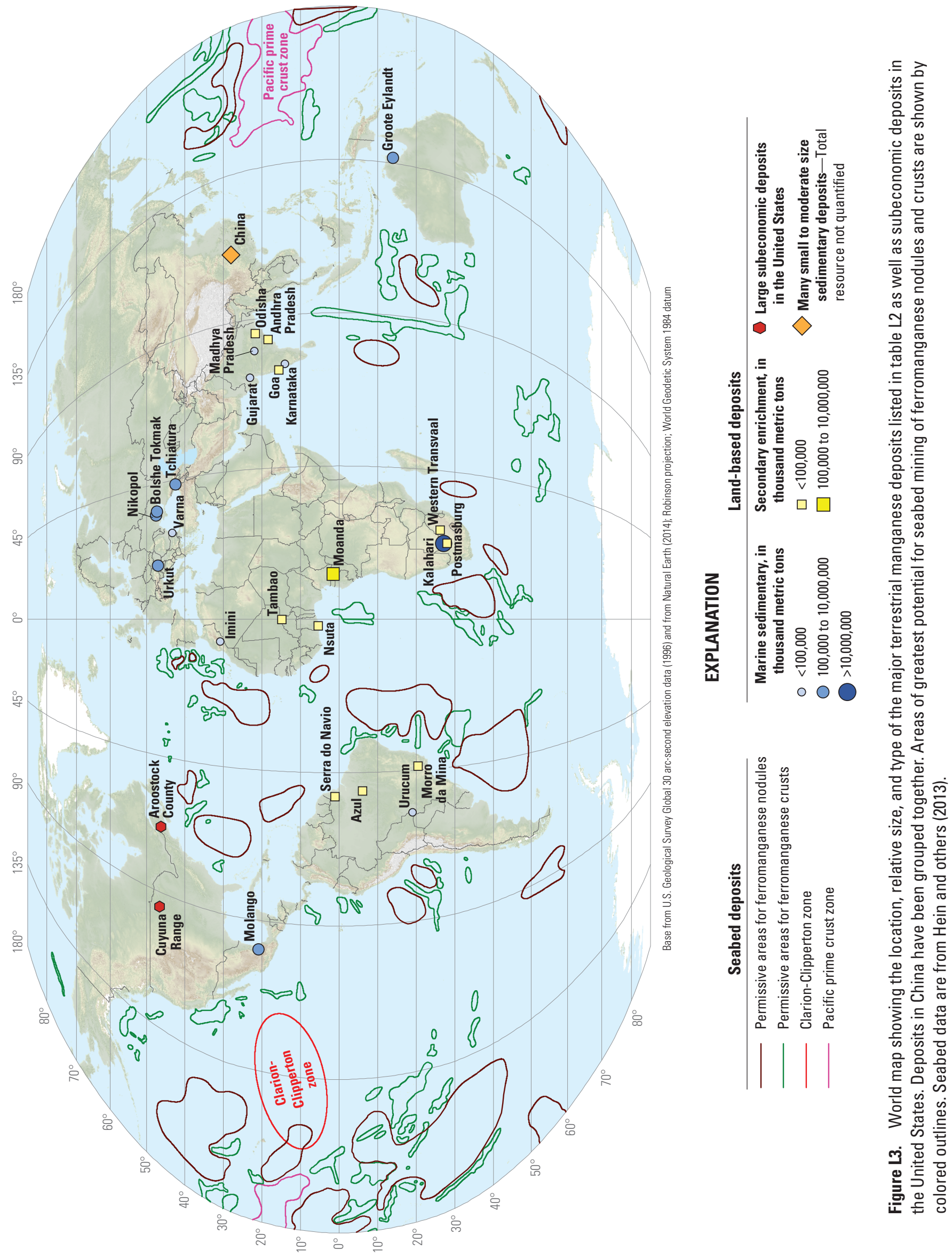

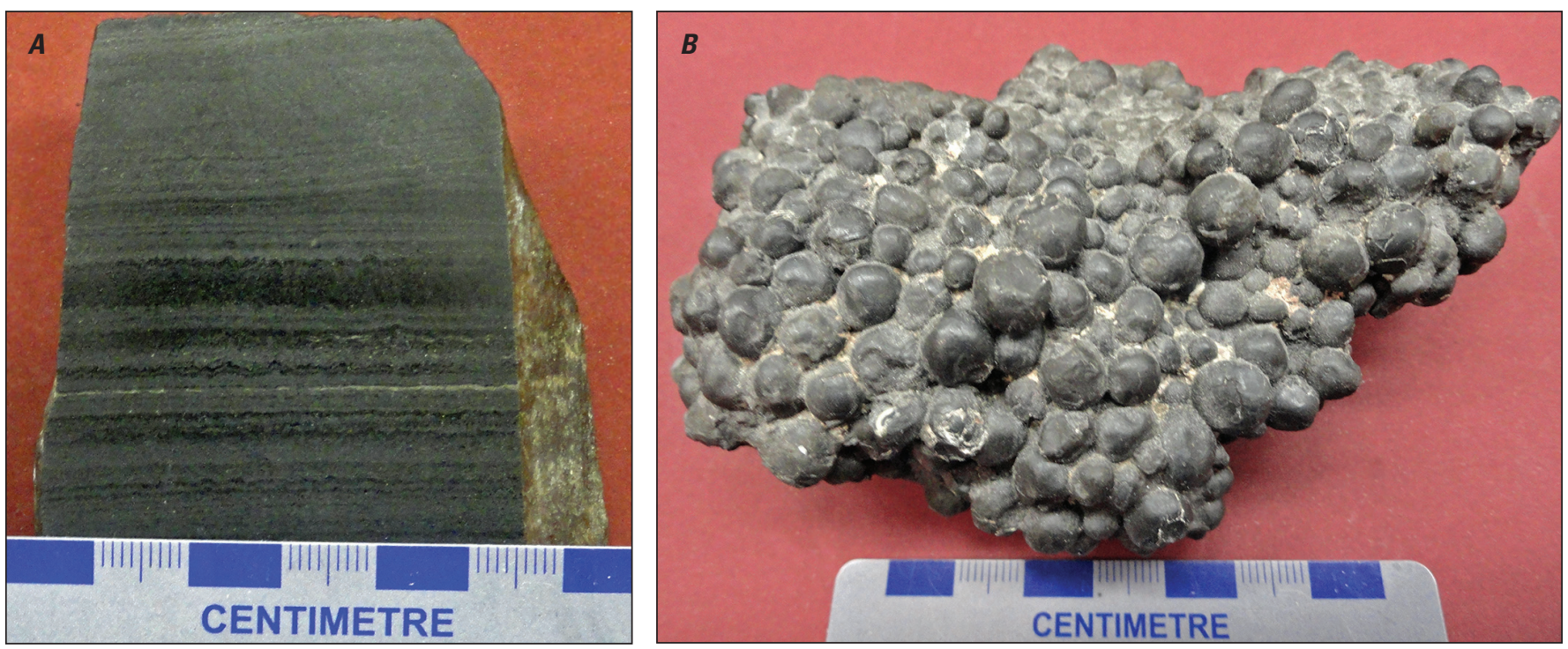

Figure L4. Photographs showing examples of contrasting types of manganese ore. A, Thinly layered ore from Molango, Mexico. The manganese mineral is rhodochrosite, which is a manganese carbonate. The delicate laminations are the result of deposition in relatively deep, quiet seawater below the zone of surface wave agitation. $B$, Pisolitic ore from Groote Eylandt, Australia. The approximately spherical masses (pisolites) are mostly pyrolusite, which is a manganese oxide. The spheres were likely formed in shallow water by progressive growth of new outer layers as the masses were rolled on the seabed by wave agitation. Photographs by William F. Cannon, U.S. Geological Survey.

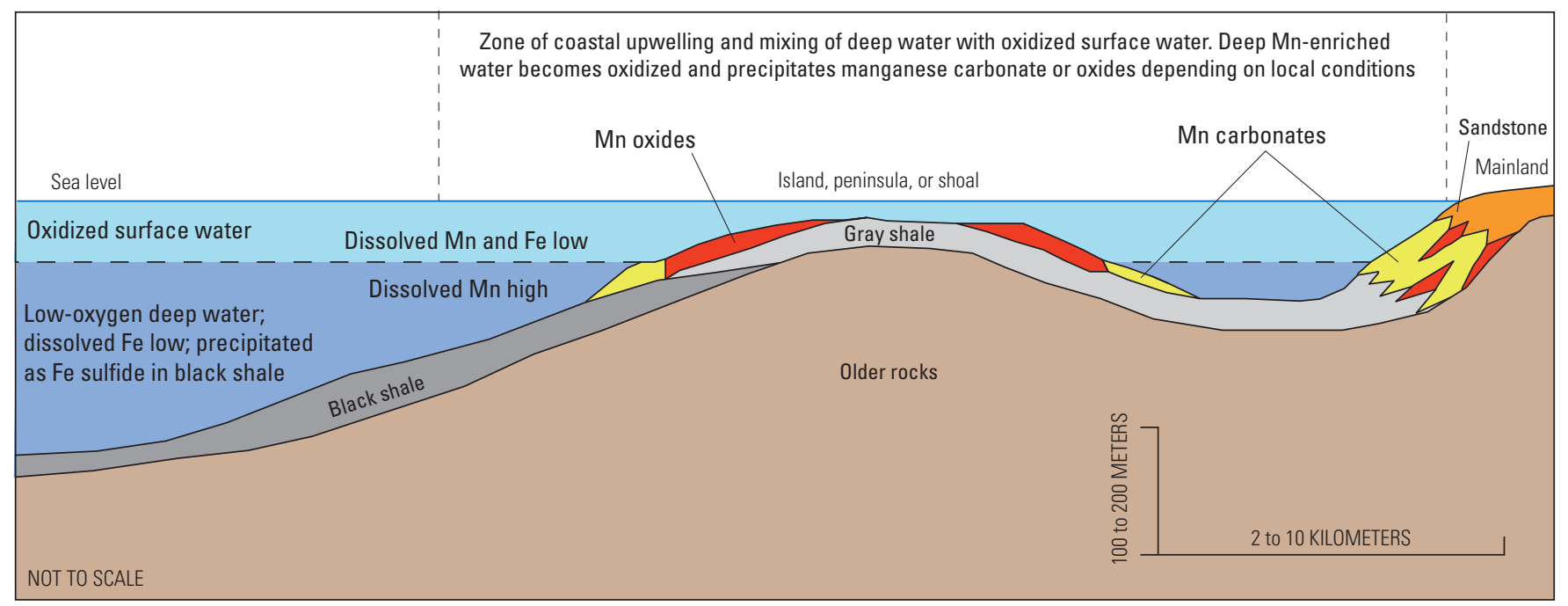

Figure L5. Schematic diagram of the oceanic conditions necessary to form sedimentary manganese deposits that are not enriched in iron. Deep seawater that is very depleted in oxygen and hydrogen sulfide reacts with iron and precipitates iron sulfides, which results in low concentrations of dissolved iron, whereas the dissolved manganese is enriched. Upwelling and mixing of this deep water with oxidized surface water causes precipitation of manganese oxide and carbonate minerals, depending on the local conditions. Diagram is modified from Cannon and Force (1983). In a variant of this model, deep water that is more oxidized and does not contain hydrogen sulfide results in high concentrations of both dissolved manganese and iron and in the precipitation of ferruginous manganese. Fe, iron; $\mathrm{Mn}$, manganese 


\section{Iron-Related Manganiferous Sedimentary Deposits}

Many occurrences of manganiferous sedimentary deposits occur interlayered with iron-rich strata, commonly in banded iron formations that are found widely in Precambrian sequences in many parts of the world. These include the vast manganese deposits of the Kalahari district in South Africa and the Urucum mining district in Brazil, and many deposits in India. There is voluminous literature on the Kalahari manganese deposits. Relatively recent summaries and the references therein contain the essential facts and interpretations of the occurrence and origin of these remarkable deposits (Tsikos and Moore, 1997; Tsikos and others, 2003). In the Kalahari, three manganese layers are within the banded iron formation known as the Hotazel iron formation. The lower of the three is the principal source of ore and varies from 15 to 45 meters (m) thick. The hallmark of such deposits is the interlayering of iron- and manganese-rich layers, which indicate that the deposit formed from an ocean in which both iron and manganese were enriched, but that the two metals were differentiated from each other at the site of deposition, perhaps by subtle changes in the oxidation state or acidity of the ocean water. In the Kalahari, for instance, the manganese layers have iron contents that are near the average crustal abundance but are enriched in manganese from 200 to nearly 400 times the average crustal abundance (Beukes and Gutzmer, 1996). The iron-rich layers, on the other hand, are enriched above the average crustal abundance by as much as fivefold in iron and from twofold to twentyfold in manganese.

The mutual enrichment of both iron and manganese, although in varying proportions between iron and manganese layers, seems inconsistent with the sulfidic ocean model in which manganese is enriched to the near exclusion of iron. Rather, a stratified ocean in which deeper waters are suboxic to anoxic, but not sulfidic, is more consistent with the origin of these deposits. In anoxic water, the solubility of both manganese and iron is enhanced, and such waters are capable of delivering those metals to sites of deposition by such processes as coastal upwelling onto continental margins, which is the mode of deposition favored by nearly all recent interpretations of these deposits. In the Kalahari, although the primary sedimentary accumulations of manganese are, in part, ore-grade material, secondary enrichment by later hydrothermal processes has increased manganese grades in some areas to form especially desirable ores (Tsikos and others, 2003).

The Urucum deposit in Brazil may have a somewhat different origin. The manganese beds are interlayered with hematitic jasper, similar to the Kalahari and other deposits, but the enclosing rocks bear strong evidence of glacial conditions when this deposit formed. Floating glacial ice or a persistent ice pack has been proposed, which cut off the atmospheric oxygen supply to the ocean water. The decay of organic matter consumed available oxygen and resulted in the anoxic conditions, which, in turn, allowed high solubility of manganese and iron that resulted in the formation of banded iron and manganese deposits (Urban and others, 1992). Manganese grades range from about 27 to 45 percent, and associated iron ranges from 13 to 30 percent, which indicates that both iron and manganese were enriched in seawater during manganese deposition.

\section{Secondary Enrichment (Supergene) Deposits}

Many of the currently mined manganese ores have been enriched in manganese by processes at the present land surface, although they commonly formed in rocks that were already manganese rich. These secondary enrichment types of deposits, or supergene deposits, form where chemical reactions taking place within tens of meters of the surface redistribute manganese at a local scale and also leach out nonmanganese components, which results in residual enrichment of the manganese. Details of many of these deposits and their origin are presented in Varentsov (1996). Significant occurrences of these types of deposits are the Moanda deposit in Gabon, the Azul and the Serra do Navio deposits in Brazil, and numerous deposits in India. By their nature, the resources of these deposits are smaller than are those of the major sedimentary-type deposits, but the deposits are still substantial in terms of both their resources and current production. These deposits include some of the highest grade ores presently being mined. The process of supergene manganese enrichment is described in general terms by Lelong and others (1976), and details of the supergene enrichment at the Moanda deposit, which is the largest known deposit of this type, is outlined by Nahon and Parc (1990).

Supergene deposits are most abundant and commonly of the highest grade in tropical regions where humid conditions and abundant vegetation are key factors in forming deep tropical soils. Supergene manganese ores can be thought of as a specialized product of such tropical soil formation. The generation of humic acids by decomposition of abundant organic matter results in the dissolution of manganese-bearing minerals and transportation of manganese downward in the soil profile. It is then reprecipitated where soil water encounters less acidic conditions. The same acidic soil solutions dissolve and remove other components as well, resulting in a residual enrichment of manganese minerals. Supergene manganese deposits tend to have developed most frequently in areas of low topographic relief, commonly on plateaus, where slow erosion allows time for these oreforming processes to take place.

\section{Seabed Deposits}

The world's ocean floors include tens of millions of square kilometers $\left(\mathrm{km}^{2}\right)$ covered with manganese-rich deposits of ferromanganese nodules and crusts. No manganese or other metals have been produced from any of these deposits in spite of several decades of research and exploration. Numerous exploration and development programs are underway that could bring part of this vast resource online in the near future. 
If this possibility materializes, seabed deposits could have a significant effect on the global production and supply of manganese and lead to a diversification of supply and a reduction in U.S. import reliance for manganese. The areas of greatest interest and potential for mining of seabed deposits are shown in figure L3.

\section{Ferromanganese Nodules}

The widespread occurrence of seabed nodules composed mostly of manganese and iron oxide and hydroxide minerals has been known since the research expedition of the H.M.S. Challenger in the 1870s; these nodules have come to be referred to as ferromanganese nodules. The locations of these nodules are shown in figure L3. In the area of prime economic interest in the Pacific Ocean, nodules range in size from 1 to 12 centimeters $(\mathrm{cm})$ and median dimensions are $8 \mathrm{~cm}, 6 \mathrm{~cm}$, and $4 \mathrm{~cm}$ for the maximum, intermediate, and minimum dimensions, respectively (fig. L6; Morgan, 2000). The abundance of nodules within known nodule fields ranges from sparse to a nearly continuous blanket covering the seabed. These nodules also contain substantial amounts of other valuable metals, such as nickel, copper, and cobalt, and potentially valuable concentrations of rare-earth elements (REEs). The amount of manganese in known nodule fields dwarfs that

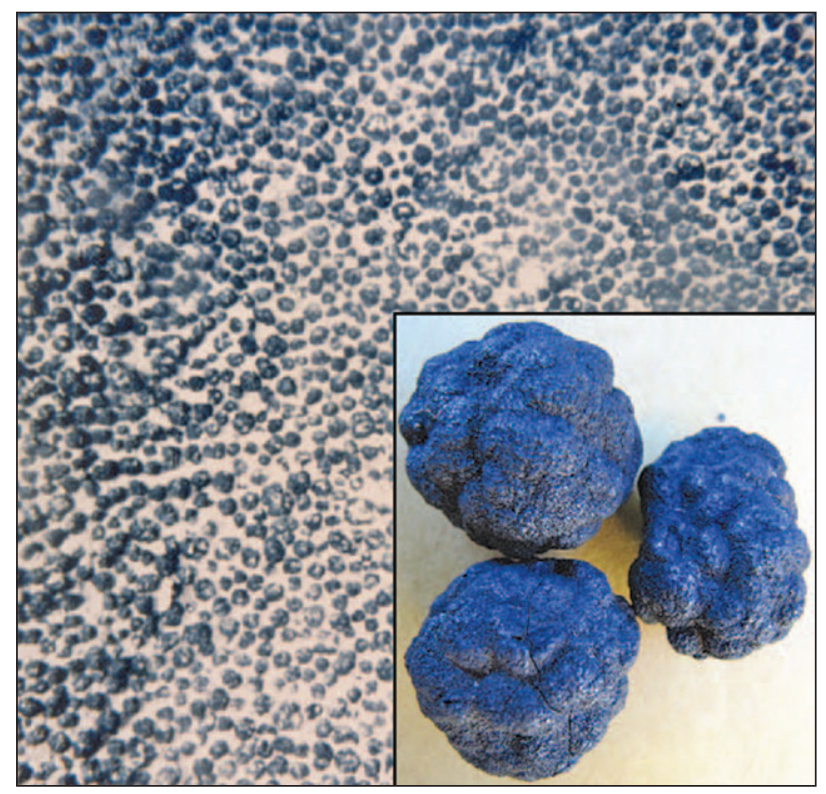

Figure L6. Photograph showing a dense carpet of ferromanganese nodules on the seabed off Johnston Island within the United States Exclusive Economic Zone near Hawaii. The field of view is about 4 meters square. The inset shows individual nodules, each of which is about 3 centimeters in diameter, from the equatorial Pacific Ocean. Photographs by James Hein, U.S. Geological Survey. found in traditional continental deposits, but its availability as a source of ore is uncertain in the near term. Considerable technological issues of mining at abyssal depths in the oceans, the economic competitiveness of seabed mining versus traditional mining, and legal issues of ownership and control of resources in international waters are still being addressed.

Recent summaries of the origin, distribution, and potential value of manganese nodules are provided by Hein (2012), and the International Seabed Authority (ISA) (2010), both of which form the basis of the following discussion. Manganese nodules occur widely in global oceans and their distribution has commonly been mapped, for both scientific and potential commercial purposes. Vast areas of ocean floor contain blankets of nodules in varying abundance at the sediment surface, and an equal amount of nodules is believed to be buried within the uppermost meter or two of underlying sediment. Nodule fields range in depth below the ocean surface of from 3,500 to $6,500 \mathrm{~m}$. The nodule fields of the greatest current commercial interest are those located in the northern equatorial Pacific Ocean and the central Indian Ocean.

Ferromanganese nodules are geologically young features and many continue to grow today. They form on the seabed at the sediment-water interface, mostly by precipitation of metals that are mobilized by redox reactions in the underlying sediments. An expert panel convened by the ISA (an organization established by the 1982 United Nations Convention on the Law of the Sea) developed a biogeochemical model for nodule formation in the northern equatorial Pacific Ocean, generally referred to as the Clarion-Clipperton zone (CCZ), and subsequently used the model to make resource estimates. According to the ISA model, the principal source of copper, manganese, and nickel is believed to be continental runoff from North America; volcanogenic sources from the East Pacific rise, including submarine hydrothermal vents; and atmospheric dust. The metals from continental sources occur in dissolved form and are also adsorbed onto fine-grained sediment particles that are carried westward by the North Pacific current. Some metals can be delivered to the sea floor through slow settling of these particles, but biological activity is also an essential part of the deposition. In the near-surface photic zone, metals are scavenged by planktonic organisms and can then be delivered to the sea floor by settling of those organisms after their death and also by incorporating metals into fecal pellets, which likewise settle to the sea floor. Thus, areas of highest metal enrichment on the sea floor correspond to areas of high surface biological productivity, such as the CCZ.

Once deposited in sea-floor sediments, metals are available to be metabolized by benthic organisms and mobilized into dissolved form by reducing reactions within the upper meter of sediments. Metal-rich pore waters so produced are the source fluids for most components of nodules. Metals dissolved 
in seawater may add additional components. As pore waters migrate to the sediment surface, they reenter oxidizing conditions where manganese is precipitated as oxide and hydroxide minerals that effectively scavenge other metals, such as nickel and copper. The precipitated minerals commonly nucleate around small solid particles and sequentially add growth layers to form the present nodules.

\section{Ferromanganese Crusts}

Ferromanganese crusts are layers of manganese and iron oxides and hydroxides, ranging from a thin veneer to 260 millimeters $(\mathrm{mm})$ thick, that have precipitated on hard rock substrates on the seabed. The geology and resource status of ferromanganese crusts are outlined by Hein and others $(2009,2010,2013)$. The principal commercial interest in ferromanganese crusts has been their concentrations of cobalt ( 0.3 to 0.67 percent) and nickel ( 0.23 to 0.46 percent). Elevated concentrations of REEs might also add to their potential economic value. Manganese grades range from
20 to 25 percent in Pacific Ocean and Indian Ocean crusts and are somewhat lower elsewhere. A detailed summary of the chemical composition of ferromanganese crusts from the world's oceans was compiled by Manheim and Lane-Bostwick (1988) and provides much more detail than this chapter.

The locations of these crusts are shown in figure L3, and an example of such crustal material is shown in figure L7.

Ferromanganese crusts are less extensive than nodule fields and are restricted to seabed topographic highs, such as volcanic edifices, seamounts, and ridges. Crusts are found at depths of 400 to 7,000 m; the thickest and most metal-rich crusts are found at depths of between 800 and 2,500 m. Ferromanganese crusts form in areas that were kept sedimentfree for millions of years, principally by bottom currents with sufficient velocity to sweep the seabed free of sediment accumulations. Crusts grow extremely slowly by precipitating manganese and other elements that occur in low concentrations in seawater. It is this very slow growth that allows the ferromanganese minerals to scavenge economically interesting concentrations of metals.

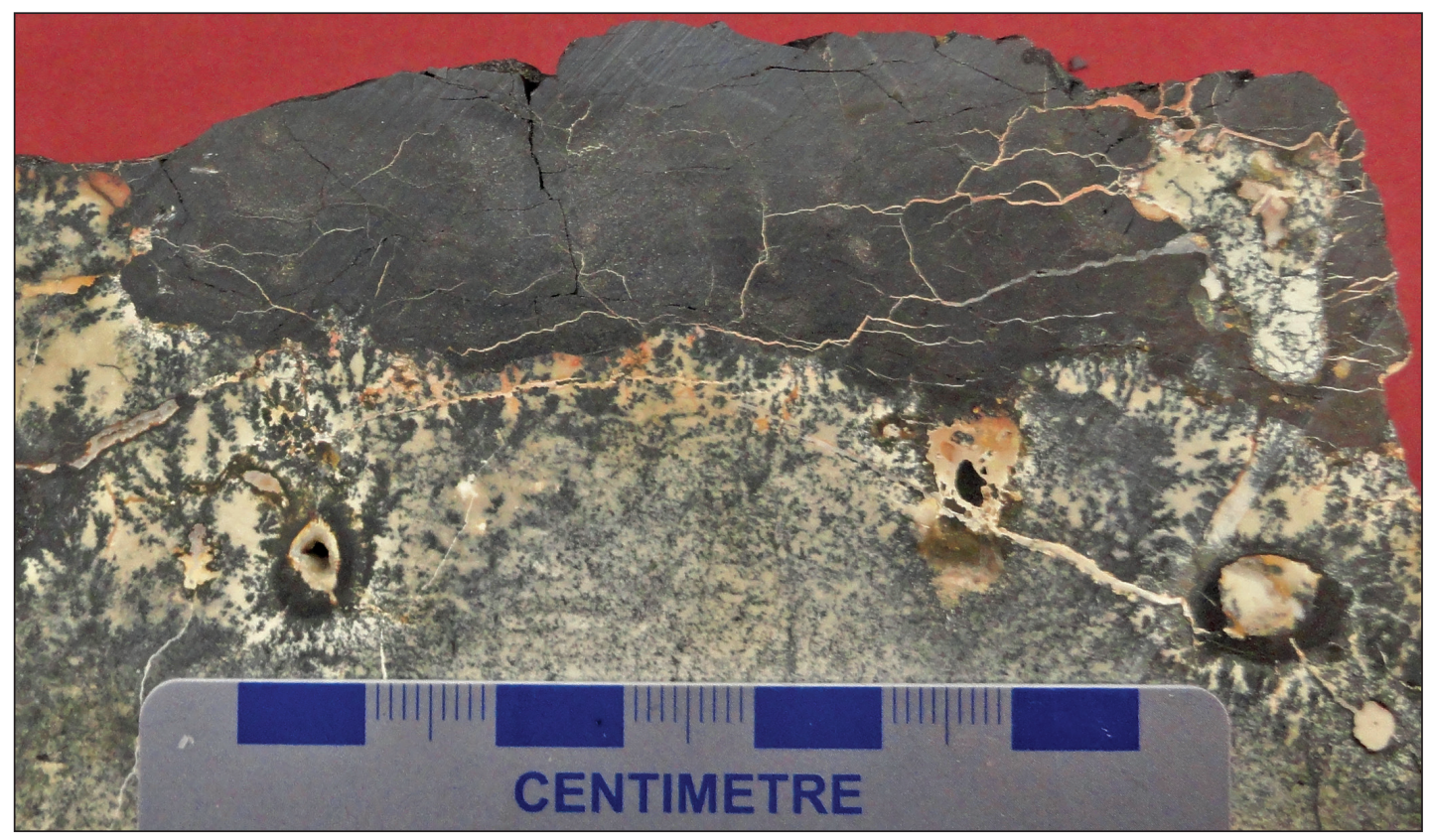

Figure L7. Photograph showing ferromanganese crust (black material above) on carbonate rock from the Blake Plateau off the southeastern coast of the United States. The surface below the black material was the seabed on which the manganese minerals were precipitated. Photograph by William F. Cannon, U.S. Geological Survey. 


\section{Resources and Production}

Manganese resources are very large relative to current and anticipated demand on a global scale, but they are unevenly distributed. Many industrialized countries, including the United States, are largely or wholly reliant on imports for their manganese supply. The United States has relatively large tonnages of resources in several districts, but the larger deposits are low grade and well below economic viability in current economic and technological scenarios.

The nature of manganese deposits presents problems for precise quantitative resource estimates. Many deposits occur as laterally extensive manganese-rich layers that do not have sharp lateral boundaries, but rather, grade gradually from higher to lower grades, in some cases over long distances. Very different resource estimates can be made for the same deposit based on what criteria are used for acceptable manganese content to be classed as a resource, as well as assumptions of how grades change in poorly explored areas. Additional variability in published resource values is introduced by a variety of resource classification schemes and definitions of resource categories used by various Governments around the world. There is no simple way to convert resource estimates between such diverse classifications into a uniform resource compilation. Global resources of manganese were estimated by the USGS and published in 1973 (Dorr and others, 1973). A more-detailed study was conducted by a panel of industry, Government, and academic experts through the U.S. National Materials Advisory Board (1981). The following year, a summary of global manganese resources was conducted through the International Strategic Minerals Inventory (ISMI), a cooperative effort of Federal geological and resource agencies from the United States, Australia, Canada, the Germany, South Africa, and the United Kingdom (DeYoung and others, 1984). Estimated resources by country and district differ substantially between the two older reports, in large part because of somewhat different definitions of resource and reserve categories used in them, as well as the criteria used to calculate resource figures. The ISMI study produced consensus estimates based both on older reports and resource values compiled by the participating Government agencies. For this summary, we have not revised older resource estimates although we recognize that depletion of resources through continued mining and addition to resources through continued exploration has modified older resource estimates to some degree. The discussion below is based on the ISMI resource values, although the same general picture of global resources could be formed from any of the three cited studies.

\section{Manganese Reserves}

The United States possesses no reserves of manganese ore containing 35 percent or more manganese or from which concentrates of such grade could be commercially produced.
As a result, manganese ore is not mined in the United States, with the exception of ultra-low-grade manganese schists that contain less than 5 percent manganese at two mines in South Carolina - the Grover and the Martin Mines. Manganese recovered from these mines is used as a brick colorant. The estimated manganese content of world manganese ore reserves in 2012 totaled 630 million metric tons (table L1). The countries with the most manganese ore reserves are, in descending order of reserves, South Africa, Ukraine, and Brazil.

\section{Other Identified Resources}

Manganese resources can be divided into (a) land-based deposits and districts, which are the traditional sources of manganese ore, and (b) seabed resources, which are deposits on the ocean floor that have been identified and characterized to varying degrees of detail. Seabed resources are enormous and dwarf traditional resources, but their technological and economic availability is unproven.

\section{Land-Based Resources}

The locations of identified manganese resources in conventional land-based deposits and mining districts are shown in figure L3. Some details of the resource amounts are in table $\mathrm{L} 2$.

Total global identified resources are in excess of 17 billion metric tons of manganiferous material. Global resources are dominated by the Kalahari manganese district of South Africa, which contains more than 70 percent of global resources (fig. L3). Kalahari ores are among the highest grade, typically about 40 percent manganese, and are widely used in industrial processes in many parts of the world. The Kalahari district clearly has the potential to provide international markets with high-quality manganese ore for a very long time. One of the larger mines in the Kalahari district, the Mamatwan Mine, is shown in figure L8. The second-ranked district in terms of total resources is the Molango district in Mexico, which has about 9 percent of the world's total resources. The resource consists of an extensive layer of manganese carbonate, with grades of approximately 28 percent manganese. Although this resource is large, economic extraction is impaired by the steep mountainous terrain of the district, which requires that most, or all, of the mining be conducted from underground operations rather than more efficient surface mines. The carbonate character of the ore also is a detriment in that it requires an additional processing step to convert the carbonate minerals to manganese oxide. Molango is an important source of manganese in Mexico, but its future significance in global manganese supply is uncertain. The third largest resource is in the Bolshe Tokmak mining district in Ukraine, which constitutes about 6 percent of global resources. The Bolshe Tokmak ore is low grade by global standards, averaging about 
Table L2. Identified resources estimated for major land-based manganese deposits of the world.

[Data are from DeYoung and others (1984). WGS 84, World Geodetic System of 1984; negative values for latitude indicate that the deposit is in the Southern Hemisphere; negative values for longitude indicate that the deposit is in the Western Hemisphere. Deposits are shown on the map in figure L3. Resource values are the sum of all manganese resource categories. —, not applicable]

\begin{tabular}{|c|c|c|c|c|c|}
\hline \multirow{2}{*}{ Country } & \multirow{2}{*}{$\begin{array}{l}\text { Deposit } \\
\text { (fig. L3) }\end{array}$} & Latitude & Longitude & \multirow{2}{*}{ Type } & \multirow{2}{*}{$\begin{array}{c}\text { Resource } \\
\text { (thousand } \\
\text { metric tons) }\end{array}$} \\
\hline & & \multicolumn{2}{|c|}{ Decimal degrees WGS 84} & & \\
\hline Australia & Groote Eylandt & -14.00 & 136.50 & Marine sedimentary & 436,000 \\
\hline Brazil & Azul & -6.13 & -50.35 & Secondary enrichment & 65,000 \\
\hline Brazil & Morro da Mina & -20.58 & -43.83 & Secondary enrichment & 4,500 \\
\hline Brazil & Serra do Navio & 1.00 & -52.00 & Secondary enrichment & 21,000 \\
\hline Brazil & Urucum & -19.13 & -57.55 & Marine sedimentary & 59,000 \\
\hline Bulgaria & Varna & 43.22 & 27.92 & Marine sedimentary & 28,000 \\
\hline Burkina Faso & Tambao & 14.78 & -0.07 & Secondary enrichment & 17,000 \\
\hline China & Hsiang-tan & 27.83 & 112.92 & Marine sedimentary & $>10,000$ \\
\hline China & Leiping & 23.33 & 109.50 & Marine sedimentary & $>10,000$ \\
\hline China & Tsun-i & 27.50 & 106.50 & Marine sedimentary & $>10,000$ \\
\hline China & Wafangtzu & 39.58 & 122.00 & Marine sedimentary & 4,000 \\
\hline Gabon & Moanda & 1.57 & 13.28 & Secondary enrichment & 220,000 \\
\hline Georgia & Tchiatura & 42.32 & 43.30 & Marine sedimentary & 155,000 \\
\hline Ghana & Nsuta & 5.28 & -1.95 & Secondary enrichment & 20,000 \\
\hline Hungary & Urkut & 47.08 & 17.67 & Marine sedimentary & 215,000 \\
\hline India & Andhra Pradesh & 18.37 & 83.45 & Secondary enrichment & 1,700 \\
\hline India & Goa & 15.50 & 73.92 & Secondary enrichment & 8,550 \\
\hline India & Gujarat & 23.00 & 72.50 & Marine sedimentary & 2,900 \\
\hline India & Karnataka & 13.93 & 75.52 & Marine sedimentary & 15,000 \\
\hline India & Madhya Pradesh & 21.83 & 80.30 & Marine sedimentary & 49,000 \\
\hline India & Odisha & 21.63 & 85.67 & Secondary enrichment & 43,600 \\
\hline Mexico & Molango & 20.83 & 98.73 & Marine sedimentary & $1,526,000$ \\
\hline Morocco & Imini & 30.73 & 6.90 & Marine sedimentary & 1,500 \\
\hline South Africa & Kalahari & -27.18 & 22.95 & Marine sedimentary & $12,565,800$ \\
\hline South Africa & Postmasburg & -28.05 & 23.05 & Secondary enrichment & 15,000 \\
\hline South Africa & Western Transvaal & -26.25 & 27.02 & Secondary enrichment & 15,000 \\
\hline Ukraine & Bolshe Tokmak & 47.25 & 35.70 & Marine sedimentary & $1,100,000$ \\
\hline Ukraine & Nikopol & 47.57 & 34.42 & Marine sedimentary & 655,000 \\
\hline World total & - & - & - & - & $>17,273,000$ \\
\hline
\end{tabular}

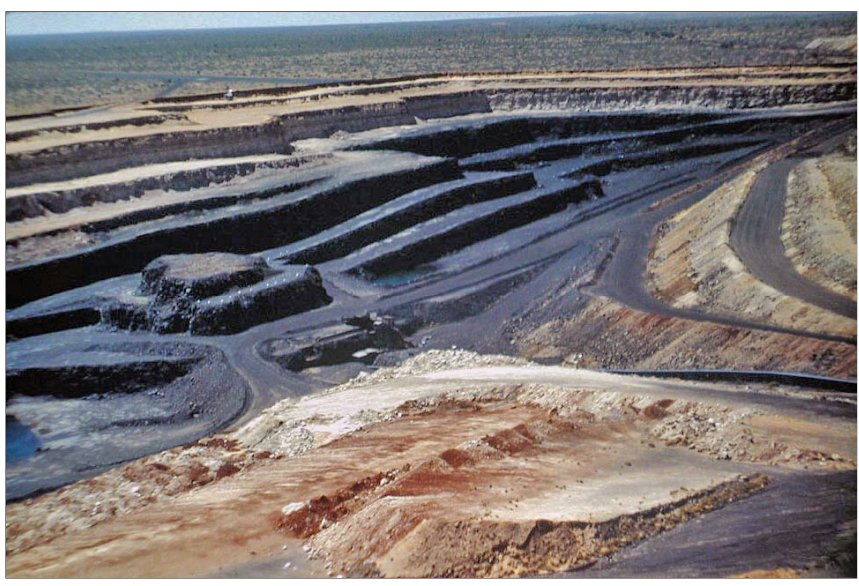

Figure L8. Photograph of the Mamatwan open pit mine in South Africa. The black manganese layer is about 45 meters thick and consists of a 20-meter-thick ore bed and two lower grade subeconomic beds. The slightly folded layering is shown by the shapes of the various mine benches. Lighter material in the background is waste that must be stripped to expose the ore bed; this waste material is used as backfill in mined areas (foreground). Photograph by William F. Cannon, U.S. Geological Survey. 
18 percent manganese. The mines at Bolshe Tokmak were significant sources of manganese to the Soviet Union, but their importance in market economies is impaired by their low grade. The Obrochishte deposit in the Varna district in Bulgaria, the Nikopol mining district in Ukraine, and the Tchiatura (also known as Chiat'ura) district in Georgia are similar to the Bolshe Tokmak district and together constitute an additional large but low-grade resource. All the deposits in these districts are of the marine sedimentary type.

A compilation of tonnage and grade for sedimentary-type deposits (Mosier, 1986) shows that their median tonnage is 7.3 million metric tons and that the largest 10 percent of the deposits (made up of three deposits) have a median tonnage of greater than 280 million metric tons (fig. L9A). The median grade is 31 percent $\mathrm{Mn}$ and the grade of the richest 10 percent of deposits is greater than 49 percent Mn (fig. L9B).

Although they constitute a relatively small percentage of total global manganese resources, other types of deposits are also important sources of high-grade manganese ore to the United States and other countries. An example is Moanda in Gabon, which was formed from secondary enrichment.

China has become a major manganese ore producer in recent decades. In 2011, it was the second-ranked producer in the world in terms of gross weight of ore and the third-ranked producer in terms of contained manganese. China's reserves are also large, consisting of about 44 million metric tons of

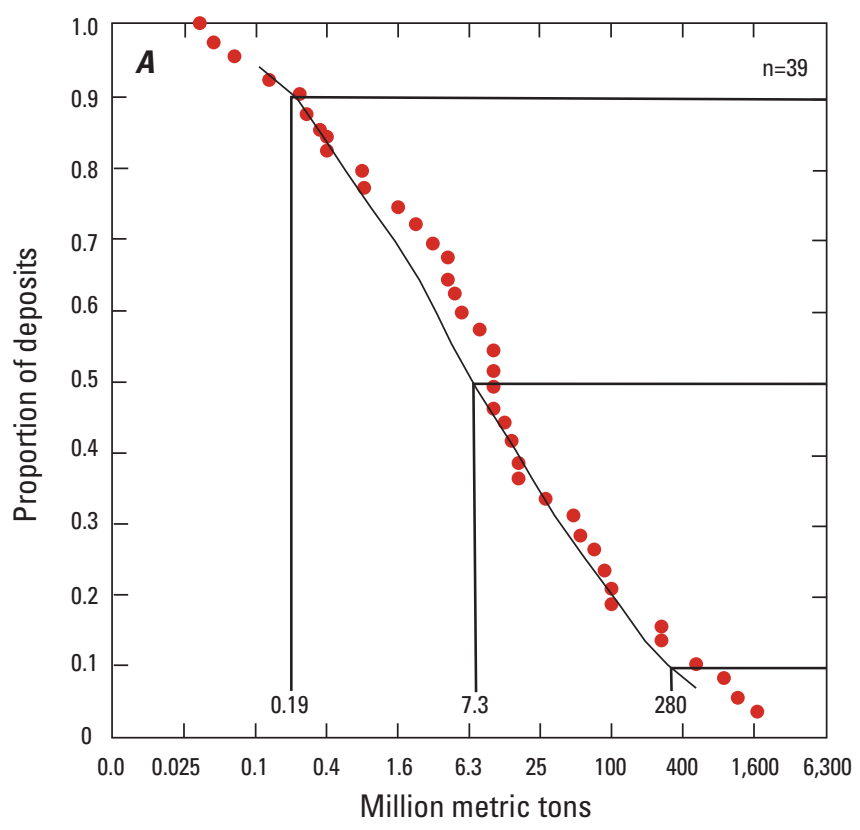

manganese ore distributed over many deposits, according to figures compiled by the USGS (Corathers, 2013b). Most Chinese deposits consist of sedimentary accumulations of manganese carbonate that average about 20 percent contained manganese and thus are of relatively low grade compared with many other deposits globally. Most ores are upgraded, many by magnetic separation of manganese-rich material from waste material, before use in manufacturing (International Manganese Institute, 2012). The total manganese resource in China is poorly known. The ISMI summary prepared by DeYoung and others (1984) lists China's proven resource at greater than 34 million metric tons, but the total resource, although not quantified, is likely much larger.

\section{Seabed Resources}

A vast resource of manganese lies on the seabed, mostly in international waters and at great depths. A strong interest in exploitation of these deposits in the late 1970s and early 1980 s, with hopes of developing mines by the late 1980s, vanished in a morass of technological, economic (low metal prices), and legal issues. More recently, with the establishment of a legal framework for exploring and mining in international waters, and a rebound in metal prices, a strong interest in exploiting these deposits has reemerged. Nevertheless, the technological and economic viability of doing so had yet

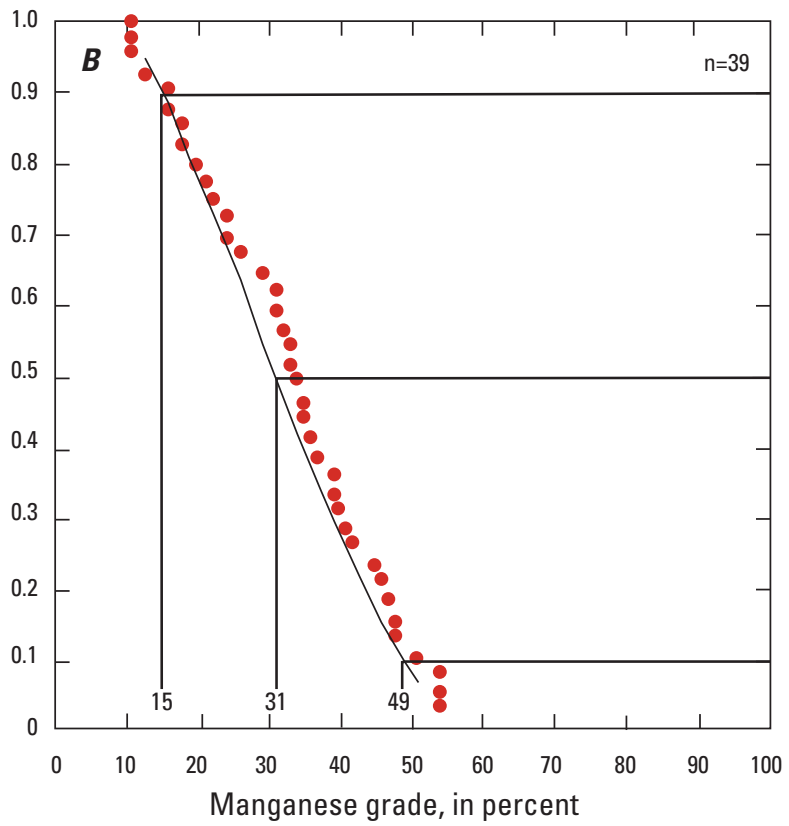

Figure L9. Graphs showing the cumulative frequency of tonnages and grades of 39 marine sedimentary manganese deposits. $A$, The median tonnage of the deposits is 7.3 million metric tons, and the largest 10 percent of the deposits has a tonnage of greater than 280 million metric tons. $B$, The median grade is 31 percent manganese, and the richest 10 percent of the deposits has a grade of greater than 49 percent manganese (Mosier, 1986). 
to be proven in 2013. Importantly, the economic interest in ferromanganese nodules is driven by such metals as, in order of economic importance, nickel, copper, and cobalt, rather than by manganese. Manganese would, at best, be a byproduct of seabed mining, and perhaps not a metal that would be economically recovered at all in some scenarios. Consequently, the availability of manganese from seabed deposits will be closely tied to the demand for those other metals. Two types of deposits of current interest - ferromanganese nodules and ferromanganese crusts - are similar in that they are composed largely of manganese and iron oxides and hydroxides, but they differ substantially in their mode of origin, chemical composition, location on the seabed, and economic potential. They are discussed separately below.

\section{Ferromanganese Nodules}

The possible commercial recovery of ferromanganese nodules, which were of little economic interest for several decades after initial investigations and conditions showed them unfavorable, has received significantly increased activity in recent years because of higher metal prices and the establishment of a legal framework for exploiting resources on the international seabed through the ISA. By 2013, 13 organizations or Governments had signed contracts with the ISA to explore and potentially mine ferromanganese nodules, mostly in the CCZ. One of the companies that signed a contract with the ISA is a U.S. company, Lockheed Martin Corp., through its British subsidiary Lockheed Martin UK, which is evaluating the feasibility of nodule mining in two areas within the CCZ (Schrope, 2013).

The ISA assessed mineral resources within the CCZ using a biogeochemical model for nodule formation and several statistical methods (International Seabed Authority, 2010, 2012). The various methods produced somewhat different results that ranged from 20 to 30 billion metric tons of nodules containing from 6 to 8.7 billion metric tons of manganese at a median grade of about 30 percent manganese. The resource covers an area of seabed of roughly 4 million $\mathrm{km}^{2}$. The central Indian Ocean, which is a $150,000-\mathrm{km}^{2}$ area in which exclusive exploration rights are held by India, is estimated to contain a nodule resource of 700 million metric tons containing 20 to 30 percent manganese (Banakar, 2010). No comparable estimates have been done for other nodule fields, but it is reasonable to assume that their combined resource would be several times that of the CCZ and the central Indian Ocean.

As previously mentioned, an important factor in the potential of ferromanganese nodules as a manganese source is that most economic interest in nodules is driven by metals other than manganese, including cobalt, copper, nickel, possibly REEs, and other metals needed for high-technology applications. (See discussion in Hein and others [2013].) Without the value provided by the presence of these metals, it is unlikely that nodules would be an economically viable source of manganese based solely on their contained manganese value. It is not clear to what extent future seabed mining and processing would recover manganese rather than dispose of it as a component of limited economic value if manganese prices remain relatively low. In any case, the processing of manganese nodules would at least result in an inventory of manganese-rich material at processing facilities that could be accessed when economically or strategically appropriate.

\section{Ferromanganese Crusts}

The area of greatest interest for ferromanganese crusts in the north Pacific was outlined by Hein and others (2009) and is referred to as the Pacific prime crust zone (fig. L3). This large area contains 155 volcanic features that could host a ferromanganese crust resource. In 2013, three nations (China, Japan, and Russia) had contracts with the ISA to explore tracts totaling 9,000 $\mathrm{km}^{2}$. A model based on geologic parameters (and not on economic considerations) predicted that about eighteen $100-\mathrm{km}^{2}$ blocks of seabed might be included in an initial mining program under the auspices of the ISA (Hein and others, 2009).

An additional area in the northeast Atlantic Ocean that lies partly within the Portuguese Exclusive Economic Zone (EEZ) has been described by Muiños and others (2013). Crusts with resources of cobalt, copper, nickel, and other trace elements that may be comparable to those in the central Pacific region have been identified on 10 seamounts. The crusts average about 15 percent manganese, so manganese would be a byproduct, at best, of mining of these deposits.

Many other areas with potential for ferromanganese crusts are known and many lie within the EEZs of various nations rather than in international waters (fig. L3). Areas within the United States EEZ lie off both the Atlantic and Pacific Coasts. The area of greatest previous economic interest is the Blake Plateau off the southeastern coast of the United States. Geologic knowledge of this area is summarized by Manheim and others (1982). Median manganese grades are about 20 percent. Median cobalt and nickel grades are roughly 0.5 percent and 0.4 percent, respectively. An estimate of the total tonnage of crusts in the area has not been made.

The future of mining of seabed ferromanganese crusts is more uncertain than for nodules. Whereas nodules are discrete masses lying unattached to the seabed, ready for the taking, crusts are firmly attached to bedrock substrate. Successful mining requires development of methods and equipment that can effectively break crusts free from their substrate with minimal incorporation of substrate into the recovered material to minimize dilution. As with nodules, the metals of principal economic interest do not include manganese, but, rather, are cobalt and nickel. Thus, future production of crusts will be driven by consumption needs and prices for those metals rather than by demand for manganese. 


\section{Resources in the United States}

\section{Land-Based Resources}

Manganese ore was last produced in the United States in 1973. Significant past production has been limited to times of war or Government subsidies and purchases for strategic stockpiles. Several deposits and districts in the United States have traditionally been included in identified resources, although all are well below manganese grades of material readily available on international markets. All would require substantial beneficiation to make usable manganese products or discovery of higher grade zones within them, which would likely be small relative to national consumption. Table L3 lists these domestic resources and some of their characteristics based on a manganese availability study conducted by the U.S. Bureau of Mines (Kilgore and Thomas, 1982). In that study, economic and technological parameters were applied to each deposit, and cost estimates were made for producing a usable manganese product. All deposits were shown to be far short of economic viability. Of these identified resources, those of Aroostook County, Maine (Maple Mountain-Hovey Mountain area and North Aroostook district) and the Cuyuna Range in Minnesota (fig. L3) are the only two that are of sufficient tonnage to be significant on a national scale of manganese demand. Others may be capable of providing some smaller amount of manganese or specialized manganese products, but the discussion below is limited to these two largest resources.

\section{Aroostook County, Maine}

The manganese deposits of Aroostook County lie in a discontinuous north-south belt about 50 kilometers $(\mathrm{km})$ long. The bulk of the manganese resource lies in the middle part of this belt in the Maple Mountain-Hovey Mountain area. These deposits and their geologic setting were comprehensively studied in the early 1960s (Pavlides, 1962). The manganeserich rocks occur in three beds of Silurian age and are of two lithologic types: (a) hematitic shale and slate and hematitic ironstone, and (b) siliceous carbonate rocks. These iron-rich layers contain manganese in both braunite and rhodochrosite. Manganese grade varies between beds and ranges from 7 to 11 percent. Iron grades range from 13 to 24 percent in the same beds. The grades are relatively uniform within individual beds. Individual manganese beds are as much as about $20 \mathrm{~m}$ thick. The deposits, although now folded and recrystallized, formed as discontinuous marine sedimentary layers in shallow, nearshore settings. The bulk of the resource as estimated by Pavlides (1962) is the hematitic variety that contains about 300 million metric tons of material averaging 7 percent manganese and 17 percent iron. The carbonate variety is much smaller and contains only 3 million metric tons of material. These figures were revised downward by a more recent study (Kilgore and Thomas, 1982), and are shown in table L3. Deposits farther north in the North Aroostook district are similar to those of the Maple Mountain-Hovey Mountain area but are significantly smaller. Together, those northern deposits contain an additional 60 million metric tons.

Although the deposits in Aroostook County contain sufficient manganese to satisfy U.S. consumption for several decades, the production of a manganese product that would be viable in current markets would require substantial beneficiation of these low-grade resources. An economic analysis of the cost of mining, beneficiation, and transport showed that these deposits are far from being economically viable (Kilgore and Thomas, 1982). Although that analysis was done 30 years ago, more recent developments have not substantially increased the economic value of these deposits. Thus, they remain a relatively large but subeconomic resource that can

Table L3. Grade, tonnage, and quantity of contained manganese for eight manganese deposits and districts in the United States.

[Data are as reported in Kilgore and Thomas (1982). Numbers for contained manganese (Mn) have been rounded to three significant figures. \%, percent; - , not applicable]

\begin{tabular}{|llcrc}
\hline \multicolumn{1}{c}{ Deposit/district } & \multicolumn{1}{c}{ State } & $\begin{array}{c}\text { Grade } \\
(\% \mathbf{M n})\end{array}$ & $\begin{array}{c}\text { Resource } \\
\text { (metric tons) }\end{array}$ & $\begin{array}{c}\text { Contained Mn } \\
\text { (thousand } \\
\text { metric tons) }\end{array}$ \\
\hline Hardshell Mine & Arizona & 15.0 & $5,895,500$ & 884 \\
\hline Maggie Mine & Arizona & 8.75 & $8,441,000$ & 739 \\
\hline Sunnyside Mine & Colorado & 10.0 & $24,909,000$ & 2,490 \\
\hline Maple Mountain-Hovey Mountain & Maine & 8.87 & $260,000,000$ & 23,100 \\
\hline North Aroostook district & Maine & 9.54 & $63,100,000$ & 6,110 \\
\hline Cuyuna Range (southwest portion) & Minnesota & 7.84 & $48,960,000$ & 3,840 \\
\hline Butte district (Emma Mine) & Montana & 18.0 & $1,232,000$ & 222 \\
\hline Three Kids Mine & Nevada & 13.2 & $7,230,000$ & 954 \\
\hline \multicolumn{1}{c}{ Total } & - & - & $\mathbf{4 1 9 , 7 6 7 , 5 0 0}$ & $\mathbf{3 8 , 3 0 0}$ \\
\hline
\end{tabular}


become a significant manganese supplier for the United States only with major advancements in processing and beneficiation technology or long-term disruption of international manganese trade.

\section{Cuyuna Range, Minnesota}

The Cuyuna Range is one of several iron ranges of the Lake Superior region that have supplied a large proportion of the iron needed to meet U.S. iron consumption. The deposits include Precambrian banded iron formations and secondary iron concentrations within them. The Cuyuna Range, which is now inactive as an iron producer, is distinct from other ranges in its relatively high content of manganese. The range produced substantial quantities of manganiferous iron ores, as distinct from manganese ore, for more than 70 years. Production ceased in 1984, at which time more than 100 million metric tons of ore had been produced, largely from open pit operations. The produced ores averaged between 13 percent and 14 percent manganese. A relatively recent summary of the geology and manganese resources of the range was provided by Morey (1990) from which most of the following summary is extracted.

The Cuyuna Range ores are supergene concentrations of iron and manganese that formed in Precambrian strata that are themselves enriched in both iron and manganese. The original strata contain 20 to 35 percent iron and from less than 1 percent to 16 percent manganese. The supergene enrichments that constitute the manganiferous iron ores range from 30 to 40 percent iron and 5 to 15 percent manganese. Several estimates of manganese resources have been made and summarized by Morey (1990). An estimate of measured resources at 39 existing (abandoned) mines is 5.5 million metric tons that average about 11.7 percent manganese (Beltrame and others, 1981). A much larger tonnage of manganiferous material has been estimated within the ferruginous strata of the district. A resource of 80 million metric tons averaging about 10.5 percent manganese and within $120 \mathrm{~m}$ of the surface was estimated by Beltrame and others (1981). The same authors estimated that an additional inferred resource of 90 million metric tons within $120 \mathrm{~m}$ of the surface exists within less well characterized parts of the district. In 1982, a summary of U.S. resources (Kilgore and Thomas, 1982) estimated a resource of about 49 million metric tons with a grade of 7.84 percent manganese. These are included in table L3.

The production of a commercial manganese product from Cuyuna Range manganiferous iron ores requires either physical processing and concentration of manganese minerals or hydrometallurgical concentration. Because a great majority of the manganese minerals are fine-grained and intergrown with other minerals, physical separation and beneficiation would be difficult. Some renewed interest in manganese production is indicated by pilot-scale testing of an innovative hydraulic mining method in which high-pressure jets of water are used to mobilize these physically soft ores into slurry within large-diameter drill holes (Crow Wing Power, 2013). The economic feasibility of this method was still being evaluated in 2013.

\section{Seabed Resources}

A large but incompletely characterized and quantified manganese resource lies within the vast area of the United States EEZ. Extensive areas of both ferromanganese crusts and, to a lesser extent, nodules, are known offshore of both the Atlantic Coast and the Pacific Coast of the U.S. mainland, including Alaska, as well as the Hawaiian Islands, and other island possessions. Most economic interest and exploration for seabed deposits has been focused on the prime nodule zone of the CCZ in international water where seabed mining of nodules is most likely to take place first. The United States EEZ, however, holds some promise to provide manganese and related metals in the future if the technology and economics of seabed mining lead to viable mining operations in the areas of current highest interest. Because most deposits within the EEZ are crusts, which are considerably more challenging to mine than nodules, the potential mining of these deposits may lag development of nodule mining operations. So, although the EEZ undoubtedly contains a very large tonnage of manganese resources, it is unlikely to have an effect on domestic and global manganese production and consumption in the short term.

\section{Undiscovered Resources}

Marine sedimentary manganese deposits of economic significance are large geologic features. They generally have been found by accidental discovery in surface rock exposures rather than by purposeful exploration or exploration for subsurface deposits. It has been many decades since the last such major discovery in spite of an increasing pace of geologic studies and mineral exploration. Currently, exploration for new deposits is mostly confined to known districts rather than exploration intended to find wholly new districts. With time, the likelihood of new discoveries of major deposits is diminished. That said, there is still some possibility of important new discoveries, especially in light of the rather unremarkable outward appearance of some manganiferous sediments, especially manganese carbonate deposits. In some cases, the manganiferous character of these rocks was realized only after discovery of supergene deposits formed from them.

Supergene deposits offer a greater potential for undiscovered deposits because of their smaller size and propensity to occur in tropical regions with poor bedrock exposure, limited access, and incomplete geologic studies. Exploration focused in suitable areas with known manganiferous sediments is likely to result in new discoveries. 


\section{Exploration for New Deposits}

There are currently 10 new land-based manganese mines under development in various parts of the world that are scheduled for completion by the end of 2014. The total annual production capacity of new production will be nearly 5.42 million metric tons of ore, more than one-half of which will be from the Kalahari manganese district in South Africa (Corathers, 2013a). These new mines attest to the continued need for manganese exploration throughout the world. Most, if not all, of these new mines are in areas of previously known manganese mineralization and do not represent newly discovered manganese districts.

The exact methods of exploration and discovery are not known for all of these deposits, but likely included surface geologic studies and exploration drilling. In some cases, geophysical methods, particularly electromagnetic surveys, aided in defining targets for drilling.

It is reasonable to assume that, for the near future, land-based exploration will continue to focus on areas where there are known manganiferous rocks and will be designed to outline areas of sufficiently high grade and tonnage to constitute an economic orebody. More-wide-ranging exploration aimed at discovery of new frontier districts or new manganiferous sedimentary units may also take place in areas where geologic conditions suggest favorable settings for manganese deposits to have formed. Significant sedimentary manganese deposits cover large areas and are at least partly exposed at the surface. As such, they represent large exploration targets. Remote sensing methods, including satellite imagery, airborne geophysical surveys, and hyperspectral mapping, may be effective exploration tools. Satellite imagery may help identify and refine favorable exploration tracts and outcropping manganiferous rocks. Airborne geophysical surveys, especially electromagnetic surveys, may be useful in mapping shallowly buried layers rich in manganese because of the electrically conductive nature of manganese oxides. Hyperspectral mapping has the potential to specifically identify manganese oxide minerals because they have a low reflectance signature relative to other common minerals. Once a manganese deposit has been identified by these methods, more-detailed ground surveys are needed to refine the size and grade of deposits to evaluate their economic viability fully. Early stages of such exploration are commonly conducted at least partly confidentially by exploration and mining companies so that the degree to which such exploration might currently be taking place is not well known.

Exploration of the seabed is also active; 13 individual entities were exploring for ferromanganese nodules in 2013. Identification of nodule-rich seabed regions is relatively simple and can be done by remote visual examination to identify areas with the greatest abundance of nodules. Physical sampling of nodules is also required, followed by chemical assays to map the distribution of nodules with the most favorable grades of manganese and other economically important metals, such as cobalt, copper, and nickel. Exploration for ferromanganese crusts is much less advanced, although in 2013, the ISA received two plans for exploration in the western Pacific Ocean.

\section{Environmental Considerations}

Manganese is ubiquitous on Earth's surface. Humans and virtually all other life forms interact with it every day. Manganese is an essential nutrient for most life, including humans, but it can produce a variety of toxic effects at anomalously high concentrations. As such, the potential for manganese mining and processing to produce such elevated concentrations must be addressed throughout the life cycle of manganese production and use. Manganese deposits and the types of operations that mine them are very diverse around the globe. Some examples of possible concerns regarding increased environmental manganese around mines and processing plants are discussed below, along with some general aspects of manganese geochemistry that could make it possible to predict potential environmental and health impacts of manganese mining.

\section{Sources and Fate in the Environment}

Examples of natural concentrations of manganese in rocks, soil, water, and air are given in table L4. Manganese contents in soils range from 7 to 9,200 milligrams per kilogram (mg/kg) (or parts per million), with higher manganese concentrations commonly occurring in soils developed from mafic rocks, soils rich in iron and (or) organic matter, and soils developed in arid or semiarid regions (Kabata-Pendias and Mukherjee, 2007). Dissolved manganese concentrations in large rivers around the world range from 0.4 to $113 \mu \mathrm{g} / \mathrm{L}$ (or parts per billion) (Gaillardet and others, 2003, and references therein), whereas the average concentration of manganese in the suspended sediment of world rivers has been reported as $1,679 \mathrm{mg} / \mathrm{kg}$ (Viers and others, 2009). Occasionally, dissolved manganese concentrations can be comparable to particulate manganese concentrations. For example, during flood events in Magela Creek in the Northern Territory, Australia, dissolved $(<0.02$ micrometer $[\mu \mathrm{m}]$-size $)$ manganese concentrations $(0.8$ to $9.6 \mu \mathrm{g} / \mathrm{L})$ are similar to particulate $(>0.02 \mu \mathrm{m}$-size $)$ manganese concentrations $(0.3$ to $7.9 \mu \mathrm{g} / \mathrm{L})$; the relatively high dissolved manganese concentrations are attributed to the acidic soils, which create favorable conditions for manganese dissolution from minerals (Hart and others, 1992). Manganese occurs naturally in the atmosphere as part of mineral dust particles. Nriagu (1989) estimated manganese emission to the atmosphere from natural sources to be 317 million kilograms per year $(\mathrm{Mkg} / \mathrm{yr})$. Air manganese concentrations in remote regions range from 0.004 to 0.02 nanograms per cubic meter $\left(\mathrm{ng} / \mathrm{m}^{3}\right)$ over the South Pole and from 2.8 to $4.5 \mathrm{ng} / \mathrm{m}^{3}$ over Greenland (Kabata-Pendias and Pendias, 2001). 
Table L4. Background and above-background concentrations of manganese in rocks, soils, waters, and air.

[DOE, U.S. Department of Energy; EPA, U.S. Environmental Protection Agency. Units of measure: cm, centimeter; mg/kg, milligram per kilogram (or part per million); $\mathrm{mg} / \mathrm{L}$, milligram per liter; $\mathrm{mg} / \mathrm{m}^{3}$, milligram per cubic meter; $\mathrm{ng} / \mathrm{m}^{3}$, nanogram per cubic meter; $\mu \mathrm{g} / \mathrm{L}$, microgram per liter; $\mu \mathrm{g} / \mathrm{m}^{3}, \mathrm{microgram}$ per cubic meter; $\mu \mathrm{m}$, micrometer]

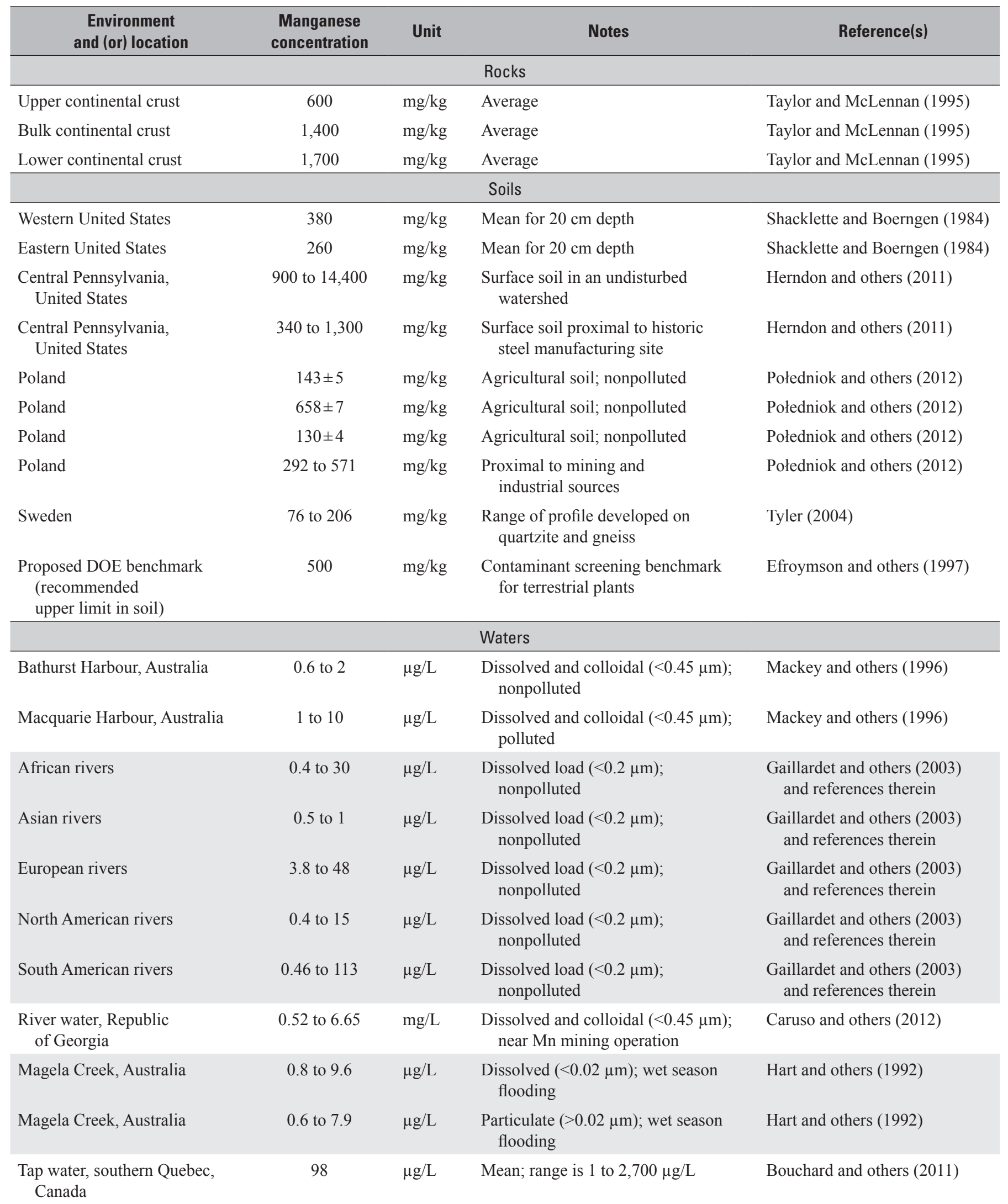


Table L4. Background and above-background concentrations of manganese in rocks, soils, waters, and air.-Continued

[DOE, U.S. Department of Energy; EPA, U.S. Environmental Protection Agency. Units of measure: cm, centimeter; mg/kg, milligram per kilogram (or part per million); $\mathrm{mg} / \mathrm{L}$, milligram per liter; $\mathrm{mg} / \mathrm{m}^{3}$, milligram per cubic meter; $\mathrm{ng} / \mathrm{m}^{3}$, nanogram per cubic meter; $\mu \mathrm{g} / \mathrm{L}$, microgram per liter; $\mu \mathrm{g} / \mathrm{m}^{3}, \mathrm{microgram}$ per cubic meter; $\mu \mathrm{m}$, micrometer]

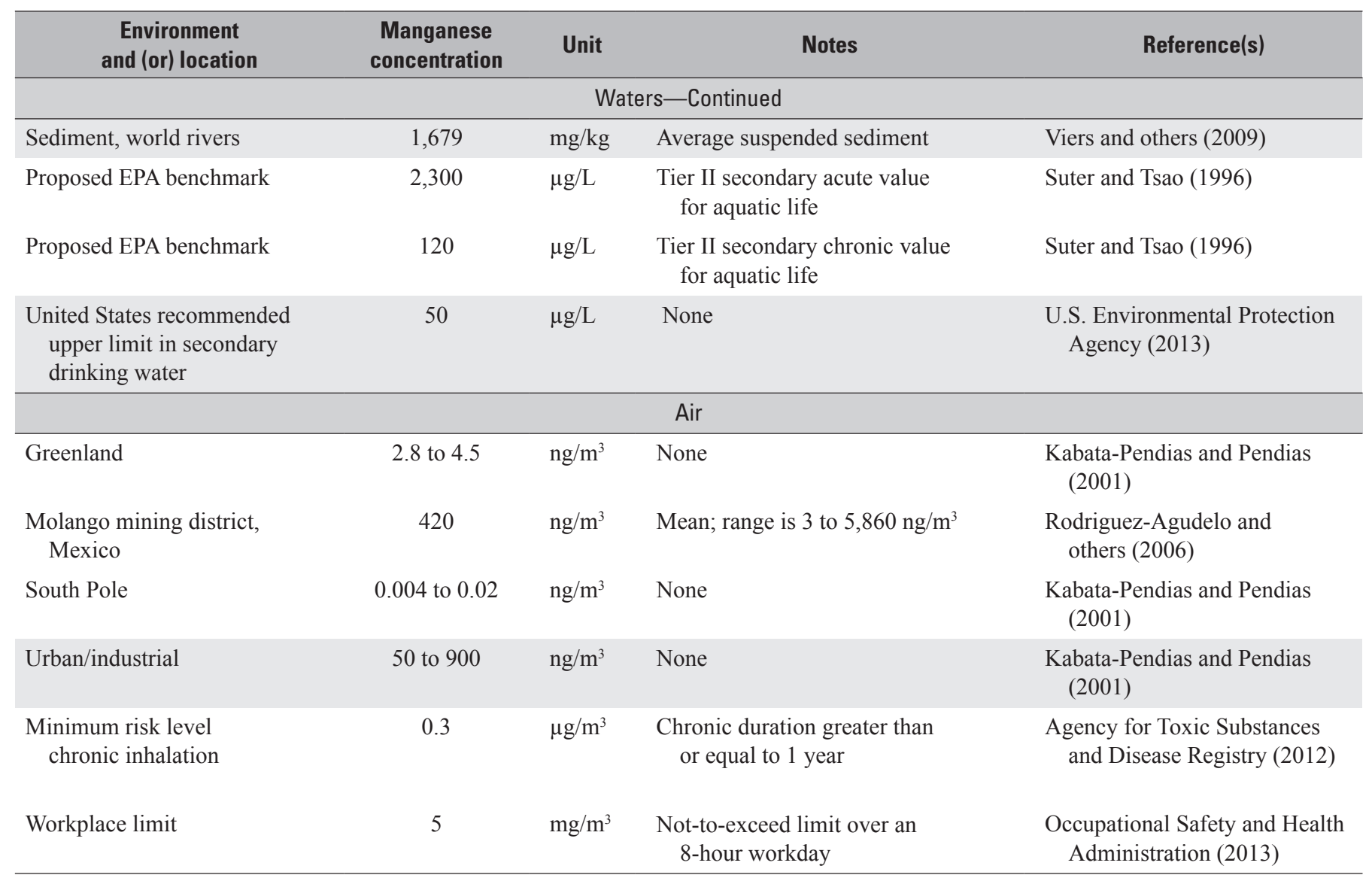

In weathering environments at Earth's surface, manganese commonly occurs in three active oxidation states.

Manganese(II) occurs as dissolved $\mathrm{Mn}^{2+}$ in solution, especially under acidic $\mathrm{pH}$ values, as insoluble carbonate minerals, and as a minor component in other minerals. Manganese(III) is thermodynamically unstable and tends to be a temporary phase during redox reactions or a minor component in manganesebearing minerals. Manganese(IV) tends to form insoluble oxide and hydroxide minerals. The manganese(III) and manganese(IV) phases are some of the strongest oxidants in the environment, so the reactivity of manganese is dominated by its tendency to participate in redox reactions (Tebo and others, 2004). In surface water, manganese tends to attach to particulate matter that is either transported downstream or deposited as sediment.

Mining and industrial activities can lead to abovebackground concentrations of manganese in the environment (table L4). For example, manganese concentrations in soils near mining and industrial sources in Poland range from 292 to $571 \mathrm{mg} / \mathrm{kg}$ (Połedniok and others, 2012). Comparable manganese concentrations in surface soils collected in central Pennsylvania from both an undisturbed watershed site and a nearby historic steel plant site (table L4) led Herndon and others (2011) to a comprehensive analysis that showed that more than one-half of the soils surveyed in North America and Europe are enriched in manganese as a result of atmospheric deposition from industrial sources. Indeed, the atmospheric concentrations of manganese in urban and industrial areas $\left(50\right.$ to $900 \mathrm{ng} / \mathrm{m}^{3}$ ) are far greater than those measured at the poles $\left(0.004\right.$ to $\left.4.5 \mathrm{ng} / \mathrm{m}^{3}\right)$. Likewise, the dissolved and colloidal $(<0.45 \mu \mathrm{m}$-sized) fraction of manganese in river water near a manganese mining site in the Republic of Georgia contains 0.5 to 6.7 milligrams per liter $(\mathrm{mg} / \mathrm{L}$ ) (Caruso and others, 2012), which is roughly an order of magnitude greater than dissolved manganese concentrations in some world rivers (table L4). Mackey and others (1996) measured dissolved and colloidal manganese concentrations of seawater in nonpolluted and polluted harbors of Tasmania and found ranges of 0.6 to $2 \mu \mathrm{g} / \mathrm{L}$ and 1 to $10 \mu \mathrm{g} / \mathrm{L}$, respectively. 
The primary anthropogenic inputs of manganese to the atmosphere are from mining and ore processing, as well as from iron and steel production. The median anthropogenic emission of manganese to the atmosphere in 1983 was estimated to be $38.3 \mathrm{Mkg} / \mathrm{yr}$ (Nriagu and Pacyna, 1988), and the median manganese concentration reported for "polluted air" is $90 \mathrm{ng} / \mathrm{m}^{3}$ (Reimann and de Caritat, 1998, and references therein).

Because manganese is so critical to steel manufacturing, society's need for manganese continues to increase. Unlike many metals, manganese recycling is relatively efficient. The recycled content (that is, the proportion of scrap) used in manganese production is between 25 and 50 percent, and the fraction of manganese in discarded products that get recycled is greater than 50 percent (Graedel and others, 2011). The factors that contribute to the economic and technologic feasibility of manganese recycling are that (a) manganese is used in large quantities, and (b) it occurs in alloys in relatively pure form, making it easier to remelt and recover (Reck and Graedel, 2012).

\section{Mine Waste Characteristics}

Manganese deposits are mined by open pit and underground methods. The mine waste generated is generally considered to be the material that originates and accumulates at a mine site that has no current economic value (Lottermoser, 2010), and includes both solid and liquid waste. Because sedimentary manganese deposits tend to be laterally extensive, the expanse of land disrupted during mining is potentially great. The largest deposits on land include the Kalahari manganese field, which covers approximately $400 \mathrm{~km}^{2}$ (Jupiter Mines Ltd., 2013), and the Molango mining district, which covers $180 \mathrm{~km}^{2}$ (Rivera-Becerril and others, 2013). Although many mines in sedimentary manganese deposits can be viewed from satellite imagery, values for the volume or tonnage of solid mine waste generated during mining are difficult to obtain. Supergene manganese deposits tend to be smaller and higher grade, so the amount of solid mine waste generated is expected to be less.

Solid mine waste includes overburden (the waste rock that overlies an orebody, which must be removed during mining) and gangue (the economically valueless material that surrounds or is mixed with the ore). The mineralogy of overburden varies depending upon the deposit, whereas the mineralogy of gangue from manganese mining can be similar among deposits. In general, gangue minerals in sedimentary manganese deposits include biogenic silica, carbonates, chert, clays, glauconite, pyrite, and quartz (Force and others, 1995). Gangue minerals in the Groote Eylandt supergene manganese deposit include gibbsite, goethite, kaolinite, and quartz, and the trace metals associated with these minerals include As, Ce, Cr, Gd, P, Pb, Sc, Th, Ti, and Zr (Pracejus and Bolton, 1992). Clarke and others (2010) have characterized mine tailings in the Kalahari manganese field as being predominantly sand-sized and containing the minerals birnessite, bixbyite, braunite, calcite, hausmannite, hematite, manganite, and todorokite. Trace metals detected in these tailings include (in milligrams per kilogram): $\mathrm{Ag}(<0.8)$, As (20), Be (0.9), $\mathrm{Cd}$ (0.6), Cr (42), Cu (41), Hg (0.1), Mo (5.9), Pb (110), Se $(<0.2)$, and $\mathrm{Th}(<0.1)$. Most of these trace metals are expected to be immobile given the tailings pore water $\mathrm{pH}$ of 8.8 .

The enrichment of trace metals (for example, $\mathrm{Co}, \mathrm{Cu}$, Mo, Ni, and REEs) in manganese oxide minerals is why manganese nodules and crusts on the seabed have become an attractive metal resource. In weathering environments, trace metals contained in manganese oxides are expected to remain immobile under oxic, near-neutral $\mathrm{pH}$ conditions $(5<\mathrm{pH}<8)$, especially in the presence of iron-rich solids (Smith and Huyck, 1999). Under anoxic and (or) acidic conditions, however, both manganese oxides and associated trace metals are expected to be mobile. In some manganese deposits, generation of acidity is possible if pyrite dissolution is not balanced by the acid-neutralizing capacity of carbonate minerals, but this scenario is expected to be rare. Dissolution of manganese oxides and associated trace elements is more likely to occur in soil environments, where organic acids can be highly concentrated in pore water, creating acidic conditions. Manganese oxide minerals are also expected to be less stable under anoxic conditions, which can develop upon burial. In anoxic subsurface environments, manganesereducing microorganisms are known to catalyze manganese oxide dissolution, thereby contributing to increased dissolved manganese and trace metal concentrations in groundwater (Myers and Nealson, 1988; Lovley, 1991).

\section{Human Health Concerns}

A wealth of information exists on the effects of manganese on human health because it is both an essential nutrient and a potential neurotoxin in cases of overexposure. The Agency for Toxic Substances and Disease Registry (ATSDR) provides a useful summary of the human toxicology of manganese (Agency for Toxic Substances and Disease Registry, 2012). The general public is exposed to manganese through consumption of food and water; inhalation of air; and skin contact with air, water, soil, and consumer products that contain manganese. The U.S. Recommended Dietary Allowance of manganese is 2 to 5 milligrams per day $(\mathrm{mg} / \mathrm{d})$ (National Research Council, 1989). Extended oral exposure above these levels can lead to adverse neurological effects. Workers at manganese mining and processing facilities are most likely to inhale manganese-rich dust. Inhaled manganese can lead to a permanent neurological disorder called manganism, which causes such symptoms as tremors, difficulty walking, and facial muscle spasms. Additionally, occupational exposure to manganese dust can lead to lung inflammation and impaired lung function. The mean air concentration within the Molango mining district in Mexico is 420 micrograms of manganese per cubic meter; in this region, 
surveyed adults exhibited decreased motor abilities with increasing air manganese concentrations (Rodríguez-Agudelo and others, 2006).

Children exposed to high levels of manganese show neurodevelopmental effects, including changes in behavior, memory, and learning ability. For example, surveyed school-age children in the Molango mining district contained significantly higher manganese levels in blood and hair relative to children in a control site; children also showed decreased intellectual function with increased manganese content in hair (Riojas-Rodríguez and others, 2010). In a similar study of school-aged children exposed to relatively high manganese levels (mean $=98$ micrograms of manganese per liter) in drinking water supplied by groundwater, higher manganese concentrations in hair were significantly correlated with higher manganese concentrations in drinking water and with decreased IQ scores (Bouchard and others, 2011).

The U.S. national secondary drinking water regulation for manganese, which is a nonenforceable guideline, is $50 \mu \mathrm{g} / \mathrm{L}$ (U.S Environmental Protection Agency, 2013). The World Health Organization's (WHO) "Guidelines for Drinking Water Quality" included manganese at $400 \mu \mathrm{g} / \mathrm{L}$ until 2011, at which point the inclusion of manganese was discontinued on the grounds that the recommended value was well above normal concentrations of manganese in drinking water (World Health Organization, 2011). Frisbie and others (2012) argue that a substantial number of surveyed countries have drinking water manganese concentrations greater than $400 \mu \mathrm{g} / \mathrm{L}$, and that given the possible negative human health effects of manganese, the earlier WHO guideline was probably too high to protect human health.

Manganese levels in soils are not regulated because of the ubiquity of manganese in soil and groundwater. The U.S. Environmental Protection Agency (EPA) does, however, require the reporting of manganese concentrations in waste streams from factories that use or produce manganese. The chronic duration (equal to or greater than 1 year) minimal risk level of 0.3 microgram per cubic meter $\left(\mu \mathrm{g} / \mathrm{m}^{3}\right) \mathrm{Mn}$ has been set for manganese inhalation by the U.S. Department of Health and Human Services (Agency for Toxic Substances and Disease Registry, 2012). Likewise, the U.S. Occupational Safety and Health Administration (OSHA) has set a limit of 5 milligrams per cubic meter $\left(\mathrm{mg} / \mathrm{m}^{3}\right)$ for the average allowable manganese concentration in workplace air over an 8-hour workday (Occupational Safety and Health Administration, 2013).

\section{Ecological Health Concerns}

Many studies focus on the ecological effects of manganese in the environment. Because fish tend to be sensitive to low concentrations of dissolved metals, they are commonly useful indicators of contamination in aquatic systems. One of several useful endpoints used in toxicity tests is the concentration that leads to 50 percent mortality (lethal concentration 50 $\left.\left[\mathrm{LC}_{50}\right]\right)$ after exposure to a substance for a certain amount of time. Chronic toxicity tests with dissolved manganese and developing rainbow trout (Oncorhynchus mykiss) revealed a mean $\mathrm{LC}_{50}$ value of $2.9 \mathrm{mg} / \mathrm{L}$ after 28 days of exposure (Birge and others, 1980). Tests on the chronic toxicity of manganese to developing brown trout (Salmo trutta Linnaeus) showed that at $30 \mathrm{mg} / \mathrm{L}$ hardness (high dissolved mineral content), decreased survival after 62 days correlated significantly with increased manganese concentrations, which ranged from 0.5 to $15.5 \mathrm{mg} / \mathrm{L}$ (Stubblefield and others, 1997). The toxic effects of manganese on this species decreased with increasing hardness because less toxic $\mathrm{Ca}^{2+}$ and $\mathrm{Mg}^{2+}$ were able to outcompete with $\mathrm{Mn}^{2+}$ for biologic sites. Decreased manganese toxicity with increasing hardness was also observed for the water flea (Ceriodaphnia dubia) (Peters and others, 2011). Some regions of the United States have adopted secondary acute and chronic screening benchmarks for manganese concentrations of $2,300 \mu \mathrm{g} / \mathrm{L}$ and $120 \mu \mathrm{g} / \mathrm{L}$, respectively, for aquatic freshwater life, as recommended by the Oakridge National Laboratory (Suter and Tsao, 1996).

Manganese is considered to be an essential nutrient for healthy plant growth, partially because of its role in supporting photosynthesis (Kabata-Pendias and Mukherjee, 2007). Land plants exhibit a range of 15 to 100 micrograms of manganese per gram dry weight (Misra and Mani, 1991). Plants vary in their ability to withstand high manganese concentrations, and those plants with higher manganese tolerance may accumulate manganese in roots and (or) precipitate manganese oxide within the epidermis (Kabata-Pendias and Mukherjee, 2007). A survey of plant roots growing in the Molango mining district in Mexico revealed that native ragweed growing in soil proximal to manganese mine waste was more resistant to manganese incorporation than ragweed growing directly in the mine waste; higher manganese resistance in the former specimen was attributed to a symbiotic relationship with mycorrhizal fungi in plant roots (Rivera-Becerril and others, 2013). As summarized by Nagajyoti and others (2010), plants that are sensitive to excessive manganese tend to develop diseases that affect their leaves. Some regions of the United States have adopted a soil-screening benchmark of 500 milligrams of manganese per kilogram of soil for terrestrial plants, as recommended by the Oakridge National Laboratory (Efroymson and others, 1997).

\section{Carbon Footprint}

Use of manganese contributes to greenhouse gas emissions. During the production of ferromanganese, which is an important component in steel, manganese oxides are mixed with iron ore and carbon and then reduced in either a blast furnace or an electric arc furnace. The energy requirements for this process can be great. Additionally, when rhodochrosite $\left(\mathrm{MnCO}_{3}\right)$ is the starting manganese ore, either for ferromanganese or nonmetallurgical applications, an initial processing step involves converting $\mathrm{MnCO}_{3}$ to pyrolusite $\left(\mathrm{MnO}_{2}\right)$ in a process known as calcination. This results in additional process-related carbon dioxide $\left(\mathrm{CO}_{2}\right)$ emissions. Using a basic emission calculation and assuming 
100 percent calcination, an emission factor of 383 kilograms of carbon dioxide per kilogram of rhodochrosite results (Hanle and others, 2006). The EPA requires facilities that emit 25,000 metric tons or more of greenhouse gases and that consume at least 2,000 metric tons per year of carbonates, such as rhodochrosite, to report their process-based $\mathrm{CO}_{2}$ emissions in addition to their energy-related greenhouse gas emissions. Certain industries, such as manganese alloy and iron and steel production, are excluded from this requirement (U.S. Environmental Protection Agency, 2011).

\section{Mine Closure}

Most recently opened and new mining operations include closure plans that address issues related to the mine footprint. A mine's footprint includes the waste left on site and locally affected soil and water, as well as ecological effects, such as habitat destruction and loss of biodiversity. The environmental impact assessment for the proposed Kalahari manganese mine in Northern Cape Province, South Africa, which is part of the Kalahari manganese field, provides examples of some mine footprint issues and possible control measures (Strategic Environmental Focus (Pty) Ltd., 2007). The manganese ore, mainly rhodochrosite, would be mined by underground methods, and both ore beneficiation and ferromanganese production would take place on site. The mine waste generated on site would include tailings (projected to be 250,000 metric tons per year) and slimes from ore treatment (projected to be 45,000 metric tons per year). The tailings pile would increase in size for about 10 years before being returned to the underground workings as backfill. Any remaining piles would be graded and covered with vegetation. Potential loss of native vegetation and disruption of faunal migrations would be addressed by a $1.5-\mathrm{km}$ no-development buffer zone along the major river that flows through the proposed mine site and by revegetation of disturbed soils with native species. Surface and groundwater quality would be monitored frequently, and potential seepage from tailings and slime dams would be prevented through engineering means. The potential for dust emissions from mining and sinter operations would be mitigated through various methods, such as wet suppression and early revegetation.

Long-term plans for closed manganese mining operations will depend on the country, State, and local regulations. Potential long-term environmental impacts that could be of concern are dust generation and seepage of metal-rich water from waste material. An additional long-term issue relates to revegetation of manganese-rich waste, which applies to both closure of current mines and attempted reclamation of abandoned mines. Some plant species may contribute to soil acidification, which could lead to solubilization of manganese from minerals and transport of dissolved manganese downstream. Attention to the type of plant species used for revegetation and close monitoring of soil parameters during soil development might prevent this from happening.

\section{Problems and Future Research}

Identified global manganese resources, including currently subeconomic deposits, are essentially inexhaustible by any scenario of future consumption. Thus, there are no geologic problems related to the adequacy of manganese resources from a global perspective. Substantial increases in the price of manganese and increases in the efficiency of mining and processing will be necessary to convert much of this vast resource to economically workable deposits, however. The unequal distribution of the global manganese resources has long been recognized as a matter of concern for the United States and other industrialized countries that have inadequate domestic resources to meet their own needs. For the United States, discovery of manganese deposits of better quality than the few known large low-grade domestic deposits would be advantageous, whether they were immediately economic or could provide a more accessible source of manganese in the event of future supply disruptions.

Perhaps the most significant area available for domestic manganese exploration is the seabed within the United States EEZ. The vast size of this area alone provides incentive for research and exploration opportunities, many of which have been only superficially addressed to date. The United States EEZ contains more than 11 million $\mathrm{km}^{2}$ of seabed, an area larger than all of the land areas of the Nation. There are substantial known deposits of ferromanganese crusts and nodules in the EEZ where the United States has sole authority for regulation and mining. A more definitive characterization of the EEZ's potential as a source of manganese could help to focus future research and exploration efforts on areas that have the highest possibility for development and production. An expanded information base regarding the occurrence, abundance, and metal grades of these deposits would be a significant step toward eventual metal production. Beyond geologic research, prime areas for research include mining and processing technology and advances in understanding and mitigating the potential impact of seabed mining on marine ecosystems.

With regard to seabed mineral resources, development of this resource would disturb potentially millions of square kilometers of the abyssal seabed, an unprecedentedly large area of mine disturbance that would constitute a new type of human impact on the environment. Significant new research would be needed to assess the effects on marine ecosystems and understand other environmental impacts of this completely new human activity and to minimize its adverse impacts. The ISA has developed guidelines for the environmental impact statement (EIS) that must be submitted by companies interested in applying for seabed mineral exploration licenses. In an EIS, developers must address all environmental and social issues and relevant mitigation measures that could result from the mining activity (International Seabed Authority, 2012). More information on these issues has been discussed in the various technical reports published online by the ISA (2014). 
Processing of manganese nodules and crusts mined on the seabed will most likely take place on land, so the same mine waste issues mentioned for terrestrial manganese ores will also apply to seabed resources. Seabed mining in the $\mathrm{CCZ}$ would involve many additional issues. In addition to overcoming the technological challenges presented by mining as deep as $6,500 \mathrm{~m}$ below sea level, perhaps one of the most controversial issues is the potential impact on benthic, midwater, and pelagic ecosystems. Benthic ecosystems developed on the abyssal plain are the ecosystems that are the most threatened by mining in the CCZ. Understanding of abyssal, benthic ecosystems has grown rapidly in the past several decades. Even so, an international effort to evaluate the biodiversity in the $\mathrm{CCZ}$ revealed that "high, unanticipated, and still poorly sampled levels of species diversity for all three sedimentdwelling faunal components (foraminifera, nematodes and polychaetes) [exist] at [the] individual study sites" (International Seabed Authority, 2008). These findings led to the recommendation that "marine protected areas" be maintained throughout the CCZ in order to preserve abyssal biodiversity (International Seabed Authority, 2008). Another major environmental concern relates to wastewater being discharged from mining ships. This waste could contain crushed nodules and trace metals and has the potential to disrupt phytoplankton and, because the wastewater would be colder and denser than the surface water, to disrupt the natural circulation patterns in the water column (Markussen, 1994). As a result, current conceptual engineering designs separate nodules from waste material (such as clay, sediments, and muddy water) and return waste to the seabed at depths of nearly $5,000 \mathrm{~m}$ below sea level so as not to disturb the midwater and pelagic regions (for example, Agarwal and others, 2012). As interest in mining seabed resources continues, additional studies would be needed to document its impacts on ocean life.

\section{References Cited}

Note: All Web links listed were active as of the access date but may no longer be available.

Agarwal, B., Hu, P., Placidi, M., Santo, H., and Zhou, J.J., 2012, Feasibility study on manganese nodules recovery in the Clarion-Clipperton zone, v. 2 of Shenoi, R.A., Wilson, P.A., and Bennett, S.S., eds., Seabed exploitationThe LRET Collegium 2012 Series: Highfield, Southhampton, United Kingdom, University of Southampton, 128 p. [Also available at http://www.southampton.ac.uk/engineering/ research/groups/fsi/lrf/lrf_collegium_2012_book_series.page.]

Agency for Toxic Substances and Disease Registry, 2012, Toxicological profile for manganese: Atlanta, Ga., U.S. Department of Health and Human Services, Public Health Services, September, 506 p. plus 3 appendixes, accessed February 15, 2013, at http://www.atsdr.cdc.gov/ ToxProfiles/tp151.pdf.

Banakar, V.K., 2010, Deep-sea ferromanganese deposits and their resource potential for India: Journal of the Indian Institute of Science, v. 90, no. 4, p. 535-541.

Beltrame, R.J., Holtzman, R.C., and Wahl, T.E., 1981, Manganese resources of the Cuyuna Range, east-central Minnesota: Saint Paul, Minn., Minnesota Geological Survey Report of Investigations 24, $22 \mathrm{p}$.

Beukes, N.J., and Gutzmer, J[ens], 1996, A volcanicexhalative origin for the world's largest (Kalahari) manganese field (Discussion): Mineralium Deposita, v. 31 , no. 3 , p. $242-245$.

Birge, W.J., Black, J.A., Westerman, A.G., and Hudson, J.E., 1980, Aquatic toxicity tests on inorganic elements occurring in oil shale, in Gale, Charles, ed., Oil shale symposiumSampling analysis and quality assurance, March 1979, Proceedings: Cincinnati, Ohio, U.S. Environmental Protection Agency, EPA-600/9-80-022, p. 519-534. [Also available at http://babel.hathitrust.org/cgi/pt?id=coo.31924004323303; view=1 up;seq=531.]

Bouchard, M.F., Sauvé, Sébastien, Barbeau, Benoit, Legrand, Melissa, Brodeur, Marie-Ève, Bouffard, Thérèse, Limoges, Elyse, Bellinger, D.C., and Mergler, Donna, 2011, Intellectual impairment in school-age children exposed to manganese from drinking water: Environmental Health Perspectives, v. 119, no.1, p. 138-143. [Also available at http://dx.doi.org/10.1289/ehp.1002321.]

Cannon, W.F., and Force, E.R., 1983, Potential for high-grade shallow-marine manganese deposits in North America, in Shanks, W.C., ed., Cameron volume on unconventional mineral deposits: New York, N.Y., American Institute of Mining, Metallurgical, and Petroleum Engineers, p. 175-189. 
Caruso, B.S., Mirtskhulava, Merab, Wireman, Michael, Schroeder, William, Kornilovich, Boris, and Griffin, Susan, 2012, Effects of manganese mining on water quality in the Caucasus Mountains, Republic of Georgia: Mine Water and the Environment, v. 31, no. 1, p. 16-28. [Also available at http://dx.doi.org/10.1007/s10230-011-0163-3.]

Clarke, C.E., Kielar, Filip, Talbot, H.M., and Johnson, K.L., 2010, Oxidative decolorization of acid azo dyes by a Mn oxide containing waste: Environmental Science and Technology, v. 44, no. 3, p. 1116-1122. [Also available at http://dx.doi.org/10.1021/es902305e.]

Corathers, L.A., 2011-16, Manganese, in Metals and minerals: U.S. Geological Survey Minerals Yearbook 2009-2012, v. I, variously paged.

Corathers, L.A., 2013a, Manganese, in Metals and minerals: U.S. Geological Survey Minerals Yearbook 2011, v. I, p. 47.1-47.20. [Also available at https://minerals.usgs.gov/ minerals/pubs/commodity/manganese/myb1-2011-manga.pdf.]

Corathers, L.A., 2013b, Manganese: U.S. Geological Survey Mineral Commodity Summaries 2013, p. 100-101. [Also available at https://minerals.usgs.gov/minerals/pubs/ commodity/manganese/mcs-2013-manga.pdf.]

Crow Wing Power, 2013, Manganese deposit in Emily Minnesota...Crow Wing Power's newest business investment....: Crow Wing Power, accessed March 10, 2014, at http://www.cwpower.com/manganese.shtml.

DeYoung, J.H., Jr., Sutphin, D.M., and Cannon, W.F., 1984, International Strategic Minerals Inventory summary reportManganese: U.S. Geological Survey Circular 930-A, 22 p. [Also available at http://pubs.er.usgs.gov/publication/cir930A/.]

Dorr, J.V.N., II, Crittenden, M.D., Jr., and Worl, R.G., 1973, Manganese, in Brobst, D.A., and Pratt, W.P. eds., United States mineral resources: U.S. Geological Survey Professional Paper 820, p. 385-399. [Also available at http://pubs.er.usgs.gov/publication/pp820/.]

Efroymson, R.A., Will, M.E., Sunter, G.W., II, and Wooten, A.C., 1997, Toxicological benchmarks for screening contaminants of potential concern for effects on terrestrial plants - 1997 revision, report prepared for the U.S. Department of Energy by Lockheed Martin Energy Systems, Inc.: Oak Ridge, Tenn., Oak Ridge National Laboratory, ES/ER/TM-85/R3, November, 68 p. and two appendixes, accessed March 4, 2013 , at http://www.esd.ornl.gov/programs/ecorisk/documents/ tm85r3.pdf.

Force, E.R., and Cannon, W.F., 1988, Depositional model for shallow-marine manganese deposits around black shale basins: Economic Geology, v. 83, p. 93-117. [Also available at http://dx.doi.org/10.2113/gsecongeo.83.1.93.]

Force, E.R., Cannon, W.F., and Klein, D.P., 1995, Sedimentary Mn deposits, chap. 33 of du Bray, E.A, ed., Preliminary compilation of descriptive geoenvironmental mineral deposit models: U.S. Geological Survey Open-File Report 95-831, p. 257-260. [Also available at http://pubs.usgs.gov/of/1995/ofr-95-0831/.]
Frakes, Larry, and Bolton, B.R., 1992, Effects of ocean chemistry, sea level, and climate on the formation of primary sedimentary manganese ore deposits: Economic Geology, v. 87, p. 1207-1217. [Also available at http://dx.doi.org/10.2113/gsecongeo.87.5.1207.]

Frisbie, S.H., Mitchell, E.J., Dustin, Hannah, Maynard, D.M., and Sarkar, Bibudhendra, 2012, World Health Organization discontinues its drinking-water guideline for manganese: Environmental Health Perspectives, v. 120, p. 775-778. [Also available at http://dx.doi.org/10.1289/ehp.1104693.]

Gaillardet, J., Viers, J., and Dupré, B., 2003, Trace elements in river waters, in Drever, J.I., ed., Surface and ground water, weathering, and soils, v. 5 of Holland, H.D., and Turekian, K.K., eds., Treatise on geochemistry: Oxford, United Kingdom, Elsevier-Pergamon, p. 225-272. [Also available at http://dx.doi.org/10.1016/B0-08-043751-6/05165-3.]

Graedel, T.E., Allwood, Julian, Birat, J.-Pi., Buchert, Matthias, Hagelüken, Christian, Reck, B.K., Sibley, S.F., and Sonnemann, Guido, 2011, What do we know about metal recycling rates?: Journal of Industrial Ecology, v. 15, no. 3, p. 355-366. [Also available at http://dx.doi.org/10.1111/ j.1530-9290.2011.00342.x.]

Hanle, Lisa, Maldonado, Pedro, Onuma, Eiichi, Tichy, Milos, and van Oss, H.G., 2006, Mineral industry emissions, in Eggleston, Simon, Buendia, Leandro, Miwa, Kyoko, Ngara, Todd, and Tanabe, Kouptp, eds., v. 3, Industrial processes and product use, of 2006 IPCC guidelines for national greenhouse gas inventories: Hayama, Japan, Institute for Global Environmental Strategies, p. 2.1-2.40. [Also available at http://www.ipcc-nggip.iges.or.jp/public/ 2006gl/vol3.html.]

Hart, B.T., Noller, B.N., Legras, C., and Currey, N., 1992, Manganese speciation in Magela Creek, northern Australia: Australian Journal of Marine and Freshwater Research, v. 43, no. 2, p. 421-441. [Also available at http://dx.doi.org/ 10.1071/MF9920421.]

Hein, J.R., 2012, Prospects for rare earth elements from marine minerals: Kingston, Jamaica, International Seabed Authority Briefing Paper 02/12, 4 p.

Hein, J.R., Conrad, T.A., and Dunham, R.E., 2009, Seamount characteristics and mine-site model applied to explorationand mining-lease-block selection for cobalt-rich ferromanganese crusts: Marine Georesources and Geotechnology, v. 27, no. 2, p. 160-176. [Also available at http://dx.doi.org/10.1080/10641190902852485.]

Hein, J.R., Conrad, T.A., and Staudigel, Hubert, 2010, Seamount mineral deposits - A source of rare metals for high-technology industries: Oceanography, v. 23, no. 1, p. 184-189. [Also available at http://dx.doi.org/10.5670/ oceanog.2010.70.] 
Hein, J.R., Mizell, Kira, Koschinsky, Andrea, and Conrad, T.A., 2013, Deep-ocean mineral deposits as a source of critical metals for high- and green-technology applicationsComparison with land-based resources: Ore Geology Reviews, v. 51, June, p. 1-14. [Also available at http://dx.doi.org/10.1016/j.oregeorev.2012.12.001.]

Herndon, E.M., Jin, Lixin, and Brantley, S.L., 2011, Soils reveal widespread manganese enrichment from industrial inputs: Environmental Science and Technology, v. 45, no. 1, p. 241-247. [Also available at http://dx.doi.org/10.1021/ es102001w.]

International Manganese Institute, 2012, Annual market research report -2011: Paris, France, International Manganese Institute, $34 \mathrm{p}$.

International Seabed Authority, 2008, Biodiversity, species ranges, and gene flow in the abyssal Pacific nodule provincePredicting and managing the impacts of deep seabed mining: Kingston, Jamaica, International Seabed Authority Technical Study no. 3, 38 p. [Also available at http://www.isa.org.jm/ files/documents/EN/Pubs/TechStudy3.pdf.]

International Seabed Authority, 2010, A geological model of polymetallic nodule deposits in the Clarion Clipperton fracture zone: Kingston, Jamaica, International Seabed Authority Technical Study no. 6, 211 p. [Also available at http://www.isa.org.jm/files/documents/EN/Pubs/ GeoMod-web.pdf.]

International Seabed Authority, 2012, Environmental management needs for exploration and exploitation of deep sea minerals: Kingston, Jamaica, International Seabed Authority Technical Study no. 10, 47 p. [Also available at http://www.isa.org.jm/files/documents/EN/Pubs/TS10/ index.html/.]

Jupiter Mines Ltd., 2013, Tshipi manganese project: Jupiter Mines Ltd., accessed March 17, 2013, at http://www.jupitermines.com/projects/manganese/ tshipi_manganese_project.phtml.

Kabata-Pendias, Alina, and Mukherjee, A.B., 2007, Trace elements from soil to human: Berlin, Germany, SpringerVerlag, $550 \mathrm{p}$.

Kabata-Pendias, Alina, and Pendias, Henryk, 2001, Trace elements in soils and plants ( $3 \mathrm{~d}$ ed.): Boca Raton, Fla., CRC Press, $413 \mathrm{p}$.

Kilgore, C.C., and Thomas, P.R., 1982, Manganese availabilityDomestic: U.S. Bureau of Mines Information Circular 8889, $14 \mathrm{p}$.

Lelong, F., Tardy, Y., Grandin, G., Trescases, J.J., and Boulange, B., 1976, Pedogenesis, chemical weathering and processes of formation of some supergene ore deposits, chap. 3 of Wolf, K.H., ed., Handbook of strata-bound and stratiform ore deposits: Amsterdam, Netherlands, Elsevier, p. 93-173. [Also available at http://horizon.documentation.ird.fr/ exl-doc/pleins_textes/pleins_textes_5/b_fdi_06-07/08437.pdf.]
Lottermoser, B.G., 2010, Mine wastes-Characterization, treatment, and environmental impacts, $3 \mathrm{~d}$ ed.: Berlin, Germany, Springer-Verlag, 400 p. [Also available at http://dx.doi.org/10.1007/978-3-642-12419-8.]

Lovley, D.R., 1991, Dissimilatory Fe(III) and Mn(IV) reduction: Microbiological Reviews, v. 55, p. 259-287. [Also available at http://www.ncbi.nlm.nih.gov/pmc/ articles/PMC372814/.]

Mackey, D.J., Butler, E.C.V., Carpenter, P.D., Higgins, H.W., O’Sullivan, J.E., and Plaschke, R.B., 1996, Trace elements and organic matter in a pristine environment - Bathurst Harbour, southwestern Tasmania: The Science of the Total Environment, v. 191, p. 137-151. [Also available at http://dx.doi.org/10.1016/0048-9697(96)05255-2.]

Manheim, F.T., and Lane-Bostwick, C.M., 1988, Chemical composition of ferromanganese crusts in the world oceanA review and comprehensive database: U.S. Geological Survey Open-File Report 89-20, 200 p. [Also available at http://pubs.er.usgs.gov/publication/ofr8920/.]

Manheim, F.T., Popenoe, Peter, Siapno, William, and Lane, C., 1982, Manganese-phosphorite deposits of the Blake Plateau (western North-Atlantic Ocean), in Halbach, P., and Winter, P., eds., Marine mineral deposits - New research results and economic prospects; Proceedings of the Clausholer workshop: Essen, Germany, Verlag Gluckauf GmbH, p. 9-44.

Markussen, J.M., 1994, Deep seabed mining and the environment-Consequences, perceptions, and regulations, in Bergesen, H.O., and Parmann, Georg, eds., Green Globe yearbook of international co-operation on environment and development: Oxford, United Kingdom, Oxford University Press, p. 31-39.

Maynard, J.B., 2003, Manganiferous sediments, rocks, and ores, in MacKenzie, F.T., ed., Sediments, diagenesis, and sedimentary rocks, v. 7 of Holland, H.D., and Turekian, K.K., eds., Treatise on geochemistry: Oxford, United Kingdom, Elsevier-Pergamon, p. 289-308. [Also available at http://www.sciencedirect.com/science/article/pii/ B0080437516070997.]

Maynard, J.B., 2010, The chemistry of manganese ores through time - A signal of increasing diversity of Earth-surface environments: Economic Geology, v. 105, p. 535-552. [Also available at http://dx.doi.org/10.2113/gsecongeo.105.3.535.]

Misra, S.G., and Mani, Dinesh, 1991, Soil pollution: New Delhi, India, Ashish Publishing House, 209 p.

Morey, G.B., 1990, Geology and manganese resources of the Cuyuna Iron Range, east-central Minnesota: Minnesota Geological Survey Information Circular 32, 28 p.

Morgan, C.L., 2000, Resource estimates of the ClarionClipperton manganese nodule deposits, chap. 6 of Cronan, D.S., ed., Handbook of marine mineral deposits: Boca Raton, Fla., CRC Press, p. 145-170. 
Mosier, D.L., 1986, Grade and tonnage model of sedimentary Mn, in Cox, D.P., and Singer, D.A., eds., Mineral deposit models: U.S. Geological Survey Bulletin 1693, p. 231-233. [Also available at https://pubs.er.usgs.gov/publication/b1693.]

Muiños, S.B., Hein, J.R., Frank, Martin, Montiero, J.H., Gaspar, Luís, Conrad, Tracey, Periera, H.G., and Arbantes, Fátima, 2013, Deep-sea Fe-Mn crusts from the northeast Atlantic Ocean-Composition and resource considerations: Marine Georesources and Geotechnology, v. 31, no. 1, p. 40-70. [Also available at http://dx.doi.org/ 10.1080/1064119X.2012.661215.]

Myers, C.R., and Nealson, K.H., 1988, Bacterial manganese reduction and growth with manganese oxide as the sole electron acceptor: Science, v. 240, no. 4857, p. 1319-1321. [Also available at http://dx.doi.org/10.1126/science. 240.4857.1319.]

Nagajyoti, P.C., Lee, K.D., and Sreekanth, T.V.M., 2010, Heavy metals, occurrence and toxicity for plants-A review: Environmental Chemistry Letters, v. 8, no. 3, p. 199-216. [Also available at http://dx.doi.org/10.1007/ s10311-010-0297-8.]

Nahon, Daniel, and Parc, Sylvie, 1990, Lateritic concentrations of manganese oxyhydroxides and oxides: Geologische Rundschau, v. 79, no. 2, p. 319-326. (In German.) [Also available at http://dx.doi.org/10.1007/BF01830628.]

National Materials Advisory Board, 1981, Manganese reserves and resources of the world and their industrial implications: Washington D.C., The National Academies Press, 334 p.

National Research Council, 1989, Recommended dietary allowances, 10th ed.: Washington, D.C., The National Academies Press, 285 p. [Also available at http://www.nap.edu/catalog/ 1349/recommended-dietary-allowances-10th-edition.]

National Research Council, 2008, Minerals, critical minerals, and the U.S. economy: Washington, D.C., The National Academies Press, 245 p. [Also available at http://www.nap.edu/catalog/ 12034/minerals-critical-minerals-and-the-us-economy.]

Natural Earth, 2014, Small scale data: Natural Earth map dataset, scale 1:110,000,000, accessed March 13, 2014, at http://www.naturalearthdata.com.

Nicholson, K., Hein, J.R., Bühn, B., and Dasgupta, S., eds., 1997, Manganese mineralization - Geochemistry and mineralogy of terrestrial and marine deposits: Bath, United Kingdom, Geological Society Special Publication no. 119, 370 p.

Nriagu, J.O., 1989, A global assessment of natural sources of atmospheric trace metals: Nature, v. 338, p. 47-49. [Also available at http://dx.doi.org/10.1038/338047a0.]

Nriagu, J.O., and Pacyna, J.M., 1988, Quantitative assessment of worldwide contamination of air, water and soils by trace metals: Nature, v. 333, no. 6169, p. 134-139. [Also available at http://dx.doi.org/10.1038/333134a0.]
Occupational Safety and Health Administration, 2013, Manganese compounds (as Mn): Occupational Safety and Health Administration, accessed March 17, 2013, at http://www.osha.gov/dts/chemicalsampling/data/ CH_250190.html.

Pavlides, Louis, 1962, Geology and manganese deposits of the Maple and Hovey Mountains area, Aroostook County, Maine, with a section on Lithology and mineralogy of the deposits, by Louis Pavlides and Charles Milton: U.S. Geological Survey Professional Paper 362, 116 p. [Also available at http://pubs.er.usgs.gov/publication/pp362/.]

Peters, Ada, Lofts, Stephen, Merrington, Graham, Brown, Bruce, Stubblefield, William, and Harlow, Kevin, 2011, Development of biotic ligand models for chronic manganese toxicity to fish, invertebrates, and algae: Environmental Toxicology and Chemistry, v. 30, no. 11, p. 2407-2415. [Also available at http://dx.doi.org/10.1002/ etc.643.]

Połedniok, Justnya, Andrzej, Kita, and Zerzucha, Piotr, 2012, Spectrophotometric and inductively coupled plasmaOptical emission spectroscopy determination of gallium in natural soils and soils polluted by industry-Relationships between elements: Communications in Soil Science and Plant Analysis, v. 43, p. 1121-1135. [Also available at http://dx.doi.org/10.1080/00103624.2012.662561.]

Pracejus, Bernhard, and Bolton, B.R., 1992, Geochemistry of supergene manganese oxide deposits, Groote Eylandt, Australia: Economic Geology, v. 87, p. 1310-1335. [Also available at http://dx.doi.org/10.2113/gsecongeo.87.5.1310.]

Reck, B.K., and Graedel, T.E., 2012, Challenges in metal recycling: Science, v. 337, no. 6095, p. 690-695. [Also available at http://dx.doi.org/10.1126/science.1217501.]

Reimann, Clemens, and de Caritat, Patrice, 1998, Chemical elements in the environment: Berlin, Germany, SpringerVerlag, 398 p.

Riojas-Rodríguez, Horacio, Solís-Vivanco, Rodolfo, Schilmann, Astrid, Montes, Sergio, Rodríguez, Sandra, Ríos, Camilo, and Rodríguez-Agudelo, Yaneth, 2010, Intellectual function in Mexican children living in a mining area and environmentally exposed to manganese: Environmental Health Perspectives, v. 118, p. 1465-1470. [Also available at http://dx.doi.org/10.1289/ehp.0901229.]

Rivera-Becerril, Facundo, Juárez-Vázquez, L.V., Hernández-Cervantes, S.C., Acevedo-Sandoval, O.A., Vela-Correa, Gilberto, Cruz-Chávez, Enrique, Moreno-Espíndola, I.P., Esquivel-Herrera, Alfonso, and de León-González, Fernando, 2013, Impacts of manganese mining activity on the environment-Interactions among soil, plants, and arbuscular mycorrhiza: Archives of Environmental Contamination and Toxicology, v. 64, no. 2, p. 219-227. [Also available at http://dx.doi.org/ 10.1007/s00244-012-9827-7.] 
Rodríguez-Agudelo, Yaneth, Riojas-Rodríguez, Horacio, Ríos, Camilo, Rosas, Irma, Pedraza, E.S., Mirandar, Javier, Siebe, Christina, Texcalac, J.L., and Santos-Burgoa, Carlos, 2006, Motor alterations associated with exposure to manganese in the environment in Mexico: Science of the Total Environment, v. 368, nos. 2-3, p. 542-556. [Also available at http://dx.doi.org/10.1016/j.scitotenv.2006.03.025.]

Roy, Supriya, 1988, Manganese metallogenesis-A review: Ore Geology Reviews, v. 4, nos. 1-2, p. 155-170.

Schrope, Mark, 2013, UK company pursues deep-sea bonanza: Nature, v. 495, March 21, p. 294.

Shacklette, H.T., and Boerngen, J.G., 1984, Element concentrations in soils and other surficial materials of the conterminous United States: U.S. Geological Survey Professional Paper 1270, 105 p. [Also available at http://pubs.er.usgs.gov/ publication/pp1270/.]

Shiller, A.M., 1997, Dissolved trace elements in the Mississippi River-Season, interannual, and decadal variability: Geochemica and Cosmochemica Acta, v. 61, no. 20, p. 4321-4330. [Also available at http://dx.doi.org/ 10.1016/S0016-7037(97)00245-7.]

Smith, K.S., and Huyck, L.O., 1999, An overview of the abundance, relative mobility, bioavailability, and human toxicity of metals, in Plumlee, G.S., and Logsdon, M.J., eds., The environmental geochemistry of mineral deposits,Part A, Processes, techniques and health issues: Littleton, Colo., Society of Economic Geologists, v. 1, p. 29-70.

Strategic Environmental Focus (Pty) Ltd., 2007, Final environmental impact assessment for the proposed Kalahari Manganese Mine, prepared for Kalahari Resources (Pty) Ltd.: Pretoria, South Africa, Strategic Environmental Focus (Pty) Ltd., Report NC30/5/1/2/2/104MR, 348 p.

Stubblefield, W.A., Brinkman, S.F., Davies, P.H., Garrison, T.D., Hockett, J.R., and McIntyre, M.W., 1997, Effects of water hardness on the toxicity of manganese to developing brown trout (Salmo trutta): Environmental Toxicology and Chemistry, v. 16, no. 10, p. 2082-2089. [Also available at http://dx.doi.org/10.1002/etc.5620161014.]

Suter, G.W., II, and Tsao, C.L., 1996, Toxicological benchmarks for screening potential contaminants of concern for effects on aquatic biota - 1996 revision: Oak Ridge, Tenn., Lockheed Martin Energy Systems Inc., ES/ER/TM-96/R2, variously paged, accessed March 3, 2013, at http://www.esd. ornl.gov/programs/ecorisk/documents/tm96r2.pdf.

Taylor, S.R., and McLennan, S.M., 1995, The geochemical evolution of the continental crust: Reviews of Geophysics, v. 33, no. 2, p. 241-265. [Also available at http://dx.doi.org/ 10.1029/95RG00262.]

Tebo, B.M., Bargar, J.R., Clement, B.G., Dick, G.J., Murray, K.J., Parker, Dorothy, Verity, Rebecca, and Webb, S.M., 2004, Biogenic manganese oxides-Properties and mechanisms of formation: Annual Reviews in Earth and Planetary Science, v. 32 , p. 287-328.
Tivey, M.K., 2007, Generation of seafloor hydrothermal vent fluids and associated mineral deposits: Oceanography, v. 20 , no. 1, p. 50-65. [Also available at http://dx.doi.org/ 10.5670/oceanog.2007.80.]

Tsikos, Harilaos, and Moore, J.M., 1997, Petrography and geochemistry of the Paleoproterozoic Hotazel iron-formation, Kalahari manganese field, South Africa-Implications for Precambrian manganese metallogenesis: Economic Geology, v. 92, p. 87-97. [Also available at http://dx.doi.org/ 10.2113/gsecongeo.92.1.87.]

Tsikos, Harilaos, Beukes, N.J., Moore, J.M., and Harris, Chris, 2003, Deposition, diagenesis, and secondary enrichment of metals in the Paleoproterozoic Hotazel iron formation, Kalahari manganese field, South Africa: Economic Geology, v. 98, p. 1449-1462. [Also available at http://dx.doi.org/ 10.2113/gsecongeo.98.7.1449.]

Tyler, Germund, 2004, Vertical distribution of major, minor, and rare elements in a Haplic Podzol: Geoderma, v. 119, nos. 3-4, p. 277-290. [Also available at http://dx.doi.org/ 10.1016/j.geoderma.2003.08.005.]

Urban, H., Stribrny, B., and Lippolt, H.J., 1992, Iron and manganese deposits of the Urucum district, Mato Grosso do Sul, Brazil: Economic Geology, v. 87, p. 1375-1392. [Also available at http://dx.doi.org/10.2113/gsecongeo.87.5.1375.]

U.S. Environmental Protection Agency, 2011, Miscellaneous uses of carbonate: Washington, D.C., U.S. Environmental Protection Agency Information Sheet EPA-430-F-09-007R, 3 p.

U.S. Environmental Protection Agency, 2013, National primary drinking water regulations: U.S. Environmental Protection Agency Web page, accessed February 15, 2013, at http://water.epa.gov/drink/contaminants/index.cfm.

U.S. Geological Survey, 1996, Global 30 arc-second elevation (GTOPO30): Reston, Va., U.S. Geological Survey dataset (digital elevation model), accessed March 13, 2014, at https://ta.cr.usgs.gov/GTOPO30.

Varentsov, I.M., 1996, Manganese ores of supergene zoneGeochemistry of formation: Dordrecht, Netherlands, Kluwer Academic Publishers, 343 p.

Viers, Jérôme, Dupré, Bernard, and Gaillardet, Jérôme, 2009, Chemical composition of suspended sediments in world rivers-New insights from a new database: Science of the Total Environment, v. 407, no. 2, p. 853-868. [Also available at http://dx.doi.org/10.1016/j.scitotenv.2008.09.053.]

World Health Organization, 2011, Guidelines for drinkingwater quality (4th ed.): Geneva, Switzerland, World Health Organization, 541 p. [Also available at http://www.who.int/ water_sanitation_health/publications/2011/dwq_guidelines/en/.] 


\section{Niobium and Tantalum}

By Klaus J. Schulz, Nadine M. Piatak, and John F. Papp

Chapter M of

Critical Mineral Resources of the United States-Economic and Environmental Geology and Prospects for Future Supply

Edited by Klaus J. Schulz, John H. DeYoung, Jr., Robert R. Seal II, and Dwight C. Bradley

Professional Paper 1802-M 


\section{Contents of Chapter M}

[Figure and table titles for all chapters are listed in the volume contents before the conversion factors table and list of abbreviations and symbols. A periodic table of the elements is on the inside front cover of the printed volume]

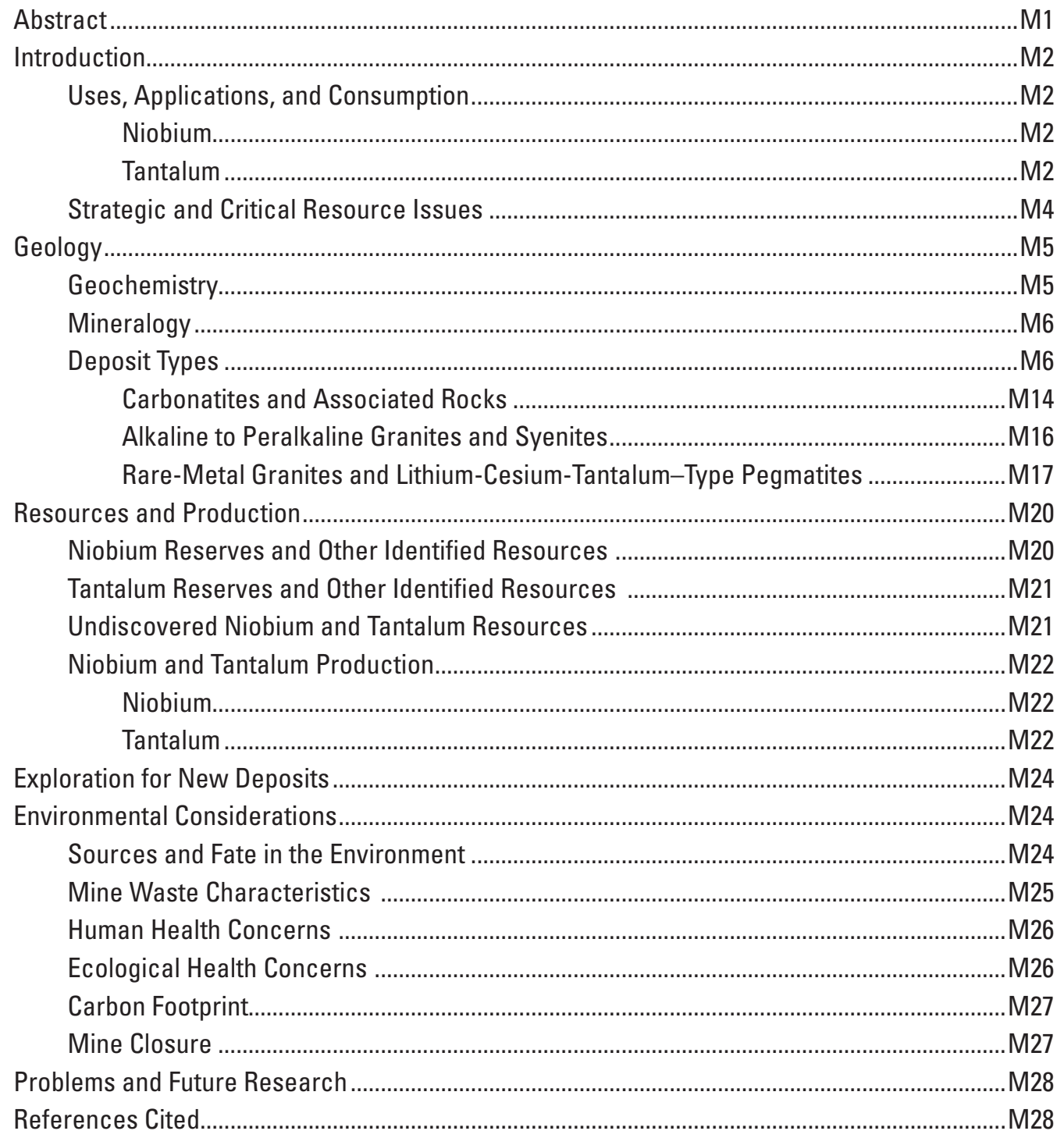




\title{
Niobium and Tantalum
}

\author{
By Klaus J. Schulz, Nadine M. Piatak, and John F. Papp
}

\section{Abstract}

Niobium and tantalum are transition metals that are almost always found together in nature because they have very similar physical and chemical properties. Their properties of hardness, conductivity, and resistance to corrosion largely determine their primary uses today. The leading use of niobium (about 75 percent) is in the production of highstrength steel alloys used in pipelines, transportation infrastructure, and structural applications. Electronic capacitors are the leading use of tantalum for high-end applications, including cell phones, computer hard drives, and such implantable medical devices as pacemakers. Niobium and tantalum are considered critical and strategic metals based on the potential risks to their supply (because current production is restricted to only a few countries) and the significant effects that a restriction in supply would have on the defense, energy, high-tech industrial, and medical sectors.

The average abundance of niobium and tantalum in bulk continental crust is relatively low -8.0 parts per million (ppm) niobium and $0.7 \mathrm{ppm}$ tantalum. Their chemical characteristics, such as small ionic size and high electronic field strength, significantly reduce the potential for these elements to substitute for more common elements in rockforming minerals and make niobium and tantalum essentially immobile in most aqueous solutions. Niobium and tantalum do not occur naturally as pure metals but are concentrated in a variety of relatively rare oxide and hydroxide minerals, as well as in a few rare silicate minerals. Niobium is primarily derived from the complex oxide minerals of the pyrochlore group $\left((\mathrm{Na}, \mathrm{Ca}, \mathrm{Ce})_{2}(\mathrm{Nb}, \mathrm{Ti}, \mathrm{Ta})_{2}(\mathrm{O}, \mathrm{OH}, \mathrm{F})_{7}\right)$, which are found in some alkaline granite-syenite complexes (that is, igneous rocks containing sodium- or potassium-rich minerals and little or no quartz) and carbonatites (that is, igneous rocks that are more than 50 percent composed of primary carbonate minerals, by volume). Tantalum is derived mostly from the mineral tantalite $\left((\mathrm{Fe}, \mathrm{Mn})(\mathrm{Ta}, \mathrm{Nb})_{2} \mathrm{O}_{6}\right)$, which is found as an accessory mineral in rare-metal granites and pegmatites that are also enriched in lithium and cesium (termed lithium-cesium-tantalum (LCT)type pegmatites).

Brazil and Canada are the leading nations that produce niobium mineral concentrates, but Brazil is by far the leading producer, accounting for about 90 percent of production, which comes mostly from weathered material derived from carbonatites. Brazil and Canada also have the largest identified niobium resources; additional resources, although they are less well reported, occur in Angola, Australia, China, Greenland, Malawi, Russia, and South Africa. Australia and Brazil have been the leading producers of tantalum mineral concentrates, although recently Ethiopia and Mozambique have also been significant suppliers of tantalum. Artisanal mining of columbite-tantalite (also called coltan) is practiced in many countries, particularly Burundi, the Democratic Republic of the Congo (Congo [Kinshasa]), Nigeria, Rwanda, and Uganda. Brazil has about 40 percent of the identified tantalum resources; other countries and regions with identified tantalum resources include, in decreasing order of resources, Australia, Asia, Russia and the Middle East, Africa, North America, and Europe. Identified niobium and tantalum resources in the United States are small, low grade, and difficult to recover and process, and are thus not commercially recoverable at current prices. Consequently, the United States meets its current and expected future needs for niobium and tantalum through imports of mineral concentrates and alloys and through recovery from foreign and domestic alloy scrap that contain the metals.

Environmentally, the main issues related to niobium and tantalum mining are land disruptions, the volume of waste materials and their disposal, and the radioactivity of some tailings and waste materials that contain thorium and uranium. Because of the relative biological inertness of niobium and tantalum, human and ecological health concerns are generally minimal under most natural conditions.

Demand for both niobium and tantalum is expected to increase as the world economy continues to recover from the downturn that began in 2008. Increased demand for niobium is linked to increased consumption of microalloyed steel, which is used in the manufacture of cars, buildings, ships, and refinery equipment. Demand for these steels will likely increase with continued economic development in such countries as Brazil, China, and India. In addition, increased global demand for cars, cell phones, computers, superconducting magnets, and other high-tech devices will likely spur increased demand for both niobium and tantalum. The estimated global reserves and 
resources of niobium and tantalum are large and appear more than sufficient to meet global demand for the foreseeable future, possibly the next 500 years. The sale of "conflict coltan" attributed to rebel forces waging a civil war in Congo (Kinshasa) has been of recent concern and has highlighted the need for a transparent and traceable global supply chain that can exclude illegal columbite-tantalite from the conventional market while discerning legitimate artisanal mine production in central Africa.

\section{Introduction}

Niobium $(\mathrm{Nb})$ and tantalum $(\mathrm{Ta})$ are transition metals that are very similar in their physical and chemical properties (table M1). They are almost always found together in nature. Both are named after tragic figures from Greek mythologyNiobium is named after Niobe, and tantalum is named after Niobe's father, Tantalus. Niobium was first discovered in 1801 by English chemist Charles Hatchett, who named it columbium after Columbia, the poetic name for North America. Columbium was used interchangeably with niobium until 1949 when niobium was officially accepted as the designated name by the International Union of Pure and Applied Chemistry. Tantalum was first discovered by Swedish scientist Anders Ekeberg in 1802, but because it was difficult to separate from niobium, tantalum was confused with niobium until 1864, when it was confirmed to be a separate element. Relatively pure tantalum metal was not produced until 1903.

Niobium is a lustrous, gray, ductile metal with a high melting point, relatively low density, and superconductor properties. Tantalum is a dark blue-gray, dense, ductile, very hard, and easily fabricated metal. It is highly conductive to heat and electricity and is renowned for its resistance to corrosion by acids. It is these special properties, especially hardness, conductivity, and resistance to corrosion, that determine the primary uses of niobium and tantalum today (table M1).

Table M1. Selected properties of niobium and tantalum.

[Source: Winter (2014). Å, angstrom; ${ }^{\circ} \mathrm{C}$, degree Celsius; $\mathrm{g} / \mathrm{cm}^{3}$, gram per cubic centimeter; $\mathrm{n} \Omega-\mathrm{m}$, nano ohm-meter]

\begin{tabular}{lcc}
\multicolumn{1}{c}{ Property } & Niobium (Nb) & Tantalum (Ta) \\
\hline Atomic number & 41 & 73 \\
\hline Atomic weight & 92.90638 & 180.94788 \\
\hline Atomic radius $(\AA)$ & 1.46 & 1.46 \\
\hline Density $\left(\mathrm{g} / \mathrm{cm}^{3}\right)$ & 8.57 & 16.65 \\
\hline Melting point $\left({ }^{\circ} \mathrm{C}\right)$ & 2,477 & 3,017 \\
\hline $\begin{array}{l}\text { Boiling point }\left({ }^{\circ} \mathrm{C}\right) \\
\text { Hardness }(\text { Mohs scale) }\end{array}$ & 4,744 & 5,458 \\
\hline $\begin{array}{l}\text { Electrical resistivity } \\
(\mathrm{n} \Omega \text {-m) }\end{array}$ & 6.0 & 6.5 \\
\hline Crystal structure & $\begin{array}{c}\text { Body-centered } \\
\text { cubic }\end{array}$ & $\begin{array}{c}\text { Body-centered } \\
\text { cubic }\end{array}$ \\
\hline
\end{tabular}

\section{Uses, Applications, and Consumption}

\author{
Niobium
}

The leading use of niobium is in ferrous metallurgy. About 75 percent of world niobium production is used by the steel industry for the production of a variety of steel alloys that contain small amounts of other metals (microalloy and low-alloy steels) to improve corrosion resistance, strength, toughness, and other properties (Papp, 2013b). Niobium acts as a grain refiner and precipitation hardener in high-strength low-alloy and microalloyed steel, simultaneously improving mechanical strength, high-temperature strength, and toughness and improving corrosion resistance. These steels are used in pipelines, transportation, and structural applications (Roskill Information Services Ltd., 2009). Appreciable amounts of niobium are contained in nickel-, cobalt-, and iron-base superalloys used for high-temperature applications, such as jet engine components, gas turbines, rocket subassemblies, turbocharger systems, and heat-resisting and combustion equipment. Niobium alloys are also used in the manufacture of superconducting magnets used in magnetic resonance imaging (MRI) and nuclear magnetic resonance instruments (NMRI), as well as in particle accelerators, such as the Large Hadron Collider in Europe, which contains the world's largest superconducting magnets (fig. M1). A new use of niobium is in a solid niobic acid that acts as a catalyst in the conversion of palm oil to biodiesel (Schwela, 2010). With increased production of biofuels in Brazil and elsewhere, this use of niobium could constitute a significant future market. Niobium's uses are specialized, and substitution is generally likely to result in reduced performance and higher cost.

World consumption of niobium, by material produced, is shown in figure M2A (Schwela, 2011). The greatest consumption is of ferroniobium, which is an iron-niobium alloy that contains 60 to 70 percent niobium. Leading uses of niobium are for steelmaking ( 87 percent), followed by niobium chemicals (5.2 percent), vacuum-grade niobium (2.7 percent), other niobium alloys (2.5 percent), and niobium metal ( 0.9 percent). In 2011, U.S. consumption of niobium (measured as elemental niobium) was 9,160 metric tons, which was an increase of more than 12 percent from consumption in 2010 (Papp, 2013b).

\section{Tantalum}

The electronics industry accounts for about one-half of tantalum consumption, mainly as powder and wire (Schwela, 2010). Electronic capacitors are the leading end use of tantalum owing to tantalum's particular ability to store and release energy. Because of this ability, components can be exceptionally small and are favored in space-sensitive, high-end applications, such as telecommunications (for cell phones), data storage (for hard drives), and implantable medical devices (for hearing aids and pacemakers). To date, 


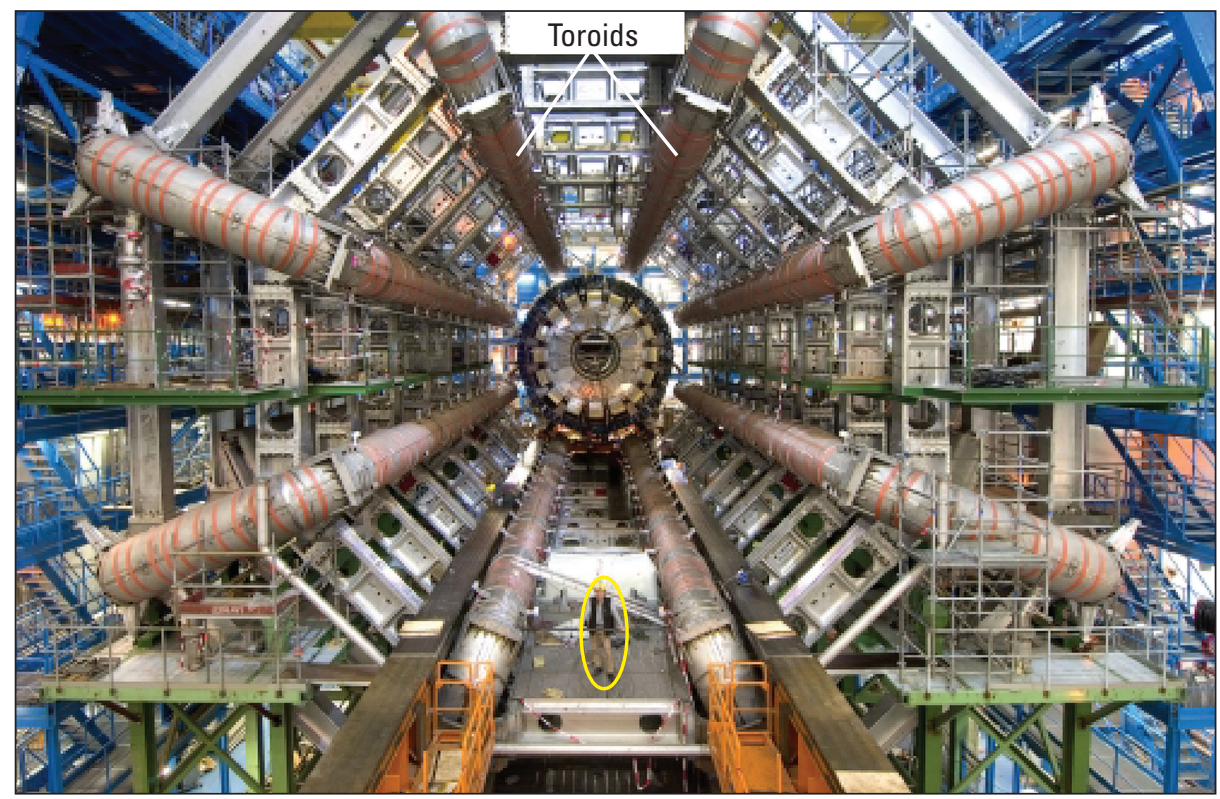

Figure M1. Photograph (central view) of the ATLAS detector in the Large Hadron Collider showing its eight superconducting barrel toroid magnets around the calorimeter. (For scale, note the person [circled] standing in the lower center portion of the photograph.) Together, these toroids make up the world's largest superconducting magnet. Photograph of the ATLAS Experiment Copyright(C) 2014 CERN.

no effective substitute has been found for tantalum in electronic devices without loss in performance. Tantalum's low mechanical strength and high biocompatibility allows it to be used as a coating on stronger substrates, such as stainless steel, for such medical applications as stents to support blood vessels, plates, bone replacements, and suture clips and wire. In addition, tantalum is used to impart strength and high temperature resistance to cracking in the manufacture of superalloys for use in aerospace applications and energy generation. Its resistance to corrosion makes tantalum useful in the chemical industry, generally as a lining to pipes, tanks, and vessels. Tantalum oxide is used to increase the refractive index of lens glass, whereas the hardness of tantalum carbide makes it ideal for cutting tools.

World consumption of tantalum, by material produced, is shown in figure M2B (Schwela, 2011). The leading uses are capacitor-grade tantalum powder (24 percent) and tantalum mill products ( 22 percent) followed by tantalum chemicals (18 percent); metallurgical-grade powder, unwrought metal, scrap, and other uses (17 percent); tantalum ingot (12 percent); and tantalum carbide ( 7 percent). In 2011, U.S. consumption of tantalum (measured as elemental tantalum) was 1,210 metric tons, which was an increase of 4 percent from consumption in 2010 (Papp, 2013c).

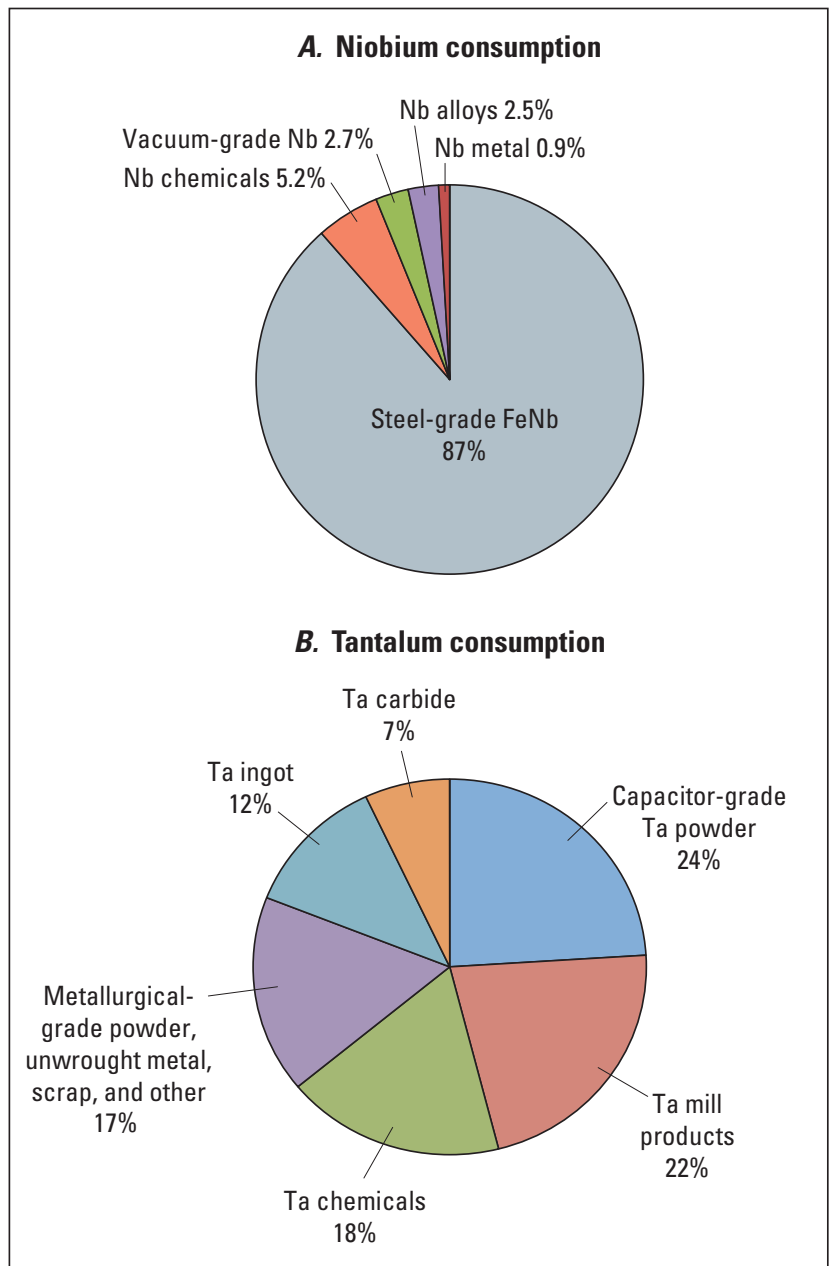

Figure M2. Pie charts showing percentage of reported world consumption of $A$, niobium, and $B$, tantalum, by material produced (Schwela, 2011). Percentages have been rounded to two significant figures and do not add to 100 . FeNb, ferroniobium; Nb, niobium; Ta, tantalum 


\section{Strategic and Critical Resource Issues}

Niobium and tantalum are considered critical and strategic metals owing to their specialized and important applications in the defense, energy, high-tech industrial, and medical sectors; because they are essential in many products and applications but generally have no effective substitutes; and because the mine production of these minerals takes place in only a few countries. The geographic concentration of niobium resources and production, and, to a lesser extent, those of tantalum, make their supply vulnerable to potential influence and disruption by such factors as civil unrest, environmental issues, market manipulation, natural disasters, and political changes. In their evaluation of the criticality of selected mineral commodities, the National Research Council (2008) ranked niobium as one of the most critical minerals, along with manganese, platinumgroup metals (especially rhodium and platinum), and rare-earth elements (REEs), and ranked tantalum as moderately critical based on risks to supply and the potential impact of supply restrictions (fig. M3). In its analysis of critical raw materials for the European Union, the European Commission reached a similar conclusion on the criticality of niobium and tantalum (European Commission, 2010).

The estimated global reserves and resources of both niobium and tantalum are large, but they are unevenly distributed geographically. The United States has had no reported mine production of niobium and tantalum since the late 1950s, and identified resources are mostly of low grade and are considered uneconomic at current commodity prices (Papp, 2013b, c). As a result, the United States has for many years been totally dependent on imports and recycling to meet its niobium and tantalum needs. This chapter gives a geologic perspective of niobium and tantalum resources with the purpose of providing an overview of how, why, and where sources of niobium and tantalum have formed and the geographic distribution of these sources around the world. Also included is a discussion of environmental issues that may derive from current and future niobium and tantalum mining.

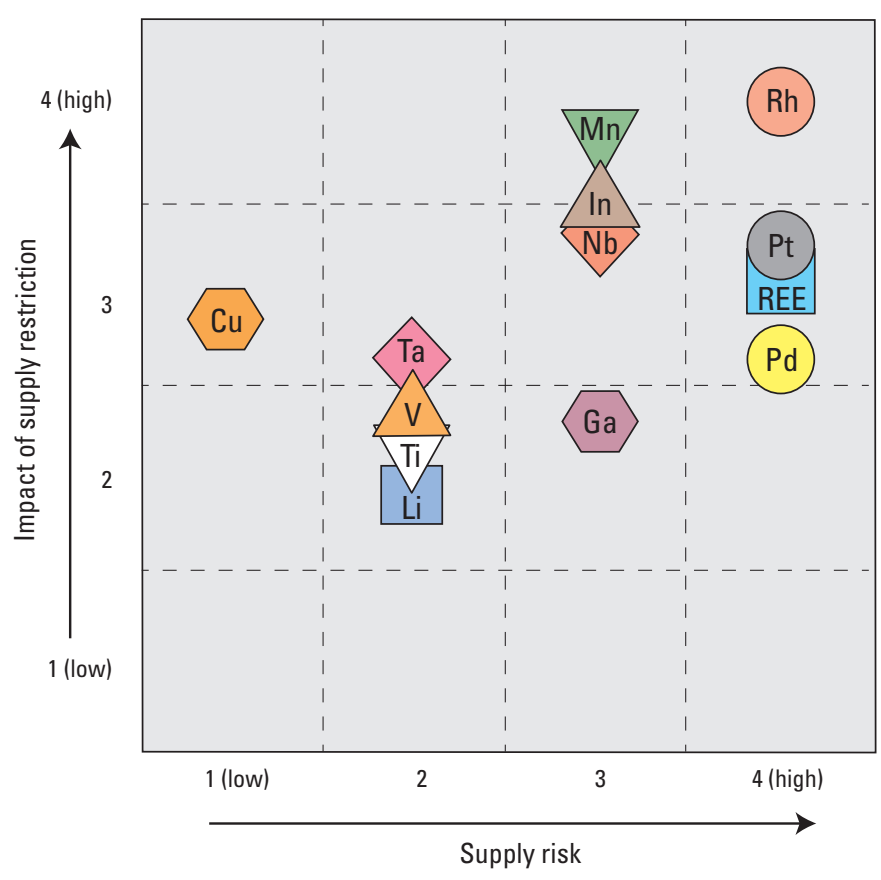

Figure M3. Criticality matrix for niobium, tantalum, and selected other mineral commodities. Of all these commodities, indium, manganese, niobium, platinumgroup metals (palladium, platinum, and rhodium), and rare-earth elements fall into the most critical zone of high supply risk and high impact of supply restriction (after National Research Council, 2008, p. 165). Cu, copper; Ga, gallium; In, indium; Li, lithium; $\mathrm{Mn}$, manganese; $\mathrm{Nb}$, niobium; $\mathrm{Pd}$, palladium; $\mathrm{Pt}$, platinum; REE, rare-earth element(s); Rh, rhodium; Ta, tantalum; Ti, titanium; and V, vanadium 


\section{Geology}

\section{Geochemistry}

Niobium and tantalum generally show strongly coherent geochemical behavior because they are identical in charge ( $5^{+}$under most geologically relevant oxidation conditions) and nearly identical in effective ionic radius (table M1). As a result, they are closely associated and found together in most rocks and minerals in which they occur. Both elements are lithophile, in that they show a strong affinity for oxygen, and they are high-field-strength elements (HFSEs), meaning that their ions are relatively small and have intense electrostatic fields. Their HFSE characteristics significantly reduce their potential to substitute for more common elements in most rock-forming minerals and make them essentially immobile under most natural conditions (Wood, 2005); as a result, their concentrations in the surface environment are generally low. The average abundance of niobium and tantalum in bulk continental crust is 8.0 parts per million (ppm) niobium and 0.7 ppm tantalum (Rudnick and Gao, 2003). In surface waters, concentrations are generally in the low parts per trillion.

Niobium and tantalum are depleted in continental crust relative to other highly incompatible elements (elements that do not readily substitute for more common elements in major rock-forming minerals), such as cesium, rubidium, thorium, and uranium, and the light REEs, including cerium and lanthanum. As a result, continental crustal rocks are typically characterized by high lanthanum to niobium ( $\mathrm{La:Nb})$ ratiosthe average crustal ratio is about 2.5 (Rudnick and Gao, 2003). The depletion of niobium and tantalum in continental crust is attributed to the formation of crustal rocks at convergent margins above subduction zones where titanium-rich minerals that host niobium and tantalum may remain as residual phases in the source region during generation of the magmas (Kelemen and others, 2003).

Although niobium and tantalum generally show coherent geochemical behavior, some chemical processes are able to separate them, which results in preferential enrichment or depletion of one or the other. These processes are still poorly understood, although crystal fractionation during magma evolution is the most commonly invoked mechanism. Niobium and tantalum show limited substitution for tin, tungsten, and zirconium in some rock-forming minerals, but particularly for titanium in such minerals as ilmenite $\left(\mathrm{FeTiO}_{3}\right)$, rutile $\left(\mathrm{TiO}_{2}\right)$, and titanite (sphene) $\left(\mathrm{CaTiSiO}_{5}\right)$. As niobium and tantalum become more highly enriched in residual igneous melts, a variety of chiefly oxide and hydroxide niobium and tantalum minerals may form (see Mineralogy section and table M2), depending on melt composition, temperature, pressure, and fluid composition. In addition, some evidence suggests that later alteration by hydrothermal (hot) fluids - in particular, concentrated fluoride solutions (Wood, 2005) - may play a role in mobilizing and enriching niobium and tantalum.

Table M2. Selected niobium and tantalum oxide minerals and their end-member $\mathrm{Nb}_{2} \mathrm{O}_{5}$ and $\mathrm{Ta}_{2} \mathrm{O}_{5}$ contents or compositional range.

[Data are from Mackay and Simandl (2014) and Parker and Fleischer (1968). $\mathrm{Nb}_{2} \mathrm{O}_{5}$, niobium pentoxide; $\mathrm{Ta}_{2} \mathrm{O}_{5}$, tantalum pentoxide; NP, not present]

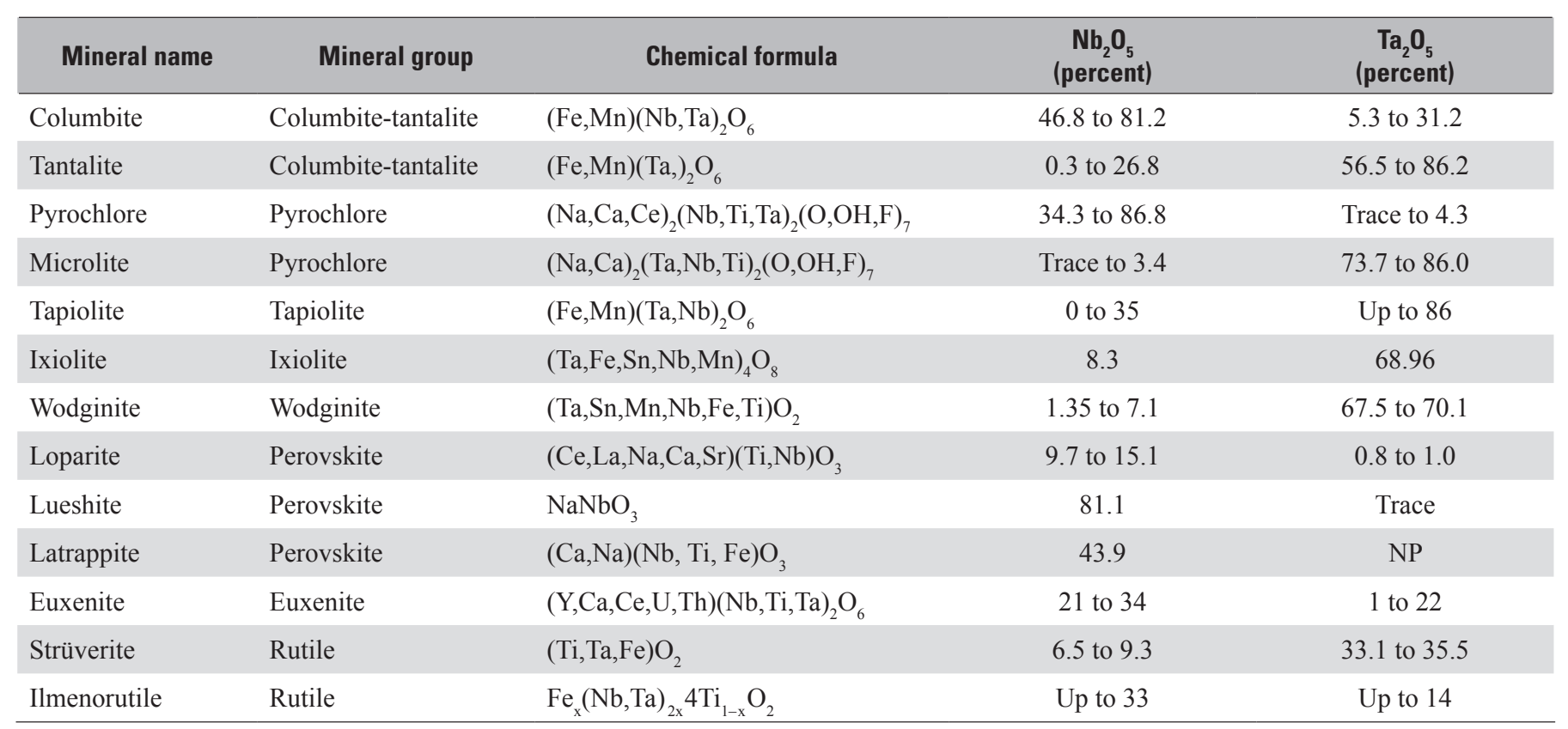




\section{Mineralogy}

Niobium and tantalum do not occur naturally as pure metals, but they are essential components in a variety of oxide and hydroxide minerals, as well as in a few rare silicates and one borate (Parker and Fleischer, 1968). The economically important mineral species are all oxides (table M2); pyrochlore is the principal ore mineral for niobium, and tantalite is the principal ore mineral for tantalum (fig. M4). Until the discovery of pyrochlore-rich deposits in the 1950s, niobium was produced as a byproduct of mining columbite-tantalitebearing pegmatites for tantalum.

The columbite-tantalite mineral group is characterized by a wide range in niobium and tantalum content as well as variable iron and manganese content. Columbite (a niobiumrich mineral) and tantalite (a tantalum-rich mineral) have very similar properties because they have the same structure and similar chemistries, but tantalite has a much higher specific gravity $(8.0+)$ than does columbite (5.2). Tantalite also has a dimorphic relation (same chemistry but different crystal structure) to the mineral tapiolite. Columbite-tantalite minerals are found as accessory phases in rare-metal granites and pegmatites (Černý, 1991a, b).

The pyrochlore mineral group also has a wide compositional range, but generally has niobium greatly enriched over tantalum (a ratio of about 200:1). In addition, pyrochlore can contain significant amounts of barium, light REEs, and uranium. Because it can contain uranium, pyrochlore tends to be radioactive and can show damage to its crystal structure from radiation. Pyrochlore is typically found as a primary mineral in alkaline igneous rocks, particularly carbonatites (for example, the Araxá carbonatite in Brazil).
Other oxide minerals, such as loparite, ixiolite, tapiolite, and the perovskite group (table M2) are less common sources of niobium and tantalum. Loparite concentrate from the Lovozero intrusion in the Kola Peninsula has been a source of niobium in Russia but is not economically competitive with pyrochlore. The calcium- and niobium-dominant perovskite-group mineral latrappite is the main ore mineral at the Oka carbonatite complex in Quebec, Canada. Microlite is the tantalum-rich end member of the pyrochlore mineral group and is generally found in pegmatites in association with columbite-tantalite. The titanium-bearing mineral strüverite has been a low-grade source of tantalum recovered from tin-mining waste in Southeast Asia. Niobium- and tantalumbearing silicate minerals are relatively rare and found mostly in alkaline igneous rocks.

\section{Deposit Types}

Niobium and tantalum minerals are found in a variety of igneous rocks around the world but only rarely in concentrations great enough to be of economic interest. Primary niobium and tantalum mineral deposits are found in three main types of igneous intrusive rocks (table M3; Küster, 2009):

1. Carbonatites and associated alkaline rocks ( $\mathrm{Nb}$ dominant),

2. Alkaline to peralkaline granites and syenites ( $\mathrm{Nb}$ dominant), and

3. Rare-metal granites and pegmatites of the lithiumcesium-tantalum (LCT) family (Ta dominant) (Černý and Ercit, 2005).

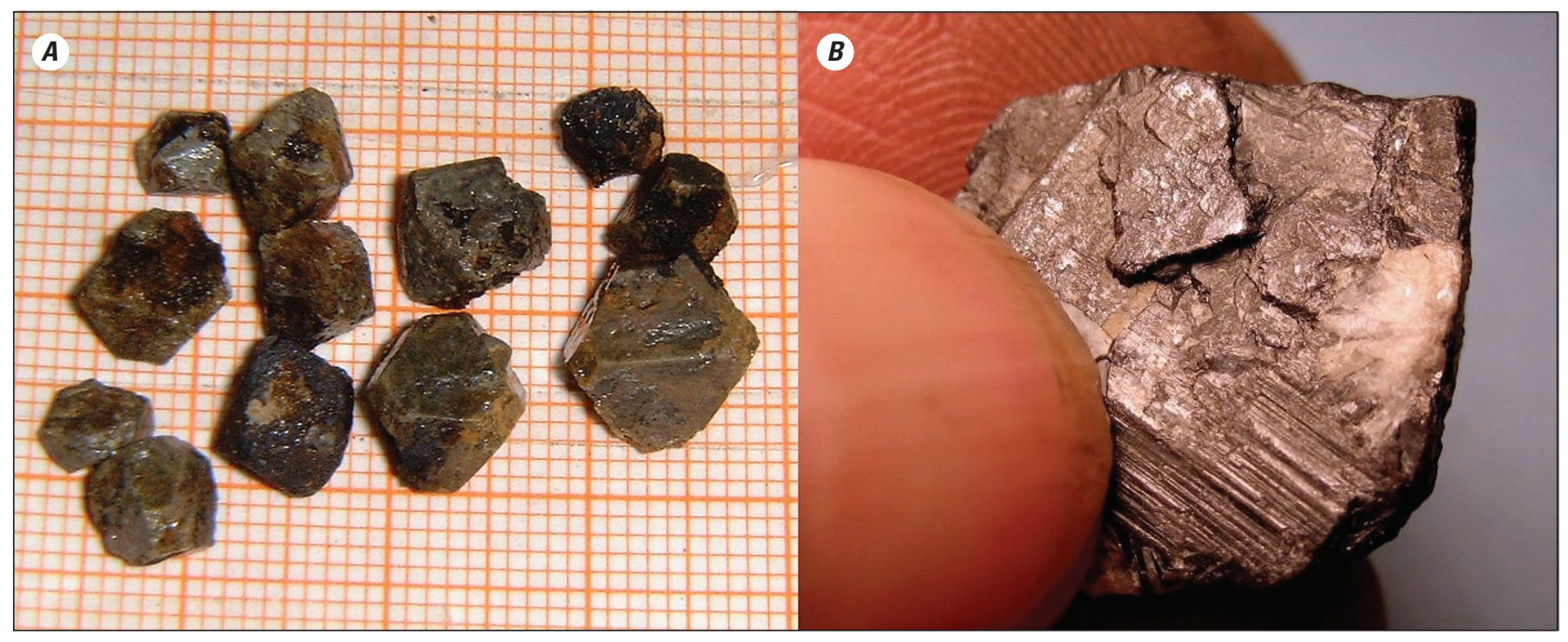

Figure M4. Photographs showing $A$, centimeter-size pyrochlore crystals from Uganda, and $B$, a tantalite crystal. Photograph $A$ is by Gunnar Ries/CC-BY-SA-3.0; photograph $B$ is by Roger Weller, Cochise College. 
In addition, some secondary concentrations have been formed by weathering of primary deposits (laterites) and by sedimentary processes (placers). The secondary deposits are of particular interest because they can be less expensive to mine and can have higher grades than primary hard-rock deposits. Because secondary deposits typically occur in close proximity to their primary sources, they are not described separately below.

Deposits of niobium and tantalum are found around the world (fig. M5, table M4), but major production is currently restricted to only a few countries. Grade and tonnage figures for these deposits are shown in figure M6. Generally, grades for niobium are higher (from about 0.1 to 3.0 percent niobium pentoxide $\left[\mathrm{Nb}_{2} \mathrm{O}_{5}\right]$ ) than those of tantalum (generally $<0.1$ percent tantalum pentoxide $\left[\mathrm{Ta}_{2} \mathrm{O}_{5}\right]$ ). Carbonatites generally have the highest grades and tonnages of niobium, although they overlap with those of alkaline granite and syenite-hosted deposits. In addition, some alkaline graniteand syenite-hosted deposits have higher tonnages at similar grades of tantalum than do rare-metal granite and pegmatitehosted deposits (fig. M6A). The ratios of niobium to tantalum in the alkaline granite and syenite deposits are much higher ( $>10$ to 20 ) because of the predominance of niobium-rich minerals, such as pyrochlore and columbite.

Table M3. Major types of niobium and tantalum deposits, with key characteristics and examples.

[Modified from British Geological Survey (2011). Grades and tonnages are highly variable among deposits, and the grades and tonnages given in this table are generalizations only. LCT, lithium-cesium-tantalum; Mt, million metric tons; $\mathrm{Nb}$, niobium; $\mathrm{Nb}_{2} \mathrm{O}_{5}$, niobium pentoxide; $\mathrm{Ta}$, tantalum; $\mathrm{Ta}_{2} \mathrm{O}_{5}$, tantalum pentoxide]

\begin{tabular}{|c|c|c|c|}
\hline Deposit type & Brief description & Typical grades and tonnage & Major examples \\
\hline $\begin{array}{l}\text { Carbonatite-hosted } \\
\text { primary deposits }\end{array}$ & $\begin{array}{l}\mathrm{Nb}>\text { Ta: Niobium deposits commonly } \\
\text { consisting of members of the } \\
\text { perovskite and pyrochlore mineral } \\
\text { groups found within carbonatite } \\
\text { intrusions in alkaline igneous } \\
\text { provinces }\end{array}$ & $\begin{array}{l}\text { Deposits show a wide range in both } \\
\text { grade and tonnage. Morro dos Seis } \\
\text { Lagos is the largest reported deposit; } \\
\text { it contains about } 2,900 \mathrm{Mt} \text { at a grade } \\
\text { of } 2.85 \text { percent } \mathrm{Nb}_{2} \mathrm{O}_{5} \text {. More typical } \\
\text { is the deposit at } \mathrm{Niobec}_{\text {, which }} \\
\text { contains about } 46 \mathrm{Mt} \text { at a grade } \\
\text { of } 0.53 \text { percent } \mathrm{Nb}_{2} \mathrm{O}_{5}\end{array}$ & $\begin{array}{l}\text { Niobec and Oka, Canada; } \\
\text { Araxá, Catalão I and II, } \\
\text { and Morro dos Seis } \\
\text { Lagos, Brazil }\end{array}$ \\
\hline $\begin{array}{l}\text { Alkaline granite } \\
\text { and syenite }\end{array}$ & $\begin{array}{l}\mathrm{Nb}>\mathrm{Ta} \text { : Deposits containing niobium } \\
\text { and lesser amounts of tantalum; } \\
\text { the deposits are related to silicic } \\
\text { alkaline granite and syenite igneous } \\
\text { intrusions }\end{array}$ & $\begin{array}{l}\text { Generally }<1,000 \mathrm{Mt} \text { at grades of } \\
0.1 \text { to } 1 \text { percent } \mathrm{Nb}_{2} \mathrm{O}_{5} \text { and } \\
<0.05 \text { percent } \mathrm{Ta}_{2} \mathrm{O}_{5}\end{array}$ & $\begin{array}{l}\text { Motzfeldt and Ilímaussaq, } \\
\text { Greenland; Lovozero, } \\
\text { Russia; Thor Lake and } \\
\text { Strange Lake, Canada }\end{array}$ \\
\hline LCT-type pegmatite & $\begin{array}{l}\mathrm{Ta}>\mathrm{Nb} \text { : Deposits containing tantalum } \\
\text { and lesser amounts of niobium; the } \\
\text { deposits are LCT-enriched-type } \\
\text { pegmatites }\end{array}$ & $\begin{array}{l}\text { Generally }<100 \mathrm{Mt} \text { at grades of } \\
\quad<0.05 \mathrm{Ta}_{2} \mathrm{O}_{5}\end{array}$ & $\begin{array}{l}\text { Greenbushes and } \\
\text { Wodgina, Australia; } \\
\text { Tanco, Canada; Volta } \\
\text { Grande, Brazil; } \\
\text { Kenticha, Ethiopia }\end{array}$ \\
\hline $\begin{array}{l}\text { Secondary (regolith) } \\
\text { deposits }\end{array}$ & $\begin{array}{l}\text { Niobium and (or) tantalum ore miner- } \\
\text { als concentrated in zones of intense } \\
\text { weathering above carbonatite and } \\
\text { granite or pegmatite intrusions, or in } \\
\text { sedimentary placer deposits derived } \\
\text { from such intrusions }\end{array}$ & $\begin{array}{l}\text { Lateritic deposits generally have } \\
<1,000 \mathrm{Mt} \text { at grades of up to } \\
3 \text { percent } \mathrm{Nb}_{2} \mathrm{O}_{5} \text {. Placer deposits, } \\
\text { such as the deposit at Tomtor, } \\
\text { can have very high grades of } \\
\text { up to } 12 \text { percent } \mathrm{Nb}_{2} \mathrm{O}_{5}\end{array}$ & $\begin{array}{l}\text { Araxá and Catalão, Brazil; } \\
\text { Tomtor, Russia; Green- } \\
\text { bushes, Australia }\end{array}$ \\
\hline
\end{tabular}




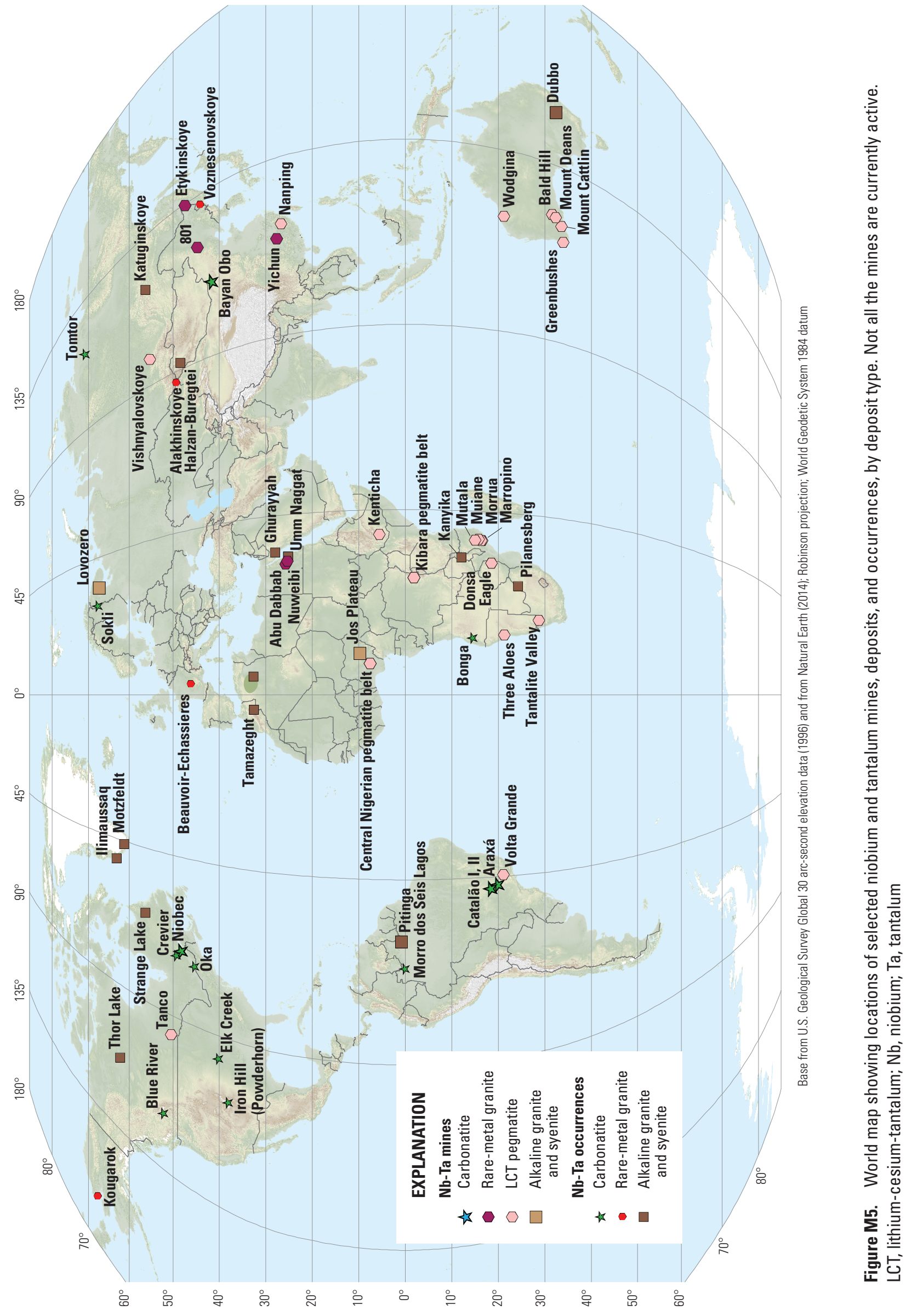



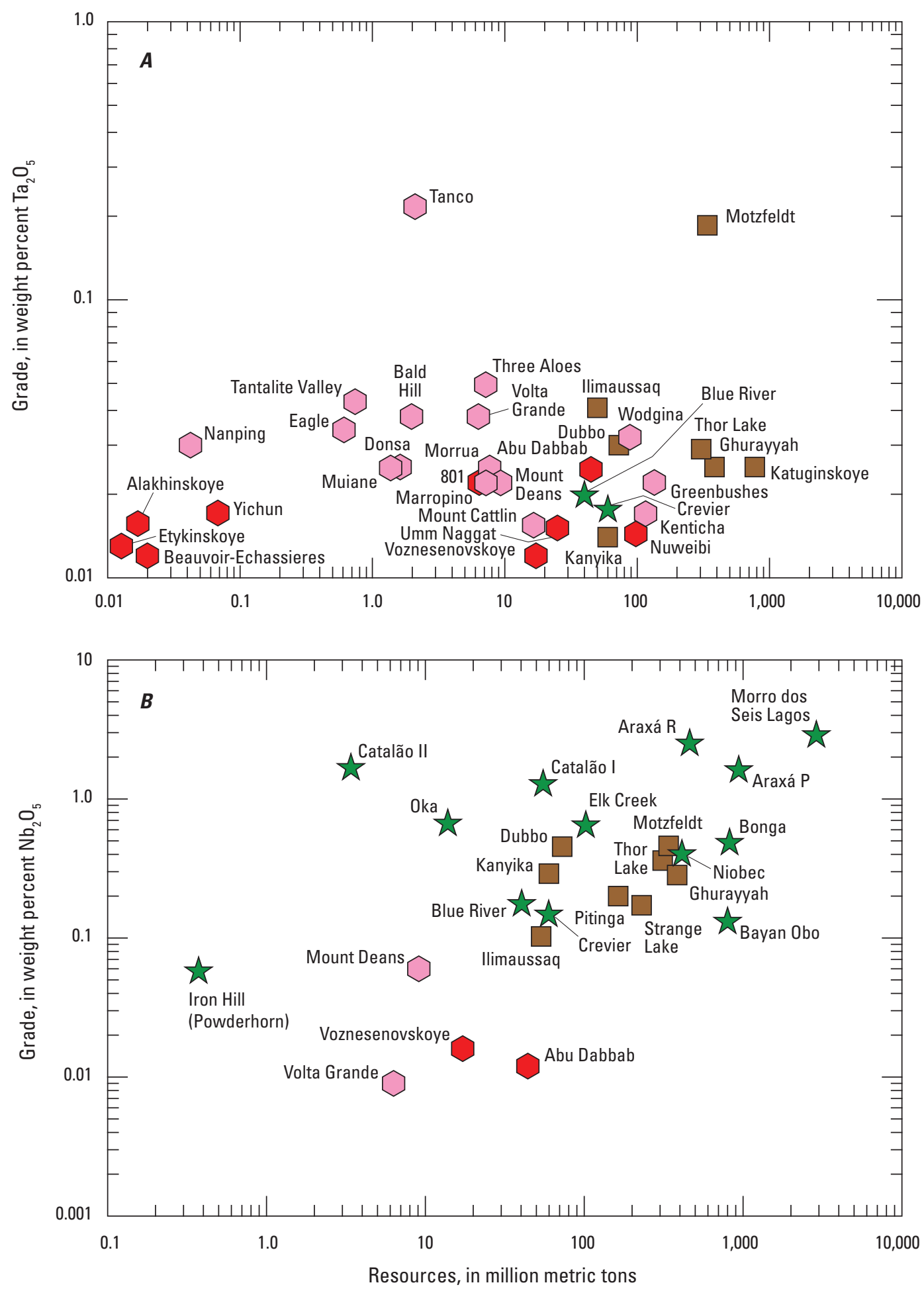

EXPLANATION
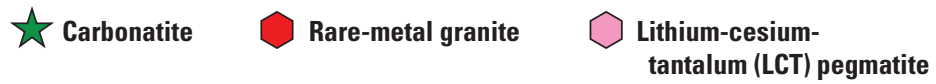

Alkaline granite and syenite

Figure M6. Log-log plots of deposit grades and tonnages of $A$, tantalum, and $B$, niobium, by deposit type. The data include different levels of probability, including measured, indicated, and inferred resources and (or) proven and probable reserves. Data and sources are given in table M4. $P$, primary deposit; $R$, residual deposit, $\mathrm{Nb}_{2} \mathrm{O}_{5^{\prime}}$, niobium pentoxide; $\mathrm{Ta}_{2} \mathrm{O}_{5^{\prime}}$, tantalum pentoxide 
Table M4. Location, grade, tonnage, and other data for selected niobium-tantalum deposits of the world.

[Symbol size (small, large) corresponds to size of symbols shown in figure M5; deposit grade and tonnage are shown graphically in figure M6. Symbol size: S, small; L, large. WGS 84, World Geodetic System of 1984; negative values for latitude indicate that the deposit is in the Southern Hemisphere; negative values for longitude indicate that the deposit is in the Western Hemisphere. $\mathrm{Nb}_{2} \mathrm{O}_{5}$, niobium pentoxide; $\mathrm{Ta}_{2} \mathrm{O}_{5}$, tantalum pentoxide. Resource categories: M+In+If, measured+indicated+inferred; In+If, indicated+inferred. LCT, lithium-cesium-tantalum; Ma, mega-annum; NA, not available]

\begin{tabular}{|c|c|c|c|c|c|}
\hline Deposit & Country & Deposit type & $\begin{array}{l}\text { Symbol } \\
\text { size }\end{array}$ & Latitude & Longitude \\
\hline Bonga & Angola & Carbonatite & $\mathrm{S}$ & -14.27 & 13.97 \\
\hline Bald Hill & Australia & LCT pegmatite & $\mathrm{L}$ & -31.52 & 122.18 \\
\hline Greenbushes & Australia & LCT pegmatite & $\mathrm{L}$ & -33.87 & 116.06 \\
\hline Mount Cattlin & Australia & LCT pegmatite & $\mathrm{L}$ & -33.56 & 120.04 \\
\hline Mount Deans & Australia & LCT pegmatite & $\mathrm{L}$ & -32.31 & 121.79 \\
\hline Wodgina & Australia & LCT pegmatite & $\mathrm{L}$ & -21.18 & 118.68 \\
\hline Dubbo & Australia & $\begin{array}{l}\text { Alkaline granite } \\
\text { and syenite }\end{array}$ & $\mathrm{L}$ & -32.42 & 148.60 \\
\hline Araxá & Brazil & Carbonatite & $\mathrm{L}$ & -19.67 & -46.95 \\
\hline Catalão I & Brazil & Carbonatite & $\mathrm{L}$ & -18.13 & -47.80 \\
\hline Catalão II & Brazil & Carbonatite & $\mathrm{L}$ & -18.03 & -47.87 \\
\hline Volta Grande & Brazil & LCT pegmatite & $\mathrm{L}$ & -21.08 & -44.58 \\
\hline Pitinga & Brazil & $\begin{array}{l}\text { Alkaline granite } \\
\text { and syenite }\end{array}$ & $\mathrm{L}$ & 0.78 & -60.08 \\
\hline Morro dos Seis Lagos & Brazil & Carbonatite & $\mathrm{S}$ & 0.28 & -66.68 \\
\hline Blue River & Canada & Carbonatite & $\mathrm{S}$ & 52.32 & -119.17 \\
\hline Tanco & Canada & LCT pegmatite & $\mathrm{L}$ & 50.43 & -95.45 \\
\hline Thor Lake & Canada & $\begin{array}{l}\text { Alkaline granite } \\
\text { and syenite }\end{array}$ & $\mathrm{S}$ & 62.11 & -112.60 \\
\hline Oka & Canada & Carbonatite & $\mathrm{S}$ & 45.50 & -74.02 \\
\hline Yichun & China & Rare-metal granite & $\mathrm{L}$ & 27.65 & 114.52 \\
\hline Nanping & China & LCT pegmatite & $\mathrm{L}$ & 26.67 & 118.10 \\
\hline 801 & China & Rare-metal granite & $\mathrm{L}$ & 44.62 & 120.97 \\
\hline Bayan Obo & China & Carbonatite & $\mathrm{L}$ & 41.80 & 109.97 \\
\hline $\begin{array}{l}\text { Kibara pegmatite } \\
\text { belt }\end{array}$ & $\begin{array}{l}\text { Democratic Republic of the } \\
\text { Congo and Rwanda }\end{array}$ & LCT pegmatite & $\mathrm{L}$ & -2.00 & 28.00 \\
\hline Abu Dabbab & Egypt & Rare-metal granite & $\mathrm{S}$ & 25.34 & 34.54 \\
\hline Nuweibi & Egypt & Rare-metal granite & $\mathrm{S}$ & 25.20 & 34.50 \\
\hline Umm Naggat & Egypt & Rare-metal granite & $\mathrm{S}$ & 25.20 & 34.50 \\
\hline Kenticha & Ethiopia & LCT pegmatite & $\mathrm{L}$ & 5.52 & 39.03 \\
\hline
\end{tabular}


Table M4. Location, grade, tonnage, and other data for selected niobium-tantalum deposits of the world.-Continued

[Symbol size (small, large) corresponds to size of symbols shown in figure M5; deposit grade and tonnage are shown graphically in figure M6. Symbol size: S, small; L, large. WGS 84, World Geodetic System of 1984; negative values for latitude indicate that the deposit is in the Southern Hemisphere; negative values for longitude indicate that the deposit is in the Western Hemisphere. $\mathrm{Nb}_{2} \mathrm{O}_{5}$, niobium pentoxide; $\mathrm{Ta}_{2} \mathrm{O}_{5}$, tantalum pentoxide. Resource categories: M+In+If, measured+indicated+inferred; In+If, indicated+inferred. LCT, lithium-cesium-tantalum; Ma, mega-annum; NA, not available]

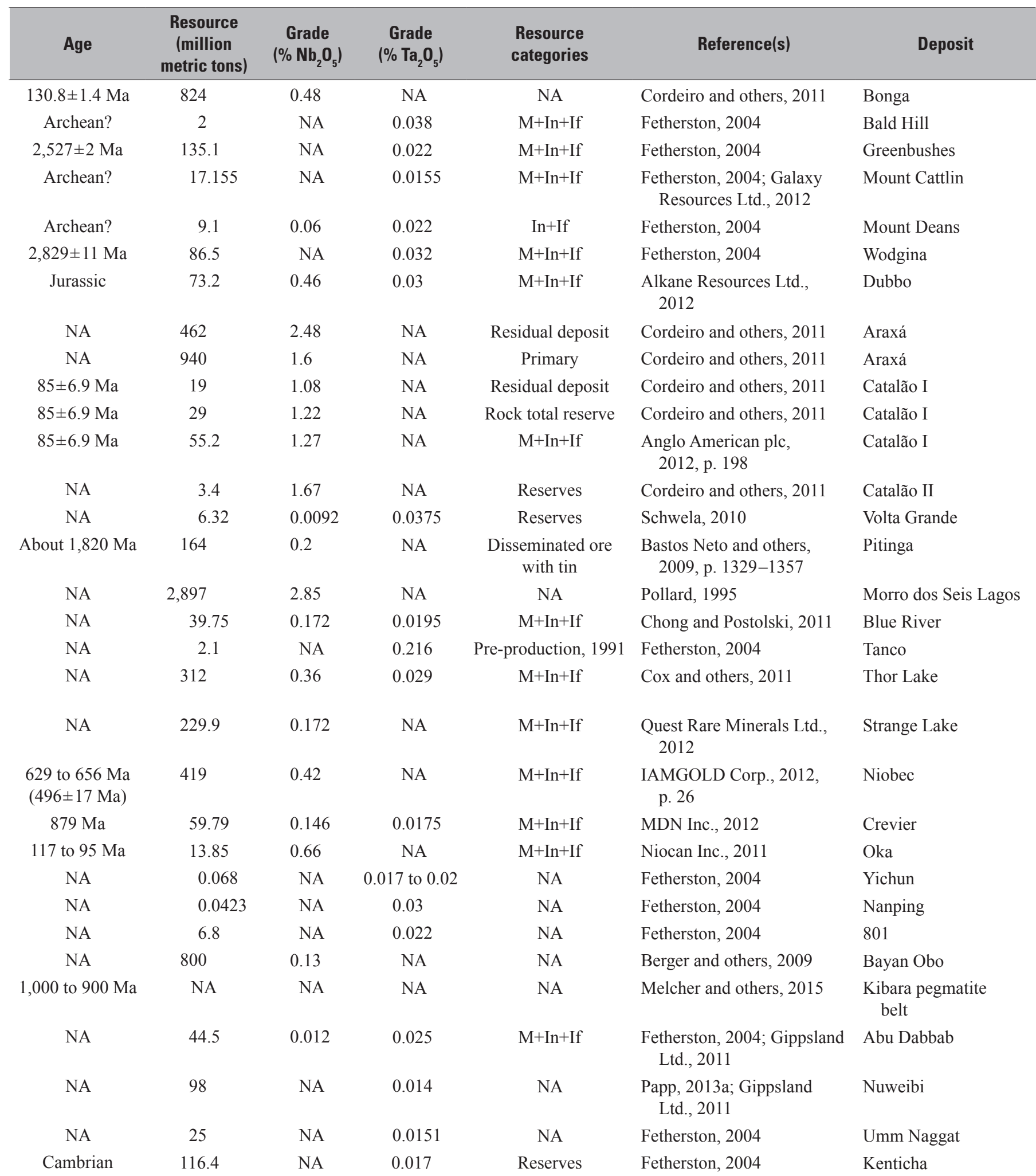


Table M4. Location, grade, tonnage, and other data for selected niobium-tantalum deposits of the world.—Continued

[Symbol size (small, large) corresponds to size of symbols shown in figure M5; deposit grade and tonnage are shown graphically in figure M6. Symbol size: S, small; L, large. WGS 84, World Geodetic System of 1984; negative values for latitude indicate that the deposit is in the Southern Hemisphere; negative values for longitude indicate that the deposit is in the Western Hemisphere. $\mathrm{Nb}_{2} \mathrm{O}_{5}$, niobium pentoxide; $\mathrm{Ta}_{2} \mathrm{O}_{5}$, tantalum pentoxide. Resource categories: M+In+If, measured+indicated+inferred; In+If, indicated+inferred. LCT, lithium-cesium-tantalum; Ma, mega-annum; NA, not available]

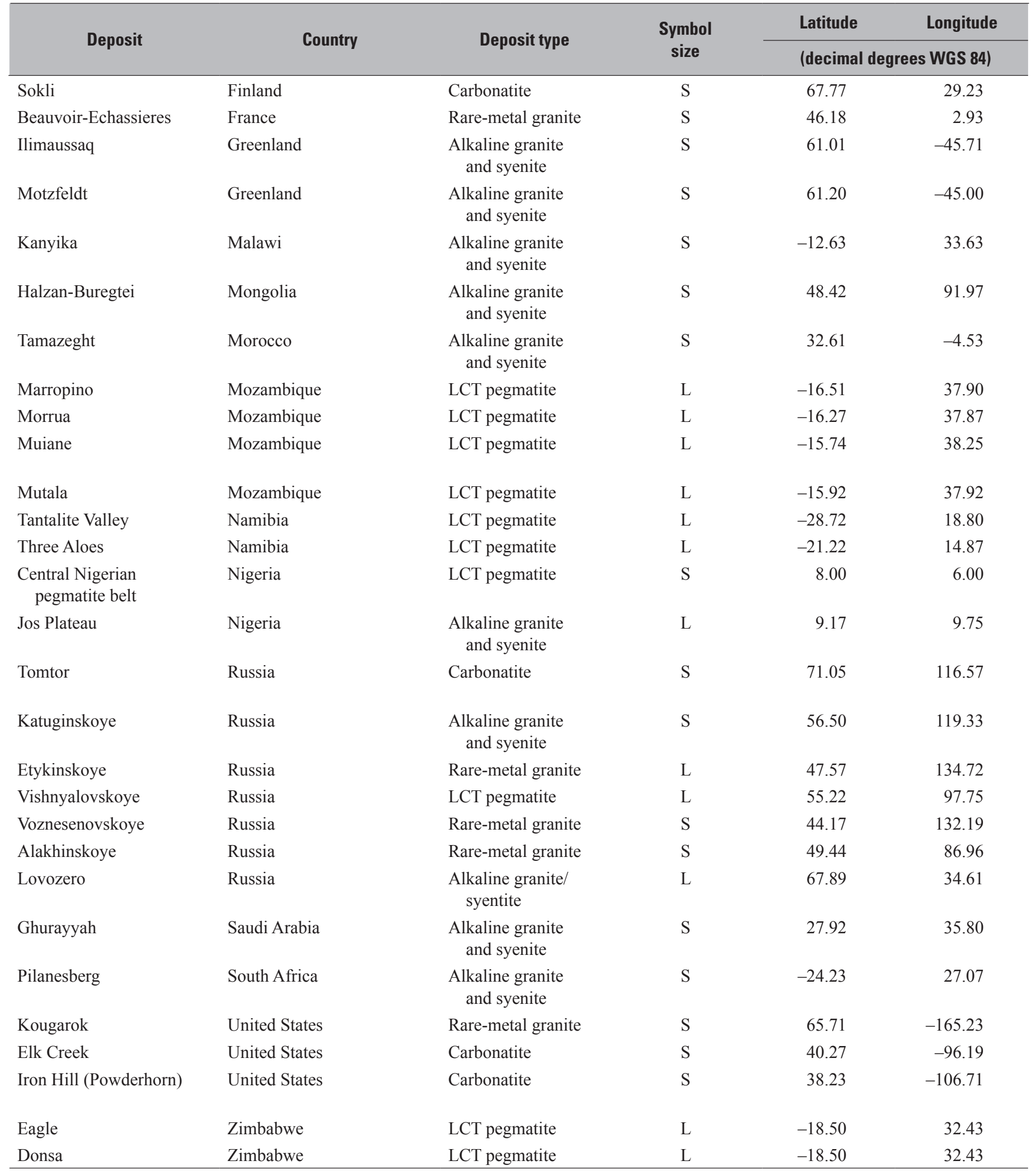


Table M4. Location, grade, tonnage, and other data for selected niobium-tantalum deposits of the world.-Continued

[Symbol size (small, large) corresponds to size of symbols shown in figure M5; deposit grade and tonnage are shown graphically in figure M6. Symbol size: S, small; L, large. WGS 84, World Geodetic System of 1984; negative values for latitude indicate that the deposit is in the Southern Hemisphere; negative values for longitude indicate that the deposit is in the Western Hemisphere. $\mathrm{Nb}_{2} \mathrm{O}_{5}$, niobium pentoxide; $\mathrm{Ta}_{2} \mathrm{O}_{5}$, tantalum pentoxide. Resource categories: M+In+If, measured+indicated+inferred; In+If, indicated+inferred. LCT, lithium-cesium-tantalum; Ma, mega-annum; NA, not available]

\begin{tabular}{|c|c|c|c|c|c|c|}
\hline Age & $\begin{array}{c}\text { Resource } \\
\text { (million } \\
\text { metric tons) }\end{array}$ & $\begin{array}{c}\text { Grade } \\
\left(\% \mathrm{Nb}_{2} \mathrm{O}_{5}\right)\end{array}$ & $\begin{array}{c}\text { Grade } \\
\left(\% \mathrm{Ta}_{2} \mathrm{O}_{5}\right)\end{array}$ & $\begin{array}{l}\text { Resource } \\
\text { categories }\end{array}$ & Reference(s) & Deposit \\
\hline NA & 110 & $?$ & NA & Hard rock ore & Siirama, 2009 & Sokli \\
\hline $308 \pm 2 \mathrm{Ma}$ & 0.02 & NA & 0.012 & NA & Raimbault and others, 1985 & Beauvoir-Echassieres \\
\hline NA & 54 & 0.11 & 0.04 & Resources & $\begin{array}{l}\text { Salvi and Williams-Jones, } \\
\text { 2005; Fetherston, } 2004\end{array}$ & Ilimaussaq \\
\hline NA & 60 & 0.29 & 0.014 & $\mathrm{M}+\mathrm{In}+\mathrm{If}$ & Papp, 2013a & Kanyika \\
\hline NA & NA & NA & NA & NA & Fetherston, 2004 & Halzan-Buregtei \\
\hline NA & 1.375 & NA & 0.025 & $\mathrm{M}+\mathrm{In}+\mathrm{If}$ & $\begin{array}{l}\text { Global Mining Services } \\
\text { Pty. Ltd., 2009, p. } 57\end{array}$ & Muiane \\
\hline NA & NA & NA & NA & NA & Papp, 2013a & Mutala \\
\hline NA & 0.74 & NA & 0.043 & NA & Fetherston, 2004 & Tantalite Valley \\
\hline NA & 7.2 & NA & 0.05 & NA & Fetherston, 2004 & Three Aloes \\
\hline 535 to $555 \mathrm{Ma}$ & NA & NA & NA & NA & $\begin{array}{l}\text { Matheis, 1987; Melcher } \\
\text { and others, } 2015\end{array}$ & $\begin{array}{r}\text { Central Nigerian } \\
\text { pegmatite belt }\end{array}$ \\
\hline About $198 \mathrm{Ma}$ & NA & NA & NA & NA & Melcher and others, 2015 & Jos Plateau \\
\hline NA & 0.015 to 0.020 & NA & 0.013 to 0.017 & NA & Fetherston, 2004 & Alakhinskoye \\
\hline NA & NA & NA & NA & NA & $\begin{array}{l}\text { Salvi and Williams-Jones, } \\
\text { 2005; Fetherston, } 2004\end{array}$ & Lovozero \\
\hline NA & 385 & 0.284 & 0.0245 & NA & Tertiary Minerals plc, 2013 & Ghurayyah \\
\hline NA & NA & NA & NA & NA & Lurie, 1986 & Pilanesberg \\
\hline NA & NA & NA & NA & NA & Fetherston, 2004 & Kougarok \\
\hline NA & 102.6 & 0.638 & NA & In+If & Daigle, 2012 & Elk Creek \\
\hline NA & 0.374 & 0.057 & NA & NA & Long and others, 2010 & $\begin{array}{l}\text { Iron Hill (Powder- } \\
\text { horn) }\end{array}$ \\
\hline NA & 0.61 & NA & 0.034 & NA & Fetherston, 2004 & Eagle \\
\hline NA & 1.62 & NA & 0.025 & NA & Fetherston, 2004 & Donsa \\
\hline
\end{tabular}




\section{Carbonatites and Associated Rocks}

Carbonatites are igneous rocks that are more than 50 percent composed of primary carbonate minerals, by volume, mainly calcite $\left(\mathrm{CaCO}_{3}\right)$, dolomite $\left(\mathrm{CaMg}\left(\mathrm{CO}_{3}\right)_{2}\right)$, and ankerite $\left(\mathrm{Ca}\left(\mathrm{Mg}, \mathrm{Fe}^{2+}, \mathrm{Mn}\right)\left(\mathrm{CO}_{3}\right)_{2}\right)$. Associated minerals commonly include alkali-rich (sodium or potassium) pyroxenes and amphiboles, phlogopite (magnesium-rich mica), magnetite, apatite (calcium phosphate), and olivine (iron-magnesium silicate). In addition, a large number of rare or exotic minerals may be present. Most carbonatites occur as relatively small (up to a few tens of square kilometers) intrusions, such as dikes, sills, and small plug- or crescentshaped bodies (fig. M7A); more rarely, they can occur as larger intrusions (plutons) or as volcanic deposits (lava flows and fragmental rocks). In three dimensions, carbonatite intrusions typically form vertical pipe-like bodies (fig. M7B). Carbonatites are commonly spatially associated with alkaline silicate rocks characterized by a wide range of sodium- or potassium-rich minerals and little or no quartz (Barker, 1989).
Many carbonatites are surrounded by an aureole of chemically altered country rocks (fenites) produced by the reaction of nearby rocks with hot sodium- and (or) potassium-rich fluids derived from the carbonatite (fig. M7).

A recent compilation by Woolley and Kjarsgaard (2008) lists 527 carbonatites worldwide. Most carbonatites (88 percent of all dated carbonatites) are located in cratons (the oldest, stable portions of continents) and were emplaced during periods of continental extension or rifting. In many carbonatite-bearing provinces, there have been repeated episodes of carbonatite emplacement, with as many as five episodes separated by hundreds of millions of years and extending from the late Archean to the present. Sixty-four percent of dated carbonatites are Paleozoic in age, however (Woolley and Bailey, 2012). Their source magmas are thought to be derived directly from the mantle by relatively small degrees of partial melting and emplaced along major faults or crustal boundaries reopened in response to major changes in global plate-tectonic movements (Woolley and Bailey, 2012).

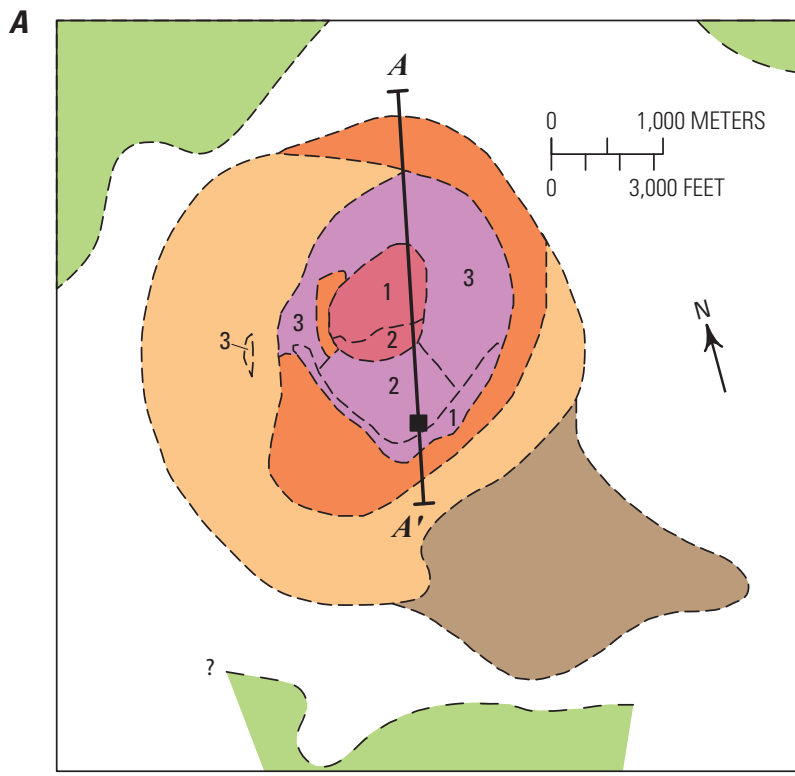

\section{EXPLANATION}

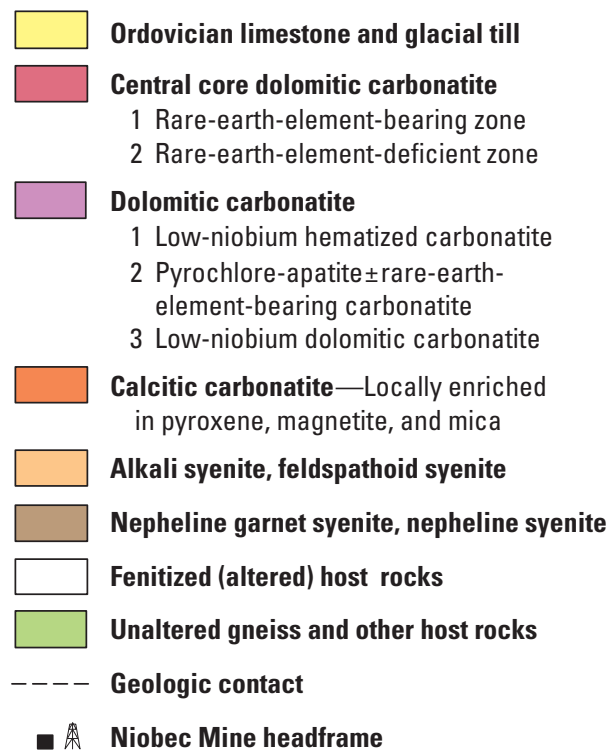

B

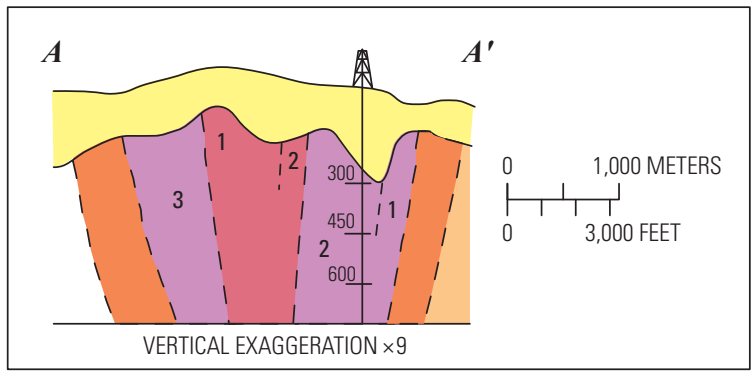

Niobec Mine headframe

Figure M7. Diagrams showing $A$, the subsurface geology of the Saint-Honoré carbonatite complex in southern Quebec, Canada, and $B$, a schematic north-south cross-section along line $A-A^{\prime}$ in $A$. The location of the Niobec underground mine is also shown. Modified from Richardson and Birkett (1996). 
Carbonatites are typically enriched in barium, fluorine, niobium, phosphorus, REEs, strontium, thorium, uranium, and zirconium. Not all carbonatites show similar enrichments in all elements, however; those related to carbohydrothermal fluids (hot fluids rich in carbon dioxide and water \pm fluorine) typically have enriched REEs and strontium, but not niobium, whereas carbonatites associated with alkaline igneous rocks are typically enriched in niobium, phosphorus, and titanium, but not REEs (Mitchell, 2005). The most common niobiumbearing minerals in carbonatites include members of the pyrochlore and perovskite mineral groups, as well as niobiumrich silicates, such as titanite. The diversity of mineral types in carbonate-hosted deposits, their diverse compositions, and textural evidence for replacement and resorption of mineral phases suggest that the niobium-bearing minerals represent transported and (or) mixed mineral assemblages and are not in situ products of crystallization (Mitchell, 2005). Along with serving as the major source of niobium, carbonatites can also host deposits of barite, copper, fluorite, magnetite, phosphate, REEs, titanium, and vermiculite (Mariano, 1989).

Brazil is the world's leading supplier of niobium (about 90 percent); its major deposits occur in Late Cretaceous carbonatite complexes. These complexes were emplaced along deep-seated faults located along the southwestern border of the ancient (Archean) São Francisco craton (Cordeiro and others, 2011). The Araxá deposit is the largest operating deposit; it has more than 460 million metric tons of weathered ore with a mean grade of 2.48 percent $\mathrm{Nb}_{2} \mathrm{O}_{5}$ (fig. M5; Cordeiro and others, 2011). The Barreiro carbonatite complex that hosts the Araxá deposit is approximately circular in shape with a diameter of about 4.5 kilometers $(\mathrm{km})$; it is composed of carbonatite, glimmerite (altered ultramafic rock composed almost entirely of biotite or phlogopite), and phoscorite (a rock composed of magnetite, apatite, and one of the silicate minerals clinopyroxene, olivine, or phylogopite) (Nasraoui and Waerenborgh, 2001). The complex is surrounded by a $2.5-\mathrm{km}-$ wide aureole of metasomatized (fluid-altered), alkali-enriched quartzite and mica schist country rocks. Phoscorite, which forms thick masses in dolomitic carbonatite in the central part of the complex, shows the highest concentrations of pyrochlore, the main niobium-bearing ore mineral, either as individual grains or in veins associated with magnetite. Intensive tropical weathering over the central part of the carbonatite complex has produced a lateritic cover up to 230 meters (m) thick that is enriched in pyrochlore and comprises the residual ore at Araxá (Nasraoui and Waerenborgh, 2001). The lateritic residual ore is exploited by open pit mining.

At Catalão, Brazil, niobium deposits are associated with two alkaline-carbonatite complexes, Catalão I and Catalão II (Cordeiro and others, 2011). The Catalão I complex consists of a vertical pipe-like, zoned intrusion about 6 $\mathrm{km}$ in diameter at the surface. Two pipe-like orebodies, the Mine II and the East Area, have been defined (Cordeiro and others, 2011). The Mine II orebody is hosted mainly by dolomitic carbonatite, and the East Area orebody is hosted by glimmerite. Both orebodies have been confirmed by drilling to extend to at least $800 \mathrm{~m}$ depth. The main niobium-bearing mineral in both deposits is pyrochlore, which in the East Area deposit is concentrated in late-stage dikes composed of nelsonite (magnetite-apatite-phlogopite rock). As at Araxá, current mining at Catalão II is in the weathered lateritic zone above the center of the complex.

The leading producer of niobium outside of Brazil is the Niobec Mine in Quebec, Canada. This mine is the only operating underground niobium mine in the world. The Niobec Mine is hosted by the Saint-Honoré carbonatite complex dated at 650 mega-annum (Ma) (Belzile, 2009), which is covered by Paleozoic limestone and glacial deposits. The ellipsoidal Saint-Honoré carbonatite complex is zoned with an outer ring of feldspathic (feldspar-bearing) and feldspathoidal (minerals that resemble feldspar but have a different structure and much lower silica content) alkaline rocks and an inner zone consisting of a series of carbonatite lenses (fig. M7). Like the Brazilian deposits, pyrochlore is the main niobium-bearing mineral, but it is very fine-grained ( 0.2 to 0.8 millimeters) and rarely visible. Although disseminated throughout the carbonatite, pyrochlore is especially concentrated in steeply dipping ( $>70$ degrees) mineralized lenses that are rich in, in order of abundance, magnetite, apatite, and biotite (Belzile, 2009). Some lenses extend to a vertical depth of at least $730 \mathrm{~m}$ and have average grades of between 0.44 and 0.51 percent $\mathrm{Nb}_{2} \mathrm{O}_{5}$. Other carbonatite complexes in Canada, including the nearby Crevier syenitecarbonatite complex, the Oka carbonatite complex to the south, and the Blue River complex in British Columbia, are currently being evaluated for their niobium resources.

Other carbonatite complexes around the world are known to host niobium mineralization, but none are currently in production. Two complexes are claimed to contain particularly large resources. The Tomtor complex in northern Siberia, Russia, is claimed to contain more niobium than the Araxá complex in Brazil along with significant REE resources (Kravchenko and Pokrovsky, 1995); grade and tonnage figures for the deposit are not publicly available. Although the central carbonatite in the Tomtor complex is reported to be mineralized, the higher grade niobium ( $>12$ percent niobium) and REE-rich ore is in weathered carbonatite and in a buried placer deposit interpreted to have formed in an ancient lake overlying the complex (Kravchenko and Pokrovsky, 1995).

The Morro dos Seis Lagos carbonatite in northwestern Brazil is poorly known but is reported to contain the world's largest single niobium deposit; its resources are said to be 2,900 million metric tons grading 2.85 percent $\mathrm{Nb}_{2} \mathrm{O}_{5}$ (Pollard, 1995).

Woolley and Kjarsgaard (2008) report 23 carbonatites in the United States. Of these, the Elk Creek carbonatite, which is located in the subsurface of Nebraska, is currently being evaluated. The inferred resources at the deposit are reported to be 102.6 million metric tons grading 0.638 percent $\mathrm{Nb}_{2} \mathrm{O}_{5}$ (Daigle, 2012). 


\section{Alkaline to Peralkaline Granites and Syenites}

The term "alkaline" encompasses a large variety of igneous rocks containing certain sodium- or potassium-rich minerals, such as feldspathoids and (or) alkali-rich pyroxenes and amphiboles and generally little or no quartz (Sørensen, 1974). Peralkaline rocks are a subset of alkaline rocks and are characterized by having a molecular amount of $\mathrm{Na}_{2} \mathrm{O}+\mathrm{K}_{2} \mathrm{O}$ that exceeds $\mathrm{Al}_{2} \mathrm{O}_{3}$ (termed the agpaitic index $>1$ ). Alkaline rocks can range from ultramafic to felsic and from silicaundersaturated (feldspathoid-bearing) to silica-oversaturated (quartz-bearing). They are most commonly found in intraplate settings, such as continental rift zones (for example, the East African rift zone) and oceanic islands (for example, the Azores, Hawaii, and Réunion), but they can also be found in some orogenic belts where they were emplaced after major tectonic deformation. An important feature of alkaline rocks, but particularly peralkaline rocks, is unusual and locally extreme enrichment in alkalis; HFSEs, including zirconium, niobium, titanium, uranium, yttrium, and REEs; and halogens, such as fluorine and chlorine (Salvi and Williams-Jones, 2005). As a result, alkaline igneous rocks can contain mineral deposits with high contents of HFSEs, including niobium, but they less commonly have high contents of tantalum.

Alkaline magmas are the product of low degrees of partial melting in a deep, chemically undepleted mantle (Niu and O'Hara, 2003). As a result, alkaline magmas are enriched over many other magma types in incompatible elements, including the HFSEs. These incompatible elements become further enriched as the alkaline magmas cool and crystallize, becoming concentrated in the most evolved, volatile-rich granitic and syenitic (same general composition as granite but with potassium feldspar dominant and little or no quartz $[<5$ percent $]$ ) melts and eventually forming disseminated ore minerals in the crystallized rocks. In addition, because the HFSEs form relatively dense minerals, they can accumulate into layers through crystal settling and be transported and mixed by currents or new injections of magma (Mitchell, 2005). Many alkaline igneous complexes also show extensive evidence of hydrothermal alteration, commonly with the most altered rocks also having the highest HFSE and REE contents. Although the role of fluids in the transport of HFSEs and REEs is still a matter of debate, growing evidence suggests that these elements are mobile in fluids that are enriched in fluorine, chlorine, and (or) carbon dioxide $\left(\mathrm{CO}_{2}\right)$ (Salvi and WilliamsJones, 2005). Typical ore minerals in mineralized peralkaline granites are usually niobium-rich pyrochlore and columbite.

Alkaline intrusive complexes are not currently major sources of niobium and tantalum production, although exploration is ongoing in some areas (for example, Strange Lake in Canada and Ghurayyah in Saudi Arabia). Examples of alkaline igneous complexes include the Pitinga complex in Brazil, the Strange Lake and Thor Lake complexes in Canada, the Ilímaussaq and Motzfeldt complexes in southern Greenland, the very large Lovozero complex in Russia, and the Pilanesberg complex in South Africa (fig. M5). Alkaline intrusive complexes have been identified in the United States, including Bokan Mountain in Alaska and Magnet Cove in Arkansas, but they are not known to contain significant niobium and tantalum resources of current economic interest.

The Devonian Lovozero alkaline complex on the Kola Peninsula of Russia and the adjacent Khibina complex together make up the largest peralkaline igneous intrusions in the world, covering an area of about 2,000 square kilometers $\left(\mathrm{km}^{2}\right)$. The Khibina complex is host to one of the largest phosphate resources in the world ( 2.7 billion metric tons averaging 17.5 percent phosphorus pentoxide $\left[\mathrm{P}_{2} \mathrm{O}_{5}\right]$ ), whereas the Lovozero complex hosts zirconium, niobium, REEs, yttrium, strontium, barium, and phosphorus, which occur as eudialyte (a zirconium-bearing silicate mineral), loparite, and apatite (Salvi and Williams-Jones, 2005). The Lovozero complex, which is exposed over an area of $650 \mathrm{~km}^{2}$, occurs as a trough-shaped intrusion composed of three main intrusive phases (fig. M8) (Kogarko and others, 2010). The oldest phase (phase 1), which accounts for about 5 percent of the total volume, consists of nepheline syenites with varied mineralogy, but it contains no loparite or eudialyte. The next phase, (phase II), which accounts for about 77 percent of the total volume, consists of layered nepheline syenites with varied mineralogy and locally accessory loparite or eudialyte. Loparite is concentrated up to 25 percent, by volume, in some layers (Kogarko and others, 2002). Loparite concentrate has been produced intermittently during the past 50 years; about 30,000 metric tons grading 8 percent $\mathrm{Nb}_{2} \mathrm{O}_{5}$ and 0.7 percent $\mathrm{Ta}_{2} \mathrm{O}_{5}$ has reportedly been produced annually (Semenov, 1997). The third intrusive phase (phase III), which is also known as the eudialyte complex, accounts for about 18 percent of the total volume and consists of nepheline syenites that, particularly in the upper part of the complex, can contain seams and lenses of almost monomineralic eudialyte (50 to 85 percent) (Kogarko and others, 2010).

The Mesoproterozoic Ilímaussaq alkaline complex in southwestern Greenland is one of the most studied alkaline complexes in the world (Sørensen, 2001). It is 1 of 10 alkaline intrusions in the Gardar igneous province, which is a failed continental rift that was active between 1,350 and 1,140 Ma (Upton and others, 2003). The Ilímaussaq alkaline complex is the type locality for the rock-type peralkaline nepheline syenite and also 27 minerals. It contains large concentrations of a number of rare elements, including beryllium, lithium, niobium, REEs, uranium and thorium, yttrium, and zirconium, contained in about 220 different minerals, of which 9 are unique to this complex (Sørensen, 2001). The complex covers $136 \mathrm{~km}^{2}$ and has an exposed vertical thickness of 1,700 m; its total depth is not known. The main rare-metal deposits with potentially exploitable niobium, REEs, yttrium, and zirconium are present in 29 separate eudialyte-rich layers interpreted to have formed by crystal settling (Sørensen, 2001). Cumulatively, these rocks are estimated to contain a resource of about 54 million metric tons grading 1.1 percent zirconium dioxide $\left(\mathrm{ZrO}_{2}\right), 0.09$ percent yttrium oxide $\left(\mathrm{Y}_{2} \mathrm{O}_{3}\right)$, 0.56 percent rare-earth oxides, and 0.11 percent $\mathrm{Nb}_{2} \mathrm{O}_{5}$ 


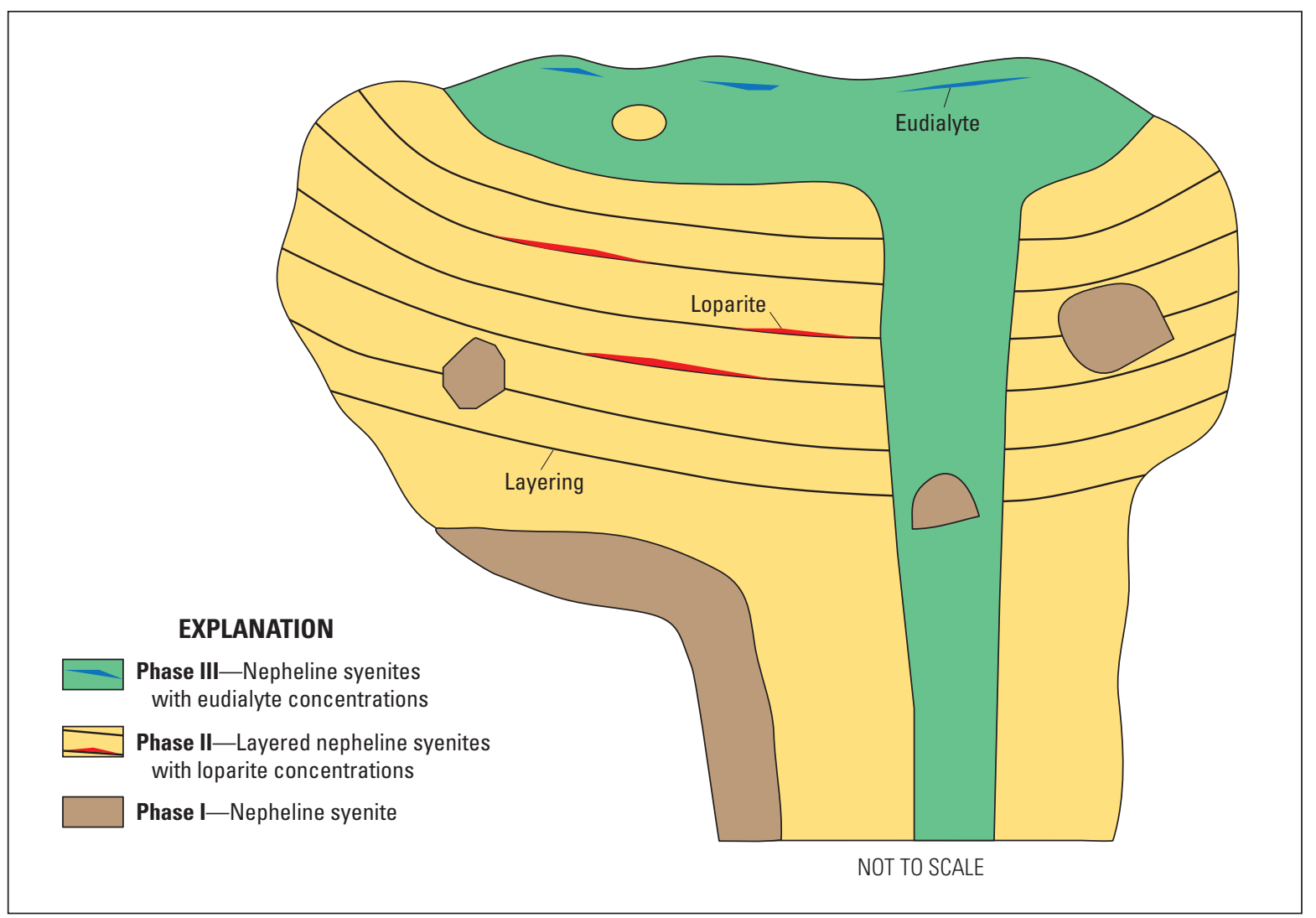

Figure M8. Schematic cross-section of the Lovozero alkaline intrusion, Kola Peninsula, Russia, showing the relation among the three intrusive phases and the niobium mineralization contained in eudialyte and loparite. After Kogarko and others (2002).

(Steenfelt, 1991). The Motzfeldt intrusion, which is another of the alkaline intrusions in the Gardar igneous province, has zones of hydrothermally altered syenite containing niobiumtantalum-REE-bearing pyrochlore mineralization (Steenfelt, 1991), which is the focus of ongoing exploration.

\section{Rare-Metal Granites and Lithium-Cesium- Tantalum-Type Pegmatites}

All economically important tantalum mineralization is related to rare-metal granites (also called rare-element granites) and lithium-cesium-tantalum (LCT)-type pegmatites. The rare-metal granites are generally peraluminous (have molecular $\left.\mathrm{Al}_{2} \mathrm{O}_{3}>\left[\mathrm{CaO}+\mathrm{Na}_{2} \mathrm{O}+\mathrm{K}_{2} \mathrm{O}\right]\right)$, muscovite- and albiterich granites that display high degrees of chemical fractionation, and represent the last stages of felsic magma evolution in upwardly differentiated granitic intrusions (Linnen and Cuney, 2005). The parental magmas are formed by partial melting of preexisting crustal rocks, particularly aluminous sediments, and are generally emplaced at shallow levels of the crust (in the upper few kilometers) during the late stages of or after major tectonic deformation and regional metamorphism in orogenic belts. They may show pervasive hydrothermal alteration and host disseminated tantalum and niobium mineralization, as well as tin and tungsten, in complex vein systems (stockworks) that developed from circulation of late-stage hydrothermal fluids. Typical mineralization consists of microlite, columbite-tantalite, tantalum-rich cassiterite (tin oxide), and lepidolite (lithium-rich mica).

LCT-type pegmatites are generally small (meters rather than kilometers in length and width) granitic intrusions characterized by extremely coarse but variable grain-size and enrichments in lithium, rubidium, cesium, beryllium, tantalum, and niobium ( $\mathrm{Ta}>\mathrm{Nb}$ ) (Černý and Ercit, 2005). They are the products of highly fractionated and volatile-rich granitic magmas generally derived from rare-metal granites. They commonly occur in aureoles surrounding the roof of their parental granite intrusion, and the mineralized and most fractionated pegmatites are found the farthest away (fig. M9). Most LCT-type pegmatites are concentrically but irregularly zoned (fig. M10), and typically have a thin border zone, a wall zone, an intermediate zone, an albite zone, and a core zone (Cameron and others, 1949; Fetherston, 2004). Tantalum mineralization is mostly concentrated in the intermediate and albite zones and generally consists of columbite-tantalite, ixiolite, microlite, and (or) wodginite. Additional mineralization may be present, including beryllium (as beryl, a beryllium aluminum silicate), cesium (as pollucite, a cesium 


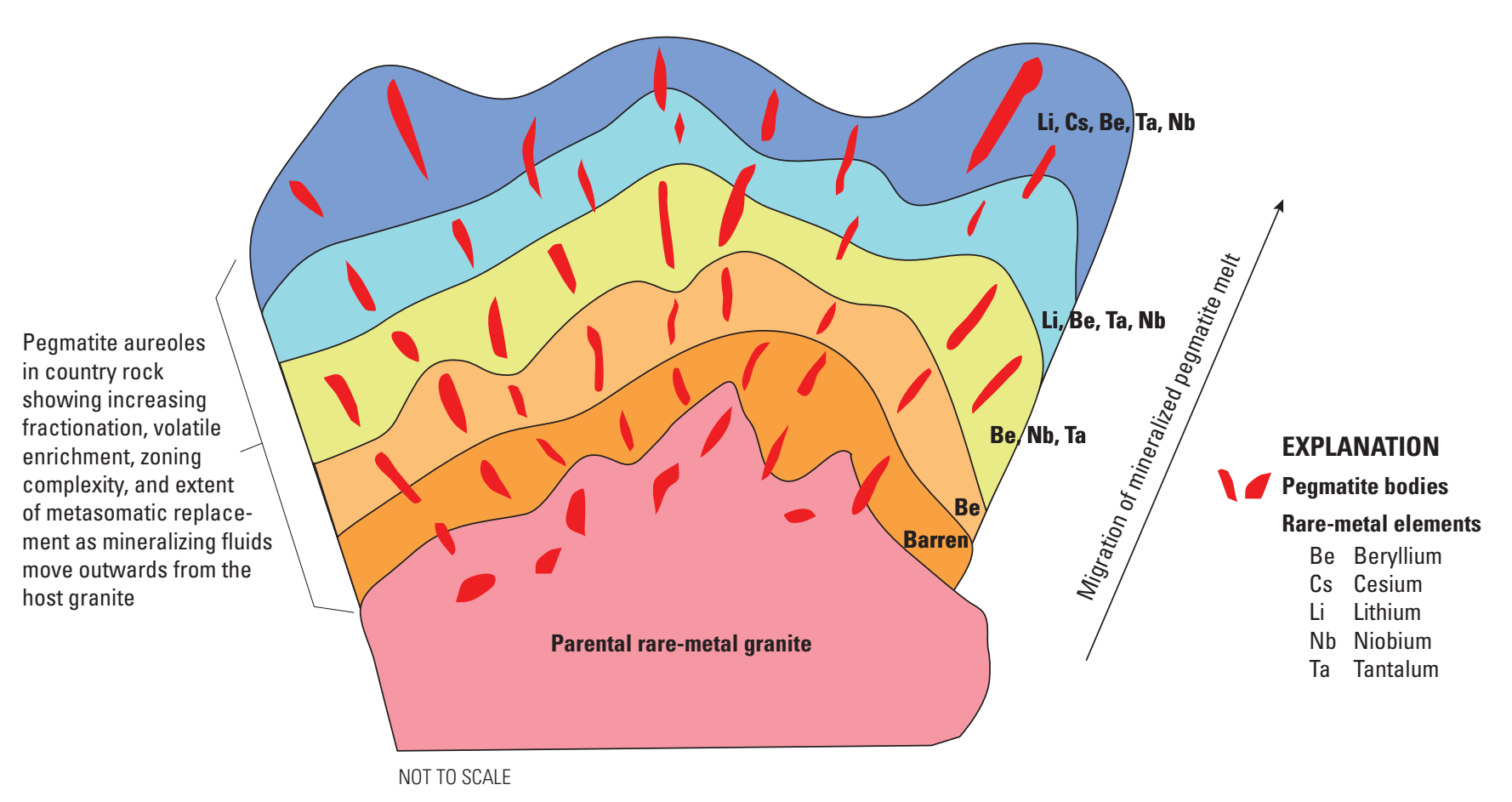

Figure M9. Schematic representation of regional lithium-cesium-tantalum (LCT) rare-metal-bearing pegmatite zoning above a parental granite. After Černý (1991b).

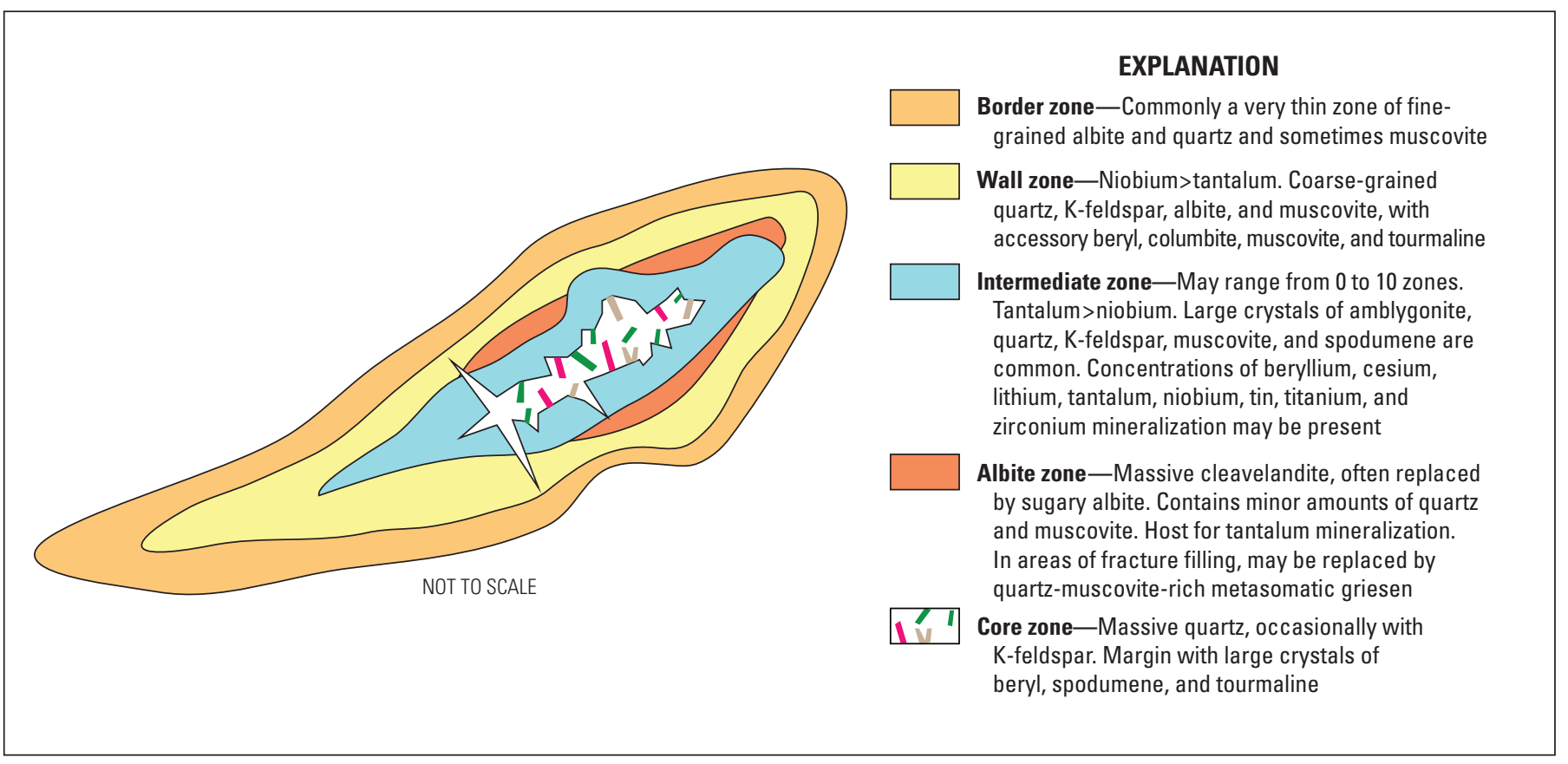

Figure M10. Schematic cross-section of a concentrically zoned lithium-cesium-tantalum (LCT) rare-metal-bearing pegmatite. After Černý (1991a) and Fetherston (2004). 
zeolite), lithium (as spodumene, a lithium pyroxene; petalite, a lithium aluminum silicate; and lepidolite), tin (as cassiterite, a tin oxide), and a number of gemstones. LCT-type pegmatites are also mined for albite, muscovite, potassium feldspar, and ultrapure quartz. Like their parental rare-metal granites, LCT-type pegmatites are widely distributed globally (fig. M5), and range in age from Archean to Mesozoic, but they are found to be concentrated particularly during times of continental collision and supercontinent assembly (Bradley and McCauley, 2013). By far the largest LCT-pegmatite-hosted mineral deposits are of Archean age, however (for example, the Greenbushes and Wodgina deposits in Australia and the Tanco deposit in Canada).

In recent years, pegmatites in the State of Western Australia, Australia, have been major world suppliers of tantalum, particularly the Greenbushes and the Wodgina Mines. The giant ( $>3 \mathrm{~km}$ long) Greenbushes pegmatite is located $250 \mathrm{~km}$ south of Perth and has been mined for tin and tantalum since 1888, and more recently also for kaolin and lithium (Partington and others, 1995). It contains the world's largest identified pegmatite-hosted tantalum resource and mining operation. The pegmatite is late Archean in age and appears to have been intruded along a crustal fault zone synchronously with deformation. Unlike many other pegmatite districts, there is no evidence for a nearby parental granite pluton for the Greenbushes pegmatite. Four major compositional zones have been identified; however, the most compositionally evolved zones (that is, the most lithium-rich) occur at the top and bottom of the pegmatite rather than at the center. Early formed tantalum minerals are mainly wodginite and ixiolite; later tantalum minerals (tantalite and tapiolite) occur within fractures, whereas microlite is related to later hydrothermal mineralization (Partington and others, 1995). The main ore zones generally occur within the more tourmaline-rich portions of albite-rich zones in the pegmatite. Most ore produced at Greenbushes since 1888 has been by open pit mining of weathered pegmatite and alluvial sources; recently, however, underground mining of hard-rock ore has also begun.

The Wodgina pegmatite district is one of more than 27 pegmatite districts located in the northern part of Western Australia, Australia; it includes the Wodgina main lode and Mount Cassiterite tantalum-mineralized pegmatites (Sweetapple and Collins, 2002). The Wodgina main lode pegmatite is a north-south-trending, easterly dipping (20 to 50 degrees) dike with a total length of about $1 \mathrm{~km}$ and a thickness ranging from 5 to $40 \mathrm{~m}$; most mining has been in the northern, thicker end. Originally discovered in 1902, the Wodgina pegmatite has intermittently produced beryl, tantalum, and tin during the past 100 years. The main tantalum mineral is manganese-rich tantalite, which, together with some manganese-rich columbite and wodginite, is found mainly in marginal cleavelandite (a platy form of albite) (Sweetapple and Collins, 2002). In the Mount Cassiterite pegmatite, which lies just south of Wodgina, wodginite is the main tantalum mineral (Sweetapple and Collins, 2002). Tantalum from both pegmatites is recovered by open pit mining. Additional tantalum-bearing pegmatites occur in Western Australia, including the producing Mount Cattlin pegmatite, as well as the Bald Hill and the Mount Deans deposits, which are under development (Fetherston, 2004).

A number of pegmatite fields are present in Africa (fig. M5). Pegmatites in Ethiopia (Kenticha) and Mozambique (Marropino) were significant tantalum producers in the 2000-13 time period (Bleiwas and others, 2015); others were undergoing exploration or development for tantalum and associated resources (for example, the Morrua and the Mutala pegmatites in Mozambique). Mining of columbite-tantalite (also called coltan) from weathered pegmatites and from secondary placer deposits derived from pegmatites in central Africa, particularly in Burundi, the Democratic Republic of the Congo (Congo [Kinshasa]), Nigeria, Rwanda, and Uganda, has been conducted mainly by artisanal family mining groups and prospectors. The Main Kenticha pegmatite in Ethiopia is a Cambrian-age intrusion exposed across a length of more than $2 \mathrm{~km}$ (Küster, 2009). The pegmatite displays asymmetric internal textural and mineral zonation with manganese-rich tantalite as well as ixiolite concentrated in the upper intermediate and core zones. The deposit also contains valuable lithium resources, although these are not currently mined. Tantalum production has been from deeply weathered regolith over the pegmatite; however, exploration drilling of the hard-rock pegmatite is being conducted to evaluate the size of the primary mineralization (Küster, 2009). To the south of Kenticha, the Alto Ligonha pegmatite province in Mozambique contains numerous mineralized pegmatites, which have been mined intermittently since 1926. Tantalum concentrate was produced from ore from the Marropino Mine, concessions were held for the Morrua and Mutala deposits, and exploration was ongoing in adjacent areas. In Egypt, rare-metal granites were the focus of ongoing exploration and development activities, including the Abu Dabbab and Nuweibi granites (Küster, 2009). These deposits consist of fine-grained columbite-tantalite minerals disseminated throughout the granite intrusions. In addition, these intrusions host tin mineralization and ceramic-grade feldspar (Bleiwas and others, 2015).

In China, the Yichun tantalum-niobium-lithium deposit is the leading tantalum producer, accounting for more than one-half of China's tantalum output (Fetherston, 2004). The deposit is in a small, sheet-like rare-metal granite that represents the most fractionated and youngest phase of the Jurassic Yanshan granite intrusion (Yin and others, 1995). The main tantalum minerals in this deposit are columbite-tantalite and tantalum-rich cassiterite along with minor microlite. The 801 Mine, which is located in the eastern part of the Inner Mongolia Autonomous Region about $640 \mathrm{~km}$ northeast of Beijing, is reported to have large resources of niobium, REEs, tantalum, and zirconium (Fetherston, 2004). Additionally, pegmatites in the Altai region of northwestern China and in the Nanping region of southeastern China have also produced columbite-tantalite. 
In South America, the Volta Grande pegmatite mine located near the city of Nazareno in the State of Minas Gerais, Brazil, is a significant supplier of lithium, niobium, and tantalum. The main deposit is in a large, about $1-\mathrm{km}-$ long, subhorizontal, zoned albite-spodumene pegmatite body of Paleoproterozoic age (Lagache and Quéméneur, 1997). Cassiterite, microlite, and tantalite are the main tantalum-niobium-bearing minerals. A distinctive feature of pegmatites in the Volta Grande district is that they are exceptionally enriched in lithium and rubidium (Lagache and Quéméneur, 1997).

The only pegmatite mine in North America producing tantalum in the 2000-13 time period was the Tanco deposit at Bernic Lake in southeastern Manitoba, Canada (Bleiwas and others, 2015). Operated briefly as a tin mine beginning in 1929, tantalum production began only in 1969 . Full-scale mining to produce lithium from spodumene (the underground mine's major product), along with cesium, rubidium, and tantalum, began in 1984. Tanco is part of the rare-metal-bearing Bernic Lake pegmatite group, which intrudes metamorphosed Archean volcanic rocks. The Tanco pegmatite occurs as a shallowly dipping sheet that is up to about $100 \mathrm{~m}$ thick and can be traced for about 1,600 $\mathrm{m}$ along strike. The pegmatite consists of nine zones, each of which has a different mineralogy, texture, and location, as well as a halo of altered mafic host rock. The deposit has a very complex mineralogy_more than 80 minerals are present, including 14 tantalum-bearing minerals (Černý, 2005). Wodginite is the principal ore mineral, and it occurs mainly in a zone lying below the quartz core (Grice and others, 1972). Numerous other tantalum-bearing pegmatites have been identified in Ontario and Manitoba (Selway and others, 2005); several were undergoing evaluation of their tantalum and associated resources. In the United States, niobium-tantalum minerals, chiefly columbite, were recovered intermittently from a number of pegmatites in the past (Barton, 1962). The Harding pegmatite in New Mexico, which is a complexly zoned lithium- and beryllium-bearing pegmatite, was an important source of tantalum briefly during World War II and supplied about 3 metric tons of microlite concentrate (Parker and Adams, 1973). There has been no reported tantalum mine production in the United States since 1959.

\section{Resources and Production}

Data on global reserves and resources of niobium and tantalum are fragmentary and incomplete (Crockett and Sutphin, 1993). Identified resources of niobium and tantalum are large, however, and are estimated to be more than sufficient to meet global demand for possibly the next 500 years (British Geological Survey, 2011). The specificity and accuracy of worldwide data for measured, indicated, and inferred resources and (or) proven and probable reserves vary widely. In general, the most accurate data are available only for individual mines or deposits, particularly those in Australia, Brazil, and Canada. Even in these cases, however, it is uncertain how reliable the national resource estimate totals are. In addition, some world demand for tantalum, and to a lesser extent, niobium, is met by production of these elements as byproducts of tin mining and metallurgy. Accurately measuring and classifying niobium and tantalum resources within the tin sector is difficult and has not been attempted (Crockett and Sutphin, 1993).

\section{Niobium Reserves and Other Identified Resources}

The current identified resources of niobium are located predominantly in Brazil (about 95 percent) and Canada (about 3.5 percent) (fig. M11) (British Geological Survey, 2011; Papp, 2013b). Additional (though less well reported) resources are located in Angola, Australia, China, Greenland, Malawi, Russia, South Africa, and the United States. The largest niobium resources are hosted by carbonatite complexes in Brazil. Resources in alkaline granite or syenite complexes are widespread and can be large, but they are generally lower in grade than carbonatite-hosted deposits (fig. M6). In addition, these deposits tend to have more complex geology and

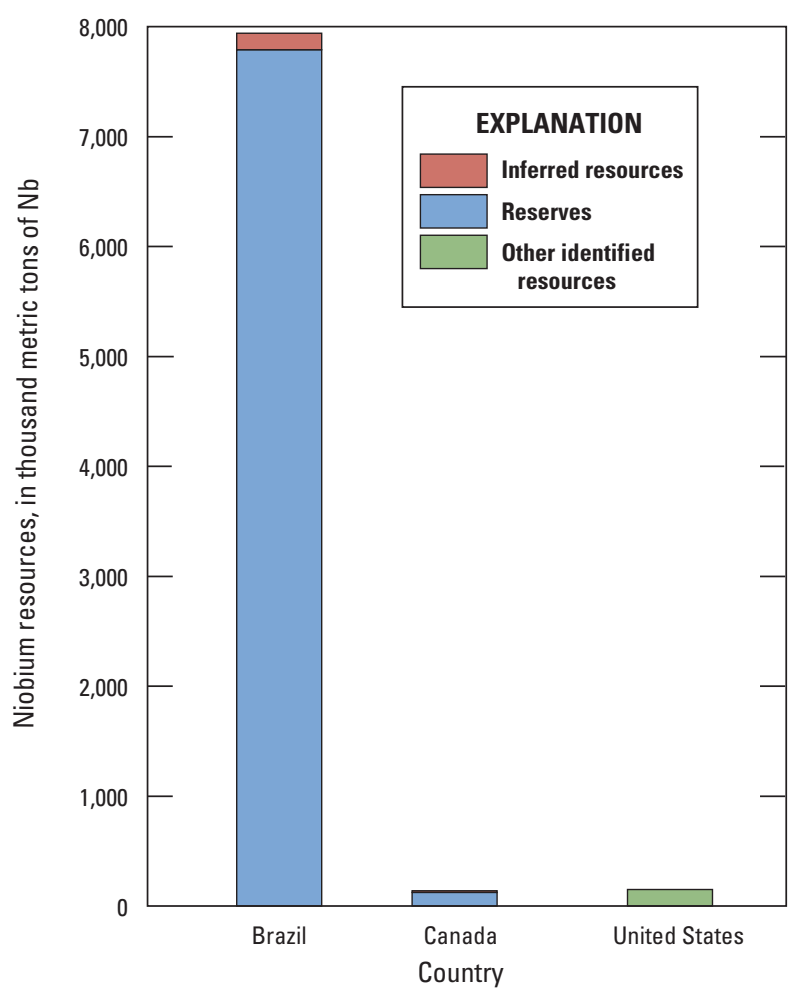

Figure M11. Bar chart showing niobium (Nb) resources and reserves in Brazil, Canada, and the United States, in thousand metric tons of $\mathrm{Nb}$ (British Geological Survey, 2011, p. 18). 
mineralogy than do carbonatites, which can affect the ease with which the niobium could be recovered.

The United States is estimated to have about 150,000 metric tons of niobium resources; these resources are associated primarily with carbonatites and alkaline intrusive complexes and, to a lesser extent, with pegmatites (Parker and Adams, 1973). The resources in the United States are all considered to be subeconomic at current niobium prices (Papp, 2013b).

\section{Tantalum Reserves and Other Identified Resources}

Tantalum resources are more widespread than those of niobium. Brazil has the largest share of global resourcesabout 106,000 metric tons of contained tantalum, which accounts for approximately 40 percent (fig. M12); the remaining 60 percent of identified tantalum resources occur in, in decreasing order of tonnage, Australia (about 54,000 metric tons), China and Southeast Asia (about 27,000 metric tons), Russia and the Middle East (about 26,000 metric tons), central Africa (about 23,000 metric tons), other Africa (about 17,500 metric tons), North America (about 4,500 metric tons), and Europe (about 1,900 metric tons). Tantalum resources in Brazil are principally associated with large pyrochlore deposits in carbonatite complexes and in the Volta Grande pegmatite district, whereas those in Australia are principally hosted by LCT-type pegmatites.

The United States has about 1,500 metric tons of identified tantalum resources, all of which are considered

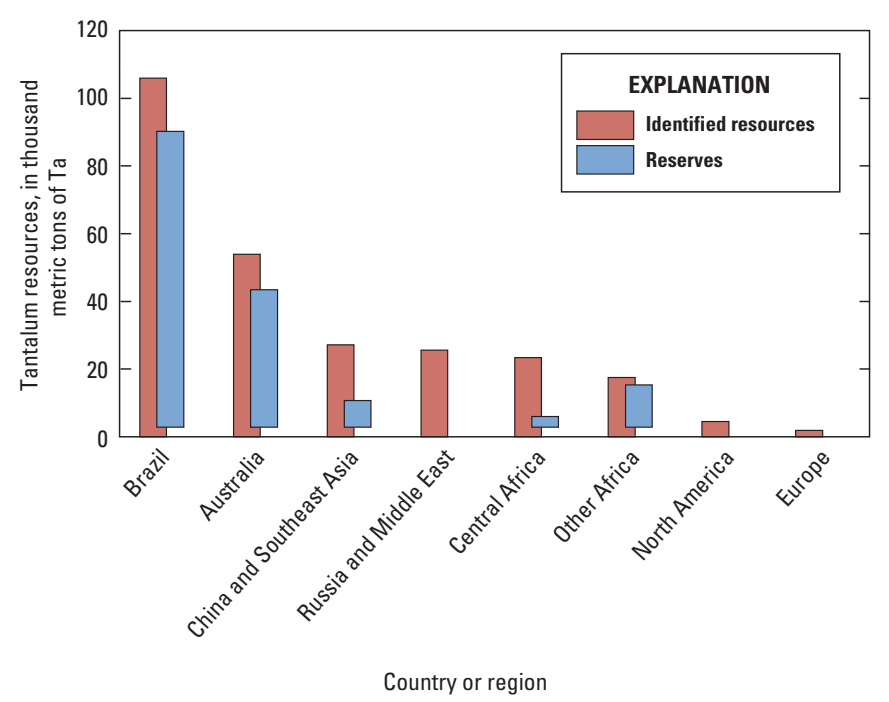

Figure M12. Bar chart showing global tantalum (Ta) resources and reserves, in thousand metric tons of Ta (British Geological Survey, 2011, p. 19). subeconomic (Papp, 2013c). These resources are primarily hosted in numerous LCT-type pegmatite districts around the country (Bradley and McCauley, 2013).

\section{Undiscovered Niobium and Tantalum Resources}

Additional niobium and tantalum resources are contained in undiscovered deposits around the world. Some of these are likely to occur in more remote or covered areas, potentially making for more challenging and expensive exploration and mining. Many of the 527 known carbonatite complexes worldwide (Woolley and Kjarsgaard, 2008) have not been fully explored and may contain undiscovered mineralization. These complexes are particularly abundant in southern Africa, parts of Asia, Brazil, Canada, and Russia (Woolley and Kjarsgaard, 2008). These same areas also commonly host alkaline granite and syenite complexes, many of which also remain to be more fully explored. A number of carbonatites and alkaline intrusions are currently undergoing exploration activity because of recent efforts to find new sources of REE resources (Long, 2011).

Most of the identified carbonatites in the United States are currently known to have only low grades of niobium (Berger and others, 2009). An exception may be the Elk Creek carbonatite in Nebraska, which has inferred niobium resources of 102.6 million metric tons grading 0.638 percent $\mathrm{Nb}_{2} \mathrm{O}_{5}$ (Daigle, 2012). Alkaline intrusions are widespread and occur in the Appalachian Mountains and the Ouachita Mountains, in west Texas, throughout the Rocky Mountain region, and in parts of Alaska (Barker, 1974). Additional alkaline granite-syenite intrusions have been identified in central Wisconsin and the Black Hills of South Dakota. Although most of these intrusions are not known to have significant niobium or tantalum mineralization, they have not all been fully explored. An exception is the Magnet Cove complex in southern Arkansas, which has a central carbonatite with niobium-rich perovskite but overall low grades (Morris, 1987). The Bokan Mountain alkaline granite intrusion in southern Alaska is being explored for REEs and uranium (Long and others, 2010). In addition, the Kougarok tin-bearing granite in the Seward Peninsula of Alaska is being evaluated for its tantalum resources. Archean rocks that could host giant LCT-type pegmatite deposits have limited occurrence in the United States, and are found mostly in northern Michigan, Minnesota, and Wyoming. Major pegmatite fields are not known in these areas, although exposures of rocks are limited in Michigan and Minnesota by glacial cover. Exploration of LCT-type pegmatites, such as those in the Appalachian Mountain and the Black Hills regions, have resulted in only subeconomic tantalum resources. 


\section{Niobium and Tantalum Production}

\section{Niobium}

World mine production of niobium rose steadily from approximately 25,000 metric tons of elemental niobium in 2000 to more than 60,000 metric tons of niobium in 2008 , and it has remained fairly steady since then (fig. M13A). The increase between 2000 and 2008 is largely linked to increased consumption of microalloyed steel, which is used in the manufacture of cars, buildings, ships, and refinery equipment. Increased demand for these steels reflects in large part industrial development in such countries as Brazil, China, and India in that time period. In addition, increased demand for mobile telephones, superconducting magnets, and other hightech devices has helped spur niobium production. Brazil and Canada have been the leading nations that produce niobium mineral concentrates, with Brazil by far the leading producer (fig. M14A). The leading companies that produced niobium ore and concentrates were Companhia Brasileira de Metalurgia e Mineração (CBMM) (Araxá Mine), Anglo American Brazil Ltd. (Catalão Mine), and Companhia Industrial Fluminense Mineração S.A. (Volta Grande Mine) in Brazil, and IAMGOLD Corp. (Niobec Mine) in Canada. Other countries, including Burundi, China (Yichun Mine), Ethiopia (Kenticha Mine), Nigeria, Russia (Lovozero Mine), Rwanda, and Uganda, also produced niobium mineral concentrates in 2011.

The leading niobium producers process the ore to make ferroniobium $(\mathrm{FeNb})$ or niobium pentoxide $\left(\mathrm{Nb}_{2} \mathrm{O}_{5}\right)$, which is then shipped to consumers. Other niobium mining operations ship niobium mineral concentrates to processing companies. The ore is crushed and ground, beneficiated by flotation and magnetic separation (to remove iron minerals) to produce a pyrochlore mineral concentrate grading 55 to 60 percent $\mathrm{Nb}_{2} \mathrm{O}_{5}$. Columbite and tin slags account for a minor amount of niobium production. Artisanal mining of columbite-tantalite (coltan) is carried out in central Africa, particularly in Burundi, Congo (Kinshasa), Nigeria, Rwanda, and Uganda.

\section{Tantalum}

Global tantalum mine production peaked in 2004 at just greater than 1,400 metric tons of elemental tantalum and mostly declined since 2006 to 770 metric tons in 2011 (fig. M13B). The decrease in tantalum production reflects the drop in tantalum prices that accompanied the global economic downturn and the increased volume of tantalum coming out of areas of armed conflict in Congo (Kinshasa). Australia and Brazil have been the leading national producers of tantalum mineral concentrates (fig. M14B), although since 2009, production from Australia has decreased, and production from Mozambique and some other countries has increased (Papp, 2013a). The leading companies producing tantalum mineral concentrates in 2011 were Companhia Industrial Fluminense Mineração S.A. (Volta Grande Mine) and Mineração Taboca S/A (Pitinga Mine) in Brazil and Noventa Ltd. (Marropino Mine) in Mozambique. The leading tantalum producer in other years was Global Advanced Metals from its Greenbushes and Wodgina Mines in Western Australia. Other countries, including Burundi, Canada (Tanco Mine), China (Yichun Mine), Congo (Kinshasa), Ethiopia (Kenticha Mine), Nigeria, Russia (Lovozero Mine), Rwanda, and Uganda also produced tantalum mineral concentrates in 2011.

About one-half of all tantalum production consists of tantalite ore, and the remainder comes from tin slag, from such other minerals as strüverite and columbite-tantalite, and from recycling and synthetic concentrates. Tin slag is produced primarily in Southeast Asia, Australia, and Brazil. Tantalum is mined from both open pit and underground operations. Heavy minerals that contain tantalum are separated from the bulk ore by gravity methods and flotation. The concentrate is then subject to electrical (electrostatic and [or] electromagnetic) separation and other methods used to separate tantalum minerals from other heavy minerals. Because most mining of tantalum recovers minerals that also contain niobium, a chemical processing step involving the addition of potassium fluoride is necessary to separate niobium from tantalum, resulting in compounds of $\mathrm{Nb}_{2} \mathrm{O}_{5}, \mathrm{Ta}_{2} \mathrm{O}_{5}$, potassium niobium fluoride $\left(\mathrm{K}_{2} \mathrm{Nb}_{2} \mathrm{~F}_{5}\right)$, and potassium tantalum fluoride $\left(\mathrm{K}_{2} \mathrm{Ta}_{2} \mathrm{~F}_{5}\right)$. The tantalum compounds are then smelted to make tantalum metal products (Roskill Information Services Ltd., 2012). The global supply of tantalum historically has been 70 percent from concentrates, 10 percent from tin slag, and 20 percent from recycling and synthetic concentrates (Schwela, 2010). Conventional mining accounted for 51 percent of the world's tantalum supply in 2011, artisanal mining accounted for 29 percent, and tin slags and synthetic concentrates accounted for 10 percent (Roskill Information Services Ltd., 2012). 

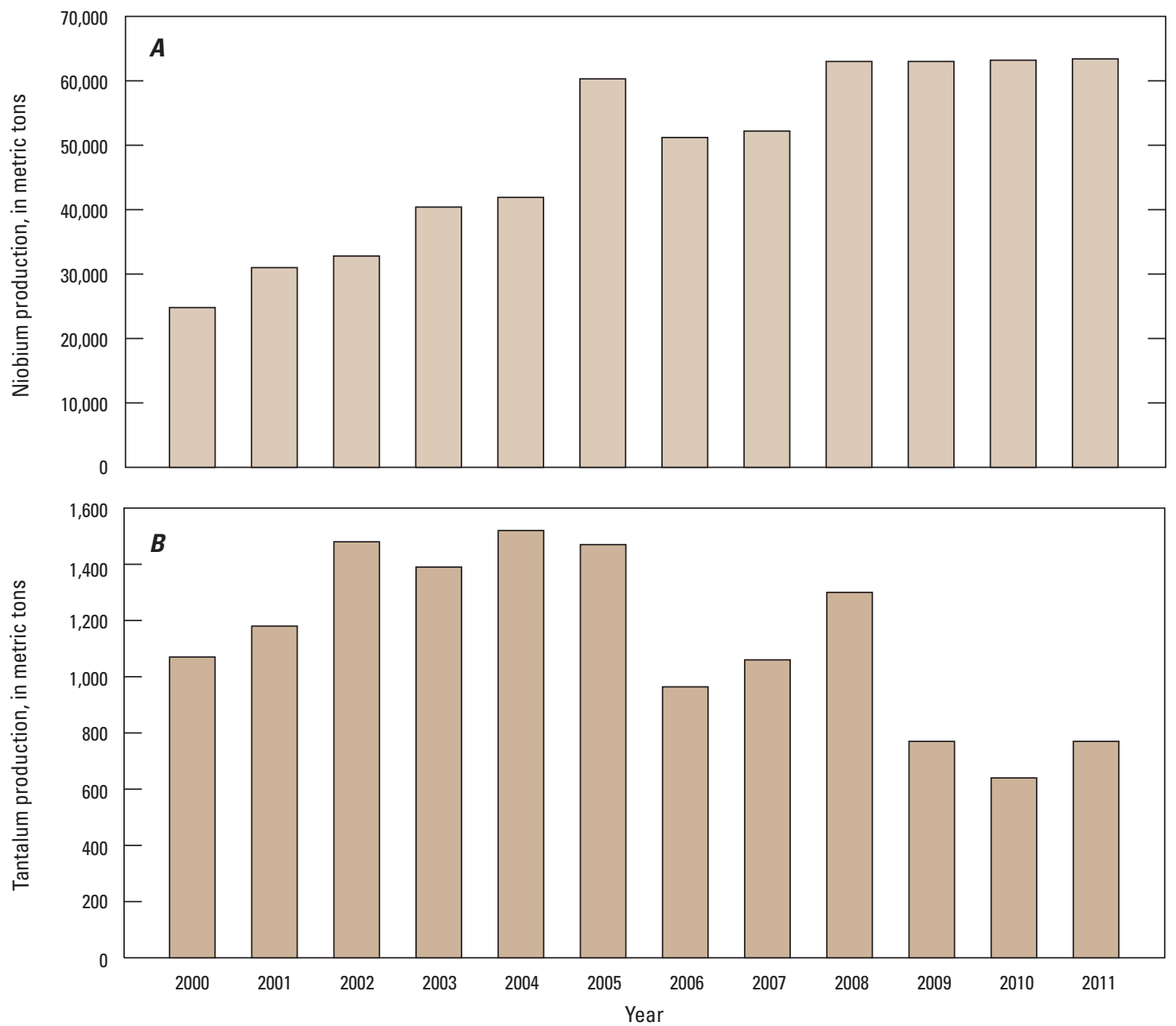

Figure M13. Bar charts showing global mine production of $A$, niobium, and $B$, tantalum, from 2000 to 2011, in metric tons of contained niobium and tantalum (Papp, 2013a).

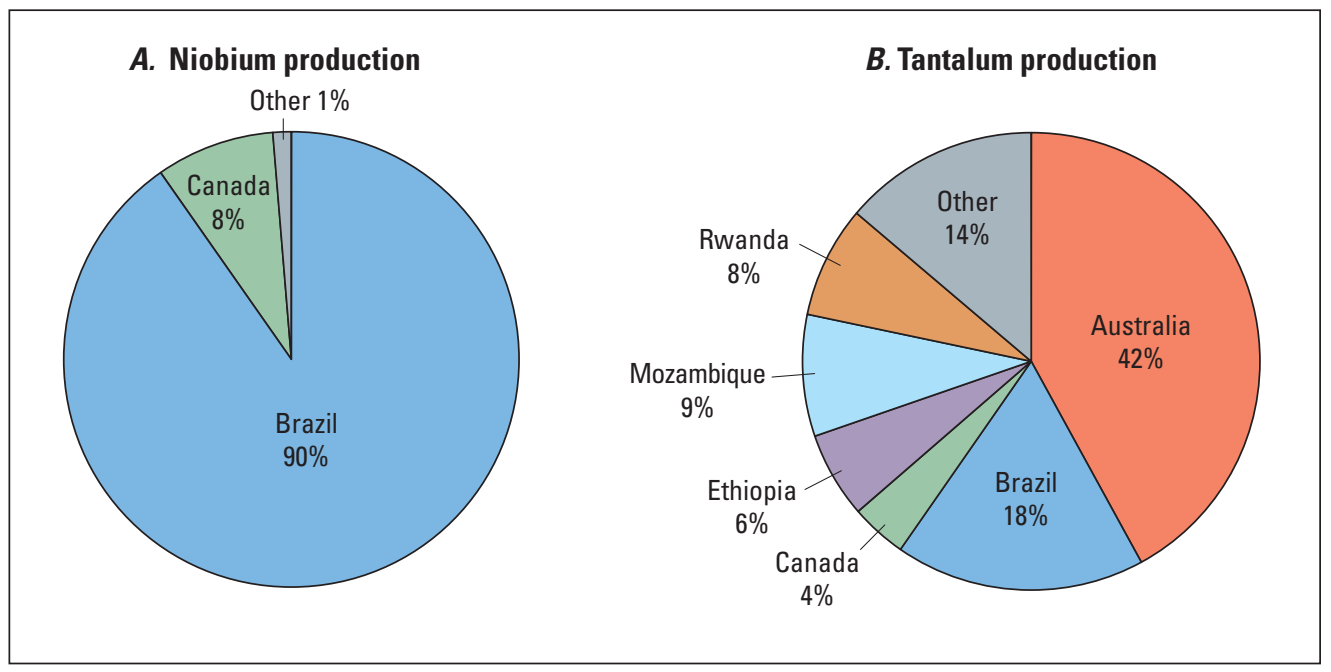

Figure M14. Pie charts showing percentage of average annual world production of $A$, niobium, and $B$, tantalum, for the period 2007-11, by country (Papp, 2013a). Australia and Canada had no reported tantalum production in 2010. The data for Ethiopia are for 2007 only. Percentages have been rounded to no more than two significant figures and do not add to 100 . 


\section{Exploration for New Deposits}

Carbonatites are an important exploration target because of their potential to host large, commonly bulk-minable niobium (with lesser amounts of tantalum) resources. About 80 percent of carbonatites are associated with silicate rocks, the majority of which are highly alkaline (Woolley and Bailey, 2012). Not all alkaline complexes and provinces contain carbonatites, however. Carbonatites are preferentially concentrated in Precambrian terranes and are associated with intracontinental rifts, such as the East African rift system (Bailey, 1974). Their common circular plan and concentric arrangement of alkaline rocks can be identified and mapped by standard geologic-mapping techniques in areas with surface rock exposures. In remote areas and covered areas, geophysical surveys, including magnetic, gravity, and electrical methods, play a critical role in exploration. The natural association of carbonatites with uranium, thorium, and potassium also makes airborne radiometric surveys a useful exploration tool. Once a target has been identified, conventional exploration procedures are used in evaluating niobium and tantalum resources, including detailed ground geophysical surveys, and trenching, drilling, and chemical analysis. Niobium and tantalum minerals typically are not easily identified and can require laboratory analysis for confirmation. In addition, the insoluble and refractory character of niobium and tantalum can require special analytical methods.

LCT-type pegmatites generally occur along large regional-scale faults in low to moderately metamorphosed terranes with mafic volcanic and sedimentary host rocks (Selway and others, 2005). The largest deposits are in Archean crust. Initial exploration typically involves a search for rare-metal peraluminous granite intrusions that can serve as the source of pegmatites. Rare-metal granites are identified by (a) high rare-metal contents (which are at least three times the average crustal abundances); (b) magnesium to lithium (Mg:Li) ratios less than 10; and (c) niobium to tantalum (Nb:Ta) ratios less than 8 (Selway and others, 2005). These granites are also characterized by white potassium feldspar, green coarse-grained mica, and distinctive accessory minerals (such as cordierite, fluorapatite, garnet, and (or) tourmaline). Rare-metal pegmatites may be found in an aureole above the granite, with the most enriched pegmatites generally the farthest (up to $10 \mathrm{~km}$ ) from the granite body. Altered country rocks can be an indication of rare-metal pegmatite bodies nearby and may contain elevated contents of boron, cesium, fluorine, lithium, and rubidium that are detectable in geochemical surveys. Pegmatites with potential to host a tantalum deposit generally have low $\mathrm{Nb}$ :Ta ratios $(<8)$ and tantalum to tin (Ta:Sn) ratios of $>1$ in bulk analyses, as well as abundant tantalum-rich oxide minerals. As with carbonatites, radiometric surveys can aid in exploration for LCT-type pegmatites.

\section{Environmental Considerations}

\section{Sources and Fate in the Environment}

The main sources of niobium and tantalum in the environment are geologic, mostly as a result of the weathering of rocks, but a potential anthropogenic source of both is from the combustion of coal (Divine and Goering, 2004; Goering and Ziegler, 2004). Tantalum compounds are less mobile than niobium compounds, which are slightly soluble under both acid and alkaline conditions and in the presence of organic complexing agents (Kabata-Pendias and Mukherjee, 2007). Gaillardet and others (2003) reported worldwide average dissolved concentrations in river waters of 2 parts per trillion (ppt) niobium and $1 \mathrm{ppt}$ tantalum. Globally, the average concentration in suspended sediments in rivers is $13.5 \mathrm{ppm}$ for niobium and $1.3 \mathrm{ppm}$ for tantalum (Viers and others, 2009). Also, surface (0 to 5 centimeters depth) soils from the conterminous United States contain an average of $9.3 \mathrm{ppm}$ niobium and range from less than $1 \mathrm{ppm}$ to $80.1 \mathrm{ppm}$; values for tantalum were not reported (Smith and others, 2013).

The concentrations of some elements may be naturally enriched in soils, sediments, and waters in the vicinity of niobium and tantalum deposits before mining begins; knowledge of these geochemical anomalies is used as an exploratory tool as well as to set realistic remediation goals after mining. The geochemical signatures around the deposits depend on the type of deposit and the compositions of associated rocks. Stream water and groundwater near deposits may not display the same geochemical signature as soils and stream sediments because some of the enriched elements occur in relatively stable insoluble minerals. In general, soils derived from various alkaline rock types commonly contain increased levels of niobium (up to $300 \mathrm{ppm}$ ) (Ure and others, 1979). The niobium in the soils can be taken up by plants, such as in the Gumi region of Russia where the niobium content (up to $10 \mathrm{ppm}$ ) of certain plant species has served as an exploration indicator for niobium deposits (Kabata-Pendias and Pendias, 2001). Soils and weathered rock associated with carbonatite deposits may be naturally enriched in $\mathrm{Fe}, \mathrm{Ba}, \mathrm{Nb}, \mathrm{P}, \mathrm{Th}, \mathrm{Ti}, \mathrm{U}, \mathrm{Zr}$ and REEs. Additionally, stream sediments downstream from deposits commonly contain anomalous abundances of $\mathrm{Ba}, \mathrm{Nb}, \mathrm{Th}$, and REEs (Modreski and others, 1995). LCT-type pegmatite deposits may exhibit enrichments in $\mathrm{B}, \mathrm{Cs}, \mathrm{F}, \mathrm{Li}$, and $\mathrm{Rb}$ in surrounding soils and waters because these elements tend to alter country rock during pegmatite emplacement (Bradley and McCauley, 2013). For example, the Tanco pegmatite in Canada has alteration halos of $\mathrm{Li}$ and $\mathrm{Rb}$ over the buried deposit (Trueman and Černý, 1982). In addition, Smith and others (1987) reported that zones of enriched As, Be, Sb, and $\mathrm{Sn}$, and of $\mathrm{B}, \mathrm{Nb}$, and $\mathrm{Ta}$ are found in lateritic soils around the Greenbushes pegmatite. 
Globally, niobium metal is one of 18 elements with a greater than 50 percent end-of-life recycling rate, which is the proportion of the element in a discarded product that is able to be used to generate a new product. In contrast to niobium, less than 1 percent of discarded tantalum metal or alloy is used to generate a new product worldwide. Tantalum is used in small quantities in complex products, such as electronics, which makes recycling technically difficult. To recover more tantalum from consumer products, additional separation in the collection and presorting of the electronics would need to be done (Graedel and others, 2011). The recycled content of products containing niobium and tantalum is high, at greater than 50 percent for niobium and between 10 and 25 percent for tantalum (Graedel and others, 2011). According to Papp (2013a), scrap recovery specifically for niobium was negligible, but significant amounts of niobium were recycled from niobium-bearing steels and superalloys. Tantalum was recycled mostly from new scrap generated during the manufacturing of cemented carbide, electronics, and superalloys.

\section{Mine Waste Characteristics}

Mine waste is generally considered to be the material generated during ore extraction and processing at the mine site that has no economic value. The volume and characteristics of the waste materials depend on the type of deposit and its size, the mineral commodity or commodities recovered, and the mining and processing methods used. Niobium and tantalum ores are treated similarly and commonly are crushed and ground before mineral separation, which may involve dry and wet gravity separation, dry screening, magnetic separation, flotation, acid leaching, and, sometimes, smelting, to remove impurities and concentrate the niobium and (or) tantalum. The removal of overburden and ore extraction and processing operations generate waste rock, tailings, and slag, which are commonly disposed of on site in dumps or in tailings ponds. The amount of waste produced at the mine sites may be significant relative to the amount of niobium or tantalum recovered because of the low grades of the ores; however, the recovery of additional commodities can reduce the waste volume.

The mining and processing of niobium and tantalum deposits commonly generates various types of waste, some with unique compositions. One example of mine waste generated from an LCT-type pegmatite deposit is waste from the Greenbushes Mine in Australia where the various ore minerals are extracted and processed separately to recover either lithium or tin and tantalum. Processing the tin-tantalum ores generates tailings composed mainly of gangue minerals (that is, predominantly quartz and feldspars). Minor amounts of antimony and sulfides are removed by flotation and roasting, and smelting is done to separate the tantalum from the tin (Fetherston, 2004); these processes create tailings and slag waste. In addition, overburden rock consisting predominantly of quartz ( 35 to 45 percent) and kaolinite ( 35 to 60 percent) is used to cover waste rock dumps to aid in rehabilitation (Hearman and Hinz, 2004).

Another example of the variety of waste generated from processing LCT-type pegmatite ore is the waste from the underground Tanco Mine in Manitoba, Canada. At this site, tantalum is processed by gravity concentrations, spodumene is processed mainly by flotation, and pollucite is treated chemically. The wastes generated include tailings and waste rock that are generally composed of the predominant gangue minerals of feldspar and quartz. For comparison to the LCT-type pegmatite deposits, mine waste generated from exploiting niobium-enriched carbonatites is usually some combination of the following common gangue minerals: amphiboles, ankerite, apatite, calcite, dolomite, magnetite, micas, pyroxenes, and olivine, among others. Mine waste from one processing step at the Araxá Mine in Brazil is predominantly hematite and magnetite; trace amounts of anatase, apatite, barite, and sulfides are likely present (Silva and others, 2012). Similar to ore from the Araxá Mine, niobium ores from the Niobec Mine in Quebec, Canada, are extracted and processed in several steps, and each generates waste of a different composition. Flotation and desliming generates carbonate-rich tailings; magnetic separation generates magnetite waste; and additional flotation generates a sulfide waste containing pyrite (Fetherston, 2004).

In general, tailings and waste produced from niobium and tantalum deposits may contain significant concentrations of uranium and (or) thorium and their daughter radionuclides. For example, tailings from the Jos area of Nigeria contain up to 4 weight percent thorium and up to 0.2 weight percent uranium (Funtua, 2001). The smelting and some chemical processes (acid leaching) of niobium ores from two operations in Brazil significantly enrich the waste in radionuclides; however, the prior physical processing (that is, magnetic separation, desliming, and flotation) of these particular ores does not significantly alter the radionuclide content of the waste compared with that of the ore (Pires do Rio and others, 2003). Also, the chemical treatment of phosphate ores from carbonatite deposits in Brazil (for example, Araxá, Catalão, and Tapia) generates waste with high radioactivity (concentrations of up to hundreds of kilobecquerels per kilogram of radium as ${ }^{226} \mathrm{Ra}$ ) (Paschoa, 1998). Although the activities of uranium and thorium in ore from the Greenbushes Mine in Australia are generally low (less than 60 becquerels per kilogram $(\mathrm{Bq} / \mathrm{kg}$ ) of uranium and less than $5 \mathrm{~Bq} / \mathrm{kg}$ of thorium), processing the ore may generate enriched waste and concentrates, such that tantalum products contain from 7.5 to 75 kilobecquerels per kilogram $(\mathrm{kBq} / \mathrm{kg})$ of uranium and thorium (Cooper, 2005). The volume of radionuclide-enhanced waste generated at the mine sites can be significant, such as at the Pitinga tintantalum-niobium mine in Brazil, where at least 10,000 metric tons of naturally occurring radioactive wastes are disposed of every year (Paschoa, 1998). 


\section{Human Health Concerns}

Niobium and tantalum are generally considered nonessential for humans and have low toxicity (Reimann and de Caritat, 1998). Because of their relative biological inertness, both, but in particular tantalum, are used in a variety of medical devices and surgical implants (Divine and Goering, 2004; Kabata-Pendias and Mukherjee, 2007). Tantalum is absorbed only minimally by the human body from oral or inhalation exposure; nearly all the tantalum that enters the human body is eliminated within a relatively short period of time. Humans exposed to large amounts of tantalum metal or to its oxide dusts may experience eye and skin irritation. Also, there is some evidence that tantalum can cause tumors (Divine and Goering, 2004). The permissible exposure limits in the United States for tantalum metal and oxide dust for an 8-hour work day is 5 milligrams per cubic meter $\left(\mathrm{mg} / \mathrm{m}^{3}\right)$ and is based on lung irritation (Occupational Safety and Health Administration, 2013). Although data are sparse and studies on humans lacking, niobium is likely similar to tantalum in that its retention time in the human body is usually relatively short, and much of it is eliminated unabsorbed (Goering and Ziegler, 2004). Studies have shown, however, that small mammals that ingested niobium compounds in drinking water had a shortened lifespan. Niobium has been shown to be associated with tumors, but is not mutagenic (Goering and Ziegler, 2004, and references therein). Niobium is considered hazardous by the Occupational Safety and Health Administration (OSHA), but OSHA has not established a permissible exposure limit for niobium dust (Occupational Safety and Health Administration, 2013).

Although niobium and tantalum may not be the cause of significant human health concerns, industrial exposure to naturally occurring radioactive materials from enhanced levels of thorium and uranium during the processing of niobium and tantalum ores may be a concern. Occupational exposure can take place from external radiation and from inhaling and ingesting radioactive particles generated during mining and milling. Smokers, who inhale twice or more the amount of radon than do nonsmokers, have an increased risk for exposure (Mangset and Sheyin, 2009). In Congo (Kinshasa), the grinding and sieving of columbite-tantalite ores during artisanal mining has been shown to expose workers to high doses of radioactivity (Mustapha and others, 2007).

Humans living near mining and processing operations may also be exposed to technically enhanced naturally occurring radioactive materials. Exposure may be a concern from waste materials used for building construction and from drinking water or eating foods contaminated with radiation. Slag and acid-leaching wastes (mostly barium sulfate) disposed of in alternating layers in waste dumps at a niobium processing facility in Brazil yielded higher radionuclide concentrations than did ores and other waste materials, and doses associated with them exceed international exposure guidelines. Also, the doses of radiation from treated effluent and drainage from waste ponds were lower than local limits but higher than some international exemption levels (Pires do Rio and others, 2003). In Nigeria, mining tin, tantalum, and niobium from placer deposits and weathered granites has resulted in large amounts of radioactive tailings dumped in and around mine sites (Funtua, 2001). The activities of radionuclides of radium and thorium in tin tailings, especially those containing significant monazite and zircon, and soils $500 \mathrm{~m}$ from the tailings were higher than background activities, and the estimated annual effective doses to the population were much higher than the recommended levels (Usikalu and others, 2011). In addition to being radioactive, tin-niobium-tantalum tailings from the Jos area of Nigeria contained concentrations of lead, manganese, and tin that exceeded soil screening levels based on residential and industrial use in the United States; these levels are used to determine whether contamination at hazardous waste sites warrant further investigation or site cleanup (Funtua, 2001; U.S. Environmental Protection Agency, 2012). After operations have ended at niobium and tantalum mines and processing sites, the use of the land may need to be restricted to minimize human exposure to radiation and high concentrations of some trace elements.

\section{Ecological Health Concerns}

Ecological health concerns associated with niobium and tantalum are generally minimal under most naturally occurring conditions. Niobium may accumulate in plants and is generally less than $0.4 \mathrm{ppm}$ dry weight in terrestrial plants from background locations and greater than $1 \mathrm{ppm}$ in plants growing near niobium deposits (Goering and Ziegler, 2004). According to one recent study, the toxicity of niobium and tantalum to freshwater amphipods (Hyalella azteca) was relatively low compared with that of other trace elements tested in laboratory experiments; 1 -week lethal concentrations of hundreds of ppb niobium and tantalum resulted in significant mortality for amphipods in soft waters, whereas those in hard waters were not affected until concentrations reached thousands of ppb (Borgmann and others, 2005).

The mining and processing of niobium and tantalum ores may have a deleterious effect on terrestrial and aquatic plants and organisms from the release of trace elements and (or) radionuclides associated with the ore or host rock into the surrounding ecosystem. If sulfides are present, even in minor to trace quantities, they can oxidize, generate acid, and exacerbate the release of trace elements; however, rocks that contain carbonates can help mitigate some deleterious effects naturally. Metal-rich and radioactive mine waste can be physically transported into local waterways, and fine-grained tailings dust and emissions from ore processing sites can be 
transported in the air for long distances; these processes can result in contaminated soils, waters, and stream sediments. The mining and processing of the ore may take place at the same location, and emissions from the processing and smelting may contain toxic elements and substances that can be released into the air and surrounding soils and waterways.

A few studies of niobium and tantalum mine sites have reported potential ecological health concerns. In Rwanda, the concentrations of arsenic in stream sediments downstream of Ruhanga and at the Nyatubindi tin-niobium-tantalum mine and lead in stream sediments at the Ruhanga site were above the threshold effect concentrations for aquatic organisms (that is, the concentrations below which effects are not likely to occur) but below probable effect concentrations (that is, the concentrations above which effects are likely to occur), which suggests potential impact to biota (MacDonald and others, 2000; Haidula and others, 2011). Also, rare but extreme mine water compositions existed within the mine workings at the Lovozero Mine. Waters were highly alkaline ( $\mathrm{pH}$ range of 10 to 12 ), enriched in fluorine (1 to 1.5 percent) and silica (1 to 1.3 percent), and contained high amounts of aluminum (up to 1,000 ppm), copper (up to 900 parts per billion [ppb]), niobium (up to $400 \mathrm{ppb}$ ), and REEs (greater than $600 \mathrm{ppb}$ ); the concentrations of aluminum and copper exceeded guidelines for aquatic ecosystem health in the United States (Kraynov and others, 1969; U.S. Environmental Protection Agency, 2013). In addition to these studies, Paschoa (1998) reported significant radioactivity (approximately $100 \mathrm{kBq} / \mathrm{kg}$ of ${ }^{226} \mathrm{Ra}$ ) for fine-grained tailings at the Araxá Mine in Brazil. Tailings are disposed of in waste ponds, thus contaminating the water (approximately 20 kilobecquerels per cubic meter of ${ }^{226} \mathrm{Ra}$ ) (Paschoa, 1998). Concentrations above 1 to $10 \mathrm{kBq} / \mathrm{kg}$, depending on the radionuclide, warrant special consideration for disposal of solid material, which may need to be buried in low-level radioactive waste disposal facilities. Beside reports of radioactivity and some high concentrations of elements, mine waste and mine waters generated at some niobium and tantalum mine sites are not of ecological health concern. For example, processing water and tailings runoff and discharge released into the environment at the world's largest pegmatitehosted tantalum resource, the Greenbushes Mine, is monitored to ensure compliance with internationally developed standards (Ingham and others, 2012). The mine waste generated from pegmatite deposits, although possibly not an issue chemically, may pose ecological health concerns because of the extensive amount of waste disposed of at the sites.

\section{Carbon Footprint}

The carbon footprint of niobium centers on its use in the production of biofuels. Niobium catalysts have recently proved to be successful in the conversion of palm oil to biodiesel. In Brazil, one large mining company has developed palm oil plantations to supply its own biodiesel needs (Schwela, 2010). The use of biofuels decreases greenhouse gas emissions compared with the use of petroleum fuels; however, whether first-generation biofuels have a less substantial carbon footprint than petroleum when other factors are taken into consideration remains controversial. Such other factors include the amount of energy consumed to convert plants to biofuel, the opportunity cost of using land to grow crop plants for biofuels that is then not available to grow food for humans and animals, and the potential increase in the amount of forest land that may be cleared to grow biofuel crops.

\section{Mine Closure}

The postmining landscape at niobium and tantalum mines depends on the type and size of the deposit, the mining and processing methods used, the mineral commodity or commodities recovered, the climate, and the relevant regulations regarding mine closure. Extraction from large igneous complexes by open pit methods, which is the most common mining method used, will leave a distinctly different signature than recovery from small artisanal mining of secondary placer deposits or weathered pegmatites. For example, the active Greenbushes Mine in Australia, which has been mined intermittently since 1888, consists of a complex landscape of several open pits, underground workings, waste rock piles, and tailings piles (Ingham and others, 2012). The largest open pit is the Cornwall Pit, which is more than $200 \mathrm{~m}$ deep. The closure cost for this site was estimated to be more than $\$ 17$ million to rehabilitate nearly 2,000 hectares of disturbed land (Ingham and others, 2012).

Artisanal and small-scale mining, such as that conducted in central Africa, is typically unregulated, and environmental issues are commonly not considered. Many such mining operations do not have mine closure plans and are left as is after recoverable ore is extracted. For example, tin (and tantalum-niobium) mining in the Jos area of Nigeria has drastically changed the landscape, and little has been done in the way of remediation efforts. Some detrimental effects of the altered landscape include disturbances of the natural flora and fauna, low crop yields on agricultural lands, local land disputes from soil erosion problems, and neglected mine excavations, mine dumps, and pits. On the other hand, flooded mine pits are a source of water for irrigation as well as for domestic and livestock uses. They can also provide sites for potential fisheries (Abegboye, 2012). Future measures may focus on remediating the affected land back to productive farm land. 


\section{Problems and Future Research}

Consumption of niobium and tantalum is expected to increase in the coming years as industrial development in such countries as Brazil, China, and India continues, and the rapidly increasing global population demands more consumer goods, such as cars, cell phones, computers, and other high-tech products. Although the estimated reserves and resources of both niobium and tantalum are large and appear more than sufficient to meet global demand for the foreseeable future (British Geological Survey, 2011), the restricted concentration of niobium resources and production, and, to a lesser extent, those of tantalum, makes their stable supply vulnerable to potential influence and disruption. The United States currently lacks domestic self-sufficiency for both mineral commodities and is dependent on imports and recycling to meet its current and future needs. For the United States, the discovery of additional deposits of niobium and tantalum of better quality and quantity than those currently identified would be advantageous. New discoveries in the United States, particularly of niobium, may be facilitated by ongoing efforts to identify additional REE resources because alkaline and carbonatite complexes can host both deposit types.

An issue of international concern specific to tantalum is the mining of columbite-tantalite (also called coltan) in central Africa, particularly in Congo (Kinshasa). Militias implicated in human rights abuses are accused of using the sale of columbite-tantalite and other mineral commodities to help fund a civil war in Congo (Kinshasa). In 2010, the U.S. Government passed the Dodd-Frank Wall Street Reform and Consumer Protection Act. Section 1502 of that Act directs that companies that report to the U.S. Securities and Exchange Commission must reveal whether they buy minerals from Congo (Kinshasa) or any of its neighbors and, if so, whether conflict minerals exist in their supply chain. This has led to efforts to develop a system that can trace the origin of columbite-tantalite ore from the region (Burt, 2012). A program related to establishing a conflict-free supply chain for columbite-tantalite was launched by the International Tin Research Institute in 2011 in Rwanda and the Katanga Province of Congo (Kinshasa), with baseline studies of almost 500 mine sites completed (Burt, 2012). This program (the Tin Supply Chain Initiative, or iTSCi) is attempting to identify legitimate mines, with the overall goal being to provide a way to exclude illegal columbite-tantalite from the conventional market while discerning legitimate small-scale artisanal mine production in central Africa.

Geologically, there are still many unanswered questions about the origin of niobium and tantalum deposits, including (a) why some carbonatites are enriched in niobium and others are enriched in REEs; (b) what is the role of fluids in the mobilization and concentrations of niobium and tantalum; (c) why are the largest pegmatite-hosted tantalum deposits of Archean age; and (d) are there additional types of tantalum deposits, particularly low-grade large-tonnage commercial deposits?

\section{References Cited}

Note: All Web links listed were active as of the access date but may no longer be available.

Abegboye, M.A., 2012, Effect of mining on farming in Jos South local government area of Plateau State: Journal of Soil Science and Environmental Management, v. 3, no. 4, p. $77-83$.

Alkane Resources Ltd., 2012, Annual report 2011: Perth, Western Australia, Australia, Alkane Resources Ltd., 56 p., accessed July 27, 2015, at http://www.alkane.com.au/pdf/ annual-reports/2011_Alkane_AR_SWF/Alkane_2011_AR_ Interactive.html.

Anglo American plc, 2012, Annual report 2011: London, United Kingdom, Anglo American plc, 212 p., accessed April 9, 2014, at http://ar11.angloamerican.com/_assets/ pdf/final/AA_AR2011.pdf.

Bailey, D.K., 1974, Continental rifting and alkaline magmatism, in Sørensen, Henning, ed., The alkaline rocks: New York, N.Y., Wiley Interscience, p. 148-159.

Barker, D.S., 1974, Alkaline rocks of North America, in Sørensen, Henning, ed., The alkaline rocks: New York, N.Y., Wiley Interscience, p. 160-171.

Barker, D.S., 1989, Field relations of carbonatites, in Bell, Keith, ed., Carbonatites - Genesis and evolution: London, United Kingdom, Unwin Hyman, p. 38-69.

Barton, W.R., 1962, Columbium and tantalum, a materials survey: U.S. Bureau of Mines Information Circular 8120, $110 \mathrm{p}$.

Bastos Neto, A.C., Pereira, V.P., Ronchi, L.H., de Lima, E.F., and Frantz, J.C., 2009, The world-class Sn, Nb, Ta, F (Y, REE, Li) deposit and the massive cryolite associated with the albite-enriched facies of the Madeira A-type granite, Pitinga mining district, Amazonas State, Brazil: Canadian Mineralogist, v. 47, no. 6, p. 1329-1357. [Also available at http://dx.doi.org/10.3749/canmin.47.6.1329.]

Belzile, Elzéar, 2009, NI 43-101 technical report for Niobec Mine, Quebec, Canada, prepared for IAMGOLD Corp. [Filing date March 9, 2009]: Toronto, Ontario, Canada, Belzile Solutions Inc., February 2009, 104 p. [Also available at http://www.sedar.com.]

Berger, V.I., Singer, D.A., and Orris, G.J., 2009, Carbonatites of the world, explored deposits of $\mathrm{Nb}$ and REE-Database and grade and tonnage models: U.S. Geological Survey Open-File Report 2009-1139, 17 p. [Also available at http://pubs.usgs.gov/of/2009/1139/.] 
Bleiwas, D.I., Papp, J.F., and Yager, T.R., 2015, Shift in global tantalum mine production, 2000-2014: U.S. Geological Survey Fact Sheet 2015-3079, 6 p.

Borgmann, Uwe, Couillard, Yves, Doyle, Patrick, and Dixon, D.G., 2005, Toxicity of sixty-three metals and metalloids to Hyalella azteca at two levels of water hardness: Environmental Toxicology and Chemistry, v. 24, no. 3, p. 641-652. [Also available at http://dx.doi.org/10.1897/04-177R.1.]

Bradley, Dwight, and McCauley, Andrew, 2013, A preliminary deposit model for lithium-cesium-tantalum (LCT) pegmatites: U.S. Geological Survey Open-File Report 2013-1008, 7 p. [Also available at http://pubs.usgs.gov/of/2013/1008/.]

British Geological Survey, 2011, Niobium-tantalum: Keyworth, Nottingham, United Kingdom, British Geological Survey Mineral Profile, April, 27 p., accessed April 19, 2012, at http://www.bgs.ac.uk/mineralsuk/ statistics/mineralProfiles.html.

Burt, Richard, 2012, A conflict-free supply chain-An update: Tantalum-Niobium International Study Center Bulletin, no. 149 , p. 1-2.

Cameron, E.N., Jahns, R.H., McNair, A.H., and Page, L.R., 1949, Internal structure of granitic pegmatites: Urbana, Ill., Economic Geology Publishing Co., Monograph 2, 155 p., folded maps.

Černý, Petr, 1991a, Rare-element granitic pegmatites, part IRegional to global environments and petrogenesis:

Geoscience Canada, v. 18, no. 2, p. 49-67.

Černý, Petr, 1991b, Rare-element granitic pegmatites, part IIRegional to global environments and petrogenesis: Geoscience Canada, v. 18, no. 2, p. 68-81.

Černý, Petr, 2005, The Tanco rare-element pegmatite deposit, Manitoba-Regional context, internal anatomy, and global comparisons, in Linnen, R.L., Samson, I.M., and Martin, R.F., eds., Rare-element geochemistry and mineral deposits: St. Johns, Newfoundland and Labrador, Canada, Geological Association of Canada, Short Course Notes, v. 17, p. 127-158.

Černý, Petr, and Ercit, T.S., 2005, The classification of granitic pegmatites revisited: Canadian Mineralogist, v. 43, no. 6, p. 2005-2026. [Also available at http://dx.doi.org/10.2113/ gscanmin.43.6.2005.]

Chong, Albert, and Postolski, Tomasz, 2011, Blue River Ta-Nb Project, NI 43-101 Technical Report: Vancouver, British Columbia, Canada, AMEC Americas Ltd., January 31, accessed April 9, 2014, at http:/www.commerceresources.com/i/pdf/ NI43-101Report-BlueRiver.pdf.
Cooper, M.B., 2005, Naturally occurring radioactive materials (NORM) in Australian industries - Review of current inventories and future generation: Stirling, Scotland, United Kingdom, EnviroRad Services Pty. Ltd., ERS-006, accessed April 2, 2013, at http://arpansa.gov.au/pubs/norm/ cooper_norm.pdf.

Cordeiro, P.F.O., Brod, J.A., Palmieri, Matheus, Oliveira, C.G., Barbosa, E.S.R., Santos, R.V., Gaspar, J.C., and Assis, L.C., 2011, The Catalão I niobium deposit, central BrazilResources, geology, and pyrochlore chemistry: Ore Geology Reviews, v. 41, no. 1, p. 112-121. [Also available at http://dx.doi.org/10.1016/j.oregeorev.2011.06.013.]

Cox, J.J., Ciuculescu, Tudorel, Goode, J.R., and Hains, D.H., 2011, Technical report on the Thor Lake project, Northwest Territories, Canada, NI 43-101 technical report, prepared for Avalon Rare Metals Inc.: Toronto, Ontario, Canada, Roscoe Postel Associates, Inc., August 25, 293 p., accessed April 21, 2014, at http://www.avalonraremetals.com/ resources/reports/RPA_Avalon_Thor_Lake_NI_43-101_ August_25_2011.pdf.

Crockett, R.N., and Sutphin, D.M., 1993, International strategic mineral inventory summary report-Niobium (columbium) and tantalum: U.S. Geological Survey Circular 930-M, 36 p.

Daigle, Paul, 2012, Elk Creek Nb Project, Nebraska, US resource estimate update, NI 43-101 report prepared for Quantum Rare Earth Developments Corp.: Toronto, Ontario, Canada, Tetra Tech Wardrop, 143 p., accessed October 15, 2012, at http:/www.quantumrareearth.com/ projects.html.

Divine, K.K., and Goering, P.L., 2004, Tantalum, chap. 21 of Merian, Ernest, Anke, Manfred, Ihnat, Milan, and Stoeppler, Markus, eds., Elements and their compounds in the environment-Occurrence, analysis and biological relevance ( $2 \mathrm{~d}$ ed.): Weinheim, Germany, Wiley-VCH Verlag $\mathrm{GmbH}$, p. 1087-1097. [Also available at http://dx.doi.org/ 10.1002/9783527619634.ch42.]

European Commission, 2010, Critical raw materials for the EUReport of the ad-hoc Working Group on defining critical raw materials: Brussels, Belgium, European Commission, July, 85 p., accessed June 28, 2012, at http://ec.europa.eu/ enterprise/policies/raw-materials/files/docs/report-b_en.pdf. [Critical raw materials list was updated in 2014; see http://ec.europa.eu/growth/sectors/raw-materials/specificinterest/critical/index_en.htm.] 
Fetherston, J.M., 2004, Tantalum in Western Australia: Geological Survey of Western Australia, Mineral Resource Bulletin 22, 162 p., 1 folded map in pocket, accessed April 9, 2014, at http://www.commerceresources.com/ i/pdf/10-Complete.pdf.

Funtua, I.I., 2001, Elemental composition of Sn-Nb-Ta mine tailings of Jos area, central Nigeria: Chemie der ErdeGeochemistry, v. 61, no. 1, p. 45-53.

Gaillardet, J., Viers, J., and Dupré, B., 2003, Trace elements in river waters, in Drever, J.I., ed., Surface and ground water, weathering, and soils, v. 5 of Holland, H.D., and Turekian, K.K.,eds., Treatise on geochemistry: Oxford, United Kingdom, Elsevier-Pergamon, p. 225-272. [Also available at http://dx.doi.org/10.1016/B0-08-0437516/05165-3.]

Galaxy Resources Ltd., 2012, Annual report 2011: West Perth, Western Australia, Australia, Galaxy Resources Ltd., 103 p., accessed September 23, 2015, at http:/www.galaxyresources.com.au/Investor/Company_ Reports.htm

Gippsland Ltd., 2011, Annual report 2011: Claremont, Western Australia, Australia, Gippsland Ltd., 82 p., accessed April 9, 2014, at http:/www.gippslandltd.com/upload/ docs/111027_Gippsland_AR_2011_LowRes_sml.pdf.

Global Mining Services Pty Ltd., 2009, Technical report on the mineral assets of Tantalum Mineração and Prospecção Limitada-NI 43-101 technical report, prepared for Pacific Wildcat Resources Corp. [Filing date May 25, 2009]: Vancouver, British Columbia, Canada, Global Mining Services Pty Ltd., April 30, 86 p. plus 2 appendixes, accessed April 21, 2014, at http://www.pacificwildcat.com/_ content/documents/387.pdf.

Goering, P.L., and Ziegler, T.L., 2004, Niobium (Nb) (columbium), chap. 19 of Merian, Ernest, Anke, Manfred, Ihnat, Milan, and Stoeppler, Markus, eds., Elements and their compounds in the environment-Occurrence, analysis and biological relevance ( $2 \mathrm{~d}$ ed.): Weinheim, Germany, WileyVCH Verlag GmbH, v. 2, p. 1039-1046. [Also available at http://dx.doi.org/10.1002/9783527619634.ch40.]

Graedel, T.E., Allwood, Julian, Birat, J.-P., Buchert, Matthias, Hagelüken, Christian, Reck, B.K., Sibley, S.F., and Sonnemann, Guido, 2011, What do we know about metal recycling rates?: Journal of Industrial Ecology, v. 15, no. 3, p. 355-366. [Also available at http://dx.doi.org/ 10.1111/j.1530-9290.2011.00342.x.)

Grice, J.D., Černý, Petr, and Ferguson, R.B., 1972, The Tanco pegmatite at Bernic Lake, Manitoba-IIWodginite, tantalite, pseudo-ixiolite and related minerals: Canadian Mineralogist, v. 11, p. 609-642.
Haidula, A.F., Ellmies, Rainer, and Kayumba, Francis, 2011, Environmental monitoring of small-scale mining areas in Rwanda: Kigali, Rwanda, Rwanda Natural Resources Authority, accessed April 8, 2013, at http://rnra.rw/fileadmin/ user_upload/documents/Rwanda_Environment_ASM_ report_2011-09-20x.pdf.

Hearman, A.J., and Hinz, Christoph, 2004, Soil colour as a indicator of erosions risk on an overburden materials at Greenbushes Mine in Western Australia, in SuperSoil 2004 - 3d Australian New Zealand Soils Conference, University of Sydney, Australia, December 5-9, 2004 [program and abstracts]: Gosford, New South Wales, Australia, The Regional Institute Ltd. [Also available at http://www.regional.org.au/ au/asssi/supersoil2004/s8/oral/1477_hearmanaj.htm.]

IAMGOLD Corp., 2012, Unlocking shareholder valueAnnual report 2011: Toronto, Ontario, Canada, IAMGOLD Corp., 28 p., accessed October 23, 2012, at http:/www.iamgold.com/files/doc_financials/2011/annual/ Annual-Report_2011-(2).pdf.

Ingham, P.D., White, I.R., and Jackson, S., 2012, Greenbushes lithium operations, NI 43-101 technical report, prepared for Talison Lithium Limited [Filing date December 21, 2012]: North Sydney, New South Wales, Australia, Behre Dolbear Australian Pty Ltd., December 21, 104 p., accessed February 7, 2013, at http:/www.talisonlithium.com/docs/ investors-centre-documents/ni-43-101-techreportgreenbushesfinal-dec12-copy.pdf.

Kabata-Pendias, Alina, and Mukherjee, A.B., 2007, Trace elements from soil to human: Berlin, Germany, SpringerVerlag, 550 p.

Kabata-Pendias, Alina, and Pendias, Henryk, 2001, Trace elements in soils and plants ( $3 \mathrm{~d}$ ed.): Boca Raton, Fla., CRC Press, 413 p.

Kelemen, P.B., Hanghøj, K., and Greene, A.R., 2003, One view of the geochemistry of subduction-related magmatic arcs, with an emphasis on primitive andesite and lower crust, in Rudnick, R.L., ed., The crust, v. 3 of Holland, H.D., and Turekian, K.K., eds., Treatise on geochemistry: Oxford, United Kingdom, Elsevier-Pergamon, v. 3, p. 593-659. [Also available at http:/www.sciencedirect.com/science/ article/pii/B0080437516030358.]

Kogarko, L.N., Lahaye, Y., and Brey, G.P., 2010, Plumerelated mantle source of super-large rare metal deposits from the Lovozero and Khibina massifs on the Kola Peninsula, eastern part of the Baltic Shield-Sr, Nd, and Hf isotope systematics: Mineralogy and Petrology, v. 98, nos. 1-4, p. 197-208. [Also available at http://dx.doi.org/ 10.1007/s00710-009-0066-1.] 
Kogarko, L.N., Williams, C.T., and Woolley, A.R., 2002, Chemical evolution and petrogenetic implications of loparite in layered, agpaitic Lovozero complex, Kola Peninsula, Russia: Mineralogy and Petrology, v. 74, no. 1, p. 1-24. [Also available at http://dx.doi.org/10.1007/ s710-002-8213-2.]

Kravchenko, S.M., and Pokrovsky, B.G., 1995, The Tomtor alkaline ultrabasic massif and related REE-Nb deposits, northern Siberia: Economic Geology, v. 90, p. 676-689. [Also available at http://dx.doi.org/10.2113/ gsecongeo.90.3.676.]

Kraynov, S.R., Mer'kov, A.N., Petrova, N.G., Baturinskaya, I.V., and Zharikova, V.M., 1969, Highly alkaline (pH 12) fluosilicate waters in the deeper zones of the Lovozero massif: Geochemistry International, v. 6, no. 4, p. 635-640.

Küster, Dirk, 2009, Granitoid-hosted Ta mineralization in the Arabian-Nubian Shield - Ore deposit types, tectonometallogenetic setting and petrogenetic framework: Ore Geology Reviews, v. 35, no. 1, p. 68-86. [Also available at http://dx.doi.org/10.1016/j.oregeorev.2008.09.008.]

Lagache, Martine, and Quéméneur, Joël, 1997, The Volta Grande pegmatites, Minas Gerais, Brazil—An example of rare-element granitic pegmatites exceptionally enriched in lithium and rubidium: Canadian Mineralogist, v. 35, no. 1, p. $153-165$.

Linnen, R.L., and Cuney, Michel, 2005, Granite-related rare-element deposits and experimental constraints on Ta-Nb-W-Sn-Zr-Hf mineralization, in Linnen, R.L., Samson, I.M., and Martin, R.F., eds., Rare-element geochemistry and mineral deposits: St. John's, Newfoundland and Labrador, Canada, Geological Association of Canada, Short Course Notes, v. 17, p. 45-68.

Long, K.R., 2011, The future of rare earth elements-Will these high-tech industry elements continue in short supply?: U.S. Geological Survey Open-File Report 2011-1189, 41 p. [Also available at http://pubs.usgs.gov/of/2011/1189/.]

Long, K.R., Van Gosen, B.S., Foley, N.K., and Cordier, Daniel, 2010, The principal rare earth elements deposits of the United States - A summary of domestic deposits and a global perspective: U.S. Geological Survey Scientific Investigations Report 2010-5220, 96 p. [Also available at http://pubs.usgs.gov/sir/2010/5220.]

Lurie, J., 1986, Mineralization of the Pilanesberg alkaline complex, in Anhaeusser, C.R., andd Maske, S., eds., Mineral deposits of southern Africa: Johannesburg, South Africa, The Geological Society of South Africa, v. II, p. 2215-2228.
MacDonald, D.D., Ingersoll, C.G., and Berger, T.A., 2000, Development and evaluation of consensus-based sediment quality guidelines for freshwater ecosystems: Archives of Environmental Contamination and Toxicology, v. 39, no. 1, p. 20-31. [Also available at http://dx.doi.org/10.1007/ s002440010075.]

Mackay, D.A.R., and Simandl, G.J., 2014, Geology, market and supply chain of niobium and tantalum-A review: Mineralium Deposita, v. 49, no. 8, p. 1025-1047.

Mangset, W.E., and Sheyin, A.T., 2009, Measurement of radionuclides in processed mine tailings in Jos, Plateau State: Bayero Journal of Pure and Applied Sciences, v. 2, no. 2, p. 56-60. [Also available at http://dx.doi.org/10.4314/ bajopas.v2i2.63765.]

Mariano, A.N., 1989, Nature of economic mineralization in carbonatites and related rocks, in Bell, Keith, ed., Carbonatites - Genesis and evolution: Boston, Mass., Unwin Hyman, p. 149-176.

Marks, M.A.W., Schilling, Julian, Coulson, I.M., Wenzel, Thomas, and Markl, Gregor, 2008, The alkaline-peralkaline Tamazeght Complex, High Atlas Mountains, Morocco-Mineral chemistry and petrological constraints for derivation from a compositionally heterogeneous mantle source: Journal of Petrology, v. 49, no. 6, p. 1097-1131. [Also available at http://dx.doi.org/10.1093/petrology/egn019.]

Matheis, Günter., 1987, Nigerian rare-metal pegmatites and their lithological framework: Geological Journal, v. 22, Supplement S2, p. 271-291. [Also available at http://dx.doi.org/ 10.1002/gj.3350220620.]

MDN Inc., 2012, 2011 annual report: Montreal, Quebec, Canada, MDN Inc., 52 p., accessed July 27, 2015, at http://www.mdn-mines.com/pdf/rapports_financiers/ Rapport_annuel_2011_ENG.pdf/.

Melcher, Frank, Graupner, Torsten, Gäbler, Hans-Eike, Sitnikova, Maria, Henjes-Kunst, Friedhelm, Oberthür, Thomas, Gerdes, Axel, and Dewaele, Stijn, 2015, Tantalum(niobium-tin) mineralisation in African pegmatites and rare metal granites - Constraints from $\mathrm{Ta}-\mathrm{Nb}$ oxide mineralogy, geochemistry and U-Pb geochronology: Ore Geology Reviews, v. 64, January, p. 667-719. [Also available at http://dx.doi.org/10.1016/j.oregeorev.2013.09.003.]

Mitchell, R.H., 2005, Mineralogical and experimental constraints on the origins of niobium mineralization in carbonatites, in Linnen, R.L., Samson, I.M., and Martin, R.F., eds., Rare-element geochemistry and mineral deposits: St. Johns, Newfoundland and Labrador, Canada, Geological Association of Canada, Short Course Notes, v. 17, p. 201-215. 
Modreski, P.J., Armbrustmacher, T.J., and Hoover, D.B., 1995, Carbonatite deposits (Model 10; Singer, 1986a), chap. 6 of du Bray, E.A., ed., Preliminary compilation of descriptive geoenvironmental mineral deposit models: U.S. Geological Survey Open-File Report 95-831, p. 47-49. [Also available at http://pubs.usgs.gov/of/1995/ofr-95-0831/.]

Morris, E.M., 1987, The Cretaceous Arkansas alkali provinceA summary of petrology and geochemistry, in Morris, E.M., and Pasteris, J.D., eds., Mantle metasomatism and alkaline magmatism: Boulder, Colo., Geological Society of America, Special Paper, v. 215, p. 217-234, includes sketch maps. [Also available at http://dx.doi.org/10.1130/SPE215-p217.]

Mustapha, A.O., Mbuzukongira, P., and Mangala, M.J., 2007, Occupational radiation exposures of artisans mining columbite-tantalite in the eastern Democratic Republic of Congo: Journal of Radiological Protection, v. 27, no. 2, p. 187-195. [Also available at http://dx.doi.org/ 10.1088/0952-4746/27/2/005.]

Nasraoui, Mohamed, and Waerenborgh, J.C., 2001, Fe speciation in weathered pyrochlore-group minerals from the Lueshe and Araxá (Barreiro) carbonatites by ${ }^{57} \mathrm{Fe}$ mössbauer spectroscopy: Canadian Mineralogist, v. 39, no. 4, p. 1373-1080. [Also available at http://dx.doi.org/ 10.2113/gscanmin.39.4.1073.]

National Research Council, 2008, Minerals, critical minerals, and the U.S. economy: Washington, D.C., The National Academies Press, 245 p. [Also available at http://www.nap.edu/catalog/12034/minerals-criticalminerals-and-the-us-economy.]

Natural Earth, 2014, Small scale data: Natural Earth map dataset, scale 1:110,000,000, accessed March 25, 2014, at http://www.naturalearthdata.com.

Niocan Inc., 2011, Annual report 2011: Montreal, Quebec, Canada, Niocan Inc., 32 p., accessed April 9, 2014, at http:/www.niocan.com/ww2/images/pdf/FinancialStatements-2011.pdf.

Niu, Yaoling, and O'Hara, M.J., 2003, Origin of ocean island basalts-A new perspective from petrology, geochemistry, and mineral physics considerations: Journal of Geophysical Research, v. 108, no. B4, p. 2209. [Also available at http://dx.doi.org/10.1029/2002JB002048.]

Noventa Ltd., 2011, Annual report and financial statements 2011: St. Helier, Jersey, United Kingdom, Noventa Ltd., 92 p., accessed July 20, 2015, at http://www.paragonresources.com/pr/PDF/docs/20111231-Noventa-LimitedFinancial-Statements.pdf.
Occupational Safety and Health Administration, 2013, Regulations (Standards 29 CFR), Part 1910 Occupational Safety and Health Standards, Toxic and Hazardous Substances: Washington, D.C., U.S. Department of Labor, accessed February 15, 2013, at http:/www.osha.gov/pls/oshaweb/ owadisp.show_document?p_table=standards\&p_id=9992.

Papp, J.F., 2013a, Niobium and tantalum, in Metals and minerals: U.S. Geological Survey Minerals Yearbook 2011, v. I, p. 52.1-52.14. [Also available at http://minerals.usgs.gov/ minerals/pubs/commodity/niobium/.]

Papp, J.F., 2013b, Niobium (columbium): U.S. Geological Survey Mineral Commodity Summaries 2013, p. 110-111. [Also available at http://minerals.usgs.gov/minerals/pubs/ mcs/2013/mcs2013.pdf.]

Papp, J.F., 2013c, Tantalum: U.S. Geological Survey Mineral Commodity Summaries 2013, p. 162-163. [Also available at http://minerals.usgs.gov/minerals/pubs/mcs/2013/ mes2013.pdf.]

Parker, R.L., and Adams, J.W., 1973, Niobium (columbium) and tantalum, in Brobst, D.A., and Pratt, W.P., eds., United States mineral resources: U.S. Geological Survey Professional Paper 820, p. 443-454. [Also available at http://pubs.er.usgs.gov/publication/pp820.]

Parker, R.L., and Fleischer, Michael, 1968, Geochemistry of niobium and tantalum: U.S. Geological Survey Professional Paper 612, 43 p. [Also available at http://pubs.er.usgs.gov/ publication/pp612.]

Partington, G.A., McNaughton, N.J., and Williams, I.S., 1995, A review of the geology, mineralization, and geochronology of the Greenbushes pegmatite, Western Australia: Economic Geology, v. 90, p. 616-635. [Also available at http://dx.doi.org/10.2113/gsecongeo.90.3.616.]

Paschoa, A.S., 1998, Potential environmental and regulatory implications of naturally occurring radioactive materials (NORM): Applied Radiation and Isotopes, v. 49, no. 3, p. 189-196. [Also available at http://dx.doi.org/10.1016/ S0969-8043(97)00239-X.]

Pires do Rio, M.A., Fernandes, H.M., Amaral, E.C.S., and Rochedo, E.R.R., 2003, Considerations about TENORMA study case on niobium facilities: Health Physics, v. 84, no. 2, p. 147-154.

Pollard, P.J., 1995, A special issue devoted to the geology of rare metal deposits - Geology of rare metal deposits - An introduction and overview: Economic Geology, v. 90, p. 489-494. [Also available at http://dx.doi.org/10.2113/ gsecongeo.90.3.489.] 
Quest Rare Minerals Ltd., 2012, Annual report 2011: Montreal, Quebec, Canada, Quest Rare Minerals Ltd., 68 p., accessed April 9, 2014, at http://www.questrareminerals.com/pdfs/ Quest RM Annual Report - Mar 26, 2012.pdf.

Raimbault, Louis, Cuney, Michel, Azencott, Claude, Duthou, J.L., and Joron, J.L., 1985, Geochemical evidence for a multistage magmatic genesis of Ta-Sn-Li mineralization in the granite at Beauvoir, French Massif Central: Economic Geology, v. 90, p. 548-576. [Also available at http://dx.doi.org/ 10.2113/gsecongeo.90.3.548.]

Ram Resources Ltd., 2012, Annual report 2012: West Perth, Western Australia, Australia, Ram Resources Ltd., 72 p., accessed April 9, 2014, at http:/web.archive.org/ web/20130425043951/http://ramresources.com.au/PDF/ annualreport12.pdf.

Reimann, C., and de Caritat, P., 1998, Chemical elements in the environment-Factsheets for the geochemist and environmental scientist: Berlin, Germany, Springer-Verlag, 397 p.

Richardson, D.G., and Birkett, T.C., 1996, Carbonatiteassociated deposits, in Eckstrand, O.R., Sinclair, W.D., and Thorpe, R.I., eds., Geology of Canadian mineral deposit types: Ottawa, Ontario, Canada, Geological Survey of Canada, Geology of Canada series, no. 8, part of Geology of North America series, v. P-1, p. 541-558.

Roskill Information Services Ltd., 2009, The economics of niobium (11th ed.): London, United Kingdom, Roskill Information Services Ltd., 222 p.

Roskill Information Services Ltd., 2012, Tantalum-Market outlook to 2016 (11 th ed.): London, United Kingdom, Roskill Information Services Ltd., 164 p.

Rudnick, R.L., and Gao, S., 2003, Composition of the continental crust, in Rudnick, R.L., ed., The crust, v. 3 of Holland, H.D., and Turekian, K.K., eds., Treatise on geochemistry, v. 3: Oxford, United Kingdom, ElsevierPergamon, p. 1-64. [Also available at http://dx.doi.org/ 10.1016/B0-08-043751-6/03016-4.]

Salvi, Stefano, and Williams-Jones, A.E., 2005, Alkaline granite-syenite deposits, in Linnen, R.L., Samson, I.M., Martin, R.F., eds., Rare-element geochemistry and mineral deposits: St. Johns, Newfoundland and Labrador, Canada, Geological Association of Canada, Short Course Notes, v. 17, p. $315-341$.

Schwela, Ulric, 2010, Mining Journal special publicationTantalum (A supplement to Mining Journal), with a section on The state of tantalum mining: London, United Kingdom, Aspermont, September, 11 p., accessed December 15, 2012, at http://www.mining-journal.com/_ data/assets/supplement file_attachment/0011/237287/Tantalum2010_scr.pdf.
Schwela, Ulric, 2011, T.I.C. statistics and transport project: Tantalum-Niobium International Study Center Bulletin, no. 145 , p. $2-8$.

Selway, J.B., Breaks, F.W., and Tindle, A.G., 2005, A review of rare-element (Li-Cs-Ta) pegmatite exploration techniques for the Superior Province, Canada, and large worldwide tantalum deposits: Exploration and Mining Geology, v. 14, nos. 1-4, p. 1-30. [Also available at http://dx.doi.org/10.2113/gsemg.14.1-4.1.]

Semenov, E., 1997, Minerals and ores of the Khibiny-Lovozero alkaline massif, Kola: Moscow, Russian Academy of Sciences, Fersman Mineralogical Museum, 70 p.

Siirama, Lauri, 2009, The Sokli Mine Project, Fennoskandian Mining and Exploration Congress, Rovaniemi, Finland, December 1-3, 2009, presentation, 17 p., accessed April 9, 2014, at http://fem.lappi.fi/c/document_library/ get_file?folderId=48927\&name=DLFE-2796.pdf.

Silva, A.C., Pereira, M.C., Oliveira, L.C.A., Cavalcante, L.C.D., Fabris, J.D., and Murad, E., 2012, An unusually stable magnetite from a niobium mine in Brazil: Clay Minerals, v. 47, no. 1, p. 69-79. [Also available at http://dx.doi.org/ 10.1180/claymin.2012.047.1.69.]

Smith, D.B., Cannon, W.F., Woodruff, L.G., Solano, Federico, Kilburn, J.E., and Fey, D.L., 2013, Geochemical and mineralogical data for soils of the conterminous United States: U.S. Geological Survey Data Series 801, 19 p. [Also available at http://pubs.usgs.gov/ds/801/.]

Smith, R.E., Perdrix, J.L., and Davis, J.M., 1987, Dispersion into pisolitic laterite from the Greenbushes mineralized Sn-Ta pegmatite system, Western Australia: Journal of Geochemical Exploration, v. 28, nos. 1-3, p. 251-265. [Also available at http://dx.doi.org/10.1016/03756742(87)90051-3.]

Sørensen, Henning, 2001, Brief introduction to the geology of the Ilímaussaq alkaline complex, South Greenland, and its exploration history, in Sørensen, Henning, ed., The Ilímaussaq Alkaline Complex, South Greenland-Status of mineralogical research with new results (Anniversary volume): Copenhagen, Denmark, Geological Survey of Denmark and Greenland, v. 190, p. 7-24.

Sørensen, Henning, ed., 1974, The alkaline rocks: New York, N.Y., Wiley Interscience, 622 p.

Steenfelt, Agnete, 1991, High technology metals in alkaline and carbonatitic rocks in Greenland-Recognition and exploration: Journal of Geochemical Exploration, v. 40, nos. 1-3, p. 263-279. [Also available at http://dx.doi.org/ 10.1016/0375-6742(91)90042-S.] 
Sweetapple, M.T., and Collins, P.L.F., 2002, Genetic framework for the classification and distribution of Archean rare metal pegmatites in the north Pilbara Craton, Western Australia: Economic Geology, v. 97, p. 873-895. [Also available at http://dx.doi.org/10.2113/gsecongeo.97.4.873.]

Tertiary Minerals plc, 2013, Ghurayyah: Macclesfield, United Kingdom, Tertiary Minerals plc Web page, accessed June 5, 2013, at http://www.tertiaryminerals.com/ ghurayyah.html.

Trueman, D.L., and Černý, Petr, 1982, Exploration for rareelement granitic pegmatites, in Cerný, P., ed., Granitic pegmatites in science and industry: Winnipeg, Manitoba, Canada, Mineralogical Association of Canada, Short Course Handbook, no. 8, p. 463-493.

U.S. Environmental Protection Agency, 2012, National recommended water quality criteria: U.S. Environmental Protection Agency Web page, accessed April 9, 2012, at http://www.epa.gov/waterscience/criteria/wqcriteria.html.

U.S. Environmental Protection Agency, 2013, Regional Screening Levels (RSL) summary table-November 2012: U.S. Environmental Protection Agency, accessed April 14, 2014, at http://www.epa.gov/reg3hwmd/risk/ human/rb-concentration_table/Generic_Tables/docs/ master_sl_table_run_NOV2013.pdf.

U.S. Geological Survey, 1996, Global 30 arc-second elevation (GTOPO30): Reston, Va., U.S. Geological Survey dataset (digital elevation model), accessed March 25, 2014, at https://lta.cr.usgs.gov/GTOPO30.

Upton, B.G.J., Emeleus, C.H., Heaman, L.M., Goodenough, K.M., and Finch, A.A., 2003, Magmatism of the mid-Proterozoic Gardar Province, South Greenland-Chronology, petrogenesis and geological setting: Lithos, v. 68, nos. 1-2, p. 43-65. [Also available at http://dx.doi.org/10.1016/ S0024-4937(03)00030-6.]

Ure, A.M., Bacon, J.R., Berrow, M.L., and Watt, J.J., 1979, The total trace element content of some Scottish soils by spark source mass spectrometry: Geoderma, v. 22, no. 1, p. 1-23. [Also available at http://dx.doi.org/10.1016/ 0016-7061(79)90036-3.]
Usikalu, M.R., Anoka, O.C., and Balogun, F.A., 2011, Radioactivity measurements of the Jos tin mine tailing in northern Nigeria: Archives of Physics Research, v. 2, no. 2, p. 80-86.

Viers, Jérôme, Dupré, Bernard, and Gaillardet, Jérôme, 2009, Chemical composition of suspended sediments in world rivers - New insights from a new database: Science of the Total Environment, v. 407, no. 2, p. 853-868. [Also available at http://dx.doi.org/10.1016/j.scitotenv.2008.09.053.]

Winter, Mark, 2014, Niobium-The essentials: WebElements, accessed April 4, 2014, at http://www.webelements.com/.

Wood, S.A., 2005, The aqueous geochemistry of zirconium, hafnium, niobium, and tantalum, in Linnen, R.L., Samson, I.M., and Martin, R.F., eds., Rare-element geochemistry and mineral deposits: St. Johns, Newfoundland and Labrador, Canada, Geological Association of Canada, Short Course Notes, v. 17, p. 217-268.

Woolley, A.R., and Bailey, D.K., 2012, The crucial role of lithospheric structure in the generation and release of carbonatites - Geological evidence: Mineralogical Magazine, v. 76, no. 2, p. 259-270. [Also available at http://dx.doi.org/10.1180/minmag.2012.076.2.02.]

Woolley, A.R., and Kjarsgaard, B.A., 2008, Carbonatite occurrences of the world-Map and database: Geological Survey of Canada Open File 5796, 28 p., 1 CD-ROM plus 1 map, scale approx. 1:19,000,000. [Also available at http://dx.doi.org/10.4095/225115.]

Yin, Lin, Pollard, P.J., Shouxi, Hu, and Taylor, R.G., 1995, Geologic and geochemical characteristics of the Yichun Ta-Nb-Li deposit, Jiangxi Province, south China: Economic Geology, v. 90, p. 577-585. [Also available at http://dx.doi.org/10.2113/gsecongeo.90.3.577.] 


\section{Platinum-Group Elements}

By Michael L. Zientek, Patricia J. Loferski, Heather L. Parks, Ruth F. Schulte, and Robert R. Seal II

Chapter $\mathrm{N}$ of

Critical Mineral Resources of the United States-Economic and Environmental Geology and Prospects for Future Supply

Edited by Klaus J. Schulz, John H. DeYoung, Jr., Robert R. Seal II, and Dwight C. Bradley

Professional Paper 1802-N 


\section{Contents of Chapter $\mathbf{N}$}

[Figure and table titles for all chapters are listed in the volume contents before the conversion factors table and list of abbreviations and symbols. A periodic table of the elements is on the inside front cover of the printed volume]

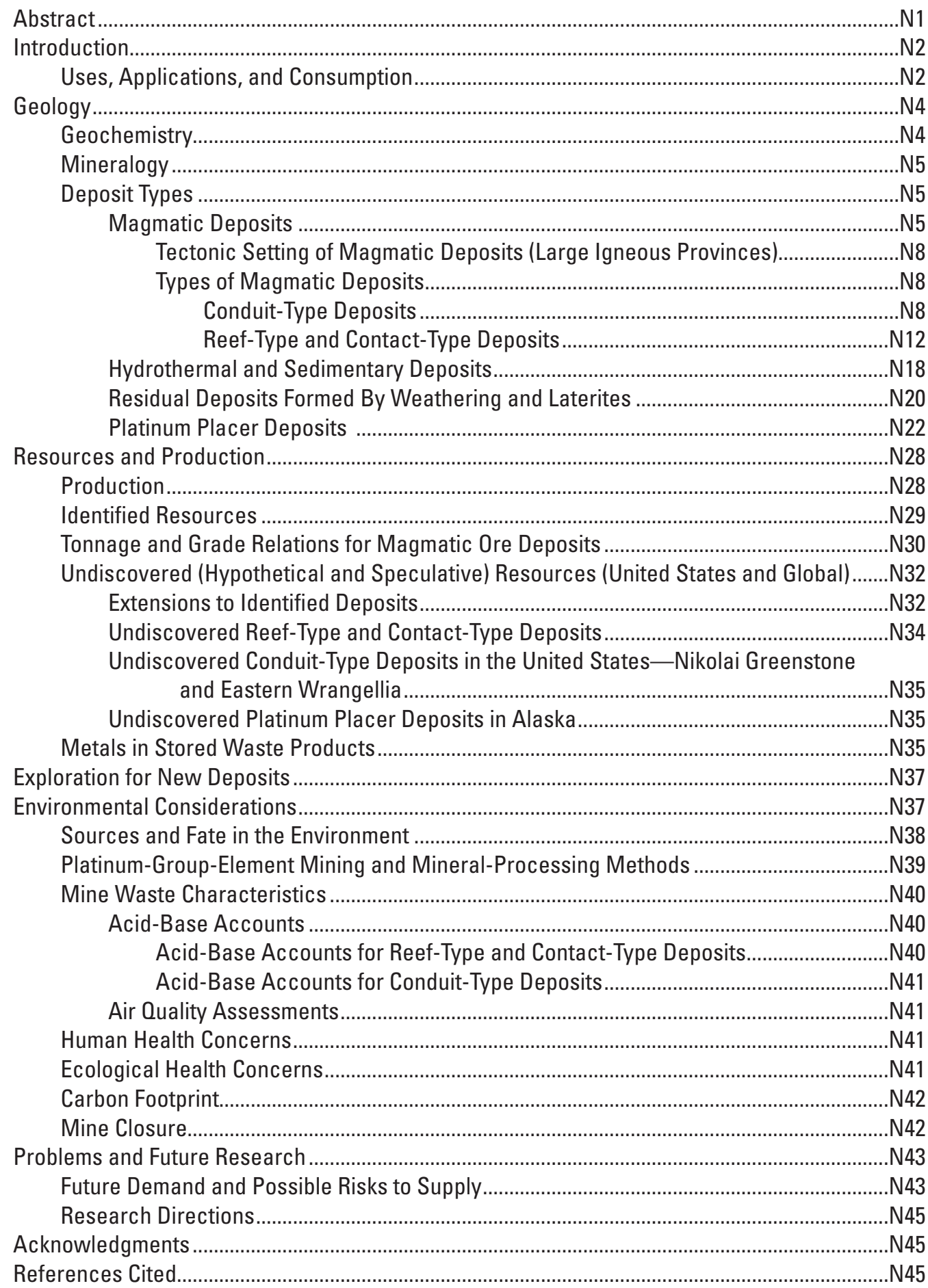

Suggested citation:

Zientek, M.L., Loferski, P.J., Parks, H.L., Schulte, R.F., and Seal, R.R., II, 2017, Platinum-group elements, chap. N of Schulz, K.J., DeYoung, J.H., Jr., Seal, R.R., II, and Bradley, D.C., eds., Critical mineral resources of the United StatesEconomic and environmental geology and prospects for future supply: U.S. Geological Survey Professional Paper 1802, p. N1-N91, http://dx.doi.org/10.3133/pp1802N. 


\title{
Platinum-Group Elements
}

\author{
By Michael L. Zientek, Patricia J. Loferski, Heather L. Parks, Ruth F. Schulte, and Robert R. Seal II
}

\section{Abstract}

The platinum-group elements (PGEs) — platinum, palladium, rhodium, ruthenium, iridium, and osmium — are metals that have similar physical and chemical properties and tend to occur together in nature. PGEs are indispensable to many industrial applications but are mined in only a few places. The availability and accessibility of PGEs could be disrupted by economic, environmental, political, and social events. The United States net import reliance as a percentage of apparent consumption is about 90 percent.

PGEs have many industrial applications. They are used in catalytic converters to reduce carbon monoxide, hydrocarbon, and nitrous oxide emissions in automobile exhaust. The chemical industry requires platinum or platinum-rhodium alloys to manufacture nitric oxide, which is the raw material used to manufacture explosives, fertilizers, and nitric acid. In the petrochemical industry, platinum-supported catalysts are needed to refine crude oil and to produce aromatic compounds and high-octane gasoline. Alloys of PGEs are exceptionally hard and durable, making them the best known coating for industrial crucibles used in the manufacture of chemicals and synthetic materials. PGEs are used by the glass manufacturing industry in the production of fiberglass and flat-panel and liquid crystal displays. In the electronics industry, PGEs are used in computer hard disks, hybridized integrated circuits, and multilayer ceramic capacitors.

Aside from their industrial applications, PGEs are used in such other fields as health, consumer goods, and finance. Platinum, for example, is used in medical implants, such as pacemakers, and PGEs are used in cancer-fighting drugs. Platinum alloys are an ideal choice for jewelry because of their white color, strength, and resistance to tarnish. Platinum, palladium, and rhodium in the form of coins and bars are also used as investment commodities, and various financial instruments based on the value of these PGEs are traded on major exchanges.

PGEs are among the rarest metals; Earth's upper crust contains only about 0.0005 part per million (ppm) platinum. Today, the average grade of PGEs in ores that are mined primarily for their PGE concentrations varies from 5 to $15 \mathrm{ppm}$, although the concentration of PGEs in hand-picked ore specimens may range from tens to hundreds of parts per million.
More than 100 different minerals have one of the PGEs as an essential component. PGE minerals occur as native metals. They also occur as compounds with other transition metals (copper, iron, mercury, nickel, and silver), post-transition metals (bismuth, lead, and tin), metalloids (antimony, arsenic, and tellurium), and nonmetals (selenium and sulfur).

From 1900 to 2011, approximately 14,200 metric tons of PGEs was produced, and roughly 95 percent of that production (13,500 metric tons) took place between 1960 and 2011. The breakdown of production by country shows that, since 1900 , about 90 percent of the production came from South Africa and Russia. The secondary supply of platinum, palladium, and rhodium is obtained through the recycling of catalytic converters from end-of-life vehicles, jewelry, and electronic equipment. Recycled platinum, palladium, and rhodium provide a significant proportion of the world's total supply; these secondary sources are sufficient to close the gap between world mine production and consumption.

Exploration and mining companies report resources of about 104,000 metric tons of PGEs (including minor amounts of gold) in mineral deposits around the world that could be developed. For PGEs, almost all the reported production and identified resources are associated with deposits in three geologic features - the Bushveld Complex, which is a layered mafic to ultramafic intrusion in South Africa; the Great Dyke, which is a layered mafic to ultramafic intrusion in Zimbabwe; and sill-like intrusions associated with flood basalts in the Noril'sk-Talnakh area of Russia.

The metallic forms of PGEs are generally considered to be inert. PGEs pose a risk to human health only in cases where individuals are occupationally exposed to synthetic PGE compounds, especially workers in precious-metal refineries. In the natural environment, background PGE concentrations are low in water, sediment, soil, and plants. Anthropogenic sources of PGEs in the environment include catalytic converters used in modern automobiles, platinum-based chemotherapy drugs, and smelter emissions.

The abundance of sulfide minerals defines the environmental and geologic characteristics of PGE-enriched magmatic sulfide deposits; those deposits with the highest amount of sulfide minerals could have the highest environmental impact. Acid rock drainage from reef-type and contact-type deposits 
is unlikely because the ores and their host rocks contain low proportions of sulfide minerals. For some conduit-type orebodies with massive ores, mineral-processing techniques separate and produce concentrates of copper-, iron-, and nickel-bearing sulfide minerals; those with copper and nickel are processed to extract metal, but the iron-sulfide minerals, mainly pyrrhotite, are discarded as waste. This results in waste material with a high acid-generating potential.

The most significant primary source of PGEs in the United States is a deposit in the Stillwater Complex, which is a layered igneous intrusion in Montana. Approximately 305 metric tons of platinum and palladium have been mined from the Stillwater Complex deposit since 1986. Exploration and development drilling indicate that another 2,200 metric tons are present. Mining has progressed to depths of 1,800 meters below the surface, but the bottom of the ore deposit has not been reached; geologic estimates suggest that another 1,000 to 6,200 metric tons of PGEs could be present at depth. In the future, PGEs may be mined from deposits found near the base of the Duluth Complex, which is a group of igneous intrusions in Minnesota.

\section{Introduction}

The platinum-group elements (PGEs) — platinum, palladium, rhodium, ruthenium, iridium, and osmium - are chemical elements that have similar physical and chemical properties and tend to occur together in nature. They are transition metals, lying in Group 8B and periods 5 and 6 of the periodic table of elements. Along with gold and silver, they are also precious metals that have high economic value determined not only by their practical uses but also by their role as investment instruments and as a store of value. The PGEs are also known as the platinum-group metals (PGMs).

Pre-Columbian peoples found naturally occurring platinum and platinum-rich alloys in stream deposits in Colombia and Ecuador. In the 1500s, Spanish colonists also found grains of these alloys mingled with gold nuggets they recovered from stream deposits in the same area; they called the metal "platina" (McDonald and Hunt, 1982). At that time, the metal had no known use and was considered worthless. The platinum-rich grains were a nuisance because they could not be separated from gold nuggets by panning. Small samples of platinum-enriched nuggets from South America reached Europe during the 1740s. Platinum was described as a new metal in 1750, followed by iridium and osmium in 1803, palladium and rhodium in 1804, and ruthenium in 1807 . The unique properties of the metals were realized later in the 19th century.

PGEs are essential for important industrial applications but are mined in only a limited number of places. Therefore, the availability and accessibility of PGEs could be disrupted by economic, environmental, political, and social events. This is not a new development. During World War I, the United States considered platinum a "vital war material" needed for the production of amplifiers, magnetos, munitions, shell primers, and sulfuric acid, and it was ranked second on the "list of strategic raw material" for which the United States was either entirely or partially dependent on foreign countries (Lael and Killen, 1982). During World War II, these metals had even greater strategic importance to science and industry, and the United States was still dependent on sources in foreign countries (DeMille, 1947; U.S. Bureau of Mines and U.S. Geological Survey, 1947). Security of supply was also a concern during the Cold War (U.S. Congress, Office of Technology Assessment, 1985; Sutphin and Page, 1986). With the dissolution of the Soviet Union and the peaceful transition of government in South Africa in the early 1990s, import vulnerability became less of an immediate concern. The United States net import reliance as a percentage of apparent consumption is still about 90 percent, however, and the main sources of these elements are still limited to a few mineral deposits in South Africa and Russia (Loferski, 2012a, b). The potential restrictions on supplies of critical raw minerals, such as the PGEs, have again become a topic for international concern and discussion (National Research Council of the National Academies, 2008; Buchert and others, 2009; European Commission, 2010; American Physical Society Panel on Public Affairs and Material Research Society, 2011; British Geological Survey, 2012).

This chapter summarizes how the PGEs are used, gives an overview of where PGEs are mined, and summarizes how much mineralized material has been found by mineral exploration companies. The geology of significant deposits is described, and the assessment for undiscovered resources is discussed, as are possible topics for future research. The report also discusses environmental aspects of the PGEs, including their sources and fate in the environment; mine waste characteristics; and human health, ecological, and carbon footprint concerns. Where indicated, data in tables 1 through 9 are taken from data prepared by the authors in table 10 (back of chapter).

\section{Uses, Applications, and Consumption}

The PGEs possess excellent catalytic and stable electrical properties. PGEs are also highly resistant to wear, tarnishing, and chemical attack, and can withstand high temperatures, making them indispensable to many industrial applications. Their leading use is as catalysts for oxidation and reduction reactions that decrease hydrocarbon, carbon monoxide, and nitrous oxide emissions in automobile exhaust (fig. N1). The chemical industry requires either platinum or platinumrhodium alloy to manufacture nitric oxide, which is a raw material used to manufacture explosives, fertilizers, and nitric acid. PGEs are also used in the production of specialty silicones, which, in turn, have many uses, such as in coatings on automobile airbags, water repellent coatings, and adhesives for sticky notes. In the petrochemical industry, platinumsupported catalysts are needed to refine crude oil and to produce high-octane gasoline and aromatic compounds. 

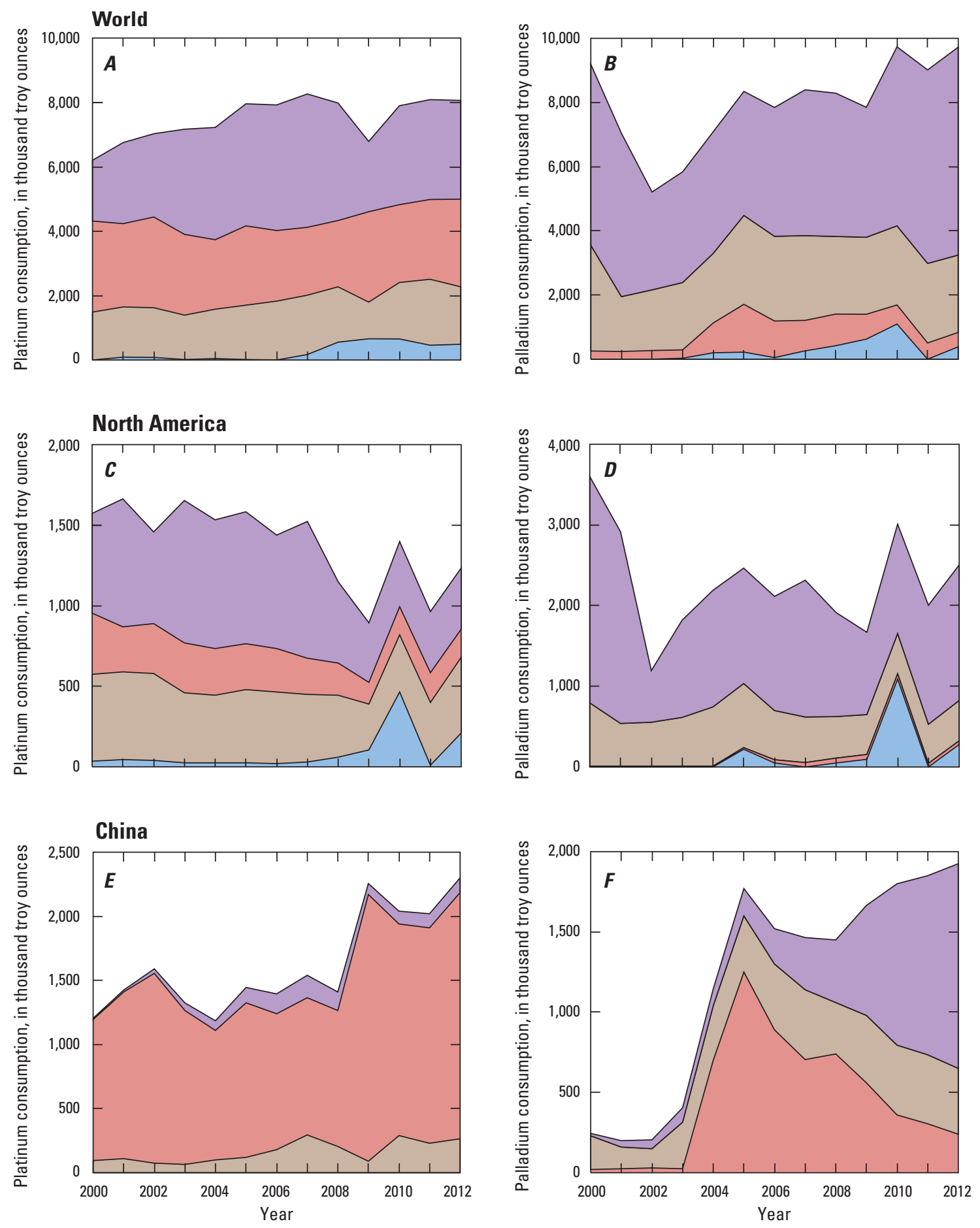

Figure N1. Graphs showing platinum and palladium consumption, by category of use, from 2000 to 2012 for the world $(A$ and $B)$, North America $(C$ and $D)$, and China $(E$ and $F)$. The decrease in platinum consumption for North America is directly related to the decreased production of cars and trucks during the same period (Organisation Internationale des Constructeurs d'Automobiles, 2013). The graphs also illustrate how consumption of platinum jewelry varies by region. In each graph, the layers are placed one above the other, forming a cumulative total. Created from data in Platinum Today (2013c).

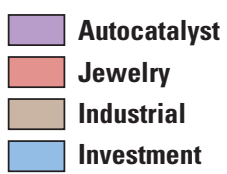


Alloys of PGEs are exceptionally hard and durable, making them the best known coating for industrial crucibles used in the manufacture of chemicals and synthetic materials, such as high-purity single crystals used in the production of light-emitting diodes (LEDs). PGEs are used by the glass manufacturing industry in the production of fiberglass and flat-panel and liquid crystal displays. In the electronics industry, PGEs are used in computer hard disks to increase storage capacity, and they are ubiquitous in electronic devices, hybridized integrated circuits, and multilayer ceramic capacitors. Platinum does not corrode inside the body, and allergic reactions to platinum are extremely rare; therefore, it is used in medical implants, such as pacemakers. PGEs are also used in cancer-fighting drugs. Other uses of PGEs include gas sensors in automobiles and homes, spark plug tips, and additives to superalloys (Impala Platinum Holdings Ltd., 2012; Loferski, 2013a; Platinum Today, 2013a).

Their white color, strength, and resistance to tarnish make platinum alloys an ideal choice for jewelry (Platinum Today, 2013b). In parts of Ecuador and Colombia before the Spanish conquest, platinum was used by indigenous peoples for the fabrication of small objects, as well as sintered with gold, and incorporated into bimetallic and platinum-clad articles (fig. N2; Scott and Bray, 1980; Meeks and others, 2002; Noguez and others, 2006). Their masterworks reflect a high degree of technical innovation because the high melting temperature of platinum (1,769 degrees Celsius $\left[{ }^{\circ} \mathrm{C}\right]$ ) requires sophisticated manufacturing techniques and craftsmanship. The modern tradition of using platinum for jewelry began in Europe in the 18th century. The works produced by Cartier and Tiffany in the late 19 th century and early 20 th century created interest in platinum jewelry, particularly in the United States. The Great Depression of the 1930s and the advent of World War II suppressed the platinum jewelry market in the United States. In the 1960s, demand for platinum jewelry in Japan surged, followed by a surge in demand in China in the mid-1990s.

Platinum, palladium, and rhodium are also used for investment in the form of physical or financial assets. Physical assets include platinum and palladium as collectible coins, or as bullion coins, bars, or wafers. Financial assets include stocks, mutual funds, and exchange-traded funds. Financial assets allow investors to own platinum, palladium, and rhodium without the difficulties associated with physically holding the metal.

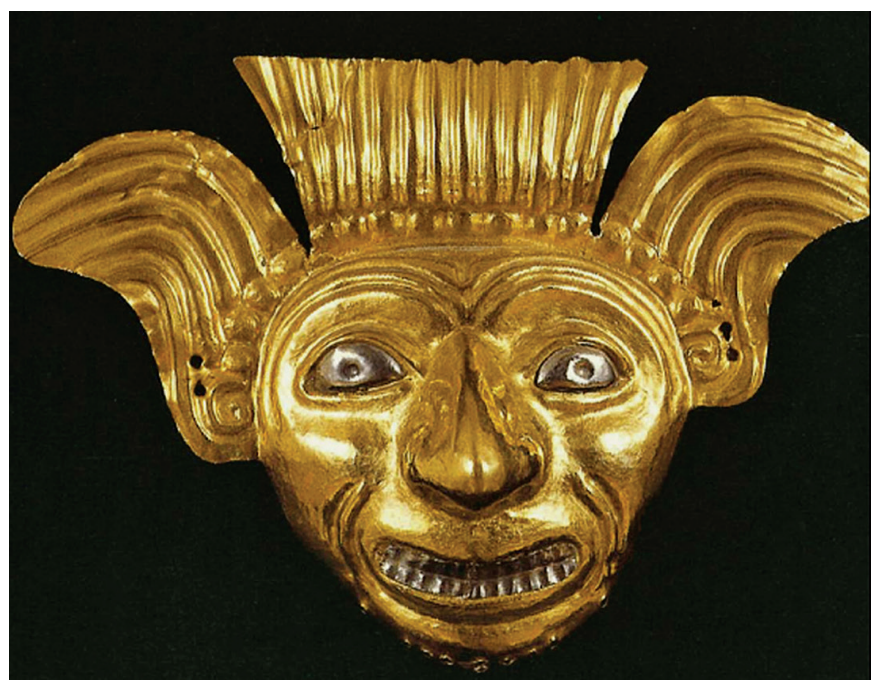

Figure N2. Photograph of gold mask with platinum highlights, from the period of La Tolita culture, Ecuador. From Museo Nacional del Banco Central del Ecuador collection.

\section{Geology \\ Geochemistry}

All chemical elements heavier than oxygen, including the PGEs, are created by nuclear fusion and nucleosynthesis processes during supernova explosions. The matter derived from supernova explosions is dispersed into the interstellar medium and enriches molecular clouds, which are sites of star and planetary formation. Earth formed from the same cloud of matter as the sun, so the bulk PGE composition of Earth is thought to be similar to that of the solar system. Carbonaceous meteorites of the Ivuna type (carbonaceous chondrites [type 1], or C1 chondrites) are used to estimate solar system abundances (Lodders, 2010). The Orgueil meteorite, which is considered most representative of the $\mathrm{C} 1$ chondrites, contains 0.947 part per million (ppm) platinum.

Early in its evolution, Earth differentiated into a metallic core, a silicate mantle, and a silicate crust. The segregation processes affected the distribution of the PGEs and resulted in concentrations progressively decreasing from core to mantle to upper crust. The range of platinum concentration in samples of iron meteorites, which are perhaps the best analogs for the composition of Earth's core, is 2.4 to $16 \mathrm{ppm}$ (Wasson and others, 1989). The average platinum concentrations of samples of the upper mantle vary from about 0.002 to $0.005 \mathrm{ppm}$ ( 2 to 5 parts per billion [ppb]) (Maier and others, 2012). In contrast, the upper crust is estimated to contain only $0.0005 \mathrm{ppm}(0.5 \mathrm{ppb}$ ) platinum (Rudnick and Gao, 2003). Today, the average grade of PGEs in ores that are mined primarily for their PGE concentrations ranges from 5 to $15 \mathrm{ppm}$; however, the concentration of PGEs in hand-picked ore specimens may range from tens to hundreds of parts per million. 


\section{Mineralogy}

The PGEs can occur as an essential component of the crystal structure of a mineral (a naturally occurring inorganic element or compound having a periodically repeating arrangement of atoms and characteristic chemical composition, resulting in distinctive physical properties). The Commission on New Minerals, Nomenclature and Classification of the International Mineralogical Association has recognized more than 100 different minerals in which at least one of the PGEs is an essential component (Cabri, 2002); they are called platinum-group minerals. Platinum-group minerals include native-metal-minerals and compounds with other transition metals (such as copper, iron, mercury, nickel, and silver), post-transition metals (such as bismuth, lead, and tin), metalloids (such as antimony, arsenic, and tellurium), and nonmetals (such as selenium and sulfur) (table N1). In most rocks, platinum-group minerals are fine-grained and range in size from less than a micron to a few hundred microns in diameter. Most geologists can spend a lifetime working on rocks enriched in PGEs and never see a platinum-group mineral in a hand specimen. Yet the platinum-group minerals are important to characterize because information about their mineralogy is needed to extract metals from their ore minerals effectively and to understand ore-forming processes.

PGEs also occur in solid solution in base-metal sulfides and sulfarsenides. In solid solution, different chemical elements can substitute in specific atomic sites without changing a mineral's crystalline structure. For example, palladium can substitute for nickel in pentlandite (Cabri, 1992); the amount of substitution can be significant and is detectable by several microanalytical techniques. PGEs also occur in solid solution in nickeliferous cobaltite (nickel-iron sulfarsenide) in ores mined at the Copper Cliff North Mine in Sudbury, Ontario, Canada (Szentpéteri and others, 2002). Low-level concentrations of PGEs in solid solution in base-metal sulfide minerals can be assessed using laser-ablation inductively coupled plasma-mass spectrometry (ICP-MS) (for example, Cabri and others, 2003; Godel and others, 2007; Pagé and others, 2012). These studies document that pentlandite is the principal base-metal sulfide mineral that hosts PGEs. Pyrrhotite $\left(\mathrm{Fe}_{1-\mathrm{x}} \mathrm{S}\right)$ can contain some iridium, osmium, rhodium, and ruthenium, but not palladium or platinum. Chalcopyrite $\left(\mathrm{CuFeS}_{2}\right)$ does not contain significant amounts of PGEs in solid solution. Platinum and gold do not partition into base-metal sulfide minerals.

\section{Deposit Types}

Mineral deposits can be classified into groups or types based on common features and associations that ultimately relate to the underlying geologic processes that formed the ore. Each mineral deposit type has characteristic geometries, distributions of tonnage and grade, and rock and mineral properties that determine the potential value of the deposit. Each deposit type also has specific characteristics that determine how much sampling will be required to delimit the deposit's mineral resources and in what manner the valuable material will be mined and processed. Furthermore, each deposit type exerts a specific impact on the environment, whether through natural weathering processes or the result of mining.

At a basic level, economic geologists recognize the following mineral deposit types: (a) magmatic_-formed during the cooling and crystallization of magma, (b) hydrothermal - formed by the interaction of hot water and rock, (c) sedimentary-formed by the precipitation or settling of minerals directly from water in oceans or lakes, (d) residual-formed by the intense weathering of rocks under hot, humid conditions, and (e) placers - formed by the physical concentration of heavy particles of rocks or minerals by the action of moving water. PGE-enriched rocks can be found in each of the deposit types listed above. The following sections describe examples of PGE mineralization found in each of these deposit types. More information is given for magmatic deposits because they are the source of almost all the PGEs recovered by mining. The locations of the world's major and minor PGE deposits are shown in figure N3.

\section{Magmatic Deposits}

PGEs are transferred from Earth's mantle to its crust by magnesium-rich magmas that were formed by the melting of a high percentage of mantle material from which magma had not been previously extracted. A high degree of partial melting is needed to release PGEs into the melt from the small quantities of sulfide minerals or alloys that are present in the mantle. Upon emplacement in the crust, the magnesium-rich magmas cool to form mafic and ultramafic igneous rocks.

Magmatic deposits are concentrations of metallic oxide or sulfide minerals that formed during the cooling and crystallization of magma. Textural and experimental evidence indicate that PGE-enriched mineralization forms when mafic to ultramafic magma becomes saturated with sulfur and an immiscible sulfide liquid exsolves from the silicate magma (Barnes and others, 2008; Holwell and McDonald, 2010; Naldrett, 2010a). The solubility of sulfur in mafic magmas is affected by changes in the bulk composition of the magma, the fugacity of sulfur and oxygen, temperature, and pressure (Ripley, 1999). Processes that change the solubility of sulfur and may cause an exsolution event include (a) fractional crystallization of the silicate magma, (b) mixing of magmas, (c) assimilation of additional sulfur from sources external to the magma, and (d) modification of the magma composition by bulk contamination, such as changing the silica content of the magma (Mungall, 2005).

The silicate magma solidifies first, followed by the sulfide liquid, which solidifies at temperatures in excess of $900{ }^{\circ} \mathrm{C}$. The textures and mineralogy of PGE ores record a prolonged and complex process of solid-state transformation and 
Table N1. Chemical formulas for selected platinum-group minerals as well as other common rock-forming minerals mentioned in this chapter.

[Sources: Deer and others (1966); Vaughan and Craig (1978); and Cabri (2002). Elements: Al, aluminum; As, arsenic; Bi, bismuth; C, carbon; $\mathrm{Ca}$, calcium; Cr, chromium; Cu, copper; Fe, iron; Hg, mercury; Ir, iridium; K, potassium; Mg, magnesium; Na, sodium; Ni, nickel; O, oxygen; Os, osmium; Rh, rhodium; Ru, ruthenium; Pb, lead; Pd, palladium; Pt, platinum; S, sulfur; Sb, antimony; Si, silicon; Sn, tin; Te, tellurium]

\begin{tabular}{|c|c|c|c|}
\hline Mineral name & Chemical formula & Mineral name & Chemical formula \\
\hline \multicolumn{2}{|c|}{ PLATINUM-GROUP MINERALS } & \multicolumn{2}{|c|}{ BASE-METAL SULFIDE MINERALS } \\
\hline \multicolumn{2}{|c|}{ Native metals } & Bornite & $\mathrm{Cu}_{5} \mathrm{FeS}_{4}$ \\
\hline Iridium & Ir & Chalcopyrite & $\mathrm{CuFeS}_{2}$ \\
\hline Osmium & Os & Covellite & $\mathrm{CuS}$ \\
\hline Palladium & $\mathrm{Pd}$ & & \\
\hline Platinum & $\mathrm{Pt}$ & Cubanite & $\mathrm{CuFe}_{2} \mathrm{~S}_{3}$ \\
\hline Rhodium & $\mathrm{Rh}$ & Marcasite & $\mathrm{FeS}_{2}$ \\
\hline Ruthenium & $\mathrm{Ru}$ & Mooihoekite & $\mathrm{Cu}_{9} \mathrm{Fe}_{9} \mathrm{~S}_{16}$ \\
\hline \multicolumn{2}{|c|}{ Compounds with transition metals } & Nickeliferous cobaltite & $\mathrm{Co}(\mathrm{Ni}) \mathrm{AsS}$ \\
\hline Isoferroplatinum & $\mathrm{Pt}_{3} \mathrm{Fe}$ & Pentlandite & $(\mathrm{Fe}, \mathrm{Ni})_{9} \mathrm{~S}_{8}$ \\
\hline Potarite & $\mathrm{PdHg}$ & Pyrite & $\mathrm{FeS}_{2}$ \\
\hline Tulameenite & $\mathrm{PtFe}_{0.5} \mathrm{Cu}_{0.5}$ & Pyrrhotite & $\mathrm{Fe}^{2} \mathrm{~S}$ \\
\hline \multicolumn{2}{|c|}{ Compounds with post-transition metals ( $\mathrm{Bi}, \mathrm{Pb}$, and $\mathrm{Sn})$} & Pyrrnotite & $\mathrm{Fe}_{(1-\mathrm{x})}^{\mathrm{S}}$ \\
\hline Atokite & $\mathrm{Pd}_{3} \mathrm{Sn}$ & Talnakhite & $\mathrm{Cu}_{9}(\mathrm{Fe}, \mathrm{Ni})_{8} \mathrm{~S}_{16}$ \\
\hline Froodite & $\mathrm{PdBi}_{2}$ & Troilite & $\mathrm{FeS}$ \\
\hline Insizwaite & $\mathrm{PtBi}_{2}$ & \multicolumn{2}{|c|}{ OTHER ROCK-FORMING MINERALS } \\
\hline Rustenburgite & $\mathrm{Pt}_{3} \mathrm{Sn}$ & Calcite & $\mathrm{CaCO}_{3}$ \\
\hline Paolovite & $\mathrm{Pd}_{2} \mathrm{Sn}$ & Chlorite & $(\mathrm{Mg}, \mathrm{Fe})_{3}(\mathrm{Si}, \mathrm{Al})_{4} \mathrm{O}_{10}(\mathrm{OH})_{2}$ \\
\hline \multicolumn{2}{|c|}{ Compounds with metalloids } & & $(\mathrm{Mg}, \mathrm{Fe})_{3}(\mathrm{OH})_{6}$ \\
\hline Genkinite & $(\mathrm{Pt}, \mathrm{Pd})_{4} \mathrm{Sb}_{3}$ & Chromite & $(\mathrm{Fe}, \mathrm{Mg})(\mathrm{Cr}, \mathrm{Al})_{2} \mathrm{O}_{4}$ \\
\hline Geversite & $\mathrm{PtSb}_{2}$ & Goethite & $\mathrm{FeO}(\mathrm{OH})$ \\
\hline Isomertieite & $\mathrm{Pd}_{11} \mathrm{Sb}_{2} \mathrm{As}_{2}$ & Gypsum & $\mathrm{CaSO}_{4}$ \\
\hline Kotulskite & PdTe & Jarosite & $\mathrm{KFe}\left(\mathrm{SO}_{4}\right)_{2}(\mathrm{OH})_{6}$ \\
\hline Merenskyite & $\mathrm{PdTe}_{2}$ & Magnetite & $\mathrm{Fe}_{3} \mathrm{O}_{4}$ \\
\hline Moncheite & $\mathrm{PtTe}_{2}$ & Native sulfur & $\mathrm{S}$ \\
\hline $\begin{array}{l}\text { Sperrylite } \\
\text { Stibiopalladinite }\end{array}$ & $\begin{array}{l}\mathrm{PtAs}_{2} \\
\mathrm{Pd}_{5+\mathrm{x}} \mathrm{Sb}_{2-\mathrm{x}}\end{array}$ & Olivine & $(\mathrm{Mg}, \mathrm{Fe})_{2} \mathrm{SiO}_{4}$ \\
\hline Stillwaterite & $\mathrm{Pd}_{8} \mathrm{As}_{3}$ & Plagioclase & $(\mathrm{Ca}, \mathrm{Na})(\mathrm{Si}, \mathrm{Al})_{4} \mathrm{O}_{8}$ \\
\hline Sudburyite & $\mathrm{PdSb}$ & Pyroxene & $\mathrm{Ca}(\mathrm{Mg}, \mathrm{Fe}) \mathrm{Si}_{2} \mathrm{O}_{6}$ to \\
\hline \multicolumn{2}{|c|}{ Compounds with nonmetals } & & $\mathrm{Mg}_{2} \mathrm{Si}_{2} \mathrm{O}_{6}$ \\
\hline Braggite & $(\mathrm{Pt}, \mathrm{Pd}) \mathrm{S}$ & Serpentine & $(\mathrm{Mg}, \mathrm{Fe})_{3} \mathrm{Si}_{2} \mathrm{O}_{5}(\mathrm{OH})_{4}$ \\
\hline Cooperite & $\mathrm{PtS}$ & Talc & $\mathrm{Mg}_{3} \mathrm{Si}_{4} \mathrm{O}_{10}(\mathrm{OH})_{2}$ \\
\hline Erlichmanite & $\mathrm{OsS}_{2}$ & & \\
\hline Laurite & $\mathrm{RuS}_{2}$ & & \\
\hline Vysotskite & $\mathrm{PdS}$ & & \\
\hline \multicolumn{2}{|c|}{ Other } & & \\
\hline Hollingworthite & RhAsS & & \\
\hline Maslovite & PtBiTe & & \\
\hline Michenerite & PdBiTe & & \\
\hline Ruarsite & RuAsS & & \\
\hline
\end{tabular}




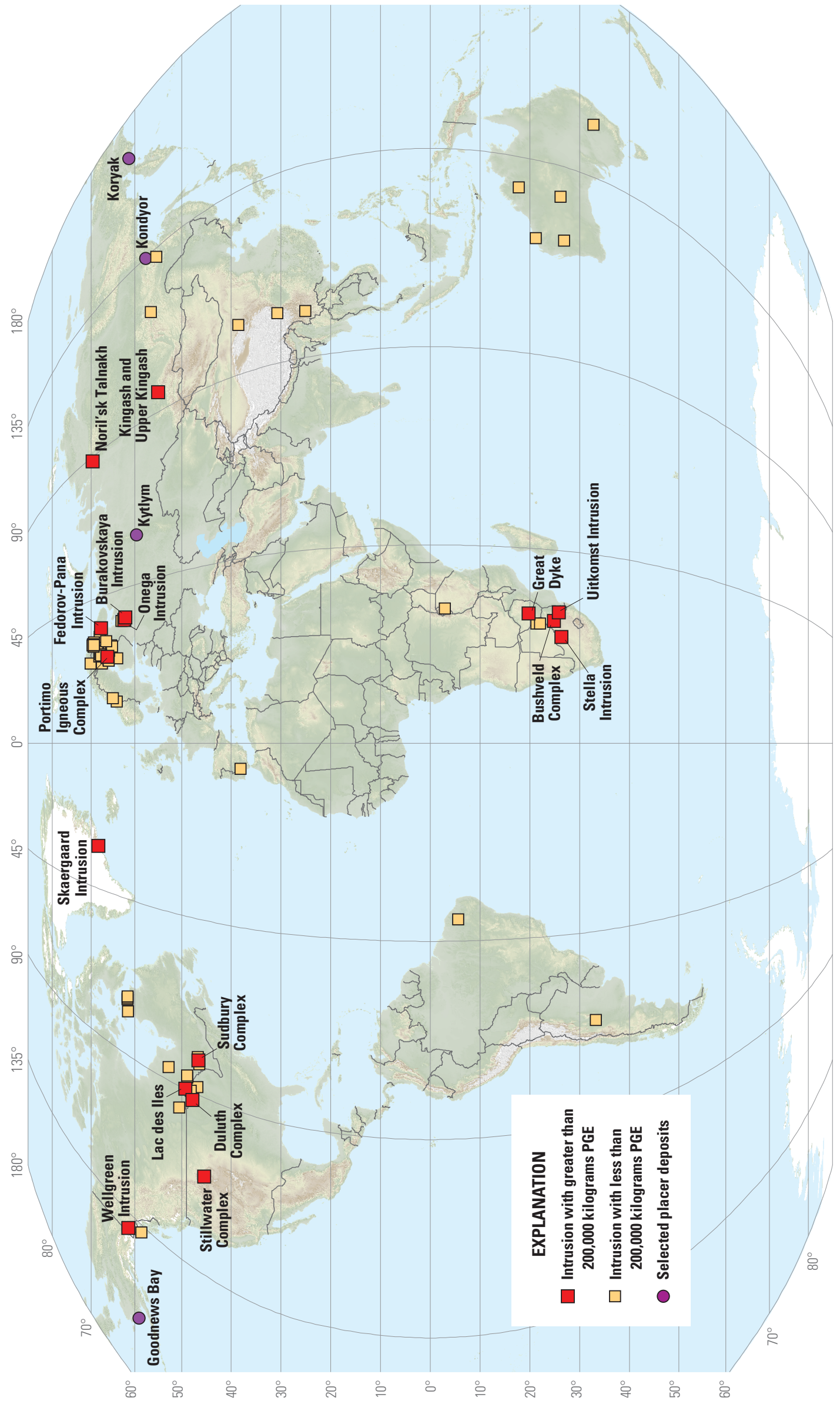

$\overline{\overline{\mathrm{j}}}$

is

离

홍

웡 응

Ш్ㅇㅇ

늠

E⿱亠丷口心

के

후요

한

틀

票

कs

흔용

항

$\stackrel{\oplus}{ \pm}$

능

范

हो

产 \&

당

흘 응

\&

징

를.

엉

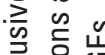

론응 뭉

릉

든

응 응

s。

$\stackrel{\square}{\circ}$ 드

品至

d

혼

o $\cong$

¿

등 을

들

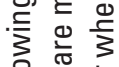

的志 흐

웧

통 홍

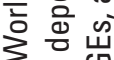

3 힘

m

言冚 
recrystallization after solidification (Barnes and others, 2008; Holwell and McDonald, 2010). At high temperature (about $1,000{ }^{\circ} \mathrm{C}$ ), osmium, iridium, and ruthenium preferentially partition from the immiscible sulfide liquid into a mineral called monosulfide solid solution (MSS). Platinum, palladium, and gold, on the other hand, behave as incompatible elements with respect to MSS and instead are concentrated in residual copper-rich sulfide liquids and associated with the minerals that crystallize from the residual immiscible sulfide liquid. Upon cooling, some of the PGEs held in sulfide crystal structures are expelled, forming discrete minerals. The final mineral assemblage consists of varied proportions of pyrrhotite, pentlandite, chalcopyrite, and bornite, with platinum and gold occurring primarily in platinum-group minerals.

Magmatic sulfide minerals in mafic to ultramafic igneous rocks do not always contain elevated concentrations of PGEs. The metal content of immiscible sulfide liquids is a function of the (a) amount of metal in the silicate magma; (b) relative affinity for metals to occur in the sulfide or silicate liquid; and (c) relative amounts of the two liquids (Campbell and Naldrett, 1979; Barnes and Maier, 1999). Such elements as copper, nickel, and PGEs originally in the silicate melt preferentially concentrate into the sulfide liquid when it exsolves. Concentration of these metals into the sulfide liquid can, under some circumstances, deplete their concentration in the silicate magma. If there is a large volume of sulfide liquid compared with that of the silicate magma, the sulfide liquids and the resulting ores will have lower concentrations of PGEs. If the sulfide liquid effectively interacts with a large volume of silicate magma, the sulfide liquids become enriched in PGEs, resulting in high-grade ores.

Economic geologists who study magmatic processes expend a lot of effort trying to understand how large mass ratios are achieved. Proposed answers have included mixing of magmas; the migration of interstitial melts (and "fluids") upward through crystal mush; and (or) the streaming of magma over sulfide liquids in a channelized lava flow, sill, or feeder dike (Barnes and Maier, 1999; Mathez, 1999; Naldrett, 2010a).

\section{Tectonic Setting of Magmatic Deposits (Large Igneous Provinces)}

As the theory of plate tectonics gained acceptance in the 1960s and its predictive power became evident, geologists, including those working on magmatic ore deposits, tried to understand magmatism and ore genesis in a plate-tectonic context (Hutchison, 1983; Sawkins, 1984). For some mafic and ultramafic rocks that are related to subduction zones and mid-oceanic ridges, this conceptual framework provided insight and clarity; however, for other types of mafic and ultramafic rocks found in intraplate settings, which include rocks that host most of the significant magmatic mineral deposit types, it did not.
Most magmatic copper-nickel-PGE deposits occur with continental flood basalts, aerially extensive mafic dike swarms, sill provinces, and large layered ultramafic-to-mafic intrusions, which are indicative of large igneous provinces (LIPs) (Coffin and Eldholm, 1994). Bryan and Ernst proposed that LIPs are magmatic provinces with areal extents greater than $1 \times 10^{5}$ square kilometers $\left(\mathrm{km}^{2}\right)$, igneous volumes greater than $1 \times 10^{5}$ cubic kilometers $\left(\mathrm{km}^{3}\right)$ and maximum lifespans of about 50 million years (m.y.) that "have intraplate tectonic settings or geochemical affinities, and are characterized by igneous pulse(s) of short duration" ( $\sim 1$ to 5 m.y.), during which time "a large proportion ( $>75$ percent) of the total igneous volume has been emplaced. [The LIPs] are dominantly mafic, but also can have significant ultramafic and silicic components, and some are dominated by silicic magmatism" (Bryan and Ernst, 2008, p. 175). Unlike the vast majority of igneous rocks that are associated with plate tectonic processes at convergent or divergent tectonic plate margins, LIP-related rocks usually occur in an intraplate tectonic setting; the association of some LIPs with hotspot tracks - for example, the North Atlantic Igneous Province and the Iceland hotspot (Storey and others, 2007) is one reason that LIPs are attributed to mantle plumes.

\section{Types of Magmatic Deposits}

Magmatic mined deposits associated with LIP-related igneous intrusions are divided into types based on such criteria as the lithology and form of associated igneous rocks, the depth of emplacement, the abundance of sulfide minerals, the relative proportion of metals, and the position of the ores within the intrusion. In this chapter, we distinguish between conduit-type deposits, which occur in intrusions that are part of sill complexes and dike swarms, and reef-type and contacttype deposits, which occur in layered intrusions (fig. N4). The most significant and representative examples for the world and the United States are the conduit-type deposits of the Noril'skTalnakh area (Russia); the reef-type deposits in South Africa (the Merensky Reef and the UG2 Chromitite), Zimbabwe (the Main Sulphide Zone), and Montana (the J-M Reef); and the contact-type deposits in South Africa (the Platreef) and Minnesota (the Duluth Complex).

\section{Conduit-Type Deposits}

The conduit-type deposits of the Noril'sk-Talnakh area of Russia are associated with an enormous outpouring of mafic magma that formed the Siberian Traps - the largest continental flood basalt province on Earth (fig. N5). The magmas erupted in a short period of time; the 3.5-kilometer (km)-thick basalt succession at Noril'sk-Talnakh was emplaced between $248.7 \pm 0.6$ and $250.3 \pm 1.1$ mega-annum (Ma) (Reichow and others, 2009). The flood basalts crop out on the Siberian craton, covering an area of approximately 2.5 million $\mathrm{km}^{2}$ (Fedorenko and others, 1996). In addition, flood basalts 


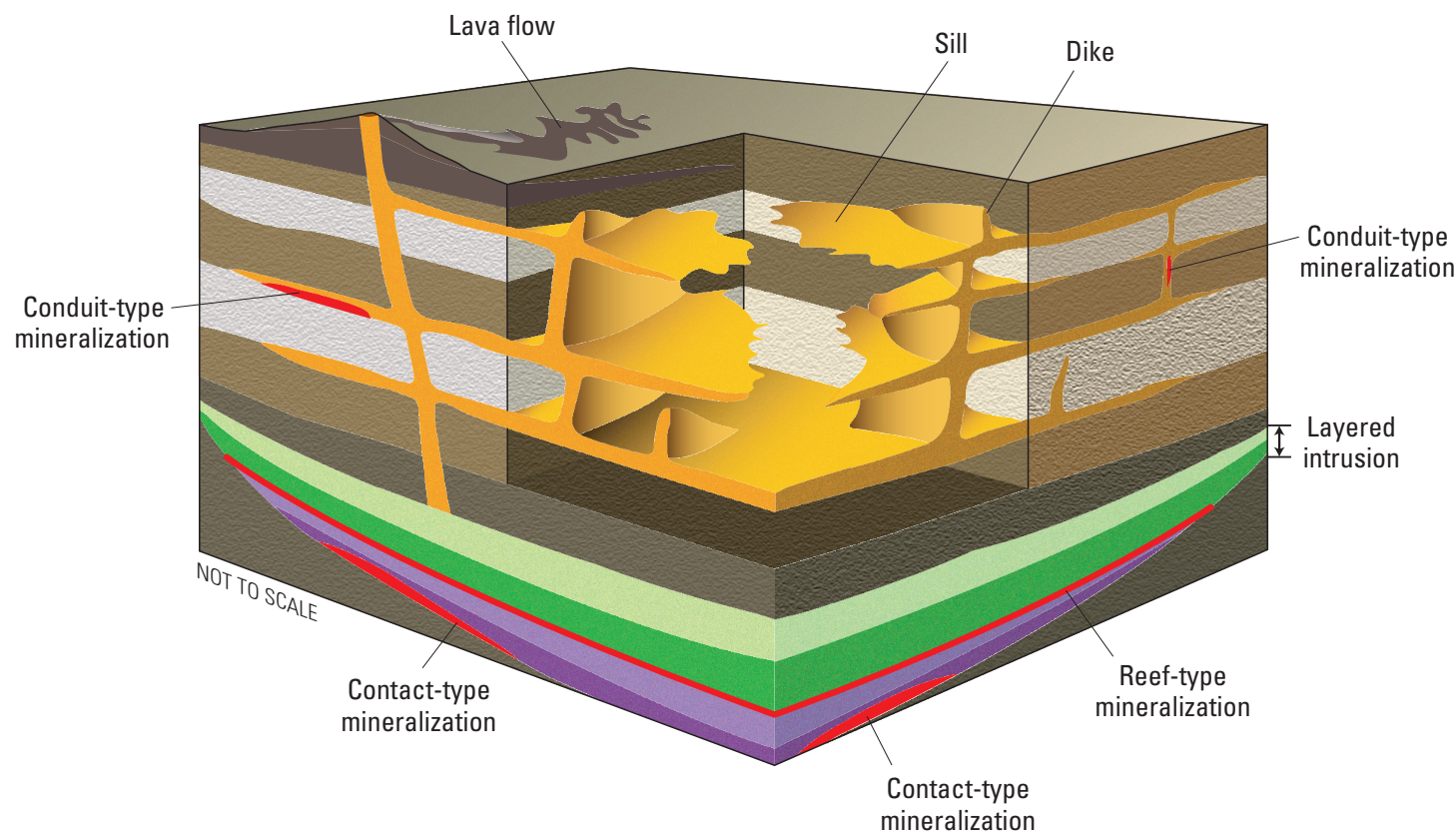

EXPLANATION

Magma or lava

Platinum-group element mineralization

Layered mafic to ultramafic intrusion

Figure N4. Schematic block diagram showing changes in the form of igneous intrusions with depth and the relative occurrence of conduit-type, contact-type, and reef-type magmatic ore deposits. Layered igneous rocks with reef-type and contact-type deposits occur at depth in large layered intrusions. Sills and dikes provide the conduits or pathways that magma follows as it rises upwards through the crust. Conduittype magmatic sulfide deposits can be localized in sills or dikes. Modified from Naus-Thijssen (2007).

are also found in the late Mesozoic fold and thrust belt in the Taimyr Peninsula and under the West Siberian Basin (Reichow and others, 2009).

A sill complex lies beneath the thick succession of volcanic flows and is exposed where the flood basalts have been removed by erosion (fig. N5). The sill complex consists of thousands of intrusions that delineate the pathways along which large volumes of magma were transported through the crust (Arndt, 2005). Sills with major nickel-copper-PGE deposits have been identified only in the Noril'sk-Talnakh area; however, copper-nickel sulfide occurrences in sills are distributed over a much larger area (fig. N5). All these occurrences of volcanic rocks and associated sills make up the Siberian Traps LIP (Ernst and Buchan, 2001).

In the Noril'sk-Talnakh area, plateaus covered by flood basalts have been dissected by erosion and exposed the underlying sill complex (fig. N6). More than 300 intrusions have been mapped, but only 33 contain elevated sulfide concentrations. Of these 33 intrusions, 16 contain relatively rich disseminated ore and only 4 contain rich massive sulfide orebodies (Diakov and others, 2002). High sulfur contents coupled with increasing $\delta^{34} \mathrm{~S}$ values is consistent with the addition of crustally derived ${ }^{34} \mathrm{~S}$-enriched sulfur to the magma of the ore-bearing intrusions (Grinenko, 1985; Li and others, 2003).

The ore-bearing intrusions have an elongate, finger-like shape; they may be up to $1 \mathrm{~km}$ wide by 500 meters $(\mathrm{m})$ thick and up to $15 \mathrm{~km}$ long. Most of the other sills form sheet-like bodies that are tens of meters thick. Rock textures of sills indicate crystallization and cooling at shallow depth. The orebearing intrusions are internally differentiated, with magnesium rocks and minerals concentrated towards the base of the sills; the laterally continuous sills show less internal differentiation. 


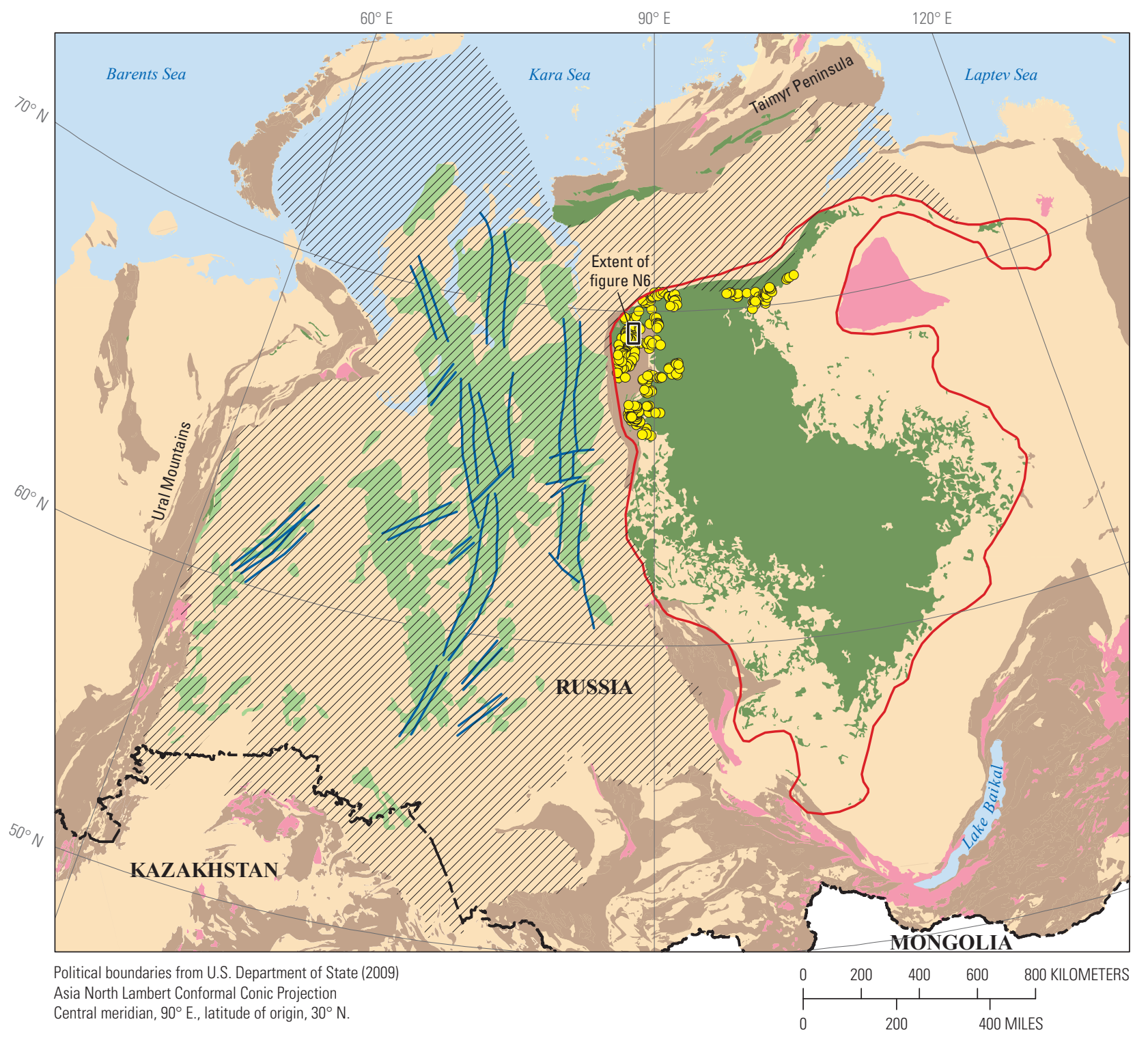

EXPLANATION

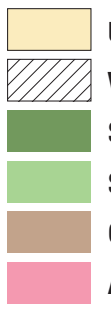

Undeformed cover of sedimentary rocks
West Siberian Basin
Siberian flood basalts, exposed
Siberian flood basalts, covered
Orogenic belts

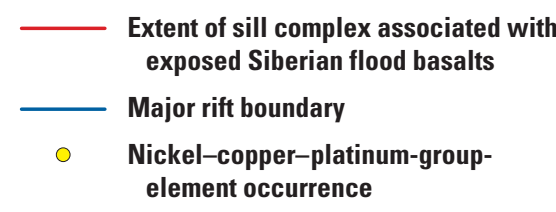

Figure N5. Map showing the geology of the Siberian flood basalt province in Russia, which is the largest flood basalt province in the world. The province includes a large area of exposed lavas and sills. It also includes an equally large area of lavas that are covered by younger deposits that make up the West Siberian Basin. The sill complex associated with the exposed lavas underlies and extends beyond the area of lavas. The deposits of the Noril'sk-Talnakh area, along with many occurrences of magmatic sulfide mineralization, have been found in the northwestern part of the province where the lavas and sills are exposed. Map includes information from Zonenshain and others (1988), Fugro Robertson, Ltd. (2008), and Reichow and others (2009). 


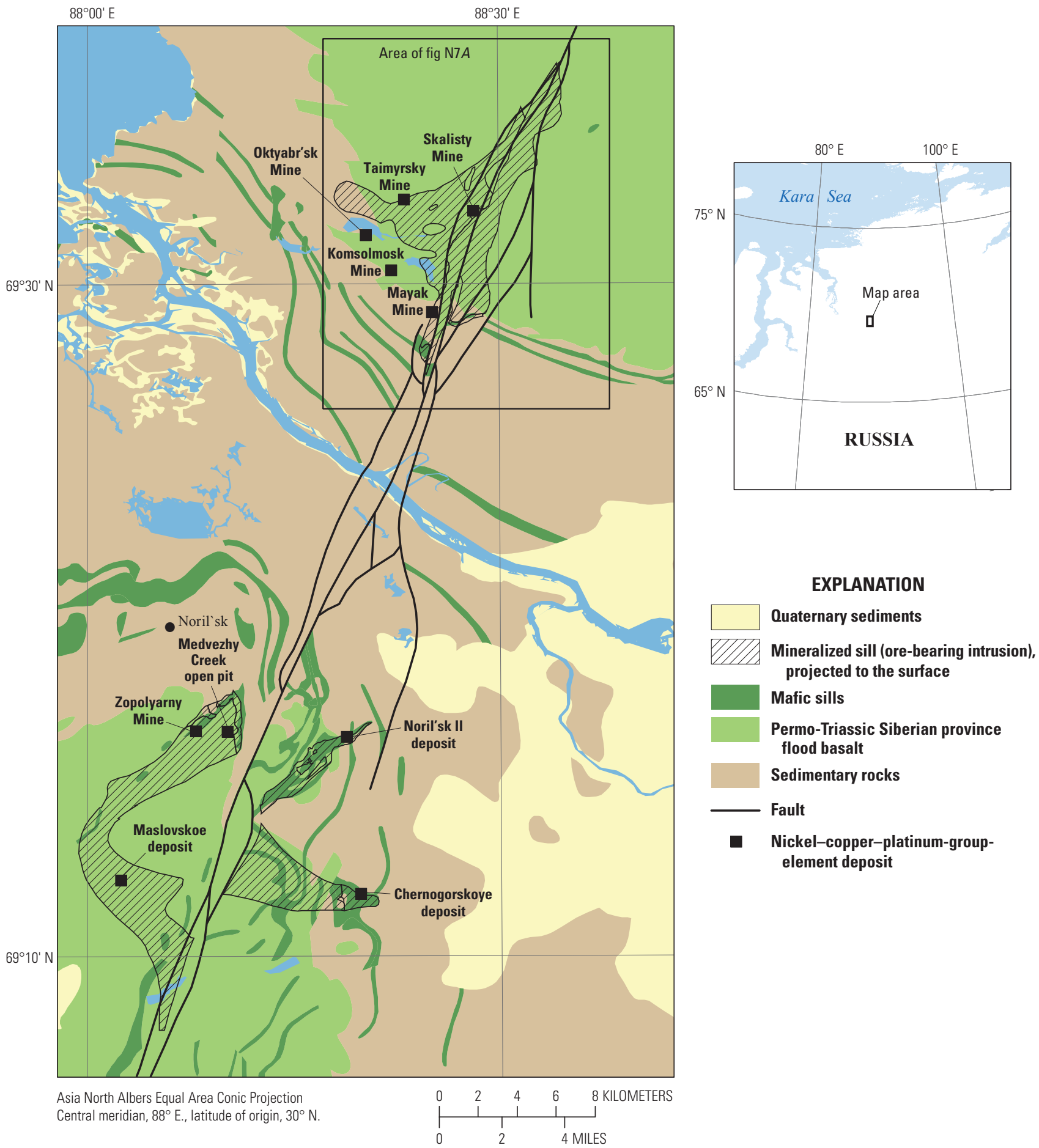

Figure N6. Map showing the geology of the Noril'sk-Talnakh area and the location of nickel-copper-platinum-groupelement (Ni-Cu-PGE) deposits. Flood basalts crop out in the northeast and the southeast; in other areas, erosion has removed the lavas and exposed the underlying sills that intrude older sedimentary rocks. The mineralized sills largely underlie the lavas. Their subsurface extent has been projected to the surface. Geology simplified from Sherman and others (1991). 


\section{N12 Critical Mineral Resources of the United States-Platinum-Group Elements}

The amount of massive sulfide ores associated with the mineralized intrusions at Talnakh is astounding. The massive sulfide ores, which are up to $45 \mathrm{~m}$ thick, underlie most of the intrusions in the Talnakh area (fig. N7A; Kunilov, 1994). The ore-bearing sills contain, or are associated with, concentrations of sulfide minerals that exceed the amount of sulfur that could have been dissolved in the volume of magma now in the sills. The sulfide mineralization also contains high concentrations of PGEs, indicating a silicate-to-sulfide ratio that is larger than the observed proportion of silicate minerals to sulfide minerals in the sills. This suggests that at the time of ore formation, the sulfide liquids equilibrated with a much larger volume of magma than is now represented by the igneous rocks in the sill. Field relations indicate lateral movement of immiscible sulfide liquids during and after solidification of the silicate igneous rocks.

In the Talnakh area, fractional crystallization of the immiscible sulfide liquids formed mineralogically and compositionally zoned orebodies (fig. N7 B). Massive ores formed by early crystallization of sulfides contain less copper and PGEs than ores that formed from sulfide liquid that are the end product of the fractional crystallization process (fig. N8). The copper- and PGE-rich late-stage ores are the likely source of most of the PGE production from the Talnakh deposits (fig. N7C). Between 1960 and 2011, Russia (including all the Soviet Union until 1991) produced about 5,000 metric tons of PGEs, most of them from the Noril'sk-Talnakh area (U.S. Bureau of Mines, 1933-96; U.S. Geological Survey, 1997-2016). Mining depths in the Noril'sk-Talnakh area range from 300 to $1,500 \mathrm{~m}$ (Kunilov, 1994).

\section{Reef-Type and Contact-Type Deposits}

LIP-related layered mafic to ultramafic intrusions contain most of the world's resources of PGEs. Layered intrusions form by crystallization of magma deep in Earth's crust and have sheet-like to dike-like shapes. They consist primarily of cumulates, which are rocks that represent accumulations (concentrations) of minerals that crystallize from magmas. Cumulus rock textures are distinctive, as they record nucleation and growth of crystals from the melt, enlargement of crystals to form a touching framework (a crystal mesh), solidification, and subsolidus grain boundary adjustments that minimize grain boundary surface energies (Hunter, 1987).

Cumulus rocks are also distinctive in that they do not have the composition of naturally occurring magmas but are instead a mixture of early formed crystals with variable proportions of trapped liquid.

As the magma crystallizes in these intrusions, layering features develop that are recognized by the variations in the modal proportions of the minerals, the rock textures, the grain size, and the mineral compositions. Individual layers range from laminations formed by the orientation of individual crystals that are millimeters in diameter to strata that are tens to hundreds of meters thick and may extend for hundreds of kilometers along strike. The layering features are so pronounced and consistent that stratigraphic principles developed for sedimentary rocks are applied to these igneous rocks. Stratigraphic columns are measured through the sequence of layered igneous rocks to define mappable units; the thickness of the layered rocks in intrusions ranges from hundreds of meters to as much as $10 \mathrm{~km}$.

Layered intrusions have two significant styles of magmatic sulfide mineralization - reef type and contact type. The analogy with sedimentary rocks extends to the terminology used for magmatic deposits in layered intrusions. Some of the magmatic deposits are strata-bound, which means that the deposit is confined to a stratigraphic unit, not to a particular bed. Other magmatic deposits are stratiform, which means that the deposit constitutes one or more of the igneous layers; an example would be the chromium deposits in layered intrusions (which correspond to igneous rock layers that are composed primarily of the mineral chromite). Reef-type and contact-type deposits are strata-bound, as described below.

Reef-type PGE deposits are disseminated copper-, iron-, nickel-, and PGE-bearing minerals that are associated with one or more strata within a layered igneous intrusion (fig. N4). The mineralized rock unit almost always contains disseminated magmatic sulfide minerals, but the rock layers are dominated by silicate minerals or oxide minerals such as chromite or magnetite. The modal abundance of sulfide minerals is usually much less than a few percent. The term "reef" is an Australian and South African mining term for a relatively flat-lying, tabular orebody. Within a layered igneous intrusion, reef-type mineralization is laterally persistent, extending for the strike length of the intrusion, which is typically tens to hundreds of kilometers. The mineralized interval is thin (generally centimeters to meters thick), however, relative to the total stratigraphic thickness of the layers in the intrusion, which can vary from hundreds to thousands of meters.

Copper-nickel-PGE contact-type deposits consist of disseminated magmatic sulfide minerals found near the lower contact or margin of mafic to ultramafic layered intrusions (fig. N4). The host rocks for the disseminated sulfide minerals are the igneous rocks of the intrusion and adjacent contact metamorphosed country rocks. Some igneous lithologies are cumulates, but other mineralized mafic and ultramafic igneous rocks are texturally and lithologically heterogeneous, exhibiting changes in texture and mineral proportions at scales of from centimeters to meters. Textures indicative of chilling or unidirectional growth of silicate minerals may also be present. Inclusions of autoliths and xenoliths are common; they are surrounded by igneous rocks that have textural, mineralogical, and isotopic features suggestive of reaction with the inclusions (Iljina and Lee, 2005). 

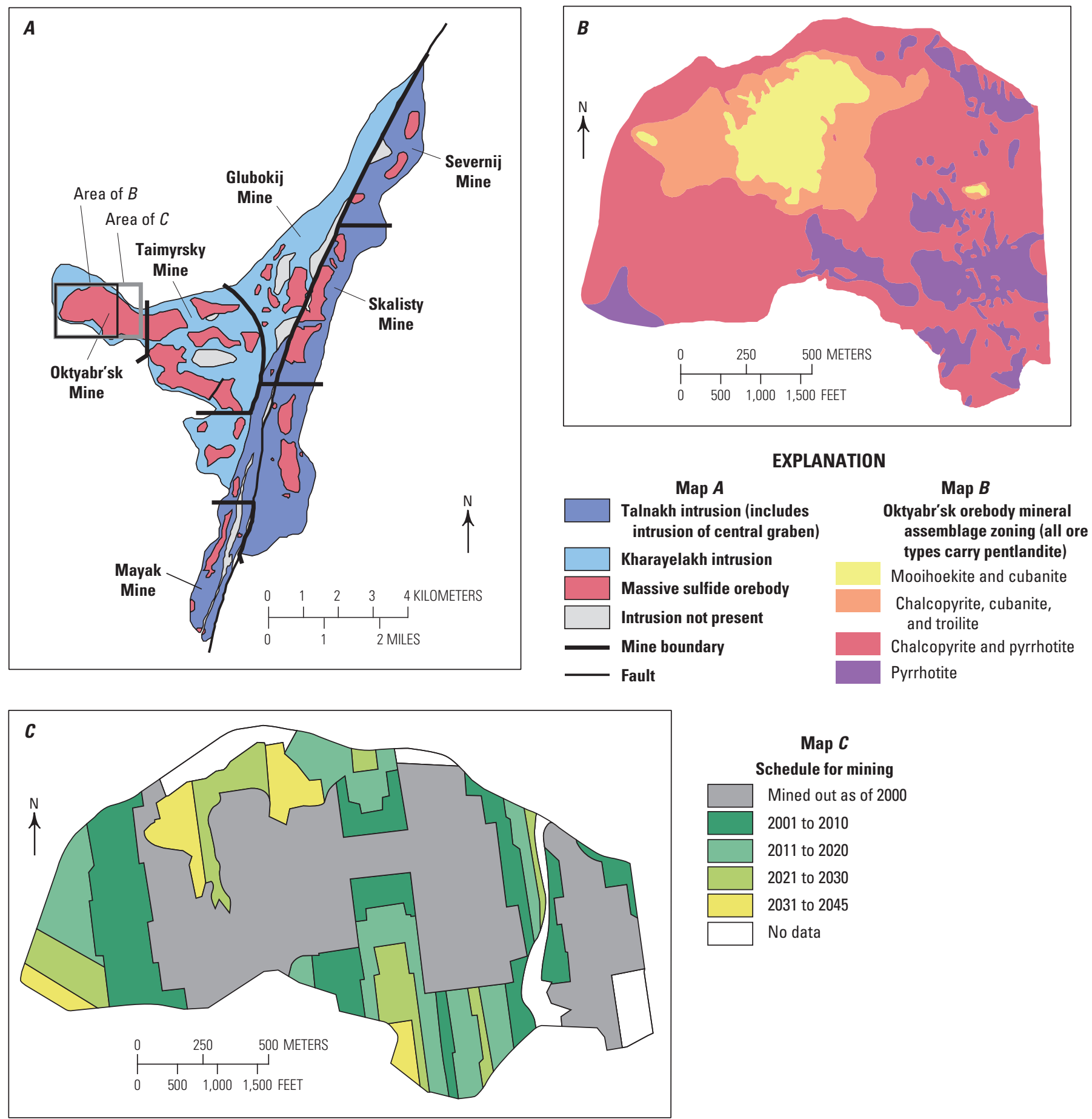

Map C

Schedule for mining

Mined out as of 2000

2001 to 2010

2011 to 2020

2021 to 2030

2031 to 2045

No data

Figure N7. Maps showing nickel-copper-platinum-group-element (Ni-Cu-PGE) deposits in the Talnakh area, Russia. $A$, Extent of two elongate sill-like intrusions (Talnakh and Kharayelakh) and the distribution of massive sulfide ores that underlie them. $B$, Zoning of sulfide minerals in the Oktyabr'sk orebody. The concentric pattern of minerals formed by fractional crystallization of immiscible sulfide melt; the pyrrhotite $\left(\mathrm{Fe}_{1-x} \mathrm{~S}\right)$ assemblage solidified first, and mooihoekite $\left(\mathrm{Cu}_{9} \mathrm{Fe}_{9} \mathrm{~S}_{16}\right)$ and cubanite $\left(\mathrm{CuFe}_{2} \mathrm{~S}_{3}\right)$ solidified last. The copper-rich ore assemblages contain the most PGEs. C, Mined-out areas of the Oktyabr'sk orebody and future mine plans to 2045. Most of the copper- and PGE-rich ores have been mined. Maps modified from Zientek and others (1994) and Naldrett (2006). 
Figure N8. Photograph of copper-rich massive sulfide ore exposed in a stope in the Oktyabr'sk Mine in the Talnakh area, Russia. The ore consists of several iron-copper-sulfide minerals, such as chalcopyrite $\left(\mathrm{CuFeS}_{2}\right)$, mooihoekite $\left(\mathrm{Cu}_{9} \mathrm{Fe}_{9} \mathrm{~S}_{16}\right)$, and talnakhite $\left(\mathrm{Cu}_{9}\left(\mathrm{Fe}, \mathrm{Ni}_{8}\right)_{16}\right)$. The minerals are brassy to golden yellow, but some develop iridescent blue and maroon colors when exposed to air. These ores represent the end product of the fractional crystallization of immiscible sulfide liquid and can contain tens to hundreds of parts per million platinum-group elements. Photograph by Michael L. Zientek, 1992.

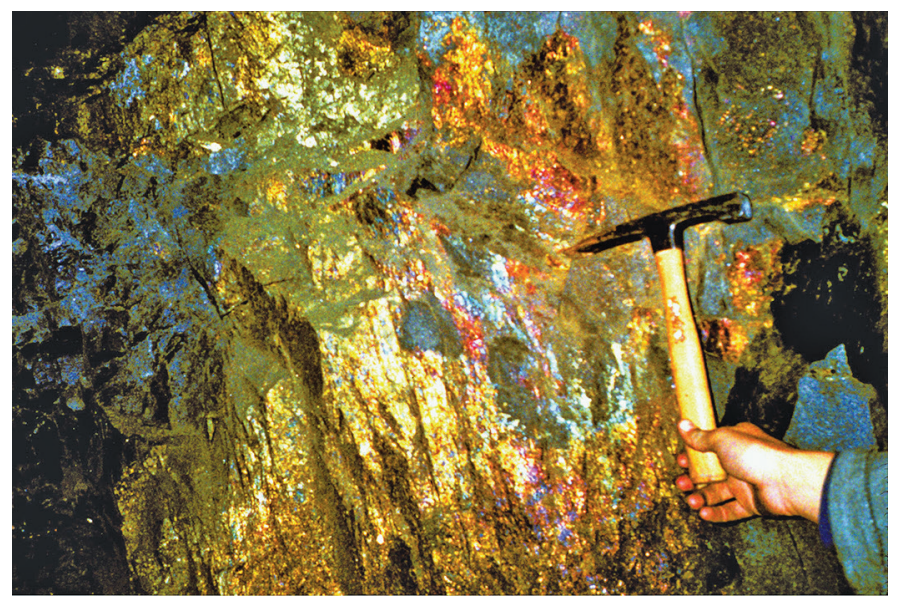

Sulfide abundance in contact-type PGE deposits is typically about 3 to 5 volume percent, although some nettextured and (or) massive sulfide ores may be present. Erratic variation in the distribution of sulfide minerals is typical, although the concentration of sulfide minerals within the intrusion generally increases towards the contact with adjacent country rocks. The mineralization can be laterally persistent, commonly extending for the entire strike length of the layered igneous intrusion. The interval that can contain magmatic sulfide minerals is generally tens to hundreds of meters in thickness, however. The proportion of sulfide minerals varies within the rock layers that can host ore; during exploration and development, economic cutoff grades are used to define the volume of rock within the igneous rock unit that could be mined. Therefore, low-grade mineralization may occur outside the cutoff limit that defines minable parts of deposits. Examples of major reef-type (a-c) and contact-type (a and d) deposits are discussed below.

(a) Merensky Reef, UG2 Chromitite, and Platreef, Bushveld Complex, South Africa. The Paleoproterozoic Bushveld Complex (2,054.4 $\pm 1.3 \mathrm{Ma}$, using the uraniumlead-zircon technique for determining age) is a large mass of igneous rock that underlies an area of approximately $69,000 \mathrm{~km}^{2}$ in South Africa (fig. N9; Hall, 1932; von Gruenewaldt, 1977; Scoates and Friedman, 2008). It is part of the Bushveld LIP (Ernst and Buchan, 2001), which also includes the Molopo Farms Complex (another large layered mafic to ultramafic intrusion in Botswana and South Africa (Prendergast, 2012); a large complex of sills related to the Bushveld Complex (Sharpe, 1981; Sharpe and Hulbert, 1985); and the Dullstroom basalts in South Africa (Buchanan and others, 1999).

The Bushveld Complex consists of several igneous suites. The most important economically is the Rustenburg Layered Suite, which is an approximately 8 -km-thick layered sequence of mafic to ultramafic cumulates (Vermaak and von Gruenewaldt, 1986; Walraven, 1986) that contain world-class deposits of chromium, PGEs, and titanium-vanadium. The cumulates of the Rustenburg Layered Suite are exposed intermittently around the periphery of the Bushveld Complex in areas referred to as limbs. Igneous layering dips gently towards the center of the Bushveld Complex. Seismic surveys trace igneous units exposed at the surface to depths exceeding $6 \mathrm{~km}$ (Sargeant, 2001; Campbell, 2011). Gravity modeling indicates that the western and eastern limbs of the Bushveld Complex are connected at depth (fig. N9, cross section $A-A$ '; Webb and others, 2004).

Two PGE-enriched reefs, the UG2 Chromitite (fig. N10) and the Merensky Reef (fig. N11; Viljoen, 1999), each occur near the base of different repetitive rock sequences (cyclic units) and can be continuously traced onstrike for the full extent of the eastern and western limbs of the complex. The grade of the UG2 Chromitite deposit is about 5 grams per metric ton $(\mathrm{g} / \mathrm{t})$ PGEs and gold; the grade of the Merensky Reef is about $6 \mathrm{~g} / \mathrm{t}$ in the western part of the complex and about $4.2 \mathrm{~g} / \mathrm{t}$ in the eastern part.

In the northern limb, varitextured pyroxenite, norite, and gabbro are found near the lower contact of the complex with metasedimentary rocks of the Transvaal Supergroup (van der Merwe, 1976). These igneous rocks host the Bushveld Complex's contact-type copper-nickel-PGE deposits (known as the Platreef). The combined PGE and gold grades for the Platreef deposits range from 0.55 to $3.7 \mathrm{~g} / \mathrm{t}$. Since the 1920 s, mining has recovered 7,200 metric tons of PGEs from the Bushveld Complex (U.S. Bureau of Mines, 1933-34; 1933-96; U.S. Geological Survey, 1997-2016).

(b) Main Sulphide Zone, Great Dyke, Zimbabwe. The Neoarchean Great Dyke (2575.4 $\pm 0.7 \mathrm{Ma}$, age determined from zircon using uranium-lead technique; Oberthür and others, 2002 ) is a long (about $550 \mathrm{~km}$ ) and narrow (about $11 \mathrm{~km}$ ) layered igneous intrusion in Zimbabwe. This intrusion and some subparallel dikes are the geologic features associated with the Great Dyke of Zimbabwe LIP (Ernst and Buchan, 2001). The rock types of the Great Dyke consist of layered mafic to ultramafic cumulates that dip inwards from the sides towards the center of the intrusion (fig. N12). Since the 1980s, mining has recovered 107 metric tons of PGEs from a reeftype PGE deposit within the Great Dyke- the Main Sulphide Zone-which occurs 10 to $50 \mathrm{~m}$ below the contact between the ultramafic and mafic sequences. The Main Sulphide Zone is typically 2 to $3 \mathrm{~m}$ thick, and the grade of the deposit varies from about 3.5 to $4 \mathrm{~g} / \mathrm{t}$ PGEs and gold (U.S. Bureau of Mines, 1933-96; Wilson, 1996; U.S. Geological Survey, 1997-2016; Wilson and Prendergast, 2001). 

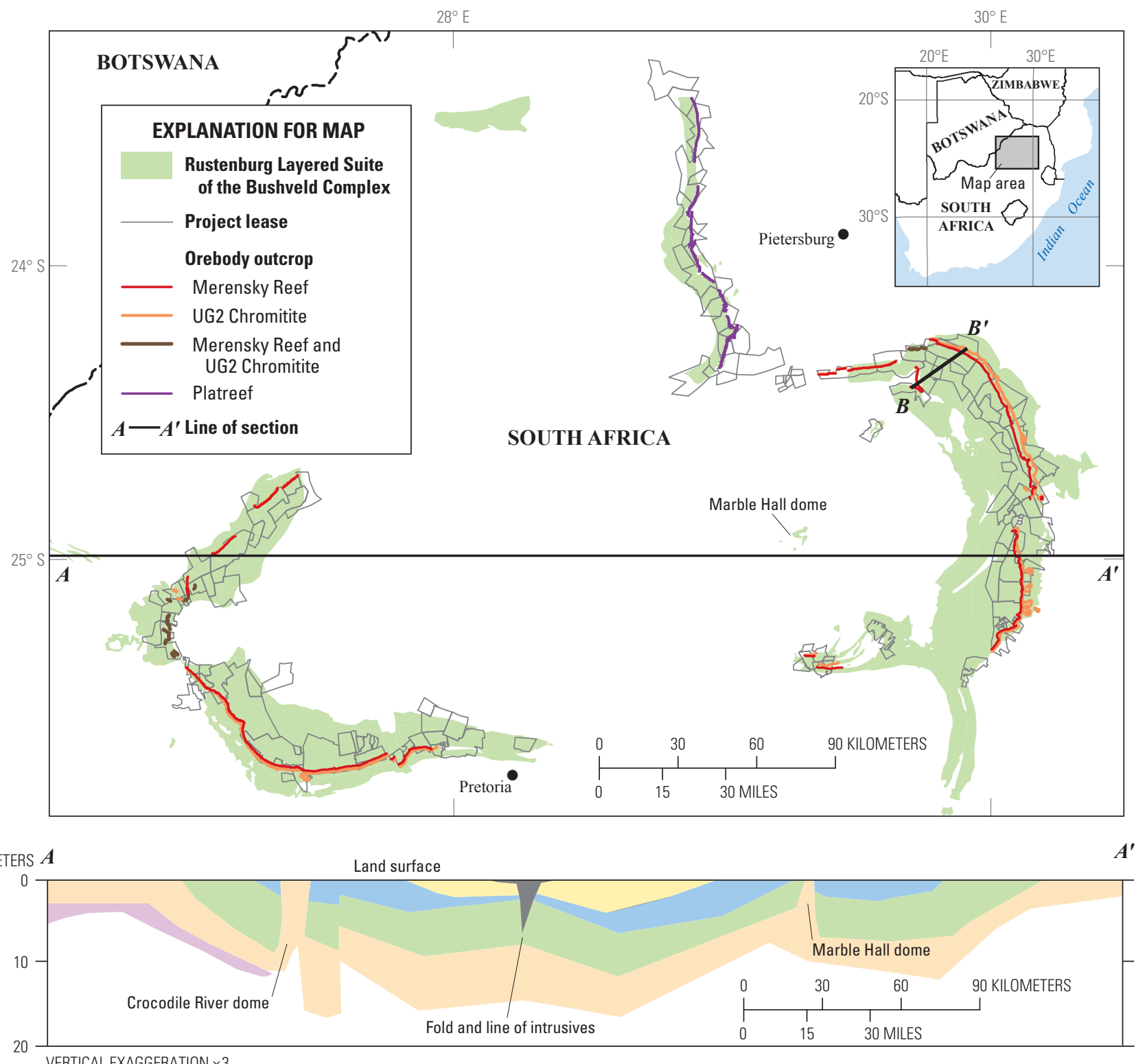

VERTICAL EXAGGERATION $\times 3$

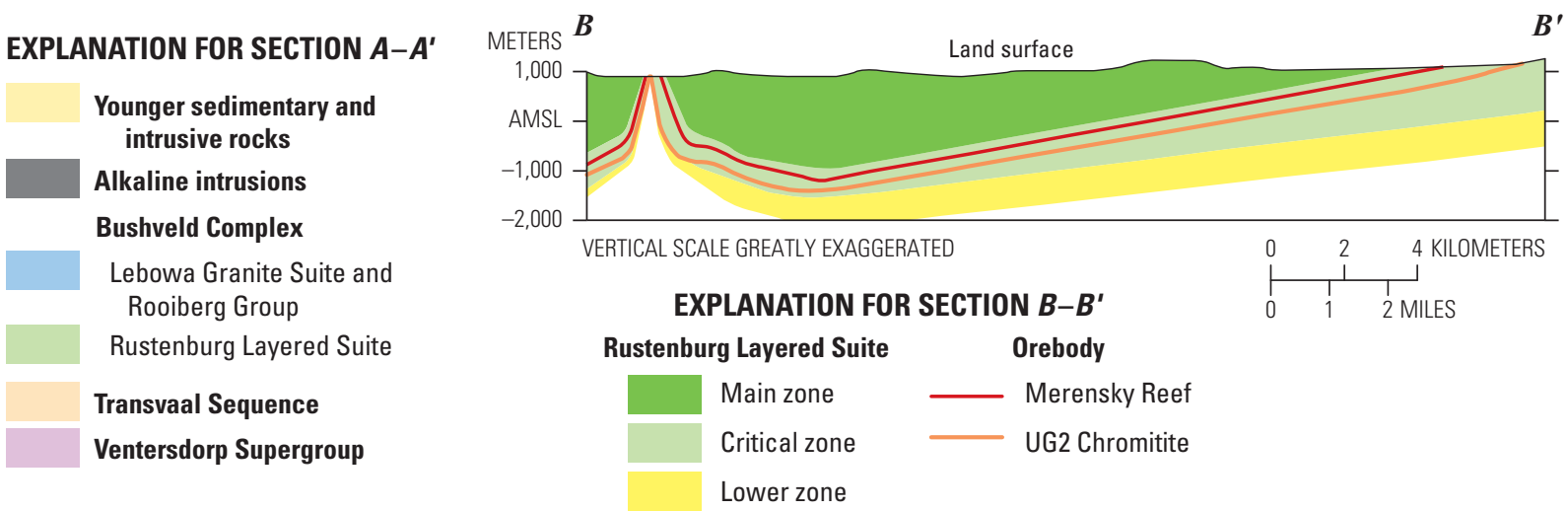

Figure N9. Map showing the Rustenburg Layered Suite of the Bushveld Complex, South Africa, the surface trace of significant orebodies, and cross sections through the central area and northeastern limb. Cross section $A-A^{\prime}$ is based on geophysical modeling and suggests that the mafic and ultramafic rocks that make up the eastern and western portion of the complex are connected at depth. Modified from Webb and others (2004). Cross section $B-B^{\prime}$ shows the remarkable continuity of the layers that host the Merensky Reef and UG2 Chromitite platinum-group-element deposits. Modified from Bauba Platinum (2012). Rustenburg Layered Suite is derived from Martini and others (2001); project leases and orebodies are from Zientek and others (2014). 
Figure N10. Photograph of the UG2 Chromitite at the Karee Mine in the western part of the Bushveld Complex, South Africa. The black layer at the base of the exposure is the main layer of the UG2 Chromitite. It has an undulating contact with the underlying, light-colored anorthosite layer. Several thin chromitite seams overlie the main chromitite layer. Most of the exposed rock is brown pyroxenite associated with the UG2 cyclic unit; a sharp contact separates the pyroxenite layer from the overlying light-colored anorthosite layer. Photograph by Wolfgang Maier, University of Cardiff, Wales, United Kingdom.

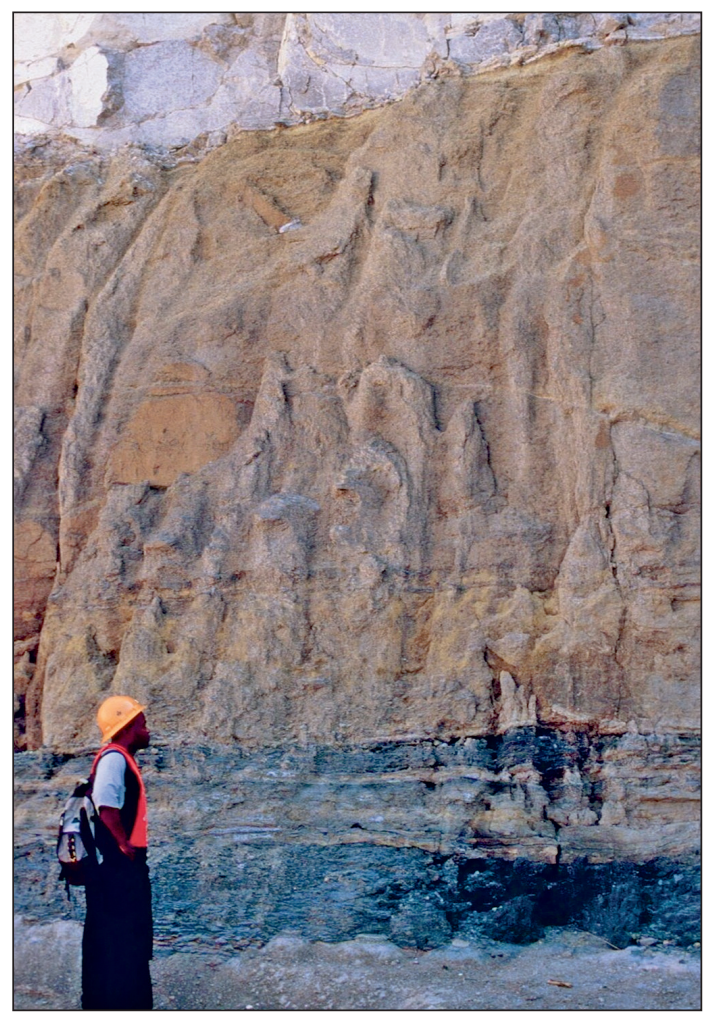

A

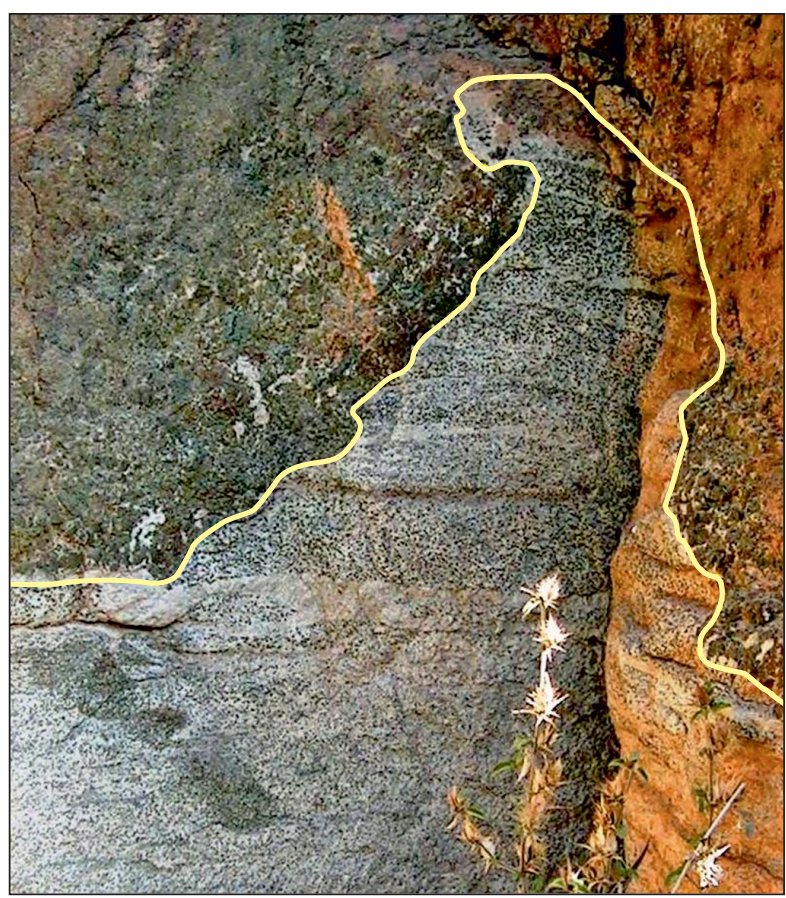

B

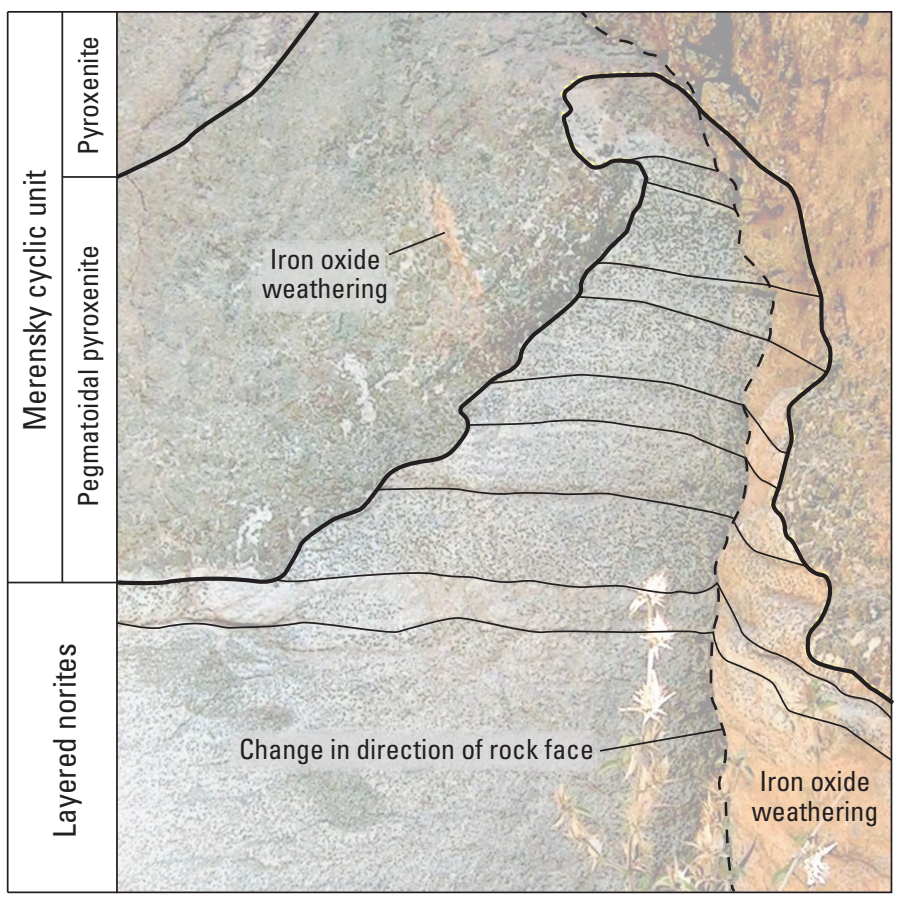

Figure N11. The base of the Merensky cyclic unit, a pegmatoidal pyroxenite, which contains the platinum-group-element-rich Merensky Reef. $A$, Photograph of the base of the Merensky cyclic unit on the Hackney farm property in the eastern part of the Bushveld Complex, South Africa. The basal contact of the cyclic unit is annotated by the yellow line. $B$, Same photograph with an overlay showing major features, including the dark, pegmatoidal pyroxenite cutting layering in the underlying lighter-colored norites. Photograph by Wolfgang Maier, University of Cardiff, Wales, United Kingdom. 

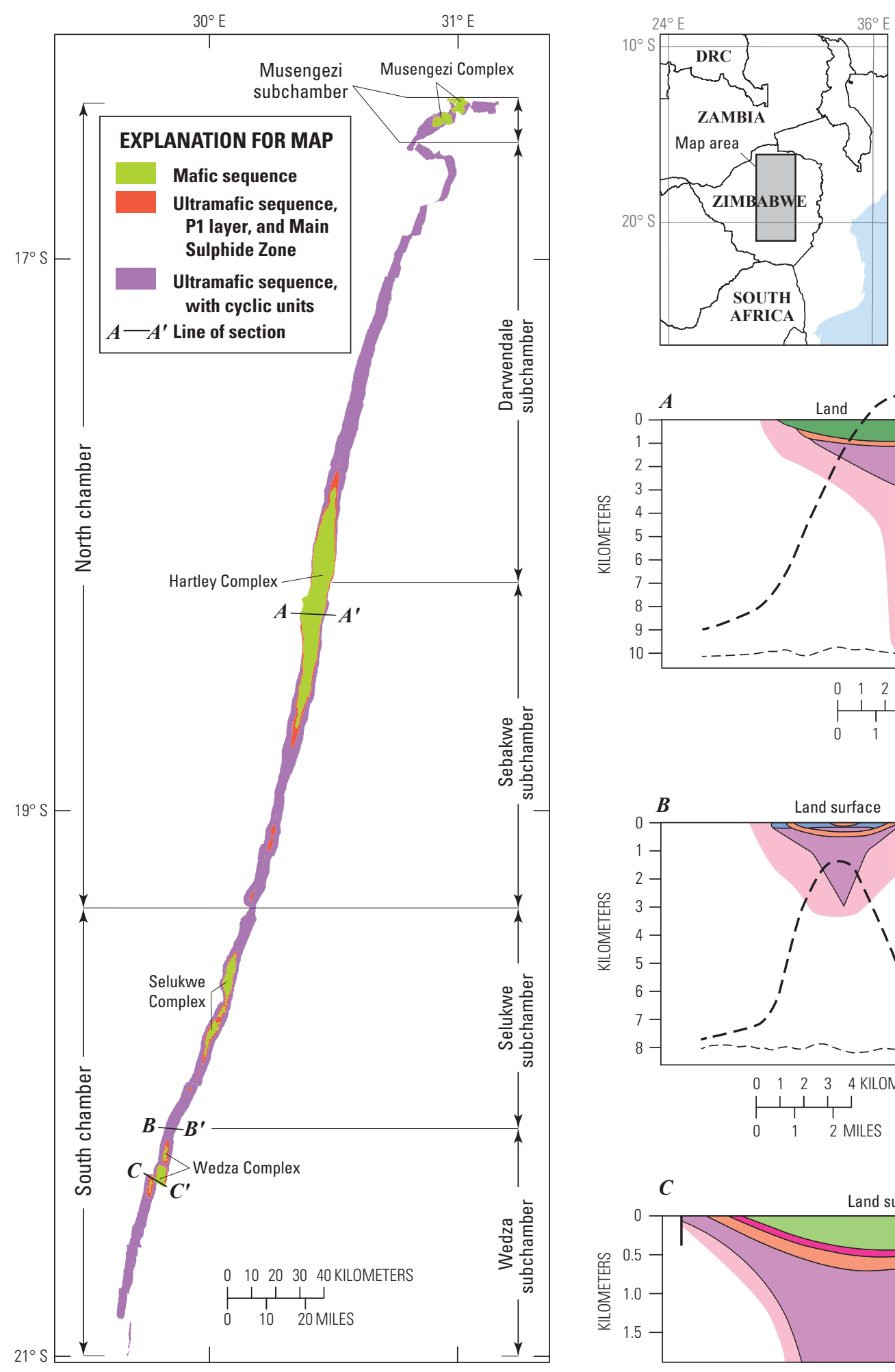

EXPLANATION FOR CROSS SECTIONS
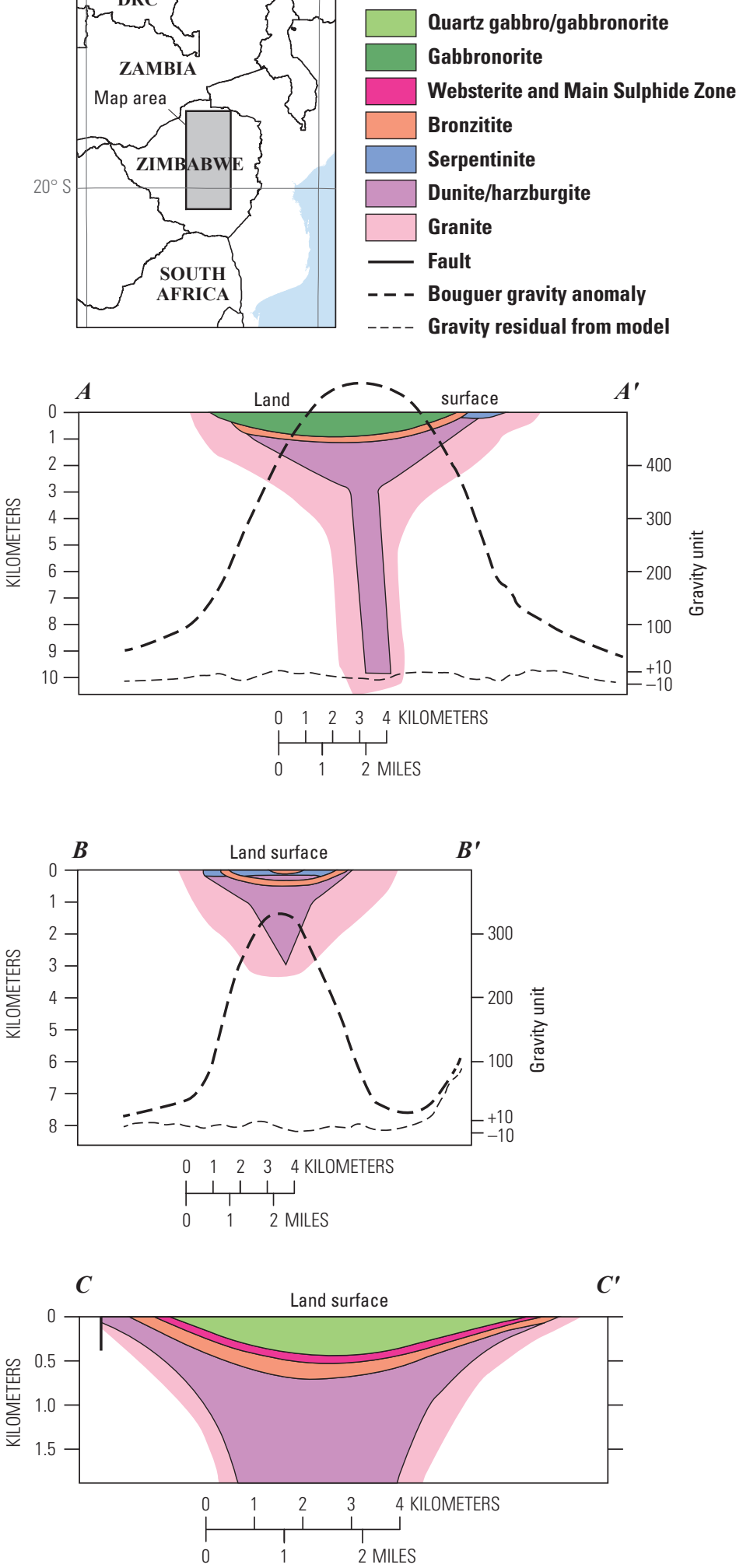

Figure N12. Geologic map and cross sections of the Great Dyke, Zimbabwe. Geologic mapping and geophysical studies show that the intrusion has a dike-like form; however, igneous layering dips gently into the center of the intrusion. The Main Sulphide Zone, which is a reef-type platinum-group-element deposit, is confined to the P1 layer of the ultramafic sequence (as shown on the map) and to the corresponding websterite layer shown on cross section $C-C^{\prime}$. Geologic map generalized from Worst (1957); geologic sections generalized from Podmore and Wilson (1987). 
(c) J-M Reef, Stillwater Complex, Montana. The Neoarchean Stillwater Complex (2,704 $\pm 5 \mathrm{Ma}$, using the uranium-lead zircon technique for determining age; Premo and others, 1990) is a mafic to ultramafic layered intrusion exposed in south-central Montana (fig. N13; Zientek and others, 2002). This intrusion is the only feature associated with the Stillwater LIP (Ernst and Buchan, 2001). More than 5,500 $\mathrm{m}$ of layered rocks are exposed, which can be traced for $48 \mathrm{~km}$ along strike. The J-M Reef, which is a reef-type PGE deposit, consists of 0.5 to 3 volume percent magmatic sulfide minerals that are associated with a distinctive olivine-bearing cyclic unit that can be mapped both on the surface and underground. The actual distribution of sulfide minerals within the cyclic unit is determined by detailed mapping, drilling, and sampling, however. The J-M Reef, which is open at depth, has been traced for $42 \mathrm{~km}$ of the $48-\mathrm{km}$ strike length of the complex and at least $2 \mathrm{~km}$ down the dip of layering. The J-M Reef is currently the sole source of primary PGE production and reserves in the United States. Since 1986, the Stillwater and East Boulder Mines (fig. N14) have produced roughly 305 metric tons of PGEs from the J-M Reef deposit. The overall deposit grade is about $15 \mathrm{~g} / \mathrm{t}$ palladium and platinum (U.S. Bureau of Mines, 1933-96; U.S. Geological Survey, 1997-2016; Abbott and others, 2011).

(d) Contact-Type Deposits, Duluth Complex, Minnesota. The Keweenawan LIP resulted from the eruption of lavas and emplacement of igneous intrusions between 1,109 and 1,087 Ma along a linear belt where Earth's crust subsided (the Midcontinent Rift). The rift extends for more than 2,500 km from Kansas northward beneath Lake Superior and then southeast through Michigan (fig. N15); however, exposures of rocks related to the rift are found only in the Lake Superior region. Igneous rocks associated with this LIP cover more than $160,000 \mathrm{~km}^{2}$ (Ernst and Buchan, 2001). LIP and rift-related igneous rocks exposed in the Lake Superior region include flood basalts, mafic intrusions, and minor rhyolite lava flows. The Mesoproterozoic Duluth Complex in Minnesota is composed of several discrete intrusions formed from mafic to felsic magmas that were emplaced between 1,108 and 1,098 Ma into older rocks, which include Paleoproterozoic sedimentary rocks and Archean granite-greenstone terranes (Peterson and Severson, 2002), and coeval LIP and rift-related flood basalts and hypabyssal (subvolcanic) intrusions.

Contact-type mineralization that includes a few percent sulfide minerals is laterally extensive along the base of some of the intrusions (mainly the South Kawishiwi and the Partridge River intrusions) along the western margin of the Duluth Complex. The mineralized interval of igneous rocks along the contact varies from tens to hundreds of meters in thickness. Mineral exploration studies since the early 1950s indicate that about 4 billion metric tons of mineralized rock containing 0.6 weight percent copper, 0.2 weight percent nickel, and $0.655 \mathrm{~g} / \mathrm{t}$ PGEs may be present (Listerud and Meineke, 1977; Naldrett, 2010b). Because the proportion of sulfide minerals varies along strike, economic cutoff grades are used to define deposits along the contact zone.

\section{Hydrothermal and Sedimentary Deposits}

Anomalous concentrations of PGEs or the presence of platinum-group minerals have been reported in a variety of hydrothermal and sedimentary deposit types (table N2 at back of chapter; Wilde and others, 2003; Wilde, 2005). Hydrothermal mineral deposits form by the interaction of hot water and rock. Water is a good solvent and hot water, called hydrothermal fluid, can efficiently move and deposit materials that occur in some mineral deposits. Sedimentary mineral deposits are economic concentrations of minerals in sedimentary rocks that formed directly from water in oceans, lakes, or in underground reservoirs. Although their occurrence is tantalizing, "a world-class deposit in which the PGE[s] are primary commodities and hydrothermal [processes] were indisputably the primary mechanism of concentration is yet to be discovered" (Wood, 2002, p. 233). Nevertheless, economic deposits of hydrothermal platinum and palladium may exist (Wilde and others, 2003).

Experimental and theoretical investigations by many authors have helped to identify the constraints under which the PGEs can be mobilized by fluids at relatively low temperatures (that is, at approximately $300{ }^{\circ} \mathrm{C}$ or less) (Wood and others, 1992; Gammons and Bloom, 1993; Wood, 2002; Hanley, 2005; Colombo and others 2008; Barnes and Liu, 2012; and references cited therein). Significant concentrations of platinum and palladium can dissolve into solution as chloride complexes only under highly oxidizing or highly acidic conditions. Palladium and platinum can be transported as bisulfide complexes in acidic to neutral solutions under reduced and moderate oxidation conditions. Hydroxide, thiosulfate, and organic complexes may be the dominant forms of dissolved platinum and palladium in low-temperature, near-surface environments.

Chloride complexes play a significant role in the mass transfer of PGEs in (a) porphyry copper deposits, especially the porphyry copper-gold subtype with island arc affinities and those associated with alkaline igneous rocks; (b) unconformity-related uranium-gold-platinumpalladium deposits; and (c) sediment-hosted strata-bound copper deposits (Wood, 2002). Bisulfide complexes may be responsible for (a) transporting platinum, palladium, and gold in the footwall copper-nickel-PGE ores at Sudbury, Ontario, and in nickel-molybdenum-PGE-gold enriched black shale deposits; (b) the remobilization of PGEs or recrystallization of platinum-group minerals in ophiolites and other ultramafic rocks during serpentinization and metamorphism; and (c) the remobilization of PGEs from mineralization of primary magmatic origin by deuteric or hydrothermal processes (Wood, 2002).

Manganese crusts that precipitate on the sides of seamounts are the definitive example of a sedimentary deposit enriched in PGEs (table N2). These crusts take millions of years to accumulate; the metals are extracted from seawater by adsorption processes (Halbach and others, 1989). 


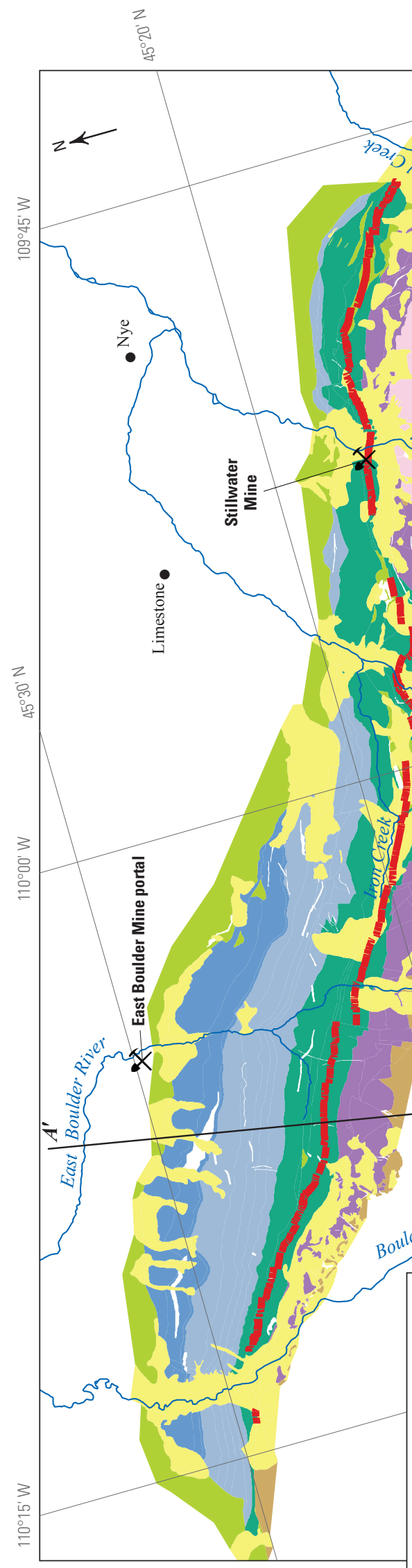

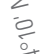
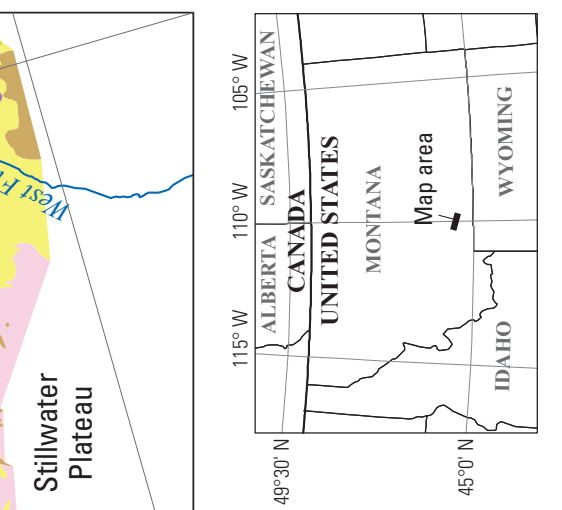

it

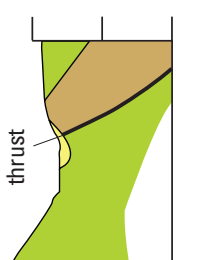

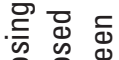

응

× 㐅⿸

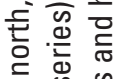

舟

o 음

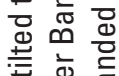

产要

递 잉

证

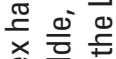

을 를

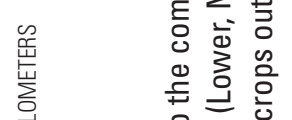

这

崖岕竞通

마-일

䒿

- -

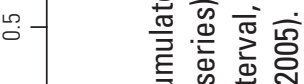

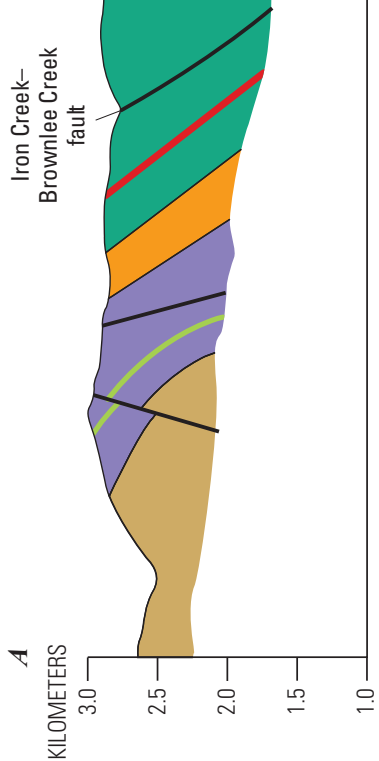

$\circ \perp$

可

에

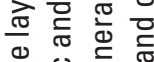

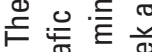

வ

政

들 흥 은

$\sum_{\substack{0 \\ 0}} \frac{1}{3}$

징응

을. 올 点

范产

离 兽 恶

芜包它

क

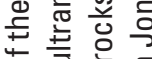

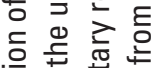

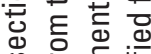

क

施

o 'क 늠

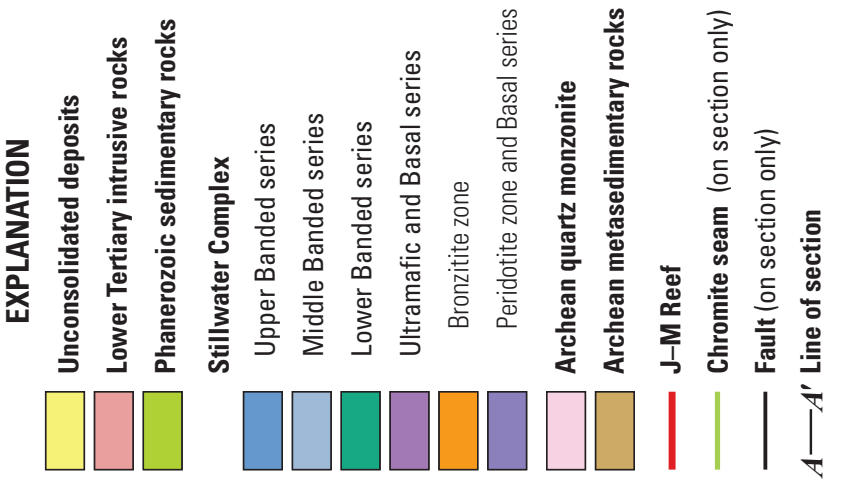

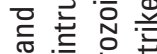

은.

ह

읗

음

임등 흥 음

ำ ํㅏㄹ

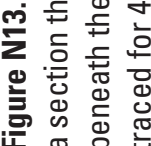




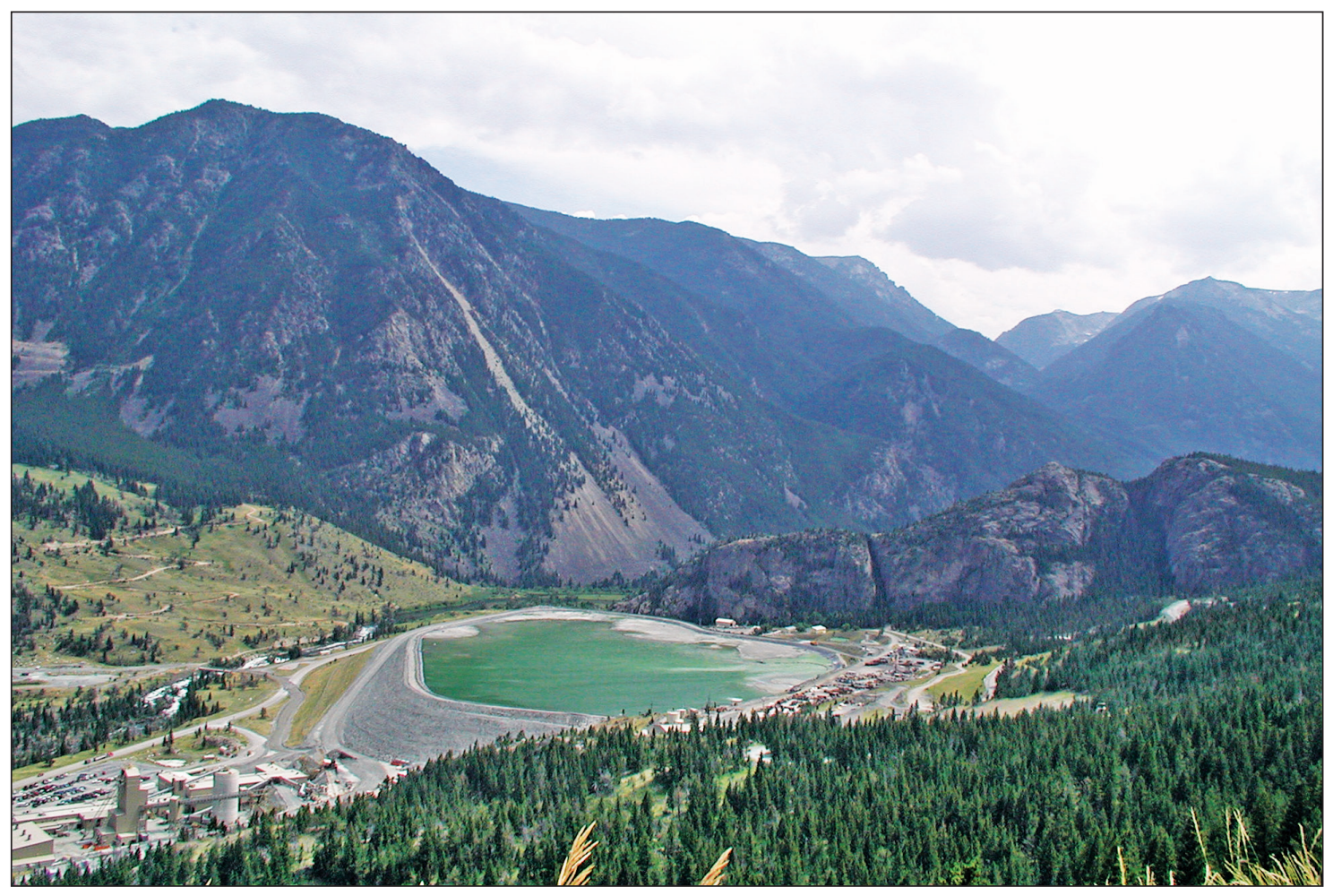

Figure N14. Photograph of the Stillwater Mine in south-central Montana, looking southeast. The pond is the tailings impoundment. The buildings in the lower left include the shaft, the mill complex, and offices. Photograph by Michael L. Zientek, 2006.

\section{Residual Deposits Formed By Weathering and Laterites}

In areas with tropical or forested warm to temperate climates, weathered red subsoil rich in secondary oxides forms on ultramafic rocks. These subsoils, or laterites, are a significant source of nickel (the other significant source of nickel is magmatic ore deposits). Laterites contain about 70 percent of the world's nickel resources, have been mined for more than 100 years, and account for about 40 percent of the world's nickel production (Gleeson and others, 2003; Dalvi and others, 2004; Mudd, 2010; Berger and others, 2011).

PGE enrichments are found in some laterites developed on ultramafic rocks, and an ongoing debate among geologists concerns whether this enrichment is related to the mobilization of the PGEs during the laterization process or to the residual accumulation of preexisting platinum-group minerals. Samples of lateritized ophiolitic mantle harzburgite from the Pirogues River area of New Caledonia contain up to 2 ppm (but average $500 \mathrm{ppb}$ ) platinum. The continuity of the PGE-enriched laterite layers relative to the discontinuous distribution of PGE-enriched chromitites in the ophiolites initially suggested that the PGEs could be concentrated through the lateritization process (Augé and Legendre, 1994); however, recent work indicates that the PGE-enriched zones are the result of the concentration of residual platinum-group mineral particles that were present in the unweathered ultramafic rock (Traoré and others, 2008). The PGE-enriched saprolitic horizon of the Falcondo nickel-laterite deposit in the Dominican Republic also appears to be a residue of primary platinum-group minerals that were dispersed in ophiolite-related ultramafic rocks (Proenza and others, 2010).

Another PGE-enriched laterite occurrence, the Syerston nickel-cobalt-platinum deposit, overlies the dunitic core of the easternmost of three plugs that make up the Tout Intrusive Complex, which is a Uralian-type intrusion in the Fifield area in New South Wales, Australia (Teluk, 2001). Preferential weathering of the ovoid dunite body formed a slab-like laterite body. The laterite extends to a depth of $40 \mathrm{~m}$ and has zones of nickel-cobalt enrichment that average $10 \mathrm{~m}$ in thickness in the middle of the weathering profile. An interval of residually concentrated platinum largely coincides with the nickel-cobalt enriched layers. Primary platinum enrichment in the host dunite may explain the distribution of platinum in the Syerston laterite profile, the exceptional grades (commonly in excess of $2.0 \mathrm{~g} / \mathrm{t}$ platinum), and the coarse grains of the platinum-group minerals. Published resources are 137 million metric tons containing $0.24 \mathrm{~g} / \mathrm{t}$ platinum; the planned nickel-cobalt open pit area (high-grade goethite zone) accounts for 91.6 million metric tons of the resource and contains 0.70 weight percent nickel and 0.12 weight percent cobalt (Teluk, 2001). 


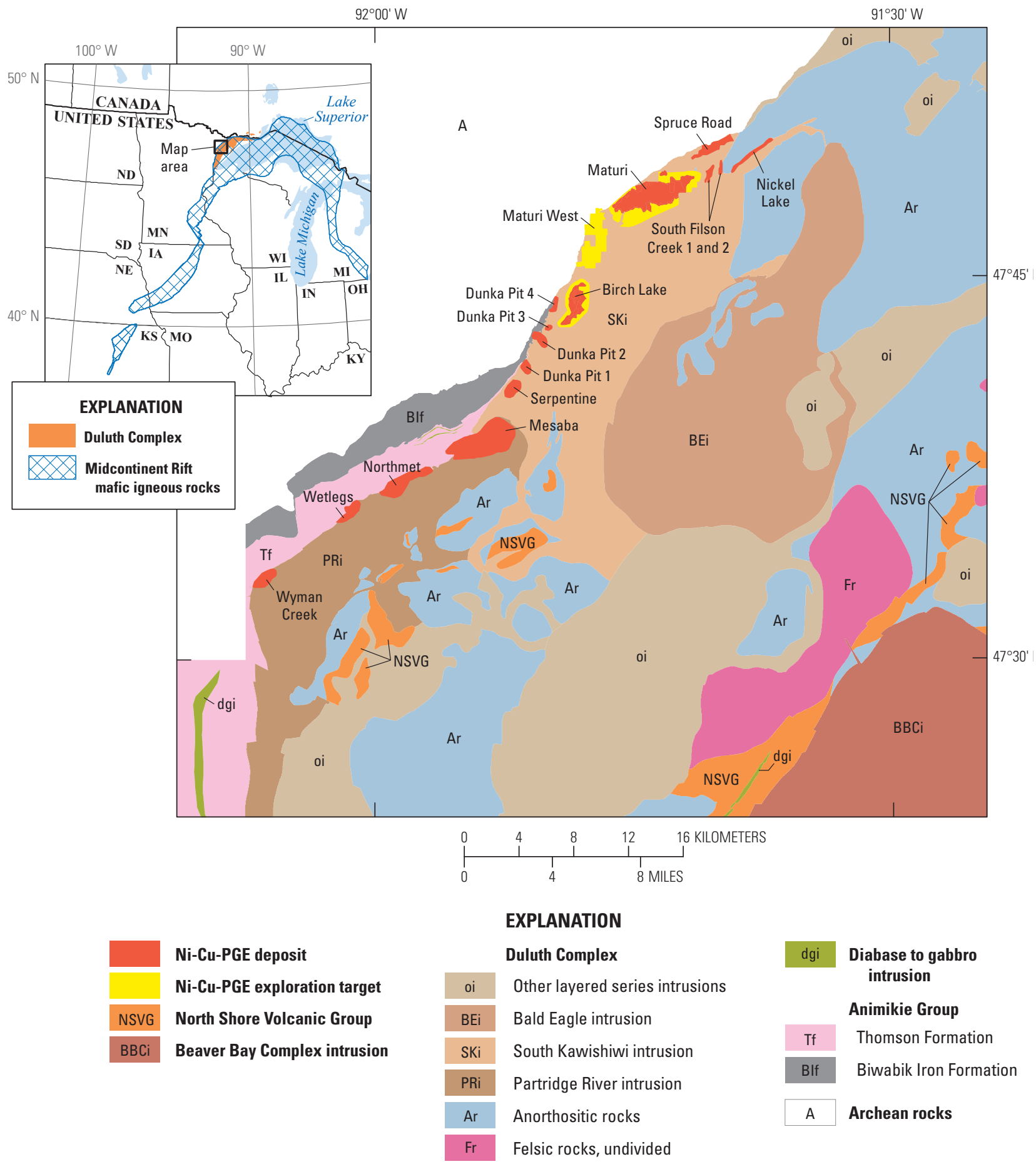

Figure N15. Map showing the geology along the western margin of the Duluth Complex, Minnesota, with the surface projection of nickel-copper-platinum-group-element (Ni-Cu-PGE) deposits and exploration targets. Exploration targets occur along the outer margins of known deposits (Birch Lake and Maturi) or as areas separated from known deposits (Maturi West). The location map shows the exposed and covered areas of the Midcontinent Rift along with the Duluth Complex. Map based on information in Miller and others (2002) and Parker and Eggleston (2012). Geology in the index map is derived from Muehlberger (1997). 


\section{Platinum Placer Deposits}

Erosion and weathering of rocks can form surficial mineral deposits. Placer deposits form when heavy particles of rocks or minerals are physically concentrated by the action of moving water. Placer deposits can form in active streams or rivers or along the shoreline of oceans or lakes. In 1824, placer platinum deposits were discovered on the Orulikha River, north of the Nizhny Tagil Massif in the central Ural Mountains (Urals) of Russia (table N3; fig. N16; Duparc and Tikonowitch, 1920; Pushkarev, 2001). From then until 1922, approximately 330 metric tons of metal was recovered from placer deposits in the Urals. At least one company is still exploring for paleoplacers that are buried beneath younger deposits of sediment and for placers that may be on river terraces along the Tylay and Kos'va Rivers in the Urals (Eurasia Mining plc, 2012). So far, the company has delineated resources in placers that contain 0.6 metric tons of platinum; average grades range from 0.303 to 0.363 gram per cubic meter (Eurasia Mining plc, 2011).

In the second half of the 20th century, platinum placer deposits were discovered at Kondyor in eastern Siberia (fig. N17; Shcheka and others, 2004) and in the Koryak area at the northern end of the Kamchatka Peninsula in eastern Russia (Tolstykh and others, 2004). The Kondyor placer deposits produced about 85 metric tons of platinum from 1984 to 2011 . After a decade of mining, approximately 45 metric tons of platinum was recovered in the Koryak area (Hurst, 2005).

The detrital platinum minerals in the placer deposits in Russia are clearly derived from small mafic to ultramafic plutons. The drainages surrounding the Nizhny Tagil Massif contained some of the most productive placer deposits in the Urals (fig. N16B). Placer mining near Nizhny Tagil began around 1839. Platinum in bedrock was first discovered in 1892 at a deposit called Krutoy Log in the Nizhny Tagil Massif (fig. N16B; Anikina and others, 2014). These plutons, which are the sources of platinum placer deposits, are circular or elliptical in plan view, pipe-like when viewed in profile (that is, in a cross-sectional view), and generally range in areal extent from about 10 to $40 \mathrm{~km}^{2}$ (Johan, 2002). The rocks that make up the plutons are a core of dunite that is concentrically surrounded by borders of clinopyroxenite, hornblendite, and gabbroic rocks. The zoned ultramafic complexes have rock textures that are consistent with (a) crystallization from magma at depth; (b) deformation, recrystallization, and annealing at high temperature; and (c) metasomatic alteration (Burg and others, 2009; Shmelev and Filippova, 2010). Rocks in these small mafic to ultramafic plutons make up a distinct rock association called Uralian-type complexes. These complexes are enigmatic because lode occurrences of platinum mineralization found in the plutons are inconsequential compared with the amount of placer platinum minerals found in the streams draining from the plutons.
Platinum mineralization in Uralian-type complexes is closely associated with chromitite pods, vein-like bodies, or schlieren within the dunite core of the plutons. In the Nizhny Tagil Massif, more than 1,600 chromitite occurrences have been mapped; most do not exceed 50 centimeters $(\mathrm{cm})$ in length and a few centimeters in thickness. Two types of chromitite are distinguished: (a) massive chromitite that grades into disseminated chromite in the dunite host, and (b) chromitite marked by serpentine rims that has a sharp boundary with the dunite host rock. The second type of chromitite is exceptionally enriched in platinum (Pushkarev and Anikina, 2002). Although the chromitites are small, the abundance of platinum can be quite high. For example, at the Krutoy Log deposit, chromite-platinum ore at the top of the orebody extended for a distance of $2 \mathrm{~m}$ in one adit. From this small volume of rock, about 30 kilograms (reported as 965 troy ounces) of native platinum metals was recovered (Mertie, 1969).

The platinum-group minerals in the placer deposits provide clues about the rocks from which they are derived. The platinum-group minerals are dominated by platinum-iron alloys but also contain some iridium and osmium alloys; few minerals with palladium or rhodium are found. The platinum nuggets in the placer deposits can be quite large (more than $10 \mathrm{~cm}$ in diameter and weighing up to several kilograms); by comparison, in most contact- and reef-type PGE ore deposits, the platinum-group minerals rarely exceed a few hundred microns in diameter $(1$ micron equals $0.0001 \mathrm{~cm})$ and weigh less than 0.0000001 kilograms. Some of the detrital platinumgroup minerals have crystal faces that reflect their internal crystalline structure (figs. N18A and N18B). Minerals that display crystal faces usually grow from a liquid or a vapor. Many nuggets contain inclusions of chromite and olivine (fig. N18C), or in some cases, form a matrix interstitial to these minerals. These textures suggest that platinum-iron alloys formed from magmas that were crystallizing chromite and olivine. Collectively, these observations indicate that the platinum nuggets are not derived from concentrations of magmatic sulfide minerals; rather, it appears that the nuggets were crystallized directly from silicate melt or a magmatic vapor.

Platinum placers are derived from similar ultramafic plutons in Alaska; British Columbia, Canada; Colombia; Ethiopia; and New South Wales, Australia (table N3). The largest alluvial PGE resource in the United States occurs south of Goodnews Bay in Alaska (fig. N19). The Goodnews Bay placer deposits were discovered in 1926 and mined between 1927 and 1975. Approximately 18 metric tons of platinum was recovered from the Salmon River and its tributaries (Johnston, 1962; Mertie, 1976; Barker, 1986; Tolstykh and others, 2002). Significant placer resources may remain in the unmined, deeply buried ground of the lower Salmon River Valley as well as in waste material (tailings) from previous dredging operations (Southworth and Foley, 1986). 
Table N3. Areas with significant placer platinum production, and estimates of cumulative production and grades.

[g/m³, gram per cubic meter; km, kilometer; n.d., no data; PGE, platinum-group element]

\begin{tabular}{|c|c|c|c|c|}
\hline Location & $\begin{array}{l}\text { Cumulative } \\
\text { production } \\
\text { (metric tons) }\end{array}$ & Dates & Grade(s) & Reference(s) \\
\hline $\begin{array}{l}\text { Ural Mountains, } \\
\text { Russia }\end{array}$ & 330 to 435 & $\begin{array}{l}1824 \text { to } \\
\text { present }\end{array}$ & $\begin{array}{l}\text { Initial tenors of placers in the Martian, Syssim, } \\
\text { Tschauch, and Wyssim Rivers, which drain } \\
\text { the Nizhniy Tagil area, were about } 400 \mathrm{~g} / \mathrm{m}^{3} \text {; } \\
\text { by World War I, the grades of placers in these } \\
\text { rivers were } 0.41 \text { to } 35 \mathrm{~g} / \mathrm{m}^{3} \text {. } \\
\text { The average grade of the placers in the Nizhniy Tagil } \\
\text { district early in its history is estimated to be about } \\
20 \mathrm{~g} / \mathrm{m}^{3} \text {. } \\
\text { Grades currently estimated for the West Kitlim placer } \\
\text { deposit are } 0.303 \text { to } 0.363 \mathrm{~g} / \mathrm{m}^{3} \text {. }\end{array}$ & $\begin{array}{l}\text { Lumb (1920); Eurasia } \\
\text { Mining plc (2011); } \\
\text { Malitch and Thalham- } \\
\text { mer (2002); Pushkarev } \\
\text { and Anikina (2002); } \\
\text { Pushkarev (2001); } \\
\text { Teluk (2001) }\end{array}$ \\
\hline Kondyor, Russia & 85 & 1984 to 2011 & $\begin{array}{l}\text { Average grade of the placer deposit is } 1.6 \mathrm{~g} / \mathrm{m}^{3} \text { PGEs. } \\
\text { Drainages within the intrusive body have grades of } \\
4 \mathrm{~g} / \mathrm{m}^{3} \text {. The grades } 50 \mathrm{~km} \text { downstream are about } \\
0.5 \mathrm{~g} / \mathrm{m}^{3} \text {. }\end{array}$ & $\begin{array}{l}\text { Russian Platinum } \\
\text { (2011a); Shcheka } \\
\text { and others (2004) }\end{array}$ \\
\hline Kamchatka, Russia & 45 & $\begin{array}{l}\text { Approximately } \\
10 \text { years of } \\
\text { mining beginning } \\
\text { after } 1991\end{array}$ & The average mined grade is $0.28 \mathrm{~g} / \mathrm{m}^{3}$ platinum. & Hurst (2005) \\
\hline $\begin{array}{l}\text { Goodnews Bay, } \\
\text { Alaska }\end{array}$ & 19 to 22 & 1927 to 1975 & $\begin{array}{l}\text { At Squirrel Creek, high-grade placers contained } \\
4.1 \mathrm{~g} / \mathrm{m}^{3} \text {, with an average tenor of } 1.2 \mathrm{~g} / \mathrm{m}^{3} \text {. } \\
\text { At Clara Creek, early small-scale mining of placers } \\
\text { with a grade of } 3.25 \mathrm{~g} / \mathrm{m}^{3} \text {, with an average tenor } \\
\text { of } 0.81 \mathrm{~g} / \mathrm{m}^{3} \text {. } \\
\text { A cleanup a short distance from the mouth of } \\
\text { Fox Gulch indicated grades of } 0.81 \text { to } 1.2 \mathrm{~g} / \mathrm{m}^{3} \text {. } \\
\text { Average grade of } 470 \text { samples is } 0.192 \mathrm{~g} / \mathrm{m}^{3} \text {, with } \\
\text { a maximum value of } 1.6 \mathrm{~g} / \mathrm{m}^{3} \text {. }\end{array}$ & $\begin{array}{c}\text { Johnston (1962); Mertie } \\
\text { (1976); Barker (1986); } \\
\text { Southworth and Foley } \\
\text { (1986); Pacific North } \\
\text { West Capital Corp. } \\
\text { (2006); Chatterjee and } \\
\text { Bandopadhyay (2011) }\end{array}$ \\
\hline Yubdo, Ethiopia & 2.0 & 1926 to 1956 & $\begin{array}{l}\text { Eluvium-Grades were initially } 0.3 \text { to } 0.5 \mathrm{~g} / \mathrm{m}^{3} \text { but } \\
\text { decreased to } 0.11 \mathrm{~g} / \mathrm{m}^{3} \text { as mining moved away } \\
\text { from the core of the intrusion. } \\
\text { Alluvium - Grades were } 0.25 \text { to } 0.83 \mathrm{~g} / \mathrm{m}^{3} \text { in test pits. }\end{array}$ & Molly (1959) \\
\hline $\begin{array}{l}\text { Tulameen district, } \\
\text { British Columbia, } \\
\text { Canada }\end{array}$ & 0.6 & 1885 to 1932 & n.d. & Mertie (1969) \\
\hline $\begin{array}{l}\text { Fifield district, New } \\
\text { South Wales, } \\
\text { Australia }\end{array}$ & 0.6 & $\begin{array}{l}1893 \text { to mid- } \\
1960 \text { s; most } \\
\text { production from } \\
\text { first few years } \\
\text { of operation }\end{array}$ & n.d. & $\begin{array}{l}\text { Mertie (1969); Platina } \\
\quad \text { Resources Ltd. (2006) }\end{array}$ \\
\hline
\end{tabular}



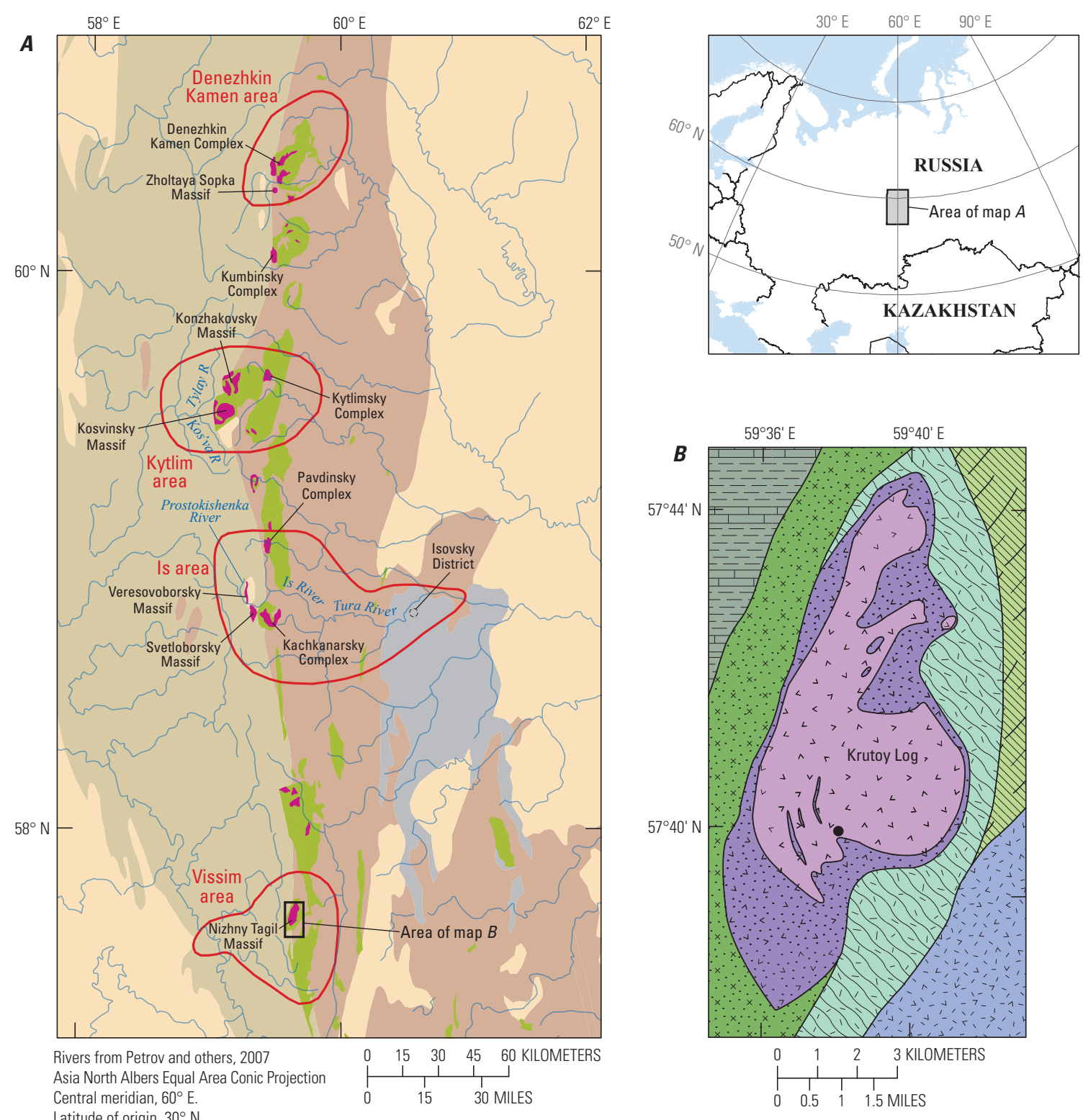

Map $A$

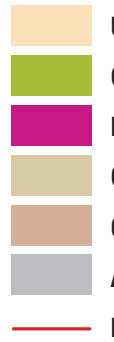

Gabbro

Pyroxenite and dunite

Orogenic belts
Undeformed cover of sedimentary rocks

Orogenic belts and passive continental margin

Archean and Proterozoic basement rocks

Platinum-producing area
EXPLANATION

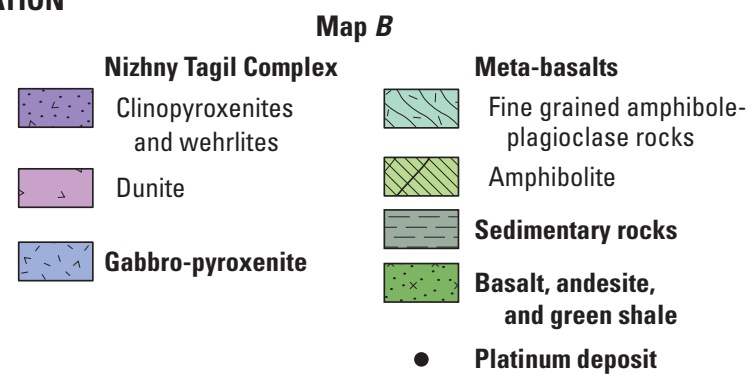

Figure N16. Maps illustrating the distribution of platinum deposits in the Ural Mountains, Russia. A, Generalized geology, location of platinum placer districts, and platinum-producing areas in the Ural Mountains, Russia. Placer platinum deposits are derived from pyroxenitic and dunitic intrusions; the platinum-iron alloy derived from the Veresovoborsky Massif and the Svetloborsky Massif occurs in placer deposits that extend about 100 kilometers downstream along the Is and Tura Rivers. Modified from Zonenshain and others (1988), Anderson and Martineau (2002), and Petrov and others (2007). B, Geology of the Uralian-type Nizhny Tagil Massif and the location of the Krutoy Log, where the first bedrock source of the platinum deposit was discovered. Platinum minerals were concentrated in chromitites that occur in the dunitic core of the lithologically zoned pluton. Modified from Levin and others (2010). 


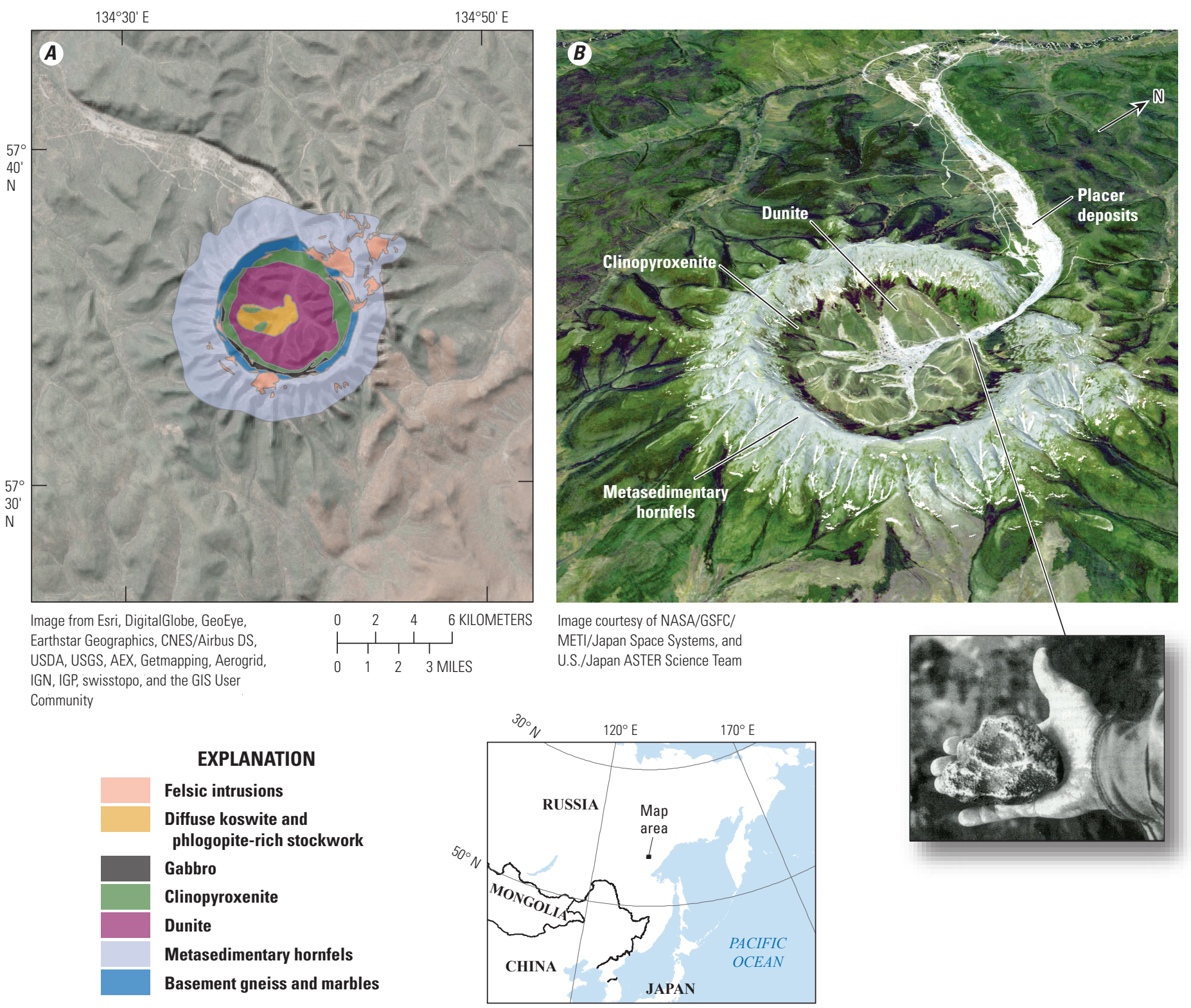

Figure N17. Geology and imagery of the Uralian-type Kondyor Massif, which is located in eastern Siberia, Russia, north of the city of Khabarovsk. A, Geologic map of the massif, showing that the circular pluton consists of a central core of dunite, which is surrounded by clinopyroxenite and gabbro. Emplacement of the pluton metamorphosed the surrounding sedimentary rocks, forming hornfels. Geology simplified from Burg and others (2009). B, Oblique view of the Kondyor Massif showing the core of dunite surrounded by clinopyroxenites. This circular intrusion is about 10 kilometers in diameter; the prominent topographic ridge, which is up to 600 meters high, is underlain by contact metamorphosed rocks that surround the intrusion. The intrusion is the source of coarse crystals of platinum-iron alloy coated with gold that are recovered in streams that drain from the complex. An example of a coarse platinum nugget recovered from the Kondyor Massif is shown in the black-and-white picture. This view was created by draping a simulated natural color Advanced Spaceborne Thermal Emission and Reflection Radiometer ASTER composite image over an ASTER-derived digital elevation model; the image was acquired on June 10, 2006. Photograph courtesy of NASA/GSFC/METI/Japan Space Systems, and U.S./Japan ASTER Science Team. The image of the platinum nugget is from Malitch (1999). 

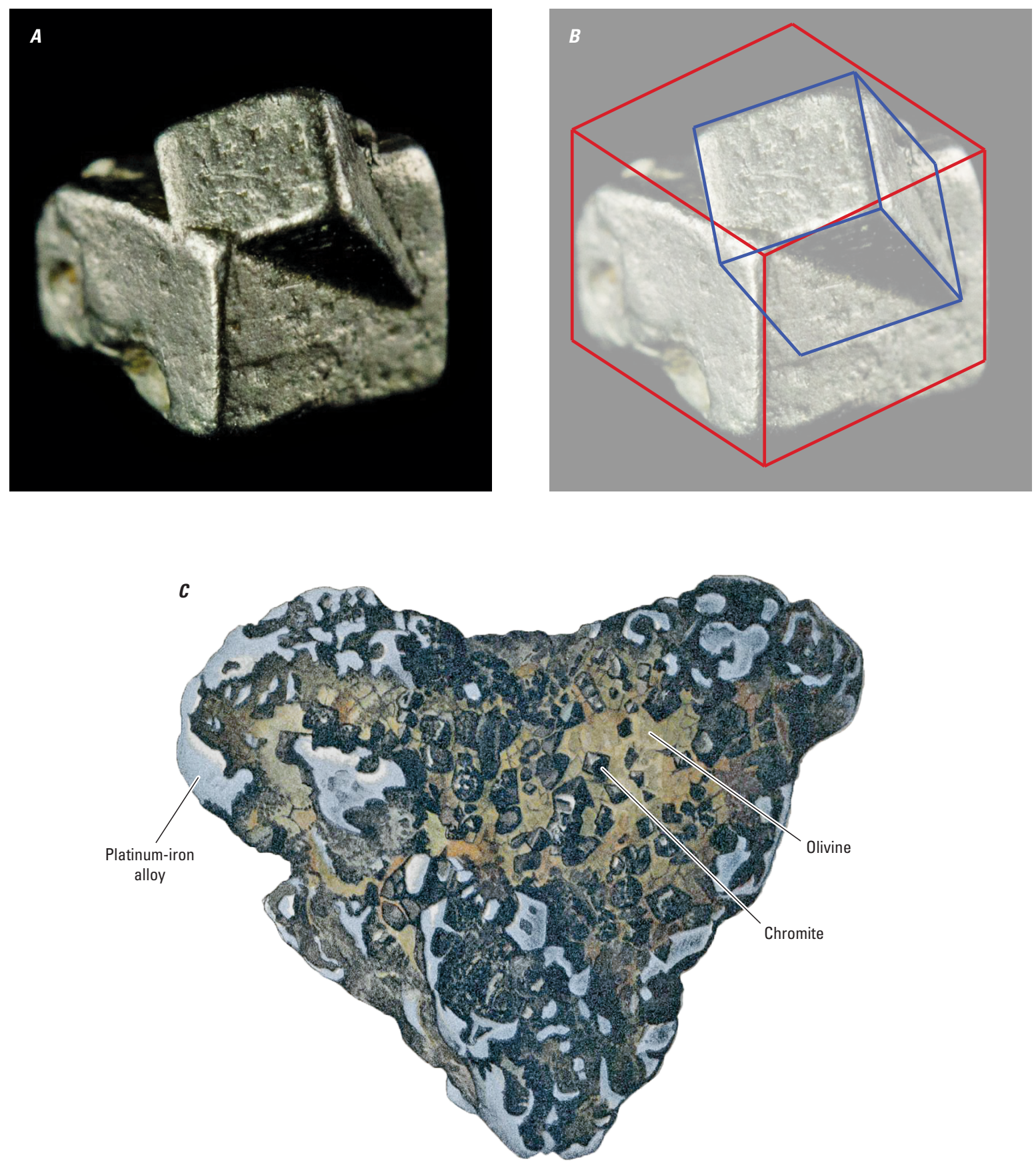

Figure N18. Photograph and lithograph showing the morphology of platinum-iron-alloy nuggets derived from Uralian-type intrusions. $A$, Photograph of silvery-gray nugget of isoferroplatinum from the Kondyor Massif, Russia. The nugget, which is about 4 millimeters $(\mathrm{mm})$ long, consists of two intergrown crystals of isoferroplatinum; each crystal forms a cube with smooth crystal faces and sharp edges and corners (Photograph courtesy of TreasureMountainMining.com). $B$, Sketch of the isoferroplatinum nugget illustrating the cube-shaped crystals. $C$, Lithograph of a platinum nugget with olivine and octahedral chromite, from the Tulameen district, British Columbia, Canada. The longest dimension on the nugget is about $10 \mathrm{~mm}$. In this nugget, platinum-iron alloy occurs interstitial to (in between) magmatic crystals of olivine and chromite. The texture implies that the platinum-iron alloy grew slightly later than the earlier formed olivine and chromite. Image is from Kemp (1902). 

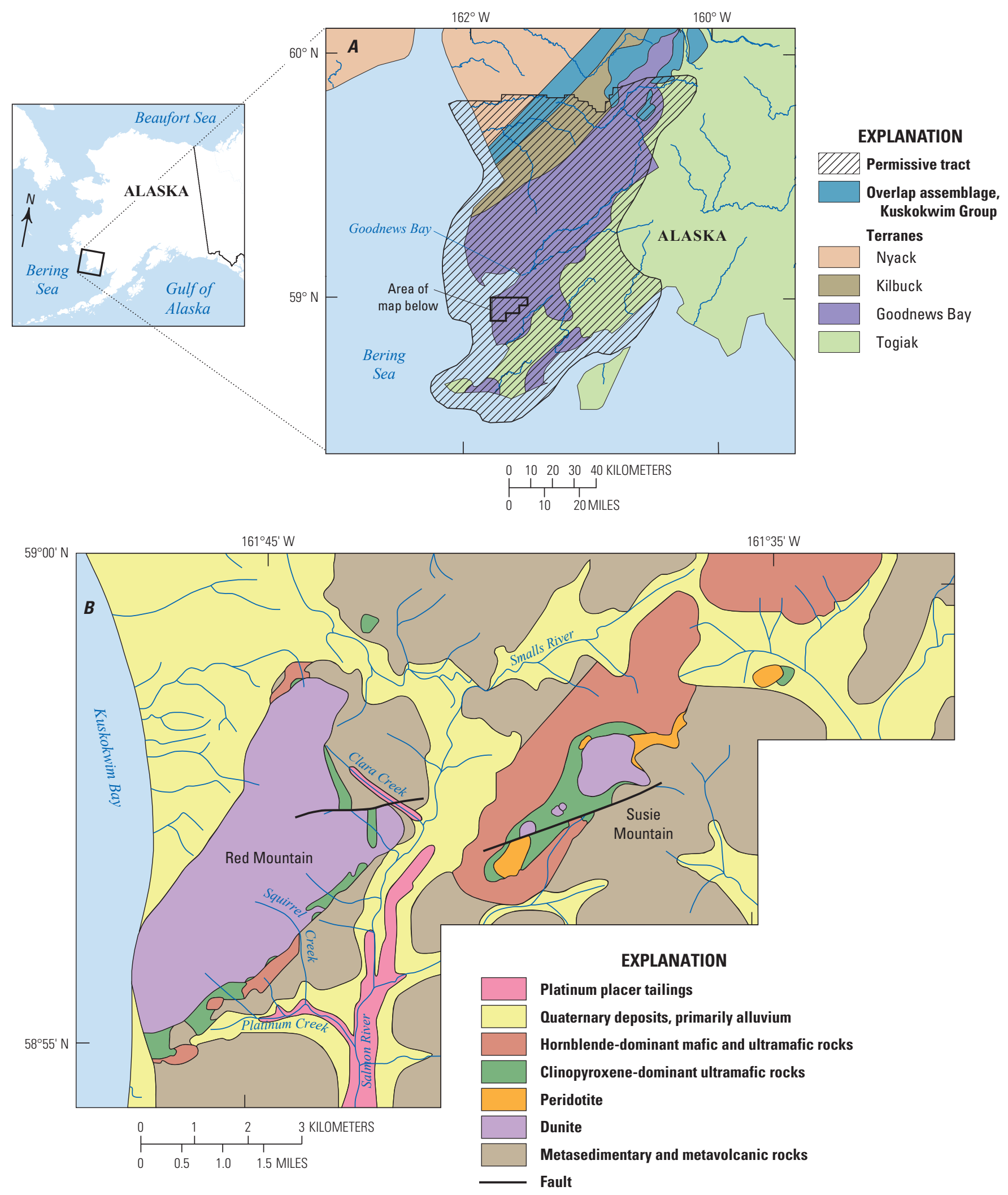

Figure N19. Maps illustrating platinum-group-element (PGE) resources in southeastern Alaska. $A$, Location of the permissive tract assessed for undiscovered placer platinum resources and the major geologic provinces (terranes) it encompasses. The permissive tract is the area where undiscovered PGE resources could be present (Schmidt and others, 2007). $B$, Geologic map of the Goodnews Bay area showing where platinum placer deposits have been mined (platinum placer tailings). The placer platinum deposits can be followed upstream to the Red Mountain pluton, a Uralian-type intrusion that could be the bedrock source of the platinum minerals found in the placers. Modified from Tolstykh and others (2002). 


\section{Resources and Production}

Discovered mineral resources include the total amount of identified mineral resources that are in the ground as well as the cumulative past production (U.S. Geological Survey National Mineral Resource Assessment Team, 2000). This section begins with an overview of historic and current primary and secondary production of PGEs. Primary production is when metal that occurs in rocks is mined and transferred to above-ground material stock; secondary production is from recycled material or scrap. The section also includes a discussion of the identified mineral resources of PGEs. Identified mineral resources refer to the mineralized material in the ground whose location, grade, quality, and quantity are known or can be estimated from specific geologic evidence (U.S. Bureau of Mines and U.S. Geological Survey, 1980). Identified mineral resources represent the current stock of material in the ground (mineral inventory) that might be mined. The amounts of identified resources discussed this chapter were current as of 2012.

\section{Production}

Up to 1920, almost all of the world's PGE production came from placer deposits in Russia and Colombia. The discovery of nickel deposits in solid rock in the Sudbury area of Ontario, Canada, in the 1800s (Giblin, 1984) roughly coincided with technological innovations that used nickel to strengthen traditional steels. This technological innovation led to extensive development of the Sudbury deposits; in the first half of the 20th century, Sudbury produced approximately 80 percent of the world's nickel (Prevec, 1997). PGEs were recovered as a byproduct of nickel mining in Sudbury; by 1934, Canada had become became the world's leading producer of PGEs.

Most of the PGEs produced today are from mineral deposits that were discovered in the Noril'sk-Talnakh area of Russia in 1919 (Kunilov, 1994; Likhachev, 1994) and in South Africa in the 1920s (Wagner, 1929). Significant development of these deposits did not begin until the 1960s when industrial demands for PGEs increased. About the same time that new and extraordinarily PGE-enriched deposits were discovered in the Noril'sk-Talnakh area in Russia (Kunilov, 1994), Anglo American Platinum Ltd. gained a controlling stake in the PGE industry in South Africa (Mattera, 2008) and South Africa had an economic boom (Rouillard, 1997).
As a result, beginning in the 1960s, PGE production increased in South Africa and the Soviet Union (Russia), such that South Africa became, and still is, the leading producer of platinum and rhodium, and Russia was and is the world's leading producer of palladium (fig. N20).

Approximately 14,200 metric tons of PGEs was produced from 1900 to 2011, and roughly 95 percent of that amount (about 13,500 metric tons) was produced from 1960 onward. The breakdown of production by country shows that about 90 percent of production since 1900 has come from South Africa and Russia; Canada, the United States, and Zimbabwe accounted for 5 percent, 2 percent, and 1 percent of production, respectively (fig. N21).

A secondary supply of platinum, palladium, and rhodium is obtained through the recycling of catalytic converters from end-of-life vehicles, jewelry, and electronic equipment. Recycling volumes are sensitive to PGE prices; higher prices typically lead to higher recycling volumes owing to the greater incentive to recycle. Recycled platinum, palladium, and rhodium provide a significant proportion of the total supply and are sufficient to close the gap between mine production and consumption. For example, in 2011, about 24 percent

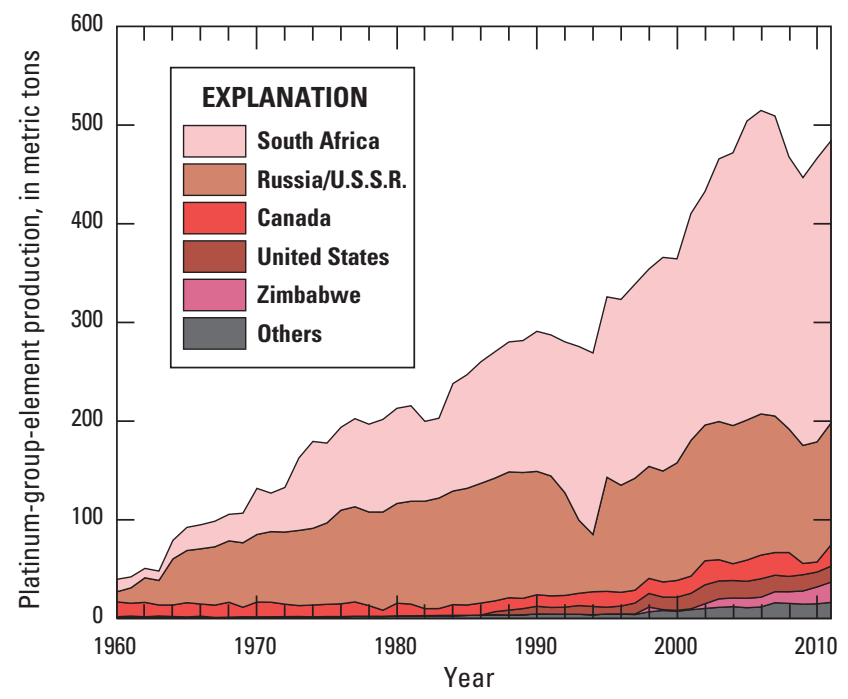

Figure N20. Graph showing world platinum-groupelement production, by country and year, from 1960 to 2011. The layers of the graph are placed one above the other, forming a cumulative total. Data are from U.S. Bureau of Mines (1933-34, 1933-96) and U.S. Geological Survey (1997-2016). 


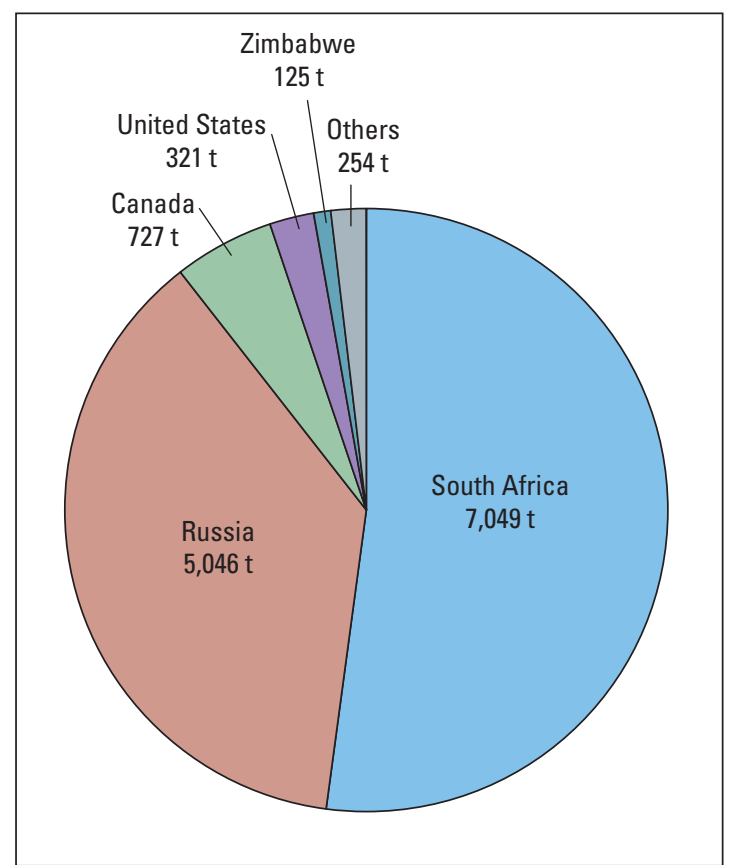

Figure N21. Pie chart showing world platinumgroup-element (PGE) production from 1960 to 2011, by country and amount (in metric tons [t]) . Data are from U.S. Bureau of Mines (1933-34,1933-96) and U.S. Geological Survey (1997-2016). of the total supply of platinum and palladium and about 27 percent of the total supply of rhodium were obtained through recycling (Butler, 2012).

\section{Identified Resources}

Exploration and mining companies have delineated approximately 100,000 metric tons of PGE (and minor amounts of gold) resources in mineral deposits around the world that remain to be developed (table N4). This estimate was derived by compiling mineral inventory information about in situ estimates of the tonnage and grade of mineralized rock with "realistic prospects of eventual economic extraction" (Weatherstone, 2008) published by exploration and mining companies and geological surveys. To be considered an identified resource for this compilation, the evaluation of tonnage and grade of mineralized rock must be based on (a) direct sampling of the ore, and (b) industry standard resource estimation practices. The estimate of 100,000 metric tons is comparable to the 91,000 metric tons recently reported by Mudd (2012) (table N4). Most of the difference is accounted for by the larger estimate for the Platreef deposit of the Bushveld Complex in this chapter. For context, the total net consumption of PGEs in 2012 was approximately 460 metric tons (Platinum Today, 2013c).

Table N4. Identified platinum-group-element and gold resources, summarized by deposit type and location.

[Data are from table N10 at the end of this chapter. Numbers may not add to totals because of rounding]

\begin{tabular}{llcr}
\hline $\begin{array}{c}\text { Deposit } \\
\text { type }\end{array}$ & \multicolumn{1}{c}{ Deposit } & $\begin{array}{c}\text { PGE and gold resources } \\
\text { compiled for this chapter } \\
\text { (metric tons) }\end{array}$ & $\begin{array}{r}\text { PGE and gold resources } \\
\text { compiled by Mudd, 2012 } \\
\text { (metric tons) }\end{array}$ \\
\hline Reef & $\begin{array}{l}\text { Merensky Reef and UG2 Chromitite, Bushveld } \\
\text { Complex, South Africa }\end{array}$ & 58,000 & 56,000 \\
& Main Sulphide Zone, Great Dyke, Zimbabwe & 8,200 & 8,700 \\
& J-M Reef, Stillwater Complex, Montana & 2,200 & 620 \\
& Other areas & 2,700 & 1,700 \\
& $\quad$ Total, reef-type deposits & $\mathbf{7 1 , 0 0 0}$ & $\mathbf{6 7 , 0 0 0}$ \\
Contact & Platreef, Bushveld Complex, South Africa & 17,000 & 1,600 \\
& Other areas & 3,100 & $\mathbf{9 , 3 0 0}$ \\
& $\quad$ Total, contact-type deposits & $\mathbf{2 0 , 0 0 0}$ & 11,000 \\
Conduit & Noril'sk-Talnakh area, Russia & 10,000 & 2,100 \\
& Other areas & 1,200 & $\mathbf{1 3 , 0 0 0}$ \\
\hline
\end{tabular}




\section{Tonnage and Grade Relations for Magmatic Ore Deposits}

Tonnage and total PGE and gold grade relations for identified resources in magmatic deposits are shown in figure N22. Estimates of total PGE and gold grade can vary over about three orders of magnitude, whereas tonnage can vary over five orders of magnitude. Tonnage and grade are not strongly correlated, which is typical for mineral deposits of a given type. Some conduit-type deposits have lower PGE and gold grades than reef-type deposits because conduit-type deposits are polymetallic deposits in which copper, nickel, PGEs, and gold all contribute to the value of the ore. In reef-type deposits, the value of the ore is primarily in the PGE and gold concentrations. In terms of contained metal, most deposits contain more than 1 metric ton of PGEs and gold. For any values less than 1 metric ton, it simply is not economic to determine the tonnage and grade. In 2012, world mine production was about 450 metric tons of PGEs and world usage was about 615 metric tons (Loferski, 2013b). The shaded area in figure N22 highlights those deposits that have more than 1 year's worth of contained PGEs, given current rates of production and usage. Only a fraction of the deposits in the world have enough contained metal to satisfy multiple years of world demand.
Mineral deposits occur rarely in Earth's crust, and large ones are especially uncommon (Singer, 1995). Most of the known metal for many mineral commodities is contained in a few, very large deposits (Singer and DeYoung, 1980). For most types of mineral deposits, the grade of the ore varies by about one order of magnitude and the tonnage varies by several orders of magnitude among deposits. As a result, contained metal correlates strongly with tonnage. For porphyry copper deposits (which are the world's leading source of copper), for example, 10 percent of the deposits accounts for approximately 60 percent of the identified copper resource whereas the bottom 50 percent of the deposits accounts for less than 5 percent of the identified copper resources (fig. N23A). For the PGEs, this correlation is more pronounced. Ten percent of PGE deposits account for more than 80 percent of identified PGE resources whereas the bottom 50 percent of the PGE deposits accounts for less than 1 percent of identified PGE resources. Thirty percent of PGE deposits contain more than 97 percent of the world's identified PGE resources, and almost all these deposits are associated with three areasthe Bushveld Complex in South Africa, the Great Dyke in Zimbabwe, and the Noril'sk-Talnakh area in Russia (fig. N23B).

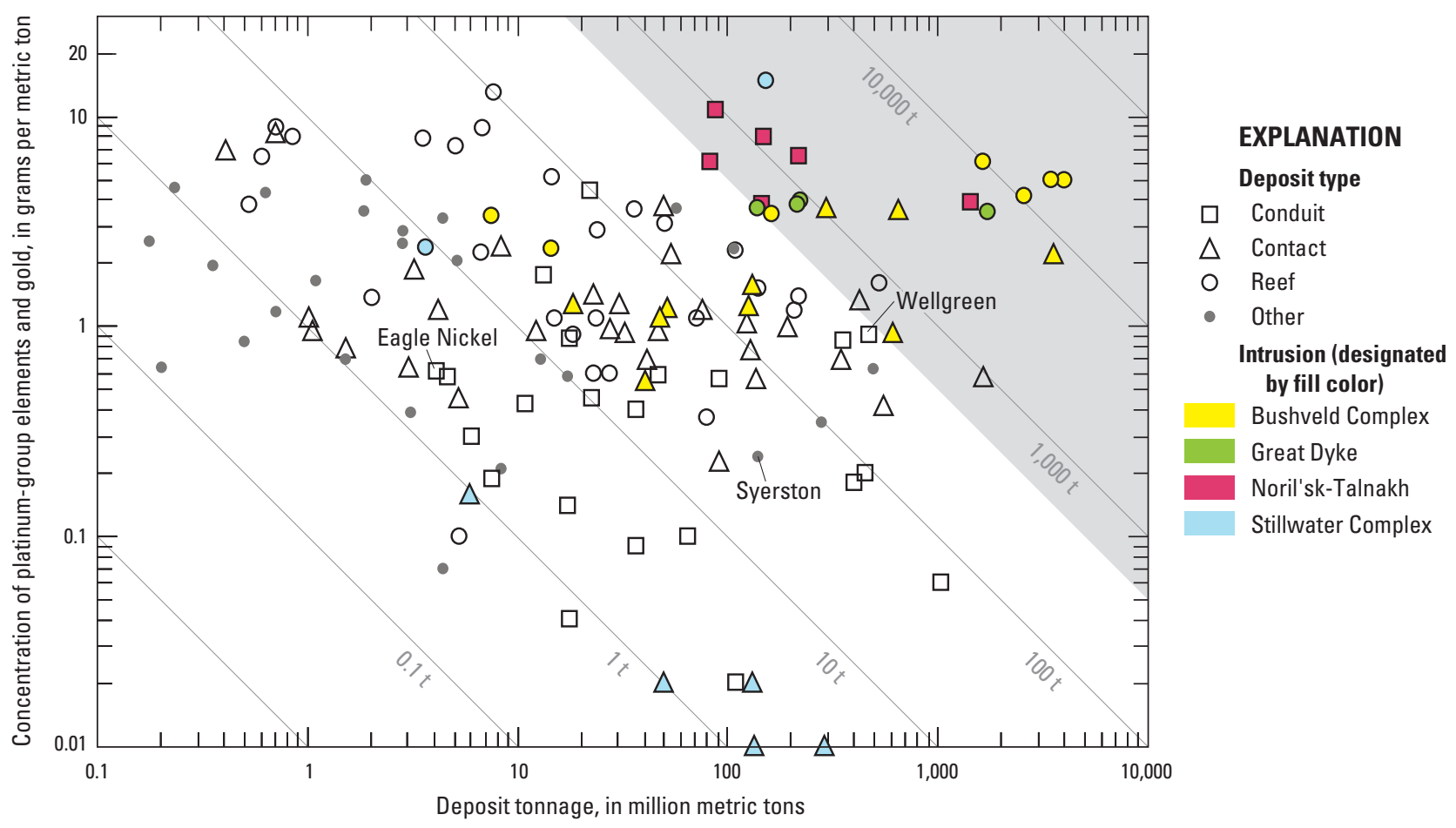

Figure N22. Plot showing the relation between tonnage and grade of remaining resources for conduit-type, reef-type, and other types of deposits enriched in platinum-group elements (PGEs). Diagonal lines are isolines that show amounts of contained PGEs and gold in the deposits, in metric tons (t). Annual world production and usage of PGEs, as of 2012, was about 450 metric tons. The shaded area on the figure highlights those deposits that are large enough to contain more than 1 year's worth of the world's PGE needs. 


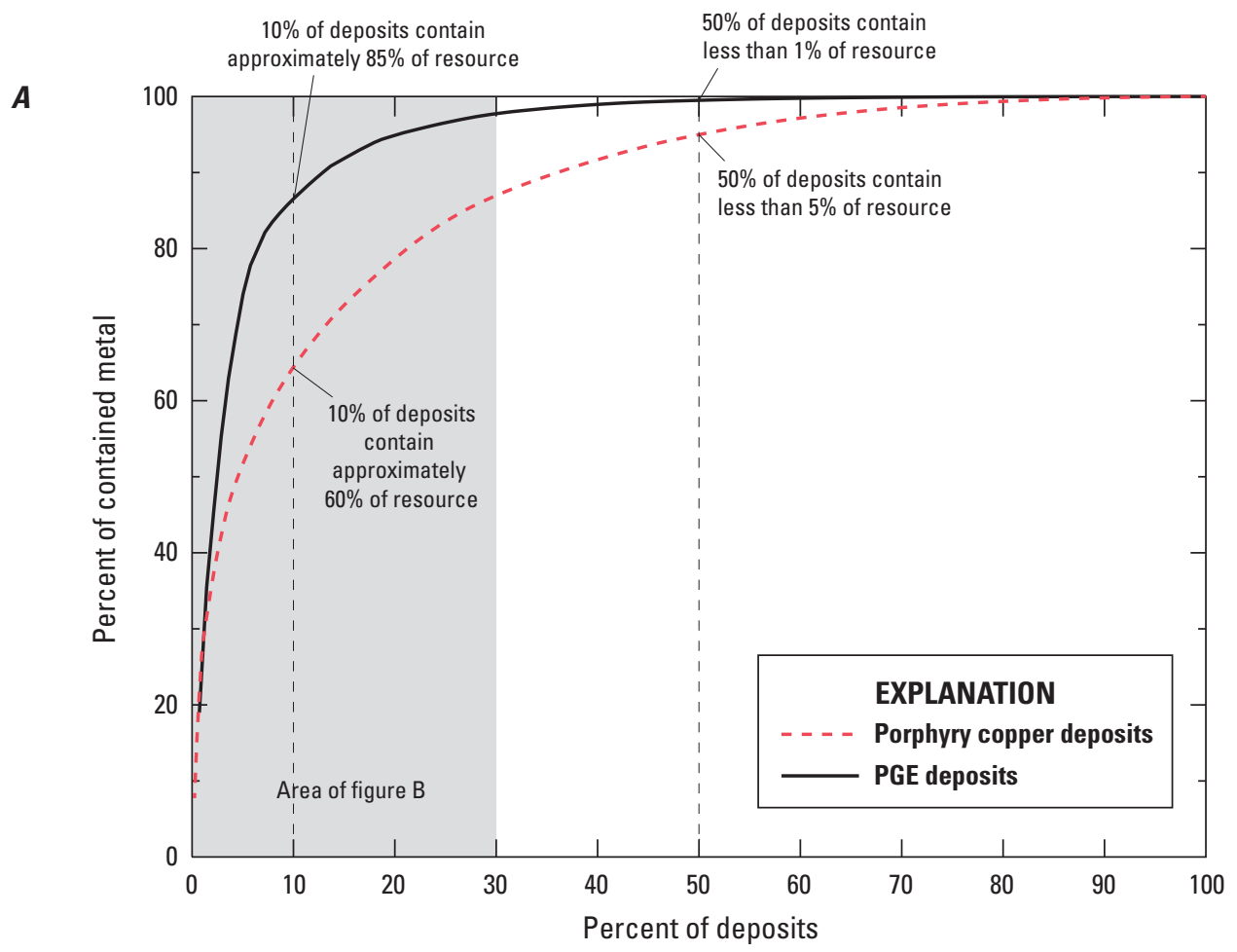

B

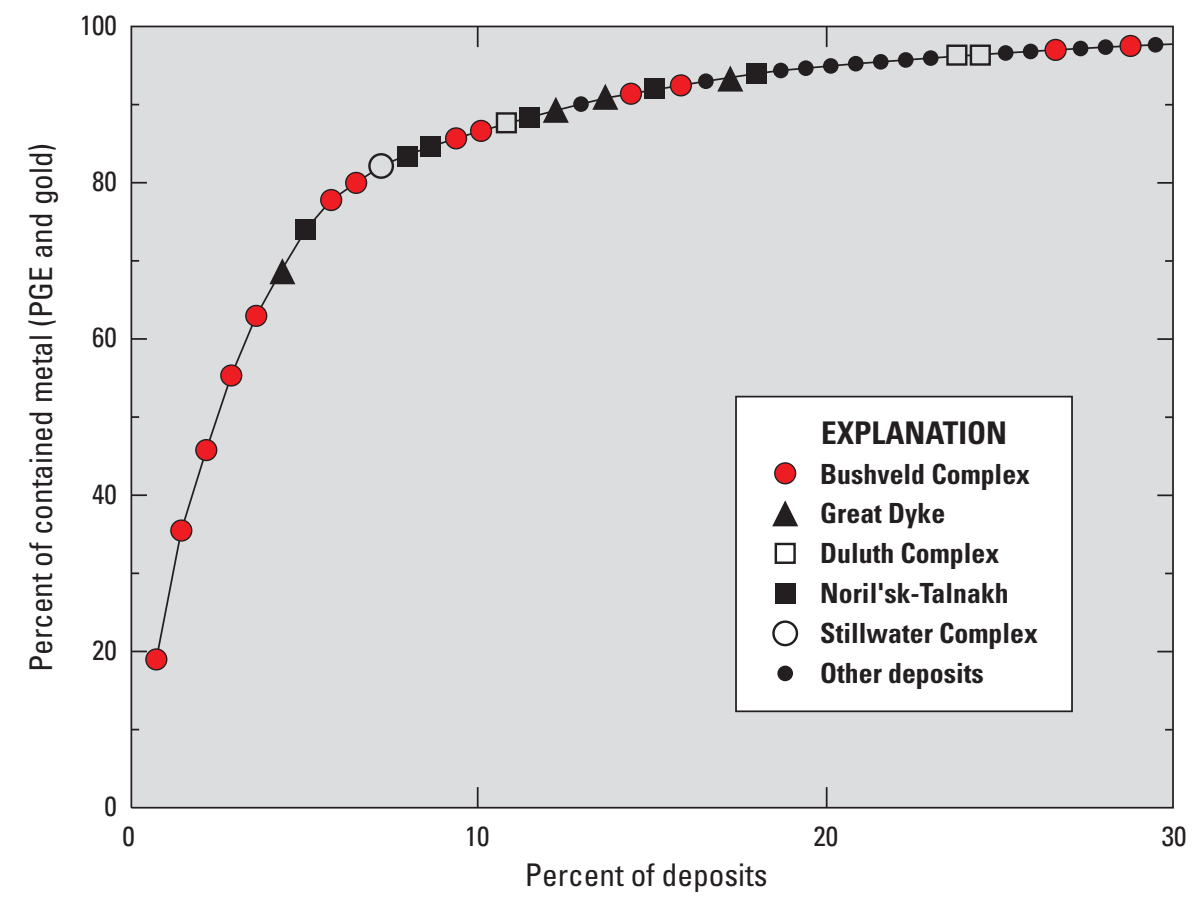

Figure N23. Graphs showing the percent of contained metal against percent of deposits for $A$, the world's platinum-group-element (PGE) and porphyry copper deposits, and $B$, the top 30 percent of the world's PGE deposits. In $A$, the curves are derived from compilations of known deposits and show that most of the contained metal in a given deposit type is associated with a small percentage of very large deposits. Both deposit types show the effect, but it is more pronounced for PGE deposits. In $B$, the curve focuses on the largest deposits, showing the data points and the name of the igneous intrusion hosting the deposit. Most of the large deposits are associated with the Bushveld Complex in South Africa, the Great Dyke in Zimbabwe, and sills in the Noril'sk-Talnakh area of Russia. Data for porphyry copper are from Singer and others (2008). PGE data are from table N10 at the end of this chapter. 
Seventy-two percent of the world's PGE resources are found in reef-type and contact-type deposits in the Bushveld Complex, South Africa (table N4). The conduit-type magmatic deposits in the Noril'sk-Talnakh area, Russia, account for 10 percent of the world's identified PGE resources. Eight percent of the world's identified PGE resources are in the Great Dyke, Zimbabwe. In fact, more than 97 percent of all the world's identified PGE resources are contained in only 14 intrusions or intrusive complexes (table N5 at back of chapter).

When considered by deposit type alone, 69 percent of identified PGE resources are associated with reef-type deposits, 20 percent are associated with contact-type deposits, and 11 percent are associated with conduit-type deposits (table N4). For reef-type deposits, 81 percent of identified resources have been delineated in the Bushveld Complex (South Africa); 12 percent in the Great Dyke (Zimbabwe); and 3 percent in the Stillwater Complex (Alaska). For contact-type deposits, 85 percent of the world's identified resources are found in the Bushveld Complex. For conduittype deposits, about 90 percent of the identified resources are found in the Noril'sk-Talnakh area of Russia.

For simplicity, the previous discussion has focused on total PGE production and resources; however, individual PGEs do have different values and uses. For example, platinum and rhodium are more valuable economically than palladium, and the iridium market is much smaller than the markets for platinum and palladium. The proportions of the PGEs differ among deposits, however (fig. N24). The deposits in South Africa and Zimbabwe have a higher proportion of platinum than any other major deposit in the world. The proportion of palladium is much higher in the deposits in the Noril'sk-Talnakh area in Russia.

\section{Undiscovered (Hypothetical and Speculative) Resources (United States and Global)}

In addition to the resources of PGEs that have been discovered (identified), additional PGEs may be present as undiscovered resources in areas adjacent to identified magmatic deposits and in deposits that remain to be discovered.

\section{Extensions to Identified Deposits}

Additional PGE resources may be present in areas adjacent to or near deposits that now dominate world supply. Although resources for reef-type and contact-type PGE deposits are formally delineated in advance of mining, the extent of the deposits is never completely delineated because the upfront costs would be too great. Instead, mining companies conduct enough research and work to ensure that the deposit contains adequate resources to justify mine development. It is possible, therefore, that some deposits are larger than previously thought.

In the Bushveld Complex, South Africa, relatively unexplored extensions of the Merensky Reef and the UG2 Chromitite deposits could contain an additional 33,000 metric tons of platinum and 32,000 metric tons of palladium to a depth of $3 \mathrm{~km}$ (Zientek and others, 2014). These reef-type PGE deposits are in the form of vast sheetlike orebodies. Mining has started at the surface and has progressed to depths of $2 \mathrm{~km}$ in some regions (fig. N25). Likewise, the Platreef in the Bushveld Complex could contain an estimated 1,100 metric tons of platinum and nearly 1,400 metric tons of palladium (based on a mean estimate to a depth of $1 \mathrm{~km}$ ). The Great Dyke of Zimbabwe
Figure N24. Graph showing contained platinum-group element (PGE) and gold metal against the ratio of palladium to platinum for the major PGE deposits of the world. The only identified deposits in which platinum is the dominant metal are associated with the Bushveld Complex in South Africa and the Great Dyke in Zimbabwe. PGE data are from table N10 at the end of this chapter. MR, Merensky Reef; Pd, palladium; Pt, platinum, UG2, UG2 Chromitite

\begin{tabular}{l}
\multicolumn{2}{c}{ EXPLANATION } \\
Intrusion or area \\
- Bushveld Complex $\quad$ Noril'sk Talnakh \\
$\square$ Duluth Complex $\quad$ O Stillwater Complex \\
$\Delta$ Great Dyke
\end{tabular}

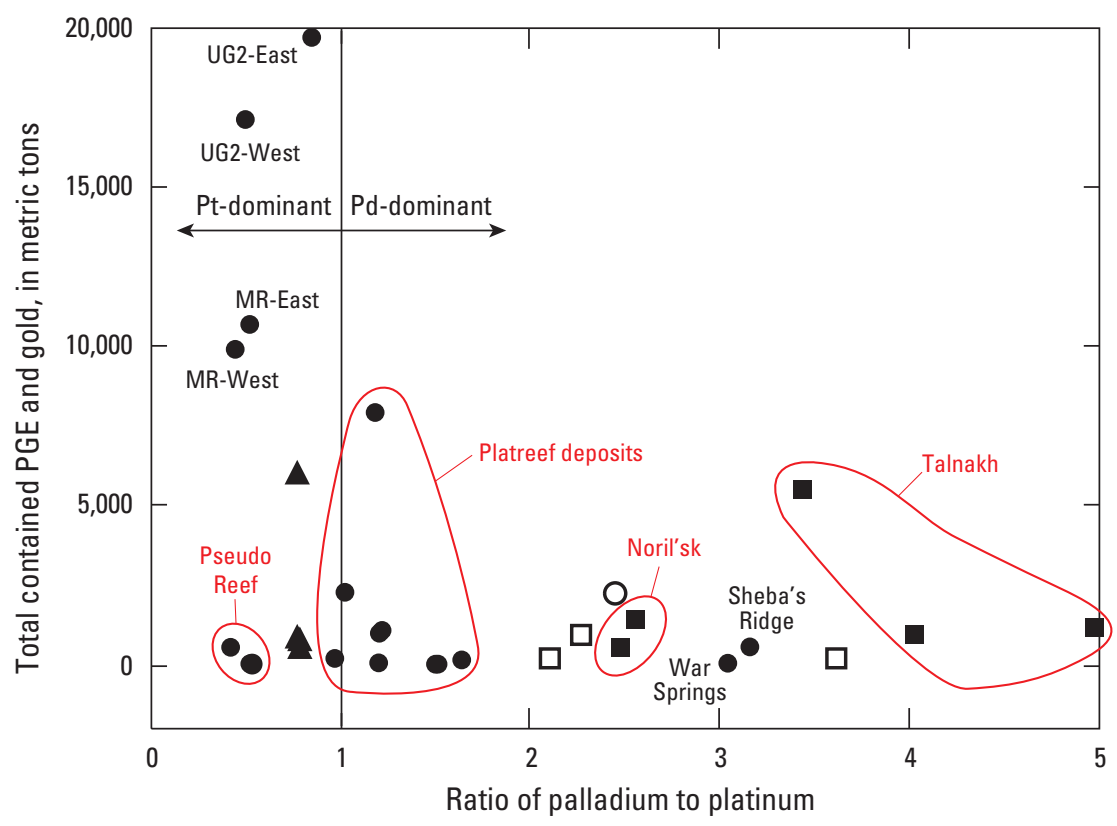




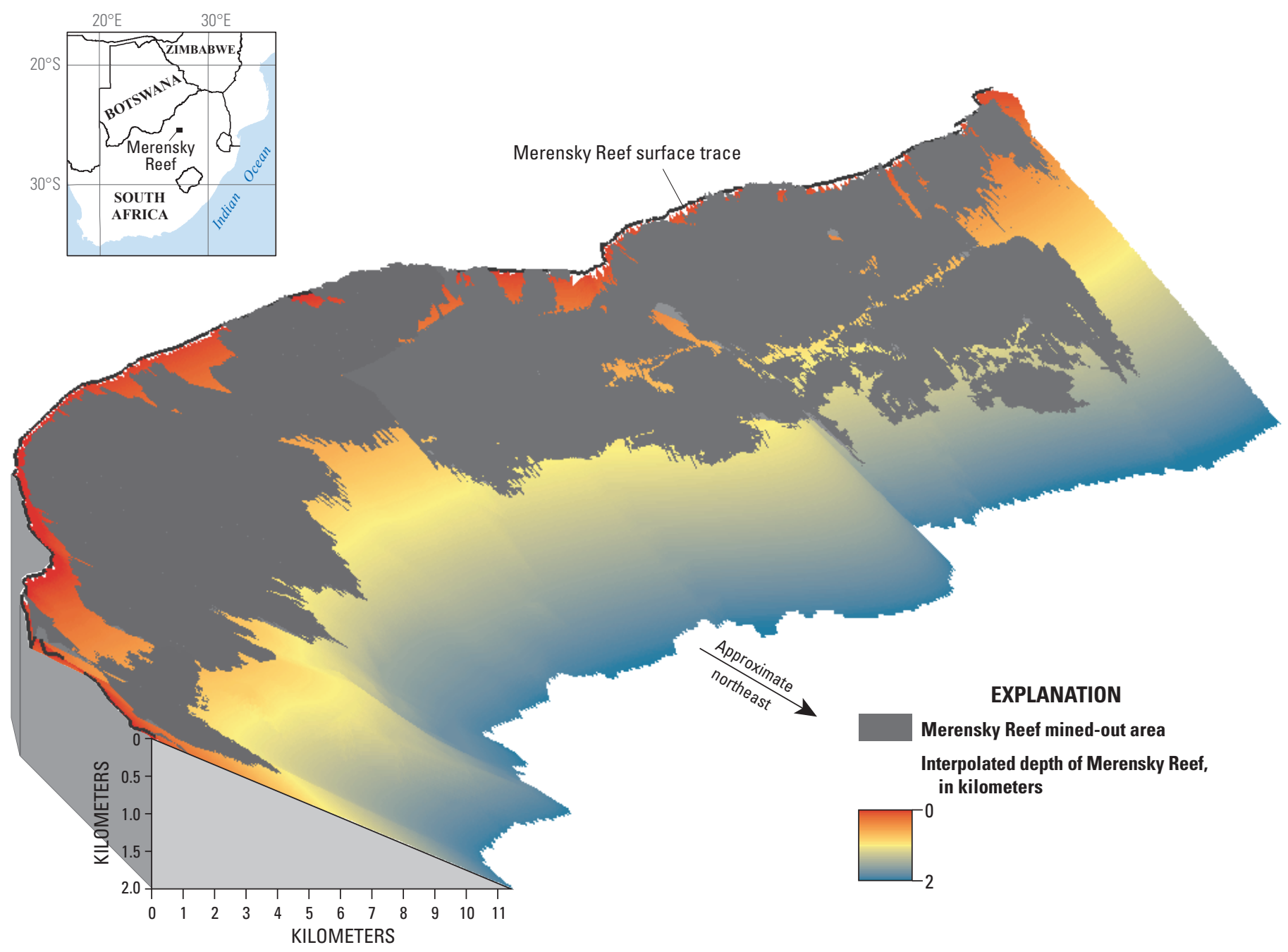

Figure N25. Three-dimensional block diagram showing the Merensky Reef interpolated down to 2 kilometers in the southern area of the western limb of the Bushveld Complex, South Africa. Mined out areas are shown in gray, and the Merensky Reef trace is shown as a black line. The Merensky Reef continues at depth beyond what is shown in this illustration.

could contain up to 6,900 metric tons of undiscovered platinum, palladium, and rhodium (Zientek and others, 2014).

Additional PGE resources in the Noril'sk-Talnakh area in Russia are difficult to assess. The extent of the orebodies for which resources are reported is not revealed in publicly accessible technical information released by the mining company. The northernmost mine in the Talnakh area, the Skalisty Mine, appears to be midway along the axis of the intrusion that hosts the massive sulfide orebodies (fig. N7 $A$ ). If existing maps, similar to the one shown in figure $\mathrm{N} 7 A$, are approximately correct, additional resources associated with massive sulfide orebodies in the Talnakh area could be present.

Roughly 305 metric tons of platinum and palladium have been produced from the J-M Reef in the Stillwater Complex in Montana, and drill-based estimates indicate that another 2,200 metric tons are present (U.S. Bureau of Mines,
1933-96; U.S. Geological Survey, 1997-2016; Abbott and others, 2011). Mining has progressed to depths of $1,800 \mathrm{~m}$ below the surface, but the bottom of the ore deposit has not been reached. Rough geologic estimates suggest that another 1,000 to 6,200 metric tons of platinum and palladium could be present at depth (Zientek, 1993; Zientek and others, 2002). As with the Bushveld Complex, the J-M Reef has been traced for longer distances along strike than down dip. The downdip projection of the J-M Reef is complicated by structural deformation associated with the uplift of the Beartooth Mountains. Gravity anomalies and inclusion suites in younger, cross-cutting intrusions, however, demonstrate that a portion of the complex is concealed at depth (Brozdowski, 1985; Kleinkopf, 1985). As a result, structural and geophysical models would be needed to constrain what rocks may be present at depth. 


\section{Undiscovered Reef-Type and Contact-Type Deposits}

Based on literature research, there are at least 200 layered intrusions in the world, although the actual number could be two to three times higher. An intrusion does not have to be large to have a reef-type deposit; intrusions as small as a few tens of kilometers in length with as little as $500 \mathrm{~m}$ of layered cumulates are known to host reef-type mineralization (table N6 at back of chapter; fig. N26). Well-explored intrusions have at the most 1- or 2-m-thick reef-type deposits (and several subeconomic occurrences) that occur in thousands of meters of layered rock. Many small intrusions could be evaluated for their reef-type potential to assess whether an economic deposit could be present.

For example, the identified PGE resources in Finland are 91 metric tons of platinum and 237 metric tons of palladium in seven reef-type and contact-type deposits. An assessment by the Geological Survey of Finland estimates that a mean number of 29 and 23 contact-type and reef-type deposits, respectively, occur in Finland. They estimate that the median contained metal contents would be 5,500 metric tons of platinum and 12,000 metric tons of palladium in the undiscovered contact-type and reef-type deposits (Rasilainen and others, 2010).

Undiscovered magmatic mineral deposits could be present in many areas of the United States and the world. The intrusions of the Duluth Complex, United States, and other smaller intrusive complexes of the Midcontinent Rift in the Lake Superior region have high potential to contain undiscovered copper-nickel-PGE sulfide deposits (fig. N15; Miller and others, 2002). In fact, recent exploration has dramatically expanded the mineral resource inventory of contact-type deposits along the western margin of the Duluth Complex. Exploration results have led to new exploration models, which indicate additional areas that may have the potential for undiscovered deposits. Furthermore, the Duluth Complex has many large layered intrusions that may have the potential to host reef-type PGE deposits. New models, new data, and tools for integration and visualization could result in discoveries of mineralized rocks.

Ernst and Buchan (2001) cataloged more than 300 LIP events worldwide; they determined that more than 100 LIP events have associated sill complexes or layered intrusions. All are prospective for the occurrence of magmatic mineral deposits. In the United States, Ernst and Buchan identified about 25 LIP events, of which several have sill complexes and layered intrusions. The obvious exploration targets for reeftype deposits in the United States are the Stillwater Complex in Montana and the dozens of intrusions that make up the Duluth Complex in Minnesota and associated rocks of the Keweenawan LIP. Other layered mafic intrusions with reeftype potential occur in the Wichita Mountains of Oklahoma,

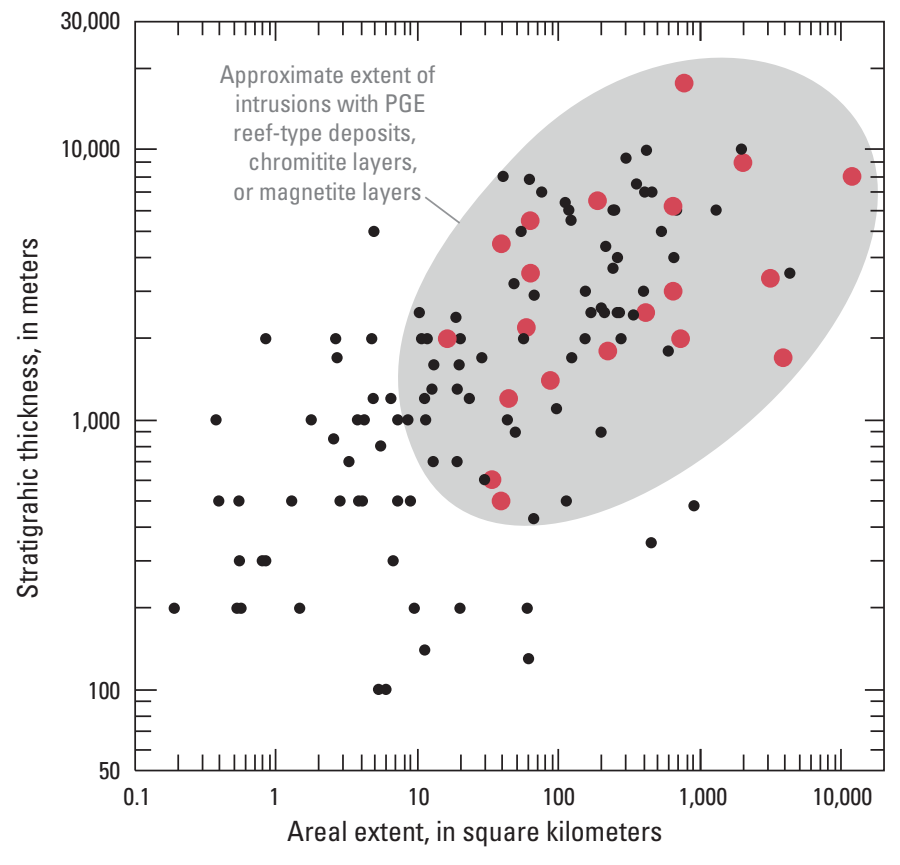

EXPLANATION

Intrusions with platinum-group-element (PGE) reef-type deposits, chromitite layers, or magnetite layers

- Intrusions with no known mineralization

Figure N26. Graph illustrating the exposed area and stratigraphic thickness of cumulates in more than 200 intrusions from around the world.

which are part of a Cambrian LIP. The Lake Owens Complex in Wyoming, which is a small layered intrusion, is also reported to have reef-type mineralization (Loucks, 1991). Other large layered intrusions are known from subsurface oil and gas exploration in west Texas and New Mexico; at present, they are too deep to be targets for mineral exploration (Keller and others, 1989; Kargi and Barnes, 1995; Adams and others, 1997).

To have a significant effect on global supply, a large-tonnage deposit would first have to be discovered. Large-tonnage reef-type deposits can occur only in large layered intrusions. A survey of the literature shows there are several large intrusions that do not have identified reef-type mineralization (such as the Tete Complex, the Dufek intrusion, the Molopo Farms Complex, the Windimurra Complex, and so on) (table N6). Some of the intrusions are poorly exposed and others have been intensely deformed and metamorphosed, which makes them difficult to explore for deposits. The economic risk associated with exploring these intrusions would be relatively high compared with identifying additional resources in extensions of known reef-type deposits. 


\section{Undiscovered Conduit-Type Deposits in the United States-Nikolai Greenstone and Eastern Wrangellia}

Several LIPs with sill complexes occur in the United States (Ernst and Buchan, 2001); however, one in particular stands out for its potential for undiscovered conduit-type nickel-copper-PGE mineralization (Hulbert, 1997; Hulbert and Stone, 2006; Schmidt and Rogers, 2007). The Wrangellia LIP is known from extensive flood basalts and related rocks of the Middle to Late Triassic Nikolai Greenstone that is part of the Wrangellia terrane accreted to the western margin of North America (Berg and others, 1972; Jones and others, 1972; Berg and others, 1978; Nokleberg and others, 1994; Plafker and Berg, 1994). The Wrangellia terrane can be traced discontinuously for more than 2,000 km from the Wrangell and Amphitheater Mountains in southern Alaska through Canada's southwestern Yukon Territory, to the Queen Charlotte and Vancouver Islands in British Columbia, Canada.

Sill-like mafic to ultramafic intrusive complexes in Wrangellia are the remnants of subvolcanic magma chambers that fed the thick, overlying flood basalts and picritic pyroclastics of the Nikolai Greenstone. A conduit-type deposit in the Wellgreen intrusion, Yukon Territory, contains a resource of 461 million metric tons grading 0.32 weight percent nickel, 0.26 weight percent copper, $0.4 \mathrm{ppm}$ platinum, $0.34 \mathrm{ppm}$ palladium, and $0.17 \mathrm{ppm}$ gold (McCracken, 2011; Carter and others, 2012).

Alaska's Amphitheater Mountains and the area of southcentral Alaska are also underlain by several mafic to ultramafic complexes that are part of the Nikolai LIP (fig. N27; Schmidt and Rogers, 2007; Glen and others, 2011). The largest and most exposed mafic to ultramafic sills include the Fish Lake and Tangle (FL-T) Complexes, which occur along the flanks of the Amphitheater Mountains synform. Smaller mafic to ultramafic complexes include Canwell, Eureka, and Rainy. The occurrence of picritic volcanic rocks (high-magnesium olivine basalt) near some of the larger mineralized ultramafic bodies is consistent with mineralized occurrences that have high nickel-to-copper ratios and elevated PGE concentrations. Grab samples from three different mafic to ultramafic complexes have extremely high metal concentrations, as follows: 2.0 weight percent nickel, 1.3 weight percent copper, and $7.9 \mathrm{~g} / \mathrm{t}$ PGE+gold+silver from Rainy; 13.6 weight percent nickel, 2.9 weight percent copper, and 26.0 g/t PGEs from Canwell; and 6.7 weight percent nickel, 1.0 weight percent copper, and $1.5 \mathrm{~g} / \mathrm{t}$ PGEs from Alpha (same as Fish Lake) (Pure Nickel, Inc., 2013).

\section{Undiscovered Platinum Placer Deposits in Alaska}

Undiscovered marine placer deposits could be associated with paleochannels or beach deposits in the Goodnews Bay region in Alaska. A geophysical survey indicates the presence of ultramafic rocks offshore, which could be a source of placer platinum (Barker and others, 1988; Barker and Lamal, 1989). Seismic analysis indicates that the bottoms of the paleochannels that drained these now-offshore ultramafic rocks are about 20 to $40 \mathrm{~m}$ deep and covered with modern sediments (Oommen, 2006; Oommen and others, 2008). Platinum may have accumulated in marine sand bars that are aligned parallel or subparallel to the current Alaskan coastline (Oommen, 2006; Oommen and others, 2008). Assuming that the sand bars represent submerged paleobeaches exposed during periods of glaciation in the Pleistocene Epoch, intensified wave sorting and concentration of heavy minerals (including entrained platinum grains) may have taken place. Spatial distribution patterns of platinum and sediments offshore of the Goodnews Bay Complex suggest relatively high platinum concentrations near Goodnews Bay and Carter Bay (Oommen, 2006; Oommen and others, 2008).

Schmidt and others (2007) delineated a permissive tract (fig. N19A) for placer PGE-gold deposits hosted in Quaternary unconsolidated alluvial and marine sediments that includes onshore regions and areas up to $10 \mathrm{~km}$ offshore that are downstream of known mafic to ultramafic complexes within the Goodnews Bay and Togiak terranes (Hoare and Coonrad, 1978; Decker and others, 1994). They estimate that the tract has a 90 percent probability of containing at least 1 metric ton of platinum and a 10 percent probability of containing at least 17 metric tons; the mean and median estimates are 5 and 7 metric tons, respectively.

\section{Metals in Stored Waste Products}

PGEs may also be present in material discarded during the mining and beneficiation of magmatic ore deposits. When ore materials are processed to recover the PGEs, some losses always occur; in other words, it is impossible to recover 100 percent of the metal in the mined material. For example, tailings derived from processing ores from the Noril'skTalnakh area in Russia may contain 800 to 1,000 metric tons of PGEs; an additional 100 metric tons of PGEs may be present in stored pyrrhotite concentrates and iron cakes (Petrov and others, 2013). Some of the metals in stored waste products could be recovered if appropriate technologies are developed. For example, ultrafine grinding techniques are currently being used to reprocess tailings from the Merensky Reef mines in South Africa (Buys and others, 2013). 

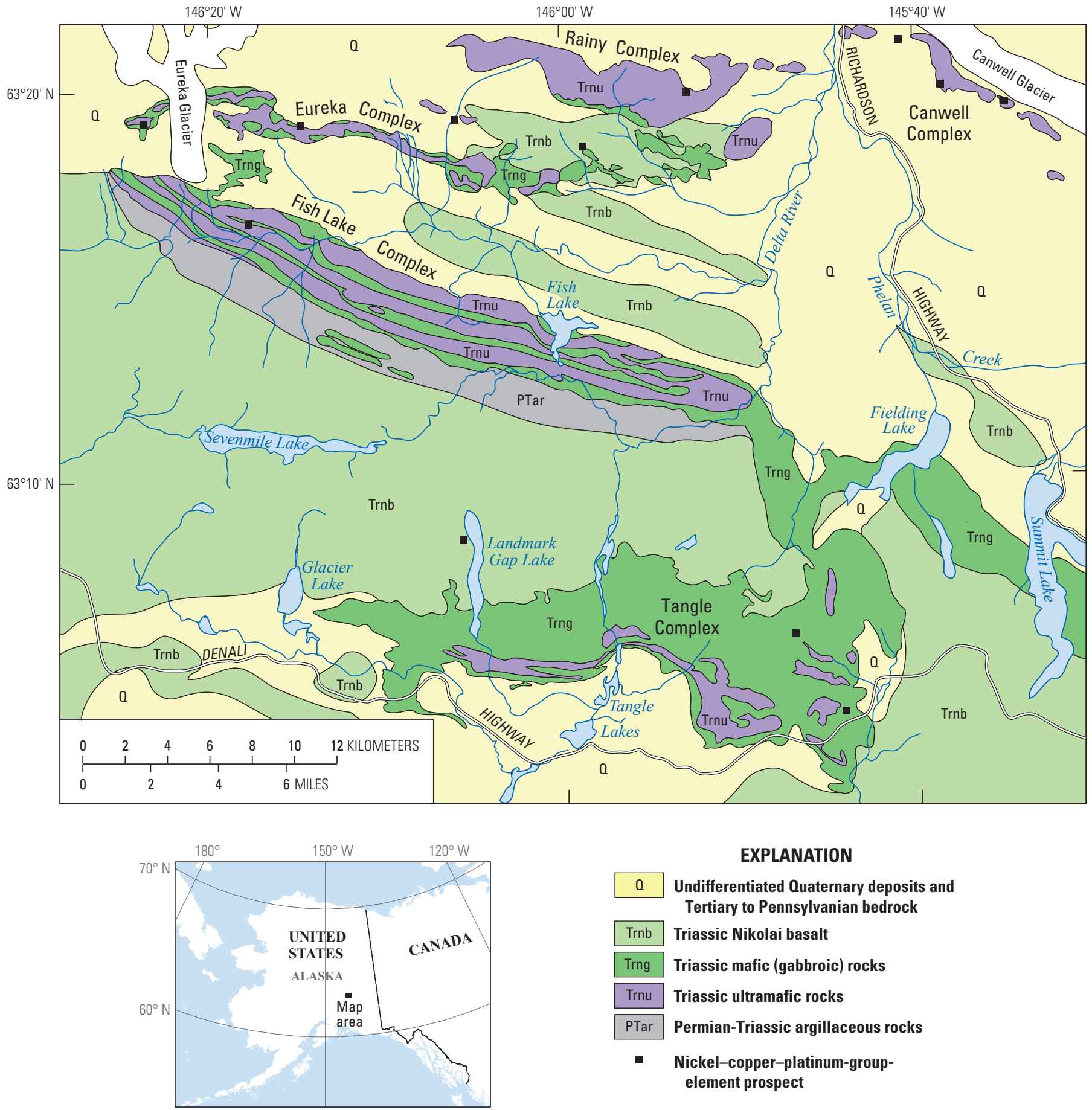

\section{EXPLANATION}

0 Undifferentiated Quaternary deposits and Tertiary to Pennsylvanian bedrock

\begin{tabular}{|c|c|}
\hline Trnb & Triassic Nikolai basalt \\
\hline Trng & Triassic mafic (gabbroic) rocks \\
\hline Trnu & Triassic ultramafic rocks \\
\hline PTar & Permian-Triassic arqillac \\
\hline
\end{tabular}

- Nickel-copper-platinum-groupelement prospect

Figure N27. Geologic map of the Amphitheater Mountains and south-central Alaska showing the location and names of mafic-ultramafic complexes that are part of the Nikolai large igneous province (Schmidt and Rogers, 2007). 


\section{Exploration for New Deposits}

The methods of locating PGE deposits can vary. In very rare cases, PGE-enriched sulfide mineralization has been found by panning. For example, the Merensky Reef of the Bushveld Complex, South Africa (fig. N9), was discovered in 1924 as the result of panning in a dry river bed and finding platinum minerals in the concentrate (Cawthorn, 1999). In most cases, chemical analysis of samples is required to identify PGE-enriched rocks. Because of the refractory nature of PGEs and their low concentration in most materials, an analytical technique that preconcentrates PGEs before analysis and ensures complete digestion of the sample is required. The preferred method to analyze for PGEs is fire assay.

A practical and effective exploration approach is to look for anomalous concentrations of copper, platinum, and palladium in residual or transported material derived from a larger volume of rock, such as soil, stream sediments, and talus fines (Cameron and Hattori, 2005). Soil chemistry has been used to delineate mineralized rocks in the Platreef of the Bushveld Complex (Frick, 1985). The J-M Reef of the Stillwater Complex (fig. N13) was discovered in 1974 by analyzing soil and talus fines for platinum and palladium (Conn, 1979; Zientek and others, 2005). Contact-type mineralization in the Duluth Complex (fig. N15) is currently being explored using regional geochemical surveys of glacial till (Duluth Metals Ltd., 2011).

Surface-water geochemistry led to the discovery of the ore deposits in the Noril'sk-Talnakh area in Russia (figs. N3 and N6; Kunilov, 1994). A surface water geochemical survey showed elevated concentrations of $\mathrm{SO}_{4}{ }^{2-}$ in samples from the Talnakh River. This led to the discovery of mineralized boulders in the area, which were traced to the base of the Kharayelakh Mountains. A study of talus along the slope of Otdel'naya Mountain led to the discovery of mineralized outcrops.

Geophysical methods used in PGE exploration map physical property contrasts, which primarily indicate the presence of magnetite, silicate minerals, and sulfide minerals that may be associated with PGE mineralization (Balch, 2005). If the PGEs are associated with base-metal sulfide minerals that have some degree of interconnection in the rock (and are electrically conductive), airborne and ground electromagnetics and induced polarization surveys can be used to detect mineralized rocks. High-resolution aeromagnetic surveys can be used to map igneous layering and tectonic structures (Campbell, 2006) but generally do not give direct indication of mineralized rock. Gravity studies are used to determine the subsurface extent of rocks with variable density and are particularly well suited to map and model the extent and volume of mafic and ultramafic igneous rocks (Webb and others, 2004). Once a rock layer that contains reef-type mineralization has been identified, seismic studies can be used to map the subsurface extent of the rocks (Davison and Chunnett, 1999; Chunnett and Rompel, 2004).
Lithogeochemical studies can be used to focus exploration activities (Maier and Barnes, 2005). For example, changes in the ratio of PGEs to sulfur or copper in rocks can be used to target specific intervals in cumulate stratigraphy where reef-type PGE mineralization could be present. In layered intrusions, nickel depletion in olivine is thought to indicate indirectly the presence of magmatic sulfide mineralization. Metal depletion in lavas flows is thought to indicate the presence of sulfide mineralization in the sills and dikes that served as feeders to the flows.

High-density drilling and sampling are required to delineate mineral resources and reserves in PGE deposits. For the J-M Reef, drilling on 15-m spacing is used to define proven mineral reserves; probable mineral reserves are delineated by projecting data $300 \mathrm{~m}$ from drill holes (Abbott and others, 2011). In the reef-type deposits in the Bushveld Complex, South Africa, measured mineral resources are defined with holes spaced 250 to $300 \mathrm{~m}$ apart, indicated resources are defined with holes spaced 500 to $600 \mathrm{~m}$ apart, and inferred mineral resources are defined with holes spaced 800 to 2,000 m apart. By comparison, massive sulfide ores in the Noril'sk-Talnakh area, Russia, are explored on a 32- by 60-m rectangular grid (Kunilov, 1994).

\section{Environmental Considerations}

The mineralogy of the ore and waste material associated with reef-type, contact-type, and conduit-type deposits are similar. Common sulfide minerals include chalcopyrite, pentlandite, and pyrrhotite. Secondary phases that typically form from primary sulfide minerals include covellite, goethite, gypsum, jarosite, marcasite, native sulfur, and pyrite (McGregor and others, 1998; Johnson and others, 2000). Common primary gangue minerals include chromite, olivine, plagioclase, and pyroxene. Alteration products include chlorite, magnetite, serpentine, talc, and minor amounts of carbonate and clay minerals.

The abundance of sulfide minerals defines the environmental and geologic characteristics of PGE-enriched magmatic sulfide deposits. The high proportion of sulfide minerals distinguishes some conduit-type deposits from reefand contact-type deposits. The overall pyrrhotite content of ore, waste rock, and tailings determines their acid-generating potential. Acid generated by the oxidative weathering of pyrrhotite can attack associated ore sulfide minerals and gangue silicate minerals, releasing a variety of potentially toxic elements - particularly cobalt, copper, iron, manganese, nickel, and, to a lesser extent, aluminum, cadmium, chromium, lead, and zinc to solution or to secondary solid phases (McGregor and others, 1998; Johnson and others, 2000). Massive ores characteristic of some conduit-type deposits have greater than 50 volume percent sulfide minerals and pose a greater challenge for mining and processing the ores without causing environmental problems. Both the low-sulfide 
reef-type and contact-type deposits have significantly lower sulfide contents, usually less than a few volume percent. Therefore, acid generation in mine wastes is less of a challenge to manage.

\section{Sources and Fate in the Environment}

The abundance of PGEs in the upper continental crust ranges from tens to hundreds of parts per trillion (ppt); platinum is the most abundant, followed by palladium, osmium, ruthenium, iridium, and rhodium (table N7; Taylor and McLennan, 1995; Park and others, 2012). Background PGE concentrations are also low in other environmental media, such as water, sediment, soil, and plants.

Experimental studies suggest that the maximum solubility of platinum in water at room temperature $\left(25^{\circ} \mathrm{C}\right)$ under oxygenated conditions ranges between 0.02 and $195 \mathrm{ppb}$, depending upon the $\mathrm{pH}$ of the water (Wood, 1991; Azaroual and others, 2001). The solubility of palladium in water at room temperature $\left(25^{\circ} \mathrm{C}\right)$ under oxygenated conditions ranges between 1 and 3,400 ppb, depending upon the $\mathrm{pH}$ of the water (Wood, 1991). Because of its greater solubility, palladium is more mobile in the environment than platinum.

PGE concentrations in water are generally in the $10^{-2} \mathrm{ppt}$ range. Rhodium $(0.082 \mathrm{ppt})$ has the highest mean concentration in seawater, followed by palladium ( $0.062 \mathrm{ppt})$, platinum (0.026 ppt), and osmium (0.005 ppt); ruthenium and iridium are present well below the ppt range (Bruland and Lohan, 2003). Platinum concentrations range from 0.22 to $78,000 \mathrm{ppt}$ in surface water and from 3 to $38 \mathrm{ppt}$ in groundwater (Ravindra and others, 2004).

Environmental baseline studies generally show low concentrations of PGEs and trace elements in water near undeveloped deposits. In the vicinity of the contact-type
NorthMet deposit in northern Minnesota, surface water downstream of the deposit in the Partridge River watershed has neutral $\mathrm{pH}$ (7.0), a low dissolved sulfate concentration (7.2 ppm), and moderate alkalinity ( $31 \mathrm{ppm}$ calcium carbonate $\left.\left[\mathrm{CaCO}_{3}\right]\right)$ and hardness $\left(30.3 \mathrm{ppm} \mathrm{CaCO}_{3}\right)$. Dissolved platinum and palladium concentration are below the detection limit $(<25 \mathrm{ppb})$, and the concentrations of other trace elements are low (table N8 at back of chapter; Minnesota Department of Natural Resources and the U.S. Army Corps of Engineers, 2009). Near the buried Eagle deposit, which is a conduit-type deposit in northern Michigan, maximum concentrations of iron (190 ppb), nickel (59 ppb), and zinc (88 ppb) in groundwater near the deposit reflect the presence of the orebody, whereas maximum concentrations of copper $(<5 \mathrm{ppb})$ and cobalt $(<10 \mathrm{ppb})$ are below their detection limits. In contrast, the concentrations of copper, nickel, and other trace elements in surface waters over the buried deposit are indistinguishable from those from regional water samples (Kennecott Eagle Minerals Co., 2006).

In fluvial and pelagic-marine sediment away from any known deposits, total PGE concentrations are less than a few tens of ppb (table N7). Platinum and palladium are found in higher concentrations than are (in decreasing order of abundance) ruthenium, iridium, osmium, and rhodium.

Fuchs and Rose (1974) investigated the geochemical behavior of platinum and palladium in the weathering cycle in soils around the Stillwater Complex in Montana. They found that palladium was depleted in the surface soil horizons but was concentrated at depth, reaching a maximum concentration of approximately $40 \mathrm{ppb}$. Platinum did not show systematic trends with depth; a maximum concentration of approximately $180 \mathrm{ppb}$ was recorded. The differences in the behavior of palladium and platinum in soils reflects the higher solubility of palladium in water compared with that of platinum in water (Fuchs and Rose, 1974).

Table N7. Platinum-group-element concentrations in samples of upper crust, loess, river sediment, and marine pelagic sediment. [n.d., no data]

\begin{tabular}{|c|c|c|c|c|c|c|c|}
\hline \multirow{2}{*}{ Material } & Platinum & Palladium & Ruthenium & Iridium & Osmium & Rhodium & \multirow{2}{*}{ Reference(s) } \\
\hline & \multicolumn{6}{|c|}{ (part per billion) } & \\
\hline $\begin{array}{l}\text { Upper continental } \\
\text { crust }\end{array}$ & 0.599 & 0.526 & 0.03 & 0.022 & 0.05 & 0.018 & $\begin{array}{l}\text { Taylor and McLennan (1995); } \\
\text { Park and others (2012) }\end{array}$ \\
\hline Loess (China) & 0.751 & 0.546 & 0.03 & 0.023 & n.d. & 0.018 & Park and others (2012) \\
\hline $\begin{array}{l}\text { River sediment } \\
\text { (Mölndal River, } \\
\text { Sweden, and } \\
\text { Stour River, } \\
\text { England) }\end{array}$ & $\begin{array}{l}<0.29 \text { to } \\
53.9\end{array}$ & $\begin{array}{l}0.08 \text { to } \\
38.7\end{array}$ & $\begin{array}{l}<0.15 \text { to } \\
3.73\end{array}$ & $\begin{array}{l}<0.03 \text { to } \\
2.69\end{array}$ & n.d. & $\begin{array}{c}<0.11 \text { to } \\
9.4\end{array}$ & $\begin{array}{l}\text { Ravindra and others (2004); } \\
\text { Moldovan and others (2001); } \\
\text { de Vos and others (2002) }\end{array}$ \\
\hline $\begin{array}{l}\text { Marine pelagic } \\
\text { sediment }\end{array}$ & $\begin{array}{c}0.4 \text { to } \\
21.9\end{array}$ & $\begin{array}{c}1.2 \text { to } \\
9.4\end{array}$ & $\begin{array}{c}<0.2 \text { to } \\
2.2\end{array}$ & $\begin{array}{c}<0.2 \text { to } \\
1.2\end{array}$ & $\begin{array}{c}<0.05 \text { to } \\
0.81\end{array}$ & n.d. & Goldberg and Koide (1990) \\
\hline
\end{tabular}


The results of an exploration program illustrate the natural background variation of platinum and palladium in a layered intrusion that hosts a major reef-type deposit. Following the studies by Fuchs and Rose, more than 10,900 samples of soil and talus fines were collected and analyzed for platinum and palladium as part of the exploration program that led to the discovery of the J-M Reef at the Stillwater Complex (Conn, 1979; Zientek and others, 2005). Palladium was below the detection limit for 14 percent of the locations; almost one-half of the samples had platinum concentrations that were below the detection limit. For most of these samples, the detection limit for palladium and platinum was $2 \mathrm{ppb}$ and $20 \mathrm{ppb}$, respectively. The median values for samples in the study above the detection limit were $8 \mathrm{ppb}$ and $20 \mathrm{ppb}$ for palladium and platinum, respectively. Maximum values measured for palladium and platinum were $6.4 \mathrm{ppm}$ and 5.76 ppm, respectively.

Platinum and palladium data are characterized by positive-skewed, multimodal distributions. More than 95 percent of the samples belong to a population consisting of unmineralized material with less than 30 to $40 \mathrm{ppb}$ palladium and less than 40 to $50 \mathrm{ppb}$ platinum. The remaining approximately 460 samples appear to be made up of two populations. The range of values for the largest population in the remaining 5 percent varies from about $40 \mathrm{ppb}$ to $200 \mathrm{ppb}$ palladium and about 50 to about $200 \mathrm{ppb}$ platinum. About 50 samples make up the third population and consist of material with more than $200 \mathrm{ppb}$ platinum or palladium.

Biogeochemical surveys show that platinum and palladium can concentrate in plants near mineralized outcrops. Riese and Arp (1983) conducted a geochemical orientation survey of the J-M Reef in the Stillwater Complex and found accumulations of platinum in stems of Douglas-fir (Pseudotsuga menziesii) up to thousands of parts per billion in ashed samples. In the northern forests of Saskatchewan, Canada, platinum and palladium tend to be concentrated in the twigs and trunks of black spruce (Picea mariana) and jack pine (Pinus banksiana) and in the stems of Labrador tea (Rhododendron groenlandicum). Spruce was sampled close to a worked-out nickel-copper deposit in northern Saskatchewan that contained 3,000 ppb platinum and 6,000 ppb palladium. The ashed twigs yielded up to $880 \mathrm{ppb}$ platinum and $1,350 \mathrm{ppb}$ palladium compared with background levels of below $10 \mathrm{ppb}$ platinum and $2 \mathrm{ppb}$ palladium (Dunn, 1986). Coker and others (1991) found greater enrichment of palladium than of platinum in vegetation around several PGE deposits in Canada-some that had been mined and some that had not been mined.

Anthropogenic sources of PGEs in the environment include catalytic converters used in modern automobiles (Ek and others, 2004; Ravindra and others, 2004; Wiseman and Zereini, 2009), platinum-based chemotherapy drugs (Ravindra and others, 2004), and smelter emissions (Chen and others, 2009). During the release of exhaust gases from automobile engines, the catalytic converters are chemically and physically stressed and release PGE-containing particulate matter. Most of the PGEs in the particles are in the metallic state, but about 1 percent is in an oxidized form that could be bioavailable (Ravindra and others, 2004). Concentrations of PGE particles are found in roadside dust, soils, and water. In platinumbearing drugs that are used to treat cancer, the platinum is excreted by the patients following treatment and ends up in the hospital sewage. The contribution of PGEs to the environment through this method is minor, however, compared with that from catalytic converters (Ravindra and others, 2004). Tiny amounts of osmium ( 0.25 to 23 femtograms per gram of water; 1 femtogram is $10^{-15}$ grams) are found in rainwater and snow from around the world (Chen and others, 2009). The most likely sources of this metal are smelters that process PGE ores. The osmium concentrations are so low that they are difficult to analyze; however, it is possible that the global appearance of osmium could someday be used as an environmental tracer.

\section{Platinum-Group-Element Mining and Mineral- Processing Methods}

Selective underground mining techniques are used for PGE deposits that occur in narrow reefs, such as those in the Bushveld Complex (South Africa) and the Stillwater Complex (Montana). The underground mining is performed by using either handheld pneumatic drills or mechanized drills to bore holes in the ore horizon, which are then filled with explosives. After blasting, the ore is removed from the mining stope and transported to the surface for further processing. Open pit mining is used for deposits in which the PGEs occur in greater thicknesses and at shallow depth, such as in the Lac des Iles Mine in Canada and the Platreef of the Bushveld Complex.

After ore is removed from the mines, it is crushed and ground to reduce the particle size and free the PGE-containing minerals from the rock matrix. The ore is then concentrated by using froth flotation circuits. For flotation, the ground rock particles are mixed with water and various reagents and air is pumped through the liquid, creating bubbles to which the PGE-containing minerals adhere. These bubbles float to the surface of the flotation vats and are removed as froth. The material is reground and refloated to produce a concentrate of nickel-iron-copper-PGE sulfide minerals for further processing. The greatest losses of PGEs occur in the early stages of processing, including crushing, milling, and froth flotation, owing to the diversity of PGE mineralogy. Much research is devoted to increasing PGE recovery rates in these early stages.

The concentrate is dried and then smelted in an electric arc furnace at temperatures that can exceed $1,500{ }^{\circ} \mathrm{C}$. During smelting, the concentrate forms a liquid, which separates into two layers. A matte containing the valuable metals is separated from a silicate- and oxide-rich slag, which is discarded. At the Stillwater Mining Co. smelter, the gases released from 
smelting operations undergo a gas-to-liquid scrubbing process, which removes approximately 99.8 percent of the sulfur dioxide. The sulfur dioxide is converted to gypsum, which is sold to local farmers for use as a soil amendment.

After smelting, the PGE-rich matte is transferred to converters, through which air is blown to remove iron and sulfur. The converter matte is processed at the base-metals refinery to separate the base metals from the PGEs by selective leach processing. The final stage is PGE refining by various hydrometallurgical techniques, including solvent extraction, precipitation, and dissolution using chloride solutions, in which the six PGEs are separated from each other to a purity of more than 99.99 percent. The refined PGEs can be produced in various forms, including as ingots, grains, or a fine powder known as "sponge."

The chromium-rich ores of the Bushveld Complex's UG2 Chromitite present special difficulties for beneficiation. The high chromium content of the ores requires especially high temperatures for smelting, and the low sulfide content both increases the matte viscosity and lowers the amount of matte formed. A processing technique, known as ConRoast, has been employed by some Bushveld processors specifically for use with high-chromium PGE ores. The ConRoast technique removes sulfur from the concentrate by roasting the ore at high temperatures in oxidizing conditions followed by smelting in a direct-current arc furnace in reducing conditions, which uses an iron-based alloy as a collector of cobalt, copper, nickel, and PGEs. The ConRoast technique can be used for concentrates containing any amount of chromite (Jones, 2002).

Ores from the Duluth Complex (Minnesota) present another challenging processing problem. Their low-grade nature makes smelting inefficient and uneconomic. A hightemperature chloride-assisted pressure-leaching process, known as PLATSOL ${ }^{\mathrm{TM}}$, has been developed to process the Duluth ores. The PLATSOL ${ }^{\text {TM }}$ process is an alternative to smelting and is capable of processing low-grade PGE ores. The nickel-copper-PGE ore concentrates are processed in an autoclave in an oxidizing environment in which PGEs, as well as gold, are solubilized and can be recovered directly after leaching by adsorption or precipitation with sulfide ions. Finally, base-metal sulfides are recovered either by precipitation, ion exchange, or solvent extraction-electrowinning (Baxter and others, 2005).

\section{Mine Waste Characteristics}

The majority of solid mine waste includes waste rock, mill tailings, slag, and smelter dust. Waste rock is uneconomic rock that must be removed to access the ore and is disposed of on site. It can also be used for construction on site if tests determine that it will not generate acid-rock drainage when it is exposed to the atmosphere and water. Tailings, which is the waste material from processing ore, can be pumped as slurry or trucked dry to a tailings storage facility on site. Tailings storage facilities are typically impoundments surrounded by a retaining dam. Tailings can also be disposed of underground in mined-out portions of the mine. The crushing and milling process increases the porosity of the solid waste and thus its volume by a factor of approximately two, which means that only about one-half of the waste from ore processing can be returned underground. Smelter slag, which is glassy waste matter separated from metals during the refining of ore, also has both physical and chemical characteristics of environmental concern and is typically held in storage facilities. Slag is also used in some mining and construction applications. Smelters produce gaseous emissions that may contain particulate material (smelter dust). If the emissions are not treated before the gases are vented to the atmosphere, the particulate material will settle near the smelter. For most modern smelting facilities, the gaseous emissions are treated to remove particulates, which are reprocessed to recover metals or put into a storage system.

Waste rock and tailings are usually found at all mines, but their proportions vary based on the mining method. The amount of waste rock is significantly greater at open pit mines than at underground mines. Reef-type deposits are generally mined by underground methods because of the narrow width of the ore horizon. Contact-type and conduit-type ores are mined by either open pit or underground methods, depending upon the geometry and depth of the orebodies.

\section{Acid-Base Accounts}

Metals and many other trace elements tend to be more soluble at low $\mathrm{pH}$ than at neutral or high $\mathrm{pH}$. Therefore, the acid-generating or acid-neutralizing potentials of waste rock, tailings, and other solid waste material help determine the possible environmental risk of mineral resource development. The balance between the acid-generating and the acidneutralizing potential of rocks and mine waste is expressed as an "acid-base account" (Price, 2009; International Network for Acid Prevention, 2011). The release of acid is primarily related to the presence of pyrrhotite in the rocks and waste. The presence of carbonate minerals, such as calcite, and some silicate minerals, such as feldspar, olivine, or pyroxene, in rocks and wastes can neutralize acidic solutions. Acid-base accounting values are commonly expressed in terms of kilograms of calcium carbonate per metric ton $\left(\mathrm{kg} \mathrm{CaCO}_{3} / \mathrm{t}\right)$ of waste material.

\section{Acid-Base Accounts for Reef-Type and Contact-Type Deposits}

Acid rock drainage from reef-type and contact-type deposits is unlikely because the ores and their host rocks contain low proportions of sulfide minerals. Jambor and others (2000) proposed a threshold of 0.3 weight percent sulfur present in sulfide minerals for acid generation. The sulfur content of ore in the J-M Reef at the Stillwater Complex 
in Montana ranges from 0.13 to 0.49 weight percent, with concentrations in tailings ranging from 0.05 to 0.08 weight percent. The sulfur content of the waste rock ranges from 0.01 to 0.04 weight percent (table N9 at back of chapter). Similarly, the ores and host rocks for the UG2 Chromitite, the Merensky Reef, and the Platreef deposits have low sulfur concentrations (Wilson and Chunnett, 2006; Naldrett and others, 2009). Acid-base accounting studies, leach tests, and site monitoring demonstrate that there is limited potential for the generation of hazardous metal leachates from ores, waste rocks, or tailings from most reef-type and contact-type deposits (table N9).

\section{Acid-Base Accounts for Conduit-Type Deposits}

For some conduit-type deposits with massive ores, the ore is processed to separate out and produce concentrates of iron-, copper-, and nickel-bearing sulfide minerals; the concentrated material is then further processed to extract the copper and nickel metals, and the iron-bearing sulfide minerals, mainly pyrrhotite, are discarded as waste. This process results in waste material with high acid-generating potential; the presence of minor amounts of carbonate minerals in the ore assemblage and the lower reactivity of the neutralizing minerals, such as olivine and pyroxene, offer minimal shortterm acid-neutralizing potential. The Eagle deposit in northern Michigan has the potential to generate acid leachate similar to that found in mineralogically similar tailings from Sudbury, Ontario, Canada (McGregor and others, 1998; Johnson and others, 2000). Johnson and others (2000) documented the generation of low $\mathrm{pH}$ (down to 3 ) waters with high dissolved concentrations of iron (up to $9,800 \mathrm{ppm}$ ), sulfate (up to 2,400 ppm), aluminum (up to 1,130 ppm), and nickel (up to 698 ppm) in groundwater in the tailings pile at the Nickel Rim Mine at Sudbury, Ontario, Canada. Copper (up to $3.5 \mathrm{ppm}$ ) and cobalt (up to $2.5 \mathrm{ppm}$ ) were also significant constituents.

\section{Air Quality Assessments}

An air quality assessment of the heavily industrialized western part of the Bushveld Complex, where the Merensky Reef and the UG2 Chromitite are mined, found that sulfur dioxide, nitrous oxide, and carbon monoxide concentrations are at acceptable levels using South African and European air quality standards (Venter and others, 2012). The major contributing sources were high-stack industry emissions for sulfur dioxide (metallurgical complexes and smelters), and household combustion for nitrous oxide and carbon monoxide. The levels of ozone and $\mathrm{PM}_{10}$ frequently exceeded standards $\left(\mathrm{PM}_{10}\right.$ refers to the total mass concentration of particulate matter up to 10 micrometers $[\mu \mathrm{m}]$ in size). Ozone is related to regional sources (wildfires, and coal and wood combustion for cooking and heating). The source of $\mathrm{PM}_{10}$ was identified as local household combustion (Hirsikko and others, 2012; Venter and others, 2012).
Mining operations in the Noril'sk-Talnakh area of Russia emit large amounts of sulfur dioxide and nickel and other metals (Council on Ethics, 2009; Bellona Foundation, 2010). According to the Norwegian Government's Council on Ethics for the Government Pension Fund-Global, atmospheric emissions of sulfur dioxide, which lead to acid rain, are about 2,000,000 metric tons per year, and atmospheric emissions of copper, nickel, and cobalt are conservatively estimated to be about 500, 450, and 50 metric tons per year, respectively. Smelting operations release metals into the atmosphere in the form of dust or particulates. Smelter emissions have been shown to cause death or significant damage to vegetation up to $200 \mathrm{~km}$ from the mining operations.

\section{Human Health Concerns}

The metallic forms of PGEs are generally considered to be inert. Health hazards specifically related to PGEs affect only individuals who are occupationally exposed to manmade PGE compounds, especially workers in preciousmetal refineries. Platinum-based drugs, such as cisplatin and carboplatin, are used in cancer treatment. Broader human health effects of PGEs appear to be limited because of the low concentrations of PGEs in the environment (Hoppstock and Sures, 2004). Ravindra and others (2004) and Hoppstock and Sures (2004) reviewed human health risks associated with PGEs, and Kielhorn and others (2002) reviewed the human health effects of palladium specifically. The more significant human health risks associated with PGE mining are related to the trace elements associated with PGE deposits.

As discussed in a previous section, the mining operations at the Noril'sk-Talnakh area in Russia affect air quality; surface and groundwater are also affected by the industrial activities. Respiratory diseases and various forms of cancer have been shown to be more prevalent in the local population of the Noril'sk-Talnakh area than in other regions of Russia (Council on Ethics, 2009). Industrial activity in this area has been shown to be related to increased incidences of acute respiratory illness and a higher prevalence of oncological disease, particularly lung cancer, and may be related to other possible negative health effects, such as weakening of the immune system, reproductive health issues, an increase in the rate of disease in children, and reduced life expectancy (Council on Ethics, 2009).

\section{Ecological Health Concerns}

The risks to the ecosystem from mining PGEs and associated minerals are mainly those related to acid mine drainage, which primarily affects aquatic environments. The surface water chemistry downstream from platinum mine waste dumps in Zimbabwe was investigated by Meck and others (2006). The surface water in the vicinity of platinum dumps was found to be near neutral or to have slightly alkaline $\mathrm{pH}$ and to contain concentrations of chromium, cobalt, copper, 
lead, and nickel that exceeded chronic surface-water criteria established by the U.S. Environmental Protection Agency (Suter, 1996; U.S. Environmental Protection Agency, 2009). Differences between upstream and downstream sample sites were most noticeable for nickel and approached a difference of $500 \mathrm{ppb}$.

Ecological risks can also be associated with soils and mill tailings. The toxicity of rehabilitated and nonrehabilitated mill tailings from reef-type deposits in South Africa to earthworms (Eisenia fetdia) was investigated by Jubileus (2008) and Maboeta and others (2008) using laboratory bioassay techniques. Sublethal impairment of earthworms (that is, effects on the growth and hatching success of cocoons) in soil samples decreased with distance from the tailing storage facilities. Anomalous concentrations of chromium, copper, nickel, and zinc were found in the tailings relative to the regional background soils. Wahl and others (2012) reached similar conclusions based on mesofauna surveys from the same tailing storage facilities.

Studies of soil and grass show anthropogenic platinum enrichment near mines in the Bushveld Complex. Thousands of soil and stream sediment samples collected at the Bushveld Complex show anomalous concentrations of precious metals related to bedrock sources and mining areas (Wilhelm and others, 1997). The results of the soil and stream sediment surveys mapped two bedrock sources of PGEs that are concordant to magmatic layering in the Bushveld Complex. The survey also mapped large anomalies near the locations of the large PGE mines in the western part of the Bushveld Complex; anomalies near the mines exceed 200 ppb PGEs. Rauch and Fatoki (2013) found about 700 ppb platinum in soils at a smelter. The maximum concentration in grass was $256 \mathrm{ppb}$ platinum, again found at the smelter.

\section{Carbon Footprint}

The PGEs and their mining have several links to carbon cycling in the environment. One of the most important uses of PGEs is in catalytic converters (Loferski, 2012a, b), which help to limit the amount of carbon and nitrogen gases and other air pollutants that enter the environment through vehicle exhaust. Fuel cells are an emerging energy technology. Proton exchange membrane (PEM) fuel cells use hydrogen as fuel, combining it with oxygen to form water; these fuel cells rely on platinum catalysts (Mehta and Cooper, 2003).

The trend towards the mining of lower grade ore in existing mines is expected to have a negative effect on greenhouse gas emissions. Lower grade ores require more energy to produce a unit of PGEs than do higher grade ores. The trend towards increased greenhouse gas emissions per unit of PGEs produced (measured in tons of carbon dioxide $\left[\mathrm{CO}_{2}\right]$ per kilogram of PGEs) over time is evident in data from
South Africa that date back to 2002 (Glaister and Mudd, 2010). In 2002, unit greenhouse gas emissions varied from about 20 to 40 metric tons for different mine properties. In 2008, the range of values increased to about 30 to 65 metric tons.

The calcium- and magnesium-rich silicate minerals common in mine wastes from PGE deposits represent an important sink for atmospheric carbon dioxide because these minerals react fairly readily with this greenhouse gas. The potential for mineral carbonation of PGE tailings was evaluated by Vogeli and others (2011). They ranked South African PGE tailings in terms of their carbonation potential on the basis of their mineralogy and the grain size and found that finer-grained, more olivine-rich, and plagioclase-poor tailings would be best for mineral carbonation. Although the mass of PGE tailings globally is inadequate to reduce global atmospheric carbon dioxide concentrations significantly, the carbonation of calcium- and magnesium-rich tailings can contribute to reducing the carbon footprint of individual mining operations.

\section{Mine Closure}

The procedures used to close PGE mines depends primarily on the method of mining and the character of the waste material. Reef-type deposits are typically developed using underground methods. Contact-type and conduit-type deposits can be developed by underground or open pit methods, depending upon the geometry of the orebody. For all these deposit types, open pit mining results in at least three different features after mining: the open pit, waste rock piles, and tailings storage facilities. Because of the scale of typical PGE mining activities, backfilling open pits is usually not practical. If the water table is above the bottom of the pit, the pit will fill with water and form a lake. The water quality of the lake will depend upon a number of factors, including the nature of the wall rock, the extent of interconnected underground mine workings that open to the pit, the water level in the pit, the local hydrology, and the climate, among others (Castendyk and Eary, 2009).

The long-term fate of tailing storage facilities depends upon the nature of the tailings and the method of construction of the facility. Some facilities can be regraded, capped, and revegetated. Others are designed to have a water cover in perpetuity to limit sulfide oxidation. Either type may have seepage that may require some form of water treatment.

The long-term fate of waste rock piles may include regrading, capping, and revegetation. Depending upon the acid-generating potential of the material, some piles may require some form of water treatment. An emerging issue for historical PGE tailings and piles is that older ore-processing techniques were not as efficient as those used today. As a consequence, historical tailings and waste piles can carry significant PGE grades. 


\section{Problems and Future Research}

The supply of PGE from primary and secondary sources currently meets society's demand for these metals. Even if demand increases (as it assuredly will), the in-ground identified mineral resources appear to be sufficient to supply the world's needs for several decades. The location of most of the in-ground resources in a few big deposits in a few places makes the primary production of PGE susceptible to supply disruption, however. The following section discusses this problem in more detail.

\section{Future Demand and Possible Risks to Supply}

The demand for PGEs continues to increase. PGE use in automobile catalytic converters is expected to increase as more-stringent automobile emission standards are adopted worldwide. An emerging industrial use for platinum is in fuel cells that provide electricity for automobiles, homes, and businesses. Fuel cells produce electricity through electrochemical reactions by combining oxygen with a hydrogen-bearing fuel over a catalyst, such as platinum, and produce only water and carbon dioxide as emissions.

Various studies have compared anticipated demand for the PGEs with the amount of PGE ore that has been positively identified by mineral exploration. Along with the anticipated supply of PGEs by recycling, the studies suggest that there are sufficient PGE resources in the ground to meet projected platinum demand well into the middle of the 21 st century (Tiax LLC, 2003; Wilburn and Bleiwas, 2004; Mudd, 2012; Wilburn, 2012). Mineral reserves in the Bushveld Complex would be sufficient to meet global platinum demand until 2040 (assuming an annual increase in platinum consumption of 2 percent). The much larger volume of mineralized rock that has been classified as mineral resources, coupled with the potential for additional undiscovered resources to be found, indicates that the potential amount of PGEs that could be mined will not be a constraint to PGE supply for many decades. Disruptions to the PGE supply are more likely to be affected by social, environmental, political, and economic factors rather than geologic issues or resource depletion (Mudd, 2012).

Variations in the annual average prices of the PGEs during the past 40 years illustrate the types of events and policies that could affect global supply and demand for mineral commodities (fig. N28). Some events, such as the oil embargo in the mid-1970s and the global recession that began in 2008, affected all metal prices (not just the prices of PGEs). Other effects can be specifically related to legislation passed by one or more Governments; for example, in the mid-1970s, catalytic converters, which use PGEs as the catalyst, were installed in automobiles to meet air standards set in the Clean Air Act Amendments of 1970 (84 Stat. 1705, P.L. 91-604; Gerard and Lave, 2005; McCarthy and others, 2011). Catalytic converters reduce harmful emissions from automobiles; the widespread adoption of catalytic converters, first in the United States in the 1970s, then in the European Union and Japan, increased demand for PGEs. Palladium supply was disrupted in 1999 and 2000 because Russian Government legislation temporarily blocked export of this metal (United Nations Conference on Trade and Development, undated). Other effects are related to problems with mineral production; for example, problems with a refinery in Rustenburg, South Africa, in 1989 caused a decrease in the world supply of rhodium. The PGE supply was also affected by work stoppages and miners' strikes in South Africa in 1986, 2011, and 2012 (Yager and others, 2012).

Production of PGEs requires power and water, both of which are in short supply in southern Africa. Africa depends on imports of oil and on production of synthetic fuels from coal to meet its fuel requirements (United Nations Conference on Trade and Development Secretariat, 1995). In January 2008, the South African mining industry briefly shut down almost all its operations because of the unpredictability of the power supply. Roughly one-quarter of the installed generating capacity was not available owing to system faults, planned maintenance, and a shortage of the coal used in power stations. The country was subject to short-notice blackouts, which made mining unsafe (Platinum Today, 2008). Expanding the mining capacity at the Bushveld Complex in South Africa is constrained by the power supply. Water is required to mine, process ore, and refine metals; if the water supply is restricted, then production is affected. In any country that is water-stressed, mining companies must strive to manage the supply and use of water to ensure continuation of operations (Anglo American Platinum Ltd., 2012).

The ultimate constraint on the development of PGE mineral resources may not be the presence of mineralized rock but rather the rock temperature. For example, the contact between the Main zone and the Lower Critical subzone in the Bushveld Complex can be traced to depths of $6 \mathrm{~km}$ in seismic surveys (Sargeant, 2001; Campbell, 2011), which indicates that mineralization associated with the Merensky Reef and the UG2 Chromitite may also be present at those depths (Cawthorn, 2010). These reefs are currently being mined at depths exceeding $2 \mathrm{~km}$ at the Northam Mine, where virgin rock temperatures of $70^{\circ} \mathrm{C}$ are measured at a depth of 2,176 m (Northam Platinum Ltd., 2008). Anglo American Platinum Ltd., whose operations include several mines in the Bushveld Complex, considers a virgin rock temperature of $75^{\circ} \mathrm{C}$ to be the limit of mining based on the anticipated technology, metal prices, and energy costs (Anglo American Platinum Ltd., 2011). By comparison, rock temperatures within the ore-bearing intrusions at the Talnakh area of Russia are up to $35^{\circ} \mathrm{C}$ in the Taimyrsky Mine, 27 to $30^{\circ} \mathrm{C}$ in the Skalisty Mine, and are anticipated to be 43 to $47^{\circ} \mathrm{C}$ in the area that will be developed by the Gluboky Mine (Kunilov, 1994). The massive sulfide ores in these Russian mines are highly reactive, however, and are prone to oxidation and spontaneous combustion. 


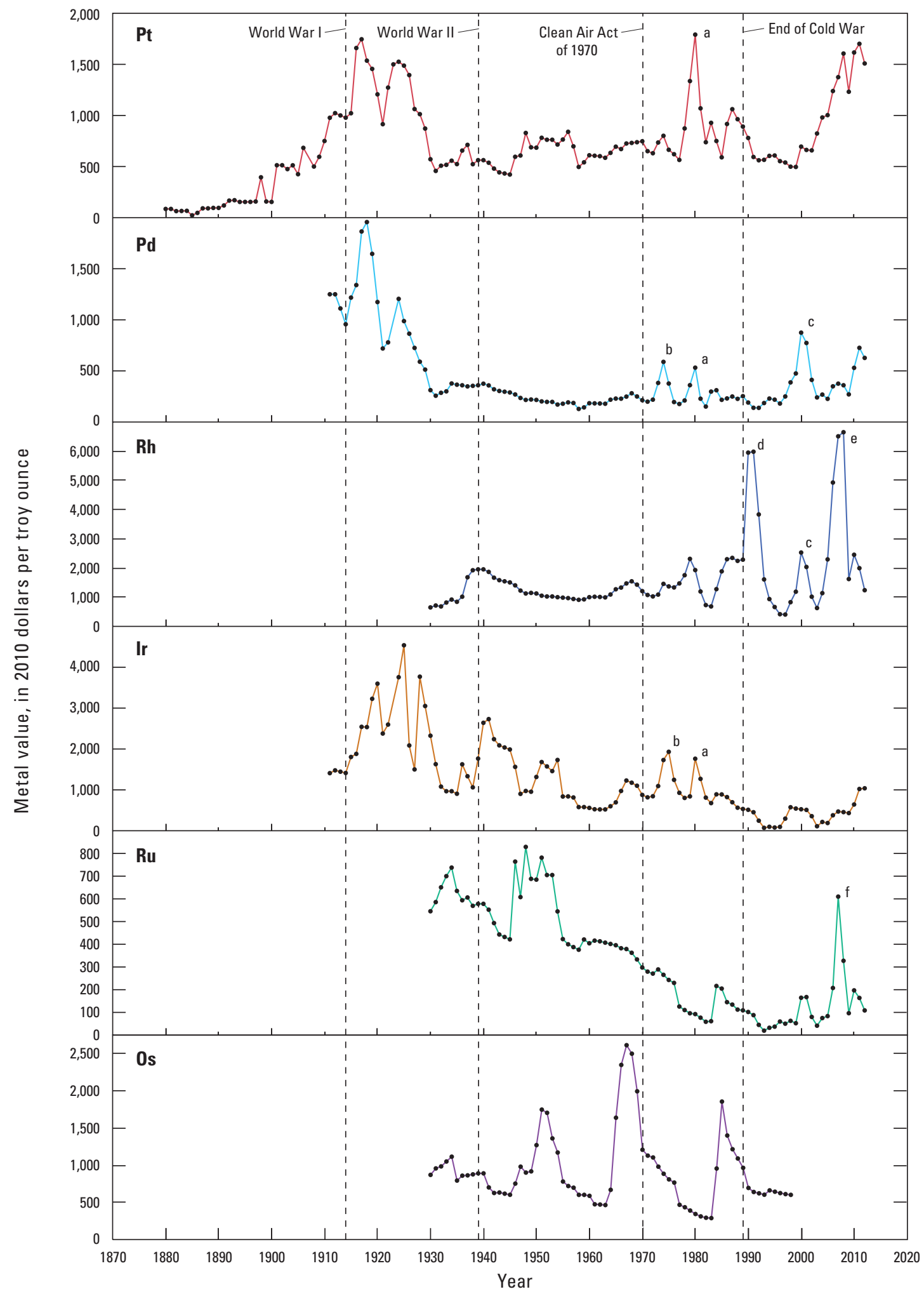

Figure N28. Graphs showing platinum-group-element prices (in constant U.S. dollars referenced to 2010) for platinum (Pt), palladium (Pd), rhodium (Rh), iridium (Ir), ruthenium (Ru), and osmium (Os) from 1880 to 2013. Major world events affecting pricing are shown as vertical dashed lines. Other major events shown are (a) investor speculation, (b) catalytic converter use begins and the Arab oil embargo, (c) shortfall of supplies of palladium from Russia, (d) disruption of supply because of problems at the Rustenburg refinery in South Africa, (e) increased demand for autocatalysts in Asian markets, and (f) increased ruthenium usage in electronics, especially in computer hard disk drives. National deflators are from the California Department of Finance (2012). Price data are from Plunkert and Jones (1999); Reese (1996); Hilliard (1998, 2000, 2004); Loferski (2012b, 2013c); and Platinum Today (2012). 


\section{Research Directions}

Successful exploration strategies for PGEs have been based on the magmatic deposit paradigm. This approach has proven highly successful and will likely result in additional discoveries. Its utility has a down side, however, in that other geologic settings in which PGEs may be concentrated have not been studied. Models strongly influence the observations made in both research and mineral exploration. For example, most economic geologists would not look for world-class PGE deposits in ophiolites. The most common magmatic ore type in ophiolites are chromitite deposits; all contain PGEs but are enriched in iridium relative to platinum (Mungall, 2002; Finnigan and others, 2008). There are a few examples of platinum-enriched chromitites in ophiolites, but these are too small to be of any economic consequence. Therefore, mineral exploration geologists have not searched for concentrations of magmatic sulfide minerals in ophiolites; however, a small magmatic sulfide deposit in the Acoje ophiolite, Philippines (Bacuta and others, 1990; Yumul, 2001), and occurrences in cumulates of the Shetland Ophiolite Complex, United Kingdom (Prichard and Lord, 1993), are examples that indicate that sulfide exsolution and PGE enrichment can take place in ophiolites. The examples of hydrothermal ore deposits with elevated PGEs are other reminders that an economic PGE deposit may be present in rocks that have not been explored.

Most researchers in the field of economic geology can supply a list of research topics that could be undertaken to alleviate concerns about the global availability of PGEs. One approach to addressing concerns is to find more deposits, but finding small deposits will not solve the problem. The deposits must be large (like one or more of the giants that currently dominate supply). Research to find new deposits can be basic, in which known deposits are mapped and characterized in order to understand how they form. The research can also be applied, in which the search for PGE deposits is extended into geologic settings where the deposits would be highly weathered, highly metamorphosed, or largely concealed. Additionally, research can focus on new ways to understand and integrate information so that new hypotheses can be proposed and tested. Research will be most effective if basic and applied research is integrated. It will also be more fruitful if expertise from many disciplines is involved in solving the problem.

\section{Acknowledgments}

Technical reviews by Art Bookstrom, Niki Wintzer, and Ennis Geraghty (Stillwater Mining Co.) greatly improved this chapter. Constructive comments were provided by Klaus Schulz and Dwight Bradley on an early version of the manuscript; John DeYoung and Suzanne Nicholson carefully looked through the document after the technical review was complete. Keith Labay helped create the world map, and Heather Parks constructed the first draft of the illustrations.

\section{References Cited}

Note: All Web links listed were active as of the access date but may no longer be available.

Abbott, D.M., Jr., Bullock, R.L., Gibbs, Betty, and Kunter, R.S., 2011, Technical report for the mining operations at Stillwater Mining Company, Stillwater Mine, $45^{\circ} 23^{\prime} \mathrm{N}$, $109^{\circ} 53^{\prime} \mathrm{W}$, East Boulder Mine, $45^{\circ} 30^{\prime} \mathrm{N}, 109^{\circ} 05^{\prime} \mathrm{W}$ : Denver, Colo., Behre Dolbear \& Company, Ltd. Project 11-030, 87 p., accessed June 25, 2013, at http://secfilings.nyse.com/ filing.php?ipage $=7682024$.

Adams, D.C., Miller, K.C., and Kargi, H., 1997, Reconciling physical properties with surface seismic data from a layered mafic intrusion: Tectonophysics, v. 271, nos. 1-2, p. 59-74.

African Rainbow Minerals Ltd., 2006, Nkomati-An open ended opportunity: African Rainbow Minerals Ltd. presentation, October 4, 2006, 47 slides, accessed April 23, 2012, at http:/www.arm.co.za/im/files/ presentations/2006/nkomati_expansion04oct06.pdf.

African Rainbow Minerals Ltd., 2010, Mineral resources and reserves 2010: African Rainbow Minerals Ltd., 31 p., accessed September 12, 2011, at http:/www.arm.co.za/im/ files/annual/2010/f/ARM_resources_reserves_2010.pdf.

African Rainbow Minerals Ltd., 2011, Mineral resources and reserves 2011: African Rainbow Minerals Ltd., 31 p., accessed January 26, 2011, at http://www.arm.co.za/im/files/ annual/2011/download/ARM-resources-and-reserves-2011.pdf.

Alapieti, T.T., and Lahtinen, J.J., 2002, Platinum-group element mineralization in layered intrusions of northern Finland and the Kola Peninsula, Russia, in Cabri, L.J., ed., The geology, geochemistry, mineralogy and mineral beneficiation of platinum-group elements: Montreal, Quebec, Canada, Canadian Institute of Mining, Metallurgy and Petroleum Special Volume 54, p. 507-546.

Allaart, J.H., comp., 1998, Geological map of Greenland map sheet no. 2, Frederikshåb Isblink-Søndre Strømfjord, in Geological Survey of Denmark and Greenland, Geological map of Greenland, 1:500,000, Frederikshåb Isblink-Søndre Strømfjord (sheet 2): Geological Survey of Denmark and Greenland, Geology of Denmark and Greenland Map Series CD 6, CD-ROM.

Alvarez, Juan, Khosrowshahi, Sia, Gonzalez, J.P., and Gatley, Stephen, 2009, Technical report on the Aguablanca Ni-Cu deposit, Extremadura region, Spain, NI 43-101 technical report, prepared for Rio Narcea Recursos S.A. (part of Lundin Mining Corp.) [Filing date March 31, 2009]: Golder Associates Global Ibérica, S.L., Report no. 08511150292, March 31, 110 p. plus 7 appendixes. [Also available at http://www.sedar.com.] 
American Physical Society Panel on Public Affairs and the Materials Research Society, 2011, Energy critical elementsSecuring materials for emerging technologies: Washington, D.C., American Physical Society, 19 p. plus 2 appendixes, accessed February 1, 2013, at http://www.aps.org/policy/ reports/popa-reports/upload/elementsreport.pdf.

Anderson, W.B., and Martineau, M.P., 2002, New discoveries of platinum and palladium in the central Urals of Russia: London, United Kingdom, Eurasia Mining plc, 4 p., accessed April 19, 2013, at http://www.nicholas.duke.edu/ people/faculty/boudreau/9thPtSymposium/Anderson Abstract.pdf.

Angeli, Nelson, 2005, Platinum group minerals in eastern Brazil: Platinum Metals Review, v. 49, no. 1, p 41-53.

Anglo American Platinum Ltd., 2009, Platinum estimates as of 31 December 2009: Anglo American Platinum Ltd. Web page, accessed September 23, 2011, at http://ar09.angloamerican.solutions.investis.com/ ore_reserves/platinum/projects.html.

Anglo American Platinum Ltd., 2011, Integrated annual report 2011: Anglo American Platinum Ltd., 322 p., accessed October 6, 2016, at http://www.angloamericanplatinum.com/ $\sim$ media/Files/A/Anglo-American-Platinum/AA\%20 Plat $\% 20-\%$ 20INTEGRATED\%20ANNUAL $\% 20$ REPORT\%202011.pdf.

Anglo American Platinum Ltd., 2012, Water, section of Hardwiring sustainability with the future in mindSustainable development report 2012: Anglo American Platinum Ltd., p. 108-115, accessed February 1, 2016, at http://www.angloamericanplatinum.com/ /media/ Files/A/Anglo-American-Platinum/annual-reports/ aapsdreport2012-150313.pdf.

Anikina, E.V., Malitch, K.N., Pushkarev, E.V., and Shmelev, V.R., 2014, The Nizhny Tagil and Volkovsky Massifs of the Uralian platinum belt, and related deposits-Field trip guidebook for International Platinum Symposium, 12th, Yekaterinburg, Russia, August 15-16, 2014: St. Petersburg, Russia, Russian Academy of Sciences, Zavaritsky Institute of Geology and Geochemistry (IGG UB RAS), 48 p., accessed September 18, 2015, at http://www.igg.uran.ru/ sites/default/files/12IPS/3b_12_ips_guidebook_nizhny_ tagil-volkovsky_deposits.pdf.

Appel, P.W.U., Dahl, Ole, Kalvig, Per, and Polat, Ali, 2011, Discovery of new PGE mineralization in the Precambrian Fiskenaesset anorthosite complex, West Greenland: Danmarks og Grønlands Geologiske Undersøgelse Rapport 2011/3, 48 p. and CD-ROM.

Aquarius Platinum Ltd., 2011, Aquarius - A platinum investmentAnnual report 2011: Aquarius Platinum Ltd., 127 p., accessed September 13, 2012, at http://aquariusplatinum.com/ sites/aquariusplatinum.com/files/ckfinder/files/2011_AQP Annual_Report_v2.pdf.
Armitage, Mike, 2007, Kun-Manie nickel project valuation, prepared for Amur Minerals Corp: Vancouver, British Columbia, Canada, SRK Consulting, February 5, 4 p.

Armitage, P., McDonald, I., and Tredoux, M., 2007, A geological investigation of the Waterberg hydrothermal platinum deposit, Mookgophong, Limpopo Province, South Africa: TransactionsInstitution of Mining and Metallurgy, Section B-Applied Earth Science, v. 116, no. 3, p. 113-129. [Also available at http://dx.doi.org/10.1179/174327507X207483.]

Armstrong, R., and Wilson, A.H., 2000, A SHRIMP U-Pb study of zircons from the layered sequence of the Great Dyke, Zimbabwe, and a granitoid anatectic dyke: Earth and Planetary Science Letters, v. 180, nos. 1-2, July 30, p. 1-12. [Also available at http://dx.doi.org/10.1016/ S0012-821X(00)00162-X.]

Arndt, N.T., 2005, The conduits of magmatic ore deposits, in Mungall, J.E., ed., Exploration for platinum-group element deposits: Mineralogical Association of Canada Short Course Series, v. 35, p. 181-201.

Augé, Thierry, and Legendre, Olivier, 1994, Platinum-group element oxides from the Pirogues ophiolitic mineralization, New Caledonia-Origin and significance: Economic Geology, v. 89, p. 1454-1468. [Also available at http://dx.doi.org/10.2113/gsecongeo.89.7.1454.]

Azaroual, M., Romand, B., Freyssinet, P., and Disnar, J.-R., 2001 , Solubility of platinum in aqueous solutions at $25^{\circ} \mathrm{C}$ and $\mathrm{pHs} 4$ to 10 under oxidizing conditions: Geochimica et Cosmochimica Acta, v. 65, no. 24, p. 4453-4466. [Also available at http://dx.doi.org/10.1016/S00167037(01)00752-9.]

Bacuta, G.C., Jr., Kay, R.W., Gibbs, A.K., and Lipin, B.R., 1990, Platinum-group element abundance and distribution in chromite deposits of the Acoje Block, Zambales ophiolite complex, Philippines: Journal of Geochemical Exploration, v. 37, no. 1, p. 113-145. [Also available at http://dx.doi.org/ 10.1016/0375-6742(90)90086-P.]

Bailey, Joshua, 2012, Technical report on the Parkin Offset properties, Sudbury, Ontario-NI 43-101 technical report [Filing date March 29, 2012; effective date December 31, 2011]: Wallbridge Mining Company Ltd., 83 p., accessed September 9, 2015, at http://www.sedar.com.)

Bailly, L., Augé, T., Cocherie, A., Trofimov, N.N., Golubev, A.I., Tkachev, A.V., and Cherkasov, S.V., 2009, New data on the age of the Burakovsky layered intrusion, Karelia: Doklady Earth Sciences, v. 426, no. 1, p. 534-538. [Also available at http://dx.doi.org/10.1134/S1028334X09040059.]

Baker, C.L., Kelly, R.I., Parker, J.R., Ayer, J.A., and Easton, R.M., eds., 2003, Summary of field work and other activities 2003, with a section on Regional geology of the Lac des Iles area, by Stone, D., Lavigne, M.J., Schnieders, B., Scott, J., and Wagner, D.: Ontario Geological Survey Open File Report 6120, p. 15-1 to 15-25. 
Balch, S.J., 2005, The geophysical signatures of PGE deposits, in Mungall, J.E., ed., Exploration for platinum-group element deposits: Mineralogical Association of Canada Short Course Series, v. 35, p. 275-285.

Ball, S.H., and Shaler, M.K., 1914, Economic geology of the Belgian Congo, Central Africa: Economic Geology, v. 9, p. 605-663.

Banakar, V.K., Hein, J.R., Rajani, R.P., and Chodankar, A.R., 2007, Platinum group elements and gold in ferromanganese crusts from Afanasiy-Nikitin seamount, equatorial Indian Ocean-Sources and fractionation: Journal of Earth Systems Science, v. 116, no. 1, p. 3-13. [Also available at http://dx.doi.org/10.1007/s12040-007-0002-x.]

Barker, J.C., 1986, Platinum-group metals, gold and chromium resource potential offshore of Platinum, Alaska, in 17th Annual Underwater Mining Conference, Biloxi, Miss., November 2-5, 14 p.

Barker, J.C., and Lamal, Kathryn, 1989, Offshore extension of platiniferous bedrock and associated sedimentation of the Goodnews Bay ultramafic complex, Alaska: Marine Mining, v. 8 , no. 4 , p. 365-390.

Barker, J.C., Lamal, Kathryn, Mardock, C.L., and Hirt, W.C., 1988, Placer platinum-group metals offshore of the Goodnews Bay Ultramafic Complex, southwest Alaska: U.S. Bureau of Mines Open-File Report 53-88, 60 p.

Barnes, S.-J., and Liu, Weihua, 2012, Pt and Pd mobility in hydrothermal fluids - Evidence from komatiites and from thermodynamic modelling: Ore Geology Reviews, v. 44, p. 49-58. [Also available at http://dx.doi.org/10.1016/ j.oregeorev.2011.08.004.]

Barnes, S.-J., and Maier, W.D., 1999, The fractionation of $\mathrm{Ni}, \mathrm{Cu}$ and the noble metals in silicate and sulphide liquids, in Keays, R.R., Lesher, C.M., Lightfoot, P.C., and Farrow, C.E.G., eds., Dynamic processes in magmatic ore deposits and their application in mineral exploration: Geological Association of Canada Short Course Notes, v. 13, p. 69-106.

Barnes, S-J., and Maier, W.D., 2002, Platinum-group element distributions in the Rustenburg Layered Suite of the Bushveld Complex, South Africa, in Cabri, L.J., ed., The geology, geochemistry, mineralogy and mineral beneficiation of platinum-group elements: Montreal, Quebec, Canada, Canadian Institute of Mining, Metallurgy and Petroleum Special Volume 54, p. 431-458.

Barnes, S.-J., McIntyre, J.R., Nisbet, B.W., and Williams, C.R., 1990, Platinum group element mineralisation in the Munni Munni Complex, Western Australia: Mineralogy and Petrology, v. 42, nos. 1-4, p. 141-164.
Barnes, S.-J., Prichard, H.M., Cox, R.A., Fisher, P.C., and Godel, Belinda, 2008, The location of the chalcophile and siderophile elements in platinum-group ore deposits (a textural, microbeam and whole rock geochemical study) - Implications for the formation of deposits: Chemical Geology, v. 248, nos. 3-4, p. 295-317. [Also available at http://dx.doi.org/10.1016/j.chemgeo.2007.08.004.]

Barrick Gold Corp., 2008, Annual information form for the year ended December 31, 2007 [Filing date March 28, 2008]: Toronto, Ontario, Canada, Barrick Gold Corp., accessed September 9, 2015, at http://www.sedar.com/.

Barrie, C.T., MacTavish, A.D., Walford, P.C., Chataway, R., and Middaugh, R., 2002, Contact-type and magnetitite reef-type $\mathrm{Pd}-\mathrm{Cu}$ mineralization in ferroan olivine gabbros of the Coldwell Complex, Ontario, in Cabri, L.J., ed., The geology, geochemistry, mineralogy and mineral beneficiation of platinum-group elements: Montreal, Quebec, Canada, Canadian Institute of Mining, Metallurgy and Petroleum Special Volume 54, p. 321-337.

Barrueto, H.R., and Hunt, W., 2010, Main features of the Pt-Pd chromitite-type ore deposit, Tróia unit, Cruzeta complex, northeast Brazil-Insights provided by microscopic and chemical approaches, in Brown, G.H., Jugo, P.J., Lesher, C.M., and Mungall, J.E., eds., Abstracts, 11 th International Platinum Symposium, 21-24 June 2010, Sudbury, Ontario, Canada: Sudbury, Ontario, Canada, Ontario Geological Survey, Miscellaneous Release-Data 269, 4 p.

Bauba Platinum, 2012, Exploration update, May 2012: Bauba Platinum Presentation, 22 slides, accessed September 3, 2012, at http://www.baubaplatinum.co.za/ ir/f/Bauba-presentation-May2012.pdf.

Baxter, K., Dreisinger, D., Ferron, J., Fleming, C.D., Hunter, D., and Murray, W., 2005, The application of the PLATSOL ${ }^{\text {TM }}$ process to copper-nickel-cobalt-PGE/PGM concentrates from Polymet Mining's NorthMet deposit: ALTA 2005 World Forum on Nickel and Cobalt Hydrometallurgy, Perth, Western Australia, Australia, May 16-18, 2005, presentation, accessed AOctober 6, 2016, at https:/www.researchgate.net/ publicatio/267920431_THE_APPLICATION_OF_THE PLATSOL_PROCESS_TO_COPPER-_NICKEL-COBALTPGEPGM_CONCENTRATES_FROM_POLYMET_ MINING'S_NORTHMET_DEPOSIT.

Bellona Foundation, 2010, Environmental challenges in the Arctic, Norilsk Nickel-The Soviet legacy of industrial pollution: Oslo, Norway, Bellona Foundation, 69 p., accessed October 6, 2016, at http://bellona.org/assets/ sites/4/Norilsk-Nickel-The-Soviet-Legacy-of-IndustrialPollution.pdf. 
Berg, H.C., Jones, D.L., and Richter, D.H., 1972, GravinaNutzotin belt-Tectonic significance of an upper Mesozoic sedimentary and volcanic sequence in southern and southeastern Alaska, in Geological Survey Research 1972: U.S. Geological Survey Professional Paper 800-D, p. D1-D24.

Berg, H.C., Jones, D.L., and Coney, P.J., 1978, Map showing pre-Cenozoic tectonostratigraphic terranes of southeastern Alaska and adjacent areas: U.S. Geological Survey OpenFile Report 78-1085, 2 sheets, scale 1:1,000,000.

Berger, V.I., Singer, D.A., Bliss, J.D., and Moring, B.C., 2011, Ni-Co laterite deposits of the world-Database and grade and tonnage models: U.S. Geological Survey Open-File Report 2011-1058, accessed May 6, 2013, at http://pubs.usgs.gov/of/2011/1058/.

Blackthorn Resources Ltd., 2009, Annual report 2009: Sydney, New South Wales, Australia, Blackthorn Resources Ltd., 58 p.

Bolton, F., 2013, Proposed establishment of a platinum mining operation and related surface infrastructure-Magazynskraal Platinum Mine: SLR Global Environmental Solutions Project No. B001-03, Environmental Impact Assessment and Environmental Management Programme Report for Richtrau No. 123 (Pty) Limited: Johannesburg, South Africa, SLR Consulting (Africa) (Pty) Ltd., March, 339 p., accessed October 6, 2016, at http://www.sahra.org.za/ sahris/sites/default/files/additionaldocs/MGZ_EIAEMP_ Public_22\%20March\%202013.pdf.

Borg, G., Tredoux, M., Maiden, K.J., Sellschop, J.P.F., and Wayward, O.F.D., 1987, PGE- and Au- distribution in riftrelated volcanics, sediments and stratabound $\mathrm{Cu} / \mathrm{Ag}$ ores of Middle Proterozoic age in central SWA/Namibia, in Prichard, H.M., Potts, P.J., Bowles, J.F.W., and Cribb, S.J., eds., Geo-Platinum 87 [Proceedings of the Geo-Platinum 87 symposium held at the Open University, Milton Keynes, United Kingdom, on April 22-23]: New York, N.Y., Elsevier, p. 303-317.

British Geological Survey, 2012, Risk list 2012-An update to the supply risk index for elements or element groups that are of economic value: Keyworth, Nottingham, United Kingdom, British Geological Survey, 12 p., accessed February 1, 2013, at http://www.bgs.ac.uk/ downloads/start.cfm?id=2643.

Brozdowski, R.A., 1985, Cumulate xenoliths in the Lodgepole, Enos Mountain and Susie Peak intrusions-A guide, in Czamanske, G.K., and Zientek, M.L., eds., The Stillwater Complex, Montana-Geology and guide: Butte, Mont., Montana Bureau of Mines and Geology Special Publication v. 92, p. $368-372$.
Bruland, K.W., and Lohan, M.C., 2003, Controls of trace metals in seawater, in Elderfield, Henry, ed., The oceans and marine geochemistry, v. 6 of Holland, H.D., and Turekian, K.K., eds., Treatise on geochemistry: Oxford, United Kingdom, Elsevier-Pergamon, p. 23-47. [Also available at http://www.sciencedirect.com/science/article/ pii/B0080437516061053.]

Bryan, S.E., and Ernst, R.E., 2008, Revised definition of large igneous provinces (LIPs): Earth-Science Reviews, v. 86, nos. 1-4, p. 175-202. [Also available at http://dx.doi.org/10.1016/j.earscirev.2007.08.008.]

Buchanan, P.C., Koeberl, Christian, and Reimold, W.U., 1999, Petrogenesis of the Dullstroom Formation, Bushveld magmatic province, South Africa: Contributions to Mineralogy and Petrology, v. 137, nos. 1-2, p. 133-146. [Also available at http://dx.doi.org/10.1007/s004100050587.]

Buchert, Matthias, Schüler, Doris, and Bleher, Daniel, 2009, Critical metals for future sustainable technologies and their recycling potential: United Nations Environment Programme \& United Nations University, 81 p., accessed February 1, 2013, at http://www.unep.fr/shared/publications/ pdf/DTIx1202xPA-Critical Metals and their Recycling Potential.pdf.

Burg, J.-P., Bodinier, J.-L., Gerya, T., Bedini, R.-M., Boudier, F., Dautria, J.-M., Prikhodko, V., Efimov, A., Pupier, E., and Balanec, J.-L., 2009, Translithospheric mantle diapirismGeological evidence and numerical modeling of the Kondyor Zoned Ultramafic Complex (Russian Far-East): Journal of Petrology, v. 50, no. 2, p. 289-321. [Also available at http://dx.doi.org/10.1093/petrology/egn083.]

Burgess, Harry, Gowans, Richard, Jacobs, Christopher, Murahwi, Charley, and Damjanović, Bogdan, 2012, NI 43-101 technical report-Feasibility study-McFaulds Lake property, Eagle's Nest project, James Bay Lowlands, Ontario, Canada, prepared for Noront Resources Ltd. [Effective date September 4, 2012]: Toronto, Ontario, Canada, Micon International Ltd., October 19, 197 p. [Also available at http://www.sedar.com.]

Butler, Jonathan, 2012, Platinum 2012: Royston, United Kingdom, Johnson Matthey Plc, 60 p.

Buttgenbach, H., 1908, Les gisements miniers du Katanga [Mineral deposits in Katanga], in Studt, F.E., Cornet, J., and Buttgenbach, H., Carte géologique du Katanga et notes descriptives [Geologic map of Katanga and descriptive notes]: Brussels, Belgium, Musée Royal de l'Afrique Central, Annales, Géophysique, Minéralogie, and Paléontologie, Série II, Katanga. I, p. 17-93. [In French.] 
Buys, Stephan, Rule, Chris, and Curry, Dan, 2013, The application of large scale stirred milling to the retreatment of Merensky platinum tailings, 14 p., in Canadian Mineral Processors Annual Operators Conference, 37th, Ottawa, Ontario, Canada, January 18-20, 2005, Proceedings (2004-2008): Ottawa, Ontario, Canada, Canadian Mineral Processors Society, CD-ROM. [Also available at http://www.isamill.com/EN/downloads/Pages/papers.aspx.]

Cabral, A.R., Lehmann, B., Kwitko, R., and Cravo Costa, C.H., 2002, The Serra Pelada Au-Pd-Pt deposit, Carajás mineral province, northern Brazil-Reconnaissance mineralogy and chemistry of very high grade palladian gold mineralization: Economic Geology, v. 97, p. 1127-1138. [Also available at http://dx.doi.org/10.2113/gsecongeo.97.5.1127.]

Cabri, L.J., 1992, The distribution of trace precious metals in minerals and mineral products: Mineralogical Magazine, v. 56, no. 384, p. 298-308. [Also available at http://dx.doi.org/ 10.1180/minmag.1992.056.384.01.]

Cabri, L.J., 2002, The platinum-group minerals, in Cabri, L.J., ed., The geology, geochemistry, mineralogy and mineral beneficiation of platinum-group elements: Montreal, Quebec, Canada, Canadian Institute of Mining, Metallurgy and Petroleum Special Volume 54, p. 13-130.

Cabri, L.J., Sylvester, P.J., Tubrett, M.N., Peregoedova, Ania, and Laflamme, J.H.G., 2003, Comparison of LAM-ICPMS and Micro-Pixe results for palladium and rhodium in selected samples of Noril'sk and Talnakh sulfides: Canadian Mineralogist, v. 41, no. 2, p. 321-329. [Also available at http://dx.doi.org/10.2113/gscanmin.41.2.321.]

California Department of Finance, 2012, National deflatorsCalendar and fiscal year-From 1950: California Department of Finance Web page, accessed December 4, 2012, at http://www.dof.ca.gov/html/fs_data/latestecondata/ FS_Price.htm.

Cameron, D.E., and Garmoe, W.J., 1987, Geology of skarn and high-grade gold in the Carr Fork Mine, Utah: Economic Geology, v. 82, p. 1319-1333. [Also available at http://dx.doi.org/10.2113/gsecongeo.82.5.1319.]

Cameron, E.M., and Hattori, K.H., 2005, Platinum-group elementsin geochemical exploration, in Mungall, J.E., ed., Exploration for platinum-group element deposits: Mineralogical Association of Canada Short Course Series, v. 35, p. 287-307.

Campbell, Geoff, 2006, High resolution aeromagnetic mapping of "loss-of-ground" features at platinum and coal mines in South Africa: South African Journal of Geology, v. 109, no. 4, p. 439-458. [Also available at http://dx.doi.org/10.2113/ gssajg.109.4.439.]
Campbell, Geoff, 2011, Exploration geophysics of the Bushveld Complex in South Africa: The Leading Edge, v. 30, no. 6, June 2011, p. 622-638. [Also available at http://dx.doi.org/10.1190/1.3599148.]

Campbell, I.H., and Naldrett, A.J., 1979, The influence of silicate-sulfide ratios on the geochemistry of magmatic sulfides: Economic Geology, v. 74, p. 1503-1505.

Carroll, Sandy, 2005, The viability of the Kalplats platinum group element deposit: Pretoria, South Africa, University of Pretoria, M.Sc. thesis, 105 p. [Also available at http://hdl.handle.net/2263/26174.]

Carter, Andrew, Corpuz, Pacifico, Bridson, Philip, and McCracken, Todd, 2012, Wellgreen Project preliminary economic assessment, Yukon, Canada, NI-43-101 technical report prepared for Prophecy Platinum: Vancouver, British Columbia, Canada, Tetra Tech-Waldrop, variously paged, accessed June 9, 2016, at http://www.sedar.com/ GetFile.do?lang $=\mathrm{EN} \&$ docClass $=24 \&$ issuerNo $=00024464 \&$ issuerType $=03 \&$ projectNo $=01924122 \&$ docId $=3168099$

Carville, D.P., Leckie, J.F., Moorhead, C.F., Rayner, J.G., and Durbin, A.A., 1990, Coronation Hill gold-platinum-palladium deposit, in Hughes, F.E., ed., Geology of the mineral deposits of Australia and Papua New Guinea: Melbourne, Victoria, Australia, Australasian Institute of Mining and Metallurgy Monograph, 2 vols., no. 14, p. 759-762.

Castendyk, D.N., and Eary, L.E., eds., 2009, Mine pit lakesCharacteristics, predictive modeling, and sustainability: Littleton, Colo., Society for Mining, Metallurgy, and Exploration, Management Technologies for Metal Mining Influenced Water Series, v. 3, 304 p.

Cawthorn, R.G., 1999, The discovery of the platiniferous Merensky Reef in 1924: South African Journal of Geology, v. 102, no. 3, p. 178-183.

Cawthorn, R.G., 2010, The platinum-group element deposits of the Bushveld Complex in South Africa: Platinum Metals Review, v. 54, no. 4, p. 205-215. [Also available at http://dx.doi.org/10.1595/147106710X520222.]

Cawthorn, R.G., Merkle, R.K.W., and Viljoen, M.J., 2002, Platinum-group element deposits in the Bushveld Complex, South Africa, in Cabri, L.J., ed., The geology, geochemistry, mineralogy and mineral beneficiation of platinum-group elements: Montreal, Quebec, Canada, Canadian Institute of Mining, Metallurgy, and Petroleum Special Volume 54, p. 389-429. 
Central African Mining \& Exploration Company Plc, 2009, Compliant mineral resource estimate for the Bokai platinum prospect: Central African Mining \& Exploration Company plc press release, July 13, 2009, accessed October 6, 2016, at http://www.georesources.net/index.php/component/ content/article/38-news/248-camec-compliant-mineralresource-estimate-for-bokai-platinum-prospect.

Chatterjee, Snehamoy, and Bandopadhyay, Sukumar, 2011, Goodnews Bay platinum resource estimation using least squares support vector regression with selection of input space dimension and hyperparameters: Natural Resources Research, v. 20, no. 2, p. 117-129. [Also available at http://dx.doi.org/10.1007/s11053-011-9140-6.]

Chen, Cynthia, Sedwick, P.N., and Sharma, Mukul, 2009, Anthropogenic osmium in rain and snow reveals globalscale atmospheric contamination: Proceedings of the National Academy of Sciences of the United States of America, v. 106, no. 19, p. 7724-7728. [Also available at http://dx.doi.org/10.1073/pnas.0811803106.]

Chunnett, G.K., and Rompel, A.K.K., 2004, Data integration for structural interpretation in the Bushveld Complex, in International Platinum Conference "Platinum Adding Value," Sun City, South Africa, October 3-7, 2004, Proceedings: Johannesburg, South Africa, South African Institute of Mining and Metallurgy, p. 265-268.

Clay, Andy, Motloung, Mpai, Patel, Khalid, and Tayelor, Richard, 2010, Independent technical statement for the Volspruit project as at 2nd December 2010, in Venmyn Rand (Pty) Ltd., Independent technical experts report on the mineral assets of Sylvania Resources Limited in the form of a competent persons report by Venmyn Rand (Pty) Limited, prepared for Sylvania Resources Ltd.: Johannesburg, South Africa, Venmyn Rand (Pty) Ltd., p. 138-144, accessed March 6, 2012, at http://www.sylvaniaplatinum.com/b/files/ cpr-sylvania-resources.pdf.

Coffin, M.F., and Eldholm, Olav, 1994, Large igneous provinces - Crustal structure, dimensions, and external consequences: Reviews in Geophysics, v. 32, no. 1, p. 1-36. [Also available at http://dx.doi.org/10.1029/93RG02508.]

Coker, W.B., Dunn, C.E., Hall, G.E.M., Rencz, A.N., DiLabio, R.N.W., Spirito, W.A., and Campbell, J.E., 1991, The behavior of platinum group elements in the surficial environment at Ferguson Lake, N.W.T., Rottenstone Lake, Sask. and Sudbury, Ont., Canada: Journal of Geochemical Exploration, v. 40, nos. 1-3, p. 165-192. [Also available at http://dx.doi.org/10.1016/0375-6742(91)90037-U.]

Cole, Glen, and El-Rassi, Dorota, 2009, Mineral resource evaluation-Thunder Bay North polymetallic project, Ontario, Canada, prepared for Magma Metals (Canada) Ltd.: Toronto, Ontario, Canada, SRK Consulting, SRK Project No. 3CM017.000, September 29, 134 p.
Colombo, C., Oates, C.J., Monhemius, A.J., and Plant, J.A., 2008, Complexation of platinum, palladium and rhodium with inorganic ligands in the environment: GeochemistryExploration, Environment, Analysis, v. 8, p. 91-101. [Also available at http://dx.doi.org/10.1144/1467-7873/07-151.]

Conn, H.K., 1979, The Johns-Manville platinum-palladium prospect, Stillwater Complex, Montana, U.S.A.: Canadian Mineralogist, v. 17, p. 463-468.

Corfu, F., and Lightfoot, P.C., 1996, U-Pb geochronology of the sublayer environment, Sudbury igneous complex, Ontario: Economic Geology, v. 91, p. 1263-1269. [Also available at http://dx.doi.org/10.2113/gsecongeo.91.7.1263.]

Council on Ethics, 2009, To the Ministry of FinanceRecommendation of 16 February 2009: Oslo, Norway, Council on Ethics for the Government Pension Fund-Global, 21 p., accessed June 26, 2013, at https://www.regjeringen.no/globalassets/upload/fin/ statens-pensjonsfond/recommendation_norilsk.pdf.

Czamanske, G.K., Haffty, Joseph, and Nabbs, S.W., 1981, $\mathrm{Pt}, \mathrm{Pd}$, and $\mathrm{Rh}$ analyses and beneficiation of mineralized mafic rocks from the La Perouse Layered Gabbro, Alaska: Economic Geology, v. 76, p. 2001-2011. [Also available at http://dx.doi.org/10.2113/gsecongeo.76.7.2001.]

Dalvi, A.D., Bacon, W.G., and Osborn, R.C., 2004, The past and the future of nickel laterites: Prospectors and Developers Association of Canada (PDAC) 2004 International Convention, Trade Show \& Investors Exchange, Toronto, Ontario, Canada, March 7-10, 2004, presentation, 27 p., accessed April 1, 2010, at http://www.pdac.ca/pdac/ publications/papers/2004/techprgm-dalvi-bacon.pdf.

Davison, G.E., and Chunnett, G.K., 1999, Seismic exploration for Merensky Reef-The way ahead: South African Journal of Geology, v. 102, no. 3, p. 261-267.

Decker, John, Bergman, S.C., Blodgett, R.B., Box, S.E., Bundtzen, T.K., Clough, J.G., Coonrad, W.L., Gilbert, W.G., Miller, M.L., Murphy, J.M., Robinson, M.S., and Wallace, W.K., 1994, Geology of southwestern Alaska, in Plafker, George, and Berg, H.C., eds., The geology of Alaska: Boulder, Colo., Geological Society of America, p. 285-310. [Also available at http://dggs.alaska.gov/pubs/id/22261.]

Deer, W.A., Howie, R.A., and Zussman, J., 1966, An introduction to rock forming minerals: London, United Kingdom, Longman Group Ltd., 528 p.

DeMille, J.B., 1947, Strategic minerals-A summary of uses, world output, stockpiles, procurement: New York, N.Y., McGraw-Hill, 626 p. 
Desautels, Pierre, and Zurowski, Gordon, 2012, Updated NI 43-101 technical report on the NorthMet depositMinnesota, USA, prepared for PolyMet Mining Corp. [Filing date October 31, 2012]: Barrie, Ontario, Canada, AGP Mining Consultants Inc., October 12, 238 p. plus 7 appendixes. [Also available at http://www.sedar.com.]

de Vos, E., Edwards, S.J., McDonald, I., Wray, D.S., and Carey, P.J., 2002, A baseline survey of the distribution and origin of platinum group elements in contemporary fluvial sediments of the Kentish Stour, England: Applied Geochemistry, v. 17, no. 8, p. 1115-1121. [Also available at http://dx.doi.org/10.1016/S0883-2927(02)00010-0.]

Diakov, Sergei, West, Richard, Schissel, Don, Krivtsov, Anatoly, Kochnev-Pervoukhov, Vladimir, and Migachev, Igor, 2002, Recent advances in the Noril'sk model and its application for exploration of Ni-Cu-PGE sulfide deposits, in Goldfarb, R.J., and Nielsen, R.L., eds., Integrated methods for discovery - Global exploration in the 21st century: Littleton, Colo., Society of Economic Geologists Special Publication 9, p. 203-226.

Discovery Metals Ltd., 2013, Dikoloti nickel project: Discovery Metals Ltd. Web page, accessed March 18, 2012, at http://web.archive.org/web/20121214171224/http:// www.discoverymetals.com/dikoloti-nickel-project.

Doran, Rod, Churchill, B.C., Cox, J.J., and McBride, Tim, 2012, Pre-feasibility report on the Broken Hammer Project, Sudbury, Ontario, Canada, NI 43-101 technical report, prepared for Wallbridge Mining Company Ltd. [Filing date November 27, 2012]: GENIVAR, Inc., Reference 1870/121-16220-00, October 8, 191 p. [Also available at http://www.sedar.com.]

Drennan, Martin, and Fell, Michael, 2010, Technical report and resource estimate-2010 update for the Geordie Lake property, northern Ontario, prepared for Marathon PGM Corp. [Filing date June 14, 2010]: Hamilton, Ontario, Canada, Python Mining Consultants Inc., June 4, 63 p. plus 6 appendixes. [Also available at http://www.sedar.com.]

Duluth Metals Ltd., 2011, Duluth Metals commences drilling program on platinum targets in the Land O'Dixie property: Duluth Metals news release, August 2, accessed November 21, 2016, at http://www.prnewswire.com/ news-releases/duluth-metals-commences-drilling-program-onplatinum-targets-on-the-land-odixie-property-126568668.html.

Dunn, C.E., 1986, Biogeochemistry as an aid to exploration for gold, platinum and palladium in the northern forests of Saskatchewan, Canada: Journal of Geochemical Exploration, v. 25, nos. 1-2, p. 21-40. [Also available at http://dx.doi.org/10.1016/0375-6742(86)90005-1.]
Duparc, L., and Tikonowitch, M.N., 1920, Le platine et les gîtes platinifères de l'Oural et du monde [Platinum and platinum deposits of the Urals and the world]: Geneva, Switzerland, Sonor, 524 p. [In French.]

Ek, K.H., Morrison, G.M., and Rauch, Sebastien, 2004, Environmental routes for platinum group elements to biological materials-A review: Science of the Total Environment, v. 334-335, p. 21-38. [Also available at http://dx.doi.org/ 10.1016/j.scitotenv.2004.04.027.]

Ernst, R.E., and Buchan, K.L., 2001, Large mafic magmatic events through time and links to mantle plume heads, in Ernst, R.E., and Buchan, K.L., eds., Mantle plumes-Their identification through time: Boulder, Colo., Geological Society of America Special Paper v. 352, p. 483-575.

Eurasia Mining plc, 2011, Exploration update-West Kytlim: London Stock Exchange RNS no. 08260, September 12, 2 p., accessed June 23, 2015, at http://otp.investis.com/ Utilities/PDFDownload.aspx?Newsid=249594.

Eurasia Mining plc, 2012, Urals alluvial platinum-West Kytlim: Eurasia Mining plc, accessed March 20, 2013, at http://www.eurasiamining.co.uk/operations/uralsalluvial.aspx.

European Commission, 2010, Critical raw materials for the EUReport of the ad-hoc Working Group on defining critical raw materials: European Commission, July, 85 p., accessed February 1, 2013, at http:/web.archive.org/web/20130127055633/ http:/ec.europa.eu/enterprise/policies/raw-materials/files/ docs/report-b_en.pdf. [Critical raw materials list was updated in 2014; see http://ec.europa.eu/growth/sectors/ raw-materials/specific-interest/critical/index_en.htm.]

Evans, D.M., Buchanan, D.L., and Parry, S.J., 1996, Böhmke Reef-Platinum-group element mineralization associated with C1d (Number 2) chromitite of the Great Dyke, Zimbabwe: Institution of Mining and Metallurgy, Transactions, Section B, Applied Earth Science, v. 105, p. 82-88.

Ewert, Wayne, Yassa, Antione, Armstrong, Tracy, Brown, F.H., and Puritch, Eugene, 2008, Technical report and resource estimate on the Ore Fault, Galaxy and Page zones of the Marathon PGM/Gossan Resources JV, Bird River Property, southeast Manitoba-NI 43-101 technical report, prepared for Marathon PGM Corporation [Filing date February 26, 2009]: Brampton, Ontario, Canada, P\&E Mining Consultants Inc., December 1, 103 p. [Also available at http://www.sedar.com.]

Fedorenko, V.A., Lightfoot, P.C., Naldrett, A.J., Czamanske, G.K., Hawkesworth, C.J., Wooden, J.L., and Ebel, D.S., 1996, Petrogenesis of the flood-basalt sequence at Noril'sk, North Central Siberia: International Geology Review, v. 38, no. 2, p. 99-135. [Also available at http://dx.doi.org/10.1080/ 00206819709465327.] 
Ferreira, D.S., and Bisnath, Avinash, 2012, Technical report-The mineral resource estimation for the Platreef for the Boikgantsho project, Limpopo Province, Republic of South Africa - NI 43-101 technical report, prepared for Anooraq Resources Corp.: Bordeaux, South Africa, Kai Batla Minerals, January 31, 68 p. [Also available at http://www.infomine.com/index/pr/PB419081.PDF.]

Ferreira-Filho, C.F., Pimentel.M.M., de Araujo, S.M., and Laux, J.H., 2010, Layered intrusions and volcanic sequences in central Brazil-Geological and geochronological constraints for Mesoproterozoic (1.25 Ga) and Neoproterozoic $(0.79 \mathrm{Ga})$ igneous associations: Precambrian Research, v. 183 , no. 1, December, p. 617-634. [Also available at http://dx.doi.org/10.1016/j.precamres.2010.06.008.]

Ferris, J.K., Storey, B.C., Vaughan, A.P.M., Kyle, P.R., and Jones, P.C., 2003, The Dufek and Forrestal intrusions, Antarctica-A centre for Ferrar large igneous province dike emplacement?: Geophysical Research Letters, v. 30, no. 6, p. 81-1 to 81-4. [Also available at http://dx.doi.org/ 10.1029/2002GL016719.]

Ferris, Julie, Johnson, Ash, and Storey, Bryan, 1998, Form and extent of the Dufek intrusion, Antarctica, from newly compiled aeromagnetic data: Earth and Planetary Science Letters, v. 154, nos. 1-4, January, p. 185-202. [Also available at http://dx.doi.org/10.1016/S0012-821X(97)00165-9.]

Finnigan, C.S., Brenan, J.M., Mungall, J.E., and McDonough, W.F., 2008, Experiments and models bearing in the role of chromite as a collector of platinum-group minerals by local reduction: Journal of Petrology, v. 49, no. 9, p. 1647-1665. [Also available at http://dx.doi.org/10.1093/petrology/egn041.]

Fletcher, R.J., 2009, Independent report on the Shalozerskoe (Burakovsky), Lukkulaisvaara and Tsipringa platinum, palladium, copper, nickel deposits in the Autonomous Republic of Karelia, Russian Federation, prepared for JSC Norit: London, United Kingdom, Behre Dolbear International Ltd., Project 07-112 Norit, 58 p., accessed March 20, 2013, at http:/www.norit-platinum.ru/ Investors/090307\%20J07-112\%20Norit $\% 20$ Draft $\% 20$ Report\%20Part\%201.pdf.

Ford, A.B., 1976, Stratigraphy of the layered gabbroic Dufek intrusion, Antarctica: U.S. Geological Survey Bulletin 1405-D, 36 p. [Also available at http://pubs.er.usgs.gov/ publication/b1405D.]

Ford, A.B., Schmidt, D.L., and Boyd, W.W., Jr., 1978, Geologic map of the Davis Valley quadrangle and part of the Cordiner Peaks quadrangle, Pensacola Mountains, Antarctica: U. S. Geological Survey Antarctic Geologic Map A-10, scale 1:250,000. [Also available at http://pubs.er.usgs.gov/publication/a10.]
Ford, A.B., Schmidt, D.L., Boyd, W.W., Jr., and Nelson, W.H., 1978, Geologic map of the Saratoga Table quadrangle, Pensacola Mountains, Antarctica: U.S. Geological Survey Antarctic Geologic Map A-9, scale 1:250,000. [Also available at http://pubs.er.usgs.gov/publication/a9.]

Frick, C., 1985, A study of the soil geochemistry of the Platreef in the Bushveld Complex: Journal of Geochemical Exploration, v. 24, no. 1, p. 51-80. [Also available at http://dx.doi.org/10.1016/0375-6742(85)90004-4.]

Fryer, B.J., Kerrich, R., Hutchinson, R.W., Peirce, M.G., and Rogers, D.S., 1979, Archaean precious-metal hydrothermal systems, Dome Mine, Abitibi greenstone belt-I -Patterns of alteration and metal distribution: Canadian Journal of Earth Sciences, v. 16, no. 3, p. 421-439. [Also available at http://dx.doi.org/10.1139/e79-040.]

Fuchs, W.A., and Rose, A.W., 1974, The geochemical behavior of platinum and palladium in the weathering cycle in the Stillwater Complex, Montana: Economic Geology, v. 69, p. 332-346. [Also available at http://dx.doi.org/10.2113/ gsecongeo.69.3.332.]

Fugro Robertson, Ltd., 2008, Fugro Tellus sedimentary basins of the world map: AAPG Datapages, accessed August 24, 2015, at http:/www.datapages.com/gis-mappublishing-program/gis-open-files/global-framework/ robertson-tellus-sedimentary-basins-of-the-world-map.

Gammons, C.H., and Bloom, M.S., 1993, Experimental investigation of the hydrothermal geochemistry of platinum and palladium - II - The solubility of PtS and PdS in aqueous sulfide solutions to $300^{\circ} \mathrm{C}$ : Geochimica et Cosmochimica Acta, v. 57, no. 11, p. 2451-2467. [Also available at http://dx.doi.org/10.1016/0016-7037(93)90409-P.]

Gerard, David, and Lave, L.B., 2005, Implementing technology-forcing policies-The 1970 Clean Air Act amendments and the introduction of advanced automotive emissions controls: Technological Forecasting and Social Change, v. 72, no. 7, p. 761-778. [Also available at http://dx.doi.org/10.1016/j.techfore.2004.08.003.]

Geological Survey of Finland, 2010, Platinum-group elements in Finland: Geological Survey of Finland database, accessed September 23, 2011, at http://web.archive.org/ web/20110805035805/http://en.gtk.fi/ExplorationFinland/ Commodities/PGE/pge_database.html. [Also available at http://en.gtk.fi/informationservices/commodities/platinum.html.]

Geological Survey of Finland, 2011, Fennoscandian ore deposit database and metallogenic map: Geological Survey of Finland, accessed March 13, 2013, at http://en.gtk.fi/ export/sites/en/informationservices/databases/fodd/ fodd20111021.xls. (Database content in MS Excel format.) 
Geological Survey of Western Australia, 2004, 1:500,000 interpreted bedrock geology of Western Australia (April 21, 2004 version): Geological Survey of Western Australia, accessed July 6, 2004, at http://web.archive.org/web/ 20040818094334/http://mapserver.mpr.wa.gov.au/datacentre/.

Giblin, P.E., 1984, History of exploration and development, of geological studies and development of geological concepts: Sudbury, Ontario, Canada, Ontario Geological Survey Special Volume 1, p. 1-23.

Glaister, B.J., and Mudd, G.M., 2010, The environmental costs of platinum-PGM mining and sustainability-Is the glass half-full or half-empty?: Mining Engineering, v. 23, no. 5, p. 438-450. [Also available at http://dx.doi.org/10.1016/ j.mineng.2009.12.007.]

Gleeson, S.A., Butt, C.R.M., and Elias, M., 2003, Nickel laterites-A review: SEG Newsletter, no. 54, p. 1, 12-18.

Glen, J.M.G., Schmidt, J.M., and Connard, G.G., 2011, Threedimensional model of an ultramafic feeder system to the Nikolai Greenstone mafic large igneous province, central Alaska Range: Geochemistry Geophysics Geosystems, v. 12 , no. 6,24 p. [Also available at http://dx.doi.org/ 10.1029/2011GC003508.]

Godel, Belinda, Barnes, S.-J., and Maier, W.D., 2007, Platinumgroup elements in sulphide minerals, platinum-group minerals, and whole-rocks of the Merensky Reef (Bushveld Complex, South Africa) - Implications for the formation of the reef: Journal of Petrology, v. 48, no. 8, p. 1569-1604. [Also available at http://dx.doi.org/10.1093/petrology/egm030.]

Goldberg, E.D., and Koide, Minora, 1990, Understanding the marine chemistries of the platinum group metals: Marine Chemistry, v. 30, p. 249-257. [Also available at http://dx.doi.org/10.1016/0304-4203(90)90074-M.]

Green, G.N., and Drouillard, P.H., 1994, The digital geologic map of Wyoming in ARC/INFO format: U.S. Geological Survey Open-File Report 94-425, scale 1:500,000. [Also available at http://pubs.er.usgs.gov/publication/ofr94425.]

Grinenko, L.I., 1985, Sources of sulfur of the nickeliferous and barren gabbro-dolerite intrusions of the Northwest Siberian Platform: International Geology Review, v. 28, no. 6, p. 695-708. [Also available at http://dx.doi.org/ 10.1080/00206818509466457.]

Grokhovskaya, T.L., Lapina, M.I., Ganin, V.A., and Grinevich, N.G., 2005, PGE mineralization in the Burakovsk layered complex, South Karelia, Russia: Geology of Ore Deposits, v. 47, no. 4, p. 283-308. [Translated from Geologiya Rudnykh Mestorozhdenii, v. 47, no. 4, p. 315-341.]
Halbach, P., Kriete, C., Prause, B., and Puteanus, D., 1989, Mechanisms to explain the platinum concentration in ferromanganese seamount crusts: Chemical Geology, v. 76, nos. 1-2, p. 95-106. [Also available at http://dx.doi.org/ 10.1016/0009-2541(89)90130-7.]

Hall, A.L., 1932, The Bushveld igneous complex of the central Transvaal: Pretoria, South Africa, Union of South Africa Dept. of Mines and Industries, Geological Survey of South Africa Memoir 28, $560 \mathrm{p}$.

Hamilton, M.A., and Brooks, C.K., 2004, A precise U-Pb zircon age for the Skaergaard intrusion-Magmatic cooling history refinement and Paleogene igneous correlations, East Greenland [abs.]: American Geophysical Union, Spring Meeting 2004, abstract no. V41A-03, accessed April 4, 2014, at http://adsabs.harvard.edu//abs/2004AGUSM.V41A..03H.

Hanley, J.J., 2005, The aqueous geochemistry of the platinumgroup elements (PGE) in surficial, low-T hydrothermal and high-T magmatic-hydrothermal environments, in Mungall, J.E., ed., Exploration for platinum-group element deposits: Mineralogical Association of Canada Short Course Series, v. 35 , p. $35-56$.

Harper, Fiona, and de Wit, D.R., 2009, The update 2009 National Instrument 43-101 technical report for the Pilanesberg Platinum Mines, North West Province, South Africa for Platmin Limited [Effective date December 31, 2009; final date May 5, 2010]: Johannesburg, South Africa, Venmyn Rand (Pty) Ltd., 64 p. plus 4 appendixes.

Hein, J.R., Koschinsky, Andrea, Bau, Michael, Manheim, F.T., Kang, J.-K., and Roberts, Leanne, 2000, Cobalt-rich ferromanganese crusts in the Pacific, in Cronan, D.S., ed., Handbook of marine mineral deposits: Boca Raton, Fla., CRC Press, p. 239-279.

Hilliard, H.E., 1998, Platinum-group metals: U.S. Geological Survey Mineral Commodity Summaries 1998, p. 126-127. [Also available at http://minerals.er.usgs.gov/minerals/pubs/ commodity/platinum/550398.pdf.]

Hilliard, H.E., 2000, Platinum-group metals: U.S. Geological Survey Mineral Commodity Summaries 2000, p. 126-127. [Also available at https://minerals.usgs.gov/minerals/pubs/ commodity/platinum/550300.pdf.]

Hilliard, H.E., 2004, Platinum-group metals: U.S. Geological Survey Mineral Commodity Summaries 2004, p. 124-125. [Also available at https://minerals.usgs.gov/minerals/pubs/ commodity/platinum/pgmmes04.pdf.]

Himmelberg, G.R., and Loney, R.A., 1981, Petrology of the ultramafic and gabbroic rocks of the Brady Glacier nickelcopper deposit, Fairweather range, southeastern Alaska: U.S. Geological Survey Professional Paper 1195, 26 p. [Also available at http://pubs.usgs.gov/pp/1195/report.pdf.] 
Hirsikko, A., Vakkari, V., Tiitta, P., Manninen, H.E., Gagné, S., Laakso, H., Kulmala, M., Mirme, A., Mirme, S., Mabaso, D., Beukes, J.P., and Laakso, L., 2012, Characterisation of sub-micron particle number concentrations and formation events in the western Bushveld igneous complex, South Africa: Atmospheric Chemistry and Physics, v. 12, no. 9, p. 3951-3967. [Also available at http://dx.doi.org/10.5194/ acp-12-3951-2012.]

Hoaglund, S.A., 2010, U-Pb geochronology of the Duluth Complex and related hypabyssal intrusions - Investigating the emplacement history of a large multiphase intrusive complex related to the $1.1 \mathrm{Ga}$ midcontinent rift: Minneapolis, Minn., University of Minnesota M.S. thesis, $112 \mathrm{p}$.

Hoare, J.M., and Coonrad, W.L., 1978, Geologic map of the Goodnews and Hagemeister Island quadrangles region, southwestern Alaska: U.S. Geological Survey Open-File Report 78-9-B, 2 sheets, scale 1:250,000. [Also available at http://pubs.er.usgs.gov/publication/ofr789B.]

Hoatson, D.M., and Blake, D.H., 2000, Geology and economic potential of the Palaeoproterozoic layered mafic-ultramafic intrusions in the East Kimberley, Western Australia: Australian Geoscience Organization Bulletin 246, 496 p.

Holwell, D.A., and McDonald, Iain, 2010, A review of the behavior of platinum group elements within natural magmatic sulfide ore systems: Platinum Metals Review, v. 54, no. 1, p. 26-36. [Also available at http://dx.doi.org/ 10.1595/147106709X480913.]

Hoppstock, Klaus, and Sures, Bernd, 2004, Platinum-group metals, chap. 20 of Merian, E., Anke, Manfred, Ihnat, M., and Stoeppler, Markus, eds., Elements and their compounds in the environment-Occurrence, analysis, and biological relevance, 2d ed: Weinheim, Germany, Wiley-VCH Verlag GmbH, p. 1047-1086. [Also available at http://dx.doi.org/ 10.1002/9783527619634.]

Houston, R.S., and Orback, C.J., 1976, Geologic map of the Lake Owen Quadrangle, Albany County, Wyoming: U.S. Geological Survey Quadrangle Map GQ-1304, scale 1:24,000. [Also available at http://pubs.er.usgs.gov/ publication/gq1304.]

Hulbert, L.J., 1997, Geology and metallogeny of the Kluane mafic-ultramafic belt, Yukon Territory, Canada-Eastern Wrangellia-A new Ni-Cu-PGE metallogenic terrane: Geological Survey of Canada Bulletin, v. 506, 265 p.

Hulbert, L.J., and Stone, W.E., 2006, Eastern WrangelliaA new Ni-Cu-PGE metallogenic terrane in North America: ASEG Extended Abstracts 2006, no. 1, 7 p. [Also available at http://dx.doi.org/10.1071/ASEG2006ab070.]
Hulbert, L.J., Carne, R.C., Gregoire, D.C., and Paktunc, Dogan, 1992, Sedimentary nickel, zinc and platinum-group-element mineralization in Devonian black shales at the Nick property, Yukon, Canada-A new deposit type: Exploration and Mining Geology, v. 1, no. 1, p. 39-62.

Hulbert, L.J., Duke, J.M., Eckstrand, O.R., Lydon, J.W., Scoates, R.F.J., Cabri, L.J., and Irvine, T.N., 1988, Geological environments of the platinum group elements: Geological Survey of Canada Open File 1440, 148 p. [Also available at http://dx.doi.org/10.4095/130338.]

Hunter, R.H., 1987, Textural equilibrium in layered igneous rocks, in Parson, Ian, ed., Origins of igneous layering: Boston, Mass., D. Reidel Publishing Co., NATO ASI Series, Series C-Mathematical and Physical Sciences, v. 196, p. 473-503.

Hurst, Sarah, 2005, Kamchatka's platinum lures minersRussia lifts veil on secretive platinum industry: The Northern Miner, v. 91, no. 27, accessed April 27, 2013, at http://www.northernminer.com/news/kamchatka-splatinum-lures-miners/1000196934/.

Hutchison, C.S., 1983, Economic deposits and their tectonic setting: New York, N.Y., John Wiley \& Sons, 365 p.

Iljina, M.J., and Lee, C.A., 2005, PGE deposits in the marginal series of layered intrusions, in Mungall, J.E., ed., Exploration for platinum-group element deposits: Mineralogical Association of Canada Short Course Series, v. 35, p. 75-96.

Iljina, Markku, Heikura, Pertti, and Salmirinne, Heikki, 2005, The Haukiaho and Kaukua PGE-Cu-Ni-Au prospects in the Koillismaa layered igneous complex, Finland: Geological Survey of Finland, Mineral Exploration Report M06/3543,3544/2005/1/10, 20 p. plus 3 appendixes. [Also available at http://tupa.gtk.fi/raportti/valtaus/ m06_3543_3544_2005_1_10.pdf.]

Impala Platinum Holdings Ltd., 2011, Mineral resource and mineral reserve statement as at 30 June 2011: Impala Platinum Holdings Ltd., 66 p., accessed September 13, 2012, at http://www.implats.co.za/implats/downloads/2011/ annual\%20reports/Implats\%20MR_Combined_LoRes.pdf.

Impala Platinum Holdings Ltd., 2012, Metals usage: Impala Platinum Holdings Ltd., accessed January 31, 2013, at http://www.implats.co.za/implats/Metals-usage.asp.

Instituto Nacional de Geologica, 1987, Carta geológica [Geologic map of Mozambique]: República Popular de Moçambique, Ministério dos Recursos Minerais, Instituto Nacional de Geologica, 1 map on 2 sheets, scale 1:1,000,000. [In Portuguese.]

International Network for Acid Prevention, 2011, Global acid rock drainage guide: International Network for Acid Prevention, accessed November 10, 2011, at http://www.gardguide.com. 
Ivanic, T.J., Korsch, R.J., Wyche, S., Jones, L.E.A., Zibra, I., Blewett, R.S., Jones, T., Milligan, P., Costelloe, R.D., Van Kranendonk, M.J., Doublier, M.P., Hall, C.E., Romano, S.S., Pawley, M.J., Gessner, K., Patison, N., Kennett, B.L.N., and Chen, S.F., 2013, Preliminary interpretation of the 2010 Youanmi deep seismic reflection lines and magnetotelluric data for the Windimurra igneous complex, in Wyche, S., Ivanic, T.J. and Zibra, I., eds., 2011 Youanmi and Southern Carnavon seismic and magnetotelluric (MT) workshop 2013: Geological Survey of Western Australia, Record 2013/6, p. 97-111.

Ivanplats (Pty) Ltd., 2013, Flatreef discovery expands to 29.2 million ounces of platinum, palladium, rhodium and gold in indicated mineral resources, plus an additional 44.0 million ounces in inferred mineral resources, at a $2.0 \mathrm{~g} / \mathrm{t}$ 4PE cutoff: Ivanplats (Pty) Ltd. press release, February 6, 9 p., accessed March 18, 2013, at https://www.ivanplats.com/assets/docs/nr/2013-02-06_NR.pdf.

Jambor, J.L., Blowes, D.W., and Ptacek, C.J., 2000, Mineralogy of mine wastes and strategies for remediation, in Vaughan, D.J., and Wogelius R.A., eds., Environmental mineralogy: European Mineralogical Union Notes in Mineralogy, v. 2. p. 255-290.

Jebwab, Jacques, 2003, Katanga platinum group minerals: Brussels, Belgium, Université Libre de Bruxelles, accessed April 8, 2013, at http:/www.ulb.ac.be//sciences/katangapgm/.

Jinshan Gold Mines, 2004, Jinshan Gold Mines releases updated resource estimate for JBS platinum/palladium/nickel project, China: Jinshan Gold Mines press release, May 13, 3 p. [Also available at http://www.businesswire.com/news/ home/20040513005173/en/Jinshan-Gold-Mines-ReleasesUpdated-Resource-Estimate\#.VfHviLEpB9M.]

Johan, Z., 2002, Alaskan-type complexes and their platinumgroup element mineralization, in Cabri, L.J., ed., The geology, geochemistry, mineralogy and mineral beneficiation of platinum-group elements: Montreal, Quebec, Canada, Canadian Institute of Mining, Metallurgy and Petroleum Special Volume 54, p. 669-719.

Johnson, R.H., Blowes, D.W., Robertson, W.D., and Jambor, J.L., 2000, The hydrogeochemistry of the Nickel Rim mine tailings impoundment, Sudbury, Ontario: Journal of Contaminant Hydrology, v. 41, nos. 1-2, p. 49-80. [Also available at http://dx.doi.org/10.1016/S0169-7722(99)00068-6.]

Johnston, C., 1962, Platinum mining in Alaska-Dredge and dragline operations at Goodnews Bay: Platinum Minerals Review, v. 6, no. 2, p. 68-74.

Jones, D. L., Irwin, W.P., and Ovenshine, A.T., 1972, Southeastern Alaska-A displaced continental fragment?: U.S. Geological Survey Professional Paper 800-B, p. B211-B217.
Jones, R.T., 2002, ConRoast-DC arc smelting of deadroasted sulphide concentrates, in Third International Sulfide Smelting Symposium (Sulfide Smelting '02), Seattle, Washington, February 17-21, 2002, Proceedings: Randburg, South Africa, Mintek, S.A., Mintek Paper no. 8527, 22 p., accessed April 18, 2013, at http://www.mintek.co.za/ Pyromet/ConRoast/Summary.htm.

Jones, W.R., Peoples, J.W., and Howland, A.L., 1960, Igneous and tectonic structures of the Stillwater Complex, Montana: U.S. Geological Survey Bulletin 1071-H, p. 281-340.

Jubileus, M.T., 2008, Assessment of platinum mine tailings storage facilities - An ecotoxicological perspective: Potchefstroom, South Africa, North-West University, unpublished Master of Science thesis, 113 p.

Kargi, Hulusi, and Barnes, C.G., 1995, A Grenville-age layered intrusion in the subsurface of west TexasPetrology, petrography, and possible tectonic setting: Canadian Journal of Earth Sciences, v. 32, no. 12, p. 2159-2166. [Also available at http://dx.doi.org/ 10.1139/e95-168.]

Keller, G.R., Hills, J.M., Baker, M.R., and Wallin, E.T., 1989, Geophysical and geochronological constraints on the extent and age of mafic intrusions in the basement of west Texas and eastern New Mexico: Geology, v. 17, no. 11, p. 1049-1052.

Kemp, J.F., 1902, The geological relations and distributions of platinum and associated metals: U.S. Geological Survey Bulletin 193, 95 p.

Kennecott Eagle Minerals Co., 2006, Eagle Project mining permit application, volume I: Marquette, Mich., Kennecott Eagle Minerals Co., 126 p., accessed June 23, 2015, at http:/www.lic.wisc.edu/glifwc/Kennecott/permitap2/ Mining/Vol1/Mine\%20Permit\%20App\%20text.pdf.

Kielhorn, Janet, Melber, Christine, Keller, Detlef, and Mangelsdorf, Inge, 2002, Palladium-A review of exposure and effects to human health: International Journal of Hygiene and Environmental Health, v. 205, no. 6, p. 417-432. [Also available at http://dx.doi.org/10.1078/1438-4639-00180.]

Kiousis, G., Economou-Eliopoulos, M., Paspaliaris, I., and Mitsis, I., 2005, Gold, palladium and platinum recovery, as by-products, from the Skouries porphyry $\mathrm{Cu}-\mathrm{Au}$ deposit, Chalkidiki area, northeastern Greece, in Jingwen, Mao, and Bierlein, F.P., eds., Mineral deposit research-Meeting the global challenge - Proceedings of the Eighth Biennial SGA meeting, Beijing, China, August 18-21, 2005: Berlin, Germany, Springer-Verlag, p. 991-994. 
Kirk, L.B., McCleary, Melanie, and Weimer, Randy, 2006, Operational validation of environmental geochemistry at the Stillwater Mine, Nye MT: Billings Land Reclamation Symposium, Billings, Mont., June 4-6, 2006, Presentation, 12 p., accessed June 26, 2013, at http://www.asmr.us/ Publications/Conference Proceedings/2006 Billings/ 0363-Kirk-MT.pdf.

Kleinkopf, M.D., 1985, Regional gravity and magnetic anomalies of the Stillwater Complex area, in Czamanske, G.K., and Zientek, M.L., eds., The Stillwater Complex, MontanaGeology and guide: Montana Bureau of Mines and Geology Special Publication 92, p. 33-38.

Kunilov, V.Ye., 1994, Geology of the Noril'sk region-The history of discovery, prospecting, exploration and mining of the Noril'sk deposits, in Lightfoot, P.C., and Naldrett, A.J., eds., Proceedings of the Sudbury-Noril'sk symposium: Sudbury, Ontario, Canada, Ontario Geological Survey Special Volume 5, p. 203-216.

Lael, R.L., and Killen, Linda, 1982, Pressure of shortagePlatinum policy and the Wilson administration during World War I: The Business History Review, v. 56, no. 4, p. 545-558.

Lahtinen, Jarmo, 1983, Yhteenveto Koillismaan kerrosintruusiokompleksin platinatutkimuksista [Summary Koillismaan layered intrusion complex, platinum studies]: Espoo, Finland, Outokumpu Oy report, 001/3541, 3543, 4523/JJL/83/5, February 18, $221 \mathrm{p}$.

Lapakko, K., and Berndt, M., 2009, Laboratory dissolution of tailings under three different conditions, in Securing the future-Mining, metals \& the environment in a sustainable society, Proceedings of the 8th International Conference on Acid Rock Drainage (ICARD), Skellefteå, Sweden, June 22-26, 2009: International Network for Acid Prevention, v. 1, p. 341-352.

Lapakko, K.A., 1994, Comparison of Duluth Complex rock dissolution in the laboratory and field, in Proceedings of the International Land Reclamation and Mine Drainage Conference and Third International Conference on the Abatement of Acidic Drainage, Pittsburgh, PA, April 24-29, 1994: Washington, D.C., U.S. Bureau of Mines Special Publication SP 06A-94, v. 1, p. 419-428.

Lechler, P.J., and Hsu, L.C., 1989, Review of hydrothermal platinum-group metal deposits with new data from Nevada: Society of Mining Engineers Preprint 89-55, 7 p.

Lechler, P.J., Hsu, L.C., and Hudson, D.M., 1988, Anomalous platinum associated with hydrothermal manganese mineralization at the Gibellini Mine, Fish Creek Range, Nevada: Nevada Bureau of Mines and Geology Open File Report 88-4, 8 p.
Levin, V.Y., Katkalov, A.V., and Laskovenkov, A.F., 2010, [Schedule of guided tours and number of participants in the XI Russian petrographic meeting, August 27-28, 2010]: Ural Branch of the Russian Academy of Sciences, accessed April 19, 2013, at http://conf.uran.ru/Data/18message219.pdf. [In Russian.]

Lewins, J.D., Hunns, S., and Badenhorst, J., 2008, The Kalahari Platinum project, in Rogers, M.H., ed., Platinum in transformation-Proceedings of the Third International Platinum Conference, Sun City, South Africa, October 6-9, 2008: Johannesburg, South Africa, The Southern African Institute of Mining and Metallurgy, p. 355-366.

Li, Chusi, Ripley, E.M., and Naldrett, A.J., 2003, Compositional variations of olivine and sulfur isotopes in the Noril'sk and Talnakh intrusions, Siberia-Implications for ore-forming processes in dynamic magma conduits: Economic Geology, v. 98, p. 69-86. [Also available at http://dx.doi.org/10.2113/gsecongeo.98.1.69.]

Lightfoot, P.C., and Lavigne, M.J., Jr., 1995, Nickel, copper, and platinum group element mineralization in Keweenawan intrusive rocks- -New targets in the Keweenawan of the Thunder Bay region, northwestern Ontario: Ontario Geological Survey Open File Report 5928, 32 p. [Also available at http://www.geologyontario.mndmf.gov.on.ca/ mndmfiles/pub/data/imaging/OFR5928/OFR5928.pdf.]

Likhachev, A.P., 1994, Ore-bearing intrusions of the Noril'sk region, in Lightfoot, P.C., and Naldrett, A.J., eds., Proceedings of the Sudbury-Noril'sk symposium: Sudbury, Ontario, Canada, Ontario Geological Survey Special Volume 5, p. 185-201.

Lishman, K.L., 2009, The acid mine drainage potential of the Platreef, northern limb of the Bushveld Complex, South Africa: Johannesburg, South Africa, University of the Witswatersrand, unpublished Master of Science thesis, $231 \mathrm{p}$.

Listerud, W.H., and Meineke, D.G., 1977, Mineral resources of a portion of the Duluth Complex and adjacent rocks in St. Louis and Lake Counties, northeastern Minnesota: Minnesota Department of Natural Resources, Division of Minerals Report 93, 49 p.

Lodders, Katharina, 2010, Solar system abundances of the elements, in Goswami, Aruna, and Reddy, B.E., eds., Principles and perspectives in cosmochemistry-Lecture notes of the Kodai school on 'Synthesis of elements in stars' held at Kodaikanal Observatory, India, April 29-May 13, 2008 : Berlin, Germany, Springer-Verlag, p. 379-417.

Loferski, P.J., 2012a, Platinum-group metals [advance release], in Metals and minerals: U.S. Geological Survey Minerals Yearbook 2011, v. I, p. 57.1-57.11. [Also available at http://minerals.usgs.gov/minerals/pubs/commodity/ platinum/myb1-2011-plati.pdf.] 
Loferski, P.J., 2012b, Platinum-group metals: U.S. Geological Survey Mineral Commodity Summaries 2012, p. 120-121. [Also available at https://minerals.usgs.gov/minerals/pubs/ commodity/platinum/mcs-2012-plati.pdf.]

Loferski, P.J., 2013a, Platinum-group metals [advance release], in Metals and minerals: U.S. Geological Survey Minerals Yearbook 2012, v. I, p. 57.1-57.12. [Also available at http://minerals.usgs.gov/minerals/pubs/commodity/ platinum/myb1-2012-plati.pdf.]

Loferski, P.J., 2013b, Platinum-group metals: U.S. Geological Survey Mineral Commodity Summaries 2013, p. 120-121. [Also available at https://minerals.usgs.gov/minerals/pubs/ commodity/platinum/mcs-2013-plati.pdf.]

Loferski, P.J., 2013c, Platinum-group metals (Ir, Os, Pd, Pt, $\mathrm{Rh}, \mathrm{Ru}$ ), in Metal prices in the United States through 2010: U.S. Geological Survey Scientific Investigations Report 2012-5188, p. 119-132, available only at http://pubs.usgs.gov/ sir/2012/5188/sir2012-5188.pdf\#Platinum-Group.

Lonmin plc, 2011, Mineral resource and mineral reserve statements-As at September 30, 2011: Lonmin plc, 46 p., accessed September 26, 2012, at https://www.lonmin.com/ downloads/Mineral_Resource_Mineral_Reserve_Statement 30Sep11_FINAL.pdf.

Loucks, R.R., 1991, Platinum-gold and vanadiferous magnetite mineralization in the Early Proterozoic Lake Owen layered mafic intrusion, Medicine Bow Mountains, Wyoming, in Mineral Resources of Wyoming-Wyoming Geological Association Forty-Second Field Conference guidebook, Laramie, Wyo., Sept. 14-18, 1991: Laramie, Wyo., Wyoming Geological Association, v. 42, p. 37-38.

Loucks, R.R., and Glasscock, J.W., 1989, Petrology and PGE mineralization of the early Proterozoic Lake Owen layered mafic intrusion, southern Wyoming, USA: Bulletin of the Geological Society of Finland, v. 61, p. 11-12.

Loukola-Ruskeeniemi, K., 1991, Geochemical evidence for the hydrothermal origin of sulphur, base metals and gold in Proterozoic metamorphosed black shales, Kainuu and Outokumpu areas, Finland: Mineralium Deposita, v. 26, no. 2, p. 152-164. [Also available at http://dx.doi.org/ 10.1007/BF00195262.]

Loukola-Ruskeeniemi, Kristi, and Heino, Timo, 1996, Geochemistry and genesis of the black shale-hosted $\mathrm{Ni}-\mathrm{Cu}-\mathrm{Zn}$ deposit at Talvivaara, Finland: Economic Geology, v. 91, p. 80-110.

Lumb, A.D., 1920, The platinum metals: London, United Kingdom, J. Murray, 63 p., 1 map.

Maboeta, M.S., van Rensburg, Leon, and van Rensburg, P.J., 2008, Earthworm (Eisenia fetida) bioassay to assess the possible effects of platinum tailings disposal facilities on the environment along a gradient: Applied Ecology and Environmental Research, v. 6, no. 2, p. 13-19.
Maier, W.D., and Barnes, S.-J., 2005, Application of lithogeochemistry to exploration for PGE deposits, in Mungall, J.E., ed., Exploration for platinum-group element deposits: Mineralogical Association of Canada Short Course Series, v. 35, p. 309-341.

Maier, W.D., Barnes, S.-J., Ashwal, L.D., and Li, C., 2001, A reconnaissance study on the magmatic $\mathrm{Cu}-\mathrm{Ni}$-PGE sulphide potential of the Tete Complex, Mozambique: South African Journal of Geology, v. 104, no. 4, p. 355-364.

Maier, W.D., Barnes, S.-J., Gartz, Volker, and Andrews, G., 2003, Pt-Pd reefs in magnetitites of the Stella layered intrusion, South Africa-A world of new exploration opportunities for platinum-group elements: Geology, v. 31, no. 10, p. 885-888. [Also available at http://dx.doi.org/ 10.1130/G19746.1.]

Maier, W.D., Peltonen, Petri, McDonald, Ian, Barnes, S.J., Barnes, S.-J., Hatton, Chris, and Viljoen, F., 2012, The concentration of platinum-group elements and gold in southern African and Karelian kimberlite-hosted mantle xenoliths - Implications for the noble metal content of the Earth's mantle: Chemical Geology, v. 302-303, p. 119-135. [Also available at http://dx.doi.org/10.1016/ j.chemgeo.2011.06.014.]

Malitch, K.N., 1999, Platinum-group elements in clinopyroxene-dunite massifs of the East Siberia (geochemistry, mineralogy, and genesis): St. Petersburg, Russia, Saint Petersburg Cartographic Factory VSEGEI Press, 296 p. [In Russian with English abstract.]

Malitch, K.N., and Thalhammer, O.A.R., 2002, Pt-Fe nuggets derived from clinopyroxenite-dunite massifs, RussiaA structural, compositional and osmium-isotope study: Canadian Mineralogist, v. 40, no. 20, p. 395-418. [Also available at http://dx.doi.org/10.2113/gscanmin.40.2.395.]

Malitch, K.N., Badanina, I.Yu., Belousova, E.A., and Tuganova, E.V., 2012, Results of U-Pb dating of zircon and baddeleyite from the Noril'sk-1 ultramafic-mafic intrusion (Russia): Russian Geology and Geophysics, v. 53, no. 2, p. 123-130. [Also available at http://dx.doi.org/10.1016/ j.rgg.2011.12.010.]

Mao, Jingwen, Lehmann, Bernd, Du, Andao, Zhang, Guangdi, Ma, Dongsheng, Wang, Yitian, Zeng, Mingguo, and Kerrich, Robert, 2002, Re-Os dating of polymetallic Ni-Mo-PGE-Au mineralization in Lower Cambrian black shales of south China and its geologic significance: Economic Geology, v. 97, p. 1051-1061. [Also available at http://dx.doi.org/10.2113/gsecongeo.97.5.1051.]

Martini, J.E.J., Vorster, C.J., Oosterhuis, W.R., and Wolmarans, L.G., 2001, Digital metallogenic map of South Africa and the Kingdoms of Lesotho and Swaziland: Council for Geoscience (Geological Survey), South Africa, scale 1:1,000,000, CD-ROM. 
Mathez, E.A., 1999, On factors controlling the concentrations of platinum group elements in layered intrusions and chromitites, in Keays, R.R., Lesher, C.M., Lightfoot, P.C., and Farrow, C.E.G., eds., Dynamic processes in magmatic ore deposits and their application in mineral exploration: Geological Association of Canada Short Course Notes, v. 13 , p. 251-285.

Mathison, C.I., and Ahmat, A.L., 1996, The Windimurra igneous complex, Western Australia, in Cawthorn, R.G., ed., Layered intrusions: Amsterdam, Netherlands, Elsevier Science B.V., p. 485-510. [Also available at http://dx.doi.org/ 10.1016/S0167-2894(96)80016-9.]

Mattera, Philip, 2008, Anglo American's track recordRhetoric or reality? - Community, worker safety, public health, and environmental problems at Anglo American mining operations: Renewable Resources Coalition, 34 p., accessed February 19, 2013, at http://www.infomine.com/ library/publications/docs/Mattera2008.pdf.

Mattila, E., Hugg, R., and Kerkkonen, O., 1976, Mustavaaran kaivoksen jätealtaan Lavotan tutkimukset [Mustavaara Mine tailings pond Lavotan studies] XI-XII v. 1975: Helsinki, Finland, Rautaruukki Oy report OU 1/76, accessed September 21, 2015, at http://tupa.gtk.fi/raportti/ arkisto/ou_1_76.pdf. [In Finnish.]

McBirney, A.R., 1989, Geological map of the Skaergaard intrusion, east Greenland: Eugene, Oregon, University of Oregon, Department of Geology, scale 1:20,000.

McCallum, I.S., Raedeke, L.D., and Mathez, E.A., 1980, Investigations of the Stillwater Complex-Part IStratigraphy and structure of the Banded zone: American Journal of Science, v. 280-A, no. 1, p. 59-87. [Also available at http://earth.geology.yale.edu/ ajs/1980/ ajs_280A_1.pdf/59.pdf.]

McCallum, M.E., Loucks, R.R., Carlson, R.R., Cooley, E.F., and Doerge, T.A., 1976, Platinum metals associated with hydrothermal copper ores of the New Rambler Mine, Medicine Bow Mountains, Wyoming: Economic Geology, v. 71, p. 1429-1450. [Also available at http://dx.doi.org/ 10.2113/gsecongeo.71.7.1429.]

McCarthy, J.E., Copeland, Claudia, Parker, Larry, and Schierow, Linda-Jo, 2011, Clean Air Act-A summary of the Act and its major requirements: Washington, D.C., Congressional Research Service Report RL30853, January $6,24 \mathrm{p}$.

McConnachie, Terry, Trevarthen, Nigel, and Carroll, Louis, 2011, Success, growth, introducing Sylvania Platinum: Sylvania Platinum Ltd. Investor Relations presentation, April 4, 25 p., accessed February 25, 2013, at http://www.sylvaniaplatinum.com/im/files/documents/ 040411-SLP-Investor-Presentation-ASX.pdf.
McCracken, Todd, 2011, Technical report and resource estimate on the Wellgreen platinum-palladium-nickel-copper project, Yukon, Canada, prepared for Prophecy Platinum Corp: Toronto, Ontario, Canada, Tetra Tech Wardrop, Document no. 1155400200-REP-R0001-03, September 15, 91 p.

McCracken, Todd, 2012, Technical report and resource estimate on the River Valley PGM project, northern Ontario-NI 43-101 technical report, prepared for Pacific North West Capital Corp. [Filing date June 14, 2012]: Toronto, Ontario, Canada, Tetra Tech Wardrop, Document No. 1193250100-REP-R0001-01, June 13, 114 p. plus 2 appendixes. [Also available at http://www.sedar.com.]

McDonald, Donald, and Hunt, L.B., 1982, History of platinum and its allied metals: London, United Kingdom, Johnson Matthey Plc, 450 p., accessed October 29, 2015, at https://books.google.co.uk/books?id=xriMAgAAQBAJ\& printsec $=$ frontcover\&hl $=\mathrm{en} \# \mathrm{v}=$ onepage $\& \mathrm{q} \& \mathrm{f}=$ false .

McGregor, R.G., Blowes, D.W., Jambor, J.L., and Robertson, W.D., 1998, Mobilization and attenuation of heavy metals within a nickel mine tailings impoundment near Sudbury, Ontario, Canada: Environmental Geology, v. 36, p. 305-319. [Also available at http://dx.doi.org/10.1007/s002540050346.]

Meck, Maideyi, Love, David, and Mapani, Benjamin, 2006, Zimbabwean mine dumps and their impacts on river water quality - A reconnaissance study: Physics and Chemistry of the Earth, Parts A/B/C, v. 31, nos. 15-16, p. 797-803. [Also available at http://dx.doi.org/10.1016/j.pce.2006.08.029.]

Meeks, N., La Niece, S., and Estévez, P., 2002, The technology of early platinum plating - A gold mask of the La Tolita culture, Ecuador: Archaeometry, v. 44, no. 2, p. 273-284. [Also available at http://dx.doi.org/10.1111/1475-4754.t01-1-00059.]

Mehta, Viral, and Cooper, J.S., 2003, Review and analysis of PEM fuel cell design and manufacturing: Journal of Power Sources, v. 114, p. 32-53. [Also available at http://dx.doi.org/ 10.1016/S0378-7753(02)00542-6.]

Mertie, J.B., Jr., 1969, Economic geology of the platinum metals: U.S. Geological Survey Professional Paper 630, 120 p. [Also available at http://pubs.er.usgs.gov/publication/pp630.)

Mertie, J.B., Jr., 1976, Platinum deposits of the Goodnews Bay District, Alaska: U.S. Geological Survey Professional Paper 938, 42 p. [Also available at http://pubs.er.usgs.gov/ publication/pp938.]

Meyers, J.S., 1985, The Fraser Complex-A major layered intrusion in Western Australia: Geological Survey of Western Australia Report 14, p. 57-66.

Miller, J.D., Jr., 1999, Geochemical evaluation of platinum group element (PGE) mineralization in the Sonju Lake intrusion, Finland, Minnesota: Minnesota Geological Survey Information Circular 44, 31 p. [Also available at http://purl.umn.edu/59409.] 
Miller, J.D., Jr., Green, J.C., Severson, M.J., Chandler, V.W., Hauck, S.A., Peterson, D.M., and Wahl, T.E., 2002, Geology and mineral potential of the Duluth Complex and related rocks of northeastern Minnesota: Minnesota Geological Survey Report of Investigations 58, 207 p.

Minnesota Department of Natural Resources and the U.S. Army Corps of Engineers, 2009, NorthMet project draft environmental impact statement, 3 vols.: St. Paul, Minn., Minnesota Department of Natural Resources, accessed May 30, 2013, at http://www.dnr.state.mn.us/ input/environmentalreview/polymet/eis_toc.html.

Mitchell, W.I., comp., 1983, Mapa geologico del area de Santo Corazon-Robore (CUAD SE 21-5 con parte de SE 21-9): Institute of Geological Sciences, Natural Environmental Research Council, United Kingdom, and Servicio Geológico de Bolivia, Proyecto Precambrico, Santo Corazon-Robore sheet, Bolivia, 1 sheet, scale 1:250,000.

Mitrofanov, F.P., Korchagin, A.U., and Lobov, S.G., 2007, PGE Fedorova project-Russia, Kola Peninsula, Lovozero area: 6th Fennoscandian Exploration and Mining meeting, November 27-29, 2007, Rovaniemi, Finland, accessed February 20, 2010, at http:/www.lapinliitto.fi/fem2007/ presentations/14lobov.pdf.

Mitrofanov, F.P., Korchagin, A.U., Dudkin, K.O., and Rundkvist, T.y.V., 2005, Fedorov-Pana layered mafic intrusion (Kola Peninsula, Russia)_Approaches, methods, and criteria for prospecting PGEs, in Mungall, J.E., ed., Exploration for platinum-group element deposits: Mineralogical Association of Canada Short Course Series, v. 35, p. 343-358.

Moldovan, Mariella, Rauch, Sébastien, Gómez, Milagros, Palacios, M.A., and Morrison G.M., 2001, Bioaccumulation of palladium, platinum and rhodium from urban particulates and sediments by the freshwater isopod Asellus aquaticus: Water Research, v. 35, no. 17, p. 4175-4183. [Also available at http://dx.doi.org/10.1016/S0043-1354(01)00136-1.]

Molly, E.W., 1959, Platinum deposits of Ethiopia: Economic Geology, v. 54, p. 467-477. [Also available at http://dx.doi.org/ 10.2113/gsecongeo.54.3.467.]

Montana Department of Environmental Quality, 2012a, Montana numeric water quality standards: Helena, Mont., Montana Department of Environmental Quality Circular DEQ-7, 76 p., accessed July 18, 2016, at https:/deq.mt.gov/Portals/112/Water/WQPB/ Standards/PDF/DEQ7/FinalApprovedDEQ7.pdf.

Montana Department of Environmental Quality, 2012b, Stillwater Mining Company's revised water management plans and Boe Ranch LAD_Final Environmental Impact StatementAppendices: Montana Department of Environmental Quality, 239 p., accessed October 6, 2016, at https://deq.mt.gov/ portals/112/DEQAdmin/EIS/Stillwater/Appendices_Final_ Web.pdf.
Montemurro, D., comp., 1984, Mapa geologico del area de Rincon del Tigre-La Gaiba (CUAD SE 21-6 con parte de SE 21-10): Institute of Geological Sciences, Natural Environmental Research Council, United Kingdom, and Servicio Geológico de Bolivia, Proyecto Precambrico, Rincon del Tigre-La Gaiba sheet, Bolivia, 1 sheet, scale 1:250,000.

Mortensen, J.K., and Hulbert, L.J., 1992, A U-Pb zircon age for a Maple Creek gabbro sill, Tatamagouche area, southwest Yukon Territory: Geological Survey of Canada Paper 91-2, p. 175-179.

Mudd, G.M., 2010, Global trends and environmental issues in nickel mining - Sulfides versus laterites: Ore Geology Reviews, v. 38, nos. 1-2, p. 9-26. [Also available at http://dx.doi.org/10.1016/j.oregeorev.2010.05.003.]

Mudd, G.M., 2012, Key trends in the resource sustainability of platinum group elements: Ore Geology Reviews, v. 46, p. 106-117. [Also available at http://dx.doi.org/10.1016/ j.oregeorev.2012.02.005.]

Muehlberger, W.R., comp., 1997, Tectonic map of North America: American Association of Petroleum Geologists Datapages 473, scale 1:5,000,000, CD-ROM.

Mungall, J., 2002, A model for co-precipitation of platinumgroup minerals with chromite from silicate melts [abs.]: 9th International Platinum Symposium, International Geologic Correlation Program, July 21-25, Billings, Mont., IGCP Project 427, 4 p.

Mungall, J.E., 2005, Magmatic geochemistry of the platinumgroup elements, in Mungall, J.E., ed., Exploration for platinum-group element deposits: Mineralogical Association of Canada Short Course Series, v. 35, p. 1-34.

Murahwi, Charley, San Martin, A.J., Gowans, R.M., and Spooner, Jane, 2011, Technical report on the updated mineral resource estimate for the Eagle's Nest property, McFaulds Lake Project, James Bay Lowlands, Ontario, Canada-NI 43-101 technical report, prepared for Noront Resources Ltd. [Filing date April 18, 2011]: Toronto, Ontario, Canada, Micon International Ltd., March 4, 106 p. plus 3 appendixes. [Also available at http://www.sedar.com.]

Myers, J.S., 1976, Stratigraphy of the Fiskenaesset anorthosite complex, southern West Greenland, and comparison with the Bushveld and Stillwater complexes: Grønlands Geologiske Undersøgelse Rapport, v. 80, p. 87-92.

Myers, J.S., 1985, Stratigraphy and structure of the Fiskenaesset Complex, southern West Greenland: Grønlands Geologiske Undersøgelse Rapport, v. 150, 72 p.

Naldrett, A.J., 2006, On the use of geochemistry to characterise mineralisation of magmatic sulfide deposits from around the world-Revised (November 10th 2006) interim report: European Network of Forensic Science Institutes, 30 p., accessed March 27, 2013, at http:/www.enfsi.eu/sites/default/files/ documents/appendix_06_geochemistry_to_characterise_ mineralisation_0.pdf. 
Naldrett, A.J., 2010a, From the mantle to the bank-The life of a Ni-Cu-(PGE) sulfide deposit: South African Journal of Geology, v. 113, no. 1, p. 1-32. [Also available at http://dx.doi.org/10.2113/gssajg.113.1-1.]

Naldrett, A.J., 2010b, Secular variation of magmatic sulfide deposits and their source magmas: Economic Geology, v. 105, p. 669-688. [Also available at http://dx.doi.org/ 10.2113/gsecongeo.105.3.669.]

Naldrett, A.J., Wilson, Allan, Kinnaird, Judith, and Chunnett, Gordon, 2009, PGE tenor and metal ratios within and below the Merensky Reef, Bushveld ComplexImplications for its genesis: Journal of Petrology, v. 50, no. 4, p. 625-659. [Also available at http://dx.doi.org/ 10.1093/petrology/egp015.]

National Research Council of the National Academies, 2008, Minerals, critical minerals, and the U.S. economy: Washington, D.C., National Academies Press, 245 p.

Natural Earth, 2014, Small scale data: Natural Earth map dataset, scale 1:110,000,000, accessed June 23, 2014, at http://www.naturalearthdata.com.

Naus-Thijssen, F.M.J., 2007, Dynamics of igneous systemsBackground: Orono, Maine, University of Maine, Department of Earth Sciences Web page, accessed April 2, 2014 , at http://www.geology.um.maine.edu/user/Felice_Naus thijssen/FDmodule/html\%20pages/background.html.

Nielsen, T.F.D., Andersen, J.C.O., and Brooks, C.K., 2005, The Platinova Reef of the Skaergaard intrusion, in Mungall, J.E., ed., Exploration for platinum-group elements deposits: Mineralogical Association of Canada Short Course Series, v. 35, p. 431-455.

Nitkina, E.A., 2006, U-Pb zircon dating of rocks of the platiniferous Fedorova-Pana layered massif, Kola Peninsula: Doklady Earth Sciences, v. 408, no. 1, p. 551-554. [Also available at http://dx.doi.org/10.1134/S1028334X06040106.]

Nixon, G.T., 2003, Platinum-group elements in the Afton $\mathrm{Cu}-\mathrm{Au}$ porphyry deposit, southern British Columbia: British Columbia Geological Survey Series 2004-1, Geological Fieldwork 2003, p. 263-290.

Noguez, M., Gargia, R., Salas, G., Robert, T., and Ramirez, J., 2006, About the pre-Hispanic Au-Pt "sintering" technique for making alloys: JOM [Journal of the Minerals, Metals, \& Materials Society], v. 58, no. 5, p. 38-43. [Also available at http://dx.doi.org/10.1007/s11837-006-0021-0.]

Nokleberg, W.J., Plafker, George, and Wilson, F.H., 1994, Geology of southcentral Alaska, in Plafker, George, and Berg, H.C., eds., The geology of Alaska: Boulder, Colo., Geological Society of America, Geology of North America series, v. G-1, p. 311-366.
North American Palladium Ltd., 2012, North American Palladium Ltd.-O Operations_-Lac des Iles Mine-Reserves \& resources: Toronto, Ontario, Canada, North American Palladium Ltd. Web page, accessed March 15, 2013, at http://www.napalladium.com/operations/reserves-andresources/.

Northam Platinum Ltd., 2008, Sustainable development report 2008: Thabazimbi, South Africa, Northam Platinum Ltd., 36 p., accessed October 29, 2015, at http://www.northam.co.za/investors-and-media/ publications/sustainable-development-reports.

Oberthür, Thomas, 2002, Platinum-group element mineralization of the Great Dyke, Zimbabwe, in Cabri, L.J., ed., The geology, geochemistry, mineralogy and mineral beneficiation of platinum-group elements: Montreal, Quebec, Canada, Canadian Institute of Mining, Metallurgy and Petroleum Special Volume 54, p. 483-506.

Oberthür, Thomas, Davis, D.W., Blenkinsop, T.G., and Höhndorf, Axel, 2002, Precise U-Pb mineral ages, Rb-Sr and Sm-Nd systematics for the Great Dyke, Zimbabweconstraints on Late Archean events in the Zimbabwe craton and Limpopo belt: Precambrian Research, v. 113, nos. 3-4, p. 293-305. [Also available at http://dx.doi.org/10.1016/ S0301-9268(01)00215-7.]

OJSC MMC Norilsk Nickel, 2009, Annual report 2009-Focus on efficiency: Moscow, Russia, OJSC MMC Norilsk Nickel, 255 p., accessed March 14, 2013, at http://www.nornik.ru/ _upload/year2009/GO_NN_2009_Eng_site.pdf.

OJSC MMC Norilsk Nickel, 2011, Mineral reserves and resources statement: Moscow, Russia, OJSC MMC Norilsk Nickel Web page, accessed March 8, 2013, at http://www.nornik.ru/ en/our_products/MineralReservesResourcesStatement/.

OJSC MMC Norilsk Nickel, 2012, Investor presentationJuly 2012: Moscow, Russia, OJSC MMC Norilsk Nickel, 27 p., accessed March 8, 2013, at http://www.nornik.ru/ _upload/editor_files/file1883.pdf.

Oommen, Thomas, 2006, Geodatabase development and GIS based analysis for resource assessment of placer platinum in the offshore region of Goodnews Bay, Alaska: Fairbanks, Alaska, University of Alaska Master's thesis, 183 p.

Oommen, Thomas, Prakash, Anumpa, Misra, Debasmita, Naidu, Sathy, Kelley, J.J., and Bandopadhyay, Sukumar, 2008, GIS based marine platinum exploration, Goodnews Bay region, southwest Alaska: Marine Georesources and Geotechnology, v. 26, no. 1, p. 1-18. [Also available at http://dx.doi.org/10.1080/10641190701706270.]

Organisation Internationale des Constructeurs d'Automobiles, 2013, Production statistics: Paris, France, Organisation Internationale des Constructeurs d'Automobiles, accessed April 8, 2013, at http://oica.net/category/production-statistics. 
Orth, C.J., Quintana, L.R., Gilmore, J.S., Barrick, J.E., Haywa, J.N., and Spesshardt, S.A., 1988, Pt-group metal anomalies in the Lower Mississippian of southern Oklahoma: Geology, v. 16, no. 7, p. 627-630.

Pacific North West Capital Corp., 2006, Pacific North West Capital acquires Goodnews Bay platinum project, Alaska: Vancouver, British Columbia, Canada, Pacific North West Capital Corp. news release, April 12, 3 p.

Pagé, Philippe, Barnes, S.-J., Bedard, J.H., and Zientek, M.L., 2012, In situ determination of Os, Ir, and Ru in chromites formed from komatiite, tholeiite and boninite magmas-Implications for chromite control of Os, Ir, and Ru during partial melting and crystal fractionation: Chemical Geology, v. 302-303, p. 3-15. [Also available at http://dx.doi.org/10.1016/j.chemgeo.2011.06.006.]

Park, J.W., Hu, Z., Gao, S., Campbell, I.H., and Gong, H., 2012, Platinum group element abundances in the upper continental crust revisited-New constraints from analyses of Chinese loess: Geochimica et Cosmochimica Acta, v. 93, p. 63-76. [Also available at http://dx.doi.org/10.1016/ j.gca.2012.06.026.]

Parker, Harry, and Eggleston, Ted, 2012, Maturi, Birch Lake, and Spruce Road Cu-Ni-PGE projects, Ely, Minnesota USA, NI 43-101 technical report, prepared for Duluth Metals Ltd. [Effective date September 15, 2012]: Sparks, Nev., AMEC E\&C Services Inc., 301 p.

Parks, Jenny, 1998, The Weld Range platinum group element deposit, in Berkman, D.A., and Mackenzie, D.H., eds., Geology of Australian and Papua New Guinean mineral deposits: Australasian Institute of Mining and Metallurgy, Monograph 22, p. 279-286.

Parks, Jenny, and Hill, R.E.T., 1986, Phase compositions and cryptic variation in a $2.2-\mathrm{km}$ section of the Windimurra layered gabbroic intrusion, Yilgarn Block, Western Australia-A comparison with the Stillwater Complex: Economic Geology, v. 81, p. 1196-1202.

Perring, R.J., and Vogt, J.H., 1991, The Panton Sill, chap. 7 of Barnes, S.-J., and Hill, R.E.T., eds., Mafic-ultramafic complexes of Western Australia-Sixth International Platinum Symposium Guidebook for the post-symposium field excursion: Perth, Western Australia, Australia, Geological Society of Australia Excursion Guidebook 3, p. 97-107.

Peterson, D.M., and Severson, M.J., 2002, Chapter 4, Archean and Paleoproterozoic rocks that form the footwall of the Duluth Complex, chap. 4 of Miller, J.D., Jr., Green J.C., Severson, M.J., Chandler, V.W., Hauck, S.A., Peterson, D.M., and Wahl, T.E., 2002, Geology and mineral potential of the Duluth Complex and related rocks of northern Minnesota: Minnesota Geological Survey Report of Investigations RI-58, p. 76-93.
Petrov, G.V., Boduen, A.J., Mardari, I.I., Ivanov, B.S., and Boginskaya, A.S., 2013, Resources of precious metals in technogenic objects of mining and metallurgical complex of Russia: International Journal of Experimental Education, no. 2, p. 54-57.

Petrov, O., Shatov, V., Kondian, K., Markov, G., Guriev, G., Seltmann, R., and Armstrong, R., eds., 2007, Mineral deposits of the Urals 1M scale map and databaseArcView 3.2 GIS package: London, United Kingdom, Natural History Museum Center for Russian and Central Asian Mineral Studies, 91 p., scale 1:1,000,000.

Pieczonka, J., Piestrzyński, A., Mucha, J., Gluszek, A., Kotarba, M.J., and Wieclaw, D., 2008, The red-bed-type precious metal deposit in the Sieroszowice-Polkowice copper mining district, SW Poland: Annales Societatis Geologorum Poloniae, v. 78, no. 3, p. 151-280.

Pimentel, M.M., Ferreira-Filho, C.F., and Armele, Alan, 2006, Neoproterozoic ages of the Niquelândia Complex, central Brazil-Further ID-TIMS U-Pb and Sm-Nd isotopic evidence: Journal of South American Earth Sciences, v. 21, no. 3, July, p. 228-238. [Also available at http://dx.doi.org/ 10.1016/j.jsames.2006.05.001.]

Plafker, George, and Berg, H.C., 1994, Overview of the geology and tectonic evolution of Alaska, in Plafker, George, and Berg, H.C., eds., The geology of Alaska: Boulder, Colo., The Geological Society of America, The Geology of North America series, v. G1, p. 989-1021.

Platina Resources Ltd., 2006, Prospectus: Varsity Lakes, Queensland, Australia, Platina Resources Ltd., 111 p.

Platina Resources Ltd., 2010, Munni Munni, WA: Varsity Lakes, Queensland, Australia, Platina Resources Ltd. Factsheet, 3 p., accessed September 23, 2011, at http://www.platinaresources.com.au/files/projects/ PC00316_Platina_Factsheet_MUNNI_MUNNI_LR.pdf.

Platina Resources Ltd., 2013, 5000 m drill program planned for Owendale platinum \& scandium project: Varsity Lakes, Queensland, Australia, Platina Resources Ltd. news release, February 6, 5 p., accessed March 15, 2013, at http:/www.platinaresources.com.au/files/announcements/ 20130206__PGM_ASX_-_Owendale_Project_Update.pdf.

Platinum Australia Ltd., 2003, Annual report 2003: West Perth, Western Australia, Australia, Platinum Australia Ltd., 37 p., accessed September 9, 2004, at http://www.gtp.com.au/ platinumaus/inews_files/Final_Annual_Report03.pdf.

Platinum Australia Ltd., 2011, Annual report for the year ended 30 June 2011: West Perth, Western Australia, Australia, Platinum Australia Ltd., 79 p., accessed October 4, 2012, at http://www.gtp.com.au/platinumaus/ inews_files/ANNUAL\%20REPORT\%202011_130911.pdf. 
Platinum Australia Ltd., 2012, Quarterly report for the period ended 31 March 2012: West Perth, Western Australia, Australia, Platinum Australia Ltd., April 30, 12 p., accessed September 10, 2015, at http://www.gtp.com.au/platinumaus/ inews_files/QR\%2031\%20MARCH\%202012\%20(jdl2).pdf.

Platinum Today, 2008, The South Africa power situation: Johnson Matthey Plc, accessed February 15, 2013, at http:/www.platinum.matthey.com/media-room/our-viewon-.-.-./the-south-african-power-situation/.

Platinum Today, 2012, Price charts [1992 to 2012]: Royston, United Kingdom, Johnson Matthey Plc, accessed August 28, 2015, at http://www.platinum.matthey.com/ prices/price-charts.

Platinum Today, 2013a, Platinum today-Applications: Royston, United Kingdom, Johnson Matthey Plc, accessed January 31, 2013, at http://www.platinum.matthey.com/ applications/.

Platinum Today, 2013b, Platinum today_Jewellery: Royston, United Kingdom, Johnson Matthey Plc, accessed April 15, 2013, at www.platinum.matthey.com/about-pgm/ applications/jewellery.

Platinum Today, 2013c, Platinum today-Market data tables: Royston, United Kingdom, Johnson Matthey Plc, accessed February 20, 2013, at http://www.platinum.matthey.com/ publications/market-data-tables.

Platmin Ltd., 2011, Annual report for the year ended December 31, 2010: Platmin Ltd., 96 p., accessed October 5, 2012, at http:/www.platmin.com/content/ reports/platmin-annual-report-2010.pdf. [Company name changed to Sedibelo Platinum Mines Ltd. in 2013.]

Plunkert, P.A., and Jones, T.S., comps., 1999, Metal prices in the United States through 1998: U.S. Geological Survey, 179 p. [Also available at http://minerals.usgs.gov/minerals/ pubs/metal_prices/.]

Podmore, F., and Wilson, A.H., 1987, A reappraisal of the structure, geology and emplacement of the Great Dyke, Zimbabwe, in Halls, H.C., and Fahrig, W.F., eds., Mafic dyke swarms: Geological Association of Canada Special Paper, v. 34, p. 317-330, folded color map.

Postle, J.T., Roscoe, W.E., Watanabe, R.Y., and Martin, P.S., 1986, Review of platinum group element deposits in Ontario: Ministry of Northern Development and Mines, Mines and Minerals Division, Mineral Policy Background Paper no. 24, 87 p. [Also available at http:/www.geology ontario.mndmf.gov.on.ca/mndmfiles/pub/data/imaging/ MPBP024/MPBP024.pdf.]
Premo, W.R., Helz, R.T., Zientek, M.L., and Langston, R.B., 1990, U-Pb and Sm-Nd ages for the Stillwater Complex and its associated sills and dikes, Beartooth Mountains, Montana-Identification of a parent magma?: Geology, v. 18, no. 11, p. 1065-1068. [Also available at http://dx.doi.org/ 10.1130/0091-7613(1990)018<1065:UPASNA>2.3.CO;2.]

Prendergast, M.D., 2000, Layering and precious metals mineralization in the Rincón del Tigre Complex, eastern Bolivia: Economic Geology, v. 95, p. 113-130.

Prendergast, M.D., 2012, The Molopo Farms complex, southern Botswana-A reconsideration of structure, evolution, and the Bushveld connection: South African Journal of Geology, v. 115, no. 1, p. 77-90. [Also available at http://dx.doi.org/10.2113/gssajg.115.1.77.]

Prendergast, M.D., and Wilson, A.H., 1989, The Great Dyke of Zimbabwe-II-Mineralization and mineral deposits, in Prendergast, M.D., and Jones, M.J., eds., Magmatic sulphides_-The Zimbabwe volume: London, United Kingdom, Institution of Mining and Metallurgy, p. 21-42.

Prevec, S.A., 1997, Magmatic ore deposits of the Sudbury igneous complex, in Institute on Lake Superior GeologyProceedings of the 43rd annual meeting, Sudbury, Ontario, Canada, May 6-11, 1997: Sudbury, Ontario, Canada, Institute on Lake Superior Geology, v. 43, part 5, 33 p., accessed January 31, 2013, at http://www.d.umn.edu/ prc/lakesuperiorgeology/Volumes/ILSG_43_1997_pt5 Sudbury.CV.pdf.

Price, W.A., 2009, Prediction manual for drainage chemistry from sulphidic geologic materials: Ottawa, Ontario, Canada, CANMET Mining and Mineral Sciences Laboratories, Natural Resources Canada, MEND Report 1.20.1, 579 p. [Also available at http://www.fs.usda.gov/Internet/ FSE_DOCUMENTS/stelprdb5336546.pdf.]

Prichard, H.M., and Lord, R.A., 1993, An overview of the PGE concentrations in the Shetland ophiolite complex, in Prichard, H.M., Alabaster, T., Harris, N.B.W., and Neary, C.R., eds., Magmatic processes and plate tectonics: Geological Society of London Special Publications, v. 76, p. 273-294. [Also available at http://dx.doi.org/10.1144/ GSL.SP.1993.076.01.13.]

Proenza, J.A., Galí, S., Labrador, M., Tauler, E., Zaccarini, F., Garuti, G., Lewis, J.F., and Longo, F., 2010, Platinum group minerals in the saprolitic horizon of Falcondo Ni-laterite deposits, Dominican Republic, in Brown, G.H., Jugo, P.J., Lesher, C.M., and Mungall, J.E., eds., 2010, Abstracts, 11th International Platinum Symposium, June 21-24, 2010, Sudbury, Ontario, Canada: Ontario Geological Survey, Miscellaneous Release-Data 269, 4 p., accessed March 29, 2013, at http://www.geologyontario.mndmf.gov.on.ca/mndmfiles/pub/ data/imaging/mrd269/MRD269.pdf. 
Pure Nickel, Inc., 2013, Factsheet: Pure Nickel Inc., 2 p., accessed April 28, 2013, at http:/www.purenickel.com/ i/pdf/FactSheet.pdf.

Puritch, E.J., Hayden, A.S., Davie, M.J., Brady, Bruce, Ewert, Wayne, Tourangeau, Serge, and Boucher, Sylvain, 2006, Technical report and preliminary economic assessment on the Mequillon, Mesamax, Expo and Ivakkak deposits, Raglan South Nickel Project, Nunavik, QuebecNI 43-101 and NI 43-101F1 technical report and preliminary economic assessment, prepared for Canadian Royalties Inc. [Filing date April 2, 2007]: Brampton, Ontario, Canada, P\&E Mining Consultants Inc. and Roche Ltd., Consulting Group, P\&E Report no. 113, May 5, 2006 (revised as of July 24, 2006), 162 p. and 4 appendixes. [Also available at http://www.sedar.com.]

Pushkarev, E.V., 2001, [Earth sciences-Platinum of the Urals]: Soros Educational Journal, v. 7, no. 11, p. 86-93, accessed April 16, 2013, at http://uralgold.ru/wiki/library/ Platina-Urala.pdf. [In Russian.]

Pushkarev, Evgeny, and Anikina, Elena, 2002, Low temperature origin of the Ural-Alaskan type platinum depositsGeological, mineralogical and geochemical evidence: 9th International Platinum Symposium, International Geologic Correlation Program, July 21-25, Billings, Montana, IGCP Project 427, 4 p.

Raedeke, L.D., and McCallum, I.S., 1984, Investigations in the Stillwater Complex-Part II. Petrology and petrogenesis of the Ultramafic series: Journal of Petrology, v. 25, no. 2, p. 395-420. [Also available at http://dx.doi.org/10.1093/ petrology/25.2.395.]

Rasilainen, Kalevi, Eilu, Paso, Halkoaho, Tapio, Iljina, Markku, and Karinen, Tuomo, 2010, Quantitative mineral resource assessment of platinum, palladium, gold, nickel, and copper in undiscovered PGE deposits in mafic-ultramafic layered intrusions in Finland: Geological Survey of Finland, Report of Investigation 180, 338 p., accessed September 4, 2015, via http://hakku.gtk.fi/en/reports.

Rauch, Sebastien, and Fatoki, O.S., 2013, Anthropogenic platinum enrichment in the vicinity of mines in the Bushveld igneous complex, South Africa: Water Air \& Soil Pollution, v. 224, no. 1395, 8 p. [Also available at http://dx.doi.org/10.1007/s11270-012-1395-y.]

Ravindra, Khaiwal, Benes, László, and Van Grieken, René, 2004, Platinum group elements in the environment and their health risk: Science of the Total Environment, v. 318, nos. 1-3, p. 1-43. [Also available at http://dx.doi.org/ 10.1016/S0048-9697(03)00372-3.]
Realm Resources Ltd., 2011, Quarterly report to 30 June 2011: Sydney, New South Wales, Australia, Realm Resources Ltd. media release, 15 p., accessed July 26, 2012, at http://realmresources.com.au/IRM/Company/ ShowPage.aspx?CPID $=1174 \& E I D=45533987$.

Reese, R.G., Jr., 1996, Platinum-group metals: U.S. Geological Survey Mineral Commodity Summaries 1996, p. 124-125. [Also available at http://minerals.usgs.gov/minerals/pubs/ commodity/platinum/platimcs96.pdf.]

Reichow, M.K., Pringle, M.S., Al'Mukhamedov, A.I., Allen, M.B., Andreichev, V.L., Buslov, M.M., Davies, C.E., Fedoseev, G.S., Fitton, J.G., Inger, S., Medvedev, A.Ya., Mitchell, C., Puchkov, V.N., Safonova, I.Yu., Scott, R.A., and Saunders, A.D., 2009, The timing and extent of the eruption of the Siberian Traps large igneous provinceImplications for the end-Permian environmental crisis: Earth and Planetary Science Letters, v. 277, nos. 1-2, p. 9-20. [Also available at http://dx.doi.org/10.1016/ j.epsl.2008.09.030.]

Riese, W.C., and Arp, G.K., 1983, Biogeochemical prospecting in the Stillwater $(\mathrm{Pt})$ Complex, Montana, in Roberts, Sheila, ed., Metallic and nonmetallic deposits of Wyoming and adjacent areas, 1983 conference proceedings: The Geological Survey of Wyoming, Public Information Circular no. 25, p. 58-65.

Ripley, E.M., 1999, Systematics of sulphur and oxygen isotopes in mafic igneous rocks and related $\mathrm{Cu}-\mathrm{Ni}$-PGE mineralization, in Keays, R.R., Lesher, C.M., Lightfoot, P.C., and Farrow, C.E.G., eds., Dynamic processes in magmatic ore deposits and their application in mineral exploration: Geological Association of Canada Short Course Series, v. 13, p. $133-158$.

Rossell, Dean, and Coombes, Steven, 2005, The geology of the Eagle nickel-copper deposit, Michigan, USA, in Appendix $\mathrm{C}$ - Geologic and geotechnical reports for the Eagle Project, prepared for Kennecott Minerals Co., April 29, 34 p., accessed March 11, 2013, at http://www.lic.wisc.edu/glifwc/Kennecott/permitap2/ Mining/Vol1/Vol1A/Eagle Deposit.pdf.

Rouillard, Paul, 1997, Paths to plenty_-The roots of the economic boom in South Africa during the 1960s: Durban, South Africa, University of Natal, Durban, Bachelor of Arts honors thesis, 73 p., accessed February 19, 2013, at http:/www.history.ukzn.ac.za/files/theses/paul rouillard.pdf.

Rudnick, R.L., and Gao, S., 2003, Composition of the continental crust, in Rudnick, R.L., ed., The crust, v. 3 of Holland, H.D., and Turekian, K.K., eds., Treatise on geochemistry: Oxford, United Kingdom, ElsevierPergamon, p. 1-64. [Also available at http://dx.doi.org/ 10.1016/B0-08-043751-6/03016-4.] 
Russian Platinum, 2011a, Artel Starateley "Amur": Moscow, Russia, Russian Platinum Web page, accessed March 8, 2013, at http://www.russian-platinum.ru/ our_business/kondyor_mine_as_amur.

Russian Platinum, 2011b, Chernogorskaya mining company: Moscow, Russia, Russian Platinum Web page, accessed March 8, 2013, at http://www.russian-platinum.ru/ our_business/chernogoskoye_deposit.

Sargeant, Fiona, 2001, The seismic stratigraphy of the Bushveld igneous complex, South Africa: Liverpool, England, University of Liverpool, Ph.D. dissertation, $425 \mathrm{p}$.

Sawkins, F.J., 1984, Metal deposits in relation to plate tectonics: Berlin, Germany, Springer-Verlag, 325 p.

Schissel, Don, Tsvetkov, A.A., Mitrofanov, F.P., and Korchagin, A.U., 2002, Basal platinum-group element mineralization in the Federov Pansky layered mafic intrusion, Kola Peninsula, Russia: Economic Geology, v. 97, p. 1657-1677. [Also available at http://dx.doi.org/10.2113/ gsecongeo.97.8.1657.]

Schmidt, J.M., and Rogers, R.K., 2007, Metallogeny of the Nikolai large igneous province (LIP) in southern Alaska and its influence on the mineral potential of the Talkeetna Mountains, in Ridgway, K.D., Trop, J.M., Glen, J.M.G., and O'Neill, J.M., eds., Tectonic growth of a collisional continental margin - Crustal evolution of southern Alaska: Geological Society of America Special Paper 431, p. 623-648. [Also available at http://dx.doi.org/10.1130/ 2007.2431(24).]

Schmidt, J.M., Light, T.D., Drew, L.J., Wilson, F.H., Miller, M.L., and Saltus, R.W., 2007, Undiscovered locatable mineral resources in the Bay Resource Management Plan Area, Alaska-A probabilistic assessment: U.S. Geological Survey Scientific Investigations Report 2007-5039, 50 p.

Schobbenhaus, Carlos, Gonçalves, J.H., Santos, J.O.S., Abram, M.B., Neto, R.L., Muniz de Matos, G.M., Vidotti, R.M., Ramos, M.A.B., and Alves de Jesus, J.D., 2004, Carta geológica do Brasil ao milionésimo-Systema de informações geográficas-SIG (edição 2004) [Geological map of Brazil, 1:1,000,000 scale, geographical information system - GIS (2004 edition)]: Brasília, Brazil, Companhia de Pesquisa de Recursos Mineirais, Serviço Geológico do Brasil, scale 1:1,000,000, CD-ROM. [Set of 41 CD-ROM disks, in Portuguese.]

Scoates, J.S., and Friedman, R.M., 2008, Precise age of the platiniferous Merensky Reef, Bushveld Complex, South Africa, by the U-Pb zircon chemical abrasion ID-TIMS technique: Economic Geology, v. 103, p. 465-471. [Also available at http://dx.doi.org/10.2113/gsecongeo.103.3.465.]
Scott, D.A., and Bray, Warwick, 1980, Ancient platinum technology in South America-Its use by the Indians in pre-Hispanic times: Platinum Metals Review, v. 24, no. 4, p. $147-157$.

Secher, K., Appel, P., and Nielsen, T.F.D., 2007, The PGE potential in Greenland: Geological Survey of Denmark and Greenland, Geology and Ore Bulletin, no. 8, February, 12 p. [Also available at http://extra.geus.info/geology_and_ore/ GO08_torsten.pdf.]

Segerstrom, Kenneth, and Carlson, R.R., 1982, Geologic map of the Banded upper zone of the Stillwater Complex and adjacent rocks, Stillwater, Sweet Grass, and Park Counties, Montana: U.S. Geological Survey Miscellaneous Investigation Series, Map I-1383, two sheets, scale 1:24,000. [Also available at http://pubs.er.usgs.gov/publication/i1383.]

Sharpe, M.R., 1981, The chronology of magma influxes to the eastern compartment of the Bushveld Complex as exemplified by its marginal border groups: Journal of the Geological Society of London, v. 138, no. 3, p. 307-326. [Also available at http://dx.doi.org/10.1144/ gsjgs.138.3.0307.]

Sharpe, M.R., and Hulbert, L.J., 1985, Ultramafic sills beneath the eastern Bushveld Complex-Mobilized suspensions of early lower zone cumulates in a parental magma with boninitic affinities: Economic Geology, v. 80, p. 849-871. [Also available at http://dx.doi.org/10.2113/ gsecongeo.80.4.849.]

Shcheka, G.G., Lehmann, Bernd, Gierth, Eike, Gömann, Karsten, and Wallianos, Alex, 2004, Macrocrystals of Pt-Fe alloy from the Kondyor PGE placer deposit, Khabarovskiy Kray, Russia-Trace element content, mineral inclusions and reaction assemblages: The Canadian Mineralogist, v. 42, no. 2, p. 601-617. [Also available at http://dx.doi.org/10.2113/gscanmin.42.2.601.]

Sherman, M.L., Malich, N.S., Mkrtichyan, A.K., and Strunin, B.M., eds., 1991, Geological map of the Norilsk ore district: Committee of Russian Federation on Geology and Use of Mineral Resources, State Geological Enterprise "Krasnoyarskgeologia" Geological Surveying Expedition, 1 map on 8 sheets, scale 1:200,000.

Shive, P.N., Houston, R.S., and Blakely, R.J., 1990, Modeling of aeromagnetic data from the Precambrian Lake Owens mafic complex, Wyoming: Geological Society of America Bulletin, v. 102, no. 9, p. 1317-1322. [Also available at http://dx.doi.org/10.1130/00167606(1990)102<1317:MOADFT>2.3.CO;2.]

Shmelev, V.R., and Filippova, S.S., 2010, Structure and formation mechanism of the Nizhny Tagil dunite-clinopyroxenite massif, central Urals: Geotectonics, v. 44, no. 4, p. 344-362. [Also available at http://dx.doi.org/10.1134/ S0016852110040047.] 
Singer, D.A., 1995, World-class base and precious metal deposits-A quantitative analysis: Economic Geology, v. 90, p. 88-104. [Also available at http://dx.doi.org/ 10.2113/gsecongeo.90.1.88.]

Singer, D.A., and DeYoung, J.H., Jr., 1980, What can grade tonnage relations really tell us?, in Guillemin, Claude, and Lagny, Phillipe, eds., Resources minérales-Mineral resources [in French and English]: Orléans, France, Mémoires Bureau de Recherches Géologique et Minières, no. 106 , p. 91-101.

Singer, D.A., Berger, V.I., and Moring, B.C., 2008, Porphyry copper deposits of the world-Database and grade and tonnage models, 2008 (version 1.0): U.S. Geological Survey Open-File Report 2008-1155, 45 p., accessed April 27, 2013, at http://pubs.usgs.gov/of/2008/1155/.

Song, Xie-Yan, Zhou, Mei-Fu, and Cao, Zhi-Min, 2004, Genetic relationships between base-metal sulfides and platinum-group minerals in the Yangliuping $\mathrm{Ni}-\mathrm{Cu}-(\mathrm{PGE})$ sulfide deposit, southwestern China: Canadian Mineralogist, v. 42, no. 2, April, p.469-483. [Also available at http://dx.doi.org/10.2113/gscanmin.42.2.469.]

Song, Xie-Yan, Zhou, Mei-Fu, Cao, Zhi-Min, Sun, Min, and Wang, Yun-Liang, 2003, Ni-Cu-(PGE) magmatic sulfide deposits in the Yangliuping area, Permian Emeishan igneous province, SW China: Mineralium Deposita, v. 38, p. 831-843. [Also available at http://dx.doi.org/10.1007/ s00126-003-0362-3.]

Sotnikov, V.I., Berzina, A.N., Economou-Eliopoulos, Maria, and Eliopoulos, D.G., 2001, Palladium, platinum and gold distribution in porphyry $\mathrm{Cu} \pm$ Mo deposits of Russia and Mongolia: Ore Geology Reviews, v. 18, nos. 1-2, p. 95-111. [Also available at http://dx.doi.org/10.1016/ S0169-1368(01)00018-X.]

Southworth, D.D., and Foley, J.Y., 1986, Lode platinum-group metals potential of the Goodnews Bay ultramafic complex, Alaska: U.S. Bureau of Mines Open-File Report 51-86, 82 p.

Spaggiari, C.V., Bodorkos, S., Barquero-Molina, M., Tyler, I.M., and Wingate, M.T.D., 2009, Interpreted bedrock geology of the south Yilgarn and central Albany-Fraser orogen, Western Australia: Geological Survey of Western Australia, Record, 2009/10, 84 p.

Stevens, H.J., 1905, The copper handbook-A manual of the copper industry of the world, vol. V, for the year 1904: Houghton, Mich., Horace J. Stevens, 882 p.

Storey, Michael, Duncan, R.A., and Tegner, Christian, 2007, Timing and duration of volcanism in the North Atlantic igneous province-Implications for geodynamics and links to the Iceland hotspot: Chemical Geology, v. 241, nos. 3-4, p. 264-281. [Also available at http://dx.doi.org/ 10.1016/j.chemgeo.2007.01.016.]
Suter, G.W., II, 1996, Toxicological benchmarks for screening contaminants of potential concern for effects on freshwater biota: Environmental Toxicology and Chemistry, v. 15 , no. 7, p. 1232-1241. [Also available at http://dx.doi.org/10.1002/etc.5620150731.]

Sutphin, D.M., and Page, N.J, 1986, International strategic minerals inventory summary report-Platinum-group metals: U.S. Geological Survey Circular 930-E, 34 p.

Szentpéteri, Krisztián, Watkinson, D.H., Molnar, Ferenc, and Jones, P.C., 2002, Platinum-group elements-Co-Ni-Fe sulfarsenides and mineral paragenesis in $\mathrm{Cu}-\mathrm{Ni}$-platinumgroup element deposits, Copper Cliff North area, Sudbury, Canada: Economic Geology, v. 97, p. 1459-1470. [Also available at $\mathrm{http} / / / \mathrm{dx}$.doi.org/10.2113/gsecongeo.97.7.1459.]

Talvivaara Mining Company plc, 2013, Operations-Mineral resources: Espoo, Finland, Talvivaara Mining Company plc, accessed April 8, 2013, at http://www.talvivaara.com/ operations/Mineral_resources.

Tarkian, M., and Koopmann, G., 1995, Platinum-group minerals in the Santo Tomas II (Philex) porphyry coppergold deposit, Luzon Island, Philippines: Mineralium Deposita, v. 30, no. 1, p. 39-47. [Also available at http://dx.doi.org/10.1007/BF00208875.]

Taylor, S.R., and McLennan, S.M., 1995, The geochemical evolution of the continental crust: Reviews of Geophysics, v. 33, no. 2, p. 241-265. [Also available at http://dx.doi.org/ 10.1029/95RG00262.]

Teluk, A.J., 2001, Fifield platinum project, NSW, AustraliaPlatinum metallogenesis, Ural-Alaskan type complexesTechnical report prepared for Rimfire Pacific Mining NL: Sydney, New South Wales, Australia, Geodyne Pty Ltd., November, 71 p., accessed March 28, 2013, at http://www.rimfire.com.au/PDF/Geodyne $\% 20$ report $\% 20$ complete $\% 20$ with $\% 20$ figs.pdf.

Tiax LLC, 2003, Platinum availability and economics for PEMFC commercialization-Report prepared for the U.S. Department of Energy: Cambridge, Mass., Tiax LLC, December, 101 p., accessed July 27, 2005, at http://www.eere.energy.gov/hydrogenandfuelcells/pdfs/ tiax_platinum.pdf.

Tolstykh, N.D., Foley, J.Y., Sidorov, E.G., and Laajoki, K.V.O., 2002, Composition of the platinum-group minerals in the Salmon River placer deposit, Goodnews Bay, Alaska: Canadian Mineralogist, v. 40, no. 2, p. 463-471. [Also available at http://dx.doi.org/10.2113/gscanmin.40.2.463.]

Tolstykh, N.D., Sidorov, E.G., and Kozlov, A.P., 2004, Platinum-group minerals in lode and placer deposits associated with the Ural-Alaskan-type Gal'moenan Complex, Koryak-Kamchatka platinum belt, Russia: Canadian Mineralogist, v. 42, no. 2, p. 619-630. [Also available at http://dx.doi.org/10.2113/gscanmin.42.2.619.] 
Traoré, Daouda, Beauvais, Anicet, Augé, Thierry, Parisot, J.C., Colin, Fabrice, and Cathelineau, Michel, 2008, Chemical and physical transfers in an ultramafic rock weathering profile-Part 2-Dissolution vs. accumulation of platinum group minerals: American Mineralogist, v. 93, no. 1, p. 31-38. [Also available at http://dx.doi.org/10.2138/am.2008.2606.]

U.S. Bureau of Mines, 1933-34, Mineral resources of the United States 1930-31: U.S. Bureau of Mines, variously paginated. [Also available via http://minerals.usgs.gov/ minerals/pubs/commodity/.]

U.S. Bureau of Mines, 1933-96, Minerals yearbook 1932-94: U.S. Bureau of Mines, variously paginated. [Also available via http://minerals.usgs.gov/minerals/ pubs/commodity/.]

U.S. Bureau of Mines and U.S. Geological Survey, 1947, Appendix - Mineral position of the United States, in Hearings before a subcommittee of the Committee on Public Lands, U.S. Senate, Eightieth Congress-First session on investigation of the factors affecting minerals, fuels, forestry, and reclamation projects-May 15, 16, and 20, 1947: Washington, D.C., U.S. Government Printing Office, p. 165-310.

U.S. Bureau of Mines and U.S. Geological Survey, 1980, Principles of a resource/reserve classification for minerals: U.S. Geological Survey Circular 831, 5 p. [Also available at http://pubs.usgs.gov/circ/1980/0831/report.pdf.]

U.S. Bureau of Mines, 1991, Mineral investigations on the Juneau Mining District, Alaska, 1984-1988: U.S. Bureau of Mines Special Publication, v. 1, Executive Summary, 49 p.

U.S. Congress, Office of Technology Assessment, 1985, Strategic materials-Technologies to reduce U.S. import vulnerability: Washington, D.C., U.S. Congress, Office of Technology Assessment, OTA-ITE-248, 409 p., accessed February 25, 2013, at http://www.princeton.edu/ ota/ disk2/1985/8525/852501.PDF.

U.S. Department of State, 2009, Small-scale digital international land boundaries (SSIB) — Lines, (10th ed.): Washginton, D.C., U.S. Department of State Boundaries and Sovereignty Encyclopedia.

U.S. Environmental Protection Agency, 2009, National recommended water quality criteria: U.S. Environmental Protection Agency Web page, accessed March 26, 2013, at http://www.epa.gov/waterscience/criteria/wqcriteria.html.

U.S. Geological Survey, 1996, Global 30 arc-second elevation (GTOPO30): Reston, Va., U.S. Geological Survey dataset (digital elevation model), accessed June 23, 2014, at https://ta.cr.usgs.gov/GTOPO30.

U.S. Geological Survey, 1997-2016, Minerals yearbook 1995-2012: U.S. Geological Survey, variously paged. [Also available at http://minerals.usgs.gov/minerals/pubs/ myb.html.]
U.S. Geological Survey National Mineral Resource Assessment Team, 2000, 1998 assessment of undiscovered deposits of gold, silver, copper, lead, and zinc in the United States: U.S. Geological Survey Circular 1178, 21 p. [A Portable Document (PDF) recompilation of USGS Open-File Report 96-96 and Circular 1178 was prepared by Paul Schruben and released as U.S. Geological Survey OpenFile Report 02-198 in 2002.] [Also available at http://pubs.usgs.gov/circ/c1178/c1178.pdf.]

United Nations Conference on Trade and Development Secretariat, 1995, Minerals and fuel price risks in southern Africa, and possibilities for risk management: United Nations Conference on Trade and Development, GE.95-53540, 47 p., accessed February 15, 2013, at http://unctad.org/en/Docs/pocomd69.en.pdf.

United Nations Conference on Trade and Development, [undated], Platinum-Economic policies: United Nations Conference on Trade and Development, accessed February 15, 2013, at http://r0.unctad.org/infocomm/ anglais/platinum/ecopolicies.htm.

Vale S.A., 2012, Form 20-F-2011: U.S. Securities and Exchange Commission, 231 p., accessed October 29, 2015, at http://www.sec.gov/Archives/edgar/data/917851/ 000104746911004222/a2202934z20-f.htm.

van der Merwe, M.J., 1976, The layered sequence of the Potgietersrus limb of the Bushveld Complex: Economic Geology, v. 71, p. 1327-1351. [Also available at http://dx.doi.org/10.2113/gsecongeo.71.7.1337.]

Vaughan, D.J., and Craig, J.R., 1978, Mineral chemistry of metal sulfides: Cambridge, United Kingdom, Cambridge University Press, 493 p.

Venter, A.D., Vakkari, Ville, Beukes, J.P., van Zyl, P.G., Laakso, Heikki, Mabaso, Desmond, Tiitta, Petri, Josipovic, Miroslav, Kulmala, Markku, Pienaar, J.J., and Laakso, Lauri, 2012, An air quality assessment in the industrialised western Bushveld igneous complex, South Africa: South African Journal of Science, v. 108, no. 9/10, 10 p. [Also available at http://dx.doi.org/10.4102/ sajs.v108i9/10.1059.]

Verbeek, Julian, and Lomberg, Ken, 2005, Rooipoort PGE, Mokopane, Limpopo Province, South Africa-Qualified persons report, prepared for Caledonia Mining Corp.: Perth, Western Australia, Australia, RSG Global Pty. Ltd., December, 56 p. plus 5 appendixes, accessed September 21, 2011, at http://www.caledoniamining.com/ pdfs/CALPres051221.pdf.

Vermaak, C.F., and von Gruenewaldt, G., 1986, Introduction to the Bushveld Complex, in Anhaeusser, C.R., and Maske, S., eds., Mineral deposits of southern Africa, v. 2: Johannesburg, South Africa, Geological Society of South Africa, p. 1021-1029. 
Viljoen, M.J., 1999, The nature and origin of the Merensky Reef of the western Bushveld Complex based on geological facies and geophysical data: South African Journal of Geology, v. 102, no. 3, p. 221-239.

Vogeli, J., Reid, D.L., Becker, M., Broadhurst, J., and Franzidis, J.-P., 2011, Investigation of the potential for mineral carbonation of PGM tailings in South Africa: Minerals Engineering, v. 24, no. 12, p. 1348-1356. [Also available at http://dx.doi.org/10.1016/j.mineng.2011.07.005.]

von Gruenewaldt, G., Behr, S.H., and Wilhelm, H.J., 1989, Some preliminary petrological investigations of the Molopo Farms Complex, Botswana, and its Ni-Cu sulphide mineralization, in Prendergast. M.D., and Jones M.J., eds., Magmatic sulphides-The Zimbabwe volume: London, United Kingdom, Institution of Mining and Metallurgy, p. $95-105$.

von Gruenewaldt, Gerhard, 1977, The mineral resources of the Bushveld Complex: Minerals Science and Engineering, v. 9 , no. 2, p. 83-95.

Wagner, P.A., 1929, The platinum deposits and mines of South Africa: London, United Kingdom, Oliver and Boyd, 326 p., 38 pls., 2 fold. profiles.

Wahl, J.J., Theron, P.D., and Maboeta, M.S., 2012, Soil mesofauna as bioindicators to assess environmental disturbance at a platinum mine in South Africa: Ecotoxicology and Environmental Safety, v. 86, no. 1, p. 250-260. [Also available at http://dx.doi.org/10.1016/j.ecoenv.2012.09.027.]

Walker, A.S.D., Key, R.M., Pouliquen, G., Gunn, G., Sharrock, J., McGeorge, I., Koketso, M., and Farr, J., 2010, Geophysical modelling of the Molopo Farms Complex in southern Botswana-Implications for its emplacement within the $\sim 2 \mathrm{Ga}$ large igneous provinces of southern and central Africa: South African Journal of Geology, v. 113, no. 4, p. 381-400. [Also available at http://dx.doi.org/10.2113/ gssajg.113.4.381.]

Walraven, F., 1986, A note on the stratigraphic terminology of the Bushveld Complex, in Anhaeusser, C.R., and Maske, S., eds., Mineral deposits of southern Africa, v. 2: Johannesburg, Geological Society of South Africa, p. 1039-1040.

Wasson, J.T., Xinwei, Ouyang, Wang, Jianmin, and Jerde, Eric, 1989, Chemical classification of iron meteorites-XI-Multi-element studies of 38 new irons and the high abundance of ungrouped irons from Antarctica: Geochimica et Cosmochimica Acta, v. 53, no. 3, p. 735-744. [Also available at http://dx.doi.org/10.1016/0016-7037(89)90016-1.]
Weatherstone, Niall, 2008, International standards for reporting of mineral resources and reserves-Status, outlook, and important issues: World Mining Congress \& Expo 2008, Krakow, Poland, September 9-12, 2008, presentation, 10 p., accessed December 26, 2011, at http://www.crirsco.com/ isr_mineral_resources_reserves0908.pdf.

Webb, S.J., Cawthorn, R.G., Nguuri, Teresia, and James, David, 2004, Gravity modeling of Bushveld Complex connectivity supported by southern Africa seismic experiment results: South African Journal of Geology, v. 107, nos. 1-2, p. 207-218. [Also available at http://dx.doi.org/10.2113/107.1-2.207.]

Western Mining Corp., 2005, Form 6-K-Report of foreign issuer-WMC Resources Ltd. [filing date January 7, 2005]: Securities and Exchange Commission, accessed September 21, 2015, at http://www.sec.gov/Archives/ edgar/data/1208222/000119312505002708/d6k.htm.

Wilburn, D.R., 2012, Global exploration and production capacity for platinum-group metals from 1995 through 2015: U.S. Geological Survey Scientific Investigations Report 2012-5164, 26 p. [Also available at http://pubs.usgs.gov/sir/2012/5164/.]

Wilburn, D.R., and Bleiwas, D.I., 2004, Platinum-group metals-World supply and demand: U.S. Geological Survey Open-File Report 2004-1224, 152 p. [Also available at http://pubs.usgs.gov/of/2004/1224/2004-1224.pdf.]

Wilde, Andy, 2005, Descriptive ore deposit models - Hydrothermal \& supergene Pt \& Pd deposits, in Mungall, J.E., ed., Exploration for platinum-group element deposits: Mineralogical Association of Canada Short Course Series, v. 35, p. 145-161.

Wilde, Andy, Edwards, Alaster, and Yakubchuk, Alexander, 2003, Unconventional deposits of Pt and Pd-A review with implications for exploration: SEG Newsletter, no. 52, p. $1,10-18$.

Wilhelm, H.J., Zhang, H., Chen, F.L., Elsenbroek, J.H., Lombard, M., and de Bruin, D., 1997, Geochemical exploration for platinum-group elements in the Bushveld Complex, South Africa: Mineralium Deposita, v. 32, no. 4, p. 349-361. [Also available at http://dx.doi.org/10.1007/ s001260050101.]

Wilson, A.H., 1996, The Great Dyke of Zimbabwe, in Cawthorn, R.G., ed., Layered intrusions: Amsterdam, Netherlands, Elsevier Science B.V., v. 15, p. 365-402. [Also available at http://dx.doi.org/10.1016/S01672894(96)80013-3.]

Wilson, A.H., and Prendergast, M.D., 1989, The Great Dyke of Zimbabwe - Guidebook for the pre-conference symposium excursion, 8th International Platinum Symposium: Harare, Zimbabwe, Geological Society of Zimbabwe, 46 p. 
Wilson, A.H., and Prendergast, M.D., 2001, Platinum-group element mineralisation in the Great Dyke, Zimbabwe, and its relationship to magma evolution and magma chamber structure: South African Journal of Geology, v. 104, no. 4, p. 319-342. [Also available at http://dx.doi.org/10.2113/ 104.4.319.]

Wilson, A.H., and Tredoux, M., 1990, Lateral and vertical distribution of platinum-group elements and petrogenetic controls on the sulfide mineralization in the P1 pyroxenite layer of the Darwendale subchamber of the Great Dyke, Zimbabwe: Economic Geology, v. 85, p. 556-584. [Also available at http://dx.doi.org/10.2113/gsecongeo.85.3.556.]

Wilson, Allan, and Chunnett, Gordon, 2006, Trace element and platinum group element distributions and the genesis of the Merensky Reef, Western Bushveld Complex, South Africa: Journal of Petrology, v. 47, no. 12, p. 2369-2403. [Also available at http://dx.doi.org/10.1093/petrology/eg1048.]

Wiseman, C.L.S., and Zereini, F., 2009, Airborne particulate matter, platinum group elements and human health-A review of recent evidence: Science of the Total Environment, v. 407, no. 8, p. 2493-2500. [Also available at http://dx.doi.org/ 10.1016/j.scitotenv.2008.12.057.]

Wood, S.A., 1991, Experimental determination of the hydrolysis constants of $\mathrm{Pt}^{2+}$ and $\mathrm{Pd}^{2+}$ at $25^{\circ} \mathrm{C}$ from the solubility of $\mathrm{Pt}$ and $\mathrm{Pd}$ in aqueous hydroxide solutions: Geochimica et Cosmochimica Acta, v. 55, no. 7, p. 1759-1767. [Also available at http://dx.doi.org/ 10.1016/0016-7037(91)90021-V.

Wood, S.A., 2002, The aqueous geochemistry of the platinumgroup elements with applications to ore deposits, in Cabri, L.J., ed., Geology, geochemistry, mineralogy and mineral beneficiation of platinum-group elements: Montreal, Quebec, Canada, Canadian Institute of Mining. Metallurgy and Petroleum Special Volume 54, p. 211-249.

Wood, S.A., Mountain B.W., and Pan, Pujing, 1992, The aqueous geochemistry of platinum, palladium and goldRecent experimental constraints and a re-evaluation of theoretical predictions: The Canadian Mineralogist, v. 30, no. 4, p. $955-982$.

World Health Organization, 2008, Guidelines for drinkingwater quality-Volume 1 -Recommendations ( $3 \mathrm{~d}$ ed., incorporating first and second addenda): Geneva,

Switzerland, World Health Organization, 668 p., accessed April 4, 2014, at http://www.who.int/water_sanitation_health/ dwq/gdwq3rev/en/index.html.

Worst, B.G., 1957, Geological map of the Great Dyke of southern Rhodesia: Southern Rhodesia Geological Survey, maps to accompany Geological Survey Bulletin No. 47, 1 map on 9 sheets, scale 1:100,000.
Xstrata plc, 2007, Xstrata Nickel-Update on Kabanga JV, Tanzania: Xstrata plc news release, February 15, 3 p., accessed March 11, 2013, at http://www.xstrata.com/ media/news/2007/02/15/0700CET/.

Xue, Ting, Sun, Xiaoming, He, Gaowen, Wang, Shengwei, Lu, Hongfeng, and Zhang, Mei, 2005, Geochemistry of $\mathrm{PGE}$ and $\mathrm{Au}$ in ferromanganese crusts from seamounts in the west Pacific Ocean, in Jingwen, Mao, and Bierlein, F.P., eds., Mineral deposit research-Meeting the global challenge-Proceedings of the eighth biennial SGA meeting, Beijing, China, August 18-21, 2005: Berlin, Germany, Springer-Verlag, p. 207-209.

Yager, T.R., Soto-Viruet, Yadira, and Barry, J.J., 2012, Recent strikes in South Africa's platinum-group metal mines -Effects upon world platinum-group metal supplies: U.S. Geological Survey Open-File Report 2012-1273, 18 p. [Also available at http://pubs.usgs.gov/of/2012/1273.]

Yao, Y., Viljoen, M.J., Viljoen, R.P., Wilson, A.H., Zhong, H., Liu., B.G., Ying, H.L., Tu, G.Z., and Luo, Y.N., 2001, Geological characteristics of PGE-bearing layered intrusions in southwest Sichuan Province, China: Johannesburg, South Africa, University of the Witwatersrand Information Circular no. 358, December, 17 p., accessed October 6, 2016, at https://www.wits.ac.za/media/ migration/files/358.pdf.

Yonglin, $\mathrm{Li}, 2005$, Prospects and opportunities for the development of Chinese nickel and cobalt industry: Jinchuan Group Co., Ltd. presentation, 30 p., accessed October 6, 2016, at http://web.archive.org/web/20110525012358/http:// www.jnmc.com/publication/meeting/zgngfzqjhjy.pdf.

Yumul, G.P., Jr., 2001, The Acoje block platiniferous dunite horizon, Zambales ophiolite complex, PhilippinesMelt type and associated geochemical controls: Resource Geology, v. 51, no. 2, p. 165-174. [Also available at http://dx.doi.org/10.1111/j.1751-3928.2001.tb00089.x.]

Zarubezhtsvetmet Austrasia Pty Ltd., 2009, Lukkulaisvaara platinum group metal field-Expert conclusion and recommendations: Zarubezhtsvetmet Austrasia Pty Ltd., 32 p., accessed March 20, 2013, at http://www.norit-platinum.ru/ Investors/Report_Pt_v\%203.doc.

Zientek, M.L., 1993, Mineral resource appraisal for locatable minerals-The Stillwater Complex, chap F of Hammarstrom, J.M., Zientek, M.L., and Elliott, J.E., eds., Mineral resource assessment of the Absaroka-Beartooth study area, Custer and Gallatin National Forests, Montana: U.S. Geological Survey Open-File Report 93-207, p. F1-F83. [Also available at http://pubs.usgs.gov/ of/1993/0207/report.pdf.] 
Zientek, M.L., Causey, J.D., Parks, H.L., and Miller, R.J., 2014, Platinum-group elements in southern Africa-Mineral inventory and an assessment of undiscovered mineral resources: U.S. Geological Survey Scientific Investigations Report 2010-5090-Q, 126 p. plus GIS data. [Also available at http://dx.doi.org/10.3133/sir20105090Q.]

Zientek, M.L., Cooper, R.W., Corson, S.R., and Geraghty, E.P., 2002, Platinum-group element mineralization in the Stillwater Complex, Montana, in Cabri, L.J., ed., The geology, geochemistry, mineralogy and mineral beneficiation of platinum-group elements: Montreal, Quebec, Canada, Canadian Institute of Mining, Metallurgy, and Petroleum Special Volume 54, p. 459-481.

Zientek, M.L., Corson, S.R., and West, R.D., 2005, Geochemical surveys of soil and talus fines and the discovery of the J-M Reef, Stillwater Complex, Montana, in Mungall, J.E., ed., Exploration for platinum-group element deposits: Mineralogical Association of Canada Short Course Series v. 35, p. 391-407.
Zientek, M.L., Likhachev, A.P., Kunilov, V.E., Barnes, S.-J., Meier, A.L., Carlson, R.R., Briggs, P.H., Fries, T.L., and Adrian, B.M., 1994, Cumulus processes and the composition of magmatic ore deposits - Examples from the Talnakh District, Russia, in Lightfoot, P.C., and Naldrett, A.J., eds., Proceedings of the Sudbury-Noril'sk symposium: Sudbury Ontario, Canada, Ontario Geological Survey Special Volume 5, p. 373-392.

Zonenshain, L.P., Mezhelovsky, N.V., and Natapov, L.M., eds., 1988, Geodynamic map of the USSR and adjacent seas: Ministry of Geology of the USSR, Industrial Geological Objedinenie for Regional Studies of the USSR Territory (AEROGEOLOGIA), 1 map on 17 sheets, scale 1:2,500,000. [In Russian with English title.] 



\section{Tables N2, N5, N6, and N8-N10}




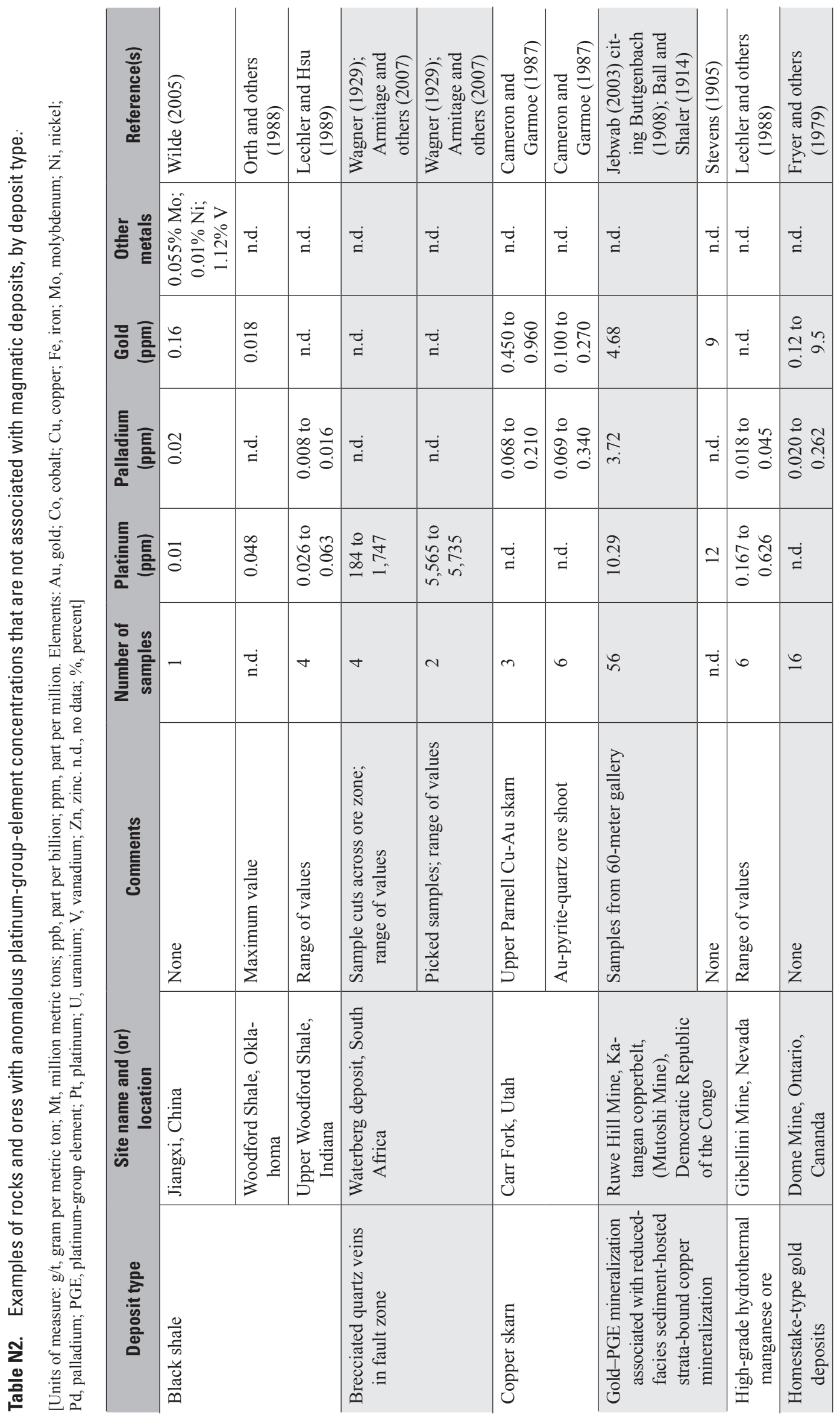




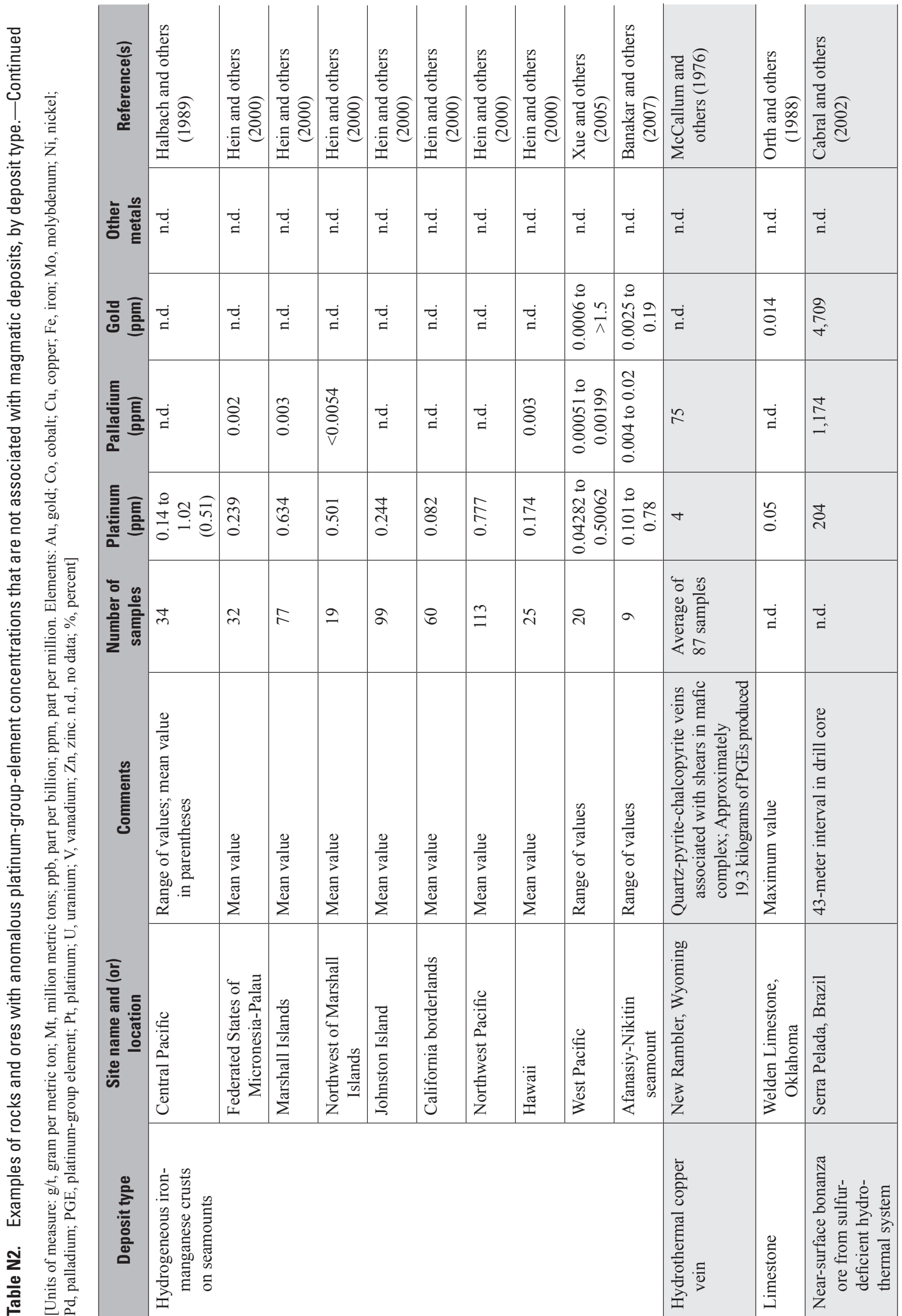



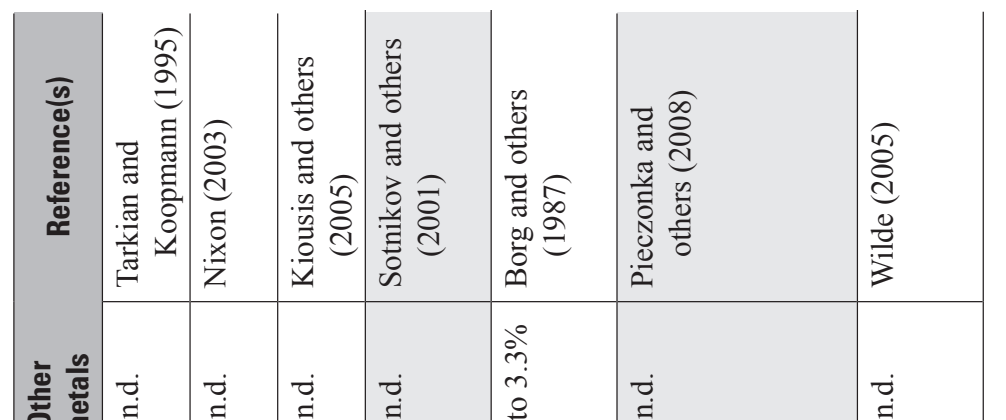

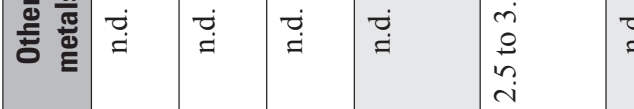

\begin{tabular}{|c|c|c|c|c|c|c|}
\hline 등 言 $\stackrel{\infty}{-}$ & 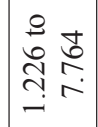 & ت্] & $\begin{array}{ll}\frac{0}{2} & \overline{0} \\
\frac{1}{0} & 0 \\
0 & 0 \\
0 & 0\end{array}$ & $\begin{array}{ll}0 & 0 \\
0 & 0 \\
0 & 0 \\
0 & 0 \\
0 & 0\end{array}$ & 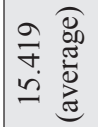 & $\begin{array}{l}0 \\
\qquad \\
\infty \\
\infty \\
\infty\end{array}$ \\
\hline
\end{tabular}

\begin{tabular}{|c|c|c|c|c|c|c|}
\hline 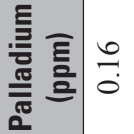 & 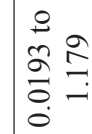 & ô & $\begin{array}{l}\stackrel{0}{0} \\
\stackrel{m}{0} \\
0 \\
0 \\
0\end{array}$ & $\begin{array}{ll}0 & \infty \\
0 & 8 \\
0 & 0\end{array}$ & 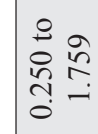 & ठै \\
\hline
\end{tabular}

\begin{tabular}{|c|c|c|c|c|c|}
\hline 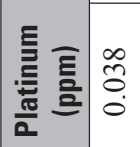 & 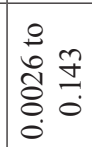 & $\frac{0}{0}$ & 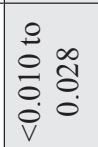 & 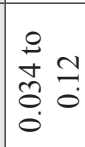 & $\begin{array}{ll}0 & \\
0 & \frac{1}{0} \\
\frac{0}{0} & 0\end{array}$ \\
\hline
\end{tabular}

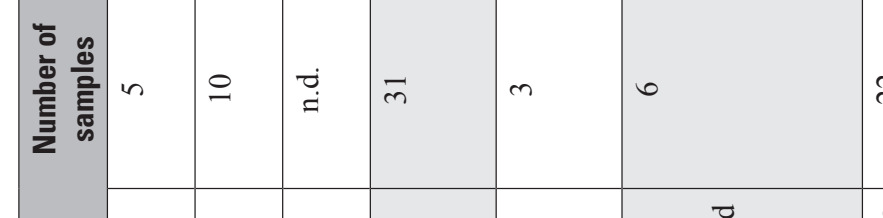

產

E्ञ

हี่ํ.:

离

镸

ही.

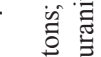

D

䙵 竞

言寻

雍

立

范

总

는

o

穿

$y$

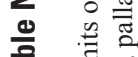

चै

|

चే

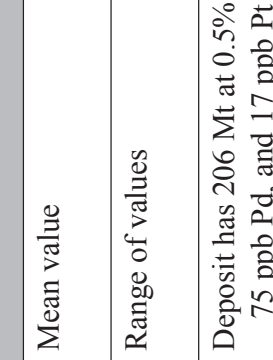

年

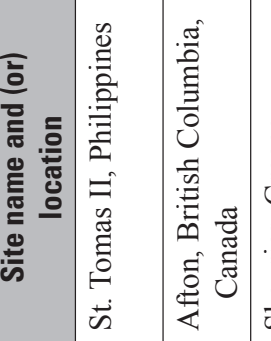

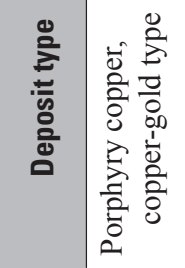
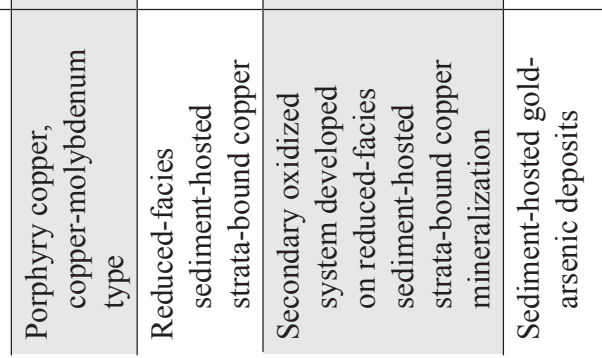

$\ddot{0}$

ส

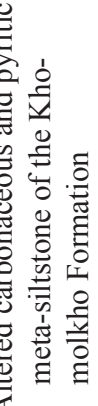

$\simeq$

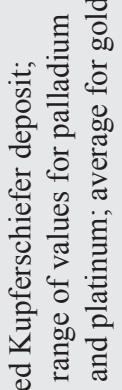

$\gtrless$

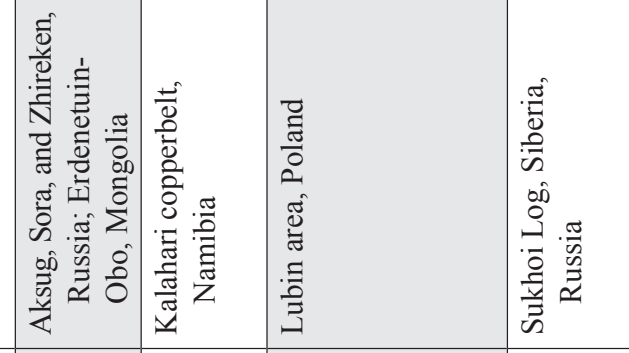




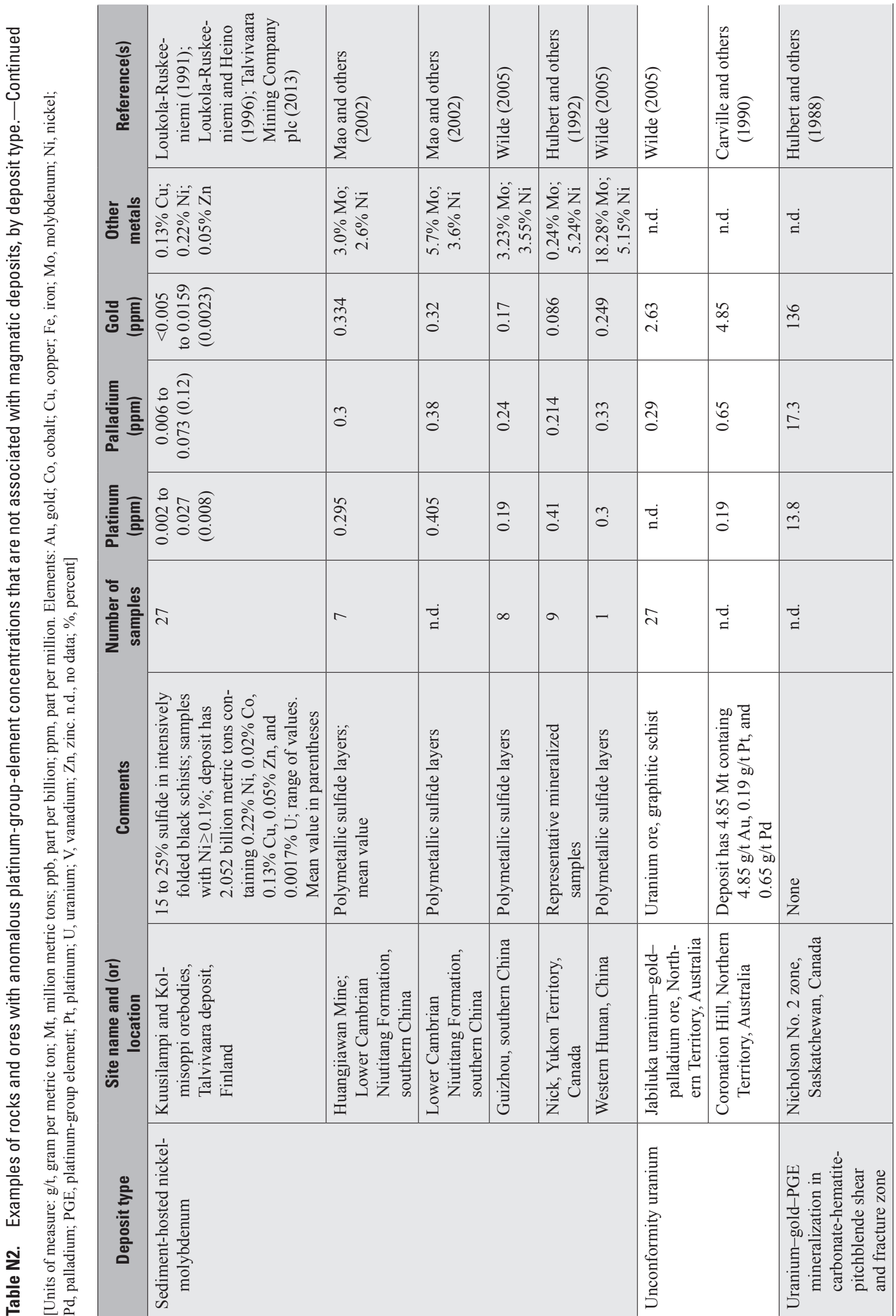




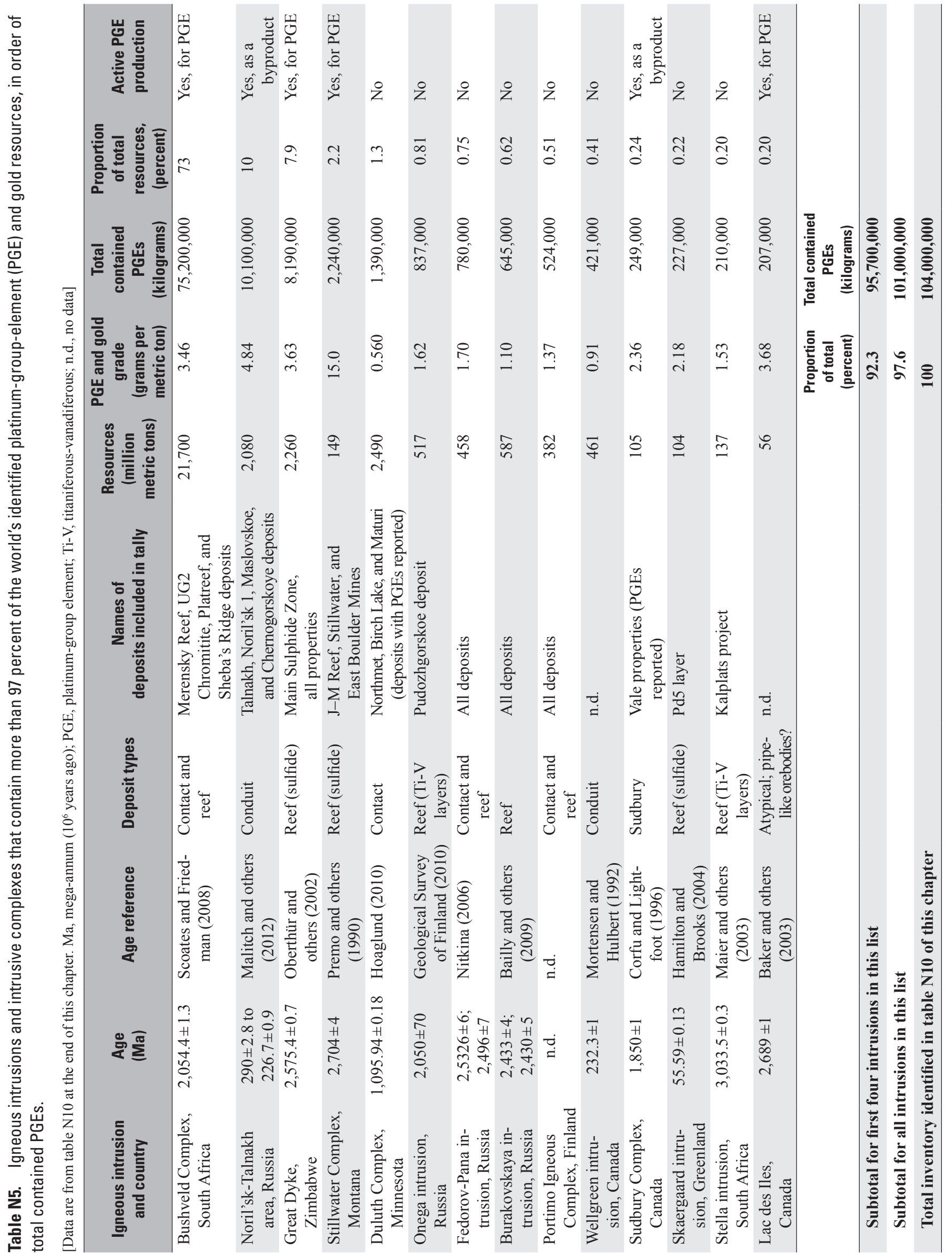


Table N6

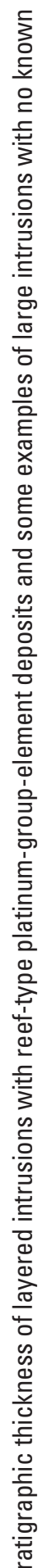

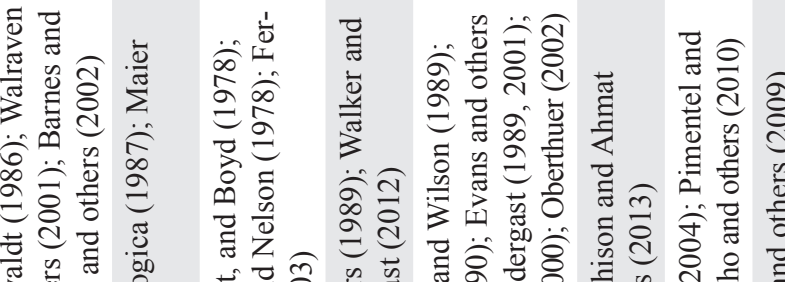

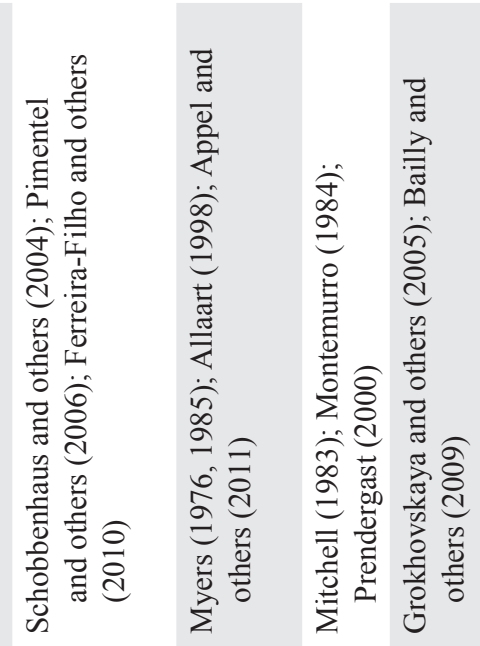

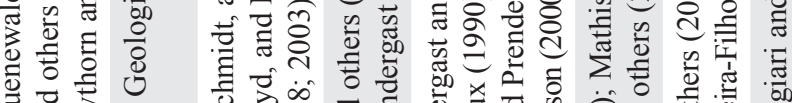

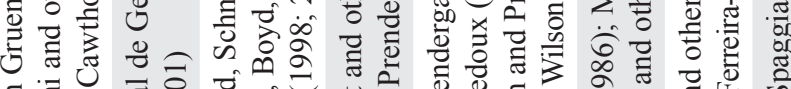

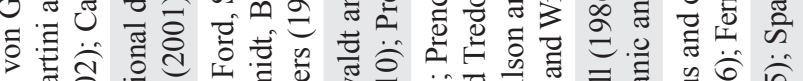

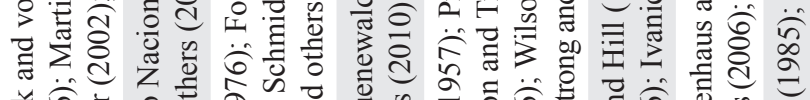

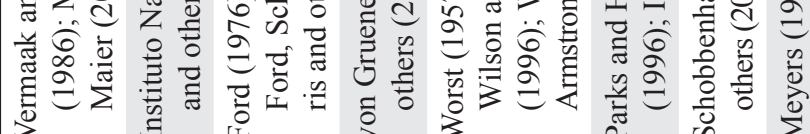

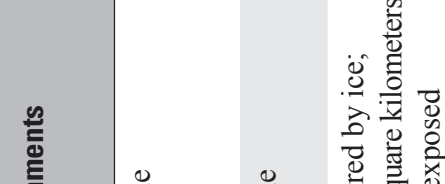

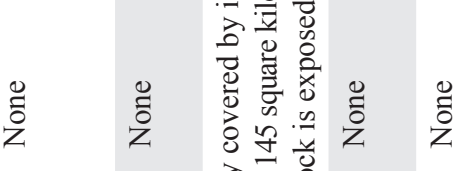

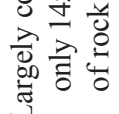
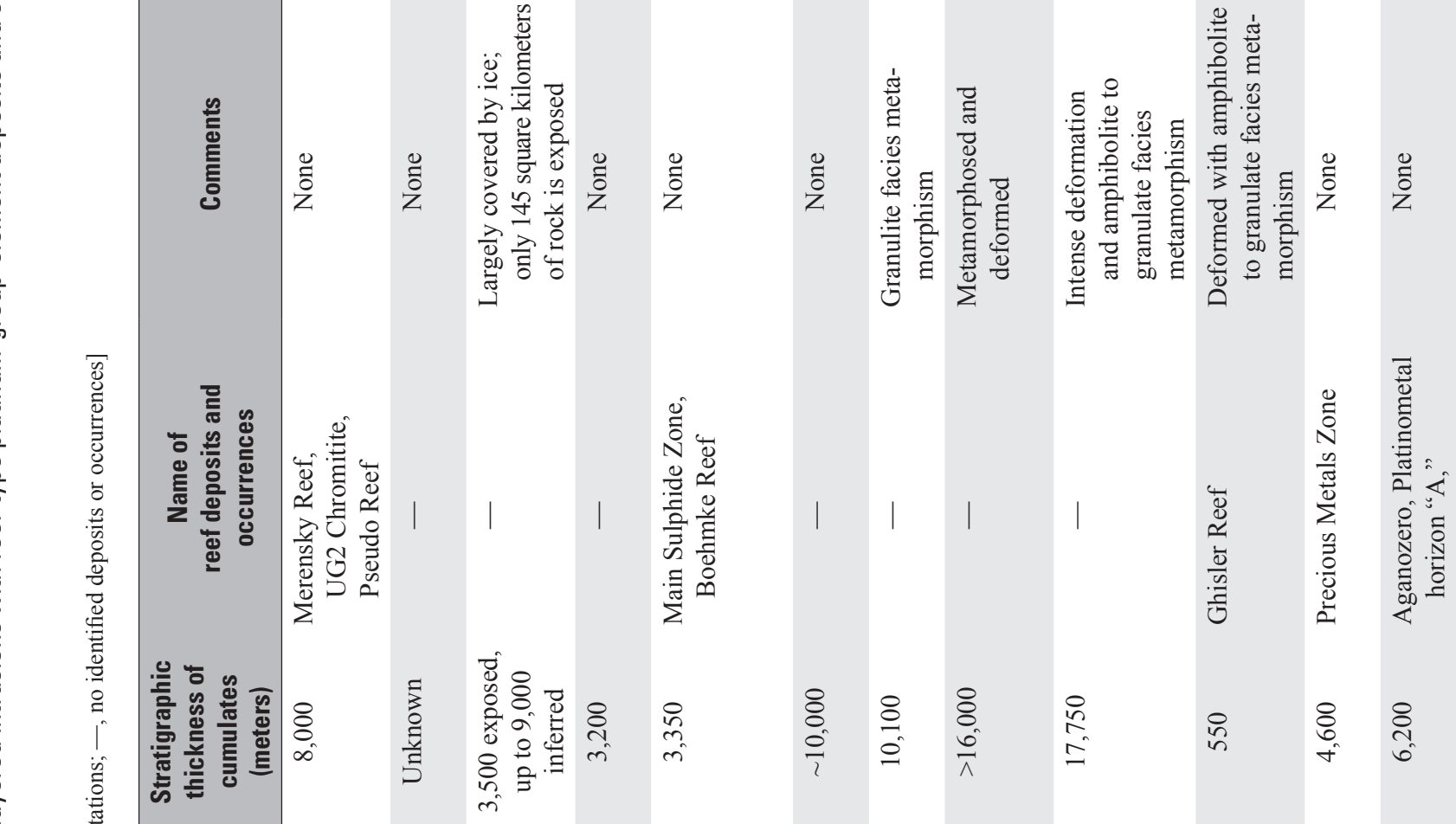

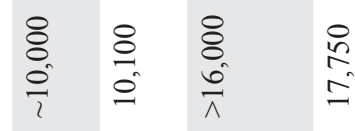
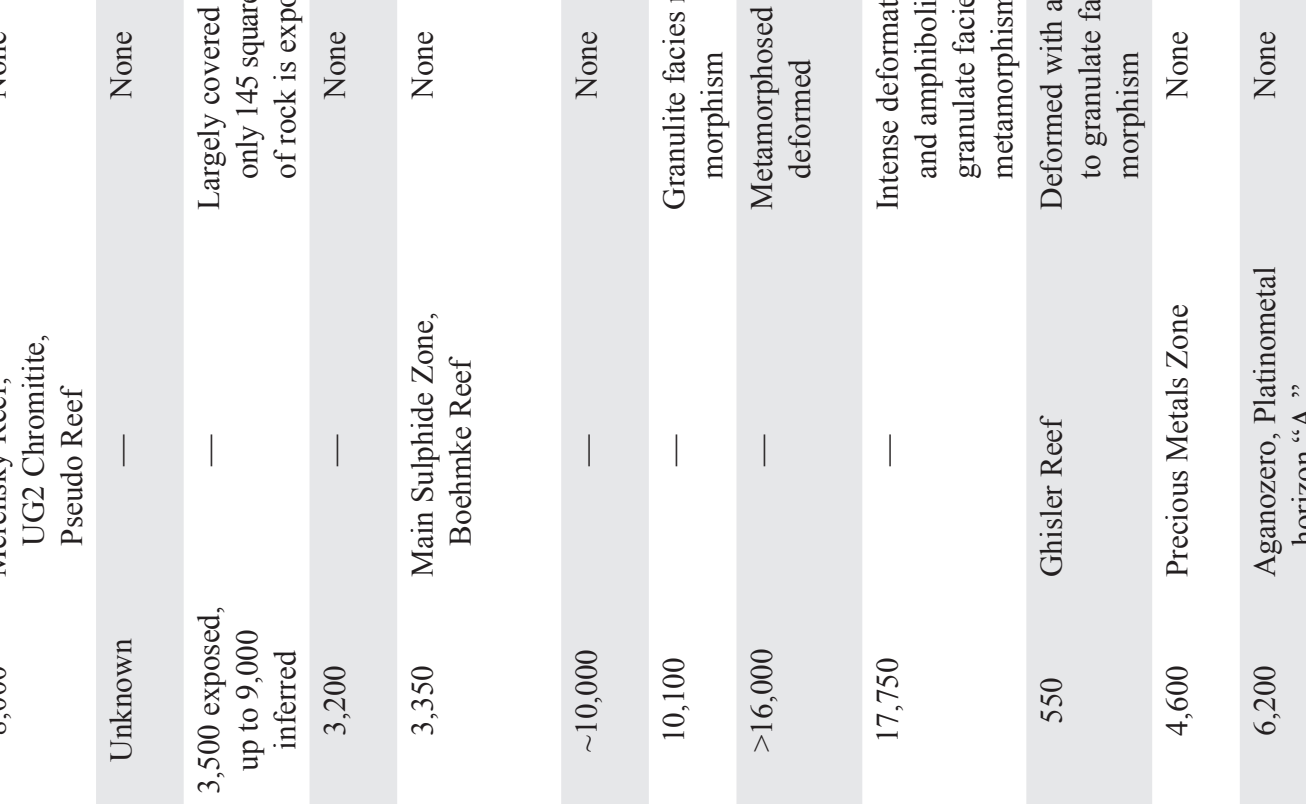

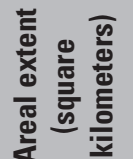

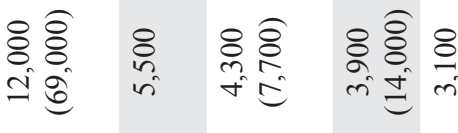

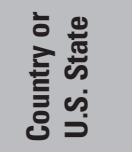
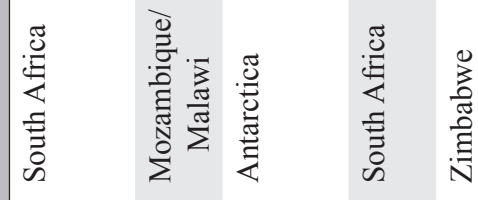

$\begin{array}{lll}8 & 8 & 8 \\ i & 8 & 0 \\ i & i & -1\end{array}$

$\stackrel{8}{i}$

융 웅 웅

竞

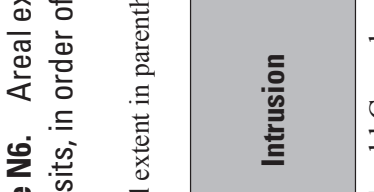
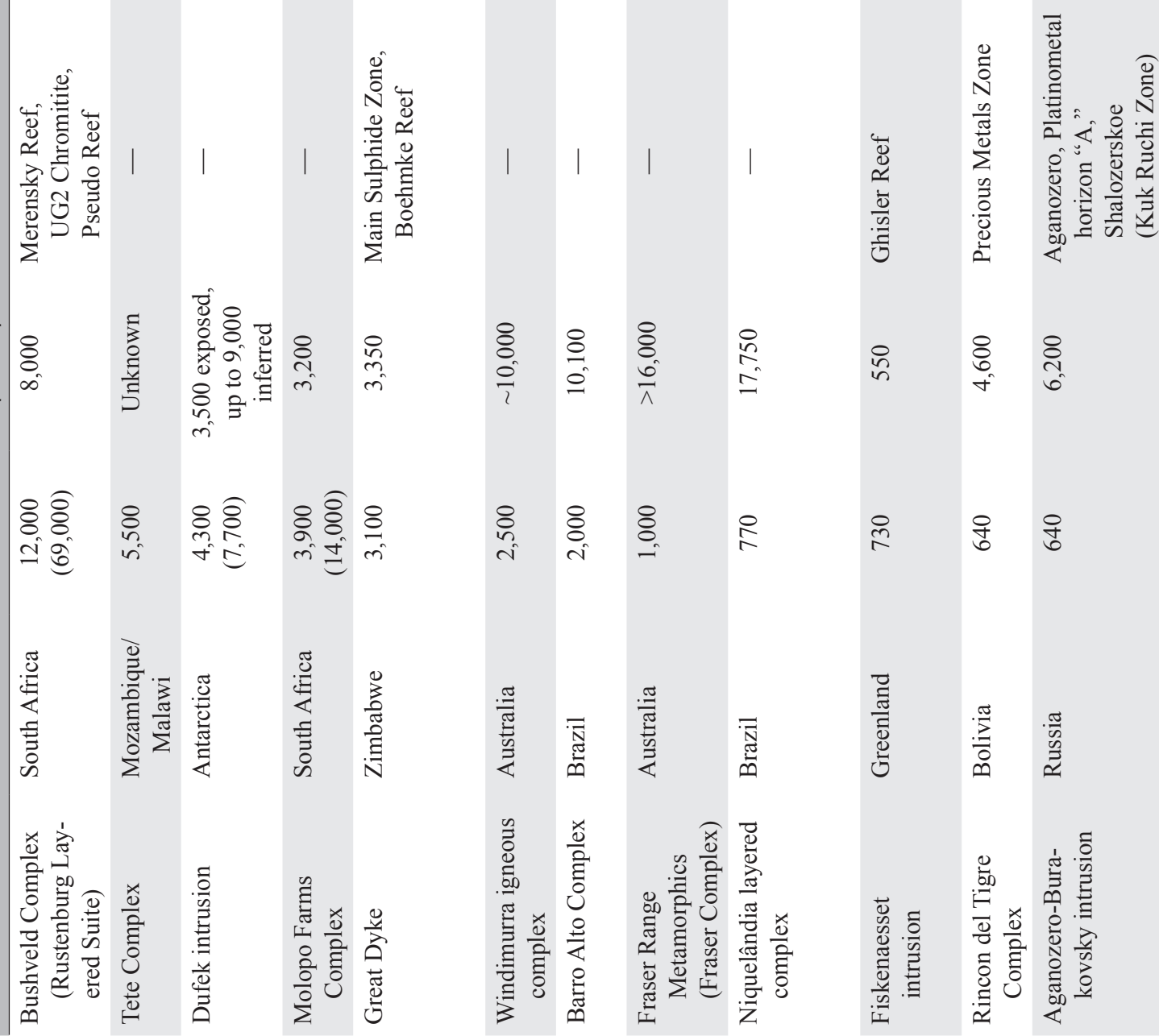

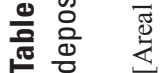
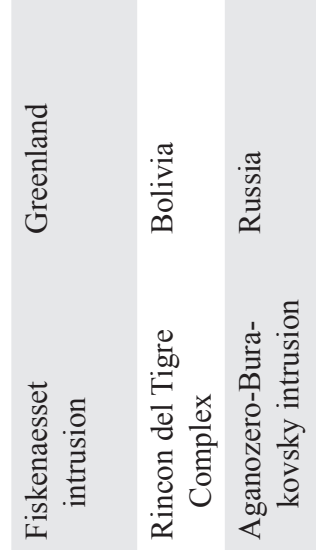


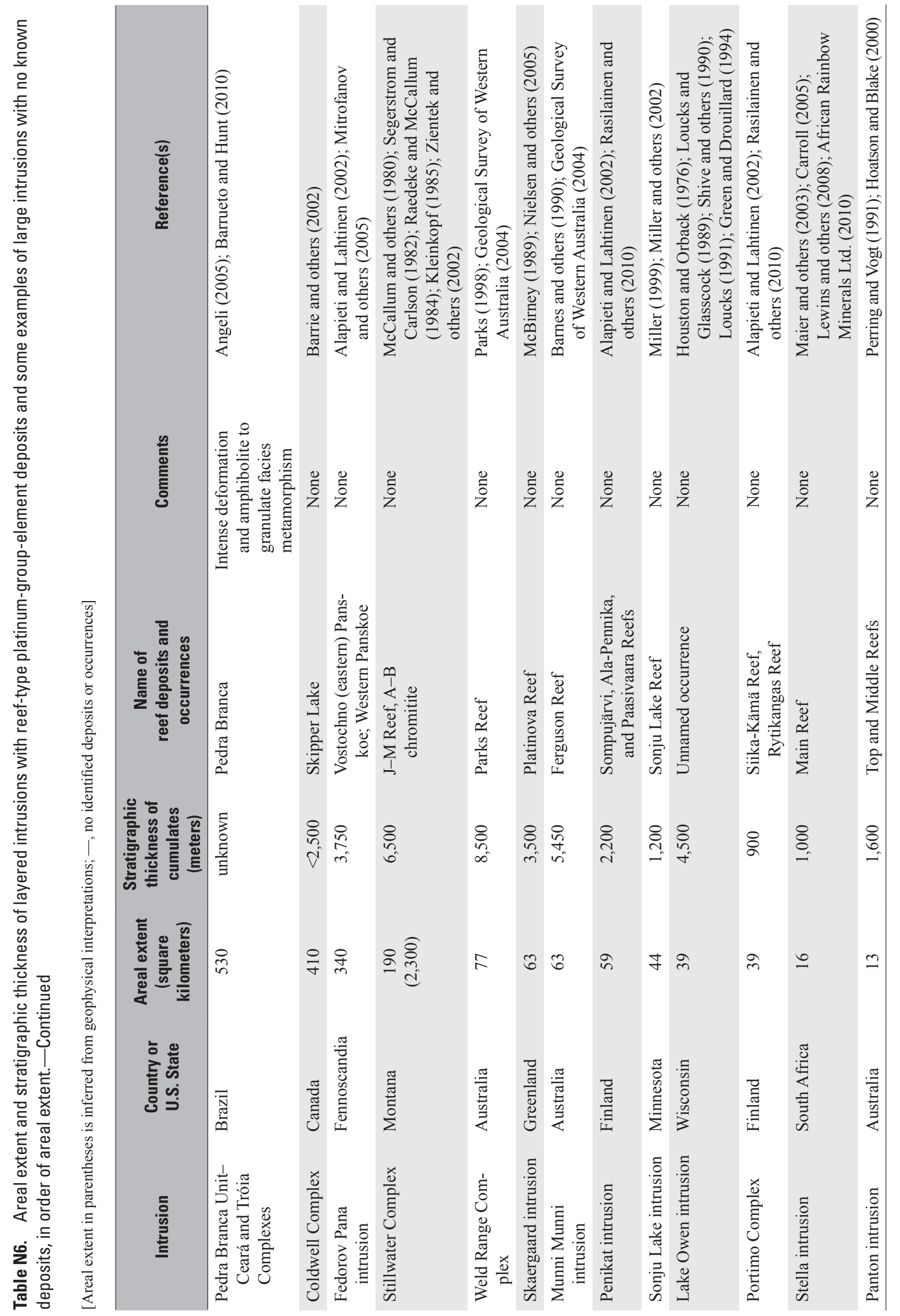




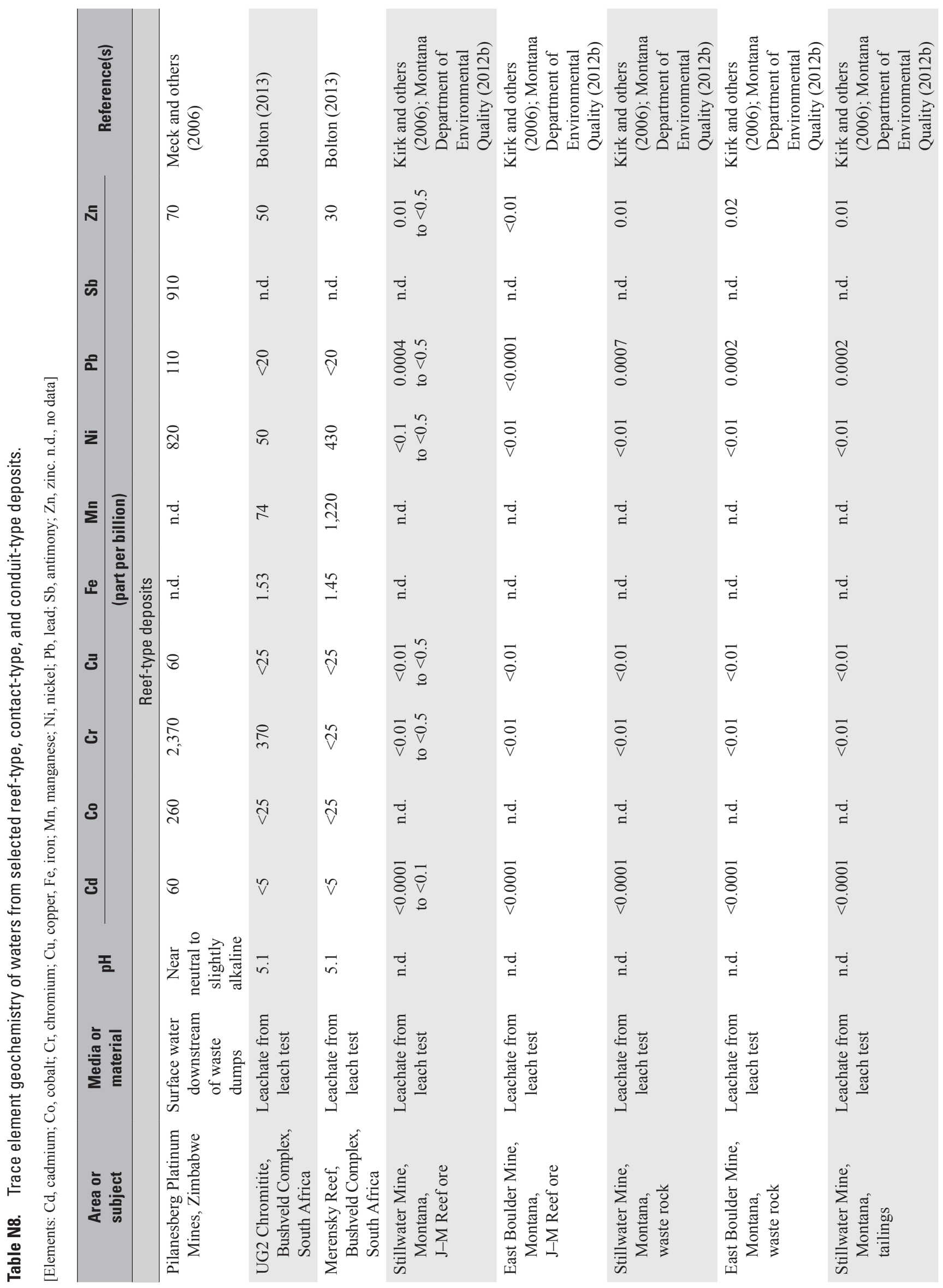




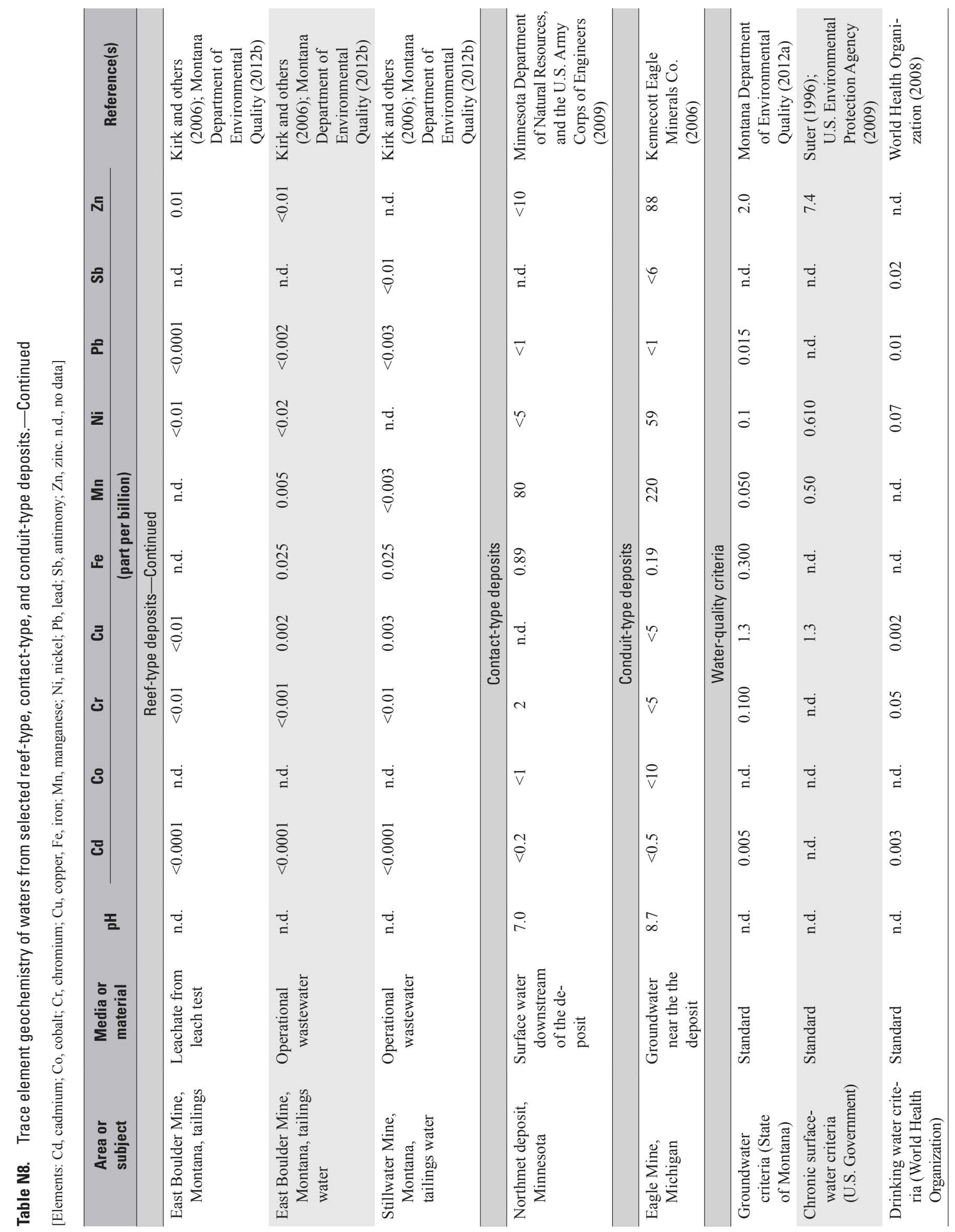




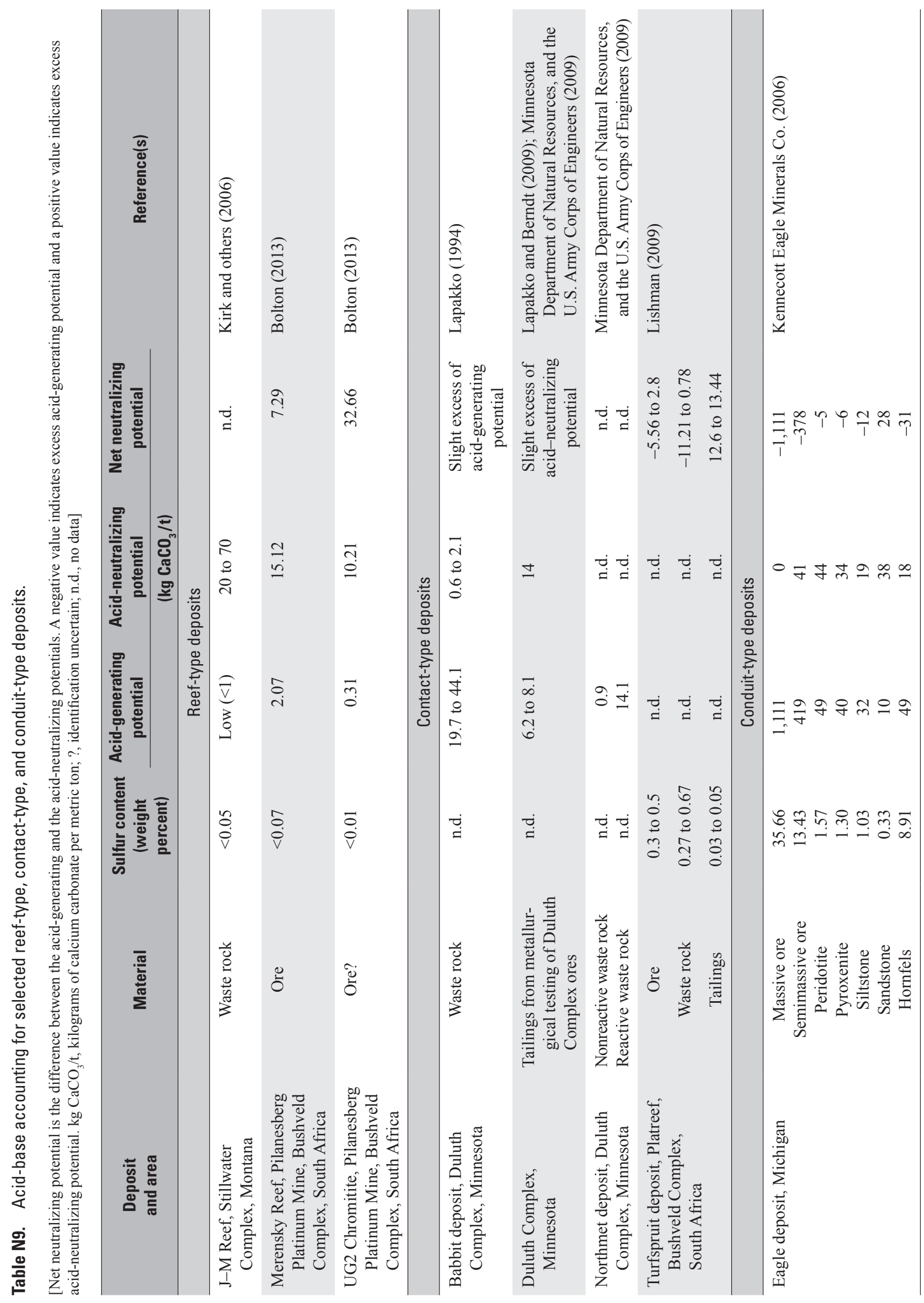




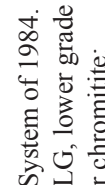

焉总

造产

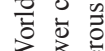

这语

to 4

$3 \overline{0}$

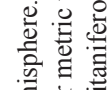

突

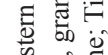

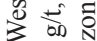

送

点

总 递宫:

舜芝至

.

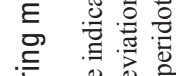

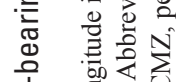

농 흐리

ฮั

ब

응 空范

힌 氙芯䍃

点

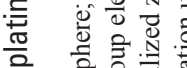

듬

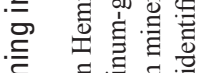

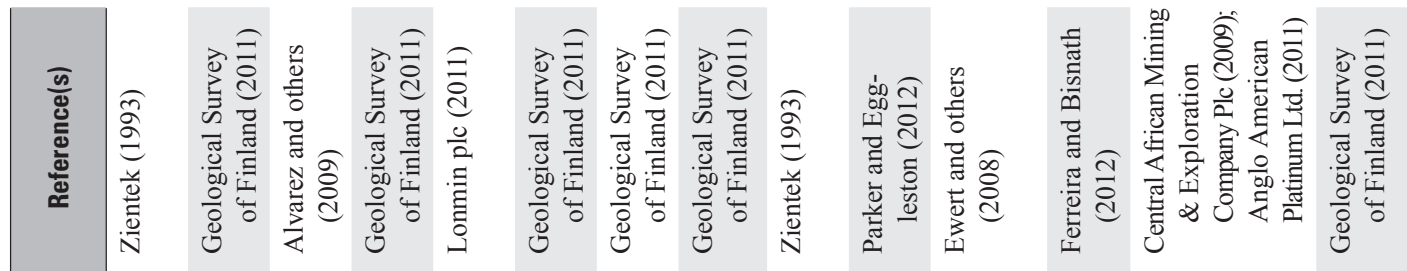

है

岩 즘

$\sin$

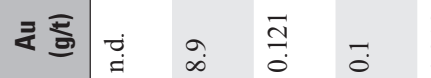

ते

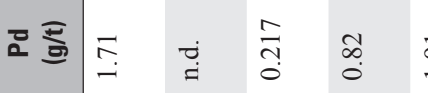

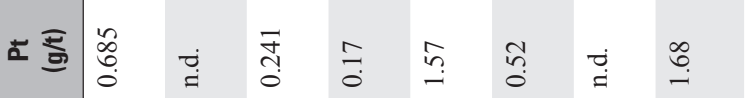

उ

$\stackrel{\infty}{\circ} \quad \check{0} \quad \frac{0}{0}$

ก)

$\stackrel{\infty}{n}$

$\frac{8}{2}$

此咅

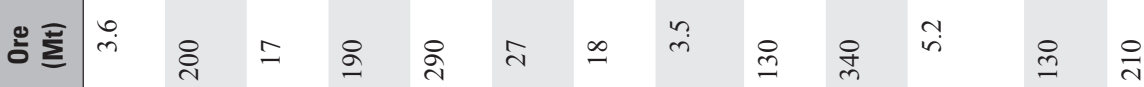

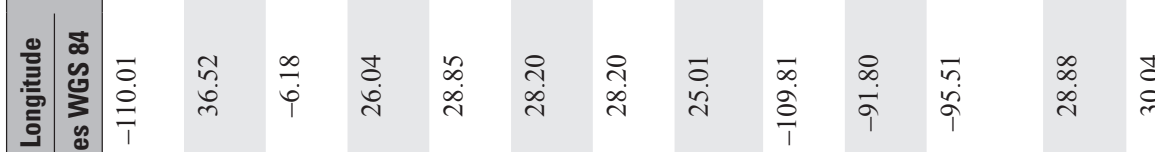

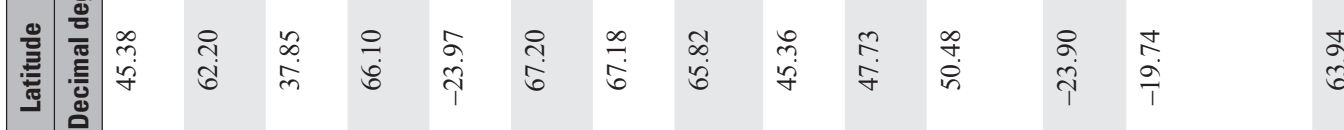

焉

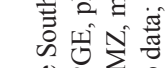

응

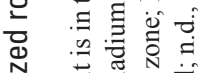

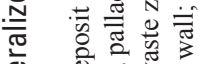

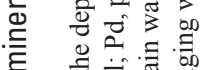

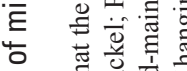

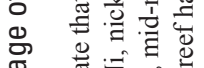

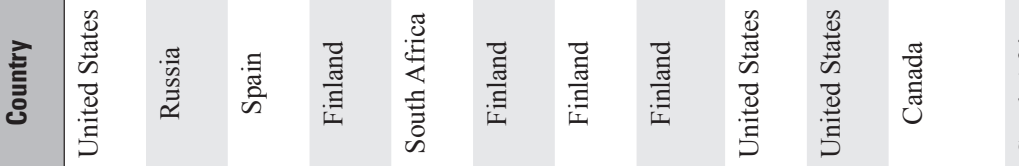

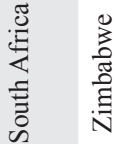

$\stackrel{\check{J}}{\sharp}$

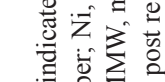

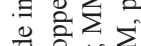

들 总额出

吾苛

๘

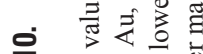

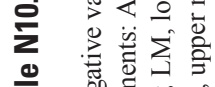

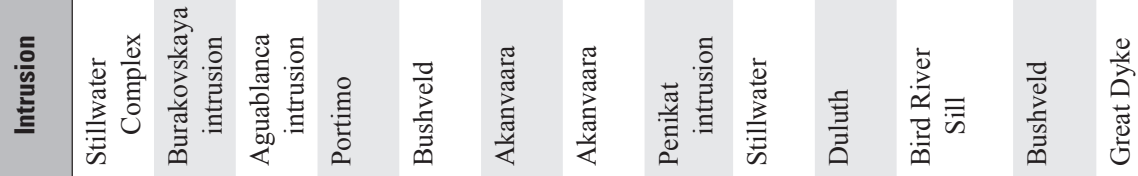

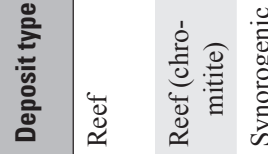

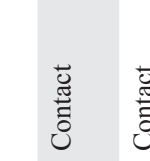

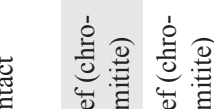

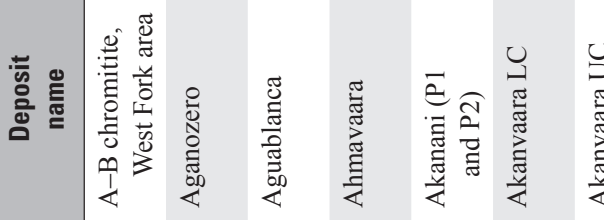

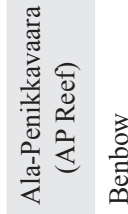

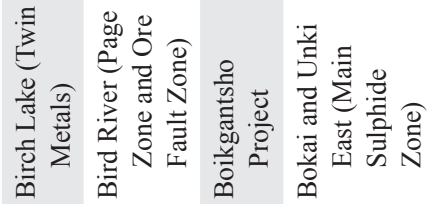

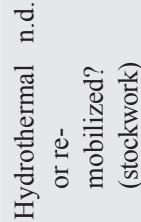




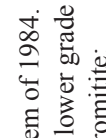

密啳

की

过 응

농

政

की

言

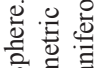

焉

을

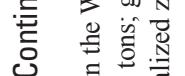

广 0

果 荡

品

웡 올

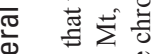

它 总

E

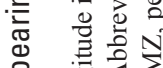

宅

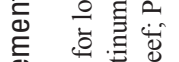

ब。

官

흥 商零

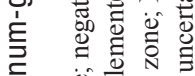

言

글

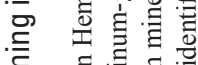

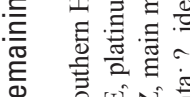

試热

능

을

总

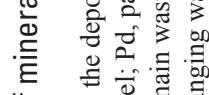

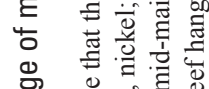

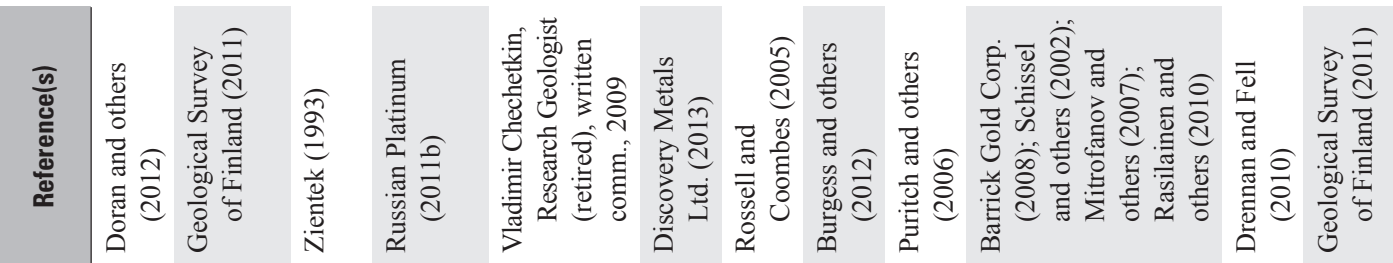

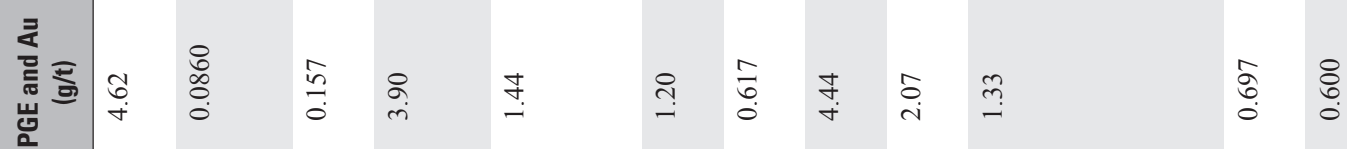

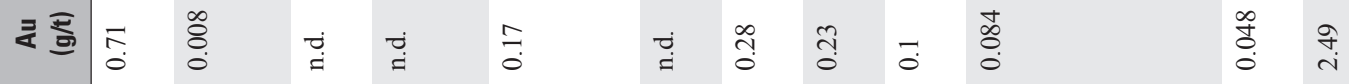

도롤

픔

घु

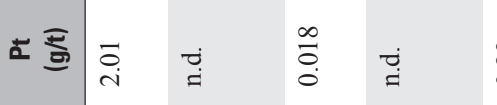

च

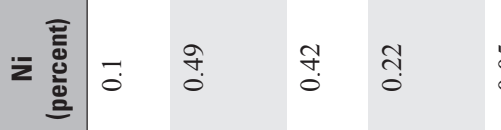

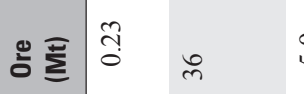

is

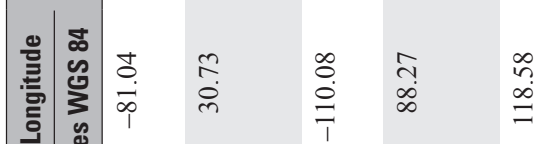

ग. व.

ت্ট்

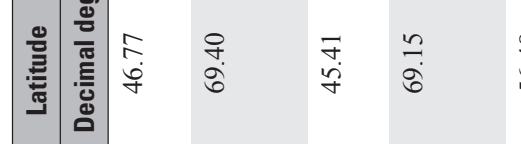

文

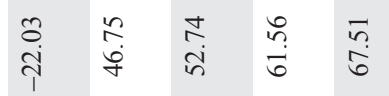

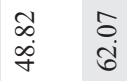

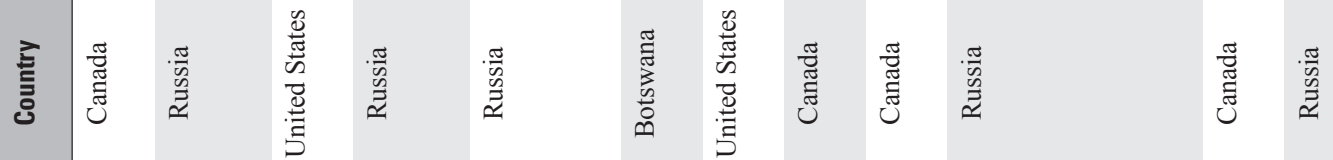

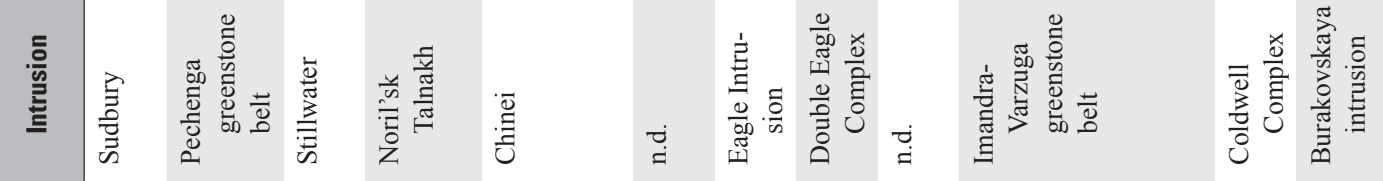

芠

을

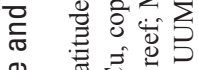

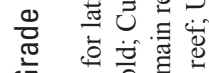

○)

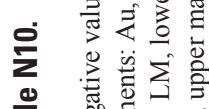

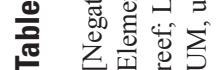

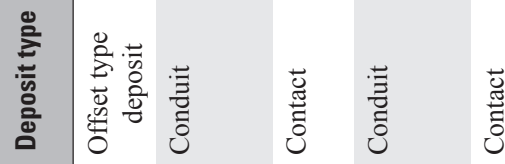

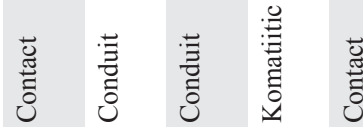

芯

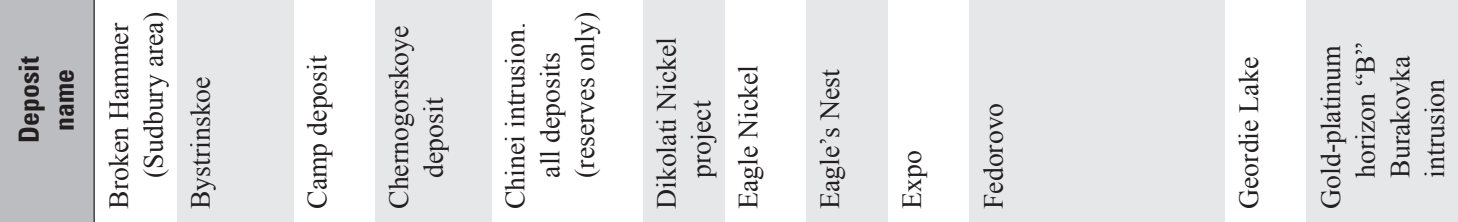




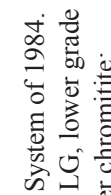

跣产

论

뫃

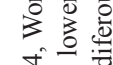

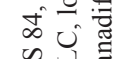

论

(

(0.0.

产

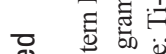

岂

突

它

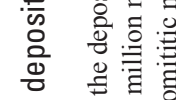

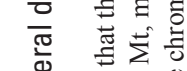

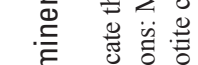

E$$
\text { (1) }
$$

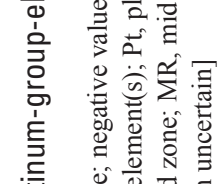

喜

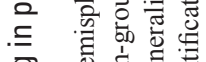

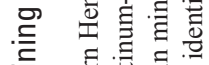

㩆影

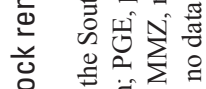

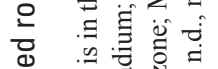

总

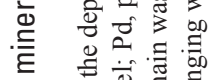

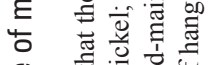

㟢

壱

흔

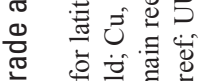

0 o

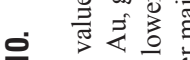

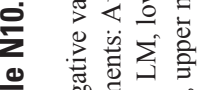

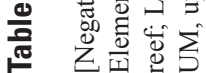

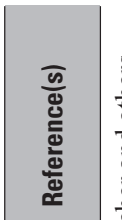

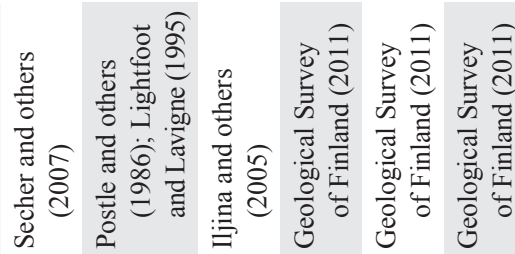

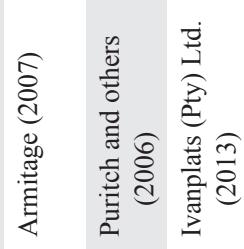

这

루ㄹㅗㅡㅇ

동 픙

ì

:

范

$\stackrel{8}{\circ}$

응

.

:

$\stackrel{0}{\frac{1}{0}}$

?

호등

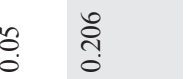

च

$z \underline{\bar{E}}$

$\stackrel{\infty}{0}$

홀

ำ

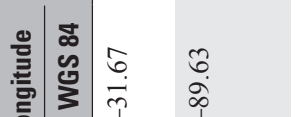

吾

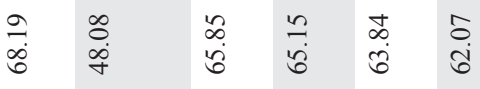

咅

픈

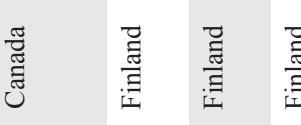

흠

荧

音

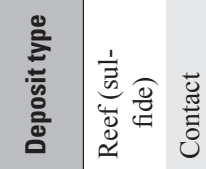

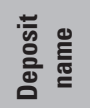

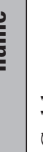

造可
苯

\section{苟}

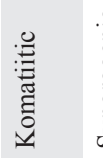

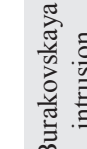

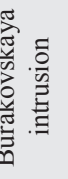

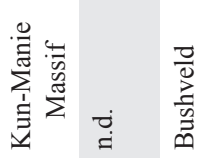

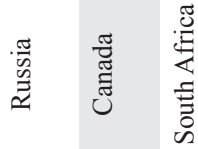

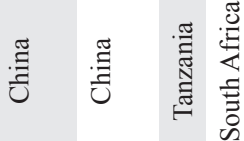

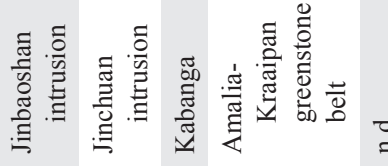

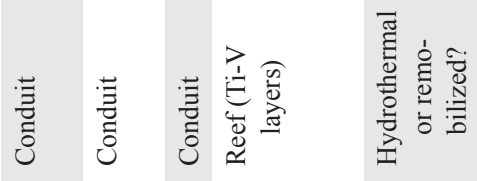

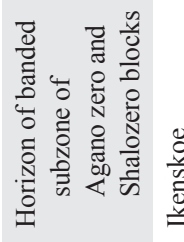

לे⿺

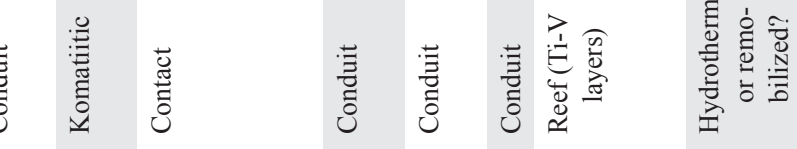

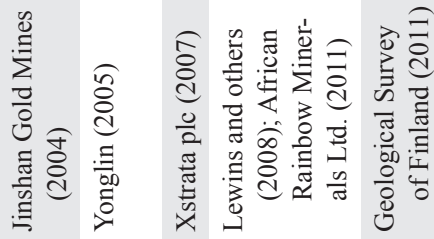

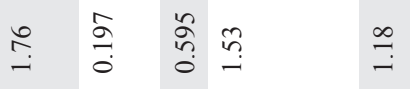

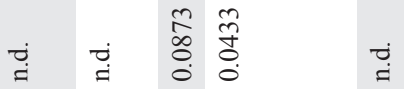

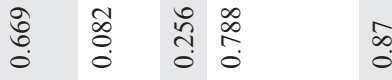

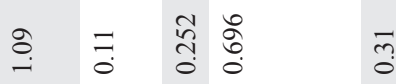

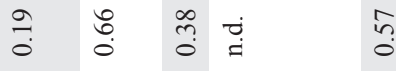

$\stackrel{\infty}{0}-\stackrel{i}{i} \stackrel{\ddot{j}}{=}$

$=$ d

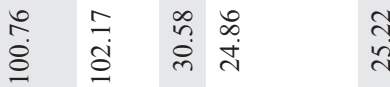

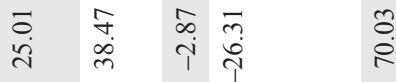

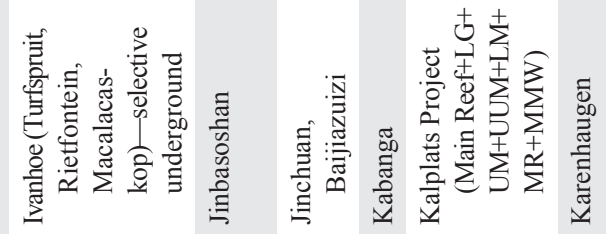




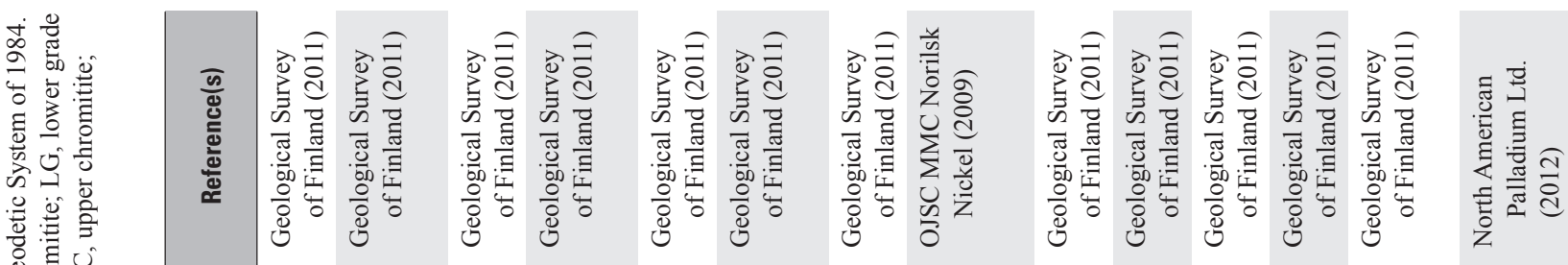

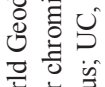

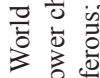

क

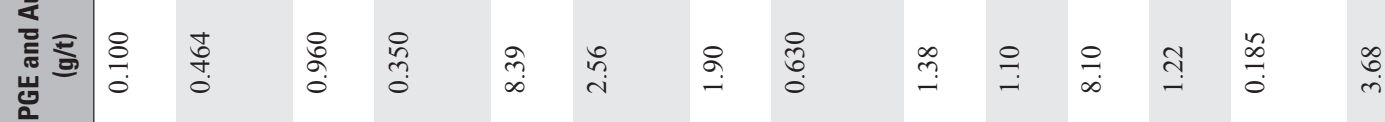

है है

这.

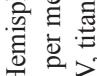

-

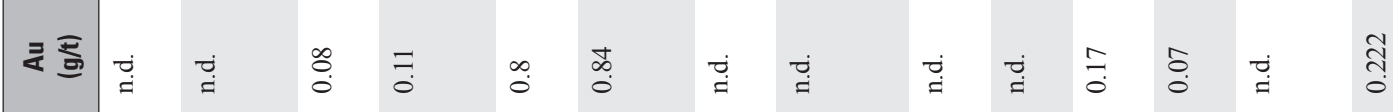

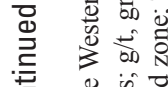

突

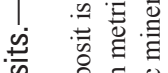

究

造

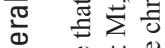

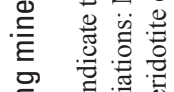

을

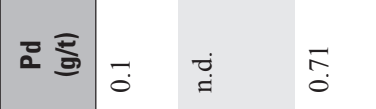

总

는

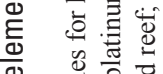

空

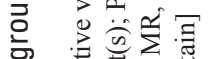

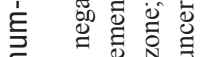

告

흘

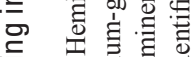

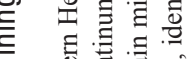

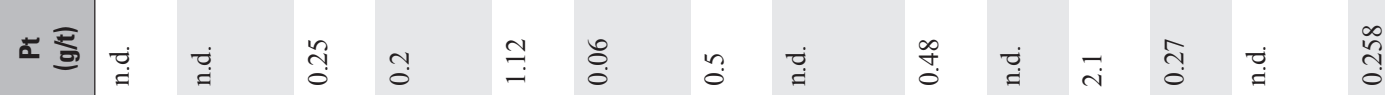

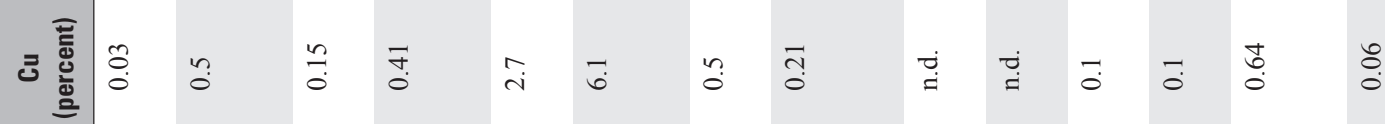

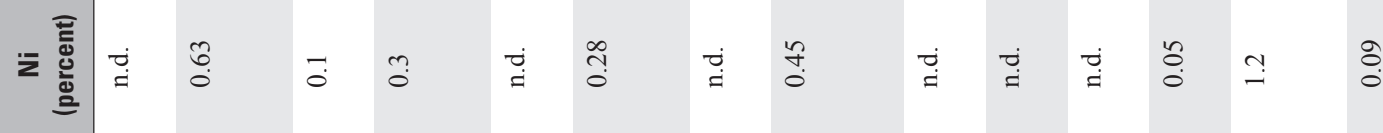

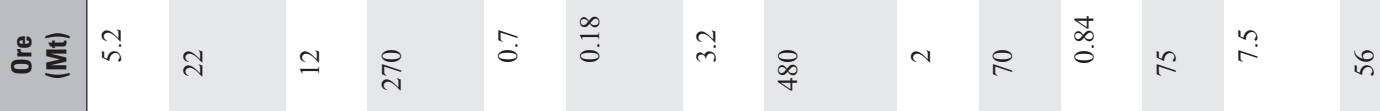

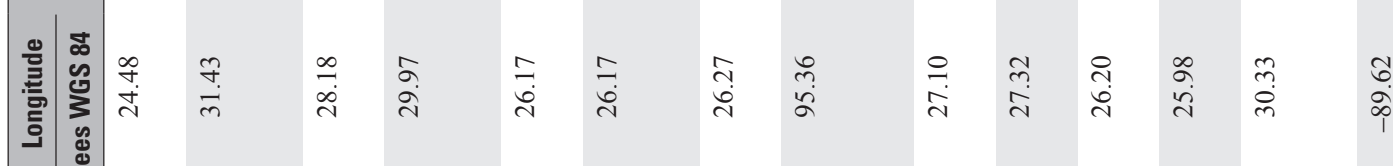

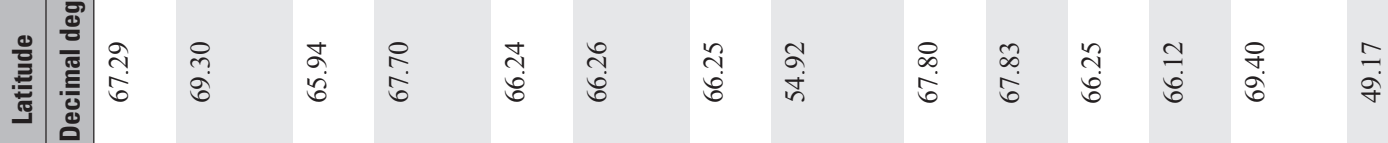

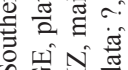

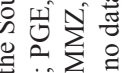

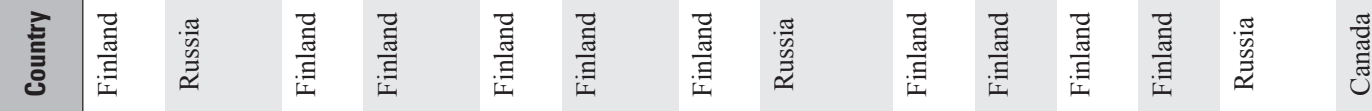

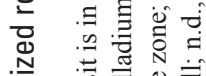

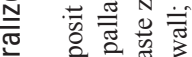

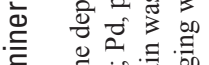

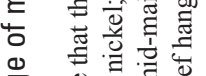

要

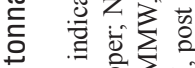

을

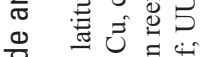

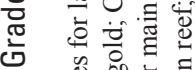

.

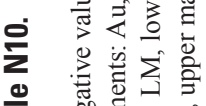

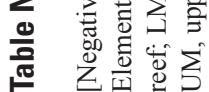

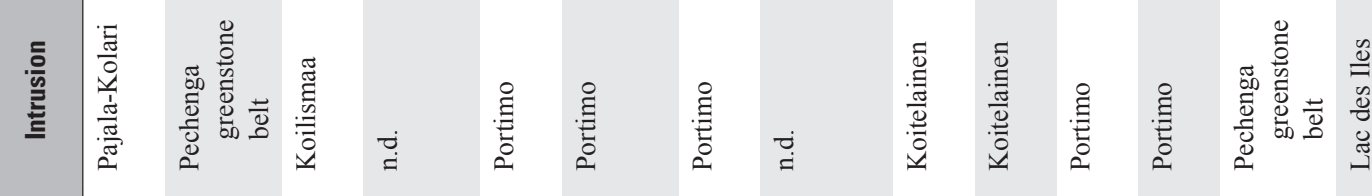

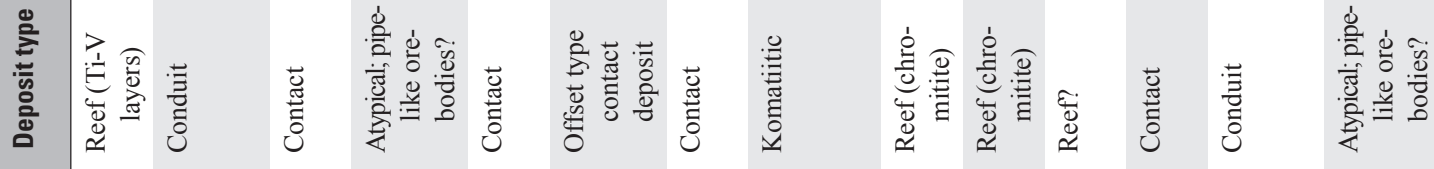

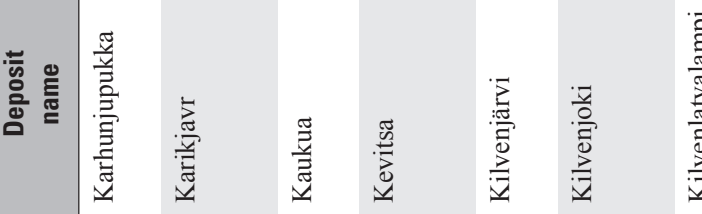

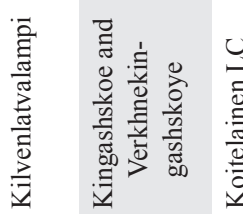
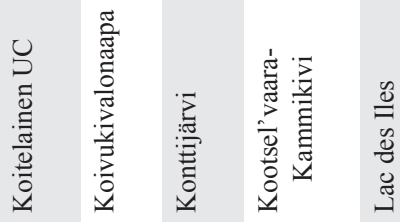


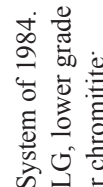

结帝

웡

究产

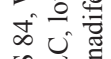

记

穿.

豙要

总

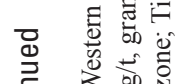

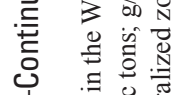

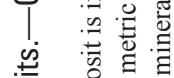

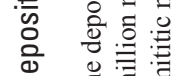

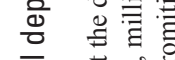

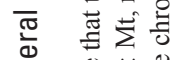

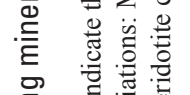

竞

要

志部方

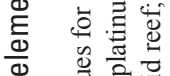

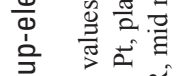

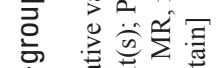

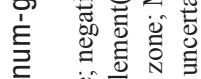

喜

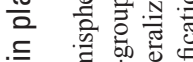

蛋 害音

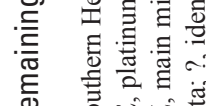

焉

응

농

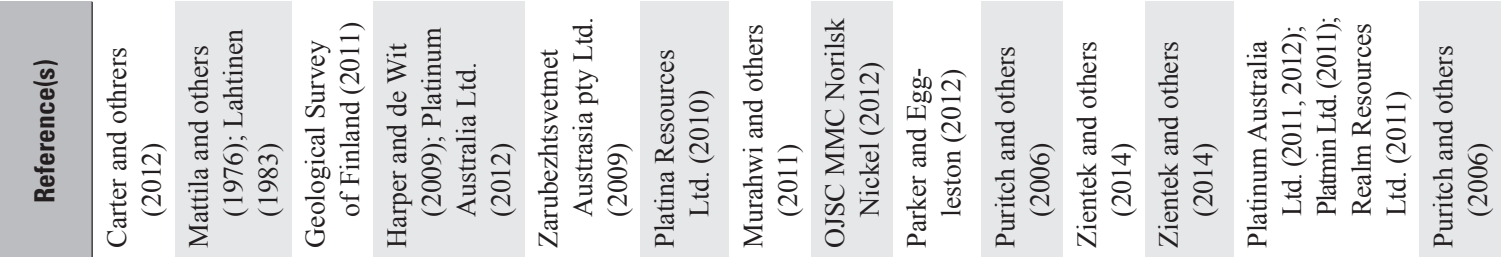

亲

㔻

इ

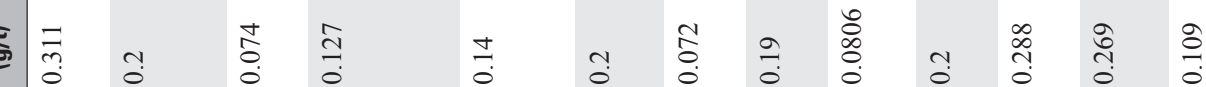

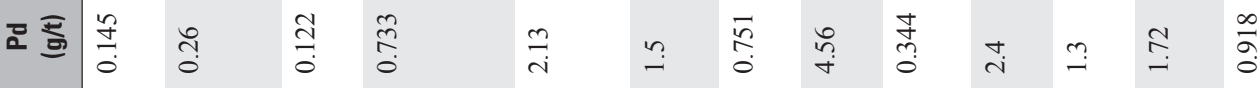

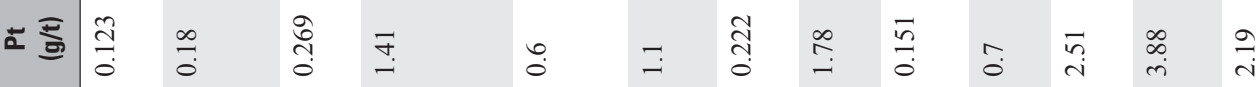

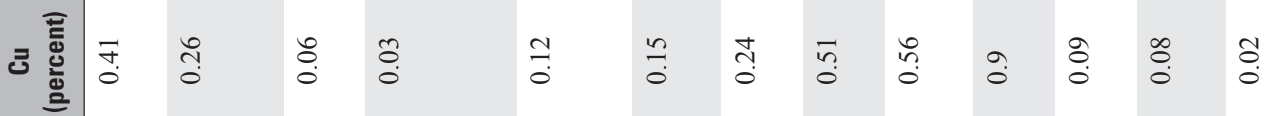

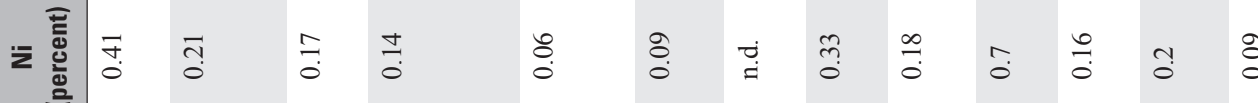

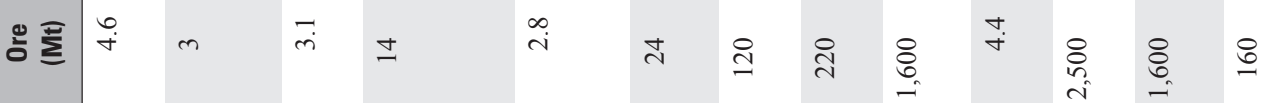

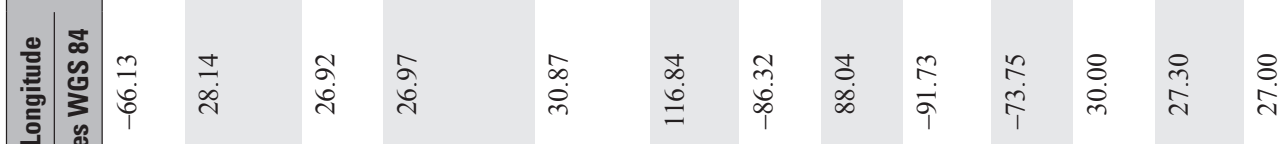

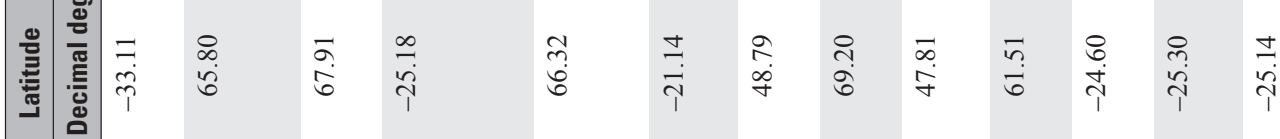

$\stackrel{\infty}{\stackrel{\infty}{6}}$

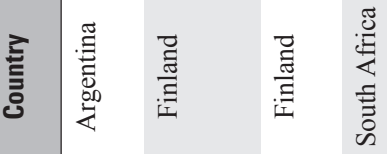

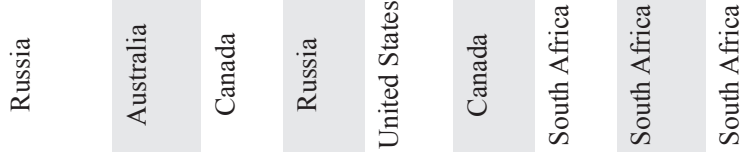

$\stackrel{\infty}{\circ}$

需

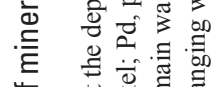

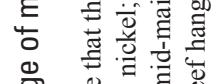

बै

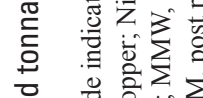

흘 을

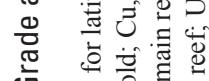

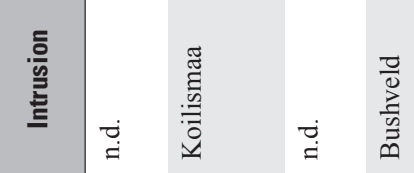

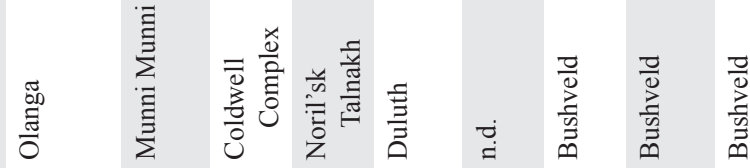

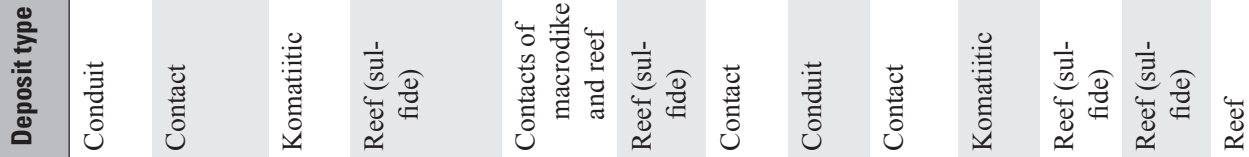

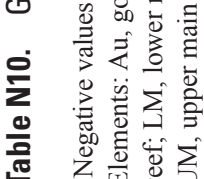

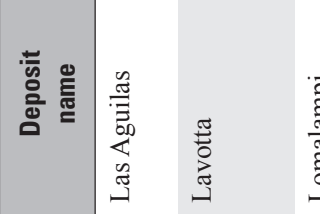

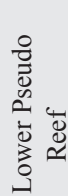
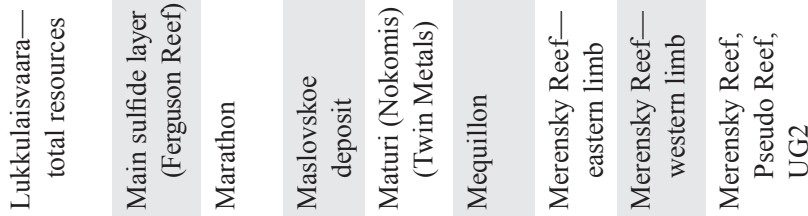


\section{进䒼 \\ 它害 \\ 空完}

की

ن

흫 㐘

范离

क्ष

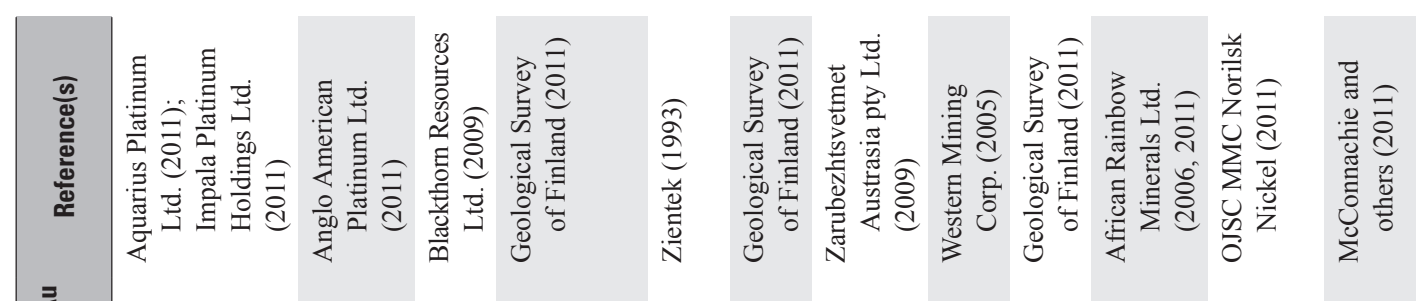

言总

एँ

की

记

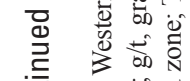

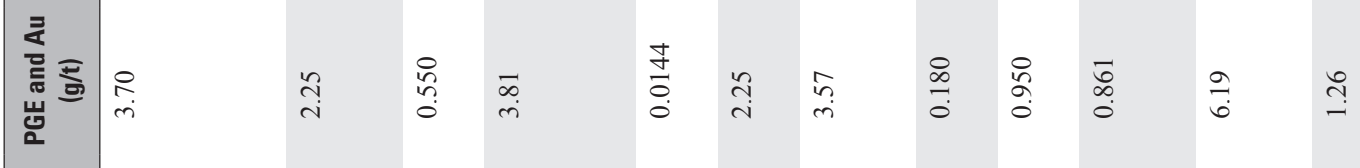

룰츠 항

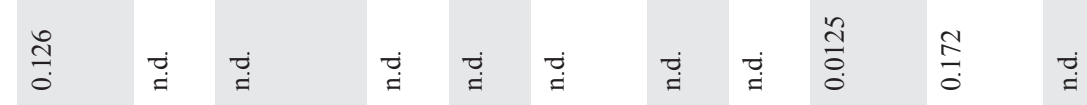

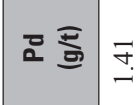

$\because$ กิ

突

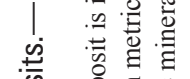

के

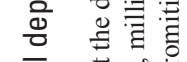

要焉芒总

产

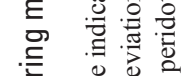

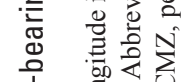

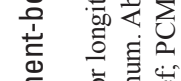

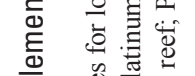

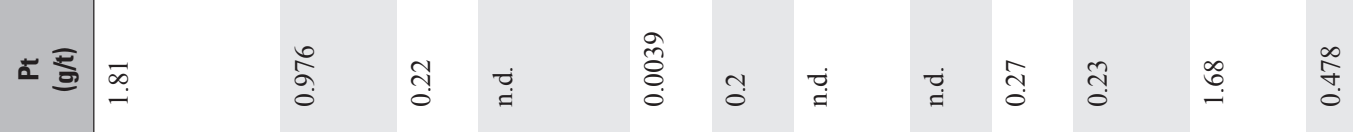

ت己

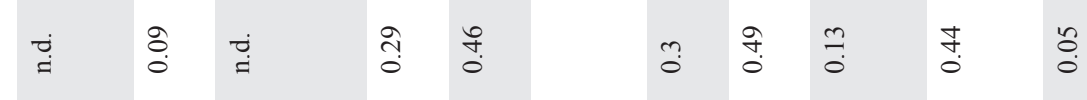

这 咅

ت্

홀

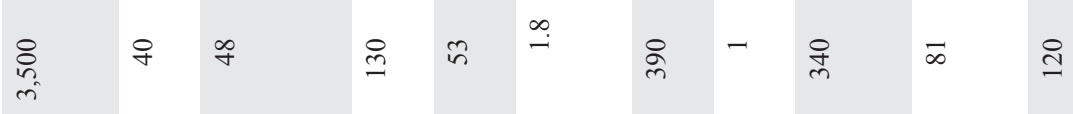

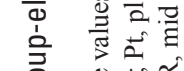

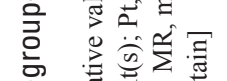

क人

竞

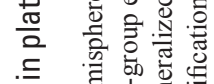

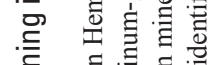

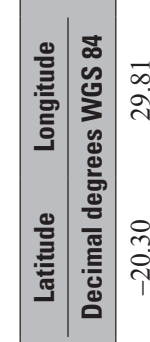

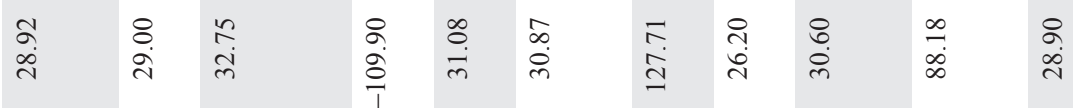

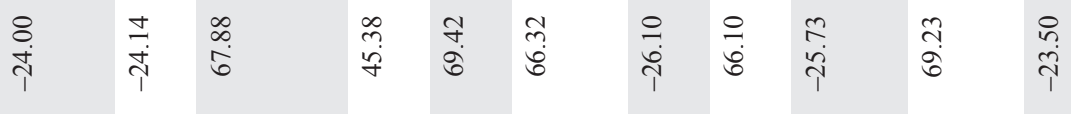

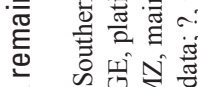

능

至

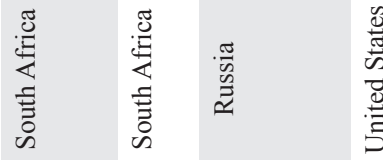

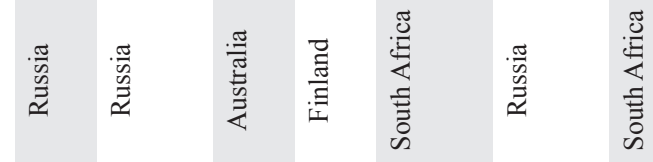

몰.

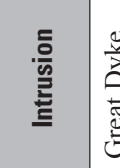

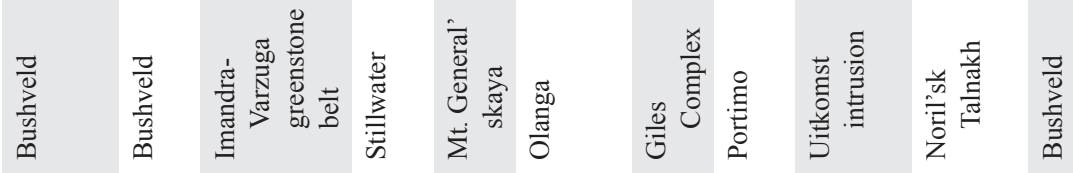

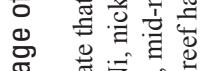

产

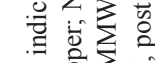

웡 $\sum_{0}$

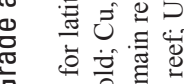

○)

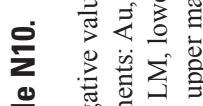

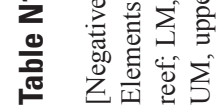

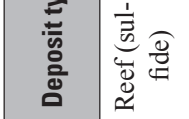

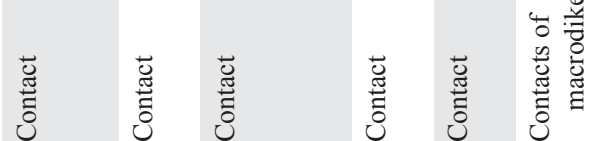

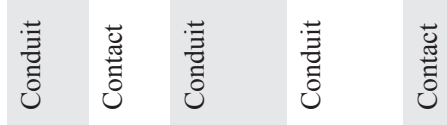

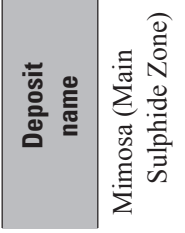

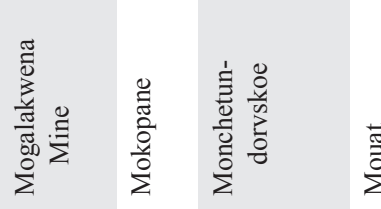

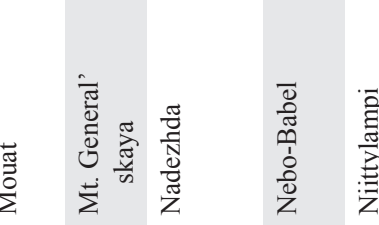

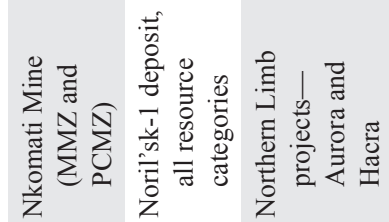



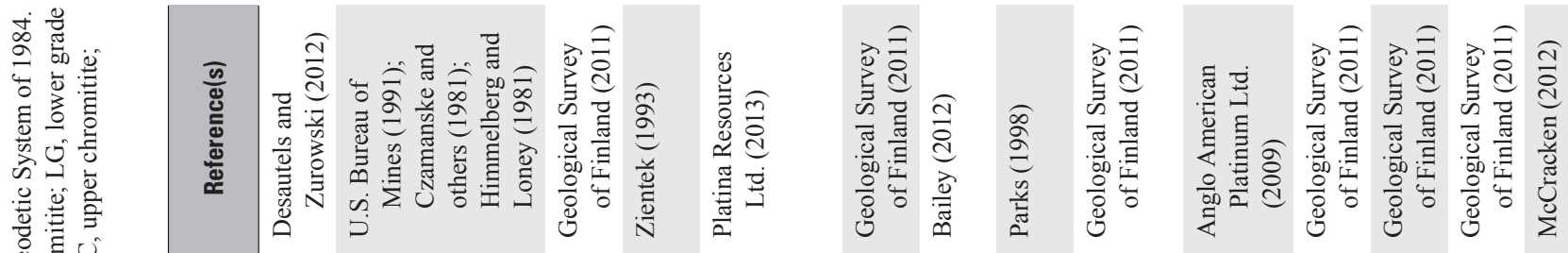

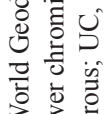

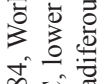

ᄅ

รั

$\stackrel{2}{\circ} \stackrel{8}{\circ}$

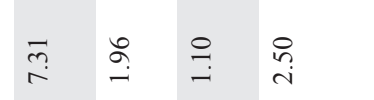

त)

प⿺⿻一⿰冫⿰亅⿱丿丶丶⿱⿰㇒一乂

3.

월

루ㄹㅗㅡ 항

$\stackrel{\square}{\circ} \stackrel{\dot{\pi}}{=}$

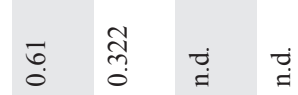

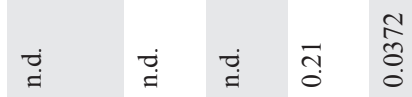

3

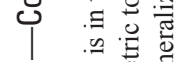

空

कo 응

응

동틈

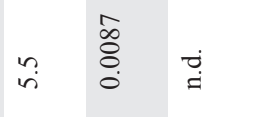

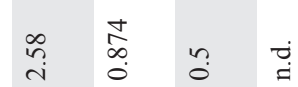

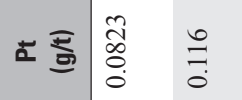

?

$\stackrel{i}{\dot{t}}$

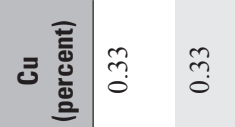

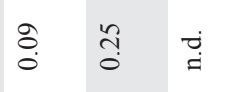

$\stackrel{\infty}{0}$

吾芝戛

.

ह

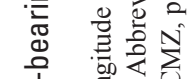

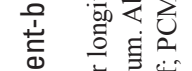

离 劳

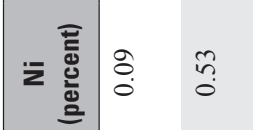

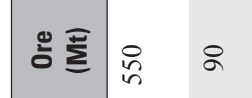

تृ

تே

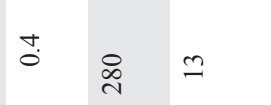

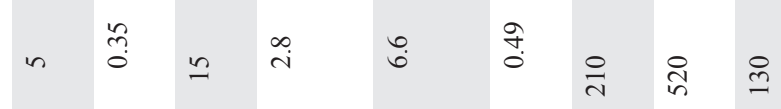

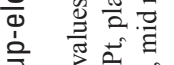

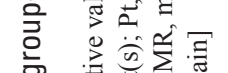

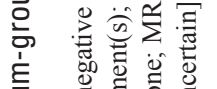

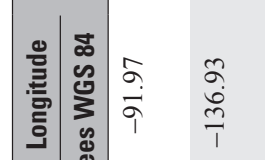

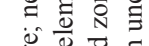

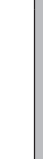

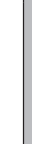

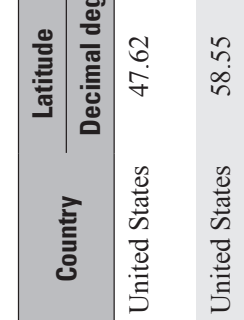

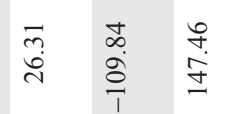

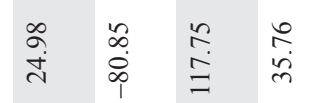

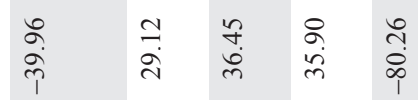

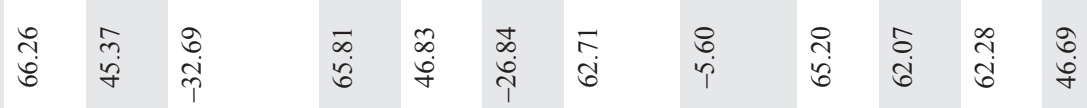

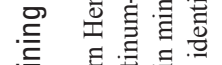

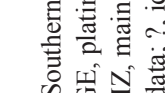

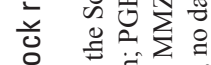

을

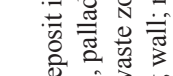

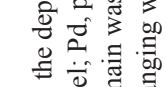

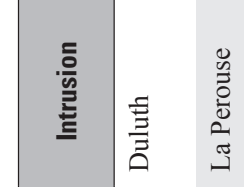

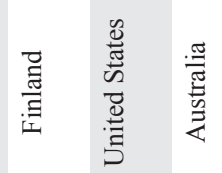

li 1

IIIH,

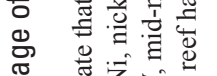

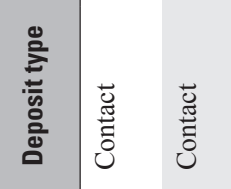

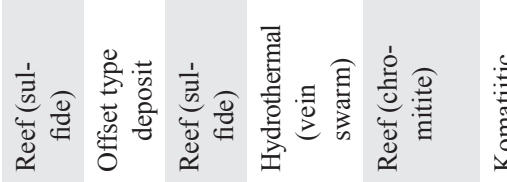

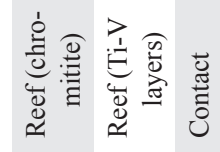

๙

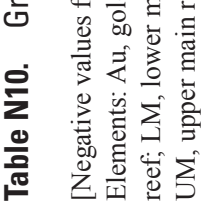

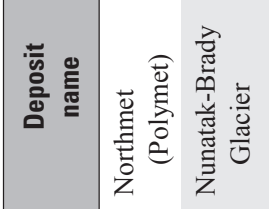

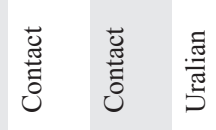

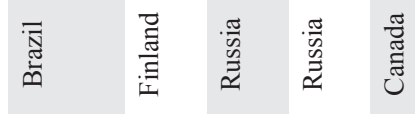

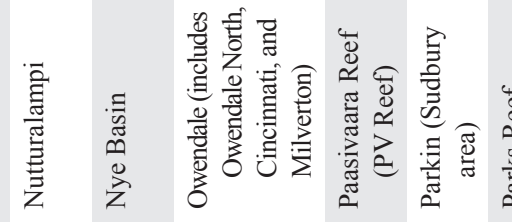

!

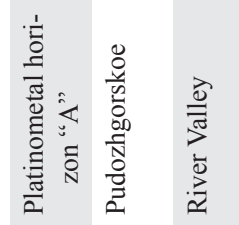




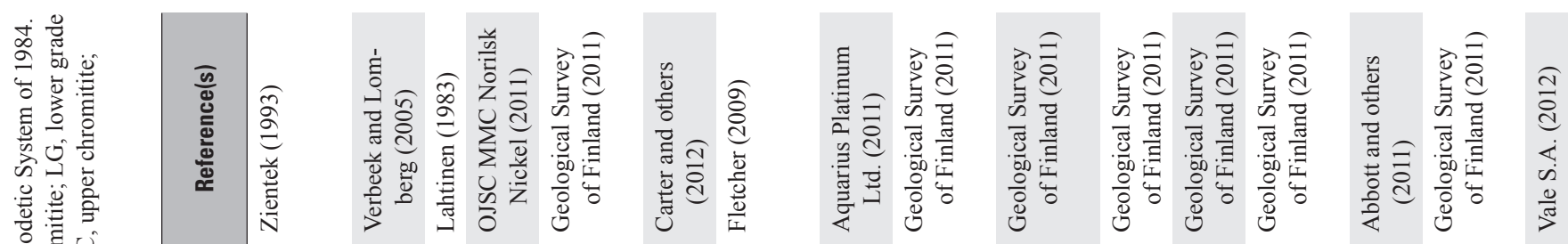

过 흥

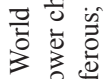

年,

范

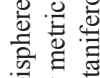

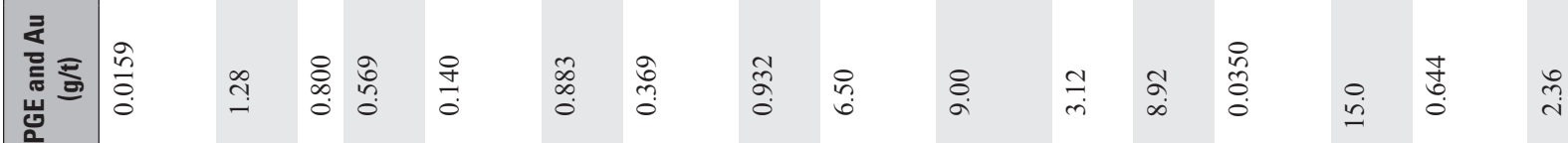

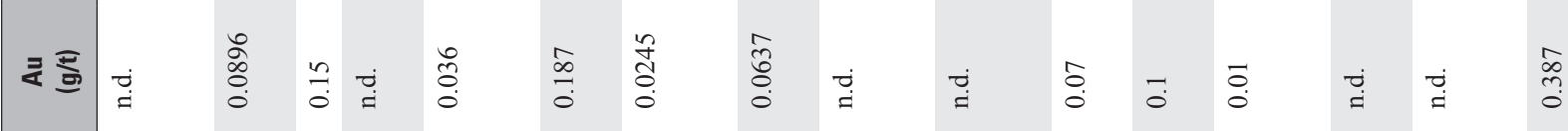

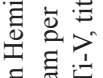

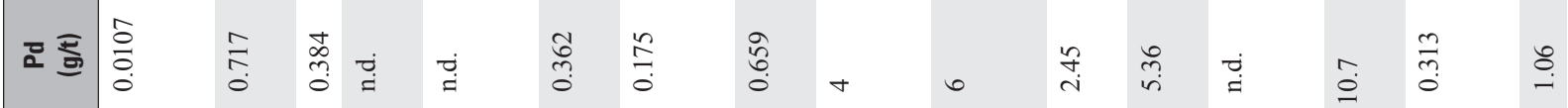

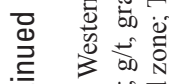

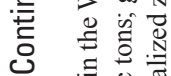

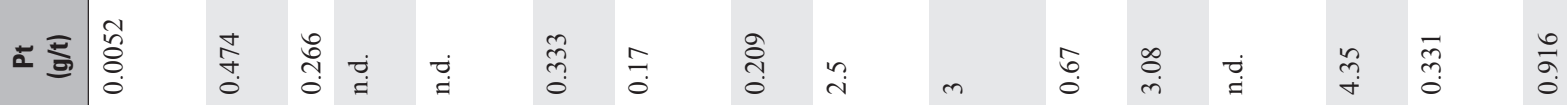

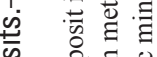

के 흥 흥

造 号夆

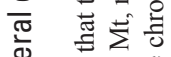

亭

을

要

흘

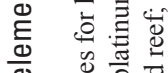

产

흘

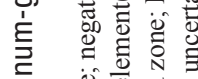

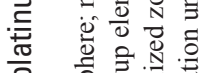

들

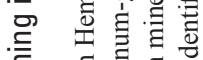

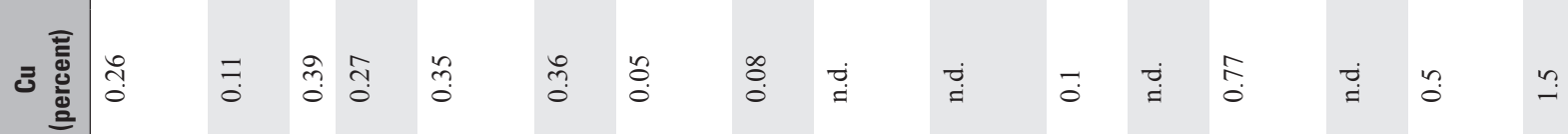

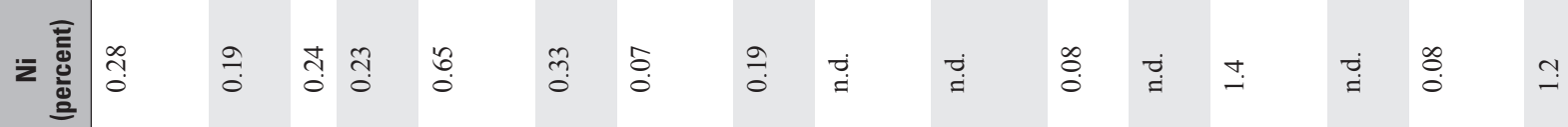

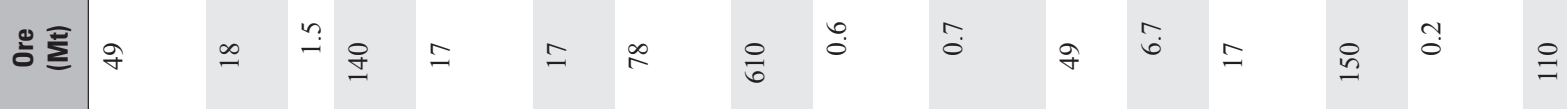

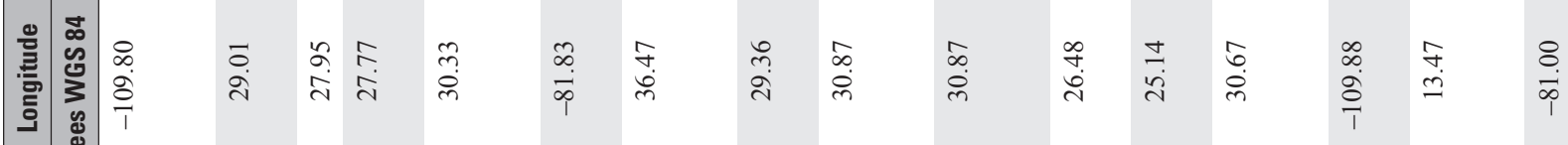

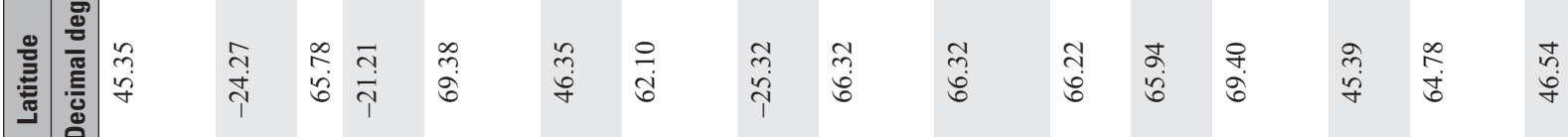

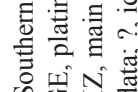

능

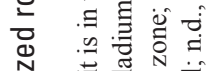

券

要

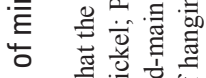

ه

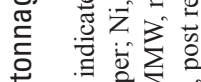

을

元

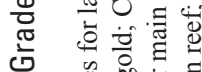

0 论

运

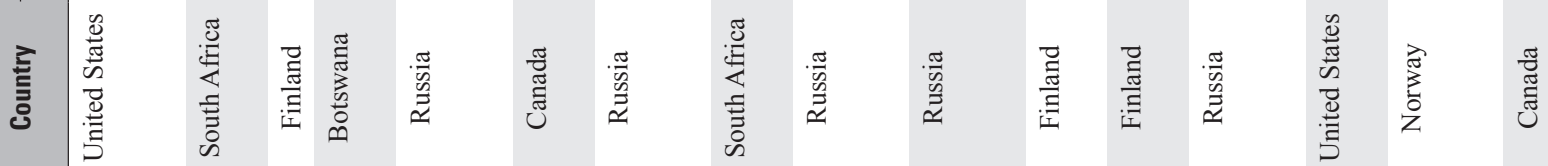

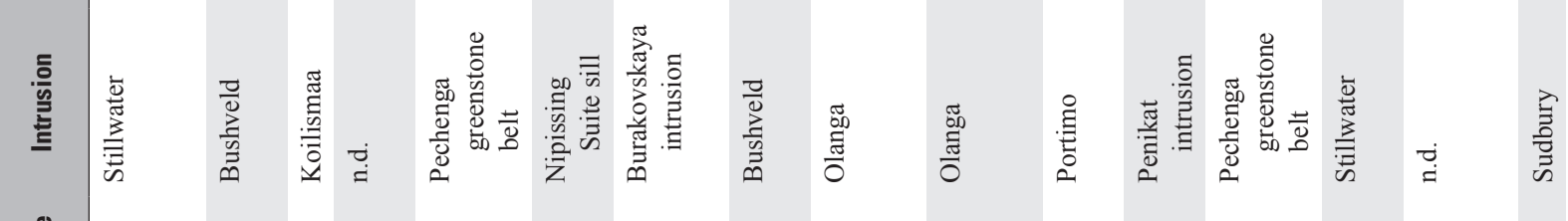

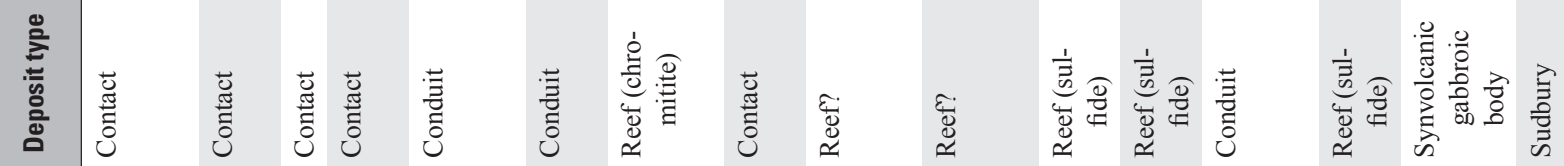

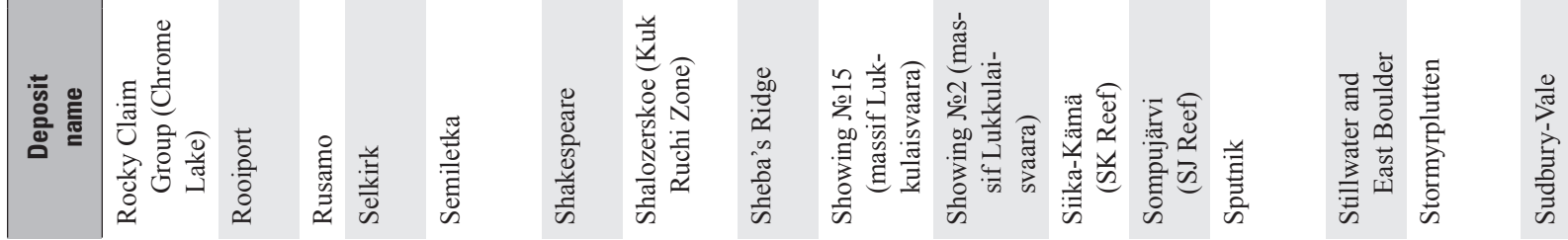




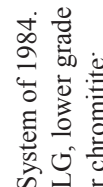

记

要焉

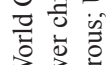

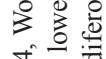

倍

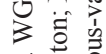

密. ․ㅠㄹ

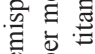

焉是

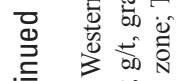

言 至产

它喓要

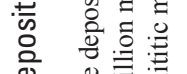

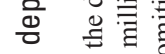

画 焉芝帝

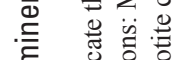

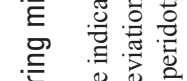

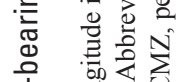

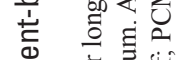

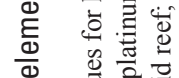

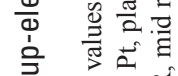

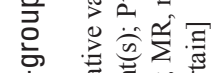

䒠

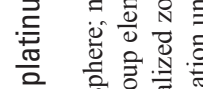

흠

总

㖣

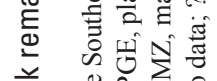

히일

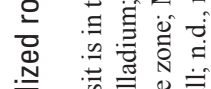

总

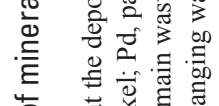

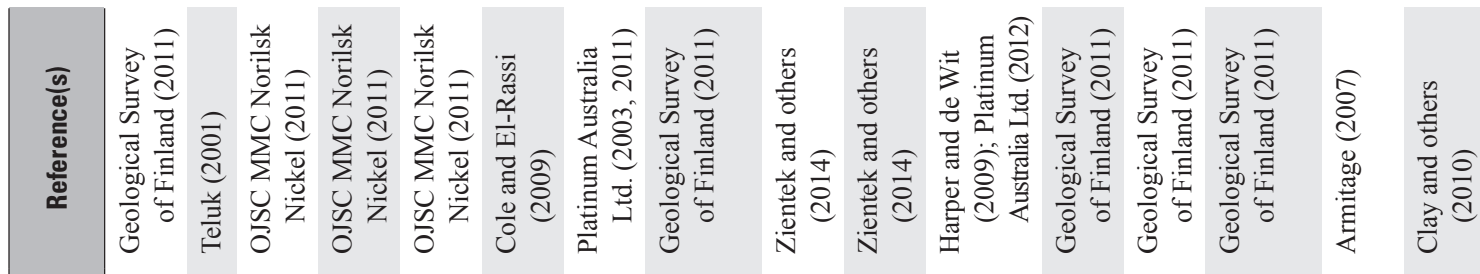

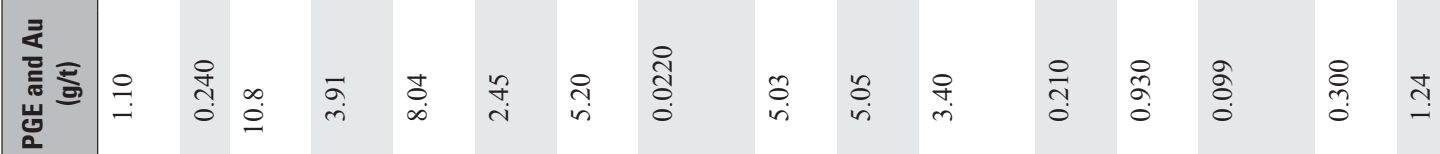

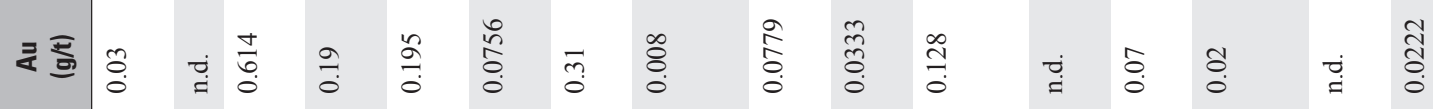

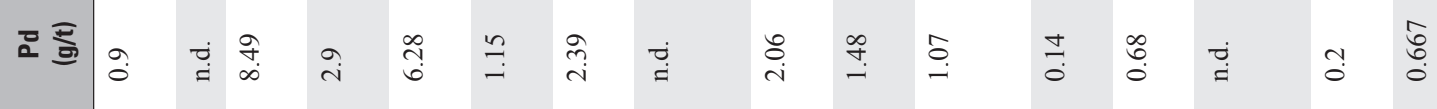

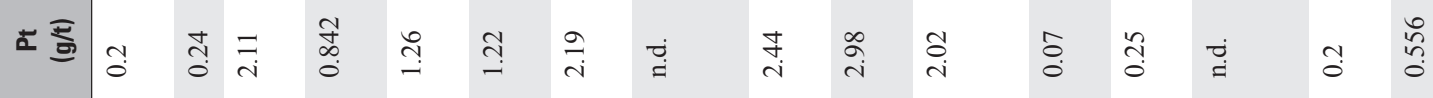

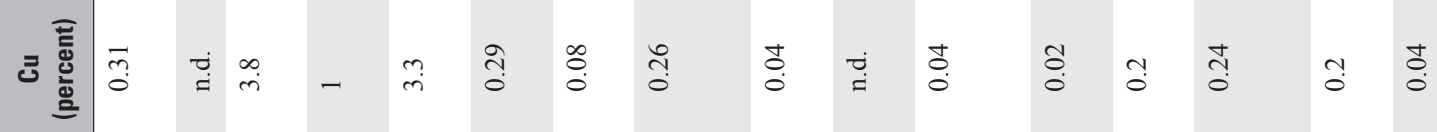

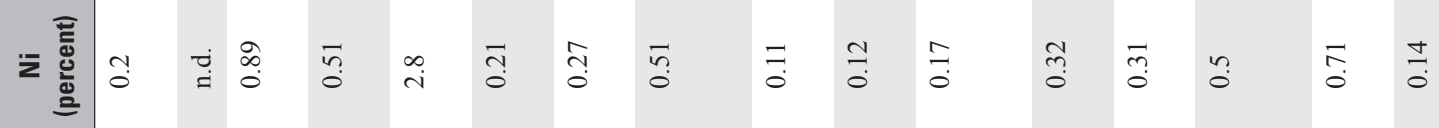

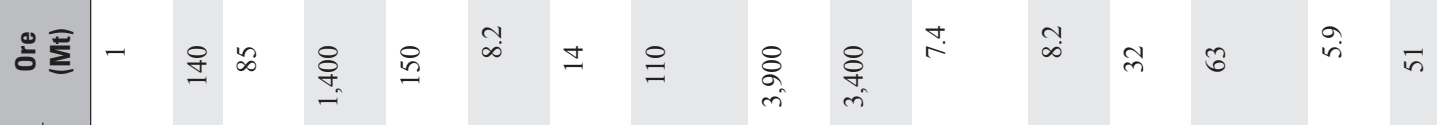

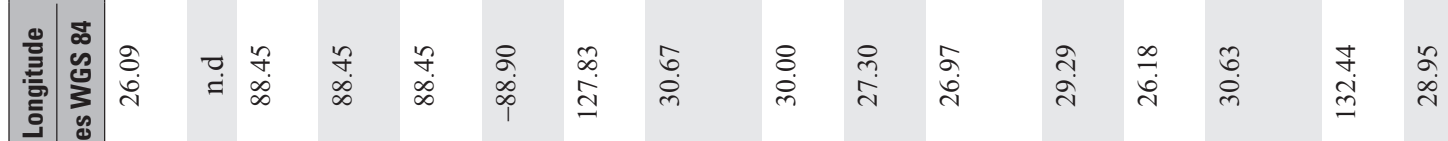

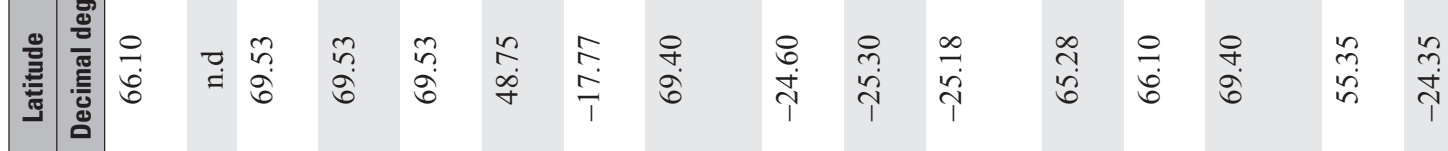

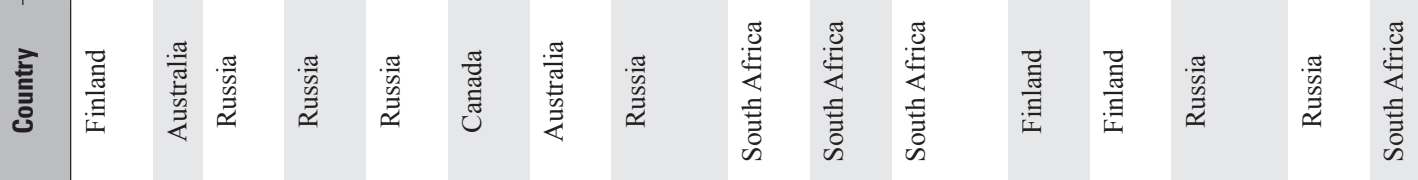

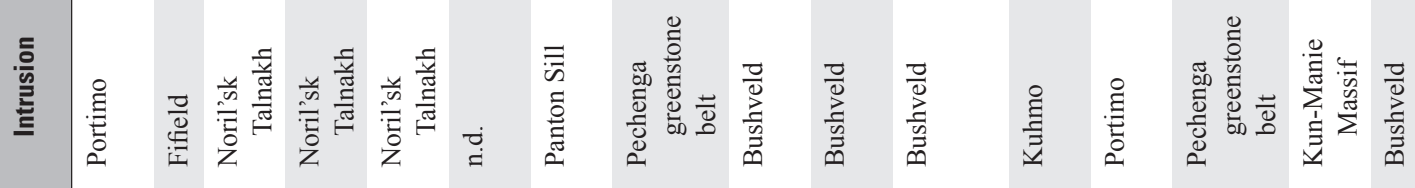

要

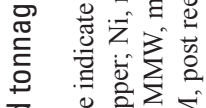

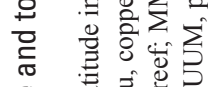

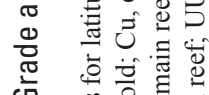

过

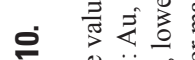

$\sum_{0}$

产

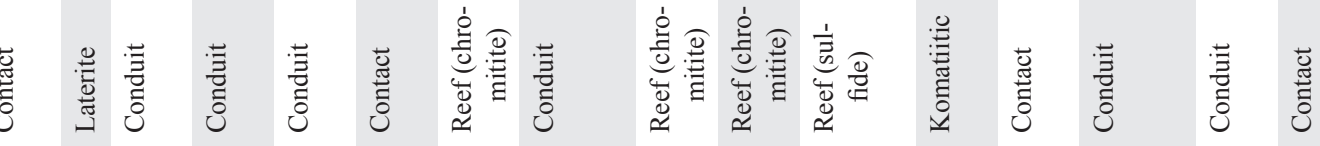

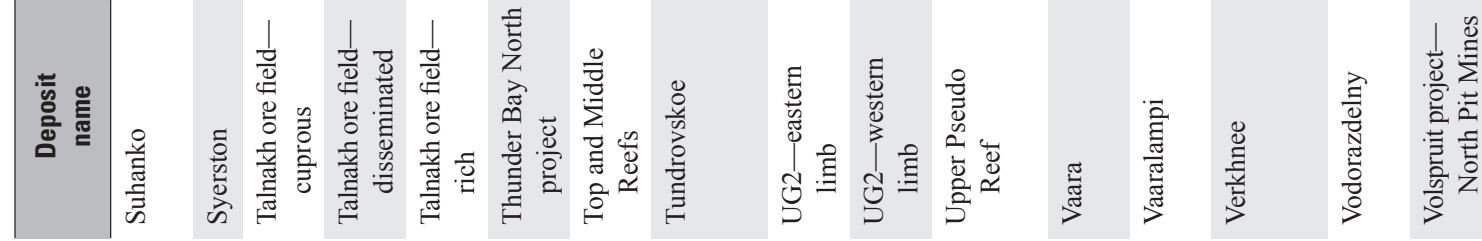




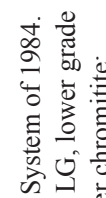

约

过

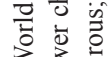

政

U.

落

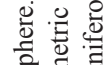

急要

- 廌

尝

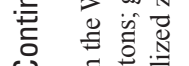

1.0

劳

离

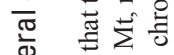

喜

ह

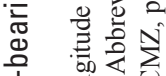

흘

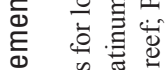

产 总

言

눈

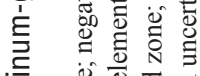

言

흘

돌

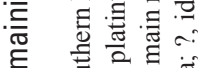

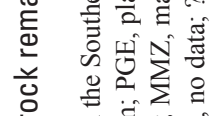

을

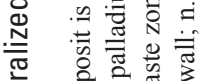

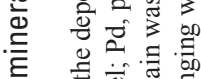

등

。

兽

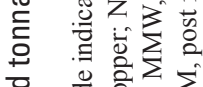

흘

悹

o

을

章

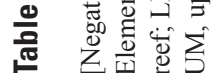

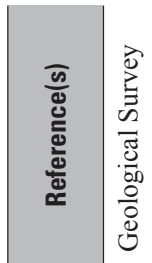

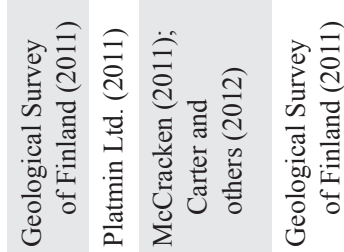

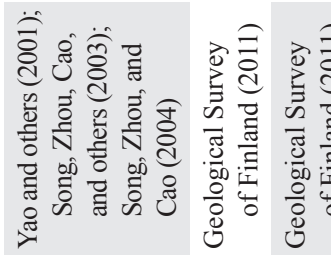

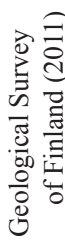

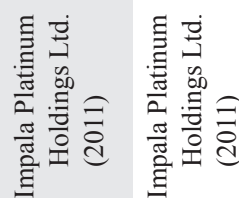

焉

루음

$\underset{m}{\dot{m}} \exists \frac{m}{\sigma}$

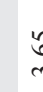

ถู่

각

$\stackrel{8}{\circ}$

$\stackrel{8}{+} \quad \stackrel{n}{m}$

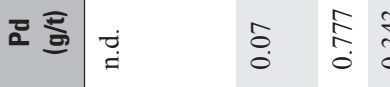

동

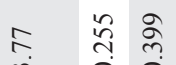

c)

$\stackrel{\ddot{घ}}{\ddot{=}}$

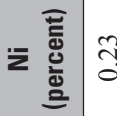

घं

올

กี่

童离

密

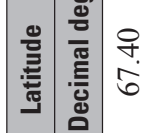

กิ่

$\stackrel{n}{?}$

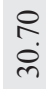

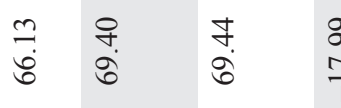

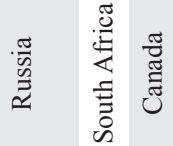

$\frac{1}{2}$

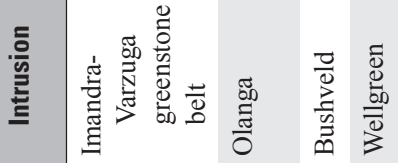

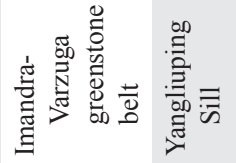

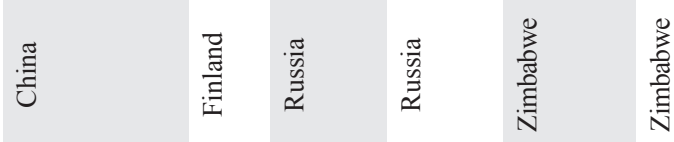

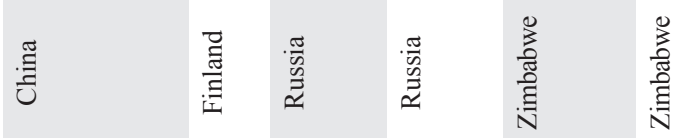

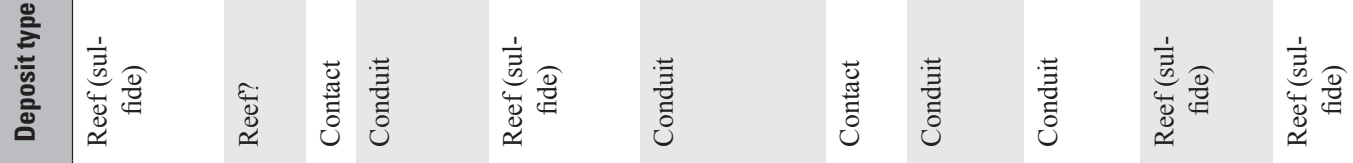

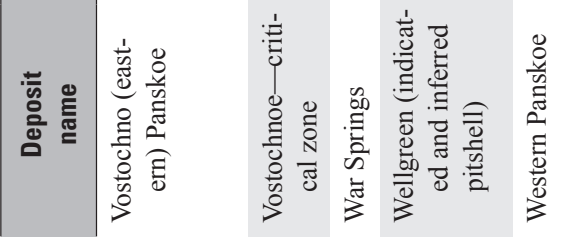

率

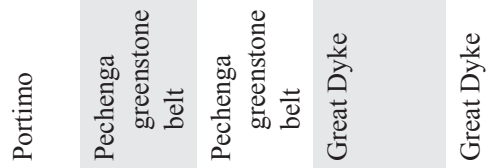





\section{Rare-Earth Elements}

By Bradley S. Van Gosen, Philip L. Verplanck, Robert R. Seal II, Keith R. Long, and Joseph Gambogi

Chapter 0 of

Critical Mineral Resources of the United States-Economic and Environmental Geology and Prospects for Future Supply

Edited by Klaus J. Schulz, John H. DeYoung, Jr., Robert R. Seal II, and Dwight C. Bradley

Professional Paper 1802-0 


\section{Contents of Chapter 0}

[Figure and table titles for all chapters are listed in the volume contents before the conversion factors table and list of abbreviations and symbols. A periodic table of the elements is on the inside front cover of the printed volume]

Abstract
Introduction
Uses and Applications
Availability of Supply
Australia
Indiana
$\quad$ Malaysia
$\quad$ United States




\title{
Rare-Earth Elements
}

\author{
By Bradley S. Van Gosen, Philip L. Verplanck, Robert R. Seal II, Keith R. Long, and Joseph Gambogi
}

\section{Abstract}

The rare-earth elements (REEs) are 15 elements that range in atomic number from 57 (lanthanum) to 71 (lutetium); they are commonly referred to as the "lanthanides." Yttrium (atomic number 39) is also commonly regarded as an REE because it shares chemical and physical similarities and has affinities with the lanthanides. Although REEs are not rare in terms of average crustal abundance, the concentrated deposits of REEs are limited in number.

Because of their unusual physical and chemical properties, the REEs have diverse defense, energy, industrial, and military technology applications. The glass industry is the leading consumer of REE raw materials, which are used for glass polishing and as additives that provide color and special optical properties to the glass. Lanthanum-based catalysts are used in petroleum refining, and cerium-based catalysts are used in automotive catalytic converters. The use of REEs in magnets is a rapidly increasing application. Neodymium-iron-boron magnets, which are the strongest known type of magnets, are used when space and weight are restrictions. Nickel-metal hydride batteries use anodes made of a lanthanum-based alloys.

China, which has led the world production of REEs for decades, accounted for more than 90 percent of global production and supply, on average, during the past decade. Citing a need to retain its limited REE resources to meet domestic requirements as well as concerns about the environmental effects of mining, China began placing restrictions on the supply of REEs in 2010 through the imposition of quotas, licenses, and taxes. As a result, the global rare-earth industry has increased its stockpiling of REEs; explored for deposits outside of China; and promoted new efforts to conserve, recycle, and substitute for REEs. New mine production began at Mount Weld in Western Australia, and numerous other exploration and development projects noted in this chapter are ongoing throughout the world.
The REE-bearing minerals are diverse and often complex in composition. At least 245 individual REE-bearing minerals are recognized; they are mainly carbonates, fluorocarbonates, and hydroxylcarbonates $(\mathrm{n}=42)$; oxides $(\mathrm{n}=59)$; silicates $(\mathrm{n}=85)$; and phosphates $(\mathrm{n}=26)$.

Many of the world's significant REE deposits occur in carbonatites, which are carbonate igneous rocks. The REEs also have a strong genetic association with alkaline magmatism. The systematic geologic and chemical processes that explain these observations are not well understood. Economic or potentially economic REE deposits have been found in (a) carbonatites, (b) peralkaline igneous systems, (c) magmatic magnetite-hematite bodies, (d) iron oxide-copper-gold (IOCG) deposits, (e) xenotime-monazite accumulations in mafic gneiss, (f) ion-absorption clay deposits, and (g) monazite-xenotimebearing placer deposits. Carbonatites have been the world's main source for the light REEs since the 1960s. Ion-adsorption clay deposits in southern China are the world's primary source of the heavy REEs. Monazite-bearing placer deposits were important sources of REEs before the mid-1960s and may be again in the future. In recent years, REEs have been produced from large carbonatite bodies mined at the Mountain Pass deposit in California and, in China, at the Bayan Obo deposit in Nei Mongol Autonomous Region, the Maoniuping deposit in Sichuan Province, the Daluxiang deposit in Sichuan Province, and the Weishan deposit in Anhui Province. Alkaline igneous complexes have recently been targeted for exploration because of their enrichments in the heavy REEs.

Information relevant to the environmental aspects of REE mining is limited. Little is known about the aquatic toxicity of REEs. The United States lacks drinking water standards for REEs. The concentrations of REEs in environmental media are influenced by their low abundances in crustal rocks and their limited solubility in most groundwaters and surface waters. The scarcity of sulfide minerals, including pyrite, minimizes or eliminates concerns about acid-mine drainage for carbonatitehosted deposits and alkaline-intrusion-related REE deposits. For now, insights into environmental responses of REE mine wastes must rely on predictive models. 


\section{Introduction}

Until recently, the rare-earth elements (REEs) were familiar to a relatively small number of people, such as chemists, some geologists, and specialized materials and technology engineers. In the 21 st century, the REEs have gained considerable visibility through news media and Internet coverage because of (a) recognition of the critical, specialized properties that the REEs contribute in components of our modern technology, combined with (b) the near monopoly on the production and supply of the REEs held by one country (China), and (c) the world's heavy dependence on this controlled supply from China (Long, 2011; Tse, 2011; Hatch, 2012a).

Since the late 1990s, China has provided more than 90 percent of the world's supply of the REEs, on average (Long and others, 2010; Tse, 2011; Hatch, 2012a). In 2010, China announced that it intended to reduce its exports of REEs (Hatch, 2012a). At the same time, the use of REEs in clean energy and defense technologies was continuing to increase (Goonan, 2011; Long, 2011; Tse, 2011; Hatch, 2012a). China's announcement regarding its REE export quotas raised concerns among nations that are highly dependent on specialized technologies, such as Japan, the United States, and members of the European Union. These countries, as well as the World Trade Organization, formally protested China's reduced export quotas for REEs (Hatch, 2012a), and China agreed in 2014 to remove the restrictions. Nonetheless, the political and economic issues surrounding the global supply of REEs in the early 21 st century has given these metals more visibility and a greater appreciation of their strategic importance than ever before. As a consequence, exploration activities to discover economic deposits of REEs and efforts to bring them into production increased dramatically. One industry analyst stated that, as of September 2012, during a high period of global exploration for REE deposits, his company was "tracking a total of 442 rareearth projects in progress associated with 270 different companies in 37 different countries" (Hatch, 2012b).

In recent years, expert panels convened by research institutes and Government agencies highlighted specific REEs as raw materials critical to evolving technologies, such as clean-energy applications, electronics, and high-tech military components. These reports also suggest that a high potential exists for disruptions in the supply of these REEs. As a result, several expert panel analyses ranked REEs high on the "criticality" factor of raw materials - that is, high importance to technologies and economies combined with high risk for supply disruptions. Recent reports by panels and agencies tasked to assess the criticality of REEs and other raw materials include those by the National Research Council (2008), U.S. Department of Energy (2010, 2011), European Commission (2014), American Physical Society (APS) Panel on Public Affairs and Materials Research Society (MRS) (2011), and the Resnick Institute (2011).
The REEs comprise 15 elements (table O1) that range in atomic number from 57 (lanthanum) to 71 (lutetium) on the periodic table of elements. They are commonly referred to as the "lanthanides." The REE promethium (atomic number 61) is not included in discussions of REE deposits because the element is extremely rare and unstable in nature. Yttrium (atomic number 39) is commonly regarded as an REE because it shares chemical and physical similarities and has affinities with the lanthanides and because it typically occurs in the same deposits as other REEs.

Traditionally, the REEs are divided into the following two groups on the basis of atomic weight: (a) the light REEs (LREEs), which include lanthanum through gadolinium (atomic numbers 57 through 64), and (b) the heavy REEs (HREEs), which include terbium through lutetium (atomic numbers 65 through 71) (table O1). Yttrium, although light (atomic number 39), is included with the HREE group because of its common chemical and physical affiliations with the other HREEs.

Table 01. List of the rare-earth elements found in natural deposits-the "lanthanides" plus yttrium.

[Average crustal abundance values are from Lide (2004, p. 17); REE, rareearth element]

\begin{tabular}{lcccc}
\hline \multicolumn{1}{c}{ Element ${ }^{1}$} & Symbol & $\begin{array}{c}\text { Atomic } \\
\text { number }\end{array}$ & $\begin{array}{c}\text { Atomic } \\
\text { weight }\end{array}$ & $\begin{array}{c}\text { Crustal } \\
\text { abundance } \\
\text { (part per } \\
\text { million) }\end{array}$ \\
\hline Lanthanum & La & 57 & 138.91 & 39 \\
Cerium & $\mathrm{Ce}$ & 58 & 140.12 & 66.5 \\
Praseodymium & $\mathrm{Pr}$ & 59 & 140.91 & 9.2 \\
Neodymium & $\mathrm{Nd}$ & 60 & 144.24 & 41.5 \\
Samarium & $\mathrm{Sm}$ & 62 & 150.36 & 7.05 \\
Europium & $\mathrm{Eu}$ & 63 & 151.96 & 2.0 \\
Gadolinium & $\mathrm{Gd}$ & 64 & 157.25 & 6.2 \\
\hline & & Heavy REEs & & \\
\hline Yttrium & $\mathrm{Y}$ & 39 & 88.91 & 33 \\
Terbium & $\mathrm{Tb}$ & 65 & 158.92 & 1.2 \\
Dysprosium & $\mathrm{Dy}$ & 66 & 162.50 & 5.2 \\
Holmium & $\mathrm{Ho}$ & 67 & 164.93 & 1.3 \\
Erbium & $\mathrm{Er}$ & 68 & 167.26 & 3.5 \\
Thulium & $\mathrm{Tm}$ & 69 & 168.93 & 0.52 \\
Ytterbium & $\mathrm{Yb}$ & 70 & 173.04 & 3.2 \\
Lutetium & $\mathrm{Lu}$ & 71 & 174.97 & 0.8 \\
\hline & & & & \\
\hline & & 69 & \\
\hline
\end{tabular}

${ }^{1}$ Promethium $(\mathrm{Pm}$, atomic number $=61)$ is not included in this list because it is extremely rare in nature. 
Most of the REEs are not as rare as the group's name suggests. They were named "rare-earth" elements because most were identified during the 18th and 19th centuries as "earths" (originally defined as materials that could not be changed further by the sources of heat), and, in comparison with other "earths," such as lime or magnesia, they were relatively rare. Cerium is the most abundant REE (table O1), and it is actually more common in Earth's crust than is copper or lead (Lide, 2004, p. 17). All the REEs except promethium are more abundant than silver, gold, or platinum in Earth's crust, on average (Lide, 2004, p. 17). Thus, REEs are not rare in terms of average crustal abundance, but concentrated and economic deposits of REEs are unusual (Adams and Staatz, 1973). Ore deposits of REEs are found in unusual rock types and uncommon minerals, as described in the sections that follow.

\section{Uses and Applications}

To take advantage of their unusual physical and chemical properties, the REEs are used in a variety of industrial and technology applications (Goonan, 2011; Long, 2011). Given their similar chemical nature, many different REEs have related or complementary uses; thus, it is more convenient to describe their uses by application rather than by individual element. In general, the lighter REEs and yttrium are cheaper, are produced in greater quantities, and are more extensively used than the heavier REEs. The least common and most expensive REEs, from holmium to lutetium, are limited to a very few, highly specialized, high-technology applications. Goonan (2011) provided a quantitative study of domestic REE consumption, including estimated consumption of individual REEs as of 2008, addressed according to consumption categories.

The glass industry is the leading consumer of REE raw materials (Goonan, 2011), principally for purposes of glass polishing and as additives to provide color and special optical properties to glass. Cerium oxide is widely used in the production of glass types that require a precision polish, such as flat panel display screens. Cerium is also used to decolorize glass. Lanthanum and lutetium greatly increase the refractive index of optical glass. Lanthanum is widely used in camera lenses, whereas the more expensive lutetium is used in immersion lithography, which requires a high-refractive index. Erbium, holmium, neodymium, praseodymium, ytterbium, and yttrium are used as special colorants and to provide filtering and glare-reduction qualities for glass. Europium is a common dopant (doping agent) for optical fibers.

Catalysts are another major use for REEs. They include lanthanum-based catalysts used in petroleum refining and cerium-based catalysts used in automotive catalytic converters (Goonan, 2011). Catalysts enriched in REEs are essential to cracking (breaking down) heavy hydrocarbon molecules into smaller molecules, which enables petroleum refineries to obtain significantly more product per barrel of oil processed.
Small amounts of neodymium, praseodymium, and yttrium are used as catalysts in catalytic converters to reduce automotive carbon monoxide emissions.

Permanent magnets made from alloys of REEs are a recent, rapidly growing application. Neodymium-iron-boron magnets are the strongest magnets known; they are used wherever space and weight are at a premium. Significant uses include hard disk drives, cell phones, electric motors for hybrid vehicles and windmills, and actuators in aircraft (Goonan, 2011; Long, 2011). Lesser amounts of dysprosium, gadolinium, and praseodymium are also used in these magnets. Dysprosium is of particular importance because substituting it for a small portion of neodymium improves high-temperature performance and resistance to demagnetization. Permanent magnets are used in such demanding applications as electric motors for hybrid cars and wind turbines. Samarium-cobalt magnets, though less powerful than neodymium magnets, have better heat tolerance and are used in lieu of neodymium magnets where heat stress is an issue.

Nickel-metal hydride batteries use a lanthanum-based alloy for anodes (Kopera, 2004). Found in many rechargeable consumer products and some hybrid vehicles, these battery alloys are also a significant application of cerium, neodymium, praseodymium, and samarium. Demand for REEs in battery applications is expected to decrease as lithium ion batteries displace nickel-metal hydride batteries (Anderson and PatiñoEcheverri, 2009). Nickel-metal hydride batteries in hybrid electric cars are significant users of lanthanum, however, employing as much as 10 to 15 kilograms per vehicle.

Cerium, lanthanum, neodymium, and praseodymium, commonly in the form of a mixed oxide known as mischmetal, are used in steelmaking to remove impurities, as well as in the production of special steel alloys (Goonan, 2011). These REEs, along with yttrium, individually or in combination, are also used in various special alloys of chromium, magnesium, molybdenum, tungsten, vanadium, and zirconium.

Many REEs, especially yttrium, cerium, lanthanum, europium, and terbium, are used individually or in combination to make phosphors for many types of cathode ray tube and flat panel display screens, and in some incandescent, fluorescent, and light-emitting diode lighting (Goonan, 2011; Long, 2011). Gadolinium phosphors are used in X-ray imaging and various medical applications, such as magnetic resonance imaging (MRI). Yttrium, lanthanum, cerium, neodymium, and praseodymium are used as pigments for ceramics.

Rare-earth elements are also used in synthetic gems, crystals for lasers, microwave equipment, superconductors, sensors, nuclear control rods, and cryo-coolers. Neodymium is the active constituent in a popular fertilizer in China. Significant potential new uses for REEs include their use as nanofilters and in memory devices, power converters, optical clocks, infrared decoy flares, and fusion energy. Future research is likely to find many new uses for the REEs. 


\section{Availability of Supply}

China has been the leading producer of REEs for decades (fig. O1), and since the late 1990s, it has accounted for more than 90 percent of global production, on average. When China began restricting the supply of REEs through the imposition of quotas, licenses, and taxes in 2010, it cited limited resources for domestic requirements and environmental concerns as the reasons (Tse, 2011). China's restrictions on REEs changed the world rare-earth industry in several ways, including by fostering increased stockpiling of REEs; increased exploration and development of deposits outside of China; and new efforts to conserve, recycle, and find substitutes for and among the REEs. This is evidenced by new mine production that began in Australia in 2011 and in the United States in 2012, and by additional exploration and development projects in many other countries (Gambogi, 2016). Global reserves of REEs were estimated on a rareearth-oxide (REO) basis to be 130 million metric tons and were led by, in decreasing order of reserves, China, Brazil, Australia, and India (Gambogi, 2015).

\section{Australia}

Heavy-mineral sands produced in Australia contain significant quantities of REEs; however, monazite has not been produced from heavy-mineral sands operations since the 1990 s to avoid the concentration of naturally occurring radioactive minerals, primarily owing to the presence of thorium in monazite. Lynas Corporation Ltd. of Australia began production of rare-earth mineral concentrates at its Mount Weld carbonatite complex in Western Australia in 2011. Shipments of mineral concentrates were delayed until 2013 while processing operations were being commissioned in Malaysia. Lynas later increased its capacity to produce mineral concentrates to 22,000 metric tons per year of contained REO. Other REE projects underway in Australia include the Nolans Bore property in the Northern Territory and the Dubbo Zirconia deposit in New South Wales, both of which were at the advanced feasibility study stage (Gambogi, 2016). Australia's reserves of REEs are estimated to be 3.2 million metric tons of REO (Gambogi, 2015).

\section{China}

China's rare-earth mine production takes place in the Provinces of Fujian, Guangdong, Hunan, Jiangxi, Shandong, Sichuan, and Yunnan, and in the Autonomous Regions of Guangxi and Nei Mongol. The largest mining operation is Baotou Rare Earth's Bayan Obo Mine, which produces iron ore as well as bastnaesite and monazite as the main rare-earth minerals. REE-bearing ion-adsorption clays are mined in various locations in the southeastern Provinces. In contrast to bastnaesite ores, ion-adsorption clays are valued for their medium REE and HREE content. Reserves of REEs in China are estimated to be 55 million metric tons of contained REO (Gambogi, 2015).

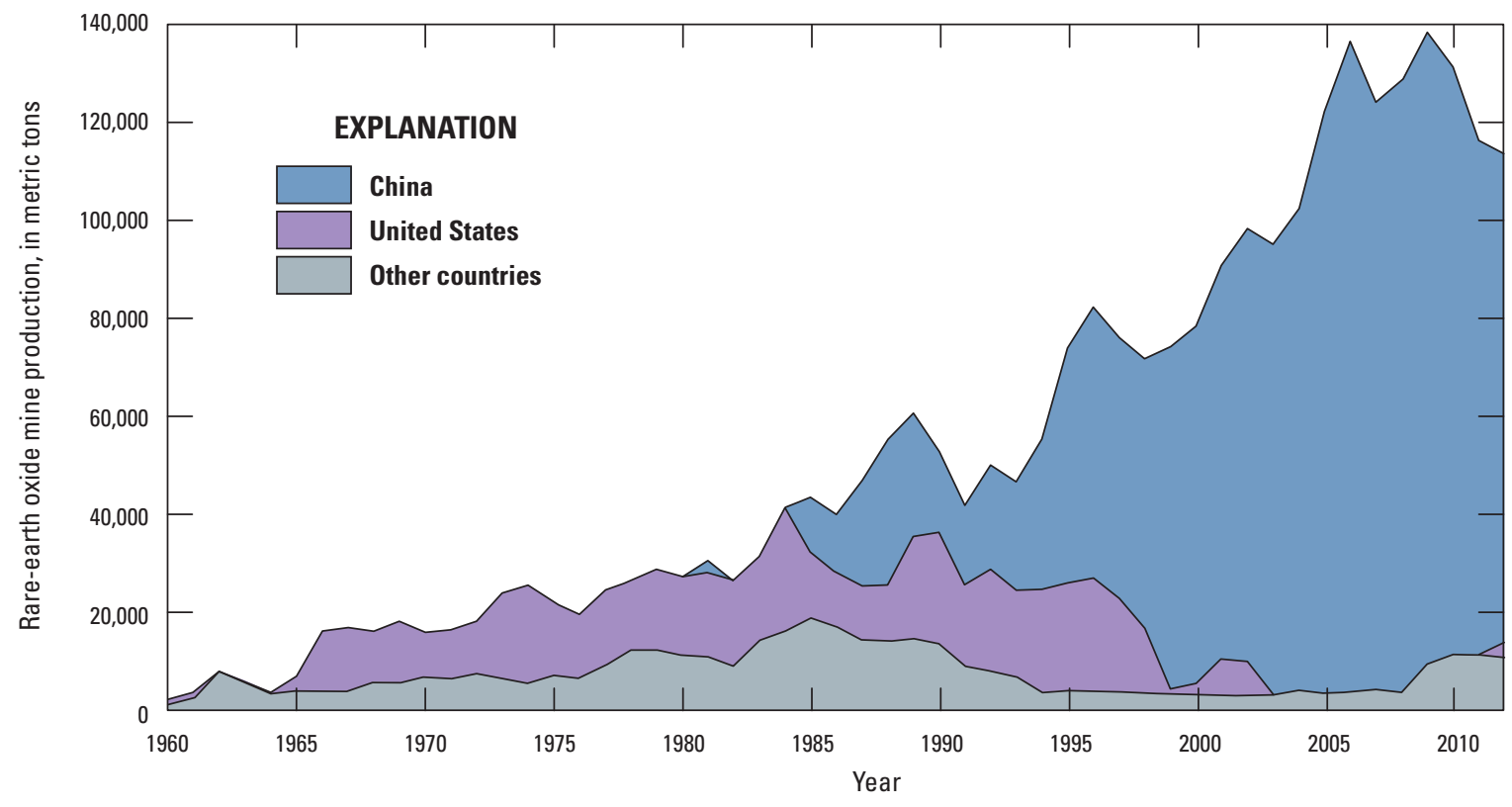

Figure 01. Graph showing world mine production of rare-earth oxides, by country and year, from 1960 to 2012. The layers of the graph are placed one above the other, forming a cumulative total. Data are from U.S. Bureau of Mines (1961-96) and U.S. Geological Survey (1997-2016). 
The leading export markets for China's REEs are Japan, the United States, and France. The supply of REEs to consumers outside of China is determined not by mine capacity but by production and export quotas set by China's Ministry of Commerce (MOFCOM) and the Ministry of Industry and Information Technology. Supply concerns were raised when the MOFCOM set China's export quota for the second half of 2010 at 7,976 metric tons (a 64 percent decrease compared with the quota set in the first half of 2010), which reduced the total exports for 2010 to 20,258 metric tons (a 40 percent decrease compared with exports for the previous year). Following the sudden drop in exports, prices for rare-earth products in 2010 increased sharply (Ministry of Commerce 2010a, b). Export quotas for 2011, 2012, and 2013 were set at 30,246 metric tons, 30,996 metric tons, and 30,999 metric tons, respectively. Prices for most rare-earth products peaked in mid-2011. In 2014, China's rare-earth export quotas were 30,611 metric tons, including 27,006 metric tons for LREEs and 3,605 metric tons for HREEs (Hatch, 2013, 2014). Chinese-owned companies were allocated 74 percent of the rare-earth products export quota, and joint ventures with foreign partners were allocated 26 percent of the quota. Following a World Trade Organization ruling in 2014, China announced the end of export restrictions on rare earths (Yap, 2015). According to the Ministry of Industry and Information Technology, the Government has ongoing efforts to reduce illegal mine production of rare earths, which was estimated to account for more than 40,000 metric tons of REE production in a single year (Global Times, 2013).

\section{India}

In India, REEs are produced from monazite contained in heavy-mineral sands. The two Government-owned producers are the Rare Earth Division of Indian Rare Earths Ltd. (IREL) and Kerala Minerals and Metals Ltd. (KMML). Heavy-mineral operations that produce monazite concentrate include IREL's Manavalakurichi operation in the State of Tamil (which had a capacity of 6,000 metric tons per year) and KMML's Chavara operation in Kerala State (240 metric tons per year) (Indian Bureau of Mines, 2015). IREL's capacity to produce rare-earth compounds from monazite was limited, but was reported to be increasing. India's reserves of REEs are estimated to be 3.1 million metric tons of REO (Gambogi, 2015).

\section{Malaysia}

In the Malaysian States of Perak and Selangor, REE-bearing monazite and xenotime are recovered from cassiterite mine tailings, which are referred to by the Malaysian mining industry as "amang." Recent monazite production from amang was less than 500 metric tons per year. Malaysia's reserves of REEs are estimated to be 30,000 metric tons of REO, which is less than 1 percent of global reserves (Gambogi, 2015, 2016).

\section{Russia}

In Russia, loparite mineral concentrates are produced at the Lovozero mining operation on the Kola Peninsula, Murmanskaya Oblast; the concentrates are shipped to the Solikamsk magnesium plant in Permskiy Kray. Rare-earth-bearing residues from the Solikamsk plant are exported for recovery of REEs. The Lovozero operation had the capacity to produce an estimated 3,700 metric tons per year of REOs contained in mineral concentrates. Within a global total of 130 million metric tons, Russia's reserves contributed to the 41 million metric tons of reserves from other counties (Gambogi, 2015).

\section{United States}

From 2012 to 2015, the United States was a leading producer of rare-earth minerals outside of China. All mine production of REEs during this period was from Molycorp, Inc.'s Mountain Pass Mine in San Bernardino County, California. Mine production at Mountain Pass began in 1952 but was discontinued from 2002 to 2011 because of low rare-earth prices and environmental permitting issues. In 2012, Molycorp commissioned new mine and processing operations that had an initial planned (but never fully realized) production capacity of 19,000 metric tons per year of REOs. Because of substantial decreases in the market prices of the REEs, however, Molycorp idled operations at the Mountain Pass Mine in 2015. Exploration and development assessment projects in the United States include Bokan Mountain, Alaska; La Paz, Arizona; Diamond Creek, Idaho; Lemhi Pass in Idaho and Montana; Pea Ridge, Missouri; Elk Creek, Nebraska; Thor Mine, Nevada; Round Top, Texas; and Bear Lodge, Wyoming. Domestic reserves of REOs were estimated to be 1.8 million metric tons (Gambogi, 2015).

\section{Conservation, Recycling, and Substitution}

Concerns about the availability of rare-earth supplies have stimulated efforts in recycling, substitution, and improving material efficiencies. These efforts are being led by the leading consumers of REEs.

In the United States, the Critical Materials Institute (a partnership of academia, Government, and industry) is working to diversify production, reduce waste, and develop substitutes for rare earths. The collaboration is expected to spend up to $\$ 120$ million during a period of 5 years to support research focused on ensuring a reliable supply of rare earths and other critical materials (U.S. Department of Energy, 2013).

Belgian-based Umicore Group has developed a batteryrecycling program for nickel-metal-hydride $(\mathrm{NiMH})$ batteries at its new recycling plant in Hoboken, Belgium. After the separation of nickel and iron, the company plans to process the REEs into a high-grade concentrate that would be separated into rare-earth materials at Rhodia Rare Earth Systems' plant at La Rochelle, France (Umicore Group, 2011). 
In the European Union, a consortium is investigating the extraction of rare-earth metals from permanent magnets in electric vehicle motors. The project is funded by the German Federal Research Ministry, and the consortium is led by Siemens AG (Recycling International, 2011b). German research agency Fraunhofer Institute for Surface Engineering and Thin Films is examining the recycling of rare-earth metals from disused lightmetal alloys and from lanthanum from fluid catalytic cracking (FCC) catalysts (Recycling International, 2011a).

In France, Rhodia formed an alliance with Umicore to recycle rare-earth minerals from NiMH rechargeable batteries. Rhodia also planned to recycle rare-earth minerals from lowenergy light bulbs and magnets. By yearend 2012, recycling plants in La Rochelle and Saint-Fons, Rhône-Alpes Region, were operational. The company planned to conserve on its consumption of terbium by using reformulated phosphors (Recycling International, 2011b, c).

In Japan, Honda Motor Co., Ltd. has been working with Japan Metals \& Chemicals Co. to recapture rare-earth metals from NiMH batteries. Honda expects to recover 80 percent of rare-earth metals contained in the used NiMH batteries and plans to collect the batteries globally (Honda Motor Co., Ltd., 2013). Japan's Hitachi, Ltd. is developing methods to recycle rare-earth magnets from hard disk drives, air conditioners, and other types of compressors. Hitachi Metals also has accelerated development of reduced-dysprosium sintered magnets using a dysprosium vapor-deposition and diffusion technology (Baba and others, 2013, p. 453).

In Vietnam, Japan's Shin-Etsu Chemical Co., Ltd. constructed processing plants for the separation of rare earths and production of rare-earth magnets. The processing plants enable the recycling of rare-earth magnets used in appliances, such as air conditioner compressor motors (Showa Denko K.K., 2010; Shin-Etsu Chemical Co., Ltd., 2014).

\section{Geology}

\section{Geochemistry}

The REEs are commonly found together in Earth's crust because they share a trivalent charge $\left(\mathrm{REEs}^{3+}\right)$ and similar ionic radii. Exceptions to the trivalent charge are cerium, which may occur in a $\mathrm{Ce}^{4+}$ valence state, and europium, which can exist as $\mathrm{Eu}^{2+}$. The lanthanides (lanthanum to lutetium) (table O1) have a unique property-with each increase in atomic number across the group, an electron is added to an inner incomplete subshell $(4 f)$ rather than to an outer level. This property of selectively filling inner levels results in a progressive decrease in the ionic radius of the trivalent lanthanide ions from $\mathrm{La}^{3+}$ to $\mathrm{Lu}^{3+}$ (fig. O2), referred to as "lanthanide contraction." The systematic decrease in ionic radii across the lanthanide group (fig. O2) has two significant consequences: (a) it affects the fractionation of the REEs to a high degree, which allows for their individual separation in geologic environments and in ore processing, and (b) it lends

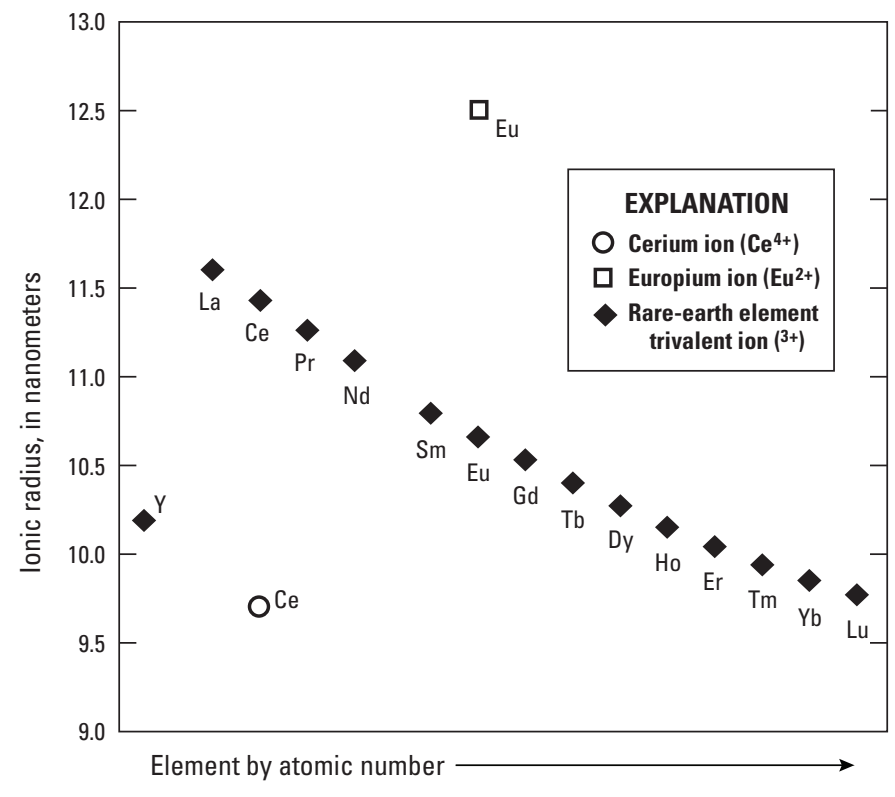

Figure 02. Graph showing radii (in nanometers) of the trivalent $\left({ }^{3+}\right)$ ions of the rare-earth elements (REEs) as well as of cerium in the +4 valence state $\left(\mathrm{Ce}^{4+}\right)$ and europium in the +2 valence state $\left(\mathrm{Eu}^{2+}\right)$. The graph illustrates the systematic decrease in the radius of the trivalent REE ions with increasing atomic number. Data plotted are for coordination number VIII. Data are from Shannon (1976). Elements, in order of increasing atomic number: $Y$, yttrium; La, lanthanum; Ce, cerium; $\mathrm{Pr}$, praseodymium; $\mathrm{Nd}$, neodymium; $\mathrm{Sm}$, samarium; Eu, europium; $\mathrm{Gd}$, gadolinium; Tb, terbium; Dy, dysprosium; Ho, holmium; Er, erbium; Tm, thulium; Yb, ytterbium; Lu, lutetium. Promethium (Pm) is not included in the list because it is extremely rare in nature.

the REEs unusual and useful chemical and physical properties, such as unique magnetic and (or) optical properties.

In magmatic systems, the high-charge of the REE ions impedes the ability of these elements to achieve charge balance and fit into the structure of the common rock-forming minerals, which have coordination sites best suited for valence states of 2 or 1. As a result, when common silicate minerals (such as amphiboles, feldspars, and olivine) crystallize, most of the REEs tend to remain in the coexisting melt. (In contrast, europium is often depleted in magmas because it is incorporated into feldspars owing to its $\mathrm{Eu}^{2+}$ valence state.) Successive generations of this process, referred to as crystal fractionation, increase the concentrations of REEs in the remaining melt until individual REE-mineral-rich phases crystallize. In addition to ionic charge (valence state), factors that can affect the partitioning of the REEs between a mineral and the coexisting magma can include temperature, pressure, fluid composition, magmatic convection, and variation in mineral settling velocities (Henderson, 1984; McKay, 1989; Kogarko and others, 2006). Elements, such as the REEs, that do not tend to participate in the early mineral-formation processes are referred to as incompatible elements. In magmatic systems, other incompatible elements may also include hafnium, niobium, phosphorus, tantalum, thorium, titanium, scandium, uranium, and zirconium. 


\section{Rare-Earth-Element-Mineral Formation in Carbonatite Magmas}

Many of the world's REE deposits are associated with carbonatites, which are igneous rocks derived from carbonaterich magmas rather than silica-rich magmas. Carbonatites are defined as igneous rocks with greater than 50 modal percent carbonate minerals, usually calcite and dolomite, and, in general, they have the highest REE concentrations of any igneous rocks (Chakhmouradian and Zaitsev, 2012). Carbonatite magmas are derived from the mantle, but the processes responsible for the formation of carbonatite magmas are in debate. Possible processes responsible for carbonatite magma generation include (a) primary mantle melts or (b) evolution from a mantle-derived alkali melt by crystal fractionation. As the carbonatite magma crystalizes, REEs can be concentrated in the primary REE mineral phases or they can become enriched in late-stage magmas or fluids. Latestage REE-rich magmas can result in ore-grade REE mineralization that contains very large concentrations of LREEs.

\section{Rare-Earth-Element-Mineral Formation in Alkaline Magmas}

In addition to carbonatites, the REEs have a strong genetic association with alkaline igneous processes, particularly peralkaline magmatism. Alkaline igneous rocks crystallize from silicate magmas and fluids enriched in alkali elements and precipitate sodium- and potassium-bearing minerals, such as sodium- or potassium-rich amphiboles and pyroxenes. Alkaline igneous rocks are typically undersaturated in silica, and they therefore contain little or no quartz. Peralkaline igneous rocks, which are defined as those in which the molecular proportion of aluminum oxide $\left(\mathrm{Al}_{2} \mathrm{O}_{3}\right)$ is less than that of sodium oxide $\left(\mathrm{Na}_{2} \mathrm{O}\right)$ and potassium oxide $\left(\mathrm{K}_{2} \mathrm{O}\right)$ combined (that is, $\mathrm{Al}_{2} \mathrm{O}_{3}<\mathrm{Na}_{2} \mathrm{O}+\mathrm{K}_{2} \mathrm{O}$ ), are associated with enrichments in REEs, typically more than most other igneous rocks.

\section{Rare-Earth-Element-Mineral Formation in Parental Magma Sources}

The REEs occur in modest concentrations in the upper mantle but by some processes can become highly enriched in carbonate and alkaline magmas that ascend from the mantle to the crust (Arzamastsev and others, 2001). A discussion of what geologic processes separate, enrich, and mobilize REEs in the upper mantle, ultimately forming ore-grade deposits of REE minerals in the crust, is beyond the scope of this chapter. Wyllie and others (1996) provide a comprehensive review and discussion of many studies that focus on the genesis of carbonatite magmas and their REE minerals. An overview of recent research toward REE sources and processes is discussed by Chakhmouradian and Zaitsev (2012).

\section{Rare-Earth-Element-Mineral Formation Through Hydrothermal Processes}

The formation of REE minerals in hydrothermal environments is a less investigated aspect of their formation, but is discussed by Gieré (1996). The mobilization of the REEs by hydrothermal processes is summarized by Williams-Jones and others (2012).

\section{Aqueous Geochemistry of Rare-Earth Elements}

With the development of inductively coupled plasmamass spectrometry (ICP-MS), analysis of REEs in aqueous solutions has become routine. As a result, the number of studies that analyze and interpret REEs has increased substantially in the past 15 years. Similar to many trace metals, the REEs occur as cations, which generally become less soluble with increasing $\mathrm{pH}$ (Verplanck and others, 2004). The REEs have a charge of +3 , but under oxidizing conditions, cerium can have a charge of +4 . Under reducing conditions, europium can have $\mathrm{a}+2$ charge, but europium in the +2 oxidation state is generally limited to high-temperature environments.

The behavior of REEs in aqueous solutions can be described as a competition between the formation of stable aqueous complexes and the tendency of REEs to partition to solid phases, either by adsorption or (co)precipitation. The dominant inorganic ligands include carbonate, fluoride, hydroxide, phosphate, and sulfate. Other factors that potentially affect the partitioning between solid and aqueous phases include the composition of solid phases, $\mathrm{pH}$, temperature, and redox conditions. The behavior of REEs in aqueous solutions is particularly relevant to REE ore deposit genesis in both magmatic and surficial environments because the stability of aqueous REE complexes plays an important role in their mobilization, transport, fractionation, and deposition (Williams-Jones and others, 2012).

\section{Mineralogy}

The minerals that contain REEs are numerous, diverse, and often complex in composition. Jones and others (1996, appendix A) list 245 individual REE-bearing minerals, which include silicates (in which category the total number of REE-bearing minerals is 85); oxides (59); carbonates, fluorocarbonates, and hydroxylcarbonates (42); phosphates (26); arsenates, sulfates, and vanadates (19); halides (6); uranylcarbonates and uranyl-silicates (5); and borates (3). Table O2 lists the REE- and yttrium-bearing minerals that historically have been important ore minerals for these elements.

Bastnaesite (also spelled bastnäsite) may be considered the most important REE mineral because it is the primary ore mineral of the world's two largest REE deposits - the carbonatite deposit at Mountain Pass in California (fig. O3) and the iron-carbonatite deposits of Bayan Obo in China. 


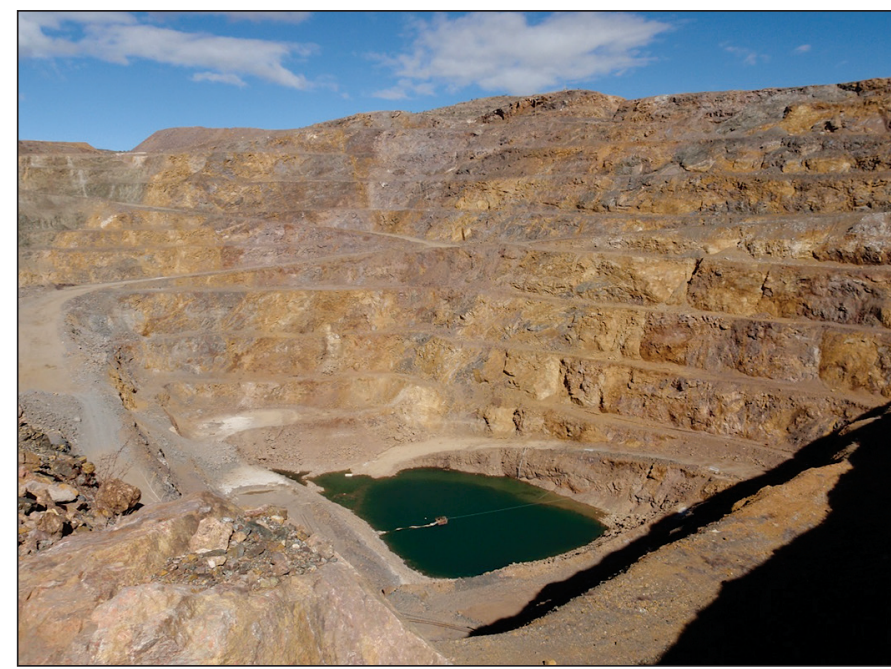

Figure 03. Photograph of the Mountain Pass Mine in San Bernardino County, California, which was the only active producer of rare-earth elements (REEs) in the United States in 2013. The orebody is a tabular carbonatite intrusion and is thought to be the largest REE resource in the United States. Molycorp, Inc. (2012), which owns and operates the mine, reported proven and probable reserves totaling 16.7 million metric tons of carbonatite ore at an average grade of 7.98 percent rare-earth oxide (REO) using a cutoff grade of 5 percent REO. The mine was placed on care-andmaintenance status in 2015. Photograph by Bradley S. Van Gosen.

The orebody of the Mountain Pass Mine - the Sulphide Queen carbonatite - contains about 10 to 15 percent bastnaesite and lesser amounts of parisite (Castor and Nason, 2004).

In carbonatites, REE mineral assemblages can be categorized by mineral-forming process into the following three groups (Mariano, 1989; Chakhmouradian and Zaitsev, 2012): (a) primary magmatic mineralization in carbonatites (Mountain Pass, Calif.), (b) hydrothermal-metasomatic mineralization (Bayan Obo, China), and (c) supergene mineralization (Mount Weld in Western Australia, Australia, and Araxá in the State of Minas Gerais, Brazil). The principal REE minerals in carbonatites are fluorocarbonates (bastnaesite, parisite, synchysite), hydrated carbonates (ancylite), and phosphates (monazite). Less abundant REE minerals in carbonatites include REE-bearing britholite, burbankite, and fluorapatite (table O2). Most carbonatites display a multiphase petrogenetic evolution, including hydrothermal overprinting of primary phases; thus, mineralogical and textural characteristics can vary and be complex.

Bastnaesite is typically the most significant source of REEs in carbonatite-related deposits, such as at Mountain Pass (California) and Bear Lodge (Wyoming) in the United States, and Bayan Obo (Nei Mongol Autonomous Region), Maoniuping (Sichuan Province), Daluxiang (Sichuan Province), and Weishan (Anhui Province) in China (fig. O4). Mariano (1989) notes that strong enrichments in the LREEs occur in carbonatite deposits in which the dominant ore mineral is bastnaesite. Mariano (1989) states that bastnaesite of hydrothermal origin typically occurs as fine-grained fibrous or platy masses in vugs, microfractures, and veinlets, which are commonly associated with, in general order of abundance, quartz, fluorite, strontianite, barite, and hematite. Ancylite is an indicator of secondary carbonate hydrothermal processes; it is found intergrown with strontianite in altered carbonatites (Mariano, 1989). The REE ore minerals in the intensely altered, upper oxidized zones of the Bear Lodge deposit are minerals of the bastnaesite group, plus cerianite (table O2) and locally abundant monazite (Dahlberg, 2014).

The vast majority of peralkaline REE deposits display complex petrogenetic evolution, which can result in variable mineralogy and intricate textures. Important REE-yttriumbearing minerals in peralkaline deposits can include, in general order of abundance, fluorapatite (fluorine-rich apatite), eudialyte, loparite, xenotime, monazite, gadolinite, bastnaesite, parisite, synchysite, kainosite, mosandrite, britholite, allanite, brannerite, thalenite, iimoriite, and fergusonite (table O2). In general, REE mineralization in peralkaline intrusions is typically more enriched in the HREEs than is the case with carbonatite-hosted deposits (fig. O5). Complex ore mineralogy with hydrothermal overprinting of primary magmatic phases is typified by the peralkaline dikes at Bokan Mountain on Prince of Wales Island in southeastern Alaska, in which more than 20 REE-yttrium-bearing minerals representing multiple generations have been identified (Barker and Van Gosen, 2012; Dostal and others, 2014). As another example, 45 REE-bearing minerals have been identified in the Khibiny alkaline complex in Murmanskaya Oblast', northwestern Russia (Chakhmouradian and Zaitsev, 2012).

In metamorphic deposits, common REE-yttrium-bearing minerals are the phosphate minerals xenotime and monazite. Examples in gneiss occur in the Music Valley area of the northern part of Joshua Tree National Park in Riverside County, Calif. (Evans, 1964; Long and others, 2010).

The primary REE-rich minerals within magmatic magnetite-hematite deposits are REE-bearing fluorapatite along with xenotime and monazite. Examples of massive magnetite-hematite deposits with REE-bearing fluorapatite, xenotime, and monazite as accessory minerals are the Pea Ridge iron deposit in Washington County, Mo., and iron deposits of the Mineville iron district in Essex County, New York (both districts are summarized in Long and others, 2010).

Nepheline syenite complexes in the Kola Peninsula region of Murmanskaya Oblast' in far northwestern Russia have been mined for their enrichments in niobium and REEs; the REEs occur mainly in loparite (table O2), which is a mineral of the perovskite group. This loparite reportedly contains more than 30 weight percent REO and is strongly enriched in the LREEs compared with the HREEs (Mariano, 1989; Chakhmouradian and Mitchell, 1998).

Deep weathering of REE-bearing alkaline igneous rocks or carbonatite in humid tropical climates with moderate to high rainfall can form thick laterite zones; these laterites can contain economic accumulations of residual REE minerals, depending on the underlying lithology. Examples of REE minerals that occur in the intensely weathered zone (laterite) 


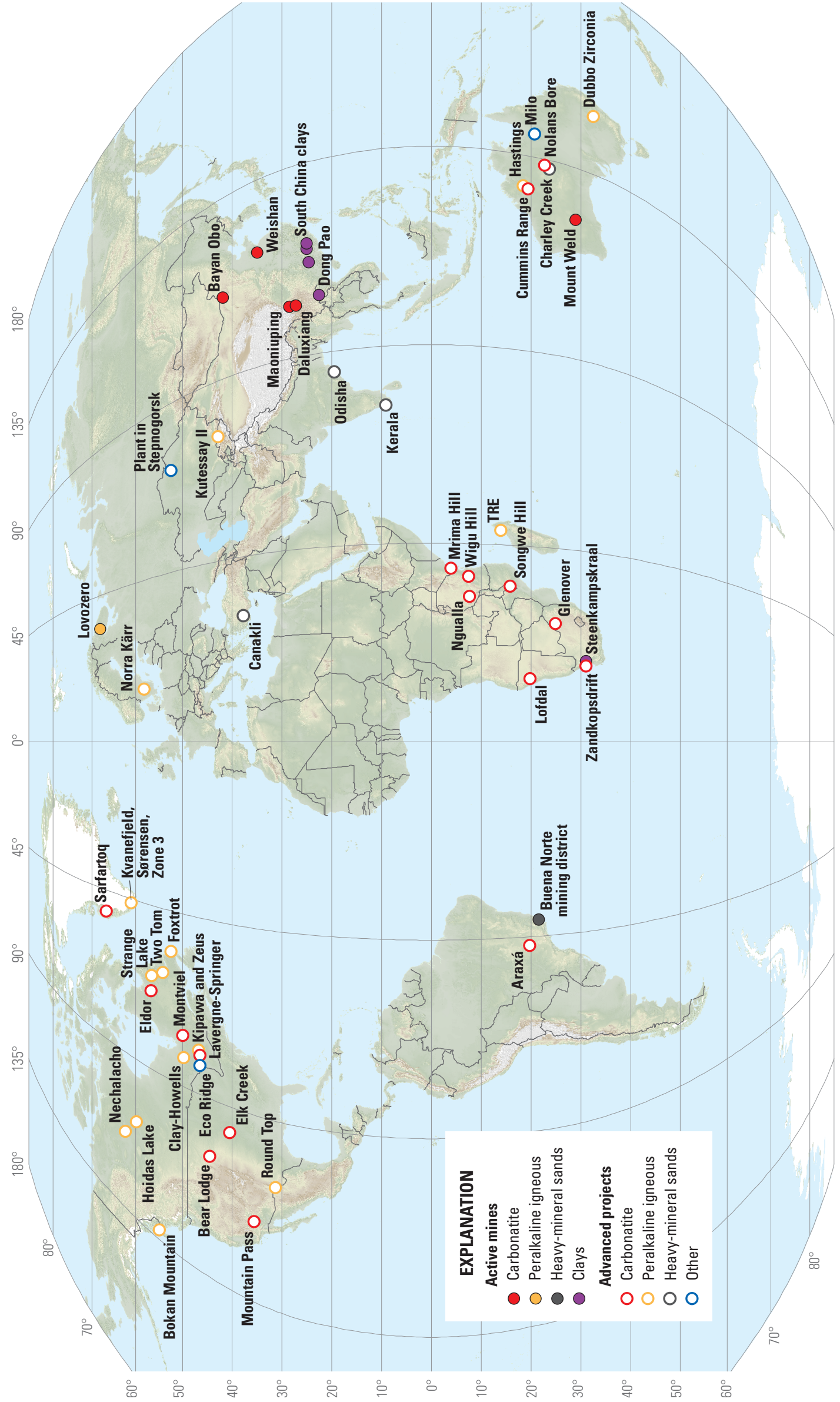

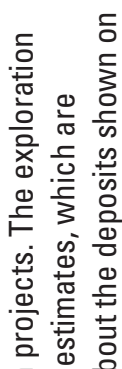

토 흥 은

응 \&

खे 눙

엄

든 응 흔

긍 ญ 음

읻이 잉

음. 을

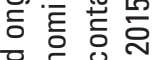

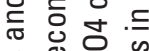

œ \&

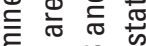

एิ

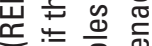

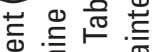

ह ह

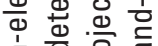

능 은

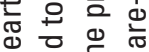

ఫ 엄

㐫 元 $\overline{\bar{\sigma}}$

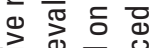

엉 힝

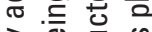

入े 홍

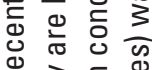

ఏ

亡。

》

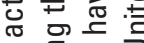

4. को

थ ฮั

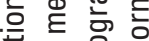

ত্ㅇ ब은

으 정

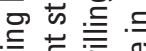

章苍

유에 Ð

E d 可

은 品

3 추웡

¿

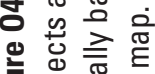

흔은 옹 
Table 02. List of selected rare-earth-element-bearing and yttrium-bearing ore minerals.

[Source: Jones and others (1996, Appendix A)]

\begin{tabular}{|c|c|}
\hline Mineral name ${ }^{1}$ & Chemical formula \\
\hline Allanite & $(\mathrm{REE}, \mathrm{Ca}, \mathrm{Y})_{2}\left(\mathrm{Al}, \mathrm{Fe}^{3+}\right)_{3}\left(\mathrm{SiO}_{4}\right)_{3}(\mathrm{OH})$ \\
\hline Ancylite & $\mathrm{Sr}(\mathrm{REE})\left(\mathrm{CO}_{3}\right)_{2}(\mathrm{OH}) \cdot \mathrm{H}_{2} \mathrm{O}$ \\
\hline Bastnaesite & $(\mathrm{REE})\left(\mathrm{CO}_{3}\right) \mathrm{F}$ \\
\hline Brannerite & $(\mathrm{U}, \mathrm{Ca}, \mathrm{Y}, \mathrm{REE})(\mathrm{Ti}, \mathrm{Fe})_{2} \mathrm{O}_{6}$ \\
\hline Britholite & $(\mathrm{REE}, \mathrm{Ca}, \mathrm{Th})_{5}\left(\mathrm{SiO}_{4}, \mathrm{PO}_{4}\right)_{3}(\mathrm{OH}, \mathrm{F})$ \\
\hline Burbankite & $(\mathrm{Na}, \mathrm{Ca})_{3}(\mathrm{Sr}, \mathrm{Ba}, \mathrm{Ce})_{3}\left(\mathrm{CO}_{3}\right)_{5}$ \\
\hline Cerianite-(Ce) & $\left(\mathrm{Ce}^{4+}, \mathrm{Th}\right) \mathrm{O}_{2}$ \\
\hline Eudialyte & $\mathrm{Na}_{4}(\mathrm{Ca}, \mathrm{REE})_{2}\left(\mathrm{Fe}^{2+}, \mathrm{Mn}, \mathrm{Y}\right) \mathrm{ZrSi}_{8} \mathrm{O}_{22}(\mathrm{OH}, \mathrm{Cl})_{2}$ \\
\hline Fergusonite-(Y) & $\mathrm{YNbO}_{4}$ \\
\hline Florencite & $(\mathrm{REE}) \mathrm{Al}_{3}\left(\mathrm{PO}_{4}\right)_{2}(\mathrm{OH})_{6}$ \\
\hline Fluorapatite & $(\mathrm{Ca}, \mathrm{REE}, \mathrm{Na})_{5}\left(\mathrm{PO}_{4}\right)_{3}(\mathrm{~F}, \mathrm{OH})$ \\
\hline Gadolinite & $(\mathrm{REE}, \mathrm{Y})_{2} \mathrm{Fe}^{2+} \mathrm{Be}_{2} \mathrm{Si}_{2} \mathrm{O}_{10}$ \\
\hline Gorceixite & $(\mathrm{Ba}, \mathrm{REE}) \mathrm{Al}_{3}\left(\mathrm{PO}_{4}\right)_{2}\left(\mathrm{OH}_{5} \cdot \mathrm{H}_{2} \mathrm{O}\right)$ \\
\hline Goyazite & $(\mathrm{Sr}, \mathrm{REE}) \mathrm{Al}_{3}\left(\mathrm{PO}_{4}\right)_{2}\left(\mathrm{OH}_{5} \cdot \mathrm{H}_{2} \mathrm{O}\right)$ \\
\hline Iimoriite-(Y) & $\mathrm{Y}_{2} \mathrm{SiO}_{4} \mathrm{CO}_{3}$ \\
\hline Kainosite & $\mathrm{Ca}_{2}(\mathrm{Y}, \mathrm{REE})_{2} \mathrm{Si}_{4} \mathrm{O}_{12} \mathrm{CO}_{3} \cdot \mathrm{H}_{2} \mathrm{O}$ \\
\hline Loparite-(Ce) & $(\mathrm{Na}, \mathrm{Ce}, \mathrm{La}, \mathrm{Ca}, \mathrm{Sr})(\mathrm{Ti}, \mathrm{Nb}) \mathrm{O}_{3}$ \\
\hline Monazite & $(\mathrm{REE}, \mathrm{Th}) \mathrm{PO}_{4}$ \\
\hline Mosandrite & $(\mathrm{Ca}, \mathrm{Na}, \mathrm{REE})_{12}(\mathrm{Ti}, \mathrm{Zr})_{2} \mathrm{Si}_{7} \mathrm{O}_{31} \mathrm{H}_{6} \mathrm{~F}_{4}$ \\
\hline Parisite & $\mathrm{Ca}(\mathrm{REE})_{2}\left(\mathrm{CO}_{3}\right)_{3} \mathrm{~F}_{2}$ \\
\hline Rhapdophane & $(\mathrm{REE}) \mathrm{PO}_{4} \cdot \mathrm{H}_{2} \mathrm{O}$ \\
\hline Synchysite & $\mathrm{Ca}(\mathrm{REE})\left(\mathrm{CO}_{3}\right)_{2} \mathrm{~F}$ \\
\hline Thalenite-(Y) & $\mathrm{Y}_{3} \mathrm{Si}_{3} \mathrm{O}_{10} \mathrm{OH}$ \\
\hline Xenotime & $\mathrm{YPO}_{4}$ \\
\hline
\end{tabular}

${ }^{1} \mathrm{~A}$ more-extensive list that includes 245 individual rare-earth-elementbearing minerals is provided in Jones and others (1996, appendix A).

include, in order of abundance, monazite, rhapdophane, crandallite-group minerals (florencite, gorceixite, goyazite), and cerianite; these are secondary rather than primary phases (Mariano, 1989). Examples of thick residual REE deposits (that is, more than 100 meters [m] thick) occur at the Araxá deposit, which overlies the Barreiro carbonatite complex in the State of Minas Gerais, Brazil; the Catalão I carbonatite complex in the State of Goiás, Brazil; and the Mount Weld carbonatite in Western Australia, Australia.

Monazite is the dominant REE mineral in sediments derived from the erosion of igneous or high-grade metamorphic rocks. These sediments are deposited in fluvial (stream and river) environments and coastal areas. Monazite is dense and resistant to chemical and physical weathering. For these reasons, more than any other REE mineral, monazite survives the arduous trip from a bedrock source to its deposition in a stream, river, or shore area. Monazite is the principal REE mineral recovered by placer mining operations, particularly in coastal deposits.

\section{Deposit Types}

Deposits of REEs occur in diverse, generally uncommon geologic settings. The discussion that follows does not attempt to encompass all the many subeconomic geologic occurrences in which REEs have been found (such as those described by Mariano and Mariano, 2012). As noted earlier, REEs are quite common, but not often in economic concentrations. The economic or potentially economic REE deposits occur primarily in the following geologic settings:

\section{- Carbonatites}

- Peralkaline igneous systems

- Magmatic magnetite-hematite bodies

- Iron oxide-copper-gold (IOCG) deposits

- Xenotime-monazite accumulations in mafic gneiss

- Ion-absorption clay deposits

- Monazite-xenotime-bearing placer deposits

Carbonatites. Carbonatites have been the world's main source for the LREEs since the 1960s. In 2016, REEs were being produced from large carbonatite bodies mined in China (Bayan Obo, Maoniuping, Daluxiang, and Weishan deposits) (table O3; fig. O4). Carbonatite intrusions occur in a variety of forms and carbonate compositions. Forms include stocks, tabular bodies, dikes, irregular-shaped masses, and veins. Carbonatites vary in composition from calcic (calcite-dominant; originally called soviet), to dolomitic (dolomite-dominant; called beforsite), to iron-carbonate (rich in ankerite $\left[\mathrm{Ca}\left(\mathrm{Mg}, \mathrm{Fe},{ }^{2+} \mathrm{Mn}\right)\left(\mathrm{CO}_{3}\right)_{2}\right]$ or siderite $\left.\left[\mathrm{Fe}^{2+} \mathrm{CO}_{3}\right]\right)$. Calcite and dolomite can also occur in roughly equal proportions. Carbonate composition can vary complexly across an individual carbonatite intrusion, such as is displayed in the Sulphide Queen carbonatite at Mountain Pass (Olson and others, 1954; Castor, 2008). Cross-cutting relations, mineralogy, and geochemistry have shown that carbonatite masses and dikes of different mineralogy and chemistry in a single district can represent multiple, discrete episodes of carbonate magma intrusion (Yang and others, 2010).

As noted earlier, in carbonatite deposits, the primary REE ore minerals are bastnaesite, parisite, and synchysite, ancylite, and monazite. Primary gangue (non-ore) minerals are carbonate minerals (calcite, dolomite, ankerite, siderite), which may be accompanied by aegerine-augite, barite, fluorite, fluorapatite, hematite, magnetite, phlogopite, quartz, and (or) strontianite. Accessory minerals - monazite, perovskite, pyrochlore, and thorite - are the most common uranium- and thorium-rich phases. 
The geology and mineralogy of the world's largest REE deposit and leading producer of LREEs - the Bayan Obo iron-carbonatite deposit in Nei Mongol Autonomous Region, China - are described by Yuan and others (1992), Xu and others (2010), Yang and others (2010, 2011), Kynicky and others (2012), and Verplanck and others (2014). The Bayan Obo deposit is a complex irregular mass of mixed iron deposits and carbonatite. Two other REE producers in China are hosted by carbonatites - the Maoniuping deposit and the Daluxiang deposit, both in Sichuan Province. Other carbonatites in China are described by Yang and Woolley (2006), $\mathrm{Xu}$ and others $(2008,2010)$, and Kynicky and others (2012).
The largest REE deposit in the United States is the Sulphide Queen carbonatite in Mountain Pass, Calif.; this is the only known carbonatite where the REE ore mineralsbastnaesite and parasite - are interpreted to have crystallized directly from the magma (Mariano, 1989; Castor, 2008). In other carbonatites, the REE-bearing minerals are interpreted to have formed by late-phase hydrothermal processes. Another type of REE enrichment in carbonatite systems - supergene processes - involves deep weathering of a carbonatite in tropical environments, which forms an REE-enriched laterite deposit. Examples of thick laterites with economic accumulations of residual REE minerals are the Araxá deposit that overlies the Barreiro carbonatite complex in Brazil; the Catalão I carbonatite

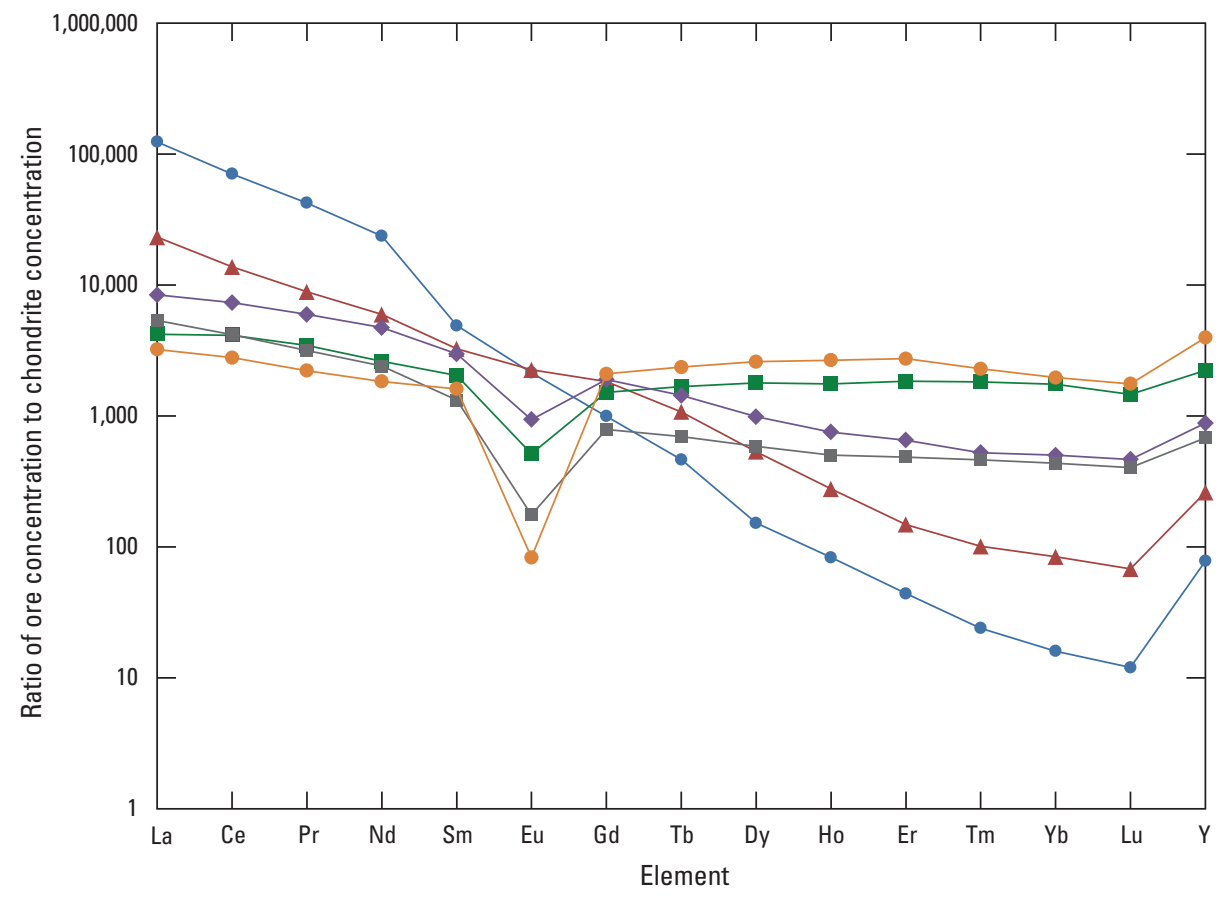

EXPLANATION

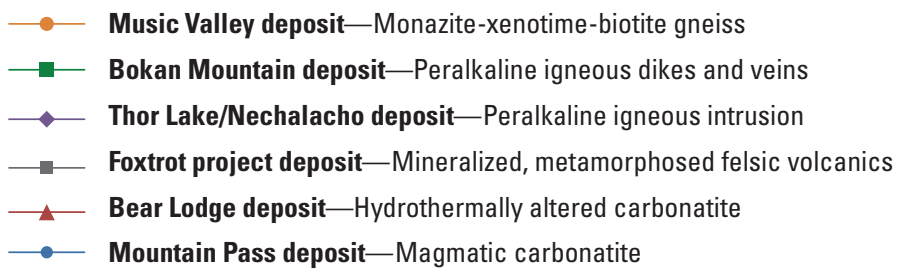

Figure 05. Chondrite-normalized plot showing the rare-earth-element (REE) distribution in six different types of North American REE deposits. The example deposits are located in Music Valley, California; Bokan Mountain, Alaska; Nechalacho (Thor Lake), Northwest Territories, Canada; Foxtrot project, Newfoundland and Labrador, Canada; Bear Lodge, Wyoming; and Mountain Pass, Calif. Notice the higher enrichments in the heavy REEs associated with peralkaline deposits, represented by the Bokan Mountain and Thor Lake deposits. Data for the Bear Lodge, Bokan Mountain, Mountain Pass, and Music Valley deposits are from author samples; Foxtrot project data are from Srivastava and others (2012); Thor Lake data are from Avalon Rare Metals Inc. (2015). Elements: La, lanthanum; Ce, cerium; Pr, praseodymium; $\mathrm{Nd}$, neodymium; Sm, samarium; Eu, europium; Gd, gadolinium; Tb, terbium; Dy, dysprosium; Ho, holmium; Er, erbium; Tm, thulium; Yb, ytterbium; Lu, lutetium; Y, yttrium 
Table 03. Active rare-earth mines, by deposit type.

[Mt, million metric tons; REE, rare-earth element; Y, yttrium; REO, rare-earth oxide; NA, not available; —; none reported]

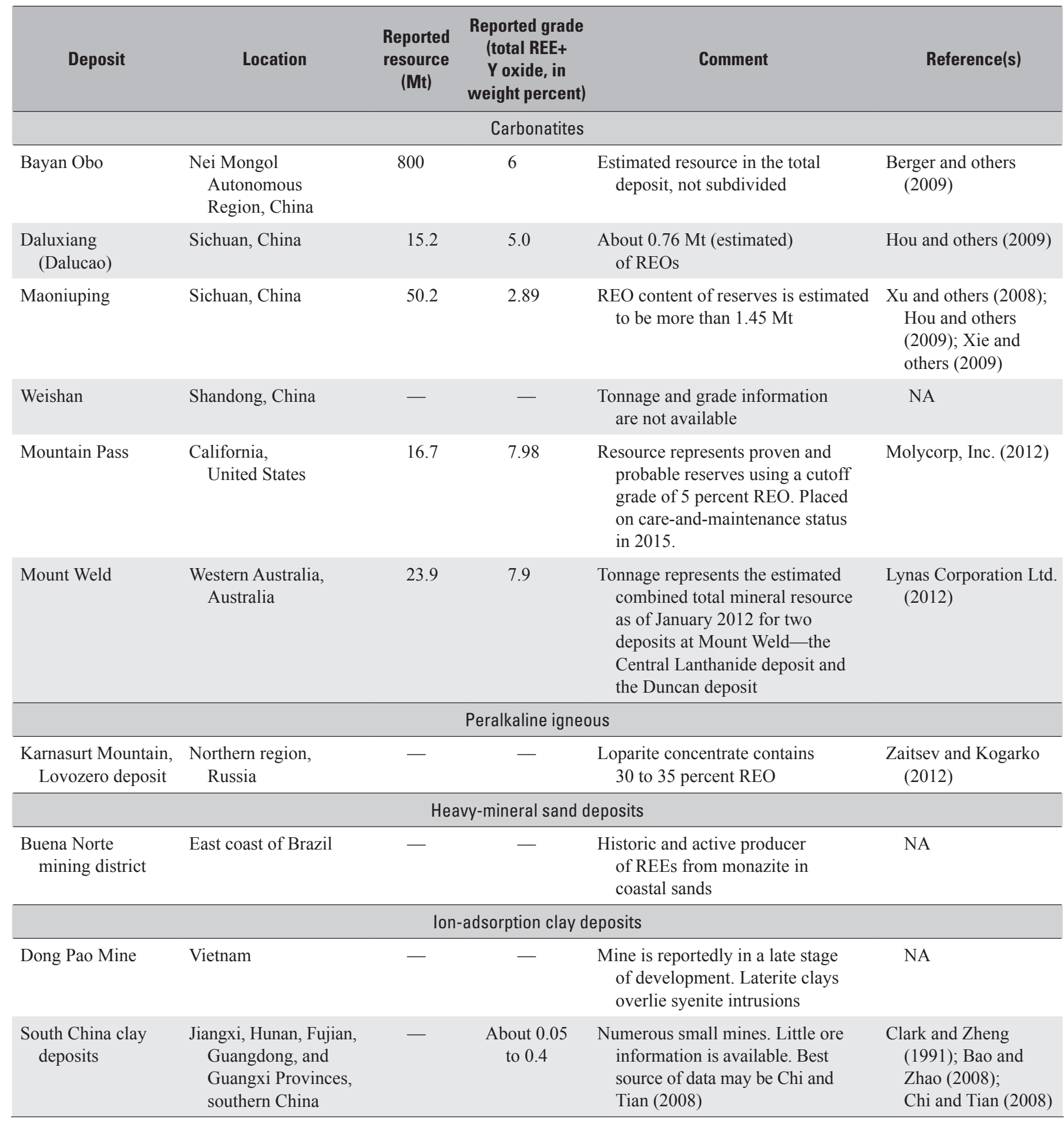


complex in Brazil; and the Mount Weld carbonatite in Australia. Laterite-hosted REE deposits are unknown in the United States.

Some carbonatite intrusions are important sources of niobium, which is hosted primarily in the mineral pyrochlore $\left[(\mathrm{Na}, \mathrm{Ca})_{2} \mathrm{Nb}_{2} \mathrm{O}_{6}(\mathrm{OH}, \mathrm{F})\right]$. More than 90 percent of the world's supply of niobium comes from laterite deposits that are several hundred meters in thickness and that overlie the Barreiro carbonatite complex near Araxá (Papp, 2011). The niobiumrich laterites at Araxá are now being evaluated for the recovery of REEs as a byproduct of niobium production. The largest identified niobium resource in the United States is the buried Elk Creek carbonatite in southeastern Nebraska (table O4; Xu, 1996; Carlson and Treves, 2005).

Peralkaline igneous systems. Peralkaline igneous systems are inherently enriched in REEs, in some instances hosting high-grade deposits. Peralkaline igneous complexes have been targeted by recent exploration (fig. O4) because of their enrichments in the HREEs (fig. O5).

Alkaline igneous rocks make up a large grouping of rock types that are generally deficient in silicon dioxide $\left(\mathrm{SiO}_{2}\right)$ relative to $\mathrm{Na}_{2} \mathrm{O}, \mathrm{K}_{2} \mathrm{O}$, and calcium oxide $(\mathrm{CaO})$. As noted earlier, peralkaline igneous rocks are a subclass of alkaline rocks, defined as those in which the molecular proportion of $\mathrm{Al}_{2} \mathrm{O}_{3}<\mathrm{Na}_{2} \mathrm{O}+\mathrm{K}_{2} \mathrm{O}$.

Peralkaline igneous systems enriched in REEs come in a variety of forms, such as the following:

- Complexes exhibiting vertical and lateral zonation: (a) Kipawa complex, Quebec, Canada (Saucier and others, 2012); (b) Strange Lake complex, Quebec and Labrador, Canada (Quest Rare Minerals Ltd., 2012); (c) Nechalacho (Thor Lake), Northwest Territories, Canada (Avalon Rare Metals Inc., 2015); (d) Kutessay II project, Chuy Oblusu, Kyrgyzstan (Stans Energy Corp., 2015); and (e) Tantalus Rare Earths (TRE) project, northern Madagascar (Tantalus Rare Earths AG, 2013).

- Complexes exhibiting layering: (a) Lovozero complex, Murmanskaya Oblast', Russia (Féménias and others, 2005; Kogarko and others, 2006; Chakhmouradian and Zaitsev, 2012), and (b) Ilimaussaq complex (includes the Kvenfjeld, Sørensen, and Zone 3 deposits), Kommune Kujalleq, Greenland (Greenland Minerals and Energy Ltd., 2012).

- Dikes and veins associated with peralkaline igneous complexes: (a) Bokan Mountain, Alaska (Robinson and others, 2011); (b) Hastings project, Western Australia, Australia (Hastings Rare Metals Ltd., 2015); and (c) Hoidas Lake deposit, Saskatchewan, Canada (Star Minerals Group Ltd., 2014).

- Plutons, stocks, plugs, and other peralkaline intrusions: (a) Norra Kärr deposit, Jönköpings län, Sweden (Tasman Metals Ltd., 2012); (b) Dubbo Zirconia project, New South Wales, Australia (Alkane Resources Ltd., 2015); (c) Two Tom deposit, Labrador, Canada (Daigle, 2012); (d) at Ghurayyah in Tabuk Province, Saudi Arabia; and (e) at Khaldzan-Buregtey in Hovd Aymag, Mongolia.
Peralkaline igneous rock types in REE-bearing systems can vary considerably from deposit to deposit; thus, it is difficult to generalize which peralkaline lithologies are consistently associated with REE deposits. The advanced exploration projects (current as of 2012), which are listed in table $\mathrm{O} 4$ and the locations of which are shown in fig. O4, indicate significant REE mineralization of 0.3 to 2.6 percent total REO in alkali granites, nepheline syenite, syenite, and trachyte. Peralkaline igneous rocks are typically more enriched in REEs, especially HREEs, than their silica-rich igneous counterparts. Still, the processes of REE transport and enrichment in peralkaline systems remain poorly understood (Chakhmouradian and Zaitsev, 2012). The recent increase of exploration and drilling into peralkaline systems (table O4) is expected to provide a better characterization of these deposits.

The uncommon mineralogy of peralkaline-related REE deposits is summarized in the Mineralogy section of this chapter and described by Chakhmouradian and Zaitsev (2012). The mineralogies encountered in REE ores in peralkaline igneous systems present challenges in ore processing. Routine metallurgical methods for processing these types of ores do not exist; procedures are developed on a deposit-by-deposit basis. The ore processing must be efficient and economic, employing methods that effectively liberate the diverse REE minerals, then sequentially separate and concentrate the individual REEs. A peralkaline igneous deposit can contain more than 20 REE-bearing minerals. Additionally, the intergrown REE minerals can occur in a variety of compositions, such as carbonates, oxides, phosphates, and silicates.

Magmatic magnetite-hematite bodies. Magmatic magnetite-hematite bodies can contain REE-bearing minerals, with the potential to recover the REEs as a byproduct during iron mining. Examples are deposits in the Pea Ridge iron district in southeastern Missouri and the Mineville iron district in upstate New York (Long and others, 2010).

The Pea Ridge magnetite-hematite orebody is hosted by Mesoproterozoic volcanic rocks of the St. Francois terrane of southeastern Missouri. The magnetite-rich body is interpreted as a high-temperature, magmatic-hydrothermal deposit (Sidder and others, 1993) in ash-flow tuffs and lavas, which may have formed in the root of a volcanic caldera (Nuelle and others, 1991). Four REE-bearing breccia pipes steeply crosscut the magnetite-hematite orebody and the altered rhyolite host rock. Exposed portions of the breccia pipes are as much as $60 \mathrm{~m}$ (197 feet [ft]) in length and as much as $15 \mathrm{~m}$ (49 ft) in width; the pipes extend below the mined levels to an undetermined depth (Seeger and others, 2001). Identified REE-bearing minerals in the breccia pipes are monazite, xenotime, and minor amounts of bastnaesite and britholite. According to Seeger and others $(2001$, p. 2), "total REO concentrations of grab samples [of breccia] range from about 2.5 to 19 weight percent." Mine tailings on the surface contain additional lanthanide resources, primarily in fine-grained REE-bearing minerals, chiefly monazite and xenotime, which form inclusions within apatite (Vierrether and Cornell, 1993). 
Table 04. Advanced rare-earth-element (REE) exploration projects and the reported estimates of their REE resources, by deposit type.

[Mt, million metric tons; t, metric ton; \%, percent; TREO, total rare-earth oxide. Chemical elements: Ag, silver; Au, gold; Cu, copper; Dy, dysprosium; Mo, molybdenum; $\mathrm{Nb}$, niobium; REE, rare-earth element; $\mathrm{U}$, uranium; $\mathrm{Zr}$, zirconium]

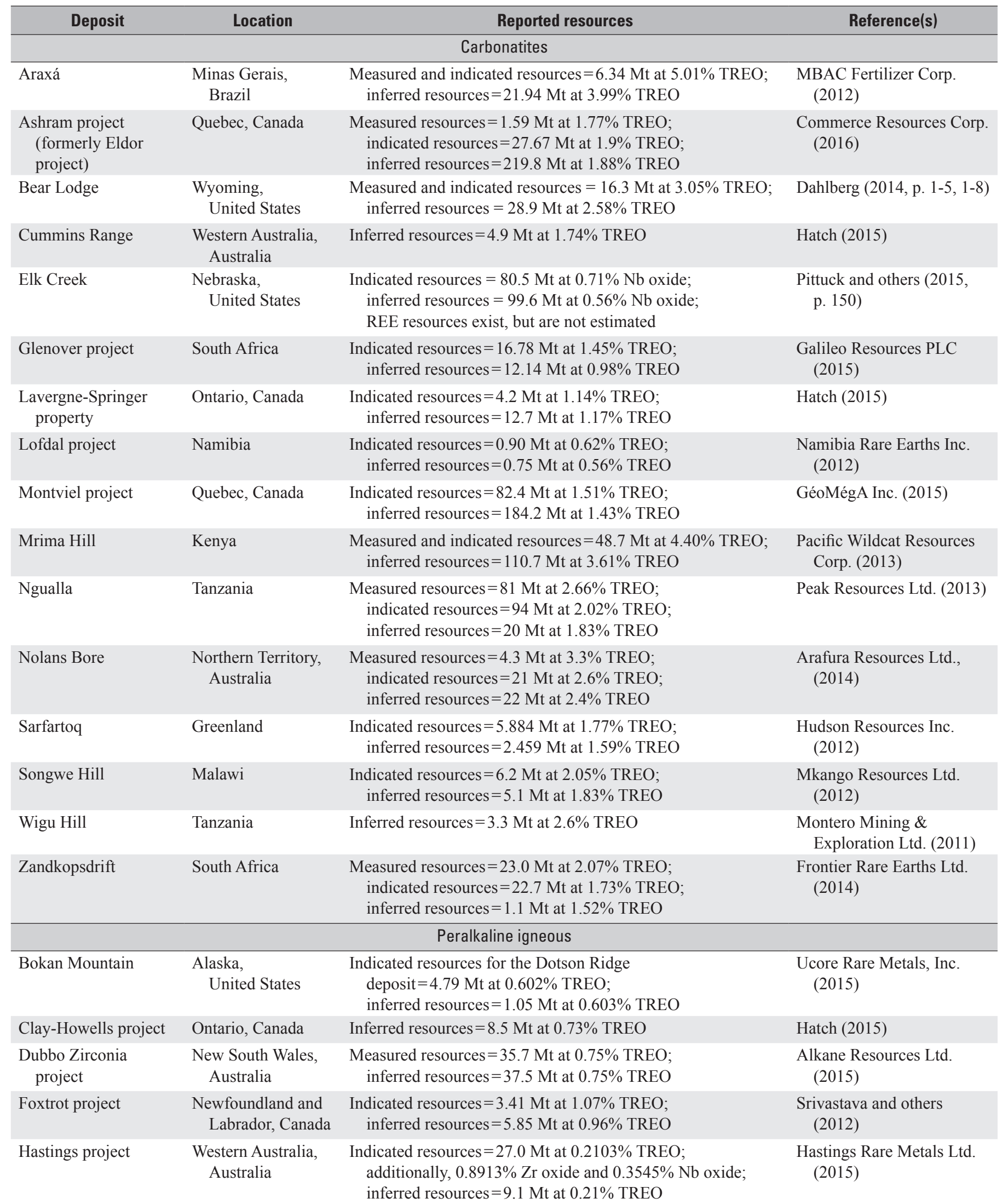


Table 04. Advanced rare-earth-element (REE) exploration projects and the reported estimates of their REE resources, by deposit type. -Continued

[Mt, million metric tons; t, metric ton; \%, percent; TREO, total rare-earth oxide. Chemical elements: Ag, silver; Au, gold; Cu, copper; Dy, dysprosium; Mo, molybdenum; Nb, niobium; REE, rare-earth element; $\mathrm{U}$, uranium; $\mathrm{Zr}$, zirconium]

\begin{tabular}{|c|c|c|c|}
\hline Deposit & Location & Reported resources & Reference(s) \\
\hline \multicolumn{4}{|c|}{ Peralkaline igneous - Continued } \\
\hline Hoidas Lake deposit & $\begin{array}{l}\text { Saskatchewan, } \\
\text { Canada }\end{array}$ & $\begin{array}{l}\text { Measured resources }=0.9638 \mathrm{Mt} \text { at } 2.568 \% \text { TREO; } \\
\text { indicated resources }=1.6 \mathrm{Mt} \text { at } 2.349 \% \text { TREO; } \\
\text { inferred resources }=0.2866 \mathrm{Mt} \text { at } 2.139 \% \text { TREO }\end{array}$ & $\begin{array}{l}\text { Star Minerals Group Ltd. } \\
\text { (2014) }\end{array}$ \\
\hline $\begin{array}{l}\text { Ilimaussaq complex, } \\
\text { Kvenfjeld deposit }\end{array}$ & Greenland & $\begin{array}{l}\text { Indicated resources }=437 \mathrm{Mt} \text { at } 1.093 \% \text { TREO; } \\
\text { inferred resources }=182 \mathrm{Mt} \text { at } 0.9763 \% \text { TREO }\end{array}$ & $\begin{array}{l}\text { Greenland Minerals and } \\
\text { Energy Ltd. (2012) }\end{array}$ \\
\hline $\begin{array}{l}\text { Ilimaussaq complex, } \\
\text { Zone } 3 \text { deposit }\end{array}$ & Greenland & Inferred resources $=95 \mathrm{Mt}$ at $1.1609 \% \mathrm{TREO}$ & $\begin{array}{l}\text { Greenland Minerals and } \\
\text { Energy Ltd. (2012) }\end{array}$ \\
\hline Kipawa & Quebec, Canada & $\begin{array}{l}\text { Indicated resources }=12.472 \mathrm{Mt} \text { at } 0.512 \% \text { TREO; } \\
\text { inferred resources }=3.842 \mathrm{Mt} \text { at } 0.463 \% \text { TREO }\end{array}$ & $\begin{array}{l}\text { Saucier and others }(2012 \text {, } \\
\text { p. } 75)\end{array}$ \\
\hline Norra Kärr & Southern Sweden & Inferred resources $=60.5 \mathrm{Mt}$ at $0.54 \% \mathrm{TREO}$ & Tasman Metals Ltd. (2012) \\
\hline Round Top & Texas, United States & $\begin{array}{l}\text { Measured and indicated resources }=480 \mathrm{Mt} \text { at } 0.063 \% \text { TREO; } \\
\text { inferred resources }=342 \mathrm{Mt} \text { at } 0.063 \% \text { TREO }\end{array}$ & $\begin{array}{l}\text { Hulse and others }(2014, \mathrm{p} \text {. } \\
\text { 152) }\end{array}$ \\
\hline Strange Lake & $\begin{array}{l}\text { Quebec, and New- } \\
\text { foundland and } \\
\text { Labrador, Canada }\end{array}$ & $\begin{array}{l}\text { Indicated resources }=278.12 \mathrm{Mt} \text { at } 0.93 \% \text { TREO; } \\
\text { inferred resources }=214.4 \mathrm{Mt} \text { at } 0.85 \% \text { TREO }\end{array}$ & $\begin{array}{l}\text { Quest Rare Minerals Ltd. } \\
\text { (2012) }\end{array}$ \\
\hline TRE project & $\begin{array}{l}\text { Northern } \\
\text { Madagascar }\end{array}$ & $\begin{array}{l}\text { Deposits include upper weathered bedrock of peralkaline } \\
\text { intrusive complex and overlying argillaceous laterites } \\
\text { (saprolite); inferred resources }=130 \mathrm{Mt} \text { at } 0.08 \% \text { TREO }\end{array}$ & $\begin{array}{l}\text { Tantalus Rare Earths AG } \\
\text { (2013) }\end{array}$ \\
\hline Milo project & $\begin{array}{l}\text { Queensland, } \\
\text { Australia }\end{array}$ & $\begin{array}{l}\text { Inferred resources }=187 \mathrm{Mt} \text { at } 0.06 \% \mathrm{TREO} \\
\text { deposit contains REEs, } \mathrm{Cu}, \mathrm{Mo}, \mathrm{Au}, \mathrm{Ag} \text {, and } \mathrm{U}\end{array}$ & $\begin{array}{l}\text { GBM Resources Ltd. } \\
\text { (2012) }\end{array}$ \\
\hline Plant in Stepnogorsk & $\begin{array}{l}\text { Northern } \\
\text { Kazakhstan }\end{array}$ & $\begin{array}{l}\text { Resources and grade are not reported. Plant is being } \\
\text { designed to extract Dy from uranium tailings }\end{array}$ & Blank (2012) \\
\hline Steenkampskraal & South Africa & $\begin{array}{l}\text { Measured resources }=85,000 \mathrm{t} \text { at } 19.5 \% \text { TREO; } \\
\text { indicated resources }=474,000 \mathrm{t} \text { at } 14.1 \% \mathrm{TREO} \\
\text { inferred resources }=60,000 \mathrm{t} \text { at } 10.5 \% \text { TREO }\end{array}$ & $\begin{array}{l}\text { Great Western Minerals } \\
\text { Group Ltd. (2014) }\end{array}$ \\
\hline \multicolumn{4}{|c|}{ Heavy-mineral sand deposits } \\
\hline $\begin{array}{l}\text { Charley Creek } \\
\text { deposits }\end{array}$ & $\begin{array}{l}\text { Northern Territory, } \\
\text { Australia }\end{array}$ & $\begin{array}{l}\text { Alluvial placers with } U \text { resources along with monazite and xe- } \\
\text { notime; inferred total resources of } 805.3 \mathrm{Mt} \text { at } 0.03 \% \text { TREO }\end{array}$ & $\begin{array}{l}\text { Hatch (2015); Pancontinen- } \\
\text { tal Uranium Corp. (2012) }\end{array}$ \\
\hline Canakli deposit & Turkey & Inferred resource $=494 \mathrm{Mt}$ at $0.07 \% \mathrm{TREO}$ & $\begin{array}{l}\text { AMR Mineral Metal Inc. } \\
\qquad(2015)\end{array}$ \\
\hline Kerala deposits & India & $\begin{array}{l}\text { Total resources of } 1.51 \mathrm{Mt} \text { of monazite reported in heavy- } \\
\text { mineral sand deposits in the State of Kerala; resource grade } \\
\text { is not reported }\end{array}$ & $\begin{array}{l}\text { Government of India, } \\
\text { Department of Atomic } \\
\text { Energy (2011) }\end{array}$ \\
\hline
\end{tabular}


Thorium and REEs reside within apatite in iron bodies once mined in the Mineville iron district, New York, which is located in the northeastern part of the Adirondack Mountains. The orebodies are magnetite deposits that are intricately folded and faulted within a complex suite of Precambrian metamorphic and igneous rocks. The host rocks have both mafic and felsic compositions that include, in general order of abundance, gabbro, diorite, augite syenites, and granite (Staatz and others, 1980). The iron deposits are mainly magnetite, martite, and apatite, with accessory augite, hornblende, albite, quartz, pyrite, and tourmaline (McKeown and Klemic, 1956). Iron deposits in the Mineville-Port Henry area contain apatite and are likewise rich in phosphorous, REEs, and thorium because these elements are concentrated within the apatite grains. In addition, the magnetite (the primary iron ore mineral) is intergrown with 1 - to 3 -millimeter (0.04- to 0.12 -inch)-long rice-shaped grains of apatite. Massive piles of tailings plus unmined parts of magnetite bodies in the Mineville district each contain REE-bearing apatite-rich rock. McKeown and Klemic (1956) reported an average REO content of 11.14 percent in 14 samples of apatite separated from the Old Bed, Joker, and Smith orebodies in this district.

Iron oxide-copper-gold (IOCG) deposits. IOCG deposits are closely related to magmatic iron deposits, described just above, and one could argue that the Pea Ridge and Mineville iron deposits represent variations within the IOCG deposit group. Strictly, IOCG deposits are defined as magmatichydrothermal iron deposits that host economic concentrations of copper and gold. This group of deposits was first described and defined after the 1975 discovery of the giant Olympic Dam copper-uranium-gold deposit in South Australia, Australia, which is one of the largest ore deposits in the world. An overview of the IOCG deposit type along with examples of significant IOCG deposits worldwide is provided by Groves and others (2010).The IOCG deposits can be very large and surrounded by alteration zones that can extend for kilometers in width. As at Olympic Dam, IOCG deposits can host REE mineralization, occurring both in iron oxides and in small carbonatites within the intrusive complex. Although an REE resource of substantial size has been identified at Olympic Dam, the mine operator has not yet recovered REEs.

Xenotime-monazite accumulations in mafic gneiss. Xenotime-monazite accumulations in mafic gneiss have not been historically important sources of REEs. Because deposits of this type tend to be preferentially enriched in the HREEs, however, they may be more economic in the future.

Example deposits occur in the Music Valley area of the northern part of Joshua Tree National Park in southern California. Pod-like xenotime deposits of the Music Valley area lie within the Pinto Gneiss of probable Precambrian age. The Pinto Gneiss consists of roughly equal amounts of quartz and plagioclase feldspar, and it averages approximately 35 percent biotite (Evans, 1964). Accessory minerals present in trace amounts in the gneiss include, in general order of abundance, sericite, apatite, magnetite, zircon, and sphene, and locally monazite, actinolite, orthoclase, microcline, perthite, and muscovite. Biotite-rich zones in the gneiss can contain abundant amounts of orange xenotime grains; xenotime commonly forms 10 to 15 percent of the biotite zones and locally as much as 35 percent (Evans, 1964). Owing to the xenotime and accompanying monazite, the biotite-rich zones can contain more than 8 percent yttrium (Evans, 1964) and elevated percentages of HREEs (fig. O5).

Ion-adsorption clay deposits. Ion-adsorption clay deposits in southern China are the world's primary sources of the HREEs. This deposit type is often informally referred to as "south China clays" (fig. O4). Despite their economic importance, little geologic research has been published that describes the south China clay deposits in detail; a study by Bao and Zhao (2008) is an exception, as well as discussions in Chi and Tian (2008) and Kynicky and others (2012).

Rare-earth-element-bearing ion-adsorption clay deposits form in tropical regions with moderate to high rainfall through the following general processes:

1. The REEs are leached by groundwater from granites (the bedrock),

2. Thick zones of laterite soils develop above the granites; this intensely weathered zone contains an abundance of clays, and

3. The mobilized REEs become weakly fixed (ionadsorption) onto the clays (kaolinite and halloysite) in the soils.

In deposits of this type in southern China, REE concentrations range from approximately 300 parts per million (ppm) to 2,000 ppm and appear to vary with the parent rocks (Bao and Zhao, 2008). These modest REE concentrations are economic for the south China deposits because (a) the REEs can be easily extracted from the clays with weak acids; (b) the deposits are often enriched in the high-value HREEs; (c) the area has low labor costs; and (d) there has been a localized lack of environmental protection (Liang and Others, 2014).

The highest REE concentrations usually occur in the B horizon (the subsoil) of the weathered zone. In addition to the highest REE content, the $\mathrm{B}$ horizon also contains the highest clay content. The overlying A horizon (the uppermost zone) is richest in organic matter, and contains much clay. The underlying $\mathrm{C}$ horizon consists of clays and pieces of the weathered granite.

Sanematsu and others (2009) conducted geochemical and sequential leaching experiments of ion-adsorption clays from deposits in Laos. They concluded that "the enrichment of REE[s] is attributed to the occurrence of ion-exchangeable clay minerals and REE phosphates in the weathered crusts and that HREE[s] are [more] selectively adsorbed on the clay minerals than are LREE[s] by weathering" (Sanematsu and others, 2009, p. 527). Laterite clay deposits of the Longnan district in Jiangxi Province in southern China produce HREErich material, whereas clay ores from the Xunwu district, also in Jiangxi Province, produce material that is rich in LREEs (O’Driscoll, 2003). 
Laterite clay deposits that are generally similar to the deposits in southern China are under development in northern Vietnam at the Dong Pao Mine in Lai Chau Province (fig. O4). In Madagascar, laterite clays formed by tropical weathering above REE-enriched dikes and sills are being explored at the TRE project (table O4; fig. O4; Tantalus Rare Earths AG, 2013).

An announced pilot project in Jamaica is intended to test the recovery of REEs from tailings of red mud produced from bauxite mining. The red mud reportedly contains 0.23 to 0.38 weight percent REEs (Wagh and Pinnock, 1987) and has higher HREE concentrations than do other representative Chinese clay samples (Mariano and Mariano, 2012).

Monazite-xenotime-bearing placer deposits. Monazitexenotime-bearing placer deposits were important sources of REEs up to the mid-1960s, but they decreased in prominence owing to the discovery of the Mountain Pass deposit in California. Placer deposits may be significant sources of REEs again in the near future. Presently, monazite is extracted from coastal sands at (a) the Buena Norte mining district on the east coast of Brazil (table O3); (b) along the southwestern coast of India in the State of Kerala (table O4); and (c) along the coastline in the State of Odisha in northeastern India (fig. O4; Government of India, Department of Atomic Energy, 2011). The monazite is recovered as a byproduct during the extraction of ilmenite $\left(\mathrm{FeTiO}_{3}\right)$, leucoxene (altered ilmenite), and rutile $\left(\mathrm{TiO}_{2}\right)$ from beach sands. The ilmenite, leucoxene, and rutile - the principal products of value - are chemically processed to remove titanium dioxide, which is used primarily as a pigment in paints.

Two broad settings for monazite-bearing placer deposits are (a) deposits of streams and rivers (fluvial deposits), and (b) coastal and nearshore deposits of sand and silt. In both deposit types, heavy dense minerals (including monazite) are physically sorted and deposited together by the combined actions of water movement and gravity. The resulting deposits of sediments, which are composed of sand and silt with thin layers of heavy minerals, are often referred to as "heavy-mineral sands."

"Heavy minerals" are commonly defined as dense minerals with a specific gravity greater than about 2.9. These minerals are generally resistant to chemical weathering and physical degradation and thus survive well in fluvial environments. Heavy minerals are eroded from bedrock sources, carried by streams or rivers until they are deposited in the stream channel system or into a coastal plain setting. In the stream, the heavy minerals are carried within a slurry mixture of sand and silt. Because of their high density, the heavy minerals can be well sorted by fluvial processes and preferentially deposited into layers through the combined effects of gravity and decreases in stream energy. The Charley Creek deposits in Northern Territory, Australia (table O4; fig. O4) are an example of REE-bearing alluvial placer deposits. At Charley Creek, the REEs occur in the heavy minerals monazite ((REE,Th) $\left.\mathrm{PO}_{4}\right)$ and xenotime $\left(\mathrm{YPO}_{4}\right)$.

Carrying heavy minerals, sediments are brought to coastal areas by streams and rivers. These sediments are reworked in nearshore (coastal) areas by the actions of waves and tides, which sort the heavy minerals into discreet layers. In these deposits, dark layers of heavy minerals are often referred to as "black sands." A notable example of such deposits is the detrital monazite deposits in the coastal regions of southern India, which are found in piedmont lakes, shallow seas, sand bars across the mouths of rivers, deltas, beaches, and sand dunes behind the beaches (Bhola and others, 1958).

In addition to modern coastal regions, heavy-mineral deposits occur in ancient coastal plain environments, which are other potential sources of monazite. Carpenter and Carpenter (1991) describe heavy-mineral deposits formed by Pliocene transgressive-regressive events in the Upper Coastal Plain region of eastern North Carolina and eastern Virginia. In 2015, Iluka Resources Ltd. was mining and processing Pliocene-age heavy-mineral sands in the coastal plain of Virginia. Iluka has also worked similar ancient nearshore heavy-mineral deposits in Australia since the 1950s. Iluka's heavy-mineral sands operations target the titanium minerals (ilmenite, leucoxene, rutile) and zircon; they do not recover the monazite.

Heavy minerals in the fluvial and coastal deposit types may include, in order of general abundance, ilmenite, leucoxene, rutile, magnetite, zircon, staurolite, kyanite, sillimanite, tourmaline, garnet, epidote, hornblende, spinel, iron oxides, sulfides, monazite, and xenotime. The typical minerals of value are ilmenite, leucoxene, and rutile for their titanium and titanium dioxide; zircon for its refractory uses (such as specialty ceramics); and in some cases, monazite, for its REEs and thorium. The heavy minerals as a suite typically make up no more than 15 percent of a deposit, and usually much less; quartz and clay minerals form the bulk of the sediment. As an example, in the Pliocene-age Upper Coastal Plain deposits of North Carolina and Virginia, the heavy-mineral suite consists of, on average, about 9 percent of the sediments and monazite occurs in trace amounts ( 0 to 0.9 weight percent of the heavy minerals) (Berquist, 1987; Carpenter and Carpenter, 1991).

The occurrence of REEs in fluvial placer or nearshore placer deposits depends on the presence of monazite and (or) xenotime in the bedrock sources upstream. Thus, exploration for monazite-bearing placer deposits must consider the mineralogy of the bedrocks that are the source of the sediments.

\section{Resources and Production}

\section{Identified Resources}

Tables $\mathrm{O} 3$ and $\mathrm{O} 4$ summarize the estimated REE resources reported for the world's most extensively explored deposits. Exploration for additional REE deposits is ongoing; therefore, the world's identified REE resources very likely will increase. The resource estimates shown in tables $\mathrm{O} 3$ and $\mathrm{O} 4$ indicate that large resources of REEs exist. If developed, these deposits may supply the world's REE needs for many decades. The process of bringing a particular deposit from the phase of orebody delineation to eventual mining and REE processing is a complex, multistage, multiyear process, however, as explained 
in Long and others (2010). The pace or ultimate success of the REE exploration projects in table $\mathrm{O} 4$ is difficult to predict.

Berger and others (2009) compiled published tonnage and grade data for 58 REE- and niobium-bearing carbonatite deposits worldwide; the carbonatites included in the dataset are mostly well explored and either partially mined or known to contain these resources. For their carbonatite dataset, they calculated a median tonnage of 49 million metric tons and median grades of 0.61 percent total REO and 0.23 percent niobium oxide.

An earlier inventory of global REE resources (Jackson and Christiansen, 1993) reported that China hosts the largest resources of REEs, followed by Namibia, the United States, Australia, and India. Jackson and Christiansen (1993, p. 43) stated that "Globally, economically recoverable REO ore resources, based on 106 properties, amount to 20.6 billion metric tons, of which 85 percent is in placers and 15 percent is in hard-rock deposits." The REOs in the ore deposits occur dominantly within the hard-rock deposits, however; according to their study, 7 percent of the REOs occur in placers and 93 percent are in hard-rock deposits.

China's Bayan Obo iron-carbonatite deposit in Nei Mongol Autonomous Region has been the world's principal source of LREEs since the mid to late 1980s (Long and others, 2010; U.S. Department of Energy, 2010, 2011). Bayan Obo is thought to be the world's largest REE deposit-it is estimated to contain about 800 million metric tons of ore material at a grade of 6 percent REO content (Berger and others, 2009).

Mining by Molycorp, Inc. in Mountain Pass, Calif., has exploited the Sulphide Queen carbonatite (Olson and others, 1954; Castor, 2008), which is the largest high-grade, LREE deposit in the United States (figs. O3, O4, and O5). This carbonatite reportedly contains 16.7 million metric tons of proven and probable reserves at a grade of 7.98 percent total REO (Molycorp, Inc., 2012).

India reports large resources of REEs, mostly in monazite within coastal sediments along its southern coastlines. According to India's Atomic Mineral Directorate for Exploration \& Research, "the reserves of monazite in India is about 10.70 million tonnes which translates to approx. 5 million tonnes of rare earth oxide" (Government of India, Department of Atomic Energy, 2011, p. 2). Also, the Directorate estimates that about 2,000 metric tons of xenotime-bearing heavy-mineral concentrate, which contains about 2 percent xenotime, occurs in riverine placer deposits in the States of Chhattīsgarh and Jharkhand. With national sponsorship, the coastal placers are mined for their titanium minerals (rutile, ilmenite) and monazite. IREL, which is a public sector entity under the Department of Atomic Energy, is constructing a monazite processing plant in the State of Odisha (Government of India, Department of Atomic Energy, 2011).

\section{Undiscovered Resources}

The increase in REE prices has led to an increase in exploration activity worldwide; as a result, many more
REE resources have been discovered or, in many cases, reinvestigated and better defined. Because REE enrichments can be found in a wide variety of rock types and environments, the probability for the occurrence of substantial undiscovered resources is high. With engineering advances in ore processing, additional deposits may become economic. The following are examples of some of the deposit types that could be potential future sources of REEs.

- Although the ion-adsorption clay deposits of southern China now serve as the world's primary source of the HREEs, these deposits appear not to be unique to southern China. Clay deposits with similar geologic settings and characteristics have been explored elsewhere, although none has yet been brought into production on a significant scale. The Dong Pao deposit in northern Vietnam, for example, is composed of laterite clays that overlie syenite intrusions. The Dong Pao Mine reportedly is in a late stage of development.

- Elevated concentrations of REEs in sea-floor sediments sampled by deepwater drill coring at numerous sites on the floors of the eastern South Pacific Ocean and central North Pacific Ocean were reported by Japanese scientists in 2011 (Kato and others, 2011). The scientists collected more than 2,000 sea-floor sediments, sampled from about $1 \mathrm{~m}$ into the sea floor, from 78 sites across the Pacific Ocean. As one example of their results, Kato and others (2011) reported that muds in the eastern South Pacific Ocean had REE contents comparable to or higher than those of the south China ion-adsorption clay deposits; also, that the HREE values were nearly twice as much as the China clays.

- Some modern and ancient coastal deposits can host large undeveloped, poorly studied deposits of monazite. Coastal deposits offer several advantages, such as that (a) these deposits are unconsolidated or weakly consolidated and thus easy to excavate; (b) the deposits are relatively easy to process in order to separate out the heavy minerals; and (c) multiple minerals can be extracted as the primary products of value, such as ilmenite and rutile for titanium and titanium dioxide, zircon for refractories, and garnet for abrasives. As one example, large undeveloped deposits of coastal sediments, ranging from Cretaceous to recent in age, occur from eastern Virginia to Florida in the Southeastern United States. Many sand and silt units in this coastal plain region contain monazite (Staatz and others, 1980; Carpenter and Carpenter, 1991).

\section{Exploration for New Deposits}

The search for REEs covers a wide variety of geologic provinces; noteworthy deposits of REE-bearing minerals have been found in alkaline igneous rocks, carbonatites, layers in 
mafic metamorphic rocks, laterite clay deposits developed upon weathered granitic plutons, and coastal and fluvial sediments. Some of these types of settings are described briefly below.

Carbonatites and peralkaline igneous complexes. According to Woolley and Kjarsgaard (2008), there are 527 known carbonatites in the world, and about 40 percent are located in the African continent. The majority of the known carbonatites are located in relatively tectonically stable regions within crustal plates, and they are often positioned on deepseated structural zones of regional extension (intra-continental rift zones). Less commonly, some carbonatites are found near plate margins, and their formation is possibly linked to processes of crustal plate separation or orogeny.

By definition, carbonatites are an igneous rock composed of at least 50 percent carbonate minerals, which sets them apart from other intrusions in igneous terrains. The gangue carbonate minerals, such as calcite and dolomite, can be identified with weak acid, as with any carbonate rock. Most carbonate minerals in carbonatites are generally subdued in outcrop, and the principal REE ore minerals are usually not colorful. In regions with deep, intense weathering, such as laterite weathering of the upper parts of carbonatites in Brazil and Australia, the laterites contain resistate ore minerals (minerals that are resistant to weathering), such as pyrochlore and monazite.

Fenite is a quartz-alkaline feldspar-rich rock that has been altered by alkaline (sodium- and [or] potassium-rich) hydrothermal fluids at the contact of a carbonatite intrusion complex. Fenitization is the alkaline mineralization formed by alkali metasomatism during the emplacement of an alkaline intrusion or carbonatite. This process can form alteration aureoles (fenite) of variable widths and intensity that are developed in the intrusion and the surrounding country rock. The presence of a fenite halo indicates that alkali hydrothermal processes took place there and is generally a favorable indication of REE enrichment.

Brief descriptions of alkaline provinces and individual alkaline complexes are available for North America and South America (Woolley, 1987), the former Soviet Union (Kogarko and others, 1995), and Africa (Woolley, 2001). These publications are useful references for those conducting REE exploration in these regions.

In an alkaline igneous complex, rock types generally progress from oldest to youngest as ultramafic to mafic lithologies (pyroxenite, biotite-shonkinite, peridotite, and jacupirangite, as examples), to felsic compositions (syenite, alkaline granites, ijolite, trachyte, and phonolite), to carbonatites. Coincidences of these alkaline rock types can indicate evolved alkaline systems. Carbonatite formation is a late (usually last) phase of the alkaline complex, and the carbonatite is often centrally located in the complex. Carbonatite dikes, if present, are also late-phase formations, and they may extend for kilometers outward from the complex. Dikes or veins of carbonatite can indicate that a larger carbonatite mass lies below or in the area.
In peralkaline intrusions, some REE deposits contain relatively rare but useful indicator REEs and alkali minerals, such as acmite (brown/green), alkali amphiboles (blue/black), eudialyte (pink/red), gadolinite (green/brown-black), rinkolite (red brown/yellow brown), and sodalite (dark blue).

Because of the presence of associated thorium-uraniumbearing minerals in alkaline complexes and carbonatites, radioactivity is a common characteristic of REE mineralization. Most of the carbonatites and alkaline-intrusion-hosted REE deposits in the United States were discovered by uranium prospectors using handheld radiation detectors, such as Geiger counters and scintillation counters (scintillometers). In most of these deposit types, the radiation is primarily a result of the presence of thorium.

The most diagnostic geochemical elements for carbonatites and peralkaline-hosted REE deposits are the high-field-strength elements, which include hafnium, niobium, REEs+yttrium, scandium, tantalum, thorium, titanium, uranium, and zirconium. Large-ion lithophile elementsbarium, cesium, potassium, rubidium, and strontiumare also enriched in carbonatites and alkaline intrusions. Associated elements can include chlorine, fluorine, manganese, and phosphorus.

Geophysical methods can be used to detect and map an ore-bearing mass that may not be exposed. Ground and airborne geophysical techniques have been used to identify and define the size of buried carbonatites and mineralized alkaline intrusions. Geophysical data can be collected and analyzed at a wide range of scales, thereby contributing to exploration at a variety of scales, from regional features to detailed characterization of an individual deposit.

Modern airborne geophysical technologies offer the capability to collect gamma-ray, magnetic, and gravity data concurrently. Electromagnetic data can also be acquired this way. The combination and integration of these methods provides significant insight into a number of physical properties, which, in combination, can significantly enhance an exploration program for intrusion-hosted REE deposits. Airborne geophysical surveys that are flown most often over prospective REE deposits are magnetic, gamma-ray, and, most recently, gravity and gravity gradiometry. The choice of airborne geophysical tool(s) and platform (helicopter or fixed wing) used to explore for an intrusion-hosted REE deposit depends on a number of factors, such as accessibility to the deposit, ruggedness of the terrain, and whether the deposit is entirely or partly exposed or is concealed by rock, glacial deposits, vegetation, or water and (or) ice.

Gravity and magnetic surveying can be especially useful to map partially or entirely concealed carbonatites and alkaline intrusions. Although these methods do not provide direct detection of REE mineralization, they can provide necessary geologic controls on the depth, geometry, and extent of the host intrusion(s). The success of these methods, as with all geophysical mapping tools, depends on there being a physical property contrast (density and magnetization) of the intrusion with the surrounding rocks. 
Magmatic magnetite-hematite deposits and iron oxidecopper-gold (IOCG) deposits. As noted earlier, IOCG deposits are typically giant deposits with broad alteration zones that can extend for several kilometers outward from the main deposit (Groves and others, 2010). Iron-dominated deposits, typified by magmatic iron and IOCG deposits, produce substantial magnetic and gravity anomalies, which are usually clearly evident in geophysical surveys at regional and local scales. The techniques traditionally employed in the exploration for precious and base-metal deposits can be likewise used to discover magmatic iron and IOCG deposits.

Xenotime-monazite deposits in metamorphic rocks. High-grade concentrations of xenotime and monazite have been found locally in some mafic gneiss, paragneiss, and migmatites (Mariano and Mariano, 2012). Thus far, none of the discovered occurrences of this type have been deemed large enough to be economic; however, their inherent enrichment in HREEs continues to attract interest.

Local exploration for these deposits can utilize the durability of xenotime and monazite; they are heavy dense minerals that are resistant to mechanical weathering and, as a result, they accumulate with the heavy-mineral suite in stream sediments. Monazite- and xenotime-bearing sediments are typically elevated in the LREEs, yttrium, and thorium.

Radioactivity owing to monazite may be detectable using high-resolution airborne gamma-ray surveys with closely spaced flight lines if the host rocks are exposed at or very near the surface. Ground surveys with a handheld radiation meter can identify monazite-rich zones.

Ion-adsorption clay deposits. On the most basic level, favorable regions for ion-adsorption clay deposits are those where tropical weathering horizons (laterites) formed atop alkaline igneous masses. In southern China, underlying bedrock includes altered "two mica" granites. In addition to the modern tropics, paleo-laterites coincident with alkaline intrusive masses can also be considered.

In many ways, discovery of these types of REE deposits have proven the most elusive thus far, outside of southern China. These clay deposits lack radioactivity (Bao and Zhao, 2008) and have relatively low concentrations of REEs.

Sampling studies of prospective laterites typically extract subsurface samples of the weathered zone at selected soil horizons; the samples are analyzed for their REE content and REE leachability.

Monazite-xenotime-bearing fluvial placer deposits. Many of the REEs and associated high-field-strength elements occur in heavy, dense minerals that are resistant to weathering (resistates); thus, heavy-mineral concentrates from stream sediments are a useful sampling technique for these deposit types. Resistate indicator minerals in the heavy concentrate portion of stream sediments can include, in order of general abundance, monazite, pyrochlore, xenotime, allanite, zircon, kainosite, thorite and uranothorianite, and euxenite (Barker and Van Gosen, 2012). Using airborne gamma-ray survey data, radioactivity caused by the presence of thorium (mainly in monazite) may outline fluvial networks that contain monazite.
Monazite-bearing coastal plain deposits. Deposits of sand and silt that contain monazite occur in many coastal environments. These sediments are carried by rivers and streams to coastal settings, including the shore. The sediments originate from the erosion of metamorphic and (or) igneous bedrock located up gradient of the coast. The monazite in these sediments occurs in close association with other heavy minerals, which are most commonly ilmenite, leucoxene, rutile, and zircon. These heavy minerals could thus be considered indicator minerals in these types of deposits. Economic "black sand" deposits in coastal settings (modern or paleo-settings) typically contain 5 percent or greater heavy-mineral content.

Exploration for coastal heavy-mineral sand deposits involves primarily any or all of the following:

- Locating ancient to modern coastal sedimentary deposits that were and (or) are sourced by terrains containing abundant metamorphic rocks and (or) igneous rocks. Favorable target areas are those that experienced transgressive-regressive marine cycles, as well as areas at the intersection of ancient shorelines and major paleorivers.

- Sampling sediments at the surface or (more thoroughly) vertically by using truck-mounted power auger drills.

- Simple panning on site to estimate the approximate heavy-mineral content of a sample. A more-exacting determination of heavy-mineral content is made by using multiple steps, including heavy liquid separation, grain counts of heavy-mineral concentrates, and thorough analyses of heavy-mineral concentrates using spirals, solutions, magnetic separators, and electrostatic separators, as described by Carpenter and Carpenter (1991).

\section{Environmental Considerations}

Rare-earth elements are currently produced from just a few mines globally, and, as a result, there are no abandoned REE mines available for study. Previous production from the Mountain Pass Mine in California started before the era of major environmental regulatory oversight; as a result, much of the environmental information associated with new mines is lacking. Further, the Bayan Obo Mine in China, which is the main current source of REEs, also has limited environmental information published. Two advanced exploration projects - the Nechalacho alkaline-intrusion-related deposit (near Thor Lake, Northwest Territories, Canada) and the Bear Lodge carbonatite deposit (Bear Lodge Mountains, northeastern Wyoming) - represent new sources of environmental data as a result of ongoing activities at these sites. At present, however, information regarding the environmental aspects of REE mining is limited. Toxicological data about the effects of REEs on aquatic, animal, or human health are also limited. 


\section{Sources and Fate in the Environment}

The concentrations of REEs in environmental media are influenced by their normal tendency to occur in diluted concentrations in crustal rocks (rather than in concentrated deposits) and their limited solubility in most groundwaters and surface waters. A significant amount of information is available on their natural abundances and distributions in environmental media, such as seawater (Elderfield and others, 1988), river water (Goldstein and Jacobsen, 1988; Sholkovitz, 1995), groundwater (de Boer and others, 1996), soil, and plants (Tyler, 2004), because of their value in tracing hydrochemical and geochemical processes. The average upper crustal abundance of all REEs combined (lanthanum through lutetium) is $146.4 \mathrm{ppm}$; the average abundance of yttrium is $22 \mathrm{ppm}$. The mean REE concentration of soils is similar to the average upper crustal abundance of these elements (Smith and others, 2013; Tyler, 2004). In humid settings with extreme weathering, however, REE concentrations in soil tend to be higher than those in the underlying rock because of leaching of major elements. Plant uptake of REEs is generally low because of the low solubility of REEs, and uptake does correlate with soil acidity (Tyler, 2004). The solubility of REEs in typical surface water or groundwater compositions is low (Wood, 1990). In seawater, the average dissolved concentration of combined REEs is 0.15 part per billion (ppb) (Elderfield and others, 1988). In major rivers, the REE concentrations average $1.6 \mathrm{ppb}$ (Sholkovitz, 1995). Under extreme acid-mine drainage conditions ( $\mathrm{pH} 1.1)$ - conditions that are not related to REE mining - dissolved REE concentrations can easily reach 2,500 ppb (Seal and others, 2008).

Information on pre-mining environmental concentrations of REEs is limited, in part because of their low concentrations. Data from solid media (rock, soil, and sediment) are more common because REEs are routinely analyzed in solid media. Analysis of REEs in water samples is less common. Environmental baseline studies have been conducted at the Bear Lodge deposit (Dahlberg, 2014) and at the Nechalacho deposit (Avalon Rare Metals Inc., 2011); both are currently advanced exploration projects. Baseline environmental data from all other REE deposit types have not been identified.

At Nechalacho, the surface water sample sites encompass an area that extends up to 6 kilometers from the deposit, but the groundwater samples are from within the deposit as reported by Avalon Rare Metals Inc. (2011). The pH of surface water and groundwater is neutral to slightly alkaline, ranging between 6.9 and 8.6. The cationic species in groundwater and surface water around the deposit are dominated by magnesium, followed by calcium and sodium. Water hardness values range between 71 and $470 \mathrm{ppm}$ calcium carbonate $\left(\mathrm{CaCO}_{3}\right)$ for both surface water and groundwater. As reflected by alkalinity values that range between 74 and $442 \mathrm{ppm}$ $\mathrm{CaCO}_{3}$, bicarbonate is the most important anionic species, followed by sulfate, chloride, and fluoride. Fluoride concentrations range from 0.06 to $4.4 \mathrm{ppm}$, which locally exceeds the U.S. Environmental Protection Agency secondary maximum contaminant limit of $2 \mathrm{ppm}$. Groundwater tends to have higher concentrations of anions than does surface water.

Trace elements are generally low in the vicinity of the Nechalacho deposit but tend to be slightly higher in groundwater compared with surface water. Baseline dissolved iron concentrations in surface water and groundwater are noteworthy and range from less than 30 to more than 10,000 ppb. Baseline dissolved copper concentrations range from 0.2 to $48 \mathrm{ppb}$. Dissolved aluminum concentrations generally range from 0.5 to $108 \mathrm{ppb}$, although one outlier sample of groundwater measured 15,300 ppb. Dissolved manganese ranges from 0.2 to $544 \mathrm{ppb}$. Baseline dissolved nickel and molybdenum concentrations range from 0.25 to $6.6 \mathrm{ppb}$ and from 0.2 to $63 \mathrm{ppb}$, respectively. Dissolved concentrations of uranium range from less than 0.05 to $20 \mathrm{ppb}$. Dissolved concentrations of arsenic and antimony are less than 5 and $0.3 \mathrm{ppb}$, respectively.

Baseline surface water and groundwater chemistry data associated with the Bear Lodge deposit (Dahlberg, 2014), are grossly similar to those from Nechalacho. The $\mathrm{pH}$ of waters at the Bear Lodge deposit spans a slightly larger range (6.0 to 8.4). Water hardness ranges from 10 to $380 \mathrm{ppm}$ $\mathrm{CaCO}_{3}$. Bicarbonate is the dominant cation as reflected by the alkalinity values of between 10 and $300 \mathrm{ppm} \mathrm{CaCO}_{3}$, and fluoride is present in concentrations of less than $1 \mathrm{ppm}$. Trace element concentrations at the Bear Lodge deposit are similar to those at Nechalacho.

\section{Mine Waste Characteristics}

The mineralogy of the dominant minerals from carbonatite and alkaline intrusion REE deposits influences the environmental character of their mine waste. The paucity of sulfide minerals, including pyrite, minimizes or eliminates concerns about acid-mine drainage for carbonatite-hosted REE deposits and alkaline-intrusion-related REE deposits. In fact, tailings from metallurgical testing at the Nechalacho deposit contain less than 0.1 weight percent total sulfur (Avalon Rare Metals Inc., 2011). The low acid-generating potential of these deposits is further offset by their high acid-neutralizing potential, particularly for carbonatite deposits, which are dominated by carbonate minerals.

In terms of trace elements, the REE ore minerals factor most prominently in the environmental character of the ores and mine wastes. The main ore minerals currently processed for REEs - bastnaesite $\left(\mathrm{LnCO}_{3} \mathrm{~F}\right)$, monazite $\left((\mathrm{Th}, \mathrm{Ln}) \mathrm{PO}_{4}\right)$, and xenotime $\left((\mathrm{Y}, \mathrm{Ln}) \mathrm{PO}_{4}\right)$ (where "Ln" [for lanthanide] indicates the place of REEs in the mineral formulas) - all contain appreciable amounts of uranium and thorium. Bastnaesite reportedly contains between 0 and 0.3 weight percent thorium dioxide $\left(\mathrm{ThO}_{2}\right)$ and 0.09 weight percent uranium dioxide $\left(\mathrm{UO}_{2}\right)$; monazite, between zero and 20 weight percent $\mathrm{ThO}_{2}$ and zero and 16 weight percent $\mathrm{UO}_{2}$; and xenotime, between zero and 5 weight percent $\mathrm{UO}_{2}$ (Long and others, 2010). The thorium and uranium contents of the ore minerals and mine 
waste represent one of the biggest environmental challenges that must be managed during mining, ore processing, and mine closure. The geochemistry of thorium and uranium influence their interactions with the environment and resulting environmental effects. Thorium is highly insoluble under most conditions. Therefore, for thorium and its radioactive decay products, solid-phase pathways, such as windblown dust from tailings piles and erosion of tailings into water bodies, are of greatest priority for mine planning. Under oxidizing conditions, uranium is highly soluble; therefore, aqueous pathways leading to surface water or groundwater are priority issues for mine planning.

According to the metallurgical testing done, the geochemistry of the tailings at Nechalacho (Avalon Rare Metals Inc., 2011) is anomalous for several elements compared with the guidelines for soil (U.S. Environmental Protection Agency, 2015) and sediment (MacDonald and others, 2000). The chromium concentration of the metallurgical reject material $(640 \mathrm{ppm})$ exceeds the residential soil guideline (280 ppm). Cadmium (6 ppm), chromium (640 ppm), and nickel (330 ppm) concentrations of the reject material exceed sediment guidelines for "probable effects concentrations" for these elements (4.98 ppm, $111 \mathrm{ppm}$, and $48.6 \mathrm{ppm}$, respectively). The "probable effects concentration" in sediment is the concentration above which harmful effects on freshwater ecosystems are likely to be observed (MacDonald and others, 2000).

\section{Human Health Concerns}

Human health risks associated with mining are typically associated either with contamination of potential sources of drinking water or ingestion of fine particulate mine waste (tailings). The human health effects of REEs have been sparsely studied since the work of Haley (1965). Ingestion and inhalation studies on cerium oxide and cerium compounds indicate minimal effects in laboratory studies on rats (U.S. Environmental Protection Agency, 2009). Exposure to cerium oxides and cerium compounds is unlikely during routine mining, although the potential for exposure is present during ore processing and refining. The United States lacks drinking water standards for the REEs. The limited data on the toxicity of REEs in drinking water has been reviewed by de Boer and others (1996).

For other trace elements, some baseline groundwater and surface waters in the vicinity of the Nechalacho deposit exceed the secondary maximum contaminant limit for fluoride. At the Bear Lodge deposit, a single baseline groundwater sample (13 ppb arsenic) is slightly above the U.S. Environmental Protection Agency drinking water standard for arsenic concentration (10 ppb). Several baseline surface water samples from the Bear Lodge Mountains as well as a single humidity-cell leachate sample from Nechalacho exceed the combined radium radioisotope $\left({ }^{226} \mathrm{Ra}+{ }^{228} \mathrm{Ra}\right)$ drinking water standard.

\section{Ecological Health Concerns}

The primary pathways for REE mining to affect aquatic ecosystems are through water or sediment contamination. Knowledge regarding the toxicity of REEs to aquatic organisms through either pathway is limited. Environmental guidelines for REEs in surface water and sediment are lacking in the United States. Guidelines for surface water and sediment for both fresh and salt water have been recommended in the Netherlands, however (Sneller and others, 2000). Several studies have documented that the toxicity and biologic uptake of REEs in surface water vary as a function of water hardness and alkalinity (Barry and Meehan, 2000; Moermond and others, 2001). Further, Weltje and others (2004) found that the toxicity of lutetium was proportional to the concentration of the free ion $\left(\mathrm{Lu}^{+3}\right)$ in microbial bioassay studies. Therefore, REE complexation with carbonate, sulfate, or other ligands in natural systems may significantly influence their toxicity (Wood, 1990). Published aqueous REE data are lacking for the Nechalacho and the Bear Lodge deposits.

Insights into potential ecological risks associated with REE deposits in North America and worldwide are limited to data associated with the baseline environmental characterization of the Nechalacho (Avalon Rare Metals Inc., 2011) and Bear Lodge (Dahlberg, 2014) deposits. Uranium is the only trace element in baseline surface water samples near both deposits. Humidity-cell leachates from Nechalacho exceed the chronic surface water benchmark for uranium (1.87 ppb) but not the acute benchmark (33.5 ppb) (Suter, 1996). Dissolved thorium concentrations are approximately one to two orders of magnitude lower than dissolved uranium concentrations at Nechalacho. Therefore, the risk of mine drainage issues associated with tailings from either alkaline-intrusion-related or carbonatite-hosted deposits is likely minimal.

Accidental release of mill tailings, either during or after closure, can pose a risk to aquatic organisms. This risk can be assessed by the comparison of the geochemical composition of mill tailings with relevant sediment-quality guidelines. In general, most concentrations of trace elements are low. The concentrations of cadmium, chromium, and nickel in a tailings sample from Nechalacho exceeded both the threshold effects concentration and the probable effects concentration (MacDonald and others, 2000). Concentrations of the REEs in the tailings sample exceeded their corresponding negligible concentrations, but not their maximum permissible concentrations (Sneller and others, 2000). Therefore, only a few elements are marginally of concern in the event of accidental release of tailings.

\section{Carbon Footprint}

There are several potential links between REEs and greenhouse gas emissions. One of the main ore minerals, bastnaesite $\left(\mathrm{Ln}\left(\mathrm{CO}_{3}\right) \mathrm{F}\right)$, contains carbonate, which is liberated during ore processing. Because of the low grades of economic 
deposits ( $<10$ percent total REOs), however, this carbon flux is not likely to be significant relative to other sources associated with mining. In addition, one of the most important uses of REEs is in permanent magnets used in "green" technologies, such as electric cars, hybrid cars, and wind turbines.

\section{Mine Closure}

Mine closure procedures depend on the mining method employed. Mountain Pass in California, Bayan Obo in China, and Mount Weld in Australia are all mined as open pits. At closure, the pits will likely fill with water, depending on the elevation of the local water table. Waste rock piles and mill tailing piles will also remain on site. Both types of piles may be regraded and revegetated. Recent operations at Mountain Pass recycled all water to avoid the need for evaporation ponds (Molycorp, Inc., 2015), which were used during previous mining at the site, to manage process water. Mill tailings disposal included paste disposal, eliminating the need for a tailings dam and its long-term maintenance. (Paste disposal produces tailings that have been significantly dewatered, and, as a result, the tailings do not have a critical flow velocity when pumped into the disposal area.)

\section{Problems and Future Research}

The fascinating new era for the REEs involves many challenges that remain to be fully addressed, including those related to economics (supply and demand and price stability issues), technology, and scientific research. In recent years, considerable news coverage and discussion have focused on the global supply and demand concerns for the REEs, underscored by their importance to modern and evolving technologies. In the foreseeable future, will processed REE compounds be readily available and affordable and in adequate supply to meet the needs of technology applications? If not, will suitable substitutes for the REEs be developed? In the fields of geologic research, although REE deposits have been studied for more than a century, many questions remain about their genesis. The questions that follow should be viewed as a partial list of the many issues likely to involve the REEs during the 21st century. These questions also represent opportunities where significant new contributions can be made.

- Will the addition of new LREE mines - such as the Mount Weld Mine (Australia) - prove to be adequate to offset reductions in the exports of REEs from China?

- Do substantial sources of HREEs occur outside of China? Are the ion-adsorption clay deposits of southern China unique? These deposits serve as the world's principal source of the HREEs and, as of 2015, other HREE deposits had not been brought into production. Can other clay deposits similarly enriched in the HREEs be brought into production outside of southern China? Will other types of HREE deposits eventually be brought into production?

- What exploration guidelines and techniques can be applied or developed that lead to discoveries of high-grade deposits of REEs, particularly hidden (concealed) deposits?

- Can advances in ore processing provide an economic advantage to some deposits? For mines that have REEs in the ores that host another primary mineral commodity, can REEs be developed as a byproduct?

- Can REEs be efficiently and economically recovered and recycled from disposed electronics, batteries, and other devices?

- Can REEs be replaced in some current applications by other metals that are less costly and more readily available? If so, will these products perform as well as those that use REEs?

- Can the complex ores of peralkaline deposits be processed by methods that are efficient and economical? This aspect is especially relevant because these deposit types often have a general enrichment in the highly sought HREEs.

- Why do REEs occur only in modest concentrations in Earth's upper mantle, yet they can be highly concentrated in carbonate and alkaline magmas that ascend to the crust, thereby forming ore deposits? The systematic geologic and chemical processes that explain these observations are not well understood, especially in comparison to many other ore-forming systems. Exploration for REEs throughout the world in recent years has provided considerable drilling and other data, which are likely to provide an abundance of materials and information useful for detailed geologic research.

Case histories for the environmental behavior of REE deposits, mines, and their mine wastes are extremely limited because there are so few past and current mines. Further, most past and current mines are located in China, where little environmental information is available. Therefore, insights into future environmental characteristics of REE mine wastes must rely on predictive models.

Little is known about the aquatic toxicity of REEs (Sneller and others, 2000). Although their low solubility likely limits their toxicity, a few studies suggest that their aquatic toxicity varies as a function of water chemistry (Barry and Meehan, 2000; Moermond and others, 2001; Weltje and others, 2004). More study is needed to evaluate the potential environmental risks associated with REEs in hydrologic systems. 


\section{References Cited}

Note: All Web links listed were active as of the access date but may no longer be available.

Adams, J.W., and Staatz, M.H., 1973, Rare-earth elements, in Brobst, D.A., and Pratt, W.P., eds., United States mineral resources: U.S. Geological Survey Professional Paper 820, p. 547-556. [Also available at http://pubs.er.usgs.gov/ publication/pp820.]

Alkane Resources Ltd., 2015, Projects: Alkane Resources Ltd. Web page, accessed October 9, 2015, at http:/www.alkane.com.au/ index.php/projects/current-projects.

American Physical Society Panel on Public Affairs and the Materials Research Society, 2011, Energy critical elements - Securing materials for emerging technologies: Washington, D.C., American Physical Society, 19 p. plus 2 appendixes. [Also available at http://www.aps.org/policy/ reports/popa-reports/upload/elementsreport.pdf.]

AMR Mineral Metal Inc., 2015, Aksu Diamas-Canakli deposit: AMR Mineral Metal Inc. Web page, accessed October 9, 2015, at http://www.amrmineralmetal.com/ aksu_diamas_canakli.asp.

Anderson, D.L., and Patiño-Echeverri, Dalia, advisor, 2009, An evaluation of current and future costs for lithium-ion batteries for use in electrified vehicle powertrains: RaleighDurham, N.C., Nicholas School of the Environment, Duke University master's thesis, 44 p., accessed October 9, 2015, at http://dukespace.lib.duke.edu/dspace/bitstream/10161/ 1007/1/Li-Ion_Battery_costs_-_MP_Final.pdf.

Arafura Resources Ltd., 2014, Nolans project-Resources and reserves: Arafura Resources Ltd. Web page, accessed September 18, 2015, at http:/www.arafuraresources.com.au/ our-projects/nolans/resources-reserves.html.

Arzamastsev, A.A., Bea, F., Glaznev, V.N., Arzamastseva, L.V., Bea, F., and Montero, P., 2001, Kola alkaline province in the Paleozoic_-Evaluation of primary mantle magma composition and magma generation conditions: Russian Journal of Earth Sciences, v. 3, no. 1, 22 p. [Also available at http://dx.doi.org/10.2205/2001ES000054.]

Avalon Rare Metals Inc., 2011, Developer's assessment report, Thor Lake project [Submitted to Mackenzie Valley Environmental Impact Review Board]: Avalon Rare Metals Inc., May, accessed January 13, 2015, via http://www.reviewboard.ca/ registry/project.php?project_id $=87$.

Avalon Rare Metals Inc., 2015, Nechalacho: Avalon Rare Metals Inc. Web page, accessed September 18, 2015, at http://avalonraremetals.com/nechalacho/nechalacho_overview/.
Baba, Kenji, Hiroshige, Yuzo, and Nemoto, Takeshi, 2013, Rare-earth magnet recycling: Hitachi Review, v. 62, no. 8, p. $452-455$.

Bao, Zhiwei, and Zhao, Zhenhua, 2008, Geochemistry of mineralization with exchangeable REY in the weathering crusts of granitic rocks in south China: Ore Geology Reviews, v. 33, nos. 3-4, p. 519-535. [Also available at http://dx.doi.org/10.1016/j.oregeorev.2007.03.005.]

Barker, J.C., and Van Gosen, B.S., 2012, Alaska's rare earth deposits and resource potential: Mining Engineering, v. 64, no. 1, p. 20-32.

Barry, M.J., and Meehan, B.J., 2000, The acute and chronic toxicity of lanthanum to Daphnia carinata: Chemosphere, v. 41, no. 10, p. 1669-1674. [Also available at http://dx.doi.org/ 10.1016/S0045-6535(00)00091-6.]

Berger, V.I., Singer, D.A., and Orris, G.J., 2009, Carbonatites of the world, explored deposits of $\mathrm{Nb}$ and REE-Database and grade and tonnage models: U.S. Geological Survey Open-File Report 2009-1139, 17 p., accessed September 18, 2015, at http://pubs.usgs.gov/of/2009/1139/.

Berquist, C.R., 1987, Minerals in high-level gravel deposits along the Fall Zone of Virginia: Virginia Minerals, v. 33, no. 4, p. 37-40.

Bhola, K.L., Chatterji, B.D., Dar, K.K., Mahadevan, C., Mahadevan, V., Mehta, N.R., Handi, N., Nanhi, H., Narayandas, G.R., Sahasrabudhe, G.H., Shirke, V.G., and Udas, G.R., 1958, A survey of uranium and thorium occurrences in India, session E5 (raw material supplies), in Proceedings of the Second United Nations International Conference on the Peaceful Uses of Atomic Energy, Geneva, Switzerland, September 1-13, 1958-Volume 2, Survey of raw material resources: Geneva, Switzerland, United Nations, v. 2, P/2516, p. 100-102.

Blank, Stephen, 2012, Kazakhstan completes major uranium and rare earths deals with Japan: Eurasia Daily Monitor, v. 9, no. 144, accessed September 15, 2015, at http://www.jamestown.org/programs/edm/single/ ?tx_ttnews[tt_news] $=39705 \& \mathrm{cHash}=4 \mathrm{e} 68 \mathrm{ec} 740 \mathrm{~b} 98 \mathrm{fe}$ 390061af8ca1769b6c\#.Uz16ivldV_5.

Carlson, M.P., and Treves, S.B., 2005, The Elk Creek carbonatite, southeast Nebraska-An overview: Natural Resources Research, v. 14, no. 1, p. 39-45. [Also available at http://dx.doi.org/10.1007/s11053-005-4677-x.]

Carpenter, R.H., and Carpenter, S.F., 1991, Heavy mineral deposits in the upper coastal plain of North Carolina and Virginia: Economic Geology, v. 86, p. 1657-1671. [Also available at http://dx.doi.org/10.2113/gsecongeo.86.8.1657.] 
Castor, S.B., 2008, The Mountain Pass rare-earth carbonatite and associated ultrapotassic rocks, California: The Canadian Mineralogist, v. 46, no. 4, p. 779-806. [Also available at http://dx.doi.org/10.3749/canmin.46.4.779.]

Castor, S.B., and Nason, G.W., 2004, Mountain Pass rare earth deposit, California, in Castor, S.B., Papke, K.G., and Meeuwig, R.O., eds., Betting on industrial minerals - Proceedings of the 39th Forum on the Geology of Industrial Minerals, Reno/Sparks, Nevada, May 18-24, 2003: Reno, Nev., Nevada Bureau of Mines and Geology Special Publication 33, p. 68-81.

Chakhmouradian, A.R., and Mitchell, R.H., 1998, Compositional variation of perovskite-group minerals from the Khibina complex, Kola Peninsula, Russia: The Canadian Mineralogist, v. 36, no. 4, p. 953-969.

Chakhmouradian, A.R., and Zaitsev, A.N., 2012, Rare earth mineralization in igneous rocks-Sources and processes: Elements, v. 8, no. 5, p. 347-353. [Also available at http://dx.doi.org/10.2113/gselements.8.5.347.]

Chi, Ruan, and Tian, Jun, 2008, Weathered crust elutiondeposited rare earth ores: New York, N.Y., Nova Science Publishers, $286 \mathrm{p}$.

Clark, A.L., and Zheng, Shuhui, 1991, China's rare earth potential, industry and policy, in Siribumrungsukha, B., Arrykul, S., Sanguansai, P., Pungrassami, T., Sikong, L., and Kooptarnond, K., eds., Proceedings of International Conference on Rare Earth Minerals and Minerals for Electronic Uses, Hat Yai, Thailand, January 23-25, 1991: Hat Yai, Thailand, Prince of Songkla University, v. 70-72, p. 577-602. [Also available at http://dx.doi.org/10.4028/ www.scientific.net/MSF.70-72.577.]

Commerce Resources Corp., 2016, Ashram rare earth element deposit [formerly Eldor project]: Commerce Resources Corp. Web page, accessed July 20, 2016, at https://www.commerceresources.com/en/projects/ ashram-rare-earth-element-deposit.

Dahlberg, P.S., 2014, Pre-feasibility study report on the reserves and development of the Bull Hill Mine, Wyoming, NI 43-101 technical report, prepared for Rare Element Resources, Ltd.: Sandy, Utah, Roche Engineering, Inc., October 9, 587 p., accessed September 14, 2015, at http://www.rareelementresources.com/bear-lodge-project/ project-related-studies-reports.

Daigle, Paul, 2012, Resource estimate and technical report for the Two Tom REE deposit of the Red Wine Complex, Labrador, Canada, NI 43-101 report prepared for Rare Earth Metals Inc.: Toronto, Ontario, Canada, Tetra Tech Wardrop, document no. 1192410100-REP-R0001-01, accessed September 18, 2015, at http://www.canadarareearth.com/upload/documents/twotom-43-101.pdf. de Boer, J.L.M., Verweij, W., van der Velde-Koerts, T., and Mennes, W., 1996, Levels of rare earth elements in Dutch drinking water and its sources-Determination by inductively coupled plasma mass spectrometry and toxicological implications-A pilot study: Water Resources, v. 30, no. 1, p. 190-198. [Also available at http://dx.doi.org/10.1016/ 0043-1354(95)00120-A.]

Dostal, Jaroslav, Kontak, D.J., and Karl, S.M, 2014, The early Jurrasic Bokan Mountain peralkaline granitic complex (southeastern Alaska) - Geochemistry, petrogenesis and rare-metal mineralization: Lithos, v. 202-203, August, p. 395-412. [Also available at http://dx.doi.org/10.1016/j.lithos.2014.06.005.]

Elderfield, H., Whitfield, M., Burton, J.D., Bacon, M.P., and Liss, P.S., 1988, The oceanic chemistry of the rare-earth elements [and discussion]: Philosophical Transactions of the Royal Society A, v. 325, no. 1583, p. 105-126. [Also available at http://dx.doi.org/10.1098/rsta.1988.0046.]

European Commission, 2014, Critical raw materials for the EUReport of the ad-hoc Working Group on defining critical raw materials: Brussels, Belgium, and Luxembourg, Luxembourg, European Commission, 41 p., accessed September 18, 2015, at http://ec.europa.eu/growth/sectors/ raw-materials/specific-interest/critical/index_en.htm.

Evans, J.R., 1964, Xenotime mineralization in the southern Music Valley area, Riverside County, California: Sacramento, Calif., California Division of Mines and Geology Special Report 79, 24 p.

Féménias, Oliver, Coussaert, Nicolas, Brassinnes, Stéphane, and Demaiffe, Daniel, 2005, Emplacement processes and cooling history of layered cyclic unit II-7 from the Lovozero alkaline massif (Kola Peninsula, Russia): Lithos, v. 83, nos. 3-4, p. 371-393. [Also available at http://dx.doi.org/10.1016/j.lithos.2005.03.012.]

Frontier Rare Earths Ltd., 2014, Projects: Frontier Rare Earths Ltd. Web page, accessed September 18, 2015, at http://www.frontierrareearths.com/projects/zandkopsdriftrare-earths-project.

Galileo Resources PLC, 2015, Glenover rare earth project: Galileo Resources PLC Web page, accessed September 18, 2015, at http://www.galileoresources.net/projects.htm.

Gambogi, Joseph, 2015, Rare earths: U.S. Geological Survey Mineral Commodity Summaries 2015, p. 128-129. [Also available at https://minerals.usgs.gov/minerals/pubs/ commodity/rare_earths/mcs-2015-raree.pdf .]

Gambogi, Joseph, 2016, Rare earths [advance release], in Metals and minerals: U.S. Geological Survey Minerals Yearbook 2013, v. I, p. 60.1-60.17, accessed May 9, 2016, at https://minerals.usgs.gov/minerals/pubs/commodity/rare_earths/ myb1-2013-raree.pdf. 
GBM Resources Ltd., 2012, GBM upgrades rare earth resource to over 110,000 tonnes as Milo grows to over a kilometre in length: GBM Resources Ltd. ASX announcement, August 9, accessed October 9, 2015, at http://www.gbmr.com.au/aurora/assets/user_content/ Milo\%20Resource\%20Increased_9thAugust_2012.pdf.

GéoMégA Inc., 2015, Montviel (REE, Nb): GéoMégA Inc. Web page, accessed October 9, 2015, at http://ressourcesgeomega.ca/montviel_page/.

Gieré, Reto, 1996, Formation of rare earth minerals in hydrothermal systems, chap. 5 of Jones, A.P., Wall, Frances, and Williams, C.T., eds., Rare earth minerals - Chemistry, origin and ore deposits (1st ed.): London, Chapman \& Hall, Mineralogical Society Series, v. 7, p. 106-150, 6 pls.

Global Times, 2013, China's rare earth industry sees progress, challenges: Global Times [Beijing, China], August 8, accessed June 11, 2015, at http://www.globaltimes.cn/ content/802521.shtml.

Goldstein, S.J., and Jacobsen, S.B., 1988, Rare earth elements in river waters: Earth and Planetary Science Letters, v. 89, no. 1, p. 35-47. [Also available at http://dx.doi.org/10.1016/ 0012-821X(88)90031-3.]

Goonan, T.G., 2011, Rare earth elements-End use and recyclability: U.S. Geological Survey Scientific Investigations Report 2011-5094, 15 p. [Also available at http://pubs.usgs.gov/sir/2011/5094/.]

Government of India, Department of Atomic Energy, 2011, Lok Sabha unstarred question no. 300-Deposits of rare earths: Government of India, Department of Atomic Energy, 2 p., accessed September 18, 2015, at http://www.dae.nic.in/ writereaddata/lsus300_231111.pdf.

Great Western Minerals Group Ltd., 2014, SteenkampskraalOur low-cost, high-grade mining operation in South Africa: Great Western Minerals Group Ltd. Web page, accessed October 9, 2015, at http://www.gwmg.ca/mining-operations/ overview.

Greenland Minerals and Energy Ltd., 2012, Ilimaussaq complexSpecialty metals (Kvanefjeld): Greenland Minerals and Energy Ltd. Web page, accessed October 9, 2015, at http://www.ggg.gl/projects/specialty-metals-kvanefjeld/.

Groves, D.I., Bierlein, F.P., Meinert, L.D., and Hitzman, M.W., 2010, Iron oxide copper-gold (IOCG) deposits through Earth history-Implications for origin, lithospheric setting, and distinction from other epigenetic iron oxide deposits: Economic Geology, v. 105, p. 641-654. [Also available at http://dx.doi.org/10.2113/gsecongeo.105.3.641.]

Haley, T.J., 1965, Pharmacology and toxicology of the rare earth elements: Journal of Pharmaceutical Sciences, v. 54, no. 5, p. 663-670. [Also available at http://dx.doi.org/ 10.1002/jps.2600540502.]
Hastings Rare Metals Ltd., 2015, Brockman project (100\%) [Hastings project]: Hastings Rare Metals Ltd. Web page, accessed October 20, 2015, at http:/hastingstechmetals.com/ index.php/projects/brockman-project/.

Hatch, G.P., 2012a, Dynamics in the global market for rare earths: Elements, v. 8, no. 5, p. 341-346. [Also available at http://dx.doi.org/10.2113/gselements.8.5.341.]

Hatch, Gareth, 2012b, September 2012 updates to the TMR advanced rare-earth projects index: Technology Metals Research, October 12, accessed October 9, 2015, at http://www.techmetalsresearch.com/2012/10/ september-2012-updates-to-the-tmr-advanced-rareearth-projects-index/.

Hatch, Gareth, 2013, The first round of Chinese rare-earth export-quota allocations for 2014: Carpentersville, Ill., Technology Metals Research, LLC, December 13, accessed October 20, 2015, at http://www.techmetalsresearch.com/ 2013/12/the-first-round-of-chinese-rare-earth-export-quotaallocations-for-2014/.

Hatch, Gareth, 2014, The second round of Chinese rare-earth export-quota allocations for 2014: Carpentersville, Ill., Technology Metals Research, LLC, July 19, accessed October 20, 2015, at http://www.techmetalsresearch. com/2014/07/the-second-round-of-chinese-rare-earthexport-quota-allocations-for-2014/.

Hatch, Gareth, 2015, TMR advanced rare-earth projects index: Technology Metals Research Web page, accessed October 9, 2015, at http://www.techmetalsresearch.com/ metrics-indices/tmr-advanced-rare-earth-projects-index/.

Henderson, Paul, 1984, General geochemical properties and abundances of the rare earth elements, chap. 1 of Henderson, Paul, ed., Rare earth element geochemistry: Amsterdam, Netherlands, Elsevier, Developments in Geochemistry series, v. 2, p. 1-32.

Honda Motor Co., Ltd., 2013, Honda established world's first process to reuse rare earth metals extracted from nickelmetal hydride batteries for hybrid vehicles: Tokyo, Japan, Honda Motor Co., Ltd. news release, March 3, accessed October 20, 2015, at http://world.honda.com/news/2013/ c130303Reuse-Rare-Earth-Metals/print.html.

Hou, Zengqian, Tian, Shihong, Xie, Yuling, Yang, Zhusen, Yuan, Zhongxin, Yin, Shuping, Yi, Longsheng, Fei, Hongcai, Zou, Tianren, Bai, Ge, and Li, Xiaoyu, 2009, The Himalayan Mianning-Dechang REE belt associated with carbonatite-alkaline complexes, eastern Indo-Asian collision zone, SW China: Ore Geology Reviews, v. 36, nos. 1-3, p. 65-89. [Also available at http://dx.doi.org/ 10.1016/j.oregeorev.2009.03.001.] 
Hudson Resources Inc., 2012, Hudson Resources reports updated mineral resource-Significant grade increases and indicated resources confirmed: Hudson Resources Inc. press release, April 26, 4 p., accessed October 9, 2015, at http://www.hudsonresources.ca/files/NR2012-02.pdf.

Hulse, D.E., Newton, M.C., III, and Malhotra, Deepak, 2014, Amended NI 43-101 preliminary economic assessment, Round Top project, Sierra Blanca, Texas, prepared for Texas Rare Earth Resources: Lakewood, Colo., Gustavson Associates LLC, April 28, 206 p., accessed October 9, 2015, at http://trer.com/_resources/reports/Amended_TRER_ NI43-101_PEA_FINAL_28April2014.pdf.

Indian Bureau of Mines, 2015, Rare earths, in Part IIIMineral reviews (53rd ed.) [advance release]: Nagpur, India, Indian Minerals Yearbook 2014, v. III, p. 43-1-4-9, accessed May 6, 2016, at http://ibm.nic.in/writereaddata/ files/12182015103018IMYB-2014_Rareearths(Adv).pdf.

Jackson, W.D., and Christiansen, Grey, 1993, International strategic minerals inventory summary report-Rare-earth oxides: U.S. Geological Survey Circular 930-N, 68 p. [Also available at http://pubs.usgs.gov/circ/1993/0930n/ report.pdf.]

Jones, A.P., Wall, Frances, and Williams, C.T., eds., 1996, Rare earth minerals - Chemistry, origin and ore deposits (1st ed.): London, United Kingdom, Chapman \& Hall, Mineralogical Society series, v. 7, 372 p., 6 pls.

Kato, Yasuhiro, Fujinaga, Koichiro, Nakamura, Kentaro, Takaya, Yutaro, Kitamura, Kenichi, Ohta, Junichiro, Toda, Ryuichi, Nakashima, Takuya, and Iwamori, Hikaru, 2011, Deep-sea mud in the Pacific Ocean as a potential resource for rare-earth elements: Nature Geoscience, v. 4, no. 8, p. 535-539. [Also available at http://dx.doi.org/10.1038/ ngeo1185.]

Kogarko, L.N., Konova, V.A., Orlova, M.P., and Woolley, A.R., 1995, Alkaline rocks and carbonatites of the world-Part two-Former USSR: London, United Kingdom, Chapman \& Hall, 226 p.

Kogarko, L.N., Williams, C.T., and Woolley, A.R., 2006, Compositional evolution and cryptic variation in pyroxenes of the peralkaline Lovozero intrusion, Kola Peninsula, Russia: Mineralogical Magazine, v. 70, no. 4, p. 347-359. [Also available at http://dx.doi.org/10.1180/0026461067040340.]

Kopera, J.J.C., 2004, Inside the nickel metal hydride battery: Cobasys LLC Web page, accessed October 9, 2015, at http://www.cobasys.com/pdf/tutorial/InsideNimhBattery/ inside_nimh_battery_technology.html.

Kynicky, Jindrich, Smith, M.P., and Xu, Cheng, 2012, Diversity of rare earth deposits - The key example of China: Elements, v. 8, no. 5, p. 361-367. [Also available at http://dx.doi.org/10.2113/gselements.8.5.361.]
Liang, Tao, Li, Kexin, and Wang, Lingqing, 2014, State of rare earth elements in different environmental components in mining areas of China: Environmental Monitoring and Assessment, v. 186, no. 3, p. 1499-1513. [Also available at http://dx.doi.org/10.1007/s10661-013-3469-8.]

Lide, D.R., ed., 2004, CRC handbook of chemistry and physics (85th ed.): Boca Raton, Fla., CRC Press, 2,712 p.

Long, K.R., 2011, The future of rare earth elements-Will these high-tech industry elements continue in short supply?: U.S. Geological Survey Open-File Report 2011-1189, 41 p. [Also available at http://pubs.usgs.gov/of/2011/1189/.]

Long, K.R., Van Gosen, B.S., Foley, N.K., and Cordier, Daniel, 2010, The principal rare earth elements deposits of the United States - A summary of domestic deposits and a global perspective: U.S. Geological Survey Scientific Investigations Report 2010-5220, 96 p. [Also available at http://pubs.usgs.gov/sir/2010/5220/.]

Lynas Corporation Ltd., 2012, Resource estimates: Lynas Corporation Ltd. Web page, accessed October 9, 2015, at http://www.lynascorp.com/Pages/rare-earths-project.aspx. (Web page no longer available as of October 20, 2015; updated resource estimate issued on October 5, 2015, at https://www.lynascorp.com/PublishingImages/ Pages/Mt-Weld-Resources-and-Reserves/ASX\%20 Announcement $\% 20-\% 20$ Ore $\% 20$ Reserves $\% 20$ and $\% 20$ Resources\%20FINAL\%20051015.pdf.)

MacDonald, D.D., Ingersoll, C.G., and Berger, T.A., 2000, Development and evaluation of consensus-based sediment quality guidelines for freshwater ecosystems: Archives of Environmental Contamination and Toxicology, v. 39, no. 1, p. 20-31. [Also available at http://dx.doi.org/ 10.1007/s002440010075.]

Mariano, A.N., 1989, Economic geology of rare earth minerals, chap. 11 of Lipin, B.R., and McKay, G.A., eds., Geochemistry and mineralogy of rare earth elements: Washington, D.C., The Mineralogical Society of America Reviews in Mineralogy series, v. 21, p. 309-337.

Mariano, A.N., and Mariano, Anthony, Jr., 2012, Rare earth mining and exploration in North America: Elements, v. 8, no. 5, p. 369-376. [Also available at http://dx.doi.org/ 10.2113/gselements.8.5.369.]

MBAC Fertilizer Corp., 2012, MBAC reports robust preliminary economic assessment for Araxá rare earth oxide/niobium/phosphate deposit-MBAC Fertilizer Corp. press release, September 13 : MBAC Fertilizer Corp. Web page, accessed July 18, 2014, at http://mbacfert.com/news/ news-details/2012/MBAC-Reports-Robust-PreliminaryEconomic-Assessment-For-Arax-Rare-Earth-OxideNiobium-Phosphate-Deposit-/default.aspx. 
McKay, G.A., 1989, Partitioning of rare earth elements between major silicate minerals and basaltic melts, chap. 3 of Lipin, B.R., and McKay, G.A., eds., Geochemistry and mineralogy of rare earth elements: Washington, D.C., The Mineralogical Society of America Reviews in Mineralogy series, v. 21, p. 45-77.

McKeown, F.A., and Klemic, Harry, 1956, Rare-earthbearing apatite at Mineville, Essex County, New York: U.S. Geological Survey Bulletin 1046-B, p. 9-23. [Also available at http://pubs.usgs.gov/bul/1046b/report.pdf.]

Ministry of Commerce, 2010a, 2010 second batch rare earth export quota: Beijing, China, Ministry of Commerce, July 7, 2 p.

Ministry of Commerce, 2010b, 2011 first batch rare earth export quota: Beijing, China, Ministry of Commerce, December 28, 2 p.

Mkango Resources Ltd., 2012, Mkango Resources Ltd.: Mkango Resources Ltd. Web page, accessed September 18, 2015, at http://www.mkango.ca/s/home.asp.

Moermond, C.T.A., Tijink, Jakolien, van Wezel, A.P., and Koelmans, A.A., 2001, Distribution, speciation, and bioavailability of lanthanides in the Rhine-Meuse estuary, the Netherlands: Environmental Toxicology and Chemistry, v. 20, no. 9, p. 1916-1926. [Also available at http://dx.doi.org/10.1002/etc.5620200909.]

Molycorp, Inc., 2012, Molycorp's rare earth reserves at Mountain Pass increase by 36\%: Molycorp, Inc. press release, April 10, accessed July 18, 2014, at http://www.molycorp.com/molycorps-rare-earthreserves-at-mountain-pass-increase-by-36/.

Molycorp, Inc., 2015, Molycorp innovations: Molycorp, Inc. Web page, accessed October 9, 2015, at http://www.molycorp.com/ technology/molycorp-innovations.

Montero Mining \& Exploration Ltd., 2011, Developing rare earth potential —Wigu Hill, Tanzania: Montero Mining \& Exploration Ltd. Web page, accessed October 9, 2015, at http://www.monteromining.com/projects/wigu.html.

Namibia Rare Earths Inc., 2012, Namibia Rare Earths files technical report for initial mineral resource for area 4 of Lofdal project: Namibia Rare Earths Inc. press release, October 30, 8 p., accessed September 18, 2015, at http://www.namibiarareearths.com/upload/08.October_30 2012_NRE_Files_Technical_Report_for_Initial_Mineral_ Resource_for_Area_4_of_Lofdal_Project.pdf.

National Research Council, 2008, Minerals, critical minerals, and the U.S. economy-Committee on Critical Mineral Impacts on the U.S. Economy, Committee on Earth Resources, Board on Earth Sciences and Resources, Division on Earth and Life Studies, National Research Council of the National Academies: Washington, D.C., National Academies Press, 245 p. [Also available at http://www.nap.edu/openbook.php?record_id=12034.]
Natural Earth, 2014, Small scale data: Natural Earth map dataset, scale 1:110,000,000, accessed October 9, 2015, at http://www.naturalearthdata.com.

Nuelle, L.M., Kisvarsanyi, E.B., Seeger, C.M., Day, W.C., and Sidder, G.B., 1991, Structural setting and control of the Pea Ridge magnetite deposit, Middle Proterozoic St. Francois terrane, Missouri [abs.]: Geological Society of America Abstracts with Programs, v. 23, no. 5, p. A292 (item no. 28986).

O’Driscoll, Michael, 2003, REgeneration in autocatalysts: Industrial Minerals, no. 424, p. 24-33.

Olson, J.C., Shawe, D.R., Pray, L.C., and Sharp, W.N., 1954, Rare-earth mineral deposits of the Mountain Pass district, San Bernardino County, California: U.S. Geological Survey Professional Paper 261, 75 p. [Also available at http://pubs.er.usgs.gov/publication/pp261.]

Pacific Wildcat Resources Corp., 2013, Mrima Hill project: Pacific Wildcat Resources Corp. Web page, accessed October 9, 2015, at http://www.pacificwildcat.com/ mrimahill.html.

Pancontinental Uranium Corp., 2012, Charley Creek REE project scoping/preliminary economic assessment study moves ahead: Pancontinental Uranium Corp. press release, October 25, 3 p., accessed October 9, 2015, at http://www.panconu.com/files/docs_pressrelease/2012/ NR Oct 25 12_v001_y151ci.pdf.

Papp, J.F., 2011, Niobium (columbium) and tantalum, in Metals and minerals: U.S. Geological Survey Minerals Yearbook 2009 , v. I, p. 52.1-52.14, accessed January 13, 2016, at http://minerals.usgs.gov/minerals/pubs/commodity/ niobium/myb1-2009-niobi.pdf.

Peak Resources Ltd., 2013, Ngualla rare earth project: Peak Resources Ltd. Web page, accessed October 9, 2015, at http://www.peakresources.com.au/irm/content/nguallarare-earth-project.aspx?RID=304.

Pele Mountain Resources, 2013, Eco Ridge Mine overview: Pele Mountain Resources Web page, accessed October 9, 2015, at http://www.pelemountain.com/overview.php.

Pittuck, M.F., Parsons, Benjamin, Ugorets, V.I., Larochelle, Eric, Dorval, Alain, Poeck, Joanna, Osborn, Jeff, Tinucci, John, Balasko, Clara, Willow, Mark, and Obie, Valerie, 2015, Amended NI 43-101 technical report-Updated preliminary economic assessment-Elk Creek niobium project-Nebraska-NI 43-101 technical report, prepared for NioCorp Developments Ltd. [Amended report date: October 16, 2015: Effective date: August 4, 2015]: Denver, Colo., SRK Consulting (U.S.), Inc. and Roche Ltd., Consulting Group, 331 p., accessed June 22, 2017, at http://www.niocorp.com/index.php/30-uncategorised/273ni-43-101-technical-report-updated-preliminary-economicassessment-elk-creek-niobium-project-nebraska. 
Quest Rare Minerals Ltd., 2012, Strange Lake rare earth project: Quest Rare Minerals Ltd. Web page, accessed October 9, 2015, at http://www.questrareminerals.com/ strange lake.php.

Recycling International, 2011a, Fraunhofer's focus on rare earth metal recycling: Recycling International Web page, November 15, accessed June 9, 2016, at http:/www.recyclinginternational.com/recyclingnews/4026/research-and-legislation/germany/ fraunhofer-s-focus-rare-earth-metal-recycling.

Recycling International, 2011b, Research into rare earths from electric motors: Recycling International Web page, December 9, accessed June 9, 2016, at http:/www.recyclinginternational.com/ recycling-news/5921/research-and-legislation/germany/ research-rare-earths-electric-motors.

Recycling International, 2011c, Rhodia expands rare earth recycling reach: Recycling International Web page, October 12, accessed June 9, 2016, at http://www.recyclinginternational.com/ recycling-news/3948/e-waste-and-batteries/france/ rhodia-expands-rare-earth-recycling-reach.

Resnick Institute, 2011, Critical materials for sustainable energy applications: Pasadena, Calif., California Institute of Technology, Resnick Institute Report, 46 p. [Also available at http://resnick.caltech.edu/docs/R_Critical.pdf.]

Sanematsu, Kenzo, Murakami, Hiroyasu, Watanabe, Yasushi, Duangsurigna, Sixomxeun, and Vilayhack, Siphandone, 2009, Enrichment of rare earth elements (REE) in granitic rocks and their weathered crusts in central and southern Laos: Bulletin of the Geological Survey of Japan, v. 60, nos. 11-12, p. 527-558. [Also available at http://dx.doi.org/ 10.9795/bullgsj.60.527.]

Saucier, Guy, Roy, André, Casgrain, Pierre, Côté, Philippe, Thomassin, Yves, Bilodeau, Michel, Cannus, Yann, and Hayden, Alfred, 2012, NI 43-101 report, Preliminary economic assessment study for Kipawa project, NI 43-101 report, prepared for Matamec Explorations Inc. [Effective date January 30, 2012]: Quebec City, Quebec, Canada, Roche Ltd. Consulting-Group and SGS Canada, Inc., ref no. $061623.001200,229$ p. [Also available at http:/www.matamec.com/vns-site/uploads/documents/ Rep_Matamec-Fin-PEA-000-20120314-SEDAR-Com.pdf.]

Seal, R.R., II, Hammarstrom, J.M., Johnson, A.N., Piatak, N.M., and Wandless, G.A., 2008, Environmental geochemistry of a Kuroko-type massive sulfide deposit at the abandoned Valzinco Mine, Virginia, USA: Applied Geochemistry, v. 23, no. 2, p. 320-342. [Also available at http://dx.doi.org/ 10.1016/j.apgeochem.2007.10.001.]
Seeger, C.M., Nuelle, L.M., Day, W.C., Sidder, G.B., Marikos, M.A., and Smith, D.C., 2001, Geologic maps and cross sections of mine levels at the Pea Ridge iron mine, Washington County, Missouri (version 1.0): U.S. Geological Survey Miscellaneous Field Studies Map 2353, 6 p. pamphlet, 5 sheets. [Also available at http://pubs.usgs.gov/mf/2001/mf-2353/.]

Shannon, R.D., 1976, Revised effective ionic radii and systematic studies of interatomic distances in halides and chalcogenides: Acta Crystallographica Section AFoundations, v. 32, no. 5, p. 751-767. [Also available at http://dx.doi.org/10.1107/s0567739476001551.]

Shin-Etsu Chemical Co., Ltd., 2014, Shin-Etsu Chemical to construct a rare earth magnet manufacturing plant in Hai Phong Province in Vietnam: Tokyo, Japan, Shin-Etsu Chemical Co., Ltd. news release, April 21, accessed October 20, 2015, at http://www.shinetsu.co.jp/en/news/ archive.php? $\mathrm{id}=365$.

Sholkovitz, E.R., 1995, The aquatic chemistry of rare earth elements in rivers and estuaries: Aquatic Chemistry, v. 1, no. 1, p. 1-34. [Also available at http://dx.doi.org/10.1007/ BF01025229.]

Showa Denko K.K., 2010, SDK subsidiary completes rare earth plant in Vietnam: Tokyo, Japan, Showa Denko K.K. news release, May 11, accessed October 20, 2015, at http://www.sdk.co.jp/english/news/2010/aanw_10_1242.html.

Sidder, G.B., Day, W.C., Nuelle, L.M., Seeger, C.M., and Kisvarsanyi, E.B., 1993, Mineralogic and fluidinclusion studies of the Pea Ridge iron-rare-earth-element deposit, southeast Missouri, chap. U of Scott, R.W., Jr., Detra, P.S., and Berger, B.R., eds., Advances related to United States and international mineral resourcesDeveloping frameworks and exploration technologies: U.S. Geological Survey Bulletin 2039, p. 205-216. [Also available at http://pubs.usgs.gov/bul/2039/ report.pdf.]

Smith, D.S., Cannon, W.F., Woodruff, L.G., Solano, Federico, Kilburn, J.E., and Fey, D.L., 2013, Geochemical and mineralogical data for soils of the conterminous United States: U.S. Geological Survey Data Series 801, 19 p. [Also available at http://pubs.usgs.gov/ds/801/.]

Sneller, F.E.C., Kalf, D.F., Weltje, L., and Van Wezel, A.P., 2000, Maximum permissible concentrations and negligible concentrations for rare earth elements (REEs): Bilthoven, Netherlands, Rijksinstituut Voor Volksgezondheid En Milieu (National Institute of Public Health and the Environment), RIVM Report 601501-011, 66 p., accessed October 9, 2015, at http://rivm.openrepository.com/rivm/ bitstream/10029/9551/1/601501011.pdf. 
Srivastava, R.M., Gauthier, Jacques, Cox, J.J., and Krutzelmann, Holger, 2012, Technical report on the Foxtrot project in Labrador, Newfoundland \& Labrador, Canada, NI 43-101 technical report, prepared for Search Minerals Inc.: Toronto, Ontario, Canada, Roscoe Postle Associates, June 15, accessed October 9, 2015, at http://www.searchminerals.ca/i/ pdf/reports/RPA-Foxtrot-July2012.pdf.

Staatz, M.H., Hall, R.B., Macke, D.L., Armbrustmacher, T.J., and Brownfield, I.K., 1980, Thorium resources of selected regions in the United States: U.S. Geological Survey Circular 824, 32 p. [Also available at http://pubs.er.usgs.gov/ publication/cir824.]

Stans Energy Corp., 2015, Kutessay II JORC results and REE percentages: Stans Energy Corp. Web page, accessed October 9, 2015, at http://www.stansenergy.com/projects/ kutessay-ii/.

Star Minerals Group Ltd., 2014, Hoidas Lake: Star Minerals Group Ltd. Web page, accessed October 9, 2015, at http://www.starminerals.ca/s/Hoidas.asp.

Suter, G.W., II, 1996, Toxicological benchmarks for screening contaminants of potential concern for effects on freshwater biota: Environmental Toxicology and Chemistry, v. 15, no. 7, p. 1232-1241. [Also available at http://dx.doi.org/ 10.1002/etc.5620150731.]

Tantalus Rare Earths AG, 2013, Tantalus Rare EarthsTRE project: Tantalus Rare Earths AG Web page, accessed October 9, 2015, at http://www.tre-ag.com/operations/ tre-project.aspx?sc_lang=en.

Tasman Metals Ltd., 2012, Norra Kärr rare element project: Tasman Metals Ltd. Web page, accessed October 9, 2015, at http://www.tasmanmetals.com/s/Norra-Karr.asp.

Tse, Pui-Kwan, 2011, China's rare-earth industry: U.S. Geological Survey Open-File Report 2011-1042, 11 p., accessed September 14, 2015, at http://pubs.usgs.gov/ of $/ 2011 / 1042 /$.

Tyler, G., 2004, Rare earth elements in soil and plant systemsA review: Plant and Soil, v. 267, nos. 1-2, p. 191-206. [Also available at http://dx.doi.org/10.1007/s11104-005-4888-2.]

Ucore Rare Metals Inc., 2015, Ucore increases resource at Bokan Dotson-Ridge: Ucore Rare Metals Inc. press release, May 11, accessed June 15, 2017, at http://ucore.com/ ucore-increases-resource-at-bokan-dotson-ridge.

Umicore Group, 2011, Umicore and Rhodia develop unique rare earth recycling process for rechargeable batteries: Umicore Group press release CP-2-11-18-R, June 16, accessed October 19, 2015, at http://www.umicore.com/ en/media/press/20110616REErecyclingEN/.
U.S. Bureau of Mines, 1961-96, Minerals yearbook 1960-94: U.S. Bureau of Mines, variously paginated. [Also available via http://minerals.usgs.gov/minerals/pubs/commodity/.]

U.S. Department of Energy, 2010, Critical materials strategy: Washington, D.C., U.S. Department of Energy, 166 p., accessed October 9, 2015, at http://energy.gov/sites/prod/ files/piprod/documents/cms_dec_17_full_web.pdf.

U.S. Department of Energy, 2011, Critical materials strategy: Washington, D.C., U.S. Department of Energy, DOE/PI-0009, 191 p., accessed October 9, 2015, at http://energy.gov/sites/ prod/files/DOE_CMS2011_FINAL_Full.pdf.

U.S. Department of Energy, 2013, U.S. Dept. of Energy, Ames Laboratory mark new era in critical materials research with new Energy Innovation Hub: U.S. Department of Energy press release, September 10, accessed March 24, 2015, at https://www.ameslab.gov/node/8475.

U.S. Environmental Protection Agency, 2009, IRIS toxicological review of cerium oxide and cerium compounds (interagency science discussion draft): Washington, D.C., U.S. Environmental Protection Agency National Center for Environmental Assessment, Report EPA/635/R-08/002, accessed October 9, 2015, at http://cfpub.epa.gov/ncea/ iris_drafts/recordisplay.cfm?deid=214572.

U.S. Environmental Protection Agency, 2015, Regional screening levels - Generic tables: U.S. Environmental Protection Agency Web page, accessed October 9, 2015, at http://www.epa.gov/region9/superfund/prg/index.html.

U.S. Geological Survey, 1996, Global 30 arc-second elevation (GTOPO30): Reston, Va., U.S. Geological Survey dataset (digital elevation model), accessed October 9, 2015, at https://ta.cr.usgs.gov/GTOPO30.

U.S. Geological Survey, 1997-2016, Minerals yearbook 1995-2012: U.S. Geological Survey, variously paged. [Also available at http://minerals.usgs.gov/minerals/pubs/myb.html.]

Verplanck, P.L., Nordstrom, D.K., Taylor, H.E., and Kimball, B.A., 2004, Rare earth element partitioning between hydrous ferric oxides and acid mine water during iron oxidation: Applied Geochemistry, v. 19, no. 8, p. 1339-1354. [Also available at http://dx.doi.org/ 10.1016/j.apgeochem.2004.01.016.]

Verplanck, P.L., Van Gosen, B.S., Seal, R.R., and McCafferty, A.E., 2014, A deposit model for carbonatite and peralkaline intrusion-related rare earth element deposits: U.S. Geological Survey Scientific Investigations Report 2010-5070-J, 58 p. [Also available at http://pubs.er.usgs.gov/publication/sir20105070J.] 
Vierrether, C.W., and Cornell, W.L., 1993, Rare-earth occurrences in the Pea Ridge tailings: U.S. Bureau of Mines Report of Investigations, RI 9453, 10 p. [Also available at http://stacks.cdc.gov/ObjectView?pid=cdc:10215\&dsid= DS1\&mimeType=application/pdf.]

Wagh, A.S., and Pinnock, W.R., 1987, Occurrence of scandium and rare earth elements in Jamaican bauxite waste: Economic Geology, v. 82, p. 757-761. [Also available at http://dx.doi.org/10.2113/gsecongeo.82.3.757.]

Weltje, L., Verhoof, L.R.C.W., Verweij, W., and Hamers, T., 2004, Lutetium speciation and toxicity in a microbial bioassay-Testing the free-ion model for lanthanides: Environmental Science and Technology, v. 38, no. 24, p. 6597-6604. [Also available at http://dx.doi.org/10.1021/ es049916m.]

Williams-Jones, A.E., Migdisov, A.A., and Samson, I.M., 2012, Hydrothermal mobilisation of the rare earth elements - A tale of "Ceria" and "Yttria": Elements, v. 8, no. 5, p. 355-360. [Also available at http://dx.doi.org/ 10.2113/gselements.8.5.355.]

Wood, S.A., 1990, The aqueous geochemistry of the rareearth elements and yttrium-1. Review of available lowtemperature data for inorganic complexes and the inorganic REE speciation of natural waters: Chemical Geology, v. 82 , nos. 1-2, p. 159-186. [Also available at http://dx.doi.org/10.1016/0009-2541(90)90080-Q.]

Woolley, A.R., 1987, Alkaline rocks and carbonatites of the world - Part 1-North and South America: London, United Kingdom, British Museum of Natural History, 216 p.

Woolley, A.R., 2001, Alkaline rocks and carbonatites of the world-Part 3-Africa: London, United Kingdom, Geological Society of London, 372 p.

Woolley, A.R., and Kjarsgaard, B.A., 2008, Carbonatite occurrences of the world-Map and database: Geological Survey of Canada Open-File Report 5796, 28 p., 1 CD-ROM, plus 1 map, scale approx. 1:19,000,000. [Also available at http://dx.doi.org/10.4095/225115.]

Wyllie, P.J., Jones, A.P., and Deng, Jinfu, 1996, Rare earth elements in carbonate-rich melts from mantle to crust, chap. 4 of Jones, A.P., Wall, Frances, and Williams, C.T., eds., Rare earth minerals - Chemistry, origin and ore deposits (1st ed.): London, United Kingdom, Chapman \& Hall, Mineralogical Society series, v. 7, p. 77-103, 6 pls.

Xie, Yuling, Hou, Zengqian, Yin, Shuping, Dominy, S.C., $\mathrm{Xu}$, Jiuhua, Tian, Shihong, and Xu, Wenyi, 2009, Continuous carbonatitic melt-fluid evolution of a REE mineralization system-Evidence from inclusions in the Maoniuping REE deposit, western Sichuan, China: Ore Geology Reviews, v. 36, nos. 1-3, p. 90-105. [Also available at http://dx.doi.org/10.1016/j.oregeorev.2008.10.006.]
Xu, Anshun, 1996, Mineralogy, petrology, geochemistry and origin of the Elk Creek carbonatite, Nebraska: Lincoln, Neb., University of Nebraska, Ph.D. dissertation, paper AAI9628256, 299 p. [Also available at http://digitalcommons.unl.edu/dissertations/AAI9628256.]

Xu, Cheng, Campbell, I.H., Kynicky, Jindrich, Allen, C.M., Chen, Yanjing, Huang, Zhilong, and Qi, Liang, 2008, Comparison of the Daluxiang and Maoniuping carbonatitic REE deposits with Bayan Obo REE deposit, China: Lithos, v. 106, nos. 1-2, p. 12-24. [Also available at http://dx.doi.org/ 10.1016/j.lithos.2008.06.005.]

Xu, Cheng, Wang, Linjun, Song, Wenlei, and Wu, Min, 2010, Carbonatites in China-A review for genesis and mineralization: Geoscience Frontiers, v. 1, no. 1, p. 105-114. [Also available at http://dx.doi.org/10.1016/j.gsf.2010.09.001.]

Yang, Kui-feng, Fan, Hong-rui, Hu, Fang-fang, and Wang, Kai-yi, 2010, Intrusion sequence of carbonatite dykes and REE enrichment mechanism in Bayan Obo district, Inner Mongolia: Acta Petrologica Sinica, v. 26, no. 5, p. 1523-1529. [Also available at http://caod.oriprobe.com/articles/26385499/ Intrusion_sequence_of_carbonatite_dykes_and_REE_ accumulation_mechanism.htm.]

Yang, Kui-Feng, Fan, Hong-Rui, Santosh, M., Hu, Fan-Fang, and Wang, Kai-Yi, 2011, Mesoproterozoic carbonatitic magmatism in the Bayan Obo deposit, Inner Mongolia, north China-Constraints for the mechanism of super accumulation of rare earth elements: Ore Geology Reviews, v. 40, no. 1, p. 122-131. [Also available at http://dx.doi.org/ 10.1016/j.oregeorev.2011.05.008.]

Yang, Zhuming, and Woolley, Alan, 2006, Carbonatites in China-A review: Journal of Asian Earth Sciences, v. 27, no. 5, p. 559-575. [Also available at http://dx.doi.org/10.1016/ j.jseaes.2005.06.009.]

Yap, Chuin-Wei, 2015, China ends rare-earth minerals export quotas: The Wall Street Journal, January 5, accessed October 20, 2015, at http://www.wsj.com/articles/chinaends-rare-earth-minerals-export-quotas-1420441285.

Yuan, Zhongxin, Bai, Ge, Wu, Chenyu, Zhang, Zhongqin, and Ye, Xianjiang, 1992, Geological features and genesis of the Bayan Obo REE ore deposit, Inner Mongolia, China: Applied Geochemistry, v. 7, no. 5, p. 429-442. [Also available at http://dx.doi.org/10.1016/0883-2927(92)90004-M.]

Zaitsev, V., and Kogarko, L., 2012, Sources and perspectives of REE in the Lovozero massif (Kola Peninsula, Russia): European Mineralogical Conference 2012, v. 1, paper EMC2012-290, accessed October 9, 2015, at http://meetingorganizer.copernicus.org/EMC2012/ EMC2012-290.pdf. 



\section{Rhenium}

By David A. John, Robert R. Seal II, and Désirée E. Polyak

Chapter P of

Critical Mineral Resources of the United States-Economic and Environmental Geology and Prospects for Future Supply

Edited by Klaus J. Schulz, John H. DeYoung, Jr., Robert R. Seal II, and Dwight C. Bradley

Professional Paper 1802-P

U.S. Department of the Interior

U.S. Geological Survey 


\section{Contents of Chapter P}

[Figure and table titles for all chapters are listed in the volume contents before the conversion factors table and list of abbreviations and symbols. A periodic table of the elements is on the inside front cover of the printed volume]

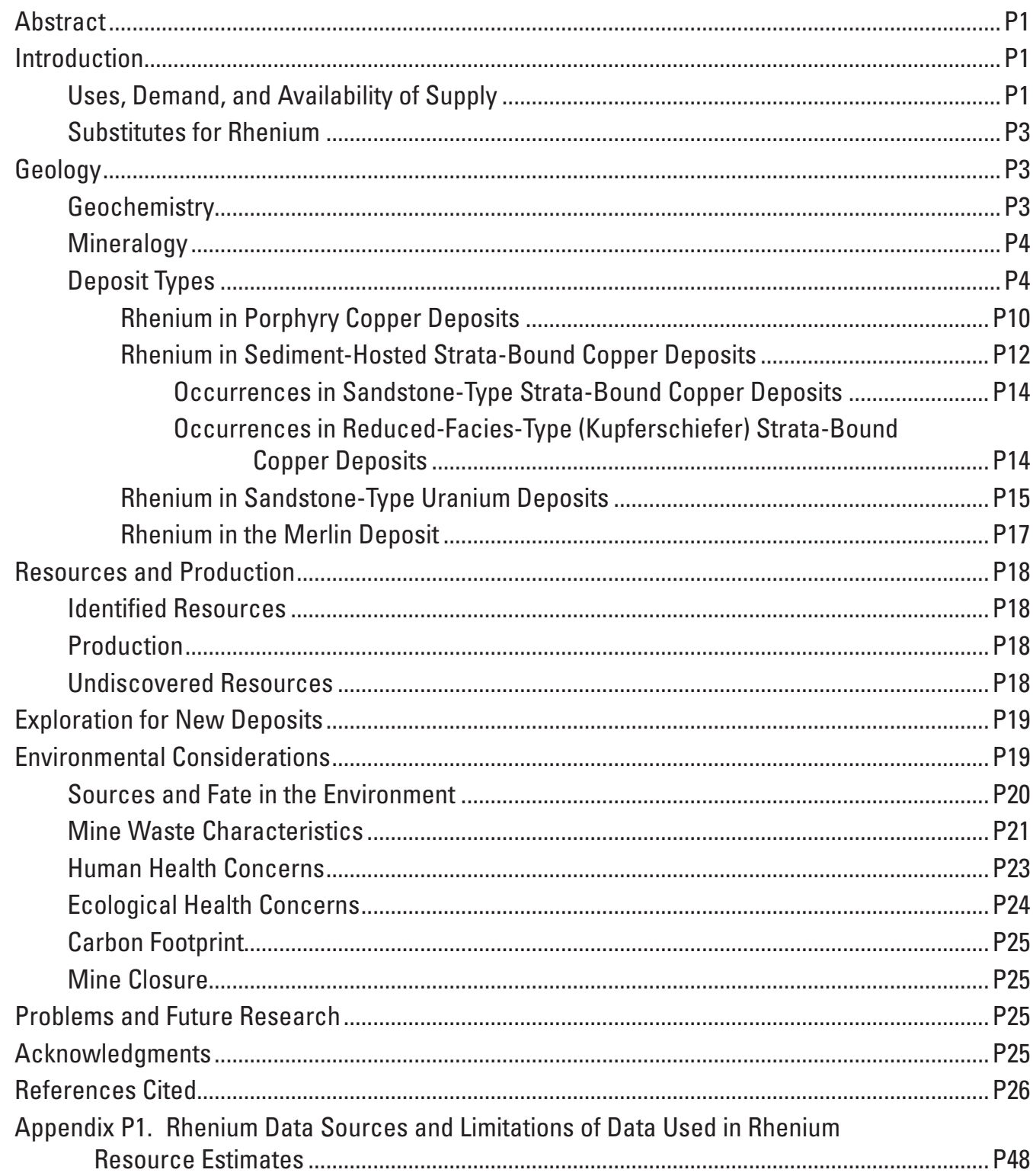

Suggested citation:

John, D.A., Seal, R.R., II, and Polyak, D.E., 2017, Rhenium, chap. P of Schulz, K.J., DeYoung, J.H., Jr., Seal, R.R., II, and Bradley, D.C., eds., Critical mineral resources of the United States-Economic and environmental geology and prospects for future supply: U.S. Geological Survey Professional Paper 1802, p. P1-P49, http://dx.doi.org/10.3133/pp1802P. 


\title{
Rhenium
}

\author{
By David A. John, Robert R. Seal II, and Désirée E. Polyak
}

\section{Abstract}

Rhenium is one of the rarest elements in Earth's continental crust; its estimated average crustal abundance is less than 1 part per billion. Rhenium is a metal that has an extremely high melting point and a heat-stable crystalline structure. More than 80 percent of the rhenium consumed in the world is used in high-temperature superalloys, especially those used to make turbine blades for jet aircraft engines. Rhenium's other major application is in platinum-rhenium catalysts used in petroleum refining.

Rhenium rarely occurs as a native element or as its own sulfide mineral; most rhenium is present as a substitute for molybdenum in molybdenite. Annual world mine production of rhenium is about 50 metric tons. Nearly all primary rhenium production (that is, rhenium produced by mining rather than through recycling) is as a byproduct of copper mining, and about 80 percent of the rhenium obtained through mining is recovered from the flue dust produced during the roasting of molybdenite concentrates from porphyry copper deposits. Molybdenite in porphyry copper deposits can contain hundreds to several thousand grams per metric ton of rhenium, although the estimated rhenium grades of these deposits range from less than 0.1 gram per metric ton to about 0.6 gram per metric ton.

Continental-arc porphyry copper-molybdenum-gold deposits supply most of the world's rhenium production and have large inferred rhenium resources. Porphyry copper mines in Chile account for about 55 percent of the world's mine production of rhenium; rhenium is also recovered from porphyry copper deposits in the United States, Armenia, Kazakhstan, Mexico, Peru, Russia, and Uzbekistan. Sediment-hosted strata-bound copper deposits in Kazakhstan (of the sandstone type) and in Poland (of the reduced-facies, or Kupferschiefer, type) account for most other rhenium produced by mining. These types of deposits also have large amounts of identified rhenium resources. The future supply of rhenium is likely to depend largely on the capacity of the specialized processing facilities needed to recover rhenium from molybdenite concentrates.
The environmental consequences of rhenium recovery are closely linked to the consequences of mining large porphyry copper and strata-bound copper deposits; no additional environmental impact from recovery of rhenium from these deposits has been identified. No information is available regarding the potential toxic effects of rhenium on humans, partly because of the low natural abundance of rhenium.

\section{Introduction}

Rhenium ( $\mathrm{Re}$ ) is one of the rarest elements in Earth's continental crust; its average crustal abundance is about 0.4 part per billion (ppb), although estimates range from 0.2 to $2 \mathrm{ppb}$ (Taylor and McLennan, 1995; Rudnick and Gao, 2003; Sun and others, 2003). This silvery-white metallic element's extremely high melting point $\left(3,180\right.$ degrees Celsius $\left.\left[{ }^{\circ} \mathrm{C}\right]\right)$ and heat-stable crystalline structure make it an excellent refractory metal (fig. P1).

Rhenium was the last stable, naturally occurring element discovered, although its existence was long predicted from the periodic table. The element was discovered in 1925 by German chemists Walter Noddack, Ida Tacke, and Otto Berg, who concentrated rhenium from gadolinite ore that contained about 10 parts per million (ppm) rhenium (Emsley, 2001). The German chemists subsequently separated 1 gram of rhenium from 660 kilograms $(\mathrm{kg})$ of molybdenum ore.

\section{Uses, Demand, and Availability of Supply}

Since the late 1980s, the two most important uses of rhenium have been in high-temperature superalloys and in platinum-rhenium catalysts (fig. P2). The high-temperature alloys in which rhenium is used include several nickel-base superalloys that are used mainly in the manufacture of turbine blades for jet aircraft engines and in power-generation applications. The high-temperature properties of rhenium allow turbine engines to be designed with closer tolerances, thus enabling increased thrust and higher operating efficiency. Because the life cycle of turbine blades in jet engines is only about 10 years, significant quantities of used blades (which 

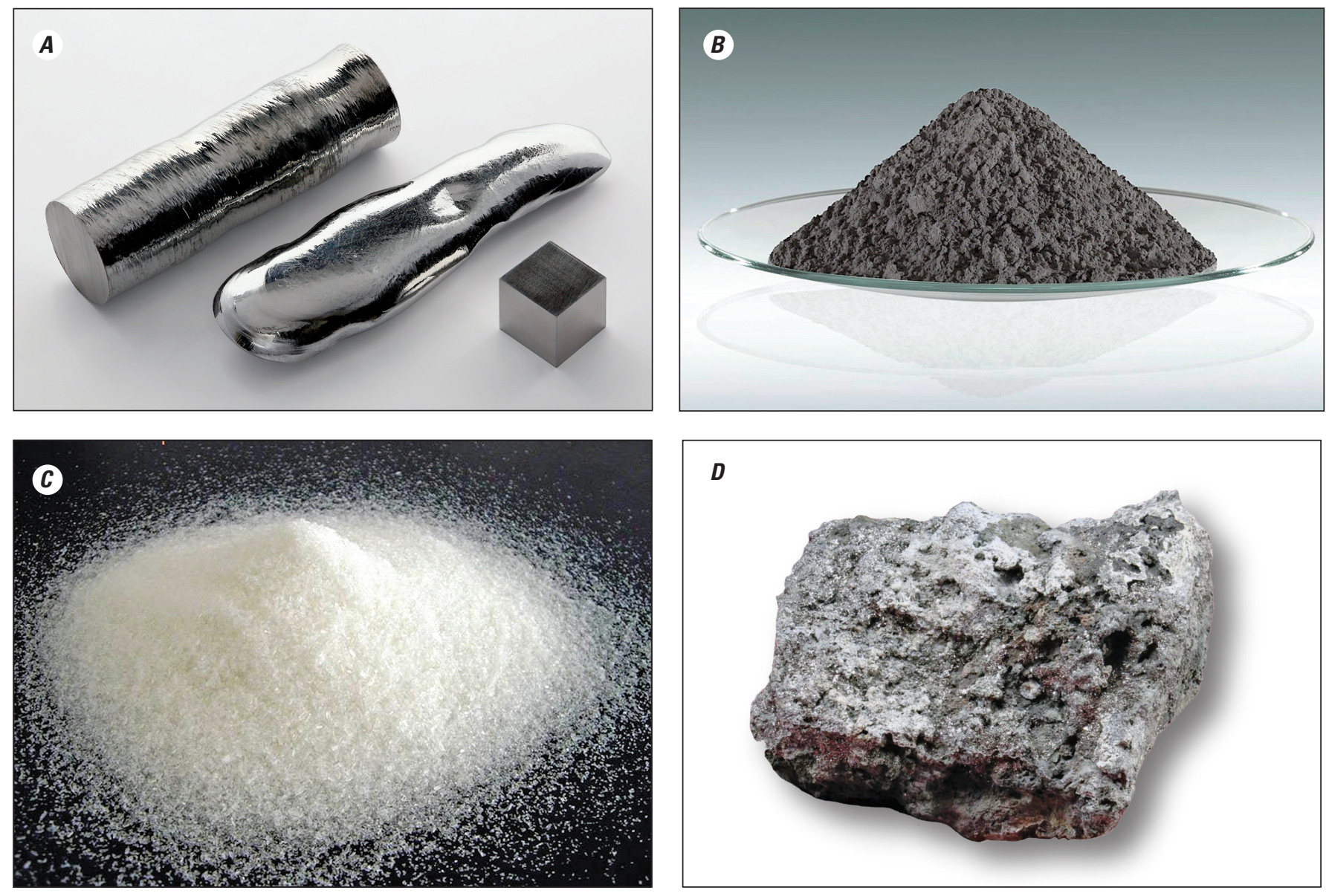

Figure P1. Photographs of rhenium and rhenium compounds. A, A single crystal of high-purity (99.999\%) rhenium (left), a remelted rhenium bar (center), and a 1-cubic-centimeter rhenium cube (right). Photograph courtesy of Alchemist-hp/CC-BY-NC-ND-3.0 (http://commons.wikimedia.org/wiki/File:Rhenium_single_crystal_bar_and_1cm3_cube.jpg). B, Rhenium powder. Photograph courtesy of H.C. Starck. C, Ammonium perrhenate $\left(\mathrm{NH}_{4} \mathrm{ReO}_{4}\right)$ powder, which is the most widely marketed form of rhenium. Photograph courtesy of Stanford Advanced Materials (http://www.samaterials.com/847/ammonium-perrhenate.jpg). $D$, Rheniite $\left(\operatorname{ReS}_{2}\right)$ crystals from hightemperature fumaroles on the Kudryavyy volcano, which is located on Iturup Island in Sakhalinskaya Oblast', Russia. Photograph courtesy of The Arkenstone, iRocks.com (http://www.irocks.com/minerals/specimen/42387).

typically contain 3 percent rhenium, although some alloys contain 6 percent rhenium) are accumulating. Technology is continuing to be developed to allow recycling of these blades to recover the rhenium, which can then be used in the manufacture of new, second-generation blades. Recycling of rhenium from used turbine blades could potentially reduce the requirement for primary rhenium (that is, rhenium produced by mining rather than through recycling) by about 50 percent. Most rhenium recycling is currently performed in the United States and Germany.

World consumption of rhenium from primary sources was estimated to be between 50 and 54 metric tons in 2012 (Polyak, 2014). Approximately 83 percent (45 metric tons) of rhenium from primary sources was used in making superalloys, mainly for the aerospace industry (fig. P2). New types of catalysts in the petrochemical industry accounted for about an additional 10 percent ( 5 metric tons). The remaining 7 percent ( 4 metric tons) of world consumption in 2012 - primarily in the form of tungsten-rhenium and molybdenum-rhenium alloys-was used in a variety of other applications, including in the manufacture of electrical contact points, flashbulbs, heating elements, vacuum tubes, and X-ray tubes and targets. An additional 15 metric tons of rhenium is recycled each year from spent catalysts and is not included in the world consumption total shown in figure P2 (Lipmann Walton \& Co. Ltd., 2010; Minor Metals Trade Association, 2012).

Platinum-rhenium catalysts are used to produce highoctane lead-free gasoline. In the early 1970s, Chevron Corp. of the United States developed a series of platinum-rhenium catalysts that do not react with sulfur. As a response to the Organization of the Petroleum Exporting Countries (OPEC) oil embargo in the 1970s and the oil crisis of the early 1980s, a second generation of more-efficient catalysts was developed with double the platinum-rhenium content, which boosted 


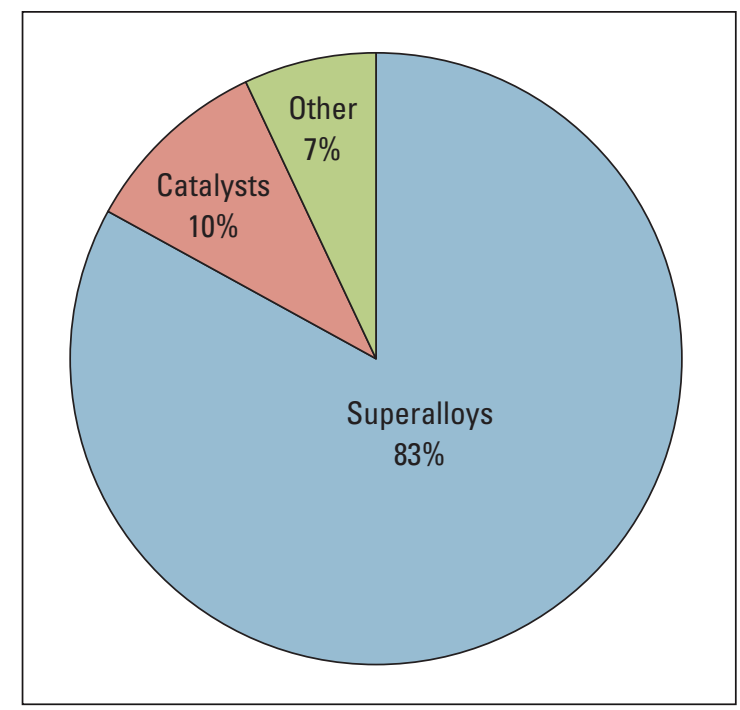

Figure P2. Pie chart showing major end uses of primary rhenium as a percentage of world consumption in 2012. Total world production for the year was between 50 and 54 metric tons. Approximately 83 percent of the rhenium from primary sources was used to make superalloys, mainly for the aerospace industry.

the refinery efficiency and the gasoline's octane levels. Ammonium perrhenate $\left(\mathrm{NH}_{4} \mathrm{ReO}_{4}\right)$ is the most common form of rhenium used by catalyst manufacturers (fig. P1C). Petroleum-reforming platinum-rhenium catalysts are used mainly in North America and Europe, where demand for gasoline and diesel fuel is highest. These are also the locations of the major rhenium-platinum catalyst manufacturers.

The recovery of rhenium from platinum-rhenium catalysts is a mature business. A closed-loop recycling system operated by catalyst manufacturers, refiners, and secondary rhenium producers ensures that consumption of newly mined rhenium is kept to a minimum. The catalysts are recycled mainly to recover the platinum content, so much of the rhenium is recycled only because of the platinum content of the catalysts.

Rhenium in molybdenite concentrates derived from porphyry copper ores is recovered at some mines as a byproduct during the molybdenite roasting process. In the United States in 2012, three molybdenum mines had roasters associated with mines, but only one of the roasters was equipped to recover rhenium. This roaster, which is located at the Sierrita facility in Arizona, is operated by FreeportMcMoran Copper \& Gold Inc. of the United States. This facility processes all the byproduct molybdenite concentrates from Freeport-McMoran mines and processes molybdenite concentrates on a toll basis for third parties. In contrast, Kennecott Utah Copper Corp. (which is owned by Rio Tinto plc of the United Kingdom) sends byproduct molybdenite concentrates from the Bingham Canyon Mine in Utah to Molymex S.A. de C.V.'s plant in Mexico for roasting; the recovered rhenium concentrate is then sent to Molibdenos $y$ Metales S.A. (Molymet) in Chile for purification.

\section{Substitutes for Rhenium}

Substitutes for rhenium in platinum-rhenium catalysts are being evaluated on an ongoing basis. Iridium and tin have achieved commercial success in one application. Other metals being evaluated as possible substitutes for rhenium in catalysts include gallium, germanium, indium, selenium, silicon, tungsten, and vanadium. The use of these and other metals in catalysts might someday decrease rhenium's share of the existing catalyst market; however, rhenium-bearing catalysts that are being considered for use in several proposed gas-toliquid projects likely would offset this decrease. Materials that can substitute for rhenium in various end uses are cobalt and tungsten for coatings on copper X-ray targets, rhodium and rhodium-iridium for high-temperature thermocouples, tungsten and platinum-ruthenium for coatings on electrical contacts, and tungsten and tantalum for electron emitters (Polyak, 2013). Aerospace superalloy producers continue to research new alloys with smaller quantities of rhenium; however, it has proven difficult to develop alloys with lower rhenium content for use in jet engines without a loss in performance.

\section{Geology}

\section{Geochemistry}

Rhenium has an atomic number of 75 and an atomic mass of 186.2 grams per mole. In the periodic table of elements, rhenium is a third row, heavy transition metal located in column $7 B$ below manganese and technetium, adjacent to tungsten and the platinum-group elements (PGEs), and diagonally below molybdenum.

Rhenium has a density of 21.02 grams per cubic centimeter, making it the fourth densest element (iridium, osmium, and platinum have higher densities). It has a hexagonal close-packed crystal structure. The $3,180^{\circ} \mathrm{C}$ melting point of rhenium is the third highest melting point of all the elements; only carbon $\left(3,500^{\circ} \mathrm{C}\right)$ and tungsten $\left(3,422^{\circ} \mathrm{C}\right)$ have higher melting points.

Rhenium has the widest range of valences of any element - nine in total, ranging from -1 to +7 - although +7 , $+6,+4$, and +2 are the most common ions. Rhenium forms three stable oxides - rhenium heptoxide $\left(\mathrm{Re}_{2} \mathrm{O}_{7}\right)$, rhenium trioxide $\left(\mathrm{ReO}_{3}\right)$, and rhenium dioxide $\left(\mathrm{ReO}_{2}\right)$ - of which rhenium heptoxide is the most common. Rhenium heptoxide is a bright yellow volatile solid that dissolves in water to form rhenic acid $\left(\mathrm{HReO}_{4}\right)$. Rhenium has a marked affinity for sulfur and occurs mostly in nature as a substitute (solid solution) for molybdenum in molybdenite $\left(\mathrm{MoS}_{2}\right)$. Unusual features of rhenium compounds include the unusually high volatility of rhenium heptoxide and the high solubility of rhenium heptoxide in water. These properties facilitate rhenium's recovery from flue dusts produced by roasting of molybdenite concentrates. 
The two dominant naturally occurring rhenium isotopes are ${ }^{185} \mathrm{Re}$, which is stable and accounts for 37.4 percent of naturally occurring rhenium, and ${ }^{187} \mathrm{Re}$, which is radiogenic and accounts for 62.6 percent of naturally occurring rhenium. Twenty-six other radioactive isotopes of rhenium have been recognized. ${ }^{187} \mathrm{Re}$ decays to ${ }^{187} \mathrm{Os}$ by beta decay and has a halflife of about $4.1 \times 10^{10}$ years. The rhenium-osmium isotopic system is used to date sulfide minerals (most commonly molybdenite) in mineral deposits (McCandless and Ruiz, 1993; Stein and others, 2001).

\section{Mineralogy}

Rhenium rarely occurs as a native element or as its own sulfide mineral. Trace amounts of native rhenium $\left(\operatorname{Re}^{0}\right)$ were recently discovered in ultramafic rocks in Ukraine (Bobrov and others, 2008). Microscopic crystals of rheniite $\left(\mathrm{ReS}_{2}\right)$ were first reported in 1986 in volcanic fumaroles on Mount Usu, Japan (Bernard and Dumortier, 1986), and megascopic crystals of rheniite were discovered in 1992 in high-temperature fumaroles on the Kudryavyy (also spelled Kudriavy) volcano on Iturup Island in Sakhalinskaya Oblast', Russia (fig. P1D; Korzhinsky and others, 1994). Rheniite also has been reported in the Pagoni Rachi porphyry copper-molybdenum prospect in northern Greece (Voudouris and others, 2009). Microscopic ( $\leq 75$ micrometers $[\mu \mathrm{m}])$ crystals of rhenium-rich tarkianite $\left((\mathrm{Cu}, \mathrm{Fe})(\mathrm{Re}, \mathrm{Mo})_{4} \mathrm{~S}_{8}\right)$ have been discovered in sulfide concentrates from the Hitura nickel-copper-PGE mine at Nivala, Finland (Kojonen and others, 2004). None of these rhenium-rich minerals are economic sources of rhenium, however.

Dzhezkazganite forms microscopic collomorphic aggregates and veinlets in bornite, chalcocite, and galena and replaces bornite in sandstone-hosted strata-bound copper deposits at the Dzhezkazgan Mine in Qaraghandy, Kazakhstan (Poplavko and others, 1962; Abisheva and others, 2001).

Dzhezkazganite was first inferred as a copper-rhenium sulfide $\left(\mathrm{CuReS}_{4}\right)$ mineral (Poplavko and others, 1962), but subsequent electron microprobe analyses suggest that it has a chemical formula of $\mathrm{ReMoCu}_{2} \mathrm{PbS}_{6}$ (Genkin and others, 1994). It is not a recognized mineral species by the International Mineralogical Association, however, because of the lack of structural data and uncertainty in its chemical formula (Fleischer, 1963).

Molybdenite is the principal source of rhenium. The rhenium content of molybdenite varies widely from less than $1 \mathrm{ppm}$ to several weight percent, but molybdenite in porphyry copper deposits typically contains about 100 to $3,000 \mathrm{ppm}$ rhenium (tables P1 and P2 at back of chapter; Fleischer, 1959; Giles and Schilling, 1972; Newberry, 1979; Berzina and others, 2005; Sinclair and others, 2009; John and Taylor, 2016).
In contrast, the rhenium content of molybdenite in porphyry molybdenum deposits generally is much lower, in many cases less than 20 ppm (table P2). Rhenium contents of molybdenite in other types of porphyry deposits and in quartz veins typically also are low ( $<10$ to about $200 \mathrm{ppm}$ ) (for example, Terada and others, 1971; Giles and Schilling, 1972; Ishihara, 1988; Sinclair and others, 2009; Millensifer and others, 2014). Molybdenite in Australia's Merlin molybdenum-rhenium deposit (discussed below), however, averages about 1,000 ppm rhenium (Brown and others, 2010).

The rhenium content of molybdenite also varies widely within some porphyry copper deposits (for example, it ranges from 130 to 2,000 ppm at Bingham, Utah) (Giles and Schilling, 1972). The variable rhenium content, both within deposits and between different types of porphyry deposits, is not completely understood. Variations in the rhenium content of molybdenite within deposits may represent multiple generations of molybdenite that have different rhenium contents (for example, the Sar Cheshmeh Mine in Kermān Province, Iran; Aminzadeh and others, 2011). Rhenium concentration differences reflect a combination of factors, including changes in temperature and pressure, fluid composition (especially $\mathrm{pH}$ and sulfur content), oxidation state, and (or) transport mechanism (that is, brine, moderate-density liquid, or low-density vapor) during the complex magmatic-hydrothermal history of these deposits (John and Taylor, 2016).

\section{Deposit Types}

Nearly all primary rhenium production (rhenium produced by mining rather than through recycling) is as a byproduct of copper mining. Rhenium resources are dominantly contained in porphyry copper-molybdenum-gold deposits, which supply about 80 percent of the rhenium produced by mining (Polyak, 2013). Rhenium in porphyry copper deposits is contained primarily as $\mathrm{ReS}_{2}$ in solid solution in molybdenite (Fleischer, 1959). Most of the remaining rhenium production is as a byproduct of mining sediment-hosted strata-bound copper deposits, both the sandstone (red bed) types in Kazakhstan and the reduced-facies (Kupferschiefer) types in Poland (Hitzman and others, 2005; Zientek and others, 2013). Smaller amounts of rhenium are recovered from the processing of roll-front-type sandstone uranium ore in Kazakhstan (Dahlkamp, 2009a). The Merlin molybdenum-rhenium zone of the Mount Dore copper deposit in Queensland, Australia, is a potential source of highgrade rhenium ore and is the only deposit known in which rhenium could be a primary commodity (Brown and others, 2010). The world's major rhenium-bearing deposits that are described in the text and (or) listed in table P1 are shown on the map in figure P3. 

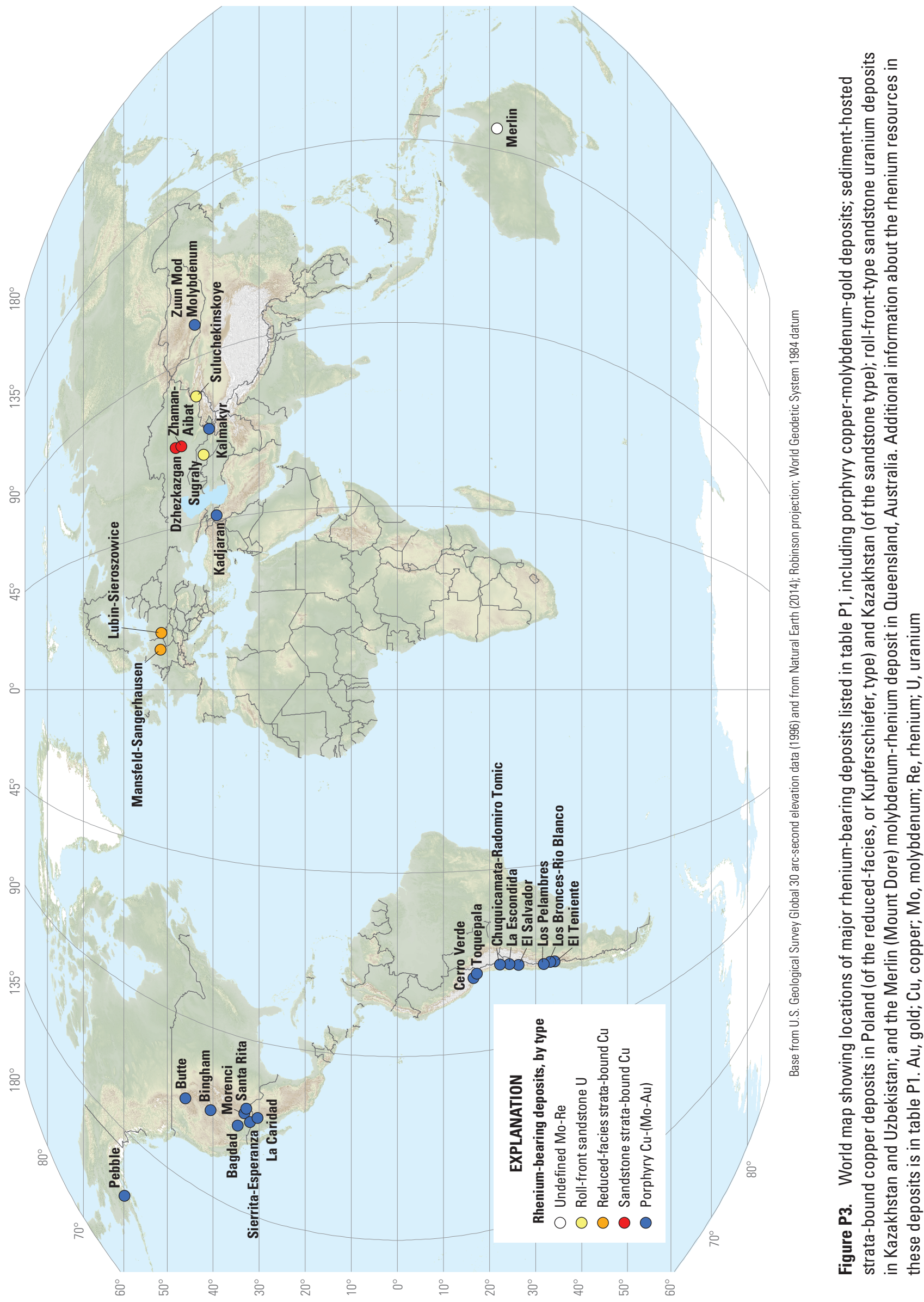
Table P1. Summary of rhenium, copper, and molybdenum grades, deposit tonnage, and amount of contained rhenium in the rheniumbearing deposits shown in figure P3.

[The names, locations, and types of most of the deposits are taken from the U.S. Geological Survey Mineral Resources Data System (MRDS) (U.S. Geological Survey, 2014). The minimum and maximum values are concentrations of rhenium in molybdenite separates; the estimated average is based on mill concentrates. Elements and compounds: $\mathrm{Au}$, gold; $\mathrm{Cu}$, copper; Mo, molybdenum; $\mathrm{MoS}_{2}$, molybdenite; Os, osmium; Re, rhenium; $\mathrm{U}$, uranium. Units of measure: g/t, gram per metric ton; Mt, million metric tons; ppm, part per million; t, metric ton; wt. \%, weight percent. —, no data; n.a., not applicable to the deposit]

\begin{tabular}{|c|c|c|c|c|c|c|c|c|c|}
\hline $\begin{array}{c}\text { Deposit } \\
\text { name }\end{array}$ & $\begin{array}{c}\text { Country } \\
\text { (State/Province) }\end{array}$ & $\begin{array}{l}\text { Deposit } \\
\text { type }\end{array}$ & $\begin{array}{l}\text { Tectonic } \\
\text { setting }\end{array}$ & $\begin{array}{c}\text { Deposit } \\
\text { tonnage } \\
\text { (Mt) }\end{array}$ & $\begin{array}{c}\text { Grade } \\
\text { (wt. \% Cu) }\end{array}$ & $\begin{array}{c}\text { Grade } \\
\text { (wt. \% Mo) }\end{array}$ & $\begin{array}{c}\text { Minimum } \\
\text { Re in } \mathrm{MoS}_{2} \\
\text { (ppm) }\end{array}$ & $\begin{array}{c}\text { Maximum } \\
\text { Re in } \mathrm{MoS}_{2} \\
\text { (ppm) }\end{array}$ & $\begin{array}{l}\text { Estimated aver- } \\
\text { age Re in } \mathrm{MoS}_{2} \\
(\text { ppm) }\end{array}$ \\
\hline Bagdad & $\begin{array}{l}\text { United States } \\
\text { (Arizona) }\end{array}$ & $\begin{array}{l}\text { Porphyry } \mathrm{Cu}- \\
\text { (Mo-Au) }\end{array}$ & $\mathrm{CA}$ & 1,600 & 0.400 & 0.01 & 330 & 642 & 460 \\
\hline Bingham & $\begin{array}{l}\text { United States } \\
\text { (Utah) }\end{array}$ & $\begin{array}{l}\text { Porphyry } \mathrm{Cu}- \\
\text { (Mo-Au) }\end{array}$ & $\mathrm{PC}$ & 3,230 & 0.882 & 0.053 & 130 & 2,000 & 250 \\
\hline Butte & $\begin{array}{c}\text { United States } \\
\text { (Montana) }\end{array}$ & $\begin{array}{l}\text { Porphyry } \mathrm{Cu}- \\
\text { (Mo-Au) }\end{array}$ & $\mathrm{CA}$ & 5,220 & 0.673 & 0.028 & - & - & 240 \\
\hline Morenci & $\begin{array}{l}\text { United States } \\
\text { (Arizona) }\end{array}$ & $\begin{array}{l}\text { Porphyry } \mathrm{Cu}- \\
\text { (Mo-Au) }\end{array}$ & $\mathrm{CA}$ & 6,470 & 0.524 & 0.0095 & 270 & 640 & 455 \\
\hline
\end{tabular}

\begin{tabular}{|c|c|c|c|c|c|c|c|c|c|}
\hline Santa Rita & $\begin{array}{l}\text { United States } \\
\qquad(\text { New Mexico) }\end{array}$ & $\begin{array}{l}\text { Porphyry Cu- } \\
\text { (Mo-Au) }\end{array}$ & $\mathrm{CA}$ & 3,030 & 0.468 & 0.008 & 700 & 1,200 & 800 \\
\hline $\begin{array}{l}\text { Sierrita- } \\
\text { Esperanza }\end{array}$ & $\begin{array}{l}\text { United States } \\
\text { (Arizona) }\end{array}$ & $\begin{array}{l}\text { Porphyry Cu- } \\
\text { (Mo-Au) }\end{array}$ & $\mathrm{CA}$ & 2,262 & 0.294 & 0.0292 & 90 & 1,800 & 238 \\
\hline $\begin{array}{l}\text { Chuquicamata- } \\
\text { Radomiro } \\
\text { Tomic }\end{array}$ & Chile & $\begin{array}{l}\text { Porphyry Cu- } \\
\text { (Mo-Au) }\end{array}$ & $\mathrm{CA}$ & 21,277 & 0.860 & 0.04 & 93 & 262 & 265 \\
\hline El Teniente & Chile & $\begin{array}{l}\text { Porphyry Cu- } \\
\text { (Mo-Au) }\end{array}$ & $\mathrm{CA}$ & 20,731 & 0.620 & 0.019 & 25 & 1,154 & 420 \\
\hline La Escondida & Chile & $\begin{array}{l}\text { Porphyry Cu- } \\
\text { (Mo-Au) }\end{array}$ & $\mathrm{CA}$ & 11,158 & 0.769 & 0.0062 & 95 & 1,805 & 886 \\
\hline La Caridad & Mexico (Sonora) & $\begin{array}{l}\text { Porphyry Cu- } \\
\text { (Mo-Au) }\end{array}$ & CA & 1,800 & 0.452 & 0.0247 & 72 & 570 & 570 \\
\hline Cerro Verde & Peru & $\begin{array}{l}\text { Porphyry Cu- } \\
\text { (Mo-Au) }\end{array}$ & $\mathrm{CA}$ & 2,258 & 0.495 & 0.01 & 3,060 & 3,497 & 3,280 \\
\hline Toquepala & Peru & $\begin{array}{l}\text { Porphyry Cu- } \\
\text { (Mo-Au) }\end{array}$ & CA & 2,320 & 0.550 & 0.04 & 387 & 1,496 & 600 \\
\hline $\begin{array}{l}\text { Kadjaran } \\
\text { (Kadzharan) }\end{array}$ & Armenia & $\begin{array}{l}\text { Porphyry Cu- } \\
\text { (Mo-Au) }\end{array}$ & $\mathrm{CA}$ & 1,700 & 0.270 & 0.055 & 33 & 2,620 & 280 \\
\hline
\end{tabular}


Table P1. Summary of rhenium, copper, and molybdenum grades, deposit tonnage, and amount of contained rhenium in the rheniumbearing deposits shown in figure 3.-Continued

[The names, locations, and types of most of the deposits are taken from the U.S. Geological Survey Mineral Resources Data System (MRDS) (U.S. Geological Survey, 2014). The minimum and maximum values are concentrations of rhenium in molybdenite separates; the estimated average is based on mill concentrates. Elements and compounds: $\mathrm{Au}$, gold; $\mathrm{Cu}$, copper; Mo, molybdenum; $\mathrm{MoS}_{2}$, molybdenite; Os, osmium; Re, rhenium; $\mathrm{U}$, uranium. Units of measure: g/t, gram per metric ton; Mt, million metric tons; ppm, part per million; t, metric ton; wt. \%, weight percent. —, no data; n.a., not applicable to the deposit]

\begin{tabular}{|c|c|c|c|c|c|c|c|}
\hline $\begin{array}{l}\text { Number } \\
\text { of Re } \\
\text { analyses }\end{array}$ & $\begin{array}{l}\text { Selected } \\
\text { sample } \\
\text { type }^{2}\end{array}$ & $\begin{array}{l}\text { Grade } \\
\text { (g/t Re) }\end{array}$ & $\begin{array}{l}\text { Contained } \\
\operatorname{Re} \\
(t)\end{array}$ & $\begin{array}{c}\text { Mo:Re } \\
\text { ratio }\end{array}$ & Notes & Data sources & $\begin{array}{l}\text { Deposit } \\
\text { name }\end{array}$ \\
\hline 9 & 2 & 0.080 & 130 & 1,200 & None & $\begin{array}{l}\text { Sutulov, 1974; Nadler, 1997; Barra and } \\
\text { others, 2003; Singer and others, } 2008\end{array}$ & Bagdad \\
\hline 43 & 1 & 0.221 & 714 & 2,400 & None & $\begin{array}{l}\text { Giles and Schilling, 1972; McCandless } \\
\text { and Ruiz, 1993; Chesley and Ruiz, } \\
\text { 1998; Singer and others, 2008; Austen } \\
\text { and Ballantyne, 2010; J. Chesley, } \\
\text { written commun., 2013 }\end{array}$ & Bingham \\
\hline 1 & 1 & 0.112 & 585 & 2,500 & None & $\begin{array}{l}\text { Giles and Schilling, 1972; Singer and } \\
\text { others, } 2008\end{array}$ & Butte \\
\hline 4 & 1 & 0.072 & 466 & 1,320 & None & $\begin{array}{l}\text { Giles and Schilling, 1972; McCandless and } \\
\text { Ruiz, 1993; Singer and others, } 2008\end{array}$ & Morenci \\
\hline 9 & 3 & 0.107 & 324 & 746 & None & $\begin{array}{l}\text { Giles and Schilling, 1972; Sutulov, 1974; } \\
\text { Singer and others, } 2008\end{array}$ & Santa Rita \\
\hline 6 & 2 & 0.116 & 262 & 2,520 & None & $\begin{array}{l}\text { Giles and Schilling, 1972; Sutulov, 1974; } \\
\text { Nadler, 1997; Singer and others, } 2008\end{array}$ & $\begin{array}{l}\text { Sierrita- } \\
\text { Esperanza }\end{array}$ \\
\hline 9 & 3 & 0.18 & 3,800 & 2,300 & None & $\begin{array}{l}\text { Giles and Schilling, 1972; Sutulov, 1974; } \\
\text { Nadler, 1997; Singer and others, 2008; } \\
\text { Barra and others, } 2013\end{array}$ & $\begin{array}{l}\text { Chuquicamata- } \\
\text { Radomiro } \\
\text { Tomic }\end{array}$ \\
\hline 3 & 3 & 0.215 & 825 & 1,020 & None & $\begin{array}{l}\text { Giles and Schilling, 1972; Sutulov, 1974; } \\
\text { Nadler, 1997; Singer and others, } 2008\end{array}$ & El Salvador \\
\hline 15 & 2 & 0.09 & 1,500 & 2,300 & None & $\begin{array}{l}\text { Mathur and others 2001; Singer and oth- } \\
\text { ers, 2008; Deckart and others, } 2013\end{array}$ & $\begin{array}{l}\text { Los Bronces- } \\
\text { Rio Blanco }\end{array}$ \\
\hline 3 & 2 & 0.150 & 1,120 & 1,000 & None & $\begin{array}{l}\text { Mathur and others 2001; Singer and } \\
\text { others, } 2008\end{array}$ & Los Pelambres \\
\hline 3 & 3 & 0.235 & 423 & 1,050 & None & $\begin{array}{l}\text { Nadler, 1997; Valencia and others, 2005; } \\
\quad \text { Singer and others, } 2008\end{array}$ & La Caridad \\
\hline 2 & 2 & 0.12 & 300 & 830 & None & $\begin{array}{l}\text { Mathur and others, 2001; Singer and } \\
\text { others, } 2008\end{array}$ & Cerro Verde \\
\hline 5 & 3 & 0.40 & 930 & 1,000 & None & $\begin{array}{l}\text { Giles and Schilling, 1972; Sutulov, 1974; } \\
\text { Nadler, 1997; Mathur and others, } \\
\text { 2001; Singer and others, } 2008\end{array}$ & Toquepala \\
\hline 238 & 1 & 0.257 & 437 & 2,140 & None & $\begin{array}{l}\text { Nadler, 1997; Berzina and others, 2005; } \\
\quad \text { Singer and others, } 2008\end{array}$ & $\begin{array}{l}\text { Kadjaran } \\
\quad \text { (Kadzharan) }\end{array}$ \\
\hline
\end{tabular}


Table P1. Summary of rhenium, copper, and molybdenum grades, deposit tonnage, and amount of contained rhenium in the rheniumbearing deposits shown in figure P3.-Continued

[The names, locations, and types of most of the deposits are taken from the U.S. Geological Survey Mineral Resources Data System (MRDS) (U.S. Geological Survey, 2014). The minimum and maximum values are concentrations of rhenium in molybdenite separates; the estimated average is based on mill concentrates. Elements and compounds: $\mathrm{Au}$, gold; $\mathrm{Cu}$, copper; Mo, molybdenum; $\mathrm{MoS}_{2}$, molybdenite; Os, osmium; Re, rhenium; $\mathrm{U}$, uranium. Units of measure: g/t, gram per metric ton; Mt, million metric tons; ppm, part per million; t, metric ton; wt. \%, weight percent. —, no data; n.a., not applicable to the deposit]

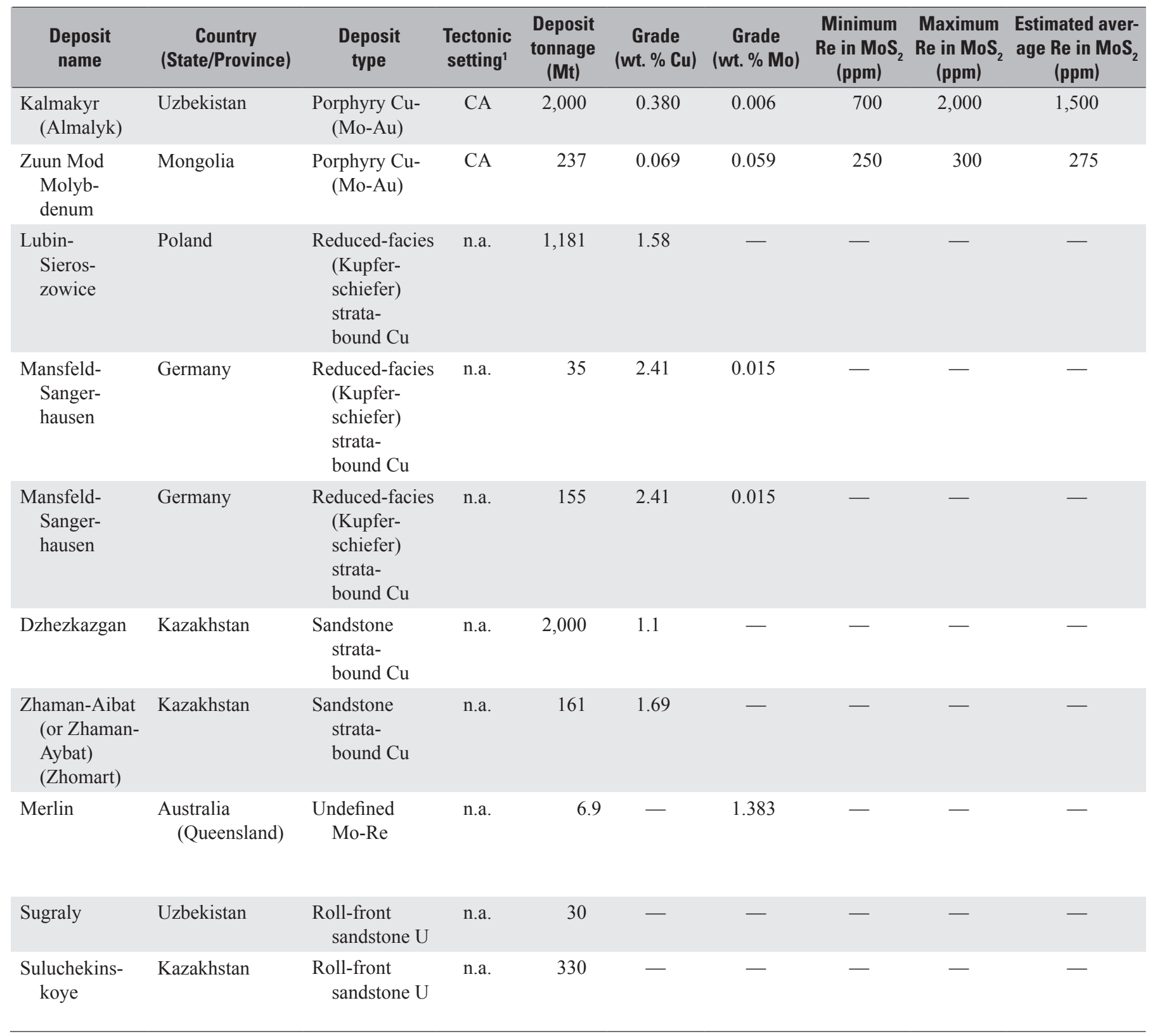

${ }^{1}$ Tectonic setting of porphyry copper deposits: CA, continental arc; PC, post-collisional.

${ }^{2}$ Sample type used in calculating Re grade: 1 , molybdenite separate; 2 , molybdenite separate used in Re-Os dating; 3 , molybdenite mill concentrate. 
Table P1. Summary of rhenium, copper, and molybdenum grades, deposit tonnage, and amount of contained rhenium in the rheniumbearing deposits shown in figure 3.-Continued

[The names, locations, and types of most of the deposits are taken from the U.S. Geological Survey Mineral Resources Data System (MRDS) (U.S. Geological Survey, 2014). The minimum and maximum values are concentrations of rhenium in molybdenite separates; the estimated average is based on mill concentrates. Elements and compounds: $\mathrm{Au}$, gold; $\mathrm{Cu}$, copper; Mo, molybdenum; $\mathrm{MoS}_{2}$, molybdenite; Os, osmium; Re, rhenium; $\mathrm{U}$, uranium. Units of measure: g/t, gram per metric ton; Mt, million metric tons; ppm, part per million; t, metric ton; wt. \%, weight percent. —, no data; n.a., not applicable to the deposit]

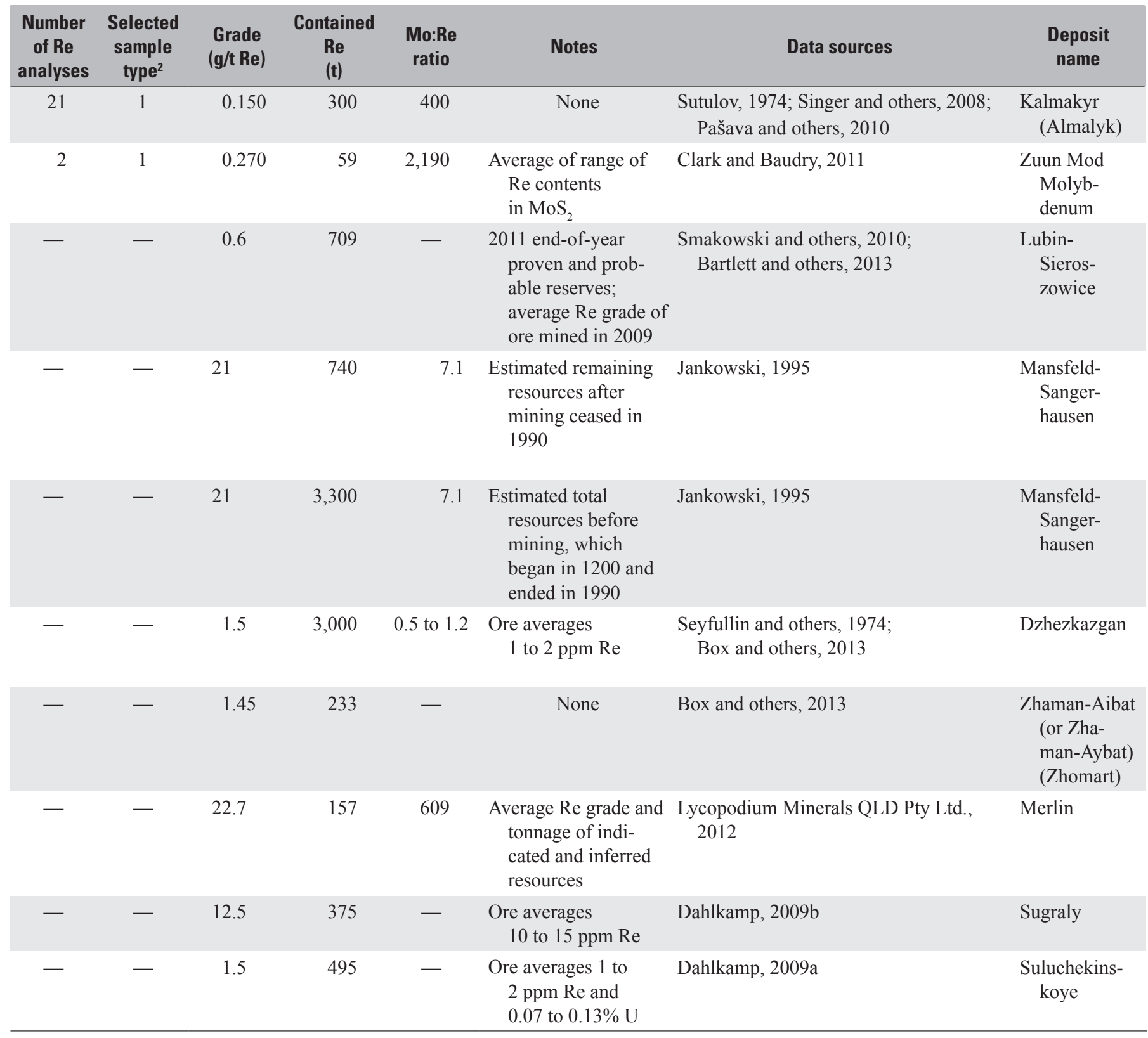




\section{Rhenium in Porphyry Copper Deposits}

Large continental-margin arc porphyry coppermolybdenum-gold deposits dominate world rhenium resources (tables P1 and P2; figs. P3 and P4; John and Taylor, 2016). Porphyry copper deposits are large (in most cases, greater than 100 million metric tons), low-to-moderate grade (in most cases, 0.3 to 2.0 percent copper), disseminated, breccia and vein-hosted copper deposits (John and others, 2010). Porphyry copper deposits are parts of larger porphyry copper systems in which large volumes ( 10 to $>100$ cubic kilometers) of hydrothermally altered rock are centered on porphyry stocks and other intrusions. The deposits may include associated skarn, carbonate-replacement, sedimenthosted, and high- and intermediate-sulfidation epithermal base and precious-metal deposits (Sillitoe, 2010). Porphyry copper systems most commonly form above active subduction zones at convergent plate margins and are associated with calc-alkaline batholiths and volcanic arcs in both continental-margin and island-arc settings (Sillitoe, 1972; Richards, 2003). Some other porphyry copper systems form in post-collisional and other tectonic settings after subduction ends (Richards, 2009; Hou and others, 2011). Copper is the dominant metal produced from porphyry copper deposits; molybdenum, gold, and lesser amounts of silver, rhenium, and PGEs (mostly palladium) are important byproducts in some deposits. Hydrothermal alteration of porphyry-copper-related intrusive rocks and their wallrocks is widely developed and includes alkali-dominated assemblages (potassic, sodic, and sodic-calcic), acid (low $\mathrm{pH}$ ) assemblages (advanced argillic and sericitic), and propylitic assemblages. Alteration zoning can be highly variable, but acidic alteration is typically distal and shallow and, where it is found in the center of a deposit, it is late relative to alkali alteration assemblages. The deeper parts of porphyry copper systems (typically paleodepths of approximately 2 to 10 kilometers [km]) contain central porphyry copper \pm molybdenum \pm gold mineralization (fig. P5A) and may contain flanking copper, gold, and (or) zinc skarn, silver-lead-zinc carbonate replacement, and gold-silver sediment-hosted deposits. The shallow, overlying parts of these systems may host high- and intermediate-sulfidation epithermal gold-silver \pm copper deposits. Copper, gold, and molybdenum mineralization is generally associated with potassic and sericitic alteration. Rhenium is invariably associated with molybdenum mineralization.

Rhenium is produced from several Tertiary porphyry copper deposits in the Andes Mountains in South America, including the giant Chuquicamata-Radomiro Tomic and El Teniente deposits in Chile, and Toquepala in Peru; from Late Cretaceous to mid-Tertiary deposits in the Western United States; and from deposits in Armenia, Kazakhstan, Russia, and Uzbekistan (fig. P3). Rhenium in porphyry copper

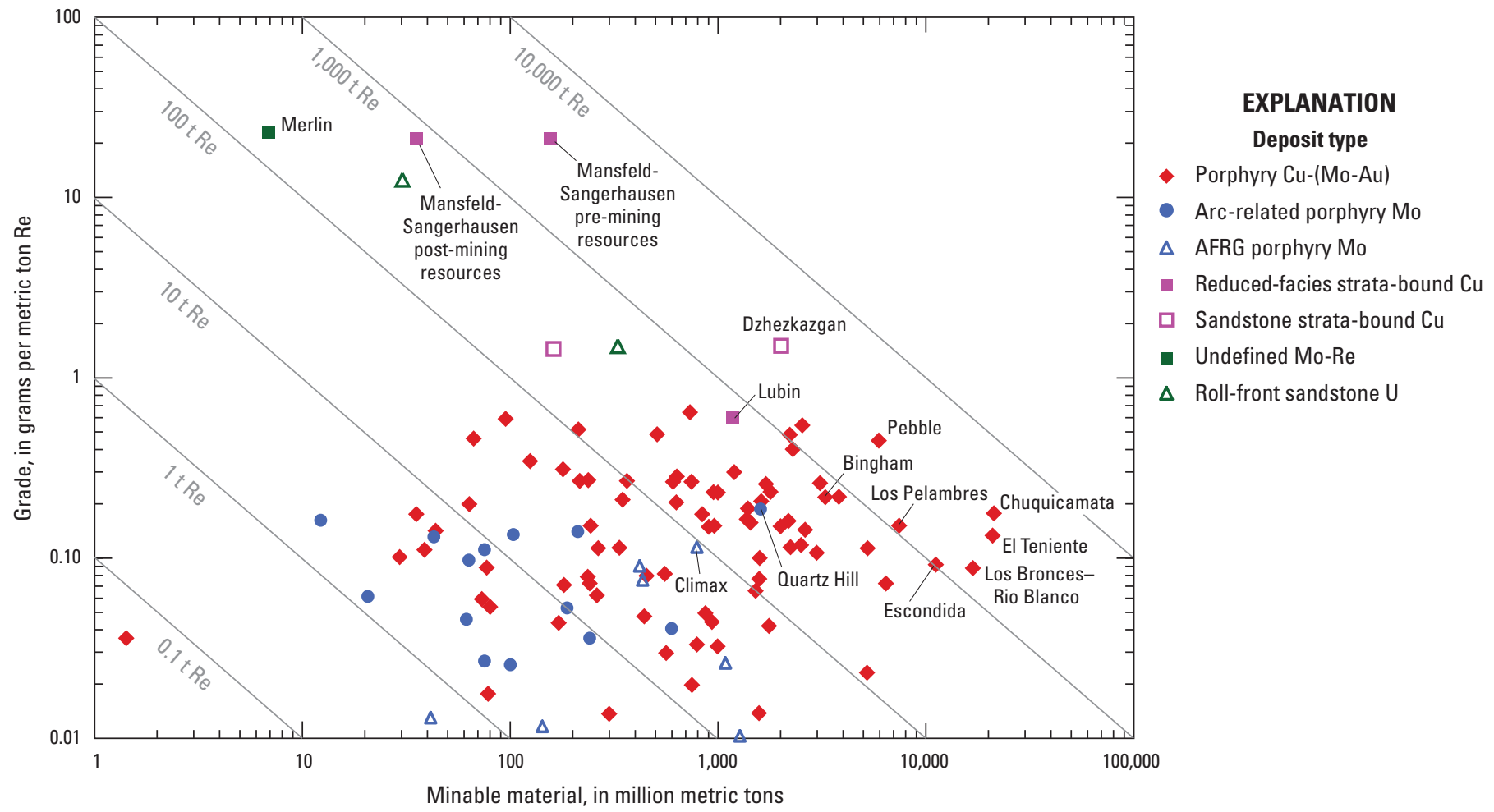

Figure P4. Plot of rhenium grade versus deposit tonnage for major rhenium-bearing deposits in the world, including those shown in figure P3. The diagonal lines are isolines of contained rhenium, in metric tons. Additional resource data for these deposits, and sources, are given in table P1. AFRG, alkali-feldspar rhyolitegranite; $\mathrm{t}$, metric ton. Elements: $\mathrm{Au}$, gold; $\mathrm{Cu}$, copper; Mo, molybdenum; Re, rhenium, $\mathrm{U}$, uranium 


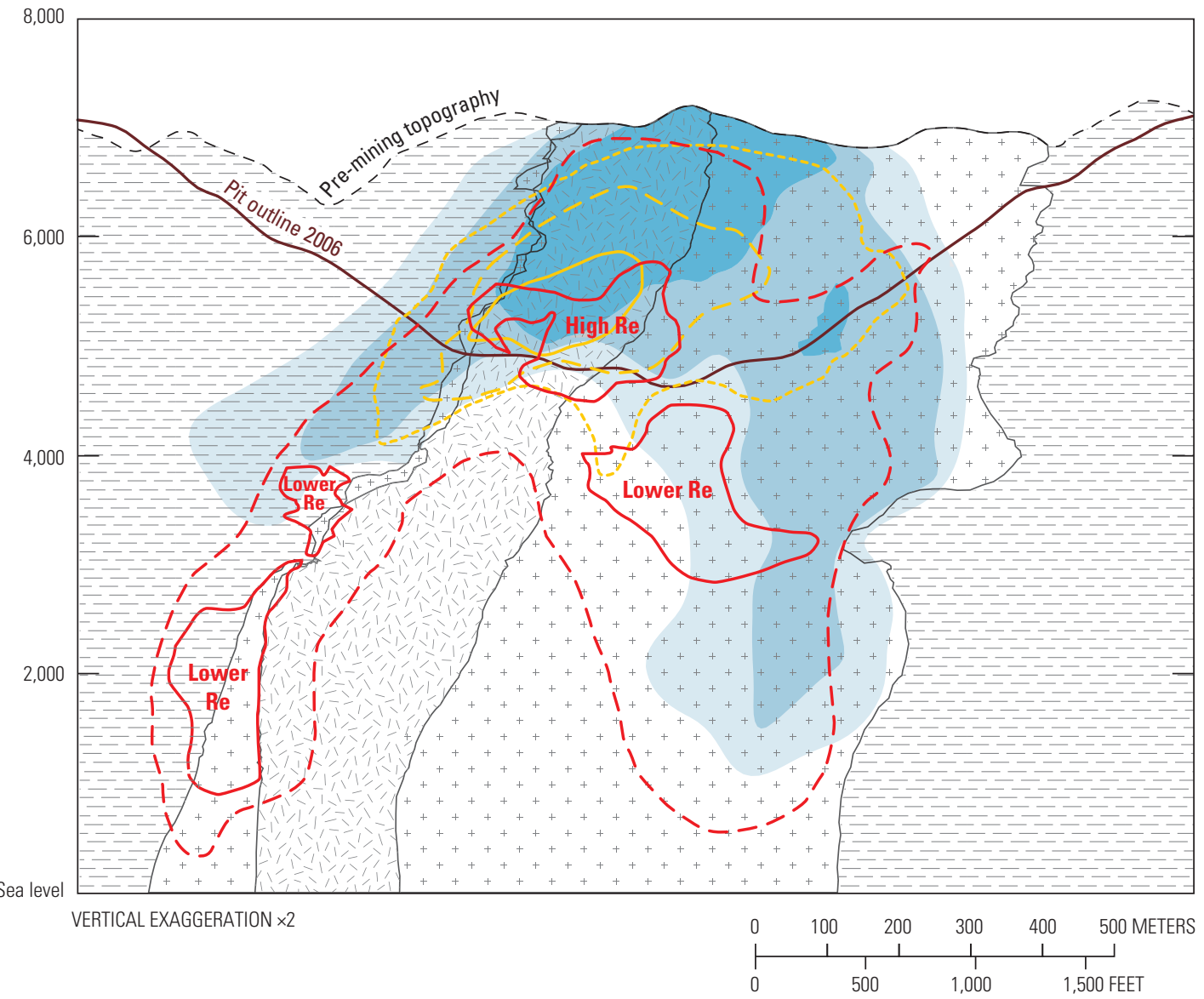

\section{EXPLANATION}

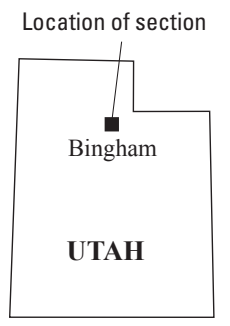

Copper-molybdenum-gold (Cu-Mo-Au) grades

\begin{tabular}{|c|c|c|}
\hline \multirow[t]{2}{*}{$\begin{array}{l}>0.15 \text { wt. } \% \mathrm{Cu} \\
>0.35 \text { wt. } \% \mathrm{Cu} \\
>0.70 \text { wt. } \% \mathrm{Cu}\end{array}$} & $\begin{array}{l}-->0.02 \text { wt. } \% \text { Mo } \\
->0.08 \text { wt. } \% \text { Mo }\end{array}$ & $\begin{aligned}- & \sim 0.15 \mathrm{ppm} \mathrm{Au} \\
-- & \sim 0.30 \mathrm{ppm} \mathrm{Au} \\
- & \sim 1.00 \mathrm{ppm} \mathrm{Au}\end{aligned}$ \\
\hline & Rock type & \\
\hline$E$ & Paleozoic sedimentary rocks & \\
\hline$+{ }_{+}^{+}+$ & Equigranular monzonite & \\
\hline EN & Quartz-monzonite porphyry & \\
\hline
\end{tabular}

Figure P5. Cross sections illustrating rhenium occurrences in major deposit types from which rhenium is recovered or potentially recoverable. $A$, Bingham Canyon porphyry copper-molybdenumgold (Cu-Mo-Au) deposit in Utah showing metal zoning around porphyry intrusions. Molybdenum (in molybdenite) is displaced to deeper levels than copper and gold, which are mostly deposited earlier than molybdenum. Rhenium (Re) grades apparently are highest in the copper-molybdenum-gold ores in the center of the deposit ("High $\mathrm{Re}^{\text {") }}$ and lower in the deep molybdenum-only ore ("Lower Re") (Austen and Ballantyne, 2010). Figure modified from Landtwing and others (2010) and Seo and others (2012). ppm, part per million; wt.\%, weight percent 
deposits is contained primarily as $\mathrm{ReS}_{2}$ in solid solution in molybdenite (Fleischer, 1959) at concentrations ranging from less than $10 \mathrm{ppm}$ to about 1 weight percent (table P1). Rhenium grades of porphyry copper deposits are low, generally less than 0.5 gram per metric ton $(\mathrm{g} / \mathrm{t})$ (table P1; fig. P4; Sinclair and others, 2009; John and Taylor, 2016), but the large tonnage of ore processed, the presence of sufficient molybdenite to make molybdenum recovery economic, and the presence of specialty circuits that allow recovery of the rhenium contained in molybdenite means that a relatively large proportion of rhenium production is from these deposits.

Rhenium contents of molybdenite in porphyry molybdenum deposits are generally much lower than in molybdenite in porphyry copper deposits (table P2; Giles and Schilling, 1972; Sinclair and others, 2009; John and Taylor, 2015). Thus, despite their higher molybdenum grades, rhenium grades of porphyry molybdenum deposits are generally less than those of porphyry copper deposits (table P2; fig. P4). The relatively low grades and small sizes of most porphyry molybdenum deposits result in small rhenium resources (table P2; fig. P4), and rhenium is not recovered from these deposits.

Rhenium is recovered from molybdenite concentrates that are separated from copper-iron sulfides by flotation methods. During roasting of the molybdenite concentrates to produce molybdenum oxide, rhenium is oxidized to $\operatorname{Re}_{2} \mathrm{O}_{7}$ and passes up the flue stack with the sulfur gases. When the flue dusts and gases are scrubbed, rhenium is dissolved in the resulting sulfuric acid and is eventually precipitated out as ammonium perrhenate $\left(\mathrm{NH}_{4} \mathrm{ReO}_{4}\right)$ (Sutulov, 1974; Nadler, 1997). Ammonium perrhenate is a white crystalline powder that contains about 69 weight percent rhenium and is the principal form in which rhenium is marketed (fig. P1C).

\section{Rhenium in Sediment-Hosted Strata-Bound Copper Deposits}

Sediment-hosted strata-bound copper deposits are the other major primary source of rhenium. Rhenium is recovered during processing of copper ores from sandstone-type (red bed) copper deposits in Kazakhstan and from reduced-facies (Kupferschiefer)-type copper-silver deposits in Poland. Sediment-hosted strata-bound copper mineralization consists of fine-grained copper and copper-iron sulfide minerals in strata-bound-to-stratiform disseminations in siliciclastic or dolomitic sedimentary rocks (Hitzman and others, 2005; Zientek and others, 2013). Ore minerals are characteristically zoned laterally and vertically across bedding from hematite to chalcocite to bornite to chalcopyrite to pyrite in the inferred direction of fluid flow (figs. P5B and P5C). Deposits are hosted in reduced sedimentary strata within or above a thick section of oxidized red beds. These deposits are inferred to form by the flow of oxidized, metal-rich brines through permeable red-bed sedimentary rocks (mostly sandstones). Interaction of the oxidized ore fluids with a reducing agent, such as hydrocarbons (oil or natural gas), reduced organic carbon, and (or) sulfide minerals, results in deposition of the zoned sequence of iron,

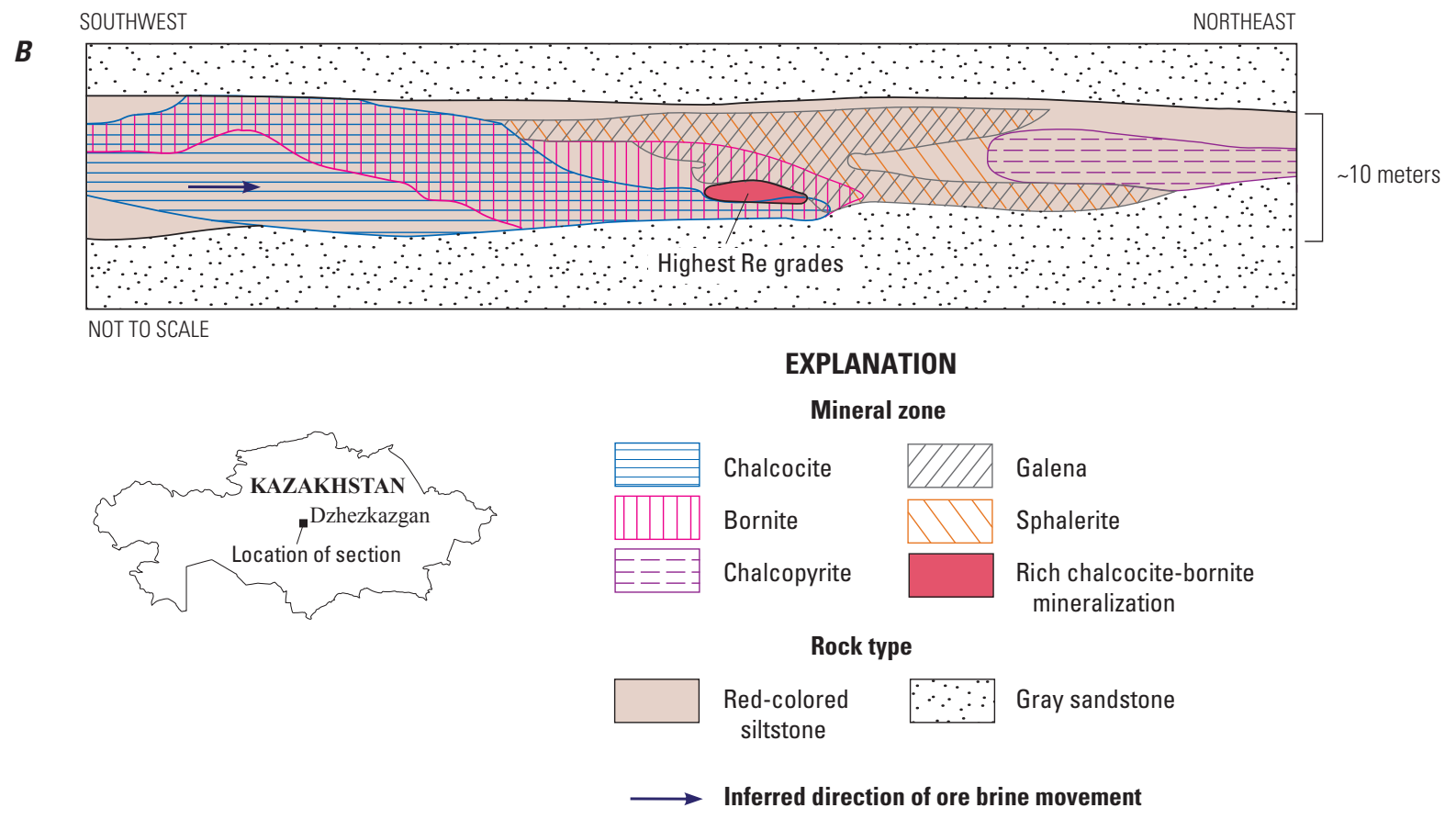

Figure P5 - Continued $B$, Sandstone-type strata-bound copper deposit at Dzhezkazgan, Qaraghandy, Kazakhstan, showing mineral zoning and rock type. Rhenium $(\mathrm{Re})$ is enriched in all the ore zones, but the highest concentrations are thought to be in the copper zones, especially in chalcocite-bornite ore (Seyfullin and others, 1974). Figure modified from Box and others (2013) based on Daukeev and others (2004). 

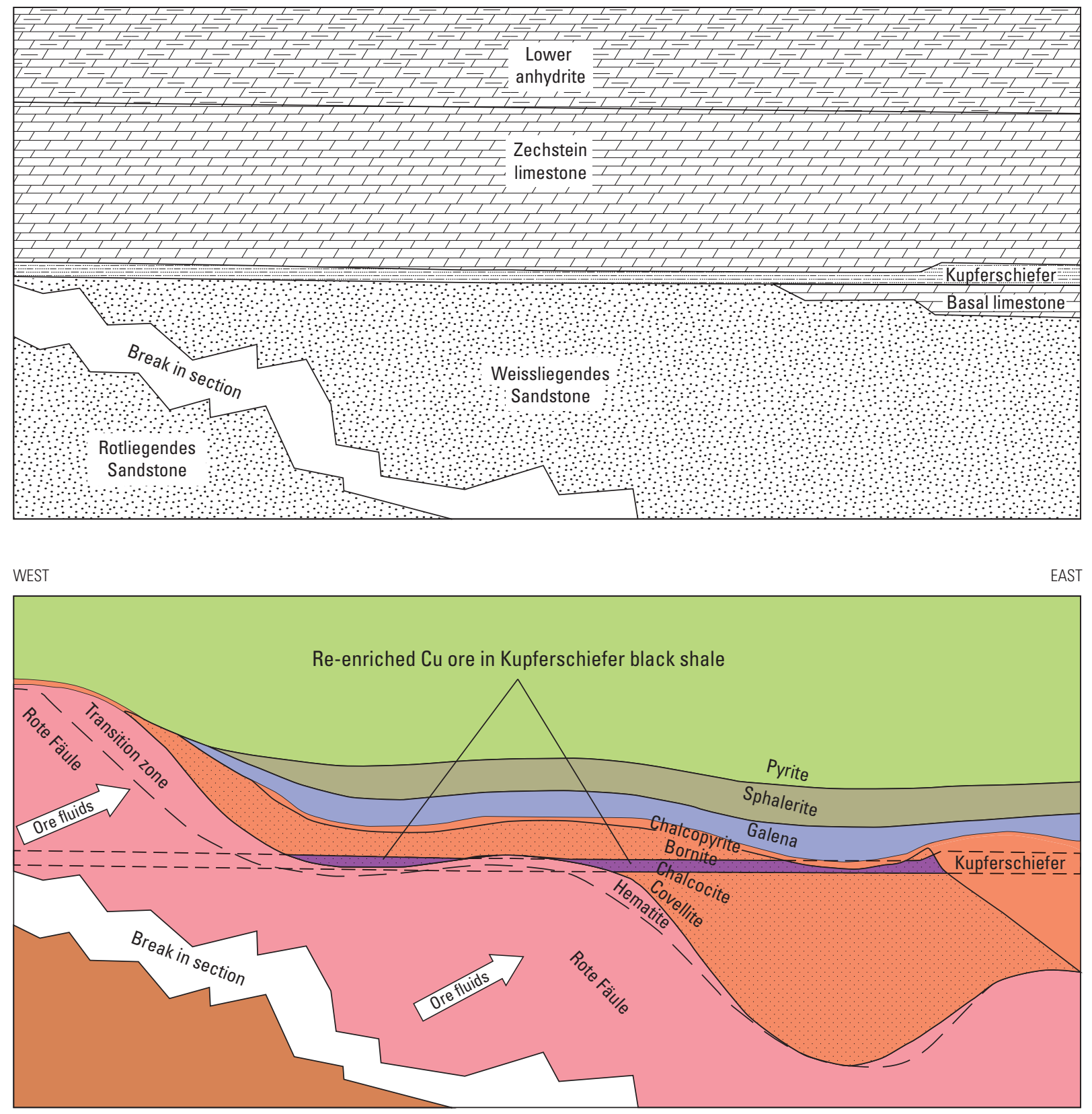

VERTICAL SCALE GREATLY EXAGGERATED

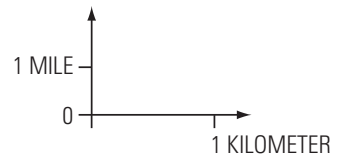

\begin{tabular}{|c|c|}
\hline & Rock type \\
\hline$\frac{7}{7}$ & Anhydrite \\
\hline 1 & Limestone \\
\hline & Shale \\
\hline & Sandstone \\
\hline
\end{tabular}

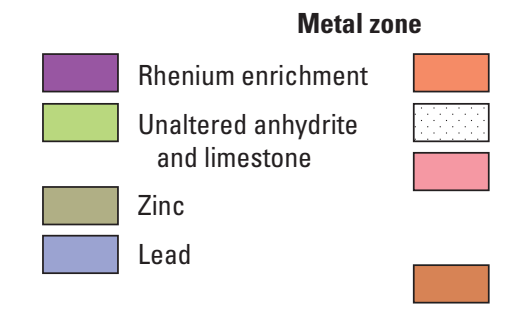

Copper

Copper ore zone

Red rock caused by hematite replacement of pyrite (Rote Fäule)

Unaltered sandstone

Figure P5.-Continued C, Kupferschiefer (reduced-facies-type) strata-bound copper deposits showing lithology (top cross section) and copper ore distribution (stippled pattern) and metal and mineral zoning (bottom cross section). Rhenium is concentrated in copper ore in the Kupferschiefer black shale. Transitions between predominant sulfide minerals are gradational. Figure is based on Jowett (1986) and Oszczepalski (1999). 
copper, lead, and zinc sulfide and oxide minerals. Unlike porphyry copper deposits, in which rhenium is clearly associated with molybdenite and is derived from magmatic sources, the site and source of rhenium in sediment-hosted strata-bound copper deposits are poorly understood.

\section{Occurrences in Sandstone-Type Strata-Bound Copper Deposits}

In central Kazakhstan, rhenium is recovered from Late Paleozoic sandstone-type strata-bound copper deposits in the Chu-Sarysu basin (Dzhezkazgan and Zhaman-Aybat [also spelled Zhaman-Aibat] deposits) (fig. P3; Box and others, 2013). The deposits consist of copper sulfide minerals (bornite, chalcocite, and chalcopyrite) that form intergranular cement and replace grains in sandstone and conglomerate within a 600 - to 1,000 -m-thick Pennsylvanian fluvial red-bed sequence. Copper grades of individual deposits range from about 0.8 to 1.7 percent and average 1.1 percent, and the deposits contain significant quantities of silver and rhenium. The copper minerals are inferred to have precipitated from an oxidized, metal-rich brine that was progressively reduced by interaction with hydrogen sulfide $\left(\mathrm{H}_{2} \mathrm{~S}\right)$-bearing petroleum fluids as it flowed through permeable sandstone beds. The copper minerals are zoned from chalcocite to bornite to chalcopyrite in the inferred direction of the fluid (brine) flow (fig. P5B). The main deposits in Kazakhstan from which rhenium is recovered are the Zhaman-Aybat deposit (which has an average rhenium grade of $1.45 \mathrm{~g} / \mathrm{t}$ and includes local zones that exceed $9 \mathrm{~g} / \mathrm{t}$ ), and the Dzhezkazgan deposit (which has an average grade of 1 to $2 \mathrm{~g} / \mathrm{t}$ rhenium). Both deposits are located in Qaraghandy Province. In the Zhaman-Aybat deposit, the highest rhenium grades $(>9 \mathrm{~g} / \mathrm{t})$ are associated with the boundary between the chalcopyrite and the bornitechalcocite zones in more central parts of the deposit.

The occurrence and mineralogy of rhenium in the Kazakhstan deposits is uncertain. Satpaeva and others (1959, summarized in Fleischer, 1960) and Seyfullin and others (1974) reported rhenium contents of different types of ores at Dzhezkazgan and other strata-bound copper deposits in Kazakhstan. Their data show that rhenium is present in appreciable abundances in lead-rich and zinc-rich ores, as well as in copper-rich ores, and that rhenium apparently is not associated with molybdenite. In particular, Seyfullin and others (1974) showed that the ratio of molybdenum to rhenium (Mo:Re) in copper ore averaged 1.2 in the Dzhezkazgan deposit and varied from 0.4 to 75 in other deposits in Kazakhstan, which indicates significant enrichment of rhenium relative to molybdenum in these deposits. For comparison, Mo:Re ratios in porphyry copper deposits range from about 100 to $>10,000$ and average about 2,050 (table P2), which is close to estimates for the average Mo:Re ratios in continental crust, which range from 2,500 to 2,750 (Taylor and McLennan, 1995; Rudnick and Gao, 2003).

Poplavko and others (1962) reported discovery of dzhezkazganite, a new rhenium mineral, at the Dzhezkazgan deposit and suggested that it had a chemical formula of $\mathrm{CuReS}_{4}$.
Subsequent electron microprobe analyses suggested a more complex formula of $\mathrm{ReMoCu}_{2} \mathrm{PbS}_{6}$ for this microscopic (typically $<1 \mu \mathrm{m}$ ) phase (Genkin and others, 1994). Recent analyses of copper ore minerals in two samples from the Dzhezkazgan deposit show that the rhenium contents of chalcopyrite and bornite range from 3.3 to $10.1 \mathrm{ppm}$ (Box and others, 2013), which are extremely high concentrations of rhenium in nonmolybdenite samples (Ruiz and Mathur, 1999; Selby and others, 2009). These data suggest that significant amounts of rhenium may be present in copper-iron sulfide minerals, although mass balance relations between copper and rhenium indicate that most of the rhenium is likely present in dzhezkazganite.

\section{Occurrences in Reduced-Facies-Type (Kupferschiefer) Strata-Bound Copper Deposits}

The thin black shale that forms the Upper Permian Kupferschiefer (copper slate) hosts the largest copper and silver deposits in Europe (Mansfeld-Sangerhausen and Lubin-Sieroszowice deposits) (fig. P3; Vaughan and others, 1989; Jankowski, 1995; Kucha, 2003; Hitzman and others, 2005). These reduced-facies-type strata-bound copper deposits also contain large rhenium resources. In the Kupferschiefer, rhenium is currently produced from the Lubin-Sieroszowice orebody in southwestern Poland (Bartlett and others, 2013), and high rhenium contents have been reported in the formerly mined Mansfeld-Sangerhausen deposits in southern Germany (Jankowski, 1995). Ore reserves in these deposits are large; 2011 end-of-year reserves for the Legnica-Glogów copper belt in Poland, which includes the Lubin-Sieroszowice orebody, were 1,181 million metric tons of ore at average grades of 1.58 percent copper and $48 \mathrm{~g} / \mathrm{t}$ silver (Bartlett and others, 2013); large undeveloped deposits have also been identified elsewhere in the Kupferschiefer in Poland. The average rhenium content of the Polish copper ores mined in 2009 was $0.6 \mathrm{~g} / \mathrm{t}$, but the rhenium grade varied from about $1.1 \mathrm{~g} / \mathrm{t}$ in shale ore to about $0.4 \mathrm{~g} / \mathrm{t}$ in sandstone ore (Smakowski and others, 2010). In contrast, Jankowski (1995) reported a much larger average rhenium content of $21 \mathrm{ppm}$ in Kupferschiefer ores in the Mansfeld-Sangerhausen deposits in Germany, suggesting that more than 2,500 metric tons of rhenium was contained in ores mined from 1200 through 1990. Only small amounts of rhenium were recovered from flue dusts near the end of mining of these deposits, however, and production data from 1962 suggests that rhenium recovery was only about $0.1 \mathrm{~g} / \mathrm{t}$ (Kruger, 2006).

The Kupferschiefer deposits occur along the southern margin of the Rotliegendes-Zechstein basin (part of an Early Permian intracontinental rift basin) where it overlies Paleozoic continental sedimentary and bimodal volcanic rocks (Vaughan and others, 1989; Kucha, 2003; Hitzman and others, 2005). The volcanic rocks in the Lower Rotliegendes are extensively albitized and may have supplied some of the copper in the Kupferschiefer deposits (Hitzman and others, 2005). The overlying Upper Rotliegendes is a thick red-bed sequence 
composed of fluvial, eolian, and playa (sabkha) deposits that is locally overlain by white eolian sandstones (Weissliegendes). The Upper Permian Kupferschiefer is a thin (typically 30 to 70 centimeters thick) organic carbon-rich black shale that covers more than 800,000 square kilometers $\left(\mathrm{km}^{2}\right)$ in central Europe. It forms the basal unit of the Zechstein layer and was deposited during the initial stages of a rapid marine transgression over the Rotliegendes-Weissliegendes sequence. The Kupferschiefer black shale is overlain by Zechstein carbonates (dolomite and limestone) and evaporites (anhydrite and halite), which may have supplied some of the sulfur in the ores. Copper, gold, PGEs, and silver are hosted by both the black shales and the underlying white sandstones (fig. P5C). Thin base-metal sulfide zones in the Kupferschiefer are tens to hundreds of square kilometers in area, and immediately adjacent hematitic alteration (in the Rote Fäule) covers more than $40,000 \mathrm{~km}^{2}$.

In the Kupferschiefer deposits, hydrothermal minerals and metals typically are zoned upward from hematite $\left(\mathrm{Fe}^{3+}\right)$ to the sequence of covellite, chalcocite, bornite, chalcopyrite (copper zone), to galena (lead zone), to sphalerite (zinc zone), and finally to pyrite $\left(\mathrm{Fe}^{2+}\right)$ (fig. P5C; Oszczepalski, 1999; Kucha, 2003; Hitzman and others, 2005). Gold and PGEs are concentrated in the transition zone between hematite and copper minerals, and silver is concentrated in the copper ores. The Kupferschiefer mineralization is complex, probably formed in multiple stages, and likely involved influx of oxidizing, metal-rich brines that moved through the oxidized red beds (Rote Fäule) from the Rotliegendes basin into the reduced Kupferschiefer (Zechstein) sediments (fig. P5C; see summary in Hitzman and others, 2005). The three main stages of ore formation involved (1) early diagenetic formation of iron monosulfides and possibly chalcocite near the sediment-water interface; (2) diagenetic replacement of iron monosulfides and (or) pyrite by copper-iron sulfides at least partly associated with Rote Fäule alteration, and (3) diagenetic remobilization of earlier copper sulfide mineralization during later Rote Fäule alteration and formation of gold-PGE mineralization (for example, Vaughan and others, 1989; Wodzicki and Piestrzynski, 1994; Kucha, 2003; Hitzman and others, 2005).

Rhenium in the Kupferschiefer is associated with molybdenum in copper-rich shale ore (Hammer and others, 1990; Kucha, 2003). Kucha (2003) stated that copper, lead, and potassium-castaingite (cuprian molybdenite) have molybdenum-to-rhenium ratio of 70:1, although he did not report actual rhenium analyses. Jankowski (1995) reported molybdenum-to-rhenium ratio of 7:1 for ores in the MansfeldSangerhausen mines but did not report rhenium mineralogy. As in the Kazakhstan strata-bound copper deposits, these molybdenum-to-rhenium ratios suggest significant rhenium enrichment relative to molybdenum.

Geochemical studies of the Sangerhausen basin in Germany show large variations in the rhenium content of rocks; the content ranges from 0.24 to $27 \mathrm{ppm}$, and the highest rhenium concentrations are in the copper facies of the Kupferschiefer (Hammer and others, 1990). Pašava and others (2010) reported rhenium concentrations ranging from 63.6 to $1,380 \mathrm{ppb}$ in six samples of unmineralized Kupferschiefer black shale in Poland (the copper content was less than or equal to $106 \mathrm{ppm}$ and the molybdenum content was between 20 and $340 \mathrm{ppm})$. In these samples, rhenium strongly correlates with molybdenum $\left(\mathrm{r}^{2}=0.93\right)$ and is concentrated in the lower part of the black shale. Pašava and others (2007b) reported rhenium concentrations ranging from 249 to $22,000 \mathrm{ppb}$ for six copper-rich black shale samples (the average copper grade was 4.9 percent and no molybdenum content was reported), whereas six samples from PGE- and gold-rich but copper-poor horizons had rhenium concentrations that ranged from 221 to $558 \mathrm{ppb}$ (Pašava and others, 2007a). Comparison of the minor element composition of unmineralized Kupferschiefer sediments in the Lower Rhine basin in northwestern Germany to black shales in the Late Devonian Exshaw Formation in Canada and to modern black shales indicate similar high levels of enrichment in arsenic, cadmium, molybdenum, nickel, rhenium, antimony, uranium, and vanadium, which are typical of syngenetic mineralization (Lüschen and others, 2000a, b). These data suggest that rhenium in Kupferschiefer ores could have been derived from the black shales and was locally remobilized into the copperrich zones.

Rhenium is produced from the Kupferschiefer deposits by roasting copper ore. During roasting, sulfur and rhenium are released as gases that precipitate in the flues. Wet scrubbing of the flue dusts produces sulfuric acid that contains dissolved rhenium. Resins are then used to adsorb the rhenium from the acid, and the rhenium is ultimately precipitated as ammonium perrhenate. All processing of Kupferschiefer ores and recovery of rhenium are done by KGHM Polska Miedź S.A. at their facilities in Lubin, Poland.

\section{Rhenium in Sandstone-Type Uranium Deposits}

Rhenium was formerly produced as a byproduct from roll-front-type sandstone uranium deposits in Uzbekistan, and rhenium is currently recovered from similar uranium deposits in Kazakhstan (figs. P3 and P5D; Dahlkamp, 2009a, b; Seltmann and others, 2012). Small amounts of rhenium were also recovered from sandstone uranium deposits in Texas from 1969 to 1974 (Millensifer, 1997). Sandstone uranium deposits are generally hosted in permeable medium- to coarse-grained sandstones that were deposited in fluvial or nearshore marine environments. The large sandstone deposits in Kazakhstan and Uzbekistan are hosted in large Cretaceous to early Tertiary continental basins. The deposits form by the dissolving of uranium from nearby strata in oxidized groundwaters that flow through the sandstones. Uranium is precipitated at a redox boundary (the "roll-front") when the oxidized ore fluids intersect and react with reducing agents in sandstone host rocks, such as carbonaceous (plant and algal) material, sulfide minerals, hydrocarbons, or interbedded volcanic rocks. Rollfront-type uranium deposits are crescent-shaped orebodies that crosscut the bedding in the sandstones (fig. P5D). 
D

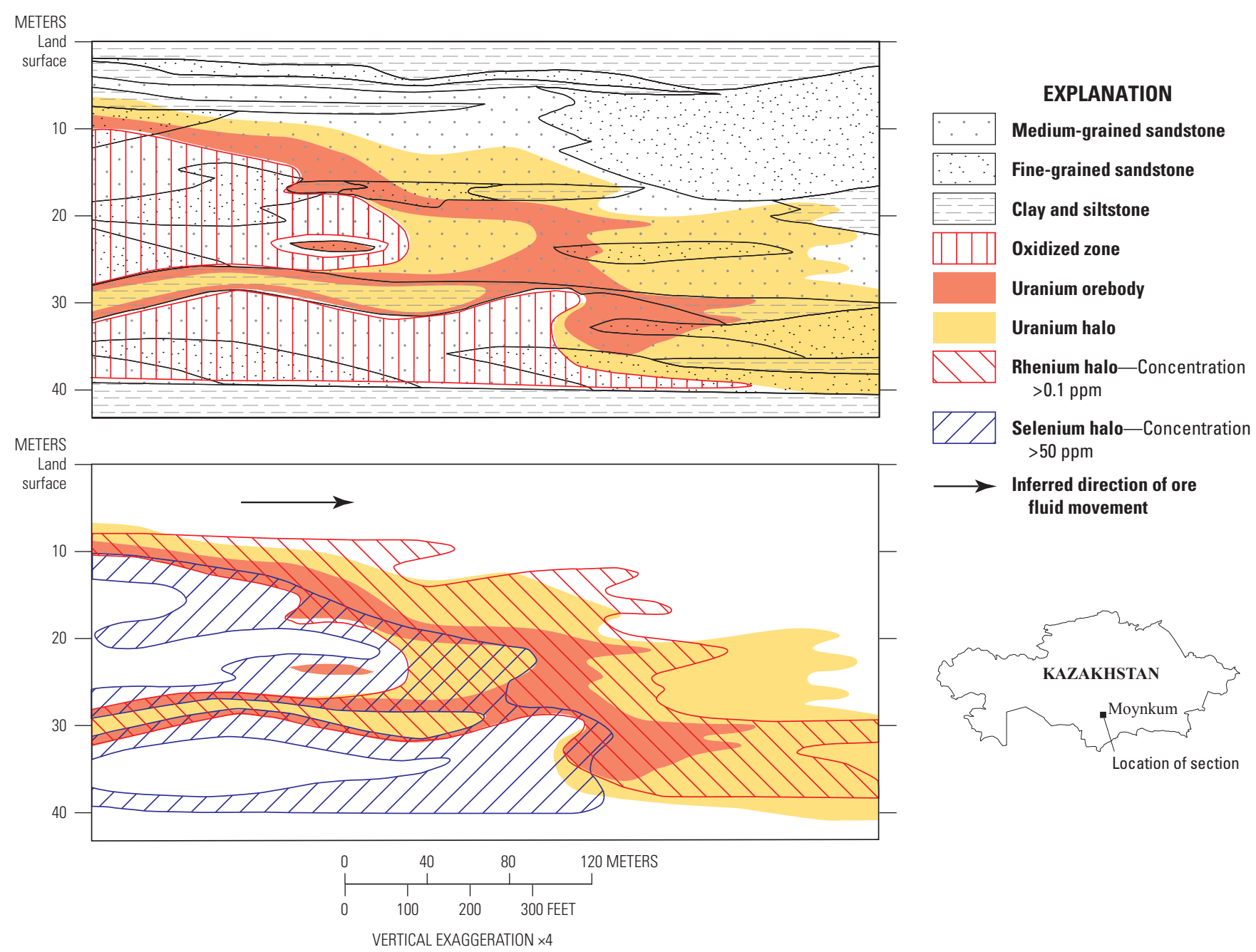

Figure P5.-Continued $\quad D$, Roll-front-type sandstone uranium deposit in the Moynkum-Tortkuduk sector of the Chu-Sarysu basin, Kazakhstan, showing lithological and reduction-oxidation (redox) control on uranium, rhenium, and selenium mineralization. Rhenium and uranium are enriched at the front of the roll in reduced rocks, whereas selenium is concentrated in oxidized rocks. The top cross section shows the oxidized zone; the bottom cross section shows the zone of selenium enrichment. Figure modified from Dahlkamp (2009a). ppm, part per million 
At the Sugraly deposit in the Zarafshan mining district in Uzbekistan, rhenium was recovered along with selenium and molybdenum as byproducts of the mining of uranium deposits in Cretaceous to Eocene sandstone strata in the Kyzylkum basin (Dahlkamp, 2009b). Underground mining began in 1977 and was later switched to in situ leaching until mining ended in 1994. The Sugraly deposit was a typical roll-front-type deposit with complex uranium-selenium-molybdenumrhenium ores that formed orebodies that were from several hundred meters to $20 \mathrm{~km}$ long and from 100 to 500 meters (m) wide. Rhenium content varied from 10 to 15 ppm (Seltmann and others, 2012). Rhenium was reportedly present in the form of $\mathrm{ReS}_{2}$ and $\mathrm{ReO}_{2}$ (Dahlkamp, 2009b).

Rhenium is reported in several roll-front-type sandstone uranium deposits in Kazakhstan (Dahlkamp, 2009a). These include deposits in the Moynkum (Moinkum), the Kanzhugan, and the Kenze-Budenovskaya mining districts in the Chu-Sarysu basin, and deposits in the Suluchekinskoye district. In the Moynkum and Kanzhugan districts, numerous uranium orebodies are associated with redox fronts in Paleogene sandstone aquifers. Rhenium grades generally range from 0.08 to $0.38 \mathrm{~g} / \mathrm{t}$ with rhenium content of as much as $4.8 \mathrm{~g} / \mathrm{t}$ in some deposits. In the Tortkuduk sector at the north end of the Moynkum deposit, uranium mineralization is contained in a 40-m-thick arenite unit sandwiched between clay-silt beds (fig. P5D). Uranium mineralization extends for about $10 \mathrm{~km}$ along a winding redox front. The forward sections of the rolls are about $20 \mathrm{~m}$ thick; tails may be up to several meters thick and more than $400 \mathrm{~m}$ long. A rhenium halo ( $>0.1 \mathrm{ppm}$ rhenium), which coincides with the uranium distribution, surrounds the front of the roll and extends for up to $60 \mathrm{~m}$ into the reduced rocks (fig. P5D). A selenium zone with greater than 50 ppm selenium is in the rear part of the roll (fig. P5D).

At the Zhalpak and the Akdala deposits in the KenzeBudenovskaya mining district, Cretaceous sandstones host roll-front uranium mineralization. Several orebodies in these deposits have rhenium content of as much as $62 \mathrm{ppm}$ (Dahlkamp, 2009a; Seltmann and others, 2012). Samples containing greater than $0.2 \mathrm{ppm}$ rhenium have higher uranium contents. In the Suluchekinskoye district in the Ily basin, rollfront-type orebodies are hosted by Cretaceous to Paleogene sandstones. Orebodies are zoned laterally from rhenium in reduced rocks, followed by a uranium-rhenium zone at the redox boundary, and then a selenium zone that forms the rear of the roll in oxidized rocks. Rhenium contents range from 1 to 24 ppm and average 1 to $2 \mathrm{ppm}$.

Uranium and rhenium in the Kazakhstan deposits are recovered using in situ leaching (also known as solution mining). In mining that uses in situ leaching, ore minerals are dissolved by circulating groundwater fortified with sulfuric or other acids through undisturbed underground deposits (World Nuclear Association, 2013). The resulting pregnant solutions are pumped to the surface, and uranium, rhenium, and other metals are recovered using methods similar to those used in processing milled uranium ore.

\section{Rhenium in the Merlin Deposit}

The Merlin molybdenum-rhenium deposit in the Mount Isa Inlier in northwestern Queensland, Australia, is a highgrade rhenium resource in which rhenium and molybdenum are the primary commodities and only minor amounts of copper are present (fig. P3; Brown and others, 2010; Lycopodium Minerals QLD Pty Ltd., 2012). Mineralized rock consists dominantly of molybdenite in veins, infilling breccias and stylolites, and disseminated grains in a zone that is about $1 \mathrm{~km}$ long and up to $20 \mathrm{~m}$ thick. Rhenium is contained in molybdenite grading an average of about 1,000 ppm rhenium. In 2012 , indicated and inferred mineral resources were 6.9 million metric tons averaging 1.38 percent molybdenum and 22.7 ppm rhenium (Lycopodium Minerals QLD Pty Ltd., 2012).

The Merlin deposit was discovered in 2008 during drilling of the northern extension of the Mount Dore copper deposit, which mostly lies above and south of the Merlin deposit (Brown and others, 2010). The Merlin and the Mount Dore deposits are hosted by Early Proterozoic carbonaceous metashale and metasiltstone that are structurally overlain by the 1,500-mega-annum (Ma) anorogenic Mount Dore Granite along a moderately dipping reverse fault. The Merlin molybdenum-rhenium mineralization is associated with silica-albite alteration and interstitial clays that formed along reactivated fractures and shear zones and replaced the matrix of structurally controlled breccias. At Mount Dore, early regional-scale sodic-calcic alteration is cut by potassic alteration and quartz veins and by breccias that host an early phase of copper mineralization. A second phase of brecciation was followed by deposition of dolomite and a second stage of copper mineralization. The molybdenum-rhenium mineralization at the Merlin deposit cuts the copper mineralization in the Mount Dore deposit but is likely part of the same system. Zircon uranium-lead dating of the Mount Dore Granite and rhenium-osmium dating of molybdenite in the Mount Dore deposit show that both formed at about 1,500 Ma and suggest that copper-molybdenum mineralization at Mount Dore probably is related to a late-stage, evolved magmatic fluid that generated potassic alteration (Duncan and others, 2011). The average Mo:Re ratio of 600 is also consistent with an igneous origin. 


\section{Resources and Production}

\section{Identified Resources}

Estimates of grades and tonnages of major rheniumbearing deposits are shown in figure $\mathrm{P} 4$ and presented in tables P1 and P2. There are no published grade and tonnage models for rhenium in porphyry deposits, although Sinclair and others (2009) and Millensifer and others (2014) present plots of rhenium grade versus deposit tonnages for some porphyry and other types of deposits. Publicly available data on rhenium contents in porphyry deposits are limited and often inconsistent when more than one data source is available. Very few grade and tonnage data are available for other types of deposits that produce rhenium. Descriptions of data compilation methods and limitations of these data are in appendix P1.

\section{Production}

Worldwide mine production of rhenium in 2012 was estimated to be $52,600 \mathrm{~kg}$, of which about $27,000 \mathrm{~kg}$, or 51 percent, was produced from porphyry copper mines in Chile (fig. P6; Polyak, 2014). Because specialized processing facilities are required to recover rhenium from molybdenite concentrates, however, a significant amount of rhenium (approximately 15 to 20 metric tons) is contained in molybdenite concentrates roasted at facilities other than where it is mined (for example, molybdenite concentrates from the Bingham Canyon Mine), thereby making estimates of the sources of rhenium difficult. In recent years, rhenium also was recovered from porphyry copper deposits in the United States, Armenia, Kazakhstan, Mexico, Peru, Russia, and Uzbekistan. Porphyry copper deposits formed in continental arcs are the main sources of both rhenium production and resources (tables P1 and P2; fig. P3). All primary rhenium production in the United States is from processing facilities at the Sierrita Mine in Arizona, where rhenium is recovered from molybdenite concentrates produced at several porphyry copper mines. Rhenium resources in the United States are located mainly in Arizona and Utah, although smaller resources are located in Montana, New Mexico, and Nevada. The Pebble deposit in Alaska also contains a large inferred rhenium resource.

Sediment-hosted strata-bound copper deposits in Poland and Kazakhstan were the other major primary sources of rhenium in 2011, and both the Kupferschiefer deposits in Poland and the Dzhezkazgan deposit in Kazakhstan have large identified rhenium resources (fig. P4). Ore reserves in the underground deposits in Kupferschiefer deposits in the Legnica-Glogów copper belt, Poland, are sufficient to maintain the current production rate of about 30 million metric tons per year for 30 to 40 years (Bartlett and others, 2013).

Sandstone uranium deposits in Kazakhstan produce some byproduct rhenium, and published grade and tonnage

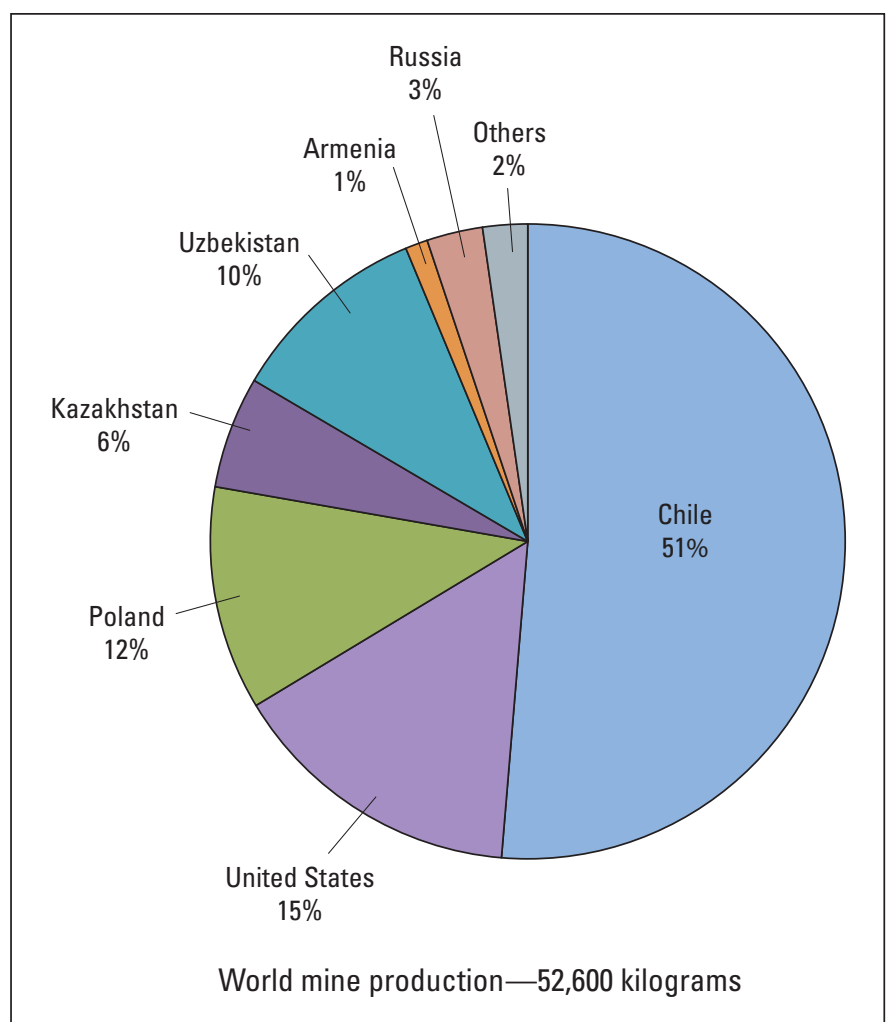

Figure P6. Pie chart showing world rhenium mine production in 2012 , by country and percent of world total. Compiled using data from Polyak (2014).

data suggest significant rhenium resources in some deposits (Dahlkamp, 2009a). The lack of grade and tonnage data for most deposits, however, precludes a thorough assessment of these resources (table P1; fig. P4). Similar deposits in the southern and middle Ural Mountains in Russia may produce rhenium, but no production or resource estimates are available (Khalezov, 2009).

The Merlin molybdenum-rhenium deposit in Queensland, Australia, is unique because rhenium is a primary commodity. Despite its high rhenium grade (22.7 ppm), the contained rhenium resources are relatively small compared with the resources of other deposit types (fig. P4).

\section{Undiscovered Resources}

Rhenium resources likely are present in undiscovered porphyry copper deposits formed in continental arcs throughout the world. Recent U.S. Geological Survey (USGS) assessments of porphyry copper deposits in the Southwestern United States (Ludington and others, 1996), the Andes Mountains in South America (Cunningham and others, 2008), Mexico (Hammarstrom and others, 2010), the Province of British Columbia and the Yukon Territory in Canada (Mihalasky and others, 2013), and the Tethys region, including Armenia, Azerbaijan, Georgia, Iran, and Turkey 
(Lukas Zürcher, U.S. Geological Survey, written commun., 2013) concluded that there is significant potential for undiscovered porphyry copper deposits in these regions. Because known porphyry copper deposits in these areas contain some of the largest identified rhenium resources in the world, it is highly probable that significant rhenium resources remain to be discovered in these areas.

In the United States, additional rhenium resources in porphyry copper deposits are most likely to occur in Arizona, where there are numerous identified deposits - several of which contain recoverable rhenium - and where there is a high probability of undiscovered deposits. Also, recent delineation of the giant Pebble porphyry copper-molybdenumgold deposit in Alaska, which has estimated rhenium resources that represent more than 40 years of production at the current level of worldwide mine production (Ghaffari and others, 2011; Lang and others, 2013), suggests that there is the potential for significant rhenium resources in undiscovered porphyry copper deposits in Alaska.

Mongolia is another area where significant porphyry copper deposits have been discovered recently (for example, the giant Oyu Tolgoi porphyry copper-gold deposit in Omnogovi Aymag) (Khashgerel and others, 2006). The incompletely defined Zuun Mod molybdenum deposit has modest rhenium resources (table P1; Clark and Baudry, 2011). The presence of these deposits suggests the potential for significant undiscovered rhenium resources in Mongolia.

According to the recent USGS assessment of sedimenthosted strata-bound copper deposits, a significant number of undiscovered reduced-facies-type strata-bound copper deposits that have large resources are likely present in the Kupferschiefer in Poland (M.L. Zientek, U.S. Geological Survey, written commun., 2013) and sandstone-type stratabound copper deposits in Kazakhstan (Box and others, 2012). Because known deposits in these areas are enriched in rhenium and contain significant rhenium resources (fig. P4), the undiscovered deposits also likely contain significant rhenium resources. Other large sediment-hosted strata-bound copper deposits, such as Udokan in the Transbaikalia Region in Russia and deposits in the Democratic Republic of the Congo, do not have reported anomalous rhenium contents (Hitzman and others, 2005; Zientek and others, 2013).

The recent discovery of the Merlin deposit in Australia opens up the possibility that there are other high-grade molybdenum-rhenium deposits in which these metals are the primary commodities. Until the genesis of the Merlin deposit is better understood, however, it is premature to speculate on the probability of the occurrence of similar deposits.

\section{Exploration for New Deposits}

With the exception of the Merlin molybdenum-rhenium deposit, all identified rhenium resources are contained in deposits mined primarily for other mineral commodities. In porphyry copper deposits, rhenium is recovered mostly from molybdenum, which is another byproduct. Until a better understanding of the genesis of the Merlin deposit emerges and it is determined that this type of deposit is economic, exploration for other primary rhenium deposits is unlikely to take place. Therefore, the discovery of significant new rhenium resources is likely to depend on successful exploration for porphyry copper deposits, especially in frontier areas, such as Alaska and Mongolia, where there have been recent discoveries of large porphyry copper deposits that may contain byproduct molybdenum and rhenium (for example, the Pebble and the Oyu Tolgoi deposits). Future exploration for porphyry copper deposits likely will involve increased remote sensing, geophysical (both potential field and electrical techniques), and lithogeochemical studies to discover covered deposits (for example, Graybeal and Vikre, 2010).

\section{Environmental Considerations}

Rhenium is present in Earth's crust at very low concentrations, and its production is nearly always as a byproduct commodity from copper mining. Therefore, the environmental characteristics of rhenium extraction are closely linked to those associated with the mining of the two types of copper deposits that represent its main sources. The primary source of rhenium is from the mineral molybdenite (the main ore mineral of molybdenum) derived from porphyry copper deposits. Rhenium is also produced from sediment-hosted copper deposits. The economic geology of the two mineral deposit types that are the predominant sources of byproduct rhenium are significantly different from one another, which means that the environmental geology of these deposit types are also different. The environmental geology of porphyry copper deposits is dominated by their large size (which means that they are commonly mined by open pit methods), their low grade, and the variable potential of their solid mine wastes to generate minor amounts of acid drainage or neutralize it (John and others, 2010). The environmental geology of sediment-hosted copper deposits is characterized by their moderate size, the tabular geometry of their ores, their low grade, and the low potential of their solid mine wastes to generate acid drainage (Hayes and others, 2015). 


\section{Sources and Fate in the Environment}

Concentrations of rhenium in the natural environment, including in groundwater, surface water, sediment, soils, and biota, are low, which is a reflection of rhenium's low crustal abundance (table P3). The distribution of rhenium in environmental samples is further influenced by its relatively higher solubility in oxygenated waters and its lower solubility in oxygen-free (anoxic) waters.

The overall concentration of rhenium in water is similarly lower than that of many other base and precious metals, as summarized by Colodner and others (1993) and Hodge and others (1996). In fact, the natural concentration of rhenium in surface water, groundwater, and seawater falls in the partsper-trillion range (table P3). Experimental studies suggest that the maximum solubility of $\mathrm{ReO}_{2}$ in water at room temperature $\left(25^{\circ} \mathrm{C}\right)$ is less than 160,000 parts per trillion $(\mathrm{ppt})(0.16 \mathrm{ppm})$, but could be as low as $20 \mathrm{ppt}$ (Kim and Boulègue, 2003; Xiong and others, 2006). Dissolved concentrations in the ocean average $8.3 \mathrm{ppt}$ and do not vary with depth (Colodner and others, 1993). Variations in rivers span four orders of magnitude, from 0.004 to $76 \mathrm{ppt}$ (Colodner and others, 1993; Rahaman and others, 2012). The geology of the watershed influences the rhenium concentration. Watersheds underlain by black shales typically have higher concentrations of rhenium than do those underlain by other rock types. Rhenium in seawater and surface water behaves conservatively, meaning that it stays dissolved and does not bind or adsorb to particulate matter, such as clays. Reducing sediments (sediments rich in organic matter and sulfide minerals) are known to be important for the removal of rhenium from the water column, however (Koide and others, 1986). The observation that black shales can serve as sources of elevated concentrations of rhenium in surface water is a reflection of this process operating in the geologic record (Rahaman and others, 2012).
In solid environmental media (soil, sediment, and biological material), the rhenium concentrations are also low, although they are higher than those typically found in water (table P3). River sediments, oxygenated marine sediments, and soils all have concentrations that are comparable to the average crustal abundance $(0.4 \mathrm{ppb})$. Organic-rich, anoxic sediments have concentrations that can be significantly higher (1.8 to $110 \mathrm{ppb}$ ) (Koide and others, 1986). Plants are known to accumulate rhenium at concentrations greater than local soil concentrations (Bozhkov and Borisova, 2003).

Information on pre-mining environmental concentrations of rhenium is limited, in part because of its low concentrations. Leybourne and Cameron (2008) investigated the concentrations of arsenic, copper, molybdenum, rhenium, and selenium in groundwater associated with the undeveloped Spence porphyry copper deposit in the Atacama Desert in northern Chile. They found that groundwater concentrations within the deposit reached a maximum rhenium concentration of $30.7 \mathrm{ppb}$. Outside of the deposit, the minimum rhenium concentration was as low as $0.2 \mathrm{ppb}$. From an environmental perspective, baseline concentrations of other trace elements and related constituents associated with porphyry copper deposits or sediment-hosted copper deposits are of greater environmental interest than are those for rhenium because these elements can be present in significantly higher concentrations.

Environmental baseline characterization studies of porphyry copper deposits are limited in the literature, particularly with regard to the diversity of climatic settings in which the deposits are found. Some information is available in mine permit applications for recently proposed mines, however. Studies from such diverse climates as the cold climate of southwestern Alaska (Fey and others, 2008); the tropical climate of Puerto Rico (Learned and Boissen, 1973; Plaza-Toledo, 2005); and the hot, arid climates of

Table P3. Rhenium concentrations in rocks, soils, biota, waters, and sediments.

[ppb, part per billion; ppt, part per trillion]

\begin{tabular}{lll}
\hline \multicolumn{1}{c}{ Environment } & \multicolumn{1}{c}{$\begin{array}{c}\text { Rhenium } \\
\text { concentration }\end{array}$} & Reference(s) \\
\hline Upper continental crust & $0.4 \mathrm{ppb}$ & Taylor and McLennan (1995) \\
Soils & 0.208 to $1.72 \mathrm{ppb}$ & Uchida and others (2005) \\
Leaves, dried, birch and fir, unimpacted & 4 to $6 \mathrm{ppb}$ & Bozhkov and Borisova (2003) \\
Leaves, dried, acacia, smelter and mine site vicinity & 902 to $2,430 \mathrm{ppb}$ & Bozhkov and Borisova (2003) \\
Seawater (Atlantic Ocean and Pacific Ocean) & $8.3 \pm 0.1 \mathrm{ppt}$ & Colodner and others (1993) \\
Rivers & 0.004 to $76.7 \mathrm{ppt}$ & Colodner and others (1993); Rahaman and others (2012) \\
Groundwater & 0.9 to $35.4 \mathrm{ppt}$ & Colodner and others (1993); Hodge and others (1996) \\
Groundwater, porphyry copper deposits & 0.09 to $30.7 \mathrm{ppb}$ & Leybourne and Cameron (2006) \\
River sediment & 0.233 to $0.285 \mathrm{ppb}$ & Uchida and others (2005) \\
Pelagic sediments & $<0.1 \mathrm{ppb}$ & Koide and others (1986) \\
Anoxic sediments & 1.8 to $110 \mathrm{ppb}$ & Koide and others (1986) \\
\hline
\end{tabular}


Arizona and Chile (Chaffee, 1976, 1977; Chaffee and others, 1981; Leybourne and Cameron, 2006, 2008) show similar geochemical features. Soils show elevated concentrations of, in decreasing order of maximum concentration, iron ( 2.3 to 7.4 weight percent), sulfur (0.02 to 0.87 weight percent), copper (3.2 to $1,830 \mathrm{ppm}$ ), zinc (36 to $142 \mathrm{ppm}$ ), arsenic ( 7 to $78 \mathrm{ppm}$ ), molybdenum (0.6 to $27.1 \mathrm{ppm}$ ), lead (7.1 to $17.4 \mathrm{ppm}$ ), and cadmium ( $<0.1$ to $0.6 \mathrm{ppm})$. Stream sediments show elevated concentrations of, in decreasing order of maximum concentration, iron (6.3 to 10.6 weight percent), copper (64 to $804 \mathrm{ppm}$ ), zinc (59 to $291 \mathrm{ppm}$ ), lead ( $<4$ to $17 \mathrm{ppm}$ ), molybdenum $(<2$ to $10 \mathrm{ppm})$, arsenic $(<10 \mathrm{ppm})$, and cadmium $(<2 \mathrm{ppm})$.

Only a limited amount of pre-mining baseline data are available in the literature for soil, stream sediment, groundwater, and surface water from a variety of deposits. Plaza-Toledo (2005) found that surface waters downstream from undeveloped porphyry copper deposits in the Cordillera Central of Puerto Rico contained maximum dissolved concentrations of $110 \mathrm{ppm}$ sulfate, $15.9 \mathrm{ppm}$ iron, $0.56 \mathrm{ppm}$ aluminum, $0.13 \mathrm{ppm}$ copper, and $0.04 \mathrm{ppm}$ zinc. The $\mathrm{pH}$ was high (7.7 to 8.6). Fey and others (2008) documented surface-water $\mathrm{pH}$ values of between 4.1 and 7.3 in the vicinity of the Pebble deposit in southwestern Alaska. Alkalinity ranged between 0 and $100 \mathrm{ppm}$ calcium carbonate $\left(\mathrm{CaCO}_{3}\right)$ equivalent; sulfate, between 1 and $85 \mathrm{ppm}$; and hardness of water, between 2 and $130 \mathrm{ppm} \mathrm{CaCO}_{3}$ equivalent. Dissolved trace element concentrations showed a range of values for, in decreasing order of maximum concentration, iron $(<20$ to $4,260 \mathrm{ppb})$, copper ( $<0.5$ to $688 \mathrm{ppb})$, zinc $(<0.5$ to $68 \mathrm{ppb}$ ), arsenic ( $<1$ to $36.2 \mathrm{ppb}$ ), molybdenum ( $<2$ to $21.9 \mathrm{ppb}$ ), lead $(<0.05$ to $18.8 \mathrm{ppb}$ ), and cadmium $(<0.2$ to $11.6 \mathrm{ppb})$. Leybourne and Cameron $(2006,2008)$ documented high salinity in groundwaters associated with the undeveloped Spence deposit where the salinity reached 10,000 to $55,000 \mathrm{ppm}$, with one outlier sample at $145,000 \mathrm{ppm}$. The $\mathrm{pH}$ of the groundwaters varied widely, between 4.7 and 9.2. Dissolved sulfate concentrations in groundwaters were between 5,000 and 10,000 ppm. Dissolved trace element concentrations showed a range of values for, in decreasing order of maximum concentration, iron (4 to $54,454 \mathrm{ppb}$ ), copper (9 to $28,991 \mathrm{ppb}$ ), zinc (5 to $1,344 \mathrm{ppb}$ ), molybdenum ( 2 to $475 \mathrm{ppb}$ ), arsenic ( $<10$ to $160.9 \mathrm{ppb}$ ), and lead (0.025 to $23.8 \mathrm{ppb}$ ).

Environmental baseline characterization studies of sediment-hosted copper deposits are more limited than those for porphyry copper deposits. For sedimentary-hosted copper deposits, soil and stream sediments may contain anomalous abundances of copper, lead, silver, and possibly arsenic, mercury, and zinc in the vicinity of the deposits (Lindsey and others, 1995). Stream-sediment samples collected in the Kafue River (Zambia) upstream from sediment-hosted copper deposits contained copper in concentrations of between 15 and $146 \mathrm{ppm}$, some of which were just below the stream-sediment criterion (that is, the probable effects concentration, or the concentration at which toxic effects would be expected for aquatic organisms) of $149 \mathrm{ppm}$ (MacDonald and others, 2000; Pettersson and others, 2000; Pettersson and Ingri, 2001). Also, soil and sediment associated with some sandstone deposits in Montana contained anomalous copper (up to 2,000 ppm), lead (greater than $150 \mathrm{ppm}$ ), and silver (greater than $0.5 \mathrm{ppm}$ ), as reported by Cazes and others (1981) and Wells and others (1981).

In contrast to some of the sediment and soils that have anomalous metal concentrations, surface water in the Kafue River upstream from the mining area in Zambia contains low levels of copper (up to $3 \mathrm{ppm}$ ) and other trace elements (Norrgren and others, 2000; Pettersson and Ingri, 2001). The draft environmental impact statement for the Montanore Project, which is a proposed mine in the Rock CreekMontanore deposit in Montana, describes the surface-water quality in streams and lakes near the proposed mine as being "excellent," which presumably means that all trace elements meet environmental criteria. The concentrations of total suspended solids, total dissolved solids, major ions, nutrient concentrations, and metal concentrations are generally low and frequently at or below detection limits. The surface waters generally contain iron, copper, and silver in low concentrations that are well below environmental guidelines. The surface waters tend to be slightly acidic (U.S. Department of Agriculture, Forest Service, and others, 2009).

\section{Mine Waste Characteristics}

The amount of mine waste associated with porphyry copper and sediment-hosted deposits varies with the size of the deposit. Porphyry copper deposits range from 30 million metric tons to more than 20 billion metric tons with a median size of 250 million metric tons. Because copper grades are typically less than 1 percent copper (median grade of 0.44 percent copper), more than 95 percent of the material mined ends up as solid mine waste of one form or another. The solid mine waste typically falls into one or more of the following three types: tailings, waste rock, and leach-pad waste. Tailings and waste rock are usually found at all mines, whereas leach-pad waste is found only at those mines where the ores are amenable to a copper extraction method known as solvent extraction-electrowinning (SX-EW). SX-EW is viable only for deposits that have been subject to prolonged periods of weathering, which has produced a zone near the surface where sulfide minerals have been oxidized to copper oxide or copper carbonate minerals. The oxide zone will overlie an unweathered sulfide zone. The oxide ore is mined and crushed to a coarse grain size and placed on lined pads. The piles are leached with a sulfuric acid solution, which is recovered to collect the leached copper. Oxide zones are not universally present at porphyry copper deposits, so this type of mine waste is not always present at porphyry copper deposits. 
Tailings are produced when the ore is crushed to a sand or silt size to facilitate the separation of the copper sulfide and other metal-sulfide ore minerals from gangue minerals (minerals of no value) using a technique known as froth flotation. After separation of gangue minerals, the tailings are discarded as a slurry or trucked dry to a tailings storage facility. Tailings storage facilities are typically impoundments surrounded by a retaining dam.

The other type of solid waste is waste rock. Because of their large size and low grade, porphyry copper deposits are commonly mined by open pit methods. Waste rock is uneconomic rock that must be removed (stripped) to access the ore. Waste rock is disposed of on site. It can also be used for construction on site if tests determine that it will not generate acid-rock drainage when it is exposed to the atmosphere and water. For open pit porphyry copper mines, waste-to-ore (stripping) ratios commonly can exceed 2:1, which means that for each ton of ore mined, two tons of waste rock must be removed (Porter and Bleiwas, 2003). Porphyry copper deposits at depth can also be mined by block caving. A vertical shaft or spiral decline is built to the base of the orebody, and the orebody is mined from below, leaving a large, unsupported cavity where the ore was removed. With this type of mining, the amount of waste rock is less than that in open pit mining and the waste material is dominated by tailings.

The size of sediment-hosted copper deposits depends upon their subtype (reduced type, red bed, or sandstone) and is smaller than most porphyry copper deposits. The volume of mine waste and tailings produced from a deposit depends on the deposit size, depth, geometry, ore grade, and mining method. Sediment-hosted copper deposits can be mined by underground or open pit methods. The reduced-facies-type deposits are generally high tonnage (the median tonnage is 33 million metric tons) with a high copper grade (the median grade is 2.3 percent) (Lindsey and others, 1995; Cox and others, 2003). Red-bed deposits are generally low tonnage (the median tonnage is 1.2 million metric tons), have an intermediate copper grade (the median grade is 1.2 percent), and are mined either by open pit or underground methods. Sandstone deposits are intermediate tonnage (the median tonnage is 14 million metric tons) but they have lower copper grades (the median grade is 0.79 percent). Because of the low copper grades, most of the mined rock is waste. Copper can be separated by froth flotation of finely ground ore or by SX-EW recovery from oxidized ores.

The mineralogy of the ore and waste in porphyry copper and sediment-hosted copper mines determines the environmental characteristics of these deposits. In terms of both ecological risks and human health risks, the mineralogy dictates the acid-generating potential of the ores and wastes and the mobility of trace elements. In porphyry copper deposits, sulfide minerals, such as bornite, chalcopyrite, enargite, galena, molybdenite, pyrite, and sphalerite, are the main hosts of the trace elements that are of environmental concern; in total, they typically constitute less than 5 percent of the ore (John and others, 2010). In sediment-hosted copper deposits, the sulfide minerals are dominated by, in general order of decreasing abundance, chalcocite, digenite, bornite, chalcopyrite, pyrite, and subordinate galena and sphalerite (Hayes and others, 2015). The trace element geochemistry of tailings and waste dumps reflects the mineralogy of the waste. For porphyry copper deposits, tailings typically contain significant concentrations of copper (475 to 5,100 ppm), manganese (67 to $700 \mathrm{ppm}$ ), molybdenum (12 to $235 \mathrm{ppm}$ ), zinc (40 to $210 \mathrm{ppm}$ ), and arsenic (3.5 to $136 \mathrm{ppm}$ ) (John and others, 2010). Tailings from sediment-hosted copper deposits generally contain 1 to 4 weight percent iron, 0.1 to 0.3 weight percent copper, and 300 to $800 \mathrm{ppm}$ cobalt (Hayes and others, 2015).

Approaches for managing solid waste depend upon its acid-generating potential. Acid generation can be considered a "master variable" for aqueous risks. Metals and many other trace elements tend to be more soluble at low $\mathrm{pH}$ (acidic) than at neutral or high $\mathrm{pH}$ (alkaline). Therefore, the acid-generating or acid-neutralizing potentials of the waste rock, tailings, and other solid waste material are of prime importance in identifying the potential environmental risks associated with mining and ore beneficiation. The acid-generating potential of mine waste is expressed in terms of the amount of calcium carbonate it would take to neutralize it; it is measured in kilograms of calcium carbonate per metric ton of mine waste $\left(\mathrm{kg} \mathrm{CaCO}_{3} / \mathrm{t}\right)$ (Price, 2009; International Network for Acid Prevention, 2011). The acid-generating potential resides primarily in pyrite. Mine waste can also have acid-neutralizing potential, which resides in carbonate minerals, such as calcite, and in some silicate minerals, such as feldspars.

The rocks associated with porphyry copper deposits, in general, tend to straddle the boundary between having net acid-generating potential and not having net acid-generating potential. During mining and processing of porphyry copper deposits, a variety of materials with differing acid-base accounts may be encountered and produced, and each type must be managed according to its acid-generating potential. Net alkaline waste does not require any special handling and can be used for construction purposes, whereas net acid waste has to be managed to mitigate acid-mine drainage problems. As an example, the net neutralizing potentials for the hypogene and supergene ores from Morenci, Arizona, range from dominantly net acid to slightly net alkaline ( -257.0 to $1.1 \mathrm{~kg} \mathrm{CaCO}_{3} / \mathrm{t}$ ) (Enders and others, 2006). The net acid-neutralization potentials reported in the literature for tailings from several porphyry copper deposits in Chile are net acid generating, ranging from -101.6 to $-18.2 \mathrm{~kg} \mathrm{CaCO}_{3} / \mathrm{t}$ (Dold and Fontboté, 2001). Tailings derived from metallurgical testing on an exploratory drill core from the Pebble deposit in southwestern Alaska have net neutralization potentials ranging from -110 to $27.2 \mathrm{~kg} \mathrm{CaCO}_{3} / \mathrm{t}$ (Pebble Partnership, 2011). 
For sediment-hosted copper deposits, the abundance of carbonate minerals and slightly less reactive minerals, principally chlorite- and epidote-group minerals, determine the acid-neutralizing capacity, whereas the acid-generating potential is determined by the abundance of sulfides, such as pyrite and chalcopyrite. Many deposits contain a significant amount of carbonate and (or) silicate minerals in the ore or host rock, which neutralize the acidity generated by sulfide weathering. As for acid-generating sulfides, the ore for all three subtypes contain low pyrite contents. The pyrite content of the host rock for all types of sediment-hosted copper deposits is less than 1 volume percent (Hayes and Einaudi, 1986).

Limited acid-base accounting data have been reported in the literature for sediment-hosted copper deposits. For tailings, no acid-generating potential has been detected in samples from the White Pine Mine in Michigan (Williams and others, 2002), whereas high acid-neutralizing capacities and neutral-to-alkaline conditions have been reported in samples from the Zambian copperbelt. For the Zambian tailings, the neutralization potential ratios are between 3.4 and 84; most samples at depth have values of greater than 20 , and the highest values are for the leached surface materials (Sracek and others, 2010).

The mean net neutralization potentials of ore, waste rock, and tailings from sandstone deposits at Montanore, Rock Creek, and Troy, Montana, were summarized in the environmental impact statement for these projects (U.S. Department of Agriculture, Forest Service, and others, 2009). Ore from the Montanore deposit has a mean net neutralization potential of $-4 \mathrm{~kg} \mathrm{CaCO}_{3} / \mathrm{t}$, with values ranging from -24 to $11 \mathrm{~kg} \mathrm{CaCO}_{3} / \mathrm{t}$, meaning that its average value has a slight acid-generating potential, but ranges from having a slight excess of acid-generating potential to having a slight excess of acid-neutralizing potential. Values for the Rock Creek and the Troy ore samples average 5 and $8 \mathrm{~kg} \mathrm{CaCO}_{3} / \mathrm{t}$, respectively, meaning that they have acid-generating potential. The mean net neutralization potentials for the tailings from these sandstone deposits range from 2.8 to $10 \mathrm{~kg} \mathrm{CaCO}_{3} / \mathrm{t}$. These acid-base accounting results reflect the low amounts of sulfides in the tailings. The mean net neutralization potentials for the mine waste from these deposits range from 3.6 to $15 \mathrm{~kg} \mathrm{CaCO}_{3} / \mathrm{t}$.

\section{Human Health Concerns}

No information is available for rhenium and its toxic effects on humans, partly (presumably) because of its low natural abundance. The U.S. Agency for Toxic Substances and Disease Registry (http://www.atsdr.cdc.gov/toxprofiles/index.asp) does not have a toxicological profile for rhenium nor does the U.S. Environmental Protection Agency have drinking-water standards or soil guidelines for rhenium. Unnatural (not naturally occurring) radioisotopes of rhenium $\left({ }^{188} \mathrm{Re}\right.$ and $\left.{ }^{186} \mathrm{Re}\right)$, however, are being investigated for management of metastatic bone pain in cancer patients (Finlay and others, 2005).
Instead, the more significant human health risks associated with rhenium production are found with the broader aspects of the mining of porphyry and sediment-hosted copper deposits. Contaminated groundwater plumes associated with tailings impoundments may threaten drinking-water supplies, depending upon the geologic and hydrologic setting and engineering aspects of the mine and the waste piles for both deposit types. Host rocks with higher acid-neutralization potentials, such as carbonate rocks, tend to limit the mobility of metals and related compounds. Hydrologic and climatic settings that have net evaporative loss of water may cause evaporative concentration of solutes that may enter groundwater used as drinking-water supplies in the vicinity of mines and waste piles. Improperly constructed water-containment structures may allow contaminated mine waters to enter surrounding groundwater. For both porphyry copper deposits and sediment-hosted deposits, elements or compounds with the greatest likelihood of causing problems for drinking-water sources include aluminum, arsenic, copper, iron, manganese, sulfate, and zinc. The U.S. Environmental Protection Agency has primary drinking-water standards, meant to protect human health, for arsenic, cadmium, copper, and lead, and nonenforceable secondary standards meant to protect the cosmetic and aesthetic qualities of water (skin or tooth discoloration, taste, odor, and color) for aluminum, cadmium, iron, lead, manganese, sulfate, and zinc (U.S. Environmental Protection Agency, 2009a). The potential for groundwater contamination depends upon the waste and water management practices at any given mine.

An additional human health risk associated with porphyry copper and sediment-hosted copper deposits is from the smelting of ore concentrates. Historically, it was more common for each mine or mining district to operate its own smelter. In contrast, modern mines typically ship ore concentrates to smelters that may be far away from the mines. Therefore, smelter sites are not a necessary feature of a proposed mine. Smelters may emit carbon monoxide, hydrocarbons, metals, nitrogen oxide, particulates, and sulfur dioxide, which can contaminate surrounding soils, although in the United States, these emissions are currently regulated to protect the environment. For example, numerous studies on the soil surrounding the Glogów and the Legnica smelters in Poland, which serve sediment-hosted copper mines, reported high metal concentrations, especially of, in decreasing order of maximum concentration, lead (90 to 18,000 ppm), copper (250 to $10,000 \mathrm{ppm})$, zinc (55 to $4,000 \mathrm{ppm}$ ), and cadmium ( 0.3 to $10.9 \mathrm{ppm}$ ), that vary with the dominant wind direction and distance from the smelter (Roszyk and Szerszen, 1988; Helios Rybicka and Jędrzejczyk, 1995; Karczewska, 1996; Pilc and others, 1999; Grzebisz and others, 2001; Kabala and Singh, 2001). The concentrations of cadmium and lead in groundwater and surface waters in the vicinity of the two smelters (Pilc and others, 1999) exceed the World Health Organization (WHO) guidelines for drinking water (World Health Organization, 2006). 


\section{Ecological Health Concerns}

No information is available for rhenium and its toxic effects on aquatic or terrestrial ecosystems, presumably because of its low crustal abundances. Therefore, as with human health risks, the more significant ecosystem risks associated with rhenium production are found with the broader aspects of the mining of porphyry and sediment-hosted copper deposits. Many of the ecological risks associated with both porphyry copper deposits and sediment-hosted deposits focus on the ability of mine wastes to generate acid, and the ability of the resulting acid-mine drainage to carry metals and other inorganic contaminants. As described above with respect to mine-waste characteristics, the acid-generating potential of mine waste is primarily found in its pyrite content, and it may be offset by the acid-neutralizing potential found in carbonate or less significantly silicate (chlorite and epidote group) minerals. Residual ore minerals in the waste material are the primary hosts of many metals and arsenic in mine drainage. Silicate minerals are common sources of aluminum, iron, and manganese in mine drainage. Sound waste management practices can mitigate these effects. Tailings are prone to being transported by waters, especially in the case of a tailings dam failure, and wind, because of the sand- to silt-size grains. Thus, they present additional potential risks to aquatic organisms through sediment contamination.

Mine-drainage data are available for porphyry copper deposits in British Columbia, Canada (Day and Rees, 2006); the Globe mining district in Arizona (Eychaner, 1991; Stollenwerk, 1994; Brown and others, 1998; Lind and others, 1998; Conklin and others, 2001); the Morenci mining district, Arizona (Enders and others, 2006); and Iran (Khorasanipour and others, 2011). Many of the values exceed relevant waterquality guidelines for the protection of aquatic ecosystems (U.S. Environmental Protection Agency, 2009b). In British Columbia, Canada, Day and Rees (2006) documented mine waters with $\mathrm{pH}$ values ranging from 2.0 to 8.5 , and sulfate was the dominant anionic species ( 1 to $30,000 \mathrm{ppm}$ ). The concentrations of trace elements varied widely: aluminum ranged from 0.001 to $1,000 \mathrm{ppm}$; copper, 0.0005 to $1,000 \mathrm{ppm}$; iron, 0.005 to $1,000 \mathrm{ppm}$; manganese, 0.001 to $100 \mathrm{ppm}$; and zinc, 0.001 to $100 \mathrm{ppm}$. Khorasanipour and others (2011) found similar geochemical trends, but in a more arid environment, for drainage associated with waste-rock dumps at the Sar Cheshmeh Mine in Kermān Province, southeastern Iran. The $\mathrm{pH}$ values ranged from 3.1 to 6.3 , and the concentration of sulfates was between 365 and 1,590 ppm. The concentrations of aluminum ranged from less than 0.05 to 60 milligrams per liter (mg/L); manganese, from 14.6 to $95.8 \mathrm{ppm}$; copper, 2.15 to $70 \mathrm{ppm}$; and zinc, 2.4 to $27.4 \mathrm{ppm}$. In the Globe mining district in Arizona, a stream was blocked by mill tailings, causing a lake to form. Water from this lake entered an alluvial aquifer by seepage, and the aquifer and a stream to the north were contaminated (Eychaner, 1991; Stollenwerk, 1994; Brown and others, 1998; Lind and others, 1998; Conklin and others, 2001). The most contaminated groundwater in the aquifer had a $\mathrm{pH}$ of 3.3 and contained about 9,600 ppm sulfate, 2,800 ppm iron, $300 \mathrm{ppm}$ aluminum, and $190 \mathrm{ppm}$ copper. As the plume traveled north through the aquifer, the concentration of constituents decreased as the plume interacted with carbonate-bearing alluvium and was diluted by uncontaminated water (including groundwater flowing upward from lower basin fill, water in uncontaminated streams that join the contaminated wash, and surface rainwater). Enders and others (2006) reported analyses of seeps and springs in the Morenci district of Arizona, which had $\mathrm{pH}$ values of between 2.6 and 4.6. Sulfate concentrations were between 550 and 4,300 ppm; copper, between 0.46 and $960 \mathrm{ppm}$; iron, between 15 and $420 \mathrm{ppm}$; aluminum, between 0.48 and $370 \mathrm{ppm}$; and zinc, between 0.8 and 159 ppm.

Pit lakes, particularly in porphyry copper mining districts that have extensive historical underground mine workings, such as the Butte district in Montana, which has a 140-year mining history, can be problematic. The Berkeley Pit lake at Butte contains more than 100 billion liters of $\mathrm{pH}-2.5$ mine water (Gammons and others, 2005; Gammons and Duaime, 2005). The pit lake has high levels of dissolved solids and elevated concentrations of copper, iron, sulfate, and zinc (Gammons and Duaime, 2005). In contrast, pit lakes in the Yerington and Robinson districts in Nevada have $\mathrm{pH}$ values that typically range from 7.0 to 8.5 with a few outliers near 4.7, which have been attributed to discharge from solventextraction operations rather than groundwater-rock interactions in the vicinity of the pits (Shevenell and others, 1999). In Nevada, the total dissolved solids are generally less than $6,000 \mathrm{ppm}$, and concentrations of manganese are less than $5 \mathrm{ppm}$; iron, less than $4.5 \mathrm{ppm}$; selenium, less than $0.14 \mathrm{ppm}$; and arsenic, less than $0.05 \mathrm{ppm}$.

Several studies provide insights into the ecosystem risks associated with sediment-hosted copper deposits. Detailed ecological studies have been carried out along the Kafue River in Zambia, which flows through the Zambian Copperbelt Province's mining district. Syakalima and others (2001) analyzed water downstream of the mining-affected areas of two national parks. This study found concentrations of lead in water of between 0.29 and $0.36 \mathrm{ppm}$ compared with the WHO drinking-water guideline of $0.01 \mathrm{ppm}$. Other studies focused on the toxic effects of metals in the Kafue River on tropical fish. River sediment collected downstream of several mines and near a city that has a major ore-processing facility was significantly more toxic to zebrafish (Pterois volitans) and tilapia (both redbreast tilapia [Tilapia rendalli] and spotted tilapia [Tilapia mariae]) than sediment collected further downstream (Mwase and others, 1998). The toxicity was directly related to the contamination of sediments by the mining activities (Mwase and others, 1998). The results of another study showed that tilapia exposed in situ to Kafue River water for 2 weeks bioaccumulated several trace elements (cadmium, chromium, cobalt, copper, and nickel) for experiments located downstream of mining activities and other industrial point sources (Norrgren and others, 2000). 
The Zambian copperbelt contains both reduced-facies and red-bed-associated deposits, and stream sediments from the Kafue River - an area affected by mining of these depositscontains up to 0.8 weight percent sulfur, 12,855 ppm copper, and 1,030 ppm cobalt (Pettersson and others, 2000; Pettersson and Ingri, 2001).

A study by the mining company to assess the local and long-term effects on Lake Superior from the discharge from the White Pine Mine in Michigan was conducted in 1991. The study indicated that discharge from the mine area was not causing measurable effects based on a lack of observable impact on the benthic community, an insignificant increase in chloride from mine discharges, and a lack of detectable effects on local water intakes (U.S. Environmental Protection Agency, 1994). According to the Surface Water Quality Division of the Michigan Department of Natural Resources, a diverse fish community exists in the nearby river that receives drainage from the mine. According to the U.S. Environmental Protection Agency (1994), the Michigan Department of Natural Resources report did show a reduced macroinvertebrate community downstream from the mine drainage compared with upstream in the river. They suggested that this reduction may be owing to major physical and natural stream quality differences in the White Pine area.

Several environmental impact statements for sandstone deposits in Montana discuss the mobility of trace elements to surface water. Tailing effluent and mine water chemistries for the Spar Lake (Troy) Mine had concentrations of cadmium, copper, and lead in the tailings outflow that exceed aquatic ecosystem guidelines (U.S. Department of Agriculture, Forest Service, and others, 1992).

\section{Carbon Footprint}

Rhenium extraction through mining does not have a unique carbon footprint beyond the general energy requirements of mining. In terms of its uses, rhenium is most directly linked to the global carbon cycle through its use in platinumrhenium catalysts to produce high-octane, lead-free gasoline (Polyak, 2013).

\section{Mine Closure}

The methods used to close porphyry copper mines and sediment-hosted copper mines depend primarily on the method of mining and the characteristics of the waste material. Open pit mining of either deposit type produces at least three different features after mining: the open pit, tailings storage facilities, and waste rock piles. Backfilling pits is typically not practical for a variety of reasons. If the water table is above the bottom of the pit, the pit will become a lake. The water quality of the lake will depend upon a number of factors, including the characteristics of the wall rock, the extent of underground mine workings that connect to the pit, the water level and volume in the pit, the local hydrology, and climate, among others (Castendyk and Eary, 2009).

The long-term fate of tailing storage facilities depends upon the nature of the tailings and the method of construction of the facility. Some tailings storage facilities can be regraded, capped, and revegetated. Others are designed to have a water cover in perpetuity to limit sulfide oxidation. Either type may have seepage that could require some form of water treatment. The long-term fate of waste rock piles typically includes regrading, capping, and revegetation. Depending upon the acid-generating potential of the waste, some piles may also require some form of water treatment.

For underground mines, tailings and waste rock may be handled similarly to how they are handled at open pit mines. Some of the tailings may be transferred back into the minedout workings, depending upon how the orebody is mined. The entire volume of tailings cannot be placed back in the mine workings, however, because of the volume expansion associated with crushing and milling the ore and the relatively small volume of the mineral commodity that is recovered.

\section{Problems and Future Research}

The lack of published data about the rhenium contents of most deposits, including many deposits from which rhenium is produced, hinders understanding of where additional resources may be located. The many uncertainties in the estimates of rhenium grades and rhenium contents of identified deposits preclude more-detailed analysis of rhenium resources.

The geology and geochemistry of rhenium-enriched deposits are not fully understood. Areas of future research will likely include investigating the following: (a) why rhenium is generally more enriched in molybdenite that occurs in porphyry copper deposits (where the rhenium content is in the hundreds to thousands of parts per million) than in molybdenite that occurs in porphyry molybdenum deposits (where the rhenium content ranges from less than one to tens of parts per million) and why molybdenite in gold-rich porphyry copper deposits tends to have higher rhenium concentrations than it does in other subtypes of porphyry copper deposits; (b) where rhenium occurs in sediment-hosted strata-bound copper deposits and in sandstone uranium deposits; (c) the source of rhenium in sediment-hosted strata-bound copper deposits; and (d) the origin of the Merlin molybdenumrhenium deposit.

\section{Acknowledgments}

Peter Vikre, Steve Ludington, and John DeYoung provided helpful reviews. David Sinclair provided unpublished data and a preprint of the Millensifer and others (2014) paper. Keith Labay helped create the deposit location map and Suzanne Nicholson provided additional editorial comments after the technical review was complete. 


\section{References Cited}

Note: All Web links listed were active as of the access date but may no longer be available.

Abisheva, Z.S., Zagorognyaya, A.N., and Bukurov, T.N., 2001, Recovery of radiogenic osmium-187 from sulfide copper ores in Kazakhstan: Platinum Metals Review, v. 45, no. 3, p. 132-135.

Aminzadeh, Balandeh, Shahbpour, Jamshid, and Maghami, Majid, 2011, Variation of rhenium contents in molybdenites from the Sar Cheshmeh porphyry Cu-Mo deposit in Iran: Resource Geology, v. 61, no. 3, p. 290-295. [Also available at http://dx.doi.org/10.1111/j.1751-3928.2011.00165.x.]

Armstrong, Tracy, Brown, Fred, and Puritch, Eugene, 2011, Technical report and updated resource estimate on the Snowfield property, Skeena Mining Division, British Columbia, Canada, NI 43-101 \& 43-101F1 technical report, prepared for Pretium Resources Inc. [Effective date February 18, 2011]:Brampton, Ontario, Canada, P\&E Mining Consultants Inc., 90 p., accessed September 21, 2015, at http://www.pretivm.com/files/doc_downloads/snowfield/ SnowfieldTechnicalReportMarch2011.pdf.

Austen, Gerry, and Ballantyne, Geoff, 2010, Geology and geochemistry of deep molybdenum mineralization at the Bingham Canyon Mine, Utah, USA, in Krahulec, Ken, and Schroeder, Kim, eds., Tops and bottoms of porphyry copper deposits - The Bingham and southwest Tintic districts, Utah - Guidebook prepared for Society of Economic Geologists field trip, September 30-October 1, 2010: Littleton, Colo., Society of Economic Geologists Guidebook Series, v. 41, p. 35-49, 1 CD-ROM.

Barra, Fernando, Alcota, Hugo, Rivera, Sergio, Valencia, Victor, Munizaga, Francisco, and Maksaev, Victor, 2013, Timing and formation of porphyry $\mathrm{Cu}-\mathrm{Mo}$ mineralization in the Chuquicamata district, northern Chile-New constraints from the Toki cluster: Mineralium Deposita, v. 48, no. 5, p. 629-651. [Also available at http://dx.doi.org/10.1007/ s00126-012-0452-1.]

Barra, Fernando, Ruiz, Joaquin, Mathur, Ryan, and Titley, Spencer, 2003, A Re-Os study of sulfide minerals from the Bagdad porphyry $\mathrm{Cu}-\mathrm{Mo}$ deposit, northern Arizona, USA: Mineralium Deposita, v. 38, no. 5, p. 585-596. [Also available at http://dx.doi.org/10.1007/s00126-002-0341-0.]

Barra, F., Ruiz, J., Valencia, V.A., Ochoa-Landin, L., Chesley, J.T., and Zurcher, L., 2005, Laramide porphyry $\mathrm{Cu}-\mathrm{Mo}$ mineralization in northern Mexico-Age constraints from Re-Os geochronology in molybdenite: Economic Geology, v. 100, p. 1605-1616. [Also available at http://dx.doi.org/10.2113/100.8.1605.]
Bartlett, S.C., Burgess, Harry, Damjanović, Bogdan, Gowans, R.M., and Lattanzi, C.R., 2013, Technical report on the copper-silver production operations of KGHM Polska Miedź S.A. in the Legnica-Glogów copper belt area of southwestern Poland, NI 43-101 technical report, prepared for KGHM Polska Miedź S.A.: Toronto, Ontario, Canada, Micon International Ltd., 159 p., accessed September 2, 2015, at http://kghm.com/en/technical-reportcopper-silver-production-operations-kghm-polska-miedzsa-legnica-glogow-copper-belt.

Bernard, A., and Dumortier, P., 1986, Identification of natural rhenium sulfide $\left(\mathrm{ReS}_{2}\right)$ in volcanic fumaroles from the Usu volcano, Hokkaido, Japan, in Imura, T., Maruse, S., and Suzuki, T., eds., Electron microscopy 1986-Proceedings of the XIth International Congress on Electron Microscopy, held in Kyoto, Japan, August 31-September 7, 1986: Tokyo, Japan, Japanese Society of Electron Microscopy, p. 1691-1692.

Berzina, A.N., and Korobeinikov, A.F., 2007, Rhenium and precious metal ( $\mathrm{Pt}, \mathrm{Pd}$, and $\mathrm{Au}$ ) abundances in porphyry Cu-Mo deposits of central-Asian mobile belt: Acta Petrologica Sinica, v. 23, p. 1957-1972.

Berzina, A.N., Sotnikov, V.I., Economou-Eliopoulos, Maria, and Eliopoulos, D.G., 2005, Distribution of rhenium in molybdenite from porphyry $\mathrm{Cu}-\mathrm{Mo}$ and $\mathrm{Mo}-\mathrm{Cu}$ deposits of Russia (Siberia) and Mongolia: Ore Geology Reviews, v. 26, nos. 1-2, p. 91-113. [Also available at http://dx.doi.org/ 10.1016/j.oregeorev.2004.12.002.]

Bobrov, Alexander, Hurskiy, D., Merkushyn, I., Voloshyn, O., Stepanyuk, L., Lysenko, O, and Goshovski, S., 2008, The first occurrence of native rhenium in natural geological systems [abs.], in 33rd International Geological Congress, 6-14 August 2008, Oslo, Norway (abstracts): International Geological Congress, 33d, Oslo, Norway, 2008, accessed February 11, 2013, at http://www.cprm.gov.br/33IGC/ 1342433.html.

Box, S.E., Syusyura, Boris, Hayes, T.S., Taylor, C.D., Zientek, M.L., Hitzman, M.W., Seltmann, Reimer, Chechetkin, Vladimir, Dolgopolova, Alla, Cossette, P.M., and Wallis, J.C., 2012, Sandstone copper assessment of the Chu-Sarysu basin, central Kazakhstan: U.S. Geological Survey Scientific Investigations Report 2010-5090-E, 63 p. and spatial data tables, accessed January 7, 2013, at http://pubs.usgs.gov/sir/2010/5090/e/sir2010-5090e_text.pdf.

Box, S.E., Syusyura, Boris, Seltmann, Reimar, Creaser, R.A., Dolgopolova, Alla, and Zientek, M.L., 2013, Dzhezkazgan and associated sandstone copper deposits of the Chu-Sarysu basin, central Kazakhstan, in Hedenquist, J.W., Harris, Michael, and Camus, Francisco, eds., Geology and genesis of major copper deposits and districts of the world-A tribute to Richard H. Sillitoe (1st ed.): Littleton, Colo., Society of Economic Geologists Special Publication no. 16, p. 303-328. 
Bozhkov, O.D., and Borisova, L.V., 2003, Extraction and determination of trace amounts of rhenium in plants: International Journal of Environmental Analytical Chemistry, v. 83 , no. 2, p. 135-141. [Also available at http://dx.doi.org/ 10.1080/0306731021000048627.]

Brown, J.G., Bassett, R.L., and Glynn, P.D., 1998, Analysis and simulation of reactive transport of metal contaminants in ground water in Pinal Creek Basin, Arizona: Journal of Hydrology, v. 209, nos. 1-4, p. 225-250. [Also available at http://dx.doi.org/10.1016/S0022-1694(98)00091-2.]

Brown, Mat, Lazo, Florinio, Caeter, Paul, Goss, Barry, and Kirwin, Doug, 2010, The geology and discovery of the Merlin Mo-Re zone of the Mount Dore deposit, Mount Isa Inlier, NW Queensland, Australia: SGA News, no. 27, p. 1, 9-15. [Also available at http://e-sga.org/fileadmin/sga/ newsletter/news27/SGANews27.pdf.]

Cannell, J.B., 2004, El Teniente porphyry copper-molybdenum deposit, central Chile: Hobart, Tasmania, Australia, University of Tasmania, Ph.D. thesis, 317 p. plus 6 appendixes.

Carten, R.B., White, W.H., and Stein, H.J., 1993, High-grade granite-related molybdenum systems - Classification and origin, in Kirkham, R.V., Sinclair, W.D., Thorpe, R.I., and Duke, J.M., eds., Mineral deposit modeling: St. John's, Newfoundland, Canada, Geological Association of Canada, Dept. of Earth Sciences, Memorial University of Newfoundland Special Paper no. 40, p. 521-554.

Castendyk, D.N., and Eary, L.E., eds., 2009, Mine pit lakesCharacteristics, predictive modeling, and sustainability: Littleton, Colo., Society for Mining, Metallurgy, and Exploration, Management Technologies for Metal Mining Influenced Water Series, v. 3, 304 p.

Cazes, D.K., Domenico, J.A., Hopkins, D.M., and Leach, D.L., 1981, Geochemical analyses of stream sediments and heavymineral concentrates collected near a stratabound $\mathrm{Cu}-\mathrm{Ag}$ occurrence in the Cabinet Mountains Wilderness, Montana: U.S. Geological Survey Open-File Report 81-665, 29 p. [Also available at http://pubs.usgs.gov/of/1981/0665/report.pdf.]

Chaffee, M.A., 1976, Geochemical exploration techniques based on distribution of selected elements in rocks, soils, and plants, Mineral Butte copper deposit, Pinal County, Arizona: U.S. Geological Survey Bulletin 1278-D, 55 p. [Also available at http://pubs.usgs.gov/bul/1278d/ report.pdf.]

Chaffee, M.A., 1977, Geochemical exploration techniques based on distribution of selected elements in rocks, soils, and plants, Vekol porphyry copper deposit area, Pinal County, Arizona: U.S. Geological Survey Bulletin 1278-E, 78 p. [Also available at http://pubs.usgs.gov/bul/1278e/ report.pdf.]
Chaffee, M.A., Hill, R.H., Sutley, S.J., and Waterson, J.R., 1981, Regional geochemical studies in the Patagonia Mountains, Santa Cruz County, Arizona: Journal of Geochemical Exploration, v. 14, p. 135-153. [Also available at http://dx.doi.org/10.1016/0375-6742(81)90109-6.]

Chen, Zhiguang, Zhang, Lianchang, Wan, Bo, Wu, Huaying, and Cleven, Nathan, 2011, Geochronology and geochemistry of the Wunugetushan porphyry Cu-Mo deposit in NE China, and their geological significance: Ore Geology Reviews,v. 43, no. 1, p. 92-105. [Also available at http://dx.doi.org/10.1016/j.oregeorev.2011.08.007.]

Chesley, J.T., and Ruiz, Joaquin, 1998, Preliminary Re-Os dating on molybdenite mineralization from the Bingham Canyon porphyry copper deposit, Utah, in John, D.A., and Ballantyne, G.H., eds. Geology and ore deposits of the Oquirrh and Wasatch Mountains, Utah: Society of Economic Geologists Guidebook Series, v. 29, p. $165-169$.

Clark, Jeremy, and Baudry, Philippe, 2011, Zuun Mod porphyry molybdenum-copper project, south-western Mongolia, NI 43-101 report prepared for Erdene Resource Development Corp.: Beijing, China, Minarco-Mine Consult, Project no. ADV-MN-00026; 64 p., accessed March 18, 2013, at http://www.erdene.com/assets/pdf/ZuunMod43-101 TechnicalReport_MinarcoJune2011.pdf.

Colodner, Debra, Sachs, Julian, Ravizza, Gregory, Turekian, Karl, Edmond, John, and Boyle, Edward, 1993, The geochemical cycle of rhenium - A reconnaissance: Earth and Planetary Science Letters, v. 117, nos. 1-2, p. 205-221. [Also available at http://dx.doi.org/10.1016/0012-821X(93)90127-U.]

Conklin, Martha, Villinski, John, and Kay, John, 2001, Geochemistry of acid mine contamination-aquifer interactions: International Journal of Occupational Medicine and Environmental Health, v. 14, no. 3, p. 249-259. [Also available at http://test.imp.lodz.pl/upload/oficyna/artykuly/pdf/full/ Conklin7-03-01.pdf.]

Cox, D.P., and Singer, D.A., 1992, Gold-Distribution of gold in porphyry copper deposits, chap C of DeYoung, J.H., Jr., and Hammarstrom, J.M., eds., Contributions to commodity geology research: U.S. Geological Survey Bulletin 1877, p. C1-C14. [Also available at http://pubs.usgs.gov/bul/1877/ report.pdf.]

Cox, D.P., Lindsey, D.A., Singer, D.A., Moring, B.C., and Diggles, M.F., 2003, Sediment-hosted copper deposits of the world-Deposit models and database (version 1.3): U.S. Geological Survey Open-File Report 03-107. [Also available at http://pubs.usgs.gov/of/2003/ of03-107/.] 
Cunningham, C.G., Zappettini, E.O., Vivallo S., Waldo, Celada, C.M., Quispe, Jorge, Singer, D.A., Briskey, J.A., Sutphin, D.M., Gajardo M., Mariano, Diaz, Alejandro, Portigliati, Carlos, Berger, V.I., Carrasco, Rodrigo, and Schulz, K.J., 2008, Quantitative mineral resource assessment of copper, molybdenum, gold, and silver in undiscovered porphyry copper deposits in the Andes Mountains of South America (version 1.0): U.S. Geological Survey OpenFile Report 2008-1253, 282 p., CD-ROM. [Also available at http://pubs.usgs.gov/of/2008/1253/ofr2008-1253.pdf.]

Dahlkamp, F.J., 2009a, Kazakhstan, in Dahlkamp, F.J., ed., Uranium deposits of the world-Asia: Berlin, Germany, Springer-Verlag, p. 181-189. [Also available at http://dx.doi.org/10.1007/978-3-540-78558-3.]

Dahlkamp, F.J., 2009b, Uzbekistan, in Dahlkamp, F.J., ed., Uranium deposits of the world-Asia: Berlin, Germany, Springer-Verlag, p. 397-400. [Also available at http://dx.doi.org/10.1007/978-3-540-78558-3.]

Daukeev, S.Z., Ushkenov, B.S., Bespaev, K.A., Miroshnichenko, L.A., Mazurov, A.K., and Sayduakasov, M.A., eds., 2004, Republic of Kazakhstan-Atlas of mineral deposit models: Almaty, Kazakhstan, K.I. Satpaev Institute of Geological Sciences, Ministry of Education and Science, $141 \mathrm{p}$.

Day, Stephen, and Rees, Ben, 2006, Geochemical controls on waste-rock dump seepage chemistry at several porphyry mines in the Canadian Cordillera, in Barnhisel, R.I., ed., 7th International Conference on Acid Rock Drainage (ICARD) - St. Louis, Missouri, USA, March 26-30, 2006: Lexington, Ky., American Society of Mining and Reclamation, p. 439-456, CD-ROM. [Also available at https:/imwa.info/docs/imwa_2006/0439-Day-BC.pdf.]

Deckart, Katja, Clark, A.H., Cuadra, Patricio, and Fanning, Mark, 2013, Refinement of the time-space evolution of the giant Mio-Pliocene Río Blanco-Los Bronces porphyry $\mathrm{Cu}-\mathrm{Mo}$ cluster, central Chile- New U-Pb (SHRIMP II) and Re-Os geochronology and ${ }^{40} \mathrm{Ar} /{ }^{39} \mathrm{Ar}$ thermochronology data: Mineralium Deposita, v. 48, no. 1, p. 57-79. [Also available at http://dx.doi.org/10.1007/s00126-012-0412-9.]

Deng, X.H., Chen, Y.J., Santosh, M., Zhao, G.C., and Yao, J.M., 2013, Metallogeny during continental outgrowth in the Columbia supercontinent-Isotopic characterization of the Zhaiwa Mo-Cu system in the North China Craton: Ore Geology Reviews, v. 51, p. 43-56. [Also available at http://dx.doi.org/10.1016/j.oregeorev.2012.11.004.]

Dold, Bernhard, and Fontboté, Lluis, 2001, Element cycling and secondary mineralogy in porphyry copper tailings as a function of climate, primary mineralogy, and mineral processing: Journal of Geochemical Exploration, v. 74, nos. 1-3, p. 3-55. [Also available at http://dx.doi.org/ 10.1016/S0375-6742(01)00174-1.]
Duncan, R.J., Stein, H.J., Evans, K.A., Hitzman, M.W., Nelson, E.P., and Kirwin, D.J., 2011, A new geochronological framework for mineralization and alteration in the Selwyn-Mount Dore corridor, eastern fold belt, Mount Isa Inlier, Australia - Genetic implications for iron oxide copper-gold deposits: Economic Geology, v. 106, p. 169-192. [Also available at http://dx.doi.org/10.2113/econgeo.106.2.169.]

Emsley, John, 2001, Rhenium, in Nature's building blocksAn A-Z guide to the elements: New York, N.Y., Oxford University Press, p. 358-360.

Enders, M.S., Knickerbocker, Chris, Titley, S.R., and Southam, Gordon, 2006, The role of bacteria in the supergene environment of the Morenci porphyry copper deposit, Greenlee County, Arizona: Economic Geology, v. 101, p. 59-70. [Also available at http://dx.doi.org/ 10.2113/101.1.59.]

Eychaner, J.H., 1991, The Globe, Arizona, research siteContaminants related to copper mining in a hydrologically integrated environment, in Mallard, G.E., and Aronson, D.A., eds., U.S. Geological Survey toxic substances hydrology program-Proceedings of the technical meeting, Monterey, California, March 11-15, 1991: U.S. Geological Survey Water-Resources Investigations Report 91-4034, p. 439-447. [Also available at http://pubs.usgs.gov/ wri/1991/4034/report.pdf.]

Fey, D.L., Granitto, Matthew, Giles, S.A., Smith, S.M., Eppinger R.G., and Kelley, K.D., 2008, Geochemical data for samples collected in 2007 near the concealed Pebble porphyry $\mathrm{Cu}-\mathrm{Au}-\mathrm{Mo}$ deposit, southwest Alaska: U.S. Geological Survey Open-File Report 2008-1132, 154 p., accessed on June 1, 2015, at http://pubs.usgs.gov/ of $/ 2008 / 1132 /$.

Finlay, I.G., Mason, M.D., and Shelley, Mike, 2005, Radioisotopes for the palliation of metastatic bone cancerA systematic review: Lancet Oncology, v. 6, no. 6, p. 392-400. [Also available at http://dx.doi.org/10.1016/ s1470-2045(05)70206-0.]

Fleischer, Michael, 1959, The geochemistry of rhenium, with special reference to its occurrence in molybdenite: Economic Geology, v. 54, p. 1406-1413. [Also available at http://dx.doi.org/10.2113/gsecongeo.54.8.1406.]

Fleischer, Michael, 1960, The geochemistry of rheniumAddendum: Economic Geology, v. 55, p. 607-609. [Also available at http://dx.doi.org/10.2113/gsecongeo.55.3.607.]

Fleischer, Michael, 1963, New mineral names-Dzhezkazganite: American Mineralogist, v. 48, January to February, p. 209. [Also available at http://www.minsocam.org/ammin/ AM48/AM48_209.pdf.] 
Gammons, C.H., and Duaime, T.E., 2005, Long term changes in the limnology and geochemistry of the Berkeley pit lake, Butte, Montana: Mine Water and the Environment, v. 25, no. 2, p. 76-85. [Also available at http://dx.doi.org/10.1007/ s10230-006-0114-6.]

Gammons, C.H., Metesh, J.J., and Duaime, T.E., 2005, An overview of the mining history and geology of Butte, Montana: Mine Water and the Environment, v. 25, no. 2, p. 70-75. [Also available at http://dx.doi.org/10.1007/ s10230-006-0113-7.]

Genkin, A.D., Poplavko, Ye.M., Gorshkov, A.I., Tsepin, A.I., and Sivtsov, A.V., 1994, Novyye dannyye o dzhezkazganitesul'fide reniya, molibdena, medi i svintsa-iz mestorozhdeiya Dzhezkazgan (Kazakhstan) [New data on dzhezkazganite-Rhenium, molybdenum, copper, and lead sulfide from ore deposits in Dzhezkazgan (Kazakhstan)]: Geologiya Rudnykh Mestorozhdeniy [Geology of Ore Deposits], v. 36, no. 6, p. 536-544.

Ghaffari, Hassan, Morrison, R.S., de Ruijter, M.A., Živković, Aleksandar, Hantelmann, Tysen, Ramsey, Douglas, and Cowie, Scott, 2011, Preliminary assessment of the Pebble project, southwest Alaska-Report prepared for Northern Dynasty Minerals Ltd.: Vancouver, British Columbia, Canada, Waldrop, Document No. 1056140100REP-R0001-00, 579 p., accessed October 31, 2013, via http://www.sedar.com/.

Giles, D.L., and Schilling, J.H., 1972, Variation in the rhenium content of molybdenite, in Program - 24th International Geological Congress, Montreal, Canada, 1972 Proceedings of sec. 10: Ottawa, Ontario, Canada, International Geological Congress, p. 145-153.

Giroux, Gary, and Casselman, Scott, 2012, Updated resource report for the Hushamu deposit, northern Vancouver Island, British Columbia, Canada-NI 43-101 technical report, prepared for Northisle Copper and Gold, Inc: Whitehorse, Yukon, Canada, Giroux Consultants Ltd., August 27, 86 p., accessed April 25, 2013, at http://www.northisle.ca/i/pdf/ techreports/NI43-101-Updated_Resource_Report_ Hushamu_Deposit_2012.pdf.

Global Metals (ARM) Ltd., 2015, Molibdeny Ashkharh LLCDastakert copper-molybdenum deposit: Global Metals (ARM) Ltd. Web page, accessed August 20, 2015, at http:// www.globalmetals.am/en/projects/molibdeny_ashkharh/.)

Graybeal, F.T., and Vikre, P.G., 2010, Porphyry copper exploration and resource assessment guides, section $\mathrm{R}$ in John, D.A., ed., Ayuso, R.A., Barton, M.D., Blakely, R.J., Bodnar, R.J., Dilles, J.H., Gray, Floyd, Graybeal, F.T., Mars, J.C., McPhee, D.K., Seal, R.R., Taylor, R.D., and Vikre, P.G., 2010, Porphyry copper deposit modelchap. B of Mineral deposit models for resource assessment: U.S. Geological Survey Scientific Investigations Report 2010-5070-B, p. 116-122. [Also available at http://pubs.usgs.gov/sir/2010/5070/b/.]
Grzebisz, W., Cieśla, L, and Diatta, J.B., 2001, Spatial distribution of copper in arable soils and in non-consumable crops (flax, oil-seed rape) cultivated near a copper smelter: Polish Journal of Environmental Studies, v. 10, no. 4, p. 269-272.

Hammarstrom, J.M., Robinson, G.R., Jr., Ludington, Steve, Gray, Floyd, Drenth, B.J., Cendejas-Cruz, Francisco, Espinosa, Enrique, Pérez-Segura, Efrén, Valencia-Moreno, Martín, Rodríguez-Castañeda, José Luis, Vásquez-Mendoza, Rigoberto, and Zürcher, Lukas, 2010, Global mineral resource assessment-Porphyry copper assessment of Mexico: U.S. Geological Survey Scientific Investigations Report 2010-5090-A, 176 p., accessed January 7, 2013, at http://pubs.usgs.gov/sir/2010/5090/a/sir2010-5090a_text.pdf.

Hammer, J., Junge, F., Rösler, H.J., Niese, S., Gleisberg, B., and Stiehl, G., 1990, Element and isotope geochemical investigations of the Kupferschiefer in the vicinity of "Rote Fäule", indicating copper mineralization (Sangerhausen basin, G.D.R.): Chemical Geology, v. 85, nos. 3-4, p. 345-360. [Also available at http://dx.doi.org/10.1016/ 0009-2541(90)90012-V.]

Hayes, T.S., and Einaudi, M.T., 1986, Genesis of the Spar Lake strata-bound copper-silver deposit, Montana-Part 1, Controls inherited from sedimentation and preore diagenesis: Economic Geology, v. 81, p. 1899-1931. [Also available at http://dx.doi.org/10.2113/gsecongeo.81.8.1899.]

Hayes, T.S., Cox, D.P., Piatak, N.M., Seal, R.R., II, Taylor, C.D., Wilson, A.B., and Denning, P.D., 2015, Sediment-hosted stratabound copper deposit model, chap. M of Mineral deposit models for resource assessment: U.S. Geological Survey Scientific Investigations Report 2010-5070-M, 147 p.

Helios Rybicka, E., and Jędrzejczyk, B., 1995, Preliminary studies on mobilisation of copper and lead from contaminated soils and readsorption on competing sorbents: Applied Clay Science, v. 10, no. 3, p. 259-268. [Also available at http://dx.doi.org/10.1016/0169-1317(95)00006-P.]

Hitzman, Murray, Kirkham, Rodney, Broughton, David, Thorson, Jon, and Selley, David, 2005, The sedimenthosted stratiform copper ore system, in Hedenquist, J.W., Thompson, J.F.H., Goldfarb, R.J., and Richards, J.P., eds., Economic Geology-One hundredth anniversary volume, 1905-2005: Littleton, Colo., Society of Economic Geologists, p. 609-642. [Appendixes are on a CD-ROM inside the back cover.]

Hodge, V.F., Johannesson, K.H., and Stetzenbach, K.J., 1996, Rhenium, molybdenum, and uranium in groundwater from the southern Great Basin, USA-Evidence for conservative behavior: Geochimica et Cosmochimica Acta, v. 60, no. 17, p. 3197-3214. [Also available at http://dx.doi.org/10.1016/ 0016-7037(96)00183-4.] 
Hou, Zengqian, Yang, Zhiming, Qu, Xiaoming, Meng, Xiangjin, Li, Zhenqing, Beaudoin, G., Rui, Zongyao, Gao, Yongfeng, and Zaw, Khin , 2009, The Miocene Gangdese porphyry copper belt generated during post-collisional extension in the Tibetan Orogen: Ore Geology Reviews, v. 36, issues 1-3, p. 25-51. [Also available at http://dx.doi.org/ 10.1016/j.oregeorev.2008.09.006.]

Hou, Zengqian, Zeng, Pusheng, Gao, Yongfeng, Du, Andao, and Deming, $\mathrm{Fu}, 2006$, Himalayan $\mathrm{Cu}-\mathrm{Mo}-\mathrm{Au}$ mineralization in the eastern Indo-Asian collision zone-Constraints from Re-Os dating of molybdenite: Mineralium Deposita, v. 41, no. 1, p. 33-45. [Also available at http://dx.doi.org/ 10.1007/s00126-005-0038-2.]

Hou, Zengqian, Zhang, Hongrui, Pan, Xiaofei, and Yang, Zhiming, 2011, Porphyry $\mathrm{Cu}$ (-Mo-Au) deposits related to melting of thickened mafic lower crust-Examples from the eastern Tethyan metallogenic domain: Ore Geology Reviews, v. 39, nos. 1-2, p. 21-45. [Also available at http://dx.doi.org/10.1016/j.oregeorev.2010.09.002.]

Hudson, Travis, Smith, J.G., and Elliot, R.L., 1979, Petrology, composition, and age of intrusive rocks associated with the Quartz Hill molybdenite deposit, southeastern Alaska: Canadian Journal of Earth Sciences, v. 16, no. 9, p. 18051822. [Also available at http://dx.doi.org/10.1139/e79-165.]

International Network for Acid Prevention, 2011, Global acid rock drainage guide: International Network for Acid Prevention, accessed November 11, 2011, at http://www.gardguide.com.

Ishihara, Shunso, 1988, Rhenium contents of molybdenites in granitoid-series rocks in Japan: Economic Geology, v. 83, p. 1047-1051. [Also available at http://dx.doi.org/10.2113/ gsecongeo.83.5.1047.]

Jankowski, Gunter, ed., 1995, Zur geschichte des Mansfelder Kupferschiefer-Bergbaus [The history of the Mansfeld copper shale mining]: Clausthal-Zellerfeld, Germany, Gesellschaft Deutscher Metallhütten- und Bergleute, 370 p., folded page with 2 maps.

John, D.A., Ayuso, R.A., Barton, M.D., Blakely, R.J., Bodnar, R.J., Dilles, J.H., Gray, Floyd, Graybeal, F.T., Mars, J.C., McPhee, D.K., Seal, R.R., Taylor, R.D., and Vikre, P.G., 2010, Porphyry copper deposit model, chap. B of Mineral deposit models for resource assessment: U.S. Geological Survey Scientific Investigations Report 2010-5070-B, 169 p. [Also available at http://pubs.usgs.gov/sir/2010/5070/b/.]

John, D.A., and Taylor, R.D., 2016, Byproducts of porphyry copper and molybdenum deposits, in Verplanck, P.L., and Hitzman, M.W., eds., Rare earth and critical elements in ore deposits: Reviews in Economic Geology, v. 18, p. 137-164.
Jowett, E.C., 1986, Section D. Kupferschiefer ore-genesis model, in Jowett, E.C., ed., Kupferschiefer and other sediment-hosted deposits in central Europe: Ottawa, Ontario, Canada, Geological Association of CanadaMineralogical Association of Canada-Canadian Geophysical Union Joint Annual Meeting Field Trip Guidebook 12, p. $42-52$.

Kabala, Cezary, and Singh, B.R., 2001, Fractionation and mobility of copper, lead, and zinc in soil profiles in the vicinity of a copper smelter: Journal of Environmental Quality, v. 30, no. 2, p. 485-492. [Also available at http://dx.doi.org/10.2134/jeq2001.302485x.]

Karczewska, Anna, 1996, Metal species distribution in top- and sub-soil in an area affected by copper smelter emissions: Applied Geochemistry, v. 11, nos. 1-2, p. 35-42. [Also available at http://dx.doi.org/10.1016/ 0883-2927(95)00063-1.]

Khalezov, A.B., 2009, Problem of rhenium mineral resources expansion in Russian Federation: Razvedka I Okhrana Nedr, no. 8, p. 13-17.

Khashgerel, B.-E., Rye, O.R., Hedenquist, J.W., and Kavalieris, Imants, 2006, Geology and reconnaissance stable isotope study of the Oyu Tolgoi porphyry $\mathrm{Cu}-\mathrm{Au}$ system, South Gobi, Mongolia: Economic Geology, v. 101, p. 503-522. [Also available at http://dx.doi.org/10.2113/ gsecongeo.101.3.503.]

Khorasanipour, Mehdi, Tangestani, M.H., Naseh, Reza, and Hajmohammadi, Hamid, 2011, Hydrochemistry, mineralogy and chemical fractionation of mine and processing wastes associated with porphyry copper mines - A case study of the Sarcheshmeh Mine, SE Iran: Applied Geochemistry, v. 26, no. 5, p. 714-730. [Also available at http://dx.doi.org/ 10.1016/j.apgeochem.2011.01.030.]

Kim, E., and Boulègue, J., 2003, Chemistry of rhenium as an analogue of technetium-Experimental studies of the dissolution of rhenium oxides in aqueous solutions: Radiochimica Acta, v. 91, no. 4, p. 211-216. [Also available at http://dx.doi.org/10.1524/ract.91.4.211.19968.]

Klemm, L.M., Pettke, Thomas, Heinrich, C.A., and Campos, E., 2007, Hydrothermal evolution of the El Teniente deposit, Chile-Porphyry Cu-Mo ore deposition from low-salinity fluids: Economic Geology, v. 102, p. 1021-1045. [Also available at http://dx.doi.org/10.2113/ gsecongeo.102.6.1021.]

Koide, M., Hodge, V.F., Yang, J.S., Stallard, M., and Goldberg, E.G., 1986, Some comparative marine chemistries of rhenium, gold, silver and molybdenum: Applied Geochemistry, v. 1, no. 6, p. 705-714. [Also available at http://dx.doi.org/10.1016/0883-2927(86)90092-2.] 
Kojonen, K.K., Roberts, A.C., Isomäki, O-.P., Knauf, V.V., Johanson, Bo, and Pakkanen, Lassi, 2004, Tarkianite, $(\mathrm{Cu}, \mathrm{Fe})(\mathrm{Re}, \mathrm{Mo})_{4} \mathrm{~S}_{8}$, a new mineral species from the Hitura Mine, Nivala, Finland: Canadian Mineralogist, v. 42, no. 2, p. 539-544. [Also available at http://dx.doi.org/ 10.2113/gscanmin.42.2.539.]

Korzhinsky, M.A., Tkachenko, S.I., Shmulovich, K.I., Taran, Y.A., and Steinberg, G.S., 1994, Discovery of a pure rhenium mineral at Kudriavy volcano: Nature, v. 369, no. 6475, p. 51-52. [Also available at http://dx.doi.org/10.1038/369051a0.]

Kruger, Joachim, 2006, Copper mining and metallurgy in prehistoric and the more recent past, in von Gleich, Arnim, Ayres, R.U., and Gößling-Reisemann, Stefan, eds., Sustainable metals management - Securing our futureSteps towards a closed loop economic efficiency in industry and science: Dordrecht, Netherlands, Springer, Eco-Efficiency in Industry and Science Series, v. 19, p. 417-448.

Kucha, H., 2003, Geology, mineralogy, and geochemistry of the Kupferschiefer, Poland, in Kelly, J.G., Andrew, C.J., Ashton, J.H., Boland, M.B., Earls, G., Fusciardi, L., and Stanley, G., eds., Europe's major base metal deposits: Dublin, Ireland, Irish Association for Economic Geology, p. 215-238, folded map as insert.

Landtwing, M.R., Furrer, Caroline, Redmond, P.B., Pettke, Thomas, Guillong, Marcel, and Heinrich, C.A., 2010, The Bingham Canyon porphyry $\mathrm{Cu}-\mathrm{Mo}-\mathrm{Au}$ deposit. III. Zoned copper-gold ore deposition by magmatic vapor expansion: Economic Geology, v. 105, p. 91-118. [Also available at http://dx.doi.org/10.2113/gsecongeo.105.1.91.]

Lang, J.R., Gregory, M.J., Rebagliati, C.M., Payne, J.G., Oliver, J.L., and Roberts, Keith, 2013, Geology and magmatic-hydrothermal evolution of the giant Pebble porphyry copper-gold-molybdenum deposit, southwest Alaska: Economic Geology, v. 108, p. 437-462. [Also available at http://dx.doi.org/10.2113/econgeo.108.3.437.]

Learned, R.E., and Boissen, Rafael, 1973, Gold, a useful pathfinder element in the search for porphyry copper deposits in Puerto Rico, in Jones, M.J., ed., Geochemical exploration, 1972 - Proceedings of the Fourth International Geochemical Exploration Symposium, London, United Kingdom, April 17-20, 1972: London, United Kingdom, Institution of Mining and Metallurgy, p. 93-103.

Leybourne, M.I., and Cameron, E.M., 2006. Composition of groundwaters associated with porphyry-Cu deposits, Atacama Desert, Chile_-Elemental and isotopic constraints on water sources and water-rock reactions: Geochimica et Cosmochimica Acta, v. 70, no. 7, p. 1616-1635. [Also available at http://dx.doi.org/10.1016/j.gca.2005.12.003.]
Leybourne, M.I., and Cameron, E.M., 2008, Source, transport, and fate of rhenium, selenium, molybdenum, arsenic, and copper in groundwater associated with porphyry-Cu deposits, Atacama Desert, Chile: Chemical Geology, v. 247, nos. 1-2, p. 208-228. [Also available at http://dx.doi.org/10.1016/j.chemgeo.2007.10.017.]

Lind, C.J., Creasey, C.L., and Angeroth, Cory, 1998, In-situ alteration of minerals by acidic ground water resulting from mining activities - Preliminary evaluation of method: Journal of Geochemical Exploration, v. 64, nos. 1-3, p. 293-305. [Also available at http://dx.doi.org/10.1016/ s0375-6742(98)00039-9.]

Lindsey, D.A., Woodruff, L.G., Cannon, W.F., Cox, D.P., and Heran, W.D., 1995, Sediment-hosted Cu deposits, chap. 28 of du Bray, E.A., ed., Preliminary compilation of descriptive geoenvironmental mineral deposit models: U.S. Geological Survey Open-File Report 95-831, p. 214-224. [Also available at http://pubs.usgs.gov/of/1995/ofr-95-0831/.]

Lipmann Walton \& Co. Ltd., 2010, Rhenium, is it critical?: Lipmann Walton \& Co. Ltd. Web page, accessed March 13, 2013, at http://www.lipmann.co.uk/articles/ metal-matters/rhenium-is-it-critical-2/.

Ludington, Steve, and Plumlee, G.S., 2009, Climax-type porphyry molybdenum deposits: U.S. Geological Survey Open-File Report 2009-1215, 16 p. [Also available at http://pubs.usgs.gov/of/2009/1215/pdf/OF09-1215.pdf.]

Ludington, Steve, Cox, D.P., and McCammon, R.B., eds., 1996, Database for a national mineral resource assessment of undiscovered deposits of gold, silver, copper, lead, and zinc - Conterminous United States: U.S. Geological Survey Open-File Report 96-96, 2,037 p., CD-ROM. [Also available at http://pubs.usgs.gov/of/1996/of96-096/.] (A portable document format (PDF) recompilation of USGS Open-File Report 96-96 and USGS Circular 1178 was released as USGS Open-File Report 02-198 in 2002 and is available at http://pubs.er.usgs.gov/publication/ofr2002198.)

Lüschen, Holger, Schnetger, Bernhard, Brumsack, Hans-Juergen, and Paul, Josef, 2000a, Trace element distribution in Palaeozoic black shales_- "Kupferschiefer" (Germany) and Exshaw Formation (Canada) [abs.], in Goldschmidt 2000 Conference, September 3-8, 2000, Oxford, United Kingdom: Journal of Conference Abstracts, v. 5, no. 2, p. 656. [Also available at http://www.the-conference.com/ JConfAbs/5/ALLABS.PDF.]

Lüschen, Holger, Schnetger, Bernhard, Brumsack, H.-J., and Paul, Josef, 2000b, Trace element distribution in Palaeozoic black shales - "Kupferschiefer" (Germany) and Exshaw Formation (Canada) [conference poster]: Oldenburg, Germany, Carl von Ossietzky University of Oldenburg, Institute for Chemistry and Biology of the Marine Environment (ICBM), accessed March 12, 2013, at http:/www.icbm.de/ fu/icbm/ag/mbgc/HolgerL/PosterKupferExshawA4.pdf. 
Lycopodium Minerals QLD Pty Ltd., 2012, NI 43-101 technical report, Merlin molybdenum rhenium project, feasibility study, northwest Queensland, Australia: Spring Hill, Queensland, Australia, Lycopodium Minerals QLD Pty Ltd., 302 p., accessed March 14, 2013, at http://www.ivanhoeaustralia.com/i/pdf/NI43-101_ Merlin_Technical_Report.pdf.

MacDonald, D.D., Ingersoll, C.G., and Berger, T.A., 2000, Development and evaluation of consensus-based sediment quality guidelines for freshwater ecosystems: Archives of Environmental Contamination and Toxicology, v. 39, no. 1, p. 20-31. [Also available at http://dx.doi.org/10.1007/ s002440010075.]

Maksaev, V., Munizaga, F., McWilliams, M., Fanning, M., Mathur, R., Ruiz, J., and Zentilli, M., 2004, New chronology for El Teniente, Chilean Andes, from U-Pb, ${ }^{40} \mathrm{Ar} /{ }^{39} \mathrm{Ar}$, $\mathrm{Re}-\mathrm{Os}$, and fission track dating-Implications for the evolution of a supergiant porphyry $\mathrm{Cu}-\mathrm{Mo}$ deposit, in Sillitoe, R.H., Perelló, J., and Vidal, C.E., eds., Andean metallogeny-New discoveries, concepts and updates: Littleton, Colo., Society of Economic Geologists Special Publication 11, p. 15-54.

Mao, J.W., Pirajno, F., Xiang, J.F., Gao, J.J., Ye, H.S., Li, Y.F., and Guo, B.J., 2011, Mesozoic molybdenum deposits in the east Qinling-Dabie orogenic belt—Characteristics and tectonic settings: Ore Geology Reviews, v. 43, no. 1, p. 264-293. [Also available at http://dx.doi.org/10.1016/ j.oregeorev.2011.07.009.]

Markey, Richard, Stein, H.J., Hannah, J.L., Zimmerman, Aaron, Selby, David, and Creaser, R.A., 2007, Standardizing Re-Os geochronology_A new molybdenite reference material (Henderson, USA) and the stoichiometry of Os salts: Chemical Geology, v. 244, nos. 1-2, p. 74-87. [Also available at http://dx.doi.org/10.1016/j.chemgeo.2007.06.002.]

Masterman, G.J., Cooke, D.R., Berry, R.F., Clark, A.H., Archibald, D.A., Mathur, Ryan, Walshe, J.L., and Durán, Manuel, 2004, ${ }^{40} \mathrm{Ar} /{ }^{39} \mathrm{Ar}$ and Re-Os geochronology of porphyry copper-molybdenum deposits and related copper-silver veins in the Collahuasi district, northern Chile: Economic Geology, v. 99, p. 673-690. [Also available at http://dx.doi.org/10.2113/gsecongeo.99.4.673.]

Mathur, R., Ruiz, J.R., and Munizaga, F.M., 2001, Insights into Andean metallogenesis from the perspective of Re-Os analyses of sulfides: Santiago, Chile, University of Chile, Department of Geology, 4 p., accessed March 7, 2013, at http://www.cec.uchile.cl/ vmaksaev/S5_Mathur.pdf.

McCandless, T.E., and Ruiz, Joaquin, 1993, Rhenium-osmium evidence for regional mineralization in southwestern North America: Science, v. 261, no. 5126, p. 1282-1286. [Also available at http://dx.doi.org/10.1126/science. 261.5126.1282.]
Mihalasky, M.J., Bookstrom, A.A., Frost, T.P., and Ludington, Steve, 2013, Porphyry copper assessment of British Columbia and Yukon Territory, Canada (version 1.1): U.S. Geological Survey Scientific Investigations Report 2010-5090-C, 128 p., January 7, 2013, at http://pubs.usgs.gov/sir/2010/5090/c/sir2010-5090c_text.pdf.

Millensifer, T.A., 1997, Rhenium background and markets, in Bryskin, D.D., ed., Rhenium and rhenium alloys: Warrendale, Pa., The Minerals, Metals and Materials Society, p. 37-47.

Millensifer, T.A., Sinclair, David, Jonasson, Ian, and Lipmann, Anthony, 2014, Rhenium, in Gunn, Gus, ed., Critical metals handbook (1st ed.): Hoboken, N.J., Wiley-Blackwell, p. $340-360$.

Minor Metals Trade Association, 2012, Minor metals in the periodic table-Rhenium: Minor Metals Trade Association Web page, accessed October 5, 2012, at http://www.mmta.co.uk/metals/Re/.

Mosher, G.Z., 2001, Technical report on the Nithi Mountain molybdenum property, British Columbia, Canada, prepared for Leeward Capital Corp., Document no. 1192110100L0001-00: Vancouver, British Columbia, Canada, Tetra Tech Wardrop, 41 p., accessed April 26, 2013, at http://leewardcapital.com/NewsFiles/1192110100-REPL0001-00\%20FINAL.pdf.

Mwase, M., Viktor, T., and Norrgren, L., 1998, Effects on tropical fish of soil sediments from Kafue River, Zambia: Bulletin of Environmental Contamination and Toxicology, v. 61, no. 1, p. 96-101. [Also available at http://dx.doi.org/ 10.1007/s001289900734.]

Nadler, H.-G., 1997, Rhenium, in Habashi, Fathi, ed., Handbook of extractive metallurgy-Precious metals, refractory metals, scattered metals, radioactive metals, rare earth metals: New York, N.Y., Wiley-VCH, v. 3, p. 1491-1501.

Natural Earth, 2014, Small scale data: Natural Earth map dataset, scale 1:110,000,000, accessed June 23, 2014, at http://www.naturalearthdata.com.

Newberry, R.J., 1979, Polytypism in molybdenite (II) Relationships between polytypism, ore deposition/alteration stages and rhenium contents: American Mineralogist, v. 64, nos. 7-8, p. 768-775.

Norrgren, L., Pettersson, U., Orn, S., and Bergqvist, P.-A., 2000, Environmental monitoring of the Kafue River, located in the copperbelt, Zambia: Archives of Environmental Contamination and Toxicology, v. 38, no. 3, p. 334-341. [Also available at http://dx.doi.org/10.1007/s002449910044.]

Oszczepalski, S., 1999, Origin of the Kupferschiefer polymetallic mineralization in Poland: Mineralium Deposita, v. 34, nos. 5-6, p. 599-613. [Also available at http://dx.doi.org/ 10.1007/s001260050222.] 
Pašava, Jan, Oszczepalski, Slawomir, and Du, Andao, 2010, Re-Os age of non-mineralized black shale from the Kupferschiefer, Poland, and implications for metal enrichment: Mineralium Deposita, v. 45, no. 2, p. 189-199. [Also available at http://dx.doi.org/10.1007/s00126-009-0269-8.]

Pašava, J., Vymazalová, A., Mao, J., Du, A., Qu, W., and Korzekwa, W., 2007a, A Re-Os study of noble metalrich black shales from the Polish Kupferschiefer, in Andrew, C.J., and others, eds., Digging deeperProceedings of the Ninth Biennial Meeting of the Society for Geology Applied to Mineral Deposits-Dublin, Ireland, August 20-23, 2007: Dublin, Ireland, Society for Geology Applied to Mineral Deposits, p. 221-224.

Pašava, J., Vymazalová, A., Qu, W., and Korzekwa, W., 2007b, Re-Os study of the Polish Kupferschiefer-Implications for source and timing of metal enrichment [abs]: Geochimica et Cosmochimica Acta, v. 71, no. 15 (Supplement-Goldschmidt Conference abstracts), p. A763.

Pebble Partnership, 2011, Pebble Project environmental baseline document 2004 through 2008-Technical summary: Anchorage, Alaska, Pebble Partnership, 426 p., accessed October 31, 2013, at http:/www.arlis.org/docs/vol2/Pebble/ EBD\%20Technical\%20Summary.pdf.

Pettersson, U.T., and Ingri, J., 2001, The geochemistry of $\mathrm{Co}$ and $\mathrm{Cu}$ in the Kafue River as it drains the copperbelt mining area, Zambia: Chemical Geology, v. 177, nos. 3-4, p. 399-414. [Also available at http://dx.doi.org/10.1016/ S0009-2541(00)00422-8.]

Pettersson, U.T., Ingri, J., and Andersson, P.S., 2000, Hydrogeochemical processes in the Kafue River upstream from the copperbelt mining area, Zambia: Aquatic Geochemistry, v. 6 , no. 4, p. 385-411. [Also available at http://dx.doi.org/ 10.1023/A:1009610327246.]

Pilc, L., Rosada, J., and Siepak, J., 1999, The influence of dust emission from the "Głogów" copper foundry on heavy metal concentrations in agrocenoses: Polish Journal of Environmental Studies, v. 8, no. 2, p. 107-110. [Also available at http://6csnfn.pjoes.com/pdf/8.2/107-110.pdf.]

Plaza-Toledo, Meralis, 2005, Natural rock drainage associated with unmined porphyry copper deposits in the Río Grande de Arecibo watershed, Puerto Rico: Mayagüez, Puerto Rico, University of Puerto Rico, unpublished Master's thesis, 162 p.

Polyak, D.E., 2013, Rhenium: U.S. Geological Survey Mineral Commodity Summaries 2013, p. 130-131, accessed April 23, 2015, at https://minerals.usgs.gov/minerals/pubs/ commodity/rhenium/mcs-2013-rheni.pdf.]

Polyak, D.E., 2014, Rhenium [advance release], in Metals and minerals: U.S. Geological Survey Minerals Yearbook 2012, v. I, p. 62.1-62.5, accessed April 23, 2015 , at http://minerals.usgs.gov/minerals/pubs/commodity/ rhenium/myb1-2012-rheni.pdf.
Poplavko, E.M., Marchukova, I.D., and Zak, C.S., 1962, A rhenium mineral in the ores of the Dzhezkazgan deposits: Doklady Akad. Nauk. SSSR, v. 146, p. 433-436. (In Russian.)

Porter, K.E., and Bleiwas, D.I., 2003, Physical aspects of waste storage from a hypothetical open pit porphyry copper operation (version 1.0): U.S. Geological Survey OpenFile Report 03-143, 63 p., accessed April 23, 2015, at http://pubs.usgs.gov/of/2003/of03-143/.

Price, W.A., 2009, Prediction manual for drainage chemistry from sulphidic geologic materialsOttawa, Ontario, Canada, CANMET Mining and Mineral Sciences Laboratories, Natural Resources Canada, MEND Report 1.20.1, 579 p. [Also available at http://www.fs.usda.gov/Internet/FSE_DOCUMENTS/stelprdb5336546.pdf.]

Rahaman, Waliur, Singh, S.K., and Shukla, A.D., 2012, Rhenium in Indian rivers-Sources, fluxes, and contribution to oceanic budget: Geochemistry, Geophysics, Geosystems, v. 13, no. 8, 21 p. [Also available at http://dx.doi.org/10.1029/ 2012gc004083.]

Richards, J.P., 2003, Tectono-magmatic precursors for porphyry $\mathrm{Cu}-(\mathrm{Mo}-\mathrm{Au})$ deposit formation: Economic Geology, v. 98, p. 1515-1533. [Also available at http://dx.doi.org/10.2113/gsecongeo.98.8.1515.]

Richards, J.P., 2009, Postsubduction porphyry Cu-Au and epithermal Au deposits - Products of remelting of subductionmodified lithosphere: Geology, v. 37, no. 3, p. 247-250. [Also available at http://dx.doi.org/10.1130/g25451a.1.]

Romero, Bárbara, Kojima, Shoji, Wong, Chilong, Barra, Fernando, Véliz, Walter, and Ruiz, Joaquin, 2010, Molybdenite mineralization and Re-Os geochronology of the Escondida and Escondida Norte porphyry deposits, northern Chile: Resource Geology, v. 61, no. 1, p. 91-100. [Also available at http://dx.doi.org/10.1111/j.17513928.2010.00150.x.]

Rosera, J.M., Coleman, D.S., and Stein, H.J., 2013, Reevaluating genetic models for porphyry Mo mineralization at Questa, New Mexico-Implications for ore deposition following silicic ignimbrite eruption: Geochemistry, Geophysics, and Geosystems, v. 14, no. 4, p. 787-805. [Also available at http://dx.doi.org/ 10.1002/ggge.20048.]

Roszyk, E., and Szerszen, L., 1988, Accumulation of heavy metals in arable layer of soils in the protection zones of copper smelters: Rocz. Glebozn, v. 39, p. 135-156.

Rudnick, R.L., and Gao, S., 2003, Composition of the continental crust, in Rudnick, R.L., ed., The crust, v. 3 of Holland, H.D., and Turekian, K.K., eds., Treatise on geochemistry: Oxford, United Kingdom, Elsevier-Pergamon, p. 1-64. [Also available at http://dx.doi.org/10.1016/ B0-08-043751-6/03016-4.] 
Ruiz, Joaquin, and Mathur, Ryan, 1999, Metallogenesis in continental margins - Re-Os evidence from porphyry copper deposits in Chile, chap. 3 of Lambert, D.D., and Ruiz, Joaquin, eds., Application of radiogenic isotopes to ore deposit research: Littleton, Colo., Reviews in Economic Geology Series, v. 12, p. 59-72.

Satpaeva, T.S., Kalinin, S.K., and Fain, E.E., 1959, On the content of rhenium in the copper ores of Dzhezkazgan: Vestnik Akad. Nauk Kazakh S.S.R., no. 5, p. 52-59. (In Russian.)

Seedorff, Eric, and Einaudi, M.T., 2004, Henderson porphyry molybdenum system, Colorado-I. Sequence and abundance of hydrothermal mineral assemblages, flow paths of evolving fluids, and evolutionary style: Economic Geology, v. 99, p. 3-37. [Also available as http://dx.doi.org/10.2113/ gsecongeo.99.1.3.]

Selby, David, and Creaser, R.A., 2001, Re-Os geochronology and systematics in molybdenite from the Endako porphyry molybdenum deposit, British Columbia, Canada: Economic Geology, v. 96, p. 197-204. [Also available at http://dx.doi.org/10.2113/gsecongeo.96.1.197.]

Selby, David, Kelley, K.D., Hitzman, M.W., and Zieg, Jerry, 2009, Re-Os sulfide (bornite, chalcopyrite and pyrite) systematics of the carbonate-hosted copper deposits at Ruby Creek, southern Brooks Range, Alaska: Economic Geology, v. 104, p. 437-444. [Also available at http://dx.doi.org/10.2113/gsecongeo.104.3.437.]

Seltmann, Reimar, Shatov, Vitaly, and Yakubchuk, Alexander, eds., 2012, Mineral deposits database and thematic maps of central Asia, ArcGIS 9.2, ArvView 3.2, and MapInfor 6.0 (7.0) GIS packages: London, Centre for Russian and Central Eurasian Mineral Studies (CERCAMS), scale 1:5,000,000. (Includes user's guide and explanatory notes, 65 p.)

Seo, J.H., Guillong, Marcel, and Heinrich, C.A., 2012, Separation of molybdenum and copper in porphyry deposits - The roles of sulfur, redox, and $\mathrm{pH}$ in ore mineral deposition at Bingham Canyon: Economic Geology, v. 107, p. 333-356. [Also available at http://dx.doi.org/10.2113/econgeo.107.2.333.]

Seyfullin, S.Sh., Kalinin, S.K., Strutynskiy, A.V., and Fayn, E.Ye., 1974, Rhenium in stratified copper deposits and showings in west central Kazakhstan: Geochemistry International, v. 11, no. 2, p. 414-418.

Shevenell, Lisa, Connors, K.A., and Henry, C.D., 1999, Controls on pit lake water quality at sixteen open-pit mines in Nevada: Applied Geochemistry, v. 14, no. 5, p. 669-687. [Also available at http://dx.doi.org/10.1016/s0883-2927 (98)00091-2.]

Sillitoe, R.H., 1972, A plate tectonic model for the origin of porphyry copper deposits: Economic Geology, v. 67, p. 184-197. [Also available at http://dx.doi.org/10.2113/ gsecongeo.67.2.184.]
Sillitoe, R.H., 2010, Porphyry copper systems: Economic Geology, v. 105, p. 3-41. [Also available at http://dx.doi.org/ 10.2113/gsecongeo.105.1.3.]

Sinclair, W.D., Jonasson, I.R., Kirkham, R.V., and Soregaroli, A.E., 2009, Rhenium and other platinum-group metals in porphyry deposits: Geological Survey of Canada Open File 6181, 1 sheet. [Also available at http://dx.doi.org/10.4095/247485.]

Singer, D.A., Berger, V.I., and Moring, B.C., 2008, Porphyry copper deposits of the world-Database and grade and tonnage models, 2008 (version 1.0): U.S. Geological Survey Open-File Report 2008-1155, 45 p., accessed April 23, 2015, at http://pubs.usgs.gov/of/2008/1155/.

Singer, D.A., Mosier, D.L., and Menzie, W.D., 1993, Digital grade and tonnage data for 50 types of mineral deposits: U.S. Geological Survey Open-File Report 93-280, accessed April 23, 2015, at http://pubs.usgs.gov/of/1993/ofr-93-0280/.

Smakowski, Tadeusz, Ney, Roman, and Galos, Krzysztof, eds., 2010, Minerals yearbook of Poland 2009: Kraków, Poland, Department of Mineral Policy, Mineral and Energy Economy Research Institute, Polish Academy of Sciences, 537 p. [Also available at http://www.min-pan.krakow.pl/ pliki/Minerals_Yearbook_of_Poland_2009.pdf.]

Sotnikov, V.I., Berzina, A.N., Economou-Eliopoulos, Maria, and Eliopoulos, D.G., 2001, Palladium, platinum and gold distribution in porphyry $\mathrm{Cu} \pm$ Mo deposits of Russia and Mongolia: Ore Geology Reviews, v. 18, nos. 1-2, p. 95-111. [Also available at http://dx.doi.org/10.1016/ s0169-1368(01)00018-x.]

Sracek, O., Milhaljevič, M., Krríbek, B., Majer, V., and Veselovský, F., 2010, Geochemistry and mineralogy of $\mathrm{Cu}$ and $\mathrm{Co}$ in mine tailings at the copperbelt, Zambia: Journal of African Earth Sciences, v. 57, nos. 1-2, p. 14-30. [Also available at http://dx.doi.org/10.1016/ j.jafrearsci.2009.07.008.]

Stein, H.J., Markey, R.J., Morgan, J.W., Hannah, J.L., and Scherstén, A., 2001, The remarkable Re-Os chronometer in molybdenite-How and why it works: Terra Nova, v. 13, no. 6, p. 479-486. [Also available at http://dx.doi.org/ 10.1046/j.1365-3121.2001.00395.x.]

Stollenwerk, K.G., 1994, Geochemical interactions between constituents in acidic groundwater and alluvium in an aquifer near Globe, Arizona: Applied Geochemistry, v. 9, no. 4, p. 353-369. [Also available at http://dx.doi.org/10.1016/ 0883-2927(94)90058-2.]

Sun, Weidong, Bennett, V.C., Eggins, S.M., Kamenetsky, V.S., and Arculus, R.J., 2003, Enhanced mantle-to-crust rhenium transfer in undegassed arc magmas: Nature, v. 422, March, p. 294-297. [Also available at http://dx.doi.org/10.1038/ nature01482.] 
Sutulov, Alexander, 1974, Copper porphyries: Salt Lake City, Utah, University of Utah Printing Services, 200 p.

Syakalima, M.S., Choongo, K.C., Chilonda, P., Ahmadu, B., Mwase, M., Onuma, M., Sugimoto, C., Tsubota, T., Fukushi, H., Yoshida, M., Itagaki, T., Yasuda, J., and Nakazato, Y., 2001, Bioaccumulation of lead in wildlife dependent on the contaminated environment of the Kafue Flats: Bulletin of Environmental Contamination and Toxicology, v. 67, no. 3, p. 438-445. [Also available at http://dx.doi.org/10.1007/s001280143.]

Taylor, R.D., Hammarstrom, J.M., Piatak, N.M., and Seal, R.R., II, 2012, Arc-related porphyry molybdenum deposit model, chap. D of Mineral deposit models for resource assessment: U.S. Geological Survey Scientific Investigations Report 2010-5070-D, 64 p. [Also available at http://pubs.usgs.gov/sir/2010/5070/d/.]

Taylor, S.R., and McLennan, S.M., 1995, The geochemical evolution of the continental crust: Reviews of Geophysics, v. 33, no. 2, p. 241-265. [Also available at http://dx.doi.org/ 10.1029/95rg00262.]

Terada, Kikuo, Osaki, Susumu, Ishihara, Shunso, and Kiba, Toshiyasu, 1971, Distribution of rhenium in molybdenites from Japan: Geochemical Journal (The Geochemical Society of Japan), v. 4, no. 3, p. 123-141. [Also available at http://dx.doi.org/10.2343/geochemj.4.123.]

Todorov, T., and Staikov, M., 1985, Rhenium content in molybdenite from ore mineralizations in Bulgaria: Geologica Balcanica, v. 15, no. 6, p. 45-58.

Uchida, Shigeo, Tagami, Keiko, and Tabei, Ken, 2005, Comparison of alkaline fusion and acid digestion methods for the determination of rhenium in rock and soil samples by ICP-MS: Analytica Chimica Acta, v. 535, nos. 1-2, p. 317-323. [Also available at http://dx.doi.org/10.1016/ j.aca.2004.11.065.]

U.S. Department of Agriculture, Forest Service, Kootenai National Forest, Montana Department of State Lands, Montana Department of Health and Environmental Sciences, and Montana Department of Natural Resources, 1992, Montanore project-Final environmental impact statement: Libby, Mont., U.S. Forest Service, Kootenai National Forest, v. 1, 625 p.

U.S. Department of Agriculture, Forest Service, Northern Region, Kootenai National Forest, and Montana Department of Environmental Quality, 2009, The draft environmental impact statement for the Montanore project: Libby, Mont., U.S. Forest Service, Kootenai National Forest, 3 v., 1, 383 p., accessed June 1, 2015, at http://deq.mt.gov/eis/hardrock/Montanore/DraftEIS/ MontanoreProjectDraftEISopt75.pdf.
U.S. Environmental Protection Agency, 1994, Technical resource document-Extraction and beneficiation of ores and minerals - Copper: Washington, D.C., U.S. Environmental Protection Agency, Office of Solid Waste, Special Waste Branch, EPA-530-R-94-031, v. 4, 80 p., accessed October 31, 2013, at http://www.epa.gov/osw/nonhaz/ industrial/special/mining/techdocs/copper/copperla.pdf.

U.S. Environmental Protection Agency, 2009a, National primary drinking water regulations: U.S. Environmental Protection Agency , EPA 816-F-09-004, May, 6 p., accessed June 1, 2015, at http://water.epa.gov/drink/ contaminants/upload/mcl-2.pdf.

U.S. Environmental Protection Agency, 2009b, National recommended water quality criteria: U.S. Environmental Protection Agency Web page, accessed March 26, 2013, at http://www.epa.gov/waterscience/criteria/wqcriteria.html.

U.S. Geological Survey, 1996, Global 30 arc-second elevation (GTOPO30): Reston, Va., U.S. Geological Survey dataset (digital elevation model), accessed June 23, 2014, at https://lta.cr.usgs.gov/GTOPO30.

U.S. Geological Survey, 2014, Mineral Resources Data System: U.S. Geological Survey database, accessed July 8, 2014, at http://mrdata.usgs.gov/mrds/.

Valencia, V.A., Ruiz, J., Barra, F., Geherls, G., Ducea, M., Titley, S.R., and Ochoa-Landin, L., 2005, U-Pb zircon and Re-Os molybdenite geochronology from La Caridad porphyry copper deposit-Insights for the duration of magmatism and mineralization in the Nacozari district, Sonora, Mexico: Mineralium Deposita, v. 40, no. 2, p. 175-191. [Also available at http://dx.doi.org/10.1007/s00126-005-0480-1.]

Vaughan, D.J., Sweeney, M.A., Friedrich, G., Diedel, R., and Haranczyk, C., 1989, The Kupferschiefer-An overview with an appraisal of the different types of mineralization: Economic Geology, v. 84, p. 1003-1027. [Also available at http://dx.doi.org/10.2113/gsecongeo.84.5.1003.]

Voudouris, P.C., Melfos, Vasilios, Spry, P.G., Bindi, Luca, Kartal, Tamara, Arikas, Kyriakos, Moritz, Robert, and Ortelli, Melissa, 2009, Rhenium-rich molybdenite and rheniite in the Pagoni Rachi Mo-Cu-Te-Ag-Au prospect, northern Greece-Implications for the Re geochemistry of porphyry-style $\mathrm{Cu}-\mathrm{Mo}$ and Mo mineralization: Canadian Mineralogist, v. 47, no. 5, p. 1013-1036. [Also available at http://dx.doi.org/10.3749/canmin.47.5.1013.]

Watanabe, Yasushi, and Stein, H.J., 2000, Re-Os ages for the Erdenet and Tsagaan Suvarga porphyry Cu-Mo deposits, Mongolia, and tectonic implications: Economic Geology, v. 95, p. 1537-1542. [Also available at http://dx.doi.org/ 10.2113/gsecongeo.95.7.1537.] 
Wells, J.D., Domenico, J.A., Frisken, J.G., and Hopkins, R.T., 1981, Geochemical survey of the Cabinet Mountains Wilderness, Lincoln and Sanders Counties, Montana, in U.S. Geological Survey and U.S. Bureau of Mines, Mineral resources of the Cabinet Mountains Wilderness, Lincoln and Sanders Counties, Montana: U.S. Geological Survey Bulletin 1501, p. 25-51, 2 pls. [Also available at http://pubs.usgs.gov/bul/1501/report.pdf.]

Williams, Tom, Schultz-Stoker, Jill, and Duvall, Elizabeth, 2002, Tailings stabilisation at White Pine: Mining Environmental Management, v. 10, no. 3, p. 6-12.

Wodzicki, A., and Piestrzynski, A., 1994, An ore genetic model for the Lubin-Sieroszowice mining district, Poland: Mineralium Deposita, v. 29, no. 1, p. 30-43.

Wolfe, W.J., 1995, Exploration and geology of the Quartz Hill molybdenum deposit, southeast Alaska, in Schroeter, T.G., ed., Porphyry deposits of the northwestern cordillera of North America: Montreal, Quebec, Canada, Canadian Institute of Mining, Metallurgy and Petroleum (CIM), Special Volume 46, p. 764-770.

World Health Organization, 2006, Guidelines for drinkingwater quality, 3d ed: Geneva, Switzerland, WHO Press, accessed March 28, 2013, at http://www.who.int/ water_sanitation_health/dwq/gdwq3rev/en/index.html.

World Nuclear Association, 2013, In situ leach (ISL) mining of uranium: World Nuclear Association Web page, accessed March 13, 2013, http://www.world-nuclear.org/info/ Nuclear-Fuel-Cycle/Mining-of-Uranium/In-Situ-LeachMining-of-Uranium/\#.UUDg7Y6xHWQ.

Xie, G.-Q., Mao, J.-W., Li, R.-L., Qu, W.-J., Pirajno, F., and Du, A.-D., 2007, Re-Os molybdenite and Ar-Ar phlogopite dating of $\mathrm{Cu}-\mathrm{Fe}-\mathrm{Au}-\mathrm{Mo}(\mathrm{W})$ deposits in southeastern Hubei, China: Mineralogy and Petrology, v. 90, nos. 3-4, p. 249-270. [Also available at http://dx.doi.org/10.1007/ s00710-006-0176-y.]
Xiong, Yongliang, Wood, Scott, and Kruszewski, Jason, 2006, Hydrothermal transport and deposition of rhenium under subcritical conditions revisited: Economic Geology, v. 101, p. 471-478. [Also available at http://dx.doi.org/10.2113/ gsecongeo.101.2.471.]

Zhao, Yiming, Bi, Chengsi, Xiaoqiu, Zou, Yali, Sun, Andao, Du, and Yumin, Zhao, 1997, The Re-Os isotopic age of molybdenite from Duobaoshan and Tongshan porphyry copper (molybdenum) deposits: Acta Geoscientica Sinica, v. 18, no. 1, p. 61-67.

Zheng, Qingdong, Liu, Jianming, Qin, Feng, and Zhang, Zuolun, 2010, Geochronology of the Xiaodonggou porphyry Mo deposit in northern margin of North China craton: Resource Geology, v. 60, no. 2, p. 192-202. [Also available at http://dx.doi.org/10.1111/j.1751-3928.2010.00125.x.]

Zientek, M.L., Hayes, T.S., and Hammarstrom, J.M., 2013, Overview of a new descriptive model for sediment-hosted stratabound copper deposits, chap. 1 of Taylor, C.D., Causey, J.D., Denning, P.D., Hammarstrom, J.M., Hayes, T.S., Horton, J.D., Kirschbaum, M.J., Parks, H.L., Wilson, A.B.,Wintzer, N.E., and Zientek, M.L., Descriptive models, grade-tonnage relations, and databases for the assessment of sediment-hosted copper deposits - With emphasis on deposits in the Central Africa Copperbelt, Democratic Republic of the Congo and Zambia: U.S. Geological Survey Scientific Investigations Report 2010-5090-J, p. 2-16. [Also available at http://pubs.usgs.gov/sir/2010/5090/j/.] 


\section{Table P2 and Appendix P1}


Table P2. Rhenium data for selected porphyry copper and porphyry molybdenum deposits of the world.

[The names, locations, and types of most of the deposits are taken from the U.S. Geological Survey Mineral Resources Data System (MRDS) (U.S. Geological Survey, 2014). The minimum and maximum values are concentrations of rhenium in molybdenite separates; the estimated average is based on mill concentrates. Elements and compound: $\mathrm{Au}$, gold; $\mathrm{Cu}$, copper; Mo, molybdenum; $\mathrm{MoS}_{2}$, molybdenite; Os, osmium; Re, rhenium. Units of measure: g/t, gram per metric ton; Mt, million metric tons; ppm, part per million; t, metric ton; wt. \%, weight percent. —, no data; None, no minimum and maximum values are available because only a single analysis was used to calculate the Re grade]

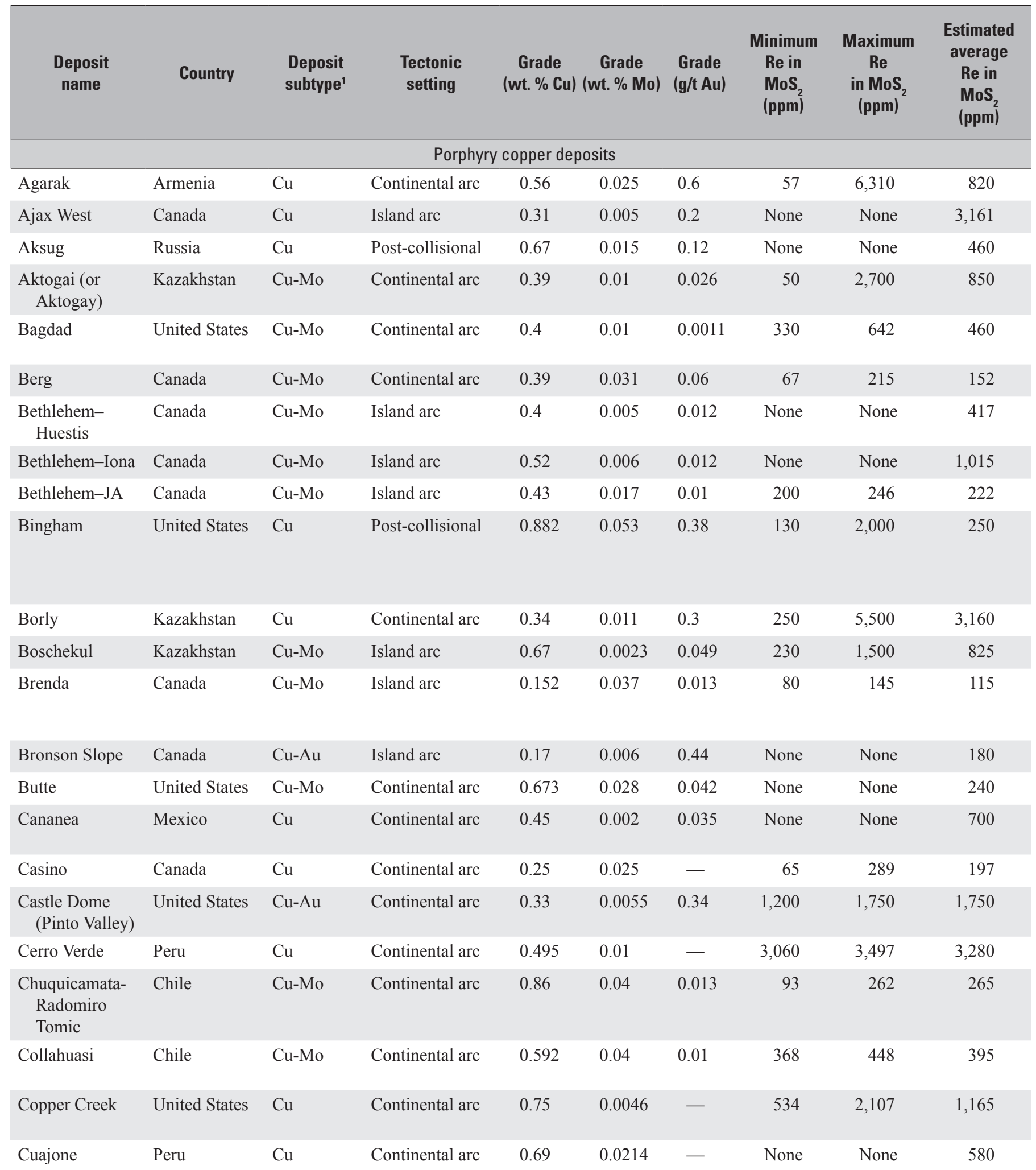


Table P2. Rhenium data for selected rhenium porphyry copper and porphyry molybdenum deposits of the world.—Continued

[The names, locations, and types of most of the deposits are taken from the U.S. Geological Survey Mineral Resources Data System (MRDS) (U.S. Geological Survey, 2014). The minimum and maximum values are concentrations of rhenium in molybdenite separates; the estimated average is based on mill concentrates. Elements and compound: $\mathrm{Au}$, gold; $\mathrm{Cu}$, copper; $\mathrm{Mo}$, molybdenum; $\mathrm{MoS}_{2}$, molybdenite; Os, osmium; Re, rhenium. Units of measure: $\mathrm{g} / \mathrm{t}$, gram per metric ton; Mt, million metric tons; ppm, part per million; t, metric ton; wt. \%, weight percent. —, no data; None, no minimum and maximum values are available because only a single analysis was used to calculate the Re grade]

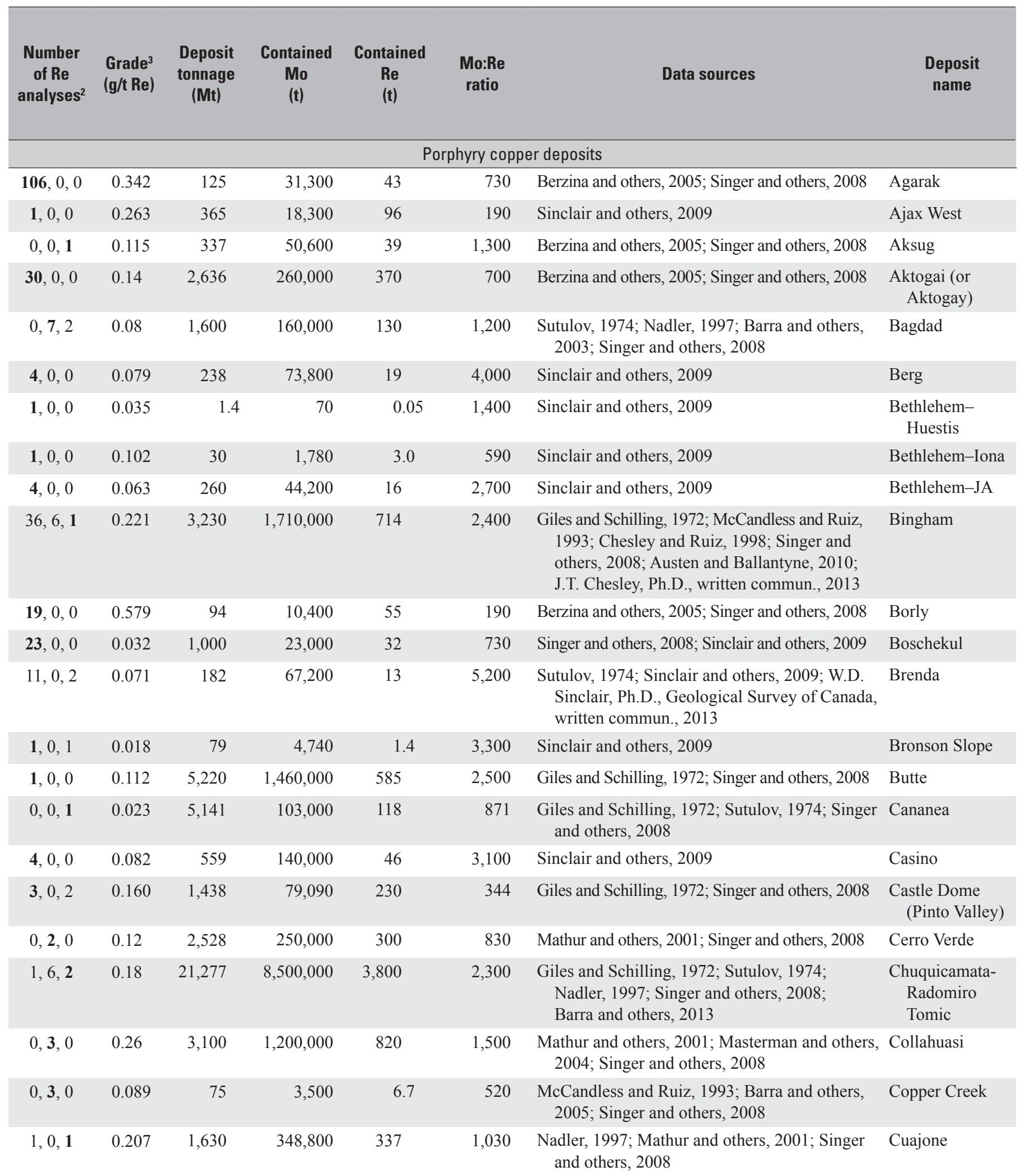


Table P2. Rhenium data for selected porphyry copper and porphyry molybdenum deposits of the world.—Continued

[The names, locations, and types of most of the deposits are taken from the U.S. Geological Survey Mineral Resources Data System (MRDS) (U.S. Geological Survey, 2014). The minimum and maximum values are concentrations of rhenium in molybdenite separates; the estimated average is based on mill concentrates. Elements and compound: Au, gold; $\mathrm{Cu}$, copper; $\mathrm{Mo}$, molybdenum; $\mathrm{MoS}_{2}$, molybdenite; Os, osmium; Re, rhenium. Units of measure: g/t, gram per metric ton; Mt, million metric tons; ppm, part per million; t, metric ton; wt. \%, weight percent. —, no data; None, no minimum and maximum values are available because only a single analysis was used to calculate the Re grade]

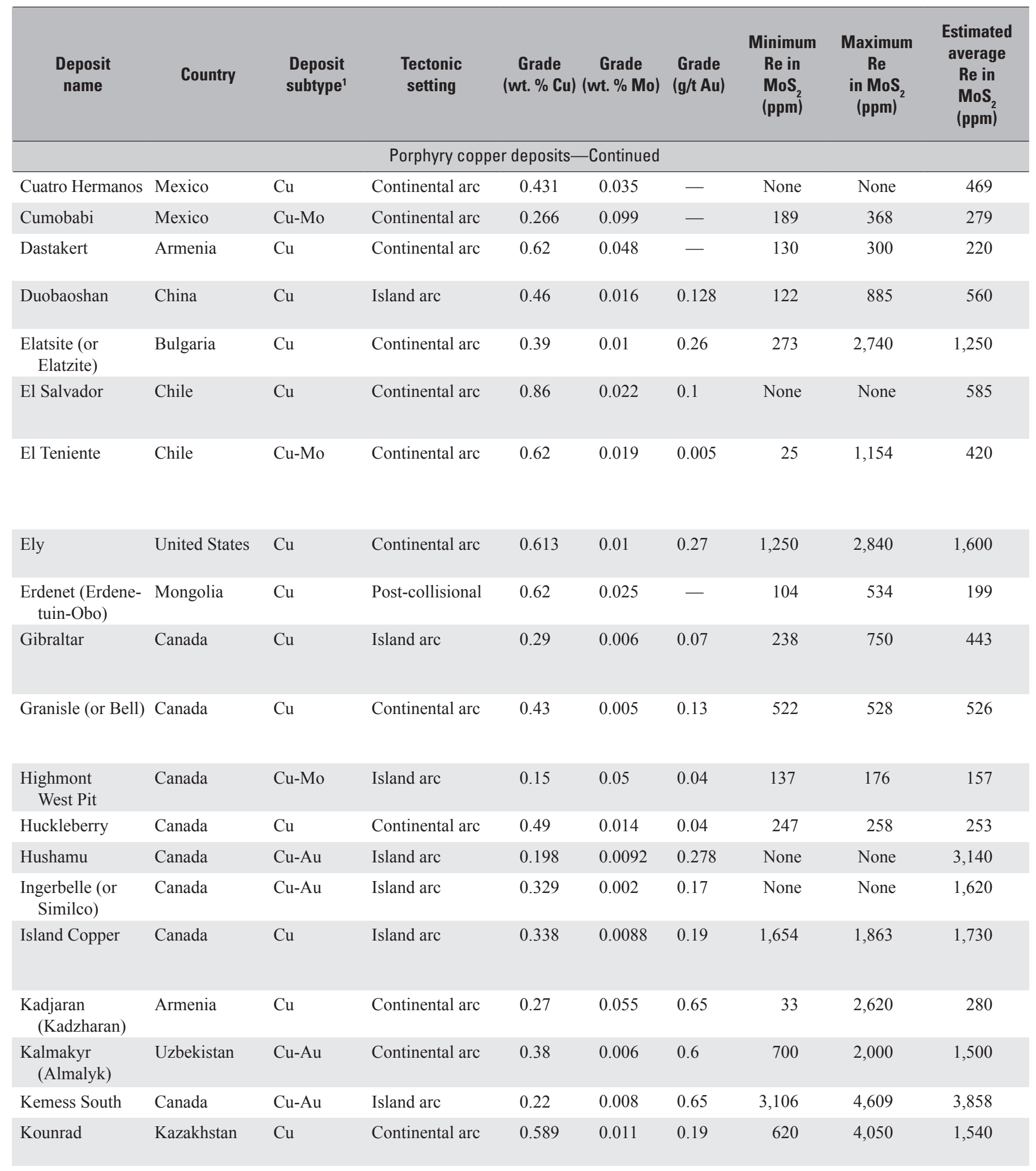


Table P2. Rhenium data for selected rhenium porphyry copper and porphyry molybdenum deposits of the world.—Continued

[The names, locations, and types of most of the deposits are taken from the U.S. Geological Survey Mineral Resources Data System (MRDS) (U.S. Geological Survey, 2014). The minimum and maximum values are concentrations of rhenium in molybdenite separates; the estimated average is based on mill concentrates. Elements and compound: $\mathrm{Au}$, gold; $\mathrm{Cu}$, copper; $\mathrm{Mo}$, molybdenum; $\mathrm{MoS}_{2}$, molybdenite; Os, osmium; Re, rhenium. Units of measure: $\mathrm{g} / \mathrm{t}$, gram per metric ton; Mt, million metric tons; ppm, part per million; t, metric ton; wt. \%, weight percent. —, no data; None, no minimum and maximum values are available because only a single analysis was used to calculate the Re grade]

\begin{tabular}{|c|c|c|c|c|c|c|c|}
\hline $\begin{array}{l}\text { Number } \\
\text { of Re } \\
\text { analyses }\end{array}$ & $\begin{array}{l}\text { Grade }^{3} \\
\text { (g/t Re) }\end{array}$ & $\begin{array}{l}\text { Deposit } \\
\text { tonnage } \\
\text { (Mt) }\end{array}$ & $\begin{array}{l}\text { Contained } \\
\text { Mo } \\
\text { (t) }\end{array}$ & $\begin{array}{l}\text { Contained } \\
\operatorname{Re} \\
(t)\end{array}$ & $\begin{array}{c}\text { Mo:Re } \\
\text { ratio }\end{array}$ & Data sources & $\begin{array}{l}\text { Deposit } \\
\text { name }\end{array}$ \\
\hline \multicolumn{8}{|c|}{ Porphyry copper deposits-Continued } \\
\hline $\mathbf{8}, 0,1$ & 0.176 & 36 & 17,000 & 6.2 & 2,700 & $\begin{array}{l}\text { Sutulov, 1974; Berzina and others, 2005; Global } \\
\text { Metals (ARM) Ltd., } 2015\end{array}$ & Dastakert \\
\hline $0, \mathbf{8}, 0$ & 0.149 & 951 & 152,000 & 142 & 1,070 & $\begin{array}{l}\text { Zhao and others, 1997; Singer and others, 2008; } \\
\text { Deng and others, } 2013\end{array}$ & Duobaoshan \\
\hline $1,14,2$ & 0.133 & 20,731 & $3,940,000$ & 2,760 & 1,430 & $\begin{array}{l}\text { Giles and Schilling, 1972; Sutulov, 1974; } \\
\text { Nadler, 1997; Maksaev and others, 2004; } \\
\text { Cannell, 2004; Klemm and others, 2007; } \\
\text { Singer and others, } 2008\end{array}$ & El Teniente \\
\hline $4,0,1$ & 0.27 & 754 & 75,000 & 200 & 380 & $\begin{array}{l}\text { Giles and Schilling, 1972; Sutulov, 1974; } \\
\text { Singer and others, } 2008\end{array}$ & Ely \\
\hline $2,1, \mathbf{1}$ & 0.043 & 1,780 & 445,000 & 77 & 5,810 & $\begin{array}{l}\text { Watanabe and Stein, 2000; Berzina and others, } \\
\text { 2005; Singer and others, } 2008\end{array}$ & $\begin{array}{l}\text { Erdenet (Erdene- } \\
\text { tuin-Obo) }\end{array}$ \\
\hline $3,0,1$ & 0.044 & 935 & 56,100 & 41 & 1,360 & $\begin{array}{l}\text { Sinclair and others, 2009; W.D. Sinclair, Ph.D., } \\
\text { Geological Survey of Canada, written com- } \\
\text { mun., } 2013\end{array}$ & Gibraltar \\
\hline $1,0,0$ & 0.481 & 510 & 46,900 & 245 & 191 & Giroux and Casselman, 2012 & Hushamu \\
\hline $\mathbf{1}, 0,0$ & 0.054 & 78 & 1,600 & 4.2 & 380 & Sinclair and others, 2009 & $\begin{array}{l}\text { Ingerbelle (or } \\
\text { Similco) }\end{array}$ \\
\hline $0,0, \mathbf{1 1}$ & 0.262 & 600 & 52,800 & 157 & 336 & $\begin{array}{l}\text { Sinclair and others, 2009; W.D. Sinclair, Ph.D., } \\
\text { Geological Survey of Canada, written com- } \\
\text { mun., } 2013\end{array}$ & Island Copper \\
\hline $\mathbf{2 3 7}, 0,1$ & 0.257 & 1,700 & 935,000 & 437 & 2,140 & $\begin{array}{l}\text { Nadler, 1997; Berzina and others, 2005; } \\
\quad \text { Singer and others, } 2008\end{array}$ & $\begin{array}{l}\text { Kadjaran } \\
\quad \text { (Kadzharan) }\end{array}$ \\
\hline $\mathbf{2 0}, 0,1$ & 0.150 & 2,000 & 120,000 & 300 & 400 & $\begin{array}{l}\text { Sutulov, 1974; Singer and others, 2008; } \\
\text { Pašava and others, } 2010\end{array}$ & $\begin{array}{l}\text { Kalmakyr } \\
\text { (Almalyk) }\end{array}$ \\
\hline $2,0,0$ & 0.514 & 213 & 17,000 & 109 & 155 & Sinclair and others, 2009 & Kemess South \\
\hline $20,0,1$ & 0.282 & 637 & 70,100 & 180 & 390 & $\begin{array}{l}\text { Sutulov, 1974; Berzina and others, 2005; } \\
\text { Singer and others, } 2008\end{array}$ & Kounrad \\
\hline
\end{tabular}


Table P2. Rhenium data for selected porphyry copper and porphyry molybdenum deposits of the world.—Continued

[The names, locations, and types of most of the deposits are taken from the U.S. Geological Survey Mineral Resources Data System (MRDS) (U.S. Geological Survey, 2014). The minimum and maximum values are concentrations of rhenium in molybdenite separates; the estimated average is based on mill concentrates. Elements and compound: $\mathrm{Au}$, gold; $\mathrm{Cu}$, copper; $\mathrm{Mo}$, molybdenum; $\mathrm{MoS}_{2}$, molybdenite; Os, osmium; Re, rhenium. Units of measure: g/t, gram per metric ton; Mt, million metric tons; ppm, part per million; t, metric ton; wt. \%, weight percent. —, no data; None, no minimum and maximum values are available because only a single analysis was used to calculate the Re grade]

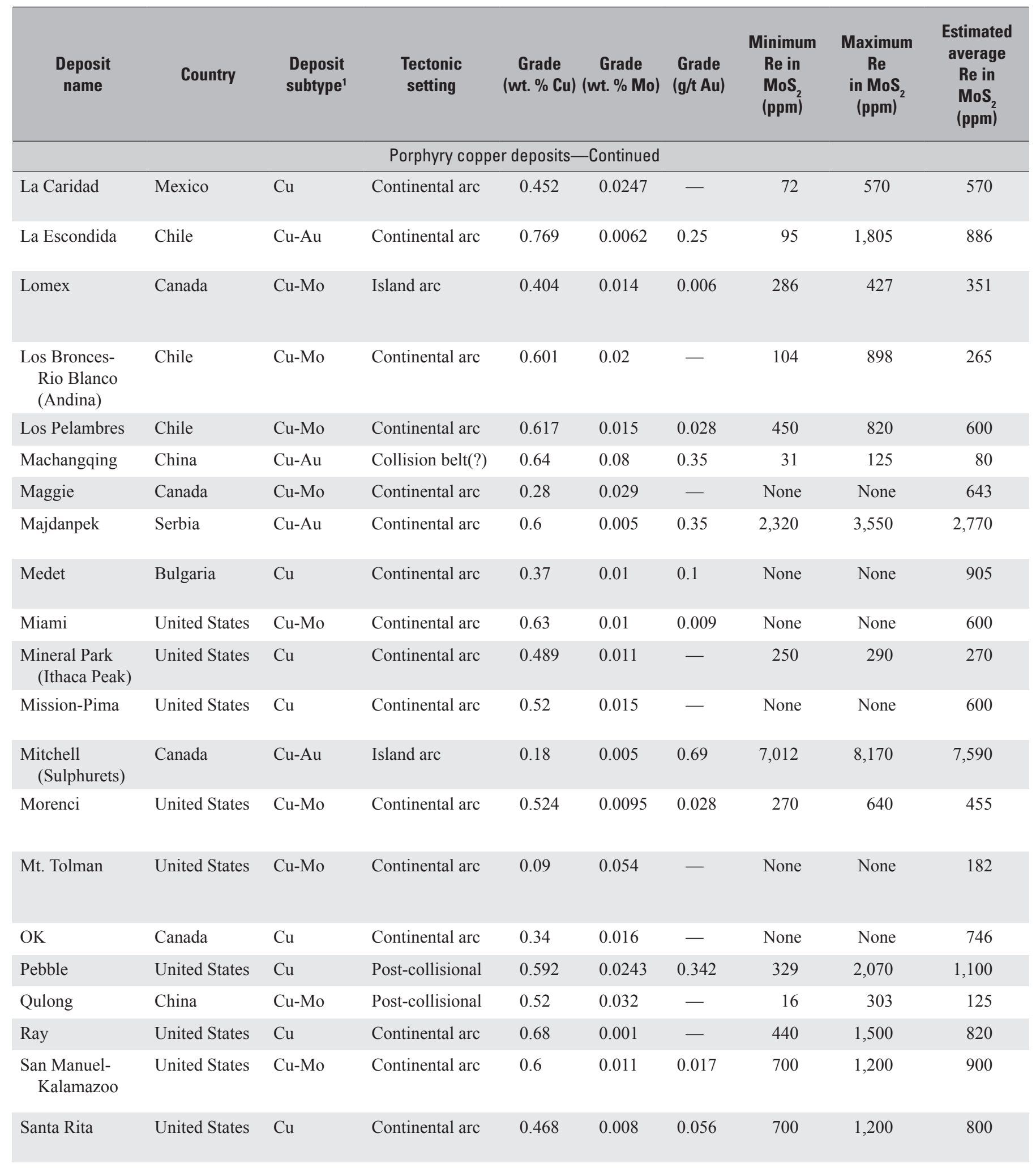


Table P2. Rhenium data for selected rhenium porphyry copper and porphyry molybdenum deposits of the world.—Continued

[The names, locations, and types of most of the deposits are taken from the U.S. Geological Survey Mineral Resources Data System (MRDS) (U.S. Geological Survey, 2014). The minimum and maximum values are concentrations of rhenium in molybdenite separates; the estimated average is based on mill concentrates. Elements and compound: $\mathrm{Au}$, gold; $\mathrm{Cu}$, copper; $\mathrm{Mo}$, molybdenum; $\mathrm{MoS}_{2}$, molybdenite; Os, osmium; Re, rhenium. Units of measure: $\mathrm{g} / \mathrm{t}$, gram per metric ton; Mt, million metric tons; ppm, part per million; t, metric ton; wt. \%, weight percent. —, no data; None, no minimum and maximum values are available because only a single analysis was used to calculate the Re grade]

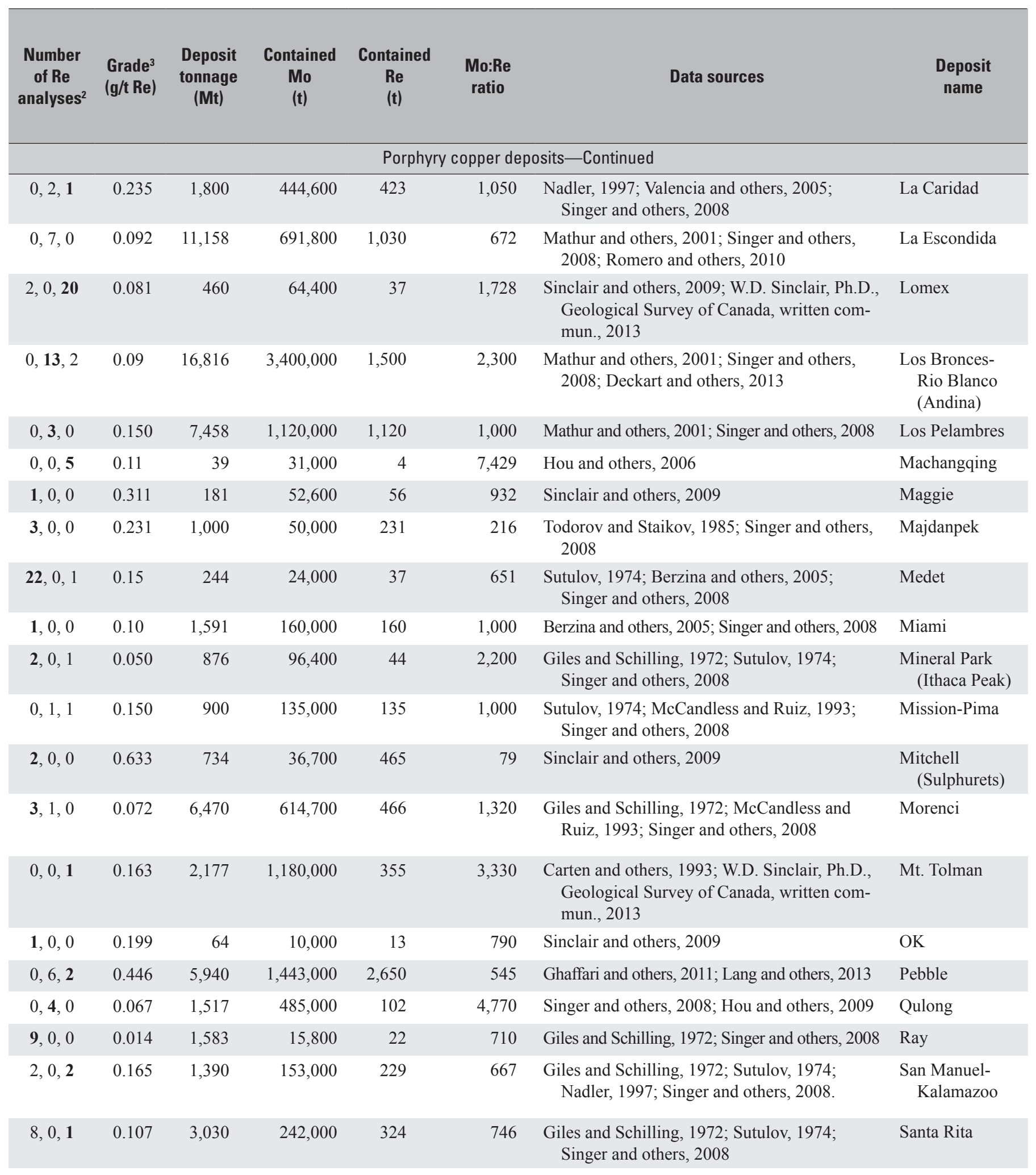


Table P2. Rhenium data for selected porphyry copper and porphyry molybdenum deposits of the world.—Continued

[The names, locations, and types of most of the deposits are taken from the U.S. Geological Survey Mineral Resources Data System (MRDS) (U.S. Geological Survey, 2014). The minimum and maximum values are concentrations of rhenium in molybdenite separates; the estimated average is based on mill concentrates. Elements and compound: Au, gold; $\mathrm{Cu}$, copper; $\mathrm{Mo}$, molybdenum; $\mathrm{MoS}_{2}$, molybdenite; Os, osmium; Re, rhenium. Units of measure: g/t, gram per metric ton; Mt, million metric tons; ppm, part per million; t, metric ton; wt. \%, weight percent. —, no data; None, no minimum and maximum values are available because only a single analysis was used to calculate the Re grade]

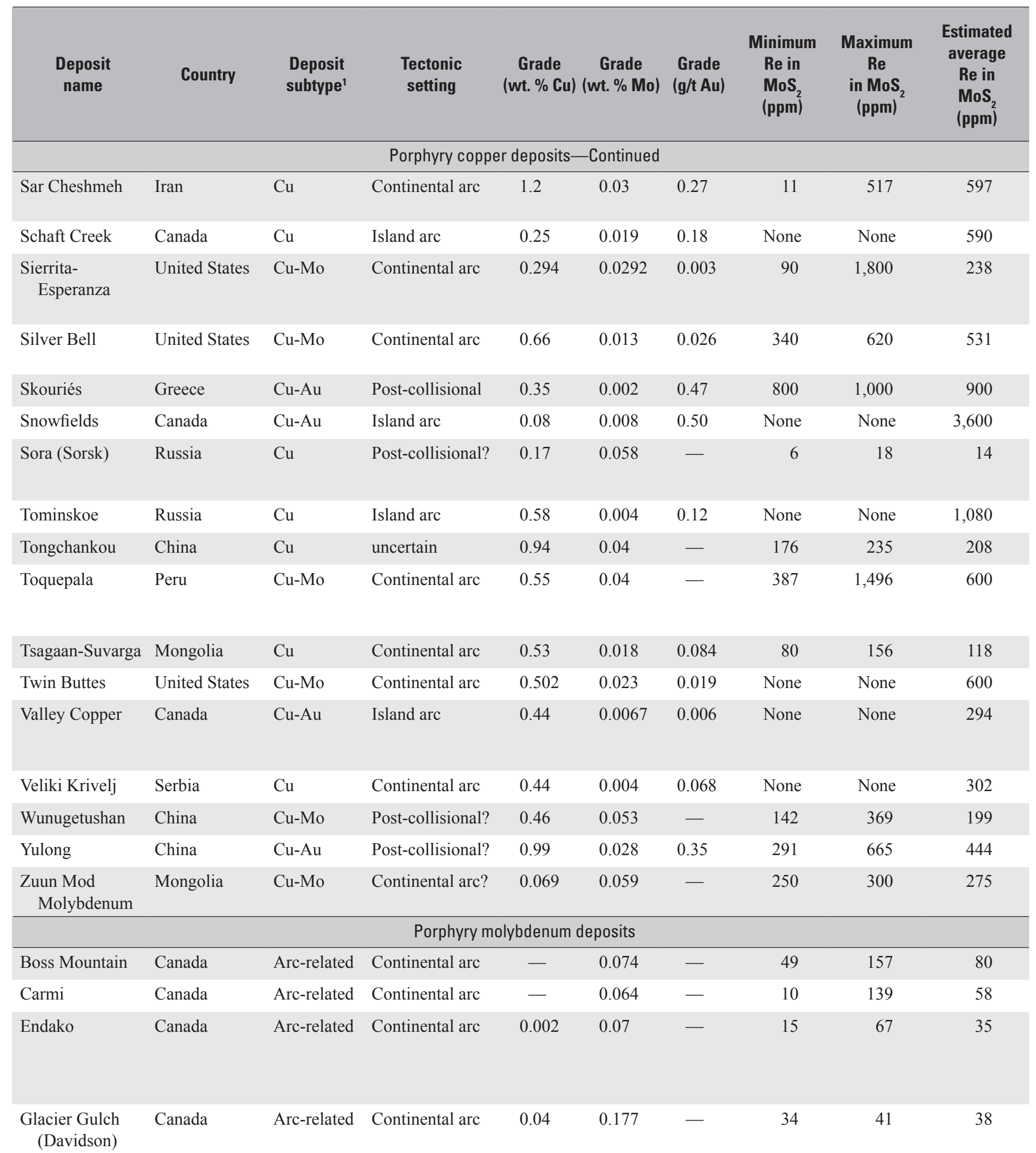


Table P2. Rhenium data for selected rhenium porphyry copper and porphyry molybdenum deposits of the world.—Continued

[The names, locations, and types of most of the deposits are taken from the U.S. Geological Survey Mineral Resources Data System (MRDS) (U.S. Geological Survey, 2014). The minimum and maximum values are concentrations of rhenium in molybdenite separates; the estimated average is based on mill concentrates. Elements and compound: $\mathrm{Au}$, gold; $\mathrm{Cu}$, copper; $\mathrm{Mo}$, molybdenum; $\mathrm{MoS}_{2}$, molybdenite; Os, osmium; Re, rhenium. Units of measure: $\mathrm{g} / \mathrm{t}$, gram per metric ton; Mt, million metric tons; ppm, part per million; t, metric ton; wt. \%, weight percent. —, no data; None, no minimum and maximum values are available because only a single analysis was used to calculate the Re grade]

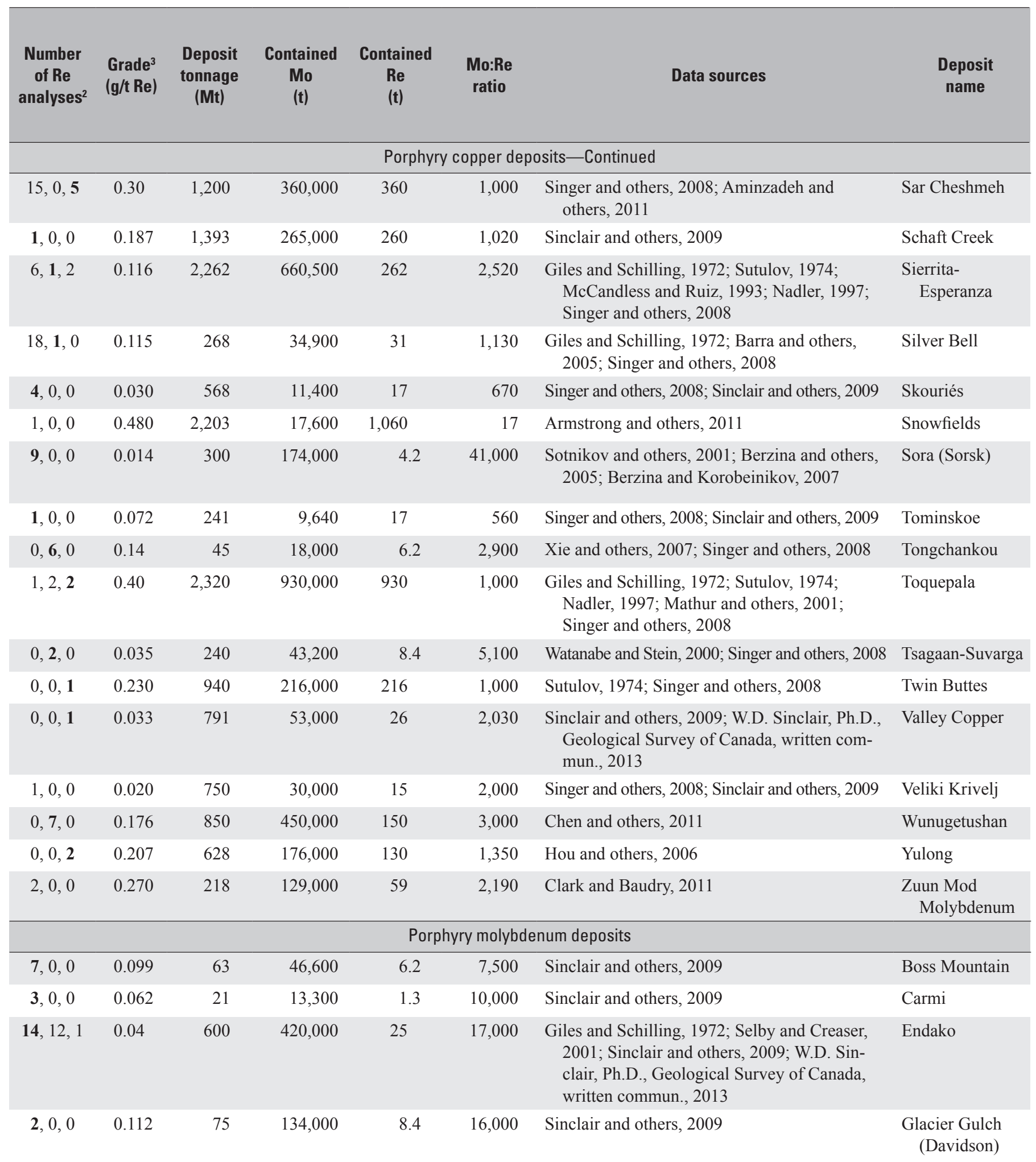


Table P2. Rhenium data for selected porphyry copper and porphyry molybdenum deposits of the world.—Continued

[The names, locations, and types of most of the deposits are taken from the U.S. Geological Survey Mineral Resources Data System (MRDS) (U.S. Geological Survey, 2014). The minimum and maximum values are concentrations of rhenium in molybdenite separates; the estimated average is based on mill concentrates. Elements and compound: $\mathrm{Au}$, gold; $\mathrm{Cu}$, copper; $\mathrm{Mo}$, molybdenum; $\mathrm{MoS}_{2}$, molybdenite; Os, osmium; Re, rhenium. Units of measure: g/t, gram per metric ton; $\mathrm{Mt}$, million metric tons; ppm, part per million; $\mathrm{t}$, metric ton; wt. \%, weight percent. —, no data; None, no minimum and maximum values are available because only a single analysis was used to calculate the Re grade]

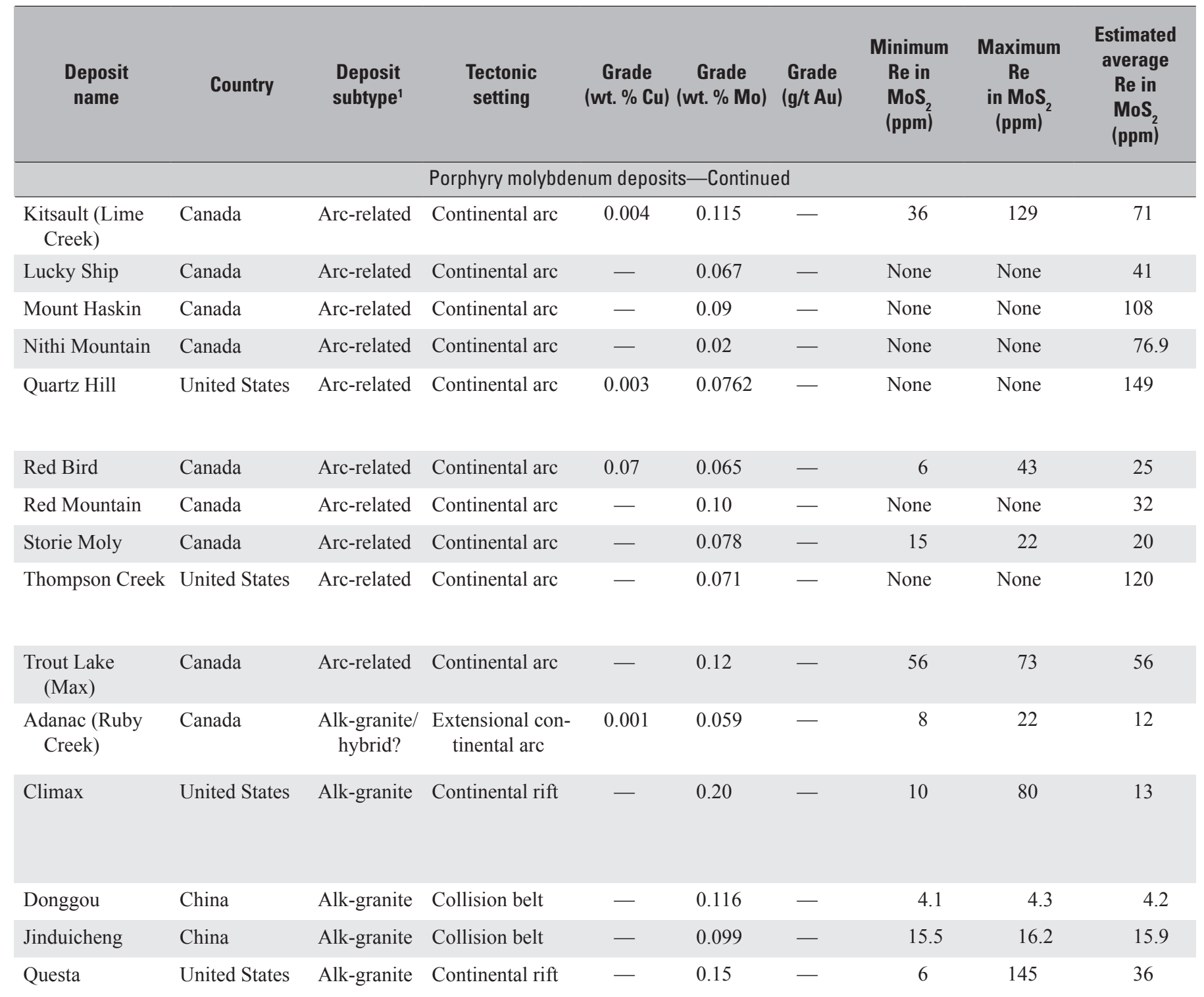

\begin{tabular}{|c|c|c|c|c|c|c|c|c|c|}
\hline Shapinggou & China & Alk-granite & Collision belt & - & 0.126 & - & 0.4 & 14.7 & 4.7 \\
\hline Urad-Henderson & United States & Alk-granite & Continental rift & - & 0.228 & - & 7 & 20 & 20 \\
\hline
\end{tabular}

\begin{tabular}{llllllll} 
Xiaodonggou & China & Alk-granite & Collision belt(?) & - & 0.109 & 4.5 & 8.4 \\
\hline
\end{tabular}

${ }^{1}$ Cox and Singer (1992) porphyry Cu models; Taylor and others (2012) and Ludington and Plumlee (2009) porphyry Mo models.

${ }^{2}$ Number of analyses of $\mathrm{MoS}_{2}$ separates, $\mathrm{MoS}_{2}$ analyzed for Re-Os dating, $\mathrm{MoS}_{2}$ mill concentrates. Number in bold indicates samples used to calculate Re grade. In cases where no number is bold, average grade of total resources calculated from drilling was used as Re grade.

${ }^{3} \mathrm{Re}$ grade calculated from mean Re content of $\mathrm{MoS}_{2}$ and Mo grade of deposit. 
Table P2. Rhenium data for selected rhenium porphyry copper and porphyry molybdenum deposits of the world.—Continued

[The names, locations, and types of most of the deposits are taken from the U.S. Geological Survey Mineral Resources Data System (MRDS) (U.S. Geological Survey, 2014). The minimum and maximum values are concentrations of rhenium in molybdenite separates; the estimated average is based on mill concentrates. Elements and compound: $\mathrm{Au}$, gold; $\mathrm{Cu}$, copper; $\mathrm{Mo}$, molybdenum; $\mathrm{MoS}_{2}$, molybdenite; Os, osmium; Re, rhenium. Units of measure: $\mathrm{g} / \mathrm{t}$, gram per metric ton; Mt, million metric tons; ppm, part per million; t, metric ton; wt. \%, weight percent. —, no data; None, no minimum and maximum values are available because only a single analysis was used to calculate the Re grade]

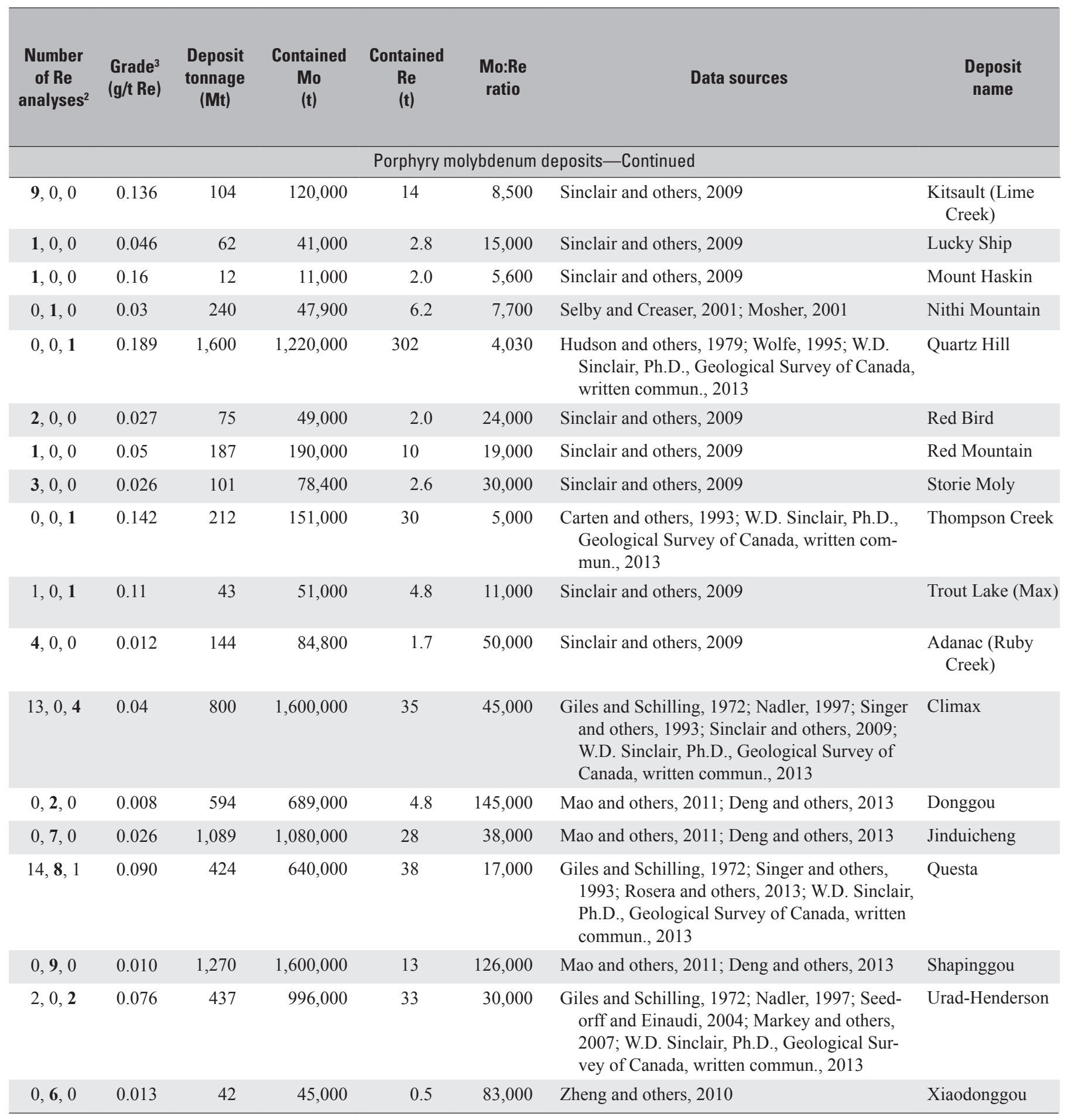




\section{Appendix P1. Rhenium Data Sources and Limitations of Data Used in Rhenium Resource Estimates}

Publicly available data for rhenium resources are limited. Of more than 225 porphyry copper deposits with published molybdenum grades and tonnages (Singer and others, 2008), rhenium concentrations are available for only about 80 deposits, several of which are represented by a single rhenium analysis (table P1; John and Taylor, 2016). There are similarly few rhenium data available for porphyry molybdenum deposits. The available rhenium analytical data are a mixture of analyses of (a) small molybdenite separates (for example, Giles and Schilling, 1972; Sinclair and others, 2009), (b) small molybdenite separates used in rhenium-osmium dating studies (for example, McCandless and Ruiz, 1993; Barra and others, 2013), and less commonly, (c) bulk molybdenite mill concentrates (mostly from Sutulov, 1974, and Nadler, 1997). The molybdenite separates and mill concentrates are subject to impurities, and some of the variation in rhenium content within deposits may be the result of variable purity of these molybdenite separates. Electron microprobe analyses of rhenium contents of molybdenites are available for some deposits (Newberry, 1979; McCandless and others, 1993), but these analyses have relatively high detection limits and low precision and were not included in the data compilation.

Calculated rhenium resources in porphyry copper and porphyry molybdenum deposits are based on the average concentration of rhenium in molybdenite, the average molybdenum grade for the entire deposit, and the total tonnage of the deposit. The type of analysis used to determine rhenium concentrations in molybdenite is indicated in table P1.

Molybdenum grades and tonnages for porphyry copper deposits are mostly from Singer and others (2008) and are subject to the rules specified in their data compilation. For example, average molybdenum grades and the associated tonnages are based on the total production, reserves, and resources at the lowest possible cutoff grade, and all mineralized and altered rock within $2 \mathrm{~km}$ are combined into one deposit. Tonnages, therefore, are pre-mining resources. Because many porphyry copper deposits have been mined for decades or longer (for example, the Bingham Canyon deposit has been mined since 1906), remaining tonnages and rhenium resources for these deposits are smaller than indicated in table P1.

Rhenium data for strata-bound copper deposits are limited to a few deposits in the Kupferschiefer in Poland and Germany and two deposits in Kazakhstan.
Kupferschiefer resources in Poland.-Ore reserves in deposits in the Legnica- Glogów copper belt, Poland, which includes the Lubin-Sieroszowice orebody, are estimated to be 1,180 million metric tons (Bartlett and others, 2013) that averages $0.6 \mathrm{ppm}$ rhenium (Smakowski and others, 2010). These tonnage and grade data suggest a rhenium resource of 709 metric tons.

Kupferschiefer resources in the Mansfeld-Sangerhausen area, Germany.-Jankowski (1995) reported production of 120 million metric tons of ore from 1200 to 1990 that had an estimated average rhenium grade of 21 grams per metric ton $(\mathrm{g} / \mathrm{t})$. This suggests that more than 2,500 metric tons of rhenium was mined (but not recovered). Jankowski (1995) lists a pre-mining resource of 155 million metric tons with an average grade of $21 \mathrm{~g} / \mathrm{t}$, which suggests a total pre-mining resource of about 3,300 metric tons of rhenium and that about 800 metric tons of rhenium remains. Jankowski (1995) also reports remaining resources of 35.4 million metric tons of ore with an average rhenium grade of $21 \mathrm{~g} / \mathrm{t}$, which suggests that about 740 metric tons of rhenium remains in these deposits.

Average rhenium grades and deposit tonnages for the Dzhezhazgan and the Zhaman-Aybat sandstone-type stratabound copper deposits in Kazakhstan are available from Box and others (2013). Rhenium grades for other similar deposits in Kazakhstan are not available.

Rhenium contents of some roll-front-type sandstone uranium deposits in Kazakhstan and Uzbekistan are reported by Dahlkamp (2009a, b). For most deposits, however, total contained uranium or total uranium production and ranges of uranium and (or) rhenium concentration data are reported, which precludes calculation of rhenium grades, tonnages, and resources.

The estimated tonnage and rhenium grade for the Merlin deposit in Australia is a Canada National Instrument 43-101-compliant estimate of indicated and inferred mineral resources made in April 2012 (Lycopodium Minerals QLD Pty Ltd., 2012).

Because of these limitations in the data for known deposits, estimated rhenium resources in table $\mathrm{P} 1$ and shown in figure P4 are likely imprecise, but are accurate enough to allow discussion of some aspects of U.S. and global rhenium resources. 


\section{Appendix P1 References Cited}

Note: All Web links listed were active as of the access date but may no longer be available.

Barra, Fernando, Alcota, Hugo, Rivera, Sergio, Valencia, Victor, Munizaga, Francisco, and Maksaev, Victor, 2013, Timing and formation of porphyry $\mathrm{Cu}-\mathrm{Mo}$ mineralization in the Chuquicamata district, northern Chile-New constraints from the Toki cluster: Mineralium Deposita, v. 48, no. 5, p. 629-651. [Also available at http://dx.doi.org/10.1007/ s00126-012-0452-1.]

Bartlett, S.C., Burgess, Harry, Damjanović, Bogdan, Gowans, R.M., and Lattanzi, C.R., 2013, Technical report on the copper-silver production operations of KGHM Polska Miedź S.A. in the Legnica-Glogów copper belt area of southwestern Poland, NI 43-101 technical report, prepared for KGHM Polska Miedź S.A.: Toronto, Ontario, Canada, Micon International Ltd., 159 p., accessed September 2, 2015, at http://kghm.com/en/technical-reportcopper-silver-production-operations-kghm-polska-miedzsa-legnica-glogow-copper-belt.

Box, S.E., Syusyura, Boris, Seltmann, Reimar, Creaser, R.A., Dolgopolova, Alla, and Zientek, M.L., 2013, Dzhezkazgan and associated sandstone copper deposits of the Chu-Sarysu basin, central Kazakhstan, in Hedenquist, J.W., Harris, Michael, and Camus, Francisco, eds., Geology and genesis of major copper deposits and districts of the world-A tribute to Richard H. Sillitoe (1st ed.): Littleton, Colo., Society of Economic Geologists Special Publication no. 16, p. 303-328.

Dahlkamp, F.J., 2009a, Kazakhstan, in Dahlkamp, F.J., ed., Uranium deposits of the world-Asia: Berlin, Germany, Springer-Verlag, p. 181-189. [Also available at http://dx.doi.org/10.1007/978-3-540-78558-3.]

Dahlkamp, F.J., 2009b, Uzbekistan, in Dahlkamp, F.J., ed., Uranium deposits of the world-Asia: Berlin, Germany, Springer-Verlag, p. 397-400. [Also available at http://dx.doi.org/10.1007/978-3-540-78558-3.]

Giles, D.L., and Schilling, J.H., 1972, Variation in the rhenium content of molybdenite, in Program - 24th International Geological Congress, Montreal, Quebec, Canada, 1972 Proceedings of sec. 10: Ottawa, Ontario, Canada, International Geological Congress, p. 145-153.

Jankowski, Gunter, ed., 1995, Zur geschichte des Mansfelder Kupferschiefer-Bergbaus [The history of the Mansfeld copper shale mining]: Clausthal-Zellerfeld, Germany, Gesellschaft Deutscher Metallhütten- und Bergleute, 370 p., folded page with 2 maps.
John, D.A., and Taylor, R.D., 2016, Byproducts of porphyry copper and molybdenum deposits, in Verplanck, P.L., and Hitzman, M.W., eds., Rare earth and critical elements in ore deposits: Reviews in Economic Geology, v. 18, p 137-164.

Lycopodium Minerals QLD Pty Ltd., 2012, NI 43-101 technical report, Merlin molybdenum rhenium project, feasibility study, northwest Queensland, Australia: Spring Hill, Queensland, Australia, Lycopodium Minerals QLD Pty Ltd., 302 p., accessed March 14, 2013, at http://www.ivanhoeaustralia.com/i/pdf/NI43-101_ Merlin_Technical_Report.pdf.

McCandless, T.E., Ruiz, Joaquin, and Campbell, A.R., 1993, Rhenium behavior in molybdenite in hypogene and nearsurface environments-Implications for Re-Os geochronometry: Geochimica et Cosmochimica Acta, v. 57, no. 4, p. 889-905. [Also available at http://dx.doi.org/10.1016/ 0016-7037(93)90176-w.]

Nadler, H.-G., 1997, Rhenium, in Habashi, Fathi, ed., Handbook of extractive metallurgy-Precious metals, refractory metals, scattered metals, radioactive metals, rare earth metals: New York, N.Y., Wiley-VCH, v. 3, p. 1491-1501.

Newberry, R.J., 1979, Polytypism in molybdenite (II)Relationships between polytypism, ore deposition/alteration stages and rhenium contents: American Mineralogist, v. 64, nos. 7-8, p. 768-775.

Sinclair, W.D., Jonasson, I.R., Kirkham, R.V., and Soregaroli, A.E., 2009, Rhenium and other platinum-group metals in porphyry deposits: Geological Survey of Canada Open File 6181, 1 sheet. [Also available at http://dx.doi.org/10.4095/247485.]

Singer, D.A., Berger, V.I., and Moring, B.C., 2008, Porphyry copper deposits of the world-Database and grade and tonnage models, 2008 (version 1.0): U.S. Geological Survey Open-File Report 2008-1155, 45 p., accessed April 23, 2015, at http://pubs.usgs.gov/of/2008/1155/.

Smakowski, Tadeusz, Ney, Roman, and Galos, Krzysztof, eds., 2010, Minerals yearbook of Poland 2009: Kraków, Poland, Department of Mineral Policy, Mineral and Energy Economy Research Institute, Polish Academy of Sciences, 537 p. [Also available at http://www.min-pan.krakow.pl/ pliki/Minerals_Yearbook_of_Poland_2009.pdf.] 



\section{Selenium}

By Lisa L. Stillings

Chapter $\mathrm{Q}$ of

Critical Mineral Resources of the United States-Economic and Environmental Geology and Prospects for Future Supply

Edited by Klaus J. Schulz, John H. DeYoung, Jr., Robert R. Seal II, and Dwight C. Bradley

Professional Paper 1802-0

U.S. Department of the Interior

U.S. Geological Survey 


\section{Contents of Chapter 0}

[Figure and table titles for all chapters are listed in the volume contents before the conversion factors table and list of abbreviations and symbols. A periodic table of the elements is on the inside front cover of the printed volume]

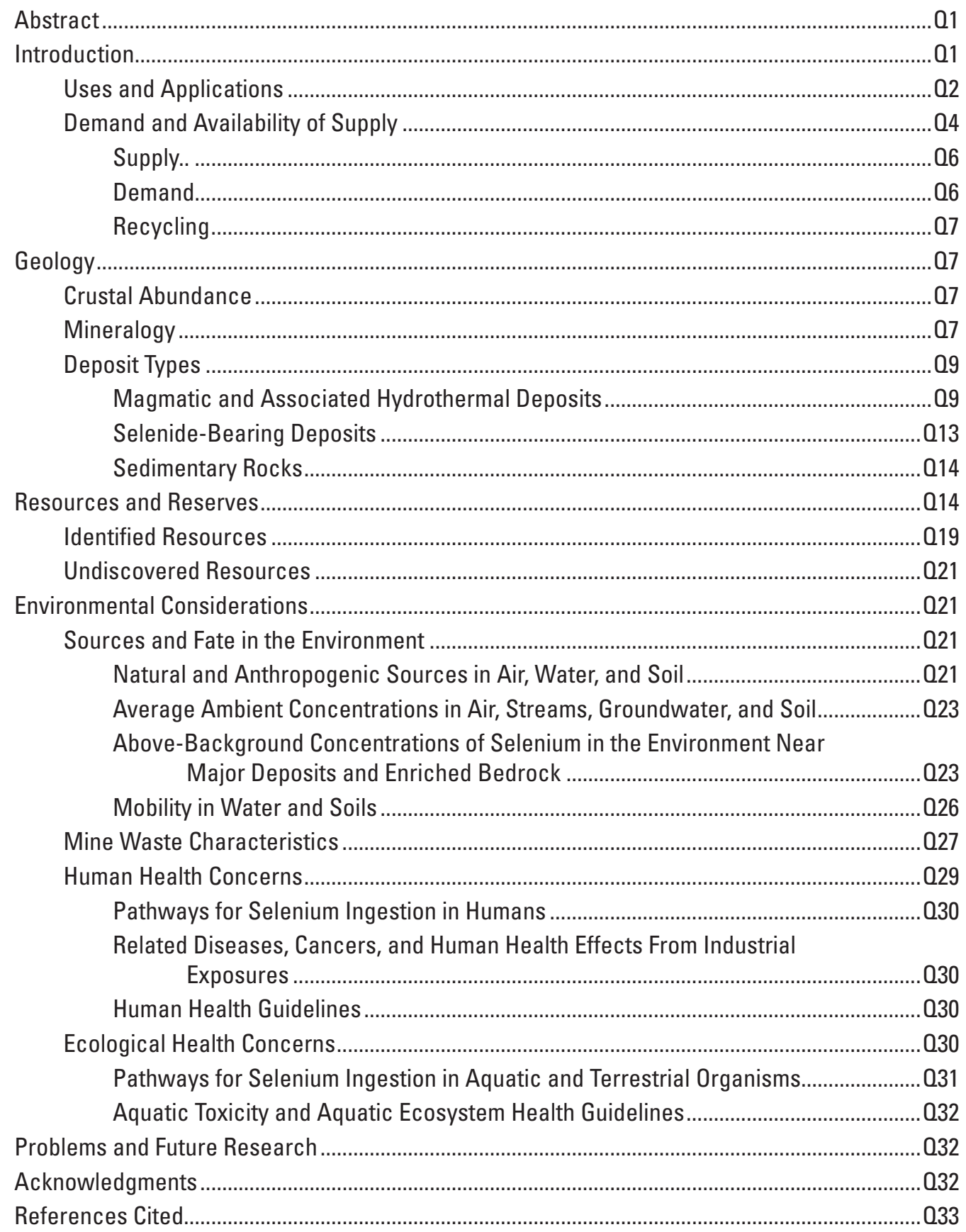

Suggested citation:

Stillings, L.L., 2017, Selenium, chap. 0 of Schulz, K.J., DeYoung, J.H., Jr., Seal, R.R., II, and Bradley, D.C., eds., Critical mineral resources of the United States-Economic and environmental geology and prospects for future supply: U.S. Geological Survey Professional Paper 1802, p. 01-055, http://dx.doi.org/10.3133/pp18020. 


\title{
Selenium
}

\author{
By Lisa L. Stillings
}

\section{Abstract}

Selenium (Se) was discovered in 1817 in pyrite from copper mines in Sweden. It is a trace element in Earth's crust, with an abundance of three to seven orders of magnitude less than the major rock-forming elements. Commercial use of selenium began in the United States in 1910, when it was used as a pigment for paints, ceramic glazes, and red glass. Since that time, it has had many other economic uses-notably, in the 1930s and 1940s, when it was used in rectifiers (which change alternating current to direct current), and in the 1960s, when it began to be used in the liner of photocopier drums. In the 21st century, other compounds have replaced selenium in these older products; modern uses for selenium include energy-efficient windows that limit heat transfer and thin-film photovoltaic cells that convert solar energy into electricity.

In Earth's crust, selenium is found as selenide minerals, selenate and selenite salts, and as substitution for sulfur in sulfide minerals. It is the sulfide minerals, most commonly those in porphyry copper deposits, that provide the bulk of the selenium produced for the international commodity market. Selenium is obtained as a byproduct of copper refining and recovered from the anode slimes generated in electrolytic production of copper. Because of this, the countries that have the largest resources and (or) reserves of copper also have the largest resources and (or) reserves of selenium.

Because selenium occurs naturally in Earth's crust, its presence in air, water, and soil results from both geologic reactions and human activity. Selenium is found concentrated naturally in soils that overlie bedrock with high selenium concentrations. Selenium mining, processing, use in industrial and agricultural applications, and disposal may all contribute selenium to the environment. A well-known case of selenium contamination from agricultural practices was discovered in 1983 in the Kesterson National Wildlife Refuge in California. There, waters draining from agricultural fields created wetlands with high concentrations of dissolved selenium in the water. The selenium was taken up by aquatic wildlife and caused massive numbers of embryonic deformities and deaths.

Regulatory agencies have since worked to safeguard ecological and human health by creating environmental exposure guidelines based upon selenium concentrations in water and in fish tissue. Any attempt to regulate selenium concentrations requires a delicate balance because selenium occurs naturally and is also a vital nutrient for the health of wildlife, domestic stock, and humans. Selenium is commonly added as a vitamin to animal feed, and in some regions of the United States and the world, it is added as an amendment to soils for uptake by agricultural crops.

The important role of selenium in economic products, energy supply, agriculture, and health will continue for well into the future. The challenge to society is to balance the benefits of selenium use with the environmental consequences of its extraction. Increased understanding of the elemental cycle of selenium in the earth may lead to new (or unconventional) sources of selenium, the discovery of new methods of extraction, and new technologies for minimizing the transfer of selenium from rock to biota, so to protect environmental and human health.

\section{Introduction}

Selenium (Se) was discovered in 1817 (and named in 1818 ) by the Swedish chemist Jöns Jacob Berzelius, who became interested in the sludge left over after the processing of pyrite from the copper mines at Falun, Sweden. The sludge was red in color and developed the unpleasant smell of rotten radishes when it was heated. Berzelius had first thought that the sludge contained tellurium but determined that the material, though having close affinities with tellurium, was a previously unknown element. Because of its affinity with tellurium (from Latin tellus, meaning Earth), the element was named selenium after the Greek word selene, meaning Moon, or satellite of Earth (Sindeeva, 1964; Lakin and Davidson, 1973; Boyd, 2011).

In the past, selenium has been described as a somewhat mysterious element, one that can be "a metal or nonmetal, a conductor or nonconductor, amorphous or crystalline, colorant or deodorant, [or] a hydrogenator or dehydrogenator" (Sargent, 1954, p. 1). It can be either red or black (Sargent, 1954) and, when ingested, either a necessary nutrient or a poison (Trelease and Beath, 1949). It is fair to say that today, almost 200 years after the discovery of selenium, scientific 
understanding has reconciled these seemingly contradictory descriptions. The complexity of selenium chemistry in economic, environmental, and geologic contexts is better understood yet remains a topic of research.

Selenium is a trace element in Earth's crust with an average crustal abundance of 0.05 part per million (ppm). Its abundance is three to seven orders of magnitude less than that of the major rock-forming elements (fig. Q1), and it is one-half to three orders of magnitude less abundant than the rare-earth elements. It is, however, more abundant (by one to four orders of magnitude) than the rarest metals, such as platinum, palladium, and gold.

Selenium is photovoltaic, meaning that it converts light into electricity. It is also photoconductive, meaning that its electrical conductivity increases with increasing light. These are the properties that make selenium useful in photovoltaic cells and solar panels, and are among the reasons why selenium has been classified as an energy-critical element (American Physical Society Panel on Public Affairs and the Materials Research Society, 2011). This chapter provides an overview of the geochemical cycle of selenium at Earth's surface and includes sections on selenium's occurrence in mineral deposits, its production and consumption, its presence in the environment, and its role in both human and environmental health.

\section{Uses and Applications}

Before World War I, according to Sargent (1954, p. 8), "selenium was regarded as the abomination of the smelterman and was discarded." Today, in comparison, selenium is considered an "energy critical element" that is important for renewable energy technologies (American Physical Society Panel on Public Affairs and the Materials Research Society, 2011), and it is also known to be an essential nutrient for humans and livestock.

Commercial use of selenium in the United States began in 1910; at that time, selenium was used as a pigment for paints, ceramic glazes, and red glass. The first large-scale commercial use of selenium began in 1915, when selenium was substituted for manganese in glassmaking. Manganese, which was used to neutralize the green tint in glass caused by iron impurities, had previously been obtained from Russia, but the supply of manganese was disrupted during World War I. Selenium, in concentrations of 0.04 to 0.14 kilogram per metric ton $(\mathrm{kg} / \mathrm{t})$ in glass, was found to be a good substitute for manganese. In addition, greater concentrations of selenium were found to provide a pink tint to glass, and at concentrations of 0.45 to $2.3 \mathrm{~kg} / \mathrm{t}$, could produce a desirable ruby red glass for use in tableware, automobile taillights, and traffic signals. The modern sheet-glass industry uses selenium in energy-efficient

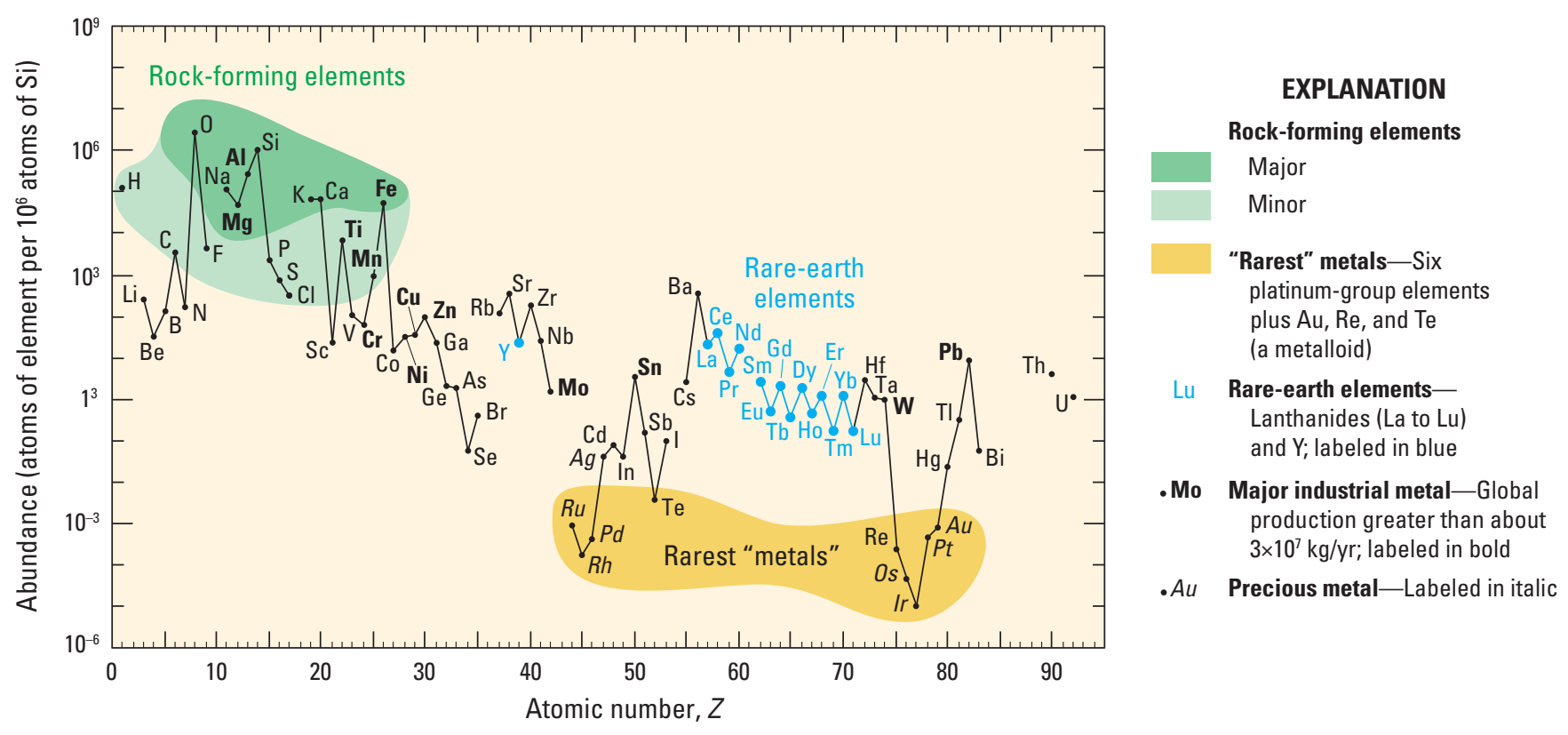

Figure 01. Graph showing relative abundance of the chemical elements in Earth's upper crust (from Haxel and others, 2002). Selenium (Se) is a trace element with an estimated concentration of approximately 0.05 part per million in Earth's crust (Greenwood and Earnshaw, 1997). See the periodic table at the front of this publication for definitions of element abbreviations. $\mathrm{kg} / \mathrm{yr}$, kilogram per year 
windows to help limit the heat transfer from sunlight (Sargent, 1954; Butterman and Brown, 2004).

After glassmaking, the next largest commercial use for selenium was the selenium rectifier. Rectifiers, which change alternating current (AC) to direct current (DC), had been known about since 1884, but they were not extensively used until inventors improved the devices in 1930 (Sargent, 1954). After this time, rectifiers began to be used in arc lamps, battery chargers, DC motors, electroplating, magnet coils, and welding. The military used selenium rectifiers in World War II for aircraft controls, ground starters for aircraft, guided missiles, radar equipment, and numerous other applications. In 1947, miniature rectifiers were developed that could be used in radio and television circuits. This miniaturization was a tremendous improvement because the new technology could deliver 200 to 500 volts of DC from a 117-volt AC source, thus eliminating the need for the older heavy and bulky transformers and rectifier tubes, and saving greater than 0.23 kilogram $(\mathrm{kg})$ of copper and $3.4 \mathrm{~kg}$ of steel per television set (Sargent, 1954).

Soon after World War II, many other uses for selenium were developed. Selenium became important in the rubber industry where it acted as an accelerator and vulcanizing agent, and it was also used to improve the resilience of rubber by increasing its resistance to heat, oxidation, and abrasion. Selenium was used as a pigment to produce orange, red, and maroon colors in the post-World War II plastics industry and in ceramics, dyes, inks, leather, paints, paper, rubber, soap, and other products. It was used to either hydrogenate or dehydrogenate organic compounds, crude oil, and coal, and it assisted in the production of edible fats, plastics, soaps, and waxes. It provided antioxidant properties to inks and oils, as well as nondrying properties to linseed, oiticica, and tung oils. Selenium began to be used in personal care products, such as dandruff and dermatitis shampoos and soaps, and in deodorants. It was also included in fungicides, herbicides, and insecticides. Finally, selenium came to be used in the steel industry to improve the machinability of stainless steel. Forging steels contained 0.18 to 0.22 percent selenium, and machining-grade steel contained 0.30 to 0.35 percent. A small amount of selenium ( 0.01 to 0.05 percent) assured a fine-grained and bubble-free texture in cast steel. Selenium was also added to copper and copper alloys to improve machinability and tensile strength (Sargent, 1954; Butterman and Brown, 2004).

The 1960s saw yet another expansion in the industrial use of selenium - as a coating on photocopier drums. Xerography, which was the forerunner to modern-day photocopying machines, was invented in 1938 and patented in 1942. It gained commercial popularity in the late 1950s when an automated process was developed using a cylindrical drum coated with selenium. Even today, in the 21 st century, the majority of paper documents are produced xerographically, either on photocopiers or laser printers, which employ a similar process but use materials other than selenium as the photoreceptor (Owen, 2004).
By 1973, 40 percent of the selenium consumed in the United States was a high-purity grade used for electrostatic printing (xerography), rectifiers, exposure meters, photoelectric cells, and optical lenses. Thirty percent went toward the manufacturing of glass. Fourteen percent was used for inorganic pigments, mainly in the form cadmium sulfoselenide, which have good light stability and heat resistance and were used in enamels, inks, paints, plastics, and rubber. In the 1990s, amorphous silicon and organic compounds started to replace selenium in xerographic drums, and the use of selenium in the photocopier industry began to decline (fig. Q2; Lakin and Davidson, 1973).

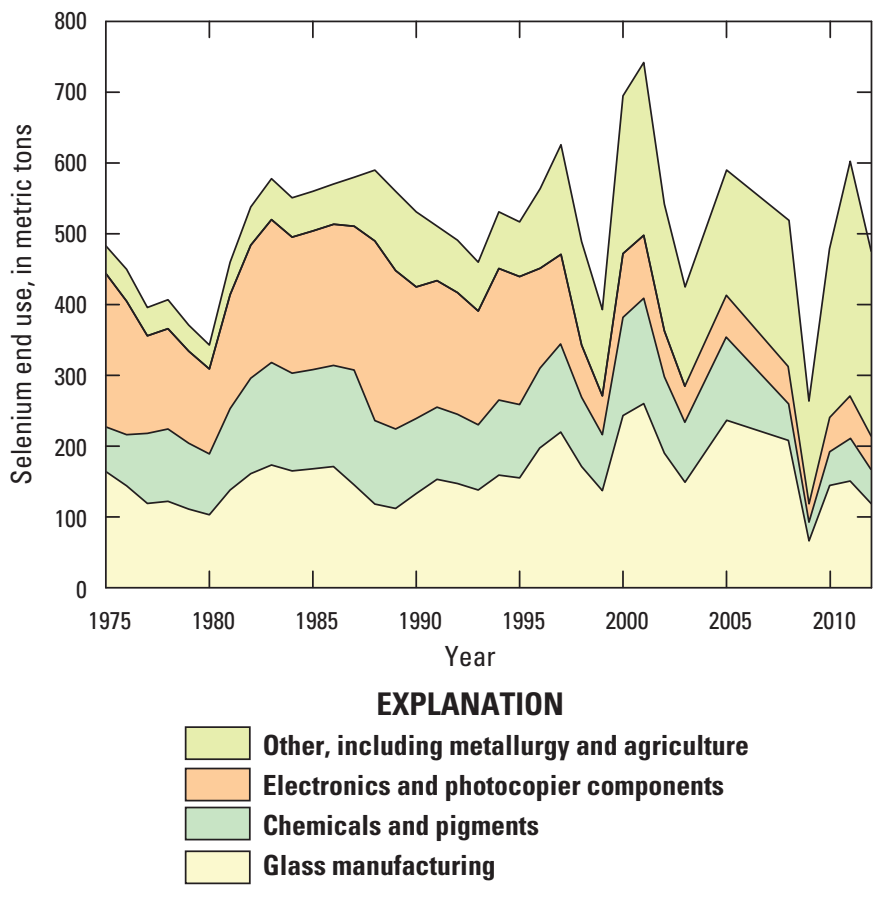

Figure 02. Graph showing end uses for selenium in the United States from 1975 to 2012. Data are unavailable for the years 2004, 2006, and 2007; hence, these data are interpolated. End use amounts for the years 2008 through 2012 are calculated as domestic apparent consumption of selenium multiplied by the fraction of world consumption attributed to each type of use. Data are from U.S. Geological Survey (2006-13, 2010-14, 2014b).

In the 21 st century, potentially large-scale demand for selenium could result from the manufacture of thin-film photovoltaic cells that employ a copper-indium-gallium-selenide (CIGS) alloy for converting solar energy into electricity. As of 2010, silicon-based photovoltaic cells still dominated the solar energy market and accounted for greater than 90 percent of all photovoltaic cells in use. These photovoltaic cells are comparatively inefficient, however, and convert only about 15 percent of adsorbed light to electricity in actual outdoor use (Bleiwas, 2010). Recent research on the second-generation 
photovoltaic thin-film cells that use CIGS technology is showing increased efficiencies of 20 to 40 percent and leading to lower production costs. Selenium is a critical element in the CIGS technology and contributes to the higher levels of light absorption and conversion to electricity demonstrated by these second-generation thin-film cells.

Bleiwas (2010) described the quantities of selenium and other metals required to produce thin-film CIGS photovoltaic cells with enough capacity (1 gigawatt) to produce 8,760 gigawatt-hours (GWh) of electricity (enough to supply 800,000 average U.S. households) annually. He calculated that 180 metric tons of selenium would be needed to produce this quantity of CIGS photovoltaic cells, which is 7.6 percent of the estimated 2013 world refinery production of selenium. The required quantities of gallium and indium necessary for this technology are 30 and 90 metric tons, or 7 percent and 11 percent of the 2014 worldwide production of these metals, respectively (Bleiwas, 2010).

\section{Demand and Availability of Supply}

Sargent (1954) provided a picture of selenium as a critical element in the post-World War II years. As noted above, 1947 was a critical year because of the development of a miniature selenium rectifier. For much of the 1940s and 1950s, selenium consumption outpaced primary refinery production, and the difference was made up from imports and releases from industry stockpiles (fig. Q3).

To safeguard the supply of selenium, the Federal Government had begun holding selenium in a strategic stockpile in the 1940s, although data on the size of the stockpile were confidential (Clark, 1950). Increased concerns regarding possible shortages became apparent when, in February 1952, the National Production Authority placed both imported and domestically produced selenium under a "complete allocation" in order to meet essential defense requirements with respect to steelmaking and rectifiers. This allocation was discontinued in early 1953, although consumption continued to be higher than domestic production through 1960 (with the exception of 1957, fig. Q3; Sargent, 1954; Massachusetts Institute of Technology, 2010; American Physical Society Panel on Public Affairs and the Materials Research Society, 2011). Ingerson (1964) noted that, throughout the 1950s and early 1960s, production and consumption of selenium was "nip and tuck," and that there was not a sufficient stockpile of selenium to last more than a few months. The situation was so "precarious" that selenium was constantly listed in Group I (that is, one of the most important) in the national stockpile list of strategic and critical materials. In 1961, the U.S. Bureau of Mines reported that the Federal stockpile held 254,000 pounds (lb) (115 metric tons) of selenium (U.S. Bureau of Mines, 1963), and, in 1964, the Office of Emergency Planning increased the stockpile objective for selenium to 475,000 lb (215 metric tons) (U.S. Bureau of Mines, 1965).
By 1970, the balance between supply and demand had shifted - selenium consumption became consistently less than the total available supply (primary refinery production plus imports plus release from stockpiles) and the excess selenium was available for export (fig. Q3; Lakin and Davidson, 1973). In August 1971, Congress authorized the disposal of the national stockpile, and the last lot was sold on May 26, 1976 (U.S. Bureau of Mines, 1973, 1978). Despite the sufficient domestic supply of selenium, however, there was some concern in 1973 of an impending shortage of selenium owing to (a) the increased use of in situ leaching for copper production from its ores, which did not allow for recovery of associated selenium, and (b) the discovery that selenium was necessary for animal nutrition. It was learned that selenium deficiency in commercial feed could result in death and disease for poultry and livestock; this happened in a number of countries and led to heavy economic losses. The deficiency could be reversed, however, by adding selenium to fertilizer for agricultural lands. Lakin and Davidson (1973) estimated that 5.7 million kilograms per year of selenium would be required to treat the most severely deficient agricultural lands in the United States.

Jensen (1985) tracked the supply of and demand for selenium from 1973 to 1983 by comparing selenium production from U.S. mines to total U.S. supply, including available stockpiles. During this period, U.S. primary refinery production peaked at 360 metric tons in 1973, dropped to a low of 140 metric tons in 1980, and recovered to 350 metric tons (revised) in 1983 (U.S. Bureau of Mines, 1989). The total U.S. supply was always higher than mine production during this period, with a high of 831 metric tons in 1974 and a low of 581 metric tons in 1977. (Jensen's calculations include the entire quantity of selenium held in stockpiles, and not the change in stockpile mass, as indicated in fig Q3.) The difference between mine production and total supply was owing to the refineries' use of U.S. Government selenium stockpiles, selenium imports, and industry stockpiles. The largest releases from the U.S. Government stockpile took place in 1973 and 1974 (150 and 55 metric tons, respectively) (U.S. Bureau of Mines, 1980). The last shipment took place in 1976, and since then, refineries have relied on an increased supply of selenium from imports (fig. Q3).

George (2013) tracked the price of selenium from 1970 to 2010 (fig. Q4). As with any commodity, the price reflects supply and demand. By using yearly prices in 1992 constant dollars, George showed that the price of selenium in the 1970s was higher than it was in 2010. Prices spiked far above 2010 prices during 1974-76 because of the elimination of the U.S. Government selenium stockpile, low commercial inventories, reduced domestic inventories, and increased demand for plain-paper copiers. Prices remained relatively steady from 1981 to 2003 , at approximately $\$ 4$ to $\$ 12$ per pound (in 1992 dollars), because there was sufficient worldwide supply, because selenium substitutes were available for many industrial applications, and because there were no new large-scale uses for selenium. The price rise and volatility for 


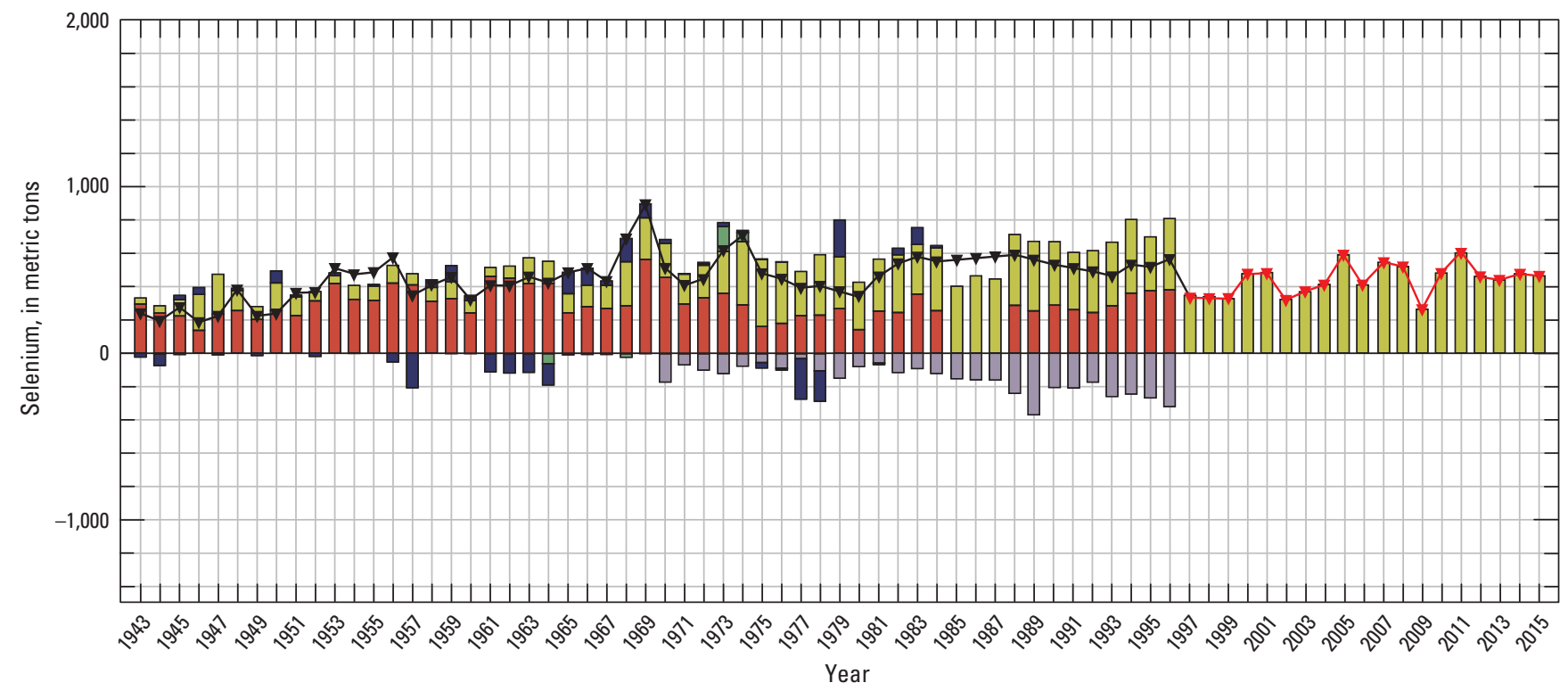

Figure 03. Graph illustrating a mass balance for selenium in the United States from 1943 to 2015. The supply of selenium to the United States is estimated from primary refinery production plus imports for consumption (meaning that material is added to the supply for that year), minus exports from the United States (removal of selenium from the supply for that year-shown as a negative quantity), plus or minus changes in Government and industry stockpiles (releases are shown as positive quantities and additions are shown as negative quantities), to calculate domestic apparent consumption.

Data from 1943 to 2014 are from U.S. Geological Survey (2014c), and data for 2015 are from U.S. Geological Survey (2017). Primary refinery production numbers are not available for 1985 to 1987, and from 1997 to 2015, they are withheld because they are proprietary; hence, no primary refinery production data are plotted for these years. For the years 1985 to 1987 , apparent consumption data have been estimated by linear interpolation. For 1997 to 2015, domestic apparent consumption data are withheld to avoid disclosing company proprietary data, and imports for consumption are used as a proxy for apparent consumption (U.S. Geological Survey, 2014c, 2017). The Federal Government held selenium in a strategic stockpile in the 1940s, but data on the size of the stockpile were confidential (Clark, 1950, p. 1342). The U.S. Bureau of Mines reported the quantity of selenium held in the national stockpile in 1961 (U.S. Bureau of Mines, 1966, p. 1071) and continued to report the size of the stockpile until the last of the selenium was sold on May 26, 1976 (U.S. Bureau of Mines, 1978, p. 1467), and there has been no stockpile since 1976. The USGS reported numbers for the industry-held stockpile from 1944 through 1984, but these values have been withheld since 1985 to avoid disclosing company proprietary data (U.S. Geological Survey, 2014c). Domestic secondary production of selenium (selenium recovered from recycled rectifiers, catalysts, and photocopier drums) was never a large percentage of domestic supply and was inconsistently reported during the period 1943-2016 and thus is not included in this compilation. 
selenium since 2003 is attributed mainly to increased demand for selenium from manganese producers in China. Manganese, which is an alloying element in steel production, is produced by an electrolytic process. Substitution of selenium dioxide $\left(\mathrm{SeO}_{2(\mathrm{~g})}\right)$ for sulfur dioxide $\left(\mathrm{SO}_{2(\mathrm{~g})}\right)$ lowers the energy requirements of the electrolytic cells, allowing manganese to be produced more cheaply.

\section{Supply}

The period from 1945 to 1960 was a period when selenium demand (apparent consumption) outpaced supply from primary refinery production (1957 was an exception). During this time, U.S. primary refinery production averaged 290 metric tons per year; U.S. producers were American Smelting \& Refining Co., U.S. Metals Refining Co., and International Smelting \& Refining Co. (fig. Q3). During 1961-64, the total supply of selenium was greater than consumption, and the extra supply was stored in industry and Government stockpiles (fig. Q3). Primary refinery production decreased in 1965-68, and selenium was released from stockpiles to meet demand. Beginning in 1969, the total supply of selenium has been sufficient to meet demand, and excess supply has been exported.

Domestic production from 1947 to 1953, which was the beginning of selenium consumption for modern technologies, contrasts markedly with production nearly 50 years later. The latest available report of domestic selenium production was for 1996, when $379,000 \mathrm{~kg}$ (379 metric tons) of selenium was produced as a primary product. Production figures were not published after 1996 to avoid disclosing proprietary data from the one or two known domestic refineries, and because selenium-containing residues and anode slimes from other domestic copper refiners were exported for processing.

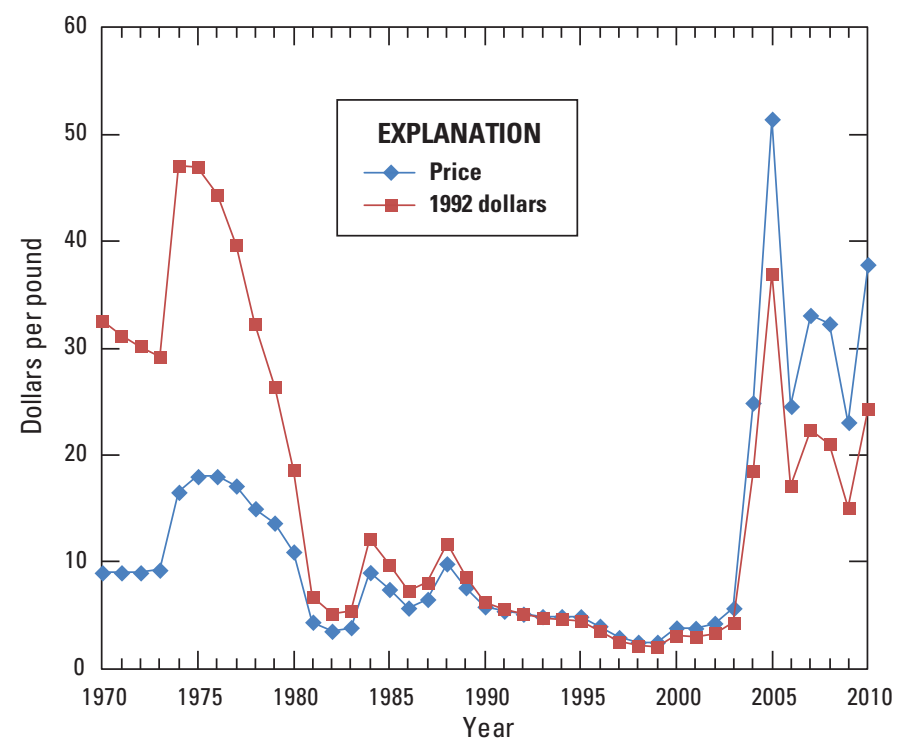

Just as U.S. domestic production of selenium increased in the years following 1947, so did global production. Sargent (1954) reported that during 1926-31, the Soviet Union produced between 2.3 and 2.7 metric tons per year of selenium. In 1946, Canada produced 237 metric tons, although this production level could not be sustained owing to a reduction in output of selenium-rich high-grade ores from the Horne Mine at Noranda, Quebec, Canada; by 1950, Canada's production fell to less than 160 metric tons. In 1951, Sweden produced 41 metric tons; Belgium, 10 metric tons; and West Germany, 7.3 metric tons. In 1952, Belgium increased its production to 17 metric tons, and Africa produced 14 metric tons. Belgium increased production again in 1953 to about 27 metric tons, and production in the Soviet Union in that year was estimated to have increased to 45 metric tons.

Total global production in 1996 (the last year for which domestic production numbers were reported) was 2,250 metric tons, and the United States accounted for almost 17 percent of global production, or about 380 metric tons. U.S. production ranked third behind Canada (694 metric tons) and Japan (588 metric tons). During the years 1997 to 2015, Japan was the leading international producer of selenium, although it briefly slipped into second place in 2005. Germany was the second-ranked international producer in 2015. China and the United States produced selenium during this time period as well, but their production numbers are not available (U.S. Geological Survey, 1997-2014).

\section{Demand}

From 1943 to 2015, U.S. consumption of selenium was between 184 (1946) and 896 (1969) metric tons per year (fig. Q3) and was affected by increased substitution

\section{Significant events affecting selenium prices since 1970}

1974-76 Government stocks liquidated by 1974; low commercial inventories; reduced domestic production from recession and copper industry strike; increased import dependence; continued growth in plain-paper copiers

1976-80 Stock buildup and reduced demand following 1973-75 recession; production level established at about one-half of 1969 peak

1981-83 Demand surged; stocks remained high; plain-paper copiers and glass manufacturing dominate demand

1984-89 World stocks declined as demand outstrips production; speculation encouraged price fluctuations; domestic demand averaged 1.3 million pounds

1990-91 World production rose; demand slackened owing to recession; stock decline was reversed

1990-99 Organic photoreceptor compounds replaced selenium compounds for plain-paper copiers

2003-10 Increased but fluctuating demand from manganese producers in China; global financial crisis in 2008 reduced demand but supplies remained tight, and prices remained relatively high

Figure 04. Graph showing average annual prices of commercial-grade selenium from 1970 to 2010. Both the nominal (unadjusted) prices and real prices (in 1992 constant dollars) are shown. Graph is from George (2013). 
of other materials for selenium and changes in technology that made many selenium products obsolete. As examples, high-purity silicon replaced, or has become a major substitute for, selenium in rectifiers; silicon can substitute for selenium in photovoltaic cells; and amorphous silicon and organic photoreceptors have replaced selenium in photocopier drums. Organic pigments can substitute for cadmium sulfoselenide pigments; cerium oxide $(\mathrm{CeO})$ can substitute for selenium in glass; tellurium can substitute for selenium in pigments and rubber compounding; bismuth, lead, and tellurium can substitute for selenium in metal alloys; and tellurium can substitute for selenium in lead-free brass. Even with a potential increased use of selenium in CIGS photovoltaic solar cells, the demand for selenium will likely remain steady for the near future.

\section{Recycling}

Traditionally, selenium has been used in U.S. manufacturing for glass decolorizers, pigments, fertilizers, animal feeds, and metal alloys. These have been termed "dissipative" uses because of the small amounts of selenium involved, the sheer number of these products, and the difficulty in recovering selenium from them because of the disposal or recycling practices for the products. Even when selenium-containing glass and metal alloys are recycled, they are not segregated from other forms of scrap, and the selenium content is probably volatilized during melting. Major nondissipative uses for selenium have been as photoreceptors in photocopier drums and as rectifiers; however, manufacturers began to replace selenium with organic photoreceptor compounds in the 1980s; consequently, there is no longer a substantial supply of photocopier drums containing selenium for recycling, and large selenium rectifiers have been replaced with ones that use silicon. Even the use of selenium in AC current rectifiers has ended, as silicon-based rectifiers have been developed that are cheaper and more reliable. As a result of this lack of supply, no selenium recycling facilities remain in operation in the United States. This may change in the future as selenium is increasingly used in the manufacture of thin-film CIGS photovoltaic cells for solar panels (George and Wagner, 2009).

\section{Geology}

The distribution of selenium in Earth's crust is closely associated with that of sulfur (S), and because of their similar ionic radii-198 picometers (pm) for Se(-II) versus $184 \mathrm{pm}$ for S(-II) - selenium readily substitutes for sulfur in structures of sulfide minerals. Selenium is less commonly found in sulfate deposits. Selenium is brought to Earth's surface by way of magmatic intrusions, where it is found in sulfide minerals, and by way of volcanic emissions, where it is vented as the gases selenium dioxide $\left(\mathrm{SeO}_{2}\right)$ and hydrogen selenide $\left(\mathrm{H}_{2} \mathrm{Se}\right)$.

\section{Crustal Abundance}

The crustal abundance of selenium has been estimated in different ways. Sindeeva (1964) estimated 0.14 ppm selenium for rocks in the Soviet Union; Brunfelt and Steinnes (1967) estimated $0.04 \mathrm{ppm}$ based on standard rock samples provided by the U.S. Geological Survey (USGS), and Wells (1967) reported an average of $0.6 \mathrm{ppm}$ selenium in volcanic ash samples from New Zealand and $0.4 \mathrm{ppm}$ in New Zealand lava flows (Lakin and Davidson, 1973, and references therein).

An indirect method for estimating selenium abundance was suggested by Goldschmidt and Strock (1935) based upon an estimated sulfur-to-selenium ratio of 6,000:1 in sulfide minerals. Starting with the crustal abundance for sulfur of $520 \mathrm{ppm}$, they divided this number by the sulfur-to-selenium ratio and arrived at an estimate of $0.09 \mathrm{ppm}$ selenium in Earth's crust. Turekian and Wedepohl (1961) revised the crustal abundance of sulfur to $300 \mathrm{ppm}$, and by using the same sulfur-to-selenium ratio of 6,000:1, they estimated $0.05 \mathrm{ppm}$ selenium in Earth's crust. This figure of $0.05 \mathrm{ppm}$ remains the accepted estimate of the crustal abundance of selenium today (fig. Q1; Greenwood and Earnshaw, 1997).

\section{Mineralogy}

Selenium forms selenide minerals and selenite and selenate salts with chalcophile elements (for example, bismuth, copper, lead, mercury, and silver). Some of the natural selenides, such as berzelianite $\left(\mathrm{Cu}_{2} \mathrm{Se}\right)$, clausthalite $(\mathrm{PbSe})$, guanajuatite $\left(\mathrm{Bi}_{2} \mathrm{Se}_{3}\right)$, krutaite $\left(\mathrm{CuSe}_{2}\right)$, tiemannite ( $\mathrm{HgSe})$, and umangite $\left(\mathrm{Cu}_{3} \mathrm{Se}_{2}\right)$ form from selenium-rich hydrothermal fluids (Pirri, 2002) in deposits that "span the magmatic-hydrothermal spectrum" (Ciobanu and others, 2006, p. 163) - from 65 to 300 degrees Celsius $\left({ }^{\circ} \mathrm{C}\right)$, as determined from fluid inclusion and isotopic studies, up to $800{ }^{\circ} \mathrm{C}$ in laboratory synthesis studies. Other selenium-bearing minerals, such as aguilarite $\left(\mathrm{Ag}_{4} \mathrm{SeS}\right)$, contain selenium and sulfur in isomorphic substitution, and some systems show a continuous solid solution between selenium and sulfur end members. Selenium forms only one oxide mineral: downeyite $\left(\mathrm{SeO}_{2}\right)$. The selenium minerals recognized by the International Mineralogical Association (IMA) are listed in table Q1 at the back of this chapter. In a literature survey of selenium concentrations reported in worldwide sulfide and selenide deposits, selenium concentrations in selenides can be as high as 70.23 weight percent, such as in trogtalite $\left(\mathrm{CoSe}_{2}\right)$, which is found in the Musonoi Mine in the Democratic Republic of the Congo (Congo [Kinshasa]), and up to 4,617 ppm in sulfides, such as in bornite $\left(\mathrm{Cu}_{5} \mathrm{FeS}_{4}\right)$ in the Glava Mine (in Sweden) and the Grusen, Moberg, Tinnsjå, and Tjøstølflaten Mines (all in Norway) (table Q2 at back of chapter).

In the Dana classification system for minerals (Gaines and others, 1997), selenium minerals are included in Classes 02 and 03 with sulfides and sulfosalts, respectively. This hierarchical 
system emphasizes the similarity between sulfides and selenides with respect to their chemistry, atomic characteristics, and crystal structure. In selenium-bearing hydrothermal systems, selenium may commonly substitute into sulfides, such as bornite, chalcocite $\left(\mathrm{Cu}_{2} \mathrm{~S}\right)$, chalcopyrite $\left(\mathrm{CuFeS}_{2}\right)$, digenite $\left(\mathrm{Cu}_{9} \mathrm{~S}_{5}\right)$, galena $(\mathrm{PbS})$, molybdenite $\left(\mathrm{MoS}_{2}\right)$, pyrite $\left(\mathrm{FeS}_{2}\right)$, and vaesite $\left(\mathrm{NiS}_{2}\right)$ (Simon and others, 1997).

Significant selenium concentrations can be found in sulfide minerals, and numerous studies have been conducted to determine whether the selenium-sulfur content represents a continuous solid solution between end members, whether a compositional gap exists in an apparent solid-solution series, or whether the presence of selenium in a sulfide mineral is merely an opportunistic isomorphic substitution.

Phases in the silver-gold-sulfur-selenium system show ready substitution of selenium for sulfur and, in some cases, continuous solid solution exists; for example, from $\alpha \mathrm{Ag}_{2} \mathrm{Se}$ to $\alpha \mathrm{Ag}_{3} \mathrm{AuSe}_{2}(\alpha$ indicates the high temperature structural modification of these phases - naumannite $\left[\mathrm{Ag}_{2} \mathrm{Se}\right]$ to fischesserite $\left[\mathrm{Ag}_{3} \mathrm{AuSe}_{2}\right]$ ) (Simon and Essene, 1996). Many mineral phases in this system are found in the Broken Hills deposit of the Hauraki goldfield in New Zealand. Using electron microprobe analysis (EMPA), Cocker and others (2013) observed phases with morphologies and compositions similar to the known minerals aguilarite and fischesserite, and uytenbogaardtite $\left(\mathrm{Ag}_{3} \mathrm{AuS}_{2}\right)$ and petrovskaite $(\mathrm{AuAg}(\mathrm{S}, \mathrm{Se}))$, but with atomic sulfur-to-(sulfur+selenium) ratios falling between the known members. For example, they observed substitution of selenium into uytenbogaardtite, with a sulfur-to-(sulfur+selenium) ratio that ranges from 0.55 to almost 1 . They noted, however, that uytenbogaardtite and fischesserite cannot be end members of a solid solution series because the two minerals possess different crystal structures (tetragonal and isometric [cubic], respectively).

Likewise, solid solution would not be expected between the phases acanthite $\left(\mathrm{Ag}_{2} \mathrm{~S}\right)$ and aguilarite $\left(\mathrm{Ag}_{4} \mathrm{SeS}\right)$ because they belong to different crystal systems. Whereas chemical analyses have shown significant substitution of sulfur and selenium between these two phases, this may be an analytical error owing to their occurrence as fine intergrowths with one another. It is unclear whether the chemical analyses come from chemically homogenous grains or whether the size of the analytical spot size produces a composite analysis. Many of the phases in the Broken Hills deposit showed compositions that do not match known minerals and may form a continuum between approximately $(\mathrm{Ag}, \mathrm{Au})_{8} \mathrm{~S}_{3}$ and $(\mathrm{Ag}, \mathrm{Au})_{8} \mathrm{Se}_{3}$ (Cocker and others, 2013).

Sometimes a solid solution may be present in only one polymorph of a mineral composition. For example, solid solution may exist between the low-temperature orthorhombic mineral structures of naumannite, and aguilarite at temperatures from below 120 to $135^{\circ} \mathrm{C}$. At higher temperatures, they invert to their cubic polymorphs (Petruk and others, 1974). EMPA analyses of Cocker and others (2013) show a compositional gap between these low-temperature orthorhombic phases, but data from Izawa and others (1990) suggest that these phases may show solid solution between atomic selenium-to-(selenium+sulfur) ratios of 0.57 to 0.88 .

Other systems with solid solution compositions include lead-sulfur-selenium systems, where solid solution has been observed between clausthalite ( $\mathrm{PbSe}$ ) and galena $(\mathrm{PbS})$ (Simon and Essene, 1996). Examples are found in various uranium-vanadium deposits of the Colorado Plateau (Coleman, 1959) and in the Niederschlema-Alberoda uraniumselenium-polymetallic deposit in Erzgebirge, Germany, where Förster (2005) documented the entire clausthalite to galena solid solution covering the range of $\mathrm{PbS}_{1.00}$ to $\mathrm{Pb}\left(\mathrm{S}_{0.04} \mathrm{Se}_{0.96}\right)$.

Complete solid solution can also be found between cinnabar $(\mathrm{HgS})$ and tiemannite $(\mathrm{HgSe})$; sphalerite $(\mathrm{ZnS})$ and stilleite $(\mathrm{ZnSe})$; and native selenium $\left(\mathrm{Se}^{0}\right)$ and native tellurium $\left(\mathrm{Te}^{0}\right)$. Quaternary systems show extensive or complete solid solution at higher temperatures (Simon and Essene, 1996). At $800{ }^{\circ} \mathrm{C}$, Drabek (1995) observed a complete solid solution between molybdenite $\left(\mathrm{MoS}_{2}\right)$ and molybdenum diselenide $\left(\mathrm{MoSe}_{2}\right)$ under dry laboratory conditions with a high fugacity of selenium to sulfur $\left(f_{\mathrm{Se} 2} / f_{\mathrm{S} 2}\right)$ ratio.

Selenium-bearing sulfides may form as a replacement texture in ore deposits. Paniagua (1995) suggested that selenium-rich vaesite $\left(\mathrm{Ni}(\mathrm{S}, \mathrm{Se})_{2}\right)$ and selenium-rich villamaninite $\left((\mathrm{Cu}, \mathrm{Ni}, \mathrm{Co}, \mathrm{Fe})(\mathrm{S}, \mathrm{Se})_{2}\right)$ of the Providencia Mine in Leon, Spain, are breakdown products of copper-nickel disulfides and that these phases show incremental substitution of sulfur by selenium with increasing copper+nickel contents because of increasing bonding distances within the structure. Many studies point to the formation of selenium-bearing sulfides during late stages of ore mineralization. For example, in epithermal gold-silver deposits in western Nevada, selenium enrichment is observed in late-stage stibnite $\left(\mathrm{Sb}_{2} \mathrm{~S}_{3}\right)$ and sphalerite, and in arsenian rims on earlier formed pyrite and marcasite $\left(\mathrm{FeS}_{2}\right.$; John and others, 2003). John and others (2003) conclude that selenides are common in late-stage ores found in veins and breccias that fill open-spaces, and form from the reaction of late-stage selenium-rich ore fluid (formed after substantial boiling and loss of hydrogen sulfide $\left[\mathrm{H}_{2} \mathrm{~S}\right]$ to vapor) with the initial alteration sulfide assembly.

Because of the close association between selenium and sulfur, Simon and Essene (1996) made a systematic thermodynamic study of the stability of selenide minerals relative to sulfides, oxides, and native elements. Their conclusions were that (a) the stability fields of selenides, in general, are more restricted than sulfide minerals, given similar fugacity values of $\mathrm{S}_{2(\mathrm{~g})}$ and $\mathrm{Se}_{2(\mathrm{~g})}$ (represented by $f \mathrm{Se}_{2(\mathrm{~g})}$ and $f \mathrm{~S}_{2(\mathrm{~g})}$, respectively); (b) in hydrothermal fluids, most oxide minerals are unstable relative to their corresponding selenide mineral; and (c) for a given selenide, the larger the stability field, the more commonly it is found in ore deposits; for example, clausthalite.

In a companion paper to the above, Simon and others (1997) discussed the thermodynamic conditions that favor deposition of selenide minerals instead of selenium-substituted sulfide minerals. They conclude that an oxidizing environment is needed to form most selenide minerals. High oxygen 
fugacity values $\left(f \mathrm{O}_{2(\mathrm{~g})}\right)$ enhance separation of selenium from sulfur, leading to high $f \mathrm{Se}_{2(\mathrm{~g})} / f \mathrm{~S}_{2(\mathrm{~g})}$, which enables deposition of selenide minerals and limits the formation of sulfide minerals. In contrast, mineralizing systems characterized by low oxygen fugacity and the presence of sulfide minerals can deposit only silver selenides and selenium-substituted sulfide minerals.

Although some selenium is produced from gold and silver selenide deposits that have anomalously high concentrations of selenium (table Q2), most of the world's production of selenium metal is from copper, copper-nickel, and some lead and zinc sulfide deposits where selenium is found in isomorphous substitution with sulfur (Bleiwas, 2010). Table Q2 illustrates the range of selenium concentrations found in sulfur and selenium minerals worldwide.

\section{Deposit Types}

The compilation of selenium deposits provided by Sindeeva (1964) remains one of the most exhaustive in today's literature. Because the information is well organized and informative in its original form, the reader is referred to table 7 (p. 174) in "Mineralogy and Types of Deposits of Selenium and Tellurium" (modified as table Q3 in this report). Here, the author noted that selenium can be found in several genetic deposit types - magmatic, volcanic, hydrothermal, and exogenic (that is, produced by chemical and mechanical weathering at Earth's surface; Jackson, 1997). In Sindeeva's table, examples from hydrothermal deposits outnumber the rest combined. In the majority of the examples, selenium is found substituted into sulfide minerals, such as chalcopyrite, cinnabar, cobaltite (CoAsS), galena, molybdenite, pentlandite $\left((\mathrm{Fe}, \mathrm{Ni}, \mathrm{Co})_{9} \mathrm{~S}_{8}\right)$, pyrite, pyrrhotite $\left(\mathrm{Fe}_{1-\mathrm{x}} \mathrm{S}\right)$, sphalerite, and stibnite. Selenide minerals are less common than seleniumbearing sulfides, but such phases as clausthalite $(\mathrm{PbSe})$, guanajuatite $\left(\mathrm{Bi}_{2} \mathrm{Se}_{3}\right)$, naumannite $\left(\mathrm{Ag}_{2} \mathrm{Se}\right)$, and penroseite (blockite) $\left((\mathrm{Ni}, \mathrm{Co}, \mathrm{Cu}) \mathrm{Se}_{2}\right)$, are found in veins and stockworks of hydrothermal deposits. The compilation includes some deposits where selenium can be found as selenites, selenates, and native selenium (for example, volcanic tuffs in Shoshone and Riverton, Wyoming).

As a result of a thorough investigation into selenium content of ore deposits and its mineral associations, Sindeeva (1964) concluded the following:

- Deposits containing independent selenium minerals are rare; instead, selenium usually occurs as an isomorphous substitution for sulfur in sulfide minerals.

- The largest resources of selenium are connected with ultrabasic and basic rocks and found in magmatic and hydrothermal chalcopyrite-pentlandite-pyrrhotite deposits, especially in sulfide veins that occur during late stages of formation.
- Pyrite deposits contain large resources of selenium, which seem to accompany late stages of mineralization.

- Copper and molybdenum deposits contain selenium, where the enrichment occurred in late-stage molybdenites.

- Polymetallic lead-zinc deposits can contain selenium.

- Gold deposits can contain selenium. Selenium will form independent minerals in these deposits if the ore contains very little sulfur; otherwise, it will be dispersed in sulfide minerals.

- Quartz-wolframite ((Fe,Mn) $\left.\mathrm{WO}_{4}\right)$-bismuth and cassiterite $\left(\mathrm{SnO}_{2}\right)$-quartz-sulfide deposits are sometimes accompanied by selenium.

- Cobaltite-selenide-telluride resources that contain selenium are not frequently observed, but selenium can be associated with chloritization in this assemblage.

- Uranium deposits carry selenium but the co-occurrence of these elements could use more study.

- Cinnabar-stibnite deposits might contain appreciable selenium and could use more study.

\section{Magmatic and Associated Hydrothermal Deposits}

Aside from selenium minerals, selenium-bearing sulfide deposits represent the greatest known concentration of selenium in Earth's crust. The reported average selenium concentration in magmatic sulfides is 0.02 percent (Sargent, 1954). In intrusive rocks, selenium will substitute for sulfur in sulfide minerals because of their similar ionic radii. Hightemperature sulfides, such as pentlandite and pyrrhotite, have a sulfur-to-selenium ratio of 7,000:1, and Goldschmidt (1954) estimated hydrothermal pyrite to have a sulfur-to-selenium ratio of between 10,000 and 20,000:1. In the Falun mining area of Sweden, selenium is present in the following sulfide minerals, in decreasing order of concentration: galena, chalcopyrite, arsenopyrite, sphalerite, pyrite, and pyrrhotite (Sindeeva, 1964).

Attempts have been made to standardize the estimate of selenium in sulfide ore minerals and the most commonly used number for the average selenium content in magmatic and associated hydrothermal sulfides is 0.02 percent. Other ratios exist; for example, in porphyry copper ore with 0.5 percent copper, the selenium content is $2.5 \mathrm{ppm}$, or a copper-toselenium ratio of 2,000:1 (Sargent, 1954; Lakin and Davidson, 1973). The U.S. Geological Survey and the former U.S. Bureau of Mines have long based their selenium production estimates on copper production figures using a factor of 0.0215 percent. Because copper ore from Canada has a higher selenium content, however, a factor of 0.064 percent is used to estimate selenium produced from its ores (for example, selenium in ore from mines located in the Sudbury basin of Ontario, Canada (table Q4; Jensen, 1985; George and Wagner, 2009). 
Table 03. Selenium concentrations in sulfide minerals and other phases, in various deposit types.

[Data are from Sindeeva, 1964. Do., do., ditto; wt. \%, weight percent; n.r., not reported, although the deposit was described as containing selenium and (or) selenide minerals; b.d.l., below detection limit; $\mathrm{Hg}$, mercury; S, sulfur; Se, selenium]

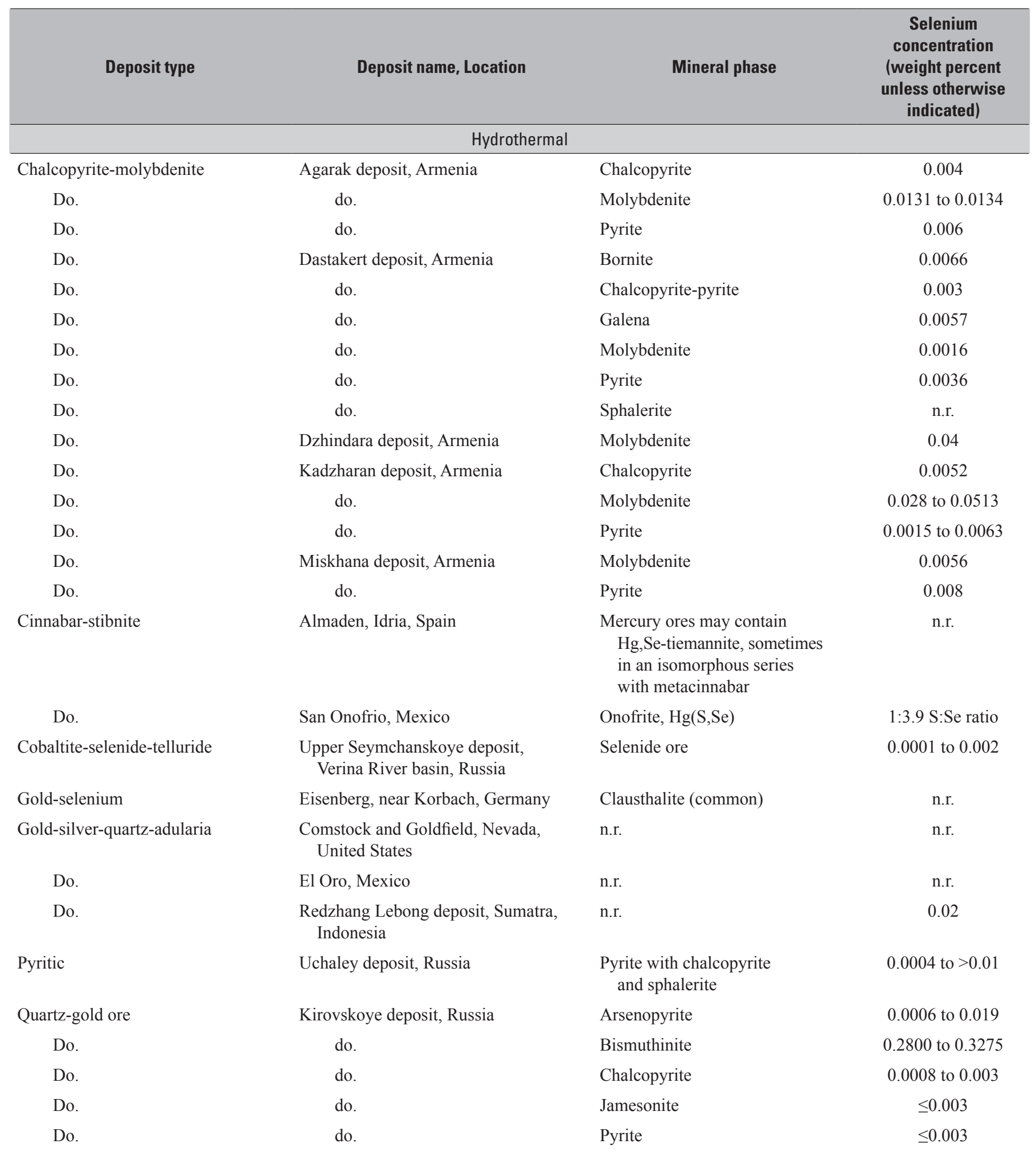


Table 03. Selenium concentrations in sulfide minerals and other phases, in various deposit types.-Continued

[Data are from Sindeeva, 1964. Do., do., ditto; wt. \%, weight percent; n.r., not reported, although the deposit was described as containing selenium and (or) selenide minerals; b.d.l., below detection limit; $\mathrm{Hg}$, mercury; S, sulfur; Se, selenium]

\begin{tabular}{|c|c|c|c|}
\hline Deposit type & Deposit name, Location & Mineral phase & $\begin{array}{c}\text { Selenium } \\
\text { concentration } \\
\text { (weight percent } \\
\text { unless otherwise } \\
\text { indicated) }\end{array}$ \\
\hline \multicolumn{4}{|c|}{ Hydrothermal-Continued } \\
\hline Quartz-wolframite-bismuth & Bukuka deposit, Russia & Bismuthinite & 0.016 \\
\hline Do. & do. & Galena & 0.0116 \\
\hline Do. & do. & Molybdenite & 0.006 \\
\hline Do. & do. & Pyrite & 0.0175 \\
\hline Do. & do. & Pyrrhotite & 0.0013 \\
\hline Do. & do. & Sphalerite & 0.0017 \\
\hline Uranite-selenide & $\begin{array}{c}\text { Katanga deposit, Democratic Republic } \\
\text { of the Congo (Congo [Kinshasa]) }\end{array}$ & Reported to contain selenides & n.r. \\
\hline Do. & $\begin{array}{l}\text { Shinkolobse deposit, Democratic } \\
\text { Republic of the Congo (Congo } \\
\text { [Kinshasa]) }\end{array}$ & Selenide minerals in 114th horizon & 19 \\
\hline \multicolumn{4}{|c|}{ Magmatic } \\
\hline Magmatic & Noril'sk, Siberia, Russia & Bornite & 0.01 to 0.015 \\
\hline Do. & do. & Chalcopyrite & 0.005 to 0.020 \\
\hline Andesite tuffs & $\begin{array}{l}\text { Shoshone, Jasper, and Riverton depos- } \\
\text { its, Wyoming, United States }\end{array}$ & n.r. & 0.003 to 0.012 \\
\hline Native sulfur & Hawaiian Islands & n.r. & 5.18 \\
\hline Do. & $\begin{array}{l}\text { Kurile Islands, additional } \\
\text { Kamchatka locations, Russia }\end{array}$ & n.r. & 0.0005 to 0.19 \\
\hline Do. & Lipari Islands, Italy & n.r. & 1.13 \\
\hline Do. & $\begin{array}{l}\text { Mendeleev Volcano, Kunashir Island, } \\
\text { Russia }\end{array}$ & n.r. & 0.12 \\
\hline Do. & $\begin{array}{l}\text { Mutnovskii Volcano, Kamchatka, } \\
\text { Russia }\end{array}$ & n.r. & 0.08 \\
\hline Do. & New Zealand & n.r. & 0.3 and 0.19 \\
\hline Do. & Paramushir Island, Russia & n.r. & 0.19 \\
\hline
\end{tabular}


Exceptions can always be found to these general estimates; for example, selenium can be present in concentrations of hundreds of parts per million in tuffaceous rocks, and concentrations of several percent can be found in sulfides that host mercury and antimony deposits (Lakin and Davidson, 1973).

In magmatic sulfide deposits associated with mafic rocks, selenium may be found substituted for sulfur in sulfide veins. Sindeeva (1964) estimated the selenium content in such deposits to vary between 0.002 and 0.01 percent, although concentrations of as high as 0.017 percent and as low as 0.0003 percent have been found. The Permian-to-Triassicage Noril'sk group of sulfide deposits, which are located in Siberia, Russia, inside the Arctic Circle, are representative of this type of mineralization (table Q3), as are the sulfide deposits from the Sudbury basin in Ontario, Canada (table Q4).

At Noril'sk, the selenium of economic interest is contained in sulfide minerals, where it occurs from isomorphous substitution for sulfur in concentrations of 2 to $74 \mathrm{ppm}$. Massive vein deposits at Noril'sk display greater concentrations of selenium than its disseminated ores, with a range of 0.0036 to 0.015 percent selenium in massive vein deposits owing to the greater proportion of copper sulfides in the vein deposits; however, no correlation has been found between selenium and any of the elements copper, lead, nickel, sulfur, or tellurium. Distribution of selenium depends upon the composition of the ore as well as the location of the sample within the orebody and with respect to the structural setting (table Q3). The rocks surrounding the ore deposits (andesites, diabases, and gabbros) contain merely 0.00001 percent (0.1 ppm) selenium (Sindeeva, 1964).

In addition to magmatic sulfide ores, Sindeeva (1964) considered the volcanic deposits of native sulfur and tuffs. She observed selenium concentrations of 0.0005 to 5.18 percent in sulfur deposits and 0.003 to 0.012 percent selenium in andesite tuffs that had partially transformed to bentonite in the Oligocene-age Jasper, Riverton, and Shoshone deposits in Wyoming (table Q3).

The porphyry copper deposits that host much of the selenium produced worldwide are large breccia and veinhosted deposits found genetically related to granitoid porphyry intrusions. They form at convergent plate margins, and most are of Cenozoic or Mesozoic age, although they can range from Archean to Quaternary (John and others, 2010). John and others (2010) argued that porphyry copper mineralization forms from magmatic fluids released during emplacement of porphyritic stocks. Selenium in sulfides of porphyry copper deposits is originally transported in hypogene fluids but may also be remobilized during hydrothermal alteration of the porphyry copper system.

Many workers have attempted to employ the seleniumto-sulfur ratio in the ore minerals to ascertain whether external sulfur was involved in the genesis of mineralization. Selenium-to-sulfur ratios ranging from 0.00023:1 to 0.00035:1 have been assigned to mantle-derived rocks (Eckstrand and Hulbert, 1987), and ratios lower than this are found when sulfur is contributed from external fluids and (or) host rocks (for example, Ripley, 1990). Fitzpatrick (2008) measured selenium-to-sulfur ratios in minerals from three deposits: a volcanogenic massive sulfide (VMS) deposit in Flin Flon, Canada; a high-sulfidation epithermal deposit in Pierina, Peru; and an iron oxide-copper-gold (IOCG) deposit in Mantoverde, Chile. By combining the selenium-to-sulfur ratios with $\delta^{34} \mathrm{~S}$ values, Fitzpatrick demonstrated that the VMS and epithermal deposits displayed high selenium-to-sulfur ratios and low $\delta^{34} \mathrm{~S}$ values, which is typical of magmatic fluids; the IOCG deposit, however, showed the opposite signal, suggesting dilution of a magmatic fluid with a seawater-derived basinal fluid. He concluded that selenium-to-sulfur ratios can help identify the fluid source(s) for mineralization, and that the addition of $\delta^{34} \mathrm{~S}$ values extended the usefulness of this tracer.

Other studies have employed selenium as an exploration 'vector' to discriminate among mineralization signatures found proximal or distal to a fluid source. Bornite and chalcocite show some potential for this work (Cook and others, 2011). Zonation of selenium concentration has also been observed in marine systems, and high selenium concentrations have been observed in black smoker deposits and iron-copper massive sulfides associated with the East Pacific Rise. Here, high selenium values occur in high-temperature mineral assemblages of the inner part of the deposit, which are in equilibrium with pure, unmixed hydrothermal fluids. The lowest selenium values are found in the outer part of the deposit, where mineralization is influenced by mixing of hydrothermal fluids and seawater (Auclair and others, 1987).

Table 04. Selenium concentrations in copper-nickel ores in the Sudbury basin, Ontario, Canada.

\begin{tabular}{llc}
\hline $\begin{array}{c}\text { Mine } \\
\text { name }\end{array}$ & \multicolumn{1}{c}{ Ore type $^{\mathbf{1}}$} & $\begin{array}{c}\text { Selenium } \\
\text { concentration }\end{array}$ \\
\hline Murray & Massive sulfide & per million) \\
(parts & Gabbro peridotite inclusion sulfide & 32 to 64 \\
Creighton & Interstitial sulfide & 82 \\
& Ragged disseminated sulfide & 26 \\
& Gabbro peridotite inclusion sulfide & 20 \\
& Massive sulfide & 42 \\
Garson & Contorted schist inclusion sulfide & 22 \\
\hline Levack & Interstitial sulfide in sublayer norite & 25 \\
\hline Frood & Disseminated sulfide in quartz diorite & 28 \\
& Interstitial sulfide & 36 \\
& Ragged disseminated sulfide & 20 \\
\hline
\end{tabular}

${ }^{1}$ Ore type classification is from Schwarcz (1973).

${ }^{2}$ Selenium analysis is from Nriagu and Wong (1983). 


\section{Selenide-Bearing Deposits}

In contrast to Sindeeva (1964), who discussed all selenium-bearing deposits whether they contained seleniumbearing sulfides, selenides, selenates, selenites, or native selenium, Simon and others (1997) discussed deposits that contained selenide minerals only. Their purpose was to "determine the conditions that favor deposition of selenide minerals over substitution of selenium in sulfide minerals" (Simon and others, 1997, p. 468). Deposits were grouped into the following four types: (a) telethermal selenide vein-type, (b) unconformity-related uranium deposits, (c) sandstonehosted uranium deposits (roll-front type), and (d) gold-silver epithermal volcanic-hosted deposits. The following brief descriptions of these four deposit types are taken mostly from Simon and others (1997):

a. Telethermal selenide vein-type deposits include selenide-bearing deposits like those of the TilkerodeZorge-Lerbach deposit in the Harz Mountains of Germany, the Pacajake and El Dragon deposits in Bolivia, the Hope's Nose deposit in the United Kingdom, and the Sierra de Umango and Sierra de Cacheuta deposits in Argentina. In these deposits, selenide minerals occur in veins or veinlets with carbonate minerals, gold, hematite $\left(\mathrm{Fe}_{2} \mathrm{O}_{3}\right)$, platinumgroup elements, and rare sulfides, and are commonly hosted in sedimentary rocks. Some of these deposits were classified as the "selenide-type" by Sindeeva (1964). Conditions for formation of these deposits include $f \mathrm{O}_{2(\mathrm{~g})}$ above the hematite-magnetite buffer (that is, in the hematite stability field) and a ratio of selenium-to-sulfur fugacities that is greater than one $\left(f \mathrm{Se}_{2(\mathrm{~g})} / f \mathrm{~S}_{2(\mathrm{~g})}>1\right)$. Simon and others (1997) argue that the high $f \mathrm{O}_{2}$ value helps to separate selenium from sulfur, thus preventing the incorporation of selenium into sulfides and allowing the system to form selenide minerals.

b. Selenide minerals in unconformity-related uranium deposits are found in vein deposits in the Bohemian Massif of the Czech Republic, the Massif Central of France, and the Athabasca area of northern Saskatchewan, Canada. Cobalt, copper, and nickel selenides in these deposits are associated with carbonates; cobalt, copper, and nickel sulfides and arsenides; hematite; and uraninite minerals. As with the vein-type deposits above, the conditions for selenide formation include $f \mathrm{O}_{2(\mathrm{~g})}$ values within the hematite stability field and a ratio of selenium-to-sulfur fugacities that is greater than one $\left(f \mathrm{Se}_{2(\mathrm{~g})} / f \mathrm{~S}_{2(\mathrm{~g})}>1\right)$.

c. Selenium-bearing sandstone-hosted uranium deposits (roll-front-type) include the uranium and vanadium sandstone deposits of the Colorado Plateau, and similar deposits in Oklahoma, Wyoming, and Texas (Davidson, 1963; Howard, 1977). Davidson (1963) surveyed uranium deposits in oxidized sandstones ranging from Paleozoic to Cenozoic age in several States across the United States and found selenium concentrations that ranged from 3 to $4,500 \mathrm{ppm}$. In a survey by Coleman and Delevaux (1957), selenium concentrations up to 3 weight percent were measured in uranium deposits of the Colorado Plateau.

In the roll-front uranium deposits, selenium is commonly found in isomorphic substitution for sulfur in chalcocite, galena, marcasite, and pyrite. It is also found as the selenide minerals ferroselite $\left(\mathrm{FeSe}_{2}\right)$, clausthalite, and native selenium. Howard (1977) provided a good description of the location of selenium mineralization with respect to the redox interface of a roll-front-type uranium orebody. He described the uranium ore deposits as forming in gently dipping permeable sandstone units, sandwiched between units of lower permeability. Mineralization occurred as oxidizing meteoric solutions moved through the host sandstone and dissolved pyrite and other redox-active minerals. At the front of the plume of meteoric water, the solution lost its oxidizing potential and deposited iron, selenium, and uranium at the interface between oxidizing and reducing environments. In this model, selenium is commonly found as native selenium in the sandstone on the oxidized side of the redox boundary, as ferroselite in both goethite $(\mathrm{FeO}(\mathrm{OH}))$-hematite and pyrite-marcasite associations on either side of the redox interface, and as ferroselite and native selenium within the uraninite-coffinite $\left(\mathrm{U}\left(\mathrm{SiO}_{4}\right)_{1-\mathrm{x}}(\mathrm{OH})_{4 \mathrm{x}}\right)$ assemblages of the orebody. In the unaltered reduced rock, selenium will be found as ferroselite or in isomorphous substitution with sulfur in pyrite. It is the continued cycle of oxidative dissolution (of reduced minerals in the unaltered rock) and redeposition (at the redox interface at the front of the groundwater plume) that serves to concentrate selenium, iron, and the uranium-ore minerals of these deposits (Howard, 1977).

d. Selenide-bearing gold-silver epithermal volcanic-hosted deposits are found at Hishikari, Japan; the western Great Basin, Nevada; the Great Barrier Island, New Zealand; Salida and Redzhang Lobong, Indonesia; Guanajuato, Mexico; and Prasolovskoye, Kunashir Island, Russia. Selenium in these deposits is primarily found in silver selenides and, less commonly, in bismuth, copper, and lead selenides, all associated with sulfides, sulfosalts, and native elements. John (2001) observed that the silver selenides aguilarite and naumannite are found in almost all low-sulfidation epithermal gold-silver deposits associated with Miocene bimodal magmatism in the Great Basin, Nevada. Selenium-bearing stibnite and sphalerite 
are found among the ore-stage minerals, and selenium can be enriched in the gold-bearing arsenian rims found on pyrite and marcasite. It is thought that these deposits formed from hydrothermal fluids with $f \mathrm{O}_{2(\mathrm{~g})}$ below the hematite-magnetite buffer and have a ratio of seleniumto-sulfur fugacities that is less than one $\left(f \mathrm{Se}_{2(\mathrm{~g})} / f \mathrm{~S}_{2(\mathrm{~g})}<1\right)$ (Simon and others, 1997). These conditions lead to a greater abundance of sulfides than selenides.

\section{Sedimentary Rocks}

The substitution of selenium for sulfur in biological processes leads to the presence of selenium in pyrite contained in black shales and coal, yet compared with magmatic rocks, the sulfur-to-selenium ratio in diagenetic pyrite is estimated to be 200,000:1 or higher (Goldschmidt, 1954). Selenium in detrital organic matter may be enriched many times above its crustal abundance. Highly organic shales may contain up to $1,500 \mathrm{ppm}$ selenium. Marine phosphorites may contain as much as $300 \mathrm{ppm}$ selenium. Coals of the United States have a geometric mean concentration of $1.7 \mathrm{ppm}$ (Coleman and others, 1993).

Selenium concentrations in coal have been a topic of interest for many decades owing to the release of trace elements to the atmosphere during coal combustion. Coal contains 5 to 300 times the amount of selenium as average sedimentary and igneous rocks, and it is enriched 82 times above the average selenium concentration in Earth's crust (table Q5; Coleman and others, 1993). The study by Coleman and others (1993) analyzed almost 9,000 coal samples from across the United States (fig. Q5) and found that the highest selenium values (with a geometric mean of $4.9 \mathrm{ppm}$ ) are found in coals from Texas. Coal found in the Atlantic Coast region (Virginia and North Carolina) and coal in Alaska have the lowest geometric means, at 0.2 and $0.42 \mathrm{ppm}$ selenium, respectively. The highest concentration in an individual sample (75 ppm) was observed in coals from northern Appalachia. Because of the close association of selenium with sulfur, it might be expected that selenium concentrations would correlate with concentrations of pyritic sulfur or organic sulfur, but this was not generally observed throughout the dataset. Coleman and others (1993) speculated that the lack of correlation may be owing to multiple sources of selenium, including detrital particles, plant matter, volcanic ash, surface water and groundwater, and epigenetic mineralization. They note, in addition, that selenium concentrations can be modified by diagenetic processes. Whereas selenium is shown to be closely associated with the organic fraction in coal, it is also found in selenium-bearing pyrite and galena, and as clausthalite. Selenium is also found in water-soluble and ion exchangeable forms.

Much of the Western United States is underlain by seleniferous sedimentary rocks whose ages range from Permian (for example, the Phosphoria Formation, which has phosphate rock members containing 1 to $1,200 \mathrm{ppm}$ selenium), to Cretaceous (for example, the Niobrara Formation and the Pierre Formation, which have selenium concentrations of 0 to $113 \mathrm{ppm}$, and 0 to $103 \mathrm{ppm}$, respectively) to Upper Cretaceous-Paleogene (for example, the Moreno Formation and the Kreyenhagen Formation of the California Coast Ranges, which have selenium concentrations that together range from 0.6 to $45 \mathrm{ppm}$ ) (table Q5; figs. Q6A-C; Presser and others, 1990). Trelease and Beath (1949) extensively mapped and documented the widespread extent of seleniferous bedrock in the Western United States as part of their study of the source of selenium in livestock food and forage (figs. Q6 $A-B$ ). Seiler and others (2003) extended this survey in their work to identify the source of selenium contamination to irrigation waters in the Western United States (fig. Q6C). Presser and others (2004) attributed the high selenium concentration in these sedimentary bedrock units to its depositional origin in marine basins with high primary biological productivity. Selenium is cycled from ocean waters into bacteria, algae, fungi, and plants with the production of selenium-containing amino acids. Deposition of these species as organic detritus on the sea floor, and subsequent loss of organic matter from diagenesis resulted in accumulation and concentration of selenium and other trace elements in the sediments. This is the general model for trace-element enrichment in the Permian Phosphoria Formation (Piper, 1994, 2001) as well as in the Cretaceous and Paleogene marine formations of the Western United States (Presser and others, 2004). Preservation of selenium and other trace elements in these rocks is attributed to their high initial concentrations, retention by the sediments (often in an organic fraction), and extremely low accumulation of other diluting phases.

\section{Resources and Reserves}

More than 80 percent of global production of selenium is obtained as a byproduct of copper refining; it is recovered from anode slimes generated in electrolytic production of copper (Brown, 2002). The blister copper (that is, the partly refined copper formed during smelting) that serves as the anode in an electrolytic cell contains an average of 0.05 percent selenium $(0.5 \mathrm{~kg}$ of selenium per metric ton of copper), but recovery ranges from 0.02 percent to 0.038 percent $(0.2$ to $0.38 \mathrm{~kg}$ of selenium per metric ton of copper; Lakin and Davidson, 1973). Other methods of refining copper, such as in situ leaching or the ISASMELT ${ }^{\text {TM }}$ technology, do not recover selenium; hence, the global production of selenium is dependent on the method of copper refining. Because selenium production is mainly a byproduct of copper refining, countries with selenium resources and (or) reserves are those with resources and (or) reserves of copper, and they include Canada, Chile, China, Congo (Kinshasa), Mexico, Peru, the Philippines, Russia, the United States, and Zambia (Jensen, 1985; John and others, 2010). Minor amounts of selenium have also been recovered from lead, nickel, and zinc ores. 


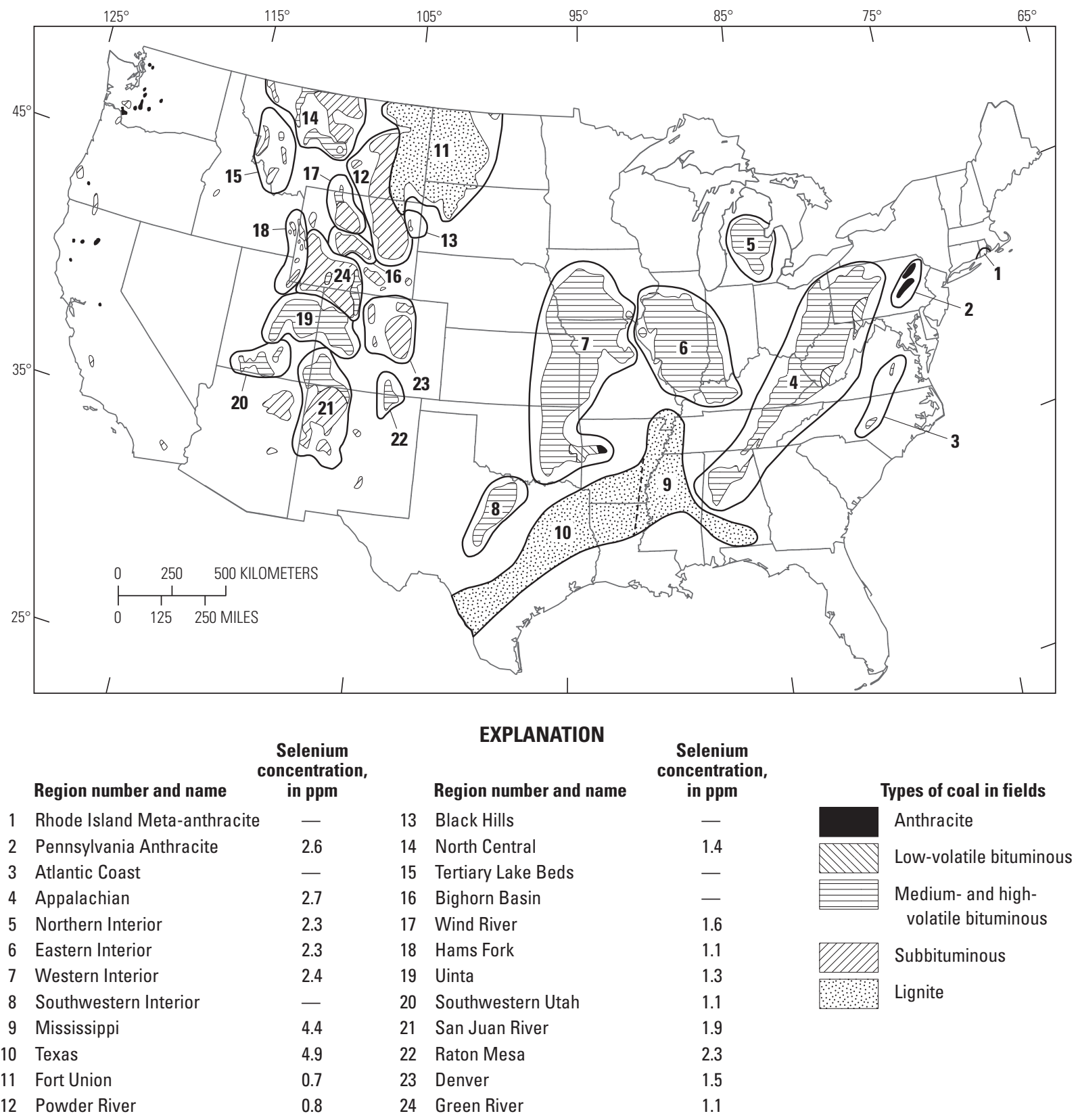

Figure 05. Map showing selenium concentrations (in parts per million) in coal samples, by region of the United States. Selenium concentrations were analyzed in almost 9,000 U.S. coal samples. Data are plotted as the geometric means of samples from 24 regions. The map shows the highest selenium values (with a geometric mean of $4.9 \mathrm{ppm}$ ) are found in coals from Texas. Coal found in the Atlantic Coast region (Virginia and North Carolina) and coal in Alaska (not shown on the map) have the lowest geometric means, at 0.2 and $0.42 \mathrm{ppm}$ selenium, respectively. The highest concentration in an individual sample $(75 \mathrm{ppm})$ was observed in coals from the northern portion of the Appalachian region. Map is from Coleman and others (1993). 
Table 05. Selenium concentrations in selected Earth and lunar materials.

[Biologic samples are dry weight unless otherwise noted. Abbreviations: ppm, part per million; ppb, part per billion; ng/L, nanogram per liter; nmol/kg, nanomole per kilogram]

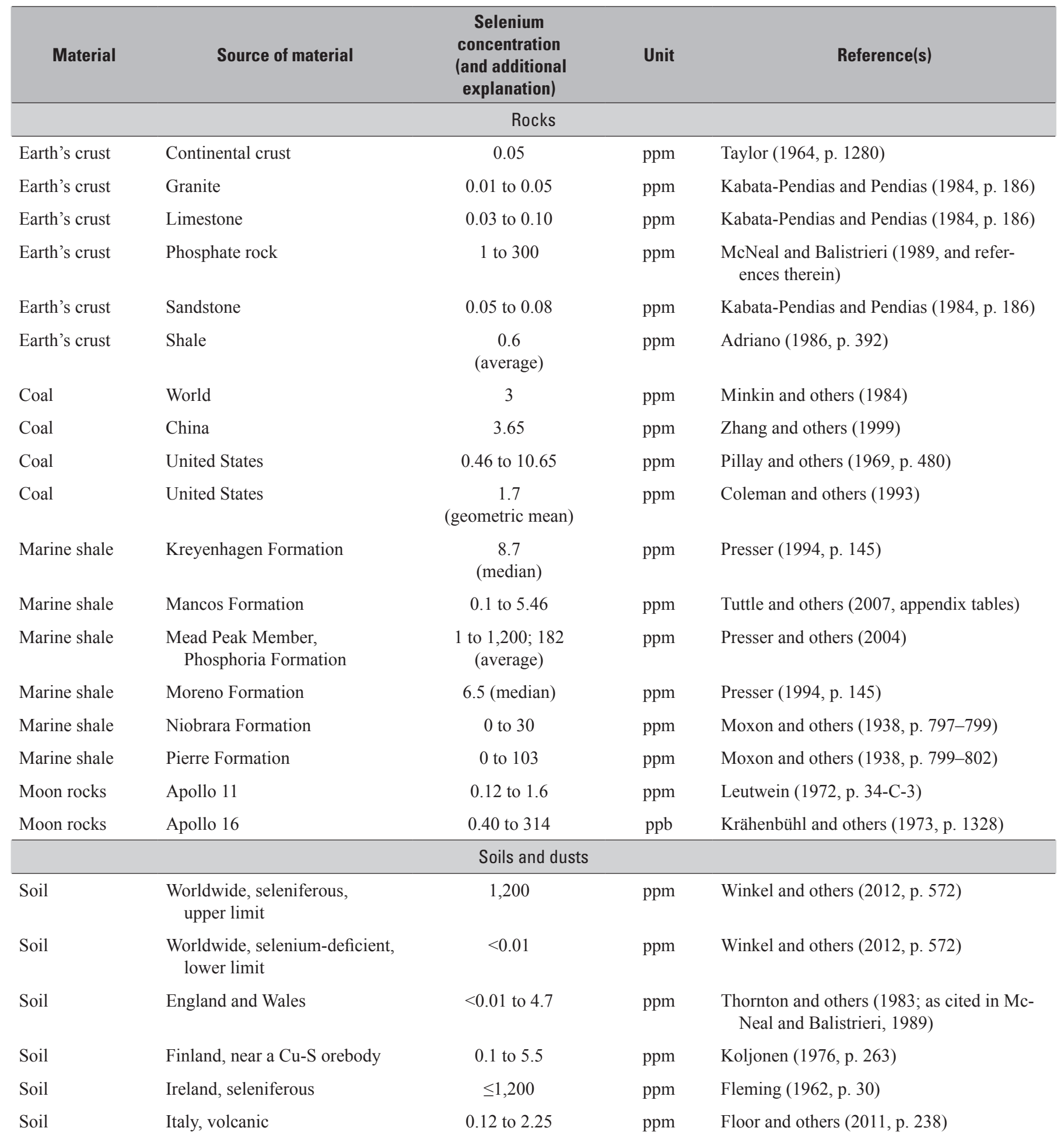


Table 05. Selenium concentrations in selected Earth and lunar materials. - Continued

[Biologic samples are dry weight unless otherwise noted. Abbreviations: ppm, part per million; ppb, part per billion; ng/L, nanogram per liter; nmol/kg, nanomole per kilogram]

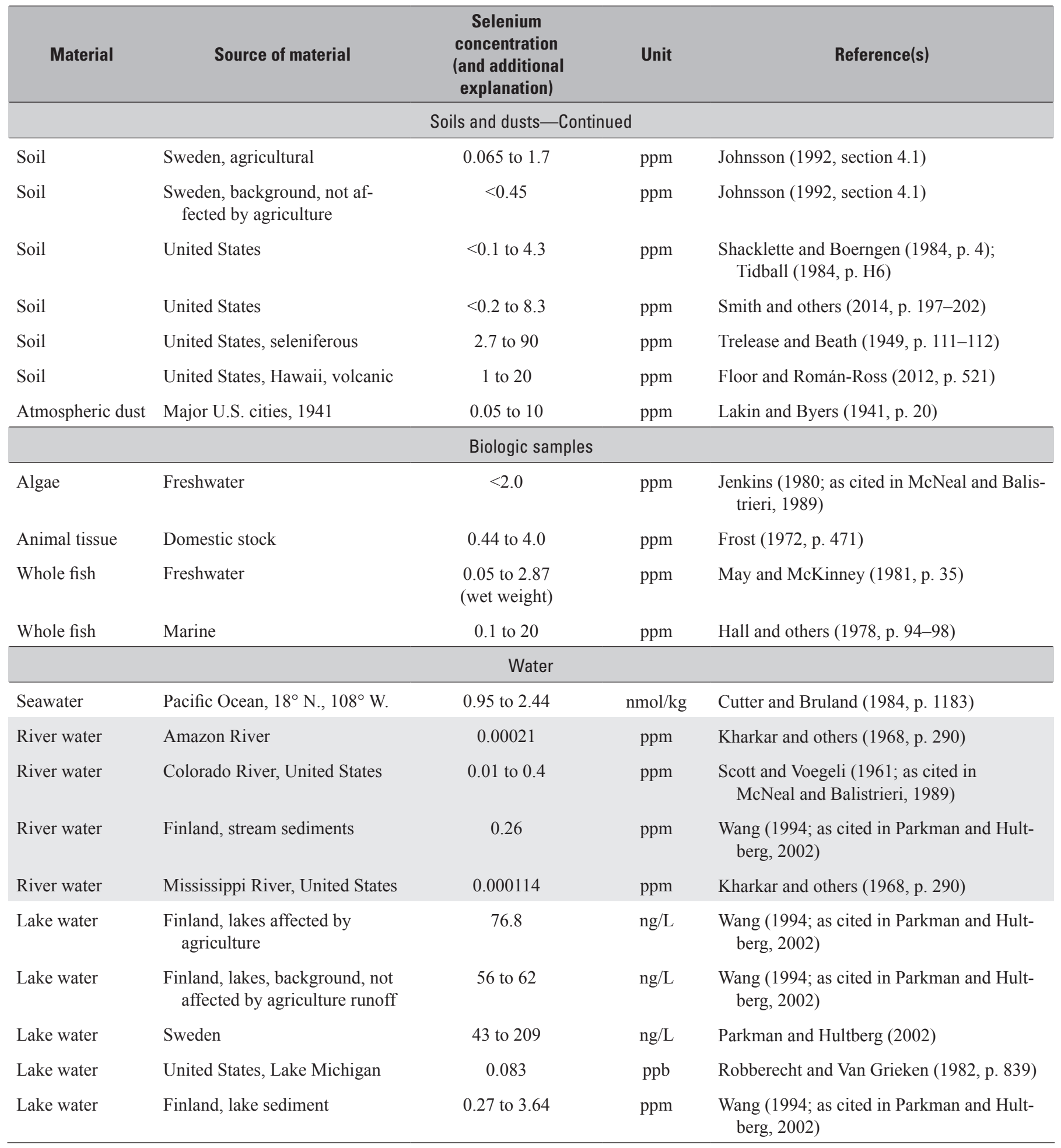


In 1973, the USGS estimated the world's identified resources of selenium to be almost 13 million metric tons (28.6 billion pounds) based upon the selenium content of identified resources of coal, copper, lead, and pyrite. Estimates from copper resources were made using a ratio of $0.325 \mathrm{~kg}$ of selenium recovered per metric ton of copper produced. Selenium from lead ores was estimated based upon an average of $10 \mathrm{ppm}$ selenium in galena and the estimate of identified lead resources. Estimates for selenium in pyrite were made assuming $10 \mathrm{ppm}$ selenium in pyrite and estimates of the sulfur resources in pyrite. Selenium resources in coal were estimated using estimates for coal resources and an average of 1.5 ppm Se in coal. Lakin and Davidson (1973) noted that although the estimated resource of selenium in coal was two orders of magnitude greater than that in copper resources, it could not be easily recovered. As of 2016, the recovery of selenium from coal is technically feasible but not economical.

In contrast, modern estimates of selenium reserves in table Q6 are based only on copper reserves and do not include selenium found in other copper resources or in lead,

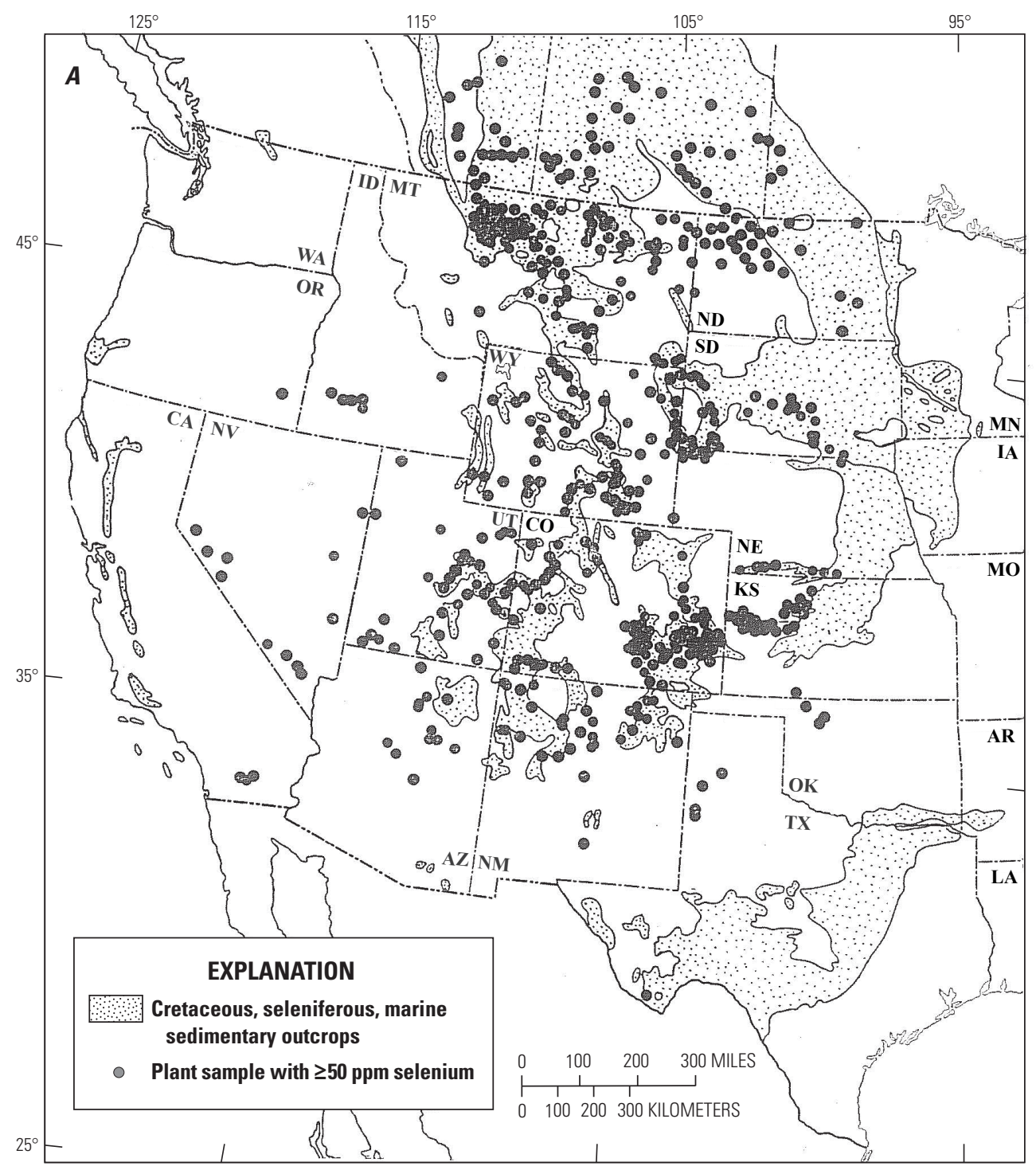

Figure 06. Maps showing locations of seleniferous sedimentary outcrops and deposits and plant samples with significant selenium content. This map, $A$, shows the spatial relation among locations of Cretaceous, seleniferous, marine sedimentary outcrops and plant samples with greater than or equal to 50 parts per million (ppm) selenium. Map $A$ is from Trelease and Beath (1949) and, with map $B$, shows the widespread extent of seleniferous bedrock across the Western United States and its correlation with selenium in plant samples. 
pyrite, and coal resources. The fraction of copper reserves expected to be recovered by leaching and electrowinning is subtracted from the total because these processes do not recover selenium. The estimates are derived, as mentioned previously, by using a recovery factor of $0.215 \mathrm{~kg}$ of selenium per metric ton of primary recoverable electrolytic copper (0.0215 percent). In Canada, where the selenium content of copper ore is higher, a factor of $0.64 \mathrm{~kg}$ of selenium per metric ton of copper (0.064 percent) is employed (Butterman and Brown, 2004; George and Wagner, 2009). Global supplies of selenium have steadily increased over the past few years owing to an increase in copper production.

\section{Identified Resources}

No deposits in the world are mined for selenium alone. Instead, as discussed above, selenium is produced mostly as a byproduct of copper refining. Whereas Japan and Germany (in order of output) were the leading producers of selenium in the world in 2015 (U.S. Geological Survey, 1997-2014), the selenium was sourced from copper concentrates and residues supplied from mining operations in Africa, Asia, Australia, and South America (Bleiwas, 2010). Of the global reserves of 120,000 metric tons of selenium, almost 60 percent is located in Chile, China, and Russia combined, whereas

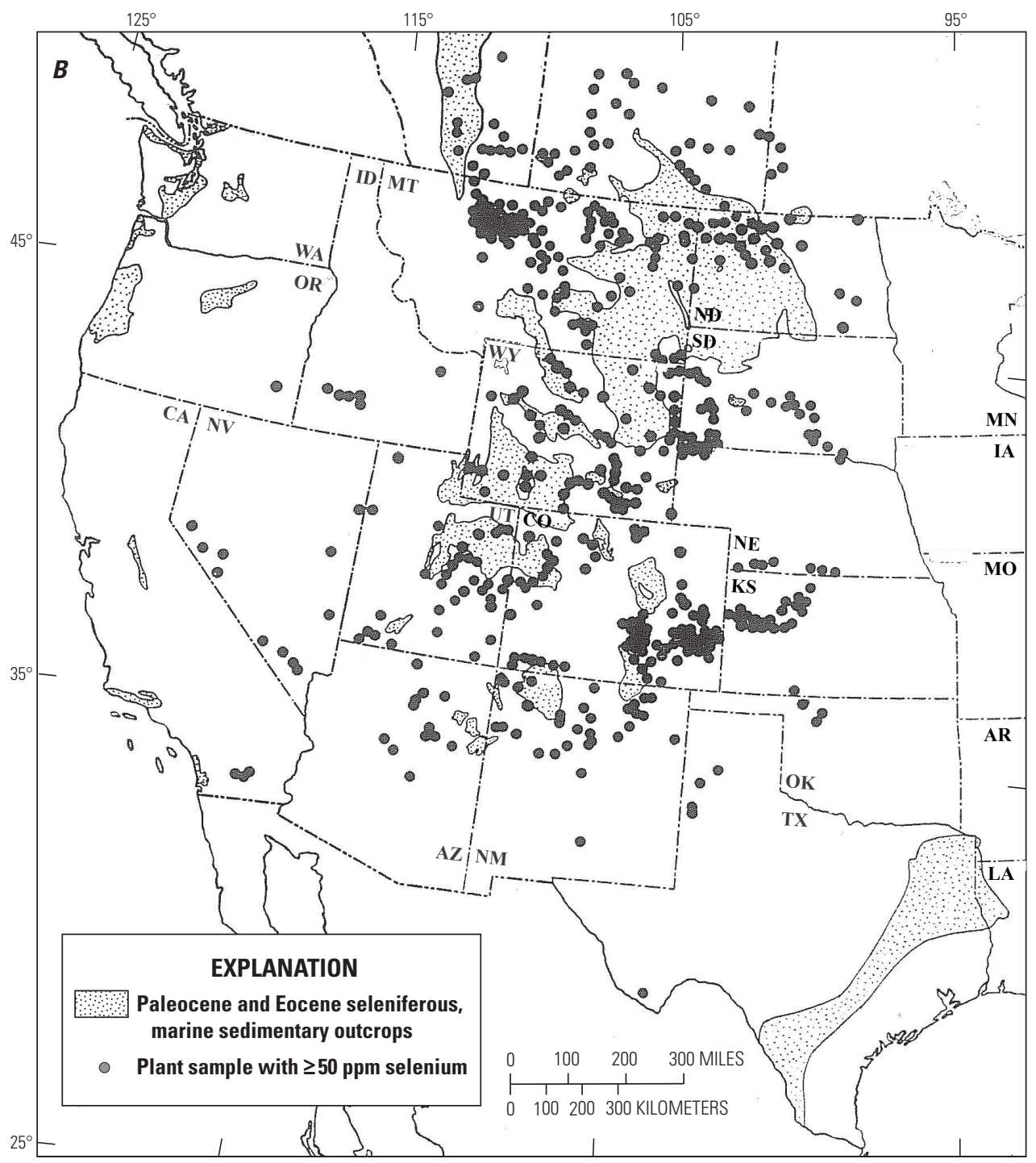

Figure 06.-Continued Maps showing locations of seleniferous sedimentary outcrops and deposits and plant samples with significant selenium content. This map, $B$, shows the spatial relation among locations of Paleocene and Eocene, seleniferous, marine sedimentary outcrops and plant samples with greater than or equal to $50 \mathrm{ppm}$ selenium. Map $B$ is from Trelease and Beath (1949) and, with map $A$, shows the widespread extent of seleniferous bedrock across the Western United States and its correlation with selenium in plant samples. 


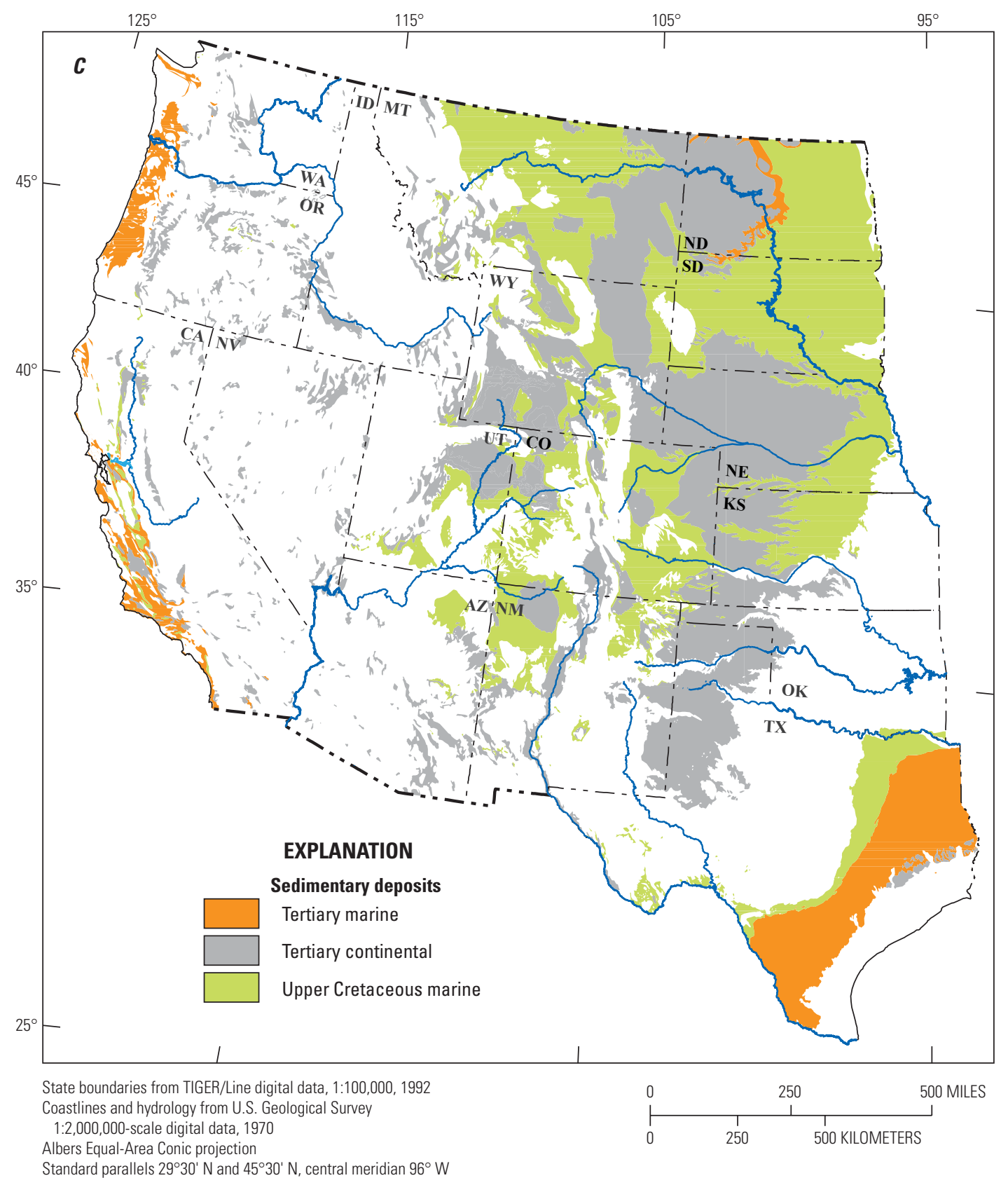

Figure 06.-Continued Maps showing locations of seleniferous sedimentary outcrops and deposits and plant samples with significant selenium content. This map, $C$, shows locations of potentially seleniferous marine and continental sedimentary deposits in the Western United States. Map $C$ is from Seiler and others (2003, p. 51, fig. 20) and shows additional areas with potentially seleniferous bedrock not identified by Trelease and Beath (1949). 
the United States has an estimated 10,000 metric tons of world selenium reserves, or about 8 percent. As of 2012, the leading copper-producing mines in the United States were located in Arizona, Nevada, New Mexico, and Utah and accounted for all U.S. domestic selenium reserves (Brininstool, 2015).

Globally, the countries with the largest mine production of copper in 2012 were Australia, Canada, Chile, China, Congo (Kinshasa), Indonesia, Kazakhstan, Mexico, Peru, Poland, Russia, the United States, and Zambia (Brininstool, 2015). Copper mines from these countries account for the global reserves of selenium and are the sources of concentrates and residues for the leading selenium producers.

\section{Undiscovered Resources}

Although selenium is produced currently from copper ores - mostly from porphyry copper deposits - it also occurs in many other types of mineral deposits and earth materials (tables Q2 through Q5). The highest concentrations of selenium are likely to occur in deposits that host selenide minerals, such as the selenide vein-type deposits described by Simon and others (1997). Although the selenium grade is high in selenide deposits, the overall tonnage is low. Deposits of native sulfur may also contain high concentrations of selenium (table Q3), yet the tonnage of these deposits compared with that of porphyry copper deposits is also low.

The close association of selenium with sulfur is the reason that copper ores are a resource for selenium. One approach to identifying new selenium resources would be to investigate this selenium-to-sulfur relationship in other rock types. Rocks enriched in organic carbon are likely to have high selenium concentrations, where selenium has substituted for sulfur in diagenetic sulfide minerals. These resources might be coal (where selenium recovery is technically feasible but not currently economic), marine phosphate deposits, or oil shales. Presser and others (2004) have mapped a global distribution of selenium-rich rocks found in sedimentary basins enriched in organic carbon (fig. Q7). Although the purpose of their mapping was to identify selenium source rocks that might create environmental concerns, their analysis might also be useful in identifying new selenium resources.

\section{Environmental Considerations}

Selenium is both a necessary nutrient and a potential hazard to Earth ecosystems, and it is present in the environment both naturally and as a result of human activity. Selenium mining, processing, use, and disposal may all potentially release selenium to the environment. Environmental considerations are integral to decisions regarding extraction and use of selenium.
Table 06. Estimated world selenium reserves in 2014, in metric tons.

[Reserves are defined as the amount of selenium that could be economically extracted at the time the estimate was made (see U.S. Geological Survey, 2014a, appendix C, for more information). Selenium reserves, including those in China, are based upon the selenium content of identified copper deposits and do not include lead ores and coal. Other countries with reserves may include Australia, India, Kazakhstan, the United Kingdom, and Zimbabwe. Data have been rounded to no more than two significant digits. Data are from George (2014).]

\begin{tabular}{lc}
\hline Country & $\begin{array}{c}\text { Reserves } \\
\text { (metric tons) }\end{array}$ \\
\hline United States & 10,000 \\
Canada & 6,000 \\
Chile & 25,000 \\
China & 26,000 \\
Peru & 13,000 \\
Poland & 3,000 \\
Russia & 20,000 \\
Other countries & 21,000 \\
World total & $\mathbf{1 2 0 , 0 0 0}$ \\
\hline
\end{tabular}

\section{Sources and Fate in the Environment}

The geochemical processes that control the presence and distribution of selenium in mineral deposits also operate, more broadly, in Earth's surface environment. The processes of oxidation and reduction, adsorption at mineral surfaces, and isomorphic substitution of selenium for sulfur also govern selenium distribution and fate, including its uptake in biological organisms.

\section{Natural and Anthropogenic Sources in Air, Water, and Soil}

Volcanoes are the primary source of selenium in Earth's upper crust and atmosphere. The selenium species $\mathrm{H}_{2} \mathrm{Se}$ and $\mathrm{SeO}_{2}$ are volatile and found along with sulfur gases in volcanic emissions. Lakin and Davidson (1973) estimated that 1 kilogram per square meter (reported as 2 pounds per square yard) of selenium has been deposited on Earth's surface from volcanic emissions over geologic time.

Selenium is produced in volcanic emissions when magmatic selenium is volatilized while in the volcanic plumbing system, and tens of kilograms of selenium can be released daily from a single volcano (Greenland and Aruscavage, 1986; Floor and others, 2011). Regardless of how selenium is emitted into the atmosphere, once there, it can be 
deposited onto surfaces by dry deposition or incorporated into water droplets and removed by wet deposition.

After selenium has been introduced to the upper crust, it cycles among the atmosphere, biosphere, and hydrosphere. Natural biologic emissions that cycle selenium between the biosphere and atmosphere account for approximately one-half to two-thirds of atmospheric selenium (Mosher and others, 1987); these emissions are composed mostly of dimethyl selenide gas from marine biogenic sources and account for 70 percent of natural biologic emissions of selenium. Other natural sources of atmospheric selenium are the continental biosphere (20 percent), volcanoes ( 8 percent), sea salt ( 2 percent), and crustal weathering (less than 1 percent) (Cahill and Eldred, 1998).

Anthropogenic selenium emissions to the atmosphere are derived mostly from coal and oil combustion (50 percent and 10 percent, respectively), and base-metal production of copper, zinc, and lead ( 20 percent, 4 percent, and 4 percent, respectively) using roasters and autoclaves (Cahill and Eldred, 1998; Winkel and others, 2012). It has been known for some time that coal combustion is a major source of selenium to the environment and that coal can contain 5 to 300 times the amount of selenium as other rocks (table Q5). Emission controls on coalfired powerplants are limited in their ability to remove volatile selenium species (Ranville and others, 2010); hence, selenium escapes into the atmosphere. Coal combustion also generates fly ash that can concentrate selenium 10 to 25 times beyond its original concentration in the coal (Lemly, 1985). Other than coal, the remaining anthropogenic selenium emissions come from other forms of combustion and from ceramic and glass manufacturing (Cahill and Eldred, 1998).

One important natural source of selenium to surface and groundwaters is weathering of marine shales. A significant portion of the bedrock in the Western United States is composed of marine shales (most notably of Cretaceous age but with a range of Permian to Paleogene ages). These shales are noted for their high selenium content (table Q5) derived from the volcanic eruptions that were especially extensive during the Cretaceous Period. Selenium became incorporated into marine sediments, often substituting for sulfur in pyrite, and then mobilized as sediments were uplifted and weathered. Selenium-rich soils in the northern Great Plains of the United States owe their selenium content to the underlying shales of the Pierre Formation and the Niobrara Formation (Trelease and Beath, 1949; Mayland, 1985). Moxon and others (1938) hypothesized that the selenium content of the Pierre Formation and the Niobrara Formation was inversely related to the rate of sediment deposition because they observed that thin stratigraphic sections (which were produced from low deposition rates) had high concentrations of selenium, whereas thicker

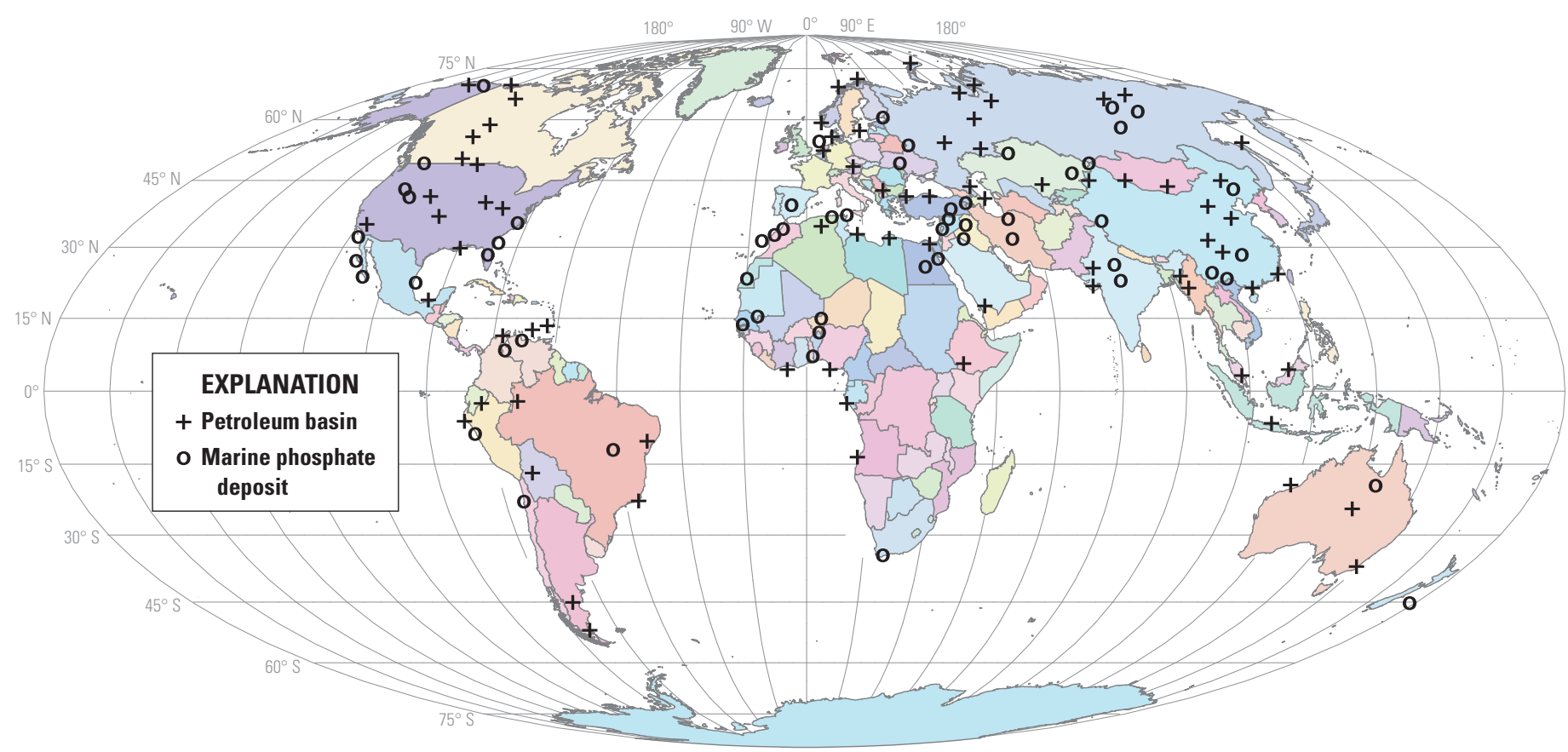

Figure 07. A predictive map of selenium source rocks associated with organic-rich depositional marine basins. This map is useful both for identifying selenium source rocks that could be of potential environmental concern and for identifying potential new selenium resources. Modified from Presser and others (2004, p. 313). 
sections (representing fast deposition rates) had low selenium concentrations. Other marine shales, such as the Meade Peak member of the Permian Phosphoria Formation in southeastern Idaho and western Wyoming (Stillings and Amacher, 2004; Presser and others, 2004), the Cretaceous-Paleocene Moreno Formation, and the Eocene-Oligocene Kreyenhagen Formation in the California Coast Range (Presser, 1994) are sources of selenium to groundwater, surface water, and soil. Additionally, coal and other organic-rich sediments release selenium through weathering (McNeal and Balistrieri, 1989).

In other regions of the United States where the soils are selenium-deficient, and in other countries, selenium is added to soils by way of selenium-containing fertilizers, lime, and manure. It is widely recognized that selenium is a necessary dietary nutrient for humans, as well as for other animals, and in the United Kingdom, selenium fertilizers are used in pastures and forage areas to increase the human intake of selenium through meat and dairy products. In Finland, a nationalscale use of selenium fertilizers began in 1984 and has resulted in a fourfold increase in the intake of dietary selenium in the human study population (Winkel and others, 2012, and references therein). Because crops take up only 5 to 20 percent of the selenium applied in fertilizers, the rest of the selenium is either immobilized in the soil through chemical reduction or leached from the soil and added to surface runoff waters. The Finnish study calculated that application of selenium fertilizers was expected to have increased selenium in soils by 20 percent, but because no increase in the soil was observed, selenium must have been leached from the soils. In Tennessee, the use of selenium in fertilizers has caused selenium runoff in surface waters, resulting in an accumulation in aquatic biota (Winkel and others, 2012, and references therein).

\section{Average Ambient Concentrations in Air, Streams, Groundwater, and Soil}

Ambient concentrations of selenium in the environment are dependent upon selenium concentrations in the underlying bedrock. Soils in the United States that overlie pre-Cretaceousage sedimentary rocks, volcanic ash, or granitic rock tend to be low in selenium because most of these bedrock materials are also low in selenium (McNeal and Balistrieri, 1989).

Recent data on soil chemistry in the conterminous United States show selenium concentrations to range from less than 0.2 to 8.3 ppm (figs. Q8A-C; Smith and others, 2014). The data were collected from three soil sections - 0 to 5 centimeters $(\mathrm{cm})$ depth, the A horizon, and the $\mathrm{C}$ horizon. Although the spatial distribution of selenium varied among the three soil sections (figs. $8 A-C$ ), the concentration range and histogram of selenium concentrations were fairly consistent among them-from less than 0.2 to $6.9 \mathrm{ppm}$ for the 0 -to-5-cm-depth section; from less than 0.2 to 8.3 ppm for the A horizon section; and from less than 0.2 to $7.5 \mathrm{ppm}$ for the $\mathrm{C}$ horizon section. Many of the general trends in selenium concentration in the Western United States, as mapped by Trelease and
Beath (1949), were confirmed by current maps, as illustrated in figs. Q8A and Q8B. A striking feature in the recent maps, however, is the trend of high concentrations of selenium in the Dakotas, and eastward through the mid-continent and into the Appalachian and New England regions. Future scientific studies may debate the authigenic versus anthropogenic origin of this selenium.

Scandinavia is another region with low selenium content in the bedrock. In Sweden, 89 percent of the mineral soils have less than $0.45 \mathrm{ppm}$ selenium, which is comparable to the blue-to-light-orange regions of the United States shown in figs. Q8A-C, and is the minimum concentration needed for forage to provide the necessary selenium for stock animals (Parkman and Hultberg, 2002, and references therein). In contrast, selenium-amended agricultural soils show increased selenium of 0.065 to $1.7 \mathrm{ppm}$. Lake waters in Sweden-both those affected by and those not affected by selenium effluentshow between 43 and 209 nanograms per liter (ng/L) of total selenium $($ total $=$ particulate + dissolved $)$, and this concentration is independent of the trophic status of the lake (Parkman and Hultberg, 2002, and references therein).

In Finland, background concentrations of dissolved selenium in lake waters are estimated to be 56 to $62 \mathrm{ng} / \mathrm{L}$, and although no seasonal variations were observed, researchers did find spatial variations caused by human activities. As a comparison, in lakes affected by agricultural runoff, the selenium concentration was $76.8 \mathrm{ng} / \mathrm{L}$. In these lakes, the total selenium concentration was distributed among (1) selenium in organic materials, such as humic acids, which was greater than or equal to 50 percent of the total; (2) particulate selenium that was approximately 10 percent of the total selenium concentration; (3) dissolved selenite and selenate, which accounted for 8 to 9 percent of the total selenium concentration; and (4) selenium associated with neutral humic acids, which made up approximately 5 percent (Parkman and Hultberg, 2002). Sediments in these lakes show an increase in selenium concentration during the 20th century, most likely because of selenium-containing fertilizers. In 1992, concentrations in nine lakes ranged between 0.27 and $3.64 \mathrm{ppm}$, and concentrations were higher in oligotrophic lakes than in mesotropic or eutrophic lakes. In stream sediments in Finland, the mean concentration of selenium was $0.26 \mathrm{ppm}$ (Parkman and Hultberg, 2002, and references therein).

\section{Above-Background Concentrations of Selenium in the Environment Near Major Deposits and Enriched Bedrock}

Soils can have highly variable selenium concentrations, ranging from less than $0.01 \mathrm{ppm}$ in deficient soils to up to 1,200 ppm in selenium-rich soils (Winkel and others, 2012, and references therein). Seleniferous soils can be found overlying selenium-rich rocks, such as black shales, carbonaceous limestones, carbonaceous cherts, mudstones, and seleniferous coal (Winkel and others, 2012). 


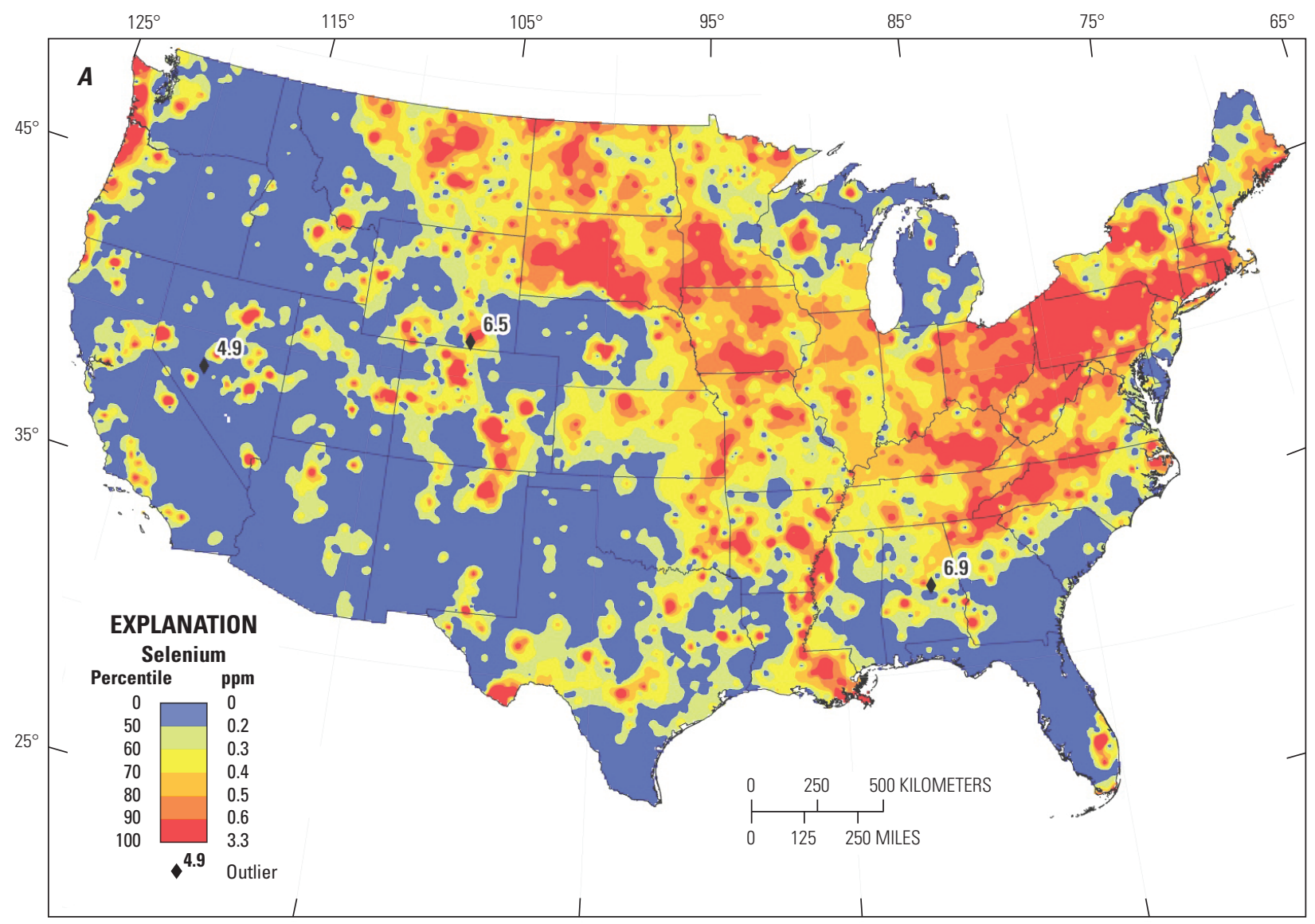

Base from U.S. Geological Survey digital files, Lambert Conformal Conic projection Standard parallels $33^{\circ} \mathrm{N}$. and $45^{\circ} \mathrm{N}$., central meridian $96^{\circ} \mathrm{W}$. Datum is North American Datum of 1983

Figure $\mathbf{0 8}$ (pages $\mathbf{0 2 4}$ and $\mathbf{0 2 5}$ ). Maps showing selenium concentrations in soils of the conterminous United States. The selenium concentrations shown are in $A$, the top 0 to 5 centimeters of surface soils, $B$, the A horizon of surface soils, and $C$, the $C$ horizon of surface soils. A visual comparison of the soils maps with the bedrock and plant maps in fig. 06 shows many correlations in the Western United States. Maps are from Smith and others (2014, p. 197-202, figs. 95, 96, and 97). ppm, parts per million

Some examples of seleniferous soils are those that develop over seleniferous marine shales in the United States. Presser (1994) found that salinized soils of alluvial fans in the San Joaquin Valley, California, could contain as much as $4.5 \mathrm{ppm}$ of selenium, with a median of $1.8 \mathrm{ppm}$. These soils developed from weathering of the Upper CretaceousPaleocene Moreno Formation and the Eocene-Oligocene Kreyenhagen Formation, which themselves contained concentrations of selenium up to $45 \mathrm{ppm}$, with median concentrations of 6.5 and 8.7 ppm, respectively (table Q5). Even higher concentrations have been recorded in shales of the Cretaceous Pierre Formation and the Niobrara Formation in the Western United States (maximums of 103 and 113 ppm, respectively) (table Q5; Moxon and others, 1938; Trelease and Beath, 1949; Presser, 1999).

High concentrations of selenium can develop in irrigation drainage waters and wetland environments when these waters interact with seleniferous soils. The wetlands of the Kesterson National Wildlife Refuge in San Joaquin Valley, Calif., were the site of an ecological crisis beginning in 1983, when it was discovered that high concentrations of dissolved selenium caused massive numbers of embryonic deformities and deaths of aquatic wildlife (Garone, 1999; Ohlendorf, 2002). The wetlands developed at the terminus of irrigation drainage within the San Joaquin Valley, and the drainage waters held high concentrations of selenium (in the range of 106 to 452 parts per billion (ppb), with an average concentration of $300 \mathrm{ppb}$ ) leached from seleniferous, salinized soils that developed over high-selenium-content marine shales. The link between high selenium concentrations and selenium toxicity is discussed in the sections of this chapter on human and ecological health.

Soils in the vicinity of sulfide orebodies may show naturally high concentrations of selenium, and this association has been cited in models for exploration geochemistry (Koljonen, 1976). The Luikonlahti copper orebody in eastern Finland displays elevated selenium concentrations in soils and glacial deposits immediately adjacent to sulfide-rich rocks ( 0.1 to $0.4 \mathrm{ppm}$ selenium), in colloid- and organic-rich river and lake sediments downstream from the orebody 

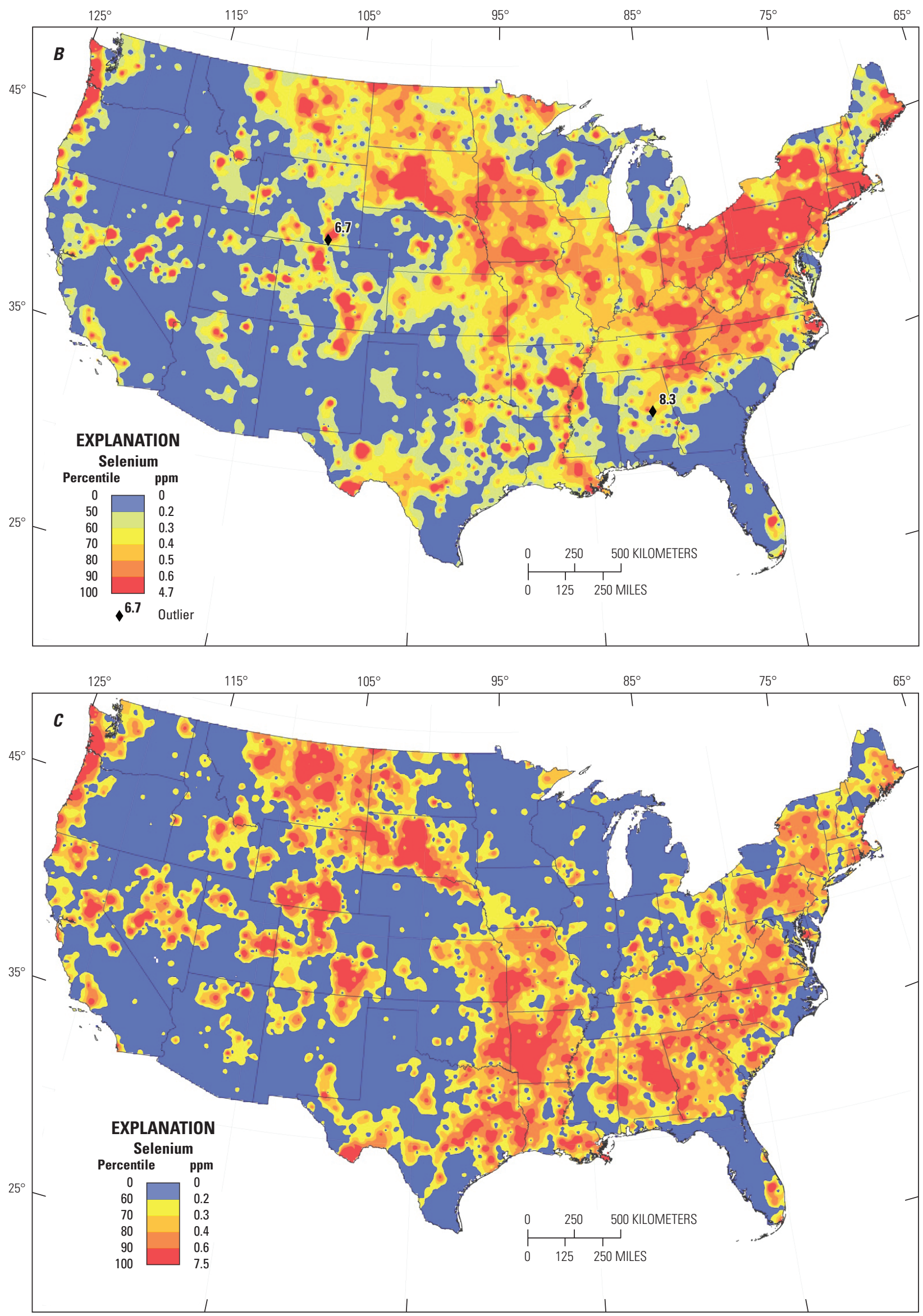
( 0.2 to $1.1 \mathrm{ppm}$ selenium), in forest mull humus atop the orebody ( 2.3 to $5.5 \mathrm{ppm}$ selenium), and in sulfate- and iron-oxide-rich gossans developed above the orebody ( 2.9 to $13.0 \mathrm{ppm}$ selenium). In contrast, similar soils and sediments from nonmineralized regions in Finland showed background selenium concentrations of 0.0 to $0.2 \mathrm{ppm}$ selenium, with iron-rich lake and bog ores containing 0.4 ppm selenium (Koljonen, 1976).

Groundwaters near an undisturbed porphyry copper deposit in the Atacama Desert of Chile also display aboveaverage concentrations of selenium. Leybourne and Cameron (2008) measured naturally occurring concentrations of up to $800 \mathrm{ppb}$ selenium within 2 kilometers $(\mathrm{km})$ downstream of the deposit. They attribute these high concentrations to Eh-pH conditions and $\mathrm{pH}$, which put the waters at the boundary between $\mathrm{Fe}$ (III) and $\mathrm{Fe}$ (II) speciation. Limited quantities of solid iron oxyhydroxides are present in environments with these values of Eh-pH; therefore, adsorption reactions with iron oxyhydroxides did not reduce dissolved concentrations of selenium.

In contrast, sorption reactions may be an important control on selenium mobility in volcanic soils (Floor and Román-Ross, 2012). High concentrations of selenium have been recorded in volcanic soils owing to weathering of seleniferous parent materials and deposition of atmospheric selenium. Floor and Román-Ross (2012) reported 1,200 ppm of selenium in volcanic soils from Ireland, and 1 to $20 \mathrm{ppm}$ of selenium in soils from Hawaii. Floor and others (2011) reported a range of 0.12 to $2.25 \mathrm{ppm}$ selenium in soils from the Mount Etna volcano in Italy, with a median of $0.39 \mathrm{ppm}$ selenium. Despite these high soil concentrations, selenium is not readily leached from soils. Strong sorption of selenium with soil compounds, such as ferrihydrite, poorly crystalline aluminosilicates, and organic matter, has been cited in volcanic soils from Hawaii, Mount Etna in Italy, and New Zealand (Floor and Román-Ross, 2012).

The strong sorption between selenium and volcanic soils may be site specific, as sorption is highly dependent upon soil chemistry and mineralogy. Whereas groundwater in volcanic aquifers can have low concentrations - often less than $0.1 \mathrm{ppb}$ selenium (Floor and Román-Ross, 2012)—-some sites show distinctly higher concentrations. Aiuppa and others (2000) sampled groundwaters near Mount Etna and found a range of 0.6 to $66.8 \mathrm{ppb}$ selenium, with an average of $2.9 \mathrm{ppb}$ selenium. At Mount Vesuvius, Italy, Aiuppa and others (2005) demonstrated that selenium can be one of the most mobile elements during rock weathering.

Plants show elevated concentrations of selenium when grown in soils with high selenium concentration, although the accumulation can vary by more than two orders of magnitude for a given selenium concentration in the soil (Winkel and others 2012, and references therein). Selenium accumulator plants include Astragalus L., as well as Oonopsis (Nutt.) Greene, Oryzopsis Michx., Xylorhiza Nutt., Mentzelia L., and Stanleya Nutt. (Moxon and others, 1938; Trelease and Beath, 1949; Cannon, 1957; Presser, 1999). Cannon (1957) reported that members of Astragalus can display selenium concentrations of several hundreds to a thousand parts per million when grown in soils that contain only $2 \mathrm{ppm}$ selenium. In addition to soil selenium, other factors that affect the plant's selenium content include the age of the plant, the stage of growth, and the part of the plant analyzed - seed, leaf, or stem (Moxon and others, 1938).

\section{Mobility in Water and Soils}

The chemical form of selenium (its speciation) determines its behavior and fate in the environment. Selenium is a metalloid that commonly takes an anionic form in oxic to suboxic conditions when dissolved, and its primary species in water are selenate $\left(\mathrm{Se}(\mathrm{VI})\right.$ or $\mathrm{SeO}_{4}{ }^{2-}$ ), selenite ( $\mathrm{Se}(\mathrm{IV})$ or $\mathrm{SeO}_{3}{ }^{2-}$ ), and organo-selenide (org-Se(-II), such as selenomethionine) (Luoma and Presser, 2009). Speciation will also determine whether selenium can be taken up by algae or microbes, or whether it can transform to particulate matter in seawater (seston) or in sediments.

In the sections above, the sources of selenium in the environment have been identified as emissions from volcanoes, biogenic processes, manufacturing and power generation, weathering of marine shale bedrock and overlying soils, and selenium leachate from fly ash and other solid waste materials. Mobilization of selenium from these sources to aquatic environments and pore waters occurs under oxidizing, slightly alkaline weathering conditions and produces soluble selenate and selenite (McNeal and Balistrieri, 1989; Presser and Swain, 1990; Piper and others, 2000).

Once selenium has transformed to aqueous selenate and selenite, it is readily mobile and bioavailable (meaning that it can be taken up by organisms). Selenate predominates in well-aerated surface waters, especially at alkaline $\mathrm{pH}$. Selenite predominates in slow-moving waters, such as lakes and reservoirs. Chemical parameters, such as $\mathrm{pH}$ and redox, and microbial respiration, can convert selenate to selenite and organo-selenium. Dissolved selenium can sometimes be predominately organo-selenium, and this species may be seasonally important (Skorupa and others, 2004). The presence of organic carbon, ferric oxyhydroxides, and clays in soils affect the partitioning of these selenium species among water and soil and (or) sediments.

Selenate (Se (VI)) does not form strong adsorption complexes on mineral surfaces. It can be easily desorbed by a change in solution chemistry (for example $\mathrm{pH}$, or ionic strength), and it exchanges readily with $\mathrm{SO}_{4}$. Ready desorption and exchange are among the reasons for the high solubility of $\mathrm{Se}(\mathrm{VI})$, which enhances its mobility (Fukushi and Sverjensky, 2007). In solutions of alkaline $\mathrm{pH}$ with high Eh values, $\mathrm{Se}(\mathrm{VI})$ is mobile and bioavailable to plants (Winkel and others, 2012). In contrast, selenite (Se(IV)) is stable in solutions of moderate 
to low Eh values, and it is more likely to adsorb irreversibly to iron oxyhydroxides, clay minerals, and organic matter than to selenate. When selenite is tightly held by mineral surfaces and organic matter, it is less mobile and less available for plant uptake (Winkel and others, 2012, and references therein).

In a system where mineral surfaces and organic matter are not present in sufficient concentrations, however, Se(IV) and organo-selenide may be more readily incorporated into biota. When selenium is taken up at the base of the food web by plants and microbes, it is converted to organo-selenide, regardless of whether it was initially present as Se(IV) or Se(VI) (Presser and others, 1994). Organo-selenide is rereleased to water as these cells die or are consumed, and it can be reoxidized to $\mathrm{Se}(\mathrm{IV})$. Slow reaction kinetics restrict reoxidation to $\mathrm{Se}(\mathrm{VI})$. This means that biologically productive systems will evolve to see a decrease in soluble $\mathrm{Se}(\mathrm{VI})$ and an increase in Se(IV) and organo-Se(-II). For example, in streams in the upper part of California's San Joaquin River watershed, dissolved selenium is almost 100 percent $\mathrm{Se}(\mathrm{VI})$, but lower in the watershed and downstream of the delta of the San Joaquin River, Se(VI), Se(IV), and organo-Se(-II) are equal in abundance (Cutter and Cutter, 2004).

Elemental (native) selenium is not soluble in water and is considered unavailable to plants. Some estimates suggest that elemental selenium may account for 30 to 60 percent of the total selenium in sediments (Zhang and others, 2004). It is often found as nanometer-sized spherical particles that are produced from microbially mediated reduction of $\mathrm{Se}(\mathrm{VI})$ and Se (IV). The extremely small size of these particles enables them to remain in colloidal suspension for weeks, and they may be able to enter cells directly, making the particles more bioavailable. A high surface-to-volume ratio makes them highly reactive, meaning that they may reoxidize to selenite and selenate. Finally, an organic polymer layer of protein that has been observed on the surface of these spherical particles may alter their surface properties and affect the distribution of elemental selenium in the environment (Winkel and others, 2012).

It was noted earlier that selenium exchanges readily with sulfur; this is because selenium and sulfur are both members of Group $6 \mathrm{~b}$ of the periodic table; hence, they exhibit similar chemical behavior because they have similar ionic radii and can have the same valence. The S(VI) competition with Se(VI) for adsorption sites on mineral surfaces and in biological uptake is a primary mechanism for $\mathrm{Se}(\mathrm{VI})$ mobilization. For example, in soils developed on the flanks of Mount Etna, it was observed that selenium is mobilized during rainwatersoil interaction. It was found that aluminum oxides and soil organic matter were the active phases to sequester selenate in soil through adsorption and complexation reactions. When sulfate was introduced from rainwater, however, sulfate exchanged with adsorbed and complexed selenate, transforming it to a soluble and therefore mobile selenium species. Yet when redox conditions allowed for selenium transformation to $\mathrm{Se}^{0}$, selenium would not be remobilized by acidic water (Floor and others, 2011).

\section{Mine Waste Characteristics}

Coal deposits and associated mine waste rock are common geologic sources for environmental selenium (fig. Q5). In the Appalachian region, coal mining companies often practice mountaintop mining to access underlying coal seams, and the waste rock is commonly placed in streams and valleys. According to the U.S. Environmental Protection Agency (EPA), an estimated 724 stream miles (1,165 stream kilometers), or 1.2 percent of streams, were covered by more than 6,800 valley fill waste piles from 1985 to 2001 in the States of Kentucky, Tennessee, Virginia, and West Virginia (U.S. Environmental Protection Agency, 2005, p. 4-5). This waste disposal practice serves to increase selenium input into aquatic systems because fresh faces on newly broken rock provide increased surface area for water-rock reaction and selenium transfer into surface waters. Bryant and others (2003) observed that the selenium concentration in Appalachian streams associated with valley fills $(<0.3$ to $37 \mathrm{ppb}$ selenium) was greater than background concentration $(<0.3 \mathrm{ppb}$ selenium $)$, and that the selenium concentrations in holding ponds at the base of valley fills ranged from 24 to $42 \mathrm{ppb}$ selenium. Surface and groundwater $\mathrm{pH}$ greatly affect selenium solubility. Unlike other trace elements associated with coal (for example, cadmium, copper, and lead), the oxic forms of selenium are soluble in waters with neutralto-alkaline $\mathrm{pH}$. This behavior is explained by the difference in adsorption potential among base cations (for example, cadmium, copper, and lead), which adsorb strongly to oxide surfaces at higher $\mathrm{pH}$ values, and oxyanion forms of selenate and selenite, which adsorb more strongly at lower $\mathrm{pH}$ values (Stumm, 1992; Elzinga and others, 2009).

Although selenium can occur naturally in soils associated with unmined coal seams, mining is known to enhance its solubility in reclaimed and revegetated mine lands, which can potentially result in aquifer contamination and elevation of selenium in plant materials. Sharmasarkar and Vance (1997) analyzed 40 soil samples (ranging in depth from 0 to $200 \mathrm{~cm}$ ) from native, reclaimed, and abandoned coal mine environments in Wyoming, and observed selenium concentrations of 0.26 to $26.13 \mathrm{ppm}$ selenium, with a mean concentration of $1.73 \mathrm{ppm}$.

Another source of selenium to natural waters is ash and other waste products produced from coal-fired powerplants. The case study for this selenium pathway was Belews Lake in North Carolina. From 1974 to 1985, lake water was withdrawn and mixed with ash generated by a nearby coal-fired electricitygenerating plant. Presser (1999) noted that fly ash may contain even higher levels of soluble selenium than the initial, seleniferous coal; that is, 50 to $500 \mathrm{ppm}$ versus 2 to $20 \mathrm{ppm}$. Solids were allowed to settle from the slurry before the wastewater, 
which contained 150 to $200 \mathrm{ppb}$ selenium, was returned to the lake, creating lake water selenium concentrations of $20 \mathrm{ppb}$. Once this disposal practice was ended, lake water selenium concentrations fell to less than $1 \mathrm{ppb}$ (Lemly, 1997).

High ash content in bone coals (coal with a high ash content) creates another source of environmental selenium. In Pingli County, Shaanxi Province, China, the Badao bone coal contains 41 to $75 \mathrm{ppm}$ of selenium, with a mean concentration of $57.5 \mathrm{ppm}$. After combustion, the coal ash fraction was found to contain $28 \mathrm{ppm}$ of selenium, indicating that the difference (approximately $30 \mathrm{ppm}$ ) is volatilized to the atmosphere. Selenium is also released to the environment through the use of bone coal ash as an agricultural soil amendment. The local environment in Pingli County was found to contain soil with a mean concentration of $7.1 \mathrm{ppm}$ selenium, surface water with concentrations of 0.3 to $1.1 \mathrm{ppm}$ selenium, and agricultural crops with concentrations of 0.57 to $2.75 \mathrm{ppm}$ selenium (Fang and others, 2003).

As discussed previously, selenium is associated with phosphate deposits, and, quite notably, in the United States, with the Meade Peak member of the Permian Phosphoria Formation in Idaho, Montana, Nevada, Utah, and Wyoming. Features of the mined environment include lakes that form in open pit mines after mining has ended, waste rock contoured into hills or emplaced as cross-valley fills, wetlands that form at the base of waste dumps, and vegetation that is reseeded onto the surface of the dumps.

A selenium mass-balance study was conducted for the wetland that formed at the base of the Wooley Valley Unit 4 waste dump in southeastern Idaho (Stillings and Amacher, 2004; Stillings and others, 2007). The waste dump was created in the 1970s from overburden and waste shale that remained after the mining of the upper and lower phosphate zones of the Meade Peak member, and the wetland developed soon thereafter. In 2002, inlet and outlet flow volumes and chemistry were measured continuously from May through September. The calculated influx of selenium was high at the beginning of May (approximately 90 grams per day [g/d] of selenium), but dropped rapidly throughout the month and became zero when the seep dried up at the end of June. The outflux of selenium ranged from approximately 0.05 to $2.0 \mathrm{~g} / \mathrm{d}$ during the entire season. The mass balance created for this time period showed that although 685 grams (g) of selenium was delivered to the wetland, only $84 \mathrm{~g}$ of selenium left the wetland, meaning that $601 \mathrm{~g}$, or 88 percent of the influx, was retained within the wetland. Further work determined that selenium was scavenged from wetland surface waters by adsorption and co-precipitation with iron oxyhydroxides that precipitated on the surface of wetland soils (Stillings and Amacher, 2004; Stillings and others, 2007).

In a related study, selenium concentrations were measured in plants grown on the waste rock dumps at Wooley Valley Units 1, 3, and 4 and compared with concentrations of plants growing on undisturbed areas of the Phosphoria Formation. Vegetation growing in highly disturbed soils, including those on the surface of waste dumps, had the highest tissue selenium concentrations. The mean concentration for legumes was $80 \mathrm{ppm}$; trees, $52 \mathrm{ppm}$; grasses, $18 \mathrm{ppm}$; shrubs, $6 \mathrm{ppm}$; and forbs, $3 \mathrm{ppm}$. The grasses collected from the wetland described in the previous paragraph showed a mean selenium concentration of $53 \mathrm{ppm}$. This second study was used to argue for the removal of legumes from seed mixtures used to revegetate the surfaces of the cross-valley waste dumps, thus decreasing selenium in browse vegetation for herbivores (Mackowiak and others, 2004).

Roll-front uranium deposits in the Western United States are another deposit type known to contain selenium; hence, selenium is likely to be present in these mine wastes as well. When uranium is mined with in situ methods (which are commonly used with roll-front deposits), the overlying rock is not disturbed and thus not exposed to oxidizing conditions at Earth's surface; however, the in situ mining methods used rely on injections of lixiviant (an oxidizing agent - either oxygen or hydrogen peroxide) into the uranium deposit to oxidize and extract the uranium ore. This fluid can leach selenium into the surrounding groundwater by oxidizing organic matter that contains selenium, and by converting insoluble organic selenides to soluble selenate and selenite. Selenium concentrations can exceed 1,000 ppm in areas that have been mined for uranium (Naftz and Rice, 1989, and references therein).

Both groundwater and surface water in areas near copper mines and processing facilities may show elevated selenium concentrations because of selenium's association with sulfide minerals. Elevated selenium concentrations $(>10 \mathrm{ppm})$ have been found in groundwater under the copper smelter and refinery facility near the Great Salt Lake, Utah. The facility is located within $1.5 \mathrm{~km}$ of the southern shore of the lake, and there is some concern that a portion of this plume could discharge into the lake (Naftz and others, 2009, p. 35, and references therein). In 2001, the facility was selected for an EPA selenium treatment/demonstration project, which field-tested three technologies for removing selenium from the Garfield Wetlands-Kessler Springs site. At the start of this project (in May 1999), the Garfield Wetlands-Kessler Springs water contained approximately 2,000 ppm selenium (MSE Technology Applications, Inc., 2001, p. 1).

Soils near a lead-zinc smelter in Kabwe, Zambia, show contamination from atmospheric dust fallout from smelting activities. Kříbek and others (2010) sampled contaminated topsoil and a reference (background) subsoil horizon at 80 to $90 \mathrm{~cm}$ depth. The topsoil had a maximum selenium concentration of 0.01 percent ( $100 \mathrm{ppm})$, which was significantly higher than the concentrations of trace metals in the subsurface soil.

There are limited reports of selenium in leachate from mine waste associated with banded iron formations in the Upper Peninsula of Michigan. In 2008, the Michigan Department of Environmental Quality (MDEQ) began to assess selenium concentrations and water quality impacts in the vicinity of the Empire Mine and the Tilden Mine in the Marquette Iron Range near Palmer, Michigan. Results of the MDEQ 
assessment showed that selenium concentration in water at many lakes near the mine sites were less than $5 \mathrm{ppb}$, which is the chronic selenium water quality standard for Michigan. Two streams that flowed through mine waste facilities carried mean values of 9.3 and $11 \mathrm{ppb}$ selenium, however, and a popular fishing site, Goose Lake, exhibited 8.8 to $10 \mathrm{ppb}$ selenium. Small streams and springs buried by waste rock piles showed selenium concentrations that ranged from 15 to $68 \mathrm{ppb}$. Sediments from streams and lakes ranged from less than 5 ppm to between 27 and 39 ppm selenium in Goose Lake (Selenium Monitoring Work Group, 2009, p. ii). Biological samples from Goose Lake Outlet showed a mean value of 8.0 to $17.35 \mathrm{ppm}$ selenium in brook trout (Salvelinus fontinalis [Mitchill, 1814]), white suckers (Catostomus commersonii [Lacepède, 1803]), fathead minnows (Pimephales promelas [Rafinesque, 1820]), and creek chubs (Semotilus [Rafinesque, 1820]) and 22.3 ppm selenium (composite sample of northern caddisfly [Limnephilidae (Kolenati, 1848)] tissue). Selenium was present in lower levels in benthic macroinvertebrates, such as leeches, snails, mayflies, and odonates (Selenium Monitoring Work Group, 2009, p. 7-8).

\section{Human Health Concerns}

Dietary selenium plays a critical role in human health owing to its importance to thyroid hormone metabolism, antioxidant defense mechanisms, and immune functions (Rayman, 2000). Insufficient selenium is associated with growth retardation, impaired bone metabolism, and abnormalities in thyroid function (Stone, 2009). Human populations with insufficient selenium in their diet can be found living in geographic areas with low selenium contents in local bedrock and soils. One example is a northeast-southwest-trending belt in China and an area of southeastern Siberia where populations are at risk for Keshan disease (which causes cardiomyopathy) and Kashin Beck disease (a chronic degenerative osteoarthritis); both are caused by a deficiency of selenium.

Keshan disease was described in Chinese medical literature 100 years ago, but it was not until the mid-1970s that selenium deficiency was identified as its primary cause. After a widespread outbreak in 1935, it was determined to be endemic in children aged 2 to 10 years and in women of child-bearing age. Symptoms are fatigue after light exercise, cardiac arrhythmia and palpitations, loss of appetite, cardiac insufficiency, cardiomegaly, and congestive heart failure (World Health Organization and Food and Agricultural Organization of the United Nations, 2004). Kashin Beck disease was also detected in Chinese children aged 5 to 13 years and in southeastern Siberia. The disease causes joint necrosis in the form of degeneration of the arm and leg joints, which results in structural shortening of bones and leads to growth retardation and stunting (World Health Organization and Food and Agricultural Organization of the United Nations, 2004).
In Finland, blood serum levels of less than $45 \mathrm{ppb}$ selenium were believed to increase the risk of cardiovascular disease and cancer. Because of this, sodium selenate has been added to agricultural fertilizers since 1985 in order to increase the dietary intake. This practice has caused selenium dietary intake to increase from a base of 30 to 40 micrograms per day $(\mu \mathrm{g} / \mathrm{d})$ to greater than $100 \mu \mathrm{g} / \mathrm{d}$ by the early $1990 \mathrm{~s}$, and the daily intake is now considered safe and adequate (Varo and others, 1994). It should be noted, however, that some research recommends lower levels of dietary intake, and finds that doses of selenium greater than $75 \mu \mathrm{g} / \mathrm{d}$, can be mildly toxic and related to an increased risk of diabetes (Winkel and others, 2012, and references therein)

Somewhat analogously, human populations living in geographic areas with high levels of selenium in local foods may suffer from selenium toxicity. This has been observed in humans and animals in the Hubei and Shaanxi Provinces in China, and in Punjab, India, where selenium levels in local foods are high and dietary intake per person is between 750 and 4,990 $\mu \mathrm{g} / \mathrm{d}$. In Punjab, the high dietary selenium values are the result of agricultural irrigation practices and high evaporation rates, which serve to concentrate selenium into irrigated soils and food crops. At doses of greater than $400 \mu \mathrm{g} / \mathrm{d}$, selenium is acutely toxic and may lead to acute respiratory distress, cardiac failure, facial flushing, hair loss, kidney failure, light headedness, muscle tenderness, myocardial infarction, severe gastrointestinal and neurological symptoms, tremors, and, in rare cases, death (National Institutes of Health, 2013, and references therein). Chronic exposure to subacute levels leads to brittle hair and nails, skin lesions, and neurological disturbances (Winkel and others, 2012, and references therein).

One outcome of modern research into selenium and human health is a better understanding of its role in the immune system. It has been found that the cardiac lesions of Keshan disease are not the result solely of selenium deficiency, but are also related to infection by the coxsackie virus, which is initially nonvirulent, but which becomes virulent and myopathogenic in individuals with selenium deficiency. This process is not unique to the coxsackie virus. It has been determined that the early preclinical stages of human immunodeficiency virus (HIV) infection are marked by a significant decrease in blood plasma selenium concentrations, and that the magnitude of this decrease is linked to the rates of development of acquired immunodeficiency syndrome (AIDS) and to mortality rates associated with AIDS (World Health Organization and Food and Agricultural Organization of the United Nations, 2004). Finally, selenium deficiency has been linked to an increase in mercury toxicity (Berry and Ralston, 2008). Because of the high binding affinity between mercury and selenium, it is thought that selenium can function to chelate mercury and reduce its toxicity; if the molar ratio of mercury to selenium is high, however (that is, greater than 1:1), then the concentration of selenium is insufficient to provide this protective effect. 


\section{Pathways for Selenium Ingestion in Humans}

Plant foods are the main dietary sources of selenium in most countries, followed by meats and seafood (National Institutes of Health, 2013). In all cases, the selenium content of food is derived from soils and the feed for livestock (World Health Organization, 2011). Although soil selenium is the source of selenium, it is important to note that total selenium concentration is not what controls selenium levels in food crops; rather, it is the concentration of bioavailable selenium that controls the levels. For example, the classical definition of selenium-deficient soils is when concentrations are less than $0.1 \mathrm{ppm}$ selenium, whereas selenium-rich soils have greater than $0.5 \mathrm{ppm}$ selenium. These concentrations refer to total selenium. Soils in areas of China where Keshan disease has occurred have an average concentration of $0.15 \mathrm{ppm}$ selenium, which would not be classified as selenium deficient; however, these soils are selenium deficient because the bioavailable selenium is low. High content of organic matter is the cause of the low bioavailable selenium concentration because it immobilizes selenium by adsorption and biochemical reduction, making it unavailable for uptake by food crops.

The dietary intake of selenium varies somewhat across the United States and Canada because of differences in local soils and food; however, most Americans consume adequate amounts of selenium. The average daily selenium intake in Americans over 2 years in age is 108.5 micrograms from food alone, and if supplements are included, this value increases to $120.8 \mu \mathrm{g} / \mathrm{d}$ (National Institutes of Health, 2013).

\section{Related Diseases, Cancers, and Human Health Effects From Industrial Exposures}

Little has been reported regarding selenium health effects from human industrial exposures, and it is selenium deficiency from an inadequate diet that is the greatest human health concern. Selenium concentrations in gas emissions from coal combustion could be one potential cause of industrial exposure, as could exposure in industries with a significant occupational metals exposure risk, such as metals recovery (Fairweather-Tait and others, 2011). The manufacturing process for modern products, such as solar panels, might represent a potential risk if selenium is present in a bioavailable form. Manufactured nanomaterials may also pose health effects, because selenium is a key component in CdSe and $\mathrm{PbSe}$ quantum dots, which are nano-sized semiconductors used in light-emitting diodes and photovoltaics. Emergent properties of these materials could elicit toxic responses that may be different from those current selenium sources (Young and others, 2010).

\section{Human Health Guidelines}

Although water is not usually a major source of selenium to the human population (Fairweather-Tait and others, 2011), the World Health Organization (WHO) has set a provisional guideline value for selenium in drinking water. The WHO recommendation is that when selenium intake from dietary sources is unknown, then $40 \mathrm{ppb}$ should be the upper limit of selenium in drinking water (World Health Organization, 2011). In Canada, the Government has set this level at $10 \mathrm{ppb}$, although the Canadian Government is revisiting the criterion and proposing a new maximum acceptable concentration for human consumption of $50 \mathrm{ppb}$ in response to a review of current scientific studies and an understanding of chronic selenosis (Health Canada, 2013). In the United States, the EPA has set the maximum contaminant level for selenium in drinking water at $50 \mathrm{ppb}$ (U.S. Environmental Protection Agency 2014a).

Because there is a narrow concentration range between dietary deficiency $(<40 \mu \mathrm{g} / \mathrm{d})$ and highly toxic levels (>400 $\mu \mathrm{g} / \mathrm{d}$ ) (Winkel and others, 2012), the WHO recommends dietary intakes of $15 \mu \mathrm{g} / \mathrm{d}$ for infants from birth to 6 months, $30 \mu \mathrm{g} / \mathrm{d}$ for children aged 4 to 8 years, and $55 \mu \mathrm{g} / \mathrm{d}$ for older children and adults (World Health Organization, 2011). Older recommendations were 0.05 to 2 milligrams per day $(\mathrm{mg} / \mathrm{d})$ for adults, with lower ranges for children (Health Canada, 1992). In the United States, the National Institutes of Health has published recommended daily allowances (RDAs) for humans; these RDAs are similar to those recommended by the WHO, and range from an adequate intake of $15 \mu \mathrm{g} / \mathrm{d}$ for infants from birth to 6 months, to $55 \mu \mathrm{g} / \mathrm{d}$ for older children and adults (table Q7). Pregnant and breast-feeding women have RDAs of 60 and $79 \mu \mathrm{g} / \mathrm{d}$, respectively (table Q7; National Institutes of Health, 2013).

\section{Ecological Health Concerns}

Research on selenium in the environment began in the 1930s when livestock in the Great Plains and Western United States were found with the symptoms of "alkali disease," including emaciation, loss of hair, deformation and shedding of hooves, loss of vitality, and erosion of joints in long bones (Science Dictionary, 2015). It became recognized that livestock poisoning was occurring because the livestock were browsing on selenium accumulator plants of the genus Astragalus; these plants grow in saline soils derived from marine Cretaceous sedimentary rocks exposed in more than 830,000 square kilometers of the Western United States (Trelease and Beath, 1949).

Once the cause of selenium poisoning was recognized, efforts were made to prevent and control the exposure of livestock to seleniferous plants using range management techniques. In 1957, however, it was learned that selenium is an essential trace element (or micronutrient) in mammals. It is an essential component of bacterial and mammalian enzyme systems, and that without it, selenium deficiency disorders, such as white muscle disease (in sheep) and mulberry heart disease (in pigs), could occur (Young and others, 2010, and references therein). 
In 1976, the sudden disappearance of popular game fish from Belews Lake, North Carolina, was attributed to selenium poisoning. It was learned that the manmade reservoir was fed by water from a coal-ash settling basin that had created lake waters with selenium concentrations of $20 \mathrm{ppb}$. This level of selenium caused chronic selenium poisoning in the Belews Lake fish populations, where the most serious symptom was reproductive failure and post-hatch mortality. As a result of the selenium toxicity, 19 of 20 species of fish in Belews Lake were eradicated (Lemly, 2002).

Soon after this, in 1983, another extinction of fish populations was discovered. This time it was at the Kesterson Reservoir in San Joaquin Valley, Calif., which is a wetland area fed by agricultural drainage from the San Joaquin Valley. Massive numbers of dead and deformed bird embryos and chicks were found to accompany the fish extinction, and the cause was determined to be selenium poisoning from bioaccumulation in the food chain (Ohlendorf, 2002). After this discovery, deformities of aquatic birds from selenium toxicosis began to be observed in similar environments; that is, wetland basins that received waters draining seleniferous soils, such as the Tulare Lake Bed Area, Calif.; the Middle Green River Basin, Utah; the Kendrick Reclamation Project Area, Wyoming; the Sun River Basin, Montana; and the Stillwater Wildlife Management Area, Nevada. Most of these study areas had climate, geology, and hydrology similar to that of the San Joaquin Valley. Results indicated that bioaccumulation of selenium was occurring in most of the wetland areas, and these data marked the initial elucidation of a biogeochemical pathway for selenium from geologic source to aquatic wildlife (Presser and others, 1994).

\section{Pathways for Selenium Ingestion in Aquatic and Terrestrial Organisms}

Just as in human health, the main pathway for selenium entry into aquatic and terrestrial organisms is through diet, and speciation is an important factor in determining the amount of selenium that enters the food chain. The primary step by which selenium accumulates in aquatic systems is found at the base of the food chain where algae and other microorganisms (trophic level 1) accumulate selenium from water by factors of up to 1 million times the aqueous concentration. Selenate (Se(VI)) is slow to be taken up by these organisms, especially in the presence of sulfate, which is more competitive. Selenite (Se(IV)) and organo-selenides are taken up more quickly. Once selenium has been accumulated by an organism, the selenium is reduced to selenide (Se(-II)) and ultimately incorporated into amino acids, primarily selenomethionine, which is the organo-selenide that bioaccumulates in food webs and produces toxicity (Luoma and Presser, 2009).

The algae and microbes, together with abiotic particlesorbed selenium, constitute the particulate selenium fraction in the water column. Particulate matter is ingested by aquatic primary consumers, such as zooplankton, insect larvae, larval fish, and bivalves (trophic level 2), thus transferring
Table 07. National Institutes of Health recommended dietary reference intakes (DRIs) for selenium.

[Data are from the Food and Nutrition Board of the Institute of Medicine, National Academy of Sciences, and published by the National Institutes of Health (2013). Recommendations are for men and for women who are not pregnant or nursing. $\mu \mathrm{g} / \mathrm{d}$, microgram per day]

\begin{tabular}{ccc}
\hline $\begin{array}{c}\text { Age } \\
\text { (years) }\end{array}$ & $\begin{array}{c}\text { Recommended } \\
\text { daily allowance } \\
(\boldsymbol{\mu} \mathbf{g} / \mathbf{d})\end{array}$ & $\begin{array}{c}\text { Tolerable upper } \\
\text { intake level } \\
(\boldsymbol{\mu} \mathbf{g} / \mathbf{d})\end{array}$ \\
\hline 0 to 0.5 & ${ }^{1} 15$ & 45 \\
0.5 to 1 & 20 & 60 \\
1 to 3 & 20 & 90 \\
4 to 8 & 30 & 150 \\
9 to 13 & 40 & 280 \\
14 to 18 & 55 & 400 \\
19 to 50 & 55 & 400 \\
$51+$ & 55 & 400 \\
\hline
\end{tabular}

${ }^{1}$ This level is called the adequate intake (AI) level because evidence is insufficient to develop a recommended daily allowance.

selenomethionine (a naturally occurring amino acid) up the food chain. Abiotic selenium, which may be ingested with particulate matter, is transformed to selenomethionine by the primary consumers, which may, in turn, be consumed by predators, such as fish and birds (trophic level 3 and above). In this manner, selenium continues to accumulate, and its concentrations magnify as it is transferred to higher trophic levels. The accumulated concentration determines whether toxicity is manifested (Luoma and Presser, 2009; Young and others, 2010; U.S. Environmental Protection Agency, 2014b).

Recycling of selenium in the aquatic environment occurs when organo-selenide, mostly in the form of selenomethionine, is returned to the water upon the death and decay of aquatic organisms. Some organo-selenide may be oxidized to Se(IV), but neither organo-selenide nor Se(IV) will be converted to $\mathrm{Se}(\mathrm{VI})$ because the reaction is very slow, with a half-life of hundreds of years. The net outcome of recycling in a watershed is an evolution of selenium from $\mathrm{Se}(\mathrm{VI})$, which is the primary form of selenium from natural and anthropogenic sources, to $\mathrm{Se}(\mathrm{IV})$ and organo-selenide (Se-II), which are the more bioavailable species (Young and others, 2010).

Selenium enters terrestrial organisms by a similar pathway. Accumulator plants take up selenium from soil water, usually as $\mathrm{Se}(\mathrm{VI})$ or $\mathrm{Se}(\mathrm{IV})$, and transform it primarily into the amino acid selenomethionine. These accumulators are able to incorporate large amounts of selenium - some as high as 15,000 ppm (Trelease and Beath, 1949). Livestock grazing on these plants accumulate selenomethionine, with potentially fatal results. 


\section{Aquatic Toxicity and Aquatic Ecosystem Health Guidelines}

Selenium is bioaccumulative, meaning that fish and other aquatic life can contain concentrations greater than the surrounding water. The primary source of selenium to aquatic life is dietary, and toxicity primarily occurs through transfer to eggs and subsequent reproductive effects. Because selenium bioaccumulation rates may vary among aquatic environments, the EPA has proposed a four-part freshwater criterion that includes elements for (1) fish eggs and ovaries, set at $15.2 \mathrm{ppm}$ selenium dry weight; (2) whole fish body tissue not to exceed $8.1 \mathrm{ppm}$ dry weight, or muscle tissue not to exceed $11.8 \mathrm{ppm}$ dry weight; (3) a 30-day average selenium concentration not to exceed $4.8 \mathrm{ppb}$ selenium in lotic (flowing) waters or $1.3 \mathrm{ppb}$ selenium in lentic (standing) waters, more than 1 time in 3 years, on average; and (4) repeated short-term exposures where the intermittent water quality concentration for both lentic and lotic waters is calculated from the 30-day concentration; the background selenium concentration; and the fraction of time (over the 30-day period) during which elevated selenium concentrations occur. The purpose of this criterion with two fish-tissue-based and two water-based elements is to protect against adverse reproductive effects of selenium on aquatic life, and the criterion apply to total selenium concentrations; that is, the sum of all forms of selenium (selenate, selenite, organic selenium, and any other forms) (U.S. Environmental Protection Agency, 2014a).

Previous to this four-part criterion, the EPA freshwater criterion for protection of aquatic life was 5 ppb selenium with a lower criterion of 2 ppb selenium for some wetland environments in California (Luoma and Presser, 2009). In marine waters, the maximum allowable concentration is $290 \mathrm{ppb}$ selenium, whereas the continuous concentration is $71 \mathrm{ppb}$ selenium (U.S. Environmental Protection Agency, 2014c). It should be noted that there is no international agreement on these guidelines. In Canada, the marine and freshwater guidelines are $2 \mathrm{ppb}$ selenium, and in Europe, selenium is not considered an ecological threat and is not subject to environmental quality standards (Luoma and Presser, 2009; European Commission Joint Research Centre Institute for Health and Consumer Protection, 2011).

\section{Problems and Future Research}

There is no "free lunch." Selenium extraction from mineral resources has led to technological development and has greatly benefited our society. At the same time, there are environmental consequences of mining that must be recognized and evaluated for every mining project. This chapter provides an overview of the selenium life cycle. Although the main focus is selenium as a mineral resource and commodity, these selenium topics cannot be presented without acknowledging the environmental concerns that accompany the presence of selenium in the environment.
Challenges abound for new research on selenium in the 21 st century. Extraction of selenium from the waste products (anode slimes) of copper ore processing has been a proven technology for many decades, but changes in processing technology will affect selenium recovery. Will it be possible to recover selenium from other sources economically? Coal and other organic carbon sources come immediately to mind; these technologies exist but are not economically favorable at present. High-grade but low-tonnage deposits with selenide minerals may be another source for selenium extraction, contingent upon available technology and favorable economics.

Other research directions would contribute to the scientific understanding of the selenium elemental cycle in Earth's crust. A very basic question concerns the amount of selenium in the crust. The current estimate of $0.05 \mathrm{ppm}$ selenium in the continental crust dates to 1961 . Could this estimate be updated and revised, given our current knowledge of selenium concentrations in various crustal reservoirs? Next, can selenium concentrations and isotopic composition be used as an exploration tool for the discovery of concealed deposits? Finally, to thoroughly understand the elemental cycle of selenium in the earth, it would be useful to compare and contrast the magmatic selenium pathway from volcanoes to enriched ore deposits, to the sedimentary selenium pathway that involves selenium uptake by algae and bacteria in productive marine basins and deposition in organic-rich sediments. Are there connections between these two pathways and does selenium cycle between them?

Research opportunities exist under the topic of selenium environmental concerns as well. Some of the most pressing topics involve the bioavailability of selenium and its incorporation into the food web and whether the understanding of this cycle can translate into ecosystem and human health guidelines. The newly proposed tissue-based criterion for selenium in aquatic systems is a direct result of years of focused scientific study. Other research might target methods to redirect or disrupt the process that transfers selenium from rock to biota. Studies that amend selenium-rich soil with sulfur, or plant non-selenium-accumulating plants on mine waste, are creative attempts to break the rock-biota selenium connection. Studies to limit selenium solubility from nanoparticles would aid in keeping new technologies environmentally safe. Regardless of the focus, research into the elemental cycle of selenium, including the manufacture and disposal of selenium-containing commodities, will continue to increase understanding of Earth processes.

\section{Acknowledgments}

The author thanks technical reviewers John DeYoung, Daniel Edelstein, Micheal George, Sandy Neuzil, Theresa Presser, Klaus Schulz, Bob Seal, and Michael Magyar for improving this manuscript with their gifts of time and insight. Bob Seal is especially commended for reminding the author that this 
chapter is part of a volume on mineral resources, not environmental processes. The USGS publications staff is gratefully acknowledged for gentle correction of the author's mistakes and poor writing habits. Keith Labay helped create the deposit location maps, and Suzanne Nicholson provided additional editorial comments after the technical review was complete.

\section{References Cited}

Note: All Web links listed were active as of the access date but may no longer be available.

Adriano, D.C., 1986, Trace elements in the terrestrial environment: New York, N.Y., Springer-Verlag, 533 p.

Aiuppa, Alessandro, Allard, Patrick, D'Alessandro, Walter, Michel, Agnes, Parello, Francesco, Treuil, Michel, and Valenza, Mariano, 2000, Mobility and fluxes of major, minor and trace metals during basalt weathering and groundwater transport at Mt. Etna volcano (Sicily): Geochimica et Cosmochimica Acta, v. 64, no. 11, p. 1827-1841. [Also available at $\mathrm{http} / / / \mathrm{dx}$.doi.org/10.1016/S00167037(00)00345-8.]

Aiuppa, Alessandro, Federico, Cinzia, Allard, Patrick, Gurrieri, Sergio, and Valenza, Mariano, 2005, Trace metal modeling of groundwater-gas-rock interactions in a volcanic aquifer-Mount Vesuvius, southern Italy: Chemical Geology, v. 216, nos. 3-4, p. 289-311. [Also available at http://dx.doi.org/10.1016/j.chemgeo.2004.11.017.]

American Physical Society Panel on Public Affairs and the Materials Research Society, 2011, Energy critical elements-Securing materials for emerging technologies: Washington, D.C., American Physical Society, 19 p. plus 2 appendixes, accessed May 13, 2016, at http://www.aps.org/ policy/reports/popa-reports/upload/elementsreport.pdf.

Auclair, Gilles, Fouquet, Yves, and Bohn, Marcel, 1987, Distribution of selenium in high-temperature hydrothermal sulfide deposits at $13^{\circ}$ north, East Pacific Rise: The Canadian Mineralogist, v. 25, no. 4, p. 577-587. [Also available at http://canmin.geoscienceworld.org/content/25/4/ 577.full.pdf + html.]

Baker, L., Gustafson, J., Wood, S., and Geist, D., 2000, Selenium chemistry in the Red Dog Mine ore, mill and tailings pond: Geological Society of America, Abstracts with Programs, v. 32, no. 7, p. 191.

Berry, M.J., and Ralston, N.V., 2008, Mercury toxicity and the mitigating role of selenium: EcoHealth, v. 5, no. 4, p. 456-459. [Also available at http://dx.doi.org/10.1007/ s10393-008-0204-y.]
Bindi, Luca, and Pratesi, Giovanni, 2005, Selenojalpaite, $\mathrm{Ag}_{3} \mathrm{CuSe}_{2}$, a new mineral species from the Skrikerum $\mathrm{Cu}-$ Ag-Tl selenide deposit, Småland, southeastern Sweden: The Canadian Mineralogist, v. 43, no. 4, p. 1373-1377. [Also available at http://dx.doi.org/10.2113/gscanmin.43.4.1373.]

Bleiwas, D.I., 2010, Byproduct mineral commodities used for the production of photovoltaic cells: U.S. Geological Survey Circular 1365, 10 p., accessed May 24, 2016, at http://pubs.er.usgs.gov/publication/cir1365.

Boyd, Russel, 2011, Selenium stories: Nature Chemistry, v. 3, p. 570. [Also available at http://www.nature.com/nchem/ journal/v3/n7/full/nchem.1076.html]

Brininstool, Mark, 2015, Copper [advance release], in Metals and minerals: U.S. Geological Survey Minerals Yearbook 2012, v. I, p. 20.1-20.27, accessed May 24, 2016, at http://minerals.usgs.gov/minerals/pubs/commodity/ copper/myb1-2012-coppe.pdf.

Brown, R.D., Jr., 2002, Selenium and tellurium, in Metals and minerals: U.S. Geological Survey Minerals Yearbook 2000, v. I, p. 67.1-67.7, accessed May 24, 2016, at http://minerals. usgs.gov/minerals/pubs/commodity/selenium/830400.pdf.

Brunfelt, A.O., and Steinnes, E., 1967, Determination of selenium in standard rocks by neutron activation analysis: Geochimica et Cosmochimica Acta, v. 31, no. 2, p. 283-285.

[Also available at http://dx.doi.org/10.1016/S00167037(67)80051-6.]

Bryant, Gary, McPhilliamy, Scott, and Childers, Hope, 2003, A survey of the water quality of streams in the primary region of mountaintop/valley fill coal mining - October 1999 to January 2001 - Final report, in Appendix D of Mountaintop mining/valley fills in Appalachia-Draft programmatic environmental impact statement: U.S. Environmental Protection Agency Report EPA-9-03-R-00013B, p. 661-789, accessed May 24, 2016, at http://nepis.epa.gov/Exe/ ZyPURL.cgi?Dockey=P100G122.txt.]

Butterman, W.C., and Brown, R.D., Jr., 2004, Mineral commodity profiles-Selenium: U.S. Geological Survey Open-File Report 03-018, 19 p. plus 1 appendix, accessed May 24, 2016, at http://pubs.usgs.gov/of/2003/of03-018/ of03-018.pdf.

Cabral, A.R., Lehmann, B., Kwitko, R., and Cravo Costa, C.H., 2002, The Serra Pelada Au-Pd-Pt deposit, Carajás mineral province, northern Brazil-Reconnaissance mineralogy and chemistry of very high grade palladian gold mineralization: Economic Geology, v. 97, p. 1127-1138. [Also available at http://dx.doi.org/10.2113/gsecongeo.97.5.1127.] 
Cahill, T.A., and Eldred, R.A., 1998, Particulate selenium in the atmosphere, in Frankenberger, W.T., Jr., and Engberg, R.A., eds., Environmental chemistry of selenium: New York, N.Y., Marcel Dekker, Inc., p. 613-632.

Cannon, H.L., 1957, Description of indicator plants and methods of botanical prospecting for uranium deposits on the Colorado Plateau: U.S. Geological Survey Bulletin 1030-M, p. 399-516. [Also available at http://pubs.usgs.gov/bul/1030m/ report.pdf.]

Chouinard, Annick, Paquette, Jeanne, and Williams-Jones, A.E., 2005, Crystallographic controls on trace-element incoporation in auriferous pyrite from the Pascua epithermal high-sulfidation deposit, Chile-Argentina: The Canadian Mineralogist, v. 43, no. 3, p. 951-963. [Also available at http://dx.doi.org/10.2113/gscanmin.43.3.951.]

Ciobanu, S.L., Cook, N.J., and Spry, P.G., 2006, PrefaceSpecial issue-Telluride and selenide minerals in gold deposits - How and why?: Mineralogy and Petrology, v. 87, no. 3, p. 163-169. [Also available at http://dx.doi.org/ 10.1007/s00710-006-0133-9.]

Clark, J.W., 1950, Minor metals, in Minerals yearbook 1948: U.S. Bureau of Mines, p. 1310-1350. [Also available at http://minerals.usgs.gov/minerals/pubs/usbmmyb.html.]

Cocker, H.A., Mauk, J.L., and Rabone, S.D.C., 2013, The origin of Ag-Au-S-Se minerals in adularia-sericite epithermal deposits - Constraints from the Broken Hills deposit, Hauraki goldfield, New Zealand: Mineralium Deposita, v. 48, no. 2, p. 249-266. [Also available at http://dx.doi.org/ 10.1007/s00126-012-0410-y.]

Coleman, Lynn, Bragg, L.J., and Finkelman, R.B., 1993, Distribution and mode of occurrence of selenium in US coals: Environmental Geochemistry and Health, v. 15, no. 4, p. 215-227. [Also available at http://dx.doi.org/ 10.1007/BF00146745.]

Coleman, R.G., 1959, The natural occurrence of galenaclausthalite solid solution series: The American Mineralogist, v. 44, January-February, p. 166-175. [Also available at http://www.minsocam.org/ammin/AM44/AM44_166.pdf.]

Coleman, R.G., and Delevaux, M.H., 1957, Occurrence of selenium in sulfides from some sedimentary rocks of the Western United States: Economic Geology, v. 52, p. 499-527. [Also available at http://dx.doi.org/10.2113/gsecongeo.52.5.499.]

Cook, N.J., Ciobanu, C.L., Danyushevsky, L.V., and Gilbert, Sarah, 2011, Minor and trace elements in bornite and associated $\mathrm{Cu}-(\mathrm{Fe})$-sulfides - A LA-ICP-MS study: Geochimica et Cosmochimica Acta, v. 75, no. 21, p. 6473-6496. [Also available at http://dx.doi.org/ 10.1016/j.gca.2011.08.021.]
Cutter, G.A., and Bruland, K.W., 1984, The marine biogeochemistry of selenium - A re-evaluation: Limnology and Oceanography, v. 29, no. 6, p. 1179-1192. [Also available at http://dx.doi.org/10.4319/1o.1984.29.6.1179.]

Cutter, G.A., and Cutter, L.S., 2004, Selenium biogeochemistry in the San Francisco Bay estuary-Changes in water column behavior: Estuarine, Coastal and Shelf Science, v. 61, no. 3, p. 463-476. [Also available at http://dx.doi.org/ 10.1016/j.ecss.2004.06.011.]

Dare, S.A.S., Barnes, S.J., and Prichard, H.M., 2010, The distribution of platinum group elements (PGE) and other chalcophile elements among sulfides from the Creighton Ni-Cu-PGE sulfide deposit, Sudbury, Canada, and the origin of palladium in pentlandite: Mineralium Deposita, v. 45, no. 8, p. 765-793. [Also available at http://dx.doi.org/ 10.1007/s00126-010-0295-6.]

Davidson, D.F., 1963, Selenium in some oxidized sandstone-type uranium deposits: U.S. Geological Survey Bulletin 1162-C, p. C1-C33. [Also available at http://pubs.usgs.gov/bul/1162c/report.pdf.]

Drabek, M., 1995, The Mo-Se-S and the Mo-Te-S systems: Neues Jahrbuch für Mineralogie-Abhandlungen, v. 169, p. 255-263.

Eckstrand, O.R., and Hulbert, L.J., 1987, Selenium and the source of sulphur in magmatic nickel and platinum deposits: Geological Association of Canada and Mineralogical Association of Canada, Program with Abstracts, v. 12, p. 40.

Elzinga, E.J., Tang, Yuanzhi, McDonald, Jason, DeSisto, Stephanie, and Reeder, R.J., 2009, Macroscopic and spectroscopic characterization of selenate, selenite, and chromate adsorption at the solid-water interface of $\gamma-\mathrm{Al}_{2} \mathrm{O}_{3}$ : Journal of Colloid and Interface Science, v. 340, no. 2, p. 153-159. [Also available at http://dx.doi.org/10.1016/j.jcis.2009.08.033.]

European Commission Joint Research Centre Institute for Health and Consumer Protection, 2011, Environmental quality standards applicable to surface water: European Commission Joint Research Centre, accessed May 24, 2016, at http://eur-lex.europa.eu/legal-content/EN/TXT/ ?uri=URISERV\%3A128180.

Fairweather-Tait, S.J., Bao, Yongping, Broadley, M.R., Collings, Rachel, Ford, Dianne, Hesketh, J.E., and Hurst, Rachel, 2011, Selenium in human health and disease: Antioxidants \& Redox Signaling, v. 14, no. 7, p. 1337-1383. [Also available at http://dx.doi.org/ 10.1089/ars.2010.3275.]

Fang, W.X., Huang, Z.Y., and Wu, P.W., 2003, Contamination of the environmental ecosystems by trace elements from mining activities of Badao bone coal mine in China: Environmental Geology, v. 44, no. 4, p. 373-378. [Also available at http://dx.doi.org/10.1007/s00254-003-0768-3.] 
Filimonova, L.Ye., 1972, Selenium and tellurium in the Boshchekul' copper-molybdenum deposit: Geochemistry International, v. 9, p. 151-156. [English translation of Russian article. Originally published in Geokhimiya, no. 2, p. 241-246.]

Fitzpatrick, A.J., 2008, The measurement of the Se/S ratios in sulphide minerals and their application to ore deposits: Kingston, Ontario, Canada, Queen's University, Ph.D. dissertation, 203 p. [Also available at https://qspace.library.queensu.ca/bitstream/1974/1045/ 1/Fitzpatrick_Alexander_J_200802_PHD.pdf.]

Fleming, G.A., 1962, Selenium in Irish soils and plants: Soil Science, v. 94, no. 1, p. 28-35.

Floor, G.H., and Román-Ross, Gabriela, 2012, Selenium in volcanic environments-A review: Applied Geochemistry, v. 27, no. 3, p. 517-531. [Also available at http://dx.doi.org/ 10.1016/j.apgeochem.2011.11.010.]

Floor, G.H., Calabrese, S., Román-Ross, G., D’Alessandro, W., and Aiuppa, A., 2011, Selenium mobilization in soils due to volcanic derived acid rain-An example from Mt Etna volcano, Sicily: Chemical Geology, v. 289, nos. 3-4, p. 235-244. [Also available at http://dx.doi.org/10.1016/ j.chemgeo.2011.08.004.]

Förster, H.J., 2005, Mineralogy of the U-Se-polymetallic deposit Niederschlema-Alberoda, Erzgebirge, Germany. IV - The continuous clausthalite-galena solid-solution series: Neues Jahrbuch für Mineralogy-Abhandlungen, v. 181, no. 2, April, p. 125-134. [Also available at http://dx.doi.org/10.1127/0077-7757/2005/0011.]

Frost, D.V., 1972, The two faces of selenium - Can selenophobia be cured?: CRC Critical Reviews in Toxicology, v. 1 , no. 4, p. 467-514.

Fukushi, Keisuke, and Sverjensky, D.A., 2007, A surface complexation model for sulfate and selenate on iron oxides consistent with spectroscopic and theoretical molecular evidence: Geochimica et Cosmochimica Acta, v. 71, no. 1, p. 1-24. [Also available at http://dx.doi.org/10.1016/ j.gca.2006.08.048.]

Gaines, R.V., Skinner, C., Foord, E.E., Mason, B., and Rosenzweig, A., 1997, Dana's new mineralogy — The system of mineralogy of James Dwight Dana and Edward Salisbury Dana (8th ed.): New York, N.Y., John Wiley \& Sons, Inc., 1,872 p.

Garone, Philip, 1999, The tragedy at Kesterson ReservoirA case study in environmental history and a lesson in ecological complexity: Environs, v. 22, no. 2, p. 107-144. [Also available at http://environs.law.ucdavis.edu/volumes/ 22/2/articles/garone.pdf.]
George, M.W., 2013, Selenium (Se), in Metal prices in the United States through 2010: U.S. Geological Survey Scientific Investigations Report 2012-5188, p. 158-160, accessed May 24, 2016, at http:/pubs.usgs.gov/sir/2012/5188.

George, M.W., 2014, Selenium, in Mineral commodity summaries 2014: U.S. Geological Survey, 196 p., accessed March 29, 2016, at https://minerals.usgs.gov/minerals/pubs/ commodity/selenium/mcs-2014-selen.pdf .

George, M.W., and Wagner, L.A., 2009, Selenium recycling in the United States in 2004, chap. T of Sibley, S.F., ed., Flow studies for recycling metal commodities in the United States: U.S. Geological Survey Circular 1196-T, p. T1-T7, accessed May 25, 2016, at http://pubs.usgs.gov/ circ/circ1196t/.

Goldschmidt, V.M., 1954, Geochemistry: Oxford, United Kingdom, Clarendon Press, 730 p.

Goldschmidt, V.M., and Strock, L.W., 1935, Zur Geochemie des Selens, II [Geochemistry of Selenium]: Nachrichten von der Gesellschaft der Wissenschaften zu Göttingen Mathematisch-Physikalische Klasse IV [Proceedings of the Society of Sciences in Göttingen, Mathematics and Physical Class 4], v. 1, no. 11, p. 123-142.

Greenland, L.P., and Aruscavage, Philip, 1986, Volcanic emission of Se, Te, and As from Kilauea volcano, Hawaii: Journal of Volcanology and Geothermal Research, v. 27, nos. 1-2, p. 195-201. [Also available at http://dx.doi.org/ 10.1016/0377-0273(86)90086-7.]

Greenwood, N.N., and Earnshaw, A., 1997, Chemistry of the elements ( 2 d ed.): Oxford, United Kingdom, Butterworth Heinemann, 1,341 p.

Gregory, M.J., Lang, J.R., Gilbert, Sarah, and Hoal, K.O., 2013, Geometallurgy of the Pebble porphyry coppergold-molybdenum deposit, Alaska-Implications for gold distribution and paragenesis: Economic Geology, v. 108, p. 463-482. [Also available at http://dx.doi.org/10.2113/ econgeo.108.3.463.]

Hall, R.A, Zook, E.G., and Meaburn, G.M., 1978, National Marine Fisheries Service survey of trace elements in the fishery resource: U.S. Department of Commerce, NOAA Technical Report NMFS SSRF-721, 313 p. [Also available at http://docs.lib.noaa.gov/noaa_documents/NMFS/special_ scientific_report_fisheries/NMFS_SSRF_721.PDF.]

Hawley, J.E., and Nichol, Ian, 1959, Selenium in some Canadian sulfides: Economic Geology, v. 54, p. 608-628. [Also available at http://dx.doi.org/10.2113/gsecongeo.54.4.608.]

Haxel, G.B., Hedrick, J.B., and Orris, G.J., 2002, Rare earth elements - Critical resources for high technology: U.S. Geological Survey Fact Sheet 087-02, 4 p. [Also available at http://geopubs.wr.usgs.gov/fact-sheet/fs087-02/.] 
Health Canada, 1992, Selenium, in Guidelines for Canadian drinking water quality [supporting document]: Ottawa, Ontario, Canada, Health Canada, Health Protection Branch, accessed May 25, 2016, at http://publications.gc.ca/ collections/Collection/H48-10-1-68-1992E.pdf.

Health Canada, 2013, Selenium in drinking water: Ottawa, Ontario, Canada, Health Canada, Water, Air, and Climate Change Bureau, accessed August 1, 2015, at http://www.hc-sc.gc.ca/ewh-semt/consult/index-eng.php\# water. [Available upon request from the Water, Air, and Climate Change Bureau.]

Howard, J.H., III, 1977, Geochemistry of selenium-Formation of ferroselite and selenium behavior in the vicinity of oxidizing sulfide and uranium deposits: Geochimica et Cosmochimica Acta, v. 41, no. 11, p. 1665-1678. [Also available at http://dx.doi.org/10.1016/0016-7037(77)90176-4.]

Huston, D.L., Sie, S.H., Suter, G.F., Cooke, D.R., and Both, R.A., 1995, Trace elements in sulfide minerals from eastern Australian volcanic-hosted massive sulfide deposits; Part I, Proton microprobe analyses of pyrite, chalcopyrite, and sphalerite, and Part II, Selenium levels in pyrite; comparison with delta ${ }^{34} \mathrm{~S}$ values and implications for the source of sulfur in volcanogenic hydrothermal systems: Economic Geology, v. 90, p. 1167-1196. [Also available at http://dx.doi.org/10.2113/gsecongeo.90.5.1167.]

Ingerson, Earl, 1964, Introduction, in Sindeeva, N.D., Mineralogy and types of deposits of selenium and tellurium: New York, N.Y., Wiley Interscience Publishers, p. v-vi.

International Mineralogical Association, 2014, The new IMA list of minerals - A work in progress: International Mineralogical Association, December, accessed March 29, 2016, at http://nrmima.nrm.se//IMA_Master_List_(2014-12).pdf.

Izawa, Eiji, Urashima, Yukitoshi, Ibaraki, Kenzo, Suzuki, Ryoichi, Yokohama, Takeo, Kawasaki, Kiyoshi, Koga, Akito, and Sachihiro, Taguchi, 1990, The Hishikari gold depositHigh-grade epithermal veins in Quaternary volcanics of southern Kyushu, Japan: Journal of Geochemical Exploration, v., 36, nos. 1-3, p. 1-56. [Also available at http://dx.doi.org/10.1016/0375-6742(90)90050-K.]

Jackson, J.A., ed., 1997, Glossary of geology (4th ed.): Alexandria, Va., American Geological Institute, 769 p.

Jenkins, D.W., 1980, Biological monitoring of toxic trace metals. v. 2, Toxic trace metals in plants and animals of the world. Part III: U.S. Environmental Protection Agency Report no. 600/3-80/0921, p. 1130-1148.

Jensen, N.L., 1985, Selenium, in Knoerr, A.W., ed., Mineral facts and problems: U.S. Bureau of Mines Bulletin 675, p. $705-711$.
John, D.A., 2001, Miocene and early Pliocene epithermal gold-silver deposits in the northern Great Basin, Western United States - Characteristics, distribution, and relationship to magmatism: Economic Geology, v. 96, p. 18271853. [Also available at http://dx.doi.org/10.2113/ gsecongeo.96.8.1827.]

John, D.A., Ayuso, R.A., Barton, M.D., Blakely, R.J., Bodnar, R.J., Dilles, J.H., Gray, Floyd, Graybeal, F.T., Mars, J.C., McPhee, D.K., Seal, R.R., Taylor, R.D., and Vikre, P.G., 2010, Porphyry copper deposit model, chap. B of Mineral deposit models for resource assessment: U.S. Geological Survey Scientific Investigations Report 2010-5070-B, 169 p. [Also available at http://pubs.usgs.gov/sir/2010/5070/b/.]

John, D.A., Hofstra, A.H., Fleck R.J., Brummer, J.E., and Saderholm, E.C., 2003, Geologic setting and genesis of the Mule Canyon low-sulfidation epithermal gold-silver deposit, north-central Nevada: Economic Geology, v. 98, p. $425-463$.

Johnsson, Lars, 1992, Selenium in Swedish soils-Factors influencing soil content and plant uptake: Uppsala, Sweden, Swedish University of Agricultural Science, Department of Soil Sciences, Reports and Dissertations 10. [Also available at http://www.vaxteko.nu/html/sll/slu/reports_diss markvetenskap/RDV10/RDV10.HTM.]

Kabata-Pendias, Alina, and Pendias, Henryk, 1984, Trace elements in soils and plants: Boca Raton, Fla., CRC Press, 413 p.

Kharkar, D.P., Turekian, K.K., and Bertine, K.K., 1968, Stream supply of dissolved silver, molybdenum, antimony, selenium, chromium, cobalt, rubidium, and cesium to the oceans: Geochimica et Cosmochimica Acta, v. 32, no. 3, p. 285-298. [Also available at http://dx.doi.org/10.1016/ 0016-7037(68)90016-1.]

Koljonen, T., 1976, Luikonlahti-Selenium in the vicinity of copper ore, in Kauranne, L.K., ed., Conceptual models in exploration geochemistry-Norden 1975: Journal of Geochemical Exploration, v. 5, no. 3, p. 263-265. [Also available at http://www.sciencedirect.com/science/journal/ 03756742/5/3.]

Kovalenker, V.A., Gladyshev, G.D., and Nosik, L.P., 1975, Isotopic composition of sulfide sulfur from deposits of Talnakh ore node in relation to their selenium content: International Geology Review, v. 17, no. 6, p. 725-734. [Also available at http://dx.doi.org/10.1080/00206817509471656.]

Krähenbühl, Urs, Ganapathy, R., Morgan, J.W., and Anders, Edward, 1973, Volatile elements in Apollo 16 samples - Implication for highland volcanism and accretion history of the moon-Lunar Science Conference, 4th, Houston, Texas, March 5-8, 1973, Proceedings, v. 2: New York, N.Y., Pergamon Press, Inc., p. 1325-1348. [Also available at http://adsabs.harvard.edu/full/1973LPSC....4.1325K.] 
Kříbek, B., Majer, V., Knésl, I., Mihaljevic, M., Ettler, V., and Sraček, O., 2010, Soil contamination and health risks associated with former smelting of $\mathrm{Pb}-\mathrm{Zn}$ ores at Kabwe, Zambia: Geochimica et Cosmochimica Acta, v. 74, no. 12, Supplement, p. A540. [Also available at http://dx.doi.org/ 10.1016/j.gca.2010.04.036.]

Lakin, H.W., and Byers, H.G., 1941, Selenium occurrence in certain soils in the United States, with a discussion of related topics - Sixth report: Washington, D.C., U.S. Department of Agriculture Technical Bulletin 783, October, 27 p. [Also available at https://naldc.nal.usda.gov/ download/CAT86200778/PDF.]

Lakin, H.W., and Davidson, D.F., 1973, Selenium, in Brobst, D.A, and Pratt, W.P., eds., United States mineral resources: U.S. Geological Survey Professional Paper 820, p. 573-576. [Also available at https://pubs.er.usgs.gov/publication/pp820.]

Lemly, A.D., 1985, Toxicology of selenium in a freshwater reservoir-Implications for environmental hazard evaluation and safety: Ecotoxicology and Environmental Safety, v. 10 , no. 3 , p. 314-338.

Lemly, A.D., 1997, Ecosystem recovery following selenium contamination in a freshwater reservoir: Ecotoxicology and Environmental Safety, v. 36, no. 3, p. 275-281.

Lemly, A.D., 2002, Symptoms and implications of selenium toxicity in fish-The Belews Lake case example: Aquatic Toxicology, v. 57, nos. 1-2, p. 39-49. [Also available at http://dx.doi.org/10.1016/S0166-445X(01)00264-8.]

Leutwein, F., 1972, Selenium 34, chaps. B through O of Wedepohl, K.H., ed., Handbook of geochemistry, v. 2, pt. 3: West Berlin, West Germany, Springer-Verlag, p. 34-B-1-34-O-1.

Leybourne, M.I., and Cameron, E.M., 2008, Source, transport, and fate of rhenium, selenium, molybdenum, arsenic, and copper in groundwater associated with porphyry- $\mathrm{Cu}$ deposits, Atacama Desert, Chile: Chemical Geology, v. 247, nos. 1-2, p. 208-228. [Also available at http://dx.doi.org/ 10.1016/j.chemgeo.2007.10.017.]

Luoma, S.N., and Presser, T.S., 2009, Emerging opportunities in management of selenium contamination: Environmental Science and Technology, v. 43, no. 22, p. 8483-8487. [Also available at http://dx.doi.org/10.1021/es900828h.]

Mackowiak, C.L., Amacher, M.C., Hall, J.O., and Herring, J.R., 2004, Uptake of selenium and other contaminant elements into plants and implications for grazing animals in southeast Idaho, chap. 19 of Hein, J.R., ed., Life cycle of the Phosphoria Formation-From deposition to the post-mining environment: Handbook of Exploration and Environmental Geochemistry, v. 8, p. 527-555. [Also available at http://dx.doi.org/10.1016/S1874-2734(04)80021-4.]
Massachusetts Institute of Technology, 2010, Critical elements for new energy technologies-An MIT Energy Initiative Workshop report: Cambridge, Mass., Massachusetts Institute of Technology, 175 p. accessed May 26, 2016, at http://mitei.mit.edu/publications/reports-studies/criticalelements-new-energy-technologies. [Also available at https://energy.mit.edu/publication/critical-elements-fornew-energy-technologies/.]

May, T.W., and McKinney, G.L., 1981, Cadmium, lead, mercury, arsenic, and selenium concentrations in freshwater fish, 1976-77-National Pesticide Monitoring Program: Pesticides Monitoring Journal, v. 15, no. 1, June, p. 14-38. [Also available at https://archive.org/details/pesticides monito15unit.]

Mayland, H.F., 1985, Selenium in soils and plants, in Maas, J., ed., Selenium responsive diseases in food animals - Proceedings of a symposium held at the Western States Veterinary Conference, Las Vegas, Nev., February 18, 1985: Princeton Junction, N.J., Veterinary Learning Systems Co., Inc., p. 5-10. [Also available at http://eprints.nwisrl.ars.usda.gov/764/.]

McNeal, J.M., and Balistrieri, L.S., 1989, Geochemistry and occurrence of selenium-An overview, in Jacobs, L.W., ed., Selenium in agriculture and the environment: SSSA Special Publication 23, p. 1-13. [Also available at http://dx.doi.org/ 10.2136/sssaspecpub23.c1.]

Mindat.org, 2015, Mindat.org online database: Hudson Institute of Mineralogy, accessed March 29, 2015, at http://www.mindat.org/.

Minkin, J.A., Finkelman, R.B., Thompson, C.L., Chao, E.C.T., Ruppert, L.F., Blank, H., and Cecil, C.B., 1984, Microcharacterization of arsenic- and selenium-bearing pyrite in Upper Freeport coal, Indiana County, Pennsylvania: Scanning Electron Microscopy, v. 4, p. 1515-1524.

Mosher, B.W., Duce, R.A., Prospero, J.M., and Savoie, D.L., 1987, Atmospheric selenium-Geographical distribution and ocean to atmosphere flux in the Pacific: Journal of Geophysical Research, v. 92, no. D11, November 20, p. 13277-13287. [Also available at http://dx.doi.org/ 10.1029/JD092iD11p13277.]

Moxon, A.L., Olson, O.E., Searight, W.V., and Sandals, K.M., 1938, The stratigraphic distribution of selenium in the Cretaceous formations of South Dakota and the selenium content of some associated vegetation: American Journal of Botany, v. 25, no. 10, p. 794-809. [Also available at http://www.jstor.org/stable/2436607.] 
MSE Technology Applications, Inc., 2001, Selenium treatment/ removal alternatives demonstration project, final report prepared for the U.S. Environmental Protection Laboratory, National Risk Management Research Laboratory, and the USDOE National Energy Technology Laboratory under Contract No. DE-AC22-96EW96405: Butte, Mont., MSE Technology Applications, Inc., EPA/600/R-01/077, June, accessed March 9, 2015, at http://www.epa.gov/nscep/ index.html. [Also available at http://nepis.epa.gov/Exe/ ZyPURL.cgi?Dockey=P1008GVL.txt.]

Naftz, D.L., and Rice, J.A., 1989, Geochemical processes controlling selenium in ground water after mining, Powder River Basin, Wyoming, U.S.A.: Applied Geochemistry, v. 4, no. 6, November-December, p. 565-575. [Also available at http://dx.doi.org/10.1016/0883-2927(89)90067-X.]

Naftz, D.L., Johnson, W.P., Freeman, M.L., Beisner, Kimberly, Diaz, Ximena, and Cross, V.A., 2009, Estimation of selenium loads entering the south arm of Great Salt Lake, Utah, from May 2006 through March 2008: U.S. Geological Survey Scientific Investigations Report 2008-5069, 40 p. [Also available at $\mathrm{http}: / /$ pubs.usgs.gov/sir/2008/5069/.]

National Institutes of Health, 2013, Selenium-Dietary supplement fact sheet: National Institutes of Health Web page, accessed March 9, 2015, at http://ods.od.nih.gov/factsheets/ Selenium-HealthProfessional/.

Nickel, E.H., 2002, An unusual occurrence of Pd, Pt, Au, Ag and $\mathrm{Hg}$ minerals in the Pilbara region of Western Australia: The Canadian Mineralogist, v. 40, no. 2, p. 419-433. [Also available at http://dx.doi.org/10.2113/gscanmin.40.2.419.]

Nriagu, J.O., and Wong, H.K., 1983, Selenium pollution of lakes near the smelters at Sudbury, Ontario: Nature, v. 301, p. 55-57. [Also available at http://dx.doi.org/10.1038/ 301055a0.]

Ohlendorf, H.M., 2002, The birds of Kesterson Reservoir-A historical perspective: Aquatic Toxicology, v. 57, nos. 1-2, p. 1-10. [Also available at http://dx.doi.org/10.1016/S0166445X(01)00266-1.]

Owen, David, 2004, Making copies: Smithsonian Magazine, August, accessed June 22, 2014, at http://www.smithsonianmag.com/ history/making-copies-2242822/.

Paniagua, A., 1995, Selenium in copper-rich disulfides of the Providencia Mine, Leon, Spain: Neues Jahrbuch für Mineralogie Abhandlungen, v. 169, no. 3, p. 291-295.

Parkman, Helena, and Hultberg, Hans, 2002, Occurrence and effects of selenium in the environment-A literature review: Stockholm, Sweden, Swedish Environmental Research Institute, IVL Report B 1486, 28 p., accessed September 1, 2013, at http://www3.ivl.se/rapporter/pdf/B1486.pdf. [Also available at http://www.ivl.se/download/18.343dc99d14e8bb0f 58b7417/1445515506056/B1486.pdf.]
Petruk, W., Owens, D.R., Stewart, J.M., and Murray E.J., 1974, Observations on acanthite, aguilarite, and naumannite: The Canadian Mineralogist, v. 12, no. 6, p. 365-369.

Pillay, K.K.S., Thomas, C.C., Jr., and Kaminski, J.W., 1969, Neutron activation analysis of the selenium content of fossil fuels: Nuclear Technology, v. 7, no. 5, p. 478-483.

Pinto, A.M.M., Relvas, J.M.R.S., Carvalho, J.R.S., Pacheco, Nelson, and Liu, Yanan, 2013, Mineralogy and distribution of indium and selenium metals within zinc-rich ore types of the Neves Corvo deposit, Portugal: Mineralogical Magazine, v. 77, no. 5, p. 1973.

Piper, D.Z., 1994, Seawater as the source of minor elements in black shales, phosphorites, and other sedimentary rocks: Chemical Geology, v. 114, nos. 1-2, p. 95-114. [Also available at http://dx.doi.org/10.1016/0009-2541(94)90044-2.]

Piper, D.Z., 2001, Marine chemistry of the Permian Phosphoria Formation and basin, southeast Idaho: Economic Geology, v. 96, p. 599-620. [Also available at http://dx.doi.org/ 10.2113/96.3.599.]

Piper, D.Z., Skorupa, J.P., Presser, T.S., Hardy, M.A., Hamilton, S.J., Huebner, M., and Gulbrandsen, R.A., 2000, The Phosphoria Formation at the Hot Springs Mine in southeast Idaho; a source of selenium and other trace elements to surface water, ground water, vegetation, and biota: U.S. Geological Survey Open-File Report 00-50, $73 \mathrm{p}$. [Also available at http://www.cerc.usgs.gov/pubs/ center/pdfDocs/91013.pdf.]

Pirard, Cassian, and Hatert, Frédéric, 2008, The sulfides and selenides of the Musconoï Mine, Kolwezi, Katanga, Democratic Republic of Congo: The Canadian Mineralogist, v. 46, no. 1, p. 219-231. [Also available at http://dx.doi.org/10.3749/ canmin.46.1.219.]

Pirri, I.V., 2002, On the occurrence of selenium in sulfides of the ore deposit of Baccu Locci (Gerrei, SE Sardinia): Neues Jahrbuch für Mineralogie-Monatshefte, v. 2002, no. 5, p. 207-224. [Also available at http://dx.doi.org/ 10.1127/0028-3649/2002/2002-0207.]

Presser, T.S., 1994, Geologic origin and pathways of selenium from the California coast ranges to the west-central San Joaquin Valley, in Frankenberger, W.T., Jr., and Benson, Sally, eds., Selenium in the environment: New York, N.Y., Marcel Dekker, Inc., p. 139-155.

Presser, T.S., 1999, Selenium pollution, in Alexander, P.E., and Fairbridge, R.W., eds., Encyclopedia of environmental science: Berlin, Germany, Springer-Verlag, p. 554-556.

Presser, T.S., and Swain, W.C., 1990, Geochemical evidence for Se mobilization by the weathering of pyritic shale, San Joaquin Valley, California, U.S.A.: Applied Geochemisry, v. 5, nos. 5-6, p. 703-713. [Also available at http://dx.doi.org/ 10.1016/0883-2927(90)90066-E.] 
Presser, T.S., Piper, D.Z., Bird, K.J., Skorupa, J.P., Hamilton, S.J., Detwiler, S.J., and Huebner, M.A., 2004, The Phosphoria Formation-A model for forecasting global selenium sources to the environment, chap. 11 of Hein, J.R., ed., Life cycle of the Phosphoria Formation-From deposition to the post-mining environment: Handbook of Exploration and Environmental Geochemistry, v. 8, p. 299-319. [Also available at http://wwwrcamnl.wr.usgs.gov/Selenium/ Library_articles/chap11_global_Se-optimized.pdf.]

Presser, T.S., Swain, W.C., Tidball, R.R., and Severson, R.C., 1990, Geologic sources, mobilization, and transport of selenium from the California coast ranges to the western San Joaquin Valley-A reconnaissance study: U.S. Geological Survey Water-Resources Investigations Report 90-4070, 66 p. [Also available at https://pubs.er.usgs.gov/publication/ wri904070.]

Presser, T.S., Sylvester, M.A., and Low, W.H., 1994, Bioaccumulation of selenium from natural geologic sources in Western States and its potential consequences: Environmental Management, v. 18, no. 3, p. 423-436. [Also available at http://dx.doi.org/10.1007/BF02393871.]

Ranville, M.A., Cutter, G.A., Buck, C.S., Landing, W.M., Cutter, L.S., Resing, J.A., and Flegal, A.R., 2010, Aeolian contamination of Se and $\mathrm{Ag}$ in the North Pacific from Asian fossil fuel combustion: Environmental Science and Technology, v. 44, no. 5, p. 1587-1593. [Also available at http://dx.doi.org/10.1021/es902523m.]

Rayman, M.P., 2000, The importance of selenium to human health: Lancet, v. 356, no. 9225, p. 233-241.

Reich, Martin, Palacios, Carlos, Barra, Fernando, and Chryssoulis, Stephen, 2013, "Invisible" silver in chalcopyrite and bornite from the Mantos Blancos $\mathrm{Cu}$ deposit, northern Chile: European Journal of Mineralogy, v. 25, no. 3, May, p. 453-460.

Ripley, E.M., 1990, Se/S ratios of the Virginia Formation and $\mathrm{Cu}-\mathrm{Ni}$ sulfide mineralization in the Babbitt area, Duluth Complex, Minnesota: Economic Geology, v. 85, p. 1935-1940. [Also available at http://dx.doi.org/10.2113/ gsecongeo.85.8.1935.]

Ripley, E.M., Chusi, Li, and Shin, Dongbok, 2002, Paragneiss assimilation in the genesis of magmatic $\mathrm{Ni}-\mathrm{Cu}-\mathrm{Co}$ sulfide mineralization at Voisey's Bay, Labrador $-\delta^{34} \mathrm{~S}, \delta^{13} \mathrm{C}$, and Se/S evidence: Economic Geology, v. 97, p. 13071318. [Also available at http://dx.doi.org/10.2113/ gsecongeo.97.6.1307.]

Robberecht, H., and Van Grieken, R., 1982, Selenium in environmental waters - Determination, speciation and concentration levels: Talanta, v. 29 , no. 10, p. 823-844.

Sargent, J.D., 1954, Selenium: U.S. Bureau of Mines Information Circular 7690, 25 p. [Also available at http://babel.hathitrust.org/ cgi/pt?id=mdp.39015006378528;view=1up;seq=5.]
Schwarcz, H.P., 1973, Sulfur isotope analyses of some Sudbury, Ontario, ores: Canadian Journal of Earth Sciences, v. 10, no. 9, p. 1444-1459. [Also available at http://dx.doi.org/ 10.1139/e73-135.]

Science Dictionary, 2015, What is Alkali disease?: Science Dictionary, accessed August 1, 2015, at http://thesciencedictionary.org/alkali-disease/.

Scott, R.C., and Voegeli, P.T., 1961, Radiochemical analyses of ground and surface water in Colorado, 1954-1961: Denver, Colo., Colorado Water Conservation Board Basic Data Report no. 7, 27 p.

Seiler, R.L., Skorupa, J.P., Naftz, D.L., and Nolan, B.T., 2003, Irrigation-induced contamination of water, sediment, and biota in the Western United States - Synthesis of data from the National Irrigation Water Quality Program: U.S. Geological Survey Professional Paper 1655, ver. 1.1, 123 p., accessed June 20, 2014, at http://pubs.usgs.gov/pp/pp1655/.

Selenium Monitoring Work Group, 2009, An assessment of environmental selenium levels around Empire and Tilden Mines, Marquette County, Michigan: Lansing, Mich., Michigan Department of Environmental Quality Report no. MI/DEQ/WB-09/038, 25 p., accessed May 24, 2016, at https://www.michigan.gov/documents/deq/wb-swasselenium-report_287994_7.pdf.

Shacklette, H.T., and Boerngen, J.G., 1984, Element concentrations in soils and other surficial materials of the conterminous United States: U.S. Geological Survey Professional Paper 1270, 105 p. [Also available at https://pubs.er.usgs.gov/ publication/pp1270.]

Sharmasarkar, S., and Vance, G.F., 1997, Extraction and distribution of soil organic and inorganic selenium in coal mine environments of Wyoming, USA: Environmental Geology, v. 29, p. 17-22. [Also available at http://dx.doi.org/10.1007/ s002540050099.]

Shimizu, M., Schmidt, S.T., Stanley, C.J., and Tsunoda, K., 1995, Kawazulite and unnamed $\mathrm{Bi}_{3}(\mathrm{Te}, \mathrm{Se}, \mathrm{S})_{4}$ in Ag-Bi-TeSe-S mineralization from the Suttsu Mine, Hokkaido, Japan: Neues Jahrbuch für Mineralogie-Abhandlungen, v. 169, p. 305-308.

Simon, Grigore, and Essene, E.J., 1996, Phase relations among selenides, sulfides, tellurides, and oxides; I, Thermodynamic properties and calculated equilibria: Economic Geology, v. 91, p. 1183-1208. [Also available at http://dx.doi.org/ 10.2113/gsecongeo.91.7.1183.]

Simon, Grigore, Kesler, S.E., and Essene, E.J., 1997, Phase relations among selenides, tellurides, and oxides; II, applications to selenide-bearing ore deposits: Economic Geology, v. 92, p. 468-484. [Also available at http://dx.doi.org/ 10.2113/gsecongeo.92.4.468.] 
Sindeeva, N.D., 1964, Mineralogy and types of deposits of selenium and tellurium: New York, N.Y., Wiley Interscience, $363 \mathrm{p}$.

Skorupa, J.P., Presser, T.S., Hamilton, S.J., Lemly, A.D., and Sample, B.E., 2004, EPA's draft tissue-based selenium criterion-A technical review-Presentation for the U.S. Environmental Protection Agency, June 16, 36 p., accessed May 26, 2016, at http://wwwrcamnl.wr.usgs.gov/ Selenium/Library_articles/skorupa_et_al_2004.pdf. [Published draft.]

Smith, D.B., Cannon, W.F., Woodruff, L.G., Solano, Federico, and Ellefsen, K.J., 2014, Geochemical and mineralogical maps for soils of the conterminous United States: U.S. Geological Survey Open-File Report 2014-1082, 386 p. [Also available at http://dx.doi.org/10.3133/ofr20141082.]

Stillings, L.L., and Amacher, M.C., 2004, Selenium attenuation in a wetland formed from mine drainage in the Phosphoria Formation, southeast Idaho, chap. 17 of Hein, J.R., ed., Life cycle of the Phosphoria Formation-From deposition to the post-mining environment: Handbook of Exploration and Environmental Geochemistry, v. 8, p. 467-482.

Stillings, L.L., Willard, P.J., and Amacher, M.C., 2007, Geochemical controls on $\mathrm{Se}-\mathrm{A}$ comparison of two wetlands, in Bullen, T.D., and Wang, Yanxin, eds., Water-rock interaction-International Symposium on Water-Rock Interaction, 12th, Kunming, Yunnan, China, July 31-August 5, 2007, Proceedings, v. 2: Boca Raton, Fla., CRC Press, p. 1271-1275.

Stone, R.A., 2009, A medical mystery in middle China: Science, v. 324, no. 5933, p. 1378-1381. [Also available at http://dx.doi.org/10.1126/science.324_1378.] (Article correction posted July 24, 2009.)

Stumm, Werner, 1992, Chemistry of the solid-water interface-Processes at the mineral-water and particle-water interface in natural systems: New York, N.Y., John Wiley Sons, $428 \mathrm{p}$.

Taylor, S.R., 1964, Abundance of chemical elements in the continental crust-A new table: Geochimica et Cosmochimica Acta, v. 28, no. 8, p. 1273-1285. [Also available at http://dx.doi.org/10.1016/0016-7037(64)90129-2.]

Thornton, I., Kinniburgh, D.G., Pullen, G., and Smith, C.A., 1983, Geochemical aspects of selenium in British soils and implications to animal health, in Hemphill, D.D., ed., Trace substances in environmental health, Conference on Trace Substances in Environmental Health, 17th, June 13-16, 1983, Proceedings: Columbia, Missouri, University of MissouriColumbia, v. 17, p. 391-398.
Tidball, R.R., 1984, Geochemical survey of Missouri-Geography of soil geochemistry of Missouri agricultural soils: U.S. Geological Survey Professional Paper 954-H, 54 p. [Also available at http://pubs.usgs.gov/pp/0954h-i/report.pdf.]

Trelease, S.F., and Beath, O.A., 1949, Selenium-Its geological occurrence and its biological effects in relation to botany, chemistry, agriculture, nutrition, and medicine: New York, N.Y., published by the authors, 292 p.

Turekian, K.K., and Wedepohl, K.H., 1961, Distribution of the elements in some major units of the Earth's crust: Geological Society of America Bulletin, v. 72, no. 2, p. 175-192. [Also available at http://dx.doi.org/10.1130/ 0016-7606(1961)72[175:DOTEIS]2.0.CO;2.]

Tuttle, M.L.W., Fahy, Juli, Grauch, R.I., Ball, B.A., Chong, G.W., Elliott, J.G., Kosovich, J.J., Livo, K.E., and Stillings, L.L., 2007, Results of chemical analyses of soil, shale, and soil/ shale extract from the Mancos Shale Formation in the Gunnison Gorge National Conservation Area, southwestern Colorado, and at Hanksville, Utah: U.S. Geological Survey Open-File Report 2007-1002D, 24 p., accessed May 26, 2016, at http://pubs.usgs.gov/of/2007/1002/D/.

U.S. Bureau of Mines, 1963, Metals and minerals (except fuels): U.S. Bureau of Mines Minerals Yearbook 1962, v. I, 1,410 p. [Also available at http://minerals.usgs.gov/ minerals/pubs/usbmmyb.html.]

U.S. Bureau of Mines, 1965, Metals and minerals (except fuels): U.S. Bureau of Mines Minerals Yearbook 1964, v. I, 1,258 p. [Also available at http://minerals.usgs.gov/ minerals/pubs/usbmmyb.html.]

U.S. Bureau of Mines, 1966, Minor metals and minerals, with a section on Selenium, by Arnold M. Lansche, in Division of Minerals Staff, Metals and minerals (except fuels): U.S. Bureau of Mines Minerals Yearbook 1965, v. I, p. 1059-1074. [Also available at http://minerals.usgs.gov/ minerals/pubs/usbmmyb.html.]

U.S. Bureau of Mines, 1973, Metals and minerals (except fuels): U.S. Bureau of Mines Minerals Yearbook 1971, v. I, 1,303 p. [Also available at http://minerals.usgs.gov/ minerals/pubs/usbmmyb.html.]

U.S. Bureau of Mines, 1978, Minor metals, with a section on Selenium, by George J. Coakley, in U.S. Bureau of Mines Staff, Metals, minerals, and fuels: U.S. Bureau of Mines Minerals Yearbook 1976, v. I, p. 1459-1474. [Also available at http://minerals.usgs.gov/minerals/pubs/usbmmyb.html.]

U.S. Bureau of Mines, 1980, Metals and minerals: U.S. Bureau of Mines Minerals Yearbook 1977, v. I, 1,066 p. [Also available at http://minerals.usgs.gov/minerals/pubs/usbmmyb.html.] 
U.S. Bureau of Mines, 1989, Metals and minerals: U.S. Bureau of Mines Minerals Yearbook 1987, v. I, 990 p. [Also available at http://minerals.usgs.gov/minerals/pubs/usbmmyb.html.]

U.S. Environmental Protection Agency, 2005, Mountaintop mining/valley fills in Appalachia-Final Programmatic Environmental Impact Statement: Washington, D.C., U.S. Environmental Protection Agency, EPA 9-03-R-05002, 507 p., accessed May 26, 2016, at http://nepis.epa.gov/ Exe/ZyPURL.cgi?Dockey=20005XA6.txt.

U.S. Environmental Protection Agency, 2014a, Basic information about selenium in drinking water: U.S. Environmental Protection Agency, NRC-065, accessed May 26, 2016, at http://pbadupws.nrc.gov/docs/ML1513/ML15131A122.pdf.

U.S. Environmental Protection Agency, 2014b, External peer review draft-Aquatic life ambient water quality criterion for selenium-Freshwater: U.S. Environmental Protection Agency, EPA 822-P-14-001, 637 p., accessed May 26, 2016, at http://www.nma.org/pdf/selenium/2014\%20External\%20 Peer\%20Review\%20Draft\%20Aquatic\%20Life\%20 Ambient\%20WQC\%20for\%20Se\%20Freshwater.pdf.

U.S. Environmental Protection Agency, 2014c, National recommended water quality criteria-Aquatic life criteria table: U.S. Environmental Protection Agency, accessed May 26, 2016, at http://water.epa.gov/scitech/swguidance/ standards/criteria/current/index.cfm\#cmc.

U.S. Geological Survey, 1997-2014, Mineral commodity summaries 1997-2014: U.S. Geological Survey, variously paged. [Also available at http://minerals.usgs.gov/minerals/ pubs/mcs/.]

U.S. Geological Survey, 2006-13, Mineral commodity summaries 2006-2013: U.S. Geological Survey, variously paged. [Also available at https://minerals.usgs.gov/minerals/ pubs/mcs/.]

U.S. Geological Survey, 2010-14, Minerals yearbook 20082012: U.S. Geological Survey, variously paged. [Also available at http://minerals.usgs.gov/minerals/pubs/myb.html.]

U.S. Geological Survey, 2014a, Mineral commodity summaries 2014: U.S. Geological Survey, 196 p., accessed March 29, 2016, at http://minerals.usgs.gov/minerals/pubs/ mcs/2014/mcs2014.pdf.

U.S. Geological Survey, 2014b, Selenium end-use statistics [through 2003; last modified September 1, 2005], in Kelly, T.D., and Matos, G.R., comps., Historical statistics for mineral and material commodities in the United States (2014 version): U.S. Geological Survey Data Series 140, 3 p., accessed November 30, 2016, at http://minerals.usgs.gov/ minerals/pubs/historical-statistics/.
U.S. Geological Survey, 2014c, Selenium statistics [through 2014; last modified January 28, 2016], in Kelly, T.D., and Matos, G.R., comps., Historical statistics for mineral and material commodities in the United States (2014 version): U.S. Geological Survey Data Series 140, 3 p., accessed March 23, 2017, at https://minerals.usgs.gov/minerals/pubs/ historical-statistics/.

U.S. Geological Survey, 2017, Mineral commodity summaries 2017: U.S. Geological Survey, 202 p. [Also available at https://minerals.usgs.gov/minerals/pubs/mcs/.]

Varo, Pertti, Alfthan, Georg, Huttunen, J.K., and Aro, Antti, 1994, Nationwide selenium supplementation in FinlandEffects on diet, blood and tissue levels, and health, chap. 11 of Burk, R.F., ed., Selenium in biology and human health: New York, N.Y., Springer-Verlag, p. 197-218.

Vikre, P.G., 2007, Sinter-vein correlations at Buckskin Mountain, National district, Humboldt County, Nevada: Economic Geology, v. 102, p. 193-224. [Also available at http://dx.doi.org/10.2113/gsecongeo.102.2.193.]

Wang, Dacheng, 1994, The environmental biogeochemistry of selenium in natural water ecosystems: Helsinki, Finland, National Public Health Institute, thesis, 124 p.

Wells, N., 1967, Selenium content of soil-forming rocks: New Zealand Journal of Geology and Geophysics, v. 10, no. 1, p. 198-208.

Willgallis, Alexander, Özgür, Nevzat, and Siegmann, Eveline, 1990, Se- and Te-bearing sulphides in copper ore deposits of Murgul, NE Turkey: European Journal of Mineralogy, v. 2, p. 145-148. [Also available at http://jeotermal.sdu.edu.tr/ assets/uploads/sites/144/files/30-03052012.pdf.]

Winkel, L.H.E., Johnson, C.A., Lenz, Markus, Grundl, Tim, Leupin, O.X., Amini, Manouchehr, and Charlet, Laurent, 2012, Environmental selenium research-From microscopic processes to global understanding: Environmental Science and Technology, v. 46, no. 2, p. 571-579. [Also available at http://dx.doi.org/10.1021/es203434d.]

World Health Organization, 2011, Selenium in drinkingwater-Background document for development of WHO Guidelines for drinking-water quality: Geneva, Switzerland, World Health Organization, WHO/HSE/WSH/10.01/14, 14 p., accessed June 19, 2014, at http://www.who.int/water sanitation_health/dwq/chemicals/selenium.pdf.

World Health Organization and Food and Agricultural Organization of the United Nations, 2004, Selenium, chap. 10 of Vitamin and mineral requirements in human nutrition, $2 d$ ed.: Geneva, Switzerland, World Health Organization, accessed March 8, 2016, at http://www.who.int/nutrition/ publications/micronutrients/9241546123/en/. 
Young, T.F., Finely, Keith, Adams, W.J., Besser, John, Hopkins, W.D., Jolley, Dianne, McNaughton, Eugenia, Presser, T.S., Shaw, D.P., and Unrine, Jason, 2010, What you need to know about selenium, in Chapman, P.M., Adams, W.J., Brooks, M.L., Delos, C.G., Luoma, S.N., Maher, W.A., Ohlendorf, H.M., Presser, T.S., and Shaw, D.P., eds., Ecological assessment of selenium in the aquatic environment: Boca Raton, Fla., CRC Press, p. 7-45.

Yushoko-Zakharova, O.Ye., Ivanov, V.V., Vorob'yeva, M.S., Duvakina, L.S., Razina, I.S., and Karpukhina, V.S., 1978, Geochemistry of selenium, tellurium, and bismuth in copper-zinc sulfide deposits in the Urals, and some problems of sulfide ore formation: Geochemistry International, v. 15 , no. 5 , p. $59-68$.
Zhang, J., Ren, D., Xu, D., and Zhao, F., 1999, Advances in the studies of selenium in coal: Coal Geology and Exploration, v. 2, p. 17-19. [In Chinese with English abstract.]

Zhang, Yiqiang, Zahir, Z.A., and Frankenberter, W.T., Jr., 2004, Fate of colloidal-particulate elemental selenium in aquatic systems: Journal of Environmental Quality, v. 33, no. 2, p. 559-564. [Also available https://dl.sciencesocieties.org/ publications/jeq/pdfs/33/2/559.] 


\section{Tables 01 and 02}


Table 01. Selenium minerals recognized by the International Mineralogical Association.

[Data are from Mindat.org (2015) and the International Mineralogical Association (IMA) (2014). ?, uncertain according to the IMA; NA, not available]

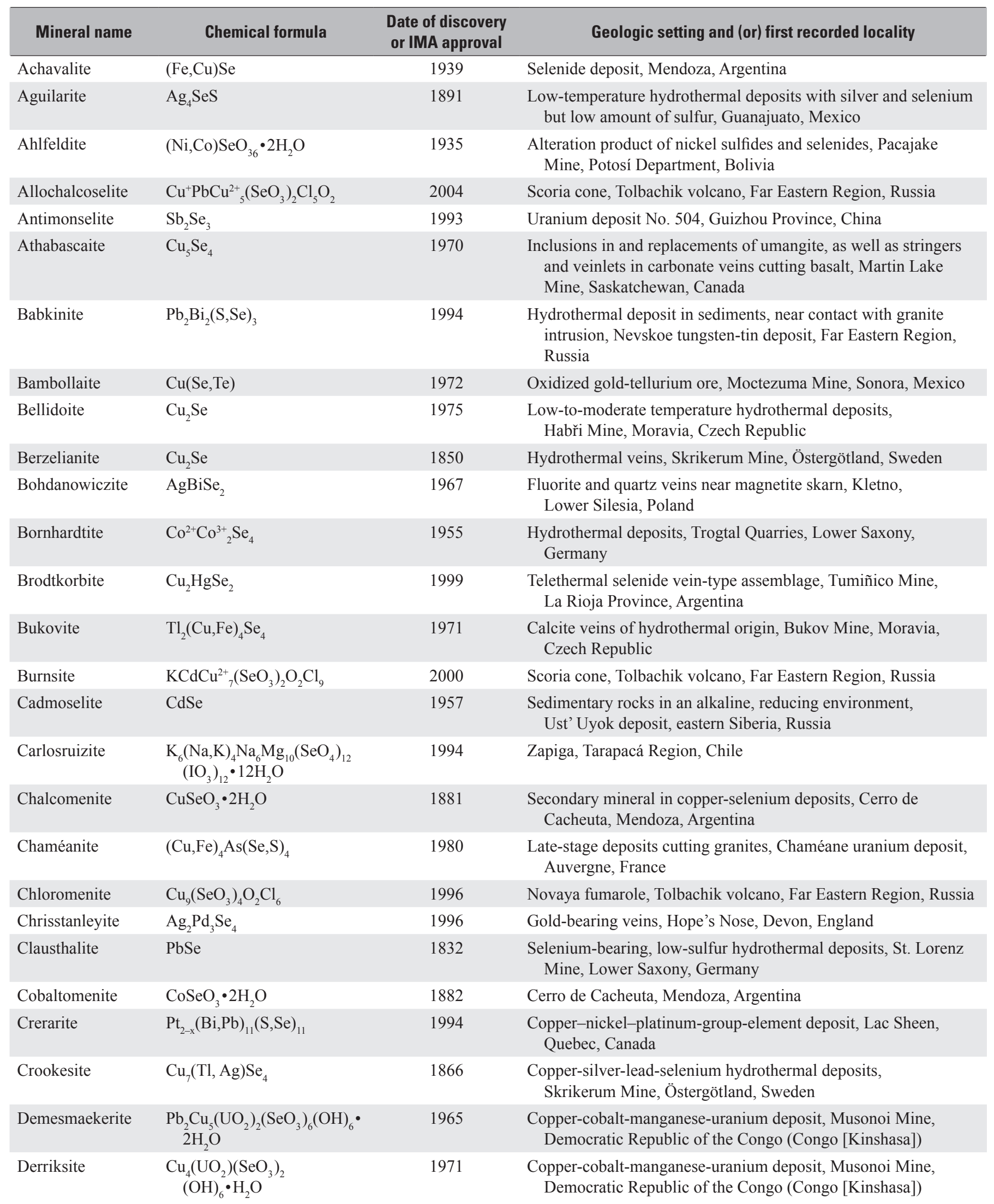


Table 01. Selenium minerals recognized by the International Mineralogical Association.-Continued

[Data are from Mindat.org (2015) and the International Mineralogical Association (IMA) (2014). ?, uncertain according to the IMA; NA, not available]

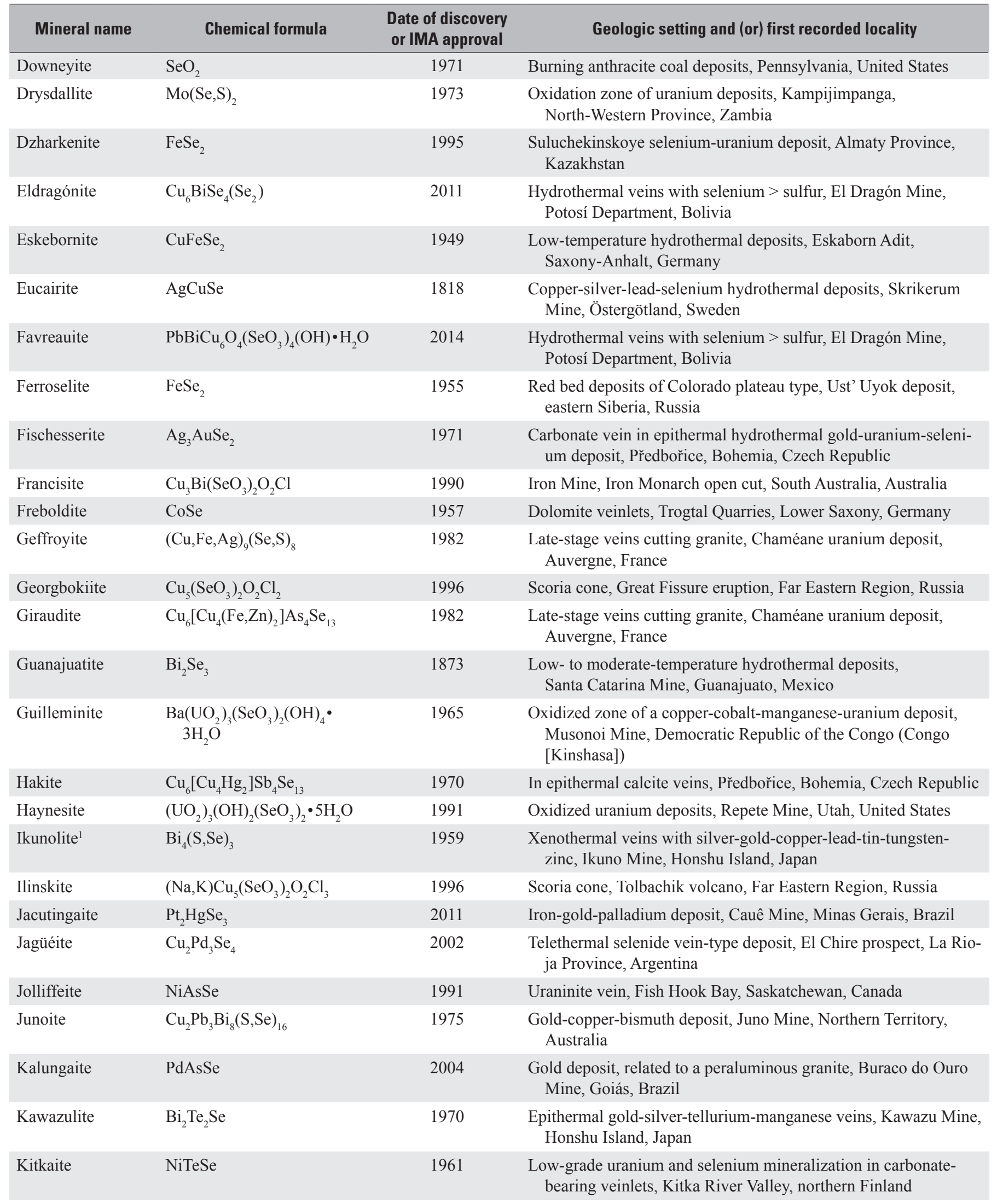


Table 01. Selenium minerals recognized by the International Mineralogical Association._Continued

[Data are from Mindat.org (2015) and the International Mineralogical Association (IMA) (2014). ?, uncertain according to the IMA; NA, not available]

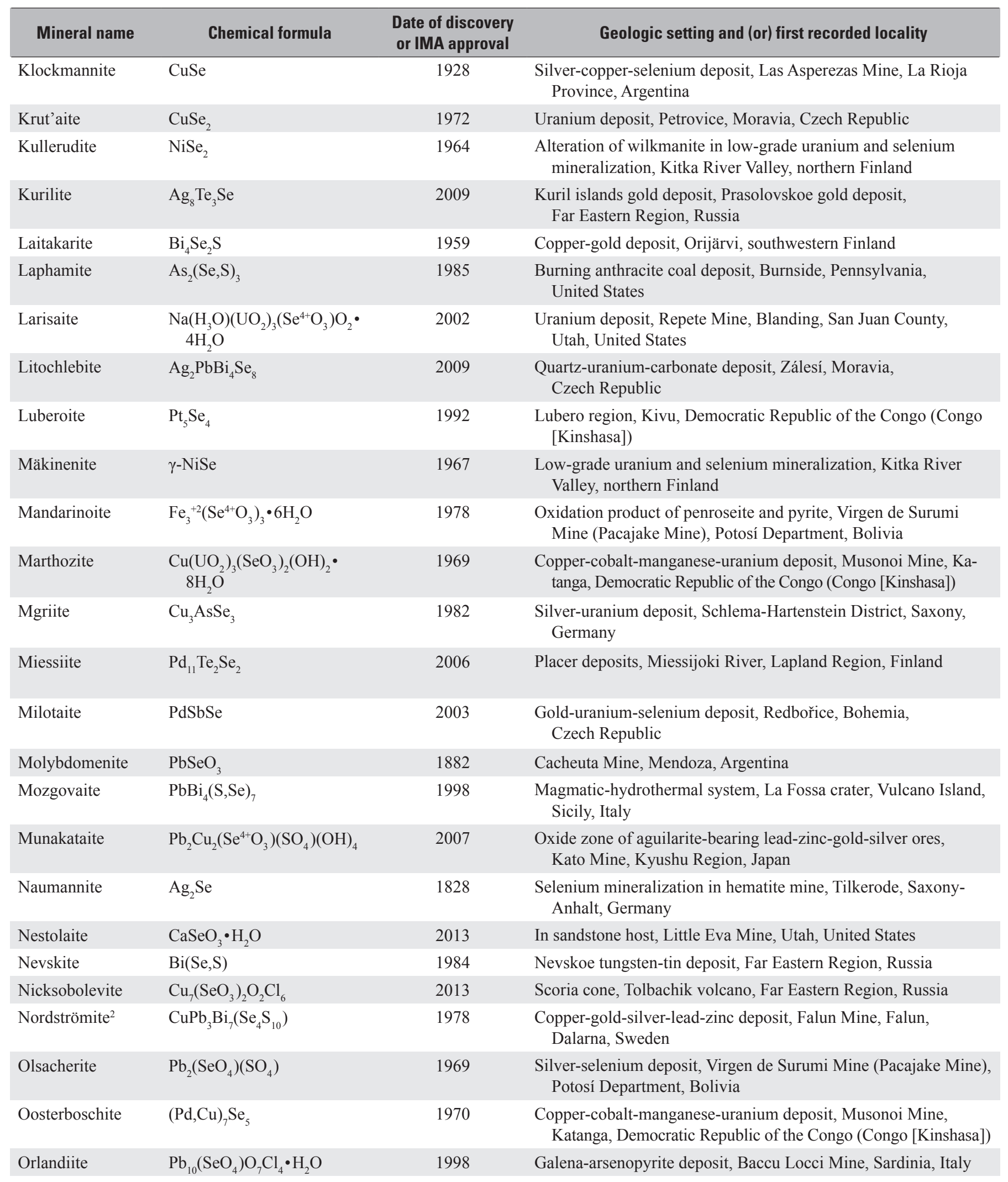


Table 01. Selenium minerals recognized by the International Mineralogical Association.-Continued

[Data are from Mindat.org (2015) and the International Mineralogical Association (IMA) (2014). ?, uncertain according to the IMA; NA, not available]

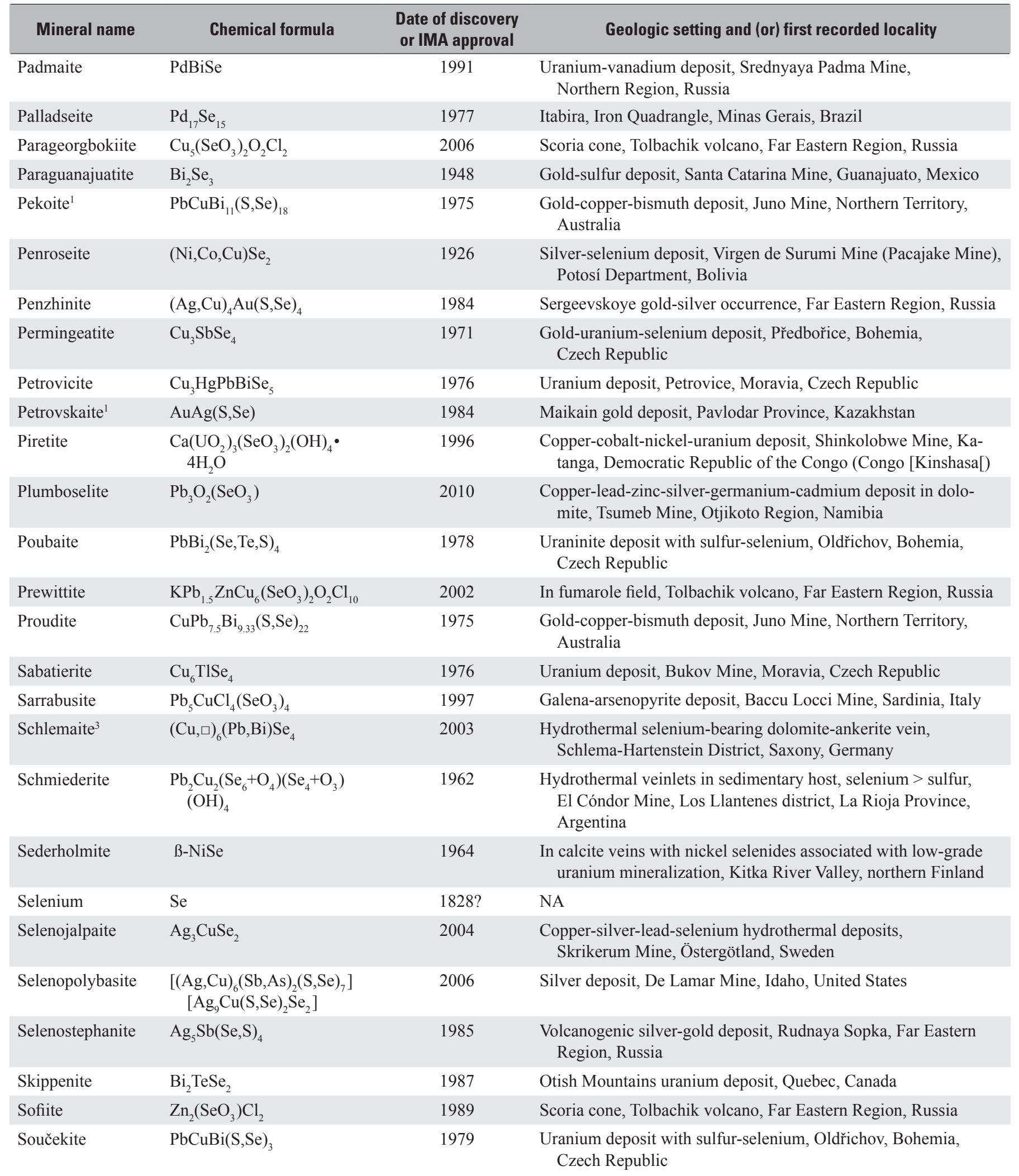


Table 01. Selenium minerals recognized by the International Mineralogical Association.—Continued

[Data are from Mindat.org (2015) and the International Mineralogical Association (IMA) (2014). ?, uncertain according to the IMA; NA, not available]

\begin{tabular}{|c|c|c|c|}
\hline Mineral name & Chemical formula & $\begin{array}{l}\text { Date of discovery } \\
\text { or IMA approval }\end{array}$ & Geologic setting and (or) first recorded locality \\
\hline Stilleite & $\mathrm{ZnSe}$ & 1956 & $\begin{array}{l}\text { Uranium deposit with copper, cobalt, and nickel, Shinkolobwe Mine, } \\
\text { Katanga, Democratic Republic of the Congo (Congo [Kinshasa]) }\end{array}$ \\
\hline Sudovikovite & $\mathrm{PtSe}_{2}$ & 1995 & $\begin{array}{l}\text { Uranium-vanadium deposit, Srednyaya Padma Mine, } \\
\text { Northern Region, Russia }\end{array}$ \\
\hline Telluronevskite & $\mathrm{Bi}_{3} \mathrm{TeSe}_{2}$ & 1993 & $\begin{array}{l}\text { Selenium and tellurium mineralization in hydrothermal veins, } \\
\text { in argillic andesite host, Poruba pod Vihorlatom, Michalovce } \\
\text { County, Košice Region, Slovakia }\end{array}$ \\
\hline Tiemannite & $\mathrm{HgSe}$ & 1855 & $\begin{array}{l}\text { Ancient lead and zinc mine, working veins of the Burgstadt } \\
\text { vein system, St. Lorenz Mine, Lower Saxony, Germany }\end{array}$ \\
\hline Tischendorfite & $\mathrm{Pd}_{8} \mathrm{Hg}_{3} \mathrm{Se}_{9}$ & 2001 & $\begin{array}{l}\text { Selenium mineralization in hematite mine, Eskaborn Adit, } \\
\text { Tilkerode, Saxony-Anhalt, Germany }\end{array}$ \\
\hline Trogtalite & $\mathrm{CoSe}_{2}$ & 1955 & $\begin{array}{l}\text { Abandoned greywacke quarries, Trogtal Quarries, } \\
\text { Lower Saxony, Germany }\end{array}$ \\
\hline Trüstedtite & $\mathrm{Ni}_{3} \mathrm{Se}_{4}$ & 1967 & $\begin{array}{l}\text { Low-grade uranium and selenium mineralization in an albite } \\
\text { diabase, Kitka River Valley, northern Finland }\end{array}$ \\
\hline Tsnigriite & $\mathrm{Ag}_{9} \mathrm{SbTe}_{3}(\mathrm{~S}, \mathrm{Se})_{3}$ & 1991 & $\begin{array}{l}\text { Black-shale-hosted Vysokovol'tnoye silver-gold deposit, } \\
\text { Bel'tau Mountains, Kyzylkum Desert, Uzbekistan }\end{array}$ \\
\hline Tyrrellite & $\mathrm{Cu}\left(\mathrm{Co}^{3+}, \mathrm{Ni}^{3+}\right)_{2} \mathrm{Se}_{4}$ & 1952 & $\begin{array}{l}\text { Ato Bay, Beaverlodge Lake, Goldfields District, Beaverlodge Region, } \\
\text { Saskatchewan, Canada; and Eagle Claims uranium-copper- } \\
\text { selenium occurrence, Eagle shaft area, Melville Lake, Gold- } \\
\text { fields District, Beaverlodge Region, Saskatchewan, Canada }\end{array}$ \\
\hline Umangite & $\mathrm{Cu}_{3} \mathrm{Se}_{2}$ & 1891 & $\begin{array}{l}\text { Las Asperezas silver mine (Sarmiento deposit, Veta Sarmiento), } \\
\text { Sierra de Cacho, Villa Castelli, General Lamadrid Department, } \\
\text { La Rioja Province, Argentina; and abandoned greywacke quarries, } \\
\text { Trogtal Quarries, Lautenthal, Harz, Lower Saxony, Germany }\end{array}$ \\
\hline Verbeekite & $\mathrm{PdSe}_{2}$ & 2001 & $\begin{array}{l}\text { Copper-cobalt-manganese-uranium deposit. Known for rare as- } \\
\text { semblage of uranyl selenites, Musonoi Mine, Kolwezi, Kolwezi } \\
\text { District, Katanga Copper Crescent, Katanga (Shaba), Demo- } \\
\text { cratic Republic of the Congo (Congo [Kinshasa]) }\end{array}$ \\
\hline Vihorlatite & $\mathrm{Bi}_{24} \mathrm{Se}_{17} \mathrm{Te}_{4}$ & 1988 & $\begin{array}{l}\text { Poruba pod Vihorlatom, Michalovce County, Košice Region, } \\
\text { Slovakia }\end{array}$ \\
\hline Watkinsonite & $\mathrm{Cu}_{2} \mathrm{PbBi}_{4}(\mathrm{Se}, \mathrm{S}, \mathrm{Te})_{8}$ & 1985 & $\begin{array}{l}\text { Otish Mountains uranium deposit, Otish Mountains, Baie-James, } \\
\text { Nord-du-Québec, Quebec, Canada }\end{array}$ \\
\hline Weibullite & $\mathrm{Pb}_{5} \mathrm{Bi}_{8} \mathrm{Se}_{7} \mathrm{~S}_{11}$ & 1910 & $\begin{array}{l}\text { Copper mine with minor amount of gold, Falun Mine, Falun, } \\
\text { Dalarna, Sweden }\end{array}$ \\
\hline Wilkmanite & $\mathrm{Ni}_{3} \mathrm{Se}_{4}$ & 1964 & $\begin{array}{l}\text { Low-grade uranium and selenium mineralization in an albite } \\
\text { diabase, Kitka River Valley, Kuusamo, northern Finland }\end{array}$ \\
\hline Wittite & $\mathrm{Pb}_{8} \mathrm{Bi}_{10}(\mathrm{~S}, \mathrm{Se})_{23}$ & 1924 & Falun Mine, Falun, Dalarna, Sweden \\
\hline Zincomenite & $\mathrm{ZnSeO}_{3}$ & 2014 & $\begin{array}{l}\text { Northern fumarole field, first scoria cone, Northern Breakthrough } \\
\text { (North Breach), and Great Fissure eruption (Main Fracture), } \\
\text { Tolbachik volcano, Far Eastern Region, Russia }\end{array}$ \\
\hline
\end{tabular}

${ }^{1}$ The IMA chemical formula does not show selenium substitution for sulfur.

${ }^{2}$ The IMA chemical formula is $\mathrm{Pb}_{3} \mathrm{CuBi}_{7}(\mathrm{~S}, \mathrm{Se})_{14}$.

${ }^{3}$ The symbol $\square$ in the chemical formula denotes an empty atomic site that can be filled (or not), depending upon compositional variation. 
Table 02. A summary of selenium concentrations in various selenides and sulfides from deposits around the world.

[avg, average; b.d.1., below detection limit; Do., do., ditto; IOCG, iron oxide-copper-gold; n.d., not detected; n.r., not reported; ppm, part per million; wt. \%, weight percent; - , none. Abbreviations for elements: Ag, silver; As, arsenic; Au, gold; Bi, bismuth; Co, cobalt; $\mathrm{Cu}$, copper; $\mathrm{Fe}$, iron; $\mathrm{Hg}$, mercury; Mo, molybdenum; Ni, nickel; Pb, lead; Pd, palladium; PGE, platinum-group element; Pt, platinum; S, sulfur; Se, selenium; Te, tellurium; Ti, titanium; $\mathrm{Tl}$, thallium; U, uranium; $\mathrm{Zn}$, zinc]

\begin{tabular}{|c|c|c|c|c|c|}
\hline $\begin{array}{l}\text { Deposit type and (or) } \\
\text { chemistry }\end{array}$ & Mine/deposit name & Mineral phases & $\begin{array}{c}\text { Selenium } \\
\text { concentration }\end{array}$ & Notes & Reference(s) \\
\hline \multicolumn{6}{|c|}{ Australia, eastern } \\
\hline $\begin{array}{l}\text { Volcanic-hosted mas- } \\
\text { sive sulfide }\end{array}$ & Agincourt deposit & Pyrite & $<6$ to $9 \mathrm{ppm}$ & - & $\begin{array}{l}\text { Huston and oth- } \\
\text { ers (1995) }\end{array}$ \\
\hline Do. & $\begin{array}{l}\text { Dry River South } \\
\text { deposit }\end{array}$ & do. & $<6$ to $760 \mathrm{ppm}$ & - & Do. \\
\hline Do. & $\begin{array}{l}\text { Mount Chalmers } \\
\text { deposit }\end{array}$ & do. & $<5$ to $200 \mathrm{ppm}$ & - & Do. \\
\hline Do. & Rosebery deposit & do. & $<6$ to $33 \mathrm{ppm}$ & - & Do. \\
\hline Do. & Waterloo deposit & do. & $<6$ to $180 \mathrm{ppm}$ & - & Do. \\
\hline \multicolumn{6}{|c|}{ Australia, southern } \\
\hline $\begin{array}{l}\text { Protoerozoic Olympic } \\
\text { Dam IOCG }\end{array}$ & Olympic Dam & Bornite & $18.8 \mathrm{ppm}$ & - & $\begin{array}{l}\text { Cook and others } \\
\text { (2011) }\end{array}$ \\
\hline Do. & do. & Chalcopyrite & $8.7 \mathrm{ppm}$ & - & Do. \\
\hline Do. & do. & Naumannite $\left(\mathrm{Ag}_{2} \mathrm{Se}\right)$ & 28.8 wt. $\%$ & - & Do. \\
\hline Do. & do. & $\begin{array}{l}\text { Oosterboschite } \\
\qquad\left(\mathrm{Pd}_{4} \mathrm{Cu}_{3} \mathrm{Se}_{5}\right)\end{array}$ & 45 wt. $\%$ & - & Do. \\
\hline Do. & do. & Umangite $\left(\mathrm{Cu}_{3} \mathrm{Se}_{2}\right)$ & 13.7 wt. $\%$ & - & Do. \\
\hline \multicolumn{6}{|c|}{ Brazil, northern } \\
\hline $\mathrm{Au}-\mathrm{Pd}-\mathrm{Pt}$ & Serra Pelada & $\begin{array}{l}\text { Bulk rock of bonanza } \\
\text { grade Au-Pd-Pt }\end{array}$ & 21 to $36 \mathrm{ppm}$ & Disaggregated, clayey material & $\begin{array}{l}\text { Cabral and oth- } \\
\text { ers (2002) }\end{array}$ \\
\hline Do. & do. & Palladseite $\left(\mathrm{Pd}_{17} \mathrm{Se}_{15}\right)$ & n.r. & - & Do. \\
\hline Do. & do. & Sudovikovite $\left(\mathrm{PtSe}_{2}\right)$ & 11.5 to 12.2 wt. $\%$ & $\begin{array}{l}\text { Pd-Pt-Se inclusions in palladian } \\
\quad \text { gold aggregates }\end{array}$ & Do. \\
\hline Do. & do. & Pyrite & $<15$ to $220 \mathrm{ppm}$ & - & Do. \\
\hline Do. & do. & Pyrrhotite & $375 \mathrm{ppm}$ & - & Do. \\
\hline \multicolumn{6}{|c|}{ Canada, New Brunswick } \\
\hline $\begin{array}{l}\text { Cu-Fe-Zn-S banded } \\
\text { ores }\end{array}$ & Heath Steele & Pyrite & $20 \mathrm{ppm}$ & - & $\begin{array}{l}\text { Hawley and } \\
\text { Nichol } \\
(1959)\end{array}$ \\
\hline $\begin{array}{l}\text { Massive } \mathrm{Cu}-\mathrm{Fe}-(\mathrm{Zn})- \\
\mathrm{S} \text { replacement, } \\
\text { banded }\end{array}$ & do. & Pyrrhotite & $21 \mathrm{ppm}$ & - & Do. \\
\hline \multicolumn{6}{|c|}{ Canada, Newfoundland and Labrador } \\
\hline $\mathrm{Ni}-\mathrm{Cu}-\mathrm{Co}$ & $\begin{array}{l}\text { Nain Plutonic Suite, } \\
\text { Voisey's Bay, } \\
\text { Ovid ore zone }\end{array}$ & Chalcopyrite & 38 to $70 \mathrm{ppm}$ & - & $\begin{array}{l}\text { Ripley and oth- } \\
\text { ers (2002) }\end{array}$ \\
\hline Do. & do. & Pentlandite & 53 to $93 \mathrm{ppm}$ & - & Do. \\
\hline
\end{tabular}


Table 02. A summary of selenium concentrations in various selenides and sulfides from deposits around the world.—Continued

[avg, average; b.d.l., below detection limit; Do., do., ditto; IOCG, iron oxide-copper-gold; n.d., not detected; n.r., not reported; ppm, part per million; wt. \%, weight percent; —, none. Abbreviations for elements: Ag, silver; As, arsenic; Au, gold; Bi, bismuth; Co, cobalt; $\mathrm{Cu}$, copper; Fe, iron; $\mathrm{Hg}$, mercury; Mo, molybdenum; Ni, nickel; Pb, lead; Pd, palladium; PGE, platinum-group element; Pt, platinum; S, sulfur; Se, selenium; Te, tellurium; Ti, titanium; Tl, thallium; U, uranium; Zn, zinc]

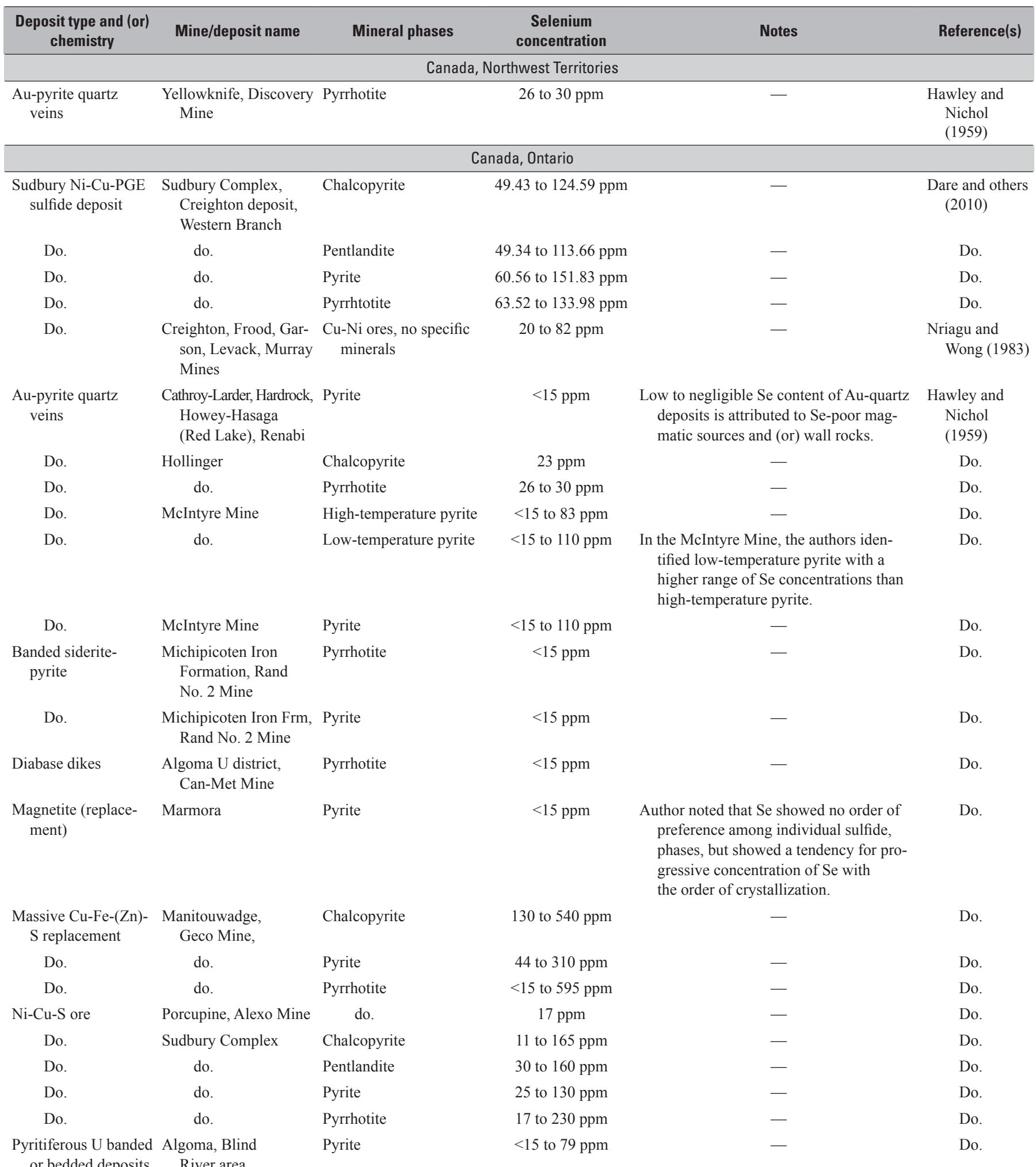


Table 02. A summary of selenium concentrations in various selenides and sulfides from deposits around the world. - Continued

[avg, average; b.d.l., below detection limit; Do., do., ditto; IOCG, iron oxide-copper-gold; n.d., not detected; n.r., not reported; ppm, part per million; wt. \%, weight percent; - , none. Abbreviations for elements: Ag, silver; As, arsenic; Au, gold; Bi, bismuth; Co, cobalt; $\mathrm{Cu}$, copper; Fe, iron; $\mathrm{Hg}$, mercury; Mo, molybdenum; Ni, nickel; Pb, lead; Pd, palladium; PGE, platinum-group element; Pt, platinum; S, sulfur; Se, selenium; Te, tellurium; Ti, titanium; Tl, thallium; U, uranium; Zn, zinc]

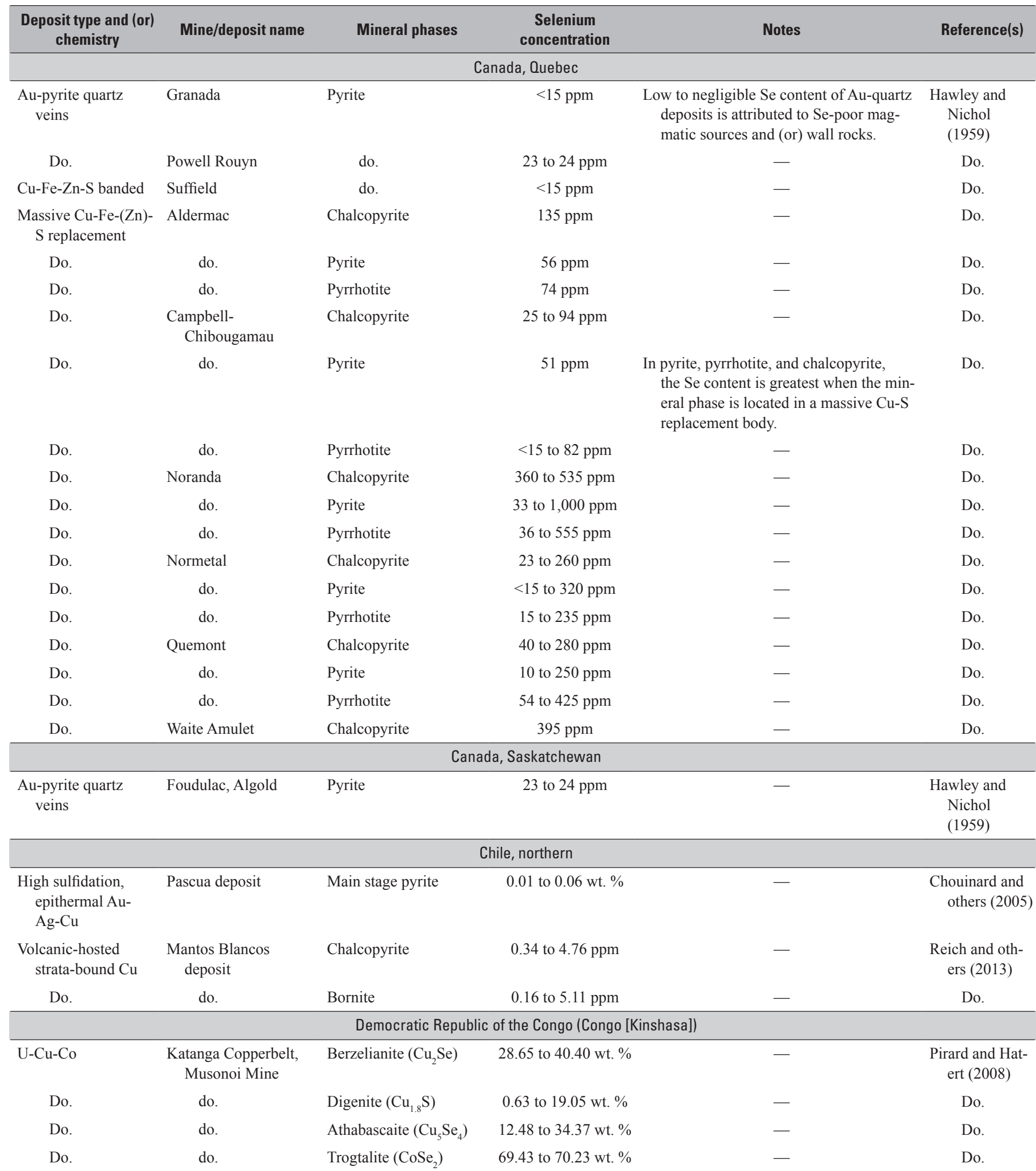


Table 02. A summary of selenium concentrations in various selenides and sulfides from deposits around the world.—Continued

[avg, average; b.d.l., below detection limit; Do., do., ditto; IOCG, iron oxide-copper-gold; n.d., not detected; n.r., not reported; ppm, part per million; wt. \%, weight percent; - , none. Abbreviations for elements: Ag, silver; As, arsenic; Au, gold; Bi, bismuth; Co, cobalt; $\mathrm{Cu}$, copper; Fe, iron; $\mathrm{Hg}$, mercury; Mo, molybdenum; Ni, nickel; Pb, lead; Pd, palladium; PGE, platinum-group element; Pt, platinum; S, sulfur; Se, selenium; Te, tellurium; Ti, titanium; Tl, thallium; U, uranium; Zn, zinc]

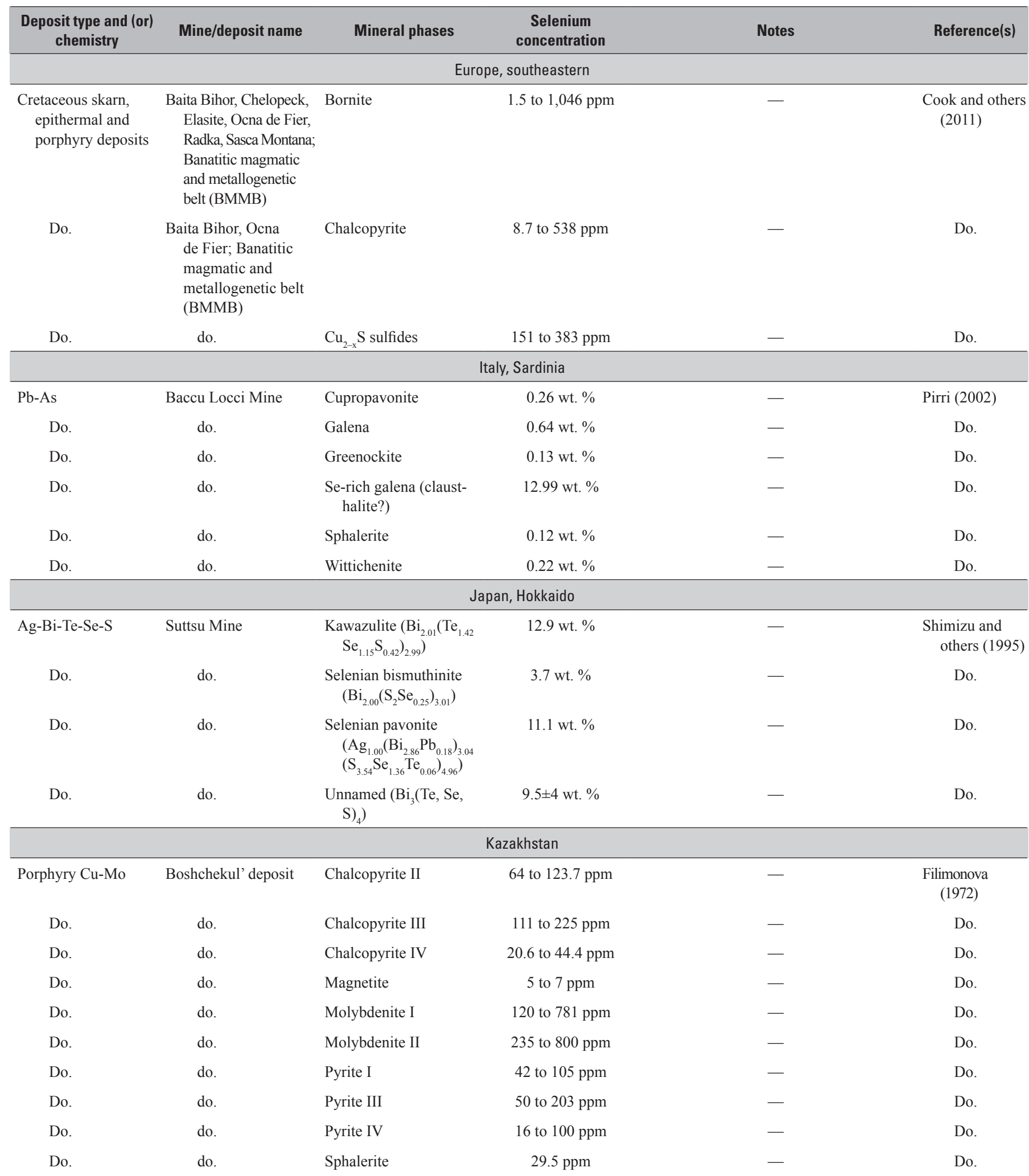


Table 02. A summary of selenium concentrations in various selenides and sulfides from deposits around the world. - Continued

[avg, average; b.d.l., below detection limit; Do., do., ditto; IOCG, iron oxide-copper-gold; n.d., not detected; n.r., not reported; ppm, part per million; wt. \%, weight percent; —, none. Abbreviations for elements: Ag, silver; As, arsenic; Au, gold; Bi, bismuth; Co, cobalt; $\mathrm{Cu}$, copper; $\mathrm{Fe}$, iron; $\mathrm{Hg}$, mercury; Mo, molybdenum; Ni, nickel; Pb, lead; Pd, palladium; PGE, platinum-group element; Pt, platinum; S, sulfur; Se, selenium; Te, tellurium; Ti, titanium; Tl, thallium; U, uranium; Zn, zinc]

\begin{tabular}{|c|c|c|c|c|c|}
\hline $\begin{array}{c}\text { Deposit type and (or) } \\
\text { chemistry }\end{array}$ & Mine/deposit name & Mineral phases & $\begin{array}{c}\text { Selenium } \\
\text { concentration }\end{array}$ & Notes & Reference(s) \\
\hline \multicolumn{6}{|c|}{ Pacific Ocean, $13^{\circ}$ North, East Pacific Rise } \\
\hline $\begin{array}{l}\text { Cu sulfides, Black } \\
\text { smoker active } \\
\text { chimneys }\end{array}$ & $\begin{array}{l}\text { Hi-T hydrothermal } \\
\text { sulfide deposits: } \\
\text { axial graben }\end{array}$ & Chalcopyrite & 100 to $2,000 \mathrm{ppm}$ & $\begin{array}{l}\text { High Se values occur in high-temperature } \\
\text { mineral assemblages, found in the inner } \\
\text { part of the deposit in equilibrium with } \\
\text { pure, unmixed hydrothermal water; } \\
\text { lowest Se values in outer part of deposit, } \\
\text { influenced by mixing of hydrothermal } \\
\text { waters and seawater. }\end{array}$ & $\begin{array}{l}\text { Auclair and oth- } \\
\text { ers (1987) }\end{array}$ \\
\hline $\begin{array}{l}\text { Fe-Cu massive sulfides, } \\
\text { mature hydrother- } \\
\text { mal edifice }\end{array}$ & Off-axis seamounts & Chalcopyrite & 0 to $2,500 \mathrm{ppm}$ & - & Do. \\
\hline Do. & do. & Pyrite & 0 to $1,500 \mathrm{ppm}$ & - & Do. \\
\hline \multicolumn{6}{|c|}{ Portugal } \\
\hline $\mathrm{Pb}-\mathrm{Zn}$ ore & $\begin{array}{l}\text { Neves Corvo deposit, } \\
\text { Zambugal orebody }\end{array}$ & do. & 3,220 ppm (avg) & - & Do. \\
\hline \multicolumn{6}{|c|}{ Russia, Siberia } \\
\hline $\mathrm{Cu}-\mathrm{Ni}-\mathrm{PGE}$ & $\begin{array}{l}\text { Noril'sk, Oktyabr } \\
\text { deposit }\end{array}$ & Chalcopyrite & 44 to $148 \mathrm{ppm}$ & - & $\begin{array}{r}\text { Kovalenker and } \\
\text { others (1975) }\end{array}$ \\
\hline Do. & do. & Cubanite $\left(\mathrm{CuFe}_{2} \mathrm{~S}_{3}\right)$ & 92 to $94 \mathrm{ppm}$ & - & Do. \\
\hline Do. & do. & Millerite, NiS & 496 ppm & - & Do. \\
\hline Do. & do. & Moikhukite & 94 ppm & - & Do. \\
\hline Do. & do. & Pentlandite & 56 to $213 \mathrm{ppm}$ & - & Do. \\
\hline Do. & do. & Pyrrhotite & 50 to $98 \mathrm{ppm}$ & - & Do. \\
\hline \multicolumn{6}{|c|}{ Russia, Ural Mountains } \\
\hline $\mathrm{Cu}-\mathrm{S}$ & Karabash group & Bornite & $18 \mathrm{ppm}$ & - & $\begin{array}{l}\text { Yushoko-Zak- } \\
\text { harova and } \\
\text { others (1978) }\end{array}$ \\
\hline Do. & do. & $\begin{array}{l}\text { Chalcopyrite (from } \mathrm{Cu} \text { - } \\
\text { sphalerite ores) }\end{array}$ & 3.8 to $216 \mathrm{ppm}$ & - & Do. \\
\hline Do. & do. & $\begin{array}{l}\text { Chalcopyrite (from late } \\
\text { quartz-carbonate } \\
\text { veinlets) }\end{array}$ & 11 to $16 \mathrm{ppm}$ & - & Do. \\
\hline Do. & do. & Galena & $0.5 \mathrm{ppm}$ & - & Do. \\
\hline Do. & do. & Pyrite & 3 to $110 \mathrm{ppm}$ & - & Do. \\
\hline Do. & do. & Sphalerite & 16 ppm & - & Do. \\
\hline Do. & do. & $\begin{array}{l}\text { Tetrahedrite-tennantite } \\
\text { (from cupreous } \\
\text { pyrite) }\end{array}$ & $81 \mathrm{ppm}$ & - & Do. \\
\hline
\end{tabular}


Table 02. A summary of selenium concentrations in various selenides and sulfides from deposits around the world.—Continued

[avg, average; b.d.l., below detection limit; Do., do., ditto; IOCG, iron oxide-copper-gold; n.d., not detected; n.r., not reported; ppm, part per million; wt. \%, weight percent; - , none. Abbreviations for elements: Ag, silver; As, arsenic; Au, gold; Bi, bismuth; Co, cobalt; $\mathrm{Cu}$, copper; Fe, iron; $\mathrm{Hg}$, mercury; Mo, molybdenum; Ni, nickel; Pb, lead; Pd, palladium; PGE, platinum-group element; Pt, platinum; S, sulfur; Se, selenium; Te, tellurium; Ti, titanium; Tl, thallium; U, uranium; Zn, zinc]

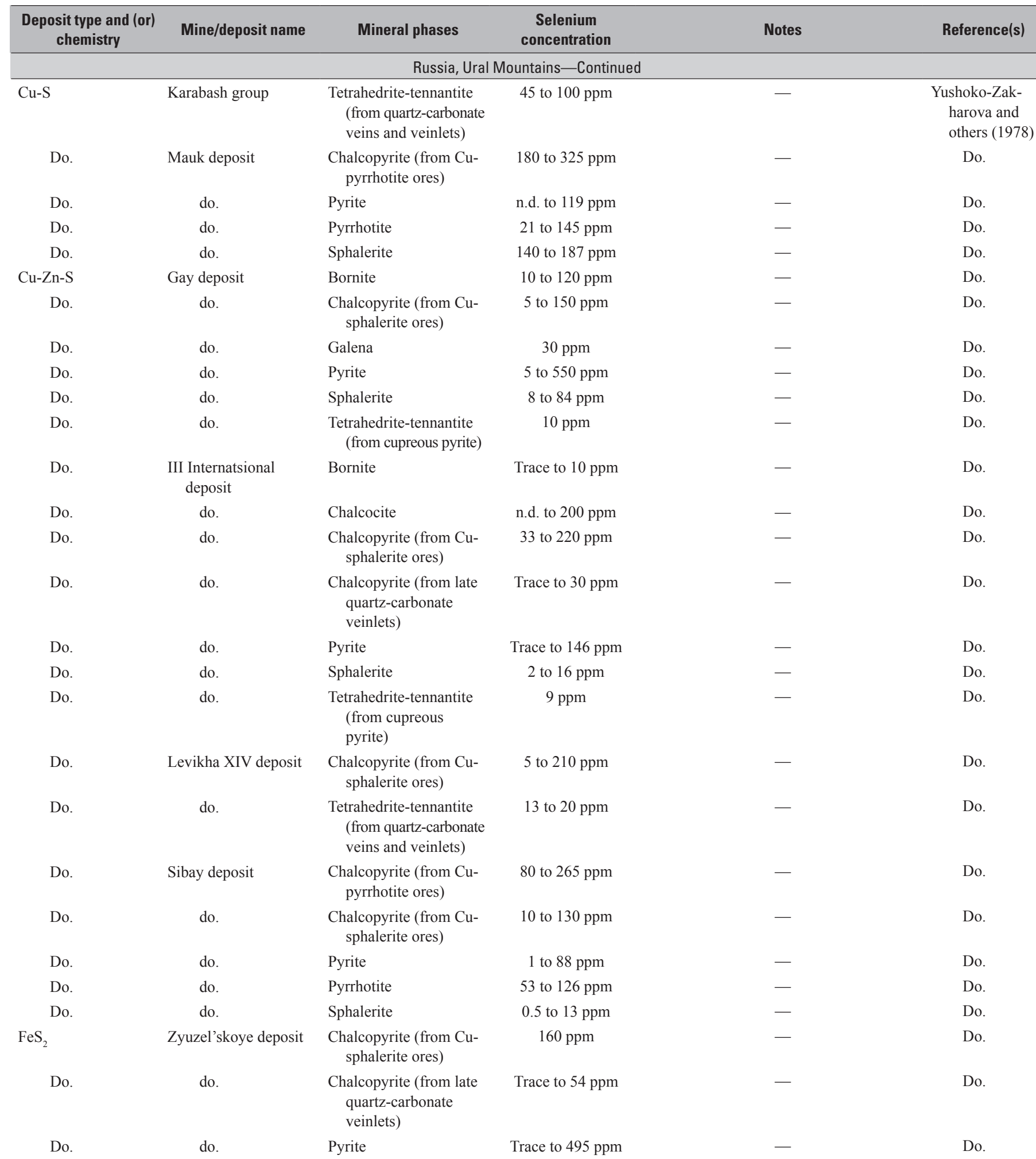


Table 02. A summary of selenium concentrations in various selenides and sulfides from deposits around the world.—Continued

[avg, average; b.d.l., below detection limit; Do., do., ditto; IOCG, iron oxide-copper-gold; n.d., not detected; n.r., not reported; ppm, part per million; wt. \%, weight percent; —, none. Abbreviations for elements: Ag, silver; As, arsenic; Au, gold; Bi, bismuth; Co, cobalt; $\mathrm{Cu}$, copper; $\mathrm{Fe}$, iron; $\mathrm{Hg}$, mercury; Mo, molybdenum; Ni, nickel; Pb, lead; Pd, palladium; PGE, platinum-group element; Pt, platinum; S, sulfur; Se, selenium; Te, tellurium; Ti, titanium; Tl, thallium; U, uranium; Zn, zinc]

\begin{tabular}{|c|c|c|c|c|c|}
\hline $\begin{array}{l}\text { Deposit type and (or) } \\
\text { chemistry }\end{array}$ & Mine/deposit name & Mineral phases & $\begin{array}{c}\text { Selenium } \\
\text { concentration }\end{array}$ & Notes & Reference(s) \\
\hline \multicolumn{6}{|c|}{ Sweden and Norway } \\
\hline $\begin{array}{l}\text { Late Proterozoic } \\
\text { metamorphic } \mathrm{Cu}- \\
\text { vein systems }\end{array}$ & $\begin{array}{l}\text { Glava, Grusen, } \\
\text { Moberg, Tinnsjå, } \\
\text { Tjøstølflaten }\end{array}$ & Bornite & 2.8 to $4,617 \mathrm{ppm}$ & $\begin{array}{l}\text { Se concentrations in bornite show promise } \\
\text { as a vector for exploration and may be } \\
\text { able to track proximal to distal zonation. }\end{array}$ & $\begin{array}{l}\text { Cook and others } \\
\text { (2011) }\end{array}$ \\
\hline Do. & Tinnsjå & Chalcopyrite & $20.7 \mathrm{ppm}$ & - & Do. \\
\hline \multicolumn{6}{|c|}{ Sweden, southeastern } \\
\hline $\mathrm{Cu}-\mathrm{Ag}-\mathrm{Tl}-\mathrm{Se}$ & $\begin{array}{l}\text { Skrikerum deposit, } \\
\text { Småland }\end{array}$ & $\begin{array}{r}\text { Selenojalpaite } \\
\left(\mathrm{Ag}_{3} \mathrm{CuSe}_{2}\right)\end{array}$ & 29.01 wt. $\%$ & - & $\begin{array}{c}\text { Bindi and Pra- } \\
\text { tesi }(2005)\end{array}$ \\
\hline \multicolumn{6}{|c|}{ Spain } \\
\hline $\begin{array}{l}\text { Carbonate-hosted } \\
\text { epithermal gold }\end{array}$ & $\begin{array}{l}\text { Providencia Mine, } \\
\text { Leon }\end{array}$ & $\begin{array}{l}\text { Villamaninite } \\
\qquad((\mathrm{Cu}, \mathrm{Ni}, \mathrm{Co}, \mathrm{Fe}) \\
\left.\quad(\mathrm{S}, \mathrm{Se}, \mathrm{Te})_{2}\right)\end{array}$ & 1.89 to 9.12 wt. $\%$ & - & $\begin{array}{r}\text { Paniagua } \\
(1995)\end{array}$ \\
\hline $\mathrm{Cu}$ & Murgul deposit & $\begin{array}{l}\text { Aikinite }) \mathrm{Pb}_{0.96} \mathrm{Cu}_{1.10} \\
\left.\qquad \mathrm{Bi}_{0.98} \mathrm{~S}_{2.73} \mathrm{Se}_{0.20} \mathrm{Te}_{0.03}\right)\end{array}$ & 2.75 wt. $\%$ & - & $\begin{array}{l}\text { Willgallis and } \\
\text { others (1990) }\end{array}$ \\
\hline Do. & do. & $\begin{array}{l}\text { Galena }\left(\mathrm{Pb}_{1.00} \mathrm{Ag}_{0.01}\right. \\
\left.\qquad \mathrm{Bi}_{0.01} \mathrm{~S}_{0.95} \mathrm{Se}_{0.03}\right)\end{array}$ & 1 wt. $\%$ & - & Do. \\
\hline Do. & do. & $\begin{array}{l}\text { Tennantite }\left(\mathrm{Cu}_{9.66} \mathrm{Zn}_{2.02}\right. \\
\mathrm{Fe}_{0.03} \mathrm{As}_{3.90} \mathrm{Bi}_{0.35} \mathrm{Te}_{0.08} \\
\mathrm{~S}_{12.95} \mathrm{Se}_{0.01} \text { and } \\
\mathrm{Cu}_{9.59} \mathrm{Zn}_{1.97} \mathrm{Fe}_{0.03} \\
\mathrm{As}_{3.76} \mathrm{Bi}_{0.44} \mathrm{Te}_{0.11} \\
\left.\mathrm{~S}_{13.03} \mathrm{Se}_{0.07}\right)\end{array}$ & $\begin{array}{c}0.05 \text { and } \\
0.36 \text { wt. } \%\end{array}$ & - & Do. \\
\hline Do. & do. & $\begin{array}{l}\text { Tetradymite }\left(\mathrm{Bi}_{1.76} \mathrm{~Pb}_{0.22} 2\right. \\
\left.\quad \mathrm{Cu}_{0.06} \mathrm{Te}_{1.72} \mathrm{~S}_{0.68} \mathrm{Se}_{0.56}\right)\end{array}$ & 6.33 wt. $\%$ & - & Do. \\
\hline \multicolumn{6}{|c|}{ United States, Minnesota } \\
\hline $\mathrm{Cu}-\mathrm{Ni}-\mathrm{PGE}$ & $\begin{array}{l}\text { Duluth Complex, Bab- } \\
\text { bitt deposit }\end{array}$ & Cubanite & 6 to $157 \mathrm{ppm}$ & - & Ripley (1990) \\
\hline Do. & do. & Pentlandite & 24 to $363 \mathrm{ppm}$ & - & Do. \\
\hline Do. & do. & Pyrrhotite & 24 to $169 \mathrm{ppm}$ & - & Do. \\
\hline \multicolumn{6}{|c|}{ United States, Nevada } \\
\hline Au-Ag veins & $\begin{array}{l}\text { Humboldt Coounty, } \\
\text { National District, } \\
\text { Buckskin Mountain }\end{array}$ & HgSeSCl phases & 2.12 to $21.91 \mathrm{wt} . \%$ & - & Vikre (2007) \\
\hline Do. & do. & Stibnite & 0.10 to 3.62 wt. $\%$ & - & Do. \\
\hline
\end{tabular}





\section{Tellurium}

By Richard J. Goldfarb, Byron R. Berger, Micheal W. George, and Robert R. Seal II

Chapter R of

Critical Mineral Resources of the United States-Economic and Environmental Geology and Prospects for Future Supply

Edited by Klaus J. Schulz, John H. DeYoung, Jr., Robert R. Seal II, and Dwight C. Bradley

Professional Paper 1802-R

U.S. Department of the Interior

U.S. Geological Survey 


\section{Contents of Chapter $\mathbf{R}$}

[Figure and table titles for all chapters are listed in the volume contents before the conversion factors table and list of abbreviations and symbols. A periodic table of the elements is on the inside front cover of the printed volume]

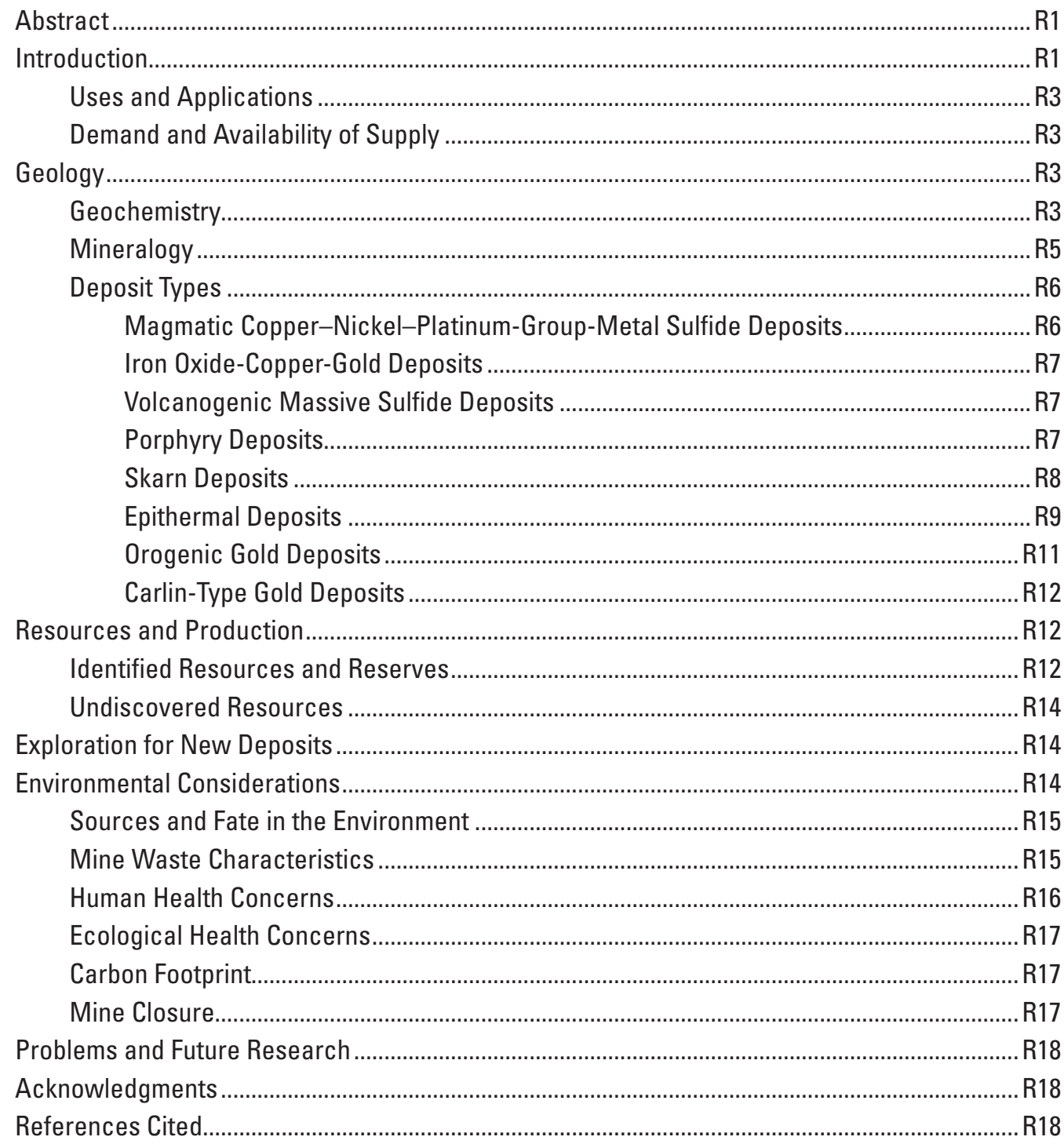




\title{
Tellurium
}

\author{
By Richard J. Goldfarb, Byron R. Berger, ${ }^{1}$ Micheal W. George, and Robert R. Seal II
}

\section{Abstract}

Tellurium (Te) is a very rare element that averages only 3 parts per billion in Earth's upper crust. It shows a close association with gold and may be present in orebodies of most gold deposit types at levels of tens to hundreds of parts per million. In large-tonnage mineral deposits, such as porphyry copper and sea-floor volcanogenic massive sulfide deposits, sulfide minerals may contain hundreds of parts per million tellurium, although the orebodies likely have overall concentrations of 0.1 to 1.0 parts per million tellurium. Tellurium is presently recovered as a primary ore from only two districts in the world; these are the gold-tellurium epithermal vein deposits located adjacent to one another at Dashuigou and Majiagou (Sichuan Province) in southwestern China, and the epithermal-like mineralization at the Kankberg deposit in the Skellefteå VMS district of Västerbotten County, Sweden. Combined, these two groups of deposits account for about 15 percent (about 70 metric tons) of the annual global production of 450 to 470 metric tons of tellurium. Most of the world's tellurium, however, is produced as a byproduct of the mining of porphyry copper deposits. These deposits typically yield concentrations of 1 to 4 percent tellurium in the anode slimes recovered during copper refining. Present production of tellurium from the United States is solely from the anode slimes at ASARCO LLC's copper refinery in Amarillo, Texas, and may total about 50 metric tons per year. The main uses of tellurium are in photovoltaic solar cells and as an additive to copper, lead, and steel alloys in various types of machinery. The environmental data available regarding the mining of tellurium are limited; most concerns to date have focused on the more-abundant metals present in the large-tonnage deposits from which tellurium is recovered as a byproduct. Global reserves of tellurium are estimated to be 24,000 metric tons, based on the amount of tellurium likely contained in global copper reserves and on a 50 percent recovery rate from refinery anode slimes during the commonly used electrolytic process, also known as solvent extraction-electrolytic refining. If the more economical solvent-leach process - a process that does not recover tellurium - is increasingly used in the future to recover lower grades of copper from porphyry and other large-tonnage deposits, then additional high-grade telluriumrich gold deposits may become new primary sources for tellurium, particularly epithermal vein deposits associated with alkaline magmatism.

\section{Introduction}

Tellurium (Te) is an element for which there is little reliable information about specific deposits and (or) primary production sources. Two vein deposits in southwestern China that are adjacent to one another and a possible deformed ancient sea-floor volcanogenic massive sulfide (VMS) deposit in Sweden may represent the only two locations in the world where tellurium is a primary resource (fig. R1).

Most tellurium is recovered as a byproduct in the anode slimes from the electrorefining of copper and other polymetallic sulfide ores, which are typically mined from porphyry, VMS, magmatic nickel-copper-platinum-group-metal (PGM), and (or) skarn deposits The tellurium received for processing at a refinery may have come from several different types of mineral deposits within a given country and (or) from another country or countries. If the tellurium is to be recovered as a final tellurium metal product at a refinery, it commonly requires upgrading to tellurium metal at a second industrial facility, which may be located in the same or a different country. In the United States, for example, all tellurium production is from a single refinery in Texas, but it is impossible to identify the specific deposits that have contributed the ore from which the tellurium is produced, although the sources are likely some of the large porphyry copper deposits scattered across the southwestern and western parts of the country.

The refined anode slimes from which tellurium is extracted are typically dominated by copper and silver, although most global refineries report contents of 1 to 4 percent tellurium in the anode slimes, and some copper refineries in central Asia and Russia report as much as 8 to 9 percent tellurium (Moats and others, 2007). A minor part of the world's tellurium is also recovered from the dust and gases produced during the smelting of sulfide-rich ores and from the skimmings (when a distillation process is used) at lead refineries. 


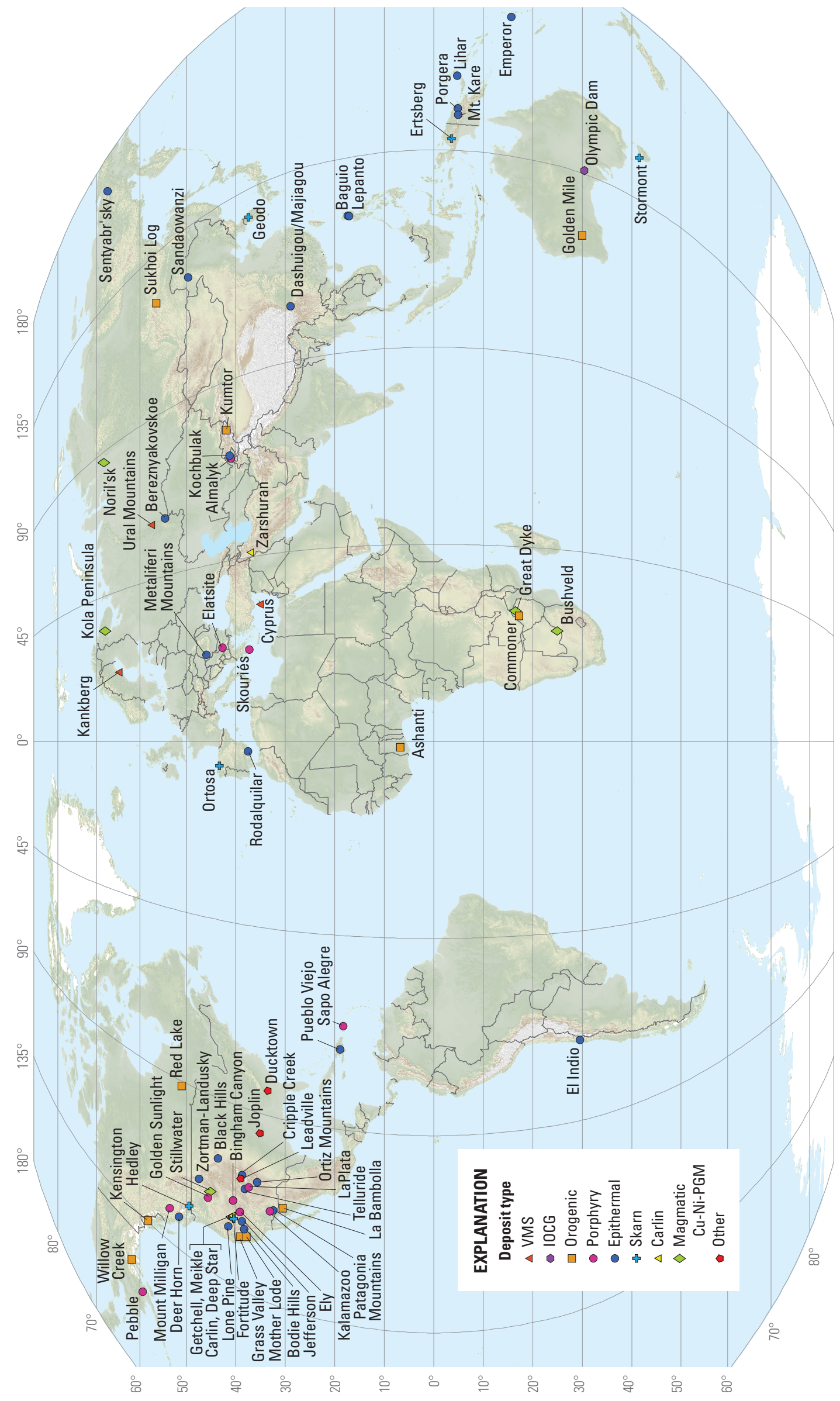

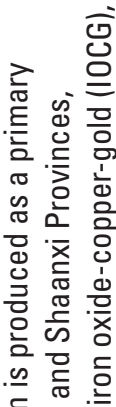

至 恶 可产立 क 으을 증 की

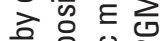
은 응 ब

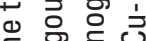
듀 $\pi$ $\subseteq: \frac{0}{\bar{\pi}} \frac{0}{0} \overline{\frac{\pi}{\pi}}$ \& ⿻े 峁 is 这

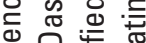
证 它焉 $\frac{1}{0}$ 믐 就苛市 ह 造㟔 它文. 든 ธิ) 立心 今

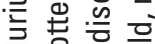
킁 응 흥 힝 히 $\Phi$ : 过 路 专 पे ప उ

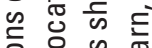
흥으 훠 数 胥 으음 웅흥 홍

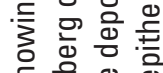

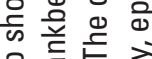
을 ฮั 은

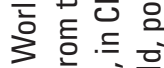
. 훙ㅎㅁ 穴 要总.

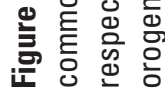




\section{Uses and Applications}

The main use of tellurium is for development of cadmium-tellurium film in photovoltaic solar cells, which is considered to be an emerging application, particularly in the growing economies of China and India. In addition, tellurium is used as an additive to copper, lead, and steel alloys to improve machine efficiency, particularly in thermoelectric cooling products. Together, the photovoltaic solar and thermoelectric uses account for more than two-thirds of the world's tellurium usage (fig. R2; Anderson, 2015). About 5 percent of tellurium usage is for improving heat resistance during vulcanization of rubber. Tellurium is also used as an alloy with selenium in photoreceptors in copying machines and as a coloring agent in ceramics and glass. It is, in addition, applied in integrated circuits, laser diodes, and medical instrumentation; all these uses have had robust growth in recent years.

\section{Demand and Availability of Supply}

The price of tellurium has fluctuated significantly since 2010. According to the U.S. Department of Energy, the supply of tellurium is not critical, although it is projected to be "nearcritical" through 2025 (U.S. Department of Energy, 2010). Significant amounts of tellurium are available globally from the mining of major base-metal-rich deposits. Enrichments in precious-metal deposits are well known, although these deposits have generally not produced significant amounts of tellurium.

The solar energy industry represents the largest share of the tellurium market today, accounting for nearly 40 percent of annual tellurium consumption. Some consumption percentages have changed since 2010, as metallurgy use has decreased to about 15 percent from approximately 30 percent of total consumption, and thermoelectric products presently account for about 30 percent (fig. R2). Because of the demand for solar cells, an estimated 30 percent of the world's produced tellurium is used by First Solar Inc., which in 2016 continued to be the world's leading producer of cadmium-tellurium solar panels.

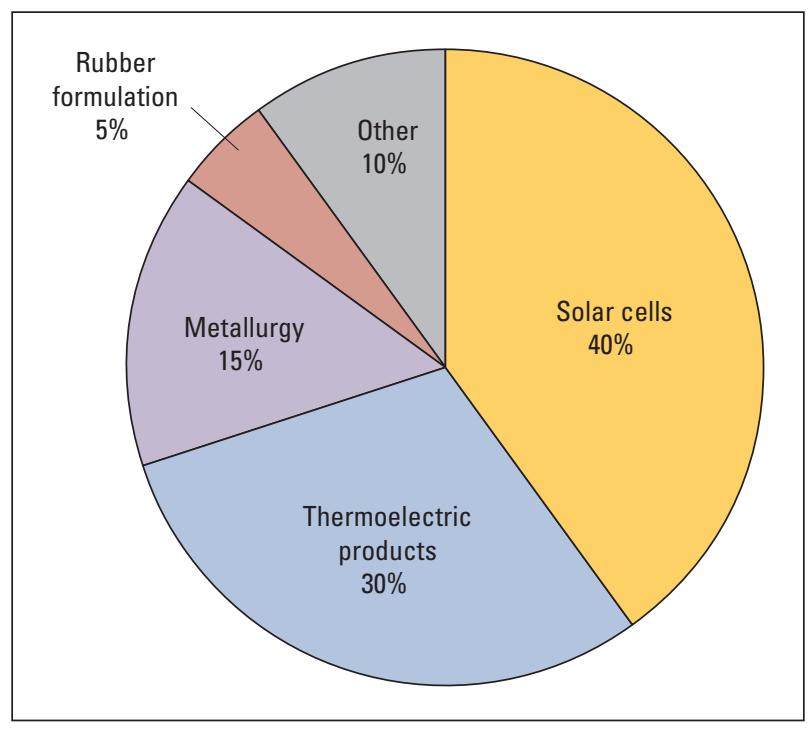

\section{Geology}

\section{Geochemistry}

Owing to its high volatility in the hydride phase and probable evaporative loss during Earth's early low-oxygen period, tellurium is an exceptionally rare chalcophile element in Earth's upper crust. Tellurium is in the family of Group 6A elements in the periodic table, which also includes oxygen, sulfur, and selenium, and its chemical behavior is similar to that of selenium and sulfur. Native tellurium typically appears as a brittle, silver-white substance. It has an atomic number of 52 and an atomic weight of 127.6. Tellurium combines with elements that are incapable of reducing their volume upon losing valence electrons (Sindeeva, 1964). The energy required to detach tellurium's first electron is much higher than for the alkaline and alkaline earth metals, and, therefore, tellurium does not tend to form ionic bonds; rather, it forms covalent and metallic bonds. Tellurium tends to combine with metals of high atomic number and similar atomic radii; for example, it typically forms minerals that also contain gold, silver, and platinum.

McDonough (2003) estimated an overall bulk Earth abundance of 300 parts per billion (ppb) tellurium, but 96 percent of Earth's tellurium remains in the core, which averages $885 \mathrm{ppb}$ tellurium. Earth's mantle may have an average concentration of about $8 \mathrm{ppb}$ tellurium, although local concentrations in peridotite can be twice that amount because residual sulfide phases in these rocks are commonly enriched in tellurium (Palme and O'Neil, 2003). Tellurium is preferentially retained in refractory sulfides in harzburgite in the mantle during melting processes (Hattori and others, 2002). Crustal tellurium values are extremely low, and $\mathrm{Li}$ and Schoonmaker (2003) estimate an average upper crustal abundance value of $3 \mathrm{ppb}$ tellurium, which is about eight times less than that for gold and makes tellurium one of the least common elements in crustal rocks. Only a limited amount of abundance data for tellurium is available, and, in fact, tellurium is not listed in many modern-day comprehensive compilations of global element abundances (for example, table 2 in Rudnick and Gao, 2003). In marine shale, however, Li and Schoonmaker (2003) indicate much higher average concentrations of $70 \mathrm{ppb}$ tellurium, which likely reflects the abundance of disseminated oceanic pyrite that has elevated levels of tellurium. Hein and others (2013) note mean values of 30 to 60 parts per million (ppm) tellurium in ironmanganese crusts formed on the floor of several oceans owing to the oxidation of tellurite (Te(IV)) to tellurate (Te(VI)).

Figure R2. Pie chart showing major end uses of tellurium as a percentage of world consumption in 2010. Compiled using data from Selenium Tellurium Development Association, Inc. (2010) and Anderson (2015). 
The solubility and transport of tellurium in magmatic and hydrothermal fluids are incompletely understood, particularly at the temperatures and pressures of igneous melt reservoirs and in high-grade metamorphic terranes. Taken together with the intrinsic low abundance of the element, the heterogeneity of the concentrations of tellurium within any mineral-deposit type and the very fine granularity of telluride minerals limit the ability to predict tellurium resources that might occur in a specific type of mineral deposit. Tellurium has a relatively low solubility in aqueous solutions; fields for the dominant aqueous tellurium species are shown as a function of $\mathrm{pH}$ and oxygen fugacity in figure R3. Given the high abundance of tellurium in some deposits, the low solubility suggests that tellurium may be transported predominantly in the vapor phase (for example, Cooke and McPhail, 2001), probably as solvated molecular species. Tellurium occurs in volcanic fumaroles, such as the high-tellurium amorphous arsenic-rich sulfurite at Vulcano, Sicilia, Italy (Garavelli and others, 2013) and in volcanic condensate sulfur from the Mendeleev volcano in the Kuril Islands, Sakhalinskaya Oblast', Russia, and the Mutnovskaya volcano on Russia's Kamchatka Peninsula (Sindeeva, 1964). Volatile transport of tellurium could also be enhanced owing to the suggested relatively high anhydrous volatility of the element, along with that of arsenic, mercury, and selenium (for example, Saunders and Brueseke, 2012), where $\mathrm{Hg}>\mathrm{As}>\mathrm{Se}>\mathrm{Te}>\mathrm{Tl}>>\mathrm{Sb}>\mathrm{Pb}>\mathrm{Ag}>\mathrm{Cu}>\mathrm{Au}$. In addition, the common enrichment of tellurium in nonmagmatic orogenic gold systems may indicate that carbon dioxide $\left(\mathrm{CO}_{2}\right)$ immiscibility also is an important factor leading to the gaseous transport and concentration of tellurium.

Although tellurium varies in oxidation state from -2 (telluride) to +4 (tellurite) to +6 (tellurate), tellurium is most soluble as tellurite in hydrothermal fluids. Hydrothermal waters in the areas of epithermal gold deposits may contain as much as 4 ppb tellurium, and some sea-floor hot springs have as much as $18 \mathrm{ppb}$ tellurium (Grundler and others, 2013). In typical reduced hydrothermal fluids (for example, $\left.\log f \mathrm{O}_{2}<-30\right), \mathrm{Te}_{2}^{2-}$ is the dominant tellurium-bearing ion (Brugger and others, 2012), although under slightly more acidic or very reduced conditions $\mathrm{HTe}^{-}$is dominant and $\mathrm{H}_{2} \mathrm{TeO}_{3}$ could be important in very acidic and less reduced solutions (fig. R3; McPhail, 1995; Grundler and others, 2013). The $\mathrm{Te}_{2}{ }^{2-}$ activity is controlled in aqueous solutions by the solubility of native tellurium, which is commonly deposited along with many telluride phases. The tellurate species are dominant under only very oxidizing conditions, such as in near-surface weathering of telluride-rich ores (fig. R3).

Some researchers have suggested that the common occurrence of gold-bearing telluride minerals implies the transport of gold as a soluble tellurium complex (for example, Jensen and Barton, 2000; Cooke and McPhail, 2001; Brugger and others, 2012), although most experimental evidence at magmatic conditions indicates the transport of gold either as a sulfide complex (Loucks and Mavrogenes, 1999) or as both chloride and sulfide complexes (Frank and others, 2011). Hydrothermal fluids with anomalous tellurium concentrations, based on the abundance of telluride minerals, include both $\mathrm{CO}_{2}$-rich fluids that form orogenic gold and alkalic-related epithermal gold deposits, and $\mathrm{CO}_{2}$-poor fluids that typify most low- and high-sulfidation precious-metal-bearing epithermal ores. Therefore, it is unlikely that $\mathrm{CO}_{2}$ plays a significant role in the transport or concentration of tellurium. Furthermore, although typical tellurium enrichments in ore deposits are assumed to reflect magmatic-hydrothermal activity, the tellurium enrichment in many orogenic gold deposits, which are widely accepted to have formed from nonmagmatic metamorphic fluids, suggests that such a magmatic association is not necessary.

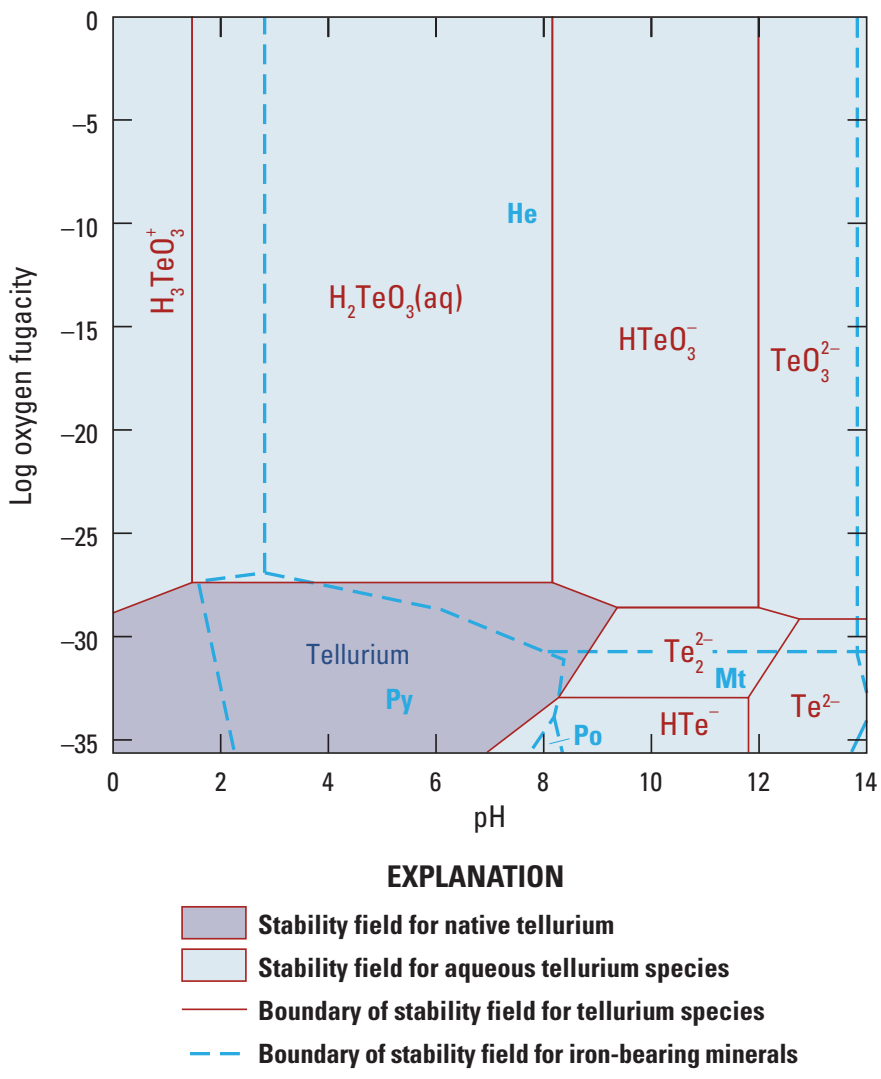

Figure R3. Phase diagram showing speciation calculations for tellurium in a hydrothermal fluid at 300 degrees Celsius $\left({ }^{\circ} \mathrm{C}\right)$, as a function of $\mathrm{pH}$ and oxygen fugacity, with the following activities: tellurium $=10^{-10}$, iron $=0.1$, sulfur $=10^{-4}$, and chlorine $=0.5$. At an activity of tellurium of $10^{-10}$, a typical near-neutral to acidic, reduced aqueous fluid cannot carry much tellurium, and native tellurium will be stable (shaded area in lower left side of diagram). The low solubility of tellurium in aqueous solutions suggests that concentration of tellurium in a vapor may be important for mineral formation unless the fluid has a very high concentration of tellurium (that is, at an activity of $\mathrm{Te}=10^{-8}$ or greater). The oxygenbearing tellurate species, although with large stability fields, are only significant under very oxidizing conditions above a log oxygen fugacity of about $10^{-29}$ for any $\mathrm{pH}$ value. After Grundler and others (2013). aq, aqueous; He, hematite; Mt, magnetite; Po, pyrrhotite; Py, pyrite; and Te, tellurium 
Studies of both liquid and vapor fluid inclusions from porphyry and epithermal deposits have indicated concentrations of hundreds of parts per million tellurium in the fluids that formed some deposits (Wallier and others, 2006; Pudack and others, 2009). For example, fluid inclusions in highsulfidation epithermal veins in Romania contained as much as 3 weight percent tellurium, which appeared to correlate with enrichments in dissolved silver and gold (Kouzmanov and others, 2010). Grundler and others $(2009,2013)$ concluded that these unusually elevated tellurium concentrations indicate that aqueous tellurite was transported in a highly oxidized magmatic fluid and (or) in a fluid with basic $\mathrm{pH}$ (approximately greater than $\mathrm{pH} 8$ ), with tellurite reduction by fluidrock interaction or by fluid mixing that caused precipitation of telluride minerals. Available information suggests that any drastic change in fluid conditions, including a decrease in temperature, wallrock sulfidation, phase separation, $\mathrm{pH}$ shifts, and (or) redox change, can destabilize telluriumbearing complexes (for example, Cooke and McPhail, 2001; Ciobanu and others, 2006; Maslennikov and others, 2013). Most hypogene telluride minerals probably were deposited at temperatures of between 300 and 100 degrees Celsius $\left({ }^{\circ} \mathrm{C}\right)$ (for example, Zhang and Spry, 1994; Shackleton and others, 2003), although in some magmatic copper-nickel-PGM deposits, palladium- and (or) lead-bearing tellurides are stable at temperatures of $400{ }^{\circ} \mathrm{C}$ (Vymazalová and Drábek, 2011).

\section{Mineralogy}

The most common tellurium-bearing minerals are listed in table R1. These minerals occur in many different types of ore deposits, but the minerals themselves are typically too low in abundance to be sources for recoverable tellurium ore.

Table R1. Tellurium-bearing minerals, many of which are mentioned in this chapter.

\begin{tabular}{|c|c|}
\hline Mineral name & Chemical formula \\
\hline Altaite & $\mathrm{PbTe}$ \\
\hline Benleonardite & $\mathrm{Ag}_{8}(\mathrm{Sb}, \mathrm{As}) \mathrm{Te}_{2} \mathrm{~S}_{3}$ \\
\hline Bezsmertnovite & $\mathrm{Au}_{4} \mathrm{Cu}(\mathrm{Te}, \mathrm{Pb})$ \\
\hline Bilibinskite & $\mathrm{PbCuAu}_{3} \mathrm{Te}_{2}$ \\
\hline Blakeite & $\left(\mathrm{Fe}_{2}\left(\mathrm{TeO}_{3}\right)_{3}\right.$ \\
\hline Bogdanovite & $\mathrm{Au}, \mathrm{Te}, \mathrm{Pb})_{3}(\mathrm{Cu}, \mathrm{Fe})$ \\
\hline Buckhornite & $\mathrm{AuPb}_{2} \mathrm{BiTe}_{2} \mathrm{~S}_{3}$ \\
\hline Calaverite & $\mathrm{AuTe}_{2}$ \\
\hline Cervelleite & $\mathrm{Ag}_{4} \mathrm{TeS}$ \\
\hline Csiklovaite & $\mathrm{Bi}_{2} \mathrm{TeS}_{2}$ \\
\hline Coloradoite & $\mathrm{HgTe}$ \\
\hline Emmonsite & $\mathrm{Fe}_{2}\left(\mathrm{TeO}_{3}\right)_{3} \cdot 2 \mathrm{H}_{2} \mathrm{O}$ \\
\hline Empressite & $\mathrm{Ag}_{5-\mathrm{x}} \mathrm{Te}_{3}$ \\
\hline Frohbergite & $\mathrm{FeTe}_{2}$ \\
\hline Goldfieldite & $\mathrm{Cu}_{12}(\mathrm{Te}, \mathrm{Sb}, \mathrm{As})_{4} \mathrm{~S}_{13}$ \\
\hline Grunlingite & $\mathrm{Bi}_{4} \mathrm{TeS}_{3}$ \\
\hline Hedleyite & $\mathrm{Bi}_{7} \mathrm{Te}_{3}$ \\
\hline Henryite & $\mathrm{Cu}_{4} \mathrm{Ag}_{3} \mathrm{Te}_{4}$ \\
\hline Hessite & $\mathrm{Ag}_{2} \mathrm{Te}$ \\
\hline Imgreite & NiTe \\
\hline Joseite & $\mathrm{Bi}_{4}(\mathrm{Te}, \mathrm{S})_{3}$ \\
\hline Kawzulite & $\mathrm{Bi}_{2}(\mathrm{Te}, \mathrm{Se}, \mathrm{S})_{3}$ \\
\hline Keithconnite & $\mathrm{PdTe}_{3}$ \\
\hline Kostovite & $\mathrm{CuAuTe}_{4}$ \\
\hline Kotulskite & PdTe \\
\hline Krennerite & $\mathrm{Au}_{4} \mathrm{AgTe}_{10}$ \\
\hline Mackayite & $\mathrm{Fe}_{2}\left(\mathrm{TeO}_{3}\right)_{3} n \mathrm{H}_{2} \mathrm{O}$ \\
\hline
\end{tabular}

\begin{tabular}{|c|c|}
\hline Mineral name & Chemical formula \\
\hline Maslovite & PtBiTe \\
\hline Melonite & $\mathrm{NiTe}_{2}$ \\
\hline Merenskyite & $\mathrm{PdTe}_{2}$ \\
\hline Michenerite & PdBiTe \\
\hline Moncheite & $\mathrm{PtTe}_{2}$ \\
\hline Montainite & $\mathrm{Bi}_{3} \mathrm{TeO}_{4}(\mathrm{OH})_{4}$ \\
\hline Montbrayite & $(\mathrm{Au}, \mathrm{Sb})_{2} \mathrm{Te}_{3}$ \\
\hline Museumite & {$\left[\mathrm{Pb}_{2}(\mathrm{~Pb}, \mathrm{Sb})_{2} \mathrm{~S}_{8}\right]\left[(\mathrm{Te}, \mathrm{Au})_{2}\right]$} \\
\hline Muthmannite & $(\mathrm{AuAg}) \mathrm{Te}$ \\
\hline Nagyágite & $\mathrm{Pb}_{5} \mathrm{Au}(\mathrm{Te}, \mathrm{Sb})_{4} \mathrm{~S}_{5-8}$ \\
\hline Native tellurium & $\mathrm{Te}$ \\
\hline Pašavaite & $\mathrm{Pd}_{3} \mathrm{~Pb}_{2} \mathrm{Te}_{2}$ \\
\hline Petzite & $\mathrm{Ag}_{3} \mathrm{AuTe}_{2}$ \\
\hline Poughite & $\mathrm{Fe}_{2}\left(\mathrm{TeO}_{3}\right) 2 \mathrm{SO}_{4} \cdot 3 \mathrm{H}_{2} \mathrm{O}$ \\
\hline Rickardite & $\mathrm{Cu}_{4-\mathrm{x}} \mathrm{Te}_{2}$ \\
\hline Rodalquilarite & $\mathrm{H}_{3} \mathrm{Fe}_{2}\left(\mathrm{TeO}_{3}\right)_{4} \mathrm{Cl}$ \\
\hline Rucklidgeite & $(\mathrm{Bi}, \mathrm{Pb})_{3} \mathrm{Te}_{4}$ \\
\hline Stutzite & $\mathrm{Ag}_{7} \mathrm{Te}_{4}$ \\
\hline Sylvanite & $\mathrm{AuAgTe}_{4}$ \\
\hline Teineite & $\mathrm{Cu}(\mathrm{Te}, \mathrm{S}) \mathrm{O}_{4} \cdot 2 \mathrm{H}_{2} \mathrm{O}$ \\
\hline Tellurantimony & $\mathrm{Sb}_{2} \mathrm{Te}_{3}$ \\
\hline Tellurobismuthite & $\mathrm{Bi}_{2} \mathrm{Te}_{3}$ \\
\hline Telluropalladinite & $\mathrm{Pd}_{9} \mathrm{Te}_{4}$ \\
\hline Tetradymite & $\mathrm{Bi}_{2} \mathrm{Te}_{2} \mathrm{~S}$ \\
\hline Tsumoite & $\mathrm{Bi}_{4} \mathrm{Te}_{2}$ \\
\hline Volynskite & $\mathrm{AgBiTe}_{2}$ \\
\hline Weissite & $\mathrm{Cu}_{2-\mathrm{x}} \mathrm{Te}$ \\
\hline
\end{tabular}


Tellurium is most strongly concentrated in telluride minerals, although some tellurium is also concentrated in sulfide minerals, particularly in sulfosalts, such as the mineral goldfieldite. In the gold-silver-tellurium system alone, 11 different tellurium-bearing phases have been identified (Zhang and Spry, 1994). Grundler and others (2013) indicate that calaverite typically coexists with native gold or the silverbearing tellurides krennerite and petzite, whereas native tellurium is more commonly associated with other silver-bearing tellurides, such as hessite, stutzite, and sylvanite. Where the ratios of tellurium to gold plus silver are high, bismuth-bearing tellurides, coloradoite, or goldfieldite have been shown to be the dominant tellurium-bearing phases (Grundler and others, 2013). There are numerous palladium-bearing tellurides in the lead-palladium-tellurium system, including keithconnite, kotulskite, merenskyite, pašavaite, and telluropalladinite, and these are sometimes common in magmatic copper-nickelPGM deposits (Vymazalová and Drábek, 2011). Moncheite is a common platinum host in the deposit type.

In most ore deposits, telluride minerals consistently are deposited in the later stages of paragenetic sequences; that is, they form after the deposition of many iron- and basemetal-bearing sulfides. At the tellurium-rich Cripple Creek district gold deposits in Teller County, Colorado, Lovering and Goddard (1950) and Saunders (1986) documented a relative chronology of telluride mineral deposition. Generally, with time, telluride composition shifts from gold-rich to silver-rich during these late hydrothermal events (for example, Dye and Smyth, 2012). There are exceptions, however, such as at the Tínos Island precious-metal deposit in Notío Aigaío, Greece, where a silver-to-copper-to-gold paragenetic sequence characterizes telluride deposition (Tombros and others, 2010).

Native tellurium is reported from many precious-metal deposits, including numerous gold deposits in Japan. Nakata and Komuro (2011) indicate that quartz, quartz-goldfieldite, quartz-stutzite-hessite-sylvanite-tetradymite, and quartzhessite-sylvanite-tellurantimony assemblages all contain native tellurium.

On the active sea floor along the Kermadec-Tonga trench in the Pacific Ocean, telluride minerals and native tellurium have been identified in massive chalcopyrite occurrences and in areas between sulfide chimneys of chalcopyrite and pyrite (Berkenbosch and others, 2012). Most of the telluride minerals are less than 5 micrometers in diameter, but some reach lengths of 80 micrometers. These are dominantly gold-rich (calaverite) and bismuth-rich (kawazulite, tellurobismuthite, and tetradymite) telluride minerals.

Oxidation of gold-rich tellurides can form tellurite and tellurate phases within the weathering zone. It can also lead to the formation of low reflectivity "mustard gold" through dissolution of calaverite and other gold-rich tellurides and subsequent reprecipitation processes (Zhao and others, 2009). In addition, gold pseudomorphs after tellurides may form. In the weathering environment, tellurium most likely undergoes sorption onto, and thus concentration within, clay-sized soil particles (Hayes and others, 2012)

\section{Deposit Types}

Tellurium is present in many different types of mineral deposits. The diversity of mineral deposit types in which it occurs may reflect enrichment of the element in the structure of sulfide grains or the formation of discrete tellurium-bearing minerals. The deposit types listed here are only those for which there is, has been, or is projected to be some economic interest in their tellurium content.

\section{Magmatic Copper-Nickel-Platinum-Group- Metal Sulfide Deposits}

Magmatic sulfide deposits are mafic and ultramafic igneous bodies that are enriched in copper, nickel, and (or) platinum-group metals (PGMs) (Naldrett, 2011). Little or no published information is available regarding tellurium production from and the concentration of tellurium in studied deposits of this type, but it is highly likely that these ores contribute to global tellurium production, as the tellurium is produced as a byproduct of the milling of the major mineral commodities. For example, some amount of tellurium is recovered in Russia from magmatic sulfide deposits. Telluride minerals, which contain the greatest concentrations of tellurium of any minerals, are present in many deposits of this type, but only in subeconomic quantities.

At the Sudbury district in Ontario, Canada, where Paleoproterozoic ore-related magmas were produced by shock waves from a meteor impact, hydrothermal activity in the footwall of the emplaced igneous complex has enriched the rocks with gold and PGMs. Much of the PGM mineralization is hosted in tellurium-rich phases that include kotulskite, merenskyite, and monocheite. In addition, bismuth-, mercury-, and silver-rich telluride phases have been noted (Péntek and others, 2013).

At Noril'sk in Krasnoyarskiy Kray, Russia, the magmatic copper-nickel-PGM deposits associated with the Triassic continental flood basalts have yielded minor amounts of byproduct tellurium (in the range of 5 metric tons per year) (Safirova, 2012). Tellurium of potential economic interest at Noril'sk is confined to sulfide minerals (Sindeeva, 1964). Chalcopyrite, for example, contains from 2 to $72 \mathrm{ppm}$ tellurium; pyrrhotite, from 4 to $45 \mathrm{ppm}$; pentlandite, $13 \mathrm{ppm}$; and bornite, from 10 to $15 \mathrm{ppm}$ tellurium (Sindeeva, 1964). Massive vein-type ores of copper contain the highest concentrations of tellurium, whereas disseminated ores contain lesser amounts of tellurium (from trace amounts to $12 \mathrm{ppm}$ ).

Some of the platinum and palladium resource in the Paleoproterozoic Merensky Reef in the eastern Bushveld Complex of Limpopo Province, South Africa, is contained in michenerite and maslovite, which are PGM-bearing bismuthotellurides that were suggested to have formed by remobilization of magmatic PGMs during an overprinting hydrothermal event (Rose and others, 2011). The minerals that host palladium and platinum most commonly in the Pana and Fedorov massifs of the Kola Peninsula, Russia, and the 
Great Dyke, Zimbabwe, are arsenides and bismuthotellurides (Oberthür, 2002; Mitrofanov and others, 2005). In the Late Archean Stillwater Complex in Montana, mineralized samples with as much as $182 \mathrm{ppm}$ palladium and $52 \mathrm{ppm}$ platinum also contain as much as $17 \mathrm{ppm}$ tellurium and significant amounts of arsenic and bismuth, reflecting a complex telluride mineralogy (Zientek and others, 1990).

\section{Iron Oxide-Copper-Gold Deposits}

Iron oxide-copper-gold (IOCG) deposits represent a poorly defined and understood group of deposits of mainly Precambrian age (Groves and others, 2010). They are generally defined as sulfur-poor magmatic-hydrothermal deposits with large resources of copper, gold, iron, and (or) uranium in extensional cratonic settings. There are few data on tellurium in IOCG deposits. The anode slime at the refinery of the giant Mesoproterozoic Olympic Dam deposit in South Australia, Australia, which is the world's largest identified IOCG deposit, averages about 3.5 percent tellurium (Moats and others, 2007) and is a source of some tellurium production. This indicates that the tellurium produced from Olympic Dam is recovered from the bornite, chalcocite, and chalcopyrite ore minerals. Discrete telluride phases at Olympic Dam have not been reported.

\section{Volcanogenic Massive Sulfide Deposits}

The volcanogenic massive sulfide (VMS) deposits consist of strata-bound sulfide minerals that formed at or near the sea floor in association with contemporaneous volcanism. The leading producers of tellurium in Russia are the VMS deposits in the Ural Mountains, which yield about 35 metric tons per year of tellurium (Safirova, 2012). Fine-grained telluride minerals are abundant in the Silurian and Devonian copper-zinc VMS deposits of the Urals (Vikentyev, 2006). Maslennikov and others (2013) described a variety of $\mathrm{Ag}-\mathrm{Pb}-\mathrm{Bi}-\mathrm{Te}$ and $\mathrm{Cu}-\mathrm{Ag}-\mathrm{Te}-\mathrm{S}$ solid-solution series phases and tellurium-rich sulfosalts in ancient sea-floor chimney structures. They suggest, however, that chalcopyrite is the most significant host for tellurium. In the Sibay VMS deposit in the Urals region of Bashkortostan Republic, Russia, tellurium is predominantly associated with copper ores (which average 11 ppm tellurium), whereas zinc-rich ores less frequently have detectable levels of tellurium (Sindeeva, 1964). In the Uchaly deposit, which is also located in the Urals region of Bashkortostan Republic, pyrite and pyrite-copper ores contain from 22 to $190 \mathrm{ppm}$ tellurium (Sindeeva, 1964). No production data are available for individual deposits; tellurium is recovered from electrolytic refining of the copper-rich VMS ores, but the discrete telluride phases are unlikely to be important contributors.

Some VMS deposits are transitional with telluride-bearing epithermal precious-metal mineral occurrences, including those as old as Archean (for example, Côté-Mantha and others, 2012). The poorly understood Kankberg deposit in the
Paleoproterozoic (circa 1,890 mega-annum [Ma]) Skellefteå district in Västerbotten County, Sweden, was originally mined as a copper-zinc deposit into the 1990s, and it was classified by some workers as a VMS deposit. The deposit has been reopened as a gold-tellurium mine that is projected to produce approximately 10 percent of the world's tellurium, or about 41 metric tons per year, from 2012 to 2020 (Boliden Group, 2011). Thus, Kankberg represents one of the few presently active mining operations in which tellurium is a primary product and telluride minerals are the source of the tellurium. The ore averages approximately 4.1 grams per metric ton $(\mathrm{g} / \mathrm{t})$ gold and $186 \mathrm{~g} / \mathrm{t}$ tellurium. The sea-floor deposit is thought to be rich in tellurium and is possibly a hybrid VMS-epithermal system that formed on a shallow part of the ocean floor. If this is correct, it would indicate that significant amounts of tellurium are available from sea-floor deposits and are not solely associated with the more classic subaerial epithermal ores described below (for example, Mercier-Langevin and others, 2013). Numerous VMS deposits - both ancient ones exposed on continents and modern ones presently forming on the sea floor-may thus be associated with an epithermal suite of trace elements (for example, Hannington and others, 2005; Berkenbosch and others, 2012) and potentially could be highly enriched in tellurium.

\section{Porphyry Deposits}

Tellurium is enriched in sulfide and (or) telluride phases in most copper porphyry deposits and thus may be a recoverable byproduct during milling of some of these copper ores. Porphyry deposits are shallowly formed magmatic-hydrothermal deposits typically developed in the cupolas to porphyritic intrusions within active continental margins above subduction zones. The deposits are generally characterized by stockwork veinlets rich in copper- and (or) molybdenum-bearing minerals. The principal source of tellurium in the United States and the world is as a byproduct of copper refining of ores from large-tonnage, low-grade copper and copper-gold porphyry deposits. For example, the giant Carboniferous copper porphyry deposits of the Almalyk district in Toshkent Province, Uzbekistan, are a source of recovered tellurium; the deposits were estimated to contain 1,098 metric tons of tellurium in 1996 (Levine, 2011, citing report from United States Trade and Development Agency, 1996). In the Almalyk district, average concentrations in ore were $16 \mathrm{ppm}$ tellurium at the Kal'makyr deposit and 7 to $8 \mathrm{ppm}$ tellurium at the Dalnee deposit. In the world-class Cretaceous Pebble copper-gold-molybdenum deposit in Alaska, calaverite and petzite have been observed to contain some of the gold. Gregory and others (2013) estimate that 2.5 to 3.0 percent of the gold in the deposit is hosted by the two telluride phases. These phases occur as inclusions in chalcopyrite, which is the main copper ore mineral at the Pebble deposit. The majority of what is conjectured to be an enormous tellurium endowment at the Pebble deposit is potentially hosted in the structure of chalcopyrite and pyrite, however, assuming these phases contain tellurium concentrations similar 
to sulfide minerals in many porphyry deposits, which provide much of the byproduct tellurium produced in the United States and the world. It is not clear whether tellurium recovery is planned if and when the Pebble deposit goes into production. Palladium is enriched in many porphyry copper-gold deposits, reflecting the presence of palladium-bearing telluride minerals as distinct grains or as inclusions in bornite and chalcopyrite. For example, merenskyite is a common tellurium-rich phase that is associated with lesser amounts of hessite and kotulskite in many porphyry deposits (Economou-Eliopoulos, 2005).

Eilers (1914) reported that the Tertiary Bingham Canyon deposit in Utah contained greater than 23 to $27 \mathrm{ppm}$ tellurium in blister copper (the almost pure copper produced during refining), although tellurium was not detected in the partially refined copper from the porphyry deposits at Ely, Nevada. High-grade copper-molybdenum-gold ore from Bingham Canyon has been estimated to average $4.8 \mathrm{ppm}$ tellurium (Austen and Ballantyne, 2011). Economou-Eliopoulos and Eliopoulos (2000) reported whole-rock concentrations of tellurium ranging from 0.33 to $2.7 \mathrm{ppm}$ in mineralized samples from the Skouriés deposit and the adjacent Fissoka prospect in the Peloponnísos region of Greece. Tokmakchieva (2002) and Tarkian and others (2003) reported as much as $106 \mathrm{ppm}$ tellurium in ore samples from the Elatsite deposit in Sofiya, Bulgaria. Economou-Eliopoulos and Eliopoulos (2000) also estimated concentrations of 4.0 and $18.5 \mathrm{ppm}$ tellurium in two samples of chalcopyrite from the Skouriés deposit. Reported differences in concentrations from the deposits likely reflect sampling variability; higher concentrations result from analyses of samples of mainly copper-bearing sulfide minerals that may contain hundreds of parts per million tellurium, whereas samples of sulfide minerals in wallrock would have much lower concentrations.

Although the main copper \pm gold ores in porphyry deposits at Ely, White Pine County, Nevada, are not enriched in tellurium, mineralized rock in the silver-rich halo is highly anomalous in tellurium, averaging about $100 \mathrm{ppm}$ tellurium (Gott and McCarthy, 1966). Watterson and others (1977) also found high concentrations of tellurium in silicified rocks in a halo surrounding the copper ores. Chaffee (1982) identified two zones with anomalous whole-rock tellurium at the Kalamazoo deposit in Pinal County, Arizona. The highest concentrations of tellurium were present in the outer pyritic halo of the porphyry deposit, whereas lower anomaly values corresponded with the copper-gold ore zone. Cox and others (1975) identified a similar zonation at the Sapo Alegre deposit in Puerto Rico. Therefore, although much of the present tellurium production is a byproduct from copper production from porphyry copper ores, future primary resources may be considered in the alteration halos of many porphyry deposits if tellurium demand increases. Because tellurium is relatively volatile compared with many other elements, it is not surprising that there are high tellurium concentrations in alteration zones surrounding the main bulk-minable copper resources.

Many of the porphyry systems with abundant telluride minerals are specifically associated with subduction-related alkalic porphyritic intrusions. These include those of the Late Triassic-Early Jurassic continental arc in British Columbia, Canada. The Mount Milligan copper-gold deposit, which is one of the larger deposits of the group, is characterized by a late-stage "subepithermal" or intermediatesulfidation overprinting event that deposited an Au-PGM-As$\mathrm{Sb}-\mathrm{Bi}-\mathrm{Te}-\mathrm{Hg}$ assemblage, perhaps by way of vapor transport (LeFort and others, 2011). Many gold-rich epithermal deposits, particularly those related to alkalic igneous rocks, contain significant tellurium concentrations and may reflect late-stage events in an evolving porphyry-epithermal magmatic-hydrothermal system. The La Plata deposit in La Plata County, Colo., may be such an example, where goldtelluride vein and replacement deposits surround an alkaline intrusion that is rich in gold and copper (Jones, 1992).

Some workers have suggested that epithermal gold-silver-tellurium mineralization is closely linked to the more molybdenum-rich alkalic porphyry deposits (Rice and others, 1985; Saunders, 1991). Spry and others (1996), for example, described the Golden Sunlight deposit in Jefferson County, Montana, as an epithermal gold deposit that developed in alteration surrounding an alkaline, low-grade molybdenum-bearing Late Cretaceous porphyry intrusion. They described bismuth-, gold-, and silver-rich telluride minerals in a breccia pipe that overprints the earlier stockwork molybdenum mineralization and represents the later stages of a magmatic-hydrothermal system. Whether or not tellurium is also concentrated in early-stage molybdenite and is recovered as a byproduct from milling of molybdenum porphyry deposits is uncertain. In the United States, all tellurium production is from ASARCO LLC's copper refinery in Amarillo, Texas, which processes copper ore but not molybdenum ore (David A. John, Research Geologist, U.S. Geological Survey, written commun., 2013); consequently, porphyry molybdenum deposits located in the Rocky Mountains of Colorado are not a present-day source of domestic tellurium production.

\section{Skarn Deposits}

Copper-bearing skarn deposits that were formed in areas of replacement of carbonate rock by garnet, pyroxene, and other calc-silicate minerals commonly are associated with porphyry copper deposits where carbonate rocks are part of the country-rock assemblage. Fuertes-Fuente and others (2000) report hedleyite in the Ortosa deposit in Asturias, Spain, and Prendergast and others (2005) report altaite, hessite, petzite, and tetradymite in the Big Gossan and Wanagon skarn deposits in the Ertsberg district of Papua Province, Indonesia. In the Darwin district of Inyo County, California, bismuth tellurides, rickardite, and tellurium-rich sulfosalts occur (Afifi and others, 1988). In many gold-rich skarns, bismuth and tellurium are both enriched (for example, at the Hedley deposit in British Columbia, Canada [Meinert, 2000]; the Fortitude deposit in Lander County, Nev. [Meinert, 2000]; the Stormont deposit in Tasmania, Australia [Cockerton and Tomkins, 2012]; and the Geodo deposit in Gangwon, Republic of Korea [Kim and 
others, 2012]). It is unknown whether skarns contribute to any of the world's tellurium production. If large refineries that recover copper from numerous porphyry deposits also handle some ores from surrounding skarns, then potentially some byproduct tellurium may have been produced from the skarns.

\section{Epithermal Deposits}

Epithermal gold and silver deposits may or may not be associated with porphyry deposits. They are more shallowly formed deposits commonly consisting of veins associated with volcanic activity. Tellurium typically is more abundant and tellurium-bearing minerals are more diverse in epithermal deposits than in porphyry and other types of magmatic deposits. Tellurium in epithermal deposits occurs in telluride minerals, as native tellurium, and as tellurium-bearing sulfosalts in unoxidized ores, as well as in the form of tellurites in secondary ores. Tellurium is enriched in both main subclasses of the epithermal type; that is, the so-called high-sulfidation and low-sulfidation epithermal varieties (for example, White and Hedenquist, 1990). The high-sulfidation subclass, which is spatially associated in many instances with porphyry deposits (Simmons and others, 2005), typically is characterized by an alteration assemblage that includes alunite, kaolinite, quartz, and pyrophyllite. The low-sulfidation subclass is typically characterized by an alteration assemblage that includes adularia, quartz, and sericite (illite). Some epithermal districts contain both high-sulfidation and low-sulfidation types of ores.

Low-sulfidation epithermal deposits occur with a wider variety of igneous rock compositions than do high-sulfidation deposits, but they also occur in some hydrothermal systems that lack any obvious magmatic input. Tellurium-bearing minerals may constitute economically significant gold ores, such as at deposits in the Cripple Creek district of Teller County, Colo., or they may be minor accessories, such as at deposits in the Telluride district of San Miguel County, Colo. Although not in all cases, economically significant tellurium-bearing ores occur in epithermal-like veins with a polymetallic character, which are sometimes referred to as intermediate-sulfidation epithermal deposits; that is, they contain significant amounts of copper, lead, and zinc sulfide and sulfosalt minerals, and are sometimes considered a transitional deposit type between epithermal and porphyry ores (Simmons and others, 2005).

Most epithermal deposits are associated with subductionrelated oceanic or continental magmatic arcs. One subtype of the low-sulfidation-type gold-silver epithermal deposit is associated with alkaline to subalkaline, light-rare-earthelement-enriched magmatism in back-arc and post-subduction settings, and is notably enriched in tellurium (Jensen and Barton, 2000; Kelley and Spry, 2016). These alkaline gold deposits include those of (a) the Rocky Mountain System of the United States (for example, the Zortman-Landusky district in Phillips County, Mont.; the northern Black Hills of South Dakota; the Cripple Creek district in Teller County, Colo.; and the Ortiz Mountains of New Mexico), (b) the Himalayan foreland of southwestern China (for example, the Dashuigou deposit and the Majiagou deposit [Sichuan Province]) (Mao and others, 2002), and (c) Papua New Guinea and Fiji (for example, in Papua New Guinea, the Porgera deposit in Enga Province, the Mt. Kare deposit in Enga Province, and the Lihir deposit in New Ireland Province; and in Fiji, the Emperor deposit in Viti Levu). In the Cripple Creek district, Gott and others (1967) reported the district-wide background as $2.7 \mathrm{ppm}$ tellurium in volcanic rocks, with an average value of $10.7 \mathrm{ppm}$ tellurium in areas of anomalous gold. In China, the adjacent Dashuigou and Majiagou deposits are rare examples in which tellurium is the main ore commodity; it is recovered mainly from tetradymite. Many deposits in this alkaline subtype are typically characterized by a fluorine-gold-tellurium-vanadium magmatic-hydrothermal geochemical signature (Jensen and Barton, 2000; Simmons and others, 2005).

Saunders and Brueseke (2012) suggested that alkaline, tellurium-rich low-sulfidation epithermal deposits of the Western United States are preferentially located over Precambrian basement rocks east of the initial ${ }^{87} \mathrm{Sr} /{ }^{86} \mathrm{Sr}=0.706$ isopleth. They show a distinct break in epithermal ore geochemistry, as tellurium is more abundant than selenium to the east and selenium is more abundant than tellurium to the west of the ancient cratonic margin. The tellurium-rich epithermal province, which extends from Montana to New Mexico, has mainly alkalic magmatism, whereas the seleniumrich ores occur with more typical calc-alkaline rocks. Saunders and Brueseke (2012) related the different patterns to differences in the volatility of the metalloids within a subducting Laramide slab; less volatile tellurium is released later and at greater depths, and thus further inboard than the selenium. There are, however, notable exceptions to this pattern, including tellurium-rich low- and high-sulfidation gold ores at Bodie in eastern California (David A. John, Research Geologist, U.S. Geological Survey, written commun., 2013).

About 5 metric tons of tellurium were produced in the early 1960s from the Lone Pine deposit in the Wilcox district in Catron County, New Mexico, where fluorite, gold, and silver have also been recovered in minor amounts (Lueth and others, 1996). Low-sulfidation ores are hosted by Oligocene rhyolitic intrusions in a caldera ring complex. Telluride minerals (krennerite?) and native tellurium are reported. The weathering of pyrite and native tellurium led to formation of many different iron tellurate minerals. The original hypogene telluride mineralization was best developed at the pyritefluorite transition, where the deposit was upwardly zoned from pyrite to pyrite-tellurides to fluorite (Lueth and others, 1996).

Pals and Spry (2003) report that telluride minerals associated with alkaline magmatism account for 10 to 50 percent of the gold in the Emperor deposit at Vatukoula in Fiji's Western Division. Sylvanite is the main precious-metal-hosting phase, although the epithermal ores also include benleonardite, coloradoite, and native tellurium. Grab samples of these ores contain as much as $345 \mathrm{ppm}$ tellurium, which correlates with very high concentrations of fluorine, gold, selenium, and silver (Kwak, 1990). 
The Dashuigou deposit in the alkalic magmatic province of southwestern China (Sichuan Province) hosts a reported 9,400-metric-ton indicated resource averaging 1.40 percent tellurium and a 20,800-metric-ton inferred resource averaging 0.51 percent tellurium, for a total resource of 240 metric tons of tellurium. The indicated and inferred resources at the similar nearby Majiagou deposit in Sichuan Province contain an estimated 272 metric tons of tellurium; the average grade of the resources is about 2 percent tellurium. The ores contain even larger bismuth resources, reflecting the composition of the tetradymite $\left(\mathrm{Bi}_{2} \mathrm{Te}_{2} \mathrm{~S}\right)-59.27$ percent bismuth, 36.19 percent tellurium, and 4.55 percent sulfur, by weight (Behre Dolbear Asia Inc., 2009). The tellurium resource occurs in low-sulfidation epithermal veins with highly variable grades that locally reach 8 percent tellurium (Behre Dolbear Asia Inc., 2009). Many parts of the orebodies consist of massive pyrrhotite, which were previously mined for iron. The ores also contain anomalous gold, which is interpreted to have been deposited after both the tellurium-bearing phases and native tellurium (Mao and others, 2002). The current annual production of these two deposits is unknown, but Anderson (2015) estimated it to be between 10 and 30 metric tons per year of tellurium.

Cook and Ciobanu (2005) importantly stressed that although there is definitely a common genetic link between tellurium-bearing gold deposits and alkalic magmatism, many low-sulfidation epithermal systems with significant volumes of telluride minerals are also associated with normal calc-alkaline magmatism. For example, calc-alkaline-related telluride ores are diverse and were historically economic across a 600-square-kilometer area in the Munţii Metaliferi (Metaliferi Mountains) in western Romania, which is one of Earth's richest epithermal ore regions (Alderton and Fallick, 2000). The western Romania telluride minerals include hedleyite, rucklidgeite, and tsumoite, which are not common in most tellurium-rich epithermal deposits and tend to occur in the shallowest parts of the deposits (Cook and Ciobanu, 2004). Over several centuries, until 1941, the Sacarimb deposit, which is located in Hunedoara County in the Metaliferi Mountains, is estimated to have cumulatively produced 30 metric tons of gold, 85 metric tons of silver, and 60 metric tons of tellurium from ores that averaged $20 \mathrm{~g} / \mathrm{t}$ tellurium and $10 \mathrm{~g} / \mathrm{t}$ gold. Ore minerals were mainly nagyagite and sylvanite that were deposited in Neogene calc-alkaline volcanic rocks (Popescu and Neacsu, 2004). This deposit is also the type locality for krennerite, museumite, muthmannite, nagyágite, petzite, and stutzite. The telluride minerals were deposited at temperatures of between 200 and $300{ }^{\circ} \mathrm{C}$ from very dilute hydrothermal solutions (Cook and others, 2005).

Other low-sulfidation epithermal deposits with an abundance of telluride minerals could be future sources of tellurium resources. For example, the Jefferson gold-silver project, which is located a few kilometers east of the giant Round Mountain low-sulfidation epithermal deposit in Nye County, Nev., has also been evaluated as a primary tellurium resource (Mexivada Mining Corp., 2008). This evaluation is still very speculative, however, as such a possibility is based solely upon a small number of drill intersections with assays of tens to hundreds of parts per million tellurium.

High-sulfidation epithermal deposits are a significant gold source, and some have produced appreciable amounts of copper (for example, the Lepanto deposit in Benguet Province, Philippines, and the El Indio deposit in the Coquimbo region of Chile). The deposits are synvolcanic in the centers of andesite-dacite volcanic complexes. Copper-arsenic-antimony sulfosalts are the principal copper-bearing minerals. Tellurium commonly substitutes for arsenic and antimony in tennantite locally and in sufficient abundance to form the tellurian endmember goldfieldite. In all well-studied high-sulfidation epithermal deposits, precious-metal telluride minerals have been documented, although they are generally less economically important than native gold and electrum. At the El Indio deposit, native tellurium is associated with high-sulfidation alteration (Siddeley and Araneda, 1986).

Kesler and others (2003) documented the distribution of tellurium in the high-sulfidation epithermal deposits of the Pueblo Viejo district in Sánchez Ramírez Province, Dominican Republic. They concluded that tellurium appears to increase steadily upward in the deposit. In the district's Monte Negro orebody, higher tellurium concentrations generally correspond to higher gold concentrations, and both increase steadily upward in the deposit. Lehmann and others (1999) discussed the abundance of telluride minerals in the Bereznyakovskoe high-sulfidation epithermal deposit in Chelyabinskaya Oblast' in the Urals. They noted that precious-metal mineralization was associated with a tetrahedrite-telluride hydrothermal stage, and that mineralized and altered rock varied from tens to hundreds of parts per million tellurium. At the Lepanto deposit, Benguet Province, Philippines, enargite grains were noted to contain many hundreds of parts per million tellurium (Deyell and Hedenquist, 2011). Chaffee and others (1981) analyzed stream sediment samples from the Patagonia Mountains in Arizona and found tellurium anomalies ( $>399 \mathrm{ppb})$ consistently associated with high-sulfidation alteration, as well as a high local background of 100 to $399 \mathrm{ppb}$ tellurium and a broader regional background of 15 to $99 \mathrm{ppb}$ tellurium in samples more distal to the mineralization.

The variety of telluride minerals in high-sulfidation deposits is not extensive. The common telluride minerals are calaverite, hessite, krennerite, petzite, and sylvanite. Arribas and others (1995) reported the occurrence of the secondary tellurite minerals blakeite, emmonsite, and rodalquilarite at Rodalquilar, Andalucia, Spain.

The Deer Horn intermediate-sulfidation epithermal deposit in west-central British Columbia, Canada, contains high gold and silver grades with abundant base-metal sulfides and telluride minerals. A National Instrument (NI) 43-101 resource evaluation (Deer Horn Metals Inc., 2012) suggested resources of 66 metric tons of tellurium, as well as 2,100 kilograms $(\mathrm{kg})(68,000$ troy ounces) of gold and $65,000 \mathrm{~kg}$ (2.1 million troy ounces) of silver. Tellurium concentrations in drill intercepts with the highest 
precious-metal grades are generally 150 to $250 \mathrm{ppm}$, and some of the highest values were in the thousands of parts per million tellurium; analyses of these zones indicate a silver-to-tellurium ratio that is generally about $1: 1$.

The Sandaowanzi intermediate-sulfidation epithermal deposit in Heilongjiang Province is one of the many extension-related Early Cretaceous epithermal and porphyry deposits of northeastern China. The deposit contains more than 15 metric tons of gold and has been mined since 2006. It is almost entirely characterized by micrometer- to millimetersize disseminated and quartz vein-hosted, coarse-grained silver- and gold-bearing telluride minerals, with lesser amounts of lead- and mercury-bearing telluride minerals; the largest grains are 3 centimeters in diameter (Liu and others, 2011, 2013). Tellurium is likely being recovered, although the amount being recovered is not available.

Some tellurium-rich deposits have descriptive attributes of both low- and high-sulfidation deposits; for example, the deposit at Kochbulak in Toshkent Province, Uzbekistan. Here, the telluride mineral assemblage is more diverse than is typical of high-sulfidation deposits, and the tellurium content of ores averages $101.6 \mathrm{ppm}$ (Plotinskaya and others, 2006). In the Baguio district, Benguet Province, Philippines, both intermediate- and high-sulfidation epithermal mineral deposits are present, whereas abundant telluride minerals are associated only with the advanced argillic alteration in the high-sulfidation ores.

\section{Orogenic Gold Deposits}

Structurally controlled gold deposits in metamorphic rocks, or orogenic gold deposits, may contain high abundances of tellurium-bearing mineral phases. High concentrations of tellurium are present in both Precambrian deposits in greenstone belts and in Phanerozoic gold deposits hosted in metasedimentary rock-dominant orogens. Similar to the epithermal deposits, these concentrations of tellurium have so far not been recovered during gold mining, although goldbearing tellurides can constitute a significant amount of the recovered gold ore. In many districts, specific deposits hosted by local intrusions, rather than those in widespread metavolcanic or metasedimentary country rocks, tend to contain a high abundance of telluride minerals (see the discussion of Kirkland Lake and Kensington below), suggesting that oxidation of ore fluids by the felsic to intermediate igneous rocks provides, in some cases, a major control on destabilizing hydrothermal tellurium complexes. Abundant tellurides and the presence of hydrothermal hematite in other deposits, such as the Golden Mile deposit in Western Australia, Australia, and the Commoner deposit in Mashonaland West, Zimbabwe, also suggest some degree of oxidation of the ore fluids.

The world's largest Archean orogenic gold deposit, the Golden Mile, which is hosted in mainly mafic metavolcanic rocks of the Yilgarn Craton of Western Australia, contains 1,500 metric tons of gold. Although the majority of the ore is hosted in arsenic-rich pyrite, about 20 percent of the resource is hosted in late-stage telluride minerals (Lindgren, 1906; Mueller and Muhling, 2013). Many of the higher-grade gold zones contain hundreds of parts per million tellurium. Recognized minerals that concentrate gold, mercury, and (or) silver, as well as the tellurium, include calaverite, coloradoite, hessite, and petzite, with a total of 19 distinct telluride phases identified. Mueller and Muhling (2013) described a zoning of telluride minerals that progressed from a core of calaverite to hessite to an outer, very late coloradoite zone. Shackleton and others (2003) noted the telluride minerals occur as fine-grained composite aggregates, massive segregations, composite grains with native gold, inclusions in and intergrowths with pyrite and tetrahedrite-group minerals, or inclusions in carbonates, quartz, and tourmaline. Eilu and others (1998) measured tellurium anomalies of greater than $10 \mathrm{ppm}$ in mafic volcanic rocks for more than 100 meters $(\mathrm{m})$ beyond the Western Australia ore zones and suggested that tellurium is a very important geochemical pathfinder for orogenic gold in the Yilgarn Craton.

Similarly, many of the world-class Archean gold deposits of the Abitibi and Yellowknife greenstone belts in Canada may have elevated concentrations of tellurium, typically in goldbearing telluride minerals. Telluride minerals are common in deposits in the Kirkland Lake and Red Lake districts of Ontario, Canada. As in other deposits, the tellurides, as well as much of the gold, are typically paragenetically late stage (for example, Thomson, 1928). Native gold in the syenitehosted gold-bearing veins at the Kirkland Lake deposit occurs with altaite, calaverite, coloradoite, and petzite, as well as sericite. Highest grade ore samples of about 200 to $400 \mathrm{ppm}$ gold also contain about 200 to $500 \mathrm{ppm}$ molybdenum and 300 to $700 \mathrm{ppm}$ tellurium, with a typical gold-molybdenumtellurium signature interpreted as representing an alkali magmatic ore fluid source that is unusual in the district (Ispolatov and others, 2008). Boyle (1979) reported that the tellurium in the ores of the Yellowknife mining district in Northwest Territories, Canada, contained, in the main sulfide stage, as much as 1,000 ppm tellurium in galena, $100 \mathrm{ppm}$ tellurium in stibnite, and $100 \mathrm{ppm}$ tellurium in lead-bearing sulfosalt minerals.

A strong gold-tellurium association is also recognized at Ashanti in Western Region, Ghana, which hosts the world's largest Paleoproterozoic orogenic gold deposit. Four microscopic telluride minerals (altaite, coloradoite, hessite, and petzite) and seven submicroscopic telluride minerals have been analyzed at Ashanti within a hematite-quartz-telluride assemblage; the assemblage was deposited with minor amounts of native gold that formed after an earlier event that deposited the bulk of the gold ore (Bowell and others, 1990). The telluride mineral distribution is zoned from an inner coloradoite-rich assemblage in the veins to an assemblage dominated by altaite along the vein walls and in the country rocks. The late telluride event was shown to reflect a cooling of fluid temperature and associated oxidation, because hypogene hematite and goethite were deposited with the telluride minerals. 
The Phanerozoic deposits in accreted metasedimentary rock belts are also commonly characterized by an abundance of gold- and silver-rich telluride minerals. Altaite, calaverite, melonite, petzite, and sylvanite are associated with the main mineralization event that formed the gold veins, stockworks, and breccias in the early Paleozoic clastic rocks at the Kumtor deposit, Ysyk-Kol Oblusu, Kyrgyzstan (Ivanov and others, 2000). The Cretaceous California Mother Lode deposits have been long recognized for their common gold-, lead-, nickel-, and silver-bearing telluride minerals that are associated with native gold (Turner and Becker, 1894). As noted above, intrusions emplaced into these terranes, which are often structurally favorable hosts for the vein deposits, tend to have greater abundances of telluride minerals. The Eocene Kensington gold deposit in the Juneau gold belt, southeastern Alaska, is dominated by veins within an intermediate stock with native gold, calaverite, and petzite, and lesser amounts of alatite, hessite, sylvanite, tellurobismuthite, and volynskite (Casey, 2000). Much of the gold endowment is hosted in the two main telluride minerals. Similarly, the tonalite-hosted Willow Creek district in the Matanuska-Susitna Borough of south-central Alaska contains abundant telluride minerals in the main ore assemblage; coloradoite is the dominant mineral, and altaite and nagyagite occur in lesser amounts (Burleigh, 1987). Interestingly, the main gold ores of the Grass Valley district of Nevada County, Calif., are hosted by north-striking veins cutting granodiorite, but these lack telluride minerals; only auriferous east-west-striking veins in adjacent mafic and ultramafic country rocks contain lead- and silver-bearing telluride minerals (Johnston, 1940).

Many Russian and central Asian Phanerozoic gold deposits report significant platinum and palladium grades. Whereas some of this may reflect high backgrounds of PGMs in black shale host rocks, some PGMs are clearly associated with numerous tellurium-bearing minerals. For example, at the Sukhoi Log gold deposit in Irkutskaya Oblast', eastern Russia, palladium-bearing telluride minerals are present, as well as many bismuth-, gold-, lead-, and silver-rich telluride minerals (Distler and Yudovskaya, 2005).

Low-grade $(<1 \mathrm{~g} / \mathrm{t}$ gold $)$ disseminated-style mineralization is associated with the bulk-tonnage open pit mining operations along the Mojave-Sonora megashear zone in northern Sonora, Mexico. A small, recently worked underground operation along the southeastern side of the shear zone, the La Bambolla deposit in the Moctezuma district (Mexivada Mining Corp., 2008; E.O. Monteagudo, unpub. data, 2009) developed ores from gold-hematite-quartzpyrite-telluride veins, which averaged, in order of value, $4 \mathrm{~g} / \mathrm{t}$ gold, $5 \mathrm{~g} / \mathrm{t}$ silver, and $2.5 \mathrm{~g} / \mathrm{t}$ tellurium; it is not clear, however, whether any of the tellurium was recovered along with the precious metals. Some mineralized grab samples were reported to contain as much as 3.2 percent tellurium. Although classification of this deposit is not clear, it occurs in a belt of orogenic gold deposits, and La Bambolla would be one rare example of an orogenic gold deposit from which tellurium is produced as a primary commodity.

\section{Carlin-Type Gold Deposits}

The Carlin-type gold deposits in Nevada are Tertiary replacement ores in carbonate-dominant rock sequences that have undergone decarbonization and sulfidation, and ores occur as submicron-sized gold in disseminated pyrite. In contrast to the epithermal and orogenic gold ores, Carlin-type ores are not widely recognized for containing abundant telluride minerals. In part, this may reflect the exceptional fine-grained nature of the ores, so that the telluride minerals are rarely visible. Nevertheless, Harris and Radtke (1976), in one of the first geochemical studies of the Carlin gold deposit itself (which is located in Eureka County, Nev.), indicated a strong gold-tellurium correlation, which would favor the presence of telluride minerals in this deposit type. Emsbo and others (2003) noted minor amounts of telluride minerals and as much as $130 \mathrm{ppm}$ tellurium in ore-related pyrite in the Meikle deposit of Elko County, Nev. Cail and Cline (2001) report values for ores of as much as $180 \mathrm{ppm}$ tellurium in the Getchell trend in Humboldt County, Nev., and Heitt and others (2003) indicate as much as 84 ppm tellurium at the Deep Star deposit in Eureka County, Nev. Ore-stage pyrites in the Carlin ores may contain thousands of parts per million tellurium (Muntean and others, 2011).

Whereas telluride minerals are typically not reported from the classic Carlin ores in Nevada, the Carlin-like Zarshuran deposit in West Azerbaijan Province, Iran, contains coloradoite and tellurium-bearing orpiment that were deposited with arsenian pyrite during the main gold event (Asadi and others, 2000). This could suggest either variability in the metal source or hydrothermal fluid chemistries among Carlin-type gold deposits, or more-significant differences in deposit type than originally thought between the defined Carlin deposits of Nevada and the Zarshuran ores.

\section{Resources and Production}

\section{Identified Resources and Reserves}

Specific global and domestic sources for tellurium are very poorly known because tellurium is mostly a byproduct of the mining of a number of different base-metal-rich deposit types. Tellurium concentrations are highest in precious-metalbearing deposits that contain abundant telluride minerals; these deposits, however, currently are not significant sources of tellurium because the ore-processing method to extract gold and silver is not amenable to tellurium recovery. Instead, tellurium concentrated in sulfide minerals in base-metal-rich deposits is the current main source of tellurium because the refining process for such base-metal-rich ores is amenable to tellurium recovery. The only certain present-day primary sources for tellurium ore are the Kankberg VMS deposit in Västerbotten County, Sweden, which produces about 10 percent of the world's tellurium, and the Dashuigou and Majiagou epithermal deposits in China, which together produce from 2 to 7 percent of the world's tellurium (fig. R1). 
Whether the orogenic gold-tellurium deposits in Sonora, Mexico, are also active primary tellurium producers is not clear (for example, La Bambolla with a possible eastern extension at AuroTellurio). Importantly, prior to leaching and recovery, most gold ores are roasted or subjected to other pre-leaching processes. Tellurium is not recovered during this pretreatment and is typically lost from later recovery.

The availability of economically recoverable tellurium depends on the production of copper as a (or the) primary product. Reliance on mining tellurium as a primary material would drastically increase its cost. At least 75 percent of the world's recovered tellurium is produced as a byproduct of copper mining, although not all the mined tellurium is recovered at the copper refineries (Anderson, 2015). Tellurium can only be extracted from copper that is refined by the electrolytic process, a technique that is cost-effectively applied to high-grade copper ores (Moss and others, 2011). In such a process, tellurium and other impurities, such as gold, silver, and platinum, are concentrated at and removed from the crude copper anodes. Typically, the slimes contain from 1 to 4 percent tellurium, although as much as 8 to 9 percent tellurium in the slimes has been reported at some refineries. These numbers reflect a recovery rate of a little less than 50 percent of the available tellurium within the slimes. For refining lower grade copper ores, the most economical process is the solvent-leach refining process, which is currently not capable of recovering tellurium. The global decrease in the supply of high-grade copper ores may constrain the future supply of tellurium from copper (Moss and others, 2011). In addition to copper refineries, as much as 8 to 10 percent of the world tellurium supply is recovered from lead refinery skimming and from the flue dust and gases of copper smelting (Moss and others, 2011). Not only are data from many of these milling operations unavailable, but also little information about the source of the ores is available. Concentrates are commonly shipped to a mill in a different country than that in which the ore is mined and, therefore, the original source of the recovered tellurium is not known.

A small amount of tellurium is currently recovered from recycled sources, such as selenium-tellurium solar cells. The leading cadmium-tellurium solar cell manufacturer has a freeof-charge recycling program for discarded photovoltaic solar cell panels, which could become more important in the future. When large volumes of currently installed panels reach their end-of-life stage, they will be recycled for secondary tellurium or cadmium-tellurium. Pilot recycling facilities recover as much as 95 percent of semiconductor material and can provide feedstock for future production of photovoltaic solar panels (Moss and others, 2011).

In the United States, tellurium demand is met partly domestically and partly by imports. Almost all the domestic commercial-grade tellurium production is from ASARCO's copper refinery in Texas, where it is recovered as a byproduct of copper anode slimes and lead refinery skimming. Resulting exports from the United States in 2012 were 47 metric tons of tellurium, whereas 36 metric tons of tellurium was imported from refineries abroad. About 66 percent of the tellurium was imported from China and Canada, and lesser amounts were imported from the Philippines and Belgium (George, 2014b).

Global reserves of tellurium were 24,000 metric tons in the beginning of 2014, which includes estimates of 3,600 metric tons in Peru, 3,500 metric tons in the United States, and 800 metric tons in Canada (George, 2014b). The lack of reserves in Chile is surprising, given that its porphyry deposits make Chile the world's leading copper producer; this indicates the lack of publicly available data for Chile, which also is characteristic of much of the global tellurium supply. Refineries around the world are estimated to produce 450 to 470 metric tons of tellurium annually as tellurium metal, crude tellurium dioxide, or crude copper telluride; the latter two commodities must be further processed to produce tellurium metal. Data for tellurium metal recovered in specific countries in 2010 include 41 metric tons from Sweden, 40 metric tons from Japan, 35 metric tons from Russia, 30 metric tons from Peru, more than 30 metric tons from China, and 6 to 10 metric tons from Canada. Data from the United States are proprietary, but the British Geological Survey estimates that 50 metric tons of tellurium are recovered in the United States (Brown and others, 2013). Other production of tellurium metal comes from refineries in Australia, Belgium, Chile, Colombia, Germany, Kazakhstan, Mexico, the Philippines, and Poland. Estimated refinery production by world region is shown in figure R4.

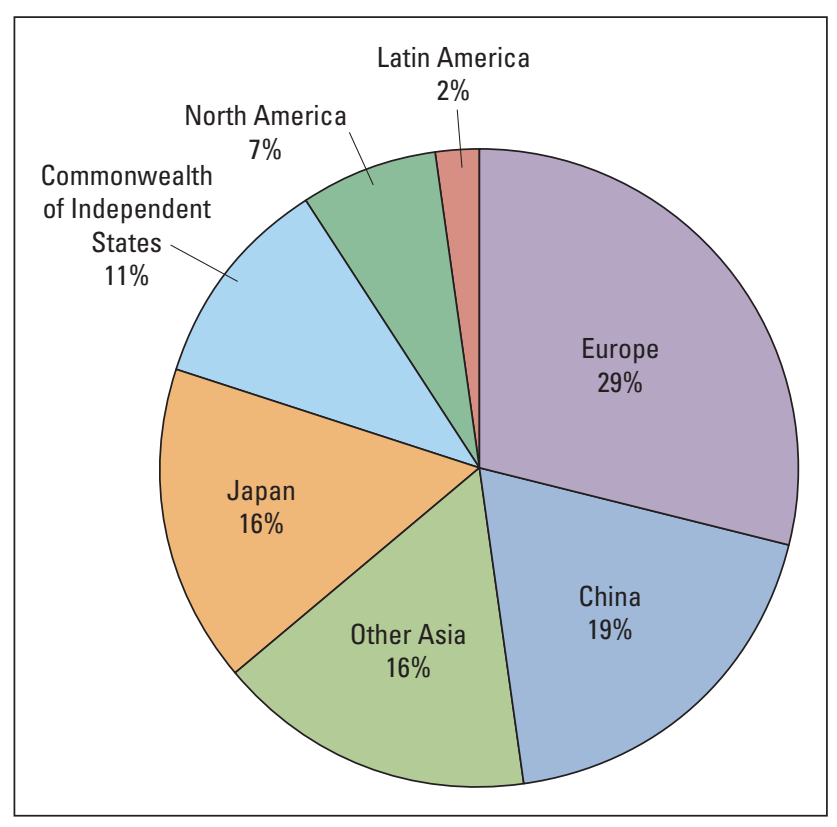

Figure R4. Pie chart showing percentage of estimated world tellurium refinery production in 2013, by country or region. Except for two primary producers in Sweden and China, which may contribute 15 percent of the annual global production of approximately 450 to 470 metric tons of tellurium, the majority of global production is as a byproduct from the refining of copper and other base-metal ores. Compiled using data from various sources, including George (2014a). 


\section{Undiscovered Resources}

There are no available estimates of undiscovered resources of tellurium. Hypothetically, existing waste piles from the milling of large-tonnage copper, iron, and other massive base-metal orebodies may contain economically recoverable amounts of tellurium. Maness (2010) suggests a potential for economic amounts of tellurium, as well as for other critical and near-critical elements, could exist in waste from massive sulfide ores in locations such as the Ducktown (Tennessee), Leadville (Colorado), and Joplin (Missouri) districts, as well as high-sulfur coal waste dumps in the United States. He pointed out that the world's best potential source for such elements could be the giant copper-slag heaps on the island of Cyprus from centuries of mining. Detailed analytical studies of sulfide-rich waste material in such old mining camps could fingerprint areas in the United States and elsewhere with the highest potential as future sources of readily recoverable tellurium (Cone, 2013).

Whereas only a few gold deposits worldwide are producers of tellurium, abundant gold-telluride minerals are the one viable source for the mining of primary tellurium ores. As noted previously, most (likely as much as 80 to 85 percent) of the world's tellurium is produced from anode slimes collected during the electrolytic refining of copper. If, however, the more economical solvent-leach procedure is increasingly used in the future to recover lower grades of copper from porphyry and other large-tonnage deposits, which is a process that does not recover tellurium, then additional high-grade, telluriumrich gold deposits may become new primary sources for tellurium. This is likely particularly true of the epithermal gold deposits associated with alkaline magmatism, such as those in the Cripple Creek district of Teller County, Colo. Improved extraction techniques for the recovery of tellurium from telluride-mineral-rich ores, coupled with lesser amounts of tellurium recovered from electrolytic refining, could lead to the production of tellurium from ore milled at deposits such as Cripple Creek.

Unconventional resources of tellurium in the world's oceans may become economic in the future should sea-floor mining become feasible. As pointed out by Hein and others (2013), iron-manganese crusts that precipitate onto the surface of seamounts, ridges, and plateaus at depths of 400 to $7,000 \mathrm{~m}$ can contain tens of parts per million tellurium. This is about three orders of magnitude greater than concentrations found in tellurium-enriched marine black shales that are now preserved on continents. It is possible that, in future decades, the global tellurium demand could be met by recovery of tellurium-rich crusts from some of the shallower marine operations.

\section{Exploration for New Deposits}

Watterson and others (1977) point out that tellurium is a useful pathfinder element to aid in the exploration for the many types of ore deposits described above. They define well-developed tellurium dispersion halos associated with porphyry, epithermal, and polymetallic vein deposit types. In the weathering zone, tellurites (for example, emmonsite and poughite) become enriched relative to sulfates because sulfates are much more soluble. They note that average concentrations of about $2 \mathrm{ppm}$ tellurium occur in gossans surrounding the porphyry copper ores in Ely, Nev. Anomalous tellurium was detected surrounding silver-lead-zinc veins in central Colorado more than a few hundred meters beyond any visible alteration (Watterson and others, 1977). Values of as much as $1 \mathrm{ppm}$ tellurium in stream sediments were noted to be excellent indicators of upstream gold-bearing telluride ores in the southwestern Pacific epithermal deposits (Rytuba and Miller, 1990). Tellurium gave the broadest halos of any pathfinder surrounding orogenic gold deposits in Western Australia, Australia (Eilu and others, 1998).

These tellurium anomalies obviously do not indicate ore deposits with tellurium as a main commodity, but rather, deposits of a variety of types where tellurium could be present at levels that would make it an important recoverable byproduct. Because tellurium as a primary commodity is extremely rare, exploration for "tellurium deposits" is essentially almost never undertaken by the private sector. Geochemical ore pathfinder elements and geophysical exploration techniques will differ by mineral deposit type, and because tellurium can be enriched in many common varieties of hydrothermal ore deposits, specific exploration guides for potential tellurium deposits are not definable.

\section{Environmental Considerations}

The environmental characteristics of tellurium extraction are closely linked to those associated with the mining of the two types of copper deposits that represent its main sources: porphyry copper and VMS deposits. These two deposit types differ from one another significantly in terms of their geology and their environmental characteristics. Tellurium also occurs at elevated concentrations in some precious-metal deposits, but tellurium is presently produced from these in only a few locations.

The environmental geology of porphyry copper deposits has recently been reviewed by John and others (2010). Because the deposits are large in size and of low grade, they are commonly mined by open pit methods. The solid mine wastes have variable potential to generate minor amounts of acid drainage or neutralize it. The environmental geology of VMS deposits has been reviewed by Seal and Hammarstrom (2003), Seal and Piatak (2012), and Shanks and 
Thurston (2012). The deposits are typically of moderate size, having lens-like or tabular ore geometries, high grades of base metals, and a high potential of solid mine wastes to generate acid drainage.

\section{Sources and Fate in the Environment}

The abundance of tellurium in the upper continental crust is quite low (3 ppb) (Li and Schoonmaker, 2003). The low environmental concentrations of tellurium in all environmental media are a reflection of its low crustal abundance. Because of its low abundance, tellurium is rarely included in environmental surveys unless there is a specific interest. Therefore, data on its concentration in environmental media are limited. Andreae (1984) reported concentrations of 0.51 and 3.32 parts per trillion (ppt) for rainwater. Seawater concentrations of tellurium are significantly lower and range between 0.03 and $0.87 \mathrm{ppt}$ (Andreae, 1984; Lee and Edmond, 1985). Under oxygenated conditions in surface water, tellurium is present as the oxidized species tellurate $(\mathrm{Te}(\mathrm{VI}))$; the solubility of tellurium at $25^{\circ} \mathrm{C}$ at $\mathrm{pH} 7$ is approximately 25 ppb (McPhail, 1995).

For solid environmental media, data are available for tellurium in soils and plants. In the national geochemical survey of soil in the United States, Smith and others (2013) reported concentrations of tellurium ranging between less than 0.1 and $50.5 \mathrm{ppm}$, with most values less than $0.1 \mathrm{ppm}$. Cowgill (1988) documented concentrations in plants with mean values (dry basis) that ranged between 4.2 and $25.9 \mathrm{ppb}$, and found a strong correlation between soil and plant concentrations.

Information on pre-mining environmental concentrations of tellurium is lacking owing to its low concentrations. From an environmental perspective, baseline concentrations of other elements of environmental interest associated with porphyry copper or VMS deposits are of greater interest than those of tellurium because of the potential during mining to significantly elevate their concentrations in the environment. Few environmental baseline studies of porphyry copper deposits have been conducted, particularly with respect to the diversity of climatic settings in which they are found; however, some pre-mining soil and sediment information is available in mine permit applications for recently proposed mines. Studies from diverse climates, such as the cold climates of southwestern Alaska (Anderson and others, 2011); tropical climates of Puerto Rico (Learned and Boissen, 1973; Plaza-Toledo, 2005); and hot, arid climates of Arizona and Chile (Chaffee, 1976, 1977; Chaffee and others, 1981; Leybourne and Cameron, 2006, 2008) show similar geochemical features. Soils and sediments show elevated concentrations of iron, arsenic, cadmium, copper, molybdenum, lead, and zinc.

Pre-mining surface water and groundwater data are also limited. Plaza-Toledo (2005) and Anderson and others (2011) conducted pre-mining water-quality studies in the humid settings of Puerto Rico and southwestern
Alaska (Pebble deposit), respectively, and Leybourne and Cameron $(2006,2008)$ investigated groundwater quality in the arid Atacama Desert of Chile. In humid settings, the $\mathrm{pH}$ ranged between 4.1 and 8.6. Alkalinity ranged between 0 and $100 \mathrm{ppm}$ calcium carbonate $\left(\mathrm{CaCO}_{3}\right)$ equivalent; sulfate, between 1 and $85 \mathrm{ppm}$; and hardness, between 2 and 130 ppm $\mathrm{CaCO}_{3}$ equivalent. Dissolved trace element concentrations showed a range of values, including arsenic ( $<1$ to $36.2 \mathrm{ppb}$ ), cadmium ( $<0.2$ to $11.6 \mathrm{ppb})$, copper ( $<0.5$ to $688 \mathrm{ppb})$, iron ( $<20$ to $15,900 \mathrm{ppb})$, lead $(<0.05$ to $18.8 \mathrm{ppb})$, molybdenum ( $<2$ to $21.9 \mathrm{ppb})$, and zinc $(<0.5$ to $68 \mathrm{ppb})$. Leybourne and Cameron $(2006,2008)$ documented high-salinity groundwater associated with the undeveloped Spence copper deposit in the Atacama Desert, Chile, reaching salinities of 1.0 to 5.5 percent, with one outlier at 14.5 percent. The $\mathrm{pH}$ of the groundwaters varied widely between 4.7 and 9.2. Dissolved sulfate concentrations in groundwaters were between 5,000 and 10,000 ppm. Dissolved trace element concentrations showed a range of values for arsenic ( $<10$ to $160.9 \mathrm{ppb}$ ), copper (9 to $28,991 \mathrm{ppb}$ ), iron (4 to $54,454 \mathrm{ppb})$, molybdenum (2 to $475 \mathrm{ppb})$, lead ( 0.025 to $23.8 \mathrm{ppb})$, and zinc (5 to $1,344 \mathrm{ppb})$.

The geologic and geochemical features of VMS deposits are manifested in the surrounding environmental media, such as soil, stream sediment, surface water, and groundwater. Soils and stream sediments surrounding undeveloped deposits can have elevated concentrations of arsenic, barium, cadmium, copper, iron, lead, nickel, and zinc. The surface water and groundwater data associated with undisturbed VMS deposits span a range in $\mathrm{pH}$ from 3 to 10 ; a range of dissolved iron (a dominant cation) from $<0.02$ to $300 \mathrm{ppm}$; and dissolved sulfate (also the product of pyrite or pyrrhotite weathering) from $<0.1$ to $4,000 \mathrm{ppm}$ (Seal and Hammarstrom, 2003; Eppinger and others, 2007; Seal and Piatak, 2012;). Other dissolved constituents surrounding undeveloped deposits span a range of values, including for aluminum $(<0.002$ to $100 \mathrm{ppm})$, arsenic $(<0.1$ to $430 \mathrm{ppb})$, cadmium ( $<0.1$ to $600 \mathrm{ppb})$, copper ( $<0.003$ to $20 \mathrm{ppm})$, lead $(<0.1$ to $500 \mathrm{ppb})$, and zinc $(<3$ to $200 \mathrm{ppm})$.

\section{Mine Waste Characteristics}

The amount of mine waste associated with porphyry copper and VMS deposits varies with the size of the deposit. Porphyry copper deposits range from 30 million metric tons to greater than 20 billion metric tons of "ore" with a median size of 250 million metric tons (John and others, 2010). Because copper grades are typically less than 1 percent copper (median grade is 0.44 percent copper), more than 95 percent of the material mined will end up as solid mine waste of one form or another. The VMS deposits are variable in size, ranging from 1 to 600 million metric tons; the copper, lead, and zinc ore grades are also very variable, but typically average 2 to 5 percent (Seal and Hammarstrom, 2003). 
Solid mine waste at porphyry copper and VMS deposits typically falls into two main types: tailings and waste rock. A third type, leach pad waste, is present only at those mines where the ores are amenable to copper extraction by the electrolytic refining process, or where a leached cap may have residual gold grades that are amenable to extraction. The electrolytic process is not amenable to tellurium recovery. Tailings are produced when the ore is crushed to a sand or silt size to facilitate the separation of the copper sulfide and other metal sulfide ore minerals using a technique known as froth flotation. This technique yields a "concentrate" of sulfide minerals, and a waste material, known as tailings, which can be pumped as a slurry or trucked dry to a tailings storage facility on site. The copper concentrate is sent to a smelter and refinery complex, where copper and other mined commodities, such as tellurium, are recovered. Tailings storage facilities are typically impoundments surrounded by a retaining dam.

Waste rock is uneconomic rock that must be removed to access the ore. Waste rock is disposed of on site. For open pit porphyry copper mines, waste-to-ore (stripping) ratios commonly exceed $2: 1$, which means that for each ton of ore mined, two tons of waste rock must be removed (Porter and Bleiwas, 2003). Porphyry copper deposits at depth can also be mined by a method known as block caving. A vertical shaft or spiral decline is built to the base of the orebody, and the ore is mined from below, leaving a large, unsupported cavity from which the ore was removed. With this type of mining, the amount of waste rock is minimal and the waste material is dominated by tailings. As with porphyry copper deposits, the amount of waste rock associated with VMS deposits depends on the mining method, which in turn depends on the geometry of the orebody.

The mineralogy of the ore and waste in porphyry copper and VMS mines serves as the foundation for understanding the environmental characteristics of these deposits. In terms of both ecological risk and human health risk, the mineralogy influences the acid-generating potential of the ores and wastes and the mobility of trace elements. In porphyry copper deposits, ore minerals such as bornite, chalcopyrite, enargite, galena, molybdenite, pyrite, and sphalerite are the main hosts of trace elements of environmental concern; in total, they typically constitute less than 5 percent of the ore (John and others, 2010). Tellurium is typically hosted by trace amounts of gold-, silver-, or PGM-bearing tellurides. In VMS deposits, the ore minerals are dominated by pyrite and pyrrhotite, with varying amounts of chalcopyrite, galena, and sphalerite, and a variety of accessory minerals (Shanks and Thurston, 2012). The trace-element geochemistry of tailings reflects the mineralogy of the waste material. For porphyry copper deposits, tailings typically contain significant concentrations of arsenic, copper, manganese, molybdenum, and zinc (John and others, 2010). Tailings from copper-dominant VMS deposits can contain elevated concentrations of aluminum, arsenic, cadmium, copper, iron, lead, sulfur, and zinc (Seal and Hammarstrom, 2003; Seal and Piatak, 2012).
Approaches for managing solid waste depend upon its acid-generating potential. Metals and many other trace elements tend to be more soluble at low $\mathrm{pH}$ rather than at neutral or high $\mathrm{pH}$. Therefore, the acid-generating or acid-neutralizing potentials of the waste rock and tailings are of prime importance in identifying the potential environmental risks associated with mining and ore beneficiation. The acid-generating potential of mine waste is expressed in terms of the amount of calcium carbonate it would take to neutralize it. Therefore, the units are kilograms of calcium carbonate per metric ton of mine waste $\left(\mathrm{kg} \mathrm{CaCO}_{3} / \mathrm{t}\right)($ Price, 2009; International Network for Acid Prevention, 2011). The acid-generating potential primarily resides in pyrite. Mine waste can also have acid-neutralizing potential that resides in carbonate minerals, such as calcite, and some silicate minerals, such as feldspars.

The rocks associated with porphyry copper deposits tend, in general, to straddle the boundary between having net acidgenerating potential and having net acid-neutralizing potential, but the amount of either is relatively small compared with the high acid-generating potential associated with VMS deposits. For example, at the Pebble porphyry copper deposit in Alaska, the various mine waste materials are expected to span a range from a net acid-generating potential of $110 \mathrm{~kg} \mathrm{CaCO}_{3} / \mathrm{t}$ to a net acid-neutralizing potential of $27 \mathrm{~kg} \mathrm{CaCO}_{3} / \mathrm{t}$ (Pebble Partnership, 2011, written commun.). In contrast, mine waste from VMS deposits typically has net acid-generating potential, commonly ranging between 100 and $350 \mathrm{~kg} \mathrm{CaCO}_{3} / \mathrm{t}$, although some waste can have net neutralizing potential locally (Lindsay and others, 2009; Seal and Piatak, 2012).

\section{Human Health Concerns}

Tellurium does not appear to be an essential trace element for human health (Kobayashi, 2004; Ba and others, 2010). No information is available on the toxic effects of tellurium on humans, presumably in part because of its low natural abundance. The Agency for Toxic Substances and Disease Registry does not have a toxicological profile for tellurium, nor does the U.S. Environmental Protection Agency have drinking water standards or soil guidelines for tellurium. Animal studies, using large doses of tellurium administered either through ingestion, inhalation, or intravenously, indicated the target sites for tellurium toxicity are the kidneys, nervous system, skin, and brain in a fetus (Taylor, 1996). The reduced species, tellurite, is more toxic than either arsenite or selenite, and, tellurite is 10 times more toxic than the oxidized species tellurate (Taylor, 1996).

The more significant human health risks associated with tellurium production are found with the broader aspects of mining porphyry copper and VMS deposits. Contaminated groundwater plumes associated with tailings impoundments may pose threats to drinking-water supplies, depending upon the geologic and hydrologic setting and the engineering aspects of the mine and the waste piles for both deposit types. Host rocks with higher neutralization potentials, such as 
carbonate rocks, tend to limit the mobility of metals and related compounds. Hydrologic and climatic settings that have net evaporative loss of water may cause evaporative concentration of solutes that may enter groundwater used as drinking-water supplies in the vicinity of mines and waste piles. Improperly constructed water-containment structures may allow contaminated mine waters to enter surrounding groundwater. For both porphyry copper deposits and VMS deposits, elements or compounds with the greatest likelihood of causing problems for drinking-water sources include aluminum, arsenic, cadmium, copper, iron, manganese, sulfate, and zinc. The potential for groundwater contamination depends upon the waste- and water-management practices in place at any given mine.

\section{Ecological Health Concerns}

As with the human health guidelines, no information is available for tellurium and its toxic effects on aquatic or terrestrial ecosystems, whether through surface water, soil, or sediment. The U.S. Environmental Protection Agency does not have surface water or sediment guidelines for tellurium. Thus, the more significant ecosystem risks associated with tellurium production are found with the broader aspects of mining porphyry copper and VMS deposits. Many of the ecological risks associated with both deposit types focus on the ability of mine wastes to generate acid, and the ability of the resulting acid mine drainage to carry metals and other inorganic contaminants. As described above with respect to mine waste characteristics, the acid-generating potential of mine waste is controlled by the pyrite content, which may be offset by the acid-neutralizing potential of carbonate or silicate minerals. Tailings are prone to water transport, particularly in the case of a tailings dam failure, and wind transport, because of the fine-size sand and silt grains. Thus, tailings present additional potential risks to aquatic organisms through sediment contamination.

Mine drainage data are available for porphyry copper deposits in British Columbia, Canada (Day and Rees, 2006); the Globe district in Arizona (Eychaner, 1991; Stollenwerk, 1994; Brown and others, 1998; Lind and others, 1998; Conklin and others, 2001); the Morenci district in Greenlee County, Ariz. (Enders and others, 2006); and the Sar Cheshmeh deposit in Iran (Khorasanipour and others, 2011). Many of these values exceed relevant water-quality guidelines for the protection of aquatic ecosystems for aluminum, copper, iron, manganese, and zinc (U.S. Environmental Protection Agency, 2009). The $\mathrm{pH}$ can commonly range from 2 to 8.5 , and sulfate, which is the dominant anion, can locally reach $30,000 \mathrm{ppm}$.

Pit lakes, particularly in porphyry copper mining districts that are riddled with historical underground mine workings, such as at Butte, Mont., which has a 140-year mining history, can be problematic. The Berkeley Pit lake at Butte contains more than 100 billion liters of $\mathrm{pH}-2.5$ mine water (Gammons and Duaime, 2005; Gammons and others, 2005). The pit lake has high dissolved solids and elevated concentrations of copper, iron, sulfate, and zinc (Gammons and Duaime, 2005). In contrast, pit lakes in the Yerington (Lyon County) and Robinson (White Pine County) districts, Nevada, have $\mathrm{pH}$ values that typically range from 7.0 to 8.5 with a few outliers near 4.7, which have been attributed to discharge from solvent-extraction operations rather than groundwater-rock interactions in the vicinity of the pits (Shevenell and others, 1999). In Nevada, total dissolved solids are generally less than 6,000 ppm; concentrations of iron reach a maximum of $4.5 \mathrm{ppm}$; arsenic, less than $0.05 \mathrm{ppm}$; manganese, less than $5 \mathrm{ppm}$; and selenium, less than $0.14 \mathrm{ppm}$.

The VMS mines are noted for their significant impacts on the aquatic ecosystem associated with abandoned historical mines, such as at Iron Mountain, Calif. Iron Mountain is unique among abandoned mines in that its effluent and seeps within the mine workings have extremely low $\mathrm{pH}(-4$ to 1.5$)$ and dissolved copper, iron, sulfate, and zinc are present in concentrations reaching hundreds of grams per liter (Alpers and others, 2003). The unusual chemistry of mine drainage at Iron Mountain is the result of an atypical combination of factors related to its geologic, hydrologic, and climatic setting. In contrast, the $\mathrm{pH}$ values from mine drainage from a broader spectrum of VMS mines are typically much lower than the values recorded at Iron Mountain, ranging from 2 to 8 , including concentrations of dissolved copper $(<0.1 \mathrm{ppb}$ to $3 \mathrm{ppm}$ ), iron (1 ppb to 3 grams per liter [g/L]), sulfate (1 ppm to $10 \mathrm{~g} / \mathrm{L}$ ), and zinc $(<1 \mathrm{ppb}$ to $1 \mathrm{~g} / \mathrm{L}$ ) (Seal and Hammarstrom, 2003). Other trace elements found in environmentally significant concentrations associated with abandoned VMS mines include arsenic, cadmium, lead, and nickel.

\section{Carbon Footprint}

Tellurium extraction through mining does not have a unique carbon footprint beyond the energy requirements of mining in general. In terms of its uses, the most direct link of tellurium to the global carbon cycle is in its use in cadmiumtelluride photovoltaic cells (Anderson, 2015).

\section{Mine Closure}

The nature of mine closure for porphyry copper and VMS deposits depends primarily on the method of mining and the characteristics of the waste material. Open pit mines for either deposit type display at least three different features after mining: the open pit, tailings storage facilities, and waste-rock piles. Because of the scale of mining, backfilling of the pits is typically not practical. If the water table is above the bottom of the pit, then it will become a lake. The water quality of the lake will depend upon a number of factors, including the characteristics of the wallrocks, the extent of interconnected underground mine workings that open to the pit, the water level in the pit, the local hydrology, and climate (Castendyk and Eary, 2009). 
The long-term fate of tailing storage facilities will depend upon the nature of the tailings and the method of construction of the facility. Some facilities can be regraded, capped, and revegetated. Others are designed to have a water cover in perpetuity to limit sulfide oxidation. Either type may have seepage that may require some form of water treatment. The long-term fate of waste-rock piles may include regrading, capping, and revegetation. Depending upon the acidgenerating potential of the material, some piles may require some form of water treatment.

For underground mines, tailings and waste rock may be handled in a similar fashion to the approaches used at open pit mines. The potential exists to dispose of some of the tailings back into the mined out workings, depending upon how the orebody is mined; however, the entire volume of tailings cannot be placed back in the mine workings because of the volume expansion associated with crushing and milling the ore.

\section{Problems and Future Research}

In the near future, recovery of lower copper grades may force recovery of oxidized copper ores by solvent extraction; in this process, it is not possible recover the tellurium as a byproduct, as is possible through the smelting of higher grade copper sulfide concentrates. This change in method could potentially lead to a greater emphasis on precious-metal deposits to meet global and domestic tellurium demands. Demand has decreased for tellurium in recent years, but as China and other developing countries adopt more solar technologies, increased demand in the near future is a possibility.

Future research may focus on methods to recover tellurium from two new sources. First, future advances in processes for sea-floor mining will be critical if tellurium is recovered from extreme enrichments in iron-manganese crusts on the ocean floor. Second, investigations of old mine and mill tailings from historic large-scale operations may fingerprint deposits and deposit types with previously unrecognized, extreme abundances of tellurium in old waste piles.

\section{Acknowledgments}

David John and Karen Kelley are thanked for their careful and valuable reviews of this report. Erin Marsh's help with the graphics is greatly appreciated, and input from John DeYoung on an earlier version was very helpful. Keith Labay helped create the deposit location map, and Suzanne Nicholson provided additional editorial comments after the technical review was complete.

\section{References Cited}

Note: All Web links listed were active as of the access date but may no longer be available.

Afifi, A.M., Kelly, W.C., and Essene, E.J., 1988, Phase relations among tellurides, sulfides, and oxides-II. Applications to telluride-bearing ore deposits: Economic Geology, v. 83, p. 395-404. [Also available at http://dx.doi.org/10.2113/gsecongeo.83.2.395.]

Alderton, D.H.M., and Fallick, A.E., 2000, The nature and genesis of gold-silver-tellurium mineralization in the Metaliferi Mountains of western Romania: Economic Geology, v. 95, p. 495-516. [Also available at http://dx.doi.org/10.2113/gsecongeo.95.3.495.]

Alpers, C.N., Nordstrom, D.K., and Spitzley, John, 2003, Extreme acid mine drainage from a pyritic massive sulfide deposit-The Iron Mountain end-member, in Jambor, J.L., Blowes, D.W., and Ritchie, A.I.M., eds., Environmental aspects of mine wastes: Mineralogical Association of Canada Short Course Series, v. 31, p. 407-430.

Anderson, C.S., 2015, Selenium and tellurium [advance release], in Metals and minerals: U.S. Geological Survey Minerals Yearbook 2013, v. I, p. 65.1-65.8, accessed November 23, 2015, at http://minerals.usgs.gov/minerals/ pubs/commodity/selenium/myb1-2013-selen.pdf.

Anderson, E.D., Smith, S.M., Giles, S.A., Granitto, Matthew, Eppinger, R.G., Bedrosian, P.A., Shah, A.K., Kelley, K.D., Fey, D.L., Minsley, B.J., and Brown, P.J., 2011, Geophysical, geochemical, and mineralogical data from Pebble $\mathrm{Cu}-\mathrm{Au}-\mathrm{Mo}$ porphyry deposit area, southwest AlaskaContributions to assessment techniques for concealed mineral resources: U.S. Geological Survey Data Series 608, 46 p., 2 pls., http://pubs.usgs.gov/ds/608.

Andreae, M.O., 1984, Determination of inorganic tellurium species in natural waters: Analytical Chemistry, v. 56, no. 12, p. 2064-2066. [Also available at http://dx.doi.org/ 10.1021/ac00276a019.]

Arribas, Antonio, Jr., Cunningham, C.G., Rytuba, J.J., Rye, R.O., Kelly, W.C., Podwysocki, M.H., McKee, E.H., and Tosdal, R.M., 1995, Geology, geochronology, fluid inclusions, and isotope geochemistry of the Rodalquilar gold alunite deposit, Spain: Economic Geology, v. 90, p. 795-822. [Also available at http://dx.doi.org/10.2113/ gsecongeo.90.4.795.]

Asadi, H.H., Voncken, J.H.L., Kuhnel, R.A., and Hale, M., 2000, Petrography, mineralogy and geochemistry of the Zarshuran Carlin-like gold deposit, northwest Iran: Mineralium Deposita, v. 35, no. 7, p. 656-671. [Also available at http://dx.doi.org/10.1007/s001260050269.] 
Austen, Gerry, and Ballantyne, Geoff, 2011, Geology and geochemistry of deep molybdenum mineralization at the Bingham Canyon Mine, Utah, USA, in Krahulec, Ken, and Schroeder, Kim, eds., Tops and bottoms of porphyry copper deposits-The Bingham and Southwest Tintic districts, Utah-Guidebook prepared for Society of Economic Geologists field trip, September 30-October 1, 2010: Littleton, Colo., Society of Economic Geologists, Guidebook Series, v. 41, p. 35-49, 1 CD-ROM.

Ba, L.A., Döring, Mandy, Jamier, Vincent, and Jacob, Claus, 2010, Tellurium-An element with great biological potency and potential: Organic and Biomolecular Chemistry, v. 8, no. 19 , p. 4203-4216. [Also available at http://dx.doi.org/ 10.1039/c0Ob00086h.]

Behre Dolbear Asia Inc., 2009, Independent technical review of the Dashuigou and Majiagou tellurium projects in Sichuan Province, The People's Republic of ChinaFinal report, prepared for Apollo Solar Energy Inc.: Denver, Colo., Behre Dolbear Group, Project 09-003, 35 p., accessed November 6, 2013, at http://www.sec.gov/ Archives/edgar/data/ 726435/000140677409000056/ exhibit992.htm.

Berkenbosch, H.A., de Ronde, C.E.J., Gemmell, J.B., McNeill, A.W., and Goemann, K., 2012, Mineralogy and formation of black smoker chimneys from Brothers submarine volcano, Kermadec arc: Economic Geology, v. 107, p. 1613-1633. [Also available at http://dx.doi.org/ 10.2113/econgeo.107.8.1613.]

Boliden Group, 2011, Kankberg-A new Boliden gold mine: Boliden Group, February 24, 16 p., accessed October 21, 2015, at http://www.boliden.com/Documents/ Press/Presentations/Kankberg.pdf.

Bowell, R.J., Foster, R.P., and Stanley, C.J., 1990, Telluride mineralization at Ashanti gold mine, Ghana: Mineralogical Magazine, v. 54, pt. 4, no. 377, p. 617-627. [Also available at http://dx.doi.org/10.1180/minmag.1990.054.377.15.]

Boyle, R.W., 1979, The geochemistry of gold and its deposits (together with a chapter on geochemical prospecting for the element): Ottawa, Ontario, Canada, Geological Survey of Canada Bulletin no. 280, 584 p., 1 pl. [Also available at http://dx.doi.org/10.4095/105577.]

Brown, J.G., Bassett, R.L., and Glynn, P.D., 1998, Analysis and simulation of reactive transport of metal contaminants in ground water in Pinal Creek Basin, Arizona: Journal of Hydrology, v. 209, nos. 1-4, p. 225-250. [Also available at http://dx.doi.org/10.1016/S0022-1694(98)00091-2.]
Brown, T.J., Shaw, R.A., Bide, T., Petavratzi, E., Raycraft, E.R., and Walters, A.S., 2013, World mineral production 2007-2011: Keyworth, Nottingham, United Kingdom, British Geological Survey, 85 p. [Also available at http://www.bgs.ac.uk/downloads/start.cfm?id=2701.]

Brugger, Joël, Etschmann, B.E., Grundler, P.V., Liu, W-H., Testemale, Denis, and Pring, Allan, 2012, XAS evidence for stability of polytellurides in hydrothermal fluids up to $599{ }^{\circ} \mathrm{C}, 800$ bar: American Mineralogist, v. 97, nos. 8-9, p. 1519-1522. [Also available at http://dx.doi.org/10.2138/ am.2012.4167.]

Burleigh, R.E., 1987, A stable isotope, fluid inclusion and ore petrographic study of gold-quartz veins in the Willow Creek mining district, Alaska: Fairbanks, Alaska, University of Alaska, M.S. thesis, $246 \mathrm{p}$.

Cail, T.L., and Cline, J.S., 2001, Alteration associated with gold deposition at the Getchell Carlin-type gold deposit, north-central Nevada: Economic Geology, v. 96, p. 1343-1359. [Also available at http://dx.doi.org/10.2113/ gsecongeo.96.6.1343.]

Casey, S.D., 2000, Mineralogy and stable isotope geochemistry of gold-silver telluride mineralization in the Berners Bay district, Alaska: Ames, Iowa, Iowa State University, M.S. thesis, $117 \mathrm{p}$.

Castendyk, D.N., and Eary, L.E., eds., 2009, Mine pit lakesCharacteristics, predictive modeling, and sustainability: Littleton, Colo., Society for Mining, Metallurgy, and Exploration, Management Technologies for Metal Mining Influenced Water Series, v. 3, 304 p.

Chaffee, M.A., 1976, Geochemical exploration techniques based on distribution of selected elements in rocks, soils, and plants, Mineral Butte copper deposit, Pinal County, Arizona: U.S. Geological Survey Bulletin 1278-D, 55 p., accessed October 21, 2013, at http://pubs.usgs.gov/bul/ 1278d/report.pdf.

Chaffee, M.A., 1977, Geochemical exploration techniques based on distribution of selected elements in rocks, soils, and plants, Vekol porphyry copper deposit area, Pinal County, Arizona: U.S. Geological Survey Bulletin 1278-E, 78 p., accessed October 21, 2013, at http://pubs.usgs.gov/ bul/1278e/report.pdf.

Chaffee, M.A., 1982, A geochemical study of the Kalamazoo porphyry copper deposit, in Titley, S.R., ed., Advances in the geology of the porphyry copper deposits-Southwestern North America: Tucson, Ariz., University of Arizona Press, p. 211-225. 
Chaffee, M.A., Hill, R.H., Sutley, S.J., and Watterson, J.R., 1981, Regional geochemical studies in the Patagonia Mountains, Santa Cruz County, Arizona: Journal of Geochemical Exploration, v. 14, p. 135-153. [Also available at http://dx.doi.org/10.1016/0375-6742(81)90109-6.]

Ciobanu, C.L., Cook, N.J., and Spry, P.G., 2006, PrefaceSpecial issue-Telluride and selenide minerals in gold deposits-How and why?: Mineralogy and Petrology, v. 87 , nos. 3-4, p. 163-169. [Also available at http://dx.doi.org/10.1007/s00710-006-0133-9.]

Cockerton, A.B.D., and Tomkins, A.G., 2012, Insights into the liquid bismuth collector model through analysis of the Bi-Au Stormont skarn prospect, northwest Tasmania: Economic Geology, v. 107, p. 667-682. [Also available at http://dx.doi.org/10.2113/econgeo.107.4.667.]

Cone, Tracie, 2013, Gold era waster could fuel cellphones, TV: The Denver [Colorado] Post, July 22, accessed November 21, 2013, at http://www.denverpost.com/nationworld/ ci_23705103/gold-era-waster-could-fuel-cellphones-tv.

Conklin, Martha, Villinski, John, and Kay, John, 2001, Geochemistry of acid mine contamination-aquifer interactions: International Journal of Occupational Medicine and Environmental Health, v. 14, no. 3, p. 249-259. [Also available at http://test.imp.lodz.pl/upload/oficyna/artykuly/pdf/full/ Conklin7-03-01.pdf.]

Cook, N.J., and Ciobanu, C.L., 2004, Bismuth tellurides and sulphosalts from the Larga hydrothermal system, Metaliferi Mts., Romania-Paragenesis and genetic significance: Mineralogical Magazine, v. 68, no. 2, p. 301-321. [Also available at http://dx.doi.org/10.1180/0026461046820188.]

Cook, N.J., and Ciobanu, C.L., 2005, Tellurides in Au deposits-Implications for modelling, in Mao, Jingwen, and Bierlein, F.P., eds. Mineral deposit research-Meeting the global challenge_-Proceedings of the Eighth Biennial SGA Meeting, Beijing, China, 18-21 August 2005: New York, N.Y., Springer, p. 1387-1390. [Also available at http://dx.doi.org/10.1007/3-540-27946-6_353.]

Cook, N.J., Ciobanu, C.L., Capraru, Nicu, Damian, Gheorghe, and Cristea, Petru, 2005, Mineral assemblages from the vein salband at Sacarimb, Golden Quadrilateral, Romania-II. Tellurides: Geochemistry, Mineralogy and Petrology, v. 43, p. 56-63. [Also available at http://www.geology.bas.bg/ mineralogy/gmp_files/gmp43/Cook.pdf.]

Cooke, D.R., and McPhail, D.C., 2001, Epithermal Au-Ag-Te mineralization, Acupan, Baguio district, PhilippinesNumerical simulations of mineral deposition: Economic Geology, v. 96, p. 109-131. [Also available at http://dx.doi.org/10.2113/gsecongeo.96.1.109.]
Côté-Mantha, Olivier, Daigneault, Réal, Gaboury, Damien, Chartrand, Francis, and Pilote, Pierre, 2012, Geology, alteration, and origin of Archean $\mathrm{Au}-\mathrm{Ag}-\mathrm{Cu}$ mineralization associated with the synvolcanic Chibougamau PlutonThe Brosman prospect, Abitibi greenstone belt, Canada: Economic Geology, v. 107, p. 909-934. [Also available at http://dx.doi.org/10.2113/econgeo.107.5.909.]

Cowgill, U.M., 1988, The tellurium content of vegetation: Biological Trace Element Research, v. 17, no. 1, p. 43-67. [Also available at http://dx.doi.org/10.1007/bf02795446.]

Cox, D.P., Gonzalez, Perez, and Nash, J.T., 1975, Geology, geochemistry, and fluid inclusion petrography of the Sapo Alegre porphyry copper prospect and its metavolcanic wallrocks, west-central Puerto Rico: Journal of Research of the U.S. Geological Survey, v. 3, no. 3, p. 313-327.

Day, Stephen, and Rees, Ben, 2006, Geochemical controls on waste-rock dump seepage chemistry at several porphyry mines in the Canadian Cordillera, in Barnhisel, R.I., ed., 7th International Conference on Acid Rock Drainage (ICARD), St. Louis, Missouri, USA, March 26-30, 2006: Lexington, Ky., American Society of Mining and Reclamation, p. 439456, CD-ROM. [Also available at https://imwa.info/docs/ imwa_2006/0439-Day-BC.pdf.]

Deer Horn Metals Inc., 2012, NI43-101 mineral resource update for the Deer Horn gold-silver-tellurium deposit shows increased tonnage and significantly higher resources of gold and silver and an initial resource for tellurium: Delta, British Columbia, Canada, Deer Horn Metals Inc. news release, April 11, 6 p., accessed October 21, 2015 , at http://www.sedar.com. (Company name changed to Deer Horn Capital Inc. in 2014.)

Deyell, C.L., and Hedenquist, J.W., 2011, Trace element geochemistry of enargite in the Mankayan district, Philippines: Economic Geology, v. 106, p. 1465-1478. [Also available at http://dx.doi.org/10.2113/econgeo.106.8.1465.]

Distler, V.V., and Yudovskaya, M.A., 2005, Polymetallic platinum group element (PGE)-Au mineralization of the Sukhoi Log deposit, Russia, in Mungall, J.E., ed., Exploration for platinum-group element deposits: Ottawa, Ontario, Canada, Mineralogical Association of Canada, Mineralogical Association of Canada Short Course Notes, v. 35 , p. 457-485, 2 pls., 1 CD-ROM.

Dye, M.D., and Smyth, J.R., 2012, The crystal structure and genesis of krennerite, $\mathrm{Au}_{3} \mathrm{AgTe}_{8}$ : The Canadian Mineralogist, v. 50, no. 1, p. 119-127. [Also available at http://dx.doi.org/10.3749/canmin.50.1.119.] 
Economou-Eliopoulos, Maria, 2005, Platinum group element potential of porphyry deposits, in Mungall, J.E., ed., Exploration for platinum-group element deposits: Ottawa, Ontario, Canada, Mineralogical Association of Canada, Mineralogical Association of Canada Short Course Notes, v. 35, p. 203-246, 2 pls., 1 CD-ROM.

Economou-Eliopoulos, Maria, and Eliopoulos, D.G., 2000, Palladium, platinum, and gold concentration in porphyry copper systems of Greece and their genetic significance: Ore Geology Reviews, v. 16, nos. 1-2, p. 59-70. [Also available at http://dx.doi.org/10.1016/s0169-1368(99)00024-4.]

Eilers, A., 1914, Notes on the occurrence of some of the rarer metals in blister copper: Transactions of the American Institute of Mining Engineers, v. 47, p. 217-218. [Also available at https://archive.org/stream/transactionsmining 47amer\#page/217/mode/1up.]

Eilu, Pasi, Mikucki, E.J., and Groves, D.I., 1998, Wallrock alteration and primary geochemical dispersion in lodegold exploration-Notes from a short course presented at the Fourth Biennial Meeting of the Society for Geology Applied to Mineral Deposits (SGA), Turku, Finland, August 11-13, 1997: Society for Geology Applied to Mineral Deposits (SGA) Short Course Series, v. 1, 65 p.

Emsbo, Poul, Hofstra, A.H., Lauha, E.A., Griffin, G.L., and Hutchinson, R.W., 2003, Origin of high-grade gold ore, source of ore fluid components, and genesis of the Meikle and neighboring Carlin-type deposits, northern Carlin trend, Nevada: Economic Geology, v. 98, p. 1069-1105.[Also available at http://dx.doi.org/10.2113/gsecongeo.98.6.1069.]

Enders, M.S., Knickerbocker, Chris, Titley, S.R., and Southam, Gordon, 2006, The role of bacteria in the supergene environment of the Morenci porphyry copper deposit, Greenlee County, Arizona: Economic Geology, v. 101, p. 59-70. [Also available at http://dx.doi.org/10.2113/ gsecongeo.101.1.59.]

Eppinger, R.G., Briggs, P.H., Dusel-Bacon, Cynthia, Giles, S.A., Gough, L.P., Hammarstrom, J.M., and Hubbard, B.E., 2007, Environmental geochemistry at Red Mountain, an unmined volcanogenic massive sulphide deposit in the Bonnifield district, Alaska Range, east-central Alaska: GeochemistryExploration, Environment, Analysis, v. 7, no. 3, p. 207-223. [Also available at http://dx.doi.org/10.1144/1467-7873/07-136.]

Eychaner, J.H., 1991, The Globe, Arizona, research siteContaminants related to copper mining in a hydrologically integrated environment, in Mallard, G.E., and Aronson, D.A., eds., U.S. Geological Survey toxic substances hydrology program-Proceedings of the technical meeting, Monterey, California, March 11-15, 1991: U.S. Geological Survey WaterResources Investigations Report 91-4034, p. 439-447. [Also available at http://pubs.er.usgs.gov/publication/wri914034.]
Frank, M.R., Simon, A.C., Pettke, Thomas, Candela, P.A., and Piccoli, P.M., 2011, Gold and copper partitioning in magmatic-hydrothermal systems at $800^{\circ} \mathrm{C}$ and $100 \mathrm{MPa}$ : Geochimica et Cosmochimica Acta, v. 75, no. 9, p. 2470-2482. [Also available at http://dx.doi.org/ 10.1016/j.gca.2011.02.012.]

Fuertes-Fuente, M., Martin-Izard, A., Nieto, J.G., Maldonado, C., and Varela, A., 2000, Preliminary mineralogical and petrological study of the Ortosa Au-Bi-Te ore depositA reduced gold skarn in the northern part of the Rio Narcea gold belt, Asturias, Spain: Journal of Geochemical Exploration, v. 71, no. 2, p. 177-190. [Also available at http://dx.doi.org/10.1016/S0375-6742(00)00151-5.]

Gammons, C.H., and Duaime, T.E., 2005, Long term changes in the limnology and geochemistry of the Berkeley pit lake, Butte, Montana: Mine Water and the Environment, v. 25, no. 2, p. 76-85. [Also available at http://dx.doi.org/10.1007/ s10230-006-0114-6.]

Gammons, C.H., Metesh, J.J., and Duaime, T.E., 2005, An overview of the mining history and geology of Butte, Montana: Mine Water and the Environment, v. 25, no. 2, p. 70-75. [Also available at http://dx.doi.org/10.1007/s10230-006-0113-7.]

Garavelli, Anna, Mitolo, Donatella, Pinto, Daniela, and Vurro, Filippo, 2013, Lucabindiite, $\left(\mathrm{K}, \mathrm{NH}_{4}\right) \mathrm{As}_{4} \mathrm{O}_{6}(\mathrm{Cl}, \mathrm{Br})$, a new fumarole mineral from the "La Fossa" crater at Vulcano, Aeolian Islands, Italy: American Mineralogist, v. 98, nos. 2-3, p. 470-477. [Also available at http://dx.doi.org/10.2138/am.2013.4194.]

George, M.W., 2014a, Selenium and tellurium, in Metals and minerals: U.S. Geological Survey Minerals Yearbook 2011, v. I, p. 65.1-65.9. [Also available at http://minerals.usgs.gov/ minerals/pubs/commodity/selenium/myb1-2011-selen.pdf.]

George, M.W., 2014b, Tellurium: U.S. Geological Survey Mineral Commodity Summaries 2014, p. 162-163. [Also available at https://minerals.usgs.gov/minerals/pubs/ commodity/selenium/mcs-2014-tellu.pdf.]

Gott, G.B., and McCarthy, J.H., Jr., 1966, Distribution of gold, silver, tellurium, and mercury in the Ely mining district, White Pine County, Nevada: U.S. Geological Survey Circular 535, 5 p., accessed October 21, 2013, at http://pubs.er.usgs.gov/publication/cir535.

Gott, G.B., McCarthy, J.H., Jr., VanSickle, G.H., and McHugh, J.B., 1967, Distribution of gold, tellurium, silver, and mercury in part of the Cripple Creek district, Colorado: U.S. Geological Survey Circular 543, 9 p., accessed October 21, 2013, at http://pubs.er.usgs.gov/publication/cir543. 
Gregory, M.J., Lang, J.R., Gilbert, Sarah, and Hoal, K.O., 2013, Geometallurgy of the Pebble porphyry copper-gold-molybdenum deposit, Alaska - Implications for gold distribution and paragenesis: Economic Geology, v. 108, p. 463-482. [Also available at http://dx.doi.org/10.2113/econgeo.108.3.463.]

Groves, D.I., Bierlein, F.P., Meinert, L.D., and Hitzman, M.W., 2010, Iron oxide copper-gold (IOCG) deposits through Earth history-Implications for origin, lithospheric setting, and distinction from other epigenetic iron oxide deposits: Economic Geology, v. 105, p. 641-654. [Also available at http://dx.doi.org/10.2113/gsecongeo.105.3.641.]

Grundler, P.V., Brugger, Joël, Etschmann, B.E., Helm, Lothar, Liu, Weihua, Spry, P.G., Tian, Yuan, Testemale, Denis, and Pring, Allan, 2013, Speciation of aqueous tellurium(IV) in hydrothermal solutions and vapors, and the role of oxidized tellurium species in Te transport and gold deposition: Geochimica et Cosmochimica Acta, v. 120, p. 298-325. [Also available at http://dx.doi.org/10.1016/j.gca.2013.06.009.]

Grundler, P.V., Pring, Allan, Brugger, Joël, Spry, P.G., and Helm, Lothar, 2009, Aqueous solubility and speciation of $\mathrm{Te}(\mathrm{IV})$ at elevated temperatures: Geochimica et Cosmochimica Acta, supplement, v. 73, no. 13, p. A472.

Hannington, M.D., de Ronde, C.E.J., and Petersen, Sven, 2005, Sea-floor tectonics and submarine hydrothermal systems, in Hedenquist, J.L., Thompson, J.F.H., Goldfarb, R.J., and Richards, J.P., eds., Economic Geology — One hundredth anniversary volume 1905-2005:Littleton, Colo., Society of Economic Geologists, p. 111-141. Appendixes are on a CD-ROM inside the back cover.] [Also available at http://eprints.uni-kiel.de/6271/.]

Harris, Michael, and Radtke, A.S., 1976, Statistical study of selected trace elements with reference to geology and genesis of the Carlin gold deposit, Nevada: U.S. Geological Survey Professional Paper 960, 21 p. [Also available at http://pubs.er.usgs.gov/publication/pp960.]

Hattori, K.H., Arai, Shoji, and Clarke, D.B., 2002, Selenium, tellurium, arsenic and antimony contents of primary mantle sulfides: The Canadian Mineralogist, v. 40, no. 2, p. 637-650. [Also available at http://dx.doi.org/10.2113/ gscanmin.40.2.637.]

Hayes, S.M., Foster, A.L., and Balistrieri, L.S., 2012, Tellurium speciation in surficial weathering environments [abs.]: Geological Society of America Annual Meeting, Charlotte, N.C., 2012, Paper no. 162-24.

Hein, J.R., Mizell, Kira, Koschinsky, Andrea, and Conrad, T.A., 2013, Deep-ocean mineral deposits as a source of critical metals for high- and green-technology applicationsComparison with land-based resources: Ore Geology Reviews, v. 51, p. 1-14. [Also available at http://dx.doi.org/ 10.1016/j.oregeorev.2012.12.001.]
Heitt, D.G., Dunbar, W.W., Thompson, T.B., and Jackson, R.G., 2003, Geology and geochemistry of the Deep Star gold deposit, Carlin trend, Nevada: Economic Geology, v. 98, p. 1107-1135. [Also available at http://dx.doi.org/10.2113/gsecongeo.98.6.1107.]

International Network for Acid Prevention, 2011, Global acid rock drainage guide: International Network for Acid Prevention, accessed February 24, 2014, at http://www.gardguide.com.

Ispolatov, V., Lafrance, B., Dubé, B., Creaser, R., and Hamilton, M., 2008, Geologic and structural setting of gold mineralization in the Kirkland Lake-Larder Lake gold belt, Ontario: Economic Geology, v. 103, p. 1309-1340. [Also available at http://dx.doi.org/ 10.2113/gsecongeo.103.6.1309.]

Ivanov, S.M., Ansdell, K.M., and Melrose, D.L., 2000, Ore texture and stable isotope constraints on ore deposition mechanisms at the Kumtor lode gold deposit: Society of Economic Geologists, Short Course poster session, extended abstract volume, p. 47-52.

Jensen, E.P., and Barton, M.D., 2000, Gold deposits related to alkaline magmatism, in Hagemann, S.G., and Brown, P.E., eds., Gold in 2000: Littleton, Colo., Society of Economic Geologists, Reviews in Economic Geology series, v. 13, p. 279-313.

John, D.A., Ayuso, R.A., Barton, M.D., Blakely, R.J., Bodnar, R.J., Dilles, J.H., Gray, Floyd, Graybeal, F.T., Mars, J.C., McPhee, D.K., Seal, R.R., II, Taylor, R.D., and Vikre, P.G., 2010, Porphyry copper deposit model, chap. B of Mineral deposit models for resource assessment: U.S. Geological Survey Scientific Investigations Report 2010-5070-B, 169 p., accessed November 12, 2013, at http://pubs.er.usgs.gov/ publication/sir20105070B.

Johnston, W.D., Jr., 1940, The gold quartz veins of Grass Valley, California: U.S. Geological Survey Professional Paper 194, 101 p., accessed October 29, 2013, at http://pubs.er.usgs.gov/publication/pp194.

Jones, B.K., 1992, Application of metal zoning to gold exploration in porphyry copper systems: Journal of Geochemical Exploration, v. 43, no. 2, p. 127-155. [Also available at http://dx.doi.org/10.1016/0375-6742(92)90003-q.]

Kelley, K.D., and Spry, P.G., 2016, Critical elements in alkaline igneous rock-related epithermal gold deposits, in Verplanck, P.L.. and Hitzman, M.W., eds., Rare earth and critical elements in ore deposits: Reviews in Economic Geology, v. 18, 195-216. 
Kesler, S.E., Russell, Norman, and McCurdy, Karr, 2003, Tracemetal content of the Pueblo Viejo precious-metal deposits and their relation to other high-sulfidation epithermal systems: Mineralium Deposita, v. 38, no. 6, p. 668-682. [Also available at http://dx.doi.org/10.1007/s00126-003-0356-1.]

Khorasanipour, Mehdi, Tangestani, M.H., Naseh, Reza, and Hajmohammadi, Hamid, 2011, Hydrochemistry, mineralogy and chemical fractionation of mine and processing wastes associated with porphyry copper mines-A case study of the Sarcheshmeh Mine, SE Iran: Applied Geochemistry, v. 26, no. 5, p. 714-730. [Also available at http://dx.doi.org/ 10.1016/j.apgeochem.2011.01.030.]

Kim, E-J., Park, M-E., and White, N.C., 2012, Skarn gold mineralization at the Geodo Mine, South Korea: Economic Geology, v. 107, p. 537-551. [Also available at http://dx.doi.org/10.2113/econgeo.107.3.537.]

Kobayashi, Ryusuke, 2004, Tellurium, chap. 8 of Meria, Ernest, Anke, Manfred, Ihnat, Milan, and Stoeppler, Markus, eds., Elements and their compounds in the environment ( $2 \mathrm{~d}$ ed.): Weinheim, Germany, Wiley-VCH, v. 3, p. 1407-1414.

Kouzmanov, Kalin, Pettke, Thomas, and Heinrich, C.A., 2010, Direct analysis of ore-precipitating fluids - Combined IR microscopy and LA-ICP-MS study of fluid inclusions in opaque ore minerals: Economic Geology, v. 105, p. 351-373. [Also available at http://dx.doi.org/10.2113/ gsecongeo.105.2.351.]

Kwak, T.A.P., 1990, Geochemical and temperature controls on ore mineralization at the Emperor gold mine, Vatukoula, Fiji: Journal of Geochemical Exploration, v. 36, nos. 1-3, p. 297-337. [Also available at http://dx.doi.org/10.1016/ 0375-6742(90)90059-j.]

Learned, R.E., and Boissen, R., 1973, Gold, a useful pathfinder element in the search for porphyry copper deposits in Puerto Rico, in Jones, M.J., ed., Geochemical exploration, 1972-Proceedings of the Fourth International Geochemical Exploration Symposium, London, United Kingdom, April 17-20, 1972: London, United Kingdom, Institution of Mining and Metallurgy, p. 93-103.

Lee, D.S., and Edmond, J.M., 1985, Tellurium species in seawater: Nature, v. 313, no. 6005, p. 782-785. [Also available at http://dx.doi.org/10.1038/313782a0.]

LeFort, Darren, Hanley, Jacob, and Guillong, Marcel, 2011, Subepithermal Au-Pd mineralization associated with an alkalic porphyry $\mathrm{Cu}-\mathrm{Au}$ deposit, Mount Milligan, Quesnel Terrane, British Columbia, Canada: Economic Geology, v. 106, p. 781-808. [Also available at http://dx.doi.org/10.2113/econgeo.106.5.781.]
Lehmann, B., Heinhorst, J., Hein, M., Neumann, M., Weisser, J.D., and Fedesejev, V., 1999, The Bereznjakovskoje gold trend, Southern Urals, Russia: Mineralium Deposita, v. 34, no. 3, p. 241-249. [Also available at http://dx.doi.org/10.1007/s001260050201.]

Levine, R.M., 2011, The mineral industry of Uzbekistan, in Area reports-International-Europe and Central Eurasia: U.S. Geological Survey Minerals Yearbook 2009, v. III, p. 49.1-49.7, accessed February 12, 2014, at http://minerals.usgs.gov/minerals/pubs/country/2009/ myb3-2009-uz.pdf.

Leybourne, M.I., and Cameron, E.M., 2006, Composition of groundwaters associated with porphyry-Cu deposits, Atacama Desert, Chile_-Elemental and isotopic constraints on water sources and water-rock reactions: Geochimica et Cosmochimica Acta, v. 70, no. 7, p. 1616-1635. [Also available at http://dx.doi.org/10.1016/j.gca.2005.12.003.]

Leybourne, M.I., and Cameron, E.M., 2008, Source, transport, and fate of rhenium, selenium, molybdenum, arsenic, and copper in groundwater associated with porphyry-Cu deposits, Atacama Desert, Chile: Chemical Geology, v. 247, nos. 1-2, p. 208-228. [Also available at http://dx.doi.org/10.1016/j.chemgeo.2007.10.017.]

Li, Y.-H., and Schoonmaker, J.E., 2003, Chemical composition and mineralogy of marine sediments, in McKenzie, F.T., ed., Sediments, diagenesis, and sedimentary rocks, v. 7 of Holland, H.D., and Turekian, K.K., eds., Treatise on geochemistry: Oxford, United Kingdom, Elsevier-Pergamon, p. 1-35. [Also available at http://dx.doi.org/10.1016/b0-08043751-6/07088-2.]

Lind, C.J., Creasey, C.L., and Angeroth, Cory, 1998, In-situ alteration of minerals by acidic ground water resulting from mining activities-Preliminary evaluation of method: Journal of Geochemical Exploration, v. 64, nos. 1-3, p. 293-305. [Also available at http://dx.doi.org/10.1016/ s0375-6742(98)00039-9.]

Lindgren, Waldemar, 1906, Metasomatic processes in the gold deposits of Western Australia: Economic Geology, v. 1, p. 530-544. [Also available at http://dx.doi.org/10.2113/ gsecongeo.1.6.530.]

Lindsay, M.B.J., Condon, P.D., Jambor, J.L., Lear, K.G., Blowes, D.W., and Ptacek, C.J., 2009, Mineralogical, geochemical, and microbial investigation of a sulfide-rich tailings deposit characterized by neutral drainage: Applied Geochemistry, v. 24, no. 12, p. 2212-2221. [Also available at http://dx.doi.org/10.1016/j.apgeochem.2009.09.012.] 
Liu, Junlai, Bai, Xiangdong, Zhao, Shengjin, Tran, Mydung, Zhang, Zhaochong, Zhao, Zhidan, Zhao, Haibin, and Lu, Jun, 2011, Geology of the Sandaowanzi telluride gold deposit of the northern Great Xing'an Range, NE ChinaGeochronology and tectonic controls: Journal of Asian Earth Sciences, v. 41, no. 2, p. 107-118. [Also available at http://dx.doi.org/10.1016/j.jseaes.2010.12.011.]

Liu, Junlai, Zhao, Shengjin, Cook, N.J., Bai, Xiangdong, Zhang, Zhaochong, Zhao, Zhidan, Zhao, Haibin, and Lu, Jun, 2013, Bonanza-grade accumulations of gold tellurides in the Early Cretaceous Sandaowanzi deposit, northeast China: Ore Geology Reviews, v. 54, p. 110126. [Also available at http://dx.doi.org/10.1016/ j.oregeorev.2013.03.003.]

Loucks, R.R., and Mavrogenes, J.A., 1999, Gold solubility in supercritical hydrothermal brines measured in synthetic fluid inclusions: Science, v. 284, no. 5423, p. 2159-2163. [Also available at http://dx.doi.org/10.1126/science.284.5423.2159.]

Lovering, T.S., and Goddard, E.N., 1950, Geology and ore deposits of the Front Range, Colorado: U.S. Geological Survey Professional Paper 223, 319 p., 28 pls., accessed October 23, 2013, http://pubs.er.usgs.gov/publication/pp223.

Lueth, V.W., Beyer, J.T., and Gibbs, R.B., 1996, Geology and tellurium minerals of the Lone Pine area, Wilcox district, Catron County, New Mexico (abs.), in Sixteenth Annual New Mexico Mineral Symposium, Socorro, N. Mex., November 11-12, 1995: Socorro, N. Mex., New Mexico Bureau of Geology and Mineral Resources, p. 20-21, accessed October 21, 2015, at http://geoinfo.nmt.edu/ museum/minsymp/abstracts/view.cfml?aid=182.

Maness, L.V., Jr., 2010, Elements of special interest: China Resources Web page, accessed January 17, 2014, at http://www.china-resources.net/Elements/

AA_Elements.html.

Mao, Jingwen, Wang, Yitian, Ding, Tiping, Chen, Yuchuan, Wei, Jiaxiu, and Yin, Jianzhao, 2002, Dashuigou tellurium deposit in Sichuan Province, China-S, C, O, and H isotope data and their implications on hydrothermal mineralization: Resource Geology, v. 52, no. 1, p. 15-23. [Also available at http://dx.doi.org/10.1111/j.1751-3928.2002.tb00113.x.]

Maslennikov, V.V., Maslennikova, S.P., Large, R.R., Danyushevsky, L.V., Herrington, R.J., and Stanley, C.J., 2013, Tellurium-bearing minerals in zoned sulfide chimneys from $\mathrm{Cu}-\mathrm{Zn}$ massive sulfide deposits of the Urals, Russia: Mineralogy and Petrology, v. 107, no. 1, p. 67-99. [Also available at http://dx.doi.org/10.1007/s00710-012-0230-x.]

McDonough, W.F., 2003, Compositional model for the Earth's core, in Carlson, R.W., ed., The mantle and core, v. 2 of Holland, H.D., and Turekian, K.K., eds., Treatise on geochemistry: Oxford, United Kingdom, Elsevier-Pergamon, p. 547-568. [Also available at http://dx.doi.org/10.1016/ B0-08-043751-6/02015-6.]
McPhail, D.C., 1995, Thermodynamic properties of aqueous tellurium species between 25 and $350^{\circ} \mathrm{C}$ : Geochimica et Cosmochimica Acta, v. 59, no. 5, p. 851-866. [Also available at http://dx.doi.org/10.1016/0016-7037(94)00353-x.]

Meinert, L.D., 2000, Gold in skarns related to epizonal intrusions, in Hagemann, S.G., and Brown, P.E., eds., Gold in 2000: Littleton, Colo., Society of Economic Geologists, Reviews in Economic Geology series, v. 13, p. 347-375.

Mercier-Langevin, Patrick, McNicoll, Vicky, Allen, R.L., Blight, J.H.S., and Dubé, Benoît, 2013, The Boliden goldrich volcanogenic massive sulfide deposit, Skellefte district, Sweden-New U-Pb age constraints and implications at deposit and district scale: Mineralium Deposita, v. 48, no. 4, p. 485-504. [Also available at http://dx.doi.org/10.1007/ s00126-012-0438-z.]

Mexivada Mining Corp., 2008, Mexivada discovers porphyry molybdenum, silver-tellurium, and gold systems at Moly Dome, Nevada; begins tellurium exploration program: Mexivana Mining Corp. Web page, accessed April 8, 2015, at http://www.mexivada.com/s/NewsReleases.asp?ReportID $=296811 \& \_$Title=Mexivada-Discovers-PorphyryMolybdenum-Silver-Tellurium-And-Gold-Systems-At....

Mitrofanov, F.P., Korghagin, A.U., Dudkin, K.O., and Rundkvist, T.V., 2005, Fedorov-Pana layered mafic intrusion, (Kola Peninsula, Russia) - Approaches, methods, and criteria for prospecting PGEs, in Mungall, J.E., ed., Exploration for platinum-group element deposits: Mineralogical Association of Canada Short Course Series, v. 35, p. 343-358.

Moats, M., Davenport, W., Demetrio, S., Robinson, T., and Kareas, G., 2007, Electrolytic copper refining — 2007 world tankhouse operating data, in Hugens, J., Houlachi, G.E., Edwards, J.D., and Robinson, T.G., eds., Proceedings of the Sixth International Copper-Cobre Conference, Toronto, Ontario, Canada, August 25-30, 2007: Montreal, Quebec, Canada, Canadian Institute of Mining, Metallurgy and Petroleum, v. 5, p. 195-241.

Moss, R.L., Tzimas, E., Kara, H., Willis, P., Kooroshy, J., and European Commission Joint Research Center Institute for Energy and Transport, 2011, Critical metals in strategic energy technologies - Assessing rare metals as supply-chain bottlenecks in low-carbon energy technologies: Luxembourg, Luxembourg European Commission Publications Office, Scientific and Technical Research Series, no. EUR 24884, 161 p. [Also available at http://dx.doi.org/10.2790/35716.]

Mueller, A.G., and Muhling, J.R., 2013, Silver-rich telluride mineralization at Mount Charlotte and Au-Ag zonation in the giant Golden Mile deposit, Kalgoorlie, Western Australia: Mineralium Deposita, v. 48, no. 3, p. 295-311. [Also available at http://dx.doi.org/10.1007/s00126-012-0425-4.] 
Muntean, J.L., Cline, J.S., Simon, A.C., and Longo, A.A., 2011, Magmatic-hydrothermal origin of Nevada's Carlintype gold deposits: Nature Geoscience, v. 4, p. 122-127. [Also available at http://dx.doi.org/10.1038/ngeo1064.]

Nakata, Masataka, and Komuro, Kosei, 2011, Chemistry and occurrences of native tellurium from epithermal gold deposits in Japan: Resource Geology, v. 61, no. 3, p. 211-223. [Also available at http://dx.doi.org/10.1111/ j.1751-3928.2011.00159.x.]

Naldrett, A.J., 2011, Fundamentals of magmatic sulfide deposits, in Li, Chusi, and Ripley, E.M., eds., Magmatic Ni-Cu and PGE deposits - Geology, geochemistry, and genesis: Littleton, Colo., Society of Economic Geologists, Reviews in Economic Geology series, v. 17, p. 1-50.

Oberthür, Thomas, 2002, Platinum-group element mineralization of the Great Dyke, Zimbabwe, in Cabri, L.J., ed., The geology, geochemistry, mineralogy and mineral beneficiation of platinum-group elements: Montreal, Quebec, Canada, Canadian Institute of Mining and Metallurgy Special Volume 54, p. 483-506.

Palme, H., and O’Neil, H.St.C., 2003, Cosmochemical estimates of mantle composition, in Carlson, R.W., ed., The mantle and core, v. 2 of Holland, H.D., and Turekian, K.K., eds., Treatise on geochemistry: Oxford, United Kingdom, Elsevier-Pergamon, p. 1-38. [Also available at http://dx.doi.org/10.1016/B0-08-043751-6/02177-0.]

Pals, D.W., and Spry, P.G., 2003, Telluride mineralogy of the low-sulfidation epithermal Emperor gold deposit, Vatukoula, Fiji: Mineralogy and Petrology, v. 79, nos. 3-4, p. 285-307. [Also available at http://dx.doi.org/10.1007/ s00710-003-0013-5.]

Péntek, Attila, Molnar, Ferenc, Tuba, Györgyi, Watkinson, D.H., and Jones, P.C., 2013, The significance of partial melting processes in hydrothermal low sulfide $\mathrm{Cu}-\mathrm{Ni}$-PGE mineralization within the footwall of the Sudbury igneous complex, Ontario, Canada: Economic Geology, v. 108, p. 59-78.

[Also available at http://dx.doi.org/10.2113/

econgeo.108.1.59.]

Plaza-Toledo, Meralis, 2005, Natural rock drainage associated with unmined porphyry copper deposits in the Río Grande de Arecibo watershed, Puerto Rico: Mayagüez, P.R., University of Puerto Rico, unpublished M.S. thesis, 162 p.

Plotinskaya, O.Yu., Kovalenker, V.A., Seltmann, R., and Stanley, C.J., 2006, Te and Se mineralogy of the highsulfidation Kochbulak and Kairagach epithermal gold telluride deposits (Kurama Ridge, Middle Tien Shan, Uzbekistan): Mineralogy and Petrology, v. 87, nos. 3-4, p. 187-207. [Also available at http://dx.doi.org/10.1007/ s00710-006-0130-z.]
Popescu, G.C., and Neacsu, Antonela, 2004, TelluriumMineralogy, resources, energetic implications, in Goldsilver-telluride deposits of the golden quadrilateral, South Apuseni Mts., Romania - Guidebook of the International Field Workshop of IGCP project 486, Alba Iulia, Romania, 31st August-7th September 2004: Alba Iulia, Romania, International Association on the Genesis of Ore Deposits (IAGOD), IAGOD Guidebook Series, v. 12, p. 19-25. [Also available at http://rjes.igr.ro/wp-content/ uploads/2012/08/019-25-Popescu-Gh-2.pdf.]

Porter, K.E., and Bleiwas, D.I., 2003, Physical aspects of waste storage from a hypothetical open pit porphyry copper operation (version 1.0): U.S. Geological Survey Open-File Report 03-143, 63 p., accessed February 12, 2014, at http://pubs.er.usgs.gov/publication/ofr03143.

Prendergast, Kylie, Clarke, G.W., Pearson, N.J., and Harris, Keith, 2005, Genesis of pyrite-Au-As-Zn-Bi-Te zones associated with $\mathrm{Cu}-\mathrm{Au}$ skarns - Evidence from the Big Gossan and Wanagon gold deposits, Ertsberg district, Papua, Indonesia: Economic Geology, v. 100, p. 1021-1050. [Also available at http://dx.doi.org/10.2113/gsecongeo.100.5.1021.]

Price, W.A., 2009, Prediction manual for drainage chemistry from sulphidic geologic materials Ottawa, Ontario, Canada, CANMET Mining and Mineral Sciences Laboratories, Natural Resources Canada, MEND Report 1.20.1, 579 p. [Also available at http://www.fs.usda.gov/Internet/FSE_ DOCUMENTS/stelprdb5336546.pdf.]

Pudack, C., Halter, W.E., Heinrich, C.A., and Pettke, T., 2009, Evolution of magmatic vapor to gold-rich epithermal liquid-The porphyry to epithermal transition at Nevados de Famatina, northwest Argentina: Economic Geology, v. 104, p. 449-477. [Also available at http://dx.doi.org/ 10.2113/gsecongeo.104.4.449.]

Rice, C.M., Harmon, R.S., and Shepherd, T.J., 1985, Central City, Colorado-The upper part of an alkaline porphyry molybdenum system: Economic Geology, v. 80, p. 1769-1796. [Also available at http://dx.doi.org/10.2113/ gsecongeo.80.7.1769.]

Rose, Derek, Viljoen, Fanus, Knoper, Mike, and Rajesh, Hariharan, 2011, Detailed assessment of platinumgroup minerals associated with chromitite stringers in the Merensky Reef of the eastern Bushveld Complex, South Africa: The Canadian Mineralogist, v. 49, no. 6, p. 1385-1396. [Also available at http://dx.doi.org/ 10.3749/canmin.49.6.1385.]

Rudnick, R.L., and Gao, S., 2003, Composition of the continental crust, in Rudnick, R.L., ed., The crust, v. 3 of Holland, H.D., and Turekian, K.K., eds., Treatise on geochemistry: Oxford, United Kingdom, Elsevier-Pergamon, p. 1-64. [Also available at http://dx.doi.org/10.1016/B0-08043751-6/03016-4.] 
Rytuba, J.J., and Miller, W.M., 1990, Geology and geochemistry of epithermal precious metal vein systems in the intra-oceanic arcs of Palau and Yap, western Pacific: Journal of Geochemical Exploration, v. 35, nos. 1-3, p. 413-447. [Also available at http://dx.doi.org/10.1016/ 0375-6742(90)90046-d.]

Safirova, Elena, 2012, The mineral industry of Russia, in Area reports-International-Europe and Central Eurasia: U.S. Geological Survey Minerals Yearbook 2010, v. III, p. 38.1-38.19, accessed January 17, 2014, at http://minerals.usgs.gov/minerals/pubs/country/2010/ myb3-2010-rs.pdf.]

Saunders, J.A., 1986, Petrology, mineralogy, and geochemistry of representative gold telluride ores from Colorado: Golden, Colo., Colorado School of Mines, Ph.D. dissertation, 171 p.

Saunders, J.A., 1991, Gold deposits of the Boulder County gold district, Colorado, in Shawe, D.R., Ashley, R.P., and Carter, L.M.H., eds., Epithermal gold deposits-Part II: U.S. Geological Survey Bulletin 1857-I, p. 137-148, accessed November 5, 2013, at http://pubs.er.usgs.gov/ publication/b1857I.

Saunders, J.A., and Brueseke, M.E., 2012, Volatility of Se and Te during subduction-related distillation and the geochemistry of epithermal ores of the Western United States: Economic Geology, v. 107, p. 165-172. [Also available at http://dx.doi.org/10.2113/econgeo.107.1.165.]

Seal, R.R., II, and Hammarstrom, J.M., 2003, Geoenvironmental models of mineral deposits-Examples from massive sulfide and gold deposits, in Jambor, J.L., Blowes, D.W., and Ritchie, A.I.M., eds., Environmental aspects of mine wastes: Mineralogical Association of Canada Short Course Series, v. 31, p. 11-50.

Seal, R.R., II, and Piatak, N.M., 2012, Geoenvironmental features, in Shanks, W.C., III, and Thurston, Roland, eds., Volcanogenic massive sulfide occurrence model, chap. C of Mineral deposit models for resource assessment: U.S. Geological Survey Scientific Investigations Report 2010-5070-C, p. 323-336, accessed February 11, 2014, at http://pubs.er.usgs.gov/publication/sir20105070C.

Selenium-Tellurium Development Association, Inc., 2010, Sources of selenium and tellurium, with a section on Major applications for tellurium: Selenium-Tellurium Development Association, Inc. Web page, accessed January 17, 2014, at http://www.stda.org/se_te.html.

Shackleton, J.M., Spry, P.G., and Bateman, Roger, 2003, Telluride mineralogy of the Golden Mile deposit, Kalgoorlie, Western Australia: Canadian Mineralogist, v. 41, no. 6, p. 1503-1524. [Also available at http://dx.doi.org/10.2113/ gscanmin.41.6.1503.]
Shanks, W.C., III, and Thurston, Roland, eds., 2012, Volcanogenic massive sulfide occurrence model: U.S. Geological Survey Scientific Investigations Report 2010-5070-C, 345 p., accessed February 11, 2014, at http://pubs.usgs.gov/ sir/2010/5070/c/.

Shevenell, Lisa, Connors, K.A., and Henry, C.D., 1999, Controls on pit lake water quality at sixteen open-pit mines in Nevada: Applied Geochemistry, v. 14, no. 5, p. 669-687. [Also available at http://dx.doi.org/10.1016/s0883-2927(98) 00091-2.]

Siddeley, G., and Araneda, R., 1986, The El Indio-Tambo gold deposits, Chile, in Macdonald, A.J., ed., Gold' 86An international symposium on the geology of goldProceedings volume: Toronto, Ontario, Canada, Geological Association of Canada, p. 445-456.

Simmons, S.F., White, N.C., and John, D.A., 2005, Geological characteristics of epithermal precious and base metal deposits, in Hedenquist, J.W., Thompson, J.F.H., Goldfarb, R.J., and Richards, J.P., eds., Economic Geology - One hundredth anniversary volume, 1905-2005: Littleton, Colo., Society of Economic Geologists, p. 485-522, 1 CD-ROM.

Sindeeva, N.D., 1964, Mineralogy and types of deposits of selenium and tellurium: New York, N.Y., Wiley Interscience, $363 \mathrm{p}$.

Smith, D.S., Cannon, W.F., Woodruff, L.G., Solano, Federico, Kilburn, J.E., and Fey, D.L., 2013, Geochemical and mineralogical data for soils of the conterminous United States: U.S. Geological Survey Data Series 801, 19 p., accessed February 5, 2014, at http://pubs.er.usgs.gov/publication/ds801.

Spry, P.G., Paredes, M.M., Foster, Fess, Truckle, J.S., and Chadwick, T.H., 1996, Evidence for a genetic link between gold-silver telluride and porphyry molybdenum mineralization at the Golden Sunlight deposit, Whitehall, MontanaFluid inclusion and stable isotope studies: Economic Geology, v. 91, p. 507-526. [Also available at http://dx.doi.org/10.2113/ gsecongeo.91.3.507.]

Stollenwerk, K.G., 1994, Geochemical interactions between constituents in acidic groundwater and alluvium in an aquifer near Globe, Arizona: Applied Geochemistry, v. 9, no. 4, p. 353-369. [Also available at http://dx.doi.org/10.1016/ 0883-2927(94)90058-2.]

Tarkian, M., Hunken, U., Tokmakchieva, M., and Bogdanov, K., 2003, Precious metal distribution and fluid inclusion petrography of the Elatsite porphyry copper deposit, Bulgaria: Mineralium Deposita, v. 38, p. 261-281.

Taylor, Andrew, 1996, Biochemistry of tellurium: Biological Trace Element Research, v. 55, no. 3, p. 231-239. [Also available at http://dx.doi.org/10.1007/bf02785282.] 
Thomson, J.E., 1928, A new telluride occurrence in Quebec: Toronto, Ontario, Canada, University of Toronto Studies, Geologic series, v. 27, p. 11-14, 2 pls.

Tokmakchieva, Margarita, 2002, Valuable minor components in the composition of porphyry copper deposits: Sofia, Bulgaria, Annual of the University of Mining and Geology “St. Ivan Rilski," v. 45, part 1, Geology, p. 71-75. [Also available at http://mgu.bg/annual/public_html/2002/en/ gpf_en/dokladi_pdf/Tokmakchieva_a.pdf.]

Tombros, S., St. Seymour, K., and Williams-Jones, A.E., 2010, Controls on tellurium in base, precious, and telluride minerals in the Panormos Bay Ag-Au-Te deposits, Tinos Island, Cyclades, Greece: Economic Geology, v. 105, p. 1097-1111. [Also available at http://dx.doi.org/10.2113/econgeo.105.6.1097.]

Turner, H.W., and Becker, G.F., 1894, Jackson folio, California: U.S. Geological Survey, Folios of the Geologic Atlas 11, 6 p., 4 pls., accessed November 18, 2013, at http://pubs.er.usgs.gov/publication/gf11.

U.S. Department of Energy, 2010, Critical materials strategy: Washington, D.C., U.S. Department of Energy, 166 p. [Also available at http://energy.gov/sites/prod/files/piprod/ documents/cms_dec_17_full_web.pdf.]

U.S. Environmental Protection Agency, 2009, National recommended water quality criteria: U.S. Environmental Protection Agency Web page, accessed March 26, 2013, at http:/www2.epa.gov/wqc/national-recommended-waterquality-criteria.

United States Trade and Development Agency, 1996, Investment opportunities in mining and minerals in Uzbekistan: Washington, D.C., United States Trade and Development Agency, June 28, 150 p.

Vikentyev, I.V., 2006, Precious metal and telluride mineralogy of large volcanic-hosted massive sulfide deposits in the Urals: Mineralogy and Petrology, v. 87, nos. 3-4, p. 305-326. [Also available at http://dx.doi.org/10.1007/ s00710-006-0129-5.]
Vymazalová, Anna, and Drábek, Milan, 2011, The system Pd$\mathrm{Pb}-\mathrm{Te}$ at $400^{\circ} \mathrm{C}$ - Phase relations involving Pašavaite and potential minerals: The Canadian Mineralogist, v. 49, no. 6 , p. 1679-1686. [Also available at http://dx.doi.org/10.3749/ canmin.49.6.1679.]

Wallier, Stefan, Rey, Roger, Kouzmanov, Kalin, Pettke, Thomas, Heinrich, C.A., Leary, Stephen, O’Connor, Gary, Tămaş, C.G., Vennemann, Torsten, and Ulrich, Thomas, 2006, Magmatic fluids in the breccia-hosted epithermal Au-Ag deposit of Roşia Montană, Romania: Economic Geology, v. 101, p. 923-954. [Also available at http://dx.doi.org/10.2113/ gsecongeo.101.5.923.]

Watterson, J.R., Gott, G.B., Neuerburg G.J., Lakin, H.W., and Cathrall, J.B., 1977, Tellurium, a guide to mineral deposits: Journal of Geochemical Exploration, v. 9, nos. 1-2, p. 31-48. [Also available at http://dx.doi.org/10.1016/b978-0-44441653-7.50010-x.]

White, N.C., and Hedenquist, J.W., 1990, Epithermal environments and styles of mineralization - Variations and their causes, and guidelines for exploration: Journal of Geochemical Exploration, v. 36, nos. 1-3, p. 445-474. [Also available at http://dx.doi.org/10.1016/0375-6742(90)90063-g.]

Zhang, Xiaomao, and Spry, P.G., 1994, Petrological, mineralogical, fluid inclusion, and stable isotope studies of the Gies gold-silver telluride deposit, Judith Mountains, Montana: Economic Geology, v. 89, p. 602-627. [Also available at http://dx.doi.org/10.2113/gsecongeo.89.3.602.]

Zhao, Jing, Brugger, Joël., Grundler, P.V., Xia, Fang, Chen, Guorong, and Pring, Allan, 2009, Mechanism and kinetics of a mineral transformation under hydrothermal conditions - Calaverite to metallic gold: American Mineralogist, v. 94, nos. 11-12, p. 1541-1555. [Also available at http://dx.doi.org/10.2138/am.2009.3252.]

Zientek, M.L., Fries, T.L., and Vian, R.W., 1990, As, Bi, Hg, $\mathrm{S}, \mathrm{Sb}, \mathrm{Sn}$, and Te geochemistry of the J-M Reef, Stillwater Complex, Montana - Constraints on the origin of PGEenriched sulfides in layered intrusions: Journal of Geochemical Exploration, v. 37, no. 1, p. 51-73. [Also available at http://dx.doi.org/10.1016/0375-6742(90)90082-1.] 



\section{Tin}

By Robert J. Kamilli, Bryn E. Kimball, and James F. Carlin, Jr.

Chapter S of

Critical Mineral Resources of the United States-Economic and Environmental Geology and Prospects for Future Supply

Edited by Klaus J. Schulz, John H. DeYoung, Jr., Robert R. Seal II, and Dwight C. Bradley

Professional Paper 1802-S

U.S. Department of the Interior

U.S. Geological Survey 


\section{Contents of Chapter S}

[Figure and table titles for all chapters are listed in the volume contents before the conversion factors table and list of abbreviations and symbols. A periodic table of the elements is on the inside front cover of the printed volume]

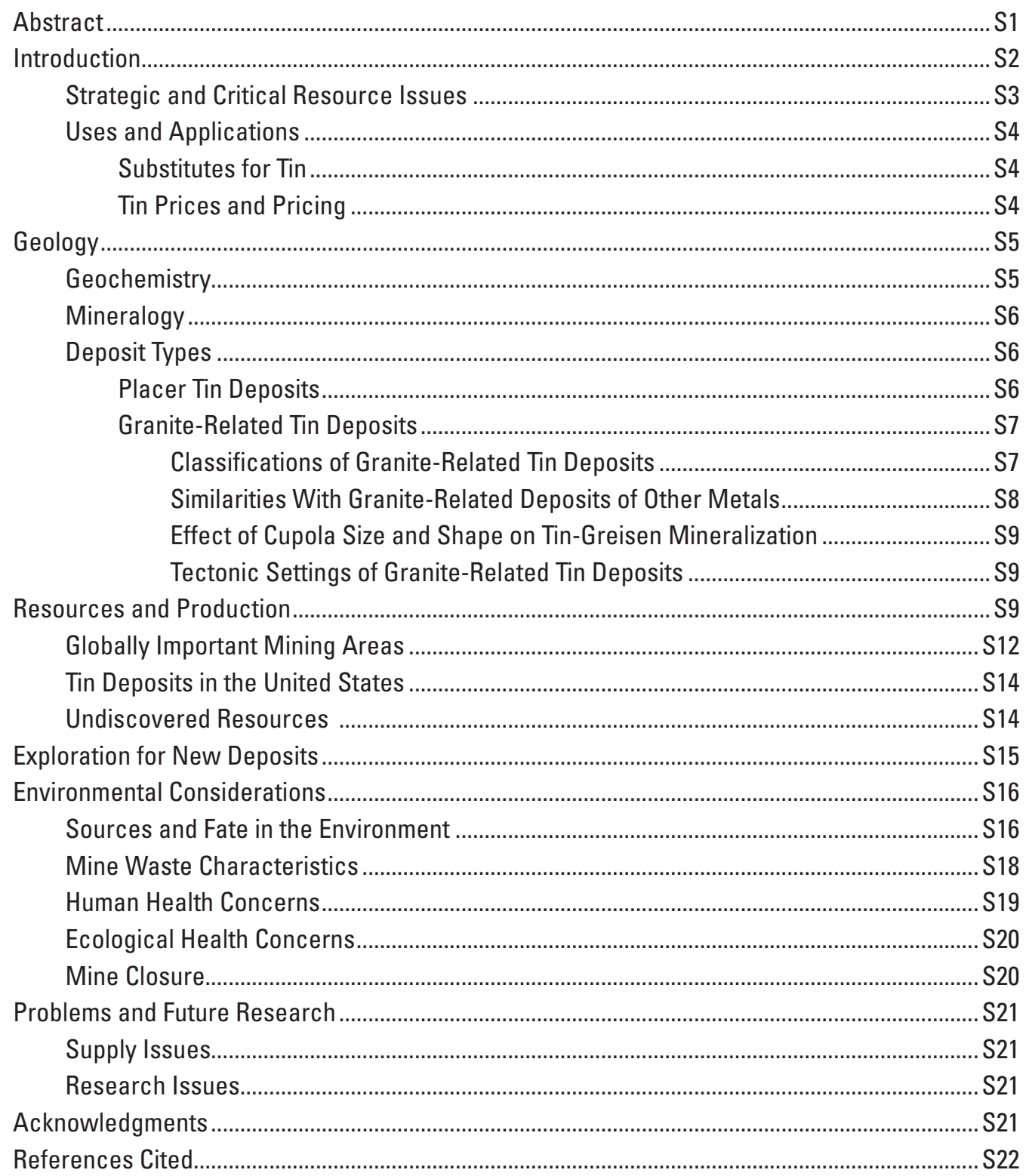




\title{
Tin
}

\author{
By Robert J. Kamilli, Bryn E. Kimball, and James F. Carlin, Jr. ${ }^{1}$
}

\section{Abstract}

Tin (Sn) is one of the first metals to be used by humans. Almost without exception, tin is used as an alloy. Because of its hardening effect on copper, tin was used in bronze implements as early as 3500 B.C. The major uses of tin today are for cans and containers, construction materials, transportation materials, and solder. The predominant ore mineral of tin, by far, is cassiterite $\left(\mathrm{SnO}_{2}\right)$. Tin has not been mined or smelted in the United States since 1993 and 1989, respectively.

In 2015, the world's total estimated mine production of tin was 289,000 metric tons of contained tin. Total world reserves at the end of 2016 were estimated to be 4,700,000 metric tons. China held about 24 percent of the world's tin reserves and accounted for 38 percent of the world's 2015 production of tin.

The proportion of scrap used in tin production is between 10 and 25 percent. Unlike many metals, tin recycling is relatively efficient, and the fraction of tin in discarded products that get recycled is greater than 50 percent.

Only about 20 percent of the world's identified tin resources occur as primary hydrothermal hard-rock veins, or lodes. These lodes contain predominantly high-temperature minerals and almost invariably occur in close association with silicic, peraluminous granites. About 80 percent of the world's identified tin resources occur as unconsolidated secondary or placer deposits in riverbeds and valleys or on the sea floor. The largest concentration of both onshore and offshore placers is in the extensive tin belt of Southeast Asia, which stretches from China in the north, through Thailand, Burma (also referred to as Myanmar), and Malaysia, to the islands of Indonesia in the south. Furthermore, tin placers are almost always found closely allied to the granites from which they originate. Other countries with significant tin resources are Australia, Bolivia, and Brazil.

Most hydrothermal tin deposits belong to what can be thought of as a superclass of porphyry-greisen deposits. The hydrothermal tin deposits are all characterized by a close spatial, temporal, and genetic association with highly differentiated, peraluminous porphyritic granite intrusions. The intrusions form pegmatites; disseminated ore; parallel or subparallel, greisen-bordered sheeted veins that either cross-cut the intrusion or are peripheral to it; skarns; and (or) limestone replacements that contain different amounts of cassiterite, molybdenite, and wolframite.

The tectonic settings of tin-bearing granites are relatively well understood and of limited variety. Tin and tungsten deposits and their associated igneous rocks are found mainly in continental settings.

Historically, prospecting for tin has been carried out by the time-honored methods of panning, drilling, trenching, and assaying. Geophysical and geochemical surveys have been employed to cover large areas more rapidly, isolating areas of possible tin deposits so that drilling can be more effective and less costly. Elemental concentrations and relationships of the lithophile elements, especially barium, lithium, niobium, potassium, rubidium, and zirconium, are the most reliable chemical indicators of ore-forming processes and tin-bearing potential.

The average human diet includes an intake of about 10 milligrams per day of tin. Ingestion of tin in significantly greater amounts than 10 milligrams per day may lead to a stomach ache, anemia, and liver and kidney problems. Exposure to some organo-tin compounds can interfere with brain and nervous system function and, in severe cases, can cause death. Extended inhalation of tin oxide - an issue mainly for those people who work in the tin industry-results in a higher potential to develop stannosis, which is a mild disease of the lungs caused by the inhalation of tin-bearing dust. Inorganic tin is poorly absorbed by the body, and no evidence exists for the carcinogenicity of metallic tin and tin compounds in humans.

Most placer tin deposits are mined by open pit and (or) dredging methods. Mining of alluvial placers in modern streambeds and riverbeds is likely to increase the amount of sediment delivered downstream. This, combined with potential diversion of rivers and streams, may negatively 
affect downstream ecosystems. Many of the placer deposits located in Burma, Indonesia, Malaysia, and Thailand are located offshore. Most offshore placer tin deposits are mined by dredging methods, which have the potential to negatively affect benthic, midwater, and pelagic ecosystems.

In a congressionally mandated U.S. Department of Defense study of strategic minerals published in 2013, tin has the greatest shortfall amount (insufficient supply to meet demand) at $\$ 416$ million; this amount is more than twice that of antimony ( $\$ 182$ million), which is the strategic mineral with the next largest shortfall amount (U.S. Department of Defense, 2013). The United States imported 75 percent of its tin supply in 2015. During the period 2012-15, these imports were from, in descending order of amount imported, Peru, Indonesia, Malaysia, and Bolivia.

A promising advancement concerning research into the origin of tin deposits is the recent development of a reliable method of analyzing tin isotopes in cassiterite. Although the mechanism of transport and deposition of tin is fairly well understood, the means by which tin is incorporated into the parent magma at the points of magma generation and ascent needs further investigation.

Tin metallogenic provinces worldwide are well known. Consequently, any undiscovered tin deposits will likely be spatially close to known deposits or extensions of the same.

\section{Introduction}

Tin was one of the earliest metals known to humanity. Aside from native gold and copper, which are found in nature, tin and lead were the first metals to be smelted. Because of its hardening effect on copper, tin was used in bronze implements as early as 3500 B.C., although the pure metal was not commonly used until about 600 B.C. Bronze, which is a copper-tin alloy that can be sharpened and is hard enough to retain a cutting edge, was used in construction tools as well as in weapons. Arsenic-containing bronzes, which were probably accidentally created by smelting arsenic- and copper-containing minerals, preceded tin bronzes by about 2,000 years (fifth millennium versus third millennium B.C.). Oven-fired Mesopotamian pottery from the Ubaid culture (about 6500 to 3800 B.C.) was contemporaneous with the origins of metallurgy. The origins of metallurgy, therefore, may have been the serendipitous outcome of firing of ceramics when ore-bearing rocks were accidentally placed in the kiln (Cowen, 1999).

Tin placer deposits commonly form in streambeds where running water removes lighter material and leaves the heavier cassiterite $\left(\mathrm{SnO}_{2}\right)$, which has a specific gravity of 6.8 to 7.1, behind. Cassiterite was probably first picked up in streambeds, as its density and translucent brown-black color make it conspicuous.
The area of Cornwall, England, was historically a leading world producer of tin. Tin deposits in Cornwall had been worked since at least Roman times, although the mining of tin likely began there as far back as the early Bronze Age. Most mining up to the 17th century was from alluvial sources. Cornwall continued to be a major world producer of tin up through the 19th century (Penhallurick, 1986, p. 148). Although the area still has identified resources of tin, the last working tin mine in Cornwall (the South Crofty Mine) was closed in 1998 (Carlin, 2000).

The predominant ore mineral of tin is cassiterite, although small amounts of tin are recovered from other tin-bearing minerals, including stannite $\left(\mathrm{Cu}_{2} \mathrm{FeSnS}_{4}\right)$, cylindrite $\left(\mathrm{Pb}_{3} \mathrm{Sn}_{3}, \mathrm{Sb}_{2} \mathrm{~S}_{14}\right)$, franckeite $\left(\mathrm{Pb}_{5} \mathrm{Sn}_{3} \mathrm{Sb}_{2} \mathrm{~S}_{14}\right)$, canfieldite $\left(\mathrm{Ag}_{8} \mathrm{SnS}_{6}\right)$, and teallite $\left(\mathrm{PbSnS}_{2}\right)$. Rock-forming minerals that may contain significant amounts of tin (that is, tens to hundreds of parts per million) are, in order of increasing tin content, muscovite, biotite (annite), titanite, and titanomagnetitite (Wang and others, 2013). Table S1 includes a more comprehensive, although not exhaustive, list of tin-bearing minerals. The chemical symbol for tin, $\mathrm{Sn}$, comes from the Latin stannum; hence, the name stannite for one of its minerals. After the Bronze Age and up to the 20th century, pewter, which is an alloy of 85 to 90 percent tin coupled with copper, antimony, and (or) lead, was the leading material for kitchenware, tableware, and other items, such as candlesticks, in households that could not afford sterling silver or gold. Tin cans, which are made mostly of steel, are so named because the steel is coated with tin to form tin plate, which has low toxicity.

Tin is silvery, malleable, and not easily oxidized in air. The metallic form of tin, or beta-tin (B-tin, also known as white tin), is stable at and above room temperature, is malleable, and has an unusual, tetragonal crystal structure. Tin becomes a superconductor below 3.72 Kelvin (-269.43 degrees Celsius [ $\left.{ }^{\circ} \mathrm{C}\right]$ ) (De Haas and others, 1935); in fact, tin was one of the first superconductors to be studied. In contrast, the nonmetallic form of tin, or alpha-tin ( $\alpha$-tin, also known as gray tin), which is stable below $13.2^{\circ} \mathrm{C}$, is brittle and has a diamond cubic crystal structure, similar to diamond, germanium, and silicon. The $\alpha$-tin has no metallic properties at all because its atoms form a covalent structure where electrons cannot move freely. It is a dull-gray powdery material with no common uses, other than a few specialized semiconductor applications (Holleman and others, 1985). The spontaneous transformation of tin from the $\beta$ form to the $\alpha$ form, a phenomenon known as "tin pest," takes place at temperatures of $13.2^{\circ} \mathrm{C}$ and below. The presence of impurities (for example, aluminum, zinc, and others) lowers the transition temperature to below $0{ }^{\circ} \mathrm{C}$; upon the introduction of antimony or bismuth, the transformation may not take place at all. The addition of these elements thus increases the durability of tin (Schwartz, 2002). 
Table S1. List of selected tin-bearing minerals.

[Data are from Fleischer (1983). NA, not available]

\begin{tabular}{|c|c|c|}
\hline Mineral name & Chemical formula & Location of geographic occurrence \\
\hline Berndtite & $\mathrm{SnS}_{2}$ & Cerro de Potosí, Bolivia \\
\hline Canfieldite & $\mathrm{Ag}_{8} \mathrm{SnS}_{6}$ & Bolivia; Tasmania, Australia \\
\hline Cassiterite & $\mathrm{SnO}_{2}$ & Worldwide \\
\hline Colusite & $\mathrm{Cu}_{3}(\mathrm{As}, \mathrm{Sn}, \mathrm{V}, \mathrm{Fe}) \mathrm{S}_{4}$ & Butte, Montana; Australia \\
\hline Cylindrite & $\mathrm{Pb}_{3} \mathrm{Sn}_{4} \mathrm{FeSb}_{2} \mathrm{~S}_{14}$ & Bolivia; Tasmania, Australia \\
\hline Franckeite & $\mathrm{Pb}_{5} \mathrm{Sn}_{3} \mathrm{Sb}_{2} \mathrm{~S}_{14}$ & Bolivia; Tasmania, Australia \\
\hline Herzenbergite & $\mathrm{SnS}$ & Bolivia \\
\hline Hulsite (also called Paigeite) & $\left(\mathrm{Fe}^{2+}, \mathrm{Mg}\right)_{2}\left(\mathrm{Fe}^{3+}, \mathrm{Sn}\right) \mathrm{BO}_{5}$ & $\begin{array}{l}\text { Brooks Range and Seward Peninsula, Alaska; eastern } \\
\text { Siberia Russia }\end{array}$ \\
\hline Malayaite & $\mathrm{CaSnSiO}_{5}$ & Malaysia; Cornwall, United Kingdom \\
\hline Mawsonite & $\mathrm{Cu}_{6}{ }^{1+} \mathrm{Fe}_{2}{ }^{3+} \mathrm{Sn}^{4+} \mathrm{S}_{8}$ & New South Wales; Tasmania, Australia \\
\hline Native tin & $\mathrm{Sn}$ & $\begin{array}{l}\text { Native tin is found in placer deposits and in unusual } \\
\text { igneous intrusions. Australia has the recognized } \\
\text { type locality. }\end{array}$ \\
\hline $\begin{array}{l}\text { Nigerite (More correctly, } \\
\text { Ferronigerite-2N1S) }\end{array}$ & $\begin{array}{l}\left(\mathrm{Zn}, \mathrm{Mg}, \mathrm{Fe}^{2+}\right)(\mathrm{Sn}, \mathrm{Zn})_{2} \\
\quad\left(\mathrm{Al}, \mathrm{Fe}^{3+}\right)_{12} \mathrm{O}_{22}(\mathrm{OH})_{2}\end{array}$ & Nigeria \\
\hline Nordenskiöldine & $\mathrm{CaSnB}_{2} \mathrm{O}_{6}$ & Norway; Namibia \\
\hline Ottemannite & $\mathrm{Sn}_{2} \mathrm{~S}_{3}$ & Bolivia \\
\hline Renierite & $\mathrm{Cu}_{3}(\mathrm{Fe}, \mathrm{Ge}, \mathrm{Zn})(\mathrm{S}, \mathrm{As})_{4}$ & $\begin{array}{l}\text { Democratic Republic of the Congo (Congo [Kinshasa]); } \\
\text { Namibia }\end{array}$ \\
\hline Sorensenite & $\mathrm{Na}_{4} \mathrm{SnBe}_{2} \mathrm{Si}_{6} \mathrm{O}_{16}(\mathrm{OH})_{4}$ & Greenland \\
\hline Stannite & $\mathrm{Cu}_{2} \mathrm{FeSnS}_{4}$ & Worldwide \\
\hline Stannomicrolite (Sukulaite) & $\mathrm{Sn}_{2} \mathrm{Ta}_{2} \mathrm{O}_{7}$ & NA \\
\hline Stokesite & $\mathrm{CaSnSi}_{3} \mathrm{O}_{9} \cdot 2 \mathrm{H}_{2} \mathrm{O}$ & Cornwall, United Kingdom \\
\hline Teallite & $\mathrm{PbSnS}_{2}$ & Bolivia \\
\hline Thoreaulite & $\mathrm{SnTa}_{2} \mathrm{O}_{6}$ & Democratic Republic of the Congo (Congo [Kinshasa]) \\
\hline Varlamoffite (?) & $(\mathrm{Sn}, \mathrm{Fe})(\mathrm{O}, \mathrm{OH})_{2}$ & $\begin{array}{l}\text { Democratic Republic of the Congo (Congo [Kinshasa]); } \\
\text { Bolivia }\end{array}$ \\
\hline
\end{tabular}

\section{Strategic and Critical Resource Issues}

The United States has no tin reserves and is dependent on imports to meet its tin requirements (Anderson, 2016b). Tin is considered a critical and strategic metal because of its importance to national security (McGroarty and Wirtz, 2012). In a congressionally mandated U.S. Department of Defense (DOD) study of strategic minerals published in 2013, tin was shown to have the greatest shortfall amount (insufficient supply to meet demand measured in monetary terms $-\$ 416$ million) in a list of strategic minerals, and more than twice the shortfall amount of the next strategic mineral, antimony ( $\$ 182$ million). The shortfall amounts result from a modeling process that, given a 4-year scenario that assumes 1 year of conflict and 3 years of recovery and regeneration, computes material demand at all levels of the U.S. economy and then compares the quantity of material supply with the quantity demanded, taking a number of conflict-related factors into account. These factors include unavailability of supply from adversaries, war damage, shipping losses, infrastructure and (or) ability degradation, anti-U.S. orientation, and foreign competition (that is, market share) (U.S. Department of Defense, 2013). 
Artisanal and small-scale mining of tin in the Democratic Republic of the Congo (Congo [Kinshasa], formerly Zaire) and neighboring countries has been identified as a potential source of funding for armed groups engaged in civil unrest. This has led the United States, through passage of Section 1502 of the Dodd-Frank Wall Street Reform and Consumer Protection Act (Pub.L. 111-203, H.R. 4173; commonly referred to as Dodd-Frank) in 2010, to make it a statutory obligation for all companies registered with the U.S. Securities and Exchange Commission (SEC) to perform due diligence to determine whether the products or components they manufacture contain tantalum, tin, tungsten, and (or) gold (3TG) minerals and, if so, to determine whether these minerals were sourced from Congo (Kinshasa) and (or) its neighboring countries. In addition, under rules issued by the SEC, publicly traded companies are required to report the sources of 3TG materials used, starting in 2014.

In 2015, the United States relied on foreign sources for 75 percent of its annual apparent consumption of tin. The major foreign sources of tin, other than scrap, during the period 2011-15 were, in descending order of amount imported, Peru, Indonesia, Malaysia, and Bolivia (Anderson, 2017). Nearly 30 percent of the U.S. tin supply from 2010 through 2014 was produced from scrap (Papp, 2016).

\section{Uses and Applications}

Almost without exception, tin is used in alloys. Although it is a metallic mineral, it is rarely used in the elemental form because it decomposes at temperatures below $13.2{ }^{\circ} \mathrm{C}$ (Sainsbury and Reed, 1973, p. 637). Up to 28 percent tin can be combined with copper, but 10 percent produces an optimum-strength alloy, and as little as 2 percent tin will harden copper (Wheeler and Maddin, 1980). U.S. consumption of tin by end-use category in 2014 was in cans and containers, 23 percent; construction, 18 percent; transportation, 17 percent; electrical, 12 percent; and other, 30 percent (Anderson, 2015). U.S. consumption of tin by end use finished product is shown in figure S1.

\section{Substitutes for Tin}

Common substitutes for tin in cans and containers are aluminum, glass, paper, plastic, or tin-free steel. Other materials that are used to substitute for tin are epoxy resins for solder; aluminum alloys, copper-base alloys, and plastics for bronze; plastics for metal bearings that contain tin; and compounds of lead and sodium for some tin chemicals (Anderson, 2016b).

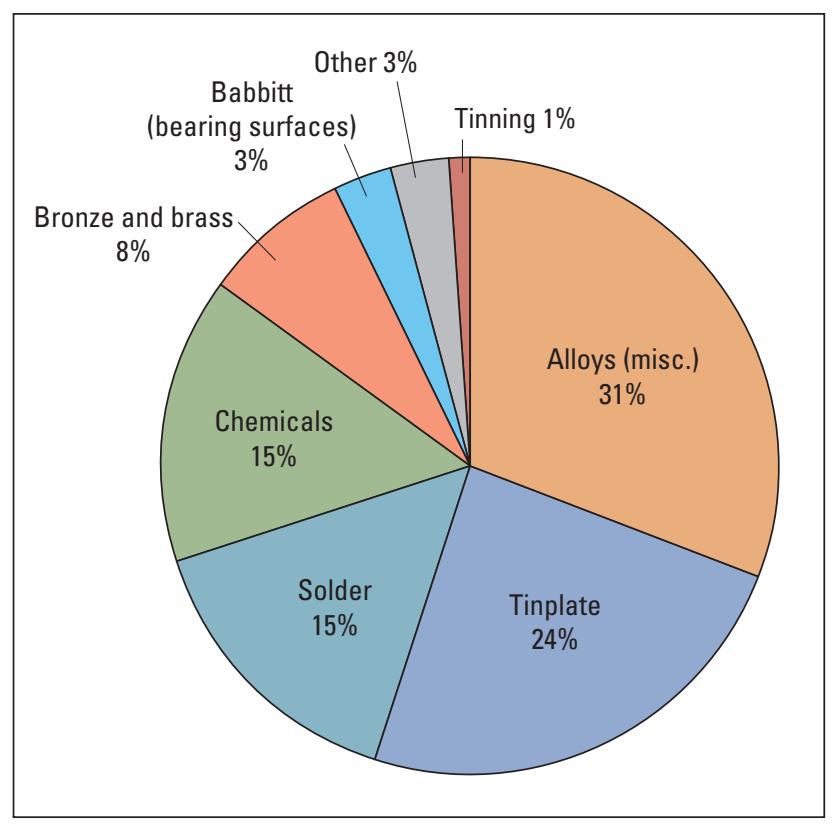

Figure S1. Pie chart showing major end uses of tin as a percentage of total consumption in the United States in 2014. Data are from Anderson (2016a, table 3). misc., miscellaneous

\section{Tin Prices and Pricing}

During the 20th century, the pricing of tin was somewhat "regulated" by a series of agreements structured between producer countries and consumer countries dating back to 1921 (Carlin, 2013). The International Tin Council, an association of leading world tin-producing and -consuming countries, was established in 1956 to try to stabilize both tin prices and the supply of and demand for tin until the organization was disbanded in 1989. The Association of Tin Producing Countries (ATPC) was chartered on August 16,1983, to perform activities complementary to those of the International Tin Council. The five charter members of the ATPC were Bolivia, Congo (Kinshasa), Indonesia, Malaysia, and Thailand, with Australia and Nigeria joining later. The ATPC was disbanded in 2001. Figure S2 shows the average annual prices of tin metal from 1970 to 2010 (Carlin, 2013). 


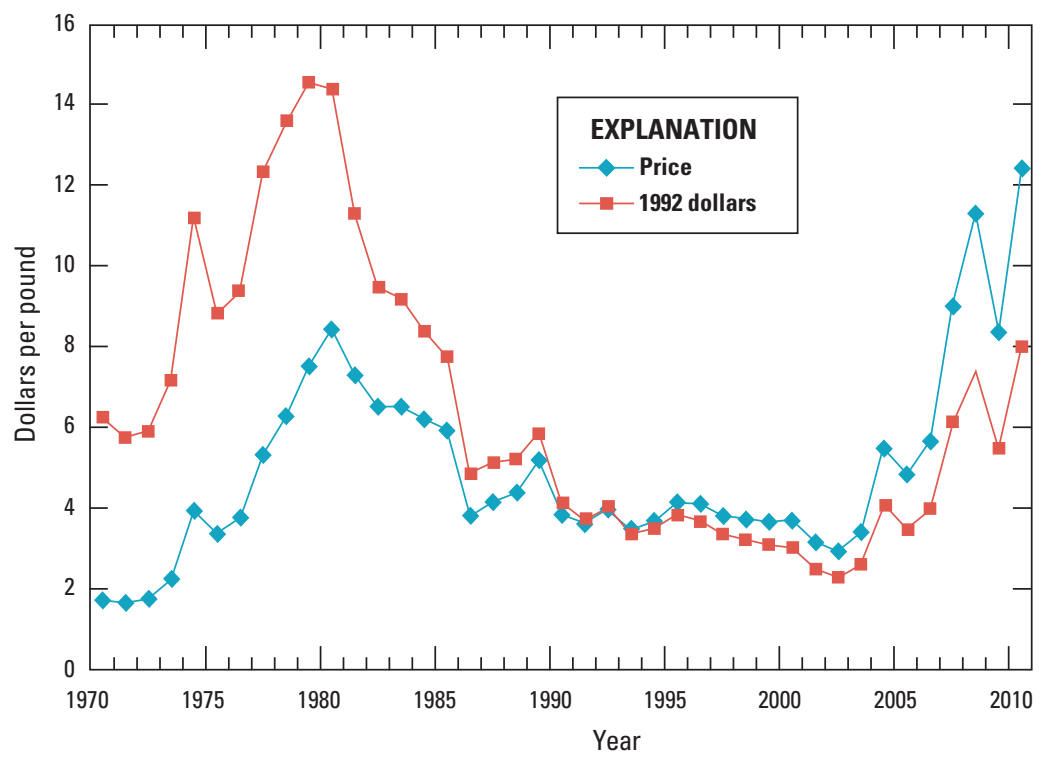

Significant events affecting tin prices since 1970

1956-85 International Tin Agreements (a continuous series of complex, global, 4-year pacts)

1973-80 Rampant inflation

1981-82 Sharp recession

1980-2010 Increased toxicity issues with lead, leading to increased tin consumption as a lead replacement

2002-08 A period of world steel company (tinplate producers) consolidations and mergers that often resulted in lower available world tinplate and increased tin pricess

2002-09 Tin mine and smelter production declined in Indonesia owing to Government closures of illegal tin smelters, smuggling, and severe weather

2008-09 Global financial crisis

Figure S2. Graph showing the average annual prices of tin metal from 1970 to 2010 . Both the nominal (unadjusted) prices and real prices (in 1992 constant dollars) are shown. Graph is from Carlin (2013).

\section{Geology}

\section{Geochemistry}

Tin has an atomic number of 50 and an atomic weight of 118.69. It has two oxidation states: +2 and +4 ; the +4 oxidation state occurs in the mineral cassiterite. Tin is the 49th most abundant element, and it has the largest number of stable isotopes (10) in the periodic table of elements. The average abundance of tin in Earth's crust is low at about 2.3 parts per million ( $\mathrm{ppm}$ ) compared with $70 \mathrm{ppm}$ for zinc, $60 \mathrm{ppm}$ for copper, and $14 \mathrm{ppm}$ for lead. Tin is both siderophile and, to a lesser extent, lithophile; thus, it has an affinity for both iron and oxygen and is associated with boron, fluorine, lithium, and rubidium in the late-stage differentiates of granites or their extrusive equivalents. In pegmatitic settings, tin is associated with beryllium, boron, lithium, niobium-tantalum, tungsten, and the rare-earth elements (Rose and others, 1979; Carlin, 1985).

According to the study of tin-bearing and tin-barren granites in northern Nigeria by Olade (1980), highly evolved biotite granites are genetically and spatially related to tin mineralization (also Falconer, 1912; Williams and others, 1956; MacLeod and others, 1971; Bowden and Kinnaird, 1978). Beus (1969) also showed that statistically significant variations are found between granites of nonstanniferous regions and granites of stanniferous regions, as well as among biotite granites in different areas of Russia. Part of the explanation for this association lies in that, in less differentiated granites, tin is locked up in early crystallized silicate minerals, such as fayalite, hornblende, and riebeckite. This conclusion is confirmed by the high contents of tin and other elements, such as niobium, in these rocks, particularly the peralkaline riebeckite granites (Bowden and Van Breemen,
1972). In contrast, biotite crystallized late within the biotite granites; consequently, tin and other elements were able to be concentrated into the volatile-rich fraction of the melt and subsequently in exsolved mineralizing fluids. Alexsiyev (1970) and Bowden and Van Breemen (1972) suggested that the enrichment of tin and related elements in tin-bearing granites is connected with albitization and the trace-element overprinting by post-magmatic fluids. Albitization is a product of subsolidus recrystallization (hydrothermal alteration) and is accompanied by the enrichment of the magma in trace elements, such as niobium, rubidium, and tin, and its depletion in barium, strontium, and zirconium. This pattern of traceelement association may be attributed to the development of an alkali-volatile-rich phase during the evolution of the granitic magmas.

Tin-bearing granites tend to show a similar pattern of enrichment in trace elements. According to Bowden and Kinnaird (1978), this enrichment may be the result of a continuum of ore-forming processes: that is, an early dispersed phase of mineralization associated with alkali-volatile-rich, early post-magmatic fluids, and a later phase of fracturecontrolled mineralization associated with hydrothermal solutions from which sulfides are commonly deposited. This is consistent with the occurrence of both types of mineralization within the same intrusive body (Olade, 1980).

Three mechanisms have been proposed by Heinrich (1995) for cassiterite precipitation. The first is acid neutralization by feldspar hydrolysis, which takes place during the formation of alteration assemblages. The second is vapor separation (boiling), which effectively removes hydrogen chloride $(\mathrm{HCl})$ and hydrogen gas $\left(\mathrm{H}_{2}\right)$ and causes cassiterite deposition. The third is mixing of hot, saline magmatic fluid with a nonmagmatic fluid. 


\section{Mineralogy}

Cassiterite is a member of the rutile group of metal oxides that includes rutile $\left(\mathrm{TiO}_{2}\right)$, pyrolusite $\left(\mathrm{MnO}_{2}\right)$, and plattnerite $\left(\mathrm{PbO}_{2}\right)$; it is tetragonal and belongs to the space group $\mathrm{P}_{2} / \mathrm{mnm}$. The structure of the conventional unit cell of $\mathrm{SnO}_{2}$, which is depicted in figure $\mathrm{S} 3$, is characterized by two lattice parameters, $a$ and $b$, and an internal parameter $u$ associated with the $\mathrm{O}$ (oxygen) atomic position. There are two formula units per primitive unit cell, with the threefoldcoordinated oxygen atoms forming distorted octahedral configurations around the tin atoms (Floriano and others, 2010). Members of the rutile group show little variation in composition and little tendency to form isomorphous series between the species. Cassiterite has an adamantine, greasy, submetallic luster (fig. S4); it ranges from transparent to opaque, and can be black, yellow, brown, red, or white. It has a Mohs hardness of 6 to 7, imperfect cleavage ( $\{100\}$ and $\{110\}$ ), and a density range of from 6.98 to 7.01 grams per cubic centimeter $\left(\mathrm{g} / \mathrm{cm}^{3}\right)$. Optically, it has very high relief and weak pleochroism and is anomalously biaxial (Hudson Institute of Mineralogy, 2016).

A radially fibrous colloform variety of cassiterite ("wood tin") (fig. S5) can form by secondary processes in the zone of oxidation of tin deposits. It can also form as a hypogene mineral both in deep-seated veins and, in particular, as colloform masses associated with rhyolite flow-dome deposits of lavas and associated tuff (Palache and others, 1944).

\section{Deposit Types}

\section{Placer Tin Deposits}

Placer deposits have traditionally been an important source of tin; in 2012, they accounted for about 70 percent of the world output of cassiterite concentrates, principally from, in order of output, Malaysia, Indonesia, China, Burma (also referred to as Myanmar), Thailand, Nigeria, and Congo (Kinshasa) (Taylor, 1979; Carlin, 2014). Because cassiterite is both heavy and chemically inactive, it is concentrated in residual placers that form over or adjacent to bedrock source areas where weathering and erosional processes remove lighter rock materials. Furthermore, gravity assists in downslope movement of heavy minerals that are released by weathering to form eluvial placers (that is, deposits that remain relatively close to the primary deposit from which they are derived). The richest placers are found in stream deposits where flowing water has concentrated heavy minerals generally derived from residual or eluvial placers. Ocean beach sands may also contain placer accumulations of tin, such as those mined offshore in Indonesia and Thailand. No extensive placer deposits have been found in the conterminous United States (Carlin, 1985).

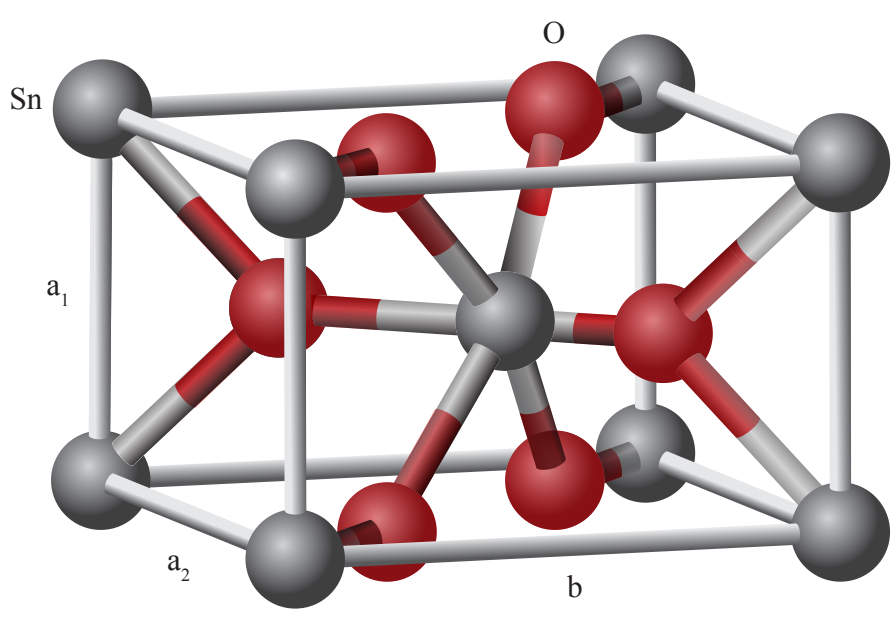

Figure S3. Ball-and-stick model of part of the crystal structure of cassiterite $\left(\mathrm{SnO}_{2}\right)$. Oxygen (0) atoms are shown in red, and tin $(\mathrm{Sn})$ atoms, in gray. Courtesy of Ben Mills.

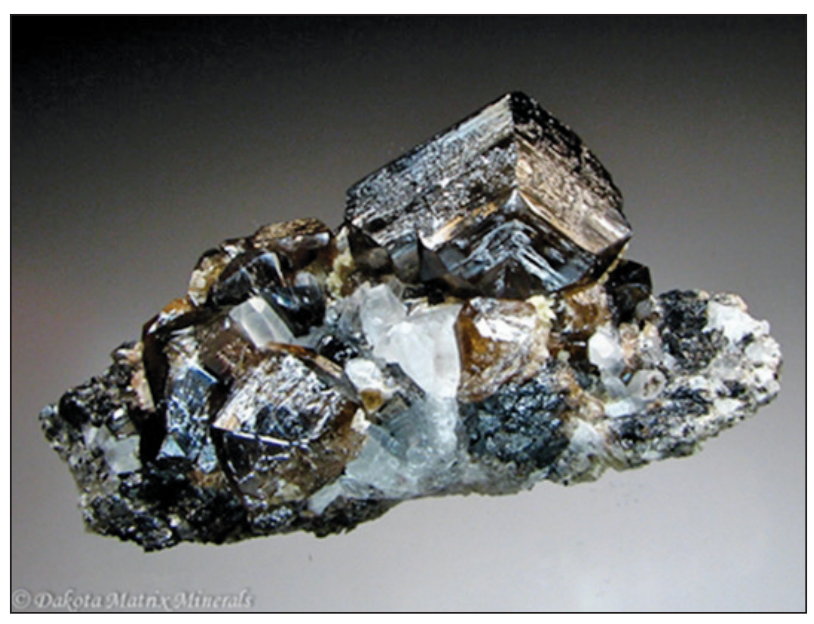

Figure S4. Photograph of cassiterite crystals. Copyright (c) Dakota Matrix Minerals; used with permission.

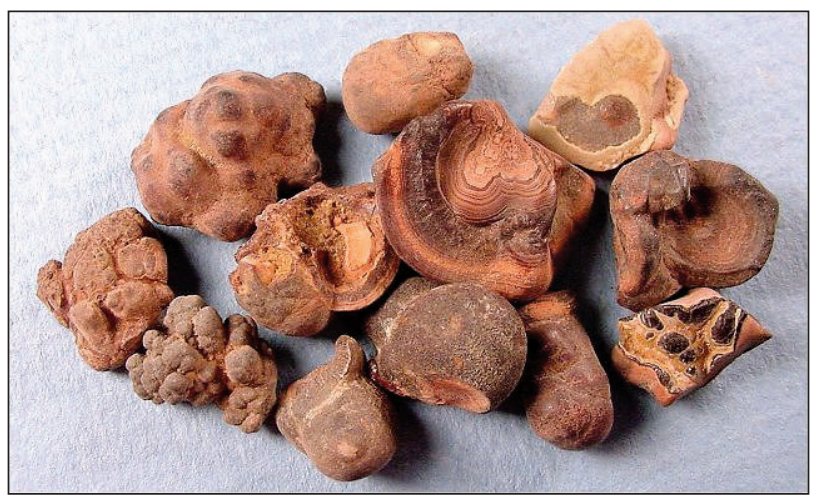

Figure S5. Photograph of wood tin cassiterite. Copyright (C) R. Weller, Cochise College; used with permission. 


\section{Granite-Related Tin Deposits}

Granite-related tin deposits are another important source of tin. Lehmann (1990) traced the history of research on granite-related deposits. According to Lehmann, the close relationship between tin deposits and granites has been well known since the mid-19th century. Research since then has mainly refined the understanding of the chemistry of the associated granites, the tectonic environment, and the mechanisms of deposition and localization of tin mineralization.

As discussed by Lehmann (1990), Alexander von Humboldt (1823) introduced the term "tin granite" as opposed to "normal granite." The first comprehensive treatise on the geology of tin and the first scientific theory of magmatichydrothermal ore formation in general was developed by Élie de Beaumont (1847). He concluded that tin ore deposits are associated with granites and are located preferentially in apical portions of granites and their immediate country rocks (fig. S6). Daubrée (1841) had already observed that tin deposits in the areas of Cornwall (United Kingdom), Bretagne (France), and Erzgebirge (Germany) are always confined to a zone extending less than $500 \mathrm{~m}$ from the granite contact. Élie de Beaumont (1847) further concluded that tin ore deposits are commonly associated with individual granite bodies extending out of larger batholiths, and that the ore occurs in rocks particularly rich in quartz, tourmaline, and fluorine-bearing minerals and that formed as a result of alteration of the original host rock (that is, greisens). Tin granites are anomalous in texture- for example, unidirectional solidification textures (USTs, also known as comb quartz layers or stockscheiders), graphic intergrowths, and pegmatitic dikes and pods (Shannon and others, 1982; White and others, 1981; Kirkham and Sinclair, 1988); they are also anomalous in composition - for example, "specialized, S-type granites" enriched in $\mathrm{Rb}, \mathrm{Cs}, \mathrm{Li}, \mathrm{Th}, \mathrm{U}, \mathrm{Nb}, \mathrm{Ta}$, and $\mathrm{W}$ and depleted in $\mathrm{Sr}, \mathrm{Eu}, \mathrm{Ba}, \mathrm{Ti}, \mathrm{Co}$, and Ni (Lehmann, 1990).

\section{Classifications of Granite-Related Tin Deposits}

Granite-related tin deposits can be classified according to the following general types. This information is modified primarily after S.S. Smirnov from Magak'yan (1968), Taylor (1979, p. 45-76), and Lehmann (1990).

Stanniferous pegmatites. - "These pegmatites are of the quartz-microcline type, with albite, muscovite, [and commonly] spodumene, topaz, and tourmaline. Cassiterite is irregularly disseminated throughout the pegmatite body and commonly in areas where secondary processes have taken place"

(Taylor, 1979, p. 46-47). Examples of stanniferous pegmatites include the Jābal as Silsilah pegmatites in Saudi Arabia

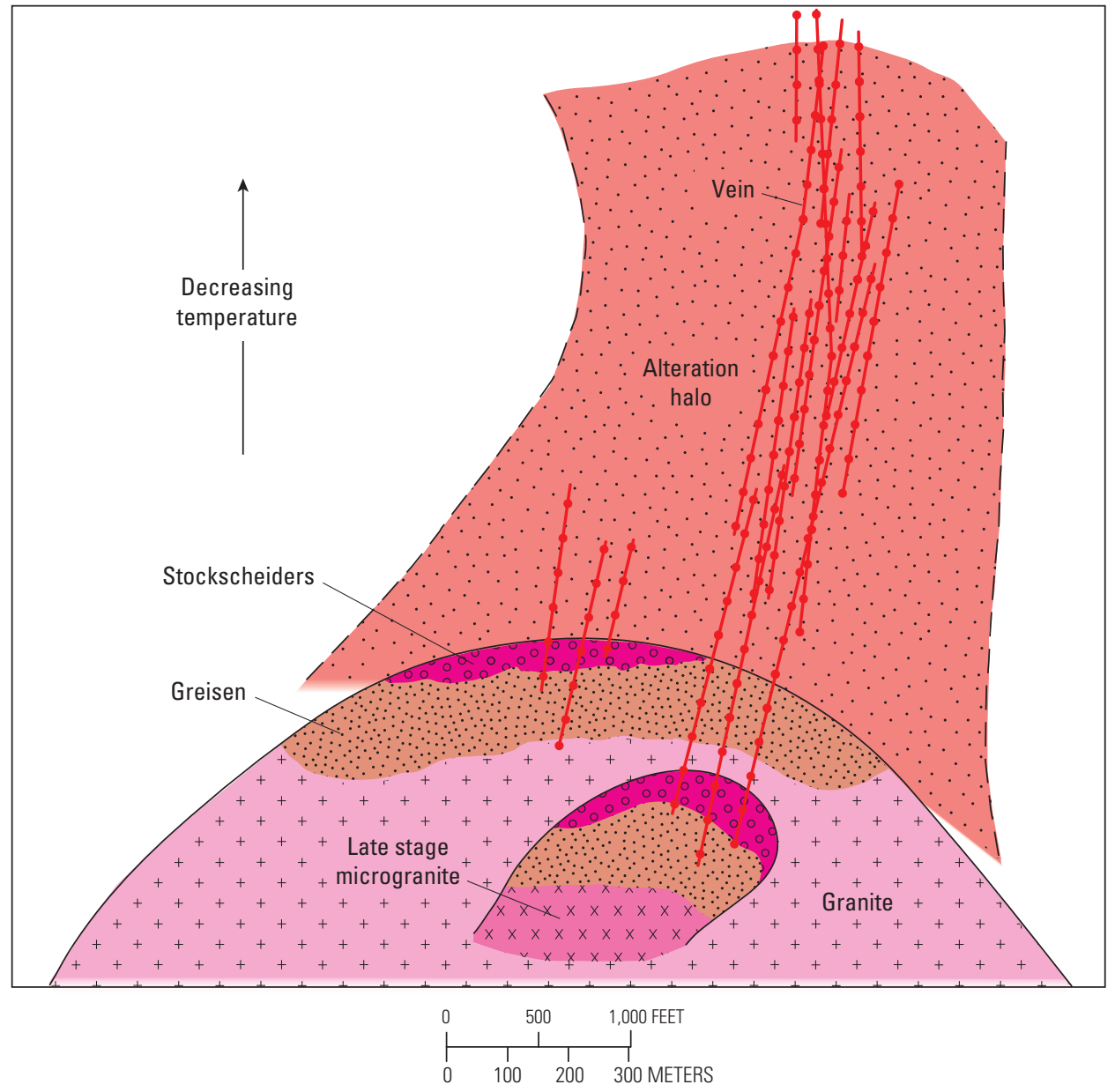

Figure S6. Schematic vertical section across a typical hydrothermal mineralized granite cupola showing salient features of a shallow graniterelated tin-mineralized system. As a tin-bearing granitic magma intrudes into existing crustal rock and cools, residual metal-rich fluids left over from the crystallization of the primary igneous minerals are injected into voids and fissures within the granite and surrounding host rock, forming bodies with high concentrations of tin. After Cérný and others (2005). 
(Kamilli and Criss, 1996) and the Wodgina and Kamativi pegmatites in Australia, which are the largest known examples (Daniel J. Kontak, Department of Earth Sciences, Laurentian University, Sudbury, Ontario, Canada, written commun., 2014).

Quartz-cassiterite veins, stockworks, and greisens that formed in close genetic association with the same granitoid intrusions to which stanniferous pegmatites are related.-This type of deposit is characterized by intense development of greisenization with abundant formation of muscovite- and topaz-rich alteration zones that host the cassiterite mineralization; in addition, these alteration zones host wolframite, bismuthinite, molybdenite, arsenopyrite, tantalo-columbite, and uranium and copper minerals. This type of mineralization is the most widely developed type of granite-related tin deposit. Large primary deposits occur rarely, but very rich placer deposits formed by weathering and erosion occur more frequently. These types of deposits (chiefly the placers) account for 60 to 70 percent of the world production of tin (Taylor, 1979, p. 46). Examples of these types of deposits include the Geevor and Wheal Jane deposits in Cornwall, United Kingdom (Dines, 1956; Garnett, 1963; Hosking, 1964; Rayment and others, 1971); the Herberton deposit in Queensland, Australia (Blake and Smith, 1970); the East Kemptville deposit in Nova Scotia, Canada (Richardson and others, 1982, 1990; Richardson, 1988; Halter and others, 1996, 1998); and the Chojlla deposit in Bolivia (Lehmann, 1990).

Sulfide-cassiterite deposits.-This type of deposit commonly occurs independently of the pegmatite and vein-stockwork-greisen deposit types discussed above. Sulfide-cassiterite deposits are more commonly known as tin porphyries; many have been mined more for their silver than for the tin they contain. They are high-to-intermediatetemperature deposits and are related to hypabyssal and near-surface granitoid intrusions. Hydrothermal minerals commonly present include cassiterite, tourmaline, chlorite, pyrrhotite, chalcopyrite, sphalerite, galena, and arsenopyrite. The most notable examples are the Llallagua (Turneaure, 1935; Dietrich and others, 2000) and the Chorolque deposits in Bolivia (Sillitoe and others, 1975; Grant and others, 1980) and the San Rafael deposit in Peru (Kontak and Clark, 2002); other examples may include the Ardlethan deposit in New South Wales, Australia (Clarke and others, 1985; Ren and others, 1995), the Zeehan deposit in Tasmania, Australia (McAndrew, 1965; Taylor, 1979), and the Akenobe deposit in Japan (Shimizu and Kato, 1991; Taylor, 1979).

Skarn and carbonate-sulfide replacement deposits in which cassiterite is associated with arsenopyrite, scheelite, pyrrohotite, marmatite, and chlorite that form in the alteration zones (that is, skarns) adjacent to intrusions.-Examples of these types of deposits include the Aberfoyle and Rossarden deposit (Collins, 1981) and the Renison Bell deposit (Patterson and others, 1981; Sutphin and others, 1990, and references therein) in Tasmania, Australia; the Cuomolong deposit in China (Hou and others, 2007); and the Lost River deposit in Alaska (Sainsbury, 1964; Dobson, 1982).
High-temperature hydrothermal deposits of "wood-tin" cassiterite in association with specular hematite and topaz in fluorine-rich, lithophysal high-silica rhyolite domes, lava flows, and associated pyroclastic rocks.-Cassiterite appears to have formed largely by precipitation from magmatically derived fluids. Redistribution of cassiterite by cooler hydrothermal fluids precipitated wood tin. The Mexican tin-bearing rhyolites have mineralogical and chemical characteristics that are similar to the topaz rhyolites of the Western United States (Burt and others, 1982; Christiansen and others, 1986).

Small deposits of this type occur in Mexico (Foshag and Fries, 1942; Huspeni and others, 1984; Ruiz, 1988), Russia (Korostelev and others, 2009), and in Nevada (Fries, 1942) and New Mexico (Fries, 1940; Rye and others, 1990) in the United States (Foshag and Fries, 1942; Huspeni and others, 1984; Ruiz, 1988).

Hydrothermal tin-silver deposits connected with near-surface stocks of rhyolite with high concentrations of silver-Examples of this type of deposit occur in Cerra Rico de Potosí, Bolivia (Sillitoe and others, 1975, 1998), and Pirquitas, Argentina (Ross, 1941).

\section{Similarities With Granite-Related Deposits of Other Metals}

Although recent literature reviews of ore-deposit models have emphasized the differences among molybdenum, tin, and tungsten deposits related to highly differentiated granites, it is also important to emphasize that there are striking similarities among these deposits. Detailed studies by Kamilli and others (1993) and Kamilli and Criss (1996) of tungsten-tin greisen and tin greisen deposits in Saudi Arabia have documented similarities among wolframite-bearing quartz vein deposits, porphyry tungsten-molybdenum deposits, disseminated tin-greisen deposits in cupolas, and Climax-type molybdenum deposits. (The late stage so-called quartz-sericite-pyrite [QSP] veins at the Henderson and Climax Mines in Colorado are steeply dipping. They contain quartz, wolframite, topaz, and fluorinebearing mica and garnet - a chemical and mineralogical greisen assemblage - even though the rock is fine-grained.) Following Burt (1981), it is useful to think of these graniterelated molybdenum, tin, and tungsten deposits as a superclass of porphyry-greisen deposits. These deposits are characterized by close spatial, temporal, and genetic association with highly differentiated peraluminous porphyritic granites and by predominantly parallel or subparallel greisen-bordered and sheeted vein-granites that either crosscut the intrusion or are peripheral to it and that contain different amounts of cassiterite and wolframite (Kamilli and Ganster, 1995).

The porphyry-greisen deposits of this superclass are all located in tectonic settings that are intracratonic, extensional, and late orogenic, and were formed during a changeover from compressional to extensional tectonics. These deposits can also be closely related to tin- and tungsten-rich porphyry deposits associated with collision-related granites in Europe and Asia (Laznicka, 2006). 


\section{Effect of Cupola Size and Shape on Tin-Greisen Mineralization}

A principal control of tin-greisen mineralization is the degree of magmatic differentiation in the different phases of the parent granite's apical cupolas. Nonetheless, differentiation alone does not explain why one intrusion does not produce any tin-greisen mineralization of consequence, although it is chemically almost identical to other intrusions that are mineralized. A possible reason is the differing geometries of the intrusions. One intrusion may be a small, plug-like cupola, whereas another intrusion may form a more extensive, flattopped mass. The concentration of greisen- and ore-producing hydrothermal fluid may be the result of the focusing effect of small cupola diameters.

An excellent example of this relation is the Mount Emmons molybdenite deposit in Colorado. The richest mineralization is at the apex of a 500-meter (m)-diameter cupola located 3,000 m above sea level, where the small cross-sectional area of the cupola and virtually vertical side contacts with the country rocks allowed accumulation of hydrothermal fluids within a small volume at the highest elevation of the intrusion. Lower grade ore zones occur on an inflection in the gently dipping flank of the same intrusion about 2 kilometers $(\mathrm{km})$ to the north at an elevation of about 2,400 m. Even lower grade mineralization is found about $1 \mathrm{~km}$ farther north, where the contact is even flatter, at an elevation of about 1,000 $\mathrm{m}$ (White and others, 1981).

In the Jābal as Silsilah tin deposit in Saudi Arabia, one intrusion of peraluminous granite in a ring structure forms a body with an area of 3.5 square kilometers $\left(\mathrm{km}^{2}\right)$ at the surface. Thus, ascending fluids in this intrusion, although trapped under an impermeable aplitic cap, would be spread out over an area of at least $3.5 \mathrm{~km}^{2}$. By contrast, the small cupolas inside the ring have an outcrop area of only $0.06 \mathrm{~km}^{2}$. Given mean tin concentrations of 58 and $145 \mathrm{ppm}$ for these two intrusions, respectively, the total amount of tin is actually more than an order of magnitude greater in the larger intrusion in the ring for any given depth than for an equivalent depth in the small cupolas. Using the mean tin content of $58 \mathrm{ppm}$ and the $0.06-\mathrm{km}^{2}$ area of the small cupolas, a magma column that is only $245 \mathrm{~m}$ high would be necessary to produce the measured resources in the small cupolas of 1.2 million metric tons grading 0.19 weight percent tin $(2,280$ metric tons of contained tin). This calculation assumes for simplicity that 100 percent of the tin was scavenged from the melt.

The relation between the volume of magma and the size of the resulting deposit also appears to apply to other deposits. The Akash granite (which is about $100 \mathrm{~km}^{2}$ in area) in Saudi Arabia contains zones of strong greisenization on its western flank that are about one order of magnitude larger than the greisen zones at Jābal as Silsilah. The Jabal Akash deposit, however, is not of potential economic importance because the Akash granite is not sufficiently differentiated to have given rise to a commercial-grade tin deposit (Kellogg and Smith, 1985). The Akash granite is chemically similar to the "precursor granites" as described by Tischendorf (1977).

\section{Tectonic Settings of Granite-Related Tin Deposits}

The tectonic settings of tin-bearing granites are relatively well understood and limited in variation. Tin deposits and their associated igneous rocks occur in continental settings worldwide. More than 25 percent partial melt during crustal anatexis is probably a precondition for large-scale magma segregation. Magma segregation and intrusion into an upper crustal level is favored by a brittle lithosphere in crustal extension zones (Lehmann, 1990). The tectonic settings of tin granites and porphyries, according to Lehmann (1990), are as follows:

1. Post-orogenic magmatism in continental collision belts; for example, the Permian-Triassic tin belt in Southeast Asia (Mitchell, 1977; Beckinsale, 1979), and the Hercynian tin provinces in Western Europe and Central Europe (Mitchell, 1974; Holder and Leveridge, 1986).

2. Internal regions of active continental margins (backarc regions), such as Tertiary tin porphyries in Bolivia, Mexico, and eastern Siberia, Russia (Sillitoe, 1976), and Cretaceous tin granites in Thailand and Burma (Beckinsale, 1979).

3. Intracratonic anorogenic and continental rift zones; for example, the Triassic and Miocene tin granites in Peru and northern Bolivia (Kontak and others, 1985), the Cretaceous tin granites in southern China (Chen, 1989), the Cretaceous tin granites in Nigeria (Bowden and Kinnaird, 1984), and the Precambrian Bushveld granites in South Africa (Hunter, 1973).

\section{Resources and Production}

The locations of selected major tin deposits and districts in the world, by deposit type, are shown in figure S7. Additional data on the major tin deposits and districts in the world are in table $\mathrm{S} 2$ at the back of this chapter.

About 80 percent of the world's identified tin resources occur in unconsolidated secondary or placer deposits in riverbeds and valleys or on the sea floor. The largest concentration of both onshore and offshore placers is in the extensive tin belt of Southeast Asia, which stretches from China in the north, through Thailand, Burma, and Malaysia, to the islands of Indonesia in the south. Most of the remainder (about 20 percent of the world's identified tin resources) occurs in primary veins, stockworks, and greisens in close association with silicic, peraluminous granites. The percentages of identified tin resources in primary versus placer deposits are estimations because many studies do not distinguish between the two types of deposits, which are commonly found together in the same districts. Furthermore, tin placer deposits are almost always found in close proximity to the granites from which they originate.

Although most tin is obtained from mining tin ores, cassiterite is also found in association with ores of tungsten, 


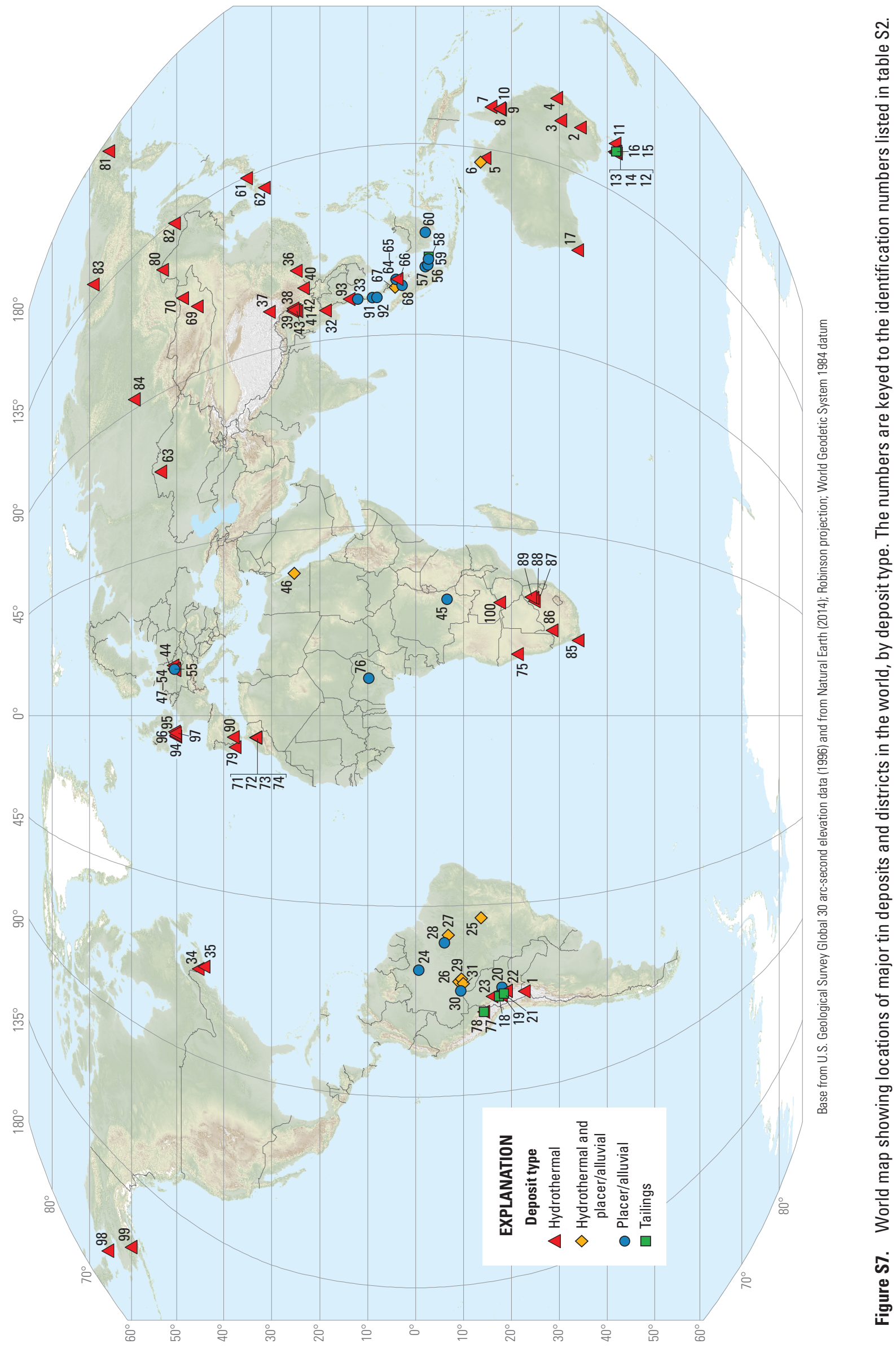


tantalum, and lead. Minor quantities of tin are recovered as byproducts of the mining of these metals. Byproduct tin from massive sulfide deposits includes production from the Neves Corvo Mine in Portugal, which is the leading producer of tin in Europe, and the Kidd Creek Mine in Canada, which is a long-time producer of tin from stannite (Daniel Kontak, Department of Earth Sciences, Laurentian University, Sudbury, Ontario, Canada, written commun., 2014).

Compared with commercially viable deposits of copper, lead, zinc, nickel, and bauxite, tin deposits are generally small. Most tin deposits fall in a grade range of 0.1 to 1 percent tin, have a resource tonnage range of from 1 million to 100 million metric tons, and have between 10,000 and 100,000 metric tons of tin content (fig. S8).

In 2016, world reserves of tin totaled 4,700,000 metric tons (table S3; C.S. Anderson, U.S. Geological Survey, written comm., December 16, 2016). The distribution of world mine tin reserves in 2016, by country, is shown in figure S9.

Total world tin mine production in 2015 was 289,000 metric tons of contained tin. The distribution of world mine production, by country, is shown in figure S10. China was the leading producer of tin (accounting for 110,000 metric tons, or 38 percent of world output), followed by Indonesia (18 percent), Burma (12 percent), Brazil (9 percent) and Bolivia and Peru (7 percent each) (Anderson, 2017).
Table S3. Tin reserves of the world in 2016, in metric tons of contained tin.

[Data are from Anderson (2017)]

\begin{tabular}{lr}
\hline & \\
\hline Australia & 370,000 \\
Bolivia & 400,000 \\
Brazil & 700,000 \\
Burma & 110,000 \\
China & $1,100,000$ \\
Democratic Republic of the Congo & 110,000 \\
$\quad$ (Congo [Kinshasa]) & \\
Indonesia & 800,000 \\
Malaysia & 250,000 \\
Peru & 100,000 \\
Russia & 350,000 \\
Thailand & 170,000 \\
Vietnam & 11,000 \\
Other countries & 180,000 \\
$\quad$ World total & $\mathbf{4 , 7 0 0 , 0 0 0}$ \\
\hline
\end{tabular}

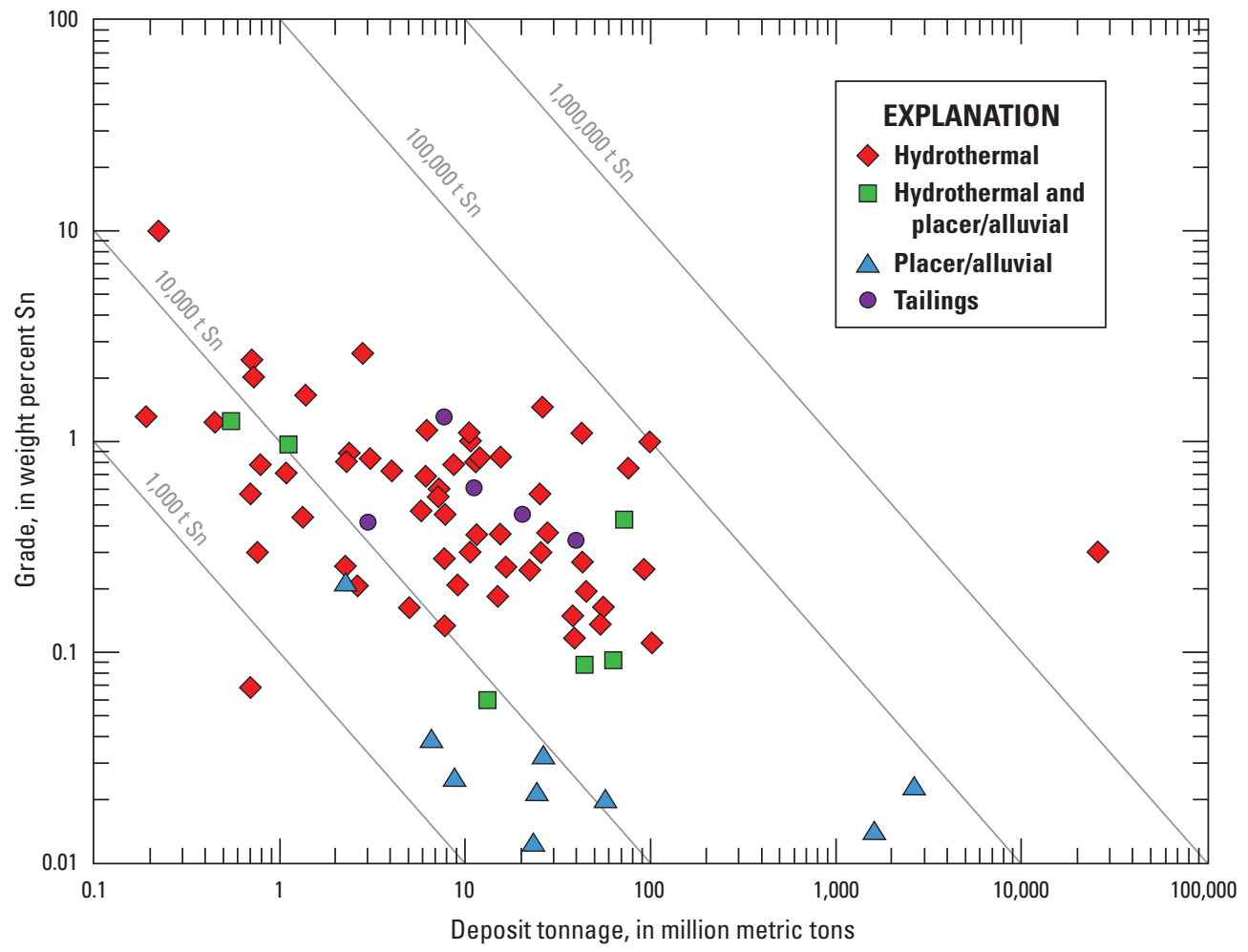

Figure S8. Graph showing grades and resource tonnages of major tin deposits in the world, by deposit type or source. Diagnonal lines are isolines of contained tin. Data are from table $\mathrm{S} 2$ and the references listed therein. $\mathrm{Sn}$, tin; t, metric ton 


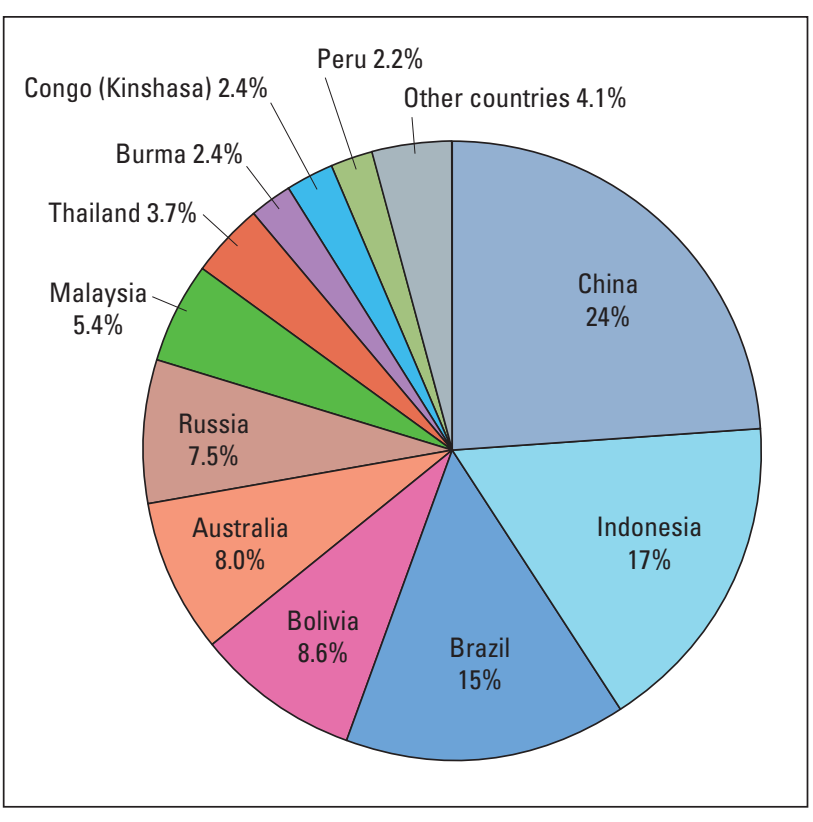

Figure S9. Pie chart showing percentage of world tin reserves in 2016, by country. Percentages have been rounded to two significant figures and do not add to 100. The world total reserves were 4.7 million metric tons. Data are from Anderson (2017). Congo (Kinshasa) is a short-form name for Democratic Republic of the Congo.

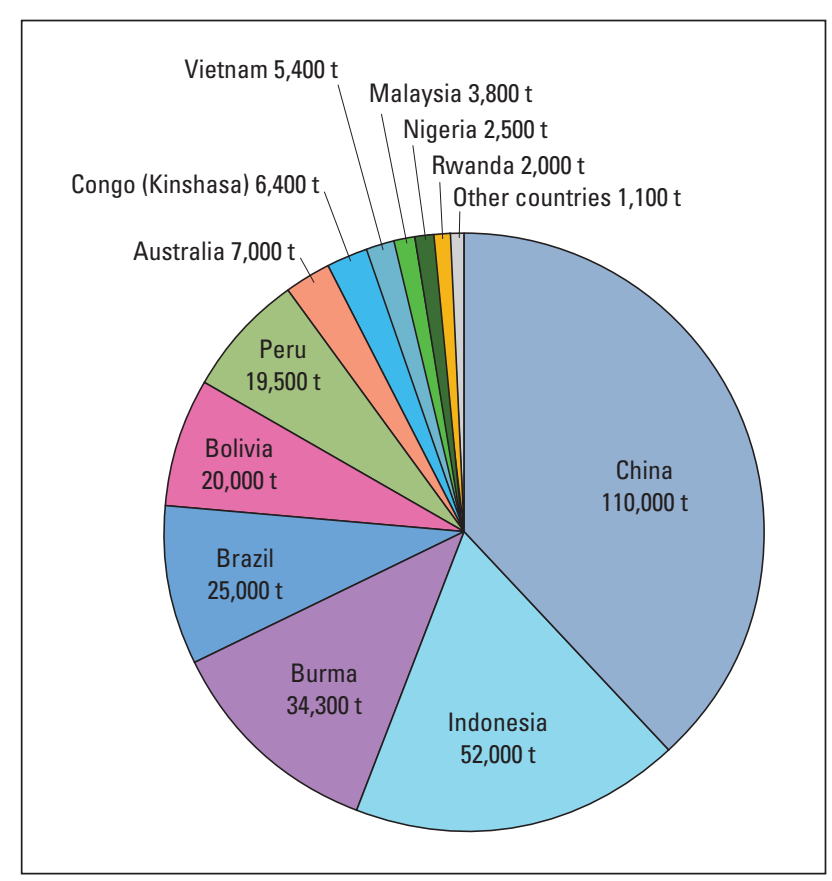

Figure S10. Pie chart showing estimated world mine production of tin in 2015 , by country and amount (in metric tons [t]). The estimated world total was $289,000 \mathrm{t}$. Data are from Anderson (2017). Congo (Kinshasa) is a short-form name for Democratic Republic of the Congo.

\section{Globally Important Mining Areas}

Major tin deposits are confined to a comparatively small number of areas. More than one-half of the world's tin ore is mined in the great tin belt of Southeast Asia. Significant deposits also occur in South America.

Australia.-Granite-related tin deposits are present through much of Australia and include Neoarchean tantalumtin pegmatite fields in western Australia and Paleozoic granite-related hydrothermal tin-tungsten deposits in the Tasmanides of eastern Australia (Solomon and Groves, 2000). A variety of deposit types are present in eastern Australia, including distal skarn tin deposits, proximal tin skarns, greisens, and quartz-cassiterite-wolframite systems. Eastern Australia has been a significant tin producer, with more than 683,000 metric tons of tin produced to the end of 1986 (Solomon and Groves, 2000). Tin was first discovered in Australia at Mount Bischoff in Tasmania in 1871.

Bolivia.-Bolivia has long been a significant producer of tin from primary deposits in the so-called Bolivian tin belt. The Bolivian tin belt extends for $1,100 \mathrm{~km}$ through the length of the Eastern Cordillera of Bolivia and is generally less than $100 \mathrm{~km}$ wide (Urquidi-Barrau, 1989). It extends from southern Peru, where tin is produced from the San Rafael Mine, to northern Argentina, where the Pirquitas Mine has been the major producer. In addition to tin, deposits in the Bolivian tin belt have produced important amounts of tungsten, silver, zinc, lead, antimony, bismuth, and gold. Most of the deposits in the northern segment of the belt are generally related to plutonic rocks of Late Triassic-Early Jurassic and Oligocene age, whereas those in the southern segment are related to subvolcanic porphyry stocks of Miocene age (Urquidi-Barrau, 1989). The northern tin-tungsten deposits occur as fissure-filling veins along fault and fracture systems in Paleozoic sedimentary rocks peripheral to granitic plutons and within these igneous bodies. The southern deposits are associated with high-level porphyry stocks and eruptive complexes with several of the largest tin deposits in Bolivia (Llallagua/Catavi, Huanuni, San José/Oruro, and Cerro Rico) occurring at or near the margins of the large Morococala and Los Frailes volcanic fields. It is suspected that additional large tin deposits occur buried beneath the volcanic fields (Urquidi-Barrau, 1989).

The Bolivian tin deposits are mostly confined to high altitudes in the rather inaccessible regions of the central Andes. As a result, access at times poses formidable infrastructure and logistical challenges. The primary hard-rock tin deposits are now relatively low grade, and Bolivian mines operate at the highest costs of all the world's primary tin mines (Urquidi-Barrau, 1989). In addition, the ores in the southern segment of the Bolivian tin belt have relatively high smelting and refining costs owing to their complex mineralogy.

Brazil.-In 2015, Brazil was the world's fourth-ranked producer of mined tin (Anderson, 2017). Almost 90 percent 
of the country's production is obtained from the Pitinga Mine, which is located about $300 \mathrm{~km}$ northeast of Manaus in the Mapuero region of the State of Amazonas (table S2; fig. S7). The Pitinga Mine produced about 230,000 metric tons of tin between 1982, when the mine opened, and January 2001 (Lenharo and others, 2003). Tin is produced mainly from alluvial deposits in and around two Paleoproterozoic granitic complexes, the Àgua Boa and Madeira igneous complexes. These complexes are composed of a variety of granitic rocks, including fine to coarse grained, equigranular to porphyritic rapakivi granite, biotite granite, topaz granite, and albite granite (Lenharo and others, 2003). In the Àgua Boa complex, primary tin mineralization occurs in cassiterite-topaz-micaquartz greisens as well as disseminated cassiterite in biotite and topaz granites. In the Madeira complex, cryolite-zirconcassiterite-pyrochlore-columbite-tantalite-xenotime mineralization occurs disseminated within the roof zone of the albite granite. Tin is produced from a saprolite developed on the albite granite.

Burma (Myanmar). - The tin deposits in Burma lie along the Thailand-Burma border and form the northern end of the Southeast Asian tin belt, a north-south elongate zone about 2,800 km long and $400 \mathrm{~km}$ wide, extending from Burma and Thailand to Peninsular Malaysia and the Indonesian Tin Islands (Schwartz and others, 1995). The Southeast Asian tin belt consists principally of Jurassic-Triassic biotite granites that host mostly simple tin-tungsten vein deposits and lesser stockwork, replacement, pegmatite, and breccia deposits (Schwartz and others, 1995). The tin deposits in Burma are similar to those in Thailand and Malaysia with both rockhosted and placer deposits related to biotite granites. The tin belt in Burma extends from the Byingyi-Mawchi district in the north about 1,200 km south to the Mergui Islands. Although small placer tin deposits are present in Burma, the mountainous terrane is not favorable for the occurrence of large placer deposits such as those found in Thailand, Malaysia, and Indonesia (Sainsbury, 1969b).

China.-China has been the leading tin-producing country since 2003, when it surpassed Indonesia. The main producing area is the Gejiu district in Yunnan Province, which is the largest primary tin district in the world; it contains about 300 million metric tons of tin ore with an average grade of 1 percent tin (Cheng and others, 2013). Tin mineralization occurs in greisen, skarn, strata-bound cassiterite-sulfide (mostly oxidized), and vein deposits in extensive hydrothermal systems centered on shallow Late Cretaceous granitic cupolas (Cheng and others, 2013). Geologic characteristics, metal zoning patterns, and new geochronologic data all support that the tin-polymetallic deposits are genetically related to the nearby granite intrusions.

Principal tin smelter production from China was 148,000 metric tons in 2012 (Tse, 2013, p. 8.14). According to Carlin (2014, p. 77.2), the Guangxi Autonomous Region and Yunnan Province accounted for 53 percent of China's mine production of tin in 2011, but production was substantially lower in 2012 owing to mine closures caused by cadmium contamination and drought-related water shortages.

Indonesia.-Indonesian tin production comes mainly from placer deposits both onshore and offshore of the islands of Bangka, Belitung (Billiton), and Singkep in the Java Sea. Bangka Island is the major source of placer tin and is produced with seagoing dredges (Sainsbury, 1969b). The largest hardrock tin deposit is the Klappa Kampit Mine on Belitung Island and consists of replacement bodies composed of cassiterite, magnetite, and sulfide minerals in shale (Sainsbury, 1969b).

Malaysia.-Historically, Malaysia furnished as much as 55 percent of the world's annual tin production (Sainsbury, 1969b). The tin deposits in Malaysia are part of the Southeast Asian tin belt and consist of both hard-rock and placer deposits, with placers being the dominant producers. The tin deposits extend through Malaysia in two north-trending belts that coincide with two mountain ranges that consist of Jurassic-Triassic batholiths and stocks of biotite granite and related rocks which intrude older sedimentary and metamorphic rocks (Sainsbury, 1969b). The two most productive tin-mining areas in Malaysia have been the Kinta Valley in the State of Perak (Rajah, 1979) and the Selangor River in the State of Selangor. Between 1876 and 1950, the Kinta Valley alone produced 1.2 million metric tons of tin (Sainsbury, 1969b).

Portugal and Spain.-An 800-km-long belt of tin- and tungsten-bearing deposits that extends southeastward through Portugal and Spain is associated with dominantly porphyritic biotite and biotite-muscovite granites (Sainsbury, 1969b). The deposits consist of veins, stockworks, and alluvial and eluvial placers. As in other tin districts, major tin deposits tend to occur within and near the borders of granite intrusions, whereas tungsten deposits tend to occur farther from the contacts in surrounding rocks. The Neves-Corvo deposit in Portugal - one of the largest and richest massive sulfide deposits in the Iberian pyrite belt - is unique because of its very high copper and tin grades. The Corvo orebody, which accounts for 95 percent of Neves-Corvo tin production of about 40 metric tons per year, has reserves of 20 million metric tons with grades of 5.20 percent copper, 3.07 percent zinc, and 0.30 percent tin (Relvas and others, 2006).

Thailand.-The modern commercial production of tin in Thailand began in about 1870 , but it was not until the early part of the 20th century that the country became a significant producer. The tin deposits in Thailand, both hard-rock and placer, are a continuation of the deposits in Malaysia and are part of the Southeast Asian tin belt. As elsewhere in Southeast Asia, placer deposits have been the major tin producers in Thailand. The principal tin placers are located on Phuket Island and near Ranong to the north (Sainsbury, 1969b). Tin production from Phuket Island has mostly been from alluvial stream-channel deposits and their submarine extensions. In northwestern and western Thailand, hard-rock fissure vein, stockwork, and pegmatite tin deposits also contain wolframite and sulfide minerals (Sainsbury, 1969b). 
United Kingdom.-Cornwall, England, has a long history as a leading producer of tin. Cornish tin deposits have been worked extensively for many centuries, dating back to at least Roman times; there is, in fact, strong evidence of tin working in Cornwall from the early Bronze Age (about 2100 to 1500 B.C.; Bancroft and Weller, 1993). Although the mines of Cornwall produced more than 2 million metric tons of tin during their operation, they are now largely exhausted (Sainsbury, 1969b). In 1860, more than 300 mines, employing 100,000 workers, were in operation in Cornwall, but by 1964 , only 2 mines were still operating (Sainsbury, 1969b). The last mine, South Crofty, closed in 1998.

The tin deposits of Cornwall are principally zoned greisens and replacement deposits developed in and around Permian biotite-muscovite, tourmaline-bearing granites intruded into deformed and metamorphosed upper Paleozoic marine mudstone-sandstone sequences (Jackson and others, 1989). The tin deposits contain cassiterite and copper, arsenic, iron, tungsten, and zinc sulfide minerals. Because of metal zoning in the deposits, some mines produced principally copper ores; others produced lead-zinc ores; and others, tin, wolframite, and minor sulfide ores (Sainsbury, 1969b). Erosion of the primary tin deposits produced tin-bearing placer deposits that were the first source of tin in the region (Bancroft and Weller, 1993).

\section{Tin Deposits in the United States}

Tin deposits are quite rare in the United States and of relatively little economic value (Carlin, 2001). They are mentioned here because they are potential sources of tin in times of limited supply.

In 1948, a byproduct plant at the Climax Mine in Colorado was built to treat tailings from the molybdenite circuit to recover cassiterite and wolframite. In 1968, about 8,200 metric tons (about 18,000,000 pounds) of tungsten trioxide $\left(\mathrm{WO}_{3}\right)$ and about 360 metric tons (about 800,000 pounds) of cassiterite had been recovered (Wallace and others, 1968). The production of tin and tungsten ceased in 1982 when the Climax Mine closed (Maurice W. Ganster, Climax Mine, Climax Molybdenum Co., written commun., 1981). The Climax Mine was reopened by Freeport-McMoRan Inc. in 2012 as an open pit operation with a new mill, but tin and tungsten were not being recovered.

One of the few primary hard-rock tin deposits in the United States is the Lost River tin-tungsten-fluorine deposit in the Seward Peninsula, Alaska. In the region of the northwestern Seward Peninsula, tin mineralization is related to at least nine Late Cretaceous, highly differentiated, fluorine-rich granites that intruded massive Ordovician-age limestones (Dobson, 1982). Other igneous rocks present in the region are diabase dikes, lamprophyre dikes, and alkali basalt. The deposits of the Seward Peninsula, which were first reported in 1900 by A.H. Brooks, have produced ore containing more than 2,200 metric tons of tin and constitute the only known domestic deposits of economic grade and size (Sainsbury, 1964, 1969a, b). In most cases, the tin mineralization is evident primarily in placers that surround the exposed cores of the intrusions that host bedrock mineralization. The lodes were a major source of ore, however. The Lost River deposit is also enriched in $\mathrm{F}, \mathrm{W}, \mathrm{Be}, \mathrm{Zn}, \mathrm{Pb}, \mathrm{Cu}$, and $\mathrm{Ag}$. Mineralization occurs in areas of intense greisenization of the intrusive granites and is characterized by the destruction of igneous textures and the replacement of feldspars and biotite by quartz with topaz, tourmaline, cassiterite, and sulfides, including galena, sphalerite, chalcopyrite, arsenopyrite, and stannite. Greisenization was apparently contemporaneous with a hydrous stage of alteration in the limestone; this alteration stage was characterized by fluorite-biotite \pm hornblende with sulfides and cassiterite. Beryllium mineralization is hosted by fluorite-white mica veins. Beryllium-bearing minerals are also present and include chrysoberyl $\left(\mathrm{BeAl}_{2} \mathrm{O}_{4}\right)$, euclase $\left(\mathrm{BeAlSiO}_{4}(\mathrm{OH})\right.$ ), phenakite $\left(\mathrm{Be}_{2} \mathrm{SiO}_{4}\right)$, and minor amounts of other beryllium-bearing minerals. Tin was precipitated prior to and contemporaneous with the deposition of sulfide minerals; the mobilization and redeposition of tin liberated from early skarn minerals by later alteration was an important process in the formation of the economic tin skarns. Early andradite garnet contains up to 6 weight percent $\mathrm{SnO}_{2}$, and idocrase and grossular contain 0.2 to 0.6 weight percent $\mathrm{SnO}_{2}$ (Dobson, 1982).

\section{Undiscovered Resources}

Tin metallogenic provinces are quite well known; thus, most undiscovered tin deposits are expected to be located spatially close to known deposits or extensions of the same. Sainsbury and Reed (1973, p. 637) observed that "The worldwide geologic association of tin with acid granitic rocks and rhyolites is so well marked that speculation as to the likelihood of finding major tin resources in new geologic environments is without redeeming value." Since then, however, Hudson and Reed (1997) have documented more than 100 tin occurrences in Alaska in several relatively recently discovered tin-mineralized areas, and the high-grade cassiterite ore in the NevesCorvo massive sulfide deposit of Portugal was a departure from conventional tin ore. Alaskan tin prospects occur from the central Alaska Range north to the Brooks Range and across interior Alaska, including the Yukon-Tanana upland, the Ruby geanticline, southwestern Alaska, and the Seward Peninsula (fig. S11). In all cases, the deposits are known or inferred to be associated with felsic igneous rocks that were generated by large-scale melting of continental crust. The widespread distribution of tin occurrences and their repeated development at different geologic times suggest that a large part of Alaska is a tin metallogenic province. Therefore, Alaska is prospective for future discoveries and eventual production, in the event that economic incentives are presented by market conditions (Hudson and Reed, 1997). 


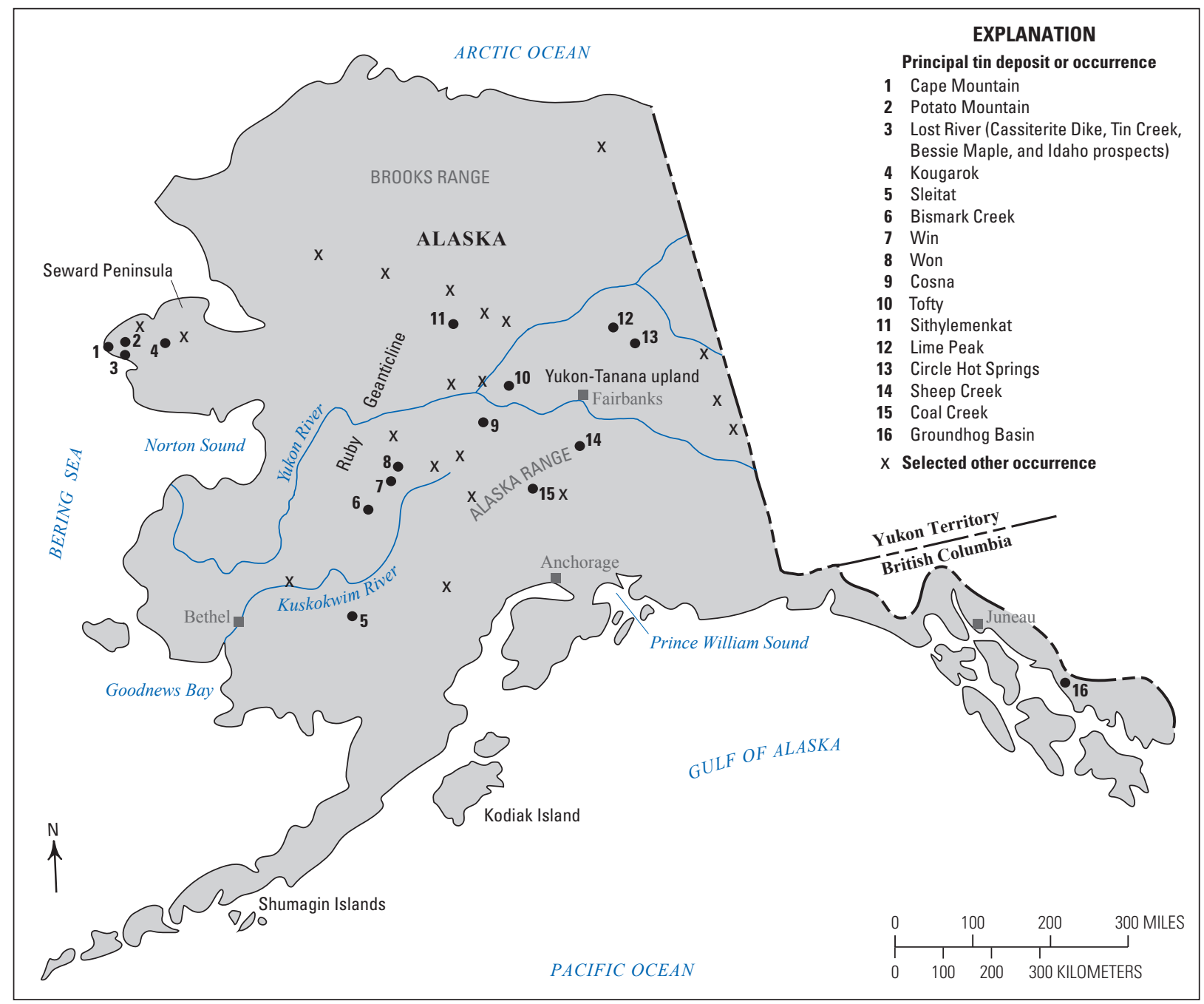

Figure S11. Map of Alaska showing the locations of selected tin deposits or occurrences. Modified from Hudson and Reed (1997).

\section{Exploration for New Deposits}

Historically, prospecting for tin has been carried out by the time-honored methods of panning, drilling, trenching, and assaying. As rich deposits were exhausted and the costs of exploration rose, the search for tin required more sophisticated methods. Geophysical and geochemical analyses have been employed to cover large areas more rapidly, isolating areas of possible tin deposits so that drilling can be more effective and less costly (Carlin, 1985).

Exploration for tin deposits is relatively simple, as the metal is invariably associated with highly differentiated, peraluminous granites or in downstream, downslope placer or alluvial deposits. As an example, the discovery of the East Kemptville deposit in Nova Scotia was based on a glacial till survey, as the deposit area is completely buried under several meters of till, and the discovery hole (EK-79-1) was centered on the highest tin content in tills (Daniel J. Kontak,
Department of Earth Sciences, Laurentian University, Sudbury, Ontario, Canada, written commun., 2014).

The tin content of residual soils and stream sediments and of vegetation has been used successfully as a guide to tin in the bedrock. The tin content of granitic rocks in the Malaysian alluvial tin fields is on the order of $60 \mathrm{ppm}$ compared to the normal granitic background of $3 \mathrm{ppm}$. Boron, fluorine, lithium, rubidium, and thorium, as well as tin, are all enriched in latestage granitic differentiates, and have been cited as local (but not universally applicable) ore guides (Rose and others, 1979).

At the Silsilah ring complex in Saudi Arabia, which contains peralkaline and peraluminous granites, the tin deposits are associated with the strongly greisenized peraluminous granites and pegmatites that have USTs containing euhedral quartz crystals, measuring up to $2 \mathrm{~m}$, which have their $c$ axes oriented perpendicular to the top of the granite cupolas (Kamilli and Criss, 1996). Nevertheless, strong albitization is associated with nonmineralized metaluminous 
granites that are intermediate in composition between the peralkaline and peraluminous granites. In summary, the strongest field indicators of economic tin deposits associated with granites are the presence of mica-bearing (biotite and [or] muscovite) pegmatites and especially zones of greisen alteration. These associations have been observed in other tin provinces worldwide.

The small, uneconomic deposits of cassiterite and wood tin that occur in Nevada, New Mexico, and Mexico are related to topaz rhyolite flow-dome complexes that are indicators of topaz granites that may host economic deposits of tin (or tungsten) in greisens or skarns at depth. Examples of these deeper formed deposits include those at East Kemptville, Nova Scotia, Canada, and at the Anchor Mine in Tasmania, Australia (Christiansen and others, 1986).

Trace-element characteristics of biotite granites can be useful in identifying individual intrusive complexes that are potentially ore bearing. Frequency distributions of tin in tin-bearing and mineralized granites are positively skewed and bimodal, with a relatively large proportion of values exceeding $25 \mathrm{ppm}$. Elemental concentrations and relationships of the lithophile elements, especially $\mathrm{Rb}, \mathrm{Li}, \mathrm{K}, \mathrm{Ba}, \mathrm{Sr}, \mathrm{Zr}, \mathrm{Nb}, \mathrm{Th}$, and $\mathrm{Mn}$, are the most reliable chemical indicators of oreforming processes and tin-bearing potential (Olade, 1980).

Finally, of course, the best places to find new orebodies or extensions of existing ones are in areas of known mining districts or metallogenic belts. Only four well-defined regions account for 80 percent of the cumulative historic tin mine output. They are as follows: (a) the Southeast Asian tin belt (Burma, Thailand, Malaysia, and Indonesia); (b) the Central Andean tin belt (southeastern Peru, Bolivia, and northwestern Argentina); (c) the south China tin belt; and (d) the Cornwall tin province (United Kingdom; Lehmann, 1990).

\section{Environmental Considerations}

\section{Sources and Fate in the Environment}

Tin commonly occurs in one of two oxidation states in weathering environments: $\mathrm{Sn}^{2+}$ and $\mathrm{Sn}^{4+}$. As summarized by Séby and others (2001, and references therein), $\mathrm{Sn}$ (IV) is relatively insoluble and most commonly occurs in the mineral cassiterite, although dissolved $\mathrm{Sn}(\mathrm{IV})$ oxyhydroxide complexes (for example, $\mathrm{SnO}(\mathrm{OH})_{3}$ and $\mathrm{SnO}(\mathrm{OH})_{2}$ ) have been observed. $\mathrm{Sn}$ (II) may form dissolved complexes with hydroxide, chloride, sulfate, phosphate, carbonate, and organic species, or, more commonly, with solid $\mathrm{Sn}$ (II) oxide and sulfide minerals. Dissolved Sn(II) species may sorb to the surfaces of clays and manganese and iron oxide minerals. Sn(IV) forms the basis of organo-tin compounds with the general formula $\mathrm{R}_{\mathrm{n}} \mathrm{SnX}_{4-\mathrm{n}}(\mathrm{n}=1$ to 4$)$, where $\mathrm{R}$ is a hydrocarbon group and $\mathrm{X}$ is an anionic species, such as chloride, fluoride, oxide, hydroxide, carboxylate, or thiolate (Anger, 2004).
Examples of natural concentrations of tin in rocks, soils, waters, and air are given in table S4. The tin content in soils generally ranges from less than 0.1 to $5 \mathrm{ppm}$ (which is equivalent to milligrams per kilogram), with higher tin concentrations occurring in more organic soils (KabataPendias and Pendias, 2001). The mean tin concentration at a depth of 20 centimeters in soils in the Western United States is $0.9 \mathrm{ppm}$ (Shacklette and Boerngen, 1984), but topsoil concentrations can be as high as $8.6 \mathrm{ppm}$ (Smith and others, 2005) in the Eastern United States. Topsoil in Sweden can be equally as concentrated in tin, but deeper soils exhibit a maximum tin concentration of nearly 3.0 ppm (Eriksson, 2001). In North Atlantic seawater, tin concentrations range from below the detection limit (that is, less than 0.2 nanogram per liter $[\mathrm{ng} / \mathrm{L}]$ ) to about $2.0 \mathrm{ng} / \mathrm{L}$, with the highest concentrations occurring at depths of from 50 to $200 \mathrm{~m}$ (Byrd and Andreae, 1986b). Dissolved and colloidal (that is $<0.45$ micrometer $[\mu \mathrm{m}]$-sized) concentrations of tin in rivers range from 0.1 to $8.4 \mathrm{ng} / \mathrm{L}$, whereas particulate (that is, $>0.45 \mu \mathrm{m})$ concentrations of tin in rivers range from 0.1 to $109 \mathrm{ng} / \mathrm{L}$ (Byrd and Andreae, 1986c). Considered together, the average concentration of tin in the suspended sediment of world rivers is $4.6 \mathrm{ppm}$ (Viers and others, 2009). Tin occurs naturally in the atmosphere as part of mineral dust particles, and ranges from 0.3 to 53 picograms per cubic meter $\left(\mathrm{pg} / \mathrm{m}^{3}\right)$ in more remote areas of the world (Byrd and Andreae, 1986a).

Mining and industrial activities can lead to above-background concentrations of tin in the environment (table S4).

The common association of tin with organic material, clays, and metal oxide minerals increases the likelihood that tin will become enriched in soils, but above-background concentrations of tin in soils are not well documented. Tin mobilized from rocks tends to concentrate in particulate matter and sediments in aquatic environments. Byrd and Andreae (1986c) studied Tasmanian and European rivers and, as noted above, found that the concentration of tin in suspended particulates was greater than dissolved concentrations of tin (table S4). Likewise, unfiltered water samples from industrial European countries contain tin concentrations that are orders of magnitude greater than dissolved tin concentrations observed in more remote regions (table S4; Byrd and Andreae, 1986c; Reimann and de Caritat, 1998; Neal and Robson, 2000).

Much of the previous research on tin in aquatic environments focused on organo-tin compounds. Tributyltin (TBT) has been a common additive in paint for ships and barges to prevent the growth of mollusks, algae, and barnacles (Evans and others, 1995). As a result, concentrations of butyltin compounds in North American and European harbors were observed to range from below the detection limit to 1,500 ng/L tin (Dirkx and others, 1993, and references therein). Because TBT also negatively affects nontarget organisms, such as mussels and fish, many countries banned the use of TBT-based paints on boats of less than $25 \mathrm{~m}$ in length in the late 1980s and early 1990s (Evans and others, 1995). 
Table S4. Tin concentrations in rocks, soils, waters, and air.

[DOE, U.S. Department of Energy; EPA, U.S. Environmental Protection Agency. Units of measure: cm, centimeter; ng $/ \mathrm{L}$, nanogram per liter; ng/m³ , nanogram per cubic meter; $\mathrm{pg} / \mathrm{L}$, picogram per liter; $\mathrm{pg} / \mathrm{m}^{3}$, picogram per cubic meter; ppm, part per million; $\mu \mathrm{g} / \mathrm{L}$, microgram per liter; $\mu \mathrm{m}$, micrometer]

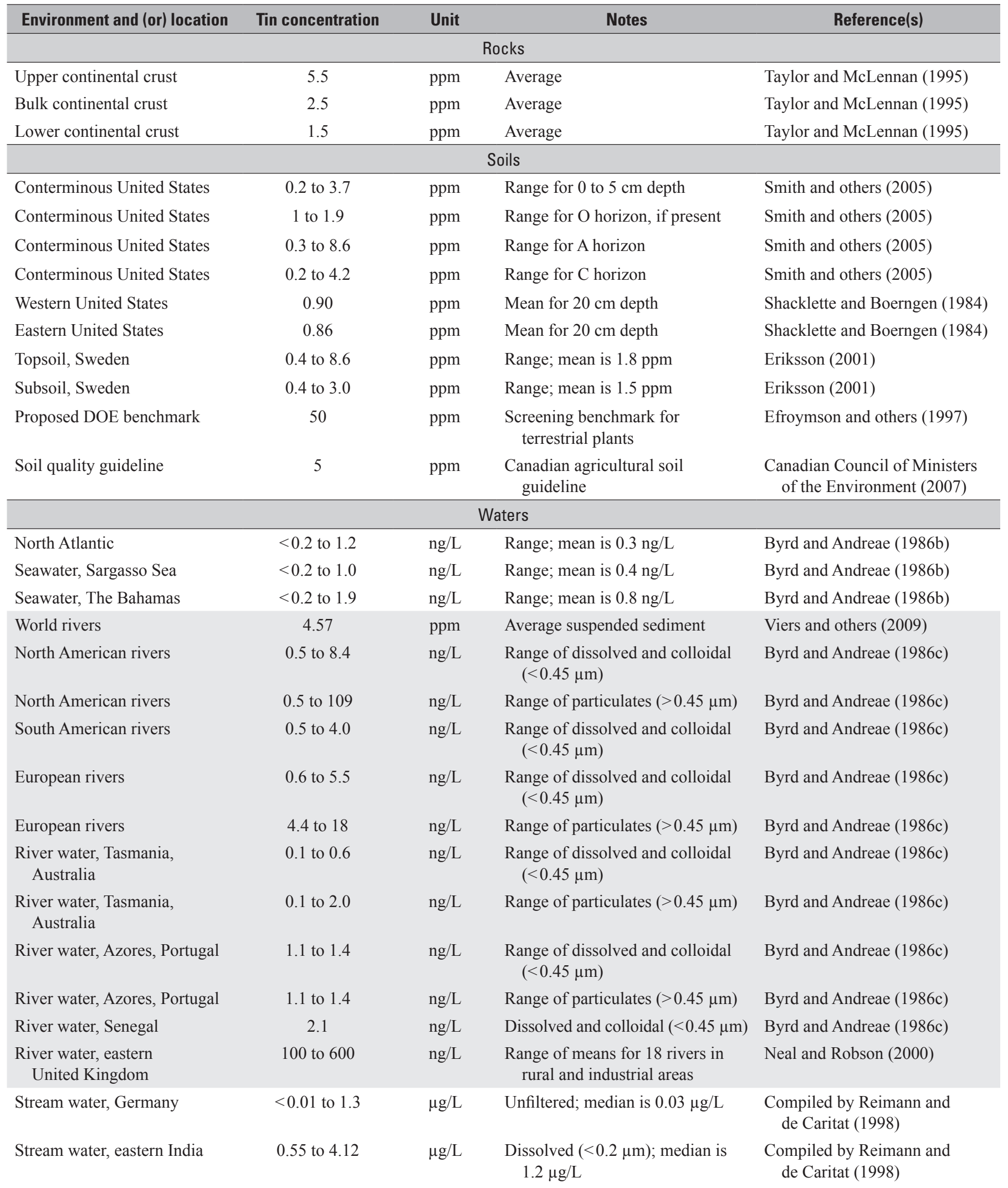


Table S4. Tin concentrations in rocks, soils, waters, and air-Continued

[DOE, U.S. Department of Energy; EPA, U.S. Environmental Protection Agency. Units of measure: cm, centimeter; ng $/ \mathrm{L}$, nanogram per liter; ng/ $\mathrm{m}^{3}$, nanogram per cubic meter; $\mathrm{pg} / \mathrm{L}$, picogram per liter; $\mathrm{pg} / \mathrm{m}^{3}$, picogram per cubic meter; ppm, part per million; $\mu \mathrm{g} / \mathrm{L}$, microgram per liter; $\mu \mathrm{m}$, micrometer]

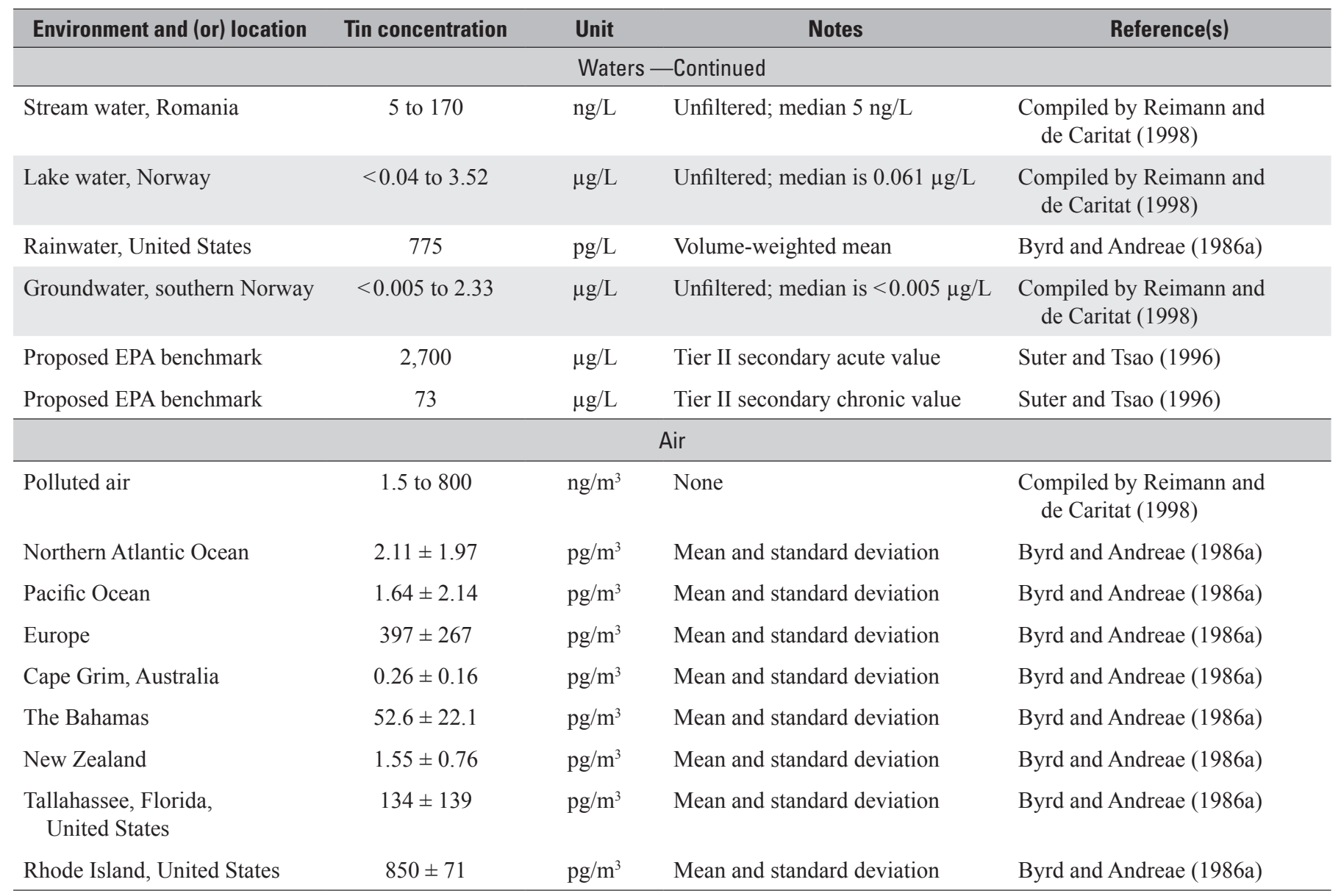

The primary inputs of tin to the atmosphere are through mining and ore processing, combustion of fuel oil and coal, and production and use of tin products. Total anthropogenic emissions of tin to the atmosphere were estimated to be 6.14 million grams in 1983 (Nriagu and Pacyna, 1988). Tin concentrations in air over urban and industrial regions range from 134 to $850 \mathrm{pg} / \mathrm{m}^{3}$ (Byrd and Andreae, 1986a). The general range of tin concentrations reported for "polluted air" is orders of magnitude higher at 1.5 to 800 nanograms per cubic meter (Reimann and de Caritat, 1998, and references therein).

Tin continues to be an important component in industrial society, so the need for tin continues to increase. Unlike many metals, tin recycling is relatively efficient. The recycled content (or the proportion of scrap) used in tin production is between 10 and 25 percent, and the fraction of tin in discarded products that get recycled is greater than 50 percent (Graedel and others, 2011, figs. 3 and 4). The factors that contribute to the economic and technologic feasibility of tin recycling are as follows: (a) tin is used in large quantities, and (b) it occurs in alloys in relatively pure form, making it easier to remelt and recover (Reck and Graedel, 2012).

\section{Mine Waste Characteristics}

Tin deposits are mined by open pit and underground methods. The mine waste generated is generally considered to be the material that originates and accumulates at the mine site that has no current economic value (Lottermoser and Ashley, 2006) and includes both solid and liquid waste. The character of mine waste varies according to the deposit type and the methods used to extract the ore. Most available information about tin mine waste relates to lode deposits. Mining of the Cerro Rico de Potosí lode deposits in Bolivia since 1545 has generated large amounts of mine waste. Two mine waste impoundment failures at Bolivia's Porco Mine in 1996 released approximately 235,000 cubic meters of tailings and fluid into the Río Pilaya (Pilaya River) (Hudson-Edwards and others, 2001). Tailings at the Jumna mill in northern 
Queensland, Australia, come from various mines in the Irvinebank lode tin deposits in the area. The mill closed in 1989, and the tailings repository on site contains an estimated $150,000 \mathrm{t}$ of tailings (Garrad and Bultitude, 1999).

The mineralogy of solid mine waste from tin mining is similar to that of the mined deposit, but the proportion of tin ore minerals is smaller. Tailings at the Porco Mine in Bolivia contain small amounts of cassiterite as well as other minerals, such as sulfides (arsenopyrite, galena, pyrite, sphalerite, and tetrahedrite), quartz, illite, and gypsum; trace metals in these tailings include $\mathrm{Ag}, \mathrm{As}, \mathrm{Cd}, \mathrm{Cu}, \mathrm{Hg}, \mathrm{Pb}, \mathrm{Sb}, \mathrm{Tl}$, and Zn (Hudson-Edwards and others, 2001). The Jumna mill tailings in Australia consist of quartz, microcline, plagioclase, muscovite, chlorite, kaolinite, sulfides (pyrite, chalcopyrite, galena, and arsenopyrite), magnetite, and small amounts of hornblende, beryl, fluorite, and expanding clays (Lottermoser and Ashley, 2006). Some of these tailings are cemented together with secondary hydrous ferric oxides (HFO) known as hardpans; the hardpan layers contain significantly higher $\mathrm{As}, \mathrm{Ca}, \mathrm{Cd}, \mathrm{Co}, \mathrm{Cu}, \mathrm{Fe}, \mathrm{In}, \mathrm{Mn}, \mathrm{Mo}, \mathrm{S}, \mathrm{Th}, \mathrm{U}, \mathrm{Y}$, and $\mathrm{Zn}$ contents than the actual tailings because of mobilization and subsequent sorption of these elements by the HFO (Lottermoser and Ashley, 2006). Tin-bearing skarns and replacement deposits, such as those at Lost River (Alaska) and Dachang (China), are hosted in carbonate rocks. Gangue minerals in these deposits may include calcite and dolomite, may have generally lower sulfide mineral contents, and (or) may include the trace metals Ag, As, B, Be, Cs, Cu, F, Li, Pb, Re, Rb, W, and $\mathrm{Zn}$ (Hammarstrom and others, 1995).

In weathering environments, trace metals in tin deposits are expected to remain immobile under oxic, near-neutral $\mathrm{pH}$ conditions $(5<\mathrm{pH}<8)$, especially in the presence of iron-rich solids (Smith and Huyck, 1999). Under anoxic and (or) acidic conditions, however, minerals and associated trace metals may dissolve. In those deposits with sulfide minerals (for example, pyrite and arsenopyrite), generation of acid effluents is possible if sulfide dissolution is not balanced by the acid-neutralizing capacity of carbonate minerals (for example, calcite and dolomite). Dissolution of sulfide minerals releases metals and sulfuric acid, and the acidic $\mathrm{pH}$ values allow higher concentrations of metals to be dissolved in solution - potentially causing the environmental problem known as acid mine drainage (AMD). Mining of hydrothermal tin lode deposits increases the potential for AMD.

Little information about mine wastes from placer tin deposits is available, particularly for the placer deposits in Southeast Asia. Because placer deposits form as a result of chemical weathering and physical erosion of lode tin deposits, many of the potentially deleterious constituents originally present in lode deposits, such as sulfide minerals, are absent from or reduced in placer deposits (Sainsbury and Reed, 1973, p. 644). Heavy and less reactive minerals that commonly occur with cassiterite in tin placer deposits include columbite-tantalite, wolframite, ilmenite, monazite, zircon, and xenotime (Sutphin and others, 1990, p. 10). Monazite and zircon may include radioactive elements, such as thorium and uranium. Mine tailings in the Jos Plateau tin placer deposit in Nigeria contain above-background levels of thorium and uranium, and radioactivity dose rates measured in the tailings were approximately 100 times those measured in nearby control sites (Ibeanu, 2003). Based on a preliminary model of tin-gold placer deposits, Bliss and Menzie (1995) showed that grades of tin do not correlate with deposit volumes, and 80 percent of the studied deposits had volumes of between 8,800 and $91,000,000$ cubic meters. These volumes can be viewed as the minimum volume of rock that would be disturbed during mining of a deposit.

\section{Human Health Concerns}

The Agency for Toxic Substances and Disease Registry (2005) provides a useful summary of the human toxicology of tin and tin compounds. The general public is most likely to be exposed to tin through consuming food directly from tin-lined cans (though currently many cans are lined with epoxy resins to protect against this), breathing tin-bearing dust, and eating seafood or using household products that contain organo-tin compounds. Occupational exposure to tin usually results from inhaling or touching tin-bearing dust at industrial and hazardous waste sites. The average human diet includes an intake of about 10 milligrams per day of tin (Anger, 2004). Exposure to oral doses of tin much greater than this amount may lead to stomach ache, anemia, and liver and kidney problems. Exposure to some organo-tin compounds can interfere with brain and nervous system function and, in severe cases, can cause death. Those exposed to extended inhalation of tin oxide - an issue mainly of concern to people who work in the tin industry-have a higher potential to develop stannosis, which is a mild disease of the lungs caused by inhalation of tin-bearing dust (Anger, 2004). Inorganic tin is poorly absorbed by the body, and no evidence exists for the carcinogenicity of metallic tin and tin compounds in humans (Agency for Toxic Substances and Disease Registry, 2005). Long-term exposure to certain organo-tin compounds, however, has been shown to cause cancer in animals (Smith and Huyck, 1999, and references therein).

Primary and secondary drinking water regulations for tin currently do not exist in the United States. Likewise, the World Health Organization has not set a recommended guideline for inorganic tin in drinking water because of the generally low concentrations of tin in aquatic systems and its minor toxicity to humans (World Health Organization, 2004). The Occupational Safety and Health Administration has set an exposure limit of 2.0 milligrams per cubic meter $\left(\mathrm{mg} / \mathrm{m}^{3}\right)$ for inorganic tin dust (Occupational Safety and Health Administration, 2013a) and $0.1 \mathrm{mg} / \mathrm{m}^{3}$ for organo-tin dust (Occupational Safety and Health Administration, 2013b) in workplace air over an 8-hour workday. 


\section{Ecological Health Concerns}

Many studies focus on the ecological impacts of tin in the environment. Because fish tend to be sensitive to low concentrations of dissolved metals, they are commonly useful indicators of contamination in aquatic systems. One of several useful endpoints used in toxicity tests is the concentration that leads to 50 percent mortality $\left(\mathrm{LC}_{50}\right)$ after exposure to a substance for a certain amount of time. Chronic toxicity tests (that is, lower doses over longer times) with dissolved tin (as tin chloride, or $\mathrm{SnCl}_{2}$ ) and developing rainbow trout (Salmo gairdneri) revealed a mean $\mathrm{LC}_{50}$ value of 0.42 milligram per liter (mg/L) after 28 days of exposure (Birge and others, 1980). Acute toxicity tests (that is, higher doses over shorter times) with tin and two marine fish species were attempted by Taylor and others (1985), but upon addition of dissolved tin chloride to seawater, most of the tin precipitated, so the highest concentration of dissolved tin that could be maintained was $0.03 \mathrm{mg} / \mathrm{L}$, a concentration that caused no mortalities over 4 days. Chronic toxicity tests with juvenile rainbow trout (Oncorhynchus mykiss) and bis(tri- $n$-butyltin) oxide (TBTO) (at a concentration of 0.5 or 2.0 micrograms per liter $[\mu \mathrm{g} / \mathrm{L}]$ ) showed that after 21 days, weight gain was significantly lower in TBTO-treated specimens relative to control specimens, and internal tin accumulation in TBTO-treated specimens increased between 7 and 21 days (Triebskorn and others, 1994). Rüdel and others (2007) show that over the two decades following Germany's ban on using organic tin compounds on small boats in 1989, concentrations of TBT and triphenyltin (TPT) decreased in the muscles of bream (Abramis brama) collected from river and lake samples. Some regions of the United States have adopted secondary acute and chronic screening benchmarks of $2,700 \mu \mathrm{g} / \mathrm{L}$ tin and $73 \mu \mathrm{g} / \mathrm{L}$ tin, respectively, for aquatic freshwater life, as recommended by the Oak Ridge National Laboratory (Suter and Tsao, 1996).

Relatively few studies focus on tin accumulation and toxicity in plants. Peterson and others (1976) surveyed the tin contents in different plant species in Malaysia and found that: (a) different plant species accumulate tin to varying levels (1.5 to 32 ppm dry weight) at control sites, and (b) plants near a tin smelter accumulated higher tin concentrations (8.4 to 2,165 ppm dry weight) than those plants in control areas. Experiments with relatively low concentrations of tributyltin chloride (TBTCl) and cells from three different vascular plant species revealed that tin concentrations within plant cells increased with increasing incubation time, which has implications for tin accumulation in the food chain (Caratozzolo and others, 2007). Some regions of the United States have adopted a soil screening benchmark of $50 \mathrm{ppm}$ tin for terrestrial plants, although the confidence in this benchmark is low because of sparse datasets (Efroymson and others, 1997). The Canadian agricultural soil quality guideline for tin is lower, at $5 \mathrm{ppm}$ (Canadian Council of Ministers of the Environment, 2007).

\section{Mine Closure}

Most recent and new mining operations include closure plans that address issues related to the mine footprint. A mine's footprint includes the waste left on site and in locally affected soil and water, as well as ecological impacts, such as habitat destruction and loss of biodiversity. Mining of both placer and lode tin deposits may generate mine waste piles. Wind-blown dust from unprotected mine waste piles may enter the atmosphere and surrounding soil and aquatic environments. In addition, these waste piles have the potential to become unstable. If using mine waste as backfill into dry mine workings is not an option, mine waste pile stability and dust-generating issues can often be addressed through grading and covering piles with vegetation.

Many lode tin deposits have the potential to generate AMD. For example, water draining from mine workings and tailings at the Ervedosa tin mine in Portugal displays a $\mathrm{pH}$ range of 3 to 6 , and high dissolved metal and arsenic concentrations (Gomes and Favas, 2006). Common methods for treating AMD include active water treatment facilities or passive limestone-lined channels or constructed wetlands (Plumlee and Logsdon, 1999). The end result of both active and passive approaches is eventual precipitation of dissolved metals. Precipitated metals in passive wetland systems tend to be more stable under the prevailing anoxic conditions, whereas the metal-rich precipitates that result from active treatment facilities form a sludge that, if not responsibly disposed of, can cause environmental problems. When the potential for AMD exists at a mine site, a common preventative measure includes conducting water quality surveys before, during, and after mining.

Placer tin deposits tend to be mined by open pit and (or) dredging methods. Mining of alluvial placers in modern stream and riverbeds is less likely to increase dissolved salt loads but is more likely to increase the amount of sediment delivered downstream. This, combined with potential diversion of rivers and streams, may negatively affect downstream ecosystems. Many of the placer deposits located in Burma, Indonesia, Malaysia, and Thailand are located offshore below sea level. Some of these deposits have been mined, whereas others may become more economical to mine in the future (United Nations, 2004). Much of the processing of tin from offshore deposits takes place on land, so many of the same mine waste issues mentioned for onshore tin deposits also apply to offshore tin deposits. Additionally, most offshore placer tin deposits are mined by dredging methods, which have the potential to negatively affect benthic, midwater, and pelagic ecosystems. Such marine ecosystem disruption could, in turn, also negatively affect the fishing industry. Future developers will need to consider all environmental and social issues that could result from the mining of offshore placer tin deposits, as well as the relevant mitigation measures that address such issues. 


\section{Problems and Future Research}

\section{Supply Issues}

Tin has not been mined or smelted in the United States since 1993 and 1989, respectively. Most tin deposits in the United States would be uneconomic to mine, even assuming higher prices for the metal. The only potentially economic deposits at present are the Lost River and Sleitat Mountain districts in Alaska (table S2, deposits 96 and 97; and fig. S11, deposits 3 and 5). The DOD recommends that material mitigation strategies for shortfalls include extra emergency purchases, substitutions, export reductions, Federal inventorying, and stockpiling. An additional strategy would be for the United States to develop its own (minimal) identified tin resources and (or) to explore for and find a major tin deposit. According to Sainsbury (1968), any future tin mining in the Seward Peninsula, Alaska, would have to mine ores with less than 2 percent tin.

Large-tonnage operations might be established on lowergrade disseminated ores, as occur in greisen-type deposits (for example, East Kemptville, Nova Scotia, Canada). To be profitable, such mines would probably also need to recover cassiterite, stannite, wolframite, and base-metal sulfides, as well as beryllium minerals and fluorite.

\section{Research Issues}

Whereas the mechanism of transport and deposition of tin is fairly well understood, the processes by which tin is incorporated into the parent magma at the points of magma generation and ascent are topics of investigation. As pointed out by Sainsbury and Reed (1973, p. 650-651), "alkali rocks in many parts of the world contain tin in amounts equal to or greater than the so-called tin-granites, yet no commercial tin lodes are ever associated with them. In a way, this fact refutes the possibility that the tin granites derive their tin from the surrounding rocks invaded by the magma or that tin deposits are formed by circulating meteoric waters."

A promising advancement concerning research into the origin of tin deposits is the recent development of a reliable method for the analysis of tin isotopes in cassiterite (Haustein and others, 2010; Yamazaki and others, 2013). The ability to fingerprint cassiterite from various deposits or regions also shows great potential for identifying the source of tin in bronze archeological artifacts, a conundrum that has plagued archaeologists for many decades, if not centuries. Isotopic variations as large as $0.77 \%$ (per mil) in ${ }^{124} \mathrm{Sn} /{ }^{120} \mathrm{Sn}$ were observed in samples from Japan and China using multiple collector-inductively coupled plasma-mass spectrometer (MC-ICP-MS) techniques. The isotopic fractionation of all the sample studies was dependent on isotope mass. McNaughton and Rosman (1991) proposed the following three possible mechanisms for tin isotopic fractionation: (a) equilibrium fractionation between cassiterite and tin-sulfide minerals; (b) kinetic fractionation, which could take place during dissolution of tin in a source region and precipitation of tin in an ore deposit; and (c) multistage enrichment processes of tin from crustal material to ore, in which each step introduces kinetic fractionation. Yamazaki and others (2013) concluded from the samples that they studied, however, that the presence of tin-sulfide minerals does not play an important role in tin isotope fractionation; they also concluded that the temperature during ore formation was not the main cause of the tin isotope fractionation in the samples studied. Although the isotopic variation seen by Yamazaki and others (2013) was smaller than those observed in cassiterite from Europe by Haustein and others (2010), the mechanism of isotopic fractionation is still unclear. This is similar to the state of knowledge for stable isotopes of carbon, oxygen, silicon, and sulfur in the late 1940s and 1950s after the development of a precise mass spectrometer by Nier (1947). The technique is reliable and constantly being improved; the field of study is promising. Nevertheless, many tin deposits occur in regions where there is much shale or slate in the country rock, as in Cornwall and Bolivia. Stable isotope research using ${ }^{124} \mathrm{Sn} /{ }^{120} \mathrm{Sn}$ values and variations may go a long way towards improving understanding of the mechanism of tin isotopic fractionation.

\section{Acknowledgments}

A co-author of this report, James F. Carlin, Jr., died while this manuscript was being written. The first author (RJK) especially would like to acknowledge the help and advice he received from Jim in understanding tin - and metals in general - as commodities that form the basis of the world economy through the production of goods, rather than just an ore to be mined and shipped to the concentrator. The first time that Jim visited me in Tucson, Ariz., he came to my house and gave me a comprehensive tour and an entertaining lecture on all the materials that went into its construction, why and how they were used, and why some of the materials should not have been used by the builders. Jim also seemed to know everyone in the world associated with the tin industry. The table of world tin deposits contained in this paper would not have been nearly as complete as it is if Jim had not put me in contact with many companies that were developing small properties.

Mr. Peter Kettle of the International Tin Research Institute helped me find the addresses of these many small startup companies and sent me large amounts of "gray literature" wherein so much of what is happening in the mining world is hidden. He also provided me with much unpublished data of his own that he had compiled.

Finally, thorough and helpful reviews by Diana Kamilli, John DeYoung, Daniel Kontak, Klaus Schulz, and Eric Seedorff improved this paper greatly. Also, Keith Labay helped create the deposit location maps, and Suzanne Nicholson provided additional editorial comments after the technical review was complete. 


\section{References Cited}

Note: All Web links listed were active as of the access date but may no longer be available.

Agency for Toxic Substances and Disease Registry, 2005, Toxicological profile for tin and tin compounds: Atlanta, Ga., U.S. Department of Health and Human Services, Public Health Service, 376 p. plus 4 appendixes. [Also available at http://www.atsdr.cdc.gov/ToxProfiles/tp55.pdf.]

Alexsiyev, E.K., 1970, Genetic significance of the REE in the younger granites of northern Nigeria and the Cameroons: Geochemistry International, v. 7, p. 127-132. [English translation.]

Amerilangui Ujin LLC, 2010, Mongolia tin mining project: Ulanbataar, Mongolia, Amerilangui Ujin LLC, 26 p.

Amin, M.S., 1947, A tin-tungsten deposit in Egypt: Economic Geology, v. 42, p. 637-671. [Also available at http://dx.doi.org/ 10.2113/gsecongeo.42.7.637.]

Anderson, C.S., 2015, Tin: U.S. Geological Survey Mineral Commodity Summaries 2015, p. 168-169. [Also available at https://minerals.usgs.gov/minerals/pubs/commodity/tin/ mcs-2015-tin.pdf.]

Anderson, C.S. 2016a, Tin [advance release], in Metals and minerals: U.S. Geological Survey Minerals Yearbook 2014, v. I, p. 77.1-7.79, accessed February 16, 2017, at https://minerals.usgs.gov/minerals/pubs/commodity/tin/ myb1-2014-tin.pdf.]

Anderson, C.S., 2016b, Tin: U.S. Geological Survey Mineral Commodity Summaries 2016, p. 174-175. [Also available at https://minerals.usgs.gov/minerals/pubs/commodity/tin/ mcs-2016-tin.pdf.]

Anderson, C.S., 2017, Tin: U.S. Geological Survey Mineral Commodity Summaries 2017, p. 174-175. Also available at https://minerals.usgs.gov/minerals/pubs/commodity/tin/ mcs-2017-tin.pdf.]

Anger, J.P., 2004, Tin, in Merian, E., Anke, M., Ihnat, M., and Stoeppler, M.S, eds., Elements and their compounds in the environment-Occurrence, analysis and biological relevance: Weinheim, Germany, Wiley-VCH Verlag GmbH, p. 1113-1124.

Angermeier, H.O., Krauss, U., Krusona, M., and Schmidt, H., 1974, Rohstoffwirtschaftliche Länderberichte, v. III, Zaire: Hannover, West Germany, Bundesanstalt für Bodenforschung, $120 \mathrm{p}$.

Australian Tin Resources Pty Ltd., 2016, Ardlethan tin mine: Australian Tin Resources Pty Ltd. Web page, accessed November 8, 2016, at http://www.atresources.com.au/index.htm.
Baker, Howard, 2012, Mineral resource estimate of the Oropesa tin project, Cordoba Province, Spain-NI 43-101 technical report, prepared for Minas de Estano de Espana [Filing date November 26, 2012]: Cardiff, Wales, United Kingdom, SRK Consulting (UK) Ltd., 127 p. plus 3 appendixes. [Also available at http://www.sedar.com.]

Bancroft, Peter, and Weller, Sam, 1993, Cornwall's famous mines: The Mineralogical Record, v. 24, no. 4, p. 259-283.

Beckinsale, R.D., 1979, Granite magmatism in the tin belt of South-east Asia, in Atherton, M.P., and Tarnay, J., eds., Origin of granite batholiths - Geochemical evidence: Orpington, United Kingdom, Shiva Publishing Ltd., p. 34-44.

Bellasis, J.W.M., and van der Heyde, C., 1962, Operations at Kamativi Tin Mines Ltd., Southern Rhodesia: Chamber of Mines Journal, v. 4, no. 9, September, p. 36-41.

Bettencourt, J.S., Damasceno, E.C., Fontanelli, W.S., Franco, J.R., and Pereira, N.M., 1981, Brazilian tin deposits and potential, in World Conference on Tin, 5th, Kuala Lumpur, Malaysia, October 19-23, 1981: London, United Kingdom, International Tin Council, paper 3 (ii), 69 p.

Beus, A.A., 1969, Geochemical criteria for assessment of the mineral potential of igneous rock series during reconnaissance exploration: Colorado School of Mines Quarterly, v. 64 , no. 1 , p. $67-74$.

Beyschlag, F., Vogt, J.H.L., and Krusch, P., 1914, The deposits of the useful minerals \& rocks - Their origin, form, and content, v. 1: London, United Kingdom, Macmillan and Co., Ltd., 514 p. [Also available at http://catalog.hathitrust.org/ Record/006563002.]

Birge, W.J., Black, J.A., Westerman, A.G., and Hudson, J.E., 1980, Aquatic toxicity tests on inorganic elements occurring in oil shale, in Gale, Charles, ed., Oil shale symposiumSampling, analysis, and quality assurance, March 1979, Proceedings: Cincinnati, Ohio, U.S. Environmental Protection Agency, EPA-600/9-80-022, p. 519-534. [Also available at http://babel.hathitrust.org/cgi/pt?id= coo.31924004323303; view=1 up;seq=531.]

Blake, D.H., and Smith, J.W., 1970, Mineralogical zoning in the Herberton tinfield, north Queensland, Australia: Economic Geology, v. 65, p. 993-997. [Also available at http://dx.doi.org/10.2113/gsecongeo.65.8.993.]

Blight, Peter, 2012, Stellar Resources Ltd.: London, United Kingdom, International Tin Research Institute Investing in Tin Seminar, November 30, presentation.

Bliss, J.D., and Menzie, W.D., 1995, Preliminary grade and volume model of alluvial Sn-Au placers: U.S. Geological Survey Open-File Report 95-649, 14 p. [Also available at http://pubs.usgs.gov/of/1995/0649/report.pdf.] 
Blissett, A.H., 1959, The geology of the Rossarden-Storeys Creek district: Tasmania Department of Mines, Geological Survey Bulletin no. 46, 117 p. [Also available at http://www.mrt.tas.gov.au/mrtdoc/dominfo/download/ GSB46/GSB46.pdf.]

Blockley, J.G., 1980, The tin deposits of Western Australia, with special reference to the associated granites: Perth, Western Australia, Australia, Geological Survey of Western Australia Mineral Resources Bulletin no. 12, 184 p.

Bowden, Peter, and Kinnaird, J.A., 1978, Younger granites of Nigeria-A zinc-rich tin province: Institution of Mining and Metallurgy Transactions, Series B, v. 87, May, p. B66-B69.

Bowden, Peter, and Kinnaird, J.A., 1984, Geology and mineralization of the Nigerian anorogenic ring complexes: Hannover, West Germany, Geologisches Jahrbuch [Geological Yearbook], v. B56, p. 3-65.

Bowden, Peter, and Van Breemen, O., 1972, Isotopic and chemical studies on younger granites from northern Nigeria, in Whiteman, A.J., and Dessauvagie, T.F.J., eds., African geology: Ibadan, Nigeria, Ibadan University Press, p. $105-120$.

Bramwell, Wayne, 2012, Kasbah Resources Ltd.: London, United Kingdom, International Tin Research Institute Investing in Tin Seminar, November 30, presentation.

Brown, W.M., Kwak, T.A.P., and Askins, P.W., 1984, Geology and geochemistry of a F-Sn-W skarn system-The Hole 16 deposit, Mt Garnet, north Queensland, Australia: Australian Journal of Earth Sciences, v. 31, no. 3, p. 317-340. [Also available at http://dx.doi.org/10.1080/14400958408527934.]

Burleigh, R.E., 1991, Evaluation of the tin-tungsten greisen mineralization and associated granite at Sleitat Mountain, southwestern Alaska: U.S. Bureau of Mines Open-File Report 35-91, 39 p. plus 2 appendixes. [Also available at http://pubs.dggsalaskagov.us/webpubs/usbm/ofr/text/ ofr035_91.pdf.]

Burt, D.M., 1981, Acidity-salinity diagrams-Application to griesen and porphyry deposits: Economic Geology, v. 76, p. 832-843. [Also available at http://dx.doi.org/10.2113/ gsecongeo.76.4.832.]

Burt, D.M., Sheridan, M.F., Bikun, J.V., and Christiansen, E.H., 1982, Topaz rhyolites - Distribution, origin, and significance for exploration: Economic Geology, v. 77, p. 1818-1836. [Also available at http://dx.doi.org/ 10.2113/gsecongeo.77.8.1818.]

Byrd, J.T., and Andreae, M.O., 1986a, Concentrations and fluxes of tin in aerosols and rain: Atmospheric Environment, v. 20, no. 5, p. 931-939. [Also available at http://dx.doi.org/ 10.1016/0004-6981(86)90277-5.]
Byrd, J.T., and Andreae, M.O., 1986b, Dissolved and particulate tin in North Atlantic seawater: Marine Chemistry, v. 19, no. 2, May, p. 193-200. [Also available at http://dx.doi.org/ 10.1016/0304-4203(86)90049-6.]

Byrd, J.T., and Andreae, M.O., 1986c, Geochemistry of tin in rivers and estuaries: Geochimica et Cosmochimica Acta, v. 50, no. 5, May, p. 835-845. [Also available at http://dx.doi.org/10.1016/0016-7037(86)90359-5.]

Campbell, D.F., 1947, The geology of the Colquiri tin mine, Bolivia: Economic Geology, v. 42, no. 1, p. 1-21. [Also available at http://dx.doi.org/10.2113/gsecongeo.42.1.1.]

Canadian Council of Ministers of the Environment, 2007, Canadian soil quality guidelines for the protection of environmental and human health, chap. 7 of Canadian environmental quality guidelines: Winnipeg, Manitoba, Canada, Canadian Council of Ministers of the Environment, accessed March 15, 2013, at http://www.ccme.ca/ publications/ceqg_rcqe.html.

Caratozzolo, R., Bellini, E., Melati, M.R., Pellerito, C., Fiore, T., D'Agati, P., Scopelliti, M., and Pellerito, L., 2007, Interference of tributyltin(IV)chloride on the vascular plant cells: Applied Organometallic Chemistry, v. 21, no. 2, p. 66-72. [Also available at http://dx.doi.org/10.1002/aoc.1175.]

Carlin, J.F., Jr., 1985, Tin, in Knoerr, A.W., ed., Mineral facts and problems, 1985 ed.: U.S. Bureau of Mines Bulletin 675, p. $847-858$.

Carlin, J.F., Jr., 2000, Tin, in Metals and minerals: U.S. Geological Survey Minerals Yearbook 1998, v. I, p. 78.1-78.13. [Also available at https://minerals.usgs.gov/minerals/pubs/ commodity/tin/660498.pdf.]

Carlin, J.F., Jr., 2001, Tin, in Metals and minerals: U.S. Geological Survey Minerals Yearbook 1999, v. I, p. 78.1-78.13. [Also available at http://minerals.usgs.gov/minerals/pubs/ commodity/tin/660499.pdf.]

Carlin, J.F., Jr., 2013, Tin (Sn), in U.S. Geological Survey National Minerals Information Center Staff, Metal prices in the United States through 2010: U.S. Geological Survey Scientific Investigations Report 2012-5188, p. 181-183, accessed September 7, 2016, at http://pubs.usgs.gov/ sir/2012/5188/sir2012-5188.pdf.

Carlin, J.F., Jr., 2014, Tin [advance release], in Metals and minerals: U.S. Geological Survey Minerals Yearbook 2012, v. I, p. 77.1-77.9, accessed March 9, 2016, at http://minerals.usgs.gov/minerals/pubs/commodity/tin/ myb1-2012-tin.pdf. 
Cérný, Petr, Blevin, P.L., Cuney, Michel, and London, David, 2005, Granite-related ore deposits, in Hedenquist, J.W., Thompson, J.F.H., Goldfarb, R.J., and Richards, J.P., eds., Economic Geology — One hundredth anniversary volume, 1905-2005: Littleton, Colo., Society of Economic Geologists, p. 337-370. [Appendixes are on a CD-ROM inside the back cover.]

Chen Gouda, 1989, Tectonics of China: Oxford, United Kingdom, Pergamon Press, 266 p.

Cheng, Yanbo, Mao, Jingwen, Chang, Zhaoshan, and Pirajno, Franco, 2013, The origin of the world class tinpolymetallic deposits in the Gejiu district, SW ChinaConstraints from metal zoning characteristics and ${ }^{40} \mathrm{Ar}-{ }^{39} \mathrm{Ar}$ geochronology: Ore Geology Reviews, v. 53, p. 50-62.

Christiansen, E.H., Sheridan, M.F., and Burt, D.M., 1986, The geology and geochemistry of Cenozoic topaz rhyolites from the Western United States: Geological Society of America Special Paper 205, 82 p. [Also available at http://dx.doi.org/ 10.1130/SPE205-p1.]

Clarke, G.W., Paterson, R.G., and Taylor, R.G., 1985, The nature and origin of brecdation [sic] and mineralization at the White Crystal ore deposit, Ardlethan tin mine, New South Wales: Australian Journal of Earth Sciences, v. 32, no. 4, p. 343-348. [Also available at http://dx.doi.org/ 10.1080/08120098508729337.]

Collins, P.L.F., 1981, The geology and genesis of the Cleveland tin deposit, western Tasmania-Fluid inclusion and stable isotope studies: Economic Geology, v. 76, p. 365-392. [Also available at http://dx.doi.org/10.2113/ gsecongeo.76.2.365.]

Consolidated Tin Mines Ltd., 2013, Geological and mineralogical summary of Gillian, Pinnacles and Windermere deposits-Mt. Garnet, Queensland: North Queensland, Australia, Consolidated Tin Mines Ltd., 24 p.

Cowen, Richard, 1999, Chapter 3-Fire and metals: Richard Cowen Web page, accessed March 2, 2016, at http://mygeologypage.ucdavis.edu/cowen/ gel115/ 115CH3.html. [Essay prepared as part of draft geology textbook manuscript.]

Dandar, S., 2009, Ore deposits and occurrence of tungsten and tin, in Lkhamsuren, J., ed., Metallic mineral deposits, v. VI: Ulaanbaatar, Mongolia, p. 115-182. [In Mongolian.]

Daubrée, A., 1841, Memoire sur le gisemont, la constitution et l'origine des amas de minerai d'etain: Annales des Mines, 3 série, tome XX, p. 65-112.

De Haas, W.J., De Boer, J., and Van den berg, G.J., 1935, The electrical resistance of cadmium, thallium and tin at low temperatures: Physica, v. 2, no. 1, p. 453-459. [Also available at http://dx.doi.org/10.1016/S0031-8914(35)90114-8.]
De Lacey, Ralph, 2012, Consolidated Tin Mines Ltd.: London, United Kingdom, International Tin Research Institute Investing in Tin Seminar, November 30, presentation.

Dietrich, Andreas, Lehmann, Bernd, and Wallianos, Alex, 2000, Bulk rock and melt inclusion geochemistry of Bolivian tin porphyry systems: Economic Geology, v. 95, p. 313-326. [Also available at http://dx.doi.org/10.2113/ gsecongeo.95.2.313.]

Dines, H.G., 1956, The metalliferous mining region of SouthWest England, v. 1 and 2, Memoirs of the Geological Survey of Great Britain: London, United Kingdom, Her Majesty's Stationery Office, 795 p.

Dirkx, Wilfried, Łobiński, Ryszard, Ceulemans, Michiel, and Adams, Freddy, 1993, Determination of methyl- and butyltin compounds in waters of the Antwerp harbour: Science of the Total Environment, v. 136, no. 3, p. 279-300.

Dobson, D.C., 1982, Geology and alteration of the Lost River tin-tungsten-fluorine deposit, Alaska: Economic Geology, v. 77, p. 1033-1052. [Also available at http://dx.doi.org/ 10.2113/gsecongeo.77.4.1033.]

Efroymson, R.A., Will, M.E., Suter, G.W., II, and Wooten, A.C., 1997, Toxicological benchmarks for screening contaminants of potential concern for effects on terrestrial plants-1997 revision, report prepared for the U.S. Department of Energy by Lockheed Martin Energy Systems, Inc.: Oak Ridge, Tenn., Oak Ridge National Laboratory, ES/ER/TM-85/R3, variously paged, accessed March 4, 2013, at http://www.esd.ornl.gov/ programs/ecorisk/documents/tm85r3.pdf.

Élie de Beaumont, Léonce, 1847, Note sur les émanantions volcaniques et métallifères [Note on volcanic and metalliferous emissions]: Bulletin de la Société Géologique de France, 2 série, tome 4, p. 1249-1334.

Eriksson, Jan, 2001, Concentrations of 61 trace elements in sewage sludge, farmyard manure, mineral fertiliser, precipitation and in oil and crops: Swedish Environmental Protection Agency Report 5159, 45 p. plus 9 appendixes. [Also available at http://swedishepa.se/Documents/ publikationer/620-6246-8.pdf.]

Evans, S.M., Leksono, T., and McKinnell, P.D., 1995, Tributyltin pollution-A diminishing problem following legislation limiting the use of TBT-based anti-fouling paints: Marine Pollution Bulletin, v. 30, no. 1, p. 14-21. [Also available at http://dx.doi.org/10.1016/0025326X(94)00181-8.]

Falconer, J.D., 1912, Nigerian tin; its occurrence and origin: Economic Geology, v. 7, p. 542-546. [Also available at http://dx.doi.org/10.2113/gsecongeo.7.6.542.]

Fleischer, Michael, 1983, Glossary of mineral species: Tucson, Ariz., Mineralogical Record, 202 p. 
Floriano, E.A., de Andrade Scalvi, L.V., Sambrano, J.R., and Geraldo, Viviany, 2010, Evaluation of bulk and surfaces adsorption edge energy of sol-gel-dip-coating $\mathrm{SnO}_{2}$ thin films: Materials Research, v. 13, no. 4, p. 437-443. [Also available at http://www.scielo.br/scielo.php?script=sci_art text\&pid=S1516-14392010000400004\&lng=en\&tlng=pt.]

Foshag, W.F., and Fries, Carl, Jr., 1942, Tin deposits of the Republic of Mexico: U.S. Geological Survey Bulletin 935-C, p. 99-176. [Also available at http://pubs.usgs.gov/ bul/0935c/report.pdf.]

Fox, D.J., 1971, Tin mining in Bolivia: Mining Magazine, v. 124, no. 1, p. 11-23.

Fries, Carl, Jr., 1940, Tin deposits of the Black Range, Catron and Sierra Counties, New Mexico-A preliminary report: U.S. Geological Survey Bulletin 922-M, p. 355-370. [Also available at http://pubs.usgs.gov/bul/0922m/report.pdf.]

Fries, Carl, Jr., 1942, Tin deposits of northern Lander County, Nevada: U. S. Geological Survey Bulletin 931-L, p. 279-294. [Also available at http://pubs.usgs.gov/ bul/09311/report.pdf.]

Garnett, R.H.T., 1963, Local mineral zoning in Geevor tin mine, Cornwall, in Symposium-Problems of postmagmatic ore deposition symposium, v. 1: Prague, Czechoslovakia, Czechoslovakia Geological Survey, p. 91-96.

Garrad, P.D., and Bultitude, R.J., 1999, Geology, mining history and mineralisation of the Hodgkinson and Kennedy provinces, Cairns Region, North Queensland: Brisbane, Queensland, Australia, Department of Mines and Energy, $306 \mathrm{p}$.

Gomes, M.E.P., and Favas, P.J.C., 2006, Mineralogical controls on mine drainage of the abandoned Ervedosa tin mine in north-eastern Portugal: Applied Geochemistry, v. 21, no. 8, p. 1322-1334. [Also available at http://dx.doi.org/ 10.1016/j.apgeochem.2006.06.007.]

Govett, M.H., and Robinson, H.A., eds., 1980, The world tin industry - Supply and demand: Sydney, New South Wales, Australia, Australian Mineral Economics Proprietary Ltd., $278 \mathrm{p}$.

Graedel, T.E., Allwood, Julian, Birat, J.-P., Buchert, Matthias, Hagelüken, Christian, Reck, B.K., Sibley, S.F., and Sonnemann, Guido, 2011, What do we know about metal recycling rates?: Journal of Industrial Ecology, v. 15, no. 3, p. 355-366. [Also available at http://dx.doi.org/10.1111/ j.1530-9290.2011.00342.x.]

Grant, J.N., Halls, C., Sheppard, S.M.F., and Avila, W., 1980, Evolution of the porphyry tin deposits of Bolivia, in Ishihara, S., and Takenouchi, S., eds., Granitic magmatism and related mineralization: Mining Geology Special Issue 8, p. 151-173.
Halley, S.W., and Walshe, J.L., 1995, A reexamination of the Mount Bischoff cassiterite sulfide skarn, western Tasmania: Economic Geology, v. 90, p. 1676-1693. [Also available at http://dx.doi.org/10.2113/gsecongeo.90.6.1676.]

Halter, W.E., Williams-Jones, A.E., and Kontak, D.J., 1996, The role of greisenization in cassiterite precipitation at the East Kemptville tin deposit, Nova Scotia: Economic Geology, v. 91, p. 368-385. [Also available at http://dx.doi.org/ 10.2113/gsecongeo.91.2.368.]

Halter, W.E., Williams-Jones, A.E., and Kontak, D.J., 1998, Origin and evolution of the greisenizing fluid at the East Kemptville tin deposit, Nova Scotia, Canada: Economic Geology, v. 93, p. 1026-1051. [Also available at http://dx.doi.org/10.2113/gsecongeo.93.7.1026.]

Hammarstrom, J.M., Elliott, J.E., Kotlyar, B.B., Theodore, T.G., Nash, J.T., John, D.A., Hoover, D.B., and Knepper, D.H.J., Jr., 1995, Sn and (or) W skarn and replacement deposits, chap. 8 of du Bray, E.A., ed., Preliminary compilation of descriptive geoenvironmental mineral deposit models: U.S. Geological Survey OpenFile Report 95-831, p. 54-61. [Also available at http://pubs.usgs.gov/of/1995/ofr-95-0831/.]

Haustein, M., Gillis, C., and Pernicka, E., 2010, Tin isotopyA new method for solving old questions: Archaeometry, v. 52, no. 5, p. 816-832. [Also available at http://dx.doi.org/ 10.1111/j.1475-4754.2010.00515.x.]

Heinrich, C.A., 1995, Geochemical evolution and hydrothermal mineral deposition in Sn(-W-base metal) and other granite-related ore systems-Some conclusions from Australian examples: Mineralogical Association of Canada Short Course Handbook, v. 23, p. 203-220.

Hill, R.S., and Brunker, E.G., 1981, The tin occurrences of the south-western Cape Province: Geological Survey of South Africa Open-File Report 1981-0136, 49 p.

Holder, M.T., and Leveridge, B.E., 1986, A model for the tectonic evolution of south Cornwall: Journal of the Geological Society of London, v. 143, no. 1, p. 125-134. [Also available at http://dx.doi.org/10.1144/gsjgs.143.1.0125.]

Holleman, A.F., Wiberg, E., and Wiberg, N., 1985, Tin, in Lehrbook der Anorganischen Chemie: Berlin, West Germany, Walter de Gruyter \& Co., 2,033 p.

Hosking, K.F.G., 1964, Permo-Carboniferous and later primary mineralisation of Cornwall and South-West Devon, in Hosking, K.F.G., and Shrimpton, G.J., eds., Present views of some aspects of the geology of Cornwall and Devon: Penzance, Cornwall, United Kingdom, Royal Geological Society of Cornwall, p. 201-245. 
Hou Zengqian, Zaw Khin, Pan Guitang, Mo Xuanxue, Xu Qiang, Hu Yunzhong, and Li Xingzhen, 2007, Sanjiang Tethyan metallogenesis in S.W. China-Tectonic setting, metallogenic epochs and deposit types: Ore Geology Reviews, v. 31, p. 48-87. [Also available at http://dx.doi.org/10.1016/ j.oregeorev.2004.12.007.]

Hudson-Edwards, K.A., Macklin, M.G., Miller, J.R., and Lechler, P.J., 2001, Sources, distribution and storage of heavy metals in the Río Pilcomayo, Bolivia: Journal of Geochemical Exploration, v. 72, no. 3, p. 229-250. [Also available at http://dx.doi.org/10.1016/S0375-6742(01)00164-9.]

Hudson Institute of Mineralogy, 2016, Cassiterite, in Mindat.org database: Hudson Institute of Mineralogy, accessed September 21, 2016, at http://www.mindat.org/min-917.html

Hudson, T.L., and Reed, B.L., 1997, Tin deposits of Alaska, in Goldfarb, R.J., and Miller, L.D., eds., Mineral deposits of Alaska: Lancaster, Pa., Economic Geology Publishing Co., Economic Geology Monograph Series, no. 9, p. 450-465.

Hunter, D.R., 1973, The localization of tin mineralization with reference to southern Africa: Minerals Science and Engineering, v. 5, p. 53-77.

Huspeni, J.R., Kesler, S.E., Ruiz, Joaquin, Tuta, Zane, Sutter, J.F., and Jones, L.M., 1984, Petrology and geochemistry of rhyolites associated with tin mineralization in northern Mexico: Economic Geology, v. 79, p. 87-105. [Also available at http://dx.doi.org/10.2113/gsecongeo.79.1.87.]

Ibeanu, I.G., 2003, Tin mining and processing in NigeriaCause for concern?: Journal of Environmental Radioactivity, v. 64, no. 1, p. 59-66.

Jackson, N.J., Willis-Richards, Jonathan, Manning, D.A., and Sams, M.S., 1989, Evolution of the Cornubian ore field, Southwest England-Part II, Mineral deposits and oreforming processes: Economic Geology, v. 84, p. 1101-1133. [Also available at http://econgeol.geoscienceworld.org/ content/84/5/1101.]

Jargalsaikhan, D., 1996, Metallic mineral deposits, in Jargalsaikhan, D., Kazmar, M., and Sanjaadori, D., eds., Guide to the geology and mineral resources of Mongolia: Ulaanbaatar, Mongolia, Geological Exploration, Consulting and Services, p. 157-158.

Kabata-Pendias, Alina, and Pendias, Henryk, 2001, Trace elements in soils and plants ( $3 \mathrm{~d}$ ed.): Boca Raton, Fla., CRC Press, 413 p.

Kamilli, R.J., and Criss, R.E., 1996, Genesis of the Silsilah tin deposit, Kingdom of Saudi Arabia: Economic Geology, v. 91, p. 1414-1434. [Also available at http://dx.doi.org/ 10.2113/gsecongeo.91.8.1414.]
Kamilli, R.J., and Ganster, M.W., 1995, Climax-type molybdenum deposits and granite-related tungsten-tin deposits considered as a porphyry-greisen deposit superclass [abs.]: Geology and Ore Deposits of the American Cordillera, a symposium sponsored by The Geological Society of Nevada, Reno/Sparks, Nevada, April 10-13, 1995, Program with Abstracts, p. A42-A43.

Kamilli, R.J., Cole, J.C., Elliott, J.E., and Criss, R.E., 1993, Geology and genesis of the Baid al Jimalah tungsten deposit, Kingdom of Saudi Arabia: Economic Geology, v. 88, p. 1743-1767. [Also available at http://dx.doi.org/ 10.2113/gsecongeo.88.7.1743.]

Kellogg, K.S., and Smith, C.W., 1985, The Akash graniteA tin-mineralized granite in the northern Arabian Shield, Kingdom of Saudi Arabia: Saudi Arabia Deputy Ministry for Mineral Resources, USGS-TR-05-6, 25 p.

Kettle, Peter, 2012, Tin industry outlook: London, United Kingdom, International Tin Research Institute Investing in Tin Seminar, 30 November, 10 p.

Khiltova, V.Ya., and Pleskach, G.P., 1997, Yenisey fold belt, chap. 13 of Rundqvist, D.V. and Gillen C., eds., Precambrian ore deposits of the East European and Siberian cratons: Amsterdam, Netherlands, Elsevier Scientific Publishing Co., Developments in Economic Geology Series, no. 30, 457 p.

Kirkham, R.V., and Sinclair, W.D., 1988, Comb quartz layers in felsic intrusions and their relationship to porphyry deposits, in Kirkham, R.V., Sinclair, W.D., Thorpe, R.I, and Duke, J.M., eds., Mineral deposit modeling: Geological Association of Canada Special Paper 40, p. 521-554.

Kontak, D.J., and Clark, A.H., 2002, Genesis of the giant, bonanza San Rafael lode tin deposit, Peru-Origin and significance of pervasive alteration: Economic Geology, v. 97, p. 1741-1777. [Also available at http://dx.doi.org/10.2113/ gsecongeo.97.8.1741.]

Kontak, D.J., Clark, A.H., Farrar, E., and Strong, D.F., 1985, The rift-associated Permo-Triassic magmatism of the Eastern Cordillera-A procursor to the Andean orogeny, in Pitcher, W.S., Atherton, M.P., Cobbing, E.J., and Beckinsale, R.D., eds., Magmatism at a plate edge-The Peruvian Andes: London, United Kingdom, Blackie and Son Ltd., p. 36-44.

Kooiman, G.J.A., McLeod, M.J., and Sinclair, W.D., 1986, Porphyry tungsten molybdenum orebodies, polymetallic veins and replacement bodies, and tin-bearing greisen zones in the Fire Tower Zone, Mount Pleasant, New Brunswick: Economic Geology, v. 81, p. 1356-1373. [Also available at http://dx.doi.org/10.2113/gsecongeo.81.6.1356.] 
Korostelev, P.G., Gonevchuk, V.G., Semenyak, B.I., Gorelikova, N.V., Karabtsov, A.A., Kokorin, A.M., Kononov, V.V., Orekhov, A.A., Safronov, P.P., and Sinyakov, E.Y., 2009, The Dzhalinda deposit in the Amur region, Russia-Genesis and position in the classification of tin deposits: Geology of Ore Deposits, v. 51, no. 4, p. 305-316. [Also available at http://dx.doi.org/10.1134/S1075701509040047.]

Krosch, N.J., 1985, Tin and tungsten potential in Queensland: Queensland Government Mining Journal, January, p. 16-25.

Kwak, T.A.P., 1987, W-Sn skarn deposits and related metamorphic skarns and granitoids: Amsterdam, Netherlands, Elsevier Scientific Publishing Co., Developments in Economic Geology Series, no. 24, 451 p.

Laznicka, Peter, 2006, Giant metallic deposits-Future sources of industrial metals: Berlin, Germany, SpringerVerlag, 732 p.

Lehmann, Bernd, 1990, Metallogeny of tin, in Bhattacharji, Somdev, Friedman, G.M., Neugebauer, H.J., and Seilacher, Adolph, eds., Lecture notes in Earth Sciences [no. 32]: Berlin, Germany, Springer-Verlag, 211 p.

Lenharo, S.L.R., Pollard, P.J., and Born, Helmut, 2003, Petrology and textural evolution of granites associated with tin and rare-metals mineralization at the Pitinga Mine, Amazonas, Brazil: Lithos, v. 66, p. 37-61.

Lindgren, Waldemar, 1933, Mineral deposits (4th ed.): New York, N.Y., McGraw-Hill Book Company, Inc., 930 p.

Lottermoser, B.G., and Ashley, P.M., 2006, Mobility and retention of trace elements in hardpan-cemented cassiterite tailings, north Queensland, Australia: Environmental Geology, v. 50, p. 835-846. [Also available at http://dx.doi.org/ 10.1007/s00254-006-0255-8.]

MacLeod, W.N., Turner, D.C., and Wright, E.P., 1971, The geology of the Jos Plateau, v. 1, The geology: Geological Survey of Nigeria Bulletin, no. 32, 112 p.

Magak’yan, I.G., 1968, Ore deposits. Tin: International Geology Review, v. 10, p. 108-121.

Mareno, Ann-Marie, 1986, The tin industry in Brazil, in The market for tin-Proceedings of the International Tin Symposium, London, United Kingdom, December 17, 1985 : London, United Kingdom, Tin International Special Issue, p. $72-78$.

McAndrew, J., 1965, Tin and lead ore deposits of Zeehan, in Madigan, R.T., ed., Geology of Australian ore deposits, v. 1 ( $2 \mathrm{~d}$ ed.) of Commonwealth Mining and Metallurgical Congress, 8th, Australia and New Zealand: Melbourne, Victoria, Australia, Australasian Institute of Mining and Metallurgy, p. 492-494.
McGroarty, Daniel, and Wirtz, Sandra, 2012, Reviewing risk-Critical minerals and national security: American Resources Policy Network Report, June 6, 34 p.

McNaughton, N.J., and Rosman, K.J.R., 1991, Tin isotope fractionation in terrestrial cassiterites: Geochimica et Cosmochimica Acta, v. 55, no. 2, p. 499-504. [Also available at http://dx.doi.org/10.1016/0016-7037(91)90007-R.]

Mining Journal, 1988, Neves-Corvo expansion: Mining Journal, v. 311, no. 7999, p. 477.

Mitchell, A.H.G., 1974, Southwest England granitesMagmatism and tin mineralization in a post-collision tectonic setting: Transactions of the Institute of Mining and Metallurgy, v. 83, B95-B97.

Mitchell, A.H.G., 1977, Tectonic settings for emplacement of Southeast Asian tin granites: Bulletin of the Geological Society of Malaysia Bulletin 9, November, p. 123-140. [Also available at http://www.gsm.org.my/products/ 702001-101295-PDF.pdf.]

Mlynarczyk, M.S.J., Sherlock, R.L., and Williams-Jones, A.E., 2003, San Rafael, Peru-Geology and structure of the worlds [sic] richest tin lode: Mineralium Deposita, v. 38, no. 5, p. 555-567. [Also available at http://dx.doi.org/10.1007/ s00126-002-0334-z.]

Mookhey, R.C., 1971, Completion report-Assessment of probable size and grade of Mount Wells tin-wolfram copper deposit, Northern Territory: Melbourne, Victoria, Australia, IMC Development Corp. report, 60 p.

Neal, C., and Robson, A.J., 2000, A summary of river water quality data collected within the Land-Ocean Interaction Study - Core data for eastern UK rivers draining to the North Sea: Science of the Total Environment, v. 251-252, May, p. 585-665. [Also available at http://dx.doi.org/10.1016/ S0048-9697(00)00397-1.]

Nier, A.O., 1947, A mass spectrometer for isotope and gas analysis: Review of Scientific Instruments, v. 18, no. 6, p. 398-411. [Also available at http://dx.doi.org/10.1016/ 0016-7037(85)90272-8.]

Nokleberg, W.J., Bundtzen, T.K., Eremin, R.A., Ratkin, V.V., Dawson, K.M., Shpikerman, V.I., Goryachev, N.A., Byalobzhesky, S.G., Frolov, Y.F., Khanchuk, A.I., Koch, R.D., Monger, J.W.H., Pozdeev, A.I., Rozenblum, I.S., Rodionov, S.M., Parfenov, L.M., Scotese, C.R., and Sidorov, A.A., 2005, Metallogenesis and tectonics of the Russian Far East, Alaska, and the Canadian Cordillera: U.S. Geological Survey Professional Paper 1697, 397 p. [Also available at http://pubs.usgs.gov/pp/pp1697/.] 
Nriagu, J.O., and Pacyna, J.M., 1988, Quantitative assessment of worldwide contamination of air, water and soils by trace-metals: Nature, v. 333, p. 134-139. [Also available at http://dx.doi.org/10.1038/333134a0.]

Nutalaya, Prinya, Campbell, K.V., MacDonald, A.S., Aranyakanon, Payome, and Suthakorn, Phairat, 1979, Review of the geology of the Thai tin fields, in Yeap, C.H., ed., Geology of tin deposits: Geological Society of Malaysia Bulletin no. 11, p. 137-159. [Also available at http://www.gsm.org.my/bulletin_archive_list.php?vol=2164.]

Occupational Safety and Health Administration, 2013a, Tin, inorganic compounds (except oxides) (as Sn): Occupational Safety and Health Administration, accessed March 10, 2013, at http://www.osha.gov/dts/chemicalsampling/data/ CH_271800.html.

Occupational Safety and Health Administration, 2013b, Tin, organic compounds (as Sn): Occupational Safety and Health Administration, accessed March 10, 2013, at http://www.osha.gov/dts/chemicalsampling/data/ CH_271900.html.

Offenberg, A.C., 1982, Geology, mineralization and exploration of the Taronga tin prospect, Emmaville, New South Wales: Sydney Mineral Exploration Group seminar, Artarmon, New South Wales, Australia, September 17, 1982, presentation.

Olade, M.A., 1980, Geochemical characteristics of tinbearing and tin-barren granites, northern Nigeria: Economic Geology, v. 75, p. 71-82. [Also available at http://dx.doi.org/ 10.2113/gsecongeo.75.1.71.]

Omer-Cooper, W.R.B., Hewitt, W.V., and van Wees, H., 1974, Exploration for cassiterite-magnetite-sulphide veins on Belitung, Indonesia, in Allen, H.W., chairman, Fourth world conference on tin, Kuala Lumpur, 1974, v. II: London, United Kingdom, International Tin Council, p. 96-119.

Outback Metals Ltd., 2014a, Maranboy/Yeuralba tin-tungstengold (copper) project: Outback Metals Ltd. Web page, accessed December 20, 2016, at https://web.archive.org/ web/20140124075955/http://outbackmetals.com/projects/ maranboy_yeuralba_tin-tungsten-gold_copper_project.aspx.

Outback Metals Ltd., 2014b, Mt Wells tin-copper-tungsten (gold-base metals) project: Outback Metals Ltd. Web page, accessed December 20, 2016, at https://web.archive.org/ web/20140124075952/http://outbackmetals.com/projects/ mt_wells_tin-copper-tungsten_gold-base_metals_project.aspx.

Palache, Charles, Berman, Harry, and Frondel, Clifford, 1944, The system of mineralogy of James Dwight Dana and Edward Salisbury Dana, Yale University, 1837-1892, Volume I-Elements, sulfides, sulfosalts, oxides: New York, N.Y., John Wiley and Sons, Inc., 834 p.
Papp, J.F., 2016, Recycling-Metals [advance release], in Metals and minerals: U.S. Geological Survey Minerals Yearbook 2014, v. I, p. 61.1-61.5, accessed September 21, 2016, at http://minerals.usgs.gov/minerals/pubs/commodity/recycle/ myb1-2014-recyc.pdf.

Patterson, D.J., Ohmoto, H., and Solomon, M., 1981, Geologic setting and genesis of cassiterite-sulfide mineralization at Renison Bell, western Tasmania: Economic Geology, v. 76, p. 393-438. [Also available at http://dx.doi.org/10.2113/ gsecongeo.76.2.393.]

Penhallurick, R.D., 1986, Tin in antiquity: London, United Kingdom, The Institute of Metals, $271 \mathrm{p}$.

Peterson, P.J., Burton, M.A.S., Gregson, M., Nye, S.M., and Porter, E.K., 1976, Tin in plants and surface waters in Malaysian ecosystems, in Trace substances in environmental health, v. 10: Columbia, Mo., University of Missouri Press, p. 123-132.

Plimer, I.R., 1984, Malayaite and tin-bearing silicates from a skarn at Doradilla via Bourke, New South Wales: Australian Journal of Earth Sciences, v. 31, no. 1, p. 147-153.

Plumlee, G.S,. and Logsdon, M.J., 1999, An Earth-system science toolkit for environmentally friendly mineral resource development, in Plumlee, G.S. and Logsdon, M.J., eds., The environmental geochemistry of mineral deposits - Part A, Processes, techniques, and health issues: Littleton, Colo., Society of Economic Geologists, Reviews in Economic Geology Series, v. 6A, p. 1-27. [Also available at http://ebooks.geoscienceworld.org/content/theenvironmental-geochemistry-of-mineral-deposits.]

Porter GeoConsultancy Pty Ltd., 1995, Krusne Hory (Erzgebirge) - Cinovec/Zinnwald, Krupka, Krasno - Czech Republic: Porter GeoConsultancy Pty Ltd. Web page, accessed November 8, 2016, at http://www.portergeo.com.au/ database/mineinfo.asp?mineid=mn1241.

Premoli, Camillo, 1986, China's tin potential—With special reference to Dachang tin field: Mining Magazine, v. 154, no. 1, p. $28-40$.

Prijono, I.A., 1986, Indonesia, in Mining annual review 1986: Mining Journal Ltd., p. 381-383.

Pringle, I.C., 1986, The Union tin mine, Naboomstruit district, in Anhaeusser, C.R., and Maske, S., eds., Mineral deposits of southern Africa: Geological Society of South Africa, p. 1301-1305.

Radonjic, Andrew, 2012, Venture Minerals Ltd.: London, United Kingdom, International Tin Research Institute Investing in Tin Seminar, November 30, presentation. 
Rajah, S.S., 1979, The Kinta tinfield, Malaysia: Geological Society of Malaysia Bulletin no. 11, p. 111-136. [Also available at http://www.gsm.org.my/bulletin_archive_ list.php?vol=2164.]

Rayment, B.D., Davis, G.R., and Willson, J.D., 1971, Controls to mineralization at Wheal Jane, Cornwall: Institution of Mining and Metallurgy Transactions, v. 80, August, p. B224-B237.

Reck, B.K., and Graedel, T.E., 2012, Challenges in metal recycling: Science, v. 337, no. 6095, p. 690-695. [Also available at http://dx.doi.org/10.1126/science.1217501.]

Reimann, Clemens, and de Caritat, Patrice, 1998, Chemical elements in the environment-Factsheets for the geochemist and environmental scientist: Berlin, Germany, SpringerVerlag, 398 p.

Relvas, J.M.R.S., Barriga, F.J.A.S., Ferreira, Alfredo, Noiva, P.C., Pacheco, Nelson, and Berriga, Gonçalo, 2006, Hydrothermal alteration and mineralization in the Neves-Corvo volcanic-hosted massive sulfide deposit, Portugal. I. Geology, mineralogy, and geochemistry: Economic Geology, v. 101, p. 753-790, accessed September 7, 2016, at http://dx.doi.org/10.2113/gsecongeo.101.4.753. (Article correction posted on September 01, 2006.)

Ren, S.K., Walshe, J.L., Paterson, R.G., Both, R.A., and Andrew, Anita, 1995, Magmatic and hydrothermal history of the porphyry-style deposits of the Ardlethan tin field, New South Wales, Australia: Economic Geology, v. 90, p. 1620-1645. [Also available at http://dx.doi.org/10.2113/ gsecongeo.90.6.1620.]

Richardson, J.M.G., 1988, Field and textural relationships of alteration and greisen-hosted mineralization at the East Kemptville tin deposit, Davis Lake complex, southwest Nova Scotia, in Taylor, R.P., and Strong, D.F., eds., Recent advances in the geology of granite-related mineral deposits: Canadian Institute of Mining and Metallurgy Special Volume 39, p. 265-279.

Richardson, J.M.G., Spooner, E.T.C., and McAuslan, D.A., 1982, The East Kemptville tin deposit, Nova Scotia-An example of a large tonnage, low grade, greisen-hosted deposit in the endocontact zone of a granite batholith: Geological Survey of Canada, Current Research, pt. B, paper $82-1$ B, p. 27-32.
Richardson, J.M., Bell, Keith, Watkinson, D.H., and Blenkinsop, John, 1990, Genesis and fluid evolution of the East Kemptville greisen-hosted tin mine, southwestern Nova Scotia, Canada, in Stein, H.J., and Hannah, J.L., eds., Ore-bearing granite systems-Petrogenesis and mineralizing processes: Geological Society of America Special Paper 246, p. 181-204. [Also available at http://dx.doi.org/10.1130/ SPE246-p181.]

Richards, T.E., 1986, Geological characteristics of rare-metal pegmatities of the Uis type in the Damara orogen, South West Africa/Namibia, in Anhseusser, C.R., and Maske, S., eds., Mineral deposits of southern Africa: Geological Society of South Africa, p. 1845-1862.

Rijks, H.R.P., and and van der Veen, A.H., 1972, The geology of the tin-bearing pegmatites in the eastern part of the Kamativi district, Rhodesia [Zimbabwe]: Mineralium Deposita, v. 7, no. 4, p. 383-395. [Also available at http://dx.doi.org/10.1007/BF00208367.]

Rose, A.W., Hawkes, H.E., and Webb, J.S., 1979, Geochemistry in mineral exploration ( $2 \mathrm{~d}$ ed.): London, United Kingdom, Academic Press, 657 p.

Roskill Information Services, Ltd., 2015, Tin-Market outlook to 2024 (9th ed.): London, United Kingdom, Roskill Information Services, Ltd., 312 p.

Ross, F., 1941, Pirquitas Mine-A tin silver property in Argentina: Engineering and Mining Journal, v. 42, no. 8, p. 153-154.

Rozendal, A., Toros, M.S., and Anderson, J.R., 1986, The Rooiberg tin deposits, west-central Transvaal, in Anheusser, C.R., and Maske, S., eds., Mineral deposits of southern Africa: Geological Society of South Africa, p. $1307-1327$.

Rubinstein, J., and Barsky, L., 2002, Non-ferrous metal oresDeposits, minerals and plants, v. 1 of Rubinstein, J., ed., Mineral deposits and resources of the former Soviet Union: New York, N.Y., Taylor and Francis, 413 p.

Rüdel, Heinz, Müller, Josef, Steinhanses, Jürgen, and Schröter-Kermani, Christa, 2007, Retrospective monitoring of organotin compounds in freshwater fish from 1988 to 2003-Results from the German environmental specimen bank: Chemosphere, v. 66, January, p. 1884-1894. [Also available at http://dx.doi.org/10.1016/j.chemosphere. 2006.08.014.] 
Ruiz, J., 1988, Petrology, distribution and origin of rhyolites associated with tin mineralization in the Sierra Madre Occidental, Mexico, in Taylor, R.P., and Strong, D.F., eds., Recent advances in the geology of granite-related mineral deposits: Canadian Institute of Mining and Metallurgy Special Volume 39, p. 322-330.

Rye, R.O., Lufkin, J.L., and Wasserman, M.D., 1990, Genesis of the rhyolite-hosted tin occurrences in the Black Range, New Mexico, as indicated by stable isotope studies, in Stein, H.J., and Hannah, J.L., eds., Ore-bearing granite systems-Petrogenesis and mineralizing processes: Geological Society of America Special Paper 246, p. 233-250. [Also available at http://dx.doi.org/10.1130/SPE246-p233.]

Sabet, A.H., Chabenenko, V., and Tsogoev, V., 1971, Tintungsten and rare metal mineralization in central eastern desert of Egypt: Annals of the Geological Survey of Egypt, v. iii, p. $75-87$.

Sainsbury, C.L., 1964, Geology of Lost River Mine area, Alaska: U.S. Geological Survey Bulletin 1129, 80 p., 10 sheets. [Also available at https://pubs.er.usgs.gov/ publication/b1129.]

Sainsbury, C.L., 1968, Tin and beryllium deposits of the central York Mountains, western Seward Peninsula, Alaska, in Ridge, J.D., ed., Ore deposits of the United States 1933 1967, v. 2: New York, N.Y., American Institute of Mining, Metallurgical, and Petroleum Engineers, The Graton-Sales Volume, p. 1555-1572.

Sainsbury, C.L., 1969a, Geology and ore deposits of the central York Mountains, western Seward Peninsula, Alaska: U.S. Geological Survey Bulletin 1287, 101 p., 6 sheets. [Also available at https://pubs.er.usgs.gov/publication/ b1287.]

Sainsbury, C.L., 1969b, Tin resources of the world: U.S. Geological Survey Bulletin 1301, 55 p. [Also available at https://pubs.er.usgs.gov/publication/b1301.]

Sainsbury, C.L., and Reed, B.L., 1973, Tin, in Brobst, D.A., and Pratt, W.P., eds., United States mineral resources: U.S. Geological Survey Professional Paper 820, p. 637-651. [Also available at http://pubs.er.usgs.gov/publication/pp820.]

Saito, M., Hashimoto, K., Sawata, H., and Shimazaki, Y., 1960, Geology and mineral resources of Japan (2d ed.): Kawasaki, Japan, Geological Survey of Japan, 314 p.

Sarin, L.P., Azazi, S.A., El Bedewi, M.A., and Ghobrial, G.A., 1976, Tin-tantalum of Abu Dabbab: Annals of The Geological Survey of Egypt, v. VI, p. 93-117.
Sato, Noritaka, and Akiyama, Yoshio, 1980, Structural control of the Akenobe tin-polymetallic deposits, southwest Japan: Mining Geology Special Issue (Tokyo), no. 8, p. 175-188.

Schwartz, Mel, 2002, Tin and alloys, properties, in Encyclopedia of materials, parts and finishes ( $2 \mathrm{~d}$ ed.): Boca Raton, Fla., CRC Press, 936 p.

Schwartz, M.O., Rajah, S.S., Askury, A.K., Putthapiban, P., and Djaswadi, S., 1995, The Southeast Asian tin belt: Earth Science Review, v. 38, p. 95-293.

Schwarz-Schampera, Ulrich, and Herzig, P.M., 2002, Indium-Geology, mineralogy, and economics: Berlin, Germany, Springer-Verlag, 257 p.

Séby, F., Potin-Gauteir, M., Giffaut, E., and Donard, O.F.X., 2001, A critical review of thermodynamic data for inorganic tin species: Geochimica et Cosmochimica Acta, v. 65, no. 18, p. 3041-3053. [Also available at http://dx.doi.org/10.1016/ S0016-7037(01)00645-7.]

Shacklette, H.T., and Boerngen, J.G., 1984, Element concentrations in soils and other surficial materials of the conterminous United States: U.S. Geological Survey Professional Paper 1270, 105 p. [Also available at http://pubs.usgs.gov/ $\mathrm{pp} / 1270 /$.

Shannon, J.R., Walker, B.M., Carten, R.B., and Geraghty, E.P., 1982, Unidirectional solidification textures and their significance in determining relative ages of intrusions at the Henderson Mine, Colorado: Geology, v. 10, no. 6, p. 293-297. [Also available at http://dx.doi.org/10.1130/ 0091-7613(1982)10<293:USTATS >2.0.CO;2.]

Shimizu, M., and Kato, A., 1991, Roquesite-bearing tin ores from the Omodani, Akenobe, Fukuoku, and Ikuno polymetallic vein-type deposits in the Inner Zone of southwestern Japan: Canadian Mineralogist, v. 29, p. 207-215.

Sillitoe, R.H., 1976, Tin mineralization above mantle hot spots: Nature, v. 248, 497-499.

Sillitoe, R.H., Halls, C., and Grant, J.N., 1975, Porphyry tin deposits in Bolivia: Economic Geology, v. 70, p. 913-927. [Also available at http://dx.doi.org/10.2113/ gsecongeo.70.5.913.]

Sillitoe, R.H., Steele, G.B., Thompson, J.F.H., and Lang, J.R., 1998, Advanced argillic lithocaps in the Bolivian tin-silver belt: Mineralium Deposita, v. 33, p. 539-546. [Also available at http://dx.doi.org/10.1007/s001260050170.]

Smirnov, V.I., ed., 1977, Ore deposits of the USSR, v. III: London, United Kingdom, Pitman Publishing Co., 492 p. 
Smith, D.B., Cannon, W.F., Woodruff, L.G., Garrett, R.G., Klassen, Rodney, Kilburn, J.E., Horton, J.D., King, H.D., Goldhaber, M.B., and Morrison, J.M., 2005, Major- and trace-element concentrations in soils from two continentalscale transects of the United States and Canada:

U.S. Geological Survey Open-File Report 2005-1253, 20 p. plus 4 tables. [Also available at http://pubs.usgs.gov/ of/2005/1253/.]

Smith, K.S., and Huyck, H.L.O., 1999, An overview of the abundance, relative mobility, bioavailability, and human toxicity of metals, in Plumlee, G.S., and Logsdon, M.J., eds., The environmental geochemistry of mineral depositsPart A, Processes, techniques and health issues: Littleton, Colo., Society of Economic Geologists, v. 1, p. 29-70.

Solomon, Michael, and Groves, D.I., 2000, The geology and origin of Australia's mineral deposits ( $2 \mathrm{~d}$ ed.): Center for Ore Deposit Research, University of Tasmania, and Centre for Global Metallogeny, University of Western Australia, by arrangement with Oxford University Press, 1,002 p.

Suter, G.W., II, and Tsao, C.L., 1996, Toxicological benchmarks for screening potential contaminants of concern for effects on aquatic biota-1996 revision: Oak Ridge, Tenn., Oak Ridge National Laboratory Report ES/ER/TM-96/R2, variously paged, accessed March 4, 2013, at http://www.esd.ornl.gov/programs/ ecorisk/documents/tm96r2.pdf.

Sutphin, D.M., Sabin, A.E., and Reed, B.L., 1990, International Strategic Minerals Inventory summary report-Tin: U.S. Geological Survey Circular 930-J, 52 p. [Also available at https://pubs.er.usgs.gov/publication/cir930J.]

Syrymbet Mining Co., 2016, Home page: Syrymbet Mining Co., accessed November 8, 2016, at http://en.syrymbet.kz/.]

Taylor, D., Maddock, B.G., and Mance, G., 1985, The acute toxicity of nine 'grey list' metals (arsenic, boron, chromium, copper, lead, nickel, tin, vanadium and zinc) to two marine fish species-Dab (Limanda limanda) and grey mullet (Chelon labrosus): Aquatic Toxicology, v. 7, no. 3, p. 135-144. [Also available at http://dx.doi.org/10.1016/ S0166-445X(85)80001-1.]

Taylor, R.G. [with chaps. by Cuff, C.], 1979, Geology of tin deposits,: Amsterdam, Netherlands, Elsevier Scientific Publishing Co., Developments in Economic Geology Series, no. $11,543 \mathrm{p}$.

Taylor, S.R., and McLennan, S.M., 1995, The geochemical evolution of the continental crust: Reviews of Geophysics, v. 33, no. 2, p. 241-265. [Also available at http://dx.doi.org/ 10.1029/95rg00262.]
Thorman, C.H., and Drew, L.J., 1988, A report on site visits to some of the largest tin deposits in Brazil: U.S. Geological Survey Open-File Report 88-594, 19 p. [Also available at https://pubs.er.usgs.gov/publication/ofr88594.]

Tischendorf, G., 1977, Geochemical and petrographic characteristics of silicic magmatic rocks associated with rare-element mineralization, in Stemprok, Miroslav, ed., Metallization associated with acid magmatism: Prague, Czechoslovakia, Czechoslovakia Geological Survey, v. 2, p. 41-96.

Triebskorn, Rita, Köhler, H.-R., Flemming, Jürgen, Braunbeck, Thomas, Negele, R.-D., and Rahmann, Hinrich, 1994, Evaluation of bis(tri-n-butyltin)oxide (TBTO) neurotoxicity in rainbow trout (Oncorhynchus mykiss). I. Behavior, weight increase, and tin content: Aquatic Toxicology, v. 30, no. 3, p. 189-197. [Also available at http://dx.doi.org/10.1016/0166-445X(94)90057-4.]

Truelove, Anthony, 2012, Saxony Mines Ltd.: London, United Kingdom, International Tin Research Institute Investing in Tin Seminar, November 30, presentation.

Tse, P.-K., 2013, The mineral industry of China, in Area reportsInternational-Asia and the Pacific: U.S. Geological Survey Minerals Yearbook 2012, v. III, p. 8.1-8.25. [Also available at https://minerals.usgs.gov/minerals/pubs/country/2012/ myb3-2012-ch.pdf.]

Turneaure, F.S., 1935, The tin deposits of Llallagua, Bolivia: Economic Geology, v. 30, p. 14-60. [Also available at http://dx.doi.org/10.2113/gsecongeo.30.1.14.]

U Khin Zaw and Daw Khin Myo Thet, 1983, A note on a fluid inclusion study of tin-tungsten mineralization at Mawchi Mine, Kayah State, Burma: Economic Geology, v. 78, p. 530-534. [Also available at http://dx.doi.org/10.2113/ gsecongeo.78.3.530.]

United Nations, 2004, Marine mineral resources-Scientific advances and economic perspectives: New York, N.Y., Joint publication by the United Nations Division for Ocean Affairs and the Law of the Sea, Office of Legal Affairs, and the International Seabed Authority, 118 p. [Also available at https://www.isa.org.jm/files/documents/EN/Pubs/ ISA-Daolos.pdf.]

Urquidi-Barrau, Fernando, 1989, Tin and tungsten deposits of the Bolivian tin belt, in Ericksen, G.E., Cañas Pinochet, M.T., and Reinemund, J.A., eds., Geology of the Andes and its relation to hydrocarbon and mineral resources: Houston, Tex., Circum-Pacific Council for Energy and Mineral Resources Earth Science Series, v. 11, p. 313-323. 
U.S. Department of Defense, 2013, Strategic and critical materials - 2013 report on stockpile requirements: Office of the Under Secretary of Defense for Acquisition, Technology and Logistics, U.S. Department of Defense, January, 18 p. plus 17 appendixes.

U.S. Geological Survey, 2016, Mineral Resources Data System [entry for Kuala Langat Mining Sdn Bhd]: U.S. Geological Survey database, accessed December 19, 2016, at http://mrdata.usgs.gov/mrds/show-mrds.php?dep_ id $=10159278$.

van Backström, J.W., 1950, Notes on a tungsten-tin deposit near Upington, Gordonia district: Geological Society of South Africa Transactions, v. 53, p. 35-51.

Velasco, Pablo, 1988, The mineral industry of Bolivia, in Area reports-International: U.S. Bureau of Mines Minerals Yearbook 1986, v. III, p. 119-128. [Also available at https://minerals.usgs.gov/minerals/pubs/usbmmyb.html.]

Velichkin, V.I., Kiseleva, G.D., Krylova, T.L., and Timofeev (Timofeyev), A.V., 2000, The superlarge tin deposit at Syrymbet, northern Kazakhstan - Geological setting and ore formation conditions [abs]: International Geological Congress, 31st, Rio de Janiero, Brazil, August 6-17, 2000, Abstracts, CD-ROM.

Vernikovsky, V.A., Vernikovskaya, A.E., Wingate, M.T.D., Popov, N.V., and Kovach, V.P., 2007, The 880-864 Ma granites of the Yenisey Ridge, western Siberian marginGeochemistry, SHRIMP geochronology, and tectonic implications: Precambrian Research, v. 154, no. 3, p. 175-191. [Also available at http://dx.doi.org/10.1016/ j.precamres.2006.12.006.]

Viers, Jérôme, Dupré, Bernard, and Gaillardet, Jérôme, 2009, Chemical composition of suspended sediments in world rivers-New insights from a new database: Science of the Total Environment, v. 407, no. 2, p. 853-868. [Also available at http://dx.doi.org/10.1016/j.scitotenv.2008.09.053.]

von Humboldt, Alexander, 1823, Geognostischer Versuch über die Lagerung der Gebirgsarten in beiden Erdhälften (German edited by Karl Cäsar Ritter von Leonhard): Strasburg, France, Levrault, 383 p. [Also available at http://www.mdz-nbn-resolving.de/urn/resolver.pl?urn= urn:nbn:de:bvb:12-bsb10283831-5.]

Wagner, Thomas, Mlynarczyk, M.S.J., Williams-Jones, A.E., and Boyce, A.J., 2009, Stable isotope constraints on ore formation at the San Rafael tin-copper deposit, southeast Peru: Economic Geology, v. 104, p. 223-248. [Also available at http://dx.doi.org/10.2113/gsecongeo.104.2.223.]
Wallace, S.R., Muncaster, N.K., Jonson, D.C., MacKenzie, W.B., Bookstrom, A.A., and Surface, V.E., 1968, Multiple intrusion and mineralization at Climax, Colorado, in Ridge, J.D., ed., Ore deposits of the United States 19331967, v. 1: New York, N.Y., American Institute of Mining, Metallurgical, and Petroleum Engineers, The Graton-Sales Volume, p. 604-640.

Walpole, B.P., 1958, The Maranboy tin-field, Northern Territory: Canberra, Australian Capital Territory, Australia, Bureau of Mineral Resources, Geology and Geophysics Bulletin no. 37, 42 p., 18 sheets. [Also available at https://d28rz98at9flks.cloudfront.net/236/Bull_037.pdf.]

Wang Ru Cheng, Xie Lei, Chen Jun, Yu Apeng, Wang Lubin, Lu Jianjun, and Zhu Jinchu, 2013, Tin-carrier minerals in metaluminous granites of the western Nanling Range (southern China) - Constraints on processes of tin mineralization in oxidized granites: Journal of Asian Earth Sciences, v. 74, September 25, p. 361-372. [Also available at http://dx.doi.org/10.1016/j.jseaes.2012.11.029.]

Wheeler, T.S., and Maddin, R., 1980, Metallurgy and ancient man, in Wertime, T.A., and Muhly, J.D., eds., The coming of the age of iron: New Haven, Conn., Yale University Press, p. 99-126.

White, W.H., Bookstrom, A.A., Kamilli, R.J., Ganster, M.W., Smith, R.P., Ranta, D.E., and Steininger, R.C., 1981, Character and origin of Climax-type molybdenum deposits, in Skinner, B.J., ed., Economic Geology - 75th anniversary volume, 1905-1980: Lancaster, Pa., Economic Geology Publishing Co., p. 270-316.

Williams, F.A., Meehan, J.A., Paulo, K.L., John, T.U., and Rushton, H.G., 1956, Economic geology of the decomposed columbite-bearing granites, Jos Plateau, Nigeria: Economic Geology, v. 51, p. 303-332. [Also available at http://dx.doi.org/ 10.2113/gsecongeo.51.4.303.]

World Health Organization, 2004, Inorganic tin in drinking water: World Health Organization, WHO/SDE/WSH/03.04/115, 6 p. [Also available at http://www.who.int/water_sanitation health/dwq/chemicals/tin.pdf.]

Yamazaki, Erika, Nakai, Shun'ich, Yokoyama, Tetsuya, Ishihara, Shunso, and Tang, Hongfeng, 2013, Tin isotope analysis of cassiterites from southeastern and eastern Asia: Geochemical Journal, v. 47, p. 21-35.

Zaaiplaats Tin Mining Co., 1983, 75th anniversary report, Zaaiplaats Tin Mining Co., South Africa, 1908-1983: [Johannesburg], South Africa, Zaaiplaats Tin Mining Co. 
Table S2 
Table S2. Location, grade, tonnage, and other data for selected tin deposits of the world with greater than 1,000 metric tons of contained tin.

[WGS 84, World Geodetic System of 1984; negative values for latitude indicate that the deposit is in the Southern Hemisphere; negative values for longitude indicate that the deposit is in the Western Hemisphere. Elements: B, boron; F, fluorine; Fe, iron; Sn, tin. Dating method: Ar-Ar, argon-argon; K-Ar, potassiumargon; Rb-Sr, rubidium-strontium; U-Pb, uranium-lead. Abbreviations: ca., circa; Ga, giga-annum, or billion years before present; ID, identification; $\mathrm{kg} / \mathrm{m}^{3}$, kilogram per cubic meter; m, meter; Ma, mega-annum, or million years before present; NA, not applicable; n.d., no data; NNE-WSW, north-northeastwest-southwest; SHRIMP, sensitive high-resolution ion microprobe; wt. \%, weight percent]

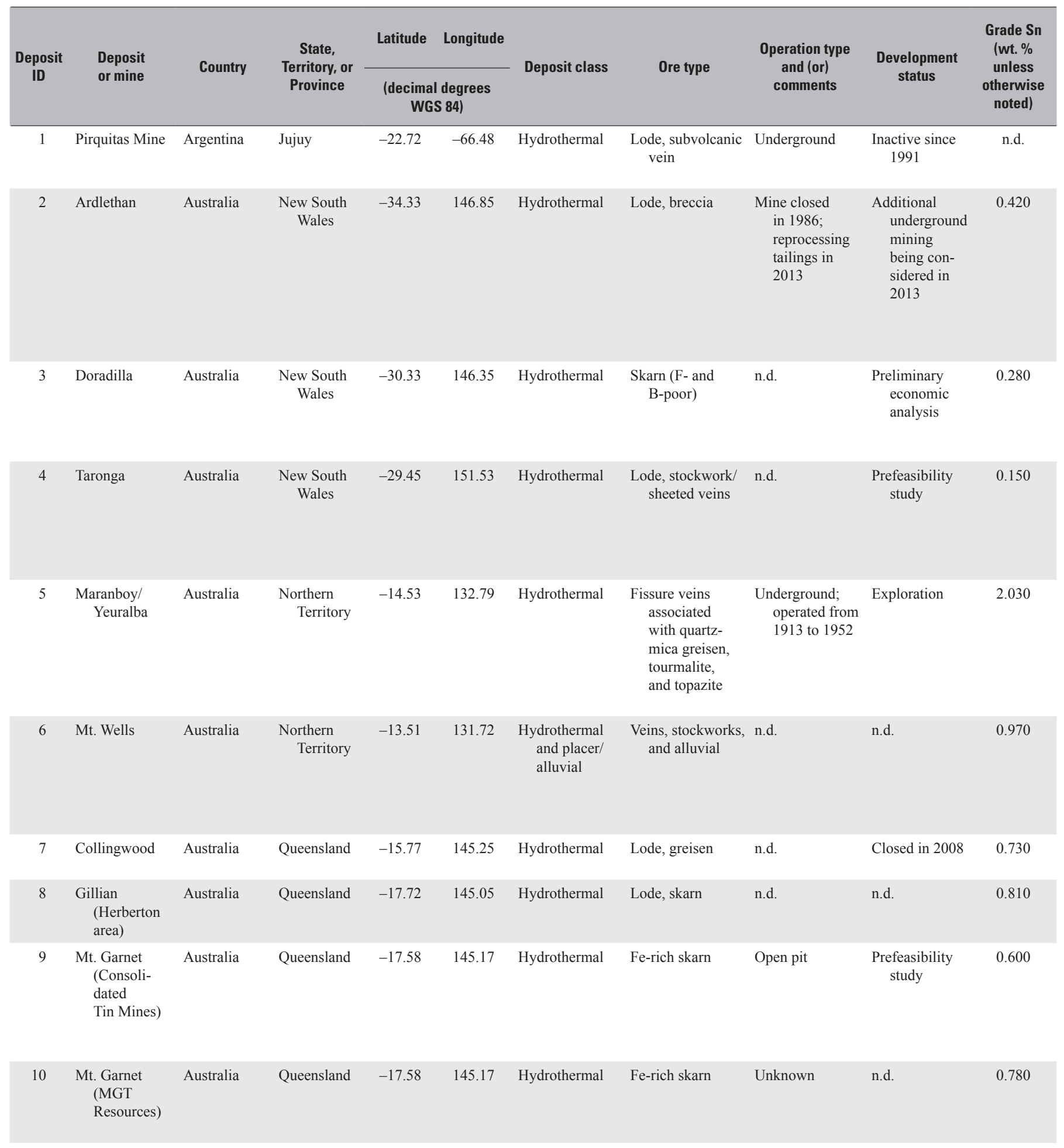


Table S2. Location, grade, tonnage, and other data for selected tin deposits of the world with greater than 1,000 metric tons of contained tin.-Continued

[WGS 84, World Geodetic System of 1984; negative values for latitude indicate that the deposit is in the Southern Hemisphere; negative values for longitude indicate that the deposit is in the Western Hemisphere. Elements: B, boron; F, fluorine; Fe, iron; Sn, tin. Dating method: Ar-Ar, argon-argon; K-Ar, potassiumargon; Rb-Sr, rubidium-strontium; U-Pb, uranium-lead. Abbreviations: ca., circa; Ga, giga-annum, or billion years before present; ID, identification; $\mathrm{kg} / \mathrm{m}^{3}$, kilogram per cubic meter; m, meter; Ma, mega-annum, or million years before present; NA, not applicable; n.d., no data; NNE-WSW, north-northeastwest-southwest; SHRIMP, sensitive high-resolution ion microprobe; wt. \%, weight percent]

\begin{tabular}{|c|c|c|c|c|c|c|c|c|}
\hline $\begin{array}{l}\text { Resource } \\
\text { tonnage } \\
\text { (million } \\
\text { metric tons) } \\
\text { (Year } \\
\text { determined) }\end{array}$ & $\begin{array}{l}\text { Cutoff } \\
\text { grade } \\
\text { (wt. \%) }\end{array}$ & Host rock & $\begin{array}{l}\text { Mineralizing } \\
\text { rock-type }\end{array}$ & $\begin{array}{l}\text { Mineralization } \\
\text { age }\end{array}$ & $\begin{array}{l}\text { Dating } \\
\text { method }\end{array}$ & $\begin{array}{l}\text { Deposit } \\
\text { dimensions } \\
\text { (in meters } \\
\text { unless } \\
\text { otherwise } \\
\text { noted) }\end{array}$ & $\begin{array}{l}\text { Deposit shape/ } \\
\text { mineralization } \\
\text { style }\end{array}$ & Primary references \\
\hline n.d. & n.d. & Schist & n.d. & n.d. & n.d. & n.d. & n.d. & $\begin{array}{l}\text { Ross (1941); Velasco } \\
\text { (1988); Sutphin and } \\
\text { others (1990) }\end{array}$ \\
\hline $\begin{array}{l}3.025 \\
(2013)\end{array}$ & n.d. & Granitic breccia & $\begin{array}{l}\text { Biotite-rich, S-type } \\
\text { granite }\end{array}$ & $417 \pm 2.5 \mathrm{Ma}$ & n.d. & n.d. & n.d. & $\begin{array}{l}\text { Ren and others (1995); } \\
\text { Clarke and others } \\
\text { (1985); Sutphin and } \\
\text { others (1990); Australian } \\
\text { Tin Resources Pty Ltd. } \\
\text { (2016); Peter Kettle, } \\
\text { International Tin Re- } \\
\text { search Institute, written } \\
\text { commun., April 8, } 2013\end{array}$ \\
\hline $\begin{array}{c}7.81 \\
(2013)\end{array}$ & n.d. & $\begin{array}{l}\text { Marble, mica schist- } \\
\text { Ordovician }\end{array}$ & $\begin{array}{l}\text { Leucoadamellite, } \\
\text { greisenized } \\
\text { quartz-feldspar } \\
\text { porphyritic dikes } \\
\text { (F- and B-poor) }\end{array}$ & $\begin{array}{l}\text { Early Devo- } \\
\text { nian }\end{array}$ & n.d. & $\begin{array}{c}13,000 \times 40 \text { to } \\
110 \times 200\end{array}$ & $\begin{array}{l}\text { Stratform, near- } \\
\text { vertical }\end{array}$ & $\begin{array}{l}\text { Kwak (1987); Plimer } \\
\quad \text { (1984) }\end{array}$ \\
\hline $\begin{array}{l}37.589 \\
(2013)\end{array}$ & n.d. & $\begin{array}{l}\text { Metamorphosed mudstone, } \\
\text { siltstone, sandstone }\end{array}$ & Adamellite & Late Triassic & n.d. & n.d. & n.d. & $\begin{array}{l}\text { Offenberg (1982); Sutphin } \\
\text { and others (1990); Peter } \\
\text { Kettle, International } \\
\text { Tin Research Institute, } \\
\text { written commun., } \\
\text { April 8, } 2013\end{array}$ \\
\hline $\begin{array}{l}0.722 \\
(2013)\end{array}$ & n.d. & $\begin{array}{l}\text { Greywacke, sandstone, } \\
\text { conglomerate, shale, } \\
\text { basalt-Neoproterozoic } \\
\text { to Middle Cambrian; } \\
\text { sandstone, conglomerate, } \\
\text { shale and siltstone- } \\
\text { Lower Cretaceous }\end{array}$ & $\begin{array}{l}\text { Adamellite, quartz } \\
\text { porphyry, and } \\
\text { adamellite por- } \\
\text { phyry }\end{array}$ & n.d. & n.d. & $\begin{array}{l}\text { Main lode- } \\
3,950 \times 2 \\
\text { to } 7.5 \times ? ; \\
\text { Stannum } \\
\text { King } \\
\text { lode-1,000 } \\
\text { x } 3.6 \times ?\end{array}$ & n.d. & $\begin{array}{l}\text { Walpole (1958); Outback } \\
\text { Metals Ltd. (2014a); } \\
\text { Peter Kettle, Internation- } \\
\text { al Tin Research Institute, } \\
\text { written commun., } \\
\text { April 8, } 2013\end{array}$ \\
\hline $\begin{array}{l}1.137 \\
(2013)\end{array}$ & n.d. & $\begin{array}{l}\text { Burrell Creek Formation: } \\
\text { greywacke, siltstone, } \\
\text { shale, biotite-sericite } \\
\text { quartzite-Early Protero- } \\
\text { zoic }(1862 \pm 3 \mathrm{Ma})\end{array}$ & $\begin{array}{l}\text { Muscovite-biotite } \\
\text { granite and horn- } \\
\text { blende granite, } \\
\text { unfoliated }\end{array}$ & $1804 \pm 50$ & $\mathrm{U}-\mathrm{Pb}$ & $2,400 \times 300 \times ?$ & n.d. & $\begin{array}{l}\text { Mookhey (1971); Outback } \\
\text { Metals Ltd. (2014b); } \\
\text { Peter Kettle, Internation- } \\
\text { al Tin Research Institute, } \\
\text { written commun., } \\
\text { April 8, } 2013\end{array}$ \\
\hline $\begin{array}{c}4.0 \\
(1984)\end{array}$ & n.d. & Greisen & Granite & Permian & n.d. & n.d. & n.d. & Krosch (1985) \\
\hline $\begin{array}{c}2.3 \\
(1982)\end{array}$ & n.d. & $\begin{array}{l}\text { Sedimentary rocks, basalt, } \\
\text { chert, granite, grano- } \\
\text { diorite }\end{array}$ & Granite & Permian & n.d. & n.d. & n.d. & $\begin{array}{l}\text { Brown and others (1984); } \\
\text { Sutphin and others } \\
(1990)\end{array}$ \\
\hline $\begin{array}{c}7.3 \\
(2013)\end{array}$ & $\begin{array}{l}\text { About } \\
0.15 \text { to } \\
0.25\end{array}$ & $\begin{array}{l}\text { Chillagoe formation } \\
\text { (sandstone, siltstone, } \\
\text { limestone, carbonates, } \\
\text { chert, basalt)—Silurian }\end{array}$ & Granite & $\begin{array}{l}\text { Carboniferous- } \\
\text { Permian }\end{array}$ & n.d. & $\begin{array}{c}6,000 \times 4 \text { to } \\
20 \times ?\end{array}$ & $\begin{array}{l}\text { Strata-bound, } \\
\text { tabular; } \\
\text { three distinct } \\
\text { orebodies }\end{array}$ & $\begin{array}{l}\text { De Lacey (2012); Con- } \\
\text { solidated Tin Mines Ltd. } \\
\text { (2013); Michael Hicks, } \\
\text { Consolidated Tin Mines } \\
\text { Ltd., written commun., } \\
\text { July 22, } 2013\end{array}$ \\
\hline $\begin{array}{l}0.793 \\
(2013)\end{array}$ & n.d. & $\begin{array}{l}\text { Chillagoe formation } \\
\text { (sandstone, siltstone, } \\
\text { limestone, carbonates, } \\
\text { chert, basalt)-Silurian }\end{array}$ & Granite & $\begin{array}{l}\text { Carboniferous- } \\
\text { Permian }\end{array}$ & n.d. & n.d. & $\begin{array}{l}\text { Strata-bound, } \\
\text { tabular }\end{array}$ & $\begin{array}{l}\text { Kettle (2012); Peter Kettle, } \\
\text { International Tin Re- } \\
\text { search Institute, written } \\
\text { commun., April 8, } 2013\end{array}$ \\
\hline
\end{tabular}


Table S2. Location, grade, tonnage, and other data for selected tin deposits of the world with greater than 1,000 metric tons of contained tin.-Continued

[WGS 84, World Geodetic System of 1984; negative values for latitude indicate that the deposit is in the Southern Hemisphere; negative values for longitude indicate that the deposit is in the Western Hemisphere. Elements: B, boron; F, fluorine; Fe, iron; Sn, tin. Dating method: Ar-Ar, argon-argon; K-Ar, potassiumargon; Rb-Sr, rubidium-strontium; U-Pb, uranium-lead. Abbreviations: ca., circa; Ga, giga-annum, or billion years before present; ID, identification; $\mathrm{kg} / \mathrm{m}^{3}$, kilogram per cubic meter; m, meter; Ma, mega-annum, or million years before present; NA, not applicable; n.d., no data; NNE-WSW, north-northeastwest-southwest; SHRIMP, sensitive high-resolution ion microprobe; wt. \%, weight percent]

\begin{tabular}{|c|c|c|c|c|c|c|c|c|c|c|}
\hline $\begin{array}{c}\text { Deposit } \\
\text { ID }\end{array}$ & $\begin{array}{l}\text { Deposit } \\
\text { or mine }\end{array}$ & Country & $\begin{array}{c}\text { State, } \\
\text { Territory, or } \\
\text { Province }\end{array}$ & $\begin{array}{r}\text { Latitude } \\
\text { (decima } \\
\text { WG }\end{array}$ & $\begin{array}{l}\text { Longitude } \\
\text { degrees } \\
\text { S 84) }\end{array}$ & Deposit class & Ore type & $\begin{array}{l}\text { Operation type } \\
\text { and (or) } \\
\text { comments }\end{array}$ & $\begin{array}{c}\text { Development } \\
\text { status }\end{array}$ & $\begin{array}{c}\text { Grade Sn } \\
\text { (wt. \% } \\
\text { unless } \\
\text { otherwise } \\
\text { noted) }\end{array}$ \\
\hline 11 & $\begin{array}{l}\text { Cleveland } \\
\text { (Aberfoyle } \\
\text { and } \\
\text { Rossarden) }\end{array}$ & Australia & Tasmania & -41.66 & 147.75 & Hydrothermal & $\begin{array}{l}\text { Greisenized } \\
\text { calcic skarns } \\
\text { and carbonate } \\
\text { replacements } \\
\text { of calcareous } \\
\text { sandstone and } \\
\text { mudstone }\end{array}$ & $\begin{array}{c}\text { Closed in the } \\
1970 \mathrm{~s}\end{array}$ & $\begin{array}{l}\text { In exploration } \\
\text { (2013) }\end{array}$ & 0.680 \\
\hline
\end{tabular}

\begin{tabular}{|c|c|c|c|c|c|c|c|c|c|c|}
\hline 12 & $\begin{array}{l}\text { Heemskirk } \\
\text { (Queen Hill) } \\
\text { (Zeehan tin } \\
\text { project) }\end{array}$ & Australia & Tasmania & -41.88 & 145.32 & Hydrothermal & $\begin{array}{l}\text { Stockwork and } \\
\text { strata-bound } \\
\text { carbonate } \\
\text { replacement } \\
\text { (three separate } \\
\text { orebodies) }\end{array}$ & UG & $\begin{array}{l}\text { Prefeasibility } \\
\text { study }\end{array}$ & 1.140 \\
\hline 13 & Mount Bischoff & Australia & Tasmania & -41.41 & 145.52 & Hydrothermal & $\begin{array}{l}\text { Lode, carbonate } \\
\text { replacement; } \\
\text { alteration of } \\
\text { quartz-ortho- } \\
\text { clase porphyry } \\
\text { dikes }\end{array}$ & Open pit & n.d. & 1.100 \\
\hline 14 & Mount Lindsay & Australia & Tasmania & -41.75 & 145.36 & Hydrothermal & $\begin{array}{l}\text { Greisenized } \\
\text { calcic skarns } \\
\text { and carbonate } \\
\text { replacements } \\
\text { of calcareous } \\
\text { sandstone and } \\
\text { mudstone }\end{array}$ & n.d. & $\begin{array}{c}\text { Bankable feasi- } \\
\text { bility study }\end{array}$ & 0.200 \\
\hline 15 & Renison-Bell & Australia & Tasmania & -41.78 & 145.78 & Hydrothermal & $\begin{array}{l}\text { Lode, carbonate } \\
\text { replacement }\end{array}$ & n.d. & n.d. & 1.460 \\
\hline
\end{tabular}

\begin{tabular}{|c|c|c|c|c|c|c|c|c|c|}
\hline 16 & Rentails & Australia & Tasmania & -41.78 & 145.78 & Tailings & NA & $\begin{array}{l}\text { Tailings from the n.d. } \\
\text { mill associ- } \\
\text { ated with the } \\
\text { Renison-Bell } \\
\text { deposit }\end{array}$ & 0.450 \\
\hline
\end{tabular}


Table S2. Location, grade, tonnage, and other data for selected tin deposits of the world with greater than 1,000 metric tons of contained tin.-Continued

[WGS 84, World Geodetic System of 1984; negative values for latitude indicate that the deposit is in the Southern Hemisphere; negative values for longitude indicate that the deposit is in the Western Hemisphere. Elements: B, boron; F, fluorine; Fe, iron; Sn, tin. Dating method: Ar-Ar, argon-argon; K-Ar, potassiumargon; Rb-Sr, rubidium-strontium; U-Pb, uranium-lead. Abbreviations: ca., circa; Ga, giga-annum, or billion years before present; ID, identification; $\mathrm{kg} / \mathrm{m}^{3}$, kilogram per cubic meter; m, meter; Ma, mega-annum, or million years before present; NA, not applicable; n.d., no data; NNE-WSW, north-northeastwest-southwest; SHRIMP, sensitive high-resolution ion microprobe; wt. \%, weight percent]

\begin{tabular}{|c|c|c|c|c|c|c|c|c|}
\hline $\begin{array}{l}\text { Resource } \\
\text { tonnage } \\
\text { (million } \\
\text { metric tons) } \\
\text { (Year } \\
\text { determined) }\end{array}$ & $\begin{array}{l}\text { Cutoff } \\
\text { grade } \\
\text { (wt. \%) }\end{array}$ & Host rock & $\begin{array}{l}\text { Mineralizing } \\
\text { rock-type }\end{array}$ & $\begin{array}{l}\text { Mineralization } \\
\text { age }\end{array}$ & $\begin{array}{l}\text { Dating } \\
\text { method }\end{array}$ & $\begin{array}{l}\text { Deposit } \\
\text { dimensions } \\
\text { (in meters } \\
\text { unless } \\
\text { otherwise } \\
\text { noted) }\end{array}$ & $\begin{array}{l}\text { Deposit shape/ } \\
\text { mineralization } \\
\text { style }\end{array}$ & Primary references \\
\hline $\begin{array}{c}6.119 \\
(2013)\end{array}$ & 0.35 & $\begin{array}{l}\text { Crimson Creek formation } \\
\text { (interbedded, volcani- } \\
\text { clastic turbiditic wacke, } \\
\text { siltstone-mudstone, and } \\
\text { tholeiitic basalt lava } \\
\text { horizons and intrusive } \\
\text { sills)-Neoproterozoic to } \\
\text { Eocambrian; Sandstone, } \\
\text { basalt, dolorite, argillite, } \\
\text { chert, limestone, grey- } \\
\text { wacke turbidite- } \\
\text { Cambrian to Devonian }\end{array}$ & $\begin{array}{l}\text { I-type biotite gran- } \\
\text { ite; composed } \\
\text { of adamellite to } \\
\text { alkali-feldspar } \\
\text { granite }\end{array}$ & $350 \mathrm{Ma}$ & $\begin{array}{l}\mathrm{K}-\mathrm{Ar} \\
\mathrm{Rb}-\mathrm{Sr}\end{array}$ & $\begin{array}{l}100 \times 100 \times \\
300\end{array}$ & n.d. & $\begin{array}{l}\text { Collins (1981); Blissett } \\
\text { (1959); Mikyla Hickey, } \\
\text { Venture Minerals Ltd., } \\
\text { written commun., } \\
\text { July 22, } 2013\end{array}$ \\
\hline $\begin{array}{c}6.280 \\
(2013)\end{array}$ & 0.6 & $\begin{array}{l}\text { Quartzite, shale, sandstone, } \\
\text { dolostone, Crimson } \\
\text { Creek Formation } \\
\text { (Interbedded, volcani- } \\
\text { clastic turbiditic wacke, } \\
\text { siltstone-mudstone and } \\
\text { tholeiitic basalt lava } \\
\text { horizons and intrusive } \\
\text { sills)-Neoproterozoic } \\
\text { and Cambrian }\end{array}$ & $\begin{array}{l}\text { I-type biotite } \\
\text { granite; } \\
\text { composed of } \\
\text { adamellite to } \\
\text { alkali-feldspar } \\
\text { granite }\end{array}$ & Devonian & n.d. & $\begin{array}{l}\text { Severn-536 } \\
\text { x } 223 \text { x } \\
192 ; \text { Queen } \\
\text { Hill-446 x } \\
134 \text { x 346; } \\
\text { Montana- } \\
312 \text { x } 89 \\
\text { x } 38\end{array}$ & n.d. & $\begin{array}{l}\text { Sutphin and others (1990); } \\
\text { Blight (2012); } \\
\text { J.A. Anderson, Aber- } \\
\text { foyle Ltd., unpub. data, } \\
\text { 1986; Stellar Resources } \\
\text { Ltd., unpub. data, 2013; } \\
\text { Peter Blight, Stellar } \\
\text { Resources Ltd., written } \\
\text { commun., July 1, } 2013\end{array}$ \\
\hline $\begin{array}{l}10.54 \\
(2013)\end{array}$ & n.d. & $\begin{array}{l}\text { Dolomite, dolomitic } \\
\text { shale, quartzite-Pre- } \\
\text { Cambrian; graywacke, } \\
\text { mudstone, chert, } \\
\text { basalts - Cambrian; } \\
\text { quartz-orthoclase por- } \\
\text { phyry dikes and sills }\end{array}$ & $\begin{array}{r}\text { Quartz-orthoclase } \\
\text { porphyry dikes }\end{array}$ & $349 \pm 4 \mathrm{Ma}$ & $\begin{array}{l}\mathrm{Rb}-\mathrm{Sr} \\
\quad \text { (whole } \\
\text { rock) }\end{array}$ & n.d. & n.d. & $\begin{array}{l}\text { Halley and Walshe (1995); } \\
\text { Mikyla Hickey, Venture } \\
\text { Minerals Ltd., written } \\
\text { commun., July 22, } 2013\end{array}$ \\
\hline $\begin{array}{c}45 \\
(2013)\end{array}$ & ca. 0.10 & $\begin{array}{l}\text { Success Creek Group (fluvi- } \\
\text { atile deposits-siliceous } \\
\text { sandstone; siliceous } \\
\text { siltstone, mudstone, } \\
\text { dolomite and stromato- } \\
\text { lite clast-bearing, oolitic, } \\
\text { chert breccia) and Crim- } \\
\text { son Creek formation } \\
\text { (interbedded, volcani- } \\
\text { clastic turbiditic wacke, } \\
\text { siltstone-mudstone, and } \\
\text { tholeiitic basalt lava } \\
\text { horizons and intrusive } \\
\text { sills)—Neoproterozoic }\end{array}$ & $\begin{array}{l}\text { I-type biotite } \\
\text { granite; } \\
\text { composed of } \\
\text { adamellite to } \\
\text { alkali-feldspar } \\
\text { granite }\end{array}$ & Devonian & n.d. & $\begin{array}{l}950 \text { to } 2,150 \\
\text { long, } \\
15 \text { to } 35 \\
\text { thick, } 4.75 \\
\text { cross-strike } \\
\text { width of } \\
\text { individual } \\
\text { skarn layers }\end{array}$ & n.d. & $\begin{array}{l}\text { Radonjic (2012); Mikyla } \\
\text { Hickey, Venture Miner- } \\
\text { als Ltd., written com- } \\
\text { mun., July 22, } 2013\end{array}$ \\
\hline $\begin{array}{c}26.0 \\
(2013)\end{array}$ & n.d. & $\begin{array}{l}\text { Dolostone, quartzite, silt- } \\
\text { stone, shale, sandstone }\end{array}$ & n.d. & Devonian & n.d. & n.d. & n.d. & $\begin{array}{l}\text { Sutphin and others (1990); } \\
\text { R. Morland, Renison } \\
\text { Associated Tin Mines, } \\
\text { unpub. data, 1986; } \\
\text { Mikyla Hickey, Venture } \\
\text { Minerals Ltd., written } \\
\text { commun., July 22, } 2013\end{array}$ \\
\hline $\begin{array}{l}20.461 \\
(2013)\end{array}$ & n.d. & n.d. & n.d. & n.d. & n.d. & n.d. & n.d. & $\begin{array}{l}\text { Peter Kettle, International } \\
\text { Tin Research Institute, } \\
\text { written commun., } \\
\text { April 8, } 2013\end{array}$ \\
\hline
\end{tabular}


Table S2. Location, grade, tonnage, and other data for selected tin deposits of the world with greater than 1,000 metric tons of contained tin.-Continued

[WGS 84, World Geodetic System of 1984; negative values for latitude indicate that the deposit is in the Southern Hemisphere; negative values for longitude indicate that the deposit is in the Western Hemisphere. Elements: B, boron; F, fluorine; Fe, iron; Sn, tin. Dating method: Ar-Ar, argon-argon; K-Ar, potassiumargon; Rb-Sr, rubidium-strontium; U-Pb, uranium-lead. Abbreviations: ca., circa; Ga, giga-annum, or billion years before present; ID, identification; $\mathrm{kg} / \mathrm{m}^{3}$, kilogram per cubic meter; m, meter; Ma, mega-annum, or million years before present; NA, not applicable; n.d., no data; NNE-WSW, north-northeastwest-southwest; SHRIMP, sensitive high-resolution ion microprobe; wt. \%, weight percent]

\begin{tabular}{|c|c|c|c|c|c|c|c|c|c|c|}
\hline $\begin{array}{l}\text { Deposit } \\
\text { ID }\end{array}$ & $\begin{array}{l}\text { Deposit } \\
\text { or mine }\end{array}$ & Country & $\begin{array}{c}\text { State, } \\
\text { Territory, or } \\
\text { Province }\end{array}$ & $\begin{array}{r}\text { Latitude } \\
\text { (decima } \\
\text { WG }\end{array}$ & $\begin{array}{l}\text { Longitude } \\
\text { degrees } \\
84)\end{array}$ & Deposit class & Ore type & $\begin{array}{l}\text { Operation type } \\
\text { and (or) } \\
\text { comments }\end{array}$ & $\begin{array}{c}\text { Development } \\
\text { status }\end{array}$ & $\begin{array}{l}\text { Grade Sn } \\
\text { (wt. \% } \\
\text { unless } \\
\text { otherwise } \\
\text { noted) }\end{array}$ \\
\hline 17 & Greenbushes & Australia & $\begin{array}{l}\text { Western } \\
\text { Australia }\end{array}$ & -33.83 & 115.98 & Hydrothermal & $\begin{array}{l}\text { Lode, pegmatite, } \\
\text { placer }\end{array}$ & Surface placer & n.d. & $\begin{array}{c}0.1175 \text { (lode); } \\
0.0268 \\
\text { (placer) }\end{array}$ \\
\hline 18 & Colquiri tailings & Bolivia & $\begin{array}{l}\text { La Paz } \\
\quad \begin{array}{l}\text { Depart- } \\
\text { ment }\end{array}\end{array}$ & -17.38 & -67.12 & Tailings & $\begin{array}{l}\text { Sn-polymetallic } \\
\text { vein }\end{array}$ & $\begin{array}{l}\text { Tailings from the } \\
\text { mill associ- } \\
\text { ated with the } \\
\text { Colquiri tin } \\
\text { mine }\end{array}$ & Uncertain & 0.600 \\
\hline 19 & $\begin{array}{l}\text { Central } \\
\text { (Llallagua, } \\
\text { (San Jose/ } \\
\text { Oruro, } \\
\text { Huanuni) }\end{array}$ & Bolivia & $\begin{array}{l}\text { Oruro } \\
\text { Depart- } \\
\text { ment }\end{array}$ & -18.00 & -67.00 & Hydrothermal & Lode, subvolcanic & n.d. & n.d. & 0.550 \\
\hline 20 & Bolivian placers & Bolivia & $\begin{array}{l}\text { Potosi } \\
\text { Depart- } \\
\text { ment }\end{array}$ & -18.00 & -65.00 & Placer/alluvial & Placer, alluvial & n.d. & n.d. & 0.021 \\
\hline 21 & Catavi tailings & Bolivia & $\begin{array}{l}\text { Potosi } \\
\text { Depart- } \\
\text { ment }\end{array}$ & -18.43 & -66.57 & Tailings & NA & $\begin{array}{l}\text { Catavi is a mill } \\
\text { that served } \\
\text { numerous } \\
\text { mines in the } \\
\text { Potosi district }\end{array}$ & n.d. & 0.350 \\
\hline 22 & $\begin{array}{l}\text { Southern } \\
\text { (Cerro Rico, } \\
\text { Chorolque) }\end{array}$ & Bolivia & $\begin{array}{l}\text { Potosi } \\
\text { Depart- } \\
\text { ment }\end{array}$ & -19.00 & -66.00 & Hydrothermal & Lode, subvolcanic & n.d. & n.d. & 0.550 \\
\hline 23 & $\begin{array}{l}\text { Northern } \\
\text { (Chojlla, } \\
\text { Colquiri) }\end{array}$ & Bolivia & $\begin{array}{l}\text { San Jose } \\
\text { Depart- } \\
\text { ment }\end{array}$ & -16.00 & -67.00 & Hydrothermal & Lode, vein & n.d. & n.d. & 0.780 \\
\hline 24 & $\begin{array}{l}\text { Mapuero tin } \\
\text { district (Pit- } \\
\text { inga Mine is } \\
\text { the largest } \\
\text { producer, ac- } \\
\text { counting for } \\
\text { about } 90 \% \\
\text { of Brazil's } \\
\text { production) }\end{array}$ & Brazil & $\begin{array}{l}\text { Amazonas } \\
\text { State }\end{array}$ & -0.75 & -60.12 & Placer/alluvial & Placer & Onshore dredge & n.d. & n.d. \\
\hline 25 & Serra Branca & Brazil & Goias State & -13.62 & -48.07 & $\begin{array}{l}\text { Hydrothermal } \\
\text { and placer/ } \\
\text { alluvial }\end{array}$ & $\begin{array}{c}\text { Placer, lode, } \\
\text { massive } \\
\text { greisen }\end{array}$ & n.d. & n.d. & 1.250 \\
\hline 26 & $\begin{array}{c}\text { Brascan Group } \\
\text { (Rondonia } \\
\text { tin province) }\end{array}$ & Brazil & NA & -9.00 & -63.00 & $\begin{array}{l}\text { Hydrothermal } \\
\text { and placer/ } \\
\text { alluvial }\end{array}$ & $\begin{array}{c}\text { Placer, lode, } \\
\text { massive } \\
\text { greisen, }\end{array}$ & n.d. & n.d. & 0.425 \\
\hline 27 & Mocambo & Brazil & Pará State & -6.83 & -51.95 & $\begin{array}{l}\text { Hydrothermal } \\
\text { and placer/ } \\
\text { alluvial }\end{array}$ & $\begin{array}{c}\text { Placer, lode, } \\
\text { massive } \\
\text { greisen }\end{array}$ & n.d. & n.d. & 0.061 \\
\hline 28 & Rhodia-Espeng & Brazil & Pará State & -6.03 & -53.72 & Placer/alluvial & Placer & Gravel pump & n.d. & 0.034 \\
\hline 29 & $\begin{array}{l}\text { Brumadinho } \\
\text { Group }\end{array}$ & Brazil & $\begin{array}{l}\text { Rondonia } \\
\text { and Goias } \\
\text { States }\end{array}$ & -9.55 & -62.42 & $\begin{array}{l}\text { Hydrothermal } \\
\text { and placer/ } \\
\text { alluvial }\end{array}$ & Placer and lode & n.d. & n.d. & 0.093 \\
\hline
\end{tabular}


Table S2. Location, grade, tonnage, and other data for selected tin deposits of the world with greater than 1,000 metric tons of contained tin.-Continued

[WGS 84, World Geodetic System of 1984; negative values for latitude indicate that the deposit is in the Southern Hemisphere; negative values for longitude indicate that the deposit is in the Western Hemisphere. Elements: B, boron; F, fluorine; Fe, iron; Sn, tin. Dating method: Ar-Ar, argon-argon; K-Ar, potassiumargon; Rb-Sr, rubidium-strontium; U-Pb, uranium-lead. Abbreviations: ca., circa; Ga, giga-annum, or billion years before present; ID, identification; $\mathrm{kg} / \mathrm{m}^{3}$, kilogram per cubic meter; m, meter; Ma, mega-annum, or million years before present; NA, not applicable; n.d., no data; NNE-WSW, north-northeastwest-southwest; SHRIMP, sensitive high-resolution ion microprobe; wt. \%, weight percent]

\begin{tabular}{|c|c|c|c|c|c|c|c|c|}
\hline $\begin{array}{l}\text { Resource } \\
\text { tonnage } \\
\text { (million } \\
\text { metric tons) } \\
\text { (Year } \\
\text { determined) }\end{array}$ & $\begin{array}{l}\text { Cutoff } \\
\text { grade } \\
\text { (wt. \%) }\end{array}$ & Host rock & $\begin{array}{l}\text { Mineralizing } \\
\text { rock-type }\end{array}$ & $\begin{array}{l}\text { Mineralization } \\
\text { age }\end{array}$ & $\begin{array}{l}\text { Dating } \\
\text { method }\end{array}$ & $\begin{array}{c}\text { Deposit } \\
\text { dimensions } \\
\text { (in meters } \\
\text { unless } \\
\text { otherwise } \\
\text { noted) }\end{array}$ & $\begin{array}{l}\text { Deposit shape/ } \\
\text { mineralization } \\
\text { style }\end{array}$ & Primary references \\
\hline $\begin{array}{c}39.0 \text { (lode); } \\
8.812 \\
\text { (placer) } \\
(1985)\end{array}$ & n.d. & $\begin{array}{l}\text { Pegmatite, laterized gravel } \\
\text { and sand }\end{array}$ & Pegmatite & $2.53 \mathrm{Ga}$ & n.d. & n.d. & n.d. & $\begin{array}{l}\text { Blockley (1980); Sutphin } \\
\text { and others (1990) }\end{array}$ \\
\hline $\begin{array}{c}11.0 \\
(2013)\end{array}$ & n.d. & $\begin{array}{l}\text { Shale, sandstone, slightly } \\
\text { metamorphosed- } \\
\text { Devonian }\end{array}$ & $\begin{array}{l}\text { Only dikes seen; } \\
\text { significance } \\
\text { unknown }\end{array}$ & Miocene & Stoping & $\begin{array}{l}3,000 \times 100 \times \\
\quad 500\end{array}$ & Tabular & $\begin{array}{l}\text { Campbell (1947); Peter } \\
\text { Kettle, International } \\
\text { Tin Research Institute, } \\
\text { written commun., } \\
\text { April 8, } 2013\end{array}$ \\
\hline $\begin{array}{l}7.116 \\
(1982 \text { and } \\
1984)\end{array}$ & n.d. & $\begin{array}{l}\text { Slate, metasediment, } \\
\text { volcanics }\end{array}$ & n.d. & Tertiary & n.d. & n.d. & n.d. & $\begin{array}{l}\text { Fox (1971); Sillitoe and } \\
\text { others (1975); Sutphin } \\
\text { and others (1990) }\end{array}$ \\
\hline $\begin{array}{l}57.709 \\
(1982)\end{array}$ & n.d. & Sediments & n.d. & n.d. & n.d. & n.d. & n.d. & $\begin{array}{l}\text { Fox (1971); Sillitoe and } \\
\text { others (1975); Sutphin } \\
\text { and others (1990) }\end{array}$ \\
\hline $\begin{array}{c}40.0 \\
(2013)\end{array}$ & n.d. & $\begin{array}{l}\text { Slightly metamorphosed } \\
\text { shale-Devonian }\end{array}$ & n.d. & n.d. & n.d. & n.d. & n.d. & $\begin{array}{l}\text { Peter Kettle, International } \\
\text { Tin Research Institute, } \\
\text { written commun., } \\
\text { April 8, } 2013\end{array}$ \\
\hline $\begin{array}{l}7.1176 \\
(1982)\end{array}$ & n.d. & n.d. & n.d. & Tertiary & n.d. & n.d. & n.d. & $\begin{array}{l}\text { Fox (1971); Sillitoe and } \\
\text { others (1975); Sutphin } \\
\text { and others (1990) }\end{array}$ \\
\hline $\begin{array}{c}8.667 \\
(1982)\end{array}$ & n.d. & $\begin{array}{l}\text { Granodiorite, quartzite, } \\
\text { shale }\end{array}$ & n.d. & Tertiary & n.d. & n.d. & n.d. & $\begin{array}{l}\text { Fox (1971); Sillitoe and } \\
\text { others (1975); Sutphin } \\
\text { and others (1990) }\end{array}$ \\
\hline $\begin{array}{c}0.500 \\
\text { contained } \\
\text { Sn (1987) }\end{array}$ & n.d. & $\begin{array}{l}\text { "Apogranite," rhyolite } \\
\text { and tuffs }\end{array}$ & $\begin{array}{l}\text { "Apogranite," } \\
\text { rhyolite and tuffs }\end{array}$ & $\begin{array}{l}\text { "Apogranite" } \\
1.9 \text { to } \\
1.5 \mathrm{Ga} \text {; } \\
\text { rhyolite and } \\
\text { tuffs - mid- } \\
\text { Proterozoic }\end{array}$ & n.d. & n.d. & n.d. & $\begin{array}{r}\text { Mareno (1986); Thorman } \\
\text { and Drew (1988); Sut- } \\
\text { phin and others (1990) }\end{array}$ \\
\hline $\begin{array}{c}0.551 \\
(1982)\end{array}$ & n.d. & Metasediments & Greisenized granite & Precambrian & n.d. & n.d. & n.d. & Sutphin and others (1990) \\
\hline $\begin{array}{l}73.833 \\
(1982)\end{array}$ & n.d. & $\begin{array}{c}\text { Granite, Rapakivi granite, } \\
\text { paleovalley sediments }\end{array}$ & Greisenized granite & Precambrian & n.d. & n.d. & n.d. & $\begin{array}{l}\text { Mareno (1986); Sutphin } \\
\text { and others (1990) }\end{array}$ \\
\hline $\begin{array}{l}13.000 \\
(1982)\end{array}$ & n.d. & Metasediments & Greisenized granite & Precambrian & n.d. & n.d. & n.d. & Sutphin and others (1990) \\
\hline $\begin{array}{l}26.647 \\
(1982)\end{array}$ & n.d. & n.d. & Granite & Precambrian? & n.d. & n.d. & n.d. & Sutphin and others (1990) \\
\hline $\begin{array}{l}65.428 \\
(1982)\end{array}$ & n.d. & $\begin{array}{l}\text { Granite, Rapakivi granite, } \\
\text { paleovalley fill }\end{array}$ & Granite & n.d. & n.d. & n.d. & n.d. & $\begin{array}{l}\text { Mareno (1986); Sutphin } \\
\text { and others (1990) }\end{array}$ \\
\hline
\end{tabular}


Table S2. Location, grade, tonnage, and other data for selected tin deposits of the world with greater than 1,000 metric tons of contained tin.-Continued

[WGS 84, World Geodetic System of 1984; negative values for latitude indicate that the deposit is in the Southern Hemisphere; negative values for longitude indicate that the deposit is in the Western Hemisphere. Elements: B, boron; F, fluorine; Fe, iron; Sn, tin. Dating method: Ar-Ar, argon-argon; K-Ar, potassiumargon; Rb-Sr, rubidium-strontium; U-Pb, uranium-lead. Abbreviations: ca., circa; Ga, giga-annum, or billion years before present; ID, identification; $\mathrm{kg} / \mathrm{m}^{3}$, kilogram per cubic meter; m, meter; Ma, mega-annum, or million years before present; NA, not applicable; n.d., no data; NNE-WSW, north-northeastwest-southwest; SHRIMP, sensitive high-resolution ion microprobe; wt. \%, weight percent]

\begin{tabular}{|c|c|c|c|c|c|c|c|c|c|c|}
\hline $\begin{array}{l}\text { Deposit } \\
\text { ID }\end{array}$ & $\begin{array}{l}\text { Deposit } \\
\text { or mine }\end{array}$ & Country & $\begin{array}{c}\text { State, } \\
\text { Territory, or } \\
\text { Province }\end{array}$ & $\begin{array}{r}\text { Latitude } \\
\begin{array}{r}\text { (decim } \\
\text { WC }\end{array}\end{array}$ & $\begin{array}{l}\text { Longitude } \\
\text { degrees } \\
\text { 84) }\end{array}$ & Deposit class & Ore type & $\begin{array}{l}\text { Operation type } \\
\text { and (or) } \\
\text { comments }\end{array}$ & $\begin{array}{c}\text { Development } \\
\text { status }\end{array}$ & $\begin{array}{c}\text { Grade Sn } \\
\text { (wt. \% } \\
\text { unless } \\
\text { otherwise } \\
\text { noted) }\end{array}$ \\
\hline 30 & Best Group & Brazil & $\begin{array}{l}\text { Rondonia } \\
\text { and Pará } \\
\text { States }\end{array}$ & -9.45 & -65.13 & Placer/alluvial & Placer & Gravel pump & n.d. & 0.023 \\
\hline 31 & C-75 Garimpo & Brazil & $\begin{array}{l}\text { Rondonia } \\
\text { State }\end{array}$ & -9.90 & -63.43 & $\begin{array}{l}\text { Hydrothermal } \\
\text { and placer/ } \\
\text { alluvial }\end{array}$ & $\begin{array}{l}\text { Placer, eluvial, } \\
\text { lode, greisen } \\
\text { and vein }\end{array}$ & n.d. & n.d. & n.d. \\
\hline 32 & Mawchi Mine & $\begin{array}{l}\text { Burma (also } \\
\text { referred } \\
\text { to as } \\
\text { Myanmar) }\end{array}$ & $\begin{array}{l}\text { Kayah } \\
\text { Province }\end{array}$ & 18.82 & 97.17 & Hydrothermal & Lode, vein & n.d. & n.d. & 0.070 \\
\hline 33 & $\begin{array}{l}\text { Tenasserim } \\
\text { Valley, } \\
\text { Southeast } \\
\text { Asian tin } \\
\text { belt }\end{array}$ & $\begin{array}{l}\text { Burma (also } \\
\text { referred } \\
\text { to as } \\
\text { Myanmar) }\end{array}$ & $\begin{array}{c}\text { Taninthayi } \\
\text { region }\end{array}$ & 12.00 & 99.00 & Placer/alluvial & Placer (alluvial) & n.d. & n.d. & n.d. \\
\hline 34 & Mount Pleasant & Canada & $\begin{array}{c}\text { New Bruns- } \\
\text { wick } \\
\text { Province }\end{array}$ & 45.43 & -66.82 & Hydrothermal & $\begin{array}{l}\text { Lode, subvolcanic } \\
\text { vein/porphyry }\end{array}$ & n.d. & $\begin{array}{l}\text { Prefeasibility } \\
\text { study }\end{array}$ & 0.370 \\
\hline 35 & East Kemptville & Canada & $\begin{array}{c}\text { Nova Scotia } \\
\text { Province }\end{array}$ & 44.10 & -65.68 & Hydrothermal & Lode, greisen & n.d. & $\begin{array}{c}\text { Preliminary } \\
\text { economic } \\
\text { analysis }\end{array}$ & 0.165 \\
\hline 36 & Dachang & China & $\begin{array}{l}\text { Guangxi } \\
\text { Province }\end{array}$ & 24.83 & 107.83 & Hydrothermal & $\begin{array}{l}\text { Lode, carbonate } \\
\text { replacement }\end{array}$ & n.d. & n.d. & 0.5 to 1.0 \\
\hline 37 & Cuomolong & China & $\begin{array}{l}\text { Sichuan } \\
\text { Province }\end{array}$ & 30.50 & 99.37 & Hydrothermal & Skarn & n.d. & n.d. & 0.22 to 1.38 \\
\hline
\end{tabular}

\begin{tabular}{|c|c|c|c|c|c|c|c|c|c|c|}
\hline 38 & Datongchang & China & $\begin{array}{l}\text { Yunnan } \\
\text { Province }\end{array}$ & 25.53 & 98.73 & Hydrothermal & $\begin{array}{l}\text { Vein, strata-bound, } \\
\text { skarn }\end{array}$ & n.d. & n.d. & 0.016 to 0.26 \\
\hline 39 & Diantan & China & $\begin{array}{l}\text { Yunnan } \\
\text { Province }\end{array}$ & 25.65 & 98.43 & Hydrothermal & Skarn & n.d. & n.d. & n.d. \\
\hline 40 & Gejiu district & China & $\begin{array}{l}\text { Yunnan } \\
\text { Province }\end{array}$ & 23.33 & 103.33 & Hydrothermal & $\begin{array}{l}\text { Lode, carbonate } \\
\text { replacement, } \\
\text { some vein-type } \\
\text { skarn }\end{array}$ & $\begin{array}{l}\text { Surface-under- } \\
\text { ground }\end{array}$ & n.d. & 1.000 \\
\hline 41 & Lailishan & China & $\begin{array}{l}\text { Yunnan } \\
\text { Province }\end{array}$ & 24.92 & 98.27 & Hydrothermal & Vein, strata-bound & n.d. & n.d. & 0.63 to 1.58 \\
\hline 42 & Laopingshan & China & $\begin{array}{l}\text { Yunnan } \\
\text { Province }\end{array}$ & 25.00 & 98.37 & Hydrothermal & Greisen & n.d. & n.d. & n.d. \\
\hline 43 & Xiaolonghe & China & $\begin{array}{l}\text { Yunnan } \\
\text { Province }\end{array}$ & 25.45 & 98.43 & Hydrothermal & Greisen & n.d. & n.d. & 0.18 to 0.42 \\
\hline
\end{tabular}


Table S2. Location, grade, tonnage, and other data for selected tin deposits of the world with greater than 1,000 metric tons of contained tin.-Continued

[WGS 84, World Geodetic System of 1984; negative values for latitude indicate that the deposit is in the Southern Hemisphere; negative values for longitude indicate that the deposit is in the Western Hemisphere. Elements: B, boron; F, fluorine; Fe, iron; Sn, tin. Dating method: Ar-Ar, argon-argon; K-Ar, potassiumargon; $\mathrm{Rb}-\mathrm{Sr}$, rubidium-strontium; U-Pb, uranium-lead. Abbreviations: ca., circa; Ga, giga-annum, or billion years before present; ID, identification; $\mathrm{kg} / \mathrm{m}^{3}$, kilogram per cubic meter; m, meter; Ma, mega-annum, or million years before present; NA, not applicable; n.d., no data; NNE-WSW, north-northeastwest-southwest; SHRIMP, sensitive high-resolution ion microprobe; wt. \%, weight percent]

\begin{tabular}{|c|c|c|c|c|c|c|c|c|}
\hline $\begin{array}{l}\text { Resource } \\
\text { tonnage } \\
\text { (million } \\
\text { metric tons) } \\
\text { (Year } \\
\text { determined) }\end{array}$ & $\begin{array}{l}\text { Cutoff } \\
\text { grade } \\
\text { (wt. \%) }\end{array}$ & Host rock & $\begin{array}{l}\text { Mineralizing } \\
\text { rock-type }\end{array}$ & $\begin{array}{l}\text { Mineralization } \\
\text { age }\end{array}$ & $\begin{array}{l}\text { Dating } \\
\text { method }\end{array}$ & $\begin{array}{c}\text { Deposit } \\
\text { dimensions } \\
\text { (in meters } \\
\text { unless } \\
\text { otherwise } \\
\text { noted) }\end{array}$ & $\begin{array}{l}\text { Deposit shape/ } \\
\text { mineralization } \\
\text { style }\end{array}$ & Primary references \\
\hline $\begin{array}{l}24.386 \\
(1982)\end{array}$ & n.d. & Paleovalley sediments & Greisen & Precambrian & n.d. & n.d. & n.d. & $\begin{array}{l}\text { Bettencourt and others } \\
\text { (1981); Sutphin and } \\
\text { others (1990) }\end{array}$ \\
\hline $\begin{array}{c}0.100 \\
\text { contained } \\
\text { Sn }(1987)\end{array}$ & n.d. & $\begin{array}{l}\text { Granite, gneiss, basement } \\
\text { rocks }\end{array}$ & Granite & 1,150 t $925 \mathrm{Ma}$ & n.d. & n.d. & n.d. & $\begin{array}{l}\text { Thorman and Drew (1988); } \\
\text { Sutphin and others } \\
\text { (1990) }\end{array}$ \\
\hline $\begin{array}{c}0.7 \\
(1983)\end{array}$ & n.d. & $\begin{array}{l}\text { Clastic and carbonate } \\
\text { metasediments, granite }\end{array}$ & Granite & $\begin{array}{l}\text { Late } \\
\text { Mesozoic- } \\
\text { Early } \\
\text { Tertiary }\end{array}$ & n.d. & n.d. & n.d. & $\begin{array}{l}\text { U Khin Zaw and Daw Khin } \\
\text { Myo Thet (1983); Sut- } \\
\text { phin and others (1990) }\end{array}$ \\
\hline n.d. & n.d. & $\begin{array}{l}\text { Eluvial and alluvial } \\
\text { sediments, granite } \\
\text { (tourmaline-rich) }\end{array}$ & Granite & $\begin{array}{l}\text { Late } \\
\text { Mesozoic-- } \\
\text { Early } \\
\text { Tertiary }\end{array}$ & n.d. & n.d. & n.d. & Sutphin and others (1990) \\
\hline $\begin{array}{c}15.2 \\
(2013)\end{array}$ & n.d. & $\begin{array}{l}\text { Granite and quartz-feldspar } \\
\text { porphyry }\end{array}$ & Granite & 340 to $330 \mathrm{Ma}$ & $\mathrm{K}-\mathrm{Ar}$ & n.d. & n.d. & $\begin{array}{l}\text { Kooiman and others } \\
\text { (1986); Sutphin and } \\
\text { others (1990) }\end{array}$ \\
\hline $\begin{array}{c}56.0 \\
(1984)\end{array}$ & n.d. & Granite and metasediments & Granite & $295 \pm 5 \mathrm{Ma}$ & $\mathrm{Ar}-\mathrm{Ar}$ & n.d. & n.d. & $\begin{array}{l}\text { Richardson and others } \\
\text { (1982); Sutphin and } \\
\text { others (1990) }\end{array}$ \\
\hline $\begin{array}{l}50-100 \\
(1985)\end{array}$ & n.d. & $\begin{array}{l}\text { Shale, marl, limestones, } \\
\text { granite }\end{array}$ & Granite & $97 \mathrm{Ma}$ & $\mathrm{K}-\mathrm{Ar}$ & n.d. & n.d. & $\begin{array}{l}\text { Premoli (1986); Sutphin } \\
\text { and others (1990) }\end{array}$ \\
\hline $\begin{array}{c}11.5 \\
(2007)\end{array}$ & n.d. & Triassic sandstone & Granite & n.d. & n.d. & $\begin{array}{l}\text { Length: to } 442 ; \\
\text { thickness: } \\
1.40 \text { to } 8.58\end{array}$ & $\begin{array}{l}\text { Lenticular, } \\
\text { strata-bound }\end{array}$ & Hou and others (2007) \\
\hline
\end{tabular}

\begin{tabular}{|c|c|c|c|c|c|c|c|c|}
\hline $\begin{array}{l}<10.0 \\
(2007)\end{array}$ & n.d. & $\begin{array}{l}\text { Dolomite, limestone, } \\
\text { arenaceous mudstone, } \\
\text { sandstone }\end{array}$ & Biotite granite & Mesozoic & n.d. & n.d. & $\begin{array}{l}\text { Vein, strata- } \\
\text { bound }\end{array}$ & Hou and others (2007) \\
\hline n.d. & n.d. & $\begin{array}{l}\text { Dolomitic limestone, } \\
\text { arenaceous mudstone, } \\
\text { sandstone }\end{array}$ & Biotite granite & Mesozoic & n.d. & n.d. & $\begin{array}{l}\text { Lens, strata- } \\
\text { bound }\end{array}$ & Hou and others (2007) \\
\hline $\begin{array}{c}100 \\
(1985)\end{array}$ & n.d. & $\begin{array}{l}\text { Limestone and dolomite, } \\
\text { minor argillite, tuff and } \\
\text { basalt, gneiss and schist, } \\
\text { biotite granite }\end{array}$ & Granite & $\begin{array}{l}\text { Porphyritic } \\
\text { biotite } \\
\text { granite, } 115 \\
\text { to } 84 \mathrm{Ma} ; \\
\text { Equigranu- } \\
\text { lar biotite } \\
\text { granite, } 80 \\
\text { to } 64 \mathrm{Ma}\end{array}$ & $\mathrm{K}-\mathrm{Ar}$ & n.d. & n.d. & $\begin{array}{c}\text { Kwak (1987); Sutphin } \\
\text { and others (1990) }\end{array}$ \\
\hline $\begin{array}{c}42.6 \\
(2007)\end{array}$ & n.d. & $\begin{array}{l}\text { Metamorphosed feldspathic } \\
\text { sandstone, argillaceous } \\
\text { siltstone, dolomite }\end{array}$ & $\begin{array}{l}\text { Alkali-feldspar } \\
\text { granite }\end{array}$ & n.d. & n.d. & $\begin{array}{l}\text { Length: } 40 \text { to } \\
600 \text {; width: } \\
0.89 \text { to } 23.8\end{array}$ & n.d. & Hou and others (2007) \\
\hline n.d. & n.d. & Sandy slate & Biotite granite & Mesozoic & n.d. & n.d. & $\begin{array}{l}\text { Vein, strata- } \\
\text { bound }\end{array}$ & Hou and others (2007) \\
\hline $\begin{array}{l}26,200 \\
(2007)\end{array}$ & n.d. & Sandy slate & Biotite granite & Mesozoic & n.d. & $\begin{array}{l}\text { Length: } 30 \\
\text { to } 300 ; \\
\text { thickness: } \\
1 \text { to } 20\end{array}$ & Irregular & Hou and others (2007) \\
\hline
\end{tabular}


Table S2. Location, grade, tonnage, and other data for selected tin deposits of the world with greater than 1,000 metric tons of contained tin.-Continued

[WGS 84, World Geodetic System of 1984; negative values for latitude indicate that the deposit is in the Southern Hemisphere; negative values for longitude indicate that the deposit is in the Western Hemisphere. Elements: B, boron; F, fluorine; Fe, iron; Sn, tin. Dating method: Ar-Ar, argon-argon; K-Ar, potassiumargon; Rb-Sr, rubidium-strontium; U-Pb, uranium-lead. Abbreviations: ca., circa; Ga, giga-annum, or billion years before present; ID, identification; $\mathrm{kg} / \mathrm{m}^{3}$, kilogram per cubic meter; m, meter; Ma, mega-annum, or million years before present; NA, not applicable; n.d., no data; NNE-WSW, north-northeastwest-southwest; SHRIMP, sensitive high-resolution ion microprobe; wt. \%, weight percent]

\begin{tabular}{|c|c|c|c|c|c|c|c|c|c|c|}
\hline $\begin{array}{l}\text { Deposit } \\
\text { ID }\end{array}$ & $\begin{array}{l}\text { Deposit } \\
\text { or mine }\end{array}$ & Country & $\begin{array}{l}\text { State, } \\
\text { Territory, or } \\
\text { Province }\end{array}$ & $\begin{array}{r}\text { Latitude } \\
\text { (decima } \\
\text { WG }\end{array}$ & $\begin{array}{l}\text { Longitude } \\
\text { degrees } \\
\text { 84) }\end{array}$ & Deposit class & Ore type & $\begin{array}{l}\text { Operation type } \\
\text { and (or) } \\
\text { comments }\end{array}$ & $\begin{array}{l}\text { Development } \\
\text { status }\end{array}$ & $\begin{array}{c}\text { Grade Sn } \\
\text { (wt. \% } \\
\text { unless } \\
\text { otherwise } \\
\text { noted) }\end{array}$ \\
\hline 44 & $\begin{array}{l}\text { Cinovec } \\
\quad \text { (Zinnwald) }\end{array}$ & $\begin{array}{l}\text { Czech } \\
\text { Republic }\end{array}$ & $\begin{array}{l}\text { Teplice } \\
\text { District }\end{array}$ & 50.73 & 13.77 & Hydrothermal & Greisen & n.d. & n.d. & 0.370 \\
\hline 45 & Kivu mines & $\begin{array}{l}\text { Democratic } \\
\text { Republic } \\
\text { of the } \\
\text { Congo } \\
\text { (Congo } \\
\text { [Kinshasa]) } \\
\text { (formerly } \\
\text { Zaire) }\end{array}$ & $\begin{array}{l}\text { North Kivu } \\
\text { Province }\end{array}$ & -6.50 & 27.50 & Placer/alluvial & Placer & Gravel pump & n.d. & n.d. \\
\hline 46 & Abu Dabbab & Egypt & $\begin{array}{c}\text { Al Bahr al } \\
\text { Ahmar } \\
\text { Gover- } \\
\text { norate }\end{array}$ & 25.34 & 34.54 & $\begin{array}{l}\text { Hydrothermal } \\
\text { and placer/ } \\
\text { alluvial }\end{array}$ & $\begin{array}{l}\text { Skarn and greisen } \\
\text { veins (primarily } \\
\text { a tantalum } \\
\text { deposit); } \\
\text { associated } \\
\text { tin placers }\end{array}$ & Open pit planned & $\begin{array}{l}\text { Feasibility } \\
\text { study }\end{array}$ & $\begin{array}{c}0.09 \\
(0.13 \%, \\
\text { according } \\
\text { to Roskill } \\
\text { Information } \\
\text { Services, } \\
\text { Ltd., 2015) }\end{array}$ \\
\hline 47 & $\begin{array}{l}\text { Antonsthal } \\
\text { district in } \\
\text { the West- } \\
\text { erzgebirge } \\
\text { (Western Ore } \\
\text { Mountains) }\end{array}$ & Germany & Saxony & 50.51 & 12.74 & Hydrothermal & $\begin{array}{l}\text { Skarn } \pm \text { schist } \\
\text { replacement }\end{array}$ & n.d. & Exploration & 0.190 \\
\hline 49 & $\begin{array}{l}\text { Breitbrunn } \\
\text { district in } \\
\text { the West- } \\
\text { erzgebirge } \\
\text { (Western Ore } \\
\text { Mountains) }\end{array}$ & Germany & Saxony & 50.48 & 12.77 & Hydrothermal & $\begin{array}{l}\text { Skarn } \pm \text { schist } \\
\text { replacement }\end{array}$ & n.d. & Exploration & 0.250 \\
\hline 50 & $\begin{array}{l}\text { Elbenstock- } \\
\text { Sosa district } \\
\text { in the West- } \\
\text { erzgebirge } \\
\text { (Western Ore } \\
\text { Mountains) }\end{array}$ & Germany & Saxony & 50.49 & 12.63 & Hydrothermal & Greisen veins & n.d. & Exploration & 0.260 \\
\hline
\end{tabular}


Table S2. Location, grade, tonnage, and other data for selected tin deposits of the world with greater than 1,000 metric tons of contained tin.-Continued

[WGS 84, World Geodetic System of 1984; negative values for latitude indicate that the deposit is in the Southern Hemisphere; negative values for longitude indicate that the deposit is in the Western Hemisphere. Elements: B, boron; F, fluorine; Fe, iron; Sn, tin. Dating method: Ar-Ar, argon-argon; K-Ar, potassiumargon; $\mathrm{Rb}-\mathrm{Sr}$, rubidium-strontium; U-Pb, uranium-lead. Abbreviations: ca., circa; Ga, giga-annum, or billion years before present; ID, identification; $\mathrm{kg} / \mathrm{m}^{3}$, kilogram per cubic meter; m, meter; Ma, mega-annum, or million years before present; NA, not applicable; n.d., no data; NNE-WSW, north-northeastwest-southwest; SHRIMP, sensitive high-resolution ion microprobe; wt. \%, weight percent]

\begin{tabular}{|c|c|c|c|c|c|c|c|c|}
\hline $\begin{array}{l}\text { Resource } \\
\text { tonnage } \\
\text { (million } \\
\text { metric tons) } \\
\text { (Year } \\
\text { determined) }\end{array}$ & $\begin{array}{l}\text { Cutoff } \\
\text { grade } \\
\text { (wt. \%) }\end{array}$ & Host rock & $\begin{array}{l}\text { Mineralizing } \\
\text { rock-type }\end{array}$ & $\begin{array}{l}\text { Mineralization } \\
\text { age }\end{array}$ & $\begin{array}{l}\text { Dating } \\
\text { method }\end{array}$ & $\begin{array}{c}\text { Deposit } \\
\text { dimensions } \\
\text { (in meters } \\
\text { unless } \\
\text { otherwise } \\
\text { noted) }\end{array}$ & $\begin{array}{c}\text { Deposit shape/ } \\
\text { mineralization } \\
\text { style }\end{array}$ & Primary references \\
\hline $\begin{array}{c}28.1 \\
(2013)\end{array}$ & n.d. & Granite & $\begin{array}{l}\text { Alkali-feldspar gran- } \\
\text { ite, rhyolite }\end{array}$ & 330 to $295 \mathrm{Ma}$ & n.d. & n.d. & $\begin{array}{l}\text { Flat-lying, sub- } \\
\text { horizontal } \\
\text { veins form } \\
\text { regular } \\
\text { domal struc- } \\
\text { tures that } \\
\text { mimic the } \\
\text { upper granite } \\
\text { cupola } \\
\text { contact }\end{array}$ & $\begin{array}{l}\text { Schwarz-Schampera and } \\
\text { Herzig (2002); Porter } \\
\text { GeoConsultancy Pty } \\
\text { Ltd. (1995); Peter } \\
\text { Kettle, International } \\
\text { Tin Research Institute, } \\
\text { written commun., } \\
\text { April 8, 2013 }\end{array}$ \\
\hline $\begin{array}{c}0.265 \\
\text { contained } \\
\text { Sn }(1986)\end{array}$ & n.d. & $\begin{array}{l}\text { Alluvium and eluvium, } \\
\text { granite, metasediments }\end{array}$ & Granite & Precambrian & n.d. & n.d. & n.d. & $\begin{array}{l}\text { Angermeier and others } \\
\text { (1974); Sutphin and } \\
\text { others (1990) }\end{array}$ \\
\hline
\end{tabular}

\begin{tabular}{|c|c|c|c|c|c|c|c|c|}
\hline $\begin{array}{c}44.5 \\
(2013)\end{array}$ & n.d. & $\begin{array}{l}\text { Quartz-bioite and quartz } \\
\text { chlorite schists with } \\
\text { intercalated beds of } \\
\text { tuff and agglomerate, } \\
\text { diabase-Neoproterozoic }\end{array}$ & $\begin{array}{l}\text { Muscovite aplite } \\
\text { leucogranite }\end{array}$ & $\begin{array}{l}\text { Neoprotero- } \\
\text { zoic }\end{array}$ & n.d. & $\begin{array}{c}400 \times 200 \times \\
480\end{array}$ & $\begin{array}{l}\text { Ellipsoidal and } \\
\text { tabular }\end{array}$ & $\begin{array}{l}\text { Amin (1947); Sabet and } \\
\text { others (1971); Sarin and } \\
\text { others (1976); Roskill } \\
\text { Information Services, } \\
\text { Ltd. (2015); Peter Kettle, } \\
\text { International Tin Re- } \\
\text { search Institute, written } \\
\text { commun., April 8, } 2013\end{array}$ \\
\hline 14.7 & n.d. & $\begin{array}{l}\text { Cambrian-Ordovician } \\
\text { sediments, mainly pelitic, } \\
\text { but with some limestone } \\
\text { beds (now marble/ } \\
\text { calc-silicate and skarn) }\end{array}$ & Granite & Hercynian & n.d. & $\begin{array}{c}2,500 \times 1,300 \\
\text { x variable } \\
\text { thickness }\end{array}$ & Veins & $\begin{array}{l}\text { Antony Truelove, Indo } \\
\text { Gold Ltd., written com- } \\
\text { mun., September 8, } 2013\end{array}$ \\
\hline 10.8 & n.d. & $\begin{array}{l}\text { Cambrian-Ordovician } \\
\text { sediments, mainly pelitic, } \\
\text { but with some limestone } \\
\text { beds (now marble/ } \\
\text { calc-silicate and skarn) }\end{array}$ & Granite & Hercynian & n.d. & $\begin{array}{l}500 \text { x } 500 \text { x } \\
\text { unknown } \\
\text { depth }\end{array}$ & Veins & $\begin{array}{l}\text { Antony Truelove, Indo } \\
\text { Gold Ltd., written com- } \\
\text { mun., August 8, } 2013\end{array}$ \\
\hline 22.3 & n.d. & $\begin{array}{l}\text { Cambrian-Ordovician } \\
\text { sediments, mainly pelitic, } \\
\text { but with some limestone } \\
\text { beds (now marble/ } \\
\text { calc-silicate and skarn) }\end{array}$ & Granite & Hercynian & n.d. & $\begin{array}{c}2,000 \times 1,400 \\
\times \text { variable } \\
\text { thickness }\end{array}$ & Strata-bound & $\begin{array}{l}\text { Antony Truelove, Indo } \\
\text { Gold Ltd., written com- } \\
\text { mun., August 8, } 2013\end{array}$ \\
\hline 2.3 & n.d. & $\begin{array}{l}\text { Cambrian-Ordovician sedi- } \\
\text { ments, mainly pelitic, but } \\
\text { with some limestone } \\
\text { beds (now marble/ } \\
\text { calc-silicate and skarn) }\end{array}$ & Granite & Hercynian & n.d. & $\begin{array}{l}200 \times 5,000 \times \\
\text { unknown } \\
\text { depth }\end{array}$ & Veins & $\begin{array}{l}\text { Antony Truelove, Indo } \\
\text { Gold Ltd., written com- } \\
\text { mun., August 8, } 2013\end{array}$ \\
\hline
\end{tabular}


Table S2. Location, grade, tonnage, and other data for selected tin deposits of the world with greater than 1,000 metric tons of contained tin.-Continued

[WGS 84, World Geodetic System of 1984; negative values for latitude indicate that the deposit is in the Southern Hemisphere; negative values for longitude indicate that the deposit is in the Western Hemisphere. Elements: B, boron; F, fluorine; Fe, iron; Sn, tin. Dating method: Ar-Ar, argon-argon; K-Ar, potassiumargon; Rb-Sr, rubidium-strontium; U-Pb, uranium-lead. Abbreviations: ca., circa; Ga, giga-annum, or billion years before present; ID, identification; $\mathrm{kg} / \mathrm{m}^{3}$, kilogram per cubic meter; m, meter; Ma, mega-annum, or million years before present; NA, not applicable; n.d., no data; NNE-WSW, north-northeastwest-southwest; SHRIMP, sensitive high-resolution ion microprobe; wt. \%, weight percent]

\begin{tabular}{|c|c|c|c|c|c|c|c|c|c|c|}
\hline $\begin{array}{l}\text { Deposit } \\
\text { ID }\end{array}$ & $\begin{array}{l}\text { Deposit } \\
\text { or mine }\end{array}$ & Country & $\begin{array}{c}\text { State, } \\
\text { Territory, or } \\
\text { Province }\end{array}$ & $\begin{array}{r}\text { Latitude } \\
\text { (decima } \\
\text { WG }\end{array}$ & $\begin{array}{l}\text { Longitude } \\
\text { degrees } \\
\text { 84) }\end{array}$ & Deposit class & Ore type & $\begin{array}{l}\text { Operation type } \\
\text { and (or) } \\
\text { comments }\end{array}$ & $\begin{array}{l}\text { Development } \\
\text { status }\end{array}$ & $\begin{array}{l}\text { Grade Sn } \\
\text { (wt. \% } \\
\text { unless } \\
\text { otherwise } \\
\text { noted) }\end{array}$ \\
\hline 51 & $\begin{array}{l}\text { Geyer- } \\
\text { Southwest }\end{array}$ & Germany & Saxony & 50.62 & 12.90 & Hydrothermal & Skarn & $\begin{array}{l}\text { Sublevel stoping } \\
\text { or more } \\
\text { selective } \\
\text { mining being } \\
\text { considered }\end{array}$ & Prefeasibility & 0.370 \\
\hline 52 & Gottesberg & Germany & Saxony & 50.42 & 12.48 & Hydrothermal & $\begin{array}{l}\text { Greisen stockwork } \\
\text { and breccia } \\
\text { pipes }\end{array}$ & $\begin{array}{l}\text { Sublevel, open } \\
\text { stoping } \\
\text { planned }\end{array}$ & Prefeasibility & 0.270 \\
\hline 53 & $\begin{array}{l}\text { Hammerlein- } \\
\text { Tellerhauser } \\
\text { district in } \\
\text { the West- } \\
\text { erzgebirge } \\
\text { (Western Ore } \\
\text { Mountains) }\end{array}$ & Germany & Saxony & 50.45 & 12.87 & Hydrothermal & $\begin{array}{l}\text { Skarn, greisen } \\
\text { veins, replace- } \\
\text { ments in schist } \\
\text { below skarn }\end{array}$ & n.d. & Exploration & 0.570 \\
\hline 54 & $\begin{array}{l}\text { Muhlleithen } \\
\text { district in } \\
\text { the West- } \\
\text { erzgebirge } \\
\text { (Western Ore } \\
\text { Mountains) }\end{array}$ & Germany & Saxony & 50.41 & 12.45 & Hydrothermal & Breccia pipe & n.d. & Exploration & 0.300 \\
\hline 55 & $\begin{array}{l}\text { Sauschwemme, } \\
\text { West- } \\
\text { erzgebirge } \\
\text { (Western Ore } \\
\text { Mountains) }\end{array}$ & Germany & Saxony & 50.44 & 12.66 & Placer/alluvial & Alluvial & n.d. & Exploration & 0.040 \\
\hline 56 & P.T. Koba Tin & Indonesia & $\begin{array}{l}\text { Bangka } \\
\text { Island }\end{array}$ & -2.58 & 106.40 & Placer/alluvial & Placer & $\begin{array}{l}\text { Gravel pump, } \\
\text { dredge }\end{array}$ & n.d. & n.d. \\
\hline 57 & $\begin{array}{l}\text { P.T. Tambang } \\
\text { Tamah }\end{array}$ & Indonesia & $\begin{array}{l}\text { Bangka } \\
\text { Island }\end{array}$ & -2.00 & 106.00 & Placer/alluvial & Placer & $\begin{array}{l}\text { Gravel pump, } \\
\text { onshore } \\
\text { dredge }\end{array}$ & n.d. & 0.220 \\
\hline 58 & Kelapa Kampit & Indonesia & $\begin{array}{l}\text { Belitung } \\
\text { Island }\end{array}$ & -2.75 & 108.08 & Tailings & Lode, vein & n.d. & n.d. & 1.670 \\
\hline 59 & $\begin{array}{l}\text { P.T. Tambang } \\
\text { Belitun }\end{array}$ & Indonesia & $\begin{array}{l}\text { Belitung } \\
\text { Island }\end{array}$ & -2.67 & 107.83 & Placer/alluvial & Placer & $\begin{array}{l}\text { Gravel pump, } \\
\text { onshore } \\
\text { dredge }\end{array}$ & n.d. & 0.013 \\
\hline 60 & $\begin{array}{l}\text { Pt Timah } \\
\text { Singkep } \\
\text { Mine }\end{array}$ & Indonesia & $\begin{array}{l}\text { Singkep } \\
\text { Island }\end{array}$ & -2.00 & 114.00 & Placer/alluvial & Placer & $\begin{array}{l}\text { Gravel pump, } \\
\text { onshore } \\
\text { dredge }\end{array}$ & n.d. & n.d. \\
\hline 61 & Akenobe & Japan & $\begin{array}{l}\text { Hyogo } \\
\text { Prefecture, } \\
\text { Honshu } \\
\text { Island }\end{array}$ & 35.22 & 134.68 & Hydrothermal & $\begin{array}{l}\text { Lode, polymetallic } \\
\text { veins }\end{array}$ & n.d. & n.d. & n.d. \\
\hline 62 & Suzuyama & Japan & $\begin{array}{l}\text { Kyushu } \\
\text { Island }\end{array}$ & 31.50 & 130.43 & Hydrothermal & $\begin{array}{l}\text { Lode, pegmatite } \\
\text { and quartz } \\
\text { veins }\end{array}$ & n.d. & n.d. & 1.250 \\
\hline
\end{tabular}


Table S2. Location, grade, tonnage, and other data for selected tin deposits of the world with greater than 1,000 metric tons of contained tin.-Continued

[WGS 84, World Geodetic System of 1984; negative values for latitude indicate that the deposit is in the Southern Hemisphere; negative values for longitude indicate that the deposit is in the Western Hemisphere. Elements: B, boron; F, fluorine; Fe, iron; Sn, tin. Dating method: Ar-Ar, argon-argon; K-Ar, potassiumargon; Rb-Sr, rubidium-strontium; U-Pb, uranium-lead. Abbreviations: ca., circa; Ga, giga-annum, or billion years before present; ID, identification; $\mathrm{kg} / \mathrm{m}^{3}$, kilogram per cubic meter; m, meter; Ma, mega-annum, or million years before present; NA, not applicable; n.d., no data; NNE-WSW, north-northeastwest-southwest; SHRIMP, sensitive high-resolution ion microprobe; wt. \%, weight percent]

\begin{tabular}{|c|c|c|c|c|c|c|c|c|}
\hline $\begin{array}{l}\text { Resource } \\
\text { tonnage } \\
\text { (million } \\
\text { metric tons) } \\
\text { (Year } \\
\text { determined) }\end{array}$ & $\begin{array}{l}\text { Cutoff } \\
\text { grade } \\
\text { (wt. \%) }\end{array}$ & Host rock & $\begin{array}{l}\text { Mineralizing } \\
\text { rock-type }\end{array}$ & $\begin{array}{l}\text { Mineralization } \\
\text { age }\end{array}$ & $\begin{array}{l}\text { Dating } \\
\text { method }\end{array}$ & $\begin{array}{c}\text { Deposit } \\
\text { dimensions } \\
\text { (in meters } \\
\text { unless } \\
\text { otherwise } \\
\text { noted) }\end{array}$ & $\begin{array}{c}\text { Deposit shape/ } \\
\text { mineralization } \\
\text { style }\end{array}$ & Primary references \\
\hline $\begin{array}{c}11.6 \\
(2013)\end{array}$ & 0.150 & $\begin{array}{l}\text { Cambrian-Ordovician } \\
\text { schists, dolomite and } \\
\text { calcite-dolomite } \\
\text { sediments }\end{array}$ & Granite & Hercynian & n.d. & $\begin{array}{l}2,600 \times 400 \\
\times ?\end{array}$ & n.d. & $\begin{array}{l}\text { Lehmann (1990); Kettle } \\
\text { (2012) }\end{array}$ \\
\hline $\begin{array}{c}42.1 \\
(2013)\end{array}$ & 0.150 & $\begin{array}{l}\text { Granite and granite } \\
\text { porphyry }\end{array}$ & Granite & Hercynian & n.d. & $\begin{array}{l}800 \times 400 \times \\
900\end{array}$ & Pipe & $\begin{array}{l}\text { Beyschlag and others (1914); } \\
\text { Lindgren (1933); } \\
\text { Lehmann (1990); } \\
\text { Kettle (2012) }\end{array}$ \\
\hline $\begin{array}{c}25.3 \\
(2013)\end{array}$ & n.d. & $\begin{array}{l}\text { Cambrian-Ordovician } \\
\text { sediments, mainly pelitic, } \\
\text { but with some limestone } \\
\text { beds (now marble/ } \\
\text { calc-silicate and skarn) }\end{array}$ & Granite & Hercynian & n.d. & $\begin{array}{l}\text { about } 5,600 \times \\
0.5 \times 2 \text { to } 3 \\
\text { (seams) }\end{array}$ & Strata-bound & $\begin{array}{l}\text { Truelove, 2012; Antony } \\
\text { Truelove, Indo Gold } \\
\text { Ltd., written commun., } \\
\text { September 8, } 2013\end{array}$ \\
\hline
\end{tabular}

\begin{tabular}{|c|c|c|c|c|c|c|c|c|}
\hline $\begin{array}{l}0.75 \\
\text { (“Soviet" } \\
\text { estimates) }\end{array}$ & n.d. & $\begin{array}{l}\text { Cambrian-Ordovician } \\
\text { sediments, mainly pelitic, } \\
\text { but with some limestone } \\
\text { beds (now marble/calc- } \\
\text { silicate and skarn) }\end{array}$ & Granite & Hercynian & n.d. & $\begin{array}{c}30 \times 30 x \geq \\
200\end{array}$ & Pipe & $\begin{array}{l}\text { Antony Truelove, Indo } \\
\text { Gold Ltd., written com- } \\
\text { mun., September 8, } 2013\end{array}$ \\
\hline $\begin{array}{l}6.5 \\
\text { (“Soviet” } \\
\text { estimates) }\end{array}$ & n.d. & Alluvium/stream sediment & n.d. & $\begin{array}{l}\text { Alpine orog- } \\
\text { eny(?) to } \\
\text { Holocene }\end{array}$ & n.d. & $\geq 1,000 \times 30$ & Alluvium & $\begin{array}{l}\text { Antony Truelove, Indo } \\
\text { Gold Ltd., written com- } \\
\text { mun., September 8, } 2013\end{array}$ \\
\hline
\end{tabular}

\begin{tabular}{|c|c|c|c|c|c|c|c|c|}
\hline $\begin{array}{l}0.0467 \\
\text { contained } \\
\text { Sn }(1982)\end{array}$ & n.d. & $\begin{array}{l}\text { Formed in current and } \\
\text { ancient channels }\end{array}$ & n.d. & n.d. & n.d. & n.d. & n.d. & $\begin{array}{l}\text { Prijono (1986); Sutphin } \\
\text { and others (1990) }\end{array}$ \\
\hline $\begin{array}{c}2.259 \\
(1982)\end{array}$ & n.d. & $\begin{array}{l}\text { Alluvial and eluvial } \\
\text { sediments }\end{array}$ & n.d. & Post-Triassic & n.d. & n.d. & n.d. & Sutphin and others (1990) \\
\hline $\begin{array}{c}1.390 \\
(1982)\end{array}$ & n.d. & $\begin{array}{l}\text { Quartzite, sandstone, } \\
\text { slate, granitoids }\end{array}$ & Granite & Lower Triassic & n.d. & n.d. & n.d. & $\begin{array}{l}\text { Omer-Cooper and others } \\
\text { (1974); Sutphin and } \\
\text { others (1990) }\end{array}$ \\
\hline n.d. & n.d. & $\begin{array}{l}\text { Bedrock is alternating beds } \\
\text { of sandstone and shale } \\
\text { intruded by stocks } \\
\text { that range from gabbro } \\
\text { to granite }\end{array}$ & Biotite granite & n.d. & n.d. & n.d. & n.d. & Sainsbury (1969b) \\
\hline $\begin{array}{l}0.448 \\
(1982)\end{array}$ & n.d. & $\begin{array}{l}\text { Granite, pegmatite, shale, } \\
\text { and sandstone }\end{array}$ & $\begin{array}{l}\text { Granite and } \\
\text { pegmatite }\end{array}$ & Tertiary & n.d. & n.d. & n.d. & $\begin{array}{l}\text { Saito and others (1960); } \\
\text { Sutphin and others } \\
\text { (1990) }\end{array}$ \\
\hline
\end{tabular}


Table S2. Location, grade, tonnage, and other data for selected tin deposits of the world with greater than 1,000 metric tons of contained tin.-Continued

[WGS 84, World Geodetic System of 1984; negative values for latitude indicate that the deposit is in the Southern Hemisphere; negative values for longitude indicate that the deposit is in the Western Hemisphere. Elements: B, boron; F, fluorine; Fe, iron; Sn, tin. Dating method: Ar-Ar, argon-argon; K-Ar, potassiumargon; Rb-Sr, rubidium-strontium; U-Pb, uranium-lead. Abbreviations: ca., circa; Ga, giga-annum, or billion years before present; ID, identification; $\mathrm{kg} / \mathrm{m}^{3}$, kilogram per cubic meter; m, meter; Ma, mega-annum, or million years before present; NA, not applicable; n.d., no data; NNE-WSW, north-northeastwest-southwest; SHRIMP, sensitive high-resolution ion microprobe; wt. \%, weight percent]

\begin{tabular}{|c|c|c|c|c|c|c|c|c|c|c|}
\hline $\begin{array}{c}\text { Deposit } \\
\text { ID }\end{array}$ & $\begin{array}{l}\text { Deposit } \\
\text { or mine }\end{array}$ & Country & $\begin{array}{c}\text { State, } \\
\text { Territory, or } \\
\text { Province }\end{array}$ & $\begin{array}{r}\text { Latitude } \\
\begin{array}{r}\text { (decima } \\
\text { WG }\end{array}\end{array}$ & $\begin{array}{l}\text { Longitude } \\
\text { degrees } \\
\text { 84) }\end{array}$ & Deposit class & Ore type & $\begin{array}{c}\text { Operation type } \\
\text { and (or) } \\
\text { comments }\end{array}$ & $\begin{array}{c}\text { Development } \\
\text { status }\end{array}$ & $\begin{array}{c}\text { Grade Sn } \\
\text { (wt. \% } \\
\text { unless } \\
\text { otherwise } \\
\text { noted) }\end{array}$ \\
\hline 63 & Syrymbet & Kazakhstan & $\begin{array}{l}\text { North } \\
\quad \text { Kazakhstan } \\
\text { Province }\end{array}$ & 53.48 & 67.98 & Hydrothermal & $\begin{array}{l}\text { Vein stockwork, } \\
\text { skarn, endo- } \\
\text { greisen }\end{array}$ & n.d. & $\begin{array}{c}\text { Feasibility } \\
\text { study }\end{array}$ & 0.840 \\
\hline
\end{tabular}

\begin{tabular}{|c|c|c|c|c|c|c|c|c|c|c|}
\hline 64 & $\begin{array}{l}\text { Malaysian } \\
\text { dredges }\end{array}$ & Malaysia & NA & 4.00 & 103.00 & Placer/alluvial & Placer & Onshore dredge & n.d. & n.d. \\
\hline 65 & $\begin{array}{l}\text { Malaysian } \\
\text { gravel pump } \\
\text { mines }\end{array}$ & Malaysia & NA & 4.00 & 103.00 & Placer/alluvial & Placer & Gravel pump & n.d. & n.d. \\
\hline 66 & $\begin{array}{l}\text { Sungai } \\
\text { Lembing }\end{array}$ & Malaysia & Pahang State & 3.87 & 103.08 & Hydrothermal & Lode, vein & n.d. & n.d. & 0.710 \\
\hline 67 & Kinta tin field & Malaysia & Perak State & 4.28 & 101.17 & $\begin{array}{l}\text { Mostly placer/ } \\
\text { alluvial and } \\
\text { minor hydro- } \\
\text { thermal lode }\end{array}$ & Placer and lode & $\begin{array}{l}\text { Gravel pump, } \\
\text { dredge }\end{array}$ & $\begin{array}{l}\text { Almost } \\
\text { completely } \\
\text { played out }\end{array}$ & n.d. \\
\hline 68 & $\begin{array}{l}\text { Kuala Langat } \\
\text { Mining } \\
\text { Sdn Bhd }\end{array}$ & Malaysia & $\begin{array}{l}\text { Selangor } \\
\text { State }\end{array}$ & 2.82 & 101.62 & Placer/alluvial & Placer & Dredge & Proposed & $0.190 \mathrm{~kg} / \mathrm{m}^{3}$ \\
\hline 69 & Oortsog Ovoo & Mongolia & $\begin{array}{l}\text { Dundgovi } \\
\text { Province }\end{array}$ & 45.57 & 108.10 & Hydrothermal & Skarn & Open pit & $\begin{array}{l}\text { Initial metallur- } \\
\text { gical study }\end{array}$ & 0.007 \\
\hline 70 & $\begin{array}{l}\text { Narsiin } \\
\text { Khundlen } \\
\text { (Amerilan- } \\
\text { gui Ujin) }\end{array}$ & Mongolia & $\begin{array}{c}\text { Khentii (or } \\
\text { Hentiy) } \\
\text { Province }\end{array}$ & 48.74 & 112.53 & Hydrothermal & Greisen veins & $\begin{array}{l}\text { Open pit and } \\
\text { underground }\end{array}$ & $\begin{array}{l}\text { Feasibility } \\
\text { study com- } \\
\text { pleted, but } \\
\text { construction } \\
\text { not yet } \\
\text { started as } \\
\text { of } 2010\end{array}$ & 0.450 \\
\hline 71 & Achmmach & Morocco & Meknes & 33.32 & -5.45 & Hydrothermal & $\begin{array}{l}\text { Veins and dis- } \\
\text { seminated } \\
\text { in alteration } \\
\text { envelopes }\end{array}$ & n.d. & $\begin{array}{c}\text { In development } \\
\text { as of } 2013\end{array}$ & $\begin{array}{c}0.85 \\
\text { (combined } \\
\text { measured, } \\
\text { indicated, } \\
\text { and inferred) }\end{array}$ \\
\hline
\end{tabular}

\begin{tabular}{|c|c|c|c|c|c|c|c|c|c|c|}
\hline 72 & Bou El Jaj & Morocco & Meknes & 33.28 & -5.48 & Hydrothermal & $\begin{array}{l}\text { Veins and dis- } \\
\text { seminated } \\
\text { in alteration } \\
\text { envelopes }\end{array}$ & n.d. & $\begin{array}{c}\text { In development } \\
\text { as of } 2014\end{array}$ & NA \\
\hline 73 & Achmmach & Morocco & $\begin{array}{l}\text { Meknes- } \\
\text { Tafilalet } \\
\text { region }\end{array}$ & 33.32 & -5.45 & Hydrothermal & $\begin{array}{l}\text { Veins and dis- } \\
\text { seminated } \\
\text { in alteration } \\
\text { envelopes }\end{array}$ & $\begin{array}{r}\text { Long-hole } \\
\text { stoping }\end{array}$ & $\begin{array}{l}\text { Drilling and } \\
\text { prefeasibility } \\
\text { (expected } \\
\text { startup in } \\
\text { 2016) }\end{array}$ & 0.850 \\
\hline
\end{tabular}


Table S2. Location, grade, tonnage, and other data for selected tin deposits of the world with greater than 1,000 metric tons of contained tin.-Continued

[WGS 84, World Geodetic System of 1984; negative values for latitude indicate that the deposit is in the Southern Hemisphere; negative values for longitude indicate that the deposit is in the Western Hemisphere. Elements: B, boron; F, fluorine; Fe, iron; Sn, tin. Dating method: Ar-Ar, argon-argon; K-Ar, potassiumargon; $\mathrm{Rb}-\mathrm{Sr}$, rubidium-strontium; U-Pb, uranium-lead. Abbreviations: ca., circa; Ga, giga-annum, or billion years before present; ID, identification; $\mathrm{kg} / \mathrm{m}^{3}$, kilogram per cubic meter; m, meter; Ma, mega-annum, or million years before present; NA, not applicable; n.d., no data; NNE-WSW, north-northeastwest-southwest; SHRIMP, sensitive high-resolution ion microprobe; wt. \%, weight percent]

\begin{tabular}{|c|c|c|c|c|c|c|c|c|}
\hline $\begin{array}{l}\text { Resource } \\
\text { tonnage } \\
\text { (million } \\
\text { metric tons) } \\
\text { (Year } \\
\text { determined) }\end{array}$ & $\begin{array}{c}\text { Cutoff } \\
\text { grade } \\
\text { (wt. \%) }\end{array}$ & Host rock & $\begin{array}{l}\text { Mineralizing } \\
\text { rock-type }\end{array}$ & $\begin{array}{c}\text { Mineralization } \\
\text { age }\end{array}$ & $\begin{array}{l}\text { Dating } \\
\text { method }\end{array}$ & $\begin{array}{l}\text { Deposit } \\
\text { dimensions } \\
\text { (in meters } \\
\text { unless } \\
\text { otherwise } \\
\text { noted) }\end{array}$ & $\begin{array}{l}\text { Deposit shape/ } \\
\text { mineralization } \\
\text { style }\end{array}$ & Primary references \\
\hline $\begin{array}{c}12.0 \\
(2013)\end{array}$ & n.d. & Neoproterozoic sediments & Leucocratic granite & $\begin{array}{l}\text { Middle } \\
\text { Devonian }\end{array}$ & n.d. & n.d. & $\begin{array}{l}\text { Stockwork } \\
\text { veins }\end{array}$ & $\begin{array}{l}\text { Velichkin and others } \\
\text { (2000); Rubinstein and } \\
\text { Barsky (2002); Syrym- } \\
\text { bet Mining Co. (2016); } \\
\text { Peter Kettle, Internation- } \\
\text { al Tin Research Institute, } \\
\text { written commun., } \\
\text { April 8, } 2013\end{array}$ \\
\hline
\end{tabular}

\begin{tabular}{|c|c|c|c|c|c|c|c|c|}
\hline $\begin{array}{c}0.509 \\
\text { contained } \\
\text { Sn }(1985)\end{array}$ & n.d. & $\begin{array}{l}\text { Alluvium, granite, sedi- } \\
\text { ments }\end{array}$ & Granite & Mesozoic & n.d. & n.d. & n.d. & $\begin{array}{l}\text { Govett and Robinson } \\
\text { (1980); Sutphin and } \\
\text { others (1990) }\end{array}$ \\
\hline $\begin{array}{c}0.900 \\
\text { contained } \\
\text { Sn }(1985)\end{array}$ & n.d. & $\begin{array}{l}\text { Alluvium, granite, } \\
\text { limestone, sandstone, } \\
\text { metasediments }\end{array}$ & Granite & Mesozoic & n.d. & n.d. & n.d. & $\begin{array}{l}\text { Govett and Robinson } \\
\text { (1980); Sutphin and } \\
\text { others (1990) }\end{array}$ \\
\hline $\begin{array}{c}1.073 \\
(1982)\end{array}$ & n.d. & n.d. & Granite & Carboniferous & n.d. & n.d. & n.d. & Sutphin and others (1990) \\
\hline n.d. & n.d. & $\begin{array}{l}\text { Mostly calcareous rocks } \\
\text { and some shale, phyllite, } \\
\text { and schist }\end{array}$ & Granite & $\begin{array}{l}\text { Probably } \\
\text { Triassic to } \\
\text { Jurassic }\end{array}$ & $\begin{array}{l}\text { Mapping } \\
\text { and } \\
\text { stratig- } \\
\text { raphy }\end{array}$ & $48 \mathrm{~km}$ & $\begin{array}{l}\text { Multiple de- } \\
\text { posits }\end{array}$ & Rajah (1979) \\
\hline n.d. & n.d. & $\begin{array}{l}\text { Mainly sedimentary terrane, } \\
\text { middle Paleozoic }\end{array}$ & n.d. & n.d. & n.d. & $6.6 \mathrm{~km}$ & n.d. & $\begin{array}{l}\text { Bliss and Menzie (1995); } \\
\text { U.S. Geological Survey } \\
\text { (2016) }\end{array}$ \\
\hline 3.700 & 0.003 & n.d. & n.d. & n.d. & n.d. & n.d. & n.d. & n.d. \\
\hline $\begin{array}{c}7.8 \\
(2013)\end{array}$ & n.d. & $\begin{array}{l}\text { Devonian volcanics and } \\
\text { Jurassic granites }\end{array}$ & Granite & Jurassic & n.d. & $\begin{array}{l}\text { Five prospects } \\
\text { with ore } \\
\text { bodies } 60 \text { to } \\
500 \mathrm{~m} \text { long } \\
\text { and } 0.8 \text { to } \\
2.5 \mathrm{~m} \text { thick }\end{array}$ & n.d. & $\begin{array}{l}\text { Amerilangui Ujin LLC } \\
\text { (2010); Dandar (2009); } \\
\text { Jargalsaikhan (1996); } \\
\text { Peter Kettle, Interna- } \\
\text { tional } \\
\text { Tin Research Institute, } \\
\text { written commun., } \\
\text { April 8, } 2013\end{array}$ \\
\hline $\begin{array}{l}15.3 \\
\text { (combined } \\
\text { measured, } \\
\text { indicated, } \\
\text { and in- } \\
\text { ferred) }\end{array}$ & n.d. & $\begin{array}{l}\text { Interbedded sandstone and } \\
\text { siltstone ( } 315 \text { to } 325 \mathrm{Ma})\end{array}$ & $\begin{array}{l}\text { Granite at depth } \\
\text { presumed }\end{array}$ & $\begin{array}{l}\text { Presumed } \\
\text { Hercynian }\end{array}$ & $\begin{array}{l}\text { Planned } \\
\text { long- } \\
\text { hole } \\
\text { stoping }\end{array}$ & $\begin{array}{c}\text { about } 600 \mathrm{x} \\
1,600\end{array}$ & $\begin{array}{l}\text { NNE-WSW- } \\
\text { striking } \\
\text { vertical } \\
\text { mineralized } \\
\text { structures in } \\
\text { a fold and } \\
\text { thrust belt }\end{array}$ & $\begin{array}{l}\text { Blight (2012); Pierre } \\
\text { Chaponniere, Kasbah } \\
\text { Resources Ltd., written } \\
\text { commun., July 11, } 2013\end{array}$ \\
\hline NA & n.d. & $\begin{array}{l}\text { Interbedded sandstone and } \\
\text { siltstone ( } 315 \text { to } 325 \mathrm{Ma})\end{array}$ & $\begin{array}{l}\text { Granite at depth } \\
\text { presumed }\end{array}$ & $\begin{array}{l}\text { Presumed } \\
\text { Hercynian }\end{array}$ & n.d. & n.d. & $\begin{array}{l}\text { NNE-WSW- } \\
\text { striking } \\
\text { vertical } \\
\text { mineralized } \\
\text { structures in } \\
\text { a fold and } \\
\text { thrust belt }\end{array}$ & $\begin{array}{l}\text { Blight (2012); Pierre } \\
\text { Chaponniere, Kasbah } \\
\text { Resources Ltd., written } \\
\text { commun., July 11, } 2013\end{array}$ \\
\hline $\begin{array}{c}15.3 \\
(2013)\end{array}$ & n.d. & $\begin{array}{l}\text { Interbedded sandstone and } \\
\text { siltstone (315 to } 325 \mathrm{Ma})\end{array}$ & Granite assumed & Late Hercynian & n.d. & $\begin{array}{l}1,600 \times 600 \times \\
\quad 400\end{array}$ & $\begin{array}{l}\text { NNE-WSW } \\
\text { vertical } \\
\text { mineralized } \\
\text { strucures }\end{array}$ & $\begin{array}{l}\text { Bramwell (2012); Wayne } \\
\text { Bramwell, Kasbah } \\
\text { Resources Ltd., written } \\
\text { commun., July 11, } 2013\end{array}$ \\
\hline
\end{tabular}


Table S2. Location, grade, tonnage, and other data for selected tin deposits of the world with greater than 1,000 metric tons of contained tin.-Continued

[WGS 84, World Geodetic System of 1984; negative values for latitude indicate that the deposit is in the Southern Hemisphere; negative values for longitude indicate that the deposit is in the Western Hemisphere. Elements: B, boron; F, fluorine; Fe, iron; Sn, tin. Dating method: Ar-Ar, argon-argon; K-Ar, potassiumargon; Rb-Sr, rubidium-strontium; U-Pb, uranium-lead. Abbreviations: ca., circa; Ga, giga-annum, or billion years before present; ID, identification; kg/m ${ }^{3}$, kilogram per cubic meter; m, meter; Ma, mega-annum, or million years before present; NA, not applicable; n.d., no data; NNE-WSW, north-northeastwest-southwest; SHRIMP, sensitive high-resolution ion microprobe; wt. \%, weight percent]

\begin{tabular}{|c|c|c|c|c|c|c|c|c|c|c|}
\hline $\begin{array}{l}\text { Deposit } \\
\text { ID }\end{array}$ & $\begin{array}{l}\text { Deposit } \\
\text { or mine }\end{array}$ & Country & $\begin{array}{c}\text { State, } \\
\text { Territory, or } \\
\text { Province }\end{array}$ & $\begin{array}{r}\text { Latitude } \\
\text { (decima } \\
\text { WG }\end{array}$ & $\begin{array}{l}\text { Longitude } \\
\text { degrees } \\
84 \text { ) }\end{array}$ & Deposit class & Ore type & $\begin{array}{l}\text { Operation type } \\
\text { and (or) } \\
\text { comments }\end{array}$ & $\begin{array}{l}\text { Development } \\
\text { status }\end{array}$ & $\begin{array}{l}\text { Grade Sn } \\
\text { (wt. \% } \\
\text { unless } \\
\text { otherwise } \\
\text { noted) }\end{array}$ \\
\hline 74 & Bou El Jaz & Morocco & $\begin{array}{l}\text { Meknes- } \\
\text { Tafilalet } \\
\text { region }\end{array}$ & 33.28 & -5.48 & Hydrothermal & $\begin{array}{l}\text { Veins and dis- } \\
\text { seminated } \\
\text { in alteration } \\
\text { envelopes }\end{array}$ & n.d. & Drilling & $\begin{array}{c}\text { Unpublished } \\
\text { as of } \\
\text { July } 2013\end{array}$ \\
\hline 75 & Uis tin mine & Namibia & $\begin{array}{l}\text { Southern } \\
\text { Damara- } \\
\text { land }\end{array}$ & -21.22 & 14.87 & Hydrothermal & $\begin{array}{c}\text { Lode, altered } \\
\text { pegmatite }\end{array}$ & n.d. & n.d. & 0.260 \\
\hline 76 & $\begin{array}{c}\text { Jos Plateau de- } \\
\text { posits (Bau- } \\
\text { chi, Benue, } \\
\text { Kano, and } \\
\text { Zaria States) }\end{array}$ & Nigeria & $\begin{array}{l}\text { Bauchi, } \\
\text { Benue, } \\
\text { Kano, } \\
\text { and Zaria } \\
\text { States }\end{array}$ & 9.75 & 8.87 & Placer/alluvial & Placer & n.d. & n.d. & n.d. \\
\hline 77 & San Rafael & Peru & $\begin{array}{l}\text { Puno Depart- } \\
\text { ment }\end{array}$ & -14.20 & -70.47 & Hydrothermal & $\begin{array}{l}\text { Lode (veins and } \\
\text { breccias) }\end{array}$ & Open stope & n.d. & 10.100 \\
\hline
\end{tabular}

\begin{tabular}{|c|c|c|c|c|c|c|c|c|c|c|}
\hline 78 & $\begin{array}{c}\text { San Rafael } \\
\text { tailings }\end{array}$ & Peru & $\begin{array}{l}\text { Puno Depart- } \\
\text { ment }\end{array}$ & -14.20 & -70.47 & Tailings & NA & $\begin{array}{l}\text { Tailings from the } \\
\text { mill associ- } \\
\text { ated with the } \\
\text { San Rafael } \\
\text { Mine }\end{array}$ & n.d. & 1.300 \\
\hline 79 & $\begin{array}{l}\text { Neves-Corvo } \\
\text { District. Four } \\
\text { principal } \\
\text { individual } \\
\text { deposits: } \\
\text { Graca, } \\
\text { Corvo, } \\
\text { Neves, } \\
\text { Zambujal } \\
\text { and } \\
\text { Lombador }\end{array}$ & Portugal & $\begin{array}{l}\text { Baixo } \\
\text { Alentejo } \\
\text { Province }\end{array}$ & 37.60 & -7.97 & Hydrothermal & $\begin{array}{l}\text { Lode, volcanic- } \\
\text { hosted massive } \\
\text { sulfide }\end{array}$ & Underground & Active & $\begin{array}{c}\text { Graca: } 0.17 \text {; } \\
\text { Corvo: } 0.30 ; \\
\text { Neves: } 0.17 \text {; } \\
\text { Zambujal and } \\
\text { Lombador: } \\
0.07 \\
(0.25 \text { overall, } \\
\text { with grades } \\
\text { up to } 60)\end{array}$ \\
\hline 80 & $\begin{array}{l}\text { Southern mining } \\
\text { regions of } \\
\text { the former } \\
\text { Soviet Union }\end{array}$ & Russia & $\begin{array}{l}\text { Chita, Khaba- } \\
\text { rovsk }\end{array}$ & 53.00 & 124.00 & Hydrothermal & Lode & n.d. & n.d. & n.d. \\
\hline 81 & Pyrkakay & Russia & $\begin{array}{l}\text { Chukotskiy } \\
\text { Avto- } \\
\text { nomnyy } \\
\text { Okrug }\end{array}$ & 65.28 & 175.78 & Hydrothermal & Porphyry tin & $\begin{array}{l}\text { Proposed open } \\
\text { pit }\end{array}$ & Prefeasibility & 0.250 \\
\hline 82 & Pravourmiyskoe & Russia & $\begin{array}{c}\text { Khabarovsk } \\
\text { Kray }\end{array}$ & 50.43 & 134.25 & Hydrothermal & Tin greisen & n.d. & n.d. & 1.000 \\
\hline
\end{tabular}


Table S2. Location, grade, tonnage, and other data for selected tin deposits of the world with greater than 1,000 metric tons of contained tin.-Continued

[WGS 84, World Geodetic System of 1984; negative values for latitude indicate that the deposit is in the Southern Hemisphere; negative values for longitude indicate that the deposit is in the Western Hemisphere. Elements: B, boron; F, fluorine; Fe, iron; Sn, tin. Dating method: Ar-Ar, argon-argon; K-Ar, potassiumargon; $\mathrm{Rb}-\mathrm{Sr}$, rubidium-strontium; U-Pb, uranium-lead. Abbreviations: ca., circa; Ga, giga-annum, or billion years before present; ID, identification; $\mathrm{kg} / \mathrm{m}^{3}$, kilogram per cubic meter; m, meter; Ma, mega-annum, or million years before present; NA, not applicable; n.d., no data; NNE-WSW, north-northeastwest-southwest; SHRIMP, sensitive high-resolution ion microprobe; wt. \%, weight percent]

\begin{tabular}{|c|c|c|c|c|c|c|c|c|}
\hline $\begin{array}{l}\text { Resource } \\
\text { tonnage } \\
\text { (million } \\
\text { metric tons) } \\
\text { (Year } \\
\text { determined) }\end{array}$ & $\begin{array}{l}\text { Cutoff } \\
\text { grade } \\
\text { (wt. \%) }\end{array}$ & Host rock & $\begin{array}{l}\text { Mineralizing } \\
\text { rock-type }\end{array}$ & $\begin{array}{l}\text { Mineralization } \\
\text { age }\end{array}$ & $\begin{array}{l}\text { Dating } \\
\text { method }\end{array}$ & $\begin{array}{l}\text { Deposit } \\
\text { dimensions } \\
\text { (in meters } \\
\text { unless } \\
\text { otherwise } \\
\text { noted) }\end{array}$ & $\begin{array}{l}\text { Deposit shape/ } \\
\text { mineralization } \\
\text { style }\end{array}$ & Primary references \\
\hline $\begin{array}{l}\text { Unpub- } \\
\text { lished } \\
\text { as of } \\
\text { July } 2013\end{array}$ & n.d. & $\begin{array}{l}\text { Interbedded sandstone and } \\
\text { siltstone ( } 315 \text { to } 325 \mathrm{Ma} \text { ) }\end{array}$ & Granite assumed & Late Hercynian & n.d. & n.d. & n.d. & $\begin{array}{l}\text { Blight (2012); Wayne } \\
\text { Bramwell, Kasbah } \\
\text { Resources Ltd., written } \\
\text { commun., July 11, } 2013\end{array}$ \\
\hline $\begin{array}{c}16.7 \\
(1977)\end{array}$ & n.d. & Quartzite schist, pegmatite & Pegmatite & Unknown & n.d. & n.d. & n.d. & $\begin{array}{l}\text { Richards (1986); Sutphin } \\
\text { and others (1990) }\end{array}$ \\
\hline $\begin{array}{c}0.111 \\
\text { contained } \\
\text { Sn }(1969)\end{array}$ & n.d. & $\begin{array}{l}\text { Alluvium and eluvium, } \\
\text { granites, basalt }\end{array}$ & Granite & Jurassic & n.d. & n.d. & n.d. & $\begin{array}{l}\text { MacLeod and others } \\
\text { (1971); Sutphin and } \\
\text { others (1990) }\end{array}$ \\
\hline $\begin{array}{c}0.223 \\
(1980)\end{array}$ & n.d. & $\begin{array}{l}\text { Metapelites and metapsam- } \\
\text { mites-Ordovician to } \\
\text { Devonian; psammites } \\
\text { and carbonates-late } \\
\text { Paleozoic; red beds and } \\
\text { intercalated volcanics- } \\
\text { mid-Permian-Triassic; } \\
\text { psammites and carbon- } \\
\text { ates-Cretaceous; } \\
\text { felsic ignimbrites and red } \\
\text { beds-Miocene-Pliocene }\end{array}$ & $\begin{array}{l}\text { Polyphase intru- } \\
\text { sion of granite, } \\
\text { leucogranite, and } \\
\text { granodiorite }\end{array}$ & $\begin{array}{l}22.7 \pm 0.7 \text { to } \\
21.9 \pm 0.2 \\
\mathrm{Ma}\end{array}$ & $\begin{array}{c}\text { Ar-Ar on } \\
\text { hydro- } \\
\text { thermal } \\
\text { adular- } \\
\text { ia and } \\
\text { musco- } \\
\text { vite }\end{array}$ & $\begin{array}{l}3,000 \times 2 \text { to } 50 \\
\times 1,300\end{array}$ & n.d. & $\begin{array}{l}\text { Mlynarczyk and others } \\
\text { (2003); Wagner and } \\
\text { others (2009) }\end{array}$ \\
\hline $\begin{array}{c}7.7 \\
(2013)\end{array}$ & n.d. & n.d. & n.d. & n.d. & n.d. & n.d. & n.d. & $\begin{array}{l}\text { Peter Kettle, International } \\
\text { Tin Research Institute, } \\
\text { written commun., } \\
\text { April 8, } 2013\end{array}$ \\
\hline $\begin{array}{l}\text { Graca: } \\
3.45 ; \\
\text { Corvo: } \\
20.47 ; \\
\text { Neves: } \\
28.72 ; \\
\text { Zambu- } \\
\text { jal and } \\
\text { Lombador: } \\
32.34(300 \\
\text { total) }\end{array}$ & n.d. & Volcanics, granite & Granite & Carboniferous & n.d. & $\begin{array}{l}\text { Graca: } 700 \text { x } \\
500 \text { x } 80 ; \\
\text { Corvo: } 600 \\
\text { x } 1,100 \text { x } \\
92 ; \text { Neves: } \\
1,200 \text { x } 700 \\
\text { x } 55 ; \text { Zam- } \\
\text { bujal: } 550 \\
\text { x } 600 \times 53 ; \\
\text { Lombador: } \\
600 \times 1,350 \\
\text { x } 100\end{array}$ & $\begin{array}{l}\text { Massive sulfide; } \\
\text { fissure; } \\
\text { stockwork }\end{array}$ & $\begin{array}{l}\text { Mining Journal (1988); } \\
\text { Sutphin and others } \\
\text { (1990); Relvas and } \\
\text { others, } 2006\end{array}$ \\
\hline $\begin{array}{c}0.150 \\
\text { contained } \\
\text { Sn }(1989)\end{array}$ & n.d. & $\begin{array}{l}\text { Quartz porphyry granite, } \\
\text { volcanic quartz porphyry } \\
\text { tuff }\end{array}$ & Granite & 97 to $91 \mathrm{Ma}$ & n.d. & n.d. & n.d. & $\begin{array}{l}\text { Smirnov (1977); Sutphin } \\
\text { and others (1990) }\end{array}$ \\
\hline $\begin{array}{c}93.0 \\
(2013)\end{array}$ & n.d. & n.d. & n.d. & $\begin{array}{l}\text { Late Cenozoic } \\
\text { sedimentary } \\
\text { rocks }\end{array}$ & n.d. & n.d. & n.d. & $\begin{array}{l}\text { Peter Kettle, International } \\
\text { Tin Research Institute, } \\
\text { written commun., } \\
\text { April 8, } 2013\end{array}$ \\
\hline $\begin{array}{c}10.7 \\
(2013)\end{array}$ & n.d. & Felsic volcanic rocks & $\begin{array}{l}\text { Granite and leuco- } \\
\text { granite (75 to } \\
85 \mathrm{Ma}, \mathrm{K}-\mathrm{Ar} ; \\
95 \text { to } 83 \mathrm{Ma}, \\
\mathrm{Rb}-\mathrm{Sr})\end{array}$ & $\begin{array}{l}\text { Late Early } \\
\text { Cretaceous }\end{array}$ & n.d. & $\begin{array}{l}6,750 \times 375 \times \\
\quad 2,250\end{array}$ & n.d. & $\begin{array}{l}\text { Nokleberg and others } \\
\text { (2005); Peter Kettle, } \\
\text { International Tin Re- } \\
\text { search Institute, written } \\
\text { commun., April 8, } 2013\end{array}$ \\
\hline
\end{tabular}


Table S2. Location, grade, tonnage, and other data for selected tin deposits of the world with greater than 1,000 metric tons of contained tin.-Continued

[WGS 84, World Geodetic System of 1984; negative values for latitude indicate that the deposit is in the Southern Hemisphere; negative values for longitude indicate that the deposit is in the Western Hemisphere. Elements: B, boron; F, fluorine; Fe, iron; Sn, tin. Dating method: Ar-Ar, argon-argon; K-Ar, potassiumargon; Rb-Sr, rubidium-strontium; U-Pb, uranium-lead. Abbreviations: ca., circa; Ga, giga-annum, or billion years before present; ID, identification; $\mathrm{kg} / \mathrm{m}^{3}$, kilogram per cubic meter; m, meter; Ma, mega-annum, or million years before present; NA, not applicable; n.d., no data; NNE-WSW, north-northeastwest-southwest; SHRIMP, sensitive high-resolution ion microprobe; wt. \%, weight percent]

\begin{tabular}{|c|c|c|c|c|c|c|c|c|c|c|}
\hline $\begin{array}{c}\text { Deposit } \\
\text { ID }\end{array}$ & $\begin{array}{l}\text { Deposit } \\
\text { or mine }\end{array}$ & Country & $\begin{array}{c}\text { State, } \\
\text { Territory, or } \\
\text { Province }\end{array}$ & $\begin{array}{r}\text { Latitude } \\
\begin{array}{r}\text { decim } \\
\text { WC }\end{array}\end{array}$ & $\begin{array}{l}\text { Longitude } \\
\text { degrees } \\
\text { ( 84) }\end{array}$ & Deposit class & Ore type & $\begin{array}{l}\text { Operation type } \\
\text { and (or) } \\
\text { comments }\end{array}$ & $\begin{array}{c}\text { Development } \\
\text { status }\end{array}$ & $\begin{array}{l}\text { Grade Sn } \\
\text { (wt. \% } \\
\text { unless } \\
\text { otherwise } \\
\text { noted) }\end{array}$ \\
\hline 83 & $\begin{array}{l}\text { Northern min- } \\
\text { ing regions } \\
\text { of the former } \\
\text { Soviet Union }\end{array}$ & Russia & $\begin{array}{l}\text { Magadan, } \\
\text { Oblast } \\
\text { and Sakha } \\
\text { Republic }\end{array}$ & 69.00 & 140.00 & Hydrothermal & Lode, vein & n.d. & n.d. & n.d. \\
\hline 84 & Lendakhskaya & Russia & $\begin{array}{l}\text { Western } \\
\text { Siberia }\end{array}$ & 59.33 & 92.85 & Hydrothermal & Cassiterite greisen & n.d. & n.d. & 0.830 \\
\hline 85 & Kuils River & South Africa & $\begin{array}{l}\text { Cape } \\
\text { Province }\end{array}$ & -33.93 & 18.73 & Hydrothermal & $\begin{array}{l}\text { Lode, greisen } \\
\text { veins }\end{array}$ & n.d. & n.d. & 2.440 \\
\hline 86 & $\begin{array}{c}\text { Van Rooi's } \\
\text { Vley }\end{array}$ & South Africa & $\begin{array}{l}\text { Cape } \\
\text { Province }\end{array}$ & -28.50 & 20.88 & Hydrothermal & $\begin{array}{l}\text { Lode, vein } \\
\text { stockwork and } \\
\text { replacement } \\
\text { pipes }\end{array}$ & n.d. & n.d. & 0.210 \\
\hline 87 & $\begin{array}{l}\text { Rooiberg tin } \\
\text { mines }\end{array}$ & South Africa & Transvaal & -24.75 & 27.75 & Hydrothermal & Lode & $\begin{array}{c}\text { Closed in } \\
1993\end{array}$ & n.d. & n.d. \\
\hline 88 & Union tin mine & South Africa & Transvaal & -24.48 & 28.50 & Hydrothermal & Lode, vein & n.d. & n.d. & n.d. \\
\hline 89 & $\begin{array}{l}\text { Zaaiplaats tin } \\
\text { mine }\end{array}$ & South Africa & Transvaal & -24.05 & 28.75 & Hydrothermal & $\begin{array}{l}\text { Lode, veins, pipes } \\
\text { and dissemi- } \\
\text { nated ores }\end{array}$ & n.d. & n.d. & 0.165 \\
\hline 90 & Oropesa & Spain & $\begin{array}{l}\text { Cordoba } \\
\text { Province }\end{array}$ & 38.00 & -5.48 & Hydrothermal & $\begin{array}{l}\text { Veins, dissem- } \\
\text { inated ore } \\
\text { associated with } \\
\text { shear zones } \\
\text { and breccias. } \\
\text { Type unclear. } \\
\text { Post-orogenic } \\
\text { system of the } \\
\text { deep subvol- } \\
\text { canic type? }\end{array}$ & Open pit & $\begin{array}{l}\text { Preliminary } \\
\text { economic } \\
\text { assessment } \\
\text { completed } \\
\text { in } 2014\end{array}$ & 0.470 \\
\hline 91 & $\begin{array}{l}\text { Thai dredging } \\
\text { operations, } \\
\text { Southeast } \\
\text { Asian tin } \\
\text { belt }\end{array}$ & Thailand & NA & 9.00 & 99.00 & Placer/alluvial & Placer & Dredge & n.d. & 0.024 \\
\hline 92 & $\begin{array}{l}\text { Thai gravel } \\
\text { pump opera- } \\
\text { tions, South- } \\
\text { east Asian } \\
\text { tin belt }\end{array}$ & Thailand & NA & 8.00 & 99.00 & Placer/alluvial & Placer & Gravel pump & n.d. & 0.015 \\
\hline 93 & $\begin{array}{l}\text { Thai hard-rock } \\
\text { and open pit } \\
\text { operations, } \\
\text { Southeast } \\
\text { Asian tin } \\
\text { belt }\end{array}$ & Thailand & NA & 13.87 & 99.12 & Hydrothermal & Lode & n.d. & n.d. & 0.136 \\
\hline
\end{tabular}


Table S2. Location, grade, tonnage, and other data for selected tin deposits of the world with greater than 1,000 metric tons of contained tin.-Continued

[WGS 84, World Geodetic System of 1984; negative values for latitude indicate that the deposit is in the Southern Hemisphere; negative values for longitude indicate that the deposit is in the Western Hemisphere. Elements: B, boron; F, fluorine; Fe, iron; Sn, tin. Dating method: Ar-Ar, argon-argon; K-Ar, potassiumargon; Rb-Sr, rubidium-strontium; U-Pb, uranium-lead. Abbreviations: ca., circa; Ga, giga-annum, or billion years before present; ID, identification; $\mathrm{kg} / \mathrm{m}^{3}$, kilogram per cubic meter; m, meter; Ma, mega-annum, or million years before present; NA, not applicable; n.d., no data; NNE-WSW, north-northeastwest-southwest; SHRIMP, sensitive high-resolution ion microprobe; wt. \%, weight percent]

\begin{tabular}{|c|c|c|c|c|c|c|c|c|}
\hline $\begin{array}{l}\text { Resource } \\
\text { tonnage } \\
\text { (million } \\
\text { metric tons) } \\
\text { (Year } \\
\text { determined) }\end{array}$ & $\begin{array}{l}\text { Cutoff } \\
\text { grade } \\
\text { (wt. \%) }\end{array}$ & Host rock & $\begin{array}{l}\text { Mineralizing } \\
\text { rock-type }\end{array}$ & $\begin{array}{l}\text { Mineralization } \\
\text { age }\end{array}$ & $\begin{array}{l}\text { Dating } \\
\text { method }\end{array}$ & $\begin{array}{l}\text { Deposit } \\
\text { dimensions } \\
\text { (in meters } \\
\text { unless } \\
\text { otherwise } \\
\text { noted) }\end{array}$ & $\begin{array}{l}\text { Deposit shape/ } \\
\text { mineralization } \\
\text { style }\end{array}$ & Primary references \\
\hline $\begin{array}{c}0.150 \\
\text { contained } \\
\text { Sn }(1989)\end{array}$ & n.d. & $\begin{array}{l}\text { Sandstone and siltstone, } \\
\text { granite }\end{array}$ & Granite & 143 to $148 \mathrm{Ma}$ & $\mathrm{K}-\mathrm{Ar}$ & n.d. & n.d. & $\begin{array}{l}\text { Smirnov (1977); Sutphin } \\
\text { and others (1990) }\end{array}$ \\
\hline $\begin{array}{c}3.1 \\
(2013)\end{array}$ & n.d. & Granite & Granite & 880 to $864 \mathrm{Ma}$ & $\begin{array}{l}\text { SHRIMP } \\
\mathrm{U}-\mathrm{Pb} \\
\text { zircon }\end{array}$ & n.d. & $\begin{array}{l}\text { Granite intru- } \\
\text { sion contacts }\end{array}$ & $\begin{array}{l}\text { Khiltova and Pleskach } \\
\text { (1997); Vernikovsky } \\
\text { and others (2007); Peter } \\
\text { Kettle, International } \\
\text { Tin Research Institute, } \\
\text { written commun., } \\
\text { April 8, } 2013\end{array}$ \\
\hline $\begin{array}{c}0.705 \\
(1973)\end{array}$ & n.d. & Cape granite suite & Granite & $553 \pm 8 \mathrm{Ma}$ & n.d. & n.d. & n.d. & $\begin{array}{l}\text { Hill and Brunker (1981); } \\
\text { Sutphin and others } \\
\text { (1990) }\end{array}$ \\
\hline $\begin{array}{c}2.5 \\
(1984)\end{array}$ & n.d. & Paragneiss & n.d. & $940 \pm 50 \mathrm{Ma}$ & n.d. & n.d. & n.d. & $\begin{array}{l}\text { van Backström (1950); } \\
\text { Sutphin and others } \\
\text { (1990) }\end{array}$ \\
\hline n.d. & n.d. & $\begin{array}{l}\text { Arkosic quartzite, } \\
\text { shaley quartzite }\end{array}$ & n.d. & ca. $1,960 \mathrm{Ma}$ & n.d. & n.d. & n.d. & $\begin{array}{l}\text { Rozendal and others } \\
\text { (1986); Sutphin and } \\
\text { others (1990) }\end{array}$ \\
\hline n.d. & n.d. & Indurated tuff, felsite & Tuff? & $2,050 \mathrm{Ma}$ & n.d. & n.d. & n.d. & $\begin{array}{l}\text { Pringle (1986); Sutphin } \\
\text { and others (1990) }\end{array}$ \\
\hline $5.0(1986)$ & n.d. & $\begin{array}{l}\text { Leucogranite to mildly } \\
\text { alkali granite, grano- } \\
\text { phyre, microgranite }\end{array}$ & Granite & ca. $1.96 \mathrm{Ga}$ & n.d. & n.d. & n.d. & $\begin{array}{l}\text { Zaaiplaats Tin Mining } \\
\text { Co. (1983); Sutphin } \\
\text { and others (1990) }\end{array}$ \\
\hline $\begin{array}{l}5.787 \\
(2013)\end{array}$ & 0.1 & $\begin{array}{l}\text { Devonian to upper Carbon- } \\
\text { iferous quartzite, slate, } \\
\text { conglomerate of shale, } \\
\text { arenite and quartzite } \\
\text { pebbles and cobbles, } \\
\text { sandstone, greywacke, } \\
\text { shale }\end{array}$ & Foliated granite(?) & $\begin{array}{l}\text { Unknown } \\
\text { (post- } \\
\text { Carbonif- } \\
\text { erous) }\end{array}$ & n.d. & $\begin{array}{l}1,300 \times 185 \times \\
200\end{array}$ & n.d. & Baker (2012) \\
\hline $\begin{array}{l}2,583.743 \\
\quad(1982)\end{array}$ & n.d. & $\begin{array}{l}\text { Alluvial and eluvial sedi- } \\
\text { ments, granite }\end{array}$ & Granite & Cretaceous & n.d. & n.d. & n.d. & Sutphin and others (1990) \\
\hline
\end{tabular}

\begin{tabular}{|c|c|c|c|c|c|c|c|c|}
\hline $\begin{array}{c}1,630.500 \\
(1984)\end{array}$ & n.d. & Detrital sediments, granite & Granite & $\begin{array}{l}\text { Tertiary and } \\
\text { Cretaceous }\end{array}$ & n.d. & n.d. & n.d. & $\begin{array}{l}\text { Nutalaya and others (1979); } \\
\text { Sutphin and others } \\
\text { (1990) }\end{array}$ \\
\hline $\begin{array}{l}54.220 \\
(1982)\end{array}$ & n.d. & Granite & Granite & Cretaceous & n.d. & n.d. & n.d. & Sutphin and others (1990) \\
\hline
\end{tabular}


Table S2. Location, grade, tonnage, and other data for selected tin deposits of the world with greater than 1,000 metric tons of contained tin.-Continued

[WGS 84, World Geodetic System of 1984; negative values for latitude indicate that the deposit is in the Southern Hemisphere; negative values for longitude indicate that the deposit is in the Western Hemisphere. Elements: B, boron; F, fluorine; Fe, iron; Sn, tin. Dating method: Ar-Ar, argon-argon; K-Ar, potassiumargon; Rb-Sr, rubidium-strontium; U-Pb, uranium-lead. Abbreviations: ca., circa; Ga, giga-annum, or billion years before present; ID, identification; $\mathrm{kg} / \mathrm{m}^{3}$, kilogram per cubic meter; m, meter; Ma, mega-annum, or million years before present; NA, not applicable; n.d., no data; NNE-WSW, north-northeastwest-southwest; SHRIMP, sensitive high-resolution ion microprobe; wt. \%, weight percent]

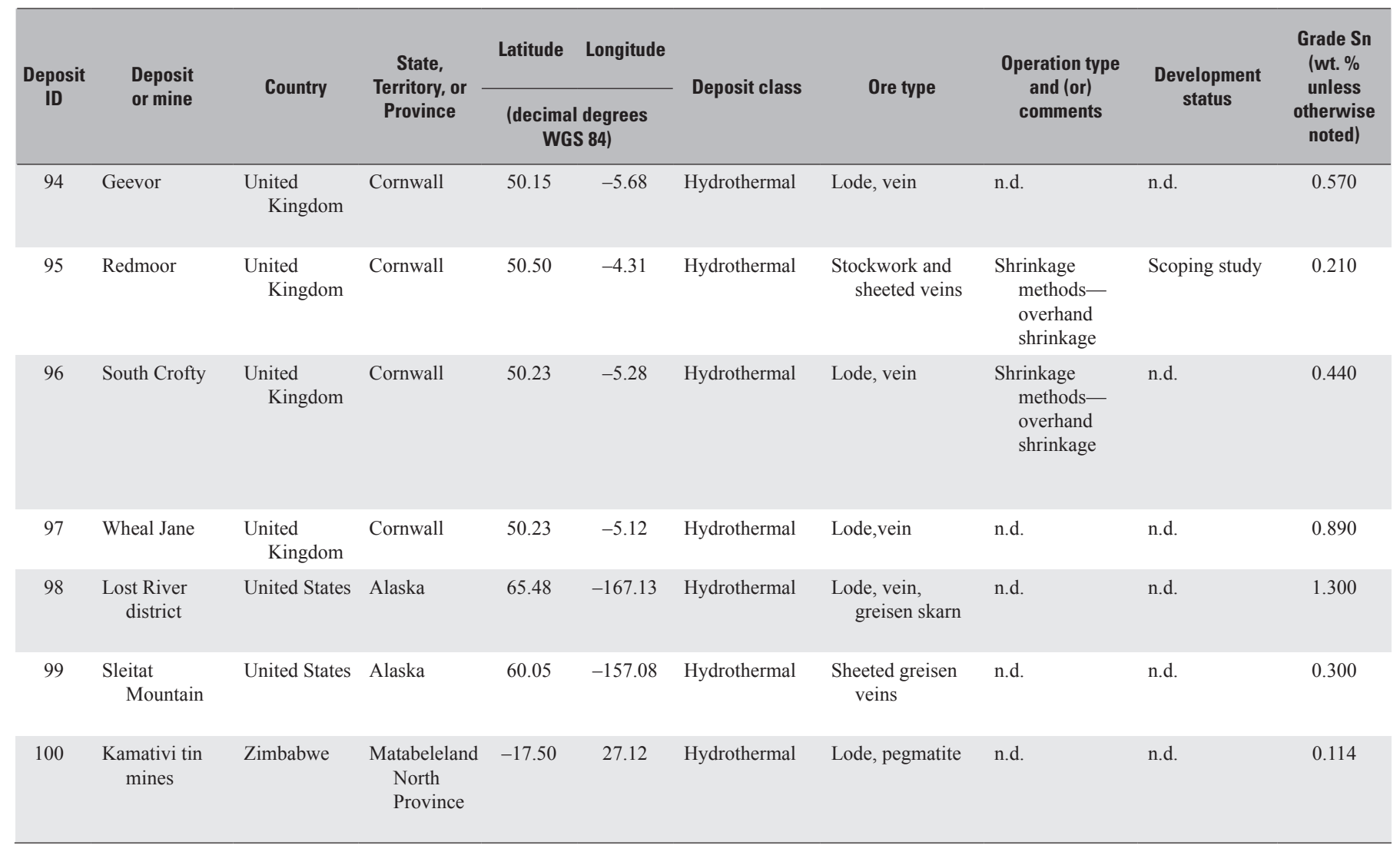


Table S2. Location, grade, tonnage, and other data for selected tin deposits of the world with greater than 1,000 metric tons of contained tin.-Continued

[WGS 84, World Geodetic System of 1984; negative values for latitude indicate that the deposit is in the Southern Hemisphere; negative values for longitude indicate that the deposit is in the Western Hemisphere. Elements: B, boron; F, fluorine; Fe, iron; Sn, tin. Dating method: Ar-Ar, argon-argon; K-Ar, potassiumargon; Rb-Sr, rubidium-strontium; U-Pb, uranium-lead. Abbreviations: ca., circa; Ga, giga-annum, or billion years before present; ID, identification; $\mathrm{kg} / \mathrm{m}^{3}$, kilogram per cubic meter; m, meter; Ma, mega-annum, or million years before present; NA, not applicable; n.d., no data; NNE-WSW, north-northeastwest-southwest; SHRIMP, sensitive high-resolution ion microprobe; wt. \%, weight percent]

\begin{tabular}{|c|c|c|c|c|c|c|c|c|}
\hline $\begin{array}{l}\text { Resource } \\
\text { tonnage } \\
\text { (million } \\
\text { metric tons) } \\
\text { (Year } \\
\text { determined) }\end{array}$ & $\begin{array}{l}\text { Cutoff } \\
\text { grade } \\
\text { (wt. \%) }\end{array}$ & Host rock & $\begin{array}{l}\text { Mineralizing } \\
\text { rock-type }\end{array}$ & $\begin{array}{l}\text { Mineralization } \\
\text { age }\end{array}$ & $\begin{array}{l}\text { Dating } \\
\text { method }\end{array}$ & $\begin{array}{l}\text { Deposit } \\
\text { dimensions } \\
\text { (in meters } \\
\text { unless } \\
\text { otherwise } \\
\text { noted) }\end{array}$ & $\begin{array}{l}\text { Deposit shape/ } \\
\text { mineralization } \\
\text { style }\end{array}$ & Primary references \\
\hline $\begin{array}{c}0.696 \\
(1986)\end{array}$ & n.d. & Slate, granite & Granite & $\begin{array}{l}270 \pm 5 \mathrm{Ma} \\
215 \pm 5 \mathrm{Ma}\end{array}$ & $\begin{array}{l}\mathrm{K}-\mathrm{Ar} \\
\mathrm{Rb}-\mathrm{Sr} \\
\mathrm{U}-\mathrm{Pb}\end{array}$ & n.d. & n.d. & $\begin{array}{l}\text { Dines (1956); Sutphin and } \\
\quad \text { others }(1990)\end{array}$ \\
\hline $\begin{array}{c}9.1 \\
(2013)\end{array}$ & n.d. & Killas slate-Devonian & Granite & $\begin{array}{l}\text { Middle Perm- } \\
\text { ian }\end{array}$ & n.d. & $500 \times 80 \times 400$ & n.d. & $\begin{array}{l}\text { Dines (1956); Peter Kettle, } \\
\text { International Tin Re- } \\
\text { search Institute, written } \\
\text { commun., April 8, } 2013\end{array}$ \\
\hline $\begin{array}{c}1.331 \\
(2013)\end{array}$ & n.d. & Granite, slate & Granite & $\begin{array}{l}270 \pm 5 \mathrm{Ma} \\
215 \pm 5 \mathrm{Ma}\end{array}$ & $\begin{array}{l}\text { K-Ar, } \\
\quad \mathrm{Rb}-\mathrm{Sr} \\
\mathrm{U}-\mathrm{Pb}\end{array}$ & n.d. & Lenticular & $\begin{array}{c}\text { Dines (1956); Sutphin and } \\
\text { others (1990); Peter } \\
\text { Kettle, International } \\
\text { Tin Research Institute, } \\
\text { written commun., } \\
\text { April 8, } 2013\end{array}$ \\
\hline $\begin{array}{c}2.380 \\
(1987)\end{array}$ & n.d. & $\begin{array}{l}\text { Slate, quartz porphyry } \\
\text { dikes }\end{array}$ & $\begin{array}{l}\text { Quartz porphyry } \\
\text { dikes }\end{array}$ & $\begin{array}{l}270 \pm 10 \mathrm{Ma} \\
215 \pm 5 \mathrm{Ma}\end{array}$ & n.d. & n.d. & n.d. & $\begin{array}{l}\text { Dines (1956); Sutphin and } \\
\quad \text { others (1990) }\end{array}$ \\
\hline $\begin{array}{c}0.0024 \\
\text { contained } \\
\text { Sn }(1963)\end{array}$ & n.d. & $\begin{array}{l}\text { Rhyolite porphyry dikes, } \\
\text { limestone, granite }\end{array}$ & Granite & $80.2 \mathrm{Ma}$ & $\begin{array}{l}\text { K-Ar on } \\
\text { biotitie }\end{array}$ & n.d. & n.d. & $\begin{array}{l}\text { Dobson (1982); Sainsbury } \\
\text { (1968); Sutphin and } \\
\text { others (1990) }\end{array}$ \\
\hline $\begin{array}{c}25.9 \\
(2013)\end{array}$ & n.d. & $\begin{array}{l}\text { Mid-Cretaceous siltstones } \\
\text { of the Kuskokwim Group }\end{array}$ & $\begin{array}{l}\text { Biotite-muscovite } \\
\text { granite }\end{array}$ & $56.8 \pm 2.8 \mathrm{Ma}$ & $\begin{array}{l}\text { K-Ar on } \\
\text { musco- } \\
\text { vite }\end{array}$ & n.d. & n.d. & $\begin{array}{l}\text { Burleigh (1991); Hudson } \\
\text { and Reed (1997) }\end{array}$ \\
\hline $\begin{array}{l}100.00 \\
(1962)\end{array}$ & n.d. & Pegmatite, schist & Pegmatite & Precambrian & n.d. & n.d. & n.d. & $\begin{array}{l}\text { Bellasis and van der Heyde } \\
\text { (1962); Rijks and van } \\
\text { der Veen (1972); Sutphin } \\
\text { and others (1990) }\end{array}$ \\
\hline
\end{tabular}





\section{Titanium}

By Laurel G. Woodruff, George M. Bedinger, and Nadine M. Piatak

Chapter T of

Critical Mineral Resources of the United States-Economic and Environmental Geology and Prospects for Future Supply

Edited by Klaus J. Schulz, John H. DeYoung, Jr., Robert R. Seal II, and Dwight C. Bradley

Professional Paper 1802-T

U.S. Department of the Interior

U.S. Geological Survey 


\section{Contents of Chapter T}

[Figure and table titles for all chapters are listed in the volume contents before the conversion factors table and list of abbreviations and symbols. A periodic table of the elements is on the inside front cover of the printed volume]

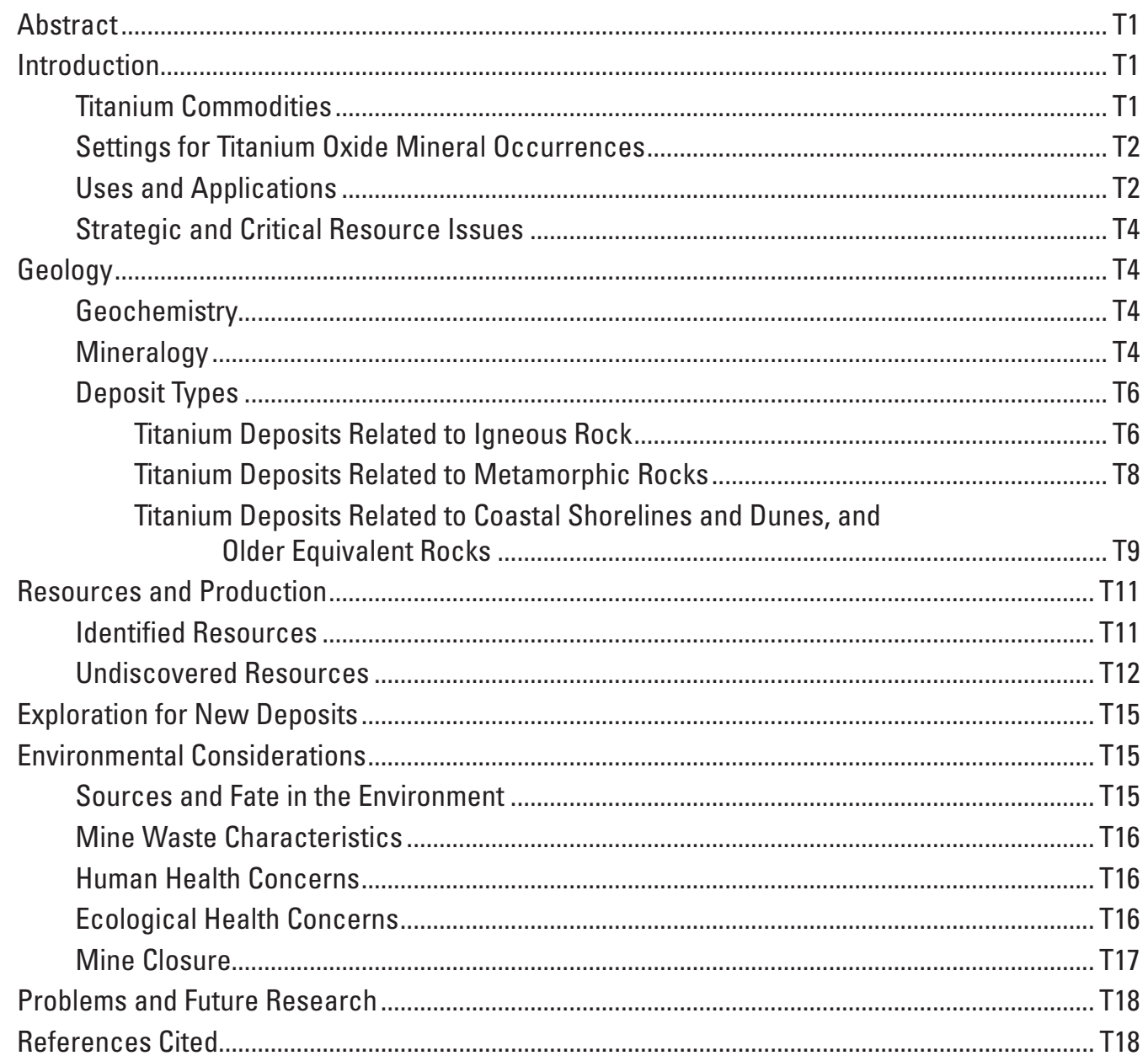




\title{
Titanium
}

\author{
By Laurel G. Woodruff, George M. Bedinger, and Nadine M. Piatak
}

\section{Abstract}

Titanium is a mineral commodity that is essential to the smooth functioning of modern industrial economies. Most of the titanium produced is refined into titanium dioxide, which has a high refractive index and is thus able to impart a durable white color to paint, paper, plastic, rubber, and wallboard. Because of their high strength-to-weight ratio and corrosion resistance, titanium metal and titanium metal alloys are used in the aerospace industry as well as for welding rod coatings, biological implants, and consumer goods.

Ilmenite and rutile are currently the principal titaniumbearing ore minerals, although other minerals, including anatase, perovskite, and titanomagnetite, could have economic importance in the future. Ilmenite is currently being mined from two large magmatic deposits hosted in rocks of Proterozoic-age anorthosite plutonic suites. Most rutile and nearly one-half of the ilmenite produced are from heavymineral alluvial, fluvial, and eolian deposits. Titanium-bearing minerals occur in diverse geologic settings, but many of the known deposits are currently subeconomic for titanium because of complications related to the mineralogy or because of the presence of trace contaminants that can compromise the pigment production process.

Global production of titanium minerals is currently dominated by Australia, Canada, Norway, and South Africa; additional amounts are produced in Brazil, India, Madagascar, Mozambique, Sierra Leone, and Sri Lanka. The United States accounts for about 4 percent of the total world production of titanium minerals and is heavily dependent on imports of titanium mineral concentrates to meet its domestic needs.

Titanium occurs only in silicate or oxide minerals and never in sulfide minerals. Environmental considerations for titanium mining are related to waste rock disposal and the impact of trace constituents on water quality. Because titanium is generally inert in the environment, human health risks from titanium and titanium mining are minimal; however, the processes required to extract titanium from titanium feedstock can produce industrial waste.

\section{Introduction}

Titanium is an abundant element that has become an important industrial commodity only within the past 150 years. Ilmenite $\left(\mathrm{FeTiO}_{3}\right)$ and rutile (which is the most common form of titanium dioxide $\left[\mathrm{TiO}_{2}\right]$ ) are the two principal minerals that are sources of titanium. Pure titanium metal was first isolated in 1910, but the metal was not commercially available until the development of the Kroll process by William Kroll in 1938. In this process, titanium is produced by reduction of titanium tetrachloride with magnesium. Titanium is now considered essential for modern industrial technology production as well as to meet other needs of modern affluent societies. Many of the uses for titanium in modern industry, including in pigments for paints and paper and in manufacturing by the aerospace industry, are described by Gambogi (2012) and Murphy and Frick (2006). Although the United States is dependent on imports of titanium mineral concentrates and titanium sponge, the United States continues to be a net exporter of $\mathrm{TiO}_{2}$ pigment and titanium wrought-metal products.

\section{Titanium Commodities}

The major titanium commodities and their industrial uses are described in Murphy and Frick (2006). Titanium commodity sources include both titanium-bearing oxide minerals extracted from natural sources and synthetic titaniumbearing materials processed from these minerals. Some 93 percent of the world's titanium resources are accounted for by the mineral ilmenite; the remaining percentage is mainly from rutile and leucoxene. Leucoxene is not a true mineral but is, rather, a finely crystalline aggregate of rutile, anatase, or brookite with greater than 70 percent $\mathrm{TiO}_{2}$ that is created by the weathering of ilmenite. Rutile, anatase, and brookite are $\mathrm{TiO}_{2}$ polymorphs; that is, minerals that share the same chemical composition of $\mathrm{TiO}_{2}$ but have different crystal forms.

Ilmenite, rutile, and leucoxene are processed mainly into titanium-rich slag or synthetic rutile and then further processed for use in pigments and as titanium metal. Titanium slag, which 
is derived by smelting ilmenite, contains about 75 to 86 percent $\mathrm{TiO}_{2}$; with further processing by high-pressure acid leaching, titanium slag can be upgraded to about 94.5 percent $\mathrm{TiO}_{2}$ (Guéguin and Cardarelli, 2007). Synthetic rutile is produced by removing iron from secondary ilmenite feed, which increases its $\mathrm{TiO}_{2}$ content to about 90 to 95 percent $\mathrm{TiO}_{2}$ from about 50 to 55 percent $\mathrm{TiO}_{2}$ (Mackey, 1994). Synthetic rutile can be used as a substitute for natural rutile.

Two main industrial processes - a sulfate process and a chloride process - are currently used to convert the raw materials of ilmenite and rutile into pure white $\mathrm{TiO}_{2}$ for use in pigment or into titanium metal (Mackey, 1994). The sulfate process is the older of the two processes; it was perfected in 1916 by two Norwegian chemists (Korneliussen and others, 2000a). In the sulfate process, finely ground ilmenite or high- $\mathrm{TiO}_{2}$ slag is digested with concentrated sulfuric acid. In the chloride process, high titanium-content feedstock, such as natural and synthetic rutile, high- $\mathrm{TiO}_{2}$ slag, or high- $\mathrm{TiO}_{2}$ ilmenite sands, is converted into titanium chlorides at high temperature. As of 1992, the sulfate and chloride processes produced about equal amounts of product; however, because it produces a superior $\mathrm{TiO}_{2}$ pigment product and fewer waste products, the chloride process has largely supplanted the sulfate process. This shift from the sulfate process to the chloride process for $\mathrm{TiO}_{2}$ pigment production has increased demand for a high-grade titanium feedstock, such as rutile, upgraded titanium-rich slag, and synthetic rutile.

\section{Settings for Titanium Oxide Mineral Occurrences}

The diverse types of economic and potentially economic titanium deposits originally categorized by rock type and environment by Force (1991) have been updated in table T1 and are described in the geology section of this chapter. Major deposit types listed in table T1 include (a) magmatic deposits in igneous and related rocks with ilmenite as the primary ore mineral; (b) metamorphic deposits with rutile as the primary ore mineral; (c) rutile in hydrothermal porphyry deposits, and (d) heavy-mineral concentrations in unconsolidated and lithified sand deposits that may include rutile, ilmenite, and alteration products, such as leucoxene. Most deposit types (for example, those in the I-8 and S-4 classes) can be further altered by weathering, at times upgrading the titanium content of the ilmenite, if present.

Ilmenite accounts for about 92 percent of the world's consumption of titanium minerals. The world's two active magmatic titanium mines - the Tellnes Mine in Norway and the Lac Tio Mine in the Province of Quebec, Canadatogether produce an estimated 32 percent of the world's titanium (Gross, 1996; Schiellerup and others, 2003). The remaining 68 percent comes from high-grade ilmenite and rutile heavy-mineral deposits in unconsolidated heavy-mineral shoreline and dune deposits, fluvial placers (surface mineral deposits formed by mechanical concentration of minerals from weathered rock), and older lithified equivalents.
Magmatic iron-titanium-oxide-rich deposits are hosted by a complex suite of mafic rocks that includes anorthosite, gabbro, and norite. The principal ore minerals are ilmenite and hemo-ilmenite, which is ilmenite that has extensive hematite $\left(\mathrm{Fe}_{2} \mathrm{O}_{3}\right)$ exsolution lamellae, so that hematite occurs as small parallel plates within larger ilmenite crystals. Titaniferous magnetite, which is a complex oxide made up primarily of magnetite $\left(\mathrm{Fe}_{3} \mathrm{O}_{4}\right)$ with iron-titanium-oxide exsolution lamellae, can also occur in these rocks in high concentrations, but it is of less economic importance because of its low titanium content.

Heavy-mineral deposits contain concentrations of iron-titanium-oxide minerals that are denser than quartz and so lag behind during erosion and weathering as lighter minerals are more rapidly transported away or broken down. A typical mineral assemblage in heavy-mineral deposits can include rutile and ilmenite (and minerals produced from the weathering of ilmenite, such as anatase, leucoxene, and pseudorutile), as well as other high-density, erosion-resistant minerals, including chromite, garnet, kyanite, monazite, staurolite, tourmaline, and zircon. Heavy-mineral deposits develop when relatively resistant iron-titanium-oxide minerals and other heavy minerals, such as monazite and zircon, are eroded from the parent rocks, transported and sorted, and finally deposited in fluvial, alluvial, or eolian settings. Many productive heavy-mineral provinces, such as the East Coast of the United States, the east and west coasts of South Africa, and the east and west coasts of Australia, are located on passive continental margins that are usually backed by elevated and often highly weathered high-grade metamorphic or mafic igneous hinterlands (Force, 1991).

\section{Uses and Applications}

About 93 percent of the world's titanium is refined into $\mathrm{TiO}_{2}$ for pigment; consequently, trends in the $\mathrm{TiO}_{2}$ pigment industry exert a large influence on the development of titanium resources (Towner and others, 1988; Murphy and Frick, 2006). Titanium dioxide has properties of whiteness, opacity, and chemical inertness that make it especially suitable for use as pigment to impart a durable white color to paints, paper, plastic, sunscreen, toothpaste, and wallboard (Miller, 1957; Stamper, 1970). The leading uses of $\mathrm{TiO}_{2}$ pigment in the United States in 2012 were paint (59 percent), plastics ( 28 percent), paper ( 9 percent), and other ( 4 percent) (Bedinger, 2013). Titanium is different than most other metallic elements in that it is mined primarily to satisfy demands for a chemical product $\left(\mathrm{TiO}_{2}\right.$ for pigment) rather than for the metal itself (Murphy and Frick, 2006). The high cost of extracting titanium metal from ore curtails broader use of titanium metal and alloys.

About 2.5 percent of the world's titanium is used for the production of corrosion-resistant titanium metal (Murphy and Frick, 2006). Titanium metal alloys are desirable for their high strength-to-weight ratio and corrosion resistance, 
Table T1. Classification of selected titanium mineral deposits based on their geologic setting and the processes through which they were formed.

[Modified from Force (1991). The relative economic importance of each deposit type, which is subjective, is indicated as follows: 1, of great current importance; 2, of probable great importance in the near future; 3 , of possible importance; 4 , of moderate importance; and 5 , of minor importance. Locality abbreviations: Ark., Arkansas; Colo., Colorado; Fla., Florida; Md., Maryland; Minn., Minnesota; N.Y., New York; Va., Virginia]

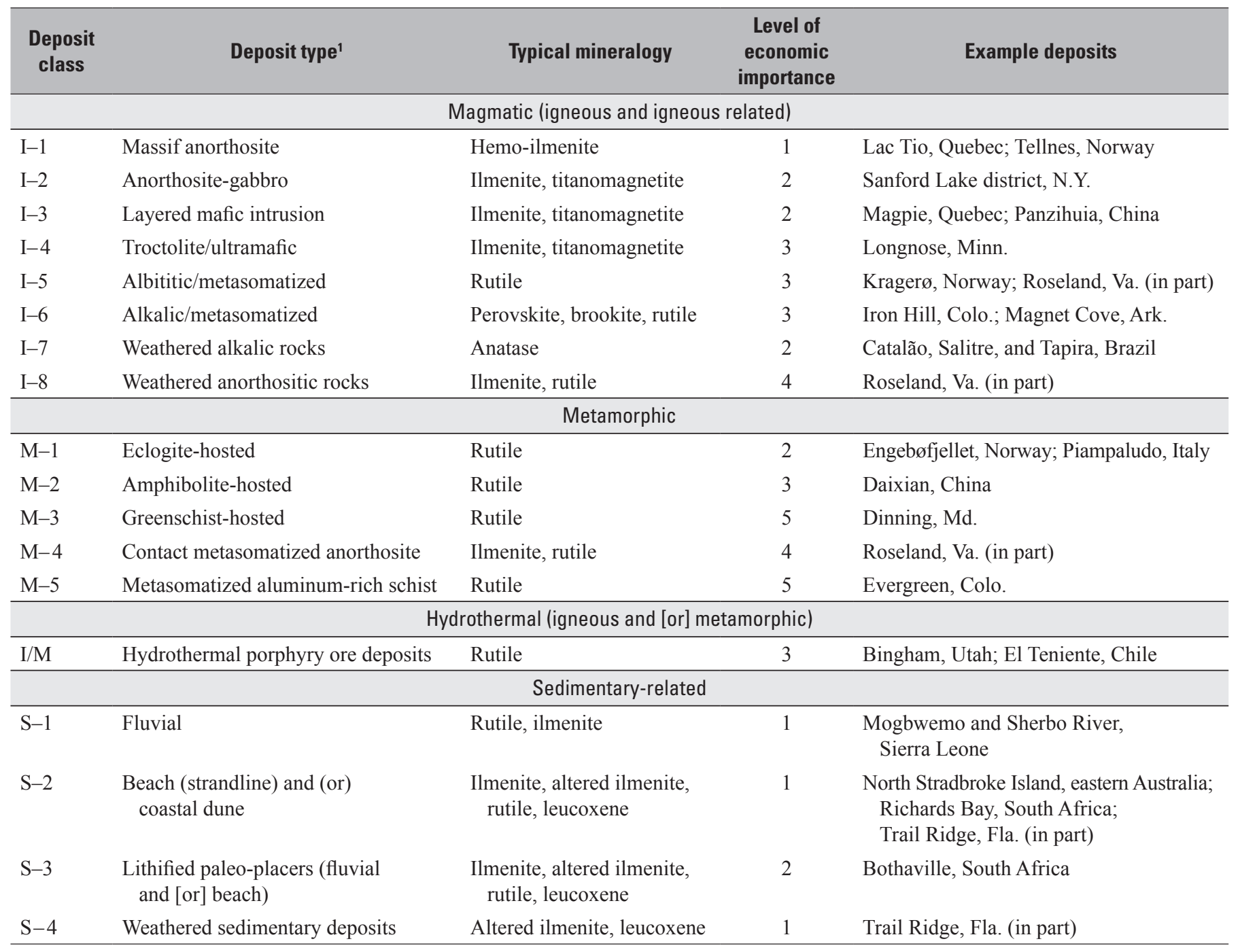

${ }^{1}$ Individual deposit types are further classified and described more fully in the text.

and they are used widely in the manufacturing of aircraft. In general, production of titanium mill products precedes aircraft deliveries by about 1 year. In 2010, mill product shipments increased by 62 percent because of increased aircraft build rates and higher inventory levels throughout the titanium supply chain (Gambogi, 2012). The aerospace industry (67 percent) was the leading end user of mill products.

Titanium has other important end uses. For example, titanium is used in welding-rod coatings, where it protects the surfaces of a weld from unwanted reaction with the atmosphere during welding, as well as in the manufacture of mineral fibers; it is used in ceramic components for electronic equipment, and in carbides and other titanium chemicals. Because of titanium's resistance to corrosion in saltwater, it is used in shipbuilding, deep-sea petroleum exploration and production, and geothermal power-generating facilities. A significant quantity of titanium in the form of ferrotitanium, scrap, and sponge (a porous form of titanium created during the first stage of processing) is consumed in the steel and nonferrous metal alloy industries. In the steel industry, titanium is used for deoxidation, grain size control, and controlling and stabilizing carbon and nitrogen content. Titanium-intensive steels include interstitial-free, stainless, and high-strength low-alloy steels. Titanium has the property of osseointegration, which means that it can be structurally accepted by bone, and because titanium is nonreactive, it is increasingly used to make medical devices, such as hip and knee joints, bone screws and plates, and dental implants. 


\section{Strategic and Critical Resource Issues}

Titanium is considered a critical and strategic mineral because of the unique properties of both titanium metal (and its alloys) and $\mathrm{TiO}_{2}$ pigment. There are no completely satisfactory substitutes for titanium, especially titanium metal (Towner and others, 1988). Titanium metal's combination of corrosion resistance, excellent weight-to-strength ratio, and very high melting point is not found with other metals. Substitutes for $\mathrm{TiO}_{2}$ pigment, such as zinc oxide, lithopone (a mixture of barium sulfate and zinc sulfide), and calcium carbonate, generally result in an inferior product and are less environmentally safe. Although lead has similar whitening properties, titanium dioxide pigment replaced lead as a whitener because of public health issues related to lead toxicity.

Consumption of titanium mineral concentrates in the United States exceeds domestic production (Gambogi, 2012). From 2008 to 2012, U.S. consumption of titanium concentrates averaged about 1,400,000 metric tons. The net import reliance for the United States in that same time period, as a percentage of apparent consumption, was between 65 and 78 percent. The primary sources of U.S. imports of titanium mineral concentrates, which include ilmenite, rutile, synthetic rutile, and titanium slag, were Australia, Canada, Mozambique, and South Africa.

The titanium feedstock industry is dominated by a relatively few companies at both ends of the supply chain; consequently, the actions of a few industry leaders can have implications for the entire industry (Murphy and Frick, 2006). Titanium resources are located in relatively few countries, which means that many industrial nations are dependent on titanium imports (Towner and others, 1988). In addition, the influence of China is an important strategic issue for the titanium industry, as increased economic growth in that nation will likely increase its consumption of titanium minerals, pigments, and metal in the long term (Gambogi, 2012). Increasing demand in China for titanium will be paced by increasing demand in the United States as the U.S. economy recovers from the recession that began in 2008 and as aerospace, defense, and industrial uses grow. For example, new lighter and fuel-efficient aircraft and ground vehicles will require significantly more titanium in their structures to reduce weight and increase durability. Global consumption of titanium by the defense industry alone was expected to increase by slightly more than 30 percent between 2010 and 2015 (Gambogi, 2012). Improving global economic conditions resulted in a 7 percent increase in domestic $\mathrm{TiO}_{2}$ pigment production from 2009 to 2010 (Gambogi, 2012). Thus, the dynamics of the global titanium industry are a complex interdependence of supply and demand, industry activities, and environmental regulations, all of which could be highly influenced by the discovery of new uses for titanium and by technological advances in the extraction and production of titanium metal and $\mathrm{TiO}_{2}$ pigment.

\section{Geology}

\section{Geochemistry}

Titanium is the ninth most abundant element in Earth's crust, with an average $\mathrm{TiO}_{2}$ abundance of 0.7 weight percent (Rudnick and Fountain, 1995). Titanium can be found in nearly all rocks and sediments, often at contents greater than 1 weight percent, and thus, unlike many other elements of economic interest, it is considered to be a major element rather than a trace element. Titanium is a transition element with atomic number 22 and an atomic mass of 47.867 atomic mass units. Titanium's chemistry has similarities to the chemistries of silicon and zirconium. The main oxidation state is $\mathrm{Ti}^{4+}$, although $\mathrm{Ti}^{2+}$ and $\mathrm{Ti}^{3+}$ are known to exist. Titanium is a lithophile element with a strong affinity for oxygen, and it typically forms oxide minerals. It is not found as a pure metal in nature, and processing is required to produce a low-density, high-strength metal. Titanium metal has excellent corrosion resistance, and it is as strong as steel but 45 percent lighter.

\section{Mineralogy}

The most economically important titanium oxides are ilmenite $\left(\mathrm{FeTiO}_{3}\right)$ and the titanium dioxide $\left(\mathrm{TiO}_{2}\right)$ polymorphs rutile, anatase, and brookite. Only some titanium-bearing oxide minerals currently have economic value. Less common, subeconomic minerals include pseudobrookite $\left(\mathrm{Fe}_{2} \mathrm{TiO}_{5}\right)$, perovskite $\left(\mathrm{CaTiO}_{3}\right)$, geikielite $\left((\mathrm{Mg}, \mathrm{Fe}) \mathrm{TiO}_{3}\right)$, pyrophanite $\left(\mathrm{MnTiO}_{3}\right)$, and titanite or sphene $\left(\mathrm{CaTiSiO}_{5}\right)$. The titanium content in titanomagnetite ranges between about 2 percent and about 20 percent, and titaniferous magnetite as a group of iron-titanium-oxide ore minerals contains between about 1 percent and about 15 percent titanium (fig. T1; Rose, 1969).

The mineralogy of iron-titanium oxides in magmatic deposits is dependent on several factors, including the initial magma composition, the magma oxygen fugacity, and the cooling history. At magmatic temperatures ( $>700$ degrees Celsius $\left[{ }^{\circ} \mathrm{C}\right]$ ), iron-titanium-rich liquids are in a single, homogenous phase after which, during cooling, the liquids will separate into two or more oxide minerals. In a hightemperature titanium-rich magma, a small amount of hematite $\left(\mathrm{Fe}_{2} \mathrm{O}_{3}\right)$ will separate out of the cooling oxide phase to form thin lamellae within ilmenite crystals. Deposits dominated by the composite mineral hemo-ilmenite (fig. T2A) are the largest and most economically important magmatic deposits. In more iron-rich magmas under varying magmatic conditions, a titanium-rich phase (usually ilmenite or ulvöspinel $\left.\left[\mathrm{Fe}_{2} \mathrm{TiO}_{4}\right]\right)$ will separate from magnetite $\left(\mathrm{Fe}_{3} \mathrm{O}_{4}\right)$ to form (a) titanomagnetite, which is a complex mixture of irontitanium oxides with thin exsolution lamellae of ilmenite or ulvöspinel in magnetite, or (b) granular, interlocking discrete grains of ilmenite, ulvöspinel, and magnetite (fig. T2B). Titaniferous magnetite is a general mining term applied to low-temperature aggregations of hematite, ilmenite, 


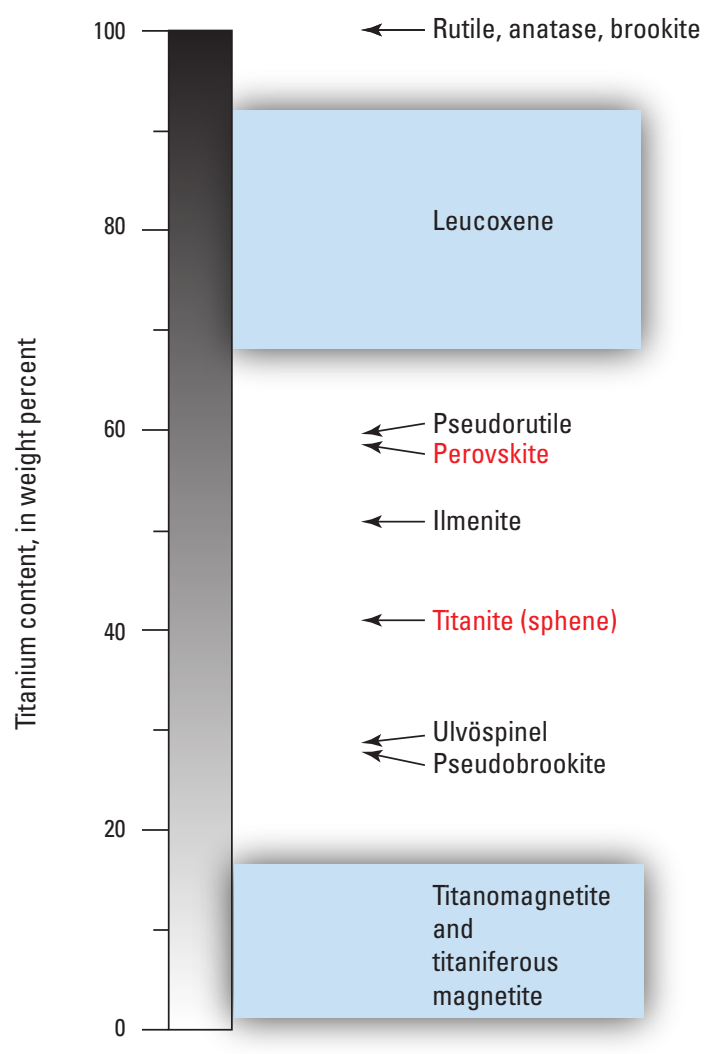

Figure T1. Chart showing common titanium-bearing oxide minerals (black text) and common titanium-bearing silicate minerals (red text) with their approximate titanium content (in weight percent). The blue shaded boxes represent the range of titanium content for the mineral species in the boxes.

magnetite, titanomagnetite, and other intermediate members of the iron-titanium-oxide solid solution series (Rose, 1969). With current technologies, deposits dominated by titaniferous magnetite are generally too high in titanium to mine for iron ore yet too low in titanium to mine for titanium; however, if metallurgical problems with extraction and separation could be resolved, then deposits containing very large resources of titaniferous magnetite could be economically viable for both elements (Rose, 1969). Substitution of aluminum, calcium, chromium, copper, magnesium, manganese, silicon, vanadium, and zinc in the ilmenite crystal structure can lower the quality of ilmenite concentrate, as these elements decrease the $\mathrm{TiO}_{2}$ grade and may affect pigment color (Chernet, 1999). Ilmenite also is a common detrital mineral, being somewhat resistant to erosion processes. Weathering of ilmenite typically involves progressive leaching of iron from its mineral structure, thereby enriching the altered ilmenite in titanium and potentially forming pseudorutile $\left(\mathrm{Fe}_{2} \mathrm{Ti}_{3} \mathrm{O}_{9}\right)$, leucoxene, and rutile (fig. T1). Because of this upgrading in titanium content, altered ilmenite is a preferred ore target.
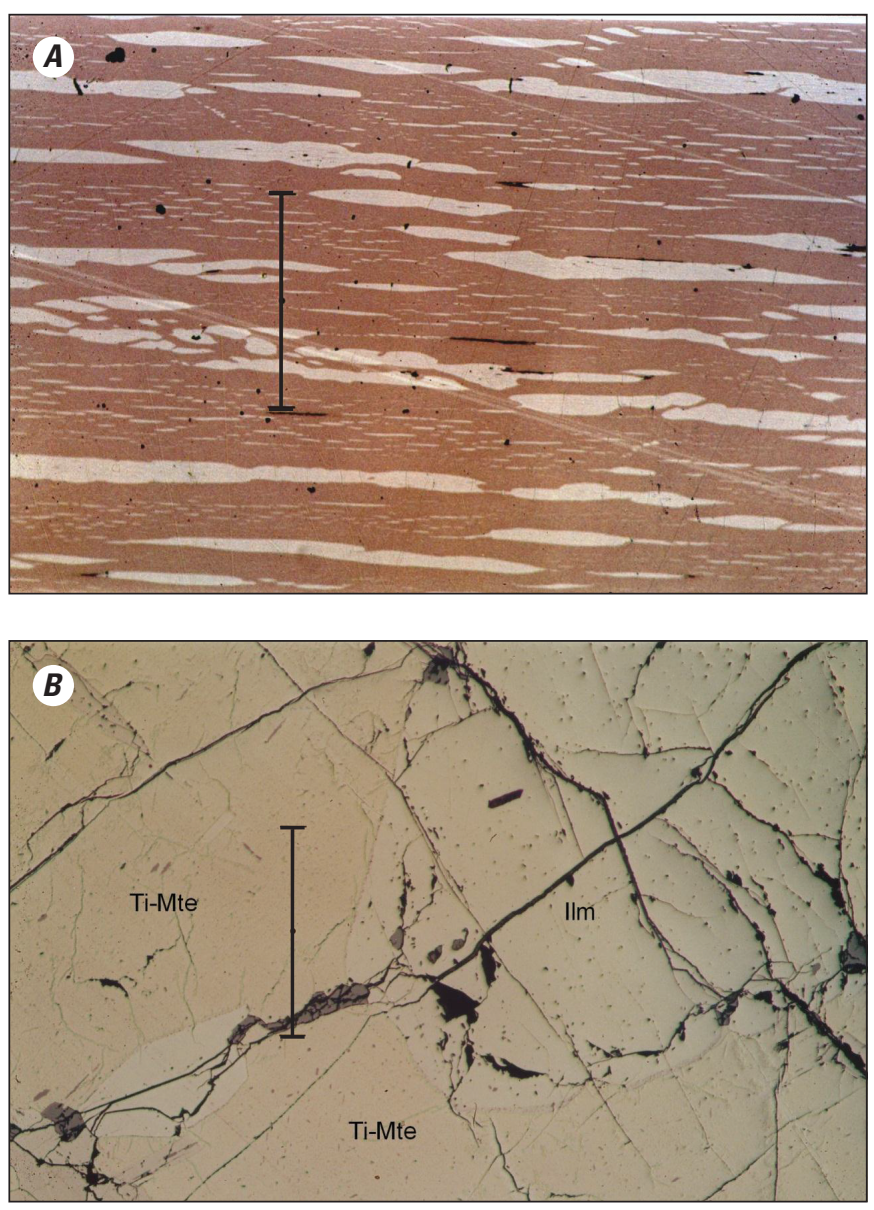

Figure T2. Reflected-light photographs showing $A$, lamellae of hematite (light-pink) in ilmenite (dark pink) in hemo-ilmenite from the magmatic Lac Tio hemo-ilmenite deposit, and $B$, titaniferous magnetite (Ti-Mte) and ilmenite (IIm) from the magmatic La Blache iron-titanium-oxide deposit. Scale bar is 0.5 millimeters in length. Photographs courtesy of Serge Perreault, SOQUEM, Inc.

Rutile is the most common of the $\mathrm{TiO}_{2}$ polymorphs. It has a high index of refraction and thus a high degree of opacity, which accounts for rutile's desirability for use in pigments. Rutile occurs as an accessory mineral in many igneous rocks and in all grades of metamorphic rocks. With increasing metamorphic grade, the breakdown of ilmenite and silicates will release titanium, which then crystallizes into rutile. Rutile is highly stable across most geologic environments, which explains its presence in a wide range of rock types and as a common detrital mineral. Rutile can be a major host mineral for niobium, tantalum, tungsten, uranium, zirconium, and ferric iron. The presence of trace elements is in part dependent on the availability of trace constituents during rutile formation. Anatase and brookite are low-temperature alteration products of ilmenite or titanite. 


\section{Deposit Types}

Table $\mathrm{T} 1$ shows the classification of titanium mineral deposit types. These classifications can have considerable overlap. For example, magmatic concentrations of iron- and titanium-bearing silicates and oxides can be metamorphosed to form rutile, weathered from parent rocks to subsequently reside in place within weathered zones, or transported and sorted by wind or water to form heavy-mineral deposits. A common thread among all the deposit types described in table $\mathrm{T} 1$ is their ultimate origin from rocks somewhat enriched in titanium by geologic processes.

The worldwide distribution of titanium deposits is shown in figure T3. The economic value and mining potential of a titanium deposit is highly dependent on its mineralogy rather than its overall titanium content. Although there are very large global resources of ilmenite and rutile combined, there is a worldwide lack of high-grade, high-quality ilmenite deposits as well as of high-quality rutile deposits (Korneliussen and others, 2000a). Mineral assemblage, grain size, morphology, texture, and type and quantity of included trace elements all contribute to the economic potential of a deposit.

Qualitative differences in the approximate $\mathrm{TiO}_{2}$ content of different deposit types are shown in figure T4. In sedimentary deposits, titanium-bearing minerals have been released from their parent rock; thus, low-grade deposits of this type may be mined if the titanium minerals are of sufficiently high quality, either through alteration of ilmenite or by the presence of rutile. Brooks (1976, p. 149), in postulating that the ultimate "cut-off grade" for each metal is its crustal abundance, acknowledges former U.S. Geological Survey Director Vincent McKelvey for pointing out that the titanium content of ilmenite beach placers mined in Florida is below the crustal abundance of titanium.

The presence or absence of discrete crystals of ilmenite is a key factor that determines the economic value of most magmatic oxide deposits. In magmatic hemo-ilmenite deposits, such as the deposit at Tellnes (Norway), ore has to be mined and crushed and the ilmenite separated from the waste rock; therefore, ore grades in these types of deposits must be high (Korneliussen and others, 2000a). Deposits with unconventional titanium ore minerals, such as Iron Hill (Colorado; also called Powderhorn in the literature), which host perovskite, are currently uneconomic; likewise, the anatase deposits in Brazil (the Catalão, Salitre, and Tapira deposits) are not being exploited for titanium at this time.

\section{Titanium Deposits Related to Igneous Rock}

Mafic intrusions of various age and rock types can contain significant iron-titanium-oxide deposits. Deposits dominated by ilmenite and hemo-ilmenite are hosted by discordant and layered bodies in Proterozoic-age massif anorthosite plutonic complexes. These unique rock suites are restricted in time, from about 0.5 to $2.5 \mathrm{Ga}$ (giga-annum, or billion years ago); the majority that contain significant titanium resources were emplaced from about 1.0 to $1.8 \mathrm{Ga}$ (Ashwal, 2010). The plutonic suites are dominated by different and often unusual mafic rock types. These rocks are called, for example, anorthosite, charnockite, jotunite, gabbro, norite, or troctolite. The different names distinguish among rocks with various proportions and compositions of plagioclase and pyroxene. Anorthosite plutonic suites of the Grenville Province in eastern Canada and parts of the Northeastern United States and the Rogaland anorthosite province in Norway contain numerous iron-titanium-oxide deposits (Rose, 1969; Krause and others, 1985; Corriveau and others, 2007). Hemo-ilmenite (with little or no magnetite) is currently being mined at Lac Tio in Quebec Province, Canada, and is hosted by the Allard Lake anorthosite in the Havre-Saint-Pierre anorthosite plutonic suite (Gross, 1996). Hemo-ilmenite is also being mined at Tellnes, which is a hemo-ilmenite-bearing norite lens in the Åna-Sira anorthosite pluton in Norway (Wilmart and others, 1989). A deposit model for titanium deposits hosted by Proterozoic-age massif anorthosite plutonic suites was completed by Woodruff and others (2013).

Deposits dominated by titaniferous magnetite with minor amounts of ilmenite are hosted in layered and massive intrusions of gabbro, leucogabbro (light-colored gabbro), and norite, which can include, but are not restricted to, Proterozoic-age massif anorthosites (Gross, 1996). These types of deposits have somewhat different characteristics than the magmatic deposits typified by Lac Tio or Tellnes, including differences in host rock form, dominant ore mineralogy, and proposed magmatic history. Examples include numerous deposits in layered and discordant anorthositenorite-gabbro intrusions in the Grenville Province, such as Magpie Mountain and Lac la Blache (Canada) and Sanford Lake district in the Adirondacks (New York), and large layered mafic intrusions of various ages, such as the Bushveld Complex (South Africa), which is currently being exploited for vanadium from titaniferous magnetite. Titanomagnetite and ilmenite are mined for iron, titanium, and vanadium from several deposits in the Permian-age Panzhihua layered mafic intrusion in China (Zhou and others, 2005).

Other magmatic occurrences are somewhat enigmatic. For example, in the Duluth Complex of Minnesota, small bodies of ilmenite and titanomagnetite hosted by ultramafic rocks that cross-cut gabbroic rocks are a significant (but presently subeconomic) titanium resource. The origin of these deposits remains under debate (Hauck and others, 1997). In Finland, the relatively small Koivusaarenneva gabbro intrusion contains layers of ilmenite (with minor amounts of magnetite) that are interpreted as iron-titanium-oxides deposited in a flow-through magmatic system that has created a large resource in a small-volume intrusion (Kärkkäinen and Bornhorst, 2003).

Formation of iron-titanium-oxide deposits in mafic intrusions requires favorable combinations of composition, oxygen fugacity, and crystallization history, which determine if a deposit is dominated by ilmenite or titaniferous magnetite (Woodruff and others, 2013). Massive hemo-ilmenite 


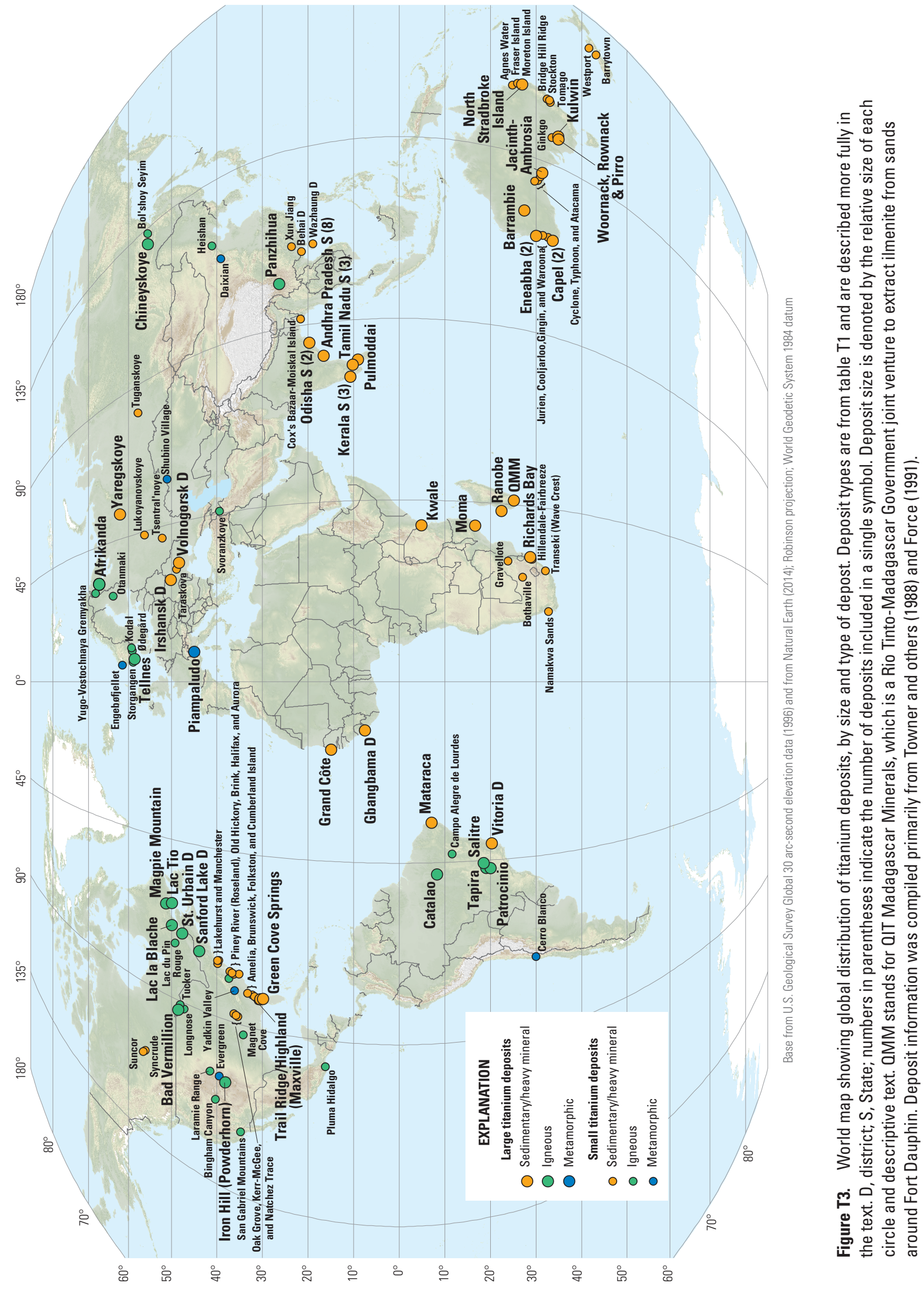


Figure T4. Bar chart comparing approximate titanium dioxide $\left(\mathrm{TiO}_{2}\right)$ content in titanium deposits of different deposit types (modified from Korneliussen and others, 2000a). The sources of ore given here as examples are average crustal abundance (Rudnick and Fountain, 1995); average rutile and ilmenite sands (sedimentary) (Force, 1991); rutile in eclogite from the Engebøfjellet deposit in Norway (metamorphic) (Korneliussen and others, 2000a); perovskite in pyroxenite at the Iron Hill (Powderhorn) deposit in Colorado (igneous) (Van Gosen, 2009); hemoilmenite in anorthosite at the Tellnes deposit in Norway (igneous) (Korneliussen and others, 2000a); and anatase in weathered rocks from the Catalão, the Salitre, and the Tapira deposits in Brazil (Force, 1991).

deposits, such as those at Lac Tio and Tellnes, are thought to have formed by early magmatic crystallization of ilmenite (Duchesne, 1999; Charlier and others, 2010). Deposits dominated by titaniferous magnetite in layered intrusions may represent late-stage concentrations of iron and titanium in magmatic liquids following extensive silicate crystallization.

When rocks are affected by metasomatism (a process that changes the chemical composition of rocks by the introduction of external fluids), titanium minerals in the host rock may be altered. For example, at the Bamble-Arendal iron-titanium province of Norway, Proterozoic-age mafic rocks were affected by local and regional alkali-metasomatism during which original ilmenite was converted to rutile by the removal of iron (Korneliussen and others, 2000a). In this district, rutile was mined at Kagerø from a rutile-rich vein (Force, 1991). At Roseland, Va., rutile that occurs in metasomatized shear zones along complex contacts of anorthosite/ferrogabbro intrusions and dikes with adjacent country rocks was mined from 1900 to 1949 (Herz and Force, 1987).

Concentrations of titanium minerals also occur in carbonatites (unusual rocks of magmatic or metasomatic origin dominated by carbonate minerals) and alkali igneous rocks. The Iron Hill (Powderhorn) carbonatite complex in Colorado is a series of successively intruded alkali rocks, including such rock types as carbonatite, nepheline, pyroxenite, and syenite (Temple and Grogan, 1965). Mainly because it contains abundant amounts of perovskite (a calcium-titanium oxide), the pyroxenite ranges from 1.9 to 9.6 weight percent $\mathrm{TiO}_{2}$ (with an average of about 5.3 weight percent $\mathrm{TiO}_{2}$ ) and significant amounts of rare-earth elements, thorium, niobium, and vanadium (Van Gosen, 2009).

In another carbonatite-hosted setting, extensive titanium (plus vanadium and niobium) mineralization is related to intrusion of the Magnet Cove carbonatite-alkalic ring dike complex in Arkansas, and accompanying metasomatic events (Fryklund and Holbrook, 1950; Flohr, 1994). At the Magnet Cove deposit, rutile occurs in feldspar-carbonate veins. Other

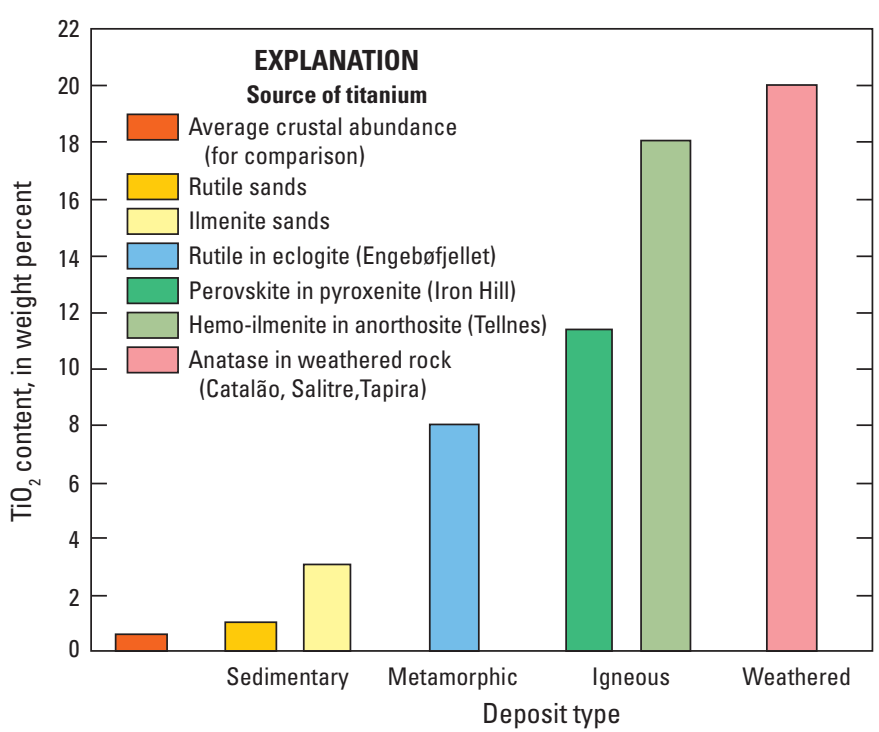

deposits at Magnet Cove that formed by contact metasomatism include the Christy titanium-niobium-vanadium deposit and the Hardy-Walsh prospect. Both deposits contain brookite in novaculite (chert) where country rock was intruded by and reacted with titanium-, vanadium-, and niobium-bearing fluids from adjacent alkali-rich rocks (Erickson and Blade, 1963; Flohr, 1994). Brookite at the Christy deposit can contain exceptionally high amounts of niobium and vanadium (Flohr, 1994).

Highly weathered rocks, such as bauxites (white-gray rock dominated by aluminum-rich oxides and hydroxides) and laterites (reddish rock dominated by iron- and aluminum-rich oxides and clays), can contain significant titanium resources. The titanium deposits at Catalão, Salitre, and Tapira (Brazil) formed by weathering of perovskite, magnetite, and titanite in titaniferous carbonatite, resulting in development of anatase in an about 200-meter (m)-thick laterite cap (Gomes and others, 1990; Force, 1991). Significant amounts of rutile and ilmenite occur in saprolite (weathered rock) over mineralized contacts of the ilmenite-bearing Roseland anorthosite pluton (Virginia), with minor transport and accumulation of both minerals in streams that cut through the saprolite (Fish, 1962).

\section{Titanium Deposits Related to Metamorphic Rocks}

Rutile is the most economically valuable mineral for titanium, but rutile sand ores are limited in volume, and, given that there are inadequate supplies of high-grade $(>55$ percent $\mathrm{TiO}_{2}$ ) ilmenite sands, much of the recent search for high-grade ore has focused on rutile potential from metamorphic rocks (Korneliussen and others, 2000a). The main exploration focus is on high-grade metamorphic rocks, such as eclogite (a rock composed primarily of garnet and pyroxene, with lesser amounts of rutile, and typically formed under highpressure conditions). Based on surveys of eclogite in Norway, Korneliussen and others (2000b) state that metamorphism of titanium-rich protoliths (the unmetamorphosed rock from 
which a metamorphic rock forms) is a requirement to generate sufficient rutile to be of economic interest. Complications for exploitation of eclogite include highly variable rutile concentrations and grain sizes, retrograde alteration of high-grade metamorphic rutile back to ilmenite or titanite, and the possible presence of impurities, such as calcium, magnesium, iron, and aluminum in trace silicates in rutile concentrates (Korneliussen and others, 2000b). For example, in northern Italy, the Piampaludo eclogite has high $\mathrm{TiO}_{2}$ content (about 6 weight percent), but during later metamorphism, some rutile was replaced by secondary ilmenite and titanite (Liou and others, 1998), making this resource less economically attractive. The only currently active rutile mines in metamorphic rocks are the Daixian rutile deposits in east-central China, which consist of lenses and layers of rutile-bearing high-grade metamorphic rocks that average about 2 weight percent $\mathrm{TiO}_{2}$ (Shi and others, 2012).

Intense alteration by hydrothermal fluids reacting with large volumes of rock can result in profound changes in the original bulk rock composition, creating aluminum-rich rocks depleted in most other elements. Metamorphism of these hydrothermally altered rocks can create a rock rich in the minerals kyanite $\left(\mathrm{Al}_{2} \mathrm{SiO}_{5}\right)$ and quartz and containing trace amounts of rutile (Marsh and Sheridan, 1976; Owens and Pasek, 2007). In addition, metamorphism of deeply weathered rocks, such as laterites and bauxites, can also result in rutile-bearing aluminum-rich rocks. Because these aluminum-rich rocks are stripped of many other elements, they potentially create a low-grade (about 1 percent or less rutile) and commonly low-tonnage but high-quality $\mathrm{TiO}_{2}$ resource that is generally free of other contaminants (Force, 1991). Rutile in such deposits can be a valuable byproduct of primary industrial commodities, such as alumina, andalusite, kaolinite, or kyanite.

Rutile also commonly occurs in mineralized zones and alteration halos of many hydrothermal and metamorphosed mineral deposits (Czamanske and others, 1981; Force, 1991; Clark and Williams-Jones, 2004). Large bodies of igneous rock that contain disseminated chalcopyrite and other sulfides are known as porphyry copper deposits. In the alteration zones around some porphyry copper deposits, such as Bingham Canyon (United States) or El Teniente (Chile), rutile can form from the breakdown of titanium-bearing silicates and oxides by the introduction of high-temperature hydrothermal fluids into the surrounding rock (Czamanske and others, 1981; Rabbia and others, 2009).

\section{Titanium Deposits Related to Coastal Shorelines and Dunes, and Older Equivalent Rocks}

Much of the high-grade ilmenite and rutile used today is extracted from unconsolidated heavy minerals (minerals that typically have a specific gravity higher than 2.85 grams per cubic centimeter) in shoreline beach placers and concentrations in sand dunes. Heavy-mineral sand deposits develop when relatively resistant titanium-bearing minerals and other heavy minerals are eroded from primary parent rocks, then transported and sorted, and finally deposited in fluvial, beach, or eolian settings. In addition to rutile and ilmenite (and minerals produced from weathering of ilmenite, such as anatase, leucoxene, and pseudorutile), other heavy minerals may enhance or detract from a deposit's value. For example, zircon is a valuable commodity for the ceramics industry, whereas monazite (a phosphate mineral that can contain rare-earth elements and thorium) can make a deposit more problematic because of potential radioactivity issues with waste disposal.

Fluvial deposits, as used here, consist of heavy minerals deposited by streams and rivers above sea level, including deltaic deposition in rivers and lakes. Fluvial heavy-mineral deposits in old drainage courses in the Ghangbama district in Sierra Leone (for example, Mogbwemo and Sherbo River) are dominated by rutile, and contain lesser amounts of zircon and ilmenite; the deposits have been eroded from deeply weathered garnet amphibolite and leucocratic garnet granulite highlands (Force, 1991). Many fluvial deposits are small and geologically young and have a heavy-mineral assemblage that closely resembles that of the unaltered source rock (Force, 1991).

The abundance and distribution of heavy minerals in active and older (mostly Pleistocene) beach placer and eolian deposits are related to the area's geology, physiography, and coastal dynamics. Many productive heavy-mineral sand provinces have the following characteristics: (a) deposits are located on passive continental margins that almost always are backed by elevated (typically highly weathered) high-grade metamorphic or mafic igneous hinterlands that supply detritus to the sands; (b) shoreline regions are dominated by sea-level changes and relatively low rates of sedimentation; (c) sands have been repeatedly reworked during marine transgressions and (or) by high-energy waves and littoral drifting; and (d) many sand bodies form topographic highs that represent former barrier island and (or) eolian dunes (Force, 1991; Hamilton, 1995; Roy, 1999; Pirkle and others, 2007; Hou and others, 2017).

Iron-titanium oxides in older, lithified heavy-mineral sand deposits may have undergone extensive post-depositional alteration, which diminishes the proportion of nonheavy minerals and enhances the conversion of ilmenite to leucoxene, causing an upgrade of the titanium content (Force, 1991). Ilmenite-rich layers of the Tertiary Cohansey Formation in New Jersey were mined at the Lakehurst deposit from 1962 until 1978 (Puffer and Cousminer, 1982). The Bothaville deposit in Late Paleozoic sandstones of the Ecca Group in the Karoo basin, South Africa, is a lithified paleo-beach deposit that contains (in order of abundance) ilmenite, rutile, and anatase (Hamilton, 1995). Heavy-mineral placers in shorelines of the Eocene-Pliocene Eucla basin (Hou and others, 2011) and the Pliocene Murray basin (Roy and Whitehouse, 2003) along the southern coast of Australia are major heavy-mineral sand provinces. 
A grade-and-tonnage model for shoreline placer titanium was developed by Attanasi and DeYoung (1992). Titanium grade and tonnage data for these deposits were combined with grade and tonnage data for titanium deposits related to both igneous and metamorphic rocks to create figure T5. The data for figure T5 are taken from disparate sources and represent a wide variety of deposit types and settings. Many of the deposits depicted in figure T5 are not economic. The high-grade and low-tonnage igneous deposits are typically characterized by the presence of abundant ilmenite and hemoilmenite (for example, Coulombe East and West, Bignel, and Lac Brûlé, all in the Grenville Province, Canada). Low-grade and high-tonnage igneous deposits are dominantly titanomagnetite (for example, Magpie Mountain and Panzhihua). Anatase is the titanium mineral at Salitre and Tapira, and perovskite is the titanium mineral at Iron Hill (Powderhorn), Colorado. Manavalakurichi is a heavy-mineral deposit in the State of Tamil Nadu, India.

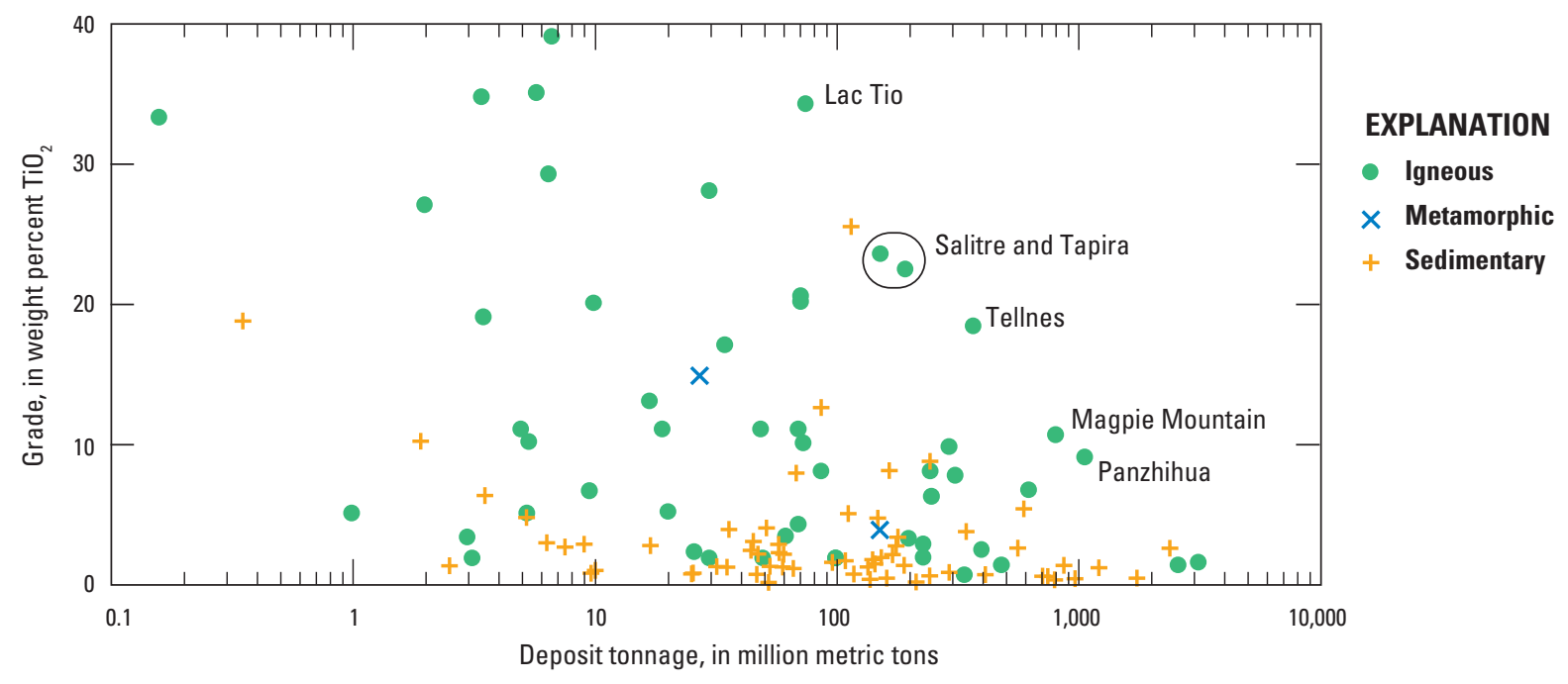

Figure T5. Plot of titanium dioxide grade and tonnage for selected igneous, metamorphic, and sedimentary deposits in the world, by deposit type. Data were compiled from Towner and others (1988), Attanasi and DeYoung (1992), Corriveau and others (2007), and the Fennoscandian Ore Deposit Database (FODD), which is maintained by the Geological Survey of Finland (2013). Deposits extracted from the FODD have titanium, titanium and vanadium, or iron and titanium listed as their main metals. Some of the major deposits discussed in the text are labeled. 


\section{Resources and Production}

\section{Identified Resources}

Figure T6 shows world ilmenite and rutile mine production and reserves for 2012 (based on the data available), which are reported as titanium mineral concentrates by the U.S. Geological Survey (Bedinger, 2013). A major difficulty in quantifying titanium resources is the range of standards that individual countries and companies apply to the categorization of resources (Murphy and Frick, 2006). Resource calculations also depend on complex mineralogical factors, such as ore mineralogy, grain size, and trace element concentrations, which are all critical to a determination of whether a deposit can be mined economically or not. Because of the widespread distribution of titanium minerals in many geologic environments, development of new technologies to extract titanium from nonconventional ore minerals and deposit types has great potential to open up large, currently untapped resources.

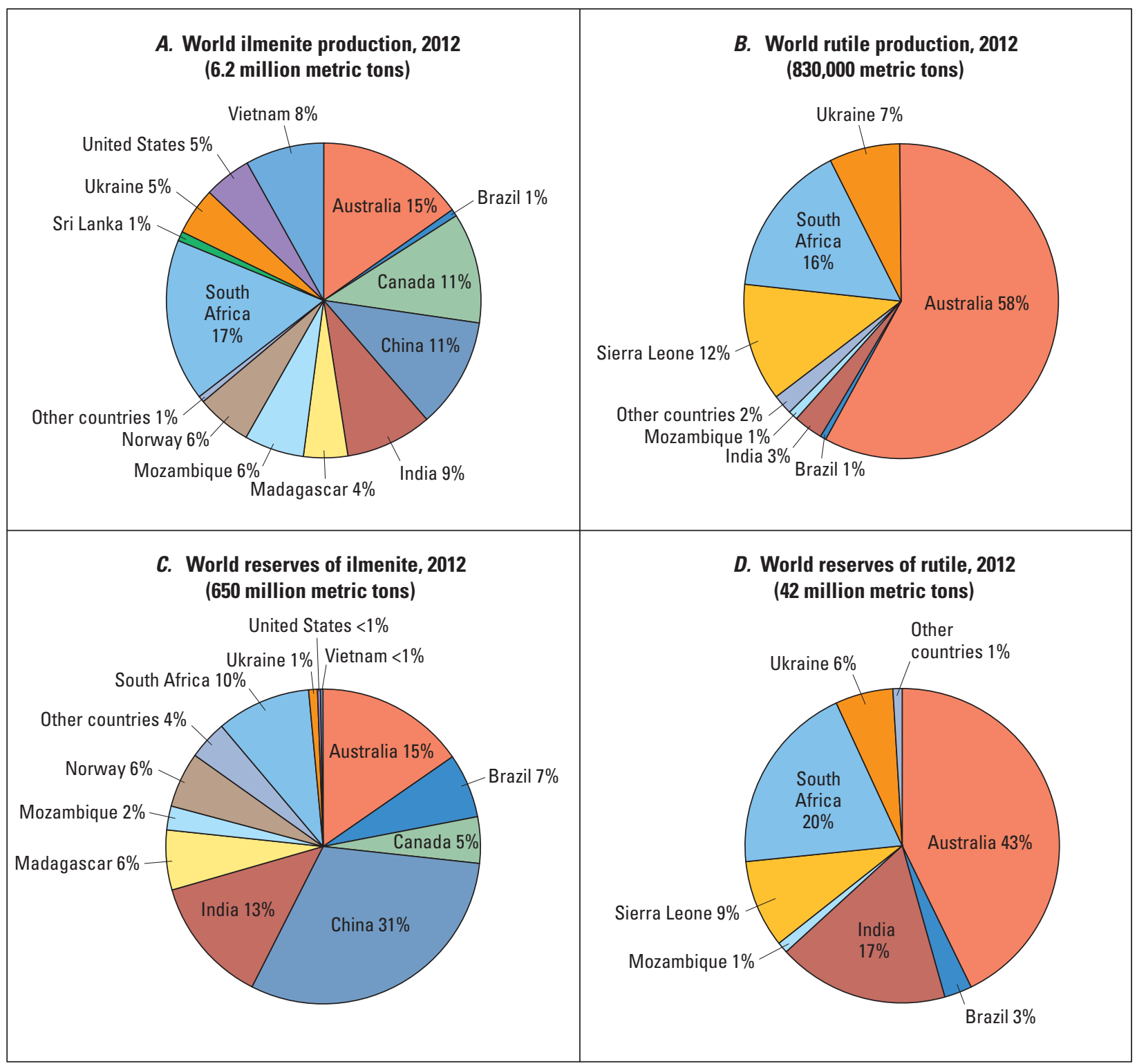

Figure T6. Pie charts showing percentage of estimated 2012 world mine production of $A$, ilmenite, and $B$, rutile, and percentage of global reserves of $C$, ilmenite, and $D$, rutile, by country. Total world mine production and reserves are also shown. Ilmenite data from the United States include rutile to avoid disclosing company proprietary data. Ilmenite reserves for Sri Lanka are not available. Data are from Bedinger (2013). Percentages are rounded and may not add to 100 . The term reserves as used here is defined as that part of the reserve base that would be economically extracted or produced at the time of determination (U.S. Bureau of Mines and U.S. Geological Survey, 1980). 
The United States has large resources of ilmenite and perovskite, as well as the potential for rutile resources. Table T2 lists the titanium mineral resources (including mineral reserves) of the United States. The East Coast of the United States is part of the eastern North America titanium province, as described by Stanaway (1996). Although deposits in the region include titanium oxides related to anorthosite and gabbro in New York (Sanford Lake district) and Virginia (Piney River [Roseland] anorthosite complex), the bulk of the resource is contained in heavy-mineral concentrations in beach, bar, dune, and stream sands along the Atlantic Coastal Plain and in large parts of the Gulf Coastal Plain (fig. T3; Pirkle and others, 2007). Nonetheless, the estimated amount of more than 100 million metric tons of contained $\mathrm{TiO}_{2}$ resources in the United States given in table T2 represents less than 10 percent of the world's titanium resources. The low grade of some U.S. resources, the possible presence of unfavorable trace constituents in ore, challenges with mineral separation and beneficiation of such nonconventional ore minerals as titaniferous magnetite and perovskite, anticipated high costs of permitting and production, and competition from foreign sources continue to curtail domestic production.

Total world resources of anatase, ilmenite, and rutile are estimated to be more than 2 billion metric tons (Bedinger, 2013). Compiled world resource estimates given in table $T 3$ total more than this amount but that is because they include hypothetical and speculative resources in addition to identified resources. Rose (1969), Towner and others (1988), and Force (1991) provide detailed geologic and location information for a number of deposits included in the estimates in table T3. Important points from table $\mathrm{T} 3$ are (a) the predominance of ilmenite resources versus rutile resources, and (b) the relative proportions of heavy-mineral sand resources compared with igneous and metamorphic sources. Discounting the speculative estimate of greater than 2,000 million metric tons of ilmenite resources in Canada, which is largely based on estimates from Gross (1996), heavy-mineral sand deposits represent the largest resource type for worldwide titanium supplies.

\section{Undiscovered Resources}

Undiscovered (hypothetical and speculative) resources of titanium are considered to be very large but difficult to quantify. Ilmenite is a common mineral in mafic and ultramafic rocks, and rutile is a highly stable mineral in metamorphic rocks. Many of the resources identified in table T3 include hypothetical and speculative titanium resources that await technological advances or favorable economics before they are likely to be exploited. For example, Rose (1969) states that high-grade magmatic ilmenite and titaniferous magnetite resources in Canada are measurable in hundreds of millions of tons, whereas low-grade deposits are potentially available in billions of tons. The Alberta oil sands also represent a very large speculative source of titanium (Towner and others, 1988). Although heavy minerals do not occur in large concentrations in these sands, the large quantity of sand processed for hydrocarbons creates a potentially significant titanium resource. The hot-water extraction process that recovers bitumen from the oil sands concentrates heavy minerals in treatment tailings, which contain on average about 11.5 percent $\mathrm{TiO}_{2}$ (Liu and others, 2006). Attempts to isolate a high-grade titanium concentrate from these tailings have met with only limited success, however (Kaminsky and others, 2008).

About 500 million metric tons of black sands on the North Island of New Zealand contain titanomagnetite (which averages about 23 percent of the raw sand) with a $\mathrm{TiO}_{2}$ content of 7 to 8 weight percent (Christie and Braithwaite, 1998). The North Island black sands are currently mined for iron with vanadium as a byproduct, but they are not yet considered economic for titanium (Christie and others, 2000). Magmatic iron-titanium-vanadium deposits in layered anorthosite-gabbro rocks that contain abundant titaniferous magnetite but only minor amounts of ilmenite represent another very large potential source of titanium. Among numerous examples are the Magpie Mountain deposits (Canada) (which hosts an estimated 1.5 billion metric tons of titaniferous magnetite ore containing 45.37 weight percent iron and 10.8 weight percent titanium; Gross, 1996) and the large Suwalki district (Poland), which contains significant resources in terms of tonnage that are not economic at this time (Charlier and others, 2009). As with perovskite at Iron Hill (Powderhorn), however, titanium mineralogy rather than the titanium content determines the economic value of the deposit.

Other speculative resources include very large but very low-grade rutile deposits in porphyry copper systems, which Force (1991) suggests have great potential because of the purity and ubiquitous nature of rutile in altered rock. In addition, shallow underwater offshore placers paralleling known exposed coastal placers are sparsely developed and largely unexplored but in some areas are known to contain commercially exploitable heavy minerals. Offshore placers represent large speculative titanium resources (Grosz and others, 1986). 
Table T2. Titanium resources of the United States.

[Values are from Force and Lynd (1984) with some updates from Force and Creely (2000), except that the Virginia heavy-mineral sands estimate is from Newton and Romeo (2006). Deposit classes are taken from table T1; - , none reported, or negligible; ?, identification uncertain]

\begin{tabular}{|c|c|c|c|c|c|}
\hline \multirow{2}{*}{ State } & \multirow{2}{*}{$\begin{array}{l}\text { District, deposit, } \\
\text { or deposit type }\end{array}$} & \multirow{2}{*}{$\begin{array}{l}\text { Deposit } \\
\text { class }\end{array}$} & \multicolumn{3}{|c|}{$\begin{array}{l}\text { Contained titanium dioxide, by primary ore mineral } \\
\text { (thousand metric tons) }\end{array}$} \\
\hline & & & Rutile & Ilmenite & Perovskite \\
\hline Alabama & Cretaceous sands & $\mathrm{S}-3$ & - & 100 & - \\
\hline Arizona & Porphyry copper ore & $\mathrm{I} / \mathrm{M}$ & 4,000 & 100 & \\
\hline Arkansas & Magnet Cove & $\mathrm{I}-7$ & 200 & - & - \\
\hline California & San Gabriel Mountains & $\mathrm{I}-2$ & - & 4,800 & - \\
\hline California & Ione placer & S-1 & - & 4,000 & - \\
\hline California & White Mountains & $\mathrm{M}-5$ & 300 & - & - \\
\hline Colorado & Iron Hill (Powderhorn) & $\mathrm{I}-7$ & - & - & 20,000 \\
\hline Colorado & Evergreen & $\mathrm{M}-5$ & 200 & - & - \\
\hline Florida & Old beach sands & $\mathrm{S}-2 / \mathrm{S}-4$ & 1,100 & 9,700 & - \\
\hline Georgia & Heavy-mineral sands & S-2 & 500 & 2,400 & - \\
\hline Maryland & Dinning & $\mathrm{M}-3 ?$ & 700 & - & - \\
\hline Minnesota & Duluth Complex & $\mathrm{I}-2$ & - & 10,000 & - \\
\hline Mississippi & Ship Island & $\mathrm{S}-2$ & - & 100 & - \\
\hline New Jersey & Lakehurst & S-3 & - & 10,100 & - \\
\hline New Mexico & Cretaceous sands & S-3 & - & 700 & - \\
\hline New York & Sanford Lake district & $\mathrm{I}-2$ & - & 8,600 & - \\
\hline New York & Port Leyden & $\mathrm{S}-1$ & - & 6,300 & - \\
\hline North Carolina & Yadkin Valley & $\mathrm{M}-2 ?$ & - & 200 & - \\
\hline North Carolina & Heavy-mineral sands & $\mathrm{S}-2$ & - & 400 & - \\
\hline Oklahoma & Wichita Mountains & $\mathrm{S}-1$ & - & - & - \\
\hline South Carolina & Heavy-mineral sands & $\mathrm{S}-2$ & 200 & 1,400 & - \\
\hline Tennessee & Cretaceous sands & S-3 & 1,300 & 8,400 & - \\
\hline Utah & Porphyry copper ore & $\mathrm{I} / \mathrm{M}$ & 4,000 & - & - \\
\hline Utah & Escalante & $\mathrm{S}-3$ & - & 200 & - \\
\hline Virginia & Heavy-mineral sands & S-2 & 150 & 2,200 & - \\
\hline Virginia & Roseland & $\mathrm{I}-5 / \mathrm{I}-8$ & 1,000 & 5,500 & - \\
\hline Virginia & Willis Mountain kyanite & $M-5$ & 300 & - & - \\
\hline Wyoming & Laramie Range & $\mathrm{I}-2$ & - & 2,700 & - \\
\hline Wyoming & Cretaceous sands & $\mathrm{S}-3$ & - & 500 & - \\
\hline Total $^{1}$ & & & 14,000 & 77,900 & 20,000 \\
\hline
\end{tabular}

${ }^{1}$ The U.S. resource total for titanium dioxide contained in the three primary ore minerals (rutile, ilmenite, and perovskite) is about 112 million metric tons of titanium dioxide. Totals have been rounded. 
Table T3. Titanium mineral resources of the world (excluding the United States) for ilmenite (including titanomagnetite and leucoxene) and rutile (including anatase and brookite).

[Numbers are estimates. Deposit classes are taken from table T1; S, sedimentary, primarily heavy-mineral sands; I, igneous, primarily ilmenite and (or) titanomagnetite in mafic rocks; M, metamorphic, primarily rutile in eclogite; - , none reported or negligible; ?, amount uncertain; $\sim$, approximately. Values for heavy-mineral sand resources (deposit class S), with the exceptions of New Zealand and Russia, are from Elsner (2010); deposit class S values for New Zealand from Christie and Braithwaite (1998) are for ilmenite on the South Island and do not include titanium in the 500-million-metric-ton titanomagnetite iron sand resources of the North Island; deposit class I values for Brazil, Italy, and Mexico are from Force (1991); deposit class I values for Canada are generalized from Rose (1969); deposit class I values for China are calculated from China Mining Association (2006); deposit class M values for China are from Shi and others (2012); deposit classes I and M values for Norway are from Korneliussen and others (2000a); deposit classes I and S values for Russia are from Bykhovskii and Tigunov (2011)]

\begin{tabular}{|c|c|c|c|c|}
\hline \multirow[t]{2}{*}{ Country } & \multirow[t]{2}{*}{ Deposit type } & \multirow{2}{*}{$\begin{array}{c}\text { Deposit } \\
\text { class }\end{array}$} & \multicolumn{2}{|c|}{$\begin{array}{l}\text { Contained titanium dioxide, } \\
\text { by primary ore mineral } \\
\text { (million metric tons) }\end{array}$} \\
\hline & & & Rutile & $\begin{array}{c}\text { Ilmenite/ } \\
\text { titanomagnetite }\end{array}$ \\
\hline Australia & Heavy-mineral sands & $\mathrm{S}$ & 39.9 & 246 \\
\hline Brazil & Heavy-mineral sands & $\mathrm{S}$ & 0.1 & 7 \\
\hline Brazil & Anatase in weathered rock & I & 150 & - \\
\hline Cameroon & Heavy-mineral sands & $\mathrm{S}$ & 2.9 & - \\
\hline Canada & Heavy minerals in oil sands & $\mathrm{S}$ & - & $183 ?$ \\
\hline Canada & Gabbro/anorthosite & I & - & $>2,000$ \\
\hline China & Heavy-mineral sands & $\mathrm{S}$ & 0.7 & 22 \\
\hline China & Titanomagnetite in layered mafic intrusions & I & - & $\sim 52$ \\
\hline China & Rutile in anthophyllite & M & 6 & - \\
\hline Egypt & Heavy-mineral sands & $\mathrm{S}$ & 0.5 & - \\
\hline India & Heavy-mineral sands & $\mathrm{S}$ & $>18.0$ & $>348$ \\
\hline Italy & Rutile in eclogite & M & 9 & - \\
\hline Kazakhstan & Heavy-mineral sands & $\mathrm{S}$ & 0.3 & $\sim 3$ \\
\hline Kenya & Heavy-mineral sands & $\mathrm{S}$ & 3 & 61 \\
\hline Madagascar & Heavy-mineral sands & $\mathrm{S}$ & - & 60 \\
\hline Malawi & Heavy-mineral sands & $\mathrm{S}$ & $>13$ & 190 \\
\hline Malaysia & Heavy-mineral sands & $\mathrm{S}$ & - & $\sim 10$ \\
\hline Mexico & Metasomatized anorthositic rocks & I & - & 3 \\
\hline Mozambique & Heavy-mineral sands & $\mathrm{S}$ & 3.2 & 237 \\
\hline Namibia & Heavy-mineral sands & S & 0.6 & 36 \\
\hline New Zealand & Heavy-mineral sands & $\mathrm{S}$ & - & 5 \\
\hline Norway & Gabbro/anorthosite & I & - & 238 \\
\hline Norway & Rutile in metamorphic/metasomatic rocks & M & 61 & - \\
\hline Russia & Titanomagnetite/ilmenite/titanite & I & - & 121 \\
\hline Russia & Heavy-mineral sands & $\mathrm{S}$ & 2.3 & 9 \\
\hline Senegal & Heavy-mineral sands & $\mathrm{S}$ & 0.6 & 22 \\
\hline Sierra Leone & Rutile/ilmenite in fluvial deposits & $\mathrm{S}$ & 10.2 & 5 \\
\hline South Africa & Heavy-mineral sands & $\mathrm{S}$ & 4.4 & 82 \\
\hline Sri Lanka & Heavy-mineral sands & $\mathrm{S}$ & 0.5 & $\sim 12$ \\
\hline Ukraine & Heavy-mineral sands & $\mathrm{S}$ & 0.5 & $\sim 14$ \\
\hline Vietnam & Heavy-mineral sands & $\mathrm{S}$ & - & 8 \\
\hline Total $^{1}$ & & & $\sim 325$ & $\sim 3,975$ \\
\hline
\end{tabular}

${ }^{1}$ The world resource total for rutile and ilmenite combined is about 4.3 billion metric tons, which includes hypothetical and speculative resources in addition to identified resources. 


\section{Exploration for New Deposits}

Heavy-mineral analysis is an effective exploration guide for titanium-bearing heavy-mineral concentrations (Hou and others, 2017). In addition to high levels of titanium, geochemical signatures include high levels of zirconium, rareearth elements, thorium, and uranium (Grosz and Schruben, 1994). For example, data indicating anomalously high levels of hafnium, rare-earth elements, titanium, and zirconium for streambed sediments collected for the U.S. Department of Energy's National Uranium Resource Evaluation program helped locate major heavy-mineral deposits in an area between the Piedmont and the Atlantic Coastal Plain in Virginia and North Carolina (Grosz and Schruben, 1994). Exploration for fluvial placer deposits is best focused on source rock lithology, as many deposits are proximal and reflect the mineralogy of their source rocks (Force, 1991). Thus, a rutile source is more promising than an ilmenite source. More recent exploration for heavy-mineral deposits has relied on increasingly sophisticated radiometric methods and on stratigraphic and sedimentological modeling (Hou and others, 2017). Multichannel gamma-ray spectrometers coupled with geologic and land-use and landcover data have allowed recognition of anomalies that could be tied to thorium radiation from monazite (Pirkle and others, 2007). In the Eucla basin in southern Australia, high-resolution satellite nighttime thermal imagery and detailed elevation data were combined with geologic data to identify beach-barrier facies and favorable heavy-mineral assemblages (Hou and others 2011, 2017). In most cases, modern beaches or interpreted older beaches must be cored to determine the presence of heavy minerals, and samples have to be characterized by mineralogy, grain size, and titanium content (Pirkle and others, 2007). The large induced polarization response of ilmenite permits exploration for offshore marine heavy-mineral deposits using shipborne geophysical methods (Wynn, 1988). Innovative and modern exploration marine exploration methods, such as induced polarization, could cover a large swath of the continental shelf (Wynn, 1988).

Exploration for magmatic iron-titanium-oxide deposits is not only focused on grade and tonnage, but also on finding ilmenite suitable for pigment processing (for example, chromium- and magnesium-poor ilmenite). Suitable mineralogy and chemistry depend on relationships among magmatic evolution, major- and trace-element chemistry, and low temperature re-equilibration. Geophysical methods have been used for exploration and to extend known deposits. Prospecting for workable and chemically suitable ilmenite resources relies in part on aeromagnetic signatures of iron-titanium-oxides that record ore microtextures that can be related back to ore chemistry (McEnroe and others, 2000). Aeromagnetic maps over favorable terranes may have a spectacular range of positive and negative anomalies because of highly contrasting rocks and possible deposit types (McEnroe and others, 2001). Concentrations of nonmagnetic hemo-ilmenite commonly have distinctive negative magnetic anomalies or mixed patterns of positive and negative magnetic anomalies. Strong positive anomalies related to magnetite content may point toward large titanomagnetite concentrations. Because of contrasting physical properties compared to silicates, iron-titanium-deposits commonly have higher gravity anomalies than surrounding anorthositic, granitic, or gneissic country rock (Gross, 1996).

Exploration for rutile in metamorphic rocks, specifically eclogite, depends on recognition of favorable geologic circumstances that would create high-grade and high-quality rutile concentrations. These favorable circumstances include (a) high-grade metamorphism of large volumes of titaniumbearing gabbroic protoliths; (b) favorable mineralogical factors, such as grain size, mineral intergrowths, modal variations, and degree of retrograde mineral alteration; (c) favorable locations with regard to deposit development, shipping, and waste treatment; and (d) potential byproducts (for example, garnet) that could enhance the economics of a deposit (Korneliussen and others, 2000b).

\section{Environmental Considerations}

\section{Sources and Fate in the Environment}

The behavior of titanium in the environment is dominated by its low solubility and the limited reactivity of titanium minerals. The main sources of anthropogenic titanium in the environment are from the combustion of fossil fuels and, to a lesser extent, incineration of titaniumcontaining products (International Programme on Chemical Safety, 1982). The mean concentration of titanium in soils worldwide is 0.33 weight percent titanium (Kabata-Pendias and Mukherjee, 2007); the average and range in titanium concentrations for soils in the conterminous United States are 0.29 weight percent and 0.007 to 2.0 weight percent, respectively (Shacklette and Boerngen, 1984). Titanium in stream waters worldwide ranges from 12 to 926 micrograms per liter $(\mu \mathrm{g} / \mathrm{L})$ (Reimann and de Caritat (1998). River waters in North America contain between 2 and $107 \mu \mathrm{g} / \mathrm{L}$ titanium, and drinking waters in the United States contain from 0.5 to $15 \mu \mathrm{g} / \mathrm{L}$ titanium (International Programme on Chemical Safety, 1982). The average concentration of titanium in suspended sediments in rivers worldwide is 0.44 weight percent (Viers and others, 2009). In the atmosphere, titanium ranges from 0.5 to 2.5 nanograms per cubic meter $\left(\mathrm{ng} / \mathrm{m}^{3}\right)$ for remote areas and from 15 to $25 \mathrm{ng} / \mathrm{m}^{3}$ for urban areas (Kabata-Pendias and Mukherjee, 2007). Atmospheric concentrations of titanium in urban areas of the United States are typically below $100 \mathrm{ng} / \mathrm{m}^{3}$, but values of up to $1,000 \mathrm{ng} / \mathrm{m}^{3}$ have been reported in some industrial regions (International Programme on Chemical Safety, 1982).

A significant amount of the titanium manufactured as a metal is recycled. For $\mathrm{TiO}_{2}$ used for pigment, however, there is no role for recycling because the compound is so profoundly 
incorporated into the end product that it cannot be recovered with today's technology (Murphy and Frick, 2006). Because the bulk of the world's titanium is used for pigment, recycling currently plays little or no role in titanium consumption or pricing trends.

\section{Mine Waste Characteristics}

Magmatic ilmenite and sedimentary-related titanium deposits produce very different volumes and types of mine waste. The open pit methods used to extract ore from massive magmatic ilmenite deposits produce large volumes of waste rock and tailings. The Storgangen Mine (Norway), which operated from 1917 to 1965, produced more than 10 million metric tons of ore (Schiellerup and others, 2003) and more than 8 million metric tons of tailings (Ettner, 1999). Annual production (1999) from the Tellnes open pit mine (Norway) is about 2 million metric tons of ore and 1.6 million metric tons of waste rock (Norges Geologiske Undersøkelse, 2012). Tailings from the Tellnes Mine are composed predominantly of feldspar, ilmenite, and pyroxene with a size range of 10 to 200 micrometers $(\mu \mathrm{m})$ (Olsgard and Hasle, 1993). Mining of the Lac Tio deposit (Quebec, Canada) began in the early 1950s. Waste-rock piles at Lac Tio are estimated to be more than 72 million metric tons and to cover approximately 100 hectares of land, and they are between 20 and $80 \mathrm{~m}$ in height (Pepin and others, 2008). Waste rock at Lac Tio is dominantly plagioclase, followed by lesser amounts of hemo-ilmenite and trace sulfides (Pepin and others, 2008). Pyrite is the main sulfide (1 to 2 weight percent) in waste rock with only trace amounts ( $<1$ weight percent) of chalcopyrite (Plante and others, 2011). Laboratory tests on the Lac Tio Mine waste to approximate weathering produced neutral to slightly alkaline leachate ( $\mathrm{pH} 6.5$ to 9.0), which is consistent with the near-neutral natural drainage from the waste piles (Plante and others, 2011). Field monitoring of experimental mine-waste cells produced drainage with a $\mathrm{pH}$ of between 4 and 8 , which mimicked the $\mathrm{pH}$ of rain water (Pepin and others, 2008). Thus, any acid generated by sulfides in mine waste from the Lac Tio Mine is neutralized by silicates; the net neutralization potentials range from -6.0 to 3.1 kilograms $(\mathrm{kg})$ of calcium carbonate $\left(\mathrm{CaCO}_{3}\right)$ per metric ton of ore, all within the uncertainty zone of $\pm 20 \mathrm{~kg}$ of $\mathrm{CaCO}_{3}$ per metric ton of ore for the test method (Plante and others, 2011).

Mining and milling methods for heavy-mineral sand deposits involve physical separation of a bulk concentrate and quartz-rich tailings by mechanical means, typically magnetic or electrostatic methods or density separation. During further concentration, the mineral-bearing sand fraction is separated from finer textured slimes (clays, silts, very fine sand), which is mixed with a flocculent to aid settling, and then pumped back as a slurry into a reclamation pit (Daniels and others, 2003).

The average grain size of heavy minerals and the percentage of slimes in a deposit are variable, which results in different amounts and types of waste material. For example, two mineral-sand blocks in India (Kuttam and Sattankulam) contain up to 10 percent heavy minerals and 15 percent slimes (Murty and others, 2007). The sands in these blocks are very homogeneous - 85 percent of the sands range from $<2$ millimeters to $63 \mu \mathrm{m}$ in size. Heavy-mineral sands on the northeastern coast of Sri Lanka (Pulmoddai sands) are very high grade; 71 percent of the beach sands are smaller than $355 \mu \mathrm{m}$, and more than 99 percent of the titanium content is in this size fraction (Premaratne and Rowson, 2003). The two blocks in India cover approximately 120 square kilometers $\left(\mathrm{km}^{2}\right)$ and contain an estimated 400 million metric tons of raw sand and 30 million metric tons of ilmenite (Murty and others, 2007). Pulmoddai sands cover an area of only $3.2 \mathrm{~km}^{2}$ with an even thickness of $6 \mathrm{~m}$ (Premaratne and Rowson, 2003); thus, the amount and type of waste generated by the two deposits in India would be very different than the waste generated at Pulmoddai.

\section{Human Health Concerns}

Human health concerns related to titanium are minimal. Titanium can enter the human body by ingestion or inhalation, but most ingested titanium is eliminated unabsorbed. An exception to this is some industrial inhalation exposures to high amounts of dust during titanium processing (KabataPendias and Mukherjee, 2007). Mining processes conducted on ilmenite ore or heavy-mineral sands may create high amounts of airborne dust, and control measures are needed to reduce workers' exposure. The U.S. Environmental Protection Agency (EPA) has not found any human or animal studies that are useful for developing toxicity values for titanium (U.S. Environmental Protection Agency, 2010).

The processing of heavy-mineral sands at mine sites may expose workers to minor amounts of radiation. The radiation levels in heavy-mineral concentrates are usually too low to be classified as radioactive; however, when radioactive minerals, such as monazite or xenotime, are separated at the dry processing stage, precautions may need to be taken to protect employees from low levels of ionizing radiation (Abuodha, 2002).

The EPA and the World Health Organization (WHO) have not established drinking water guidelines for titanium nor has the EPA established soil screening levels for industrial or residential land use for remediation purposes. In fact, $\mathrm{TiO}_{2}$ replaced lead carbonate and lead oxide as the whiteners in paints in the United States because of its low toxicity to humans.

\section{Ecological Health Concerns}

The EPA also has not established water-quality criteria for the protection of aquatic life for titanium because titanium minerals are generally insoluble and not bioaccessible. 
Recent findings do suggest that $\mathrm{TiO}_{2}$ nanoparticles, commonly defined as particles smaller than 100 nanometers in at least two dimensions, may be toxic to some aquatic and terrestrial organisms (Federici and others, 2007; Wang and others, 2008; Sharma, 2009). Titanium dioxide nanoparticles are used in a range of products, including sunscreen, cosmetics, paint, and building materials, and have been shown to behave differently in the environment than larger particles of the same composition (Sharma, 2009). Applications for nanoparticles are increasing and, consequently, this form of titanium may be of increasing environmental concern in the future.

Titanium deposits and related waste products are usually sulfide-poor and generally generate near-neutral $\mathrm{pH}$ drainage after interacting with rain, surface water, or groundwater. Therefore, acid mine drainage, which is a common potential problem for many types of ore deposits, is not a significant concern at titanium mines. Although titanium may not be an environmental concern, other metals found in trace sulfides may be deleterious to the environment. Some metals, such as cobalt, nickel, and zinc, will remain in solution even at neutral $\mathrm{pH}$. Drainage water with near-neutral $\mathrm{pH}$ and some quantity of dissolved metals is termed "contaminated neutral drainage." Nickel values greater than 0.5 milligram per liter $(\mathrm{mg} / \mathrm{L})$ have been reported from waters draining waste piles at the Lac Tio Mine, at times exceeding U.S. and Canadian water-quality guidelines for the protection of aquatic life (Plante and others, 2010). Initially, nickel was adsorbed by residual ilmenite and plagioclase in fresh waste rock, but as mine waste weathered, adsorption sites filled and a lowered adsorptive capacity resulted in increased nickel in drainage waters, creating contaminated neutral drainage (Plante and others, 2010). This interpretation is consistent with field observations on mine waste experimental cells at Lac Tio that produced drainage with higher concentrations of nickel ( 0.1 to $0.4 \mathrm{mg} / \mathrm{L})$ from approximately 25 -year-old mine waste compared with drainage concentrations of nickel $(<0.05 \mathrm{mg} / \mathrm{L})$ from freshly blasted waste rock (Pepin and others, 2008). These studies suggest that ecosystem health concerns from high nickel concentrations in mine drainage waters may increase as mine wastes weather.

Approximately 750,000 cubic meters of water drains annually from a tailings impoundment for the closed Storgangen Mine (Norway) (Ettner, 2007). Runoff from the former mine that subsequently reaches the North Sea at a distance of about 5 kilometers downstream has a neutral $\mathrm{pH}$ and nickel concentrations of up to $6 \mathrm{mg} / \mathrm{L}$ (Ettner, 2007). An anaerobic passive treatment system was installed in 2003 to remove nickel, and initially it had variable efficacy because of the immaturity of the system and extreme rain storms; since 2007 , however, the system has successfully removed nickel from the tailings runoff (Ettner, 2007).

Mine tailings from Tellnes are almost inert and are nontoxic to marine life (Olsgard and Hasle, 1993). Disposal of tailings underwater can lead to increased water turbidity, however, and, depending on the sedimentation rate, to the smothering of organisms living in bottom sediment. At Tellnes, about 2 million metric tons per year of tailings were deposited into a local fjord throughout the 1980s, which resulted in the reduction in number and diversity of species. After underwater tailings deposition ceased in 1994, bottom fauna in the fjord began to recover. Although there was a reduction in species richness compared with that of unaffected background locations for several years after tailings deposition ceased, within 4 years, all the main macrobenthic phyla were represented (Olsgard and Hasle, 1993). Some of the waste rock at the Lac Tio Mine is adjacent to a water body called Lac Petit Pas. A study by the operating company of the Lac Tio Mine showed that there were elevated concentrations of some metals in the first several centimeters of sediment within the lake but concluded that the sediments act as a retention medium (Rio Tinto, 2009).

\section{Mine Closure}

The post-mining landscape at titanium mines depends on the type of deposit exploited and the mining methods employed. Pit lakes remaining from open pit magmatic titanium deposits could contain low concentrations of trace elements typically found in ores, such as cobalt, chromium, nickel, vanadium, and zinc. In the Sanford Lake district of New York, the pit lake at the McIntyre Mine, which was closed in 1982, has a neutral $\mathrm{pH}$ of 8 and low to nondetectable concentrations of trace elements (Woodruff and others, 2013; S. Hollmeyer, undergraduate student, University of Vermont, unpub. data, December 2003).

Titanium minerals from heavy-mineral sand deposits are most commonly mined using surface methods, including wet dredging and dry mining techniques. Pits are backfilled with tailings and slimes. Commonly, topsoil initially removed at a site is stored during active mining and later mixed with tailings and slimes to facilitate the return of vegetation. Daniels and others (2003) examined soil profiles within reclamation pits at the Old Hickory Mine site (Virginia). Soils were a mixture of dewatered slimes and tailings with added soil amendments, such as biosolids, fertilizer, and lime. Amended surface soils from reclaimed pits had near neutral $\mathrm{pH}$ values and up to 1.5 percent organic matter. Reclaimed mine soils from the Green Cove Springs Mine in Florida are similar, with organic-rich topsoil-amended surface layers and quartz-rich tailings in the subsurface (Daniels and others, 1992).

Surface mining of mineral sands has the potential to disturb prime agricultural farmlands along the eastern coast of the United States (Daniels and others, 1992). Orndorff and others (2011) and Zimmerman and others (2008), however, suggest that disturbed lands around such sites could be successfully returned to local regional agricultural levels if best agricultural and science-based practices, such as replacement of topsoil, $\mathrm{pH}$ adjustments with lime, and addition of fertilizers and biosolids, are applied. 


\section{Problems and Future Research}

Titanium is an abundant element; it is found at concentrations higher than 20 percent in many minerals (see fig. T1). It is currently not possible to extract a high-grade titanium product from titanite and perovskite, however, and largescale recovery of titanium from low-titanium oxides, such as titanomagnetite, is mainly in the research stage. A role for future research for titanium resources revolves around the ability to develop cost-effective extraction methods for titanium minerals other than anatase, brookite, ilmenite, and rutile. Depletion of rutile resources and the shift from the sulfate process to the chloride process, which requires higher-grade $\mathrm{TiO}_{2}$ feedstock compared with the older sulfate process, increases the need to develop low-cost, energyefficient hydrometallurgical processes to, in effect, upgrade the more abundant ilmenite (Zhang and others, 2011). If these issues of mineralogy could be resolved, there are many large titanium resources - some of which are in advanced stages of exploration - that could become economic.

Rutile is in high demand, so the search for additional resources is likely to focus on exploration for large, high-grade domestic rutile resources. Increased examination of the myriad geologic environments where rutile occurs (see, for example, Meinhold, 2010) might make it possible to discover previously unrecognized or underutilized rutile sources, such as porphyry systems, metamorphic terranes, or highly weathered rock. Rutile as a magmatic mineral is described for some massif anorthosite ilmenite deposits in the Saint-Urbain and Lac Allard anorthosite plutonic suites (Quebec). Morisset and others (2010) attribute this occurrence to an exceptionally high alumina content of parent magmas and the subsequent oxide crystallization path. Rutile also occurs along the metasomatized margins of the Roseland anorthosite (Virginia) and in the Pluma Hidalgo anorthosite district (Mexico), where swarms of anorthosite dikes and sills cut country rock (Force, 1991). In these two deposits, anorthosite has a more alkali composition than is typical for most other anorthositehosted magmatic deposits, which Force (1991) links to the relative abundance of rutile. Thus, research into a possible relation between host anorthosite chemistry and occurrences of abundant rutile with ilmenite in magmatic deposits could result in delineation and identification of favorable environments for higher grade rutile-bearing magmatic deposits.

Recent research in anorthosite plutonic terranes that host ilmenite-dominated magmatic systems, such as Lac Tio and Tellnes, has led to recognition of the role that magmatic processes, such as contamination, mineral fractionation, and flow dynamics, play in the development of world-class titanium orebodies (Wilmart and others, 1989; Charlier and others, 2010). An updated deposit model for the formation of these types of titanium deposits (Woodruff and others, 2013) could guide exploration for this type of mineralization as either a direct source or as protoliths for weathered ore deposits.

\section{References Cited}

Note: All Web links listed were active as of the access date but may no longer be available.

Abuodha, J.O.Z., 2002, Environmental impact assessment of the proposed titanium mining project in Kwale district, Kenya: Marine Georesources and Geotechnology, v. 20, no. 3, p. 199-207. [Also available at http://dx.doi.org/ 10.1080/03608860290051895.]

Ashwal, L.D., 2010, The temporality of anorthosites: Canadian Mineralogist, v. 48, no. 4, p. 711-728. [Also available at http://dx.doi.org/10.3749/canmin.48.4.711.]

Attanasi, E.D., and DeYoung, J.H., Jr., 1992, Grade and tonnage model of shoreline placer Ti-Model 39c, in Cox, D.P., and Singer, D.A., eds., Mineral deposit models: U.S. Geological Survey Bulletin 1693, p. 270-273. [Also available at https://pubs.er.usgs.gov/publication/b1693/.]

Bedinger, G.M., 2013, Titanium mineral concentrates: U.S. Geological Survey Mineral Commodity Summaries 2013, p. 174-175, accessed March 15, 2013, at https://minerals.usgs.gov/minerals/pubs/commodity/ titanium/mcs-2013-timin.pdf.

Brooks, D.B., 1976, Mineral supply as a stock, in Vogely, W.A., ed., Economics of the mineral industries: New York, N.Y., American Institute of Mining, Metal, and Petroleum Engineers, p. 127-207.

Bykhovskii, L.Z., and Tigunov, L.P., 2011, Titanium raw materials of Russia: Russian Journal of General Chemistry, v. 81, no. 6, p. 1328-1344. [Also available at http://dx.doi.org/10.1134/S1070363211060387.]

Charlier, Bernard, Namur, Olivier, Duchesne, Jean-Clair, Wiszniewska, Janina, Parecki, Antonia, and Vander Auwera, Jacqueline, 2009, Cumulate origin and polybaric crystallization of Fe-Ti oxide ores in the Suwalki anorthosite, northeastern Poland: Economic Geology, v. 104, p. 205-221. [Also available at http://dx.doi.org/ 10.2113/gsecongeo.104.2.205.]

Charlier, Bernard, Namur, Olivier, Malpas, Simon, de Marneffe, Cedric, Duchesne, Jean-Clair, Vander Auwera, Jacqueline, and Bolle, Olivier, 2010, Origin of the giant Allard Lake ilmenite ore deposit (Canada) by fractional crystallization, multiple magma pulses and mixing: Lithos, v. 117, June, p. 119-134. [Also available at http://dx.doi.org/10.1016/j.lithos.2010.02.009.]

Chernet, T., 1999, Effect of mineralogy and texture in the $\mathrm{TiO}_{2}$ pigment production process of the Tellnes ilmenite concentrate: Mineralogy and Petrology, v. 67, nos. 1-2, p. 21-32. [Also available at http://dx.doi.org/10.1007/BF01165113.] 
China Mining Association, 2006, Metallic mineral resourcesSection 3.5 titanium: China Mining Association, accessed November 13, 2012, at http://www.chinamining.org/Facts/ index-64.html.

Christie, A.B., and Braithwaite, R.L., 1998, Mineral commodity report 16-Titanium: New Zealand Mining, v. 23 , p. $15-25$.

Christie, Tony, Douch, Colin, Winfield, Barry, and Thompson, Bruce, 2000, Industrial minerals in New Zealand: New Zealand Mining, v. 27, p. 14-25, accessed March 28, 2014, at http:/www.nzpam.govt.nz/cms/ pdf-library/minerals/publications/Commodity Reports/ report20a_indmins.pdf/view/.

Clark, J.R., and Williams-Jones, A.E., 2004, Rutile as a potential indicator mineral for metamorphosed metallic ore deposits: Montreal, Quebec, Canada, DIVEX, Rapport Final Sous-project SC2, 17 p. [Also available at http://www.divex.ca/ projets/doc/SC2-Williams-Jones-2004.pdf.]

Corriveau, Louise, Perreault, Serge, and Davidson, Anthony, 2007, Prospective metallogenic settings of the Grenville Province, in Goodfellow W.D., ed., Mineral deposits of Canada - A synthesis of major deposit-types, district metallogeny, the evolution of geological provinces, and exploration methods: Geological Association of Canada Special Publication no. 5, p. 819-848.

Czamanske, G.K., Force, E.R., and Moore, W.J., 1981, Some geologic and potential resource aspects of rutile in porphyry copper deposits: Economic Geology, v. 76, p. 2240-2256. [Also available at http://dx.doi.org/10.2113/ gsecongeo.76.8.2240.]

Daniels, W.L., Genthner, M.H., and Hodges, R.L., 1992, Soil development in sandy tailings derived from mineral sands mining in Florida, in Achieving land use potential through reclamation-Proceedings of the 9th Annual Meeting of the American Society for Surface Mining and Reclamation, Duluth, Minn., June 14-18, 1992: Princeton, W. Va., American Society for Surface Mining and Reclamation, p. 37-47. [Also available at http://www.asmr.us/Portals/0/ Documents/Conference-Proceedings/1992/0037-Daniels.pdf.]

Daniels, W.L., Orndorff, Z.W., and Schroeder, P.D., 2003, Chemical and physical properties of mineral sands mine soils in southeastern Virginia, in Barnhisel, R.I., ed., Working together for innovative reclamation-Proceedings of a Joint Conference of [the] 9th Billings Land Reclamation Symposium and American Society of Mining and Reclamation 20th Annual National Conference, Billings, Mont., June 3-6, 2003: Lexington, Ky., American Society of Mining and Reclamation, p. 209-228. [Also available at http://www.asmr.us/Publications/Conference Proceedings/ 2003/0209-Daniels.pdf.]
Duchesne, J.-C., 1999, Fe-Ti deposits in Rogaland anorthosites (south Norway) - Geochemical characteristics and problems of interpretation: Mineralium Deposita, v. 34, p. 182-198. [Also available at http://dx.doi.org/10.1007/ s001260050195.]

Elsner, Harald, 2010, Heavy minerals of economic importance-Assessment manual: Hanover, Germany, Bundesanstalt für Geowissenschaften und Rohstoffe, 218 p.. [Also available at http://www.bgr.bund.de/DE/Themen/ Min_rohstoffe/Downloads/heavy-minerals-economicimportance.pdf?_blob=publicationFile\&v=5.]

Erickson, R.L., and Blade, L.V., 1963, Geochemistry and petrology of the alkalic igneous complex at Magnet Cove, Arkansas: U.S. Geological Survey Professional Paper 425, 95 p. [Also available at http://pubs.usgs.gov/pp/0425/report.pdf.]

Ettner, D.C., 1999, Pilot scale constructed wetland for the removal of nickel from tailings drainage, southern Norway, in Mine, Water \& Environment, 1999 International Mine Water Association (IMWA) Congress, Sevilla, Spain, Proceedings: Wendelstein, Germany, International Mine Water Association, p. 207-211. [Also available at http://www.mwen.info/docs/imwa_1999/IMWA1999_ Ettner_207.pdf.]

Ettner, D.C., 2007, Passive mine water treatment in Norway, in Cidu, R., and Frau, F., eds., Water in mining environments-International Mine Water Association (IMWA) Symposium 2007, Cagliari, Italy, May 27-31, 2007: Wendelstein, Germany, International Mine Water Association, 5 p., accessed January 28, 2012, at http://www.imwa.info/docs/ imwa_2007/IMWA2007_Ettner.pdf.

Federici, Gillian, Shaw, B.J., and Handy, R.D., 2007, Toxicity of titanium dioxide nanoparticles to rainbow trout (Oncorhynchus mykiss); gill injury, oxidative stress, and other physiological effects: Aquatic Toxicology, v. 84, no. 4, p. 415-430. [Also available at http://dx.doi.org/10.1016/ j.aquatox.2007.07.009.]

Fish, G.E., 1962, Titanium resources of Nelson and Amherst Counties, Virginia (in two parts) - Part 1-Saprolite ores: U.S. Bureau of Mines Report of Investigations 6429, 25 p.

Flohr, M.J.K., 1994, Titanium, vanadium, and niobium mineralization and alkali metasomatism from the Magnet Cove Complex, Arkansas: Economic Geology, v. 89, p. 105-130. [Also available at http://dx.doi.org/10.2113/gsecongeo.89.1.105.]

Force, E.R., 1991, Geology of titanium-mineral deposits: Geological Society of America Special Paper 259, 112 p. [Also available at http://dx.doi.org/10.1130/SPE259-p1.] 
Force, E.R., and Creely, Scott, 2000, Titanium mineral resources of the Western U.S.-An update: U.S. Geological Survey Open-File Report 00-442, 37 p.

Force, E.R., and Lynd, L.E., 1984, Titanium mineral resources of the United States-Definitions and documentation: U.S. Geological Survey Bulletin 1558-B, p. B1-B11. [Also available at http://pubs.usgs.gov/bul/1558a-b/report.pdf.]

Fryklund, V.C., and Holbrook, D.F., 1950, Titanium ore deposits of Hot Spring County, Arkansas: Arkansas Resources and Development Commission Division of Geology Bulletin no. 16, 173 p.

Gambogi, Joseph, 2012, Titanium, in Metals and minerals: U.S. Geological Survey Minerals Yearbook 2010, v. I, p. 78.1-78.17. [Also available at http://minerals.usgs.gov/ minerals/pubs/commodity/titanium/myb1-2010-titan.pdf.]

Geological Survey of Finland, 2013, Fennoscandian Ore Deposit Database (FODD): Geological Survey of Finland, accessed April 17, 2013, at http://en.gtk.fi/information services/databases/fodd/index.html.

Gomes, C.B., Ruperti, E., and Morbidelli, Lucio, 1990, Carbonatite complexes from Brazil-A review: Journal of South American Earth Sciences, v. 3, no. 1, p. 51-63. [Also available at http://dx.doi.org/10.1016/08959811(90)90017-U.]

Gross, G.A., 1996, Mafic intrusion-hosted titanium-iron, in Eckstrand, O.R., Sinclair, W.D., and Thorpe, R.I., eds., Geology of Canadian mineral deposit types: Geological Survey of Canada Geology of Canada series, no. 8, p. 573-582. [Also available at http://publications.gc.ca/ collections/collection_2016/rncan-nrcan/M40-49-831-eng.pdf.]

Grosz, A.E., and Schruben, P.G., 1994, NURE geochemical and geophysical surveys-Defining prospective terranes for United States placer exploration: U.S. Geological Survey Bulletin 2097, 9 p., available at http://pubs.usgs.gov/ bul/2097/report.pdf.

Grosz, A.E., Hathaway, J.C., and Escowitz, E.C., 1986, Placer deposits of heavy minerals in Atlantic Continental Shelf sediments, in Proceedings of the 17th Offshore Technology Conference, Houston, Texas, May 5-8, 1985: Richardson, Texas, Offshore Technology Conference, p. 387-394. [Also available at http://dx.doi.org/10.4043/5198-MS.]

Guéguin, Michel, and Cardarelli, François, 2007, Chemistry and mineralogy of titania-rich slags, Part 1-Hemoilmenite, sulphate, and upgraded titania slags: Mineral Processing and Extractive Metallurgy Review, v. 28, no. 1, p. 1-58. [Also available at http://dx.doi.org/10.1080/08827500600564242.]
Hamilton, N.T.M., 1995, Controls on the global distribution of coastal titanium-zirconium placers: International Geology Review, v. 37, no. 9, p. 755-779. [Also available at http://dx.doi.org/10.1080/00206819509465426.]

Hauck, S.A., Severson, M.J., Zanko, L.M., Barnes, Sarah-Jane, Morton, Penelope, Alminas, H.V., Foord, E.E., and Dahlberg, E.H., 1997, An overview of the geology and oxide, sulfide, and platinum-group element mineralization along the western and northern contacts of the Duluth Complex, in Ojakangas, R.W., Dickas, A.B., and Green, J.C., eds., Middle Proterozoic to Cambrian rifting, central North America: Geological Society of America Special Paper 312, p. 137-185. [Also available at http://dx.doi.org/10.1130/ 0-8137-2312-4.137.]

Herz, Norman, and Force, E.R., 1987, Geology and mineral deposits of the Roseland district of central Virginia: U.S. Geological Survey Professional Paper 1371, 56 p. [Also available at http://pubs.er.usgs.gov/publication/ pp1371/.]

Hou, Baohong, Keeling, John, Reid, Anthony, Fairclough, Martin, Warland, Ian, Belousova, Elena, Frakes, Larry, and Hocking, Roger, 2011, Heavy mineral sands in the Eucla basin, southern Australia - Deposition and province-scale prospectivity: Economic Geology, v. 106, p. 687-712. [Also available at http://dx.doi.org/10.2113/econgeo.106.4.687.]

Hou, Baohong, Keeling, John, and Van Gosen, B.S., 2017, Geological and exploration models of beach placer deposits, integrated from case-studies of southern Australia: Ore Geology Reviews, v. 80, p. 437-459. [Also available at http://dx.doi.org/10.1016/j.oregeorev.2016.07.016.]

International Programme on Chemical Safety, 1982, Environmental Health Criteria 24-Titanium: World Health Organization, accessed January 9, 2013, at http://www.inchem.org/documents/ehc/ehc/ehc24.htm.

Kabata-Pendias, Alina, and Mukherjee, A.B., 2007, Trace elements from soil to human: Berlin, Germany, SpringerVerlag, $550 \mathrm{p}$.

Kaminsky, H.A.W., Etsell, T.H., Ivey, D.G., and Omotoso, Oladipo, 2008, Characterization of heavy minerals in the Athabasca oil sands: Minerals Engineering, v. 21, no. 4, p. 264-271. [Also available at http://dx.doi.org/10.1016/ j.mineng.2007.09.011.]

Kärkkäinen, N.K., and Bornhorst, T.J., 2003, The Svecofennian gabbro-hosted Koivusaarenneva magmatic ilmenite deposit, Kälviä, Finland: Mineralium Deposita, v. 38, no. 2, p. 169-184. [Also available at http://link.springer.com/article/ 10.1007\%2Fs00126-002-0297-0.) 
Korneliussen, Are, McEnroe, S.A., Nilsson, L.P., Schiellerup, Henrik, Gautneb, Håvard, Meyer, G.B., and Størseth, L.R., 2000a, An overview of titanium deposits in Norway: Norges Geologiske Underskøleske Bulletin 436, p. 27-38. [Also available at http://www.ngu.no/ FileArchive/102/Bulletin436_3.pdf.]

Korneliussen, Are, McLimans, Roger, Braathen, Alvar, Erambert, Muriel, Lutro, Ole, and Ragnhildstveit, Jomar, 2000 b, Rutile in eclogites as a mineral resource in the Sunnfjord region, western Norway: Norges Geologiske Underskøleske Bulletin 436, p. 39-47, available at http:/www.ngu.no/FileArchive/102/Bulletin436_4.pdf.

Krause, H., Gierth, E., and Schott, W., 1985, Fe-Ti deposits in the South Rogaland igneous complex, with special reference to the Åna-Sira anorthosite massif: Norges Geologiske Underskøleske Bulletin 402, p. 25-37.

Liou, J.G., Zhang, Ruyuan, Ernst, W.G., Liu, Jun, and McLimans, Roger, 1998, Mineral paragenesis in the Piampaludo eclogitic body, Gruppo di Voltri, Western Ligurian Alps: Schweizerische Mineralogische und Petrographische Mitteilungen-Bulletin Suisse de Mineralogie et Petrographie, v. 78, no. 2, p. 317-335.

Liu, Qi, Cui, Z., and Etsell, T.H., 2006, Characterization of Athabasca oil sands froth treatment tailings for heavy mineral recovery: Fuel, v. 85, nos. 5-6, p. 807-814. [Also available at http://dx.doi.org/10.1016/j.fuel.2005.08.032.]

Mackey, T.S., 1994, Upgrading ilmenite into a high-grade synthetic rutile: Journal of Metals, v. 46, no. 4, p. 59-64. [Also available at http://dx.doi.org/10.1007/BF03220676.]

Marsh, S.P., and Sheridan, D.M., 1976, Rutile in Precambrian sillimanite-quartz gneiss and related rocks, east-central Front Range, Colorado: U.S. Geological Survey Professional Paper 959-G, 17 p. [Also available at http://pubs.er.usgs.gov/publication/pp959G.]

McEnroe, S.A., Robinson, P., and Panish, P.T., 2000, Chemical and petrographic characterization of ilmenite and magnetite in oxide-rich cumulates of the Sokndal region, Rogaland, Norway: Norges Geologiske Undersøkelse Bulletin 436, p. 49-56. [Also available at http://www.ngu.no/FileArchive/ 102/Bulletin436_5.pdf.]

McEnroe, S.A., Robinson, Peter, and Panish, P.T., 2001, Aeromagnetic anomalies, magnetic petrology, and rock magnetism of hemo-ilmenite- and magnetite-rich cumulate rocks from the Sokndal region, South Rogaland, Norway: American Mineralogist, v. 86, p. 1447-1468. [Also available at http://ammin.geoscienceworld.org/ content/86/11-12/1447.full.]
Meinhold, Guido, 2010, Rutile and its applications in earth sciences: Earth-Science Reviews, v. 102, p. 1-28. [Correction to incorrect formula published as Meinhold, Guido, 2013, Erratum to "Rutile and its applications in earth sciences" (Earth-Science Reviews 102 (2010) 1-28): Earth-Science Reviews, v. 116, p. 211.]

Miller, J.A., 1957, Titanium-A materials survey: U.S. Bureau of Mines Information Circular 7791, 202 p.

Morisset, Caroline-Emmanuelle, Scoates, J.S., Weis, Dominique, Suavé, Martin, and Stanaway, K.J., 2010, Rutile-bearing ilmenite deposits associated with the Proterozoic SaintUrbain and Lac Allard anorthosite massifs, Grenville Province, Quebec: Canadian Mineralogist, v. 48, no. 4, p. 821-849. [Also available at http://dx.doi.org/10.3749/ canmin.48.4.821.]

Murphy, Philip, and Frick, Louise, 2006, Titanium, in Kogel, J.E., Trivedi, N.C., Barker, J.M., and Krukowski, S.T., eds., Industrial minerals and rocks (7th ed.): Littleton, Colo., Society for Mining, Metallurgy, and Exploration, Inc., p. 987-1003.

Murty, Ch.V.G.K., Gurung, R., Upadhyay, R., and Asokan, S., 2007, Tata Steel's Titania project - Challenges in slimes disposal, in Heavy minerals conference-Back to basics, 6th, Zulu Nyala, Hluhluwe, South Africa, September 10-14, 2007: Johannesburg, South Africa, Southern African Institute of Mining and Metallurgy, Symposium Series, v. 48, p. 111-118. [Also available at http://www.saimm.co.za/Conferences/ HMC2007/111-118_Murty.pdf.]

Natural Earth, 2014, Small scale data-Natural Earth map dataset, scale 1:110,000,000, accessed June 23, 2014, at http://www.naturalearthdata.com.

Newton, M.C., III, and Romeo, A.J., 2006, Geology of the Old Hickory mineral sand deposit, Dinwiddie and Sussex Counties, Virginia, in Reid, J.C., ed., Proceedings of the 42nd Forum on the Geology of Industrial Minerals, Asheville, North Carolina, May 7-13, 2006: North Carolina Geological Survey Information Circular 34, p. 464-480.

Norges Geologiske Undersøkelse, 2012, Deposit area-Tellnes, in The ore database: Norges Geologiske Undersøkelse database, accessed January 8, 2013, at http://aps.ngu.no/pls/oradb/ minres_deposit_fakta.Main?p_objid=4998\&p_spraak=E.

Olsgard, Frode, and Hasle, J.R., 1993, Impact of waste from titanium mining on benthic fauna: Journal of Experimental Marine Biology and Ecology, v. 172, nos. 1-2, p. 185-213. [Also available at http://dx.doi.org/10.1016/00220981(93)90097-8.] 
Orndorff, Z.W., Daniels, W.L., Meredith, K.R., Alley, M.M., and Wick, A.F., 2011, Effects of prime farmland soil reconstruction methods on post-mining productivity of mineral sands mine soils in Virginia, in Barnhisel, R.I., ed., Reclamation-Sciences leading to success, Proceedings of the 28th Annual National Conference of the American Society of Mining and Reclamation, Bismarck, North Dakota, June 11-16, 2011: Lexington, Ky., American Society of Mining and Reclamation, p. 504-518. [Also available at http://landrehab.org/UserFiles/DataItems/7A5A56505 64671794835553D/Orndorff\%20et\%20al.,\%202011\%20 ASMR\%20Effects\%20of\%20prime\%20farmland.pdf.]

Owens, B.E., and Pasek, M.A., 2007, Kyanite quartzites in the Piedmont province of Virginia-Evidence for a possible high-sulfidation system: Economic Geology, v. 102, p. 495-509. [Also available at http://dx.doi.org/10.2113/ gsecongeo.102.3.495.]

Pepin, Geneviève, Bussière, Bruno, Aubertin, Michel, Benzaazoua, Mostafa, Plante, Benoît, Laflamme, Donald, and Zagury, G.J., 2008, Field experimental cells to evaluate the generation of contaminated neutral drainage by waste rock at the Tio Mine, Quebec, Canada, in Rapantova, N., and Hrkal, Z., eds., Proceedings of the 10th International Mine Water Association (IMWA) Congress on Mine Water and the Environment, Karlsbad, Czech Republic. June 2-5, 2008: International Mine Water Association, p. 309-312, accessed January 14, 2013, at http://www.imwa.info/docs/imwa_2008/ IMWA2008_136_Pepin.pdf.

Pirkle, F.L., Pirkle, W.A., and Pirkle, E.C., 2007, Heavymineral sands of the Atlantic and Gulf coastal plains, USA, chap. 45 of Mange, M.A., and Wright, D.T., eds., Heavy minerals in use: Boston, Mass., Elsevier Developments in Sedimentology Series, v. 58, p. 1145-1232. [Also available at http://dx.doi.org/10.1016/S0070-4571(07)58045-3.]

Plante, B., Benzaazoua, M., and Bussière, B., 2011, Predicting geochemical behavior of waste rock with low acid generating potential using laboratory kinetic tests: Mine Water and the Environment, v. 30, no. 1, p. 2-21. [Also available at http://dx.doi.org/10.1007/s10230-010-0127-z.]

Plante, B., Benzaazoua, M., Bussière, B., Biesinger, M.C., and Pratt, A.R., 2010, Study of Ni sorption onto Tio Mine waste rock surfaces: Applied Geochemistry, v. 25 , no. 12, p. 1830-1844. [Also available at http://dx.doi.org/10.1016/j.apgeochem.2010.09.010.]

Premaratne, W.A.P.J., and Rowson, N.A., 2003, The processing of beach sand from Sri Lanka for the recovery of titanium using magnetic separation: Physical Separation in Science and Engineering, v. 12, no. 1, p. 13-22. [Also available at http://dx.doi.org/10.1080/1478647031000101232.]
Puffer, J.H., and Cousminer, H.L., 1982, Factors controlling the accumulation of titanium-iron oxide-rich sands in the Cohansey Formation, Lakehurst area, New Jersey: Economic Geology, v. 77, p. 379-391. [Also available at http://dx.doi.org/10.2113/gsecongeo.77.2.379.]

Rabbia, O.M., Hernández, L.B., French, D.H., King, R.W., and Ayers, J.C., 2009, The El Teniente porphyry Cu-Mo deposit from a hydrothermal rutile perspective: Mineralium Deposita, v. 44, no. 8, p. 849-866. [Also available at http://dx.doi.org/10.1007/s00126-009-0252-4.]

Reimann, Clemens, and de Caritat, Patrice, 1998, Chemical elements in the environment: Berlin, Germany, SpringerVerlag, $398 \mathrm{p}$.

Rio Tinto, 2009, Health, safety and environment, chap. 3 of Adaptation sustanaible [sic] development report: SorelTracy, Quebec, Canada, Rio Tinto Fer et Titane, p. 13-25, accessed January 8, 2013, at http://www.riotinto.com/ documents/ReportsPublications/RTFT_SD09_eng.pdf.

Rose, E.R., 1969, Geology of titanium and titaniferous deposits of Canada: Geological Survey of Canada, Economic Geology Report no. 25, 177 p.

Roy, P.S., 1999, Heavy mineral beach placers in southeastern Australia-Their nature and genesis: Economic Geology, v. 94, p. 567-588. [Also available at http://dx.doi.org/ 10.2113/gsecongeo.94.4.567.]

Roy, P.S., and Whitehouse, John, 2003, Changing Pliocene sea levels and the formation of heavy minerals beach placers in the Murray basin, southeastern Australia: Economic Geology, v. 98, p. 975-983. [Also available at http://dx.doi.org/10.2113/gsecongeo.98.5.975.]

Rudnick, R.L., and Fountain, D.M., 1995, Nature and composition of the continental crust-A lower crustal perspective: Reviews of Geophysics, v. 33, no. 3, p. 267-309. [Also available at http://dx.doi.org/10.1029/95RG01302.]

Schiellerup, Henrik, Korneliussen, Are, Heldal, Tom, Marker, Mogens, Bjerkgård, Terje, and Nilsson, Lars-Petter, 2003, Mineral resources in the Rogaland Anorthosite Province, south Norway: Origins, history and recent developments, in Duchesne, Jean-Clair, and Korneliussen, Are, eds., Ilmenite deposits and their geological environment: Norges Geologiske Undersøkelse Special Publication 9, p. 117-135.

Shacklette, H.T., and Boerngen, J.G., 1984, Element concentrations in soils and other surficial materials of the conterminous United States: U.S. Geological Survey Professional Paper 1270, 105 p. [Also available at http://pubs.usgs.gov/ $\mathrm{pp} / 1270 /$. 
Sharma, V.K., 2009, Aggregation and toxicity of titanium dioxide nanoparticles in aquatic environment-A review: Journal of Environmental Science and Health Part A, v. 44, no. 14 , p. 1485-1495. [Also available at http://dx.doi.org/ 10.1080/10934520903263231.]

Shi, Guanghai, Li, Xianhua, Li, Qiuli, Chen, Zhenyu, Deng, Jun, Liu, Yingxin, Kang, Zhujuan, Pang, Ercheng, $\mathrm{Xu}$, Yongjin, and Jia, Xiuming, 2012, Ion microprobe U-Pb age and $\mathrm{Zr}$-in-rutile thermometry of rutiles from the Daixian rutile deposit in the Hengshan Mountains, Shanxi Province, China: Economic Geology, v. 107, p. 525-535. [Also available at http://dx.doi.org/10.2113/econgeo.107.3.525.]

Stamper, J.W., 1970, Titanium, in Mineral facts and problems 1970: U.S. Bureau of Mines Bulletin 650, p. 773-794.

Stanaway, Kerry, 1996, The Eastern North America titanium province-A review: Lithology and Mineral Resources, v. 32 , p. 509-517.

Temple, A.K., and Grogan, R.M., 1965, Carbonatite and related alkalic rocks at Powderhorn, Colorado: Economic Geology, v. 60, p. 672-692. [Also available at http://dx.doi.org/10.2113/gsecongeo.60.4.672.]

Towner, R.R., Gray, J.M., and Porter, L.M., 1988, International Strategic Minerals Inventory summary report-Titanium: U.S. Geological Survey Circular 930-G, 59 p. [Also available at http://pubs.er.usgs.gov/publication/cir930G.]

U.S. Bureau of Mines and U.S. Geological Survey, 1980, Principles of a resource/reserve classification for minerals: U.S. Geological Survey Circular 831, 5 p. [Also available at http://pubs.er.usgs.gov/publication/cir831.

U.S. Environmental Protection Agency, 2010, Provisional peer-reviewed toxicity values for titanium: U.S. Environmental Protection Agency Chemical Assessment Summary, CASRN 7440-32-6, accessed January 9, 2013, at http://hhpprtv.ornl.gov/issue_papers/Titanium.pdf.

U.S. Geological Survey, 1996, Global 30 arc-second elevation (GTOPO30): Reston, Va., U.S Geological Survey dataset (digital elevation model), accessed June 23, 2014, at https://lta.cr.usgs.gov/GTOPO30.

Van Gosen, B.S., 2009, The Iron Hill (Powderhorn) carbonatite complex, Gunnison County, Colorado-A potential source of several uncommon mineral resources: U.S. Geological Survey Open-File Report 2009-1005, 28 p. [Also available at http://pubs.usgs.gov/of/2009/1005/.]

Viers, Jérôme, Dupré, Bernard, and Gaillardet, Jérôme, 2009, Chemical composition of suspended sediments in the world rivers-New insights from a new database: Science of the Total Environment, v. 407, no. 2, p. 853-868. [Also available at http://dx.doi.org/10.1016/j.scitotenv.2008.09.053.]
Wang, Jiangxue, Liu, Ying, Jiao, Fang, Lao, Fang, Li, Wei, Gu, Yiqun, Li, Yufeng, Ge, Cuicui, Zhou, Guoqiang, Li, Bai, Zhao, Yuliang, Chai, Zhifang, and Chen, Chunying, 2008, Time-dependent translocation and potential impairment on central nervous system by intranasally instilled $\mathrm{TiO}_{2}$ nanoparticles: Toxicology, v. 254, nos. 1-2, p. 82-90. [Also available at http://dx.doi.org/10.1016/ j.tox.2008.09.014.]

Wilmart, E., Demaiffe, D., and Duchesne, J.-C., 1989, Geochemical constraints on the genesis of the Tellnes ilmenite deposit, southwest Norway: Economic Geology, v. 84, p. 1047-1056. [Also available at http://dx.doi.org/10.2113/gsecongeo.84.5.1047.]

Woodruff, L.G., Nicholson, S.W., and Fey, D.L., 2013, A deposit model for magmatic iron-titanium-oxide deposits related to Proterozoic massif anorthosite plutonic suites: U.S. Geological Survey Scientific Investigations Report 2010-5070-K, 47 p. [This USGS publication supersedes Scientific Investigations Report 2013-5091; also available at http://pubs.usgs.gov/sir/2010/5070/k/]

Wynn, J.C., 1988, Titanium geophysics-The application of induced polarization to sea-floor mineral exploration: Geophysics, v. 53, no. 3, p. 386-401. [Also available at http://dx.doi.org/10.1190/1.1442472.]

Zhang, Weinsheng, Zhu, Zhaowu, and Cheng, C.Y., 2011, A literature review of titanium metallurgical processes: Hydrometallurgy, v. 108, nos. 3-4, p. 177-188. [Also available at http://dx.doi.org/10.1016/j.hydromet.2011.04.005.]

Zhou, M.F., Robinson, P.T., Lesher, C.M., Keays, R.R., Zhang, C.-J., and Malpas, John, 2005, Geochemistry, petrogenesis and metallogenesis of the Panzhihua gabbroic layered intrusion and associated Fe-Ti-V oxide deposits, Sichuan Province, SW China: Journal of Petrology, v. 46, no. 11, p. 2253-2280. [Also available at http://dx.doi.org/ 10.1093/petrology/egi054.]

Zimmerman, Clint, Stilson, Chuck, and Daniels, W.L., 2008, Reclamation of mineral sands mine and topsoil replacement study, in Proceedings of the 25th Annual Meeting of the American Society of Mining and Reclamation and 10th meeting of the IALR, Richmond, VA, June 14-19, 2008: Lexington, Ky., American Society of Mining and Reclamation, p. 1429-1444. [Also available at http://landrehab.org/ UserFiles/DataItems/61326B4E366357773754493D/ Zimmerman\%20et\%20al.,\%202008\%20ASMR\%20 Reclamation\%20of\%20Mineral-VA.pdf.] 



\section{Vanadium}

By Karen D. Kelley, Clinton T. Scott, Désirée E. Polyak, and Bryn E. Kimball

Chapter U of

Critical Mineral Resources of the United States-Economic and Environmental Geology and Prospects for Future Supply

Edited by Klaus J. Schulz, John H. DeYoung, Jr., Robert R. Seal II, and Dwight C. Bradley

Professional Paper 1802-U

U.S. Department of the Interior

U.S. Geological Survey 


\section{Contents of Chapter U}

[Figure and table titles for all chapters are listed in the volume contents before the conversion factors table and list of abbreviations and symbols. A periodic table of the elements is on the inside front cover of the printed volume]

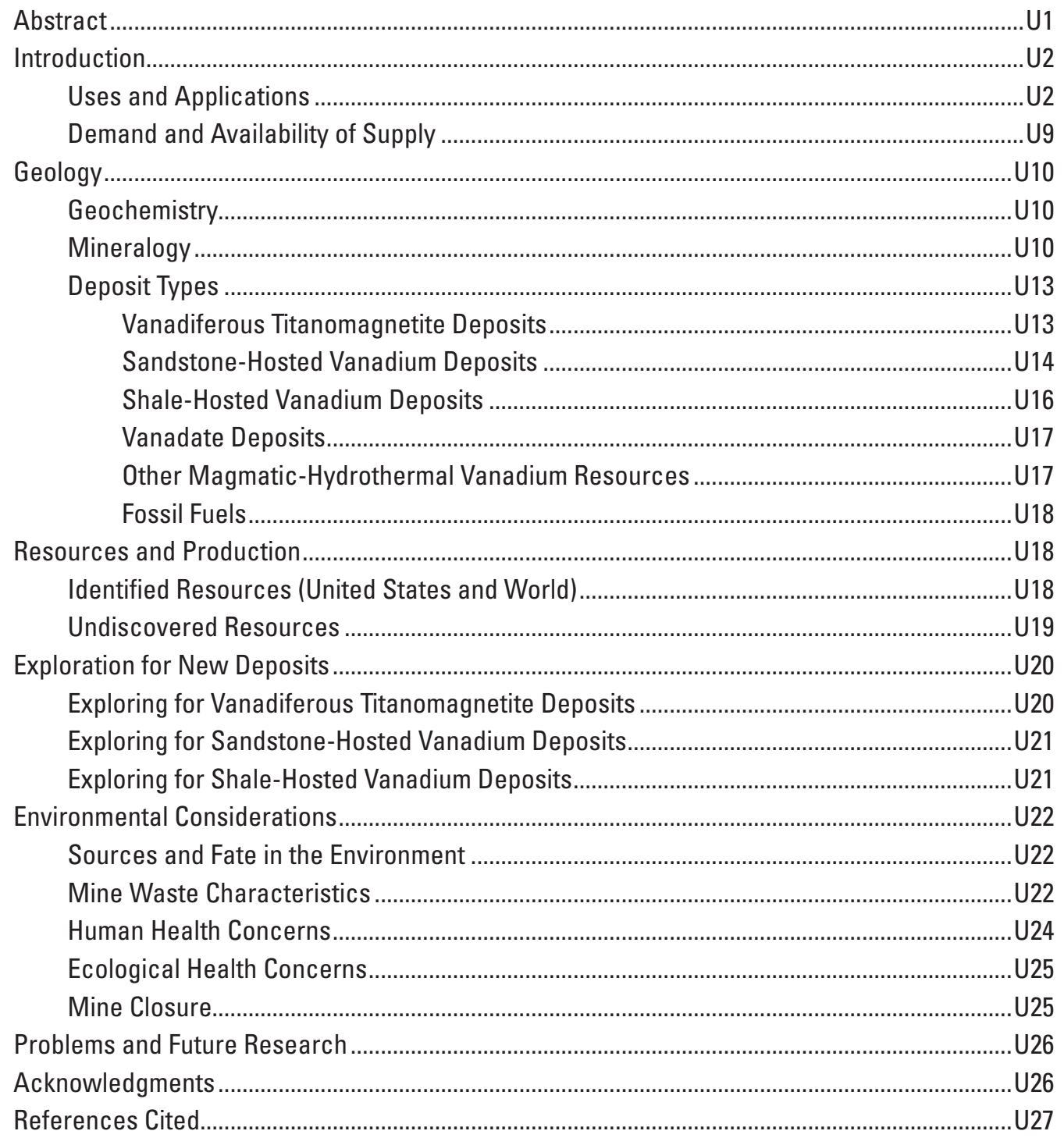




\title{
Vanadium
}

\author{
By Karen D. Kelley, Clinton T. Scott, Désirée E. Polyak, and Bryn E. Kimball
}

\section{Abstract}

Vanadium is used primarily in the production of steel alloys; as a catalyst for the chemical industry; in the making of ceramics, glasses, and pigments; and in vanadium redox-flow batteries (VRBs) for large-scale storage of electricity. World vanadium resources in 2012 were estimated to be 63 million metric tons, which include about 14 million metric tons of reserves. The majority of the vanadium produced in 2012 was from China, Russia, and South Africa.

Vanadium is extracted from several different types of mineral deposits and from fossil fuels. These deposits include vanadiferous titanomagnetite (VTM) deposits, sandstonehosted vanadium (with or without uranium) deposits (SSV deposits), and vanadium-rich black shales. VTM deposits are the principal source of vanadium and consist of magmatic accumulations of ilmenite and magnetite containing 0.2 to 1 weight percent vanadium pentoxide $\left(\mathrm{V}_{2} \mathrm{O}_{5}\right)$. SSV deposits are another important source; these deposits have average ore grades that range from 0.1 to greater than 1 weight percent $\mathrm{V}_{2} \mathrm{O}_{5}$. The United States has been and is currently the main producer of vanadium from SSV deposits, particularly those on the Colorado Plateau. Vanadium-rich black shales occur in marine successions that were deposited in epeiric (inland) seas and on continental margins. Concentrations in these shales regularly exceed 0.18 weight percent $\mathrm{V}_{2} \mathrm{O}_{5}$ and can be as high as 1.7 weight percent $\mathrm{V}_{2} \mathrm{O}_{5}$. Small amounts of vanadium have been produced from the Alum Shale in Sweden and from ferrophosphorus slag generated during the reduction of phosphate to elemental phosphorus in ore from shales of the Phosphoria Formation in Idaho and Wyoming. Because vanadium enrichment occurs in beds that are typically only a few meters thick, most of the vanadiferous black shales are not currently economic, although they may become an important resource in the future. Significant amounts of vanadium are recovered as byproducts of petroleum refining, and processing of coal, tar sands, and oil shales may be important future sources.
Vanadium occurs in one of four oxidation states in nature: $+2,+3,+4$, and +5 . The $\mathrm{V}^{3+}$ ion has an octahedral radius that is almost identical to that of $\mathrm{Fe}^{3+}$ and $\mathrm{Al}^{3+}$ and, therefore, it substitutes in ferromagnesian minerals. During weathering, much of the vanadium may partition into newly formed clay minerals, and it either remains in the +3 valence state or oxidizes to the +4 valence state, both of which are relatively insoluble. If erosion is insignificant but chemical leaching is intense, the residual material may be enriched in vanadium, as are some bauxites and laterites. During the weathering of igneous, residual, or sedimentary rocks, some vanadium oxidizes to the +5 valence state, especially in the intensive oxidizing conditions that are characteristic of arid climates.

The average contents of vanadium in the environment are as follows: soils (10 to 500 parts per million [ppm]); streams and rivers ( 0.2 to 2.9 parts per billion [ppb]); and coastal seawater ( 0.3 to $2.8 \mathrm{ppb}$ ). Concentrations of vanadium in soils (548 to 7,160 ppm) collected near vanadium mines in China, the Czech Republic, and South Africa are many times greater than natural concentrations in soils. Additionally, if deposits contain sulfide minerals such as chalcocite, pyrite, and sphalerite, high levels of acidity may be present if sulfide dissolution is not balanced by the presence of acid-neutralizing carbonate minerals. Some of the vanadium-bearing deposit types, particularly some SSV and black shale deposits, contain appreciable amounts of carbonate minerals, which lowers the acid-generation potential.

Vanadium is a micronutrient with a postulated requirement for humans of less than 10 micrograms per day, which can be met through dietary intake. Primary and secondary drinking water regulations for vanadium are not currently in place in the United States. Vanadium toxicity is thought to result from an intake of more than 10 to 20 milligrams per day. Vanadium is essential for some biological processes and organisms. For example, some nitrogen-fixing bacteria require vanadium for producing enzymes necessary to convert nitrogen from the atmosphere into ammonia, which is a more biologically accessible form of nitrogen. 


\section{Introduction}

Vanadium (V) is a strategic metal that is used principally in the production of metal alloys, such as high-strength steel and alloys for use in the aerospace industry. Secondary uses are as catalysts for the chemical industry, and in ceramics, glasses, and pigments. In its native state, vanadium is a hard, silvery gray, ductile, and malleable transition metal. Vanadium consumption trends are heavily influenced by trends in steel production.

The emerging need for large-scale electricity storage makes vanadium redox-flow batteries (VRBs) a major potential future use of vanadium. Because of their largescale storage capacity, development of VRBs could prompt increases in the use of wind, solar, and other renewable, intermittent power sources. Lithium-vanadium-phosphate batteries produce high voltages and high energy-to-weight ratios, which make them ideal for use in electric cars. Vanadium use in lithium batteries is expected to increase to 1,700 metric tons in 2017 from 200 metric tons in 2012 (Perles, 2013).

Vanadium is the $22 \mathrm{~d}$ most abundant element in Earth's crust, and it is an essential constituent of many minerals. A total of 156 minerals contain vanadium as a major ( $>10$ weight percent) constituent. Several diverse mineral deposit types contain vanadium-bearing minerals, and vanadium is a common component of petroleum and other fossil fuels. Vanadium deposits are globally distributed (fig. U1) and comprise four principal deposit types: vanadiferous titanomagnetite (VTM), sandstone-hosted vanadium (SSV), shale-hosted vanadium, and vanadate deposits (table U1). Additionally, significant amounts of vanadium are available for commercial use as a byproduct of petroleum refining, and processing of coal, tar sands, and oil shales may be important future sources. World vanadium resources in 2012 were estimated to be 63 million metric tons of vanadium. Reserves were estimated to be 14 million metric tons. The majority of vanadium production in 2012 was from China (37 percent), South Africa (35 percent), and Russia (25 percent) (fig. U2; Polyak, 2013).

\section{Uses and Applications}

The vanadium market closely follows that of the steel industry, which in turn follows economic trends. Metallurgical applications in steel continued to dominate United States vanadium usage in 2011 (fig. U3), accounting for 93 percent of reported consumption (Polyak, 2013). Vanadium is used in steel to impart strength, toughness, and wear resistance. The formation of vanadium-rich carbides and nitrides imparts the strength to steel; the addition of only a few kilograms of vanadium per ton of steel increases the strength of the steel by as much as 25 percent. Apart from its strengthening characteristic, vanadium also inhibits corrosion and oxidation.

There are many sources of vanadium, and it is used in a number of common products (fig. U4). Commercial products developed through the processing of vanadium ores are mainly ferrovanadium (FeV), which is an iron-vanadium alloy, and vanadium pentoxide $\left(\mathrm{V}_{2} \mathrm{O}_{5}\right)$. Most vanadium is added to steel as ferrovanadium. Ferrovanadium is available in compositions containing 45 to 50 percent vanadium and 80 percent vanadium. The 45- to 50-percent grade is produced from slag and other vanadium-bearing residues; the 80-percent grade is produced by the reduction of $\mathrm{V}_{2} \mathrm{O}_{5}$.

The high-strength, low-alloy (HSLA) steels containing vanadium are widely used for the construction of auto parts, buildings, bridges, cranes, pipelines, rail cars, ships, and truck bodies, including armor plating for military vehicles (Polyak, 2012). Such HSLA steels are increasingly being used in the oil and gas industry to meet demand for pipelines with higher strength and higher low-temperature toughness (Roskill Information Services, Ltd., 2010, p. 150). Vanadium is used in tool steels in various combinations with chromium, niobium (columbium), manganese, molybdenum, titanium, and tungsten. Only a limited degree of substitution is possible among these metals, however. Replacement of vanadium with other mineral commodities requires significant technical adjustments to the steel production process to ensure that product specifications and quality are not compromised. For example, use of vanadium generally requires less energy consumption during production than does niobium to give equivalent steel properties. Therefore, substitution for vanadium is normally not considered for short-term changes in market conditions because of the considerable effort involved in implementing the change.

Vanadium is irreplaceable for its role in aerospace applications because vanadium-titanium alloys have the best strength-to-weight ratio of any engineered material yet discovered. Vanadium, when combined with titanium, produces a stronger and more stable alloy, and when combined with aluminum produces a material suitable for jet engines and high-speed airframes. No acceptable substitutes exist for vanadium in aerospace titanium alloys.

Nonmetallurgical applications of vanadium include catalysts, ceramics, electronics, and vanadium chemicals. For catalytic uses, platinum and nickel can replace vanadium compounds in some chemical processes. Vanadium dioxide is used in the production of glass coatings that block infrared radiation.

Vanadium is becoming more widely used in green technology applications, especially in battery technology. One battery technology that continues to show promise in stabilizing energy distribution in renewable systems is the VRB, which consists of an assembly of power cells in which two vanadium-based electrolytes are separated by a proton exchange membrane. The main advantages of the VRBs are (a) their nearly unlimited capacity, which is made possible simply by using sequentially larger storage tanks; (b) their ability to be left completely discharged for long periods of time with no detrimental effects; (c) the ease of recharging them by replacing the electrolyte if no power source is available to charge it; and (d) their ability to withstand permanent damage if the electrolytes are accidentally mixed (Polyak, 2012). 


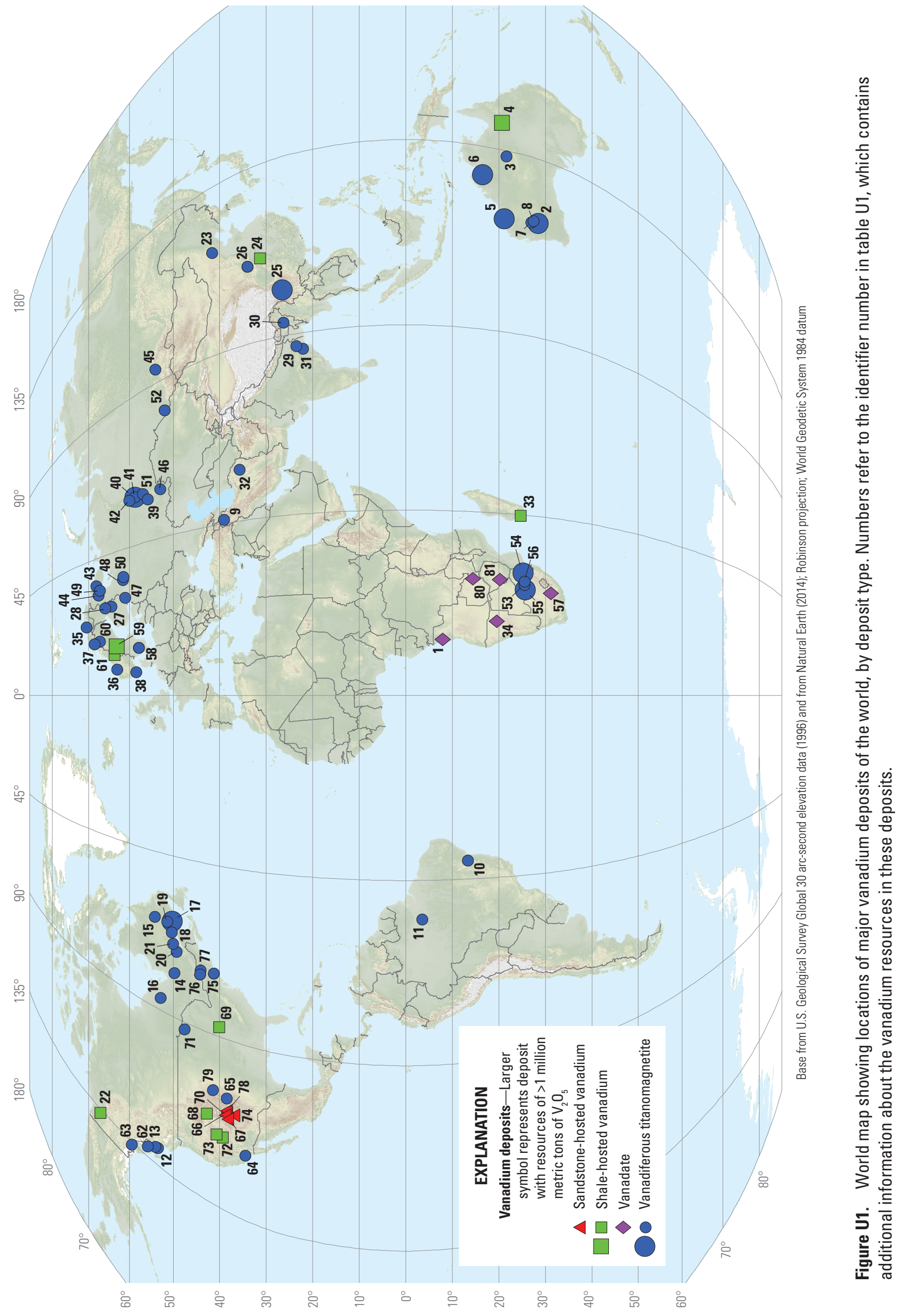


Table U1. Location, grade, tonnage, and other data for selected vanadium deposits of the world.

[ID, identifier, shown in figs. U1 and U5; WGS 84, World Geodetic System of 1984; negative values for latitude indicate that the deposit is in the Southern Hemisphere; negative values for longitude indicate that the deposit is in the Western Hemisphere; \%, percent; $\mathrm{V}_{2} \mathrm{O}_{5}$, vanadium oxide; VTM, vanadiferous titanomagnetite; n.d., no data available; NA, not available; t, metric ton; SSV, sandstone-hosted vanadium]

\begin{tabular}{|c|c|c|c|c|c|c|c|c|c|c|c|}
\hline ID & Deposit & Country & $\begin{array}{l}\text { District, } \\
\text { region, } \\
\text { or State/ } \\
\text { Province }\end{array}$ & $\begin{array}{l}\text { Deposit } \\
\text { type }\end{array}$ & $\begin{array}{r}\text { Latitude } \\
\text { (decima } \\
\text { WG }\end{array}$ & $\begin{array}{l}\text { degrees, } \\
\text { S 84) }\end{array}$ & $\begin{array}{c}\text { Resource } \\
\text { tonnage } \\
\text { (million } \\
\text { metric } \\
\text { tons) }\end{array}$ & $\begin{array}{c}\text { Grade } \\
\left(\% \mathrm{~V}_{2} \mathrm{O}_{5}\right)\end{array}$ & $\begin{array}{c}\mathrm{V}_{2} \mathrm{O}_{5} \\
\text { content } \\
\text { (million } \\
\text { metric } \\
\text { tons) }\end{array}$ & $\begin{array}{l}\text { Production, } \\
\text { resources, } \\
\text { or reserves }\end{array}$ & $\begin{array}{l}\text { Source } \\
\text { of data }\end{array}$ \\
\hline 1 & Lueca Mine & Angola & NA & $\begin{array}{l}\text { Vana- } \\
\text { date }\end{array}$ & -7.92 & 13.65 & n.d. & n.d. & n.d. & n.d. & $\begin{array}{l}\text { Fischer } \\
\qquad(1975 a)\end{array}$ \\
\hline 3 & Mount Peake & Australia & $\begin{array}{l}\text { Northern } \\
\text { Territory }\end{array}$ & VTM & -21.66 & 133.66 & 160 & 0.3 & 0.48 & Resources & $\begin{array}{l}\text { TNG Ltd. } \\
\text { (2015) }\end{array}$ \\
\hline 4 & Julia Creek & Australia & Queensland & $\begin{array}{l}\text { Shale- } \\
\text { hosted }\end{array}$ & -20.65 & 141.73 & 411 & 0.44 & 1.1 & Resources & $\begin{array}{l}\text { Lewis and oth- } \\
\quad \text { ers (2010) }\end{array}$ \\
\hline 7 & Gabanintha & Australia & $\begin{array}{l}\text { Western } \\
\text { Australia }\end{array}$ & VTM & -27.00 & 118.60 & 125.8 & 0.7 & 0.88 & Resources & $\begin{array}{l}\text { Britt and oth- } \\
\quad \text { ers (2014) }\end{array}$ \\
\hline 8 & Barrambie & Australia & $\begin{array}{l}\text { Western } \\
\text { Australia }\end{array}$ & VTM & -27.42 & 119.11 & 47.2 & 0.63 & 0.3 & Resources & $\begin{array}{l}\text { Britt and oth- } \\
\quad \text { ers (2014) }\end{array}$ \\
\hline 9 & Svorantskoe & Azerbaijan & $\begin{array}{l}\text { Chelyabin- } \\
\text { skaya } \\
\text { Oblast }\end{array}$ & VTM & 39.00 & 46.00 & n.d. & n.d. & n.d. & n.d. & $\begin{array}{l}\text { Fischer } \\
\qquad(1975 b)\end{array}$ \\
\hline 10 & Maracas & Brazil & Bahia & VTM & -13.41 & -40.43 & 24.6 & 1.11 & 0.27 & Resources & $\begin{array}{l}\text { Fischer } \\
\qquad(1975 b)\end{array}$ \\
\hline 15 & $\begin{array}{l}\text { Lake Michi- } \\
\text { kamau }\end{array}$ & Canada & $\begin{array}{l}\text { Newfound- } \\
\text { land and } \\
\text { Labrador }\end{array}$ & VTM & 54.12 & -63.98 & n.d. & n.d. & n.d. & n.d. & $\begin{array}{l}\text { Fischer } \\
\qquad(1975 b)\end{array}$ \\
\hline 16 & Ring of Fire & Canada & Ontario & VTM & 52.80 & -86.50 & n.d. & n.d. & n.d. & n.d. & $\begin{array}{l}\text { Fischer } \\
\qquad(1975 b)\end{array}$ \\
\hline 17 & $\begin{array}{r}\text { Lac Tio (Al- } \\
\text { lard Lake) }\end{array}$ & Canada & Quebec & VTM & 50.56 & 63.41 & 350 & 0.3 & 1.05 & Resources & $\begin{array}{l}\text { Fischer } \\
\text { (1975b) }\end{array}$ \\
\hline 18 & Sept Îles & Canada & Quebec & VTM & 50.34 & -66.51 & n.d. & n.d. & n.d. & n.d. & $\begin{array}{l}\text { Fischer } \\
\qquad(1975 b)\end{array}$ \\
\hline 19 & $\begin{array}{l}\text { Magpie } \\
\text { Mountain }\end{array}$ & Canada & Quebec & VTM & 51.38 & -64.07 & n.d. & n.d. & n.d. & n.d. & $\begin{array}{l}\text { Fischer } \\
\qquad(1975 b)\end{array}$ \\
\hline 20 & Lac St. Jean & Canada & Quebec & VTM & 49.33 & -71.50 & n.d. & n.d. & n.d. & n.d. & $\begin{array}{l}\text { Fischer } \\
\qquad(1975 b)\end{array}$ \\
\hline
\end{tabular}


Table U1. Location, grade, tonnage, and other data for selected vanadium deposits of the world._Continued

[ID, identifier, shown in figs. U1 and U5; WGS 84, World Geodetic System of 1984; negative values for latitude indicate that the deposit is in the Southern Hemisphere; negative values for longitude indicate that the deposit is in the Western Hemisphere; \%, percent; $\mathrm{V}_{2} \mathrm{O}_{5}$, vanadium oxide; VTM, vanadiferous titanomagnetite; n.d., no data available; NA, not available; t, metric ton; SSV, sandstone-hosted vanadium]

\begin{tabular}{|c|c|c|c|c|c|c|c|c|c|c|c|}
\hline ID & Deposit & Country & $\begin{array}{l}\text { District, } \\
\text { region, } \\
\text { or State/ } \\
\text { Province }\end{array}$ & $\begin{array}{l}\text { Deposit } \\
\text { type }\end{array}$ & $\begin{array}{r}\text { Latitude } \\
\text { (decimal } \\
\text { WG }\end{array}$ & $\begin{array}{l}\text { degrees, } \\
\text { ( 84) }\end{array}$ & $\begin{array}{c}\text { Resource } \\
\text { tonnage } \\
\text { (million } \\
\text { metric } \\
\text { tons) }\end{array}$ & $\begin{array}{c}\text { Grade } \\
\left(\% \mathrm{~V}_{2} \mathrm{O}_{5}\right)\end{array}$ & $\begin{array}{c}\mathrm{V}_{2} \mathrm{O}_{5} \\
\text { content } \\
\text { (million } \\
\text { metric } \\
\text { tons) }\end{array}$ & $\begin{array}{l}\text { Production, } \\
\text { resources, } \\
\text { or reserves }\end{array}$ & $\begin{array}{l}\text { Source } \\
\text { of data }\end{array}$ \\
\hline 21 & $\begin{array}{l}\text { LaBlache- } \\
\text { Hervieux- } \\
\text { Shmoo } \\
\text { Lakes }\end{array}$ & Canada & Quebec & VTM & 50.06 & -69.63 & 101.7 & 0.18 & 0.18 & Resources & $\begin{array}{l}\text { Fischer } \\
\text { (1975b) }\end{array}$ \\
\hline 22 & Nick & Canada & Yukon & $\begin{array}{l}\text { Shale- } \\
\text { hosted }\end{array}$ & 68.65 & -135.25 & n.d. & n.d. & n.d. & n.d. & $\begin{array}{l}\text { Hulbert and } \\
\text { others (1992) }\end{array}$ \\
\hline 23 & Luanping & China & $\begin{array}{l}\text { Hubei } \\
\text { Province }\end{array}$ & VTM & 41.50 & 117.50 & n.d. & n.d. & n.d. & n.d. & $\begin{array}{l}\text { Fischer } \\
\qquad(1975 b)\end{array}$ \\
\hline 24 & $\begin{array}{l}\text { Maocaoping, } \\
\text { Baig- } \\
\text { uoyuan }\end{array}$ & China & $\begin{array}{l}\text { Hubei } \\
\text { Province }\end{array}$ & $\begin{array}{l}\text { Shale- } \\
\text { hosted }\end{array}$ & 31.27 & 111.08 & n.d. & n.d. & n.d. & n.d. & $\begin{array}{l}\text { Coveney and } \\
\text { Nansheng } \\
\text { (1991) }\end{array}$ \\
\hline 26 & Shanyang & China & $\begin{array}{l}\text { Shaanxi } \\
\text { Province }\end{array}$ & VTM & 33.87 & 109.94 & n.d. & n.d. & n.d. & n.d. & $\begin{array}{l}\text { Fischer } \\
\text { (1975b) }\end{array}$ \\
\hline 27 & Otanmaki & Finland & $\begin{array}{l}\text { Kajaani, } \\
\text { Kainuu } \\
\text { Region }\end{array}$ & VTM & 64.13 & 27.10 & n.d. & n.d. & n.d. & n.d. & $\begin{array}{l}\text { Fischer } \\
\qquad(1975 b)\end{array}$ \\
\hline 28 & Mustavaara & Finland & $\begin{array}{l}\text { Oulu, North } \\
\text { Ostro- } \\
\text { bothnia } \\
\text { Region }\end{array}$ & VTM & 65.78 & 27.99 & n.d. & n.d. & n.d. & n.d. & $\begin{array}{l}\text { Fischer } \\
\qquad(1975 b)\end{array}$ \\
\hline 31 & Shaltora & India & West Bengal & VTM & 23.42 & 86.92 & n.d. & n.d. & n.d. & n.d. & $\begin{array}{l}\text { Fischer } \\
\text { (1975b) }\end{array}$ \\
\hline 32 & Rivash & Iran & $\begin{array}{l}\text { Razavi } \\
\text { Khorasan } \\
\text { Province }\end{array}$ & VTM & 35.64 & 58.33 & n.d. & n.d. & n.d. & n.d. & $\begin{array}{l}\text { Fischer } \\
\qquad(1975 b)\end{array}$ \\
\hline 33 & Green giant & Madagascar & $\begin{array}{l}\text { Tulear } \\
\text { Region }\end{array}$ & $\begin{array}{l}\text { Shale- } \\
\text { hosted } \\
\text { (meta) }\end{array}$ & -24.69 & 44.75 & 49.9 & 0.693 & 0.35 & Resources & $\begin{array}{l}\text { Energizer } \\
\text { Resources, } \\
\text { Inc. (2013) }\end{array}$ \\
\hline 34 & $\begin{array}{c}\text { Berg Aukas, } \\
\text { Abenad, } \\
\text { Tsumeb }\end{array}$ & Namibia & $\begin{array}{l}\text { Otavi Moun- } \\
\text { tainland }\end{array}$ & $\begin{array}{l}\text { Vana- } \\
\text { date }\end{array}$ & -19.51 & 18.25 & 3.2 & 0.75 & 0.024 & Resources & $\begin{array}{l}\text { Fischer (1975a); } \\
\text { Boni and } \\
\text { others } \\
(2007)\end{array}$ \\
\hline 35 & $\begin{array}{l}\text { Stjernoy- } \\
\text { Seiland }\end{array}$ & Norway & $\begin{array}{l}\text { Finnmark } \\
\text { County }\end{array}$ & VTM & 70.50 & 23.00 & n.d. & n.d. & n.d. & n.d. & $\begin{array}{l}\text { Fischer } \\
\qquad(1975 b)\end{array}$ \\
\hline
\end{tabular}


Table U1. Location, grade, tonnage, and other data for selected vanadium deposits of the world.-Continued

[ID, identifier, shown in figs. U1 and U5; WGS 84, World Geodetic System of 1984; negative values for latitude indicate that the deposit is in the Southern Hemisphere; negative values for longitude indicate that the deposit is in the Western Hemisphere; \%, percent; $\mathrm{V}_{2} \mathrm{O}_{5}$, vanadium oxide; VTM, vanadiferous titanomagnetite; n.d., no data available; NA, not available; t, metric ton; SSV, sandstone-hosted vanadium]

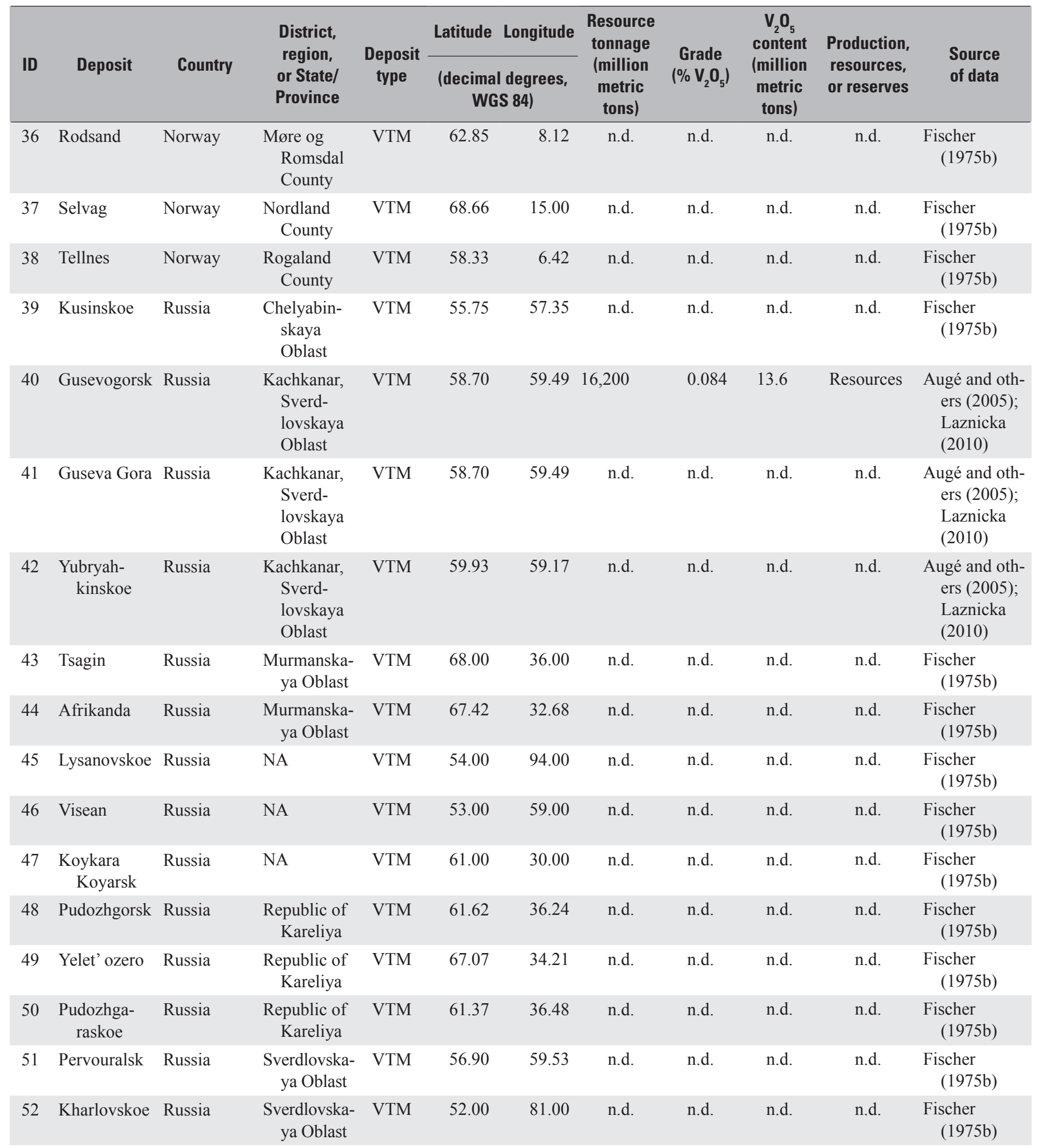


Table U1. Location, grade, tonnage, and other data for selected vanadium deposits of the world.—Continued

[ID, identifier, shown in figs. U1 and U5; WGS 84, World Geodetic System of 1984; negative values for latitude indicate that the deposit is in the Southern Hemisphere; negative values for longitude indicate that the deposit is in the Western Hemisphere; \%, percent; $\mathrm{V}_{2} \mathrm{O}_{5}$, vanadium oxide; VTM, vanadiferous titanomagnetite; n.d., no data available; NA, not available; t, metric ton; SSV, sandstone-hosted vanadium]

\begin{tabular}{|c|c|c|c|c|c|c|c|c|c|c|c|}
\hline ID & Deposit & Country & $\begin{array}{l}\text { District, } \\
\text { region, } \\
\text { or State/ } \\
\text { Province }\end{array}$ & $\begin{array}{l}\text { Deposit } \\
\text { type }\end{array}$ & $\begin{array}{r}\text { Latitude } \\
\text { (decima } \\
\text { WG }\end{array}$ & $\begin{array}{l}\text { degrees, } \\
\text { S 84) }\end{array}$ & $\begin{array}{l}\text { Resource } \\
\text { tonnage } \\
\text { (million } \\
\text { metric } \\
\text { tons) }\end{array}$ & $\begin{array}{c}\text { Grade } \\
\left(\% \mathrm{~V}_{2} \mathrm{O}_{5}\right)\end{array}$ & $\begin{array}{c}\mathrm{V}_{2} \mathrm{O}_{5} \\
\text { content } \\
\text { (million } \\
\text { metric } \\
\text { tons) }\end{array}$ & $\begin{array}{l}\text { Production, } \\
\text { resources, } \\
\text { or reserves }\end{array}$ & $\begin{array}{l}\text { Source } \\
\text { of data }\end{array}$ \\
\hline 53 & Vantra & $\begin{array}{l}\text { South } \\
\text { Africa }\end{array}$ & $\begin{array}{c}\text { Brits, North } \\
\text { West } \\
\text { Province }\end{array}$ & VTM & -25.63 & 27.78 & n.d. & n.d. & n.d. & n.d. & $\begin{array}{l}\text { Fischer } \\
\text { (1975b) }\end{array}$ \\
\hline 55 & $\begin{array}{r}\text { Rhovan } \\
\text { Mine }\end{array}$ & $\begin{array}{l}\text { South } \\
\text { Africa }\end{array}$ & $\begin{array}{l}\text { Bushveld } \\
\text { Igneous } \\
\text { Complex, } \\
\text { Limpopo } \\
\text { Province }\end{array}$ & VTM & -25.57 & 27.57 & 203 & 0.52 & 1.06 & Resources & $\begin{array}{l}\text { Reynolds } \\
\text { (1985); } \\
\text { Rohrmann } \\
\text { (1985) }\end{array}$ \\
\hline 56 & $\begin{array}{l}\text { Kroko- } \\
\text { dilkraal } \\
\text { Mine }\end{array}$ & $\begin{array}{l}\text { South } \\
\text { Africa }\end{array}$ & $\begin{array}{l}\text { Bushveld } \\
\text { Igneous } \\
\text { Complex, } \\
\text { North West } \\
\text { Province }\end{array}$ & VTM & -25.60 & 28.18 & n.d. & n.d. & n.d. & n.d. & $\begin{array}{l}\text { Reynolds } \\
\text { (1985); } \\
\text { Rohrmann } \\
\text { (1985) }\end{array}$ \\
\hline 57 & $\begin{array}{l}\text { Kafferskrall } \\
\text { Farm }\end{array}$ & $\begin{array}{l}\text { South } \\
\text { Africa }\end{array}$ & $\begin{array}{l}\text { North West } \\
\text { Province }\end{array}$ & $\begin{array}{l}\text { Vana- } \\
\text { date }\end{array}$ & -31.15 & 25.85 & n.d. & n.d. & n.d. & n.d. & $\begin{array}{l}\text { Fischer } \\
\qquad(1975 a)\end{array}$ \\
\hline 58 & Taberg & Sweden & $\begin{array}{c}\text { Jönköping } \\
\text { County }\end{array}$ & VTM & 57.75 & 14.17 & n.d. & n.d. & n.d. & n.d. & $\begin{array}{l}\text { Fischer } \\
\qquad(1975 b)\end{array}$ \\
\hline 59 & Viken & Sweden & $\begin{array}{l}\text { Myrviken, } \\
\text { Jämtland } \\
\text { County }\end{array}$ & $\begin{array}{l}\text { Shale- } \\
\text { hosted }\end{array}$ & 63.12 & 14.36 & 685 & 0.29 & 1.98 & Resources & $\begin{array}{l}\text { Aura Energy } \\
\text { (2012) }\end{array}$ \\
\hline 62 & Union Bay & $\begin{array}{l}\text { United } \\
\text { States }\end{array}$ & Alaska & VTM & 55.77 & -132.10 & n.d. & n.d. & n.d. & n.d. & $\begin{array}{l}\text { Fischer } \\
\qquad(1975 b)\end{array}$ \\
\hline 63 & $\begin{array}{l}\text { Klukwan } \\
\text { Fan }\end{array}$ & $\begin{array}{l}\text { United } \\
\text { States }\end{array}$ & Alaska & VTM & 59.42 & -135.88 & n.d. & n.d. & n.d. & n.d. & $\begin{array}{l}\text { Fischer } \\
\text { (1975b) }\end{array}$ \\
\hline 64 & $\begin{array}{l}\text { San Gabriel } \\
\text { Mountains }\end{array}$ & $\begin{array}{l}\text { United } \\
\text { States }\end{array}$ & California & VTM & 34.37 & -118.30 & n.d. & n.d. & n.d. & n.d. & $\begin{array}{l}\text { Fischer } \\
\qquad(1975 b)\end{array}$ \\
\hline 65 & $\begin{array}{l}\text { McClure } \\
\text { Mountain }\end{array}$ & $\begin{array}{l}\text { United } \\
\text { States }\end{array}$ & Colorado & VTM & 38.34 & -105.42 & n.d. & n.d. & n.d. & n.d. & $\begin{array}{l}\text { Fischer } \\
\quad(1975 b)\end{array}$ \\
\hline 66 & $\begin{array}{l}\text { Buckmaster } \\
\text { Draw }\end{array}$ & $\begin{array}{l}\text { United } \\
\text { States }\end{array}$ & $\begin{array}{l}\text { Green River, } \\
\text { Utah }\end{array}$ & SSV & 38.68 & -110.03 & 0.67 & 0.19 & 0.0012 & n.d. & $\begin{array}{l}\text { Fischer } \\
\text { (1968) }\end{array}$ \\
\hline 67 & $\begin{array}{l}\text { Tony M, } \\
\text { Frank M }\end{array}$ & $\begin{array}{l}\text { United } \\
\text { States }\end{array}$ & $\begin{array}{l}\text { Henry Mtns., } \\
\text { Utah }\end{array}$ & SSV & 38.11 & -110.81 & n.d. & n.d. & n.d. & n.d. & $\begin{array}{l}\text { Johnson } \\
\text { (1959) }\end{array}$ \\
\hline
\end{tabular}


Table U1. Location, grade, tonnage, and other data for selected vanadium deposits of the world.—Continued

[ID, identifier, shown in figs. U1 and U5; WGS 84, World Geodetic System of 1984; negative values for latitude indicate that the deposit is in the Southern Hemisphere; negative values for longitude indicate that the deposit is in the Western Hemisphere; \%, percent; $\mathrm{V}_{2} \mathrm{O}_{5}$, vanadium oxide; VTM, vanadiferous titanomagnetite; n.d., no data available; NA, not available; t, metric ton; SSV, sandstone-hosted vanadium]

\begin{tabular}{|c|c|c|c|c|c|c|c|c|c|c|c|}
\hline ID & Deposit & Country & $\begin{array}{l}\text { District, } \\
\text { region, } \\
\text { or State/ } \\
\text { Province }\end{array}$ & $\begin{array}{l}\text { Deposit } \\
\text { type }\end{array}$ & $\begin{array}{r}\text { Latitude } \\
\begin{array}{r}\text { (decimal } \\
\text { WG }\end{array}\end{array}$ & $\begin{array}{l}\text { degrees, } \\
\text { S 84) }\end{array}$ & $\begin{array}{c}\text { Resource } \\
\text { tonnage } \\
\text { (million } \\
\text { metric } \\
\text { tons) }\end{array}$ & $\begin{array}{c}\text { Grade } \\
\left(\% \mathrm{~V}_{2} \mathrm{O}_{5}\right)\end{array}$ & $\begin{array}{c}\mathrm{V}_{2} \mathrm{O}_{5} \\
\text { content } \\
\text { (million } \\
\text { metric } \\
\text { tons) }\end{array}$ & $\begin{array}{l}\text { Production, } \\
\text { resources, } \\
\text { or reserves }\end{array}$ & $\begin{array}{l}\text { Source } \\
\text { of data }\end{array}$ \\
\hline 68 & Phosphoria & $\begin{array}{l}\text { United } \\
\text { States }\end{array}$ & Idaho & $\begin{array}{l}\text { Shale- } \\
\text { hosted }\end{array}$ & 42.70 & -111.83 & n.d. & n.d. & n.d. & n.d. & $\begin{array}{l}\text { Love and oth- } \\
\text { ers (2003); } \\
\text { Jasinski } \\
\text { (2004) }\end{array}$ \\
\hline 69 & $\begin{array}{l}\text { Mecca } \\
\text { Quarry } \\
\text { shale }\end{array}$ & $\begin{array}{l}\text { United } \\
\text { States }\end{array}$ & $\begin{array}{c}\text { Illinois and } \\
\text { Indiana }\end{array}$ & $\begin{array}{l}\text { Shale- } \\
\text { hosted }\end{array}$ & 40.02 & -87.53 & n.d. & n.d. & n.d. & n.d. & $\begin{array}{l}\text { Fischer } \\
\qquad(1975 b)\end{array}$ \\
\hline 70 & $\begin{array}{l}\text { Mike, Pan- } \\
\text { dora Mine }\end{array}$ & $\begin{array}{l}\text { United } \\
\text { States }\end{array}$ & $\begin{array}{l}\text { La Sal } \\
\text { district, } \\
\text { Utah }\end{array}$ & SSV & 38.31 & -109.25 & 0.989 & 1.46 & 0.0144 & Production & $\begin{array}{l}\text { Fischer (1968) } \\
\text { Shawe } \\
(2011)\end{array}$ \\
\hline 72 & Gibellini & $\begin{array}{l}\text { United } \\
\text { States }\end{array}$ & Nevada & $\begin{array}{l}\text { Shale- } \\
\text { hosted }\end{array}$ & 39.21 & -116.09 & 0.082 & 0.29 & 0.00017 & Resources & $\begin{array}{l}\text { American } \\
\text { Vanadium } \\
\text { Corp. (2012) }\end{array}$ \\
\hline 73 & $\begin{array}{l}\text { Carlin Vana- } \\
\text { dium }\end{array}$ & $\begin{array}{l}\text { United } \\
\text { States }\end{array}$ & Nevada & $\begin{array}{l}\text { Shale- } \\
\text { hosted }\end{array}$ & 40.61 & -116.12 & 25.4 & 0.51 & 0.13 & Resources & $\begin{array}{l}\text { Scandium In- } \\
\text { ternational } \\
\text { Mining } \\
\text { Corp. }(2010)\end{array}$ \\
\hline 74 & $\begin{array}{l}\text { King Tut, } \\
\text { Carrizo, } \\
\text { Lukachu- } \\
\text { kai Moun- } \\
\text { tains }\end{array}$ & $\begin{array}{l}\text { United } \\
\text { States }\end{array}$ & $\begin{array}{c}\text { New Mexico } \\
\text { and } \\
\text { Arizona }\end{array}$ & SSV & 36.74 & -109.01 & 0.846 & 1.15 & 0.01 & Production & $\begin{array}{l}\text { McLemore } \\
\text { and Che- } \\
\text { noweth } \\
\text { (1997) }\end{array}$ \\
\hline 78 & $\begin{array}{l}\text { Slick Rock } \\
\text { Mill, } \\
\text { Uravan }\end{array}$ & $\begin{array}{l}\text { United } \\
\text { States }\end{array}$ & $\begin{array}{c}\text { Uravan Min- } \\
\text { eral Belt, } \\
\text { Colorado }\end{array}$ & SSV & 38.37 & -108.74 & 13.99 & 1.29 & 0.18 & Production & $\begin{array}{l}\text { Fischer (1968) } \\
\text { Shawe } \\
(2011)\end{array}$ \\
\hline 79 & $\begin{array}{l}\text { Iron Moun- } \\
\text { tain }\end{array}$ & $\begin{array}{l}\text { United } \\
\text { States }\end{array}$ & Wyoming & VTM & 41.38 & -104.83 & n.d. & n.d. & n.d. & n.d. & $\begin{array}{l}\text { Fischer } \\
\quad(1975 b)\end{array}$ \\
\hline 80 & Broken Hill & Zambia & $\begin{array}{l}\text { Kabwe, } \\
\text { Central } \\
\text { Province }\end{array}$ & $\begin{array}{l}\text { Vana- } \\
\text { date }\end{array}$ & -14.42 & 28.55 & n.d. & n.d. & n.d. & n.d. & $\begin{array}{l}\text { Fischer } \\
\quad(1975 a)\end{array}$ \\
\hline 81 & Bulawayo & Zimbabwe & Bulawayo & $\begin{array}{l}\text { Vana- } \\
\text { date }\end{array}$ & -20.17 & 28.58 & n.d. & n.d. & n.d. & n.d. & $\begin{array}{l}\text { Fischer } \\
\quad(1975 \mathrm{a})\end{array}$ \\
\hline
\end{tabular}

\footnotetext{
${ }^{1}$ Also includes some production and reserves.
} 


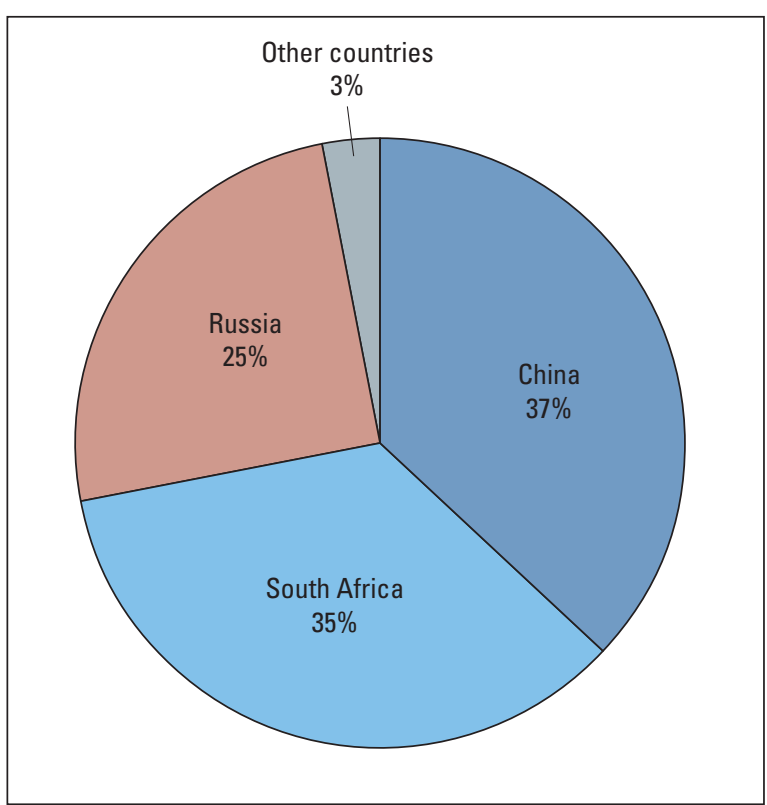

Figure U2. Pie chart showing percentage of world vanadium production in 2012, by country. Compiled using data from Polyak (2013, table 7).

\section{Demand and Availability of Supply}

World vanadium resources in 2012 were estimated to total more than 63 million metric tons of vanadium. Reserves were estimated to be 14 million metric tons of vanadium. Because vanadium is usually recovered as a byproduct or coproduct, the identified world resources of this mineral commodity are understated and therefore not fully indicative of available supply. Although domestic resources and secondary recovery are adequate to supply a large portion of domestic needs, a substantial part of U.S. demand is currently met by foreign material (Polyak, 2013). Future demand is expected to increase primarily because such countries as China and Japan are increasing the amount of vanadium used in steelmaking to match the quality of steel produced from other countries, as well as in anticipation of the probable increase in alternative renewable sources of energy that require the use of VRBs (Roskill Information Services, Ltd., 2013).

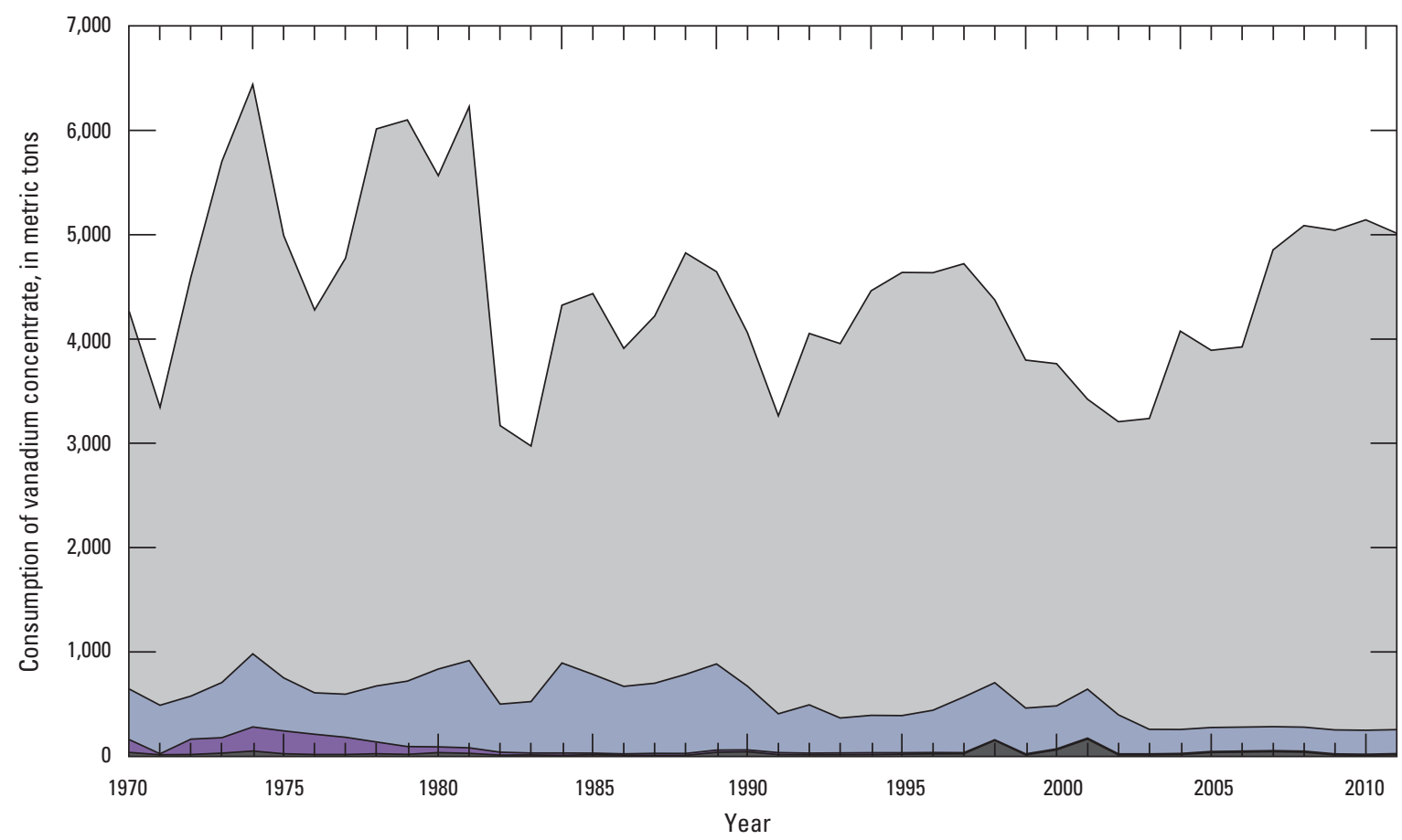

EXPLANATION

Steel $\square$ Cast iron and other alloys

Chemicals and ceramics

Superalloys

Figure U3. Graph showing major end uses of vanadium in the United States from 1970 to 2011. The layers of the graph are placed one above the other, forming a cumulative total. Compiled using data from U.S. Bureau of Mines (1972-76, 1992-96) and U.S. Geological Survey (1997-2013, 2014). 


\section{Geology}

\section{Geochemistry}

Vanadium is a trace element that is widely distributed in nature. The average abundance of vanadium in the upper continental crust is approximately 60 parts per million (ppm) (Taylor and McLennan, 1995). Vanadium is produced from the combustion of fossil fuels, the mining of ores, and hightemperature industrial activities, including steel refining and the processing of phosphate ores.

The natural oxidation states of vanadium are $+2,+3$, +4 , and +5 . The trivalent ion $\mathrm{V}^{3+}$ has an octahedral radius (0.061 nanometers [nm]) that is almost identical with that of ferric iron $\left(\mathrm{Fe}^{3+}, 0.063 \mathrm{~nm}\right)$. As a consequence, vanadium substitutes in iron-rich minerals, such as amphibole, biotite, magnetite, and pyroxene, and for aluminum $\left(\mathrm{Al}^{3+}, 0.054 \mathrm{~nm}\right)$ in iron and ferromagnesian minerals (Fischer, 1973). Vanadium is present in large amounts in mafic igneous rocks (about $250 \mathrm{ppm}$ ), is less abundant in ultramafic and intermediatecomposition rocks (about $50 \mathrm{ppm}$ ), and is present in only small amounts in felsic rocks (about $20 \mathrm{ppm}$ ). Vanadium is concentrated in magmatic magnetite deposits, especially those that are titaniferous; the vanadium concentrations in these deposits commonly range from 1,000 to $5,000 \mathrm{ppm}$.

Vanadium is also closely associated with organic-rich sediments. The average concentrations in shale are about 130 to $205 \mathrm{ppm}$, but some carbonaceous shales may have up to $5,000 \mathrm{ppm}$ vanadium (for example, shales in eastern Kentucky; Robl and others, 1983). The addition of vanadium to sediments rich in organic carbon is owing to reduction, adsorption, and complexation. Dissolved vanadate species $\left(5^{+}\right)$ in oxic seawater are reduced to vanadyl ions $\left(4^{+}\right)$by organic compounds or hydrogen sulfide $\left(\mathrm{H}_{2} \mathrm{~S}\right)$ and are readily adsorbed to particle surfaces as they settle during sedimentation. Vanadium $^{3+}$ may also substitute for aluminum in the octahedral sites of clays (Breit and Wanty, 1991).

Because most vanadium in primary minerals is in the weakly soluble +3 valence state, very little vanadium is transported by hydrothermal fluids; therefore, most hydrothermal ore deposits contain low concentrations (10 to $100 \mathrm{ppm}$ ) of vanadium. Some hydrothermal deposits related to alkaline igneous rocks contain high concentrations of vanadium, however. Altered titanium-rich syenite intrusions at Potash Sulphur Springs in Garland County, Arkansas, contain high concentrations of vanadium (McCormick, 1978) as do some gold-quartz veins associated with alkaline igneous rocks, especially those with gold-telluride minerals (for example, Spry and Scherbarth, 2006).

During weathering in humid climates, much of the vanadium contained in ferromagnesian minerals apparently partitions into newly formed clay minerals, but it remains in the +3 valence state or oxidizes to the +4 valence state, both of which are relatively insoluble. If erosion is insignificant but chemical leaching is intense, the residual material may be enriched in vanadium, as are some bauxites and laterites
(Patterson, Kurtz, and others, 1986). During the weathering of igneous, residual, or sedimentary rocks, some vanadium oxidizes to the +5 valence state (vanadate), especially in the intensive oxidizing conditions that are characteristic of arid climates. In this oxidized valence state and under relatively alkaline conditions, vanadium is enriched in surface waters or groundwaters and remains in solution (Wright and Belitz, 2010). It can be precipitated from solution and locally concentrated in rocks by the following processes (Fischer, 1973, p. 682):

(a) Coprecipitation and adsorption with hydroxides of aluminum or ferric iron. This process forms or enriches the vanadium concentration in some bauxites and in residual or sedimentary iron ores;

(b) Reaction with cations of heavy metals, such as copper, lead, uranium, and zinc. This process forms epigenetic vanadate minerals in the oxidized zones of base-metal deposits; and

(c) Reduction in the presence of organic material or biologically generated $\mathrm{H}_{2} \mathrm{~S}$. Interactions of vanadium-bearing solutions with wall rocks during fluid flow may produce epigenetic ore deposits, such as those occurring in sandstones of the Colorado Plateau province in the United States. On the other hand, if the vanadium is carried to the oceans by surface waters, it may concentrate syngenetically in carbonaceous phosphorites, marls, and shales. Furthermore, if the organic materials in these shales are converted to liquid hydrocarbons, the vanadium may be moved with the petroleum in vanadiumorganic compounds and in fine inorganic particulates; some crude oils contain as much as several hundred parts per million vanadium. Vanadium accumulates in the ashes of these oils and also in the residues resulting from their natural or industrial distillation. These ashes and residues have been used as commercial sources of vanadium (Fischer, 1973, p. 682; Breit, 1992).

\section{Mineralogy}

Vanadium occurs in nature in a wide variety of minerals (table U2). The following four principal types of mineral deposits are recognized: vanadiferous titanomagnetite (VTM) deposits, sandstone-hosted vanadium (SSV) deposits, shalehosted deposits, and vanadate deposits. Magnetite $\left(\mathrm{Fe}_{3} \mathrm{O}_{4}\right)$ and ilmenite $\left(\mathrm{FeTiO}_{3}\right)$ are the principal vanadium-bearing ore minerals in VTM deposits (fig. $\mathrm{U} 4 A)$, but hematite $\left(\mathrm{Fe}_{2} \mathrm{O}_{3}\right)$, perovskite $\left(\mathrm{CaTiO}_{3}\right)$, and rutile $\left(\mathrm{TiO}_{2}\right)$ are present in some deposits (Fischer, 1975b). These minerals occur in medium- to fine-grained intergrowths and in exsolution and solid-solution relations; ulvospinel and titanomagnetite are two mineral names commonly applied to some of these exsolution and solid-solution forms. Small blebs and exsolution blades of coulsonite $\left(\mathrm{FeV}_{2} \mathrm{O}_{4}\right)$ in magnetite have been recognized in a few VTM deposits (Balsley, 1943).

Ore minerals below the zone of oxidation in SSV deposits are low-valence oxides and silicates of uranium and vanadium. Coffinite, montroseite, paramontroseite, uraninite, and 
Table U2. Selected vanadium-bearing minerals, by deposit type.

\begin{tabular}{|c|c|}
\hline Mineral name & Chemical formula or description \\
\hline \multicolumn{2}{|c|}{ Vanadiferous titanomagnetite (VTM) deposits } \\
\hline Coulsonite & $(\mathrm{Fe}, \mathrm{V})_{3} \mathrm{O}_{4}$ \\
\hline Hematite & $\mathrm{Fe}_{2} \mathrm{O}_{3}$ \\
\hline Ilmenite $^{1}$ & $\mathrm{FeTiO}_{3}$ \\
\hline Magnetite $^{1}$ & $\mathrm{Fe}_{3} \mathrm{O}_{4}$ \\
\hline Perovskite & $\mathrm{CaTiO}_{3}$ \\
\hline Rutile & $\mathrm{TiO}_{2}$ \\
\hline \multicolumn{2}{|c|}{ Sandstone-hosted vanadium (SSV) deposits } \\
\hline Carnotite & $\mathrm{K}_{2}\left(\mathrm{UO}_{2}\right)_{2}\left(\mathrm{VO}_{8}\right) \cdot 1-3 \mathrm{H}_{2} \mathrm{O}$ \\
\hline Coffinite & $\mathrm{U}\left(\mathrm{SiO}_{4}\right)_{1-\mathrm{x}}(\mathrm{OH})_{4 \mathrm{x}}$ \\
\hline Corvusite & $(\mathrm{Na}, \mathrm{Ca}, \mathrm{K}) \mathrm{V}_{8} \mathrm{O}_{2} \cdot 4 \mathrm{H}_{2} \mathrm{O}$ \\
\hline Doloresite & $\mathrm{H}_{8} \mathrm{~V}_{6} \mathrm{O}_{16}$ \\
\hline Hewettite & $\mathrm{CaV}_{6}^{5+} \mathrm{O}_{16} \cdot 9 \mathrm{H}_{2} \mathrm{O}$ \\
\hline Montroseite & $\left(\mathrm{V}^{3+} \mathrm{Fe}^{3+}, \mathrm{V}^{4+}\right) \mathrm{O}(\mathrm{OH})$ \\
\hline Paramontroseite & $\mathrm{VO}_{2}$ \\
\hline Pascoite & $\mathrm{Ca}_{3}\left(\mathrm{~V}_{10} \mathrm{O}_{28}\right) \cdot 17 \mathrm{H}_{2} \mathrm{O}$ \\
\hline Roscoelite & $\mathrm{K}\left(\mathrm{V}^{3+}, \mathrm{Al}, \mathrm{Mg}\right)\left[(\mathrm{Si}, \mathrm{Al})_{4} \mathrm{O}_{10}\right](\mathrm{OH})_{2}$ \\
\hline Tyuyamunite & $\mathrm{Ca}\left(\mathrm{UO}_{2}\right) 2 \mathrm{~V}_{2} \mathrm{O}_{8} \cdot 5-8 \mathrm{H}_{2} \mathrm{O}$ \\
\hline Uraninite & $\mathrm{UO}_{2}$ (with $\mathrm{Pb}, \mathrm{Th}, \mathrm{V}, \mathrm{Zr}$ ) \\
\hline Vanadium clays & Vanadium-bearing hydrous mica \\
\hline Vanadian chlorite & Vanadium-bearing chlorite \\
\hline Volborthite & $\mathrm{Cu}_{3} \mathrm{~V}_{2} \mathrm{O}_{7}(\mathrm{OH})_{2} \cdot 2 \mathrm{H}_{2} \mathrm{O}$ \\
\hline \multicolumn{2}{|c|}{ Shale-hosted vanadium deposits } \\
\hline Illite-smectite $^{3}$ & $\mathrm{~K}_{0.8}\left(\mathrm{Al}_{2.8} \mathrm{Mg}_{0.5} \mathrm{Fe}_{0.4} \mathrm{~V}_{0.3}\right)\left(\mathrm{Si}_{7.2} \mathrm{Al}_{0.8}\right) \mathrm{O}_{20}(\mathrm{OH})_{4}$ \\
\hline Metahewettite & $\mathrm{CaV}_{6} \mathrm{O}_{16} \mathrm{H}_{2} \mathrm{O}$ \\
\hline Quisqueite $^{2}$ & Vanadium-bearing organic matter \\
\hline Patronite $^{2}$ & $\mathrm{~V}^{4+}\left(\mathrm{S}_{2}^{2-}\right)_{2}$ \\
\hline
\end{tabular}

\begin{tabular}{|c|c|}
\hline Mineral name & Chemical formula or description \\
\hline & Vanadate deposits \\
\hline Brachebuschite & $\mathrm{Pb}_{2}(\mathrm{Mn}, \mathrm{Fe})\left(\mathrm{VO}_{4}\right)_{2} \cdot \mathrm{H}_{2} \mathrm{O}$ \\
\hline Calciovolborthite & $\mathrm{CaCuVO}_{4}(\mathrm{OH})$ \\
\hline Chervetite & $\mathrm{Pb}_{2} \mathrm{~V}_{2} \mathrm{O}_{7}$ \\
\hline Curienite & $\mathrm{Pb}\left(\mathrm{UO}_{2}\right)_{2}\left(\mathrm{VO}_{4}\right)_{2} \cdot 5 \mathrm{H}_{2} \mathrm{O}$ \\
\hline Descloizite $^{1}$ & $\mathrm{PbZn}\left(\mathrm{VO}_{4}\right)(\mathrm{OH})$ \\
\hline Francevillite & $(\mathrm{Ba}, \mathrm{Pb})\left(\mathrm{UO}_{2}\right)_{2}\left(\mathrm{VO}_{4}\right)_{2} \cdot 5 \mathrm{H}_{2} \mathrm{O}$ \\
\hline Heyite & $\mathrm{Pb}_{5} \mathrm{Fe}_{2}\left(\mathrm{VO}_{4}\right)_{2} \mathrm{O}_{4}$ \\
\hline Mottramite $^{1}$ & $\mathrm{PbCu}\left(\mathrm{VO}_{4}\right)(\mathrm{OH})$ \\
\hline Mounanaite & $\mathrm{PbFe}_{2}\left(\mathrm{VO}_{4}\right)_{2}(\mathrm{OH})$ \\
\hline Pyrobelonite & $\mathrm{PbMnVO}_{4}(\mathrm{OH})$ \\
\hline Sengierite & $\mathrm{Cu}\left(\mathrm{UO}_{2}\right)_{2}\left(\mathrm{VO}_{4}\right)_{2} \cdot 8$ or $10 \mathrm{H}_{2} \mathrm{O}$ \\
\hline Turanite & $\mathrm{Cu}_{5}\left(\mathrm{VO}_{4}\right)_{2}(\mathrm{OH})_{4}$ \\
\hline Vanadinite $^{1}$ & $\mathrm{~Pb}_{5}\left(\mathrm{VO}_{4}\right)_{3} \mathrm{Cl}$ \\
\hline Volborthite & $\mathrm{Cu}_{3}\left(\mathrm{VO}_{4}\right)_{2} \cdot 3 \mathrm{H}_{2} \mathrm{O}$ \\
\hline
\end{tabular}

\begin{tabular}{|c|c|}
\hline \multicolumn{2}{|c|}{ Epithermal/porphyry/magmatic deposits } \\
\hline Duttonite & $\mathrm{V}^{4+} \mathrm{O}(\mathrm{OH})_{2}$ \\
\hline Fervanite & $\mathrm{Fe}_{4}^{3+}\left(\mathrm{VO}_{4}\right)_{4} \cdot 5 \mathrm{H}_{2} \mathrm{O}$ \\
\hline Hewettite & $\mathrm{CaV}_{6}^{5+} \mathrm{O}_{16} \cdot 9 \mathrm{H}_{2} \mathrm{O}$ \\
\hline Karelianite ${ }^{4}$ & $\mathrm{~V}_{2} \mathrm{O}_{3}$ \\
\hline Metatyuyamunite $^{6}$ & $\left.\mathrm{Ca}\left(\mathrm{UO}_{2}\right)_{2} \mathrm{VO}_{4}\right)_{2} \cdot 5-7 \mathrm{H}_{2} \mathrm{O}$ \\
\hline Montroseite & $\left(\mathrm{V}^{3+}, \mathrm{Fe}^{3+}, \mathrm{V}^{4+}\right) \mathrm{O}(\mathrm{OH})$ \\
\hline Nolanite $^{4}$ & $(\mathrm{~V}, \mathrm{Fe}, \mathrm{Al})_{10} \mathrm{O}_{14}(\mathrm{OH})_{2}$ \\
\hline Roscoelite & $\mathrm{K}\left(\mathrm{V}^{3+}, \mathrm{Al}, \mathrm{Mg}\right)\left[(\mathrm{Si}, \mathrm{Al})_{4} \mathrm{O}_{10}\right](\mathrm{OH})_{2}$ \\
\hline Rutile, brookite & $\mathrm{TiO}_{2}$ \\
\hline Schreyerite $^{4}$ & $\mathrm{VSiO}_{3}(\mathrm{OH})$ \\
\hline Vanadium andradite ${ }^{5}$ & $\mathrm{Ca}^{3}\left(\mathrm{Fe}^{3+}, \mathrm{V}^{3+}\right)_{2}\left(\mathrm{SiO}_{4}\right)_{3}$ \\
\hline Vanadium muscovite ${ }^{4}$ & Vanadium-bearing muscovite \\
\hline Vanadium silicates $^{4}$ & $\mathrm{Si}_{3} \mathrm{O}_{9} \mathrm{~V}_{2}$ \\
\hline $\begin{array}{l}\text { Vanadium- and } \\
\text { titanium-bearing } \\
\text { mixed layer clay }\end{array}$ & $\begin{array}{l}\left(\mathrm{Ca}_{0.08} \mathrm{~K}_{0.02} \mathrm{Na}_{0.03}\right)_{0.13} \\
\quad\left(\mathrm{Al}_{0.11} \mathrm{~V}_{0.90} \mathrm{Ti}_{0.19} \mathrm{Fe}_{0.64} \mathrm{Mg}_{0.14}\right)_{1.98} \\
\quad\left(\mathrm{Si}_{3.79} \mathrm{Al}_{0.21}\right)_{4} \mathrm{O}_{10}(\mathrm{OH})_{2} \cdot \mathrm{nH}_{2} \mathrm{O}\end{array}$ \\
\hline
\end{tabular}

${ }^{1}$ Most common.

${ }^{2}$ Mina Ragra, Peru (Fischer, 1973).

${ }^{3}$ Mecca Quarry Shale, Illinois and Indiana (Peacor and others, 2000).

${ }^{4}$ Tuvatu deposit, Fiji (Spry and Scherbarth, 2006).

${ }^{5}$ Potash Sulphur Springs or Wilson Springs, Arkansas (Howard and Owens, 1995).

${ }^{6}$ Weeks and others, 1959.

${ }^{7}$ Potash Sulphur Springs or Wilson Springs, Arkansas (McCormick, 1978). 

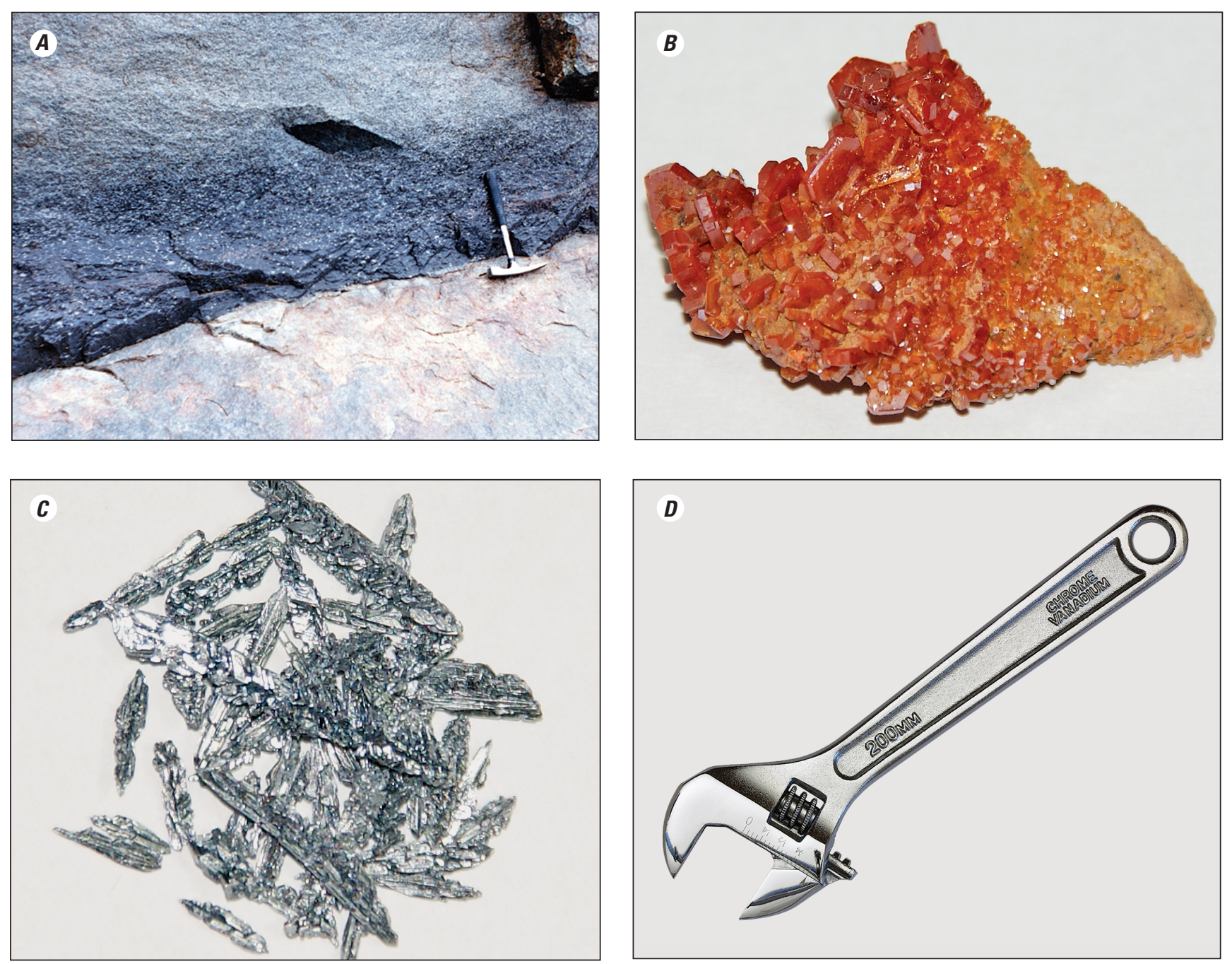

Figure U4. Photographs showing four examples of vanadium. A, Magnetite layer (dark) from the Bushveld Complex, South Africa. It is these layers that commonly host vanadium. $B$, Natural vanadinite, which is a main source of vanadium from vanadate deposits. $C$, Vanadium metal crystals made by electrolysis (the largest crystal is 2 centimeters in length). $D$, Common hand wrench made with vanadium alloy steel. Photograph $A$ courtesy of Kevin Walsh/CC BY 2.0 (https://creativecommons.org/licenses/by/2.0/). Photographs $B$ and $C$ courtesy of Juergen Kummer, Jumk.de Web Projects/CC BY 3.0 (http://images-of-elements.com/vanadium.php). Photograph D courtesy of MrX/CC-BY-SA-3.0 (https://commons.wikimedia.org/wiki/File:Chrome_Vanadium_Adjustable_Wrench.jpg).

vanadium-rich clay or mica (roscoelite), vanadian chlorite, and vanadium-rich clay minerals are the most common (table U2). Chalcopyrite, clausthalite, ferroselite, galena, naumannite, pyrite, sphalerite, and other sulfides and selenides are common trace minerals (Shawe, 2011). Copper sulfides are widespread in sparse amounts but are abundant enough in a few deposits to constitute ore minerals (Fischer, 1968). Partially oxidized orebodies (for example, those immediately above the water table) contain minerals similar to those of deposits below the zone of oxidation, but with the addition of corvusite-group minerals and hewettite (Shawe, 2011). Oxidized deposits contain carnotite and tyuyamunite, together with vanadium clays and chlorite. The most common authigenic gangue minerals in SSV deposits are barite, carbonates (mostly calcite), and quartz (Breit and Goldhaber, 1996). Ore minerals are typically disseminated in the sandstone or form radiating acicular aggregates that fill open pore spaces (Wanty and others, 1990). The ore minerals are typically concentrated near carbonaceous material (Fischer, 1968; Shawe, 2011).

Vanadate deposits contain a wide variety of vanadiumbearing minerals (table U2). Vanadate minerals are formally described as containing an oxoanion of vanadium generally in its highest oxidation state of +5 . Most vanadate minerals are compounds of copper, iron, or lead because these deposits form within the oxidized zones of base-metal deposits in areas of arid climate and deep oxidation (Fischer, 1975a). Descloizite, mottramite, and vanadinite (fig. U4B) are the most common vanadium minerals, although numerous others are known (table U2). Wulfenite $\left(\mathrm{PbMoO}_{4}\right)$, which is a molybdate of lead, is also common in vanadate deposits (Fischer, 1975a). Where paragenetic relations are reported, the vanadium-bearing minerals are late in the sequence. For example, the association 
of vanadinite and descloizite is paragenetically late in the Berg Aukas and Abenab deposits in the Otavi Mountainland, Namibia (Boni and others, 2007). Fischer (1975a) suggests that vanadate minerals typically coat and partly replace supergene base-metal minerals in deposits in Arizona, but in most cases, the vanadates overlap or precede the last stage of supergene mineral formation (Boni and others, 2007). Once formed, vanadate minerals are stable in the environment of the oxidized zone; these minerals persist from the surface to the bottom of the oxidized zone, and leaching and corrosion of them are rarely reported (Fischer, 1975a). In the Kabwe district (formerly known as Broken Hill), Zambia, the vanadate minerals are persistent to depths of 350 meters $(\mathrm{m})$ below the surface, which defines the lowest depth of oxidation.

Some hydrothermal deposits contain vanadium-bearing minerals, particularly deposits genetically and (or) spatially associated with alkaline igneous rocks. In epithermal gold deposits, roscoelite is the most common mineral, but vanadium-bearing rutile or brookite, karelianite, nolanite, shreyerite, and vanadium-rich muscovite and silicate minerals have also been identified (Spry and Scherbarth, 2006).

\section{Deposit Types}

Vanadium is present in economic concentrations in four main types of mineral deposits and as a minor constituent in several other types. Fossil fuels are another important source of vanadium.

\section{Vanadiferous Titanomagnetite Deposits}

Vanadiferous titanomagnetite (VTM) deposits (Fischer, 1975b) are found throughout the world and are the principal source of vanadium (fig. U1). The most economically significant VTM deposits or regions, both in the past and currently, include the Bushveld Complex in South Africa (Reynolds, 1985); the Panzhihua layered intrusion in Sichuan Province, China (Zhou and others, 2005); the Kachkanar massif in the Ural Mountains in Russia; the Windimurra Complex in Western Australia (Ivanic and others, 2010); and the Bell River Complex (Matagami deposit) and the Lac Doré Complex in Quebec, Canada (fig. U1; Taner and others, 1998).

The VTM deposits consist of magmatic accumulations of magnetite and ilmenite, defined arbitrarily as having grades of more than about 1 percent rutile (Fischer, 1975b). They commonly contain 0.2 to 1 percent $\mathrm{V}_{2} \mathrm{O}_{5}$, but some zones (for example, the Bushveld Complex) contain greater than 1.5 percent $\mathrm{V}_{2} \mathrm{O}_{5}$ (Reynolds, 1985). Most exposed VTM deposits are Archean or Proterozoic in age, having formed in intraplate continental tectonic settings; a few deposits (for example, the Panzhihua region in Sichuan Province, China) are younger (table U1; fig. U1). Most deposits are associated with large igneous province (LIP) magmatism; some layered intrusive complexes are linked to mantle plumes and hotspot tracks (Hatton, 1995; Ernst and others, 2005).
VTM deposits are hosted mainly within mafic and ultramafic igneous rocks, most commonly anorthosite and gabbro. Lithologies within the igneous complexes that contain the vanadium-rich ores vary considerably, however. For example, in the Bushveld Complex, lithologies range from dunite and pyroxenite to anorthosite and pure oxide layers (Eales and Cawthorn, 1996). Some vanadiferous deposits are hosted in zoned mafic to ultramafic complexes with high levels of chromium and platinum-group elements (PGEs); these complexes are sometimes referred to as Alaska-type PGE deposits; and examples include the Union Bay deposit in Alaska (United States), and the Kachkanar complex in Sverdlovsk Oblast, Russia. A few deposits are associated with alkalic igneous rocks (for example, syenodiorite is genetically related to layered gabbro in the Panzhihua district of Sichuan Province, China [Shellnut and Jahn, 2010] and in the Ganjang deposit in Assam, northeastern India [Saha and others, 2010]). The mafic to ultramafic igneous host rocks are typically of deep-seated origin, and they occur in stratiform tabular bodies, such as sills and laccoliths that are thick and laterally extensive. For example, the Mesoarchean gabbroic Windimurra Complex in the Yilgarn craton (Western Australia, Australia) covers an area of about 2,500 square kilometers $\left(\mathrm{km}^{2}\right)$ and contains layers of gabbroic and ultramafic rocks with cumulative thicknesses of 13 kilometers $(\mathrm{km})$ (Ivanic and others, 2010). The Paleoproterozoic Bushveld Complex (dated at 2.06 giga-annum [Ga]) in the Transvaal basin in South Africa contains layers with cumulative thicknesses (about $9 \mathrm{~km}$ ) that are comparable to those of the Windimurra Complex, and it has an areal extent of about $65,000 \mathrm{~km}^{2}$ (Eales and Cawthorn, 1996).

In contrast to laterally extensive and thick tabular bodies, some titaniferous magnetite deposits are hosted in relatively complex intrusive or lens-shaped bodies (Fischer, 1975b). Such deposits are variable in size and shape. In the Panzhihua region of China, the maximum size of the lens-shaped ore bodies is $160 \mathrm{~m}$ long and $30 \mathrm{~m}$ wide (Zhou and others, 2005). Vanadium-bearing titanomagnetite previously mined in the Sanford Lake District of New York and the Taberg deposit in Jönköping County, Sweden, was contained in small (550 m by $180 \mathrm{~m}$ ) bodies of gabbro and anorthosite (Balsley, 1943; Gross, 1968; Fischer, 1973, 1975b).

The textures and mineralogy of VTM ores are remarkably similar among the largest known deposits, including the Panzhihua deposit and the Bushveld and Windimurra deposits (Fischer, 1975b; Reynolds, 1985; Rohrmann, 1985; Zhou and others, 2005; Ivanic and others, 2010). Ores typically form discrete layers that are concordant with the igneous layering, which varies between 0.1 and $10 \mathrm{~m}$ in thickness, although some oxide layers in deposits in the Panzhihua region of southwestern China attain thicknesses of $60 \mathrm{~m}$ (Zhou and others, 2005). Similar to the silicate rocks that host them, the oxide layers are laterally extensive, and they can be traced for hundreds of kilometers in the case of the Bushveld Complex (Rohrmann, 1985; Reynolds, 1985). Most oxide layers have sharp lower boundaries that host silicate rocks and have 
gradational tops; some oxide layers contain thin intercalations of gabbro (Eales and Cawthorn, 1996; Zhou and others, 2005). Most of the vanadium in titaniferous magnetite deposits is concentrated as a solid solution in magnetite-ulvospinel, where $\mathrm{V}^{3+}$ has replaced $\mathrm{Fe}^{3+}$ (Fischer, 1975b); the vanadium-rich spinel mineral coulsonite $\left(\mathrm{FeV}_{2} \mathrm{O}_{4}\right)$ was reported as small blebs and exsolution blades in magnetite in a few deposits (Balsley, 1943; Fischer, 1975b). Ilmenite, hematite, rutile, and perovskite commonly accompany magnetite (Fischer, 1975b). Where exposed to weathering, the magnetite may oxidize to vanadomaghemite $\left((\mathrm{FeTi})_{2} \mathrm{O}_{3}\right)$ and small concentrations of hematite without any change in the texture of the ore (Rohrmann, 1985).

Ores may be either massive or disseminated. Massive ores typically consist of closely packed, nearly equant grains of more than 80 percent titanomagnetite and contain variable amounts of clinopyroxene, olivine, and plagioclase. If silicate minerals are present, they are completely surrounded by oxides (Zhou and others, 2005). Disseminated ores are generally coarse grained and are composed of about 50 percent titanomagnetite, about 20 percent clinopyroxene, about 20 percent plagioclase, about 10 percent ilmenite, and small amounts of olivine (Rohrmann, 1985; Eales and Cawthorn, 1996; Zhou and others, 2005).

The mechanisms by which millions of tons of vanadium become concentrated in massive iron-titanium oxide deposits remain poorly understood, but most researchers agree that partial melting of mantle rocks and extensive fractionation of the derivative magma are critical early-stage processes. Large-scale, in situ crystallization of plagioclase and other anhydrous phases (olivine, pyroxene) in the basal parts of magma chambers results in an increase in total iron and water contents of the residual magma with eventual formation of immiscible oxide melts (Reynolds, 1985; Eales and Cawthorn, 1996; Ivanic and others, 2010; Shellnut and Jahn, 2010). Such oxide ore melts are denser than silicate melts and therefore settle to the bottom of the magma chamber, where the oxide melts accumulate (Eales and Cawthorn, 1996; Zhou and others, 2005). Many layered intrusions show evidence of multiple magma injections (Eales and Cawthorn, 1996), suggesting that magma mixing may have played a role in the development of some titaniferous magnetite deposits (Von Gruenwaldt, 1993). Other factors involved in forming immiscible oxide melts from silicate magmas are abrupt changes in oxygen fugacity, and (or) an introduction of fluids (Reynolds, 1985; Zhou and others, 2005). The presence of minor disseminated sulfides and apatite (for example, the Panzhihua deposits) suggests that sulfur and phosphorus may have acted as fluxing agents that promoted the concentration of immiscible liquids that led to formation of the Panzhihua deposits (Zhou and others, 2005).

Associated metals.-The igneous rocks that host significant vanadium resources are commonly temporally and spatially associated with magmatic chromium, copper, nickel, and PGE deposits (Cawthorn and others, 2002; Naldrett, 2010; Zientek, 2012). At least minor amounts of copper-nickel-PGE enrichment occurs in igneous complexes adjacent to the vanadiferous zones in the Windimurra region of Australia (Ivanic and others, 2010), the Panzhihua region of China (Zhou and others, 2005), and Kachkanar in the Urals region of Russia (Augé and others, 2005). The largest resources of PGEs and chromium in the world are contained within the Bushveld Complex of South Africa in layers that lie below the vanadiferous zones (Eales and Cawthorn, 1996; Naldrett and others, 2009). Additionally, high contents of scandium (up to 500 grams per metric ton of scandium oxide $\left[\mathrm{Sc}_{2} \mathrm{O}_{3}\right]$ ) occur in some of the VTM deposits in Russia (Bykhovsky and Tigunov, 2008).

\section{Sandstone-Hosted Vanadium Deposits}

Sandstone-hosted uranium deposits have been identified on all continents, and many are known to have enrichments of vanadium (Dahlkamp, 2010). These deposits of vanadiumand uranium-bearing sandstone (known as sandstone-hosted vanadium [SSV] deposits) have average resource and ore grades that range from 0.1 to 1 weight percent vanadium (George Breit, U.S. Geological Survey [retired], written commun., 2013). On a global scale, the United States has been and is currently the main producer of vanadium from SSV deposits, particularly from those on the Colorado Plateau. Additionally, these SSV deposits are the chief domestic source of vanadium in the United States (Fischer, 1968, 1973; Polyak, 2012, 2013). Most deposits are located in western Colorado and eastern Utah, although some are also located in northern Arizona and New Mexico (fig. U1). Vanadium enrichments in sandstones elsewhere in the world include the Bigrlyi deposit in Northern Territory, Australia, which has a grade of 0.13 weight percent vanadium (McKay and Miezitis, 2001); deposits in the Tonco-Amblyo district in Argentina, which have grades of 0.1 to 0.3 weight percent vanadium (Dahlkamp, 2010); and a deposit in the Karamurun district of Almaty Oblysy, Kazakhstan (Dahlkamp, 2009).

The Colorado Plateau province covers an area of $337,000 \mathrm{~km}^{2}$ and was developed through a series of geologic and tectonic events. Important processes in this region that promoted the formation of SSV deposits include deposition of evaporitic-sapropelic strata from which brine fluids were derived; deposition of fluvial, fine-grained, locally carbonaceous sandstone that served as host rocks for the deposits; and magma generation and emplacement of laccoliths during the Tertiary that may have heated and driven brine fluids upwards along favorable structures (Shawe, 2011).

The SSV deposits occur in fluvial sandstone lenses of the Chinle Formation (Upper Triassic) and the Jurassic Morrison and aeolian Entrada Formations. The most economically significant vanadium deposits occur within the Salt Wash Member, which is the basal unit of the Morrison Formation (Northrop and others, 1990; McLemore and Chenoweth, 1997; Shawe, 2011). The Salt Wash Member is 30 to $150 \mathrm{~m}$ thick and contains laterally continuous fluvial sandstone and interbedded mudstone. This member was deposited by a west-to-east aggrading alluvial system (Shawe, 2011). 
The SSV deposits form subhorizontal lenses or tabular bodies that are variable in thickness but are typically less than a few meters thick (Northrop and others, 1990; McLemore and Chenoweth, 1997) and up to $150 \mathrm{~m}$ long (Shawe, 2011). Some elongate mineralized zones are parallel to paleostream channels in the fluvial sandstone (McLemore and Chenoweth, 1997; Shawe, 2011). Deposits are typically concordant with bedding, although discordant lenses of uranium-vanadium minerals cut bedding planes locally. Most commonly, the orebodies are entirely within sandstone, although some occur at the interface between sandstone and less permeable shale or siltstone (Northrop and others, 1990; McLemore and Chenoweth, 1997). Tabular bodies display sharp to gradational transitions into unmineralized sandstone, and generally terminate abruptly against mudstone or claystone seams (Shawe, 2011). The SSV deposits are typically found in areas with local accumulations of detrital carbonaceous material. Pyrite is common within all forms of carbonized plant material (Shawe, 2011). Northrop and others (1990) reported that pyrite from mineralized intervals has distinctly lower sulfur isotope compositions ( -4.8 to -2 per mil) than pyrite in unmineralized rocks (which average 12.1 per mil). Some tabular deposits have been reworked over time by groundwater, resulting in the formation of redistributed orebodies (Shawe, 2011).

Vanadium concentrations in SSV ores (expressed as $\mathrm{V}_{2} \mathrm{O}_{5}$ ) are commonly 1 percent or greater, and some deposits in southwestern Colorado have grades of more than 2.5 percent (Shawe, 2011). Vanadium-to-uranium weight ratios in deposits within the Morrison Formation vary from 2:1 to 6:1 among most areas of production, and therefore, are considered vanadium deposits with accessory uranium (Northrop and others, 1990; Shawe, 2011). Deposits with high vanadium-to-uranium weight ratios are located in southeastern Utah and southwestern Colorado; those in east-central Utah and west-central Colorado are characterized by lower vanadium-to-uranium weight ratios (George Breit, U.S. Geological Survey [retired], written commun., 2013). Many deposits have multiple ore zones, consisting of two (or more) closely spaced intervals enriched in vanadium and uranium, separated by an interval (or intervals) containing no uranium but enriched in vanadium (Northrop and others, 1990). The uranium-vanadium minerals form the matrix of the mineralized sandstones and locally replace detrital quartz and feldspar grains (Kovschak and Nylund, 1981; McLemore and Chenoweth, 1997). Vanadium, as $+2,+3,+4$, or +5 , occurs as oxide phases or is combined with other elements, forming more than 40 different minerals in SSV ores (Weeks and others, 1959). Primary SSV ores are characterized by a consistent black-mineral suite composed of coffinite, montroseite, uraninite, and vanadium aluminosilicates (that is, low-valence $\mathrm{V}^{3+}$ minerals). These primary minerals are modified by progressive secondary oxidation above the water table to form an oxidized mineral assemblage dominated by carnotite, corvusite, and tyuyamunite (Weeks and others, 1959). Tabular vanadium-uranium deposits in the Salt Wash Member are unusual in that one of the major ore phases is typically roscoelite (a vanadium-bearing mica) accompanied by chlorite, mixed layer "chloritemontmorillonite" (chlorite-smectite), mixed-layer illite-montmorillonite, and "vanadium-hydromicas" (vanadium-bearing illite) (Northrop and others, 1990; Wanty and others, 1990). Gangue minerals that have been introduced or redistributed during formation of the deposits are anatase, barite, carbonates (mostly calcite and dolomite), and quartz (mostly calcite and dolomite) containing appreciable amounts of iron and (or) magnesium (Breit and Goldhaber, 1996).

Most proposed models for the formation of SSV deposits suggest that deposition occurred at an interface between two fluids of different chemical compositions and (or) states of oxidation-reduction (Fischer, 1968; Northrop and others, 1990; Shawe, 2011). Deposition involving two fluids was proposed many years ago during the early stages of exploration and production, and subsequent models, such as the brine-interface model, have refined or incorporated portions of these early theories. Although details differ, most models suggest that these deposits form by multistage processes: (1) shallow burial and diagenesis $(<400 \mathrm{~m})$, and reduction of dissolved uranium and vanadium by organic matter and bacteriogenic hydrogen sulfide that create local ore-grade accumulations; (2) progressive burial of the sandstone, creating changes in pore-water composition, pressure, and temperature and recrystallization of ore phases; and (3) migration of brines that move upward along faults and outward into permeable sandstone, mix with dilute meteoric water, and result in alteration of existing uranium and vanadium deposits (Breit and Goldhaber, 1996). The source of the vanadium is not well constrained, but is likely from the dissolution of iron-titanium-oxide minerals (ilmenite and magnetite) in volcanic detritus and sandstones within the Morrison Formation, or from unspecified source rocks that could be either younger or older than the host formation (Thamm and others, 1981; Northrop and others, 1990). Critical to the development of brines and the location of the SSV deposits in the Salt Wash Member was the deposition of evaporitic-sapropelic sedimentary units of Middle and Late Pennsylvanian age beneath the Morrison Formation (Shawe, 2011). Determinations of the age of formation of the deposits varies greatly; some estimates are that primary ores formed close to the time of deposition of the host rock (about 130 mega-annum [Ma]), whereas others suggest a much later time (about $30 \mathrm{Ma}$ or latest Oligocene) (Shawe, 2011).

Associated metals.-Uranium occurs with vanadium in all SSV deposits, although the uranium-to-vanadium ratio varies greatly. Most deposits in the southwestern part of the United States (New Mexico and Arizona) have high uraniumto-vanadium ratios that decrease to the north (because of the increasing contents of vanadium). After initial mining for uranium, these deposits were sought as a source of radium. In the 1930s and 1940s, the deposits were of interest mainly for vanadium. Most mines were closed for nearly a decade, but mining resumed again in 1949 (until about 1983) for major production of uranium, with vanadium as a byproduct (Shawe, 2011). Copper accompanies uranium or vanadium in many of the deposits (Shawe, 2011). 


\section{Shale-Hosted Vanadium Deposits}

Vanadium-rich metalliferous black shales occur primarily in late Proterozoic and Phanerozoic marine successions. The term shale is used here broadly to include a range of carbonaceous rocks that include marls and mudstones. These finegrained sedimentary rocks were deposited in epeiric (inland) seas and on continental margins. They typically contain high concentrations of organic matter (greater than 5 percent) and reduced sulfur (greater than 1 percent; mainly as pyrite), as well as a suite of metals, such as copper, molybdenum, nickel, PGEs, silver, uranium, vanadium, and zinc (Desborough and others, 1979; Coveney and Martin, 1983; Coveney and others, 1992; Hatch and Leventhal, 1992; Piper, 1999). Concentrations regularly exceed 0.18 percent $\mathrm{V}_{2} \mathrm{O}_{5}$ and can be as high as 1.7 percent $\mathrm{V}_{2} \mathrm{O}_{5}$. Vanadiferous black shales are commonly found with phosphorite deposits and marine oil shales and, in North America, are marine equivalents of coal-bearing cyclothems. Well-characterized vanadiferous black shales include the Woodruff Formation in Nevada (Desborough and others, 1979), the Meade Peak Phosphatic Shale Member of the Phosphoria Formation in Idaho and Wyoming (McKelvey and others, 1986; Love and others, 2003), the Mecca Quarry Shale Member of Illinois and Indiana (Coveney and others, 1987), the Doushantuo Formation in Hubei Province in southern China (Fan and others, 1992), and portions of the Toolebuc Formation in Queensland, Australia (Lewis and others, 2010). Although these black shales have long been recognized as potential sources of vanadium, they are not currently exploited. Project development is underway at the Gibellini vanadium prospect in Nevada (Woodruff Formation), and if production begins, it will be the first primary shalehosted producer of vanadium in the United States. The Julia Creek deposit (Toolebuc Formation) is also in the planning stages. The Green Giant deposit in southern Madagascar (Energizer Resources, Inc., 2013) consists of metamorphosed vanadiferous shale that extends for at least $21 \mathrm{~km}$ along strike and is reported to contain about 350,000 metric tons of $\mathrm{V}_{2} \mathrm{O}_{5}$ (table U1; fig. U1).

The ultimate source of vanadium in metalliferous black shales is dissolved vanadium in seawater (Breit and Wanty, 1991; Piper, 1994). Whereas the specific mechanisms of enrichment are disputed, all require the reduction of dissolved $\mathrm{V}^{5+}$ (Breit and Wanty, 1991), which is the predominant redox state in the oceans (Collier, 1984). Vanadium is used by various phytoplankton species (Robson and others, 1986; Moore and others, 1996), and sedimentation of phytoplankton debris likely acts as a minor source of vanadium in black shales (Piper, 1994). In oxygen-deficient bottom waters and pore waters, dissolved vanadium is reduced to particle-reactive $\mathrm{V}^{4+}$ and is incorporated into the sedimentary fraction (Wehrli and Stumm, 1989). Further reduction to $\mathrm{V}^{3+}$ requires the presence of dissolved aqueous sulfide $\left(\mathrm{H}_{2} \mathrm{~S}\right)$ and promotes the incorporation of vanadium into sedimentary organic matter and authigenic clays (Lewan and Maynard, 1982; Lewan, 1984; Breit and Wanty, 1991).
Vanadium concentrations correlate with organic carbon in black shales, suggesting that vanadium is incorporated into organic matter upon burial (Breit and Wanty, 1991). Black shales that have been buried to depths sufficient to pass through the oil window typically produce petroleum that has high vanadium concentrations (Lewan and Maynard, 1982; Lewan, 1984). Conversely, vanadium can become incorporated into illite upon burial (Peacor and others, 2000). Because no modern analogues for vanadiferous black shales are known, the processes of vanadium enrichment are not well understood.

Vanadium-rich black shales of North America occur in Devonian to Permian marine successions. Black shale of the Upper Devonian Woodruff Formation (Nevada) contains 0.5 to 1.2 percent $\mathrm{V}_{2} \mathrm{O}_{5}$ in unaltered rocks containing high concentrations of organic matter (greater than 10 percent) (Desborough and others, 1979, 1981). Oxidized zones of the Woodruff Formation contain 1.1 to 1.4 percent $\mathrm{V}_{2} \mathrm{O}_{5}$, reflecting secondary enrichment of vanadium during oxidation; the principal vanadium mineral in the oxidized shales is metahewettite $\left(\mathrm{CaV}_{6} \mathrm{O}_{162} \cdot \mathrm{H}_{2} \mathrm{O}\right)$.

Vanadiferous black shales are also found with Pennsylvanian cyclothems of North America (Coveney and Martin, 1983; Coveney and others, 1987; Coveney and Glascock, 1989; Hatch and Leventhal, 1992). These typically thin, metalliferous black shales occur throughout the midcontinent region. The Mecca Quarry Shale of Illinois and Indiana is conspicuously rich in various metals, including vanadium, with concentrations of up to $10,000 \mathrm{ppm}$ (Coveney and Martin, 1983). These concentrations of vanadium exceed that of many VTM deposits; however, because the Mecca Quarry Shale is only a few tens of centimeters thick, it is not considered an economically viable vanadium resource (Coveney and Martin, 1983). Vanadium enrichments in the Mecca Quarry Shale could be related to the action of basinal brines, similar to processes that concentrate lead-zinc in Mississippi Valleytype (MVT) deposits (Coveney and Glascock, 1989), although direct evidence for this mineralizing process is lacking.

The Permian Phosphoria Formation in Idaho and Wyoming contains a world-class phosphate deposit that also includes vanadium-rich strata (McKelvey and others, 1986; Piper, 1999). The black-shale interval within the Meade Peak Phosphatic Shale Member contains an average of 1.2 percent $\mathrm{V}_{2} \mathrm{O}_{5}$ (Piper, 1999) and, since the early 1940s, has been considered a potential economic source of vanadium (Love and others, 2003). In the 1960s, vanadium and uranium were produced from ferrophosphorus, a byproduct of an elemental phosphorus plant in southeastern Idaho (McKelvey and others, 1986). The occurrence of vanadium-rich shale with black-shale-hosted phosphorite deposits is common worldwide and suggests that steep and (or) fluctuating redox gradients existed within bottom waters and pore waters of the sedimentary basin (Piper, 1994).

The Julia Creek deposit in the Cretaceous Toolebuc Formation in Queensland, Australia, is an example of a vanadium-rich oil shale (Riley and Saxby, 1982; Patterson, Ramsden, and others, 1986). The oil shale was deposited in a shallow, epicontinental sea under reducing bottom water 
conditions that promoted the enrichment of vanadium. Concentrations range from 0.1 to 1.0 percent $\mathrm{V}_{2} \mathrm{O}_{5}$. Other known vanadium-rich (greater than 0.17 percent $\mathrm{V}_{2} \mathrm{O}_{5}$ ) oil shales include the Mississippian Heath Formation in Montana (Desborough and others, 1981; Derkey and others, 1985) and the Cretaceous La Luna Formation, which is a major petroleum source rock in Colombia and Venezuela (AlberdiGenolet and Tocco, 1999).

Associated metals.-Vanadium-rich black shales commonly contain high contents of other metals, such as silver, barium, cobalt, copper, molybdenum, nickel, phosphorus, PGEs, uranium, and zinc. Well-characterized deposits include the following (metals associated with vanadium are in parentheses): Julia Creek (molybdenum) in Queensland, Australia (Lewis and others, 2010); Nick (nickel, PGEs, and zinc) in Yukon Territory, Canada (Hulbert and others, 1992); and Viken (molybdenum, nickel, phosphorus, and uranium) and Häggån (uranium, molybdenum, and nickel) in Sweden (Hallberg, 2012; Aura Energy, 2012). As reported by Coveney and others (1992), carbonaceous and phosphatic black shales of Cambrian age in China, which have reported values exceeding 4 percent $\mathrm{V}_{2} \mathrm{O}_{5}$, contain exceptionally high grades of nickel (from 2 to 4 percent) and molybdenum (>2 percent), and high concentrations of PGEs (20 to 80 parts per billion for platinum and palladium combined). Although vanadium has not been recovered from these strata, molybdenum and nickel have been mined on a small scale in China since about 1985. Metamorphosed sulfide- and phosphate-rich black shale in southwestern Catalonia, Spain, contains unusually high concentrations of vanadium and chromium (as silicates and oxides) together with palladium and platinum minerals (Canet and others, 2003). The Talvivaara deposit in Finland has elevated contents of vanadium (averages $600 \mathrm{ppm}$ ) (Loukola-Ruskeeniemi and Heino, 1996; Loukola-Ruskeeniemi and Lahtinen, 2013), and until recently, was mined for cobalt, copper, nickel, and zinc, all of which were extracted using a bioheapleach mineral processing method (Jowitt and Keays, 2011; Saari and Riekkola-Vanhanen, 2012; LoukolaRuskeeniemi and Lahtinen, 2013). Vanadium is not currently recovered by this process, however.

\section{Vanadate Deposits}

Vanadates of lead, zinc, and copper (vanadinite and minerals of the descloizite-mottramite series) form in the oxidized zones of base-metal deposits, especially in areas of arid climate and deep oxidation (Fischer, 1975a). The copper-lead-zinc vanadate ores in the Otavi Mountainland of northern Namibia were once considered to be among the largest vanadium deposits in the world, with an estimated resource of several million metric tons (Boni and others, 2007). Other areas with known vanadate deposits include Angola, South Africa, Zambia (Broken Hill district, now known as the Kabwe Mine), and Zimbabwe (fig. U1). Small deposits occur in Argentina, Mexico, and the United States (Arizona, California, Nevada, and New Mexico), but are unlikely ever to be economically significant resources.
Vanadates as a supply of vanadium essentially ceased in 1978 when the last producing vanadium mine at Berg Aukas (Otavi Mountainland) in Namibia was closed.

Vanadate minerals and wulfenite (a lead molybdate mineral) within these deposits form crusts on open cavities or are intergrown with residual clays (Fischer, 1975a). The vanadate ores in the Otavi Mountainland occur in collapse breccias and solution cavities related to karst development in Neoproterozoic carbonate rocks of the Otavi Supergroup and are spatially associated with primary sulfide orebodies within the carbonate strata (Boni and others, 2007). Mottramite and copper descloizite are particularly abundant around copper sulfide deposits (Tsumeb type), whereas descloizite occurs in areas surrounding primary sphalerite-willemite (a zinc silicate mineral) orebodies (Berg Aukas type).

Vanadate deposits are secondary accumulations that form during supergene processes. The vanadate ores of the Otavi Supergroup are interpreted to have formed during several stages, preferentially within a karstic network. The vanadate ores, formed by low-temperature fluids related to weathering, are clearly distinct in age from that of the associated primary sulfide concentrations (Boni and others, 2007). The source of vanadium in such deposits is most likely the surrounding country rocks, especially shales (Fischer, 1975a), or in the case of the Otavi Mountainland deposits, mafic rocks of the older Paleoproterozoic basement (Boni and others, 2007).

\section{Other Magmatic-Hydrothermal Vanadium Resources}

Some magmatic-hydrothermal niobium-titanium deposits contain elevated concentrations of vanadium. Deposits at Potash Sulphur Springs (also called Wilson Springs) in Arkansas were the most important sources of vanadium in North America in the 1970s and 1980s, and nearly 4.3 million metric tons of 1.2 percent $\mathrm{V}_{2} \mathrm{O}_{5}$ was produced. By 1990, all the mines at Wilson Springs were closed (Howard and Owens, 1995). The deposits are located within secondary enrichment zones and fenite that formed during and after intrusion of syenite and mafic alkalic igneous rocks (McCormick, 1978). The Wilson Springs deposits host a variety of vanadiumbearing minerals (Howard and Owens, 1995), including several minerals specific to these deposits (table U2). Adjacent carbonatite and alkaline igneous complexes at the Christy deposit within the Magnet Cove complex in Arkansas have high concentrations of vanadium together with titanium, niobium, and (or) rare-earth elements (Verplanck and Van Gosen, 2011; Flohr, 1994), and carbonatites and related rocks in Kenya are enriched in vanadium (Barber, 1974). Typical vanadium concentrations in such deposits are about 1 percent and are contained in magnetite and titanium minerals. At Magnet Cove and Wilson Springs, sodic pyroxene and magnetite contain up to 3.19 and 1.43 weight percent $\mathrm{V}_{2} \mathrm{O}_{3}$, respectively, and high concentrations occur in goethite (Flohr, 1994; Howard and Owens, 1995).

Several other deposit types contain vanadium concentrations that are noteworthy, but all are presently uneconomic and 
are unlikely to be considered vanadium resources in the future. For example, heavy-mineral-concentrate samples from iron ores (Kiruna-type apatite-magnetite deposits) in Sweden and Chile have reported high concentrations (1,000 to 2,000 ppm) of vanadium (Nyström and Henríquez, 1994) and iron oxide mineral separates (magnetite and hematite) from such deposits contain up to 0.479 weight percent vanadium (Dupuis and Beaudoin, 2011). Vanadium concentrations of a few tenths of a percent are also common in titanium-bearing minerals, such as rutile and brookite (table U2) in some epithermal gold-silver and porphyry copper deposits (Fischer, 1973). For example, porphyry deposits in Australia contain rutile with vanadium contents of 0.2 and 1.3 weight percent (Scott, 2005), and rutile from the Pebble porphyry deposit in Alaska has vanadium concentrations that average 6.3 weight percent (Kelley and others, 2011). Even iron-rich minerals that do not contain titanium, such as magnetite and hematite, in some porphyry deposits contain elevated concentrations (up to 0.619 weight percent) of vanadium (Dupuis and Beaudoin, 2011).

In some gold-quartz veins, especially those containing gold-telluride minerals, roscoelite and other vanadium-bearing minerals are common as fine-grained intergrowths with quartz and other gangue minerals (Richards, 1995). In the Tuvatu gold-telluride deposit in Viti Levu, Fiji, vanadium occurs in roscoelite together with karelianite, vanadian muscovite, titanium-free nolanite, vanadian rutile, schreyerite, and an unnamed vanadium silicate mineral (Spry and Scherbarth, 2006). Rutile in the Tuvatu deposit contains up to 5.2 weight percent $\mathrm{V}_{2} \mathrm{O}_{3}$; roscoelite contains 32.71 weight percent $\mathrm{V}_{2} \mathrm{O}_{3}$, which is among the highest reported vanadium value for roscoelite from an epithermal gold-tellurium deposit (Spry and Scherbarth, 2006). The source of the vanadium is probably magnetite-bearing mafic alkalic igneous rocks that are spatially associated with the gold ores (Spry and Scherbarth, 2006).

\section{Fossil Fuels}

Vanadium closely correlates with organic carbon and, therefore, is enriched in many oil shales. It follows that significant amounts of vanadium are available for commercial use as a byproduct of petroleum, and minor amounts are produced as byproducts of coal and tar sands (Breit, 1992; Polyak, 2012, 2013). At least 10 percent of the world's supply of vanadium comes from coal, crude oil, and petroleum (Polyak, 2012, 2013). The highest concentrations of vanadium are in heavy crude oils (Breit, 1992). Most of the world's heavy oil and vanadiferous petroleum resources are located in Venezuela. These oilfields contain consistently high (up to $1,400 \mathrm{ppm}$ ) concentrations of vanadium (Kapo, 1978). Other oils with greater than $50 \mathrm{ppm}$ vanadium are produced in Iran and Japan, and from several fields within the United States, including Alaska, Arkansas, California, Louisiana, Mississippi, Oklahoma, Texas, and Wyoming. Vanadium is recovered from oil by processing ash generated in thermoelectric powerplants, petroleum coke residues generated during refining of heavy oils, and residues plated onto catalysts (Breit, 1992).

Vanadium abundances in ashes formed by burning coals generally range from 0.01 to 0.3 weight percent, with some as high as 8 percent (Reynolds, 1948). The lowest values are contained in coals formed from subaerial plant material; the highest concentrations are in marine sapropelic coals (Breit, 1992). Although China is the only producer of vanadium from coal, coal deposits in Venezuela contain high vanadium contents. The average vanadium content of coal in the United States is $20 \mathrm{ppm}$ (Swanson and others, 1976).

Tar sands are large deposits of bitumen or extremely heavy crude oil. The sands were originally named for those in the Athabasca region in northeastern Alberta, Canada, and tar sand deposits in this region are the best known examples in the world. Other documented occurrences are in Alabama, Alaska, California, Kansas, Kentucky, Oklahoma, Missouri, New Mexico, Texas, and Utah in the United States (Wever and Kustin, 1990), and in other countries, such as Jordan (Breit, 1992; Dill and others, 2009). The oil sands consist of a mixture of crude bitumen (a semisolid form of crude oil), silica sand, clay minerals, and water. Production of refinery-grade oil from the tar sand deposits generates a substantial amount of petroleum coke fly ash that may contain appreciable amounts of valuable metals, such as nickel, titanium, and vanadium. The amount and form of vanadium varies, depending on the nature of the sands. Tar sands in the Athabasca region average several hundred ppm vanadium, whereas other localities contain lower concentrations (Wever and Kustin, 1990; Breit, 1992).

\section{Resources and Production}

\section{Identified Resources (United States and World)}

A majority of the world's supply of vanadium (approximately 80 to 85 percent) is derived from mined ore that comes either directly from deposits or from steelmaking slags produced by processing the ores mined from VTM deposits. The remaining 15 to 20 percent of the world's supply of vanadium comes from (a) spent catalysts that collected vanadium during the refining of crude oils; (b) residues from the production of alumina, uranium, and some hydrocarbons; and (c) ash derived from burning high-vanadium-content coal or petroleum. Although the leading vanadium-producing countries in 2012 (fig. U2) were China (37 percent), South Africa ( 35 percent), and Russia (25 percent), Australia is poised to become a major world producer of vanadium in the future (Moskalyk and Alfantazi, 2003). World vanadium resources in 2012 were estimated to be 63 million metric tons of vanadium, and world reserves were estimated to be 14 million metric tons (Polyak, 2013). Because vanadium is usually recovered as a byproduct or coproduct, the demonstrated world resources of this mineral commodity are 
understated and. therefore. not fully indicative of available supply. Although domestic resources and secondary recovery are adequate to supply a large portion of domestic needs, a substantial part of U.S. demand is currently met by foreign material (Polyak, 2013).

Among the vanadium-rich ore deposits currently being mined, VTM deposits contain the largest tonnages of ore (table U1; fig. U5) and are the reason that China, South Africa, and Russia lead the world in vanadium production. Sandstonehosted deposits commonly have the highest grades of vanadium, but most are small; that is, they have less than 1 million metric tons of ore (table U1; fig. U5). Among the three deposit types, however, the leading producers of vanadium in the United States have been SSV deposits. In 2010, production from a mill facility in Utah that recovered vanadium from SSV ores was sufficient to meet 20 percent of the vanadium demand for the United States, which amounted to nearly 2 percent of global vanadium production (Polyak, 2011).

Some carbonaceous and phosphatic shale-hosted deposits (Julia Creek, Australia; Viken, Sweden; and Green Giant, Madagascar) have reported high tonnages of vanadium, but these deposits are not currently in production. Technology to recover vanadium profitably in current markets is still being developed. Small amounts of vanadium were produced during World War II from the organic-rich Alum Shale in southern and central Sweden (Dyni, 2006). Also, until 1999, approximately 2,000 metric tons of $\mathrm{V}_{2} \mathrm{O}_{5}$ was produced annually from the ferrophosphorus slag generated during the reduction of phosphate to elemental phosphorus in ore from the Phosphoria Formation in Idaho and Wyoming (Jasinski, 2004).

Bauxite is another source of vanadium. The vanadium content depends on the origin and nature of the bauxite, but average $\mathrm{V}_{2} \mathrm{O}_{5}$ contents typically range from 0.05 to 0.25 percent. France, Germany, and India host important occurrences of vanadium-rich bauxite (Patterson, Kurtz, and others, 1986). During the processing of bauxite and the production of alumina, vanadium accumulates in residual sludge (red mud) and other byproducts that contain as much as 10 to 18 percent $\mathrm{V}_{2} \mathrm{O}_{5}$.

Vanadium is present in crude oil or the residues (bitumen or asphalts) of crude oils remaining in petroleum source rocks. Japan and the United States have recovered significant quantities of vanadium from petroleum residues. Asphaltine or bitumen in the Mina Ragra deposit in the Pasco Region of Peru, was extensively exploited for vanadium from 1907 until 1955. It was the principal source of vanadium in the world in the early 1900s (Fischer, 1973). Unoxidized ore at Mina Ragra consists of quisqueite (a vanadium hydrocarbon) and patronite (vanadium sulfide) (table U2). Vanadates and vanadium oxide minerals form the near-surface oxidized ore, some of which is extremely rich and contains as much as 40 percent $\mathrm{V}_{2} \mathrm{O}_{5}$ (Fischer, 1973). Bitumen and asphaltine that contain vanadium-rich minerals occur in fractures and as disseminations in the host shale, forming a lens-shaped body (Fischer, 1973).

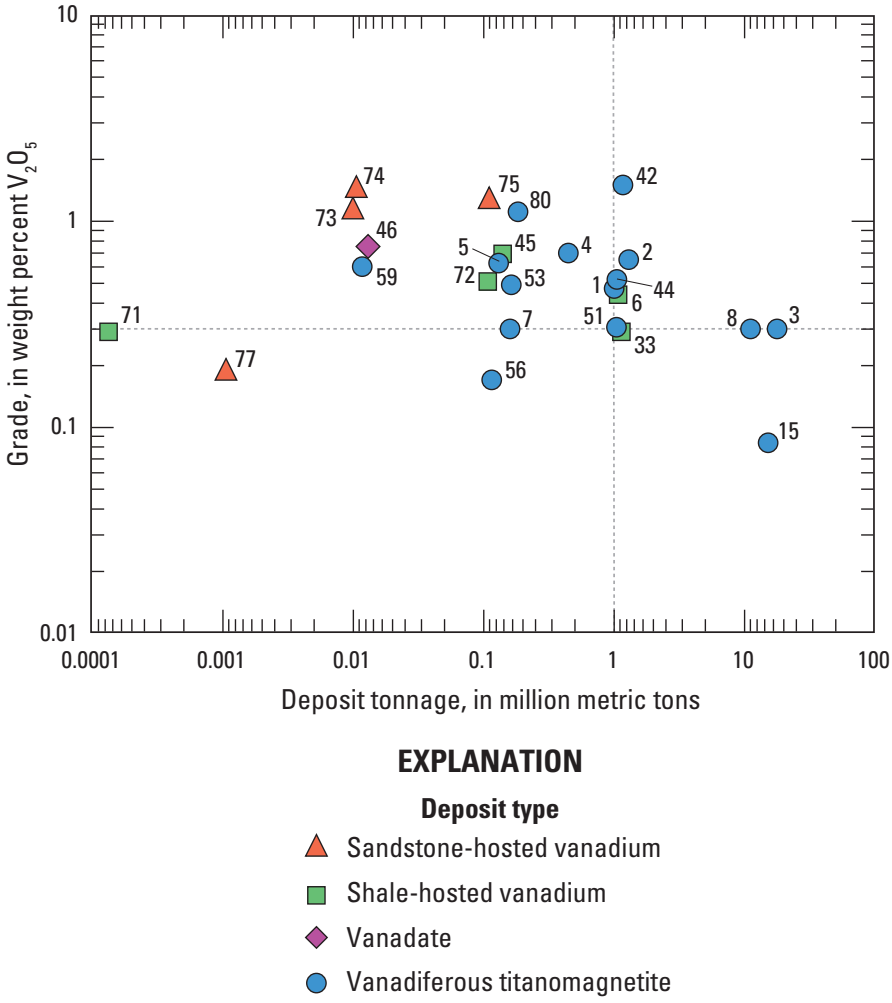

Figure U5. Plot of grade and tonnage of vanadium deposits for which data were available. Each symbol represents an individual deposit. Numbers next to the symbol correspond to the deposit numbers given in table U1 and figure U1. The deposits with the highest grades (greater than or equal to 0.3 percent vanadium oxide $\left[\mathrm{V}_{2} \mathrm{O}_{5}\right]$ ) and tonnages (greater than 1 million metric tons of $\mathrm{V}_{2} \mathrm{O}_{5}$ ) are located in Africa, Australia, Canada, and China.

\section{Undiscovered Resources}

Given that most of the present-day vanadium comes from VTM deposits and steelmaking slags produced from these deposits, it is likely that additional vanadium resources will come predominantly from VTM deposits and districts. VTM deposits in Australia, Brazil, Canada, Chile, India, and Malaysia have been identified only recently, and the full extent of the resources has not yet been evaluated fully. Among the largest regions with potential for widespread VTM resources is the 5,000- $\mathrm{km}^{2}$ region known as the "Ring of Fire" in northern Ontario (fig. U1). Results from early exploration programs indicate that vanadium grades for deposits within mafic and ultramafic complexes in this region (for example, 0.64 percent $\mathrm{V}_{2} \mathrm{O}_{5}$ at the Butler Lake area, Ontario, Canada; MacDonald Mines Exploration Ltd., 2013) are comparable to economic deposits elsewhere in the world.

Some uranium SSV ores in southwestern South Dakota and northeastern Wyoming are part of the Wyoming basin's uranium province and have recently been distinguished from 
deposits elsewhere in the province by their substantially higher vanadium contents (George Breit, U.S. Geological Survey [retired], written commun., 2013). These are possible deposits for future vanadium production in the United States.

The amount of vanadium recovered from processing crude oils, coals, and tar sands will undoubtedly increase with future technological advances. Oil from large fields in the Caribbean Basin, the Middle East, and Russia are known to contain anomalously high vanadium contents (Mukhametshin and Punanova, 2011). Tar sands in North America may become an important resource of vanadium in the future. The effectiveness of recovery of vanadium is dependent on the silica and alumina contents of the fly ash; high silica and alumina contents tie up metal values in a silica-alumina matrix (Gomez-Bueno and others, 1981). Results of experimental work show that such matrixes can be broken down by application of a saline water roast of the carbon-free fly ash (Gomez-Bueno and others, 1981). Additional research on development of processing techniques of fly ash may lead to further enhanced recoveries of vanadium (Holloway and Etsell, 2006).

Iron sands are another potential source of vanadium. Iron sands are placer deposits that contain abundant concentrations of iron-bearing heavy minerals, including vanadium-rich magnetite. These iron sands are distributed extensively on the west coast of New Zealand's North Island (Sweatman and others, 2012), but other placer occurrences most likely are present on the east coast of the conterminous United States and the coasts of Africa and Brazil, as well as fluvial irontitanium-vanadium placer deposits (for example, interior Iran; Razmara and Asadi, 2010). Vanadium concentrations in the New Zealand sands are as high as 0.5 percent. Although vanadium is currently not produced as a byproduct, research that is focused on methods to optimize its recovery is reportedly underway (Sweatman and others, 2012).

Most known occurrences of vanadium in shale are currently uneconomic but are estimated to contain large resources (table U1). Targets may become more viable in the future with advances in extraction technology. For example, development of a method to extract vanadium from the Gibellini vanadium deposit in central Nevada (American Vanadium Corp., 2012) is underway. Similar efforts to produce vanadium from metashales are reported for the Green Giant deposit in Madagascar (Energizer Resources, Inc., 2013). Graphitic deposits in Alabama and China (Liu Mao Mine) contain mica and garnet with elevated vanadium concentrations (up to 0.2 percent $\mathrm{V}_{2} \mathrm{O}_{5}$ ) that may be similar to the Green Giant deposit (Pallister and Thoenen, 1948; this volume, chap. J). Other vanadiferous shales include the lowto medium-grade Okcheon metamorphic belt in Korea (Jowitt and Keays, 2011), where metalliferous black shales were used locally as fuel, and contain up to 2.04 percent vanadium, together with high concentrations of gold, molybdenum, nickel, PGEs, and uranium (Jeong, 2006). The Alum Shale in Sweden is an organic-rich marine sequence that is 15 to $60 \mathrm{~m}$ thick and contains up to $3,100 \mathrm{ppm}$ vanadium and high concentrations of molybdenum, nickel, uranium, and zinc (Dyni, 2006). Although small amounts of vanadium have already been produced from the Alum Shale, new technologies may allow industrial-scale extraction from this laterally extensive unit (Dyni, 2006; Aura Energy, 2012; Hallberg, 2012). Black shales in Russia that occur within the Mongolia/Ural and Pacific gold belts have local concentrations of vanadium and uranium and therefore are also potential resources for these metals (Karpuzov and others, 2008). Although it lies at great depths (about 2,000 $\mathrm{m}$ below the surface), the oil-bearing Bazhenov Formation in the West Siberian Basin is another potential source of byproduct metals (Laznicka, 2010), with reported average concentrations of $105 \mathrm{ppm}$ uranium, $285 \mathrm{ppm}$ molybdenum, and $1,015 \mathrm{ppm}$ vanadium in a laterally extensive interval that is at least 15 to $20 \mathrm{~m}$ thick.

\section{Exploration for New Deposits}

Exploration methods for vanadium-rich ores vary with deposit type. An understanding of how each type of deposit forms is essential for predicting the potential for undiscovered deposits.

\section{Exploring for Vanadiferous Titanomagnetite Deposits}

Most vanadiferous titanomagnetite (VTM) deposits that formed on cratons of Archean to Proterozoic age are closely associated with LIPs; consequently, exploration for this deposit type is focused on LIPs. Mafic to ultramafic complexes that host VTM deposits are generally apparent as aeromagnetic anomalies, even if not exposed at the surface. Most commonly, airborne geophysical surveys that show coincident magnetic and electromagnetic anomalies are further investigated with followup ground geophysical surveys, including gravity, induced polarization, resistivity, and electromagnetic methods. Modeling of aeromagnetic and gravity data can indicate the extent, thickness, and form of intrusions (Cawthorn and Webb, 2001; Ivanic and others, 2010), which can help delineate intrusive bodies having the potential to host vanadium-rich magnetite layers. Paleomagnetic investigations of the Bushveld Complex have shown that different mineralized zones have different paleomagnetic signatures (that is, ages), allowing for regional correlation and delineation of the lateral extent of selected zones (Eales and others, 1993).

An important frontier issue in the exploration for VTM deposits is development of better exploration models that integrate the characteristics of these deposits with an improved understanding of LIP plumbing systems (Ernst and others, 2005). LIPs can have direct links to ore deposits (as hosts or heat engines) or indirect links, and can be used as guides for determining Precambrian paleocontinental reconstructions and related tracing of metallogenic belts between formerly adjacent tectonic blocks (Ernst and Peck, 2010). 
Moreover, the compositions of igneous rocks in LIPs can be used to assess fertility and ore potential. For example, specific element ratios can be used to identify whether particular igneous rocks are permissive for hosting vanadium mineralization (Ernst and Peck, 2010). Lithogeochemistry, therefore, provides a guide for selecting the most prospective LIPs and LIP segments for exploration for VTM deposits, or for associated chromium, copper-nickel, or PGE deposits (Augé and others, 2005; Ivanic and others, 2010).

Major known ore-bearing magmatic intrusions are widespread within, or can be traced to the edge of, host continental blocks, suggesting that the intrusions likely continued into a formerly adjacent block. Examples include intrusions such as the Bushveld Complex (Kaapvaal craton), and the Great Dyke of Zimbabwe (Zimbabwe craton). From an exploration standpoint, robust Precambrian reconstructions aid in tracking well-documented metallogenic belts from heavily explored to frontier regions. New methods that use comprehensive data for LIPs can make such Precambrian reconstructions much more efficient (Ernst and Peck, 2010).

\section{Exploring for Sandstone-Hosted Vanadium Deposits}

All sandstone-hosted vanadium (SSV) deposits in the Colorado Plateau province contain uranium; therefore, methods used to explore for uranium deposits of this type are applicable to the search for vanadium. The recognition and documentation of meander bends and possible bifurcating paleochannels in the sandstone host rocks are important broad characteristics. Features that may be used as guides to ore include sandstone-mudstone facies, trunk channel systems, stratigraphic pinchouts, individual channels, thick sandstone lenses, and carbonaceous material (Kovschak and Nylund, 1981). Models for the formation of SSV deposits suggest that bacteriogenic hydrogen sulfide acted as a reducing agent for ore formation (Northrop and others, 1990; Wanty and others, 1990). In addition, pyrite in mineralized zones typically has lower sulfur isotope values than pyrite above or below the zone (Northrop and others, 1990), indicating that isotopically light pyrite is an indicator of mineralizing processes in an area.

Some deposits have readily recognizable alteration zones, whereas others show only subtle differences between unmineralized, altered, and mineralized zones. Principal criteria used to distinguish the alteration zones are color, pyrite morphology, kaolinization of feldspar, and low gamma-ray counts commonly accompanied by gamma-ray anomalies at the upper and lower margins of the altered zone (Rackley and others, 1968). The presence of limonite stains, green and blue secondary copper minerals, gray-green alteration of brown or reddish mudstone seams or lenses, and iron and (or) copper sulfide minerals were used as guides to ore in the 1950s (Johnson, 1959).

Geophysical methods assist in determining regional subsurface geology as it may relate to SSV deposits. Conspicuous gravity lows may indicate evaporite units that typically underlie the deposits, although many units may be too thin for detection. Magnetic anomalies highlight depths to basement, major faults that serve as conduits for ore fluids, and the presence of laccolithic intrusions that are interpreted as a possible source of metals in some deposits (Case and Joesting, 1972). More refined geophysical methods are needed to resolve the shape and position of channel sands. Airborne electromagnetic techniques have recently been applied in Nebraska to map the three-dimensional configuration of aquifers and paleochannels (Abraham and Cannia, 2011) and may be useful for delineating channels that are SSV ore hosts.

\section{Exploring for Shale-Hosted Vanadium Deposits}

High vanadium concentrations in shales are closely correlated with elevated contents (greater than 5 percent) of organic carbon. Many vanadiferous shales with more than 20 percent organic carbon are considered oil shales (for example, Julia Creek deposit, Queensland, Australia). Deposits of oil shale occur worldwide, and include major deposits in the United States (INTEK, Inc., 2011). Some of these oil shales are known to have high vanadium contents (for example, Heath Formation in Montana; La Luna Formation in Venezuela), but many others likely have not been analyzed for trace metals. Existing and new geochemical data for vanadium and other trace elements in shales would need to be examined to locate potential shale-hosted vanadium deposits.

A good understanding of how vanadiferous shales form is critical for exploration. It is generally accepted that the source of vanadium is seawater, but the enrichment mechanism is uncertain. The close occurrence of vanadium-rich shales with black-shale-hosted phosphate deposits suggests control by fluctuating redox gradients within a sedimentary basin (Piper, 1994). If this suggestion is correct, then exploration will likely be focused in marine successions that were deposited along continental margins or inland seas, where redox gradients are likely to have occurred. Furthermore, because shales can be laterally extensive but have variable grades, understanding the distribution of metal enrichments may help target areas of interest.

National-scale geochemical datasets also may be useful in highlighting regions with black shales that are permissive for hosting vanadium deposits. Preliminary soil and sediment maps of the United States (Smith and others, 2015) show arcuate highs for a range of elements, including cobalt, molybdenum, nickel, and vanadium in central Kentuckyan area that is underlain by the New Albany Shale (Ripley and others, 1990) and stratigraphically equivalent shales that are known to contain high concentrations of these metals. Although less pronounced, similar high concentrations are evident in east-central Nevada and could be related to shales of the metal-rich Woodruff Formation.

Geophysical methods may prove valuable for delineating the distribution of black shales, although many of these shales may not contain significant concentrations of vanadium. 
Shales are good conductors, particularly if graphite is present, and therefore, electromagnetic and resistivity surveys may prove useful in delineating the extent of shale units under shallow cover. Recent studies show that combined seismic and electromagnetic methods are effective in highlighting zones of high gas potential in shale reservoirs (Kumar and Hoversten, 2012); such methods could be tested for use in the search for high-organic intervals in shales. Because many vanadium-rich carbonaceous shales also contain high uranium concentrations, downhole geophysical techniques (gamma logs) may be useful in identifying the position of metalliferous shales. Aerial radiometric surveys may also resolve the outcrop position of uranium-rich (and, by association, other metal-rich) shales (Pirkle and others, 1982). The arcuate trend of metals in surficial materials described above for Kentucky is readily mapped in an aeroradiometric survey (Hill and others, 2009).

\section{Environmental Considerations}

\section{Sources and Fate in the Environment}

Vanadium commonly occurs in one of three oxidation states in weathering environments: $+3,+4$, and +5 . Vanadium +3 and +4 are relatively insoluble ions because they tend to form solid (oxy)hydroxides (for example $\mathrm{V}(\mathrm{OH})_{3}$ and $\mathrm{VO}(\mathrm{OH})$ ), respectively, but the $\mathrm{V}^{5+}$ state is generally dissolved in solution as various oxyanions (for example $\mathrm{VO}_{4}{ }^{3-}, \mathrm{HVO}_{4}{ }^{2-}$, and $\mathrm{H}_{2} \mathrm{VO}_{4}^{-}$). Under a wide $\mathrm{pH}$ range, these high-valence vanadium oxyanions may sorb to iron and aluminum (oxyhydr)oxide minerals. Most dissolved vanadium in rivers and streams derives from the weathering of silicate minerals (Shiller and Mao, 2000). Dissolved $\mathrm{V}^{4+}$ and $\mathrm{V}^{3+}$ are known to form strong complexes with organic compounds, many of which originated as $\mathrm{V}^{5+}$-organic complexes that were reduced. The formation of strong vanadium-organic compound complexes is one of the mechanisms by which fossil fuels and black shales may become enriched in vanadium.

Examples of natural concentrations of vanadium in rocks, soils, water, and air are given in table U3. Vanadium contents in soils away from known vanadium deposits, mines, or smelters range from 13 to $227 \mathrm{ppm}$ (Shacklette and Boerngen, 1984; Tyler, 2004), whereas streams and rivers contain vanadium concentrations that range from 0.23 to 3.7 micrograms per liter $(\mu \mathrm{g} / \mathrm{L}$ ) or ppb (Shiller and Mao, 2000; Gaillardet and others, 2003). The concentration of vanadium in suspended particulates in world rivers averages $129 \mathrm{mg} / \mathrm{kg}$ (Viers and others, 2009). Dissolved vanadium in coastal seawater ranges from 0.31 to $2.8 \mu \mathrm{g} / \mathrm{L}$ (Shiller and Mao, 1999; Wang and Sañudo-Wilhelmy, 2008; Strady and others, 2009). In North Pacific seawater, dissolved vanadium concentrations generally increase with depth with a total range of 1.5 to $1.9 \mu \mathrm{g} / \mathrm{L}$ (Collier, 1984). In contrast, concentrations in particulate matter (with diameters greater than 53 micrometers) decrease in the upper 100 to $200 \mathrm{~m}$ of seawater, then remain relatively constant over a range of 0.0001 to $0.0004 \mu \mathrm{g} / \mathrm{L}$ (Collier, 1984).
Among nearly 9,000 samples of filtered and unfiltered groundwaters collected in California, 90 percent contained vanadium concentrations ranging from 3 to $24 \mu / \mathrm{L}$ (Wright and Belitz, 2010). Vanadium occurs naturally in the atmosphere as part of mineral dust particles, and ranges in concentration from 0.0006 to 0.002 nanogram per cubic meter $\left(\mathrm{ng} / \mathrm{m}^{3}\right)$ over the South Pole and from 0.8 to $1.4 \mathrm{ng} / \mathrm{m}^{3}$ over Greenland (KabataPendias and Pendias, 2001).

Mining and industrial activities can lead to abovebackground concentrations of vanadium in the environment (table U3). For example, the concentration of vanadium in soils (548 to 7,160 ppm) collected near a vanadium mine in the North West Province of South Africa (Mandiwana and Panichev, 2004) is roughly an order of magnitude greater than natural concentrations in soils. In the Panzhihua region, China, soil vanadium concentrations depend upon the predominant land use and decrease in the following order: smelting (208 to $938 \mathrm{ppm}$ ), mining (112 to $591 \mathrm{ppm}$ ), agricultural (86 to $227 \mathrm{ppm}$ ), and urban use (94 to $184 \mathrm{ppm}$ ) (Teng and others, 2011). The Bílina River in the Czech Republic receives drainage from municipal and industrial areas; vanadium concentrations range from 2.5 to $85.6 \mu \mathrm{g} / \mathrm{L}$, with the highest concentrations observed in the industrial region (Kohušová and others, 2011). Primary inputs of vanadium to the atmosphere result from mining, ore processing, and combustion of fuel oils and coal. Vanadium concentrations in air in urban and industrial areas range from 5 to $200 \mathrm{ng} / \mathrm{m}^{3}$ (Kabata-Pendias and Pendias, 2001).

\section{Mine Waste Characteristics}

Mine waste is generally considered to be the material that originates and accumulates at a mine site but has no current economic value (Lottermoser, 2010), and it includes both solid and liquid waste. Because vanadium can be recovered as a byproduct of the mining of bauxite, carnotite, phosphate, and titanomagnetite ores, the character of the mine waste will vary according to the methods used to extract the primary ore. Vanadium mining of black shales and copper-lead-zinc vanadate deposits, as well as recovery of vanadium from fly ash, generates additional types of mine and processing waste. Mining of vanadium from VTM deposits in Australia is projected to generate 12 million cubic meters of waste rock at the Windimurra deposit (Environmental Protection Authority, 2008) and 59 million metric tons of tailings at the Balla Balla deposit (Environmental Protection Authority, 2009). American Vanadium Corp. is planning to mine vanadium from the Gibellini vanadium deposit in Nevada. Production is to involve open pit mining and processing on site by heap leaching; the total amount of ore and waste to be extracted is projected to be 24 million metric tons (Hanson and others, 2011). Plans to mine vanadium at the metashale-hosted Green Giant deposit in Madagascar includes a well-known process called alkaline press leaching, which is expected to produce a battery-grade form of $\mathrm{V}_{2} \mathrm{O}_{5}$ that has a purity of greater than 99.5 percent. 
Table U3. Vanadium concentrations in rocks, soils, waters, and air.

[DOE, U.S. Department of Energy; EPA, U.S. Environmental Protection Agency; V, vanadium; cm, centimeter; $\mu \mathrm{g} / \mathrm{L}$, microgram per liter; $\mu \mathrm{m}$, micrometer; $\mathrm{ng} / \mathrm{m}^{3}$, nanogram per cubic meter; ppm, part per million; \%, percent]

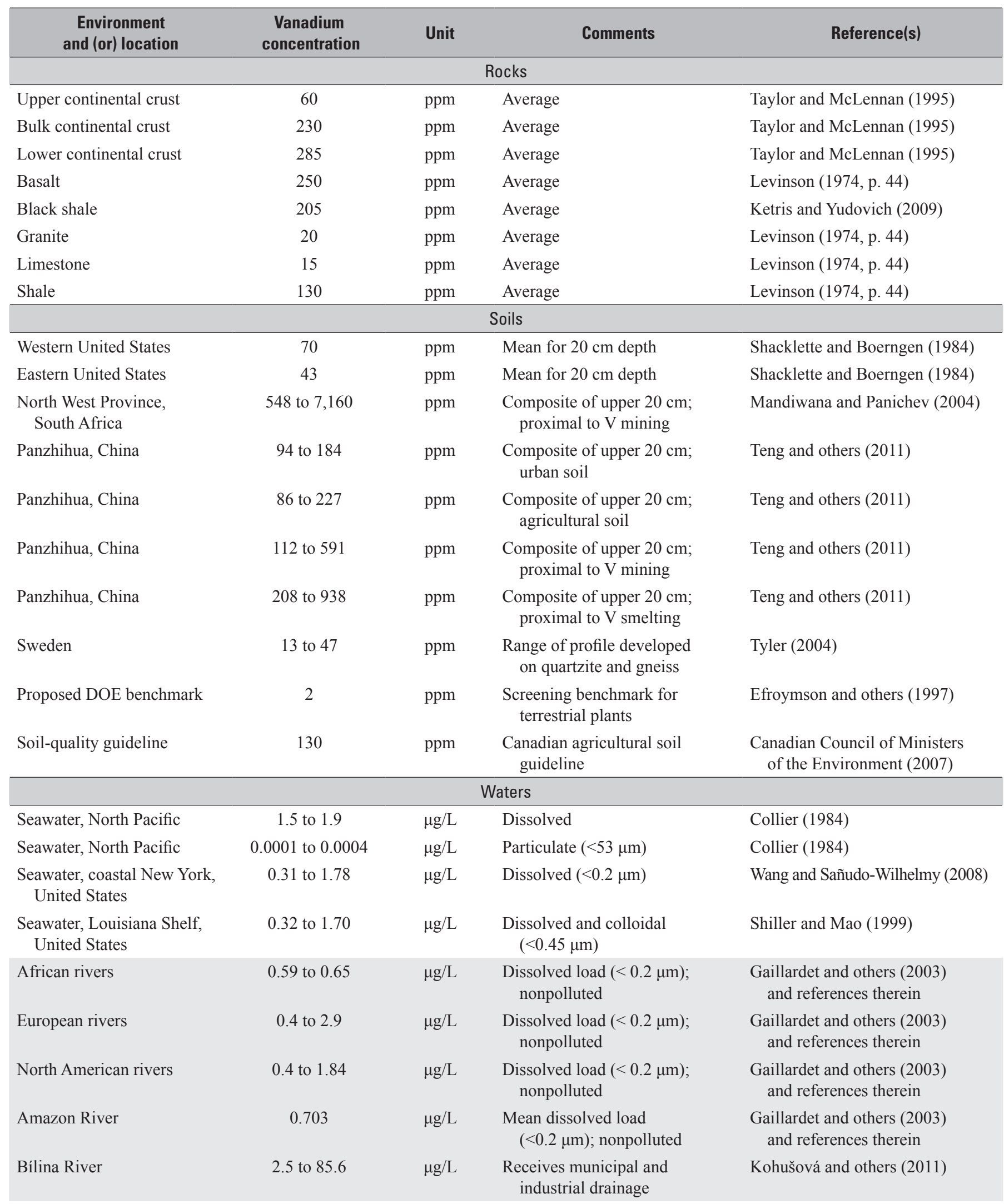


Table U3. Vanadium concentrations in rocks, soils, waters, and air.-Continued

[DOE, U.S. Department of Energy; EPA, U.S. Environmental Protection Agency; V, vanadium; cm, centimeter; $\mu \mathrm{g} / \mathrm{L}$, microgram per liter; $\mu \mathrm{m}$, micrometer; $\mathrm{ng} / \mathrm{m}^{3}$, nanogram per cubic meter; ppm, part per million; \%, percent]

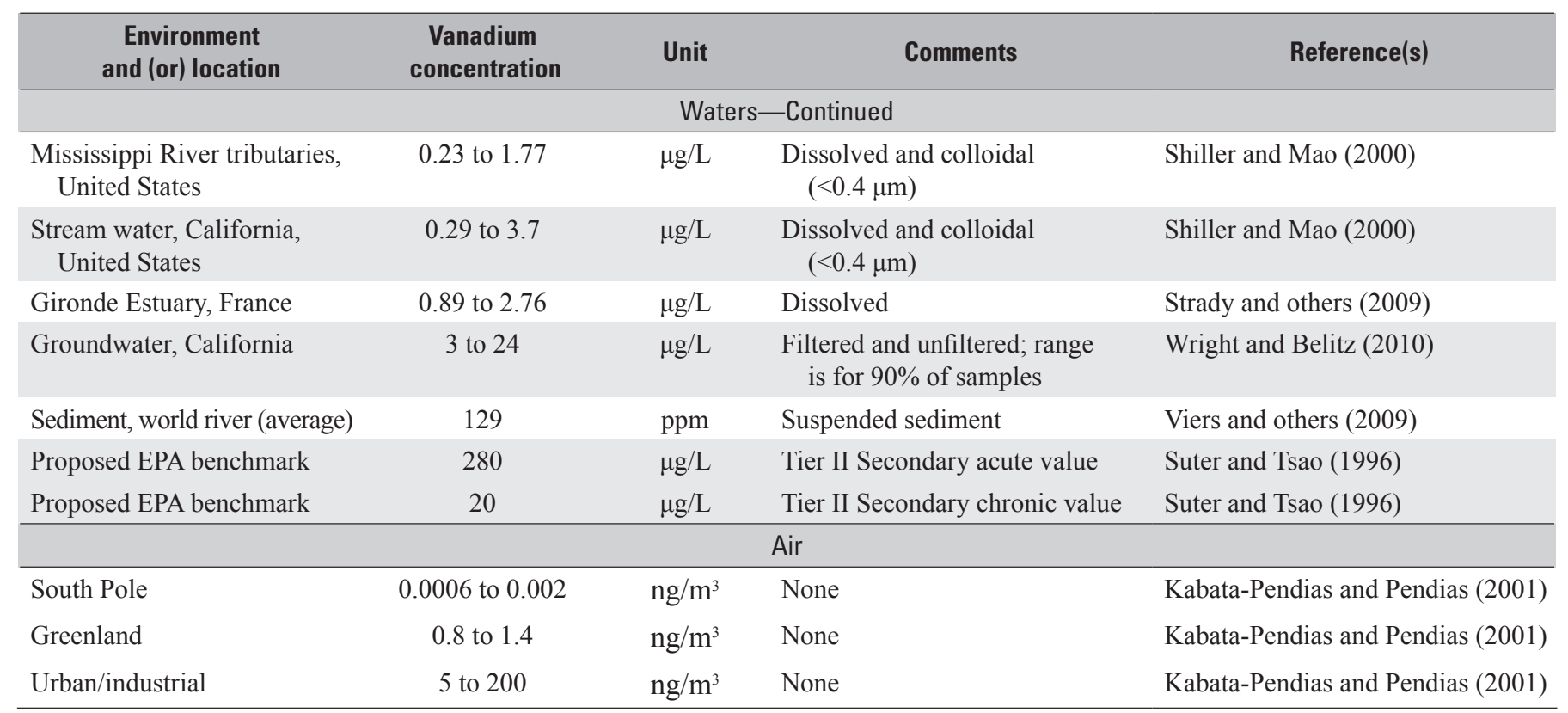

The mineralogy of solid mine waste derived from vanadium mining is similar to that of the deposit from which it is extracted, but the proportion of vanadium minerals is smaller. Tailings from the VTM deposit in Panzhihua, China, contain ilmenite (15 to 18 mass percent), augite (46 mass percent), plagioclase (31 to 34 mass percent), and pyrite (2 to 3 mass percent) (Dahe, 2004). The Slick Rock SSV deposit in Colorado typically contains low contents of uranium and vanadium ore minerals, as well as anatase, barite, calcite, jordisite, pyrite, and quartz; selenium- and copper-bearing minerals are found in some deposits (Shawe, 2011). In the Gibellini vanadium deposit, vanadium is concentrated in organic material; associated phases are apatite, calcite, clay, microcline, pyrite, and sphalerite (Desborough and others, 1979). Copper-lead-zinc vanadate deposits may contain the ore minerals descloizite, mottramite, and vanadinite (table U2), which at the Otavi Mountainland deposits in Namibia host trace amounts of arsenic, cadmium, chromium, iron, manganese, molybdenum, nickel, and phosphorus (Boni and others, 2007). The most common gangue minerals in the Otavi Mountainland deposits are calcite and dolomite, which have high concentrations of iron, phosphorus, and lead and trace amounts of arsenic, barium, cadmium, copper, nickel, strontium, and vanadium (Boni and others, 2007).

In weathering environments, trace metals in vanadium deposits are expected to remain immobile under oxic, nearneutral $\mathrm{pH}$ conditions $(5<\mathrm{pH}<8)$, especially in the presence of iron-rich solids (Smith and Huyck, 1999). Under anoxic and (or) acidic conditions, however, vanadium minerals, some gangue minerals, and associated trace metals may dissolve. In those deposits that contain sulfide minerals (for example, chalcocite, pyrite, and sphalerite), generation of acidity is possible if sulfide dissolution is not balanced by the acid-neutralizing capacity of carbonate minerals (for example calcite and dolomite). The dissolution of sulfide minerals releases metals and produces sulfuric acid, and the subsequent acidic $\mathrm{pH}$ values of the solutions allow higher concentrations of metals to be dissolved - potentially causing the environmental problem known as acid mine drainage (AMD). Mining of VTM, SSV, and black shale deposits that contain sulfides and lack appreciable quantities of carbonate minerals increases the potential for AMD generation. Alternatively, some of these deposit types, particularly some SSV and black shale deposits, contain appreciable amounts of carbonate minerals, thereby lowering the acid-generation potential.

Recovery of vanadium from mine tailings and other wastes is becoming an increasingly important source, particularly because the fraction of vanadium in discarded products that are recycled is less than 1 percent (Graedel and others, 2011). The main challenge of vanadium recycling is that it is often included in alloys in small amounts, making recovery technologically and economically unfeasible (Reck and Graedel, 2012).

\section{Human Health Concerns}

The Agency for Toxic Substances and Disease Registry provides a useful summary of the human toxicology of vanadium (Agency for Toxic Substances and Disease Registry, 2012). 
The general public is most likely to be exposed to vanadium through consumption of contaminated food. Occupational exposure to vanadium usually results from the inhalation of $\mathrm{V}_{2} \mathrm{O}_{5}$ dust during the production of $\mathrm{FeV}$ and steel. Exposure to high oral doses of vanadium may lead to nausea, diarrhea, stomach cramps, decreased numbers of red blood cells, and increased blood pressure. Inhalation of $\mathrm{V}_{2} \mathrm{O}_{5}$ may cause extended coughing and is suspected to cause cancer.

Vanadium is believed to be a micronutrient, with a postulated requirement for humans of less than 10 micrograms per day, which can be met through dietary intake (Anke, 2004, and references therein). Vanadium in the form of vanadyl sulfate and sodium metavanadate has been administered to diabetic patients as a dietary supplement because these compounds have been observed to mimic the actions of insulin in isolated cell systems (Anke, 2004, and references therein), but clear therapeutic benefit has yet to be established (Wiernsperger and Rapin, 2010). Primary and secondary drinking-water regulations for vanadium currently do not exist in the United States, but the Occupational Safety and Health Administration has set an exposure limit of 0.05 milligrams per cubic meter $\left(\mathrm{mg} / \mathrm{m}^{3}\right)$ for $\mathrm{V}_{2} \mathrm{O}_{5}$ dust (Occupational Safety and Health Administration, $2013 \mathrm{~b}$ ) and $0.1 \mathrm{mg} / \mathrm{m}^{3}$ for $\mathrm{V}_{2} \mathrm{O}_{5}$ fumes (Occupational Safety and Health Administration, 2013a) in workplace air over an 8-hour workday. Vanadium toxicity is believed to result from an intake of more than 10 to 20 milligrams per day (Anke, 2004).

\section{Ecological Health Concerns}

Vanadium is essential for some biological processes and organisms, as well as a potential toxicant. For example, some nitrogen-fixing bacteria require vanadium for producing vanadium nitrogenase, an enzyme used to convert nitrogen $\left(\mathrm{N}_{2}\right)$ from the atmosphere into ammonia, which is a more biologically accessible form of nitrogen (Madigan and others, 2003). This process is critical to the health of the biosphere. Vanadium is also essential to certain species of algae for chlorophyll production and overall growth (Anke, 2004).

Compared with other metals and metalloids, the ecological impacts of vanadium in the environment are not well known. Because fish tend to be sensitive to low concentrations of dissolved metals, they are often indicators of contamination in aquatic systems. One of several useful endpoints used in toxicity tests is that which determines the lethal concentration that leads to 50 percent mortality $\left(\mathrm{LC}_{50}\right)$ after exposure to a substance for a specified amount of time. Chronic toxicity tests (that is, lower doses over longer time periods) of dissolved vanadium in developing rainbow trout (Oncorhynchus mykiss) revealed a mean $\mathrm{LC}_{50}$ value of 0.17 milligrams per liter (mg/L) after 28 days of exposure (Birge and others, 1980). Acute toxicity tests (higher doses over shorter times) of vanadium to a fish known as the threespine stickleback (Gasterosteus aculeatus) revealed $\mathrm{LC}_{50}$ values that ranged from 2.4 to $4.1 \mathrm{mg} / \mathrm{L}$ after 4 days of exposure (Gravenmier and others, 2005). Similar acute toxicity tests of vanadium to three species of endangered fish from the Green River, Utah, which runs through carnotite deposits, showed no difference in sensitivity among species, but $\mathrm{LC}_{50}$ values ranged from 5.3 to $8.8 \mathrm{mg} / \mathrm{L}$ for young specimens and 2.2 to $5.1 \mathrm{mg} / \mathrm{L}$ for older stages (Hamilton, 1995) after 4 days of exposure. These dissolved vanadium concentrations are much greater than those observed in many rivers and streams (table U3). Some regions of the United States have adopted secondary acute and chronic screening benchmarks of 280 micrograms of vanadium per liter of water ( $\mu \mathrm{g} \mathrm{V} / \mathrm{L})$ and $20 \mu \mathrm{g} \mathrm{V} / \mathrm{L}$, respectively, for aquatic freshwater life (Suter and Tsao, 1996).

The essentiality of vanadium to higher plants is debated, but clear evidence exists for vanadium phytotoxicity. After amending soils with vanadium in the form of dissolved ammonium metavanadate $\left(\mathrm{NH}_{4} \mathrm{VO}_{3}\right)$, Wang and Liu (1999) found that soybean seedling growth was markedly stunted in flood plain soils (fluvaquents) with greater than $30 \mathrm{ppm}$ of vanadium, whereas little to no stunting occurred in red earth soil (Oxisol), even at vanadium concentrations as high as $75 \mathrm{ppm}$. Likewise, in phytotoxicity tests with forb (a herbaceous flowering plant), crop, and grass species, $\mathrm{LC}_{50}$ values ranged from 21 to $59 \mathrm{ppm}$ of $\mathrm{V}_{2} \mathrm{O}_{5}$ after exposure for 4 to 5 weeks; higher $\mathrm{LC}_{50}$ values (90 to greater than 130 ppm of $\mathrm{V}_{2} \mathrm{O}_{5}$ ) were observed under similar conditions, but with greater soil nutrient levels (Smith and others, 2013). These studies highlight how vanadium toxicity to plants varies, depending upon the prevailing soil conditions, the type of plant species, and the chemical form of vanadium, which determines its bioaccessibility. The chemical form of vanadium in ecotoxicity studies may be more bioaccessible than the chemical form of vanadium in soils. Furthermore, the amount of bioaccessible vanadium is likely to be smaller than the amount of total vanadium in soils. For example, the concentration of bioaccessible vanadium in soils of Northern Ireland was determined to be about 7.5 to 17 percent of the total soil vanadium content (Barsby and others, 2012). Some regions of the United States have adopted a soil screening benchmark of 2 ppm of vanadium for terrestrial plants (Efroymson and others, 1997). The Canadian agricultural soil quality guideline for vanadium is $130 \mathrm{ppm}$ of vanadium (Canadian Council of Ministers of the Environment, 2007).

\section{Mine Closure}

Most recent and new mining operations include closure plans that address issues related to the mine footprint. A mine's footprint includes the waste left on site and the locally affected soil and water, as well as ecological impacts, such as habitat destruction and loss of biodiversity. Mine closure issues that could have the greatest environmental impacts depend upon the type of deposit being mined, and if applicable, the methods employed to process the ore on site. Given the variety of deposit types from which vanadium is obtained, all mine closure issues related to vanadium mining are too numerous to 
describe here. Instead, the focus is on potential issues related to mining of the largest and economically most important deposit type (VTM deposits), and to the new mining operation planned in the Gibellini vanadium deposit in Nevada.

Some VTM and shale-hosted deposits contain sulfide minerals, and, therefore, the potential for AMD exists at both types of mine sites. Acidic drainage may seep from waste piles or tailings ponds. Common methods for treating AMD include active water-treatment facilities, passive limestone-lined channels, and constructed wetlands (Plumlee and Logsdon, 1999). The end result of both active and passive approaches is eventual precipitation of dissolved metals. Precipitated metals in passive wetland systems tend to be more stable under the prevailing anoxic conditions, whereas the metal-rich precipitates that result from active treatment facilities form a sludge that can cause environmental problems if not disposed of responsibly. When the potential for AMD exists at a mine site, common preventative measures include conducting water quality surveys before, during, and after mining.

The great size of VTM deposits tends to result in large mine waste piles. These waste piles have the potential to become unstable and can be a source of metal-rich dust. If using mine waste as backfill into dry mine workings is not an option, problems of mine-waste-pile stability and dust generation can often be addressed through grading and covering the piles with vegetation.

Vanadium-rich black shale at the Gibellini vanadium deposit is planned to be processed on site using acid heap leaching and solvent extraction-a recovery process that has yet to be applied to vanadium ores (Hanson and others, 2011). Acid heap leaching is commonly used on low-grade cobalt, copper, and nickel ores. In general, heap leaching involves placing crushed ores on top of impervious liners to form a slightly sloped leach pad, applying leach solutions to the pad, then collecting the leachates delivered by the impervious liners into ponds or tanks for further processing. During solvent extraction, leachates are mixed with a vanadium-optimized organic extractant (that is, a chelating agent), thereby forming vanadium-organic complexes that can be separated from other undesired metals present in the solution. At the Gibellini vanadium deposit, the resulting metal solution is planned to be recirculated back through the leaching process, while the vanadium-organic solution will undergo acidic stripping of vanadium from the organics, followed by precipitation of $\mathrm{V}_{2} \mathrm{O}_{5}$ (Hanson and others, 2011). Potential seepage or spillage of leachates into local surface and groundwater can have negative impacts on the environment, however, given that leachates may contain metals, such as arsenic, cadmium, chromium, copper, mercury, lead, and zinc (U.S. Environmental Protection Agency, 1994). Best practices for this type of operation include engineering for leak prevention, ongoing seepage testing, and post-closure monitoring of mine waste discharges and downstream water quality (U.S. Environmental Protection Agency, 1994).

\section{Problems and Future Research}

Infrastructure development and the need for steel products are the main sources of demand for vanadium worldwide. The current worldwide resources of about 63 million metric tons of vanadium appear to be adequate to meet current demand. Future demand is expected to increase because of the following factors (Roskill Information Services, Ltd., 2013):

- China is the top steel producer and consumer of vanadium in the world (the country accounted for about 34 percent of the world's vanadium consumption in 2012), and China's demand for vanadium to use in the production of steel is expected to remain strong for the next 10 to 20 years.

- China and Japan have legislated increased vanadium content in steel rebar so that the quality of their steel matches that of other major steel-producing countries; therefore, use of vanadium for steel production in China and Japan is expected to increase dramatically.

- India's steel production is projected to almost double owing to industrialization of that country.

- Development of alternate renewable sources of energy will likely require increased use of VRBs.

With the anticipated increase in demand for vanadium and the limited supply, maintaining a constant supply would likely mean that new sources of vanadium would need to be identified and the extraction of vanadium from currently defined sources would need to be optimized. Many future resources are likely contained within VTM deposits in unexplored regions. Another potential source is vanadium-rich shale because known deposits of this type have large tonnages and grades that are similar to those of presently mined VTM deposits (fig. U5). For shale-hosted deposits to be a viable resource, however, methods of profitably extracting the vanadium and producing a product that could be used in VRBs would be required, and future research would need to be designed to optimize these methods. Other sources, such as iron sands (placers) likely exist in many parts of the world; identification and quantification of these sands in terms of tonnage and vanadium content could be undertaken. Research on optimizing the recovery of vanadium from crude oil, bauxite, and tar sands also may increase global identified resources of this valuable metal.

\section{Acknowledgments}

We would like to thank USGS geologists John Slack and George Breit for their helpful technical reviews of this manuscript. John DeYoung and Suzanne Nicholson also provided useful reviews of the manuscript. Discussions with George Breit greatly aided our understanding of fossil fuel and shale-hosted vanadium deposits. Keith Labay is thanked for help with drafting the figures. 


\section{References Cited}

Note: All Web links listed were active as of the access date but may no longer be available.

Abraham, J.D., and Cannia, J.C., 2011, Airborne electromagnetic surveys for 3D geological mapping, in Russell, H.A.J., Berg, R.C., and Thorleifson, L.H., eds., Three-dimensional geological mapping-Workshop extended abstractsMinneapolis, Minnesota-October 8, 2011: Minneapolis, Minn., Geological Survey of Canada, Open File 6998, p. 1-6. [Also available at http://dx.doi.org/10.4095/289609.]

Agency for Toxic Substances and Disease Registry, 2012, Toxicological profile for vanadium: Atlanta, Ga., U.S. Department of Health and Human Services, Public Health Service, September, 200 p. plus 4 appendixes, accessed July 18, 2013, at http://www.atsdr.cdc.gov/ ToxProfiles/tp58.pdf.

Alberdi-Genolet, Margarita, and Tocco, Rafael, 1999, Trace metals and organic geochemistry of the Machiques Member (Aptian-Albian) and La Luna Formation (CenomanianCampanian), Venezuela: Chemical Geology, v. 160, nos. 1-2, p. 19-38. [Also available at http://dx.doi.org/ 10.1016/s0009-2541(99)00044-3.]

American Vanadium Corp., 2012, Gibellini project: Vancouver, British Columbia, Canada, American Vanadium Corp. Web page, accessed March 10, 2013, at http:/www.americanvanadium.com/gibellini-project.php.

Anke, M.K., 2004, Vanadium, chap. 27 of Merian, E., Anke, M., Ihnat, M. and Stoeppler, M.S, eds., Elements and their compounds in the environment-Occurrence, analysis and biological relevance ( $2 \mathrm{~d}$ ed.): Weinheim, Germany, Wiley-VCH Verlag, p. 1171-1191. [Also available at http://dx.doi.org/10.1002/9783527619634.ch48.]

Augé, Thierry, Genna, Antonin, and Legendre, Olivier, 2005, Primary platinum mineralization in the Nizhny Tagil and Kachkanar ultramafic complexes, Urals, Russia - A genetic model for PGE concentration in chromite-rich zones: Economic Geology, v. 100, p. 707-732. [Also available at http://dx.doi.org/10.2113/gsecongeo.100.4.707.]

Aura Energy, 2012, ASX announcement-Updating scoping study further supports Häggån project viability: West Perth, Western Australia, Australia, Aura Energy, 4 p., accessed January 22, 2013, at http://www.auraenergy.com.au/assets/ ASX_Revised_scoping_study_29May12_final_for release.pdf.

Balsley, J.R., Jr., 1943, Vanadium-bearing magnetite-ilmenite deposits near Lake Sanford, Essex County, New York: U.S. Geological Survey Bulletin 940-D, p. 99-123. [Also available at http://pubs.er.usgs.gov/publication/b940D.]
Barber, Christopher, 1974, The geochemistry of carbonatites and related rocks from two carbonatite complexes, south Nyanza, Kenya: Lithos, v. 7, no. 1, p. 53-63. [Also available at http://dx.doi.org/10.1016/0024-4937(74)90038-3.]

Barsby, Amy, McKinley, J.M., Ofterdinger, Ulrich, Young, Mike, Cave, M.R., and Wragg, Joanna, 2012, Bioaccessibility of trace elements in soils in Northern Ireland: Science of the Total Environment, v. 433, September, p. 398-417. [Also available at http://dx.doi.org/10.1016/j.scitotenv.2012.05.099.]

Birge, W.J., Black, J.A., Westerman, A.G., and Hudson, J.E., 1980, Aquatic toxicity tests on inorganic elements occurring in oil shale, in Gale, Charles, ed., Oil shale symposiumSampling, analysis and quality assurance, March 1979, Proceedings: Cincinnati, Ohio, U.S. Environmental Protection Agency, EPA-600/9-80-022, p. 519-534. [Also available at http://babel.hathitrust.org/cgi/pt?id= coo.31924004323303; view=1up;seq=531.]

Boni, Maria, Terracciano, Rosario, Evans, N.J., Laukamp, Carsten, Schneider, Jens, and Bechstädt, Thilo, 2007, Genesis of vanadium ores in the Otavi Mountainland, Namibia: Economic Geology, v. 102, p. 441-469. [Also available at http://dx.doi.org/10.2113/gsecongeo.102.3.441.]

Breit, G.N., 1992, Resources in fossil fuels, chap. K of DeYoung, J.H., Jr., and Hammarstrom, J.M., eds., Contributions to commodity geology research: U.S. Geological Survey Bulletin 1877, p. K1-K8. [Also available at http://pubs.er.usgs.gov/publication/b1877.]

Breit, G.N., and Goldhaber, M.B., 1996, Diagenesis of sandstones in the Morrison Formation within the Paradox basin, in Huffman, A.C., Jr., Lund, W.R., and Godwin, L.H., eds., Geology and resources of the Paradox basin: Salt Lake City, Utah, Utah Geological Association, Utah Geological Association Guidebook series, no. 25, p. 197-210.

Breit, G.N., and Wanty, R.B., 1991, Vanadium accumulation in carbonaceous rocks - A review of geochemical controls during deposition and diagenesis: Chemical Geology, v. 91, no. 2, p. 83-97. [Also available at http://dx.doi.org/10.1016/ 0009-2541(91)90083-4.]

Britt, A.F., Whitaker, A., Cadman, S., Summerfield, D., Kay, P., Champion, D.C., McKay, A., Miezitis, Y., Porritt, K., Schofield, A., and Jaireth, S., 2014, Australia's identified mineral resources 2014-Vanadium: Canberra, Australian Capital Territory, Australia, Geoscience Australia, accessed December 14, 2015, at http://www.australianminesatlas.gov.au/aimr/commodity/ vanadium.html\#vanadium.

Bykhovsky, Lev, and Tigunov, Leonid, 2008, Titanomagnetite ore deposits of Russia-Prospects for development and complex use [abs.], in International Geological Congress, 33d, Oslo, Norway, August 6-14, 2008, Proceedings, accessed January 26, 2013, at http:/www.cprm.gov.br/ 33IGC/1259033.html. 
Canadian Council of Ministers of the Environment, 2007, Canadian soil quality guidelines for the protection of environmental and human health, chap. 7 of Canadian environmental quality guidelines: Winnipeg, Manitoba, Canada, Canadian Council of Ministers of the Environment, accessed March 1, 2013, at http://www.ccme.ca/publications/ ceqg_rcqe.html.

Canet, Carles, Alfonso, Pura, Melgarejo, J.-C., and Jorge, Susana, 2003, V-rich minerals in contact-metamorphosed Silurian Sedex deposits in the Poblet area, southwestern Catalonia, Spain: The Canadian Mineralogist, v. 41, no. 3, p. 561-579. [Also available at http://dx.doi.org/10.2113/ gscanmin.41.3.561.]

Case, J.E., and Joesting, H.R., 1972, Regional geophysical investigations in the central Colorado Plateau: U.S. Geological Survey Professional Paper 736, 31 p., 3 pls., accessed February 2, 2013, at http://pubs.er.usgs.gov/publication/pp736.

Cawthorn, R.G., and Webb, S.J., 2001, Connectivity between the western and eastern limbs of the Bushveld Complex: Tectonophysics, v. 330, nos. 3-4, p. 195-209. [Also available at http://dx.doi.org/10.1016/s0040-1951(00)00227-4.]

Cawthorn, R.G., Merkle, R.K.W., and Viljoen, M.J., 2002, Platinum-group element deposits in the Bushveld Complex, South Africa, in Cabri, L.J., ed., The geology, geochemistry, mineralogy and mineral beneficiation of platinum-group elements: Montreal, Quebec, Canada, Canadian Institute of Mining, Metallurgy, and Petroleum Special Volume 54, p. 389-429.

Collier, R.W., 1984, Particulate and dissolved vanadium in the North Pacific Ocean: Nature, v. 309, no. 5967, p. 441-444. [Also available at http://dx.doi.org/10.1038/309441a0.]

Coveney, R.M., Jr., and Glascock, M.D., 1989, A review of the origins of metal-rich Pennsylvanian black shales, central U.S.A., with an inferred role for basinal brines: Applied Geochemistry, v. 4, no. 4, p. 347-367. [Also available at http://dx.doi.org/10.1016/0883-2927(89)90012-7.]

Coveney, R.M., Jr., and Martin, S.P., 1983, Molybdenum and other heavy metals of the Mecca Quarry and Logan Quarry shales: Economic Geology, v. 78, p. 132-149. [Also available at http://dx.doi.org/10.2113/gsecongeo.78.1.132.]

Coveney, R.M., Jr., and Nansheng, C., 1991, Ni-Mo-PGEAu-rich ores in Chinese black shales and speculations on possible analogues in the United States: Mineralium Deposita, v. 26, no. 2, p. 83-88. [Also available at http://dx.doi.org/10.1007/bf00195253.]

Coveney, R.M., Jr., Leventhal, J.S., Glascock, M.D., and Hatch, J.R., 1987, Origins of metals and organic matter in the Mecca Quarry Shale Member and stratigraphically equivalent beds across the Midwest: Economic Geology, v. 82, p. 915-933. [Also available at http://dx.doi.org/ 10.2113/gsecongeo.82.4.915.]
Coveney, R.M., Jr., Murowchick, J.B., Grauch, R.I., Glascock, M.D., and Denison, J.R., 1992, Gold and platinum in shales with evidence against extraterrestrial sources of metals: Chemical Geology, v. 99, nos. 1-3, p. 101-114. [Also available at http://dx.doi.org/10.1016/0009-2541(92)90033-2.]

Dahe, Xiong, 2004, SLon magnetic separators applied in the ilmenite processing industry: Physical Separation in Science and Engineering, v. 13, nos. 3-4, p. 119-126. [Also available at http://dx.doi.org/10.1080/14786470412331316081.]

Dahlkamp, F.J., 2009, Uranium deposits of the world-Asia: Berlin, Germany, Springer-Verlag, 945 p. [Also available at http://dx.doi.org/10.1007/978-3-540-78558-3.]

Dahlkamp, F.J., 2010, Uranium deposits of the world-USA and Latin America: Berlin, Germany, Springer-Verlag, 423 p. [Also available at http://dx.doi.org/10.1007/ 978-3-540-78943-7.]

Derkey, P.D., Abercrombie, F.N., Duke, S.M., and Daniel, J.A., 1985, Geology and oil shale resources of the Heath Formation, Ferguson County, Montana: Montana Bureau of Mines and Geology Memoir 57, 100 p., 2 sheets.

Desborough, G.A., Poole, F.G., and Green, G.N., 1981, Metalliferous oil shales in central Montana and northeastern Nevada: U.S. Geological Survey Open-File Report 81-121, 14 p. [Also available at http://pubs.er.usgs.gov/publication/ ofr81121.]

Desborough, G.A., Poole, F.G., Hose, R.K., and Radtke, A.S., 1979, Metals in Devonian kerogenous marine strata at Gibellini and Bisoni properties in southern Fish Creek Range, Eureka County, Nevada: U.S. Geological Survey Open-File Report 79-530, 31 p. [Also available at http://pubs.er.usgs.gov/publication/ofr79530.]

Dill, H.G., Kus, Jolanta, Abed, A.M., Sachsenhofer, R.F., and Abul Khair, Hani, 2009, Diagenetic and epigenetic alteration of Cretaceous to Paleogene organic-rich sedimentary successions in northwestern Jordan, typical of the western margin of the Arabian Plate: GeoArabia (Manama), v. 14, no. 2, p. 101-140. [Also available at https://www.researchgate.net/ publication/261724988_Diagenetic_and_epigenetic alteration_of_Cretaceous_to_Paleogene_organic_rich_ sedimentary_successions_in_northwestern_Jordan_typical_ of the_western_margin_of_the_Arabian_Plate.]

Dupuis, Céline, and Beaudoin, Georges, 2011, Discriminant diagrams for iron oxide trace element fingerprinting of mineral deposit types: Mineralium Deposita, v. 46, no. 4, p. 319-335. [Also available at http://dx.doi.org/10.1007/ s00126-011-0334-y.]

Dyni, J.R., 2006, Geology and resources of some world oilshale deposits: U.S. Geological Survey Scientific Investigations Report 2005-5294, 42 p., accessed February 24, 2013, at http://pubs.er.usgs.gov/publication/sir29955294. 
Eales, H.V., and Cawthorn, R.G., 1996, The Bushveld Complex, in Cawthorn, R.G., ed., Layered intrusions: New York, N.Y., Elsevier, Developments in Petrology Series, v. 15, p. 181-229. [Also available at http://dx.doi.org/10.1016/ S0167-2894(96)80008-X.]

Eales, H.V., Botha, W.J., Hattingh, P.J., de Klerk, W.J., Maier, W.D., and Odgers, A.T.R., 1993, The mafic rocks of the Bushveld Complex-A review of emplacement and crystallization history, and mineralization, in the light of recent data: Journal of African Earth Sciences (and the Middle East), v. 16, nos. 1-2, p. 121-142. [Also available at http://dx.doi.org/10.1016/0899-5362(93)90163-k.]

Efroymson, R.A., Will, M.E., Suter, G.W., II, and Wooten, A.C., 1997, Toxicological benchmarks for screening contaminants of potential concern for effects on terrestrial plants-1997 revision, report prepared for the U.S. Department of Energy by Lockheed Martin Energy Systems, Inc.: Oak Ridge, Tenn., Oak Ridge National Laboratory, ES/ER/TM-85/R3, November, 68 p. and two appendixes, accessed March 4, 2013, at http://www.esd.ornl.gov/programs/ecorisk/documents/ tm85r3.pdf.

Energizer Resources, Inc., 2013, The Green Giant vanadium project: Toronto, Ontario, Canada, Energizer Resources, Inc. Web page, accessed March 12, 2013 at http://www.energizerresources.com/29-properties/ madagascar/271-green-giant-vanadium.

Environmental Protection Authority, 2008, Windimurra vanadium project-Land clearing and mining below the base of weathering - Windimurra Vanadium Limited: Perth, Western Australia, Australia, Environmental Protection Authority, Bulletin no. 1288, 14 p. plus 2 appendixes. [Also available at http://epa.wa.gov.au/sites/default/files/EPA_Report/ 2725_Bull1288.pdf.]

Environmental Protection Authority, 2009, Balla Balla magnetite project-Ferro Metals Australia Pty LtdReport and recommendations of the Environmental Protection Authority: Perth, Western Australia, Australia, Environmental Protection Authority, Report 1309, 21 p. [Also available at http://epa.wa.gov.au/sites/default/files/ EPA_Report/2841_1309BallaEPS5109.pdf.]

Ernst, R.E., and Peck, D.C., 2010, Using large igneous provinces for mineral exploration (e.g., for Ni-Cu-PGE deposits) [abs.], in Brown, G.H., Jugo, P.J., Lesher, C.M., and Mungall, J.E., eds., Abstracts, 11th International Platinum Symposium, 21-24 June 2010, Sudbury, Ontario, Canada: Ontario Geological Survey Miscellaneous Release Data Series (MRD), no. 269, 4 p., 1 CD-ROM. [Also available at http://www.geologyontario.mndm.gov.on.ca/mndmaccess/ mndm_dir.asp?type=pub\&id=MRD269.]

Ernst, R.E., Buchan, K.L., and Campbell, I.H., 2005, Frontiers in large igneous province research: Lithos, v. 79, nos 3-4, p. 271-297. [Also available at http://dx.doi.org/10.1016/ j.lithos.2004.09.004.]
Fan, Delian, Jie, Ye, and Tiebing, Lui, 1992, Black shale series-hosted silver-vanadium deposits of the Upper Sinian Doushantuo Formation, western Hubei Province, China: Exploration and Mining Geology, v. 1, no. 1, p. 29-38.

Fischer, R.P., 1968, The uranium and vanadium deposits of the Colorado Plateau region, in Ridge, J.D., ed., Ore deposits of the United States, 1933-1967: New York, N.Y., American Institute of Mining, Metallurgical, and Petroleum Engineers, v. 1, p. $735-746$.

Fischer, R.P., 1973, Vanadium, in Brobst, D.A., and Pratt, W.P., eds., United States mineral resources: U.S. Geological Survey Professional Paper 820, p. 679-688, accessed January 1, 2013, at http://pubs.er.usgs.gov/publication/pp820.

Fischer, R.P., 1975a, Geology and resources of base-metal vanadate deposits: U.S. Geological Survey Professional Paper 926-A, 13 p. [Also available at http://pubs.er.usgs.gov/ publication/pp926A.]

Fischer, R.P., 1975b, Vanadium resources in titaniferous magnetite deposits: U.S. Geological Survey Professional Paper 926-B, 9 p., accessed January 11, 2013, at http://pubs.er.usgs.gov/publication/pp926B.

Flohr, M.J.K., 1994, Titanium, vanadium, and niobium mineralization and alkali metasomatism from the Magnet Cove Complex, Arkansas: Economic Geology, v. 89, p. 105-130. [Also available at http://dx.doi.org/10.2113/ gsecongeo.89.1.105.]

Gaillardet, J., Viers, J., and Dupré, B., 2003, Trace elements in river waters, in Drever, J.I., ed., Surface and ground water, weathering, and soils, v. 5 of Holland, H.D., and Turekian, K.K., eds., Treatise on geochemistry: Oxford, United Kingdom, Elsevier-Pergamon, p. 225-272. [Also available at http://dx.doi.org/10.1016/B0-08-043751-6/05165-3.]

Gomez-Bueno, C.O., Spink, D.R., and Rempel, G.L., 1981, Extraction of vanadium from Athabasca tar sands fly ash: Metallurgical Transactions B, v. 12, no. 2, p. 341-352. [Also available at http://dx.doi.org/10.1007/bf02654468.]

Graedel, T.E., Allwood, Julian, Birat, J.-P., Buchert, Matthias, Hagelüken, Christian, Reck, B.K., Sibley, S.F., and Sonnemann, Guido, 2011, What do we know about metal recycling rates?: Journal of Industrial Ecology, v. 15, no. 3, p. 355-366. [Also available at http://dx.doi.org/10.1111/ j.1530-9290.2011.00342.x.]

Gravenmier, J.J., Johnston, D.W., and Arnold, W.R., 2005, Acute toxicity of vanadium to the threespine stickleback, Gasterosteus aculeatus: Environmental Toxicology, v. 20, no. 1, p. 18-22. [Also available at http://dx.doi.org/10.1002/ tox.20073.]

Gross, S.O., 1968, Titaniferous ores of the Sanford Lake district, New York: Ore deposits of the United States, 1933-1967, v. 1, p. 140-153. 
Hallberg, A., 2012, Caledonian black shale U-Mo-V, in Eilu, Pasi, ed., Mineral deposits and metallogeny of Fennoscandia: Espoo, Finland, Geological Survey of Finland, Special Paper 53, sec. S017, p. 169-170. [Also available at http://hakku.gtk.fi/en/reports. The direct link to the large downloadable file (63.82 MB) is at http://tupa.gtk.fi/julkaisu/ specialpaper/sp_053.pdf.]

Hamilton, S.J., 1995, Hazard assessment of inorganics to three endangered fish in the Green River, Utah: Ecotoxicology and Environmental Safety, v. 30, no. 2, p. 134-142. [Also available at http://dx.doi.org/10.1006/eesa.1995.1017.]

Hanson, Kirk, Orbock, E.J.C., III, Hertel, Mark, and Drozd, Michael, 2011, American Vanadium-Gibellini vanadium project —Eureka County, Nevada, USA NI 43-101 technical report on feasibility study, prepare for American Vanadium Corp.: Sparks, Nev., AMEC E\&C Services, Inc., August 31, variously paged, accessed February 2, 2013, at http:/www.americanvanadium.com/ cms-assets/documents/35354-835295.gibellini-tr-final6-oct-2011.pdf.

Hatch, J.R., and Leventhal, J.S., 1992, Relationship between inferred redox potential of the depositional environment and geochemistry of the Upper Pennsylvanian (Missourian) Stark Shale Member of the Dennis Limestone, Wabaunsee County, Kansas, U.S.A.: Chemical Geology, v. 99, nos. 1-3, p. 65-82. [Also available at http://dx.doi.org/10.1016/00092541(92)90031-Y.]

Hatton, C.J., 1995, Mantle plume origin for the Bushveld and Ventersdorp magmatic provinces: Journal of African Earth Sciences, v. 21, no. 4, p. 571-577. [Also available at http://dx.doi.org/10.1016/0899-5362(95)00106-9.]

Hill, P.L., Kucks, R.P., and Ravat, Dhananjay, 2009, Aeromagnetic and aeroradiometric data for the conterminous United States and Alaska from the National Uranium Resource Evaluation (NURE) Program of the U.S. Department of Energy-Kentucky and Tennessee NURE Aeromagnetic and Aeroradiometric Data: U.S. Geological Survey Open-File Report 2009-1129, accessed March 12, 2013, at http://pubs.usgs.gov/ of/2009/1129/state/nure_kytn.htm.

Holloway, P.C., and Etsell, T.H., 2006, Process for the complete utilization of oil sands fly ash: Canadian Metallurgical Quarterly, v. 45, no. 1, p. 25-32. [Also available at http://dx.doi.org/10.1179/cmq.2006.45.1.25.]

Howard, J.M., and Owens, D.R., 1995, Minerals of the Wilson Springs vanadium mines-Potash Sulphur Springs, Arkansas: Rocks and Minerals, v. 70, no. 3, p. 154-170. [Also available at http://dx.doi.org/10.1080/00357529. 1995.9926616.]
Hulbert, L.J., Carne, R.C., Gregoire, D.C., and Paktunc, Dogan, 1992, Sedimentary nickel, zinc, and platiunum-groupelement mineralization in Devonian black shales at the Nick Property, Yukon, Canada-A new deposit type: Exploration and Mining Geology, v. 1, no. 1, p. 39-62.

INTEK, Inc., 2011, Review of emerging resources-U.S. shale gas and shale oil plays, report prepared for the U.S. Energy Information Administration by INTEK, Inc.: Washington, D.C., U.S. Energy Information Administration, accessed March 14, 2013, at http://www.eia.gov/analysis/studies/ usshalegas/pdf/usshaleplays.pdf.

Ivanic, T.J., Wingate, M.T.D., Kirkland, C.L., Van Kranendonk, M.J., and Wyche, S., 2010, Age and significance of voluminous mafic-ultramafic magmatic events in the Murchison domain, Yilgarn Craton: Australian Journal of Earth Sciences, v. 57, no. 5, p. 597-614. [Also available at http://dx.doi.org/10.1080/08120099.2010.494765.]

Jasinski, S.M., 2004, Societal relevance, processing, and material flow of western phosphate-Refreshments, fertilizer, and weed killer, chap. 22 of Hein, J.R., ed., Life cycle of the Phosphoria Formation-From deposition to the postmining environment: Boston, Mass., Elsevier, Handbook of Exploration and Environmental Geochemistry Series, v. 8, p. 599-610, 1 CD-ROM. [Also available at http://dx.doi.org/ 10.1016/S1874-2734(04)80024-X.]

Jeong, G.Y., 2006, Mineralogy and geochemistry of metalliferous black slates in the Okcheon metamorphic belt, Korea-A metamorphic analogue of black shales in the South China block: Mineralium Deposita, v. 41, no. 5, p. 469-481. [Also available at http://dx.doi.org/10.1007/ s00126-006-0067-5.]

Johnson, H.S., Jr., 1959, Uranium resources of the Green River and Henry Mountains districts, Utah-A regional synthesis: U.S. Geological Survey Bulletin 1087-C, 44 p. [Also available at http://pubs.er.usgs.gov/publication/b1087C.]

Jowitt, S.M., and Keays, R.R., 2011, Shale-hosted Ni-(CuPGE) mineralisation-A global overview: Applied Earth Science, v. 120, no. 4, p. 187-197. [Also available at http://dx.doi.org/10.1179/1743275812z.00000000026.]

Kabata-Pendias, Alina, and Pendias, Henryk, 2001, Trace elements in soils and plants ( $3 \mathrm{~d}$ ed.): Boca Raton, Fla., CRC Press, 413 p.

Kapo, George, 1978, Vanadium-Key to Venezuelan fossil hydrocarbons, chap. 9 of Chilingarian, G.V., and Yen, T.F., eds., Bitumens, asphalts and tar sands: New York, N.Y., Elsevier, Developments in Petroleum Science Series, no. 7, p. 213-241. [Also available at http://dx.doi.org/10.1016/ s0376-7361(08)70068-2.] 
Karpuzov, A.F., Karpunin, A.M., Sobolev, N.N., Mozoleva, I.N., and Karpuzov, A.A., 2008, Mineral'no-syr'yevoy potentsial chernoslantsevykh formatsiy skladchatykh poyasov Rossii [The mineral resource potential of black shale formations of the Russian fold belts]: Mineral'nyye Resursy Rossii; Ekonomika I Upravleniye, v. 2008, no. 5, p. 2-15. [In Russian with English abstract.]

Kelley, K.D., Eppinger, R.G., Lang, J., Smith, S.M., and Fey, D.L., 2011, Porphyry $\mathrm{Cu}$ indicator minerals in till as an exploration tool-Example from the giant Pebble porphyry $\mathrm{Cu}$ Au-Mo deposit, Alaska, USA: Geochemistry-Exploration, Environment, Analysis, v. 11, no. 4, p. 321-334. [Also available at http://dx.doi.org/10.1144/1467-7873/10-im-041.]

Ketris, M.P., and Yudovich, Ya.E., 2009, Estimations of Clarkes for carbonaceous biolithes - World averages for trace element contents in black shales and coals: International Journal of Coal Geology, v. 78, no. 2, p. 135-148. [Also available at http://dx.doi.org/10.1016/j.coal.2009.01.002.]

Kohušová, Kateřina, Havel, Ladislav, Vlasák, Petr, and Tonika, Jaroslav, 2011, A long-term survey of heavy metals and specific organic compounds in biofilms, sediments, and surface water in a heavily affected river in the Czech Republic: Environmental Monitoring and Assessment, v. 174, nos. 1-4, p. 555-572. [Also available at http://dx.doi.org/10.1007/s10661-010-1478-4.]

Kovschak, A.A., Jr., and Nylund, R.L., 1981, General geology of uranium-vanadium deposits of Salt Wash sandstones, La Sal area, San Juan County, Utah, in Epis, R.C., and Callender, J.F., Western slope Colorado-Western Colorado and eastern Utah-New Mexico Geological Society, ThirtySecond Field Conference, October 8-10, 1981, Socorro, N. Mex: Socorro, N. Mex., New Mexico Geological Society, Guidebook of the Field Conference Series, no. 32, p. 171-176.

Kumar, D., and Hoversten, G.M., 2012, Geophysical model response in a shale gas: Geohorizons, January 2012, p. 31-37.

Laznicka, Peter, 2010, Giant metallic deposits-Future sources of industrial metals: Berlin, Germany, SpringerVerlag, 950 p. [Also available at http://dx.doi.org/10.1007/ 978-3-642-12405-1.]

Levinson, A.A., 1974, Introduction to exploration geochemistry: Calgary, Alberta, Canada, Applied Publishing, 924 p.

Lewan, M.D., 1984, Factors controlling the proportionality of vanadium to nickel in crude oils: Geochimica et Cosmochimica Acta, v. 48, no. 11, p. 2231-2238. [Also available at http://dx.doi.org/10.1016/0016-7037(84)90219-9.]
Lewan, M.D., and Maynard, J.B., 1982, Factors controlling enrichment of vanadium and nickel in the bitumen of organic sedimentary rocks: Geochimica et Cosmochimica Acta, v. 46, no. 12, p. 2547-2560. [Also available at http://dx.doi.org/10.1016/0016-7037(82)90377-5.]

Lewis, S.E., Henderson, R.A., Dickens, G.R., Shields, G.A., and Coxhell, Simon, 2010, The geochemistry of primary and weathered oil shale and coquina across the Julia Creek vanadium deposit (Queensland, Australia): Mineralium Deposita, v. 45, no. 6, p. 599-620. [Also available at http://dx.doi.org/10.1007/s00126-010-0287-6.]

Lottermoser, B.G., 2010, Mine wastes - Characterization, treatment, and environmental impacts ( $3 \mathrm{~d}$ ed.): Berlin, Germany, Springer-Verlag, 330 p. [Also available at http://dx.doi.org/10.1007/978-3-642-12419-8.]

Loukola-Ruskeeniemi, Kirsti, and Heino, Timo, 1996, Geochemistry and genesis of the black shale-hosted Ni-CuZn deposit at Talvivaara, Finland: Economic Geology, v. 91, p. 80-110. [Also available at http://dx.doi.org/10.2113/ gsecongeo.91.1.80.]

Loukola-Ruskeeniemi, Kirsti, and Lahtinen, Hannu, 2013, Multiphase evolution in the black-shale-hosted Ni-Cu-ZnCo deposit at Talvivaara, Finland: Ore Geology Reviews, v. 52, August, p. 85-99. [Also available at http://dx.doi.org/ 10.1016/j.oregeorev.2012.10.006.]

Love, J.D., Smith, L.E., Browne, D.G., and Carter, L.M., 2003, Vanadium deposits in the Lower Permian Phosphoria Formation, Afton area, Lincoln County, western Wyoming: U.S. Geological Survey Professional Paper 1637, 28 p., 16 pls., 1 CD-ROM. [Also available at http://pubs.er.usgs.gov/ publication/pp1637.]

MacDonald Mines Exploration Ltd., 2013, Butler property: MacDonald Mines Web page, accessed March 12, 2013, at http://www.macdonaldmines.com/index.php?option=com content\&view $=$ article $\& i d=101 \&$ Itemid $=120$.

Madigan, M.T., Martinko, J.M., and Parker, Jack, 2003, Brock biology of microorganisms (10th ed.): Upper Saddle River, N.J., Prentice Hall, 1,019 p.

Mandiwana, K.L., and Panichev, Nikolay, 2004, Electrothermal atomic absorption spectrometric determination of vanadium(V) in soil after leaching with $\mathrm{Na}_{2} \mathrm{CO}_{3}$ : Analytica Chimica Acta, v. 517, nos. 1-2, p. 201-206. [Also available at http://dx.doi.org/10.1016/j.aca.2004.04.068.]

McCormick, G.R., 1978, Vanadium-titanium-bearing mixedlayered clay from Potash Sulphur Springs, Ark.: Clays and Clay Minerals, v. 26, no. 2, p. 93-100. [Also available at http://dx.doi.org/10.1346/ccmn.1978.0260203.] 
McKay, A.D., and Miezitis, Yanis, 2001, Australia's uranium resources, geology and development of deposits: Canberra, Australian Capital Territory, Australia, Australian Geological Survey Organisation (AGSO)-Geoscience Australia, Mineral Resource Report 1, 196 p. [Also available at https://d28rz98at9flks.cloudfront.net/37672/37672_bigobj_ version.pdf.]

McKelvey, V.E., Strobell, J.D., Jr., and Slaughter, A.L., 1986, The vanadiferous zone of the Phosphoria Formation in western Wyoming and southeastern Idaho: U.S. Geological Survey Professional Paper 1465, 27 p., 2 pls. [Also available at https://pubs.er.usgs.gov/publication/pp1465.]

McLemore, V.T., and Chenoweth, W.L., 1997, Geology and uranium-vanadium deposits in the Salt Wash Member, Morrison Formation, King Tutt Mesa area, San Juan County, New Mexico, in Anderson, O.J., Kues, B.S., and Lucas, S.G., eds., Mesozoic geology and paleontology of the Four Corners region-New Mexico Geological Society, Forty-Eighth Annual Field Conference, October 1-4, 1997: Socorro, N. Mex. New Mexico Geological Society-Guidebook of the Field Conference Series, no. 48, p. 273-278. [Also available at https://nmgs.nmt.edu/publications/ guidebooks/downloads/48/48_p0273_p0278.pdf.]

Moore, R.M., Webb, M., Tokarczyk, R., and Wever, R., 1996, Bromoperoxidase and iodoperoxidase enzymes and production of halogenated methanes in marine diatom cultures: Journal of Geophysical Research, v. 101, no. C9, p. 20899-20908. [Also available at http://dx.doi.org/ 10.1029/96jc01248.]

Moskalyk, R.R., and Alfantazi, A.M., 2003, Processing of vanadium-A review: Minerals Engineering, v. 16, no. 9, p. 783-805. [Also available at http://dx.doi.org/10.1016/ s0892-6875(03)00213-9.]

Mukhametshin, R.Z., and Punanova, S.A., 2011, Geokhimicheskiye osobennosti neftey Uralo-Povolzh'ya v svyazi s usloviyami formirovaniya mestorozhdeniy [Geochemistry of crude oils in the Ural-Volga region with regard to their origin]: Geologiya Nefti I Gaza, v. 2011, no. 4, p. 74-83. [In Russian with English abstract.]

Naldrett, A.J., 2010, Secular variation of magmatic sulfide deposits and their source magmas: Economic Geology, v. 105, p. 669-688. [Also available at http://dx.doi.org/ 10.2113/gsecongeo.105.3.669.]

Naldrett, A.J., Wilson, Allan, Kinnaird, Judith, and Chunnett, Gordon, 2009, PGE tenor and metal ratios within and below the Merensky Reef, Bushveld ComplexImplications for its genesis: Journal of Petrology, v. 50, no. 4, p. 625-659. [Also available at http://dx.doi.org/ 10.1093/petrology/egp015.]
Northrop, H.R., Goldhaber, M.B., Landis, G.P., Unruh, J.W., Reynolds, R.L., Campbell, J.A., Wanty, R.B., Grauch, R.I., Whitney, G., and Rye, R.O., 1990, Genesis of the tabulartype vanadium-uranium deposits of the Henry basin, Utah: Economic Geology, v. 85, p. 215-269. [Also available at http://dx.doi.org/10.2113/gsecongeo.85.2.215.]

Nyström, J.O., and Henríquez, Fernando, 1994, Magmatic features of iron ores of the Kiruna type in Chile and Sweden-Ore textures and magnetite geochemistry: Economic Geology, v. 89, p. 820-839. [Also available at http://dx.doi.org/10.2113/gsecongeo.89.4.820.]

Occupational Safety and Health Administration, 2013a, Vanadium fume (as $\mathrm{V}_{2} \mathrm{O}_{5}$ ): U.S. Department of Labor Occupational Safety and Health Administration Web page, accessed March 4, 2013, at http://www.osha.gov/dts/ chemicalsampling/data/CH_275000.html.

Occupational Safety and Health Administration, 2013b, Vanadium, respirable dust $\left(\right.$ as $\mathrm{V}_{2} \mathrm{O}_{5}$ ): U.S. Department of Labor Occupational Safety and Health Administration Web page, accessed March 4, 2013, at http://www.osha.gov/ dts/chemicalsampling/data/CH_275100.html.

Pallister, H.D., and Thoenen, J.R., 1948, Flake graphite and vanadium investigations in Clay, Coosa, and Chilton Counties, Alabama: U.S. Bureau of Mines Report of Investigations 4366, 84 p. [Also available at http://hdl.handle.net/2027/mdp.39015078537084.]

Patterson, J.H., Ramsden, A.R., Dale, L.S., and Fardy, J.J., 1986, Geochemistry and mineralogical residences of trace elements in the oil shales from Julia Creek, Queensland, Australia: Chemical Geology, v. 55, nos. 1-2, p. 1-16. [Also available at http://dx.doi.org/10.1016/0009-2541(86)90123-3.]

Patterson, S.H., Kurtz, H.F., Olson, J.C., and Neeley, C.L., 1986, World bauxite resources: U.S. Geological Survey Professional Paper 1076-B, 151 p., accessed March 14, 2013, at http://pubs.er.usgs.gov/publication/pp1076B.

Peacor, D.R., Coveney, R.M., Jr., and Zhao, Gengmei, 2000, Authigenic illite and organic matter-The principal hosts of vanadium in the Mecca Quarry shale at Velpen, Indiana: Clays and Clay Minerals, v. 48, no. 3, p. 311-316. [Also available at http://dx.doi.org/10.1346/ccmn.2000.0480301.]

Perles, Terry, comp., 2013, Atlantic Ltd.-Vanadium market outlook presentation: Perth, Western Australia, Australia, Atlantic Ltd., 25 p., accessed March 22, 2013, at http://atlanticltd.com.au/upload/documents/Vanadium Information/VanadiumMarketOutlook.pdf.

Piper, D.Z., 1994, Seawater as the source of minor elements in black shales, phosphorites and other sedimentary rocks: Chemical Geology, v. 114, nos. 1-2, p. 95-114. [Also available as http://dx.doi.org/10.1016/0009-2541(94)90044-2.] 
Piper, D.Z., 1999, Trace elements and major-element oxides in the Phosphoria Formation at Enoch Valley, Idaho-Permian sources and current reactivities: U.S. Geological Survey Open-File Report 99-163, 66 p., accessed January 26, 2013, at http://pubs.er.usgs.gov/publication/ofr99163.

Pirkle, F.L., Beckman, R.J., and Fleischhauer, H.L., Jr., 1982, A multivariate uranium favorability index using aerial radiometric data: Journal of Geology, v. 90, no. 1, p. 109-124. [Also available at http://dx.doi.org/10.1086/628654.]

Plumlee, G.S., and Logsdon, M.J., 1999, An Earth-system science toolkit for environmentally friendly mineral resource development, in Plumlee, G.S., and Logsdon, M.J., eds., The environmental geochemistry of mineral depositsPart A, Processes, techniques, and health issues: Littleton, Colo., Society of Economic Geologists, Reviews In Economic Geology Series, v. 6A, p. 1-27. [Also available at http://ebooks.geoscienceworld.org/content/theenvironmental-geochemistry-of-mineral-deposits.]

Polyak, D.E., 2011, Vanadium [advance release], in Metals and minerals: U.S. Geological Survey Minerals Yearbook 2009 , v. I, p. 80.1-80.10, accessed March 4, 2013, at http://minerals.usgs.gov/minerals/pubs/commodity/ vanadium/myb1-2009-vanad.pdf.

Polyak, D.E., 2012, Vanadium, in Metals and minerals: U.S. Geological Survey Minerals Yearbook 2011, v. I, p. 80.1-80.9, accessed December 10, 2015, at http://minerals.usgs.gov/minerals/pubs/commodity/ vanadium/myb1-2011-vanad.pdf.

Polyak, D.E., 2013, Vanadium: U.S. Geological Survey Mineral Commodity Summaries 2013, p. 178-179, accessed March 4, 2013, at http://minerals.usgs.gov/minerals/pubs/ commodity/vanadium/mcs-2013-vanad.pdf.

Rackley, R.I., Shockey, P.N., and Dahill, M.P., 1968, Concepts and methods of uranium exploration, in Wulf, G.R., ed., Black Hills area, South Dakota, Montana, Wyoming: Casper, Wyo., Wyoming Geological Association, 20th Field Conference Guidebook, p. 115-124. [Also available at http://archives.datapages.com/data/wga/data/069/069001/ 115_wga0690115.htm.]

Razmara, Morteza, and Asadi, M., 2010, Petrology, geochemistry and Ti-Fe-vanadium oxide mineralization in the NW of Rivash area, in International Applied Geological Congress, 1st, Mashad, Iran, April 26-28, 2010: Mashad, Khorasan Razavi, Iran, Islamic Azud University, Department of Geology, p. 1209-1212. [Also available at http://profdoc.um.ac.ir/articles/a/1019644.pdf.]

Reck, B.K., and Graedel, T.E., 2012, Challenges in metal recycling: Science, v. 337, no. 6095, p. 690-695. [Also available at http://dx.doi.org/10.1126/science.1217501.]
Reynolds, F.M., 1948, The occurrence of vanadium, chromium, and other unusual elements in certain coals: Journal of the Society of Chemical Industry, v. 67, no. 9, p. 341-345. [Also available at http://dx.doi.org/10.1002/ jctb.5000670902.]

Reynolds, I.M., 1985, The nature and origin of titaniferous magnetite-rich layers in the upper zone of the Bushveld Complex-A review and synthesis: Economic Geology, v. 80, p. 1089-1108. [Also available at http://dx.doi.org/ 10.2113/gsecongeo.80.4.1089.]

Richards, J.P., 1995, Alkalic-type epithermal gold depositsA review, in Thompson, J.F.H., ed., Magmas, fluids, and ore deposits: Mineralogical Association of Canada Short Course Series, v. 23, p. 367-400.

Riley, K.W., and Saxby, J.D., 1982, Association of organic matter and vanadium in oil shale from the Toolebuc Formation of the Eromanga basin, Australia: Chemical Geology, v. 37, nos. 3-4, p. 265-275. [Also available at http://dx.doi.org/10.1016/0009-2541(82)90082-1.]

Ripley, E.M., Shaffer, N.R., and Gilstrap, M.S., 1990, Distribution and geochemical characteristics of metal enrichment in the New Albany Shale (Devonian-Mississippian), Indiana: Economic Geology, v. 85, p. 1790-1807. [Also available at http://dx.doi.org/10.2113/gsecongeo.85.8.1790.]

Robl, T.L., Bland, A.E., Koppenaal, D.W., and Barron, L.S., 1983, Geochemistry of oil shales in eastern Kentucky, chap. 9 of Miknis, F.P., and McKay, J.F., eds., Geochemistry and chemistry of oil shales-Based on a symposium sponsored by the ACS Divisions of Geochemistry, Fuel Chemistry, and Petroleum Chemistry at the 185th Meeting of the American Chemical Society, Seattle, Washington, March 20-25, 1983: Washington, D.C., American Chemical Society ACS Symposium Series, v. 230, p. 159-180. [Also available at http://dx.doi.org/10.1021/bk-1983-0230.ch009.]

Robson, R.L., Eady, R.R., Richardson, T.H., Miller, R.W., Hawkins, Marie, and Postgate, J.R., 1986, The alternative nitrogenase of Azobacter chroococcum is a vanadium enzyme: Nature, v. 322, p. 388-390. [Also available at http://dx.doi.org/10.1038/322388a0.]

Rohrmann, B., 1985, Vanadium in South Africa (Metal review series no. 2): Journal of the South African Institute of Mining and Metallurgy, v. 85, no. 5, p. 141-150.

[Also available at http://www.saimm.co.za/Journal/ v085n05p141.pdf.]

Roskill Information Services, Ltd., 2010, Vanadium-Global industry markets and outlook (12th ed.): London, United Kingdom, Roskill Information Services, Ltd., 203 p., 1 CD-ROM. 
Roskill Information Services, Ltd., 2013, VanadiumGlobal industry markets and outlook (13th ed.): London, United Kingdom, Roskill Information Services, Ltd., 253 p., accessed on July 23, 2013, at http://www.roskill.com/ reports/steel-alloys/vanadium.

Saari, P., and Riekkola-Vanhanen, M., 2012, Talvivaara bioheapleaching process: Journal of Southern African Institute of Mining and Metallurgy, v. 112, no. 12, p. 1013-1020. [Also available at http://www.saimm.co.za/ Journal/v112n12p1013.pdf.]

Saha, Abhishek, Ganguly, Sohini, Ray, Jyptisankar, and Dhang, Avik, 2010, Vanadium bearing titaniferous magnetite ore bodies of Ganjang, Karbit-Anglong district, northeastern India: Journal of the Geological Society of India, v. 76, no. 1, p. 26-32. [Also available at http://dx.doi.org/10.1007/s12594-010-0075-z.]

Scandium International Mining Corp., 2010, EMC metals files independent technical report and resource estimate on Carlin vanadium project, Nevada: Scandium International Mining Corp. news release, May 27, accessed December 11, 2015, at http://www.emcmetals.com/s/ NewsReleases.asp?ReportID=499095.

Scott, K.M., 2005, Rutile geochemistry as a guide to porphyry $\mathrm{Cu}-\mathrm{Au}$ mineralization, Northparkes, New South Wales, Australia: Geochemistry-Exploration, Environment, Analysis, v. 5, no. 3, p. 247-253. [Also available at http://dx.doi.org/10.1144/1467-7873/03-055.]

Shacklette, H.T., and Boerngen, J.G., 1984, Element concentrations in soils and other surficial materials of the conterminous United States: U.S. Geological Survey Professional Paper 1270, 105 p., accessed March 22, 2013, at http://pubs.er.usgs.gov/publication/pp1270.

Shawe, D.R., 2011, Uranium-vanadium deposits of the Slick Rock district, Colorado: U.S. Geological Survey Professional Paper 576-F, 67 p., 20 pls., accessed March 12, 2013, http://pubs.er.usgs.gov/publication/pp576F.

Shellnut, J.G., and Jahn, B.-M., 2010, Formation of the Late Permian Panzhihua plutonic-hypabyssal-volcanic igneous complex-Implications for the genesis of Fe-Ti oxide deposits and A-type granites of SW China: Earth and Planetary Science Letters, v. 289, nos. 3-4, p. 509-519. [Also available at http://dx.doi.org/10.1016/j.epsl.2009.11.044.]

Shiller, A.M., and Mao, Lunjin, 1999, Dissolved vanadium on the Louisiana Shelf-Effect of oxygen depletion: Continental Shelf Research, v. 19, no. 8, p. 1007-1020. [Also available at http://dx.doi.org/10.1016/s02784343(99)00005-9.]
Shiller, A.M., and Mao, Lunjin, 2000, Dissolved vanadium in rivers-Effects of silicate weathering: Chemical Geology, v. 165, nos. 1-2, p. 13-22. [Also available at http://dx.doi.org/ 10.1016/s0009-2541(99)00160-6.]

Smith, K.S., and Huyck, H.L.O., 1999, An overview of the abundance, relative mobility, bioavailability, and human toxicity of metals, in Plumlee, G.S. and Logsdon, M.J., eds., The environmental geochemistry of mineral deposits-Part A, Processes, techniques and health issues: Littleton, Colo., Society of Economic Geologists, v. 1, p. 29-70.

Smith, P.G., Boutin, Céline, and Knopper, Loren, 2013, Vanadium pentoxide phytotoxicity-Effects of species selection and nutrient concentration: Archives of Environmental Contamination and Toxicology, v. 64, no. 1 , p. 87-96. [Also available at http://dx.doi.org/10.1007/ s00244-012-9806-z.]

Smith, S.M., Neilson, R.T., and Giles, S.A., 2015, Levelling and merging of two discrete national-scale geochemical databases-A case study showing the surficial expression of metalliferous black shales [abs.]: 27th International Applied Geochemistry Symposium, Tucson, Ariz., April 20-24, 2015, Abstracts. [Also available at http://www.researchgate.net/ publication/278019670.]

Spry, P.G., and Scherbarth, N.L., 2006, The gold-vanadiumtellurium association at the Tuvatu gold-silver prospect, Fiji-Conditions of ore deposition: Mineralogy and Petrology, v. 87, nos. 3-4, p. 171-186. [Also available at http://dx.doi.org/10.1007/s00710-006-0128-6.]

Strady, Emilie, Blanc, Gérard, Schäfer, Jörg, Coynel, Alexandra, and Dabrin, Aymeric, 2009, Dissolved uranium, vanadium and molybdenum behaviours during contrasting freshwater discharges in the Gironde Estuary (SW France): Estuarine, Coastal and Shelf Science, v. 83, no. 4, p. 550-560. [Also available at http://dx.doi.org/10.1016/j.ecss.2009.05.006.]

Suter, G.W., II, and Tsao, C.L., 1996, Toxicological benchmarks for screening potential contaminants of concern for effects on aquatic biota-1996 revision: Oak Ridge, Tenn., Lockheed Martin Energy Systems Inc., ES/ER/TM-96/R2, variously paged, accessed March 3, 2013, at http://www.esd.ornl.gov/ programs/ecorisk/documents/tm96r2.pdf.

Swanson, V.E., Medlin, J.H., Hatch, J.R., Coleman, S.L., Wood, G.H., Jr., Woodruff, S.D., and Hildebrand, R.T., 1976, Collection, chemical analysis, and evaluation of coal samples in 1975: U.S. Geological Survey Open-File Report 76-468, 503 p., accessed April 12, 2013, at http://pubs.er.usgs.gov/publication/ofr76468. 
Sweatman, W.L., Wake, G.C., Fullard, Luke, and Bruna, Maria, 2012, Recovering vanadium during the production of steel from iron sand: ANZIAM Journal, v. 53, p. M1-M21. [Also available at http://journal.austms.org.au/ojs/index.php/ ANZIAMJ/article/view/4674.]

Taner, M.F., Ercit, T.S., and Gault, R.A., 1998, Vanadiumbearing magnetite from the Matagami and Chibougamau mining districts, Abitibi, Québec, Canada: Exploration and Mining Geology, v. 7, no. 4, p. 299-311. [Also available at http://www.researchgate.net/publication/270579726 Vanadium-bearing_Magnetite_from_the_Matagami_and Chibougamau_Mining_Districts_Abitibi_Qubec_Canada.]

Taylor, S.R., and McLennan, S.M., 1995, The geochemical evolution of the continental crust: Reviews of Geophysics, v. 33, no. 2, p. 241-265. [Also available at http://dx.doi.org/ 10.1029/95rg00262.]

Teng, Yanguo, Yang, Jie, Sun, Zongjian, Wang, Jinsheng, Zuo, Rui, and Zheng, Jieqiong, 2011, Environmental vanadium distribution, mobility and bioaccumulation in different land-use districts in Panzhihua region, SW China: Environmental Monitoring and Assessment, v. 176, nos. 1-4, p. 605-620. [Also available at http://dx.doi.org/ 10.1007/s10661-010-1607-0.]

Thamm, J.K., Kovschak, A.A., Jr., and Adams, S.S., 1981, National uranium resource evaluation-Geology and recognition criteria for sandstone uranium deposits of the Salt Wash type, Colorado Plateau province-Final report: Grand Junction, Colo., U.S. Department of Energy Report no. GJBX-6(81), 135 p. [Also available at http://dx.doi.org/ 10.2172/6512174.]

TNG Ltd., 2015, Developing a world-class vanadiumtitanium-iron project-Mount Peake, Northern Territory: TNG Ltd. Information Memorandum, 12 p., accessed December 11, 2015, at http://www.tngltd.com.au/images/ 4-mount_peake_information_memorandum.pdf.

Tyler, Germund, 2004, Vertical distribution of major, minor, and rare elements in a Haplic podzol: Geoderma, v. 119, nos. 3-4, p. 277-290. [Also available at http://dx.doi.org/ 10.1016/j.geoderma.2003.08.005.]

U.S. Bureau of Mines, 1972-76, Minerals yearbook 1970-1974: U.S. Bureau of Mines, variously paged. [Also available at http://minerals.usgs.gov/minerals/ pubs/usbmmyb.html.]

U.S. Bureau of Mines, 1992-96, Minerals yearbook 1990-1994: U.S. Bureau of Mines, variously paged. [Also available at http://minerals.usgs.gov/minerals/ pubs/usbmmyb.html.]
U.S. Environmental Protection Agency, 1994, Background for NEPA reviewers - Non-coal mining operations: Washington, D.C., U.S. Environmental Protection Agency, variously paged, EPA/530/R-95/043. [Also available at http://nepis.epa.gov/Exe/ZyPURL.cgi?Dockey=900V0E00.txt.]

U.S. Geological Survey, 2014, Vanadium end-use statistics [through 2003; last modified September 1, 2005], in Kelly, T.D., and Matos, G.R., comps., Historical statistics for mineral and material commodities in the United States (2014 version): U.S. Geological Survey Data Series 140, accessed March 4, 2017, at http://minerals.usgs.gov/ minerals/pubs/historical-statistics/.

U.S. Geological Survey, 1997-2013, Minerals yearbook 1995-2011: U.S. Geological Survey, variously paged. [Also available at http://minerals.usgs.gov/minerals/pubs/ myb.html.]

Verplanck, P.L., and Van Gosen, B.S., 2011, Carbonatite and alkaline intrusion-related rare earth element depositsA deposit model: U.S. Geological Survey Open-File Report 2011-1256, 6 p., accessed April 15, 2013, at http://pubs.er.usgs.gov/publication/ofr20111256.]

Viers, Jérôme, Dupré, Bernard, and Gaillardet, Jérôme, 2009, Chemical composition of suspended sediments in world rivers-New insights from a new database: Science of the Total Environment, v. 407, no. 2, p. 853-868. [Also available at http://dx.doi.org/10.1016/j.scitotenv.2008.09.053.]

Von Gruenwaldt, G., 1993, Ilmenite-apatite enrichment in the upper zone of the Bushveld Complex-A major titaniumrock phosphate resource: International Geology Review v. 35, no. 11, p. 987-1000. [Also available at http://dx.doi.org/ 10.1080/00206819309465570.]

Wang, Deli., and Sañudo-Wilhelmy, S.A., 2008, Development of an analytical protocol for the determination of $\mathrm{V}(\mathrm{IV})$ and $\mathrm{V}(\mathrm{V})$ in seawater-Application to coastal environments: Marine Chemistry, v. 112, nos. 1-2, p. 72-80. [Also available at http://dx.doi.org/10.1016/j.marchem.2008.05.011.]

Wang, J.F., and Liu, Z., 1999, Effect of vanadium on the growth of soybean seedlings: Plant and Soil, v. 216, nos. 1-2, p. 47-51. [Also available at http://dx.doi.org/ 10.1023/A:1004723509113.]

Wanty, R.B., Goldhaber, M.B., and Northrop, H.R., 1990, Geochemistry of vanadium in an epigenetic, sandstonehosted vanadium-uranium deposit, Henry basin, Utah: Economic Geology, v. 85, p. 270-284. [Also available at http://dx.doi.org/10.2113/gsecongeo.85.2.270.] 
Weeks, A.D., Coleman, R.G., and Thompson, M.E., 1959, Summary of the ore mineralogy, part 5 of Garrels, R.M., and Larsen, E.S., III, comps., Geochemistry and mineralogy of the Colorado Plateau uranium ores ( $3 \mathrm{~d}$ ed.): U.S. Geological Survey Professional Paper 320, p. 65-79, accessed March 14, 2013, at http://pubs.er.usgs.gov/ publication/pp320.

Wehrli, B., and Stumm, W., 1989, Vanadyl in natural watersAdsorption and hydrolysis promote oxygenation: Geochimica et Cosmochimica Acta, v. 53, p. 69-77. [Also available at http://dx.doi.org/10.1016/0016-7037(89)90273-1.]

Wever, Ron, and Kustin, Kenneth, 1990, Vanadium-A biologically relevant element, in Sykes, A.G., ed., Advances in inorganic chemistry: San Diego, Calif., Academic Press, Advances In Inorganic Chemistry Series, v. 35, p. 81-115. [Also available at http://dx.doi.org/10.1016/S0898-8838 (08)60161-0.]

Wiernsperger, Nicolas, and Rapin, J.-R., 2010, Trace elements in glucometabolic disorders-An update: Diabetology and Metabolic Syndrome, v. 2, no. 70, 9 p. [Also available at http://dx.doi.org/10.1186/1758-5996-2-70.]
Wright, M.T., and Belitz, Kenneth, 2010, Factors controlling the regional distribution of vanadium in groundwater: Ground Water, v. 48, no. 4, p. 515-525. [Also available at http://dx.doi.org/10.1111/j.1745-6584.2009.00666.x.]

Zhou, M.-F., Robinson, P.T., Lesher, C.M., Keays, R.R., Zhang, C.-J., and Malpas, John, 2005, Geochemistry, petrogenesis and metallogenesis of the Panzhihua gabbroic layered intrusion and associated Fe-Ti-V oxide deposits, Sichuan Province, SW China: Journal of Petrology, v. 46, no. 11, p. 2253-2280. [Also available at http://dx.doi.org/ 10.1093/petrology/egi054.]

Zientek, M.L., 2012, Magmatic ore deposits in layered intrusions-Descriptive model for reef-type PGE and contacttype Cu-Ni-PGE deposits: U.S. Geological Survey OpenFile Report 2012-1010, 54 p., accessed January 12, 2013, at http://pubs.er.usgs.gov/publication/ofr20121010. 


\section{Zirconium and Hafnium}

By James V. Jones III, Nadine M. Piatak, and George M. Bedinger

Chapter V of

Critical Mineral Resources of the United States-Economic and Environmental Geology and Prospects for Future Supply

Edited by Klaus J. Schulz, John H. DeYoung, Jr., Robert R. Seal II, and Dwight C. Bradley

Professional Paper 1802-V

U.S. Department of the Interior

U.S. Geological Survey 


\section{Contents of Chapter V}

[Figure and table titles for all chapters are listed in the volume contents before the conversion factors table and list of abbreviations and symbols. A periodic table of the elements is on the inside front cover of the printed volume]

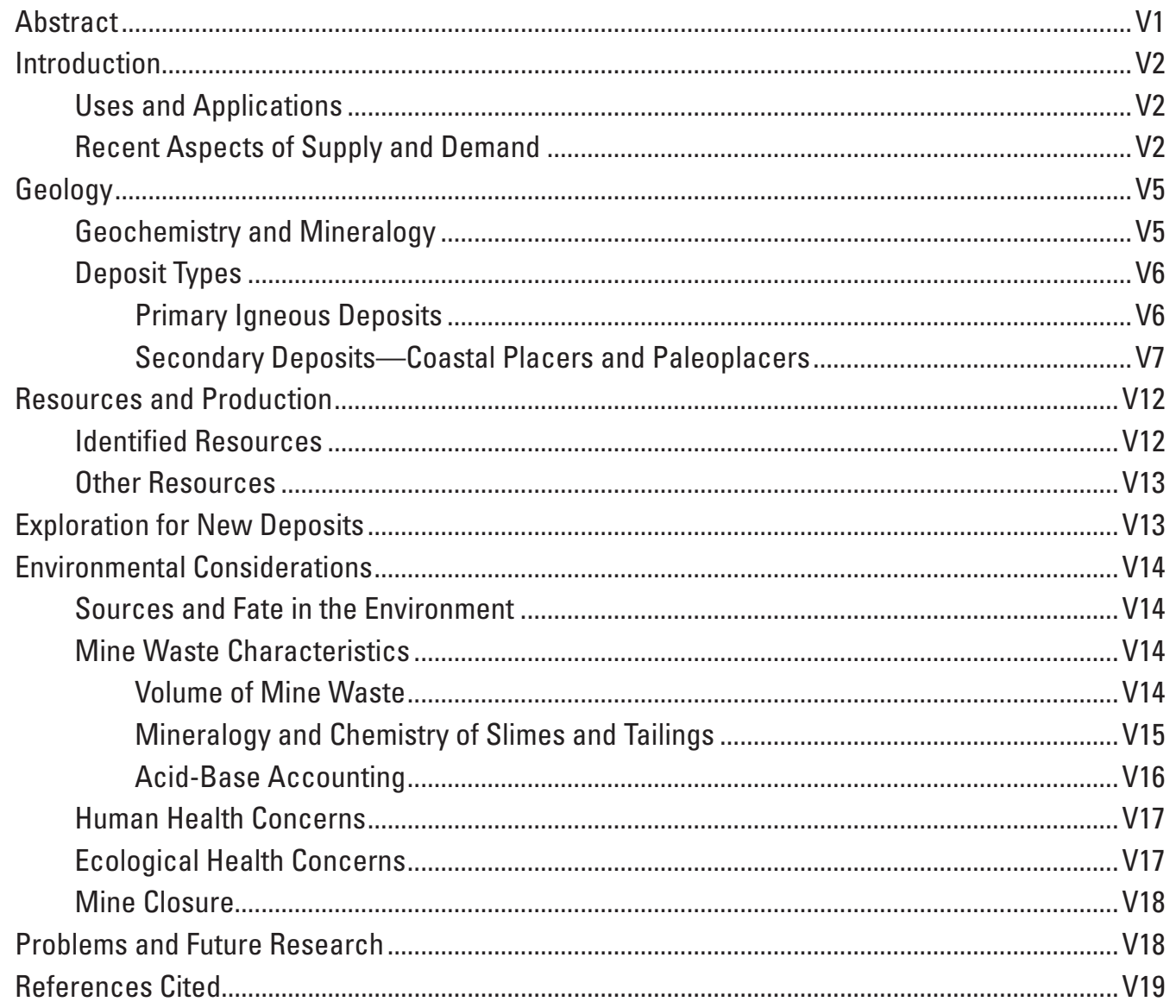




\title{
Zirconium and Hafnium
}

\author{
By James V. Jones III, Nadine M. Piatak, and George M. Bedinger
}

\section{Abstract}

Zirconium and hafnium are corrosion-resistant metals that are widely used in the chemical and nuclear industries. Most zirconium is consumed in the form of the main ore mineral zircon $\left(\mathrm{ZrSiO}_{4}\right)$, or as zirconium oxide or other zirconium chemicals. Zirconium and hafnium are both refractory lithophile elements that have nearly identical charge, ionic radii, and ionic potentials. As a result, their geochemical behavior is generally similar. Both elements are classified as incompatible because they have physical and crystallochemical properties that exclude them from the crystal lattices of most rock-forming minerals. Zircon and another, less common, ore mineral, baddeleyite $\left(\mathrm{ZrO}_{2}\right)$, form primarily as accessory minerals in igneous rocks. The presence and abundance of these ore minerals in igneous rocks are largely controlled by the element concentrations in the magma source and by the processes of melt generation and evolution. The world's largest primary deposits of zirconium and hafnium are associated with alkaline igneous rocks, and, in one locality on the Kola Peninsula of Murmanskaya Oblast, Russia, baddeleyite is recovered as a byproduct of apatite and magnetite mining. Otherwise, there are few primary igneous deposits of zirconium- and hafnium-bearing minerals with economic value at present. The main ore deposits worldwide are heavy-mineral sands produced by the weathering and erosion of preexisting rocks and the concentration of zircon and other economically important heavy minerals, such as ilmenite and rutile (for titanium), chromite (for chromium), and monazite (for rareearth elements) in sedimentary systems, particularly in coastal environments. In coastal deposits, heavy-mineral enrichment occurs where sediment is repeatedly reworked by wind, waves, currents, and tidal processes. The resulting heavy-mineral sand deposits, called placers or paleoplacers, preferentially form at relatively low latitudes on passive continental margins and supply 100 percent of the world's zircon. Zircon makes up a relatively small percentage of the economic heavy minerals in most deposits and is produced primarily as a byproduct of heavy-mineral sand mining for titanium minerals.
From 2003 to 2012, world zirconium mineral concentrates production increased by more than 40 percent, and Australia and South Africa were the leading producers. Global consumption of zirconium mineral concentrates generally increased during the same time period, largely as a result of increased demand in developing economies in Asia and the Middle East. Global demand weakened in 2012, causing a decrease in world production of zirconium mineral concentrates and delaying the development of several new mining projects. Global consumption is expected to increase in the future, however, as demand from the ceramics, chemicals, and metals industries increases (driven by renewed growth in developing economies) and demand for zirconium and hafnium metal increases (driven by the construction and operation of new nuclear powerplants).

The behaviors of zirconium and hafnium in the environment are very similar to one another in that most zirconium- and hafnium-bearing minerals have limited solubility and reactivity. Anthropogenic sources of zirconium, and likely hafnium, are from industrial zirconium-containing byproducts and emissions from the processing of sponge zirconium, and exposure to the general population from these sources is small. Zirconium and hafnium are likely not essential to human health and generally are considered to be of low toxicity to humans. The main exposure risks are associated with industrial inhalation and dermal exposure. Because of the low solubility of zirconium and hafnium, ecological health concerns in the aquatic environment and in soils are minimal. Heavy-mineral sand mining may lead to increased erosion rates when the mining is managed improperly. In addition, surface mining requires removal of the overlying organic soil layer and produces waste material that includes tailings and slimes. The soil removal and mining activity disturbs the surrounding ecosystem and alters the character of the landscape. Dry mineral separation processes create high amounts of airborne dust, whereas wet mineral separation processes do not. In operations that restore the landscape to pre-mining conditions, the volume of waste and the impact on the landscape may be relatively temporary. 


\section{V2 Critical Mineral Resources of the United States-Zirconium and Hafnium}

\section{Introduction}

\section{Uses and Applications}

Zirconium (Zr) and hafnium (Hf) are metals (figs. V1A and $\mathrm{V} 1 B$, respectively) that are used in the chemical and nuclear-reactor industries in applications for which corrosion resistance, structural stability at high temperatures, and specific alloying properties and (or) specific neutronabsorption characteristics are required. The main ore mineral for both elements is zircon $\left(\mathrm{ZrSiO}_{4}\right)$ (figs. $\mathrm{V} 1 C$ and $\mathrm{V} 1 D$ ), which typically has a zirconium to hafnium ( $\mathrm{Zr}: \mathrm{Hf}$ ) ratio of 50:1. Baddeleyite $\left(\mathrm{ZrO}_{2}\right)$ (fig. V1E) is a less common but commercially important mineral that contains both zirconium and hafnium, but in a ratio of approximately 73:1. Zircon and baddeleyite are formed primarily as accessory minerals in igneous rocks and are typically present at relatively low abundances. They also occur naturally in a wide variety of rock types and geologic environments. The main ore deposits worldwide are heavy-mineral sands (figs. $\mathrm{V} 1 F$ and $\mathrm{V} 1 G$ ) produced by the weathering and erosion of preexisting rocks and the concentration of zircon in sedimentary systems, particularly in coastal environments.

Approximately 95 percent of all zirconium consumed is in the form of zircon, zirconium oxide, or other zirconium chemicals (Nielson and Wilfling, 2002; Gambogi, 2012b). Zircon is highly refractive, with a melting point of 2,550 degrees Celsius $\left({ }^{\circ} \mathrm{C}\right)$ or greater. Thus, zircon is used for facings on foundry molds, and milled or ground zircon is used in refractory paints for coating the surfaces of molds. Zircon bricks and blocks are used in furnaces and hearths for containing molten metals, and glass tank furnaces use fused-cast and bonded alumina-zirconia-silica-based refractory metal. Zircon is also used in minor quantities as a gemstone and may be processed to produce cubic zirconia, which is a synthetic gemstone and diamond simulant. Baddeleyite is used in the manufacture of alumina-zirconia abrasives and in ceramic colors and refractories.

Zirconia, which is a form of zirconium oxide, is produced by reacting zircon ore with caustic soda and then chlorinating it to produce zirconium oxychloride. The zirconium oxychloride is then calcined and precipitated to form zirconia powder. Zirconia has a high melting point $\left(2,700^{\circ} \mathrm{C}\right)$ and low thermal conductivity, and it is an important constituent of ceramic colors and glazes. Zirconia undergoes a phase transformation during heating, however, and must be stabilized for other uses by adding such oxides as calcium oxide $(\mathrm{CaO})$, magnesium oxide $(\mathrm{MgO})$, and yttrium oxide (yttria; $\mathrm{Y}_{2} \mathrm{O}_{3}$ ) into the zirconia structure. Yttria-stabilized zirconia is used in the manufacture of cubic zirconia, fiber-optic connector components, refractory coatings, engineering and structural ceramics, and oxygen sensors that control combustion in automobile engines. Because it has increased fracture resistance and strength relative to similar alumina products, yttria-stabilized zirconia is also used in dental applications, such as bridges, crowns, and inlays, and in joint-replacement procedures. Other zirconium chemicals include the following: zirconium boride used as a diffusion barrier in semiconductors, as a container for molten metals, and as a burnable absorber in nuclear reactor cores; zirconium carbonates used in antiperspirants and in printing and paper manufacturing; zirconium hydride used for flares, fuses, and combustion charges in pyrotechnics and as a binding or brazing component in abrasive wheels and polishing discs; zirconium nitride used as a wear-resistant coating on drill and tool bits; zirconium phosphates used for cation exchange applications, such as dialysis, drug delivery, and nuclear waste management; and zirconium sulfates used in leather tanning, as catalysts, and as coatings for titanium oxide pigment powder (Nielson and Wilfling, 2002).

Zirconium and hafnium metals are produced by the Kroll process, which involves reduction of zirconium oxychloride by magnesium metal in an inert atmosphere. The resulting metal contains a mixture of zirconium and up to 2 percent hafnium and is used for nonnuclear applications in corrosive environments and in specialty alloys. For nuclear-grade applications, the metals must be separated because of their different neutron absorption characteristics. Hafnium-free zirconium metal has a low thermal neutron-absorption cross section, so it is used for structural materials in nuclear reactors and as cladding for nuclear fuel rods. Hafnium has a relatively high thermal neutron absorption cross section and thus is used in nuclear control rods. Reactor-grade zirconium and hafnium are produced by dissolving zirconium oxychloride and chemically separating the hafnium from the solution. The zirconium and hafnium components are separately processed to form chlorides, which are then reduced to metals by the Kroll process. Hafnium is also used in high-temperature ceramics, nickel-base superalloys, and nozzles for plasma arc metal cutting.

\section{Recent Aspects of Supply and Demand}

Global production of zirconium mineral concentrates increased by more than 50 percent between 2003 and 2012 (fig. V2A); the main source of the output was zircon from heavy-mineral sands. A relatively small quantity of zirconium was derived from baddeleyite produced from a single source on the Kola Peninsula of Murmanskaya Oblast, Russia. Excluding the United States, world production reached approximately 1.68 million metric tons of zirconium mineral concentrates in 2011, followed by a significant decrease to 1.45 million metric tons in 2012 (fig. V2A; U.S. Geological Survey, 2014). In 2012, Australia and South Africa were the leading world zircon producers, accounting for approximately 70 percent of all production outside of the United States (fig. V2B; Bedinger, 2015a). China was the leading consuming country.

Global consumption of zircon increased in 2011, largely as a result of increased demand in developing economies in Asia and the Middle East (Gambogi, 2012b), and the prices of zirconium ores and concentrates rose dramatically during the same period. In 2011, prices of domestic standard-grade bulk zircon increased to between $\$ 2,550$ and $\$ 2,750$ per metric ton 

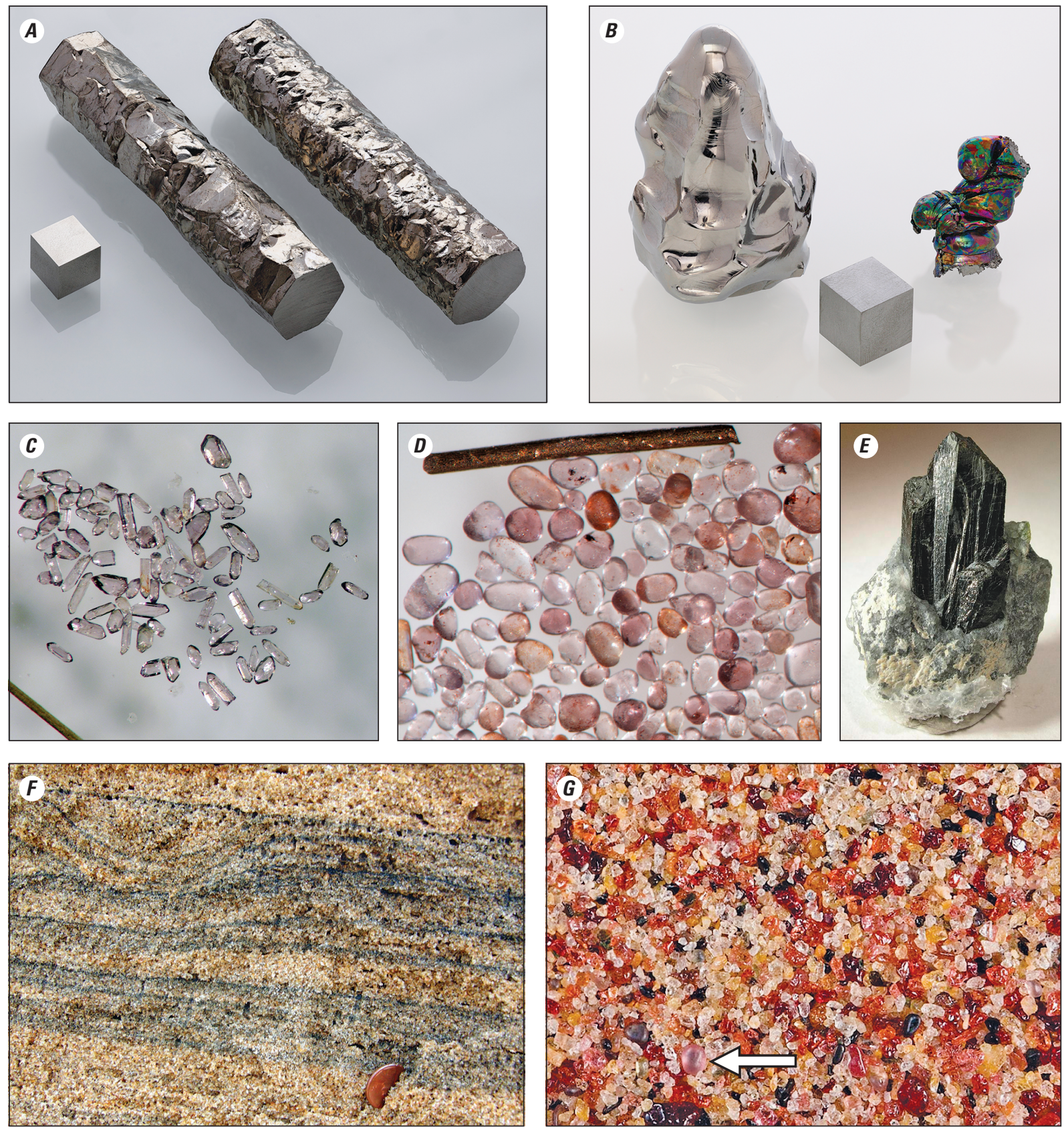

Figure V1. Examples of sources and uses of zirconium and hafnium. $A$, Cube and crystal bars of highly pure zirconium metal (greater than 99.95 percent purity). The cube is 1 cubic centimeter in volume. $B$, (left) A pure (99.98 percent) melted tip of a hafnium electrode used in an electron beam remelting furnace for manufacturing metal parts; (right) an oxidized hafnium electron beam remelted ingot (color is from thin film effects in the oxide layer); and (center) a cubic centimeter of hafnium metal. Photographs $A$ and $B$ are by Heinrich Pniok (http://pse-mendelejew.de). C, Primary igneous zircon grains separated from granite. Note the prismatic character of most of the grains and the double termination on some. The wire (for scale) in the lower left-hand corner of the photograph is approximately 0.1 millimeter $(\mathrm{mm})$ in diameter. $D$, Detrital zircon grains separated from metamorphosed sandstone. The rounding of the grains likely occurred during sedimentary transport and reworking. The wire (for scale) at the top of the photograph is approximately $0.1 \mathrm{~mm}$ in diameter. Photographs $C$ and $D$ are by James V. Jones. E, Baddeleyite crystals from the Palabora carbonatite deposit, Limpopo Province, South Africa. Photograph by Rob Lavinsky (www.iRocks.com). F, Heavy-mineral concentrations (dark seams) in weakly indurated outcrops of quartz beach sand from Chennai, India. The penny embedded in the sand (lower right) is for scale. Photograph by Mark Wilson (College of Wooster, Ohio). G, Photomicrograph of heavy-mineral sands from Sri Lanka that are rich in red to brown spinel. Note the larger, well-rounded pink zircon grain indicated by the white arrow. The width of the view is $20 \mathrm{~mm}$. Photograph by Simm Sepp (www.sandatlas.org). 
from between $\$ 830$ and $\$ 890$ per metric ton (fig. V2C; Loferski, 2013a). The average unit value of imported zirconium ore and concentrates (primarily zircon sand) was $\$ 2,170$ per metric ton in 2011 (fig. V2C; Loferski, 2013a). The subsequent decrease in world production of zirconium mineral concentrates in 2012 was in response to weakened demand, particularly in China, because of a slowdown in housing construction. Global consumption of zirconium mineral concentrates is expected to increase in the future, as demand from such consumers as the ceramics, chemicals, and metals industries increases, driven by renewed growth in developing economies. Construction and operation of new nuclear powerplants throughout the world are also expected to result in future demand increases for zirconium and hafnium metal. Although new zircon mines were brought online in recent years, the global financial situation led to decreased production and delayed the development of several mining projects. Thus, constricted supply together with the projected increase in demand could create a scarcity of zircon in the future (Loferski, 2013a). Despite this possibility, zirconium ranks relatively low on the British Geological Survey's risk list, possibly reflecting the political and (or) economic stability of the countries that are major sources of this mineral commodity and the fact that production comes from several areas worldwide (British Geological Survey, 2012).

Figure V2. Graphs showing global zirconium production (not including U.S. production) and U.S. trade information for zirconium ores and concentrates. $A$, World zirconium mine production from 2003 to 2012. Data are from Gambogi (2010), U.S. Geological Survey (2010-13), and Bedinger (2014). B, Global zirconium mine production, by country, from 2007 to 2012. Data are from U.S. Geological Survey (2010-13) and Bedinger (2014).

$C$, U.S. exports and imports of zirconium ores and concentrates, by amount, value, and price, from 2003 to 2011. Data are from U.S. Geological Survey (2006-9, 2010-13), Gambogi (2010), and Bedinger (2014).

\section{A. World zirconium mineral concentrates mine production ${ }^{1}$}

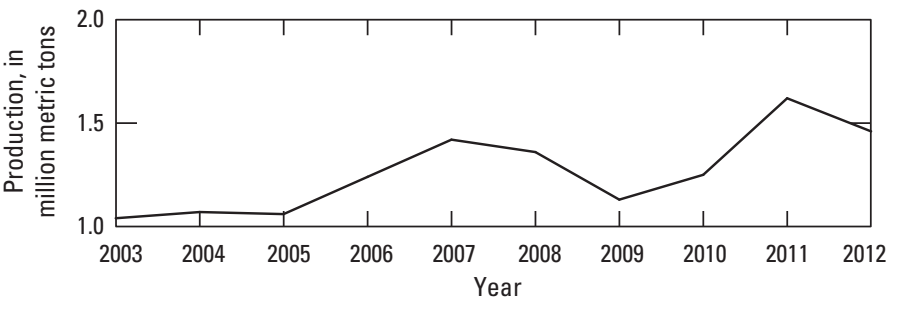

B. Zirconium mineral concentrates mine production by country ${ }^{1}$

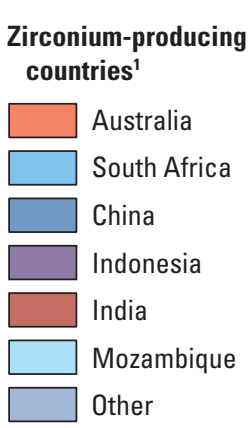

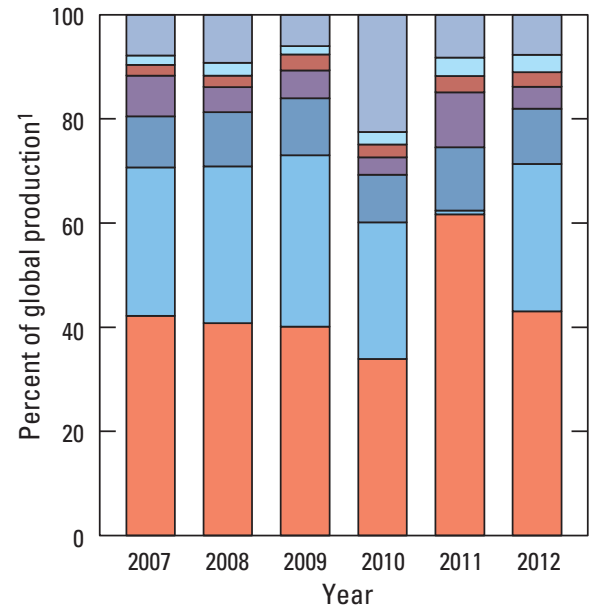

C. Amount, value, and price of U.S. exports and imports of zirconium ores and concentrates
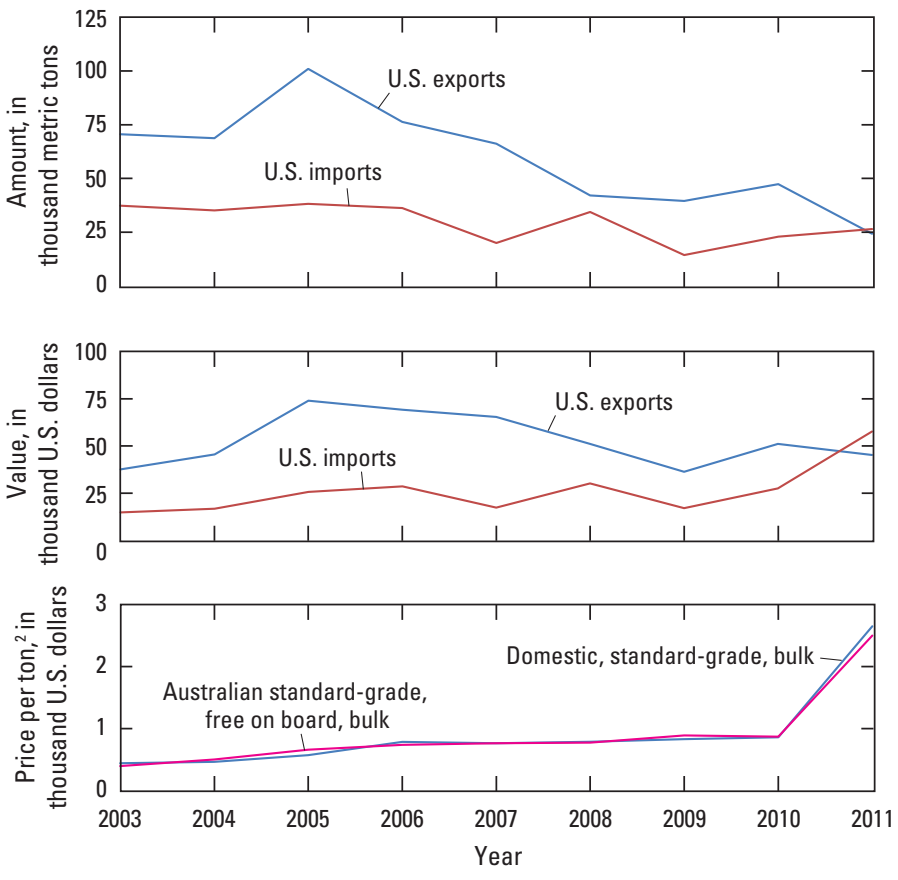

${ }^{1}$ Does not include the United States

${ }^{2}$ Average price 


\section{Geology}

\section{Geochemistry and Mineralogy}

Zirconium and hafnium are refractory lithophile elements that have nearly identical charge, ionic radii, and ionic potentials. They are classified as incompatible elements because they have physical and crystallochemical properties that exclude them from the crystal lattices of most rockforming minerals. In particular, zirconium and hafnium cations have relatively high charges $\left(\mathrm{Zr}^{4+}\right.$ and $\left.\mathrm{Hf}^{4+}\right)$ and small ionic radii. Thus, they and other similar elements, such as niobium, thorium, and uranium, develop intense electrostatic fields and do not substitute for the major elements in ordinary minerals. Instead, these elements, known as high field-strength elements (HFSE), concentrate in less common accessory minerals. Zirconium and hafnium are enriched in Earth's crust relative to the mantle and have estimated average crustal abundances of 100 parts per million (ppm) and 3 ppm, respectively (Taylor and McLennan, 1995). Both elements are concentrated in the upper crust relative to the lower crust by a factor of approximately 1.5 (Taylor and McLennan, 1995).

Zircon $\left(\mathrm{ZrSiO}_{4}\right)$ is the most common naturally occurring zirconium- and hafnium-bearing mineral. Most zircon forms as a product of primary crystallization in igneous rocks; in most rocks, zircon is the main mineral and zirconium is an essential structural constituent (Hoskin and Schaltegger, 2003). Most natural zircon has a $\mathrm{Zr}: \mathrm{Hf}$ ratio of 33.6:1, which is about the same as the average crustal abundance ratio of those elements (Taylor and McLennan, 1995). The hafnium content of zircon can vary widely, however (from 6,000 to 11,600 ppm) (Ahrens and Erlank, 1969; Heaman and others, 1990), depending on the composition of the magma from which the zircon crystallized.

The natural color of zircon crystals varies from colorless to yellow, reddish-pink, purple, brown, blue, and green. Crystal sizes range in diameter and length from microns to a few centimeters, and well-formed zircon crystals are foursided prisms terminated by pyramids on each end (fig. V1C). Zircon exhibits a wide range of morphologies, however, which can provide clues about the conditions of formation or the subsequent history of the grain (Pupin, 1980; Corfu and others, 2003). In igneous rocks, zircon is generally present as small, early formed crystals enclosed in later-formed minerals. In some cases, such as granite pegmatites and nepheline syenites, zircon forms large, well-developed crystals. Once zircon has crystallized, its refractory nature allows it to persist through repeated cycles of igneous activity, and inherited zircon is common in a variety of igneous rocks, either as complete grains or as internal cores of younger zircon crystals. In metamorphic rocks, zircon can form by recrystallization of existing grains or by growth of new material. At lower temperature and pressure, new zircon is rare, and metamorphic zircon is formed by partial to complete recrystallization of existing grains. Under more intense metamorphic conditions, new zircon forms more readily at subsolidus conditions and also during partial melting (Schaltegger and others, 1999; Rubatto and others, 1999). Rare authigenic zircon has been reported in sedimentary rocks (Saxena, 1966), but sedimentary zircon is derived primarily from the weathering of preexisting igneous, sedimentary, or metamorphic rocks. Detrital zircon (fig. V1D) in sediment and sedimentary rocks is highly durable and chemically inert and, therefore, can survive numerous cycles of reworking and concentration in the sedimentary environment.

Baddeleyite $\left(\mathrm{ZrO}_{2}\right)$ is a less common zirconium ore mineral that occurs in alkaline rocks, mafic and ultramafic rocks, and some metamorphosed carbonate rocks. It may occur with zircon and has been recognized as an accessory phase in a wide variety of rock types. Baddeleyite is most common in the late-stage, most chemically fractionated portions of mafic magmas (Heaman and LeCheminant, 1993), and it is the main zirconium-bearing phase in carbonatite rocks (fig. V $1 E$ ) because of the generally lower silica activity in carbonatite melts. As with zircon, the Zr:Hf ratio in baddeleyite can vary considerably, and baddeleyite has been shown to fractionate zirconium from hafnium, particularly in carbonatite systems (Scharer and others, 1997; Klemme and Meyer, 2003). In pristine mafic rocks, baddeleyite crystals are usually light tan to dark brown in color and form euhedral, wafer-thin blades that commonly contain striated crystal faces (Heaman and LeCheminant, 1993). Crystals are typically very small, often less than 30 microns in width (Söderlund and Johansson, 2002).

Eudialyte $\left(\mathrm{Na}_{15} \mathrm{Ca}_{6} \mathrm{Fe}_{3} \mathrm{Zr}_{3} \mathrm{Si}_{26} \mathrm{O}_{73}(\mathrm{OH})_{4} \mathrm{Cl}_{2}\right)$ is a relatively rare zirconium-bearing mineral that is locally abundant in some types of potassium- and sodium-rich rocks (Kogarko, 1990). It is an essential mineral in a variety of peralkaline nepheline syenites and nepheline syenite pegmatites, particularly those classified as agpaitic (Sørenson, 1997; Le Maitre, 2002). Eudialyte-bearing rocks have been identified in multiple alkalic intrusive complexes worldwide (Marks and others, 2011); the Lovozero Massif on the Kola Peninsula in Murmanskaya Oblast, Russia, hosts nearly monomineralic eudialyte ores that contain 10 percent $\mathrm{ZrO}_{2}$ (Kogarko, 1990).

Hafnon $\left((\mathrm{Hf}, \mathrm{Zr}) \mathrm{SiO}_{4}\right)$ is a rare hafnium-rich mineral that exhibits continuous solid solution with zircon. Synthetic hafnon has been produced with 100 percent hafnium substitution (Speer and Cooper, 1982), but naturally occurring hafnon crystals typically have $\mathrm{Zr}$ :Hf ratios of 0.03 to 0.08 . Hafnon occurs in tantalum-bearing granite pegmatites in the Zambézia district of Mozambique (Correia Neves and others, 1974), and hafnian zircon has been identified in a niobiumtantalum-rich granitic complex in China (Wang and others, 1996) and in several occurrences of granitic pegmatite worldwide (for example, Levinson and Borup, 1960; Černý and Siivola, 1980; Nickel and Robinson, 1985).

Zirconium and hafnium ore minerals are all primarily formed by crystallization from magma. The stability of zirconium- and hafnium-bearing phases in igneous systems is largely controlled by the concentration of the low-abundance 
elements (Watson and Harrison, 1984), so the element concentrations depend, in large part, on the magma source. Trace element patterns from basalts generated along mid-ocean ridges indicate that the upper mantle - the main source of melt generation beneath oceanic spreading centers - is relatively depleted in zirconium, hafnium, and other incompatible elements. Partial melting of the depleted upper mantle produces mainly tholeiitic or subalkaline basalts that have relatively low concentrations of zirconium and hafnium. In contrast, alkaline basalts formed in tectonic settings, such as oceanic islands and continental rifts, are relatively enriched in zirconium and hafnium because they are derived from deeper, more heterogeneous, undepleted, or locally enriched parts of the mantle (for example, Pearce and Norry, 1979; Fitton, 1987; Weaver and others, 1987). Mantle enrichment occurs through metasomatism; that is, through chemical alteration that results from interactions between rocks and fluid. This process can replenish lithophile elements in the mantle prior to melt extraction; however, the nature of mantle metasomatism and its role in the generation of alkaline basalts is still under debate (Bailey, 1987; Menzies, 1987; Hoffman, 1997).

Zirconium and hafnium concentrations in igneous systems are also a function of the processes of melt generation and liquid evolution. Alkaline magmas are derived from enriched or less depleted sources, but they also are formed from relatively low fractions of partial melt (Thompson and others, 1984; McKenzie, 1985). Small fractions of partial melt preferentially extract alkalis and other incompatible elements, thus concentrating these elements even more relative to the magma source. As a result, zirconium concentration in igneous rock suites derived from alkaline basalts is significantly greater than igneous rock suites derived from tholeiitic or subalkaline basalts (Engel and others, 1965). Zirconium and hafnium are further concentrated during crystallization of alkaline systems, as these elements tend to remain in the residual liquid because of their higher solubility in magmas rich in sodium, potassium, fluorine, chlorine, and hydroxide. In the Skaergaard intrusion of East Greenland, late-stage differentiates of the layered mafic-ultramafic complex have unusually strong enrichment of zirconium; that is, greater than $1,000 \mathrm{ppm}$. The enrichment is particularly significant because the initial magma concentration was $94 \mathrm{ppm}$, which is similar to the average zirconium content of tholeiitic or subalkaline basalts (Wager and Mitchell, 1951; Brooks, 1969).

Zirconium, hafnium, and other HFSEs are generally depleted in subduction zone magmas relative to mid-oceanridge, ocean-island, and rift-related basalts (Perfit and others, 1980). Rubatto and Hermann (2003) demonstrated that zircon is stable as a residual phase in subducted basalt and sediment and thus could limit the liberation of HFSEs into subduction zone fluids and melts. Melts generated in subduction zones are relatively rich in water, and the solubility of zirconium, hafnium, and other HFSEs in aqueous solutions is much lower than that for other incompatible elements, such as potassium (Gill, 1981, and references therein). As a result, some incompatible elements are scavenged and relatively enriched in subduction zone magmas, whereas others are more immobile and remain in the country rocks. As hydrous melts migrate through the mantle wedge, interaction with the depleted upper mantle leads to preferential HFSE depletion in the ascending magma (Kelemen and others, 1980). Less-depleted magmas in subduction zone systems may be produced if the melts interact with enriched pockets of lithospheric mantle beneath the crust (Edgar, 1987) or with metasomatized regions of the continental or oceanic crust. These effects are relatively localized, however, and the resulting concentrations of zirconium, hafnium, and associated HFSEs are still relatively low.

Because zirconium and hafnium are nearly identical in chemical properties, the geochemical behavior of hafnium during magma formation and differentiation is generally similar to that of zirconium. This is particularly true in mafic to intermediate magmas, which represent relatively pure silicate melts and have $\mathrm{Zr}$ :Hf ratios similar to the chondritic model of bulk silicate Earth composition (Bau, 1996; David and others, 2000). In other magmas, particularly highly evolved melts rich in boron, chlorine, fluorine, lithium, phosphorus, or water, $\mathrm{Zr}: \mathrm{Hf}$ ratios vary substantially and indicate decoupled fractionation of the two elements (Ellison and Hess, 1986). The general behavior of trace elements in highly evolved melts rich in volatiles is difficult to model quantitatively (Bau, 1996), and yet these are the kinds of magmas in which zirconium and hafnium are naturally concentrated. As a result, the hafnium content of the resulting ore minerals and (or) the presence of hafnon in igneous systems are variable and difficult to predict. In the Skaergaard intrusion, differentiation produced $\mathrm{Zr}: \mathrm{Hf}$ ratios that range from 59 in the most mafic portions to 85 in the most silica- and alkali-rich parts of the mafic-ultramafic complex (Brooks, 1970). In calc-alkaline suites, the Zr:Hf ratios of zircon range from 50 to 70 in gabbro to 30 to 35 in granite and suggest hafnium enrichment during magma evolution (Condie and Lo, 1971). Zircon from silica-undersaturated rocks, such as syenite and nepheline syenite, has low hafnium content and high $\mathrm{Zr}$ :Hf ratios relative to granite, whereas peralkaline granite, granitic pegmatite, and lithium-tantalum-bearing granite and pegmatite are the only rocks known to contain both hafnon (Correia Neves and others, 1974) and also zircon with high concentrations of hafnium (>30 percent) (von Knorring and Hornung, 1961; Wang and others, 1996) and also unusually low Zr:Hf ratios $(<20)$ (Wang and others, 1996).

\section{Deposit Types}

\section{Primary Igneous Deposits}

The world's largest primary deposits of zirconium and hafnium are associated with alkaline igneous rocks (Kogarko, 1990). These rocks also host much of the niobium, tantalum, and rare-earth elements (REEs) on Earth (Kogarko, 1990; Chakhmouradian and Wall, 2012), and they have a strong association with economic deposits of apatite (Kogarko, 1987; Singer, 1992) and diamond (Bergman, 1987; Dawson, 1987; 
Cox, 1992). Volumetrically, alkaline rocks account for less than 1 percent of all igneous rocks, however, and individual intrusions are typically of limited spatial extent and volume. Also, the concentration of zirconium and hafnium in these enriched igneous systems is still relatively low. Thus, only a few primary igneous deposits of zirconium- and hafniumbearing minerals are economic to mine at present.

The Kovdor deposit lies within the Paleozoic Kola alkaline province, which is located on the southwestern part of the Kola Peninsula in Murmanskaya Oblast, Russia (fig. V3). This deposit, from which baddeleyite is recovered as a byproduct of apatite and magnetite mining, is the only igneous deposit in the world that is currently producing zirconium (Singer, 1992). The Kovdor deposit is made up primarily of carbonatite and phoscorite; the carbonatites are represented by both calcite and dolomite carbonatite varieties. Phoscorites have carbonate mineral assemblages similar to those in the carbonatites but also include magnetite and silicate minerals, such as apatite, forsterite, and phlogopite (Rodionov and others, 2012). The ore complex (which covers a 0.8 -by-1.3-kilometer [km] area) is part of a 40 -squarekilometer $\left(\mathrm{km}^{2}\right)$ multiphase, concentric intrusion that also includes ultramafic rocks (clinopyroxenite and dunite) and nepheline syenite (Verhulst and others, 2000, and references therein). The intrusion extends down to $12 \mathrm{~km}$ with steeply dipping to vertical contacts (Arzamastsev and others, 2000), and it is surrounded by Archean biotite gneiss and granitic gneiss. The Kovdor intrusive complex was emplaced along the Kandalaksha Deep Fracture Zone, which is one of the most prominent structural features of the eastern Baltic Shield (Bell and others, 1996).

The broader Kola alkaline province consists of more than 24 intrusive complexes of Devonian age (380 to 360 megaannum [Ma]) (Kramm and others, 1993; Rodionov and others, 2012) that are exposed across more than $100,000 \mathrm{~km}^{2}$ from western Finland to the eastern part of the Kola Peninsula. Petrogenetic models for the Kola alkaline province suggest melt derivation from lithospheric mantle that was metasomatized prior to melting, and that the trigger for melting might have been a mantle plume (Sindern and others, 2004; Downes and others, 2005). Melt generation, migration, and emplacement were controlled by rifting perpendicular to and along regional northwest-southeast-trending structures with Precambrian ancestry (Dudkin and Mitrofanov, 1994). Associated intrusive complexes - namely the Lovozero and the Khibiny complexes - represent the largest agpaitic intrusions and contain the largest magmatic apatite deposits in the world (Kogarko, 1990). These intrusions also have localized phases that are enriched in zirconium, such as veins of pegmatitic nepheline syenite in the Khibiny complex that contain eudialyte. The Lovozero complex contains more widespread eudialyte-bearing nepheline syenite, called lujavrite, as well as ore horizons that contain up to 10 percent $\mathrm{ZrO}_{2}$ and between 50 and 90 percent eudialyte (Kogarko, 1990). Locally, lujavrite forms plate-like bodies up to 800 meters (m) thick. Despite the enrichment of eudialyte in both of these intrusions, neither Lovozero nor Khibiny is presently being mined for zirconium.

\section{Secondary Deposits-Coastal Placers and Paleoplacers}

Zirconium and hafnium ore minerals, particularly zircon, are present in a wide variety of rocks, but rarely in economic concentrations. Thus, most economic deposits are formed in sedimentary environments wherein zircon and other ore minerals are separated from their primary host rocks by weathering and erosion and transported and concentrated in surficial deposits. Zircon is chemically stable and hard (has a hardness of 7 on the Mohs scale) and is consequently quite durable in the sedimentary environment (Morton and Hallsworth, 1999). Zircon and other related ore minerals also have high densities and therefore accumulate under the influence of gravity in wind and water. The resulting heavy-mineral deposits, called placers, exhibit a wide range of physical characteristics, form in many different environments, and host a variety of minerals; for example, they are valuable resources for gold, iron, tin, and titanium (Slingerland and Smith, 1986; Garnett and Bassett, 2005). Alluvial placers form in rivers and streams, and they contain concentrations of zircon and other heavy minerals derived from source rocks within a drainage network. Additional concentration can take place as sediment moves downstream and as older river deposits are reworked by younger systems, although downstream dilution is more common.

In sediment deposited along the coasts, heavy-mineral enrichment takes place primarily in the foreshore and uppermost part of the shoreface environment (fig. V4D) where sediment is repeatedly reworked by wind, waves, and waveinduced currents. Coastal placer and paleoplacer systems, or beach placers, form along wave-dominated coastlines where reworking is most intense. They supply all of the world's current primary production of zircon and constitute the most important deposit type for zirconium and hafnium (Garnett and Bassett, 2005). Rigorously defined, a coastal placer is a concentration of heavy minerals within sediment deposited in a range of coastal sedimentary environments that are typically dominated by eolian, wave, and tidal processes (Hamilton, 1995). The concentrating agent at the site of deposition is primarily mechanical, and the presence and concentration of zircon and other economically important minerals, such as ilmenite and rutile (for titanium), chromite (for chromium), and monazite (for REEs) are dependent on a variety of factors described below. Most deposits range in age from the Eocene Epoch to the present, and economically viable deposits occur along numerous modern beaches on nearly every continent (fig. V3; for example, Peterson and others, 1986; Mallik and others, 1987; Hamilton, 1995; MacDonald and Rozendaal, 1995; Hou and others, 2011). Rare examples of much older paleoplacers, such as the Archean Witwatersrand deposit in South Africa, have been successfully mined, although primarily for gold (Minter, 2006). 


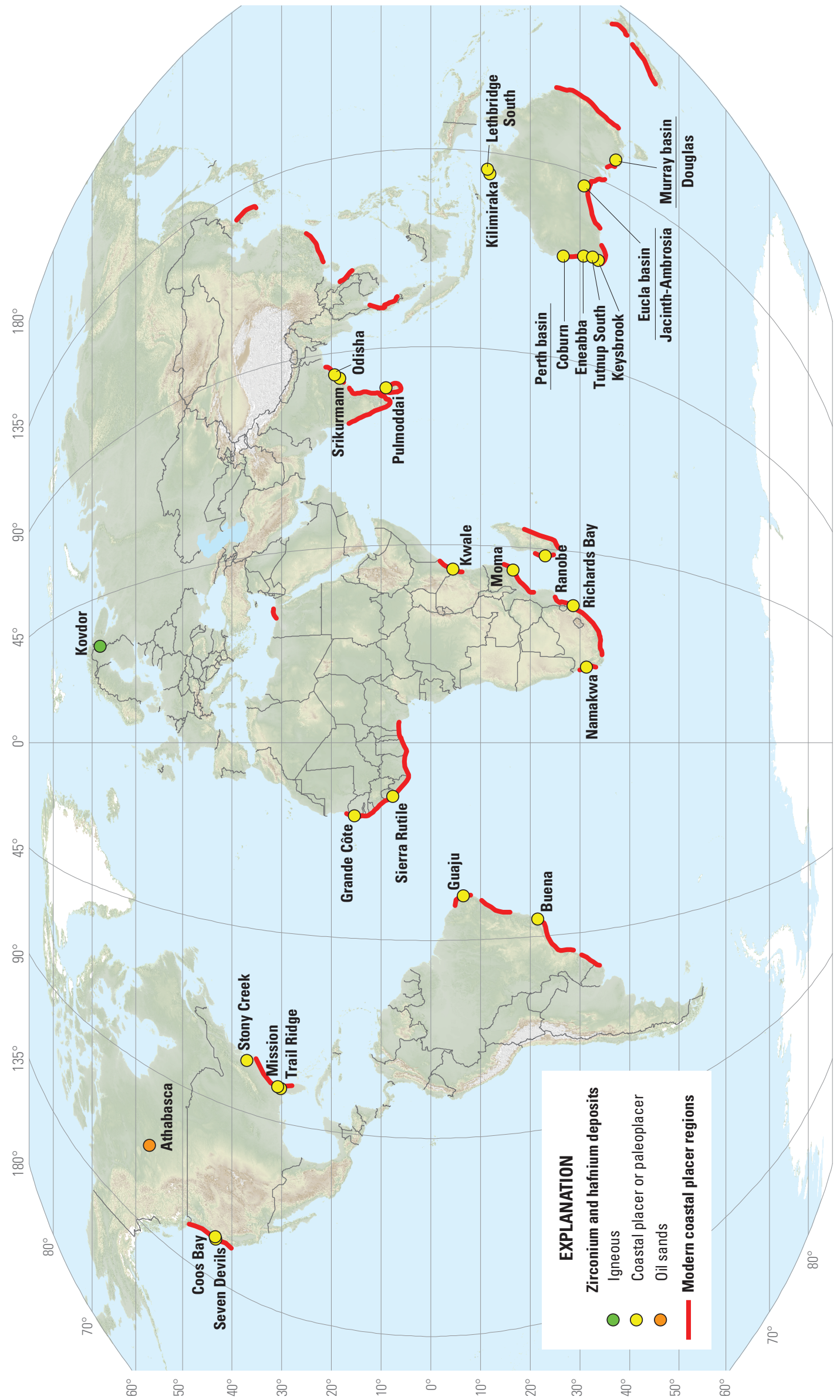

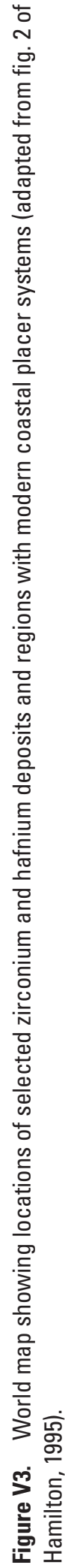


Coastal placers are typically fed by detritus derived from deeply weathered bedrock source terranes that include abundant felsic to intermediate crystalline rocks (fig. V4A). Host sands form coast-parallel surficial bodies, such as barrier islands (figs. V $4 B$ and $\mathrm{V} 4 C$ ), and older sand bodies form topographic highs inland of the modern coastline that represent former barrier islands or eolian dunes (fig. V4A; Force and Rich, 1989). Sand bodies are formed in the foreshore, shoreface, dune, tidal delta, and washover environments (figs. V4B and V4D; Roy and others, 1994); the economic heavy-mineral concentrations within these systems are typically about $10 \mathrm{~m}$ thick, $1 \mathrm{~km}$ wide, and more than $5 \mathrm{~km}$ long. In some cases, economic deposits are made up of amalgamated smaller sand bodies of similar origins or superimposed composite bodies from different environments (Force, 1991). The mineral grains in most economic deposits are medium- to fine-grained sand-sized, well sorted, generally well rounded, and typically unindurated (fig. V1G). Welldeveloped weathering profiles are superimposed on most sand bodies, and local cementation by iron oxides, clay minerals, or humate is common. The proportions of heavy minerals vary considerably both within deposits and among sand bodies (fig. V1F); the average concentration of total heavy minerals in economic deposits ranges from less than 1 percent to about 25 percent. Zircon makes up a relatively small percentage of the economic heavy minerals in most deposits; thus, zircon is primarily a byproduct of heavy-mineral sand mining for the titanium minerals ilmenite and rutile.

In a review of some of the world's major coastal titanium- and zirconium-placer-forming regions, Hamilton (1995) noted the following three major factors that were common to all of them: (a) placer-forming regions lie on a trailing continental margin (Inman and Nordstrom, 1971), (b) margins are bounded by escarpments, and (c) heavy minerals were derived from Precambrian metamorphic bedrock regions and intermediate sedimentary hosts. Otherwise, individual deposits vary considerably in terms of their structure, location, and conditions of formation. Hamilton (1995) examined the controls on placer formation that act at different spatial and temporal scales and developed a conceptual model focused on the genetic characteristics of the placer-forming regions. The conceptual model is shown as a flow chart in figure V $5 \mathrm{~A}$, with broader controls, such as the tectonic setting and bedrock geology of a region, at the top and more localized controls, such as coastal plain morphology and coastal physiography, at the bottom. The shading and hatched patterns indicate the time scales at which the different controls occur, and the arrows indicate potential interactions between different controls within the placer-forming system. The rest of this section discusses some of these key controls and how they influence placer formation.

The most important long-term control on placer formation is tectonic setting. In general, major placer-forming regions form on passive margins, as illustrated by modern coastal placer regions on passive tectonic margins, such as the eastern coast of North America and South America and the western and southeastern coasts of Africa (fig. V3). Coastal placers can also form along both convergent and transform margins, as evidenced by placers along the Oregon coast (Coos Bay, Seven Devils Mine) (Peterson and others, 1986) and both the main islands of New Zealand (Brathwaite and Christie, 2006). The size of these deposits is small compared with those in some other regions, such as southern Australia and South Africa, however. Most major placer-forming regions overlie broad coastal plains of Mesozoic sediments, and all have an escarpment that separates the low-lying coastal plain from the hinterland, or the broad inland region behind the coastal plain that includes the piedmont and more distal regions of basement bedrock outcrops (fig. V4A). Escarpments are relatively dynamic features that act over intermediate time scales, and they are important because they (a) provide a mechanism for initiating erosion of bedrock through headwall retreat, (b) provide a mechanism to rejuvenate fluvial landscapes and evacuate stream valleys during periods of low sea level, thus providing sediment to the outer edge of the coastal plain for subsequent reworking and enrichment, (c) provide a distinct landward barrier to marine transgression that restricts the location of repeated reworking of coastal sediments during periods of rapid sea-level change, and (d) indicate tectonic instability or flexure along the margin that can elevate and preserve heavy-mineral concentrations near the escarpment (Hamilton, 1995).

The lithology of the hinterland region is the most variable aspect of the tectonic setting of major placer-forming regions. Most placers are adjacent to provinces underlain by Precambrian crystalline bedrock, whereas others were derived from basaltic terranes or Phanerozoic orogenic belts. Thus, Hamilton (1995) points out that, although lithology is an important control on the presence and abundance of economic minerals, there are other key influences on the degree of concentration and, therefore, the economic potential of placers and paleoplacers. The weathering history of the source region is perhaps most important in determining the likelihood of concentration of a suitable mineral suite. The most enriched modern placer systems are located at latitudes lower than $35^{\circ}$ (fig. V3; Force, 1991). Climatic change during the Cenozoic Era played an important role in the development of paleoplacer deposits worldwide directly through more intense weathering and, more indirectly, through repeated cycles of sea-level change (Force, 1991). Many of the major placer coastlines of the world underwent a shift from arid to tropical conditions during the Quaternary Period. This longer term trend, coupled with more rapid and repeated shifts in climate, produced large volumes of regolith in source areas, preferentially removed unstable minerals from existing coastal placers, and led to alternating periods of high and low sediment delivery to the coast. Repeated sea-level change associated with glacial-interglacial cycles caused multiple marine excursions across the continental margins, leading to extensive sediment reworking, heavy-mineral enrichment, and preservation of strandlines associated with sea-level highstands (fig. V4A). These processes were most significant 


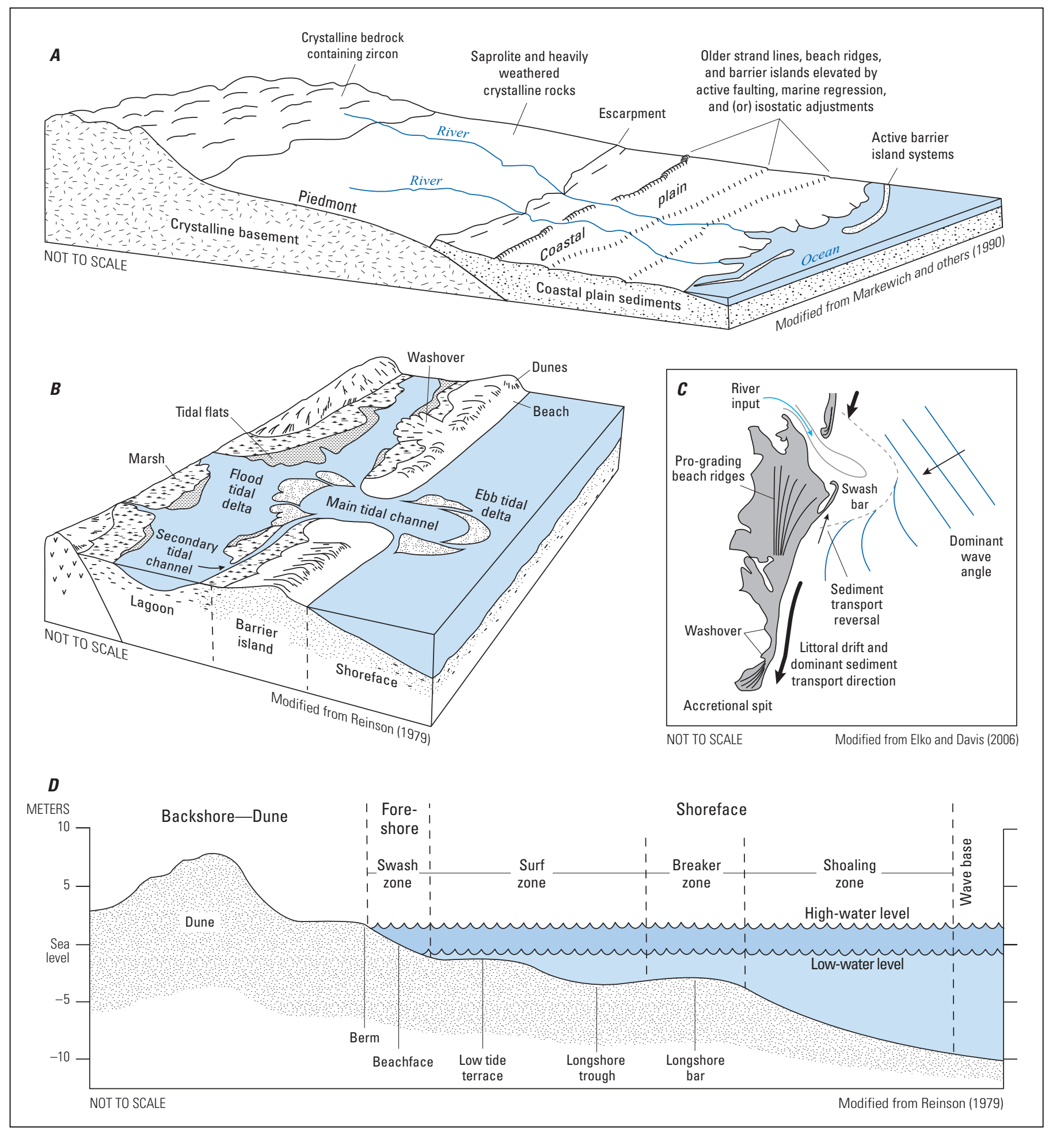

Figure V4. Examples of coastal depositional systems with an emphasis on barrier island location, morphology, and depositional environments. $A$, Schematic model for coastal placer systems. Zircon is derived from deeply weathered crystalline bedrock, delivered to the coast by river systems, and concentrated by a variety of factors, including wind and waves, storm events, tidal action, and ocean currents. Zircon may also be derived from older coastal plain sediment or offshore sediment. $B$, Depositional environments associated with barrier island systems. The highest concentration of zircon and other heavy minerals are found primarily in the beach, dune, and washover environments. $C$, Process-response model and features of a drumstick barrier island system along coasts, such as that of the Southeastern United States, that have a consistent supply of sediment from major rivers. Sediment is redistributed from river input in the direction of littoral drift (bold arrows), and heavy-mineral concentration occurs in the beach and washover environments. $D$, Generalized profile of barrier beach and shoreface environments. 
Figure V5. Influences on and locations of placer formation in coastal environments. $A$, Conceptual model showing influences on placer formation in coastal environments. Influences of the different components of the coastal system are indicated by arrows, and relative time scales for variability of select components are indicated by shading and diagonal lines. $B$ and $C$, Models for enrichment of heavy minerals in the coastal environment by $(B)$ littoral drift and $(C)$ washover in transgressive barriers. $D$, Schematic cross-section through an idealized barrier island complex showing four different types of heavy-mineral deposits and their association with host barrier environments: (1) lag deposits, which are formed along erosional discontinuities or surfaces between barrier islands of different ages; (2) transgressive deposits, which are formed at the rear of barrier islands immediately landward of the strand plain during periods of rising sea level; (3) regressive deposits, which are formed in barrier islands that have a consistent supply of sediment during periods of falling sea level; and (4) eolian dune deposits with relatively low-grade disseminated heavy-mineral deposits formed downwind from heavy-mineral-rich beaches.
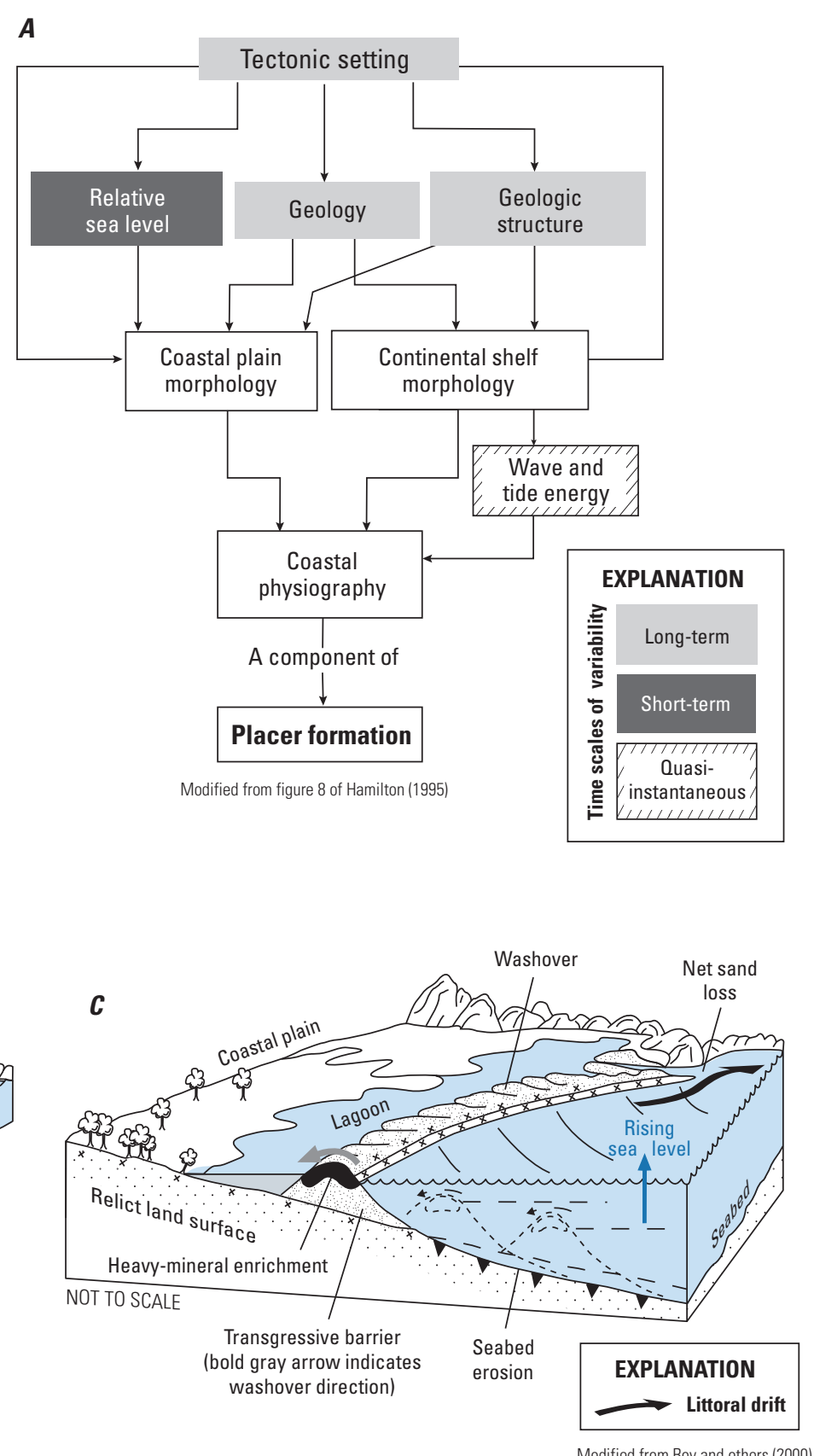

Modified from Roy and others (2000)
Modified from Roy and others (2000)

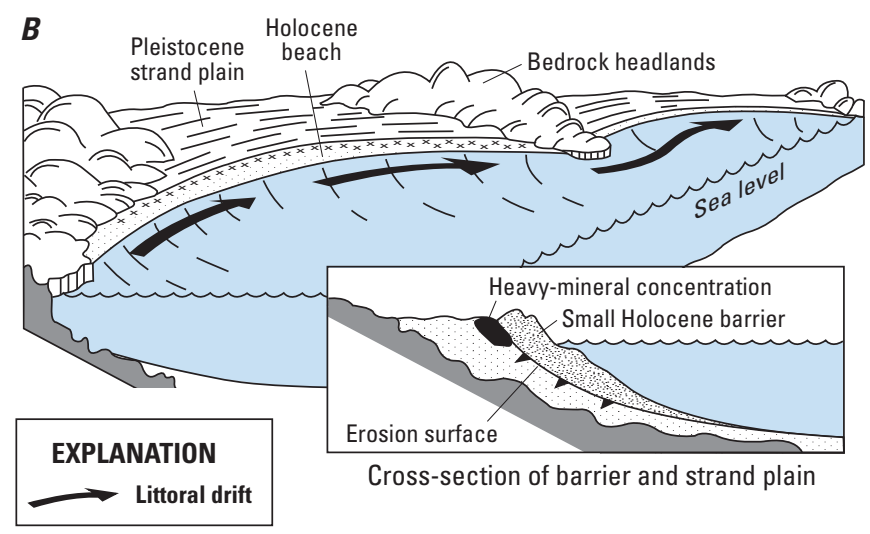

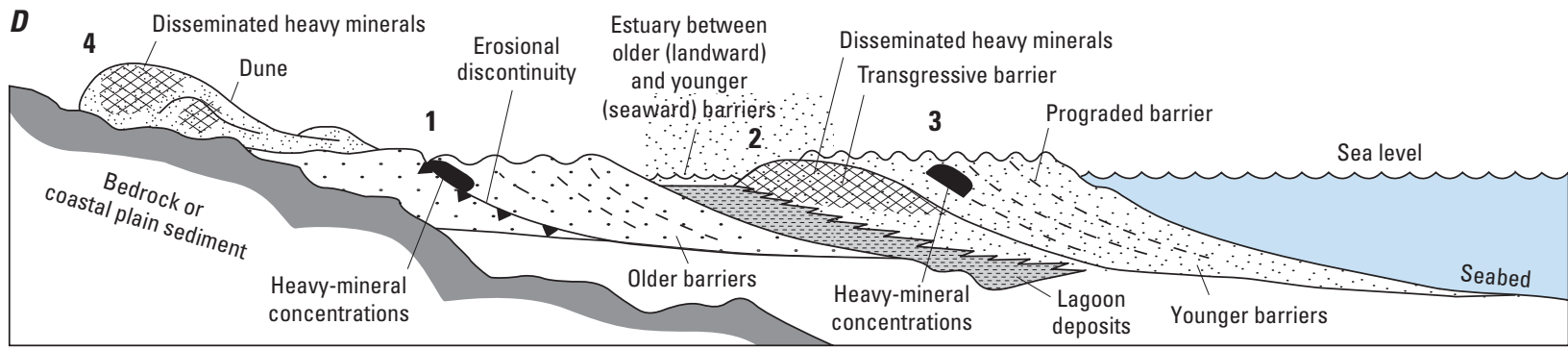

NOT TO SCALE 
for placers lying near the coast during the Quaternary Period, but similar processes have also been cited as important in Eocene to Pliocene deposits as well (Puffer and Cousminer, 1982; Carpenter and Carpenter, 1991; Hou and others, 2011).

Factors that vary over short-term, quasi-instantaneous time periods include tides, storms, winds, and waves. Microtidal coasts - that is, those with tidal ranges of less than $2 \mathrm{~m}$, such as those in southwestern Australia-have long been considered to be the most favorable for coastal placer development (Sutherland, 1985). In these systems, placers of beach (foreshore environment) and eolian (backshore or dune environment) origin are common (figs. V4B and V4D; for example, Hou and others, 2011). In mesotidal ( 2 to $4 \mathrm{~m}$ ) to macrotidal ( $>4 \mathrm{~m}$ ) systems, such as those of the Southeastern United States and eastern India, placers are more likely to be found in finer grained progradational beach-ridge systems associated with river mouths (fig. V4C; for example, Pirkle and others, 1984). Storms, winds, and waves can have more variable effects on coastal morphology and placer development. Storm events can significantly modify coastal geomorphology, and storm surges can erode offshore sand deposits along the continental shelf and produce substantial heavy-mineral enrichment in the shoreface and washover environments (figs. V4B and V4D; Leatherman and others, 1977; Roy, 1999; Roy and others, 2000; Buynevich and others, 2004). Strong onshore winds winnow shoreface deposits at low tide and ultimately transport sediment inland from the beach or foreshore environment, trapping deposits in the backshore environment well above sea level (figs. V4D and V5D; Roy, 1999). Economically important dune deposits formed by strong onshore winds are found in all regions except South Africa, where longshore winds are more significant for placer formation (MacDonald and Rozendaal, 1995). Trail Ridge, which is a prominent physiographic feature that extends for more than $160 \mathrm{~km}$ across Florida and Georgia, formed as a coast-parallel dune complex during a major Pleistocene sea-level highstand and has been an important domestic source of titanium minerals and zircon production since 1949 (fig. V3; Force and Rich, 1989).

Waves and ocean currents are perhaps the most important agents in producing economic heavy-mineral sand deposits. In areas such as southeastern Australia, where sands are not derived directly from rivers, waves drive large sand fluxes onshore and in longshore transport currents that move the sand along the coast from south to north in a process known as littoral drift (figs. V5B, and V5C; Roy, 1999). Prominent bedrock headlands along the drift-aligned coastlines trap heavy minerals on the up-drift side of embayments, and enrichment takes place along erosional surfaces between different-aged barriers (fig. V5B; Roy, 1999). Similar processes have been described in beach placers along the Oregon coast, where reversing seasonal currents serve to both winnow and subsequently preserve heavymineral sands in pockets adjacent to the headland (Komar and Wang, 1984; Peterson and others, 1986, 1987).
In areas with more consistent sediment supply from external sources, such as inland river systems or scouring of the sea bed, heavy minerals are concentrated in sand-rich barrier-island systems (figs. V4A and V4B). Reworking and concentration takes place primarily in the upper shoreface environment in the beach and washover environments, and heavy-mineral-rich sands are distributed and further fractionated during transport along the length of the barriers by littoral drift (figs. V4C and V5C; Roy, 1999). Many economic deposits in the Florida and Georgia coastal plain of the Southeastern United States occur where Pleistocene and Holocene beach ridges intersect ancestral to modern river systems, thus illustrating the importance of rivers as a source of heavy minerals in this particular coastal system (Hails and Hoyt, 1972; Pirkle and others, 1974, 1984). The deposits extend in the direction of littoral drift (south) for kilometers from the river intersection and help to define a series of long linear ridges that represent relict shorelines formed during a succession of marine transgressions from the Pleistocene Epoch to the present (Winker and Howard, 1977). Economic deposits occur locally in modern barrier islands adjacent to river mouths along the Florida and Georgia coasts, and some of these have been mined in the past (Pirkle and others, 2007).

Other factors may also exert local control over placer formation and distribution. These include tectonic effects, such as active faulting (Peterson and others, 1987; Roy and others, 2000), flexure (Cronin and others, 1984), or isostatic uplift (Opdyke and others, 1984) that might increase sediment supply, promote reworking, or enhance the potential for preservation. These effects, however, must be analyzed in the context of the other variables described above to adequately assess the prospectivity of a particular deposit or region.

\section{Resources and Production}

\section{Identified Resources}

World zircon reserves are estimated to be 78 million metric tons of contained zirconium oxide $\left(\mathrm{ZrO}_{2}\right)$ (Bedinger, 2015b). Domestic zirconium reserves are estimated to be 500,000 metric tons of $\mathrm{ZrO}_{2}$, and estimated resources include approximately 14 million metric tons of zircon associated with titanium resources in heavy-mineral sand deposits (Bedinger, 2015b).

Zircon production in the United States is a byproduct of mining and processing heavy-mineral sands for titanium minerals in Florida and Virginia. U.S. companies usually consider data on domestic production and consumption of zircon concentrates to be proprietary and generally withhold these data. U.S. exports of zirconium ore and concentrates generally declined from 2005 to 2011 (fig. V2C), and the United States was a net importer of zirconium ore and concentrate in 2011 for the first time since 1998 (Gambogi, 2012a). The United States is one of the leading world producers of zirconium and hafnium metal, along with France and Russia (Gambogi, 2012a). 
New heavy-mineral sand mines have been brought online in Kenya, Senegal, and South Africa in recent years. The Kwale project in Kenya began production in 2014 and was expected to produce 30,000 metric tons per year over a 60 -year mine life. The Tormin project in South Africa was expected to produce 48,000 metric tons per year of nonmagnetic concentrate grading 81 percent zircon and 11.6 percent rutile over a 4-year mine life. In Senegal, the Grand Côte project was expected to produce 85,000 metric tons per year during a mine life of 20 years. In the United States, a new zircon mine started up in southeastern Georgia in 2014, and a second mine was expected to begin production in late 2015 (Bedinger, 2015b).

\section{Other Resources}

Because of its relative ubiquity in crustal rocks and its high specific gravity, zircon is likely present in most if not all placer deposits, but it is not always recovered during placer mining. Placers and paleoplacers have been mined since humans first used metals (Garnett and Bassett, 2005), but the first economic extraction of zircon took place only in the first half of the 20th century (Elsner, 2010). Global zircon production has historically been a byproduct of titanium mineral extraction, and, thus, potentially significant economic concentrations of zircon might remain in tailings processed exclusively for titanium and other commodities, such as gold, iron, REEs, and tin. In KwaZulu, Natal, South Africa, a mine tailings treatment plant was commissioned at Richards Bay (fig. V3) to recover heavy-mineral concentrates, including zircon, from approximately 30 years of accumulated mine tailings initially processed primarily for titanium minerals (Gambogi, 2012a). Similar treatment plants are in development to recover titanium minerals and zircon from tailings of the Athabasca oil sands project in the Province of Alberta, Canada (fig. V3). Depending on future price fluctuations, economic concentrations of zirconium and hafnium ore minerals might also be recovered from tailings of primary igneous deposits, particularly in alkaline igneous provinces, such as in central Arkansas (Flohr and Ross, 1990). These two examples highlight the potential for recoverable resources from tailings in a wide variety of settings where zircon is not or was not the primary commodity of interest in the past but may be present at economic concentrations and is also relatively easy to extract.

In addition, older, lithified sedimentary units sourced from more fertile bedrock regions (Dickinson, 2008) could yield economic concentrations of zircon, especially in areas where the bedrock was deeply weathered. One such example is the Cretaceous Tokio Formation that is exposed in southwestern Arkansas, which contains ilmenite-bearing sands derived in part from deeply weathered alkaline intrusions in the surrounding area (Hanson, 1997). Zircon could be recovered during quarrying operations for sand, gravel, and aggregate in environments or regions where relatively fertile bedrock might be exposed (for example, continental rift systems or uplifts of crystalline bedrock) or where surficial heavy-mineral concentrations might exist (for example, river valleys, dunes, or high-energy coastal deposits).

\section{Exploration for New Deposits}

The process of identifying and evaluating heavy-mineral sand deposits requires careful consideration and assessment of the many variables outlined above. Exploration of modern to recent coastal placer systems is aided by the relative ease of identifying the coastal morphology and physiography, sediment supply and distribution systems, geologic setting, and climate history. Identifying and understanding the distribution, geometry, and evolution of paleoshorelines is more difficult because of the complex interactions between medium- to short-term factors and increased potential for reworking and burial. One notable example - the discovery and development of the Ambrosia and Jacinth heavy-mineral sand deposits in the Eucla basin of southern Australia (fig. V3; Hou and others, 2011) - provides a possible template for exploration. The Eucla basin initially was recognized as an extensive area of preserved Cenozoic marine sediment spanning approximately 50 million years (m.y.) of deposition with a high degree of preservation and high prospectivity for heavy-mineral deposits (Clarke and others, 2003, and references therein); however, early exploration revealed a need to better understand the geometry and evolution of the paleoshorelines to provide a focus for exploration. The reconstruction of complex sequences of coastal deposition constrained by a detailed chronology of major sea-level events (McGowran and others, 1997) and models for heavy-mineral concentration (Roy, 1999; Roy and others, 2000) led to successful prediction of new prospective sites and key discoveries (Hou and others, 2011). Mining at the Jacinth deposit was commissioned in 2009 , and more than 12 separate heavy-mineral prospects where zircon is the dominant component of the heavy-mineral assemblage have been identified (Hou and others, 2011). The Eucla basin represents an important new region of heavymineral sand resources; deposits in the region are capable of producing approximately 300,000 metric tons of zircon in their initial years of production.

Other regions with long records of Cenozoic coastal deposition remain the most prospective worldwide. Similar to the Eucla basin in Australia, the Gulf of Mexico Basin in the southern United States records more than 60 m.y. of sediment deposition and coastline evolution. Sufficient outcrop, seismic, and borehole data have been collected to describe the extent of various sedimentary facies associated with numerous depositional episodes in the Gulf of Mexico Basin. The basin includes volumetrically significant Paleocene through Miocene coastal plain and shore zone facies deposits (Galloway and others, 2000). The Gulf of Mexico Basin has been extensively evaluated for petroleum resources, but units representing paleoshorelines have not been thoroughly studied for the occurrence of heavy-mineral resources. 


\section{Environmental Considerations}

\section{Sources and Fate in the Environment}

The behaviors of zirconium and hafnium in the environment are very similar to one another-most notably, that zirconium- and hafnium-bearing minerals have limited solubility and reactivity in the environment. More literature is available on the behavior of zirconium than of hafnium, but the studies on zirconium are generally applicable to hafnium for the following reasons: the elements are extremely similar chemically (that is, they have almost identical atomic sizes and analogous electronic structures); they nearly always occur together; hafnium occurs in solid solution with zirconium in zircon; and hafnium is recovered as a byproduct during zirconium extraction. Anthropogenic sources of zirconium, and likely those of hafnium, are from industrial zirconiumcontaining byproducts and emissions from the processing of sponge zirconium; exposure to the general population from these elements is generally considered small (Schaller, 2004).

The concentrations of zirconium in soils, waters, and the air are significantly higher than those of hafnium because of the higher crustal abundance of zirconium. The mean concentration in soils worldwide is $300 \mathrm{ppm}$ (or 300 milligrams per kilogram [mg/kg]; the range is from 30 to $2,500 \mathrm{ppm}$ ) for zirconium compared with a mean concentration of $3 \mathrm{ppm}$ (and a range of from 2 to $20 \mathrm{ppm}$ ) for hafnium (KabataPendias and Mukherjee, 2007). According to Shacklette and Boerngen (1984), soils in the conterminous United States have zirconium concentrations that average $230 \mathrm{ppm}$ and range from less than 20 to 2,000 ppm; hafnium concentrations were not reported (Shacklette and Boerngen, 1984). According to Govindaraju (1994), reference soils from the United States contain between 2.5 to $17 \mathrm{ppm}$ hafnium, and average $7.3 \mathrm{ppm}$. The ratio of zirconium to hafnium concentrations in waters is usually similar to their ratio in soils, but their concentrations are commonly very low because they are relatively immobile compared with some other elements (Gaillardet and others, 2003). Concentrations of less than 1 part per billion (ppb) (or 1 microgram per liter) for zirconium are common for natural waters, and concentrations for hafnium are typically less by an order of magnitude. According to Reimann and de Caritat (1998), the median dissolved and total concentrations in stream waters worldwide range from 0.01 to $0.9 \mathrm{ppb}$ for zirconium and from 0.009 to $0.03 \mathrm{ppb}$ for hafnium. Gaillardet and others (2003) reported average global dissolved concentrations in rivers of $0.04 \mathrm{ppb}$ for zirconium and $0.006 \mathrm{ppb}$ for hafnium. Industrial emissions likely do not increase these concentrations significantly (Schaller, 2004). Zirconium and hafnium are found in higher proportions in sediment in rivers than in the dissolved fraction. Globally, the average concentration in suspended sediments in rivers is $160 \mathrm{ppm}$ for zirconium and $4.4 \mathrm{ppm}$ for hafnium (Viers and others, 2009). In the atmosphere, zirconium concentrations for industrial regions range from 0.2 to 7 parts per trillion (ppt) (or 0.7 to 26 nanograms per cubic meter $\left[\mathrm{ng} / \mathrm{m}^{3}\right]$ ) for zirconium and reach more than
$0.09 \mathrm{ppt}\left(0.32 \mathrm{ng} / \mathrm{m}^{3}\right)$ for hafnium (Reimann and de Caritat, 1998; Kabata-Pendias and Mukherjee, 2007).

Little reported information is available on the pre-mining geochemical signatures of soils, sediment, and waters around heavy-mineral sand deposits and around the carbonatite deposit in Russia that is currently being mined for zirconium and hafnium. In general, carbonatites, soils, stream sediments, and weathered rock may be enriched in iron, niobium, phosphorus, REEs, thorium, and uranium before mining (Modreski and others, 1995); if baddeleyite is present, zirconium and hafnium may also be enriched. Because most of these elements (that is, hafnium, niobium, REEs, thorium, uranium, and zirconium) occur in relatively stable insoluble minerals, the stream water and groundwater around the deposits may not display the same geochemical signature as the soils and stream sediments (Modreski and others, 1995).

Only small amounts of zirconium and hafnium are recycled. Less than 1 percent of discarded zirconium and hafnium metal or alloy is recycled or reused worldwide, and the recycled content of zirconium in products globally is only between 1 and 10 percent; estimates were not available for hafnium (Graedel and others, 2011). The recycled content includes both new (loss during manufacturing products that is transferred to the scrap market) and old (post-consumer) scrap (Graedel and others, 2011). Most of the zirconium recycled is from scrap generated during metal production and fabrication, and hafnium metal recycling is insignificant (Loferski, 2013b). The low proportions of these minerals that are recycled may be a reflection of the complex materials, such as electronic equipment, that they are used in; the technical difficulty of recycling them; and the small amounts used in these products. Also, the long lifetime of some products in which zirconium and hafnium are used make the minerals' return to production very slow. One recent research study suggests a new method for economically recovering and recycling zirconium from used nuclear fuel cladding (Collins and others, 2011).

\section{Mine Waste Characteristics}

The volume and characteristics of mine waste produced from the recovery of zirconium and hafnium depend on the deposit type exploited and its size. Currently, the most important deposits for zirconium and hafnium are heavymineral sands and carbonatites.

\section{Volume of Mine Waste}

Processing heavy-mineral sands at a mine site produces waste material that includes tailings and slimes. Mechanical separation produces quartz-rich tailings after the heavy minerals are separated out. During wet concentration, slimes, which consist of a slurry of fine-grained materials (commonly clay minerals) are separated from the quartz and heavy minerals and mixed with a flocculent to cause settlement of the clay minerals and other clay-sized particles. 
The percentages of heavy minerals and clay minerals in a deposit are variable and consequently result in various amounts of the different types of waste. Generally, heavy minerals make up from 1 to 25 percent of the material in economic deposits but additional natural sorting can concentrate them further. Zircon is only a small fraction of the total heavy-mineral content of a deposit. Heavy-mineral sand deposits in Western Australia, two deposits in India (Sattankulam and Kuttam), and one deposit in southeastern Virginia (Old Hickory) contain up to 10 percent heavy minerals (Murty and others, 2007; Zimmerman and others, 2008). In contrast, heavy-mineral sands on the northeast coast of Sri Lanka (the Pulmoddai deposit) are very high grade and contain up to 80 percent heavy minerals, including ilmenite (70 percent), zircon ( 8 to 10 percent), rutile ( 8 percent $)$, sillimanite ( 1 percent $)$ and monazite $(0.3$ percent $)$; approximately 2 percent of the sand is clay sized (Premaratne and Rowson, 2003). Approximately 15 percent, by volume, of the two heavy-mineral sands deposits in India is clay sized and would be separated out and disposed of as slime (Murty and others, 2007). The measured reserves of these two deposits are estimated to be 400 million metric tons of raw sand that covers approximately $120 \mathrm{~km}^{2}$ (Murty and others, 2007). The amount of waste generated by these two deposits would be much greater than for the smaller $\left(3.2 \mathrm{~km}^{2}\right)$ but higher grade deposit in Sri Lanka (Premaratne and Rowson, 2003). For another comparison, up to $50 \mathrm{~km}^{2}$ of land could potentially be mined for heavy minerals $\mathrm{d}$ in the coastal plain region of the Southeastern United States (Daniels and others, 2003). The modern mining of these deposits, along with many other heavy-mineral sand deposits worldwide, commonly involves removing the organic soil layer (if present), mining the sands, and then backfilling with tailings and slimes and replacing the organic soil layer. For operations that restore the landscape to pre-mining conditions, the volume of waste and its impact on the landscape is generally only a temporary land-use issue.

A variety of types of mine waste have been produced at the Kovdor Mine in Murmanskaya Oblast, Russia, which is the only carbonatite deposit from which zirconium and hafnium are currently being recovered. The Kovdor carbonatite complex in Russia has been mined for a variety of ores that include apatite-baddeleyite-magnetite, phlogopite, and vermiculite, and estimating the large expanses of mine waste within the complex is challenging. One report by the Kola Science Center of the Russian Academy of Sciences (1999) reported volume estimates for waste produced before the end of 1994. The amount of overburden rock stripped and stored at the mine site was estimated to be more than 700 million metric tons; a small fraction of the overburden was used for construction purposes. In addition to overburden, mine waste included more than 61 million metric tons of low-iron-content rock and approximately 10 million metric tons of apatite-staffelitebearing rock. (Staffelite is carbonate-rich fluorapatite.) The site contained a total of nearly 200 million metric tons of tailings, including 64 million metric tons from the processing of magnetite ore that was available for recovery of apatite and baddeleyite. As of 1994, 6 million metric tons of tailings had already been processed to recover apatite, baddeleyite, and magnetite (Russian Academy of Sciences, 1999).

\section{Mineralogy and Chemistry of Slimes and Tailings}

The mineralogy and chemistry of the slimes and tailings produced at heavy-mineral sand mines worldwide have many similarities; however, differences in the proportions of some minerals result in some variations. For example, slimes from the mineral-sand deposits in India contain mostly hematite, kaolinite, and quartz (Murty and others, 2007), whereas slimes from the Yoganup North Mine in Western Australia contain predominantly kaolinite ( 80 percent) and lesser amounts of quartz (10 percent) and goethite (10 percent) (Fujiyasu and others, 2000). Another example is the heavy-mineral sand deposit on the northeast coast of Sri Lanka, where the separation process for the concentrate generates a low-density fraction ( 24 percent) of quartz-rich tailings, a nonmagnetic heavy fraction (21 percent) that contains rutile and zircon, and a magnetic heavy fraction (55 percent) of mostly ilmenite and pseudorutile (Premaratne and Rowson, 2003).

Several studies have been conducted that characterize the composition of waste dumps in various stages of reclamation (that is, of reclamation pits) at heavy-mineral sand processing sites in Florida and Virginia (Daniels and others, 1992, 2003; Orndorff and others, 2005). In 2007, the deposit at the Old Hickory Mine in Virginia contained an average of 7 percent heavy minerals and an average of 35 percent clay minerals (the range of clay minerals was from 5 to 50 percent) (Zimmerman and others, 2008); the heavy minerals found at this mine were very similar to those contained in the nearby Brink and Concord deposits and included ilmenite, leucoxene, rutile, and zircon. One study examined soil profiles from within the reclamation pits at the Old Hickory Mine (these materials are referred to as "soils" despite being altered by mining). The reclamation pit soils were mixed slimes and tailings deposited as a slurry and left to dewater; then, soil amendments, including biosolids, fertilizer, and lime, were added. The slimes, which were composed mostly of kaolinite and lesser amounts of other clay minerals (vermiculite and smectites), were shown to separate from the quartz-rich tailings in the pits, which leads to lateral and vertical variability within the pits. The surface horizon (that is, the upper 10 to 24 centimeters) in the pits, most of which had been amended with biosolids and lime, had near neutral $\mathrm{pH}$ values and contained up to 1.5 percent organic matter. In contrast, samples collected from below the surface material were generally acidic and contained little organic matter (Orndorff and others, 2005). Extractable concentrations of several elements, including phosphorus $(<100 \mathrm{ppm})$, magnesium $(<300 \mathrm{ppm})$, potassium $(<400 \mathrm{ppm})$, and calcium $(<3,000 \mathrm{ppm})$, were generally low in both surface and subsurface samples, despite fertilizer and lime additions (Daniels and others, 2003). Although no obvious deficiency symptoms were noted in 
vegetation growing on the pits, the acid extractable amounts of some micronutrients, such as copper $(<2 \mathrm{ppm})$, zinc $(<6 \mathrm{ppm})$, and boron $(<1 \mathrm{ppm})$ were low (Daniels and others, 2003). Another study (Daniels and others, 1992) examined mine soils from the Green Cove Springs Mine in Florida. The reclamation pit soils there are similar to those at the Old Hickory Mine in that the amended surface layers are more organic-rich than the subsurface samples; in contrast to the Virginia sites, however, very little clay material was found in the Florida deposit (Daniels and others, 1992). Both the natural and mine soils in the subsurface are acidic at the site in Florida.

The composition of mine waste produced from the recovery of baddeleyite from igneous deposits is very different from that produced from the recovery of zircon from heavy-mineral sand deposits. At the Kovdor deposit in Russia, baddeleyite is recovered as a byproduct of apatite and magnetite mining. Currently, the minerals are recovered from the ore in three sequential steps that begin with separating out the magnetite by magnetic concentration. The tailings from this first step are then processed by flotation to recover apatite and, finally, the post-apatite tailings are used to recover baddeleyite. According to Petrov (2004), the final tailings at the Kovdor Mine consist almost entirely of calcite and forsterite. Tailings produced before the recovery of apatite (recovery began in 1975) and baddeleyite (recovery began in 1977) are currently being reprocessed to recover these minerals. Kononov and others (1992) reported that these tailings contain the following: forsterite (50 to 60 weight percent), carbonates (20 to 25 weight percent), apatite ( 5 to 10 weight percent), and baddeleyite $(<0.15$ weight percent). Similarly, Zosin and others (2011) reported that the mineralogy of the tailings currently being produced at the site is dominated by apatite, carbonates, and forsterite (greater than 25 weight percent each), along with some phlogopite (approximately 12 weight percent), and lesser amounts of diopside and magnetite. In addition to tailings, overburden is an additional waste product and contains mostly pyroxene and amphibole (approximately 40 weight percent combined total), carbonate (approximately 20 weight percent), and minor amounts of apatite, forsterite, mica, and other minor minerals ( $<12$ weight percent each) (Zosin and others, 2011).

In addition to the Kovdor deposit, baddeleyite has been recovered in the past as a byproduct of copper and phosphate (apatite) mining of the Palabora carbonatite complex in Limpopo Province, South Africa. Tailings from the main operation circuit were reprocessed by gravity separation to recover baddeleyite and uranium oxides. In 1990, approximately 15,000 metric tons of baddeleyite were recovered from 29 million metric tons of ore (Towner, 1992, p. 4). The mine waste and tailings produced from exploiting this complex have a different mineralogy and chemistry than those generated at Kovdor because of differences in the compositions of the ores. In addition to apatite, baddeleyite, magnetite and vermiculite, the Palabora ore also contains economic amounts of copper sulfides (primarily chalcopyrite and bornite) and uranium minerals (uraninite-thorite).

\section{Acid-Base Accounting}

Little information quantifying the acid-generating and acid-neutralizing potentials of mine waste from heavymineral sands and from the Kovdor carbonatite complex is available. One study in Australia examined the potential of heavy-mineral sands to generate acid at a specific deposit (Landers and Usher, 2012). This work revealed that potentially acid-generating material was found within the deposit owing to the presence of pyrite. Sulfur at this deposit is present almost entirely as sulfide and occurs in the organic-rich layers of overburden materials (at a median grade of 0.66 percent sulfur) and in the orebody (at a median grade of 1.10 percent sulfur). The maximum potential acidity (that is, the maximum amount of sulfuric acid that could be produced) was low to moderate, with median values of 20 and 34 kilograms of calcium carbonate per metric ton $\left(\mathrm{kg} \mathrm{CaCO}_{3} / \mathrm{t}\right)$ reported for organic-rich overburden and ore, respectively. The acid neutralizing capacity (that is, the amount of acid the sample can neutralize) was extremely low, and the paste $\mathrm{pH}$ (that is, the $\mathrm{pH}$ of water after it is mixed with a sample) values were highly acidic for ore and organic-rich overburden (Landers and Usher, 2012). Overall, much of the heavy-mineral sands ore material and some of the overburden have the potential to generate acid; the overburden that is not organic-rich is unlikely to generate acid. In general, heavy-mineral sands do not contain significant amounts of carbonates and offer little buffering capacity. Therefore, even trace amounts of sulfides can result in an acid-generating material. At the Green Cove Springs Mine in Florida, natural as well as reclamation pit soils were acidic (Daniels and others, 1992) and, at the Old Hickory Mine in Virginia, the subsurface material in the reclamation pits was generally acidic $(\mathrm{pH}<5.5)$ (Orndorff and others, 2005). At the Old Hickory Mine, the clay-rich layers within the waste piles were commonly strongly acidic and any neutral soil $\mathrm{pH}$ was at the surface because of the addition of lime to the piles.

In contrast to heavy-mineral sand deposits that commonly lack carbonate minerals, carbonatite deposits are carbonate rich. Pyrite, pyrrhotite, and several other sulfides that may be present in carbonatites have the potential to produce metal-rich acidic drainage but, in most cases, carbonates in the host rocks neutralize the acidity (Modreski and others, 1995). The Kovdor carbonatite deposit contains chalcopyrite, pyrite, and pyrrhotite but is dominated by calcite and dolomite (Petrov, 2004). Reshetnyak and others (2008) noted high concentrations of sulfate as well as high $\mathrm{pH}$ for groundwater draining from the Kovdor Mine site. The source of sulfate is likely from the oxidation of sulfides, which can produce acid, depending on the sulfide mineralogy; the high $\mathrm{pH}$ results from buffering during the dissolution of carbonates. 


\section{Human Health Concerns}

Zirconium and hafnium are likely not essential for human health and generally are considered elements of low toxicity to humans (Reimann and de Caritat, 1998). They can enter the human body by ingestion, inhalation, or dermal contact. Guidelines for drinking water and the consumption of aquatic organisms have not been established by the U.S. Environmental Protection Agency (EPA) for zirconium or hafnium and their toxicities have not been reviewed by the Agency for Toxic Substances and Disease Registry (ATSDR) or the World Health Organization (WHO). Also, the carcinogenic potentials of zirconium and hafnium have not been examined by the International Agency for Research on Cancer (IARC) (U.S. Environmental Protection Agency, 2012).

Human health concerns regarding exposure to zirconium and hafnium may be associated with industrial inhalation and dermal exposure. The EPA, in an attempt to define a toxicity value for soluble zirconium to be used at hazardous waste sites, reviewed relevant toxicity literature on human and animal studies from 1900 to 2012 and found that not enough information was available to derive a Provisional PeerReviewed Toxicity Value for Superfund (U.S. Environmental Protection Agency, 2012). The EPA has not conducted a comparable investigation on hafnium toxicity. The following is a summary of the findings reported by the EPA on zirconium (U.S. Environmental Protection Agency, 2012):

- Ingestion of large quantities of zirconium was shown to cause health issues in humans in one study, but this type of oral exposure is not likely to occur even in industrial settings.

- Some inhalation studies of workers producing or working with zirconium and hafnium metals and compounds have reported respiratory tract irritation, dermatitis, pulmonary fibrosis, and one case of an acute allergic hypersensitivity reaction that led to death.

- Several other industrial inhalation exposure studies on zirconium compounds found no abnormities or health issues.

- A few dermal exposure studies suggest zirconium may cause dermal lesions.

In addition to the EPA report (U.S. Environmental Protection Agency, 2012) and references therein, evidence that human exposure to zirconium compounds may cause inflammation of the skin was reported in Schaller (2004). The only toxicity symptoms reported from hafnium were for individual allergic sensitivity (Kabata-Pendias and Mukherjee, 2007).

Mining and dry separation processes conducted on heavy-mineral sands creates high amounts of airborne dust, which leads to inhalation and, to a lesser extent, dermal exposure. Elevated concentrations of zirconium have been detected in the lungs, blood, and urine of heavy-mineral sands miners (Patty and others, 1981). In the United States, the permissible exposure limits for zirconium and hafnium compounds in an 8-hour workday are 1.3 and $0.07 \mathrm{ppm}$ (5 and 0.5 milligrams per cubic meter), respectively (Occupational Safety and Health Administration, 2013). The radioactivity of the dust is also a concern during processing steps that concentrate radioactive minerals. For example, dry processing heavy-mineral sands to concentrate monazite increases radiation levels. Control measures, such as adequate ventilation and air filters, reduce the exposure levels to just the dust encountered during mining and milling operations.

\section{Ecological Health Concerns}

Because of the low solubility of zirconium and hafnium, ecological health concerns in the aquatic environment are minimal. Suter (1996) proposed values of between 982 and $54.9 \mathrm{ppb}$ zirconium as secondary acute and chronic toxicological benchmarks, respectively, for freshwater biota; hafnium was not considered. The benchmarks were established using fewer data than required to establish EPA aquatic water-quality criteria (Suter, 1996). For comparison to the benchmarks, mean concentrations of zirconium in stream waters worldwide are between 0.9 and $90 \mathrm{ppb}$ (Reimann and de Caritat, 1998). An estimated lowest chronic toxicity value for fish is $548 \mathrm{ppb}$ based on a lethal concentration for 50 percent $\left(\mathrm{LC}_{50}\right)$ of the test animals (Suter, 1996). Borgmann and others (2005) reported that the toxicity risk of hafnium to freshwater amphipods (Hyalella azteca) is low and comparable to that of zirconium. The $\mathrm{LC}_{50}$ in controlled laboratory tests was estimated to be greater than $1,000 \mathrm{ppb}$ for both zirconium and hafnium (Borgmann and others, 2005) values that are more than 10 times greater than the worldwide mean concentrations.

Similar to the aquatic environment, ecological health concerns from zirconium and hafnium in soils are minimal. Only a small proportion of zirconium in soil is taken up by plants, and it does not accumulate in the food chain. Also, the low mobility of zirconium within the plant organs is evidenced by its commonly higher concentrations in the roots than in the top vegetation (Kabata-Pendias and Mukherjee, 2007). Despite the low soil mobility and bioavailability of zirconium, Shahid and others (2013) and references therein reported some cases of reduced plant growth and modifications in enzyme activities owing to zirconium uptake by plants.

Although zirconium and hafnium are usually not of environmental concern from mining, other associated metals are potentially deleterious to the environment, especially if concentrated in mine waste or tailings. Tailings from some carbonatite mines in particular contain significant concentrations of thorium and uranium (Modreski and others, 1995) and other heavy metals. For example, waters draining tailings piles at the Kovdor Mine in Russia contain copper, manganese, 
and strontium in concentrations higher than local water quality guidelines (Zosin and others, 2011). Also, apatite, baddeleyite, and zircon from the Kovdor deposit have been shown to be enriched in thorium and uranium (Amelin and Zaitsev, 2002) and tailings containing these minerals have the potential to be radioactive. The final baddeleyite concentrate at the Kovdor Mine was reported to contain low radioactivity ( 59 becquerels per gram) (Petrov, 2004), suggesting that the tailings, likewise, are only minimally radioactive.

Another ecological concern specifically related to mine sites involves the failure of tailings dams. This hazard poses an ecological concern at heavy-mineral sand mines and igneous rock deposits. In 2010, a settling pond at the Moma heavy-mineral sands mine in Mozambique breached its retaining wall and released water, sand, and clay that flooded a nearby village, causing one fatality and extensive damage to property (Gambogi, 2012a). Also, the release of large amounts of mining waste into downstream waterways physically suffocates aquatic biota and releases metals into waters and sediments. No known tailings dam failure at a heavy-mineral sand mine has taken place in the United States.

\section{Mine Closure}

Heavy-mineral sand mining leads to increased erosion rates when improperly managed, disturbs the surrounding ecosystem, and alters the character of the land. Tailings and slimes are used as backfill or disposed of in large waste piles. Commonly, the topsoil initially removed at a site is stored during mining and either mixed with tailings and slimes or placed on top of waste piles; topsoil and other amendments, such as lime, fertilizers, and biosolids, added to the waste facilitate the return of vegetation. The disturbed mined lands can be successfully returned to local region agricultural levels when these sorts of reclamation practices are used based on results reported in Orndorff and others (2011) and Zimmerman and others (2008) from the Old Hickory Mine in Virginia. At the Green Cove Springs Mine in Florida, returning the land to pine forest involved rebuilding the landform with tailings, replacing topsoil, reestablishing the growth of the pines and ensuring surface stabilization from re-colonization of grasses (Brooks, 2000). In Australia, farmland in Western Australia was reclaimed for grazing by mixing clay slimes into the soils to improve their capacity to hold water and adsorb plant nutrients. Also in Australia, sand dunes mined in New South Wales and Queensland were reclaimed by reestablishing the original slope and landforms and performing surface stabilization and revegetation (Brooks, 2000). In general, many of the lands mined for heavy-mineral sands have been reclaimed to native conditions and returned to productive uses.
Closure plans for the current mining operation at the Kovdor complex will involve management of the large open pit as well as the extensive waste piles. Future plans for the mine, which is expected to continue operations until at least 2032, include developing a deeper mine pit that will reach a depth of $900 \mathrm{~m}$ by expanding the current Zhelezny open pit operation that is $2.4 \mathrm{~km}$ long, $1.6 \mathrm{~km}$ wide, and $170 \mathrm{~m}$ deep without any significant enlargement of the pit rim (Ellenbecker, 2011). At mine closure, the large open pit is likely to be partially backfilled and flooded. Also, overburden, mine waste, and tailings piles that are presently several kilometers in length are expected to be expanded by future operations (Russian Academy of Sciences, 1999). Reclamation options for the waste piles include regrading, capping, adding soil amendments, revegetating, and possibly treating drainage and seepage waters.

\section{Problems and Future Research}

Because of the relative ubiquity of zircon in crustal rocks and the worldwide distribution of coastal environments with favorable geometries and conditions for placer formation (fig. V3), the outlook for zirconium and hafnium supply is generally favorable. In modern coastal environments, an integrated understanding of coastal morphology, sediment supply and distribution systems, geologic setting, and climate history is key for identifying and delineating heavy-mineral concentrations. In older coastal systems, relatively recent discoveries of significant heavy-mineral deposits in the Eucla basin of southern Australia (fig. V3; Hou and others, 2011) highlight the potential usefulness of a detailed reconstruction of major sea-level events combined with models for heavy-mineral concentration. The Gulf of Mexico Basin of the southern United States is a particularly prospective region with a long history of Cenozoic deposition and volumetrically significant Paleogene through Miocene coastal plain and shore zone facies deposits (Galloway and others, 2000). There is also potential for recoverable zirconium and hafnium resources in a wide variety of settings, including from tailings, where zircon is or was not the primary commodity of interest but may still be present at economic concentrations and is also relatively easy to extract.

Zirconium- and hafnium-bearing minerals have generally low solubility and reactivity; consequently, these elements do not pose significant threats to human health or the health of ecological systems. In heavy-mineral sand mining operations, the main environmental impact is landscape disruption by surface mining. It is common for modern mineral-sand mines to restore the landscape to pre-mining conditions. Thus, in many cases, the volume of mine waste and its impact on the landscape is generally only a temporary land-use issue. 


\section{References Cited}

Note: All Web links listed were active as of the access date but may no longer be available.

Ahrens, L.H, and Erlank, A.J., 1969, Hafnium, in Wedepohl, K.H., ed., Handbook of geochemistry, v. 2, pt. 5: Berlin, West Germany, Springer-Verlag.

Amelin, Yuri, and Zaitsev, A.N., 2002, Precise geochronology of phoscorites and carbonatites - The critical role of U-series disequilibrium in age interpretations: Geochimica et Cosmochimica Acta, v. 66, no. 13, p. 2399-2419. [Also available at http://dx.doi.org/10.1016/s0016-7037(02)00831-1.]

Arzamastsev, A.A., Glaznev, V.N., Raevsky, A.B., and Arzamastseva, L.V., 2000, Morphology and internal structure of the Kola alkaline intrusions, NE Fennoscandian Shield - 3D density modeling and geological implications: Journal of Asian Earth Sciences, v. 18, no. 2, p. 213-228. [Also available at http://dx.doi.org/10.1016/s1367-9120 (99)00052-8.]

Bailey, D.K., 1987, Mantle metasomatism-Perspective and prospect, in Fitton, J.G., and Upton, B.G.J., eds., Alkaline igneous rocks: Oxford, United Kingdom, Blackwell Scientific, Geological Society of London Special Publications Series, v. 30, p. 1-13. [Also available at http://dx.doi.org/10.1144/gsl.sp.1987.030.01.02.]

Bau, Michael, 1996, Controls on the fractionation of isovalent trace elements in magmatic and aqueous systemsEvidence from $\mathrm{Y} / \mathrm{Ho}, \mathrm{Zr} / \mathrm{Hf}$, and lanthanide tetrad effect: Contributions to Mineralogy and Petrology, v. 123, no. 3, p. 323-333. [Also available at http://dx.doi.org/10.1007/ s004100050159.]

Bedinger, G.M., 2014, Zirconium and hafnium [advance release], in Metals and minerals: U.S. Geological Survey Minerals Yearbook 2012, v. I, p. 85.1-85.8, accessed June 3, 2016, at https://minerals.usgs.gov/minerals/pubs/ commodity/zirconium/myb1-2012-zirco.pdf.

Bedinger, G.M., 2015a, Zirconium and hafnium [advance release], in Metals and minerals: U.S. Geological Survey Minerals Yearbook 2013, v. I, p. 85.1-85.7, accessed June 3, 2016, at https://minerals.usgs.gov/minerals/pubs/ commodity/zirconium/myb1-2013-zirco.pdf.

Bedinger, G.M., 2015b, Zirconium and hafnium: U.S. Geological Survey Mineral Commodity Summaries 2015, p. 188-189. [Also available at http://minerals.usgs.gov/minerals/pubs/ commodity/zirconium/mcs-2015-zirco.pdf.]

Bell, Keith, Dunworth, E.A., Bulakh, A.G., and Ivanikov, V.V., 1996, Alkaline rocks of the Turiy Peninsula, Russia, including type-locality turjaite and turjite-A review: Canadian Mineralogist, v. 34, pt. 2, p. 265-280. [Also available at http://rruff.info/doclib/cm/vol34/CM34_265.pdf.]
Bergman, S.C., 1987, Lamproites and other potassium-rich igneous rocks - A review of their occurrence, mineralogy and geochemistry, in Fitton, J.G., and Upton, B.G.J., eds., Alkaline igneous rocks: Oxford, United Kingdom, Blackwell Scientific, Geological Society of London Special Publications Series, v. 30, p. 103-190. [Also available at http://dx.doi.org/10.1144/gsl.sp.1987.030.01.08.]

Borgmann, Uwe, Couillard, Yves, Doyle, Patrick, and Dixon, D.G., 2005, Toxicity of sixty-three metals and metalloids to Hyalella azteca at two levels of water hardness: Environmental Toxicology and Chemistry, v. 24, no. 3, p. 641-652. [Also available at http://dx.doi.org/10.1897/04-177r.1.]

Brathwaite, R.L., and Christie, A.B., 2006, Review of shoreline placer ilmenite deposits in New Zealand, in Christie, A.B., and Brathwaite, R.L., eds., Geology and exploration of New Zealand mineral deposits: Australasian Institute of Mining and Metallurgy Monograph series, v. 25, p. 43-48.

British Geological Survey, 2012, Risk list 2012-An update to the supply risk index for elements or element groups that are of economic value: Keyworth, Nottingham, United Kingdom, British Geological Survey, 12 p., accessed June 19, 2013, at https://www.bgs.ac.uk/downloads/ start.cfm?id=2643.

Brooks, C.K., 1969, On the distribution of zirconium and hafnium in the Skaergaard intrusion, East Greenland: Geochimica et Cosmochimica Acta, v. 33, no. 3, p. 357-374. [Also available at http://dx.doi.org/10.1016/0016-7037 (69)90168-9.]

Brooks, C.K., 1970, The concentrations of zirconium and hafnium in some igneous and metamorphic rocks and minerals: Geochimica et Cosmochimica Acta, v. 34, no. 3, p. 411-416. [Also available at http://dx.doi.org/10.1016/ 0016-7037(70)90117-1.]

Brooks, D.R., 2000, Reclamation of lands disturbed by mining of heavy minerals, in Barnhisel, R.I., Darmondy, R.G., and Daniels, W.L., eds., Reclamation of drastically disturbed lands: Madison, Wis., American Society of Agronomy, Crop Science Society of America, Soil Science Society of America, Agronomy monograph 41, p. 725-754. [Also available at http://dx.doi.org/10.2134/agronmonogr41.c29.]

Buynevich, I.V., FitzGerald, D.M., and van Heteren, Sytze, 2004, Sedimentary records of intense storms in Holocene barrier sequences, Maine, USA: Marine Geology, v. 210, nos. 1-4, p. 135-148. [Also available at http://dx.doi.org/ 10.1016/j.margeo.2004.05.007.]

Carpenter, R.H., and Carpenter, S.F., 1991, Heavy mineral deposits in the upper coastal plain of North Carolina and Virginia: Economic Geology, v. 86, p. 1657-1671. [Also available at http://dx.doi.org/10.2113/gsecongeo.86.8.1657.]

Černý, P., and Siivola, J., 1980, The Tanco pegmatite at Bernic Lake, Manitoba, XII. Hafnian zircon: Canadian Mineralogist, v. 18, pt. 3, p. 313-321. 
Chakhmouradian, A.R., and Wall, Frances, 2012, Rare earth elements-Minerals, mines, magnets (and more): Elements, v. 8, no. 5, p. 333-340. [Also available at http://dx.doi.org/ 10.2113/gselements.8.5.333.]

Clarke, J.D.A., Gammon, P.R., Hou, B., and Gallagher, S.J., 2003, Middle to late Eocene stratigraphic nomenclature and deposition in the Eucla basin: Australian Journal of Earth Sciences, v. 50, no. 2, p. 231-248. [Also available at http://dx.doi.org/10.1046/j.1440-0952.2003.00995.x.]

Collins, E.D., Del Cul, G.D., Terekhov, D.S., and Emmanuel, N.V., 2011, Recycle of zirconium from used nuclear fuel claddingA major element of waste reduction: WM2011, 37th Annual Radioactive Waste Management Symposium, February 27March 3, 2011, Phoenix, Ariz., Proceedings, 6 p., accessed February 1, 2013, at http://www.wmsym.org/archives/2011/ papers/11336.pdf.

Condie, K.C., and Lo, H.H., 1971, Trace element geochemistry of the Louis Lake batholith of early Precambrian age, Wyoming: Geochimica et Cosmochimica Acta, v. 35, no. 11, p. 1099-1119. [Also available at http://dx.doi.org/ 10.1016/0016-7037(71)90028-7.]

Corfu, Fernando, Hanchar, J.M., Hoskin, P.W.O., and Kinny, Peter, 2003, Atlas of zircon textures, chap. 16 of Hanchar, J.M., and Hoskin, P.W.O., eds., Zircon: Washington, D.C., Mineralogical Society of America, Reviews in Mineralogy and Geochemistry Series, v. 53, p. 469-500. [Also available at http://dx.doi.org/10.2113/0530469.]

Correia Neves, J.M., Lopes Nunes, J.E., and Sahama, T.G., 1974, High hafnium members of the zircon-hafnon series from the granite pegmatites of Zambezia, Mozambique: Contributions to Mineralogy and Petrology, v. 48, no. 1, p. 73-80. [Also available at http://dx.doi.org/10.1007/bf00399111.]

Cox, D.P., 1992, Descriptive model of diamond pipesModel 12, in Cox, D.P., and Singer, D.A., eds., Mineral deposit models: U.S. Geological Survey Bulletin 1693, p. 54. [Also available at http://pubs.er.usgs.gov/publication/b1693.]

Cronin, T.M., Bybell, L.M., Poore, R.Z., Blackwelder, B.W., Liddicoat, J.C., and Hazel, J.E., 1984, Age and correlation of emerged Pliocene and Pleistocene deposits, U.S. Atlantic Coastal Plain: Palaeogeography, Palaeoclimatology, Palaeoecology, v. 47, nos. 1-2, p. 21-51. [Also available at http://dx.doi.org/10.1016/0031-0182(84)90079-8.]

Daniels, W.L., Genthner, M.H., and Hodges, R.L., 1992, Soil development in sandy tailings derived from mineral sands mining in Florida, in Achieving land use potential through reclamation-Proceedings of the 9th Annual Meeting of the American Society for Surface Mining and Reclamation, Duluth, Minn., June 14-18, 1992: Princeton, W.Va., American Society for Surface Mining and Reclamation, p. 37-47. [Also available at http:/www.asmr.us/Portals/0/Documents/ Conference-Proceedings/1992/0037-Daniels.pdf.]
Daniels, W.L., Orndorff, Z.W., and Schroeder, P.D., 2003, Chemical and physical properties of mineral sands mine soils in southeastern Virginia, in Barnhisel, R.I., ed., Working together for innovative reclamation-Proceedings of a Joint Conference of [the] 9th Billings Land Reclamation Symposium and American Society of Mining and Reclamation 20th Annual National Conference, Billings, Mont., June 3-6, 2003: Lexington, Ky., American Society of Mining and Reclamation, p. 209-228. [Also available at http:/www.asmr.us/Publications/Conference Proceedings 2003/0209-Daniels.pdf.]

David, K., Schiano, P., and Allegre, C.J., 2000, Assessment of the $\mathrm{Zr} / \mathrm{Hf}$ fractionation in oceanic basalts and continental materials during petrogenetic processes: Earth and Planetary Science Letters, v. 178, nos. 3-4, p. 285-301. [Also available at http://dx.doi.org/10.1016/s0012-821x(00)00088-1.]

Dawson, J.B., 1987, The kimberlite clan-Relationship with olivine and leucite lamproites, and inferences for uppermantle metasomatism, in Fitton, J.G., and Upton, B.G.J., eds., Alkaline igneous rocks: Oxford, United Kingdom, Blackwell Scientific, Geological Society of London Special Publications Series, v. 30, p. 95-102. [Also available at http://dx.doi.org/10.1144/gsl.sp.1987.030.01.07.]

Dickinson, W.R., 2008, Impact of differential zircon fertility of granitoid basement rocks in North America on age populations of detrital zircon and implications for granite petrogenesis: Earth and Planetary Science Letters, v. 275, nos. 1-2, p. 80-92. [Also available at http://dx.doi.org/10.1016/j.epsl.2008.08.003.]

Downes, Hilary, Balaganskaya, Elena, Beard, A.D., Liferovish, Ruslan, and Demaiffe, Daniel, 2005, Petrogenetic processes in the ultramafic, alkaline and carbonatitic magmatism in the Kola alkaline provinceA review: Lithos, v. 85, nos. 1-4, p. 48-75. [Also available at http://dx.doi.org/10.1016/j.lithos.2005.03.020.]

Dudkin, O.B., and Mitrofanov, F.P., 1994, Features of the Kola alkali province: Geochemistry International, v. 31, no. 3, p. 1-11.

Edgar, A.D., 1987, The genesis of alkaline magmas with emphasis on their source regions-Inferences from experimental studies, in Fitton, J.G., and Upton, B.G.J., eds., Alkaline igneous rocks: Oxford, United Kingdom, Blackwell Scientific, Geological Society of London Special Publications Series, v. 30, p. 29-52. [Also available at http://dx.doi.org/10.1144/gsl.sp.1987.030.01.04.]

Elko, N.A., and Davis, R.A., Jr., 2006, Morphologic evolution of similar barrier islands with different coastal management: Journal of Coastal Research, special issue, v. I, no. 39, p. $127-131$.

Ellenbecker, Scott, 2011, Russian producer prepares to go super-deep: Engineering \& Mining Journal, v. 212, December, p. 120-121, accessed February 12, 2013, at http://emj.epubxp.com/i/50645/121. 
Ellison, A.J., and Hess, P.C., 1986, Solution behavior of +4 cations in high silica melts - Petrologic and geochemical implications: Contributions to Mineralogy and Petrology, v. 94, no. 3, p. 343-351. [Also available at http://dx.doi.org/ 10.1007/BF00371443.]

Elsner, Harald, 2010, Assessment manual-Heavy minerals of economic importance: Hannover, Germany, Bundesanstalt für Geowissenschaften und Rohstoffe (BGR) [Federal Institute for Geosciences and Natural Resources], 218 p., accessed June 19, 2013, at http://www.bgr.bund.de/DE/Themen/ Min_rohstoffe/Downloads/heavy-minerals-economicimportance.pdf;jsessionid=1F6B0D5639695587638EFA19 F7DCDACA. 1 cid297? blob=publicationFile \&v $=5$.

Engel, A.E.J., Engel, C.G., and Havens, R.G., 1965, Chemical characteristics of oceanic basalts and the upper mantle: Geological Society of America Bulletin, v. 76, no. 7, p. 719-734. [Also available at http://dx.doi.org/10.1130/ 0016-7606(1965)76[719:ccooba]2.0.co;2.]

Fitton, J.G., 1987, The Cameroon line, West Africa-A comparison between oceanic and continental alkaline volcanism, in Fitton, J.G., and Upton, B.G.J., eds., Alkaline igneous rocks: Oxford, United Kingdom, Blackwell Scientific, Geological Society of London Special Publications Series, v. 30, p. 279-291.

Flohr, M.J.K., and Ross, Malcolm, 1990, Alkaline igneous rocks of Magnet Cove, Arkansas-Mineralogy and geochemistry of syenites: Lithos, v. 26, nos. 1-2, p. 67-98. [Also available at http://dx.doi.org/10.1016/ 0024-4937(90)90041-x.]

Force, E.R., 1991, Geology of titanium-mineral deposits: Geological Society of America Special Paper 259, 112 p. [Also available at http://dx.doi.org/10.1130/spe259-p1.]

Force, E.R., and Rich, F.J., 1989, Geologic evolution of Trail Ridge eolian heavy-mineral sand and underlying peat, northern Florida: U.S. Geological Survey Professional Paper 1499, 16 p. [Also available at http://pubs.er.usgs.gov/ publication/pp1499.]

Fujiyasu, Yoshimasa, Fahey, Martin, and Newson, Tim, 2000, Field investigation of evaporation from freshwater tailings: Journal of Geotechnical and Geoenvironmental Engineering, v. 126 , no. 6, p. 556-567. [Also available at http://dx.doi.org/ 10.1061/(asce)1090-0241(2000)126:6(556).]

Gaillardet, J., Viers, J., and Dupré, B., 2003, Trace elements in river waters, in Drever, J.I., ed., Surface and ground water, weathering and soils, v. 5 of Holland, H.D., and Turekian, K.K., eds., Treatise on geochemistry: Oxford, United Kingdom, Elsevier-Pergamon, p. 225-272. [Also available at http://dx.doi.org/10.1016/b0-08-043751-6/05165-3.]

Galloway, W.E., Ganey-Curry, P.E., Li, Xiang, and Buffler, R.T., 2000, Cenozoic depositional history of the Gulf of Mexico Basin: AAPG Bulletin, v. 84, no. 11, p. 1743-1774. [Also available at http://dx.doi.org/10.1306/8626c37f-173b-11d78645000102c1865d.]
Gambogi, Joseph, 2010, Zirconium and hafnium, in Metals and minerals: U.S. Geological Survey Minerals Yearbook 2007, v. I, p. 85.1-85.9. [Also available at http://minerals.usgs.gov/minerals/pubs/commodity/ zirconium/myb1-2007-zirco.pdf.]

Gambogi, Joseph, 2012a, Zirconium and hafnium, in Metals and minerals: U.S. Geological Survey Minerals Yearbook 2010, v. I, p. 85.1-85.8. [Also available at http://minerals.usgs.gov/minerals/pubs/commodity/ zirconium/myb1-2010-zirco.pdf.]

Gambogi, Joseph, 2012b, Zirconium and hafnium: U.S. Geological Survey Mineral Commodity Summaries 2012, p. 190-191. [Also available at https://minerals.usgs.gov/ minerals/pubs/commodity/zirconium/mcs-2012-zirco.pdf.]

Garnett, R.H.T., and Bassett, N.C., 2005, Placer deposits, in Economic Geology - One hundredth anniversary volume: Littleton, Colo., Society of Economic Geologists, p. 813-843, 1 CD-ROM.

Gill, J.B., 1981, Orogenic andesites and plate tectonics: New York, N.Y., Springer, Minerals and Rocks Series, v. 16, 390 p.

Govindaraju, K., 1994, 1994 compilation of working values and sample description for 383 geostandards: Geostandards Newsletter, v. 18, Issue Supplement S1, 158 p. [Also available at http://dx.doi.org/10.1046/ j.1365-2494.1998.53202081.x-i1.]

Graedel, T.E., Allwood, Julian, Birat, J.-P., Buchert, Matthias, Hagelüken, Christian, Reck, B.K., Sibley, S.F., and Sonnemann, Guido, 2011, What do we know about metal recycling rates?: Journal of Industrial Ecology, v. 15, no. 3, p. 355-366. [Also available at http://dx.doi.org/10.1111/j.1530-9290.2011.00342.x.]

Hails, J.R., and Hoyt, J.H., 1972, The nature and occurrence of heavy minerals in Pleistocene and Holocene sediments of the lower Georgia coastal plain: Journal of Sedimentary Petrology, v. 42, no. 3, p. 646-666. [Also available at http://dx.doi.org/10.1306/74d725ea-2b21-11d7$8648000102 \mathrm{c} 1865 \mathrm{~d}$.]

Hamilton, N.T.M., 1995, Controls on the global distribution of coastal titanium-zirconium placers: International Geology Review, v. 37, no. 9, p. 755-779. [Also available at http://dx.doi.org/10.1080/00206819509465426.]

Hanson, W.D., 1997, Heavy-mineral sands of the Tokio Formation in southwest Arkansas: Little Rock, Ark., Arkansas Geological Commission Information Circular, IC-34, $9 \mathrm{p}$.

Heaman, L.M., and LeCheminant, A.N., 1993, Paragenesis and $\mathrm{U}-\mathrm{Pb}$ systematics of baddeleyite $\left(\mathrm{ZrO}_{2}\right)$ : Chemical Geology, v. 110, nos. 1-4, p. 95-126. [Also available at http://dx.doi.org/10.1016/0009-2541(93)90249-i.] 
Heaman, L.M., Bowins, Robert, and Crocket, James, 1990, The chemical composition of igneous zircon suitesImplications for geochemical tracer studies: Geochimica et Cosmochimica Acta, v. 54, no. 6, p. 1597-1607. [Also available at http://dx.doi.org/10.1016/00167037(90)90394-z.]

Hoffman, A.W., 1997, Mantle geochemistry_The message from ocean volcanism: Nature, v. 385, no. 6613, p. 219-229. [Also available at http://dx.doi.org/10.1038/385219a0.]

Hoskin, P.W.O., and Schaltegger, Urs, 2003, The composition of zircon and igneous and metamorphic petrogenesis, chap. 2 of Hanchar, J.M., and Hoskin, P.W.O., eds., Zircon: Reviews in Mineralogy and Geochemistry, v. 53, p. 27-62. [Also available at http://dx.doi.org/10.2113/0530027.]

Hou, Baohong, Keeling, John, Reid, Anthony, Fairclough, Martin, Warland, Ian, Belousova, Elena, Frakes, Larry, and Hocking, Roger, 2011, Heavy mineral sands in the Eucla basin, southern Australia-Deposition and province-scale prospectivity: Economic Geology, v. 106, p. 687-712. [Also available at http://dx.doi.org/10.2113/econgeo.106.4.687.]

Inman, D.L., and Nordstrom, C.E., 1971, On the tectonic and morphologic classification of coasts: Journal of Geology, v. 79, no. 1, p. 1-21. [Also available at http://dx.doi.org/ 10.1086/627583.]

Kabata-Pendias, Alina, and Mukherjee, A.B., 2007, Trace elements from soil to human: Berlin, Germany, SpringerVerlag, 550 p. [Also available at http://dx.doi.org/ 10.1007/978-3-540-32714-1.]

Kelemen, P.B., Johnson, K.T.M., Kinzler, R.J., and Irving, A.J., 1980, High-field-strength element depletions in arc basalts due to mantle-magma interaction: Nature, v. 345 , no. 6275 , p. 521-524. [Also available at http://dx.doi.org/10.1038/ 345521a0.]

Klemme, Stephan, and Meyer, Hans-Peter, 2003, Trace element partitioning between baddeleyite and carbonatite melt at high pressures and high temperatures: Chemical Geology, v. 199, nos. 3-4, p. 233-242. [Also available at http://dx.doi.org/10.1016/s0009-2541(03)00081-0.]

Kogarko, L.N., 1987, Alkaline rocks of the eastern part of the Baltic Shield (Kola Peninsula), in Fitton, J.G., and Upton, B.G.J., eds., Alkaline igneous rocks: Oxford, United Kingdom, Blackwell Scientific, Geological Society of London Special Publications Series, v. 30, p. 531-544. [Also available at http://dx.doi.org/10.1144/gsl.sp.1987.030.01.26.]

Kogarko, L.N., 1990, Ore-forming potential of alkaline magmas: Lithos, v. 26, nos. 1-2, p. 167-175. [Also available at http://dx.doi.org/10.1016/0024-4937(90)90046-4.]

Komar, P.D., and Wang, Chi, 1984, Processes of selective grain transport and the formation of placers on beaches: Journal of Geology, v. 92, no. 6, p. 637-655. [Also available at http://dx.doi.org/10.1086/628903.]
Kononov, M.E., Beloborodov, V.I., Nikitenko, N.G., and Zorina, T.A., 1992, Investigations of baddeleyite-forsterite products from the Kovdorsk mining-beneficiation combine: Refractories, v. 33, no. 3, p. 209-211. [Also available at http://dx.doi.org/10.1007/bf01283567.]

Kramm, U., Kogarko, L.N., Kononova, V.A., and Vartiainen, H., 1993, The Kola alkaline province of the CIS and FinlandPrecise Rb-Sr ages define 380-360 Ma age range for all magmatism: Lithos, v. 30, no. 1, p. 33-44. [Also available at http://dx.doi.org/10.1016/0024-4937(93)90004-v.]

Landers, Matt, and Usher, Brent, 2012, Acid metalliferous leaching of a mineral sands deposit-From field to laboratory, in McCullough, C.D., Lund, M.A., and Wyse, Lorraine, eds., International Mine Water Association Symposium 2012-Mine Water and the Environment, Bunbury, Western Australia, Australia, 29 September4 October 2012, Proceedings: Red Hook, N.Y., Curran Associates, p. 215-221. [Also available at http://www.mwen.info/ docs/imwa_2012/IMWA2012_Landers_215.pdf.]

Leatherman, S.P., Williams, A.T., and Fisher, J.S., 1977, Overwash sedimentation associated with a large-scale northeaster: Marine Geology, v. 24, no. 2, p. 109-121. [Also available at http://dx.doi.org/10.1016/00253227(77)90004-4.]

Le Maitre, R.W., ed., with Streckeisen, A., Zanettin, B., Le Bas, M.J., Bonin, B., Bateman, P., Bellieni, G., Dudek, A., Efremova, S., Keller, J., Lameyre, J., Sabine, P.A., Schmid, R., Sørensen, H., and Woolley, A.R., 2002, Igneous rocks-A classification and glossary of terms - Recommendations of the International Union of Geological Sciences Subcommission on the Systematics of Igneous Rocks: New York, N.Y., Cambridge University Press, 236 p.

Levinson, A.A., and Borup, R.A., 1960, High hafnium zircon from Norway: American Mineralogist, v. 45, nos. 5-6, p. 562-565.

Loferski, P.J., 2013a, Zirconium and hafnium [advance release], in Metals and minerals: U.S. Geological Survey Minerals Yearbook 2011, v. I, p. 85.1-85.8. [Also available at http://minerals.usgs.gov/minerals/pubs/commodity/ zirconium/myb1-2011-zirco.pdf.]

Loferski, P.J., 2013b, Zirconium and hafnium: U.S. Geological Survey Mineral Commodity Summaries 2013, p. 190-191. [Also available at https://minerals.usgs.gov/minerals/pubs/ commodity/zirconium/mcs-2013-zirco.pdf.]

MacDonald, W.G., and Rozendaal, A., 1995, The Geelwal Karoo heavy mineral deposit-A modern day beach placer: Journal of African Earth Sciences, v. 21, no. 1, p. 187-200. [Also available at http://dx.doi.org/10.1016/0899-5362(95)00082-5.]

Mallik, T.K., Vasudevan, V., Aby Verghese, P., and Machado, Terry, 1987, The black sand placer deposits of Kerala Beach, southwest India: Marine Geology, v. 77, nos. 1-2, p. 129-150. [Also available at http://dx.doi.org/ 10.1016/0025-3227(87)90088-0.] 
Markewich, H.W., Pavich, M.J., and Buell, G.R., 1990, Contrasting soils and landscapes of the Piedmont and coastal plain, eastern United States: Geomorphology, v. 3, nos. 3-4, p. 417-447. [Also available at http://dx.doi.org/10.1016/0169-555x(90)90015-i.]

Marks, M.A.W., Hettmann, Kai, Schilling, Julian, Frost, B.R., and Markl, Gregor, 2011, The mineralogical diversity of alkaline igneous rocks - Critical factors for the transition from miaskitic to agpaitic phase assemblages: Journal of Petrology, v. 52, no. 3, p. 439-455. [Also available at http://dx.doi.org/10.1093/petrology/egq086.]

McGowran, Brian, Li, Qianyu, and Moss, Graham, 1997, The Cenozoic neritic record in southern Australia-The biogeohistorical framework, in James, N.P., and Clarke, J.A.D., eds., Cool-water carbonates: Tulsa, Okla., Society for Sedimentary Geology Special Publication Series, v. 56, p. 185-203. [Also available at http://dx.doi.org/10.2110/pec.97.56.0185.]

McKenzie, Dan, 1985, The extraction of magma from the crust and mantle: Earth and Planetary Science Letters, v. 74, no. 1, p. 81-91. [Also available at http://dx.doi.org/ 10.1016/0012-821x(85)90168-2.]

Menzies, Martin, 1987, Alkaline rocks and their inclusionsA window on the Earth's interior, in Fitton, J.G., and Upton, B.G.J., eds., Alkaline igneous rocks: Oxford, United Kingdom, Blackwell Scientific, Geological Society of London Special Publications Series, v. 30, p. 15-28. [Also available at http://dx.doi.org/10.1144/gsl.sp.1987.030.01.03.]

Minter, W.E.L., 2006, The sedimentary setting of Witwatersrand placer mineral deposits in an Archean atmosphere, in Kesler, S.E., and Ohmoto, Hiroshi, eds., Evolution of early Earth's atmosphere, hydrosphere, and biosphereConstraints from ore deposits: Boulder, Colo., Geological Society of America Memoir Series, v. 198, p. 105-119. [Also available at http://dx.doi.org/10.1130/2006.1198(06).]

Modreski, P.J., Armbrustmacher, T.J., and Hoover, D.B., 1995, Carbonatite deposits (Model 10; Singer, 1986a), chap. 6 of du Bray, E.A., ed., Preliminary compilation of descriptive geoenvironmental mineral deposit models: U.S. Geological Survey Open-File Report 95-831, p. 47-49. [Also available at http://pubs.usgs.gov/of/1995/ofr-95-0831/.]

Morton, A.C., and Hallsworth, C.R., 1999, Processes controlling the composition of heavy mineral assemblages in sandstones: Sedimentary Geology, v. 124, nos. 1-4, p. 3-29. [Also available at http://dx.doi.org/10.1016/ s0037-0738(98)00118-3.]

Murty, Ch.V.G.K., Gurung, R., Upadhyay, R., and Asokan, S., 2007, Tata Steel's Titania project - Challenges in slimes disposal, in Heavy minerals conference-Back to basics, 6th, Zulu Nyala, Hluhluwe, South Africa, September 10-14, 2007: Johannesburg, South Africa, Southern African Institute of Mining and Metallurgy, Symposium Series, v. 48, p. 111-118. [Also available at http://www.saimm.co.za/Conferences/ HMC2007/111-118_Murty.pdf.]
Natural Earth, 2014, Small scale data: Natural Earth map dataset, scale 1:110,000,000, accessed June 23, 2014, at http://www.naturalearthdata.com.

Nickel, E.H., and Robinson, B.W., 1985, Kimrobinsonite, a new tantalum mineral from Western Australia, and its association with cesstibtantite: Canadian Mineralogist, v. 23 , pt. 4 , p. $573-576$.

Nielson, R.H., and Wilfling, Gerhard, 2002, Zirconium and zirconium compounds, in Ullmann's encyclopedia of industrial chemistry: Weinheim, Germany, Wiley-VCH Verlag GmbH \& Co., accessed January 10, 2013, at http://dx.doi.org/10.1002/14356007.a28_543.pub2.

Occupational Safety and Health Administration, 2013, Table Z-1-Limits for air contaminants - Occupational Safety and Health Standard number 1910.1000: U.S. Department of Labor, Occupational Safety and Health Administration, accessed February 15, 2013, at http://www.osha.gov/pls/oshaweb/owadisp.show_ document?p_table=standards\&p_id $=9992$.

Opdyke, N.D., Spangler, D.P., Smith, D.L., Jones, D.S., and Lindquist, R.C., 1984, Origin of the epeirogenic uplift of Pliocene-Pleistocene beach ridges in Florida and development of the Florida karst: Geology, v. 12, no. 4, p. 226-228. [Also available at http://dx.doi.org/10.1130/0091-7613(1984) 12\%3C226:ooteuo\%3E2.0.co;2.]

Orndorff, Z.W., Daniels, W.L., and Galbraith, J.M., 2005, Properties and classification of mineral sands mine soils in southeastern Virginia, in Barnhisel, R.I., ed., Proceedings of a joint conference of the American Society of Mining and Reclamation, 22d, Breckenridge, Colo., June 19-23, 2005: Breckenridge, Colo., American Society of Mining and Reclamation, p. 842-861. [Also available at http://asmr.us/ Publications/Conference\%20Proceedings/2005/0842Orndorff-VA.pdf.]

Orndorff, Z.W., Daniels, W.L., Meredith, K.R., Alley, M.M., and Wick, A.F., 2011, Effects of prime farmland soil reconstruction methods on post-mining productivity of mineral sands mine soils in Virginia, in Barnhisel, R.I., ed., Reclamation-Sciences leading to success, Proceedings of the 28th Annual Meeting of the American Society of Mining and Reclamation-Bismarck, North Dakota, June 11-16, 2011: Lexington, Ky., American Society of Mining and Reclamation, p. 504-518. [Also available at http://landrehab.org/UserFiles/DataItems/7A5A565056 4671794835553D/Orndorff\%20et\%20al.,\%202011\%20 ASMR $\% 20$ Effects $\% 20$ of $\% 20$ prime $\% 20$ farmland.pdf.]

Patty, F.A., Clayton, G.D., and Clayton, F.E., eds., 1981, Patty's industrial hygiene and toxicology, v. 2 (3d rev. ed.): New York, N.Y., John Wiley \& Sons, 1,420 p.

Pearce, J.A., and Norry, M.J., 1979, Petrogenetic implications of $\mathrm{Ti}, \mathrm{Zr}, \mathrm{Y}$, and $\mathrm{Nb}$ variations in volcanic rocks: Contributions to Mineralogy and Petrology, v. 69, no. 1, p. 33-47. [Also available at http://dx.doi.org/10.1007/bf00375192.] 
Perfit, M.R., Gust, D.A., Bence, A.E., Arculus, R.J., and Taylor, S.R., 1980, Chemical characteristics of islandarc basalts-Implications for mantle sources: Chemical Geology, v. 30, no. 3, p. 227-256. [Also available at http://dx.doi.org/10.1016/0009-2541(80)90107-2.]

Peterson, C.D., Gleeson, G.W., and Wetzel, Nick, 1987, Stratigraphic development, mineral resources and preservation of marine placers from Pleistocene terraces in southern Oregon, U.S.A.: Sedimentary Geology, v. 53, nos. 3-4, p. 203-229. [Also available at http://dx.doi.org/ 10.1016/0037-0738(87)90035-2.]

Peterson, C.D., Komar, P.D., and Scheidegger, K.F., 1986, Distribution, geometry, and origin of heavy mineral placer deposits on Oregon beaches: Journal of Sedimentary Research, v. 56, no. 1, p. 67-77. [Also available at http://dx.doi.org/10.1306/212f8887-2b24-11d7$8648000102 \mathrm{c} 1865 \mathrm{~d}$.]

Petrov, S.V., 2004, Economic deposits associated with the alkaline and ultrabasic complexes of the Kola Peninsula, in Wall, F., and Zaitsev, A.N., eds., Phoscorites and carbonatites from mantle to mine- The key example of the Kola alkaline province: London, United Kingdom, Mineralogical Society of Great Britain and Ireland, The Mineralogical Society Series, v. 10, p. 469-490.

Pirkle, E.C., Pirkle, F.L., Pirkle, W.A., and Stayert, P.R., 1984, The Yulee heavy mineral sand deposits of northeastern Florida: Economic Geology, v. 79, p. 725-737. [Also available at http://dx.doi.org/10.2113/gsecongeo.79.4.725.]

Pirkle, E.C., Pirkle, W.A., and Yoho, W.H., 1974, The Green Cove Springs and Boulougne heavy-mineral sand deposits of Florida: Economic Geology, v. 69, p. 1129-1137. [Also available at http://dx.doi.org/10.2113/gsecongeo.69.7.1129.]

Pirkle, F.L., Pirkle, W.A., and Pirkle, E.C., 2007, Heavymineral sands of the Atlantic and Gulf Coastal Plains, USA, chap. 45 of Mange, M.A., and Wright, D.T., eds., Heavy minerals in use: Boston, Mass., Elsevier, Developments in Sedimentology Series, v. 58, p. 1145-1232. [Also available at http://dx.doi.org/10.1016/s0070-4571(07)58045-3.]

Premaratne, W.A.P.J., and Rowson, N.A., 2003, The processing of beach sand from Sri Lanka for the recovery of titanium using magnetic separation: Physical Separation in Science and Engineering, v. 12, no. 1, p. 13-22. [Also available at http://dx.doi.org/10.1080/1478647031000101232.]

Puffer, J.H., and Cousminer, H.L., 1982, Factors controlling the accumulation of titanium-iron oxide-rich sands in the Cohansey Formation, Lakehurst area, New Jersey: Economic Geology, v. 77, p. 379-391. [Also available at http://dx.doi.org/10.2113/gsecongeo.77.2.379.]

Pupin, J.P., 1980, Zircon and granite petrology: Contributions to Mineralogy and Petrology, v. 73, no. 3, p. 207-220. [Also available at http://dx.doi.org/10.1007/bf00381441.]
Reimann, Clemens, and de Caritat, Patrice, 1998, Chemical elements in the environment-Factsheets for the geochemist and environmental scientist: Berlin, Germany, SpringerVerlag, $398 \mathrm{p}$.

Reinson, G.E., 1979, Facies models 14. Barrier island systems: Geoscience Canada, v. 6, no. 2, p. 51-68. [Also available at https://journals.lib.unb.ca/index.php/GC/article/ view/3154/3671.]

Reshetnyak, Serguei, Melikhova, Galina, Fedotova, Yulia, and Melikhov, Mikhail, 2008, Problems of deep open pits closure in the Kola Peninsula, in Rapantova, Nada, and Hrkal, Zybnek, eds., Mine Water and the EnvironmentProceedings of the 10th IMWA Congress 2008, Karlsbad, Czech Republic, June 2-5, 2008: Wendelstein, Germany, International Mine Water Association, p. 171-174. [Also available at https://www.imwa.info/docs/imwa_2008/ IMWA2008_166_Reshetnyak.pdf.]

Rodionov, N.V., Belyatsky, B.V., Antonov, A.V., Kapitonov, I.N., and Sergeev, S.A., 2012, Comparative in-situ U-Th-Pb geochronology and trace element composition of baddeleyite and low-U zircon from carbonatites of the Paleozoic Kovdor alkaline-ultramafic complex, Kola Peninsula, Russia: Gondwana Research, v. 21, no. 4, p. 728-744. [Also available at http://dx.doi.org/10.1016/ j.gr.2011.10.005.]

Roy, P.S., 1999, Heavy mineral beach placers in southeastern Australia-Their nature and genesis: Economic Geology, v. 94, p. 567-588. [Also available at http://dx.doi.org/ 10.2113/gsecongeo.94.4.567.]

Roy, P.S., Cowell, P.J., Ferland, M.A., and Thom, B.G., 1994, Wave-dominated coasts, chap. 4 of Carter, R.W.G., and Woodroffe, C.D., eds., Coastal evolution-Late Quaternary shoreline morphodynamics: New York, N.Y., Cambridge University Press, p. 121-186.

Roy, P.S., Whitehouse, John, Cowell, P.J., and Oakes, Geoff, 2000, Mineral sands occurrences in the Murray basin, southeastern Australia: Economic Geology, v. 95, p. 1107-1128. [Also available at http://dx.doi.org/10.2113/ gsecongeo.95.5.1107.]

Rubatto, Daniela, and Hermann, Jörg, 2003, Zircon formation during fluid circulation in eclogites (Monviso, Western Alps)-Implications for $\mathrm{Zr}$ and $\mathrm{Hf}$ budget in subduction zones: Geochimica et Cosmochimica Acta, v. 67, no. 12, p. 2173-2187. [Also available at http://dx.doi.org/10.1016/ s0016-7037(02)01321-2.]

Rubatto, Daniela, Gebauer, Dieter, and Compagnoni, Roberto, 1999, Dating of eclogite-facies zircons - The age of Alpine metamorphism in the Sesia-Lanzo zone (Western Alps): Earth and Planetary Science Letters, v. 167, nos. 3-4, p. 141-158. [Also available at http://dx.doi.org/10.1016/ s0012-821x(99)00031-x.] 
Russian Academy of Sciences, 1999, Кадастр отходов горнометаллургического производства [Inventory of waste mining and metallurgical production]: Государственный комитет по охране окружающей среды Мурманской области, Кольский научный центр Горный институт [State Committee for Environmental Protection of the Murmansk Region, Kola Science Center of the Institute of Mines, RAS, accessed February 21, 2013, at http://www.murman.ru/ecology/cadastre/.

Saxena, S.K., 1966, Evolution of zircons in sedimentary and metamorphic rocks: Sedimentology, v. 6, no. 1, p. 1-33. [Also available at http://dx.doi.org/10.1111/ j.1365-3091.1966.tb01568.x.]

Schaller, K.-H., 2004, Zirconium, chap. 30 of Merian, E., Anke, M., Ihnat, M., and Stoeppler, M., eds., Elements and their compounds in the environment ( $2 \mathrm{~d}$ ed.): Weinheim, Germany, Wiley-VCH Verlag GmbH \& Co., p. 1241-1247. [Also available at http://dx.doi.org/ 10.1002/9783527619634.ch51.]

Schaltegger, U., Fanning, C.M., Günther, D., Maurin, J.C., Schulmann, K., and Gebauer, D., 1999, Growth, annealing and recrystallization of zircon and preservation of monazite in high-grade metamorphism - Conventional and in-situ $\mathrm{U}-\mathrm{Pb}$ isotope, cathodoluminescence and microchemical evidence: Contributions to Mineralogy and Petrology, v. 134, nos. 2-3, p. 186-201. [Also available at http://dx.doi.org/10.1007/s004100050478.]

Scharer, Urs, Corfu, Fernando, and Demaiffe, Daniel, 1997, $\mathrm{U}-\mathrm{Pb}$ and Lu-Hf isotopes in baddeleyite and zircon megacrysts from the Mbuji-Mayi kimberlite - Constraints on the subcontinental mantle: Chemical Geology, v. 143, nos. 1-2, p. 1-16. [Also available at http://dx.doi.org/10.1016/ s0009-2541(97)00094-6.]

Shacklette, H.T., and Boerngen, J.G., 1984, Element concentrations in soils and other surficial materials of the conterminous United States: U.S. Geological Survey Professional Paper 1270, 105 p. [Also available at http://pubs.usgs.gov/pp/1270/.]

Shahid, Muhammad, Ferrand, Emmanuel, Schreck, Eva, and Dumat, Camille, 2013, Behavior and impact of zirconium in the soil-plant system-Plant uptake and phytotoxicity, chap. 2 of Whitacre, D.M., ed., Reviews of environmental contamination and toxicology: Springer, New York, N.Y., Reviews of Environmental Toxicology Series, v. 221, p. 107-127. [Also available at http://dx.doi.org/10.1007/ 978-1-4614-4448-0_2.]

Sindern, S., Zaitsev, A.N., Demény, A., Bell, K., Chakmouradian, A.R., Kramm, U., Moutte, J., and Rukhlov, A.S., 2004, Mineralogy and geochemistry of silicate dyke rocks associated with carbonatites from the Khibina complex (Kola, Russia)-Isotope constraints on genesis and small-scale mantle sources: Mineralogy and Petrology, v. 80, nos. 3-4, p. 215-239. [Also available at http://dx.doi.org/10.1007/s00710-003-0016-2.]
Singer, D.A., 1992, Descriptive model of carbonatite deposits,-Model 10, in Cox, D.P., and Singer, D.A., eds., Mineral deposit models: U.S. Geological Survey Bulletin 1693, p. 51. [Also available at https://pubs.er.usgs.gov/ publication/b1693.]

Slingerland, Rudy, and Smith, N.D., 1986, Occurrence and formation of water-laid placers: Annual Reviews of Earth and Planetary Sciences, v. 14, p. 113-147. [Also available at http://dx.doi.org/10.1146/annurev.earth.14.1.113.]

Söderlund, Ulf, and Johansson, Leif, 2002, A simple way to extract baddeleyite $\left(\mathrm{ZrO}_{2}\right)$ : Geochemistry, Geophysics, Geosystems, v. 3, no. 2, 7 p. [Also available at http://dx.doi.org/10.1029/2001GC000212.]

Sørenson, Henning, 1997, The agpaitic rocks-An overview: Mineralogical Magazine, v. 61, no. 407, p. 485-498.

Speer, J.A., and Cooper, B.J., 1982, Crystal structure of synthetic hafnon, $\mathrm{HfSiO}_{4}$, comparison with zircon and the actinide orthosilicates: American Mineralogist, v. 67, nos. 7-8, p. 804-808.

Suter, G.W., II, 1996, Toxicological benchmarks for screening contaminants of potential concern for effects on freshwater biota: Environmental Toxicology and Chemistry, v. 15, no. 7, p. 1232-1241. [Also available at http://dx.doi.org/ 10.1002/etc.5620150731.]

Sutherland, D.G., 1985, Geomorphological controls on the distribution of placer deposits: Journal of the Geological Society, v. 142, no. 5, p. 727-737. [Also available at http://dx.doi.org/10.1144/gsjgs.142.5.0727.]

Taylor, S.R., and McLennan, S.M., 1995, The geochemical evolution of the continental crust: Reviews of Geophysics, v. 33, no. 2, p. 241-265. [Also available at http://dx.doi.org/ 10.1029/95rg00262.]

Thompson, R.N., Morrison, M.A., Hendry, G.L., Parry, S.J., Simpson, P.R., Hutchison, R., and O'Hara, M.J., 1984, An assessment of the relative roles of crust and mantle in magma genesis - An elemental approach [and discussion]: Philosophical Transactions of the Royal Society of London, Series A, v. 310, no. 1514, p. 549-590. [Also available at http://dx.doi.org/10.1098/rsta.1984.0008.]

Towner, R.R., 1992, International Strategic Minerals Inventory summary report-Zirconium: U.S. Geological Survey Circular 930-L, 47 p. [Also available http://pubs.er.usgs.gov/ publication/cir930L.]

U.S. Environmental Protection Agency, 2012, Provisional peer-reviewed toxicity values for soluble zirconium compounds: U.S. Environmental Protection Agency, Chemical Assessment Summary, CASRN 7440-67-7, accessed February 21, 2013, at http://hhpprtv.ornl.gov/ issue_papers/Zirconium.pdf. 
U.S. Geological Survey, 1996, Global 30 arc-second elevation (GTOPO30): Reston, Va., U.S. Geological Survey dataset (digital elevation model), accessed June 23, 2014, at https://lta.cr.usgs.gov/GTOPO30.

U.S. Geological Survey, 2006-9, Metals and minerals: U.S. Geological Survey Minerals Yearbook 2004-2006, v. I, variously paged. [Also available at http://minerals.usgs.gov/ minerals/pubs/myb.html.]

U.S. Geological Survey, 2010-13, Metals and minerals: U.S. Geological Survey Minerals Yearbook 2008-2011, v. I, variously paged. [Also available at http://minerals.usgs.gov/ minerals/pubs/myb.html.]

U.S. Geological Survey, 2014, Zirconium mineral concentrates statistics [through 2014; last modified January 28, 2016], in Kelly, T.D., and Matos, G.R., comps., Historical statistics for mineral and material commodities in the United States (2014 version): U.S. Geological Survey Data Series 140, accessed March 4, 2017, at http://minerals.usgs.gov/ minerals/pubs/historical-statistics/.

Verhulst, A., Balaganskaya, E., Kirnarsky, Y., and Demaiffe, D., 2000, Petrological and geochemical (trace elements and Sr-Nd isotopes) characteristics of the Paleozoic Kovdor ultramafic, alkaline and carbonatite intrusion (Kola Peninsula, NW Russia): Lithos, v. 51, nos. 1-2, p. 1-25. [Also available at http://dx.doi.org/ 10.1016/s0024-4937(99)00072-9.]

Viers, Jérôme, Dupré, Bernard, and Gaillardet, Jérôme, 2009, Chemical composition of suspended sediments in world rivers-New insights from a new database: Science of the Total Environment, v. 407, no. 2, p. 853-868. [Also available at http://dx.doi.org/10.1016/j.scitotenv.2008.09.053.]

von Knorring, O., and Hornung, G., 1961, Hafnian zircons: Nature, v. 190, no. 4781, p. 1098-1099. [Also available at http://dx.doi.org/10.1038/1901098a0.]

Wager, L.R., and Mitchell, R.L., 1951, The distribution of trace elements during strong fractionation of basic magma-A further study of the Skaergaard intrusion, East Greenland: Geochimica et Cosmochimica Acta, v. 1, no. 3, p. 129-208. [Also available at http://dx.doi.org/10.1016/0016-7037 (51)90016-6.]
Wang, R.C., Fontan, Francois, Xu, Shijin, Chen, Xiaoming, and Monchoux, Pierre, 1996, Hafnian zircon from the apical part of the Suzhou granite, China: Canadian Mineralogist, v. 34, pt. 5, p. 1001-1010.

Watson, E.B., and Harrison, T.M., 1984, Accessory minerals and the geochemical evolution of crustal magmatic systems - A summary and prospectus of experimental approaches: Physics of the Earth and Planetary Interiors, v. 35, nos. 1-3, p. 19-30. [Also available at http://dx.doi.org/ 10.1016/0031-9201(84)90031-1.]

Weaver, B.L., Wood, D.A., Tarney, John, and Joron, J.L., 1987, Geochemistry of ocean island basalts from the South Atlantic-Ascension, Bouvet, St. Helena, Gough and Tristan da Cunha, in Fitton, J.G., and Upton, B.G.J., eds., Alkaline igneous rocks: Oxford, United Kingdom, Blackwell Scientific, Geological Society of London Special Publications Series, v. 30, p. 253-267. [Also available at http://dx.doi.org/10.1144/gsl.sp.1987.030.01.11.]

Winker, C.D., and Howard, J.D., 1977, Correlation of tectonically deformed shorelines on the southern Atlantic Coastal Plain: Geology, v. 5, no. 2, p. 123-127. [Also available at http://dx.doi.org/10.1130/0091-7613(1977)5\%3C123: cotdso $\% 3 \mathrm{E} 2.0 . \operatorname{co} ; 2$.

Zimmerman, Clint, Stilson, Chuck, and Daniels, W.L., 2008, Reclamation of mineral sands mine and topsoil replacement study, in Proceedings of the 25th Annual Meeting of the American Society of Mining and Reclamation and 10th meeting of the IALR, Richmond, VA, June 14-19, 2008 : Lexington, Ky., American Society of Mining and Reclamation, p. 1429-1444. [Also available at http://landrehab.org/ UserFiles/DataItems/61326B4E366357773754493D/ Zimmerman\%20et\%20al.,\%202008\%20ASMR\%20 Reclamation\%20of\%20Mineral-VA.pdf.]

Zosin, A.P., Priimak, T.I., Masloboev, V.A., Sulimenko, L.P., and Mingaleva, T.A., 2011, Variation in wastewater composition in the water use system of Kovdorskii mining-and-processing integrated works: Water Resources, v. 38, no. 1, p. 113-123. [Also available at http://dx.doi.org/10.1134/s0097807810061065.] 
For more information concerning this report, please contact:

Mineral Resources Program Coordinator

U.S. Geological Survey

913 National Center

Reston, VA 20192

Telephone: 703-648-6100

Fax: 703-648-6057

Email: minerals@usgs.gov

Home page: https://minerals.usgs.gov

Prepared by the USGS Science Publishing Network Reston Publishing Service Center

Edited by J.C. Ishee and Stokely J. Klasovsky

Illustrations by Caryl J. Wipperfurth

Layout by Caryl J. Wipperfurth and Cathy Y. Knutson

Posting by Angela E. Hall 
